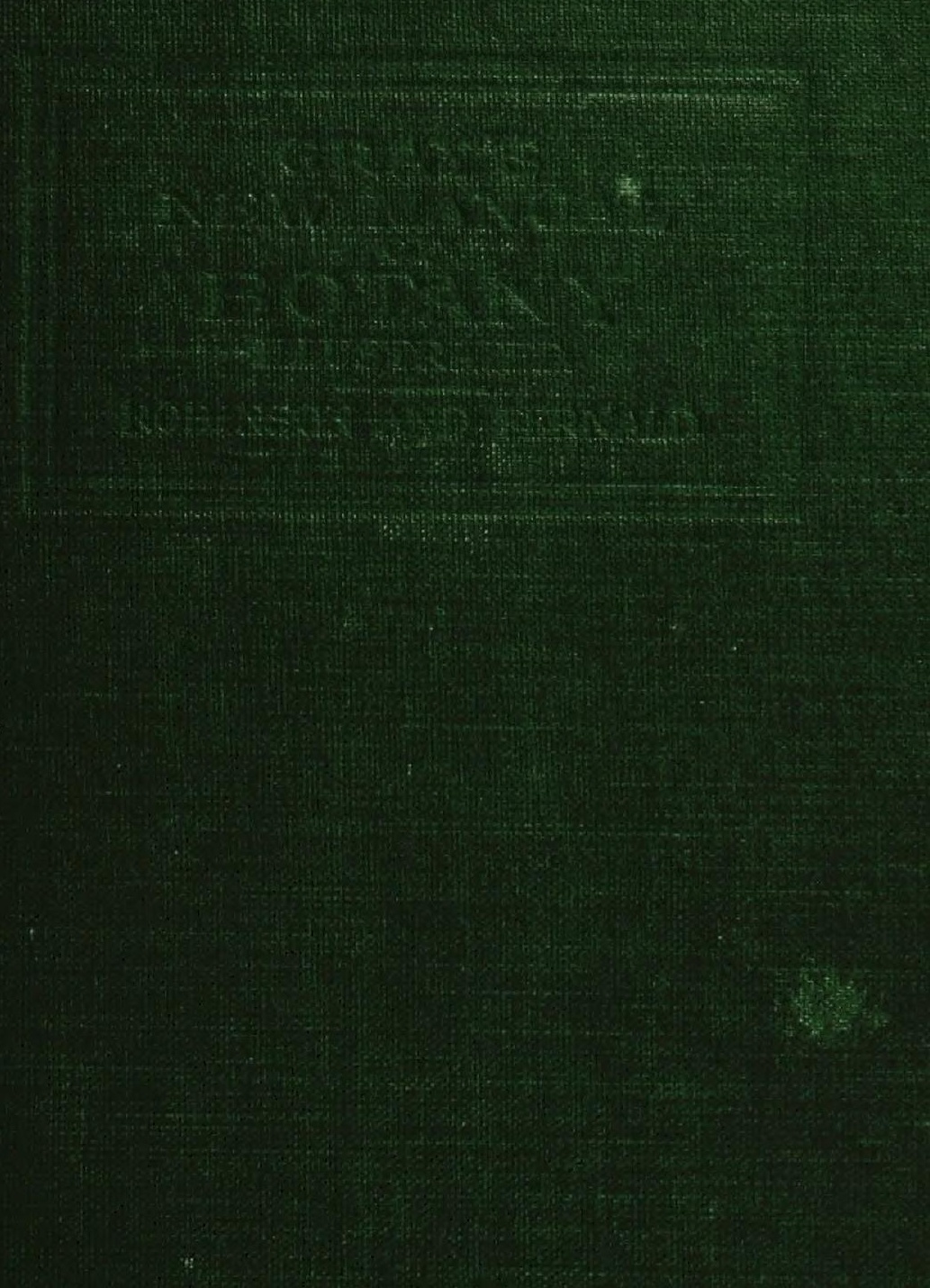




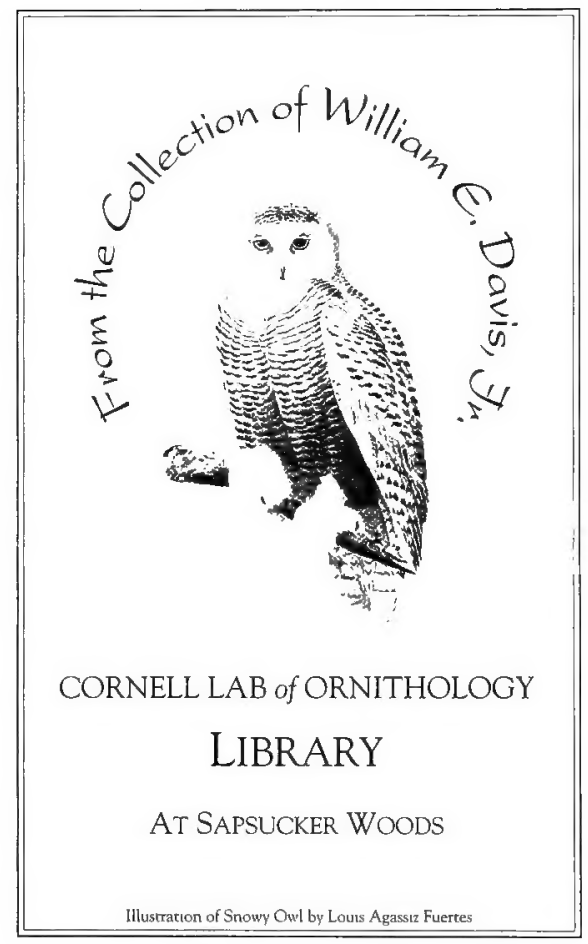


DATE DUE

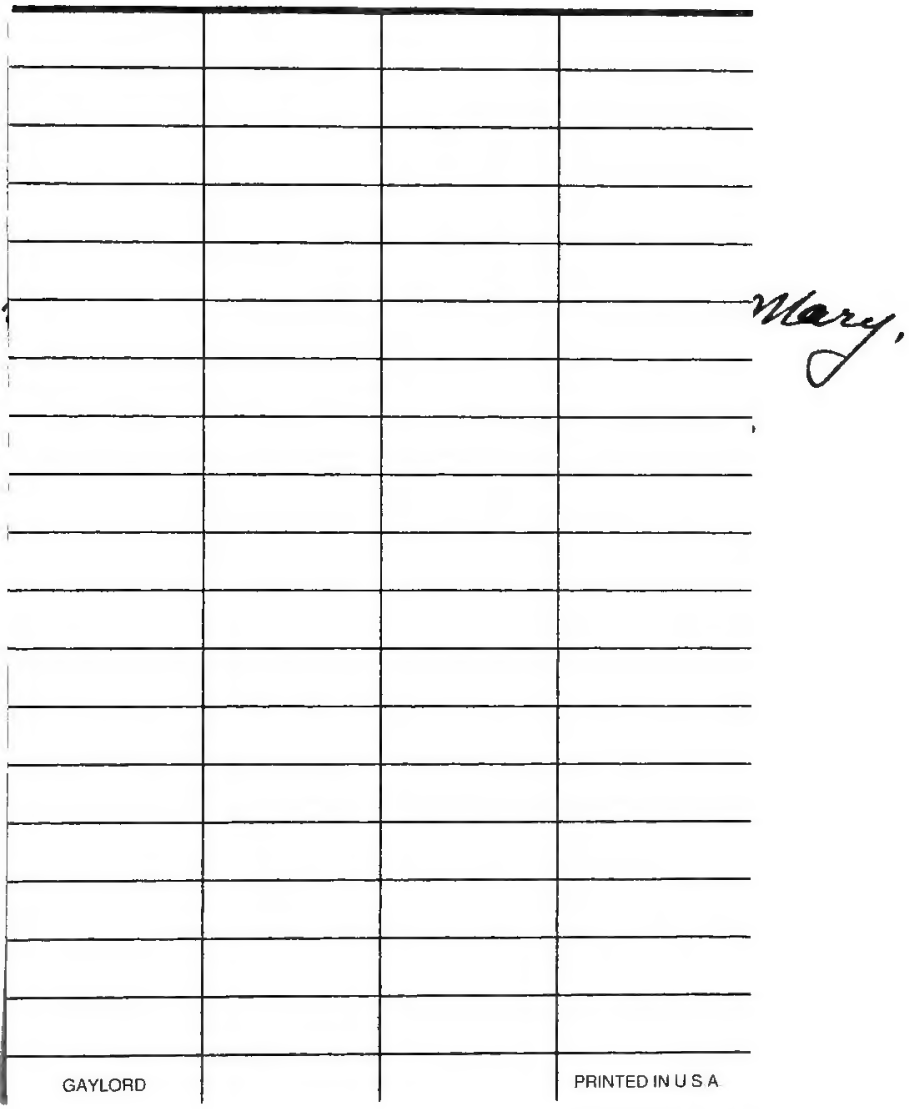




\section{Cornell University Library}

The original of this book is in the Cornell University Library.

There are no known copyright restrictions in the United States on the use of the text. 
GRAY'S NEW MANUAL OF BO'TANY (SEVENTH EDITION - ILLUSTRAIED)

\author{
A HANDBOOK OF THE
}

\title{
FLOWERING PLANTS AND FERNS
}

\author{
OF THE CENTRAL AND NORTHEASTERN UNITED STATES \\ AND ADJACENT CANADA
}

REARRANGED AND EXTENSIVELY REVISED BY

BENJAMIN LINCOLN ROBINSON

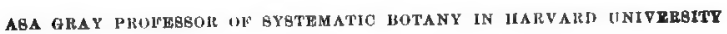
AND

MERRIT'T LYNDON FERNALD ABEIBTANT PROFIBGOR OF IOTANY IN IIARVARD UNIVEIRSTT

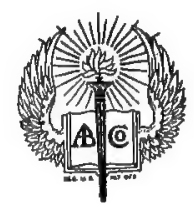

NEW YORK :: CINCINNATI :: CHICAGO AMERICAN BOOK COMPANY 


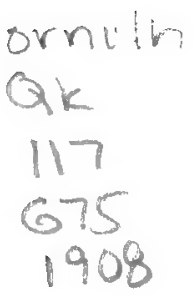

COPYRIGHT, 1908, BY

THE PRESIDENT AND FELLOWS OF HARVARD COLLEGE ENTERED at S'TATIONER' Hall, LONDON

W. P. 10 


\section{CÓNTENTS}

\section{Preface}

PAGE

Analytical Ket to the Families.

Tabular View of the Families . . . . . . . 23

Summar by Divisions, Classes, etc. - . $\quad$ o . . 27

Summary bY Minor Groups . . . . . . . . 27

Explanation of Abbreviations of Authors' Names - • - . 28

Other Abbretiations and Signs employed . . . . . . . 31

Descriptive Flora . . . . . . . . . . . 33

GLOSSARY . • . . . . . . . . 875

IrdeX . . . . . . . . . . . 885 



\section{PREFACE}

Is bringing Dr. Asa Grar's well-known Manual to date and into accord with modern views of classification and nomenclature, the present editors have tound it necessary to rearrange it throughout, rewrite considerable portions, modify at least slightly nearly all the descriptions, and adopt certain principles of nomenclature (notably the one relating to the first specific name) somewhat at variance with Dr. Gray's practice. Although these changes have been numerous and in some respects fundamental, it is believed that they are all in thorough accord with the liberal spirit of progress which characterized his own successive publications. Wherever possible and in all cases of doubt, the wording of the sixth edition, prepared by Dr: Sereno Watson and Professor John Merle Coulter, and published in January, 1890, has been retained.

In the arrangement of the plant-families and in grouping them in orders, the admirable system of Eichler, in recent years mucb elaborated and perfected by Engler and Prantl, has been followed with a few deviations of minor importance.

The term order, used by Dr. Gray as synonymous with family, is here employed, according to the recommendation of the International Botanical Congress at Vienna, to designate a group of superior rank; the same, in fact, which has sometimes been called a cohort. Orders, in this sense, are not capable of sharp definition in the manner of species, genera, or even families, nor is it to be supposed that one order begins in development where the preceding ends. They are rather to be conceived as representing somewhat parallel and long. disconnected lines or tendencies in evolutionary development. The grouping of the families into orders is shown in the tabular view on pages 23-27.

To cover a more natural floral area and to make the Manual con. venient for a greater number of users, some alterations have been made in the geographic limits adopted in the sixth edition. These changes result in (1) the exclusion of the territory at the west between the 96 th and 100th meridians, a region now known to include a con. 
siderable percentage of plants characteristic of the Great Plains and not harmonious with the flora which the present work is especially designed to treat; and (2) the inclusion of the Canadian provinces of Nova Scotia, Prince Edward Island, New Brunswick, and the greater part of Quebec and Ontario. As thus modified, the limits are as follows: on the north, the 48th parallel from the Gulf of St. Lawrence to Lake Superior, and the international boundary thence to the northwest corner of Minnesota; on the west, the western boundary of Minnesota and northwestern Iowa, thence southward along the 96th meridian; on the south, the sonthern boundaries of eastern Kansas, Missouri, Kentucky, and Virginia.

In the preparation of this edition valued assistance has been received from Professor A. S. Нгтснсоск of the United States Department of Agriculture, who has elaborated the Gramineae; Mr. OAKes Ames, Assistant Director of the Botanic Garden of Harvard University, who has treated the Orchidaceae; President Ezra Brainerd of Middlebury College, who has revised the genus Viola; Mr. A. A. EATon of the Ames Botanical Laboratory, who has treated the technical genera Equisetum and Isoëtes; Dr. J. M. Greerman of the Field Museum of Natural History, who has revised Senecio; Mr. W. W. EgGLeston, who has revised the exceedingly difficult genus Crataegus; and Miss MARY A. DAr, Librarian of the Gray Herbarium, who has given much clerical and bibliographical assistance throughout the preparation and proof reading of the text. Many of the older figures, formerly grouped in plates, have been redrawn and for greater convenience placed in the text, and to these have been added a much larger number of new ones drawn chiefly by Mr. F. Schuyler Mathews, but in part also by Professor J. Franklin Colulns of Brown University and Mr. P. B. Whexplex. All the illustrations of the Orchidaceae have been not only skillfully executed but generously contributed by Mrs. OAKes Ames. The fact that it has been possible thus to extend the illustration of the Manual has been due in great part to the interest and liberality of the Visiting Committee of the Gray HerbaRIUM. Many botanists throughout the country, notably the members of the New England Botanical Club, have furnished specimens and notes which have been exceedingly helpful in determining the geographic range and limits of variation. To all who have thus in different ways aided in the preparation of the present work, the editors wish to express their sincere appreciation and cordial thanks. At the International Botanical Congress, held at Vienna, June, 
1905, it was fortunately possible to reach a substantial agreement on the controversial subject of nomenclature. Some mutual concessions were necessary, but it is believed that they will be cheerfully made by those who are really seeking harmony in this matter. The editors have, therefore, scrupulously endeavored to bring the nomenclature of the Manual into accord with the Vienna agreement, in order that American botanical nomenclature may be freed as speedily as possible from peculiarity or provincialism and assume the form which has received international sanction. The most important change in this respect which characterizes the present edition in distinction from the previous editions is the adoption of the earliest specific name instead of that specific name which was first combined with the correct generic name. With this change it becomes more important to trace the previous use of specific names under other genera, and, to facilitate this, it seems wise to adopt the double citation of authorities. In the capitalization of specific and varietal names, it has been thought best to adopt the custom of many prominent botanists from Linnaeus himself to the distinguished editors of the Index Kewensis. The chief change in this respect from the usage of previous editions consists in the decapitalization of geographic adjectives, such as canadensis, americana, and the like. In regard to these words it should be borne in mind that they are not English and therefore not subject to the rules of English grammar. They are a part of an international system of Latin nomenclature, which should not be modified by different nations by introducing peculiarities of their several languages. Many generic and other names, which were in use prior to 1753 , were adopted by Linnaeus and his followers. These names are indicated in the Manual by brackets inclosing the name of the pre-Linnean author; thus, Polypodium [Tourn.] L.

In the treatment of the ever increasing number of foreign plants which have been recorded within our range, it has seemed desirable to include in the Manual only those which have given some evidence of self-dissemination and shown some tendency to become permanent members of our flora. Waifs, ballast-weeds, and plants persisting locally after cultivation have in general been omitted.

During the last twenty years there has been an unprecedented activity in the characterization of new species and varieties within our range. The present editors have considerably delayed the issue of this work in order to examine these new propositions and give them recognition in all cases where their merit could be 
demonstrated. In a few instances, however, it has been impossible from lack of material or data either to include as valid or to reduce definitely to synonymy such species and varieties, and it has accord. ingly seemed best not to mention them. It is not thereby meant that they are not of value, but merely that evidence of their distinctness has not been available.

Botanical names, being in many instances latinized forms of geographic, aboriginal, or personal designations, are not always capable of easy or consistent pronunciation. From long-established custom they are usually pronounced in English-speaking countries according to the pronunciation of Latin after the English method, exceptions being frequent in such names as Michauxiana, which is commonly pronounced mêshōiànă, or by others mēshōziànẳ, to avoid the awkward pronunciation which the word would have according to the English rules. The subject is one into which considerations of taste, convenience, and custom enter to such an extent that it is most difficult to lay down definite principles free from pedantry. However, as a general guide, the names in this, as in previous editions, are marked with accents, - the accented syllable being determined as far as possible by the well-known rules of Latin quantity. In cases of doubtful quantity, in such names as Berlandiera, Palmeri, Bacopa, etc., it has seemed best to treat the penultimate vowel as long, according to the usage of most British and Continental writers. 'Two accents are used, the grave (") to indicate the long English sound of the vowel, the acute (') to show the shortened or otherwise modified sound. For aid in determining the accented syllable, the editors are in several instances indebted to Dr. A. S. PEAse.

In consideration of recent differences in nomenclatorial practice, and with a wish to make the Manual as convenient as possible for all users, synonyms have been inserted freely to show the equivalence of different names, especially of those permitted by the Rochester and American Codes but not sanctioned by the International Rules. It has been necessary to make these citations exceedingly brief, the specific name, when the same, being omitted; e.g. under Ranunculus Cymbalaria Pursh, the synonym Oxygraphis Prantl means that the species has been treated by Prantl under the identical specific name (Cymbalaria) in Oxygraphis, a genus not maintained in the present work.

B. L. R.

M. I. F. 


\section{ANALYTICAL KEY TO THE FAMILIES}

(Carried out, in some cases, to subfamilies and genera)

\section{Drvision I. PTERIDÓPHYTA}

Fern-like, moss-like, rush-like, or aquatic plants withont true flowers. Reproduction by spores (without embryos).

A. Floating plants with small 2-ranked leaves; sporocarps borne on the under side of the stem

SaLVINIACEAT, 50

A. Terrestrial or submersed plants, not floating B.

B. Stems conspicuously jointed, their nodes covered by toothed sheaths; sporangia on the scales of terminal dry cone-like -spikes

Equisetaceae, 51

B. Stems without conspicuous sheathed joints C.

C. Leaves closely imbricated or very narrow; sporangia sessile, axillary.

Stem short, corm-like; leaves elongate, awl-shape or linear, in a rosette

ISOËTACEAE, 58

Stem elongate, creeping (sometimes underground) or branch-

ing; leaves very short, crowded or imbricated.

Sporangia of two kinds, some containing many minute spores (microspores), others bearing few (usually 3-4)

much larger macrospores

SeLAginelLaceae, 57

Sporangia bearing uniform minute spores

LYCOPODIACEAE, 54

c. Leaves (fronds) not elosely imbricated; if narrow, without axillary sporangia $\mathbf{D}$.

D. Leaves (fronds) 4-foliolate, clover-like; sporocarps (inclosing the sporangia) stalked from the creeping stem Marsileaceat, 49

D. Leaves.(fronds) not 4-foliolate, simple or variously cleft; sporangia not inclosed in basal sporocarps $\mathbf{E}$.

E. Fertile fronds, or fertile portions of the fronds conspicuously unlike the sterile F.

F. Slender twining or climbing plant, the frond with alternate paired and stalked palmately lobed divisions Lygodium, 46

F. Neither twining nor climbing $G$.

G. Sterile fronds linear-filiform, tortuous; the fertile filiform, tipped by a 1-sided short (3-8 $\mathrm{mm}$. long) pinnate fertile portion

Schizaea, 45

G. Sterile fronds (or segments) broader $\mathrm{H}$.

H. Sterile segment of the frond simple; the fertile a long-stalked simple spike

OPHIOGLOSSACEAE, 4.7

H. Sterile and fertile fronds or segments more or less

cleft I. 
I. Rootstock almost none, the solitary (rarely 2) fronds appearing to lise from a cluster of fleshy roots; lower segment sterile, upper fertile and bearing 2-rowed globular sporangia

Botrychium, 47

I. Rootstock well developed, elongate or stout, the roots fibrous; fronds numerous or the fertile and sterile clearly distinct $\mathrm{J}$.

J. Fertile fronds or segments scarcely or not at all leaf-like, the sporangia globose or in bead-like rows.

Sporangia globose, thin-walled, 2-valved, densely crowded, not 2-ranked

OSMUNDACEAE, 46 Sporangia globose and distinct or connected in beadlike chains, firm, 2-ranked

J. Fertile fronds or segments green and leaf-like, at least above; the sporangia not globose

Polypodiaceae, 33

E. Fertile fronds or segments essentially like the sterile.

Sporangia sessile at the base of a bristle-like receptacle and surrounded by a cup-like involucre; frond of a single layer of cells

HYMENOPHY LLACEAE, 33

Sporangia stalked, with no bristle-like receptacle; frond of more than one layer of cells

Poly podtaceae, 33

\section{Division II. SPERMATÓPHYTA}

Plants with true flowers containing stamens, pistils, or both. Reproduction normally by seeds containiug an embryo.

\section{SUBDIVISION I. GYMNOSPÉRMAE}

Ovules not in a closed ovary. Trees and shrubs with needle-shaped, linear, or scale-like mostly evergreen leaves, and monoecious or dioecious flowers $\mathbf{K}$.

K. Flowers themselves catkin-like or borne in catkins, which be-

come cones or berry-like

Pinackat, 62

K. Flowers solitary, axillary; seed solitary, more or less enveloped in a pulpy disk

Taxacean, 62

\section{Subdivision II. ANGIOSPÉRMAE}

Ovules borne in a closed ovary, which at maturity becomes the fruit.

\section{CLASS 1. MONOCOTYLEDÒNEAE}

Stems without central pith or annular layers, but having the woody fibers distributed through them (a transverse slice showing the fibers as dots scattered through the cellular tissue). Embryo with a single cotyledon, the early leaves always alternate. Parts of the flower usually in threes or sixes, never in fives. Leaves mostly parallel-veined. Our species, except in the genus Smilax, herbaceous $\mathrm{L}$.

L. Small lens-shaped, ellipsoidal, or flask-shaped free-swimming aquatics without true leaves

LEMNACEAE, 259

J. Plants with stems and leaves (sometimes scale-like) $M_{\text {, }}$ 
M. Perianth free from the ovary or none N.

N. Perianth wanting or of scale-like or bristle-form divisions $\mathbf{O}$.

O. Flowers inclosed or subtended by imbricated husk-like scales (glumes); grass-like plants with jointed stems, sheathing (mostly narrow) leaves, and 1-seeded fruit.

Stems hollow, round or flattened; leaf-sheaths split; anthers attached by the middle

Gramneat, 86

Stems usually more or less triangular, solid; leaf-sheaths not split; anthers attached at the base

o. Flowers not inclosed in husk-like scales (though sometimes in involucrate heads) $P$.

P. Immersed aquatics, branching and leafy, the upper leaves often floating.

Flowers perfect

NAJADACEAE, 69

Flowers monoecious or dioecious.

Flowers in globose heads

Flowers axillary, solitary

Sparganiac Fae, 68

NAJADACEAE, 69

P. Terrestrial or marsh plants $Q$.

Q. Leaves petioled, the blade net-veined

Q. Leaves linear or sword-shaped, parallel-veined, not petioled $R$.

R. Flowers monoecious or dioecious.

Flowers in cylindrical spikes

TrPhaceae, 67

Flowers in heads.

Heads spheroida], pubescent, involucrate Eriocaulaceat, 260

Heads globose, glabrous, not involucrate SPARganiaceae, 68

R. Flowers perfect.

Flowers in a dense spike, this borne on the margin of a 2-edged scape; root aromatic

Acorus, 258

Scapes or peduncles cylindrical.

Ovaries 3-6, separating at least when ripe JuNCAGINACEAE, 79 Ovary single, 3-carpeled

JUNCACEAE, 267

N. Perianth always present, herbaceous or colored, neither scale-,

like nor bristle-form $\mathrm{S}$.

S. Pistils numerous in a head or ring

S. Pistil one, compound (cells or placentae mostly 3) T.

T. Stamens 3.

Moss-like, aquatic; flowers solitary

Rush-like marsh or bog plants; flowers in spikes, racemes, or heads.

Flowers racemose or spicate

Flowers in dense scaly heads

Alismaceat, 80

T. Stamens 4

T. Stamens 6 U.

U. Stamens all alike and fertile.

Gray scurfy moss-like epiphyte

JUNCAGINACEAE, 79

XYRIDACEAR, 262

Maianthemum, 291

Not epiphytic.

Ovary of nearly separate carpels

Ovary (often angled or lobed) not deeply cleft.

Divisions of the perianth alike or nearly so.

Perianth woolly

Ha emodoracea e, 296

Perianth not woolly.

Plant rush-like; perianth small, greenish or purplish brown

JUNCACEAE, 267 
Plant not rush-like

LiliaceA, 279

Divisions of the perianth unlike, 3 green sepals and

3 colored petals.

Stem-leaves ovate or oblong, 3 in a whorl

Trillium, 293

Stem-leaves linear or nearly so; flowers umbeled

COMMELINACEAE, 264

U. Stamens dissimilar, or only 3 with fertile anthers.

Perianth of 3 herbaceous sepals and 3 colored ephemeral petals

COMMELINACEAE, 264

Perianth tubular, 6-lobed

Pontederiaceae, 266

M. Perianth present, adnate to the ovary V.

V. Stamens 1-2; flowers irregular.

Anthers 2-celled; seeds many

ORCHIDACEAE, 304

Anthers 1-celled; seeds solitary

MarantACEAE, 304

V. Stamens 3 or more; flowers mostly regular or nearly so W.

W. Climbing plant with net-veined ovate leaves

Dioscoreaceae, 297

W. Not climbing; leaves parallel-veined.

Perianth woolly, only partially adnate to the ovary

Ha emodoraceae, 296

Perianth not woolly, adnate to the whole surface of the ovary.

Aquatics; flowers dioecious or polygamous Hrdrocharitaceas, 85 Terrestrial; flowers perfect.

Stamens 6

Amaryllidaceae, 297

Stamens 3.

Leaves 2-ranked, equitant; stamens opposite the outer segments of the perianth

IRTDACEAE, 299

Leaves not 2-ranked, the cauline scale-like; stamens opposite the inner segments of the perianth

Burmanniaceat, 304

\section{CLASB 2. DICOTYLEDÒNEAE}

Stems formed of bark, wood, and pith; the wood forming a zone between the other two, and increasing, when the stem continues from year to year, by the aunual addition of a new layer to the outside, next the bark. Leaves net-veined. Embryo with a pair of opposite cotyledons. Parts of the flower mostly in four's or fives $\mathrm{X}$.

X. Corolla none; calyx present or absent $\mathrm{Y}$.

Y. Flowers monoecious of dioecious, one of both sorts in catkins $\mathbf{Z}$.

Z. Only one sort of flowers in catkins or catkin-like heads.

Fertile flowers in a short catkin or catkin-like bead URticaceaE, 344

Fertile flowers single or clustered; the sterile in slender catkins (except in Fugus).

Leaves pinnate; fertile flowers and frujt naked JUGLANDACEAE, 330

Leaves simple; fertile flowers 1-3 in a cup or involucre FAGACEAE, 337

Z. Both sterile and fertile flowers in catkins or catkin-like heads $u$.

$a$. Ovary many-ovuled; fruit many-seeded. .

Ovary and pod 2-celled; seeds not tufted

Ovary and pod 1-celled; seeds hairy-tufted

Liquidambar, 453

Salicaceat, 320 
a. Ovary 1-2-celled; cells 1-ovuled; fruit 1-seeded.

Parasitic on trees; fruit a berry

LORANTHACEAE, 351

Trees and shrubs, not parasitic.

Calyx regular, in fertile flower succulent in fruit

Calyx none or rudimentary and scale-like.

Style and stigma 1, simple.

Leaves palmately angled or lobed

Leaves ovate or oblong, entire

Platanachae, 454

Styles or long stigmas 2.

LEITNGRIACEAT, 330

Fertile flowers 2 or 3 at each scale of the catkin Betulaceae, 332

Fertile flowers single under each scale; nutlets naked, waxy-coated, or drupe-like

MYricachae, 329

Y. Flowers not in catkins $b$.

b. Ovary or its cells containing only 1-2 (rarely $3-4$ ) ovules $t$.

c. Pistils more than 1 , distinct or nearly so.

Stamens inserted on the calyx; leaves with stipules

Stamens inserted on the receptacle.

Leaves punctate with transparent dots

Leaves not dotted.

Calyx present, usually colored or petal-like RANunculaceate, 392

Calyx none; flowers spiked

RosaceaE, 454

Zanthoxylum, 537

Piperaceat, 320

ت. Pistil 1, simple or compound $d$.

d. Ovary free from the calyx, which is sometimes wanting $e$.

e. Stipules (ocreae) sheathing the stem $\mathrm{a}^{+}$the nodes.

Tree; calyx none

Platanaceae, 454

Herbs; calyx present, commonly corolla-like

Polygonaceat, 353

e. Stipules not sheathing the stem, or none $f$.

$f$. Herbs $g$.

g. Aquatic, submerged or nearly so.

Leaves whorled, dissected; style 1 Ceratophyllaceae, 389

Leaves opposite, entire; styles 2; ovary 4-celled

Callitrichacea h, 549

$g$. Not aquatics $h$.

h. Styles 10; ovary and berry 10-celled Phytolaccaceat, 374

h. Style, if any, and stigma 1.

Flowers unisexual; ovary of the fertile flowers 1-celled

URTICACEAE, $34 t$

Flowers perfect; pod 2-celled, 2-seeded

$h$. Styles 2-3 or branched; ovary 1-4-celled $i$.

$i$. Leaves palmately Jobed or divided

Lepidium, 425

i. Leaves not palinately lobed or divided $j$.

j. Ovary and pod 3-celled; juice usually milky.

Flowers in basal spikes; stamens 4 ; filaments thick, flattened

BuXACEAE, 550

Inflorescence various, not of basal spikes;

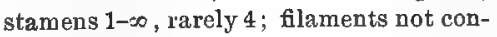

spicuously thick

EUPHorbiachat, 540

- j. Ovary not 3-celled; juice not inilky $k$.

$k$. Flowers in numerous small involucrate

heads; fruit a 3-angled achene

Eriogonum, 35 ?

$k$. Flowers not involuerate.

Leaves covered at least belleath with stellate hairs; embryo straight Euphorblaceat, 540 
Leaves without stellate hairs; embryo curved or coiled.

Stipules scarious

ILLECEBRACEAE, 376

Stipules none.

Leaves opposite.

Plant fleshy

Salicornia, 369

Not fleshy.

Flowers in heads or spikes, these often panicled; anthers 1-celled AMara NTHACEaE, 371

Flowers sessi]e in forks of branching inflorescence ILLECEBRACEAE, $376^{\circ}$

Leaves alternate.

Flowers and bracts scarious AMARANTHACEAE, 371

Flowers small, chiefly greenish; no scarious

f. Shrubs or trees. bracts

Chenopodiaceae, 364

Leaves small, linear or scale-like; low heath-like shrubs

Leaves oblong to orbicular; never heath-like.

EMPETRACEAE, 551

Leaves opposite.

Fruit 3-celled, not winged

Fruit 2-celled, a double samara

Rhamnachat, 560

Fruit 1-celled, a single samara

ACERACEAE, 557

Oreaceae, 650

Leaves alternate.

Ovary 3-celled

RhamnaCeat, 560

Ovary 1-2-celled.

Styles and stigmas 2

URTICACEAE, 344

Style and stigma 1.

Anthers opening lengthwise

Anthers opening by uplifted lids

Thymelaeaceae, 589

IJAURACEAE, 413

d. Ovary inferior or so elosely and permanently invested by the

calyx as to appear so.

Parasites on the branches of trees

LORANTHACEAE, 351

Aquatic herbs

Haloragidaceae, 602

Terrestrial.

Herbs with calyx colored like a corolla.

Leaves opposite, simple

Leaves alteruate, pinnate

Nyctaginaceae, 375

Sanguisorba, 494

Leaves alternate, simple

Comandra, 350

Shrubs or trees.

Leaves scurfy

Leaves not scurfy, opposite

Elaeagnaceae, 590

Nestronia, 350

Leaves not scurfy, alternate.

Style 1, stigmatic down one side; flowers solitary, in pairs, or in umbel-like cluster's

$N y s s a, 625$

Style 1, short; stigma terminal ; flowers racemose Pymlaria, 350 Styles 2

HAMAMELIDACEAE, 452

$b$. Ovary or its cells containing many ovules $l$.

$l$. Caly $\mathrm{x}$ none; ovary and fruit naked.

Aquatic herb

Podostemachae, 441

Tree or shrub

Ham a MELTACFAE, 452

- Calyx present $m$.

$m$. Ovary superior. 
Ovaries 2 or more, separate

Ranunculaceat, 392

Ovary single.

Ovary 5-celled, 5-beaked; leaves scattered

Penthorum, 442

Ovary 3-5-celled; leaves opposite or whorled

Ovary 1-2-celled.

Leaves compound

Aizoaceate, 377

Leaves simple.

Calyx of separate sepals

Calyx 5-toothed or -cleft

Calyx 4-toothed

Ranunculaceae, 392

CARYOPHYLLACEAE, $37 \%$

Glaux, 647

LYTHRACEA E, 591

$m$. Ovary and pod inferior.

Ovary 6-celled; stamens 6-12

Aristolochiacea e, 351

Ovary 4-celled; stamens 4

Ovary 1-celled; stamens 8-10

Ludvigia, 594

Chrysosplenium, 448

$X$. Both calyx and corolla present $n$.

$n$. Corolla of separate petals 0 .

u. Stamens numerous, at least more than 10 (rarely 9-10 in Polanisia), and more than twice as many as the sepals or calyxlobes $p$.

p. Calyx entirely free and separate from the pistil or pistils $q$.

$g$. Pistils several or many, wholly distinct or united at base

into a strongly lobed or several-beaked ovary $r$.

$r$. Aquatics with peltate leaves

NYM PHAEACEAE, 389

$r$. Terrestrial plants.

Climbers.

Leaves alternate

Leaves opposite

F. Menispermacea e, 410

Not climbing.

Filaments united into a tube

Clematis, 402

Filaments not united.

Leaves opposite, entire

Malvaceae, 566

Leaves alternate.

Stamens on the caly $x$

Stamens on the receptacle or disk.

Trees or shrubs.

Sepals and petals imbricated

Sepals and petals valvate

- Herbs

Calycanthaceat, 409

RosACEAE, 454

Magnoliaceat, 408

ANONACEAE, 410

Resedaceat, 439

q. Pistils strictly one as to ovary; the styles or stigmas may

be several $s$.

s. Leaves punctate with translucent dots

HYPERICACEAE, 571

$s$. Leaves not punctate $t$.

t. Ovary simple, 1-celled.

Ovules 2

RosAcea E, 454

Ovules many.

Leaves 2-3-ternately compound or dissected

Leaves peltate, lobed

RaNunculaceAe, 392

Podophyllum, 411

$t$. Ovary compound.

Ovary 1-celled.

Sepals 2 (rarely 3), caducous; juice milky or colored; placentae parietal

Papaverackae, 414

Sepals 2; juice watery; placentae central Portulacacrat; 387 
Sepals 4 ; juice watery; placentae parietal CAPPARIDACEAE, 438 Sepals 3 or 5 , persistent; juice watery; placentae parietal Cistackat, 576

Ovary several-celled.

Calyx valvate in bud.

Herbs or rarely shrubs; stamens united; anthers 1-celled

Trees; anthers 2-celled

MaLVaceae, 566

Tiliacear, 565

Calyx imbricate in bud.

Shrubs; stamens on the base of the petals

Ternstrommiaceak, 570

Aquatic or marsh-dwelling herbs.

Leaves tubular or trumpet-shaped; placentae in the axis

Strracentaceae, 439

Leaves (when mature) flattish, never tubular or trumpet-shaped; ovules on the partitions of the ovary

NYMPHAEACEAR, 389

p. Calyx more or less adherent to a compound ovary.

Ovary 7-30-celied.

Cells many-ovuled; aquatic herbs

Cells 10, each 1-ovuled; trees or shrubs

Nymphataceate, 389

Amelanchier, 459

Ovary 6-celled

Asarum, 352

Ovary 1-5-celled.

Fleshy-stemmed, without true foliage; petals many

Leaves present.

Cactaceae, 588

Sepals or calyx-lobes 2 ; ovules arising from the base of a

1-celled ovary

Portulacaceae, 387

Sepals or calyx-lobes more than 2 .

Leaves opposite; stipules none

Saximragaceae, 444

Leaves alternate.

Stipules present

Rosaceae, 454

Stipules none.

Herbs with rough-pubescent leaves

Trees or shrubs

LOASACHaE, 588

Styracachat, 649

o. Stamens not more than twice as many as the petals $u$.

$u$. Stamens of the same number as the petals and opposite them.

Ovaries 3-6, separate; woody vines

Ovary only one.

Menispermacear, 410

Ovary 2-4-celled.

Calyx-lobes minute or obsolete; petals valvate

Calyx 4-5-cleft; petals involute

VITACEAE, 562

Rhamachae, 500

Ovary 1-celled.

Anthers opening by uplifted lids

Anthers not opening by uplifted lids.

Style 1, unbranched; stigma 1

Styles, style-branches, or stigmas more than 1.

Sepals or calyx-lobes 2

Sepals or calyx-lobes 3-5.

Flowers monoecious

Flowers perfect

Berberida CEAE, 41:

Primolaceae, 643

Portulacaceate, 387

Crotonopsis, 542

Plumbaginaceae, 643

$u$. Stamens not of the same number as the petals, or if of the same

number alternate with them $v$.

c. Calyx free from the ovary, i.e. ovary wholly superior $w$. 
w. Ovaries 2 or more, wholly separate or somewhat united $x$.

$x$. Stamens united with each other and with a large thick stigma

common to the 2 ovaries

ASCLIPIA DACEAR, 663

$x$. Stamens free from each other and from the pistils $y$.

$y$. Stamens on the receptacle, free from the calyx.

Leaves punctate with translucent dots.'

Rutaceae, 537

Leaves without translucent dots.

Trees or shrubs; leaves pinnate.

Low shrub; leaflets mostly 5

Tree; leaflets 11 or more

Zanthorhiza, 408

Herbs.

Ailanthus, 538

Leaves fleshy

Leaves not fleshy.

Ovaries or lobes of the ovary $2-5$, with a common style.

Ovary 2-3-lobed

Ovary 5-lobed

Ovaries with separate styles or sessile stigmas

LIMNANTFACEAE, 551

GeraNiaC EAK, 534

RANUNCULACEAE, 392

$y$. Stamens inserted on the calyx.

Plant fleshy; stamens just twice as many as the pistils

Crassulaceae, 441

Plant not fleshy; stamens not twice as many as the pistils.

Stipules present

ROSACEAE, 454

Stipules none

SAXIFRAGACEAE, 444

w. Ovary $1 z$.

$z$. Ovary simple with 1 parietal placenta

z. Ovary compound, as shown by the number of its cells, placentae, styles, or stigmas A.

A. Ovary 1-celled.

Corrolla irregular.

Petals 4 ; stamens 6

Fumariaceat, 416

Petals and stamens 5

VIOLACEAE, 579

Corolla regular or nearly so.

Ovule solitary.

Trees or shrubs

Herbs

ANACARDIACEAE, 552

Cruciferak, 418

Ovules more than one.

Orules at the center or bottom of the cell.

Petals not inserted on the calyx

Caryophyluaceate, 377

Petals inserted on the throat of a bell-shaped or tubular calyx

LYTHRACEAE, 591

Ovules on 2 or more parietal placentae.

Leaves punctate with translucent dots

HYPERTCACEAE, 571

Leaves beset with gland-tipped bristles

Droseraceae, 440

Leaves neither punctate nor bristly-glandular.

Petals 4.

Stamens essentially equal; pod usually stiped

Capparidaceae, 438

Stamens unequal, 2 being shorter than the other 4 ; pod sessitle

Cruciferae. 418

Petals 3 or 5.

Ovary stiped

Passifloraceae, 587

Ovary sessile.

GRAY'S MANUAL - 2 
Calyx 5-lobed or of 5 equal sepals

Calyx of 3 equal or 5 very unequal sepals

A. Ovary 2-several-celled B.

B. Flowers irregular C.

C Anthers opening at the top.

Anthers 6-8, 1-celled

Anthers 10, 2-celled
SAXIFRAGACEAE, 444

Cistaceae, 576;

C. Anthers opening lengthwise.

Polygalaceae, 538

Rhododendron, 631

Stamens 12 and petals 6 on the throat of the gibbous calyx Cuphea, 59.

Stameus 5-10 and petals hypogynous or nearly so.

Ovary 3-celled; trees or shrubs

Aesculus, 559

Ovary 5-celled; herbs

BALSAMINACEAE, 560

B. Flowers regular or nearly so $\mathbf{D}$.

J. Stamens neither just as many nor twice as many as the petals.

Trees or shrubs.

Stamens fewer than the 4 petals

Olmaceat, 650

Stamens more numerous than the petals

ACERACEAE, 557

Herbs.

Petals 5

HXPERICACEAE, 571

Petals 4

Cruciffrae, 418

v. Stamens just as many or twice as many as the petals E.

E. Ovules and seeds only 1 or 2 in each cell.

Herbs.

Flowers monoecious or dioecious

EURHORBIACEAE, 540

Flowers perfect and symmetrical.

Cells of the ovary as many as the sepals.

Ovary 2-3-celled

Ovary 5-celled

LIMNANTHACEAE, 551

Geraniac hae, 534

Cells of the ovary twice as many as the sepals.

Leaves abruptly pinnate

Leaves simple

ZYGOPHYLLACEA E, 536

LINACEAE, 531

Shrubs or trees.

Leaves compound.

Leaves 3-foliolate, punctate

Leaves pinnate, not punetate

Leaves simple.

Leaves palmately veined

Leaves pinnately veined.

Leaves alternate.

Climbing shrub

Erect shrubs or trees.

Flowers racemose

Flowers solitary or cymose

Leaves opposite

Ptelea, 537

Sapindachae, 559

ACeracena, 557

Celastrus, 55r

Crrillaceaf, 553

AQUIFOliaceat, 554

Celastraceate, 556

E. Ovules, and usually seeds, several or many in each cell F.

F. 'Leaves compound.

Tree or shrub

STAPHYLEACEAE, 557

Herbs; leaves alternate, or all radical.

Leaflets 3 , obcordate

Leaflets more numerous, pointisl

F. Leaves simple

Stipules present between opposite leaves
Oxalmaceae, 532

Astilbe, 44

Elatinacear, 575 
Stipules none when the leaves are opposite.

Stamens 5, united at base into a 10-toothed cup or tube; leaves all radical

Galax, 642

Stamens free from each other.

Style 1.

Stamens free from the calyx

Stamens inserted on the caly $x$

Ericactae, 625

Styles 2-5, or splitting into 2 in fruit.

Stamens free from the calyx; leaves

opposite

Caryophyllaceae, 377

Stamens inserted on the calyx

э. Calyx-tube adherent to the ovary, at least to its lower half G.

Ericaceate, 625

G. Tendril-bearing and often succulent herbs

Cucurbitaceae, 764

G. Not tendril-bearing $\mathbf{H}$.

H. Ovules and seeds more than 1 in each cell.

Ovary 1-celled.

Sepals or calyx-lobes 2 ; ovules borne at the base of the ovary

Portulacaceat, 387

Sepals or calyx-lobes 4-5; placentae 2-3, parietal Saxifragaceae, 444 Ovary 2-many-celled.

Anthers opening by pores at the apex

Melastomaceae, 593

Anthers not opening by pores.

Stamens inserted on or about a flat disk which covers the ovary

Chuastrachae, 556

Stamens inserted on the calyx.

Style 1; stamens 4 or 8 (rarely 5)

Styles 2-3, distinet; stamens 5 or 10

ONAGraceae, 594

SAXIfragaceat, 444

H. Ovules and seeds only 1 in each cell.

Stamens 5 or 10 .

Trees or shrubs.

Leaves simple, not prickly

Leaves compound, or prickly

Crataegus, 460

Herbs.

Fruit dry, splitting at maturity ; styles 2

Araliaceae, 605

Stamens 2, 4, or 8 .

Style and stigma 1; fruit a drupe

Araliaceae, 605

Styles or stigmatic branches or sessile stigmas usually

more than 1; fruit not drupaceous.

Shrubs or trees

HAMAMELIDACEAE, 452

Herbs.

Style 1 ; stigma 2-4-lobed

ONAGRACEAE, 694

Styles or sessile stigmas 4

n. Petals more or less united I.

HaLoragidaceaE, 602

I. Stamens more numerous than the lobes of the corolla J.

J. Ovary 1-celled.

Placenta 1, parietal

Leguminosam, 499

Placentae 2, parietal

Fumariaceat, 416

Placenta at the center or base of the ovary

STYRACACEAE, 649

.T. Ovary 2-celled; cells 1-ovuled

Polygalaceae, 538

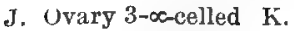

K. Stamens free from the corolla.

Style 1; leaves simple

Styles 5; leaves 3-foliolate

Ericacea e, 625

OXALIDACEAE, 532 
K. Stamens attached to the base or tube of the corolla.

Saprophytic herbs without green foliage

Monotropoideae, 626

Not saprophytic; foliage green.

Trees, shrubs, or undershrubs; anthers mostly 2-celled.

Filaments united in to $1-5$ groups.

Ovary superior

Ovary at least⿳亠口冋. partly inferior

Ternstromimiaceae, 570

Filaments free from each other.

Style 1

Styles 4

Ertoageae, 625

Ebenaceat, 648

Herbs; anthers 1-celled.

Filaments united into a tube

Malvaceate, 566

Filaments distinct, 2 at each notch of the corolla

Adoxa, 761

I. Stamens not more numerous than the corolla-lobes $\mathbf{L}$.

L. Stamens of the same number as the corolla-lobes and opposite them.

Corolla appendaged with scales inside; ovary 5-celled; trees or shrubs

SAPOTACEAE, 648

Corolla not appendaged with scales inside; ovary 1-celled; herbs.

Style 1; fruit a several-many-seeded capsule

Styles 5; fruit a 1-seeded utricle

Primulaceae, 643

Plumbaginaceae, 643

L. Stamens alternate with the corolla-lobes or fewer $\mathbf{M}$.

M. Ovary free from the calyx-tube (superior) $N$.

N. Corolla regular 0 .

O. Stamens as many as the corolla-lobes $P$.

$P$. Ovaries more than 1 , or, if 1 , deeply lobed $Q$.

Q. Ovaries 2, or, if 1, 2-horned.

Stamens united

Asclepladacear, 663

Stamens distinct.

Stipules or stipular membrane or line between opposite leaves; ovary 2-horned

LOGANLACEAE, 652

Stipules none; ovaries 2.

Leaves kidney-shaped, alternate

Dichondra, 669

Leaves not kidney-shaped, chiefly opposite

APocy NaCEAE, 661

Q. Ovary deeply 4-lobed.

Leaves alternate

Boraginacear, 679

Leaves opposite

LABIATA

P. Ovary 1, not deeply lobed $\mathbf{R}$.

R. Ovary 1-celled.

Seed 1 ; corolla scarious

Seeds several-many.

Leaves entire, opposite

Leaves toothed, lobed, or compound.

Whole upper surface of corolla white-bearded; leaflets 3 , entire

Menyanthes, 660

Corolla not conspicuously bearded; leaves, if compound, with toothed leaflets

HYDROPHYLLACEAE, 676

R. Ovary 2-10-celled.

Leafless twining parasites

Leaves opposite, their bases connected by a stipular

line

LOGANIACEA E, 652 
Leaves alternate or if opposite with no trace of stipules.

Stamens free from the corolla or nearly so.

Style 1

ERicACEAE, 625

Style none

AQUifollaceaE, 554

Stamens in the notches of the corolla; style 1 Diapensiaceat, 642 Stamens on the tube of the corolla.

Stamens 4.

Leafy-stemmed; leaves opposite; corolla petaloid

Acaulescent; corolla scarious

VERBENACEAE, 688

Stamens 5 or rarely more.

Fruit of 2 or 4 seed-like nutlets

Fruit a few-many-seeded pod.

Styles 3

Styles 2.

Pod few (mostly 4)-seeded

Pod many-seeded

Plantaginacean, 743

BoragiNaCEAE, 679

Style 1, often branched.

Branches of the style (or at least the lobes of the stigma) 3.

Not twining

Polemontacena, 673

Twining

Ipomoea, 670

Branches of the style or lobes of the stigma 2 or rarely 4.

Seeds few, mostly 4

Seeds many

Convolyulaceae, 668

Solanaceae, 712

o. Stamens fewer than the corolla-lobes.

Stamens with anthers 4 , in pairs.

Ovary 2-celled; cells several-seeded

Ovary 2-4-celled; cells 1-seeded

ACANTHACEAE, 742

VerbenaCEAE, 688

Stamens with anthers only 2 or rarely 3.

Ovary 4-lobed

Lycopus, 709

Ovary 2-celled, not 4-lobed.

Herbs.

Acaulescent; corolla scarious

Leafy-stemmed; corolla not scarious

Plantaginaceae, 743

Veronica, 726

Trees or shrubs

Olmaceat, 650

N. Corolla irregular S.

S. Stamens with anthers 5.

Stamens free from the corolla; anther-cells opening at the

apex

Stamens inserted on the corolla.

Ovary deeply 4-lobed around the style

Ovary not deeply lobed, many-ovuled.

Filaments or some of them woolly

Filaments not woolly

s. Stamens with anthers 2 or 4 .

Ovules solitary in the $1-4$ cells.

Ovary 4-lobed; style rising from between the lobes

Ovary not lobed; style from its apex.

Ovary 1-celled; fruit turned downwards

Ovary 2-4-celled; fruit not turned downwards

ovules 2-many in each cell.
Rhododendron, 631

Echium, 688

Verbascum, 719

Hyoscyamus, 716

LABIATAE, 690

PhrymaCeA F, 743

VERRENACEAE, 688 
Ovary imperfectly 4-5-celled

MARTYNIACEAF, 741

Ovary 1-2-celled.

Ovary 1-celled.

Parasites without green foliage, terrestrial; stamens 4

OROBANCHACEAE, 739

Not parasitic, chiefly aquatic or mud plants; stamens 2

LENTIBULARIACEAE, 736

Ovary 2-celled.

Trees or woody climbers; placentae parietal BignoniaceaE, 740 Herbs, rarely trees; placentae in the axis.

Seeds (mostly numerous) not borne on hooks

SCROPHUTARIACEAE, 717

Seeds (2-12) borne on hook-like processes of the placentae

ACANTHACFAF, 742

M. Ovary adherent to the calyx-tube (inferior) $T$.

T. Tendril-bearing herbs; anthers often united

Cucurbitaceae, 764

T. Tendrils none $U$.

U. Stamens separate V.

V. Stamens free from the corolla or nearly so, as many as its lobes; stipules none; juice milky

Campanulaceae, 765

V. Stamens inserted on the corolla.

Stamens 1-3, always fewer than the corolla-lobes VALERIANACEAE, 761

Stamens 4-5; leaves opposite or whorled.

Ovary 2-5-celled.

Leaves opposite or perfoliate, but neither whorled nor provided with true stipules

CAPRIFOLIACEAE, 754

Leaves either opposite and stipulate, or whorled and destitute of stipules

Rubiaceae, 746

Ovary 1-celled; flowers iu dense involucrate heads DIPSACACEA E, 763

J. Stamens united by their anthers; these joined in a ring or tube.

Flowers separate, not involucrate; corolla irregular LoBELIACEA E, 768

Flowers in an involucrate head

Compositae, 770 


\section{TABULAR VIEW OF THE FAMILIES TREATED IN THIS WORK}

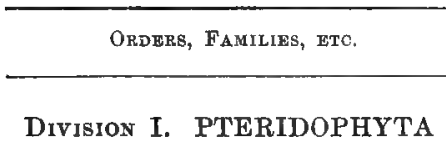

Order I. Filioalers

Fam. 1. Hymenophyllaceae.

"2. Polypodlaceas .

" 8. Schizreacere

"4. Osmundacege -

“5. Ophioglossacere .

“ 6. Marsileaceae. . . .

"

(1)

Fam. 8. Equisetacene

Ord. III. LYCOPODIALEG

Fram. 9. Lycopodiaceae .

"10. Selaginellaceae.

“ 11. Isoctacene

\section{Division II. SPERMATOPHYTA}

Subdivision I. Gymnospermat

Ord. IV. Coniferales

Fam. 12. Taxaceae

“ 18. Pinaceae

Subdiviston II. Angtospermat

CLASS I. MONOCOTYLEDONEAE

Ord. V. Pandanales

Fam, 14, Typhaceae . . . . . 1

" 15. Sparganiaceae . . . . . 1

Ord. VI. NAJADALEB

Fam. 16. Najadaceae . . . . , . 5

" 17. Juncagioaceae . . . . . .

“ 18. Alismacease. . . . . . 4

“ 19. Hydrocharitaceae. . . . 8

Ord. Vil. Graminades

Fam. 20, Gramineae . . . . . 68

"21. Cyperaceae . . . . . . 18

Ord. VIII. ARALES . . . . . . . .

Fam. 22. A racere . . . . . . 6

"28. Lemnacere . . . . . 4

Ord. IX. XYridaleis

Fam. 24. Eriocaulaceae

“6 25. Xyridaceae . . . . 1

“26. Mayroaseay . . 1

"27. Commelinacere . . . 2

"28. Bromeliacere... . . . 1

“29. Pontederiacese

GGNera.

-

Sincies.

VARIETIES AND NAMED FORMS.

Introd.

Native. Introd.

22

5

7

2

2

10

1

1

1 


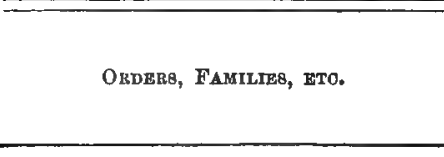

Ord. $\mathrm{X}$. Lillales

Fam, 80. Juncaceae

“81. Liliaceae

" 82. Haemodoracea . . . . .

“ 88. Dloscureacene . . . . . I

" 84. Amaryllidaceno . . . . . . 5

"35. Iridacere. . . . . . . .

Ord. XI. Bertaminales

Fam. 86. Marantaceae

Ord. XII, Orohidales

Fam. 87. Burmanniacene ..... 1

“ 88. Orchidacene.. . . . . . . 18

ClASS II. DICOT FLEDONEAE

Subclass I. Archichlamydeae

Ord. XIII. Piperales

Fam. 89. I'iperaceae

Ord. XIV. SAlicales

Fam. 40. Salicaceae

Ord. XV. MYríCALES

Fam. 41. Myricacene ........

Ord. XVI, LEITNRRIALEB

Fam. 42, Leitneriaceae

Ord, XVII. JugLANDALBg

Fam, 48. Juglandacea . . . . .

Ord. XVIII. Fagaleg

Tam. 44. Betulacere . . . . .

“45. Fagaceae......... .

Ord. XIX. URTIOALES

Fam. 46. Urticaceae . . . . . . 11

Ord. XX. Santalalueg

Fam. 47. Santalnceqe . . . , . . g

"48. Loranthacea . . . . . . 2

Ord. XXI. ARIgtolcontalis

Fam, 49, Aristolochiacere . . . . 2

Ord. XXII. Polygonales

Fam, 50. Polygonaceae

Qrd. XXIII. Cizenorodiales

Fam. 51. Chenopodiacene

$\cdot \cdot \cdot$

58. Phytolaccncear. . . . . 1

"54, Nyctrglnacear...... 1

" 55. Illecebracea . . . . . . 2

"56. Aizuncene . . . . . . . 1

Ord. XXIV. Caryophyllates

Fam. 57. Caryophyllacene . . . . 7

" 58. Portulacacea . . . . . . 4

Ord. XXV. RanUNoula lies

Fam. 59. Ceratophyllaceae . . . . . 1

"60. Nymphaeacero. . . . . . 5

"61. Ranunculacene... . . . 19

"62. Magnoliacere . . . . . . "

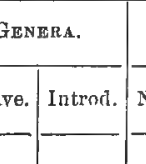

Introd. NAMED FORMS, 


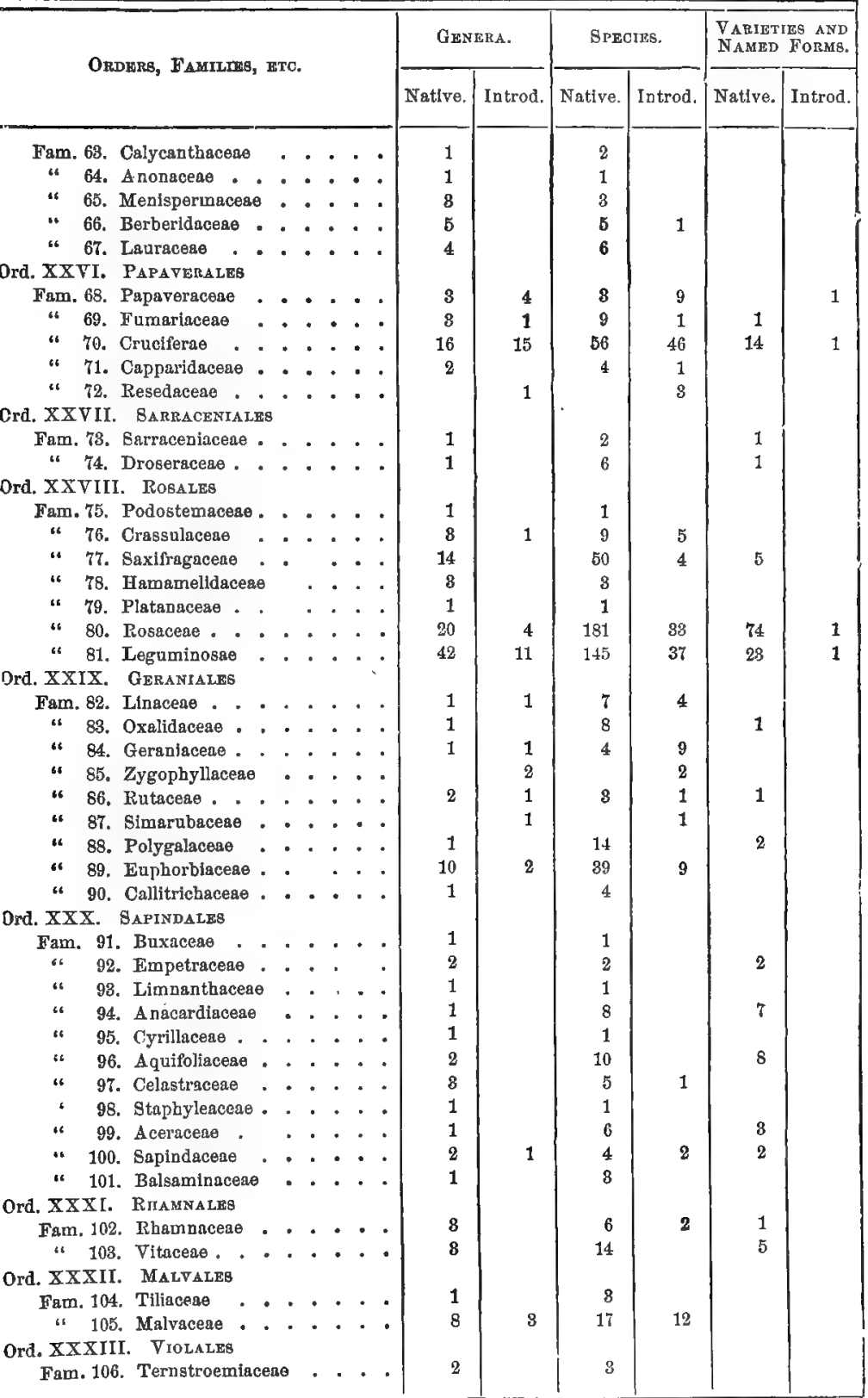




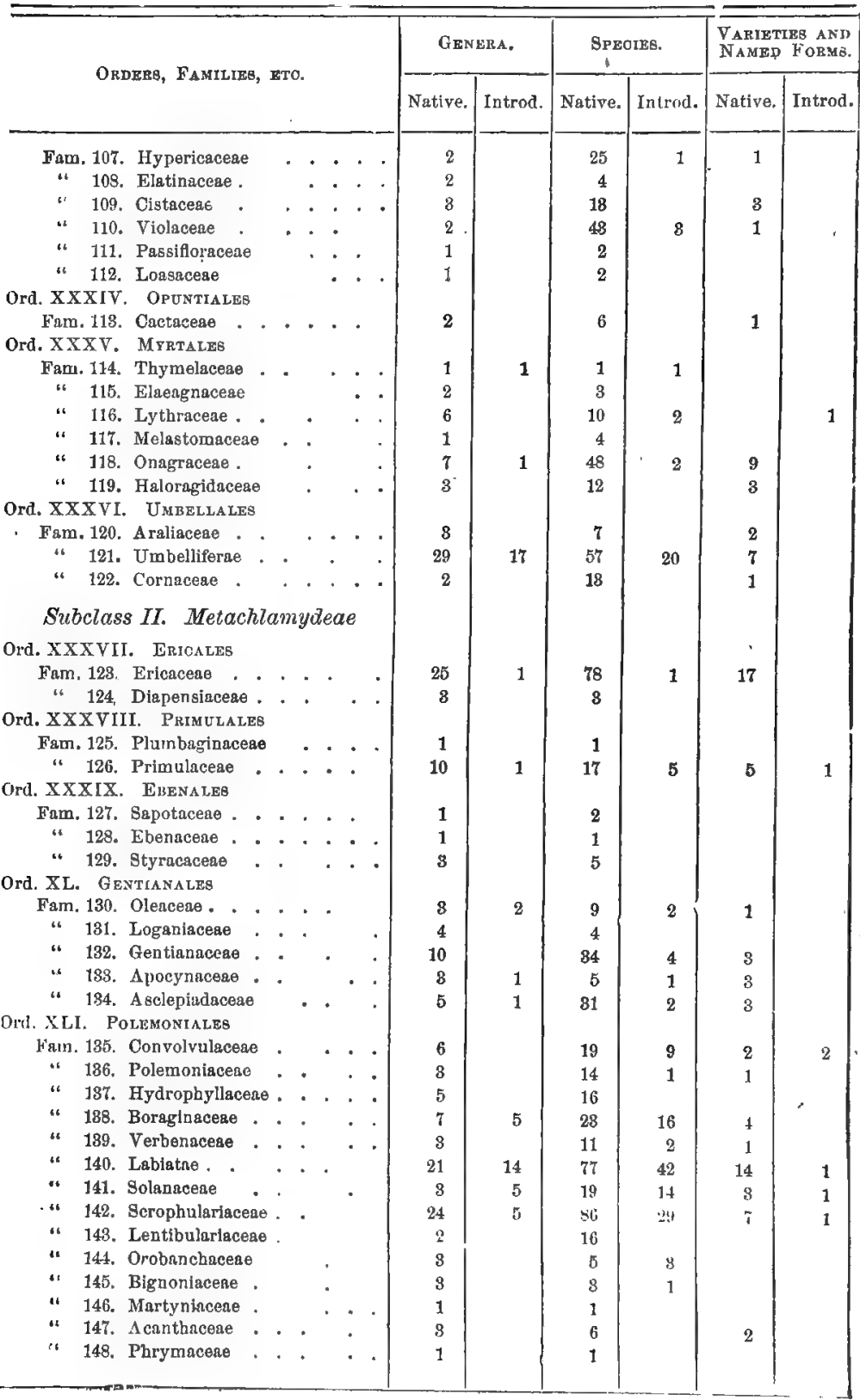




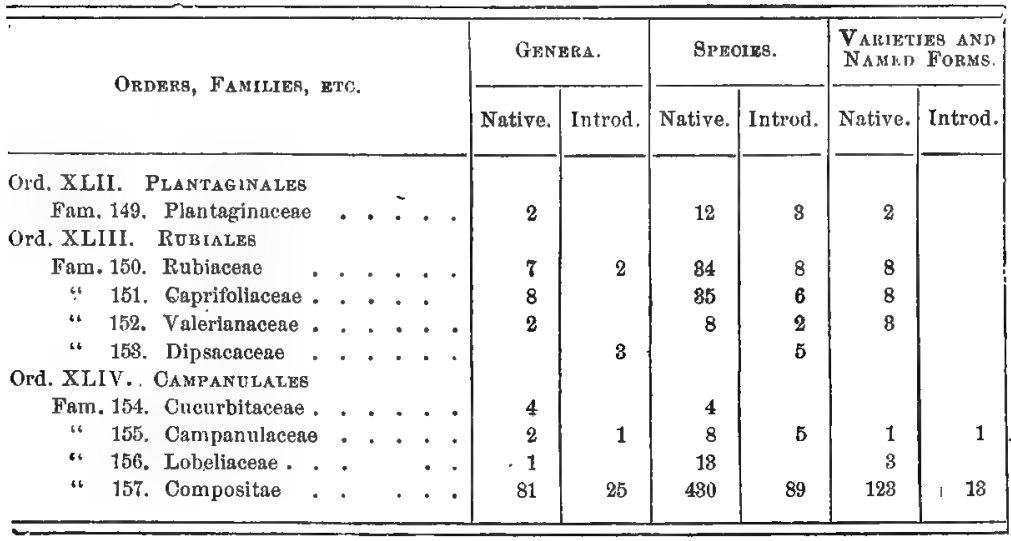

\section{SUMMARY BY DIVISIONS, CLASSES, ETC.}

\begin{tabular}{|c|c|c|c|c|c|c|c|c|c|c|c|c|}
\hline \multirow{2}{*}{ DIFIBION, } & \multirow{2}{*}{\multicolumn{2}{|c|}{ Class, }} & \multirow{2}{*}{\multicolumn{3}{|c|}{ ETC. }} & & \multicolumn{2}{|c|}{ GENElia. } & \multicolumn{2}{|c|}{ SPEOIRS. } & \multicolumn{2}{|c|}{$\begin{array}{l}\text { VARIETIES AND } \\
\text { NAMED FoRMB. }\end{array}$} \\
\hline & & & & & & & Native. & Introd. & Native. & Introd. & Native. & Introd. \\
\hline Pteridophyta & & - & . . & . & $\therefore$ & - & 31 & & 115 & & 81 & \\
\hline Spermatophyta . . & & & & - & . & . & 790 & 180 & 3298 & 666 & 705 & 40 \\
\hline Gymoospermae & • & • & . . & . & • & . & 10 & & 25 & 8 & 2 & \\
\hline Angiospermae . & & . & . & & 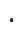 & - . & 780 & 180 & 3273 & 668 & 708 & 40 \\
\hline Monocotyledoneae & e & * & - & - & - & & 184 & 26 & 998 & 92 & 286 & 5 \\
\hline Dicotyledoneae & . & . & . & & . & & 596 & 154 & 2280 & 571 & 467 & 85 \\
\hline Archichlamydea & te. & . & - & & $\cdot$ & - . & 885 & 88 & 1249 & 321 & 253 & 15 \\
\hline Metachlamydeae & e . & & & . & & . . & 261 & 66 & 1081 & 250 & 814 & 20 \\
\hline
\end{tabular}

\section{SUMMARY BY MINOR GROUPS}

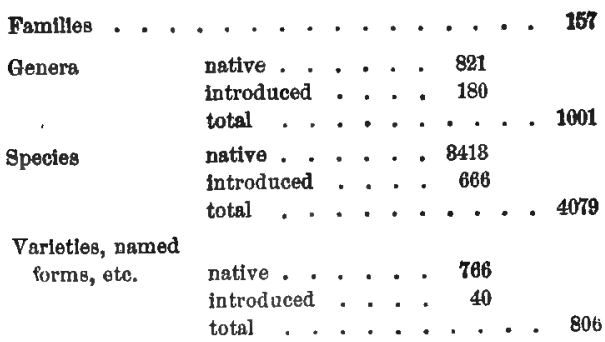

Whole number of different plants (species, varieties, and named forms) treated in 


\section{EXPLANATION OF ABBREVIATIONS OF AUTHORS' NAMES}

A. Br.-Braun, Alexander.

Adans.-Adanson, Michel.

A. $D C$. - De Candolle, Alphonse.

Ait.-Aiton, William.

Ait.f. - Aiton, William Townsend.

All. - Allioni, Carlo.

Anders. - Andersson, Nils Johan.

Andr.-Andrews, Henry C.

Andrz. - Andrzejowski, Anton Lukiano-

wicz.

Ard.-Arduino, Pietro.

Arn. - Arnott, George A. Walker.

Asch. - Ascherson, Paul.

Aust. - Austin, Coe Finch.

$B$. d $H$. - Bentham, George, and Hooker,

Joseph Dalton.

$B a b$. - Babington, Charles Carảale.

Baill. - Baillon, Henri Ernest.

Baldw. - Baldwin, William.

Barn. - Barneoud, F. Marius.

Bartl. - Bartling, Friedrich Gottlieb.

Bartr. - Bartram, William.

Beauv. - Beaurois, A. M. F. J. Palisot de.

Benn. - Bennett, Arthur.

Benth.-Bentham, George.

Bernh. - Bernhardi, Johann Jacob.

Bess. - Besser, Wilhelm S. J. G. von.

Bieb.-Bieberstein, Friedrich August,

Marsehall von.

Bigel. - Bigelow, Jacob.

Bjornstr. - Bjornström, Friedrich Johann.

B. Juss. - Jussieu, Bernard de.

Boeckl. - Boeckeler, Otto.

Boenn. - Boenninghausen, C. M. F. von.

Boerh.-Boerhaave, Hermann.

Boiss. - Boissier, Edmond.

Borkh. - Borkhausen, M. B.

$B r ., A . B r .-$ Braun, Alexander.

$B r ., P$. Br. - Browne, Patrick.

$B r ., R$. Br. 一 Brown, Robert.

Brack. - Brackenridge, William D.

Briq. - Briquet, John.

\section{BSP. - Britton, Nathaniel Lord, Sterns,}

E. E., and Poggenberg, Justus F.

Burm. f.-Burman, Nikolaus Laurens. C. \& S. - Chamisso, Adalbert von, and

Schlechtendal, D. F. L. von.

C. A. Mey. - Meyer, Carl Anton.

Carr. - Carrière, Élie Abel.

Cusp.-Caspary, Robert.

Cass. -- Cassini, Heuri.

Cav. - Cavanilles, Antonio José.

Čelak. - Člakorsky, Ladislav.

Cerv. - Cervantes, Vicente.

Cham. - Chamisso, Adalbert von.

Chapm. - Chapman, Alvan Wentworth.

Chois. - Choisy, Jacques-Denis.

Clayt. - Clayton, John.

Coult. - Coulter, Jobn Merle.

Cyrill. - Cirillo, Domenico.

Darl. - Darlington, William.

Davenp. - Davenport, George Edward

$D C$. - De Candolle, Augustin Pyramus.

$D C ., A . D C .-$ De Candolle, Alphonse.

Dene. - Decaisne, Joseph.

Desf. - Desfontaines, Réné Louiche.

Desr. - Desrousseaux.

Desv. - Desvaux, Augustin Nicaise.

Dietr. - Dietrich, Albert.

Dill. - Dillenius, Johann Jacob.

Dougl. - Douglas, David.

Duff. - Dufresne, Pierre.

Duham. - Du Hamel du Monceau, H. L.

Dumont. - Du Mont de Courset, G. L. M

Dumort.-Dumortier, Barthelemy C.

Dur. - Durieu de Maisonneuve.

Eat. - Eaton, Amos.

Ehrh.-Ehrhart, Friedrich.

Ell.-Elliott, Stephen.

Endl. - Endlicher, Stephan Ladislaus.

Engelm. - Engelmann, George.

Esch. - Eschscholtz, Johann Friedrich.

Fisch.-Fischer, F. E. Ludwig von.

Forst. - Forster, J. R. and George.

Foug. - Fougeroux, Auguste Denis. 
Fourn.-Fournier, Eugène.

Fresn.-Fresenius, J. Y', G. W.

Froel. - Froelich, Joseph Aloys.

Gaertn. - Gaertner, Joseph.

Gal.-Galeotti, Henri.

Gúud. - Gaudichaud-Beaupré, Charles.

G. F. W. Mey.-Meyer, Georg Friedrich Wilbelm.

Gilib. - Gilibert, Jean Emmanuel.

Gmel.-Gmelin, Samuel Gottlieb.

Gniel., J. F. Gmel. - Gmelin, Johann Friedrich.

Gmel., J. G. Gmel. - Gmelin, Johann Georg.

Godr.-Godron, Dominique Alexandre.

Good. - Goodenough, Samuel.

Grab. - Grabowski, Hein rich Emanuel.

Graebn.-Graebner, Paul.

Gren.-Grenier, Charles.

Grev. - Greville, Robert Kaye.

Griseb.-Grisebach, Heinrich R. A.

Gronov.-Gronovius, Jan Fredrik.

Gunn.-Gunnerus, Johann Ernst.

Guss. - Gussoni, Giovanni.

H. \& A. - Hooker, William Jackson, and

Arnott, G. A. Walker.

Hack. - Hackel, Eduard.

Hartm. - Hartman, Carl Johan.

Hassk. - Hasskarl, Justus Carl.

Haussk. - Haussknecht, Carl.

Haw. - Haworth, Adrian Hardy.

$H B K$. - Humboldt, F. Alexander von,

Bonpland, Aimé, and Kunth, C. S.

Hegel. - Hegelmaier, Friedrich.

Heist. - Heister, Lorentz.

Herb. - Herbert, William.

Hitchc.-Hitchcock, Albert Spear.

Hoffn.-Hoffmann, Gecrg Franz.

Hook. - Hooker, William Jackson.

Hook. f.-Hooker, Joseph Dalton.

Hornem. - Hornemann, Jens Wilken.

Huds. - Hua on, William.

Jncq. - Jacquin, Nicolaus Joseph.

J. D. Sm. - Smith, John Donnell.

J.F. Gmel. - Gmelin, Johann Friedrich.

J. G. Gmel. - Fmelin, Johann Georg.

J. G.S Sm. - Smith, Jared Gage.

J. Sm, - Smith, John.

Jord. - Jordan, Alexis.

Juss. - Jussieu, Antoine Laurent de.

Juss., B. Juss. - Jussieu, Bernard de.

Karst. - Karsten, Hermann.

Krock. - Krocker, Anton Johann.
Ktze. - Kuntze, Otto.

L. - Linnaeus, Carolus, or Linné, Car! von.

L. f.-Linné, Carl von (the son).

Laestad. - Laestadius, Lars Levi.

Lag. - Lagasca, Mariano.

Lall. - Ave-Lallemant, J. L. E.

Lam. - Lamarck, J. B. A. P. Monnet.

Lamb. - Lambert, Aylmer Bourke.

Lat.-Latourette, M. A. L.

Leavenu. - Leavenworth, Melines C.

Ledeb. - Ledebour, Carl F. von.

Lehm.-Lehmann, J. G. C.

Lesp.\& Thév.-Lespinasse, Gustave, and

Théveneau, $\mathrm{A}$.

Less. - Lessing, Christian Friedrich.

L'Hér. - L'Héritier de Brutelle, C. L.

Lightf. - Lightfoot, John.

Lindl. - Lindley, John.

Lodd. - Loddiges, Conrad.

Loefl. - Loefling, Pehr.

Loisel. - Loiseleur-Deslongchamps, J

L. A.

Loud.-Loudon, John Claudius.

Lour. - Loureiro, Juan.

MacM. - MacMillan, Conway.

Marsh. - Marshall, Iumphrey.

Maxim. - Maximowicz, Carl Johann.

Medic. - Medicus, Friedrich Casimir.

Meisn. - Meisner, Carl Friedrich.

Merr. - Merrill, Elmer D.

Mett.-Mettenius, Georg Heinrich.

Mey. - Meyer, Ernst Heinrich F.

Mey., C. A. Mey. - Meyer, Carl Anton.

Mey., G. F. W. Mey.-Meyer, Georg

Friedrich Wilhelm.

Mich.-Micheli, Pier' Antonio.

Michx. - Michaux, André.

Michx.f.-Michaux, François André.

Mill. - Miller, Philip.

Moq. - Moquin-Tandon, Alfred.

Muell. Arg. - Mueller, Jean (of Aar-

gau).

Muench. - Muenchhausen, Otto Freiherr

von.

Muhl. - Muhlenberg, G. H. E.

Murr.-Murray, Johann Andreas.

Neck. - Necker, Noel Joseph de.

Nees-Nees von Esenbeck, Christian

Gottfried.

Nees \& Eberm. - Nees von Esenbeck, T

F. L., and Ebermaier, K. H.

Newm. - Newman, Edward. 
Nutt. - Nuttall, Thomas.

Pall. - Pallas, Peter Simon.

Parl. $\rightarrow$ Parlatore, Filippo.

$P$. Br. - Browne, Patrick.

Pers. - Persoon, Christian Hendrik.

Peterm. - Petermann, Wilhelm Ludwig.

Planch. - Planchon, Jules Ëmile.

Plum. - Plumier, Charles.

Poir. - Poiret, Jean Louis Marie.

Poll.-Pollich, Johann Adam.

$R$. \& P.-Ruiz Lopez, Hipolito, and Pavon, Josef.

R. \& S. - Roemer, J. J., and Schultes, August.

Raf. - Rafinesque-Schmaltz, C. S.

$R, B r,-$ Brown, Robert.

Reichenb, - Reichenbach, H. G. L.

Retz. - Retzius, Auders Johan.

Richards. - Richardson, John.

Roem. - Roemer, M. J.

Rostk. - Rostkovius, F. W. G.

Rottb. - Rottboell, Christen Fries.

Rupp.--Ruppius, Heinrich Bernhard.

Rupr. - Ruprecht, Franz J.

$R y d b$. - Rydberg, Per Axel.

Salisb. - Salisbury, Richard Anthony.

Sarg. - Sargent, Charles Sprague.

$\boldsymbol{S}$ ch. Bip. - Schultz, Karl Heinrich (dis-

tinguished as Bipontinus, i.e. of

Zweibrucken).

Schleich. - Schleicher, J. C.

Schleid. - Schleiden, Matthias Jacob.

Schrad.-Schrader, Heinrich Adolph.

Schreb. - Schreber, Johann D. C. von.

Schwein. - Schweinitz, Lewis David de.

Scop. - Scopoli, Johann Anton.

Seribn. - Lamson-Scribner, Frank.

Ser. - Seringe, Nicolas Charles.

Shuttlo. - Shuttleworth, Robert.

Sibth. - Sibthorp, John.

Sieb. \& Zucc.-Siebold, P. F. von, and

Zuccarini, J. G.
Sm. - Smith, James Edward.

$S m ., J . S m$. - Smith, John.

Sm., J. D. Sm. - Smith, John Donnell

Sm., J. G. Sm. - Smith, Jared Gage.

Soland. - Solander, Daniel.

Spreng. - Sprengel, Kurt.

Sternb. - Sternberg, Caspar.

Steud. - Steudel, Ernst Gottlieb.

Stev. - Steven, Christian.

St. Hrt. - St. Hilaire, Auguste de.

Sulliv. - Sullivant, William Starling.

Sw. - Swartz, Olaf.

T. \& G. - Torrey, John, and Gray, Asa.

Thunb. - Thunberg, Carl Pehr.

Torr. - Torrey, John.

Tourn. - Tournefort, Joseph Pitton de.

Trel. - Trelease, William.

Trev. - Treviranus, Christian Ludolf.

Trin. - Trinius, Karl Bernhard.

Tuckerm. - Tuckerman, Edward.

Turcz. - Turczaninow, Nicolaus.

Undemo. - Underwood. Iucien Marcus.

Vaill. - Vaillant, Sébastien.

Vent. - Ventenat, Étienne Pierre.

Vill. - Villars, Dominique.

Wahlb. - Wahlberg, Pebr Fredrik.

Wahlerb. - Wahlenberg, Georg.

Waldst. \& Kit. - Waldstein, F. A. von and Kitaibel, $\mathbf{P}$.

Wallr. - Wallroth, K, F. W.

Walp. - Walpers, Wilhelm Gerhard.

Walt. - Walter, Thomas.

Wang. - Wangenheim, F. A. J. von.

Wats. - Watson, Sereno.

Wettst. - Wettstein, Richard von.

Willd. - Willdenow, Carl Ludwig.

Wimm.--Wimmer, Friedrich.

With. - Withering, William.

Wormsk. - Wormskiold, M. von.

Wulf. - Wulfen, Franz Xavier. 


\section{FURTHER ABBREVIATIONS AND SIGNS EMPLOYED IN THIS WORK}

(The customary and well known abbreviations for the states of the Union and months of the year are omitted from this list.)

$A d v .$, adventive, i.e. as yet only casual and sporadic.

Afr., Africa.

Alb., Alberta.

$A m$., America or American.

Assina., Assiniboia.

Austr., Australia.

auth., authors.

B. C., British Columbia.

cm., centimeter (or centimeters), the hundred th part of a meter, = about two-fifths of an inch.

cosmop., cosmopolitan.

distr., distributed.

$d m$., decimeter (or decimeters), the tenth part of a meter, = about four inches.

e., east or eastern.

eastro., eastward.

$E u .$, Europe.

Eurasia, Europe and Asia.

$f$., filius, son, or the younger.

$E^{\prime} l$., flowel's or flowering.

Fr., fruit or fruiting.

Greenl., Greenland.

Huds. B., Hudson Bay.

$I .$, island.

Introd., introduced, i.e. brought in intentionally, as through horticulture, etc.

I. T., Indian Telritory.

$L .$, lake.

Lab., Labrador.

L. I., Long Island, New York.

m., meter (or meters), = about $39 \frac{1}{3}$ inches.

Man., Manitoba.

Man. ed. 6, Sixth edition of Gray's Manual of Botany.

Mez., Mexico. mm., millimeter (or millimeters), = about one twenty-fifth of an inch $m t$, mts., mountain, mountains.

$n .$, north or northern.

N. A., North America.

nat., naturalized, i.e. thoroughly established.

N. B., New Brunswick.

n. e., northeast.

$N f d$., New foundland.

no., number.

northw., northward.

N. S., Nova Scotia.

n. w., northwest.

Okla., Oklahoma.

Ont., Ontario.

P. E. I., Prince Edward Island.

Que., Province of Quebec.

$R$., river.

s., south or southern.

$S$. A., South America.

Sask., Saskatchewan.

s. e., southeast.

Siber., Siberia.

southw., southward.

Subtrop., sub-tropical.

$s . w$., southwest.

Temp., temperate.

Trop., tropics or tropical.

w., west or western.

westw., westward.

W. $I .$, West Indies.

$\mu$ (pronounced $\mathrm{mu}$ ). A micron, the millionth part of a meter, a measure used in microscopic studies.

- Figures or words connected by the 
short dash indicate the extremes of variation, as " $5-12 \mathrm{~mm}$. long, few-many-flowered," i.e. varying from five to twelve millimeters in length and from few to many flowered.

$\S$ section.

$\infty$ Of isdefinite number, usually many.
1 A mark of affirmation or authentication.

? indicates doubt.

o Bearing stamens or antheridia but neither pistils nor archegonia.

q Bearing pistils or archegonia but neither stamens nor antheridia.

$x$ crossed with, the sign of a hybrid.

100 Millimeters

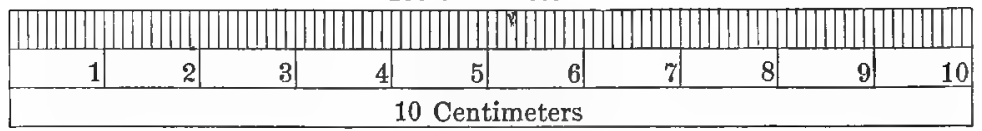

1/10 Meter, or 1 Decimeter 


\section{DESCRIPTIVE FLORA}

\section{Division I. PTERIDÓPHYTA}

\section{(Frens and Fern Allies)}

Male generative cells (spermatozoids) spirally coiled motile bodies, not developing into a tube. Plants with more cr less distinct alternation of generations. The sexual stage, a small thalloid body; the asexual provided with vascular tissue and (with rare exceptions) differentiated into stem and leaves (fronds), some of these modified to bear asexual reproductive bodies or spores (without embryo), which again give rise to the sexual generation.-Often called Vascular Cryptogams or Higher Flowerless Plants.

\section{hYMENOPHYLLÀceAe (Filmy Fern Family)}

Delicate ferns with slender often filiform creeping rootstocks. Fronds pellucid, of a single layer of cells. Sporangia sessile on a bristle-like receptacle within a cup-shaped, tubular, or bivalvular involucre, from the apex of a vein, the ring transverse and complete. Chiefly tropical, inhabiting damp places, often epiphytic. Fronds circinate in vernation.

\section{TRIChómanes L. Filmy Fern}

Involucre tubular-funnel-shaped, the mouth nearly or quite truncate. Sporangia bursting vertically. - Ours a small creeping fern with much divided fronds. (In ancient Greek name for some fern.)

1. T. Boschiànum Sturm. Fronds oblong-lanceolate, 1-2 dm. long, 12-35 mm. wide, bipinnatifid; rhachis narrowly winged; pinnae triangular-orate, the divisions toothed or again lobed; capillary receptacle often much exserted. (T. radicans Man. ed. 6, not $\mathrm{Sw}$.) - On moist and dripping sandstone cliffs, Ky. to Ala.

\section{POLYPOdIÀCEAE (Fern FamiLy)}

Leafy plants (ours herbaceous), with creeping rhizones. Spores borne in sporangia (spore-cases), these collected in dots, lines, or variously shaped clusters (sori or fruit dots) on the bxcle or margins of the frond or its divisions, cellularreticulated, stalked, the stalk running into a vertical incomplete many-jointed ring, which by straightening at maturity ruptures the sporangium transversely on the inner side, discharging the spores. Fruit dots often covered (at least 
when young) by a membrane called the indusium (or less properly the involucre: growizg either from the back or the margin of the frond.

(*. Indusium none or abortive and obsoure $b$.

h. Sterile fronds simply pinnatifid (the segments rarely toothed or lobed).

Fertile fronds similar to the sterile, flat and leaf-like

Fertile fronds much contracted ; segments pod-like

1. Polypodim

$b$ Sterile fromi-2-1-pinnate or -pinnatifid.

Sterile fronds green on both surfaces.

Fertile fronds similar to the sterile, leaf-like

Fertile fronds much contracted; segments pod-ilke

Sterile fronds whitened beneath

- 18. ONOOLEa.

2. Phequiteris

18. ONOCLLA.

3. Notilolaena.

u. Indusium present $c$.

c. Indusium formed entirely or in part by the revolute edge of the frond $a$.

d. Sori clearly distinct.

Indusium single, covering the sorus

4. ADLANTUM.

Indusium double, cup-like or 2-valved . . . . . . 17. Dioksonis.

d. Sori soon confluent as a more or less continuous marginal band.

Stipe stout (8-4 mm. in diam.), commonly solitary.

Stipes fliform $(0.5-1.3 \mathrm{~mm}$. in diam.), elustered.

Segments of the sterile frond glabrous.

Green or greenish.

Segments petio'ulate or articulated at cordate or rounded base

Begments of sterile frond cuneate at sessile unarticulated base

Chalky-white beneath.

Begments of the sterile frond pubescent

c. Indusium not continuons with the edge of the frond $e$.

e. Indusium peltate or laterally attached, covering the sorus when young $f$.

$f$. Sori more or less elongated.

Sori parallel to the midrib.

Sori parallel to the oblique lateral veins.

Veins free; fronds 1-3-pinnate. Sori separate, straight or horseshoe-shaped
Sori linear, confluent in pairs (appearing like single sori
but with indusia on both sides)

$f$. Sor orbicular or reniform $g$.

g. Indusium evident at least when young; fertile fronds leaf-like $h$.

h. Indusium fixed by the center.

Indusium orbicular-peltate, without a sinus .

Indusium reniform or if orbicular with a narrow sinus.

$h$. Indusium attached at the side

g. Indusium obscure, lunate; fertile segments much contricted, pod-like

e. Indusium inferlor, cup-like or involucre-like.

Indusium 2-valved, cup-like . . . . . . 17. Dioksonta.

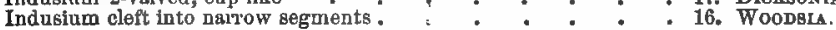

\section{POLYPÒDIUM [Tourn.] L. POLYPODY}

Fruit dots round, naked, arranged on the back of the frond in one nr more rows each side of the midrib or central vein, or irregularly scattered, each borne in our species on the end of a free yeinlet. Rootstocks creeping, branched, often covered with chaffy scales, bearing scattered roundish knobs, to which the stipes

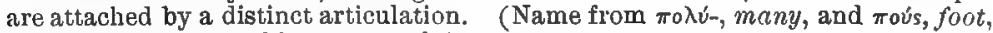
alluding to the branching rootstock.)

1. P. vulgàre L. Fronds evergreen, oblong, smooth both sides, $8-40 \mathrm{~cm}$ high, simple and deeply pinnatifid; the divisions linear-oblong, obtuse or somewhat acute, remotely and obscurely toothed; veins once or twice forked; fruit dots large, midway between the midrib and the margin. - Rocks; common. July. (Eu., etc.) Variable. Some of the more noteworthy forms have been distinguished as: Var. ATTENua Tum Milde, with segments attenuate-acmminate, serrulate toward the end. Var. A URìum Willd., with the lowest segments auri. cled. Var. скмвгісuм (L.) Willd., with the segments more or less strongly toothed or pinnatifid. Var. cristatum Moore, with segments 1-several times forked at the ends.

$\checkmark$ 2. P. polypodioides (L.) Hitche. Frond evergreen and coriaceous, oblong, 6-25 cm. high, grayish and very scurfy underneath with peltate scales, simply pinnatifid ; the divisions oblong-linear, obtuse; fruit dots rather small, near the margin; veins forking, free in the $\mathrm{N}$. American plant! ( $P$. incanum $\mathrm{Sw}_{\mathrm{w}}$ ) Rocks and trunks of trees, Va. and $O$. to Ia., and southw.; reported on Staten I., N. Y. (Trop.) 


\section{PHegópteris (Presl) Fée. Beech Fern}

Fruit dots small, round, naked (no indusium), borne on the back of the veins below the apex. Stipe continuous with the rootstock. - Our species have free veins and bright green membranaceous fronds, decaying in early autumn. (Name composed of $\phi \eta \gamma \delta s$, an oalc or beech, and $\pi \tau \epsilon \rho c$, fern.)

* Fronds twice pinnatifid; pinnae all sessile, adnate to the winged rhachis.

1. P. polypodioìdes Fée. Fronds triangular, longer than broad $(8-26 \mathrm{~cm}$. long), hairy on the veins, especially beneath; pinnae linear-lanceolate, the lowest pair deflexed and standing forward; their divisions oblong, obtuse, entire, the basal decurrent upon the main rhacbis ; fruit dots all near the margin. ( $P$. Phegopteris Underw.) - Damp woods, Nfd. to N. Y., "Va.," Wisc., Ia., Wash., and Alaska. (Eurasia.)

V 2. P. hexagonóptera (Michx.) Fée. Fronds triangular, usually broader than long (14-30 cm. broad), slightly pubescent and often finely glandular beneath: pinnae lanceolate; upper segments oblong, obtuse, toothed or entire, those of the very large lowest pinnae often elongated and pinnately lobed, basal ones very inuch decurrent and forming a continuols many-angled wing along the main rhachis; fruit dots near the margin; some also between the sinus and the midrib. - Rather open woods, centr. Me. to w. Que., w. to Minn., and southw.; common. - Larger and broader than the last, which it often closely resembles.'

* * Fronds ternate, the three divisions petioled; whachis wingless.

3. P. Dryópteris (L.) Fée. (OAK FERN.) Fronds smooth, broadly triangular (1-1.5 dm. wide), the three triangular primary divisions all wadely spreading, 1-2-pinnate; segments oblong, obtuse, entire or toothed; fruit dots near the margin. - Rocky woods ; common northw. (Eurasia.)

4. P. Robertiàna (Holfm.) A. Br. Fronds minutely glandular and somewhat rigid, dull green; lowest inferior pinnae of the lateral divisions smaller in proportion than in the last species. ( $\boldsymbol{P}$. calcarea Fée.) - Shaded limestone, "Lab." and Anticosti to N. B., Ia., and Man. ; rare. (Eu.)

\section{NOtholatèa R. Br. Cloak Fern}

Fruit dots roundish or oblong, placed near the ends of the veins, soon more or less confluent into an irregular marginal band, with no proper involucre. Veins always free. Fronds of small size, 1-4-pinnate, the lower surface almost. always either hairy, tomentose, chaffy, or covered with a fine waxy white or

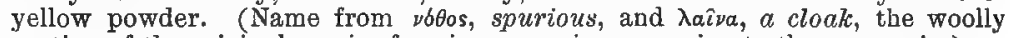
coating of the original species forming a spurious covering to the sporangia.)

1. N. dealbàta (Pursh) Kunze. Fronds triangular-ovate, $3-8 \mathrm{~cm}$. long, 3-4-pinnate; rhachis and branches straight, black and shining; ultimate pinnules ovate-oblong, scarcely $2 \mathrm{~mm}$. long, white and powdery on the lower surface. ( $N$. nivea, var. Davenp.) - Clefts of dry calcareous rocks, Mo., Kan., and southwestw. July, August.

\section{Adiántum [Tourn.] L. Matdenhatr}

Fruit dots marginal, short, borne on the under side of a transversely oblong, crescent-shaped or roundish, more or less altered margin of a lobe of the frond reflexed to form an indusium; the sporangia attached to the approximated tips of the free forking veins. - Main rib (costa) of the pinnules none (in our species) or at the lower margin. Stipes black and polished. (The ancient name, from $\mathrm{g}$ - privative and $\delta \iota^{\prime}(\nu \omega$, meaning unwetted, the foliage repelling rain-drops.) $\checkmark$ 1. A. pedatum L. Frond forked at the summit of the upright slender stalk (2-5 dm. high), the recurved branches bearing on one side several slender spreading pinnate divisions; pinnules numerous, short-stalked and obliquely triangular-oblong, entire on the lower margin, from which the vines all proceed, and cleft and fruit-bearing on the other, - Rich moist woods. July. 
2. A. Capillus-Véneris L. Fronds (1-5 dm. high) with a continuous main rhachis, ovate-lanceolate, often pendent, 2-3-pinnate at the base, the upper third or half simply pinnate; pinnules wedge-obovate or rhomboid, 15-32 mrn. long, deeply and irregularly incised; veinlets flabellately forking from the base ; involucres lunulate or transversely oblong. - Moist rocky places, s. N. Y. (?) ; s.e. Pa. to Ky, and Fla.; also S. Dak, and southwestw. (Widely distr.)

\section{PtĖRIS L. Brake or Bracken}

Sporangia in a continuous slender line of fructification, occupying the entire margin of the fertile frond, and covered by its reflexed narrow edge which forms a continuous membranaceous indusium, attached to an uninterrupted transverse vein-like receptacle connecting the tips of the forked free veins, with or without an obscure inner indusium. Fronds 1-3-pinnate or decompound. (The ancient Greek name of Ferns, from $\pi \tau \epsilon \rho \delta \nu$, a wing, on account of the prevalent pinnate or feathery fronds.)

1. P. aquilìna L. (Common Braks.) Frond dull green (2-9 dm. wide), ternate at the summit of an erect stout stalk (2-9 dm. ligh), the widely spreading branches twice pinnate; pinnules oblong-lanceolate; the upper undivided; the lower more or less pinnatifid, with oblong obtuse lobes, margined all round with the indusium, which is really double in this species. (Pteridium Kubn.) - Thickets and hillsides, common. Aug. (Widely distr.) Var. PsecDocatDÁTA Clute is a form with many of the pinnules, especially the terminal ones, narrow, entire, and much elongated. - Mass. to N. J., southw. to Fla. and Tex.

\section{CHEILÁNTHES Sw.}

Sporangia borne on the thickened ends of free veinlets, forming small and roundish distinct or nearly contiguous marginal fruit dots, covered by a mostly whitish and membranaceous, sometimes herbaceous, common indusium, formed of the reflexed margin of separate lobes or of the whole pinnule. - Low, mostly with 2-3-pinnate and hairy or chaffy, rarely smooth fronds, the sterile and fertile nearly alike, the divisions with the principal vein central. Some species with continuous indusium connect this genus very closely with the next. (Name

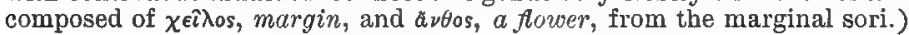

\section{* Fronds smooth, or at most hairy.}

1. C. alabaménsis (Buckley) Kunze. Fronds snmooth, chartaceous (7-20 cm. long), ovate-lanceolate, bipinnate; pinnae numerous, oblong-lanceolate; pinnules triangular-oblong, rather acute, often auriculate or lobed; indusium continnous, rather broad, pale, and of firm consistence. - On rocks, $\mathrm{mts}$. of $\mathrm{Va}$. to Ky., southw. and westw. (Mex.)

2. C. landsa (Michx.) Watt. Fronds (1-4 dm. high) lanceolate-oblong, hirsute, as are the brown and shining stipes, with straightish prominently articulated rusty hairs, twice pinnate; pinnae rather distant, triangular-ovate; pinnules oblong, crowded (4-8 mm. long), more or less incised, the ends of the roundish or oblong lobes reflexed and forming separate herbaceous involucres, which are pushed back by the ripened sporangia. (C. vestita $\mathbf{S w}$.) - Clefts of rocks, Ct. to Minn., Wyo., and southw.

\section{* Fronds woolly or tomentose.}

3. C. tomentòsa Link. Fronds ( $1.5-5 \mathrm{dm}$. high) lanceolate-ohlong, densely tomentose with slender and entangled whitish obscurely articulated hairs, thrice pinnate; primary and secondary pinnae oblong or ovate-oblong; pinnules distinct, minute (1-2 $\mathrm{mm}$. long), roundish-obovate, sessile or adnate-decurrent, the upper surface less woolly, the reflexed narrow margin forming a continuous somewhat membranaceous indusium. - Mts. of Va. and $\mathrm{Ky}$. ; thence $\mathrm{w}$. and southw, - Stipe and rhachis rather stout, brown, covered with narrow chaffy scales and whitish hairs. (Mex., W. I.)

4. C. Feèi Monre. Stipes slender, at first hairy, black or brown, shining; 
fronds (8-17 cm. high) ovate-lanceolate, woolly with soft whitish distinctly articulated flattened hairs, becoming smoother above, twice or thrice pinnate; pinnae (8-12 mm. long) ovate, the lowest distant, the others contiguous ; pinnules crenately pinnatifid, or mostly divided into minute and roundish densely crowded segments (1-2 mm. long), the herbaceous margin recurved and forming an almost continuous indusium. (C. lanuginosa Nutt.) - In dense tufts, on dry rocks and cliffs, Ill. to Minn., thence w. and southw.

\section{PEllak̀ Link. ClifF Brake}

Sporangia in roundish or elongated clusters on the upper part of the free veins, distinct, or confluent laterally so as to initate the marginal continuous line of fructification of Pteris, commonly covered by a broad membranaceous and continuous (rarely interrupted) general indusium, which consists of the reflexed and altered margin of the fertile pinnule or division. - Small ferns, with 1-3. pinnate fronds, the fertile ones with narrower divisions than the sterile, but otherwise similar. Stipes generally dark-colored, smooth, and shining. (Name from $\pi \epsilon \lambda \lambda b s$, dusky, alluding to the stipe.)

1. P. atropurpû̀rea (L.) Link. Snooth, except some bristly-chaffy hairs on the midribs and especially on the dark purple and polished stalk and rhachis, 1-6 dm. high ; fronds coriareous, pale, once or below twice pinnate; the divisions broadly linear or oblong, or the sterile sometimes oval, chiefly entire, somewhat heart-shaped or else truncate at the stalked base; veins about twice forked. -Dry calcareous rocks, "N. H." and Vt. to R. I., Ga., and westw. ; not common. July. Var. CRistATA Trel. is a form with dichotomously forked pinnae, somewhat crowded toward the summit of the frond. - Eureka, Mo. (G. Pauls).

\section{CRYPTOGRÁmMa R. Br. Rock Brake}

Fruit dots roundish or elongated and extending far down on the free forking veins. Margins of the fertile segments herbaceous or more or less scarions, at first reflexed and meeting at the midrib, at length opening out flat and exposing the confluent sporangia. - Low ferns, with smooth 2-3-pinnate tufted fronds, the fertile ones taller than the sterile, and with narrower divisions. (Name

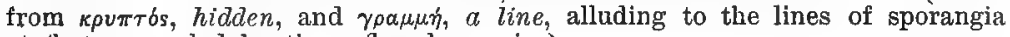
at first concealed by the reflexed margin.)

* Revolute margins of the fertile frond bearing a distinct scarious indusial border; ultimate segments of the sterile fronds lance-linear, acute.

1. C. đénsa (Brack.) Diels. Fronds not very dissimilar, 8-20 cm. high ; stipes purplish brown; segments of the sterile fronds lance-linear, very acute, incisely serrate. (Pellaea Hook.) - Calcareous or serpentine walls of ravines, etc., Mt. Albert, Gaspé Co., Que. ; Grey Co., Ont. ; and in the far west.

* * Revolute margins of the fertile frond scarcely modified; ultimate segments of the sterile fronds broader.

2. C. acrostichoides R. Br. Fronds markedly dissimilar; segments of the fertile linear (6-10 mm. long), of the sterile ovate-oblong, obtuse, serrulate; stipes straw-colored, scaly especially toward the base.-Crevices of rocks, Arctic Am. to L. Huron, I. Superior, Col., and Cal.

3. C. Stellèri (Gmel.) Prantl. Fronds markedly dissimilar; segments of the fertile linear-oblong to lance-linear; those of the sterile ovate to obovateflabelliform, crenulate, decurrent at their cuneate bases. (Pellaed gracilis Hook.) - Shaded chiefly calcareous rocks, Que. and N. B. to Vt., Ct., n. Pa., Ill., and northwestw.; local. (Asia.)

\section{WOODWARdia Sm. Chain FerN}

Fruit dots oblong or linear, arranged in one or more chain-like rows on transverse anastomosing veinlets parallel and near to the midrib. Indusinm fixed by 
its outer margin to the fruitful veinlet, free and opening en the side next the midrib. Veins more or less reticulated, free toward the margin of the frond. - Large ferns, with pinnatifid or pinnate fronds. (Named for Thomas J. Woodvoard, an English botanist.) §1. ANCHISTEA (Presl) Hook. Stemile and fertile fronds alice; veins form-
ing only one row of meshes (areoles).

V1. W. virgínica (L.) Sm. Fronds (6-14 dm. high) pinnate, with numerous lanceolate pinnatifid pinnae; segments oblong; veins forming a row of narrow areoles along the midrib both of the pinnae and of the lobes, the outer veinlets free; fruit dots oblong, one to each areole, confluent when ripe. - Wet swamps, N. S. to Fla., La., Mich, and Ont. Rootstocks creeping, often $2-3 \mathrm{~m}$. long ! July.

§ 2. LORINSERIA (Presl) Hook. Sterile and fertile fronds untike; veins of the sterile fronds forming many rows of meshes.

2. W. areolata (L.) Moore. Fronds pinnatifid; sterile ones (2-6 dm. high) with lanceolate serrulate divisions united by a broad wing; fertile fronds taller. with narrowly linear almost disconnected divisions, the areoles and fruit dots (8-10 mm. long) in a single row each side of the secondary midrib; rootstocks creeping. ( $\mathrm{W}$. angustifolia Sm.) - Wet woods, s. Me. to Fla. and Tex. ; also Ark. and Mich.; rare. Aug., Sept.

\section{ASPLENIUM I. SPLeENwort}

Fruit dots oblong or linear, oblique, separate; the straight or rarely curved indusium fixed lengthwise by one edge to the upper (inner) side of the fertile vein; - in some species a part of the fruit dots are double, the fertile vein bearing two indusia placed back to back. Veins free in all our species. (Name from $a$ - privative and $\sigma \pi \lambda \eta \eta^{\prime}$, the spleen, for supposed remedial properties.)

§1. EUASPLENIUM (Endl.) Klotzsch. Indusium straight or slightiy curved, attached to the upper side of the vein, rarely double; small evergreen ferns; stipes filiform or nearly so, with vascular bundles separate and peripheral or if united toward the summit forming a lunate bundle; scales of the rhizome and stipes narrow, of firm texture and with thick-walled cells.

* Fronds pinnatifi, or pinnate only near the base.

1. A. pinnatifidum Nutt. Fronds (7-20 cm. long) lanceolate, pinnatifid or pinnate below, tapering above into a slender prolongation, "the apex sometimes rooting" ; lobes roundish-ovate, obtuse, or the lowest long-acuminate; fruit dots irregular, those next the midrib often double, even the slender prolongation fertile; stipes brownish, becoming green above, and so passing into the broad pale green midrib. - On cliffs and rocks, Ct. to Mo., and southw, ; very rare. July. - Resembles the Walking Leaf (Camptosorus), but the veins are free.

$\times$ A. ebenoides R. R. Scott. Fronds (1-2 dm. high) broadly lanceolate, pinnatifid, below pinnate, the apex prownged and slender; divisions lanceolate from a broad base, the lower ones shorter, often proliferous, as is the apex of the frond; fruit dots much as in the last; stipes black and polished, as is the lower part of the midrib, especially beneath. - Iimestone cliffs, Vt. (Miss Moolson, Miss Smith) to Mo., and southw. ; very rare. A noteworthy hybrid bttween A. platyneuron and Camptosorus rhizophyllus; its origin early suspected by M. G. Berkeley and recently demonstrated by Miss Margaret Slosson. This fern is more abundant and probably self-perpetuating in Ala.

* Fronds narrow, linear-oblong to oblong-lanceolate, pinnate, with numerous pinnae; these entire to serrate or rarely incised.

\section{+ Pinnae not auricled.}

2. A. viride Huds. Fronds $(5-13 \mathrm{~cm}$, tall) tufted, linear in outline, pale green, softly herbaceous; pinnae roundish-ovate or orate-rhomboid, shortstalked, creantely toothed ( $4-0 \mathrm{~mm}$. long), the midvein indistiuct and forking; 
the slender stipe brownish and passing into a green herbaceous rhachis. — Shaded limestone; Nfd, to n. N. F., w. and northw ; rare. (Widely distr.)

3. A. Trichómanes L. Fronds (8-22 cm. long) in dense spreading tufts, linear in outiine, dark green und more rigid; pinnae roundish-oblong or oval (3-7 mm. long), entire or crenulate, rarely incised, unequal-sided, obliquely wedge-truncate at base, attached by a narrow point, the midvein forking and evanescent; the thread-like stipe and rhachis purple-brown and shining. - Shaded rocks. July. (Widely distr.) Forma INcisum Moore with deeply pinnatifid pinnae has been reported from Vt. (Miss Grout, Mrs. Horton).

\section{+ + Pinnae more or less auricled.}

4. A. párvulum Mart. \& Gal. Fronds upright ( $1-25 \mathrm{dm}$. high), narrowly linear-oblanceolate; pinnae (4-12 $\mathrm{mm}$. long) rigid and thickish, mostly opposite, nearly sessile, somewhat deflexed, oblong, obtuse, entire or crenulate, auricled on the upper or both sides; sori rather few, as near the margin as to the continuous midvein ; stipe and rhachis black and shining. ( $A$. resiliens Kunze.) - Mts. of Va. to Kan., and southw. - Intermediate between the last and the next.

$V$ 5. A. platyneùron ( $\mathrm{L}$ ) Oakes. Fronds upright $(2-5 \mathrm{dm}$. tall), linearoblanceolate in outline, fertile ones nuch the taller; pinnce (1-3 cm. long) firmly membranaceous, mostly alternate, sessile, spreading, oblong or oblonglinear, finely serrate or even incised, the base auricled on the upper or both sides; sori many, nearer the elongated midvein than the margin; stipe and rhachis blackish-purple and shining. (A. ebeneum Ait.) - Rocky open woods, s. Me. to Col., and southw. (W.I., S. Am., Afr.) Var. serratum (E. S. Miller) BSP. is a form with at least some of the pinnae deeply jagged-serrate. Var. Incisum (E. C. Howe) Robuson has very brittle stipes and the pinnae deeply pinnatifid. (A. ebeneum, var. Hortonae Davenp.) - Vt. to Md., Mo., and "Ark." ; rare.

6. A. Bradlèyi D. C. Eaton. Fronds oblong-lanceolate (4-20 cm. tall); stipe blackish and somewhat shining; pinnae membranaceous, rather numerous, the lower ones no larger than the middle ones, all short-stalked, oblong-ovate, obtuse, incised or pinnatifid into oblong toothed lobes. - On rocks. e. N. Y. to Ky., "Mo.," and southw. ; rare.

*** Fronds ovate-lanceolate to deltoid, 2-3-pinnate or -pinnatifid.

7. A montànum Willd. Fronds ovate-lanceolate from a broad base (j-13 cm. long), subcoriaceous, pinnate; pinnae ovate-oblong, the lowest pinnately cleft into oblong or ovate cut-toothed lobes, the upper gradually simpler; rhachis green, broad and flat; stipe browon at base. - Cliffs and rocks, from Ct. to O., Ky., "Ark.," and southw. July.

8. A. Rùta-murària L. Fronds deltoid-ovate $(3-7 \mathrm{~cm}$. long exclusive of the green stipe), subcoriaceous, laxly 2-3-pinnate at base, the pinnae alternate; ultimate segments few, stalked (3-14 mm. long), from narrowly cuneate to roundish-obovate, toothed or incised at the apex; veins forking; sori 2-4 on a segment; rhachis and stipe green.--Limestone cliffs, Vt. to Ont., Mich., Mo., and southw.; scarce. July. (Eurasia.)

§ 2. ATHÝRIUM (Roth) J. Sm. Indusium straight or more often curved, frequently crossing the vein; fronds tall, strictly herbaceous; the stipes green or greenish not filiform, the bundles concentric and uniting above into a 3-4-armed central bundle; scales delicate, of thin-walled cells. - Athyrium Roth as redefined by Milde.

* Fronds simply pinnate; indusium straight or but slightly curved.

9. A. angustifolium Michx. Fronds 6-12 dm. high; pinnae $(8-12 \mathrm{~cm}$. long) numerous, short-stalked, linear-lanceolate, acuminate, entire or crenulate, those of the fertile frond narrower; fruit dots linear, 20-40 each side of the midvein; indusia slightly convex. (Athyrium Milde.) - Rich woods, w. Que. and N. H. to Minn., and southw. Sept.

* * Fronds bipinnatifin; ; indusium straight or slightly curved.

10. A. acrostichoides $\mathrm{Sw}$. fronds (6-11 dm, high) pinnate; pinna? deeply 
pinnatifi, linear-lanceolate $(7-13 \mathrm{~cm}$. long) ; the lobes oblong, obtuse, minutely toothed, crowded, each berring 3-6 pairs of oblong fruit dots, some of them double. (A. thelypteroides Michx.; Athyvium acrostichoides Diels.) - Rich woods, N.S. to Ga., Ala., and Minn.; not rare. (Asia.)

* * Fronds bipinnate; indusia at least in part reniform or horseshoe-shaped.

$\checkmark$ 11. A. Filix-fémina (L.) Bernh. (LADY FERr.) Fronds (4-10 dm. high) ovate-oblong or broadly lanceolate, twice pinnate; pinnae lanceolate, numerous; pinnules confiuent on the secondary rhachis by a narrow unargin, oblong and doubly serrate, or elongated and pinnately incised with cut-toothed segments; fruit dots short, variously curved, at length confiuent. (Athyrium koth.) Moist woods; comwon and presenting many varying forms. July. (Cosmop.)

\section{SCOLOPENDRIUM Adans. HART'S TONGUE}

Fruit dots linear, elongated, almost at right angles to the midrib, contiguous by twos, one on the upper side of one veinlet, and the next on the lower side of the next superior veinlet, thus appearing to have a double indusium opening along the middle. (The ancient Greek name, employed because the numerous parallel lines of fruit resemble the feet of the centipede, or Sculopendra.)

1. S. vulgàre Sm. Frond oblong-lanceolate from an auricled-heart-shaped base, entire or wavy-margined (12-45 $\mathrm{cm}$. long, 2-6 $\mathrm{cm}$. broad), bright green. (Phyllitis Scolopendrium Newm.) - Shaded ravines and under limestone cliffs; Woodstock, N. B. ; Grey and Bruce Cos., Ont.; centr. N. Y.; and Tenn. ; very rare. Aug. (Mex., Eurasia.)

\section{CaMPTOSÒRUS Link. Walking Leaf}

Fruit dots oblong or linear, as in Asplenium, but irregularly scattered on either side of the reticulated veins of the simple frond, those next the midrib single, the outer ones inclined to approximate in pairs (so that their two indusia open face to face) or to become confluent at their ends, thus forming crooked

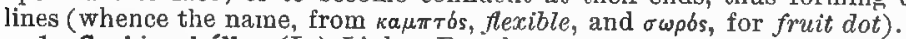

1. C. rhizophýllus (L.) Link. Fronds evergreen, subcoriaceous, growing in tufts, spreading or procumbent ( $1-3 \mathrm{dm}$. long), gradually narrowed from a cordate or auricled base to a long and slender acumination, which often roots at the end and forms a new plant. - Shaded, especially calcareous rocks; centr. Me. to Ottawa, thence to Minn., and southw. to Kan. and Ga. - The auricles are sometimes greatly elongated, and even rooting; in another form they are lacking.

\section{POLYSTICHUM Roth}

Fronds tufted at the end of a stout rootstock, chiefly of firm or leathery texture, evergreen; stipes and rhachises chaffy, Sori orbicular, opening on all

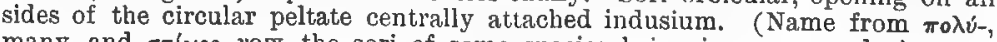
many, and $\sigma \tau l \chi$ s s, row, the sori of some species being in many ranks.j

* Fronds narrovly obiong or lanceolate, simply pinnate, the pinnae sometimes again cleft.

\section{+- Upper (spore-bearing) pinnae of the fertile fronds much contracted.}

l 1. P. acrostichoides (Michx.) Schott. (Christmas Fern.) Fronds 2-5 dm. long, the scaly stipe $5-15 \mathrm{~cm}$. in length; pinnae linear-lanceolate, half-halberdshaped at the slightly stalked base, serrulate with appressed bristly teeth; the smaller upper pinnae bearing two rows of sori, which in age becoming confluent cover their entire lower surface. (Aspidium $\mathrm{Sw}$.) - Conmon in rocky woods. Var. Schwervirzir (Beck) Small (Aspidium acrostichoides, var. incisum Gray) is a variable form with larger fronds, toothed or pinnatifid pinnae, the fertile less reduced and the sori less confluent, chiefly near the tips of the pinnae. - Not rare. + + Upper (spore-bearing) pinnae similar to the other's.

2. P. Lonchitis (L.) Roth. (HOLLT FERN.) Fronds linear-lanceolate, very 
short-stalked, rigid (1-6 dra. long) ; pinnae broadly lanceolate-scythe-shaped, acute, the lovest short-triangular, strongly auricled on the upper side, spinulosedentate; sori biseriate, at length subconfiuent. (Aspidium $\mathbf{S} w$. ) - Rocky (calcareous) woods, Gulf of St. Lawrence ; and from Niagara Falls, Ont., to L. Superior, westw. and northw. (Eu )

\section{* Fronds bipinnate.}

3. P. Braúnii (Spenner) Fée. Fronds ovate- or oblong-lanceolate (4-9 dm. long) tapering to a very short-stiped base; pinnules ovate or oblong, obtuse, truncate and almost rectangular at base, short-stalked, or the upper confluent, sharply toothed, beset with long and soft as well as chaffy hairs. (Aspidium aculeatum, var. Döll.) - Rich, mostly upland woods, Nfd. to N. Y., and L. Superior. (Eu.)

\section{ASpídium Sw. Shield Fern. Wood FerN}

Fronds tufted, 1-3-pinnate; veins simple or branched. Sori orbicular, borne on the back of the scarcely modified fertile frond. Indusium reniform or, if orbicular, exhibiting a distinct narrow depression or sinus at one side, although centrally attached. Stipes not articulated at the base. (Name from dor ló $_{\text {iov, }}$ a small shield, from the shape of the indusium.) Nepнrodium Rich.

$u$. Veins simple or once forked; frouds not evergreen; stipes and slender rootstocks nearly naked.

Lowest pinnae scarcely smaller than the middle ones. Fortile veins once forked. Fertile veins simple.

Lower pinnae gradually decreasing in size, the lowest very small , Veins, at least the lowest, more than once forked ; fronds mostly evergreen; stipes and rootstocks scaly $b$.

b. Pinnae 40-60, small, 4-8 num. broad

b. Pinnae fewer, $12-90 \mathrm{~mm}$. broad $c$.

c. Frond bipinnatifid or bipinnate (or sub-tripinnatifid near the base). Sori marginal.

Sori not marginal.

Basal scales lance-linear, caudate-attenuate . . . . 6. A. Filiw-mas.

Basal scales ovate-oblong to deltoid.

Basal scales firm, shining, dark chestnut-eolored
Basal scales thin, dull, membranous, light brown.

Indusium glandular-puberulent.

Lobes of frond with incurved teeth; sori $1.5-1.8 \mathrm{~mm}$. in diameter

(9) A. cristatum, var. Clintonianum. Lobes with spreading teeth ; sori $1-1.2 \mathrm{~mm}$. in diameter.

Indusium glabrous.

Frond conspicuously narrowed at, the base

Frond scarcely or not at all narrowed at the base. Lobes incurved-serrate. Lobes spinulose-dentate

c. Fronds tripinnate or tripinnatifid $d$.

- (9) A. cristatum, var. Clintonianum.

$d$. Fronds tripinnatifid.

Basal scales large, lance-oblong, dark brown

Basal scales small, deltoid-ovate, light brown.

Indusium glandless

Indusium glandular-puberulent

d. Fronds tripinnate

1. A. Thelypteris.

2. A. simulatum.

3. A. noveboracense.

4. A. fragrans.

5. A, marginale.

7. A. Goldianum.

8. A. Boottit.

9. A. cristatum.

10. A. Apinulosum.
A.

(10) A, spinutosum, var, dilatatum.

(10) A. spinulosum.

(10) A. spinulosum, var. intermedium. (10) A. spinolurum, var. concordianum.

1. A. Thelýpteris (L.) Sw. Fronds pinnate, lanceolate in outline; pinnae horjzontal or slightly recurved, linear-lanceolate, deeply pinnatifid; lobes oblong, entire, obtuse or appearing acute when in fruit from the strongly revolute margins; veins forked, bearing the (numerous and sonn confluent) fruit dots near their middle; indusium minute, smooth and naked. (Nephrodium Strempel ; Dryopteris Gray.) - Marshes; common. Aug. (Cosmop.) Forma Pufrerae (A. A. Eaton) Robinson is a form with pinnae variously forked at the tip.

2. A. simulàtum Davenp. In habit similar to the preceding; veins simple; fruit dots few (3-10 on each lobe); indusium glandular-ciliolate. (Dryopteris Davenp.) - Boggy woods, etc., Me. to Vt. and Md. ; reported from Mo.

1. A. noveboracénse (L.) Sw. Fronds pinnate, lanceolate in outliue, tapei'ing both ways from the middle; pinnae lanceolats, the lowest 2 or more paire 
gradually shorter and deflexed; lobes flat, oblong, basal ones often enlarged and incised; veins simple, or forked in the basal lobes; fruit dots distinct, near the margin ; indusium minute, the margin glanduliferous. (Dryopteris Gray.) - Rich woods; common. July. - Frond pale green, delicate and membranaceous, hairy beneath along the midribs and veins.

4. A. fràgrans (L.) Sw. Fronds (1-3.5 dm. high, glandular and aromatic, narrowly lanceolate, with linear-oblong pinnately-parted pinnae; their crowded divisions ( $2-4 \mathrm{~mm}$. long) oblong, obtuse, toothed or almost entire, nearly covered beneath with the very large thin imbricated indusia, which are orbicular with a narrow sinus, the margin sparingly glanduliferous and often ragged. (Nephrodium Richards. ; Diyopteris Schott.) - Chiefly on limestone cliffs, N. B.. and n. N. E. to Minn., Alaska, and Greenl. (Caucasus, Asia.)

5. A. marginàle (L.) Sw. Frond evergreen, smooth, thickish and almost coriaceous, ovate-oblong in outline ( $3-7 \mathrm{dm}$. long) ; pinnae lanceolate, acuminate, slightly broadest above the base; pinnules oblong or oblong-scythe-shaped, crowded, obtuse or pointed, entire or crenate; fruit dots close to the margin. (Nephrodium Michx.; Dryopteris Gray.) - Rocky hillsides in rich woods: common, especially northw. Ang. Var. Elegans J. Robinson is a form with large fronds $(2-2.5 \mathrm{dm}$. broad) which have the pinnules or most of them toothed or lobed.

6. A. Filix-más (L.) Sw. Frond lanceolate (3-11 dm. long); pinnae linear-lanceolate, tapering from base to apex; pinnules oblong, very obtuse, serrate at the apex and obscurely so at the sides, the basal incisely lobed, dis tinct, the upper confluent; fruit dots nearer the midvein than the margin. usually confined to the lower half of each fertile pinnule. (Dryopteris Schott.) - Rocky woods, Nfd., N. S., n. Vt., L. Huron, L. Superior, Dak., Ariz., and northw. (Cosmop.)

7. A. Goldiànum Hook. Frond broadly ovate, or the fertile ovate-oblong (6-10 dm. long); pinnae (1.5-2.3 dm. long) oblong-lanceolate, broadest in the middle, pinnately parted; the divisions (about 20 pairs) oblong-linear, slightly scythe-shaped ( $2-3 \mathrm{~cm}$. long), serrate with appressed teeth ; veins pinnately forking and bearing the fruit dots very near the midvein; indusium very large, orbicular, with a deep narrow sinus, smooth and without marginal glands. (Nephrodium Hook. \& Grev. ; Dryopteris Gray.) - Rich woods, centr. Me. to Minn., Ia., and N. Car.

Var. célsum (Palmer) Robinson. Fronds more narrowly ovate-oblong, slightly firmer, the lowest pinnae on rather long stalks; pinnules subremote. (Dryopteris Goldieana, subsp. Palmer.) - On cypress knees and decaying logs, Dismal Swamp, Va. (Palmer).

8. A. Bobttii Tuckerm. Scales of the stipe pale-brown; fronds (4-6.5 dm. long) elongated-lanceolate in outline, somewhat narrowed at base ; lowest pinnae triangular-ovate, the upper longer and narrower; pinnules oblong-ovate, "sharply spinulose-serrate or the lower pinnatifid ; indusinm minutely glandular. (Nephrodium Davenp. ; Dryopteris Underw.) - Low wet thickets, etc. - Many differing forms have been referred to this species. Plants corresponding to the original material have been seen only from N. H., e. Mass., Ct., and e. P'a. 'They are suspiciously intermediate between $A$. cristatum and A. spinulosum, var, intermedium.

9. A. cristàtum (L.) Sw. Frond linear-ohlong or lanceolate in outline (3-6 dm. long) ; pinnae ( $5-8 \mathrm{~cm}$. long) triangular-oblong, or the lowest nearly triangular-ovate, from a somewhat heart-shaped base, acute, deeply pinnatifid; the divisions (6-10 pairs) oblong, very obtuse, finely serrate or cut-toothed, the lowest pinnatifid-lobed; fruit dots as near the midvein as the margin; indusium round-reniform, the sinus mostly shallow, smnoth and naked. (Nephrodium Michx. ; Dryopteris Gray.) - Swamps, etc. ; common. July. - Stipes and the stout creeping rootstock bearing broad aud deciduous chaffy scales. (Eu.)

Var. Clintoniànum D. C. Eaton. Frond in every way much laryer $(4-13 \mathrm{dm}$. long); pinnae oblong-lanceolate, broadest at base $(8-15 \mathrm{~cm}$. long, $2-5 \mathrm{~cm}$. broad), deeply pinnatifid; the divisions (8-16 pairs) crowded or distant, linear-oblona. obtuse, obscurely serrate or cut-toothed, the basal sometimes pinnately lobed; 
veins pinnately forking, the lowest anterior veinlets bearing the fruit dots near the nidvein; indusium orbicular with a shallow sinus, smooth and naked. (Dryopteris cristata, var. Underw.) - Swampy woods, N. H. to N. C., and westw. to Wisc. July. - Rootstock stont, creeping, chaffy (like the stipes) with large bright-brown scales. A ppears to hybridize with $\boldsymbol{A}$. marginale, as does also the typical form of the species.

$\checkmark$ 10. A. spinuldsum (O. F. Müller) Sw. Stipes with a few pale-brovon deciduous scales; frond ovate-lanceolate, twice pinnate; pinnae oblique to the rhachis, elongated-triangular, the lower pairs broadly triangular; pinnules set obliquely on the midribs, connected by a very narrow wing, oblong, acute, incisely serrate or pinnatifid with spinulose-toothed lobes; indusium smooth and without marginal glands. (Nephrodium Strempel ; Dryopters Kuntze.) - Rich woods, Nfd. to Va., Ky., and northwestw. (Greenl., Eu.) A. PITTSFordínse (Slosson) Eastman, a supposed hybrid with $A$. marginale, occurs in Vt. and on Staten I., N. Y.

Var. intermèdium (Muhl.) D. C. Eaton. Scales of the stipe few, brown with a darker center; frond broadly oblong-ovate, tripinnatifid; pinnae spreading, oblong-lanceolate, the lower unequally triangular-ovate; pinnules crowded, ovate-oblong, spreading, pinnately cleft; the oblong lobes spinulose-toothed at the apex; margin of the indusium denticulate and beset with minute stalked glands. (Nephrodium spinulosum, var. Davenp.; Dryopteris spinulosa, var. Underw.) - Woods, common.

Var. dilatàtum (Hoffm.) Hook. Scales of the stipe large, brown with a dark center; frond broader, ovate or triangular-ovate in outline, tripinnatifid; pinnules lance-oblong, the lowest often much elongated; indusium glandularciliolate. (Nephrodium spinulosum, var. fructuosum Gilbert). - N. S. to Va., and $\mathrm{N}$. Y. (Eu.) Forma AxADENuU Robinson is in all respects like var. dilatatum, but with the indusium destitute of glands (the var. dilatatum of Am. auth. cliefly, not Hook.) - Common, chiefly in rocky upland woods. (Asia.)

Var. concordiànum (Davenp.) Eastman. Fronds tripinnate; pinnules (of the $3 \mathrm{~d}$ order) small ( $4 \mathrm{~mm}$. long), elliptical, spinulose-denticulate; indusium glandular-puberulent. - Concord, Mass. (Purdie).

\section{CYSTÓpteris Bernh. Bladder Fern}

Fruit dots roundish, borne on the back of a straight fork of the free velus; the delicate indusium hood-like or arched, attached by a broad base on the inner side (toward the midrib) partly under the fruit dot, early opening free at the other side, which looks toward the apex of the lobe, and is somewhat jagged, soon thrown back or withering away. - Delicate ferns with 2-3-pinnate fronds;

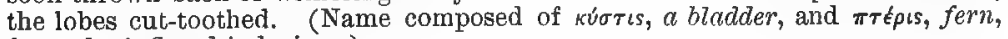
from the inflated indusium.)

1. C. bulbífera (L.) Bernh. Frond lanceolate, elongated, attenuate (3-6 dm. long), 2-pinnate; the pinnae lanceolate-oblong, pointed, horizontal; the rhachis and pinnae often bearing bulblets underneath, wingless; pinnules crowded, oblong, obtuse, toothed or pinuatifid; indusium short, truncate on the free side. (Filix Underw.) -- Shaded ravines, chiefiy on calcareous rocks. July.

2. C. frágilis (L.) Bernh. Frond oblong-lanceolate (1-3 dm. long, besides the brittle stalk which is fully, as long), 2-3-pinnate; the pinnae and pinnules ovate or lanceolate in outline, irregularly pinnatifid or cut-toothed, mostly acute, decurrent on the morgined or winged rhochis; indusium tapering or acute at the free end. (Filix Underw.) - Shaded cliffs, rocky woods, etc. : common and varying greatly in the shape and cutting of the pinnules. July. (Cosmop.)

\section{WOÓDSIA R. Br.}

Fruit dots round, borne on the back of simply forked free veins; the very thin and often evanescent indusium attached by its base all around the receptacle, under the sporangia, either swall and open, or else early bursting at the top into 
irregular pieces or lobes. - Small and tufted pinnately divided ferns. (Dedicated to Joseph Woods, an English botanist.)

* Stalks obscurely articulated some distance from the base; fronds chaffy or smooth, never glandular; indusium divided nearly to the center into slender hairs which are curled over the sporangia.

1. W. ilvênsis (L.) R. Br. Frond oblong-lanceolate $(5-15 \mathrm{~cm}$. long, 2-4 $\mathrm{cm}$.wide), smoothish and green above, thickly clothed underneath as well as the stalk with rusty bristle-like chaff, pinnate; the pinnae crowded, oblong, obtuse, sessile, pinnately parted, the numerous crowded segments oblong, obtuse, obscurely crenate; the fruit dots near the margin, somewhat confluent when old. - Exposed rocks; aretic Am., s. to N. E., the Great L. region, and in the mts. to N. C. June. (Eurasia.)

2. W. alpina (Bolton) S. F. Gray. Frond narrowly oblong-lanceolate (4-13 $\mathrm{cm}$. long, 6-34 mm. wide), smooth above, sparingly paleaceous-hirsute beneath, pinnate; the pinnae triangular-ovate, obtuse, pinnately lobed, the lobes few and nearly entire; fruit dots rarely confluent. ( $W$. hyperborea $\mathbf{R} . \mathrm{Br}$.) - N. B., Que., n. Vt., n. N. Y., Ont., and northw.; rare. (Eurasia.)

3. W. glabella R. Br. Smooth and naked throughout; frond linear and very delicate (4-16 cm. high), pinnate; pinnae roundish-uvate, the lower ones rather remote ( $3-9 \mathrm{~mm}$. long), obtuse, crenately lobed; fruit dots scanty ; the hairs of the indusium fewer than in the last two species. - On moist mossy rocks, Nfd. to n. N. E., N. Y., Minn., and_northw, to Alaska and Green] (Eurasia.)

* Stalks not articulated; fronds never chaffy, often glandular-pubescent.

- Indusium of a fev broad segments, at first covering the sorus completely.

4. W. obtùsa (Spreng.) Torr. Frond broadly lanceolate, minutely glandular-hairy (2-5 dm. high), pinnate or nearly bipinnate; pinnae rather remote, triangular-ovate or oblong $(2-6 \mathrm{~cm}$. long), bluntish, pinnately parted; segments oblong, obtuse, crenately toothed, the lower pinnatifid with toothed lobes; veins forked, and bearing the fruit dots on or below the minutely toothed lobes; indusium at length splitting into several spreading jagged lobes. - Rocky banks and cliffs, "N. S.," and centr. Me. to Ga., and westw. Var. ANGísta Peck is a form with very narrow fronds ( $35 \mathrm{~cm}$. long and $4 \mathrm{~cm}$. wide) and pinnae. - Highlands, N.Y.

\section{+ + Indusium entirely concealed beneath the sorus, divided into very narrow segments or reduced to minute hairs.}

5. W. oregàna D. C. Eaton. Glabrous; fronds bright green, soft in texture, nav'owly lance-oblong (12-2:3 mm. wide), bipinnatifid, pinnae triangular-oblong, obtuse; the segments oblong or ovate, obtuse, crenate-serrulate, the teeth or margin nearly always reflexed. - Limestone cliffs and ledges, Bic, Que. ; s. shore of L. Superior (Roblins), nolthw. and westw.

6. W. Cathcartiàna Robinson. Finely glandular-puberulent; fronds (2-3 dm. high) rather dull green, of firm texture, lanceolate (25-55 mm. broad), bipinnatifid; pinnae oblong, the lower distant; segments usually separated by wide sinuses, oblong, denticulate. ( $W$. scopnlina Man. ed. 6 , not D. C. Eaton.) - Rocky river L.anks, w. Mich. (Wheeler), and n.e. Minn. (Miss Ellen Cathcart.)

7. W. scopulina D. C. Eaton. Loosely hispidulous with minute white hairs, and finely glandular-puberulent; segments approximate, crenate-serrulate. Limestone cliffs; Gaspé Co., Que.; S. Dak.; Rocky Mts., etc. ; reported from Minn. and n.w. Ia.

\section{DICKSÒNIA L'Hér.}

Fruit dots small, globular, marginal, each placed on the apex of a free vein or fork; the sporangia borne on an elevated globular receptacle, inclosed in a membranaceous cup-shaped indusium which is open at the top, and on the outer side partly adherent to a reflexed toothlet of the frond. (Named for James Dickson, an English cryptogamic botanist.) 
1. D. punctil6bula (Michx.) Gray. (HaY-Scented Fern.) Fronds minutely glandular and hairy (5-10 dm. high), ovate-lanceolate and acuminate in outline, pale green, very thin, with strong chaftless stalks rising from slender extensively creeping naked rootstocks, mostly bipinnate; primary pinnae lanceolate, pointed, the secondary pinnatifid into oblong and obtuse cut-toothed lobes; fruit dots juinute, each on a recurved toothlet, usually one at the upper margin of each lıbe. (D. pilosiuscula Willd.; Dennstaedtia punctilobula Moore.) - Common in moist and shady places, N.S. to Ala., rarer westw. to Minn. - Frond sweetscented especially in drying. Forma cristàta (Maxon) Clute has the pinnae cristate-forked at tip. - Mass. and Vt. Forma schizopHỳlla Clute has fronds often more deeply forked and the ultimate segments incised. - Mass. and Ct.

\section{ONOCLĖA L.}

Sporangia borne on elevated receptacles, forming roundish sori imperfectly covered by very delicate hood-shaped indusia attached to the base of the receptacles. Fertile fronds erect, rigid, with contracted pod-like or berry-like divisions at first completely concealing the sporangia, and at last, when dry and indurated, cracking open and allowing the spores to escape. Sterile fronds foliaceous. hootstocks creeping and constantly forming new plants. (Name employed by Dioscorides for some probably boraginaceous plant.)

\section{§1. EUONOCLEA Hook. Fertile fronds bipinnate.}

1. 0. sensibilis L. (Sensitive Fern.) Fronds scattered; the sterile ones long-stalked, the lamina $1-3 \mathrm{dm}$. long, deltoid-ovate, pinnatifid into a few oblong-lanceolate sinuately lobed or nearly entire segments; veins reticulated with fine meshes; fertile fronds contracted, closely bipinnate, the pinnules rolled up into berry-like bodies. - Moist meadows and thickets, very common. (E. Asia.) Sports are frequent, especially bipinnatifid foliaceous fronds with rounded lobes, free veins, and sometimes abortive sori, - the so-called var. oвtusitobata (Schkubr) Torr.

\section{\$2. STRUTHIÓPTERIS Mett. F'ertile fronds pinnate.}

2. 0. Struthiópteris (L.) Hoffm, (Ostrich FerN.) Fronds growing in a crown; sterile ones short-stalked ( $6-30 \mathrm{dm}$. high), broadly lanceolate, narrowed toward the base, with many linear-lanceolate pinnatifid pinnae ; veins free, the veinlets simple; fertile frnnd shorter, with pod-like or somewhat necklaceshaped pinmae. (Matteuccia Todaro.) - Alluvial soil, Nfd. to Va., and northwestw. July. - The rootstock sends out slender underground stolons, which bear fronds the next year. (Eurasia.)

\section{SCHIZAEÀCEAE (Curly Grass Family)}

Sterile fronds tufted and linear-filiform (Schizaea) or resembling a twining aerial stem with alternate paired palmately lobed leaves (Lygodium). Sporangia borne in double rows on narrow fertile segments, ovate, sessile, having a complete transverse ring at the apex, and opening by a longitudinal slit.

1. Schizaea. Sterile fronds rigid, simple or dichotomously branched. Plant dwarf, not ciimbing.

2. Lygodium. Fronds with paired alternate stipitate leaf-like segments.

\section{SchizakA Sm. Cukly Grass}

Sporangia large, ovoid, striate-rayed at the apex, opening by a longitudinal cleft, naked, vertically sessile in a double row along the single vein of the narrow divisions of the pinnate (or radiate) fertile appendages to the slender and 
simply linear, or (in foreign species) fan-shaped or dichotomously many-cleft. fronds (whence the name, from $\sigma_{\chi} \downarrow \xi \omega$, to split).

1. S. pusílla Pursh. Sterile fronds linear, very slender, flattened and tortuous; the fertile ones equally slender $(0.5 \mathrm{~mm}$, wide), but taller $(5-12 \mathrm{~cm})$. and bearing at the top the fertile appendage consisting of about 5 pairs of crowded pinnae (each $2-3 \mathrm{~mm}$. long). - Low grounds, pine barrens of N.J.; N. S. ; very local. Sept. (Nfd.)

\section{Lygoddum Sw. Chimbing Feri}

Fronds twining or climbing, bearing stalked and variously lobed (or compound) divisions in pairs, with mostly free veins; the fructification on separate contracted divisions or spike-like lobes, one side of which is covered with a double row of imbricated hooded scale-like indusia, fixed by a broad base to short oblique veinlets. Sporangia much as in Schizaea, but oblique, fixed to the veinlet by the inner side next the base, one or rarely two covered by each indusium. (Name from $\lambda v \gamma w \delta \emptyset s$, flexible.)

1. L. palmàtum (Bernh.) Sw. Very smooth; stalk-like fronds slender. flexile and twining ( $3-10 \mathrm{dm}$. long), from slender running rootstocks; the short alternate branches or petioles '2-forked; each fork bearing a round-heartshaped palmately 4-7-lobed frondlet; fertile frondlets above, contracted and several times forked, forming a terminal panicle. - Low moist thickets and open woods, s. N. H. to Fla., Tenn., and $\mathrm{Ky}$. ; local. Sept.

\section{OSMUNdAceae (Flowering Ferm Familt)}

Leafy plants (ours herbaceous), with creeping rhizomes. Sporangia naked, globose, mostly pediceled, reticulated, with no ring or with mere traces of one near the apex, opening into two valves by a longitudinal slit. Stipes winged at the base.

\section{OSMÚNDA [Tourn.] L. Flowering Frri}

Fertile fronds or fertile portions of the frond destitute of chlorophyll, very much contracted, and bearing on the margins of the narrow rhachis-like divisions short-pediceled and naked sporangia; these globular, thin and reticulated, large, opening by a longitudinal cleft into two valves, and bearing near the apex a small patch of thickened oblong cells, the rudiment of a transverse ring. - Fronds tall and upright, growing in large crowns from thickened rootstocks, once or twice pinnate; veins forking and free. Spores green. (Osmunder, a Saxon name of the Celtic divinity, Thor.)

\section{* Sterile fronds truly bipinnate.}

V 1. 0. regàlis L. (Flowering FrRN.) Very smooth, pale green (0.3-1.6 m. high); sterile pinnules 13-25, varying from oblong-oval to lance-oblong, finely serrulate, especially toward the apex, otherwise entire, or crenately lobed toward the rounded, oblique and truncate, or even cordate and semi-auriculate base, sessile or short-stalked (2-5 cm. long); the fertile racemose-panicled at the summit of the frond. (O. spectabilis Willd.) - Swamps and wet woods, common. The cordate piunules sometimes found here are commoner in Europe. May, June. (Eu.) Forma orbiculdit Clute has narrow fronds and few (3-7) roundish crowded pinmules on each pinna. - Hartland, Vt. (Ruggles).

* * Sterile fronds once pinnate; pinnae deeply pinnatifid; the lobes entire.

v 2. 0. Claytoniàna L. Clothed with loose wool when young, soon smooth; fertile fronds taller than the sterile (6-12 dm. high) ; pinnae oblong-lanceolate, with oblong obtuse divisions ; some (2-5 pairs) of the midalle pinnae fertile, these entirely pinmate; sporangia greenish, turning brown. - Low grounds, common. May. - Fruiting as it unfolds. (IIimalayas.) Var. DürIa Grout is a peculiar 
form with the pinnules of the sterile frond widely separated, the outer ones enlarged and pinnatifid, in s. Vt. (Grout).

$\checkmark$ 3. 0. cinnamomea $L$. (Cinsamon FerN.) Clothed with rusty wool when young; sterile fronds tallest (at length 0.8-1.6 m. high), smooth when full grown, the lanceolate pinnae pinnatifid into broadly oblong obtuse divisions; iertile fronds separate, appearing earlier from the same rootstock and soon withering (2-9 dm. high), contracted, twice pinnate, covered with the cinnamon-colored sporangia. - Swamps and low copses, common. (Eurasia.) Var. prondosa Gray is an occasional state in which some of the fronds are sterile below and more sparsely fertile at their summit, or rarely in the middle. Var. INcisa $J$. W. Huntington is a form with the inner pinnules of some of the pinnae more or less cut or pinnatifid.

Var. glandulosa Waters. Rhachis and lower surface of the sterile frond permanently glandular-pubescent, - R. I., N. J., and Md.

\section{ophioglossàceat (Adner's Tongue Family)}

Leafy and often somewhat fleshy plants; the leaves (fronds) simple or branched, often fern-like in appearance, erect in vexnation, developed from underground buds formed either inside the base of the old stalk or by the side of it, and bearing in special spikes or panicles rather large subcoriaceous bivalvular sporangia formed from the main tissue of the fruiting branches. Prothallus underground, not green, monoecious. - A small family, separated from Ferns on account of the different nature of the sporangia, the erect vernation, etc.

1. Ophioglossum. Sporangia cohering in a simple spike. Veins reticalated.

2. Botrychium. Sporangia in pinnate or compound spikes, distinct. Veins free.

\section{OPHIOGLÓSSUM [Tourn.] L. AdDer's Tongde}

Rootstock erect, fleshy and sometimes tuberous, with slender fleshy roots which are sometimes proliferous; bud placed by the side of the base of the naked stalk ; fronds with anterior and posterior segments as in Botrychium, but the coriaceous sporangia connate and coherent in two ranks on the edges of a simple spike. Sterile segment fleshy, simple in our species; the veins reticulated. Spores copious, sulphur-yellow. (Name from obis, a serpent, and $\gamma \lambda \hat{\omega} \sigma \sigma \alpha$, tongue.)

$V^{2}$ 1. 0. vulgàtum L. Fronds from at slender rootstock, $5-42 \mathrm{~cm}$. high, mostly solitary; sterile segment sessile near the middle of the plant, ovate or elliptic-oblong (5-9 cm. long), rounded or obtuse at the apex; midvein indistinct or none; principal veins forming a loose network, the meshes nearly free from secondary veins. - Meadows and pastures, rarely on dry slopes; not common. June-Aug. (Eurasia.)

Var. mìnus Moore. Smaller; fronds often in pairs, the sterile segment shightly fleshy, yellowish-green, attached usually much below the middle of the plant. (O. Grayi Beck, acc. to Moore; O. poiyphyllum A. Br.; O. arenarium E. G. Britton.) - Sandy ground, N. H. to w. N. Y. and N. J. (Fu., n. Afr.)

2. 0. Engelmánni Prantl. Habit of the preceding species; sterile segment thicker, cuspidate; secondary veins numerous, forming a fine but readily discernible network within the meshes of the principal ones. - "Va." ; Mo. (Bush), 'Tex., and Cal.

\section{BOTRÝCHIUM SW. MOONWORT}

Rootstock very short, erect, with clustered fleshy roots; the base of the sheathed stalk containing the bud for the next year's frond; frond with an anterior fertile and a posterinr sterile segment; the former mostly 1-3-pinnate, the contracted divisions bearing a double row of sessile naked sporangia; these 
distinct, rather coriaceous, not reticulated, globular, without a ring, and opening transversely into two valves. Sterile segment of the frond ternately or pinnately divided or compound; veins all free. Spores copious, sulphur-color. (Name a diminutive of $\beta$ ótpus, $a$ cluster of grapes, from the appearance of the fructification.)

\$1. EUBOTRÝCHIUM Milde. Base of the stalk (containing the bud) completely closed; sterile segment more or less fleshy; the cells of the epidermis straight.

* Sterile segment sessile or on a short petiole (less than $1 \mathrm{~cm}$. long).

1. B. Lunària (L.) Sw. Very fleshy $(8-18 \mathrm{~cm}$. high); sterile segment subsessile, borne near the middle of the plant, oblong, simply pinnate with 5-15

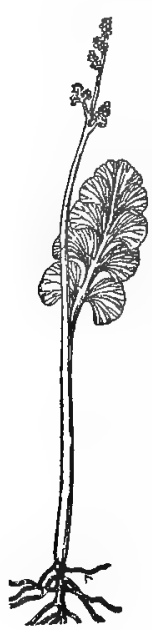

1. B. Lunaria. $\times 2 \%$. lunate or fan-shaped very obtuse crenate, incised, or nearly entire, fleshy divisions, more or less excised at the base on the lower or on both sides, the veins radiating from the base and repeatedly forking; fertile segment panicled, 2-3-pinnate. - Open places, e. Que. to Vt., n. O., L. Superior, and northw.; rare. (Widely distr.) Fig. 1. Also on wooded cliffs near Syracuse, N. Y., where tending to a more slender form with decidedly stipitate sterile segment and subremote more narrowly cuneate pinnae ( $B$. ononilagense Lnderw.).

2. B. símplex E. Hitchcock. Fronds small (5-10, or rarely $25 \mathrm{~cm}$. high); sterile segment short-petioled from near base, middle, or summit of the stalk, thickish, simple, and roundish, or pinnately 3-7-lobed; the lobes roundishobovate, nearly entire, decurrent on the broad and flat indeterminate rhachis, the terminal one usually emarginate; the veins all forking from the base; fertile segment simple or 1-2pinnate. (B. tenebrosum A. A. Eaton.) - N. S. to Md., Ont., Minn., and Rocky Mts.; rare. (Eu.) Fig. 2. Var. compósıtum Lasch. Sterile

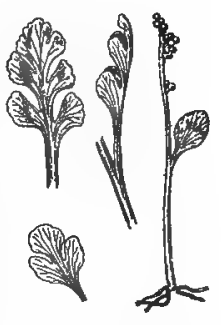

2. B. simplex. $\times \%$. segment binate or ternate; the divisions pinnatifid, - Occurring with and clearly passing into the typical form.

3. B. lanceolatum (Gmel.) Ångstroem, var. angustisegméntum Pease \& Moore. Fronds small (1-2.5 dm. high); the sterile segment closely sessile at the top of the long and slender stalk, scarcely fleshy, tviangular, ternately twice pinnatifid; the acute lobes lanceolate, incised or toothed; veinlets forking from a continuous midvein; fertile part 2-3-pinnate. -N. S. to N. J., O., and L. Superior.

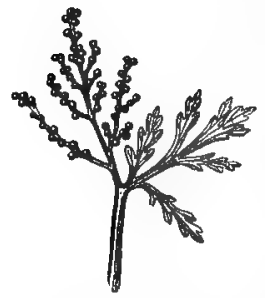

8. B. lanc., 'v. ang. $\times 2 / 3$. July, Aug. Fig. 3. The typical European form has the segments of the sterile frond broader and more approximate.

4. B. ramosum (Roth) Aschers. Fronds small (1-2.5 dm. high); the sterile segment nearly sessile at the top of the long and slender common stalk, moderately fleshy, ovate or triangular, varying from pinnate to bipinnatifid; the lobes oblong-ovate and obtuse; midvein dissipated into forking veinlets; fertile part 2-3-pinnate. (B. $m a-$ tricariaefolium A. Br.; B. neglectum Wood.) - Rich soil, e. Que. to Md., and westw. June, July. (Eurasia.) Frg. 4

* The sterile segmen: on a long petiole (2-10 $\mathrm{cm}$. in lengt $\left.k_{1}\right)$.

5. B. obliquum Muhl. Subcoriaceous (1-4 dm. high), sparsely hairy or glabrous: sterile segment long-petioled, springing from near the base of the plant, broadly triangular or somewhat pen-

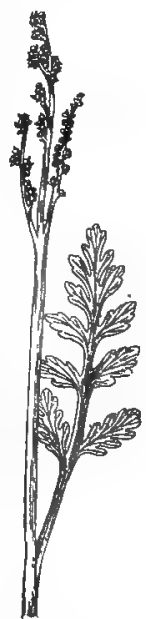

4. B. ramoคum. $x^{2 / 2}$. 
tagonal, ternate and varionsly decompound with stalked divisions, these ovateoblong, acutish, usually two or three times as long as broad, crenate-serrulate, obliquely cordate or subcordate; fertile segment erect, 2-4-pinnate. (B. ternatum, var. obliquum Milde.) - Pastures and open woods, N. B. to Ont., Minn., and southw. Fra. 5, $a$. Polymorphous. The chief forms are: Var. ONEIDÉNSE (Gilbert) Waters. Fig. 5, $b$. Ultimate divisions broadly oblong, rounded at the apex, crenulate-serrulate. - Vt. (Miss Gilman) to centr. N. Y. (Gilbert, Haberer), etc. Var. TENUIFóliUM (Underw.) Gilbert. Divisions few, usually 9, thin; otherwise much like the typical form. - N. Y. (acc. to Gilbert); Mo. (Bush), and southw. to the Gulf. Var, ElonGAтUM Gilbert \& Haberer. Fı. 5, c. Divisions lanceolate, elongated, acute. - Mass. to centr. N. Y. and D. C. ' Var. Disséctom (Spreng.) Clute. Fig. 5, d. Divisions incisely manytoothed. - Often with the typical form in N. E., N. Y., and $O$.

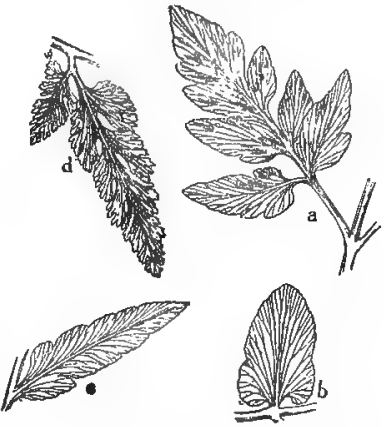

5. B. obliquum and vark. $\times 2 / 3$.

6. B. ternàtum (Thunb.) Sw., var. intermèdium D. C. Eaton. Stout, decidedly fleshy, loosely pubescent to subglabrous, $1.5-\mathbf{4} \mathrm{dm}$. high; habit and fertile segment as in the preceding; sterile segment becoming

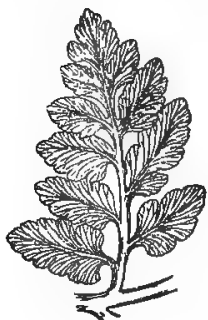

6. B. tern., v. interm. $\times \%$. large (sometimes $2 \mathrm{dm}$. broad), its ultimate divisions numerous, ovate or obovate, commonly subcuneate or semicordate at the base, crenulate and more or less lobed, usually obtuse or rounded at the apex. (Including var. australe D. C. Eaton, as to Am. plant.) - Sandy soil, pastures and open woods, common, N. E., N. Y., and (?) 1. Mich. Fig. 6. Passing insensibly into var. Rutaefóldum (A. Br.) D. C. Eaton. More slender, rarely over $1.7 \mathrm{dm}$. high; sterile segment commonly about $5 \mathrm{~cm}$. broad, its divisions few, broadly ovate, the lowest sublunate. (B. Matricariae Spreng.; B. rutaceum Sw.) - Nfd. to s. N. H., and n. Mich. (Eurasia.)

§ 2. OSMUNDÓPTERIS Milde. Base of the stalk (containing the bud) open along one side; sterile segment membranacious; the cells of the epidermis flexuous.

V 7. B. virginiànum (L.) Sw. (Rattcesnake Feri.) Fronds 3-6 dm. tall, ample; sterile segment sessile above the middle of the plant, broadly triangular, thin and membranaceous, ternate; the short-stalked primary divisions once or twice pinnate, and then once or twice pinnatifid; the oblong lobes cut-toothed toward the apex; veins forking from a midvein; fertile part 2-3-pinnate. Rich woods, common. June, July. (Widely distr.)

\section{MARSILEACEAE}

Perennial plants rooted in mud, having a slender creeping rhizome and either filiform or 4-parted long-petioled leaves; the somewhat crustaceous several-celled sporocarps borne on peduncles which rise from the rhizome near the leaf-stalks, or are more or less consolidated with the latter, and contain both macrospores and microspores.

\section{MARSILEA L.}

Submersed or emersed aquatic plants. Leaves 4-foliolate. Sporocarps with 2 teeth near the base, 2-celled vertically, with many transverse nartitions, splitting into 2 valves at maturity, and emitting an elastic cord or band of tissue, which 
Corries the sporangia on a series of short branches or lobes. (Named for Aloysius Marsili, an early Italian naturalist.)

1. M. quadrifolia L. Leaflets broadly obovate-cuneate, glabrous; sporocarps usually 2 or 3 on a short peduncle from near the base of the petioles, pediceled, glabrous or somewhat hairy, the basal teeth smal, obtuse, or the upper one acute. - In water, the leaflets commonly floating on the surface, frequently cultivated and now somewhat extensively introduced from material taken chiefly from Bantam Lake, Litchtield, $\mathrm{Ct}_{\text {., }}$ where perhaps casually introduced from Eu.

2. M. vestita Hook. \& Grev. Leaflets broadly cuneate, usually hairy, entire (5-15 mm. long and broad); petioles $2-11 \mathrm{~cm}$. long; peduncles free from the petiole, very short; sporocarps solitary, hairy when young (about $4 \mathrm{~mm}$. long), with upper basal tooth longest, acute, straight, or curved, lower tooth acute, the sinus between them rounded. - In swamps which become dry in summer; Ia. and southwestw.

\section{SALVINIÀCEAE}

Floating plants of small size, having a more or less elongated and sometimes branching axis, bearing apparently distichous leaves; sporocarps (sori) very soft and thin-walled, two or more on a common stalk, one-celled and having a central, often branched receptacle which bears either macrosporangia containing solitary macrospores, or microsporangia with numerous microspores, $\mathbf{A}$ small and interesting family of plants without close affinity to other groups.

\section{AZólla Lam.}

Small moss-like plants, the stems pinnately branched, covered with minute 2-lobed imbricated leaves, and emitting rootlets on the under side. Sporocarps in pairs beneath the stem; the smaller ones acorn-shaped, containing at the base a single macrospore with a few attached bodies of doubtful function above it; the larger ones globose, and having a basal placenta which bears many pedicellate misrosporangia which contain masses of microspores. (Name not satisfactorily explained.)

1. A. caroliniàna Willd. Plants somewhat deltoid in outline (6-25 $\mathrm{mm}$. broad), much branched; leaves with ovate lobes, the lower lobe reddish, the upper one green with a reddish border; macrospore with three attendant corpuscles, its surface minutely granulate; masses of microspores glochidiate. Floating on quiet waters, from L. Ontario westw. and southw. - Appearing like a redish hepatic moss.

\section{SAlvínIA [Mich.] Adans.}

Leaves apparently 2-ranked, horizontally floating or subaërial, a third series of foliar structures developed ventrally on the stem taking the form of fascicles of root-like fibers. Sporangia subsessile, clustered, depressed-globose, longitudinally sulcate, formed from the tips of short basal divisions of the filiform ventral leaves. Sori basal within the fruit, the macrosporangia subsessile, the microsporangia (in separate fruits) borne on filiform pedicels. (Named for Prof. Antonio Maria Salvini of Florence, 1633-1729.)

1. S. nàtans (L.) All. Foliage-leaves suborbicular-oblong, thickish, mostly 10-15 $\mathrm{inm}$. long, hairy or papillose on both sides, the lower surface commonly brownish or purplish. - Marshes and ponds, Minn. and Mo.-Long ago reported by Pursh as "floating, like Lemna, on the surface of stagnant waters: in several of the small lakes in the western parts of New York," but not detected in this region by recent botanists. (Eurasia.) 


\title{
EQUISETÀCEAE (Horgetail Family)
}

\author{
(Revised by A. A. Eaton.)
}

Rush-like, often branching plants, with jointed and mostly hollow stems from running rootstocks, having sheaths at the joints, and, when fortile, terminated by the conical or spike-like fructification composed of shield-shaped stalked scales bearing the spore-cases beneath. - A single genus.

\section{EQUISÈTUM [Tourn.] L. Horsetail}

Rootstocks perennial, jointed, branched, wide-creeping, dull and blackish, felted or naked, often tuber-bearing, the nodes provided with toothed, often felted sheaths; roots in verticils from the nodes, annual, felted. Stems usually erect, simple or branched, cylindrical, jointed, the surface regularly striated, overlaid with teeth, dots, bands, rosettes, or a smooth coat of silex; the stomata in the grooves in regular rows or broad bands; the internodes (except in $E$. scirpoides) bearing a large central air-cavity (centrum), a medium sized one (vallecular) under each groove, with which the stomata connect, and a smaller one (carinal) under each ridge. The nodes are closed and solid, each bearing a whorl of reduced leaves joined by their edges into cylindrical sheaths, their tips thinner and prolonged into persistent or deciduous teeth. Branches, when present, mostly in whorls from the nodes. Fruit in a terminal cone formed of regular verticils of stalked sporophylls, the 6 or 7 sporangia opening down the inner side and discharging many loose green spores, each provided with four elastic hygroscopic clavate bands. Prothallus in damp places, dioecious, green, variously lobed. ('The ancient name from equus, horse, and seta, bristle.)

\$1. Btems annual; spikes rounded; stomata scattered in the grooves. EuEQ̨u Iвझे Tu Sadebeck $a$.

a. Fruiting stem succulent, appearing before the sterile.

Fertile stems branchless, soon perishing; silex of sterile stems in dots.

Fertile stems becoming brapched.

Branches simple; silex in 3 rows of broad spinules on the ridges .

Branches compound; silex in 2 rows of hooked spinules

c. Fertile and sterile stems alike, branched or simple.

Centrum one sixth of the total diameter of stem; teeth grooved, black, with broad white margins.

Centrum haif the tutal diameter or more.

Centrum not more than two thirds the diameter; vallecular holes present; sheaths loose; fruit abortive

Centrum four fifths the diameter; vallecular boles mostly absent; sheaths tight

52. Stems evergreen (except in $E^{*}$. lasigigatum and $E$. variegatum, ${ }^{\circ}$. Nelsoni), mostly sinple; spikes apiculate; stomata in single regular serjes. - Hip pochà̀re Milde $b$.

b. Silex iu cross-bands on ridges and grooves $c$.

c. Vallecular bast cutting the green parenchyma, carinal not doing so ; sheaths ampliated, green.

Teeth decidnous, leaving black triangular bases; centrum wide

Teeth persistent, broadly white-bordered; centrum small

(9) E. variegatum, v. Nelsoni.

c. Vallecular bast not cutting the parenchyma, the carinal larger; sheaths usually with black and white bands.

Sheaths much longer than broad, ampliated; plants similar to $E$. laevigatum in appearance.

Sheaths little longer than broad, tight

(8) E. hyemale, v. intermedium. (8) E. hyenale, v. robustum.

b. Ridges biangnlate (excent in $E$. variegatum, v. Nelsoni); silex of the grooves in rosulae $d$.

d. Teeth deciduons; ridges slightly biangulate . . . . $\quad$ 8. E. hyemale.

$d$. Teeth persistent, white-bordered $B$.

\%. Centrum one third of the diameter of the stem.

Ridges distinctly biangulate; bristle-tips of teeth deciduous . 9. E. variegatum.

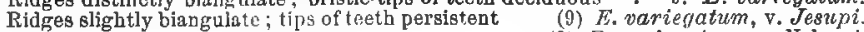
Ridges rounded.

(9) $F$ rariegatum, $\nabla$. Nelsoni

o. Culrum absent; stems 6-angled

10. E. scirpoides. 
§1. EUEQUISÈTUM Sadebeck. Stems annual, nostly with regular verticils of branches; spikes not apiculate; stomata in one or two broad bands in each groove, their surfaces overlaid with a silex plate that bears a vertical slit in the center.

1. E. arvénse L. (Common H.) Fertile stems $0.5-2.5 \mathrm{dm}$. high, with

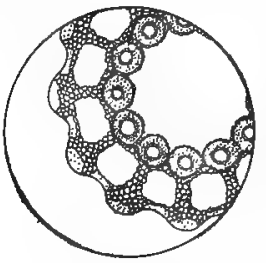

7. L. arvense. CrossBection of stem $\times 12$. lnose 8-12-tootbed sheaths, not rarely developing a few branches in wet places; sterile stems prostrate or erect, 0.5-5 dm. high, 10-14-furrowed, variously branched; silex in punctiform dots; branches 3-4-angled, mostly simple, solid, winged, the teeth of their sheaths triangular-lanceolate, with sharp erect acuminate points; rootstocks tuberiferous, felted ; centrum $\frac{1}{2}-\frac{2}{3}$ the total diameter of the stem. - Common. (Widely distr. ) Fug. 7.

2. E. praténse Ehrh. Sterile and finally fertile stems developing simple horizontal triangular branches whose first internodes do not exceed the stem-sheaths; teeth of branch-sheaths deltoid, acute; stems 2-3 dm. high, 8-20-ridged, beset with tlat spines of silex, arranged

in threes; centrum $\frac{1}{8}$ the total diameter.-Alluvial soil, N. S. and Que. to Alaska, southw. to w. Mass., N. J., and la., chiefly in calcareous regions. April, May. (Eurasia.) Figs. $8,9$.

3. E. sylváticum L. Stems 0.7-4.5 dm. high ; both kinds developing compound branches; centrum half the diameter; ridges 8-14, fat, with a row of recurved spinules on each side; sheaths green, with the papery brown teeth coherent; primary branches

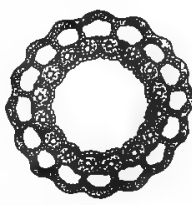

8. E. pratense. Cross-section of stem $\times 12$.

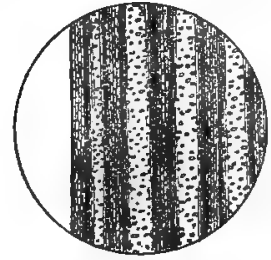

๑. E. pratense. Epidermis $\times 12$. 4-5-angled, the secondary 3-angled. -Damp, shady places, Nfd. to Alaska,

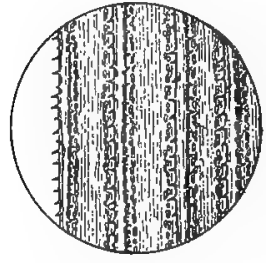

10. E. sylvaticum. Epidermis $\times 12$.

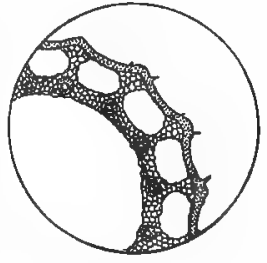

11. E. sylvaticum. Crosssection of stem $\times 12$. southw. to Va., O., and Ia. ; common northw. May, June. (Eurasia.) Figs. 10, 11.

4. E. paltustre L. Rootstocks shining, black, solid at center; stems $2.5-9 \mathrm{dm}$. high, deeply 5-10grooved; ridges narrow, sharply elevated; sheaths widened upward; leaves centrally grooved; teeth lance-subalate, black, with broad white margins; silex in cross-bands ; centrum $\frac{1}{6}$ the total diameter; branches bollow, 4-7angled. - Wet places, Nfd. to Alaska, southw. to Ct. (Graves), Ill. (Brendel), etc. June-Aug. (Eurasia.) FIGs. $12,13$.

5. E. litoràle Kühlewein. Stems diffuse to erect, simple to densely branched, 2-9 dn. high, 6-18grooved; centrum $\frac{1}{2}-\frac{2}{3}$ the total diameter; vallecular holes present; sheaths slightly spreading; teeth dark brown, acute, coherent in groups ; branches $2.5-15 \mathrm{~cm}$. long, 3-5-angled, winged, often solid, similar to those of $E$. arvense; spikes usually abortive. - Wet,

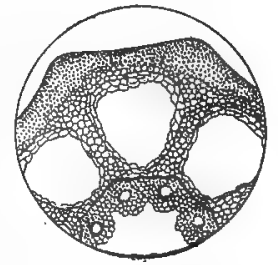

12. E. palustre. Crosssection of stem $\times 12$.

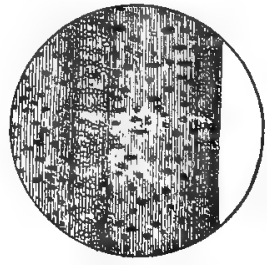

18. E. palustre. Epidermis $\times 12$. 
sandy shores, N. B. to Pa, Minn, and westw. May, June. (Eu.) - Possibly a hybrid. Figs. 14, 15.

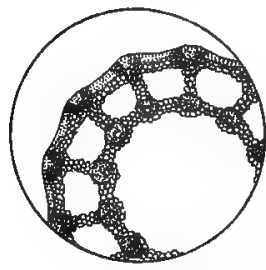

14. E. litorale. Crosssection of stem $\times 12$.

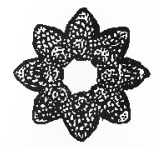

15. E. litorale. Cross-section of stem near apex $\times 12$.

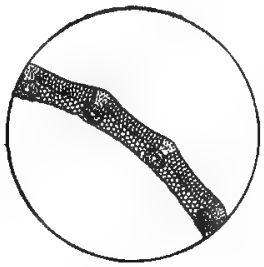

16. E. fluviatile, Crosssection of stem $\times 12$.

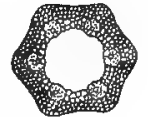

17. E. Huviatile. Crosssection of stem near spex $\times 12$.

6. E. fluviátile L. (Prpes.) Stems erect, 3-15 dm. high, with $10-30$ shallow grooves, simple, or branched in the middle; centrum $\frac{4}{5}$ the total diameter; vallecular holes absent except at bases of largest stems; branches $2.5-16 \mathrm{~cm}$. long, 4-6-angled, hollow, not winged, horizontal, with erect tips; sheaths appressed; teeth dark brown, narrow, acute, rigid, distinct. ( $E$. limosum L.) -Shallow water and mud-banks, common. June, July. (Eu.) Figs. 16, 17.

§ 2. HIPPOCHAETE Milde. Stems mostly evergreen, simple or becoming sparingly branched, mostly rough; spikes apiculate; stomata (in ours) in a single regular row on each side of the groove, overlaid by the siliceous coat of the stem, having access to the air through an irregular hole.

7. E. laevigàtum A. Br. Stems mostly aunual, diffuse and rough or erect and nearly smooth, 1-12 dm. long, simple or with few to many rough branches; centrum $\frac{3}{4}$ the diameter of stem; sheaths widened upward, green with narrow black limb; teeth of the stemsheaths mostly deciouous, leaving black triangular bases, those of the branches persistent; leaves flat above, ridged below; green parenchyma continuous under the keels, separated by the vallecular bast. - Alluvial soils, 0 . to B.C. and Tex. June-Aug. Fig. 18.

V. E. hyemàle L. (Scodring Rush.). Stems erect, mostly simple, 3 to $9 \mathrm{dm}$. high, the ridges slightly grooved on the back with a row of tubercles on each side; sheaths longer than broad, tight, with two black rings separated by an ashy one; teeth mostly deciduous; centrum usually $\frac{2}{3}$ the total diameter; green paren-

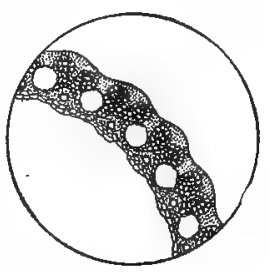

18. E. laevigatum. Crosssection of stem $\times 12$. chyma continuous over the vallecular holes, separated by the bast under the ridges. - Eu.

Var. intermedium A. A. Eaton. Stems evergreen, simple, erect, 3-12 dm. high, smoothish or rough with cross-bands of silex; sheaths widened upward, the lower with basal and terminal black rings separated by an ashy band, ail similarly marked the second year; green parenchyma contintious over the vallecular holes, separated by the carinal bast. - Moist sandy soils, Ct., N. Y., and Mich. to Tex. and Cal. May-Aug. - Often confused with $E$. laevigatum. FrG. 19.

Var. affine (Engelm.) A. A. Eaton. Differs from the type only in having the ridges rounded instead of biangulate. - Can. to Mex.; common in N. E., less common than the next further west.

Var. robùstum (A. Br.) A. A. Eaton. Mostly stout, 12-30 dm. bigh, 6-18 mm. thick; ridges rounded; sheaths nearly as broad as long; leaves with a central and two lateral ridges; teeth mostly persistent. (E. robustum A. Br.) - 
Md. to Mich., southwestw. and westw.; rare east of the Miss. R. (Mex., Asia.) Figs. 20, 21.

9. E. variegàtum Schleich. Stems tufted, ascending, 1.5 to $3 \mathrm{dm}$. high, slender, 5-10-grooved; ridges with broad central grooves; centrum $\frac{1}{8}$ the

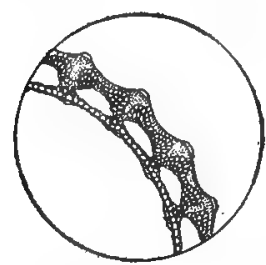

19. E. hyemale, $\vee$. intermedium. Cross-section of stem $\times 12$.

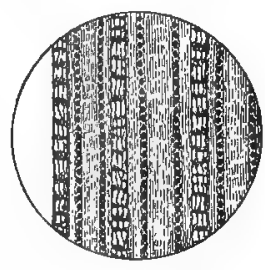

20. E. hyemale, v. robustum. Epidermis $\times 12$.

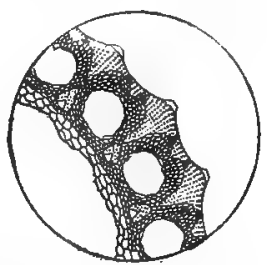

21. E. hyemale, $\nabla$. robustum. Cross-section of stem $\times 12$.

total diameter ; green parenchyma continuous under the keels, interrupted in the grooves; sheatlis loose, green below, black-girdled above; leaves 4-carinate; teeth black, with broad hyaline white borders, persistent, with long filiform deciduous tips, - Lab, to Alaska, southw. to Me., N. Y., and Wyo.; rare. (Eurasia.)

Var. Jesùpi A. A. Eaton. Stems ascending or erect, 2-4 dm. high, 10-12furrowed; ridges with slight central grooves; centrum $\frac{1}{2}-\frac{2}{5}$ the total diameter; carinal bast cutting the parenchyma, the vallecular small; sheaths green, with black limbs, becoming ashy with black bases; teeth brown-centered, white-bordered, with flexuous persistent awn-points, often becoming papery and withering. - Que. and Ont., southw. to Ct. and Ill.

Var. Nelsoni A. A. Eaton. Stems annual, tufted, slender, 1.5-4 dm. high; angles rounded; sheaths ampliated, green, with narrow black limb, becoming

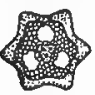

22. E. scirpoides. Cross-section of stem $\times 12$. dusky; teeth centrally grooved, with dark centers and broad white borders, bearing deciduous awn-points; centrum $\frac{1}{9}$ the total diameter of stem ; bast similar to the type. -N. Y. to Mich. and Ill.

10. E. scirpoìdes Michx. Stems many in a tuft, filiform, 0.75 to $1.5 \mathrm{dm}$. high, flexuous and curving, solid at the center, 6-ridged through the deep grooving of the 3 angles; sheaths with 3 persistent hyaline-bordered filiform-tipped teeth. - Moist evergreen woods and low fields; Lab. to Pa., Ill., and northwestw. (Eurasia.) Fig. 22.

\section{LYCOPOdIÀceAe (CLdB Moss Famutr)}

Low plants, usually of moss-like aspect, with elongated and often much branched stems covered with small lanceolate or subulate, rarely oblong or

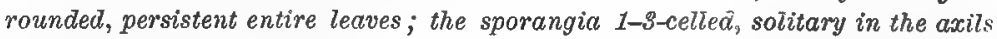
of the leaves, or on their upper surface, when ripe opening into two or three valves, and shedding the numerous yellow spores, which are all of one kind. The Family, as here defined, consists mainly of the large genus

\section{LYCOPÒDIUM L. ChUB Moss}

Spore-cases coriaceous, flattened, usually kidney-shaped, 1-celled, 2-valved, mostly by a transverse line round the margin, discharging the subtile spores, in the form of a copious sulphur-colored inflammable powder. - l'erennials, with evergreen one-nerved leaves imbricated or crowded in 4-16 ranks. (Name compounded of $\lambda u ́ k o s, a$ wolf, and roús, foot, from a fancied resemblance.) 
a. Spore cases in the axils of ordinary dark-green shining leaves, not form-

ing a wall marked terminal spike; gemmae commonly present.

Leaves uniform

Leaves in zones, alternately shorter and longer

a. Spore cases only in the axils of the upper (bracteal) leaves, forming a spike $b$.

b. Bracteal leaves scarcely or not at all modified in form or texture.

Braeteal leaves lance-linear or linear, scarcely broader at the base . Bracteal leaves linear-attenuate from a distinctly broadened ovate base

b. Bracteal leaves scale-like, yeliowish, very different from those of the sterile parts of the stem $c$.

c. Sterile branches convex and uniformly leafy on all sides.

Free part of leaves $4-8 \mathrm{~mm}$. long; fertile branches mostly $1.5-$ $2.5 \mathrm{dm}$. high.

Fertile branches leafy up to the spikes.

Creeping stem deep in the ground, the upright branches repeatedly forked, tree-like . . (7) L. obscu

Creeping stem on or near the surface of the ground, its numerous erect branches mostly subsimple or sparingly forked

Fertile branches modifled beneath the spikes into scaly peduncles Free parts of the leaves $1-3 \mathrm{~mm}$. long; fertile branches usually
$5-13 \mathrm{~cm}$. high

c. Sterle branches tlattened or concave benenth, the leaves usually reduced or modified on the lower surface $d$.

d. Fertile bianches leafy essentially to the spikes

d. Sptkes borne on scaly peduncles $e$.

$e$. Peduncles terminating upright leafy branches.

Fertile branches usually $5-10$, ralely $15 \mathrm{~cm}$. high; free part of lateral leaves linear-subulate, spreading, nearly or quite as long as the adnate part

Fertíle branches usually $1.5-3 \mathrm{dm}$. high ; free part of lateral laves deltoid-subulate, scarcely more than one third to ou. half the length of the adnate part.

Ranning stems deep in the ground; branches narrowly linear, $1.3-1.8 \mathrm{~mm}$. broad, their divisions very numer-

ous and crowded buning steins at or near the surface of the ground; branches 2-4 mm. broad, more loosely and openly forked

o. Peduncles springing directly frcm a short horizontal rootstock

1. L. Selago.

2. L. lucidulum.

8. L. alopecuroides.

4. L. inundatum.
5. L. annolinum.

6. L. clavatum.

8. L. sitchense.

7. L. obscumum.

9. L. sabinaefolium

12. L. tristachyum.

11. L. complanatum.

10. L. carolinianum.

1. L. Selàgo L. Stems erect and rigid, dichotomous, from a short slender rootstock, forming a level-topped tuft $(0.5-2.5 \mathrm{dm}$, high); leaves ur iform, lance-attenuate, crowded, ascending, glossy, pale green or yellowish, sharppointed, entire or denticulate; sporangia in the axils of unaltered leaves. Crevices of exposed or cold rock, chiefly alpine; Greenl. to Alaska, s. to N. E., L. Superior, Mont., and Wash., and on the higher Alleghenies to Va. (Widely distr.) - Commonly genmiparous in the upper axils. Var. APPRÉssum Desv. Leaves closely crowded, appressed. - Usually more abundant, extending s. to N. C.

Var. pàtens (Beauv.) Desv. Leaves linear-attenuate and wide-spreading, dark green. - Cool calcareous cliffs, Que. and n. Vt.

L2. L. lucidulum Michx. Stems assurgent, the old elongate bases very persistent; leaves pointed, toothed, at first spreading, then deflexed, distinctly nroader above the middle, arranged in alternate zones of shorter and longer leaves, the shorter leaves more frequently bearing sporangia in their axils; proliferous gernmae usually abundant but caducous. - Cold, damp woods ; Nfd. to Ont., Minn., Ia., Ind., and southw. in the Alleghenies to S. C.

Var. poróphilum (Lloyd \& Underw.) Clute. Leaves lance-linear, attenuate, narrowed from base to apex, nearly or quite entire. ( $L$. porophilum Lloyd \& Underw.) - Mts. and cold ravines, local; Nfd. and e. Que. to Wisc., s. to S. C. and Ala.

3. L. alopecuroides L. Stems stout, very densely leafy throughout; the sterile branches recurved-procumbent and creeping; the fertile of the same thickness, $13-33 \mathrm{~cm}$. high ; leaves narrowly linear-avol-shaped, spinulose-pointed, spreading, conspicuousty bristle-turthed below the middle; those of the cylindricai spike with long setrceous tips. (L. adpressum Lloyd \& Underw, in 
part.) - Pine-barrens and sandy swamps, Nantucket (Mrs. Owen, Dame, Floyd), L. I., and southw. Aug., Sept. - Stems, including the dense leaves, 15 Inm. in thickness; the comose spike, with its longer spreading leaves, 18-22 mm. thick. (S. A.)

4. L. inundàtum L. Dwarf; creeping sterile stems forking, flaccid, 3-10 (rarely 15) cm. high, bearing a short thick spike; sporophylls usually toothed near the ovate base, their attenuate tips herbaceous, loosely spreading; leaves lanceolate or lance-awl-shaped, acute, soft, spreading, mostly entire, those of the prostrate stems curving upward. - Sandy shores and in sphagnum, Nfd. to N. J., and northwestw. to Alaska. (Eurasia.) V Var. Bigelòvı Tuckerm. Taller (the fertile branches 1-3 dm. high); sporophylls more incurved or appressed, commonly somewhat stramineous, mostly entire. ( $L$. adpressum Lloyd \& Underw. in part.) - Sandy shores, e. Mass. to Md.

5. L. annótinum L. Much branched; stems prostrate and creeping (3-12 dm. long); the ascending branches similar (1-2.5 dm. high), sparingly forked sterile ones making yearly growths from the summit; leaves equal, spreading, in about 5 ranks, rigid, lanceolate, pointed, minutely serrulate (pale green); spike solitary, thickish-cylindrical. - Open woods, Nfd. to Ct., Minn., Col., Alaska, and Greenl. (Eurasia.) In exposed and alpine situations replaced by var. PúNGENS Desv., a form with short thick more rigid leaves which are 3-4 mm. long and erectish. - Nfd. to n. N. Y., and northwestw. (Eurasia.)

6. L. clavàtum L. (Comron C.) Stems creeping extensively, with similar ascending short and very leafy branches; the fertile terminated by a slender peduncle ( $1-1.5 \mathrm{dm}$. long), bearing about $2-4$ slender cylindrical spikes; leaves linear-awl-shaped, incurved-spreading (light green), tipped, as also the bracts, with a fine bristle. - Dry woods; common especially northw. July. (Cosmop.) Var. MonostAchyos Grev. \& Hook. Spike solitary on each peduncle commonly of larger size (sometimes $8 \mathrm{~cm}$. long). - E. Que. to Ct. and northwestw. Var. BREvisPredTuM Peck. Spikes solitary or in pairs, very short (1.3-2.4 $\mathrm{cm}$. long), thickish, blunt; peduncles $3-5 \mathrm{~cm}$. long. - Wallface Mt., $\mathbf{N}$. $\mathbf{Y}$. $(P e c k)$. A sterile form with greatly elongated peduncles is sometimes found: Taconic Mts., W. Mass. (Harrison), and Green Mts., Vt. (Fent).

7. L. obscùrum L. Rootstock cord-like, subterranean, bearing scattered erect tree-like stems dividing at the summit into several densely dichotomous spreading branches; leaves linear-lanceolate, decurrent, entire, acute, 6-ranked, those of the two upper and two lower ranks smaller and appressed, the lateral ones incurved-spreading; spikes 1-3, erect, essentially sessile; bracts scarious-margined, broadly ovate, abruptly apiculate. - Rich woods, N. E. to Va. - Passing imperceptibly into

Var. dendroídeum (Michx.) D. C. Eaton. Leaves equal, erect or incurved ; branches scarcely or not at all dorsiventral, usually erect and crowded; spikes 1-15. (L. dendroideum Michx.) - The more common form, in woods or on open hillsides, Nfd. to N. C. and L. Superior.

8. L. sitchénse Rupr. Glaucous; rootstock long, nearly superficial ; stems short, nimmerous, erect, divided from near the base into numerous erect subsimple crowded branches (; $3-7 \mathrm{~cm}$. high), equally leafy all round; leaves equal, few-ranked, ascending, about $2 \mathrm{~mm}$. long, slender, very acute; spikes on short but usually distinct scaly peduncles; sporophylls green with scarious erose margin, the tip spreading. - Coniferous woods, e. Que. and n. Me.; Mt. Katahdin ; Mt. Washington, N. H. (Eggleston); Adirondack Mts., N. Y. (Peck); u. shore of L. Superior; Alaska.

9. L. sabinaefolium Willd. In habit similar to the preceding; branches 5-10 cm. long, flexuous, dorsiventral; the leaves on the lower surface smaller; peduncles 2-3 cm. long. - Dry woods, e. Que. to Vt. ; Staten Isl., N. Y. (Buchheister); and L. Superior (G. S. Miller).

10. L. carolinianum I. Sterile stems and their few short branches entirely creeping (leafless and rooting on the under side), thickly clothed with broadly lanceolate acute and somewhat oblique 1-nerved lateral leaves voidely spreading in $2 \mathrm{ranks}$, and a shorter intermediate row appressed on the upper side; also sending up a slender simple peduncle $(7-21 \mathrm{~cm}$. long, clothed merely with 
small bract-l1k日 arru appressed awl-shaped leaves) bearing $\ell$ surgıe oylindrical spike. - Wet pine-barrens, N. J. to Va., and southw.

11. L. complanatum L. Rootstock nearly superficial; stems erect, irregularly branched or forked, the branches very flat, more or less glaucous, fewforked, the divisions $(0.5-1.5 \mathrm{dm}$. long, 2-4 mm. wide) erect or but slightly spreading, all clothed with minute imbricated-appressed awl-shaped leaves in 4 ranks with decurrent adnate bases, the lateral with tooth-like tips; peduncles (about $3 \mathrm{~cm}$. long) bearing 1-3 erect spikes. - Dry coniferous woods, Nfd. to Me., Ida., and Alaska. (Eurasia.)

Var. flabellifórme Fernald. (GRodnd Pins.) Brighter green; the branches several-forked and spreading in a fan-like manner, the terminal divisions $0.5-4 \mathrm{~cm}$. long and $1.5-3 \mathrm{~mm}$. broad; peduncles (averaging $7 \mathrm{~cm}$. long) mostly 4-spiked. - Dry woods, N. S. to W. Va., Ky., Ia., and Minn.; common. Var. WíBBE Haberer is a form with peduncles only 1-spiked. - N. Vt. and centr. N. Y.

12. L. tristàchyum Pursh. Very glaucous; rootstock deep (5-12 $\mathrm{cm}$. below the surface); stems erect, the branches numerous, crowded, erect, 1-2 $\mathrm{mm}$. broad; peduncles (8-12 cm. long) with a few scattered attenuate bracts and bearing 1-5 (mostly 4) spikes. (L. Chamaecyparissus A. Br. ; L. complanatum, var. Chamaecyparissus Milde.) - Dry sandy soil, n. Me. to Del., and L. Superior; southw. in the mts. to N. C. (Eu.)

\section{SELAGINELLÀCEAE}

Leafy plants, terrestrial or rooted in mud, never very large; stems branching; leaves small and 4-6-rowed; sporangia one-celled, solitary, axillary or borne on the upper surface of the leaf at its base and enwrapped in its margins, some containing large spores (macrospores) and others small spores (microspores). The macrospores are in the shape of a low triangular pyramid with a hemispherical base, and marked with elevated ribs along the angles. In germination they develop a minute prothallus which bears archegonia to be fertiljzed by antherozoids developed from the microspores.

\section{SELAGINÉLLA Beauv.}

Fructification of two kinds, namely, of minute and oblong or globular sporecases, containing reddish or orange-colored powdery microspores; and of mostly 2-valved tumid larger ones, flled by 3 or 4 (rarely 1-6) much larger globose-angular macrospores; the former usually in the upper and the latter in the lower axils of the leafy 4-ranked sessile spike, but sometimes the two kinds on opposite sides all along the spike. (Name a diminutive of Selago, an ancient name of a Lycopodium, from which this genus is separated, and which the plants greatly resemble in habit and foliage.)

* Leaves all alike and uniformly imbricated; those of the spike similar.

1. S. selaginoides (L.) Link. Sterile stems prostrate or creeping, small and slender; the fertile thicker, ascending, simple $(3-8 \mathrm{~cm}$. high) ; leaves lanceolate, acute, spreading, sparsely spinulose-ciliate. (S. spinosa Beauv.) - Wet places, Nfd. to N. H. (Pursh), Mich., L. Superior, Col., and northw, ; rare. - Habit of Lycopodium inundatum. Leaves larger on the fertile stems, yellowish-green. (Eu.)

2. S. rupestris (L.) Spring. Much branched in close tufts (2-6 cm. high); leaves densely appressed-imbricated, linear-lanceolate, convex and with a grooved keel, minutely ciliate, bristle-tipped; those of the strongly quadrangular spike rather broader. - Dry and exposed rocks, somewhat local but not rare: Grayish-green in aspect, resembling a rigid moss. (Eurasia.) 
* Leaves shorter above and below, stipule-like; the lateral larger, 2-ranked.

3. S. àpus (L.) Spring. Stems tufted and prostrate, creeping, much branched, flaccid; leaves pellucid-membranaceous, the larger spreading horizontally, ovate, oblique, mostly obtuse, the smaller appressed, taper-pointed; those of the short spikes nearly similar; larger spore-cases copious at the lower part of the spike. - Low, shady places, s. Me., southw. and westw. - A delicate little plant, resembling a Moss or Jungermannia. (S. A.)

\section{ISOËTÅCEAE (QUILLWORT FAMILY)}

\section{(Revised bY A. A. Eaton.)}

Small aquatic or palustrine herbs of grass-like or rush-like aspect. Stem short, thick, and corm-like, crowned with numerous subulate leaves. Spores of two kinds in distinct axillary solitary sporangia. - A single genus; the species similar in habit and to be distinguished with certainty only by the aid of the compound microscope.

\section{ISÖËTES C. QUILLWORT}

Stem fleshy, more or less depressed, the roots arising from the 2-5-lobed base, the flattened top bearing the leaves from a central bud or crown. Leaves

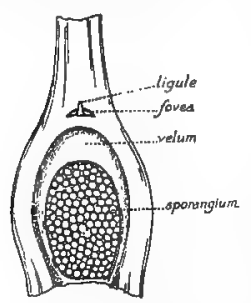

23. Isoëtes (diagrammatic). Inner surfice of leaf-base. Spores dimorphous, the female or gynospores large (250-1000 $\mu$ or more in diameter), spherical, with an elevated ridge (equator) around the middle and three others (commissures) arising from this and meeting at the summit of the upper hemisphere, the surface variously beset with siliceons elevations, rarely smooth; the male or androspores in separate sporangia, mostly in alternate cycles with the female, very minute (20-45 $\mu$ long), obliquely oblong, triangular in section. The trunks of all our species but $I$. Tuckermani and $I$. saccharata, var. Amesii are habitually bilobed. (Name used by Pliny, presumably for a house-leek.) Figs. 23, 24.

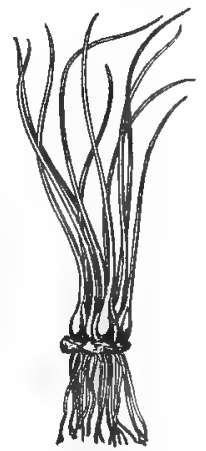

24. I. riparia, sluuw. ing generic habit $\times 1 / 8$

\$ 1. Submersed; leaves cylindrical, fleshy, without bast-bundles or stomata. - AqúlTione A. Br. $a$.

u. Leaves stout, rigid, erect.

Gynospores honeycomb-reticulated below

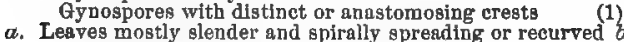

b. Gynospores with thin jagged honeycomb-reticulated crests.

Leaves $1 \mathrm{~min}$, or less in diameter.

Leaves reddish or olive, often with a few stomata ; spores $600 \mu$ or less in diameter

Leaves green, recurved at "end, not "spiral; spores averaglng $650 \mu$ in diameter. Leaves $2.5-8$ mm. In diameter
b. Gynospores with thick vermiform free or anastomosing ridges

(2) I. Tuckermani, r. borealis

1. 1. maorospora I. inacrospora, ₹. heterosporita.

I. Tuckermani, v. Harreyi.

5. Plants of inundated shores or tirlal flats, fruiting as the water recedes

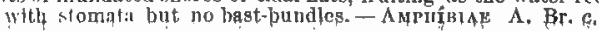

3. I. hieroglyphica. 
c. Leaves reddish or ollve-green.

Gynospores averaging $440 \mu$ in diameter, with small pits

Gynospores averaging $510 \mu$ in diameter, with thin walls

c. Leaves green $\dot{d}$.

$d$. Gynospores with jagged crests.

Gynospoles averaging $600 \mu$ in diameter; crests tall, mostly simple

Gynospores averaging léss than $550 \mu$ in diameter; cresti low, simple or reticulated.

Leaves 1-2.5 mo. in diameter; trunk s 2-lobed

Leaves $1-1.5 \mathrm{~mm}$. in diameter ; trunks 2-5-lobed

a. Gynospores with slender or jagged spines.

Leaves short, stout, spreading

Leaves long, fine, spiral

irregular

4. I. foveolata.

(4) I. foveolata, v. plenospor . $_{\text {. }}$

ts of the extreme edges of ponds or streams, emersed most of the

summer, with stoniata and bast-bundles.-PAifóriess A. A.

Eaton e.

o. Bast-bundles 4 , one at each front angle and one at each end of the dorsi-ventral partition $f$.

f. Polygamous; androsporangia rare; gynospores appenring abortive. Bast-bundles often absent; gynospores with labyrinthiform ridges

Bast-bundles always present; gynospores with truncaté columns.

f. Monoecious.

Gynospores with coarse irregular crests.

Crests loose; sporangia slightly spotted

Crests crowded; sporangia densely spotted

Gynospores reticulated.

Plants of medium size; androspores smooth

Plants large; androspores spinulose.

6. Bast-bundles 4, with accessory ones in the periphery.

Monoeeious; gynospores crested, somewhat reticulated (11) $I$. Engelmanni, v. fontana.

Polygarnous; gynospores small, smooth or with low tubereles or

\$4. Plants of dry situations; leaves setaceous ; bast-bundies $4 ;$ stomata
many; velum none. - Trinkles

8. 1. Eatund.

9. I. Gravesii.

10. I. Dodget.

(10) I. Dodgei, v. Robbinoti.

11. I. Engelmanni

(11) I, Engelmanni, v. valida.

12. I. melanopoda.

18. I. Butleri.

1. I. macróspora Dur. Leaves $10-30,2 \mathrm{~mm}$. in diameter, erect, round, dark green, rather blunt; velum covering $\frac{1}{3}$ of the unspotted sporangium; gynospores $600-800 \mu$ in diameter, the upper faces traversed by thin parallel walls, the lower hemisphere reticulated; androspores $36-47 \mu$ (average $42 \mu$ ) long, smooth. - Gaspé Co., Que., and Me. to Ont. and Minn. FIG. 25.

Var. heteróspora A. A. Eaton. Leaves $50-150,2 \mathrm{~mm}$. in diameter, $5-8 \mathrm{~cm}$. long, rigid, erect, tapering to a sharp point; sporangia spotted $\frac{1}{3}-\frac{2}{3}$ indusiate; gynospores $540-675 \mu$ (some abnormally $1100-1134 \mu$ ) in diameter, densely covered with thick jagged convoluted crests, often reticulated below; androspores $30-40 \mu$ (average $35 \mu$ ) long, dark brown, papillose.

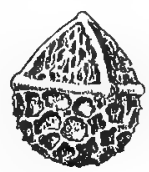

25. I. macrospora. Gynospore $\times 15$. (I. heterospora A. A. Eaton.) - Jordan Pond, Mt. Desert, Me.

2. I. Tuckermàni A. Br. Trunk often 3-lobed, small; leaves $10-40,1 \mathrm{~mm}$. or less in diameter, 4-15 cm. long, reddish or olive green, sometimes with a few stomata but no bast-bundles; sporangia small, rarely spotted, $\frac{1}{3}$ or more covered by the velum; gynospores $450-750 \mu$ (average $600 \mu$ ) in diameter, parallel-walled or reticulated above, more or less reticulated below; androspores $25-38 \mu$ (average $30 \mu$ ) long, slightly rough. - Sandy ponds, Me. to Ct.

Var. borealis A. A. Eaton. Trunk bilobed; leaves 10-100, 3-25 cm. long, $1-1.5 \mathrm{~mm}$. thick, green or reddish, straight or recurved; stomata none; gynospores 600-785 $\mu$ in diameter, more coarsely reticulated; androspores $42 \mu$ long, finely spinulose. -- N. Y. to N. H. and Lab.

Var. Harvêyi (A. A. Eaton) Clute. Trunk 2-lobed, 1.6-3 cm. in diameter; leaves 50-140, purple-bronze, $2.5-3 \mathrm{~mm}$. in diameter, $5-6 \mathrm{~cm}$. long, strongly recurved ; stomata none; sporangia unspotted, $\frac{1}{4}-\frac{1}{8}$ covered by the velum ; gynospores 526-648 $\mu$ (average $560 \mu$ ) in diameter: androspores $30-39.6 \mu$ (average $34 \mu$ ) long. (I. Harveyi A. A. Eaton.) - N. Y. and Mass. to Nfd.

3. I. hieroglýphica A. A. Eaton. Leaves $10-20,6-7.5 \mathrm{~cm}$. long, $1-2 \mathrm{~mm}$. in diameter, blunt, recurved; sporangia not spotted, $\frac{1}{s}$ covered by the velum; 
gynospores $486-720 \mu$ (average $600 \mu$ ) in diameter, sparingly covered with thick vermiform subconfluent or reticulated ridges except just beneath the equator ; androspores $31-44 \mu$ (average $36 \mu$ ) long, verrucose. - Ponds
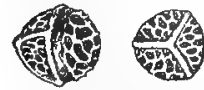

26. I. hieroglyphica, Gynospore $\times 15$.
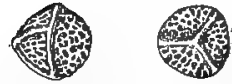

27. I. foveolata. Gynospore $\times 15$. and lakes, N. S., Que., and Me. Fig."26.

4. I. foveolàta A. A. Eaton. Polygamous ; leaves 50-150, $5-15 \mathrm{~cm}$. long, $2 \mathrm{~mm}$. in diameter, round, pinkish or olivegreen; sporangia thickly dark-spotted, $\frac{1}{5}-\frac{1}{3}$ covered by the velum; gynospores $380-560 \mu$ (average $44 J \mu$ ) in diameter, the low 3 r surface covered with little holes, the upper a little more open; androspores 22-35 $\mu$ long, reticulated or papillose. - Ponds and river borders; N. H. and Ct. FIG. 27.

Var. plenóspora A. A. Eaton. Leaves $30-110,1.5 \mathrm{~mm}$. in diameter, $20-40 \mathrm{~cm}$. long ; sporangia thickly dark-spotted, $\frac{1}{4}-\frac{1}{2}$ covered by the velum; gynospores white or ashy, 450$600 \mu$ (average $510 \mu$ ) in diameter, covered with tall thin mostly honeycomb-reticulated walls ; androspores $27-33 \mu$ long, finely granular or tuberculate. - Gravelly shores of ponds in a thin layer of silt, s. e. Mass.

5. I. ripària Engelm. ()ften polygamous; leaves $10-30,1-3 \mathrm{~mm}$. in diameter, $10-25 \mathrm{~cm}$. long, erect, dark green; sporangia densely spotted, $\frac{1}{4}-\frac{8}{4}$ covered by the velum; gynospores $450-756 \mu$ (averaging $570 \mu$ ) in diameter, covered with high isolated, united, or reticulated jagged crests ; androspores 28-32 $\mu$ (average $29 \mu$ ) long, sparingly tubercled. — Tidal shores of Del. R., in gravel. - A species misinterpreted in the past, and seemingly of restricted range.

6. I. saccharàta Engelm. Leaves 10-30, 1-2.5 mm. in diameter, $3-25 \mathrm{~cm}$. long, spreading or recurved; velum very narrow to half covering the thickly spotted sporangium; gynospores $420-510 \mu$ (average $480 \mu$ ) in diameter, covered with low granules, reticulated walls or tall rough crests; androspores $22-30 \mu$ (average $28 \mu$ ) long, sparingly papillose. - Fresh-water tidal flats, $n$, arm of Chesapeake Bay and Del. R. - Very variable and closely approaching the last in some of its forms.

Var. Amèsii A. A. Eaton. Trunks 2-5-lobed; leaves $8-30 \mathrm{~cm}$. long, 1-1.5 mm. in diameter, slender, finely pointed, quadrangular ; sporangia with few spots, $\frac{1}{3}-\frac{2}{3}$ covered by the velum; gynospores $420-300 \mu$ (average $510 \mu$ ) in diameter, marked with fine granules and thin short often reticulated walls; androspores 28-32 $\mu$ long. - Gravelly shores overlaid by fine silt, chiefly in shallow water, s. Mass. to N. Y.

7. I. echinóspora Dur. Leaves $10-30,5-15 \mathrm{~cm}$. long, 1.5-2 mm. broad, dark green, finely pointed; velum about one half covering the sporangium; gynospores 350-560 $\mu$ (average $500 \mu$ ) in diameter, covered with simple or forked spinules; androspores 26-30 $\mu$ long, smooth. - Ea. - A species represented in America by the following varieties.

Var. Braúnii (I)ur.) Engelm. Differs from the type in having stomata on the leaves, a broader velum, spotted sporangium, and not rarely broad jagged crests on the gynospores. (Var. robusta Engelm.; I. Brottii A. Br.) - Muddy or sandy river and pond borders, Gaspé Co., Que. to B. C., s. to Cal. and Pa. ; variable. Fig. 28.

Var. muricàta (Dur.) Engelm. Submersed leaves 10-30, flaccid, spiral, 15-40 cm. long, $1 \mathrm{~mm}$. in diameter; emersed ones 5-8 cm. long, slender, recurved; sporangia pale-spotted, $\frac{1}{2}-\frac{2}{3}$ indusiate ; gynospores $400-620 \mu$ (average $510 \mu$ ) in diameter, covered with slender round spines and flat, blunt,
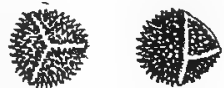

28. I, echinospora, $r$. Lrainil. Gynospore $\times 15$. or retuse lamellae; androspores $25-31 \mu$ long, smootl or slightly granular. Firm soil in shallow waters, mostly submersed; N. S. to n. Me. and N. J. - Grades into the last.

8. I. Eatòni Dodge. Polygamous; leaves $30-200,40-70 \mathrm{~cm}$. long, $3-4 \mathrm{~mm}$. in diameter, flat above; stomata abundant; bast-bundles usually present; velum very narrow; sporangia densely light-brown spotted, not filled by spores ; gynospores round below, upper half depressed, $300-450 \mu$ (average $390 \mu$ ) in diameter, with labyrinthiform-convolute ridges; androsporangia very rare, 
usually scattered among the gynosporangia, the spores $25-30 \mu$ (aterage $28 \mu$ ) long, minutely tuberculate. - Borders of ponds and streams, s. N. H. to N. J. - Our largest species.

9. I. Gravèsii A. A. Eaton. Polygamous; leaves $20-150,12-30 \mathrm{~cm}$. long, 2-3 mm. in diameter, erect, reddish or dark green; sporangia with an abundance of light brown cells, $\frac{1}{5}-\frac{1}{3}$ covered by the velum; gynospores 351 $405 \mu$ in diameter, the upper hemisphere depressed, covered with short truncate single columns; androspores $22-30 \mu$ (average $26 \mu$ ) long, high-cristate or tuberculate. - Mass. to $\mathrm{Ct}$.

10. I. Dódgei A. A. Eaton. Leaves $10-75$, the submersed $20-45 \mathrm{~cm}$. long, 1.5-2 $\mathrm{mm}$. wide, erect or spiral; emersed $10-15 \mathrm{~cm}$. long, interlaced; stornata many; bast-bundles usually present; sporangia sprinkled with light cells, $\frac{1}{5}$ covered by the velum; gynospores $500-675 \mu$ (average $560 \mu$ ) in diameter, sparsely beset with irregular often anastomosing walls; androspores $22-44 \mu$ (average $32 \mu$ ) long, wrinkled. (I. riparia, var. canadensis Engelm.; I. canadensis A. A. Eaton.) - Firm soil, borders of ponds and streams, Me. to B. C., southw. to Pa. FIG. 29.

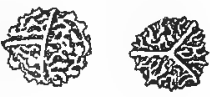

29. I. Dodgei. Gyno. spore $\times 15$.

Var. Robbínsii A. A. Eaton. Leaves 15-30, 10-38 cm. long, 1-1.5 mm. wide, dark green, rigidly erect, fine-pointed; sporangia $\frac{1}{5}-\frac{1}{3}$ indusiate, covered with brown cells; gynospores $460-600 \mu$ (average $500 \mu$ ) in diameter, thickly beset with anastomosing jagged walls ; androspores $28.7-32.8 \mu$ long, rough or slightly papiliose. (I. canadensis, var. Robbinsii A. A. Eaton.) - Borders of ponds and streams, s. Mass, to N. Y.

11. I. Engelmánni A. Br. Leaves $10-40,1-4 \mathrm{dm}$. long, 1-2 mm. in diameter, light green ; sporangia unspotted, $\frac{1}{4}$ or less indusiate ; gynospores $350-570 \mu$
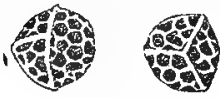

30. I. Engelmanni.

Gynospore × 15 . (average $450 \mu$ ) in diameter, honeycomb-reticulated with thin walls; androspores 24-29 $\mu$ long, smooth. - Ponds, ctreams, and ditches, mostly in clay, $\mathrm{N}$. $\mathrm{H}$. and $\mathrm{Vt}$, to $\mathrm{Pa}$. and Mo; mostly near the coast. Frg. 30. Var. Gr\&́cIlis Engelm. is an attenuate form in shade or deep water.

Var. válida Engelm. Plants larger ; leaves 50-100, 3-6 dm. tall, $2-3 \mathrm{~mm}$. wide, often with 6 bast-bundles; sporangia $\frac{1}{3}-\frac{2}{3}$ indusiate; gynospores $320-570 \mu$ (average $480 \mu$ ) in diameter; androspores 24-30 $\mu$ (average $28 \mu$ ) long, blunt-spinulose. - N. J. to Va.

Var. fontàna A. A. Eaton. Trunk 1-2 cm. in diameter; leaves 30-50, $15-20 \mathrm{~cm}$. long, $2 \mathrm{~mm}$. wide, erect, with many stomata and six large and several small bast-bundles; velum narrow ; sporangia sparingly spotted with lightbrown cells; gynospores $400-750 \mu$ (average $500 \mu$ ) in diameter, covered with coarser more or less broken alveolations; androspores as in the type. - Pa. and Va. ; local.

12. I. melan6́poda J. Gay. Polygamous; leaves $15-60,1.5-3.5 \mathrm{~mm}$. broad, 12-45 cm. tall, chestnut or black at base, with numerous peripheral bastbundles; sporangia less than $\frac{2}{5}$ indusiate, thickly spotted; gynospores $250-400 \mu$ (average $330 \mu$ ) in diameter, nearly smooth or with low often confluent tubercles; androspores 23-30 $\mu$ (average 25 $\mu$ ) long, spinulose. - Inundated fields and shallow ponds, Ill. and Ia. to Okl. and Cal. FIG. 31. Variety PÁlLIDA Engelm. of the Southwest, occasionally found mixed

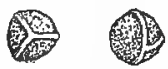
with the type in our range, differs only in having pale leaf-bases.

31. I. melanopoda. Gynospore $\times 15$.

13. I. Butlèri Engelm. Dioecious; leaves 8-60, $7.5-22 \mathrm{~cm}$. long, $0.5 \mathrm{~mm}$. in diameter, rigid, triangular-setaceous, with wide dissepiments, narrow aircanals, and four stout bast-bundles; sheaths granular on the

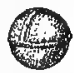

82. I. Butleri. Gynospore $\times 15$. backs; velum none or very narrow ; sporangia mostly spotted; gynospores $400-630 \mu$ (average $570 \mu$ ) in diameter, roughened with very small warts or fragmentary crests ; androspores 28-34 $\mu$ long, coarsely tubercled. - Moist hillsides and shallow depressions, Ill. and Kan. to Tenn. and Okl. Frg. 32. Var. Immaculata Engelm. is a form without spots on the sporangia, growing with the typical form of the species. 


\section{Division II. SPERMATÓPHYTA}

\section{(Seed-Plants, Phanerogamia, or Flowering Plantg)}

Male generative cells (with rare extra-limital exceptions) passive, developing an elongated tube. Flowers with stamens, or pistils, or both. Normal reproduction by seeds containing an embryo or minute plant.

\section{TAXÀCEAE (Yew FamiLY)}

Trees or shrubs, ours with evergreen. linear leaves, and dioecious (or more rarely monoecious) flowers (borne on short scaly peduncles), the sterile globular, formed of a few naked stamens with anther-cells under a shield-like somewhat lobed connective, the fertile consisting of an erect ovule, which becomes a bony. coated seed nore or less surrounded by a large fleshy disk (or scale). Now generally treated as a family distinct from the Pinaceae.

\section{TÁXUS [Tourn.] L. $\mathrm{Y}_{\mathrm{EW}}$}

Annular disk of the fertile flowers cup-shaped, globular, at length pulpy, red, and berry-like. Cotyledons 2. - Leaves flat, mucronate, rigid, scattered, 2ranked. (The classical name, probably from $\tau 6 \xi_{0 v}, a$ bow, the wood anciently used for bows.)

1. T. canadénsis Marsh. (American Y., Grotnd Hemlock.) A low straggling bush ; stems diffuse (or rarely arborescent and $2 \mathrm{~m}$. high); leaves linear, green on both sides. - Evergreen woods, Nfd. to Va., Ia., and Man.

\section{PINÀCEAE (Pine FAMILT)}

Trees and shrubs, with resinous juice, mostly awot-shaped or needle-shaped entire leaves, and monoecious or rarely dioecious flowers borne in or having the form of scaly catkins, of which the fertile become cones or berry-like. Ovules 2 or more at the base of each scale. Mostly evergreen. In the following treatment the term catkin (or ament) is retained as the most convenient designation for the catkin-like aggregates of scales bearing or inclosing either stamens or ovules. The morphology of the confferous inflorescence is still doubtful. It seems probable that the staminate catkin is a single flower, but paleophytological evidence suggests that the ovule-bearing cones are inflorescences.

Tribe I. ABIÈTEAE. Fertile flowers consisting of nuwerous open spirally imbricated carpels in the form of scales, each scale in the axil of a persistent bract; in fruit forming a cone. Ovtles 2, arherent to the base of each scale, inverted. Seeds winged. Cotyledons 3-16. Anthers spirally arranged upon the stamineal column, which fs subtended by involucral scales. Budo scaly. Lueaves linear to needle-shaped.

* Leaves in bundles of two or more.

1. Pinus. Leaves $2-5$ in each bundle, evergreen.

2. Larix. Leaves many in esch cluster, deciduous.

$$
\text { * Leaves solitary. }
$$

- Lesves keeled on both surfaces (tetragonal) ; scales of the cone persistent upon the axis.

8. Picea. Leaves not 2-ranked.

$$
++ \text { Leaves flattish, whitened along two lines benesth. }
$$

4. Abies. Cone large $(5-10 \mathrm{~cm}$. long), the scales falling away before the axls.

5. Tsuga. Cone small ( $12-35 \mathrm{~mm}$. long), the scales persisting on the axis. 
Tribe II. TAXODIEAE. Fertile flowers of several spirally arranged imbricated scales without bracts, becoming a globular woody cone. Ovules 2 or more at the base of each scale, erect. Leaves linear, alternate; leaf-buds nut scaly.

6. Taxodium. Seeds 2 to each scale. Leaves 2-ranked, deciduous.

Tribe III. CUPRESSEAE. Seales of the fertile flower few, derussately opposite or teraate, becoming a small closed cone or sort of drupe. Ovules 2 or more in their axils, erect. Cotyledons is (rarely more). Leaves decussately opposite or ternate, usually scale-like and adnate, the earlier free and subulate; leaf-buds not scaly.

* Monoecious ; fruit a small cone ; leaves opposite and more or less 2-ranked.

7. Chamaecyparis. Cone globose; scales peltate. Seeds 1 or 2 , narrowly winged.

8. Thuja. Cone pendulous, ellipsoid, of $8-12$ imbricated scales. Seeds 2,2 -winged, * * Dioecious ; fruit berry-like, with bony ovate seeds.

9. Juniperus. Fruit-scales 3-6, coalescent. Foliage not 2-ranked.

\section{PINUS [Tourn.] L. Pine}

Filaments short; connective scale-like; anther-cells 2, opening lengthwise. Pollen of 3 united cells, the 2 lateral ones empty. Fruit a cone formed of the imbricated woody scales, which are persistent, spreading when ripe and dry ; the 2 nut-like seeds partly sunk in excavations at the base of the scale. Cotyledons 3-12, linear. - Primary leaves thin and chaff-like, merely bud-scales ; from their axils immediately proceed the secondary needle-shaped evergreen leaves, in fascicles of 2 to 5 , from slender buds, some thin scarious bud-scales sheathing the base of the cluster. Leaves when in pairs semicylindrical, becoming channeled; when more than 2 triangular; their edges in our species serrulate. Blossoms developed in spring; the cones maturing in the second autumn. (The classical Latin name.)

Leaves 5 in a fascicle; cone-scales thin

Leaves $2-3$ in a fascicle; cone-scales thickened at the end.

Cone-seales unarined.

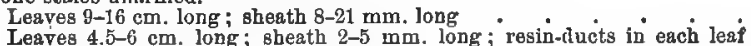

Leaves $4.5-6 \mathrm{~cm}$. long; sheath $2-5 \mathrm{~mm}$. long; resin-ducts in each leaf
numerous, peripheral or nearly 80.

Leaves $1.5-4$ cm. long; resin-ducts mostly 2 , deeply embedded in the leaf-

Cone-scales armed with a sharp dorsal spine or prickle.

Cone very large, 15-25 cm. long

Cone 3-12 cm. long.

Spine of cone-scales stout, 5-6 mm. long .

Spine of cone-scales smaller, 1-3 $\mathrm{mm}$. long.

Leaves somewhat rigid, 1.8-8 mm. broad.

Leaves in 2's, 1.5-4 cm. long

Leaves in 8 's, $5-12 \mathrm{~cm}$. long

Leaves in 8 's, 15-25 cm. long

Leaves tlaccid, $0.7-1.5 \mathrm{~mm}$. broad.

Old eones when open subcylindric-ovoid, sbout $10 \mathrm{~cm}$. long, usually

old cones when open broady ovoid, $\dot{4}-7 \mathrm{~cm}$. long, dull.

Spine of cone-scale 2-3 mm. long; lesves in $2^{\prime} \mathrm{b}, 4-8 \mathrm{~cm}$. long Spine of cone-scale minute, about $1 \mathrm{~mm}$. long; leaves in 2 's or 8 's, 7-18 cin. long

1. P. Strobus L. (White P.) Tree $20-50 \mathrm{~m}$. high; leaves in 5's, very slender, glaucous ; sterile flowers oval ( $8-10 \mathrm{~mm}$. long), with 6-8 involucral scales at base ; fertile catkins long-stalked, cylindrical ; cones narrow, cylindrical, nodding, often curved (1-1.5 dm. long); seed smooth; cotyledons 8-10. Nfd. to Pa., along the mts. to Ga., west to Man. and e. Ia.

:2. P. Taèda L. (Lobloldy or OLD-Fierd P.) Leaves long $(14-23 \mathrm{~cm}$.), in 3 's or sometimes 2's, with elongated sheaths, light green; cone-scales tipped with a stout incurved spine. - Wet clay, or dry sandy soil, S. T. J. to Fla., near the coast, thence to 'Tex. and Ark. - A tree $15-45 \mathrm{~m}$ high, staminate flowers slender, $5 \mathrm{~cm}$. long, usually with 10-13 involucral scales; seeds with 3 strong rough ridges on the under side. 
3. P. rígida Mill. (Рiтch P.) Leaves (5-12 cra. long) dark green, from short sheaths; cones ovoid-conical or ovoid ( $3-\theta \mathrm{cm}$. long), often in clusters; scales with a short stout generally recurved prickle. - Sandy or barren soil, N. B. to L. Ontario, e. 'Tenn., and n. Ga. - A tree 10-25 m. high, with very rough dark bark and hard resinous wood; sterile flowers shorter ; scales 6-8.

4. P. serótina Michx. (Pond or MARsh P.) Similar to the last but readily distinguished by its much longer leaves (15-25 cm. in length) and sheaths, as well as the short more deciduous prickles of the cone.-Coastal swamps, Va. (Harper) to Ela.

5. P. púngens Lamb. (TaBle Modntain P.) Leaves stout, short, in 2's or 3 's (3-6 cm. long), crowded, bluish; the sheath short (very short on old foliage); the scales armed with a strong hooked spine.-Allegheny Mts., N. J. and Pa., to Ga. and Tenn. - A rather small tree (6-18 m. high); cones longpersistent.

L-6. P. virginiàna Mill. (JERSEY or ScRub P.) Leaves short $(4-8 \mathrm{~cm}$. long), in 2's; cones sometimes curved, the scales tipped with a straight or recurved awol-shaped prickle. ( $P$. inops Ait.) - Barrens and sterile hills, L. I. to S.C., Ala., and s. Ind. - A straggling tree (5-12 $\mathrm{m}$. high), with spreading or drooping branchlets; larger westward. Young shoots with a purplish glaucous bloom.

7. P. Banksiàna Iamb. (Gray or NortherN Scrub P.) Leaves in 2's, very short and thick (usually $2-3 \mathrm{~cm}$. long), oblique, divergent; cones conical, oblong, usually curved ( $4-5 \mathrm{~cm}$. long), swooth, the scales pointless, or with a minute obsolescent prickle. ( $P$. divaricata auth.) - Barren, sandy, or rocky soil, N. S. to n. N. Y., w. to n. Ill., Minn., and northw. - A low tree, usually 5-10 (rarely 20 ) $\mathrm{m}$. high.

L. P. echinàta Mill. (YeLlow P.) Leaves in 2's or 3's, slender, mostly about $1 \mathrm{dm}$. long, with long sheaths; cone-scales with a minute weck prickle. ( $P$. mitis Michx.) - Usually dry or sandy soil, Staten I. to Kan., and southw. A straight tree $(15-30 \mathrm{~m}$. high), with dark green leaves more soft and slender than the preceding. The western form has unore rigid leaves and more tuberculate and spiny cones.

9. P. Sylvéstris L. (Sсотсh P., Sсотсн Frr.) Leaves in 2's, dark green; cones 4-6 cm. long, the thickened rhombic scales with central tubercle but not spinous. - Much cultivated, and thoroughly naturalized at some points on the N. E. coast. - A valuable long-lived tree attaining considerable height, but the trunk rarely straight, the bark gray. (Nat. from Eu.)

10. P. resinòsa Ait. (RED P.) Leaves in 2's, dark green ; cones ovoidconical, smooth (about $5 \mathrm{~cm}$. long), their scqles slightly thickened, pointless; sterile flowers oblong-linear (12-18 mm. long), subtended by about 6 involucral scales which are early deciduous by an articulation above the base. - Dry woods, Mass. to n. Pa., Mich., and Minn., and northw.-A tall tree, with reddish rather smooth bark and hard wood, not very resinous.

11. P. palústris Mill. (Long-Leaved, Yellow, or Georgia P.) Leaves in 3 's from long sheaths, very long, crowded at the summit of very scaly branches; sterile flowers 6-8 cm. long, rose-purple; cones large, cylindrical or conicalcylindric, the thick scales armed with a short recurved spine. ( $P$. australis Michx.) - Sandy soil, s. Va. to Fla. and Tex. - A large tree, with thin-scaled bark and exceedingly hard and resinous wood.

\section{LẦIX [Tourn.] Adans. LARCH}

Catkins lateral, terminating short spurs on branches of a year's growth or more, short or globular, developed in early spring; the sterile from leafess buds ; the fertile mostly with leaves below. Anther-culls opening transversely. Pollengrains simple, globular. Cone-scales persistent. - Leaves needle-sluaped, soft, deciduous, very many in a fascicle, developed in early spring from lateral scaly and globular buds. Fertile catkins crimson or red in flower. (The ancient name. ) 
1. L. laricina (DuRoi) Koch. (Americhy or Black L., Tamarack, Hackmatack.) Leaves 1-2.5 cm. long; cones ovoid, 1.2-2 cm. long, of few rounded scales. (L. americana Michx.) - Chiefly in cold swamps, Lab. and Nfd. to $\mathrm{n}$. Pa., n. Ill., centr. Minn., and far northw. - A slender tree (8-30 m. high), with hard and very resinous wood.

2. L. DEcidua Mill. (L. europaea DC.), with longer leaves and larger cones, is often cultivated, and occasionally established, as in Ct. (Bissell). (Introd. from $\mathrm{Eu}$.)

\section{PÍCEA Link. SPRUCE}

Sterile flowers on branchlets of the preceding year; anthers tipped with a rounded recurved appendage, their cells opening lengthwise. Cones maturing the first year, becoming pendulous; their scales thin, not thickened nor pricklytipped, persistent. - Leaves scattered, needle-shaped and keeled above and below (4-sided), pointing every way. Otherwise nearly as in Pinus. (The classical Latin name of a pine.)

1. P. canadénsis (Mill.) BSP. (WhITE or $\mathrm{C}_{\mathrm{AT}} \mathrm{S}$.) Branchlets glabrous; leaves slender, pale or glaucous ; cones cylindrical, about $5 \mathrm{~cm}$. long, deciduous, the thin scales with an entire edge. (P. alba Link.) - N. S. and N. B. to N. Y., L. Superior and northw. - A handsome tree $(15-45 \mathrm{~m}$. high), in aspect resembling the Balsam Fir.

2. P. rübra (DuRoi) Dietr. (RED S.) Branchlets pubescent; leaves mostly slender, $12-15 \mathrm{~mm}$. long, usually acute or acutish, dark green or yellowish green; cones elongated-ovoid, mostly $3-4 \mathrm{~cm}$. long, clear brown or reddish brown, the scales rounded, entire or slightly erose. ( $P$. rubens Sarg.; $P$. australis Small.) - Rocky upland woods, Nfd. to Pa., s. in the Alleghenies to Ga., w. to Minn., and northw. - A valued timber tree, 20-35 m. high.

3. P. mariàna (Mill.) BSP. (BLACK or BoG S.) Branchlets pubescent; leaves short and thickish, mostly 6-10 (rarely 13) mm. long, pale bluish green, with strong whitish bloom; cones short-ovoid or subglobose, $2-3 \mathrm{~cm}$. long, dull grayish brown, persisting for several years; the scales more decidedly erose, rounded or often somewhat narrowed toward the apex. ( $P$. nigra Link; $P$. brevifolia Peck.) - Cold bogs and mountain slopes, Nfd. to N. J., along the Great Lakes and northw. - Chiefly a low tree $(8-12 \mathrm{~m}$.) rarely attaining $30 \mathrm{~m}$. in height.

4. P. Anies (L.) Karst. ( $P$. excelsa Link), the Norway S., often cultivated as a shade tree, and now established (acc. to Bissell) at several places in Ct., has subglabrous branchlets, slender sharp-pointed dark green glossy leaves, and large cones (1-1.5 dm. long). (Introd, from Eu.)

\section{ABIES [Tourn.] Hill. Frr}

Sterile flowers from the axils of last year's leaves; anthers tipped with a knob, their cells bursting transversely; pollen as in Pinus. Cones erect on the upper side of spreading branches, maturing the first year; their thin scales and bracts deciduous at maturity. Seeds and bark with balsam-bearing vesicles. - Leaves scattered, sessile, flat, with the midrib prominent on the whitened lower surface, on horizontal branches appearing 2-ranked. (The classical Latin name.)

1. A. balsamea (L.) Mill. (Balsam or BaLm-of-Gilead F.) Leaves narrowly linear, obtusely pointed or retuse $(1-3.2 \mathrm{~cm}$. long); cones cylindrical (6-10 cm. long ; 2-3 cm. thick), at first violet-colored ; the bracts obovate, serrulate, tipped with an abrupt slender point, shorter than the scales. - Damp woods and mt. swamps, Nfd. to Pa., along the mts. to Va., W. to centr. Ia., and northw. A slender tree or at high elevations a low or prostrate shrub.

2. A. Frasềi (Pursh) Poir. Leaves narrowly linear, commonly retuse; bracts of the cones dentate or erose-lacerate on the margin, often emarginate and bearing a slender cusp at the apex, longer than the scales. - Mts. of Va., and N. C. 


\section{TSUGA (Endl.) Carr. Hemlock}

Sterile flowers a subglobose cluster of stamens, from the axils of last year's leaves, the long stipe surrounded by numerous bud-scales; anthers tipped with a short spur or knob, their conflnent cells opening transversely ; pollen-grains simple. Cones on the end of last year's branchlets, maturing the first year, pendulous; their scales thin, persistent. - Leaves scattered, flat, whitened beneath, appearing 2-ranked. ('The Japanese name of one of the species.)

1. T. canadensis (L.) Carr. Leaves petioled, short-linear, obtuse, 8-13 mm. long; cones ovvid, 1.5-2.5 cm. long, the scales suborbicular. (Abies Michx.) Mostly hilly or rocky woods, N. B. and N. S. to I lel., and along the mts. to Ala., w. to Minn, - A tall tree, with light and spreading spray and delicate foliage, bright green above, silvery beneath.

2. T. caroliniàna Engelm. Leaves petioled, linear, 15-18 mm. long; cones ovoid, 2-3.5 cm. long; scales oblong, in age loosely imbricated, widely and irregularly spreading. - Mts. of Va. to Ga.

\section{TAXòdIUM Richard. BaLd Cypress}

Flowers monoecious, the two kinds on the same branches. Sterile flowers spiked-panicled, of few stamens; filaments scale-like, shield-shaped, bearing 2-5 anther-cells. Fertile catkins ovoid, in small clusters, scaly, with a pair of ovules at the base of each scale. Cone globular, closed, composed of very thick and angular somewhat shield-shaped scales, bearing 2 angled seeds at the base. Cotyledons 6-9. - Trees, with light green deciduous leaves; a part of the slender leafy branchlets of the season also deciduous in autumn. (Name compounded of rákos, the yew, and eldos, resemblance, the leaves being yew-like.)

$\downarrow$ 1. T. dístichum (L.) Richard. Leaves linear and spreading; also some awl-shaped and imbricated on flowering branchlets. - Swamps, s. Del. to s. Ill., Mo. and Tex. March, April.

\section{Chamaecýparis Spach. White Cedar. Cypress}

Flowers monoecious on different branches, in terminal small catkins. Sterile flowers composed of shield-shaped scale-like filaments bearing $2-4$ anther-cells under the lower margin. Fertile catkins globular, of shield-shaped scales decussate in pairs, bearing few (1-4) erect bottle-shaped ovules at base. Cone globular, firmly closed, but opening at maturity; the scales thick, pointed or bossed in the middle; the few angled or somewhat winged seeds attached to their contracted base or stalk. Cotyledons 2 or 3 . - Strong-scented evergreen trees, with very small and scale-like or some awl-shaped closely appressedimbricated leaves, distichous branchlets, and exceedingly durable wood. (From

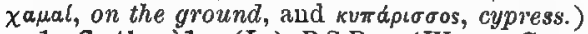

1. C. thyoides (L.) BS P. (White Cedar.) Leaves minute, pale, often with a small gland on the back, closely imbricated in 4 rows; cones small (6-9 $\mathrm{mm}$. in diameter) of about 3 pairs of scales; seeds slightly winged. ( $C$. sphaeroidea Spach.) - Swamps, s. N. H. to Fla. and Miss. - A tree 10-25 m. high, resembling Arbor Vitae. Doubtfully indigenous in N. S., and said to have been originally collected in Canada by Kalm.

\section{ThƯJa L. Arbor Vitae}

Flowers mostly monoecious on different branches, in very small terminal ovoid catkins. Stamens with a scale-like filament or connective, bearing 4 anther-cells. Fertile catkins of few imbricated scales (fixed by the base) each bearing 2 erect ovules; dry and spreading at maturity. Cotyledons 2. - Small evergreen trees, with very flat 2-ranked spray, and closely imbricated small appressed persistent leaves; these of two sorts, on different or successive branchlets; one awl-shaped; the other scale-like, blunt, short, and adnate to the branch. (Evla or $\theta \dot{u} a$, the ancient vame of some resin-bearing evergreen.) 
1. T. occidentàlis L. (Arbor Vitae, Whitse Cedar.) Leaves appressedimbricated in 4 rows on the 2-edged branchlets; scales of the cones pointless; seeds broadly winged all round. - Swamps and cool rocky banks, e. Que. to Pa., along the mts. to N. C. west to Minn. and Man.-A tree 10-20 m. high, with pale shreddy bark, and light, soft, but very durable wood.

\section{JUNIPERUS [Tourn.] L. JUNIPER}

Flowers dioecious, or occasionally monoecious, in very small lateral catkins. Anther-cells 3-6, attached to the lower edge of the shield-shaped scale. Fertile catkins ovoid, of 3-6 fleshy coalescent scales, each 1-ovuled, in fruit forming a sort of berry, which is scaly-bracted underneath, bluish-black with white bloom. Seeds 1-3, ovate, wingless, bony. Cotyledons 2. - Evergreen trees or shrubs. (The classical name.)

\$1. OXÝCEDRUS Spach. Catkins axillary; leaves in whorls of 3 , free and jointed at base, linear-subulate, prickly-pointed, channeled and whiteglaucous above.

1. J. commùnis L. (Cомmon J.) Arborescent, $2-4 \mathrm{~m}$. high; leaves thin, straight, long and relatively narrow (12-21 num. in length, $1.5 \mathrm{~mm}$. broad at the base), widely spreading, grayish beneath, needle-pointed ; berry subglobose, 6-8 mm. in diameter. - Dry soil, e. Mass. (where rare) to Pa., Man., and southw. in the mts. to N. C. and N. Mex. (Eu.)

Var. depréssa Pursh. Decumbent, forming large mats, 3-10 dm. high and often several $\mathrm{m}$. in diameter ; leaves $8-13 \mathrm{~mm}$. long, straight or nearly so, sharppointed and with a white stripe beneath ; berry 6-10 mm. in diameter. ( $J$ communis, var. canadensis Loud.; var. alpina Man. ed. 6, in part.) - Common in poor, rocky soil, pastures, etc., Nfd. to Ct., along the Great Lakes and northwestw.

Var. montàna Ait. Very depressed and trailing; leaves short and relatively broad, curved, subappressed, 6-9 $\mathrm{mm}$. long, 1.6-2 mm. broad, short-pointed, with a conspicuous white stripe beneath. (Var. alpina Gaud.; J. nana Willd.) - Exposed rocky places, coast of $\boldsymbol{n}$. Mass. (where doubtful) to Nfd.; also in the Rocky Mts, and Alaska. (Eurasia.)

\$2. SABINA Spach. Catkins terminal; leaves mostly opposite, sometimes awl-shaped and loose, sometimes scale-shaped, appressed-imbricated and crowded, the latter with a resiniferous gland on the back.

2. J. horizontàlis Moench. A procumbent, prostrate, or sometimes creeping shrub; scale-like leaves acutely cuspidate; berry on short recurved peduncles, 6-10 mm. in diameter. (J. Sabina, var. procumbens Pursh.) - Rocky or sandy banks, borders of swamps, etc., Nfd. to N. E., N. Y., n. Minn., and northw. J. Sabina L., the Savis of Europe, bas its scale-like leaves obtuse and more closely appressed.

¿3. J. virginiàna L. (Red Cedar or SAvin.) From a shrub to a tree $15-25 \mathrm{~m}$. high, pyramidal in form; scale-like leaves obtuse or acutish, entire: berries on straight peduncles, about $6 \mathrm{~mm}$. in diameter. -Dry hills or deep swamps, s. Me., westw. and southw. - Bark shreddy, and heart-wood red and aromatic.

\section{TYPHẢCEAE (CAT-TAIl Familt)}

Marsh or aquatic herbs, with nerved and linear sessile leaves, and monoecious: fowers on a spadix, destitute of proper floral envelopes. Ovary 1-celled, with persistent style and elongated 1-sided stigma; cell 1-ovuled. Fruit nut-like. Seed suspended, anatropous; ernbryo straight in copious albumen Roo' peremnial. 


\section{TỲPHa [Tourn.] L. Cat-tail Flag}

Flowers in a long and very dense cylindrical spike terminating the stem; the upper part consisting of stamens only, inserted directly on the axis, and intermixed with long hairs ; the lower part consisting of stipitate 1-celled ovaries, the stipes bearing club-shaped bristles, which form the copious down of the fruit. Nutlets minute, very long-stalked. - Spathes merely deciduous bracts, or none. Rootstocks creeping. Leaves long, sbeathing the base of the simple jointless stems, erect, thickish. Flowering in summer. (Tú $\phi \eta$, the old Greek name.)

$\checkmark$ 1. T. latifòlia L. (Common Cat-Tail.) Stout and tall (1-2 m. high), the flat sheathing leaves $6-23 \mathrm{~mm}$. broad, exceeding the stem; the staminate and dark brown pistillate parts of the spike (each $8-15 \mathrm{~cm}$. long or more) usually contiguous, the latter at length $2.5 \mathrm{~cm}$. in diameter; pistillate flowers without bractlets; stigma rhombic-lanceolate; pollen-grains in fours. - In marshes, throughout temperate N. A. (Cosmop.)

$V$ 2. T. angustifolia $\mathrm{L}$. I Leaves narrower $(6-12 \mathrm{~mm}$. broad), somewhat convex on the back; pistillate and staminate parts of spike usually separated by $a$ short interval, the fertile portion becoming $10-12 \mathrm{~mm}$. in diameter; pollengrains simple; pistillate flowers with a linear stigma and, a hair-like bractlet slightly dilated at the summit. - S. Me. to N. C. and westw., less frequent than the preceding, and mainly near the coast. (Eurasia, etc.)

\section{SPARGANIÀCEAE (BUR-REEd FAMILX)}

Marsh or aquatic plants with alternate sessile linear 2-ranked leaves and nunoecious flowers in globular sessile or pedunculate heads. Upper heads bearing sessile 3-androus naked flowers and minute scales irregularly interposed. The lower heads consisting of numerous sessile or shortly pediceled pistillate flowers with a calyx-like perianth of 3-6 linear or spatulate scales. Ovary 1-2-celled. Fruit obovoid or spindle-shaped, 1-2-seeded.

\section{SPARgANIUM [Tourn.] L. BUR-ReEd}

Heads scattered along the upper part of the simple or sparingly branched leafy stem, the bracts caducous or the lower persisting and leaf-like. - Perennials with fibrous roots and creeping horizontal rootstocks. Flowering through the summer. The fertile heads becoming bur-like from the divergent beaks, but the pistils at maturity falling away separately. (Name ancient, probably from $\sigma \pi d \rho f \gamma a \nu o \nu, a$ band, in allusion to the ribbon-like leaves.)

Fertile flowers closely sessile; fruit broadly obovold _ . . . . 1. S. eurycarpum.

Fertile flowers shortly pedicellate; fruit fusiform.

Beak of fruit long and slender; stigma linear.

Pistillate heads strictly axillary.

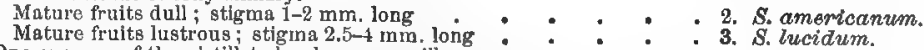

One or more of the plstillate heads supia-axillary.

Ereot plants of muddy shores; leaf-blades translucent and reticulated 4. S. aiversifolinm.
Distinetly aquatic; leaves with loug floatiog opaque blades.

Acbones rather abruptly slender-beaked; leaf-blades $1.5-4 \mathrm{~mm}$. broad ; stigma rarely over $1.2 \mathrm{~mm}$. long

Achones gradually acumlnate; leaf-blades $4-9$ imm. broad ; stigm:

Beak of fruit stouter and falcate or short and conicnl or none; stigma ovoid or S. simplen.

Fruiting heads $2 \mathrm{~cm}$. in dian.; bonk gladiate-falcate

Fruiting heads $1 \mathrm{~cm}$. in diam.

Boak short, conical.

Beak none, stigma sessile

1. S. eurycárpum Engelm. Stems stout, erect ( $8-13 \mathrm{dm}$. high); leaves mostly fiat and merely keeled; pistil attenuate into a short style bearing 1 or 2 elnngated stigmas; fruit heads $2-6$ or more, $2-3 \mathrm{~cm}$. in diameter; fruit angled, often 
2-seeded, 7-8 $\mathrm{mm}$. long when mature, with a broad and depressed or retuse summit abruptly tipped in the center. - Borders of ponds, lakes, and rivers, N. S. and Me., southw., and westw. to the Pacific, chiefly at low altitude.

2. S. americànum Nutt. Stoutish, 3-7 dm. high; leaves thin and snft, 6-12 $\mathrm{mm}$. broad; bracts divaricate or arcuate-ascending; inflorescence strictly simple; pistillate herds all axillary, sessile or nearly so, in fruit $1.8-2.6 \mathrm{~cm}$. in diameter; fruit dull, the beak 2.5-4 mm. long. (S. simplex, var. Nuttallii Engelu.) - Bogs and muddy shores, N. B. to Id. and Va. (E. Asia.)

Var. andrócladum (Engelrn.) Fernald \& Eames. Inflorescence bearing from its lower axils 1-2 weak branches. (S. simplex, var. Engelm.) - Similar piaces, Nfd. to Minn., Mr., and Fla.

3. S. lùcidum Fernald \& Eames. Similar, but taller $(7.5-9 \mathrm{dm}$. high); leaves firmer, strongly carinate, much overtopping the simple or forking inflorescence; pistillate heads in maturity $3 \mathrm{~cm}$. or more in diameter ; fruit lustrous, the beak 5-7 mm. long. - Muddy shores, Mass. to Pa. ; also 1ll. and Mo.

4. S. diversifolium Graebner. Erect, stontish, 3-6 dm. bigh; leaves delicate, celiular-reticulated, 4-9 $\mathrm{mm}$. wide, with a broad scarious margin toward the base; heads chiefly sessile at least the lower supra-axillary, in fruit $2-2.5 \mathrm{~cm}$. in diameter. (S. simplex Man. ed. 6, in great part.) - E. Que. to Ct. and S. Dak.

Var. acaúle (Beeby) Fernald \& Eames. Dwarf, 1-3 dm. high; pistillate heads smaller, $1.5-2 \mathrm{~cm}$. in diameter, mostly crowded. (Var. nanum Graebner.) -Nfd. to Ia. and W. Va.

5 S. angustifolium Michx. Slender aquatic; stems 3-12 dm. long; leaves eaceeaingly long and narrow, opaque; inflorescence simple; heads somewhat supra-axillary, the lower ones often peduncled, in fruit $1.3-2 \mathrm{~cm}$. in diameter. -Ponds and slow streams, Nfd. to N. E., westw. and northw. to Ore. and Alaska.

6. S. símplex Huds. Coarser and in America distinctly aquatic; stems 3-10 $\mathrm{dm}$. long; ieaves 4-9 mm. broad; inflorescence simple, elongated; heads mostly supra-axillary, the lowermost long-peduncled, in fruit $2-2.5 \mathrm{~cm}$. in diameter. Nfd. and 12. N. E. to Cal., and northw.

7. S. flúctuans (Morong) Robinson. Of medium size for the genus, $0.5-1 \mathrm{~m}$. high ; leaves 7-12 $\mathrm{mm}$. broad; inflorescence branched; each of 2 or 3 branches bearing $3-5$ heads, usually but $1-3$ of the lowermost fertile; these at maturity $2 \mathrm{~cm}$. in diameter; nutlets with outer coat of firm texture, beaked by a persistent gladiate-falcate style, tipped with a short ovoid or oblong stigma. (S. androcladum, var. fuctuans Morong, at least in part; $S$. simplex, var. fluitans Engelm.) - Margins of cool lakes, usually at a depth of about 1 m., n. N. B. and adjacent Que. to Pa. and Minn.

8. S. minimum Fries. Slender, 1-4 dm. high; leaves grass-like, flat, thin, usually floating, $2-4 \mathrm{~mm}$. broad; inflorescence simple; heads mostly sessile, the fertile at length $1 \mathrm{~cm}$, in diameter; the nutlets smooth, conically narrowed to a short but slender straightish beak tipped with a short ovoid or oblong stigma. Cold shallow water, N. B. to Pa., Mich., Col., Wash., and northw. (Eurasia.)

9. S. hyperbòreum Laestad. Slender, flexuous, $2-4 \mathrm{dm}$. high ; leaves $1-4 \mathrm{~mm}$. broad, the cauline somewhat gaccate at the base; inflorescence simple; the lower heads usually peduncled, in fruit $8-10 \mathrm{~mm}$. in diameter; nutlets obovoid, rounded at the summit and tipped with a sessile short-oblong stigma. - Cape Breton (acc. to Macoun) and northw. to Greenl. (N. Eurasia.)

\section{NAJAdÀCEAE (Pondweed Family)}

Marsh or mostly immersed, aquatic herbs, with stems ,iointed and leafy, leaves sheathing at base or stipulate, and flowers perfect or unisexual, often spathaceous, with perianth of 4 or 6 herbaceous distinct valvate segments, or membranous and tubular or cup-shaped, or none. Stamens 1, 2, 4, or 6, with extrorse anthers. Ovaries 1-6, distinct, 1-celled, usually 1-ovuled, in fruis indehiscent. 
* Flovers perfect, spiked or clustered ; anthers 4 or 2, sessile; leaves alternate.

1. Potamogeton. Spike peduncled. Sepals 4, herbaceous. Anthers t. Ovaries 4, sessile.

2. Ruppia. Flowers on an inclosed spadix, at length long-exserted, without perianth. Anther: cells 4, distinct. Ovaries 4 , becoming stipitate.

** INlowere monoecious or dioecious, axillary, naked, monandrous; leaves opposite (alternate in $\mathrm{n}, 4)$.

3. Zannichellia. Monoeclous. Plstils (2-5) from a cup-shaped involucre or sheath.

4. Zostera. Pistils and stamens alternate in 2 vertical rows on the inner side of a leaf-like in. closed spadix. Stigmas 2, linear. Stem creeping.

5. Najas. Dioecious. Pistil solitary, naked. Stamen inclosed in a membranous apathe. Stems floating, with opposite or ternate leaves.

\section{POTAMOGETON [Tourn.] L. PONDWEed.}

Sepals 4, rounded, valvate in the bud. Stamens 4, opposite the sepals; anthers 2-celled. Ovaries 4 (rarely only one), with an ascending campylotropous ovule; stigma sessile or on a short style. Fruit drupe-like when fresh, more or less compressed; endocarp (seed) crustacous. Embryo hooked, annular, or cochleate, the radicular end pointing downward. - Herbs of ponds and streams, with jointed mostly rooting stems, and 2-ranked leaves, which are usually alternate or imperfectly opposite; the submersed ones pellucid, the floating ones often dilated and of a firmer texture. Stipules membranous, more or less united and sheathing. Spikes sheathed by the stipules in the bud, mostly raised on a peduncle to the surface of the water. (An ancient name, composed of $\pi \circ \tau a \mu \delta s, a$ river, and $\gamma \epsilon i \tau \omega \nu, a$ neighbor, from the place of growth.) - By fruit, the full-grown fresh or macerated fruit is intended; by seed, that with the fleshy outer portion or epicarp removed. All measurements are from dried specimens. The month mentioned indicates the time of ripening of the fruit.

$\boldsymbol{u}$. Leaves of two sorts; floating ones more or less coriaceous, with a dilated petioled blade, different in form from the thinner submersed ones $b$.

b. Submersed leaves fliform or very nartowly linear, at most $2 \mathrm{~mm}$. wide $c$.

c. Spikes all alike, oylindrical $d$.

d. Blades of floating lesves $2.5 \mathrm{~cm}$. or more long, mostly shorter than the elongate petioles; spikes $1.5 \mathrm{~cm}$. or more long.

Seed with a depression on each side.

Beed with plane sides, not at all impressed

d. Blades of floating leaves less than $1.5 \mathrm{~cm}$. long, equaling or longer than the petioles; sptkes less than $1 \mathrm{~cm}$. long.

Fruit compressed, distinctly keeled, tipped by the curved style

Fruit plump, slightly grooved on the sides, but not keeled; stigma nearly sessile .

c. Splkes of two kinds ; one emersed, cylindrical, and manj-flowered; the other submersed, globular, and few-flowered.

Peduncles of the submersed spikes equaling or exceeding the

spikes
Peduncles shorter than the snbmersed splkes

b. Submersed leaves lanceolate to ovate, if linear more than 2 min. wide $\theta^{*}$

o. Submersed leaves linear and ribbon-like, with a broad coarsely cellular-reticulate space each side of the midrib

c. Submersed leaves broader $f$.

$f$. Principal floating leaves heart-shaned at bese.

Fruit $3-1 \mathrm{~mm}$. long, compressed, and distinctly 8 -keeled .

Fruit 1.5-2 mm. long, plump, and obscurely 8-keeled

$f$. Flosting loaves rounded or tapering at base, not heart-shaped $g$.

g. Floating leaves $30-50$-nerved
$g$. Floating leaves with fewer nerves $h$.

$h$. Mature fruit $2.5 \mathrm{~mm}$. or more long $i$. i. Mature splkes 4-5 5 cm. long (ff rarely shorter, with floatlng
leaves $18-24-11$ rved).

submersed leaves mucronate

Submersed lenves merely acuminate.

Submersed lenves broadly lanceolate or oblong-olliptical; fruit tipped by the prominent style

submersed leaves narrowly lanceolate; fruit tipped by the nearly sessile stigma

1. P. natans.

2. P. Oakesianus.

27. P. Vaseyi.

26. P. lateralis.

82. P. hybrialus.

88. P. dimorphus.

4. P. epinydrus.

7. P. pulcher.

8. P. polygonifolius

8. P. amplifolius.

11. $P$, angustifolius.

9. P. illinoensis.

6. P. tmericanus. 
i. Mature spikes $1.5-3.5 \mathrm{~cm}$. long (if rarely longer, with floating leaves 10-18-nerred).

Foliage and spikes strongly suffused with red; 8 or 4 carpele of each fower usually ripening

Foliage and spikes greenish; 1 (rarely 2) carpels ripening $h$. Mature fruit 1.5-2 inm. long

u. Leaves all submersed and similar $j$.

j. Leaves lanceolate, oblong or broader $k$.

k. Leaves sessile or short-petioled, not clasping $z$.

$l$. Leaves finely and sharply serrulate

$i$. Leaves entire, but sometimes with puckered or undulate, not serulate, margins $m$.

m. Mature sulke $8.8-5.5 \mathrm{~cm}$. long.

Fruit distinctly 8-keeled .

Fruit with rounded, scarcely keoled sldes

$m$. Matur' spike shorter $n$.

$n$. Spike more than $1 \mathrm{~cm}$. long.

Foliage and spikes strongly suffused with red; 8 or 4 carpels of each flower usually ripening

Foliage and spikes greenish ; 1 (rarely 2) carpeli ripening

n. Spike 4-7 mm. long

z. Leaves clasping or half-clasping $o$.

$o$. Leaves half-clasping, elongate, with rounded cucullate tips; stipules conspicuous \&nd persistent; fruit sharply keeled

o. Leaves cordate-clasping, if elongate with tapering plane tips; stipules inconspicuous or soon reduced to shreds; fruit rounded on tbe bsck or obtusely keeled $p$.

$p$. Leaves undulate or crisped, with 8-7 prominent nerves; fruit $8.5-4.5 \mathrm{~mm}$. long.

Stipules 1-2 cm. long, persisting as shreds; leaves lance-

Stipules short and inconspicuous; leaves from suborbicular to oblong-lanceolate

$p$. Leaves flat, scarcely crisped, with 1 prominent nerve; fruit $2.5-3.2 \mathrm{~mm}$. long; stipules, when developed, short and inconspicuous

i. Leaves linear to setaceous $q$.

q. Leaves ribbon-like, 2 inm. or more wide, with a broad coarsely cellular-reticulate space each side of the midrib .

$q$. Leaves narrower, if occasionally $2 \mathrm{~mm}$. wide, without a broad cellular-reticulate space $r$.

$r$. Le\&ves free from the stipules, or, if elightly adnate to them, bearing globose subsessile or short-stalked spikes in their axils. s.

o. Fruit flat, cochleate; the globular spikes borne in the axils of the principal leaves.

Peduncles equaling or exceeding the spikes

8. Fruit plump; spikes terminal or borne "on the uppermost branches $t$.

$t$. Principal leaves more than $1 \mathrm{~mm}$. broad $u$.

$u$. Leaves with very many fine nerves.

Spikes many-towered, in fruit $1.5-9 \mathrm{~cm}$. long

Spikes 4-8-flowered, in fruit $5-8 \mathrm{~mm}$. long

$u$. Leaves with $3-7$ nerves $v$.

v. Mature fruit $8.5-4.5 \mathrm{~mm}$. long.

Stipules $0.5-1 \mathrm{~cm}$. long; leaves acute; splkes capitate

Stipules 1.2-2 cm. long; leaves obtuse, mucronate; spikes subcylindric-ovoid

v. Mature fruit 2-3 mm. long 20 .

20. Bases of the leaves bearing translucent glands ; fruit plump, obscurely or bluntly keeled.

Leaves 5-7-nerved; stipules 1-2 cm. long

Leaves 3-nerved; stipules less than $1 \mathrm{~cm}$. long

20. Bases of leaves ghandless; fruit flattened, with a thin

t. Principal leaves less than $1 \mathrm{~mm}$. brosd

(30) P. foliosus, v. niagarensis.

$x$. Plant bearing winter-buds formed by the hardened ends of branches closely : avested by imbricated leaves and stipules $y$.

$y$. Winter-buds bora' primarily on very short axillary branches.

Leaves of the winter-buds widely divaricate

Leaves of the wirter-buds loosely ascending

$\boldsymbol{~}$. Winter-buds borne at the tips of elongate branches.

Leaves bristle-form, with very fine slender tips.

Leaves flat or revolute, acute or short-acuininate. Lenves rigid, revolute; winter-buds $1-2 \mathrm{~cm}$. Iong leqves soft; wizter-puds about $1 \mathrm{~cm}$. long
5. P. alpinus.

10. $P$. heterophyllus.

B. P. polygonifolius.

18. P. crispus.

11. $P$. angustifolius.

12. $P$. lucens.

5. P. alpinus.

10. $P$. helerophyllus.

17. P. mysticus.

18. P. prastongus.

14. $P$. Richardsoniz.

15. P. perfoliatus.

16. P. bupleuroides.

4. P. epinydmí.

82. P. hybrialue.

88. P. dimorphus.

19. P. zosterifolius. 20. $P$. acutifolíus.

21. P. Hillit.

22. P. obtusifolius.

28. P. Friesii.

25. P. pusillus. 


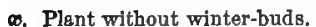

Leaves bi-giandular at base.

Stipules 1-2 cm. long, persistent . - 29. P. mithus.

Stipules less than 1 cul. long, scorcely persistent $\quad 25$, $P$. pusillus.

Leaves glandless at basc.

Spikes short-peduncled, axillary; leaves broader than the diameter of the stems

Spikes long-peduncled, terminal ; leaves narrower than

r. Stipules united with the sheathing base of the lesf; spikes inter80. P. folioeus.

81. $P$. confervoides. rupted $s$.

\%. Leaves at most $8 \mathrm{~mm}$. wide, entire.

Stigma broad and depresseá, sessile.

Stigma nearly central, the ventral face of the fruit curved; leaves filiform, taper-pointed.

Stigma nearly in line with the straightish ventral face of the fruit; leaves narrowly linear, with blunt or rounded thps.

Stigma capitate, tipping the definite style.

Fruit not keeled

Fruit prominently keeled

3. Leaves $48 \mathrm{~mm}$. wide, ciliate-serrulate

\section{P. fliformis.}

85. $P$. interior.

86. $P$. pectinavus.

37. P. interruptus.

88. P. Robbinsii.

1. P. nàtans L. Stem simple or sparingly branched; floating leaves $2.5-10$ cm. long, elliptical or ovate, somewliat cordate at base, obtuse but with a blunt point, 21-29-nerved, flexible at base, as if jointed to the petiole; upper submersed leaves lanceolate, early perishing, the lower (later in the season) very slender (7-18 cm. long, barely $2 \mathrm{~mm}$. wide); upper stipules very long, acute; peduncle about the thickness of the stem; spikes 3-6 cm. long; fruit obliquely obovoid; sides of the turgid seed with a small deep impression in the middle; embryo coiled into an incomplete elliptical ring. - Ponds and quiet streams, common. July-Sept. (Widely distr. in temp. and subtrop. regions.)

2. P. Oakesiànus Robbins. Stem more slender, much branched; floating leaves smaller $(2-5 \mathrm{~cm}$. long), ovate- or oblong-elliptical, obtuse, fewer $(17-23)-$ nerved; lowest submersed ones almost capillary (barely $1 \mathrm{~mm}$. wide), continuing through the flowering season; spikes shorter (1.5-3 cm. long), on peduncles much thicker than stem; fruit smaller and more acute; sides of the seed not at all impressed; curvature of the embryo nearly circular, its apex directed to a point above its base. - Ponds, and especially pools and quiet streams, local, Anticosti to n. N. Y. and N. J. July-Sept.

3. P. polygonifolius Pourret. Stem slender, freely creeping, and sending up short leafy branches; floating leaves elliptic-lanceolate to cordate-ovate, rather thin, 2.5-9 $\mathrm{cm}$. long, 1-4 cm. broad, 11-33-nerved, not apparently jointed to the petioles; submersed leaves (when present) lanceolate, short, mostly exceeding the petioles; stipules blunt, $2-4 \mathrm{~cm}$. long; spikes $2-4 \mathrm{~cm}$. long, very slender; fruit plump, 3-keeled, 1.5-2 mm. long. - Shallow pools, Sable I., N. S. and Nfd. Aug. (Greenl., Eurasia, Afr., Austr.)

4. P. epihỹdrus Raf. Stems compressed, often simple from the creeping rootstocks; floating leaves chiefly opposite (3-7.5 cm. long, 1-2.5 cm. broad), 11-27-nerved, oblong, tapering in to a short petiole, the lower gradually narrowing and passing into the submersed ones, which are very numerous and approximate, conspicuously 2-ranked (5-13 cm. long, 2-6 mm. wide), 5-7-nerved, the lateral nerves slender and nearly marginal, the space within the inner nerves coarsely cellular-reticulated; stipules very obtuse; spikes numerous, about the length of the thickened peduncle; fruit round-obovoid, flattish, 3-keeled when dry, 2.5-3.5 mm. long; seed distinctly impressed on the sides; curvature of the embryo transversely oval. ( $P$. pensylvanicus Willd.; $P$.'Nuttallii C. \& S.) - Still or flowing water. July-Sept.

Var. cayugénsis (Wiegand) Benn. Stouter; floating leaves $5-8 \mathrm{~cm}$. long, 2-3.5 cm. vide, 29-41-nerved; submersed ones less distichous, $1.2-2.2 \mathrm{dm}$. long, 0.5-1 cm. wide, 9-13-nerved; fruit 3.5-4.5 mm. long. - N. B. and Que. to Wash., s. to centr N. Y., Mich., and Ia. (Japan.)

5. P. alpinus Balbis. Stems mnstly simple ; floating leaves (often wanting) 3.5-8 cm. long, rather thin, wedae-oblanceolate, narroved into a short petiole, 11-21-nerved; submersed leaves almost sessile, lanceolate and lance-oblong, 
smooth on the margin, fewer-nerved ; stipules broad, hyaline, obtuse, upper ones acuminate; spike $1.5-3.5 \mathrm{~cm}$. long, often somewhat compound; fruit oboroid, lenticular, pitted when immature, with an acute margin and pointed with the rather long style; embryo incompletely annular. (P. rufescens Schrad.) - In streams or ponds, Lab. to Alaska, s. to Mass., N. J., Mich., Minn., Utah, and Cal. July-Sept. (Greenl., Eurasia.)

$\times$ P. Faxóni Morong from Ferrisburg, Vt, and $\times$ P. REcrifólius Benn. from Chicago, Ill, are infertile hybrids of nos. 5 and 6 .

6. P. americanus C.\& S. Stem often branching below; floating leaves thinnish, lance-oblong or long-elliptical, often acute, long-petioled, 4-11 cm. long, 1-3 $\mathrm{cm}$. wide, 17-23-nerved; submersed leaves very long $(0.8-3 \mathrm{dm}$. long, $0.4-2.5$ $\mathrm{cm}$. wide), lanceolate and lance-linear, 7-15-nerved, coarsely reticulated ; peduncles somewhat thickened upward; fruit obliquely obovoid, obscurely 3-keeled when fresh, and distinctly so when dry, the middle keel winged above and sometimes with 3-5 shallow indentations; the rounded slightly curved face surmounted by the short style; seed with the sides scarcely impressed; upper part of the embryo circularly incurved. ( $P$. fluitans Man. ed. 6 , not Roth ; $\boldsymbol{P}$. lonchites Tuckerm.) - In streams or rarely in ponds, N. B. to B. C. and southw. Aug., Sept. (Eurasia, n. Afr., W. I.)

Var. novaeboracénsis (Morong) Benn. Floating leaves large and thick, broadly elliptic, rounded or obtuse at apez and base, 2.5-4.5 cm. wide. - Ct. to Wisc. (Eu.)

ᄂ 7. P. púlcher Tuckerm. Stem simple (very rarely branched), black-spotted; leaves of three kinds; floating ones becoming very large $(4.5-11) \mathrm{cm}$. long, 2-7 cm. wide), roundish-ovate and cordate or ovate-oblong, 25-37-nerved, all alternate; upper submersed ones (3-5) usuclly lanceolate, acute at base and very long-acuminate, 10-15-nerved, very thin, cellular each side of the midrib, undulate, short-petioled; lowest (2-4 near the base of the stem) thicker, plane, oval or oblong with a rounded base, or spatulate-oblong; on longer petioles; peduncles thicker than the stem; spikes $2-4 \mathrm{~cm}$. long; fruit with a rounded back and angular face, pointed, distinctly 3-keeled when fresh, sharply so when dry; seed with two deep dorsal furrows, and a sinus below the angle in front; sides flat; embryo circularly much incurved above.-Ponds, local, s. Me. to Fla.; and near St. Louis, Mo. June, July.

8. P. amplifolius Tuckerm. Stems simple, of very variable length; floating leaves (sometimes wanting) large, oblong, lance-ovate or broadly elliptic, abruptly acutish, 30-50-nerved, on rather long petioles; submersed leaves often very large (0.8-2 dm. long, $2.5-7 \mathrm{~cm}$. broad), lanceolate or oval, acute at each end, usually much recurved, undulate, mostly on short petioles; stipules very long and tapering to a point, soon becoming loose ; peduncles thickened upward, in deep water much elongated; spikes $3.5-8 \mathrm{~cm}$. long; fruit very large $(4-5.5$ mm. long), rather obliquely obovoid, 3-keeled, with a broad stout beak; seed slightly impressed on the sides; upper part of the embryo curved into a ring. Ponds and rivers, N. S. to B. C., s. to N. J., Ky., Kan., and Cal. July-Sept.

9. P. illinoénsis Morong. Stem stout, branching towards the summit; floating leaves opposite, oval or elliptic $(0.5-1.5 \mathrm{dm}$. long, 4-9 cm. broad), 19-27-nerved, rounded or narrowed at base, with a short blunt point, on short petioles; submersed leaves oblong-elliptical, acute at each end, usually ample (1-2 dm. long); stipules coarse, obtuse, strongly bicarinate (5-7 cm. long); peduncles often clustered at the summit, thickening upward; spikes $4-5 \mathrm{~cm}$. long; fruit roundish-obovate ( $3.5-4.5 \mathrm{~mm}$. long), 3-keeled on the back, middle keel prominent; seed flattened and slightly impressed on the sides, obtuse or pointed at base; apex of embryo directed transversely inward. - Streams and ditches, Ill., Ia., and Minn. July, Aug.

10. P. heterophýllus Schreb. Stem slender, very branching below; floating leaves mostly thin, variable, but with a short blunt point, $9-17$-nerved, $1.5-7 \mathrm{~cm}$. long, $0.5-2.5 \mathrm{~cm}$. wide; submersed ones lanceolate, oblanceolate or linearlanceolate, acuminate or cuspidate, narrowed toward the base, some what stiffish, 2.5-8 cm. long, 0.2-1.3 cm. wide, about 7-nerved on the stem and 3-nerved on the branches; upper ones petioled, lower sessile; stipules obtuse, loose ; pedun- 
cles somewhat thickened upward, mostly less than $1 \mathrm{dm}$. long; fruit small $(2.5-3$ $\mathrm{mm}$. long), roundish, compressed, scarcely keeled; embryo annular above. Still or flowing water, common. July-Sept. (Greenl., Lurasia.) - Varies exceedingly in its subrnersed leaves, peduncles, etc. Forma Graminifòmids (Fries) Morong. Steins much elongated and less branched, and the flaccid linear-lanceolate submersed leaves $0.5-1.5 \mathrm{dm}$. long, $2-6 \mathrm{~mm}$. wide; spikes $1.5-$; $\mathrm{cm}$. long. Forma Longipedunculates (Merat) Morong. Subsimple, the internodes very elongate (the uppermost $1-3 \mathrm{dm}$. long); submerged leaves lanceolate; peduncles 1-2.5 dm. long. - Nfd, to Ct., Mich., and westw. Forma MYRIOPHÝrLus (Robbins) Morong. Sending up from running rootstocks many short repeatedly dichotomous and densely leafy stems; fertile stems very slender; floating leaves small, delicate, lance-oblong, on long filiform petioles; submersed stem-leaves larger, early perishing; those of the branches (deep green) linear-oblanceolate, very small (1.5-3 cm. long, $2-4 \mathrm{~mm}$. wide), acute; spike slender, loosely flowered, $1.2-2.5 \mathrm{~cm}$. long. - N. E. Forma máximus Morong. Floating leaves $0.6-1.6 \mathrm{dm}$. long, $1-8 \mathrm{~cm}$. wide, very acute; subraersed leaves $0.5-1.6 \mathrm{dm}$. long, $0.6-1.6 \mathrm{~cm}$. wide, 5-9-nerved. Forma terrésTRIS Schlecht. Freely creeping in exsiccated places, producing numerous very short branches which bear tufts of oblong or oval coriaceous leaves but no fruit. - Que. and N. E.

11. P. angustifolius Berchtold \& Presl. Resembling P. lucens, but smaller, slender, much branched at base ; upper leaves coriaceous or subcoriaceous, longpetioled and sometimes emersed, 0.4-1 dm. long, 1-2.5 cm. wide, 13-21-nerved; the others subsessile, all usually numerous, lanceolate or oblanceolate, mucronate, undulate and crisped, shining, $0.5-1.5 \mathrm{dm}$. long, $0.5-3 \mathrm{~cm}$. broad, 7-17nerved; stipules obtuse, $1.5-4 \mathrm{~cm}$. long; peduncle elongated; fruit distinctly 3-keeled, $3-4 \mathrm{~mm}$. long. (P. Zizii Mertens \& Koch.) - Lakes, rarely streams, local, Mass. to Mich., westw. and southw. June-Sept. (W. I., Eurasia, Afr.) Var. Connecticutésis (Robbins) Benn. Larger throughout; leaves all submersed; fruit 4-4.5 mm. long. (P. lucens, var. Robbins.) - Lakes, Vt., Ct., and e. N. Y.

$\times P$. Spathanfórmis Tuckerm. ( $P$. spathulaeformis Morong) in Mystic Pond, Medford, Mass., is an infertile hybrid of nos. 11 and 10.

12. P. lùcens L. Stem thick, branching, sometimes very large; leaves all submersed and similar, more or less petioled, oval or lanceolate, mucronate, often crisped, frequentily shining, 6-20 cm. long, about 13-nerved; peduncles often elongated ; fruit roundish and compressed, with obtuse margins, scarcely keeled; embryo circularly incurved above. - Ponds, local, N. S. to Fla., w. to the I'acific. Aug.-Oct. (Mex., W. I., Eurasia, n. Afr.)

13. P. praelóngus Wulf. Stem white, very long, branching, flexuous; leaves bright green, lance-oblong or lanceolate $(0.5-3 \mathrm{dm}$. long), half-clasping, obtuse with a boat-shaped cavity at the extremity, thence splitting on pressure; stipules white, scarious, very obtuse, $1.5-8 \mathrm{~cm}$. long ; peduncles very long (sometimes reaching $5 \mathrm{dm}$.); spikes rather loose-flowered; fruit obliquely obovoid, compressed, sharply keeled when dry, 4-5 mm. long; style terminating the nearly straight face; curve of the embryo oval and longitudinal. - Ponds and lakes, N. S. to B. C., s. to Ct., N. J., the Great Lakes, Ia., Mont., and Cal. Fruiting in June and July, withdrawing the stems to deep water to mature the fruit. (Eurasia.)

14. P. Richardsonii (Benn.) Rydb. Stem branching; leaves long-lanceolate from a cordate-clasping base, acuminate, wavy, pale bright green, 3-11 cm. long, 13-23-nerved; stipules conspicuous, at least as sureds; peduncles thickened upward, of somewhat spongy texture, elongating sometimes to $1 \mathrm{dm}$. or more; spikes $1.5-3.5 \mathrm{~cm}$. long; fruit irregularly obovoid, distinctly beaked, obscurely 3-keeled, $4 \mathrm{~mm}$. long, the green epicarp puckered in drying. ( $P$. perfoliatus, var. lancenlatus Robbins.) - Quiet water, Que. to Mackenzie and B. C., s. to N. E., N. Y., the Great Lake region, Neb., etc. July-Sept.

15. P. perfoliatus L. Similar; leaves orbicular, ovate or lanceolate from $a$ cordate-clasping base, usually obtuse and crisped, 2-6 cm. long, 15-27-nerved; stimules raply leveloped, less than $1 \mathrm{~cm}$. long; pednneles spongy and thichish, 
3-4 cm. long; spikes 2-2.5 cm. long; fruit similar. - Ponds and slow streams, local, N. E. to the Great Lakes. Sept., Oct. (Eu.)

16. P. bupleuroides Fernald. Very slender, branching; leaves orbicular to lanceolate, obtuse, flat, not crisped, drying blackish green or bronze, $1-3.5 \mathrm{~cm}$. long, 7-17-nerved; stipules rarely developed, appressed and inconspicuous; pechuncles slender, scarcely spongy, 2-6 cm. long; spikes $0.7-2 \mathrm{~cm}$. long; fruit narrowly obovoid, 2.5-3.2 $\mathrm{mm}$. long, the sides flat and deeply pitted, the back rounded, slightly 3 -keeled; style slender and prominent; the olive or brownish cpicarp closely investing the seed. ( $P$. perfoliatus Man. ed. 6, in part, not L.) - Brackish, occasionally fresh, ponds and quiet streams, Nfd. and e. Que. to Fla., rarely inland to w. N. Y. and Mich. July-Sept.

$\times \mathrm{P}$. Mìtens Weber and plants closely simulating it in America are infertile and appear to be hybrids of no. 10 with no. 14,15 , or 16.

17. P. mýsticus Morong. Stem very slender and irregularly branching, nearly filiform; leaves oblong-linear (1.5-4 cm. long, 4-6 mm. wide), 5-7nerved, finely undulate and entire, obtuse or bluntly pointed, abruptly narrowing at base, sessile or partly clasping; spikes few, capitate (4-6-Howered), on erect peduncles; fruit (immature) obovoid, small (less than $2 \mathrm{~mm}$. long), obscurely 3-keeled on the back, a little beaked by the slender recurved style. Locally in brackish ponds, Mass. and Md. - Infertile, and probably a hybrid of nos. $16^{\circ}$ and 25.

18. P. Crfspus L. Stem compressed; leaves linear-oblong, sessile or halfclasping, obtuse, serrulate, crisped-qoavy, 3-5-nerved; fruit long-beaked; upper portion of the embryo incurved in a large circle. - Fresh or brackish waters, Mass. to Ont. and Va. . June, July. - l'ropagating chiefly by bur-like winterbuds formed by hardened abbreviated branches and indurated bases of leaves. (Nat. from Eu.)

19. P. zosterifolius Schumacher. Stem branching, wing-flattened; leaves linear and grass-like (0.5-2 dm. long, 2-4 mm. wide), abruptly pointed, with many fine and 3 larger nerves; stipules oblong, very obtuse ; spikes cylindrical, 12-15. flowered, not half so long as the peduncle; fruit obliquely obovoid, $3.5-4.5 \mathrm{~mm}$. long, somewhat keeled and with slight teeth on the back, the sides not inpressed, the face arching and terminated by the short style; summit of the large embryo lying transverse to the fruit. - Still and slow-flowing waters, N. B. to B. C., s. to N. J., the Great Lake region, Ia., etc. June-Aug. - Freely propagating by large winter-buds.

20. P. acutifdlius Link. Similar; leaves many-nerved, sharp-acuminate; spices globose, 4-8-flowered; fruit conspicuously crested, the sides flat. - Collected at Lancaster, Pa., by Muhlenberg nearly a century ago; not since found in Am. July, Aug. (Eurasia, Austr.)

21. P. Híllii Morong. Stem slender, widely branching, flattish; leaves linear, acute (2.5-6.5 cm. long, 1-2.2 mm. widle), 3-nerved, the lateral nerves delicate and near the margin; stipules whitish, striate, obtuse; spikes capitate (3-6-fruited), on short spreading or recurved peduncles; fruit as in the last, but the sides rounded. - Lakes and ponds, Ct. to Pa., Mich., and Ont. July, Augr.

22. P. obtusifdlius Mertens \& Koch. Stem flattened, very branching; leave: linear, tapering toward the base, obtuse and mucronate, $1.5-3.5 \mathrm{~mm}$. broad, 3 (rarely 5 or 7 )-nerved, bearing 2 large translucent glands at base ; spike continuous, 5-8-flowered (8-24-fruited, most of the carpels maturing), about the length of the peduncle; fruit ovoid, apiculate with the style, not keeled when fresh, upper portion of embryo coiled inward and lying transverse to the fruit.Clear streams and ponds, e. Que. to Athabasca, s. to e. N. Y., Pa., Mich., Wisc., Minn., and Wyo. July-Sept. - Freely propagating by large winter-buds. (Eurasia.)

2\%. P. Frièsii Rupr. Resembling no. 25; stem more flattened and less branching; leaves broader (1-3 mm. wide), 5-7-nerved; winter-buds abundant; stipules conspicuous, white-hyaline ; glands small and dull; spikes interrupted, in fruit $0.8-1.6 \mathrm{~cm}$. long. ( $P$. mucronatus Man. ed. 6, not Schrad.?) -Local. P. E. I. to B.C., s. to Ct.. N. Y.. Mich.. Wisc., Minn., and N. Dak. July, Aug. (Eu.) 
24. P. strictifolius Benn. Stems slender, wiry, simple below, freely and stiffly branched above, the ascending branches mostly tipped by large winterbuds; leaves spreading-ascending, very rigid, 2-3.5 cm. long, 0.4-1 mm. wide, revolute, 3-nerved, the central nerve prominent; stipules as long as the upper internodes, appressed and veiny; peduncles rigid; spikes slightly interrupted, 6-10 mm. long, 3-8-fruited ; fruit obliquely eilipsoidal, $2 \mathrm{~mm}$. long, plump and rounded on the back, the style nearly in line with the straightish ventral face. (P. pusillus, var. pseudo-rutilus Benn.) - Que. to e. Mass., and Mich. JulySept. - Perhaps a variety of no. 25.

25. P. pusíllus L. Stem stender, flattish or nearly cylindrical, often very branching; leaves narrow-linear, acute or subacute, 2-6 cm. long, 0.5-1.5 mm. wide, 3-nerved, furnished with translucent glands on each side at the base; winter-buds occasional ; stipules at first obtuse, soon deciruous; spikes interrupted or capitate, 2-10-flowered, on rather long $(0.5-3 \mathrm{~cm}$.) peduncles ; fruit obliquely ellipsoid, scarcely keeled, 1.5-2 mm. long; apex of embryo incurved and directed obliquely downward. - Yools, ditches, and ponds, generally distr. July-Sept. (Eurasia, Trop. Am.) Passing freely to the following varieties.

Var. tenuíssimus Mertens \& Koch. Leaves setaceous, 0.2-0.5 mm. wide, 13-nerved. - Range of species.

Var. polyphýllus Morong. A dwarf bushy-branched sterile plant, bearing very abundant winter-buds. - Ponds, Me. and Mass.

Var. capitàtus Benn. Internodes very long, inostly much exceeding the leaves; peduncles elongate, mostly 3-6 cm. long. - P. E. I. and N. S. to Sask., B. C., and Ore.

Var. Sturróckii Benn. Leaves obtuse, pellucid ana bright green, 0.8-2 mm. broad; fruit smaller than in the species. - Gaspé Co., Que., to Ct.

26. P. lateràlis Morong. Plants of two sorts, only the fruiting producing floating leaves; stem filiform, branching; floating leaves elliptical $(0.8-1.2 \mathrm{~cm}$. long, 2-4 mm. wide), with 5-7 nerves deeply impressed beneath, tapering into a somewhat dilated petiole; submersed leaves linear, acute $(2.5-7 \mathrm{~cm}$. long, $0.2-$ $0.9 \mathrm{~mm}$. wide), 1-3-nerved, the midnerve with fine veins or cellular reticulations on each side, bi-glandular at base; stipules short, deciduous; peduncles videly spreading at maturity, sometimes even recurved, often thicker than the stem ; spikes often interrupted (2-4-flowered); fruit obliquely obovoid (hardly $2 \mathrm{~mm}$. long), the back much curved, with two fine grooves upon it; embryo oval in its curve, the apex nearly tonching the base.-Mass. and $\mathrm{Ct}$. to Mich.; rare. July, Aug. - Undeveloped specimens resemble no. 25. Propagated by winter-buds on short lateral branches.

27. P. Vasèyi Robbins. Similar; very delicate; stem almost capillary; floating leaves obovate (0.7-1.4 cm. lnng, 3-6.5 mm. wide), the length of their filiform petioles, with 5-9 nerves deeply impressed beneath, cross-veins distinct; submersed leaves filiform-linear, very attenuate $(2.5-5 \mathrm{~cm}$. long, $0.1-0.5 \mathrm{~mm}$. wide) and acute; stipules scarious, long, acute; spikes all emersed, few, interrupted-cylindric, 3-5-flowered, on a thickish peduncle; fruit oblique, roundobovoid, compressed, slightly sharp-margined, tipped with a distinct recurved style, the sides impressed and face acute; upper portion of the embryo circularly incurved, its apex transverse to the fruit. - Me. to Ont., s. to Ct., N. X., O., Ill., and Minr., local. June-Aug. - The fruiting form, with floating leaves, rare; the submerged form, bearing winter-buds, apparently much more abundant.

28. P. gemmíparus Robbins. Stem filiform, branching, terete, varying greatly in height; leaves hair-like, sometimes not as broad as the stem, often with no apparent midrib, tapering to the finest point (1.5-8 cm. long), bi-glandular at base; stimules $1.2-2.5 \mathrm{~cm}$. long, obtuse, early deciduous; spikes few (36-flowered), interrupted, on long filiform peduncles; winter-buds very numer. ous; fruit like that of $P$. pusillus, but flattened and impressed on the sides, very rare. - Slow-moving streams and still water, centr. Me. to R. I., local. Aug., Sept.

29. P. rùtilus Wolfgang. Stems very slender, simple or slightly branching at base; winter-buds usually wanting; leaves erect, narrowly linear, attenuate, 
sharp-acuminate, soon revolute, 3-5-nerved, the prominent midnib often compound, bi-glandular at base; stipules 1-2 cm. long, acuminate, scarious and strongly nerved, persistent; peduncies $1.3-3.5 \mathrm{~cm}$. long ; spikes elongate, 6-8flowered; fruit narrowly oblique-obovold, about $2 \mathrm{~mm}$. long, the erect style nearly in line with the straightish ventral face.-Gaspe Co., Que., to Hudson Bay, s. to Me., Vt., Mich., and Minn., local. (Eu.)

30. P. foliosus Raf. Stem filiform, fattish and very branching; leaves narrowly linear (2-6 cm. long, $0.3-1 \mathrm{~mm}$. wide), acute, obscurely 3-nerved; stipules obtuse; spilies capitate, 1-4(usually 2)-flowered, on shor t club-shaped peduncles ; fruit roundish-lenticular, the back more or less crested; upper portion of the embryo incurved in a circle. ( $P$. pauciflor N.E. to B.C., and southw. July-Sept.

Var. niagarénsis (Tuckeim.) Morong. Stem often longer; leaves larger (4-9 cm. long, 1-2.4 mm. wide), 3-5-nerved at base, very acute and mucronate, narrowed to the subpetiolate base. - Rumning water, Me. to Ont., and southw,; also in Cal.

31. P. confervoides Reichenb. Very slender and delicate from a creeping rootstock, of a fine light green; stem filiform with several short and repeatedly dichotomous leaf-bearing branches; leaves flaccid, thin and flat, but setaceons and tapering nearly to the fineness of a hair $(2.5-6.5 \mathrm{~cm}$. long, 0.1-0.5 $\mathrm{mm}$. wide), obscurely 1-3-nerved, with a few coarse reticulations; stipules rather persistent below, $5 \mathrm{~mm}$. long, obtuse; peduncle solitary, very long $(0.5-2 \mathrm{dm}$.), rather thickened upward; spite 4-8-fluwered, in fruit continuous, cylindrical; fruit thick-lenticular, obscurely 3-keeled; seed slighlly impressed on the sides; epicarp thick and hard; embryo nearly anmular. (P. Tuckermani Robbins.) Cold ponds, local, Me. to N. Y., N. J., and Pa. June-Aug.

32. P. hýbridus Michx. Floating leaves (when present) oval to lance-oblong (the largest $2.6 \mathrm{~cm}$. long, $1.2 \mathrm{~cm}$. wide), often acute, longer than the filiform petioles, with about 5-7 nerves beneath deeply impressed; submersed leaves very numerous, almost setaceous (2-7 cm. long, $0.1-0.5 \mathrm{~mm}$. wide); stipules obtuse, adnate to the base of the lower leaves; emersed spikes $0.5-1.5 \mathrm{~cm}$. long; submersed spikes 1-4-flowered, their peduncles frequently recurved; fruit about $1 \mathrm{~mm}$. long, about 8-toothed on the margin, the lateral keels smooth; embryo coiled 1 turns. ( $P$. diversifolius Raf.) - Shallow quiet waters, Me. to Fla.; also Mich. to Mont. and Tex. July-Sept. (Mex., W. I, ) Var. Molti-denticuLATus (Morong) Asch. \& Graebn. Fruit 12-toothed on the margin, the lateral keels 6-8-toothed. - Ct. to Fla. and La.

33. P. dimórphus Raf. Coarser; blades of the floating leaves with rather dilated petioles, with 5-many nerves beneath deeply impressed ; upper submersed leaves either with or without a lance-oblong or broad-linear proper blade; the numerous lower ones narrow-linear, tapering toward the obtuse apex $(2-4 \mathrm{~cm}$. long, about $1 \mathrm{~mm}$. wide); stipules early lacerate; submersed flowers 1-4, on very short erect peduncles; fruit with the back either winged and with 4-5 distinct teeth or wingless and entive; embryo coiled $1 \frac{3}{4}$ turns. ( $P$. Spirillus Tuckerm.) - N. B. to Ont., s. to Va., W. Va., and Mo. June-Sept.

34. P. filiformis Pers. Stems from elongate tuberiferous rootstocks, filiform, branching at base, low and very leafy; leaves pale, filiform, less than $0.5 \mathrm{~mm}$. wide; peduncles much elongated and overtopping the leaves (in one form shorter); spikes of 2-5 whorls, the lowest whorls $0.6-1.5 \mathrm{~cm}$. apart; fruit 2.5-3 mm. long, globose-obovoid, not keeled upon the rounded back, tipped with the broad sessile stigma; embryo annular. ( $P$. marinus auth., not L. ?) Shallow water in calcareous regions, e. Que. to Alb., s. to n. Me., n. Vt., w. N. Y., Mich., and the Rocky Mts. July-Sept. (Eurasia, Afr., Austr.)

35. ' $\mathbf{P}$. intềrior Rydb. Coarser; the comparatively stout stems flattened, freely branching above, elongate ; leaves dark green, narrowly linear, 0.5-2 mm. wide; peduncles of various lengths; spikes of 4-9 whorls, the upper whorls crowded, the lowest 4-9 mm. cpart; fruit compressed, narrowly oblique-obovoid. the ventral face straightish. (P. filiformis, vars. Macounit and occidentalis Morong.) - Mostly in brackish water, P. E. I. ; Huds. B. to Assina. and Athabasca, s. to Neb., Col., and Nev. July-Sept. 
36. P. pectinatus L. Stem filiform, repeatedly dichotomous; leaves very narrowiy linear or setaceous, attenuate to the apex, 1-nerved wilh a tew transverse veins; peduncles filiform; spikes of $2-6$ remote whorls; finctit obliquely broad-obovoid, compressed, 3.5-4.5 $\mathrm{mm}$. long, rounded on the back, obscurely ridged on the sides; embryo spirally incurved - Chiefly in brakish water, e. Que. to B. C., s. along the coast to Fla., and in the interior to Pa., the Great Lake region, Kan., Col., etc. July-Sept. (Cosmop.)

37. P. interrúptus Kitajbel. Similar; leaves usiıally broader $(0.5-2 \mathrm{~mm}$. wide); edges of the stipules less scarious; fruit more compressed, sharply keeled. - Coast of e. N. B.; Mich.; probably of wide distrib. July-Sept. (Eu.)

38. P. Robbínsii Oakes. Stem ascending from a creeping base, rigid, very branching, invested by the bases of the leaves and stipules; leaves crowded in two ranks, recurved-spreading, narrow-lanceolate or linear, 7-12 em. long, acuminate, ciliate-serrulate with translucent teeth, many-nerved; stipules obtuse when young, their nerves soon beconing bristles; spikes numerous, loosely fewflowered, on short peduncles; fruit oblong-obovoid, keeled with a broadish wing, acutely beaked; embryo stout, ovally annular. - In quiet water, N. B. to B. C., s. to Del., Pa., Ind., Wyo., Ida., and Ore. ; rarely fruiting. July-Sept.

\section{RÚPPia L. Ditch Grass}

Flowers 2 or more (approximate on a slender spadix, which is at frst inclosed in the sheathing spathe-like base of a leaf), consisting of 2 sessile stamens, each with 2 large and separate anther-cells, and 4 small sessile ovaries, with solitary campylotropous suspended ovules; stigma sessile, depressed. Fruit small obliquely ovoid pointed drupes, each raised on a slender stalk which appears after flowering; the spadix itself also then raised on an elongated thread-form peduncle. Embryo ovoid, with a short and pointed plumule from the upper end, by the side of the short cotyledon. - Marine herbs, growing under water, with long and thread-like forking stems, and slender almost capillary alternate leaves sheathing at the base. Flowers rising to the surface at the time of expansion. (Dedicated to H. E. Ruppius, a German botanist of the 18th century.)

1. R. maritima L. Leaves linear-capillary; fruit obliquely erect; fruiting peduncles capillary ( $1-3 \mathrm{dm}$. long) ; stipes $0.5-4 \mathrm{~cm}$. long. - Shallow bays and streams, along the entire coast; also occasionally in saline places in the interior. (Cosmop.)

\section{ZaNNICERtila [Mich.] L. Horned Pondweed}

Flowers monoecious, sessile, naked, usually both kinds from the same axil ; the sterile consisting of a single stamen, with a slender filament bearing a 2-4celled anther; the fertile of $2-5$ (usually 4 ) sessile pistils in the same cup-shaped involucre, forming obliquely oblong nutlets in fruit, beaked with a short styje, which is tipped by an obliquely disk-slaped or somewhat 2-lobed stigma. Seed orthotropous, suspended, straight. Cotylednn taper, bent and coiled. - Slender branching herbs, growing under water, with mostly opposite long and linear thread-form entire leaves, and sheathing membranous stipules. (Named in honor of $G$. $G$. Zannichelli, a Venetian botanist.)

1. 1. Z. pa! ústris L. Style at least balf as long as the fruit, which is flattish, somewhat nilcurved, even, or occasionally more or less toothed on the back (not wing-margined in our plant), nearly sessile; or, in var. PEdunculdrA J. (ny, both the clister and the separate fruits evidently peduncled. - Ponds and slow streams, chiefly brackish, throughout N. A. July. (Cosmop.)

\section{4. zostèra L. Grags Wrack. Ege Grass}

Flowers monoecious; the two kinds naked and sessile ancl alternately arranged in two rows on the midrib of one side of a linear leaf-like spadix, which is hidden in a long and sheath-like base of a leaf (spathe); the sterile flower's consisting of single ovate or oval 1-celled sessile anthers, as large as the ovaries, 
and contain:ing a tuft of threads in place of ordinary pollen; the fertile of single ovate-oblong ovaries attached near their apex, tapering upward into an awlshaped sty: and bristle-form, deciduous. Utricle bursting irregularly, inclosing an oblong longitudinally ribbed seed (or nutlet). Embryo short and thick (proper cotyledon almost obsolete), with an open chink or cleft its whole length, from which protrudes a doubly curved slender plumule. - Grass-like marine herbs, growing wholly under water, from a jointed creeping stem or rootstock, sheathed by the bases of the very long and linear obtuse entire grass-like ribbon-shaped leaves (whence the name, from $\xi \omega \sigma \tau \eta \rho, a$ belt).

1. Z. marina $\mathrm{L}$. Leaves obscurely 3-5-nerved. - Shoal water of bays along the coast, Nfd. to Ela. ; Pacific coast. (Eurasia.)

\section{NAJJAS L. NAIAD}

Flowers dioecious or monoecious, axillary, solitary, and sessile; the sterile consisting of a single stamen inclosed in a little membranous spathe; anther at first nearly' sessile, the filameut at lengtlis clongated. Fertile flowers consisting of a single ovary tapering into a short style; stigmas 2-4, awl-shaped; ovule erect, anatropous. Fruit a little seed-like nutlet, inclosed in a loose and separable membranous epicarp. Embryo straight, the radicular end downward. Slender branching herbs, growing under water, with opposite and linear leaves, somewhat crowded into whorls, spiuulose-toothed, sessile and dilated at base. Flowers very small, solitary, but often clustered with the branch-leaves in the axils; in summer. (Naiás, a water-nymph.)

1. N. marina L. Stem rather stout and often armed with broad prickles; leaves broadly linear ( $2 \mathrm{~mm}$. lroad), coarsely and sharrly toothed, the dilated base entire; fruit 4-5 mm. long; seed very finely lineate, oblong, slightly compressed. - Marshes and salt springs of w. N.Y., Micl., and Minn.; Fla.; Utah to Mex. - Teeth of one or more brownish cells upon a many-celled base. (W. I., Eurasia, Austr.)

Var. grácilis Morong. Internodes long (5-8 cm.) and nearly naked, with only a few teeth above; leaves very narrow $(0.5 \mathrm{~mm}$. wide) with $8-12$ teeth on each margin, the dilated base also toothed ; fruit smaller. - Canoga marshes, w. N. Y.; Fla.

Var. recurvata IJudley. Stems short, inclined to be dichotomously branched, recurved-spreading; leaves usually recurved, the teeth prominent, 2-7 on each margin, the dilated base with a projecting tooth each side. - N. Y.; Utah and Ariz.

2. N. fléxilis (Willd.) Rostk. \& Schmidt. Stems usually very slender; lerves very narrowly linear (less than $1 \mathrm{~mm}$. wide), very minutely serrulate, tapering gradually to the serrulate base; fruit $2.5-3 \mathrm{~mm}$. long, narrowly oblong; seeds lance-oval, smooth and shining. - Ponds and slow streams, Lab. to B. C., s. to S. C. and Mo. - T'eeth on the margins of the leaves 1-celled. (Eu.) Var. robústa Morong. Stem stout, few-leaved, sparsely branching, elongated; leaves flat, strongly ascenrling, linear-tapering. - Mass, to Mich. and Tex.

V.). N. guadalupensis (Spreng.) Morong. Similar; leaves with 20-45 very minute teeth on each margin; fruit $2 \mathrm{~mm}$. long; seeds dull, conspicucusly reticulate. ( $N$. microdon A. Br.) - Pa. to Neb., and southw. (Trop. Am.)

4. N. gracillima (A. Br.) Magnus. Branches alternate; leaves very nalrowly linear, nearly capillary, straight, serrate, the rounded labes of the sheathing base spinulose-ciliate; fruit linear, impresseb-dotted betreen the numerous ribs. (N. indica, var. A. Br.) - Local, e. Mass. to e. N. Y., N. J., and Pa. ; Mo. - Teeth of 3 cells each.

\section{JUNCaginaceate (Arrow Grass Familt)}

Marsh plants, with terete bladeless leaves. Flowers perfect, spicate or racemose, with herbaceous 6 (rarely 3 )-lobed perianth. Carpels 3 or 6 , more or less united, separating at maturity. Seeds anatropous; embryo straight. Fr"uit follicular or capsular. 
1. Scheuchzeria. Ovaries 3 , nearly distinct, at length divergent. Flowers bracteate, in a loose raceme upon a leafy stem.

2. Triglochin. Ovaries 3-6, united until maturity. Lesves radical. Flowers bractless, in a spike-like raceme terminating a jointlese scape.

\section{SCHEUCHZÈRIA L.}

Sepals and petals oblong, spreading, nearly alike (greenish yellow), but the latter narrower, persistent. Stamens 6 ; anther's linear. Ovaries \&, globular, slightly united at base, 2-3-ovuled, bearing flat sessile stigmas, in fruit forming 3 diverging and inflated 1-2-seeded pods, opening along the inside. - A low bogherb, with a creeping jointed rootstock, tapering into the ascending simple stem, which is zigzag, partly sheathed by the bases of the grass-like conduplicate leaves, and termimated by a loose raceme of a few flowers, with sheathing bracts; leaves tubular at the apex. (Named for Johann and Johann Jacob Scheuchzer, distinguished Swiss botanists early in the 18th century.)

1. S. palústris L. - Peat-bogs, and wet shores, e. Que. to N. J., westw. across the continent. June. (Eurasia.)

\section{TrigldChIN L. Arrow Grass}

Sepals and petals nearly alike (greenish), ovate, concave, deciduous. Stamens 3-6; anthers oval, on very short filaments. Pistils united into a 3-6celled compound ovary; stigmas sessile; ovules solitary. Capsule splitting when ripe into 3-6 carpels, which separate from a persistent central axis. Perennials, with rush-like fleshy leaves below sheathing the base of the wandlike naked and jointless scape. Flowers small, in a spiked raceme, bractless. (Name composed of $\tau p \in \hat{\imath}$, three, and $\gamma \lambda \omega \chi\langle\nu$, point, from the three points of the ripe fruit in no. 3 when dehiscent.)

Fruit thicker than long

Fruit longer than thick.

Fruit (with $8=6$ carpels) ovoid-prismatic, about twice as long as thick . . 2. T. mamitima.

Fruit (8-carpelled) clavate- or linear-prismatic, 8-5 times as long as thick.

- 1. T. striata.

- 8. T. palustris.

1. T. striàta R. \& P. Scape $(8-34 \mathrm{~cm}$. high) and leaves slender ; flowers very small; sepals and stamens 3 ; fruit globose-triangular, or when dry 3-lobed. ( $T$. triandra Michx.) - Salt marshes, near seashore, Md. to Fla. and La. (S. A.)

2. T. marítima L. Scape (1.5-7.5 dm. high) and leaves thickish; fruit ovoid or short-prismatic, acutish; carpels 3- (more often) 6, rounded at base and slightly grooved on the back, the edges acutish. - Salt marshes near the coast, Lab. to N. J., and in saline, boggy, or wet places across the continent. (Eurasia., n. Afr.)

3. T. palístris L. Scape $(5-50 \mathrm{~cm}$. high) and leaves slender ; stamens 6 ; fruit linear-club-shaped; carpels when ripe separating from below upward, leaving a triangular axis, awl-pointed at base.-Marshes (usually brackish) and bogs, Greenl. to the coast of s. Me.; also inland along the St. John and St. Lawrence R., Great Lakes and northwestw. (Eurasia.)

\section{ALISMÀCEAE (WATER-PLANTAin Familt)}

Marsh herbs, with scape-like stems, sheathing leaves, and perfect, monoecious, or dioecious flowers; perianth of 3 herbaceous persistent sepals and as many (often conspicuous) white deciduous petals, which are imbricate or involute in bud; stamens 6 or more, included; ovaries numerous, distinct, 1-celled and mostly 1-ovuled, becoming achenes in fruit (in our genera); seeds erect, campylotropous. - Roots fibrous; leaves radical, petiolate and strongly nerved with transverse veinlets, the earlier sometimes without blade ; flowers long-pedicellate, 
mostly verticillate, in a loose raceme or panicie, with lanceolate scarious bracts slightly connate at base.

1. Sagittaria. Monoecious (or dloecious), lower (Arst developed) flowers pistillate, the upper (later) ones staminate. Stamens indefinite, mostly numerous. Carpels strongly flattened, in a dense head.

2. Lophotocarpus. Polygamous; lower flowers perfect, the upper staminate, Stamens 9-15. Carpels strongly Hattened, in a dense head.

8. Echinodorus. Flowers all perfect. Stamens 6-21, mostly definite. Carpels somewhat turgld, in a dense head.

4. Alisma. Flowers all perfect. Stamens usually 6. Carpels strongly flattened, in a single riag.

\section{SAgitTÁRIA I. ARrow-hEAD}

Sepals loosely spreading or reflexed in fruit. Petals imbricated in the bud. Ovaries crowded in a spherical or somewhat triangular depressed head on a globular receptacle, in fruit forming flat membranaceous winged achenes. Marsh or aquatic, mostly perennial, stoloniferous herbs, with milky juice; the scapes sheathed at base by the bases of the long cellular petioles, of which the primary ones, and sometimes all, are destitute of any proper blade (i.e. are phyllodia); when present the blade is arrow-shaped or lanceolate. Flowers produced all summer, whorled in threes, with membranous bracts. (Name from sagitta, an arrow, from the prevalent form of the leaves.)

a. Beak of the achene erect or nearly so $b$.

b. Beak long, usually half to three-fourths the length of the body.

Leaves babitually sagittate, the basal lobes nearly or quite as long as the terminal portion of the blade.

Stout; leaf-blades broadly ovate-oblong . . . . . 1. S. longirostra.

Slender; lenf-blades linear : : : : : 8. S. Engelmanniana.

Leaves lanceolate to elliptical, the basal lobes when present
much shorter than the terminal portion.$\quad$ 8. S. heterophylla.

b. Beak very short, not one-fourth the length of the body.

Leaves all or most of them sagittate, ovate.

Lowest bract $0.5-1.5 \mathrm{~cm}$. long ; leaf-blades $2-18 \mathrm{~cm}$. long

Lowest bracts $2-4 \mathrm{cr}$. loug; leaf-blades $2.5-5 \mathrm{dm}$, long .

Leaves never sagittate.

Fruiting pedicels thickish, recurved

Fruiting pedicels slender, ascending or epreading

a. Beak of the achene strongly incurved, alluost or quite horizontal $c$.

c. Leaves habitually sagittate, the basal lobes nearly or quite as long as the terminal portion

c. Leaves linear to elliptic-ovate, entire or rarely sagittate at the base, the basal lohes when present much shorter than the terminal portion of the blade.

Fertile pedicels thickened, recurved ; western

Fertile pedicels slender, ascending or spreading. -

Filaments thickened at the base, short

Filaments slender, longer than the anthers, pubescent

Filaments slender, longer than the anthers, glabrous

\section{S. arifolia. \\ - 5. Srevirostra. \\ 11. S. subulata. \\ 10. S. teres.}

\section{S. latifolla.}

12. S. platyphylla.

9. S. graminea.

6. S. lancifolia.

7. S. ambigua.

\section{* Filaments numprous, narrow, as long as or longer than the linear-oblong anthers; bracts 3, distinct; fruiting heads large.}

1. S. longiróstra (M. Micheli) J. G. Sm. Robust, $3-6 \mathrm{dm}$. high, monoecious ; leaves broadly ovate-oblong, obtusish, sagittate with broad basal lobes; fertile whorls 2-4; fertile pedicels about $1 \mathrm{~cm}$. long; body of the mature achene obovate, winged all round, $3 \mathrm{~mm}$. long, the beak nearly erect from the inner angle, 1.5 -2 mm. long. - About springs, etc., Ct. (Harger), N. J., and Pa. to Ky., Del., and Ala. Fig. 33.

2. S. latifolia Willd. Glabrous; scape 1-9 dm. high, angled, with one or more of the lower whorls fertile; leaves ovate, acute, almost always sagittate, the basal lobes triangular, acute; pericels of the fertile flowers at least half the length of the sterile ones; petals wholly white; filamenis glabrous, nearly twice the length of the anthers; achenes obovate (about $2 \mathrm{~mm}$. long),

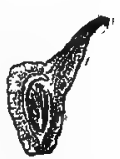

38. S. longlrostra Achene $\times 3$.

GRAY'S MANUAI - 6 
winged on both margins, with a curved usually horizontal beak. (S. variabil Iningelm.) - In water or wet places, very common; exceedingly variable as to leaf-contour. FIG. 34. The following forms, although ill defined,

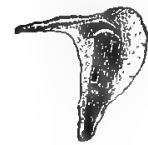

84. S. latifulit.

Achene $\times 8$. are in most instances recognizable: Forma oвTưsa (Muhl.) Robinson. (S. obtusa Muhl.) Leaves very broad, sagittate, obtuse. Forma mastàta (Pursh) Robinson. (S. hastata Pursh.) Jeaf-blades and their basal lobes oblong-lanceolate, acute. Forma GRACILIs (Pursh) Robinson. ( $S$. gracilis Pursh.) Leaf-blades and their basal lobes narrowly linear. Forma Diversifòla (Engelm.) Robinson. (S. variabilis, var. Engelm.) Leaf-blades partly sagittate and partly lanceolate or elliptic without basal lobes.

$\nu$ Var. pubéscens (Muhl.) J. G. Sm. Robust, pubescent, broadleaved; bracts shorter than in the other forms, 6-9 $\mathrm{mm}$. long, broadly ovate, obtusish, and very pubescent. - N. J. and Pa. to N. C.

3. S. Engelmanniàna J. G. Sm. Slender; lobes of the sagittate leaves very narrowly linear ( $1-3 \mathrm{~mm}$. wide); achene narrowly cuneate-obovate $(4 \mathrm{~mm}$. long), the beak elongated, erect or recurved, the sides usually strongly 1-3-crested. ( $\mathcal{S}$. variabilis, var. gracilis Engelm.) - About ponds, etc., "N. H." and Mass. to Del. Fig. 35.

\section{S. arifdlia Nutt. Monoecious, glabrous; scape $2-4 \mathrm{dm}$.}

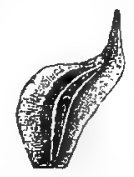

35. \$. Engel. manniana. Achene $\times 8$ lighl, simple or rarely branched; fertile whorls 1-(rarely) 3 ; fertile pedicels 3-11 mm. long; leaf-blades sagittate-hastate, ovate, acute; achenes wingerd all

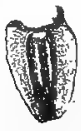

uit. S. arifolia. Achene $\times$ ?. round, bearing at the upper inner angle a minute erect beak. Que. to centr. Me., Vt., Ct., Mich., Kan, Dak., and westw. When in deep water producing lance-linear phyllodia at the base and developing elongated petioles of the blade-bearing leaves (S. cuneata Sheldon). Fig. 36.

5. S. breviróstra Mackenzie \& Bush. Very stout; scape 6-12 $\mathrm{dm}$. high; leaf-blades all sagittate, basal lobes ovate-lanceolate, acute, about as long as the terminal portion; inforescence simple or slightly branched, $2-5 \mathrm{dm}$. long; bracts lanceolate, attenuate; fruiting pedicels $1-2 \mathrm{~cm}$. long; fruiting heads $2-3 \mathrm{~cm}$. in diameter; achenes cuneate-obovate, with dorsal wing prominent; beak suberect, but little surpassing the wing at the summit. - Sloughs and bottoms, Ind. to Kan.

$\checkmark$ 6. S. lancifdlia L. Scape 8-15 dm. high, with several of the lower whoris fertile; leaves lanceolate or lance-oblong, rarely linear, all with a tapering base, thick or coriaceous (1.5-4.5 dm. long on a long and stout petiole, never sagittate), the nerves mostly arising from the very thick midrib; bracts ovate, acute or acuminate; pedicels slender, the fertile scarcely shorter than the sterile ones; flaments pubescent; achenes falcate, winged on the back, pointed with an incurved beak. - Swamps, Md. to Ky., Mo., and southw. (W. I.) FIG. 37.

7. S. ambigua J. G. Sm. Scape $4-6 \mathrm{dm}$. high ; leaves as in the preceding; raceme simple; pedicels $1.5-2.5 \mathrm{~cm}$. long; bracts lanceolate, small ( $8 \mathrm{~mm}$. long); filaments glabrous; achenes

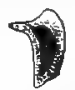

37. S. lancifolin. Achene $\times$ : with a short incurved beak, scarcely winged. - Borders of ponds, etc., Kan. and souhtw.

* Filaments very short, with enlarged mostly glandular base; anthers ovate or short-oblong; fruiting heads small; bracts more or less connate; leaves very

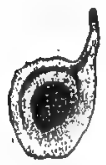
rarely sagittate.

8. S. heterophýlla Pursh. Scape weak (1.5-8 dm, high), at length procumbent; leaves lanceolate or lance-oval, entire, or with one or two narrow basal sagittate appendages; bracts roundish, obtuse; flowers of the lowest whorl fertile and almost sessile; the sterile on long pedicels; filaments glandular-

38. \$. heterophylln. pubescent; achenes narrovly obovate with a long erect beak. Achene $\times 3$.

N. E. to Fla., w. to Minn. and Mo. - Varies as to foliage, tho 
leaves being broad (var. ELlfptica Engelm.), or rigid, narrowly lanceulate and acute, unappendaged at the base, and with stout petioles (var. RIGIDA (Pursh) Engelm.), or nearly linear (var. angustifólia Engelm.). Fig. 38.

9. S. graminea Michx. Scape 0.8-5 dm. high; phyllodia flat, mostly broad-linear, acuminate; leaves ovate-lanceolate to linear, on long slendel petioles, sometimes reduced to the petiole merely; bracts rather obtuse; whorls of flowers often few, all staminate or the lower fertile; pedicels slender, spreading, nearly equal; flowers white or roseate ; filaments $10-13$ " -20 ," glandular-pubescent; achene small ( $1 \mathrm{~mm}$. long), narrowly obovate, almost beakless, vinged on the back, flat and scarcely costate on the sides. (S. Eatoni J. G. Sm.) - Nfd. to Ont., s, to the Gulf ; very variable. FiG. 39. S. Cristhta Engelm. is apparently a form of this species with achenes somewhat wingcrested.

10. S. tères Wats. Phyllodia terete, very acutely attenuate upward, $9-34 \mathrm{~cm}$. long, very rarely bearing a narrow blade; scape $1-5$ dm. high; bracts connate at base; pedicels in 1-3 whorls, all very slender and spreading, 1 or 2 fruiting, 1-3 cm. long; filaments 12, dilated, pubescent; achene obovate, $2-2.4 \mathrm{~mm}$. long, with an erect beak, the margins and sides crenately several-crested. ( $S$. isoëtiformis J. G. Sm.) - In sballow water, Cape Cod, Mass., and L. I: to Fla. - Phyllodia usually very 40. S. teres. whrongly nodose. Fig. 40.

Achene $\times 3$. 11 . S. subulàta (L.) Buchenau. Usually dwarf; lecues linear, strap-shaped, obtuse or acutish, 3-20 cm. long, equaling or shorter than the scape, very rarely with a narrow blade; pedicels in $1-3$ whorls, only 1 or :2 fruiting. stouter and recurved; bracts connate or spathe-like; filaments 6-8, glabrous; achene obovate, short-beaked, $2 \mathrm{~mm}$. long, the margins and sides crenately crested. (S. natans, var. lorata Chapm. ; S. pusilla Nutt.) - In mud or slial low water, near the coast; $\mathrm{Ct}$. to Fla. - In the South often becoming more robust.

Var. (?) gracillima (Wats.) J. G. Sm. Scape and the almost or wholly bladeless leaves very slender and greatly elongated (6-12 dm. long, $2 \mathrm{~mm}$. wide); pedicels all elongated, in usually distant whorls, the lower pistillate, slender and spreading ; fruit unknown. (S. natans, var. Wats.) - In deep water of streams in e. Mass. (Hitchings, Boott, C. E. Faxon, etc.), R. I. (J. F. Collins), aud Ct. (Bissell). - Wholly submerged, only 1 or 2 flowers appearing at a time, floating on the surface. The fruit has not yet been collected.

12. S. platyphýlla (Engelm.) J. G. Sm. Scape $2-5 \mathrm{dm}$. high ; leaves elliptic-lanceolnte, acute at both ends, rarely biauriculate at the base, 9-11-nerved; fertile whorls usually 2 ; fertile pedicels about $2 \mathrm{~cm}$. long, soon recurved; stamens about 20 , the broad base of the filament pubescent. (S. graminea, var. Engelm.) - 41. . platypliylla. River sloughs, s. Mo. and Kan. to Tex. Fig. 41.

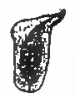

\section{LOPHOTOCÁRPUS Th. Durand}

Sepals strongly concave, erect and appressed to the fruit. - Perennials with

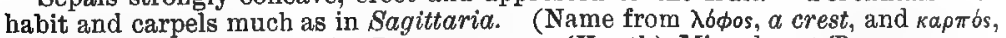
fruit, not very applicable.) Lophiocarpus (Kunth) Miquel, not Turcz.

* Chiefly maritime; leaves mostly thick spongy phyllodia, the blades when present small, lance-oblong, entire, or ovate and sagittate, the auricles relatively small, linear-oblong, divergent.

1. I. spongiosus (Engelm.) J. G. Sm. Low (1-3 dm. high); leaf-blades $0.5-2.5 \mathrm{~cm}$. broad; the thick spongy petioles septate-nodulose; scapes $4-15 \mathrm{~cm}$. high, recurved, bearing mostly 2 whorls of flowers; head of carpels 7-10 mu. in diameter. (L. spatulatus J. G. Sm.; Sagittaria calycina, var. Engelm.) - On tidal mud of brackish estuaries, etc., N. B. (Fowoler) to De1. ; rarely inland, Mo. ( $L$. depauperatus J. G. Sm., at least in part). 


\section{* Species of the interior; leaf-blades relatively lurge, sagittate with broad triangular auricles.}

2. L. calycinus (Engelm.) J. G. Sm. Taller (1.5-4 dm. high); leaf-blades reeply sagittate, thin, 10-15-nerved, 4-8 cm. broad, the auricles triangular, acute, nearly or quite as long as the terminal portion of the blade; stipes recurving or procumbent, $1-\mathbf{4} \mathrm{dm}$. long, usually bearing 3-4 whorls of flowers; near of carpels about $1 \mathrm{~cm}$. in diameter. (Sagittaria Engelm.) - Muddy banks, Mich. to Dak. and southw.

Var. máximus (Engelm.) Robinson. Leaf-blades very large (3 $\mathrm{dm}$. wide), 18-21-nerved, considerably broader than long, the auricles almost divaricare; infiorescence stout, sometimes branched. (Nagittaria calycina, var. Engelm.i -O. (Moseley) and southw.

\section{ECHINÓDORUS Richard.}

Petals imbricated in the bud. Stamens 6-21 or more.-Mostly annuals, with the habit of Sagittrivia, the naked stems sparingly branched or simple, and the

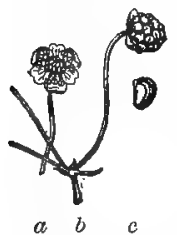

42. E. tenellus.

flowers on rather short pedicels, in whorls of $3-6$ or more. Fl. summer and autumn. (Name from É $\chi\llcorner\nu \omega \delta \eta \xi$, prickly,

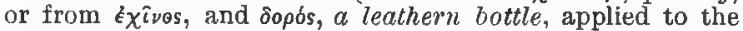
ovary, which is in most species armed with the persistent style, so as to form a sort of prickly head of fruit.)

$\checkmark 1$. E. tenéllus (Martius) Buchenau. Scapes 1.5-10 cm. high; shoots often creeping and proliferous; submersed leaves lance-lineur phyllodia, emersed leaves petiolate with a lanceolate blade, acute (1-3 cm. long); umbel single, 2-8-flowered; pedicels reflexed in fruit; flower $6 \mathrm{~mm}$. broar:; stamens 9 ; styles much shorter than the ovary; achenes beakless, 8-ribbed, reddish brown, without glands.

(Alisma Martius; Helianthium Britton; $E$. parvulus c. Achene 3 .

Engelm.) - Submersed or on mud, e. Mass., Mich., Minn., and southw. (S. A.) Fig. 42.

2. E. cordifolius (L.) Griseb. Scape erect, 1-6 dm high, longer than the leaves; leaves broadly ovate, cordate or truncate at base, obtuse (the blade 2-11 cm. long); umbel proliferous, in a branched panicle; flower $8-10 \mathrm{~mm}$. broad; stamens 12 ; styles longer than the ovary; achenes with a conspicuous erect beck. (E. rostratus Engelm.) - Borders of ponds and ditches, Ill. to Kan.,

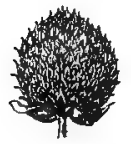

it

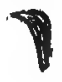

$b$ s. Cal., and Fla. Frg. 43. Var. lanceolatos (Engelm.) Mackenzie \& Bush is a low form which bas the leaves lanceolate with an acute base. - Ill., Mo.

3. E. radìcans (Nutt.) Engelm. Stems or scape prostrate, creeping (6-12 dm. long), proliferous, bearing many whorls of flowers; leaves somewhat truncately heart-shaped, obtuse (5-20 cm. broad), long-petioled; flowers 12-20 mm. broad; stamens about 21 ; styles shorter than the ovary; achenes with a short incurved beak, the keeled back denticulate.

44. E. radicans. a. Fr. $\times 1$.

b. Achene $\times 3$.

- About ponds, etc., Ill. to N. C. and Fla., w. to Kan. and Tex. FIg, 44 .

\section{4. alísma L. Water Plantain}

Petals involute in the bud. Ovaries many in a simple circle on a flattened receptacle, forming flattened coriaceous achenes, which are dilated and 2-3keeled on the back. - Scape with whorled panicled branches. Flowers small, white or pale rose-color. (The Greek name; of uncertain derivation.)

1. 1. A. Plantago-aquática Y. Perential by a stout proliferous corm; leaves long-petivled, ovate or oblong, acute, mostly rounded or heart-shaped at base, 3-9-nerved; scapes 1 or 2; panicle loose, pyramidal, 3-6 dm. long, much overtop- 
ping the leaves, with verticils of 2 or 3 orders ; rays and slender pedicels ascending at an angle of about $45^{\circ}$; sepals 10 -striate, the hyaline margins whitish; petals 2-4 mm. long, white, with yellowish claw; stamens twice as long as the carpels; these furrowed along the back, not meeting at the center of the disk. - Shallow water and ditches, across the continent. (Eurasia.) Fig. 45.

2. A. Geyèri Torr. Scapes 2-4, the shorter overtopped by the long-petioled linear-lanceolate to elliptic leaves; panicles usually less diffuse, the verticils in 1 or 2 orders; the thickish

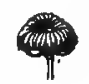
peticels strungly divergent in fruit; sepals 10-14-striate, the margins rose-color ; petals 1-2 mm. long, rose-color, with yellow basal spot; stamens about equaling the carpels; these ridged on the back, meeting at the center of the disk. - Locally from N. Y. to N. Dak. and the Pacific. (Eurasia.)

\section{HYDROCHARITÀCEAE (FroG's Bit FAMILY)}

Aquatic herbs, with dioecious or polygamous regular flowers, sessile or on scape-like peduncles from a spathe, and simple or double floral envelopes, which in the fertile flowers are united into a tube and coherent with the 1-3-celled ovary. Stamens 3-12, distinct or monadelphous; anthers 2-celled. Stigmas 3 or 6. Fruit ripening under water, indehiscent, many-seeded.

1. Elodea. Stem elongated, Eubmerged, leafy. Spathes small, sessile.

2. Vallisneria. Stemless. Leaves uarrow, elongated. Spathes pedunculate.

8. Limnobium. Stem very short. Leaves crowded; blades broad and spongy. Spathes pedunculate.

\section{ELODÈA Michx. WATER-WEEd}

Flowers polygamo-dioecious, solitary and sessile from a sessile tubular 2-cleft axillary spathe. Sterile flowers small or minute, with 3 sepals barely united at base, and usually 3 similar or narrower petals; filaments short and united at base, or none; anthers :3-9, oval. Fertile flowers pistillate or apparently perfect; limb of the perianth 6-parted; the small lobes obovate, spreading. Uvary 1-celled, with 3 parietal placentae, each bearing a few orthotropous ovules; the capillary style coherent with the tube of the perianth; stigmas 3, large, 2-lobed or notched, exserted. Fruit oblong, coriaceous, few-seeded. - Perennial slender herbs, with pellucid veinless 1-nerved sessile whorled or opposite leaves. The staminate flowers (rarely seen) commonly break off and float on the surface, where they expand and shed their pollen around the stigmas of the fertile flowers, raised to the surface by the prolonged calyx-tube. (Name from $\dot{\epsilon} \lambda \hat{\omega} \delta \eta s$, marshy.)

$\checkmark$ 1. E. canadensis Michx. Leaves varying from linear to oval-oblong, minutely serrulate; stamens 9 in the sterile flowers, 3 or 6 almost sessile anthers in the fertile. (Anacharis Planch.; Philotric Britton.) - Slow streams and ponds, common. July. (Nat. in Eu.)

\section{VALLISNÈRIA [Mich.] L. Tape Grass. Eet Grass}

Flowers dioecious; the sterile crowded in a head, inclosed in an ovate at length 3-valved spathe borne on a short scape; stamens mostly 3 . Fertile flowers solitary and sessile in a tubular spatlie on an exceedingly lengthened scape. Calyx 3 -parted in the sterile flowers; in the fertile with a linear tube coherent with the 1-celled ovary, but not extended beyond it, 3-lobed (the lobes obovate). Petals 3, linear, small. Stigmas 3, large, nearly sessile, 2-lobed. Ovules very numerous, scattered over the walls, orthotropous. Fruit elongated, cylindrical, berry-like. - Long linear leaves wholly submerged or their ends floating. The staminate flower-buds themselves break from their short pedicels and float on the surface, were they shed their pollen around the fertile flowern, 
which are raised to the surface by sudden growth at the same time; aftr.rwards the thread-form scapes (6-12 dm. long) coil up spirally, drawing the fruit under water to ripen. (Named for Antonio Vauisneri, an early Italian botanist.)

1. V. spiràlis $\mathrm{C}$. Leaves thin, ribbon-like $(0.3-2 \mathrm{~m}$. long), obscurely serrulate, obtuse, somewhat nerved and netted-veined. - Common in slow waters, N. S. to Fla., w. to Minn. and Tex. (Eurasia, Austr.)

\section{LimndbiUM Richard. American Frog's Bit}

Flowers dioecious (or monoecious?), from sessile or somewhat peduncled spathes; the sterile spathe 1-leaved, producing about 3 long-pediceled flowers; the fertile 2-leaved, with single short-pediceled flower. Calyx 3-parted or -cleft; sepals oblong-oval. Petals 3 , oblong-linear. Filaments in the sterile flowers entirely united in a central solid column, bearing 6-12 linear anthers at unequal heights; stamens in the fertile flowers 3-6 awl-shaped rudiments. 0vary 6-9-celled, with as many placentae in the axis, forming an ovoid manyseeded berry in fruit; stigmas as many as the cells, but 2-parted, awl-shaped. Floating in stagnant water and proliferous by runners. Leaves round-heart-

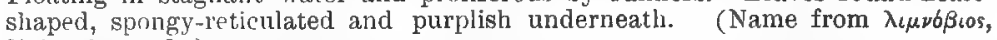
living in pools.)

1. L. Spóngia (Bosc) Richard. Leaves $2.5-5 \mathrm{~cm}$. long, faintly 5-nerved; pedincle of the sterile tiower about $7.5 \mathrm{~cm}$. long and filiform, of the fertile only $2.5 \mathrm{~cm}$. long and stout. - Stagnant water, N. J. to Fla.; also L. Ont. to Ill, Mo., and Tex.

\section{Gramíneae (Grass Family)}

\section{(REvised BY $\Lambda$. S. Hitchicock)}

Herbs (shrubs or trees in Bambuseae) with usually hollow stems (culms) closed at the nuth's, and 2-rantied parallel-veined leaves these consisting of two parts, the sheath and the blade, the sheath enveloping the culm with the mar. gins overlapping or rarply grown together; at the junction of the sheath and blade, on the inside, is a membranaceous hyaline or hairy appendage (the ligule) rarely obsolete. Flowers perfect (rarely unisexual), very small, without a distinct perianth, arranged in spikelets consisting of a shortened axis (rhachill $\alpha$ ) and 2-many distichous bracts, the lowest two of which (the glumes) are empty (rarely 1 or both obsolete); in the axil of each succeeding bract (the lemma) is borne a single flower, subtended and usually enveloped by a (normally) 2-nerved bract or prophyllum (the palea), with its back to the rhachilla; at the base of the flower, between it and the lemma, are usually 2 very small hyaline scales (the lodicules), rarely a third lodicule between the flower and the palea; stamens 3 (rarely 1,2 , or 6 ), with very delicate filaments and 2 -celled versatile anthers; pistil, one, with a 1-celled 1-ovuled ovary, 2 (rarely 1 or 3) styles, and mostly plumose stigmas. Fruit a caryopsis with starchy endospcrin and a small embryo at the base on the side opposite the hilum. Grain usually inclosed at maturity in the lemma and palea, free or adnate to the palen. The lemna with its palea and flower constitute the floret. The lemma may be variously modified; and may be sterile or neuter, that is, containing a palea or rudiment of one, without a flower, or empty; or may itself be rudimentary (as in some of the Chlorideae) ; in such cases the spikelet contains at least one perfect floret; the sterile or modified lemmas, one or more, above or below it. The palea, is rarely obsolete. Spikelets arranged in spikes, racemes, or panicles, the branches of which are bractless. 


\section{SubFamey I. PANICOfDEAE}

Spikelets 1-, rarely 2-flowered, when 2-flowered the terminal flower perfect, the lower staminate or neuter; rhachilla articulated below the glumes, the more or less dorsally compressed spikelets falling from the pedicels entire, singly, in groups, or together with joints of an articulate rhachis.

This first grand division of the Gramineae is based upon two characters int combination, the articulation of the pedicels just below the spikelets or cluster of spikelets and the single perfect flower, which may or may not have a staminate or imperfect flower below it. The lemma of the imperfect flower is similar to the glumes in texture in Paniceae and like the fertile lemma in the other tribes. In a few genera the first glume is obsolete, but in these cases the articulation below the dorsally compressed spikelets indicates their relation.

Tribe I. MAÝDEAE. Pistillute and staminate spikelets in different inflorescences or in different parts of the same inflorescence; awnless; glumes indurated.

1. Tripsacum. Staminate spikelets above the pistillate, in pairs at eacb joint of a spike-like raceme; pistillate single, imbedded in the jointed rhachis.

Tribe II, ANDROPOGÒNEAE. Spikelets in pairs or threes on the usually articulate rhachis of a spike like rnceme, une sessile and fertile, the other pediceled and perfect, staminate, neuter or rudimentary; glumes more or less indurated; lemmas smaller and hyaline, that of the fertile flower usually awned.

2. Rottboellia. Rhachis naked; pediceled spikelets neuter, often rudimentary; fertile spikelets awnless.

3. Erianthus. Rhachis hairy; spikelets all perfect and fertile, awned.

4. Andropogon. Rhachis hairy; pediceled spikelets sterile, often rudimentary; fortile spikelets awned.

5. Sorghastrum. Racemes reduced to one or two joints, on slender peduncles, arranged in open panieles; second spikelet reduced to a pedicel.

Tribe III. PANicEAE. Spikelets all perfect (in our genera) in racemes or panicles; glumes membranaceous, unequal, the first usually small, sometimes obsolete; a lemmi of like texture, empty or with a hyaline palea, rarely inclosing a staminate flower, subtends the perfect floret and simulates a third glume; fertile lemma and palea indurated, firmly clasped together; inclosing tha free grain, awnless (pointed in Echinochloa).

* Spikelets without an involucre of bristles.

- Lemma leathery-indurated with byaline margins not inrolled; spikelets lanceolate; first glume sometimes wanting.

6. Digitaria. Spikelets in slender spike-like racemes, aggregated toward the summit of the ('ullils.

r. Leptoloma. Spikelets long-pediceled in a diffuse panicle.

++ Lemma chartaceous-indurated; margins not hyaline, inrolied except in Amphicarpon. + Glumes and lemmas awnless.

8. Amphicarpon. Spikelets of $2 \mathrm{kinds}$, one in terminal panicle, not fruitful ; the other subterarean, perfecting frult; margins of lemma not inrolled.

9. Paspalum. Spikelets all alike, plano-convex, sessile or nenriy so, solitary or in pairs in 2 rows on one side of a Hattened rhachis; first glume obsolete (rarely present); spikelets placed with back of fertile lemma toward the rbachis.

10. Axonopus. Spikelets all alike, compressed, biconvex, sessile, solitary In 2 rows on one side of a tlattened rhachis; first glume obsolete; spikelets placed with the back of the fertile leama from the rhachis.

11. Panicum. Spikelets all alike, biconvex, in panicles (rurely racemes); first glume present; second gilume and sterihe lemma similar.

12. Sacciolepis. Spikelets all alike, in spike-like panicles; second glume saccate at base, 11-1) red; sterile leuma flat, 3-5-nerred, 
++ Sterle lemma awned or pointed; frutt acuminate; palea not inelu

18. Echinochloa. Bplkelets crowded In one-slded racemes, these arranged in a panicle.

* Spikelets with an involucre of brietles.

14. Setaria. Spikelets In a dense cyltndrical spike-like panlele; bristles persistent.

15. Cenchrus. Splkelets (1-5 together) Inclosed in a globular spiny bur-like Involucre; this falling with splkelets inclosed.

\section{Subfamilt 1I. POACOIDEAE}

Spikelets 1-many-flowered, the imperfect or rudimentary floret, if any, usualy uppermost, rhachilla usually articulated above the glumes which are persistent on the pedicel or rhachis after the fall of the florets; when 2-many-flowered a manifest internode of the rinachilla separates the florets, and is articulated below them; spikelets more or less laterally compressed (except in Mitium). The spikelets are articulated below the glumes in Oryzeae, Alopecurus, Cinna, Polypogon, Holcus, Sphenopholis, Spartina, and Beckmannia; these are distin. guished from SuBFamiLy I by the laterally compressed spikelets.

Tribe IV. ORYZEAE. Splkelets unisexual or perfect, in loose panicles; rhachilla artleulated below the glumes; glumes often wanting; stamens often 6.

16. Zizania. Splkelets unisexanl, unllke in appearance; panicle plstillate above, staminate below.

17. Zizaniopsis. Spikelets anisexual, much alike in appearance, intermixed in the same panicle.

18. Leersia. Flowers perfect, splkelets much flattened laterally; lemma carinate, awnless; palea 1-keeled.

Tribe V. PHALARfDEAE. Bplkelets laterally compressed, 1(rarely 8)-Howered: two sterile lemmas below the fertile floret, and fallng attached to it, usually empty and unlike the fertile lemma, sometimes reduced to briatles, or sometimes with a staminate flower in Hierochloe ; fertile lemma with a 1-i-nerved or nerveless palea and a perfect flower.

19. Phalaris. Sterlle lemmas very narrow, much shorter than the indurated fertile lemma, whlch is much exceeded by the equal glumes.

20. Anthoxanthum. Sterlie leminas dorsally awned, larger than the slightly indurated fertile lemma; glumes very unequal.

21. Hierochloë. Sterlle lemmas larger than the fortlle lemma, indurated, inclosing a 2-nerved palea and usually a staminate flower; glumes subeg:al, scarcely exceeding the florets.

Tribe VI. AGROSTfDEAE. Spikelets 1-flowered; rhacbilla sometimes prolonged bebind the palea into a naked or plumose bristle; glumes subequal, usually equaling or exceeding the lemma; palea 2-nerved, rarely nervelese or wanting (1-nerved in one specles of Cinna).

\section{* Lemma Indurated.}

+ Spikelets awnless; callus none; margins of lemms inrolled.

22. Milium. Spikelets dorsally compressed.

++ Spikelets with a terminal awn; margins of lemma not inrolled; a callus at base. - STiplisar

23. Oryzopsis. Awn simple, deciduous; callus short, obtuse.

24. Stipa. A wn simple, persistent; callus usually acute.

25. Aristida. Awn 8-fid, the branches divarlcate; callus acute.

* Lemma membranaceous.

+ Lemma awned from the tip or mueronato, closely lafolding the grain ; callus acute.

26. Mublenbergia. Rhacblla not prolonged behind the palea; lemma pointed or awned.

27. Brachyelytrum. Rhachilla prolonged into a bristle behind the jalea lemma long-awned.

++ Temma awnless or dorsally awned, loosely embracing the grain.

$\rightarrow$ Glumes consplenously compressed-carinate; spikelets In dense splke-like pnnteles. - Pulctisa.

28. Heleochloë. Lemma menbranaceous l1ke the glumes, awnless; glumes not aristate; pant cle partly Inoluded, ovold. 
29. Phleum. Lemma hyaline, awnlese, glumes abruptly artstate; panicle exserted, cylindrical.

80. Alopecurus. Lemma hyaline, awned below the middle; palea none; glumes not aristate; panicle exserted, cylindrical.

\# \#lumes not conspicuously compressed; spikelets in open or narrow panicles. - Agrostinat.

- Lemma 1 (rarely 3) -nerved, awnlese; pericarp readily separating from the grain.

81. Sporobolus. Lemma as long as or longer than the glumes; culms wiry or rigid.

$=-$ Lemma 8-5-nerved, awned or awnless; pericarp adherent to the grain.

a. Floret not stipltate; palea 2-nerved; stamens 3.

b. Rhachilla not prolonged behlnd the palea.

32. Agrostis. Glumes longer than the floret, awnless; panicle usually open.

83. Polypogon. Glumes longer then the floret, awned; panicle spike-like.

34. Calamovilfa. Glumes shorter than the floret, awnless.

$b b$. Rhachilla prolonged behind the palea, bristle-like.

85. Calamagrostis. Perennial; panicle loose or contracted; prolonged rhachilla and callus with long hairs; lemma short-awned below the middle.

36. Ammophila. Perennial ; panicle dense and spike-like; prolonged rhachilla and callus with short hairs ; lemma awnless.

37. Apera. Annual; panicle loose; the prolonged rhachilla naked ; lemma long-awned below the bifid apex.

a a. Floret atipitate; palea 1-2-nerved ; stamen 1.

88. Cinna. Spikelete in a loose panicle.

Tribe VII. AVENEAE. Spikelets 2-several-flowered, panicled; rhachilla prolonged behind the palea of uppermost floret except in Aira; glumes usually longer than the first floret; 1 or more of the florets awned on the back or from the teeth of the bifid apex (or usually awnless in Sphenopholis and Koeleria); the callus and usually the rhachilla-joints hairy.

* Rhachilla not prolonged behind the palea of uppermost floret; spikelets 2-tlowered, both perfect.

39. Aira. Florets approximate; glumes broad, boat-shaped.

** Rhechilla prolonged behind the palea of uppermost floret; spikelets 2-several-flowered.

+ Articulation below the glumes; spikelets falling entire or the glumes and lowest floret together. + Glumes much exceeding the two florets.

40. Holcus. Lower floret stfpitate, awnless, upper with a book-like awn.

+ ++ Glumes exceeded by upper floret.

41. Sphenopholis. Glumes dissimilar, the second obovate; florets usually awnless.

++ Articulation above the glumes.

$+\dot{A}$ wns wanting or but a mucronate tip.

42. Koeleria. Glumes unequal, exceeded by the upper floret. ++ Awns present.

- Awns dorsal, not flattened.

a. Spikelets 2-several-flowered; florets all perfect or the uppernost imperfo

b. Spikelets less than $1 \mathrm{~cm}$. long; grain free.

43. Trisetum. Lemma keeled, bidentate, awn arising from above the middle.

44. Deschampsia. Lemma convex, awn from the middle or below.

$b b$. Spikelets more than $1 \mathrm{~cm}$. long; grain adberent to the palen.

45. Avena. Florets approximate, exceeded by the striate glumes.

a a. Spikelets 2-flowered; lower floret staminate, upper perfect.

46. Arrhenatherum. Lower floret long-awneă, upper usually awnless.

- - A wns from between the treth of the biclentate apex of the lemma, flattened, twisted.

4i. Dantmonia. Florets severul, not closely approximate, glumes equaling or exceeding the uppermost. 


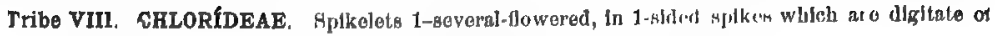
jaufeulato, sonetimos solitury.

" Bptkatcits all allkc.

+ Splkelets strictly 1.flowered, no sterlo lemma.

+4 Rhaclilla articulated bolow the glumen.

14. Bpartina. Glunes narrow, unequal.

40. Beckmannia. Glumes broad, boat-shaped, Inflated, equal.

++ ++ Rhachllin artlculated above the glumes.

50. Cynodon. Splkes digitate; plants extenwlvely creeping.

51. Schedonnardus. Splkes panleulate; jlants caespltoso.

+ + Splkelets with more than 1 floret.

++ Perfect floret 1, additional florats staminate, neuter or rudimentary.

- lowrat floret perfect.

52. Gymnopogon. Srikelots remote, nplureskicrl.

5\%. Chloris. Splkolets lubrleated; fertlle lemmu 1-awned or awniess; mylkos more or less whoried or digitato.

54. Bouteloua. Splkolets Imbricuted; fertlle lemma 3-awnod; splkes racinoso. $-m$ Lawest, Horets neulor, third perfect.

55. Ctenium. Bplke solitary; second glume bearlng a stout dlvergont dorsal awn.

++ Perfect flowets 2 or more.

- Splken few, strut. digitate.

5\%. Dactyloctenium. Rhachis of splke prolonged beyond the aplkelets; second glume and at lrast lowest lemana cusplate.

57. Eleusine. Thachis of eplke not prolonged beyond the sjplkelets, nether glumes nor lommas cuspidate.

- Splkes numorous, very slender, racomoso.

5. Leptochloa. Sifkelets not crowded, often slightly jedireclide.

* Eplkolets unjsexual, dlssimilar ; plante dlocclous n' monoeclous.

5). Buchloë. Staminate splkes exsorted, racomose; plstillate splkelets netrly capitato, jartially includer in broad sheatbs.

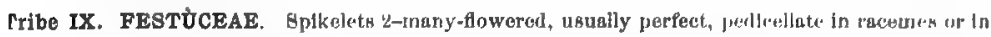
luese or define punleles; glumes shortru than the lowent florot; lemman I-neveral-uerved, awnless or with 1-8everal stralght awns, terminal or burne just below the arex.

* Rhurhllla clother? with long sllky hairs, exceeding the florets.

60. Phragmites. J,uwest floret atamlnate, the otbers perfect.

* Rhrchilla naked or with balrs much shorter than the Aorets.

+ Callus and norv's of lemma dennely bearded (not cotw eliby)

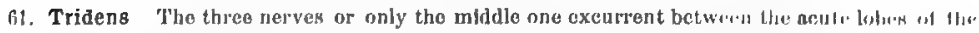
lumuna; palea surt clltatu-frtnged.

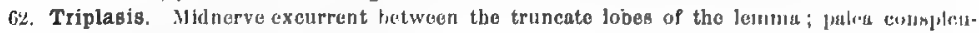
(ins)y viliate-firinged; florets remote.

$\leftarrow+$ Callus and nerves glabrous or cobwebby, or callus aprarscly bearderl.

+t Lemus corlaceous, smooth and shining, without a scarlous margin.

- Spikelets dloeclous.

68. Distichlis. Splkelets large, compressed, in a mall crowded pauis le.

- Bplkelots perfect.

67. Uniola. I, I, 1-4 lemmss empty.

60. Dtarrhena. Ifur $2-4$ lemmas empty.

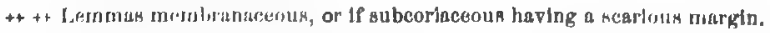

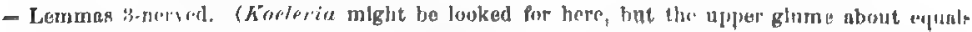
the low

68. Eragrostís. Sipikulats :-miny-flowered. 
04. Catabrosa, Aplkulets 2-fluwererl,

b- L- LAmunas b-many-nerved (nelvos oflen obsenre in Bbiza).

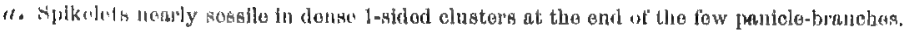

713. Dactylis. Hpikelota flattoned; glumos aud leumas kooled, tho koela hlapld-ciliate.

a *. Splkolots not in donse 1-sided clustere.

b. Spikulets as broad as loug, somewhat heart-shaped.

(iA. Briza. "Florets crowded in the spikelets, almost horizontal; lemmas bont-shaped or ventricose b b. Spikelets much longer. than brond, not heart-shaped.

c. Lornmas keolod.

71. Poa. Base of flupets often cobwebby.

c) c. Lommas convex or keoled only tht tho summit.

d. Uppermost lemmas shaper like the lower, fortile or sterlle.

*. Nervas of lemma prominist, parallel.

73. Glyceria. Spikelets compressed-cylindrical or little flattenod ; lommas scarious at aummit.

e e. Nerves of lemma not prominont.

f. Leunmas obtuse, awnless.

74. Puccinellia. Aluma inuch shorter than the lowest lemma; callus not halry; nerves not excurrout.

72. Scholochloa. Olumos nenrly as long as lowest temma; eallus hafry; one or more nerves of lemma oxouront.

\section{$f f:$ Leminas acute, often awned.}

75. Festuca. Lemmas entire, often awned from tha apox.

70. Bromus. Loinmes 2-toothed, ustally awned fust bolow the apex; grain adherent to the palen, puboscent at the summit.

15. Molica. Lonmas nwed fust bolow the apex, grnin free, glabrous.

d d. Uppermost lemmas broad or cucullato, convolute, fornirig a club-shaped mass.

6D. Melica. Lemmas subcorlaceous with a scarious margin, obtuso.

Tribe X. HÓRDEAE, Splkolots (1-stvornl-flowered, with uppermost floret iraperfeot) aessile on opposite sides of a zigzar jointed chnneled rhachis, forming a spike; glumes sometimes abnrthe or wanthg, aften placed logethew in fhont of the spikelet; leaf-bladea bonring at bare a more or less well-marked palx of aurioulnte uppendages,

* Spikelets solitary at ench joint of the rhnohts.

+ Splkelets 1-flowered, falling attrched to joints of the disartioulating rhachis.

78. Lepturus. Splkolets awnless; low branchlng annuals.

$$
\text { + + Sptkelets 2-many-flowered. }
$$

77. Lolium. Spikelets placed with one edge to the rhnohls.

79. Agropyron. Splkelets placed with the slde to the rhachis.

- Wpikelots 2 or 9 , rarely solitary, at enoh joint of the rhachis, placed with the florets dorso. vontiral to the rhadils.

+ Sprikalets not all alike.

80. Hordeum. Spikelets 1(rarely '-3)-llowered, in 3 's at onch jolnt, the lateral pair pedicelel, IIsually abortive; glumes awn-llke.

$$
++ \text { Spikelets all allke, 2-6-flowered. }
$$

81. Elymus, Glumes usually equaling the florets; spikes mostly dense.

82. Hystrix. (A)umas reduced to short bristles, one or both often obsolete; sptkes very loose.

Tribe XI. BAMB JSEAE. Tall woody reods; the tlat bindes with $n$ short potiolo artioulated with the sluonth; spikelets fow-many-flowered, flattened, in panleles or rncunes.

83. Aruadinaria. I.emmns rounded on tho bnek, many-nerved, aeuminate or bristle-polnted: grinmos vely small, 


\section{Trípsacum L. Gama Grass. Segame Grasb}

Spikelets unisexual, the staminate spikelets in pairs at the joints of the continuous rhachis above; the pistillate spikelets solitary, embedded in each oblong

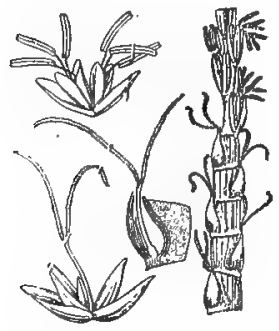

46. T. dactylolrles.

Part of splke $\times 1 \frac{1}{2}$.

o spikelet embelded $\times 1$. o Spikelet freed $\times 1$.

$\sigma^{7}$ Spikelet $\times 1$. joint of the cartilaginous thickened articulate rhachis below in the same inflorescence, which terminates the culm or its branches; glumes of the staminate spikelet subcoriaceous, the first dorsally flattened, the second boat-shaped; the first lemma often empty, membranaceous with a hyaline palea, like the second which incloses a staminate flower; first glume of pistillate spikelet ovate, at length cartilaginous and closing the recess in the rhachis, second boat-shaped, coriaceous; florets 2, the lemmas and paleas hyaline, the lower sterile, the upper pistillate. - Tall stout perennials from very thick creeping rootstocks, with broad flat leaves, and terminal and axillary spikes separating spontaneously into joints at maturity. (Name trom $\tau \rho l \beta \epsilon \iota \nu$, to $r u \bar{b}$, perhaps in allusion to the polished spike.)

1. T. dactyloìdes L. Culms $1-2.5 \mathrm{~m}$. high ; leaves $3 \mathrm{dm}$, or more long, $1.5-3.5 \mathrm{~cm}$. wide; spikes $2-3$ togethar at the summit, when their contiguous sides are more or less flattened, or solitary and terete; ıxillary spikes solitary. - Moist soil, Ct. to Kan., s. to Fla. and Tex. July, Iug. Frg. 46.

\section{ROTTBOELLIA L. f.}

Spikelets in pairs in the excavations at the nodes of a cylindrical articulated $d x$ is ; one sessile and periect, the other pediceled, sterie, with its pedicel adnate to the rhachis; glumes of the perfect spikelet awnless, the first coriaceous and covering the excavation in the rbachis, the second thinner, boat-shaped; sterile lemma empty or with a rudimentary flower, and, like the lemma and palea, hyaline; glumes of sterile spikelet membranaceous. - Perennials with flat narrow leaves, and single cartilaginous spikes which disarticulate at maturity, terminating the stem and branches; chiefly subtropical. (Named for Prof. C. $F$. Rott-

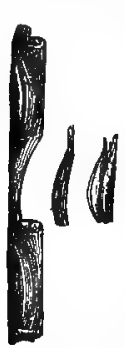
boell, an excellent IJanish botanist, who wrote much upon Gramineae, Cyperaceae, etc.)

1. R. rugosa Nutt. Culms tufted, compressed, 6-12 dm. high; sheaths flattened; leaves 5-10 mm. wide; spikes 2-7 cm. $\operatorname{long}$, the lateral ones on short clustered branches in the axils, often partly included in inflated sheaths; first glume of fertile spikelet transversely rugose. (Manisuris Ktze.) - Low pine barrens, Del. and southw., near the coast. Aug., Sept. Fig. 47.

2. R. cylíndrica (Michx.) Torr. Culns terete from a short rootstock; leaves $2-3 \mathrm{~mm}$.

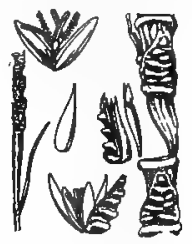

47. R. rugosa.

Base of inflorescence $\times 1 / 2$.

Part of same with fertile and pediceled sterile spikelet separated $\times 2$.

Fertile spikelet $\times$.

Its flower removed $\times 2$.

Lemma $\times 2$.

48. R. cylindrica wide; spikes slender, usually curved, 5-15 cnt. long, terminating $\times 2 . \quad$ the culm, on elongated axillary pednncles; sterile spikelet rudimentary: first glume of fertile spikelet obscurely pitted longitudinally. (Manisuris Ktze.) - Prairies, Mo. and southw. June-Aug. Fig. 48.

\section{3. ertánthus Michx. Woolly Beard Grass}

Spikelets in pairs, one sessile, the other pediceled, along the articulate and readily disjointing rhachis, both alike, perfect; glumes subequal, firm-membranaceous, the first dorsally flattened, more or less bicarinate, the second keeled above; sterile lemma empty, hyaline, awnless; fertile lemma with an awn 1-2 cm. 
long ; palea minute, nerveless. - Tall and stout reed-like perennials, with elongated flat leaves, racemes crowded in a panicle and clothed with long silky hairs, especially in a tuft around the base of each spikelet (whence the name, fron

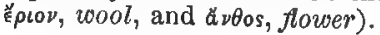

\section{* Awn terete, straight.}

+ Hairs at base of spikelets copious, as long as the glumes or longer; panicle-axis and upper part of culm densely appressed-villous.

+ Panicle loose and open; hairs longer than the glumes.

1. E. saccharoides Michx. Culnu 1-2 m. high, usually with a dense ring of appressed hairs at the nodes; leaves $1-2.5 \mathrm{~cm}$. wide, villous ; panicle tawny or purple. - Moist ground, N. J. and southw., rare. Sept., Oct. FIG. 49.

\section{++ Panicle dense and compact; hairs about as long as the glumes.}

2. E. compáctus Nash. Culm 1-3 m. high, villous at the nodes; blades $6-12 \mathrm{~mm}$. wide, usually villous only on the upper surface near the base; panicle tawny. - Moist ground, N. J. and southw. Aug., Sept.

+ + Hairs at base of spikelets rather sparse or wanting, shorter than the glumes; culm and axis of panicle glabrous or sparsely villous.

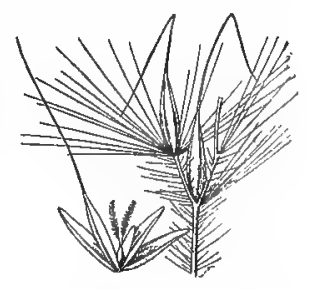

49. E. saccharoides $\times 11 / 2$.

3. E. brevibárbis Michx. Calm 1-2 m. high, sparingly villıus at the nodes; sheatbs glabrous; blades 6-10 mm. wide, scabrous; panicle purple, narrow, the branches appressed, sparingly silky, appearing striate from the stiff straight arons. - Moist ground, Del, and southw. Sept., Oct.

\section{* * Awn flattened and twisted.}

+ Panicle pale, axis very villous ; basal hairs copious, exceeding the glumes.

4. E. divaricàtus (L.) Hitchc. Culm 1.5-3 m. high, nodes and upper portion appressed-villous; sheaths glabrous ; leaves $1.5-2.5 \mathrm{~cm}$. wide ; panicle loose, silky. ( $\boldsymbol{E}$. alopecuroides Ell.) - Moist ground, N. J. to Ga., w. to Ky. and s. Mo. Sept. +- Panicle dark, axis sparsely villous; basal hairs rather sparse, scarcely as long as the glumes.

5. E. contórtus Baldw. Culm 1-2 m. high, nodes soon glabrous ; sheaths glabrous ; leaves $5-15 \mathrm{~mm}$. wide ; panicle narrow, less silky than in the preceding. - Low meadows, Va. to Ky., and southw.

\section{ANDROPÒGON [Royen] L. Beard Grass}

Spikelets in pairs (one sessile and perfect, the other pediceled, sterile, often rudimentary) at each joint of the articulate rhachis; glumes of fertile spikelet subequal, indurated, the first dorsally flattened, with a strong nerve near each margin, the midnerve faint; second glume keeled above; first lemma empty, hyaline; fertile lemma membranaceous or hyaline, awned; palea liyaline, sometimes obsolete. - Tall tufted perennials; spikes lateral and terminal, the rhachis and usually the pedicels long-villous with silky hairs (whence the name, composed of $\alpha \nu \eta \dot{p}, \operatorname{man}$, and $\pi \omega \gamma \omega \nu$, beard.)

Racemes solitary; joints of the rhachis clavate .

Raceines in fascides of $2-6$; joints of the rhachis not clavate.

Pedicellate spikelot reanced to the pedicel or the glumes only; racemes usually subtended by a foliaceous spathe (the upper sheath); rhachisjoints very slender.

Racemes not longer than the spathe, which incloses the common pedunele. Branches of inflorescence in a dense terminal corymbiform chuster Branches of inflorescence scattered along the culms

Racemes, or some of them, on peduncles exserted beyond the spathes. Upper shenths inflated; racemes delicate, flexuous . Upper sheaths not inHated; racenses stouter, strict.

1. A. scoparizs.

Pedicellate spikelet ataminate, with glumes and lemmas

2. A. glomeratus.

8. A. virginicus.

4. A. Elliottii.

5. A. ternarius

6. A. furcatue. 


\section{\$1. SCHIZACHÝRIUM (Nees) Trin. Racemes solitary; joints of the rhach. clavate.}

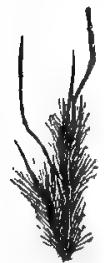

50. ג. scoparius. Two spikelets $\times 11 / 8$.

1. A. scopàrius Michx. Culms tufted, 4-12 dm. high; branches single or in pairs from the upper sheaths; sheath; glabrous or hairy; blades often hairy above near the base; racemes slender, $2-6 \mathrm{~cm}$. long, joints and sterile pedicels hairy on the margins; sterile spikelet a single awn-pointed glume, 2-4 $\mathrm{mm}$. long; fertile spikelet about $7 \mathrm{~mm}$. long; awn bent and twisted. - Dry ground, N. B. to Sask., and southw. July-Sept. Fig. 50.

Var. littoralis (Nash) Hitchc. Culms in large tufts ; the innovations and lower sheaths strongly compressed, glaucous. (A. littoralis Nash.) - Sand dunes along the coast, N.Y. and southw.

\section{§2. CAMPYLOMf́SCHUS Fourn. Racemes in fascicles of 2-6; joints of the rhachis not clavate.}

* Pedicellate spikelet sterile, consisting of 1-2 glumes or reduced to a pedicel. + Spathes equaling or exceeding the racemes; sheaths keeled.

2. A. glomeràtus (Walt.) BSP. Culms stout, $0.5-1.5 \mathrm{~m}$. high, leafy; sheaths usually sparsely birsute; inflorescence bushy branched at the summit of the culm; spathes very scabrous; racemes 2; the slender joints of the rhachis and the sterile pedicel clothed with long silky hairs. (A. macrourus Michx.; A. corymbosus Nash.) - Sandy ground near the coast, Mass. and southw. Sept., Oct.

3. A. virginicus $\mathrm{L}$. Culms rather slender, 5-12 dm. high, sparingly branched above; sheaths smooth or somewhat hirsute on the margin; blades usually hirsute above near the base; spathes smooth; racemes 2 or 3, slender; hairs long and silky. - Open ground, Mass. to Ill., Fla., and Tex. FIG. 51 .

\section{++ Racemes, or some of them, on peduncles exserted beyond the spathes.}

4. A. Ellióttii Chapm. Culms in tufts, flattened at base, 5-10 dm. high; lower sheaths and leaves appresser-birsute or becoming nearly glabrous, upper sheaths aggregated and much enlarged; racemes usually 2, very slender, flexuous, softly and loosely silky; spilielets $4 \mathrm{~mm}$. long. - Dry sandy or gravelly soil, Del. to Mo., and southw. Sept., Oct.

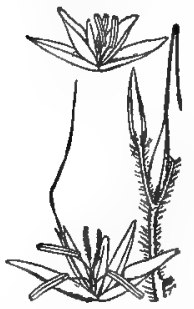

5‥ A. fureatus $\times 11 / 6$.

5. A. ternàrius Michx. Culms somewhat stouter and taller than in the preceding; sheaths usually smooth, the upper sheaths not crowded nor enlarged (or the upper one only somewhat enlarged) ; $r a$ -

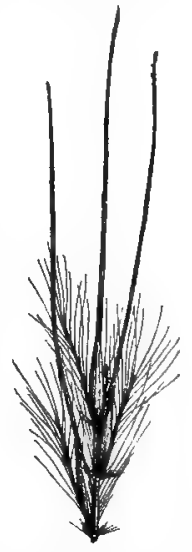

51. A. virginious. Three spikelets $\times 2 \% 3$. cemes 2 or 3 , stouter, more strict, densely silky; spikelets $6 \mathrm{~mm}$. long. (A. argyraeus Schultes.) - Dry sandy soil, Del. to Tenn., and southw. Aug.-Oct.

* Pedicellate spikelet staminate; racemes 2-6 on a long exserted peduncle; rhachis-joints stout.

6. A. furcàtus Muhl. Culms robust, in large tufts, $1-1.5 \mathrm{~m}$. high, branching from the upper nodes; sheaths glabrous; blades elongated, 4-8 $\mathrm{mm}$. wide, scabrous on the margins and often hirsule on the upper surface near the base; racemes $5-12 \mathrm{~cm}$. long, stout, nsually purplish; rhachis-joints and pedicels hairy on the sides and at the summit; sessile slykelets $8-9 \mathrm{~mm}$. long ; staminate spikelet slightly longer - Dry open ground, Me. to siask., and southw. Fio. 52. 


\section{SORGHẢSTRUM Nash}

Spikelets sessile at each joint of the slender rhachis of the peduucled racemes, which are reduced to 2 or 3 joints, the sterile spikelets reduced (in our species) to hairy pedicels; glumes indurated as in Andropogon; sterile lemma thinly hyaline, the fertile lemma reduced to hyaline appendages to the strong awn; palea obsolete. - Perennial grasses with tall stout culms, the racemes arranged in npen panicles. (Named from its resemblance to Sorghum.)

1. S. nùtans (L.) Nash. (Indian Grass, Wood Grass.) 1-2 m. high ; leaves 6-10 $\mathrm{mm}$. wide, scabrous, glaucous; sheaths smooth; panicle narrowly oblong, at first open, contracted after flowering, 1-3 dm. long; the spikelets lanceolate, at length arooping, yellowish or reddish brown and shining, clothed, especially toward the base, with fawn-colored hairs; the twisted awn longer than the spikelet. (Andropogon L.; Chrysopogon Benth.) - Dry soil, Me. to Man., and southw. Fig. 53.

Sórghum halepénse (L.) Pers., Johnson Grass, a more robust plant, is found as an escape or a weed, chiefly along the southern border of our range. It differs from Sorghastrum in having two pediceled spikelets (of the group of three) staminate or empty; and in having a more spreading panicle and a Culm simple, firmer lemma. This is thought by some to be the original of the cultivated. sorghums. (Introd, from Eu.)

\section{Digitària Scop. Finger Grass}

Spikelets 1-flowered, lanceolate-elliptic, sessile or short-pediceled, solitary or in 2's or 3's, in two rows on one side of a continuous narrow or winged rhachis, forming simple slender racemes which are aggregated toward the summit of the culm; glumes 1-3-nerved, the first sometimes obsolete; sterile lemma 5-nerved ; fertile lemma leathery-indurated, papillose-striate, with a hyaline margin not inrolled, inclosing a palea of like texture.-Annual, mostly weedy grasses, with branching culms, thin leaves, and subdigitate inflorescence. (Name from digitus, a finger.) Srntherisma Walt.

* Rhachis of racemes with angles wingless; first glume obsolete; culms erect.

1. D. filiformis (L.) Koeler. Usually tufted, branching and leafy at the base; culms slender or almost filiform, $2-7 \mathrm{dm}$. high; lower sheaths hirsute; blades $0.5-2 \mathrm{dm}$. long, $4 \mathrm{~mm}$. or less wide (rarely wider), hirsute or glabrous on the lower, scabrous on the upper surface; racemes $1-5$, unequal, $3-10 \mathrm{~cm}$. (rarely $15 \mathrm{~cm}$.) long, very slender; spikelets $1.7 \mathrm{~mm}$. long, mostly in 3's, appressed, the second and third on slender flexuous pedicels; glume and sterile lemma densely or sparsely villous between the nerves with white gland-tipped hairs; the glume shorter and narrow, exposing the dark brown acute fertile lemma. (Panicum L.) --Sterile or sandy soil, N. H. to Mich., I. T., and southw. July-Sept.

2. D. villdsa (Walt.) Ell. Similar to the preceding, usually taller, less slender and more densely and constantly hirsute on the shecths and on both surfaces of the blades; racemes $2-8$, more distant (sometimes $3 \mathrm{~cm}$. apart), 5-20 cm. long, much interrupted toward the base; spikelet-clusters usually rather distant; spikelets $2.25 \mathrm{~mm}$. long; the glume and sterile lenma densely mattedvillous between the nerves with'gland-tipped hairs. - Sandy soil, Va. to Mo., and southw. July-Oct.

$$
\begin{gathered}
\text { * Rhachis of racemes with lateral angles winged; culms spreading. } \\
+ \text { Pedicels terete; first glume obsolete. }
\end{gathered}
$$

3. D. нuмifùsa Pers. Glabrous; culms 1.5-4 dm. high, much branched below, ascending or nearly prostrate; leaves $2-10 \mathrm{~cm}$. long (rarely longer), 3-6 mm. wide; racemes 2-6, aggregated, divergent, often curved, 3-10 cm. long; 
spikelets solitary or in 2's, $2.2 \mathrm{~mm}$. long; the glume and steriie lemma equal, densely short-villous between the nerves, as long as the dart hrown fertile lemma.

(Panicum lineare Krock; $\boldsymbol{P}$. glabrum Gaud.) - Cultivated and waste ground, N. S. to S. Dak., and soutbw. Aug.-Oct. (Nat. from Eu,) Fig. 54 .

4. D. serótina Michx. Extensively creeping, forming dense mats ; the crowded sheaths pilose; blades $2-8 \mathrm{~cm}$. long, 4-7 $\mathrm{mm}$. wide, pilose on both surfaces; racemes $3-8$, at the apex of

54. D. bumifusa. Spikelet $\times 4$. ascending branches (1-3 d.m. high), 3-10 cm. long; spikelets mostly in 2's, $1.6 \mathrm{~mm}$. long, sparsely pubescent between the nerves; the glume scarcely $\frac{1}{2}$ as long as the pale fertile lemma. (Panicum Trin.) - Low sandy ground near the coast, s. Pa., Del., and southw. June-Aug.

++ Pedicels sharply angled; first glume present, minute.

5. D. sanguinalis (L.) Scop. (Crab Grass.) Culms erect or ascending from a decumbent often creeping base, 3-12 dm. long; nodes and sheaths more or less papillose-hirsute; blades lax, 5-12 cm. long, 4-10 mm. wide, scabrous, often more or less pilose; racemes $3-12$, subfasciculate, $5-18 \mathrm{~cm}$. long ; spikelets in pairs, $3-3.5 \mathrm{~mm}$. long, usually appressedpubescent between the smooth or scabrous nerves; second glume about $\frac{1}{2}$ as long as the pale or grayish fertile lemma. (Panicum L.; Syntherisma fimbriata Nash.) - Cultivated and waste grounds, throughout our range, and southw. Aug.-Oct Very variable. (Nat. from Eu.) Fig. 55.

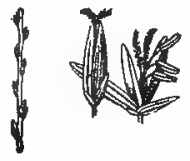

55. D. Ganguinslis. Part of intlorescence $\times 1 / 8$. Splkelets $\times 8$.

\section{LEPTOLOMA Chase}

Spikelets 1-flowered, fusiform, solitary on long capillary 3-angled pedicels : first glume obsolete or very minute, the second 3-nerved, nearly as long as the 5-7-nerved sterile lemma ; fertile lemma cartilaginous-indurated, papillose, with a delicate hyaline margin not inrolled, inclosing a palea of like texture; grain free within the lemma and palea. - Tufted perennials, with flat leaves and very diffuse terminal panicles, which break away at maturity and become tumbleweeds. (Name from $\lambda \epsilon \pi \tau \delta$, delicate, and $\lambda \omega \mu a$, border, in reference to the hyaline margins of the lemma.)

1. L. cognàtum (Schultes) Chase. (Fall Witch Grass.) Pale green, much branched at the base, erect or geniculate below, very brittle, $3-7 \mathrm{dm}$. high ; lower sheaths pilose, the upper usually glabrous; ligule membranaceous, $1 \mathrm{~mm}$. long; blades 5-8 cm. long, 4-6 $\mathrm{mm}$. wide, rather rigid, usually glabrous, scabrous on the margins; panicle $\frac{1}{3} \frac{1}{2}$ the entire height of the plant, short-exserted, very diffuse, as broad as lorig or broader; the capillary scabrous subflexuous branches at first ascending, soon widely spreading, naked below, pilose in the axils; spikelets on scabrous pedicels, $1-4 \mathrm{~cm}$. long, acuminate, $2.7-3 \mathrm{~mm}$. long; glume and sterite lemma with a stripe of appressed silky pubescence between the nerves and on the margins, or the hairs becoming loose and spreading especially on the margins, very variable in the same panicle; fruit acuminate, chestnut, the margins of the lemma white. (Panicum Schultes; $P$. autumnale Bosc.) - Dry soil and sand hills, N. H. to Fla.; 1ll. to Minn., southw. and southwestw.

\section{AMPHICÁRFON Kunth}

Spikelets 1-flowered, of 2 kinds, one in a terminal panicle, perfect but not fruitful, the other subterranean, clelstogamous, on slender leafless stems at the bass of the culm ; the first glume of the aërial spikelets variable in size or obso. lete; the second and the sterile lemma subequal; lemma and palea indurated, margins of lemma neither hyaline nor inrolled: cleistogamous spikelets mucb 
targer, glumes many-nerved; sterile lemma- subrigid; fertile lemma and palea much indurated, acuminate, margins of lenma neither hyaline nor inrolled.-Erect annuals or perennials with flat leaves. (Name from

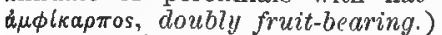

1. A. Púrshii Kunth. Annual; culms erect, branching, 3-6 dm. high; sheaths and blades coarsely hispid; terminal panicle contracted; spikelets about $4 \mathrm{~mm}$. long; fertile spikelets solitary, about $6 \mathrm{~mm}$. long, at the ends of the slender subterranean branches. (Milium Amphicarpon Pursh; A. Amphicarpon Nash.) - Moist sandy pine barrens, N. J. to Fla. Sept. Frg. 50.

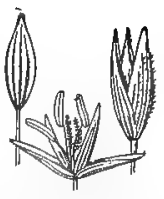

56. A. Purshii.

Sterlle вplkelet closed $\times 4$ Same wide open $\times 2$.

Basal fertile spikelet, partly open $\times 2$.

\section{PÁSPALUM L.}

Spikelets 1-flowered, plano-convex, nearly sessile, solitary or in pairs, in 2 rows on one side of a continuous narrow or dilated rhachis, forming simple spikelike racemes; spikelets placed with the back of the fertile lemma toward the rhachis; first glume obsolete (rarely present); lemma and palea chartaceousindurated, margins of the lemma in rolled. - Perennials, with 1-several racemes digitate or racemose at the summit of the culm and branches. (Mac $\pi d \lambda_{0}$, a Greek name for millet.)

a. Racemes 1-several, 1 terminal and often 1 or more lateral $z$.

b. Rhachis membranaceous, $2 \mathrm{~mm}$. or more broad.

Spikelets $1.5 \mathrm{~mm}$. long, elliptical, pubescent . . . . 2. s. mucronatum.

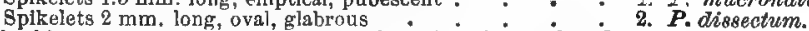

i. Rhachis narrow, not membranaceous, less than $1 \mathrm{~mm}$. broad (except in $\dot{P}$. Boscianum) $c$.

- Axillary peduncles 1 or more frum uppermost sheath; leaves ciliate on the margin $d$.

d. Spikelets 2 min. long e.

e. Leaves glabrous on both surfaces . . . . . 5. P. ciliatifolium.

e. Leaves pubeseent on one or both surfaces $f$.

f. Spikelets glabrous.

Leaves densely long-pubescent.

Culm hirsute below raceme.

Culm glabrous.
Leaves puberulent and sometimes sparsely vilions:
8. P. Straminengert.

f. Spikelets pubescent; leaves short-pubescent.

Culms erect.

Culms urostrate

d. Bpikelets $1.5 \mathrm{~mm}$. long.

Spikelets glabrous

Spikelets pubescent

c. Axillary peduncles none $g$.

g. Spikelets glabrous $h$.

$\boldsymbol{h}$. Spikelets singly disposed so as to appenr in 1-2 rows. Spikelets $2.5 \mathrm{~mm}$. long.

Plants glabrous or sparingly pilosé.

Leaf-blades of culm 1-2 dm. long; racemes 8-5

Leaf-blades of culm '2-4 dm. long; racemes 8-10 cm. long

Plants with pubescent sbeaths and blades:

Spikelets 3 mnl. long; sheaths papillose-hirsute

Spikelets $4 \mathrm{~mm}$. longr.

Leaf-blades less than $1.5 \mathrm{dm}$. long . . . . 16. $P$. difforme.

Leaf-blades $2-4 \mathrm{dm}$. long : : : : 15. P. foridanum.

h. Spikelets in pairs so as to appear in four rows.

Spikelets stramioeous at maturity.

Spikelets dark brown at maturity .

a. Spikelets eiliate
a. Racemes a pair at the summit of the cuim

\section{P. Zacos.}

12. $P$. angustifolium

13. P. plenipilum.

14. P. circulare.

17. $P$. laeviglume.

18. P. Boscianum.

19. P. Allatatum.

20. P. distichum.

* Racemes with a broad, thin-membranaceous, or foliaceous and keeled, rhachis, $2 \mathrm{~mm}$. wide or more, the incurved margins partly inclosing the small 2-rowed spikelets. (Aquatic or nearly so, decumbent or floating.)

1. P. mucronàtum Muhl. Sheaths papillose-hiirsute or nearly smooth, inflated; blades lanceolate, $2.5-15 \mathrm{~cm}$. long, 6-14 mm. wide, scabrous; racemes 10-50, finally spreading; rhachis extending beyond the spikelets, which are ellip. 
tical, about 1-5 $\mathrm{mm}$. long, sparsely pubescent with minutely glandular hairs ( $P$. fluitains Ell.) - In water or mud, Va. to Okla., and southw.

2. P. disséctum L. Sheaths glabrous; blades 1-5 cm. long, 2-4 mm. wide: racemes $3-7$; spikelets oval, glabrous, $2-2.3 \mathrm{~mm}$. long. ( $P$. membranaceum Walt. ; $\boldsymbol{P}$. Walterianum Schultes.) - Wet places, N. J. to s. Ill., and southw;

* Racemes with a narrow wingless rhachis; sheaths compressed.

- One raceme terminal, often 1-several lateral.

- One or more naked raceme-bearing branches from the uppermost sheath; culms tufted, often reclining; racemes slender, often curved; spilcelels in pairs, 1.5-2 mm. long, broadly oval or obovate; leaves ciliate on the margin.

$$
\text { = Spikelets } 1.5 \mathrm{~mm} \text {. long. }
$$

3. P. longipedunculàtum Le Conte. Culms reclining, 3-5 dm. long; leaves mostly near the base, 3-9 cm. long, 4-6 mm. wide, midnerve and margins ciliate; sheaths pilose at the throat; racemes 1 or $2,3-6 \mathrm{~cm}$. long, usually curved, on long siender peduncles; spikelets glabrous. - Sandy soil, Ky. and southw.

4. P. setàceum Michx. Culms slender, erect or ascending, 4-6 dm. high, smooth; sheaths hirsute, especially the lower ones?; blades about 1-2 dm. long, 2-6 $\mathrm{mm}$. wide (upper reduced), densely pubescent; racemes slender, usually single, long-peduncled, $5-10 \mathrm{~cm}$. long; spilcelets ovate, finely pubescent and glandular-spotted. - Dry sandy fields and pine barrens, N. H. to Neb., Fla., and Tex. Aug.-Oct.

$$
\begin{gathered}
==\text { Spikelets } 2 \text { mm. long. } \\
\text { a. Spikelets glabrous. }
\end{gathered}
$$

5. P. ciliatifolium Michx. Erect, 4-8 dm. high; leaves 0.7-2.5 dm. long, 6-15 mm. wide, glabrous; racemes usually single, $5-10 \mathrm{~cm}$. long; spikelets about $2 \mathrm{~mm}$. long, glabrous, green. - Sandy soil, Md. to Fla., and Miss.

6. P. pubéscens Muhl. Culms slender, erect, 4-8 dm. high, hirsute belom the racemes; sheaths usually glabrous; blades 1-2 dm. long, 3-6 mm. vid̄e, long-pubescent on both surfaces; racemes usually single; spikelets $2 \mathrm{~mm}$. long, glabrous. - Fields and dry woods, N. Y. to Del., Miss., and Tex. Aug., Sepu.

7. P. Muhlenbérgii Nash. Culms more robust than in the preceding, spreading or reclining, glabrous; sheaths pubescent or nearly glabrous ; blades hardly 2 din. long, 7-10 $\mathrm{mm}$. wide, long-pubescent on both surfaces; racemes usually single; spikelets $2 \mathrm{~mm}$. long, glabrous. - Fields and sandy soil, N. H. to Mo., southw. to Fla. and Tex. Aug.-Oct.

8. P. stramineum Nash. Culms spreading or prostrate, 2-8 dm. long; sheaths ciliate on the margin, otherwise glabrous or the lowest pubescent; blades about $1 \mathrm{dm}$. long, crinkly on the ciliate margin, finely pubescent, often with a few scattered long hairs; racemes 1-3 (mostly 2), 4-10 cm. long; spikelets straw-colored, $2 \mathrm{~mm}$. long; orbicular, smooth. - Sandy soil, Neb. to Mo. and southw. July-Sept.

$$
\text { a a. Spikelets pubescent. }
$$

9. P. Búshii Nash. Culms erect, 8-10 dm. high; lovoer sheaths pubescent, the upper pilose on the margin only; blades 5-20 cm. long, 5-15 mm. wide, softly and densely pubescent on both surfaces; racemes 2 or $3,10-12 \mathrm{~cm}$. long; spikelets 2-2.2 mm. long, oval, densely pubescent. - Dry soil, Neb. to Mo., and Tex. Aug.

10. P. psammóphilum Nash. Culms prostrate; similar to P. straminenm but sheaths, both surfaces of the blades, and the oval spikelets softly and densely pubescent; leaves averaging a little longer. ( $P$. prostratum Nash., not Scribn. \& Merr.) - Sandy soil, s. N.Y. to Del. Aug., Sept.

+ No lateral peduncle; culms stout and often tall.

= Spikelets obtuse, glabrous.

a. Spikelets singly disposed.

11. P. laève Michx. Culms spreading or prostrate, $3-6 \mathrm{dm}$. long; plant 
glabrous, or the upper surface of the leaf-blades (1-2 dm. long) with a few hairs; racemes 2-3, 3-5 cm. long; spikelets about $2.5 \mathrm{~mm}$. long. - Sandy soil, Md. to Fla. and Tex, Fig. 57. Var. Australe Nash. Leaves hairy on the upper surface, sheaths hivsute on the margin. - Va. to Fla. and Miss.

12. P. angustifolium Le Conte. Culms erect or spreading, glabrous, averuging taller than the preceding; sheaths glabrous or somewhat pilose, especially on the margin; blades elongated (2-4 dm.), often sparingly pilose on upper surface; racemes 3-5, longer than in the preceding, 6-10 cm. long, spreading. - Sandy soil, Md. to Hla., Kan., and Tex.

13. P. plenípilum Nash. Resembles $P$. laeve; but usually taller (5-10 dm.), erect or spreading; anc pilose on sheaths and blades; racemes $2-4,4-8 \mathrm{~cm}$. long. ( $P$. praelongum Nash.) - Fields and open ground, N. J. to Fla, Ala., and Mo.

14. P. circulàre Nash. Culms 5-10 dm. Ligh; sheaths

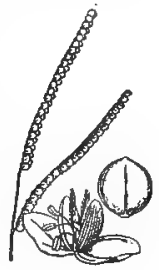

5个. $P$. laeve $\times 1 / 2$ Spikelets $\times 2 \frac{1}{2}$. sparsely papillose-hirsute with ascending hairs; blades 2-3 dm, long, 5-8 mm. wide, sparsely hirsute on the upper surface, usually glabrous on the lower; racemes $2-4$, erect or ascending, 6-10 cm. long; spikelets orbicular, about $3 \mathrm{~mm}$. long. - Open moist ground, N. Y. and Mo., southw.

15. P. floridànum Michx. Culms robust, 1-2 $\mathrm{m}$. high, from a stout scaly rootstock, glabrous; sheaths hirsute; blades 3-6 dm. long, 6-10 $\mathrm{mm}$. wide, hirsute on both surfaces; racemes usually 2-4, stout, erect or ascending, 7-12 cm. long; spikelets about $4 \mathrm{~mm}$. long. - Low ground, Va. to Fla. and Tex. Var. GLABRÃTUM Engelm. Glabrous and often glaucous; racemes often 4-7. ( $P$. arundinaceum Poil.) - Del. to s. Kan., and southw.

16. P. difforme Le Conte. Similar to the preceding, less robust, glaucous ; culms 5-10 dn. high, leafy at the base; sheaths often papillose-hirsute near the summit; blades 12-15 cm. long, 6-10 $\mathrm{mm}$. wide (the uppermost nuch reduced), glabrous or sparsely hirsute; racemes $2-3$ (rarely 4 ), ascending, $3.5-8 \mathrm{~cm}$. long; spikelets 3-3.5 mm. long. - Low sandy ground, N. J. to Fla. and Tex.

a a. Spikelets in pairs, appearing 4-seriate; sterile lemma 5-nerved; culms usually geniculate and rooting at the lower nodes.

17. P. laeviglùme Scribn. Culms stout, 5-15 dm. high, nodes pubesceut; sheaths usually pilose on the scarious margin, otherwise glabrous; blades 1-3 lm. long, 1-1.5 cm. wide, glabrous or with a few hairs at base; racemes 4-8, :-10 cm. long; spikelets $3 \mathrm{~mm}$. long, obovate, stramineous. - Moist fields and wood-borders, Md. and Ky. to N. C. and Tex. Sept., Oct.

18. P. Bosciànum Flügge. Culms stout, 5-12 dm. high; sheaths lax, glabrous, or the lower pubescent; blades $1.5-4.5 \mathrm{dm}$. long, 6-12 mm. wide, glabrous or hirsute near base; racemes numerous, $2-6 \mathrm{~cm}$. long, with a winged rhachis $2 \mathrm{~mm}$. wide; spikelets $2 \mathrm{~mm}$. long; glume and sterile lemma brownish; fruit dark brown. - Low woodlands, and along ditches!, Va. to Fla. and Tex. Aug., Sept.

$$
==\text { Spilcelets acute, ciliate. }
$$

19. P. dilatàtum Poir. Culms stout, 5-17 dm. kigh , growing in clumps; glabrous throughout except the densely crowded spiktlets; leaves elongated, 4-10 $\mathrm{mm}$. wide; racemes $2-10,5-10 \mathrm{~cm}$. long, somewhat spreading; spikelets $3 \mathrm{~mm}$. long, ovate; glume and sterile lemma long-cilia.te. - In meadows, waste ground, and along ditches, Va. to Fla. and Tex.

\section{+ + Racemes a pair at the summit of the culm.}

20. P. distichum L. Creeping and rooting at the nodes, with ascending culms, 1-6 dm. high ; leaves short, usially crowded, sometimes sparsely hairy on the margins; racemes $3-5 \mathrm{~cm}$. long; spikelets singly disposed, $2.5-3 \mathrm{~mm}$. long, ovate, acute, sparsely pubescent; first glume occasionally present. (Digitaria paspalodes Michx.) - Ditches and muddy or sandy shores, Va. to Fla., and westw. June-Oct. 


\section{AXónOPUS Beaù̃.}

Spikeiets 1-flowered, compressed bi-convex, sessile, solitary in two rows on une side of a flattened rhachis (which is naked in ours), placed with the back of the fertile lemma turned from the rhachis, forming simple spikes ; first glume obsolete; lemma and palea indurated but less so than usual in Paspalum, margins of the lemma inrolled. - Perennials with 2-several slender spikes digitate or sub-digitate at the summit of the culm. (Name from $a \xi \omega \nu$, axis; and $\pi$ oús, foot:) Anastrophus Schlecht.

1. A. furcàtus (Flügge) Hitchc. 'Tufted, soft, $3-10 \mathrm{dm}$. high, with long creeping leafy stolons; leaves obtuse ; racemes a pair at the summit of the culm, 7-10 cm. long; spikelets acute, nearly glabrous, about $4 \mathrm{~mm}$. long. (Paspalus Flügge ; $\boldsymbol{P}$. Elliottii Wats.) - Low moist ground, Va. to Fla. and Tex.

\section{Pánicum L. Panic Grass}

Spikelets 1-flowered or rarely with a staminate flower below the terminal perfect one, in panicles, rarely in racemes; glumes very unequal, the first often minute, the second subequal to the sterile lemma which often incloses a hyaline palea and rarely a staminate flower ; fertile lemma and palea chartaceous-indurated, nerves obsolete, the margins of the lemma inrolled; grain free within the rigid firmly closed lemma and palea. - Annuals or perennials of various habit. (An ancient Latin name of the Italian millet, Setaria italica, of uncertain origin and meaning.)

a. Annuals $b$.

b. Spikelets tuberculste

b. Spikelets smooth $c$.

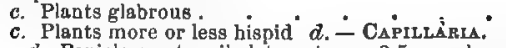

d. Panicle erect, spikelets not over $8.5 \mathrm{~mm}$. long $e$

6. Panicle more than balf the length of the entire plant. Panicle diffuso; spikelets 2-2.5 mm. long Panicle uarrow; spikelets 3-3.5 mm. long

e. Panicle not over one third the length of the entire plant. Culms stout; blades about $1 \mathrm{~cm}$, wide.

Culms delicate; blades not orer $6 \mathrm{~mm}$. wide. :
d. Panicle drooping; spikelets $5 \mathrm{~mm}$. long

Culms delicate; blades not orer $6 \mathrm{~mm}$. wide. .
a. Perennials $f$.

$f$. Splkelets short-pediceled along one side of a rhachis forming spikelike rrcemes panicles $g$.

$f$. Basal leaves similar to culm-leaves, not forming a winter rosette; culme simple or sometimes produeing panicles from the upper nodes $h$.

h. Spikelets long-pediceled. - VIrgata.

Branches of panicle spreading.

Branches of panicle ascending.

Splkelets $4.5 \mathrm{~mm}$. long; l'?res crowded at base of culm

Spikelets $6 \mathrm{~mm}$. long ; leaves not crowded at base of culm
h. Spikelets short-pediceled along the main branches of the panicle $i_{\text {. }}-\mathrm{AgrosToídiA.}$

i. Rootstocks present

i. Rootstocks absent; plants compressed at the leafy base. Fruit stipitate; spikelets conspicuously eecund Fruit not stipitate; spikelets not conspicuously secund.

Splkelets $2 \mathrm{~mm}$. long, crowded; a few long hairs on the pedicels ${ }^{\circ}$.

Spikelets $2.5-3 \mathrm{~mm}$. Jong; no hairs on the ped
Panicles few-flowered, branches spreading

Panicles densely flowered, branches erect

o. Basal lesves usually distinctlv different from the culm-leaves, forming a winter rosette; oums simple In spring but usually much branched later in the seasun; secondary panicles smaller, less exserted than the primary, $j$. - Dronóroma.

j. Spikelets 3 min. or more long $k$.'

$k$. Leaves linear-elongated, not over $5 \mathrm{~mm}$. wide; secondary panicles at the base ouly.

Spikelets pointed

spikelets blunt.

2. P. verrucosum.

8. P. dichotomiforum.

- P. Papillare.

5. P. floxile.

4. P. Gattingeri.

6. P. philadelphicum. 7. $\boldsymbol{P}$. miliaceum.

1. $P$, hemitomum.
11. P. viryatum.

9. P. amarum.

10. P. amaroides.

16. P. anceps.

14. $P$. stipitatum.

13. P. agrostoides.

12. $P$. longifolium.

15. $P$, condensum. 
k. Leaves oblong-lanceolate to ovate-lanceolate, more than $5 \mathrm{~mm}$.

wide, or if narrower not conspicuously elongated $l$.

l. Blades more than $1.5 \mathrm{~cm}$. wide $m$.

$m$. Spikelets $3 \mathrm{~mm}$. long ; at least the lower sheaths papillose-hispid 71. P. clandestinum.

m. Spikelets 3.5-4 $\mathrm{mm}$. long.

Nodes bearded ; plants often pubescent.

Blades lanceolate, thick, glabrous above, densely papillose-

pubescent boneath
Blades opate-lanceolate, thin; pubescence when present

Nodes not bearded; plants glabrous or nearly so.

Panicle spreading ; blades $2.5 \mathrm{~cm}$. or more wide

2. Blades not over $1.5 \mathrm{~cm}$, wide $n$.

Panicle narrow ; blades rarely over $1.8 \mathrm{~cm}$. wide

$n$. Panicle narrow; blades erect.

Plants glabrous or nearly so

Plants papillose-bispid.

Spikelets not over $8 \mathrm{~mm}$. long.

Spikelets $4 \mathrm{~mm}$. long .

n. Panicle spreading, about as wide as long ${ }^{\circ}$.

o. Spikelets $3 \mathrm{~mm}$. long; blades $1.2-2 \mathrm{dm}$. long.

Blades oiliate, glaucous, smooth : $:$ :
Blades not ciliate, green, scabrous :
pikelets $8.5-4$ mm. long; blades not over $1 \mathrm{dm}$. long.

Nodes bearder ; ligule $8-4 \mathrm{~mm}$. long.

Nodes not bearded; ligule $1-2 \mathrm{~mm}$, long.

Spikelets obovoid-turgid, blunt; pubescence spread-

Spikelets narrowly obovoid, subacute; pubescence

7. Spikelets less than 3 lum. long $\dot{p}$.

p. Spikelets glabrous $q$.

q. Spikelets not over $1.5 \mathrm{~mm}$. long.

Plants pubescent
Plants glabrous, except bearded nodes : : : : : :

65. P. Ravenelit.

72. P. Boscit.

78. P. latifolium.

66. $P$, aanthophysum.

66. P. xanthophysum.

67. $P$. Wileosurnum.

64. P. Leibergii.

59. $P$. mutabile.

70. P. aculeatum.

65. P. Raveneliz.

68. P. Sertbnerianum

62. P. oligosanthes.

22. $P$. strigoswm.

81. P. microcarpon.

$q$. Spikelets $2-2.5 \mathrm{~mm}$, long $r$.

$r$. Spikelets $2 \mathrm{~mm}$. long.

Spikelets obovoid-turgid; culms crisp-puberulent

Spik+lets elliptical ; culros glabrous.

Autumnal state erect, branched like a little tree; second glume shorter than the fruit and sterile lemma.

Autumnal state topheavy-reclining; fruit covered by

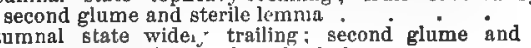

Autumnal state wider trailing : second glume and

r. Spikelets $2.5 \mathrm{~mm}$. long.

Culms 2-4 dm. high; second glume and sterile lemma equaling fruit

Culms 5-12 dm, high; second glume and sterile lemma

60. P. lancearium.

27. P. dichotomum.

28. P. barbulatum.

80. P. lucidum.

26. P. Bicknellit.

29. P. yadkinense.

p. Spikelets pubescent 8 . from the base only, or nore.

Bheaths giabrous

Sheatbs pilose.

Spikelets turgid, blunt; panicle-branches ascending; culms few in a tuft .

Spikelets subacute; panicle-branches spreading; culms
numerous in a tuft . Bumbicuously elongated; secondary panicles not at the base $t$.

$t$. Bpikelets obovate-turgid, blunt, attenuate at baso.

Spikelets $2 \mathrm{~mm}$. long

Spikelets $2.5 \mathrm{~mm}$. long.

Spilelets not papillose ; culms glabrous
Spikelets rugose-papillose; culms pubescent, at leasi below.
Nodes benrded ; paniclo-branches ascending.

Noces not bearded ; panicle-branches spreading

20. P. Wernert.

18. $P$. perlongum.

19. P. linearifolium.

25. P. aciculare.

26. P. Bicknelliz.

24. P.consanquineum 28. $P$. anyustifolium,

t. Splkelets not attenuate at base $u$.

$u$. Sheaths conspicuously retror'se-pilose; culms simple, forming soft sufts

21. P. aalapense.

w. Sheaths not retrorsely pilose $v$.

$v$. Shenths, or all but the lowest, glabrous $w$.

2o. Ligule 2-5 $\mathrm{mm}$. long.

Spikelets $2.2 \mathrm{~mm}$. ing

Spikelets $1.5 \mathrm{~mm}$. long.

Panicle not mors than half as wide as lung;

Panicle about as wide as long; spikelets nbrivoid

47. P. acoparioides.

35. P. spretum.

36. P. Lindheimeri. 
20. Ligule less than $1 \mathrm{~mm}$. long $\boldsymbol{c}$.

$x$. Blades velvety on both surfaces; nodes bearded

w. Blides not velvety; nodes not bearded $y$.

$y$. Culms crisp-puberulent .

$y$. Culms glabrous $z$.

๙. Spikelets 1.5-1.8 mm. long.

Culm-blades not over $2 \mathrm{~cm}$. long; spikelets elliptical

Culm-blades 6-20 cm. long; spikelets spheroidal.

Panicle not more than half as wide as long; blades strongly nerved Panicle nearly as wide "as long; blides' not

s. Splkelets $2,2-2.8 \mathrm{~mm}$. long.

Blades cordate, 1.2-2 cm. wide

Blades not cordate, $0.6-1.2 \mathrm{~cm}$. wide.

Blades erect ; fruit covered - . 32. P. borenle.

s. Shenths pubescent $a$.

a. Sheaths puberulent, not jilose.

Spikelets elliptical, $2.6 \mathrm{~mm}$. long

Spikelets obovold-turgid, $2 \mathrm{~mm}$. long.

Plants erect or apreading; blades glabrous above

Plants prostrate or creeping; blades pubenulent on both surfaces

a. Sheaths spreading- or appressed-pilose or velvety $b$.

b. Plants grayish-velvety througnout.

Spikelets $2.6 \mathrm{~mm}$, long.

Spikelets $1.8 \mathrm{~mm}$. long :

Spikelets 1.3-1. . . + 44. P. lanuginosum.

b. Plants not velvety $c$.

c. Spikelets $2.7-3 \mathrm{~mm}$. long.

Blades papillose-hirsute on both surfaces

Blades glabrous or sparsely silky above

o. Spikelets less than $2.5 \mathrm{~mm}$. long $d$.

d. Spikelets ovate, pointed; blades $1.5-2.5 \mathrm{dm}$. Iong; pani-

d. Splkelets obovate or elliptical, blunt; blades and panicle shorter e.

8. Pubescence spreading $f$.

$f$. Spikelets $2.2-2.4 \mathrm{~mm}$. long.

Plants very villous; autumnal state prostrate

Plants papillose-hispid on sheaths and sparsely

$f$. Spikelets 1.8-1.9 $\mathrm{mm}$. long $g$ hispid on blades; autumnal state erect .

g. Blades stiff, glabrous above or with a few hairs

g. Blades pubescent above, or if glabrous lax $h$.

h. Upper surface of blades with erect hairs $3-5 \mathrm{~mm}$. long.

Culms branching very early; spikelets $1.8-$ $1.9 \mathrm{~mm}$. long

Culms branching after maturity of primary panicle; spikelets not over $1.5 \mathrm{~mm}$. long. Axis of panicle long-pilose

Axis of panicle nearly glabrous : :

h. Upper surface of blades with short or some. what appressed pubescence.

Blades stiff; spikelets obovate .

Blades lax; spikelets elliptical

- Pubescsnce not spreading $i$.

1. Culms crisp-ptberulent or crisp-pubescent; ligule nearly obsolete.

Splkelets $1.9 \mathrm{~mm}$. long; blades $5-6 \mathrm{~cm}$. long;

plants blue-green
Splkelets $1.7 \mathrm{~mm}$, long; blades $3-5 \mathrm{~cm}$. long;
plants gray-green

4. Culms with short or long appressed pubescence " $j$

3. Ligule obsolete or nearly so.

Spikelets $25 \mathrm{~mm}$. long .

Spikelets $2-2.2 \mathrm{~mm}$. long

5. Ligule $2-3 \mathrm{~mm}$. long.

Pubescence on lower shenths sprending

Puboscence on lower sheaths appressed.

Blades glabrous on upper surface; splkelets $1.2 \mathrm{~mm}$. long

Blades p'ubescent on upper surface; spikelets $1.5-1.9 \mathrm{~mm}$, long.

Spikelets $1.5 \mathrm{~mm}$. long; panicles not over

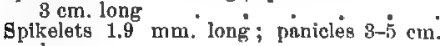
long.

52. P. tougetorum.
58. $P$. columbianum.

46. P.praecooius.

39. P. implicatum.

40. $P$, meridionale.

88. P. hrachucae.

67. P. Wilcoxianum.

49. P. ovale.

69. P. scabrizsculum.

48. P. villosissimum

47. P. scoparioddes.

48. P. tennesseente.

uachucae, v. silvicola.

50. P. Commonsianum

51. P. Adaisonii.

40. $P$. meridionale.

87. P. letuoothrio.

41. P. omicola.

42. P. swbilloswm. 
\$1. PASPALOIDEA Nash. Spikelets acute, glabrous, subsessite in one-sided racemes, these racemose on an elongated axis.

1. P. hemítomum Schultes, Culms thick, 9-12 dm. long, rooting and branching at the lower nodes; sheaths locse, glabrous or hairy on the margins ; blades 1-2 dm. long, about $1 \mathrm{~cm}$. wide; panicle 1-2 dm. long, very narrow, the remote racemes appressed, spikelet-bearing to the base; spikelets $2.8 \mathrm{~mm}$. long, lanceolate ; fruit less indurated and rigid than in true Panicum; palea not inclosed at the apex. ( $P$. Curtisii Chapm.; $P$. digitarioides Carpenter.) - Ponds, Del, to Fla. and Tex.

\section{รొ 2. EUPÁNICUM Gren. \& Godr. Spikelets disposed in more or less spread-} ing panicles; palea included at the summit.

* VerRdodsa. - Spikelets tuberculate; branching annuals, rooting at the lower nodes.

2. P. verrucòsum Muhl. Glabrous; culms slender, spreading or ascending, 3-6 dm. high ; leaves $1-1.5 \mathrm{dm}$. long, 4-6 mm. wide, shining; panicle diffuse, few-flowered, $0.7-2.5 \mathrm{dm}$. long (reduced panicles often produced from the base), branches capillary, spreading, spikeletbearing toward the ends; spikelets $1.5 \mathrm{~mm}$. long, subacute; first glume about one fourth as long as the faintly nerved warty second glume and sterize lemma; fruit apiculate. Moist sandy soil, Mass. to Fla.; also in Ind. at the $\mathrm{s}$. end of L. Michigan. Fig. 58.

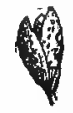

58. P. verrucosum. Spikelet $\times 9$.

* CAPILLARIA.-Branching annuals, hispid as a whole; panicles diffuse; spikelets glabrous, strongly nerved; first glume about one half the length of the. second, broad, clasping the base of the spikelet, acute; second glume and sterite lemma slightly or greatly exceeding the elliptical smooth and shining fruit.

3. P. capillàre L. (OLD-witch GRAss.) Culms stout, sparingly branched, ascending; sheaths and usually the leaves (5-15 mm. wide) copiously papillose-

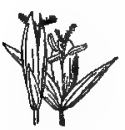

59. P. capillare. Spikelets $\times 4$. hispid; panicle very large and diffuse, often half the length of the entire plant, included at base until maturity; spikelets 2-2.5 mm. long; second glume and sterile lemma acuminate, exceeding the fruit. - Sandy soil, and as a weed in fields, N. S. to B. C., and southw. Aug.-Oct. - At maturity lower paniclebranches diverge and the panicles break away and act like tumble weeds. Fig. 59.

4. P. Gattingèri Nash. Culms widely spreading or decumbent, sometimes as much as $1 \mathrm{in}$. long, branching at all the nodes, the branches again branching; the numerous exserted panicles oval, smaller and less diffuse than in the preceding; spikelets more turgid; leaves less hirsute. ( $P$. capillare, var. campestre Gattinger.) - Moist open ground, Me. to N. C., Ill, and Mo.Depauperate plants forming very small prostrate mats occur in N. E. and N. Y.

5. P. fiexile (Gattinger) Scribn. Slender, erect, 3-6 $\mathrm{dm}$. high, with a few erect branches at base ; leaves $1-2.5 \mathrm{dm}$. long, 2-6 $\mathrm{mm}$. wide, rarely wider, sometimes nearly glabrous, erect; panicles usually one half the length of the entive plant, narrowly oblong with ascending bränches; spilcelets $3-3.5 \mathrm{~mm}$. long, solitary at the ends of the branchlets; the long acuminate secrnd glume and sterile lemma one third longer than the fruit. - Moist sandy soil, Pa. and Mich., southw.

6. P. philadélphicum Bernh. Slender, erect or ascending, usually decumbent at base, freely branching, zigzag, $1.5-4 \mathrm{dm}$. high; leaves less than $1 \mathrm{dm}$. long, 2-6 mm. wide; panicle about one third the entire height of the plant, rather few-flowered, spikelets in 2's or sometimes solitary, at the ends of the divergent flexuous branchlets, 1.7-1.8 mm. long; second glume and sterile lenma acute, barely exceeding the fruit. ( $P$, minus Nash, according to description; $P$. minimum Scribn. \& ! (err.) - Dry woods, clearings, and sandy shores, Me. to I. T., and southw. 
7. P. miliceum L. (Edropean Millet.) Culms 2-5 dm. high, erect or decumbent; sheaths papillose-hispid; leaves $1-2.5 \mathrm{dm}$. long, $2.5 \mathrm{~cm}$. or less wide ; panicle dense, drooping at maturity; spikelets ovoid, $5 \mathrm{~mm}$. long, turgid. - Waste places, Me. to Pa., westw. to Neb. (Adv. from Eu.)

* * DiснотомггLòrA. - Branching annual, glabrous throughout.

8. P. dichotomiflorum Michx. Culms compressed, thick, suc-

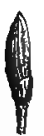
culent, spreading or ascending from a decumbent base, 3-18 dm. long ; leaves $2-4 \mathrm{dm}$. long, $8-15 \mathrm{~mm}$. wide, scabrous above ; panicles 1.2-4 dm. long, diffuse; spikelets short-pediceled; mostly secund toward the ends of the branchlets, $3 \mathrm{~mm}$. Iong, acute; first glume obtuse, second and sterile lemma pointed beyond the fruit. ( $P$. proliferum Am, auth. not Lam.) - Low waste

60. $P$, dichotomiflorum.

Spikelet $\times 8$. grounds and cultivated fields, Me. to Neb., and southw. JulyOct. - Slender, depauperate, erect or prostrate specimens occur in sterile ground. FIG. 60.

* * VIrgata. - Stout simple mostly glabrous perennials, woith long-pediceled spikelets and stout creeping rootstocks.

9. P. amàrum Ell. Glaucous, caespitose in large bunches, 5-15 dm. high; leaves crowded at the base, involute, the uppermost exceeding the contracted panicle, which is 4-8 dm. long, the long slender branches erect; spikelets 4.5 $m$. long; first glume $\frac{1}{2}-\frac{2}{3}$ as long as the spikelet, second glume and sterile lemina pointed beyond the grayish fruit. - Sandy seashores, Va., and southw. Aug., Sept. - Foliage bitter.

10. P. amaroìdes Scribn. \& Merr. Glaucous; culms 5-8 dm. high, scattered from a stout creeping rootstock; leaves 1-3 am. long, flat or somewhat involute; panicle 1.5-4 dm. long, very narrow, the short branches appressed; spikelets 6 $m m$. long; first glume 3 as long as the spikelet or more. ( $P$. amarum, var. minor Vasey \& Scribn.) - Sandy seashores, Ct., and southw. Aug., Sept.

11. P. virgàtum L. (Swiтch GRAss.) Tufted, from strong creeping rootstocks, 0.9-2 m. high, sometimes glaucous; leaves elongated, flat; panicles $1.5-$ $5 \mathrm{dm}$. long, nearly as wide, the branches ascending or spreading, naked at the base; spikelets $4-4.5 \mathrm{~mm}$. long; the second glume and sterile lemma spreading and pointed, exceeding the fruit.Low open ground or salt mar'shes along the coast, also on prairies in the interior, Me. to Man., and southw. - Very variable; leaves sometimes pilose above near the base; marsh plants often very luxuriant, with panicles $6 \mathrm{dm}$. or more long. Frg. 61.

Var. obtùsum Wood. More slender, $1 \mathrm{~m}$. high or less; leaves not over $8 \mathrm{~mm}$. wide; panicle $1.5 \mathrm{dm}$. long or less, rather nar-

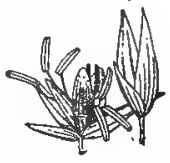

61. P. virgatum. Spikelets $\times 8$. row; spikelets $3 \mathrm{~mm}$. long; the second glume and sterile lenma blunt and scarcely exceeding the fruit. ( $P$. virgatum, var. breviramosum Nash.) - Sand barrens, N. Y., N. J., and southw,

***** Agrostofdia. - Erect perennials; spikelets lanceolate, pointed, shortpediceled along the elongated nain branches of the panicle; fruit narrowly elliptical, exceeded by the second glume and sterile lemma.

+- Rootstocks absent; plants tufted from a short caudex, compressed at the leafy base, glabrous.

12. P. longifdlium Torr. Culms slender, b-10 dm. high ; leaves flat or involute toward the ends, the uppermost often equaling the panicle, $3-5 \mathrm{~mm}$. vide; panicle purplish, 1-2.5 dm. long, rather fev-flowered; branches solitary or in 2's, remote, very slender, finally spreading, naked at the base; spikelets 2.8-3 $m m$. long; first glume $\frac{1}{2}$ as long as the second which exceeds the sterile lemma. - Moist sandy ground, Ct. to D. C., and southw., mostly coasta!. July-Sept.

13. P. agrostoides Spreng. Culms 4-10 dm. high, rather stout; sheaths loose; blades $2-3.6 \mathrm{~cm}$. long, fiat, $0.6-1 \mathrm{~cm}$. vide; panicle often purplish, oblongovate, 1.5-3 dm. long, the stiff branches ascending, naked at the base, with 
divergent densely flowered branchlets mostly from the lower side; spitkelets $2 \mathrm{~mm}$. long, crowded; a few long hairs on the short pedicel; second glume and sterile lenima subequal. - Wet meadows and shores, Me. to Minn., and southw. Aug., Sept. Fig. 62.

14. P. stipitàtum Nash. Similar to the preceding; leaves and panicles commonly dark purple, the latter narrower and closer ; lateral panicles short-peduncled from the upper nodes; spikelets narrower, more pointed, distinctly secund upon the branchlets; second glume longer than the sterile lemma; fruit stipitate; no hairs at base of spikelets.-- Moist soil, N. J. to

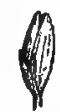

62. P. agrostoides. Spikelet $\times 5$. $\mathrm{Ky}$, and southw.

15. P. condénsum Nash. Culms stout, $0.8-1.3 \mathrm{~m}$. high, sometimes geniculate below ; leaves $2.5-5 \mathrm{dm}$. long, 8-12 mm. wide, flat or folded; panicle 1-3 dm. long, narrowly oblong, the densely flowered branches erect or narrowly ascending, the lower ones naked at the base; smaller long-peduncled panicles often produced from the upper nodes; spikelets $2.5 \mathrm{~mm}$. long, rather turgid; second glume and sterile lemma subequal, the points usually spreading at maturity. Borders of streains and wet places, Pa. (Porter); Alexandria Co., Va.; S. C. and southw.

\section{++ Plants from stout scaly rootstocks, not conspicuously compressed at base.}

16. P. ánceps Michx. Erect or ascending, 6-12 dm. high; sheaths subcompressed, glabrous or sparsely pilose; blades $1.5-5 \mathrm{dm}$. long, 6-10 $\mathrm{mm}$. wide, flat; panicles $2-5 \mathrm{dm}$. long, very loose and open, the slender remote branches spreading; small long-peduncled panicles produced from the upper nodes; spikelets more or less secund, $3.5 \mathrm{~mm}$. long; the acuminate second glume and sterile lemma curved at the apex, about $\frac{1}{3}$ longer than the fruit which bears a minute tujt of hairs at the apex. ( $P$. rostratum Muhl.) - Moist sandy soil, $R$. I. to Kan., and southw. July-Sept.

****** Dгсно́тома.-Perennials producing simple culms in the spring which later branch more or less profusely, this autumnal state often strikingly different in habit from the spring state; winter rosettes of basal leaves persistent in spring and usunlly different in shape from culm-leaves; primary panicles produced in spring or early summer seldom perfecting seed, the secondary panicles smaller, often much reduced, the latest included in the sherths, usually cleistogamous and fruitful; the secondary leaves usually much reduced, often crowded by the dwarfing of the lateral internodes.

- 1. Depauperàta. - Culms tufted, slender, sparingly branching at the base, simple above; leaves long-linear, scabrous above, the basal ones shorter but not forming a distinct flat rosette in the autumn; the reduced secondary panicles, produced from short branches from the lowest nodes, more or less concealed in the leaves at the base; ligule a ring of hairs about $0.5 \mathrm{~mm}$. long.

17. P. depauperatum Muhl. Erect or ascending, 2-4 dm. high; nodes ascending-pubescent; sheaths except the lowest shorter than the internodes, glabrous or pilose; blades 6-15 $\mathrm{cm}$. long, $2-5 \mathrm{~mm}$. wide, often involute in drying; panicles not much exceeding the leaves, 4-8 cm. long, few-flowered, the rather strict remote branches ascending; spikelets $3.2-3.8 \mathrm{~mm}$. long, glabrous or sparsely pubescent, strongly nerved ; first glume $\frac{1}{3}-\frac{1}{2}$ the length of the spikelet, subacute; second glume and sterile lemma acuminate, extending in a point beyond the fruit which is $2.3 \mathrm{~mm}$. long.- Sterile woods, Me. to Minn., and southw.

18. P. perlóngum Nash. Similar to the preceding, more strict in habit, usually papillose-pilose; blades averaging longer and narrower (sometimes 2.5 dm. long), pubescent on the lower surface; panicles smaller, narrow, the branches nearly erect; spikelets 2.7-3 mm. long, oval, blunt, sparingly pilose, strongly nerved; first glume $\frac{1}{4}-\frac{1}{3}$ the length of the spikelet; second glume and sterile lemma equaling the fruit at maturity, obtuse; fruit $2.4 \mathrm{~mm}$. long; secondary panicles usually more numerous than in the last, sometimes produced from the second node, - Prairies and dry soil, Mich, and S, Dak. to Tex, 
19. P. linearifolium Scribn. Densely tufted, 2-4.5 dm. high; culms very slender, erect, spreading or almost drooping at the summit; sheaths usually equaling or exceeding the internodes, sparsely to densely papillose-pilose ; blades $1-3.5 d^{d} \mathrm{~m}$. long, $2-4 \mathrm{~mm}$. wide, usually exceeding the panicle until maturity, often pubescent below; panicles finally long-exserted, $5-10 \mathrm{~cm}$. long, rather fewflowered, the remote flexuous branches spreading; spikelets $2.4-2.7 \mathrm{~mm}$. long, subacute, sparsely pilose; first glume $\frac{1}{4}-\frac{1}{3}$ the length of the spikelet, triangularovate; second glume and sterite lemma equaling the fruit at maturity; fruit 2 mm. long. - Woods, Me. to Md., w. to Mich. and Kan.

20. P. Wernèri Scribn. Similar to the preceding; in small tufts, glabrous except for a few long hairs at the nodes and base of blades; culms strict; leaves firmer, $1.5 \mathrm{dm}$. long or less, $3-6 \mathrm{~mm}$. wide; spilcelets $2.2-2.3 \mathrm{~mm}$. long, nearly or quite glabrous; secondary panicles usually wanting. - Sterile woods and knolls, Me. to Unt., Pa., O., and Mo. - In the field resembles $P$. depauperatum.

+ 2. Laxiflòra.--Plants in soft tufts, light green; culms slender, simple or rarely branching flom the lower nodes; basal leaves short, in a dense soft tuft, but not distinctly different from culm-leaves in shape; spikelets obovate, turgid.

21. P. xalapénse HBK. Ascending or spreading, 1-4 dm. high ; culms lax, glabrous; nodes bearded; sheaths papillose-pilose with reflexed hairs; blades mostly 8-12 cm. long, 7-11 mm. wide, sparingly pilose or nearly glabrous except the ciliate margins; panicle fnally exserted, $6-10 \mathrm{~cm}$. long, lax, the capillary flexuous branches spreading or drooping, few-flowered; spikelets $2 \mathrm{~mm}$. long; first glume glabrous; second glume and sterile lemma villous, the glume shorter than the fruit which is $1.5 \mathrm{~mm}$. long and ininutely umbonate. ( $P$. laxiflor Am. auth., not Lam.) - Low woods, Md. to Mo., and southw.

22. P. strigosum Muhl. Erect or ascending, $2-4.5 \mathrm{dm}$. high; culnis pilose; sheaths and blades long-pilose, clustered at the base, 4-8 cm. long, 6-9 mm. wide, upper blades reduced; panicle finally long-exserted, 4-10 cm. long, the axis pilose, the capillary branches ascending, with numerous long-pediceled glabrous spikelets $(1.3-1.5 \mathrm{~mm}$. long); second glume and sterile lemma equal, as long as the fruit. - Sandy woods, se. Va, to 'Tenn., and southw.

+ 3. Angustifólia. - Mostly grayish-green, caespitose; primary culms with elongated leaves (tapering to each end) and long-exserted few-flowered primary panicles; blades conspicuously striate-nerved; ligule a ring of stiff hairs less than 1 mm. long; autumnal state repeatedly bushy-branched above, often genieulate-decumbent; spikelets obovoid, turgid, altenuate at the base, pubescent (rarely glabrons); first glume 1-nerved; second glume and sterile lemma equal, i-9-nerved; fruit broadly ellipsoidal.

$\checkmark$ 23. P. angustifolium Ell. Culms slender, erect or spreading at the top, 3-8 dm. high, appressed-pubescent; nodes not bearled; sheaths shorter than the internodes, papillose-pilose, lower commonly purplish; blades ciliate toward the base, 8-15 cm. long, 3-6 mm. wide, somewhat spreading, the lower shorter and often broader; panicle 4-9 $\mathrm{cm}$. long, the slender flexuous branches widely spreuding, sometimes drooping, bearing a few long-pediceled spikelets about 2.5 $m m$. long; first glume obtuse, glabrous, $\frac{1}{3}$ the length of the spikelet or less; second glume and sterile lemma obtuse, short-villous, equaling the fruit, which is minutely pubescent at the obscurely umbonate apex. Branching state leaning, not prostrate; leaves reduced, very narrow, flat, or involute on the margins only. - Low sandy woods, Del., Va., and southw. - Variable in the amount of pubescence.

24. P. consanguineum Kunth. In the simple state similar to the preceding, but spreading or ascending, more softly and densely villous; nodes bearded; the leaves often conspicuously longitudinally wrinkled; panicles smaller, the branches narrowly ascending; spikelets more turgid, more densely villous. Branching state decumbent; the numerous leaves soft and flat, rarely over $5 \mathrm{~cm}$. long. (P. villosum Ell.) - Low sandy woods, se. Va., and southw.

25. P. aciculàre Deș. Ascending-pilose ; culms at first ascending or spread- 
ing, 3-5 dm. high, very slender; sheaths usually less than half as long as the internodes; biades mostly spreading, flat or involute above, $4-8 \mathrm{~cm}$. long, $4 \mathrm{~mm}$. wide or less, the lower wider; panicle $3-5 \mathrm{~cm}$. long, the flexuous branches spreading; spikelets $2 \mathrm{~mm}$. long; first glume $\frac{1}{4}$ the length of the spikelet, rounded; second glume and sterile lemma densely pubescent, equaling the fruit which is minutely pubescent at the apex. In the branching state forming dense prostrate mats, with very numerous crowded short involute-setaccous often falcale leaves. ( $P$. filirameum Ashe; $P$. neuranthum of Britton's Man., not Griseb.) - Sandy soil, mostly near the coast, se. Va., and southw.

26. P. Bicknéllii Nash. Culms usually stiff, erect or ascending, $2-4 \mathrm{dm}$. high (rarely higher); nodes and lower part of the sheaths and margins sparsely hairy; blades $7-14 \mathrm{~cm}$. long, 3-8 num. wide (ravely wider), ciliate at the base, rather rigid, spreading, flat, the uppermost usually the longest; panicles 5-8 c 1 n. long, the stiff slender branches bearing a few long-pediceled spikelets; these $2.5 \mathrm{~mm}$ long; first glume loose, $\frac{1}{3}$ the length of the spikelet; second glume and sterile lemma sparsely pilose or rarely glabrous, equaling the fruit or very slightly exceeding it. Autumnal state ascending or erect, rather sparingly branching from the upper nodes with iumerous long rather stiff leaves overtopping the reduced panicles of long-pediceled spikelets. ( $P$. nemopanthum Ashe; $P$. Bushii Nash.) - Sterile open woods and hillsides, Ct. to N. C., and Mo.

- 4. Eudichótoma. - Culms solitary or in small tufts, slender, at first simple, with lanceolate leaves and open teminal panicles; later profusely branching, often learing or decumbent; basal leaves short, forming flat rosettes in the autumn; ligule a ring of hairs less than $0.5 \mathrm{~mm}$. long; spikelets ellipticai-oôlong, not turgid; seconä glume and sterile lemma 7-nerved.

\section{+ Spikelets glabrous.}

27. P. dichótomum L. Glabrons, often purplish; culms 3-5 dm. high, erect from short knotted rootstocks; sheaths less than half the length of the internodes, rarely ciliate on the margins; blades spreading, 5-11 $\mathrm{cm}$. long, 4-8 mm. wide; paniele 4-9 cm. long, the flexuons branches spreading, spikelet-bearing toward the ends; spikelets $2 \mathrm{~mm}$. long, rather faintly nerved; the second glume shorter than the fruit, exposing its summit at maturity. Branching state erect, bushy-branched at the top, like a litlle tree; the leaves crowded and spreading, more or less involute. -Woods, Me. to Mich., Fla., and Tex. - Spikelets or lower

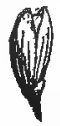

63. P. dichotomum. Spikelet $\times 5$. sheaths rarely minutely pubescent. FIG. 63.

28. $\mathbf{P}$. barbulatum Michx. In the simple state resembling large specimens of the preceding, in larger tufts; culms sometimes $8 \mathrm{dm}$. high; lower nodes often sparsely bearded; sheaths usually with a puberulent ring at the summit; blades 6-10 cm. long, 6-10 mm. wide; panicles 6-11 cm. long, as wide or wider, the lower branches drooping at maturity, spikelet-bearing at the ends ; spikelets $2 \mathrm{~mm}$. long; second glume and sterile lemma equal, covering the frut at maturity. Autumnal state diffusely branched, forming very large top-hrory reclining bunches, the slender branches recurved. - Rocky woods and hillsides, Ct. to Mich., Mo., and southw.

$\checkmark$ 29. P. yadkinénse Ashe. Similar to $P$. dichotomum; culms taller (sometimes $1 \mathrm{~m}$. high) and stronger; sheaths usually bearing pale glandular spots; blades $9-13 \mathrm{~cm}$. long, $8-11 \mathrm{~mm}$. wide; the basal and rameal leaves correspondingly larger than those of $P$. dichotomum; panicle about $10-12 \mathrm{~cm}$. long, the slender branches rather strict; spikelets $2.5 \mathrm{~mm}$. long, acute; second glume and sterile lemma equal, exceeding the fruit, forming a slight beak beyond it. Auunnal state leaning, not profusely branched. - Moist woods and thickets, Pa. and D. C. to Ga.; and Ill.

30. P. lúcidum Ashe. At first resembling $P$, dichotonum, but bright green, shining, and with erect leaves; the weok culms soon becoming decumbent, sometimes rooting at the nodes; sheaths usually ciliate on the margin; blades 4-7 cm. long, spreading in the decumbent state ; panicle fewer-flowered ; spikelets a $\mathrm{mm}$. long; nerves more prominent than in $P$. dichotomum; second glume ano 
sterile lemma both shorter than the fruit. In late summer the delicate culms are almost creeping and vine-like, repeatedly branching, the hranches elmingted and diverging at a wide angle, not fascicled; the waxy flat leaves $2-4 \mathrm{~cm}$. long. Wet woods and sphagnum swamps, N. J., I). C., and southw.

31. P. microcárpon Muhl. Culms at first erect, in large clumps; nodes swollen, densely bearded with reflexel hairs; sheaths less than half as long as the internodes, ciliate on the margin, the lower sometimes pilose; blades $10-12 \mathrm{~cm}$. long, 10-12 mm. wide, thin, spreading or deflexed, ciliate at base, otherwise glabrous; basal leaves shorter and broader; panicles long-exserted, 10-12 cm. long, branches ascending, with numerous spilkelets $1.6 \mathrm{~mm}$. long; second glume slightly longer than the fiuit. Becaming diffusely. branched, reclining or prostrate, with densely crowded small flat leaves and numerous very small panicles. (Muhl. in Ell., not Muhl. Gran., which is $P$. polyanthes Schultes; $P$. barbulatum Am. auth., not Michx.) - Wet woods and swampy places, Mass. to Ill., s. to Fla. and Tex. - Spikelets rarely sparsely pubescent.

+ Spicelets pubescent.

32. P. boreàle Nash. Culms $3-5 \mathrm{dm}$. high, slender, erect, or in weak forms geniculate at base; nodes sometimes with a few hairs ; sheaths often overlapping, ciliate on the margin, glabrous, or the lower sparsely pubescent; blades 6-12 $\mathrm{cm}$. long, 7-12 $\mathrm{mm}$. wide, erect, sparingly ciliate toward the rounded base, otherwise glabrous (rarely puberulent beneath); panicle 5-10 $\mathrm{cm}$. long, hardly as wide, loosely flowered, the slender branches ascending or spreading; spikelets $2.2 \mathrm{~mm}$. long, obtuse; first glume $\frac{1}{3}$ as long as the subequal second glume and sterile lemma, which are as long as the fruit. Sparingly branched from all the nodes in late summer; leaves and panicles not greatly reduced. - Moist open ground or woods, Nfd. to Ont., s. to N. E., N. Y., n. Ind., and Minn.

33. P. mattamuskeeténse Ashe. Often purplish ; culms $0.4-1 \mathrm{~m}$. high, erect or geniculate at base, glabrous; nodes puberulent; sheaths loose, short, urper glabrous except on the margin and sometimes the summit, lower usually softly pilose ; blades 6-9 $\mathrm{cm}$. long, 6-12 $\mathrm{mm}$. wide (upper and lower smaller), spreading, often refiexed, glabrous; panicle 6-10 $\mathrm{cm}$. long, the flexuous branches spreading, spikelet-bearing almost to the base; spikelets 2.3 nun. long; second glume and sterile lemma subequal, both shorter. than the subacute fruit. Remaining erect, branching from the middle nodes in late summer, the branches rather appressed; rameal leaves stifly ascending. (P. Clutei Nash.) - Sandy borders of cranberry bogs and swamps, Mass., N. J., and southw.

34. P. ánnulum Ashe. Purplish; culms erect, 5-7 dm. high, in small clumps; nodes densely bearded; sheaths glabrous or the lower softly pubescent; blades 6-12 cm. long, 7-13 mm. wide, spreading, velvety-pubescent on both surfaces, margins ciliate toward the base; panicles $5-9 \mathrm{dm}$. long, open; spikelets $2 \mathrm{~mm}$. long; second glume slightly shorter than the fruit. Erect and sparingly branched from the upper nodes in late summer, soon dying to the ground. - Dry woods, N. J., Pa., and D. C. to Ga. ; apparently rare.

+5. Sprèta. - Plants mostly glabrous or at least not spreading-pilose ; blad.es firm; ligule dense, 2-5 mm. long; spikelets densely pubescent, $1.6 \mathrm{~mm}$. long or less.

35. P. sprêtum Schultes. Culms erect or slightly decumbent at base, glabrous; nodes swollen, usually naked; sheaths loose, shorter than the internodes, usually ciliate on the margin above, otherwise glabrous, or the lower

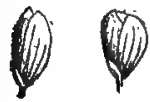
sparsely pubescent; ligale $2-3 \mathrm{~mm}$. long; blades $7-10 \mathrm{~cm}$. Inng, 4-8 $\mathrm{mm}$. wide, ascending, often reflexed, sparingly long-ciliate at base, otherwise glabrous; panicle 8-12 cm. long, less than half as wide, rather dense, the fascicled branches ascending or 64. P. spretum. appressed, short spikelet-bearing branches at the base of the
Splkelets $\times 5$. fascicles; spikelets $1.5-1.6 \mathrm{~mm}$. long, elliptic, obscurely pointed; second glume and sterile lemma equal, slightly exceeding the fruit. Somewhat reclining in the autumnal state, the tufted branches shorter than the elongated primary internodes; the reduced crowded leaves often conduplicate, 
sometimes minutely pubescent on the lower surface. ( $P$. nitidum of recent auth., not Lam. P. Eatoni Nash ; P. paucipilum Nash.) - Moist, usually sandy soil, Me., and southw, near the coast; and in Ind. near L. Michigan. FIG. 64. $\checkmark 36$. P. Lindheimèri Nash. Culms stiffly ascending or spreading, $5-10 \mathrm{dm}$. long, glabrous or pubescent below; nodes swollen; sheaths less than half as long as the elongated internodes, ciliate on the margin, otherwise glabrous, or the lowermost pubescent; ligule $4-5 \mathrm{~mm}$. long; blades 5-8 cm. long, 6-8 mm. wide, ascending, often reflexed when old, with a few hairs on the margins at base, glabrous on both surfaces, or minutely puberulent below; panicle 4-7 $\mathrm{cm}$. long, nearly as wide, branches ascending or spreading, loosely flowered; spikelets $1.5 \mathrm{~mm}$. long, obovate, obtuse; second glume shorter than the fruit. Culms elongated and radiating-prostrate in the autumn, earlier branches long, the later ones in short tufts, all appressed; leaves much reduced, involute-pointed; the hairs at base often conspicuous. - Sandy woods and open ground, Ct. to Fla., w. to Ill. and Cal.

37. P. leucóthrix Nash. Light olive green, or often purplish ; culms 2.5-4.5 am. high, erect, appressed-papillose, the hairs on the sleaths more spreading; ligule $3 \mathrm{~mm}$. long; blades ascending, 2.5-4.5 cm. $l o n g, 3-7 \mathrm{~mm}$. wide, papilloseciliate at the rounded base, velvety beneath; panicle $3-5 \mathrm{~cm}$. long, $2-4 \mathrm{~cm}$. wide, rather densely flowered, axis appressed-pubescent, with tufts of long hairs in the axils of the ascending branches; spikelets $1.2 \mathrm{~mm}$. long, obovate-elliptic, densely papillose-pubescent; second glume and sterile lernma equal, barely covering the obscurely pointed fruit. Branching state erect or nearly so, branches mostly from the lower nodes, not in fascicles; leaves and panicles not greatly reduced. - Low sandy ground, mostly pine land, s. N. J., and southw.

- 6. Lanugindsa. - Plants pilose at least on culms and sheaths; ligule 2-5 mm. long (rarely less); spitcelets pubescent. (P. pubescens Am. authors, not Lam.)

38. P. huachùcae Ashe. Plants typically stiff, with copoius spreading papillose pubescence, harsh to the touch, commonly olivaceous, often purplish; culms 2-6 dm. high, erect or nearly so ; nodes bearded with spreading hairs; blades firm, erect or ascending, 4-8 cm. long, 6-8 $\mathrm{mm}$. wide, veins inconspicuous, upper surface copiously short-pilose especially toward the base, lower surface densely pubescent; ligule 3-4 $\mathrm{mm}$. long; panicle 4-6 crm. long, nearly as wide, rather densely flowered, the axis and often the branches pilose; the flexuous fascicled branches ascending or spreading, short spikelet-bearing branchlets at the base of the fascicles; spikelets 1.6-1.7 $\mathrm{mm}$. long, obovate, obtuse, turgid; first glume $\frac{1}{4}-\frac{1}{3}$ as long as the spikelet; second glume and sterile lemma papillose-pilose, subequal, slightly shorter than the obscurely apiculate fruit. Stiffy ascending or spreading in the autumnal state; culms and sheaths sometimes papillose only, the branches fascicled, the reduced crowded leaves ascending. ( $P$. unciphyllum of recent Am. auth., not Trin.) - Prairies and open ground, Me. to Minn., and southwestw. - A variable species, apparently intergrading with the following and with $P$. implicatum.

Var, silvícola Hitchc. \& Chase. Taller and more slender, brighter green, less densely pubescent; blades thin, lax, and spreading, 5-10 cm. long, 6-10 mm. wide, upper surface less densely pilose, lower surface appressed-pubescent, with a satiny luster; panicle $6-8$ (rarely 10 ) $\mathrm{cm}$. long, the branches more spreading : spikelets the same length but elliptical and less turgid, with shorter pubescence. More or less decumbent in the autumnal state, the numerous fascicled branches shorter than the primary internodes, at least late in the season, the reduced spreading leaves sometimes nearly glabrous above except for a few long hairs near the base. ( $P$. lanuginosum as described by Scribner \& Merrill, not Ell.) - Woods and clearings, range of the typical form, but more common southw.

39. P. implicàtum Scribn. Erect, 2-5.5 dın. high; slender culms and sheaths papillose-pilose ; ligule 4-5 mm. long; blades $3-6 \mathrm{~cm}$. long, $3-6 \mathrm{~mm}$. wide, rather firm, erect or ascending; upper surface pilose vith erect hairs 3-4 mm. long; lower surface appressed-pubescent; panicle $3-5 \mathrm{~cm}$. long, nearly as wide, 
the axis long-pilose, the very flexuous branches often tangled, the lower usually. drooping; spikelets $1.5 \mathrm{~mm}$. long, obovate, obtuse, papillose-pilose; second glume and sterile lemma equal, as long as the fruit. In late summer ascending or spreading with fascicled branches from the lower nodes, the crowded reduced leaves pilose as in the simple state. - Wet meadows, bogs, and wooded swainps, N. B. to Minn., s. to D. C.

40. P. meridionale Ashe. Differs from the preceding as follows: more slender, not over $4 \mathrm{dm}$. high ; upper internodes and sheaths minutely appressedpubescent only; panicles not over $4 \mathrm{~cm}$. long, axis nearly glabrous; branches ascending or spreading; spikelets 1.3-1.4 $\mathrm{mm}$. long. The slender culms beconing geniculate-decumbent, with slender fascicled branches at all the nodes; leaves not greatly reduced. ( $P$. filiculme Ashe, not Hack.) - Sandy or sterile woods or clearings, $\mathrm{Ct}$. to Ind., N. C., and Ga.

41. P. orícola Hitchc. \& Chase. Grayish or purplish, densely tufted, spreading, early branching and prostrate, forming dense mats; culms 1-3 dm. long, appressedor ascending-pilose, the hairs on the nodes spreading; sheaths rather loose, appressed-pilose; ligule 1-1.5 $\mathrm{mm}$. long; blades 2-5 cm. long, 2-4 mm. wide, firm, erect or ascending; upper surface covered with hairs 3-5 mm. long, becoming sparse on the later leaves; lower surface appressed-pubescent, a few long laairs intermixed; panicles short-exserted, $1.8-3 \mathrm{~cm}$. long, 1-2 cm. worde; spikelets $1.5 \mathrm{~mm}$. long, rounded-obovoid, very turgid, pubescent with short spreading hairs; first glume abruptly pointed, $\frac{1}{3} \frac{1}{2}$ as long as the equal second glume and sterile lemma, which are barely as long as the fruit. Leaves and panicles not greatly reduced in the branching state. - Sands along the coast, Mass. to Va. Most readily distinguished by prostrate and early branching habit, and small panicles of rounded spikelets, large in proportion to the panicle.

42. P. subvilldsum Ashe. Slender, 1-3.5 dm. high, leafy at the base, widely spreading; culms and sheaths sparsely ascending-pilose; nodes short-bearded, a glabrous ring below; ligule $1 \mathrm{~mm}$. long, with a ring of hairs "3-4 $\mathrm{mm}$. long above it; blades firm, ascending, 4-6 $\mathrm{cm}$. long, 4-6 mm. wide; both surfaces pilose, the hairs on the upper 3-5 mm. long; panicle long-exserted, 3-5 cm. long, rather narrow, the lower branches ascending or appressed, rather densely flowered, axis pubescent or pilose; spikelets $1.9 \mathrm{~mm}$. long, obtuse, turgid; first glume about $\frac{1}{2}$ as long as the spikelet, acuminate; second glume and sterile lemma subequal, the glume slightly shorter than the fruit. Widely spreading and zranched from the lower nodes in autumn; leaves and panicles not greatly reduced ; leaves less pilose than the earlier ones. ( $P$. unciphyllum, forma pilosum Scribn. \& Merr., not P. pilosum Sw.) - Dry woods and sandy ground, Me. to Minn. ; and in $\mathrm{n}$. Ind.

43. P. tennesseénse Ashe. Bright green, often purplish ; culnıs $2.5-6 \mathrm{dm}$.high, slender, stifly spreading; internodes and sheaths papillose-pilose with spreading hairs, or the upper sometimes nearly glabrous; blades firm, ascending or suberect, 6-9 cm. long, 5-8 mm. wide (upper much smaller), with a thin white cartilaginous margin, often sparsely ciliate at base; veins conspicuous; upper surface glabrous or with a few long hairs at the base, appressed-pubescent or nearly glabrous beneath; ligule dense, 4-5 mm. long; panicle purplish, 4-7 cm. long, nearly as wide, rather densely flowered, the lower branches ascending; spikclets 1.6-1.7 mm. long, obtuse, turgid; first glume about $\frac{1}{4}$ as long as the spikelet, glabrous; second glume shorter than the fruit at maturity. Autumnal state widely spreading or decumbent and with numerous fascicled branches as long as or longer than the primary internodes; leaves much reduced, usually ciliate at base. Open rather moist ground and wood-borders, Me. to Micn., s. to N. C. and 'Tex. $\checkmark$ 44. P. lanuginòsum Ell. Grayish olive-green, velvety-villous all over; culms 4-6 dm. high, slender, spreading ; leaves $5-10 \mathrm{~cm}$. long (uppermost much smaller), thickish but not stiff, margins sometimes papillose-ciliate, long soft hairs interunixed with the velvety pubescence on the upper surface; ligule $3-4 \mathrm{~mm}$. long; panicle 5-11 cm. long, about as wide, loosely flowered, the filiform branches finally wide-spreading; spikelets $1.8 \mathrm{~mm}$. long, obovate-elliptic, obtuse, villous with soft spreading hairs ; first glume $\frac{1}{3}$ as long as the spikelet ; second glume and sterile lemma equal, slightly shorter than the subacute fruit. Documbent and 
repeatedly branching in the autumn, branches much exceeding the internodes, leaves much reduced, usually ciliate. - Moist sandy woods, mostly near the coast, N. J. to Fla. and La. - Resenbling $P$. scoparium in color and pubescence, but smaller and much more slender.

45. P. aubúrne Ashe. Similar to the preceding but smaller in all its parts, early becoming diffusely branched and decumbent; upper surface of the blades with copious long silly hairs intermixed with the velvety pubescence; primary panicle short-exserted, 3-4 cm. long: about as wide, axis velvety with long silky hairs intermixed, branches spreading; spikelets $1.3-1.4 \mathrm{~mm}$. long, obovate, very turgid, densely papillose-pubescent; first glume $\frac{1}{3}-\frac{1}{2}$ as long as the spikelet, second glume and sterile lemma equal, covering the fruit. - Sandy pine and oak woods on the coastal plain. N. J. to Fla.

46. P. praecocius Hitchc. \& Chase. Culns very slender, wiry, early branching, 1.5-4 dm. high, soon becoming geniculate and somewhat spreading, copiously pilose with weak spreading hairs 3-4 $\mathrm{mm}$. long, as are the sheaths, which are much shorter than the long internodes; ligule 3-4 mm. long; blades rather firm, 5-8 $\mathrm{cm}$. long, 4-6 mm. wide, those of the branches as large as the primary blades, often involute toward the end, long-pilose on both sides; the hairs on the upper surface erect, 4-5 $\mathrm{mm}$. long; primary panicle 4-6 cm. long, nearly as wide, loosely flowered, axis pilose, branches spreading or ascending; secondary panicles numerous, appearing before the maturity of the primary one; spitcelets 1.8-1.9 mm. long, obovate. turgid, long-pilose with weak spreading hairs; first glume $\frac{1-1}{3}$ as long as the spikelet; second glume and sterile lemma subequal, the glume slightly shorter than the fruit. - Dry prairies and clearings, Mich. and III. to Okla. and Tex. - Scarcely has a simple state, branches appearing often before the primary panicle is expanded.

47. P. scoparioides Ashe. Culms erect, papillose-hispid, a glabrous or papillose ring below the bearded nodes; lower sheaths distant, the upper sometimes overlapping on the shortened internodes, papillose-hispid (rarely nearly glabrous); ligule 2-3 $\mathrm{mm}$. long; blades $\mathrm{frm}$, ascending or spreading, $7-10 \mathrm{~cm}$. long, 6-7 mm. wide, papillose-pubescent beneath, sparsely hispid above; panicle pale, rather densely flowered, sometimes included at the base, $4-7 \mathrm{~cm}$. Iong, about 2 as wide; branches ascending or spreading; spikelets $2.2-2.3 \mathrm{~mm}$. long, obovate, obtuse, papillose-pubescent, strongly nerved; first glume about $\frac{1}{4}$ as long as the spikelet, second barely as long as the fruit. Autumnal state with short branches at the middle and upper nodes, the reduced blades involute-pointed, much exceeding the panicles. - Dry gravelly or serpentine soil, Ct. to Dèl.; apparently rare.

48. P. villosíssimum Nash. Olive-green; culnıs $2.5-4.5 \mathrm{dm}$. high, erect or ascending, slender, villous with spreading hairs $3 \mathrm{~mm}$. long, as are the sheaths; ligule 4-5 mm. long; blades rather firm, especially those of the branches, ascending, 6-10 cm. long, 5-10 $\mathrm{mm}$. wide, often subinvolute toward the end, pilose on both surfaces, hairs of the upper surface appressed, long and less copious; primary panicles often equaled by the uppermost leaf, 4-8 cm. long, about as wide, loosely flowered; spikelets $2.2-2.5 \mathrm{~mm}$. $l o n g$, oblong-elliptic, obtuse, papillcse-pubescent; first glume $\frac{1}{3}-\frac{1}{2}$ as long as the subequal second glume and sterile lemma which are scarcely as long as the subacute fruit. Culms in autumnal state widely spreading, often with geniculate nodes and arched internodes; late in the season prostrate, leaves of the fascicled branches appressed, the clump having a flat combed-out appearance, a character conspicnons in the field but less so in the herbarium; blades not much reduced. ( $P$. atlanticum Nash; $P$. haemacarpon Ashe; $P$. xanthospermum Scribn. \& Mohr.) - Sandy or sterile soil, open woods and hillsides, Mass. to Minn., s. to Fla. ; common.

49. P. ovale Ell. Light olive-green; culms $2-4 \mathrm{dm}$. high, erect or ascending, rather stout, villous with ascending or appressed long silky hairs; nodes densely bearded with spreading hairs; sheaths nearly as long as the internodes, the upper sometimes overlapping, villous like the culm, or upper rarely nearly glabrons ; liaule $2 \mathrm{~mm}$. long; blades 6-10 cm. long, $5-9 \mathrm{~mm}$. wide, firm, ascending, rounded at base, more or less appressed-pilose toward the margins and base above, appressed-pubescent below ; panicle usually short-exserted, $5-8 \mathrm{~cm}$. long, 
3-6 cri. wide, rather loosely flowered, branches somewhat contracted after flowering; spikelets $2.7-2.9 \mathrm{~mm}$. long, oblong-elliptic, obtuse, villous with silky hairs; first glume 3-nerved, $\frac{1-\frac{1}{2}}{3}$ as long as the equal second glume and sterile emina which barely cover the obtuse fruit. In late summer the stiff ascending or erect culms bear numerous short crowded branches with firm sometimes nearly glabrous blades, but little reduced. ( $P$. ovale Ell. as to specimen so labeled in Elliott herbarium and of description in part. 'The author confused a puberulent narrow-leaved $P$. commutatum with this species, and his description is made to cover both. Not $P$. ovale of Small's Fl.) - Dry sand, N. J. to Fla. ; and about L. Mich. in Mich. and Ind.

$\therefore$ 7. Columbiàna. - Culms rather stiff, appressed-pubescent at least below: blades firm, thick, ascending, cartilaginous-margined, appressed-puberulent on lover surface, usually glabrous on upper surface; sheaths appressedpubescent; ligule less than 1 mm., usually about $0.5 \mathrm{~mm}$. long; spikelets obovate, turgid, pubescent; the first glume $\frac{1}{3}-\frac{1}{2}$ as long as spikelet. Habitat, sandy soil.

50. P. Commonsiànum Ashe. In large tufts ; culms ascending or spreađing, densely appressed-pilose, as are the sheaths ; blades flat, $6-10 \mathrm{~cm}$. long, $5-6 \mathrm{~mm}$. wide (the upper and lower smaller), at least the lower appressed-pilose beneath ; paricle 4-8 cm. long, about as broad, the branches spreading, usually with few spikelets ( $2.5-2.7 \mathrm{~mm}$. long); the first glume rather remote, $\frac{1}{2}$ as long as the spikclet, narrow, acute; second glume and sterile lemma equaling the fruit. Branching state often purple, widely and stifly spreading, flat on the sand, with short-fascicled branches mostly from the upper nodes, and crowded stiff subinvolute leaves. - Dunes and sandy woods, mostly near the coast, Ct. ; s. N. J. and southw.

51. P. Addisonii Nash. Often purplish; cuims stout, rigid, 2-4 dm. high, erect or ascending, densely long-appressed-pubescent, the pubescence on the sheaths shorter; blades 5-7 $\mathrm{cm}$. long, 4-6 $\mathrm{mm}$. wide, glabrous above (or a few hairs near the margin); panicle $3-5 \mathrm{~cm}$. long, $2-3 \mathrm{~cm}$. wide, rather densely flowered, branches ascending; spikelets 2-2.2 mm. long; first glume about half as long as the spikelet; second glume and sterile lemma barely equaling the fruit. In late summer ascending or spreading, with short appressed branches from the middle and upper nodes, the reduced blades involute toward the summit. - Sand barrens, Ct. to N. C.

52. P. tsugetorum Nash. Bluish green, sometimes purplish; culms slender, $2.5-5 \mathrm{~cm}$. high, ascending or spreading, often geniculate below, crisp-appressedpubescent, as are the sheaths ; blades 5-6 cm. long (rarely longer), 4-7 mm. wide, glabrous above or with a few long hairs near the base and margins; panicle 3-5 cm. long, about as wide, rather loosely flowered, branches ascending or spreading; spikelets $1.9 \mathrm{~mm}$. long; first glume about $\frac{1}{3}$ as long as the spikelet; second glume and sterile lemma equaling the fruit. More or less spreading in autumnal state, freely branching from middle nodes, branches ascending; leaves not greatly reduced, scarcely involute. - Sandy woods, N. Y. and N. J.; also about the Great Lakes. - Some forms hardly distinguishable from the next.

53. P. columbiànum Scribn. Culms rather slender, erect or ascending, $2-4 \mathrm{dm}$. high, ascending-crisp-pubescent, as are the sheaths; blades $5 \mathrm{~cm}$. long or less, 4-5 $\mathrm{mm}$. wide, mostly glabrous above; panicles finally long-exserted, $3-5 \mathrm{~cm}$. long, somewhat narrower, branches ascending or spreading; spikelets $1.7 \mathrm{~mm}$. long; first glume $\frac{1}{3}-\frac{1}{2}$ as long as the spikelet; second glume and sterile lemma equaling the fruit. Willely spreading but not decumbent in the autumnal state, repeatedly branching from the middle nodes, the branches erect; the reduced leaves involute-pointed, glabrous above. (P. psammophilum Nash.) - Dry sandy soil, N. E. to Ala., mostly near the coast.

Var. thinium Hitchc. \& Chase. Like small specimens of the species in the simple state, but branching earlier and more profusely, decumbent, forming dense mats; the small leaves (1-2 cm. long) with scattered long hairs on the upper surface; spikelets 1.3-1.4 mm. long. - With the species, dry sands, N. . $_{\text {. }}$ and Del. 
- 8. Ensifòlia. - Delicate, densely tufted, mostly glabrous; spikelets not over $1.5 \mathrm{~mm}$. long; ligule obsolete.

54. P. ensifòlium Baldw. Culms 2-3.5 dm. high, glabrous, ascending or spreading, from dense tufts of ascending basal leaves; these:;-7 $\mathrm{cm}$. long, $4-5 \mathrm{~mm}$. wide, remaining green throughout the summer; sheaths glabrous, much shorter than the loug internodes; culm-blades $0.7-2 \mathrm{~cm}$. long, 1-2 mm. wide, symcading, usually puberulent beneath; panicle $1.5-3 \mathrm{~cm}$. long, nearly as wide, rather fewflowered; spicelets $1.5 \mathrm{~mm}$. long, obovate-elliptic, turgid at maturity, densely puberulent; second glume slightly shorter than the obtuse fruit. Branching from the upper nodes in the autumnal state, culms usually decumbent, branches short, not very numerous. ( $P$. Brittoni Nash.) - Borders of cranberry bogs, S. N. J., and low pine lands southw.

P. Tínue Muhl. ( $P$. unciphyllum Trin.; $P$. albo-marginatum Nash) has been collected in the Great Dismal Swamp, Va. (Chase). This is characterized by the larger and firmer leaves clustered at the base of the culms and having: especially when dry, conspicuous cartilaginous white margins.

- 9. Sphaerocárpa. - Rather stout, glabrous; blades firm, cordate at base, scabrous on upper surface, margins cartilaginous; ligule nearly obsolete; spikelets obovoid-sphericai, puberulent; second glume and sterile lemma 7-nerved, equaling fruit at maturity. Sparingly branched or nearly simple in autumn.

55. P. sphaerocárpon Ell. Dull green; culns 2-5.5 dm. high, usually widely spreading, nodes appressed-pubescent; sheatlus nearly as long as the internodes or overlapping, loose toward the summit, ciliate on the margin; blades 6-10 cm. long, 7-14 mm. wide (uppermost smaller, thick, ascending, stiff-ciliate toward the base, nerves inconspicuous; panicle long-exserted, 5-10 cm. long, nearly as wide, rather loosely flowered, with viscid spots on the axis and ascending branches; spikelets usually purple, 1.6-1.8 mm. long; fruit chinawhite. Sparingly branching from the lower nodes late in the season; leaves and panicles not much reduced. - Sandy ground, Mass. to Kan., and southw. FIG. 65.

56. P. polyánthes Schultes, Light green, erect; culms 3-9 dm. high, nodes glabrous; sheaths very long, usually overlapping, margin finely ciliate; blcues 12-23 cm. long, 1.5-2.5 cm. wide (uppermost not smaller), strongly nerved, ciliate toward the base; panicle 8-25 cm. long, not more than half as wide, densely flowered, lower branches nearly erect, often distant; spikelets green, 1.5-1.6 min. long; fruit stramineous. Culms simple or very sparingly branched from the lower or middle nodes late in the season. ( $P$. microcarpon Muhl. Gram., not Ell.) - Damp ground, woods and openings, N. Y. to I. T., and southw.

+ 10. Commutàta. - Stout, erect, glabrous or puberulent only; leaves cordate, over $1 \mathrm{~cm}$. wide (sometimes less in $P$. Ashei); ligule nearly obsolete; panicles open, loosely flowered; spikelets oblong or elliptic, not turgid, pubescent, 2.6-3 $\mathrm{mm}$. long; second glume and sterile lemma strongly 7-nerved.

57. P. commutàtum Schultes. In large or small clumps; culms 4-7.5 dm. high, usually stiff, erect and glabrous, nodes puberulent; sheaths glabrous or puberu. lent toward the summit, a pubescent ring at the junction with the blade, wiargin ciliate; blades rather firm, spreading or ascending, 5-12 cm. long, 1.2-2 cm. wide (rarely longer or wider), glabrous on both surfaces (rarely puberulent), margins ciliate toward the base; panicle $6-11 \mathrm{~cm}$. long, as wide or wider; spikelets 2.6-2.8 $\mathrm{mm}$. long, oblong-elliptic, obtuse; second glume and sterile lemma equal, barely covering the minutely umbonate fiuit. In autumnal state culms ascending or spreading, with somewhat divaricate simple branches from the middle nodes; the leaves crowded but hardly reduced. ( $P$. subsimplex Ashe.) -Woods and copses, Del. to Fla., w. to Ill, and 'Tex.

58. P. Áshei Pearson. Usually purplish, in loose clumps from a knotted crown; culms $2.5-5 \mathrm{dm}$. high, erect, stiff, wiry, densely crisp-puberulent; sheaths 
1ess densely puberulent, short-ciliate on the margin; blades often approximate toward the summit, 5-8 $\mathrm{cm}$. long, 5-12 $\mathrm{mm}$. wide, rigid, spreading or ascending, ciliate at the subcordate base, otherwise glabrous ; panicle $5-10 \mathrm{~cm}$. long, hardly as wide; spikelets $2.6 \mathrm{~mm}$. long, oblong-elliptic, obtuse ; second glume and sterile lemma subequal, obtuse or withering to a point, slightly exposing the minutely umbonate fruit. In autumnal state the culms bearing widely divergent branches from all or sometimes from only the upper nodes; the crowded leaves rigid, voidely spreading; plants often top-heavy and reclining from repeated branching: leaves little reduced except those of late autumn. - Dry, especially rocky, woods, Mass. to Ga., w. to Mich. and Mo.

59. P. mutábile Scribn, \& Smith. Blue green, almost glaucous, erect, rather slender, 5-8 dm. high, solitary or few in a tuft; culms glabrous or crisppuberulent below; sheaths ciliate, otherwise glabrous; blades 8-12 cm. long, 1-1.6 cm. wide, horizontally spreading, conspicuously ciliate, especially the wider basal ones, otherwise glabrous; panicles $8-10 \mathrm{~cm}$. long, about as wide; spikelets purple, $3 \mathrm{~mm}$. long, elliptical; first glume $\frac{1}{3}-\frac{1}{2}$ as long as the spikelet, the second barely as long as the fruit. Internodes much elongated in the autumnal state, culms somewhat spreading, early branches elongated, later ones short and somewhat crowded. - Sandy soil, mostly in shade, se. Va. to N. C. and Miss.

+ 11. Lanceària. - Densely tufted; olive-green; culms slender, wiry, puberulent; blades short, flat, firm, the thin cartilaginous margins papillose-ciliate toward the base; ligule obsolete or nearly so; spikelets pyriform, turgid, stronglg nerved.

60. P. lanceàrium 'Trin. Culms erect or geniculate at base, often reddish, $1.5-4 \mathrm{dm}$. high, crisp-puberulent as are the short sheaths; blades ascending or spreading, $2.5-4.5 \mathrm{~cm}$. long, 3-5 mm. wide, usually ciliate for $\frac{1}{8}-\frac{1}{2}$ their length, puberulent beneath, glabrous above; panicles short-exserted, loosely flowered, 3-5 cm. long, $\frac{3}{3-\frac{3}{4}}$ as wide, the few very flexuous branches spreading or drooping, spikelet-bearing from the base; spikelets $2 \mathrm{~mm}$. long, $1 \mathrm{~mm}$. wide; first glume about $\frac{1}{3}$ as long as the glabrous or puberulent subequal second glume and sterile lemma, the glume scarcely covering the fruit, which is obscurely pubescent at the apex. Autumnal state decumbent, ascending at the ends, with short fascicled branches from the upper nodes; the densely crowded leaves reduced, involutepointed. ( $P$. Nashianum Scribn.) - Low pine lands near the coast, se. Va, to Miss.

61. P. pátulum (Scribn. \& Merr.) Hitchc. Culms lax, prostrate, 2-6 dm. long ; sheaths and both surfaces of the blades softly pubescent; the blades thin, spreading, $4.5-8 \mathrm{~cm}$. long, $5-8 \mathrm{~mm}$. wide, often ciliate nearly to the apex; panicles $4.5-7 \mathrm{~cm}$. long, hardly as wide, the slender branches spreading, spikelet-bearing from near the base; spikelets $2 \mathrm{~mm}$. long, $1.3 \mathrm{~mm}$. voide; first glume about $\frac{1}{2}$ as Jong as the densely papillose-pubescent second glume and sterile lemma, the glume scarcely covering the fruit, which is obscurely pubescent at the apex. Autumnal state widely spreading, almost vine-7ike, the numerous branches slender and elongated; leaves and panicles not greatly reduced. ( $\boldsymbol{P}$. Nashianum, var. Scribn. \& Merr.) - Moist sandy soil, se. Va. to Fla., near the coast.

+ 12. Oligosánthia. - Culms stout, erect; blades firm, rarely over $1.5 \mathrm{~cm}$. vide, usually narrower'; ligule from nearly obsolete to $3 \mathrm{~mm}$. long; spikelets obovate, turgid, usually papillose-hispid, 3-4 $\mathrm{mm}$. long.

62. P. oligosánthes Schultes. In small tufts ; culms 3-8 dm. high, often purplish, appressed-pubescent below; sheaths rather loose, ascending-papillose-pubescent; ligule 1-2 mm. long, with long hairs intermixed; blades stiffly spreading or ascending, 6-10 $\mathrm{cm}$. long, $5-8$ (rarely 10 ) $\mathrm{mm}$. wide, sharply acuminate, glabrous on the upper, harshly puberulent on the lower surface ; panicles 6-10 cm. long, nearly as wide, loosely flowered, branches ascending; spikelets $8.5-4 \mathrm{~mm}$. long, narrowly obovate, subacute, sparsely pubescent; first glume less than $\frac{1}{2}$ the length of the second glume, which is shorter than the fruit. In the autumnal state somewhat spreading, branching sparingly from the lower nodes, and 
profusely from the upper, the short branches aggregated at the summit; the crowded leaves widely spreading. ( $P$, pauciflorum Ell, not $\mathrm{R}$. Br.) - Sandy soil, Del. to D. C., and southw.; and in n. Ind., near L. Michigan.

63. P. Scribneriànum Nash. Similar to the preceding, usually in larger clumps; culms not so tall, ustally less pubescent; sheaths papillose-hispid or sometimes nearly glabrous; ligule about $1 \mathrm{~mm}$. long; blades ascending or erect, averaging wider (6-10 mm., rarely wider), usually ciliate toward the subcordate base ; paniole short-exserted, 4-7 rarely $9 \mathrm{~cm}$. long, about as wide; spikelets $3.2-3.3 \mathrm{~mm}$. $7 \mathrm{ong}$, very turgid, obtuse, sparsely pubescent or nearly glabrous; second glume slightly shorter than the minutely apiculate fruit. Branching late, mostly from the lower nodes, forming short tufts. ( $P$. scoparium Wats. \& Coult., not Lam.) - Sandy soil or dry prairies, Me. to Ont, and westw. to the Pacific, s. to Va. and Tex. Fig, 66.

64. P. Leibérgii (Vasey) Scribn. Culms 3-8 dm. high,

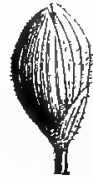

66. P. Scribnerianum. Spikelet $\times 4 \frac{\mathrm{t}}{2}$. scabrous, at least below the nodes; sheaths strongly papillose-hispid, with spreading hairs; ligule very minute; blades ascending, 8-15 crn. long, 8-12 mm. wide, papillose-hispid on both surfaces, often sparsely so above; panicle 8-15 cm. long, less than $\frac{1}{2}$ as wide, the branches narrowly ascending; spikelets $4 \mathrm{~mm}$. long, less turgid than in the last, papillose-hispid with long spreading hairs; first glume over $\frac{1}{2}$ as long as the spikelet, acuminate, second equaling the fruit. Sparingly branched from the lower nodes in late summer, the branches mostly simple, erect; blades not much reduced. - Prairies, $\mathrm{O}$, and Mich. to S. Dak. and Mo.

65. P. Ravenèlii Scribn. \& Merr. Erect or ascending; culms 3 6 dm. high, densely papillose-pubescent with ascending hairs; nodes short-bearded; sheaths distant below, the upper overlapping, pubescent like the culm; ligule $3-4 \mathrm{~mm}$. long; blades thick, ascending, 8-15 cm. long, 1-1.5 mm. wide, rarely wider, ciliate nearly to the apex, densely pubescent beneath, glabrous above; panicle short-exserted or included at base, $7-10 \mathrm{~cm}$. long, about as wide, branches finally spreading; spikelets $4 \mathrm{~mm}$. long, broadly obovate, very turgid, sparsely pubescent; first glume about $\frac{1}{5}$ as long as the spikelet, second glume slightly shorter than the fruit. Autumnal state more or less spreading, bushy-branched above; the crowded leaves ascending. - Sandy or gravelly soil, Md. and D. C., southw.

66. P. xanthophysum Gray. Yellowisb green ; culms ascending, in swall tufts, 2-6 dm. high, scabrous; sheaths loose, at least the lower overlapping, sparsely papillose-pilose, bearded at the summit ; ligule minute ; blades erect or nearly so, rather thin, strongly nerved, 1-1.5 dm. long, 1-1.8 cm. wide, narrowed to the rounded ciliate base, otherwise glabrous; panicle finally long-exserted, 0.5-1.2 dm. long, very narrow, few-flowered, the branches erect; spikelets $4 \mathrm{~mm}$. long, broadly obovate, very turgid, pubescent, rarely glabrous; first glume nearly $\frac{1}{2}$ as long as the spikelet, pointed, second scarcely covering the fruit. Branching in midsummer from the second and third nodes, branches erect, mostly simple; the large erect leaves making the plant appear very leafy in the middle. - Dry soil, Me. to Man., and Pa.

67. P. Wilcoxianum Vasey. Culms erect, 1-2 dm. high, copiously papillosepilose as are the usually overlapping sheaths (rarely nearly glabrous); ligule about $1 \mathrm{~mm}$. long; blades erect, 5-6.5 cm. long, 3-5 $\mathrm{mm}$. wide, densely $70 n g-$ pilose on both surfaces; panicle finally exserted, 2-4 cm. long, about half as vide, rather densely flowered, branches ascending; spikelets $2.7-3 \mathrm{~mm}$. long, oblong-obovate, pubescent; first glume about $\frac{1}{3}$ as long as the spikelet, second hardly covering the fruit. Autumnal state branching from all the nodes, forming bushy tufts with rigid erect leaves much overtopping the reduced panicles. Prairies, Ia. to S. Dak. and Kan.

- 13. Scopària. - Culms tall and stout, finally vide-spreading; blades flat, elongated, not over $1.5 \mathrm{~cm}$. wide; ligule short; spikelets abruptly pointed, strongly 7-9-nerved.

68. P. scopàrium Lam. Grayish olive-green, velvety-pubescent all over except as noted; culms 8-13 dm. high. erect or ascending, often geniculate at base, 
nodes bearded with reflexed hairs, a glabrous viscid ring below; sheaths about 1 as long as the internodes, the velvety pubescence wanting on the back toward the summit, the nalced surface viscid when fresh; ligule $1 \mathrm{~mm}$. long; blades rather thick, spreading, often reflexed in age, $1.2-2 \mathrm{dm}$. long, 1-1.5 cm. wide, uppermost reduced; panicle 1-1.5 dm. long, nearly as vide, inany-flowered; axis, branches and pedicels with viscid blotches; branches spreading or ascending, spikelet-bearing to the base; spikelets $2.6 \mathrm{~mm}$. long, obovate, turgid, papillose-pubescent; second glume shorter than the apiculate fruit. Culms leaning or spreading in the autumnal state, repeatedly branching from the middle nodes, the fascicles of branches usually fan-shaped and shorter than the very long internodes, or elongated and scorpioid; sheatlus swollen above, constricted at the throat. - Wet ground, N. J. to I. T., and southw.

69. P. scabriúsculum Ell. Culms 1-2 m. high, roughened at least below the nodes, often puberulent; sheaths loose, constricted and bearded at the throat, densely papillose-hispid to nearly glabrous, often spotted; ligule minute, membranaceous, usually a ring of hairs above it ; blades stiffly ascending or spreading, often reflexed, $1.5-2.5 \mathrm{dm}$. long, 9-12 (rarely 15) $\mathrm{mm}$. wide, usually harshpubescent beneath and glabrous above; panicle 1.2-2.5 dm. long, about $\frac{2}{3}$ as wide, rather densely flowered, the lower branches ascending, axis, branches and pedicels prominently viscid-spotted, branches spikelet-bearing to the base; spikelets $2.4 \mathrm{~mm}$. long, ovate, acuminate, minutely puberulent; first glume $\frac{1}{6}-\frac{1}{5}$ as long as the spikelet, second glume and sterile lemma exceeding the fruit. Autumnal state leaning or widely spreading, repeatedly branching from the middle nodes; branches erect, later ones short; the crowded reduced blades often harsh-pubescent on both surfaces. - Swamps, W. Va., Va., and southw.

70. P. aculeàtum Hitchc. \& Chase. Resembles the preceding; culms slender, in very large clumps, scabrous, harsh-pubescent below; sheaths not so loose as in the last, papillose-hispid with stiff sharp-pointed hairs, uppermost usually glabrous; ligule minute, membranaceous, ciliate; blades stiffly ascending or spreading, 1.2-2 dm. long, 9-15 mm. wide, very scabrous on the upper surface and townrd the apex beneath ; panicle 8-12 cm. long, about as wide, few-flowered, axis and branches not viscid or with a few spots only, lower branches spreading; spikelets $3 \mathrm{~mm}$. long, elliptical, minutely pubescent; first glume $\frac{1}{2}-\frac{1}{9}$ as long as the spikelet, second glume and sterile lemma slightly exceeding the fruit. Autumnal state somewhat spreading, branched from the middle nodes, the branches divaricate, not much crowded. - Swampy woods, D. C. and N. C.; apparently rare.

+ 14. Latifòlia. Culnzs erect, stout; blades 2 cm. or more wide, cordate-clasping at base, strongly nerved, acuminate; ligule minute; panicle open; spikelets 3-4 mm. long, pubescent, strongly nerved.

71. P. clandestinum L. Usually in very large clumps, 5-12 dm. high ; culnus, nodes and sheaths strongly papillose-hispid, or the upper nearly glabrous; blades

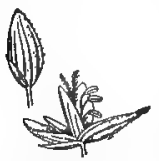

67. P. clandestinum. Closed and open spikelet $\times 8$ ascending, 1-2 dm. long, $1.8-2.5 \mathrm{~cm}$. wide, scabrous toward the ends; panicle exerted, 1-1.5 dm. long, about as wide, rather denselv flowered, the fascicled branches ascending; spikelets $3 \mathrm{~mm}$. long, elliptic, second glume shorter than the subacute fruit. Autumnal state with appressed branches with shortened internodes, the overlapping sheaths usually more strongly papillose-hispid than the earlier ones, the later branchlets very short, the leaves crowded at the summit, the panicles entirely inclosed in the sheaths. ( $P$. decoloratum Nash.) Moist ground, Me. to Minn., and southw. FIG. 67.

72. P. Bóscii Poir. Culms 3-7 dm. high, minutely pubescent or glabrous, at least the lower nodes bearded with reflexed hairs; sheaths puberulent, a dense ring of pubescence at the summit; blades $8-12 \mathrm{~cm}$. long, 2.5-3 $\mathrm{mm}$. wide, rarely wider, pubescent beneath, sparsely so (rarely glabrous) above, short-ciliate on the margins toward the base; panicle $6-10 \mathrm{~cm}$. long, usually nearly as wide, the lower branches spreading or ascending; spizelets 4-4.5 mm. long, obovate; first glume $\frac{1}{3}-\frac{1}{4}$ as long as the spikelet, second glume 
and sterile lemma scarcely equaling the fruit which is minutely pubescent at the apiculate tip. More or less spreading in the autumnal state, branching from the middle nodes, the upper leaves of the branches crowded and spreading. ( . latifolium Am, auth., not L.) - Woods, Me. to Minn., and southw.

Var. mólle (Vasey) Hitchc. \& Chase. Usually not so tall, downy-pubescent throughout. ( $P$. latifolium, var. Vasey; P. pubifolium Nash.) - Commoner southw.

73. P. latifòlium L. Like P. Boscii, but usually taller; culms and sheaths (except the ciliate margin and pubescent ring at the summit of the sheaths) glabrous or rarely pubescent below, nodes glabrous; blades commonly 1.5 dn. long, $3 \mathrm{~cm}$. wide, sometimes wider, ciliate toward the very broad base, otherwise glabrous, rarely minutely pubescent; panicle $8-15 \mathrm{~cm}$. long, the long few-flowered branches ascending; spikelets $3.5-3.8 \mathrm{~mm}$. long, obovate-elliptic, the apiculate tip of the fruit usually glabrous. Autumnal state as in $P$. Boscii. (P. macrocarpon Le Conte.) - Rocky woods and saud dunes, Me. to Wisc., and southw.

Steinchísma Hìns (Ell.) Nash, a lax perennial with narrow flat leaves and terminal panicles with spreading branches naked at base, and crowded spikelets, the palea of the sterile lemma subindurated, enlarged and forcing the spikelet open, has been collected in se. Mo. (Bush); common in the South.

\section{SACCIÓLEPIS Nash.}

Second glume gibbous at the base, 11-nerved, equal to the 3-5-nerved sterile lemma (which incloses a large palea and often a staminate flower), about twice as long as the slightly stipitate fruit; lemma thinner at the apex, the palea free at the tip; spikelets otherwise as in Panicum. Semi-aquatic perennials with narrow spike-like panicles. (Name from $\sigma a k \kappa o s, b a g$, and $\lambda \epsilon \pi i s$, scale, alluding to the saccate second glume.)

1. S. striàta (L.) Nash. Perennial, stoloniferous; culms erect from a creeping base, 3-9 dm. high, branching; sheaths birsute, at least on the margins; blades $0.8-2 \mathrm{dm}$. long, about $1 \mathrm{~cm}$. wide, flat, glabrous ; panicle $10-15 \mathrm{~cm}$. long, contracted, spike-like; spikelets $3.5 \mathrm{~mm}$. long, lanceolate, acute. (Panicum gibbum Lil.) - Low wet ground, Va. to I. T., and southw.

\section{ECHINÓCHLOA Beauv.}

Spikelets 1-flowered, sometimes a staminate flower below the perfect terminal one, nearly sessile in 1-sided racemes; glumes unequal, spiny-hispid, mucronate; sterile lemma similar and awned from the apex (sometimes mucronate only), inclosing a hyaline palea; fertile lemma and palea chartaceous, acuminate; margins of the glume inrolled except at the summit, where the palea is not included. - Coarse annuals with compressed sheaths, iong leaves and terminal panicles of stout racemes. (Name frow $\epsilon \chi i \nu 0 s, a$ hedgehog, and $\chi \lambda 6 a$, grass, in allusion to the bristling awns.)

1. E. Crusgáli (L.) Beauv. (Barnyard Grass.) Culms stout, rather succulent, branching from the base, ascending or erect, $3-18 \mathrm{dm}$. high; sheaths ana' blades glabrous; panicle dense, 1-3 dm. long, of numerous erect or spreading racemes, very variable, deep purple to pale green, erect or drooping; spikelets long-awned or nearly awnless, densely and irregularly crowded in 3 or 4 rows, about $3 \mathrm{~mm}$. long. (Panicum L.) - Moist, chiefly manured soil and waste ground, river banks, etc., common thronghout, except in the extreme North. Aug.-Oct. (Nat. from Eu.) Fig.68.

E. FrUmentacka (Roxb.) Link (Panicum Roxb.), Japanese Barnyard Miljet, or Billion-Dollar Grass, is an occasional escape from cultivation. It is distinguished from short-awned

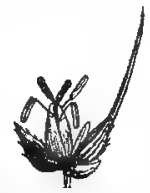

68. E. crusgalli. Spikelet $\times 3$. forms of the preceding chiefly by the more compact panicles with short often incurved branches.

2. E. Waltèri (Pursh) Nash. Resembling the preceding, usually taller, at least the loter sheaths coarsely papillose-hispid; panicle usually long, more 
drooping; spikelets long-awned, the awn sometimes as much as $5 \mathrm{~cm}$. long.(Panicum Pursh; P. hispidum Muhl.) - Marshes and ditches chiefly near the coast, N. H. to Fla.; and in w. Ont. and n. Ill. Aug.-Oct.

3. E. colona (L.) Link. (Jungle Rice.) Tufted, erect or ascending, sparingly branched, 3-6 dm. high; sheaths and blades smooth; panicle of 5-10 tense racemes (1-6 cm. long) rather distant and racemose along the axis ; spikelets about $3 \mathrm{~mm}$. long; glumes and sterile lemma pubescent, mucronate-pointed but not awned. (Panicum L.) - Ditches and low ground, Va. and Kan., southw. (Warm regions generally.)

\section{SETÀria Beauv. Bristly Foxtail Grass}

Spikelets as in Panicum but surrounded by few or many persistent awnlike branches which spring from the rhachis below the articulation of the spikelets, - Annual introduced weeds in cultivated or manured grounds, or native perennials, with linear or lanceolate flat leaves and cylindrical spikelike panicles. (Name from seta, a bristle.) Снаетоснцо Scribn.

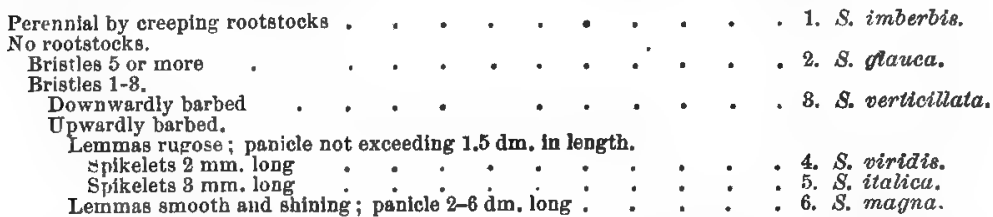

1. S. imberbis R. \& S. Culms more or less caespitose, 3-7 dm. high, slender, compressed, erect or ascending, often geniculate at base ; sheaths overlapping, compressed, glabrous; blades 1-3 dm. long, 3-7 mm. wide, attenuate toward the apex; panicle $2-5 \mathrm{~cm}$. long, nearly $1 \mathrm{~cm}$. thick, exclusive of bristles ; bristles 8-12,5-10 $\mathrm{mm}$. long, pale yellowish, sometimes purplish, upwardly scabrous; spikelets $2 \mathrm{~mm}$. long; first glume about $\frac{1}{3}$ as long as the spikelet, second $\frac{1}{2}-\frac{2}{5}$ as long, acute, 5-7-nerved, the midnerve excurrent; sterile lemma equaling the elliptical-ovate acute striate transversely rugose fertile lemma.

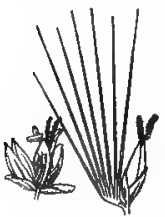

69. S. glauea.

Spikelet with sub. tending bristles. Same open, showing fertile and neutral flower $\times 8$. - Moist soil, Ct. to Kan., and southw. (Trop. Am.)

Var. perénnis (Hall) Hitchc. Culms scarcely tufted, very slender, wiry, 6-12 dm. high; blades long and narrow; panicles $2-7 \mathrm{~cm}$. long, more slender; spikelets and bristles usually purplish. (Chaetochloa versicolor Bicknell.) - Brackish marshes along the coast, $\mathrm{Ct}$. to Fla. ; and in saline soil, Kan. and I. T. June-Sept. - Intergrades with the species.

2. S. glaúca (L.) Beauv. (Foxtail, Pigeon Grass.) Annual; culms branching at the base, compressed, erect or ascending, 3-12 dm. high ; leaves flat, linear-lanceolate, glaucous ; panicle $2-10 \mathrm{~cm}$. long, about $1 \mathrm{~cm}$. thick; bristles $3-8 \mathrm{~mm}$. long, upwardly scabrous; spikelets $3 \mathrm{~mm}$. long; first glume $\frac{1}{2}$, second $\frac{2}{3}$ as long as the striate undulate-rugose fertile lenma. - Cultivated ground and waste places, common throughout. (Nat. from Eu.) Fig. 69.

3. S. verticillata (L.) Beauv. Anmual, tufted; culms 3-6 dm. high; leaves linear-lanceolate, scabrous; panicles green, $5-10 \mathrm{~cm}$. long, somewhat compound, interrupted at base, tapering above; bristles stout, downwardly barbed, 3-6 $\mathrm{mm}$. long; spikelets 2-2.6 $\mathrm{mm}$. Iong ; first glume $\frac{1}{3}$ as long as the second which equals the sterile lemma and slightly exceeds the abruptly apiculate obscurely transverserugose fertile lemma. - Near dwellings, widely distributed in eastern U.S. (Nat. from Eu.) Fig. 70.

4. S. virinis (L.) Beauv. (Green F., Bottle Grass.) Annual, tufted; culms 2-9 cm. high ; leaves $0.5-2.5 \mathrm{dm}$. long, 4-10 mon. wide, scabrous on the margins; panicles rather thick,

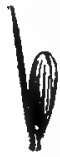

70. 9. verticil. lata. Spike let $\times 4$. 
rhachis villous; bristles slender, upwardly barbed, usually 7-12 $\mathrm{mm}$. long: spikelets $2 \mathrm{~mm}$. long ; second glume and sterile lemma equal, covering the obtusf striate faintly wrinkled fertile lemma. - Cultivated grounds and waste places, throughout. (Nat. from Eu.) FiG. 71. Var. sBeviskita (Döll) Hitchc. Bristles scarcely longer than the spikelets. Sterile soil, n. Me. and adjacent Que.

5. S. ITKLICA (L.) Beallv. Annual; panicle compound, interrupted at base, thick, nodding, 8-20 cm. long, but in escaped specimens smaller, yellowish or purplish; bristles 2 or 3 in a cluster, longer than the spikelets. - Cultivated under the name of MiLcET, German Millet, or Hungarian Grass, and rarely spontaneous, as is also Var. Germánioa (Mill.) Richter, Golden-Wonder Millet, which is more slender and has bristles shorter than the spikelets. (Introd. from $\mathrm{Eu}$.)

6. S. mágna Griseb. Probably perennial ; culm stout, erect, 1-3 m. high; sheaths loose, spreading, compressed, margins densely ciliate near the summit; blades 3-6 dm. long, 1-3 cm. wide, attenuate, scabrous; panicles usually interrupted below, 2-5 cm. thick, tapering to both ends; rhachis densely pilose; bristles 8-11 $\mathrm{mm}$. long, upwardly scabrous; spikelets $2 \mathrm{~mm}$. long; first glume broad, about $\frac{1}{3}$ as long as the second, which equals the sterile lemma and with it covers the acute apiculate smooth and shining (not striate nor rugose) fertile lemma. - Low grounds and marshes, Del., Va., and southw. (Trop. Am.)

\section{CÉNChrus L. Sandbur. Bdr Grass}

Spikelets 1-flowered, acuminate, 2-6 together, subtended by a short-pediceled ovoid or globular involucre of rigid connate spines which is deciduous with them at maturity; glumes shorter than the lemmas; sterile lemma with a hyaline palea, fertile lemma and palea less indurated than in Panicum, falcate-acuminate, the leinma not inrolled at the margins. - Our species annual, with sinıple racemes of spiny burs terminating the culm and branches. (An ancient Greek name of Setaria italica.)

1. C. caroliniànus Walt. Culms flattened, much branched, ascending or spreading, 3-8 dm. long; leaves flat; racemes of 8-20 involucres, about $8 \mathrm{~mm}$.

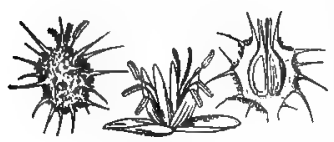

72. C. carolinianus $\times 1 \frac{1}{2}$

Closed involucre, at left Longitudinal section of same, at right. Open spikelet, in middle. thick, the 6-8 pubescent divisions spine-pointed, spines spreading or reflexed; spikelets $2-3$. ( $C$. tribuloides Am. auth., not L.) - Sandy soil, on river banks, etc., s. Me. to Fla., and westw. across the continent. Aug. (Trop. regions.) FIG. 72.

2. C. tribuloides L. Culms more robust, often extensively branching or trailing, 3-9 dm. long; sheaths loose, usually hirsute along the margins, ligule conspicuously ciliate; blades more or less involute; racemes usually included at the base; involucres 12-14 mm. thick, densely long-pubescent; the stout spines spreading or ascending. (C. macrocephalus Scribn.) - Sands along the coast, N. J. and southw.

\section{ZIZÀnIA [Gronov.] L. WATER or Indian Rron}

Spikelets unisexual, 1-flowered, the pistillate linear, awned, articulated and tardily deciduous on club-shaped pedicels on the appressed upper branches, the staminate lanceolate, early deciduous, on the expanded lower branches of the same panicle; glumes none in the pistillate spikelet; lemma closely clasp. ing the palea by a pair of strong lateral nerves, a long hispid awn from the summit ; first glume of staminate spikelet 5 -, the second 3-nerved ; stamens 6 ; grrain cylindrical, $1.5-2 \mathrm{~cm}$. long, closely enveloped in the membranaceous lemma and 3 -nerved palea. - A tall aquatic grass with long leaves and large terminal pani-

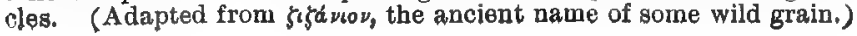


1. Z. palústris Is. (INdian Rice, Water OAts.) Annual; culms 2-3 m. high ; leaves flat, 5-10 dm. long, $1.5-4 \mathrm{c} \mathrm{m}$. wide. (Z. aquatica of auth. not L.) -

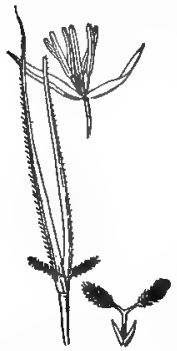

78. Z. aquatica $\times 1$. of spikelet. Q spikelet. Pistil with scales. Swampy borders of streams and in shallow water; common, especially northwestw. July, Aug. (Asia.) Fig.73.

2. Z. aquática $\mathrm{L}$. Culms about $1 \mathrm{~m}$. high; leaves narrower (less than $1 \mathrm{~cm}$. wide); pistillate portion of panicle more appressed. - Me. to Minn., and northw.

\section{ZIZANiópsis Döll \& Asch.}

Spikelets unisexual, the pistillate above, the staminate below on each branch of the panicle, much alike in appearance, laterally compressed; glumes subequal, membranaceous, the first glume of the pistillate spikelet with a short terminal awn, the leinma acute, palea none; glumes and lemma of staminate spikelet acute, nerveless, palea none; stamens 6 ; grain ovoid, with a chartaceous easily separable pericarp, loosely inclosed in the glumes. - A tall aquatic grass with long leaves and long narrow terminal panicles. (Name from Zizania and $\delta \psi(s$, appearance, from likeness to the preceding genus.)

1. Z. miliàcea (Michx.) Döll \& Asch. Perennial by a creeping rootstock; culns 1-4 m. high, geniculate at the lower nodes; leaves flat, 3-10 dm. long; 1-3 cm. wide. (Zizania Michx.) - Swamps, Va., O., and southw. May.

\section{Lé́rsia Sw. Cut-grass. White Grass}

Spikelets 1-flowered, flattened laterally, perfect, but those in the open panicles usually sterile, those inclosed in the sheaths cleistogamous and fruitful; glumes none, lemma boat-shaped, somewhat indurated, awnless, clasping the palea by a pair of strong marginal nerves; palea of like texture, much narrower, 1-llerved; stamens 1-6. Perennials of moist ground, with rough leaves and short racemes of imbricated spikelets arranged in open panicles. (Named after Johann Daniel Leers, a German botanist of the 18th century.) Homatoclinchrus Mieg.

\section{* Spikelets narrowly oblong, rather loosely crowded.}

1. L. virgínica Willd. (Whith Grass.) Culms weak, branched, ascending, with clustered scaly rootstocks; panicle simple, the slender branches stiffly spread-

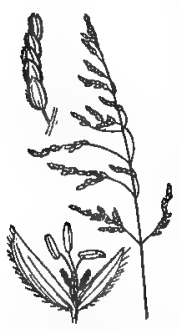

45. L. ol'vzoides.

Inflorescence $\times 1 / 5$. A bit of same $\times 2 / 3$. 0 pen spilzelet $\times 2$. ing; spikelets 2.5-3 mm. long, closely appressed; lemma hispid on the keel ; stamens 2.-Wet woods, Me. to Ont., and southw.

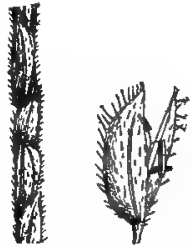

74. L. virginica.

A bit of in Horescence $\times 3$.

Spikelet $\times 5$. Ang. Fig. 74 .

2. L. oryzoìdes (L.) Sw. (Rice Cliturgass.) Culms rather stout, branched, ascending from a decumbent base with sicnder crerping rootstocks; leaves very rongh; panicle diffusely branched, lax; spikelets 4-5 $\mathrm{mm}$. long; lemma hispid, strongly bristly ciliate on the keel. - Swamps or stream borders, ditches, ete., Nfd. to Ont., and southw. Aug., Sept. (S. A., Eurasia.) Fig. 75.

\section{* Spikelets broadly oval, inbricately covering each other.}

3. L. lenticulàris Michx. (Catcrifry Grass.) Culms nearly simple, erect or decumbent at base, with scaly rootstocks; sheaths and blades sometimes nearly smooth; panicle nearly simple; spikelets very flat, $5 \mathrm{~mm}$. long, strongly bristly. ciliate. - Low grounds, Va, to Minn., and southw. 


\section{Phálaris L, Canary Grass}

Spikelets 1-flowered, laterally flattened; glumes equal, boat-shaped, much exceeding the florets; sterile lemmas small and narrow, appearing like hairy scales attached to the fertile floret; fertile lemma indurated and shining in fruit, inclosing a faintly 2 -nerved palea. - Annuals or perennials, with flat leaves and dense spike-like panicles. (The ancient Greek name, $\phi a \lambda a \rho l s$, alluding presumably to the crest-like inflorescence.)

\section{§ 1. EUPHALARIS Godron. Panicle very dense, spike-like; glumes wing-keeled.}

1. P. canariénsis L. (Canary Grass.) Annual, $3-8 \mathrm{dm}$. high; panicle oval, 2-3 cm. long; spikelets broadly obovate, 5-6 mm. long, imbricated; glumes white with green veins, the keel entire; fertile lemma brown. Waste places and roadsides. (Adv. from $\mathrm{Eu}$. )

P. MìnoR Retz. bas been collected at St. John, N. B. (Fowler) and on ballast at Camden, N. J. (Pollard). The spikes are oblong and the glumes are narrowed at the pointed apex, the exposed portion of the keel being somewhat toothed.

\$2. DIGRAPHIS (Trin.) Endl, Panicle branched, the clusters open in anthesis; glumes not winged on the back.

2. P. arundinàcea L. (Reed C.) Perennial, 6-15 dm. high; leaves flat, 6-10 mm. wide; panicle 6-15 dm. long; spikelets lanceolate, $5 \mathrm{~mm}$. long, pale; sterile lemmas reduced to minute hairy scales. - Wet grounds; coromon, especially northw. June, July. Fig. 76. Var. Pfota L., the leaves striped with white, is the familiar RiBBon Grass of the garden. (Iurasia.)

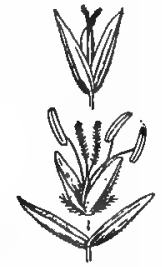

76. $P$. arundinacea $\times 2$.

Spikelet ; same with glumes sep arated.

\section{ANTHOXÁNThUM L. Sweet Vkrnal Grass}

Spikelets 1-flowered; glumes very unequal ; sterile lemmas 2-lobed, hairy, dorsally awned, longer than the fertile floret and falling with it; fertile lemma truncate, awnless, inclosing a faintly 1-nerved palea and per-

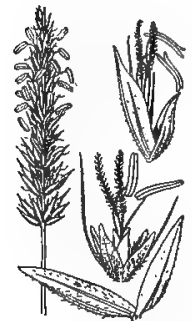

77. A. odoratum. Inflorescence $\times 1 / 2$. Spikelet; same with glumes separated $\times 1 / 2$. fect flower; stamens 2.- Aromatic plants with flat leaves and narrow spike-like panicles. (Name compounded of $\not \nu \theta o s$, flower, and $\xi a \nu \theta b s$, yellow.)

1. A. odoratum L. Perennial; culms slender, erect, 2-6 dm. high; leaves rough above; panicles $3-8 \mathrm{~cm}$. long; spikelets brownish green, 8-10 $\mathrm{mm}$. long, spreading at flowering time; glumes sparsely pilose; first sterile lemma shortawned below the apex, second bearing a strong bent scarcely exserted awn near its base. - Meadows, pastures, and waste places, throughout, especially eastw. May-July. - Sweetscented. (Nat. from Eu.) Fig. 77.

2. A. Poìlir Lecoq \& Lamotte. Smaller, annual; panicles 1-4 cm. long; spikelets whitish green, 5-7 $\mathrm{mm}$. long; the glabrous glumes narrower than in no. 1 ; the long-exserted awn blackish at base. - Dry fields and waste places, N. E. to Ont. and Pa.; sometimes cultivated westw. and southw. (Nat. from Eu.)

\section{HIERÓCHLOE் [Gmel.] R. Br. Holy Grass}

Spikelets 3-flowered, the terminal flower perfect, the others staminate or empty; glumes subequal, about the length of the spikelet, boat-shaped, shining; sterile lemmas nearly as long as the glumes, boat-shaped, indurated and hairy, each inclosing a 2 -nerved hyaline palea and a flower of 3 stamens; fertile lemma similar but smaller, inclosing a 1-nerved palea end perfect flower with 2 stamens. 
- Fragrant perennials, with flat leaves and terminal panicles. (Name from iepos, sacred, and $\chi^{\lambda} \dot{b} \eta, g r a s s$; these sweet-scented grasses being strewn before churchdoors on saints' days in the North of Europe.) Savastana Schrank.

1. H. odoräta (L.) Wahlenb. (Vanilla or Seneca Grass.) Culing 3-6 dm.

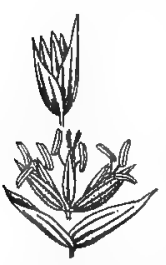

To. H. odurata.

Closed spikelet; same opened and with glumes sep. arated $\times 2$. high, from a creeping rootstock; leaves short, lanceolate, scabrous or smoothish; those of the sterile shoots long and scabrous; panicle pyramidal, $4-12 \mathrm{~cm}$. long, usually compact but sometimes loose, the slender branches drooping; spikelets $5 \mathrm{~mm}$. long, brownish ; staminate lemmas hispid-ciliate on the margins and below the apex on the keel, awnless; fertile lemma hairy at the apex. (H. borealis R. \& S.) - Moist meadows, chiefly northw., near the coast, and along the Great Lakes. May-July. (Eurasia.) Fig. 78.- The loose-panicled form, Savastana Nashii Bicknell, is not specifically distinct.

2. H. alpìna (Sw.) R. \& S. Culms 1-4 dm. high, tufted; upper sheaths inflated; blades very small, the lowest and those of the sterile shoots long and linear, smooth; panicle contracted, $2-5 \mathrm{~cm}$. long; spikelets $7-8 \mathrm{~mm}$. long, olivaceous ; staminate lemmas ciliate on the margins, the first short-awned below the apex, the second with a longer ( $5-8 \mathrm{~mm}$.) bent axn from below the middle; fertile lemma mucronate. - Alpine regions, N. E., N. Y., and north'r. July, Aug. (Eu.)

\section{Mílium [Tourn.] L. Mrllet Grass}

Spikelets 1-flowered, rhachilla articulated below the floret; glumes equal; lemma slightly shorter, shining, indurated, the margins inroiled over a sirnilar palea; grain inclosed within the lemma and palea, free. - Our species perennial with flat leaves and open prisicles. (The ancient Latin name of the milletwhich, how 'ver, belongs to a different genus - of uncertain meaning.)

1. I. f.hsum L. Smooth; culms rather slender, simple, 1-1.5 m. kifh ; leaves $1-3 \mathrm{dm}$. long, 8-15 mm. wide; panicle 1-2 dm. lors, the slender branches in remote pairs or fascicles, widely spriading or drooping, spikelet-bearing from about the middle; sprikelets $3-3.5 \mathrm{~mm}$. long; glumes minutely scabrous. - Cold dainp woods and mountain meadows, N. S. to Ill., and northw.-The fruit (mature floret) resembles that of Panicum. June-Aug. (Eu.) Fig. 79.

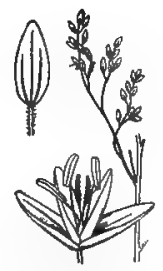

79. M. effusum. Part of panicle $\times 1 / 8$. Closed and open spikelets $\times 3$.

\section{ORYZÓPSIS Michx. Mountain Rice}

Spikelets 1-flowered, in narrow few-flowered panicles; glumes rather broad. obtuse or abruptly acute; floret with a short obtuse callus; lemma (not over $1 \mathrm{~cm}$. long) convolute, somewhat indurated, including the rather large palea and perfect flower, terminating in a deciduous simple slender awn; grain oblongellipsoid, tightly included in the indurated lemma. - Tufted perennials. (Name composed of $b \rho v \zeta a$, rice, and $6 \psi t s$, appearance, from a fancied resemblance to that grain.)

\section{* Spikelets, excluding awn, 3-4 mm. long.}

1. 0. púngens (Torr.) Hitchc. Culms densely tufted, 2-5 dm. high, erect, slender, simple; sheaths usually crowded at the base, smooth or slightly scabrous ; blades involute-filiform, the basal ones sometimes as long as the culw, usually half its length, those of the culm short; panicle 3-6 cm. long, branches erect or ascending; glumes subequal, obscurely 5-nerved; lemma nsually as long as the glumes, appressed-pubescent; awn 1-2 (rarely 5) um. long, sometimes wanting; palea as long as the lemma. (O. canadensis Man.ed.6; 0 . juncea BSP.) - Dry rocky or sandy soil, Lab. to N. $Y_{,}$and westw, 
** Spikelets, excluding awn, 6-9 mm. long.

2. 0. asperifolia Michx. Culms tufted, $2-7 \mathrm{dm}$. high, erect or geniculate at the lowest node; sheaths usually crovoded at the base; blades erect, scabrous especially on the glaucous lower surface, those of the base often exceeding the culm, 5-8 $\mathrm{mm}$. wide, flat or involute on the margins, attenuate; culm-leaves usually less than $1 \mathrm{~cm}$. long; panicle contracted, 5-12 cm. long, the branches simple, erect; spikelets, excluding awn, 6-8 $\mathrm{mm}$. long; glumes subequal, short-ciliate at the apiculate summit; lemma nearly or quite as long as the second glume, sparingly pubescent; avo 5-10 $\mathrm{mm}$.

long; lodicules 3 the length of the palea. Wooded hillsides, along waterways, etc., Nfd. to B. C., s. to Pa., Minn., and N. Mex. June. Fig. 80.

3. 0. racemòsa ( $\mathrm{Sm}$.) Ricker. Culms tufted, erect, 3-12 dm. high, leafy to the summit; leaves 1-3.5 $\mathrm{rm}$. long, 4-15 mm. wide, flat, narrowed toward the base, taper-pointed, scabrous below, pubescent above; panicle 7-25 $\mathrm{cm}$. long, branches

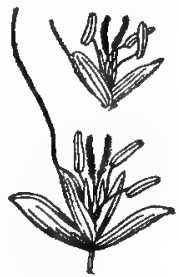

80. 0 . asperifolia $\times 11 \%$.

Spikelet (below). Floret (above). nearly simple, usurally ascending; spikelet, excluding awn, 7-9 min. 81. O. racemosa. long; glumes equal, acute; lemma somewhat shorter, pubescent,
Spikelet $\times 1$. becoming black in fruit; awn 1.5-2.5 cm. long; lodicules minute. Spikelet $\times 1$. (Milium Sm.; O. melanocarpa Muhl.) - Rocky woods, Me. to Ont., southw. to Del. and Ia. June-Oct. Fig. 81.

\section{STipa I. Feather Grags}

Spikelets 1-flowered, in terminal panicles; glumes narrow, acute or bristletipped ; floret with a bearded usually sharp-pointed callus; lemma convolute, indurated, including the small palea and perfect flower, terminating in a simple strong persistent geniculate twisted awn; grain cylindrical, tightly included in the indurated fruiting lemma. - Rather large tufted perennials with involute leaves. (Name from $\sigma \tau u r \eta$, tow, in allusion to the flaxen appearance of the feathery awns of the original species.)

\section{* Glumes 4-12 mm. long.}

\section{- Callus blunt; awn $1 \mathrm{~cm}$. or less long.}

1. S. canadensis Poir. Culms tufted, 3-6 dm. high; leaves 4-12 cm. long, narrow, involute, scabrous; panicle loose, 5-12 cm. long, the opposite fewflowered branches ascending; glumes subequal, oblong, subacute, $4 \mathrm{~mm}$. long, slightly exceeding the pubescent oblong lemma; awn $6-10 \mathrm{~mm}$. long. ( $S^{\prime}$. Richardsani Man. ed. 6, not Link; S. Macounii Scribn.) - Woods and thickets, N. B., Me., N. H., N. Y., n. shore of L. Superior, Sask., and northw.

$$
\text { + + Callus acute; awn more than } 1.5 \mathrm{~cm} \text { long. }
$$

2. S. viridula Trin. Culms clustered, 5-10 dm. high, sparingly branched; basal sheaths overlapping, the long usually scabrous involute or sub-involute blades elongated, upper blades shorter, mostly setaceous; panicle narrow, erect, 1-2 dm. long, the branches mostly in pairs, erect, rather densely flowered from near the base; glumes 7-9 mm. long, acuminate-setaceous, exceeding the pale appressedpubescent lemnia; awn 2-4 cm. long; callus usually rather short. - Prairies and meadows, w. Minn., the Dakotas, and sonthwestw. July, Aug. - Variable.

3. S. avenàcea L. (Brack OAT Grass.) Culms tufted, slender, erect or ascending, 3-10 dm. high, leafy at the base ; sheaths shorter than the internodes; blades $1-1.5 \mathrm{~mm}$. wide, usually involute, the basal ones $\frac{1}{3}-\frac{1}{2}$ the length of the culms,

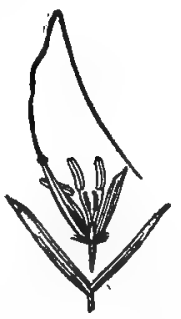

82. S. avenacea $\times 1 \%$ Flower and glumes. 
those of the culm 4-10 cm. long; panicle loose, 1-2 dm. long, the slender branches in pairs, lax, finally spreading; glumes often purplish, $8-10 \mathrm{~mm}$. long, acute, about equaling the dark-brown lemma, which is smooth below, scabrous above and bears a fringe of short hairs at the summit; awn 4-7.5 cm. long; callus acuminate, covered with dense brownish hairs. - Dry woods, Mass. to Fla., w. to Wis. and T'ex. May, June. Fig. 82.

\section{* Glumes $2 \mathrm{~cm}$. long or more.}

4. S. comàta Trin. \& Rupr. Culms erect, simple, $2-12 \mathrm{dm}$. high ; sheaths mostly crowded at the base, the upper often loose and inclosing the base of the panicle; basal blades usually about $\frac{1}{2}$ the length of the culm, mostly involute-

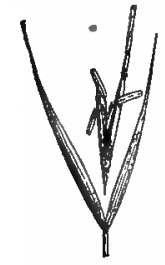

83. S. sputtu $\times 2 / 3$.

Floret and hise of awn. Glumes. filiform, those of the culm $0.5-1.5 \mathrm{dm}$. long, 2-4 inm. wide, flat or involute ; panicle loose, 1-4 dm. long, branches distant, erect or somewhat spreading, naked below; glumes $2-2.8 \mathrm{~cm}$. long, tapering into a slender fragile awn, much exceeding the sparsely pubescent lemma; awn 10-24 cm. long, pubescent to the geniculation, scabrous and curved beyond; callus acute. Dry plains and hills, Ia., and westw. June, July.

5. S. spártea 'Trin. (Porcurine Grass.) Culm rather stout, simple, 0.5-1.2 m. high; sheaths mostly overlapping; blades usually involute, basal ones $\frac{2}{5}$ the length of the culm, those of the culm 1-3 dm. long; panicle finally exserted, narrow, 1-3 dm. long, branches erect, naked below; glumes $2.8-3.5 \mathrm{~cm}$. long, attenuate, exceeding the brownish leinma, which is appressed-pubescent below, and nearly or quite glabrous above; awn 11-20 cm. long, rigid, scabrous, minutely pubescent below; callus acuminate, very sharp-pointed, densely clothed with silky appressed hairs. - Plains and prairies, Mich. to Mo., and westw. Fig. 83.

\section{ARÍstida L. Triple-awned Grass}

Spikelets 1-flowered, in usually narrow panicles; glumes unequal, narrow, acute or acuminate; a hard obconical hairy callus below the floret; lemma somewhat indurated, convolute, including the thin palea and perfect flower, terminating in a trifid awn; grain elongated, tightly included in the lemun. - Tufted annuals or perennials with narrow leaves. (Name from arista, a beard or awn.)

Annuals.

Awns separate to the base.

Lateral awns much shorter than the middle one.

Middle awn coiled at base. Glumes $7-8 \mathrm{~mm}$ long Glumes $12-14 \mathrm{~min}$. long Glumes 15-20 min. long

Middle awn not coiled at base, horizontal

Lateral awns not much shorter than the middile one.

Glumes $7-9 \mathrm{~mm}$. long ; awns $1.4-2.2 \mathrm{~cm}$. long

Glumes $20-30 \mathrm{~mm}$. long; awns $8.5-7 \mathrm{~cm}$. long : Awns unjted below in a long twisted neck Pereunials.

Awns $5-10 \mathrm{~cm}$. long

A wns not over $3 \mathrm{em}$. long.

Sheaths glabrous

Sheaths woolly.

1. A. dichótoma Michx. (Poverty Grass.) Culms tufted, wiry, much branched at the base and usually forking at every node, but in depauperate specimens sometimes nearly simple, 1-6 dm. high; sheaths loose; blades mostly involute; panicles few-flowered, simple, narrow, the lateral ones often sessile and partially inclosed in the sheaths ; glumes subequal, $7-8 \mathrm{~mm}$. long, cuspidate; lemmas about $6 \mathrm{~mm}$. long, excluding the awns; lateral awons reduced to minutt 
erect teeth, middle awn 3-6 mm. long, horizontal, coiled at the base in maturity. - Sterile sandy or gravelly soil, Me. to Mo. and southw. Aug.-Oct. Fıg.84.

Var. Curtíssii Gray. Differs in being less freely branched; panicles looser; glumes unequal, the second $10-12 \mathrm{~mm}$. long, the first $\frac{2}{3}-\frac{3}{4}$ as long; lemna 7-10 mm. long, excluding the awns. - Va, to Mo., and southw.

2. A. basiràmea Engelm. Resembling A. dichıtoma, freely branching at the base; culms sparingly branched; leaves averaging longer ; panicles looser, the terminal often partly included in the upper sheaths, small panicles commonly borne in the basal sheaths; glumes acuminate, unequal, second 12-14 $\mathrm{mm}$. long, the first about $\frac{2}{3}$ as long; lemma about $1 \mathrm{~cm}$. long, excluding the awns; lateral awns $2-7 \mathrm{~mm}$. long, erect or spreading, middle awn 1-2 cm. long. - Dry soil and prairies, Ill. to Minn. and Neb. Aug., Sept.

3. A. ramosíssima Engelm. Culms tufted, wiry, repeatedly branching, the branches divergent; leaves mostly setaceous ; panicle loose, few-flowered ; glumes $1.5-2.5 \mathrm{~cm}$. long, awned from a bifid apex, unequal, the second equaling the

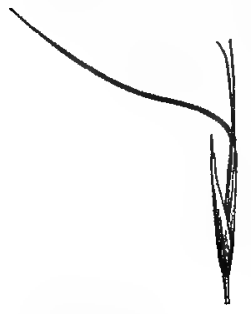

85. A. gracilis. Spikelet $\times 2$. leinma (exciuding the awns); lemma $2-2.3 \mathrm{~cm}$. long; lateral awns minute, erect, middle awn $2-3 \mathrm{~cm}$. long, reflexed by a loose spiral at base. - Dry prairies, Ind. and Ill. to Tenn. and Mo. Aug., Sept.

4. A. grácilis Ell. Culms slender, in small tufts or solitary, branched at the base, simple or sparingly branched above, $1.5-5 \mathrm{~cm}$. high; sheaths not loose; blades $2 \mathrm{~mm}$. or less wide, usually involute in drying; spikelets mostly in a slender raceme (if a panicle, the branches rarely bearing more than 2 spikelets), rather distant below, often crowded above; glumes unequal, the second equaling the floret; lemma about $6 \mathrm{~mm}$. long, usially mothed; middle awn horizontal, $8-15 \mathrm{~mm}$. long, lateral awns erect, 2-6 mm. long. - Sandy soil, N.H. to Mo., and southw. Sept. FIG. 85 .

5. A. intermedia Scribn. \& Ball. Similar to the preceding but much larger; culms 3-7 dm. high, more freely branching, often geniculate at base; leaves $5-15 \mathrm{~cm}$. long, rigid, involute ; panicle $2-4 \mathrm{dm}$. long, slender, branches short, appressed; glumes attenuate-aristate, subequal or the second longer, 7-9 mm. long, scabrous, slightly shorter than the floret; lemma scabrous above the middle, sometimes mottled; awns all spreading, the middle one 18-22 $\mathrm{mm}$. long, lateral ones 14-17 $\mathrm{mm}$. long, all variable. Dry soil, Ia. and Kran. to Miss. and Tex. Aug., Sept.

6. A. oligántha Michx. C'ulms tufted, wiry, branched at base and at all the nodes, 3-6 dm. high; sheaths loose ; blades long, usually involute; panicle or raceme few-Howered, the axis often flexuous and spikelets spreading; glumes unequal, long-awned from a bifid apex, exceeding the floret, the second strongly 7-nerved; lemma 17-20 mm. long, scabrous above; awns nearly equal, divergent, 3.5-7 cm. long. - Dry sterile soil, N. J. to Neb., and southw. Fig. 86.

7. A. tuberculdsa Nutt. Culms branched below, 1.5-5 dm. high, tumid at the joints; leaves long and involute; panicles rigid, loose, the branches in pairs, one short and about 2-flowered, the other elongated and several-flowered; glumes $2.5 \mathrm{~cm}$. long, including their slender-awned tips; lemma 12-15 mm. long, the twisted base of the awns of equal length; awns divergent, subequal, spikelet $\times 2 / 3$. 86. A. oligantha. 3.5-5 em. long. - Dry sandy soil near the coast, Mass. to Miss. ; and about the Great Lakes. Aug.-Oct. (Mex.) FIG. 87. 
8. A. purpùrea Nutt. Culms simple, $3 \mathrm{dm}$. high or less, densely tufted, spreading; leaves involute and filiform; ligule pilose; panicle loose, of rather

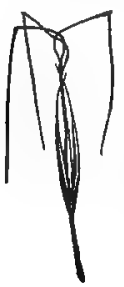

87. A. tuberculusa. Spikelet $\times 2 \%$. few slender-pediceled spikelets; glumes 1-nerved, the first about half the length of the second, which is $1 . \overline{0}-2 \mathrm{~cm}$. long, awns 5-10 cm. long. - Dry prairies, Minn. southw. and westw.

9. A. purpuráscens Poir. In small tufts, glabrous, 3-6 dur. high ; culms erect, simple or sparingly branched; leaves 1-2 dm. long, 1-4 mm. wide, usually involute toward the ends; panicle purplish, very slender, ${ }_{3}^{1}-\frac{1}{2}$ the entire length of the plant, loosely or rather densely flowered; glumes 10-12 mm. long, 1-nerved, scabrous, the first slightly the longer, attenuate-aristate, the second aristate from a bidentate apex; lemma 6-7 $\mathrm{mm}$. long; awns divergent, not twisted, $1.5-3 \mathrm{~cm}$. long; the middle somewhat longer than the lateral. - Sandy or gravelly soil, Mass. to Minn., and soutbw. (W. I.) FIG. 88. -Variable; a very delicate, apparently annual, form occurs in wet sands and drying sloughs in $\mathrm{n}$. Ind.

10. A. landsa Muhl. Culms stout, erect, simple, 6-12.dm. high; sheaths (at least the lower) woolly; blades flat, 3-6 dm. long, 3-6 mm. wide; panicles nearly half the length of the entire plant, narrow, rather loosely flowered, nodding; glumes subequal, 1-1.4 cm. long, the first slightly the longer, acuminate, the second mucronate from a bidentate apex; lemma spotted, about $1 \mathrm{~cm}$. long; lateral awns $10 \mathrm{inm}$. long, the

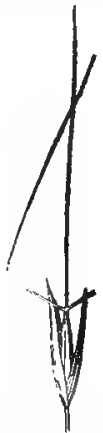

ห. A. purpursscens. Spikelet $\times 1$. divergent middle awn $1.5-2 \mathrm{~cm}$. long. (A. lanata Poir., not Forsk.) - Dry pine barrens, mostly near the coast, Del. to Tex. and I. T. Sept., Oct.

\section{MUHLENBERGIA Schreb.}

Spikelets 1-flowered, in contracted (rarely open) panicles; a short usually barbate callus below the floret; glumes thin, often aristate; lemma narrow, membranaceous, 3-nerved, awned or awnless, inclosing a thin subequal palea; grain closely enveloped by the lemma. - Our species perennial, often with scaly rootstocks, flat or involute leaves and small spikelets. (Dedicated to the Rev. Dr. Henry Muhlenberg, a distinguished American botanist, 1753-1815.)

a. Panicle more or less contracted, not diffuse; culms branched; leaves flat $b$.

$b$. Glumes at least one-half as long as the floret $c$.

c. Glumes broadly ovate, more or less clasping, one-half to two-thirds as long as the floret.

Splkelets 1.5-2 mm. long ; lemunas awnless . . . . . . 1. M. subolifera.

Splkelets 3-4 mm. long; lembias awned : : : : : : 8. $M$. tenuiflora.

c. Glumes lanceolate, acute to aristate-pointed.

Glumes not longer' than the lemmas.

Panicles linear or fliform, spikelets not crowded . . . . 3. M. sylvatica,

Panleles oblong or cylindrical, long-exserted, spikelets orowded, nore or less glomerste.

Panicles ovoid or subpyramidal, "numerous, short-exeerted or partlally included

Glumes much exceeding the awnless lemmsi

b. Glumes not more than one-fourth as long as the florets.

c. Panicle diffuse; culms simple; leaves involute

\section{M. foliosa.}

5. $M$. meacicana.

6. M. racemosu.

8. M. capillaris.

§ 1. EUMUHLENBERGIA Dalla Torre \& Harms. Panicles contracted or glom. erate, on branching culms usually from scaly creeping rootstocks; leaves flat.

* Glumes at least? as long as the floret, scahrous on the keel; all the species with clusters of scaly rootstocks.

- Glumes broadly ovate, $\frac{1}{2}-\frac{8}{4}$ as long as the floret, which is often conspicuously hairy at base.

1. M. sobolifera (Muhl.) Trin. Culms erect or ascending, sparingly branched, 4-8 dm. high, scabrous below the glabrous nodes, leafy toward the summit, 
lower leaves distant; blades 8-12 $\mathrm{cm}$. long, 4-6 mm. wide, spreading, scabrous; panicles very slender, usually loose-flowered, $1-1.5 \mathrm{dm}$. Iong (lateral paniclés if present much shorter); spikelets $1.5-2 \mathrm{~mm}$. long; the acute or abruptly cuspidate glumes $\frac{2}{3}-\frac{3}{4}$ as long as the scabrous acute lemma. - Rocky woods, N. $\mathrm{N}$. to Miun., and southw. Sept., Oct.

2. M. tenuiflora (Willd.) BSP. Similar to the preceding; culms often taller, retrorsely puberulent, at least below, nodes pubescent; panicle $1.5-3 \mathrm{dn}$. long, loosely flowered; spikelets 3-4 $\mathrm{nm}$. long; the glumes abruptly acuminate, scitbrous, $\frac{1}{2}-\frac{2}{3}$ as long as the floret, the first very broad, clasping; lemma taperiug into a slender awn 5-10 mm. long. ( $M$. Willdenowii 'Trin.) - Rocky woods and ravines, Mass. to Ont., Minn., and southw. Aug., Sept.

\section{+ + Glumes lanceolate, acute or aristate-pointed.}

" 4 Glumes not longer than the lemma; culms more or less compressed, retrorsely strigose below the glabrous nodes; leaves scabrous, ascending. (These three species are exceedingly variable; each has an awned and an awnless form. 'T'he length of the glumes, which are acuminate to aristate, is an unstable character, often varying to the extremes in the same panicle.)

3. M. sylvática Torr. Culms erect or ascending, 6-9 dm. high, freely branching, leafy ; leaves $5-18 \mathrm{~cm}$. long, $2-6 \mathrm{~mm}$. wide ; panicles usually short-exserted. 1-2 dm. long, linear or filiform; spikelets not crowded, on rather long erect branches, usually green or stramineous, 2.5-3 $\mathrm{mm}$. long; glumes acuminate, sometimes aristate, shorter than the scabrous lemma, which is mucronate or tipped with a slender awn as much as 6-12 mm. long. - Moist rocky woods and wooded banks, N. B. to Ont., Ia., and southw. Aug.-Oct.

4. M. foliòsa Trin. Similar to the preceding in size, habit and foliage; panicles long-exserted, $8-15 \mathrm{~cm}$. long, oblong or cylindrical, glomerate; spikelets more or less densely crowded on the rather short ascending or appressed branches, usually purple; glumes mucronate or aristate, nearly or quite as lony as the awned or awnless lemma. (M. ambigua Torr.) - Swampy ground, Me. to Ont., S. Dak., and southw. Sept.

5. M. mexicàna (L.) Trin. Similar to $M$. foliosa, often branching at the base; the culms decumbent and rooting at the lower nodes; panicles numerous, 5-10 $\mathrm{cm}$. long, ovoid or subpyramidal, terminal on the culm and its many rather short branches, usually partly inclosed within the upper sheath; glumes acuminate or

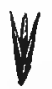

84. M. mexicana. Spikelet $\times 3$.

aristate, about as long as the acute, acuminate or awned lemma which is sometimes smooth. (M. polystachya Mackenzie \& Bush.) - Sandy and gravelly stream-banks and waste ground, N. B, to Ont., S. Dak., and southw. Aug., Sept. Frg. 89.

\section{+ Glumes aristate, much exceeding the awonless lemma.}

6. M. racemòsa (Michx.) BSP. Culms erect, 3-9 dm. high, simple or sparingly branched; blades 5-12 dm. long, scabrous ; panicles 5-10 cm. long, dense and spike-like, or interrupted at base; spikelets 4-6 mm. long; the aristate glumes subequal, much exceeding the acute lemna. ( $\boldsymbol{M}$. glomerata Trin.) - Moist meadows and low ground, Nfd, to N.J., and westw. Aug.-Oct. Fig. 90.

* Glumes not more than $\frac{1}{4}$ the length of the floret; no clusters of scaly rootstocks.

90. M. racemosa.

Splkelet $\times 3$.

7. M. Schrebèri J. F. Gmel. (Drop-Seed, Nimble Will.) Culms 3-8 dm. long, erect or ascending from a decumbent base, often rooting at the lower nodes, diffusely much branched ; blades $3-8 \mathrm{~cm}$. long, $2-4 \mathrm{~mm}$. wide; panicles $5-15 \mathrm{~cm}$. long, numerous, slender, the erect branches rather densely flowered; spikelets (excluding the awn) $2 \mathrm{~mm}$. long; first glume obsolete or nearly so, the second minute, truncate; lemma tapering into a slender awn 3-5 mm. long. (M. diffusa Schreb.) - Dry woods, hillsides and waste pıaces, Me. to Ont., Minn., and southw. Aug., Sept. 
Var. palústris Scribn. Similar to the species; culms reclining or ascending, very slender or alnost filform; leaves $2-4 \mathrm{~cm}$. long, 2-3 $\mathrm{mm}$. wide; panicles 5-10 cm. long, very slender, more loosely flowered; spikelets (ezcluding the awn) $2.5 \mathrm{~mm}$. long, usually purple; glumes acute, unequal,

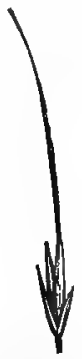
the first about $\frac{1}{5}$, the second about $\frac{1}{4}$ the length of the bidentate anoned lenma; awn flexuous, $4-6 \mathrm{~mm}$. long. ( $M$. palustris Scribn.) - Swampy ground, D. C. and Ill. Sept., Oct.

§2. TRICHÓCHLOA (Beauv.) Trin. Panicle very loose and open, the long branches and pedicels capillary; leaves narrow, often convolute-bristle-form.

8. M. capillàris (Lam.) 'Trin. (HaIr Grass.) Caespitose, erect, with simple rigid culms, 6-10 dm. high ; sheaths overlapping; blades $1-3 \mathrm{dm}$. long, involute, rigid; panicle about $\frac{1}{3}$ the entire height of the plant, its spreading sapillary branches lonsely flowered; spikelets purple, $4 \mathrm{~mm}$. long (excluding the awn); glumes subequal, acute, or the second aristate-pointed, about $\frac{1}{2}$ as long as the lemma which bears a delicate awn 5-20 mm. long. 41. M. capillaris. Dry sandy or gravelly soil, Mass. to Fla., west to Mo. and Tex. Spikelet $\times 8$. FIG. 91 .

\section{BRACHYELYTRUM Beauv.}

Spikelets 1-flowered, in a few-flowered narrow panicle; glumes minute, unequal; floret with a short callus, the rhachilla prolonged behind the palea into a slender naked bristle; lemma firm, narrow, 5-nerved, terminating in a long strajght awn; palea firm, nearly as long as the lemma; grain oblong, inclosed in the lemma and palea. - Perennials, with simple culms from

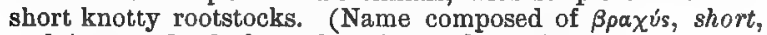

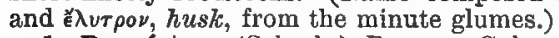

1. B. eréctum (Schreb.) Beauv. Culms erect, 5-10 dm. high; sheaths sparsely retrorse-hispid ; blades $8-15 \mathrm{~cm}$. long, 1-1.8 mm. wide, lanceolate, very scabrous, pilose on the nerves beneath; panicle narrow, 1-2 dm. long; spikelets $1 \mathrm{~cm}$. long (excluding the awns), on capillary pedicels ; first glume often obsolete, second sometimes aristate; floret scabrous. (B. aristatum Beauv.) - Rocky woods, Nfd. to Minn., and southw. July, Aug. Fig. 92.

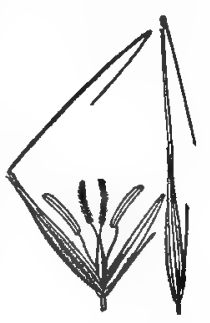

92. B. erectunt. Spikelets $\times 11 / 8$.

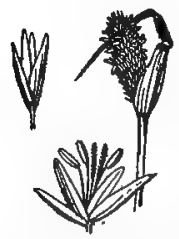

93. H. schoenoides. Inflorescence $\times 1 / 2$. Spikelets $\times 8$.

\section{HELEÓCHLOA Host}

Spikelets 1-flowered, flattened, in dense oblong-ovoid spikelike panicles; glumes awnless, shorter than the 1-nerved lemma which subtends a palea of nearly equal lengti $\mathrm{L}_{2}$ - Low caespitose branching annuais, the numerous spike-like panicles partly included in the inflated sheaths. (Name from $z$ inos, a meadow, and $\chi^{\lambda 6 a, \text { grass.) }}$

1. H. sCHOENotDes (L.) Host. Usually almost prostrate; leaves rather rigid, tapering to a sharp point; spike $1.5-4 \mathrm{~cm}$. long. - Waste places, N. Y. to Del. and e. Pa. ; also Chicago, III. (Bebb). (Adv, from Eu.) Fig. 93.

\section{PHLEेUM L.}

Spikelets 1-flowered, flattened, in dense oylindrical spike-like panicies; glumes equal, ciliate on the keels, and abruptly awn-pointed, longer than the 
broad truncate 5-nerved hyaline lemma; palea nearly equal, narrow. - Erect simple peremnials, with flat leaves and terminal spike-like panicles. (From $\phi \lambda \hat{\epsilon} \omega s$, a Greek name for a kind of reed.)

1. P. praténse L. (Timothy, Herd's Grass.) Culms 4-10 $\mathrm{lm}$. high, from a swollen base; panicle long-cylindrical; awn of glumes $1 \mathrm{~mm}$. $70 \mathrm{ng}-$ Meadows, commonly cultivated for hay. (Nat. from Fu.) Fig. 94.

2. P. alpinum L. Culms 2-6 dm. high; panicle narrowly ellipsoid or short-cylindrical; awn of glumes $2 \mathrm{~mm}$. long.Alpine regions of N.E. and northw.; also Upper Mich. (Eurasia.)

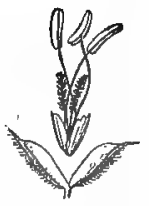

94. P. pratense. Floret raised from the glumes $\times 3$.

\section{ALOpect̀rus L. Foxtail Grass}

Spikelets 1-flowered, flattened, falling from the axis entire, in slender spike like panicles; glumes equal, awnless, usually connate at the base, ciliate on the keel, the broad j-nerved obtuse lemma nearly equal in length, with a slender erect dorsal awn from below the middle; nargins connate near the base; palea none. - Branching perennials with tlat leaves and soft dense spike-like panicles. (Name from $d \lambda \dot{\omega} \pi \eta \xi$, $f o x$, and ovjod, tail, from the shape of the spike.)

1. A. PRaténsis L. (Meadow F.) Erect, glabrous; culms $3-9 \mathrm{dm}$. high, from short creeping rootstocks; sheaths loose, the upper usually inflated; leaves scabrous; panicle 5-10 cm. Iong; spikelets $5 \mathrm{~mm}$. lon!;

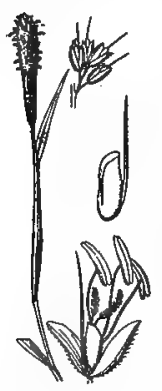

95. A. geniculatus. Inflorescence $\times 1 / 4$. Bit of same $\times 1$. Spikelet and lemma $\times 3$. the lemma equaling the acute long-ciliate glumes; awn usually exserted about $5 \mathrm{~mm}$. - Meadows and pastures, eastw. May. (Nat. from Eu.)

2. A. geniculàtus L. (Flonting F.) Glabrous or nearly so ; culms slender, decumbent and branched at base, then erect or ascending, $1.5-6 \mathrm{dm}$. high; leaves slightly scabrous; panicles slender, $2.5-7.5 \mathrm{~cm}$. long; spikelets about $3 \mathrm{~mm}$. long; lemma shorter than the obtuse long-ciliate glumes; awn bent, the exserted portion usually twoice as long as the glumes. Moist meadows, banks of streams and ditches, Nfd. to B. C., and throughout U.S. June-Aug. (Eurasia.) Fig. 95.

Var. aristulàtus Torr. Spikelets slightly smaller, awn very slender and scarcely exserted. - In water and wet places, common. June-Aug. - In the Western States these two forms seem inseparable and indigenous, but in the eastern portion of our range the former appears to be introduced and is easily distinguished by its longer awns and usually geniculate or creeping base. The variety appears to be the same as $\boldsymbol{A}$. fulvus Sm. of Eurasia.

1. 3. A. AgRéstis L. Glabrous; culms erect or decumbent at base, 3-6 dm. high; leaves scabrous; panicle rather slender, $3.5-10 \mathrm{~cm}$. long; spikelets 6-7 $\mathrm{mm}$. long; glumes very short-ciliate on the keels, connate for $\frac{1}{3}$ their length, slightly shorter than the lemma; awn twice the length of the glumes or more. - Waste places and ballast, Mass., N. J., Pa.; and on Pacific coast. (Adv. from Eu.)

\section{SPORÓbOLUS R. Br. Drop-seed. Rush Grass}

Spikelets 1-flowered, awnless, in narrow and spike-like, or loose and spreading, often partly included, panicles; lemma as long as or longer than the usually unequal glumes, 1-nerved; palea equaling or exceeding the lemma, often splitting between the strong nerves at maturity; grain readily falling from the spikelet, pericarp loosely inclosing the seed, often thin and evanescent. - Annuals or perennials with involute or flat leaves. (Name from $\sigma \pi o \rho a ́, ~ s e e d$, and $\beta a ́ \lambda \lambda \epsilon \iota, t o$ cast forth.)

GRAY'S MANUAL -9 
Panicles contrieted.

Rootstocks short or slender or none; culms tufted or solitary.

Panicle not more than one-third the entire height of the plant. Perennials.

Spikelets 5 uлm. long or more; panicle dense.

Floret appressed-pubescent below.

Lemma two-thirds as long as palea. . . . 1. $\boldsymbol{B}$. clandertinus.

Lemma and palea subequal

Floret glabrous

Spikelets not over $4 \mathrm{~mm}$. long; panicle in terrupted.

Culms smooth; ligule $0.5 \mathrm{~mm}$. long

Culms minutely roughened by septae; ligule 2 mm. long

Annunls.

Bipikelets $4 \mathrm{~mm}$. long ; lemma pubescent

Spikelets $2.5-3 \mathrm{~mm}$. long; Jemma glabrous

Panicle one-third to one-half the entire height of the plant

liootstocks stout, extensively creeping

Panlcles open (often contracted in no. 10).

Glumes very unequal.

Spikelets 2.5-3 mm. long; glumes opate or lanceolate.

Sheaths bearded at the throat; blades flat .

Sheaths not bearded; blades involute

Spikelets 4-6 mm. long; frst glume awl-shaped

clumes subequal.

Plants compressed at base; leaves conduplicate

Plants not compressed; leaves flat

- S. canovirens.

- 3. S. asper.

4. S. brevifolius.

5. S. Richardsonis.

6. S. vaginiflor 18 .

7. S. neglectus.

8. S. indicus.

9. S. virginicus.

1. S. clandestinus (Spreng.) Hitchc. Tufted culms 4-12 dm. high ; lowe1 leaves long, subrigid, the margins and involute-filiform tips acabrous; panicle

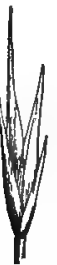
$5-15 \mathrm{~cm}$. long, often partially inclosed in the upper sheath; spikelets 6-8 $\mathrm{mm}$. long; glumes unequal, acute, the first $\frac{1}{2}$ the length of the acute lemma, the second $\frac{1}{2}$ that of the $70 n g$-acuminate pointed palea; lemma and palea appressed-pubescent toward the base, the lemma the length of the palea. ( $S$. asper Man. ed. 6.) - Sandy fields and dry hills, Ct. to Ill., Mo., and southw. Sept. Fig. 96.

2. S. canovirens Nash. Similar to the preceding but smaller; the shorter leaves hirsute near the base; panicle smaller; spikelets about $6 \mathrm{~mm}$. long; lemma and palea acute, subequal. - Sandy soil, Tenn., Mo., and southw.

3. S. ásper (Michx.) Kunth. Culms stout, 3.6-10 dm. bigh ; 96. S. cland. sheaths overlapping; blades neally as long as the culm, the upper Spikelet $\times 3$. exceeding the panicle, pilose above at the flat base, the long involutefiliform tip scabrous; terminal panicle 8-2.5 cm. long, partly included in the inflated upper sheaths, lateral panicles small, usually hidden in the sheaths, or none; spikelets $5-6 \mathrm{~mm}$. long; glumes unequal, obtuse or subacute, the first about $\frac{1}{2}$ as long as the floret; lemma and palea glabrous, the lemma slightly the longer. (S. longifolius Wood.)-Dry sandy soil, Me. to S. Dak., and southw. Fig. 97.

4. S. brevifolius (Nutt.) Scribn. Tufted culms 3-6 dm. high, very slender; leaves involnte-filiform ; ligule $0.5 \mathrm{~mm}$. long, erose-truncate; panicle very slender, loosely flowered, 5-10 cm. long; spikelets about $4 \mathrm{~mm}$. long; glumes acuminate, subequal, is as long as the short-cuspidate lemmn, which slightly exceeds the palea. ( $S$. cuspidatus Wood.) - Dry open ground, Wis, to Mo., and westw.

5. S. Richardsdnis (Trin.) Merr. Similar to the preceding,

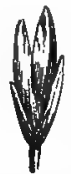

97. S. asper. Spikelet $\times 8$. 2-5 dm. high; culms erect or ascending from a slender horizontal rootstock, minutely roughened by septae; ligule $2 \mathrm{~mm}$. long, acute; panicle 1-6 (rarely 10) $\mathrm{cm}$. long ; spikelets somewhat crowded, $3 \mathrm{~mm}$. long; glumes acute, less than as long as the cuspidate lemma (the cusp about $1 \mathrm{~mm}$. long) which exceeds the palea. ( $S$. cuspidatus, in part, and $S$. depauperatus Man. ed. 6 ; $S$. brevifolius Nash, as to description, not Scribn.) - Meadows and along rivers, N. B. and Me. ; Neb., and in the far West. Aug.

6. S. vaginiflorus (Torr.) Wood. Tufted culms 2-6 dm. high, slender, prect to widely sprearling ; leaves about $2 \mathrm{~mm}$. wide, involute toward the end : gnnicles numerous, partially included in the inflated sheaths, or the termina 
panicle exserted, $2-4 \mathrm{~cm}$. long; spikelets $4 \mathrm{~mm}$. long; the acuminate glumes usually subequal, nearly as long as the acuninate scabrous minntely appressedpubescent lemma, which is exceeded by the sharp-pointed palea. - Sterle fields and waste places, s. Me. to S. Dak, and southw. Sept.

7. S. neglectus Nash. Similar to the preceding, usually more slender; the panicles smaller, more completely inclosed; spikelets $2.5-3$ mm. long; giumes, lemma, and palea ail subequal, acute, thinner in texture, glabrous, white and shining. - Sterile or sandy so:l, N. B. to S. Dak., s. to Va. and Tex. Fig, 98.

8. S. fndicus (L.) R. Br. (Smut Grass.) Tufted culms 3-10 dm. high, erect, wiry; leaves $10-30 \mathrm{~cm}$. in length, longattenuate; panicle $\frac{1}{3}-\frac{3}{2}$ the entire height of the plant; spikelets $2 \mathrm{~mm}$. long, shining, crowded on the slender erect branches; glumes obtuse, unequal, the second $\frac{1}{2}$ as long as the acuminate lemma which is slightly longer than the obtuse palea. - Waste ground and fields, Va. to Ark, and southw. Aug., Sept. Panicle frequently affected with a black fungus, hence the common name. (Nat. from trop. regions.)

9. S. virginicus (I.) Kunth. Glabrous; culms erect, 1.5-5 dm. high; sheaths overlapping; blade's fum, involute, conspicuously distichous on the numerous sterile shoots; panicles exserted, $3-6 \mathrm{~cm}$. long ; spikelets $3 \mathrm{~mm}$. long; the glumes unequal, the second exceediug the glabrous floret. -

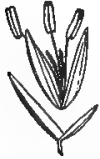

99. S. cryptandrus. Open spikelet with glumes detached $\times 4$.

11. S. júnceus (Michx.) Kunth. Tufted, glabrous, 4-7 dm. high; culms wiry, erect, leafy at the base, naked above; the involute-setaceous basal leaves 12-24 cm. long, spreading; panicle purplish or chestnut, the short verticillate branches spreading; spikelets $3 \mathrm{~mm}$. long; first glume about $\frac{1}{3}$ the length of the second, which is as long as the glabrous subacute equal lemma and palea. ( $S$. gracilis Merr.; S. ejuncidus Nash.) - Dry sandy soil, Va. to Fla., w. to Tex. Aug. Fig. 100.

12. S. heterólepis Gray. Tufted, 6-9 dm. high; culms rather stout, wiry, erect; basal leaves about $\frac{1}{2}$ as long as the culm, involute-setaceous; panicles long-exserted, 7-25 cm. long, brańches ascending; spikelets $4-6 \mathrm{~mm}$. long; first glume about $\frac{1}{2}-\frac{2}{3}$ the length of the floret, the second acuminate, often cuspidate (varying in length in the same

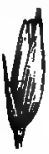

101. S. heterolepis. Spikelet $\times 3$. panicle), exceeding the glabrous obtuse or subacute equal lemma and palea; grain very large, pericarp shining, indurated, splitting the palea. - Dry soil and prairies, w. Que. to Man., s. to Ct., Pa., Mo. and 'I'ex. Aug., Sept. - Strongscented. FJG. 101.

13. S. compréssus (Torr.) Kunth. Perennial from short scaly rootstocks, flattened at base; culms :-6 dm. high, leafy to the top; the slieaths overlapping; leaves conduplicate; panicle $\frac{1}{4}$ the length of the entire plant, loosely flowered; spikelets $2 \mathrm{~mm}$. long; the acute glumes shorter than the striate scabrous lemma which equals the palea. ( $S$. Torreyanus Nash.) - Bogs in pine barrens, L. I. and N. J. Sept. - Spikelets rarely 2-flowered.

14. S. uniflorus (Mull.) Scribn. \& Merr. Rootstocks very slender; culms delicate, tufted, erect, $2-4 \mathrm{dm}$. high; leaves 1-2 mm. wide; panicle $\frac{1}{3}-\frac{1}{8}$ the length of the culm, lousely

102. S. uniflorus. Spikelet 25 
flowered, branches solitary, much divided; spikelets $1.5 \mathrm{~mm}$. long; the obtuse or erose glumes about $\frac{1}{3}$ as long as the equal glabrous obtuse lemma and palea. ( $S$. serotinus Gray.) - Bogs and wet sandy soil, Me. to N. J. and Mich. Aug., Sept. Fig. 102.

\section{AGRÓSTIS L. BENT Grass}

Spikelets 1-flowered; glumes subequal and acute, longer than the broad obtuse lemma which is awnless or dorsally awned ; palea hyaline, shorter than the lemma, or obsolete ; grain loosely inclosed in the lemma. - Annuals or perennials with usually flat scabrous leaves, membranaceous ligules and open or contracted panicles. (Name from árpos, a field, the place of growth.)

Palea at least one-half as long as the lemma, 2-nerved.

Culms erect or decumbent at base

Culms prostrate, rooting at the nodes

Palea minute and nerveless or wanting.

Awn long and very delicate

Awn short or none.

Panicle diffuse, branches long and capillary .

Panicle spreading but not diffuse.

Lemma awnless

Lemma awned.

Spikelets $2 \mathrm{~mm}$. long

Spikelets $3 \mathrm{~mm}$. long

1. A. álba L. (Fronin or White B., RED Top.) Rootstocks creeping or stoloniferous; culms $3-10 \mathrm{dm}$. high, often decumbent at base; leaves flat, stiff and upright to lax and spreading, the ligule 4-5 mm. long; panicle $5-30 \mathrm{~cm}$.

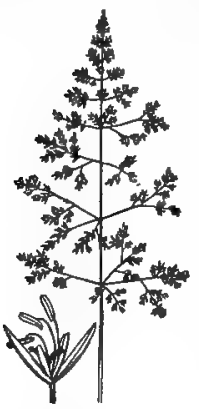

103. A. albn, v, vuig. Panicle $\times 1 / 4$. Spikelet $\times 3$. long, contracted after flowering, greenish, purplish, or brownish, the branches slightly rough; lemma nearly equaling the glumes, 3-nerved, rarely short-awned, the palea $\frac{1}{2}-\frac{2}{3}$ as long. Meadows and fields; a valuable grass naturalized from Eu. and native northw, and westw. Var. vclgAkIs (With.) 'Thurb. (Red Top, Hend's Grass of Pa., etc.) Culms lower, more slender, with narrow leaves; panicle smaller and more divaricate, not contracted after flowering; ligule short and truncate. ( $A$. vulgaris With.) - Dry knolls and hills. (Nat. from Eu. and cultivated, also perhaps indigenous.) Fig. 103. -One form (A. stolonifera auth., not L.) is cultivated as a lawn grass under the name Crefing Bert. A teratological form (due to the presence of nematodes in the abortive ovaries) with floral parts elongated (A. sylvatica L.), occurs in N. E.

Var. aristàta Gray. Culms slender and strict, with small open panicle; lemma awned from near the base. (A. stricta Willd.) - Open ground, Me. to Va. - In habit resembling A. canina, with which it is often confused.

Var. marítima (Lam.) G. F. W. Mey. Culms densely tufted, prostrate, rooting at the nodes; leaves mostly short and appressed; panicle contracted, dense, about 1 dn. long. (A. coarctata Ehrh.) - Brackish meadorrs oi wet sands along the const, Me. to Del. (Eu.)

2. A. Elliottiàna Schultes. Culms delicate, 1-4 dm. high; leaves very slender; panicle open, weak, and drooping; glumes nearly equal, roughish on the kee: and margins, the lemma shorter, with 2 minute bristles at the truncate apex; awn $5 \mathrm{~mm}$. long; palea minute. - In dry soil, Mo. to Ky., Tenn., and S. C. May-July.

$\checkmark$ 3. A. hyemàlis (Walt.) BSP. (HAIr Grass.) Culms very slender, erect, 3-6 dm. high; leaves short and narrow, the tufted basal ones soon involute, the upper $2-7 \mathrm{~cm}$. long, less than $2 \mathrm{~mm}$. wide; panicle purplish, the whorled scabrous branches spikelet-bearing at the ends; spikelets $1.5-2 \mathrm{~mm}$. long; lemma awnless or rarely short-awned on the back, shorter than the rather unequal very acute glumes; palea obsolete. (A. scabra Willd.) - I)ry or moist open woodland, sandy low land, rocks, etc., common. June-Aug. - $\mathbf{A}$ form with 
awned lemmas occurs from Me. to Tenn., and especially in the White Mountains; at higher altitudes this and also the awnless form tend to be more tufted, with namerous short radical leaves. (Trichodium montanum Torr.; A. laxiflora, var. montana 'Tuckerm.; A. scabra, var. montana Man. ed. 6.)

4. A. perénnans (Walt.) Tuckerm. (Thin Grass.) Culms erect or somewhat decumbent, varying from weak and lax to stout and tall, $3-10 \mathrm{dm}$. high; leaves numerous, 1-2 din. long, 1-6 mm. wide; panicle ovoid-subcylindric, the slender ascending branches dividing and spikelet-bearing from about the middle, the pedicels often divergent; spikelets $2-3 \mathrm{~mm}$. long; lemma. shorter than the acuminate unequal glumes. (A. intermedia Scribn.) - Low open ground or damp shaded places, Me. to Minn., and southw. Sept., Oct. - Variable in habit; in deep shade the culms weak and decumbent, the panicles more open with fewer branches, conspicuously divaricate. Flowers later than any other species of Agrostis in the eastern states. FIG. 104. Var. ELATA (Pursh) Hitche. Differs in having more slender and elongated culms, but particularly in the crowding of the spikelets at the ends of the branches, giving them a more drooping appearauce. (A. elata Trin.; $A$. altissima Tuckerm.; Cornucopiae altissima Walt. is doubtful, probably A. alba L.) Swamps near the coast, N. J. to Miss.

5. A. canina I. (Brown Bent Grass.) Culms $2-6 \mathrm{dm}$. high, erect, slender ; basal leaves involute-setaceous, those of the culm flat and broader; panicle at first loose, contracted in fruit; spikelets $2 \mathrm{~mm}$. long; glumes subequal, acute;

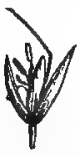

105. A. borealis. Spikelet $\times 3 \frac{1}{2}$. awn inserted about the middle, longer than the glumes, bent.Meadows, sparingly naturalized eastw.; cultivated as a lawn grass under the name Rhode Istand Bext. (Nat. from Eurasia.)

6. A. boreàlis Hartm. Culms tufted, 1-4 dm. high; leaves tufted at base, few on the culm; panicle open, the lower branches whorled and spreading; spikelets 2.5-3 mm. long; awn exserted 1-3 $\mathrm{mm}$. beyond the glumes, rarely short or obsolete. (A. rubra auth., not I. ; $A$. crnina, var. alpina Oakes; $A$. novae-angliae Vasey.) - Lab. to Alaska and mts. of N. E. and N. F.; also Roan Mt., N. C. (Eu.) - Dwarf forms of high altitudes and latitudes approach dwarf forms of $A$. hyemalis. Some of these have been referred to $A$. rupestris All., which seems not to occur in N. A. Fra. 105.

\section{POLYPògON Desf. Beard Grass}

Spikelets 1-flowered, in a dense spike-like panicle; glumes subequal, entire or 2-lobed, bearing a straight awn from the apex; lemma much shorter than the glumes, broad, emarginate or bifid at the apex, awned; palea smaller than the lemma; stamens 1-3.-

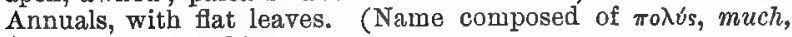
and $\pi \omega \gamma \omega \dot{\omega}$, beard.)

1. P. Monspelínsis (L.) Desf. Culms $2-6 \mathrm{dm}$. high, erect from a decumbent base, usually tufted; blades linear, scabrous ; panicle $3-10 \mathrm{~cm}$. long, dense, interrupted, pale, and soft silky, often partly included in the uppermost sheath; spikelets $2.5-3$ mm. long. - Waste places, Me., and southw., mostly near the coast. June-Sept. (Nat. from Eu.) FiG. 106.

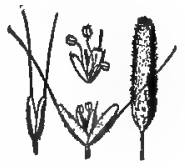

106. P. monsp. Inflorescence $\times 1 / 5$ Spikelet, floret, and glumes $\times 2$.

\section{CALAMOVILFA . Hack.}

Spikelets 1-flowered, awnless; callus densely bearded; glumes rather firm, unequal, acute; lemma 1-nerved, acute ; palea as long as the lemma, broad, deeply furrowed between the strong nerves. - Rather tall rigid perennials, with

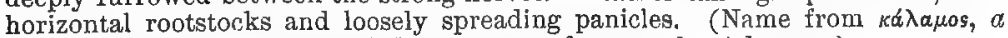
reed, and Vilfa, a name applied to a genus of grasses by Adanson.)

1. C. brevipilis ('Torr.) Hack. Culms 6-12 dm. high, tufted, from a short horizontal rootstock; the basal sheaths indurated and keeled; biades long, linear, 
nearly flat or involute; panicle purplish, 1-2 $\mathrm{cm}$. long, pyramidal, the slende1 branches ascending; pedicels hairy at the summit; spikelets $5 \mathrm{~mm}$. long; glumes

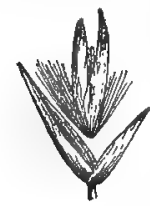

107. C, longtfolia. Spikelet with detached glumes $\times 2$. shorter than the floret, mucronate; callus-hairs less than half the length of the scabrous lemma and palea, which are bristlybearded along the keels. (Calamagrostis Beck.) - Sandy swamps, pine-barrens of N. J. and N. C., rare.

2. C. longifdlia (Hook.) Hack. Culms solitary, 6-18 dm. high, from running rootstocks, stout; sbeaths usually pubescent, at least on the margins; leaves elongated, involute above and tapering into a long thread-like point; panicle pale, 1.5-4.5 $d m$. long, narrow, the slender smooth branches erect or ascending ; spitiplets 6-7 $\mathrm{mm}$. long; glumes acute, the second equal to or exceeding the Aoret; callus-hairs more than half the length of the smooth lemma and palea. (Calamagrostis Hook.) Sandy shores, Ont. to Rocky Mts., southw. to Ill. and Kan., and southwestw. July-Sept. Fra. 107.

\section{Calamagróstis Adans. Reed Bent Grass}

Spikelets 1-flowered; rhachilla prolonged behind the palea into a hairy bristle or pedicel; glumes subequal, usually longer than the floret; lemma awned on the back, usually from below the middle, surrounded at base with copious long hairs; palea shorter than the lemma, faintly 2-nerved. - Tall often reed-like perenuials, with running rootstocks, simple mostly erect culms and many-

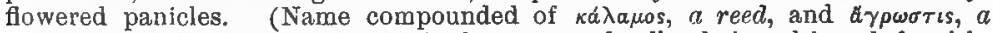
grass.) A difficult genus in which the awns and callus-hairs, although furnishing the most used diagnostic features, are exceedingly variable.

Awn bent, exserted more or less.

Sheatbs not bearder at the summit

Shenths bearded at the summit.

Palea dbout as long as the lemma; callus bairs one fourth to one third as long .

Palea and callus-hairs three fourths as long as the lemma : :

Awn straight, included.

Panicle Inose and open, even after flowering.

Spikelets $3-3.5 \mathrm{~mm}$. long

Spikelets 5-6 inm. long

Panicle contracted, strict, the short branches erect or appressed after Howering.

Rudiment hairy throughout.

Panicle dense, more or less spike-like; leaves involute.

Leaves smooth, soft; rootstock slender

Leaves roughish, rigid; rootstocks stouter

Panicle looser, the branches spreading at flowering time

Rudiment with copions long halrg at the tip.

\section{C. Piakeringii.}

2. C. Porteri.

8. C. perplexa.

4. C. canadensis.

5. C. Langsdorfiz.

* Acon strongly bent, exserted more or less; callus-hairs usually much shorter than the lemma.

1. C. Pickeríngii Gray. Culms solitary or few, 3-5 dm. high, somewhat rigid, scabrous below the panicle; sheaths smooth; blades flat, 4-10 cm. long, 4.j $\mathrm{mm}$. wide, erect; panicle purplish, 7-12 $\mathrm{cm}$. long, the branches erect or ascending; spikelets $4 \mathrm{~mm}$. long; glumes acute, exceeding the obtuse scabrous lemma, which bears a short stout bent (not twisted) awn from below the middle; callus-hairs $\frac{1}{5} \frac{1}{4}$ the length of the lemma, wanting at the back. ( $C$. breviseta Scribn.) - Mts. of N. Y. and N. E. to Nfd., and northw.; locally at Andover, Mass. (J. Robinson). Aug.-Sept.

Var. lacústris (Kearney) Hitchc. Culms taller (5-10 dm. high); rootstocks stouter; leaves more or less involute; panicle usually longer ; callus-hairs $\frac{1}{2}-\frac{2}{3}$ as long as the lemma. - Mts. of N. E., and along the Great Lakes to Minn.

2. C. Portèri Gray. Culms slender, 6-12 dm. high; blades 1.5-3 dm. long, 4-8 $\mathrm{mm}$. wide, flat, toper-pointed, very rough, bearded in the sides at the base; ligule 4-5 $\mathrm{mm}$. long; panicle narrow, $8-16 \mathrm{~cm}$. long, rather loosely flowered, the 
short branches erect; spikelets 4-5 mm. long; glumes acute, slightly exceeding the floret; lemma obscurely dentate, awn twisted below; paled about as long as the lemma, callus-hairs scanty, $\frac{1}{4}$ as long. - Dry woods, N. Y and Pa. Aug.

3. C. perplexa Scribn. Similar to the preceding, slightly glaucous; panicle oblong-lanceolate, contracted, 1-1.5. dm. long, the slender fascicled branches erect or ascending, densely flowered; spikelets $3.5-4 \mathrm{~mm}$. long; glumes acuminate; awn slightly twisted below; palea and copious callus-hairs $\frac{8}{4}$ the length of the lemma. (C. nemoralis Kearney, not Philippi.) - Rocky woods, Me. and W. N. Y., local.

* Awn straight or nearly so, included; callus-hairs usually not much shorter than the lemma.

- Panicle loose and open, even after flowering; the mostly purple-tinged or lexd-colored strigose-scabrous glumes not closing in fruit, copious callushaivs about equaling the lemma, not surpassed by those of the rudiment; awn delicate.

4. C. canadénsis (Michx.) Beauv. (Blue-Jornt Grass.) Culms 6-15 dm. high, clustered ; leaves $1.5-4 \mathrm{dm}$. long, flat, involute in drying, glaucous ; panicle 1-3 $\mathrm{dm}$. long, the slender fascicled branches ascending or spreading; spikelets $3-3.5$ nim. long; glumes equal, acute, scarcely exceeding the thin erose-truncate lemma; awn inconspicuous; callus-hairs copious, about as long as the floret. Wet places, e. Que. to N. J., and westw. June, July. Fig. 108. Var. acominata Vasey. Glumes 4-5 mm. long, attenuate, exceeding the acute lemma; awn less delicate and longer.Lab., Nfd.; White Mts., N. H.; Roan Mt., N. C.; and in Rocky Mts.

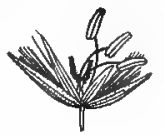

5. C. Langsdórfi (Link) Trin. Similar to the preceding; panicles usually smaller; spikelets $5-6 \mathrm{~mm}$. long; glumes acuminate, somewhat exceeding the dentate lemma; awn as long as the floret, less delicate than in $C$. canadensis. Moist meadows, Lab., mts. of N. E., L. Superior, and northwestw. Aug. (Greenl., Eurasia.)

- + Panicle contracted, strict, its short branches aṕpressed or erect after flowering; the scabrous glumes mostly closed; lemma less delicate, sometimes as firm in texture as the glumes; awn stouter.

6. C. neglécta (Ehrh.) Gaertner, Meyer \& Scherbius. Rootstock slender; culms slender, 4-6.5 dm. high ; leaves soft, 1-3 cm. long, smooth; panicle narrow, glomerate and lobed, $5-10 \mathrm{~cm}$. long; spikelets about $4 \mathrm{~mm}$. long; glumes acute; callus-hairs a little shorter than the floret, and as long as those of the rudinent; awn from the middle of the thin lemuna or lower, barely exceeding it. (C. stricta Man. ed. 6, noi Trin.) - Wet shores and mountains, $n$. N. E., L. Superior, northw. and westw. (Eurasia.)

7. C. hyperborea Lange. Culms and rootstocks stouter than in the preceding ; culms tufted, 4-10 dm. high ; leaves involute, rigid, roughish; panicles 7-15 cm.

long, dense; spikelets $4-4.5 \mathrm{~mm}$. long; glumes acute, exceeding

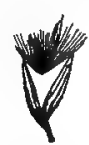

109. C. inexpansa. Spikelet with detached glumes $\times 2$. $4 \mathrm{~mm}$. long; glumes rather rigid, sharp-pointed, about $\frac{1}{4}$ longel
than the toothed lemma; awn scarcely exceeding the lemma; callus-liairs 1-1 shorter than the lemma. ( $C$. confinis Man. ed. 6, not Nutt.) - Swamps amd ¿ow prairies, N, Y. and N. J.; Minn. to Mo. and westw. July. Fı. 109. 


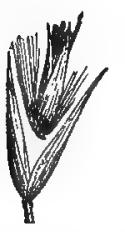

110. C. cinnotdes. Spikelet with detached glumes $\times 3$. 110 . 110.

9. C. cinnoides (Mubl.) Barton. Glaucous; culms stout, 1-1.8 m. high, solitary or few, erect or leaning; leaves very scabrous, sometimes sparingly hirsute, 1.5-3 dm. 1ong, 5-10 mm. wide (those of the innovations shorter, narrow) ; panicles 8-17 cm.long, tapering to summit, usually much contracted; spikelets 6-7 mm. long; glumes keeled, very scabrous, acuminatearistate, the tips usually curved outward, exceeding the acuminate lemna which is awned above the middle; callus-hairs about $\frac{1}{2}$ the length of the floret, those of the rudiment copious, confined to the tip, almost equaling the lemma. (C. Nuttalliana Steud.) - Moist ground, Me. to O. and southw. Fig.

\section{AMMÓPHILA Host}

Spikelets 1-flowered, large, awnless, crowded in a long spike-like panicle; rhachilla prolonged behind the palea into a hairy bristle; glumes firm, subequal, compressed-keeled, acute; lemma of like texture, surrounded at base with short hairs, 2-toothed at the apex and mucronate between the teeth; palea nearly as long, rather firm, the two nerves close together. - A coarse perennial with creeping rootstocks, rigid culms and involute leaves. (Name from $d \mu \mu o s$, sand, and $\phi i \lambda \in \hat{\imath} \nu$, to love.)

1. A. arenària (L.) Link. (Sea Sand-Reed, Psamma, Marram, Beach Grass.) Culm stout, 0.5-1 m. high, branching at the base, from firm running rootstocks; leaves long, soon involute; panicle 1-4 dm. long; spikelets compressed; glumes and lemma scabrous. (A. arnendinacea Host.)-Sandy beaches, along the coast, N. B. to N. C. ; and on the Great Lakes. Aug., Sept. (Eu.) - An important sand-binder. FIG. 111.

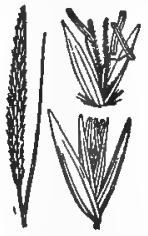

111. A. arenaria.

Inflorescence $\times 1 / 10$ Spikelets $\times 1$.

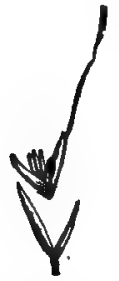

i12. A. Bpica-venti. Spikelet with detached glumes $\times 8$.

\section{APL̀RA Adans.}

Spikelets 1-flowered; rhachilla prolonged behind the palea into a minute naked bristle; glumes thin in texture, subequal, and slightly exceeding the lemma which bears a siender awn from just below the apex; palea nearly as long as the lemma, 2-toothed. - Annuals with flat leaves and diffuse panicles. (Name froin $\star \pi \eta p o s$, unmaimed; application obscure.)

1. A. Spìca-véntr (L.) Beauv. Culms slender, 3-7 dm. high, tufted, erect or geniculate at the lower nodes; blades linear; panicle 1-3.5 dm. long, the very slender branches verticillate, spikelet-bearing near the ends; spikelets $2 \mathrm{~mm}$. long, shining; lemma scabrous, awn 5-7 mm. long. - Sparingly naturalized eastw. June, July. (Nat. from Eu.) Fig. 112.

\section{Cinna d. Wood Reed Grass}

Spikelets 1-flowered; rhachilla articulated below the glumes, forming a short naked stipe helow the floret, and prolonged behind the palea into a minute bristle; glumes narrow, hispidulous on the keel; lemma 3-5-nerved, with a short awn from between the minute teeth of the bifid apex; palea 1-nerved, or 2-nervea, the nerves close together ; stamen 1. - Tall perennials with fiat leaves, conspicuous hyaline ligules, and many-flowered nodding panicles. (From kivva, a name used by Dioscorides for a kind of grass.)

1. C. arundinàcea L. Culms $0.5-1.5 \mathrm{~m}$. high, erect, solitary or few together. blades 2-3 dm. long, $1 \mathrm{~cm}$. or less wide (rarely wider), slightly scabrous; panicle 
1.5-3 dm. long, the slender branches ascending, somewhat contracted after flowering; spikelets $5 \mathrm{~mm}$. long; glumes scabrous, unequal, the second as long as the scabrous lemma which bears a minute awn or is sometimes awnless; palea 1-nerved. - Moist woods and shaded swamps; N. S. to Ont. and southw. Aug., Sept. FIG. 113.

2. C. latifolia (Trev.) Griseb. Similar to the preceding; blades $1.5-2.5 \mathrm{dm}$. long, $1-1.5 \mathrm{~cm}$. wide, rarely narrower, scabrous; panicle 1.5-3.5 dm. long, the flexuous capillary branches spreading or drooping; spikelets $4 \mathrm{~mm}$. long; glumes scabrous, subequal, and about equaling the scabrous short-awned lemma; palea 2-nerved, the nerves close together. (C. pendula Trin.) - Damp woods, Nfd. to B. C., s. to N. E., II. Y., the Great Lake region, and westw.; also on mts. of N. C. (Fu.)

\section{AÌra L. Hair Grass}

Spikelets 2-flowered, both flowers perfect; glumes thin, somewhat scarious, subequal, acute, awnless, longer than the approximate florets; lemmas bidentate, awned on the back or the lower awnless; palea a little shorter than the lemma; grain included in the slightly indurated lemma and palea, and usually adherent to them. - Delicate annuals. (An ancient Greek name for Darnel.)

1. A. CAR y Ophy l LÉ L. Culms solitary or few, slender, erect, $8-30 \mathrm{~cm}$. high : blades short, setaceous; panicle open, the silvery shining spikelets clustered

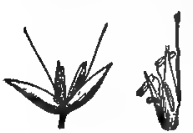

114. A. caryophyllea. Spikelet $\times 8$.

Flower $\times 4 \frac{1}{2}$. touard the ends of the spreading capillary branches, $3 \mathrm{~mm}$. long, nearly as broad; lemma of bolh florets with a geniculate awn 3-4 mm. long from below the middle, the teeth of the apex setaceous. - Waste places, Nantucket to 0 , and southw. June. (Nat. from Eu.) Fig. 114.

2. A. Capillaris Host. Similar to the preceding; panicle more diffuse; spikelets scattered at the ends of the branches, $2.5 \mathrm{~mm}$. long; lemma of lower floret awnless or with a minute awn just belno the apex, the teeth of which are short; lemma of upper floret bearing a geniculate awn $3 \mathrm{~mm}$. long from below the middle, teeth of apex setaceous. - On the coast, Va., and southw. May, June. (Nat. from Eu.) $\checkmark$ 3. A. Prakecox L. Culms tufted, $0.5-20 \mathrm{~cm}$. high, slender, erect or lower nodes geniculate; sheaths slightly inflated; blades setaceous; panicle narrow and dense, the short branches erect, 1-3 cm. long; spikelets yellowish, shining, 3.5-4 mm. long; lemmas of both florets bidentate at apex, and bearing a geniculate awn 2-4 mm. long from below the middle, the awn of lower floret shorter than that of the upper. - Sandy fields, N. J. and Del. to Va. May-July. (Nat. from Eu.)

\section{HóLCUS L.}

Spikelets 2-flowered, articulated below the glumes; the lower floret perfect, raised on a curved stipe, awnless; the upper floret staminate (rarely perfect), its lemma bearing a dorsal awn from below the apex; glumes thin, subequal, compressed, boat-shaped, longer than the florets; lemmas somewhat indurated, boat-shaped; paleas thin, nearly as long as the lemmas. - Perennials with fiat leaves and densely flowered terminal panicles. (A name used by Pliny for a kind of grass, from ó $\lambda$ cós, attractive.)

5 H. lanatus L. (Velvet Grass.) Entire plant grayish, velvety-pubescent; culms erect, $3-6 \mathrm{dm}$. high; leaves $15 \mathrm{~cm}$. long or less, rarely longer, 5-10 mm. wide; panicle purplish, $5-10 \mathrm{~cm}$. long, narrow; spikelets $4 \mathrm{~mm}$. long, nearly as broad; glumes villous, hirsute on the nerves, the second broader than the first, 3-nerved; lemmas ciliate at the apex; awn of second

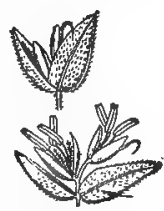

115. H. lanatus. Spikelet $\times 2 \%$. Same opened $\times 2 \frac{1}{2}$ finret hooklike. - Moist meadows, N. S. to Ill., and southw. June, July; Nat, from Eu,) Fia. 115, 


\section{SPHENOPHOLIS Scribn.}

Spikelets 2-8-flowered, the pedicels jointed just below the glumes; rhachilla prolonged behind the upper palea in a slender pedicel, articulated between the florets, the glumes and lower floret with joint of pedicel tardily falling together ; glumes subequal, exceeded by the uppermost floret, the first narrow, the second much broader, usually obovate, becoming subcoriaceous in fruit, 3-nerved; lemma chartaceous, nerves obscure, awnless or awned below the sumnit, awn usually straight or divergent; palea hyaline, narrowed toward the base; grain inclosed within the rigid lemma, free.-Slender perennials with usually flat leaves and narrow terminal panicles. (Name from $\sigma \phi \eta v, a$ wedge, and $\phi_{0} \lambda l s, a$ scale, referring to the broadly obovate or wedge-shaped second glume.) Earonia Endlicher and later authors, not Raf.

Spikelets awnless or with the second floret short-awned; glumes dissimilar, the

frst linear, second obovate, becoming chartaceous.

Panicle narrow, densely flowered; second glume as broad as long, subcucullate in fruit.

Panicle lax, branches" more or jess spreading, at least in flower.

Glumes subequal, second broadly obovate, obtuse; florets obtuee, the second very scabrous * ${ }^{\circ}$ in the narrowly obovate second one; filorets mostly acute, glabrous.

Bpikelets awned; glumes similar.

Lower thoret usually awnless.

Both florets awned

4) S. palustris, v. palustris.

8. S. pallens.

$\checkmark$ 1. S. obtusata (Michx.) Scribn. Culms slender to rather stout, 3-10 dm. high ; sheaths pubescent to nearly glabrous; leaves 4-15 cm. long, glabrous ; panicle

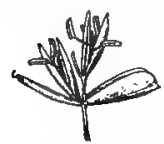

116. 8. obtusata. Spikelet $\times 3$. 6-18 cm. long, often glomerate; spikelets $2.5-3 \mathrm{~mm}$. long; ghmes subequal, the second subcucullate, the broad chartaceous margins smooth and shining; lemmas similar or the second a little scabrous. - Dry soil, Ct. to Fla., westw. to Mo. and 'Tex. June, July. Fig. 116. Var. pubéscens (Scribn. \& Merr.) Scribn. Sheaths and sometimes culms and leaves pubescent. - Ct. to Mich. and southw. Var. цовג TA (Trin.) Scribn. Sheaths and leaves scabrous, not pubescent; panicle cylindrical, sometimes interrupted below ; spikelets densely crovoded on the short appressed branches. - Dry soil, and prairies, Me. to Fla., westw, throughout the U. S. ; the commoner form in the North.

$\checkmark 2$. S. nitida (Spreng.) Scribn. Culms slender, $3-6 \mathrm{dm}$. high; sheaths pubescent; leaves 3-6 cm. long, 2-5 mm. wide, pubescent; panicle 5-20 cm. long, loosely flowered, widely spreading in flower, finally erect; spikelets $3 \mathrm{~mm}$. long, cuneiform ; glumes subequal, the broad second glume rounded or abruptly apiculate; lemmas oblong, obtuse, rarely short-awned just below the apex, second lemma scabrous especially near the tip and keel. (Eatonia Dudleyi Vasey.) Woods, Vt. to Mich., and southw. May, June. Var. GLẢ Bra (Nash) Scribu. Sheathe and leaves glabrous. - Va., and southw.

3. 8. pállens (Spreng.) Scribn. Culms 3-10 dm. high, usually slender; sheathe nsually glabrous, sometimes pubescent; leaves $5-20 \mathrm{~cm}$. long, $4.6 \mathrm{~mm}$. vide, scabrous on the nerves, sometimes sparsely pilose above; panicles lax, nodding, 8-20 crn. long; spikelets 3-4 mm. long, oblong-lanceolate; glumes unequal, scabrous on the keels, the first linear, $\frac{1}{2}-\frac{3}{4}$ as long as the broadly oblanceolate usually acute second glume; lemmas lanceolate, acute, glabrous except on the keel near the apex, the second projecting beyond the second glume, sometimes awned below the apex. (Eatonia pennsylvanica Gray.) - Me. to N. C., W. to Wisc., Kan., and Tex. - In the

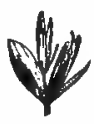

117. S. pallens, Spikelet $\times 8$.

Mississippi Valley this species occurs on prairies, and has a denser panicle ; in the Atlantic States, especially southward, it occurs in meadows and along ditches, and has a more lax panicle. Fig. 117. Var. MAJor (Torr.) Scribn. Panicles narrowly lanceolate or oblong, rather densely finvered, the first glume nearly equaling the rather narrow second one, (Entunia intermedia Rydb.) Nfd. to Wash., s. to Ill., Col., and Ariz. 
4. S. palústris (Michx.) Soribn. Culms 6-10 dm. high; sheaths and leaves glabrous, or lower sheaths sometimes pubescent; leaves 8-12 cm. long, 3-6 mm. wide, scabrous; panicles $10-20 \mathrm{~cm}$. long, narrow; spikelets 6-7 mm. long; glumes similar, lanceolate, acute, subequal; lemmas lanceolate, the first acute or acuminate-pointed, awnless, rarely short-awned; the second bearing a slender divergent awn below the acute or 2-toothed apex; awn 4-5 mm. long. (Trisetum pennsylvanicum Man. ed. 6, not Avena pennsylvanica L. ; T. palustre Trin.) - Low grounds, Mass. to Ill. and soutbw. Var. Flexuos A Scribn, Culms 4-6 dm. high; panicles 8-12 dm. long, open, the flexuous branches widely spreading at least in flower; spikelets 4-5 $\mathrm{mm}$. long, the first floret usually awned. - Del. (Commons), Pa. (Heller). Fig. 118.

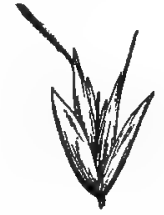

118. S. pal., r. flex. Spikelet $\times 3$.

\section{KOELERIA Pers.}

Spikelets 2-4-flowered; rhachilla prolonged into a naked pedicel behind the upper palea; glumes unequal, slightly shorter than the florets, membranaceous, acute, the first 1-nerved, the second 3-nerved; lemma char-

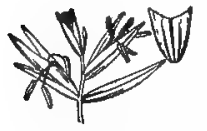

119. K. cristata $\times 21 / 2$. Spikelet. Lower part of lemma spread open. taceous-membranaceous, the margins scarious, faintly 3-5nerved, acute or mucronate; palea hyaline; grain loosely inclosed within the subrigid lemina, free.-Tufted perennials with narrow leaves and densely flowered terminal spike-like panicles. (Named for Prof. G. L. Koeler, an early writer on grasses.)

1. K. cristàta (L.) Pers. Culms erect, 3-6 dm, high, leafy at the base; sheaths retrorsely pubescent, at least the lower; blades flat or becoming involute ; panicle cylindrical, 4-15 cm. long, often interrupted at base, pale and shining; spikelets 4-5 mm. long; the glumes and lemmas scabrous. - Dry soil, Ont. and O. to B. C., and southw.; introduced in N. E. (Eurasia.) - Very variable. Fig. 119.

\section{TRISÈTOM Pers.}

Spikelets 2(rarely 3-5)-flowered, rhachilla prolonged behind the upper palea as a hairy bristle or pedicel; glumes unequal, the second about as long as the florets, keeled; lemma membranaceous, keeled, 2-toothed at the apex, bearing a slender dorsal awn; palea narrow, 2-toothed; grain smooth, inclosed in the lemma and palea but free from them. - Tufted perennials with narrow or spike-like or loose terminal panicles. (Name from tres, three, and seta, a bristle.)

1. T. spicàtum (L.) Richter. Culms slender, erect, 1.5-6 $\mathrm{dm}$. high ; sheaths and blades more or less puberulent, blades 2-10 cm. long, 1-3 min. wide ; panicle shining, spike-like, 3-12 $\mathrm{cm}$. long, often interrupted below; spitelets $5-6 \mathrm{~mm}$. long; the second glume broader than the first, 3-nerved; lemma minuteiy scabrous, the awn inserted about $\frac{1}{3}$ below the acuminate-toothed apex, 4-5 mm. long, divergent. (T. subspicatum Beauv. and var. molle Gray.) - Mts. and rocky banks, Lab. to Alaska, s. to Ct., N. Y., the Great Lakes; and along the

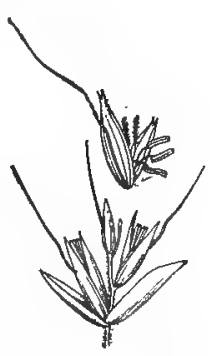

120. T. spicatum $\times 3$. Bpikelet and floret. mts. to N. C. (Eurasia.) Fig. 120.

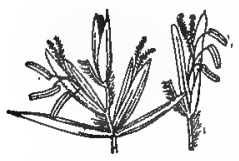

121. T. mel., v. maj. $\times 2$. Spikelet and floret.

2. T. melicoides (Michx.) Vasey. Culm 3-8 dm. high; sheaths and blades roughish ; panicle shining, lax, nodding, 10-12 cm. long; spikelets $7 \mathrm{~mm}$. long; callus hairy ; lemma minutely scabrous, bluntly 2-toothed at the apex, awn 1-2 mm. long, straight, erect. (Graphephorum Desv.) - Gulf of St. Lawrence to the Great Lakes, s. to N. B., Me., and Vt. Var. Màus (Gray) Hitche. Lower sheaths pubescent; upper surface of the leaves pilose; lemmas 
entire at the acute apex, awnless. (Dupontia Cooleyi Gray ; Graphephorum melicoides, var. major Gray.) - Gravelly or rocky shores, Me., Vt., Ont., and Mich Fig. 121.

\section{DESCHÁMIPSIA Beauv.}

Spikelets 2(rarely 3)-flowered; rhachilla hairy, prolonged behind the upper palea as a hairy bristle; glumes subequal, thin or scarious; lemmas thin, 4-nerved

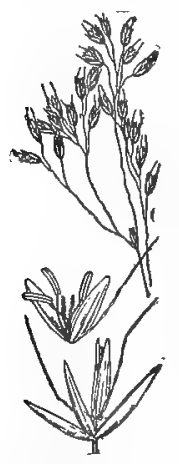

122. D. flexuosa.

Part of panicle $\times 1 / 2$. Spikelet and floret $\times 2 \frac{1}{2}$. (the midnerve becoming an awn), truncate, 2-4-toothed, bearing a slender dorsal awn from or below the middle. - Tufted perennials (our species) with flat or involute leaves and shining spikelets in loose or narrow panicles. (Named for LoiseleurDeslongchamps, a French botanist, 1774-1849.)

\section{* Glumes somewhat shorter than the florets.}

1. D. flexuosa (L.) Trin. (Сомmon HaIr Grass.) Culms erect, 3-8 dm. high, slender, nearly naked above, the numerous involute-setaceous basal leaves 5-20 cm. long; sheaths scabrous; blades setaceous; panicle 5-12 cm. long, very loose, ${ }_{-\infty}$ rather few-flowered, the smooth capillary flexuous branches spikeletbearing near the ends; spikelets $4-5 \mathrm{~mm}$. long; glumes acute; florets approximate, lemmas scabrous, 4-toothed, awn inserted near the base, 5-7 $\mathrm{mm}$. long, twisted; palea nearly as long as the lemma, scabrous. - Dry places, Nfd., Ont., Wisc., and northr., s. to N. C. and Tenn. June, July. (Eu.) Fig. 122.

2. D. caespitòsa (L.) Beauv. Culms erect, 6-12 dm. high, slender; basal leaves flat or becoming involute, not setaceous, $5-15 \mathrm{~cm}$. long; sheaths smooth; blades flat, scabrous on the upper surface; panicle $10-20 \mathrm{~cm}$. long, the scabrous slender branches spikelet-bearing near the ends; spikelets $4 \mathrm{~mm}$. long; glumes acute or blunt; florets distant (rhachilla half the length of lower sessile foret); lemmas smooth, erose-truncate; awn from near the base, but little longer than its lemma, straight, articulated at the base and deciduous; palea nearly equaling the lemma. - Moist soil, mostly along streams, Nfd. to Alaska, s. to N. J. and Ill. June, July. (Eu.) - Spikelets rarely 3-flowered. Fig. 123.

$$
\text { * Glumes longer than the florets. }
$$

3. D. atropurpùrea (Wahlenb.) Scheele. Culms erect, 1.5-5 dm. high, slender, leafy; no tufts of basal leaves; sheaths 128. D. caespitosa. smooth; blades flat, $5-10 \mathrm{~cm}$. long, $3-5 \mathrm{~mm}$. wide, nearly Spikelet $\times 81 / 2$. glabrous ; panicle $4-10 \mathrm{~cm}$. long, rather few-flowered; the few

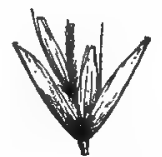
smooth capillary flexuous branches spreading, sometimes drooping, spikeletbearing at the ends; spikelets $5-6 \mathrm{~mm}$. long ; glumes acuminate; florets rather distant; lemmas strigose near the summit, erose-truncate and short-ciliate at apex; awn inserted about the middle, bent, $3-4 \mathrm{~mm}$. long ; palea nearly equaling the lemma. - Alpine summits of N. E. and N. Y. to Lab. and northwestw. July, Aug. (Eurasia.)

\section{AVÈNA [Tourn.] L. OAT}

Spikelets 2-6-flowered ; rhachilla bearded below the florets ; glumes subequal, membranaceous, many-nerved, longer than the lemmas, usually exceeding the nppermost floret; lemmas indurated except toward the summit, 5-9-nerved, bidentate at the apex, bearing a long dorsal twisted awn (the awn straight or wanting in cultivated forms); grain pubescent at least at the summit, often adhering to the lemma and palea. - Annuals or perennials with termiual panicles of large spikelets. (The classical Latin namo.) 


\section{* Spikelets more than $2 \mathrm{~cm}$. long; annuals.}

1. A. Fátua L. Culms 4-12 dm, high, in small tufts, erect, stout; blades long, $5.8 \mathrm{~mm}$. wide; panicle loose and open, the slender branches ascending; spikelets pendulous, $2.2-2.5 \mathrm{~cm}$. long, excluding the awns; glumes smooth, striate, acuminate; florets approximate; lemmus with a ring of hairs at base and more or less appressed-pubescent with long stiff brownish hairs; awn inserted about the middle, bent and twisted, $3 \mathrm{~cm}$. long or more. - Fields and waste places, Ont. and 0 . (rare); Wise. Ill., and westw. (Nat. from Eu.) FIg. 124.

2. A. STÉrilis L. (ANimated OATs.) Larger than the preceding, the spikelets $3.5-4.5 \mathrm{~cm}$. long, excluding the awns; lemmas usually more densely bairy; arons 5-7 cm. long. - Occurs sparingly in N. J. and near Philadelphia, Pa. (Adv. from Eu.)

A. SATiva L., the cultivated oat, commonly occurs in waste places in cities, etc. (Introd, from Eurasia.)

* * Spikelets less than $1.5 \mathrm{~cm}$. long; perennials.

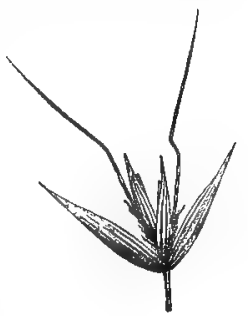

124. A. fatua. Spikelet $\times 2 / 8$.

3. A. PUBÉscens Huds, Culms $6-9 \mathrm{~cm}$, high, in small tufts, erect, slender; sheaths and blades, at least the lower, retrorsely pubescent; panicle rather narrow, the slender flexuous branches erect; spikelets upright, 1.2-1.3 cm. long, excluding the awns; glumes 3-nerved, the nerves scabrous ; florets approximate, rhachilla-joints clothed with long white hairs; lemmas scabrous, a tuft of white hairs at the base, a bent and twisted awn inserted about the middle, 2-2.5 mm. long. - Fields, Vt., N. J. (Adv. from Eu.)

\section{ARRHENÁTherUM Beauv. OAt Grags}

Spikelets 2-flowered, the florets approximate, the lower staminate, its lemma bearing a geniculate and twisted awn on the back near the base; the upper perfect, its lemma short-awned from or near the apex, or awnless ; rhachilla hairy, prolonged behind the upper palea into a bristle; glumes unequal, acute, thin and scarions; lemmas of firmer texture, 5-7.nerved; palea ciliate on the nerves. - Tall perennials with flat leaves and long narrow panicles. (Natne from $a \dot{\rho} \rho \dot{\eta} \nu$, masculine, and $\alpha^{\prime} \theta \dot{n} \rho$, awn, in reference to the awned staninate floret.)

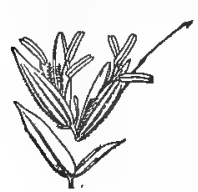

125. 1. elatius. Jyikelet with glumes detached $\times 2$. L 1. A. elátides (L.) Beauv. (Tall O.) Culms $1 \mathrm{~m}$. or more high, erect; leaves long, linear, $0.5-1 \mathrm{~cm}$. wide, scabrous on both surfaces; panicle pale or purplish and shining, $15-30 \mathrm{~cm}$. long, narrow, the short branches verticillate, nsually spikelet-bearing from the base; spikelets $7-8 \mathrm{~mm}$. long; glumes minutely scabrous, the second about equaling the florets; lemmas scabrous, the awn of the staminate floret about twice the length of its lemma; paleas as long as their lemmas. (A. avenaceum Beaur.) - Meadows and waste places, Nfd. to Va., Ont., Minn., etc.; often eultivated. June, July. (Nat. from Eu.) Fig. 125.

\section{DANTHONIA DC. WiLd OAT Grass}

Spikelets several-flowered ; florets not closely approximate, uppermost imperfect or rudimentary; glumes subequal, much longer than the lemmas, usually exceeding the uppermost floret; lemma convex, 2-toothed or bifid at the apex, with a twisted awn between the teeth ; awn flat, formed by the extension of the 3 middle nerves of the lemma. - Tufted erect perennials with narrow leaves and small terminal panicles or racemes. (Named for Étienne Danthoine, a botanist of Marseilles.) 
Teeth of the lemma triangular, not aristate

Teeth of the lemwa aristate.

Florets not over $5 \mathrm{~mm}$. long

Florets 7-8 mm. long.

Spikelets nearly sessile, in sruall crowded psnicle, purple .

Spikelets in loose panicle, pale green.

Sheaths and blades vllous; lemma silky-hairy
Shenths and blades glabrous; lemma pubescent on margins and base only

1. D. spicàta (L.) Beanv. Culms 2-7 dm. high terete; sheaths and involute blades glabrous or sparsely pilose, the numerous basal leaves often curled, those

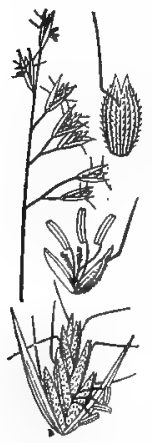

126. D. spicata.

Panicle $\times 1 / 2$.

Spikelet and floret $\times 11 / 2$.

Lemma $\times 2$. of the culm erect; panicle few-flowered, the few short branches erect or ascending, often reduced to a raceme; spikelets 10-12 mm. long, on short stiff pedicels; glumes acuminate : lemmas 4-5 mm. long, sparsely clothed with stiff hairs, teeth triangular, the awn longer than the lemma. - Dry and sterile or rocky soil. June-Aug. FIg. 126.

2. D. compréssa Aust. Usually taller than the preceding : culms flattened, often decumbent at base; leaves elongated; 2-3 mm. wide, flat or involute on the margins only; panicle more open; teeth of the lemma aristate, at least $2 \mathrm{~mm}$. long. - Dry woods, Me. to N. Y., and southw.

3. D. intermèdia Vasey. Culms $1-4 \mathrm{dm}$. high, with numerous mostly involute basal leaves; culm-leaves 5-15 cm. long, involute; spikelets $15 \mathrm{~mm}$. long, rather crouded in a raceme or simple few-flowered panicle; glumes briad, acuminate, purplish, with pale scarious margins; lemma 7-8 $\mathrm{mm}$. long, glabrous except at the base and margins below the middle, the teeth aristate; awn 7-8 mm. long. - Mt. Albert, Gaspé Co., Que.; n. Mich. (Farwell), and westw. July, Aug.

4. D. serína Nutt. Culms 5-9 dm. high; sheaths and blades villous, at least the lower ones; basal blades elongated, mostly involute, those of culms flat or involute; panicle 6-10 cm. long, rarely longer, rather loose, the branches ascending or spreading; spikelets about $1.5 \mathrm{~mm}$. long; glumes narrow, acuminate, pale; lemma densely clothed with long silky hairs, the aristate teeth more than $\frac{1}{3}$ the pntive length of the lemma, avon 12-15 $\mathrm{mm}$. long. - 127. D. serices. Sandy soil, Mass. to Pa., and southw. Fig. 127.

5. D. Epilis Scribn. Very similar to the preceding, not so tall; sheaths and blades glabrous; panicle smaller; lemma glabrous, except at the base and on the margins below the middle. (D. glabra Nash, not Philippi.) - Sandy soil, N. J., and sonthw., rare. May. - Possibly only a variety of the preceding.

\section{SPARTINA Schreb. Cord or Marsh Grass}

Spikelets 1-flowered, flattened laterally, sessile and closely imbricated in 2 rows along one side of a continuous rhachis, forming unilateral spikes which are scattered along a common axis; glumes unequal, keeled, acute or bristlepointed, the second usually exceeding the obtuse thimner 1-nerved lemma; palea equaling or exceeding the lemma. - Coarse perennials with strong creeping rootstocks, rigid simple culms, and long tough leaves. (Whence the name, from $\sigma \pi a \rho \tau i \nu \eta, a$ cord, such as was made from the bark of the Spartium or broom.)

* Culms stout, usuully over $1 \mathrm{~m}$. high; leaves $1 \mathrm{~cm}$. or more wide, flat ".r nearly so when fresh.

1. S. Michauxiàna Hitche. (Slovgh Grass.) Culms 1-2 m. high; leaves 6-12 $\mathrm{dm}$. long, $15 \mathrm{~mm}$. wide or less, tapering to a very slender point, 
keeled, flat, but quickly involute in drying, smooth except the margins; spikes $5-20$, scattered, spreading, $0.5-10 \mathrm{~cm}$. long; rhachis rough on the margins; glumes serrulate-hispid on the keel, the first acuminate and uqualing the floret, the second tapering into an awn $7 \mathrm{~mm}$. long; lemma 7-9 mm. long, glabrous except the serrulatescabrous midnerve which abruptly terminates below the emarginate or 2-toothed apex. ( $\boldsymbol{S}$. cynosuroides Am, auth., not Roth.) - Banks of rivers and lakes, or on wet prairies, N. S. to Assina., s. to N. J. and Okla. Aug.-Oct. Fig. 128.

2. S. cynosuroìdes (L.) Roth. (Salt ReEd Grass.) Culms stout, 1-3 $\mathrm{m}$. high, often $2 \mathrm{~cm}$. in diameter near the base ; leaves $1-2.5 \mathrm{~cm}$. wide, flat or nearly so, roughish underueath as well

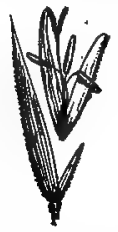

129. S. cynosuroides. Spikelet with ginmes detached $\times 2$. as on the margins ; spikes 20-50, forming a dense oblong purplish raceme; glumes barely mucronate, the first $\frac{1}{2}$ the length of the lemma, of which the rough hispid midrib

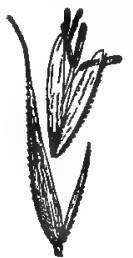

128. S. Vichauxiana. Spikelet with glımes detached $\times \%$.

Salt and brackish marshes, Ct, and southw. Aug.-Oct. - Specimens from
Dismal Swamp, Va., have only $10-15$ spikes. Fig. 129.

3. S. glàbra Muhl. (SALT MARsh Grass.) Culms 0.6$2.4 \mathrm{~m}$. high, leafy to the top; leaves $5-7 \mathrm{dm}$. long, $1-1.5 \mathrm{~cm}$. wide, usually flat, sometimes involute; spikes appressed, $5-15 \mathrm{~cm}$. long, the rhachis slightly projecting beyond the spikelets; spikelets 10-14 mm. long; glumes glabrous or sparingly scabrous on the keel, the first scarcely ${ }_{3}^{2}$ the length of the second; lemma 8-10 $\mathrm{mm}$. long. (S. stricta, var. Gray.) - Salt marshes, Va., and southw. - Odor strong and rancid. Var. PILósA Merr. has glumes with scabrous keels and lemmas sparingly pilosé, thus approaching the European S. stricta Roth. - Mass., and southw. FIg. 130.

Var. alterniflora (Loisel.) Merr. Spikes more slender, 7-12 cin. long, the spikelets somewhat remote, barely overlapping, the rhachis continued into a more conspicuous bract-like appendage; lemma sparingly pilose; otherwise as in the preceding form, into which it passes. (S. stricta, var. Gray.) - Lower St. Lawrence, and southw. (Eu.)

\section{* Culms slender, rarely $1 \mathrm{~m}$. high; leaves not over $5 \mathrm{~mm}$. wide, strongly involute when fresh.}

4. S. pàtens (Ait.) Muhl. Culms slender, wiry, 3-8 dm. high, from -long slender rootstocks; sheaths overlapping; blades 1-3.5 dm. long, involute, spreading; panicle short-exserted or included at base, of 2 to several ascending spikes ( $2-5 \mathrm{~cm}$. long); rhach is smooth; spikelets 10-12 mm. long; first glume linear, mucronate, scarcely

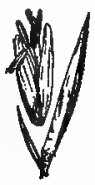

181. S. pat., v. junc. Spikelet with glumes detached $\times 2$. half as long as the lanceolate acuminate second glume, which is scabrous on the nerves; lemma $5-6 \mathrm{~mm}$. long, thin, obtuse, slightly emarginate; palea slightly longer. - Salt marshes and sandy coasts, Nfd. and e. Que. to Va. July, Aug.

Var. júncea (Michx.) Hitchc. Differs from the species in its greater size, culms 5-12 dm. high, longer erect or ascending leaves, and stouter rootstocks; panicles exserted; spikes nearly erect; spikelets 7-10 mm. long. (S. juncea Willd.) Salt marshes and sandy beaches along the coast, N. H. to Fla. and Tex. June-Sept. Fig. 131.

Var. caespitosa (A. A. Eaton) Hitchc. Differs from the species in its tuftod habit, no creeping rootstocks, taller culms, and awned second glume; blades approximate near the middle of the stem, glaucous above, as much as $6 \mathrm{dm}$. long, with long involute scabrous points. (S. caespitosa A. A. Eaton.) - Border of brackish marshes, N. H. and Mass. 


\section{BECKMÁNNIA Host}

Spikelets 1-flowered in our species, broad, laterally compressed, closely imbricated in 2 rows along one side of a continuous rhachis, forming short unilateral spikes; rhachilla articulated below the glumes; glumes subequal, inflated, boat.

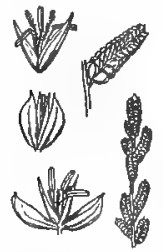

132. B. erucatermis.

Part of inforescence $\times 1 / 6$. Part of eame $\times 1 / 2$. Spikelets and floret $\times 2$. shaped, chartaceous, nargin scarious; lemma lanceolatt; acuminate, palea nearly as long; grain free within the rigid lemma and palea.-A rather tall erect perennial, with flat leaves and a terwinal elongated narrow nearly simple panicle. (Named for Johann Beckmann, 173n1811, professor of botany at Goettingen.)

1. B. erucaefórmis ( $\mathrm{L}_{\text {. }}$ ) Host. Light green ; culms 5-10 dm. high; sheaths loose, overlapping; blades 1-2.5 $\mathrm{dm}$. long, 5-8 mm. wide, scabrous; panicle $1-2.5 \mathrm{dm}$. long, the spikes appressed; spikelets nearly circular, $3 \mathrm{~mm}$. long; the glumes transversely wrinkled; the acuminate apex of the lemma protruding beyond the glumes. - Wet ground, Minn., Ia., and westw.; adv. in O. FIG. 132.

\section{CÝNOdON Richard. Bermuda or Scotch Grass}

Spikelets 1-flowered, laterally compressed, awnless, singly sessile in 2 rows along one sije of a slender continuous axis, forming unilateral spikes; rhachilla prolonged behind the palea into a blunt pedicel; glumes unequal, narrow, acute, keeled; lemma broad, boat-shaped, obtuse, ciliate on the keel ; palea as long as the lemma, the prominent keels close together, ciliolate; grain free within the lemma and palea. - Low diffusely branched and extensively creeping perennials, with flat leaves and slender spikes digitate at the apex of the upright branches. (Name composed of $\kappa \dot{v} \omega \nu$, a dog, and boous, a tooth.) CAPRIol,a Adans.

1. C. DÁtryon (L.) Pers. Glabrous; culms flattened, wiry; ligule a conspicuous ring of white hairs; spikes $4-5$, $2-5 \mathrm{~cm}$. long; spikelets imbricated, $2 \mathrm{~mm}$. long; lemma longer than the glumes. (Capriola Ktze.) - Fields and waste places, Mass., and southw., where it is cultivated for pasturage. (Nat. from Eu.) - Seldom perfects seed. FIG. 133 .

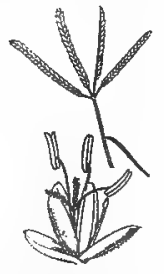

188. C. Dactylon. Infloreseence $\times 1 / 4$. Spikelet $\times 4$.

\section{SCHEDONNÁRDUS Steud.}

Spikelets 1-flowered, sessile and appressed, alternate and distant along one side of a slender triangular rhachis, forming very slender spikes; glumes narrow, unequal, with strong rigid keels, pointed, shorter than the

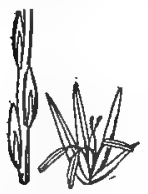
lanceolate acuminate scabrous lemma; palea nearly as long as the lemma; grain free within the subrigid lemma and palea. - A low diffusely branching annual with short narrow leaves and slender paniculate spikes. (Name from $\sigma \chi \epsilon \delta 6 \nu$, near, and Nardus, from its resemblance to that genus.)

1. S. paniculàtus (Nutt.) Trel. Culms 3-5 dim. high, erect or decumbent at base, leafy below; sheaths and blades smooth; panicle half or more than half the entire heigbt of the plant, its axis usually falcate, the spikes sclitary and remote, mostly along the convex side, rigid; spikelets $4 \mathrm{~mm}$. long. (S. tex-

and Tex. - At maturity the panicle becomes much elongated and decumbent,

184. S. paniculatus. Part of spike $\times 1 \frac{1}{4}$. Spikelet $\times 3$. the axis extending in a large loose spiral. FIG. 134. 


\section{GYMNOPOGON Beauv}

Spikelets with 1 perfect flower, sometimes 1 or 2 neuter or staminate subsessile florets above the perfect one, remote along one side of a filiform continuous rhachis, forming slender unilateral spikes; rhachilla prolonged beyond the floret as a slender often awned rudiment; glumes narrow, subequal, vigid, scabrous on the strong keel, equaling or exceeding the florets; lemma thin, bearing a slender straight awn from just below the apex; palea about as long as the lemma. - Perennials, with short rather broad rigid leaves and numerous slender spikes, at first erect, at length widely divaricate or reflexed. (Name composed of $\gamma u \mu \nu \delta s$, $n a k e d$, and $\pi \dot{\omega} \gamma \omega \nu, a$ beard, alluding to the reduction of the abortive flower to a bare awn.)

1. G. ambiguus (Michx.) BSP. Culms tufted from a short rootstock, .rigid, erect or ascending, $2-5 \mathrm{dm}$. high ; sheaths overlapping, blades often approximate, thick, rigid, spreading, 4-6 cm. long, $1 \mathrm{~cm}$. or more wide; spikes solitary or in $2^{\prime} \mathrm{s}$ along a striate axis, becoming widely divaricate when exserted from the sheath, spikelet-bearing to the base; awn of floret longer than the glabrous lemma; rudiment long-awned. (C. racemosus Beauv.) - Sterile sandy or gravelly ground, N. J. to Mo., Fla., and Tex. Aug., Sept. Fig. 135.

2. G. brevifolius Trin. Resembling the preceding; culms

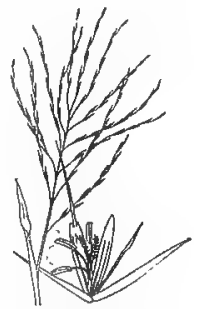

135. G. ambigu.us. Inflorescence $\times 1 / \%$. Spikelet $\times 2 \frac{1}{2}$.

more slender, from a decumbent base; leaves $2-4 \mathrm{dm}$. long, 4-9 mm. wide, involute in drying; spikes usually less numerous, more distant, naked at the base, spikelet-bearing from about the midale; awn shorter than the hairy lemma; one or two sterile florets sometimes present, rudiment usually awnless. - Sandy ground, N. J., and southw.

\section{CHLÒRIS Sw.}

Spikelets with 1 perfect floret, sessile in 2 rows along one side of a continuous rhachis, forming unilateral spikes; rhachilla prolonged behind the palea and bearing 1 or more rudimentary awred sterile lemmas; glumes unequal, narrow,

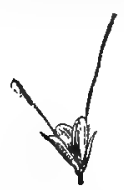

136. C. verticillata.

Spikelet $\times 2$. acute, keeled; lemma often ciliate on the back or margins, 1-3-nerved, the mid-nerve nearly always prolonged into a slender awn; palea about equaling the lemma; grain free within the lemma and palea. - Usually perennial grasses with flat leaves and digitate spikes. (Named for Chloris, the goddess of flowers.)

1. C. verticiliàta Nutú. Culms 1-4 dm. high, erect, or decumbent and rooting at the nodes; sheaths compressed; leaves obtuse, light green; spikes several in 1-3 whorls, slender, $5-10 \mathrm{~cm}$. long; spikelets $3 \mathrm{~mm}$. long, with awns about $5 \mathrm{~mm}$. long; sterile lemma one.-Prairies, $c$. Kan. and southwestw. June. - At maturity the inflorescence breaks away and forms a tumbleweed. FIG. 136.

\section{BoUteloùa Lag. Mesquite Grass}

Spikelets 1-2-flowered, crowded and sessile in 2 rows along one side of a continuous flattened rhachis, which usually projects beyond the spikelets ; rhachilla prolonged beyond the perfect floret and bearing a sterile (rarely staminate) floret, a second or third rudiment often present; glumes unequal, keeled; lemma broader, 3-5-nerved, 3-5-toothed or cleft, 3 of the divisions usually awn-pointed ; palea about the length of the lemma, bidentate, the 2 keels scabrous; sterile floret sometimes reduced to the awns, rarely obsolete. - Our species perennial with narrow flat or convolute leaves, and unilateral spikes nearly sessile along a common axis. (Named for Claudio Boutelou, a Spanish writer upon florj. culture and agricultuxe.) 
\$ 1. CHONDRÓSIUM (Desv.) Gray. Spikes 1-4, usually curved, of 25 on more densely crowded pectinate spikelets.

1. B. oligostàchya (Nutt.) Tors. Culms slender, erect, from a short root. stock, leafy at the base, $1.5-5 \mathrm{dm}$. high; sheaths and blades glabrous, the latter about $\tilde{z} \mathrm{~mm}$. wide, flat or becoming convolute; spikes $]-3$,

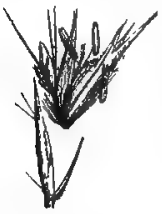

137. B. oligostachva. Spikelet with glnines detached $x:$. $2-5 \mathrm{~cm}$. long; spikelets $5-6 \mathrm{~mm}$. long; glumes narrow, the first about $\frac{1}{2}$ as long as the second, which is sparsely papillosepilose on the keel; fertile lemma pilose, 3-cleft, the divisions awned; sterile lemma consisting of 2 truncate lobes and 3 divergent equal awns with a tuft of long hairs at base, second rudiment obtuse, awnless, - Prairies, Wis. and N. Dak. to Tex. ; casual eastw. (Mex.) July-Sept. FIG. 137.

2. B. hirsùta Lag. Culms tufted, erect, 2-5 dm. high, leafy at the base ; sheaths smooth; blades about $3 \mathrm{~mm}$. wide, flat, sparsely papillose-hairy, especially on the margins; spikes $1-4,1.5-5 \mathrm{~cm}$. long; the rhachis of the spike produced into a prominent point beyond the uppermost spikelets; spikelets about $5 \mathrm{~mm}$. long; first glume setaceous, the second equaling the floret, conspicuously tuberculate-hirsute on the back; fertile lemma pubescent, 3-cleft, the divisions awn-pointed; sterile floret of 2 obtuse lobes and 3 equal awns margined below, no tuft of hairs at the base. - Sandy plains, Wis. to Mo, and southwestw. to Mex. July-Sept. Fig. 138.

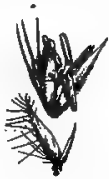

188. B. hirsuta.

Spikelet with glumes detached $\times 3$.

\section{§2. ATHEROPỎGON (Muhl.) Gray. Spikes 15 or more, of 12 or fever ascend-} ing spikelets.

3. B. curtipéndula (Michx.) Torr. Culms erect from short running rootstocks, 3-10 dm. high; sheaths pubescent toward the summit; blades $1-3 \mathrm{dm}$.

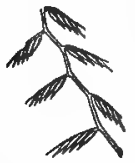

189. B. curtipendula.

Part of inflorescence $\times 1 / 2$.

long, $3-5 \mathrm{~mm}$. wide, flat or involute and setaceous toward the end, scabrous above, sometimes pubescent beneath ; spikes numerous, 8-16 mm. long, spreading or reflexed, in a long mostly 1-sided raceme, the rhachis bifid at the extended apex; spikelets 7-10 $\mathrm{mm}$. long; first glume less than $\frac{1}{2}$ the length of the second which is very scabrous on the thickened keel, exceeding the floret; lenma scabrous, ending in 3 short slender awns; teeth of palea aristate; sterile lemma with 2 acute lobes and 3 straight awns, the lateral ones much shorter than the middle awn. (B. racemosa Lag.) - Dry hills and plains, Ct. to Minn., s. to Tex. and Mex. JulySept. - The sterile lemma variable, rarely reduced to a single awn. Fig. 139.

\section{CTENIUM Panzer. Toothache Grass}

Spikelets with 1 perfect flower and 2-5 sterile lemmas, crowded and sessile, pectinate in 1-sided spikes; glumes very unequal, first minute, second nearly as long as the spikelet, bearing a stout horizontally divergent dorsal awn from about the middle; first and second lemmas empty or sometimes with a hyaline palea, awned below the apex, awn erect or ascending ; third lemma similar, containing a perfect flower; fourth awnless, staminate or empty; a fifth rudimentary lemma often present. - Rather tall perennials with solitary terminal more or less curved spikes. (Name from krevlov, a small comb, from the pectinate appearance of the spike.) Campulosus Desv.

1. C. aromáticum (Walt.) Hitchc. Culms 1-1.5 m. high, erect, from scaly rootstocks, old sheaths persistent at the base; blades long, fiat or involute, stiff; spike 0.5-1.5 dm.

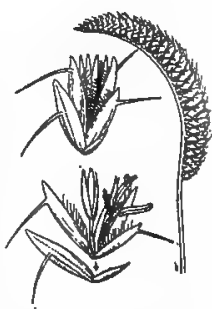

140. C, aromaticum Inflorescence $\times 1 / 2$. Spikelet $\times 2$. Saine with glumes detached $\times 2$. 
long; spikelets 5-7 mm. long; first glume warty-tuberculate on the nerves; florets stiffly ciliate on the margins. (C. americanum Spreng.) - Wet pine barrens, Va., and southw. - Taste very pungent. FIG. 140.

\section{DaCTYLOCTENIUM Willd, Crowfoot Grass}

Spikelets several-flowered, the uppermost inperfect, sessile and crowded in ? rows along one side of a continuous rhachis, which extends beyoud the spikelets in a naked point; glumes broad, keeled; lemmas boatshaped, cuspidate; palea equaling the lemma, acute, deeply folded between the ciliate-winged keels ; grain reddish brown, the loose pericarp transversely wrinkled. - Annual, with more or less decumbent and creeping base, and 2-6 stout unilateral spikes digitate at the apex of the culm. (Name from $\delta a k \tau v i$ os, finger, and $\kappa \tau \epsilon$ vlov, a little comb, alluding to the digitate and pectinate spikes.;

1. D. AEǴ́PTIUM (L.) Richter. Usually glabrous; culms rooting at the lower nodes; spikes $1.5-5 \mathrm{~cm}$. long; glumes scabrous on the keel, the second cuspidate; the awned tip of lower lemma inflexed, that of the others straight or curved. (D. aegyptiacum Willd. ; Eleusine aegyptia Pers.) - Yards and cultivated fields, N. Y., IH., and southw. (Nat. from tiopics of the Old World.) Fig. 141.

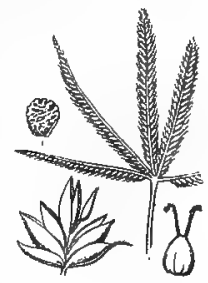

141. D. aegyptium. Inflorescence $\times 1 / 2$. Spikelet $\times 2$. Fruit $\times 8$. Seed $\times 4$.

\section{ELEUSìne Gaertn. Gooste Grass. Yard Grass}

Spikelets several-flowered, awnless, florets perfect or uppermost staminate, sessile and closely imbricated in 2 rows along one side of a continuous rhachis,

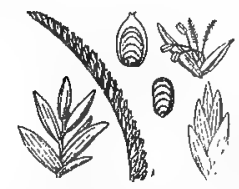

142. E. indica. which does not extend beyond the terminal spikelet; glumes unequal, shorter than the fioret, scabrous on the keels; lemmas broader, with a thickened 5-ribbed keel; palea shorter, acute, the narrowly winged keels distant; grain black, the loose pericarp marked with comb-like lines, free within the subrigid lemma and palea. - Coarse tufted annuals with stout unilateral spikes digitate or approximate at the apex of the culms. (Name from

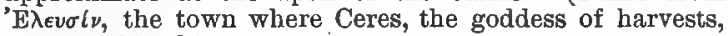

Part of inflorescence $\times 1 / 2$.
Spikelet and floret $\times 2$.

Fruit and seed $\times 4$.

1. E. fNDICA Gaertn. Glabrous; culms flattened, decumbent at base ; sheaths loose, overlapping, compressed ; spikes 2-10, 2.5-8 cm. long; spikelets appressed, 3-5-flowered, about $5 \mathrm{~mm}$. long. - Yards and waste ground, Mass., n. Ill., Kan., and southw. (Nat. from tropios of the Old World.) Fig. 142.

\section{LEPTÓCHLOA Beauv.}

Spikelets 2-several-flowered, the uppermost floret usually imperfect or rudimentary, sessile or nearly so, in 2 rows along one side of the slender continuous rhachis; glumes and lemmas keeled, the latter 3-nerved, acute, awnless or shortawned, exceeding the palea. - Usually tall annuals with flat leaves and elongated simple panicles composed of the numexous very slender spikes scattered along the main axis. (Name composed of $\lambda \epsilon \pi r \delta s$, slender, and $\chi \lambda b a, g r a s s$, from the long attenuated spikes.)

1. L. filiformis (Lam.) Beauv. Culms 4-12 dm. high; sheaths papillose-hairy ; spikes $20-40,5-10 \mathrm{~cm}$. long, ascending; spikelets about $3 \mathrm{~mm}$. long; glumes more or less moronate, nearly equaling the 3-4 awnless florets. ( $L$. micronata Kunth; L. attenuata Steud.) - Fields, Va. to Ill., Mo., and suuthw. Aug. Fig. 14?.

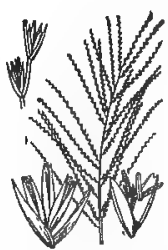

148. L, flìformis. Inflorescence $\times 1 / 10$. A part of same with 2 spikelets $\times 1 \frac{1}{2}$. Spikelet and floret $\times 3$. 
2. L. fasciculàris (Fam.) Gray. Smooth; leaves longer than the erect or geniculate-decumbeat and branching culms, the upper sheathing the base of the panicle; spikes 8-12 $\mathrm{cm}$. long; spikelets slightly pediceled, 7-11-flowered, the florets much longer tran the lanceolate glumes; lemmas hairy-margined toward the base, with 2 small lateral teeth and a short awn in the cleft of the apex. (Diplachne Beauv.; D. acumincta and procumbens Nash.) - Brackish meadows, fron Mass. southw. along the coast; and from Ill. southw. along the Miss. $R$. Aug., Sept.

\section{BỨchlö̈ Engelm. Bưfalo Grass}

Spikelets unisexual ; plants monoecious or dioecious ; staminate spikelets 2-3flowered, sessile in 2 rows along the short 1-sided spikes; glumes unequal,

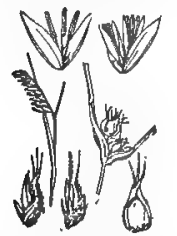

144. B. dactyloider.

$d$ and $q$ inflorescence $\times 1 / 2$. o' Si,ikelet and florot (above) $\times 11 / 2$.

○ Spikelet, section of same, and outer glume $\times 11 / 2$. obtuse; lenmas larger, Зे-nerved; palea a little shorter than the lemma; pistillate spikelets 1-flowered, in nearly capitate 1-sided spikes which are scarcely exserted from the broad sheaths of the upper leaves; glumes indurated, trifid at the apex, united at base and resembling an involucre; lemma narrow, hyaline, inclosing the 2-nerved palea ; grain free within the hardened glumes. - A creeping or stoloniferous perennial with narrow flat leaves, and dissimilar staminate and pistillate spikelets borne on the same or on distinct plants. (Name strongly contracted from $\beta o v ́ \beta a \lambda o s$, buffalo, and $\chi \lambda \dot{\gamma} \eta$, grass.)

1. B. dactyloides (Nutt.) Engelm. Culms of the staminate inflorescence $1-3 \mathrm{dm}$. high; the spikes longexserted; culms of pistillate inflorescence low, much exceeded by the leaves; sheaths overlapping; blades $2 \mathrm{~mm}$. wide or less; staminate spikes 2 or $3,6-12 \mathrm{~mm}$. long ; cluster of pistillate spikelets ovoid, $6 \mathrm{~mm}$. long. (Bulbilis Raf.) - Plains of the Sask. to Mirn., Kan., and Tex. - One of the most valuable grasses of the plains. Seedlings are monoecious, but the staminate and pistillate branches propagate their own kind. FIG. 144.

\section{PHRAGMİTES Trin. REED}

Spikelets loosely 3-7-flowered ; rhachilla clothed with long silky hairs; glumes unequal, lanceolate, acute ; lemmas narrow, long-acuminate, that of the lowest floret somewhat longer, equaling the uppermost florets, empty or subtending a staminate flower, the other florets perfect; paleas $\frac{1}{2}-\frac{2}{3}$ the length of their lemmas. - Tall reedlike perennials with stout leafy culms and large terminal panicles. (Name from $\phi \rho a \gamma \mu l \tau \eta s$, grovoing in hedges, apparently from its hedge-like growth along ditches.)

1. P. commùnis Trin. Culms erect, stout, $1.5-4 \mathrm{~m}$. high, from long creeping rootstocks; sheaths overlapping; blades 1.5-6 dm. long, $1-5 \mathrm{~cm}$. wide, flat, glabrous; panicle tawny, 1.5-4 dm. long, branches ascending, rather densely flowered; spikelets $12-15 \mathrm{~mm}$. long; the florets exceeded by the hairs of the rhachilla. ( $P$. vulgaris BSP.; $P$. Phragmites Karst.) - In wet places, edges of ponds, ditches, etc.

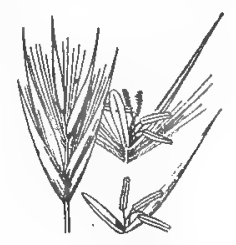

145. P. communis. spikelet. $\Varangle$ and $\delta$ foret $\times 1 \%$. - Rarely perfecting seed, spreading freely from the rootstocks, the leafy stolons often running on the surface of the ground for a distance of 5-10 m. (Eurasia.) Fic. 145.

Aurno Dixix I., the Graxt Reen, is cultivated for ornament and is oceasionally spontaneous southward. Resembling Phragmites but taller, spikelets 3-4-flowered; flower's all perfect; rharhilla naked; lemas clothed with long silku hairs, short-awned from the lifit apex. 


\section{TRIDENS R. \& S.}

Spikelets 3-19-flowered in open or strict panicles; florets perfect or the uppermust staminate; glumes unequal, keeled, shorter than the spikelet; lemma subcoriaceous, convex below, bidentate, 3-nerved, the nerves silky-villous below and at least the middle one extending in a mucronate point between the teeth; palea broad, the nerves nearly marginal. - Perennials with long narrow leaves and terminal panicles. (Name from tres, three, and dens, tooth.) Triodia $\mathrm{R}$. Br.

1. T. flàvus (L.) Hitchc. (TALl ReD Tor.) Culms erect, 1-2 m. high, viscid in the axis of the panicle and below it; sheaths bearded at the summit, otherwise glabrous as are the long flat or involute tapering blades; the showy panicles $24.5 \mathrm{dm}$. long, almost as wide, loose and open, the slender branches spreading, naked below; spikelets purple, 7-8 mm. long, 5-8-flowered, on long pedicels; glumes shorter than the lowest florets, nucronate; the three nerves of the lemmas

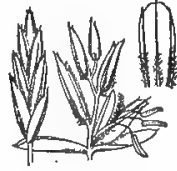

146. T. Hayus $\times 2$. Spikelet.

Same displayed. Lemma unrolled. excurrent. (Pua flava L.; Triodia seslerioides Benth.; T. cuprea Jacq.) Dry or sandy fields, Ct, to Mo, and southw. Aug., Sept. Fig. 146.

2. T. stríctus (Nutt.) Nash. Caespitose, 12-14 dm. high; cuims stout, erect; leaves long and rigid; panicle pale or purplish, dense and spike-like, 1-3 dm. long; spikelets about $5 \mathrm{~mm}$. long, 5-8-flowered, nearly sessile; glumes exceeding the lower florets, mucronate; only the midnerve of the lemma excurrent. (Triodia strieta Benth.) - Moist soil, s.e. Kan., and southw. July-Sept.

\section{TRÍPLASIS Beauv.}

Spikelets 3-6-flowered, the florets remote, the lowest stipitate, perfect or the uppermost staminate; glumes unequal, keeled, shorter than the florets; lenimas 2-cleft, the 3 nerves strongly ciliate, the midnerve excurrent as a short awn

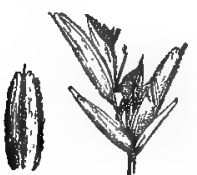

147. T. purpurea $\times 2$. spikelet and lemma. between the lobes; palea shorter, broad, the nerves nearly marginal and densely long-ciliate from the middle to the apex. - Perennials with small nearly simple panicles. (Name from $\tau \rho \iota \pi \lambda a ́ \sigma o s$, thrice as many.)

1. T. purpùrea (Walt.) Chapm. (SAND Grass.) Culms tufted, widely spreading or ascending, wiry, 3-8 dm. long, nodes bearded; sheaths and the small rigid blades scabrous; terminal panicles $3-7 \mathrm{~cm}$. long, the few stiff branches fiually divergent; smaller panicles (partially hidden in the sheaths) produced at the nodes late in the season; spikelets shortpediceled, usually rose-purple, 5-8 $\mathrm{mm}$. long; the awn of the lemma scarcely exceeding the truncate lobes. (Tricuspis Gray; Triodia Hack.) - In sand, Me. to Va., along the coast, and southw. ; also along the Great Lakes and southwestw. Aug., Sept. - Plant acid to the taste. FIG. 147.

\section{ERAGRÓSTIS Beauv.}

Spikelets strongly compressed, 3-many-flowered; the uppermost floret sterile; rhachilla articulated but sometimes not disjointing until after the fall of the glumes and lenımas with the grain; glumes keeled, much shorter than the spikelets; lemmas 3-nerved, broad, keeled; paleas shorter than their lemmas, often persistent after their fall, the strong nerves ciliate. Annuals or perennials with loose or dense terminal panicles. (Name from $j \rho$, spring, and ópowis, $a$ grass.)

\section{Annuals.}

Culms creeping: plants polvgamons,
Culms erect, ascending or decumbent; flowers perfect.

Spikelets 2-5-flowered, $2-8 \mathrm{~mm}$. long.

Spikelets on lung capillary pedicels; culms branched only at the base . 2. E. capillaris,

Spikelets on pedicels not over $5 \mathrm{~mm}$. long; culme branched at the nodes 3 . E. Frankit. 
Splkelets 5-many-flowered, $5 \mathrm{~mm}$, or more long.

Sptkelets not more than $1.5 \mathrm{~mm}$. wide

Spikelets 2-3 mm. wide.

Florets densely imbricated; rhachilla-joints and base of florets hidden

Flovets rather loosely imbricated ; rhachilla-joints or base of florets

Perennibls. visible

Panicle elongated, the branches flexuous

Panicle diffuse, the branches stiff and spreading.

Pedicels as long as the spikelets or longer.

Pedicels shorter than the sppressed spikelets

1. E. hypnoides (Lam.) BSP. Extensively creeping; culms slender, $2-5 \mathrm{dm}$. song, with short erect or ascending panicle-bearing branches $5-12 \mathrm{~cm}$. high; leaves $1-4 \mathrm{~cm}$. long; panicles nearly simple, of rather few lanceolate-oblong spikelets (or in the more fertile plant almost capitate); spikelets 10-35-flowered, 5-15 mm. long, the flowers perfect and fertile, staminate or pistillate; glumes and lemmas acuminate. (E. reptans Nees.) - Gravelly or sandy

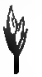

148. E. capillaris.

Spikelet $\times 2$. shores and ditches, Vt. to Ont., westw. and southw. Aug.

2. E. capillàris (L.) Nees. Slender, erect, $1.5-6 \mathrm{dm}$. high, branching at the base, simple above; sheaths overlapping, sparingly pilose or nearly glabrous; blades long and narrow; panicle more than half the entive height of the plant, oblong-ovoid, the capillary branches spreading, the lover ascending; spikelets 2-3 $\mathrm{mm}$. long, on long divergent pedicels; glumes and lemmas acute, the latter faintly 3-nerved. - Sandy dry soil, N. E. to Mo., and southw. Aug., Sept. Often lemon-scented. Fig. 148.

3. E. Fránkii (Fisch, Mey. \& Iall.) Steud. Erect froma decumbent base, or spreading, diffusely branched, 1.5-4 dm. high; sheaths glabrous; ligule pilose; blades 5-12 cm. long, $2-4 \mathrm{~mm}$. wide, scabrous above; panicles oblong, less than half the length of the plant, many-flowered, the short branches spreading; spikelets 2-3 $\mathrm{inm}$. long, on nore or less appressed pedicels, 1-5 $\mathrm{mm}$. long; glumes and lemmas very acute, the latter faintly 3-nerved, - Low or sandy ground, Mass. to Kan., and southwestw. Aug. - The taller sparingly branched forms, with rather loose panicles, are difficult to distinguish from glabrous specirnens of the preceding; the relative length of the panicle is the best distinction.

4. E. pildsa (L.) Beauv. Erect, decumbent at base or spreading, $1.5-4.5 \mathrm{dm}$. high; culms slender, diffusely branching near the base; sheaths sparingly pilose at the summit; blades 3-12 cm. long, 2-3 mm. wide; panicle diffuse, 0.8-2 dm. long,

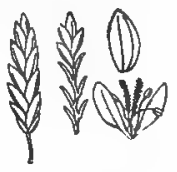

149. E. pilosa.

Spikelets $\times 2$.

Floret and lemma $\times 4$.

lower axils usually sparingly bearded; spilelets 5-18-flowered, becoming linear, 4-9 mm. long, 1-1.5 mm. wide, equaling or shorter than the pedicels; lemmas

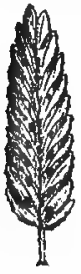

150. E. megastrehyr. Splkelet $\times 2$.

subacute, the lateral nerves faint or rather strong. - Sandy or gravelly open ground, Me. to Minn., and southwestw. July, Aug. (Mex., Eu., etc.) Fig. 149. - Variable, the commoner form in the north, with rather appressed spikelets (1.5 mm. wide) about equaling the pedicels, is considered distinct by some ( $E$. Purshii Schrad.), but the characters used to distinguish it are very inconstant.

5. E. MFGASTACHYA (Koeler) Link. Erect or ascending from a decumbent base, rather flaccid, freely branching; culms 2-9 dm. high; leares 5-15 $\mathrm{cm}$. long, 3-6 mm. wide; panicles greenish-lead-color, 5-15 cm. long, rather densely flowered; spikelets ó-15 mm. long, $3 \mathrm{~mm}$. vide, 10-40-Howered, the florets closely imbricated; pedicels and keels of the acute glumes and lemmas sparingly glandular; lemmas thin, scabrous, the lateral nerves prominent. ( $\boldsymbol{E}$. major Host.) - Waste places, common, especially southw. June-Sept. - Strong-scented, hence called STink or Snake Grass. (Nat. from Eu.) Fig. 150.

6. E. Minor Host. Similar to the preceding, smaller, more slender; panicles less dansely flowered; spikelets $5-10 \mathrm{~mm}$. long, 2-2.5 mm. wide, 8-20-flowered, 
the florets less densely imbricated, the bases or rhachilla-joints visible; lemmas nearly smooth. ( $\boldsymbol{E}$. Eragrostis Karst.) - Waste ground, not common, N.E. to $\mathrm{Va}_{\bullet}$, and southw. (Nat. from Eu.) FJg. 151 .

7. E. trichddes (Nutt.) Nash. Erect, 6-15 dm. high; sheaths everlapping, smooth, pilose at the throat; blades 1-7 din. long, 2-6 $\mathrm{mm}$. wide, rather rigid, involute-taper-pointed; panicles pale,

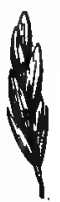
oblong, the lower axils sparingly pilose; spikelets 3-10-flowered, $5-10 \mathrm{~mm}$. long, on capiliary flexuous usually long pedicels; glumes and lemmas acute, scakrous. (E. tenuis Gray, not Steud.) -

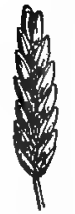

151. E. minor. Splkelet $\times 2$.

Sandy soil, O. to Ill., Kan., and southw. Aug.-Oet. Fig. 152.

8. E. pectinacea (Michx.) Steud. Erect or ascending, 3-8 dzn. high ; culms rigid, from short stout rootstocks ; sheaths overlapping, sparingly pilose, densely bearded at the throat; blades 152. E. trichodes. 1-3 dm. long, 4-8 mm. wide, often involute in drying; panicles Splkelet $\times 2$. purple, included at base or exserted after the upper spikelets have fallen, branches pilose in the axils ; spitelets 5-10-flowered, 3-8 $\mathrm{mm}$. long, on stiff pedicels; glumes and lemmas acute, minutely scabrous. Sandy dry ground, Me. to S. Dak., and southw. July-Oct. FIG. 153. Var. SPECTABILIS Gray. Sheaths glabrous or nearly so; panicles rather more exserted than in the species; spikelets 8-15-flowered.-Range of the species, but the commoner form toward the west.

9. E. refrácta (Muhl.) Scribu. Erect; culms less stout than in the last, 3-9 dm. bigh; sheaths overlapping, glabrous, sparingly villous at the throat; blades $1-3 \mathrm{dm}$. long, $2-4 \mathrm{~mm}$. wide, nearly smootl ; panicle usually included at the base, the slender. remote branches sparsely pilose in the axils and bearing few short-pediceled appressed spikelets 6-25-flowered, 6-12 $\mathrm{mm}$. long; glumes and lemmas acuminate. ( $E$. campestris Trin.; $\boldsymbol{E}$. pectinacea, var. refracta Chapm.; Poa refracta Muhl.) - Sandy open ground, Del. and Md to Fla. and Ala.

\section{Catabrósa Beauv.}

Spikelets usually 2-flowered; glumes unequal, shorter than the lemmas, erose at the broad summit; lemmas subcoriaceous, erose-truncate, strongly 3-nerved; palea as long as the lemma, the strong nerves near the margin. - A creeping perennial aquatic with flat leaves and open panicles of small spikelets. (Name

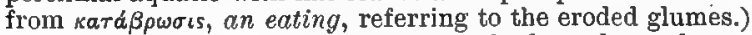

1. C. aquática (L.) Beauv. Smooth throughout, decumbent and rooting at the lower nodes, the ascending culins 1-6 dm. high; the loose sheaths overlappıng ; blades soft, 2-12 cm. long, 2-6 mm. wide; panicle $0.5-2 \mathrm{dm}$. long, the whorled branches spreading; spikelets $3-4 \mathrm{~mm}$. long. - In water or wet places, coast, of N. B., Nfd., and northw. (Eurasia.)

\section{Melica L. Melic Grags}

Spikelets 2-several-flowered; rhachilla prolonged beyond the fertile florets, and bearing 2 or 3 gradually smaller empty lemmas, convolute together or inclosing one another at the apex; glumes large, unequal, membranaceous, or papery, scarious-margined, 3-5-nerved, little shorter than the florets; lemmas convex, 7-13-nerved, firm, with scarious margins, awnless or awned below the bifid apex; paleas shorter than their lemmas, the strong nerves nearly marginal. - Perennials with simple culms, closed sheaths, usually soft flat leaves and rathel large spikelets in usually narrow panicles. (An old Italian name for Sorghim, from mel, honey.) 
\$1. EUMELICA Scribn. Glumes broad and papery; sterile lemmas broad and truncate, convolute around each other; lemmas awnless.

* Glumes subequal, nearly as long as the 2-flowered spikelets.

1. M. mùtica Walt. Culms erect from knotted rootstocks, wiry, 6-9 dm. high ; sheaths usually overlapping, scabrous; lower blades short, the upper $10-20 \mathrm{~cm}$. long, 2-10 mm. wide; panicle $0.8-2.5 \mathrm{dm}$. long, simple, with

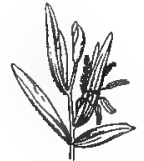

154. M. mutica. Splkelet displayed $\times 2$. filiform ascending branches or reduced to a raceme; spikelets 7-10 $\mathrm{mm}$. long, pendulous on short pedicels, florets spreading, 6-8 mm. long; lemmas scabrous, obtuse, the intermediate nerves vanishing above; enipty lemmas cucullate above, exceeded by the fertile ones. - Dry rocky open woods and thickets, Pa. to Fla., w. to Wis., Ia., and 'Tex. Apr., May. FIg. 154,- From Va. southw. occasional specimens have sparsely pubescent sheaths and the blades somewhat pubescent on the lower sur. face. (11. diffusa Pursh ; M. mutica, var. diffusa Gray); not varietally distinct.

* Glumes unequal, shorter than the 3-5-flowered spikelets.

2. M. nitens Nutt. Culms 8-12 dm. high, erect from a short horizontal rootstock; sheaths overlapping, glabrous; blades $1-2 \mathrm{dm}$. long, 4-8 mm. wide; panicle $1.5-2.5 \mathrm{dm}$. long, the slender spreading branches solitary or in pairs, simple or sparingly branched; spikelets numerous, 10-12 $\mathrm{mm}$. Jong, usually 3-flowered, pendulous on short pedicels; lemmas 7-9 mm. long, scabrous, acute; empty lemmas broad at the summit, exceeded by the fertile ones. ( $\boldsymbol{M}$. diffuso, of recent authors, not Pursh.) - Rocky woods, Pa. to Neb., and southw. May, June.

3. M. Portèri Scribn. Culms erect, slender, 5-7.5 dm. high; sheaths overlapping, scabrous; blades 12-23 cm. long, 2-6 $\mathrm{mm}$. wide, scabrous; panicle 1.5-2.5 dm. long; the narrow spikelets pendulous and racemose-along the slender ascending branches, 4-6 flowered, 10-13 mm. long; lemmas 7-8 mm. long, subacute, scabrous; empty lemmas like the fertile ones and exceeding them. (M. parviftora Scribn.) - Bluffs and stony hillsides, Ia. to Mo., and westw.

§2. BROMELICA Thurb. Glumes narrow, scarious-margined; sterile lemmas similar to the fertite which are awned below the bidentate apex; spikelets 5-9-flowered.

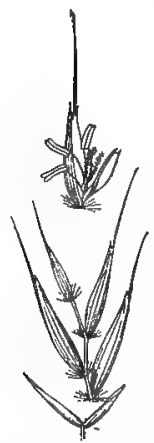

136. M. striata $\times 1$. Spikelet witb glumes separated.

Floret,
4. M. Smíthii (Porter) Vasey. Culms erect, slender, 7-12 dm. high; sheaths scabrous; blades $10-20 \mathrm{~cm}$. long, 6-12 $\mathrm{mm}$. wide, lax, scabrous; panicle 1.2-2.5 dm. long, the solitary remote spreading branches spikelet-bearing toward the ends; spikelets 3-6-flowered, 18-20 mm. long, more or less tinged with purplish chestnut; glumes acute; lemmas glabrous, about $10 \mathrm{~mm}$. long, excluding the awn, which is $\frac{1}{3} \frac{1}{2}$ as long. (Avena Porter.) - Moist woodlands, n. Mich. and westw. May-July. Fig. 155.

5. M. striàta (Michx.) Hitchc. Similar to the preceding, usually not so tall and more slender; leaves narrower; sheaths closed to the summit, the ligule sheathing the culm; paniclebranches ascending or spreading at the ends; spikelets 2.2$2.5 \mathrm{~cm}$. long; glumes broader, conspicuously colored as are often the florets which are short-bearded at the base; avon as long as the lemma or longer. (Aveno Michx.) - Rocky wooded lands, e. Que. to Pa., Minn, and westw. Fic. 156 , 


\section{DIARRHÈNA Beauv.}

Spikelets 3-5-flowered, the uppermost florets sterile; glumes unequal, much shorter than the florets; lemmas broad, coriaceous, rigid, smooth and shining, convex below, 3-nerved, acuminate or mucronate-pointed; palea firm, 2-keeled; stamens 2 , rarely 1 ; grain large, usually exceeding the lemma and palea, obliquely ovoid, obtusely beaked, with a shining coriaceous pericarp. - Nearly smooth perennials, with simple culms from a creeping rootstock, flat leaves and narrow few-flowered panicles. (Name composed of $\delta l_{s}, t w o$, and $a \rho \rho \eta \nu$, man, from the two stamens.)

1. D. diánđra (Michx.) Wood. Culms 6-9 dm. high; leaves nearly as long as the culm, $1-1.8 \mathrm{~cm}$. wide; panicle very simple, 1-2.5 dm. long; spikelets short-pediceled, 10-16

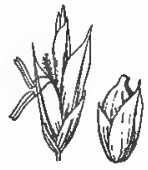

15?. D. diandra $\times 1$. Spikelet and finit. mm. long. (Festuca Michx.; Korycarpus Ktze.; D. americana Beauv.) Shaded river banks and woods, O. to S. Dak., and southw. July, Aug. Fig. 157.

\section{UNİOLA L. Spike Grass}

Spikelets compressed, 3-many-flowered, the lower 1-4 lemmas empty ; glumes compressed-keeled, acute or acuminate; lemmas firm-coriaceous, compressed-

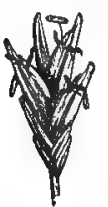

158. U. laxa. Spikelet $\times 3$. keeled, faintly many-nerved; palea rigid, the keels broadly winged, nearly marginal; stamens 1 or 3 . - Erect perennials, with simple culms, flat or involute leaves and terminal panicles. (Ancient name of some plant, a diminutive of unio, unity.)

\section{* Panicle contracted, wand-like; spilcelets few-flowered}

1. U. láxa (I.) BSP. Culms slender, 6-12 dm. high, in clumps with knotted rootstocks; leaves long and narrow; panicles 1.5-4.5 $\mathrm{dm}$. long, the slender branches erect; spikelets short-pediceled, 3-6-flowered, 5-7 mm. long; lemmas 3-4 mm. long, acuminate, spreading at matuvity; palea arched. (U. gracilis Michx.) Sandy soil, L. I. to Fla., w. to Ky. and Tex. Aug., Sept. FIG. 158.

\section{* Panicle expanded, nodding; the spikelets many-flowered.}

2. U. latifdlia Michx. Culms 6-15 dm. high; sheaths shorter than the internodes, ligule 1 mm. long, lacerate; blades spreading, 10-22 cm. long, 0.5-2 cm. wide, often ciliate at the base, margins scabrous; panicle $1-2.5 \mathrm{dm}$. long, the filiform branches bearing a few pendulous broadly oval spikelets; these 1.5-3 cm. long, 6-12-flowered; lemmas 9-12 mm. long, hispidulous on the winged keel; stamen 1. - Shaded slopes and low thickets, Pa. to Kan., and southw. Aug., Sept. Fig. 159.

3. U. paniculàta L. (SeA OATs.) Culms stout, $9-15 \mathrm{dm}$. high, with numerous long rigid leaves involute in drying; ligule a ring of hairs about $1 \mathrm{~mm}$. long; panicles $2-3 \mathrm{dm}$. long, the slender branches bearing many short-pediceled oblongoval stramineous spikelets; these 1-2 cm. long, 8-16-flowered; lemmas 8-10 mm. long, scabrous on the keel; stamens 3. Sand hills and drifting sands coast, Va. to Tex. Sept., Oct. (Mex., S. A.)

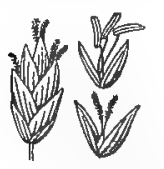

1(f0. 1). spicata $\times 1$. q Spikelet and floret. के Floret.

\section{DISTÍchlis Raf. Spike Grass. Alkali Grass}

Spikelets dioecious, 8-16-flowered, compressed; glumes unequal, firm, keeled, acute; lemmas coriaceous, rigid, faintly many-nerved. - Rigid erect perennials with extensively creeping rootstocks, involute leaves and small crowded panicles of large smooth spikelets. (Name from $\delta l \sigma \tau \iota \chi \circ$, troo-ranked.)

1. D. spicàta (L.) Greene, Pale or glaucous; culms 
1.5-6 dm. high; sheaths overlapping; blades often conspicuously distichous, rigidly ascending; the narrow panicle $2-6 \mathrm{~cm}$. long (rarely longer); spikelets 8-18 mm. long, the florets closely imbricated. ( $D$. maritima Raf.) - Salt marshes along the coast, N.S. to Tex.; also in alkaline soil in the interior. (Mex.) Fig. 160.

\section{BRìzA L. Quaking Grags}

Spikelets few-several-flowered, broad, often heart-shaped; florets crowded, almost horizontal, the uppermost usually imperfect ; glumes subequal, firm-membranaceous, with broad scarious wargins; lemmas 5-many-nerved (nerves often obscure), firm, subchartaceous with a scarious margin, boat-shaped or ventricose, heart-shaped at base; palea much smaller than its lemma. - Annuals or perennials with flat leaves and showy terminal panicles.

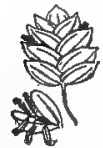

161. B. media $\times 1 \frac{1}{2}$.

(Bolya, the Greek name of a kind of grain.)

1. B. Mìda L. Perennial, erect, 4-7 dm. high; sheaths longer than the narrow blades; panicle erect, the stiff capillary branches spreading; spikelets nodding, 5-9-flowered, $6 \mathrm{~mm}$. long, nearly as broad, brown and shining; lemmas boat-shaped. - Fields and waste places, Ont. and N. E. June. Spikolet and floret. (Adv. from Eu.) Fig. 161.

2. B. MYNor L. Annual; culms 1-4 dm. high, often branching at the base; leaves 4-12 cm. long, 4-8 mm. wide; panicle erect, its slender branohes finally spreading, bearing fascicled branchlets ; spikelets hardly nodding, 3-6-flowered, pale or plum-color, broadly heart-shaped, $3 \mathrm{~mm}$. long, slightly broader; lemmas strongly ventricose below. - Waste places, N. J., Va., and southw. June. (Adv. from Eu.)

\section{DÃCtylis L. Orchard Grass}

Spikelets 2-5-flowered, compressed, nearly sessile in dense fascicles, these arranged in a panicle; glumes unequal, hispid-ciliate on the keel, acute or mucronate; lemmas 5-nerved, ciliate-keeled, short awn-pointed; paleas a little shorter than their lemmas. - Perennial with flat leaves and glomerate panicles. (Dactylos, a name used by Pliny for a

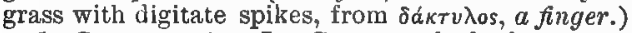

1. D. glomsrata L. Coarse, tufted, glaucous, scabrous ; culms erect, 9-12 din. high; leaves broadly linear; panicle $8-15 \mathrm{~cm}$. long, the few stiff branches naked below, contracted after flowering; spikelets crowded in dense one-sided clusters at the ends of the branches. - Fields and waste places. June. (Nat. from Eu.) Fig. 162.

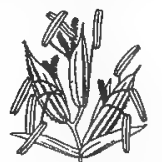

162. D. glomerata $\times 2$. Spikelet displayed.

Cynosùrus Cristàtus L. (Dog's-tail Grass), a slender erect perennial 4-7 dm. high, with narrow leaves and erect dense spike-like panicles, the spikelets unisexual, arranged in clusters, the terminal ones fertile, the lower larger and sterile, with very narrow lemmas, strongly scabrous on the keel, occurs sparingly in fields and by waysides, Nfd. to Ont. (Adv, from Eu.)

\section{POA L, Meadow Grass, Spear Grass}

Spikelets 2-6-flowered, the upperinost floret imperfect or rudimentary ; glumes 1-3-nerved, keeled; lemmas herbaceous or membranaceous, mostly scarious-tipped, acute or obtuse, keeled, awnless, 5-nerved (the intermediate pair of nerves sometimes very obseure), the dorsal or marginal nerves usually soft-hairy, often with a tuft of long cobwebby hairs at the base; palea 2 -toothed. - Annuals or perennials, with simple culms, narrow usually flat leaves ending in a cucullate point, and terminal panicles. (Iha, an ancient Greẹk name fọ grass or fodder.) 
Annials.

Florets not webby at the base; lemunas distinctly 5-nerved

Florets webby at the base; Intermediate pair of nerves obsoure

Perennials.

Culms from extensively creeping rootstocks, not tufted.

Culms that tened ; splkelets not over $6 \mathrm{~mm}$. long

Culns terete; spikelets $8 \mathrm{~mm}$, or more long.

Culms tufted.

Creeping rootstocks present.

Panjele crowded; culms much exceeding tho leaves.

Panicle diffuse ; culum scarcely exceeding the basal leavas

No creeping rootstocks, but culms sometimes decumbent at base.

Lemma glabrous.

Lemma pubescent at least on the keel.

Culms upright from a stout crown or caudex; leaves short and flat

Culms from a more slender base forming loose tufts, often decumbent.

Culms rarely over $3 \mathrm{dm}$. high, with lax leaves, the decumbent bases of the culms forming loose tufte; lemma yubescent but very sparsely webbed; alpine or northern plants

Culms taller, or if low, stiff and with scarcely decumbent brses. Lemma not webbed at base.

Panicle narrow; lemma glabrous between the nerves below Panicle spreading; lemma pubescent between the nerves below.

Lemma webbed at base.

Marginal nerves glabrous.

Lemma prominently nerved; sheaths seabrous.

Lemma obscurely nerved; sheaths smooth

Marginal nerves pubescent.

Intermediate nerves of lemma obscure ; florets acute.

Panicle erect, 0.4-1 dm. long (rarely longer), branches sscending .

Panicle drooplng, 1-8 dm. 'long, branches spreading

Intermediate nerpes of lemma prominent; florets obtuse or acutisis.

Branches of panicle spikelet-bearing from the middle; spikelets $3-4 \mathrm{~mm}$. long

Branches of panicle elongated, spikelet-bearing only at the ends; spikelets 5-6 mm. long

\section{* Annuals, rarely over $2.5 \mathrm{dm}$. high, tufted.}

1. P. annua.

2. P. Chapmaniana.

3. P. compressa,

4. P.eminens.

10. P. pratensis.

17. P. brachyphylut.

18. P. debilis.

5. P. alpina.

6. P. lana.

7. P. glauca.

16. P. artumnalds.

11. P. trioiales.

14. P. alsodes

8. P. nemoralis.

9. P. triflora.

12. P. sylvestrids.

15. $P$. Wolfit.

$\checkmark$ 1. P. annua L. (Low Spear Grass.) Culms flattened, decumbent at base, sometimes rooting at the lower nodes; sheaths loose; leaves very soft; panicle pyramidal, 3-8. cm. long, rarely longer ; spikelets crowded, 3-6-flowered, about $4 \mathrm{~mm}$. long; lemma distinctly 5-nerved, the nerves hairy below. - Cultivated and waste grounds, everywhere. Apr.-()ct. (Nat. from Eu.)

2. P. Chapmaniàna Scribn. Similar to the preceding but more strict in habit; culms terete, erect; sheaths close, mostly at the base; panicle more oblong; florets webbed at the base, the intermediate nerves of lemmas very obscure, the middle and marginal nerves sometimes hairy below. - Dry soil. Va. to s. Ill., and southw. Apr., May.

\section{* Perennials.}

- Culms from extensively creeping rootstocks, not tufted.

3. P. Compressa L. (CANada BLuE Grass. WIRE Grass.) Bluish-green, 2-6 dm. high; culms geniculateascending, wiry, flattened; panicles 2-8 cm. long, narrow, the usually short branches in pairs, spikelet-bearing to the base; spikelets crowded, subsessile, 3-6(rarely 9)-flowered, 4-6 mm. long; lemmas obscurely nerved, more or less bronzed at the summit. - Dry mostly sterile soil, Nfd. to S.C., and westw.; also cultivated as a pasture grass. May-Sept. (Nat. from Eu.) Fig. 163.

4. P. éminens J. S. Presl. Glaucous, glabrous, 3-9 dm. high; culms stout, erect, terete; sheaths overlapping, clust.ered on the sterile shoots; blades thick, 3-8 mm. wide; panicle heavy, 8-16 cm. long, contracted; spikelets 3-5-flowered, 8-12 mm. long; lemmas 4-5 mm. long, distinctly

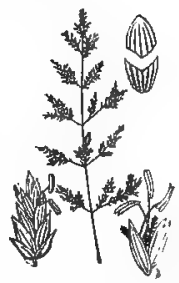

168. P. compressa.

Panicle $\times 1 / 4$.

Spikelet and floret $\times 2$,

Lemma $\times 3$. 
nerved. (P.glumaris Trin.) - Gravelly seashores, Lower St. Lawrence R., and northw.; also Alaska. (E. Asia.)

to t- Culms tufted.

+* Alpine or high northern plants; culms 4 dnin. high or less.

5. P. alpina L. Culms erect from a stout croun or caudex, rather stout; 0.5-1 dm. high; upper blades much shorter than their sheaths, 3-6 mm. wide; panicle pyramidal, $3-7 \mathrm{~cm}$. long, the filiforn branches spreading, mostly naked at the base; spikelets rather crowded, broadly ovate, 3-6-Howered, ó-6 mm. long; lemmas 4 mu. long, villous on the midrib and margins. - Brooksides, open mountain slopes, etc., N. S., Isle Royale, northern shore of L. Superior, and northw. June-Aug. (Eurasia.)

6. P. láxa Haenke. Moss-green, forming loose tufts; culms slender, $2-4 \mathrm{dm}$. high; blades about 2 mm. wide; panicle $2.5-7 \mathrm{~cm}$. long, simple, often one-sided and nodding, loosely fluwered, the filiform branches erect or ascending, spikelet-bearing at the ends; spikelets 2-4-flowered, about $5 \mathrm{~mm}$. long; lemina 3-3.5 $\mathrm{mm}$. long, pilose on the midrib and margins toward the base. - Alpine regions, N. E., n. N. Y., and high northw. (Eu.)

+ Not strictly alpine; culms taller or if low not decumbent at base.

$=$ Panicle narrow; lemma not webbed at the base.

7. P. glaúca Vahl. Glaucous; culms strict, rather rigid, $1.5-6 \mathrm{dm}$. high, sheaths crowded at the base; blades $3-5 \mathrm{~cm}$. long, about $2 \mathrm{~mm}$. wide; ligule not over $1 \mathrm{~mm}$. long; panicle 3-7 cm. long, rather compact, the short scabrous branches erect; spikelets often purplish, 2-5-flowered, 5-6 $\mathrm{mm}$. long; glumes acute or acuminate; lemmas $3-3.5 \mathrm{~mm}$. long, villous on the keel and marginal nerves below; intermediate nerves obscure. ( $P$. caesia Sm.) - Rocky shores and mts., e. Que. and n. N. E. to n. Minn,, northw. and westw. (Eurasia.)

$==$ Panicle open, branches naked toward the base; Temma webbed at the base except in no. 16.

a. Spizelets numerous, more or less crowded.

b. Marginal and nidnerve silky-pubescent.

8. P. nemoràlis L. Grass-gxeen, $3-7 d m$. high, rarely higher; culms slender, less rigid than in the preceding, leafy throughout; leaves lax, 3-8 cm.long, $2 \mathrm{~mm}$. wide; panicle 4-10 $\mathrm{cm}$. $l \mathrm{ong}$, open and spreading; spikelets 2-5-flowered, 3-5 mm. long; glumes sharply acuminate; lemmas $2-3 \mathrm{~mm}$. long, intermediate nerves obscure, a few webby hairs at base. - Meadows and open woods, Nfd. to Pa., w. to Minn., northw. and westw. June-Sept. (Eurasia.) 164. P. nemoralis. Frg. 164. - Alpine forms may be low and erect, 1-2 dm. high,
spikelet $\times 3$. Spikelet $\times 3$. tude may be creeping at base.

9. P. triflora Gilib. (Fow MEa Dow Grass.) Culms 3-15 dm.high; sheaths rather loose; ligule 3-5 $\mathrm{mm}$. long; blades 8-15 cm. long, 2-4 mm. wide, soft; panicle often purplish, 1-3 dm. long, pyramidal or oblong, the filform spreading branches in remote fascicles of 3-10, naked at the base; spikelets 2-4-flowered, about $4 \mathrm{~mm}$. long, hardly crowded; lemmas $2.5-3 \mathrm{~mm}$. long, intermediate nerves obscure, webby hair's copious. ( $P$. flava Am. auth., not L.; $P$. serotina Ehrh.) - Wet meadows, Pa. to Ia., and northw; also cultivated. July, Aug. (Eurasia, n. Afr.) FIg. 165.

$\checkmark$ 10. P. praténsis L. (June Grass, Spear Grass, Kentucky

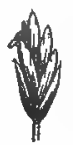

165. P: triflora. Spikelet $\times 3$.

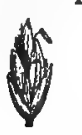
Bude Grass.) Culms 3-12 dm. high, sending out nomerous running rootstocks from the base; sheaths compressed, overlapping below, ligule $1.5 \mathrm{~mm}$. long; blades $1-6 \mathrm{~mm}$. wide, those of the culm 5-15 cm. long, the basal ones much longer; panicle pyramidal, the slender branches in rather remote fascicles of $3-5$, 166. P. pratensin. ascending, naked at base; spikelets croncded, 3-5-flowered, 4-5 Spikelpt $\times$. $\mathrm{mm}$. long; leinmas $3 \mathrm{~mm}$. long, copiously webbed at base; 
intermediate nerves strong, glabrous. - Fields and meadows throughout the U. S. and B. C., naturalized in the East, indigenous in the North and West. MayJuly. (Eurasia.) FIG, 166.

\section{b b. Marginal nerves glabrous.}

V11. P. Trivialis L. (Rough-staliked Meadow Grass.) Culms erect from a somewhat decumbent base, 3-9 din. high, scabrous below the panicle; sheaths and blades retrorsely scabrous, ligule $4-6 \mathrm{~mm}$. long; panicle $6-15 \mathrm{~cm}$. long, resembling that of $P$. pratensis; spikelets $2-3$-flowered, about $3 \mathrm{~mm}$. long; lemma strongly nerved, silky-pubescent on the keel only. - Moist meadows and roadsides, e. Que. to S. C. and La, rarely inland. May-Aug. (Nat. from Eu.)

a a. Spikelets fewer, scattered on slender peckcels; plants soft and smooth, flowering early.

b. Spilcelets 2-4 mm. long; lemnas öroad, obtuse.

12. P. sylvéstris Gray. Culms subcompressed, 3-12 dm. high; sheaths shorter than the internodes; ligule $1 \mathrm{~mm}$. long or less; blades $2-6 \mathrm{~mm}$. wide, those of the culm $3-15 \mathrm{~cm}$. long, the basal ones much longer; panicle 1-2 $\mathrm{dm}$. long, oblong-pyramidal, the short flexuous filiform branches spreading or reflexed; spikelets 2-4-flowered, 2.5-4 min. long; first glume 1-, the second 3 -nerved; lemmas about $2.5 \mathrm{~mm}$. long, often pubescent below, midnerve pubescent to the summit. - Rich woods and thickets, N. Y. to Wis., Neb., and southw. Apr.-July.

13. P. débilis Torr. Culms terete, weate, $3-10 \mathrm{dm}$. high ; sheaths compressed, much shorter than the interuodes; ligule 1-2 $\mathrm{mm}$. long; blades $2.5-11 \mathrm{~cm}$. long, 2 mm. wide or less (rarely widler); panicle nodding, 4-12 $\mathrm{cm}$. long, the fevo long capillary branches ascending or spreading at the ends, few-flowered; spikelets 2-4-flowered, 3-4 mm. long; lemnas glabrous, except the webbed base.Rocky woodlands, e. Que. to Ont., soutliw. to Pa. and Ia. May, June.

\section{b b. Spikelets 5-6 $\mathrm{mm}$. long; lemmas lanceolate, acute.}

14. P. alsodes Gray. Culms 2-6 dm. high; sheaths thin, the uppermost elongated, often sheathing the base of the panicle; blades 1.2-3 dm. long, 2-5 mm. wide; panicle 1-2 dm. long, the filiform branches in 3's or 4's, finally spreading, or the lowest whorl ascending; spikelets 2-3flowered, about $5 \mathrm{~mm}$. long; lemmas faintly nerved, villous on the keel below. - Wooded billsides and thickets, e. Que. to Minn., and southw. May, June. Fig. 167.

15. P. Wolfii Scribn. Culms slender, $4-9$ din. high; leaves mostly clustered at the base, 2 mm. wide or less, those of the culms $5-10 \mathrm{~cm}$. long, the basal ones much longer; pauicle $8-15 \mathrm{~cm}$. long; the spikelets somewhat clustered toward the ends of the ascending capillary branches, 2-4-flowered, 5-6 mm. long; lemmas strongly nerved, the marginal nerves and midnerve villous. - Minn. and Ill. to Tenn., rare.

b b b. Spikelets 6-8 mm. long; lemmas oblong, conspicuously scarious at the obtuse apex; panicle diffuse, few-flowered.

- 16. P. autumnàlis Muhl. Culms slender, $3-9 \mathrm{dm}$. high; leaves $5-12 \mathrm{~cm}$. long, 2-3 $\mathrm{mm}$. wide; panicle $8-20 \mathrm{~cm}$. long, about as broad, the capillary flexuous spreading branches with a few spikelets near the ends; spikelets 4-6flowered, about $6 \mathrm{~mm}$. Inng; lenmas pubescent below between the strong nerves, not webbed at base. (P. flexuosa Muhl.) - Woods, N. J. and Pa. to Mo., and southw. Mar.-May.

17. P. brachyphýlla Schultes. Culms 3-5 dm. high from running rootstocks, 2-3-leaved; the upper leaves 1-5 cm. long, the basal ones about equaling the culm. abruptly cuspidate-tipped; panicle $7-12 \mathrm{~cm}$. long, the branches mostly in pairs, spreading, spikelt-bearing at the ends; spikelets 3-4-flowered; lemma webbed at base, keel and marginal nerves sparingly pubescent, intermediate nerves prominent, naked. (P. brevifolia Muhl.) - Rncky or hilly woodlands, Pa., Va., and sparingly westw. to $\mathrm{Ky}$, and Ill. Apr., May. 


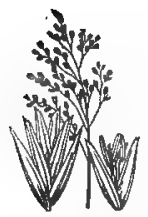

168. S. festucacea.

Panicle $\times 1 / 10^{\circ}$

Spikelet and floret $\times 1$.
72. SCOLÓCHLOA Link.

Spikelets 3-4-flowered; callus hairy ; glumes acute; lemmas firn, convex below, the nerves unequal, one or more excurrent as slender teeth; palea as long as its lemma or longer, 2-toothed; ovary hairy at the summit. - Tall peren. nials with flat leaves and ample spreading panicles. (Name, probably from $\sigma \kappa \hat{\omega} \lambda$ os, a prickle, and $\chi \lambda \hat{a} a$, grass.)

1. S. festucàcea (Willd.) Link. (SPRANGLE-ToP.) Culms stout, erect, from thick soft rootstocks, 1-2 m. high ; leaves 2-3 du. long; panicles 1.5-3.5 dm. long, the fascicled branches spreading; spikelets $6-12 \mathrm{~mm}$. long; glumes nearly as long as the florets, 3-5-nerved. - Marshes and shallow water, Ia., Minn., and northwestw. June, July. Fig. 168.

\section{GLYCÈRIA R. Br. Manna Grass}

Spikelets few-many-flowered, subterete or slightly compressed, in narrow or spreading panicles; glumes unequal, shorter than the florets; lemmas convex, firm, with a scarious margin or apex, and 5-9 strong parallel nerves; paleas equaling or a little longer than their lemmas, the strong nerves nearly marginal. Usually tall aquatic perennials, with simple culms, often partially closed sheatlis,

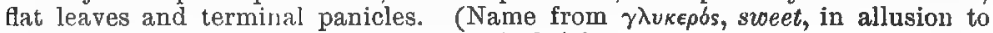
the taste of the grain.) Panicularia Fabricius.

Spikelets 2-7 mm. long, ovate or oblong.

Panicle contracted, narrow.

Panicle linear, 1.5-8 dm. long

Panile oblong, dense, $7-12 \mathrm{~cm}$. long

Panicle oper, lax.

Spikelet.s 3-4 mm. wide; lemmas obscurely nerved.

Spikelets ovate, 5-10-flowered Spikelets oblong, 8-5-flowered

Spikelets not over $2.5 \mathrm{~mm}$. wide; lemmas strongly nerved. Second glume $1 \mathrm{~mm}$. long.

Second glume $2-2.5 \mathrm{~mm}$. long.

Panicles ample, many-flowered, $2 \mathrm{dm}$. or more long

Panicles narrow, few-flowered, rarely $1.5 \mathrm{dm}$. long

Spikelets $1-4 \mathrm{~cm}$. long, compressed-cylindric.

Lemma obtuse; palea about the same length.

Lemma $6 \mathrm{~mm}$, long

Lemma 3-4.5 mm. long.

Bpikelets 1.5-2 cu. long, subsessile or nearly so

Spikelets $1-1.5 \mathrm{~cm}$. Iong, on slencler pedicels one third to two thirds as long

Lemma acute, much exceeded by the palea

1. G. Tomroyana.

2. G. obtusa.

3. G. canadensis.

4. G. lasea.

5. G. nerrota.

6. G. grandis.

7. G. pallida.

8. G. fivitans.

9. G. septentrionalis.

10. G. borealis.

11. G, acutiflore.

1. G. Torreyàna (Spreng.) Hitchc. Culms solitary or few, erect from : running rootstock, 6-9 dm. high; the smooth sheaths closed nearly to the summit; blades $3 \mathrm{dm}$. or more long, 3-6 mm. wide, scabrous ; panicle linear, $1.5-3$ dm. long, nodding at the summit; spikelets appressed, 3-4-Howered, about $4 \mathrm{~mm}$. long. (G. elongata Trin.) - Wet woods, Que. to Minn. and Pa., and in the mts. to N. C. July, Aug.

2. G. obtùsa (Muhl.) Trin. Culms stout, erect, 3-12 dm. high ; sheaths closed about half their length, the lower overlapping; blades 2-5 dm. long, $4-8 \mathrm{~mm}$. wide, smooth below, rough above; panicle finally exserted, oblong, dense, 6-18 cm. long; spikelets 3-7-flowered, $5-6 \mathrm{~mm}$. long; the scarious apex of the lemma often revinte. - Bogs and swampy places, N. B. to Pa., and southw. near the coast. July, Aug.

3. G. canadénsis (Michx.) Trin. Ratrularaice Grass. Culms solitary or few, stout, erect, 6-10 dm. high ; sheaths overlapping below, compressed; blades 1.5-3.5 dm. long, 4-8 $\mathrm{mm}$. wide, scabrulus; manic7o $1.5-3 \mathrm{dm}$. long, nearly as wide, rery loose and upen, the capillary remote branches druopiny, naked

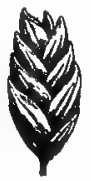

169. G. canadensis. Spikelet $\times 8$. 
below ; spikelets 5-10-flowered, ovate, tumid, Briza-like, 5-7 mm. long; lemmas nbtuse or abruptly acute. - Bogs and wet places, Nfd. to Ont. and Minn., s. to N. J. and e. Kan. July. Fig. 169.

4. G. láxa Scribn. Similar to tall forms of the preceding, 1-1.5 m. high; blades sometimes $6 \mathrm{dm}$. or more long; panicle diffuse, 3-4 dra. long, nearly as wide ; spikelets 3-5-flowered, 4-5 mm. long, $3 \mathrm{~mm}$. wide, oblong; florets , irm but not tumid; lemmas abruptly acuminate; palea nearly as long. - Swampy places, Me. to N. J. July-Sept.

5. G. nervata (Willd.) I'rin. Fowl MEadow Grass. Often in large clumps; culms erect, 3-10 dm. high; sheaths scabrous, closed almost to the summit, the lower overlapping ; blades 1.5-3 dm. long, 4-10 mm. wide, scabrous above; panicle expanded, nodding, 1-2 dm. long, the capillary branches drooping, uaked below; spikelets purplish, 3-7flowered, 3-4 mm. long; glumes minute, the second about 1 mm. long, twice as long as the first. - Moist meadows and wet places, common, Nfd. to Fla., and westw. June.

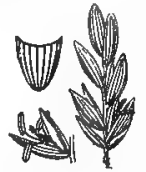

170. G, nervata. Spikelet and floret $\times 4$. Base of lemma $\times 6$. (Eu.) Fig. 170. - A low strict form (var. strfcta Scribn.) occurs from Nfd. to $\mathrm{s}$. Me., and also in western mts.

6. G. grándis Wats. (Reed Mradow Grass.) Culms clustered, stout, erect, 1-1.5 m. high ; sheaths loose, the lower rough, overlapping; blades $1.8-3 \mathrm{dm}$. long, 6-15 $\mathrm{mm}$. wide, smooth or slightly scabrous; panicle 2-4 dm. long, very compound, loose and open, nodding at the summit; spikelets numerous, with purple florets and whitish glumes, 4-7-flowered, 5-6 $\mathrm{mm}$. long; the palea nearly as long as the 7-nerved lemma. (Panicularia americana MacM.) - Banks of streams, wet meadows, ditches, etc., e. Que. to Alaska, s, to Pa., and westw. July.

7. G. pállida (Tom:) Trin. Culms slender, 3-10 dm. high, ascending from a creeping base; leaves 5-15 cm. long, 2-8 mm. wide; panicles lax, few-flowered, $7-15 \mathrm{~cm}$. long, the few slender branches ascending or spreading at the ends, naked at the base; spikelets pale green, loosely 4-9-flowered, 6-7 mm. long; glumes obtuse; lemmas 7-nerved, scabrous, dentate or erose at the obtuse apex. - Shallow water, N. S. to Va., w. to Ont., Ind., and Ky. May, June.

Var. Fernáldii Hitchc. Culms very slender, usually geniculate and spreading, 2-4 dm. high ; leaves 4-8 cm. long, $2-3 \mathrm{~mm}$. wide ; panicles $5-7 \mathrm{~cm}$. long, the fascicled branches lax, flexuous; spikelets 3-5-flowered, 4-5 mm. long; glumes and lemmas obtuse, usually erose at the summit. - Wet places, e. Que. to Me. and Minn. July, Aug.

8. G. flùitans (L.) R. Br. Culms somewhat flattened, erect from a creeping base, 6-10 dm. high; sheaths overlapping, closed nearly to the summit, smooth;

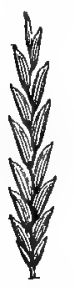

171. G. septentrionalis. Epikelet $\times 1 \frac{1}{2}$. blades 6-12 cm. long, 4-8 $\mathrm{mm}$. wide; panicle finally exserted, 2.5-4 dm. long, very slender, the few remote branches appressed or finally horizontal, a spikelet subsessile in each axil ; spikelets 7-12-flowered, 2-2.5 cm. long, nearly sessile ; glumes acute, scarious and shining; lemmas 7-nerved, scabrous, with a shining scarious margin and summit, narrowed above but obtuse, erose; the tip of the palea exceeding the lemma. (Panicularia brachyphylla Nash.) - Shallow water, Gulf of St. Lawrence ; near N. Y. City. June-Aug. (Eurasia.)

9. G. septentrionalis Hitchc. Culms erect, $1-1.5 \mathrm{~m}$. high, thick and soft; sheaths overlapping, loose, smooth, the upper closed nearly to the summit, ligule 5-6 $\mathrm{mm}$. long, decurrent; blades 1.2-2.5 dm. long, 6-8 $\mathrm{mm}$. wide, nearly smooth, rather obtuse; panicle $2-2.5 \mathrm{dm}$. long, the subflexuous branches ascending, a spikelet subsessile in each axil ; spikelets 8-12-flowered, $1.5-2 \mathrm{~cm}$. long, subsessile or on short pedicels; glumes obtuse, scarious and shining; lemmas 4-4.5 mm. long, faintly 7-nerved, hispidulous, with a shining scarious summit, erose-obtuse, slightly exceeded by the tip of the palea. ' $G$. fuitans $\mathrm{Am}$. auth., not $\mathrm{R}$. Br.) - In shallow water, N. F. to Va., and westw. - Intermediate between $G$. fluitans and the following, but usually stouter and broader leaved than either. FiG. 171. 
10. G. borealis (Nash) Batchelder. Similar to G. fluitans; the leaves commonly conduplicate; panicles $1.5-5 \mathrm{dm}$. long, often nearly simple, the slender branches erect or spreading toward the ends, a pediceled spikelet in each axil ; spilelets usually more numerous, 7-19-flowered, 1-1.5 cm. long, on slender pedicels $\frac{1}{3}-\frac{2}{3}$ as long; glumes subacute; lemmas 3.5-4 mm. long, thinner, strongly 7-nerved, minutely scabrous or glabrous, only the nerves hispidulous, obtuse and erose at the shining scarious summit, slightly exceeding their paleas. - In wet vlaces or shallow water, Nfd. to Ia., and northwestw. June-Aug.

11. G. acutiflòra Torr. Culms flattened, weak and slender, 3-9 dm, high ; sheaths overlapping, the uppermost inclosing the base of the panicle; blades 0.8-1.5 dm. long, scabrous above; panicle simple, 1.5-3.5 dm. long, the stiff branches appressed or finally spreading ; spikelets subsessile, 5-12-flowered, 2-4 $\mathrm{cm}$. long; lemmas 6-8 mm. long, acute, scabrous, exceeded by the long-acuminate bicuspidate paleas. - Wet soil and in shallow water, Me. to Del., w. to $\mathrm{O}$. May, June.

\section{PUCCINÉLlia Parl.}

Spikelets as in Glyceria but lemmas firmer, the nerves obsoure, often subacute and minutely pubescent at base. - Tufted perennials, mostly glaucous

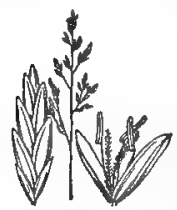

172. P, naritima.

Panicle $\times 1 / 10$.

Spikelet $\times 2$.

Floret $\times 21 / 2$. saline species. (Named for Prof. Benedetto Puccinelli, an Italian botanist. ).

1. P. maritima (Huds.) Parl. (Goose Grass, Sea Spear Grass.) Culms erect, $3-5 \mathrm{dm}$. high, from slender rootstocks; leaves flat or involute, acute or pungent; panicles $8-12 \mathrm{~cm}$. long; lower branches solitary or in pairs, appressed or expanded; spikelets 4-10-flowered, 6-12 $\mathrm{mm}$. long; lemmas obtuse or truncate, $8-4 \mathrm{~mm}$. long. - Salt marshes and beaches along the coast, Mass., and northw. July, Aug. - Somewhat variable in the form of the panicle and size of the florets. (Eu.) Fig. 172.

2. P. angustàta (R. Br.) Rand \& Redfield. Culms erect or ascending, 1.5-4 din. high, from very slender rootstocks; leaves very narrow and involute; ligule long; panicles $3-8 \mathrm{~cm}$. long, narrow, the solitary branches appressed or finally ascending; spikelets 2-4-flowered, 3-6 $\mathrm{mm}$. long; lemmas obtuse or subacute, $3 \mathrm{~mm}$. or less long. ( $P$. maritima, var. (?) minor Wats.) - Salt marshes and sandy coasts, Ct., and northw. June, July.

3. P. dístans (L.) Parl. No rootstocks ; culms rather stout, 3-6 dm. high, geniculate below ; leaves mostly flat, short; ligule short; pañicles 5-18 cm. long, the branches in 4's or 5's, soon spreading and finally deflexed, usually naked below; spikelets 3-6-flowered, 3-6 mm. long, crowded; frst glume less than half as long as lowest floret; lemwas truncate-obtuse, about $2 \mathrm{~mm}$. long. - Salt warshes along the coast and on ballast, Del. to N. B. June-Aug. - Apparently much rarer than the last, and perhaps not native. (Eurasia, n. Afr.) Fig. 173.

4. P. airoides (Nutt.) Wats. \& Coult. Similar in babit to the preceding; blades $5-10 \mathrm{~cm}$. long, often involute; panicle-

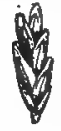

173. P. distans. Spikelet $\times 8$. branches ascending or erect or the lowest finally spreading or reflexed; spikelets 2-7-flowered, not crowded; glumes acute or subacute, the first more than half as long as the lowest floret. - In saline soil from the Dakotas southw. and westw.; occasionally eastw. in Minn. and Mich.; adv. in s. Me. (Parlin).

5. P. Borrisi (Bab.) Hitchc. Panicle compact, the branches mostly spikelet-bearing from base and not deflexed. - On ballast and waste places along the coast, from Del. to N. S. (Adv. from Eu.)

\section{FESTÙCA L. Fescue Grass}

Spikelets 2-many-flowered; glumes unequal, narrow, acute, the first 1-, the second 3-nerved; lemma firm in texture, at least below, usually narrow, convex or subcarinate, 5-nerved, acute (obtuse in 2 species) or tapering into a straight 
awn; palea usually about equaling the lemma. - Perennials or annuals with terminal panioles. (An ancient Latin name of some kind of grass, of uncertatn neaning.)

§1. Anuuals; stemen usually one.-Vólpia (C. C. Qmel.) Reichenb.

Awn more than twiee as long as the lemma; sjikelets 1-5-flowered.

First glume one third to one half as long as the second

First glume two thirds to three fourtlis as long as the second.

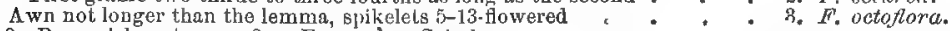

\$2. Perennials; stamens 3. - Eurestuca Griseh.

Leaves iuvolute; lemma awl-shaped, awned or pointed.

Innovations extrnyaginal; spikelets more or less glaucous . . . 4. F. mbra.

Innovations intravaginal; spikelets green. Awns longer than the membranaceous lemmas . . . . . . 5. $F_{\text {. ocoidentalis }}$

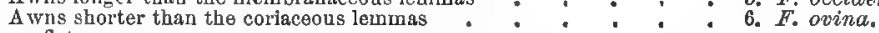

Leaves flat.

Lemma indurated, not at all keeled, awnless or tapering into á short awn. Lemma $5-7 \mathrm{~mm}$. long; panicle narrow, with short erect branches
Lemma $4-4.5 \mathrm{~mm}$. long; panicle with long spreading or ascending branches.

Lemoa subacute; spikelets loosely scattered

Lemma obcuse; spikelets somewhat aggregated:

Lemma membranaceous, indurated only noar the base, keeled above, awned from a cleft apex

\section{7. $F_{\text {, elatior. }}$}

8. Hi. nutans.

9. Fi. Shortiz.

10. F. gigantea.

1. F. мYURos L. Culms erect or geniculate at base, solitary or in small tufts, 2-6 dm. ligh ; sheaths smooth, overlapping; blades smooth, linear, involute or rarely flat; panicle $7-20 \mathrm{~cm}$. long, narrow, the branches appressed, the tips somewhat nodding; spikelets 4-5-flowered, 8-11 mm. long; glumes very unequal, the first 1-1.5 mm., the second 4-5 mm. long; lemma linear-lanceolate, scabrous above, attenuate into a scabrous awn about twice its length. - Dry fields and waste places, N. E. to O., and southw. June, July. (Nat. from Eu.)

2. F. sciùrea Nutt. Similar to the preceding, usually lower; panicle erect; spikelets 4-5 mm. long; first glume $2 \mathrm{~mm}$., second $3.5 \mathrm{~mm}$. long; lemma sparsely short pubescent. - Sandy ground, s.e. Va., and southw. May, June.

$\checkmark$ 3. F. octoflora Walt. Culms slender, erect, often tufted, $0.5-4 \mathrm{dm}$. high ; sheaths shorter than the internodes; blades narrowly linear, involute or rarely flat, soft, erect or ascending; panicle narrow, erect, $3-12 \mathrm{~cm}$. long, usually reduced to a more or less secund raceme; spikelets $5-12 \mathrm{~mm}$. long; glumes subulate-lanceolate; lemma lanceolate, attelluate into a scabrous straight awn 1-7 mm. long. (F. tenella Willd.) - Dry sterile soil, w. Que. to B. C., and throughout the U. S., especially southw. Fra. 174.

4. F. rùbra L. Culms solitary or few, erect from creeping rootstocks, 4-9 dm. high; sheaths and blades smooth; panicle $5-20 \mathrm{~cm}$. long, usually contracted, the branches erect; spikelets 4-6(rarely 10)-flowered, mostly 7-8 mm. long, often glaucnus-purplish; glumes smooth; lemma 5-7 mm. long, smooth or sca brous towald the apex, terminating in a scabrous awn usually about half as long. - Brackish meadows or low sandy soil, mostly near the coast, Lab. to Va. (Eu.) Var. PRolffera Piper. Floral organs abnormally elongated. - Mts. of N. E. and Que. Var. MEGástachys Gandin. Spikelets 10-12 mm. long. - Que., N. J. (Eu.) Var. Multiflóra (Hoffm.) Asch. \& Graebn. Blades flat; spikelets green. - Me. (Eu.) Var. subvillósa Meít. \& Koch. Spikelets pubescent with short hairs. - Local, e. Que. to N. H. (Briggs) and Vt. (Jones). (Eu.)

5. F. occidentàlis Hook. Culms densely tufted, no rootstocks, erect, slender, glabrous and shining, 5-8 dm. high ; basal leaves numerous, filiform-involute, soft; panicle loose, subsecund, flexuous, 8-20 cm. long; spikelets loosely 3-5-flowered, 6-10 $\mathrm{mm}$. long; glumes uncqual, variable even on the same plant, mostly acute or acuminate ; lenma 5-6.5 mm. long, awn about as long.

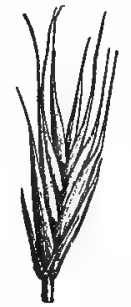

174. F, octoflora Spikelet $\times 3$. -Open woods, Keweenaw Co., Mich. (Farwell); and in the Northwest.

6. F. ovina L. (Shese's Fescue.) Densely tufted ; culms erect, $1.5-6 \mathrm{dm}$. high; leaves pale green, capillary, strongly involute, firm, the basal ones 5-12 $\mathrm{cm}$. long, those of the culm often very short; panicle contracted after blooning. 


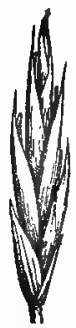

175. H. ovina. Spikelet $\times 5$.

5-10 cm. long, branches ascending; spikelets $5-7.5 \mathrm{~mm}$. long, 3-6(rarely 9)-flowered, usually pale; florets rather close; lemma smooth or slightly scabrous, $3-3.5 \mathrm{~mm}$. long, attenuate into an awn $1 \mathrm{~mm}$. long or more. - Occurs native in nearly typical form about the Great Lakes and in the White Mts.; also introduced from Eu. FIG. 175. - The native form tends to have a strict narrow panicle, differing in this respect from the typical European plant. Var. HispfDula Hack. Lemmas hirsute.-- sparingly introduced, N. Y. and Pa. (Eu.). Var. CapIllata (Lam.) Hack. Lemma awnless; leaves very slender. - Me. to N. J., Mich., and northw. (Nat. from Eu.) Var. BREvifólia (R. Br.) Hack. Culms 5-10 cm. high; sheaths closed; blades soft. - Calcareous cliffs, Nfd., e. Que., Vt., and northw. Var. duriúscola (L.) Koch. Leafblades thick, flattened, 0.7-1 mm. wide. - Sparingly introduced, Wis. and Ia. (Adv, from Eu.)

7. F. elatior L. (Taller or Meadow Fescue.) Loosely tufted, often with short creeping rootstocks; cul. is erect, 5-12 dm. high, smooth; blades 1-6 dm. long, 4-8 mm. wide, scabrous above; panicle erect, 1-2 dm. long, contracted after blooming, branches spikeletbearing nearly to the base; spikelets $9-11 \mathrm{~mm}$. long; glumes lanceolate; lemma oblong-lanceolate, scabrous at the summit, the scarious apex acute, rarely short-awned. ( $F$. pratensis Huds.) - Meadows and waste places, throughout the U. S. and s. Can. June-Aug. (Nat, from Eu.) Fig. 176.

v 8. F. nùtans Spreng. Culms solitary or few, erect, 4-12 dm. high; sheaths glabrous or pubescent; blades 1-3 dm. long, 4-7 mm. wide, scabrous, sometimes puberulent above ; panicle very loose, 1-2 dm. long, usually subsecund, and more or less nodding, branches spikelet-bearing near the ends, at first erect, finally spreading; spikelets $3-5$-flowered,

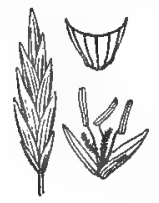

176. $F$, elatior $\times 1 \frac{1}{2}$. Spikelet, floret, and base of lemma (opened). 5-7 $\mathrm{mm}$. long; glumes firm, the first $3 \mathrm{~mm}$., the second $4 \mathrm{~mm}$. long; lemma smooth, oblong-ovate, subacute, the narrow margin hyaline. -

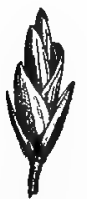
Moist woods and copses, N. S. to Minn., and southw. June, July. Fis. 177.

9. F. Shortii Kunth. Similar to the preceding; panicle more compact, the branches spikelet-bearing from about the middle; the glumes slightly longer; the lemma broader, more obtuse.Wet prairies, Ill., Ia., Kan., and southw.

10. F. Gigantika (L.) Vill. Culms 6-12 dm. high; blades 1.2-4 dm. long, 5-15 mm. wide, paler and roughened on the 177. F. nutans. upper surface, margins very scabrous; panicle 1-4 dm. long, at Spikelet $\times 8$. upper surface, margins very scalorous; panicle $1-4$ spreading, somewhat drooping; spikelets $10-13 \mathrm{~mm}$. long, 5-9-flowered; glumes hyaline-margined; lemma sparsely scabrous, bidentate at the scarious apex, bearing an awn more than troice as long. - Waste places, near the coast, Me. to N. Y., rare. (Adv. from Eu.)

\section{BROMUS L. Brome Grass}

Spikelets few-many-flowered; glumes unequal, acute, 1-5-nerved; lemmas longer than the glumes, convex or sometimes keeled, 5-9-nerved, usually 2-toothed at the apex, awnless or awned from between the teeth or just below; palea a little shorter than the lemma, 2-keeled; grain furrowed, adnate to the palea. - Annuals, biennials, or perennials with flat leaves and terminal panicles of rather large spikelets. (An ancient name for the oat, from $\beta \rho \omega \mu a$, food.)

Annuals or biennials.

Lemma broadly elliptical ; awn wanting or not over $1 \mathrm{~cm}$. long.

Awn, if present, straight.

Sheaths glabrous

Sheatbs pubescent.

4 wn about as long as the narrow lemmas.

Panlele rather dense, erect

1. B. secatinus.

2. B. hordeccets. 
Panicle open.

Lemma less then $7 \mathrm{~mm}$. long.

Prnicle 2-8 dm. long.

Panicle less than $1 \mathrm{dm}$. long : : : : $:$ 8. B. racemosus.

Lemma 9-10 mm. long ; panjcle drooping . . . . : 4. B. commutatus.

Awn short or none; lemmss very broad. : $: \quad: \quad: \quad$ : $\quad$ : B. briadeformis. Awn bent or twisted

Lemma narrow; awn over $1 \mathrm{~cm}$. long.

Panicle open, drooping.

Awn about $1.5 \mathrm{~cm}$. Jong

A w $12-3 \mathrm{~cm}$. long

Panicle compact, ovoid, erect

Perennials.

Panicles large, open and drooping.

Sheaths shorter than the internodes.

Leuna amooth on the back, ciliate-pubescent along the margins Lemma evenly pubescent all over

Sheaths longer than the internodes, much overlapping.

Sheaths sparsely pubescent except a conspiouous ring at summit Sheaths densely pubescent

Panicles small, narrow, erect or nearly so.

First glume 3-nerved

First glume 1-nerved

§1. EUBRÒMUS Godron. Annuals or biennials; glumes rather broad; lemmas broadly elliptical. Species all introduced.

1. B. Secalinus L. (Cheat or Chess.) Culmos 4-9 dm. high; sheaths smooth and strongly nerved; blades sparingly pilose above; panicle open, its branches sonewhat drooping; spilkelets 5-15-flowered, glabrous; glumes 5-7 mm. long; lemma 8-11 mm. long, becoming at maturity convex, thick and inrolled at the margins, awns short and rather weak. - Fields and waste places, common. - The florets are somewhat distant, so that, in side view, openings are visible along the rhachilla at the base of the florets. (Nat. from Eu.) FIG. 178 .

2. B. hordeaceds L. (Soft Chess.) Culms 1-6 dm. high ; whole plant more or less pubescent; panicle erect and contracted; spikelets 6-10-flowered ; temma 9-10 $\mathrm{mm}$. long, softly

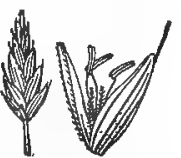

178. B. secalinus. Spikelet $\times 1 / 2$. Floret $\times 1 \frac{1}{2}$. pilose, awn about $1 \mathrm{~cm}$. long. ( $\boldsymbol{B}$. mollis L.) - Fields and waste places, infrequent, N. S. to Va. Var. Leptóstachys (Pers.) Beck. Spikelets glabrous or merely scabrous. - Del, to D. C. (Adv. from Eu.)

3. B. RaCemosus L. Culms 3-6 din. high; sheaths pubescent; panicle short (not over $7 \mathrm{~cm}$. long), upright; spikelets 5-8-flowered, glabrous; glumes 6-8 $\mathrm{mm}$. long; lemma $7 \mathrm{~mm}$. long, with an awn about $6 \mathrm{~mm}$. long. - Waste places, Que. to Del., rare. (Adv. from Lu.)

4. B. соммuтAтus Schrad. Differs from the preceding in having an open drooping panicle as much as $1.5 \mathrm{dm}$. long, and usually longer awns. - Waste places throughout, especially in the East. - Florets more closely imbricated than in $B$. secalinus, so that in side view no openings are seen at base of florets; lemmas thinner and not inrolled at the margins. (Adv. from Eu.)

5. B. ARvénsis L. Culms 3-9 dm. high, erect or geniculate at the base; sheaths pubescont; panicle large, open, with long drooping branches; glumes $4.5-6^{\circ} \mathrm{mm}$. long; lemma $7-8 \mathrm{~mm}$. long, smooth or minutely scabrous; awn about as long, straight or slightly bent. - O. (Stair) and Mo. (Bush). (Adv. from Fin.)

6. B. Brizaefórmis Fisch. \& Mey. Culms 1-4 dm. high; panicle open and drooping; spikelets broadly ovate, the larger as much as $2 \mathrm{~cm}$. long atıd $1.3 \mathrm{~cm}$. wide, awnless. - Mass. to Del., Mich., and Ind. (C. P. Smith) ; rare. (Adv. from Eu.)

7. B. JAPónicus Thunb. Culms $1.5-6 \mathrm{dm}$. high ; panicle open and drooping, one-sided; spikelets linear, $2.5 \mathrm{~cm}$. long, 6-12-flowered; lemmas glabrous, 9 $\mathrm{mm}$. long, with a bent or twisted awn about $12 \mathrm{~mm}$. long. (B. patulus Mertens \& Koch.) - Near Boston, Mass. (Swan); Lafayette, Ind. (Dorner). (Adv. from Eu.) 


\section{§2. STENOBROMUS Griseb. Annuals or biennials, with narrow glumes} and lemnas and long awns. Introduced.

8. B. тесто́ um L. Culms slender, tufted, $3-6 \mathrm{dm}$, high ; sheaths and blades pubescent; panicle broad, rather dense, secund, drooping, 6-15 cm. long; spikelets $13-20 \mathrm{~mm}$. long, nodding ; lemma pubescent ; awn $13-15 \mathrm{~mm}$.

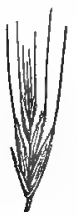
long. - Waste places, Me. to Mll., and southw. (Nat. from Eu.) Fig. 179.

9. B. stériurs L. Similar to the preceding, sometimes less pubescent; culms usually taller and geniculate at base; panicle 1-2 am. long, broad, lax, drooping, the slender branches usually bearing but one spicelet; spikelets 2.5-3. $5 \mathrm{~cm}$. long, drooping; lemma scabrous or scabrous-puberulent; awn 2-3 cm. long. Waste places and river banks, Mass. to D. C., O., and Ill.;

179. B. tectorum. also on Pacific coast. June. (Nat. from. Eu.)
Spikelet $\times 1$.
10 , B. RỦrens $L$. Panicle erect, compact, ovoid, usually Spikelet $\times 1$. purplish, 4-7 cm. long; awns about $2 \mathrm{~cm}$. long. - Waste ground, N. Billerica, Mass. (Swan); introduced on Pacific coast. (Adv. from Eu.)

§ 3. ZERNA (Panzer) Ledeb. Short-lived erect perennials, with weak drooping panicles and more or less pubescent florets. Nearly all native.

11. B. ciliàtus L. Culms rather slender, 7-12 dm. high ; sheaths retrorsely pubescent or nearly smooth; blades $2.5-3.5 \mathrm{dm}$. $7 \mathrm{ong}, 1 \mathrm{~cm}$. wide, typically sparse pilose on both surfaces, but sometimes almost smooth ; panicle broad, lax and drooping, about 1.5-2.5 dm. long, branches spikelet-bearing near the ends; spikelets 5-9-flowered, 1.5-2.2 cm. long; glumes narrow, smooth; lemmas 10-12 $\mathrm{mm}$. long, smooth on the back, ciliate-pubescent along the margins, distinctly 3-nerved or faintly 5-7-nerved, obtuse and slightly bifid at the apex; awn straight, 3-5 mm. long. - Moist woods and banks, Nfd. to N. Y., W. to Man. and Minn. July, Aug. Fig. 180.

12. B. púrgans L. Culms rather stout, $7-14 \mathrm{dm}$. high ; sheaths, at least the lower, usually sparsely retrorse-pilose; blades $1.5-3 \mathrm{dm}$. long, 5-15 $\mathrm{mm}$. wide, pubescent on the nerves above or smooth; panicle large, lax, nodding; spikelets mostly 7-11-flowered, 2-2.5

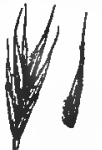

180. B, ciliatus $\times 3 / 4$.

Spikelet and lemma. cm. long; glumes sparsely pubescent; lemmas 10-12 mm. long, acute or subacute, densely pubescent all over, distinctly 5-nerved, or another pair of nerves showing at maturity, emarginate; awn straight, 4-6 mm. long. (B. ciliatus, var. Gray.) - Moist rocky woodlands, w. N. E. to Fla., w. to Wyo. and Tex.

13. B. altíssimus Pursh. Differs from the preceding in having overlapping sheaths, furnished at the summit with a pubescent ring, otherwise sparsely pubescent, and in having broader and distinctly 7-nerved lemmas, the pubes-

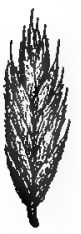

181. B. Kalmii Spikelet $\times 1$. cence more silky and increasing in density toward the base. (B. purgans, var. latiglunis Shear.) - Wooded hills, Ct. to Pa., w. to Mont. and Mo.

14. B. incànus (Shear) Hitchc. Similar to the preceding, sheaths densely and softly short-pilose; spikelets much as in $\boldsymbol{B}$. purgans, but flowering later than that species, with which it is associated. (B. purgans, var. Shear.) - Wooded hills, Pa. to Va., s. Dak., and Tex.

15. B. Kálmii Gray. (W ILn Cress.) Culm slender, 0.5-1 m. high ; sheaths and blades conspicuously or sparingly villous; panicle 7-10 cm. long; spikelets drooping on capillary peduncles, closely 7-12-flowered, $1.5-2.5 \mathrm{~cm}$. long, densely silky all over; first glume distinctly 3-nerved, the second 5-nerved; lemma 8-10 mm. long, 7-nerved, obtuse ; awn straight, 2-3 mm. long. - Dry ground, w. N. E. to Pa., Mo., Minn., and northw. June, July. Fig, 181.

16. B. ERÉros Huds. Culms erect, 6-9 dm. high, glabrous; sheaths nearly glabrous; biades narrowly linear, sparingly pilose; panicle 1-2 dm. long, with few ascending branches; spikelets narrow; first glume 1-nerved, second 3-nerved; 
lemma 10-12 mm. long, acuminate, 5-nerved, evenly scabrous-pubescent on back; awn 5-6 mm. long. - Fields, Me. 10 Ont., local. (Adv. from Ea.)

\section{LÒLIUM L. DARNeL}

Spikelets several-flowered, solitary in alternate notches of the continuous rhachis, one edge of each spikelet placed against the rhachis, the glume on that edge wanting; second glume rigid, 5-7-nerved, exceeding the lowest floret; rhachilla flattened; lemmas convex, 5-7-nerved, nerves converging above, awned or awnless; grain adherent to the palea. - $\Lambda$ nnuals or perennials with simple erect culms, flat leaves and terminal spikes. (Ancient Latin name.)

6 1. L. Perenne L. (Common D., Perennial Ray or Rye Grass.) Short-lived perennial; culms 3-6 dm. high, glabrous; the axis of infiorescence glabrous except the angles; leaves usually not over $4 \mathrm{~mm}$. wide, folded in the bud; glume shorter than the 8-10-flowered spikelet; lemma

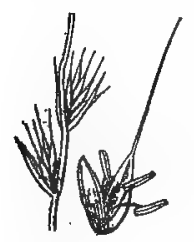
about 5-6 mm. long, awnless. - Fields and roadsides, chiefly eastw. June. - This and the following are cultivated as meadow grasses. (Nat. from Eu.) FIG. 182.

2. L. Multiflónum Lam. (Italian Rre Grass.) Differs from the preceding in having the upper portion of the culm

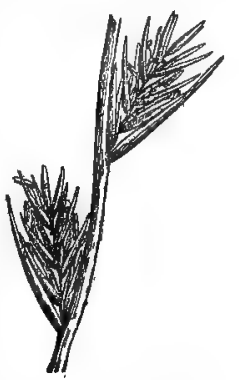

182. L. perenne.

Two spikelets $\times 11 / 2$. and the convex side of the axis of inflorescence roughened; leaves convolute in the bud; spikelets 10-20-flowered; lemmas 7-8 mm. long, usually at least the upper awned. (L. italicum 188. L. temulontum. R. Br.) - Fields and roadsides. June. (Nat. from Eu.) Spikelets $\times 1 / 2$. I 3. L. Temuléntum L. (Beatiden D.) Annual; culms Floret $\times 11 / 4$. taller; glume fully equaling the 5-7-fluwered spikelets; awn longer or shorter than the lemma. - Grain fields and waste places, rare. (Adv. trom Eu.) Fig. 183.

L. FEsTuCACEuM Iink, a glabrous perennial with approximate spikelets, or the lower remote, the glume shorter than the awnless florets, occurs occasionally on ballast and waste grounds in N. J. and Wilmington, Del. (Adv. from Eu.)

\section{LEPTÙRUS R. Br.}

Spikelets 1-2-flowered, awnless, solitary, alternate in excavations of the articulate rhachis; glumes equal, placed edge to edge in front of the florets, except in the terminal spikelet, coriaceous, rigid, 5-nerved, acute; lemma much smaller than the glumes, hyaline, keeled. - Our species a low branching annual, with slender cylindrical straight or curved terminal spikes which disarticulate at maturity, the joints falling with the appressed spikelets attached. (Name from $\lambda \in \pi \tau 6 s$, narrow, and oujpa, tail, or spike.)

1. L. FILIFórmis (Roth) Trín. Tufted, ]-2 dm. high, decumbent at base, glabrous ; leaves short and narrow; spikes 3-10 dm. long, included at the base in the sheath, joints and spikelets $5 \mathrm{~mm}$. long. - Borders of brackish marshes, Md. and Va.; and on ballast northw. (Adv. from Eu.) Fig. 184.

\section{AGROPỲRON Gaertn.}

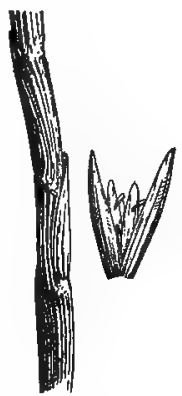

184. L. fliformis $\times 3$. Part of inflorescence and spikelet.

Spikelets 3-many-flowered, solitary (rarely in pairs) in alternate notches of the continuous (rarely articulate) rhachis, the side of the spikelet placed against the rbachis; glumes equal, opposite or placed edge to edge on the outer side 
of the spikelot, usually subcoriaceous and rigid, several-nerved, usually shorter than the florets, acute or awned; lemmas convex or slightly keeled above, 5-7nerved, acute or awned from the apex; palea shorter than its lemma, bristly. ciliate on the keels; grain pubescent at the summit, usually adherent to the palee. - Yerennials with simple culms and terminal spikes. (Name from áypós a field, and $\pi$ oós, wheat.)

Culms solitary or few, erect from creeping rootstocks.

Lemmas rensely pubescent.

Lemmas glabrous or scabrous.

Leaves tlat, thin, with fine scarcely prominent nerves

Leaves becoming in volute, thick, with prominent thick nerves.

Glumes faintly nerved, long-acuminate
Glumes strongly nerved, abruptly narrowed to a rather blunt point 2 . A. Pmithts.

Culms tufted; no creeping rootstocks.

A wn not longer than the lemme.

Glumes thin, widened above the middle.

Glumes firm, varrowed from below the middle

A wn about twice the length of the lemma.

Snike nodding, sy mmetrical

Spike erect, one-sided

1. A. Smithii Rydb. (Blue-Joint.) Glaucous ; culms rigid, 3-15 dm, high; leaves rigid, bluish green, scabrous, becoming involute, 1-2 dm. long,

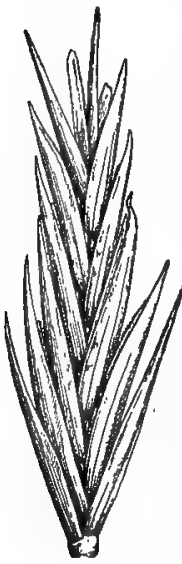

185. A. Smithli.

Spikelet $\times 3$. 4-6 mm. wide, basal leaves longer; spikes $0.8-1.5 \mathrm{dm}$. long; spikelets 7-13-flowered, 1.2-2 cm. long, usually somewhat distant, glabrous or nearly so, acute, compressed, divergent, sometimes in pairs; glumes acuminate, $\frac{1}{2}$ or $\frac{2}{3}$ as long as spikelet, nerves usually faint; lemmas mucronate or awn-pointed, hard, faintly nerved. (A. occidentale Scribn. ; $A$. spicatum Scribn. \& J. G. Sm., as to description, not Festuca spicata Pursh.) Prairies, Mich. to Kan., and westw. July.- Rootstock and lower portion of culms gray or tawny, not bright yellow-green as in $A$. repens. Frg. 185.

2. A. Púngens (Pers.) R. \& S. Glaucous; culms slender, rigid, 6-9 dm. high; leaves 18-24 cm. long, narroved into a rigid involute point; spikes 1-1.2 dm. long, flattened parallel to the rhachis; the broad compressed spikelets along each side of the rhachis, overlapping, usually alternately diverging to the right and left, thus appearing 4-ranked, 7-11-flowered, 1.5-2 cm. long; glumes abruptly narrowed to a blunt point, 8-9 mm. long; lemmas about $1 \mathrm{~cm}$. long, acute, mucronate or very short-awned. (A. tetrastachys Scribn. \& J. G. Sm.) - Sandy seacoast of Me. July. (Nat. from Eu.)

3. A. Rìpens (L.) Beauv. (Cöch, Quitch, or Quion Grass.) Bright green or glaucous, 3-12 dm. high ; sheaths glabrous or the lower sparsely pilose; blades flat or inrolled, scabrous or sparsely pilose above; spikes $0.5-1.5 \mathrm{dm}$. long, slender or stout; spikelets about 5-flowered, 1-1.5 cm. long; glumes 8-10 mm. long, acuminate or awn-pointed, strongly nerved ; lemmas about $1 \mathrm{~cm}$. long, glabrous or more or less scabrous,

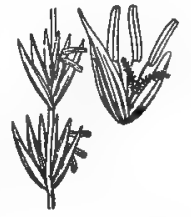

186. A. repens. Splkelets $\times 2 / s$. Floret $\times 11 / 2$. strongly nerver, pointed or terminating in an awn as much as $5 \mathrm{~mm}$. long. Fields, roadsides and waste places, common. - The internodes of the long creeping rootstock and the lower portion of the culm are colıred bright greenish yellow; scales of the rootstock distant and often conspicuous. (Nat. from Eu.) Fig. 186.

4. A. dasystàchyum (Hook.) Scribn. Resembling the last, glaucous; leaves narrow and often involute ; the 5-9-flowered usually subterete spikelets densely downy-hairy all over except the strongly nerved glumes; lemmas thinner with scarious margins, mostly long-acuminate. - Sandy shores of Lakes Huron and Michigan, and northw. Aug.

5. A. biflorum (Brignoli) R. \& S. Culms usually decumbent at base, 3-6 dm. 
high; leaves often lax, 2-5 mm. wide; spike dense, $5-10 \mathrm{~cm}$. long, usually tinged with purple; glumes conspicuously 5-7nerved, the nargins thin and widened above the middle, rather abruptly narrowed into a short awn; lemma 8-10 $\mathrm{mm}$. long, glabrous or nearly so, terminating in an awn shorter than itself.

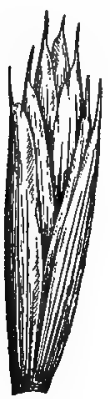

(A. violaceum Lange.) - Alpine regions of the White Mts., L. Superior, northw. and westw. June-Sept. (Eu.) Frg. 187.

6. A. ténerum Vasey. Culms erect, 5-10 dm. high, rigid ; leaves subrigid, narrow, flat or involute in drying; spike usually almost cylindrical, green or siraw-color, 1-1.5 dm. long; glumes firm, nearly as long as the spikelet, the scarious margin narrow, tapering more gradually into the awned point ; lemma short-awned. - Nfd. to Pa.

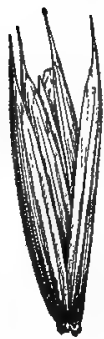
and Minn., and common in the far West. July, Aug. - The typical form has slender spikes with rather distant spikelets, which are nearly inclosed in the glumes; this is common westw. and extends into Minn.; also introduced on the coast of Mass. (Eaton.) Frg. 188. Passing into a form with stouter and denser spikes and broader

158. A. tenerum,

Spikelet $\times 3$. less rigid leaves which extends eastw. to Nfd. and $\mathrm{N}$. E. ; this is A. novae-angliae Scribn. and essentially A. pseudorepens Scribn. \& J. G. Sm.

7. A. caninum (L.) Beauv. (Awnid Wheat Grass.) Culms erect, 3-10 dm. high ; leaves flat, rather lax, 8-20 cm. long, 2-6 $\mathrm{mm}$. wide, scabrous; spike more or less nodding, at least in fruit, rather dense, $7-15 \mathrm{~cm}$. long; spikelets $1.2-1.5 \mathrm{~cm}$. long excluding the awns; glumes pointed or awned; lemmas 3-5-nerved; awns straight or somewhat spreading, fully twice the length of the lemma. - Sparingly naturalized in cultivated grounds and meadows; indigenous along our nortnern borders, and westw. July-Sept. (Eu.) Fig. 189.

8. A. Richardsonii Schrad. Similar to the preceding; culms usually taller and stouter; spike larger, as much as $2 \mathrm{dm}$. long, erect, 1-sided, "spikelets $2 \mathrm{~cm}$. long, excluding the awns, which

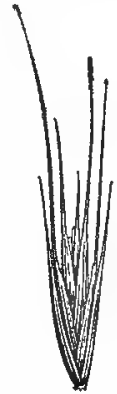

189. A. caninum. Sptkelet $\times 1 \frac{1}{2}$. are often as much as 3-4 cm. long. - Prairies and shores, e. Que.; Minn., Ia., and northwestw. June-Sept.

\section{HóRDEUM [Tourn.] L. BaRLEY}

Spikelets 1(rarely 2)-flowered, 3 together in our species at each joint of the

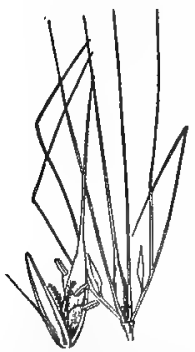

190. H. jubaturn.

Three spikelets $\times 1$. Middle, fertile spikeJet $\times 11 / 2$. flattened articulate rhachis, the middle one sessile, perfect, the lateral pair usually pediceled, often reduced to awns and together with the glumes of the perfect spikelet simulating a bristly involucre at each joint of the rhachis; rhachilla prolonged behind the paled as an awn, sometimes with at rudimentary floret; glumes equal, rigid, narrow-lanceolate, subulate or setaceous, placed at the sides of the dorsally compressed floret which is turned with the back of the palea against the rhachis of the spike; lemma obscurely 5-ner-ved, tapering into an awn; palea slightly shorter, the 2 strong nerves near the markin; grain hairy at the summit, usually adherent to the palea at maturity. - Caespitose annuals or perennials with terminal spikes which disarticulate at maturity, the joints falling with the spikelets attached. (The ancient Latin name.)

1. H. jubàtum L. (Squirrel-Tail Grass). Biennials, 3-7 dm. bigh, erect or geniculate at base; leaves $5 \mathrm{~mm}$. wide or less, scabrous; spike nodding, 5-12 cm. long, about as 
wide; lateral pair of spikelets each reduced to 1-3 spreading awns; glumes of perfect spikelets awn-like, $3-6 \mathrm{~cm}$. long, spreading; lemma 6-8 mm. long, with

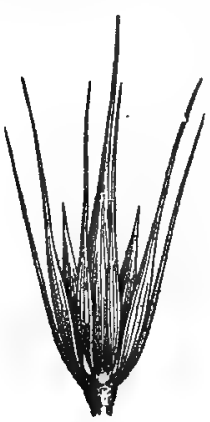

191. II. pusillum.

Three spikelots $\times 3$. an awn as long as the glumes; all the awns very slender, scabrons. - Coast, Lab. to N. J.; prairies and waste ground, Ont. to Ill., Kan., and westw. June-Aug: — Often a troublesome weed. (Iurasia.) Fig. 190.

2. H. pusíllum Nutt. Annual, 1-4 dm. high; leaves $6 \mathrm{~cm}$. or less long, erect, scabrous; spikes erect, 2-7 cm. long, $1-1.5 \mathrm{~cm}$. wide; lateral pair of spikelets abortive; first glume of each, and both glumes of fertile spilcelet, dilated above the base, attenuate into a slender awn 8-15 mm. long, equaling the awned lemma.-Plains, especially in saline soil, $O$. to Mo., and westw. ; sparingly introduced, D. C., Va., and southw. along the coast. May, June. FIQ. 191.

3. H. noddsum L. Similar to the preceding, usually taller; spike $2-8 \mathrm{~cm}$. long, about $1.5 \mathrm{~cm}$. wide; all the glumes aronlike, 1-1.5 mm. long. - Thin dry soils, Ind., Minn., and northw., s. to Tenn, and Tex. (Eurasia.) Fig. 192.

4. H. Pammèli Scribn. \& Ball. Perennial, erect or geniculate at base, 6-10 dm. high ; leaves $1.2-2 \mathrm{dm}$. long, 5-8 $\mathrm{mm}$.

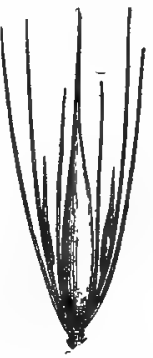

192. H. nodosum. wide, long-acuminate, scabrous ; spikes nodding, $8-17 \mathrm{~cm}$. long, $2-3 \mathrm{~cm}$. wide : the lateral pair of spicelets nearly sessile, perfect; the middle spikelet 2-flowered or often with the rudiment of a third floret; glumes $2.3-3.5 \mathrm{~cm}$. long, subulateattenuate into slender acons. - Prairies, Ill., Ia., S. Dak., and Wyo. JuneAug. - Intermediate between Hordeum and Elymus; closely related to cultivated barley.

\section{1. Élymus L. Wild Rye, Lyme Grass}

Spikelets 2-6-flowered (uppermost florets imperfect), in pairs (sometimes solitary below, rarely in 3 's or 4's), sessile at the alternate notches of the continuous rhachis; rhachilla articulated above the glumes and between the florets; glumes equal, rigid, narrow, 1-3-nerved, acute or awn-pointed, placed edge to edge in front or toward the sides of the florets (which are dorso-ventral to the rhachis of the spike) simulating an involucre at each joint of the rhachis ; lemmas convex, obscurely 5-nerved, obtuse, acute or awned from the apex; paleas a little shorter than their lemmas; grain hairy at the summit, adherent to the lemma and palea. - Erect tufted perennials with flat leaves and closely flowered terminal spikes. (Name from $\epsilon \lambda \dot{\epsilon} \in \boldsymbol{v}$, to roll up, an ancient one for some grain.)

\footnotetext{
Glumes as long as the florets or nearly so.

Lemmas awned.

Spikelets spreading.

Glumes awl-shaped

Glumes narrowly lnnceolate.

Glumes indurated below; splke erect. Awn long and spreading

Awn short and erect
Glumes not indurated bolow; spike noddi ? Spike large and densely fowered throughout
Spike more slender and less densely flowered, interrupted below.

Lemma hirsute

Lomma minutoly scabrous

Bpikelets appressed to rhachis. Spikelets in pairs

Spikelets mostly solttary

Lommas awnless .

Glumes reduced to short awns

6. E. striatus.

2. E. anstralis.

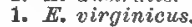

4. E. robustus.

8. E. canadensis.

5. E. brachystachys

8. $E$. plaucus.

7. E. Mueounii.

9. E. arenarizis.

10. $E$. diversighumis.
} 


\section{* Glumes as long as the lemmas or nearly so.} + Glumes and lemmas rigid, all or only the latter awned.

* Glumes bowed out, the base yellow and indurated for 1-2 $\mathrm{mm}$.

1. E. virgínicus L. Green or glaucous ; culms stout, 6-10 dm. high; sheatlis smooth or hairy; blades $1.5-3 \mathrm{dm}$. long, 4-8 mm. wille, scabrous; spike $4-14 \mathrm{~cm}$. long, $12 \mathrm{~mm}$. thick, rigidly upright, often included at the base in the upper sheath; spikelets 2-3-flowered; the lemmas smooth, bearing a scabrous dwn 4-18 mm. long, exceeding the lanceolate strongly-nerved awn-pointed glabrous glumes. - River banks, moist woodlands, etc., N. S. to Fla., and westw. July-Sept. - In the Limnean specimen the spike is exserted and the awn is about the length of the lemma. Fig. 193. Var. hirsutiglơmis (Scribn.) Hitchc. Glumes and lemmas hirsute, glumes somewhat narrower; spike usually more slender. - Me. to Va. and Neb. Var. sunmisicus Hook. Lemma and glumes awnless or short awn-pointed, scabrous. - O . to Minn., Kan., and westw.

\section{++ ++ Glumes straight, not or but little indurated at base.}

$=$ Culms stout; spikes 1-2 cm. thick.

2. E. austràlis Scribn. \& Ball. Intermediate between $E$. virginicus and the next, green; culms $0.7-1.5 \mathrm{~m}$. high, rather slender; leaves $2-4 \mathrm{dm}$. long, narrowed toward the base; spike exserted, erect, 8-14 cm. long, 1.5-2 cm. thick;

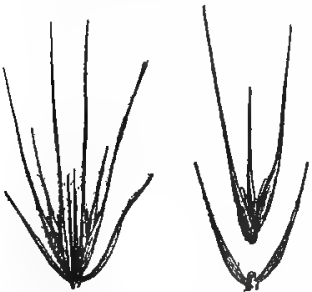

194. E. canadensis $\times 2 / 8$.

Two spikelets.

Spikelet with glumes deteched. glumes and leminas hirsute; awns spreading, often $2 \mathrm{~cm}$. long. - Woods and prairies, Ct. to Mo., and southw. - Glumes slightly indurated at base.

3. E. canadénsis L. Green or glaucous; culms $6-15 \mathrm{dm}$. high; leaves often $1-2 \mathrm{~cm}$. broad; spike 1-2 dm. long, exserted, soon nodding, loose or interrupted below; glumes and lemmas hirsute, with long spreading awns. - Sandy soil, N. S. to Man., and southw. FIG. 194. Var, GLA UcıFóliss (Muhl.) Gray is the very glaucous form but corresponds more nearly with the Linnean type.

4. E. robústus Scribn. \& J. G. Sm. Differs from the preceding in having a more robust and densely flowered spike; spikelets closely imbricated, not interrupted at base; the long awns divaricately spread. ing. - Low prairies, Ill., and westw.

5. E. brachýstachys Scribn. \& Ball. Resembles small specimens of $\boldsymbol{E}$. cana densis ; culms 3-9 dm. high; leaves $1-2 \mathrm{dm}$. long, 6-10 mm. wide, often somewhat involute, scabrous ; spike ratber dense, or loose below, somewhat nodding, 8-15 cm. long; glumes and florets scabrous only, not hirsute; awns divergent. - Moist open or shaded grounds, Md. to Mich., S. Dak., and Mex.

$$
==\text { Culms slender. }
$$

a. Spikelets spreading.

6. E. striatus Willd. More or less pubescent; culms $5-10 \mathrm{dm}$. high ; leaves $15-20 \mathrm{~cm}$. long, pubescent on the upper surface; spike $7-10 \mathrm{~cm}$. long, about $2.5 \mathrm{~cm}$. thick, dense, usually nodding; spikelets 1-2(rarely 3)-flowered; glumes awl-shaped, hispid or hirsute, 2 or 3 times the length of the hirsute floret which is only $6 \mathrm{~mm}$. long, excluding the capillary awn (2-3 cm. in length.) - Rocky woods and banks, Me. to S. Dak., s. to N. J. and Ark. July, Aug. Fig. 195. Var. ARKANsanus (Scribn. \& Ball) Hitchc. Glunes
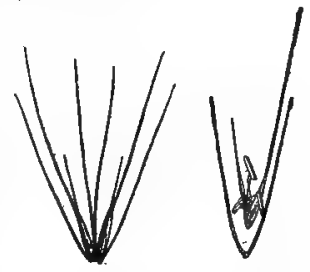

195. E. striatus $\times 2 / 3$.

Two spikelets.

Spikelet with glumes detached. and lemmas glabrous or minutely scabrous. - Md., Ia., and southw. 


\section{$a$ a. Spikelets appressed to the rhachis.}

7. E. Macoúnii Vasey. Culms $3-8 \mathrm{dm}$. ligh ; sheaths glabrous or the lower sparsely pilose; blades $8-16 \mathrm{~cm}$. long, $4 \mathrm{~mm}$. wide or less, erect, often involute

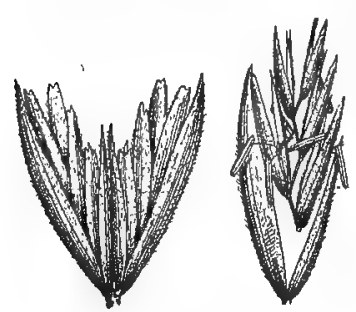

196. E. arenarius $\times 2 / 8$.

Two spikelets.

Spikelet with glumes detached. in drying, scabrous, the lower usually pilose on the upper surface; spikes narrow, $6-10 \mathrm{~cm}$. long ; spikeiets 1-3-flowered, the lower solitary and often apparently with 3 glumes, the missing spilcelet being reduced to a single glume; glumes linear. lanceolate, 3-nerved, scabrous, tapering into an awn; lemnas 8-10 $\mathrm{mm}$. long, scabrous above, with a slender awn 6-10 mm. long. - Prairies, Minn., Ia., and westw.

8. E. glaúcus Buckley. Glabrous ; culms 5-10 $\mathrm{dm}$. high ; leaves 1.5-2 dm. long, 4-8 $\mathrm{mm}$. wide, rather thin, flat, scabrous; spikes slender, the internodes 8-10 mm. long; spilielets 3-6-flowered; glumes linear-lancenlate, 3-5-nerved, smooth or scabrous on the nerves, short-awned, shorter than the nearly smooth lemma which bears an awn twice its own length. - Moist soil, Ont. to Mich., and westw. July, Aug.

++ Glumes and lemmas not rigid, conless; plants reed-iike.

9. E. arenàrius L. Culms stout, 6-12 dm. high, from extensively creeping rootstocks; leaves firm, setaceous-involite toward the ends, the basal ones crowded, 2-3 cm. long, the upper shorter; spike stiff, dense, $8-25 \mathrm{~cm}$. long, 1.5-2 cm. thick; spikelets in pairs or solitary, 3-7-flowered, $2.5-3 \mathrm{~cm}$. long, often glaucous; glumes and lemmas acuminate or mucronate, short-villous. ( $E$. mollis Trin.) - Maritime sands, Lab. to Me.; and shores of the Great Lakes. (Eurasia.) Fig. 196.

\section{* Glumes reduced to short arons.}

10. E. diversiglùmis Scribn. \& Ball. Culms stout, 9-12 dm. high; leaves lax, 1.5-2.5 dm. long, 6-12 mm. wide, scabrous, setaceous-pointed; spike loose below, 1-1.5 dm. long; spikelets 2-flowered; glumes subulate, scabrous, varying from a mere point to $1.5 \mathrm{~cm}$. long in the same spike; florets 8-10 mm. long, hirsute, especially toward the summit, with a divergent awn $2-3 \mathrm{~cm}$. long. Thickets and open woods, Wis., Minn., and westw. - Approaches Hystrix.

SitAnion longlfòlium J. G. Sm., a western tufted perennial $3-5 \mathrm{dm}$. high, with crowded basal sheaths, long spreading upper leaves, partially included loose long-awned disarticulating spikes about $1 \mathrm{dm}$. Iong, the glumes divided to the base into 2 long divergent awns (6-8 cm. long), occurs in central Kan, and westw, and is reported from central Minn. EIG. 197.

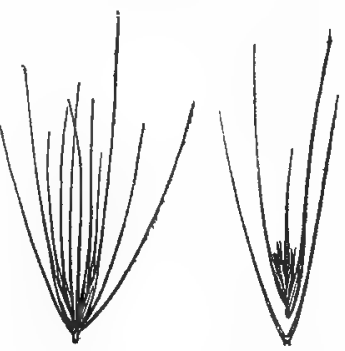

197. S. longifotum $\times 2 \%$.

Two spikelets.

Spikelet with glumes detached.

\section{HÝSTRIX Moench, BotTle-Brush Grass}

Spikelets 2-4-flowered, on very short pedicels, 1-3 together at each joint of the flattened continuous rhachis, facing it as in Elymus, widely divergent at maturity; glumes reduced to short or minute awns, the first usually obsolete, both often wanting in the upper spikelets; lemnas convex, rigid, tapering into a iong awn; palea strongly 2-keeled; grain pubescent at the summit, free within the lemma and palea. - Perennials with simple culms, flat leaves and lousely flowered spikes, (Name fron $v^{\prime} \sigma \rho \iota \xi$, a hedgehog, alluding to the bristly spikes.) 
1. H. pátula Moench. Culms 6-12 dm. high ; leaves spreading, 1-2 dm. long, $8-1.5 \mathrm{~mm}$. wide, tapering to both ends, scabrous; spike short-exserted or partially included, 6-12 cm. long; spikelets usually distant, at first erect, soon widely diverging, 1-1.5 $\mathrm{cm}$. long excluding the awns; lemmas pubescent at least at the summit or nearly glabrous; awns 1.5-4 cm. long. (Asprella Willd.; H. Hystrix Millsp.) - Moist woods, N. B. to Minn., and southw. Junt-Aug. Fıg. 198.

\section{ARUNDINÀRIA Michx. CANE}

Spikelets 2-many-flowered, perfect or the upper imperfect, laterally compressed, in racemes or panicles; glumes unequal, shorter than the lemmas, the first sometimes obsolete; lemmas firm, keeled, many-nerved, acute or mucronate; paleas nearly as long as their lemmas, 2-keeled and several-nerved; lodicules 3 ; styles 2 or 3; grain free within the lemma and palea.-Arbo-

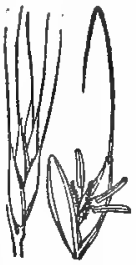

108. II. patula. Spikelot $\times 1$. Floret $\times 1 \frac{1}{2}$. rescent or shrubby grasses with terminal and lateral panicles of large spikelets. (Name from arundo, a reed.)

V 1. A macrospérma Michx. (LaRge C.) Culms arborescent, 3-10 $\mathrm{m}$. high and 1-7 $\mathrm{cm}$. thick at base, rigid, simple the first year, branching the second, afterwards fruiting at indefinite periods; leaves

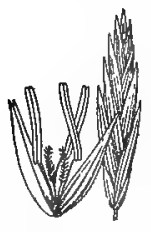

199. A. macrosperma. Spikelet $\times 1 / 2$. Fioret $\times \frac{2}{3}$. lanceolate, 2-5 cm. long, $1.5-3 \mathrm{~cm}$. wide, smoothish or pubescent, the sheath ciliate on the margin, fimbriate at the summit; panicle lateral, composed of few simple unequal racemes; spikelets $3-5 \mathrm{~cm}$. long, 5-15-flowered, purplish or pale, erect. - River banks, s. Va., $\mathrm{Ky}$., and southw., forming cane brakes. Apr. Fig. 199.

2. A. técta (Walt.) Muhl. (Switch C., Small C.) Lower and more slender, $1-4 \mathrm{~m}$. high, branching above; leaves $8-20 \mathrm{~cm}$. long, $0.8-3 \mathrm{~cm}$. wide, more tapering at base ; panicles of few aggregated spikelets on long slender branches with rather loose sheaths, the blades very minute; spikelets 2.5-4 cm. long, 5-10-flowered. (A. macrosperma, var. suffruticosa Munro.) - Swamps, moist soil, or in water, Md., s. Ind., Ill., Mo., and southw. - Sometimes blooming several years in succession.

\section{CYPERÀCEAe (Sedge Family)}

Grass-like or rush-like herbs, with fibrous roots, mostly solid stems (culms), closed sheaths, and spiked chiefly 3-androus flowers, one in the axil of each of the glume-like imbricated bracts (scales, glumes), destitute of any perianth, or with hypogynous bristles or scales in its place; the 1-celled ovary with a single erect anatropous ovule, in fruit forming an achene. Style 2-cleft with the fruit. flattened or lenticular, or 3-cleft and fruit 3-angular. Embryo minute at the base of the somewhat floury albumen. Stem-leaves when present 3-ranked. - A large, widely diffused family.

V. $B$. - In this family, unless otherwise noted, the figures representing the inflorescence or a portion of it are on a scale of $\frac{2}{3}$, while those representing the achene or perigynium are on a scale of $2 \frac{2}{5}$. In a few cases a bit of the surface of the achene is shown on a scale of 10 .

I. Flowers all perfect, rarely some of them with stamens or pistil abortive; spikes all of one sort.

Tribe I. ScfRPEAE. Spikelets mostly many-flowered, with only 1 (rarely more) of the lower scales empty.

* Scales of the spikolet strictly 2 -ranked, conduplicate and keeled. 
Flowers destitute of bristles and of beak to the achene; inflorescence terminal.

1. Cyperus. Spikelets few-many-fluwered, usually elongated or slender.

2. Kvllinga. Spikelets 1-flowered (but of 3 or 4 scales), glonerate in a sessile head.

+ - Flower furnished with bristles; achene beaked; inflorescence axillary.

3. Dulichium. Spikelets 6-10-flowered, slender, clustered on an axillary peduncle.

* * Ecales of the several-many-flowered spikelet imbricated all round (subdistichous in no. 5).

- Achene crowned with the bulbous persistent base of the style; flowers without inner scaler (bractlets).

廿 Hypogynous bristles (perianth) generally present; culm naked.

4. Eleocharis. Bpikelet solitary, terminating the naked culm. Stamens 2-8.

++ + Bristles always none; culm leafy.

5. Dichromena. Spikelets crowded into a leafy-involucrate bead, laterally flattened, the scales more or less conduplicate and keeled. Many of the fowers imperfect or abortive.

6. Psilocarya. Spikelets in broad open cymes. Style almost wholly persistent.

7. Stenophyllus. Spikelets in an involuerate umbel. Style-base persistent. ++ Achene not crowned by the bulbous base of the style.

* Flowers without inzer scales.

- Style-base bulbous, deciduous; perianth none.

8. Fimbristylis. Spikelets in an involucrate umbel. Culm leafy at base. Style wholly deciduous.

- - Style-base not thickened; perianth.bristles usualiy present.

9. Scirpus. Spikelets solitary or clustered, or in a compound umbel; the stem often leafy at base and inflorescence involucrate. Bristles $1-s$, or none. Stamens 2 or 3 .

10. Eriophorum. As Scirpus, but the silky elongate bristles very numerous. Stamens 1-8.

+++ Flower with one or more inner scales.

11. Fuirena. Scales of the spikelet awned below the apex. Flower surrounded by 3 stalked petal-like scales alternating with 3 bristles.

12. Hemicarpha. Flower with a single very minute hyaline scale next the axis of the spikelet. Bristles none.

18. Lipocarpha. Flower inclosed by 2 inner scales, one next the axis, the other in front of the achene. Bristles none.

Tribe II. RYNCHOSPóREAE. Spikelets mostly 1-2-flowered, with 2-many of the lower scales empty.

14. Rynchospora. Spikelets terete or flattish; scales convex, either loosely enwrapping or regularly imbricated. Achene crowned witl a persistent tuberele or beak, and commonly sur. rounded by bristlez.

15. Cladium. Spikelets terete, few-flowered, the scales, etc., as in the preceding. Achene destitute of tubercle. No bristles.

\section{Flowers unisexual.}

Tribe III. SCLERIEAE. Flowers monoecious; the staminate and pistillate in the same or in differ. ent clustered spikes. A chene naked, bony or crustaceous, supported on a hardened disk.

16. Scleria. Spikes few-flowered; lower scales empty. No bristles or inner scnles,

Tribe IV. CARícEAE. Flowers monoecious in the same (androgynous) or in separate spikes, or sometimes dioecious. Achene inclosed in a sac (perigynium) or spathe.

17. Kobresia. Achene in the axil of a spathe-like mlnme.

18. Carex. Achene completely surrounded by the perigynium, the style protruding through a small aperture at the top.

\section{CYPÈRUS [Tourn.] L. Galimgale}

Spikelets many-few-flowered, mostly flat, variously arranged, mostly in clusters or heads, which are commonly disposed in a simple or compound ter. minal umbel. Scales 2-ranked (their decurrent base often forming margins or 
wings to the hollow of the joint of the axis next below), deciduous when old. Stamens 1-3. Style 2-3-cleft, deciduous. Achene lenticular or triangular, naked at the ayjex. - Culms mostly triangular, simple, leafy at base, and with one or more leaves at the summit, forming an involucre to the umbel or head. Peduncles or rays unequal, sheathed at base. All flowering in late summer or autumn. (Kúreıpos, the ancient name.)

$\$ 1$. Scales deciduous, readily falling away from the somewhat persistent rhachilla of the flattened spikelet $a$.

a. Style 2 -cleft ; acheve lenticular, laterally compressed (the edge turned to the rbaehilla); rhachilla narrow, not winged; annuals $b$.

b. Achenes much shorter than the subtending scales $c$.

c. Achenes orbicular, with narrowly oblong superficial cells .

c. Achenes obovate or narrower, the superficial cells broad $\dot{d}$.

d. Achenes oblong-obovate $e$.

6. Spikelets lance-oblong; scales marked with dark brown or purple, or merely greenish.

Stamens 2 ; style-branohes conspicuously exserted .

Stamens 8; style-branches scarcely exserted

6. Spikelets lance-linear; scales oblong, yellow or yellowishbrown throughout; stamens 2

d. Achenes linear-oblong or clavate; scales ovate or oblong.

Spikelets brownish, 1.5-2 mm. broad

Spikelets greenish, sbout $1 \mathrm{~mm}$. broad :

b. Achenes nearly as long as the subtending scales : :

a. Style 3-cleft; achene trigonous $f$.

$f$. Annuals $g$.

g. Scales tapering to recurved slender tips

$\vartheta$. Scales without recurved tips $h$.

$h$. Seales 2.5-3.5 $\mathrm{mm}$. long

$h$. Scales 2 mm. or less long $\dot{i}$.

$i$. Spikelets in globose heads ; rhachilla wingless or only obscurely winged.

Spikelets green or whitish-brown, oblong; scales acute

Spikelets reddish-brown or purplish, linear; scales blunt or barely mucronate

i. Spikelets in cylindric or elongate heads; rhachilia bearing

$f$. Perennials, the bases hardened and corm-like or stoloniferous $j$.

$j$. Scales strongly several-ribbed; achenes $2-3 \mathrm{~mm}$. long.

Spikelets in oblong or narrowly obovoid heads

Spikelets in globose or subglobose heads .

j. Scales faintly few-nerved or nerveless; achenes less than $2 \dot{m m}$. long $k$.

k. Culms naked or nearly so, the lower sheath nearly or quite bladeless

76. Culms leafy below $Z$.

l. Plant not stoloniferous; rhachilla wingless; stamen 1 .

i. Plant loosely stoloniferous; scales decurrent on the rhachilla as wings; stamens $3 \mathrm{~m}$.

$m$. Achenes short-obovoid; scales with free or spreading

m. Achenes linear- to oblong-cylindric; scales appressed; blunt or barely mucronate $n$.

n. Scales chestaut-color.

Involucre shorter than the rays of the umbel, or 1

bract slightly longer
Involncral braots numerous and much overtopping the umbel

n. Scales straw-color or pale browu

§2. Rhachillas of the spíkelets soon breaking away from the main rhachis ; the scales falling only in extreme age 0 .

o. Annuals.

Flowers remote, the successive scales not reaching the bases of

the ones above on the same side
Flowers approximate, the successive scales orerlapping the bases of those above

D. Perennials, with hard corm-like ba
p. Spikelets very strongly flattened

$p$. Spikelets terete, subterete, or only slightly flattened $q$.

$q$. Spikelets reflexed, in thick cylindric or obovoid hends $r$

$r$. Culms smooth and glabrous.

Spikelets loosely spicate; achenes $2.6-3 \mathrm{~mm}$. long

Spikelets densely spicate and overlapping; achenes less than $2.5 \mathrm{~mm}$, long.

Spikelets 8-6-flowered, linear-cylindric, not rigid

Soikelets 1-2-flovered. subulute, rigid

1. C. flavercens.

2. C. diandrus.

8. C. rivularis.

4. C. Nutlallii.

5. C. microdontus.

6. C. Gatesiz.

7. C. flavicomus

8. C. Aristatus.

9. C. compressus.

11. C. acuminatus.

18. C.fuscus.

19. C. erythrorhisos.

10. C. Schnorinitzi.

84. O. filiculmis.

14. C. haspan.

12. O. pseudovegetus.

15. c. dentatus.

16. C. rotunaus.

17. C. Hallii.

18. C. esculentus.

21. C. Engelmanni.

20. C.ferax.

22. C. strigosus.

23. C. refractus.

24. C. lancastriensis. 25. C. hystricinus. 
r. Culms scabrous, at least above.

Heads cylindric or subcylindtic

Heads obovoid, conspicuously contracted at base

$\boldsymbol{q}$. Bptkelets spreading, or only the basal refracted in age, in glo-

bose or densely sh.rt-cylindric beads 8 .

๙. Bcales appressed, each diutinctly overlapping the next above; spikelets 1-4-flowered $t$.

t. Heads mostly on distinct rays; achenes linear-oblong, 0.5 min. broad $u$.

$u$. Spikelets very densely crowded and overlapplng.

Heads globose or broadly obovoid . .

Heads cyliudric .

u. Spikelets slightly crowded, the tips mostly divergent

t. Heads all sessile in a glomerule; achenes ellipsoid or ovoid, $1 \mathrm{~mm}$. broad

8. Scales not appressed ; spikelets 5 (rarely 4)-15-flowered $v$.

v. Achenes narrowly obovoid or oblong, about balf as broad as long.

Spikelets in denso heads; each successive scale reaching

the middle of the one above on the same side
Spikelets in loose heads; each successive scale reaching unly the bases of the ones abuve on the same side

v. Achenes trigonous-ovoid, two thirds as broad as long

26. C. dipsaciformus

27. C. retrofricatus,
28. C. ovularis.

- 29. C. cylindricus

80. C. echinatus.

81. C. Aavus.

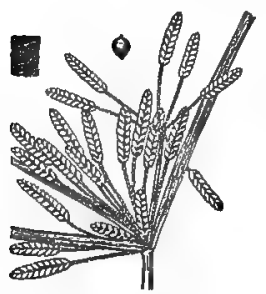

200 C. Havescens.

1. C. flavéscens $\mathrm{L}$. Culms $0.5-4 \mathrm{dm}$. high; involucre 3-leaved, very unequal; spikelets $0.5-1.5 \mathrm{~cm}$. long, $1.5-2.5 \mathrm{~mm}$. broad, becoming linear, obtuse, clustered on the 2-4 very short rays; scales obtuse, straw-yellow; stamens 3 ; achene shining, urbicular, its superficial cells oblong. - Low grounds, N. Y. to Mich., Ill., and soutluw. (Eurasia, Afr., Trop. Am.) Fig. 200.

2. C. diandrus Torr. Similar; spikelets lance-oblong, 0.5-1 cm. long, 2-3 mm. broad, rather loosely flowered, scattered or clustered on the $2-5$ very short or unequal rays ; scales rather obtuse, with a narrow purple-brown

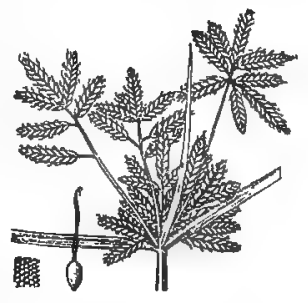

201. C. diandrus.
84. C. flliculmis.

32. C. Grayii. 33. C. Houghtonii.

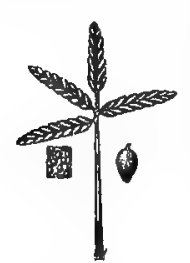

202. C. rivularis. margin or merely brown-flecked, thin and membranous ; achene dull, oblong-obovate, the superficial cells more or less quadrate; otherwise much like the last. - Low grounds, N. B. to Ont., Neb., and southw. Fig. 201.

3. C. rivulàris Kuntb. Similar; the densely flowered spikelets mostly 1-2 $\mathrm{cm}$. long; scales firmer, subcoriaceous, slightly lucid, with broad brown margins, or brown all over, or rarely pale; style-branches slightly or not at all exserted. (C. diandrus, var. castaneus Torr.) - Low ground, with the last or

by itself. Fre. 202.

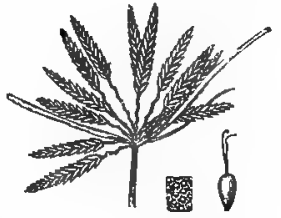

208. C. Nuttallii.

4. C. Nuttállii Eddy. Culms 0.5-3 dm. high; spikelets lance-linear, acute

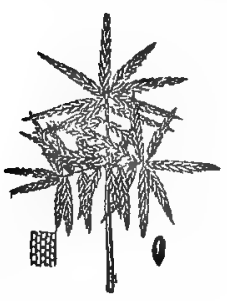

20t. C. inicrodontus. and very flat, 1-3 $\mathrm{cm}$. long, 2-3 $\mathrm{mm}$. broad, crowded on the few usually very short (or some of them obvious) simple rays; scales oblong, yellowish-brown, rather loose; stamens 2 ; achene oblong to oblong-obavate (0.6-0.8 $\mathrm{mm}$. broad), bluntly pointed, minutely bullate and more or less reticulated, rull. - Mostly in brackish marshes, along the coast, from Me. to Fla. Fig. 203.

5. C. microdóntus Torr. Culms slender, 1-7 dm. high ; leaves and somewhat spreading elongated bracts of involucre $1-4 \mathrm{~mm}$. wide; spikelets few to many on the 4-8 rays, linear, acute, 0.8-3 chi. loug, 1.5-2 $\mathrm{mm}$. thick, the ruachis often branched; scales thin, ovate or oblong, acute, closely imbri- 
cated, pale brown; stamens 2 ; achene linear-oblong or clavate (0.3-0.5 $\mathrm{mm}$. broad), short-pointed, grayish and minutely pitted. (C. polystachyus, var. leptostachyus Boeckl.) - Shores, mostly near the.coast, N. J. to Fla and Tex. FIG. 204.

6. C. Gatèsii Torr. Similar; very slender; leaves and very long ascending involucral bracts $1-2.5 \mathrm{~mm}$.

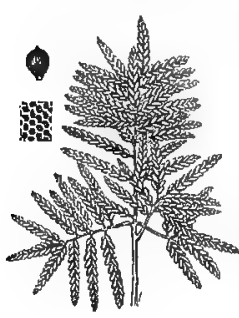

206. C. flavicomus. broad; spikelets $0.4-1.5 \mathrm{~cm}$. long; the oblong scales greenish; achenes slightly smaller.Low grounds, Va. to Fla., Ark, and 'Tex. Fig. 205.

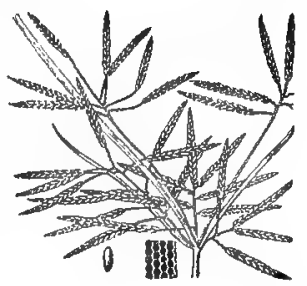

205. C. Gintesi1

7. C. flavícomus Michx. Culm stout, $3-9 \mathrm{dm}$. high; leaves of the involucre 3-5, very long; spikelets linear, $0.7-2 \mathrm{~cm}$. long, spiked and crowded on the whole length of the branches of the several-r, ved umbe, spreading; scales voal, very obtuse, yellowish and brymish, with a broad scarious whitish margin; stame:ns 3 , chene obovate, mucronate, blackish. - Low grounds, Va to Fla. Fig. 206.

8. C. aristàtus Rottb. Dwarf (2-20 cm. bigh); involucre 2-3-leaved; spikelets brown, oblong becoming linear, 7-20-Howered, 3-10 mm. long, in 1-5 ovoid or subglobose heads (sessile and clustered, or short-peduncled); scales nerved, tapering to a long recurved point; stamen 1 ; achene oblong-obovate, obtuse. (C. inflexus

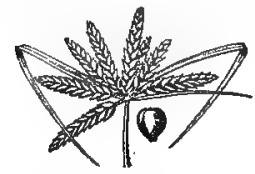

208. C. compressus. , Muhl.) - Sandy wet shores, local, N. B. to B. C., and southw. - I)ry plant with odor of Slippery Elm. Fig. 207.

9. C. compréssus L. Culms $0.5-3.5 \mathrm{dm}$. high, with a simple sessile or a few umbellate clusters of oblong to linear spikelets (15-30-flowered and 0.7-2.5 cm. long), with crowded strongly keeled and very acute greenish many-nerved scales; stamens 3 ;

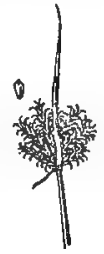

20\%. C. aristatus. achene oboroid, sharply trigonous. - Sterile fields along the coast, Pa. to Fla. and Tex. Fig. 208.

10. C. Schweinitzii Torr. Perennial, propagating by hard clustered corms; culm rough on the angles (2-8 dm. high); umbel 3-10-rayed, rays very unequal,

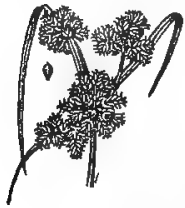

2\%. C. acuminatus.

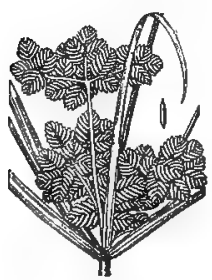

211. C. pseudovegetus. erect; spikelets loosely or somewhat remotely 6-16-flowered, with convex manynerved greenish-brown acute or acuminate scales $(3.5-4.5 \mathrm{~mm}$. long); joints of the rhachilla narrowly winged. - Dry sandy shores and ridges, w. N. Y. and e. Ont. to Man. and Kan. Fig. 209.

11. C. acuminàtus Torr. \& Hook. Slender $(0.5-3.5 \mathrm{dm}$. high); involucre 2-3-leaved; spikelets ovate, becoming oblong, 16-30-flowered, pale, in globular heads; scales obscurely 3-nerved, shorttipped; stamen 1 ; achene oblong, pointed at both ends, much exceeded by the scale. - Low ground, Lil. to Dak., and southw. Fig. 210.

12. C. pseudorégetus Steud. Tall perennial $(0,3-1 m$. high); culm obtusely

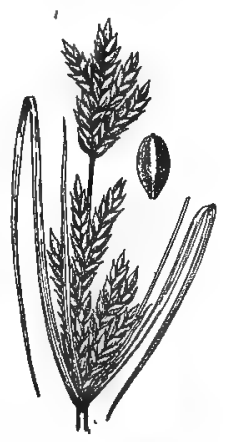

209. C. Schweinitzii. triangular; leaves and involucre very long, keeled; umbel compound, many-rayed; spikelets ovate (3-6 mim. long), in numerous small greenish heads; achenes pale, linear, on a slender stipe; scales narrow, acutish, obscurely 
3-nerved. (C. calcaratus Nees.) - Wet places, Del. to Fla. and Tex. ; northw in the flat country to Mo. and Kan. Fig. 211.

13. C. Fúscus I, Low (1-3 dm. high); spikelets linear, $3-8 \mathrm{~mm}$. long, the

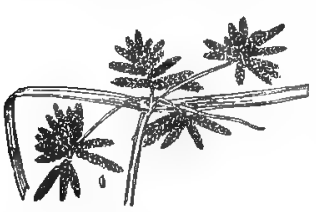

212. C. fuscus. thin brown scales (greenish inly on the keel) very faintly nerved; stamens 2 ; achenes equaling the scales. - Locally on ballast, Mass. to N.J. (Adv. from Eu.) Fig. 212.

14. C. háspan L. Culms sharply angled (2-8 dm. high); leaves linear, oftell reduced to membranous sheaths; umbel spreading, the fliform rays mostly longer than the 2-leaved involucre; spikelets narrowly linear; scales light reddish-brown, oblong, mucronate, 3-nerved; wings of rhachilla persistently attached; achenes round-

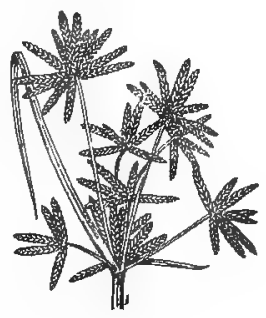

213. C. haspan. obovoid. - Ponds and ditches, Va. to Fla. and Tex. Fig. 213.

15. C. dentàtus Torr. Perennial by slender rootstocks

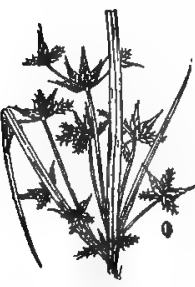

214. C. dentras. and tuber-bearing stolons; culms slender ( $1-6 \mathrm{dm}$. high); leaves rigid and keeled; umbel erect, shorter than the 3-4leaved involucre; spikelets 5-13-flowered; scales reddishbrown, with green keel, ovate, acute, 7-nerved, the mucronate tips prominent. - Sandy shores, Me. to N. Y., and southw. - Spikelets often abortive and changed into leafy tufts. Frg. 214.

Var. ctenostachys Fernald, Spikelets 1540-flowered ; scale-tips less prominent. - Mass. to N.J. FIG. 215.

16. C. rotúndus L. (Nut Grass.) Peren-

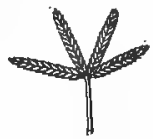

215. C. dentatus, v. ctenostachys.

nial by tuber-bearing stolons; culm slender (1-6 dm. high), longer than the

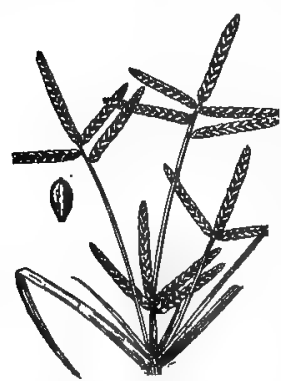

216. C. rotundus. leaves; umbel simple or slightly compound, about equaling the involucre; the ferv rays each bearing 4-9 dark chestnut-purple 12-40-flowered acute spikelets (0.8-2.5 cm. long) ; scales ovate, closely appressed, nerveless except on the keel; achenes linearoblong. - Sandy fields, $\nabla a$. to Fla. and Tex.; also adv. near Phila. and N. Y. City. (Trop. and subtrop. regions.) Fic. 216.

17. C. Hállii Britton. Similar; culm stout, 4-9 dm. high, scarcely exceeding the broad (0.5-1 cm.) leaves; umbel compound, the numerous rays much exceeded by

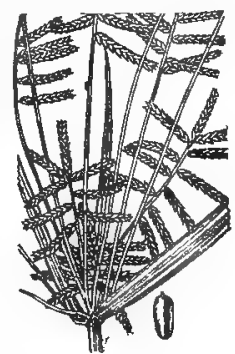

217. C. esculentus.

the involucral bracts; spikelets chestnut-purple, 1-1.5 cm. long; the acutish scales distinctly nerved. - Kan. to Tex.

18. C. esculéntus $L$. Sinilar ; culms (3-9 dm. high) equaling the leaves ; umbel often compound, 4-7-rayed, much shorter than the long involucre; spikelets numerous, light chestnut or straw-color, acutish, $0.5-1.5$

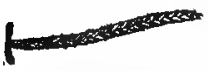

218. C. esculentus, v. leptostachyus. $\mathrm{cm}$. long; scales ovate or ovate-oblong, narrowly scariousmargined, nerved, the acutish tips rather loose; achene oblong-obovoid. - Low grounds, along rivers, etc. ; spreading extensively by its small nut-like tubers and sometimes becoming a pest in cultivated grounds. (Eurasia.) FIG. 217.

Var. Leptostachyos Boeckl., with spikelets $1.8-3.5 \mathrm{~cm}$. long, is less frequent. Fig. 218. 
19. C. erythrorhizos Muhl. Annual; culm obtusely triangular (1-8 dm. high); umbel many-rayed; involucre 4-5-leaved, very long; involucels bristle-form; spikelets very numerous, crowded in oblong or cylindrical nearly sessile heads, spreading horizontally, linear, flattish (3-10 mm. long), bright chestnut-colored; scales

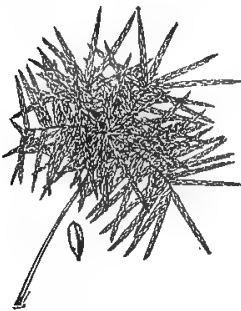

220. C. ferax. lanceolate, mucronulate. (C. Halei I3ritton, in part, not 'T'orr.) - Alluvial banks, Mass. to Ont., Minn., and southw. Fig. 219.-1)warf tufted plants are sometimes separated as Var. PÙmuLus Engelm.

20. C. fèrax Rich. Culm stout, mostly low (0.3-8 dm. high) ; rays

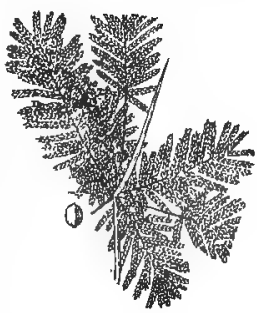

219. C. erythrorhizos. of the simple or compound umbel mostly all short and crowded; spikelets 10-20-flowered, yellowish-brown or drab at maturity (0.5-1.8 cm. long), the short joints of its axis winged with very broad scaly margins which embrace the ovoid-triangular achene; the firm scales ovate, obtusish, overlapping. (C. speciosus Vahl.) - Low grounds and sandy banks, Mass. to Fla., w. to Ont., Minn., and ''ex. ; Cal. (Trop. reglons.) Fig. 220.

21. C. Engelmánni Steud. Similar; but the spikelets more slender and terete, somewhat remotely 5-15-fowered, the zigzag joints of the axis slender and narrowly winged, and the oblong or oval broadly scarious scales proportionally shorter, so as to expose a part of the axis of each joint; achene oblong-linear, very small. -

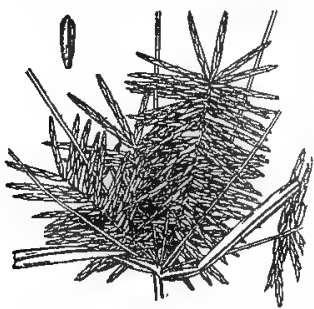

222. C. strigosus.

Low grounds, Mass. to Wisc., and southw. FIG. 221.

22. C. strigòsus L. Perennial, with hard corm-like tubers; culm 0.1-1 m. high ; leaves flat, soft; most of the rays of the simple or coinpound umbel elongated, their sheaths 2-bristled; spikelets several-flowered, $0.7-1.8 \mathrm{~cm}$.

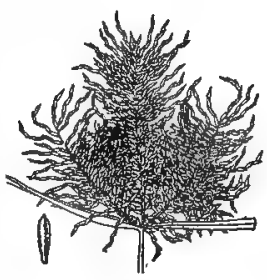

¿2. C. Engelmanni. long, spreading, in loose heads ; scales oblonglanceolate, appressed, several-nerved, much longer than the linear-oblong achene. - Damp or fertile soil, Me. to Ont., Minn., southw. and westw. Fig. 222. - Very variable; dwarf plants with the rays scarcely developed are Var. capitatus Boeckl.

Var. robústior Kunth. Spikelets 2-3 cm. long. - Local, Mass. to Fla, and Mo.

Var. compósitus Britton. Umbel compound; spikelets 0.5$1.3 \mathrm{~cm}$. long, in dense cylindric heads. - Local, Mass. to Fla., La, and Ia.

23. C. refráctus Engelm. Culm smooth, 3-9 dm. high; leaves soft and flat, 4-8 $\mathrm{mm}$. broad, slightly scabrous; rays usually more or less elongated, smooth; spikelets very slender, acuminate, subterete, in rather loose heads, divaricate or more or less reflexed, 2-6-flowered, 1-3 cm. long; scales appressed, several-nerved, the lower empty and often persistent after the fall of the rest; joints of the rhachilla winged, inclosing the linear achene. - Dry woods and banks, N. J. to Ga. and Mo. Fig. 223.

24. C. lancastriénsis Porter. Culm stoutish, triangular, smooth, 3-8 dm. high; leaves rather broad (0.5-1 cm.) ; umbel of 6-9 mostly elongated rays; spitcelets very numerous in

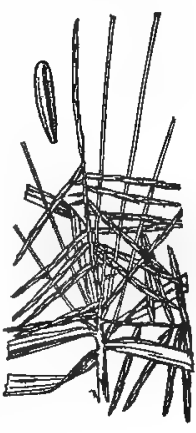

228. C. refractus. 


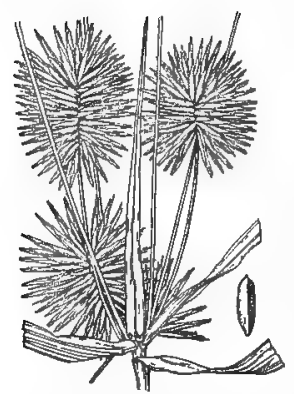

224. (: lancastriensis.

short-cylindric or obovoid close heads, soon reflexed, 0.8 . $1.5 \mathrm{~cm}$. long, of 3-6 narrow scales, the upper and lower empty, nearly twice the length of the linear-oblong achene. - Kich soil, N. J. and Pa. to Ga. Fig. 224.

25. C. hystricìnus Fernald. Slender; the smuoth rigid culm $2-5$ din. high, much exceeding the stiff narrow (2-5 mm. broad) smooth leaves; umbel of $8-10$ simple smooth rays, mostly shorter than the involucre; spitielets 1-2flowered, subulate, rigid, 3-7 mm. long, densely

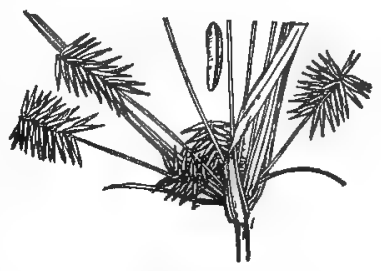

225. C. hystricinus.

crowded in cylindric or narrowly obuvoid heads (1-2.5 cm. long), strongly reflexed, golden-brown at maturity; scales closely appressed, the fertile strongly nerved, the terminal involute-subulate; achene linear, 2-2.5 $\mathrm{mm}$. long. - Dry sand, N. J. to Ga. Fig. 225.

26. C. dipsaciformis Fernald. Culm scabrous, at least above, $2.5-8 \mathrm{dm}$. high; leaves shorter than the culm, scabrous-hispid above, 4-9 $\mathrm{mm}$. wide; urnbei

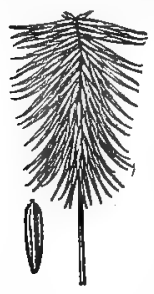

226. C. dipsaciformis.

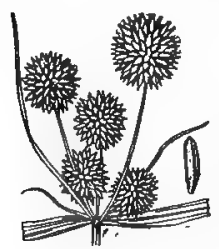

2.:S. C. ovularis.

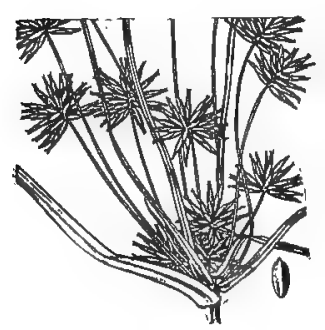

880. C eohinatur. 4-1?-rayed, some of the smooth rays equaling the involucre; spilcelets 1-i-tiowered, subulate, rigid, 6-11 $\mathrm{mm}$. $\mathrm{long}$, crowded in cylindric or subcylindric heads $(1.5-4 \mathrm{~cm}$. long), strongly deflexed, yellow brown at maturity; fertile scales with green midribs; achene $3 \mathrm{~mm}$. long. - Sandy barrens and dry woods, N. J. to $\mathrm{Ky}$. and Ga. FIs. 226.

27. C. retrofráctus (L.) Torr. Culm (0.3-1 m. high) minutely downy and rough on the obtusish angles; leaves hairy, short and stiff, 0.4-1 cm. wide, the margins becoming revolute; umbel with 4-12 upright usually scabrous rays mostly longer than the

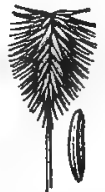

227. C. retrofraetus. involucre; spikelets slender-awl-shaped, very numerous in turbinate-obovoid greenish or drab heads (1-2.5 cm. long), soon strongly reflexed, 1-2-flowered in the middle (5-8 mm. long); scales usually 4 or 5, the two lowest ovate and empty, the fertile lanceolate and pointed, the uppermost involute-awl-shaped; qchene linear, 2.5-3 mm. long. - Sandy or rocky soil, N. J. to Fla. and Tex. ; northw. in the low country to Mo. FIG. 227.

28. c. ovulàris (Michx.) Torr. Culm

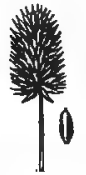

229. C. cylindricus. smooth, sharply triangular (2.5-7 dm. high); umbel 1-6-rayed ; spikelets (50-100) in a globular head, 3-flowered, oblong, blunt ( $3-5 \mathrm{~mm}$. long); scales ovate, obtuse, a little longer than the linearoblong achene. - Sandy dry soil, s. N. Y. to Ill., Kan., and southw. ; rarely on ballast, Mass. Fig. 228. Var. RoBústos Boeckl. is a form with large heads, the spikelets 3-4-flowered (7-10 mm. long). - Ill. to Ark., and southw.

29. C. cylfindricus (Fll.) Britton. Similar to the last, but the heads short-cylindrical; spikelets usually 2-flowered. (C. Torreyi Britton.) - I. I. to Fla., w. to Tex. FIg. 229.

30. C. echinatus (Ell.) Wood, Culm smooth 


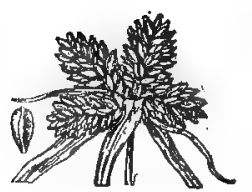

:u1. C. flavus.

(1.5-6 dm. high), much exceeding the smooth (or scabrousmargined) Hat (2-5 mm. wide) leaves; umbel with uumerous ascending rays, the longest half as long as the involucre ; heads globose, $1-1.5 \mathrm{~cm}$. in diameter; spilielets $20-40$, greenish, rather loosely spreading, lance-cylindric, slightly compressed, of 5-8 membranous veiny ovate-lanceolate scules (the 2 lowest and the subulate terminal one empty); achene oblong, 1.5-2 mm. long. - - Rich sandy soil, Va. and Mo., southw. FIG. 230.

:1. C. Fuàvos (Vahl) Boeckl. Culıns sharply angled, smooth and wiry (2-5 dm. high), much exceeding the smooth flat leaves; heads $3-6$, cylindric (1-1.7 $\mathrm{cm}$. lng g), sessile in a glonerule; involucral bracts divergent or reflexed; spikelets crowded, 2.5-5 uım. long, dull, pale brown; scales thin and veiny, the lovest often persistent. - Waste ground, about Yhiladelphia. (Ady. from the Tropics.) Fig. 231.

32. C. Gràyii Torr. Culm thread-form, wiry (0.5-3 dm. high); leaves almost bristle-shaped, channeled;

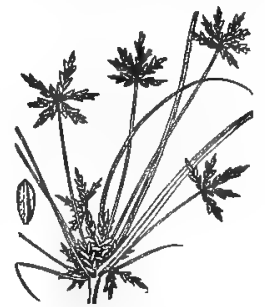

292. C. Grayii.

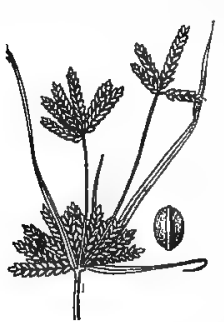

283. C. Foughtonfi. umbel sinple, 4-1U-rayed; spilielets in a loose head, spreading; joints of the axis winged; scales rather obtuse, greenish-chestnut-color, barely exceeding the oblong or narrowly obovoid achene. - Barren sands, Mass. to N.J., near the coast. FIG. 232 .

33. C. Houghtònii Tórr. Culms obtnsely angled (2-7 dm. high), much exceeding the smooth narrow leaves; umbel subsessile or with a few elongate uprigbt rays, mostly shorter than the inrolucre; spikelets linear-oblong, in loose heads, spreading-ascending; scales roundish, strongly nerved, mucronate, yellowbrown, barely exceeding the broad-obovoid achene. Sandy soil, w. N. F. to Man, and Ore, locally s. to Va., Kan., and Ariz. Fig. 233.

34. C. filicúlmis Vahl. Culm slender, wiry, often

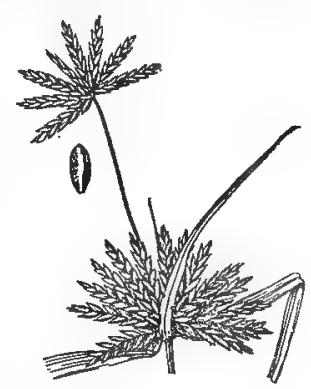

294. C. filiculmis.

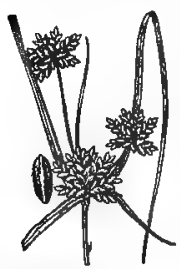
reclined (1.5-6 dm. high); leaves linear or flliform; spikelets numerous and clustered in one sessile dense head, or in 1-7 additional looser heads on spreading rays of an irregular umbel, those of the principal glomerules 8-12-flowered (1-1.6 $\mathrm{cm}$. long); joints of the axis naked or winged; scales blunt, or the upper mucronate, thin, yellowish-green; achene $2 \mathrm{~mm}$. long. (C. Bushii Britton.) - Dry sterile soil, Mass. to Ia., and southw.; rare northw. Fig. 234.

Var. macilentus Fernald. Usually low ; spikelets 4-8flowered (3-8 mm. long); scales firm, greenish; achenes 235. C. fil., v. macil. shorter. - Me. to Ont., s. to Va., O., and Ill. Fig. 235.

\section{KYLLINGA Rottb.}

Spikelets of 3 or 4 two-ranked scales, $1-1 \frac{1}{2}$-flowered; the 2 lower scales minute and empty; style 2-cleft and achene lenticular; spikes densely aggregated in solitary or triple sessile heads. - Culms leafy at base; involucre 3-leaved. (Named after Peder Kylling, a Danish botanist of the 17th century.)

1. K. pùmila Michx. Annual ; culms $0.5-3 \mathrm{dm}$. high ; head globular or 3-lobed, whitish-green, 4-8 inm. broad; spikelets

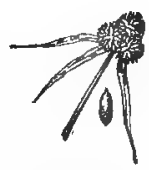

236. K. pumatla. 
strictly 1-flowered; upper scales ovate, pointed, rough on the keel ; stamens and styles 2 ; leaves linear. - Low grounds, Md. to O., Ill., and southw. Aug.-Oct. Fig. 236.

\section{DULÍCHUM Pers.}

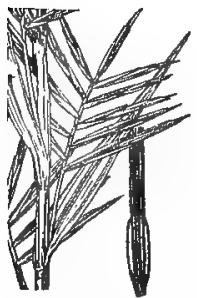

Spikelets linear, flattened, sessile in 2 ranks on peduncles emerging from the sheaths of the leaves; scales lanceolate, decurrent, forming flat wing-like margins on the joint below. Perianth of $6-9$ downwardly barbed bristles. Stamens 3 . Style 2-cleft above. Achene flattened, linear-oblong, beaked with the long persistent style. - A perennial herb, with terete simple hollow culm (2-10 dm. high), jointed and leafy to the summit; leaves short and flat, linear, 3-ranked. (Name of uncertain origin.)

1. D. arundinàceum (L.) Britton. (D. spathaceum Pers. ' - Wet swamps and borders of ponds, Nfd. to Wash., 287. D. arundinaceum. and southw. July-()ct. Fig. 237.

\section{ELEÓCHARIS R. Br. SpIre Rush}

Spikelet few-many-flowered. Scales imbricated in many (rarely in 2 or 8) ranks. Perianth of $3-12$ (commonly 6 ) bristles, usually rough or barbed downward, rarely obsolete. Style 2-3-cleft, its bulbous base persistent as a tubercle jointed upon the apex of the lenticular or triagular achene. - Leafless (rarely with basal capillary leaves), chiefly perennial, with tufted culms sheathed at the base, from matted or creeping rootstocks; flowering in summer. (Name

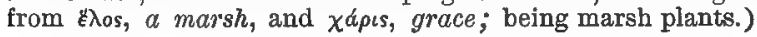

a. Spikelot hardly if at all thicker than the epongy-cellular cuim ; scales firmly persiatent.

Spikelot cylindric, many-flowered; scales coriaceous, faintly nerved or nerveless,

Culm terete

Culm sharply 4-angled :
Spikelet linear- or lance-awl-shaped, fow-flowered ; scaler herbsceous, distinctly nerved

u. Spikelet much thicker than the oulm (or, if slender, with deciduous st:gless) $b$.

b. Achenes lenticular or biconvex; styles mostly 2-cleft $c$.

c. Upper sheaths loose, with white scarious tips. Seales white, with green midribs.

Scales purple-brown, with green inidribs

c. Upper sheaths close and firm, green, not scarious, the tips often dark-margined $d$.

d. Plants tufted, mostly annual, without conspicuous rootstocks $\theta$. o. Mature nchenes black ; tubercle saucor-shaped; upper sheath oblique at tip, the elongate tooth narrow-deltoid.

Spikelet 1.5-2 mm. thick; achene 0.5 mm. long .

Spikelet $2.5-8 \mathrm{~mm}$. thick; achene $1 \mathrm{~mm}$. long.

Bcales whitish-brown, with greenish rib; achenes jet black

Scales purple-brown; achenes purple-black:

o. Mature achenes whitish to pale brown; tubercle conic or deltoid; upper sheath with nearly truncate tip, the short tooth broad-deltoid $f$.

$f$. Tubercle less than two-thirds as broad as the achene.

Tubercle depressed turban-shape, broader than high ;

bristles wantiog or rudinentary
Tubercle deltoid-conic, higher than broad; bristles

much exceeding the achene
f. Tubercle nearly or quite as broad as the achene.
Tubercledepressod-conle, concared toward the tlp, onethird ns high as the achene; bristles much exceeding the achene

Tubercle flat-deltoid, with straight sides, one-fourth as bigh as the achene, bristles scarcely or not at all exceeding the achene.

Bristles about equaling the achene

Bristles rudimentury or wanting

a. Plants not tufted, perennial from elongate rootstocks

1. I. interstincta.

2. E. quadrangulata.

8. R. Robbinsii.

\section{E. ochreata. \\ 5. E. olivacea.}

\section{B. atropurpurea.}

7. E. capitata.

(7) $E$. capitata, v. dispar

(7)

\section{E. dianara.}

9. E. ovata.

\section{0. $\mathcal{E}$. obtusa.}

11. E. Engelmanni. (11) E. Engolmanni, v. dotonsa - 12. E. palustris. 
b. Achenes triangular or turgid ; style 3-cleft $g$.

a. Achenes regularly reticulate or cross-lined.

Spikelets flattened, 8-9-Howered; the thin seales 2-8-ranked . 18. E. acioularle.

Spikelets terete; the seales many-ranked.

Upper sheaths loose, with white scrious tips; achenes finely cross-lined between the strong ribs.

Upper sheaths close and firm, not scarious; achenes distinctly reticulate.

Tubercle conic-subulate, much smaller than the achene

'Tubercle cap-shaped, as large as the acbene

14. $E$. Wolfi.

15. E. tortitis.

g. Achenes smooth or papillose, not regularly reticulate $h$.

h. Tuberclo depressed, as broad as high or broader.

i. Achenes white Achenes yellow, brown, or black $j$.

j. Achenes smooth.

Tubercle flattened and closely covering the top of the black achene

Tubercle short-conic, constricted below, narrower than' the olive-brown achene

d. Achenes papillose-roughened.

A chene with prominent keel-like angles .

Achene with the angles not keeled.

Tips of the upper sheaths dark-girdled; achenes golden-yellow or orange-brown (in age drab), conspicuously papillose-roughened, plump, with rounded angles.

Culms filiform, 4-angled

Culms flattened.

Tips of the upper sheaths whitish; achenes whitishyellow, minutely roughened, with distinct angles

k. Tubercle long-conic, higher than broad.

Tubercle clearly distinct from the achene.

Tubercle conic-subulate, mach narrower than the plump achone.

Bristles excoeding the achene .

16. $E_{\text {. tuberculosa. }}$

17. E. Torreyana.

- 24. $E$. intermedia. Tubercle conic-deltoid, nearly as broad as the compressed

Tubercle seemingly confluent with the achene

18. II. melanocarpa

19. E, albida.

20. E. tricostata.

21. $\boldsymbol{F}$. tenuis.

22. E. acuminata.

28. E. nitida.

25. H. Macounit.

26. $E$. rostellata.

1. E. interstíncta (Vahl.) R. \& S. Culms large and stout (0.5-1 m. high), knotted as if jointed by many cross-partitions; basal sheaths often leaf-bearing; spikelets $2-4 \mathrm{~cm}$. long; scales

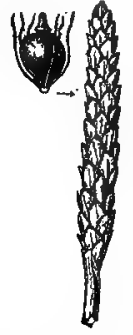

289. E. quadrangulata. in several ranks, pale, with scarious margins; achene with transversely linear-rectangular reticulation and a conical-beaked tubercle; bristles 6 , rigid, or wanting. ( $E$. equisetoides Torr.) - Shallow water, Mass. to Fla., w. to Mich, and TEx. (W. I., S. A.) Fig. 238.

2. E. quadrangulàta (Michx.) R. \& S. Similar; culm continuous and sharply

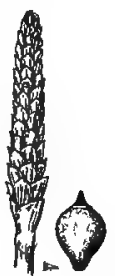

238. L. interstincta. 4-angled; spikelet $2-6 \mathrm{~cm}$. long; achene finely reticulated, with a conical flattened distinct tubercle. ( $E$. mutata Britton, not R. \& S.) - Shallow water, Ct. to Mich., and southw., lare. FIG. 239.

3. E. Robbínsii Oakes. Flower-bearing cuims exactly triangular, rather slender, erect ( $2-7 \mathrm{dm}$. high), also producing tufts of capillary abortive stems or fine leaves, which float in the water; sheath obliquely

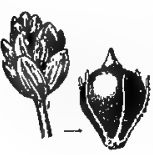

241. E. ochreata. Spikelet $\times 2 \%$. Achene $\times 10$, truncate; spikelet 1-2.5 mm. long; scales only 3-9, few-ranked, convolute-clasping the long flattened joints of the axis, lanceolate, with thin scarious margins; achene oblong-obovate, triangular, minutely reticulated, about half the

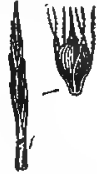

240. E. Robbinsii. length of the bristles, tipped with a flattened awl-shaped tubercle. - Shallow water, N. B. to Fla., w. to Mich. and Ind. FIG. 240.

4. E. ochreata (Nees) Steud. Similar in habit to the next; the capillary culms $3-30 \mathrm{~cm}$. high ; spikelets $2-6 \mathrm{~mm}$. long; scales 
very pale and thin, $1.5-2.5 \mathrm{~mm}$. long; achene often equaling the bristles, tipped by a short slender conical tubercle. - Wet places, Va. to Fla. (W. I., S. A.) FIG. 241.

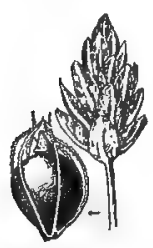

242. E. olivacen. $\mathrm{S}_{\text {pikelet }} \times 2 \frac{2}{8}$. Achene $\times 10$.

5. E. olivàcea Torr. Culmus flattish, grooved, diffusely tûtted on usually slender matted rootstocks, 2-15 cm. high; spikelet oblong-ovoid, acutish, 20-30-flowered, 3-7 mm. long; scales ovate, obtuse, rather loosely imbricated, $2-3 \mathrm{~mm}$. long, with a slightly scarious margin ; achene obovoid, dull, green to blackish, $1 \mathrm{~mm}$. long, shorter than the 6-8 bristles; tubercle capping $\frac{1}{4}$ of the summit of the achene, saucer-shaped, tipped by a long conicsubulate beak. - Wet shores, Me. to Ont., ๙. to N. C., Pa., O., and Mich. Fig. 242.

6. E. atropurpùrea (Retz.) Kunth. Dwarf tufted annual; culms capillary, arcuate, 3-7 $\mathrm{cm}$. long; spikelet oblong-ovoid, $2-4 \mathrm{~mm}$. long; scales ovate, thin-membranqceous, blunt, dark brovon, with pale midrib and margin; achene lenticular-obovoid,

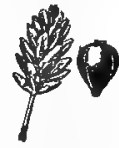

243. E. atropurpurea. Spikelet $\times 2 \%$. Achene $\times 10$. lustrous, black, with a minute saucer-shaped tubercle; bristles white, shorter than the achene. - Wet sand, "Ia." to Col., and southw. (Eurasia, W. I.) Fig. 243

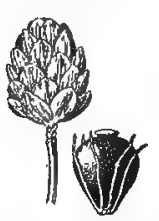

244. E. capitata. Splkelet $\times 2 \%$. Achen $\mathrm{x} \times 10$.

7. E. capitàta (L.) R. Br. Culms terete, $0.3-3 \mathrm{dm}$. high ; spitcelets ovoid to cylindric (3-5 mm. long), obtuse, 15-40-flowered; scales thickish, round-ovate, obtuse, pale brown, with green keel and paler margins; stamens 2 ; achene obovoid, black, about equaling the 6-8 bristles, tipped with a flattened or saucer-shaped tubercle. - In sand or gravel near sloughs, Md. to Fla. and Tex. (W. I., S. A.) Fig. 244.

Var. dispar (E. J. Hill) Fernald. Scales purplebrown; achenes purple-black. (E. dispar E. J. Hill.) - Wet sand, Lake Co., Ind.

8. E. diánđra C. Wright. Erect or depressed ; culms $0.1-5 \mathrm{dm}$. long; spikelet ovoid, obtuse or acutish, $2-7 \mathrm{~mm}$. long, $2-3.5 \mathrm{~mm}$. thick; scales barely appressed, ovate to ovateoblong, blunt, dull, pale brovon, with prominent green midrib; achene obovoid or inverted-pyriform, $1 \mathrm{~mm}$. long. - Sandy shores of the Androscoggin, Merrimac and Connecticut Rivers, and of

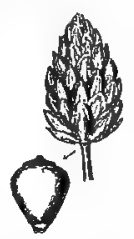

245. E, diandra. Spikelet $\times 2 \%$. Achene $\times 10$. Oneida L. (N. Y.) - Differing constantly from the next in its depressed tubercle and paler scales, as well as in the absence of bristles. Fig. 245.

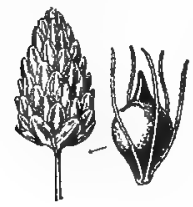

246. E. ovata. Splkelet $\times 2 \%$. Achene $\times 10$.

9. E. ovàta (Roth) R. \& S. Erect or depressed; culms 0.3-5 dm. long; spikelet globose-ovoid to ovoid-cylindric, obtuse, densely flowered, 2-7 $\mathrm{mm}$. long, 2-4 mm. thick; scales oblong to narrowly ovate, obtuse, purple-brovon, with pale midrib and white scarious margin; achene obovoid or inverted-pyriform, about $1 \mathrm{~mm}$. long. - Wet places, N. B. to Ct. and Mich.; Ore. (Eurasia.) Fı. 246. $\checkmark$ 10. E. obtùsa (Willd.) Schultes. Similar ; culms 0.5-7 dm. ligh ; spikelet globoseovnid to ovoid-oblong, obtuse, $2-13 \mathrm{~mm}$. long, 2-5 mm. thick; scales ovate-oblong to suborbicular, with rounded tips, densely crowded in many ranks, dull hrown; stylc 3(rarely 2)-cleft; achene turbinate-obovoid with narrow base, pale brownish, shining, shorter than the 6-8 bristles, slightly broader than the short-deltoid acute and fattened tubercle. ( $E$. ovata Man. ed. 6.) - Muddy places, N. S. to Ont., and southw.; B. C. and Wash. FIG. 247. - Like all the annual species, very variable in size and habit.

V'11. E. Engelmánni Steud. Similar; culms $1.5-3 \mathrm{dm}$.

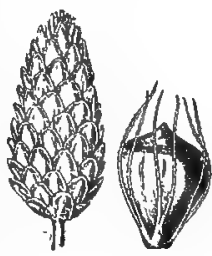

247. E. obtusa. Spikelet $\times 2 \%$. Achene $\times 10$. 
nigh ; spikelet cylindric, 5-20 mm. long, 2-4 mm. thick, acutish ; scales closeappressed, brown; achenes with broad much flattened tubercle; bristles about equaling the achene. - Local, Mass. to Mo. Fig. 248. Var. Dtiónsa Gray. Bristles wanting or rudimentary. - More frequent, Mass. to Neb., s. to Pa., Ind., and Ariz.

12. E. palústris (L.) R.\& S. Culms nearly terete, striate,

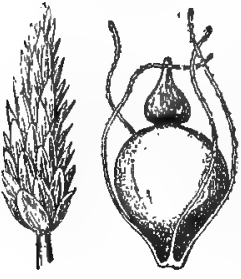

849. E. palustris. Spikelet $\times 2$. Achene $\times 10$. $0.1-1.5 \mathrm{in}$. high; spikelet slender, subcylindric, pointed, many-flowered; scales ovate-oblong, loosely imbricated, reddishbrown with a broad and translucent whitish margin and a greenish keel, the upper acutish, the lowest rounded and often enlarged; achene obovoid, somewhat shining, crowned with a short ovate or ovate-triangular flattened tubercle, shorter than the usually 4 bristles. Very common and variable, either in water, where it is rather stout and tall, or in wet grassy grounds, where it is slender and lower. (Eurasia.) Fig 249. Var. Glacćsscens (Willd.) Gray. Culms slender or

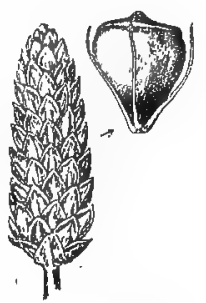

248, E. Engelmanni. Spikelet $\times 2 \%$. Achene $\times 10$. filiform; tubercle narrower, acute, beak-like, sometimes half as long as the achene. - With the type. Var. chlva (Torr.) Gray. Bristles none; tubercle short, but narrower than in the type. - Local. Var. vìens Bailey. Culms very stout, rigid; achene more broadly obovoid. - Lake margirs, northw.

13. E. aciculàris (L.) R. \& S. Culms finely capillary, 3-10 cin. high (becoming much elongate when submersed), more or

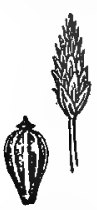

251. E. Wolfit.

Spikelet $\times 2$.

Achene $\times 10$.

less 4-angular; spikelet 2-6 wm. long; scales ovate-oblong, rather obtuse (greenish with purple sides); acluenes obovate-oblong, only the lowest maturing, with 3-ribbed angles and 2-3 times as many smaller intermediate ribs, also transversely striate, longar than the 3-4 very fugacious bristles; tubercle conical-triangular. - Muddy shores, across the continent. (W. I., Eurasia.) Fig. 250.

14. E. W6lfii Gray. Culms slender (2-3 dm. high), from very small creeping rhizomes, 2-edged; spikelet slender-ovoid, acute, 0.5-1 cm. long; scales ovate-oblong, obtuse, scarious, pale purple; achene pyriform, shining, with 9 nearly equidistant obtuse ribs having transverse wrinkles between them; tubercle depressed, truncate, more or less apiculate; bristles none. - Wet prairies, Ill., Minn., and Ia. FIG. 251.

15. E. tórtilis (Link) Schultes. Culms tufted from fibrous roots, sharply triangular, capillary, twisting when dry ; spikelet turgid-ovoid, 3-6 mm. long, few-flowered; scales firmmembranaceous, persistent, ovate; bristles stout, barbed,

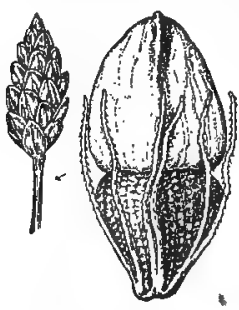

258. E, tuberculosa. Spikelet $\times 2$. Achene $\times 10$, as long as the striate and pitted-reticulate achene and its conic-beaked tubercle. - N. J. to Fla. FIG. 252.

16. E. tuberculosa (Michx.) R. \& S. Similar ; culn s flattish, striate; spike. let 5-13 mm. long, many-flowered; tubercle flattish-cap-shaped. - Wet sandy soil, from Mass, along the coast to Fla. Fig. 253.

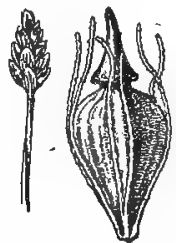

252. I: tortilis. Spikelet $\times 2$. Achene $\times 10$.

17. E. Torreyàna Boeckl. Tufted culms capillary, 1-6 dm. high; spikelet small (2-5 mm. long), sometimes proliferous, the one or more short new culms from the axil of its lowest scale, which persists as an herbaceous bract; scales thin, ovate, acutish, whitish-green and brown; achene tiny, white, wilh sharp angles and a short 


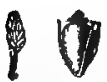

254. E. Torreyana.

Splkelet $\times 2$.

Achene $\times 10$.

conical tubercle, which is hardly equaled by the $3-6$ slender bristles. - Wet pine-barrens, etc., Ct. to Fla. FIG. 254.

18. E. melanocárpa Torr. 'Tufted, from a short thicle caudex; culms flattened, grooved, wiry, erect (2.5-7 dm. bigh), the close basal sheaths with truncate mucronate tips; spikelet cylindrical-ovoid, thick, obtuse, densely many-flowered (7-15 mm. long); scales closely many-ranked, roundish-ovate, very obtuse, brownish, with broad scarious margins; achene glossy, obovoid-top-shaped, obtusely triangular, the broad summit entirely covered by the flat depressed tubercle, which is raised in the center into a short abrupt triangular point; bristles often obsolete; achene soon blackish. - Wet sand, Mass. to Fla.; also $n$. Ind., where the culms are sometimes proliferous at tip (Hill). (Bermuda.) Fig. 255.

19. E. álbida Torr. Tufted, from a slender creeping base; culms slender, wiry, striate, 1-4 dm. high, the basal

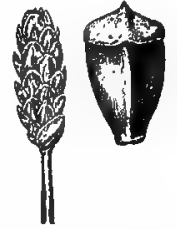

255. E. melanocarpa Epikelet $\times 2$. Achene $\times 10$. sheaths with very oblique tips; spikelet cylindric-ovoid, blunt, 4-9

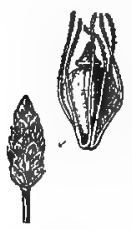

256. E. albian. Spikelet $\times 2$. Achene $\times 10$. $\mathrm{mm}$. long; scales obtuse, whitish to light brown, with narrow scarious margin; achenes smootb, not glossy, trigonouspyriform, $1 \mathrm{~mm}$. long, contracted below the conicdeltoid pale tubercle, and usually exceeded by the reddish bristles. - Damp chiefly brackish soil, $\mathrm{Md}$. to Fla., etc. (Mex., W. I.) Fig. 256.

20. E. tricostàta Torr. Rootstock stout and tough ; culms flattish (2-6 dm. high); spilelet soon cylindrical, densely many-flowered (6-18 $\mathrm{mm}$. long); scales ovate, very obtuse, rusty brown, with broad scarious margins ; achene obovoid, with 3 prominent angles, minutely rough-wrinkled, crowned with a short-conical acute tubercle; bristles none. - N. Y. to Fla. Fig.257.

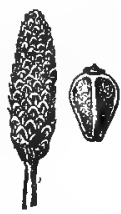

257. E. tricostata. Spikelet $\times 2$. Achene $\times 10$.

21. E. ténuis (Willd.) Schultes. Culms almost capillary, erect from running

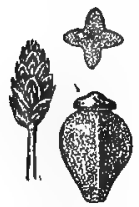

258. E. tenuis.

Spikelet $\times 2$. Achene $\times 10$. Crose-section of culm $\times 5$. rootstocks, 4-angular (0.5-7 dm. high), the sides concave; spikslet ellipsoidal, acutish, 20-30-tlowered (3-10 $\mathrm{mm}$. long); scales ovate, obtuse, chestnut-purple, with a broad scarious margin and green keel, the outer 2 or $3 \mathrm{~mm}$. long; achene plump, obovoid, roughishwrinkled, 1-1.3 mm. long, crowned with a small depressed tubercle, persistent after the fall of the scales; bristles 3 as long as the achene or none. - Iffd. to Man., and southw. June-Aug. Fig. 258.

22. E. acuminata (Muhl.) Nees. Similar; rootstock generally stouter and stiffer; culms flat, striate, tufted, usually coarser; scales lance-ovate, the uppermost acute. (E. compressa Sulliv.) - Wet places, oftenest in calcareous soil, N. Y. and Ont., southw. FIG. 259. - Perhaps a variety of the last.

23. E. nítida Fernald. P'erennial, from slender rootstock ;

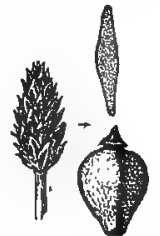

259. E. acuminata. Spikelet $\times 2$. Achene $\times 10$. Cross-section of culn $\times 5$.

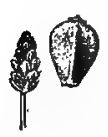

260. E. nitida.

Spikelet $\times 2$. Achene $\times 10$

culms capillary, 4-angled, striate, $2-8 \mathrm{~cm}$. high; spikelet ovoid, acutish, $2.5-4.5 \mathrm{~mm}$. long, 1.5-2.5 mm. thick, 8-20-flowered; scales elliptic-oblong, with rounded tips, purplish-brown, with greenish ribs and very narrow scarious margins, the lowermost $1-1.2 \mathrm{~mm}$. long; achenes whitish-straw-color, narrowly obovoid, sharply trigonous, very minutely (under a lens) roughened, 0.7-1 mm. long, the very narrow crown-like tubercle with a short point in the middle. - Springy spots, valley of the Ottawa R., Can. ( $T$. Macoun). Early June. Fig. 260.

24. E. intermèdia (Muhl.) Schultes. Culms capillary, striate-grooved, densely tufted from fibrous roots, diffusely spreading or reclining $(0.2-4 \mathrm{dm}$. 
long); sheaths with oblique tips; spikelet cylindric-ovoid, acutish, loosely 5-20-flowered (2-7 mm. long); seales oblong, obtuse,

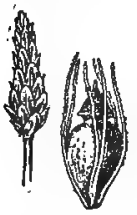

262. E. Macounii.

Spikelet $\times 2$.

Achene $\times 10$. green-keeled, the sides purplish-brown; achene obovoid with a narrowed base, beaked with a slender conical-awl-shaped tubercle, which nearly equals the 6 bristles. - Wet places, Gaspé Co., Que., to w. Ont., s. to n. Me., w. Ct., N. J., Pa., O., and Ia. Fig., 261. Var. HABERER Fernald. Bristles absent or rudimentary. - Shores of Oneida L., N. Y. (J. V. Haberer).

25. E. Macoúnii Fernald. Annual ; culms weak, 2 or $2.5 \mathrm{dm}$. long; spikelet lance-ellipsoid, $1 \mathrm{~cm}$. long, densely flowered; scales ovate-lanceolate, acutish or blunt, dark brown; achene much compressed, trigonous-obovoid, twice as long as the broad deltoid-conical tubercle. - Border of marsh, North Wakefield, Que. (J. M. Macoun). Fig. 262.

26. E. rostellàta Torr. Perennial, from short thick caudex; culms flattened and striate-grooved, wiry, erect (3-12 $\mathrm{dm}$. long), the sterile ones reclining, rooting and proliferous from the apex, the sheath transversely truncate; spikelet spindle-shaped, 12-20-flowered, 6-15 mm. long; scales ovate, obtuse (light brown); achene obovoid-triangular, narrowed into confluent pyramidal tubercle, which is overtopped by the $4-6$ bristles. - Salt marshes, N. H. to Fla., and locally in alkaline situations inland. (Mex., Cuba.) Fig. 263.

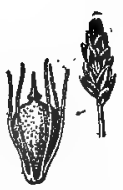

261. E. intermedia.

Spikelet $\times 2$.

Achene $\times 10$.

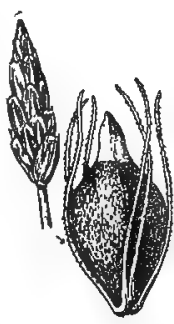

265. E. rostellata.

Spikelet $\times 2$.

Achene $\times 10$.

\section{DICHRÓMENA Michx.}

Spikelets few-flowered, all but 3 or 4 of the flowers usually imperfect or abortive. Scales imbricated somewhat in 2 ranks, more or less conduplicate or

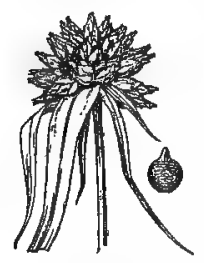

264. D. colorata. boat-shaped, keeled, white or whitish. Stamens 3. Style 2-cleft. Perianth, bristles, etc., none. Achene lenticular, wrinkled transversely, crowned with the persistent and broad tubercled base of the style. - Culms leafy, from creeping perennial rootstocks; the leaves of the involucre mostly white at the base (whence the name, from $\delta i s$, double, and $\chi \rho \hat{\omega} \mu \alpha$, color).

1. D. coloràta (L.) Hitchc. Culn triangular (0.25-1 m. high) ; leaves narrow; those of the involucre 4-7, linear; achene truncate, not margined. (D. leucocephala Michx.) - Damp pine-barrens, N. J. to Fla. and Tex.; very rare northw. July-Sept. (Mex., W. I.) Fig. 264.

2. D. latifolia Baldw. Culm stouter, nearly terete; leaves broadly linear; those of the involucre linear-lanceolate, 8 or 9 , tapering from base to apex; achene roundobovoid, faintly wrinkled, the tubercle decurrent on its

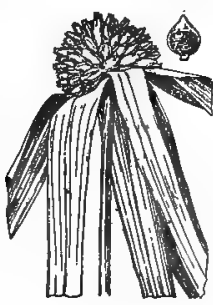

265. D. latifolia. edges. - Low pine-barrens, Va. to Fla. and Tex. Fig. 265.

\section{PSILOCÀRYA Torr. BALD RUSH}

Spikelets ovoid, terete, the numerous scales all alike and regularly imbricated, each with a perfect flower. Stamens mostly 2. Style 2-cleft, its base enlarging and hardening to form the beak of the lenticular or tumid more or less wrinkled achene. - Annuals, with leafy culms, the spikelets in terminal and

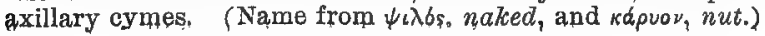




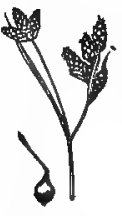

266i. P. scirpoides.

1. P. scirpoides Torr. Annual (0.2-3 dm. high), leafy; leaves flat; spikelets 20-30-flowered; scales oblong-ovate, acute, chestnut-colored; achene finely roughened, somewhat margined, beaked with a long sword-shaped almost wholly persistent style. - Wet sandy shores and swarnps, Mass. and R. I.; I. Ind. Aug.-Oct. Fig. 266.

2. P. nitens ( Vahl) Wood. Similar; often becoming 5-7 dm. high; faces of the achene with strong transverse ribs; tubercle depressed, broader than high. - Wet, sandy shores and bogs, L. I. and 267. P. nitens, Del., southw.; n. Ind. Aug.-Oet. Fig. 267.

\section{STENOPHÝLLUS Raf.}

Spikelets as in Fimbristylis, the comparatively large scales in few ranks. Stamens 2 or 3. Style 2-3-cleft, filiform, glabrous, its base swollen and forming a persistent colored tubercle. Otherwise as in Fimbristylis; standing in the same relation to that genus as Eleocharis to Scirpus. -- Leaves primarily basal,

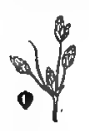

268. 8. capillaris. narrowly linear or fliform, the sheaths hairy or ciliate. (Name from $\sigma \tau \epsilon \nu b s$, narrow, and $\phi v \lambda \lambda_{0} \nu$, leaf.)

1. S. capillàris (L.) Britton. Low annual, densely tufted (0.3-3 dm. high); culms and leaves nearly capillary, the latter short, minutely ciliate; umbels compound or panicled, loose or compact (in dwarf plant often much reduced); spikelets ovoidoblong; brown to blackish ; stamens 2 ; achene acutely triangular, minutely wrinkled, very blunt. (Fimbristylis Gray.) - Sandy fields, Me. to Fla., w. to the Pacific. July-Oct. (Trop. Am.) Fig. 268.

\section{FIMBRISTYLIS Vahl.}

Spikelets several-manv-flowered, terete; scales all floriferous, regularly imbricated in several ranks. "Stamens 1-3. Style 2-3-cleft, often with a dilated or tumid base, which is deciduous from the apex of the naked lenticular or triangular achene. (Otherwise as in Scirpus. Spikelets in our species umbelled, and the involucre 2-3-leaved. (Name compounded of fimbria, a fringe, and stylus, style, which is fringed with hairs in the genuine species.)

* Style 2-cleft; achene lenticular.

- Spikelets mostly on elongate rays; style ciliate.

1. F. spadícea (L.) Vahl. Perennial, rigid; the thickened base covered with firm dart sheaths; culms wiry, $0.3-1 \mathrm{~m}$.

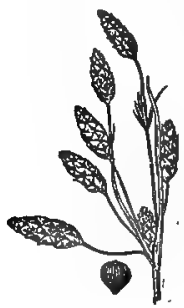

270. F. crstanea. high, nearly naked; leaves pale and firm, involute; umbel 3-10-rayed, the rays very unequal, some simple, others forking; spikelets ovoid to short-cylindric, 0.7-1.7 cm. long, the firm somewhat lustrous dark scales all glabrous; stamens 2 or 3 ; achene broadly obovate, lustrous, minutely striate aud reticulated. - Sand-dunes and brackish shores, Va. to Fla. and Tex. Aug.-Oct. (Trop. Am.) Fig. 269.

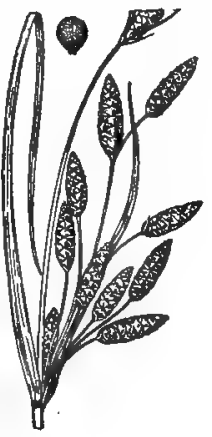

269. F. spadices.

2. F. castànea (Michx.) Vahl. Similar ; more slender $(1.5-7 \mathrm{dm}$. high) and freely stoloniferous; the basal sheaths softer and thinner; the culms and the threal-form or convolute-rinanneled leaves smooth and somewhat rigid; spikelets ovoid-ellipsoid 0.5-1 cm. long, becoming cylindrical, chestnut-color; the scales softer and thinner, at least the lower puberulent. (F. spadicea, var. Gray.) Salt marshes and sand, along the coast from N. Y. to Fla. and Tex.; extending murthw. in the interior to Ont., Mich., Ill., and Neb. July-Oct. Fig, 270. 
Var. pubérula (Michx.) Britton. Leaves and scapes pubescent. - Ga, and Fla, to Iex.; also n. in the flat country to Ind., Ill., and Mo.

3. F. láxa Vahl, Culms slender $(0.5-7 \mathrm{dm}$. high) from an annual root, weak, grooved and tattish; leaves linear, fat, ciliate-denticulate, glaucous, sometimes hairy; spike-

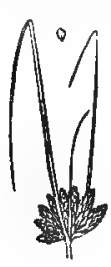
lets ovoid, acute (0.4-1 cm. long) ; stamen 1 ; achene conspicuously 6-8-ribbed on each side, and with finer cross-lines. - Low ground, near the coast, Pa. to Fla and Tex.; $n$. in the flat country to Ill. and Mo. July-Oct. (Trop. Am.) FIG. 271.

+ + Spikelets glomemulate; style glabrous.

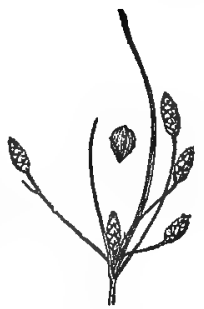

271. F. laxs.

4. F. Váhlii (Lam.) Link. Dwarf tufted annual $(0.3-\varepsilon \mathrm{dm}$. high); the culms, leaves and very elongated upright bracts fili272. F. Vahli, form; glomerule $0.3-1 \mathrm{~cm}$. in diameter; spikelets $3-8$, subcylindric, greenish or pale brown, the narrow scales acuminate; achene minute, transversely reticulate. - Damp sands, etc., N. C. to Fla., Tex, and Mo.; introd. near Phila. July-Oct. Fig. 272.

\section{* S'tyle 3-cleft; achene triangular.}

5. F. autumnalis (L.) R. \& S. Annual (1-4 dm. high), in tufts; culms flat, slender, diffuse or erect; leares flat, acute; umbel compound or decompound, the very numerous slender-cylindric to fusiform brown spikelets 4-10 mm. long; the mucronate-acuminate ovatelanceolate scales appressed; stamens 1-3; achenes very

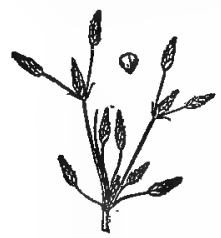

874. F. Frankil. minute, $0.5 \mathrm{~mm}$. long, smooth or minutely roughened. - Low grounds, Pa., Ill., and Mo., southw. JulySept. (Trop. Am.) FIG. 273.

6. F. Fránkii Steud. Similar,

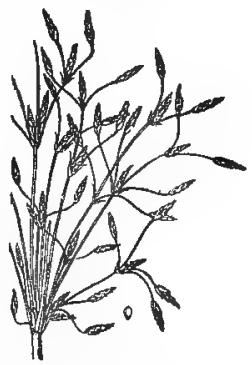

278. F. antumnalts. 0.1-2 dm. high; the umbel simple or slightly compound (or the spikelets solitary in dwarf plants); spikelets ellipsoid or narrowly ovoid, castaneous, the slender tips of the scales slightly spreading; achenes $0.75 \mathrm{~mm}$. long. ( $F$. autuminalis Man. ed. 6, in part.) - Sandy shores, Me. to Ont., and southw. Aug.-Oct. Fig. 274.

\section{SCfrpus [Tourn.] L. Bulrugh or Club Rugh}

Spikelets few-many-flowered, solitary or in a terminal cluster when it is subtended by a 1-several-leaved involucre (this when simple often appearing like a continuation of the culm); the scales in several ranks, or rarely inclining to be 2-ranked. Flowers to all the scales, or to all but one or two of the lowest, ali perfect. Perianth of $1-6$ (or 8 ) bristles, or sometimes wanting. Stamens 2 or 8. Style 2-3-cleft, simple, wholly deciduous, or sometimes leaving a tip or point to the lenticular or triangular achene. - Culms sheathed at base. (The Latin name of the bulrush.)

a. Involucre none, or merely the modiffed onter caducous scale of the solle tary terminal small $(2.5-7 \mathrm{~mm}$. long) spikelet; achene trigonous, smooth $b$.

b. Perianth-bristles terete and setulose.

Seales of the flattened spikelet membranous and awnless; bristles retrorsely barbed; achenes beaked.

Achene 1.mm. long, constricted below the beak

Achene $2-2.5 \mathrm{~mm}$. long, the pale berk continuous with the body

Seales of the terete spikelet with firm green midribs, that of the

1. S. nanus.

2. S. pauciflorus. outermost prolonged into a blunt awn; bristles setulose with spreading or ascending the hairs; achenos beakless. 
Only the ontermost scale awned

b. Perian th-bristles ligulate and barbless; scales chartaceous, the midrib of at least the outer prolonged into a rigid awn.

Culms terete and emooth at tip; achene $2 \mathrm{~mm}$. long, slightly exceeded by the perianth.

Culms trigonous and scabrous above; achene about $1 \mathrm{~mm}$. long; the perianth becoming $2-3 \mathrm{~cm}$. long .

b Involucre foliaceous or appearing to be a continuation of the culm 4 .

c: Involucral bract 1 (occasionally with a secondary small involucel), appearing to be a continuation of the culm $d$.

d. Spikelet solitary; culms flaccid

d. Spikelets normally more than 1 ; culms firm $e$.

e. Spikelets crowded into a subterminal short spike

e. Spikelets distinet, paniculate or glomerulate $f$.

$f$. Spikelets sessile or in glomerules $g$.

g. Annuals with tufted roots; culıns terete or obtusely angled.

Achenes transversely wrinkled

Achenes smooth or merely pitted.

Achenes unequally biconvex or lenticular.

Bristles surpessing the achene

Bristles wanting
Achenes plano-convex, one face distinctly flattened.

Brist]es wanting

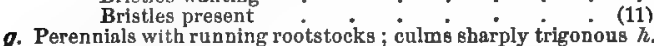

$h$. Involueral leaf erect.

Involucral leaf $+15 \mathrm{~cm}$. long ; spikelets pointed.

Scales reddish-brown, ciliace, awn-tipped; achene planoconvex, broadly obovoid, short-mucronate

Scales yellowish-brown, entire, mucronate; achene trigonous, oblong-obovoid, long-mucronate .

Involucral les $1-3 \mathrm{~cm}$. long; spikelets obtuse .

$\hbar$. Involucral leaf strungly divergent.

f. Spikelets more or less loosely umbellulate or paniculate $i$.

i. Culms triangular, from a shor't rootstock; basal sheath bearing a long triangular leaf; involucral leaf keeled, mach overtopping the loose umbel

8. Culna and short involucral leaf terete, the latter shorter than the 1-sided compound umbel-like panicle of tawny spikelets; basal sheaths mostly bladeless $j$.

f. Achenes lenticular; bristles $4-6$, subequal, about as long as the achenes.

Achenes 2 inm. Iong, nearly equaling the scales

Achenes 2.5-3 mu. long, much exceeded by the scales

f. Achenes trigonous; bristles very unequal, mostly shorter then the achenes

c. Involucral bracts 2 or more, Ieaf-like ; culms leafy $k$.

7. Sptkelets large, 1-5 cm. long, $0.5-1 \mathrm{~cm}$. thick; midrib of the scales extended beyond the somewhat lacerate or 2-cleft apex as an awn; culms sharply trigonous; rootstocks cord-like, with frequent tuber-like thickenings.

Achenes sharply and equally trigonous

Achenes lenticular, plano-convex or obscurely trigonous.

Scales of the spikelets rufescent, bearing numerous elongate red markings .

Scales whitish to castaneous, not rufescent.

Bcales whitish-brown .

Scales drab to castaneous.

Spikelets all or mostly in a dense glomerule.

spikelets 1 -several on mostly elongate rays.

Spikelets long-cylindric, $2-5 \mathrm{~cm}$. long

Spikelets ovoid, $1-2 \mathrm{~cm}$. long

k. Spikelets small, 2-15 mm. long, $1-3 \mathrm{~mm}$. decompound umbelliform panicles $l$

l. Bristles retrorsely barbed ; spikelets in glomerules : culms mostly solitary; the short caudex bearing thick scaly stolons $m$.

m. Lower shenths (at least) red-tinged; bristles barbed nearly to base $n$.

7. Achenes lenticular ; style-branches 2 ; bristles 4.

Primary and secondary rays of the inflorescence mostly elongate, the ultimate glomerules mostly peduncled

Primary and secondary rays abbreviated, most of the ultimate glomerules crowded in irregular masses (2S) S. rubrotinctus, v. confertuse

n. Achenes trigonous; style.branches 3 ; bristles 3 or 6 . Spikelets narrowly ovoild, $3-5 \mathrm{~mm}$. long Spikelets cylindric, 6-14 $\mathrm{mm}$. long m. Sheaths uniformly greenish, not red; bristles berbed only above
the middle $o$.
8. S. Clintonii.

4. S. planifolius.

5. S. caespitosus.

6. S. hudsonianus.

7. S. subterminalis,

8. S. rufus.

9. S. Ballit.

10. S. debizis.

debilis, v. Williamsit.

11. S. Smithii.

S. Smithii, v. setoeus.
12. \$. americanus.

13. S. Torreyi.

14. S. Olneyi.

15. S. mucronatus.

16. S. etuberculatus.

17. S. validus

18. S. occidentalis.

19. S. heterochaetus.

20. S. fiuviatilis.

21. S, robustus.

22. S. campestris.

(22) S. campestris, v. paludosus.

(22) S. campestris, v. novae-angliae. . (22) S. campesiris, v. Fernaldi. 
o. Bristles shorter than or about equaling the achene $p$.

p. Lower leaves and sheaths nodulose-reticulate; bristles nearly or quite equaling the achene.

Scales of the spikelet dark brown, orbicular-ovate, abruptly mucronate, 1.5-2 min. long, one-third longer than the achenes.

Bome of the rays of the inflorescence elongate and definite

All the rays abbreviated and hidden in the dense inflorescence (25) $S$, atroviren

Scales of the spikelet light brown, elliptic-ovate, narrowed to a long setulose awn, about twice as long as the achenes.

p. Lower leaves and sheaths smooth and hardly nodulose; bristles shorter than the achene or often wanting.

v. Bristles twice as long as the achene.

Spikelets ovoid, $2.5-3.5 \mathrm{~mm}$. long.

Spikelets cylindric, 5-8 mm. long : (28) S. polyph
l. Bristles smooth or with few scattered or ascending hairs (not

25. S. atrovirene.

regularly retrorse-barbed), bent or curled ; non-stoloniferous

plants in tufts or stools $q$.

$q$. Bristles at maturity scarcely excoeding the scales.

Bristles firm, appressed, shorter than or about equaling the achene

Bristles weak, loosely ascending, about twice as long as the achene.

scales with the strong green nildrib prolonged into a sharp point.

Scales blunt, the midrib inconspicious:

$\boldsymbol{q}$. Bristles at maturity much exceeding the scsles $r$.

$r$. Splkelets all in glomerules of 3 to 15 .

Involucels reddish-iown.

Spikelets ovoid, 3-6 $\mathrm{mm}$. long

Spikelets cylindric, $7-10 \mathrm{~mm}$. long

Involucels dull brown or drab, with blackish bases. Rays elongate, the glomerules mostly distinet .

Rays abbreviated, the glomerules erowded in dense irreg
ular masses
(32) S. oypert

т. Lateral spikelets of each group mostly pediceled (pedicels short and obscure only in a variety with congested panicles) 8 .

8. Involucels brown or reddish.

Involucels bright red-brown or terra-cotta

Involucels dull brown, not reddisb.

Spikelets 3-6 mm. long, pale brown to straw-color Spikelets 7-10 mm. long, drab

29. S. divaricaths.

26. S. pallidus.

27. S. georgianus.

28. S. polyphyllus.

yllus, v. macrostachys. Involucels black. Rays mostly elongate, the raylets usually definite ${ }^{*} \cdot 35$. S. atrocinctus. Rays and raylets abbrevirted, the spikelets crowded in irregular masses. . . . (85) S. atrocinctus, v. brachypodus.

1. S. nànus Spreng. Culms densely tufted, bristle-like, flattened and grooved (1-7 cm. high); spikelet ovoid, 3-8-flowered ; scales ovate, the upper rather acute; bristles mostly longer than the ovoid achene, sometimes wanting. (Eleocharis pygmaea Torr.) - Brackish marshes of the Atlantic coast, locally iuland in N. Y., Mich., and Minn. July-Sept. (Eu., n. Afr., Mex., Cuba.) Frg. 275.

80. S. Lineatus.

81. S. Peckii.

32. S. cyperinus. 38. S. Eriophorum. 34. S. pedicellatus. pedicellatus, v. pullus.

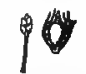

275. B. nanus.

2. S. pauciflorus Lightf. Culms striate-angled, very slender

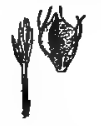
$(0.5-4 \mathrm{dm}$. high), scarcely tufted, on slender running rootstocks, with a short truncate sheath at base; scales chestnutbrown, pointless, all flower-bearing, the two lower larger; bristles 3-6, about as long as the achene. (Eleocharis Link.) 276. 8. pauciflorus - Wet calcareous soil, Que. to B. C., s. to n. N. E., N. Y., Pa., Ill., etc. June-Sept. (Eurasia.) Fig. 276.

3. S. Clintonii Gray. Culms acutely triangular, almost bristle-like ; sheaths at the base bearing a very slender almost bristle-shaped leaf shorter (usually very much shorter) than the culm; outer scale mostly shorter than the pale-chestnut ovoid spikelet; achene $1.5-2 \mathrm{~mm}$. long, compressed, broadly obovoid, equaled or exceeded by the bristles. - Dry banks, N. B. and Me. to w. N. Y. and Mich:; "N. C." May, June. Frg. 277.

4. S. planifolius Muhl. Culms triangular, leafy at base ; leaves linear, flat, 
as long as the culm, and like it rough-edged; outer scale usually overtopping the ovoid or subcylindric straw-colored or brownish spikelet; bristles mostly abuut as long as the achene. - Dry open woods, Mass. and Vt. to Del., Pa., and Mo. May, June. Fig. 278.

278. S. planifollus.

5. S. caespitosus L. Culms terete, wiry, 1-5 dm. high, densely sheathed at base, in compact turfy tufts; the upper sheath bearing a very short aw shaped leaf; spikelet ovoid, rust-color; outer rigid-pointed scale scarcely surpassing the spikelet; bristles smowth, longer than the abruptly short-pointed achene. - Mts., cold shores and swamps, Lab. to Alaska, s. to N. S., n. N. E., N. Y., Ill.,

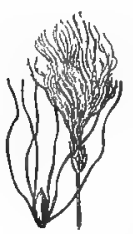

280. S. hudsonianus. Minn., etc.; and on the summits of the s. Alleghenies. (Eurasia.) Fig. 279.

6. S. hudsoniànus (Michx.) Fernald. Culms slender, many in a row from a running rootstock (1.5-4 dm. high), suabrous, naked; sheaths at the base awl-tipped; scales brownish, oblong-lanceolate; bristles white, crisped, many times exceeding the narrowly obovoid apiculate achene. (Eviophorum alpinum L., not $S$. alpinus Schleich.) - Cold bogs and wet shores Nfd, to Hudson Bay and B. C., ¿. to Ct., N. Y., Mich.. and Minn. May-Aug. (Eu.) Fıg. 280.

7. S. subterminàlis Torr, Aquatic, rarely emersed; rootstock slender; culms (0.3-1 m. loug, thickish-filiform) partly and the shorter filiform leaves wholly submersed, cellular; the filiform green bract $1-5 \mathrm{~cm}$. long, surpassing the subcylindric to ovoid spikelet $(6-13 \mathrm{~mm}$. long); scales green or straw-color, somewhat pointed; bristles bearded downward, rather shorter than the abruptly pointed achene.

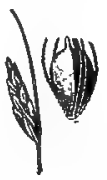
- Slow streams and ponds, Nfd. to B. C., s. to N. J., Pa., 281. s. subterminalis. Mich., n. Ind., etc. Frg. 281.

8. S. rùfus (Huds.) Schrad. Freely stoloniferous; culms smooth, subterete, coinpressed, 1-6 cm. high, taller than the subterete channeled callous-tipped firm mostly basal leaves; spitce distichous, 1-2 cm. long, consisting of closely crowded 2-5-flowered spikelets; involucre 1-5 cm. long, sometimes wanting; scales castaneous, conduplicate, pointed ; bristles 0 , or $3-6$, upwardly barbellate, much shorter than the plano-convex ellipsoid long-beaked 282. S. rufus. achene (4.5-5.5 $\mathrm{mm}$. long). - Brackish marshes, e. N.B. and Que. July, Aug. (Eurasia.) Fig. 282.

9. S. Hállii Gray. Culms slender, terete, 1-4 dm. high; upper sheath rarely distinctly leaf-bearing; spilselets $1-7$ in a sessile or sometimes geminately proliferous cluster, ovoid becoming cylindrical, acute, greenish (0.5-1.5 cm. long); scales ovate, strongly keeled, cuspidate-acuminate; stamens 2 or 3 ; style 2 -cleft; bristles none; achene obovate-orbicular, mucronate, plano-convex, stronaly wrinkled transversely. (S. supinus, var. Gray.) - Wet shores, Ill. to Fla. and 'Tex.; also Winter Pond, Winchester, Mass. Aug.,

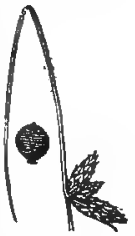
Sept. Fig. 283.

10. S. débilis Pursh. Culms obtusely triangular, with somewhat hollowed

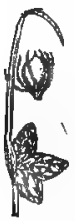
sides, 1-6 dm. high, yellowish-green, shining; spikelets 1-12, capitate, ovoid, obtuse $(0.5-1 \mathrm{~cm}$. long); involucral leaf often horizontal at maturity; scales roundish, with tawny margins; stamens 3 ; style 2-3-cleft; bristles 6 , stout, downwardly barbed, equaling or two surpassing the broadly obovoid turgid abruptly mucronate-pointed achene, - Sandy or muddy shores, $\mathrm{Me}$. to Minn., and southw. Aug., Sept. Fig. 284. Var. Williásir Fermald. Bristles wanting. - Massapoag I., Sharon, Mass.

11. S. Smithil Gray. Culms terete, slendrr, 0.5-4 dm. high, 234. S. debills, often leaf-bearing from the upper sheath, dull green as are the 
1-6 ovoid acutish spikelets $(0.5-1 \mathrm{~cm}$. long); involucral leaf always erect; scales oblong-oval; style 2-cleft; bristles 1 or 2 minute rudiments or none; achene cuneate-obovate. - Wet shores, local, Me. to Pa., Ill., Mich., and Ont. July-Sept. Fig. 285. Var. setósus Fernald. Perianth of 4 or 5 slender retrorsely barbed

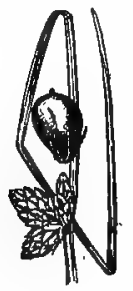

286. S. americanus. bristles, mostly exceeding the achenes, - Me.; Mass. ; and Ill.

12. S. americànus Pers. Running rootstocks long and stout; culms sharply 3-angled throughout $(0.2-1 \mathrm{~m}$. high) with concave sides; leaves $1-3$, elongated (1-3 dm. long), keeled and chan-

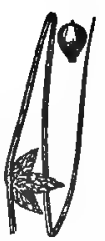

285. S. Smitlili. neled; involucral leaf pointed; spikelets 1-6, capitate, ovoid, mostly $0.5-1 \mathrm{~cm}$. long; scales ovate, sparingly ciliate, 2-cleft at the apex; anthers tipped with an awl-shaped minutely fringed appendage; style 2-cleft (rarely 3-cleft); bristles 2-6, shorter than the smooth achene. (S. pungens Vahl.) - Borders of salt and fresh ponds and streams, temperate N.A. Aug.-Oct. (Eu., S. A.) Fig. 286.

13. S. Torrèyi Olney. Rootstocks slender and weak; culm 3-angled, with concave sides, rather slender (0.4-1.5 m. high), leafy at base; leaves 2 or 3 , more than half the length of the culm, triangular-channeled, slender; involucral leaf blunt; spikelets 1-4, oblong or spindle-shaped, acute, distinct, 1-1.5 cm. long; scales ovate, smooth, barely mucronate; style 3-cleft; bristles longer than the unequally triangular very smooth long-pointed achene.-Borders of ponds, brackish

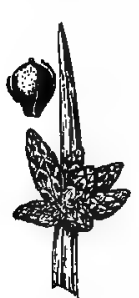
and fresh, Me. to Pa., Ia., and Man. Aug., Sept. Frg. 287.

$\checkmark$ 14. S. Olnèyi Gray. Culm 3-wing-angled, with deeply excavated sides, stout (0.5-2 m. high), the upper sheath bearing a triangular leaf or none; spikelets 6-12, closely capitate, ovoid, obtuse, overtopped by the short involucral leaf; scales orbicular, smooth, the inconspicuous mucronate point shorter

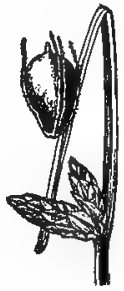
than the scarious apex; anthers with $a$ very short and blunt minutely bearded tip; style 2-cleft; bristles 6 , scarcely equaling the narrowly obovate plano-convex and mucronate achene. - Salt 288. S. Olneyl. marshes, N. H. to Fla.; also in Mich., and on the Pacific coast. July-Sept. (W. I.) Frg. 288.

15. S. MUCRONATUS L. Resembling the last, $3-9 \mathrm{dm}$, high ; involucral leaf divergent; spikelets numerous in a dense cluster, oblong-ovoid; scales ovate, mucronate, firm, scarcely at all scarious; style 3-cleft; achene unequally trigonous, broadly obovate. - In a single locality in Delaware Co., Pa.; probably introd. from s. Eu.

16. S. etuberculàtus (Steud.) Ktze. $C u l m$ (1-2 m. high) 3-angled, usually sharply so above, obtusely below, the sheath at base extended into a long slender triangular and channeled leaf; involucral leaf similar (1-2.5 dm. long), continuing the culm; spikelets cylindric (1-2 cm. long), single or sometimes proliferously 2 or 3 together, nodding on the apex of the 5-9 long filiform and flattened peduncles or rays of the dichotonous umbel-like corymb, or the central one nearly sessile; scales loosely imbricated, oblong-ovate, acute, pale, thin and scarious, with a greenish nerved back; bristles 6 , firm, furnished above with spreading hairs rather than barbs, equaling the slender abrupt beak of the abovoid-triangular shining achene (4 mm. long). (S. Canbyi Gray; S. cylindricus Britton.) -Swamps and ponds, Md. to Fla., ete. June-Aug. Fig. 289.

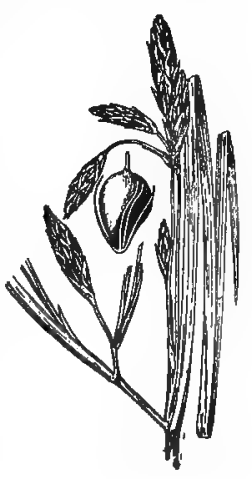

289. 8. etuberculatus. 
17. S. válidus Vahl. (Great B.) Rootstock stout, scaly, horizontal; culm 0.5-2.5 m. high, $0.8-2.5 \mathrm{~cm}$. thick at base, soft, light green; basal

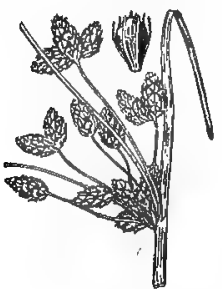

290. 8. valitus. sheaths soft, with soon lacerate hyaline margin; decompound panicle lax, the rays 1-6 $\mathrm{cm}$. long, slender and flexuous; bractlets brownish, pubescent at tip, fimbriateciliate, wilh strongly excurrent midrib; spikelets solitary or in glomerules of 2-5, rufescent, ovoid, acutish, 5-10 $\mathrm{mm}$. long; scales suborbicular, a little pubescent on the back, ciliate, mucronate; style 2-cleft; achene fuscous or dull black when ripe, broad-obovoid, plano-convex, mucronate, $1.3-1.5 \mathrm{~mm}$. broad. (S. lacustris, mostly of A m. auth., not L.) - Margins of ponds and quiet streams. July, Aug. FIG. 290.

18. S. occidentalis (Wats.) Chase. Similar; the culms harder, olive-green; basal sheaths firmer, the margins becoming fibrillose; panicle compound, the rays $0.5-5 \mathrm{~cm}$. long, stiff; bractlets red-spotted, viscid at tip, lacerate-fimbriate, abruptly mucronate; spikelets mostly in glomerules of $2-7$, rarely solitary, drab to reddish-brown, subcylindric, 1-2 cm. long; scales oblong-ovate, aristate, red-dotted, viscid above; achene biconvex, 1.7-1.9 $\mathrm{mm}$. broad. - Lake-borders, Nfd. to B. C., s. to Mass., N. Y., Great Lakes, Mo., etc. Aug., Sept. Fig. 291.

19. S. heterochaètus Chase. Similar; the culms slender, rarely $1 \mathrm{~cm}$. thick at base, pale green; panicle compound, the suberect very slender rays $1-9 \mathrm{~cm}$.

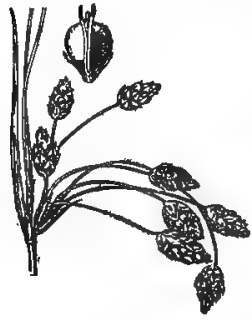

292. \$. heterochaetus.

long ; bractlets pale, aristate-acuminate, glabrous; spikelets solitary, ellipsoid, 8-14 mm. long, pale brown; scales ovate-oblong, exceeding the achenes, emarginate, shortaristate, slightly red-dotted, glabrous, voith erose-fimbriate margins; style 3-cleft; bristles fragile, 2-4; achene greenish or yellowish, 2.5-3 mm. long, 1.7-2 min. broad. - Marshes and sheltered shores, e. Mass. and Vt. to Ill., Neb., and Ore. July, Aug. Fig. 292.

20. S. fluviátilis (Torr.) Gray, (RIVER B.) Culm very stout, 1-1.5 m. high; leaves flat, broadly linear $(0.7-2 \mathrm{~cm}$. wide), tapering gradually to a point, the upper and those of the very long involucre very much exceeding the compound umbel; rays 5-12, elongated, recurved-spreading, each bearing 1-5 ovoid to cylindrical acute pale-brown spikelets (1.5-4 cm. Iong); scales slightly lacerate, the awns

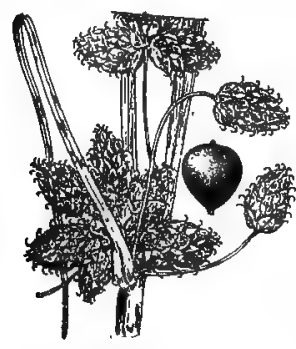

294. B. robustus. much exceeding the cleft tip; achene obovoid, sharply and exactly triangular, conspicuously pointed, opaque, about equaling the 6 rigid bristles.

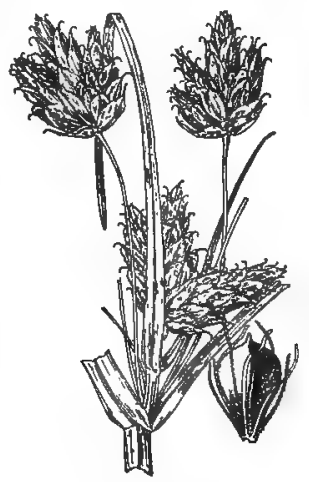

298. S. fluviatilis.

-Borders of lakes and large streams, e. Mass. and Vt. to D. C., w. to Minn., Kan,, etc. July-Sept. FIG. 293.

21. S. robústus I'ursl. Leaves flat, green, 4-10 mm. broad, as long as or longer than the stout culm $(0.7-$ $1.2 \mathrm{~m}$. high), those of the involucre 3 or 4 , very unequal, the longest 2.5-4 dm. long; spikelets 1-1E, rufescent, ovoid to cylindric, $1.5-3 \mathrm{~cm}$. long, 6-12 $\mathrm{mm}$. thick, some sessile, the others borne on short (2-6 cm. long) 
rays; scales all pubescent, the awns soon recurved and many times exceeding the cleft tip; achene broadly to narrowly obovoid, compressed, flat on one side, convex or obtuse-angled on the other, short-pointed, shining; the bristles unequal and deciduous or obsolete. ( $\$$. maritimus, in part, Am. authors.) - Brackish or salt marshes, Mass. to Fla. and 'l'ex. July-Sept. Fig. 294.

22. S. campéstris Britton. Culms $0.3-1 \mathrm{~m}$. high, usually exceeding the stiff pale leaves (3-9 $\mathrm{mm}$. broad); involucral leaves $2($ or 3$)$, the longer $1-2 \mathrm{dm}$. long; spikelets whitish-brown, ovoid to cylindric, 1-2 cm. long, 6-10 min. thick, 211 in a dense glomerule, occasionally a few in a secondary glomerule; scales puberulent, or the outermost glabrous except at tip, the slightly curved awn twice or thrice exceeding the cleft tip. ( $\boldsymbol{S}$. maritimus, in part, of authors.) l'rairies, etc., Man. and Minn., westw. and southw. Var. Paludósus (A. Nelson) Fernald. Similar, but with the scales drab to castaneous. (S. paludosus A. Nelson.) - Alkaline situations inland, and in salt marshes, Gulf of St. Lawrence to N. J. July-Sept. Fig. 295. Var. Nòva-Ánglae (Britton) Fernald. Usually taller (1-2 m. high); the involucral leaves 3 to 5 , the longest 2-3.5 din. long; the looser inforescence with 3 to 9 curved rays (2-10 $\mathrm{cm}$. long); spikelets dark brown, cylindric, $2-5 \mathrm{~cm}$. long. ( $S$.

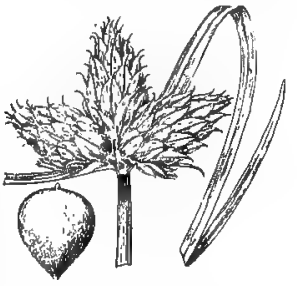

295. S. camp., v. palud. novae-angliae Britton.) - Mass. to s. N. Y.; also w. N. Y. Passing to Var. Fernáld (Bicknell) Bartlett. Spikelets short-ovoid, 1-2 cm. long, on mostly elongate rays. (S. Fernaldi Bicknell.) - Me. to Mass.

23. S. rubrotínctus Fernald. Culm rather stout, 4-9 dm. high; leaves

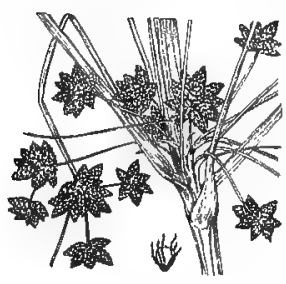

296. S. rubrotinctus. broadly linear, the upper equaling or slightly exceeding the inflorescence, the sheaths mostly red-tinged at base, the blades smooth, 4-13 mm. broad; involucral leaves mostly 3 , the longest equaling or exceeding the inflorescence; rays numerous, the 3-5 longest ones 0.5-1.5 dm. long, stiff, ascending, subequal, the many shorter ascending and divergent; spikelets 4-9 $\mathrm{mm}$. lung, ovoid to cylindric, in glomerules of from 3 to many ; scales ovate, blunt, or the terminal mucronate, finely suffused with green and black; stamens 2 . ( $S$. sylvati,us, var. digynus Man. ed. 6, not Boeckl.) Damp open soil, Nfd. to Assina., s, to Ct., N. Y., Great Lakes, etc. Fr. July, early Aug. Fig. 296. Var. confÉrt us Fernald. Glomerules compacted into dense clusters $1.5-4 \mathrm{~cm}$. across. - Nfd. to Me., local.

24. S. sylváticus L. Similar ; tall and coarse, 0.5-2 m. high ; upper sheaths mostly green, leaf-blades with scabvous margins, 1-2 cm. broad ; rays very uumerous, mostly ascending but flexuous, the 1-4 longest 0.5-4 dm. long; spikelets $3-5 \mathrm{~mm}$. long, ovoid, in glomerules of from 2-8; stamens 3. - By brooks and in wet swamps, s. Me. to Fla., and Mich. Fr. Aug. (Eurasia.) FIg. 297.

Var. Bisséllii Fernald. Spikelets cylindric, 6-14 $\mathrm{mm}$. long, mostly 5-20 in a glomerule. - Local, Ct. and N. Y. - An anomalous plant, combining characteristics of $S$. "sylvaticus and $S$. rubrotinctus; fruiting earlier than the former, later than the latter.

25. S. atróvirens Muhl. Rather stout, 0.8-1.5 m. high; leaves pale green, with scabrous margins. 7-15 mm. wide, at least the lover nodulose-reticu. late, the ribs $0.25-0.3 \mathrm{~mm}$. apart; spikelets dull greenish-brown or rufescent, narrowly ovoid to

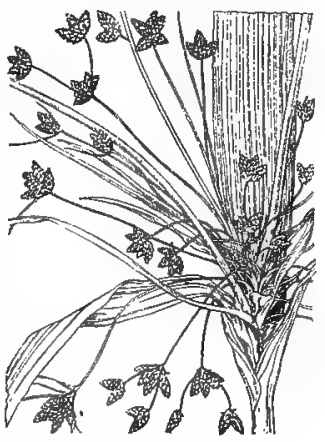

297. S. sylraticus. 
rylindric, 3.5-8 (rarely 10) mm. long, in glomerules of 10-30; scales $1.5-2 \mathrm{~mm}$. ling; bristles sjarsely and strongly barbed, nearly straight, as long as the

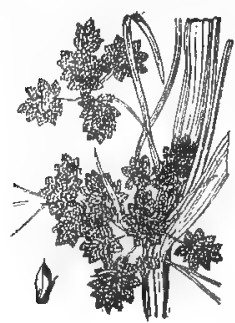

2y8. \$. atrovirens. conspicuously pointed and obovoid-oblong trigonous achene. - Meadows and bogs, Me. to Sask., s. to Ga. and Mo. Fr. late July, Aug. Frg. 298. Var. Pycnocéphacts Fernald. Rays abbreviated; glomerules crowded in a dense irregular head. - Flats of the Mohawk R., N. Y., local (Haberer).

26. S. pállidus (Britton) Fernald. Similar ; leaves very pale; spikelets pale brown, very numerous in irregular flomerules; scales 2-3 mm. long, with the conspicuous pale midribs prolonged into long setulose awns. (S. atrovirens, var. Britton.) - Man. to Kan. and the Rocky Mts. Fr. July. Fig. 299.

27. S. georgiànus Harper. Slender, 3-12 dm. high, bright green; leaves smooth, rarely 299. s. pallidus. nodulose below, numerous, crowded at base,

$0.5-1 \mathrm{~cm}$. broad, the ribs $0.15-0.2 \mathrm{~mm}$. apart; spikelets $2-4 \mathrm{~mm}$. long, numerous in the glomerules; the greenish-brown or rufescent scales mucronate, $1-1.5 \mathrm{~mm}$.

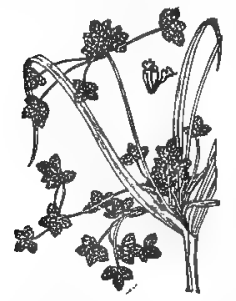

300. S. polyphyllus. long, slightly exceeding the ellipsoid achenes. - Que. to Mich., Ga., and Ark. Fr. July. - Occasionally proliferous. 28. S. polyphýllus Vahl. Culm usually very leafy; spikelets yellow-brown or reddish, ovoid, $2.5-3 \mathrm{~mm}$. long, clustered 3-8 together in small heads on the short uitimate divisions of the open decompound umbel; scales rounded, mucronate, $1-1.5 \mathrm{~mm}$. long, about equaling the broadly obovoid short-tipped achene; bristles 6 , usually troice bent, about twice the length of the achene. - Swamps and borders of ponds, w. N. E. to Ga., w. to Minn. and Ark. July-Sept, - Often proliferous. FIG. 300. Var. MACRósTACHYS Boeckl. Spikelets cylindric, 5-8 mm. long. Local, Ct. and N. Y.

29. S. divaricàtus Ell. Slender, weak, 0.5-1.5 m. high; leaves very numerous, deep green, soft and smooth, 4-10 $\mathrm{mm}$. wide; inflorescence loose, often proliferous, with elongated widely divergent flexuous rays; spikelets mostly pediceled, very slender, cylindric, at first 3 or $4 \mathrm{~mm}$. long, the axis elongating to $1 \mathrm{~cm} ., 1-2 \mathrm{~mm}$. thick; scales whitish or pale brown, blunt, incurved, with broal green midrib; achene

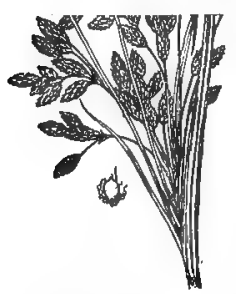

802. S. linertus. firm, sharply trigonous, ovoid, apiculate. - Swamps, etc., Va. to Mo., and southw. June-Aug. Frc. 301.

30. S. lineàtus Michx. Culms remotely leafy, $0.5-1.5 \mathrm{~m}$. high; leaves linear, flat, pale grean, stiff, rather broad (0.5-1 cm. wide), rough on the margins; involucre and involucels pale brown at base; umbels terminal and sometimes axillary, loose, $0.5-2 \mathrm{dm}$. high, subsecund, the terminal with a

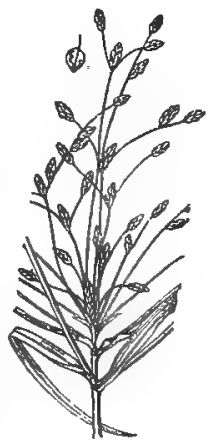

301. S. divaricatus. 1-3-leaved involucre much shorter than the long slender ascending, nodding-tipped rays; spikelets oblong, becoming cylindrical (0.5-1 cm. long), on thread-like drooping pedicels; scales pale brown, ovate, green-keeled, pointed, the tips ascending, not appressed; achene firm, brown, sharp-pointed. (Eviophorum B. \& H.) - Low grounds, Vt. to Ga., and westw. June-Aug. FIG. 302.

31. S. Péckii Britton. Culms slender, 0.8-1.7 m. high; ledves pale green, $5-9 \mathrm{~mm}$. broad, the margins scabrous; involucre and involucels blackish at base; inflorescence $0.5-2 \mathrm{dm}$. high, the $2-5$ longest stiff rays ascending, the others shorter, ascending or divergent, the tips scarcely trooping; spikelets oblong.cylindric, 5-9 mm. long, mostly sessile or subsessile in glomerules of 
2-7; scales oblong-ovate, acutish or obtuse, blackishferruginous above the pale base; achene soft, whitish, oblong. - Meadows and bogs, N. H., Vt., and n. N. Y'. July, Aug. Fig. 303.

32. S. cyperìnus (L.) Kunth. (Wool Grass.) Culm nearly terete (1-1.5 m. high); leaves narrowly linear,

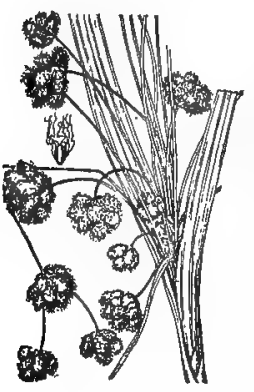

304. S cyperinus. long, rigid, those of the involucre 3-5, longer than the loose umbel (1.5-3 dm. long), the tips of the rays at length drooping; involucels reddish-brown; spikelets exceedingly numerous, ovoid, clustered, woolly

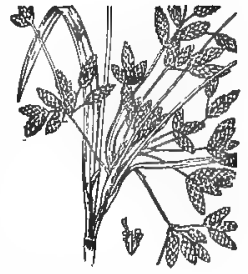

303. S. Peckii.

at maturity (3-6 mm. long); the rust-colored bristles much longer than the pointless reddish-brown scales; achene short-pointed. (Eviophorum L.) - Wet meadows and swamps, N. E. to Va., Tenn, and Ark. Aug., Sept. Fig. 304. Var. ANDréwsiI Fernald. Involucels redaish-brown; spikelets cylindric, 7-10 mm. long. - Local, Ct.

Var. pèlius Fernald. Involucels blackish at base; bristles drab or smoke-color. - The common form northw.; Iifd. to Ont., s. to Ct., N. Y., and Mich. - Perhaps distinct. Var. condensitus Fernald. Similar, but with rays all or nearly all abbreviated, the glomerules in dense irregular masses. - Local, range of last. Aug.-Oct.

33. S. Eriophorum Michx. Coarse and tall (1-2 m.) ; the culm 2.5-6 mm. thick below the ample (1.5-3 dm. high) intlorescence; leaves pale green, firm. 6-11 $\mathrm{mm}$. broad; rays very elongate, mostly ascending, drooping at tip; the involucels deep red-brown or terra-cotta; spikelets ovoid, 3-6 mm. long, the lateral pediceled; scales red-brown; wool slightly paler. - Mostly near the coast, Ct. to Fla., La., and Ark. July-Sept.

34. S. pedicellàtus Fernald. Similar; the culm rather stout $(2-4 \mathrm{~mm}$. thick below the inflorescence); leaves pale green, firm, 3-10 $m m$. broad; inflorescence ample, 1-2.5 dm. high, the numerous ascending subequal rays very slender, with nodding tips; involucels brown to dull straw-color; spikelets $3-6 \mathrm{~mm}$. long; scales pale brown; wool whitish-brown. - Alluvial thickets and swamps, e. Que, to Ct., N. Y., and Wis., mostly in the interior. July, Aug. Fig. 305. - Ordinarily very distinct, occasionally approaching the preceding or the following as in Var. PúLlus Fernald. Spikelets dull brown or drab, 7-10 $\mathrm{mm}$.

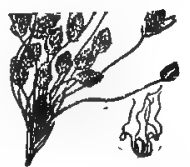

305. S. pedicellatus. long. - Local, and perhaps as nearly related to the next (including $\boldsymbol{S}$. atrocinctus, var. grandis Fernald).

35. S. atrocinctus Fernald. Slender $(0.5-1.2 \mathrm{~m}$. high); the culm 1-2 $\mathrm{mm}$. in diameter below the inflorescence; leaves bright green, rather soft, $2-5 \mathrm{~mm}$. broad; inflorescence $0.5-1.8 \mathrm{dm}$. bigh, the slender rays very unequal; involucels and base of involucre black; spikelets $2.5-6 \mathrm{~mm}$. long, mostly pediceled; scales greenish-black; wool drab or olive-brown. - Meadows and swamps, abundant northw.; Nfd. to Hudson Bay and Sask., s. to Ct., Pa., Mich., and Ia. June, July (Aug. in colder regions). Var. BRACHÝPoDUs Fernald. Spikelets on shortened pedicels, in irregular dense clusters; rays usually much reduced. - Frequently occupying large areas, especially northw. and at higher altitudes than the typical form.

\section{ERIÓphordm L. Cotton Grass}

Bristles naked, very numerous, silky and becoming greatly elongated. Otherwise as in Scirpus. - Spikelets single or clustered or umbellate, when involucrate with leaf-like bracts, upon a leafy or naked stem ; scales membranaceous, 1-5-nerved, some of the lowest usually empty. Style very slender and elongated, 
3-cleft. Achene acutely triangular. (Name composed of '́p pov, wool or cotton, and $\phi o p b s$, bearing.)

\$1. Spikelet solitary ; involucre none; the lowest seale of the spikelet enlarged and thickened; stem-leaves reduced to mostly b]adeless sheaths $a$.

a. Stoloniferous, culms solitary ; empty scales at base of splkelet few (7 or less); flowering spikelot cylindric, in fruit becom. ing obovoid.

Bristles reddish or cinnamon-color .

Bristles white

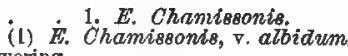

w. Nonstoloniferous, culms tufted; empty scales 10-15; flowering spikelet obovoid or globose, in fruit becoming depressedglobose.

Densely tufted, the culms very many; upper sheaths distinctly inflated; culm trigonous and scabrous at tip

Loosely tufted, culms very few; upper sheath close; culm terete, glabrous at tip.

\$2. Spikelets 2-several; involucre of 1-several leafy bracts $b$.

2. E. callitrix.

3. E. opacum.

thronghout; involucre a single erect short bract.
throes

Upper cauline leaf with the sheath longer than the blade

Upper cauline leaf with the sheath ohorter than the blade

b. Leaves broader, flat at least below the middle; involueral

4. E. gracile.

5. E. tenellum. bracts 2 or more $c$.

c. Scales of spikelet with only 1 prominent rib; stamens 8 .

Midrib of scale prominent only below the membranous tip ; upper leaf-sbeaths dark-girdled at summit.

Leaves $1.5-4 \mathrm{~mm}$. broad

Leaves $5-8 \mathrm{~mm}$, broad

6. E. angustifolium.

Midrib prominent to the tip of the scale; leaf-sheathi (6) E. angustifolium, dark-girdled.

Spikelots mostly peduncled

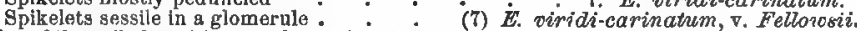

c. Scales of the spikelet with several prominent ribs ; stamen 1 .

Bristles copper-color or brown . . . . 8. E. virginicum,

Bristles white except at base. : - : - (8) E. virginicum, v, album.

1. C. Chamissonis C. A. Mey. Culms soft, subterete, 1-8 dm. high; basal leaves slender, channeled, the upper scarcely inflated sheaths mostly bladeless; flowering spikelet $1.5-2 \mathrm{~cm}$. long; its scales brownish lead-color with broad whitish margins, bluntish; bristles reddish. (E. russeolum Fries.) - Locally in bogs, Lab. to N. S. and N. B. ; Ont.; Rocky Mts., etc. Fr. July, Aug. (Eurasia.) Var. Álbidum (F. Nylander) Fernald. Bristles white.-Que. and N. B. ; Alaska, etc. (Eurasia.)

2. E. cállitrix Cham. (HARE's TAIL.) Culms stiff and wiry, densely tufted, 1.5-7 dm. high; basal leaves filiform-trigonous, scabrous; upper bladeless sheaths inflated; flowering spikelet obovoid or globose, $0.8-1.5 \mathrm{~cm}$. long; scales lead-color with pale margins, ovate to ovate-lanceolate, long-acuminate; fruiting spikelet $2.5-5 \mathrm{~cm}$. broad; bristles bright white. ( $E$. vaginatum Am. authors, not L.). - Bogs and mountain slopes, Lab. to Alaska, s. to Pa., Mich., Wis., and Man. Fr. May-July. (Asia.)

3. E. opàcum (Björmstr.) Fernald. Similar; culms terete, glabrous, filiform, forming loose small tufts; leaves glabrous; upper sheaths close; flowering spikelet rarely $1 \mathrm{~cm}$. long; scales lead-color, lance-attenuate; fruiting spikelet 2-3.5 cm. broad ; bristles sordid white. - Locally on bogs, South Ashburnham, Mass. (Forbes); Ont. to Sask. and the Rocky Mts. Fr. June, July. (Eurasia.,

4. E. grácile Roth. Weals and slender, glabrous, the subterete culm 2-6 dm. high, with no young basal leaves developed at flowering season; upper cruline leaf-blade smooth, round-tipped, 1-4 cm. long; involucre dark at base; spikelets $2-5$, mostly on short slender pubescent peduncles $(0.5-3 \mathrm{~cm}$. long), in anthesis 7-10 mm. long, in fruit 1.5-2 cm. long; scales lead-color or blackish; achenes 1.5-2 mm. long; bristles white. - Cold bogs and swamps, Gulf of St. Lawrence to B.C., s. to Ct., Pa., Mich., Neb., and Cal. Fr. May-July. (Eurasia.)

5. E. tenéllum Nutt. Culms stiff, obtusely trigonous, scabrous above, 3-9 dm. high, with long slender green pointed basal leaves; upper cauline leaf-blade scabrous, pointed, $3-18 \mathrm{~cm}$. Jong; involucre brown or strcu-color at base; spikelets $3-6$, un scabrous peduncles, in fruit $2-2.8 \mathrm{~cm}$. long; scales greenish 
straw-color to reddish-brown; achenes 2.5-3 mm. long; bristles whitish (E. gracile, var, paucinervium Engelm.; E. paucinervium. A. A. Eaton.) Swamps and bogs, Nfd. to Ont., s. to N. J. and Ill. Fr. July, Aug.

6. E. angustifolium koth. Culms 2-6 dm. high, slender, obtusely angled; basal leaves broad, conduplicate above the middle; cauline leaves few, stiff, flat at base, 1.5-1.5 $\mathrm{cm}$. long, 1.5-4 mm. broad, scabrous on the margins; spikelets $2-10$, mostly on stout glabrous or glabrate peduncles $(0.5-7 \mathrm{~cm}$. long), in anthesis ovoid, 1-2 cm. long, in fruit 2.5-4.5 cm. long; scales lead-color to castaneous, 4-10 $\mathrm{mm}$. long, the nerveless tip menoranous; anthers $2.5-5 \mathrm{~mm}$. long; achenes 2.7-3.5 mn. long; bristles bright white. (E. polystachion L., in part.) - Cold bogs, $\Lambda$ retic Am., s. to Nfd., N. S., N. B., Me., L. Superior, ete. Fr. June, July. (Eurasia.) Var. MAJus Schultz. Stout and tall (3-9 dm.) ; the leaves 4-8 mm. broad. - South to Me., Ont., Ill., Wisc., Ia, etc. (Eurasia.)

7. E. víridi-carinàtum (Engelm.) Fernald. Culms 2-9 dm. high; leaves flat except at tip, 2-6 min. wille; spikelets 3-30, on slender siniple or forked minutely hairy peduncles, in anthesis slender-ovoid, 6-10 $\mathrm{mm}$. long, in fruit 1.5-3 cm. long; scales greenish-drab to lead-color, the prominent often scabrous midrib extending to the tip; anthers 1-1.25 $\mathrm{mm}$. long; bristles whitish or pale buff. (E. polystrechion of inost Am. authors.) - Bogs and wet meadows, Nfd. to Sask. and B. C., s. to Ct., N. Y., O., Mich., Wis., and said to extend to Ga. Fr. May-Aug. Var. Feldówsı Fernald. Spikelets all sessile. - Local, Me. and Mass.

8. E. virgínicum Ls. Culms wiry, terete below, trigonous above, smooth, 4-12 dm. high ; loaves flat, stif, elongate-linear, with close sheaths, the uppermost 1-2.5 dm. long, 1.5-4 min. wide; involucral bracts somewhat divergent; spikelets mostly crowoded in a dense glomerule, in anthesis 6-10 mm. long, in fruit 1-2 cm. long; sccles with strongly striate-ribbed greenish or straw-colored body and thin nerveless red-brown margin; brislles tawny or copper-color. Bogs and meadows, Nfd. to Cnt. and Minn., s. to Ga. Fr. Julv-Sept. Var. ÁLBUM Gray. Bristles whitish. - Ct. and N. Y.

\section{FUIRÈnA Rottb. UMBRelLA Grass}

Spikelets many-flowered, terete, clustered or solitary, axillary and terminal. Scales imbricated in many ranks, awned below the apex, all floriferous. Perianth of 3 ovate or heart-shaped petaloid scales, mostly on claws, and usually with as many alternating small bristles. Stamens 3. Style 3-cleft. Achene triangular, pointed with the persistent base of the style. - Culms from a usually perennial root, obtusely triangular. (Named for G. Fuiren, a Danish botanist.)

1. F. squarròsa Michx. Annual, $0.5-3 \mathrm{dm}$. high; stems glabrous; leaf-sheaths more or less hispid; spikelets $2-8$; perianth-scales narrowly to broadly oblong or ovate, longstipitate and attenuate to a long retrorsely barbed awn; barbed bristles usually exceeding the yellow-brown achene, which is equaled by the persistent style. (Var. pumila Torr.) - Sandy shores and swamps, Mass. to Fla.; Mich. and Ind. Aug.-Oet. Fra. 306.

2. F. híspida Ell. Perennial, stem (2.5-8 dm. high) leafy; leaves and sheaths densely hairy; spikelets ellipsoid $(0.5-1.2 \mathrm{~cm}$. lnng), bristly with the spreading awns of the scales; perianth-scales rhombic or deltoid-

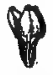
ovate, with a short thick smooth terminal awn or point, the interposed mostly barbed bristles shorter than the yellow achene, which is twice as long as the persistent style. ( $F$. squnrrosa, var. 807. F. hispida. Chapm.) -- Sandy wet places, N. J. to Fla. and 'l'ex., n. in the Fruit $\times 2 \%$. low country to Ky. and I. T. July-Oct. F1G. 307 . 
3. F. símplex Vahl. Perennial, 1-8 dm. high; leaf-sheath hairy; perianth-scales ovate-oblong, the retrorsely barbed awns arising from below the tip, bristles equaling or exceeding the 30x. F. simplex, white achene. - Sandy or saline soil, Mo, and Kan. to Mex. Fruit $\times 2 \%$. Aug.-Oct. Fig. 308 .

\section{HEMICÁRPHA Nees \& Arn.}

Spikelet, flowers, etc., as in Scirpus, except that there is a minute translucent scale (readily overlooked) between the flower and the axis of the spikelet. Stamen only 1. Style 2-cleft. Bristles or other perianth

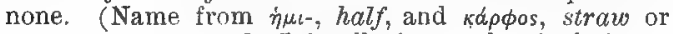

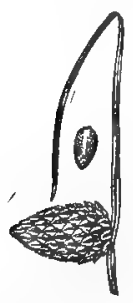

310. H. Drummondi. Spikelet $\times 22 / 3$ Achene $x$ io. chaff, in allusion to the single inner scalelet.)

1. H. micrántha (Vahl) Britton. Dwarf or minute annual $(0.2-15 \mathrm{dm}$. high); involucre 1-leaved, as if a continuation of the bristle-like culm, and usually with another minute

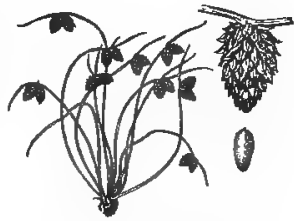

309. H. micrantha.

Plant $\times 2 / 8$. Spikelet $\times 22 / 3$. Achene $\times 10$. leaf ; spikelets,1-3, short-cylindric or ovoid (2-4 mm. long); scales oblong or narrowly obovate, brown, tipped with a short recurved point; achenes cylindric, brown, slightly reticulated, with many close rows of crowded low papillae. (H. subr squarrosa Nees.) - Sandy borders of ponds and rivers, N. H. to Fla., w. to the Pacific; chiefly on the coastal plain and in the flat country of the interior. Aug.-Oet. (Mex., S. A.) Fig. 309.

2. H. Drummóndi Nees. Similar; scales broadly obovate or rhombic, the broad green midrib barply projecting as a blunt appressed tip ; achenes narrowly obovoid, ashy, scarcely reticulated, the papillae fewer and somewhat remote. - Damp sand, etc., w. Ont., Ind., and Ill. to Ark., Kan., and Tex. JulyOet. FIG, 310 .

3. H. occidentàlis Gray. Spikelets globose, the wide-spreading lanceolate or narrowly ovate scales tapering to slender recurved awns (as long as the blades); achenes as in the latter. -Damp sand, w. Ont.; Wash. to Cal. July-Oct. Fig. 311.

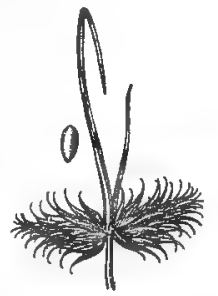

311. H. occidentalis. Spikelets $\times 2 \%$. Achene $\times 10$.

\section{LIPOCÁRPHA R. Br.}

Spikelets terete, many-flowered, in a terminal close cluster involucrate by leafy bracts. Scales spatulate, regularly imbricated in many ranks, awnless, deciduous, a few of the lowest empty. Inner scales (bractlets) 2 to each flower, thin, one between the scale of the spikelet and the flower, one between the latter and the axis of the spikelet. Stamens 1 or 2. Style 2-3-cleft. Achene flattish or triangular, naked at the tip. - Culms leafy at base. (Name formed of $\lambda / \pi \circ$ s, fat, and kápфos, chaff, from the thickness of the inner scales of some species.)

1. L. maculata (Michx.) Torr. Annual; culm (0.5-2.5 dm. high) much longer than the linear concave leaves; spikelets (3-7 mm. long) green and dark-spotted; inner scales delicate; stamen 1; achene oblong with a contracted
or miry places, Va. to Fla.; near Puiladelphia, probably adv. 312. L, maetrata. base. - Springy or miry
Tำเy-Oct. FIG. 312. 


\section{RYNCHÓSPORA Vahl. BEAK RESH}

Spikelets panicled or variously clustered, ovate, globular, or spindle-shaped: terete, or sometimes flattish; but the scales open or barely concave (not boatshaped nor keeled); the lower commonly loosely imbricated and empty, the uppermost often subtending imperfect flowers. Perianth of bristles. Stamens mostly 3. Achene lenticular, globular, or Hat, crowned with a conspicuous tubercle or beak consisting of the persistent indurated base or even of the greater part of the style. - Chiefly perennials, with more or less triangular and leafy culms; the spikelets in terminal and axillary clusters ; flowering in summer. (Name composed

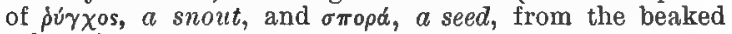
achene.)

§ 1. Spikelets lanceolate, acuminate, in frutit flattish, cymose-panicled, of only one perfect and 1-4 staminate flowers; scales few; bristles rigid, minutely scabrous upward; style simple or barely 2-toothed, filiform

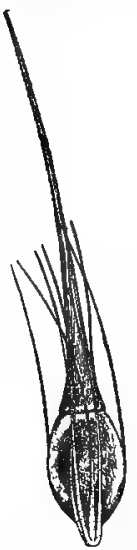
and gradually thickened downward, in fruit persistent as an exserted slender awl-shaped upwardly roughened beak, several times longer than the smooth flat obovate achene; coarse perennials; spikelets in flower 1-1.5, in fruit (including the projecting beaki) 2-3 cm. long.

1. R. corniculata (Lam.) Gray. (Horned Rusir.) Culm 0.5-2 m. high;

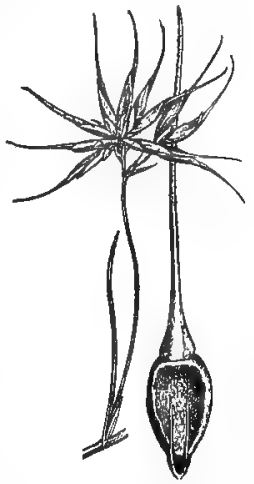

818. R. corniculata. leaves $0.6-2 \mathrm{~cm}$. wide; cymes decompound, diffuse; bristles awl-shaped, stout, unequal, shorter than the achene.-Wet places on the coastal plain, Del. and Pa. to Fla. and I'ex., locally northw. in the Miss. Basin to Mo., Ind., and 0 . June-Sept. Fig. 313.

2. R. macrostàchya Torr. Erect and rather stiff; the glomerules mostly of 10-50 spikelets, strongly ascending, sessile or on fero short rays; bristles capillary, tuice the length of the achene. - Borders of ponds, Mass. to Fla. and Tex., locally northw. in the Miss. Basin to Kan. and Ind. Aug.-Oct. Fig. 314.

Var. inundata (Oakes) Fernald. Cyme loosely decom-
314. R. nacrostachya. pound, the numerous rays wide-spreading or flexuous ; the spike
or $2-6$ in loose glomerules. (Var. patula Chapm.) - Mass. to Fla.

§2. Spikelets terete or biconvex, few-many-fowered; style conspicuously 2 cleft, its base only forming the tubercle of the mostly lenticular achene; bristles usually present, merely rough or barbed-denticulate (rarely plumose).

* Achene transversely wrinkled; bristles mostly 6, upwardly denticulate.

3. R. cymosa Ell. Culm slender 0.3-1 m. high, triangular; leaves linear (1-4 mm. wide); cymes corymbose, the brown spikelets crowded and clustered; achene round-obovoid, faintly wrinkled,

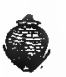

316. P. con-

pressa. stout; lexves pale and firm, 3-7 mm. wide; achene twice the length of the bristles, four times the length of the depressed-conical narrow tubercle. Low grounds, N.J., Pa., Ill., and southw. June Aug. (W. I., S. A.) FIG. 315. strongly wrinkled, the tuberrle with broad depressed thin-edged base. - Ga. and Fla. to La., llulthw. in the low country to Mo. July. Fig, 316.

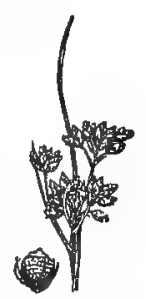

315. R. cinosa 


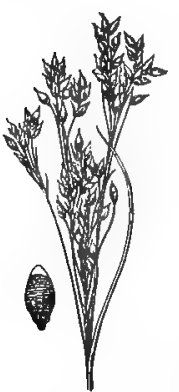

317. R, Torreyana.

5. R. Torreyána Gray. Culm nearly terete, slender; leaves involute-filiform; cymes panicled, somewhat loose, the ascending brown spikelets mostly pediceled; rchene compressed, oblong-obovoid, longer than the bristles, thrice the length of the broad compressed-conical tubercle. - Swamps and bogs, East Washington, N. H. (C. F. Parker); pine-barrens of N. J. to Ga. July-Oct. Fig. 317.

6. R. inexpánsa (Michx.) Vahl. Culm triangular, slender; leaves narrowly linear, 2-3 mm. wide, becoming involute; spikelets spindle-shaped, mostly pediceled, in drooping panicles; achene oblong, half the length of the slender bristles, twice the length of the triangular-subulate tubercle. - Low grounds, Va. to Ga. July-Sept. Fig. 318.

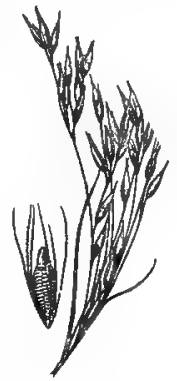

$$
\text { * Achene smooth and even. }
$$

318. K. inexpansa.

- Bristles 6, long and conspicuous, upwardly denticulate.

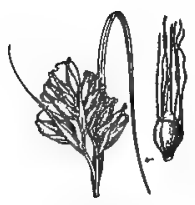

319. R. fusce.

7. R. fúsca (L.) Ait. f. Loosely stoloniferous; culm 2-6 dm. high; leaves bristle-form, channeled; spikelets ovoidfusiform, few, clustered in 1-4 loose heads (chestnut-color) overtopped by the slender bracts; achene obovoid, about $\frac{1}{5}$ the length of the bristles, nearly equaling the triangular-sword-shaped acute tubercle, which is rough-serrulate on the margins. - Boggy places, Nfd. to Ont., s. to Del. and Mich. July-Sept. (Eu.) Fis. 319.

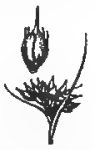

8. R. gracilenta Gray. Culms very slender, $3-8 \mathrm{dm}$. high; 320 . R. gracilenta. leaves narrowly linear; spikelets ovoid, in 2-4 small clusters,

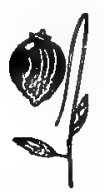
the lateral long-peduncled; achene ovoid, rather shorter than the bristles, about the length of the flat-awl-shaped tubercle.Low grounds, s. N. Y. and N. J. to Fla. Aug., Sept. (W. I., S. A.) Fig. 320 .

9. $\mathbf{R}$. oligantha Gray. Culm and leaves filiform, 1.5-4 $\mathrm{dm}$. high; spikelets very few (1-4), ovoid-fusiform; bristles plumose below the middle; achene obovoid-oblong, bearing a conical tubercle $\frac{1}{3}$ its length. - Del. to Fla. July, Aug. 821. R. oligantha. FIG. 321 .

+ + Bristles none, or 1-3 and minute; spikelets pale, 1-flowered.

10. R. pállida M. A. Curtis. Culm (3-8 dm, high) acutely triangular; leaves and spikelets as in the next species, but only a terminal dense cluster, which is less white or turns pale reddish-tawny; achene obovoid-lenticular, tipped with a minute depressed and apiculate tubercle; the delicate bristles 4-5 times shorter or obsolete.-Bogs in pine-barrens, N. J. and N.C. Aug., Sept. (W. I., S. A.) Frg. 322.

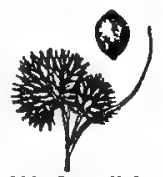

822. R. pallida,

+- +- +- Bristles long, denticulate downward, or both ways in no. 15.

+ Spikelets white or whitish, becoming tawny with age, perfecting only a single flower; stamens usually 2 ; bristles $9-12$, or even 20 .

11. R. alba (L.) Vahl. Culm slender (1.5-6 dm. high), triangular above; leaves narrowly linear or almost bristle-form; spikelets lanceolate, densely crowded in a head-like terminal corymb $(0.5-1.5 \mathrm{~cm}$. broad) and usually one or two lateral ones; achene oblong-obovate with a narrowed base, scarcely longer than the flattened-awl-shaped tubercle, shortcr than the bristles, - Bogs, Nfd. 
to Alaska, s. to Fla., Ky., the Great Lake region, and n. Cal, July-Sept. (Eurasia, Porto Rico.) Fıg. 323. Var. màcra Clarke. Coarser, 4-8 dm. high; terminal corymb often $2-4 \mathrm{~cm}$. broad. The common southern form, extending $n$. to central N. Y. and Mass.

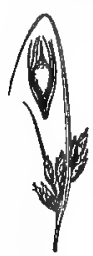

324. R. capillacea. $\rightarrow$ Spikelets chestnut-colored, few-several-flowered; stamens 8 ; bristles usually 6 .

12. R. capillàcea Torr. Culm $1-4.5$ du. high, slender; leaves bristle-form; spikelets $3-6$ in a terninal cluster, and commonly 1 or 2 on approximate or remote axilliary peduncles, oblong-lanceolate (pale chestnut-color); achene oblong-ovoid, stipitate, very obscurely wrinkled, about half the length of the (6, rarely 12) stout bristles, and twice the length of the lanceolate-beaked tubercle. - Marly bogs and wet limestone rocks, e. Que. to w. Ont., s. very locally to N. J., Pa., O., Mich., and Mo. JulySept. Fig. 324. Var. Levisteta E. J. Hill. Bristles perfectly swooth. - Tocal, Me., Ont., Mich., and Ind.

13. R. Knieskérnii Carey. Culm 1-6 dm. high, slender; leaves narrowly linear, short; spikelets numerous, crowded in 4-6 distant clusters, oblong-ovoid, 2-3 mm. long; achene obovoid, narrowed at base, equaling the bristles, twice the length of the triangular flattened tubercle. - Pine-barrens of N.J. (on bog iron ore exclusively) to Va. ; rare. July-Sept. Fig. 325.

14. R. glomerata (L.) Vahl. Culms 0.1-1 in. high ; leaves

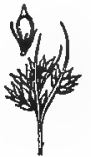

325. R. Knieskernii. linear, flat; spikelets numerous in distant clusters or heads $(0.5-1.5 \mathrm{~cm}$. broad)

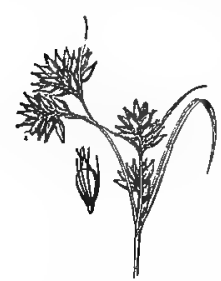

326. 'R. glomerata. often in pairs from the same sheath, ovoid-oblong; achene obovoid, margined, narrowed at base, as long as the lanceawl-shaped flattened tubercle, which equals the always downwardly barbed bristles. - Low grounds, N. B. to Ont., and southw. July-Sept. Fig. 326. Var. niscùtiens Clarke. Bristles barbed only at the tip or quite smooth.

- N. J., and southw.

Var. paniculàta (Gray) Chapm. Coarse and tall (1-2 m.); the very elongate inflorescence bearing numerous loose clusters of heads. - Md. and Ind., southw.

15. R. axillàris (Lam.) Britton. Culm stout (0.4-1.2 m. high); leaves narrouly linear, flat, keeled; spikelets very numerous, crowded in 2 or 3 or more dense globular heads $(1.5-2.5 \mathrm{~cm}$. thick), which are distant (and often in pairs), oblong-lanceolate, dark brown; achene orbicular-obovoid, margined, narrowed at base, $2-2.5 \mathrm{~mm}$. long, about as long as the awl-shaped beak; bristles twice longer,

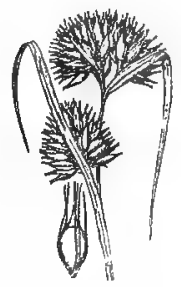

327. R. axillaris. stout, barbed downward and sometimes also upward. ( $R$. cephalantha Gray.) - Sandy swamps, L. I. and N. J. to Fla. and La. Aug.-Oct. Fig. 327.

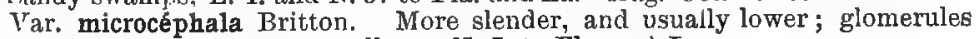
$0.7-1.5 \mathrm{~cm}$. thick; achenes smaller. - N. J. to Fla. and La.

\section{CLAdIUM P. Br. Twig Rush}

Spikelets ovoid or oblong, of several loosely imbricated scales; the lower empty, one or two above bearing a staminate or imperfect flower; the terminal flower perfeci and fertile. Perianth none. Stamens 2. Style 2-3-cleft, deciduous. Achene ovoid or globular, somewhat corky at the summit, or pointed, without any tubercle, in which it differs from Rynchospora. (Diminutive of $k \lambda d$ dos, $a$ branch, from the repeatedly branched cyme of the origina. species.)

1. C. marișcoides (Muhl.) 'Torr. Perennial; culm obscurely triangular 


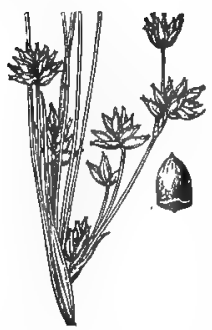

3ะ9. C. mariscoides.

(0.4-1 m. high); leaves narrow (1-3 mm. wide), channeled, scarcely rough-margined; panicle $0.5-3 \mathrm{dm}$. long, $2-5 \mathrm{~cm}$. broad, of 2-4 umbelliform cymes, the rays rigidly ascending; spikelets clustered in heads 3-10 together on few peduncles; achene mitershaped, the truncate base slightly flaring. - Bogs and wet sandy shores, either fresh or brackish, N. S. to Ont., s. to Fla., Ky., Ind., and Ia. Aug.-Oct. FIG. 328.

2. C. jamaicénse Crantz. ( $\mathrm{S}_{4} \mathrm{w}$ Grass.) 'Tall (1-3 m.) and coarse; leaves broad $(0.5-1 \mathrm{~cm}$.$) , stiff and flat,$ the margins and midrib beneath harshly serrate; panicle 3-0 dm. long, the jumerous rays bearing abundant fascicled small chestnut-colored spikelets; achene obovoid, the truncate base not flaring. ( $C$. effusum Torr.) - Shallow water, Va. to Fla. and Tex. (W. I.) Fıa. 329.

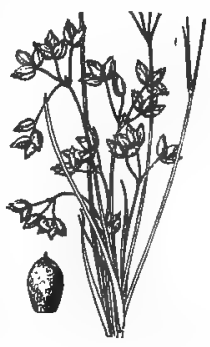

329. C. jamsicense.

\section{SCLÈrA Bergius. NuT RusH}

Flowers monoecious; the fertile spikelets 1-flowered, usually intermixed with clusters of few-flowered staminate spikelets. Scales loosely imbricated, the lower empty. Stamens 1-3. Style 3-cleft. Achene globular, stony, bony, or

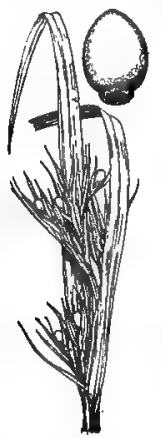

680. S. trixlomerata. enamel-like in texture. - Perennials, with triangular leafy culms, mostly from creeping rootstocks ; flowering in summer; all in low ground or swamps. Inflorescence, in our species, of terminal and axillary clusters, the lower clusters usually peduncled. (Name $\sigma \kappa \lambda \eta \rho i a$, hardness, from the indurated fruit.) * Achene smooth.

1. S. triglomeràta Michx. Culm (0.5-1 m. highn) and broadly linear ( $3.5-9 \mathrm{~mm}$. wide) leaves roughish; fascicles of spikelets few, the lowest peduncled, the upper somewhat in threes; achene ovoid-globose or depressed, $2-3 \mathrm{~mm}$. long, on an obscure crustaceous disk. - Low, usually sandy soil, e. Mass. and Vt. (according to John Torrey) to Ont., Ia., and southw. June-Aug. Fig. 330. Var. GRAcilis Britton. Culms slender (3-6 dm. long); leaves narrower; fascicles few-flowered, the lower (2-3-flowered) on very long filiform peduncles; achene narrower, 1-1.5 mm. long, acutish. (Var. minor

Britton.) - N. Y. and N. J.

12. S. oligántha Michx. Culms slender, the angles somewhat

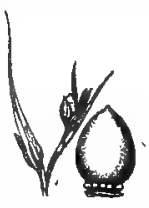
831. S. oligantha. winged; leaves linear ( $3-5 \mathrm{~mm}$. wide), smooth except the scabrous apex; lateral fascicles 1 or 2 , usually on long exserted peduncles ; achene ovoid, on a tuberculate disk. - Woods, D. C. to Fla. and Tex. May-July. FIG. 3:31.

\section{* Achene papillose, granulose or varty.}

$V$ 3. S. paucifldra Muhl. Smoothish or slightly hairy; culm slender (2-6 dm. high); leaves narrowly linear, 1-3 mm. broad; fascicles few-flowered, the lateral peounculate, sessile, or wanting; bracts ciliate; achene globose, $1.5-2 \mathrm{~mm}$. in diameter; the disk a narrow ring bearing 3 pairs of distinct minute tubercles. - Barrens and dryish meadows, N. J. to O., s. to Fla. and Tex. June-Aug. (W. I.) FIr. 332.

Var. caroliniàna (Willd.) Wood. Very slender ; leaves, culms

B32. S. pauclthra. and scales verv pubescent. - Local. Mass., O., Ind., and southw. 
Var. kansàna Fernald. Very slender and pubescent; each pair of tubercles bearing a smaller intermediate one. - Sandy soil, Cherokee Co., Kan. Fig. 333.

4. S. ciliàta Michx. Usually coarser,

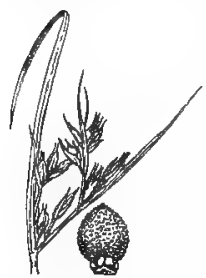

384. 5, ciliata. $0.5-1 \mathrm{~m}$. high, glabrous, or slightly pubescent below; leaves firm, 1-2.5 $\mathrm{mm}$. wide, becoming revolute; fascicles 1 or 2 , usually solitary, $0.7-2.5 \mathrm{~cm}$. long ; bracts ciliate; scales smooth; achene $2-3 \mathrm{~mm}$. in diameter, the disk bearing 3 broad shallow entire or barely notched tubercles, - Pine-barrens, etc., Va. and Mo. to Fla, and Tex. July, Aug. (W. I.) Fig. 334.

5. S. Ellióttii Chapm. Coarser and lower, $3-5 \mathrm{dm}$. high ; the culnes and flat leaves (2.5-6 $\mathrm{mm}$. wide) pubescent; fascicles 2 or 3 , usually subapproximate, forming an interrupted head $1.5-3.5 \mathrm{~cm}$. long; bracts coarsely ciliate; scales ciliate on the back; achene with 2 low broad tubercles, each 2 -lobed. - Pine-barrens and

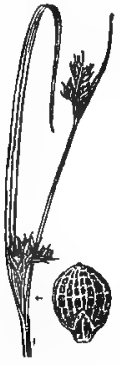

856. S. reticularis. dry ground, Va. and Mo., southw. MayJuly. (W.I.) FIg. 335.

\section{*** Achene reticulated or wrinkled.}

6. S. reticulàris Michx. Culms slender,

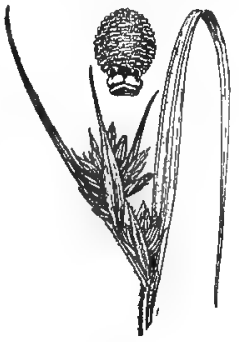

885. S. Elliottii. erect, smooth (1.5-7 dm. high); leaves linear (1.5-4 mm. wide), smooth; lateral fascicles $1-3$, loose, remote, nearly erect, on short often included peduncles; bracts glabrous; achene globose, regularly reticulated and pitted, the pits often vertically arranged, not hairy, resting upon a double greenish conspicuously 3-lubed disk, the inner appressed to and deciduous with the achene. - Damp sand and pine-barrens, local, e. 337. S. retic., Mass. to Fla.; n. Ind. Aug., Sept. Fig. 336.

Var, pubéscens Britton. Culms weak, diffuse, 0.3-1 m. high, slightly scabrous or smooth; leaves linear (2-7 mm. wide), smooth; lateral fascicles loose, on more or less elongated and drooping filiform peduncles; achene ivegularly pitted-reticulated or pitted-r'ugose with the ridges often somewhat spirally arranged and more or less hairy. (S. Tor-

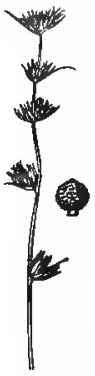

838. \$. verticillata. reyana Walp.; S. trichopoda C. Wright.) - Pine-barrens, etc., Ct. and Ind. to Fla. and Tex. (W.I.) FIG. 337.

7. S. verticillàta Muhl. Smooth; culms simple, slender (1-9 $\mathrm{dm}$. high); leaves narrowly linear ; fascicles 4-6, few-flowered, sessile in an interrupted spike; achene globose, somewhat triangular at base, rough-wrincled with short elevated vidges; disk obsolete. Pine-barrens, damp sand, and wet rocks, Mass. to Ont., Minn., and southw. July-Sept. (W. I.) FIG. 338.

\section{KOBRESIA Willd.}

Spikelets unisexual and one-flowered, or with two flowers (one pistillate, one staminate) in short spikes aggregated in elongate heads or panicles; the pistillate flower consisting of a spathiform glume (homologous with the perigynium of Carex) wrapping about the base of the achene and subtended by the scale of the spikelet. - Perennial herbs of northern regions, resembling the first group (Vigneae) of Carex, but with the perigynium replaced by the open glume which has its margins connate at base. Nimed for von Kobres, a nobleman of Augsburg and patron of botany in Willdenow's time.)

1. K. elachycárpa Fernald. Densely tufted ; the wiry compressed culms 2-6.6 


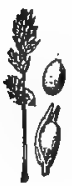

B89. K. elachycarpa.

dm. high, scabrous above; leaves $1-2 \mathrm{~mm}$. wide, flat, about lalf as long as the culms; heads slender, $1-2.5 \mathrm{~cm}$. long, of 2-7 renote appressed-ascending spikes; spikes either staminate (clavate), androgynous, or pistillate (ovoid); bracts ovate, concave; glumes ovate, subspathiform, emarginate at tip, more or less marked with green and brown; style with 2 elongate branches, the slender base becoming chartaceous and subpersistent, finally separating from the truncate subterete nerveless pale achene $1.2-1.5 \mathrm{~mm}$. lon(); stamens 2 , the anthers much exceeding the filaments. Wet banks of Aroostook R., Me.; local. June, July. Fig. 339.

\section{CẢrEX [Ruppius] L. SEDGE}

Flowers unisexual, destitute of floral envelopes, disposed in spikes; the staminate consisting of three stamens, in the axil of a bract, or scale; the pistiliate comprising a single pistil with a bifid or trifid style, forming in fruit a hard achene, which is inclosed in a sac (perigynium) borne in the axil of a bract, or seale. Staminate and pistillate flowers borne in different parts of the spike (spike androgynous), or in separate spikes on the same culm, or rarely the plant divecious. - Perennial grass-like herbs with mostly triangular culms, 3-ranked leaves, and spikes in the axils of leafy or scale-like bracts, often aggregated into heads. An exceedingly critical genus, the study of which should be attempted only with complete and fully mature specimens. ${ }^{1}$ (The classical Latin name, of obscure signification; derived by some from $\kappa \varepsilon l \rho \varepsilon \nu$, to cut, on account of the sharp leaves - as indicated in the English name Shear-grass.)

$\S 1$. Spikes mostly uniform and sessile, bearing the staninate flowers at base or apex or sometimes scatlered amongst the pistillate; stigmas 2 and achenes lenticular. - VIGNEAE [Beauv.] Koch. (For § 2, see p. 209.)

A. Staminate flowers scattered or at the base of the spikes conly in exceptional individuals and in the often dioecious (? gynoerates and $C$. exilis the entire spike staminate) $B$.

B. PRrig YNia With tili OR WINGED MargINs $C$.

C. Perigynia ascending, the tips only sometimes wide-spreading or recurved, not spongy at base, the margins winged at least toward the beak $D$.

$D$. Bracts wanting or setaceous, if broad at most twice as long as the inflorescence $\mathbb{E}$.

E. Strongly stoloniferous; culns rising from an elongated rootstock ; perigynia firm, $5-6 \mathrm{~mm}$. long

25. Not strongly stoloniferous; culms solitary or in stools $F^{\circ}$.

$F$. Perigynia less than 2 mm. broad $G$.

$G$. Perigynia $5 \mathrm{~mm}$. or more long $H$.

H. Perigynia $\tilde{\tau}-10 \mathrm{~mm}$. long; splkes long-eylindrie, pointed, $1.5-2.5 \mathrm{~cm}$. long

H. Perigynia shorter (or, when exceptionally $7 \mathrm{~mm}$. long; in shorter spikes) $I$.

I. Perigynia half as broad as lozg, plump, nerveless or obscurely short-nerved on inner face .

l. Perigynia one third as brond as long $J$.

$J$. Perigynia thin, scalo-like, scarcely distended over the achenes, distinctly nerved on the inner face and prominently exceeding the subtending scales.

Leaves at most $8 \mathrm{~mm}$. wide; spikes 8-9, glossy brown or straw-colnred, pointed.

Inflorescence oblong-orold or subcyltadric, with ascending approximate spikes .

Inflorescence monilitorm $:$ (2) $C: s$

Inflorescence subglobose or broad-ovoid, spikes crowded and divergent.
es more than $3 \mathrm{~mm}$. wide; spikes $8-14$, Lenves more than $8 \mathrm{~mm}$. wide; sptkes '8-14,
green or dull brown, blunt.

4. C. siecata

1. C. muskingumensis,

22. C. aenea.

2. C. scoparia

C. scoparia, v. condensa.

8. C.tribulotaes.

1 The perigynial characters are here based on study of mature plants. In gęneral the perigynia at the tip of the spike are less characteristic than those nearer the middle; and, if possible, the latter alone should be ased in eritical comparisons. 
J. Perigynia firm, obviously distended over the achenes, nerreless or obscurely nerved on the inver face, equaled by tho subtending scales

i Ferigynia less than $5 \mathrm{~mm}$. long $K$.

k. Perigynla thin, scale-like, scarcely distended over the achenes; leaves 3-s inm, broad.

Perigy uia with appressed tips.

Intorescence eylindric; spikes approximate

In Horescence monliform; spikes scattejed

Perigynia with spreading tips intlorescen .

Perigynia tirm, obviously distended over the achenes

$L$. Perigynia elongate-lanceolate or subulate, less than one thirl as broad as long, at most $1.4 \mathrm{~mm}$. broad.

Tips of the perjgynia conspicuously exceeding the lancesubulate dull seales.

Culuns 1-4 dm. high; leaves 1-2.5 mm. wido; spikos 8-7 $\mathrm{mm}$. long

Culms taller; leaves bioader; spikes $8-11^{\circ} \mathrm{mm}$. long

Tips of the perigynia equaled by the ovate bluntish glossy

L. Perigynia broader, nearly or quite haif as broad as long $M$.

14. Tips of perigy nia distinctly excesding the subtending scales $N$.

$N$. Leaves $2.5 \mathrm{~mm}$, or more wide $O$.

$O$. Spikes compactly flowered, the mature perigynia with recurved or spreading tips concealing the scales.

o. Spikes with ascending or slightly spreading perigynia; scales apparent $P$.

$\boldsymbol{P}$. Mature perigynia greenish or pale straw-colored, in loose spikes; intlorescence more thıtn $2.2 \mathrm{~cm}$. long (if shorter, with dark ehestnut scales).

Spikes approximate in ovoid or short-cylindric heads. Scales pale, not strongly contrasting with the perigynia .

Scales dark chestnut, strongly contrasting with the perigynia.

Spikes scattered in a moniliform inflosence (10)

$P$. Mature perigynia brown, in dense spikes; heads at most $2.2 \mathrm{~cm}$ long. in dent

$N$. Leaves narrower.

Inflorescence stiff, with crowded closely flowered spikes

Inflorescence flexuous and moniliform, or at least with the loosely flowered spikes scattered

M. Tips of perigynia eq waled by the subtending scales $Q$.

$Q$. Inflorescence stiff and erect, or at least with spikes approximate.

Spikes brown or ferruginous

$\$$ pikes brownish-white.

Q. Intlorescence flexuons, or at least with the lower spikes remote.

Perigynia nerveless or minutely short-nerved on the inner face.

Mature perigynia straw-colored or pale brown, one third as broad as lone

Mature perigynia olive-green or bronze, half as broad as long

Perigynia with strong ribs the length of the inner face spikes silvery-green.

F. Perigynia $2 \mathrm{~mm}$. or more broad $R$.

$R$. Tips of the perigynia distinctly exceeding the subtending scales $S$.

$S$. Perigynia thin and scale-like, barely distended over the achenes, one fourth to one third as broad as loug.

Perigynia $7-10 \mathrm{inm}$. long

S. Perigynia firmer, obviously distended over the achenes, Dearly or quite half as broad as long $T$.

$T$. Peligynia lance-ovate, abont half as broad as long $U$.

$U$. Leaves $2.5 \mathrm{~mm}$, or more broad

$U$. Leaves narrower.

Perigynia ristinetly about 10-nerved on the inner faces, 4-6 $\mathrm{mm}$. long.

Spikes S-12 in . long; perigynia $4.86 \mathrm{~mm}$. long

Spikes 5-8 mm. long: perigynia $4-5 \mathrm{~mm}$. long

Perigynia 3-5-nerved on the inner faces, mostly less than $4 \mathrm{~mm}$ lung.

Perigyvia with ascending inconspicuous tips

Perigynia with divergent conspieuous tips

$T$. Periarynia with broad-ovate to orbicular bodies $r$.

- 11. C. straminea.

(11) C. strominea, v, echinodes
5. C. Crawfordii.

C. Craufordit, v. vigens.

6. O. oronensis.
8. O. cristata.

10. C. mirabilis.

(1) C. mirabilis, v. tincta. mirtbilis, v, perlonga.

18. C. Bebbii.

18. C. Beblit.

11. C. straminea.

20. C. leporina.

21. C. xerantica.

7. C.pratensis.

22. C. aenea.

19. C. fornea.

1. C. muskingumensis.

2. C. scoparia.

10. C. mirabilis.

12. C. homathodes. ' hormathodes, v. invisu

$y$. Inflorescence moniliform and flexuous, with mostly clavatebased spikes. 
Spikes brownish-wbite, of closely appressed ob-

scurely beaked firm perigynia
Spikes ferruginous; the abrupt slender beaks of

the perigynia with loosely ascending or spreading tips

V. Inflorescence stiff (or, if flexuous, with brown or ferruginous spikes) $W$.

W. Perigynia 5.6-7.7 mm, long, very thin, scale-like, almost transparent; scales blunt a

W. Perigynia less thain $5.6 \mathrm{~mm}$. long, firm and opaque (when exceptionslly longer in $C$, alata, with arlstate veales) $X$.

X. Scales long-acuminate or aristate; perigynia $4-5.5 \mathrm{~mm}$. long; achenes oblong.

Spikes green or finally dull brown; scales lancesubulate; perigynia obovate, $2.8-3.7 \mathrm{~mm}$. broad, abruptly narrowed at base

15. O. alata.

Spikes becouning dark brown or ferruginous: perigynia $2.3-2.8 \mathrm{~mm}$. broad.

Spikes closely approximate; scales ovatelanceolate; perigynia ovate, tapering gradually to the beak

Splkes scattered in a flexuous inflorescence: acales lanceolate; perigynia orbiculas,
abruptly slender-beaked. (12) C. hormathodes, v. Richit

14. C. silicea.

C. harmathodes, v. Rich in

13. C. Bicknellit.

16. C. suberecta.

$\boldsymbol{X}$. Scales blunt or at most acutish.
Splkes gray-green or finally dull brown, with Splkes gray-green or finally dull brown, with
strongly appressed-sacending very firm perigynia $3.5-4$ (very rarely 4.5) $\mathrm{mm}$. long Spikes straw-colored or ferruginous, with spreading-uscending perigynia $4-5.5 \mathrm{~mm}$. long.

Inflorescence of 5-10 mostly distinet spikes. 17. C. festucacen.

Inflorescence of 3-6 approximate spikes (1i) C. festucacea, v. brevir.

D. Typs of the perigvnia equaled by the subtending scales $Y$.

$\boldsymbol{Y}$. Infloresconce stiff and erect, or at least with approximato spikes $Z$.

Z. Spikes whitish or gray-green.

Perigynia lance-ovate, $4-4.8 \mathrm{~mm}$. long, nerveless on the inner face, golden-y ellow at base.

Perigynia broad-ovate to suborbicular.

Perigynia strongly ribbed the length of the inner

face, $2 \mathrm{~mm}$. broad faintly nerved on the inuer
Perigynia nerveless or faintlo face, broader

8. Spikes bronze or ferruginous.

Perdgynia distinctly concave on the usually nerved inner face; achene $1 \mathrm{~mm}$. broad

Perigynia flat or convex on the usially" nerveless inner face, very plump; achene $2 \mathrm{~mm}$. broad .

$\boldsymbol{Y}$. Inflorescenco flexuous, at least the lower spikes remote $a$.

a. Perigynia nerveless or only faintly short-nerved on the inner face.

Perigynia ovate-lanceolate, one third as broad as long; achene $1 \mathrm{~mm}$. broad Perigynia ovate, half as broad as long ; schene $1.5 \mathrm{~mm}$.

a. Perigynia distinctly nerved on the inzer face.

Perigynia 2.8-4.4 mm. long, at most $2.4 \mathrm{~mm}$. broad, $7-13$-ribbed on the inner face, abruptly beaked.

Inflorescence of 4-9 spikes 6-10 mm. long; perigynia 2.8-4 mm. lovg.

Inflorescence of 6-15 spikes 10-it $\mathrm{mm}$. long: perigynia $3.5-4.4 \mathrm{~mm}$. long - (19)

Perigynia $1-5.3$ mm. long, $2.5-8 \mathrm{~mm}$. broad, 8-5nerped on the inner face, obscurely broad-beaked

D. Bracts leaf-like, much prolonged, the lowest $1-2 \mathrm{dm}$. long splkes crowded; perigynis subulate when mature, spongy

C. Perigynia horizontally spreading or reflexed when mature,

b. Spikes solitary and terminal, pistillate or staminate, or with flower's variously scattered.

Stoloniferous; the filiform culms at most $3 \mathrm{dm}$. high, from fll-

form rootstocks
Not stoloniferous ; the wiry culmi $2-i \mathrm{dm}$. high, in crespitose

b. Splkes 2 -several c.

c. Perigynia broadest at base; beak rough or serrulate $d$.

d. Perigynia at most half as broad as loug, finally yellowish, with sleuder beak nearly equalivg the body; Bcalos pointed 6 .

21. C. oerantica.

19. C. foenea.

9. C. albolutescens.

20. C. leporina.

23. O. adusta.

7. C. pratenois.

22. O. aønea.

19. C. foenea.

C. foenea, v. perplera

14. C. silioba.

24. C. sychnocephala.
25. C. gynoorates.

26. C. exilis. 
e. Perigynia ovate, 8-4 mm. long.

Spikes at most 12-flowered.

Inflorescence $1-8 \mathrm{~cm}$. long, the $2-6$ spikes subapproximate

Inflorescence $2-6 \mathrm{~cm}$. long, the $2-4$ spikes very re-

27. C. stelluluta. mote, the torminal with a clavate base $0.5-1$ $\mathrm{cm}$. long . . . (27)

(27) $($ stellulata, v. ormantha.

Splkes with more flowerg.

Leaves 1-2,5 mm. broed; spikos scattered, 12-20flowered; perigynia less than half as broad as long . . . . (27)

- Leaves 2-4 inm, broad; spikes mostly approximate 15-40-flowered; perigynia half as broad as

long
e. Perigynia lanccolate or ovate-lanceolate, $2.5-3$ imm. long;

C. stellulata, $v$, excelsior. intlorescence of 2-6 approximate spikes. (27)

d. Perigynla more than half as broad as long (narrower only
in var. of no. 29), firm, brownish or dark green beak one fourth to one half as long as the body.

Scales sharp-pointed; leaves $2.5-4.5 \mathrm{~mm}$. broad; inflorescence $1.5-3.5 \mathrm{~cm}$. loag; spikes $15-50$-flowered; coarse plant

Soales blunt; leaves narrower; inflorescence $1-\dot{2} \mathrm{~cm}$. long; spikes 5-15-flowered; slender plants.

Leaves $1-2 \mathrm{~mm}$. broad; perigynia faintly nerved or nerveless on the inner fice.

Perigyuia deltoid-ovate, spreading

Perigynia lance-subulate, ascending.

29. C. scirpoides.

Leaves narrower; perigynia strongly nerved (29) C. scirpoides, $\mathrm{v}$ capillacea.

c. Perigynia broadest near the middle, less than $2 \mathrm{~mm}$. broad,

very thin and conspicuously nerved, with short smooth beak; spikes remote

B. Perigria hot this-Winged, ascending from thé first, pLano-

30. C. seorsa. CONVEX $f$.

f. Yerigynia $4 \mathrm{mma}$ or more long, long-beaked.

Spikes lance-cylindric, in a loose linear-cylindric inflorescence perigynia $1-1.3 \mathrm{~mm}$. broad, strongly nerved; scales ob-

long; leaves 1-2.5 mm. broad
Spikes ovoid or ovoid-cylindric; perigynia 1.6-1.9 mm, broad, faintly nerved or nerveless; scales ovate; leaves $2-5 \mathrm{~mm}$. broad in

$f$. Perlgynia less than ${ }^{\prime}$. Perigynia with serculate beaks or majgins $h$.

g. Perigynia with serrulate beaks or margins $h$.
k. Inflorescence elongate, from slender to thickish-cylindric $i$

$i$. Perigynia ovate, broadest at base; spikes mostly or all approximate in a thick cylindric inflorescence.

i. Perigynia broadest near the middle.

Plant glaucous; leaves $2-4 \mathrm{~mm}$. broad; spikes with many appressed-ascending glaucous obscurely beaked perigynia.

Spikes 6-10 mm. long, approximate or the lowest rarely $1.5 \mathrm{~cm}$, apart; perigynia $2.3-3 \mathrm{~mm}$. long .

Spikes 4-7 mm. long, subapproximate or remote: perigynia about $2 \mathrm{~mm}$, long . . . (32) $C$.

Spikes 6-12 mm. Jong, remote, the lowest $2-4 \mathrm{~cm}$. apart green, not glaucous; leaves $1-2.5$ min. broad;

Plant green, not glaucous; leaves $1-2.5$ min. broad
spikes with few loosely spreading dark green or brown distinctly beaked perigynia.

n. Inflorescence subglobose, of $2-4$ closely approximate subglobose loosely flowered silvery spikes; perigynia oblong, beakless, rerved, 3-8.4 mm. long . . .

7. Perigynia smooth throughout $j$.

5. Spikes whitish, silvery green or pale brown.

Inflorescence elongate, at least the lower spikes scattered. Uppermost spikes divaricate-pedunculate, lowermost abtended by a leaf-like bract; perigynia usually more than $3 \mathrm{~mm}$, long.

Leaves flat, 1-2 mm. broad.

Leaves setaceons, $0.8-0.5 \mathrm{~mm}$. broad : : (87) C. trigpema, v. Billingkii.

spikes continuous in a linear-cylindric loose inflorescence, bractless or only short-bracted; perigynia $2-3 \mathrm{~cm}$. long

Inflorescence subglobose, of $2-4$ closely approximate sub. globose loosely flowered spikes; perlgynia beakless. $8 \mathrm{~mm}$. or more long 36

7. Splkes ferruginous or dark brown; terminal spikes with

84. C. bromoides.

35. C. Deweyana.

31. C. arcta.

32, C. canescens.

canescens, $\nabla$. subloliacea.

C. canescens, v. disjunctu.

33. C. Brunnescens.

36. C. tenuifiora. conspicuous clavate base; perigynia abruptly beaked culms amooth (or barsh only at tips).

32. C. canescens.

C. tenvifiora. 
Spikes distinct; the lowest $4-5 \mathrm{~mm}$. thick; the terminal $\mathrm{i}-1$. 5 cm. long; perigy nia pale, about equaled by the yellowish-brown blunt scales.

Spikes approximatt ; the lowest less than $4 \mathrm{~mm}$. thick;
phnt weak, lax; leaves involute, $0.5-1.5 \mathrm{~mm}$. broad plant weak, lax; leaves involuterigynia pale brown or drab.

Perigynia fusiform

Perigy nia sovil
A. Staminate flowers borne at the top of the spikes

34. $\because$ norvegica.

i. Feribynia ellipsoid-ovoid, scarcely compressed, nearly terete

i. Perigynia compressed $l$.

l. Spikes 2 or more in a simple or compound spicate or paniculate intlorescence $m$.

$m$. Rootstocks short and thíck; culms in terminal tufts or stools $n$.

it. Spikes green or nearly so when wature (becoming brown only when over-rine) 0 .

o. Broadest leaves $1-4.5 \mathrm{~nm}$. wide $p$.

$p$. Perigynia very spongy below the middle, the nerve-like margine inflexed $q$.

q. Perigynia with minutely serrulate margins; scales blunt; spikes mostly remote.

Perigynia quickly becoming squariose.

CuJms erect; spikes 6-15-flowered

Culms loosely spreading; spikes 2-6.flowered

Perigynia ascending in fruit

q. Perigynia with smooth margins; scales acuminate; spikes mostly approximate.

Perigynia ovoid

Perigynia lance-subulate p. Perigynia of essentially uniform (membianons) texture middle; margins slightly if at all intlexed $r$.

$r$. Perigynia 4-6 $\mathrm{mm}$. long

$r$. Perigynia less than $4 \mathrm{~mm}$. long $s$.

8. Leaves and culms stiff and wiry; heads 2 (rarely $1.5)-4 \mathrm{~cm}$. long.

Perigynia distinctly nerved $: \quad: \quad$ (44) C. Muhlenburgienbergï.
Perigynia nerveless

๙. Leaves and cutlus soft; heads $0.7-1.5$ (rarely 1.8) em. long.

Perigynia elliptic-ovate, broadest below the middle, narrowest at base

Perigynia cordate-deltoid, broadest at the cor. date or subcordate base

o. Legves 5-10 (the narrowest rarely 4.5 ) mm. wide $t$.

41. C. rosea.

(41) C. rosea, v. radiatrt.

(41) O. rosea, v. minor.

42. C. retrofiena.

C. retrofea $a, \nabla$. texensis.

43. C. muricata.

44. C. Muhlenbergï.

39. C. glareosa.

40. C. tenella.

t. Perigynia uniformly firm throughout, the outer face nerveless or vely faintly nerved $u$.

$u$. Perigynia wing-margined to the base; spikes mostly distinct in a moniliform inflorescence.

$u$. Perigynia wing-margined only above the midale; spikes approximate in a cylindric or ovoid head.

Perigynia broad-ovate to suborbicular, nearly equaled by the long-pointed scales.

Culms 2-5 dm. high; leaves subbasal.

Culns 6-12 dm. bigh; leaves remote

45. C. cephatophora.

46. C. Leavenoorthii.

Perigynia lance-ovate, twice as long as the thin white scale. . .

t. Perigynia spongy below the middle, the outer face prominently ribbed

n. Spikes yellowish or tawny when mature $v$.

v. Perigynia firm and uniform in texture, not spongy nor conspleuonsly inflated below, the beak shorter than or barely equaling the body $w$.

w. Perigynia straw-color, thin, distinetly flattened on the inner face $\infty$.

x. Membranous band of the leaf-shenth not cross-puckered; scales acuminate, rarely awned $y$.

$y$. Leaves $2-3 \mathrm{~mm}$. wide; culms firm, without thin wing-margins

y. Leaves 4-8 mm. wide; culms soft, with almost winglike angles.

Beak nenrly as long as the narrow-ovate body of the perigynum am

Beak one third as long as the broad-ovate or sub" orbicular boily of the perigy nium.

Culms 2-5 dm. high ; leaves subbasal

Culms 6-12 dm. high; leaves remote

(50)

47. C. sparganoides.

50. C. gravida.

C. grarida, v. Lasifolia

48. C. cephaloidea.

55. C. eonjuncta.

48. C. muricata.

49. $C$, alopecoidea.

50. C. gravida.

C. gravida, v. Lacifolia.

c. Membrnuous or chartaceous band of the leaf-shenth cross-puckered, at least in age ; scales awn-tipped. 
Leaves equaliog or exceeding the culms

Leaves distinctly shorter than the eulus Purigy nia lanceolate or lance-ovate

Perigynia broad-uvate to suborbieular

w. Perigynia drab to dark brown or yurplish, plump, sumawhat biconvex.

Perigynia obovoid, narrow-margined, abruptly shortbeaked

rerigynia ovoid, with 'rousded' margins, tapering gradually to a beak.

Inllorescence dark brown, stiff, dense, spiciform

Intlorescence light brown, flexuous, loose, subpaniculate

v. Perlgynia prominently enlarged and spongy at base, conspiouously nerved, the slender beak much Ionger than the body.

Perigynla 4-5 mm. long, tapering gradually from base to tip

Perigynia 6-9 mim. long, abruptly énlarged below intó a disk-like base

$m$. Rootstock slender and elongate ; culms mostly scattered, or if tufted bearing slender stolons at base $z$.

z. Perigynia thiu-inargined; heads elongate, 2-S cm. long, of numerous distinct spikes.

Perirynia wing-margined ; inner side of leaf-sheath cartilaginons to chartaceous, nerveless

Perigynia not wing-margined; leaf-sheath green and uniform]y ribbed, except at the orifice

z. Perigynia plump, not thin-margined; heads ovoid to globose, $0.5-1.5 \mathrm{~cm}$. long, of few congested spikes.

Perigynia tlat on the inner face, faintly nerved

Perigynia plano convex, strongly nerved

l. Spike solitary, terminal, globular or short-ovoid
- 51. C. vulpinoidea.

52. O. setacea.

C) setacea, $\nabla_{4}$ ambigua.

54. C. diandra.

C. diandra, $\nabla$. ramosu.

56. O. stipata.

57. C. crus-corvi.

58. C. arenaria.

59. C. Sartwellid

60. C. stenophyllit.

61. C. chordorithizu.

62. C. capitata.

\$2. Some of the spikes strictly pistillate; stigmas 3 and achenes trigonous; or, if stigneas 2 and achenes lenticular, some of the spilces peduncled. EUCAREX Griseb. $A$.

A. Achenes lenticular or plano-convex: stigmas $\mathbf{2}$ (very rarely and exceptionally 3); perigynia beakless or very short-beaked, with entire or merely emarginate orifice $B$.

$B$. Perigynia dull $C$.

C. Scales aristate or subulate-tipped, much exceeding the perigynia; pistillate spikes all peduncled $D$.

D. Seales appressed-ascending; basal sheaths rarely fibrillose.

Awns longer than the blades of the scales; spikes on widespreading or drooping capillary peduncles; old leaves revolute

Awns shorter than the biades of the scales; spikes strongly ascending; old leaves involute

D. Seales spreading ; basal leafless sheaths fibrillose.

68. C. maritima.

Leaf-sheatlis glabrous.

Perigynia inflated, wrinkled in drying.

Spikes flexuous or drooping, the pistillate $8.5-10 \mathrm{~cm}$

long. spikes suberect or spreading, i-3.5 cm. iong.

Perigynia tight, not inflated

(65) C. crinita, v. minor.

Leaf-sheaths scabrous-hispid.

Pistillate spikes $2.5-10 \mathrm{~cm}$. long, drooping . . (65) C. crinita, $\nabla$. gynandra.

Pistillate spikes suberect or spreading, $1-3.5 \mathrm{~cm}$. long $(65) C$. crintta, v. simulan.

$C$. Scales obtuse or acute, not aristate; if subulate-tipped with the upper spikes mostly sessile $E$.

$E$. Perigynia compressed, leaticular or plano-convex $F$.

$F$. Culms solitary or few; lower shonths slightly if at all fibritlose $\theta$.

$\theta$. Perigynia nerveless $H$.

$H$. Perigynia plane, not twisted at tip $I$.

I. Culms leafy and tall, somewhat caespitose; leaves scabrous on the veins and margins; basal offshoots chiefly erect $J$.

J. Green, scarcely glaucous; pistillate spikes atten-

"uate at tip
Strongly glaucous; pistillnte spikes full and

64. C. salina, v. cuspidata. rounded at tip.

Scales conspicuous, dark, nearly or quite equaling the perigynia.

Scales blunt or acutish.

Pistillate spikes 8-1.5 mm. thick . fic. C. (rourtilis.

GRAY'S MANUAL -14 
Pistillate spikes 5-8 $\mathrm{mm}$, thick Seales cuspidate. Scales hidden by the perigunia
(66) C. aquatilis, v. elation. (66) C. aquatilis, v, cuspidata (66) C. aquatilis, v. virescens.

I. Culms low; leaves mostly basal, smooth; basal offsloots chiefly repent

I1. Perigynia elongate, with an empty twisted tip . $G$. Perigynia verved.

Caespitose, not stoloniferous; green central portion of the scale about as broad as the darker margins .

Stoloniferous; green midrib of the purple or blackish scale very slender

$F$. Culms numerous in stools; lower sheaths fibrillose.

Perigynia elliptic, tapering about equally to base and apex.

Pistillate spikes dense, mostly full at base; scales blunt, slightly if at all exceeding the perigynia.

Pistillate spikes ?- $7 \mathrm{~cm}$. long

Pistillate spikes $0.5-1.5 \mathrm{~cm}$. long :

Pistillate spikes rather loose, long-attenuaté at base scales acutish . . . . . (i1)

Perigynia obovate or orbicular, shorter than the attenuate scales

E. Ferigynia plump, subterete.

Mature perigynia fleshy, pyriform or subglobose, orange or

brownish, glabrous ileshy, elipsoid, slender-stipitate,
Mature perigynia not

$\boldsymbol{B}$. Perigynia lustrous

Perigynia nerved.

Leaves flat; bracts ascending

Leaves soon involute; bracts divergent

Perigynia nerveless.

Leaves flat; pistillate spikes subglobose or short-cylindric, $5-8 \mathrm{~mm}$, thick

Leaves involute or filiform ; pistillate spikes slender, $8-\tau^{\circ} \mathrm{mm}$. thick

A. Achenes trigonous; stigmas 3 (very rarely and exceptionally 2 ) $K$.

$Z^{2}$. SPIKES GOLtTARY, TERMINAL $L$.

$L$. Spikes naked or without large leafy bracts $M$.

M. Leaves tongue-shaped, $2-4 \mathrm{~cm}$. broad

$\boldsymbol{M}$. Leaves grass-like, narrow $N$.

$N$. Spikes monoecious, green or straw-eolor; perigynla glabrous 0 .

o. Spikes staminate at tip, few-flowered ; perigynia with entire tips.

Perigynia appressed-ascending, in a linear-cylindric spike, beakless.

Perigynia 2.5-3.5 mm. long; achenes lustrous, not puncticulate, obtusely trigonous.

Perigynia 4-5 mm. long; achenes puncticulate, barely Justrous, sharply trigonous

Perigynia soon refracted, slender-beaked

o. Spikes staminate at base, many-flowered; perigynfo' with long bidentate beaks.

Scales of pistillate flowers subulate-tipped

Scales blunt

$\boldsymbol{N}$. Splkes dioecious, purplsh-brown; perigynis pubescent.

Culms shorter than the leaves; scales short-aristate, exceeding the perigynia

Culms exceeding the leaves; scales blunt, shorter than the perigynia.

L. Spikes subtended by long leafy bracts.

Perigynia somewhat 2-edged.

Scales all bracteate, overtopping the perigynia

Only the lowest scales overtopping the perigynia

Perigynia globose, with slender cylind lic beak

$\boldsymbol{Z}$. SPIKES 2 OR MORE $P$.

P. Perigynia not rigidly billentate, the orifice entire or emarginate, the teeth if present soft and thin $Q$.

Q. Terminal spike bearini some pistillate flowers $R$.

$R$. Terminal spike pistillate throughout, brown or purpllsh, the lower spike much smaller"; perigynin hniry

$\boldsymbol{R}$. Terminal spike with both stamirate and pistlllate flowers $\dot{S}$

$\mathcal{S}$. Terminal sijike plstillate only at baso: the capillary peduneles often basal; perigynia sharply angled .

S. Telminnl spike pistillate at summit, or if pistillate at base, the spikes mostly near the tip of the culm $T$.

T. Perigynia ascending $U$.

J. Schles brown to purplish-black; splkes globose, ovold or thick-eylindric $\boldsymbol{V}$.
67. C. rigida.

68, C.torta.

69. C. lenticularis.

70. C. Goodenonit.

71, C. stricte.

c. stricta, V. curtissima.

C. stricta, צ. angustutu.

(71) C. stricta, v. decoru.

72. C. aurea.

78. C. bicolor.

180. C. Grahami.

181. C. rotundata.

179. C. saxatilis.

C. saxatilis, จ. miliaris

77. C. Frasert.

75. C. Leptalea.

76. C. Harperi.

74. C. pauciflora.

161. C. squarrosa.

162. C. typhinoides.

116. C.picta.

92. C. scirpoidea.

89. C. Backit.

90. C. Willdenovoii.

91. C. Jambsii.

92. C. acimpoidea.

118. C. pedunculata. 
F. Scales shorter than or about equaling the perigynia. Scales rough-\&wned; coarse southern plant. Scales blunt; slender northern plants. Spikes sessile, closely approximate in an irregular head Spikes mostly peduncled, spreading or drooping.

$V$. Scales much exceeding the perigynia. Sprkes sessile, erect spikes peduncled, spreading or drooping

$U$. Scales white or greenish, or if very brownish the splkes linear-cylindric $W$.

$W$. Spikes mostly sessile or subsessile and erect $X$.

$X$. Spikes mostly remote; leaves glabrous, short and broad (4-10 $\mathrm{mm}$. broad)

$\boldsymbol{X}$. Spikes approximate or overlapping; leaves long and slender (1-4 mm. broad), at least the sheaths hairy.

Perigynla swooth, or when young slightly hairy. Leaves smooth. Leaves hairy

Perigynia very hairy.

Terminal spike (including the staminate base) 1.8-4 $\mathrm{cm}$. long, one tenth to one serenth as thick

Terminal spike 9-18 mm. long, one fifth to one third as thick

W. Spikes mostly peduncled, spreading or drooping $Y$.

$\boldsymbol{Y}$. Perigynia $2 \mathrm{~mm}$. or more thick.

Seales blunt or cuspidate, wuch shorter than the perigynia

Scales long-awned, usually equaling the perigynia.

$\boldsymbol{Y}$. Perigynia less than $2 \mathrm{~mm}$, thick $Z$.

$Z$. Bracts with distinct long sheaths; perigynia bluntly angled $a$.

a. Perigynia rounded or narrowed but not definitely stipitate at base $b$.

b. Perigynia less than $4 \mathrm{~mm}$. long, beakless. Sheaths glabrous; perigynia obtuse Sheaths jubescent; perigynia aontish

b. Perigynia $4 \mathrm{~mm}$, or more long. Leaves hairy ; perigynia beakless

Leaves smooth ; perigynin beaked.

Scales white or whitish; perigynia with long conic-cylindric beaks

Bcales with dark-brown margins ; perigynia with short-conic beaks

4t. Perigynia with slender stipitate bases

T. Perigynia wide-spreading or reflexed.

Perigynia orbicular to broadly elliptic, compressed, nerveless, with tiny short point: bracts erect

Perigynia terete, beaked, strong-ribbed; bracts divergent.

Beak about as long as body of perigynium.

Beak much shorter than body of perigynium . : .

Q. Teluibal spike staminate throughout $c$.

c. Lowest foliaceous bracts of the inflorescence sheathless, or with short colored sheaths or colored auricles, sometimes wanting or reduced to mere colored sheaths $d$.

d. Perigynia pubescent (if rarely glabrous, the spikes mostly crowded at the base of the densely tufted leaves) $e$.

*. Spikes subtended by colored tubular sheaths which are without green blades.

Pistillate splkes cylindric, 1-2 cm. long ; scales exceeding the perigynia

Pistillate spikes subglobose, 4-7 $\mathrm{mm}$. long; scales much shorter than the perigrnia

6. Spikes bractless or the jowermost with green foliaceous bracts $f$

$f$. Leaves and culms soft-pubescent . . . • • . 101. C. pubescens.

$f$. Leaves and culms glabrous $g$.

$g$. Leaves mostly basal, the culms naked or with short reduced leaves $h$.

h. Scales rough-cuspidate ; perigynia yellowish-brown

$h$. Bcales smooth; perigynfa green or whitish $i$.

i. Plant atrongly stoloniferous, the elongate often leafless stolons scaly-bracted and creeping.

Beak one fourth to one fifth as long as the body of the perigynium.

Beak about as long as the body'

i. Plant caespitose or slightly stoloniferous, the basa] leafy shoots strongly assurgent $j$.

j. Some (or all) of the culms short and more or less

hidden by the bases of the leaves $k$.
149. O. verrucosa

78. C. Hullemi.

79. C. atrata, v, ovata.

80. C. polygama.

111. O. paupercula.

185. C. granularis.

(81) C. triceps, v. Smithii 81. C. triceps, $\nabla$. hirsuta.

82. C. virescens.

C. virescens, v. Shoanit.

88. C. formosa.

84. C. Davisit.

85. C. gracillima.

86. C. aestivalis.

87. C. oxylepis.

146. C. debilis, vars.

147. C. venusta, v. minor 145. C. arctata.

115. C. prasina.

88. C. Shortiana.

138. C.flava.

139. C. Oederi.

120. C. Richardsoni.

119. C. concinna.

102. C. camyophyllea. 
k. Remnants of the old leaves persisting as stiff tufted sheds; scales noumbate, sharp-polntod, nourly or quite equaling the perderynia.

Porligynia 1.7-2.4 inm, thlek.

Boak nearly ur quite as long as the body of the porlgynlutr.

Perigyula puberulont

Perlgynla glabrous

Beak one thid as long as tho body

2. Perigynla 1.8-1.6 mm. thick soales blunt or acuto, wuch shortor than the perlgynia

3. Culms olongnte, none of thom hlddon nt the base of the plant $l$.

z. Porigynin inuoh oxceoding the scalos; spifres olosely

l. Porigynia nearly or quito equinled by tho scales in.

$m$. Matiro lonvos $8-5 \mathrm{~mm}$. wide. (If excoptlonally narrower, the splkas r'moto)

$m$. Maturo lesvas $1-2.5 \mathrm{~mm}$. Wide (if exceptlonally bronder, the eptkes approximate).

Stitulnate and piatlliato splkes all sosslle.

Bcales of pletiliate splkes whitlab ur greenlsh .

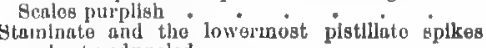
sliert-pedunclod

o. Culms loafy, the leavos olongato $n$.

n. Pistiliate splkos sessilo or subsessilo; basal sheathe fibrillose.

Staminato aplke overtopping the pistllate.

Btaminato splke shortor than the plstlliate.

08. O. umbellata.

(08) O. umbellata, v. lonea. mbellata, v. brevirostris. 94. C.nioro-marginala.

95. C. deflowa.

90. $\mathrm{I}^{2}$ allicans.

97. C. communis.

98. C. varia.

(98) C. varia, v. colorrilu.

99. O. novar-angliat.

154. C. neattia

n. Pistillate spikes (or nt lonst the lower) distinotly poduncled; sheaths not ibrilloso.

Leaves solt, rlbbon-llko, dark green, the lower bract excoedling the euln; porfigynh long-beaked .

Leaves firm, short, glaucous; tho bracts short; perigynla baroly beakod

l. Perligynla glabrous o.

o. Lasves detaceous, basal ; culms sotaceous, naked; bracts reduced to pale tubular sheaths

o. Leaves flat or plicula $p$.

p. Lenves lanceolate, $1,5-3 \mathrm{~cm}$. bioad, flrm and evergreen; culms slender, bearing numerous tubular colored shonths and remoto slendor spikus

y. Teaves linear or linen"-lanceolate, jesa than 1.5 cin, broad " $q$.

$q$. Perlgynta boakless or with minute ontile benks $r$.

$r$. Plstilato spikes mostly on capillary peduncles, wide-spreadlug or drooplug \&.

w. Soalos brownlsh or purplish, nearly equaling or excoed. Ing the compressed short-tipped pertgynin $t$.

$t$. Splkes globoso to oblong-cylindric, rarely $2 \mathrm{~cm}$. long; senles uxceoding the pelirynin $t$.

$u$. Scales long-nttenuate wilh subulate tipe, much oxceecling the perlgy nia,

Scales dark bruwn or purplish throughout.

Plstillate aplkes 4-8 inu. long

Plstillate splkos 1-1.6 om. long

Scales green with pale-brown or yollowish marptus

111. O. panperoula.

150. O. scabrata.

108. C. glauca.

117. O. eburnea.

191. O. plantaginea.

(Ii1) C. pauperoula, v, pullena

u. Scales obtuso or aoute, barely excooding thu porfigynin.

Leaves involutu, $0.5-1$ mm. wlde, glaueurs; scalas

Leavos flat, $1-8 \mathrm{~mm}$. wille, dark "groun; scales

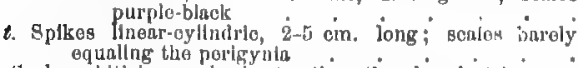

equallng the porlsynta
o. Scales whitlah, inuch shortor thin tho gharply trigonons
attonuato perlgynla

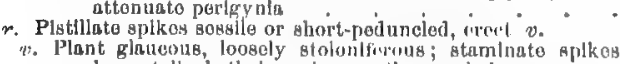
long-stalkad, thelr scules mostly purplo-brown.

Lonves 2.5-5 imm. wicle, revolute in dyylug, barsh; culms harsla; perlgynia bruwn .

Leaves $1-8 \mathrm{~mm}$. wldo, becomlng pllonto or involute,

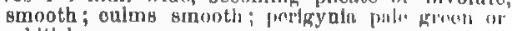

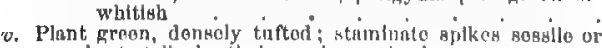

112. O. Umosa.

118. C. rarifiora.

11. O. litloralts.

115. O. prastna

108. O. olawiot.

114.4. r. limitit. mhort-Btalked, thatr soalos !mlu brown or straw culor. 
Spikes all sessile and approximate; perigynia obovoid, prominently ribbed, retuse, with a distinct short entire beak

Lowest spiko periuncled; perigynia narrowly' obovoid, faintly nervod or nervoless, narrowed to tho beakless tip.

q. Perigynia dístinetly beaked io.

w. Spikes sessile, or the lowermost short-pediceled, erect or oblique; the bracts very long and much exceding the inflorescence, rarely 5 mul. brond.

Leaves involute

Leaves flat.

Boak about equaling body of perigynium .

Benk much shorter than body of perigynium

w. Syikes mostly long-pediceled, sprending or drooping, if sessile and eroct the bracts more than $5 \mathrm{~mm}$. wide $\infty$,

x. Leaves broad (usually $5 \mathrm{~mm}$. or more); scales strongribbed; spikes dense, the perigynia firm, dull, videspreading $\%$.

$y$. Leaves soft, ribbon-like, dark green; lower bract $5-10$ $\mathrm{mm}$. wide, much exoeeding the inflorescence . .

y. Lerves firm, glaucous; lower bract $1-4 \mathrm{~mm}$. wide, about equaling the inforescence.

Perigynin spreading-ascending, glaucous, faintly-nerved or nerveless, gradually tapering to the short beak.

Perigynia squarose, deep green oi brownish, strongly Ininy-ribbed, abruptly beaked .

$x$. Leaves narrow (usually less than $5 \mathrm{~mm}$, wide); Bcales thin nerveless or slightly nerved; spikes loosely flowered, the thin lustrous perigynia strongly ascending $z$.

*. Perigynia abruptly contractod to an awl-shaped beak as long as the body

*. Perigynia gralually contracted to the beak.

Leaves pubescent; pistillate spikes $5-8 \mathrm{~mm}$. thick

Leaves glabrous; pistillate spikes $2-4 \mathrm{~mm}$. thick .

o. Lowest foliaceous bract of the inflorescence with a prominent closed green sheath $a$.

a. Perigynia nerveless or with few nerves most prominant toward the base, not uniformly and conspicuously nerved from base to orifice (excepting the marginal nerves) $\boldsymbol{b}$.

b. Plant caespitose, scarcely stoloniferous, the rootstock short and thick; perigynia with long-attenuate beaks $c$.

c. Perigynia abruptly contracted to a slender beak as long as the body.

Perigynia hairy, remote

Perigynia smooth, approximate

v. Perigynia gradually contracted to the beak $\boldsymbol{d}$.

$d$. Pistillate spikes oblong-cylindric, densely flowered.

Spikes 5-10 mm. thick.

Leaves glabrous; scales whit

Leaves pubescent; scales brown

Spikes 2-4 mm, thick.

Plant $0.5-1.5 \mathrm{dm}$. high; spikes approximate .

Plant taller; spikes remote

d. Pistillate spikes linerr-cylindric $e$

c. Basal sheaths reddish-purplo or castaneous $f$.

$f$. Basal lenves 6-10 mm. broad, scabrous at base; perigynia stipitate, ovoid-trigonous

3. Basal leaves 3-7 mm. broad, sinooth at bise; perigynia fusiform, obscurely trigonous

Perigynia glabrous.

Perigynia mostly overlapping.

Perigynia 6-9 mm. long, twice as long as the

white scales
Perigynia 4.5-6.5 mm. "long; the scales strawcolor or greenish-brown.

Porigynin twice as long as the scales; leaves $2-4$ mm. wide

Perigynia one third longer than the scales; leaves 4-6 mm. wide (146)

Perigynia alternate and mostly remote, not over-

$$
\text { lapping }
$$

Perigy nia hairy

e. Basal sbeaths dull pale brown
109. C. abbreviatu.

110 C. pallescens.
187. C. extensa

138. C.fava.

189. C. Oederi.
150. C. scabrato.

148. C. vermucosa.

149. C. macrokotea.

141. C. Zongirostris.

143. C. castansa.

144. O. capillaris.
140. C. assiniboinensis

141. C. longirostris.
142. C. cherokeensis.

148. C. castanea.

144. C. capillaris.

144) C. capillaris, v. elongata
145. O. arctata.

146. C. aebulis.

b. Plant loosely stoloniferous, the elongate rootstoks slender perigynia beakless or with short or abrupt beak $\boldsymbol{g}$.

g. Perigynia hairy

g. Perigynia not hairy $\boldsymbol{h}$.

(146) C. debilis, v. interjecta (146) C. debilis, v. pubera (127) C. lawifiora, $\mathrm{v}$. leptonervia h. Perigynta beakless or with a very short oblique tip i.

102. C. caryophyhea, 
i. Perigynia granulose-roughened; spikes very remote, sessile or short-stalked, in nearly all the leaf-axils

\section{O. Crawoer.}

i. Perigynia not granulose ; spikes (except ín lare cases loug-stalked basal ones) borne only toward the summit of the culm $j$.

j. Leaves white-glaucous, quickly becoming plicate or involuto . . . .

f. Lenvos green, shightly if at all glaucous, flat, in age becoming revoluto.

Culms obtusely angled, smooth throughout

Culms acutely angled, scabrous at summit. Spikes slender-cylindric, $3.6 \mathrm{~mm}$. thick.

Sptkes mostly close-tlowered, the perigynia overlapping

Spikes loosely flowered, most of the perigynia remote $(106)$

104. C. livida.

105. C. panicea.

106. C. tetanica. Spikes oblong-cylindric, $6-10 \mathrm{~mm}$, thick . : (106) C. ettuict, v. Afeadti.

$\boldsymbol{h}$. Perlgynis with a straightish slender beak.

Culm stiff, harsl above; spikes stiffly erect, densely manyHowered

Culm flexuous, smooth" throughout; spikes spreading or drooping, loosely few-flowered . . a. Perigynia with numerous uniform nerves from base to orifice (ex-
treme specimens of nos. $106,107,108$ might be sought here) $k$.

107. C. polymorpha.

108. C. vaginata. $k$ Tall and slender, with linear-cylindric spikes

$\boldsymbol{k}$. I.ow, or if tall with thick-cylindric to globose spikes $\boldsymbol{l}$,

$\boldsymbol{l}$. Perigynia sharply angled, with flane foces (for'ws of $\left\{^{2}\right.$. laxi-

fora might be sought here) $\boldsymbol{m}$.

m. Perigynia $5-\boldsymbol{t}$ inm. long; staminate spikes dark brown or purplish

m. Perigynia $2-4^{\circ} \mathrm{mm}$. long; staminate spike straw-color or pale brown $\boldsymbol{x}$.

$\boldsymbol{n}$. Basal leaves $1-\hat{\mathrm{cm}} \mathrm{cm}$ broad; pistillate spikes sessile and erect

n. Basal leaves narrower, or, if rarely $i \mathrm{~cm}$. broad, the spikes flexuous on capillary peduncles.

Scales acuminate or aristate; lowest bract slightly if at all overtopping the inflorescence.

Basal leaves 6-12 $\mathrm{mm}$. broad.

Perigynia 2.5-3.2 mo. long

Perigynia 3.8-4 mm. long .

Basal leaves $2-5 \mathrm{~mm}$, broad florescence

2. Perigynia obtusely angled, or plump and scarcely if at all angled

147. C.venusta, v. minor.

122. C. Careyana.

123. C. platyphylla.

124. C. laxiculmis.

(124) C. laxiculnis, v. copulata. 125. O. digitalis.

126. C.ptychocarpa.

o. Perigynia strongly ascending, beakless or with broadly conic oblique tips; spikes mostly scattered; bracts strongly ascending $\boldsymbol{p}$.

$\boldsymbol{p}$. Perigynia fusiform to fusiform-obovold, tapering subequally to the conic tip and the long gradually contracted base, obtusely trigonous $\boldsymbol{q}$.

$\boldsymbol{q}$. Perigynia bearing distinct elevated ribs; scales smooth $\boldsymbol{r}$. $\boldsymbol{v}$. Perigynía with soveral ribs on each face $s$.

s. Staminate spike prominent, usually projecting above the pistillate; culms slightly if at all ancipital $\boldsymbol{t}$.

t. Plstillate spikes distinct, not closely crowded. Perigynia plurnp-obovoid, the short beak abruptly bent to one side.

Plstillate spikes mostly $1.5-8 \mathrm{~cm}$. long .

Pistillate spikes mostly $0.5-1.3 \mathrm{~cm}$. long

(127) $C$. lasififora, r. gracillima

Perigynin ellipsoid-fusiform, the elongate beak slightly oblique.

Perigynia appressed-ascending in an alternate-flowered spike. (12T) $C^{\gamma}$. laxįfora, v. patulifolia.

Perigynia oblique or divergent, mostly overlapping in the densish spike.

Basal leaves $\tau-12 \mathrm{~mm}$. broad

Basal leaves $3-6 \mathrm{~mm}$. wide.
t. Uppermost pistillate spikes approximate at the

(127) C. Laxifiora, v. Michauxii.

base of the staminate

127. C. laxelfora. among splke small and nearly or quite

Basal leaves elongate, linear-lanceolate, 5-14 mm. brond

Basal leaves lanceolate, i.5-4 $\mathrm{cm}$. broad

(12') C. laxiflora, v. blanda. - (127) C. laxeiftora. v. Latifolia. ə. Perigynia nerveless or with $1-3$ nerves on eqch face

(127) C. laxifiora, v. leptonerrin 
$\boldsymbol{q}$. Perigynia closely impressed-nerved; scales roughawned.

Sheaths pubescent

Sheatbs glabrous

p. Perigynia oblong-ovoid to obovoid or" glabose, rounded to the sessile a abruptly skort-stipitate base $\boldsymbol{u}$.

$\boldsymbol{u}$. Closely caesjitose, not stoloniferous $v$.

$v$. Culms 1-6 cin. high, more than twice exceeded by the leaves and bracts.

$\boldsymbol{v}$. Culms taller; bracts proportionately shorter $\boldsymbol{w}$.

$\boldsymbol{w}$. Uppermost bract slightly if at all overtopping the staminate spike; perigynia impressed-nerved

w. Uppermost hract much overtopping the staminate spike (if rarely shorter, the perigynia with prominent ribs) $x$.

$\boldsymbol{x}$. Perigynia impressed-nerved $\boldsymbol{y}$.

$y$. Style jointed below the middle.

Leaves thin and soft, slightly if at all glaucous.

Spikes borne princlpally in the upper axils.

Perigynia oblong.

Perigynia turgid, beakless, scarcely angled

Porigyuin scarcely turgid, trigonous, narrowed to a beak

Perigynia subglobose
Spikes borne from the lowest as well as the upper axil

182) $C$. grisea, v. globosa.

Leaves thick and firin, very glaucous

$\boldsymbol{y}$. Style jointless; perigynia golden-brown:

$\boldsymbol{x}$. Perigynia with elevated ribs and short point or beak.

Perigynia plump-ovoid to globose

Perigynia oblong

$\boldsymbol{u}$. Culms solitary, from slender stoloniferous base (135)
Perigynia wide-spreading or squarrose, slender-beaked

(is5) 135. C. granularis. spikes mostly toward the summit of the culm; bracts divergent $\approx$.

z. Leaves involuts ; perigynia spreading-ascending

$\boldsymbol{z}$. Leaves flat; perigynia squarrose $a a$.

aa. Beak about as long as the body of the perigynium, often bent, at least in maturity.

Staminate spike sessile or yery short-stalked, sometimes pistillate at tip; pistillate spikes mostly contiguous.

Fruiting spikes $9-12 \mathrm{~mm}$. thick, short-cylindric or globose; benks spreading in all directions

Fruiting spikes $6.5-8 \mathrm{~mm}$. thick, mostly shortcylindric perigynia mostly wide-spreading and straigh tish

Staminate spike usually peduncled ; pistillate mostly remole, the curved perigynia usually retrorse

132. C. grisea.

128. C. Fitchcockiana

129. C. olagocarpa.

180. C. katahdinensis.

181. C. conoidea.

82) C. grisea, v. rigida.

C. grisea, v, angustifolia.

138. C. glaucodea.

134. C. flaccosperma. 186. C. Crawei.

\section{7. $C$, extensa.}

138. C. flava.

8) C. fiava, v. rectirustro

(138) C. flava, v. elatior.

aa. Beak distinctly shorter than body of the perigynium, straight or slightly bent, ascending or horizontally spreading.

Staminate spike usually peduncled; pistillate scat-

tered
Staminate spikc usually sessile, often more or lesi
pistillate ; pistillate spikes mostly approximate

P. Bertk or tip of perigynium sharply bidentate, the teeth aoerose bb.

139. C. Oederi.

bb. Ferigynia firm and tough, closely investing the achene ca.

on. Teeth less than $1 \mathrm{~mm}$. long, ereot $d d$.

idd. Perloynia pubescent.

Leaves involute-filiform

Leaves broad and tlat.

Scales mostly equaling the densely hairy perigynla . . 152, C. lanuginosa.

Seales mostly shorter than the sparsely hairy perigynia 158, C. Boughtoniz.

dd. Perigynia glabrous.

Perigynia broadly ovoid

Perigynia narrowly ovoid.

Perigynia more than $5 \mathrm{~mm}$. long, becoming lustrous. . 159. C. riparia.

Perigynia less than $5 \mathrm{~mm}$. long, dull and minutely papillose ${ }^{\circ} 160$. C. acutiformis.

cc. Teeth more than $1 \mathrm{~mm}$. long, divergent or recurved ee.

ee. Seales of staminate spike hairy.

ee. Scales of staminate spike glabrous.

Perigynia hairy.

Perigynia ovoid, in slender cylindric spikes

Perigynia lance-subulate, in short-cylindric or ovoid spikes

Periry nia glabrous.

157. C. hirta.

158. C. trichocarpa.

- (158) C. trichocurpa, v. turlinata. 
Perigynia obscurely ribbed.

Perigynia prominently ribbed.

Sheaths hairy

Sheaths glabrous

60. Perigynia thim and papery, usually more or less inflated $f f$

(158) C. trichocarpa, v. Deweyt

ff. Staminate spike solitary or none or the terminal only partly

staminate (rarely a very short secondary eplke at the base of the other) $\not g$.

$g$ g. Leaves involute-filiform; perigynla broadly conic-ovoid, 5-6 mon. long

gg. Leaves flat $h$.

$h h$. Perigynia obeonic or brondly obovold, truneate or abraptly rounded above to long subulate beaks; terminal spike often mostly pistillate.

Perigynia longer than the scales.

Pistillate scales subulate-tipped or awned

Pistillate scales blunt

Perigynia stiorter than the rough-awned scales.

$h h$. Perigynia from subulate to ovoid or globose, if abruptly beaked the termival spike staminate $i z$.

$i$. Pistillite splkes oblong-cylindric or narrower $y$.

j3. Perigynia scarcely inflated, rigid, lance-subulate, slenderstipitate, with prominent rigid crowded ribs, soon retrorse.

Teeth of the perigynia nearly parallel.

Teeth of the perigynia strongly divergent:

$j i$. Perigy nia inflated, if stipitate large and bladder-like $k k$.

$k k$. Mature perigy uia less than $12 \mathrm{~mm}$. long $l l$.

il. Pistillate scales mostly with thin serrulate awns; perigynia not falcate $\mathrm{mm}$.

$m m$. Staminate scales with rough awas; plants crespitoso.

Perigynia slightly inflated, narrowly conic; achenes obovoid . . .

Perigynia with bladdery-inflated subglobose bodies and abrupt beaks; achenes narrowly ellipsoid-ovoid.

Pistillate spikes 1.5-2 cm. thick; perigynia 7-10 $\mathrm{mm}$, long

Pistillate spikes $1-1.8^{\circ} \mathrm{cm}$. thick; perigynia $5-\dot{7}$

mm, long
$m m$. Staminate scales smooth, scarcely if at all awned;
plant loosely stoloniferous

plant loosely stoloniferous
n. Pistillate scales smooth, or only the lowest
serrulate $n n$.
nn. Plant caespitose, forming tussocks; perigynia

n. Pistillate scales smooth, or only the lowest
serrulate $n n$.
nn. Plant caespitose, forming tussocks; perigynia somewhat falcate.

Spikes mostly clustered and sessile at the tip of the culms; perigynia retrorse.

Perigy nia 8-10 mm. long

Perlgynia 5-6 mm. long . 169 . C. retrorsa.

spikes scattered, mostly long-peduncied.

Perigynia wide-spreading or retrorse

Perigynis ascending

nn. Plant not caespitose, the culms solitary from slen-

dor rootstocks; perigynia not falcate . 170. C. Halei.

kk. Mature perigynia more thar, $12 \mathrm{~mm}$. long.

Achene rhomboid-ovotd, the angles prominently nipplo-tipped

Achene narrowly ellipsoid-ovoid, the angles scarcely nipple-tipped.

Plotillate spikes mostly crowded, sessile or sub-

sessile

156. C. oligosperma.

161. C. squarrosa.

162. O. typhinoides.

163. C. Frankit.

164. C. Pseudo-Oyperus.

165. C. comosa.

166. C. hystericina.

167. C. Iuriata.

67) C. lurida,. gracilis.

168. C. Schwoiniteii.

C. retrorsa, v. Robinsonii.

(169) C. retrorsa, F. Hartii. C. retrorsa, v. Dracounii.

172. C. lupuliformis. remote * * (178) C. lupulina, . perlunculata.

3i. Pistillate spikes globose or subglobose oo.

oo. Staminate scales prolnnged into rough thin awas

oo. Strminate scales smooth $p p$.

$p p$. 'Teeth of the beak erect or ascending $q q$.

qq. Mature perigy nia green.

Perigy nia elongate-risomboid, cuneate at base.

Perigynia glabrous

Perigynia hispidulous:
Perigynia ovoid to narrowly conic, rounded at вика.

Perigynia ovoid-conic, half as broad as long

Perigynia lance-conic, one fourth to one third

- 167. C. Zurida. as broad as long

(175) C. intumescens, v, Fennaldit.

$q q$. Mature per'igynia straw-colored.

174. C. Grayi.

14) C. Grayi, v. hispidula.

175. c. intumescens. 
Leaves $0.5-1.5 \mathrm{~cm}$. broad

Leaves $1.5-3.5 \mathrm{~mm}$. broad $p p$. Teeth of the beak strongly refineted

f. Staminate spikes 2 or more $r r$.

$r r$. Achene distinotly broader than long, its faces strongly concaved

mr. A chene longer than broad, the faces flat or slightly convex $s$. ss. Culin thick and spongy at base, generally smooth and bluntly angled above; leaves prominently nodulose.

Perigynia Hask-shaped, rather abruptly contracted to the beak, 3-6 mm. long.

Stout ; spikes cylindric, $2-10 \mathrm{~cm}$. long

Slender; spikes globose or short-cylindric, $1-2 . \dot{5} \mathrm{~cm}$

Perigynia tapering gradually to the beak, $0.5-1 \mathrm{~cm}$. long (183)

s8. Culm scarcely spongy at base, sharp-angled above, often harsh; leaves slighily if at all nodulose $t$.

tt. Beak of the perigynia usually slightly roughened or serrulate.

Pistillate spikes cylindric, $2.5-5 \mathrm{~cm}$. long. $1-1.5 \mathrm{~cm}$, thick

Pistillate spikes globose to thick-cylindric, 1-4 cul. long, $1.5-2 \mathrm{~cm}$. thick

tt. Beak of perigynia smooth $u u$.

uv. Mature perigynia 5-6.5 mm. thick .

$u \eta$. Mature perigynia not more than $4 \mathrm{~mm}$. thick $v v$.

vv. Perigynia ascending, straight; leaves firm, $2-7 \mathrm{~mm}$. wide.

Perigynia bladdery inflated.

Perigynia ovoid-conic, tapering gradually to the

Perigynia rounded-ovoid, rather abruptly tapering to the beak.

Perigynia $6 \mathrm{~mm}$. long.

Spikes eylindric, $2-7 \mathrm{~cm}$. Iong .

Spikes globose to short-cylindric, $1-2.5 \mathrm{~cm}$

Perigynia 4-5 mm. long

Perigynia barely inflated, conic-subulate

wn. Perigynia retrorse or wide-spreading. slirhtly falcate

leares soft and ribbon like, $0.5-1 \mathrm{~cm}$. wide

1. C. muskinguménsis Schwein. Culms 1 m. or less high, very leafy ; leaves subcordate at their junction with

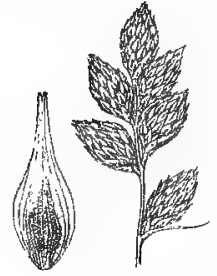

341. C. scoparia. the loose green sheatls, those of the sterile shoots crowded and almost distichous; inflorescence oblong, of 5-12 appressed-ascending pointed spikes; perigynia very thin and scale-like, barely distended over the achenes. Meadows, swamps, and wet woods, O. to Man. and Mo. July, Aug. FIG. 340.

2. C. scopària Schkuhr. Culms 0.2-1 m. high, mostly slender and erect; leaves narrow (at most $3 \mathrm{~mm}$. wide), shorter than the culm; inflorescence of 3-9 straw-colored or brownish nostly shining and ascending approximate ovoid pointed spilces (0.5-1.5 cw. long) ; perigynia 5 (rarely 4)-6.5 mm. long. - Low ground or even dry open soil, rarely in woods, Nfd. to Sask, and

184. C. bullata.

176. C. folliculatr.

177. O. Micharxiana.

178. O. subulata.

171. C. gigantea.

183. C. rostrata.

C. rostrata, v. ambigens.

C. rostratu, v. utriculata.

184) C. bullcita, v. Greeniz.

185. O. Tuckesmani.

182. C. vesicaria.

182) C. vesicaria, v, monile.

C. vesicuria, v. distenta

(182) O. vesicaria, v. jejund C. vesıcaria, v. Raeana 169. C. retrorsa.

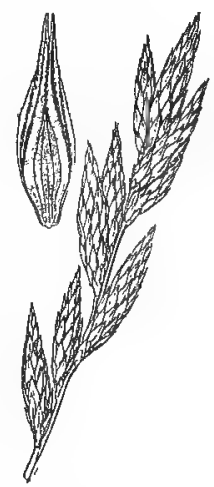

340. C. muskingumensib.

Ore, and southw. May-Aug. Fig. 341. Var. Monilifórmis Tuckerm. Spikes scattered, the lowest remote. - Less common. Var. condensa Fernald. Spikes spreuding, crowded in a globose or subglobose head. - N. B. to Ont. and Ct. Fig. 342.

$\checkmark$ 3. C. tribuloides Wahlenb. Culms loose, 0.3-1 m. high, sharply trigonous; leaves soft and loose, 3-8 mm. broad, numer-

342. C. scoparia, ous, the upper often nearly or quite overtopping the culm, those r. condenss, of the sterile shoots crowded and somewhat distichous; info- 


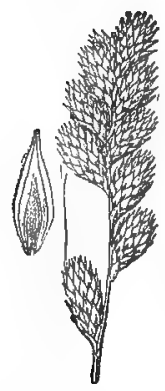

348, C. tribuloides.

rescence compact, the 8-14 obovoid ascending somewhat crowded gray-green or dull-brown spikes 7-12 $\mathrm{mm}$. long; perigynia 3.7-5 $\mathrm{mm}$. long, their tips appressed. - Swales and rich open woods, N. B. to Sask, and southw. June-Sept. Fir. 343. Var. TURBATA Bailey. Spikes remote. Less common.

Var. redúcta Bailey. Inflorescence usually flexuous, at least the lowest spikes scattered ; perigynia with loosely recurved tips. (Var. moniliformis Britton, in part.) - Gulf of St. Lawrence to Ont., s. to Ct., N. Y., and Ia. FIG. 344.

4. C. siccàta Dewey: Culms slender, 1-6 dm. high; leaves stiff, 1-3 $\mathrm{mm}$.

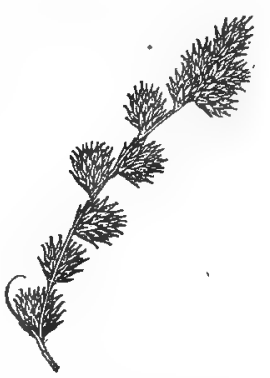

344. C. trib., v. reducta.

wide; inflorescence of 3-7 approximate or scattered glossy brown spilces, the staminate and pistillate flowers variously mixed or in distinct spikes; perigynia

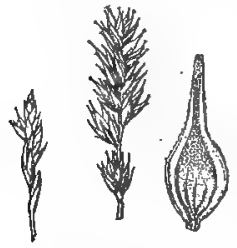

345. C. siccata. obviously distended over the achene, $2 \mathrm{~mm}$. broad, usually with distinet serrulate wings. - Dry or sandy soil, Me. to B. C. and Alaska, s. to Mass., Ct., N..Y., O., Mich., and westw. May-July. Frg. 345.

5. C. Crawfordii Fernald. Slender, the cuims forming close stools; leaves narrow (1-2.5 mm. wide), often equaling or exceeding the culms ; inflorescence dull brown, subcylindric or ovoid, often subtended by an elongate filiform bract; spikes 3-12, subcylindric or narrovoly ovoid, ascending, 3-7 $\mathrm{mm}$. long, approximate; the linearlanceolate perigynia plump at base, about $1 \mathrm{~mm}$. wide. (C.

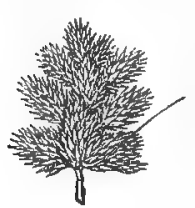

34i. C. Crawfordii, v. vigens. scoparia, var. minor Boott.) - Open soil, rarely in woods, Nfd. to B. C., s. to n. Ct., and Mich. JuneSept. Fig. 346. Var. vìgens Fernald. Stouter throughout; culms $3-6 \mathrm{dn}$. high; leaves $2.5-3 \mathrm{~mm}$. broad; spikes mostly greener and longer, densely crowded. - Less common. Fig. 347.

6. C. oronénsis Fernald. Culms few in loose stogls, tall and erect, 0.5-1 m. high, sharply angled and harsh above; leaves smooth, 2.5-4 mm. broad, much shorter than the culms ; influrescence thick-cylindric, erect; spikes 3-9, ascending, dark broun, rhomboid-ovoid, pointed, 0.5-1 cm. long; scales dark, voith pale scarious margins; perigynia appressed, about $4 \mathrm{~mm}$. long, $1.3 \mathrm{~mm}$. broad, very narrowly winged above.-Dry

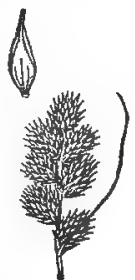

346. C. Crawfordir

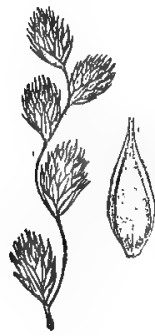

49. C. pratensis. fields, thickets, open woods, and gravelly banks, Orono and Bangor, Me. June-July. Fig. 348.

7. c. praténsis Drejer. Culms smooth and slender, 3-6 $\mathrm{dm}$. high, overtopping the smooth flat (2-3.5 $\mathrm{mm}$. broad) leaves; inflorescence slender, flexuous, moniliform; spikes 3-7, silvery-brown, mostly remote, pointed, few-flowered, $7-1.7 \mathrm{~mm}$. long, mostly long-clavate at base; perigynia ovate-lanceolate, 4.5-6.5 mm. long, 1.5-2 mm. broad. - Open woods, clearings, and prairies, Lab. to B. C., s. to N. S., n. Me., L. Superior, ete. June-Aug. (Greenl.) Fig. 349.

8. C. cristata Schwein. Culms $1 \mathrm{~m}$. or less high, harsh above; leaves soft and fat, 3-7 $\mathrm{mm}$. broad, often equaling 
the culms, sheaths loose; inflorescence usually dense, cylinaric to ellipsoid; spiles $6-15$, globose, closely flowered, greenish or dull brown, 0.5-1 cm. long; perigynia 3-4 mm.

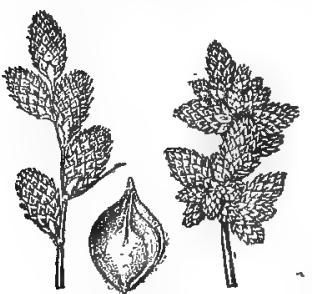

851. C, albolutescens. long, their tips rosulate-spreading. (C. tribuloides, var. Bailey; C.cristatella Britton.) - Swales and wet woods, e. Mass, and Vt. to P'a., Mo., Sask., and B. C. June-Aug. FIG. 350.

9. C. albolutéscens Schwein. Culms stout and stiff, $2-8 \mathrm{dm}$. high ; leaves erect, long-pointed, pale green, 2-5 mm. wide, shorter than the culms; inflorescence

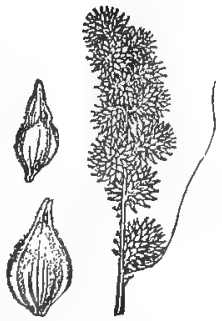

350. C. cristata. stiff, linear-cylindric to subglobose, with or without elongated bracts; spikes 3-30 (sometimes compound), conic-ovoid to subglobose, $0.6-1 \mathrm{~cm}$. long; perigynia $2-3 \mathrm{~mm}$. broad, rhombicovate to suborbicular, pale, with short deltoid firm greenish tips. (C. straminea, vars. foenea 'Torr, and cumulcta Bailey.) - Damp or even dry soil, chiefly on the coastal plain, N. B. to Fla. and Mex., rarely inland; also L. Huron to Man. July-Sept. Fig. 351.

10. C. mirábilis Dewey. Culms 0.8$1.5 \mathrm{~m}$. high, very loose and smooth; leaves soft and thin, 2.5-6 $\mathrm{mm}$. wide, the sheaths rather loose; spikes 4-12, greenish, subglobose or ovoid, 5-9 mm. long, mostly approximate; perigynia lance-ovate, 3-4 $\mathrm{mm}$. long, with divergent tips. ( $C$. straminea, var. Tuckerm.) - Dry banks, open woods, and rich copses, Me. to Man., N. C. and Mo. June, July. Fig. 352. Var. PerLónga Fernald. Spikes remote. - Less common. Fig. 353.

Var. tíncta Fernald. Spikes 3-7, ovoid, approximate, brown-tinged; scales brown with a pale margin. - iv. B. and n. N. E. - Plant comparatively small.

11. C. stramínea Willd. Culms very 353. C. mir., v. perl. slender, 3-7 dm. high, smooth except at summit; leaves 0.5-2 mm. wide; spikes 3-8, yellow-brown, or rarely green ovoid or subglobose, 4-8 mm. long, usually forming a moniliform or linear-

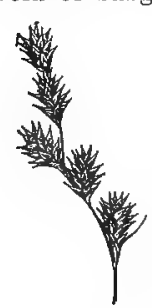

855. C. str., ఛ. echin. cylindric flexuous inflorescence; perigynia rarely $4 \mathrm{~mm}$. long, lance-ovate, the inner faces 3-5-nerved or nerveless, the ascending tips inconspicuous. (C. tenera Dewey.) - Meadows, dry banks, or open woods, N. B. to B. C., Ky., and Ark. June-Aug. Frg. 354.

Var. echinddes Fernald. Tips of the slightly longer perigynia divergent and conspicuous. - Vt. (Brainerd); Ont. and Mich. to Ia. FIG. 355.

12. C. hormathodes Fernald. Culms slender and flexuous, sharply angled, smooth except at summit, 3-9 dm. high; leaves shorter than or rarely exceeding the culms, very ascending, $1-2.5 \mathrm{~mm}$. wide; inflorescence slender, moniliform (or on late culms congested), of : $3-!$ broxdly ovoid brownish spikes (8-12 mm. lona), with or without subtending elongated bracts ; perigynia

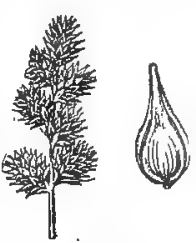

1.

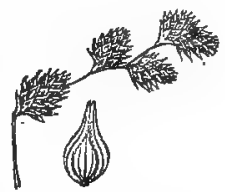

354. ('. straminea

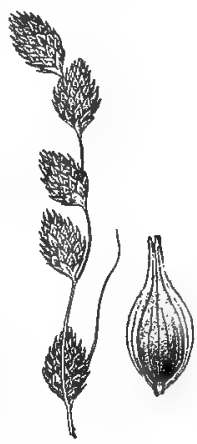

856, C. hormathodes, 


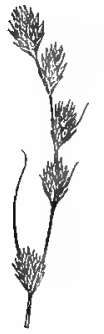

357. C. holm. v. invisa,

elongate-ovate, ascending or rarely spreading, distinctly about 10 . nerved un each jace; scales lance-attentuate or aristate. ( $C$. straminea, var. (aperta Boutt; C. tenera Britton, not Dewey.) Fresh or brackish narshes, commonest near the coast, e. Que. to Del. and İ.; B. C. June-Aug. Fis. 356. - Lower sma!l-spiked (5-8 mm. long) plants have been separated as var. INviss (W. Boott) Fernald. Fig. 357.

Var. Ríchii Fernald. Perigynia 4-5 mm. long, with suborbicular bodies abruplly contracted to conspicuous loosely ascending or spreading tips. ( $C$. tenera, var. Fernald.) - Mass. to I. C. Fig. 358.

13. C. Bicknéllii Britton. Culms comparatively stout, 4-9 dm. high, smonth except at summit; leaves ascending, rather short and firm, $2-4.5 \mathrm{~mm}$. broad ;

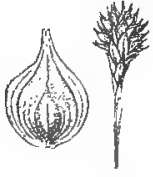

358. C. borm , v. Richit.

Terminal spike and perigynium.

inflorescence of 3-7 silvery-brozon or greenish ovoid, obovoid or subglobose approximate or sliqhtly remote spikes (8-1t mm. long); perigynia ascending,

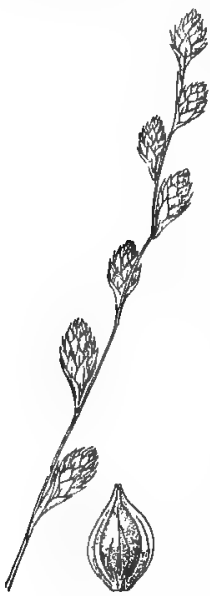

360. C. silicea. with broadly ovate or suborbialler bodies, the tips becoming conspicuous, broadly ving-maryimed, when miture becoming "lmost translucent and about 10 nerved on each face. ( $C$. strominea, var. Crawe $i$ Buott. ) - Dry or rocky soil, Me. to Man,, N. J., O., and Ark. - May-July. Fig. 859.

14. C. silícea Olney. Culms slender, stiff, 3-8 dm. high ; leaves erectish, usually g7aucous, 2-4.5 mm. wide, often becoming involut:;

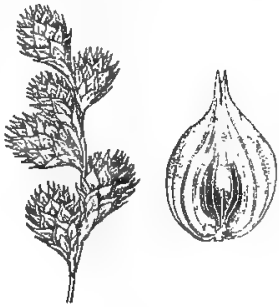

859. C. Bicknellii. intlorescence of $3-12$ usually remote conic-ovoid and clavate based whitish spiliss (1-1.5 cm. long); perigynia firm and opaque, 4-5 mm. long, 2.2-3 $\mathrm{mm}$. broad, short-beaked, broad-winged, the body distinctly 3-5-nerved on the inner, 6-12-nerved on the outer face. (C. foenea, var. subulonum Gray.) - Sands and rocks near the sea, Gulf of St. Lawrence to N. J. June-Aug. Fig. 360.

15. C. alàta Torr. Culms rather stout, smooth except at summit, 0.5-1 m. high; leaves mostly short and har:h, $2.5-4.5 \mathrm{~mm}$. wide, the sheath green and strongly nerved nearly or quite to the narrow subchartaceous auricle; head oblong or ovoid, of 3-8 compact approximate conic-ovoid or subulindric spikes ( $8-15 \mathrm{~mm}$. iong); perigynia appressed-ascending, firm and opaque, broadwinged, very faintly nerced or nerveless, much broader

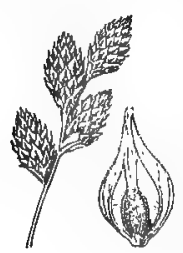

862, C. suberecta. than the usually rough-awned scales. (C. straminea, var. Bailey.) - Marshes

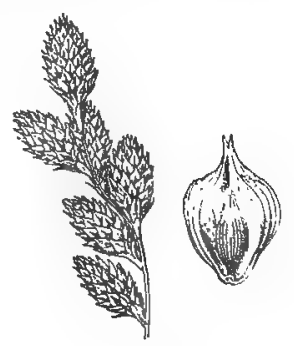

361. C. alata. and wet woods, N. H. to Mich. and Fla.; mostly coastal. June, July. Fig. 301.

16. C. suberécta (Olney) Britton. Similar; slender; the 3-5 irregulurly clustered spikes finally towny or ferruginous; perigynia weate, $4-5 \mathrm{~mm}$. long, $2.3-2.8 \mathrm{~mm}$. broad; scales lance-ovate, mostly aunless. (C.tenera, var. Olney; $C$. alata, var. ferruginea Fernald.) - Ont. and O. to Mich., Ill., and Ia. Frc. 362.

17. C. festucàcea Schkuhr. Culms stiff, 0.j̃-1 m. high; 
leaves stiff, erect, shorter than the culms, $2-4 \mathrm{~mm}$. wide, the sheath with a thin barely nerved or nerveless pale band extending down from the membranous auricle; inflorescence cylindric, rarely ovoid, of 5-10 distinct or rarely approximate subglobose or broadly ovoid-conic yellow-brown or greenbrown ascending spikes (7-12 $\mathrm{mm}$. long); perigynia broadovate to suborbicular, strongly 7-15-nerved on the outer, nerveless or faintly nerved on the inner face; achenes suborbicular. (C. straminea, var. 'I'uckerm.) - Dry or rocky soil, Me. to Man. and Pa. June-Aug. Fig. 363.

Var. brèvior (Dewey) Fernald. Lower,

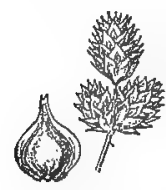

3t). C. fest.,

v. brevior. rarely more than $0.6 \mathrm{~m}$. high, and more slender; spikes 3-6, approximate or subapproximate. (C. straminea, var. Dewey.) Commoner, reaching B. C., Ark., etc. MayJuly. Fig. 364.

18. C. Bébbii Olney. Culms rather slender, 2-6 dm. high, smooth except at tip; lecues mostly shorter, ascending but not stiff,

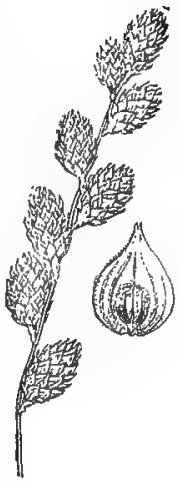

363. C. festuencea. $1.7-4.5 \mathrm{~mm}$. wide; inflorescence short, com-

pact, ovoid to ellipsoid, brown, 1-2 cm. long, of 3-12 globose or ellipsoid

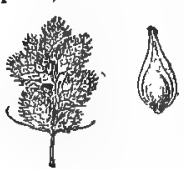
ascending spikes (5-8 $\mathrm{mm}$. long); perigynia narrowly ovate, 3-3.5 mm. long, 1.5-2 mm. broad, mostly dull brown, and loosely ascending, faintly few-nerved or nerveless; scales oblong, bluntly acuminate. (C.tribuloides, var. Bailey.) - Low grounds, Nfil. to w. Mass., N. Y., Ill., Col., B. C., and northw. June-Aug. Fig. 365. 19. C. foènea Willd. culms slender and 365. C. Bebbil. lax, smooth except at tip, $3-9 \mathrm{dm}$. high ; leaves soft and loose, pale green or glaucous, mostly shorter, $2-4 \mathrm{~mm}$. broad; inflorescence linear-cylindric or moniliform, erect or flexuous, of 4-9 globose or ovoid clavate-based appressedascending whitish-green or silvery-brown spikes (6-10 $\mathrm{mm}$.

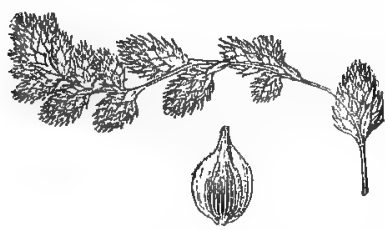

367. O. foenea, v. perplexa. long) ; perigynia ovate, 3-4 mm. long, 1.8-2.2 $\mathrm{mm}$. broad, appressed-ascending, finally a little spreading. - Dry woods and banks, Me. to B. C. and Md. July. Fig. 366. Var.

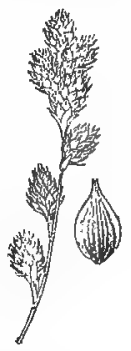

866. C. foenea. PERPLíxA Bailey. Coarser, and often taller; inflorescence heavier, mostly nodding, the 6-15 spilies larger (1-1.7 cm. long), the terminal ones often crowded; perigynia 3.5-4.4 mm. long. - Commoner, Nfd. to Man. and Va. June-Aug. Fra. 367.

20. C. LePorina L. Culms stiff and ascending, 2-8 dm. high ; leaves mostly short and firm, $1.5-4 \mathrm{~mm}$. broad ; inflorescence from subglobose to cylindric, of 3-6 obovoid or ellipsoid approximate or subapproximate brown or ferruginous ascending spikes (0.8-1.4 cm. long); perigynia $3.8-4.5 \mathrm{~mm}$. long, 1.8-2.3 mm. broad, ascending. - Dry hillsides, rockg banks, etc., local, Nfd. to Mass. and N. Y. ; and occasional on ballast southw. JuneAng. (Nat. from Eu.) Fig. 368.

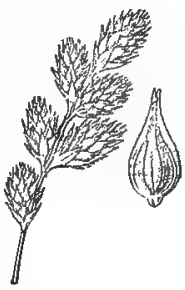

868. C. leporing.

21. C. xerántica Bailey. Culms stiff, scabrous above, $3-6 \mathrm{dm}$. high; leaves short, mostly near the base, 2-3) $\mathrm{mm}$. broad; inftorescence linear-cylindric, of 3-6 distinct ascending ellipsoidal brownish-white spikes (8-13 $\mathrm{mm}$. long); 369. C. xerantica. perigynia appressed, 4-4.8 $\mathrm{mm}$. loug, 2-2.3 $\mathrm{mm}$. broad, the inner 
face nerveless or only slightly nerved at the golden-yellow base. - Open prairies, Man. to Kan., and westw. July. FiG. 369.

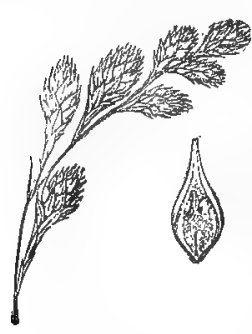

370. C. aeneg.

22. C. aènea Fernald. Culms smooth and wiry, but more or less flexuous at tip, $0.25-1.2 \mathrm{~m}$. high; leaves much shorter, rather soft and flat, $2-4 \mathrm{~mm}$. broad; inflorescence loosely cylindric or monitiform, of 3-12 obovoid mostly clavate-based brownish or ferruginous spikes $(0.8-2.5 \mathrm{~cm}$. long, in luxuriant plants often peduncled or compound); perigynia loosely ascending, dark green or brown when mature, 4-5 mm. long, 1.9-2.7 mm. broad; achene 1.3-1.7 $\mathrm{mm}$. broad. - Open woods, dry banks, or rarely in low ground, Iab. to B. C., s. to Ct., Mich., etc. May-July. Figr. 370.

23. C. adústa Boott. Culms stifly erect, smooth, 2-8 dm. high ; leaves usually shorter, $2-5 \mathrm{Inm}$. broad; inflorescence erect, dense and stiff, ovoid or cylindric,

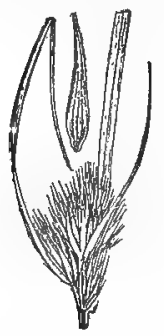
often subtended by a stiff prominent bract, of $3-15$ simple or compound full and rounded brownish

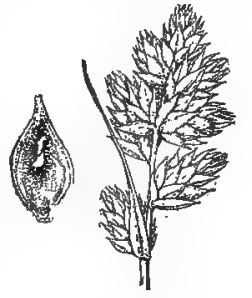

371. C. adusta. spikes (6-12 $\mathrm{mm}$. long); perigynia 4-5 mm. long, 2-3 mm. broad; achene 1.8-2.1 $\mathrm{mm}$. broad. -- Dry woods, gravelly banks, etc., Nfd. to Mt. Desert I., Me., w. to Minn. and far northw. June-Sept. Fig. 371.

24. C. sychnocéphala Carey. Culms smooth, 2-6 dm. high; leaves soft, ascending, $2-4 \mathrm{~mm}$. wide; bracts very unequal; spikes 4-10, subcylindric, 8-15 $\mathrm{mm}$. long, forming a dense ovoid or ellipsoid head; perigynia lance-subulate, $5 \mathrm{~mm}$. long, barely $1 \mathrm{~nm}$. wide, firm, slightly nerved or nerveless. - Meadows, ditches, and wet 372. C. sychnocephala. sandy soil, N. Y. and Ont. to Ia., Sask., and B. C. July, Aug. Fig. 372.

25. C. gynócrates Wormsk. Culms 0.6-3 dm. high, mostly exceeding the setaceous leaves; spikes $0.5-2 \mathrm{~cm}$. long, some staminate and linear, with oblong mostly blunt-tipped scales,

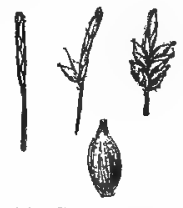

378. C. gynocrates. others staminate above, with one or more pistillate flowers below, others thickcylindric and strictly pistillate, with 6-12 rather plump subterete but thin-edged

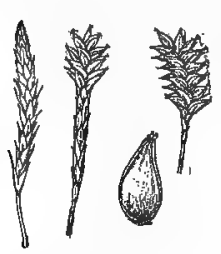

374. C. exilis. strongly nerved conic-beaked perigynia. (C. Redowskiana Bailey, not C. A. Mey.) - Swamps and bogs, Lab. to Alaska, s. to N. B., Me., N. Y., w. Pa., Mich., and Col. June-Aug. (Eurasia.) Fig. 373.

26. C. exilis Dewey. Culms rigid, usually much exceeding the filiform stiff leaves; spikes mostly solitary, $1-3 \mathrm{~cm}$. long, staminate, pistillate, or with the flowers variously situated; perigynia ovate-lanceolate, with sermlate thin margins, strongly convex on the outer, flatish and fero-nerved or nerveless on the inner face. $\longrightarrow$ Bogs and meadows near the coast, locally from Lab. to N. J. ; rarely inland to Vt., Ont., N. Y., Mich., and Minn. May-Aug. Frg. 374.

27. C. stellulata Good. Caespitose; the culms rather wiry, 1-4 dm. high; lenves shorter than or equaling the culms, 1-2.5 mm. wirle; inflorescence linear-cylindric, i-3 cm. long, of 2-6 subapproximate or slightly remote

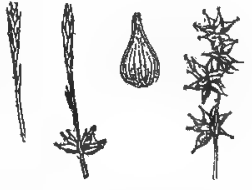

375. C. stellulatn. subglobose or subcyliudric 3-12-flowered spikes; perigynia finally yellonish, navrowly ovate, early ascending, later wide-spreading, faintly nerved or nerveless 
on the inner face, 3-4 $\mathrm{mm}$. long, $\frac{1}{3}$ or $\frac{1}{2}$ exceeding the ovate pointed brownish scale. (C. echinata, var. microstachys Boeckl. ; C. sterilis Anr. auth., not Willd.) - Open low grourd, Lab. to Alaska, s, to

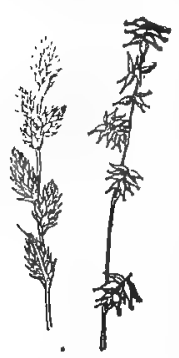

377. C. stell., v. excelsior. Md., O., Mich,, etc. June-Aug. (Furasia.) Fra. 375.

Var. ormántha Fernald. Inforescence 2- $; \mathrm{cm}$. long, of 2-4 very remote 3-9-flower" spilces, the terminal one with a clavate base $0.5-1 \mathrm{~cm}$. long; perigynia as in the typical form, mostly twice as lons as the scales. - Less common. Firi. 376.

Var. excélsior (Bailey) Fernald. Tall and slender, $0.3-1 \mathrm{~m}$. high; inflorescence $3-5.5 \mathrm{~cm}$. long, spikes 3-9, distinct, only the lowermost remote, 12-20-flowered, at first ellipsoid, with the perigynia ascending, later subglobose, with strongly reflexed perigynia $\frac{1}{s}$ longer than the scales. - Nfd. to Mich. and N. C. FIG. 377.

Var. cephalántha (Bailey) Fernald. The coarsest form, 3-7 dm. high; inforescence cylindric or slightly moniliform, $3-7.5 \mathrm{~cm}$. long, the 4-8 short-cylindric spikes 15-40-fonered; perigynia ovate. (C. echinata, var. Bailey.) - Nfd. to Mich., B. C., and N. C. FIG. 378.

Var. angustàta Carey. Extremely slender or almost setaceous, 1-2 dm. high (in shade often higher); leaves $0.5-1.5 \mathrm{~mm}$. wide, inflorescence $0.75-2.5 \mathrm{~cm}$. long, the few 3-15flowered spikes approximate; the divaricate perigynia lanceolate or lance-ovate, 2.5-3 $\mathrm{mm}$. long, twice exceeding the scales. (O. echinata, var. Bailey; C. sterilis, var. Bailey.) - N. S. co Ct., w. Que., Ill., and Wisc. FIG. 379.

28. C. stérilis Willd. Coarse, $1 \mathrm{~m}$. or less tall; 379. C. stell., $\checkmark$. angustata.

leaves flat, shorter than or equaling the culms; inflorescence of $3-6$ subglobose or thick-cylindric densely flowered olive-green crovided or distinct spikes; the thick strongly many-nerved perigynia broad-ovate, 3-3.5 $\mathrm{mm}$. long, 2-3 mm.

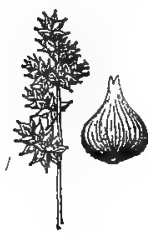
broad, squarrose or with recurved tips. (C. echinata, var. conferta and $C$. atlantica Bailey.) Coastal bogs and pine-barrens, Nfd. to Fla., rarely inland to n. Me., Adirondack Mts., N. Y., and Mt. Sorrow, Pa. June, July. Fig. 380.

29. C. scirpoides Schkuhr. Slender, 1.5-5 dm. high; the leaves $1-2.5 \mathrm{~mm}$. wide; the $2-5$ spikes

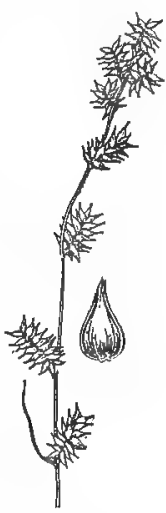

375. C. stell. v. cephalantha. all fertile, all sterile, or variously mixed, usually subglobose, 4-5 $\mathrm{mm}$. in dianeter, the terminal long-clavate at base; peri380. C. sterilis, gynia firm, plump, olive-green or -brown, more or less nerved or essentially nerveless, broadly deltoid-ovate, obscurely shortbeaked and with slightly thickened margin, 2.3-3.2 $\mathrm{mm}$. long, 1.5-2 mm. broad, finally wide-spreading or recurved, much exceeding the oblong or ovate blunt scales. (C. interior Bailey.) - Damp or wet soil, e. Que. to Hudson Bay, B. C., Fla., and Ariz. May-Aug. Fig. 381.

Var. capillàcea (Bailey) Fernald. Stiff, culms almost bristle-like; leaves about $0.5 \mathrm{~mm}$. broad, often involute; perigynia strongly nerved. (C. interior, var. Bailey.) - N. H. to N. Y., N.J., and Pa.

Var. Josselýnii Fernald. Perigynia lance-subu-

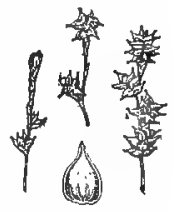

late, barely 1 mm. broad, mostly ascending. - By St. John R., Me.

30. C. seórsa E. C. Howe. Culms soft, in loose stools, 3.5-6.6 $\mathrm{dm}$. high; leaves shorter, soft, pale, 2-4 inm. broad; inflorescence B82. C. seorsa. 2.5-7 cm. long, of 2-6 mostly remote subglobose or ellipsoid 6-20. 
Bowered green spikes $(3.5-7 \mathrm{~mm}$. Iong), the terminal usually with a long-clavate base, the lower often subtended by a setiform bract; perigynia elliptic-ovate, with a narrow substipitate base, wilde-spreading or recurved, much exceeding

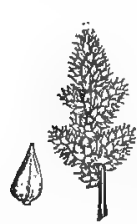

383. C. arota. the acutish scales. - Wet woods and swamps, e. Mass, to centr. N. Y, and Del. May, June. Frg. 382.

31. C. árcta Boott. Pale green or somewhat glaucous; culms rery soft, in loose stools, $1.5-6 \mathrm{dm}$. high, often overtopped by the soft flit leare (2.5-4 min. broad); intlorescence of ij-19 ovoid or subcylindric spikelets (6-11 wm. lıng); perigynia cordate-ovate, with a rather definite beak, strongly nerved on the outer, faintly on the inner face, 2-3 mm. long, 1.2-1.5 mm. broad, somewhat exceeding the acute often brown-tinged scales.

(C. canescens, var. polystachya Boott.) - Wet woods, alluvial thickets, etc., Me. and Que. to B. C., s. to Mass., N. Y., Mich., and Minn. June-Aug. Fic. 383.

32. C. canéscens I. Culms soft, in loose stools, $1.5-6 \mathrm{dm}$. bigh; lerves soft and flat, shorter than or exceeding the culms;

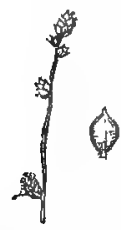

885. C. canesc., จ. subloliacea. inflorescence 2.5-5 cm. long, of 4-7 short-cylindric to narrowly obovoid appressed-ascending approximate or slightly remote spikes; perigynia ovoid-

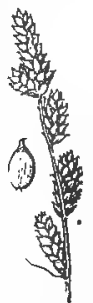

884. C. canesces. oblong, usually serrulate toward the short-pointed tip, 1.3-1.7 mm. broad, more or less nerved on both faces, somewhat exceeding the ovate pointed scale. - Wet places, Lab. to B. C., locally s. to Ct., and Mich. May-Aug. (Eurasia.) FIG. 384 .

Var. subloliàcea Laestad. Smaller; the spikes short-oblong or subglobose ; perigynia smaller, barely $2 \mathrm{~mm}$. long, smooth throughout. - Similar range. (Eu.) Fig. 385.

Var. disjúncta Fernald. Tall and lax, 3-8 dm. high ; inflorescence elongated, flexuous, 0.5-1.5 dm. long; spikes 5-8, ellip-

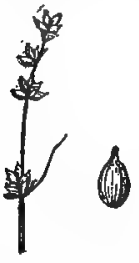

B87. C. brunnescens. soid to cyliudric, all but the terminal remote; perigynia as in the species. - Nfd. to Wisc., O., and $\mathrm{Pa}$, common. FIG. 386.

33. C. brunnéscens Poir. Very slender and lax; culms 1.5-7 dm. high; leaves soft, flat; inflorescence 1-6 cm. long, of 3-6 more or less remote or approximate subglobose or ellipsoid spikes (3-7 mm. long); perigynia 2-2.7 $\mathrm{mm}$. long, 1-1.5 mm. broad, serrulate at the base of the distinct beak, loosely spreading when mature. ( $C$. canescens, vars, alpicola Wahlenb. and vulgaris Bailey.) - Open woods and dry rocky banks, Nfd, to B. C., s. to N. (.., Mich., Wisc., etc.

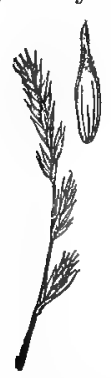
June-Aug. (Eu.) FIg. 387.

$\checkmark$ 34. C. bromoìdes Schkulur. Very slender and lax, green, scarcely glaucous; the culms $3-8 \mathrm{dm}$. long, mostly exceeding the soft flat leaves; inflorescence loosely subcylindric, $2-5.5 \mathrm{~cm}$. long, of 2-6 approximate or slightly scattered spikes (0.6-2. cm. lonq); beak of the perigynium $\frac{1}{2}-\frac{2}{8}$ as long as the strongly nerved body, slightly exceeding the oblong pointed scale. - Rich low woods and swamps, N. S. to Ont, and southw. May-July. Fig. 388.

35. C. Deweyàna Schwein. Very lax, glautcous; the culms $2-12 \mathrm{dm}$. long, much exceeding the soft flat leaves; inflorescence flexuous, $2-6$ sas C. bromoldes. cm. long; the 2-7 snikes. 3-12-Aiowered (5-12

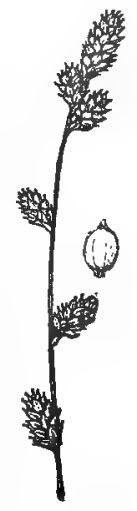

886. Ci, canesc. v. disjuncta.

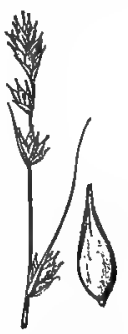


$m m$. long), the upper subapproximate or scattered, the lowest very remote, usually subtended by an elongate slender bract; beak about $\frac{1}{2}$ as long as the body of the perigynium, somewhat exceeding the ovate acuminate or short-cuspidate pale scale. - Rich open woods and banks, Que. to B. C., s. to Pa., Mich., Wisc., N. Mex., etc. May-Aug. Fig. 389.

36. C. tenuiflora Wahlenb. Lax, the culms $2-6 \mathrm{dm}$. long, mostly exceeding the very narrow $(0.7-2 \mathrm{~mm}$. broad) pale green

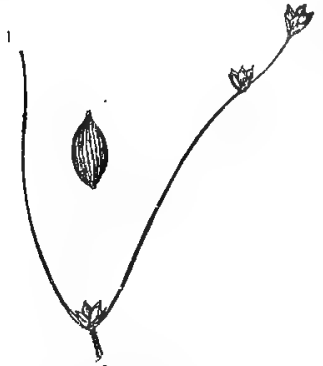

391. C. trisperma. leaves; spikes :3-10-flowered; perigynia $1.5-1.7 \mathrm{~mm}$. broad, with the bluntish tips smooth or rarely with 1 or 2 teeth, about equaled by the

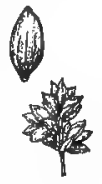
ovate or ovate-oblong white scale. - Bogs and wet inossy woods, local, Hudson Bay to Man., s. to N. B., Me., Mass., N. Y., Mich., Wisc., and Minn. June, July. (Eu.) - Apparently hybridizes with C. trisperma in n. Me. Fig. 390.

37. C. trispérma Dewey. Culms almost filiform, 2-7 dm. long, usually much overtopping the soft narrow (1-2 mm. wide) leaves; the 2 or 3 spilces 2-5-flowered; the finely many-nerved beaked perigynia $3.3-3.8 \mathrm{~mm}$. long, $1.6-1.8 \mathrm{~mm}$. broad, slightly exceeding the ovateoblong pale obtuse to mucronateacuminate scales. - Mossy' woods and bogs, Nfd. to Sask., s. to Md., the Great Lakes, and Neb. June-Aug. Fig. 391.

Var. Billingsii Knight. Leaves nearly setaceous, $0.8-0.5 \mathrm{~mm}$. wide; the 1 or 2 spikes 1 - or 2-flowered; perigynium 2.5-3.3 mm. long. - Boggy spots, local, N. S. and Me. to N. J.

38. C. norvégica Willd. Glaucous and freely stoloniferous; culms smooth and soft, 1-4.5 dm. high, mostly overtopping the soft flat rather narrow (1-2.5 mm. broad) leaves; inflorescence $1.5-5.5 \mathrm{~cm}$. Iong, of 2-6 ovoid or thick-cylindric spikes, the lower 5-12 mm. long; perigynia faintly nerved, $2.5-3.3 \mathrm{~mm}$. long, 1.6-2 mm. broad, conic-rostrate, usually abruptly contracted

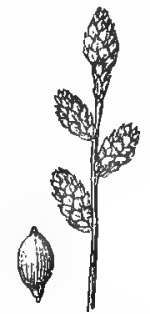
to a substipitate base. - Damp, usually brackish soil, locally on the coast from Me, northw. June-Aug. (Eu.) Fig. 392.

$\times$ C. Hélola Blytt is a hybrid of this with no. 32, occurring in N. B. and n. Eu.

39. C. glaredsa Wahlenb. Culms acutely angled, mostly curved, scabrous at tip, 1-3 dm. high, once and a half or twice exceeding the flaccid narrow blue-green leaves; inflorescence narrowly ellipsoid or obovoid, $0.7-2 \mathrm{~cm}$. long, with 2-4 appressed-ascending obovoid spikes, the lower 4-9 mm. long, the terminal larger, 6-11 mm. long; perigynia fusiform, with narrow smooth beak, striate-nerved, $2.5-3 \mathrm{~mm}$. long, barely $1 \mathrm{~mm}$. broad, exceeding the ferruginous or purplish whiteedged ovate acutish or obtuse scales. - Shores of the lower St. Lawrence, Que., and northw., local. June-Aug. (Iu.)

Var. amphigena Fernald. Perigynia broadly

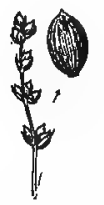

894. C. tenello. ellipsoid, ovoid or obovoid, 1.3-1.9 mm. long, abruptly beaked. - Commoner, Arctic coast to

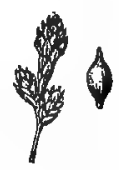

898. C. glareosa, v. amphigena. Que. and N. B. (Eurasia.) Fig. 393.

40. C. tenélla Schkuhr. Exceedingly slender, 1-6 dm. high, in loose tufts ; leaves flat, soft, and weak, mostly shorter than the culm; spikes 1-3-flowered, or the terminal 4-6-flowered, scattered on the upper part of the culm, the bracis obsolete or the lowest present and very short; perigynium very plump, finely nerved, the minute beak entire, longer than the white scale, usually at length splitting and exposing the dark achene. - Cold swamps and wet woods, Nfd. to B. C., s. to N. J., Pa., Mich., Col., etc. May-Aug. (Eu.) Frg. 394. 
41. C. rosea Schkuhr. Always slender and weak, erect, 2-7 dm. high. cultns exceeding the narrow (1.5-3 mm. broad) leaves ; spikes 3-8, 6-15-flowered, the uppermost aggregated, the others $0.5-2.5 \mathrm{~cm}$. apart, the lowest usually with a setaceous bract; perigynium lance-ovoid, planoconvex, shining, nerveless, rough on the edges above, with a flat bidentate beak, perfectly squarrose, very green, $2.5-4 \mathrm{~mm}$. long, about twice longer than the transincent white scale. - Open dry woods, N. S. to Man., and southw. May-July. Fig. 395.

Var. radiàta Dewey. Much more slender, the loose culms sometimes almost capillary; spikes 2-5, scattered, 2-4-flowered; perigynium mostly narrower. - Rich woods, e. Que. to Ont, and southw.; commonest in the Alleghenies.

Var. minor Boott. Erect, very slender; spikes 3-10-flowered; perigynia ascending. - Local, s. Me. to Mich.

395. C. rosea.

42. C. retroflexa Mubl. Similar; stiff, 1-6 dm. high; spites $3-8$, mostly aggregated, the lower 1 or 2 slightly

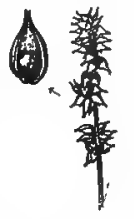
separated and commonly subtended by a conspicuous bract, often 896 . C. retroflexa brownish; perigynium ovoid, smooth throughout, very promi-

nently corky and swollen at the base, at maturity widely spreading; scales brownish and sharp, at length deciduous. (C. rosea, var. 'Torr.) - Dry open woods, Mass. to Ont. and Tex. May, June. FIG. 396.

Var. texénsis (Torr.) Fermald. Spikes 3-5 ; perigynium lanceovoid or lance-subulate. (C. rosea, var. Torr. C. texensis Bailey.) - Ky. to Mo., and southw.

43. C. muricata L. Culm 1.5-8 dm. high, rougb, longer than the narrow leaves; spikes $5-10$, variously disposed, but usually some of them scattered, frequently all aggregated, rarely tawny; perigynium heavy, ovate, 897. 0. muricats. 4-6 mm. long, shining, nerveless, the long beak minutely rough, spreading, a little longer than the sharp green or brownish scale. - Dry fields, local, s. Me. to Va. and $O$. (Nat. from Eu.) Fig. 397.

44. C. Muhlenbérgii Schkuhr. Plant very stiff throughout, pale, growing in small tufts, 2.5-8 dm. high ; culms much prolanged beyond the few narrow (2.5-4 mm. broad) and at length plicate or involute leaves; head 1.5-4 cm. long, the 398 . C. Mublenbergii. individual spikes clearly defined; spikes globular, $3-10$; peri-

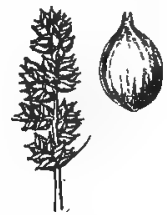

gynium nearly circular, very strongly nerved on both faces, broader than the rough-cusped scale and about as long.Open sterile soils; s. Me. to Ont., and southw. June, July. FIG. 398. Var. ENERvis Boott. Perigynium nearly or entirely nerveless. (Var, xalapensis Britton.)-Mass, to Neb., and southw.

45. C. cephalóphora Muhl. Strict but soft, 899. c. cephalophora. 2-7 dm. high; leaves $2-4.5 \mathrm{~mm}$. wide; head small, 0.7-1.8 $\mathrm{mm}$. long, globular or very shortcylindric, never interrupted, the lower 1 or 2 spikes usually bearing a very setaceous short bract; perigynium elliptic-ovate, about $2 \mathrm{~mm}$. long, slightly longer than the acute or rough-cusped scale. - Dry woods and knolls, Me. to Ont., and southw. MayJuly. Fig. 399.

46. C. Leavenworthii Dewey. In habit resembling the last,

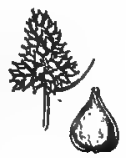
400. C. Lenven worthii. usually more lax, 1-5 dm. high ; leaves $1-3 \mathrm{~mm}$. wide; head $0.7-1.5 \mathrm{~cm}$. long; perigynia cordate-deltoid, exceeding the acutish rarely cuspidate scale. ( $C$. cephalophora, var. angustifolia Boott.) - Damp woods and banks, Ont. to $\mathrm{Ky}$, Fla., and Tex. May, June. Frg. 400.

47. C. sparganioides Muhl. Culm 4-10 dm. high; leaves very broad 
(5-9 mm.) and flat, their sheaths conspicuously clothing the base of the culn?; spikes 6-12, the 2 or 3 upper ones contiguous, the remainder entirely separate, very green, shortcylindric, the lowest often compound, all truncate at top; perigynium ovate, $3-4 \mathrm{~mm}$. long, rough on the short beak, often obscurely nerved on the outer face, considerably longer than the whitish sharp-pointed scale. - Rich woods, N. H. to Ont., Mo., and Va. June, July. Fig. 401.

48. C. cephaloidea Dewey. Lax, very green, 3-9 dm.

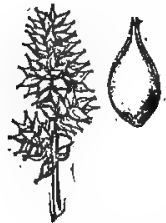

402. C. cephaloidea. high ; leaves broad (5-8 mm.) and thin, shorter than the long soft culm; head 1.8-3.8 $\mathrm{cm}$. long, rather dense; perigynium narrowly ovate, $3.5-4.5 \mathrm{~mm}$. long, pale green, nerveless, with long rough beak, spreading. Rich woods and thickets, local, N. B. to Pa., Wisc., and Ont. May-July. Fig. 402. 49. C. alopecoídea Tuckerm. Stout but rather soft, 4-9 dm. high ; culm rather sharp, thick and soft in texture; leaves 4-8 $\mathrm{mm}$. wide, about the length of the culn, very

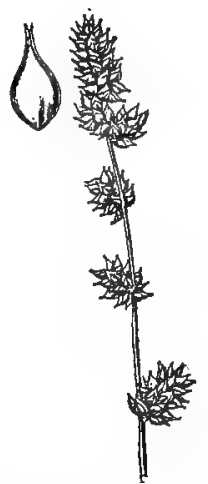

401. C. sparganioides.

green ; head 2-6 cm. long, straw-color or tawny, occasionally a little compound, the spikes many and compactly or somewhat loosely disposed or the lowest often separate and all mostly short-cylindric; perigynium 344 $\mathrm{mm}$. long, 1.5-2 mm. broad, tapering into a rough beak, very prominently stipitate, with a few brown nerves on the outer face, ascending, about equaling or a little exceeding the scale; achene obovate, $1 \mathrm{~mm}$. broad, style not thickened at base. -

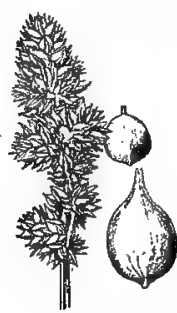

Open swales and low thickets, Me. to Ont. and Ill.; local. June, July. FIG. 403.

50. C. grávida Bailey. Low, the oulm thin and sharply angled, 2-5 dm. high; leaves rather firm, shorter than the culm ; head 2-4

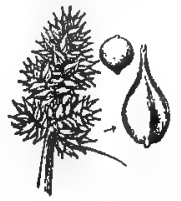

408. C. alopecoidea. $\mathrm{cm}$. long, greenish to pale brown, short-cylindric, the lowest spikes rarely distinct; spikes globular; perigynium $3-4.5 \mathrm{~mm}$. long, 2-3 mm. broad, sessile, plump and somewhat polished at maturity, prominently spreading ; achene suborbicular, 1.5-2 mm. broad, style bulbousthickened at base. - Ind. and Wisc. to Neb., and southw. FIG. 404. Var. IAXIFòLIA Bailey. Much larger, 6-12 dm. high ; leaves 404. C. gravida. broader and lax; head large and dense, oroid or thick-cylindric, scarcely interrupted. - Ky. to S. Dak. and Mo.

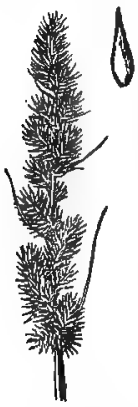

51. C. vulpinoídea Michx. Mostly rather stiff, $0.3-1 \mathrm{~m}$. high ; culm very rough, at least above; leaves $2-5 \mathrm{~mm}$. broad, mostly flat and longer than the culm; head $2-15 \mathrm{~cm}$. long, usually much interrupted or dense or somewhat compound, varying from dull brown to almost green at maturity, commonly provided with many very setaceous short bracts; spikes very numerous, ascending and densely flowered ; perigynium ovate or lance-ovate, mostly ascending,

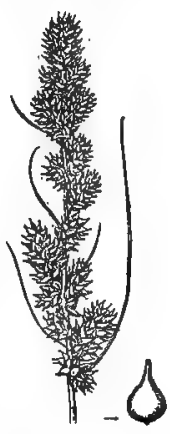

40i. C. vulpinoidea. $1.7-3 \mathrm{~cm}$. long; scales mostly long-awned. - Low places, variable. June-Aug. FIG. 405.

52. C. setàcea Dewey. Resembling the last; culms stiff, 0.4-1 $\mathrm{m}$, high, much exceeding the rather broad $(2-7 \mathrm{~mm}$.) stiffish leaves; head usually simple, 3.5-9 $\mathrm{cm}$. long, of approximate or remote spikes; perigynia lanceolate to lance-ovate, tapering

406. C. setacea. gradually to the serrulate beak, usually dull brown or $d r a b$ in 


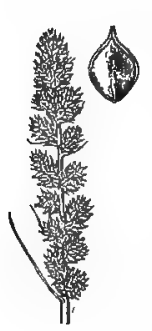

407. C. set., v. ambigua.

maturity ; scales short-awned. - Vt. to Ont. and $\mathrm{Ky}$. ; June-Aug. Fig. 406.

Var. ambigua (Barratt) Fernald. I'erigynia broad-ovate to orbicular, abruptly short-beaked, often golden-brown. (C. vulpinoidea, var. ambigua Barratt ; C. xanthocarpa Bicknell.) - Dry soil, s. Me. to Ia., and southw. FIG. 407 .

53. C. decompósita Muhl. Stout, exceedingly deep green, $0.5-1 \mathrm{~m}$. high, in stools ; culm very obtusely angled, almost terete below; leaves firm, chanueled below, 5-8 mm. wide, longer than the culm; panicle 1-1.5 dm. long, the lower branches ascending and $1.5-3.5 \mathrm{~cm}$. long ; perigynium very small, few-nerved, hard and at maturity shining, the abrupt short beak entire or very nearly so; scale acute, about the length of the perigynium.-Swamps, N. Y. to Mich., and soutbw.; local. July, Aug. FIG. 408.

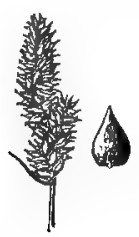

54. C. diándra Schrank. Slender but mostly erect, 3-8 dm. high, in loose stools; culm rather obtuse, rough at the top, mostly longer than the narrow (1-3 mn. broad) plicate leaves; head 1.5-5 cm. long, 0.5-1 $\mathrm{cm}$. thick; perigynium very small, truncate

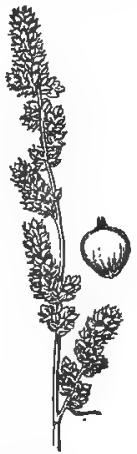
below, bearing a few inconspicuous short nerves on the outer side, stipitate, firm and at maturity blackish and shining, the short beak lighter colored; scale the length of 409. C. diandra. the perigynium. (C. teretiuscula Good.) Bogs and wet meadows, e. Que. to the Yukon, s. to Ct., Pa., Mich., Neb., etc. May-July. (Eu.) FIg. 409.

Var. ramosa (Boott) Fernald. Tall $(0.5-1.2 \mathrm{~m}$ ) ; head $3-8 \mathrm{~cm}$. long, the upper portion often nodding, the usually pale spikes

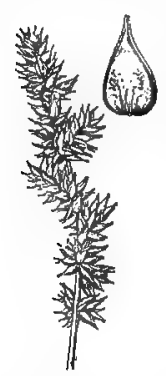
scattered and the lowest often slightly compound; perigynia brown. (C: teretiuscula, var. prairea Britton.) - Bogs, e. Que. to B. C., s. to Ct., Pa., O., Ill., Minn., and Utah. Fig. 410 .

55. C. conjúncta Boott. Strict but rather weak, 0.5-1 m. high; culm soft and sharply triangular or nearly wing-angled, beconing ribbon-like when pressed; leaves soft, 5-10 $\mathrm{mm}$. broad; head 3.5-7.5 cm. long, interrupted, pale green, infrequently bearing a few setaceous bracts; perigynium lance-ovate, light-colored, whitish and thickened below, the beak lightly notched and roughish, almost equaling or a little exceeding the cuspidate scale. - Swales and glades, $\mathrm{Pa}$. to Ky., Ill., Ia., and 411. C. conjuneta. Minn.; local. June. FIG. 411.

56. C. stipàta Muhl. Stout, 0.2-1 m. high, in clumps; culm rather soft, very sharp; leaves flat and soft, 4-15 min, wide; head $2-10 \mathrm{~cm}$. long, often somewhat compound at base, interrupted, the lowest spikes $0.7-2 \mathrm{~cm}$. long; perigynium lanceolate, brown-nerved, the beak toothed and roughish, about twice the length of the body, and much longer than the scale. - Swales, common and variable. May-Aug. Fig. 412 .

57. C. crus-córvi Shuttlw. Stout, glaucous, 0.5-1 m. high ; culm rough, at least above; leaves flat and very wide (6-12 $\mathrm{mm}$.); head much branched and compound, 6.5-23 cm. long; perigynium

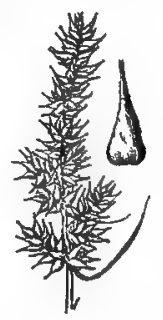

412. C. stip)ata. long-lanceolate, the short base very thick and disk-like, the roughish and very slender beak thrice the length of the body or more, 3-4 times the lengtb 
of the inconspicuous scale. - Swamps and bottoms, Ind. to Minn., Neb., and southw.; rare northw. June, July. FIG. 413.

58. C. Arenaria L. Extensively creeping, 0.7-5 dm. high; leaves very narrow and very long-pointed, shorter

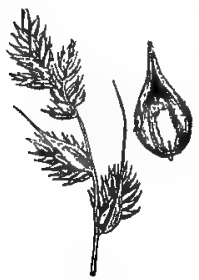

414. C. aremaria. than the culm; head dense or sometimes interrupted, ovoid or cylindric; spikes few to many, those at the apex of the head usually staminate, the intermediate ones staminate at the summit, the lowest entirely pistillate and subtended by a bract $1-3 \mathrm{~cm}$.

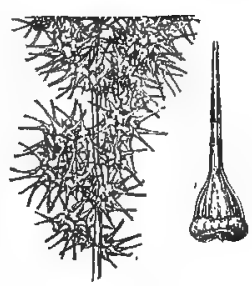

418. C. crus-corvi. long; perigynium very strongly nerved on both faces, wingmargined above, sharply long-toothed, about the length of the brown subulate-acuminate scale. - Sea-beaches near Norfolk, Va. (Nat. from Eu.) FIG. 414.

59. C. Sartwéllii Dewey. Culms stiff and strict, $0.8-1.2$ $\mathrm{m}$. high, from an elongate dar/ rootstock; leaves $2-5 \mathrm{~mm}$. wide) produced into a long slender point, mostly shorter than the culm ; staminate flowers variously disposed, frequently whole spikes being sterile; head 2.5-7 cm. long and rather narrow, the individual spikes usually clearly defined, or occasionally the head interrupted below, tawny-brown; perigynium 3-5 $\mathrm{mm}$. long, elliptic or lance-elliptic, nerved on both sides, very gradually contracted into a short beak; scale blunt, smooth, hyalineedged, about the length of the perigynium. - Bogs, centr. N. Y.

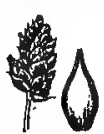

416. C. stenophylla. to B. C., s. to O., Ill., Ia., S. Dak., etc. June, July. Fig. 415.

60. C. stenophýlla Wahlenb. Stiff, tufted, 0.5-2.5 dm. high; leaves pale, involute and shorter than the culm; perigynium ovate, gradually contracted into a short and entire rough-edged beak, tightly inclosing the achene,

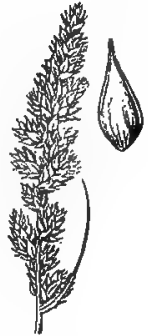

at maturity longer than the hyaline acutish scale. - Dry grounds, n. Ia to the Rocky Mts., and northw. June, July. (Eurasia.) FIG. 416.

61. C. chordorrhìza L.f. Very extensively stoloniferous; culms mostly lateral and solitary, 1-4.5 dm. long; leaves involute, shorter than the culm ; perigynium compressed-ovoid

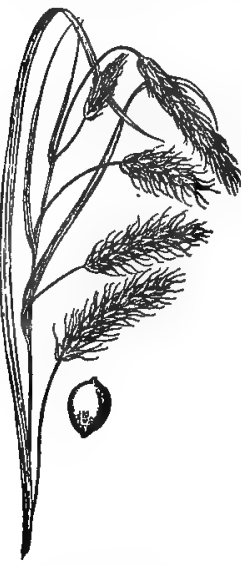

419. C, maritima. to $s u b$-globose, short-pointed and entire, about the length of the acute scale. Cold bogs and soft lake-borders, Que. to B. C., s. to Me., Vt., Pa., Ill., Ia., etc.; infrequent. May-July. (Eurasia.) Fig. 417.

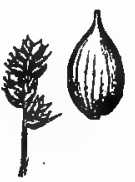

417. C. chordorrhiza,

62. C. capitàta L. Rigid, $0.7-5 \mathrm{dm}$. high ; leaves filiform, shorter than the culm; head uniformly staminate above, brown, very small, 0.5-1 cm. long; perigynium broadly ovate, very thin, whitish, prominently beaked, nerveless or nearly so, erect and appressed, longer than the very thin and obtuse scale. - Alpine region of Mt. Washington, N. H. June-Aug. (Eu.) 418. C. capitatı. FIG. 418 .

63. C. marítima O. F. Mueller. Mostly stout; culn sharp, smooth or rough above, 2-7 dm. high, usually overtopped by the leafy tufts and the broad bracts; leaves smooth and flat, strongly ribbed, $3.5-10 \mathrm{~mm}$. broad; pistillate spikes $2-6$, scattered, $2-8 \mathrm{~cm}$. $10 \mathrm{ng}$, $0.8-2 \mathrm{~cm}$. thick, often staminate at tip; staminate spikes 2-4, unequal, the terminal $2-6 \mathrm{~cm}$. long; perigynium nearly orbicular; 
pale, few-nerved or nerveless, the beak very short and entire, or nearly so; scale whitish or brown, produced into a pale rough aun 3-8 times as long as the perigynium. - Brackish or saline shores, Lab. to Mass. Jume-Aug. (Eu.) Fig. 419.

64. C. salina Wahlenb., var. cuspidàta Wahlenb. Rather stout, 3-9 dm. high; culm rather sharp, smooth ; leaves narrow (2-5 mm. wide) but flat ; pistillate spikes $2-4$, somewhat approximate, erect, $2-7 \mathrm{~cm}$. long and rather thick, the lower subtended by leaf-like bracts; staminate spikes 1-3; perigynium elliptic, somewhat granular, marked with 2 or 3 nerves, or nerveless, the minute beak entire; scale brown-margined, mostly produced into a lighter and rough awn much exceeding the perigynium. - Salt marshes, Lab. to Mass. - Apparently hybridizes with C. stricta. July, Ang. (Eu.)

$\checkmark 65$. C. crinita Lam. Robust and mostly stout, $0.3-1.6 \mathrm{~m}$. high; culm sharp and rough or sometimes smooth; leaves $4-10 \mathrm{~mm}$. broad, flat, more or less rough on the nerves and margins, the lower short and at the base of the culm reduced to smooth fibrillose sheaths; pistillate spikes 3-6, somewhat scattered, all variously peduncled, mostly secund, $3.5-10 \mathrm{~cm}$. $l o n g$, narrowly and evenly cylindric, often staminate at tip; staminate spikes usually 2 , rarely pistillate at tip; perigynia suborbicular to ovate, $2-3 \mathrm{~mm}$. long, thin and inflated, becoming wrinkled in drying, nerveless, puncticulate or granular, with a minute entire beak; scales greenish-brown and rough-awned, 2 -? times as long as the perigynia. - Swales and damp thickets, generally common. - Hybridizes with $C$. torta and C. scabrata. June-Aug.

Var. minor Boott. Much smaller in all parts ; 4-6 dm. high ; leaves 4-5 mm. wide; spikes 1-3.5 cm. long, ascending; perigynia $2 \mathrm{~mm}$. long; scales less prominent. - Me. to N. Y., scarce.

Var. Portèri (Olney) Fernald. Like small $C$. crinita, but spikes very slender ; perigynia compact, not inflated, oblong-lanceolate, distinctly beaked; scales lance-attenuate. (C. gynandra, var. Porteri Britton.) - Moosehead Lake, Me. (Porter).

Var. gynándra (Schwein.) Schwein. \& Torr. Harsher; leaves broad (4-12 $\mathrm{mm}$.), the sheaths hispidulous; culms tall; staminate spikes 1 or 2, generally pistillate above; pistillate spikes soft, loosely flowered, drooping, $2.5-10 \mathrm{~cm}$. long; perigynia ascending, elliptic or ovate-lanceolate, $3-4 \mathrm{~mm}$. long, subinilated. (C. gynandra Schwein.) - Nfd. to Wisc., and in the mts. to Ga.

Var. simulans Fernald. Harsh as in var. gynandra; low ; leaves 4-6 mm. broad; spikes suberect, the terminal androgynous, 1-3.5 cm. long, scarcely drooping; perigynia $3 \mathrm{~mm}$. long. - Nfd. to $\mathrm{Vt}$. and Mass., chiefly in the ints.

66. C. aquátilis Wahlenb. Glaucous, $3-9 \mathrm{dm}$. high; culm very obtuse and smooth; leaves exceedingly long, 4-7 mm. broad, the bracts broad and prolonged far beyond the culm; pistillate spikes $3-5,1.5-5.5 \mathrm{~cm}$. long, very compact or the lowest sometimes attenuate below, erect; perigynia round-ovate or broadly elliptic, nerveless, greenish, imbricated; scales dark, shorter than or equaling the perigynia. - Swamps and lake margins, Que. to B. C., s. to the Potomac R., w. N. Y., Ind., etc. June-Aug. (Eurasia.)

Var. elàtior Bab. Robust, 0.9-1.5 m. high; leaves $5-8 \mathrm{~mm}$. broad; pistillate spikes stout and heavy, $3.5-8 \mathrm{~cm}$. long. - Me. to Man., s. to N. Y., O., and Mich.

Var. cuspidàta Laestad. Spikes slender, 3-4 mm. thick; scales cuspidate, exceeding the perigynia. - Local, Que. to N. J.

Var. viréscens Anders. Scales pale and short, hidden by the crowded peri. gynia. - Local, Vt. to Ont. and Mich.

67. C. rigida Good. Somewhat stoloniferous, low (0.5-4.5 dm. high); leaves shorter than the mostly smooth oulms, rather crowded at base, smooth, dark green, firm, broad (3-7 mm.), becoming revolute in drying; pistillate spikes $1-5$, subglobose to short-cylindric, dense, $0.5-2.5 \mathrm{~cm}$. long, 4-6 $\mathrm{mm}$. thick, the lowest bractless or leafy-bracted ; staminate spike 1 (rarely 2), sometimes pistillate at base; perigynia elliptic, greenish or purplish; scales elliptic, brown to purple-black. - Arctic regions, south to mts. of Que., Rocky Mts., etc. July, Aug. (Furasia.) - Passing to the formal Var. BIGELdwII (Torr.) Tuckerm., with pistillate spikes elongate $(1.5-4 \mathrm{~cm}$. long, $25-5 \mathrm{~mm}$. thick), the lower attenuate at base.- Extending s. to mts. of $\mathrm{n}$. N. F. and N. Y. (Eu.) 
88. C. tórta Boott. Slender but erect, 2-9 dm. high, in clumps, with exceedIngly tough and cord-like roots; culm rather sharp, smooth or roughish above; leaves flat and rather soft, those of the culm very short $(2-5 \mathrm{~mm}$. wide); pistillate spikes $2-6$ (rarely compound), mostly somewhat approximate or the lower remote, the upper sessile and ascending, but the others often spreading or drooping, long and slender (1.5-9 $\mathrm{cm}$. long, 3-6 mm. thick); staminate spike 1(ra rely 2 )-peduncled, $1.5-4 \mathrm{~cm}$. long, occasionally with some pistillate flowers; perigynium lance-ovate, green, the slim uppar half empty and more or less tortuous, the beak entire or erose; scale purple-margined and very obtuse, shorter than the perigynium. - By streams, rarely in swamps, e. Que. to Minn., s. to N. C. and Mo. May-July. FIG. 420.

69. C. lenticulàris Michx. Rather slender but erect, pale throughout, 1-6 dm. high ; culm sharp, usually slightly rough above; leaves very narrow (1-3 mm. wide), numerous, much surpassing the culm; spikes 3-8, more or less aggregated or the lowest remote, the terminal androgynous or staminate, mostly sessile, erect, 1-4.5 cm. long, 2.5-4 mu. thick; perigynia ovate, minutely granular, brown-nerved, the tip empty and entire; scales obtuse, about $\frac{1}{2}$ the length of the perigynia. - Gravelly or sandy shores, Lab. to the Mackenzie, s. to Mass., N. Y., Mich., Minn., etc. June-sept. Fig. 421.

70. C. Goodendwii J. Gay. Loose or slightly caespitose, 0.5-9 dm. high; culm sharp, smooth or rather rough above; leaves narrow (1-3 mm. wide) and stiff, shorter than the culm, glaucous-blue, the margins involute in drying; pistillate spikes $1-4$, all sessile or rarely the lowest very short-stalked, short and erect $(0.8-4.5 \mathrm{~cm}$. long, 4-6 mm. thick), very densely flowered or sometimes becoming loose below, the lowest usually 421. C. Ienticularis. subtended by a bract $2-19 \mathrm{~cm}$. long; perigynia appressed, oval or round-ovate, mostly fine-striate toward the base, the beak entire or very nearly so, bright green becoming tawny; scale ovate and very obtuse, conspicuously narrower and shorter than the perigynia. (C.vulgaris Fries.) - Across the continent northw., extending s. in swales and open places, chiefly along the seaboard, to Mass. and e. Pa. May-Sept. (Eurasia.)

71. C. strícta Lam. Tall and slender but erect, 0.5-1.3 m. high, generally in dense clumps when old, or rarely in small tufts; culm sharp, rough above; leaves long and narrow (2-4 mm. wide), rough on the edges, the lowest sheaths usually becoming prominently fibrillose; 1 or 2 lowest bracts leafy and equaling the culm; pistillate spikes $2-6$, scattered, the lowest often more or less neduncled and clavate and the others sessile, erect or ascending, oblong or cylindric, 2-7 cm. long, 3-6 $\mathrm{mm}$. thick, compactly flowered above but often attenuate at base, the upper often staminate at top, all greenish-purple or pallid ; perigynia becoming tawny, mostly lightly few-nerved and somewhat granular, the beak very short and commonly entire; scale brown, with a pale middle, nearly or quite equaling the perigynia. - Swales, throughout; abundant and variable. May-Aug. - Hybridizes with C. filiformis and C. salina, var. cuspidata.

Var. curtíssima Peck. Scales of the very short $(0.5-1.5 \mathrm{~cm}$. long) pistillute spikes much shorter than the perigynia. - N. B. to Ct. and N. Y., rare.

Var, angustàta (Boott) Bailey. Spikes longer and narrower $(3-11 \mathrm{~cm}$. $7 \mathrm{nng}$ 2-4 $\mathrm{mm}$. thick), more approximate and mostly attenuate at base, usually with long staminate tips; scales narrower, mostly longer than the perigynia. (In cluding var. xerocarpa Britton.) - Same range as the type, but less common.

Var. decora Bailey. Usually smaller; basal sheaths less fibrillose; spikes 1-4 cm. long, 4-7 mm. thick, sessile or very nearly so, ravely attenuate at base, 
slightly if at all staminate at tip; scales very sharp and spreading, longer than the perigynia. (C. Haydeni Dewey.) - Me. to Ky., Ont., and Ia.

72. C. aúrea Nutt. Low and slender, 0.5-5 dm. high; leaves pale green, narrow (1-3 mm. wide); 2 or 3 of the bracts exceeding the culm; spikes $3-5$,

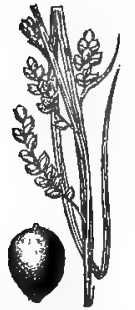

422. C. auren.

all but the lowest usually approximate, peduncled or the upper one or two sessile, erect, loosely few-flowered or sometimes becoming $2 \mathrm{~cm}$. long, at maturity yellow or brown, the terminal one frequently pistillate above; perigynium fleshy at maturity, plump, nerved, about $2 \mathrm{~mm}$. long, rounded or slightly depressed at tip, longer than the blunt white or pale-brown scale. Wet meadows and springy banks, Nfd. to B. C., s. to n. Ct., centr. N. Y., n.w. Pa., Ind., Wisc., etc., mostly in calcareous regions. June-July. Fig. 422.

73. C. bicolor All. Similar; spikes mostly crowded, only the lowermost subtended by an elongated bract, the others short-bracted or bractless, the terminal mostly pistillate; mature perigynia dry and firm, white, pulverulent, tapering to the short tip; scales dark brown or purptish. - Wet ledges and

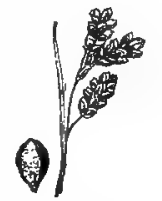

423. C. bicolor. gravelly shores, Lab. to n. Me.; n. shore L. Superior. June-Aug. (Greenl., Eu.) Fig. 423 .

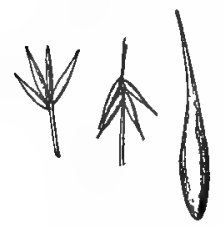

424. C. pauciflors.

74. C. pauciflora Lightf. Very slender but erect, stiff, 0.5-6 dm. high; leaves very narrow, usually much shorter than the culn; staminate and pistillate flowers 2-5; perigynia straw-color, subulate, severa] times longer than the inconspicnous scales, at maturity deflexed and easily detached. - Cold bogs, Nfd. to Alaska, locally s. to Ct., Pa., Mich., Minn., etc. June, July. (Eu.) FIg. 424.

75. C. leptàlea Wahlenb. Capillary, erect or slightly diffuse, $0.5-5 \mathrm{dm}$. high ; leaves mostly shorter than the culm ; spike $0.4-1.6 \mathrm{~cm}$. long,
staminate portion small, the subalternate thin green nervose oblong or narrowly

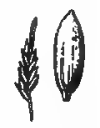

425. C. leptalea. ellipsoid blunt perigynia about twice longer than the brozonish mostly obtuse caducous scales. (C. polytrichoides Muhl.) - Bogs and wet

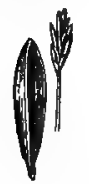
meadows, Nfd. to B. C., s. to Pa., the Great Lakes, M.., Col., and Ore.; and in the mts. to N. C. June-Aug. FIG. 425.

76. C. Harpèri Fernald. Similar, $2.5-7 \mathrm{dm}$. high; the more crowded spike with strongly overlapping linear-oblong perigynia and whitish acuminate scales. - Bogs and swampy woods, Pa. to Fla. and Tex. May-July. Fig. 426.

426. C. Harperi.

77. C. Frasèri Andrews. Caespitose ; culm 2-5 dm. high, naked or the lower portion included in loosely sheathing leaves, smooth and stiff ; leaves broad, destitute of midrib, closely many-ribbed, very thick and persistent, pale, $1.5-6 \mathrm{dm}$. long; spilce solitary. the pistillate portion globular, the longer staminate tip oblong; perigynia

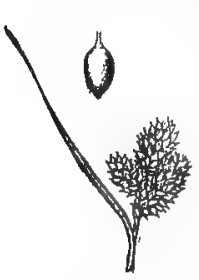

straw-colored, papery, ovoid, faintly nerved, much longer than the whitish scales. - Rich mountain woods, Va., W. Va, and southw.;

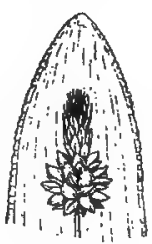

42\%. C. Fraseri $\times 2 / 5$. Inflorescence and leaf-tip. local. May-July. Fig. 427.

78. C. Hallèri Gunn. Small and slender, 1-6 dm. high ; culm thin and obtuse, smooth or roughish, naked above; leaves narrow and flat, shorter than the culm ; spikes 2-4, aggregaled, 4-8 $\mathrm{mm}$. iong, sessile or rarely the lowest short-stalked ; perigynia orbicular to elliptic, nerveless or nearly so, the short beak slightly notched, a little longer than the ovate purple-brown obtuse scales. (C. alpina $\mathrm{Sw}$.) - Cold wet rocks, e. Que., I. Superior region, 428. C. Hallerl, Rocky Mts., and far northw. July, Aug. (Eu.) FIG. 428, 
79. C atrata L., var. ovàta (Rudge) Boott. Very slender but erect, 2-9 dw. high; culm rather sharp, roughish above; leaves narrow but flat, shorter than the culin; spikes $3-6$, all but the terminal one on slender stalks, drooping when mature, 1-2.5 cm. long, ellipsoid or short cylindric, reddish-brown to purplish-black; perigynia broadly ovate, thin and puncticulate, very shortbeaked, the orifice slightly notched; scales blunt, thin-

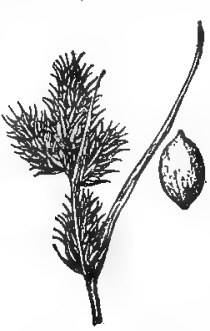

430. C. polygama. margined, about as long as the perigynia. (C. atratiformis Britton.) - By streams and in cold ravines, Nfd. to Athabasca, locally s. to the mts. of n. N. E. JuneAug. FIG. 429.

80. C. polýgama Schkuhr. Rather slender but stitr, 2-9 dm. high; culm sliarp, roughish above; leaves very narrow, rough, mostly shorter than the 429 . C. atrata, vo ovata. culm ; spikes $2-7$, the terminal rarely all

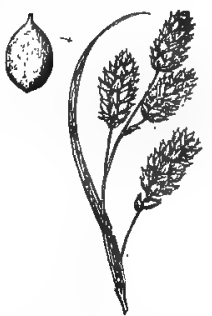
staminate, sessile and approximate or the lowest very shortstalked, from globular to narrowly cylindric, $0.7-5 \mathrm{~cm}$. long, dark brozm or variegated; perigynia elliptic and beakless, whitish and granular, nearly nerveless, the orifice entire; staminate scales very long-lanceolate, the pistillate lance-ovate and very sharp, conspicuously longer than the perigynia. (C. fusca Man. ed. 6, not All.; C. Buxbaumii Wahlenb.) - Bogs and wet shores, e. Que. to Alaska, s. to Pa., Great Lake region, Mo., Utah, and Cal.; and in the nuts. to N. C. May-July. (Eu.) Fig. 430 .

81. C. triceps Michx., var. hirsùta (Willd.) Bailey. Slender; leaves narrow, hairy; spikes 2-4 (usually 3), all contiguous or occasionally the lowest somewhat removed, sessile, thick-cylindric to globular, green or brown (4-7 mm. thick); perigynia broad-

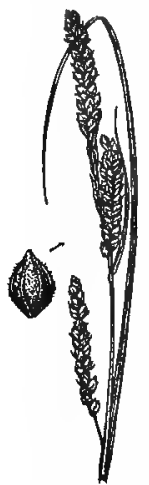

432. C. viresccus. ovoid, flattish, very obtuse, often sparsely hirsute when young but smooth at maturity; staminate scales very sharp; pistillate scales acute or shortawned, about the length of or shorter than the perigynia. (C. triceps Britton in part, not Michx.) - Copses and dryish meadows, N. E. to Ont., and southw., rare northeastw. May-July. FIG. 431. - Hybridizes with C. gracillima.

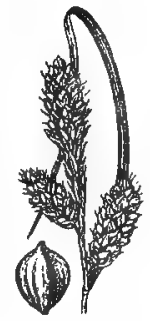

431. C. triceps, v. hirsuta.

Var. Smithii Porter. 'Tall, slender, olive-green, the leaves very long, very nearly smooth; spikes small, globular to cylindric, the lowest often somewhat remote, all more inclined to be peduncled; perigynia globular and turgid, brown, squarrose, exceeding the brownish scales. (C. caroliniana Schwein.) Fields and woodlands, Gulf States, locally n. to N. Y., Ill., and Mo. May, June.

82. C. viréscens Muhl. Slender, erect or spreading, $0.4-1 \mathrm{~m}$. high; ledves very narrow, more or less hairy; spikes 2-4, sessile or slightly stalked, compact, linear-cylindric, 2-4 mm. thick; perigynia ellipsoid-ovoid, compressed, costate, usually longer than the thin whitish acute scales. (Var. costata Dewey ; $C$. costellato Britton.) - Dry banks and copses, s. Me. to s. Ont., and southw. June, July. (W. I.) Frg. 432.- Hybridizes with $C$. arctata and $C$. debilis, var. Rudgei.

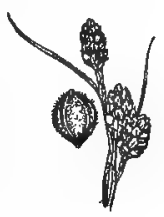

489. C. vir., จ. Swanti.

Var. Swanii Fernald. Lower, 1.5-8 dm. high, the 2-5 thick-cylindric to subglobose spikes $3-5 \mathrm{~mm}$. thick; the perigynia less strongly ribbed. (C. virescens Man. ed. 6, not Muhl.) - Similar range. FIG. 433.

83. C. formosa Dewey. Slender, erect, $3-9 \mathrm{dm}$. high; leaves flat, often pubescent, 3-7 $\mathrm{mm}$. broad, those of the culm short; spikes 3-5, scattered, ellip soid or cylindrical, 1-3 cm. long, compact, all flexuose or' drooping; perigynia 


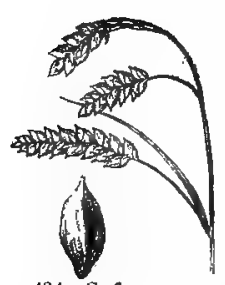

434. C. formosa.

greenish, inflated, ovoid, puncticulate, obscurely nerved, short-beaked with a slightly notched orifice, all but the lowest one or two twice longer than the blunt or cuspidntt whitish scales. - Woods and copses, w. N. E. to Ont. and Mich.; local. May, June. Fra. 434.

84. C. Davisii Sehwein. \& Torr. Similar; spikes, $3-7$, heavier, $1.5-4.5 \mathrm{~cm}$. long; perigynia more inflated, strongly nerved and prominently toothed, equaled by the conspicuously awned and spreading scales. - Meadows and wet woods, w. Mass. to s. Minn., and southw. ; rare eastw. and northw. May, June. Fig. 435 .

85. C. gracillima Schwein. Tall and slender, sometimes diffuse, $0.3-1 \mathrm{~m}$. high; leaves broad and flat (the radical 5-9 $m m$. wide), very dark and bright green ; spikes $3-6$, scattered,

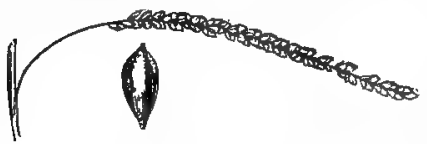

436. C. gracillima. the terminal rarely staminate, densely flowered except at base, peduncled and drooping, or sometimes ascending, green, 2-6 cm. long, 2-3 $\mathrm{mm}$. thick ; perigynia ovoid, thin and slightiy swollen, nerved, obtuse, orifice entire, twice longer than the very obtuse whitish scale,-Woodlands and meadows, generally common. May-July. Fig. 436. - Var. HümLIs Bailey is apparently a starved form. Hybridizes with C. triceps, var. hirsuta, C. pubescens, and C. aestivalis.

86. C. aestivàlis M. A. Curtis. Slender but erect, 2.5-6 $\mathrm{dm}$. high; leaves very narrow, 1.5-3 $\mathrm{mm}$. wide, flat, shorter than the culm, the sheaths pubescent; spikes 3-5, erect or spreading, $1.5-4.5 \mathrm{~cm}$. long and very loosely flowered, shortstalked; perigynia ovoid, scarcely pointed and the orifice

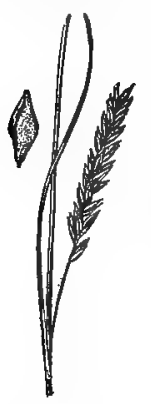
entire, few-nerved, about twice longer than the obtuse or mucronate scale. - Rocky woods, mostly on upland slopes, N. H. to Ga., rare. June-Aug. FIG. 437.

L. 87. C. oxýlepis Torr. \& Hook. Similar; $2-8 \mathrm{dm}$. high ; leaves $3-7 \mathrm{~mm}$. wide; perigynia 4-5 mm. long, ellipsoid, acute, prominently few-nerved, glandular-dotted, slightly exceeding the long-acuminate white scales. - Rich woods, S. C. to Mo., and southw. April, May. FIG. 438.

88. C. Shortiàna Dewey. Tall, 3-9 dm. high, in small clumps; leaves $0.4-1 \mathrm{~cm}$. broad, flat, rough on the nerves; spikes $3-6$, somewhat approximate near the top of the culm, the lowest 2 or 3 short-peduncled, erect, 1-3.5 488. C. oxylepis, em. long, 4-6 mm. thick, evenly cyindrical, exceedingly densely flowered; perigynia scabrous, sharp-edged, the orifice entire, squarrose; scales thin and blunt, about the length of the perigynia. - Meadows and low woods, Pa. to Ont., Ia, and southw. May, June. Fit. 439.

89. C. Báckii Boott. Forming dense mats; leares dark green, $3-5 \mathrm{~mm}$. broad, stiff, very abundant and overtopping the very unequal culms; spikes solitary, terminating short and long slender culms $(0.1-3 \mathrm{dm}$. long); staminate fowers

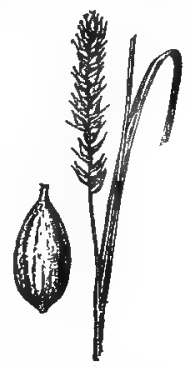

435. C. Davisii.

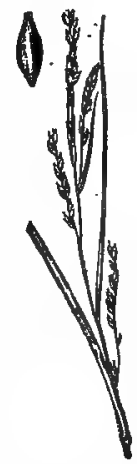

437. C. aestivalis

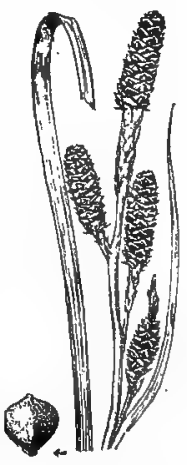

439. C. Shortiant 


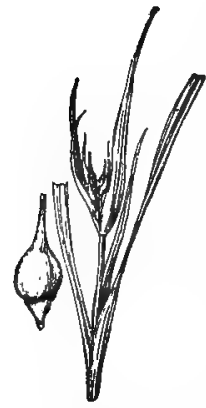

440. C. Backii.

about 3 ; pistillate $2-5$; perigynia gradually beaked; scales very broad and leaf-like, entirely enveloping the spike. ( $C$. durifolia Bailey.) - Dry rocky or sandy wooded slopes, e. Que. to Assina. and B. C., locally s. to Mass., N. Y., the Great Lake region, Neb., and.westw. May-July. Fig. 440.

90. C. Willdenòwii Schkuhr. Similar, softer and paler; leaves 1.5-4 mm. wide; spike compact ; pistillate flowers 3-9, staminate $6-12$; perigynia with a rougher beak; scales chaffy, nerved, as broad as and somewhat longer than the perigynia, or the lowest rarely overtopping the spike. - Rocky woods, Mass. to Mich., and southw., local. May-July. Fig. 441.

91. C. Jamèsii Schwein. Similar; leaves 1-2 mm. wide, much surpassing the culm; 441. C. Willdenowil. 4pike very small; staminate flowers $8-20$;

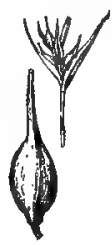
pistillate 1-3 and loosely disposed; perigynia produced into a very long and roughened nearly entire beak; scales narrov, the lowest often elongate, the

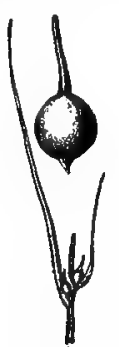

442. C. Jamesii. upper often shorter than the perigynia. - Woods, N. Y. and Ont. to Mo., and southw.; frequent. May, June. Fig. 442.

92. C. scirpoidea Michx, Strict, the pistillate plant mostly stiff, 1-7 dm. high; staminate plant smaller; leaves flat, shorter than the culm; spilce 1.5-4 cm. long, densely cylindrical, very rarely with a rudimentary second spike at its base; perigynia ovoid, short-pointed, very hairy, exceeding the ciliate purple scales. - Arctic regions, s. by cold streams and in alpine districts to Cape Breton, N. S., n. N. E., n. N. Y., L. Huron, Rocky Mts., etc. June-Aug. (Eurasia.) Fig. 443.

93. C. umbellàta Schkuhr. Low and conspicuously caespitose, forming dense mats;

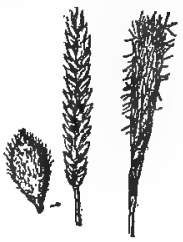

443. C. scirpoidea. leaves rather stiff, $0.5-4.5 \mathrm{dm}$. long, $1-4.5 \mathrm{~mm}$.

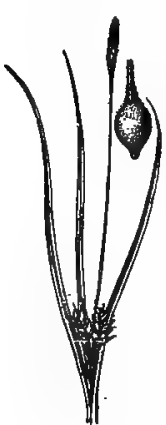
wide ; culms mostly short and crovoded at the base of the leaves, or some elongate (rarely $2 \mathrm{dm}$.), bearing either staminate or pistillate spikes, or both; pistillate spikes $0.5-1 \mathrm{~cm}$. long, mostly sessile ; perigynia plump, stipitate, puórulent, $3.2-4.7 \mathrm{~mm}$. long, the slender beak nearly equaling the ellipsoidovoid to subglobose body, and about equaled by the acuminate green or purple-tinged scales. (C. deflexa, var. media Bailey and var. Farwellii Britton.) - Dry sandy or rocky soil, P. E. I. to centr. Me., w. to Sask. and B. C., s. to N. J., D. C., and I. T. Apr.July. Frg. 444. Var. Tóssa Fernald. Similar; perigynia glabrous or merely puberulent on the angles of the long beak. - Locäl. Fig. 445.

Var. breviróstris Boott. Perigynia smaller, the

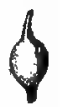

445. C. umb., v. tonsa. broad beak about $\frac{1}{3}$ as long as the hairy body. - Que. to Sask. and B. C., s. to n. N. E., N. Mex. and Cal. Fig. 446.

94. C. nigro-marginàta Schwein. Leaves mostly stiffer, often 2-4 dm. long, 2-4 mm. wide; some of the culms prolonged; perigynia smooth or nearly so, fusiform, 3-4 mm. long; scales ordinarily purple-margined, giving the spikes a very dark or variegated appenrance, equaling or exceeding the perigynia.Dry sandy or rocky soil, on the coastal plain, extending localiy n. to Ct. Apr.-June, Fig. 447 .

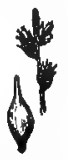


95. C. defléxa Hornem. Diffuse and low, tufted; leaves soft, 1-3 mm wide; culms $0.2-4 \mathrm{dm}$. high, setaceous, more or less curved or spreading: little exceeding or shorter than the leaves; staminate spike small, sometimes invisible in the head; pistillate spikes 2-3, 2-8flowered, green, or green and brown, all aggregated into a head, or the lowest one slighty remote, short-peduncled and subtended by a leafy bract; radical spikes usually present; perigynia very 448. C. deflexa. small and much contracted below, sparsely hairy or nearly smooth, the beak flat and very short, longer than the scales. (Including var. Deanei Bailey.) - Open woods, clearings, and mountain slopes, Nfd. to Alaska, s. to Mass., Pa., Mich., Minn., Wash., etc. May-Aug. (Greenl.) FIG. 448.

96. C. álbicans Willd. Slightly caespitose ; culms straightish, 1-5.5 dm. tall, much exceeding the soft narrow (1.5-3 $\mathrm{mm}$. wide) pale leaves; pistillate spikes globose or short-ovoid, 1-3, all approximate, or the lowest slightly remote, naked or subtended by a narrow bract; staminate spike sessile, often hidden in the head; perigynia ellipsoid, pubescent, with a short cylindric beak, mostly exceeding the brond scales. - Open woods or cool rocky banks, chiefly in calcareous regions, e. Que. to the Yukon, s. to Mass., Pa., Mich., and Minn. MayJuly. FIG. 449.

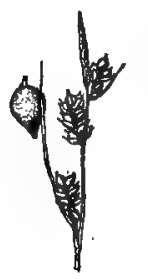

97. C. commùnis Bailey. Forming small tufts, never stoloniferous; culms 1-6 dm. high, much exceeding the leaves; leaves flat, becoming $2-5.5 \mathrm{~mm}$. wide; inflorescence $1-8 \mathrm{~cm}$. long; the 1-5 pistillate spikes mostly distinct, often remote, rarely $1 \mathrm{~cm}$. long, the lowest often leafy-bracted; staminate spike from green to chestnut, sessile or stalked, 3.5-20 mm. long; perigynia hairy, 2.5-4 $\mathrm{mm}$. long, the body subglobose to broadly ellipsoid, the base elongate and spongy, the beak broad; scales ovate, acuminate, greenish-brown to reddish, about equaling the perigynia. (Including var. Wheeleri Bailey ; C. pedicellata Britton ; C. pilulifera Fernald, not L.) - Dry open woods, etc., e. Que. 450. C. communis. to B. C., s. to Pa., O., Wisc., and Ia.; and along the ints. to Ga. May-July. Fia. 450.

w 98. C. vària Muhl. Densely tufted; leaves soft and very narrow; the capillary culms variable in length, lax, often twice longer than the leaves, 1-5 dm. long; pistillate spikes closely aggregated, or rarely somewhat loosely disposed but never scattered, all strictly sessile, green; radical spikes none; lower bract usually present; perigynia about the length of the sharp scale. - Banks and dry woods, Me. to Ont., and southw. Apr.July. Fro. 451. In var. cororata Bailey the scales are purple.

99. C. novae-ángliae Schwein. Very slender and

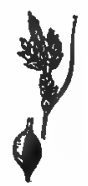

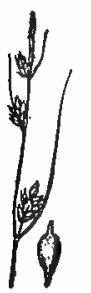

452, C. novaeangliae. soft, loosely caespitose, 1-4 dm. high; culms little longer than the very narrow pale-green leaves; staminate spike exceedingly narrow (0.5-1 cm. long, 0.5-1 mm.thick), mostly minutely peduncled; pistillate spikes 2 , or rarely $\Omega$, the upper one near the base of the staminate spike, the lower very short-peduncled and remote and sultended by a leafy bract which nearly or quite equals the culm, rather loosely 3-10flowered; perigynia very narrow, small, very thin, slightly hairy, the beak sharp and prominent. - Open woods, Que. and N. S. to Mass. and N. Y.; common northw., rare southw. June, July. Fig. 452 .

100. C. pennsylvánica Lam. Strongly stoloniferous, the small tufts with reddish bases and usually with persistent brush-like tufts of fibers; leaves $1.5-3.5 \mathrm{~mm}$. broad, shorter than,

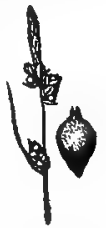

453. C. penn. sylvanica. equaling or often exceeding the slender culms (0.5-4 dm. high); pistillate spikes 1-4, globose or ovoid, approximate or remote, the lowest often leafy-bracted; 
staminate spike clavate, 1-2 cm. long, sessile or short-stalked, nsually reddish, rarely paler; perigynia puberulent, globose to obovoid, the short beals $\frac{1}{4}$ to $\frac{1}{5}$ as long as the body; the scales usually red-tinged. - Diy or sandy soil, s. Me. to Alb., and southw. May, June. Fig. 453.

Var. lucorum (Willd.) Feruald. Perigynia puberulent to glabrate, the conspicuous slender beak about as long as the body.Richer, usually damper soil, Me. to Mich., and the mits. of N. C. May-July. Fig. 454.

101. C. pubéscens Muhl. Lax, 2-8 dm. high, pubescent through-

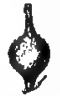

454. С. penr., v. lucorum.

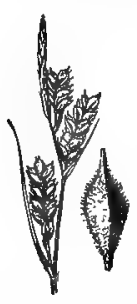

155. C. pubescens. out; leaves flat $(0.5-1 \mathrm{~cm}$. wide) and soft, shorter than the culm; spikes $2-4$, the upper approximate, the lower 1 or 2 short-peduncled, short-cylindric, $0.7-2.3 \mathrm{~cm}$. long, loosely flowered, erect; perigynia very hairy, sharply 3-angled, conspicuously beaked and minutely toothed, straight, about the length of the truncate and rough-cuspiclate thin scales. - copses and moist meadows, N. E. to Ky., and westw., local. May, June. Fig. 455.

102. C. CARYOPHYLLit Lat. Slightly stoloniferons, stiff; the culm sometimes curved, $0.3-3 \mathrm{dm}$. high ; leaves flat, shorter than the culm; staminate spike prominently clavate, mostly sessile; pistillate spikes $2-3$, all contiguous, sessile or the lowest very shortpeduncled and subtended by a bract scarcely as long as itself, all ellipsoid or short-cylindric, the lowest $0.7-1.5 \mathrm{~cm}$. long; peri-

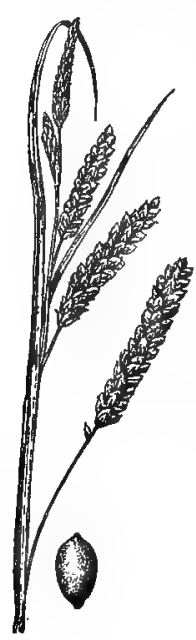

457. C. glauco.

gynia trigonous-obovoid, the very short beak entire or erose, thinly hispid-hirsute. (C. praecox Jacq.) - Fields, Me. to D. C.. local. May, June. (Nat. from Eu.) FIg. 456.

103. C. GLAÚCA Scop. Very stoloniferous

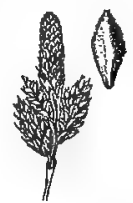

456. C. caryoph, and glaucous; the culms stiff, 1-6 dm. high; leaves shorter, firm, with revolute scabrous margins, 3-6 mm. broad; staminate spikes 2 (rarely 1 ), clavate, the terminal $2-3.5 \mathrm{~cm}$. long, peduncled; pistillate 1-3, cylindric, $1.5-3.5$ $\mathrm{cm}$. long, 4-6 mm. thick, remote, mostly peduncled, erect; the subglobose or ellipsoid puncticulate perigynia slightly exceeding the oblong blunt or mucronate purplish scales. - Dry open soil, local, N.S., Que., and Ont. June, July. (Nat. from Eu.) Fig. 457.

104. C. lívida (Wahlenb.) Willd. Very glaucous and stoloniferous; culms $1.5-6$ $\mathrm{dm}$. high; leaves narrow, often becoming involute; pistillate spikes 1 or 2 , sub-

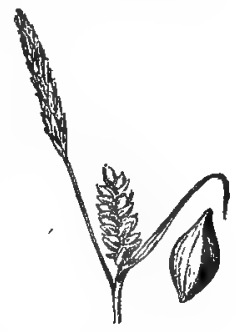

453. C. livida. approximate or remote, sessile or nearly so, erect, or rarely basal and long-stalked, narrow, $0.7-2.5 \mathrm{~cm}$. long, 3-6 $\mathrm{mm}$. thick; perigynia ovoid-oblong, nerved, granular, beakless, the point straight or nearly so, orifice entire; scale obtuse, brown-or purple-margined, mostly a little shorter than the perigynia. - Bogs, chiefly in calcareous regions, Lab. and Nfd. to Alaska, locally s. to Ct., N. J., Mich., Minn., ete. MayJuly. (Eu.) Fig. 458.

105. C. panícea L. Strict, often stiff, glaucous-blue, 1.5-6 dm. high ; culm smooth; bracts brood and short, 1-6 cm. high ; pistillate spikes $1-3$, scatlered, colored, mostly peduncled, erect, rather compact or loose below, 1-3 cm. long, 5-7 mm. thick; perigynia ovoid, yellow or purple, somewhat turgid, scarcely nerved, the point usually curved, mostly longer than the purple-

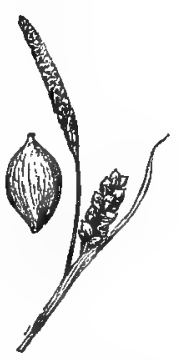

459. C. panicea. 


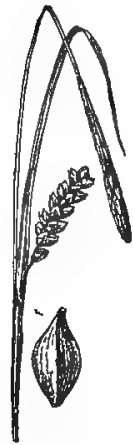

160. C. tetanica.

margined scale. - Bogs and meadows, near the coast, $\mathbf{N}$. S. to Ct., local. May-July. (Perhaps introd. from Eu.) FIG. 459.

106. C. tetánica Schkuhr. Slender, rarely glaucous, somewhat stoloniferous; culms scabrous, at least above, 1-6 dm. high; leaves $1.5-4.5 \mathrm{~mm}$. wide; spikes all peduncled, the upper one very shortly so, pale, all more or less attenuate below, 0.7-4 cm. long, the lower borne in the axils of bracts 0.5-2 dm. long; perigynia not turgid, greenish, somewhat nerved, the beak strongly bent; scale obtuse or abruptly mucronate, all except the lowest mostly shorter than the perigynia. - Meadows and bogs, w. N. F. to Man., and southw. May-July. FIG. 460. Var. Woónir (Dewey) Bailey. Very slender; leaves narrow, very long and lax; spikes mostly alternate-flowered throughout; scales often sharper. Mass. to Ont., Mich., and D. C., local.

Var. Meadii (Dewey) Bailey. Stiffer; leaves mostly broader (2.5-5 mm. broad) and stricter; spikes thick and densely flowered, not attenuate at base, the upper one often sessile; perigynia larger. (Var. Canbyi Porter; C. Meadii Dewey.) - Pa. to Man., and southw. Fig. 461.

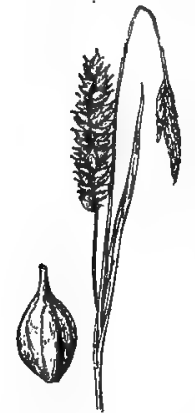

462. C. polymorpha.

107. C. polymorpha Muhl. Stout, 3-6 dm. high, from stout cord-like rootstocks; leaves rather broad $(3.5-5 \mathrm{~mm}$.), short; spikes 1-2, short-stalked, erect, compact or rarely loose, usually staminate at the apex, 1.5-4 cm. long, 5-9 mm. thick; perigynia longovoid, obscurely nerved; the very long and nearly straight beak oblique or lipped at the orifice; scales reddish-brown, obtuse, shorter than the perigynia. - Open woods and meadows, s. Me. to N.C., local. June-Aug. Fig. 462.

108. C. vaginata Tausch. Very slender and more or less diffuse, strongly stoloniferous, $2-8 \mathrm{dm}$. high ; leaves narrow $(1.5-5 \mathrm{~mm}$. broad $)$ and soft, shorter than the culm; spikes 1-3, scattered, all peduncled and more or less spreading, loosely 3-20-flowered; perigynia small, nearly nerveless, thin, the beak strajghtish; scales loose, acute, shorter than the perigynia. (C. saltuensis Bailey; C. altocaulis Britton.) - Bogs and mossy woods, Lab. to the Yukon, s. to N. B., n. N. E., N. Y., Mich., Minn., Alb., and B. C. June-Aug. Frg. 463.

109. C. abbreviàta Prescott. Stiff, 1.5-5 dm. high; culm

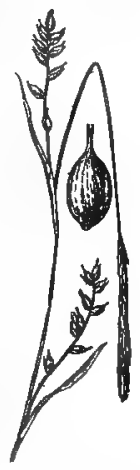

and leaves thinly pubescent; spikes globose to thick-cylindric. $0.5-1.5 \mathrm{~cm}$. Jong; perigynia equaling or exceeding the mostly cuspidate scales. (C. Torreyi Tuckerm.)-Wooded slopes, Minn. to Sask. and Col.; supposed to have been collected in N.Y. by Torrey, and in Pa. by Schweinitz. June, July. Fig. 464.

110. C. palléscens L. Slender, erect, 1-6 dm. high; leaves narrow, flat, the lower slightly pubescent, particularly on the sheaths; spikes 2-4, 0.5-2 dm. long, densely flowered, all but the upper one very shortly peduncled, erect or spreading; perigynia about the length of the cuspidate scales. - Glades and meadows,
isc., and (Ont. May-Aug. (Eu.) Fra. 465. 464. C. abbreviata.

Nfd. to Pa., Wisc., and (Int. May-Aug. (Eu.) Fra. 465.
111. C. paupercula Michx. Slender but erect, tufted, 1-2.5 dm. high, glabrous; leaves flat and lax, somowhat shorter than the culm; lowest bract as wille as the leaves or nearly

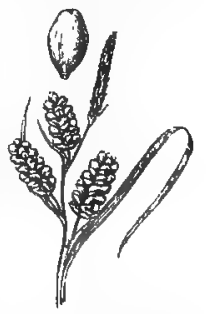

465. C. pallescens. 
Bo and exceeding the cu?m; spikes 2-3, approximate, all slenderly stalked, spreading or drooping, 4-8 mm. 7ong; perigynia orbicular or broad-ovate, nerved in the middle, $\frac{1}{2}-\frac{9}{8}$ the length of the castaneous scales. - Alpine bogs, e. Que. Aug.

Var. irrígua (Wahlenb.) Fernald. Taller, 1-8 dm. high ; culm glabrous; spikes cylindric, 1-1.6 cm. long; scales castcneous. (C. magellanica Man. ed. 6, not Lam.)-Bogs, Arctic regions, s. to Mass., Pa., Ont., and Utah. June-Aug. (Eu.) Fig. 466.

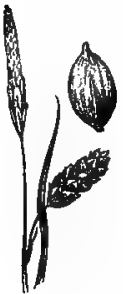

467. C. limosa.

Var. pallens Fernald. Tall, the culms usually scabrous; spikes cylindric, $1-1.8 \mathrm{~cm}$. long ; scales green with pale brown or yellowish margins.Bogs and mossy woods, e. Que. to B. C., s. to Ct., N. Y., Mich., and Minn. June, July.

112. C. limosa $L$. Slender but rather stiff, 1.5-6 dim. high, very stoloniferous; culm sharp,

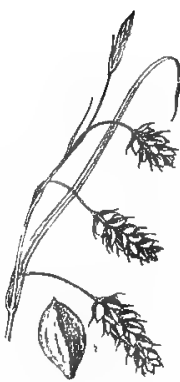

466. C. paup., v. irrigua.

rough above; spikes 1-2, nodding on short stalks or the upper one erect, subcylindric, $1-2.5 \mathrm{~cm}$. long, springing from the axil of a very narrow bract which is nearly always shorter than the culm; perigynia very short-pointed, about the length of the broad brown or purplish scales. - Bogs, e. Que. to Sask. and B. C., s. to Pa., Great Lake region, Col., and Cal. May-Aug. (Eu.) Fig. 467.

113. C. rariflora Smith. Ver'y small but stiff, $0.7-3.5 \mathrm{dm}$. high, slightly stoloniferous; culm obtuse and very smooth; spikes

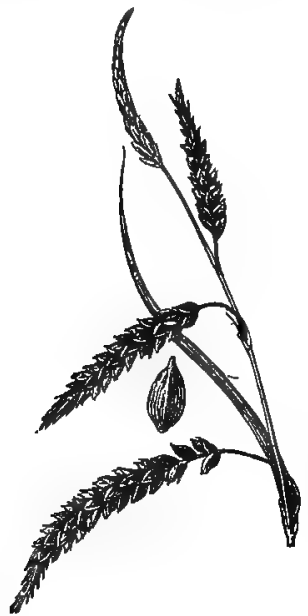

469. C. littoralis. 1-3, only 3-10-flowered, drooping, borne in the axil of a minute awl-like and purple-auricled bract; perigynia ovate, nearly pointless, obscurely nerved, mostly a little shorter than

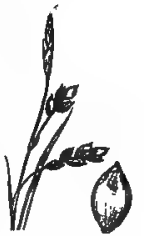

468. C. rariflori, the purple-black enveloping scales. - Cold bogs and granitic slopes, Arctic regions; very locally s. to Gulf of St. Lawrence; Table-topped Mt., Gaspé Co., Que.; and Mt. Katahdin, Me. (Goodale). (Eu.) FIG. 408.

114. C. littoràlis Schwein. Somewhat slender but erect, 4-9 dm. high, stoloniferous; leaves $3-6 \mathrm{~mm}$. broad, stiff, flat, glaucous, shorter than the sharp and nearly smooth often solitary culms; staminate spikes 1-3, dark purple, $5.5 \mathrm{~cm}$. long or less, the scales obtuse; pistillate spikes 1-4, somewhat approximate, on threadlike peduncles, narrowly cylindric (2-5 cm. long, 5-7 $\mathrm{mm}$. thick), usually staminate at top; perigynia lance-oval, faintly nerved, the minute beak entire, mostly longer than the obtuse purple scale; bracts prominently purple-auricled. - Wet woods and bogs, oftenest near the coast, Ct., and southw., local. May, June. Fig. 469.

115. C. prásina Wahlenb. Slender, somewhat flexuous, 3-7 dm. high; culm rather sharp, smooth; leaves $2.5-5 \mathrm{~mm}$. wide, soft and flat, rough; spikes 2-4, lineav'cylindric, peduncled and spreading or drooping, somewhat approximate, green, $1.5-6 \mathrm{~cm}$.

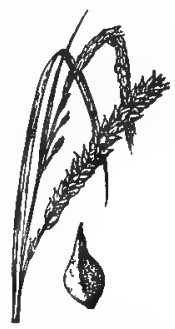

470. C. prasina. long, loosely flowered; perigynia pale, thin, nearly nerveless, produced into a short but slender entire or minutely toothed beak; scale very thin and acute, nearly colorless. - Wet woods and glades, w. Me. to Ont., Mich., D. C., and Iel. : and along the mts. to Ga. May-July. Fig. 470.

116. C. pícta Steud. Rather weak, $1.5-3 \mathrm{dm}$. high; leuves flat and firm; 
persisting through the winter, at least twice longer than the culm; a sheathing purple scale at the base of the spike; staminate spike $2.5-6 \mathrm{~cm}$. long, clavate in

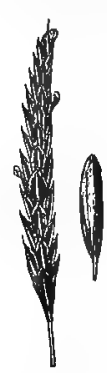
anthesis, the purple scales ending in a very short and blunt whitish tip; pistillate spilke narrower and mostly longer, the scales more abruptly contracted into a colored cusp and at length deciduous; perigynia much contracted below into a stipe-like base, very strongly nerved, pointless, hairy above, covered by the scales. - In a wooded ravine near Bloomington, Ind. (Dudley); also Ala. and La. Fic.471.

117. C. ebúrnea Boott. Tufted from a rigid pale brown stoloniferous base; culms capillary, wiry, 1-4 dm. high ; leaves involute-fitiform, shorter than the culm; staminate spike very small (4-8 mm. long), sessile or very short-peduncled, overtopped by the two upper pistillate spikes; pistillate spikes 2-4, approximate or the lowest remote, all stalked, erect, 2-6flowered; perigynia very small (1.5-2 $\mathrm{mm}$. long), 471. C. picta. almost nerveless, smooth and becoming black and shining at full maturity ; scales white and thin, obtuse,

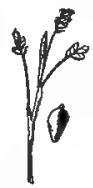

shorter than the perigynia. (C. setifotia Britton.) - Limestone ledges or shingle,

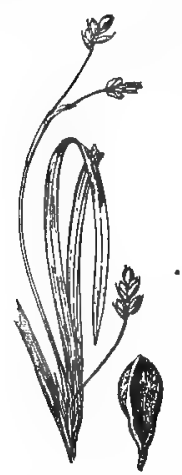

4:": C. pedunculnta. rarely in sand, e. Que. to the Mackenzie, s. locally to Va., Ky., Mo., and Neb. May-Aug. FIG. 472.

118. c. pedunculata Muhl. Low and diffuse, $0.5-3 \mathrm{dm}$. high, forming mats; leaves abundant, very green, flat and firm, 2-5 min. wide, mostly longer than the voeak culms; staminate spike small, usually slightly pistillate at base; pistillate spikes 2-4 on each culm, scattered and long-peduncled from green sheaths, erect or spreading, many other spikes nearly or quite radical and very long-stalked, all 3-8-flowered; perigynia smooth or very slightly pubescent above, the short and nearly entire beak somewhat oblique; scales green to purple, truncate and cuspidate, mostly a little longer than the perigynia. - Rich woods and banks, e. Que. to Sask., s. to Va., O., Mich., and Minn. Apr.June. FIG. 473.

119. C. concínna $\mathrm{R}$. Br. Loosely caespitose ; culms slender, curving, 0.5-2 dm. high ; leaves dark green, mostly shorter, 1-3 mm. wide; staminate spike 4-7 mm. long, sessile or short-peduncled; pistillate 2 or 3 , the upper

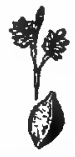

474. C. conoinna,

9sssile and approximate, 3-10-flowered; perigynia narrowly trigonous-ovoid, hairy, blunt, 2.5-3 mm. long, much exceeding the dark pale-

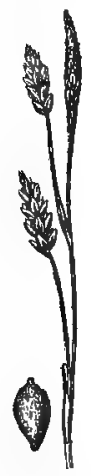
margined roundish scales. - Mossy knolls and cold wooded banks, e. Que. to the Mackenzie, s. to n. N. B., Ont., and Mont. June, July. Fig, 474.

120. C. Richardsoni $\mathrm{R}$. Br. Rather stiff, 1-3 dm. high ; stoloniferous; sheaths short, purple or brown; leaves $2-1$ mm. wide; staminate spike stout and mostly short-peduncled, $1.5-2.5 \mathrm{~cm}$. long; pistillate spikes $1-3$, the very short stalks included, erect, compact; perigynia obovoid, firm, hairy, the very short beak entire or erose ; scales brown, with a conspicuous white-hyaline margin, obtuse or pointless. - Dry ground, Ont. to B. C., s. to w. N. Y., Ill., Ia., S. Dak., etc. May, June. Fig. 475 .

121. C. plantaginea Lam. Slender but erect, $2.5-5.5 \mathrm{dm}$. high; leaves very firm, appearing after the flowers and persisting over winter, shorter than the culm; staminate spike purple and clavate, stalked, $1.3-2.5 \mathrm{~cm}$. Inng; pistillate spikes $3-4$, scattered, lonsely few-flowered, $1-2.5 \mathrm{~cm}$. long, erect, the peduncles mostly included in the leafess sheaths; perigynia 475. O Richnrdsoni. 3-4.5 mm. long, sharply 3-angled, prominently beaked, slightly 
Yonger than the sharp scales, - Rich woods, N. B. to Man., s. to N. C., Ind., and Ill. $\Lambda$ pr.-June. Fig. 476.

122. C. Careyàna Torr. Tảll and slender, mostly erect, 3-8 dm. high; leaves bright green, firm, $1-1.5 \mathrm{~cm}$. wide, shurter than the long culm; bracts leafy; staminate

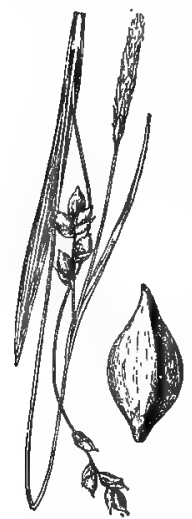

477. C. Careyana. spike heavy and stalked, 1.3-2.3 cm. long; pistiliate spikes 2-3 (mostly 2), ercet, the upper usually near the terminal spike, and nearly sessile, the other remote and long-peduncled, loosely 2-8flowered; perigynia very sharply angled, the beak oblique, finely many-nerved, twice longer than the sharp scales. Rich woods, N. Y. and Ont. to Mich, and D. C., local. May, June. Fig. 477.

123. C. platyphýlla Carey. Low, spreading, glaucous, 1-4 dm. high ; leaves mostly shorter than the culms; bracts with thin and sharp-pointed leaf-like tips; staminate spike stalked; pistillate spikes $2-3$, scattered, all more or less peduncled, alternately 2-10-flowered; perigynia strongly many-striate, about the length of the acute or cuspidate scales. - Rich shady woods and banks, s. Me. to Ont., s. to Va. and Ill. May, June. Fig. 478.

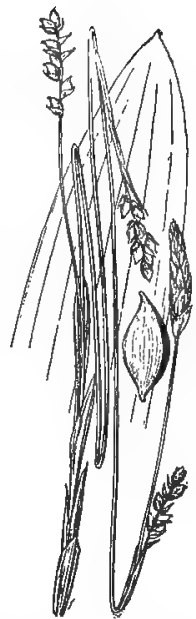

476. C. plantaginea $\times \frac{2}{3}$. Fruiting culm, perigynium, and leaf-tip.

-124. C. laxicúlmis Schwein. Caespitose; culms slender and lax, 1.5-5.5 dm. long; leaves usually very glaucous, mostly shorter than the culms, broad (6-12 mm.); staminate spike usually peduncled, $1-2 \mathrm{~cm}$. long; pistillate $3-5$, very remote, on capillary flexuous peduncles, $0.7-1.5 \mathrm{~cm}$. long, $3.5-5 \mathrm{~mm}$. thick; the spreading-ascending
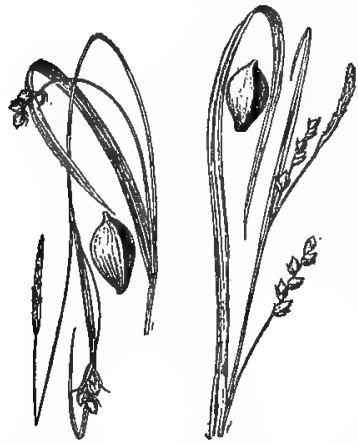

479, C. laxiculmis. sharply trigonous-ovoid perigynia 2.8-3.2 mm. long, equaling or exceeding the scales. - Glades and rich woods, s. Me. to Va., and Mo. May-July. Fig. 479. In the interior passing to var. copdrata (Bailey) Fernald. Glaucous or sometimes deep green ; spikes 1-2 cm. long; perigynia 3.3-4 mm. long. (C. digitalis, var., Bailey.) - Vt. to Del., O., Mich., and Ont.

125. C. digitàlis Willd. Very slender, bright green, tufted, 1.5-5 dm. high; leaves narrow; staminate spike

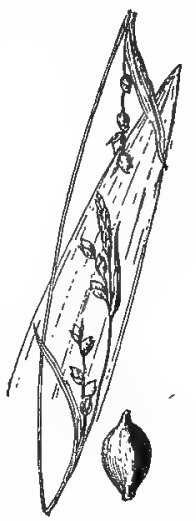

478. A. platyphylia.

2-4, on filiform stalks, ascending or slightly spreading, linear, $1-3 \mathrm{~cm}$. long, alternately flowered; perigynia 2.5-3 $\mathrm{mm}$. long, longer than the acute whitish scales. - Dryish woods and glades, Me. to Ont., Mich., and southw. May-July. FIG. 480.

126. C. ptychocárpa Steud. Low, glaucous; culms $0.3-1.8 \mathrm{dm}$. high; leaves flat and rather broad (4-8 $\mathrm{mm}$.), much exceeding the culms; bracts leafy and much prolonged; staminate spike very small and sessile, mostly overtopped by the upper pistillate spike; pistillate spikes $2-3$, sessile or short-stalked or rarely the lowest long-peduncled, erect, $0.7-1.5 \mathrm{~cm}$. long; perigynia tawny, narrowly 


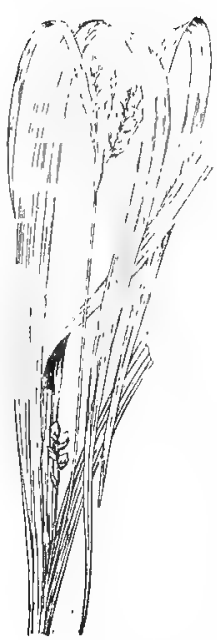

t\$1. C. ptychocarpa.

trigonous-ovoid, twice longer than the very thin obtuse scales. - Low woods, Mass. to Fla. and La., local. June, July. Fig. 481.

$\checkmark$ 127. C. Iaxiflora Lam. Slender but mostly erect, 2-5.7 dm. high; basal leaves $2.5-i \mathrm{~mm}$. wide, rather soft; stami. nate spike peduncled or at least conspicuous; pistillate spikes 2-4, scattered, peduncled or the upper one sessile, loosely flowered, cylinaric, 1.5-3 cm. long, erect or the lower loosely spreading; perigynia obovoid, conspicuously nerved, the short entire beat much bent or recurved; scales thin and white, blunt or cuspidate, mostly shorter than the perigynia._Rich woods and meadows, e. Que. to w. Ont., and southw. May-July. FIG. 482. - Exceedingly variable, passing by many transitions to the following.

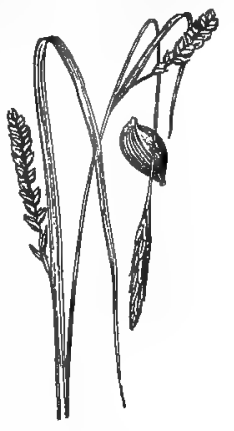

482. C. laxiflora.

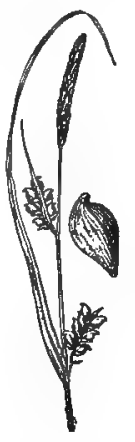

483. C. lax., v. gracillima.

Var. gracillima Bontt. Similar; but with short $(0.5-1.3 \mathrm{~cm}$. long) obtong closer-flowered spikes. - Vt. to Ont., and southw. Fig. 483.

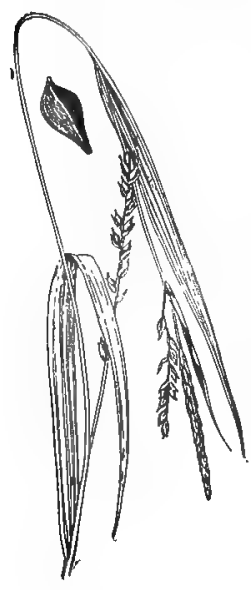

464. C'. hax., v. pat.

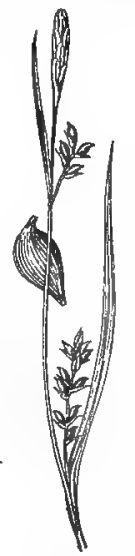

485. C. $\ln x$.

จ. Mich.

Var. patulifdlia (Dewey) Carey. Leaves 0.6-2 cm. broad; staminate spike prominent, mostly stalked; pistitlate spikes long (2-4.5 $\mathrm{cm}$.) and alternately flowered, scattered and peduncled ; perigynia $2.5-4 \mathrm{~mm}$. long, ellipsoid, attenuate at both ends, mostly less prominently nerved, and the beak not strongly recurved. - Me. to Va., O., Mich., and Ont. Frg. 484.

Var. Michaúxii Bailey. Tall and comparatively stout, $4-6 \mathrm{dm}$. high; leaves $0.7-1.2 \mathrm{~cm}$. broad ; staminate spike large and stalked ; pistillate spikes scattered, all but the upper one prominently peduncled, $1.2-3 \mathrm{~cm}$. long; perigynia very iarge, 4-5 mm. long, divaricate. (Var. divaricata Bailey.) - Pa. to Ala, and Tex. Fig. 485.

Var. stylofléxa (Buckley) Boott. Very weak and slender, 3-9 dm. high ; leaves $3-6 \mathrm{~mm}$. wide; staminate spike usually peduncled; pistillate 2-3, scattered, few-flowered, 0.5-2 cm. long, lowest drooping; perigynia oblong-fusiform, 4-5 mm. long, very long-pointed; scales often brown-tinged. ( $C$. styloflexa Buckley.) - Ct, to Fla. and Tex. Fig. 486.

Var. varians Bailey. Culms often ancipital, 2.5-5 dm. high; leaves $0.3-1.2 \mathrm{~cm}$. broad; pistillate spikes $1-3 \mathrm{~cm}$. long, linearcylindric to nanrow-oblong, the two upper more or less contiguous

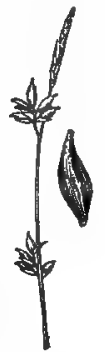

486. C. lax, v. styl. to the staminate spike and sessile or nearly so; bracts leafy and prolonged. Me. to Ont., Ia., and southw.

Var. blánda (Dewey) Boott. Leaves $0.5-1.4 \mathrm{~cm}$. broad; culms soft, ancipital, 1,5-6 dm. high; pistillate spikes oblong, 0.5-2 cm. long, the upper sessile 
and aggregated about the inconspicuous staminate spike, the lowest usually long-exserted. (Var. striaiula (arey.) - Vt. and e. Mass, to Ont., and southw. Eig. 487 .

Var. latifolia Boott. Rather low, 2-6 dm. high ; culms winged; leaves 1.5-4 cm. broad; staminate silke sessile or very nearly so, hidden by the pistillate; pistillate spiles cylindric and loose, $1.5-3 \mathrm{~cm}$. long, the upper one or two contiguous; bracts very broad. (C. albursina Sheldon.) - Deep rich woods, w. Que. and Vt. to Ont., and southw. Fig. 488.

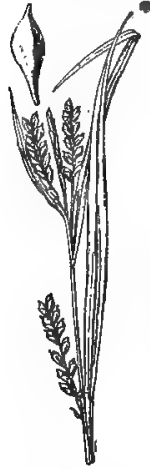

499. C. lax., i. lept.

Var. Jeptonérvia Fernald. Slender, 1.5-7 drn. high; leaves $0.5-1 \mathrm{~cm}$. broad; pistillate spikes linear-cylindric, loosely flowered, $1-2.5 \mathrm{~cm}$. long, the 2 or 3 upper crowded

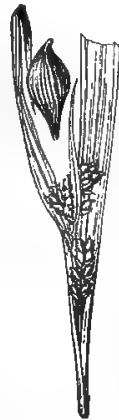

487. C, lax. $\mathrm{v}$. blanda. at the base of the staminate, the lower remote; perigynia oblong-fusiform, faintly nerved or nerveless. - Nfd. to Ont., s. to n. N. F., N. Y., and Mich. ; and in the mts. to N. C. FIG. 489.

128. C. Hitchcoçkiàna Dewey.

Erect, 3-7 dın. high; leaves $3-7 \mathrm{~mm}$. broad; spikes 2-4, all nore or less peduncled, very lousely few flowered, erect, $1-2.5 \mathrm{~cm}$. long, the bracts elongate and leafy ; perigynia triangular-ovoid, many-striate. 4-5 $\mathrm{mm}$. long, the strong beak prominently oblique shorter than the scales. - Rich woods, Vt. to Ont. s. to $\mathrm{Ky}$. and Mo. May-July. FIG. 490.

490. C. Hitchcoekiana.

129. C. oligocárpa Schkuhr. Diffuse, 1-5 dm. high; leaves 2-4.5 mm. wide; bracts elongate, spreading; staminate spike sessile or stalked; pistillate spikes 2-4, scattered, stalked or the uppermost sessile, loosely 2-8flowered, erect, $0.5-1.5 \mathrm{~cm}$. Iong; perigynia $3.5-4 \mathrm{~mm}$. long,

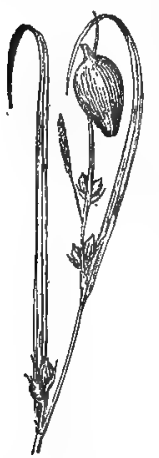
hard, finely impressed-nerved, abruptly contracted into a conspicuous mostly oblique beak, the orifice entire; scales very loosely. spreading, longer than the perigynia, - Dry woods and copses, Vt. to Ont., Ia., and southw. May-July. Hig, 491.

130. C. katahainénsis Fernald. Densely caespitose; leaves $1-2.5 \mathrm{dm}$. long, $3-4 \mathrm{~mm}$. broad, with the similar bracts much (2-6 times) overtopping the low (1-6 cm. high) rough-angled culms; pistillate spikes 3 or 4 , approximate, or the lowest remote, shortpediceled, 8-14 $\mathrm{mm}$. long, 5-10-flowered; staminate spike 5-8. mm. long, generally hidden among the pistillate; perigynia ellipsoid, 3-4 mm. long, many-nerved, beakless, mostly exceeding the whitish green-awned scales. - Graveliy shore of a pond, Mt. Katahdin, Me. ; rocky bank, Lake St. John, 491. C. oligocarpa. Que. (Brainerd). July, Aug. FIG. 492. 131. C. conoidea Schkuhr. Slender but

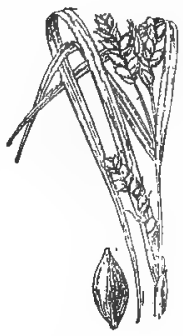

492. C. katahdineusis.

strict, 1.5-7 dm. high; staminate spike long-peduncled or rarely nearly sessile; pistillate spikes 2-3, scattered, short-stalked or the upper one sessile (the lowest frequently very long-stalked), narrowly ellipsoid, $0.7-2.5 \mathrm{~cm}$. long, rath ir closely flowered, erect; perigynia oblong-conical, 3-4 $\mathrm{mm}$. long, impressednervi(l, gradually narrowed to a point, the orifice entire; scales loosely spreading and rough-nwmed, equaling or exceeding the perigynia. - Moist grassy 


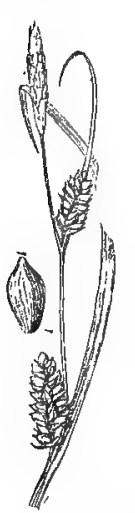

places, N. B. to Ont., s. to Pa, and Ia.; and in the mts. to N. C. May-Aug. Frg. 493.

$\checkmark$ 132. C. grísea Wahlenb. Stout, 3-8 dm. high; leaves 3-7 $\mathrm{mm}$. broad, slightly glaucous; bracts broad and leaflitee, diverging, very much exceeding the culm; staminate spike small and sessile; pistillate spikes $3-5$, oblong, $0.7-2.5 \mathrm{~cm}$. long, 4-7 $\mathrm{mm}$. thick, the highest two usually contiguous to the staminate spike and sessile, the others somewhat remote and peduncled (but not from the lowest axils), all erect; perigynia oblong, pointless, marked with impressed nerves, turgid and cylindric, appressed-ascending, 4.5-5.5 mm. long, all but the lowest longer than the narrow, cuspidate or blunt, nerved scale. - Low woods and meadows, s. Me., westw. and southw. May, June. Fig. 494. Var. Rígida Bailey. Much more slender; leaves scarcely half so vide; the bracts, especially, much narrower and shorter 498. C. conoidea. and more erect; spikes slender; perigynia scarcely inflated, triangular-oblong, bearing a beak-like point, 2-ranked. (Var. angustifolia Man. ed. 6, not Boott.) - Local, Mass, and N. Y., southw. Var. GLoBòsA

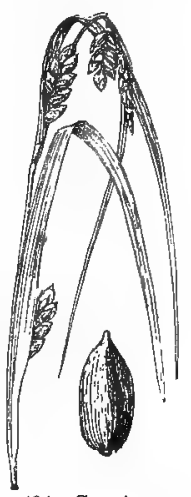

494. C. grisea. Bailey. Very slender; spikes few-flowered, often with but 2 or 3

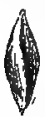

495, O. grís

$\nabla$, ang.

perigynia; perigynium short, inflated, very blunt, nearly globose or obovoid; scale short, not prominently cuspidate or the upper ones wholly blunt. - Mo., Kan., and southw. long and erect; staminate spike often peduncled; pistillate spikes very scattered, all more or less stalked, the lowest borne from near the base; perigynia triangular-oblong, hard, longer than the cuspidate ascending scale. (C. amphibola Stend.) -D. C. to Fla. and Tex. Fig. 495.

133. C. glaucodea Tuckerm. Lax or somewhat strict (1-6 dm. high), densely glaucous; leaves flat, thick and firm, 0.5-1 cm. wide; spikes as in C. grisea; perigynia firm, not

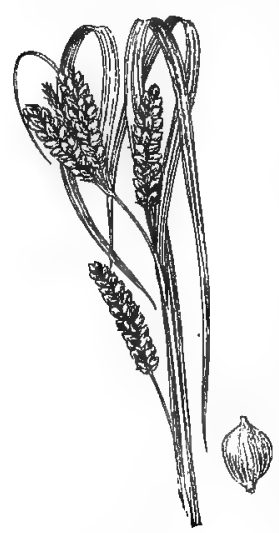

498. C. granularis.
Var. angustifolia Boott. Leaves rather narrow,

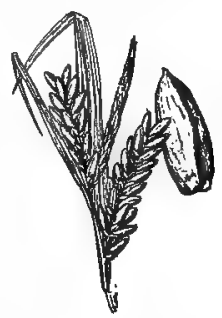

497. C. faccosperma. 496. C. glaucodes. inflated, prominently in pressed-nerved, glaucous, 3-4 $\mathrm{mm}$. long, mostly exceeding the short-cuspidate or blunt thin and appressed scale.

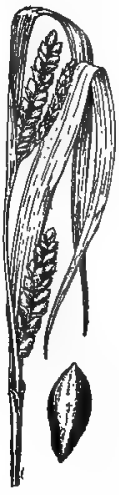

- Upland woods and rich meadows, e. Mass. and Vt. to Ont., and southw., local. June, July. Fig. 496.

134. C. tlaccospérma Dewey. Similar; leaves slight7y or scarcely glaucous, thinner; perigynia 4.5-6 mm. long, 2-3 times exceeding the brownish scales. - Rich woods and swamps, N. C. to Mo., and southw. May, June. FIG. 497.

135. C. granulàris Muhl. Erect or spreading, 2.5-9 dm. high, somerohat glaucous; leaves flat, the basal 5-12 $\mathrm{mm}$. wide; bracts broad and long, much exceeding the culn; spikes $2-4$, scattered, all but the upper peduncled, erect or ascending, compact, short-ellipsoid to cylindric, 0.8-3 cm. long, 5-6 mm. thick; staminate spike small and usually sessile; perigynia ovoid to globose, 2-3.5 $\mathrm{mm}$. 
long, very strongly nerved, the nearly entire short beak usually bent; scale thin and pointed, about $\frac{1}{2}$ the length of the perigynia.- Woods and meadows, Vt. to Ont., and soutiw. June, July. Fri, 498.

Var. Haleàna (Olney) Porter. Lower and more slender; pistillate spikes more slender, 3-5 mm. thick; perigynia oblong. (C'.

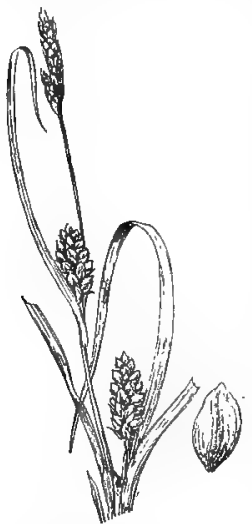

500. C. Grawei. Shriveri Britton.) - Me. to Sask, s. to Va., 499. C. gran., O., Mich., and Wisc. FIti. 499.

136. C. Cràwei Dewey. Low, strict, stoloniferous, $0.5-4 \mathrm{dm}$. high; leaves $2-4 \mathrm{~nm}$. wide; bracts scarcely exceeding the culm; spikes $2-5$, scattered, the lowest radical or nearly so, short-peduncled or the upper sessile, erect, compact, $1-2.7 \mathrm{~cm}$. long; staminate spike generally peduncled; periqunia ovoid, usually resinous-dotted, nearly nerveless or few-nerved, very short-pointed, longer than the obtuse or short-pointed scale. Moist places, in calcareous districts, Cape Breton I. to Man., locally s. to $\mathrm{n}$. Me., n. Pa., the Great Lake region, and Kan. June, July. Frg. 500.

137. C. Extéxsa Good. Slender but strict, 3-8 dm. high ; leaves involute; spikes $2-4$, the lowest remote and short-peduncled, the remainder approximate and sessile, short (0.8-2.5 cm. long) and compact; perigynia ovoid, narrowed at the base, very strongly nerved, ascending, the short stout beak sharply ${ }^{-}$toothed, longer than the blunt brown-edged scale.

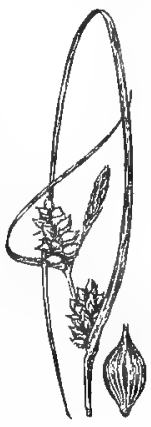

501. C. extensa. - Sandy shores, Long Island and Coney Island, N. Y.; Norfolk, va. June-Aug. (Nat. from Fu.) Fig. 501.

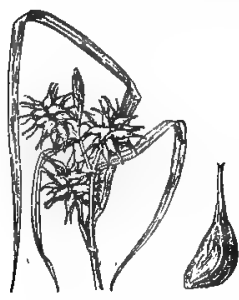

502. C. Hava.

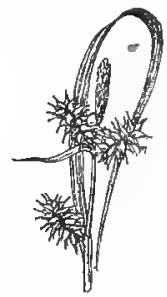

รัก. C. Hava, r. rect,

138. C. flàva L. Tufted, $2-8 \mathrm{dm}$. high, yellowish throughout; leaves flat, 2-5 $\mathrm{mm}$. wide, mostly shorter than the culms, bracts prominent, divergent; pistillate spikes 2-6, aggregated, on the lowest distinct, subglobose or short-cylindric, $0.8-1.5 \mathrm{~cm}$. long ; perigynia ovoid, yellowbrown, produced into a long deflexed beak, strongly nerved, twice or thrice longer than the blunt brown scale. - Damp places, Nfd. to Sask. and Alb., s. to Ct., n. N. J., w. Pa., Mich., Minn., and Mont.

June-Sept. (Eu.) FIG. 502.-Hybridizes with C. Oederi.

Var. rectiróstra Gaudin. Low and slender ; leaves 1-3 $\mathrm{mm}$. wide; the smaller straightish perigynic greenish or greenish-yellow. (Var. graminis Bailey.) - Nfd. to R. I. and Mich. (Eu.) Fig. 503.

Var. elatior Schlecht. Pistillate spizes remote, 6-9 min. thick, the curved perigynia spreading or usually very retrorse. (C. lepidocarpa 'Tausch.) Gaspé Co., Que., to R. I. and N. Y. (Fu.) FIG. 504. 139. C. Oedèri Retz. Similar, plant greenish, $0.5-3 \mathrm{dm}$. ligh; leaves $1-3 \mathrm{~mm}$. wide; pistillate spikes 2-4, mostiy scattered, 5-15 mm. long, 4-8 $\mathrm{mm}$. thick; the plump greenish-brown short-beaked peri-

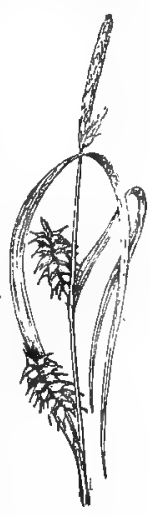

504. C. Hava, v. elatior. gynia ascending or wide-spreading, $\frac{1}{2}$ longer than the obtuse scale. Bogs, meadows and shores, Nfd. to Hudson Bay and Me. June505. C. Oederi, Aug, (Eu.) Fig. 505, - Hybridizes with C. flava. 


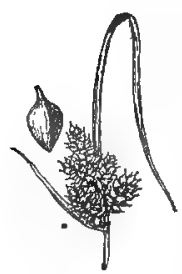

506. C. Vederi, v. jumila.

Var. pùmila (Cosson \& Germain) Fernald. Plant 0.5-6 dm high; pistillate spikes $3-10$, mostly crovoded. ( $C$. vividula Michx.; (. flava, var. viridula Bailey.) - Nfd. to B. C., s. to N. E., Pa., O., Ind., etc. (liu.) FIG. 506 .

140.- C. assiníboinénsis W. Boott. Tufted, slender, 4.5-9 dm. high, purptish-brown at base; leaves $2-3 \mathrm{~mm}$. wide, the bracts short, rarely prolonged; staminate spike long-stalked, $2-3 \mathrm{~cm}$. long; pistillate spikes 2 , very remote, peduncled, with 3-6 remote alternate flowers; perigynia 5-6.5 mm. long, lance-subulate, about equaling the scales. - Damp thickets and gravelly shores, Man. and n. Minn. June. Fig. 507.

141. C. longiróstris Torr. Slender but erect, $0.3-1 \mathrm{~m}$. high, growing in stools, the base dull brown and retaining coarse shreddy tufts; leaves $3-4 \mathrm{~mm}$. wide, flat, loose; staminate spikes $1-4$, peduncled; pistillate spikes 2-5, 1-5 cm. long,

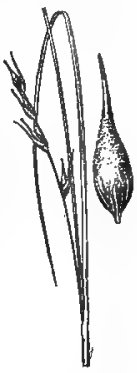

507. O. assiniboinensis. loosely flowered, slender-peduncled and mostly drooping: perigynia thin, slightly inflated, green, spreading, about the length of the awned scales. - Rocky woods or dry alluvial thickets, N. B. to Sask., N. J., Pa., and Neb., local. MayJuly. Fig. 508.

142. C. cherokeénsis Schwein. Rather slender, 2-7 dm high, the base castaneous; leaves flat, the basal 3-6 mm. broad ; staminate spikes $2-4$, whitish; pistillate $2-10$, remote, often in $2^{\prime}$ 's or $3^{4} s, 1.5-5 \mathrm{~cm}$. long ; perigynia conicovoid, pale green or straw-color, prominently few-ribbed, slightly exceeding the broad pale scales. - Woods and river swamps, Ga. and Fla. to Tex.; northw. in the flat country to Mo. April, May. FIG. 509.

143. C. castànea Wahlenb. Slender but erect, 3-9 dm. high ; leaves, 3-6 mm. broad, flat, hairy, much shorter than the rough culm; staminate spike $0.7-2 \mathrm{~mm}$. long, very short-peduncled; pistillate spikes 2-5, approximate, widely spreading or

508. C. longirostris. drooping on filiform stalks, $0.8-2.5 \mathrm{~cm}$. long, rather dense, tawny ; perigynia narrowly conic, the beak $\frac{1}{2}$ as long as the

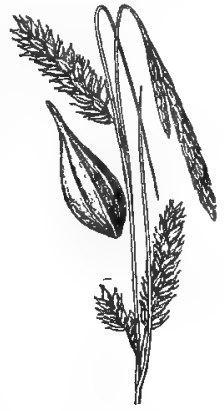

509. C. cherokeensis.

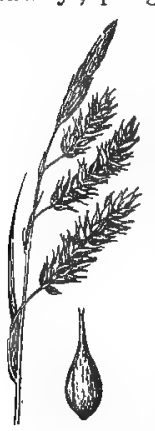

510. C. castanea.

body, thin, with a nerve on each side, longer than the brown acute thin scales. - Alluvial woods and thickets, rarely in bogs. in calcareous districts, Nfd. to Ont., locally s. to Ct., N.Y., and the Great Lake region. May-July. Fig. 510. - Hybridizes with C. arctata.

144. C. capillàris L. Densely tufted, very slender but erect, $0.3-2.5 \mathrm{dm}$. high; culm smooth, longer than the narrow flat or at length involute leaves; spilces $2-4$, approximate, the lonest vareil, $2 \mathrm{~cm}$. apart, all more or less long-peduncled and drooping, borne in the axils of sheathing bracts, very small (3-12flowered); perigynium thin, very small, oblongobovoid, the beak hyaline-lipped, longer than the very obtuse white scale. - Alpine or subalpine regions, Mt. Kineo, Me. ; Mt. Washington, N. H. ; and high northw. July, Aug. (Eu.) Fia. 511.

Var. elongata Olney. Loose and tall (1.5-8

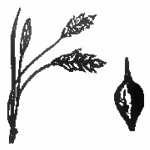
dm.); the spiles remote the lovest $2.5-10 \mathrm{~cm}$. 511. C. capillaris. 
apart. - Wet rocks and mossy woods, in calcareous regions, Nfd. to Alaska, southw. to s. N. B., Me., N. Y., Mich., Col., etc. June, July.

145. C. arctàta Boott. Slender, erect, 2.5-10 dm. high ; radical leaves much shorter than the culm and very broad, flat; bracts broad and short, long-sheathing; spikes $3-5$, usually spreading or drooping on filiform stalks, $1.5-8 \mathrm{~cm}$. long, slender; perigynia $3.5-4.5 \mathrm{~mm}$. long, abruptly and conspicuously stipitate and abruptly contracted into a beak, 3-comered, prominently

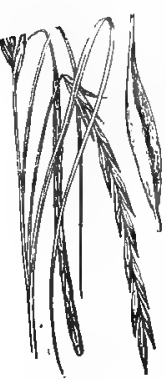

513. C. debìis. few-nerved, green, mostly spreading, slightly longer than the very sharp or cuspidate scale. (Including var. Faxoni Bailey, which was based on pathological material.) - Woods and copses, e. Que. to Ont., s. to Pa., Mich., and Minn. June-Aug. Frg. 512.-Hybridizes with $C$. castanea and $C$. vinescens.

146. C. débilis Michx. Resembling the last; very slender and lax, 0.3-1.2 m. high; leaves narrow and lax; spikes 3 or 4 , the upper approximate, the lower remote, mostly overtopped by the leafy bracts, slender-pediceled and flexuous, $3-6 \mathrm{~cm}$. long ; perigynia soft and thin, 6-9 mm. long, faintly nerved

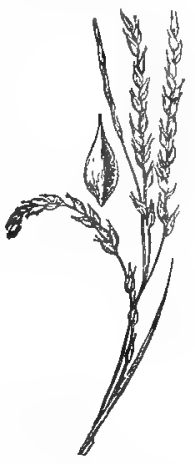

5). C. arctata. or nerveless, the white-edged scales blunt. - Woods and copses, D. C. to Fla. and Tex. May, Jume. Fig. 513.

Var. Rúdgei Bailey. Culms 0.1-1 m. high; spikes $1.5-6 \mathrm{~cm}$. long; perigynia 4.5-6 mm. long, rusty when ripe, appressed, twice longer than the tawny scales. (C. tenuis Rudge.) - Open woods, thickets and meadows, Nfd. to

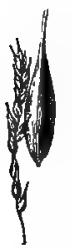

614. C. deb. v. Rudgei. Wisc., s, to N. C. June-Aug. Fxt. 514, - Hybridizes with $C$. virescens. Var. strfction Bailey. Usually tall, strict; leaves broader and firmer; spiles stiffer, simply spreading or even evect; perigynia mostly shorter and greener, often little exceeding the scales. - White Mts., N. H.

Var. interjécta Bailey. Perigynia firmer, more trigonous, scattered; the alternate-flowered spikes 4-8 cm. long. - Ct. to O. and n. N. J., local.

Var. pùbera Gray. Perigynia usually more slender, more nerved and minutely pubescent. - Pa. to N. C., local.

147. C. venústa Dewey, var. minor Boeckl. Slender but strict, 3-8 dm. high; basal leaves 4-12 mm. wide, strict, the upper and the bracts about as long as the culm; spikes 2-5, the upper pistillate ones approxi-

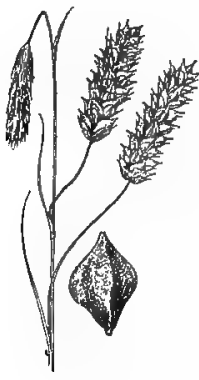

516. C. verrucosa. mate, usually ascending, the terminal sometimes staminate at top, $1.5-5 \mathrm{~cm}$. long; peri-

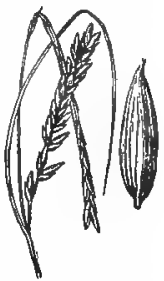

515. C. ven, v. minor. gynia ascending, $5.5-8 \mathrm{~mm}$. long, firm, proninently nerved, the very short and stout beak prominently toothed, thrice loigger than the rusty narrow scale. (C. oblita Steud.) Sphagnous swamps and low woods, N. Y. and N. J., southw., local. June. FiG. 515.

148. C. verrucdsa Muhl. Glaucous, stont and stiff, $0.6^{2}$ $1.5 \mathrm{~m}$. high; leaves long, rough-angled, becoming revolute; spikes $3-10,2-6 \mathrm{~cm}$. long, 6-9 $\mathrm{mm}$. thick, scattered to loosely aggregated, ascending or pendulous, often somewhat staminate above, variously peduncled; scales thin, brown, emarginate, shorter than the ovoid glaucous perigynia, but the hispid awn from 2-3 times longer to nearly obsolete; beak short, entire. - Swamps and wet shores, Va., Mo., and southw. July-Sept. Fig. 516.

149. C. macrokdlea Steud. Similar, slender, 4-7 dm. high; spikes 2-5, 1.5-4 $\mathrm{cm}$. long, ascending, on slender peduncles; scales lanceolate to ovate, 


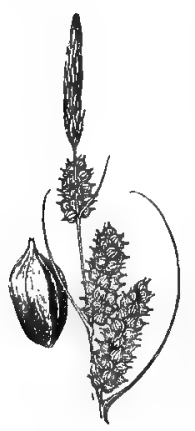

short-awned, exceeded by the plump subglobose or obovoid strongly ribbed abruptly beaked perigynia. (C. Jonrit Bailey.) - Swamps and wet shores, Mo. to Fla. and Tex. Aug. Fig. 517.

150. C. scabràta Schwein. Rather stout, very leafy, 2-8 dm. high; culm sharply and very roughly angled; leaves $6-18 \mathrm{~mm}$. broad, flat, very rough; spikes $3-6$, scattered, the upper 1 or 2 sessile, the remainder often long-peduncled and sometimes nodding, 1-6 cm. long, narrowly cylindrical and compactly flowered : perigynia broadly ovoid, prominently few-nerved, rough, the beak nearly as long as the body and slightly toothed; scales acute and roughtipped, green-nerved, about as long as the 517. C. macrokoles. body of the perigynia. - Wet meadows and glades, e. Que. to Ont., s. to the mts. of S. C. and Tenn., O., and Mich. June-Aug. F1G. 518.Hybridizes with $C$, crinita.

151. C. filifórmis L. Tall and very slender but erect, 0.5-1.2 m. high; culm obtuse, smooth; leaves very long,

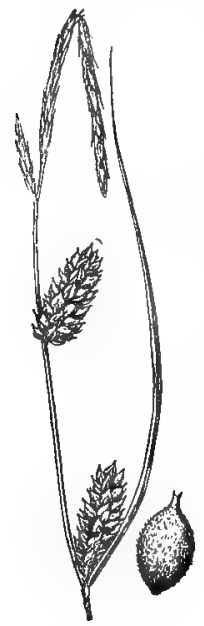

519. C. filiformis, involute-filiform, rough; spikes $1-3$, sessile, somewhat scattered, erect, short and thick, 1-5 cm. long, 5-7 mm. thick ; perigynia very short-ovoid, the teeth very

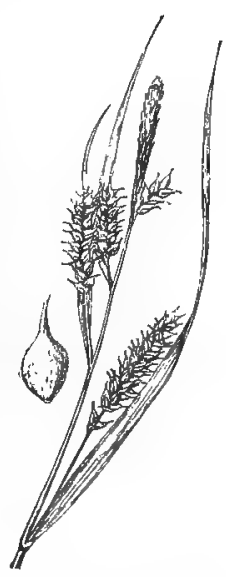

518. C. scabrata. short, the few nerves obscur'd by the dense stiff hairs; scales thin and blunt, about as long as the perigynia.-Bogs and shallow water, Nfd. to B. C., s. to Pa. and the Great Lake region. May-Aug. (Eu.) FIG. 519.

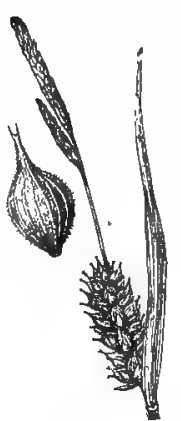

520. C. Houghtonii.

152. C. lanuginòsa Michx. Similar; lower; culm mostly rough above; leaves flat, 2-5 $\mathrm{mm}$. broad; spikes usually somewhat slimmer, the lowest usually peduncled; scales mostly sharper and longer. (C. filiformis, var. latifolia Boeckl.) - Swales and low meadows, N. B. to Sask. and B. C., s. to Pa., Ill., Kaw., etc. June-July.

153. C. Houghtonii Torr. Stiff, 1.5-6.5 dm. high, extensively creeping; culm rather sharply angled, rough, exceeding the leaves; leaves flat and very sharp-pointed; spikes $1-3$, sessile or the lowest short-stalked, erect, varying from nearly globular to cylindric, $1-4.5 \mathrm{~cm}$. long, 7-12 $\mathrm{mm}$. thick, compact; perigyinia short-ovoid, stiffly pubescent, prominently nerved and toothed; scales thin-margined, acute or awned. - Iry sandy or gravelly soil, e. Que. to A thabasca, s. to 11. N. E., N. Y., Mich., and Minn. May-Aug. Fig. 520.

154. C. vestita Willd. Stout and stiff, $3-8 \mathrm{dm}$. high, freely stoloniferous; culm sharply angled, smooth or somewhat rough ; leaves narrow and rather short, roughish; staminate spike 1 , rarely 2, sessile or nearly so, 2-5 $\mathrm{cm}$. long; pistillate spikes 1-3, subapproximate, or rarely the lowest subradical, often staminate at top, ellipsoid or short-cylindric, $0.8-2.8 \mathrm{~cm}$. long, compactly Howered; perigynia ovoid, nerved, stifly hairy, short-beaked, the beak often purple and white-hyaline at the orifice, which becomes more or less split with age; scales thin and blunt or acute, shorter

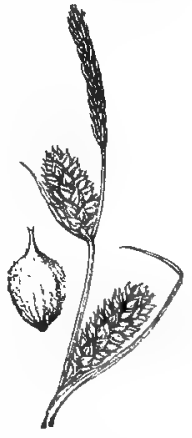

521. C. vestita. 
than the perigynia. - In sandy soils, from s. Me. to e. N. X., and D. C. : "south to Ga." May-July. Fig. 521. Var. Kennédy I Fernald. Stanimate spike about $1 \mathrm{~cm}$. long, hidden by the pistillate. - Wilmington, Mass. (Kennedy).

155. C. striàta Michx., var. brèvis Bailey. Stiff, 3-8 $\mathrm{dm}$. high, extensively creeping; culm sharply angled, smooth or slightly rough above, mostly exceeding the leaves; leaves narrow and stiff, becoming involute; spikes 1-2, mostly closely sessile, considerably separated when two, short (1-5 cm. long) and rather thick, erect; perigynia broadovoid with impressed nerves, smooth, ascending, shortbeaked and very short-toothed; scales thin, obtuse or

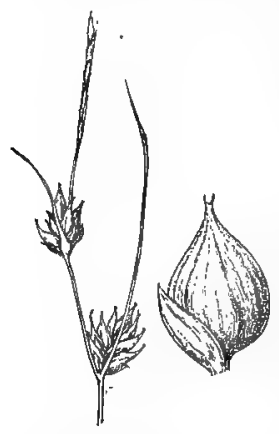

528. C. oligosperma. acutish, mostly about $\frac{1}{2}$ as long as - the perigynia. (C.Walteriana, var. Bailey.) - Pine-barren swamps, s.e. Mass., southw., local. June-Aug, FIG. 522.

156. C. oligospérma Michx. Very slender, but stiff, 2.5-9 dm. high; culms solitary or few from a slender stoloniferous base; leaves and bracts very narrow, becoming involute; staminate spike peduncled; pistillate spikes 1 or 2 , rarely 3 , sessile or the lowest very shortpeduncled, globular or short-oblong (0.7-2 cm. long) few-flowered; perigynia turgid, shining, gradually

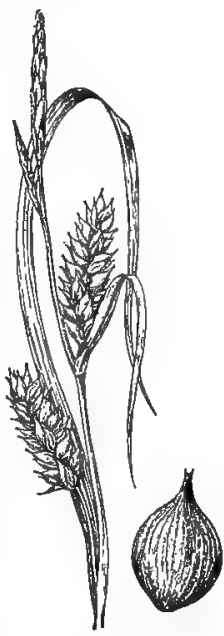

522. C. striata, ч. brev. contracted into a very short and minutely toothed beak, prominently few-nerved, yellowish, nearly twice longer than the blunt scales. - Bogs and wet shores, Lab and Nfd. to the Mackenzie, s. to Pa., and the Great Lake region. June-Aug. FIG. 523.

157. C. ufRta L. Variable in size $(2-6 \mathrm{dm}$. high), widely creeping; culm rather slender but erect, obtuse and smooth or slightly rough above; leaves soft and flat, generally sparsely hairy and the sheaths very hirsute, rarely smooth; spikes $2-3$, distant, more

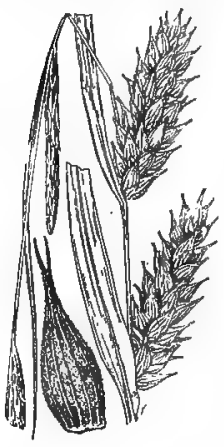

525. C. trichocarpa. or less shortly peduncled, erect or nearly so, $1.5-4 \mathrm{~cm}$. long, rather loose; perigynia longovoid, nerved, soft-hairy, the prominent beak slender-toothed; scales thin and green-nerved, awned, mostly a little shorter. - Groves, fields, and made-lands, e. Mass. to centr. N. Y. and Pa.; local. June-Aug. (Nat. from Eu.) FIG. 524.

158. C. trichocárpa Muhl. Stout and tall, 0.6-1.2 m. higì ; culm sharply angled, rough above; leaves numerous, flat, $3-6 \mathrm{~mm}$. wide, very rough, but not hairy, much exceeding the culnı; spikes $2-5$, scattered, the lower stalked and more or less spreading, $3-8 \mathrm{~cm}$. long, 1-1.5 cm. thick, heavy, but loosely flowered at base ; perigynia ovoid, many-costate, sparsely short-hairy, about twice as long as the membranaceous, acute or acuminate scales. - 524. C. hirts Marshes, s. w. Vt. to Ont., s. to Pa. and Ill.

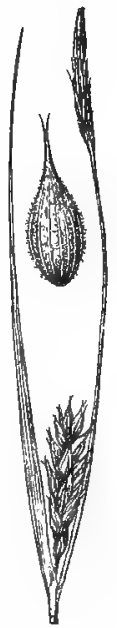

June-Aug. Fig. 525. Var, turbinata Dewey. Spikes 2-2.5 cm. long, 1.3-1.8 $\mathrm{cm}$. thick; perigynia lance-subulate. - Dutchess Co., N. Y.

Var. Dewèyi Bailey. Leaves narrower, often becoming somewhat involute, smoother; spikes short, $1.5-5 \mathrm{~cm}$. long, all but the lowest one sessile; perigynio 
smooth, thick in texture, becoming polished with age, the nerves impressed,

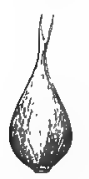

526. C. trich., scales sharp, mostly a little shorter than the perigynia. - Ia. to Kan, and northwestw. Fig. 526.

Var. aristàta (R. Br.) Bailey. Mostly stouter; leaves 4-10 $\mathrm{mm}$. wide, more or less hairy on the under surface and sheaths; perigynia lance-ovoid, smooth, the teeth longer and more spreading; scales long and sharp. ( $C$. aristata R. Br.) - Ont. to Sask. and B. C., s. to N. Y., Mich., Wisc., Neb., etc. Fig. 527. Var. пмв́́rbis Gray. $\checkmark$ Deweyi.

Sheaths glabrous. - Ont. to N. Dak, and Mo.

159. C. riparia $W$. Curtis. Very large and stout, 0.6-1.3 m. high, stoloniferous ; leaves $0.5-1.5 \mathrm{~cm}$. broad, flat, rough,

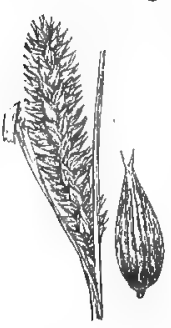

529 C. riparia. glaucous, much longer than the sharply angled culm; spikes $2-4$, scattered and all more or less peduncled, the lowest often very long-stalked, vary-

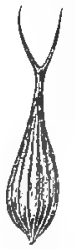

527. C. trich, v. aristata. ing from almost globular to slender-cylindric, $2-10 \mathrm{~cm}$. long, erect or the lower somewhat drooping, loosely flowered below; perigynia lance-oroid, coriaceous, rather lightly many-nerved, the beak short and thick; scales varying from blunt to awned, shorter or longer than the perigynia. - Swarmps and wet shores, N. B. to Man., and southw. May-July. (Eu.) Fig. 528.

160. C. Acurifóruis Ehrh. Stout, 0.4$1.2 \mathrm{~m}$. high; culm thick and sharp, mostly smooth; leaves broad, flat and glaucous, much prolonged; spikes $2-5$, all but the uppermost peduncled, spread-

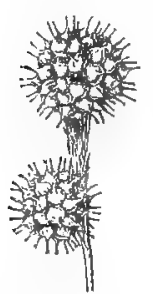

630. C. squarrosa. stalked, erect or stig

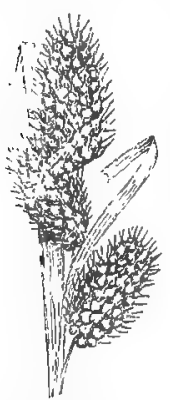

531. C. typhinoides, very much longer than the culm; terminal spike often pistillate at top; other spikes $3-7$, the uppermost sessile on the than the perigynia. - Boggy meadow, New Bedford, and formerly at Dorchester, Mass. June, July. (Nat. from Eu.) Fig. 629. angled, more or less rough above; leaves 2.5-6 mm. broad, weak, roughish, exceeding the culm; bracts slender, elongate; spikes $1-4$, thick, the terminal always two thirds pistillate or more, the remainder more or less lightly nodding, globular or short-cylindric, 1.5-3 cm. long, 1.5-2 cm. thick, brown, exceedingly densely flowered; perigynia squarrose, the beak rough; scale short and usually hidden. - Swamps and wet woods, w. N. E. to Neb. and southw., local. June-Sept. Frg. 330.

162. C. typhinoides Scliwein. Coarser, the glaucus or palo leaves $0.5-1 \mathrm{~cm}$. broad; spikes 1.5-5 cm. long, 1-2.2 'm. thick, pale brown ; perigynia less squarrose, the beaks ascending. - Meadows and alluvial woods, w. Que. and w. N. E. to Ia. and southw. June-Oct. FIG. 531 .

163. C. Fránkii Kunth. Stout and very leafy, 5-8 dm. high ; culm obtusely angled, very smooth; leaves $4-9 \mathrm{~mm}$. broad, rough
on the nerves, the upper and the bracts

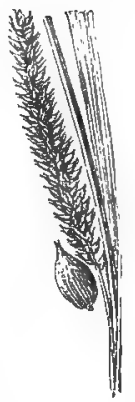

529. C. acutiformis.

161. C. squarrosa L. Caespitose, $3-9 \mathrm{dm}$. high ; culm sharply

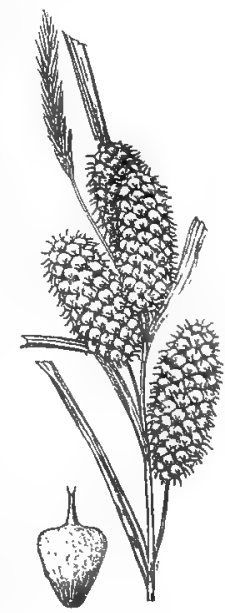

53\%. C. Frunkii. 
zigzal rhachis, $1.5-4 \mathrm{crn}$. Iong, $1 \mathrm{~cm}$. thick, evenly cylindricul, of ten staminate at top ; perigynia very abruplly contracted into a short but slender toothed beak. (C. stenolepis 'Iorr.) - Swamps and meadows, I'a. to Ill. and southw. June-Sept. Fig. 532.

114. C. Pseùdo-Cypèrus L. Tall and rather stout, 0.5-1 $\mathrm{m}$. ligh, in clumps; culm thick and very sharply triangular, rough throughout; leaves very long, rough-margined, $0.5-1 \mathrm{~cm}$. wide; spilies $3-5$, slenderly peduncled and more or less drooping, somewhat contiguous, $2.5-7.5 \mathrm{~cm}$. long, $n a r-$ rowly cylinarical (8-11 mm. thick), very compactly flowered; perigynia strongly reflexed, more or less 2-edged, inany-costate, the beak shorter than the body, with erect short (0.5-1 mm. long) teeth;

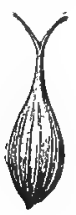

534. C. comosa. scales very rough-awned, about the length of the perigynia. - Bogs and shallow water, Gulf of St. Lawrence to Sask., locally s. to Ct., centr. N. Y. and the Great Lakes. JuneAug. (Eu.) Fig. 533 .

165. C. comosa Boott. Mostly stouter $(0.5-1.5 \mathrm{~m}$. high), the leaves broader (6-16 mm. wide); spikes $1.3-1.7 \mathrm{~cm}$. thick, more loosely flow-

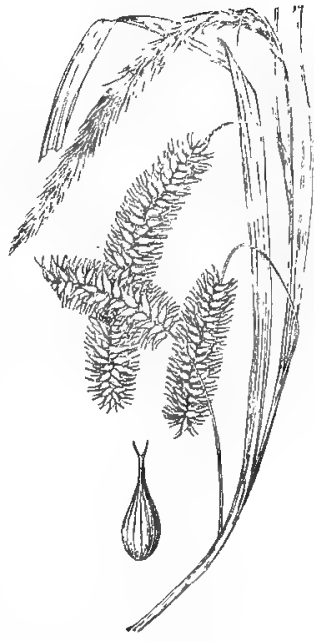

583. C. Pseuda-Cyperus.

ered; perigynia longer, the beak mostly longer than the body and the tecth long (1.2-2 mm.) and spreading. (C. Psendo-Cupervs, var. americana Hoclist.)

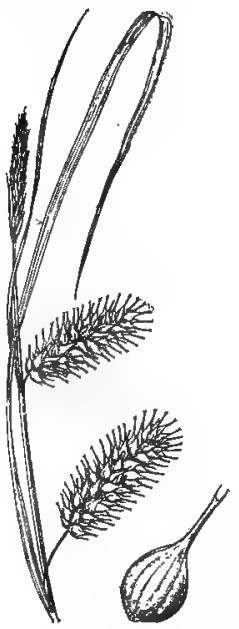

535. C. hystericiua. - Swamps, N. S. to Wash., s. to Fla., La., and s. Cal. June-Aug. Fig. 534.

166. C. hystericina Muhl. Slender but erect, $2.5-1 \mathrm{~m}$. high ; culm very sharply angled and rough, at least above ; leaves $3-10 \mathrm{~mm}$. broad, roughislı; spikes $2-5$, borne near the top of the culm, rarely very remote, the upper often sessile, the remainder on more or less filiform stalks, spreading or drooping, $1.5-6 \mathrm{~cm}$. long, 1-1.5 cm. thick, compactly flowered; perigynia greenish or straw-colored, strongly 15-20nerved, the very slender beak strongly toothed; scale nearly or quite as long as the perigynium. - Swales, throughout; frequent. June-Aug. (Jamaica). Fig. 535. - Tall specimens with long pendulous spikes have been separated as the scarcely distinguishable var. Coolèr. Dewey (val. Dudleyi Bailey).

$\checkmark 167$. C. lùrida Wahlenb. Variable in size, $0.2-1 \mathrm{~m}$. high, stout; culm rather obtusely angled and smooth; leaves long and loose, 4-6 $\mathrm{mm}$. wide, rough, the bracts leafy, elongated; spikes 2-4, vari-

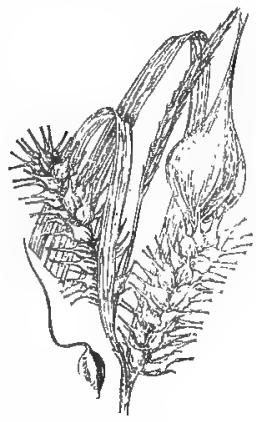

586. C. lurida.

ously disposed, the 1 or 2 upper sessile, nearly erect or often drooping, the others more or less peduncled, approxinate or remote, very densely flowered, globose to thick-cylindric, $1.5-6 \mathrm{~cm}$. long, $1.5-2 \mathrm{~cm}$. thick; perigynia thin and turgid, somewhat shining, about 10-nerved, the body barely equaling the slender long-conic beak; staminate spike single; scales linear, half as long as the perigynia or more - Swamps and wet woods, N. S. to Ont., and southw.; 
abundant eastw. FIG. 536.-Hybridizes with C. lupulina. Very variabie, passing to inany scarcely distinguishable forms, and to

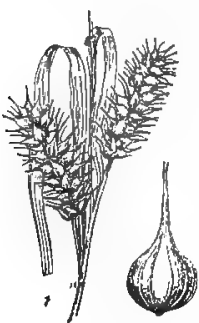

837. C. lur., v, gr'ae.

Var. grácilis (Boott) Bailey. Slender, $3-7 \mathrm{dm}$, high ; leaves 2-:) mm. wide; spikes $1-4 \mathrm{~cm}$. long, 1-1.3 cm. thick. (C. Baileyi Britton). - Cool woods and meadows, Me. to w. N. Y., and in the mts. to Tenn., local. Fig. 537.

168. C. Schweinftzii Dewey. Soft but erect, $2.5-7 \mathrm{dm}$. high, yellowish-green, becoming straw-colored in dry ing; culn solitary, from creeping rootstock, flattish and smooth; leaves $0.5-1 \mathrm{~cm}$ : broad, the rarlical longer than the culm, the others mostly short; spikes $3-5$, the lower one or two short-peduncled, the others subsessile and approximate, narrowly long-cylindrical (2.5-7.5 $\mathrm{cm}$. long, 8-13 mm. thick), ascending; perigynia thin and somewhat inflated, fewnerved, the long beak short-toothed, ascending; scales awned and commonly rough at the tip, a little shorter than the perigynia. - Swamps and wet calcareous soil, s. Vt. to Ont., s. to Ct., n. N. J., and Mich. June, July. Fig. 538.

169. C. retrórsa Schwein. Stout, 0.4-1 m. high; culm obtusely angled and smooth or nearly so; leaves and bracts $0.4-1 \mathrm{~cm}$. broad, soft, roughish, much longer than the culnı; staminate spikes 1-4, sessile or shortpeduncled; pistillate spikes 3-8, approximate near the top of the culm or the lowest lemote, all but the lowest

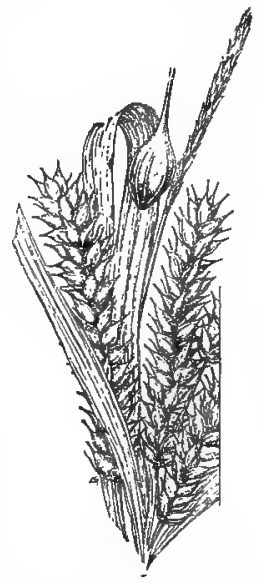

538. C. Schweinitzii. 1 or 2 sessile or subsessile, $1.5-5 \mathrm{~cm}$. long, $1.7-2 \mathrm{~cm}$. thick, compactly flowered, erect or spreading; perigynia very thin and papery, much inflated, prominently nerved, strongly reflexed, conic-ovoid, longbeaked, 8-10 mm. long, much exceeding the acuminate scales. - Wet places, e. Que. to the Saskatchewan and B. C., s. to Pa., the Great Lakes, Ia., Ida., and Ore. July-Oct. Fig. 539. Hybridizes with C. rostrata. Var. Robinsònir Fernald. Spikes slender, $1.2-1.5 \mathrm{~cm}$. thick. - Local, Me. to Ida.

Var. Hártii (Dewey) Gray.

589. C. retrorsa. The remote, often long-peduncled spikes usually more slender, 2-8 cm. long; perigynia wide-spreading. - Local, N. H. to Ont, and Mich.

Var. Macoúnii (Dewey) Fernald. Similar to the last, but perigynia ascending. (C. lupulina $\times$ retrorsa Dudley.) - N. Y., Ont, and Mich.

170. C. Halei Carey. Culms solitary, slender, smooth, 2-6 dm. high; leaves and bracts soft, roughish, $3-6 \mathrm{~mm}$.

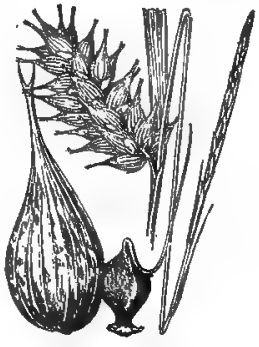

540, C. Halei. broad, over-topping the inflorescence; staminate spike long-peduncled; pistillate 2-4, mostly scattered, sessile, or the lowest short-peduncled, short-cylindric to subglobose, $2-3.5 \mathrm{~cm}$. long, $2-2.5 \mathrm{~cm}$. thick; the rather few perigynia conic-ovoid, thin, bladdery, 10-12 mm. long, with a rather abrupt slender-conic beak, twice as long as the firm ovate acuminate scales. (C. louisianica Bailey.) - Swamps, Ela. to Tex., northw. in the lowlands to Mo. June-Aug. Fig. 540. 
171. C. gigantèa Rudge. Loosely caespitose or somewhat stoloniferous, stout, $0.5-1.2 \mathrm{~m}$. high ; leaves $0.7-1.5 \mathrm{~cm}$. brood; staminate spikes $2-4$; pistillate $2-4$, scattered, the lowest long-peduncled and remote, rather loosely flowered, 3-7 cm. long, 2-2.7 cm. thick; periyynia swollen below but very abruptly contracted into a slender beak 3-4 times as long as the body, spreading

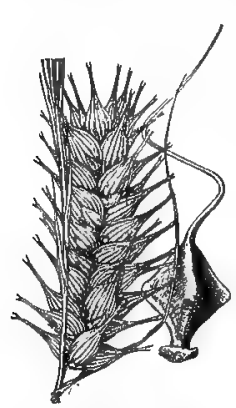

542. C. lupuliformis. at right angles or nearly so, never becoming yellow; scales narrow, smooth. (C. grandis Bailey.) Swamps, Del., Ky., and Mo., southw. July-Sept. Fig. 541.

172. C. Iupulifórmis Sartwell. Stout, tall, 0.6-1.2 m. high ; leaves $0.6-1.3 \mathrm{~cm}$. broad, conspicuously elongate; bracts broad and far exceeding the culm; staminate spike usually peduncled; pistillate spikes $3-5,3-8 \mathrm{~cm}$. long, cylindrical (2-3.5 cm. thick), at least the lower pe-

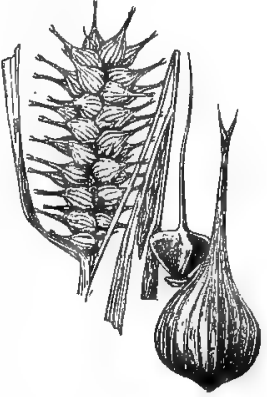

541. C.'gigantea. duncled, erect or ascending, somewhat scattered or the upper approximate, becoming yellowish brown; perigynia narrowly conic-ovoid, $1.3-2 \mathrm{~cm}$. long, mostly twice exceeding the firm lance-attenuate scales, ascending. (C. lupulina, var. polystachya Schwein. \& 'Torr.) - Rich swamps, meadows, and prairies, Vt. to Minn., s. to Del., Ill., and La. July-Oct. Fig. 542.

173. C. lupulina Muhl. Very stout and leafy, $4-9 \mathrm{dm}$. high ; leaves $0.6-1 \mathrm{~cm}$. broad, loose; bracts broad and elongate; pistillate spikes 2-6, approximate at the top of the culm, all closely sessile or the lower sometimes shortpeduncled, thick-cylindrical to subglobose, very heavy and densely flowered, 3-6 cm. long, 2-3 cm. thick; staminate spike sessile; perigynia much inflated, rather soft, $1.3-2$ $\mathrm{cm}$. long, erect or but slightly spreading, giving the spike a hop-like aspect (whence the name); scales firm, lanceovate, mostly much shorter than the perigynia. - Swamps

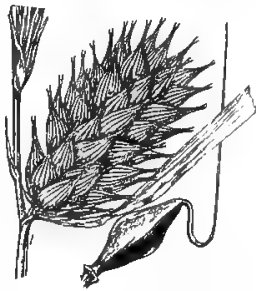

543. C. lupulina.

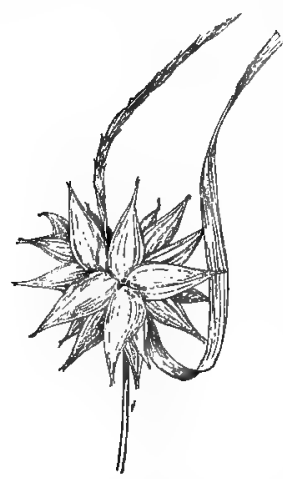

544. C. Grayil. and wet woods N. B., to Ont., Ia., and southw. July Oct. Fig. 543. - Frequently hybridizes with other species.

Var. pedunculàta Dewey. Often taller; spikes more or less scattered, some or all prominently peduncled; staminate spite usually conspicuous, generally peduncled; perigynia more spreading. - Locally more abundant.

174. C. Gràyii Carey. Rather stout, 0.3-1 m. high; leaves 6-11 mm. wide, flat, harsh, pale green; pistillate spikes 1 or 2, the lowest often peduncled, perfectly globular and compactly 6-30-flowered, the perigynia firm, much inflated, glabrous, $1.5-2 \mathrm{~cm}$. long, spreading or deflexed and prominently many-nerved. ( $C$. Asa-Grayi Bailey.) - Wet alluvial woods and meadows, w. N. E. to Ont, Ia., and Mo., local. June-Oct. FIG. 544.

Var. hispidula Gray. Perigynia hispidulous. - Ct. to Mo., and southw.

175. C. intuméscens Rudge. Slender, 0.3-1 m. high; leaves and bracts 3-8 mm. wide, soft, much elongate, dark green; pistil. late spikes 1-3, subglobose or short-ovoid, loosely 1-12-flowered; the perigynia thin, bladdery, green, 1-1.5 cm. long, 5-8 mm. thick, spreading, many. nerved. - Swamps, meadows, and allavial woods, throughout; the typical 


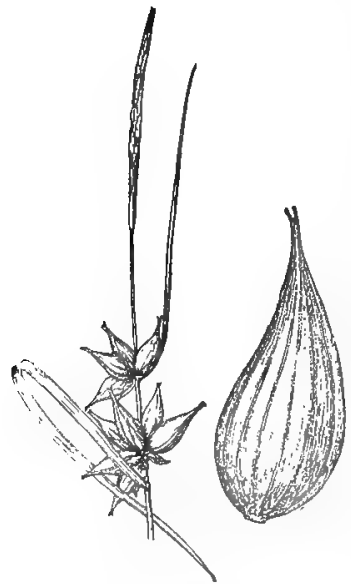

545. C. intumescers,

form commonest from Mass, southw. June-Sept FiG. 545.

Var. Fernáldii Bailey. Perigynia more slender: less inflated, $1.2-1.7 \mathrm{~cm}$. long, $3-5 \mathrm{~mm}$. thick. Nfd. to Man., s. to Mass., N. Y., Mich., and Wisc.; and on the mts. of N. C.; the common form northw.

176. C. folliculàta L.' Rather slender, 0.3$1.2 \mathrm{~m}$. higl ; leaves very broad and flat, yellowishgreen, zax; pistillate spitces $2-5$, mostly scattered, all but the uppermost prominently peduncled; perigynia conicsubulate, very slightly inflated, many-nerved, 1-1.5 $\mathrm{cm}$. long; scales awned and often nearly as long. - Wet woods, meadows and bogs, Nfd. to Ont., s. to Md., W. Va., and Mich.; locally abundant. June-Aug. Fig. 546.

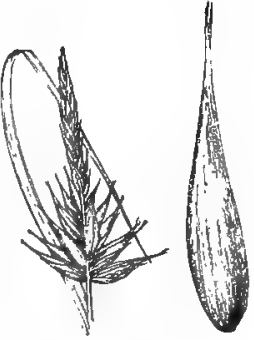

546. C. follieulata.

177. C. Michauxiàna Boeckl. Slender but stiff and ereet, 2.5-6 dm. high, yellowish ; leaves narrow and firm, shorter than the culm; spikes 2-4, the lowest

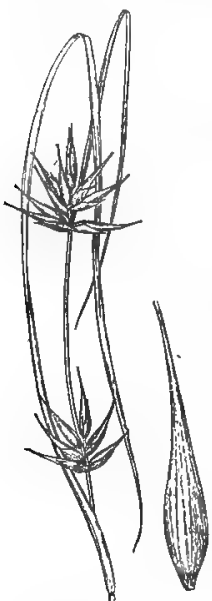

54i C. Michauxisno. usually remote and short-peduncled, the remainder aggregated and sessile; perigynia lance-subulate, not inflated, 8-13 mm. long, erect or spreading, twice longer than the blunt scales. (C. abacta Bailey.) - Bogs and lakeborders, Nfd. to L. Mistassini, s. to n. N. E., n. N. Y., and Mich.; local. June, July. Fig. 547.

178. C. subulàta Michx. Green, very slender but erect, $1.5-6 \mathrm{dm}$. high ; leaves soft, 1.5-4 $\mathrm{mm}$. wide, shorter than the culm; bracts leafy, sheathing; pistillate spities $2-5$, scattered, 2-6-flovered ; perigynia subulate, 1-1.5 cm. long, deflexed. (C. Collinsii Nutt.) - Bogs and white cedar swamps, R. I. to e. $\mathrm{Pa}$., and southw.; very local. June, July. FIg. 548.

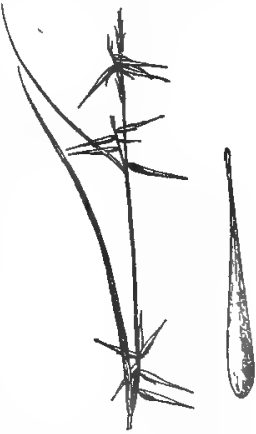

its. C. subulata.

179. C. saxátilis L. Low, 2-3 dm. high; leaves $2-5 \mathrm{~mm}$. wide, flat, becoming involute, nearly or quite equaling the culm; staminate spike 1 (rarely 2); pistillate 1-3, sessile or short-peduncled, subglobose or short-cylindric, $0.5-2 \mathrm{~cm}$. loug, in-8 mm. thick ; perigynia purple or purple-tinge.?, usually nerveless, ovoid, $3-4 \mathrm{~mm}$. long, with a short subentire beak, slightly exceeding the blunt purple scrtet; stigmas usually 2. - By an alpine pond, $\mathrm{Mt}$. Katahdin, Me.; Lab. and Greenl, July, Aug. (Eu.) FIG. 549.

Var. miliàris (Michx.) Bailey. Slender and taller, $2.5-6 \mathrm{dm}$. high; leaves nearly filifurm: pistillate spikes mostly paler and more stendir, $1-2.5$ c'm. long,

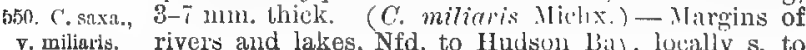

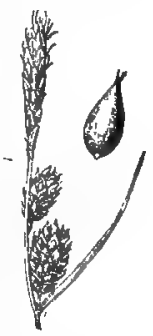

549. C, saxatilis, 
s. N. B. and centr. Me. July-Sept. Fig. 550.-Apparently lyybridizes with $C$. vesicaria.

180. C. Grahàmi Boott. Slender, 2-7 dm. high; leaves tat, $1.5-3 \mathrm{~mm}$. wide; staminate spikes $1-3$; pistillate $1-3$, the lowest mostly short-peduncled, slightly spreading or ascending, $1.2-1.8 \mathrm{~cm}$. long, 6-10 $\mathrm{mm}$. thick; perigynia straw-colored, thin,

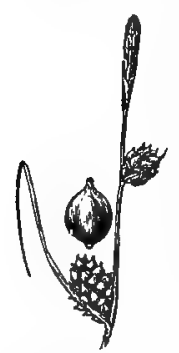

552. C. rotundata. ovoid, 4-5 mm, long, frw-nerved, with a slender subentire beak, ascending, twice as long as the biunt purple scale.-Margin of a pond, $\mathrm{Mt}$. Katahdin, Me. July, Aug. (Scotland.) FIG. 551. - Much of the American material previously referred to this species is apparently a hybrid between $C$. saxatilis, var. miliaris and forms of $C$. vesicaria. (C. miliaris, var, aurea Bailey; C. Raeana Britton, not Boott; C. mainensis Porter.)

181. C. rotundàta Wahlenb. Slender, $6 \mathrm{dm}$. or less high; leaves soon becoming involute; staminate spike 1 (rarely 2 or 3 ); pistillate 1 or 2, sessile, short and compact, 8-13 $\mathrm{mm}$. long, 6-8 mm. thick, the lower subtended by a

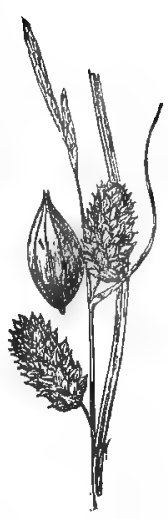

551. C. Grahami. divergent bract (4-5 $\mathrm{cm}$. long); perigynia pale or ferruginous, plump, subglobose-ovoid, few-nerved, about $3 \mathrm{~mm}$. long, abruptly short-beaked, the beak entire or short-toothed, one half longer than the purplish scales. - Outlet of Moosehead L., Me. Aug. (Greenl., n. Eu.) Fig. 552.

182. C. vesicària L. Comparatively slender, 0.4-1 m. high; the culnus sharply angled and generally harsh above, usually overtopped by the bracts; leaves $4-7 \mathrm{~mm}$. wide, loosely ascending or spreading; staminate spikes mostly 2 or 3 , peduncled; pistillate spikes $2-3$, remote,

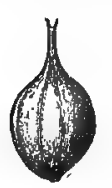
sessile or short-peduncled, cylindric, 2-7 cmi. long, 1-1.5 cm. thick; perigynia slightly turgid, ovoid to oblong-conic, gradually tapering to the beak, when mature 7-9 $\mathrm{mm}$. long, twice exceeding the ovate-lanceolate acute or acuminate scales. - Mearlows and low ground, e. Que. to B. C., s. to Pa., the Great Lake region, etc. June-Aug. (Eu.) FIg. 553. - A very variable northern species, pass554 C. ves., ing freely with us into the following arbitrarily v. monile. ing freely with us into the following arbitrarily Fernald. Leaves $2-5 \mathrm{~mm}$. wide; pistillate spikes as in the species; perigynia more turgid, roundish-ovoid, about $6 \mathrm{~mm}$. long, rather abruptly tapering to the beak. (C.

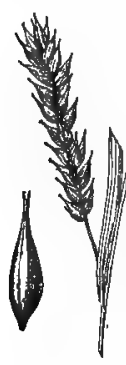
monile Tuckerm.) - Nfd. to Sask., Ky., and Mo., generally common. FIG. 554. Var. JEJÙnA Fernald. Smaller and more slender; pistillate spikes thinner, 5-8 mm. thick.-Common northw. Var. Disténta Fries. Siender; pistillate spikes 1 or 2, short and thick, 1-2.5 cm. long, 1-1.5 cm. thich;

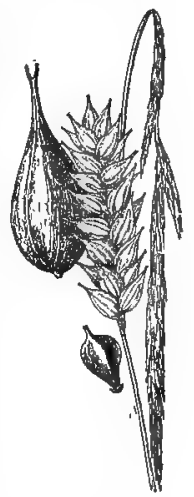

553. C. resicaria. perigynia subglobose or ovoid, abruptly beaked. - Local, Nfd, and Que. to Me. and Vt. Var. RAEAna (Boott) Fernald. Very slender; leaves 2 mm. wide, tending to become involute at tip; pistillate spikes slender, 4-8 $\mathrm{mm}$. thick; perigynia scarcely inflated, narrow and elongate. - Local, Que, to Athabasca, s. to Me. Fig. 555 .

183. C. rostràta Stokes. Culm $0.3-1 \mathrm{~m}$. high, rather stout, 555. C. ves., thickish and spongy at base, generally smooth and bluntly angled จ. Raeana.

above; leaves elongated, flat, usually equaling or exceeding the culms, pale green or glaucous, 0.2-1 cm. wide, promminily nodulose, especially after drying; staminate inflorescence peduncled, of 2-4 distinct spikes, pistillate spikes mostly 2-4, sessile or the lower peduncled, cylindric, dense, 
2-10 cm. long, 6-12 $\mathrm{mm}$. thick; perigynia ascending or slightly spreading, flask-shaped, 3-6 mm. long, the abrupt cylindric beak somewhat exceeding

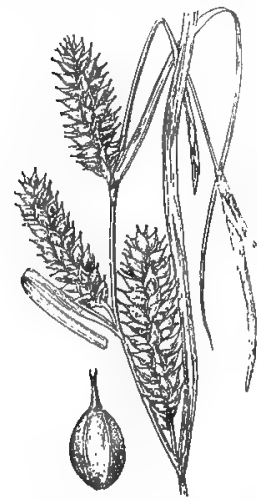

556. C. rostrate. the bluntish or acute oblong or lanceolate purple-tinged scale. (C. utriculata, var. minor Boott.) - Wet swarnps and shallow water, Ntd. and Lab. to Sask. and B. C.. s. to Ct., N. Y., Ill, Utah, and Cal. ; common northw., local southw. (Eu.) Fis. 556.

Var. utriculàta (Boott) Bailey. Coarser; mature spikes 1-2 cm. thick, often longer than in the species; perigynia ellipsoid-ovoid to conic-cylindric, 0.5-1 cm.long, tapering gradually to the beale. (C. utricuiate Boott.) - Extending s. to N. J., O., etc. Fig. 557.

Var. ámbigens Fernald. Very slender, 3-5 dm. bigh; culms barely $1 \mathrm{~mm}$.

in diameter below the spikes; leaves $2-5$ $\mathrm{mm}$. broad; staminate spikes 1 or 2 ; pis-

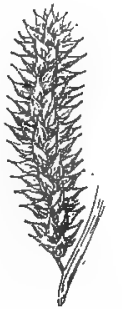
tillate 1-3, 1-2.5 cm. long; perigynia as 558. C. bullata. in the species. - Que., N. B., and n. Me.

184. C. bullàta Schkuhr. Slender, 4-9 dm. high, the long stiff leaves 4-6 nin. wide; staminate spikes mostly 2 or 3 , long-peduncled; pistillate swikzs

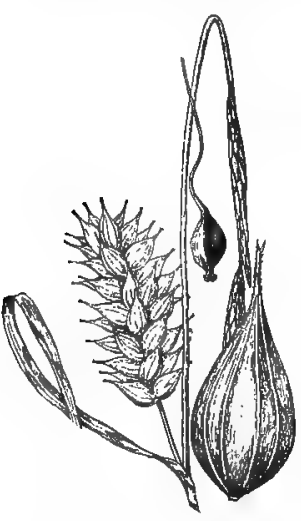

559. G. bullata, v. Greenil. mostly 2, remote, eylindric, densely flowered, 2.5-5 $\mathrm{cm}$. long, $1-1.5 \mathrm{~cm}$. thick ; perigynia strongly nerved, firm, dull or slightly shining, very turgid, $5-8 \mathrm{~mm}$. long, spreading-ascending, the usually serrulate or slightly roughish conic-cylindric beak much exceeding the acute or bluntish scale. ( $C$. Olneyi Boott; $C$. bullata $\times$ utriculata Bailey.) - Swales and wet meadows, local, Mass. to Del. June, July. Fig. 558.

Var. Greènii (Boeckl.) Fernald. More slender and lower; leaves 2-4 mm. wide; pistillate spite 1 (or if 2 , remote), shorter and thiclier, rather loosely flowered; perigynia iustrous, 6-9 mm. long. (C. bullata Man. ed. 6.) - Commoner, s. Me. to Pa. and Ga. Fig. 559.

185. C. Tuckermàni Dewey. Culms slender, $1 \mathrm{~m}$. or less high, forming loose stools; leaves 3-5 min. wide; bracts very leaf-like and usually much prolonged; staminate spikes 2 or 3, long-peduncled; pistillate spikes 2 or 3, slender-peduncled or the upper sessile, thickcylindric, 2-6 cm. long, $1.2-1.8 \mathrm{~cm}$. thick, loosely flowered; perigynia glossy, extremely membranaceous and bladderlike, strongly nerved, globose-ovoid, $1 \mathrm{~cm}$. long, 5-6.5 $\mathrm{mm}$.

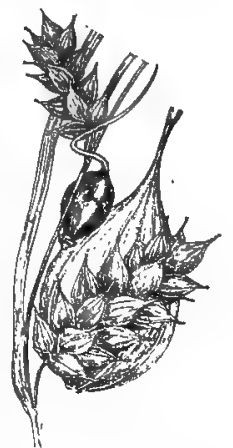

560. C. Tuckermani. thick, tapering grarlually to the slender cyliudric beak, much exceeding the oblong-ovate acute or acuminate scales. - Rjch alluvial shores, rarely in swamps, N. B. to Lake St. John, Que., and Ont., s. to N. J., Ind., and Minn. JuneAug. Fig. 560 


\section{ARACEAE (ARUM FAMILT)}

Plants with acrid or pungent juice, simple or compound often veiny leaves. and flowers crowded on a spadix, which is usually surrounded by a spathe. -. Floral envelopes none, or of $4-6$ sepals. Fruit usually a berry. Seeds with fleshy albumen, or none, but filled with the large fleshy embryo. A large family, chiefly tropical. Herbage abounding in slender rhaphides. - The genuine Araceae have no floral envelopes, and are almost all monoecious or dioecious ; but the genera of the third and fourth sections, with more highly developed flowers, are not to be separated.

'Spadix elongated, enveloped in a spathe; flowers destitute of perianth, monoecious or dioecious.

1. Arisaema. Flowers covering only the base of the spadix. Leaves not sagittate.

2. Peltandra. Flowers covering the spadix. Leaves sagittate.

* Spadix short-cylindric, subtended by an open spreading petaloid spathe; flowers (at least the lower ones) perfect, without perianth.

8. Calla. Flowers covering the whole spadix.

* * Spadix globose, enveloped in a very fleshy ovold spathe; flowers perfect and perisnth present.

4. Symplocarpus. Sepals 4, hooded.

**** Spadix cylindrical without obvious spathe ; flowers perfect, perlanth present.

5. Orontium. Spadix narrow, naked, terminating the terete scape.

6. Acorus. Spadix cylindrical, borne on the side of a leaf-like scape.

\section{ARISAÈma Martius. Indian Turnip. Dragon Arum}

Spathe convolute below and mostly arched above. Flowers monoecious or by abortion dioecious. Sterile flowers above the fertile, each of a cluster of almost sessile 2-4-celled anthers, opening by pores or chinks at the top. Fertile flowers a 1-celled ovary containing 5 or 6 erect orthotropous ovules; in fruit a 1-few-seeded scarlet berry. - Low perennial herbs, with a tuberous rootstock or corm, sending up a simple scape sheathed with the petioles of the simple or compound veiny leaves. (Name from dpls, a kind of arum, and ai $\mu a, b l o o d$, from the spotted leaves of some species.)

$\checkmark$ 1. A. triphýllum (L.) Schott. (INdian TURnip, JACK-1N-The-Pulpit.) Leaves mostly 2, divided into 3 elliptical-ovate pointed leaftets; spadix mostly dioecious, subcylindric or club-shaped, obtuse, much shorter than the spathe, which is smooth or corrugated in its tubular part and incurved-hooded at its flat ovate-lanceolate pointed summit. (A. pusillum Nash; A. Stewardsonii Britton.) - Rich woods. May. - Corm turnip-shaped, wrinkled, farinaceous, with an intensely acrid juice; spathe with the petioles and sheaths pale green, or often dark purple or variegated with dark purple and whitish stripes or spots.

2. A. Dracóntium (L.) Schott. (Green Dragon, Dragon Roor.) Leaf usually solitary, pedately divided into 7-11 oblong-lanceolate pointed leaflets; spadix often androgynous, tapering to a long and slender point beyond the oblong and convolute-pointed greenish spathe. - Low grounds, w. N. E. to Fla., w. to Ont., Minn., e. Kan., and Tex. June. - Corms clustered; petiole 3-6 dm. long, much exceeding the peduncle.

\section{Peltándra Raf. Arrow Ardm}

Spathe elongated, convolute throughout or with a dilated blade above. F"lowers thickly covering the long and tapering spadix throughout (or only its apex naked). Anther-masses sessile, naked, covering all the uppe:? part of the spadix, each of 4-6 pairs of cells embedded in the margin of a thick and shieldshaped connective, opening by terminal pores. Ovaries at the base of the spadix, each surrounded by 4-5 distinct, scale-like white staminodia, 1-celled, bearing 1-few amphitropous ovules at the base. Berries in an ovoid fleshy

GRAY'S MANUAL - 17 
head enveloped by the base of the leathery spathe. - Stemless herbs, with arrow. shaped or hastate palmately 3-nerved and pinnately veined leaves, and simple scapes from a thick fibrous or subtuberous root. (Name from $\pi \dot{\epsilon} \lambda \tau$, a small shield, and a $2 \eta^{\prime} \rho$, for stamen, from the shape of the latter.)

2 1. P. virgínica (L.) Kunth. Scape 2-3.5 dm. high, about equaling the leaves; basal lobes of the leaves rather long and often acutish ; spathe convolute throughout, wavy on the margin, mostly green; sterile portion of the spadix several times longer than the pistillate; ovules several; fruitrgreen; seeds $1(-3)$. ( $P$. undulata Raf.) - Shallow water, s. Me. to Fla., w. to s. Ont., Mich., and Mo. June.

\section{Calla L. Water Arum}

Spathe ovate (abruptly pointed, the upper surface white), persistent. Lower flowers perfect and 6-audrous; the upper often of stamens only. Filaments slender; anthers 2-celled, opening lengthwise. Ovary 1-celled, with 5-9 erect anatropous ovules. Berries (red) distinct, few-seeded.-A low perennial herb, growing in cold bogs, with a long creeping rootstock, bearing heart-shaped longpetioled reaves, and solitary scapes. (An ancient name, of unknown meaning.)

1. C. palústris L. - Cold bogs, N. S. to N. J., W. to Mich. and Minn. gnd northw. June. - Seeds surrounded with jelly. (Eurasia.)

\section{SYMPlOCÁRPUS Salisb. Skunk Carbage}

Stamens 4, opposite the sepals, with at length rather slender filaments; anthers extrorse, 2-celled, opening lengthwise. Style 4-angled and awl-shaped ; stigna small. Ovule solitary, suspended, anatropous. Fruit a globular or ovoid mass, composed of the enlarged and spongy spadix, inclosing the spherical seeds just beneath the surface, which is roughened with the persistent fleshy sepals and pyramidal styles. - Perennial herb, with a strong odor like that of the skunk, and also somewhat alliaceous ; a very thick rootstock, and a cluster of very large and broad entire veiny leaves, preceded in earliest spring by the nearly sessile spathes, which barely rise out of the ground. (Name from $\sigma v \mu \pi \lambda_{0} \eta^{\prime}$, connection, and $k a \rho \pi b s$, fruit, in allusion to the coalescence of the ovaries into a compound fruit.)

L 1. S. foétidus (L.) Nutt. Leaves ovate, cordate, becoming $3-6 \mathrm{dm}$. long, short-petioled; spathe spotted and striped with purple and Jellowish-green, ovate, incurved. (Spathyena Raf.) - Bogs and moist grounds, N. S. to N. C., w. to Ont., Minn., and Ia.

\section{5. oRóntium L. Golden Cleb}

Spathe incomplete and distant, merely a leaf-sheath investing the lower part of the slender scape, ard bearing a small and imperfect bract-like blade. Lower flowers with 6 concave sepals and 6 stanens; the upper ones with 4 . Filaments flattened; anthers 2-celled, opening obliquely lengthwise. Ovary 1-celled, with an anatropons ovule. Fruit a green utricle.-An aquatic perennial, with a deep rootstock, and long-petioled entire oblong and nerved floating leaves. (Origin of the name obscure.)

$\checkmark$ 1. 0. aquáticum L. - Ponds, Mass. to Fla. May.

\section{6. Ácorus L. Sweet Flag. Calamus}

Sepals 6, concave. Stamens 6; flaments linear; anthers kidney-shaped, 1-celled, opening across. Ovary 2-3-celled, with several pendulous orthotropous ovules in each cell. Fruit at length dry, gelatinous inside, 1-few-seeded. - Aromatic, especially the thick creeping rootstocks (calcmus of the shops). Leaves sword-like; the upper and more foliaceons prolongation of the scape may be considered as a kind of open spathe. ("Akopas, the ancient name, of no known meaning.)

1. A. Cálamus I. Scape leaf-like and prolonged far beyond the (yellowishgree») spadix. - Margins of rivulets, swamps, etc. (Eurasia.) 


\section{LEMNACEAE (DuCKWEed Family)}

Minute stemless plants, floating free on the water, destitute of distinct stem and fnliage, being merely a frond, producing one or few monoecious flowers from the edge or upper surface, and commonly hanging roots from underneath; ovules rising from the base of the cell. Frnit a 1-7-seeded utricle. Seed large. Embryo straight. - 'The simplest, and some of them the smallest of flowering plants, propagating by the proliferous growth of a new individual from a cleft in the edge or base of the parent frond, also by autumnal fronds in the form of minute bulblets, which sink to the bottom of the water, but rise and vegetate in spring; the flowers (in summer) and fruit scarce, in some species hardly ever seen. - These plants may be regarded as very simplified Araceae.

1. Spirodela. Frond 5-15-norved, with several rootlets.

2. Lemna. Frond 1-5-nerved, with a single rootlet.

3. Wolffla. Frond thick, ovold or ellipsoidal, very minute (0.5-1.3 mm. long), without rootlets.

4. Wolffiella. Fronds strap-shaped, thin, without rootlets.

\section{SPIRODĖLA Schleid.}

Anther-cells bilocellate by a vertical partition and iongitudinally dehiscent Ovules 2. Rootlets several, with axile vascular tissue. Otherwise as Lemna (From $\sigma \pi \epsilon \hat{\imath} \rho \alpha, a$ cord, and $\delta \hat{\eta} \lambda{ }^{\prime} s$, evident.)

1. S. polyrhiza (L.) Schleid. Fronds round-obovate (3-8 mm. long), thick, purple and rather convex beneath, dark green above, palnately (mostly

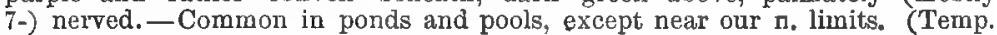
and trop. regions.)

\section{LÉmina L. DUCKWEed. Duck's-meat}

Flowers produced from a cleft in the margin of the frond, usually three together surrounded by a spathe; two of them staminate, consisting of a stamen only; the other pistillate, of a simple pistil; the whole therefore imitating a single diandrous flower. Ster. Fl. Filament slender; anther 2-celled, didymous; the cells dehiscent transversely. Fert. Fl. Ovary 1-celled; style and truncate or funnel-shaped stigma simple. Ovules and seeds 1-7.- Fronds 1-5-nerved, producing a single rootlet beneath (which is destitute of vascular tissue), proliferous from a cleft in the margin toward the base. (An old Greek name of uncertain meaning.)

* Fronds oblong, long-stalked at base, vemaining connected.

1. L. trisúlca L. Fronds oblong to oblong-lanceolate $(6-10 \mathrm{~mm}$. long), attenuate at base into a slender stalk, denticulate at the tip, very obscurely 3-nerved, often without rootlets, usually several series of offshoots remaining connected; spathe sac-like; seeds ovate, amphitropous, with smail round operculum. Ponds and springy places, N. S. to N. J., Tex, and w. to the Pacific. (Temp. and trop. regions.)

* Fronds oblong to elliptical or round-ovate, sessile, soon separating.

2. L. valdiviàna Philippi. Fronds elliptic-oblong, small $(2.5-4 \mathrm{~mm}$. long), rather thick, usually somewhat falcate, obscurely 1-nerved; spathe broad-reniform; utricle long-ovate, pointed by the long style ; seed orthotropous, oblong, with a prominent acute operculum. ( $L$. minor, var. cyclostasa Ell.; L. cyclostasa of auth.) - Pools, Mass. to Fla. and westw. across the continent. (S. A.)

3. L. perpusilla Torr. Fronds obovate or roundish-obotute, oblique (2-3 $\mathrm{mm}$. long), obscurely 3-nerved; utricle ovate; style rather long; seed orthotro pous, ovate or oval, obtuse, with scarcely apiculate operculum. - Mass. to Fla., and w. to Dak. and Kan. Var. TRINÉkvis Aust. has larger distinctly 3-nerved fronds, and an equally cordate seed. - N. J. to Kall. and I. T. 
4. L. minor L. Fronds round- to elliptic-obovate (2-5 $\mathrm{mm}$. in diameter), rather thick, very obscurely 3-nerved; spathe sac-like; utricle short-urn-shaped, tipped with a short style; seed oblong-obovate, amphitropous, with prominent rounded operculum. - Stagnant waters, except along our $\mathrm{n}$. borders. (Temp. regions.)

\section{WÓLFFIA Horkel.}

Flowers central, bursting through the npper surface of the globular (or in some foreign species flat) and loosely cellular frond, only 2 ; 'one consisting of a single stamen with a 1-celled 2-valved anther; the other of a globular ovary, tipped with a very short style and a depressed stigma. Ovule orthotropous, rather oblique in the cell. Utricle spherical. Albumen thin. - Fronds rootless, proliferous from a cleft or funnel-shaped opening at the base, the offspring soon detached; no rhaphides. - The simplest and smallest of flowering plants, floating as little grains in or on the water. (Named for Johann Friedrich Wolff, who wrote on Lemna in 1801.)

Not dotted; upper surface strongly convex

Dotted.

Upper surface flattish

Upper surface low-conical

1. W. columbiàna Karst. Globose or globular, 0.7-1.5 mm. long, very loosely cellular, light green all over, not dotted; stomata $1-6$; the opening at the base circular and with a thin border.-Floating rather beneath the surface of stagnant waters, Ct. to Fla., w. to Minn. and La.

2. W. punctàta Griseb. Oblong, smaller and more densely cellular, flattish and deep green with many stomata above, tumid and pale below, brown-dotted all over, anterior edge sharp; opening at base circular. ( $W$. brasiliensis of auth., not Weddell.) - Ont. to the Gulf of Mex. - Growing with the preceding but floating on the surface.

3. W. papulffera C. H. Thompson. Lower surface hemispherical, the upper flattish at the margin, rising at the center to a single low papilla; flowers unknown. - Mo. (Bush, Thompson).

\section{WOLFFIÉLLA Hegelm.}

Flowers and fruit unknown. Fronds (in oura) linear-attenuate or fiagellate, falcate or sigmoid, many times longer than wide, punctate, solitary or cohering at the base and radiating in a stellate manner. Pouch single, triangular, basal. - Small genus of imperfectly known plants. (Name a diminutive of Wolffica.

1. W. floridàna (J. D. Sm.) Thompson. Fronds hollow, gradually attenuate from base to flagelliform apex, 6-8 $\mathrm{mm}$. long. (Wolffia gladiata, var. J. D. Sm.) - Mo. to Fla. and Tex.

\section{ERIOCAULÀCeAe (Pipewort Familt)}

Aquatic or marsh herbs, stemless or short-stemmed, with a tuft of fibrous roots, a cluster of narrovo and often loosely cellular grass-like leaves, and naked scapes sheathed at the base, bearing dense heads of monoecious or rarely dioecious small 2-3-merous ,flowers, each in the axil of a scarious bract; the perianth druble or rarely simple, chaffy; anthers introrse; the fruit a 2-3celled 2-3-seeded capsule; seeds pendulous, orthotropous ; embryo at the apex of mealy albumen, - Chiefly tropical plants, a few in northern temperate regions.

1. Eriocaulon. Perianth double, the inner (corolln) tubular-funnel-form in the staminate Howers. Strmens twice as many as the corolln-lobes (4). Anthers 2-celled.

2. Syngonanthus. Perianth as in the last. Stamens only as many as the corolla-lobes (8). Anthers 2-cellext.

3. Lachnocaulon. Perinth simple, of 8 sepals. Stamens 8 , monadelphous below. Anthers 1-celled. 


\section{ERIOCAÚlon [Gronov.] L. PiPewort}

Flowers monoecious and androgynous, i.e. both kinds in the same head, either intermixed, or the central ones sterile and the exterior fertile, rarely dioecious. Ster. Fl. Calyx of 2 or 3 keeled or boat-shaped sepals, usually spatulate or dilated upward. Corolla tubular, 2-3-lobed, each of the lobes bearing a black gland or spot. Stamens inserted one at the base of each lobe and one in each sinus. Pistils rudimentary. Fert. $F l$. Calyx as in the sterile flowers, often remote from the rest of the flower (therefore perhaps to be viewed as a pair of bractlets). Corolla of 2 or 3 separate narrow petals. Stamens none. Ovary often stalked, 2-3-lobed; style 1 ; stigmas 2 or 3, slender. Capsule membranaceous, loculicidal. - Leaves mostly smooth, loosely cellular and pellucid, flat or concave above. Flowers, also the tips of the bracts, etc., usually white-bearded or woolly. (Name compounded of Épıv, wool, ard kavios, a stalk, from the wool at the base of the scape.) - Our species are all stemless, wholly glabrous excepting at the base and the flowers, with a depressed head and dimerous flowers.

1. E. decangulàre L. Leaves obtuse, varying from lanceolate to linear-awlshaped, rather rigid, 6-40 cm. long; scapes 10-12-ribbed (3-9 dm. high); head hemispherical, becoming globose (6-14 $\mathrm{mm}$. in diameter); scales of the involucre acutish, straw-color or light brown; chaff (bracts among the flowers) pointed. - Pine-barren swamps, N. J. and Pa. to Fla. and Tex.

2. E. compréssum Lam. Leaves spreading (5-12 cm. long), grassy-awlshaped, rigid, or when submersed thin and pellucid, tapering gradually to a sharp point, inostly shorter than the sheath of the 10-ribbed scape; scales of the involucre very obtuse, turning lead-color; chaff obtuse. (E. gnaphalodes Michx.) - Pine-barren swamps, N. J. to Fla.

3. E. articulàtum (Huds.) Morong. Peduncles 1-several; leaves $2-8 \mathrm{~cm}$. long, awl-shaped, pellucid, soft and very cellular; scape 4-7-striate, slender, 5-15 $\mathrm{cm}$. high or when submersed becoming $3-20 \mathrm{dm}$. long according to the depth of the water; chaff acutish; head $5-9 \mathrm{~mm}$. broad, at length depressed-globose; bracts, chaff, etc., lead-colored except where whitened by short but coarse beard; anthers longer than broad. (E. septangulare With.) - In ponds or along their borders, Nfd. to N. J., w. to Ind., Mich., Minn., and Ont. July, Aug. (Ireland and adjacent islands.)

4. E. Parkèri Robinson. Leaves lance-linear, $3-6 \mathrm{~cm}$. long, attenuate from a base 3-4 mm. broad to a very sharp tip ; peduncles 10-22, erect, slightly rigid; heads small ( $3-4 \mathrm{~mm}$. in diameter), even in fruit surrounded by a campanulate involucre; chaff and flowers nearly glabrous; anthers as broad as long. Banks of the Delaware R. near Camden, N. J. (T. P. James, Parker.)

\section{SYIGONÁNTHUS Ruhland.}

Stamens as many as the (often involute) lobes of the funnel-form corolla in the sterile flowers, and opposite them, commonly 3 , and the flower ternary. Petals of the fertile flowers united to the middle. Otherwise nearly as in

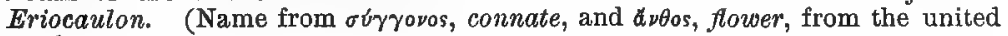
petals.)

1. S. flavidulus (Michx.) Ruhland. Tufted, stemless; leaves bristle-awlshaped (2-7 cm. long); scapes (1-4 dm. high) very slender, simple, minutely pubescent, 5-angled; bracts of the involucre oblong, pale straw-color, those among the flowers mostly obsolete; perianth glabrous; sepals and petals of the fertile flowers linear-lanceolate, scarious-white. (Paepalanthus Kunth.) - Low pine-barrens, s. Va. to Fla. and Ala.

\section{LAChNOCAÚlon Kunth. Hatry Pipetort}

Flowers monoecious, ete, as in Eriocaulon. Calyx of 3 sepals. Corolla none! Ster. Fl. Stamens 3; flaments below coalescent into a club-shaped tube around the rudiment of a pistil, above separate and elongated; anthers 1-celled ! Fert. Fl. Ovary 3-celled, surrounded by 3 tufts of hairs (in place of 
1 corolla). Stigmas 3, two-cleft. - Scape slender, bearing a single lıcad, 2-3.

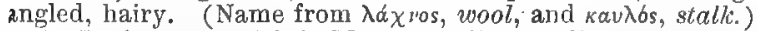

1. L. ánceps (Walt.) Morong. Leaves linear-awl-shaped, tufted, villous (L. Michauxi Kunth.) - Low pine-barrens, Va. to Fla. and 'Tex.

\section{XYRIDẢCEAE (YLLLOW-EYED GRASs FAMILY)}

Rush-litce herbs, with narrow leaves sheathing the base of a naked scape, which is terninated by a head of perfect 3-androus flowers, with extrorse anther's, glu. maceous calyx, and a regular colored curolla; the 3-valved mostly 1-celled rapsulp containing several or many orthotropous seeds with a minute embryo at the apex of fleshy albumen.

\section{XỲRIS [Gronov.] L. YELLOW-EYED GRAsS}

Fiowers single in the axils of coriaceous scale-like bracts, which are densely imbricated in a head. Sepals 3 ; the 2 lateral boat-shaped and persistent; the anterior one larger, enwrapping the corolla in the bud and deciduous with it. Petals 3, yellow (rarely white), with claws, which cohere more or less. Fertile stamens 3 , inserted on the claws of the petals, alternating with 3 sterile filaments, which are cleft and in our species plumose or bearded at the apex. Style 3-cleft. Capsule oblong, free, 1 -celled, with 3 parietal more or less projecting placentae, 3-valved, many-seeded. - ()urs apparently all perennials. (范upls, a name of

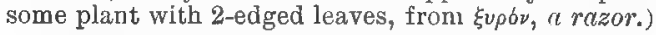

Lateral sepals about equaling the subtending luracts and concerled by them.

Base not bulbous; keel of the lateral sepals with an erose wing.

Heads ovoid.

Leaf-blades strictly linear or broadest at the base; scape narrowly 2 margined.

Heads nal'owly ovold; flower-bearing scales few (4-7) at longth dark

brown
Heads broadly ovoid; flower-bearing seales usually numeruns, greenish
or pale brown

Leaf-blades broadest in the iniddle; scape inuch flattened, conspleuously 2-winged

Hends ellipsoidal or subcylindric (sonthern)

Base bulbous; keel of the laternl sepals clliolate

Lateral sepals evident, much exceeding the subtending bracts or exserted laterally.

Keel of the lateral sepals slightly lacerate or erose.

Keel of tho lateral sapals conspicuously fringed.

Base neither bulbous nor indurated

Base bulbous and indurated, dark brown

1. X. montana.

2. X. carociniana.

8. $\boldsymbol{T}$. difformis.

4. $\bar{X}$. elata.

5. X. flexuosa.

1. X. montàna Ries. Dwarf and very slender, 1-(rarely) $3 \mathrm{dm}$. high, somewhat caespitose from a more or less branching rootstock; leaves narrowly linear,

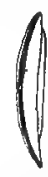

501. $\mathrm{X}$, montana,

Lateral sepal $\times 8 \frac{1}{3}$. Beed $\times 83$. rarely more than $4 \mathrm{~cm}$. long, about one fourth or one third the length of the nearly filiform stipes; heads at maturity 4-6 mm. thick; seeds subcylindric-spindle-shaped, rerrularly ribbed. ( $\boldsymbol{X}$. flexuosa, var. pusilla Gray.) - Chietly in peat bogs, Nfd, to Mt. Desert, Me., the uplands of N. Y., and e. Pa. ; also on L. Superior. Fig. 561.

2. X. caroliniàna Walt. Varying much in size; leaves grasś-like, mostly $6-20 \mathrm{~cm}$. long, one third to two thirds as long as the slightly ancipital scipe; roots a tuft of delicate fibers; rootstock apparently not developed; fruiting heads $8-10 \mathrm{~mm}$. in diamcter; seeds ovoid-spindle-shaped somewhat irregularly about 13 -ribbed, when ripe claret-colored. - Wet sandy shores
of lakes and pools, centr. Me. to Ind., and southw. Fig. 562 .
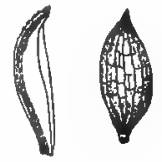

562. X. caroliniana. Lateral sepal $\times 81 / 8$. Seed $\times 38$.

3. X. difformis Chapm. Rather stout; leaves lance-linear, 7-12 mm. broao in the niddlle, Ifickish, scape strongly flattened, conspicuously 2-winged, 2-i 
$\mathrm{mm}$. broad; heads subglobose, in fruit about $1 \mathrm{~cm}$. in diameter ; seeds about 25 . ribbed. - Sandy shores, Md. (Canby), and southw.

4. X. elàta Chapm. Tall (4-8 dm. high); leaves grass-like (2-4 dm. long), linear or gladiate from broadened strongly equitant bases; scape slender, only moderately compressed, ancipital but not winged; heads ellipsoidal or subcylindric, $1.4-3 \mathrm{~cm}$. long ; floriferous scales numerous, suborbicular. - Sandy shores, Va. to Fla. and Miss.

5. X. flexudsa Muhl. Leaves narrowly linear, pale green, thickish, twisted, from a small bulb-like base ; stipe 3-6 dm. high, twisted and flexuous, slightly compressed toward the summit, not winged; head subglobose, about $1 \mathrm{~cm}$. in diameter; scales suborbicular, pale brown, the greenish area small and illdefined ; lateral sepals ciliolate on the keel. -

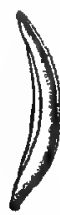

564. X. Smalliana. Lateral sepal $\times 81 / 3$. Wet places, chiefly in sandy soil, e. Mass. to Minn., Tex., and S. C. Fig. 563.

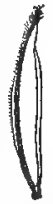

563. X. Hlexuosa. Lateral sepal $\times 3 \%$.

6. X. Smalliana Nash. Tall (4-9 dm. high) ; leaves broadly linear or sword-shaped, 2.j-6 dm. long, often nearly $2 \mathrm{~cm}$. broad at the equitant and commonly proliferous base, neither twisted nor flexuous; scape rather slender, straight, compressed near the summit; heads obovoid or ovoid-ellipsoidal, at maturity about $10-12 \mathrm{~mm}$. in diameter; scales broadly ovate, green with a stramineous or pale-brown border; lateral sepals long and narrow, erose-lacerate on the usually narrow wing; seeds for the genus long, subcylindric, regularly ribbed, pale in color. - Chiefly on boggy shores rich in decaying vegetation, often in water, e. Mass. to Fla.- The northern form, which has the lateral sepals a little less lacerate on the keel, has been published as $X$. CongZoni Small. Fig. 564.

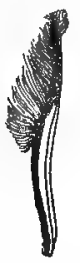

566. X. arenicola. Lateral sepal $\times 31 / 8$.
7. X. fimbriata Ell. Tall. strict; leaves broadly linear, straight; scape straight or nearly so, 5-8 dm. high, compressed and roughened on the edges toward the summit; heads ellipsoidal, about 12-15 mm. in diameter, nearly $2 \mathrm{~cm}$. long ; fringed sepals conspicuous, nearly twice as long as the bracts. - Pinebarrens, N. J. to Fla. and Miss. Fig. 565.

8. $\mathbf{X}$ arenícola Small. Base thick and bulb-like, surrounded by broad chestnut-

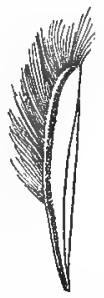

565. X. fimbriata. Lateral sepal $\times 3 \frac{1}{2}$. colored scales, the enlarged and hardened persistent bases of former leaves; slender stipe and very narrow thickish leaves twisted and flexuous; head cylindric, $1-2.5 \mathrm{~cm}$. long, acutish, 8-10 mm. thick; fringed sepals conspicuous. ( $X$. torta of anth., not Sm.)Pine-barrens, N. J. to Fla. and Miss. Fig. 566.

\section{MAYACÀCEAE (MAY}

Moss-like aquatic plants, densely leafy, with narrowly linear sessile pellucid leaves, axillary naked peduncles terminated by a solitary perfect 3-androus flower, herbaceous calyx, white corolla, and a 3-valved 1-celled several-seeded capsule. - A single genus.

\section{MAYACA Aublet.}

Perianth persistent, of 3 herbaceous lanceolate sepals, and 3 obovate petals. Stamens alternate with the petals. Ovary with 3 parietal few-ovuled placentae; style filiform; stigma simple. - Creeping or floating in shallow water; leaves entire, minutely notched at the tip; peduncle solitary, sheathed at base. (An aboriginal name.)

1. M. Aublèti Michx. Peduncles deflexed in fruit; capsules about 9-seeded. (M. Michauxii Schott \& Endl.) - Va. and O. to Fla. and Tex. 


\section{COMMELITACEAE (SPiderwort Family)}

Herbs, with fibrous or sometimes thickened roots, jointed and often branching leafy stems, and chiefly perfect and 6-androus often irregular flowers, with the perianth free from the 2-3-celled ovary, and having a distinct calyx and corolla; viz., 3 persistent commonly herbaceous sepals, and 3 petals, ephemeral, decaying or deciduous. Stamens hypogynous, often some of them sterile; anthers with 2 separated cells. Style 1 ; stigma undivided. Capsule 2-3-celled, 2-3valved, loculicidal, 3-several-seeded. Seeds orthotropous. Leaves entire, parallel-veined, sheathed at base; the uppermost often dissimilar and forming a kind of spathe. - Chiefly tropical.

1. Tradescantia. Bracts leaf-like or small and scarious. Petals equal. Perfect stamens 6; filaments bearded.

2. Commelina. Cyme sessile withtn a exrdate or connate brict (spatbe). Petals unequal. Perfect stamens 3; flaments naked.

\section{TRADESCÁNTIA [Rupp.] L. SPIDERWORT}

Flowers regular. Sepals herbaceous. Petals all alike, ovate, sessile. Stamens all fertile; filaments bearded. Capsule 2-3-celled, the cells 1-2-seeded. Perennials. Stems mucilaginous, mostly upright, nearly simple, leafy. Leaves keeled. Flowers ephemeral, in umbeled clusters, axillary and terminal, produced through the summer; floral leaves nearly like the others. (Nawed for the elder Tradescant, gardener to Charles the First of England.)

Umbels long-peduncled; bracts short, subscarious . . . . . . 1. T, rosea.

Umabels sessile or nearly so, much surpassed by the leaf-like bracts.

Dwnrf, rarely over $1 \mathrm{dm}$, bigh, villous; pedicels $2-6 \mathrm{~cm}$. long, thread-like . 2. T. brevicautis.

Taller, 3-8 dm. high.

Stem geniculate, the subsessile umbels axlliary as well as terminal . . 3. T. pilosa.

Stem straight, simple or branched; umbels terminal.

Sepals entirely glabrous. or one or more of them with a taft of hairs near tho involute slightly hooded apex . . . . . . 4. T. refleca.

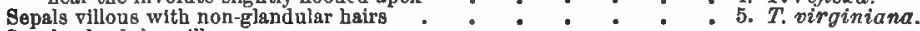

Sepals glendiuler-villous.

Bracts broader than the leaves . . . . . . . 6. T. bracteata.

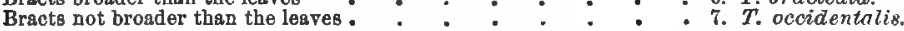

1. T. ròsea Vent. Small, slender (1.5-4 dm. high), smooth, erect from a running rootstock; leaves linear, grass-like, 1-5 (rarely as much as 11) $\mathrm{mm}$. broad. - Sandy woods, Md. to Fla., w. to Mo. and "Tex."

2. T. brevicaúlis Raf. Often stemless or nearly so, very hairy ; roots a cluster of dark more or less thickened fibers; leaves lance-linear; sepals ovate-lanceolate, 1-1.5 cm. long, villous; petals large, purplish-blue or more often rosecolored. ( $T$. virginica, var. villosa Wats.) - Moist sandy soil, centr. Ind. ( $H$. H. Bartlett) to Ky., Tex., and Kar. Apr., May.

3. T. pilosa Lehm. Tall, stout, 4-7 dm. high, zigzag; leaves large, flat, often 3-4 cm. wide, dark green above, finely pubescent on both surfaces, rarely subglabrous; sepals pilose or smoothish, ovate-oblong, 6-9 mm. long; petals blue. (T. flexuosa Raf.) - Woods and shaded banks of streams, Pa. to Mo. and Ga.

4. T. refléxa Raf. Slender, glabrous or nearly so, glaucous; leaves narrow, linear-attenuate from a lanceolate base, strongly involute; umbels terminal on the stems and branches, many-flowered; narrow bructs and glabrous pedicels soon deflexed; sepals ovate-lanceolate, 8-13 mm. long, glabrous except at the often tufted tip; petals blue, 10-14 mm. long. -- Wet places, O. to Mich., Minn., Kan., Tex., and S. C.

5. T. virginiàna $L$. Green; leaves flat, linear or lance-linear, the upper more or less pubescent; bracts leaf-like, elongated, usually ascending; pedicels and sepals villous, the latter about $1.5 \mathrm{~cm}$. long; petals rich purplish-blue, 1.6-2 cra. long. - Alluvial soil, Ct. to Pa. and S. C, ; also introd. northw, 
6. T. bracteàta Small. Soraid glandular-villous above; bracts relatively large, conduplicate, recurved, their bases $2-2.8 \mathrm{~cm}$. broad; flowers large, 2.5-3 cm. in diameter. - Prairies, "Minn.," and Ia. to 'T'ex. and B. C.

7. T. occidentàlis (Britton) Smyth. Slender, $3 \mathrm{dm}$, high; leaves narrowly linear, involute, their bases often enlarged and scarious; the bracts scarcely if at all broader than the foliar leaves; sepals glandular-pubescent, about $1 \mathrm{~cm}$. long ; petals blue (or roseate), about $1.4 \mathrm{~cm}$. long. - "Ia." to Neb., Tex., and N. Mex.

T. MontANa Shuttlw., not Heyne, a southern speeies distinguished from $T$. virginiana ohiefly by its smaller flowers and smoother calyz and from $T$. reflexa by its broader greener leaves, is said to extend as far north as Va. and $\mathrm{Ky}$.

\section{COMMelina [Plum.] I. Day-flower}

Flowers irregular. Sepals somewhat colored, unequal; the 2 lateral partly united. Two lateral petals rounded or kidney-shaped, on long claws, the odd one smaller. Stamens unequal, 3 of them fertile, one of which is bent inward ; 3 of them sterile and smaller, with imperfect cross-shaped anthers; filaments aaked. - Often procumbent and rooting at the joints. Leaves contracted at base into sheathing petioles; the floral one heart-shaped and clasping, folded together or hooded, forming a spathe inclosing the flowers, which expand for a single morning and are recurved on their pedicel before and afterward. Petals blue. Flowering all summer. Ours all with perennial roots, or propagating by striking root from the joints. (Dedicated to the early Dutch botanists $J$. and $\mathcal{G}_{\text {. }}$ Commelin.)

*Ventral cells 2-ovuled (usually 2-seeded), the dorsal 1-ovuled.

1. C. commùnis L. Slender and creeping, nearly glabrous; leaves lanceolate, 2-5 cm. long; spathe cordate, acute, with margins not united; seeds shallovoly pitted, granulate-reticulated. (C. nudiflora auth., not L.) - Alluvial banks, Del. to Fla., w. to Kan. and Tex. - A frequent weed of dooryards and gardens, northeastw. to e. Mass. (E. Asia, 'Trop. reg.)

2. C. hirtélla Vahl. Stout, erect, 6-12 dm. high; leaves large, lanceolate, the sheaths brown-bearded; spathes crowded, with margins united; seeds smooth. - River-banks, Pa. to Fla., w. to I. T. and 'Tex.

* Cells 1-ovuled, 1-seeded; seeds smocth; spathe cucullate; roots subtuberous.

3. C. erécta L. Slender, often low; leaves linear; cells all dehiscent.-Pa. to Fla. and Tex.

4. C. virgínica L. Slender, usually tall ; leaves lanceolate to linear ; dorsal cell indehiscent, scabrous. - Damp rich woods and banks, s. N. Y. to Fla., w. to Mich., Kan., and Tex.

\section{BROMeliaceae (Pineapple Familt)}

Herbs (or scarcely wonody plants, nearly all tropical), the greater part epiphytes, with persistent dry or fleshy and channeled crowded leaves, sheathing at the base, usually covered with scurf.

\section{TILLÁNdSIA L. Long Moss}

Perianth plainly double, 6-parted; the 3 outer divisions (sepals) membranaceous; the 3 inner (petals) colored; all connivent below into a tube, spreading above, lanceolate. Stamens 6, hypogynous or the alternate ones adhering to the base of the petals; anthers introrse. Ovary free; style thread-shaped; stigmas 3. Capsule cartilaginous, 3-celled. Seeds several or many in each cell, anatropous, club-shaped, pointed, raised on a long hairy-tufted otalk, like a coma. - Scurfy-leaved epiphytes. (Named for Prof. Tillands of Abo.)

1. T. usneoides L. (Common Lowg Moss or BLACK Moss.) Stems thread. 
shaped, branching, pendulous; leaves thread-shaped; peduncle short, 1-flow. ered; flower yellow. - K. Va., s. to Fla., and westw, growing on the branches of trees, forming long hanging tufts.

\section{PONTEDeriàceat (Pickerel-Weed Famli)}

Aquatic herbs, with perfect more or less irregular flowers from a spathe; the petal-like 6-merous perianth free from the 3-celled ovary; the 3 or 6 mostly unequal or dissimilar stamens inserted in its throat. - Perianth with the divisions colored alike, imbricated in 2 rows in the bud, the whole together sometimes revolute-coiled after flowering, then withering away, or the base thickened-persistent and inclosing the fruit. Anthers introrse. Ovules anatropous. Style 1; stigma 3-lobeā or 6-toothed. Fruit a perfectly or incompletely 3-celled many-seeded capsule or a 1-celled 1-seeded utricle. Embryo slender, in floury albumen.

1. Pontederia. Spike many-flowered. Perianth 2-lipped, its fleshy persistent base inclosing the 1-seeded utricle. Stamens 6.

2. Heteranthera. Spathe 1-few-flowered. Perianth salver-shaped. Stamens 3. Capsale many-seeded.

\section{PONTEdéria L. Pickerel-weed}

Perianth funnel-form, 2-lipped; the 3 upper divisions united to form the 2 . lobed upper lip; the 3 lower spreading, and their claws, which form the lower part of the curving tube, more or less separate or separable to the base; tube after flowering revolute-coiled. Stamens 6 ; the 3 anterior long-exserted; the 3 posterior (often sterile or imperfect) with very short filaments, unequally inserted lower down; anthers versatile, oval, blue. Ovary 3-celled; two of the cells empty, the other with a single suspended ovule. Utricle 1-celled. - Stout herbs, with thick creeping rootstocks, producing erect long-petioled leaves, and a 1-leaved stem, bearing a spike of violet-blue ephemeral flowers. Root-leaves with a sheathing stipule within the petiole. (Dedicated to Pontedera, Professor at Padua in the 18th century.)

1. P. cordata L. Leaves heart-shaped, blunt; spike dense, from a spathelike bract; upper lobe of perianth marked with a pair of yellow spots (rarely all white); calyx-tube in fruit crested with 6-toothed ridges. - N. S. to Ont., Minn., and Tex. July-Sept. (Trop. Am.) Var. Ang ostifolia Torr. Leaves lanceolate or triangular-attenuate, roundish or truncate at base. - Same range.

\section{Heteranthèra R. \& P. Mud Plantain}

Perianth with a slender tube ; the limb somewhat equally 6-parted, ephemeral. Stamens in the throat, usually unequal; anthers erect. Capsule 1-celled or jucompletely 3-celled by intrusion of the placentae. - Low herbs, in mud or shallow water, with a l-few-flowered spathe bursting from the sheathing side

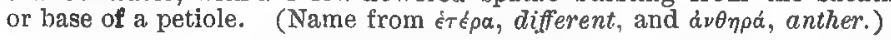

* Stamens unequal; 2 posterior filaments with ovate yellow anthers; the other longer, with a larger oblong or sagittate greenish anther; capsule inconpletely 3-celled; leaves rounded, long-petioled; creeping or floating plants.

1. H. reniformis R. \& P. Leaves round-kidney-shaped to cordite and acute; spathe 3-5-flowered; flowers white or pale blue. - Ct. to Neb., and southw. (S. A.)

2. H. limosa (Sw.) Willd. Leaves oblong or lance-oblong, obtuse at both ends; spathe 1-flowered; flowers larger. blue. - Va, to Neb., and southw. (S. A.) 
Stamens alike, with sagittate anthers; capsule 1-celled, with 3 pamietal placentae; leaves linear, translucent, sessile; submerged grass-like herbs, with only the flowers reaching the surface.

3. H. dùbia (Jacq.) MacM. The slender branching stems clothed with leaves and bearing a terminal 1-flowered spathe (becoming lateral); flowers small, pale yellow, with a very long thread-like tube. (H. graminea Vahl.) - N. E. to Ont., westw, and southw.

\section{JUNCÅCEAE (Rush FAMILT)}

Grass-like or rush-like herbs, with small regular and hypogynous persistent fowers, 3 glumaceous sepals, and 3 similar petals, 6 or rarely 3 stamens with 2-celled anthers, a single short style, 3 filiform hairy stigmas, and an ovary either 3-celled or 1-celled with 3 parietal placentae, forming a loculicidal 3-valved eapsule. Seeds anatropous, with a minute embryo inclosed at the base of the fleshy albumen. - Flowers liliaceous in structure, but sedge-like in aspect and texture.

1. Juncus. Capsule 3-celled (sometimes imperfectly so), many-soeded. Plants never hairy,

2. Luzula. Capsule 1-celled, 8-seeded. Plants often hairy.

\section{JÚNCUS [Tourn.] L. RUsh. Bog Rush}

Capsule 3-celled, or 1-celled by the placentae not reaching the axis. Stamens when 3 opposite the 3 sepals, - Chiefly perennials, and in wet soil or water, with pithy or hollow and simple (rarely branching) stems, and cymose or clustered small (greenish or brownish) flowers, chiefly in summer. (The classical name, from jungere, to join, alluding to the use of the stems for bands.)

a. Inflorescence appearing lateral; the involucral leaf erect, similar to and continuing the naked or essentially naked scape; rootatock creeping $b$.

b. Sheaths at base of the scape leafless.

Stameas 3 .

Capsule tipped by a crown-like blunt mucro, formed by the thick base of the style; inflorescence densely capitate .

Capsule truncate or emarginate at tip, without a distinct muero.

Inflorescence loose, the primary branches conspicuous.

Inflorescence a dense head, the prinary branches short and

Stamens 6 .

inconspicuous . . . . . (16) $J$. effusus, v. compactus.

Flowers greenish; capsule broadly ovoid, barely mucronate, about equaling the calyx

Flowers brow

Calyx 2-2.7 mm. long, much exceeded by the copsule

Calyx 3.5-5 mm. long, nearly or quite equaling the capsule

17. $J$. conglomeratus.

16. $J$. effusus.

15. J. Aliformis.

18. J. Smithii.

14. J. baltious, จ. Zittoralis,

b. Sheaths (or at least the inner ones) bearing long terete scape-like leaves.

Flowers solitary at the tips of the ultimate ramifications of the cyme; capsule subglobose, $3-4 \mathrm{~mm}$. in diameter, about equaled by the spreading sepals

Flowers clustered at the lips of the ultimate branchlets; capsule
trigonous, barely 2 mu. broad; sepals and petals appressedtrigonous, barely $2 \mathrm{~mm}$. broad; sepals and petals appressed-
ascending.
Capsule broadly ovold, about equaling the calyx; seeds ovoid,

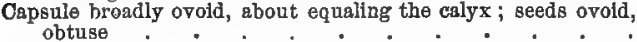
Capsule ellipsoid, exceeding the calyx; seeds with long caudate

tips.
u. Inflorescence terminal $c$.
c. Leaves tat, or somewhat terete, or setaceous and channeled, but c. Leaves flat, or some
never septate $d$.

a. Annuals with soft bases and fibrous roots.

Sepals much shorter than the rigid petals; flowers in dense

clusters; stanens 3 ; capsule subulate
Sepnls equaling or exceeding the petals; stamens 6 ; capsule

10. J. selaceus.

19. J. Roemerianus.

20. J. maritimus ellipsoid or ovoid.

42. J. repens. 
Sepals and petals all long-attenuate and exceeding the capsule; seeds ovoid, apiculate.

Flowers scattered singly along the one-sided usually dichotomous branches.

Flowers clustered.
Petals blunt or obtuse, shorter than or only slightly exceed-

d. Perennials o.

ing the capsule; seeds truncate. . . (1) J. bufonius, v. halophilus.

e. Flowers prophyllate, i.e. subtended by bracteoles (2) in addi-

tion to the bractlet at base of pedtcel $f$.

f. Leaf'sheaths with fimbriate auricles; flowers 1-4, 5-20 times exceeded by the thread-like subtending leaf.

Basal sheaths with setiform scarcely leaf-like blades; canline lesves inostly erowded at the summit; flowers usualiy $2-4$

Basn] sheaths bearing long leaves ; cauline leaves scattered; flowers usually solitary . . . . . (2) $J$

$f$. Leaf-sheaths with entire (or merely erose) auricles; flowers (except in depauperate individuals) numerous $g$.

g. Leaf-sheaths covering one half the stem or more; the brown and greenish sepals obtuse, and incurved at tip.

g. Leaf-sbeaths covering one fourth the stem or less; sepals acute or acuminate $h$.

h. Seeds with long caudate appendages.

Inflorescence exceeding the erect bracts ; capsule $4,6-6$ mm. long, usually exceering the calyx . . Inflorescence exceeded by the bracts; eapsule much shorter than the calyx

h. Seeds short-pointed or blunt $i$.

$i$. Capsule reddish or castaneous, ellipsoid, much exceeding the calyx . . . . .

t. Cepeule green or straw-colored (brown in age), shorter than or about equaling the calyx $j$.

j. Leaves lat (or in age becoming involute) $k$.

$k$. Auricles at the summit of the sheaths acarious, whitish, conspicuously extended beyond the point of insertion; bracts exceoding the inflorescence $l$.

2. Oapsule at least two thirds as long as the spreading-ascending sepals,

Flowers mostly clustered at the tips of the branches of the intlorescence

Flowers scattered and secund along the branches.

Branches of inflorescence loosely ascending, elongate, the ultimate floriferous branchlets elongate and ascending (4)

Ultimate fioriferous branculets widely spreading, $0.5-2 \mathrm{~cm}$. long ${ }^{2}$ less than one hall as long as the closely

2. Capsule less than one har as long as the closely
appressed sepals J. tenuis, v, anthelatus

11. J. Faseyt.

12. J. oronenots.

18. J. Greened.

4. J. tenuis.

k. Aurtcles at the summit of the sheaths not conspicuously extended beyond the point of insertion.

Bracts shorter than the cymes; flowers 2.5-3.5 $\mathrm{mm}$. long, scattered and secund slong the ascending or incurved branches

Bracts (or at least the lowermost) exceeding the cymes; flowers mostly larger, not conspicuously secund.

Inflorescence and basal sheaths straw-colored or the latter somewhat darker.

Sheaths and auricles membranaceous, pale; perianth erect

Sheaths and auricles cartilaginous, darker; perlanth spreading .

Inflorescence brownish: inner basal sheeths strongly purple-tinged
erete, or at most slightly grooped along the

1. Leaves terete, or at most slightly grooved along the
upper surface upper surface
c. Wowers eprophyllate, i.e. with only the brictlet at the base of
the very short pedicel $m$.

$m$. Capsules at must $4 \mathrm{~mm}$. long, rarely exceeding the calyx; flowers glomerulate, mostly in freely branched cymes.

Leaves terete, scape-like.

Capsule broadly ovold, sbout equaling the calyx; seeds ovold, obtuse

Oapsule ellipsold, slightly exceeding the calyx; seeds with

long caudate tips

J. tenuis, v. Williamsii

6. J. monostichus.

7. J. secundius.
5. J. interior.
8. J. Dudleyi.

omus, v. platyphyllus

9. J. dichotomus.

Leaves flat, grass-like.

19. J. Rosmerianus.

30. I. maritimus. 
Btamens included in fruit.

Petals ovate or oblong, blunt .

Petals lanco-atten uate, aristate

Stumons persistent and exserted in fruit :
m. Copsules 6-9 mm. long, much exceeding the calyx ; Hower's

43. J. marginalus.

fow, in 14 terminal glomerules. $41 . d$. stygius, v. americanus.

c. Leaves hollow, nodulose, $i .6$. with septa at regular intervals $n$.

$n$. Seeds with definite caudate tips 0 .

o. Leaves papillose-scabrous; stamens 6 ; seeds $2-8 \mathrm{~mm}$. long

o. Leaves smonth; stamens 8 ; seeds shorter $p$.

$p$. Flowers with the mature fruit about 2.5 (rarely 8.5 ) $\mathrm{mm}$. long; sepals obtuse; seed ellipsold, barely $1 \mathrm{~mm}$. long, with very short tails

p. Flowers with matıre fruit about $4 \mathrm{~mm}$. long; petals attenuate, rcute; seed spindle-shaped, with conspicuous tails.

Intlorescence (when well developed) ovoid or broader, one third longer than broad ; the glomerules many-flowered; capsule equaling or slightly exceeding the colyx.

Capsule abruptly short-pointed; seed 1-1.8 mm. long

Capsule gradually tapering to tip; seed scarcely $1 \mathrm{~mm}$. long
. (24) J. caner

Inflorescence olongate, strict, and narrow, 8-6 times longer
than broad; capsule much exceeding the caly $x$, gradually tapering; seed about $1 \mathrm{~mm}$. long .

n. Seeds merely pointed or blunt, not caudate $g$.

q. Stamens $8 \mathrm{r}$

$r$. Capsule attenuate to tip or subulate, distinctly exceeding the calyx \&.

o. Heads 2-7-flowered ; capsule not subulate.

Mature fruft $3.5 \mathrm{~mm}$. long .

Mature fruit $5 \mathrm{~mm}$. long

8. Heads densely many-flowered ; capsule subujate.

Leaves flattened, obscurely septate; sheaths without auricles at summit ; cyme large, with widely divergent branches and branchlets

Leaves terete, distinctly septate; sheaths with définite auricles at summit; branches and branchlets ascending.

Blade of the uppermost leaf much shorter than its sheath

Blade of uppermost leaf much longer than its sheath.

$\boldsymbol{r}$. Capsule shorter than or about equaling the calyx, if longer, abruptly tipped (not subulate) $t$.

t. Capsule half or two thirds as long as the calyx, tapering gradually to a conic-subulate beak; glomerules spherical; the rigid subulate sepals much exceeding the petals ; rootstock thick, white, horizontal

t. Capsule nearly equaling or exceeding the calyx, abruptly tipped; glomerules hemispherical; sepals and petals subequal; stems tufted or with merely thickened base.

Basal leaves abundant, tufted from a thickened base, often eiongate and flosting, obscurely septate; stems lax, decumbent or repent, $0.5-2.5 \mathrm{dm}$. high; petals blunt

Basal leaves few, erect; plant ereet, $3 \mathrm{dm}$. or more high; petals acumiuate.

Heads 1-50, on ascen ding-spreading branchee; flowers 8-3.5 mm. long ' videly divergent branches; filowers

q. Stamens $6 u$. ( 5 mon

22. J. Orachycephalus.

marginatus, v. setosus. 44. J. aristulatus.

21. J. asper.

24. J. canadensis.

densis, v. subcaudatus.

23. J. brevicaudatus.

36. J. debilis.

37. $J$. diffusissimus.

29. J. polycephalus.

34. J. megacephalus.

33. J. scirpoides.

32. J. brachycarpus.

27. J. ZuLbosns.

85. J. acuminatus.

38. J. robustus.

$u$. Upper cauline leaves bladeless (or essentially so), consisting of firm tawny or colored sheaths $2.5-5 \mathrm{~cm}$. long; the middle leaf orect, much over topping the inflorescence

u. Upper cauline leaves with blades, or, if bladeless, very small $v$.

v. Flowers solitary or in 2's, often accompanied or replaced by fascicles of small leaves.

Stem erect, from a horizontal rootstock; flowers secund on the branchlets of a loose dichotomous cyme; fascicles of reduced leaves confined to the inflorescence; anthers wuch exceeding the filaments

Stem repent or floating, bearing scattered fascicles of reduced leaves; roots tufted ; flower's 1 or 2 on sxillary or subterminal peduncles; anthers about equaled by the fllaments.

$v$. Flowers more numerous, in glomerules $w$.

wo. Lover leaves elongate, filiform, flonting, upper stouter ; glomerules mostly bearing fascicles of small leaves ; capsule blunt

w. Leaves iniform, none floating ; glomerules without fasci.

28. J. militaris.

25. J. pelocarpus

26. I. aubtilis. cles of leaves $x$. 
x. Glomerules spherical; sepals subulate; capsules subulate or lancesubulate; involucral bract usually exceeding the ifflorescence.

Flowers $3-4 \mathrm{~mm}$. Jong, reddish-brown; petals equaling or exceeding the sepals

Flowers 4-5 mm. long, greenish or dull brown; petals much shorter than the sepals

क. Glomerules hemispherical; sepals blunt or acuminate, at most mucronate-tipped; capsules ovoid or ellipsoid; involueral bract much shorter than the inflorescence $y$.

$y$. Sepals acuminate; branches of the inflorescence widely divergent. Flower brown or brownish; capsule dark brown, $3-4 \mathrm{~mm}$. long, gradually tapering to the mucronate tip

Flower greenish; capsule pale brown, 2.5-3 rum. long, abruptly mucronate

$\boldsymbol{y}$. Sepals blint, often incer or strongly ascending.

Branches strictly erect; glomerules loosely few-flowered, generally with one or more flowers elevated on slightly elongate pedicels.

Flowers castaneous

Flowers greenish or straw-colored

Branches spreading-ascending ; glomerules compactly and regularly flowered.

80. J. nodosus.

81. J. Tomegis

40. $T$. articulatus.

rticulatus, จ. obtusatus

89. J. alpinus.

(89) J. alpinus, จ. fuscescens.

\$1. Flowers prophyllate, i.e. subtended by bracteoles (2) in addition to the bractlet at base of pedicel.

* Inflorescences mostly terminal; leaves flat or canaliculate, rarely terete.

1. J. bufdnius L. Stems low and slender (0.3-3.5 dm. high), leafy, often branched from the base; cyme spreading; flowers remote, greenish (3-7 mm.

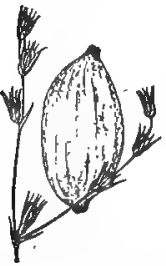

567. J. bufonius.

Part of intlorescence $\times 3 / 3$.

Seed $\times 50$. long), rarely viviparous, or even converted into leafy tufts; sepals and petals linear-lanceolate, awl-pointed; stamens short; flaments slightly longer than the anthers; seeds narrowly ovoid or ellipsoidal (0.3-0.5 mm. long). - I)amp open ground, roadsides, etc., common. June-Nov. (Cosmop.) Fig. 567.

Var. congéstus Wahlb. Flowers mostly in glomerules. - Infrequent. (Eu.)

Var. halóphilus Buchenau \& Fernald. More fleshy throughout; flowers mostly in 2's or 3's; whitish petals obtuse; s'eds short-cylindric, abruptly truncate at one end. Brackish shores, Gulf of St. Lawrence to Mass. ; Neb. to Rocky Mts., etc. June-Sept. (Eu.) FIG. 568.

2. J. trifidus L. Stems densely tufted from nutted creeping rootstocks, erect (1-4 dm. high), sheathed and mostly leafless at base, 2-3-leaved at the summit; flowers brown (3-4 mm. long); sepals ovate-lanceolate, acute, equaling or rather shorter than the ovate beak-pointed deep-brown capsule; anthers much longer than the filaments; seeds few, oblong, angled (1.5-2) mm. long), short-tailed. - Alpine summits, Lab. to N. E. and N. Y. June-Aug. (Greenl., Eurasia.)

Var, monánthos (Jacq.) Bluff \& Fingerbuth. Taller (2.5-6

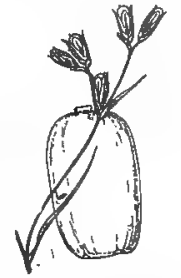

568. J. buf, , hal.

Part of inflorescence $\mathrm{dm}$, high) the numerous basal leaves often equaling the culms $\times 2 / 3$.

- Local, mts. of s. N. Y. to Va. and N. C. (Eu.)

3. J. Gerárdi Loisel. (Bla A Grass.) Stems scarcely flattened, rigid (1.5$8 \mathrm{dm}$. high); cyme contracted, usually longer thall the bracteal leaf; flowers 3-4 mm. long; sepals oval-oblong, nearly or quite as long as the ovoid obtuse and mucronate capsule; anthers much longer than the short filaments; style as long as the ovary ; seeds (0.4-0.5 mm. long) obovoid, delicately ribbed and crosslined. - Salt marshes; common along the coast, rarely inland in Me., $V^{r}$ t., N. Y., and about the Great Lakes. June-Sept. (Furasia, n. Afr.)

$\checkmark$ 4. J. ténuis Willd. Sten wiry (0.5-6 dm. high) ; cụme 1-8 cm. long, loose, or barely crowded; flowers green (3-4.5 mm. long), mostly ay!regated at the tips of the branches; sepals lanceolate, vcry acute, spleading in fruit, lovger than 


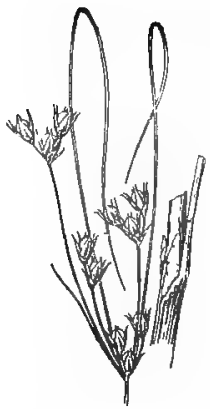

569. J. tenuis.

Inflorescence $\times 2 / 3$.

Sbeath with auricles $\times 2$. ing branches, the flowers 3-4 mm. long; capsule obscurely 3-celled; anthers much shorter than the filaments; seeds $3.5-5 \mathrm{~mm}$. long. - Prairies, Ill. to Wyo. and 'Tex. Apr.-July. Frg. 570.

6. J. monóstichus Bartlett. Erect, 3-5 dm. tall ; culms compressed; leaves basal, $\frac{1}{2}-\frac{8}{4}$ as long as the culms, the blades involute in drying, the auricles as in

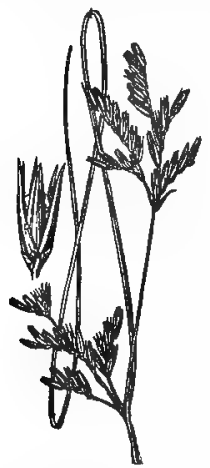

571. J. monostichus. Inflorescence $\times 2 \%$. Fruiting flower $\times 8$.

the ovoid retuse scarcely pointed green falsely 1-celled capsule; anthers much shorter than the filameuts; style very short; seeds small (3-4 mu. long), delicately ribbed and cross-lined. - Ficlds and roadsides, very

common. June-Sept. (Eu., n. Afr.) FIG. 569.

Var. anthelàtus Wiegand. Tall (4-9 (ln. high) and loose; cyme loose, 6-18 cm. long; flowers usually 2.5-3.5 mm. long. - Me. to Mo. and 'rex.

Var. Williámsii Fernald. Comparatively low (2.5-5 dm. high) and slender ; inflorescence $3-8 \mathrm{~cm}$. long; capsule about equaling the calyx. - Gulf of St. Lawrence to Ct. and $\mathrm{N}$. Y. (Eu.)

5. J. intèrior Wiegand. Comparatively stout, 4.5-9 dm. high; leaves about one third as long as the scapes; inflorescence $3-10 \mathrm{dm}$. long, with very ascend$J$. tenuis; inflorescence $4-8 \mathrm{~cm}$. long, much exceeded by the lowest bract, finally stramineous, the branches $1-2.5 \mathrm{~cm}$. long, often incurved, bearing 3-9 secund flowers; perianth 4-5 $\mathrm{mm}$. long, the sepals lance-acuminate, entirely concealing the trigonous-ovoid falsely 1-celled capsule (2 mm. long); seeds ovoid, coarsely reticulate, with longitudinally oblong areoles. - Ind. and Ark. FIg. 571.

7. J. secúndus Beauv. Strict $(1-8 \mathrm{dm}$. high); the short flat leaves mostly tufted, rarely more than one third as long as the scapes; sheaths with rounded membranous auricles; inflorescence 3-14 cm. long, the branches closely flowered; sepals erect, barely exceeding the distinctly 3-celled capsule; anthers exceeding the filaments. ( $J$. tenuis, var. secundus Engelm.) - Sandy or sterile soil, Me. to Vt. and N. C.; also in the Miss. Val. from Tenn. to Ill. and Mo. June-Oct. FIG. 572.

8. J. Dudlèyi Wiegand. Stiff $(0.3-1 \mathrm{~m}$. 572. J. secundus. high); leaves about half as long as the Inflorescence $\times 2 / 3$. scapes; inflorescence $1.5-7 \mathrm{~cm}$. long, the

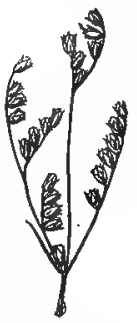

flowers rather closely aggregated, 4-5 $\mathrm{mm}$. long, the segments spreadingascending, yellowish-green, barely exceeding the imperfectly 1-celled trigonous capsule; filaments slightly exceeding the anthers; seeds $3.5-4.5$ mm. long. - Damp or open (mostly calcareous) soil, Que. to Sask, and the Rocky Mts., s. to Pa., Mich., Wisc., Minn., and Kan. June-Sept. Fig. 573.

$V$ 8. J. dichótomus Ell. Stems rigid (0.4-1 m. high) from a tumid base; leaves filiform, two thirds as long as the scapes, the broad brown or purplish sheaths with rounded cartilaginous auricles; cyme loose or dense (2-8 cm. long), often with 1-sided forked branches, mostly longer than the involucral leaf: flowers greenish brown (3.5-4 $\mathrm{mm}$. long); sepals lanceolate, sharp-pointed, spreading in fruit, as long as the ovoid

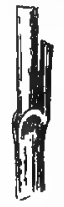

578. J. Dudleyl. Sheath with auri cles $\times 2$. 


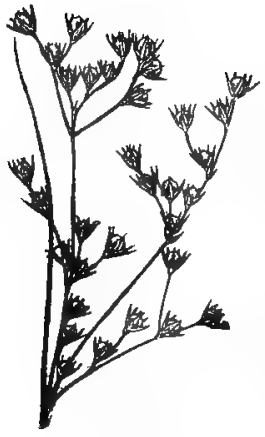

574. J. dichotomus. Inflorescence $\times \frac{2}{8}$.

beaked light mahogany-colored obscurely 1-celled capsule; anthers nearly as long as the filaments. - Low sandy grounds, L. I. to Fla. (Trop. Am.) Fig. 574.

Var. platyphýllus Wiegand. Leaves flat or merely involute as in $J$. tenuis; auricles less cartilaginous, often nearly scarious; cyme loose. - Along the coast, Mass. to Tex.

10. J. setàceus Rostk. Scape slender $(0.3-1 \mathrm{~m}$. high ) ; cyme loose, rather few-flowered; flowers greenish (3-4 mm. long); sepals and petals lanceolate, sharp-pointed, especially the 3 shining sepals; capsule beak-pointed, greenish or light brown; anthers as long as the filaments; style conspicuous ; seeds (0.6-0.8 min. long) irregularly obconic, long-stipitate, ribbed and cross-lined. - Low usually brack-

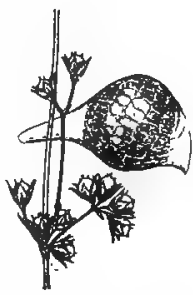

575. J. Betaceus. Inflorescence $\times 2 / 8$ Seed $\times 25$. ish ground, Del. and Mo. to Fla. and La. June-Sept. Fig. 575.

11. J. Vasèyi Engelm. Stems rigid (2.5-8 dm. high), densely tufted; leaves nearly terete, very slightly channeled on the inner side; cyme $1-4 \mathrm{~cm}$. long,

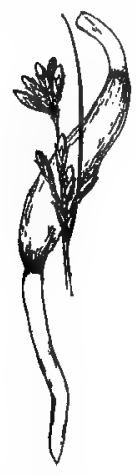

5i6. J. Vaseyi.

Inflorescence $\times \frac{2}{8}$. Seed $\times 40$. often longer than the involucral leaf; flowers few, often onesided; capsule oblong, greenish; sepals lanceolate, acute, appressed; anthers as long as the filaments; style very short; seeds slender ( $1 \mathrm{~mm}$. or more long), the tails half as long as

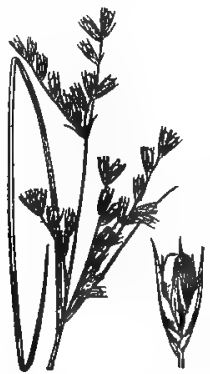

577. J. oroneasis.

Inflorescence $\times \%$.

Fruiting flower $\times 3$. the dark body. - Damp thickets, shores, etc., n. N. B. to Sask., s. to centr. Me., n. N. Y., Mich., Ill., Ia., and Col. July-Aug. Fig. 576.

12. J. oronénsis Fernald. Similar; of paler straw-color throughout; the inflorescence elongate, 2.5-9 dm. long, subdichotomous, the flowers secund and distinct along the secund suberect branches; capsule oblongtrigonous, truncate-emarginate, the sides flat or a little concave toward the tip, much shorter than the sepals; seeds $1 \mathrm{~mm}$. long, the tails $\frac{1}{2}$ as loug as the body. - Thickets, Me., local. FIG. 577.

13. J. Greènei Oakes \& Tuckerm. Stems rigid (2-8 $\mathrm{dm}$. high); leaves nearly terete, very deeply channeled (almost involute) on the inner side ; cyme 1-6 cm. long, usually much shorter than the principal erect involucral leaf, generally dense, the numerous flowers often one-sided (4-5 mm. long); sepals lanceolate, acute, light brown, appressed ; anthers as long as the filaments ; style very short; seeds ovoid ( $0.5 \mathrm{~mm}$. long), ribbed and delicately cross-lined. - Sandy or barren soil, Me. to Vt. and N.J.; locally about the Great Lakes. June-Sept. Fig. 578.

\section{* Inforescence appearing lateral; the involucral leaf erect, similar to and continuing the naked scape; leaves wanting.}

14. J. baliticus Willd., var. littoràlis Engelm. Scapes rigid (0.3-1 m. high); cymes loose or dense (1-9 cm. long) ; flowers

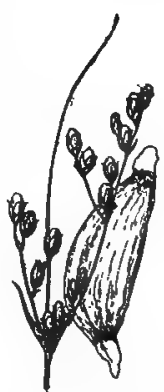

578. J. Greenei. Inflorescence $\times \% / 8$ Seod $\times 50$. chestnut-brown with green; sepals ovate-lanceolate, sharp-pointed, petals obtusish; capsule ellipsoidal, rather triangular, obtuse and mucronate, deep brown; anthers much longer than the broad filaments; style about the length 


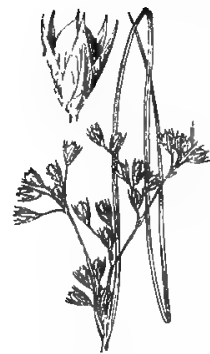

579. J. balt., v. lit.

Inflorescence $\times 2 / 3$. Fruiting flower $\times 3$.

of the ovary; seeds rather large (abont $1 \mathrm{~mm}$. long), nearly obtuse, delicately ribbed and cross-lined. - Sandy (mostly brackish) shores, Nfd, to N. Y. and Pa.; the Great Lakes, and westw. Fig. 579 .

15. J. filifórmis L. Scape very slender (1.5-6 dm. high), pliant; cyme few-flowered, almost simple; flowers $3 \mathrm{~mm}$. lons; sepals lanceolate, petals a little shorter and less acute, mostly longer than the obtuse greenish capsule; anthers shorter than the filaments; style very short; seed ( $0.5 \mathrm{~mm}$. long) short-pointed at both ends, indistinctly reticulated. - Wet shores and bogs, 'Nfd. to Sask., Pa., Mich., Rocky Mts., etc. June-Aug. (Eurasia, Patagonia.) Fig. 580.

16. J. effùsus L. (Сомmon or Sort Rush.) Scape soft and pliant (3-12 dm. high); inner sheaths awned ; cyme diffusely much branched, many-flowered; prophyllum below the individual flowers broad-ovate; flowers small (2-2.5 mm. long), greenish; sepals lanceolate, very acute, as long as the narrow triangular-obovoid retuse and pointless greenish-brown capsule ; anthers as long as the filaments; style very short; seeds smail $(0.5 \mathrm{~mm}$. long), with short pale points. - Marshy ground, very common. (Cosmop.) Var. compíctus Lejeune \& Courtois. Inflerescence dense, glomerulate. - Less common, except in N. S., where abundant.

17. J. conglomeràtus L. Similar to the last; scapes more rigid ( $3-7 \mathrm{dm}$. high), distinctly sulcate or even costate below the inflorescence; glomerule 1-2

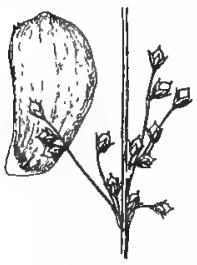

581. J. Smithii. Inflorescence $\times 2 / 3$. Beed $\times 20$, $\mathrm{cm}$. in diameter ; prophyllum lanceolate ; flowers about $3 \mathrm{~mm}$. long, brown or greenish; sepals somewhat exceeding the short-mucronate capsule; anthers shorter than the filaments. (J. Leersii Marsson). - Ditches, etc., Nfd, and N. S. (Eurasia.)

18. J. Smithii Engelm. Scape rather slender $(6-9 \mathrm{dm}$. high); cyme few-flowered, nearly simple; sepals lanceolate, acute; petals a little shorter, obtusish, shorter than the broadly ovoid rather triangular acute deep chestnut-brown capsule; anthers as long as the filaments; style short; seeds large (nearly $1 \mathrm{~mm}$. long), obtuse, short-appendaged at both ends, many-ribbed and reticulated. (J. gymnocarpu. Coville). - Sphagnous swamps and wet woods, very local, Schuylkill Co., Pa.; Walton Co., Fla. Fra. 581.

\$2. Flowers eprophyllate, i.e. with only the bractlet at base of the very short. pedicel.

* Leaves terete, scape-like, not septate.

19. J. Roemeriànus Scheele. Scape stout and rigid $(0.5-1.5 \mathrm{~m}$. high), its apex as well as the leaves pungent; cyme compound, open and spreading, brown; 3-6 greenish or light brown flowers (3-3.5 mm. long) in a cluster ; sepals lanceolate, sharp-pointed, longer than the obtusish petals; anthers much longer than the broad filaments; styles shorter than the ovary; seeds $(0.7 \mathrm{~mm}$. long) very delicately ribbed. - Brackish marshes, N. J. to Fla. and Tex.

20. J. marítimus Lam. Resembling the last, but with a rigid contracted green cyme, an ovary attenuated into a style of nearly its own length, a greenish acute capsule which usually exceeds the acute sepals, and seeds with distinct tails and stronger ribs. - Coney Island, N. Y. (Widely distr.)

* Leaves nodulose, i.e. with septa at regular intervals.

21. J. ásper Ingelm. Stems tufted, erect $(0.4-1 \mathrm{~m}$. high), terete, stout, rigid, and with the rigid leaves rough; cyme with rigicl slightly spreading 


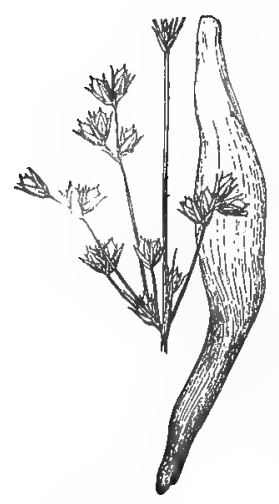

582. J. asjer.

Part of inflorescence $\times 2 / 8$. Beed $\times 25$.

branches, bearing scattered few (2-6)-Hlowered heads; flowers greenish with brown ( $4.5 \mathrm{~mm}$. long); sepals ovate-lanceolate, awl-pointed, rigid and strongly nerved, shorter than the similar petals, these a little shorter than the triangular-ovoid beaked incompletely 3-celled brown capsule ; ovary tapering in to a conspicuous style ; seeds large, subcylindric, with white or often reddish appendages. (J.caesarien. sis Coville). - Sphagnous swamps, s. N. J., very local. Aug.-Sept. Fir. 582.

22. J. brachycéphalus (Engelm.) Buchenau. Stem slender (2.5-7 dm. high), bearirg numerous small 3-5flowered heads in a large (0.5-2.5 dm. long) spreading cyme; flowers greenish or liglt brown; sepals shorter than the petals and

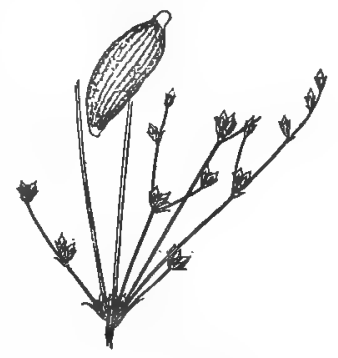

583. J. brachycephalus, Part of inflorescence $\times 2 / 8$. Seed $\times 18$.

the brown abruptly short-pointed capsule. ( $J$. canadensis, var. Engeim.) -

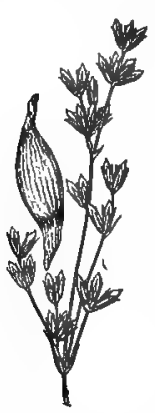

54. .1. Urevicaudatus.

Inflorescence $\times \%$. Seed $\times 16$. Marshes and wet shores, 11. Me. to Wisc., s. to Ct., Pa., and Ill. July-Sept. Fig. 583.

23. J. brevicâudàtus (Engelm.) Fernald. Stem slender (1.5-7 dm. high), bearing few deep-brown 3-7flowered heads in a somewhat erect contracted cyme $(2.5-15 \mathrm{~cm}$, long); flowers $2.5 \mathrm{~mm}$. long; sepals acute, the petals rarely obtusish, much shorter than the prismatic gradually pointed deep-brown capsule. (J. canadensis, vars. brevicaudatus and coarctatus $\mathrm{Fn}$ gelm.) - Muddy or damp places, Nfd. to Ont., W. Va., and Minn. JuneSept. FIG. 584.

24. J. canadénsis J. Gay. Stems tufted, stout and rigid (4-12 dm. high), bearing in a decompound somewhat spreading cyme the numerous 5-50-

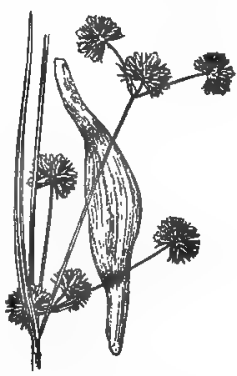

585. J. canadensis. Part of inflorescence $\times \%$. Seed $\times 18$.

flowered heads; flowers greenish or light brown $(2.5-3.5 \mathrm{~mm}$. long); sepals and petals awl-pointed, mostly shorter than the abruptly short-pointed capsule; seeds

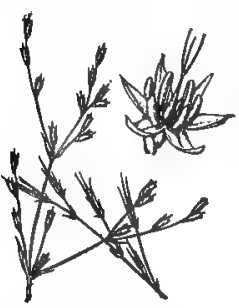

5is. J. pelocarpus.

Part of inflorescence $\times 2 / 3$. Dame, proliferous $\times \frac{\%}{3}$. Elower $\times 8$. conspicuously tail-pointed. - Marshy places, Nfd. tc Minn., Ga., and La. Aug.-Oct. (S. A.) Fig. 585.

Var. subcaudà tus Engelm. Stem slender, often decumbent (3-8 dm. high), bearing in simpler spreading cymes fewer 8-20-flowered heads; flowers greenish; sepals awlshaped, out not so rigid; capsule mostly tapering; seeds with short white membranous appendages. $-\mathrm{R}$. I. to $\mathrm{Pa}$. and Ga. - Perhaps specifically distinct.

25. J. pelocárpus Mey. Stems slender (0.5-5 din. high), bearing few thread-like slightly knotted leaves, branching above into a compound spreading cyme; flowers small (2.5 mm. long), greenish with red; sepals and petals oblong, obtuse, the petals longer, but shorter than the slender taper-beaked 1-celled capsule; style slender; seeds ( $0.5 \mathrm{~mm}$. long) obovoid, short-pointed. - Sandy, wet or swampy places, Nfd. to N. J., Pa., Minn., and 
Ont. Aug., Sept. - The proliferous plants are usually sterile and much larger, with larger diffuse panicles. FIG. 586.

26. J. súbtilis Mey. Creeping or floating, capillary, reddish, in water

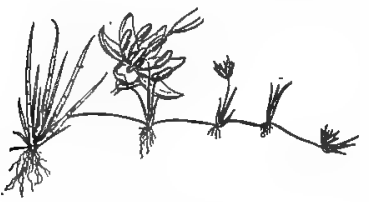

587. J. subtilis.

Plant $\times 2 / 3$. Flower $\times 3$. becoming 4 or $5 \mathrm{dm}$. long, with elongate capillary leaves, on shore forming rosettes $(0.5-2 \mathrm{dm}$. broad) with a tuft of primary leaves ( 2 or $3 \mathrm{~cm}$. long) and repent branches bearing small fascicles of small leaves and axillary or terminal flowers either sessile or shortpeduncled ; flowers and capsule much as in preceding, but filaments longer. ( $J$. pelocarpus, var. Engeim. ) - Margins and shores of ponds and streams, Nfd., Que., and Me. Aug., Sept. Frg. 587.

27. J. bulbòsus L. Similar, but with hardened bulbous bases, coarser habit, several-flowered glomerules, sharper sepals and petals, and biunt capsule. - Margins and shores of ponds, streams or pools (generally floating). - Lab., Nfd., and N. S. (Eu., n. Afr., Pacific I.) Frg. 588.

28. J. militàris Bigel. Stem stout (3.5-9 dm. high), from a thick creeping rootstock, bearing a solitary stout erect leaf (3-7 dm. long) below the middle, which overtops the crowded and rather contracted cyme; heads numerous, 5-12(rarely 25)flowered; flowers brownish ( $3 \mathrm{~mm}$. long); sepals and petals

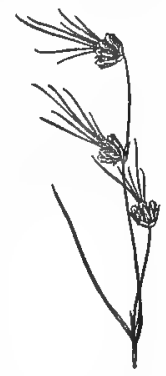

588. J. bulbosus, Inflorescence $\times 2 / 3$.

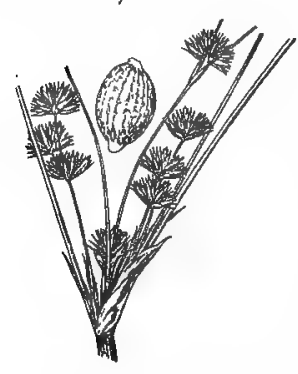

589. J. millitaris.

Part of inflorescence $\times \%$. Seed $\times 18$. lanceolate, the sepals awl-pointed, as long as the narrowly-ovoid triangular taper-beaked 1-celled capsule; anthers longer than the filaments; ovary attenuate into a slender style; seeds (0.6 mm. long) globose-obovoid, obtuse, abruptly pointed. - Margins of ponds and streams, N. S. to n. N. Y. and Ala.Sometimes producing, in deep water, numberless long capillary submersed leaves from the rootstock. Fig. 589.

29. J. polycéphalus Michx. Stout (0.5-1.2 m. high), from a stout horizontal rootstock; leaves laterally flattened (3-9 min. wide); cyme large (1-3 dm. long), spreading, bearing many distant heads (nearly

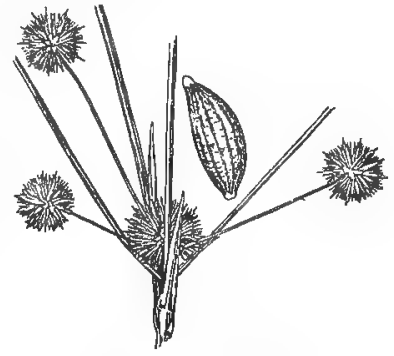

590. J. polycephalus.

Part of inflorescence $\times 2 / 8$.

Seed $\times 30$.

$1 \mathrm{~cm}$. in diameter); flowers $3.5 \mathrm{~mm}$. long; the subulate sepals longer than the similar petals; anthers about as long as the filaments. ( $J$. scirpoides, var. Engelm). - Swamps, s. Va. to Fla. and Tex. FIG. 590.

30. J. nodosus L. Stem erect (1.5-6 dm. high), slender, from $a$ creeping thread-like and tuber-bearing rootstock, mostly with 2 or 3 slender leaves; heads few or several, rarely singie, 8-20-flowered (7-11 $\mathrm{mm}$. in diameter), overtopped by the involucral leaf; sepals nearly as long as the slender triangular taper-pcinted 1-celled capsule; anthers oblong, shorter than the filaments; style very short; seeds $(0.5 \mathrm{~mm}$. long) obovoid, abruptly mucronate. - Swamps and gravelly banks, e. Que. to Sask., s, to Va., Ill., and Neb. July, Aug. Fig. 591 .

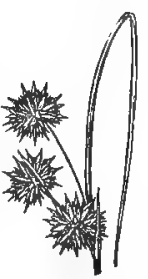

591. J. Hodosis, Inflorescence $\times 2 \%$ 
31. J. Torrèyi Coville. Similar to the last; stem stouter (0.4-1 m. high). with thick leaves; heads few and large (1-1.5 cm. in diameter), 30-80-flowered;

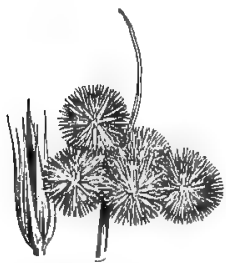

592. J. Torreyi.

Inflorescence $\times 2 / 3$. Fruiting flower $\times$ ?.

33. J. scirpoides Lam. Stem erect $(2.5-9 \mathrm{dm}$. high), anthers linear, shorter than the filaments. (J. nodosus,
var. megacephalus Torr.) - Low sandy soil, Mass. to Sask., westw. and southw. July-Oct. Fig. 592 .

32. J. brachycárpus Engelm. Stem erect (4-9 dm. high), from a thick white horizontal rootstock, bedring about 2 leaves and $2-10$ densely flowered spherical heaás ( $7-11 \mathrm{~mm}$. in diameter) in a slightly spreading crowded cyme much exceeding the involucral leaf ; flowers pale green (4 mm. long); anthers much shorter than the filaments; style very short; seeds (0.3 mm. long) abruptly apiculate. - Damp light soil, Mass. to N. C. ; Ont. to Miss. and 'Tex. June-Aug. Fig. 593. rather slender, from a thick horizontal rootstock, bearing about 2 terete leaves with wide and open sheaths, and a cyme of few or many densely flowered pale green irregularly spherical heads, much longer than the involucral leaf, its branches erect and often elongated; heads $(6-13 \mathrm{~mm}$. in diameter) $1 \overline{3}-40$-flowered ; flowers $3-4 \mathrm{~mm}$. long; sepals and petals rigid, awl-shaped and (especially the sepals) bristly-pointed, at length pungent, as long as the stamens and nearly equaling the oblong-triangular taper-pointed 1-celled capsule; anthers very small; style elongated or very short; seeds ovoid,

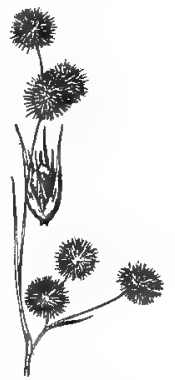

598. J. brachycarpua Inflorescence $\times 2 / 3$. Fruiting flower $x$; abruptly pointed at each end $(0.5 \mathrm{~mm}$. long.) - Wet sandy soil, N. Y. to Fla., Mo., and Tex. Jnly-Sept.

34. J. megacéphalus M. A. Curtis. Stouter; leaves terete; branches of the compact cyme short; heads larger, spherical, 40-80-flowered; flowers $4 \mathrm{~mm}$.

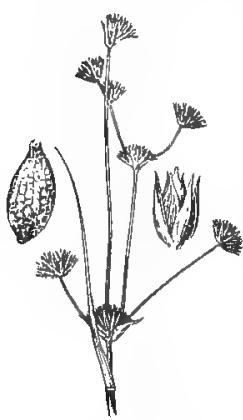

501. J. acuminatus. Inflorescence $\times \frac{2}{3}$. Fruiting flower $\times$ : Seod $\times 25$. long; sepals and petals narrower and more sharply pointed, the sepals a little longer than the petals; stamens shorter and anthers longer than in the preceding, and seeds rather smaller and more slender. (J. scivpoides, var. echinatus Engelm.) - Va. (?) to Fla.

15. J acuminâtus Michx. Stems tufted, erect, slender (3-7 dm. high), bearing about 2 leaves and a very loose spreading cyme; heads rather few and large $(0.5-1 \mathrm{~cm}$. broad), 5-many-flowered, greeuish, at length straw-colored or darker; sepals and petals lance-awlshaped, sharp-pointed, equal, as long as the ovoid-prismatic short-pointed 1-celled straw-colored or light browu capsule : anthers a little shorter than the filaments; style almost none; seeds small (0.3-0.4 $\mathrm{mm}$. long), acute at both ends, ribbed and reticulated. - N. E. to Ga., Minn., and Tex. May-Aug. - Heads often proliferous in autumn. (Mex.) Fig. 594.

36. J. débilis Gray. Stems slender (2-8 dm.long), flaccid, erect, decumbent, or even rooting at the nodes; heads green, 2-7-flowered, in a loose oyme $(0.5-2.5 \mathrm{dm}$. long); flower's small ( $2.5 \mathrm{~mm}$. long);

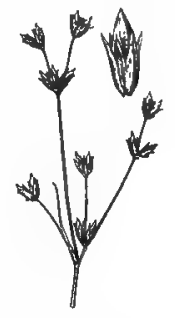

595. J. debilis. capsule oblong-prismatic, short-mucronate. (J. acuminatus, var. Inflorescence $\times 2 / 3$. Engelm.) - Wet sandy soil, R. I. to Mo., and suluthw. May- Frutting flower $\times 3$, Aug. Fig. 695 .

37. J. diffusissimus Buckley. Slender and erect ( $2.5-6 \mathrm{du}$. high); heads very numerous, 2-7-flowered, in a very diffuse and lonsely dichotomous cyme (1-2.5 $\mathrm{dm}$. long), the branches suberect ; flowers greenish or pale brown, :3 nm. long, tho 


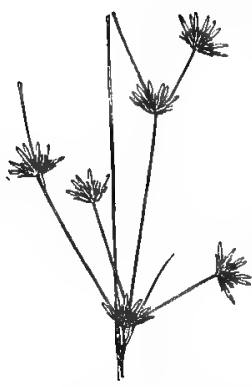

596. T. diftusissimus.

Part of inflorescence $\times 2 / 3$.

linear-subulate sepals and petals subequal; capsule linearprismatic. - Ind. to Ga. and Tex. June, July. FIG. 596. 38. J. robústus (Engelm.) Coville. Stem stout, tall $(0.5-1.2 \mathrm{~m}$.), bearing 2 or 3 long erect distinctly septate leaves, numerous 5-8-flowered light brown heads in a large much branched cyme (1-3 dm. long) ; ovoid-prismatic capsules scarcely longer than the sepals; seeds fusiform-ovoid. (J. acuminatus, var. Engelm.) - Deep swamps, Ill. to La. and Tex. June, July. Fig. 597.

39. J. alpìnus Vill. Stem erect or slightly decumbent $(0.5-3.5 \mathrm{dm}$. high), from a creeping rootstock, with 1 or 2 slender erect leaves; cyme meager ( $1-15 \mathrm{~cm}$. long), with erect branches bearing distant dark-brown heads, each of $3-10$ flowers (2-2.5 inm. long) and usually with one or more

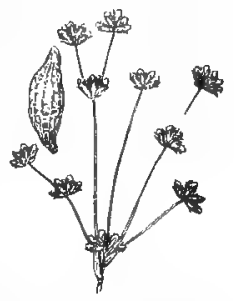

597. J. robustus.

Part of inflorescence $\times 2 / 3$

Seed $\times 30$

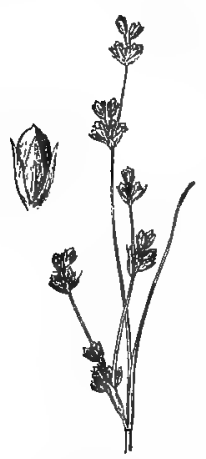

598. J. alpinus.

Inflorescence $\times 2 / 3$. Fruiting flower $\times 3$. flowers elevated on slender pedicels ; sepals oblong, obtuse, mucronate or cuspidate and usually longer than the rounded oblong petals, as long as or shorter than the obtuse shortpointed incompletely 3-celled castaneous capsule; anthers as long as the filaments; style short; seeds $(0.5 \mathrm{~mm}$. in length) spindle-shaped. - Wet shores and marshes, Aretic Am., s. to Nfd., N. B., n. Me., n. Vt., Oneida Co., N. Y. (Haberer), and L. Superior. July, Aug. (Eurasia.) Frg. 598.

Var. insignis Fries. Similar, usually taller (sometimes $6 \mathrm{dm}$. high); the flowers greenish or straw-color ; the capsult pale brown. (J. Richa,dsonianus Schultes.)-Sandy shores, etc., e. Que. to B. C., s. to centr. Me., Pa., O., Ind., Ill., etc. (Furasia.)

Var. fuscéscens Fernald. Branches spreadingascending; glomerules compactly and regularly flowered, only exceptionally with any of the greenish or straw-colored flowers raised on elongate pedicels. - Vt. to B. C. and Mo. 40. J. articulatus L. Stems $(1.5-6 \mathrm{dm}$. high), tufted from a short creeping rootstock, with 1-3 slender leaves; cyme short $(2-9 \mathrm{~cm}$. long), spreading, the crowded heads 3-10flowered; flowers brown (2.5-3 mm. long); petals a little longer than the sepals, shorter than the slender-conic incompletely 3-celled deep chestmut-brown shining capsule; anthers as long as the filaments; ovary attenuate in to a short style; seeds (0.5 mm. long) obovoid, attemuate below, abruptly pointed above. -

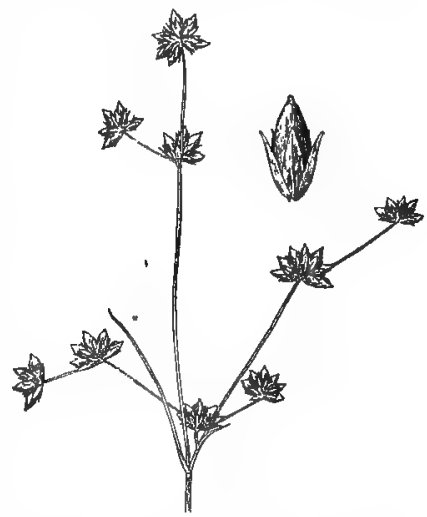

599. J. articulatus.

Inflorescence $\times 2 / 3$. Fruiting tlower $\times 8$. Wet grounds, Nfd, to N. J., Ont, and Mich. July, Aug. (Eurasia.) Fig. 599.

Var. obtusàtus Engelm. Inflorescence pale, usually larger (sometimes 1.5 dm. long), the green flowers smaller, the abruptly mucronate pale capsule shorter and duller. - Me. to N. J. and Vt, oftenest in brackish soil.

$$
\text { * * Leaves flat and grass-like or filiform, not septate. }
$$

41. J. stýgius L. Stems (1-3 dm. high) from slender branching rootstocks, 1-3-leaved below, naked aivove, the leares fiiform; heads 1-4, of 1-4 flowers, 
about the length of the sheathing scarious awl-pointerl bract; flowers pale and redish ( $3-4 \mathrm{~mm}$. long); sepals lanceolate, acute; petals obtusish, $\frac{3}{4}$ the length of the trigonous-ovoid acute or acuminate pale capsule $(5-6 \mathrm{~mm}$. long), as long as the slender stamens; filaments many times longer than the oblong anthers; recurved stigmas shorter than the style; seeds oblong, with a very lorse coat prolonged at both ends ( $2-2.5 \mathrm{~mm}$. long), - Eurasia.

Var. americànus Buchenau. Often taller (1-4.5 dm. high); heads 1 or 2; flowers larger (4., $-5.5 \mathrm{~mm}$. long); the distinctly mucronate-tipped capsule

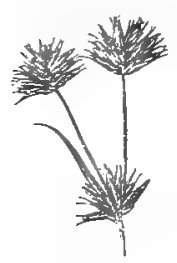

600. J. repens. Inflorescence $\times 2 / 3$. longer (6-9 mm. long); seeds :-4 mm. loug. - Peat-bogs, Lab. and Nfd. to Ont., s. to X. S., Me., N. Y., Mich., and Yimn, very local. July, Aug. (E. Prussia.)

42. J. tèpens Michx. Stems ascending (0.5-2 dm. high) from a fibrous annual root, at length creeping or floating; leaves short, linear, those of the stem nearly opposite and fascicled; heads few in a loose leafy cyme, 3-12-flowered; flowers green $(0.5-1 \mathrm{~cm}$. long) ; sepals and petals rigid, lancesubulate, sepals as long as the linear triangular obtuse capsule, the petals much longer; stamens as long as the sepals; filaments much longer than the oblong anthers; seeds oboroid, slightly pointed, very delicately ribbed and cross-lined. - Miry banks and ditches, Del. to Fla, and La. June-Oct. Fir. 6ijo. $\checkmark$ 43. J. marginàtus Rostk. item erect, from a bulbous and stoloniferous base ( $2-7 \mathrm{dm}$. high); leaves linear; heads 3-12-flowered, in simple or compound cymes; flowers purplish and green ( $3.5 \mathrm{~mm}$. long); sepals and petals oblong, the sepals acute and slightly awned, petals longer, mostly obtise, as long as the subglobose scarcely mucronate capsule; stamens shorter than the sepals, early shriveling; anthers shorter than the filaments; style very short; seeds (about 0.5 mm. long) slender, pointed at both ends and strongly ribbed. -

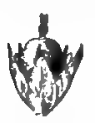

602. J. arintulatus. Fruiting flower $\times 3$.

Moist sandy places, Me. to Ont., Neb., and southw. July-Sept. Fig. 601.

Var. setosus Coville. Similar to the species, but with lance-attenuate aristate petals. Kan. to La, and Tex.

44. J. aristulàtus Míchx. Coarser $(0.4-1 \mathrm{~m}$. high); the larger inflorescerce $(0.5-2 \mathrm{dm}$. high)

with abundant 2-5-flowered brown heads; stamens equaling or excerling the sepals, persistent and usually exserted in fruit. (J. morginatus, rar. biforus Engelm.) - Wet sandy barrens, Mass. to Mich., and southw, mostly near the coast. Fig. 602.

\section{LÙZULA DC. Wood Rcse}

Capsule 1-celled, 3-eeded, 1 seed to each parietal placenta. - Perennials, often hairy, usually in dry ground, with flat and soft usuall hairy leaves, and spiked, crowded, or umbeled flowers. (From Gramen Luzular, or Luxulae. diminutive of lux, light, $\rightarrow$ a name given to one of the species from its shining with dew.) Joncoides [Dill.] Adans. Juncodes Ktze.

$a$. Flowers solitary at the tips of the nltimate branches of the inflorescence.

Inflorescence an umbel, the filiform peduncles 1 (rarely 2 )-flowered; flowers $3-4.5 \mathrm{~mm}$. long

Inflorescence loose

w. Flowers crowded in spikes or glomerules $b$.

b. Flowers white.

b. Flowers brown or straw-colored (rarely green in shade) c.

c. Flowers in dense nodding spike-like panicle

c. Flowers in mostly peduncled glomeru.es $d$.

d. Jeaves flat, with blunt callous tips; bracts at base of the flowers entire or inerely lacerate.

Flowers castaneous

Flowers ferruginous, pale brown or yellowish. Pays all strongly ascending

Rays (or some of them) strongly divergent
d. Leaves with in rolute subulate tips; bracts at base of flowers ciliate-
fimbriate

(6) L. campestris, v.frigiaa.

3. L. nemorosa.

5. L. spicata. fimbriate
6. L. campentriv s. multiflora. (6) L. campestris, v. bulbowa. 4. $L$ confusa. 
V 1. L. saltuénsis Fernald. Plant loosely caespitose, often stoloniferous, $1-4$ $\mathrm{dm}$. high ; leaves lance-linear, hairy, the basal $0.5-1 \mathrm{~cm}$. wide; umbel mostly simple, the peduncles loosely ascending or spreading; sepals and petals broadly lanceolate, pale brown or straw-colored, with hyaline margins, shorter than the conic-ovoid pointed capsule; seeds with a long curved appendage. ( $L$. vernalis Man. ed. 6, not DC.; J. pilosum Coville, not Ktze.) - Woods and banks, Nfd. to Sask., N. Y., Mich., and Minn., and in the mts. to Ga. Apr., May. (E. Asia.)

2. L. parviflòra (Ehrh.) Desv. Nearly smooth $(1.5-9 \cdot \mathrm{dm}$. high); leaves broadly linear, the basal 7-13 $\mathrm{mm}$. wide; corymb decompound, loose; pedicels drooping; sepals pointed, straw-color, about the length of the minutely pointed and brown (tardily black) capsule; seeds not appendaged. (L. spadicea, var. melanocarpa Mey.) - Low woods and mountain slopes, Lab. to Alaska., s. to N. B., Me., White Mts., w. Mass., n. N. Y., Great Lakes; and in the Rocky Mts. June, July. (Eurasia.)

3. L. nemorósa (Poll.) Mey. Loosely caespitose (4-8 dm. high); leaves long, linear, erect, more or less hairy, the basal $3-5 \mathrm{~mm}$. wide; inflorescence diffusely corymbiform, $3-15 \mathrm{~cm}$. long, the ultimate branchlets terminated by 3-8-flowered glomerules; sepals and petals lanceolate, acute, the sepals dis. tinctly shorter, about equaled by the apiculate-beaked trigonous-ovoid dark capsule. - Open woods, Riverdale, N. Y.; Niagara Falls, Ont. June, July. (Introd. from $\mathrm{Eu}$.)

4. L. confùsa Lindeberg. Caespitose $(0.5-3 \mathrm{dm}$. high); leaves linear, channeled; spikes $1-5$, on unequal ascending or rarely recurved peduncles, ovoid, chestnut-brown, the largest 5-8 nım. thick; sepals taper-pointed, longer than the obtuse capsule; seeds not appendaged. (L. arcuata Man. ed. 6, not Mey.; L. hyperborea R. Br., in part.) - Alpine sumuits, Me., N. H., and far northw. July, Aug. (Eurasia.)

5. L. spicàta (L.) DC. Densely caespitose (1-5 dm. high); leaves channeled, narrowly linear; flowers in sessile clusters, forming an interrupted spiked panicte, brown ; sepals bristle-pointed, scarcely as long as the abruptly short-pointed capsule; seeds merely with a roundish projection at base. - Alpine regious, N. E. and n. N. Y., and far northw. Jume-Aug. (Eurasia.)

6. L. campéstris (L.) DC. Loosely caespitose and strongly stoloniferous (0.5-2 dm. high); leaves linear, flat, hairy; spikes $2-6$, globose (6-7 mm. thick), irregularly umbeled, 1 or 2 subsessile, the others on wide-spreading or decurved peduncles ; flowers castaneous, $3 \mathrm{~mm}$. long; sepals bristle-pointed, longer than the obtuse capsule; seeds with a conical appendage at base. - Eurasia.

Var. multiflora (Ehrh.) Čelak. Densely caespitose (1.5-6 dm. high); spikes $3-12$, subglobose or subcylindric (5-6 mm. thick), mostly on ascending or erect: simple or slightly forked peduncles (sometimes congested); the ferruginous or pale brown (rarely green) calyx 2.5-3 mm. long, often equaled by the capsula. (L. campestris Am. auth., not DC.) - Fields, meadows, and open woods, very common, Nfd. to the Pacific, s. to Pa., Great Lakes, etc. Apr.-July. (Eurasia.)

Var. frigida Buchenau. Similar to var. multifora, but with the subglobose short-peduncled heads castaneous or nearly black. - Lab. and Nfd. to N. B. and Me. (N. Eu.)

Yar. bulbosa A. Wood. Somewhat resembling var. multiflora, but with some or all of the rays divergent, and the base sometimes but not always producing small bulblets. (Juncoides Small.) - Woods, generally near streams, D. C. to Ind., Kan., and southw.

\section{LILIÅCEAE (LILT Famili)}

Herbs, or ravely woody plants, with regular and symmetrical almost always 6-androus flowers; the perianth not glumaceous, free from the chiefly 3-crlled ovary; the stamens 1 before each of its divisions or lobes ( $i$ e. 6, in one instance 4 ), with 2-celled anthers; fruit a few-many-sceded pod or beriy; the small entryo inclused in copious albumen. Seeds anatropous or auphitropous 
(orthotropous in Smilax). Flowers not from a spathe, except in Allium; the outer and inner ranks of the pelianth colored alike (or nearly so) and genera!ly similar, except in Thillium.

Tribe I. NARTHEcleAE. Flowers perfect, small, spicate-racemose. Perianth of 6 distinit segments. Style none; stigma small, slightly lobed or undivided. Fruit a loculteidal carsule.

1. Narthecium. Filaments woolly. Perianth-segrnents linear-lanceolate, yellowish. Capsule short-cylindric, attenuate, many-seeded.

Tribe II. HELONIEAE. Flowers (small) yerfect or dioecious, racemo-spicate. Perianth of o distinct segments. Styles 3 , distinct. Fruit a loculicidal capsule.

2. Xerophyllum. Flowers perfect. Seeds 2 in each cell.

3. Helonias. Flowers perfect. Seeds many in each cell, linear and with a tapering appendage at each end.

4. Chamaelirium. Flowers dioecious. Seeds numerous, somewhat wing-appendaged at the ends.

Tribe III. VERATREAE. Flowers perfect or polygamously monoecious. Perianth of 6 nearly or quite distinct segments. Styles 8 , distinet. Fruit a septiciảal capsule,

5. Toffeldia. Flowers perfect. Anthers 2-celled. Leaves 2-ranked, equitant.

6. Amianthium. Flowers perfect. Anthers confluently 1-celled. Leaves several-ranked. Perianth-segments glandless.

7. Stenanthium. Flowers polyganous. Perianth-segments ianceolate, acuminate, glandless. Stem from a bulbous base.

8. Zygadenus. Flowers perfect or monoenions. Leaves several-ranked, linear. Perianth. segments glandular at the base, ovate or oblong. Stem glabrous.

9. Melanthium. Flowers polygamo-monoeeious. Stem pubescent above, from a running rootstock. Perianth-segments free from the ovary, their long claws adnate to the filaments.

10. Veratrum. Flower's polygamo-monoecious. Stem pubescent above, from a running rootstock. Perianth-segments without claws, slightiy adnate to the ovary.

Tribe. IV. UvUlaríteaE. Flowers perfect. Perianth-segments distinct. Style 3-cleft to below the middle. Fruit a loculicidal capsule. Flowers terminal or axillary. Stem leafy.

11. Uvularia. Stem terete. Leaves perfoliate. Flowers terminal. Capsule truncate, 8-lobed.

12. Oakesia. Stem angled. Leavas sessile but not perfoliate. Flowers appearing opposite the leaves. Capsule rounded or mors or less pointed at the summit, acutely 3-winged.

Tribe V. ALlieaE. Flowers perfect, umbellate, Perianth-seginents 6 , nearly or quite distinet, 1-nerved. Stylo single, long; stigma uncleft, or only slightly 3-lobed. Fruit a loculicidal capsule, Seeds few $(1-i)$ in each cell.

13. Allium. Seeds $1-2$ in each cell. Plants with a strong odor.

14. Nothoscordum. Seeds several in each cell. Plants without strong odor.

Tribe VI. HEMerocallídeaE. Flowers perfect. Perianth-segments united below the middle into a funnel-shaped tube, not conspicuously roughened. Style single, long, declined, not cleft. Fruit a loculicidal capsule.

15. Hemerocallis. Flowers large. Perianth yellow or brownish-red.

Tribe VII. LILIEAE. Flowers perfect. Perianth-segments distinct, petaloid. Style single, clongated, uncleft. Fruit a loculicidal capsule. Seeds bumerous in each cell. Stem from a scaly bulb or from a corm.

16. Lilium. Stem leafy, from a scaly bulb. Seeds flattened.

17. Erythronium. Stem a scape from a solid bulb. Leaves 2, basal. Seens obovoid.

Tribe VIII scílLEAE. Flowers perfect. Perinth-segments distinct and 8-several-ner-ped, or united into an urceolate short-toothed tube, not roughened exterually. Style single, slender, uncleft. Fruit a loculicidal capsnle. Stem scapose from a tunicate bulb.

18. Camassia. Flowers light blue, long-racemose. Filaments filiform. Periantb-seguents distinct.

19. Ornithogalum. Flowers greenish-white, subcorymbose. Filaments dilated. Perianth-sug. ments distinct.

20. Muscari. Flowers blue. Perianth gamophyllous, globose-urceolnte; limb short-toothed. 
Tribe IX. YÚCCEAE. Flowers perfect, racemo-paniculate. Perianth campanulate; its segments (large) distinct or somewhat connate near the base. Fleshy 3-lobed stigmatophore nearly or quite sessile. Fruit a loculicidal capsule, Cells many-seeded.

21. Yucca. Leaves sword-shaped, rigid.

Tribe X. POLYGONATEAE. Flowers perfect. Style single, entire or shortly 8-cleft at the summit. Fruit a berry.

* Proper leaves reduced to scarious scales, the apparent (phyllodial) leaves filiform.

22. Asparagus. Stem excessively branched. Flowers small, axillary.

* * Leaves neither scale-like nor filiform.

+ Perianth-segments distínct.

23. Clintonia. Scapose. Flowers umbellate or subumbellate.

24. Smilacina. Leafy-stemmed. Flowers 6-parted, racemose or paniculate.

25. Maianthemum. Low ; stem 1-8-leaved. Flowers 4-parted.

26. Disporum. Leafy-stemmed. Flowers few in terminal umbels.

27. Streptopus. Leafy-stemmed. Flowers axillary on bent pedicels. $+\div$ Perianth-segments connate.

28. Polygonatum. Stem leafy. Peduncles axillary, 1-8-flowered. Perianth cylindrical.

29. Convallaria. Leaves sheathing the scape. Flowers racemose. Perianth bell-shaped.

Tribe XI. PARfDEAE. Flowers perfect. Periarth-segments distinct. Style-branches distinet.

Fruit a berry. Cauline leaves whorled.

30. Medeola. Cauline leaves in 2 whorls. Flowers umbellate. Styles filiform.

31. Trillium. Cauline leaves 3 in in single whorl. Styles short, thick, the stigmatic surfawe irregular.

Tribe XII. ALEtTREAE. Flowers perfect. Perianth (small, white or yellow) gamophylions, conspicuously roughened. Style single, slightly cleft at the summit. Ovary partly inferior. Fruit a loculicidal many-seeded capsule.

32. Aletris. Scapose. Flowers in a spicate raceme.

Tribe XIII. SMILÀCEAE. Flowers dioecious, umbellate. Firuit baccate. Leaves net-veined, Tendrils usually present.

33. Smilax. Periant'i-segments distinct, deeiduous, small, greenish or yellowish.

\section{Artificial Ket to Genera}

a. Flowers dioecious.

Inflorescence umbellate ; fruit a berry

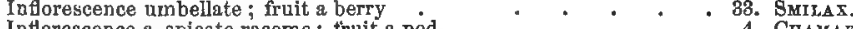

a. Flowors perfect or monoecious $b$.

$b$. Perianth gamophyllous, urceolate or campanulate, with a shortly toothed limb.

Stem leafy; leaves ovate, oblong, or lanceolate

Stem scapoid, leafy only at the base.

Leaves oblong ; perianth white.

Leaves very narrow, lanceolate to linear or terete.

Perianth smooth, blue

Perianth roughened, white or yellow

$b$. Perianth cleft at least to the middle or divided to the base $c$.

c. Fruit a berry $d$.

d. Cauline leaves whorled.

Cauline leaves 3 , in a single involucre-like whorl

Cauline leaves in 2 whorls

d. Cauline leaves alternate or none.

Leaves all basal

Leafy-stemmed.

Real leaves scale-like; apparent leaves fliform

Leaves foliaceous, never filiform.

Flowers 4-parted

Flowers 6-parted.

Flowers racemose or paniculate.

Flowers umbellate

Flowers axillary, solitary or in pairs

c. Fruit a capsule e.

B. Style none or very short and fleshy, (See also Tulipa, P. 289)

Flowers small; leaves distichous.

Flowers large; leaves several-many-ranked.

- 28. Polygonatim.

20. Convatidalia.

20. Mugcari.

32. Aletris.

81. Trillium.

30. Medeola.

- 23. Clintonia.

- 22. Asparague.

25. Maiantilemum.

24. SMilacina.

26. Disporom.

些. STREPTOFUB.

1. Nartiecium.

21. YUCOA. 
e. Style or styles fllform $f$.

$f$. Style single, entire or more or less deeply parted $g$.

g. Style 8-parted to below the middle.

Leaves gessile, not perfoliate:

g. Style entire or slightly 8 -lobed at the summit $\dot{h}$.

$h$. Stern rhizomatose at the bese

$h$. Stem bulbous at the base $t$.

i. Bulb solid (a cural); leaves 2, basal . - . . . 17. Errthronum.

i. Bulb scaly; stem leafy

i. Bulb tunicate.

Perianth-seginents 1-nerved.

Herbage with the odor of onion . 18. Allium.

Herbage without strong odor

Perianth-segruents 8 -several-nerved.

Perianth blue; filaments thread-like

Peranth 18. Camassia.

f. Styles 8 , distinet to the base $j$.

j. Stigmas linear.

Perianth-serments purplish; seeds many in each cell.

Perianth-segments white; seeds 2 in each cell

1. Btigmas terminal.

Anthers 2-celled

Anthers confluently 1-celied.

Stem pubescent.

Perianth-segments clawed

Perianth-segments essentially 'sessile

Stem glabrous.

Perianth-segments glandular near the base

Perianth-segments not glandular.

Flowers polyganous

Flowers perfect

\section{NARTHĖCIUM [Möhring] Juss. Bog AgPhodel}

Sepals 6, linear-lanceolate, yellowish, persistent. Anthers linear, introrse. Seeds ascending, appendaged at each end with a long bristle-form tail. - Rootstock creeping, bearing linear equitant leaves, and a simple stem or scape terminated by a simple dense bracteate raceme; pedicels bearing a linear bractlet. (Name an anagram of Anthericum, from a a $\theta \epsilon \rho$ sos, supposed to have been the Asphodel.)

1. N. americànum Ker. Stem 2.5-4 dm. high; leavas $0.7-1.5 \mathrm{~mm}$. wide, 7-9-nerved; raceme dense (2-5 cm. long); perianth-segments narrowly linear (4-5 mm. long), scarcely exceeding the stamens. (Abama Morong.) - Sandy bogs, pine-barrens of N. J. June, July.

\section{XEROPHÝLLUM Michx.}

Perianth widely spreading; sepals petal-like (white), oval, distinct, without glands or claws, 5-7-nerved, at lengtl withering, about the length of the awlshaped filaments. Anthers 2-celled, short, extrorse. Styles thread-like, stigmatic down the inner side, persistent. Capsule globular, 3-lobed, obtuse (small). Seeds collateral, 3-angled, not margined. - Herb with the stem simple, from a thick tuberous rootstock, bearing a simple dense bracteate raceme of showy flowers, and thickly beset with needle-shaped leaves, the upper reduced to bristle-like bracts; those from the root in a dense tuft, reclined, rough on the

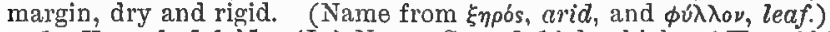

1. X. asphodeloides (L.) Nutt. Stem 3-12 dm. high. ( $X$. setifolium Michx.) - Pine-barrens, N. J. to e. Tenn., and Fla. June.

\section{HELONIAS L.}

Perianth of 6 spatulate-oblong purple segments, persistent, several-nerved, glandless, turning green, shorter than the thread-like filaments. Anthers 2 -celled, roundish-oval, blue, extrorse. Styles revolute, stigmatic down the inner side, deciduous. Capsule obcordately 3-lobed, loculicidally 3-valved ; the valves divergently 2-lobed. - A smooth perenuial, with many oblong-spatulate 
or oblanceolate evergreen flat leaves, from a tuberous rootstock, producing in early spring a stout hollow sparsely bracteate scape ( $3-6 \mathrm{dn}$. high), sheathed with broad bracts at the base, and terminated by a simple and short dense raceme. Bracts obsolete; pedicels shorter than the flowers. (Name probably from e a swamp, the place of growth.)

1. H. bullàta L. - Wet places, s. N. Y., and e. Pa. to Va., rare and local.

\section{Chamaelírium Willd. Devil's Bit}

Perianth of 6 spatulate-linear (white) spreading 1-nerved sepals, witheringpresistent. Filaments and (white) anthers, as in Helonias; fertile flowers with rudimentary stamens. Styles linear-club-shaped, stignatic along the inner side. Capsule ellipsoid, not lobed, of a thin texture, loculicidally 3-valved from the apex. Seeds linear-oblong. - Smooth herb, with a wand-like sters from a (bitter) thick and abrupt tuberous rootstock, terminated by a wandlike spiked raceme (1-3 dm. long) of small bractless flowers; fertile plant more leafy than the staminate. Leaves flat, lanceolate, the lowest spatulate, tapering

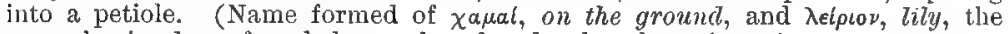
genus having been founded on a dwarf undeveloped specimen.)

1. C. lùteum (I.) Gray. (Blazing Star.) Stem 3-12 dm. high; fruiting pedicels 1-5 mm. long; capsule 7-10 mm. long. (C. carolinianum Willd.) Low grounds, w. Mass. to Fla., w. to Mich., Neb., and Ark. June.

2. C. obovàle Small. Sinilar ; flowers larger; fruiting pedicels about equaling the larger (12-14 mm. long) capsules. - Woods, N. Y., N. J.; and in the mts. from W. Va. to N. C. and Ala. - Species not seen.

\section{TOFIELdia Huds. False Asphodel}

Perianth more or less spreading, persistent; the sepals (white or greenish) concave, oblong or obovate, without claws, 3-nerved. Filanients awl-shaped; anthers short, innate or somewhat introrse, 2-celled. Styles awl-shaped; stigmas terminal. Seeds oblong, horizontal. - Slender perennials, mostly tufted, with short or creeping rhizomes, and simple stems leafy only at the base, bearing small flowers in a close raceme or spike. Leaves 2 -ranked, equitant, linear, grasslike. (Named for Mr. Tofield, an obscure English botanist of the 18th century.)

* Glabrous; pedicels solitary, in a short raceme or head; seeds not appendaged.

1. T. palústris Huds. Scape leafless or neariy so $(6-19 \mathrm{~cm}$. high), slender, bearing a globular or subcylindric head or short raceme of whitish flowers; leaves tufted, 2-4 cm. long. - Gaspé Co., Que., to Minn., and northw. (Greenl., Eu.) * Stem and inflorescence pubescent; pedicels fascicled in threes; seeds caudate.

2. T. glutindsa (Michx.) Pers. Stem (1.5-4.5 dm. high) and pedicels very glutinous with dark glands; leaves broadly linear, short; perianth not becoming rigid ; capsule thin; seeds with a contorted tail at each end. - Moist grounds, Nfd. to centr. Me., Ill., Minn., northw. and westw.; also s. in the Alleghenies. June, July.

3. T. racemosa (Walt.) BSP. Stem ( $3-9 \mathrm{dm}$. high) and pedicels roughened with minute glands; leaves longer and narrower; perianth rigid about the firm capsule : seeds with a short white appendage at each end. (T.pubens Michx.) - Pine-barrens, N. J. to Fla. and Ala. July.

\section{6. amánthum Gray. Flt Porson}

Perianth widely spreading; the free white segments oval or obovate, without claws or glands, persistent. Filaments capillary. Anthers, capsules, etc., nearly as in Melanthium. Styles thread-like. Seeds 1-4 in each cell. - Glabrous, with simple stems from a bulbous base or coated bulb, scape-like, few-leaved, terminated by a simple dense raceme of handsome flowers, turning greenish with age. (From dulavros, unspotted, and abtos, flower; a name formed with more regard to euphony than to good construction, alluding to the glandless perianth.) 
1. A. muscaetóxicum (Wait.) Gray. (FLy Poison.) Leaves broadly linear. elongated, obtuse (4-27 mm. wide); raceme simple; capsule abruptly 3-horned . seeds oblong with a fleshy red coat. (Chrosperma Ktze.) - Open woods, L. I. to Fla., w. to Ky. and Ark. June, July.

\section{STENÅNTHIUM (Gray) Kunth.}

Perianth spreading; the sepals narrowly lanceolate, tapering to a point from the broader base, where they are coherent to the base of the ovary, much longer than the short stamens. Seeds nearly wingless. - Smooth, with a wand-like leafy stem from a bulbous base, long and grass-like conduplicate-keeled leaves, and numerous small flowers in compound racemes, forming a long terminal panicle; flowering in summer. (Name composed of $\sigma \tau \epsilon \nu b s$, narrow, and a $\nu \theta 0 s$, flover, from the slender sepals and panicles.)

1. S. gramíneum (Ker) Kunth. Stem leafy (1-1.6 m. high), slender; leaves 4-10 mm. broad; panicle elongated, very open, with slender flexuous branches or subsimple; flowers nearly sessile or the fertile on short pedicels ; sepals linearlanceolate (white), 4-8 mm. long; capsule mostly reflexed, narrowly oblongovate, with spreading beaks. (S. angustifolium Kunth.) - In the Alleghenies from Va. to Ga., westw. to Mo. S. RoBústum Wats, separated on its stouter habit, dense panicle, broader leaves, and erect capsule, is doubtfully distinct.

\section{ZYGÁDENUS Michr.}

Flowers perfect or polygamous. Perianth withering-persistent, spreading; the petal-like oblong or ovate sepals 1-2-glandular near the more or less narrowed but not unguiculate base. Stamens free from the sepals and about their length. Anthers, styles, and capsule nearly as in Melanthium. Seeds angled, rarely at all margined. - Smooth and somewhat glaucous perennials, with rather large panicled greenish-white flowers in summer. (Name composed of surós, a yoke, and $\alpha \delta \eta v$, a gland, the glands being sometimes in pairs.)

* Stern from a creeping rootstock; 2 conspicuous orbicular glands on each division of the perianth above the claw.

1. Z. glabérrimus Michx. Stems $3-9 \mathrm{dm}$. high ; leaves grass-like, channeled, conspicuously nerved, elongated, tapering to a point; panicle pyramidal, manyflowered; flowers perfect; sepals nearly free (12 $\mathrm{mm}$. long), ovate, becoming lance-ovate, with a short claw. - Grassy low grounds, Va. to Fla. and Ala.

* Stem from a more or less bulbous base; glands less obvious, covering the base of the perianth-segments.

2. Z. chloránthus Richards. Stem 3-9 dm. high; leaves flat, carinate; raceme simple or sparingly branched and few-flowered; bracts ovate-lanceolate; base of the perianth coherent with the base of the ovary, the thin ovate or obovate sepals marked with a large obcordate gland, the inner abruptly contracted to a broad claw. (Z. elegans of auth., not Pursh.) - Calcareous soils, Gaspé Co., Que., to Man., southw. to n. N. B., n. Vt., n. N. Y., n. O., n. Ill., and (?) Mo.

:) Z. Nuttallii Gray. Like the last; raceme rather densely flowered, with narrow bracts; perianth free; sepals with an ill-defined gland at base, not at all clawed; seeds larger ( $6 \mathrm{~mm}$. long), - Kan. to Tex.

4. Z. leimanthoides Gray. Stem 7-15 dm. high, slender; leaves narrowly linear ; flowers small ( $8 \mathrm{~mm}$. in diameter) and numerous, in a few crowded panicled racemes; only a yellowish spot on the contracted base of each division of the free perianth. - Low grounds, pine-barrens, L. I. to Ga.

\section{MELÅNTHIUM L.}

Perianth of 6 separate and free widely spreading somewhat heart-shaped or oblong and halberd-shaped or oblanceolat's sepals, raised on slender claws, ream-colored or greenish. Filaments shorter than the divisions of the perianth, 
adhering to their claws often to near the summit, persistent. Anthers heartshaped or kidney-shaped, confluently 1-celled, shield-shaped after opening, extrorse. Causule ovoid-conical, 3 -lobed, of 3 inflated membranaceous severalseeded carpels; seeds flat, broadly winged. -- Stens tall and leafy, from a thick rootstock, roughisli-clowny above, as well as the open and ample pyramidal panicle (composed chiedy of simple racemes), the terminal part mostly fertile. Leaves linear to oblanceolate or oval, not plaited. (Name composed of $\mu \epsilon \lambda a s$, black, and dwtos, flover, from the darker color which the persistent perianth assumes after blossoming.)

* Perianth-divisions with a conspicuous double gland at the summit of the claw.

1. M. virgínicum L. (Bunch-rlower.) Stem 8-16 dm, higb, leafy, rather slender ; ieaves linear ( $1-3 \mathrm{~cm}$. wide); divisions of the perianth flat, ovate to oblong or slightly hastate (5-8 mm. long); capsule $1.4 \mathrm{~cm}$. long; seeds $10 \mathrm{in}$ each cell, 4-6 mm. long. - IVet meadows, "R. I.," N. Y. to Minn., Tex., and Ga.

2. M. latifolium Desr. Leaves more oblanceolate, often $5 \mathrm{~cm}$. broad; divisions of the perianth undulate ( $5 \mathrm{~mm}$ : long), the very narrow claw nearly equaling the orbicular or ovate blade; capsule $12-16 \mathrm{~mm}$. long, on pedicels 8-18 mm. in length; seeds $4-8$ in each cell, $6-8 \mathrm{~mm}$. long. (M. racemosum Michx.) - Ct. to S. C.

Var. longipedicellatum A. Brown. Leaves somewhat narrower; pedicels 2-2.5 cm. long. - Wooded slopes, w. Va. (Judge Brown).

* Perianth-divisions oblanceolate, without glands.

3. M. parviflorum (Michx.) Wats. Stem rather slender (0.6-1.6 m. high), sparingly leafy, naked above; leaves oval to oblanceolate $(5-10 \mathrm{~cm}$. wide), on long petioles; perianth-divisions 4-6 mm. long, oblanceolate or spatulate, those of the sterile flowers on claws; stamens very short; capsule $1.5 \mathrm{~cm}$. long; seeds 4-6 in each cell, $5 \mathrm{~mm}$. long. (Veratrum Michx.) - In the Alleghenies, Va. to S. C.

\section{VERÀTRUM [Tourn.] L. False Hellebore}

Perianth of 6 spreading and separate obovate-oblong (greenish or brownish) divisions, more or less contracted at the base (but not clawed), nearly free from the ovary, not gland-bearing. Filaments free from and shorter than the sepals, recurving. Anthers, pistils, fruit, etc., nearly as in Melanthium. - Somewhat pubescent perennials, with simple stems from a thickened base producing coarse fibrous roots (very poisonous), 3-ranked plaited and strongly veined leaves, and racemed-panicled dull or dingy flowers; in summer. (Name from vere, truly, and ater, black.)

1. V. víride Ait. (American White Hellebore, Indan Poke.) Stem stout, very leafy to the top $(6-20 \mathrm{dm}$. high); leaves broadly oval, pointed, sheath-clasping; panicle pyramidal, the dense spike-like racemes spreading; perianth yellowish-green, moderately spreading, the segments ciliate-sermilate; ovary glabrous; capsule many-seeded. - Swamps and low grounds.

2. V. Woódii Robbins. Stem slender, sparingly leafy (8-14 dm. high); leaves oblanceolate, only the lowest sheathing; panicle very narrow; perianth greenish-purple, with entire segments; ovary tomentose, soon glabrate; capsule few-seeded. - Woods and hilly barrens, s. Ind. to Mo.

\section{UVULÀRIA L. BeILLWORT}

Perianth narrowly bell-shaped, lily-like, deciduous; the 6 divisions spatulatelanceolate, acuminate, obtusely gibbous at base, with a deep honey-bearing groove within bordered on each side by a callus-like ridge. Stamens much shorter, barely adherent to their base. Capsule truncate, coriaceuus, 3-lobed, loculicidal at the summit. Seeds few'in each cell, obovoid, with a thin white aril. - Stems terete, from a short rootstock with fleshy roots, naked or scaly at base, forking above, bearing oblong perfoliate flat and membranaceous leaves 
with smooth margins, and yellowish drooping flowers, in spring, solitary on terminal peduncles. (Name "from the flowers hanging like the uvula, or palate.") 1. U. perfoliàta L. Glaucous throughout, 2-5 dm, high, with 1-is leaves below the fork; leaves glabrous, oblong- to ovate-lanceolate, acute; perianth segments granular-pubescent within (1.8-3.6 $\mathrm{cm}$. long); stamens shorter than the styles; tip of the connective acuminate; cells of the capsule with 2 dorsal ridges and 2-beaked at the apex. - Rich woods, e. Mass, to Ont., Dak. and southw.

Z. U. grandiflora Sm. Yellowish green, not glaucous; stem naked or with a single leaf below the fork; leaves whitish-pubescent beneath, usually some. what acuminate; perianth-segments smooth within or nearly so $(2.5-4.5 \mathrm{~cm}$. long); stamens, exceeding the styles, obtusely tipped; capsule obtusely lobed. (U. flava Sm.) - Rich woods, w. N. H. to Ga., westw. to Minn. and Kan.

\section{OAKESIA Wats.}

Flowers resembling those of Uvularia, but the segments obtuse or acutish, carinately gibbous and without ridges within. Capsule membranous, elliptical, acutish at each end or shortly stipitate, triquetrous and acutely winged, very tardily dehiscent. Seeds globose, with a very tumid spongy rhaphe. - Stem acutely angled, from a slender creeping rootstock, with sessile clasping leaves scabrous on the margin, and 1 or 2 flowers terminal on slender peduncles but soon appearing opposite the leaves by the growth of the branches. (Dedicated to William Oakes, New England botanist, 1799-1848.)

L 1. 0. sessilifdlia (L.) Wats. Leaves lance-oblong, acute at each end, pale, glaucous beneath, sessile or partly clasping; divisions of the perianth 1.4-2.5 $\mathrm{cm}$. long; anthers obtuse; capsule short-stipitate, $1.2-2 \mathrm{~cm}$. long. (Uvularia L.) - Woods and thickets.

2. 0. pubérula (Michx.) Wats. Slightly puberulent; leaves bright green both sides and sbining, oval, mostly rounded at base, with rougher edges; styles separate to near the base, not exceeding the acute anthers; capsule not stipitate, $2-2.5 \mathrm{~cm}$. long. (Uvularia Michx. ; 0 . sessilifolia, var. nitida Britton.) - Pine-barren swamps and mountain woods, N. J. to S. C.

\section{9. Állium [Tourn.] L. Onion. Garlic}

Perianth of 6 entirely colored sepals, which are distinct, or united at the very base, 1-nerved, often becoming dry and scarious and more or less persistent; the 6 filaments awl-shaped or dilated at base. Style persistent, thread-like; stigma simple or only slightly 3-lobed. Capsule lobed, loculicidal, 3-valved, with 1-2 ovoid-kidney-shaped amphitropous or campylotropous black seeds in each cell. - Strong-scented and pungent herbs; the leaves and usually scapose stem from a coated bulb; flowers in a simple umbel, some or all of them frequently replaced by bulblets; spathe scarious, 1-2-valved. (The ancient Latin name of the Garlic.)

() vary not crosted.

Capsule strongly 3-lobed, cells 1-ovuled ; leaves elliptic-lanceolate, 2-5 cm. broad

Capsule oroid to obovoid, slightly lobed; cells i2-several-ovaled ; lesves linear or terete.

Umbel capitate; the pedicels shorter than or little exceeding the perianth

Umbel open (except when as in $\dot{A}$. oninadense and $A$. vinsale the flowers are more or Jess replaced by sessile bulblets); the pedicels much exceeding the perlanth.

Stern leafy to or above the middle; bulb-coats fibro-membranous, not strongly reticulated

Stem leafy only near the base; bulb-conts in age strongly netted. Umbel fow-howerel, nearly always converted partially or wholly Umbel many-floweled : bulblets none

1. A. tricoocum.

2. A. Schoenoprasum

8. A, vineale.

6. A. connadense. and capsule conspicnously crested.

Umbel nodding

Utmbel erect; stamens and style exserted :

Umbel erect; stamens and stylo included:

7. A. mutabile.

8. A. cernukm.

4. A, stellitum.

- 5. A. reticulatum. 
1. A. tricóccum Ait. (WILD LEeK.) Scape (1.5-4 dm. high, from clustered pointed bulbs 3.5-5 cm. long) bearing an erect many-flowered unbel; leaves $10-23 \mathrm{~cm}$. long and $3-6 \mathrm{~cm}$. wide; segments of the perianth oblong (greenish white), equaling the nearly distinct filaments; capsule strongly 3-lobed. - Rich woods, N. B. to Minn. and Ia., s. in the mts. to N. C.-Leaves appearing in early spring and dying before the flowers are developed.

2. A. Schoenóprasum L., var. sibíricum (L.) Hartm. Scape (2-4 dm. high) bearing a globular capitate umbel of many rose-purple flowers; segments of the perianth lanceolate, pointed, longer than the simple downwardly dilated filaments; leaves awl-shaped, hollow; capsule not crested. - Ledgy shores, Nfd. to Alaska, s. to N. S., n. N. E., the Great Lake region, etc. (Eurasia.) - The typical form of the species (the Chives of vegetable gardens) is a lower and more slender but not sharply separable plant.

3. A. cérnuum Roth. (WILD ONION.) Scape angular (2.5-6 dm. high), nodding at the apex, bearing a loose or drooping few-many-flowered umbel; leaves linear, flattened, sharply keeled ( $3 \mathrm{dm}$. long); segments of the perianth oblong-ovate, acute, rose-color to purple, shorter than the slender filaments and style; capsule 6-crested. (? A. allegheniense Small.) - N. Y. to S. C., and westw.

4. A. stellàtum Ker. Scape terete $(3-5 \mathrm{dm}$. high), slender, bearing an erect umbel; bulb-coats membranous ; capsule prominently 6-crested. - Rocky slopes, Minn. to w. Ill., Mo., and westw.

5. A. reticulàtum Don. Scape 1-1.8 dm. high; bulbs densely and coarsely fibrous-coated; spathe 2-valved; umbel rarely bulbiferous; sepals ovate to narrowly lanceolate, thin and lax in fruit, a third longer than the stamens; capsule crested. - Sask. to Ia. and N. Mex.

$\checkmark 6$. A. canadénse L. (Wild Garlic.) Scape $3 \mathrm{dm}$. high or more; bulb small $(1.2-1.8 \mathrm{~cm}$. in diameter); bulb-coats somewhat fibrous; umbel densely bulbiferous, the flowers few or often none; segnients of the perianth narrowly lanceolate, equaling or exceeding the stamens; capsule not crested. - Moist meadows, N. B. to Ont., s. to Fla. and Tex. May, June.

7. A. mutábile Michx. Similar in stature, habit, and flowers to preceding; umbels not normally bulbiferous, many (16-43)-flowered; bulbs $2-3 \mathrm{~cm}$. in diameter. - Prairies and borders of woods, Mo. (Bush.) to Fla., Tex., and Neb. V 8. A. vineale L. (Field Garlic.) Stem slender (3-9 dm. high), slothed with the sheathing bases of the leaves below the middle; leaves terete and hollow, slender, channeled above; umbel often densely bulbiferous; filaments much ditated, the alternate ones cuspidate on each side of the anther. - Moist meadows and fields, locally abundant, Mass. to Mo., and Va. June. (Nat. from Eu.)

\section{NOTHOSCÓRDUM Kunth.}

Flowers greenish or yellowish white. Capsule obovoid, somewhat lobed, obtuse, with the style obscurely jointed on the summit; cells several-ovuled and -seeded. Filaments filiform, distinct, adnate at base, - Bulb tunicated, not alliaceous. Otherwise as in Allium. (Name from vótos, false, and $\sigma \kappa \delta \rho \delta\llcorner o v$, garlic.)

1. N. biválve (L.) Britton. Scape 1.5-3.5 dm. high; bulb small, often bulbiferous at base; leaves narrowly linear; flowers few, on slender pedicels, the segments narrowly oblong, about $1 \mathrm{~cm}$. long; ovules 4-7 in each cell. ( $N$. striatum Kunth.) - Prairies and open woods, Va. to O., Neb., and southw.

\section{HEMEROCÁlLis L. DAy LiLy}

Perianth funnel-form, lily-like; the short tube inclosing the ovary, the spreading limb 6-parted; the 6 stamens inserted on its throat. Anthers as in Lilium, but introrse. Filaments and style long and thread-like, declined and ascending; stigma simple. Capsule (at first rather fleshy) 3-angled, loculicidally 3-valved. with several black spherical seeds in each cell. - Showy 
perenuials, with fleshy-flbrous roots; the long and linear keeled leaves 2-ranked at the base of the tall scapes, which bear at the summit several bracted and large flowers; these collapse and decay after expanding for a single day (whence

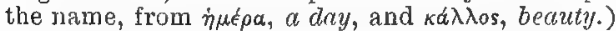

1. H. Fúva L. (Commos D.) Inner divisions (petals) of the tawny orange perianth wavy and obtuse. - Roadsides, esraped from gardens. (Introd. from Eu.)

\section{LÍLIUM [Tourn.] L. LILY}

Perianth funnel-form or bell-shaped, colored, of 6 divisions, spreading or recurved above, deciduous. Anthers linear, extrorsely attached near the middle to the tapering apex of the long filament, which is at first included, at length versatile; the cells dehiscent by a lateral or slightly introrse line. Style elongated; stigma 3-lobed. Capsule subcylindric; seeds densely packed in 2 rows in each cell. Bulbs scaly, producing simple stems, with numerous alternatescattered or whorled narrow sessile leaves, and from one to several large and showy flowers in summer. (The classical Latin name, from the Greek $\lambda$ elplov.)

* Flowers evect; sepals narrowed below into claws; bulbs not rhizomatous.

1. I. philadélphicum L. (Wild ORaNGe-Rei) L., Wood L.) Stem 4-9 $\mathrm{dm}$. high; leaves linear-lanceolate, chiefly whorled; flowers 1-3, open-bellshaped, reddish-orange, spotted with purplish inside; the lanceolate segments little or not at all recurved at the obtusish or shortly acuminate summit; pod somewhat rounded at base. - Dry or sandy ground, N. E. to Ont. and N.C. - Separated by no constant character from

Var. andìnum (Nutt.) Ker. Leaves, all but the uppermost, scattered ; perianth divisions mostly deep red; pod atteruate at the base. (L. umbellatum Pursh; L. lanceolatum Fitzpatrick, - Rich soil of prairies, and in bogs, Ont. and 0 . to Ark., and northwestw.

2. L. Catesbaèi Walt. (SodtherN ReD L.) Leaves linear-lanceolnte, scattered; flower solitary, open-bell-shaped, the large and long-clawed divisions of the perianth wavy on the margin and recurved at the caudate-attenuate sunmit, scarlet, spotted with dark purple and yellow inside; bulb-scales thin, marrow and leaf-bearing. - Pine-barrens, N. C. to Fla., w. to "Ky.," "s. Ill.," and "Mo."

\section{* Flowers nodding; sepals sessile; bulbs rhizomatous.}

3. L. supérbum L. (TrRK's-CAP L.) Stem 9-23 dm. high; lower leaves whorled, lanceolate, attenuate at both ends, 3-nerved, smooth; flowers (3-40) in a pyramidal raceme; perianth-divisions ( $7-8 \mathrm{~cm}$. long) strongly revolute, orange, with numerous dark purple spots inside. - Rich low grounds, N. B. to Va., w. to Minn. and Mo.

4. L. caroliniànum Michx. Nearly related to the preceding and with very similar flowers; stem 4-7 dm. high, 1-3 flowered; leaves obovate to oblanceolate, obtusish or short-acuminate. - Borders of mountain woods, Va. (Small), and southw.

5. L. canadénse L. (WILD Yellow L.) Stem 6-20 dm, high; leaves remotely whorled, lanceolate, strongly 3-nerved, the margins and nerves rough; flowers long-peduncled, narrowly bell-shaped, the perianth-divisions (5-8 cm. long) recurved-spreading above, yellow or orange, usually spotted with brown. Moist meadows and bogs, e. Que. to Ga., w. to Mo., Minn., and Ont.

6. L. Gràyi Wats. Stems 6-9 dm. high; leaves in whorls of 4-8, lanceolate, acute or slightly acuminate, smooth; flowers 1 or 2 , nearly horizontal, the perianth-divisions (3.5-6 cm. long) but little spreading above the rather broad base, rather abruptly acute, deep reddish-orange, thickly spotted within. - Peaks of Otter, Va., and southw. in the mts. to N. C.

7. L. TIGRindm Ker. (Trger L.) Tall, pr.bescent above; leaves scattered narrowly lanceolate, dark green, 5-7-nerved, the upper axils bulbiferous; flower large, resembling those of $I$. superbum. - An escape from gardens. (Introd from N. Asia.: 


\section{ERYTHRONIUM L. DOG'S-TOOTH VIOLET}

Perianth lily-like, of 6 lanceolate recurved or spreading divisions, deciduous, the 3 inner usually with a callous tooth on each side of the base, and a groove in the middle. Filainents 6, awl-shaped; anthers oblong-linear. Style elongated. Capsule obovoid, contracted at base, 3 -valved, loculicidal. Seeds rather numerous. - Nearly stemless herbs, with two smooth and shining flat leaves tapering into petioles and sheathing the bise of the commonly one-tlowered scape, rising from a deep solid scaly bulb. Flowers rather large, nodding, in spring. (The Greek name for the purple-flowered European species, from épu $\theta \rho \delta s$, red.)

1. E. americànum Ker. (Yeliow Adoen's-Tongue). Scape $1.5-2 \mathrm{dm}$. high; leaves elliptical-lanceolate, pale green, mottled witli purplish and whitish and often minutely dotted; perianth light yellow, often spotted near the base (2-4 cm. long); style club-shaped; stigmas united. - Rich ground, N. B. to Fla., w. to Ont. and Ark.

2. E. álbidum Nutt. (White Dog's-тоoтh Violet.) Producing subterranean offshoots from the base of the corm; leaves elliptical-lanceolate, less or not at all spotted; perianth pinkish-white; inner divisions toothless ; style more slender except at the apex, bearing 3 short spreading stigmas. - Rich ground, Ont. to N. J., w. to Minn. and Tex.

3. E. mesochòreum Knerr. No basal offshoots; leaves narrowly lanceoblong or linear-lanceolate, not mottled; perianth-divisions bluish or lavendertinted, scarcely or not at all revolute; stigmas spreading. - Prairies, w. Ia. (Burgess) and Mo. to Kan. and Neb.

4. E. propullans Gray. Offshoot arising from the stem, near the middle; leaves smaller and more acuminate; flowers bright rose-color, yellowish at base (12 mm. long); style slender; stigmas united. - In rich soil, Minn. and Ont.

TùLIPA SYLVÉstris L., a wild tulip of Europe, readily recognized by its solitary subscapose large yellow flowers, 6-divided perianth and thickish subsessile stigna, is said to be established in e. Pa. (Fretz). (Adv. from Eu.)

\section{CAMÁSSIA Lindl.}

Perianth slightly irregular, of 6 blue or purple spreading 3-7-nerved divisions, filaments filiform. Style thread-like, the base persistent. Capsule short and thick, 3-angled, loculicidal, 3-valved, with several black roundish seeds in each cell. - Scape and linear leaves from a coated bulb; the flowers in a simple raceme, mostly bracted, on jointed pedicels. (From the native Indian name quamash or comass.)

1. C. esculénta (Ker) Robinson. (EAstern Camass, Wild Hyacinth.) Scape 1.5-7 dm. high; leaves keeled; raceme elongated; bracts longer than the pedicels; divisions of the perianth pale blue, 3-nerved, 10-14 mm. long; capsule acutely triangular-globose. (Scilla Ker; C. Fraseri Torr.; Quanasia esculenta Coville; Q. hyacinthina Britton.) - Rich ground, w. Pa. to Minn., Tex., and Ga. - This species should be carefully distinguished from the larger flowered plant of the Northwest, which has long passed as C. esculenta Lindl., -a name which must be replaced by Camassia quamash Greene.

\section{ORNithógalom ['Tourn.] L. Star of Bethlehem}

Perianth of 6 (white) spreading 3-7-nerved divisions. Filaments 6, flattenedawl-shaped. Style 3-sided; stigma 3-arigled. Capsule roundish-angular, with few dark and roundish seeds in each cell, loculicidal. - Scape and linear channeled leaves from a coated bulb. Flowers corymbed, bracted; pedicels not jointed. (A whimsical name from $\delta \rho \nu$ s, $a$ bird, and $\gamma a \dot{\lambda} a$, milk.)

1. 0. UмвеlсAтом L. Scape 1-2.5 din. high; flowers 5-8, on long and spreading pedicels; perianth-divisions green in the middle on the outside. - Es. caped from gardens. (Introd. from Eu.) 
2. 0. Nùtans L. Scape $3 \mathrm{dm}$. high or more; flowers 5-6, large $2-2.5 \mathrm{~cm}$ long', nodding on very short pedicels; flaments very broad, - Rarely escapec. from gardens; Pa. to D. C. (Introd. from Eu.)

\section{MUSCÅRI [Tourn.] Mill. Grape Hyacinth}

Perianth globular or ovoid, minutely 6 -toothed (blue, rarely pink or white) Stmmens 6, included; anthers short, introrse. Style short. Capsule loculicidal, with 2 black angular seeds in each cell. - Leaves and scape (in early spring) from a coated bulb; the small flowers in a dense raceme, sometimes muskscented (whence the name).

1. M. Botr yoines (L.) Mill. Leaves linear, 6-10 mm. broad ; flowers globular ( $3-5 \mathrm{~mm}$. long), deep blue, appearing like minute grapes. - Escaped from gardens into copses and fence-rows. (Introd. from Eu.)

2. M. Rachmòsdm (L.) Mill. Leaves $2-3 \mathrm{~mm}$. broad; flowers ablong-urceolate (4-5 mm. long), deep blue, fragrant. - Rare escape, s. N. Y. to Va. (Introd. from Eu.)

\section{YÚCCa [Rupp.] L. Bear Grass. Spanigh Bayonet}

Perianth of 6 large white or greenish oval or oblong and acute flat with. ering-persistent segments, the 3 inner broader, longer than the 6 stamens. Stigmas 3, sessile. Capsule oblong, somewhat 6-sided, 3-celled, or imperfectly 6-celled by a partition from the back, fleshy, at length loculicidally 3-valved from the apex. Seeds very many in each cell, flattened, - Stems woody, in ours very short, bearing persistent rigid linear or sword-shaped leaves, and an ample panicle or raceme of showy flowers. (The native Haytian name for the root of the Cassava-plant.)

1. Y. glaúca Nutt. Leaves very stiff and pungent, 2-6 dm. long, 4-12 mm. wide, filiferous on the margin ; raceme mostly simple, nearly sessile (3-12 dm. long); Hlowers $3.5-6 \mathrm{~cm}$. wide; stigmas green, shorter than the ovary ; capsule 6-sided (7 cm. long); seeds 10-12 mm. broad. ( $Y$. angustifolia Pursh.) — Dak. to Ia., Mo., N. Mex., and Wyo. May, June.

2. Y. filamentosa L. (ADAM's Needle.) Caudex $3 \mathrm{dm}$. high or less, from a running rootstock; leaves numerous, coriaceous, more or less tapering to a short point, rough on the back, 4-6 dm. long, 2-4 cm. wide, filiferous on the margin ; panicle pyramidal, densely flowered, on a stout bracteate scape, $1-3 \mathrm{~m}$. high; flowers large; stigmas pale, elongated; capsule $3.5 \mathrm{~cm}$. long; seeds 6 mm. broad. - Near the coast, Md. (where of the formal var. LATifólia Engelm. with leaves 5-9 cm. wide) to Fla. and La. July. - Very variable. Occasionally spontaneous about old gardens.

\section{ASPÁRAGUS [Tourn.] L. Asparagus}

Perennials, with much branched stems from thick and matted rootstocks, and small greenish-yellow axillary flowers on jointed pedicels. The narrow, courmonly thread-like, so-called leaves are really branchlets, acting as leaves, clustered in the axils of little scales which are the true leaves. (The ancient Greek name.)

1. A. officinalis L. (Garden A.) - A frequent escape. Jume. (Introd. from Eu.)

\section{CLINTÒNLA Raf.}

Perianth of 6 divisions, lily-like, deciduous. Filaments long and thread-like; anthers extrorsely fixed by a point above the base. Ovary ovoid-subcylindric, 2-3-celled; style long. - Short-stemined perennials, with slender creeping root. stocks, bearing a naked peduncle sheathed at the base by the stalks of $2-4$ large oblong or oval ciliate leaves; flowers umbeled, rarely single. (Dedicated to De Witt Clinton, prominent statesman, several times governor of New York.) 
1. C. boreàlis (Ait.) Raf. Scape and leaves $14-25 \mathrm{~cm}$. long ; terminal umbel 3-6-flowered (sessile lateral umbels often present on the same scape); perianth greenish-yellow, somewhat downy outside (12-18 mm. long); berry ovoid, blue ; ovules 20 or more. - Cold moist woods, Lab. to N. C., w. to Man. and Minn.

2. C. umbellulàta (Michx.) Morong. Flowers half as large as in the last, white, speckled with green or purplish dots; umbel many-flowered; berry globular, black; ovules 2 in each cell. (C. umbellata Torr.)-Rich woods, N. Y., N. J., and in the Alleghenies to Ga.

\section{Smilacina Desf. Fatse Solomon's Seal}

Perianth 6-parted, spreading, withering-persistent. Filaments 6, slender; anthers short, introrse. Ovary 3 -celled, with 2 ovules in each cell; style short and thick; stigma obscurely 3-lobed. Berry globular, 1-2-seeded, at tirst greenish or yellowish-white speckled with madder brown, at length a dull subtranslucent ruby red. - Perennial herbs, with simple stems from creeping or thickish rootstocks, alternate nerved mostly sessile leaves, and white, sometimes fragrant flowers. (Name a diminutive of Smilax.)

* Flowers on very short pedicels in a terminal racemose panicle; stamens exceeding the small (2 mm. long) segments; ovules collateral; rootstock stout, fleshy.

1. S. racemòsa (L.) Desf. (False Spikenard.) Minutely downy (4-10 $\mathrm{dm}$. high); leaves numerous, oblong or oval-lanceolate, taper-pointed, ciliate, abruptly somewhat petioled. (Vagnera Morong.) - Moist copses and banks.

** Flowers larger (4-5 mm. long), on solitary pedicels in a simple few-flowered raceme; stamens included; ovules not collateral; rootstock rather slender.

2. S. stellàta (I.) Desf. Plant (2-5 dm. high) nearly glabrous, or the 7-12 oblong-lanceolate leaves minutely downy beneath when young, slightly clasping; raceme sessile or nearly so. (Vagnera Morong.) - Moist banks, frequent. (Eu.)

3. S. trifdlia (L.) Desf. Glabrous, dwarf (1.3-2 dm. high); leaves 3 (sometimes 2 or 4 ), oblong, tapering to a sheathing base; raceme peduncled. (Vagnera Morong.) - Cold bogs, Lab. to N.J., westw. to B. C. (Siber.)

\section{MAIÁNTHEMUM [Weber in] Wiggers.}

Perianth 4-parted, and stamens 4. Ovary 2-celled; stigma 2-lobed. Otherwise as in Smilacina. - Flowers solitary or fascicled, in a simple raceme upon a low 2-3-leaved stem. Leaves ovate- to lanceolate-cordate. (Name fron Maius, May, and d $z \theta \in$ Mov, $_{\text {, }}$ fower.)

1. M. canadénse Desf. Pubescent or glabrous (6-22 cm. high); leaves lanceolate or ovate, cordate at base with a very narrow sinus, sessile or very shortly petioled; perianth-segments $2 \mathrm{~mm}$. long. (Unifolium Greene.) - Moist woods, Lab. to N. C., w. to Ia., Dak., and Man.

\section{DÍSPORUM Salisb.}

Perianth narrowly bell-shaped, the 6 lancenlate or linear divisions deciduous. Filaments thread-like, much longer than the linear-oblong blunt anthers. Ovary with 2 ovules (in our species) suspended from the summit of each cell; style one; stigmas 3 , short, recurved-spreading, or sometimes united into one! Berry ovoid or subcylindric, pointed, 3-6-seeded, red. - Downy low lierbs, with creeping rootstocks, erect stews sparingly branched above, closely sessile ovate thin leaves, and greenish-yellow drooping flowers on slender terminal peduncles, solitary or few in an umbel. (Name from $\delta l s$, double, and $\sigma \pi o \rho \alpha$, seed, in allusion to the 2 ovules in each cell.)

1. D. lanuginosum (Michx.) Nichols. Leaves taper-pointed, rounded or 
slightly heart-shaped at base ; flowers solitary or in pairs; perianth (18 $\mathrm{mm}$. long) soon spreading, twice the length of the stamens, greenish; stigmas 3.Rich woods, Ont, and w. N. Y. to O., Tenn., and Ga.

\section{STRÉPTOPUS Michx. TWisted-STaLk}

Perianth recurved-spreading from a bell-shaped base, deciduous; the 6 divisions lanceolate, acute, the 3 inner keeled. Anthers arrow-shaped, extrorse, fixed near the base to the short flattened filaments, tapering above to a slender entire or 2-cleft point. Belry red, roundish-ovoid, many-seeded.--Herbs, with rather stout stems from a short or creeping rootstock, ordinarily forking and divergent branches, ovate and taper-pointed rounded-clasping membranaceous leaves, and small (extra-) axillary flowers, either solitary or in pairs, on slender thread-like peduncles, which are abruptly bent or contorted near the middle (whence the name, from $\sigma \tau \rho \epsilon \pi \tau \delta s$, twoisted, and $\pi$ ovis, foot or stalk).

1. S. amplexifolius (L.) DC. Sten 3-9 dm. high, glabrous; lecves very smooth, glaucous underneath, strongly clasping; flower greenish-wohite (about $1 \mathrm{~cm}$. long) ; perianth-segments uide-spreading or recurved from near the middle; anthers many times exceeding the filaments, tapering to a slender entive point; stigma entire, truncate; fruit ellipsoid or globose, 1-2 cm. long, scarlet. - Cold moist woods, Greenl. to Alaska, s. to N. E., Pa., O., Minn., and in the mts. tc N. C. and N. Mex. (Eurasia.)

2. S. ròseus Michz. Lower (2-6 dm. high); rootstock short and thick; leaves green both sides, finely ciliate; the branches sparingly beset with slort bristly hairs; flower rose-purple ( $8-12 \mathrm{~mm}$. long), more than half the length of the slightly bent peduncle, the perianth-segments with only the tips recurved in age; anthers ovate, 2-horned, about equaling the filaments; stigma 3-cleft; fruit subglobose, $1 \mathrm{~cm}$. in diameter, cherry-red.-Cold damp woods, Nfd. to the mts. of Ga., w. to Wisc. and Man. May, June.

3. S. longipes Fernald. Similar; rootstock slender and wide-creeping; stem ciliate-hispid above, 3-4 dm. high; leaves ciliate, sessile, pale beneath; perianth campanulate, reddish; anthers and stigmas as in no. 2. - Woods, Marquette Co., Mich.

\section{POLYGÓNATUM [Tourn.] Hill. Solomon's SeaL}

Perianth cylindrical, 6-lobed at the summit; the 6 stamens inserted on or above the middle of the tube, included; anthers introrse. Ovary 3-celled, with $2-6$ ovules in each cell ; style slender, deciduous by a joint; stigma obtuse or capitate, obscurely 3-lobed. Berry globular, black or blue; the cells 1-2. seeded. - Perennial herbs, with simple stems from creeping knotted rootstocks, naked below, above bearing nearly sessile or half-clasping nerved leaves, and axillary nodding greenish flowers; pedicels jointed near the flower. (Name from $\pi \circ \lambda \dot{v}=$, many, and $\gamma^{\prime} \nu v, k n e e$, alluding to the numerous joints of the rootstock.)

1. P. biflorum (Walt.) Ell. (SmaLL S.) Glabrous, except the ovate-oblong or lance-oblong nearly sessile leaves, which are commonly minutely pubescent as well as pale or glaucous underneath; stem slender ( $3-9 \mathrm{dm}$. high); peduncles 1-3- but mostly 2-flowered; perianth 10-12 mm. long; filaments papillose-roughened, inserted toward the summit of the perianth. (? $P$. boreale Greene; $P$. cuneatum Greene; Salomonia biflora Farwell.) - Wooded hillsides, N. B. to Fla., w. to Ont., e, Kan., and Tex.

$\leftarrow$ 2. P. commutatum (i. \& S.) Dietr. (Great S.) Glabrous throughout, stem stout $(0.6-2 \mathrm{~m}$. high), terete; leaves ovate, pavtly clasping (12-18 cm. long), or the upper oblong and neally sessile, many-nerved; peduncles several (2-8)-flowered, jointed below the flower ; flowers $12-20 \mathrm{~mm}$. long; filaments smooth and naked, or nearly so, inserted on the middle of the tube. ( $P$. aiganteum Dietr.;? P. virgini'um Greene; Salomonia commutata Farwell.) Meadows and river banks, w. N. H. and R. I. to Ga. and w. to the Rocky IMts rune. 


\section{CONVALLÀria L, LiLy OF THE VALLEY}

Perianth bell-shaped, white, with 6 short recurved lobes. Stamens 6 , included, inserted on the base of the perianth; anthers introrse. Ovary 3-celled, tapering into a stout style ; stigma triangular. Ovules 4-6 in each cell. Berry few-seeded, red. - Perennial herb, glabrous, stemless, with slender running rootstocks, 2 or 3 oblong leaves, and an angled scape bearing a one-sided raceme of sweet-scented nodding flowers. (From Lilium convallium, the popular name.)

1. C. majàlis L. - High mountains, Va. to S. C. - Apparently identical with the European LILY of THE VALLEY of the gardens which occurs as an occasional escape from cultivation elsewhere within our limits.

\section{MEDÉOLa [Gronov.] L. Indian Cucumber-Root}

Perianth recurved; the 3 sepals and 3 petals oblong and alike, pale greenishyellow, deciduous. Stamens 6 ; anthers shorter than the slender filaments, oblong. Styles stigmatic down the upper side, recurved-diverging from the globose ovary, long and thread-for'm, deciduous. Berry globose, dark purple, 3-celled, few-seeded.-A perennial herb, with a simple slender stem (3-9 dm. high, clothed with flocculent and deciduous wool), rising from a horizontal white tuber (with taste of cucumber), bearing near the middle a whorl of 5-9 obovate-lanceolate leaves; also another of 3 (rarely 4 or 5 ) much smaller ovate ones at the top, subtending a sessile umbel of small recurved flowers. (Named after the sorceress Medea, for its supposed great medicinal virtues.)

L 1. M. virginiàna L. - Rich damp woods, N. B. to Ont., Minn, and Fla. June.

\section{TRÍllium L. Wake Robin. Birthroot}

Sepals 3, lanceolate, spreading, herbaceous, persistent. Petals 3, larger, withering in age. Stamens 6; anthers linear, on short filaments, adnate. Styles awl-shaped or slender, spreading or recurved above, persistent, stigmatic down the inner side. Seeds ovate, horizontal, several in each cell. Low perennial herbs, with a stout and simple stem rising from a short and praemorse tuber-]ike rootstock, bearing at the summit a whorl of 3 ample, commonly broadly ovate, more or less ribbed but netted-veined leaves, and a terminal large flower; in spring. (Name from tres, three; all the parts being in threes.) - Monstrosities are not rare with the calyx and sometimes petals changed to leaves, or the parts of the flower increased in number.

* Ovary and fruit 6-angled and more or less winged.

- Flower sessile; leaves usually mottled.

1. T. séssile L. Leaves sessile; sepals spreading; sessile petals erect-spreading, narrowly lanceolate or oblanceolate, dark and dull purple, varying to greenish ; fruit globose, $1.2 \mathrm{~cm}$. long. - Moist woods, Pa. to Minn. and southw.

2. T. víride Beck. Larger ( $3-4 \mathrm{dm}$. high); leaves sessile, ovate, acuminate ; sepals spreading; petals linear, $3-5 \mathrm{~cm}$. long, greenish. - Rich woods and open hilisides, Kan., Mo., and southeastw.

3. T. recurvàtum Beck. Leaves contracted at the base into a petiole, ovate, oblong, or obonate; sepals reflexed; petals pointed, the base narrowed into a claw, oblong-lanceolate to -ovate, dark purple; fruit ovoid, strongly winged above, $1.8 \mathrm{~cm}$. long. - Rich woods, O. to Minn., Ark., "Miss.," and Tenn.

+ + Flower pediceled; connective narrow, not produced; leaves subsessile. +- Anthers at anthesis exceeding the stigmas.

4. T. eréctum L. Leaves very broadly rhombic, slortly acuminate; peduncle $(2-8 \mathrm{~cm}$. long) usually more or less inclined or declinate; petals ovate to lanceolate (18-36 mm. long), brown-purple or often white or greenish or pinkish; stamens exceeding the stout distinct spreading or recurved stigmas; ovary purple; fruit ovoid, $2.5 \mathrm{~cm}$. long, reddish. - Rich woods, e. Que. to Ont." southw. to $\mathrm{Pa}$ and in the mts. to N. C, - Flowers ill-scented. 
5. T. grandiflorum (Michx.) Salisb. Leaves less broadly rhombic-ovate: pedicel erect or ascending; petals oblanceolate, often broadly so (4-6 cm. long), white turning rose-color or marked with green; stamens with stout flaments (persistently green about the fruit) and anthers, exceeding the very slender evect or suberect and somewhat coherent stigmas; fruit subglobose. - Rich woods, w. Que. and w. Vt. to Minn., Mo., and N. C.

$$
\text { + Anthers at anthesis surpassed by the stigmas. }
$$

6. T. cérnuum L. Leaves very broadly rhombic-ovate; peduncles $(8-33 \mathrm{~mm}$. long) usually recurved; petals white or pink, ovate- to oblong-lanceolate (12$24 \mathrm{~mm}$. long), wavy, recurved-spreading; filaments nearly or quile equaling the anthers; ovary white or pinkish; stigmas stoutish, tapering from the base to the apex; fruit ovoid. - Moist woods, Nfd. to Man., southw. to Pa., Mich., Minn., and in the mts. to Ga.

7. T. declinatum (Gray) Gleason. Leaves broadly rhombic ; peduncles (4-6 cm. long) usually horizontal; petals white, ovate-oblong $(2-3.5 \mathrm{~cm}$. long); filaments less than half as long as the anthers; stigmas short, stout, tapering from the base to the apex; ovary white or pinkish. ( $T$. erectum, var. Gray.) Woods, O. and s. Mich. to s. Minn. and Mo.

* Ovary and fruit 3-lobed or -angled, not winged; filaments slender, about equaling the anthers; pedicel erect or inclined; leaves petiolate.

8. T. nivàle Riddell. (DwarF Winte or Snow T.) Small (5-10 cm. high); leaves oval or ovate, obtuse (2.5-5 cm. long); petals obtong, obtuse (12-30 $\mathrm{mm}$. long), white, scarcely wavy, spreading from an erect base, equaling the peduncle; styles long and slender; fruit depressed-globose, with 3 rounded lobes, 6-8 mm. long. - Rich woods, w. Pa. and Ky. to Minn. and Ia.

9. T. undulatum Willd. ('MINTID T.) Leaves ovate, taper-pointed; petals ovate or oval-lanceolate, pointed, wavy, widely spreading, white painted with purple stripes at the base, shorter than the peduncle; fruit broad-ovoid, obtuse, 14-18 mm. long. ( T. erythrocarpum Michx.) - Cold damp woods and bogs, e. Que. to Ont. and Wisc., southw. in the mts. to Ga.

\section{2. Áletris L. Colic-root. Star Grass}

Perianth cylindrical, wrinkled and roughened outside by thickly set points, the tube adhering below to the base of the ovary, 6-cleft at the summit. Stamens 6 , inserted at the base of the lobes; filaments and anthers short, included. Style awl-shaped, 3-cleft at the apex; stigmas minutely 2-lobed. Capsule ovoid, beaked, inclosed in the roughened perianth; seeds numerous, minute, costate.-Perennial and smooth stemless herbs, very bitter, with fibrous roots, and a spreading cluster of thin and that lanceolate leaves; the small flowers in a spike-like raceme, terminating a naked slender scape $(4-10$ dm. high). ('A $\lambda \epsilon \tau \rho$ ts, a female slave who grinds corn; in allusion to the apparent mealiness of the blossoms.)

$\checkmark$ 1. A. farinosa L. Flowers tubular, white ; lobes lanceolate-oblong. - Grassy or sandy woods, s. Me. to Fla., Ark., and Minn. July, Aug.

2. A. aúrea Walt. Flowers bell-shaped, yellow, fewer and shorter than in the preceding; lobes short-ovate.-Barrens, "Va.," S. C. to Fla. and Tex.

\section{SMillax [Toum.] L. Green Brier. Cat Brier}

Flowers dioecious in umbels on axillary peduncles, small, greenish or yellowish, regular, the perianth-segments distinct, deciduous. Filaments linear, inserted on the very base, the introrse anthers linear or oblong, fixed by the base, apparently 1-celled. Ovary of fertile flowers 3-celled (1-celled, with single stigma in $S$. laurifolia) ; stigmas thick and spreading, almost sessile; ovules 1 or 2 in each cell, pendulous, orthotropous. Fruit a small berry. - Shrubby or herbaceous, usually climbing or supported by a pair of tendrils on the petiole of the 
ribbed and netted-veined simple leaves. (An ancient Greek name, of obscure meaning.)

\section{\$1. Stems herbaceous, not prickly; flowers carrion-scented; ovules 2 in each cell; leaves menbranous, mucronate-tipped; berries bluish-black with a bloom.}

1. S. herbàcea L. (CARrion-Flower.) Stem climbing, 1-5 m. high; leaves ovate or rounded, mostly heart-shaped or truncate at base, abruptly acute to short-acuminate, 7-9-nerved, smooth; petioles 1-4 cm. long; peduncles 4-20 $\mathrm{cm}$. loung, often much exceeding the leaves, 20-40-flowered; seeds 2-6. - Moist meadows and river-banks, common, N. B. to Man. and Tex. June.-Variable. Var. Pulverulénta (Michx.) Gray. Leaves sparingly to densely puberulent on the veins beneath. (S. pulverulente Michx.) - Pa. to Ont., w. to Mont, and Kan.

2. S. tamnifolia Michx. Stem upright or climbing; leaves mostly 5-nerved, smooth, broadly ovate to lanceolate, truncate or cordate at base, abruptly acute to acuminate, some of them hastate with broad rounded lobes; peduncles longer than the petioles; berry smaller, 2-3-seeded. - Pine-barrens, Pa. and N. J. to S. C.

3. S. ecirrhata (Engelm.) Wats. Erect, $1.5-9 \mathrm{dm}$. high, without tendrils (or only the uppermost petioles tendril-bearing); lower leaves reduced to narrow scale-like bracts, the rest thin, 5-7-nerved, broadly ovate-elliptical to roundisl, acute, mostly cordate at base, $4-12 \mathrm{~cm}$. long; pubescent beneath; peduncles and petioles 3-7 cm. long; umbels 10-20-flowered; berry :3-seeded. - 0 . and $\mathbf{M d}$. to S. C., Wisc., "Minn.," and Mo.

\section{§2. Stems woody, often prickly; ovules solitary; glabrous throughout.}

* Leaves ovate or roundish, etc., most of them rounded or heart-shaped at hase, and 5-9-nerved, the three middle nerves or ribs stronger and more conspicuous.

- Peduncles (4-13 mm. long) shorter or scarcely longer than the petioles, flattened; leaves thickish, green both sides.

4. S. Waltèri Pursh. Stem low, somewhat angled, prickly near the base or unarmed; leaves ovate to ovate-lanceolate or oblong, somewhat heart-shaped or rounded at base (5-11 cm. long); berries coral-red. - Pine-barrens, N. J. to Fla.

5. S. rotundifolia L. (Common Green Brier, Horse Brier.) Stem as well as the terete branches armed with scattered prickles; branchlets more or less 4-angular; lecves ovate or round-ovate, often broader than long, slightly heartshaped, abruptly short-pointed, obscurely denticulate or entire; berries blueblack, with a bloom.- Moist thickets, N.S. to Ga., w. to Minn. and Tex. - Very variable, passing into var. QUa dranGULÀris (Mubl.) Wood., which has branches, and especially branchlets, 4-angular, and is more common westw.

++ Peduncle longer than but seldom twice the length of the short petiole, flattened; leaves tardity deciduous or partly persistent; berries black, with a bloom.

6. S. glaúca Walt. (S^w Brier.) Terete branches and somewhat 4-angular glaucous branchlets armed with scattered stout prickles, or naked; leaves ovate, rarely subcordate, glaucous beneath and sometimes also above $(5-7 \mathrm{~cm}$. long), abruptly mucronate, the edges smooth and naked.-Dry thickets, e, Mass. to Fla., w. to Tex.

7. S. Bona-nox L. Branches and the angular (often square) branchlets sparsely armed with short rigid prickles; leaves varying from round-heartshaped and slightly contracted above the dilated base to fiddle-shajed and halberd-shaped or 3-lobed, green and shining both sides, cuspidate-pointed, the margins often somewhat bristly-ciliate or spinulose. (S. tamnoides Man. ed. 5 ; probably not L.) - - Thickets ; Tintucket, Mass.; N. J. to Fla., w. to Ill., Mo., and Tex. 
+++ Peduncle 2-4 times the length of the petiole; leaves ample (7-12 cm. long), thin or thinnish, green both sides; berries black; stem terete and branchlets nearly so.

8. S. híspida Muhl. Rootstock cylindrical, elongated; stem (climbing high) below densely beset with long and weak blackish bristly prickles, the flowering branchlets mostly naked; leaves ovate and the larger heart-shaped, pointed, slightly rough-margined, membranaceous and decidnous; peduncles $2-5 \mathrm{~cm}$ long; perianth-divisions lanceolate, almost $6 \mathrm{~mm}$. long. - Moist thickets, Ct. to Va., w. to Ont., Minn., Kan., and Tex. June.

9. S. pseùdo-chìna L. Rootstock tuberous; stems and branches unarmed, or with very few weak prickles; leaves ovate-heart-shaped, or on the branchlets ovate-oblong, cuspidate-pointed, often rough-ciliate, becoming firm in texture; peduncles flat (5-7 cm. long). - Dry or sandy soil, N. J. to Fla., w. to s. Ind. and Kan. July.

* Leaves varying from oblong-lanceolate to linear, narroned at base into u short petiole, 3-5-nerved, shining above, paler or glaucous beneath, many without tendrils; peduncles short, seldom exceeding the petioles, terete; the umbels sometimes panicled; branches terete, unai med.

10. S. lanceolàta L. Leaves thinnish, rather deciduous, ovate-lanceolate or lance-oblong; stigmas 3 ; berries dull red. - Rich woods and margins of swamps, Va. to Fla., w. to Ark. and Tex. June.

$\checkmark$ 11. S. laurifolia L. Leaves thick and coriaceous, evergreen, varying from oblong-lanceolate to linear (6-12 cm. Iong); stigmas solitary and ovary 1-celled; berries black when ripe, 1-seeded, maturing in the second year. - Pine-barrens, N. J. to Fla., w. to Ark., and Tex. July, Aug.

\section{HAEMODORÀCEAE (BLOODWORT FAMILY)}

Perennial stoloniferous herbs with fibrous roots, equitant leaves, and perfect 3-6-androus regular woolly flowers; the tube of the 6-lobed perianth coherent with the whole surface, or with merely the lower part, of the 3-celled ovary. Anthers introrse. Capsule crowned or inclosed by the persistent perianth, 3-celled, loculicidal, 3-many-seeded. A small family; chiefly of the southern hemisphere. Ours with dense compound cymes of dingy yellow flowers.

1. Lachnanthes. Stamens 8. Ovary inferior.

2. Lophiola. Stamens 6. Ovary nearly free.

\section{LACHNÁNTHES Ell. RED-ROOT}

Perianth 6-parted down to the adherent ovary. Stamens opposite the 3 larger or inner divisions; filaments long, exserted; anthers soon curved or coiled, attached near the base. Style thread-like, exserted, declined. Capsule globular. Seeds few on each fleshy placenta, fat and rounded, fixed by the middle. Leaves clustered at the base and scattered on the stem, which is hairy at the top and terminated by a dense compound cyme of dingy jellow and loosely

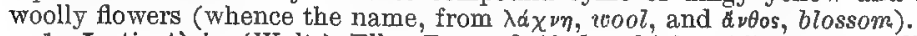

1. L. tinctòria (Walt.) Ell. Erect, 3-10 dm. high. (Gyrotheca Salisb.) Sandy swamps, near the coast, Cape Cod, Mass., R. I., and N. J. to Fla. JulySept.

\section{LOPHIOLA Ker.}

Divisions of the perianth nearly equal, spreading, longer than the 6 stamens, which are inserted at their base. Anthers fixed by the base. Capsule oroid, free from the perianth except at the base, pointed with the awl-shaped style, which finally splits into 3 divisions, one terminating each valve. Seeds numer. ous, oblong, ribbed, anatropous. - Slender herb with lineal and nearly smooth 
leaves; inflorescence and upper part of the stem whitened with soft matted wool. Perianth-lobes naked only toward the tip, each clothed with a woolly tuft

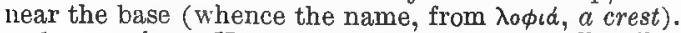

1. L. aúrea Kex. Perianth-segments dull yellow within. ( $L$, americana Coville.) - Boggy pine-barrens, N. J. to Fla. June-Aug.

\section{DIOSCOREÀCEAE (Yam Family)}

Plants with twining stems from large tuberous roots or knotted rootstocks, and ribbed and netted-veined petioled leaves, small dioecious 6-androus and regular flowers, with the 6-cleft calyx-like perianth adherent in the fertile plant to the 3-celled ovary. Styles 3, distinct. - Ovules 1 or 2 in each cell, anatropous. Fruit usually a membranaceous 3-angled or-winged capsule.

\section{DIOSCOREA [Plumier] L, YAM}

Flowers very small, in axillary panicles or racemes. Capsule loculicidally 3-valved by splitting through the winged angles. Seeds flat, with a membranaceous wing. (Dedicated to the Greek naturalist, Dioscorides.)

1. D. villosa L. (WILD YAM-RooT.) Herbaceous; stems slender, from knotty and matted rootstocks, twining over bushes; leaves mostly alternate, sometimes nearly opposite or in fours, more or less downy beneath, heart-shaped, conspicuously pointed, 9-11-ribbed; flowers pale greenish-yellow, the sterile in drooping panicles, the fertile in drooping simple racemes; capsules $1.6-2.5 \mathrm{~mm}$. long. - 'l'hickets, s. N. E, to Fla., w, to Ont., Minn., Kan., and Tex. - According to $C$. $G$. Lloyd the typical villous-leaved form has a matted rootstock the divisions of which are scarcely thicker than the stems. He distinguishes, as var. GLABRA Lloyd, a form with a thick knotted rootstock and glabrous leaves. This form or possibly state, occurring in $\mathbf{K y}$. and probably elsewhere, is said to be inferior for pharmaceutical use. The relation between the smooth foliage and thickened rootstock does not, however, appear to be definite.

\section{AMARYLLIDẢCEAE (Amaryllis Family)}

Chiefly bulbous and scape-bearing herbs, not scurfy or woolly, with linear flat root-leaves, and regular (or nearly so) and perfect 6-androus flowers, the tube of the corolline 6-parted perianth coherent with the 3-celled ovary; the lobes inbricated in the bud. - Anthers introrse. Style single. Capsule 3-celled, severalmany-seeded. Seeds anatropous or nearly so, with a straight embryo in the axis of fleshy albumen.

\footnotetext{
* Fruit a 3-valved loculieidal eapsule; plant glabrous.

+ Perlanth with a conspicuous crown in the throat.
}

1. Hymenocallis. Perianth-tube slender, the lobes narrow, recurved; a cup-shaped crown connecting the filaments.

2. Narcissus. Perianth-tube produced at the base of the spreading ovate lobes into a true crown. Filaments without a connecting cup.

$$
++ \text { Perianth naked in the throat. }
$$

+ Low bulbous plants with 1-flowered scapes.

3. Zephyranthes. Anthers versatile on filiform somewhát elongated flaments; tube of the perianth shorter than the throat and limb.

4. Cooperia. Anthers dorsifixed near the base; flaments short; tube of the perianth much ex ceeding the throat and limb.

$$
\text { \#+ Tall, not bulbous; flowers spleate. }
$$

5. Agave. Perianth equally 6-cleft, without crown; leaves tioshy.

$$
\text { * * Fruit indehiscent; anthers sagittate; plant villous. }
$$

6. Hypoxis. Perianth 6-parted nearly down to the ovary, persistent ; bulb solid. 


\section{HYMENOCÀLLIS Salisb.}

Capsule thin, 2-3-lobed; seeds usually 2 in each cell, basal, fleshy, often like bulblets. - Scapes and leaves from a coated bulb. Flowers white, fragrant, large and showy, sessile in an umbel-like head or cluster, subtended by 2 or more sca-

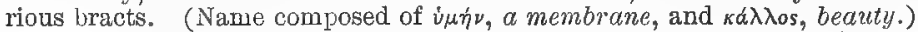

1. H. occidentàlis (Le Conte) Kunth. Leaves strap-shaped, glaucous, 3-5 dm. long, 18 34 mm. broad; scape 3-6-flowered; bracts narrow, $5 \mathrm{~cm}$. long; perianth-tube about $8-10 \mathrm{~cm}$. long, the linear segments scarcely shorter; the crown 2.5-3 cm. long, tubular below, broadly funnel-form above, the margin deltoid and entire, or 2 -toothed and erose, between the white filaments, which are twice longer; anthers yellow; style green.-Marshy banks of streams, s. Mo. and s. Ill. to n. Ga., and Ala.

\section{NARCÍSSUS [Tourn.] L.}

Capsule thin, 3-celled; seeds numerous in each cell, affixed in 2 series to the axile placenta. Flowers (iu our species) solitary on leafless scapes subtended by a deciduous or narcescent spathe. (Name of the youth who, according to a Greek myth, was changed into this flower.)

1. N. Pseudo-Narcfssus L. (Daffodil.) Crown at least as long as the periantl-segments, yellow. - Established in meadows, $\mathrm{Pa}$. and N. J. (Introd. from $\mathrm{Eu}$. )

$\checkmark 2$. N. Poéticus L. (Poet's Narcissus.) Crown less than half as long as the perianth-segments, white edged with pink. - Established in meadows, N. E. L. I., and Pa. (Introd. from Eu.)

\section{ZEPHYRÁNTHES Herb}

Perianth fumnel-form, from a tubular base; the 6 divisions petal-like and similar, spreading above; the (i stamens inserted in its naked throat. Pod membranaceous, 3-lobed. (From jépupos, a wind, and àvos, flower.)

1. Z. Atamásco (L.) Herb. (AтAмasco Licr.) Leaves bright green and shining, very narrow, channeled, the margins acute; scape $2-3.5 \mathrm{dm}$. high ; peduncle short; spathe 2-cleft at the apex ; perianth white and pink, 6-9 $\mathrm{cm}$. long ; stamens and style declined. (Atamosco Greene.) - Pa. to Fla. June.

\section{COOPÈRIA Herb.}

Perianth-tube very long and slender, the limb widely spreading, 6-parted, the short stamens borne $c n$ the throat. Spathe single, membranaceous. Capsule depressed-globose; seeds numerous. - Leaves grass-like from a tunicate bulb. (Named in honor of Daniel Cooper, an English botanist of the early part of the 10th century.)

1. C. Drummóndii Herb. Scape slender, $2-5 \mathrm{dm}$, high ; perianth white or rose-tinged, the stalk-like tube often $1 \mathrm{dm}$. in length. - Prairies, s. Kan. and southwestw.

\section{AgÀve L. American Alok}

Perianth tubular-funnel-form, persistent, 6-parted ; the divisions nearly equal, narrow. Stamens 6 ; anthers linear, versatile. Capsule coriaceous, manj-seeded; seeds flattenod. - Icaves thick and fleshy, often with cartilaginous or spiny teeth, clustered at the base of the many-flowered scape, from a thick fibronsrooted crown. (Name from aravń, noble, - not inappropriate as applied to A. americhNa, the CENTURT J'LANT.)

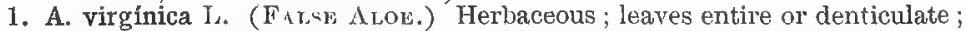
scape 1-2 m. high ; flowers scattered in a loose wand-like spike, greenish-yellow, fragraat; perianth 18-24 $\mathrm{mm}$. long, its narrow tube twice longer than the erect lobes. - Dry or rocky banks, Md. and Va. to Fla., w. to s. O., s. Ind., Mo, and lox. 


\section{HYPóxis L. Star Grass}

Perianth spreading. Fruit crowned with the withered or closed perianth. Seed globular. - Stemless small herbs, with grassy and hairy linear leaves and slender few-flowered scapes. (An old name for a plant having sourish leaves: from üro

1. H. hirsùta (L.) Coville. Leaves linear, grass-like, longer than the umbellately 1-4-flowered scape; divisions of the perianth hairy and greenish outside, yellow (rarely whitish) within. ( $H$. erecta L.) - Meadows and open woods, s. W. Me. to Fla., Assina., e. Kan. and Tex.

\section{IRIdÀceae (Iris Family)}

Herbs, with equitant 2-ranked leaves, and regular or irregular perfect flowers; the 3 petals and 3 petal-like sepals convolute in the bud, the tube adnate to the :3-celled ovary, and 3 distinct or monadelphous stamens, altemate with the petals, with extrorse anthers. - Flowers from a spathe of 2 or more leaves or bracts, usually showy. Style single, usually 3-cleft; stigmas 3, opposite the cells of the ovary, or 6 by the parting of the style-branches. Capsule 3-celled, loculicidal, many-seeded. Seeds anatropous; embryo straight in fleshy albumen. Rootstocks, tubers, or corms mostly acrid

* Branches of the style (or stigmas) opposite the anthers.

1. Iris. Sepals spresding or recurved. Petals spreading or erect. Stigmas petal-like.

** Branches of the style alternate with the anthers; flower regular.

2. Nemastylis. Stem from a coated bulb. Filaments united. Style-branches 2-cleft.

3. Belamcanda. Stems from a creeping rhizome. Filaments distinct. Stigmas dilated.

4. Sisyrinchium. Root fibrous. Filaments united. Stigmas thread-like.

\section{1. ÎRIS [Tourn.] L. FLeUR-DE-LIS}

Tube of the flower more or less prolonged beyond the ovary. Stamens distinct ; the oblong or linear anthers sheltered under the over-arching petal-like stigmas (or rather branches of the style, bearing the true stigma in the form of a thin lip or plate under the apex); most of the style connate with the sepals and petals into a tube. Capsule 3-6-angled, coriaceous. Seeds depressedflattened, usually in 2 rows in each cell. - Perennials, with sword-shaped or grassy leaves, and large showy flowers; ours with creeping and more or less tuberous rootstocks. ("I

* Stems leafy and rather tall, from usually thickened rootstocks, often branching; tube much shorter than the sepals, which are usually much larger than the petals.

- Sepals neither bearded nor crested.

- Spathes all terminal or at the tips of elongate peduncles.

- Flowers violet-blue, variegated with green, yellow, or white, and purple-veined.

a. Ovary and capsule obtusely angled.

1. Seeds in 2 rows in each cell.

1. I. versicolor L. (Larger Blue Flag.) Stem stout, angled on one side, $1.5-9 \mathrm{dm}$. high; leaves sword-shaped $(0.5-2.5 \mathrm{~cm}$. wide), giaucous; ovary obtusely triangular, with flat sides; flowers $(5-8 \mathrm{~cm}$. long) short-pediceled, variegated with green, yellow and white toward the center, the funnel-form tube shorter than the ovary; petals flat, oblanceolate or narrowly obovate, half as long as the sepals; style-branches with slightly overlapping petaloid lobes; capsule firm, subcylindric, turgid, with rounded angles, stout-beaked; seeds 4-6 mm. 
broad, flattened on the sides, the rhaphe not apparent. - Wet places, Nfd. to Man. and southw. May-July.

2. I. setòsa Pall., var. canadénsis Foster. Stems slender, terete, 1.5-5 dm high, mostly flecked at base with purplish; leaves bright green, strongly nerved $0.5-1 \mathrm{~cm}$. broad ; flowers short-pediceled, strongly marked with white towarc the center; the inconspicuous involute or tubular pointed petals $\frac{1}{4}$ as long as the sepals; style-branches with spreading lobes; capsule subcylindric or ovoid, blunt or barely mucronate, the thin elastic walls pale, flecked with purple, the angles obtuse or rounded; seeds $2-3.5 \mathrm{~mm}$. broad, with plump sides and prominent rhaphe. (I. Hookeri Penny.) - Seabeaches and headlands, Lab. and Nfd. to the lower St. Lawrence; and along the coast to e. Me. June, July.

\section{Seeds in 1 row in each cell.}

3. I. caroliniàna Wats. Tall (1 m. or less high); leaves bright green, soft, 1-3 cm. broad; flowers subsessile or short-pediceled, "lilac, variegated with yellow, purple and brown;" petals more than half the length of the sepals; seeds, with flattened sides, 8-10 mm. broad. - Swamps, s. Va. to Ga. and La. June.

\section{a a. Ovary and capsule sharply angled.}

4. I. prismática Pursh. (Slender Blve FLaG.) Stem very slendor, terete, 2.5-9 dm. high, from a slender rootstock; leaves narrowly linear $(3-7 \mathrm{~mm}$. wide); flowers slender-pediceled (4-6 cm. long), the tube extremely short; ovary 3-angled. - Marshes near the coast, N. S. to Ga. June, July.

\section{$==$ Flowers brown or yellowo.}

5. I. fúlva Ker. Stem and leaves as in no. 1 ; flowers copper-colored or dull reddish-brown, variegated with blue and green; petals widely spreading; tube cylindrical, as long as the 6-angled ovary; style-branches narrow. - Swamps, s. Ill. and Mo. to La. and Ga. May.

I. PSEUDÁcorus L., the YELlow Irrs of European marshes, with several very long linear leaves, bright yellow beardless flowers, and erect petals, is becoming established in N. E., N. Y., and N. J.

I. orrentalis Mill. (I. ochroleuca L.), an Asiatic species, with stem-leaves few and reduced, and pale-yellow or whitish flowers, is freely cultivated, and tends to become naturalized in marshes on the coast of Ct. (Mrs. $\boldsymbol{M} . \boldsymbol{E}$. Russell).

\section{* Spathes mostly subsessile or on inconspicuous peduncles in the axils of the} upper conspicuous leaves; flowers large, blue-violet.

6. I. hexágona Walt. Stem terete, flexuous, 3-9 dm. tall ; leaves green, not glaucous, the upper very elongated and much overtopping the flowers, $1-3 \mathrm{~cm}$. broad; flowers mostly axillary, resembling those of no. 1, but larger; capsule very firm, 6-angled, sbort-beaked; seeds in 2 rows in each cell. ( $I$. foliosa Mack. \& Bush.) - Rich low woods and shores, local, O. to Mo., and southw. to S. C., Fla., and Tex. May, June.

\section{+ + Claw and lower part of blade of sepals beaded.}

7. ¿. GERMÁNICA I. (FLEUR-DE-LIS.) Leaves broad, glaucous ; spathes 2-3fowered; perianth-tube greenish, cylindrical ; sepals dark violet-purple, pendent with bright yellow beard; petals equaling the sepals in length and breadth, ilac; capsule trigonous, - Established in Va. and W. Va. (Introd. from Eu.)

* * Stens low (0.5-1.5 dm. high), from tufted and creeping slender (or here and there tuberous-thickened) rootstocks, 1-3-flowered; tube of the perianth long and slender; the violet-blue sepals and petals nearly equal.

L- 8. I. vérna L. (Dwarf IrIs.) Leaves linear, grass-like (3-10 mm. wide), rather glaucous; the thread-like tube about the length of the sepals and petals, which are oblong-obovate and on slender claws, the sepals slightly hairy down the orange-yellow base, crestless; capsule obtusely triangular. - Wooded hillsides, $\mathrm{Pa}$. to Ky., and southw. Apr., May. - Flowers sometimes white with yellowish center. 
9. I. cristàta Ait. (CRested DwARF IRIS.) Leaves lanceolate (1-2 dm. long when grown, 1-2 cm. broad); those of the spathe ovate-lanceolate, shorter than the thread-like tube, which is $4-5 \mathrm{~cm}$. long and much longer than the lightblue obovate short-clawed sepals and petals; sepals crested but beardless; capsule sharply triangular. - Rich woods, Md. to Ga., locally w. to O., Ind., and Mo. Apr., May. - Flowers fragrant.

10. I. lacústris Nutt. (LAKE DWARF IRIs.) Tube rather shorter than the sepals and petals (yellowish, 1-2 cm. long), dilated upward, not exceeding the spathe ; otherwise as in the last, and too near it. - Gravelly shores of Lakes Huron, Michigan, and Superior. May.

\section{NEMASTỲLIS Nutt.}

Sepals and petals similar and nearly equal, spreading. Style short, its slender 2-parted branches exserted between the anthers; stigmas minute, terminal. Capsule obovoid, truncate, dehiscent at the summit. Seeds globose or angled. - Stems terete, with few plicate leaves, and few fugacious flowers from 2-bracted spathes. (Name from $\nu \hat{\eta} \mu a, a$ thread, and $\sigma \tau v \lambda(s$, style, for the slender stylebranches.)

1. N. acùta (Bart.) Herb. Stem 1-6 dm. high; spathes 2-flowered; flowers pale blue-purple, $4-7 \mathrm{~cm}$. broad, the divisions oblong-obovate ; capsule $1-1.3 \mathrm{~cm}$. long. ( $N$. geminiflora Nutt.) - Prairies and barrens, Mo. to Tenn., La., and Tex. Apr.-June.

\section{BELAMCÁNDA Adans. Blackberry LiLy}

Sepals and petals widely and equally spreading, all nearly alike, oblong with a narrowed base, naked. Stamens monadelphous only at base; anthers oblong. Style club-shaped, 3-cleft. Capsule pear-shaped; the valves at length falling away, leaving the central column covered with the globose black and fleshycoated seeds, imitating a blackberry (whence the popular name).-Perennial, with rootstocks, foliage, etc., of an Iris; the branching stems (0.5-1 m. high) loosely many-flowered; the orange-yellow flower mottled with crimson-purple spots. (An East Indian name for the species.) Gemmingia Fabricius.

1. B. Chinénsis (L.) DC. - Roadside thickets, open woods, etc., near towns, Ct. to Kan. and Ga. ; common southw. June, July. (Nat. from Asia.)

\section{SisyrínChiUm L. Blue-eyed Grass}

Sepals and petals (perianth) alike, spreading. Capsule globular, 3-angled. Seeds globular. - Low slender perennials, with fibrous roots, grassy or lanceolate leaves, 2-edged or winged stems, and fugacious umbeled-clustered sinall tlowers from a usually 2-leaved spathe. (A meaningless name, of Greek origin.)

u. Spathes sessile and terminal $b$.

b. Spathes 2, with a single outer leaf-like bruct.

Steins subterete, scarcely wing-margined; flaments free above;

anthers $4.5 \mathrm{~mm}$. long
Stems flattened, distinctly wing-margined; filaments united to the

3. Spathes solitary. summit; anthers at most $2.5 \mathrm{~mm}$. long . . . . .

Flowers yellow

Flowers blue, violet, or white.

Outer elongate bract with the rargins free to the base; capsules pale . . . . .

Outer bract with the margins united above the base.

Pedicels loosely spreading, much exceeding the inner bract; capsules 2-4 mm. high .

Pedicels suberect, scarcely exceeding the innor bract; capsules 4-6 mm. higb.

Capsules drab or dull brown . . . .

1. S. hastile.

2. S. albidum.

3. S.flaviflorum.

4. S. campestre.

5. S. mucronatum

6. S. angustifolium

7. S. montanum. 
a. Spathes poduncled from the axil of the leaf-like bract $a$.

c. Old leaf-uases perststing as tufts of straight bristle-like fibers. Capsules pale straw.color or whitish, 3-4 mm. high .

Capsules dark brown, 4-6 inm. high .

c. Old leaf-bases soon deciduous, or, if persisting, merely loose irregular soft shreds $a$.

a. Capsules pale straw-color or whitieh; peduncles and pedicels strictly erect

d. Capsules brown or drab.

Inner bract of the spathe $1.5-3 \mathrm{~cm}$. long ; stems broadly winged. Pedicels loosely spreading, much exceeding the inner bract. Pedicels strongly ascending, rarely exceeding the inner bract. Inner bract of the spathe $1-1.5 \mathrm{~cm}$. long; stems slender and narrowly margined.

Capsules not beaked

Capsules tipped by a short stout mucro

\section{S. Farnolut \\ i. S. arenicola.}

\section{S. strictum.}

11. S. gramineum.

6. S. angustifolium

12. S. atlanticum.

13. S. apiculatum.

1. S. hastile Bicknell. Stiff and erect, dull green, about $4 \mathrm{dm}$. high, the stem (1-1.5 $\mathrm{mm}$. wide) narrovoly margined but not voinged; leaves firm and stiff, slender and conduplicate, barely $1 \mathrm{~mm}$. broad, except at the flattened base; the 2 spathes closely sessile, each 4 -bracted, the lanceattenuate strongly nerved inner bracts $1.5-2.5 \mathrm{~cm}$. long, much exceeded by the linear outer bract; pedicels barely exserted beyond the inner bracts. - Sandy shores, Belle Isle, Detroit R., Mich. May, June.

2. S. álbidum Raf. Erect, pale green or glancous, 1.5-4.5 dm. high; stems 1-3 min. wide, usually twice exceeding the flat leaves; spathes with lance-acuminate pale or purple-tinged inner bracts (1.3-2.3 cm. long), usually twice exceeded by the erect onter bract; pedicels with slightly spreading exserted tips; flowers about $1 \mathrm{~cm}$. long, white to violet; capsules subglobose $(2.5-4 \mathrm{~mm}$. high),

608. S. albidum $\times 2 / 5$. pale straw-color. - $\mathrm{O}$. and $\mathrm{w}$. Ont, to Wisc., and southw; locally introd. in Ct. May, June. Fig. 603.

3. S. flaviflorum Bicknell. Erect (2-2.5 dm. high), pale green or glaucous; stems flat, wing-margined, $1.5-3 \mathrm{~mm}$. broad, usually exceeding the flat slightly broader leaves; bracts of the spathe pale green with conspicuous narrow hyaline margins, the inner bract $2-3 \mathrm{~cm}$. long, twice exceeded by the outer; pedicels shorter than the inner bract. Open woods, borders of prairies, w. Mo. May, June.

4. S. campéstre Bicknell. Caespitose, glaucous, slender (1-5 dm. high); the flat stems (1-3 $\mathrm{mm}$. broad) winged, somewhat exceeding the leaves; spathes gibbous, green or tinged with pink, the outer bract $(2.5-4.5 \mathrm{~cm}$. long) with marguns free to the base, rarely twice exceeding the inner; pedicels with curved tips, equaling or exceeding the inner bract; perianth pale blue or white; capsules 2-t mm. high. - Prairies, Wisc. to N. Dak.,

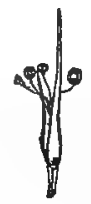
white; capsules $2- \pm$ mm. high. - Prail

5. S. mucronàtum Michx. Similar but greener; stems $0.5-1.5 \mathrm{~mm}$. broad, narrowly winged, usually twice longer than the slightly broader leaves; spathes

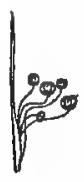
usually purple-tinged, not gibbous, the outer bract with the margins united a little above the base, $2-7 \mathrm{~cm}$. long, the inner $1-2 \mathrm{~cm}$. long; perianth violet (rarely white); capsules straw-color on greenish-yellow. - Meadows, fields, and open woods, w. Mass. to Va. and Mich. May, June. Fig. 605.

$\checkmark 6 . \quad S$. angustifolium Mill. Erect or ascending, stiff, glaucous, 1-5 dm. high; the simple (rarely

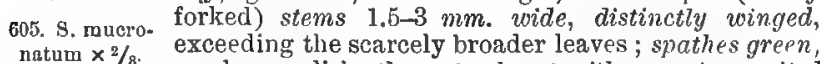
natum $\times 2 / 8$. $\quad$ rarely purplish, the outer bract with margins united 3-6 mm. above the basf, 2-6.5 cm. long, the inner 1-3 cm. long; perianth violet (rarely white); capsules dull brown or purpletinged. - Meadows, fields, and damp sandy soil, Nfd. to B. C., s. to Va., Pa., Mich., Minn.; and in the Rocky Mts. May-July. Fis. 606.

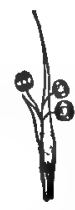

606. A. angusti folium $\times \%$. 
7. S. montànum Greene. Similar, pale green or glaucescent; spathes pale green or straw-color, the outer bract $3.5-8 \mathrm{~cm}$. long, the inner $1.5-3.5 \mathrm{~cm}$. long; capsule whitish-green to straw-color. — Gaspé Penins., Que.; Mich.; Minn. ; Rocky Mts. June, July.

V S. intermìum Bicknell appears to include inconstant and not very clearly marked forms intermediate between $S$. mucronatum, $S$. angustifolium, and S. gramineum.

8. S. Farwéllii Bicknell. Loosely tufted, from a fibrous-sheathed base; stems flexuous, branched, slightly glaucous, 2-3 dm. high, 1-2 mm. broad, winged, twice exceeding the slightly broader leaves; bracteal leaf loosely clasping, shorter than the (4-11 cm. long) curved slendro peduncles; spathes 1.7-2 dm. long, the bracts subequal, yellowish-green, thin and membranous; flowers pale blue, on flexuons exserted pedicels. - Local, s. e. Mich.

9. S. arenícola Bicknell. Similar, but usually blackening in drying, and

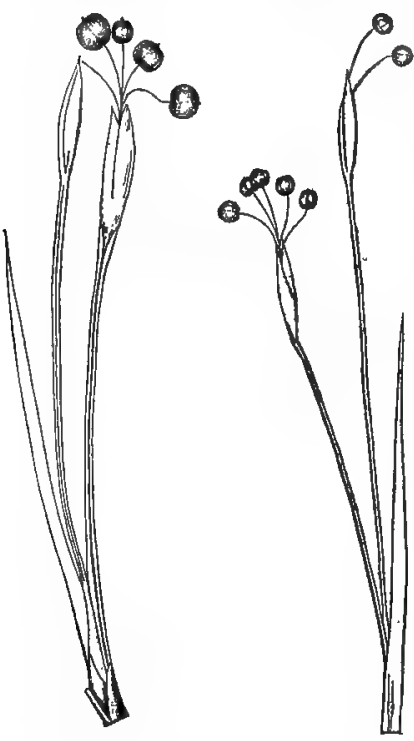

607. 8. gramineum $\times 2 / 3$
608. S. atlanticum $x^{2} / 3$ rather stout $r$, the violet flowers on erect or only slightly curved pedicels. - Sandy soil, near the coast, Mass. to N.J.

10. S. stríctum Bicknell. Bright green, $3 \mathrm{dm}$. high; the winged stems $1.5-2 \mathrm{~mm}$. wide, slightly exceeding the scarccly broader leaves; bracteal leaf about equating the strict peduncles, 6-9 cm. long; spathes $1.5-2 \mathrm{~cm}$. long, pale green, tinged with purple, the bracts subequal, or the inner longer; pedicels strict, barely exserted; flowers violet. Montcalm Co., Mich.

L 11. S. gramíneum Curtis. Looselytufted, bright green or glaucescent, 1-5 dm. high, the ascending flexuous or eron geniculate broad-winged flat stems 2-0 nim. vide, usually exceeding tho grass-like leaves; bracteal leaf broad, usually shorter than the flat peduncles; spathes green, erect, the bracts subequal, $1.5-2 \mathrm{~cm}$. long, or the outer somewhat elongated; flowers blue; capsules subglobose, 4-6 mm. high. ( $S$. anceps Mall. ed. 6 ; S. graminoides Bicknell.) - Wet meadows and damp woods, N. H. to Minu., and southw. Apr.-June. FIG. 607 .

12. S. atlánticum Bicknell. Loosely tufted, pale and glaucous, 2-7 dm. high; stems wiry and slender, flexuous or geniculate, narrowly margined, 1-3 $\mathrm{mm}$. wide, much exceeding the narrow leaves; bracteal leaf csually shorter than the slender peduncles; spathes often oblique and tinged with pint, the subequal bracts thin, 1-1.5 cm. long, the outer acute, the inner obtuse; pedicels erect, scarcely exserted; perianth violet; capsules sligbtly higher than broad, 3-4.5 mm. high.-Damp soil, Me. to Vt. and Fla., mostly on the coastal plain. FIG. 608 .

13. S. apiculàtum Bicknell. Similar; stems $3 \mathrm{dm}$. high,

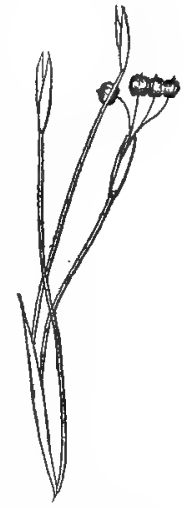

609. \$. apleulatum $\times 2 / g$. nearly or quite twice as long as the narrowly linear grass-like basal leaves; the pedicels (1-1.8 cm. long) distinctly exserted, and the rather smaller capsules tipped by stout short beaks. - Lake shores, etc., Muskegon Co., Mich. Fig. 60 . 


\section{MARANTĀCEAE (Arrowroot Family)}

Herbs with distichous pinnately veined commonly asymmetrical leaves, irregular perfect flowers, and strongly reduced asymmetrical androecium, only one half of one anther polleniferous, the other half as well as the anthers of the remaining stamens sterile and petaloid. - Ovary inferior ; cells 3 or by abortion fewer, 1-ovuled. Style single, more or less unilateral or declined. Seeds arillate; embryo curved in copious albumen.

\section{THÀLIA L.}

Erect scapose aquatic herbs with ovate-lanceolate long-petioled leaves, colored caducous bracts, and open panicles of showy usually purple flowers. Sepals 3 , equal or nearly so, usually much shorter than the 3 nearly or quite distinct petals. Staminodia somewhat connate, petaloid, one of them enlarged, deflexed and lip-like. (Named for Johann Thal, a German physician and naturalist who died in 1583.)

1. T. dealbàta Roscoe. White-powdery; scapes 1-2 m. high; leaf-blades ovate-lanceolate, acute at apex, rounded or subcordate at base; corolla and bracts pale blue, the staminodia purple or violet. - Marshes, Mo. to S. C. and Tex.

\section{burmanniàceae (Burmania Family)}

Small annual herbs, often with minute and scale-like leaves, or those at the root grass-like; the flowers perfect, with a 6-cleft corolla-like perianth, the tube of which adheres to the 1-celled or 3-celled ovary; stamens 3 and listinct, opposite the inner divisions of the perianth; capsule many-seeded, the seeds very minute. - A small, chiefly tropical family.

\section{BURMÁNNIA L.}

Ovary 3-celled, with the thick placentae in the axis. Filaments 3, very short. Style slender; stigma capitate-3-lobed. Capsule often 3-winged. (Named for $J$. Burmann, an early Dutch botanist.)

1. B. bifiora L. Slender (7-12 cm. high), 1-several-flowered; perianth (5 mm. long) bright blue, 3-winged. - Peaty bogs, Va. to Fla. and La.

\section{ORCHIdÀCEAE (Orchis Familt)}

\section{Revised by OAKes Ames}

Herbs, distinguished by perfect zygomorphic gynandrous flowers, with 6-merous (sometimes apparently 5-merous) perianth adnate to the 1-celled ovary, with innumerable ovules on 3 pavietal placentae, and with either 1 or 2 fertile stamens, the pollen cohering in masses. Perianth usually of 6 divisions; the 3 outer (sepals) mostly of the same texture as the 3 inner (petals). Of the inner series, one, termed the lip, differs from the rest in shape, and is sometimes prolonged at the base into a spur. The lip is really the posterior petal, but by a twist of the pedicel or ovary of half a turn it is more commonly directed fownward and becomes apparently anterior. At the base of the lip, in the axis of the flower, is the column, composed of a single fertile stamen, or, in 
Cypripedium, of two stamens and the rudiment of a third, variously coalescent with the style. Anther 2-celled, each cell containing one or more masses of pollen (pollinia), or the pollen granular (in Cypripedium). Stigma viscid or (in Cypripediun ) rough. Fruit a 1-celled 3-valved capsule. Flowers solitary, racemed, or spiked, often showy, each flower usually subtended by a bract. Leaves parallel-nerved, solitary, or several and alternate, sometimes apparently opposite or whorled. Perennials, often with corms or with tuberoid roots; sometimes rootless saprophytes. - A cosmopolitan family comprising about 7000 species largely dependent on insects for pollination.

\section{Fertile anthers 2.}

Tribe I. CYPRIPEDíaE. Perfect anthers lateral, the sterile one forming a dilated fleshy appendage above the terminal atigma. Pollen granular, not in masses.

1. Cypripedium. Stems more or less leafy. Perianth spreading; lip an inflated sac.

II. Fertile anther solitary.

* Anthers persistent.

Tribe II. OPHRÝDEaE. Pollinis prolonged at the base of the anthers into flaments or caudicles which are attached to viscid dioks or glands.

2. Orchis. Viscid disks contained in a pouch, or bursicule, of the rostellum.

8. Habenaria. Fiscid disks naked, not contained in a pouch, or bursioule, of the rostellum.

* Anthers caducous or readily detachable.

Tribe II. NeOtTìae. Pollen-masses usually soft or granulose.

+ Anther termital.

4. Pogonia. Iip without hypochil, free. Column not winged.

5. Calopogon. Lip without hypochil, free. Column winged at apex.

6. Arethusa. Lip without hypochil, united to the base of the gynostemium. Column winged to the base.

7. Serapias. Lip provided with a hypochil.

$$
\text { + + Anther dorsal. }
$$

廿 Upper sepal and petals connivent or lightly adherent.

8. Spiranthes. Pollen waxy or powdery, not divided into a large number of definite masses. Lip with appendages at the base; not saccate.

a. Epipactis. Pollen divided into a large number of deflnite masses. Lip saccate, unappendaged.

10. Listera. Lip retuse or cleft.

$$
\#+\text { Sepals and petals free. }
$$

Pribe IV. EPIDENDREAE. Pollen-masses smooth and waxy.

$$
\text { - Pollen-masses 4, unappendaged. }
$$

$$
\text { a. Leafless plants. }
$$

11. Corallorrhiza. Plants brownish or yellowish, with coralline rhizomes.

$$
\text { b. Plauts with leaves. }
$$

12. Malaris. Lip not saccate, cordate at base. Leaves several.

18. Microstylis. Lip not eaccate. Leaf solitary on the stem.

14. Liparis. Lip not saccate, obovate. Leaves several.

15. Calypso. Lip saccate. Leaf solitary.

16. Aplectrum. Lip not eaceate. Leaf solitary from a tuber.

- - Pollen-masses 4, each attached by a very short filament to the viscid disk or gland.

17. Tipularia. Flowers small, greenish, in a many-flowered raceme. Lip 8-lobed.

$$
m-\text { Pollen-masses } 8 .
$$

18. Hexalectris. Leaflese plante. 


\section{Artifichal Ket to Genera}

a. Two fertile anthers; lip an inflated sac.

1. OTPRIPEDIUM,

a. One fertile anther $b$.

b. Flowers with a distinct slender spur (this at lesst $2 \mathrm{~mm}$. long).

Jeaves present at flowering time.

Caudicles of pollinia divergent, not contalned in a speclal pouch or bursicule.

Caudicles of pollinia convergent, contained in a special" pouch or bursicule.

Leaves absent at flowering time "the lip sometimes saccate

b. Flowers without a conspicuous spur, the lip sometimes saccate c.
c. Leaves one or more (in Spiranthes, Arethusa, and Aplectrum sometimes absent or inconspicuous at tlowering time); plant green $d$.

d. Perianth at least $15 \mathrm{~mm}$, across ; sepals and petels more or less spreading, not strongly recurved $e$.

s, Lespes linear to linear-lanceolate, grass-like, sheathing the scape neal the base.

Flowers several, resupinate, with one floral bract

Flowers solitary, rarely 2 , not resupinate, with 2 foral bracts, one posterior, the other anterior, subtending the ovary

e. Leaves elliptic-oblong, ovate, or cordate, sometimes whorled.

Lip saccate, bearded

Lip not saccate, with a longitudinal more or less tuberculate crest or beard

Lip saccate, not bearded

a. Perianth less than $15 \mathrm{~mm}$. across; sepals and petals connivent of spreading.

Petals joined to the upper sepal but not coalescent with it.

Lip saccate at base, devoid of basal callosities; leaves variegated

Lip not distinctly saccato, with a horn-like callosity within on each side at base; leaves not variegated

3. HABENARIA

2. JROHIS.

17. 'TtPULARY

Petals and sepals free.

Petals fliform or Hnear, less than $2 \mathrm{~mm}$. broad. Leaf solitary

Leaves 2, near the middie of the stem

Leaves 2, basal; lip not pointed

Leaves basal; lip pointed.

C : . : . . 12. Malaxis.

Petals not filiform, at least 2 mm. broad : : : : 16. A plectrim.

c. Lesves wanting; scaly saprophytes with yellowish or purplish stems.

Lip with a callus on each side of the mid-nerve at base

Lip with 5 or 6 longitudinal oresta

5. Calopogon.

6. Arethusa.

15. Calypso.

4. Pogonla.

7. Shrapiag.

9. EPLPACTIS.

8. SPIRANTHEB.

18. Mionostylis,

10. LISTERA.

14. Lipa eis.

11. Corallorrhiza. 18. Hexalegtris.

\section{CYPRIPÈdIOM L. LAdY's SLIPPER, Moccasin Flower}

Sepals spreading, all three distinct or in most cases two of them united into one under the inflated sac-like lip. Petals mostly spreading, linear or oblong. Column declined, on each side a fertile stamen with its short filament bearing a 2-celled anther; pollen loose and pulpy or powdery-granular, the face of the anther converted into a viscid film; on the upper side of the column a dilated petaloid, but thickish staminode, or infertile stamen ; stigma terminal, obscurely 3-lobed, moist and roughish. - Roots coarsely fibrous. Leaves many-nerved and plaited, sheathing at the base. Stems pubescent. Flowers solitary or few,

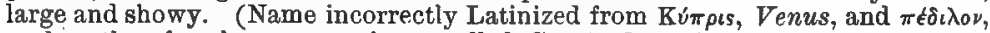
a shoe, therefore by some authors spelled Cypripedilum.)

\section{$\S 1$. The three sepals separate.}

1. C. arietìnum R. Br. (RAM's HeAd L.) Stem slender, 15-30 cm. high ; leaves 3 or 4, elliptic-lanceolate, nearly glabrous; upper sepal ovate-lanceolate, acute, lower sepals and the petals linear, similar, madder-purple, 1.5-2 cm. long, exceeding the whitish crimson-veined lip, which is silky pubescent within. (Criosanthes borealis Raf.) - Swamps and rich woods, rare and local, Que. to Man., s. to Me., Mass., N. Y., and Minn. May, June. (China.)

$\S 2$. The two lower sepals united.

* Stem elongated, leafy to the top, 1-3-flowered; lip stipper-shaped, not fissured in front, but with a rounded open orifice.

- Sepals and linear troisted petals acute, longer than the lip. + Lip yellow.

2. C. parviflorum Salisb. (Smallkr Yeulow L.) Stem $19-60 \mathrm{~cm}$. high; petals and sepals gtepnish. much suffused with madder-purple, $3-5 \mathrm{~cm}$. long; 
lip 2-3 cm. long. - Mostly in swampy or boggy places. - Frequently indistinguishable from the following variety, into which it seems to pass. Both the species and the variety widely distributed throughout our range. May-July.

2 Var. pubéscens (Willd.) Knight. (LARGer Yellow L.) Stein 23-70 cm. high ; leaves oval, acute, 11-20 cm. long, 5-11 cm. wide, mostly distant on the stem at anthesis; sepals ovate-lanceolate, greenish-yellow, dotted and streaked with madder-purple markings, usually exceeding $5 \mathrm{~cm}$. in length; lip goldenyellow, 3.5-5 cm. long. (C. pubescens Willd.; C. hirsutum auth., not Mill.) - Mostly in woods.

\section{+ Lip white.}

3. C. cándidum Muhl. (SMald White L.) Stem 16-28 cm. high, 1-flowered ; leaves oval-lanceolate, acute, mostly crowded at anthesis; petals and sepals greenish, spotted with madder-purple; sepals ovate-lanceolate; lip 18-20 mm. long, striped with purple inside at base. - Swamps, N. Y. and N. J. to s. Minn., n. e. Neb., s. to Mo, and Ky. May, June.

- + Sepals and petals not twisted, shorter than the lip, or nearly equaling it.

4. C. hirsùtum Mill. (Showy L.) Stem 4-8 dm. high, hirsute; leaves ovate, acute ; sepals round-ovate, or orbicular, rather longer than the oblong petals; lip much inflated, white, crimson-magenta in front, about $4 \mathrm{~cm}$. long. (C. spectabile Salisb.) - Swamps and wet mossy woods, Nfd. to Ga. and Wisc. June, July.

5. C. passerinum Richards. Stem about $2 \mathrm{dm}$. high, villous-pubescent; leaves elliptic-lanceolate, acute; upper sepal yellowish, nearly orbicular, about $1.5 \mathrm{~cm}$. long; lip spherical, pale magenta, spotted with deep magenta at the base within. - Woods, n. Ont. ; L. Superior, westw. and northwestw.

* * Stems short, 2-leaved; leaves basal, next the ground; scape terminated by a solitary bract, 1-flowered; sepals and petals greenish-brown, shorter than the drooping lip, which is fissured in front.

$\checkmark$ 6. C. acaúle Ait. (STrmLess L.) Leaves oval; scape 15-38 cm. high ; sepals ovate-lanceolate, nearly as long as the linear-lanceolate petals; lip obovoid, crimson-pink (rarely white, and petals yellow-green), nearly $5 \mathrm{~cm}$. long, veiny; staminode rbomboid. (Fissipes Small.) - Dry woods, Nfd. to Minn., Winnipeg, and northwestw.; s. to N. C. and Tenn. May, June.

\section{ORCHIS [Tourn.] L.}

Flowers ringent. Sepals and petals nearly equal. Lip turned downward, coalescing with the base of the column, spurred below. Anther-cells contiguous and paralle?. FGlen cohering in numerous coarse waxy grains, which are collected on a cobwebby elastic tissue into two large masses (one filling each anther cell) borne on slender stalks, the bases of which are attached to the glands or viscid disks of the stigma; the two glands contained in a common little pouch, or bursicule, placed just above the orifice of the spur. Flowers magenta-pink, showy; in a loose raceme. Leaves

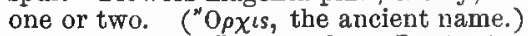

1. 0. rotundifolia Banks. Leaf solitary, varying from almost orbicular to oblong, 3-8 cm. long; scape naked, $12-23 \mathrm{~cm}$. high ; flowers magenta; lip white, spotted with magenta, 3-lobed (the lateral lobes oblong and the larger middle lobe dilated and notched at the apex), 6-8 $\mathrm{mm}$. long, exceeding in length the ovate-oblong petals and sepals and the slender depending spur. (Habenaria Richards.) - Damp wocds and swamps, local, e. Que. to N. Y.,

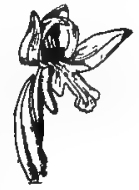

610. O. rotandifolia $\times 1$. Wisc., northw. and northwestw.' June, July. FrG. 610. $\checkmark 2$. 0. spectábilis L. (Sноw $\mathrm{O}$.) Leaves two, basal, oblong-obovate, shining, 7-15 cm. long ; scape 4-5-angled, 4-17 cm. high; bracts leaf-like, lanceolate; floral bracts exceeding the flowers; sepals and petals contiguous, forming a vaulted galea behind the cclumn; lip ovate, white, or rarely magenta-pink, undivided. (Galeorchis Rydb.) - Rich woods, N. B. and N. E., s. to Ga., westw. to Mo. and Dak. May, June. 


\section{3. habenaria Willd. Rern Orchis. Fringed Orchis}

Flowers usually small, in loose or dense racemes. Sepals spreading, mostly similar; petals erect, connivent with the upper sepal. Lip entire, toothed or fringed laterally, or tripartite, the divisions wedge-shaped and variously toothed or fimbriate. Spur shorter or longer than the lip. Glands or viscid disks (to which the pollen masses are attached) naked and exposed, separate, sometimes widely so. In some of our species the stigma has two or three appendages. - Glabrous plants with one or more leaves. Tuberoids elongated, fusiform, or (in no. 1) somewhat palmate. (Name from habena, a thong or rein, in allusion to the shape of the lip or spur of some species.) An amphigean genus often separated by authors into numerous genera.

\section{* Lip not fringed.}

+- Leaves cauline, several, at least more than two.

\section{+ Lip 3-toothed at the apex.}

1. H. bracteàta (Willd.) R. Br. Stem $15-60 \mathrm{~cm}$. high, rather stout; lower leaves oblanceolate to obovate, the upper oblong to lanceolate, acute; floral bracts 2-4 times the length of the green flowers; raceme 10-30fowered; petals linear; lip oblong or slightly spatulate, 2-3toothed at the apex, more than twice the length of the saccate whitish spur; tuberoids somewhat palmate, the divisions elongated, tapering. (C'oeloglossum Parl.) - Damp woods and thickets, N. S. to Alaska, s. to Wash., Minn., and Pa.; and along the mts. to N. C. May-Aug. (China and Japan.) Fig. 511.

\section{+ + Lip hastate, with a tubercle at the base.}

611. H. bracteata $\times 1$.

2. H. flàva (L.) Gray. Stem $25-55 \mathrm{~cm}$. high; leaves ovate-oblong or oblong-lanceolate, the uppermost linear-lanceolate, passing into the bracts of the elongated raceme; petals ovate; lip truncate, sometimes retuse, with a tooth or protuberance on the median line near the base; spur slender,

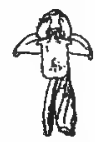
4-6 $\mathrm{mm}$. long. ( $\boldsymbol{H}$. virescens Spreng. ; Perularia flava Farwell.) - Wet places, N. S. to Minn., and common southw. June, July. Fig. 612.

$$
++++ \text { Lip lanceolate, entire. }
$$

3. H. hyperborea (L.) R. Br. Stem leafy, leaves oblong-lanceolate; raceme loose or dense; flowers greenish; upper sepal ovate, lateral sepals somewhar lanceolate; petals lanceolate, erect ; lip lanceolate, deflexed, or curved upwards; spur about as long as the lip, slender, or clavate at the apex;

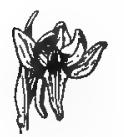

613. H. dilatata $\times 1$. glands of the stigma orbicular. (Limnorchis Rydb.) - Peat bogs and wet cold woods, N̦fd. to Alaska, southw. to Pa., Neb., and westw. June-Aug. (Iceland.) - A species variable in height, in the length and breadth of the leaves, in the size of the flowers, and in the relative length of the lip and spur; therefore supposed by some authors to include several species.

4. H. dilatàta (Pursh) Gray. Sirnilar to the preceding; flowers white, more delicate in texture; lip lanceolate with a dilated rhomboidal base; stigma narrow. (Limnorchis Rydb.) - Meadows, bogs, and wet woods, Nfd. to Alaska, N. J., Minn., and westw. May-Aug. (Iceland.) Fig. 613.

Var. mèdia (Rydb.) Ames. A greenish-flowered form of the species distinguishable by the rhomboidal base of the lip from $H$. hyperborea.

5. H. nivea (Nutt.) Spreng. Stem slender, $3-6 \mathrm{dm}$. Jong ; leaves

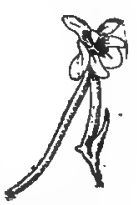

614. H. niver $\times 1 \%$.

nunierous, the lower ones lance-linear, $10-16 \mathrm{~cm}$, long, the others passing into linear bracts; raceme lax or dense; flowers white, numerous; petals and lip narrowly oblong; spur slender, ascending, as long as the white untwisted ovary; 
appendages of the stigma oblong. (Gymnadeniopsis Rydb.) - Swamps along the coast, Del, to Fla., westw. to Ark. and Tex. June-Aug. Fig. 614.

\section{++ Leaves cauline, one or two.}

ش Lip crenulate.

6. H. integra (Nutt.) Spreng. Stem about $37 \mathrm{~cm}$. high, several-leaved; the lower leaves elongated, oblong-lanceolate, the others Lecoming smaller and bract-like; raceme densely many-fiowered, cylindrical ; flowers small, yellow; lip ovate, entire or slightly clenulate, or short-toothed along the margin, shorter than the awl-shaped descending spur; appendages of the stigma two, lateral, oblong, fleshy. (Gymnadeniopsis liydb.) - Wet pine-barrens, N. J. to Fla., w. to T'enn. and Tex. July, Aug.

\section{$\rightarrow$ Lip 3-toothed at the apex.}

7. H. clavellàta (Michx.) Spreng. Stem $19-40 \mathrm{~cm}$. high, slender, with one or two oblong or oblanceolate obtuse leaves, and two or three linear-lanceolate bracts above; raceme 3-16-flowered, subcylindric ; flowers greenish-white; lip wedge-oblong, truncate, with three short apical teeth or lobes; spur slender, slightly clavate, curved upwards, longer than the ovary; appendages of the stigma 3, oblong, clavate-tuberculate, one outside each orbicular gland, and one between them rising as high as the anther-cells. (H. tridentata Hook.; Gymnadeniopsis clavellata Rydb.) - Bogs and moist soil, Nfd. to Minn. and southw. July, Aug. Fig. 615.

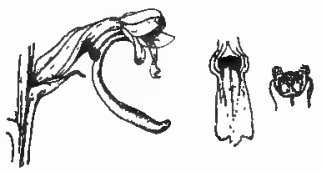

615. H. clavellata.

Flower $\times 1$. Lin $\times 11 / 8$. Column $\times 2$.

\section{++ + Leaves radical.}

+ Lip less than 5 mm. long.

8. H. unalascénsis (Spreng.) Wats. Plant slender, 3-5 dm. high, leafy at base; leaves oblanceolate, withering before the flower's open; sepals slightly gibbous at base, 1-nerved, narrowly oval, lateral ones adnate at base to the lip; petals lanceolate, obtuse; lip oblong-hastate; spur filiform or slightly clavate, shorter than the ovary. (Piperia liydb.) - Damp woods, Anticosti I., Que.; Ont., westw. to Alaska and Cal. June-Sept.

\section{+ + Lip more than 5 mm. long. \\ $=$ Spur about equal to the lip.}

9. H. obtusàta (Pursh) Richards. Plants $10-26 \mathrm{~cm}$. high; leaf solitary, basal, obovate or spatulate-oblong; flowers greenish or whitish, 5-15 in a loose raceme at the summit of a naked scape; upper sepal broad and

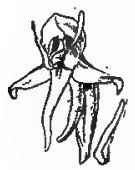

616. H. obtusata $\times 11 / 3$. rounded, lateral sepals and the petals lance-oblong; lip entire, linear-lanceolate, defiexed, $6 \mathrm{~mm}$. long, about the length of the tapering curved spur. (Lysiella Rydb.) - Swamps and rich woods, Nfd. to Alaska, s. to N. Y., Minn. and Col. July, Aug. (Eu.) Fig. 616. $==$ Spur two or more times longer than the lip.

10. H. Hookèri Torr. Leaves orbicular or elliptical, near the ground, 3.5-10 cm. broad; scape usually ebracteate, 12-16 $\mathrm{cm}$. high, having 8-20 upright yellowish-green flowers in a strict raceme $2-4 \mathrm{~cm}$. through; sepals ovate-lanceolate, the upper sepal dilated at base, acumi-

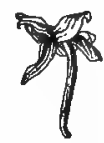

617. H. Iookeri $\times 2 / 3$. nate; lip lanreolate, pointed, about $1 \mathrm{~cm}$. long; spur slender, acute, $2 \mathrm{~cm}$. long. (Lysias Hookeriana Rydb.) - Dry or damp woods, e. Que. to Pa., w. to Minn June, July. Fia. 617.

11. H. orbiculàta (Pursh) Torr. Leaves orbicular or elliptical, 6-19 cm. broad, spreading flat on the ground, shining above, silvery beneath; scape with one or more lanceolate bracts, $6-32 \mathrm{~cm}$. high, having $10-20$ or more greenishwhite flowers in a loose raceme 4-6 cm. through; upper sepal orbicular, lateral 
ones ovate; lip oblong-linear, obtuse, $1.5-2 \mathrm{~cm}$. long; spur $1.5-2.5 \mathrm{~cm}$. long; anther-cells strongly projecting at the free beak-like base ; glands nearly $6 \mathrm{~mm}$. apart. (Lysias Rydb.) - Kich deep woods, Lab. to Alaska, s. to S. C., Minn., and Wash. July, Aug.

12. H. macrophýlla Goldie. Similar to the preceding, but larger in all its parts; spur 3-4 cm. long. - Moist coniferous woods, Nfd. to Ont., s. to Ct. and Mich. June-Aug.

\section{* Lip fringed, not divided or tripartite. (Blephariglottis Raf.)}

13. H. cristata (Michx,) R. Br. Stem 2-6 dm. high; lower leaves linearlanceolate, elongated, the upper becoming gradually reduced to acute bracts;

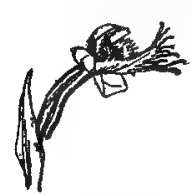

618. H, cristata $\times 12 / 8$. floral bracts nearly as long as the orange-yellow flowers; raceme $2-3 \mathrm{~cm}$. through; sepais elliptical; petals oblong, fringed at the top; lip ovate, copiously fringed, $5 \mathrm{~mm}$. long; spur slender, 5-9 mm. long, longer than the lip. - Bogs, N. J. to Ark., and southw. July, Aug. Fig. 618.

14. H. ciliàris (L.) R. Br. (Yellow Fringed O.) Stem 4-6 dm. high; leaves linear-oblong or lanceolate, the upper ones passing into pointed bracts shorter than the ovaries; raceme 4-6 cm. through ; flowers orange-yellow; lateral sepals orbicular; petals linear-oblong or linear-lanceolate, toothed at the apex ; lip oblong, $1 \mathrm{~cm}$. long, copiously fringed, the basal segments of ten branched; spur $2-2.5 \mathrm{~cm}$. long. - Peaty bogs and meadows, Vt. and Mass. to Mich., Mo., and southw. July, Aug.

15. H. blephariglóttis (Willd.) Torr. (WhIte Fringed O.) Similar to the preceding in habit; flowers white; lateral sepals orbicular, upper sepal elliptical, concave; petals linear-oblong, somewhat pointed, cristate above or toothed ; lip narrowly ovatelanceolate, 8-10 mm. long, fringed, the segments once divided or simple; spur about $2 \mathrm{~cm}$. long. - Bogs and peaty land, Nfd. to Fla., w. to Mich. and Miss. July, Aug. Fig. 619. Var. conspfou (Nash) Ames. Racemes lax; spur $4 \mathrm{~cm}$. long.Occurring southw. Var. HoLOPÉTALA (Lindi.) Gray. Petals narrower, with the toothing obsolete and the lip less fringed.

$\times$ H. Cánbyi Ames. ( $H$. blephariglottis $\times H$. cristata.) Lip about $7 \mathrm{~mm}$. long, deeply fringed; spur $12 \mathrm{~mm}$. long. -.Swamp near Lewes, Del., July, 1878 (Canby). Intermediate in color and size of flowers between the parent species.

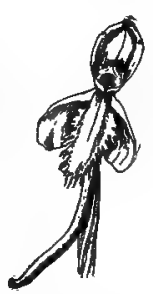

619. H. blepharl. glottis $\times \mathbf{1}$.

\section{- Lip 3-parted, divisions toothed or fringed. \\ - Flovers greenish or whitish. \\ - Petals entire.}

16. H. 1ácera (Michx.) R. Br. (RagGed Fringed O.) Stems 3-6 dm. high; leaves oblong or lanceolate; raceme loose or dense, many-flowered; petals

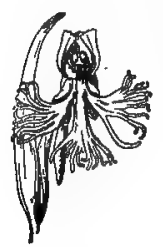

620. H. lacera $\times 1$. oblong, divisions of the lip narrow, deeply incised, the segments capillary; spur about the length of the ovary, $1.5 \mathrm{~cm}$. long; glands oblong-linear, as long as the stalk of the pcllen-masses. Wet or moist open ground, Nfd. to Minn., southw. to Mo. and Ala. July, Aug. Frg. 620 .

\section{*+ 4 Petals minutely cut-toothed.}

17. H. leucophaè (Nutt.) Gray. Stem Q-12 dm. high; leaves oblong-lanceolate; raceme commonly elongated, loose ; the large flowers fragrant; petals obovate; divisions of the lip 17-20 mm. long, many cleft to the middle into a copious fringe; spur $3.5 \mathrm{~cm}$. long; glands transversely oval. - Wet meadows and prairies, N. S. and Me, to Minn., southw. W. of the Allegheny Mts. to La. June, July. 


\section{+ + Flowers pale or deep magenta (purplish).}

18. H. psycddes (L.) Sw. Usually about $5 \mathrm{dm}$. high; lower leaves $2-4$, oval to lanceolate or oblanceolate, passing into the linear-lanceolate bracts; raceme cylindrical, about $3-3.5 \mathrm{~cm}$. through, often densely manyflowered; lower sepals round-oval; petals variable, mostly wedge-obovate to spatulate, more or less denticulate; lip spreading, 3-parted, usually 1-1.2 cm. broad, the three divisions mostly fringed less than $\frac{1}{3}$ their depth. - Wet open meadows and swamps, Nfd. to Minn., south w, to N. C. July, Aug. FIG. 621.

$\times$ H. Andréwsii White. (H. lacera $\times H$. psycodes.) Lower leaves as in $H$. lacera; raceme loosely flowered; flowers white, rose-tinted; petals cuneate-spatulate, obtuse or slightly retuse, denticulate above; divisions of lip narrowly cuneate, deeply cleft as in H. lacera. - Pownal, Vt. ; S. Chesterville, Me. July, Aug.

19. H. fimbriàta (Ait.) R. Br. Usually a little taller than the preceding species; lower leaves $3-5$, oval to lanceolate and oblanceolate, passing into lanceolate bracts; spike usually subcylindrical, mostly 5-6 cm. through, loosely flowered; lower sepals ovate ; petals more or less oblong, denticulate; lip usually $1.8-2 \mathrm{~cm}$. wide, 3-parted ; the divisions mostly fringed to $\frac{1}{3}$ of their depth or more. ( $H$. grandiffora Torr.) - Rich wet deciduous woods and borders, Nfd. to N. Y.; southw. in the ints. to N. C. Late June to early Aug. - Most obviously distinguished from $H$. psycodes by the larger paler flowers and greater diameter of the raceme; leaves broader; generally blooming somewhat earlier than $H$. psycodes.

20. H. peramoèna Gray. Lower leaves oblong-ovate, the upper lanceolate; spike cylindrical, densely flowered; lower sepals round-ovate; petals roundedobovate, raised on a claw; divisions of the large lip very broadly vedge-shaped, irregularly eroded-toothed at the broadly dilated summit, the lateral ones truncate, the middle one 2-lobed. - Moist meadows and banks, Pa. and N.J. to IIl., s. to Mo.; and in the $\mathrm{mts}$. to Ala. June-Aug. - Flowers large and showy (violet-purple); lip 16-20 mm. long, variably toothed, but not fringed.

\section{POGdNIA Juss.}

Sepals and petals free. Lip papillose-crested. Column free, slender below the summit; anther terminal, operculate, with a distinct stalk, fleshy, thick;

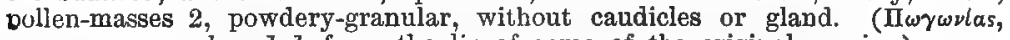
bearded, from the lip of some of the original species.)

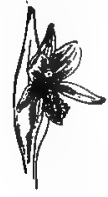

622. P. ophioglossoides $\times 1 / 8$.

* Lip lacerate-toothed, otherwise not lobed.

1. P. ophioglossoides (L.) Ker. Plants 1-3 dm. or more high, glabrous, bearing a single oval or lance-ovate leaf near the middle and a bract below the usually solitary terminal flower; sepals narrowly oval, about $2 \mathrm{~cm}$. long ; petals similar, but broader; lip spatulate, inclosing the column at base; crest yellow to white, otherwise the flowers magenta-pink, very rarely white. - Bogs, Nfd. to Minn., southw. to Fla. June, July. Fig. 622 .

\section{* * Lip three-lobed, merely fimbrillate-margined. \\ - Leaves several, distinctly alternate, not whorled.}

2. P. trianthóphora (Sw.) BSP. Plants $3-20 \mathrm{~cm}$. high, from ovoid or subcylindrical tuberoids; leaves $1-4$, broadly ovate, about $1 \mathrm{~cm}$. long; flowers several, drooping, transitory, borne in the axils of the upper leaves, or slender pedicels; perianth about $15 \mathrm{~mm}$. long; lip ovate, slightly papillose along the middle, lateral lobes obtuse. ( $P$. penduta Lindl.; Triphora pendulo Nutt.) - Woods, Me. to Wisc. and Mo., southw. Aug. 


\section{++ Leaf solitary.}

3. P. divaricata (L.) R. Br. Plants $3-6 \mathrm{dm}$. high, bearing above the middle an oblong-lanceolate leaf 6-18 $\mathrm{cm}$. long, and next the flower a leafy bract;

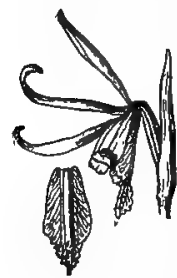

628. P. dívaricate $\times 1 / 8$. sepals brownish, ascending, linear-lanceolate, 4-5 cm. long, exceeding the spatulate magenta-pink or whitish petals; lip wedge-oblong, the lobes apical and rounded, with a lineargrooved partly papillose erest along the middle. - Swamps and moist pine-barrens, N. J. to Ga. May, June. FIG. 623.

\section{++ Leaves 5 in a whorl at the top of the stem.}

1. 4. P. verticillàta (Willd.) Nutt. Plants $2-3 \mathrm{dm}$. high, naked except for a few scales at base and a whorl of five obovate or lanceolate sessile leaves at the summit; flowers solitary, rarely 2 ; sepals madder-purple, linear, conduplicate, $4.5 \mathrm{~cm}$. long; petals oblong-lanceolate; lip wedge-oblong, 3-lobed near the apex, with a linear partly papillose crest down the middle; leaves about $4 \mathrm{~cm}$. long at flowering time, larger when the erect fruit matures. (Isotria Raí.) - Woods, N. E. to Fla. w. to Wisc. ; not common. May, June. Fig. 624 .

$\checkmark$ 5. P. affìnis Aust. Plants about $2 \mathrm{dm}$. high; leaves nar-

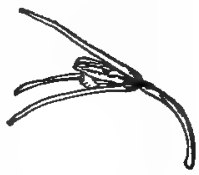

624. P. verticillata $\times 1 \%$. rower than in the preceding, $2-5 \mathrm{~cm}$. long ; flowers (not rarely in pairs) yellow. ish or greenish; peduncle much shorter than the ovary and capsules; sepals as long as or longer than the petals, somewhat narrowed at base; lip crested over the whole face and on the middle of the lobes. (Isotria Rydb.) - Woods, very local, Vt. (Mrs. Henry Holt) and Mass. tc N. J. and Pa.

\section{CALOPÒGON $\mathrm{R}$. Br.}

Flowers in a loose raceme, resupinate. Sepals and petals spreading, distinct. Lip linear-oblong at base, dilated and bearded above with numerous clavate hairs, papillose at the apex. Column free, slender, winged at the summit; anther terminal, operculate; pollen-masses 4 (2 in each anther-cell); pollengrains conuected by filaments. Scape from a solid bulb, sheathed below by the

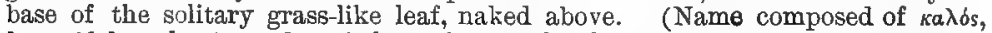
beautiful, and $\pi \dot{\omega} \gamma \omega \nu$, beard, from the bearded lip.) I, IоDORUM L., in part.

1. C. pulchéllus (Sw.) R. Br. Plant $15-40 \mathrm{~cm}$. high; raceme 4-12-flowered; flowers magenta-crimson, rarely white; lateral sepals ovate-lanceolate, falcate, upper sepal narrower; petals lanceolate, obtuse, constricted near the middle; lip as if hinged at base, its hairs yellow and magenta-crimson. - In open bogs and meadows, Nfd. to Fla., w. to Minn, and Mo. July (in our range).

\section{ARETHÙSA [Gronov.] L.}

Flowers ringent. Sepals and petals nearly alike, erect, united at base, arching over the column. Lip partly erect, the apical half abruptly recurved. Column adberent to the lip, dilated above, petal-like; anther lid-like, attached by a well defined membrane, 2-celled; pollen-masses 2 in each cell of the anther, powdery, granular. - Scape smooth from a solid white or greenish bulb. Ieaf solitary, linear, nerved, hidden in the sheaths of the scape, protruding after the flower opens. (Named for the nymph Arethusa.)

1. A. bulbòsa L. Plant $10-25 \mathrm{~cm}$, high from an ovoid bulb; scape terminated by a solitary flower $2.5-5 \mathrm{~cm}$. long, rarely 2 -flowered; sepals and petals magenta-pink, rarely white, the former oblong, acute or obtuse, the lateral ones falcate, the petals oblong, obtuse or obscurely pointed; lip oblong, narrower toward the base, with $3-5$ fringed yellow or white crests; margin of lip fimbrillate, spotted and striated with magenta-crimson or plain; column denticulate of 
toothed at the dilated apex ; stigma protuberant, turned down. - Bogs, Nfd. to Ont. and Minn, Pa., and mis. of S. C. May, June.

\section{SERÀPIAS L.}

Flowers in a loose or somewhat dense bracteose raceme. Sepals ovate. lanceolate, strongly keeled. Petals shorter, ovate, acute. Lip strongly saccate at base, the apical part broadly cordate, acute, with a raised acallus in the middle and two inconspicuous nipple-like protuberances on each side near the point of union with the sac. Column broad at the top, the basal part narrower; anther sessile, behind the broad truncate stigma on a slender-jointed base; pollen farinaceous, becoming attached to the gland capping the small rounded beak of the stignua. - Stem leafy. (Named for the Egyptian deity Serapis.) EPIPactis of auth, not Boehm.

1. S. Helleborine L. Plants $25-60 \mathrm{~cm}$. high ; leaves clasping the stem, conspicuously nerved, broadly ovate to lanceolate, acute; perianth about $8 \mathrm{~mm}$. long, green suffused with madderpurple; lip similarly colored, but darker within, the apical portion as if jointed with the sac, bituberculate at base. (Epipactis Crantz; $\boldsymbol{E}$. latifolia All. ; $\boldsymbol{E}$. viridiflora Reichenb.) - Rare and $\times 2 / 3$.

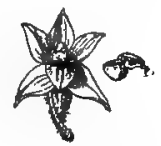
local, Que. and Ont. to Mass., N. Y., and Pa. - Probably introduced from Europe in early times on account of supposed medicinal value. July-Aug. (Eu.) Fig. 625 .

\section{SPIRÁNTHES Richard. Ladies' Tregses}

Perianth somewhat ringent. Lateral sepals lanceolate, the upper sepal united with the oblong petals. Lip short-stalked, with a callus protuberant within on each side of the base, the somewhat dilated summit spreading or recurved, crisped, wavy, or rarely toothed or lobed. Column short, bearing the ovate stigma on the front, and the sessile or short-stalked (mostly acute or pointed) 2-celled erect anther on the back; pollen-masses 2 ( 1 in each cell), narrowly obovoid, each 2-cleft and split into thin and tender plates of granuiar pollen united by elastic filaments, coherent to the narrow viscid gland, which is set in the slender or tapering thin beak which terminates the column. After the removal of the gland, the beak is left as a 2-toothed or forked tip.-Roots clustered. Stem bracted above, leaf-bearing below or at the base. Flowers small, white, yellowish- or greenish-white in a more or less spirally twisted raceme (whence the name, from $\sigma \pi \epsilon i p a$, a coil or curl, and a a $\theta_{0 s}$, a flower). Grrostachys Pers.; IвIDIUM Salisb.

* Flowers in a single rank, often secund.

+ Leaves fugacious, ovate or elliptic. ++ Root solitary; lip white.

1. S. Béckii Lindl. Plants with a solitary subcylindrical or spindle-shaped root, and bearing a small slender raceme of white flowers; perianth $2-3 \mathrm{~mm}$. long. (S. simplex Gray.) - Dry soil, near the coast, Mass, to Fla. and Tex., inland in the Miss. Valley to Ky. and Ark. Aug., Sept. FJa. 626. - Root of preceding year often persistent.

$$
\text { +t ++ Roots fasciculate; lip green. }
$$

2. S. grácilis (Bigel.) Beck. Plants from a cluster of thickened roots, slender, $2-8 \mathrm{dm}$. high, bearing a slender many-flowered mostly one-sided or spirally twisted raceme; perianth about $5 \mathrm{~mm}$. long; lip greenish, with a white crisped margin. - Dry soil, N. S.

626. S. Beckii. to L. Winripeg and Tex. July-Sept. $x 1$.

+ + Leaves persistent, oblong-lanceolate to linear-lanceolate.

+ Lip ovate to ovate-oblong, pubescent beneath.

3. S. vernàlis Fngelm. \& Gray. Plant 15-56 cm. high; roots elongated, fusiform; leaves $7-15 \mathrm{~cm}$. long, $8-9 \mathrm{~mm}$. wide, tapering to both ends, mostly 
basal, the lower ones usually withering before flowering-time; scape smooth below, densely pubescent above; floral bracts longer than the ovaries, with distinct hyalins margins; raceme elongated, slender, 1-ranked, $8-15 \mathrm{~cm}$. long; perianth 8-10 mm. long, yellowish. (S. praecox Man. ed.6, in part.) - Dry soil along the coast, Mass. to Fla. and N. Mex.; northw. through the Miss. Valley to Ill. and Kan.; rare. Aug., Sept.

$\times$ S. intermèdia Ames ( $\$$. gracilis $\times S$. vernalis.) Resembling $S$. vernalis, but slenderer throughout, with shorter narrowly elliptic-lanceolate leaves; lip nearly oblong, greenish with green callosities. - Dry fields, Easton, Mass. (A. A. Eraton).

$$
\text { + Lip oblong, smooth beneath. }
$$

4. S. praècox (Walt.) Wats. \& Coult. Scape 4-8 dm. high, slender, glabrous below, slightly pubescent above; roots clustered, fleshy; leaves linear, grasslike, 1-2.5 dm. long, upper ones passing into acute sheathing hyaline-margined bracts; perianth $6-9 \mathrm{~mm}$. long; flowers white, often veined with green, in more or less one-sided racemes. - A southern species, extending along the Atlantic coast from N. J. to Tex. Spring; Aug., Sept, at the North.

\section{* Flowers apparently in several ranks. \\ + Lip not constricted, or only rarely so. \\ + Lip quadrate, yellow (May-July).}

5. S. lùcida (H. H. Eaton) Ames. Scape 7-20 cm. high ; leaves oblong or oblong-lanceolate, $9 \mathrm{~cm}$. long, $1 \mathrm{~cm}$. wide on the average, 3-5-nerved, contracted into a sheathing base; raceme slender, 2-7 cm. long; perianth 5-7 mm. Ions; lip yellowish. (S. latifolia Torr.; Neottia lucida H. H. Eaton.) - Moist banks, Me. to Ont. and Wisc., s. to Va. May-July.

$$
\text { + + Lip ovate (Sept., Oct.). }
$$

6. S. ovàlis Lindl. Similar to the preceding in habit; perianth $4-5 \mathrm{~mm}$. long; lip few-nerved, membranaceous. (S. cernua, var. parviflora Chapm.) - In shady moist woods and on high wooded hills, rare, Ill. and Mo. to Ga., Miss., and Tex. Sept., Oct.

$$
\text { ++ ++ Lip ovate-oblong. }
$$

\section{$=$ Leaves mostly radical, lovermost longest.}

7. S. cérnua (L.) Richard. Plants $14-38 \mathrm{~cm}$. high, from slender fleshy roots, leafy below; leaves linẻar-lanceolate, variable, sometimes distinctly petioled; cauline bracts 4 or 5, usually closely appressed to the scape; scape pubescent above; floral bracts exceeding the ovaries by about half the length of the perianth ; flower's in two or three spiral or vertical ranks; racemes $3-12 \mathrm{~cm}$. long; perianth 7-10 mm. long; lip ovate-oblong, about as long as the sepals, apical margin crisped or erose. - Bogs and wet land, Nfd. to Ga., Minn., and Neb. Sept., Oct. - Very variable in size and foliage, often losing the root-leaves at flowering time. Var. ochrole òcA (Rydb.) Ames. Growing in dry ground and blooming somewhat later, having greenish, cream-colored, or white flowers and longer floral bracts. - Me. to S. Dak., s. to Ga. and N. Mex. Sept., Oct.

$$
==\text { Leaves extending up the stem. }
$$

8. S. odorata (Nutt.) Lindl. Plant $4-10.5 \mathrm{dm}$. high; roots coarse, fleshy; leaves several, mostly basal, lanceolate, acute, about $12 \mathrm{~cm}$. long, $2 \mathrm{~cm}$. wide; perianth $8 \mathrm{~mm}$. long, yellowish-white, often white, fragrant; basal half of the lip dilated, rhomboidal, tapering to the obtuse erose-margined apex, veined and suffused with greenish-yellow, callosities prominent. - Swamps and wet ground, Coast States, Va. to Tex. Sept.-Dec.

$$
++ \text { Lip constricted at the middle or near the apex. }
$$

9. S. Romanzoffiana Cham. Plants $8-47 \mathrm{~cm}$, tall, from roots $5-8 \mathrm{~mm}$. thick, leafy below and leafy-bracted above; leaves varying from oblong-lanceolate to linear; scape giandular-pubescent above; canline bracts 2-3; raceme dense, cylindrical, variable in length; perianth yellowish or whitish, 6-12 mm. long; 
bracts of the raceme often much longer than the flowers; sepals and petals all connivent, forming a galea above the column; lip pandurate, apex strongly recurved, callosities minute, globular. (Includes Gyrostachys stricta Rydb.) Swamps and moist soil, Nfd. to Alaska, s. to Ct., N. Y., the Great Lake region, S. D., Col., Utah, and Cal. July-Sept. (Ireland.)

\section{9. epipáctis [Haller] Boehm. Rattlegnake Plantain}

Lip saccate, with a straight or recurved tip, sessile, entire, without callosities at base. Upper sepal and the petals united into a hood over the lip. Anther borne on the back of the short column; pollen-masses 2 , the narrow gland to which they are attached held between the forked or 2-toothed beak which terminates the column. - Root of thick fibres from a somewhat fleshy creeping rootstock. Leaves all basal, dark green, or reticulate-veined with white. Scape, raceme, and the whitish flowers glandular-downy. (Ancient Greek name of Helleborus.) Peramum Salisb. Goodyera, R. Br.

* Raceme loosely flowered; saccate lip with an elongated tip and flaring or recurved margin.

+ Flowers in a 1-sided raceme; anther short, blunt, or with a short blunt tip; beak shorter than the body of the stigma.

1. E. rèpens (L.) Crantz. Stem 1-2.5 dm. high; leaves ovate to oblonglanceolate, 1-3 cm. long, 5-nerved with subhorizontal dark veins ; raceme about $4.5 \mathrm{~cm}$. long; perianth $4 \mathrm{~mm}$. long; lip strongly saccate, inflated, with a recurved tip. (Goodyera $\mathrm{R}$. Br.) An old world species, represented in eastern N. A. by the following variety.

Var. ophioides (Fernald) A. A. Eaton. Generally a little lower than the species; veins of the leaves conspicuously bordered with white. - Cold mossy woods, Nfd. to Man., s. to N.E., N. Y., 627 . E. repheides $\times 11^{2} / s^{-}$ and Mich., and in the mts. to S. C. July, Aug. Fig. 627.

+ + Filowers mostly in a loose spiral; anther acuminate; beak as long as, or longer than, the body of the stigma.

2. E. tesselàta (Lodd.) A. A. Eaton. Stem averaging $2 \mathrm{dm}$. high; leaves $3-8 \mathrm{~cm}$. long, ovate to oblong-lanceolate, extremely variable, faintly or sometimes conspicuously penciled with white; raceme about $6 \mathrm{~cm}$.

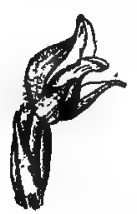

628. E. decipiens $\times 1^{2} / \mathrm{s}$. long; perianth $5 \mathrm{~mm}$. long. (Goodyera Lodd.) - In upland coniferous woods, Nfd. to Ont., s. to N. E. and N. Y. July, Aug. * * Raceme rather densely flowered, 1-sided; lip scarcely saccate, elongated, with the margin involute.

3. E. decipiens (Hook.) Ames. Stem stout, 3.5-4.5 dm. high ; leaves 5-10 cm. long, ovate-lanceolate, dark green, plain or partly reticulate-veined with white; raceme about $10 \mathrm{~cm}$. long; perianth 8-9 mm. long, anther ovate, long, acuminate; slender beak longer than the body of the stigma. - (Spiranthes Hook.; Good.yera Menziesii Lindl.) - Dry woods, e. Que. to B. C., s. to N. S., N. B., n. Me., L. Huron, and Ariz. and Cal. July, Aug. Fig. 628 .

* * Raceme densely many-flowered; lip strongly saccate, with a short blunt tip, the margin not recurved or flaring.

4. E. pubéscens (Willd.) A. A. Eaton. Stem stout, 1.5-4 dm. high ; leaves dark green, ovate to ovate-lanceolate, $3-6.5 \mathrm{~cm}$. long with 5 or 7 white nerves and many fine white reticulating veins; raceme about 7 (3-11) cm. long; perianth $4-5.5 \mathrm{~mm}$. long; lip globose, ventricose; anther blunt; stigma with 2 short

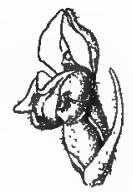

629. E. pubescens $\times 1 \frac{2}{8}$. teeth. (Goodyera R. Br.) - Common; generally in dry coniferous woods, rarer in deciduous woods, N. E. to Fla. and Minn. Aug., Sept. Fig. 629. 


\section{LISTÈRA R. Br. Twayblade}

Sepals and petals nearly alike, spreading or reflexed; lip mostly drooping, longer than the sepals, 2-lobed or 2-cleft at the summit. Column wingless. Stigma with a rounded beak; anther borne on the back of the column at the summit, erect, ovate; pollen powdery, in two masses, joined to a minute gland. -Roots fibrous. Stem bearing in the middle a pair of nearly opposite sessile leaves. The small flowers greenish or madder-purple in a terminal raceme. (Dedicated to Martin Lister, 1638-1711, a celebrated English naturalist.)

* Column very short ( $0.5 \mathrm{~mm}$. or less); lip not dilated above.

- Lip with a tooth on each side at base; raceme glabrous.

1. L. cordàta (L.) R. Br. Leaves round-ovate, somewhat heart-shaped, 12-25 mm. long; stem pubescent just above the leaves; flowers about $3 \mathrm{~mm}$.

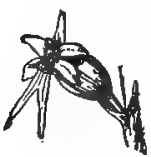

630. L. cordata $\times 12 / 3$. across, on pedicels not longer than the ovary; lip narrowly oblong, 2-cleft. - Mossy woods and swamps, Lab. to N. J., w. to Mich., Col., and Cal., northw. to the Arctic coast. (Greenl., Iceland, Eu., and Japan.) Fis. 630.

\section{+ + Lip not toothed at base; raceme glandular.}

2. L. austràlis Lindl. Leaves ovate; raceme loose and slen. der; flowers small, on minutely glandular-pubescent pedicels which equal or exceed the glabrous ovaries; lip linear, 6-10 mm. long, cleft one third to two thirds the way down into linear-setaceous divisions. Shady woods, La. and Fla. to N. $\Upsilon_{0}$; Oswego Co., N. Y.; Ottawa, Ont.

$$
\text { * Column 2-3 mm. long. }
$$

- Lip auriculate at base, more or iess ciliate.

3. L. auriculàta Wiegand. Leaves elliptic-oval or elliptic-ovate, 35-50 mm. long, inserted above the middle of the stem; flowers numerous, in a loose raceme; rhachis pubescent; pedicels glabrous, mostly shorter than the glabrous ovaries; lip 6-8 mm. long, slightly ciliate, oblong, cleft one third to one fourth of its length, auricles incurved.-Cedar swamps and mossy banks, e. Que. to n. N. H. and n.Vt. Fig. 631.

$$
+ \text { + Lip not auriculate at base. }
$$

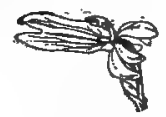

681. L. auriculata $\times 11 / 3$.

4. I. convallarioides (Sw.) Torr. Leaves oval or roundish and sometimes slightly heart-shaped, 3-5 cm. long; raceme many-flowered, loose; rhachis densely glandular-pubescent; pedicels glandular, slightly longer than the ovaries;

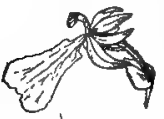

632. L. convallarioldes $\times 1$. lip 9-11 $\mathrm{mm}$. long, ciliate on the margin, narrowly cuneate, retuse, lobes rounded, on each side of base a short triangular tooth.-Moist woods, Nfd. to n. N. E., Mich., and the Rocky Mts., westw. and northw. Fig.632.

\section{$\rightarrow$ Ovary glabrous.}

5. L. Smállii Wiegand. Leaves borne at or below the middle of the stem, 15-25 mm. long, ovate-reniform, mucronate, often apiculate; raceme loose, few-flowered; rhachis glandular; pedicels glabrous, equaling or exceeding the ovaries in length; lip $9 \mathrm{~mm}$. long, not ciliate, broadly obovate, cleft at the apex, on each side of base a curved oblong obtuse tooth. Dal,p woods in the mts., Pa, to N.C. (E. Asia.)

\section{CORALLORRHiza [Haller] R. Br. CORAL ROOT}

Perianth somewhat ringent, gibbous or obscurely spurred at base. Sepals and petals oblong-lanceolate, nearly alike, 1-3-nerved ; lateral sepals ascending, forming wit' the lip the gibbosity or short spur which is mostly adnate to the 
ovary. Lip slightly adherent to the base of the compressed column. Anther terminal; pollen-masses 4, soft-waxy, free. - Brownish or yellowish herbs destitute of green foliage, with wuch branched and toothed coral-like underground rootless stems, sending up a simple scape which has sheaths in place of leaves, and a raceme of lurid flowers. Fruit retlexed. (Name composed of kopá $\lambda$ isov, coral, and $p(j a$, root.)

$$
\begin{aligned}
& \text { * Lip :3-lobed, or with a curved tooth on each side of base. } \\
& + \text { + Lip white, not spotted. }
\end{aligned}
$$

1. C. trifida Chatelan. Plant slender, yellowish, 4-19 cu. high, 4-12-flowered; perianth $5 \mathrm{~mm}$. long; lip white, somewhat hastately 3-lobed above the base, with thick rather short lamellae; spur a very small protuberance; capsule ovoid or ellipsoid, green un til mature. (C. innata R. Br.; C. Corallorrhiza Karst.) - Wet shaded situations, Nfd. to Alaska, s. to N. J., Pa., O., Mich., Minn., and in the mts. to Ga. MayJuly. (Eurasia.) Fig. 633.

$$
++ \text { Lip white, spotted with magenta-crimson. }
$$

2. C. maculata Raf. Plant stout, madder-purple or yellowish, 2-4 dm. high, 10-30-flowered; perianth 5-18 mm. long; lip deeply 3-lobed, lateral lobes smail, middle lobe rather square, rounded at the apex; two narrow longitudinal lamellae near

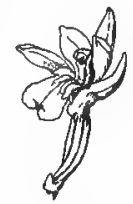

683. C. trifids $\times 2$. middle of lip; column yellow, with magenta spots on the inner surface; capsule smooth, inflated, compressed. (C. multiflora Nutt.) - Woods. July, Aug. -Pale forms, without spots on the lip, petals or sepals, occur rarely.

* Lip entire or margin denticulate.

\section{+ Lip without striations or conspicuous veins.}

3. C. Wisteriàna Conrad. Plant 1.5-4 dm. high, yellowish or madder-purple; flowers $12-16$ in a loose raceme; perianth about $7 \mathrm{~mm}$. long; sepals and petals more or less spreading; lip $5 \mathrm{~mm}$. long, $4 \mathrm{~mm}$. broad, oval or suborbicular, retuse, margin denticulate or undulate; callosities linear. ( $C$. maculata Greene, not Raf.) - Woods, $\mathrm{Pa}$. and southw. Spring.

4. C. odontorhiza Nutt. Plant slender, bulbous-thickened at base, light brown or madder-purple, about $16 \mathrm{~cm}$. high, 6-20-flowered; perianth about $4 \mathrm{~mm}$. long; sepals and petals scarcely spreading, one-nerved; lip 2.5-3 mm. long, white, spotted with inagenta-crimson, oval or broadly ovate, abruptly contracted at base, with two short inconspicuous lamellae; capsule globular or ovoid; column nearly as long as the petals. (Includes C. micrantha Chapm.) - Woods; a southern species extending sparingly northw. to s. Me., s. Ont. and Ill. Aug., Sept.

$$
\text { + + Lip conspicuously striate-veined with madder-purple. }
$$

5. C. striàta Lindl. Plants stout, madder-purple, $15-40 \mathrm{~cm}$. high, 15-25flowered; perianth about $8 \mathrm{~mm}$. long; sepals and petals with three madderpurple nerves; lip somewhat concave, ovale, with two short lamellae near the base ; capsule cylindrical. - - Woods; a northwestern species, rare and local as far east as Mich. and Ont. May, June.

\section{MALÁXIS Soland.}

Sepals lanceolate, spreading. Petals much smaller. Iip 3-nerved, lanceolate, apiculate, shorter than the lateral sepals. - Small plants with minute flowers in elongated racemes. (Má $\lambda a \xi \iota s$, a softening, perhaps in allusion to the tender nature of the plant.)

1. M. paludosa (L.) Sw. Scape filiform, 7-10 cm. high; leaves 2-5, basal, ovate, obtuse. - New York Mills, Otter Tail Co., Minn. (II. L. Lyon), the only American station known. (Eurasia.) 


\section{MiCROSTỲlis (Nutt.) Eaton. AdDER's Mođth}

Sepals oblong, spreading. Petals filiform or linear, spreading. Lip auricled or ovate at base, narrowing toward the summit, entire or nearly so. Column

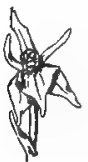

634. M. monophyllos $\times 31 / 3$. very small, terete, with 2 teeth or auricles at the summit and the erect anther between them; pollen-masses 4 , in one row ( 2 in each anther-cell), cohering in pairs, waxy, without stalks, filaments, or gland. - Low herbs from solid bulbs producing simple stems which bear a single leaf and a raceme of numerous minute greenish

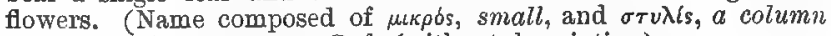
or style.) Achroantrhes Raf. (without description).

1. M. monophýllos (L.) Lindl. Scape slender, 10-15 cm. ligh, with a sheathing, ovate-elliptical leaf above base; raceme spiked, long and slender, about $7 \mathrm{~mm}$. in diameter; pedicels nearly equal to the ovaries in length; lip roundish at base, terminating in a long point. - In damp shady woods or swamps, occasional from Que. to Man., s. to Pa., Ind., and Minn., rare southw. June, July. (Eurasia.) FIG. 634.

2. M. unifolia (Michx.) BSP. Plant 7-22 cm. high; leaf near the middle, ovate, clasping; raceme short, $8-20 \mathrm{~mm}$. in diameter; pedicels much longer than the ovaries; lip truncate, 3-lobed at the summit, the middle lobe small. (M. ophioglossoides Eaton.) - Occasional in bogs and woods, Nfd. to Man., and southw. July, Aug. Fig. 635.

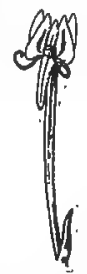

635. M. unifolia $\times 81 / 3$.

\section{LIPARIS Richard. TwayBLADE}

Sepals oblong-lanceolate. Petals linear or filifortn. Lip entire. Column $2 \rightarrow 3 \mathrm{~mm}$. long, curved, stout at base, with narrow wings above ; anther terminal, operculate; pollen-masses 4 ( 2 in each anther-cell), slightly united in pairs,

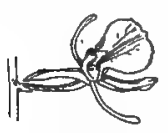

(t) 6. L. liliifolia $\times 2 / 3$. without stalks, filaments, or gland. - Low berbs, with solid bulbs, producing two root-leaves and a low scape which bears

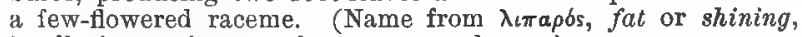
in allusion to the smooth or unctuous leaves.)

1. L. liliifolia (L.) Richard. Plants $10-17 \mathrm{~cm}$. high; leaves elliptical or ovate, acute or obtuse, glossy; scape angled; flowers $5-15$; sepals oblong-lanceolate, similar; petals pendent, madder-purple; tip wedge-obovate, translucent, madder-purple; column with 2 gland-like tubercles on the inner face at base. - Woods, $\mathbf{N}$. H. and Mass. to Minn., Mo., and Ala. June, July. Fig. 636.

2. L. Loesèlii (L.) Richard. Plants $8-22 \mathrm{~cm}$. high; leaves elliptic-lanceolate or oblong, keeled; lip obovate or oblong, $5 \mathrm{~mm}$. long, yellowish-green; column about $2 \mathrm{~mm}$. long. - Swamps, damp fields, and moist thickets, rather local, becoming rare southw. June, July. (Eu.)

\section{CALÝPSO Salisb.}

Sepals and petals similar, ascending, spreading, oblong-lanceolate, acute, magenta-crimson, rarely white. Lip larger than the rest of the flower, saccate, with three longitudinal rows of yellow (or white) glass-like hairs in front and with a translucent apron-like appendage (formed by the overlapping of the lip) spotted with madder-purple, the sac (bearing two conspicuous horns at its base) whitish, with irregular purple-madder markings. Column winged, having the operculate anther just below the apex; pollen-masses waxy, 2, each 2-parted, all sessile on a square gland. - Leaf solitary. Scape one-flowered. (Named for the goddess Calypso.)

1. C. bulbosa (I.) Oakes. Plant 6-18 cm. high; leaf oval or ovate, veiny, its margin wavy, the petiole triangular; scape srnooth, with membranaceous sheathing bracts; both leaf and scape produced separately from the summit of a rounded or elongated corm; pedicel of the flower subtended by a petaloid 
bract. (C. boreatis Salisb.) -Deep mossy woods, across the continent northw., very locally south to n. N. E., Mich., Minn., Ariz., and Cal. May-July.

(Eu.)

\section{Apléctrum (Nutt.) Torr. Pottr-root. Adam-And-Eve}

Perianth neither gibbous nor with any trace of a spur or sac at base. Lil free, 3-lobed, with three longitudinal erests. Column compressed; pollenmasses 4. - Scape about $4 \mathrm{dm}$. high, from near the summit of a globular bulb. Leaf solitary; petiole distinct. The slender naked rootstock produces each year a globular solid bulb or corm, often $2.5 \mathrm{~cm}$. in diameter (filled with exceedingly glutinous matter), which sends up late in summer a large oval many-nerved plaited leaf lasting through the winter; early in the succeeding summer the scape appears, ter minated by a loose raceme of lurid flowers. (The name is composed of $a$-plivative, and $\pi \lambda \hat{n} \kappa \tau \rho \circ \nu, a$ spur, from the total want of the latter.)

L 1. A. hyemàle (Muhl.) Torr. Flowers about 10 ; sepals oblong, greenish or yellowish, tinged with madder-purple; petals shorter, arching over the column, oblong, obtuse, yellowish, tinged with madder-purple above; lip white or nearly so, spar-

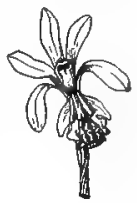

687. A. hyemale $\times 2 / 3$. ingly marked with magenta. (A. Shortii Rydb.) - Rich woods, Vt. to Sask., and southw., local. May, June. Fig. 637. - Pale forms occur devoid of markings on the perianth.

\section{TiPUlària Nutt. Crañe Fly Orchis}

Flowers greenish, tinged with madder-purple, numerous in an elongated loose bractless raceme. Sepals oblong-oval, obtuse, upper sepal narrower.

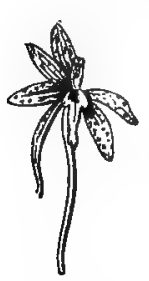

688. T. discolor $\times 2 / 8$.

Petals oblong, obtuse. Lip with a slender spur, 3-lobed; lateral lobes obtuse, obscurely toothed; apical lobes broad at base, margin deflexed at the middle, apex expanded. Column wingless; anther operculate, terminal ; pollen-masses 2, waxy, each 2-parted, connected by a linear stalk with the transverse small gland. - Corms connected in a horizontal series, producing in autunn a single ovate slender-petioled nerved and plaited leaf, purplish beneath, and in summer a long slender scape. (Name from a fancied resemblance of the flowers to insects of the genus Tipula.)

1. T. díscolor (Pursh) Nutt. Leaf green above, purplish beneath, disappearing before the flowers are produced; scape $25-45 \mathrm{~cm}$. high; spur about $2 \mathrm{~cm}$. long, twice longer than the ovary. ( $T$. unifolia BSP.) - A southern species, extending northw. to N. J.; reported but unverified from farther north. Fig. 638.

\section{HEXALÉCTRIS Raf.}

Sepals and petals nearly equal, free, somewhat spreading, several-nerved; perianth not gibbous or spurred at base. Lip obovate, 3-lobed, with 5 or 6 prominent ridges down the middle, the middle lobe somewhat concave. Pollen-masses 8 , united into a single fascicle. - Leafless plants with stout or somewhat coralline annulated rootstocks. (Name probably derived from $\xi \xi$, six, and $\ell_{\lambda \epsilon \kappa} \rho v \omega \omega$, , a cock, from the crest of the lip.)

1. H. aphýlla (Nutt.) Raf. Plants $3-6 \mathrm{dm}$. high, with short sheathing purplish scales; flowers racemed, bracteate, madder-purple, about $2 \mathrm{~cm}$. long; sepals narrowly oval, obtuse; petals shorter, similar. (Arethusa spicata Walt. ?) - Rich woods, Ky., Mo.. and southw. July, Aug. Fig.639.

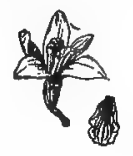

689. H. aphylla $\times 2 / 8$. Filower. Expanded lip. 


\section{PIPERÀcEAe (Pepper FAMiLY)}

Herbs, with joined stems, alternate entire leaves, and perfect flowers in spikes, entirely destitute of florul envelopes, and with:3-5 more or less separate or united ovaries; ovules feu, orthotropous. - The characters are those of the Tribe Saurureae, the Piperaceae proper (wholly tropical) differing in having a 1-celled and 1-ovuled ovary.

\section{SAURỦRUS [Plum.] L. Lizard's TaIL}

Stamens mostly 6 or 7 , hypogynous, with distinct filaments. Fruit somewhat fleshy, wrinkled, of 3-4 indehiscent carpels united at base. Stigmas recurved. Seeds usually solitary, ascending. - Perennial marsh herbs, with heart-shaped converging-ribbed petioled leaves, without distinct stipules; flowers (each with a small bract adnate to or borne on the pedicel) crowded in a slender wand-like and naked-peduncled terminal spike or raceme (its appearance giving rise to the name, from oavoos, a lizard, and ouph, tail).

I. S. cérnuus I. Flowers white, fragrant; spike nodding at the end; bract lanceolate; filaments long and capillary. - Swamps and shallow water, near the coast, R. I. to Fla. ; and from s. Ont. and $O$. to Minn. and southw. June-Aug.

\section{SALICȦCEAE (WILLOW FAMILY)}

Dioecious (or by exception monoecious) trees or shrubs, with both kinds of flowers in catkins, one to each bract (scale), without perianth; the fruit a 1-celled and 2-4-valved pod, with 2-4 parietal or basal placentae, bearing numerous seeds furnished with long silky down. --Stigmas 2, often 2-lobed. Seeds ascending, anatropous, without albumen. Cotyledons flattened. Leaves alternate, undivided, with scale-like and deciduous, or else leaf-like and persistent, stipules. Wood soft and light; bark bitter.

1. Salix. Scales entire or merely toothed. Flowers with small glands at base; disk none. Stamens few. Stigmas short. Buds with a single scale.

2. Populus. Scales lacerate. Flowers with a broad or cup-shaped disk. Stamens namerous. Stigmas elongated. Buds covered by several scales.

\section{SÀlIX [Tourn.] L. WILlow. OsIer}

Sterile fowers of $3-10$, mostly 2 , distinct or united stamens, accompanied by 1 or 2 small glands. Fertile flowers also with a small flat gland at the base of the ovary; stigmas short. - Trees or shrubs, with mostly terete and lithe branches. Leaves mostly long and pointed, entire or glandular-toothed. Buds covered by a single scale, with an inner usually adherent membrane. Catkins appearing before or with the leaves. (The classical Latin name.) Species largely wind-pollinated and very freely hybridizing.

$N$. B. - In this genus, unless otherwise noted, the figures of the leaves are on a scale of $\frac{1}{3}$, while those of the fruit are on a scale of $3 \frac{1}{3}$.

\$1. Aments bome on short lateral leafy branchlets; scales yellowish, falling before the capsules mature; filaments hairy below, all free; style very short or obsolete; stigmas thick, notched.

* Stamens 3-5 or more.

- Leaves with no petiolar glands; sterile aments elongated, slender-cylindrical; flowers somewhat remotely subverticillate; scales crisp-villous on the inside.

$\checkmark$ 1. S. nigra Marsh. (Black W.) Shrub, or, when well developed, a roughbarked tree 5-30 $\mathrm{m}$. high ; leaves narrowly lanceolate, very lang-attenuate from 


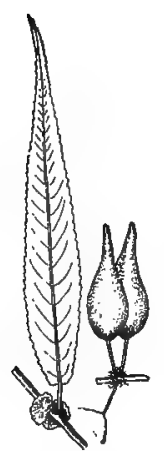

4). s. nigra.

near the roundish or acute base to the tip, often downy when young, at length green and glabrous except the short ( $2-0 \mathrm{~mm}$. long) petiole and midrib, closely seriulate with fine incurved teeth; stipules large, semicordate, pointed and persistent, or small, ovate and deciduous; scales softpubescent outside; fruiting aments $(3-7 \mathrm{~cm}$. long) more or less dense; capsules ovoidconical, gibbous below, glabrous, $3-5 \mathrm{~mm}$. long, the wide-spreading slender pedicels 1-2 inm. long, much exceeding the gland. Banks of streams and lakes, N. B. to Ont., Dak., and southw. Fig. 640. Var. FALcata (Pursh) Torr. Leaves narrower and scythe-shaped. - Commoner northeastw.

2. S. Wardi Bebb. (W W.RD's W.) Similar; small tree; leaves lanceolate or ovatelanceolate, conspicuously glaucous and veined eneath; petioles $2-7 \mathrm{~mm}$. long; stipules large, round-reniform, persistent; ameats long, loosely flowered, 5-11 cm. long; scales glabrous outside except at base; capsules globoseconical, 4.5-6 mm. long, glandular-

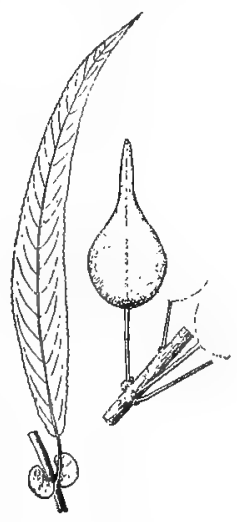

641. S. Wardi. granulose. (S. nigra, var. Bebb; S. longipes Britton, not Shuttlew.) - Rocky and gravelly shores, Md. to Va., Ky., and Mo. Fig. 641 .

3. S. amygdaloides Anders. (Peach-Leaved W.) Leares lanceolate or ovate-lanceolate, attenuate-cuspidate, pale or glaucous beneath; petioles slender, 1-3 cm. long; stipules minute, very early deciduous; fertile aments becrming very loose in fruit, 4-10 cm. long; capsule globose-conical, glabrous, 4-6 mm. long, slender-pediceled. - W. Que. and centr. N. Y. to B. C. and Tex.; common westw. Fig. 642.

+ + Petioles glandular at apex; sterile aments thick, shortcylindrical or ellipsoid-ovoid, densely flowered; leaves

642. S. arnygdaloides. lustrous above, glandular-serrate; branchlets lustrous.

- Leaves green on both surfaces, fruit mature in early summer.

= Capsule conic-subulate; pedicel twice exceeding the gland; mature leaves short-acuminate.

4. S. PEntándra L. (BAy-LEaved W.) Leaves ovate or oblong-ovate, rounded at base, finely and closely glandular-serrate, glabrous from the first, in maturity $3.5-10 \mathrm{~cm}$. long, $2-5 \mathrm{~cm}$. broad; staminate aments $2.5-5 \mathrm{~cm}$. long, $1-1.5 \mathrm{~cm}$. thick, the fertile becoming $2.5-5 \mathrm{~cm}$. long; the mature straw-colored or pale brown slightly lustrous capsule rounded or cordate at base, 5-8 $\mathrm{rm}$. long; shrub or small tree. - Cultivated and rarely escaping, N. E. to $O$. (Introd. from Eu.) FIG. 643.

$==$ Capsule conic-ovoid; pedicel 3 or 4 times exceeding the gland; mature leaves with long-acuminate curved tips.

5. S. lùcida Muhl. (ShIning W.) Leaves ovate-lanceolate or narrower, finely serrate, when young pubescpnt with crisp rufescent or sordid caducous hairs, in maturity coriaceous, shining on both sides, $5-15 \mathrm{~cm}$. long, $2-5 \mathrm{~cm}$. broad; stipules small, oblong or semicircular; staminate aments 2-5 $\mathrm{cm}$. long; fertile becoming $3-5 \mathrm{~cm}$. long; the straw-colored or pale-brown or greenish dull capsules ronnded at base, 4.5-6.5 mm. long; shrub or small tree. - Wet ground and

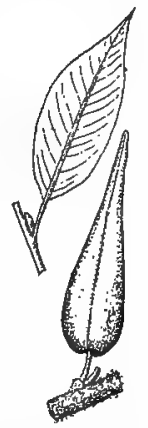

643. S. pentandra 


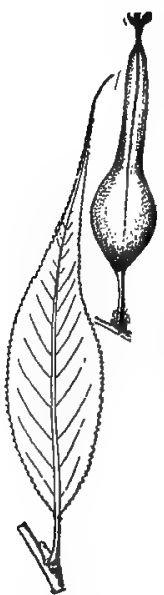

644. B. Iucids.

banks of streams, Nfd. to Man., s. to Pa, Mll, and Neb. Fie. 644. Var. Angustiròlia Anders. Leaves glabrous, elongatelanceolate, $1-1.5 \mathrm{~cm}$. broad. - Nfd. and e. Can.

Var. intónsa Fernald. Branchlets of the first year and under surfaces of the elliptic-lanceolate attenuate-based leaves permanently pubescent with sordid or rufous hairs. - Que., N. B. and $\mathrm{n}$. and w. N. E.

\section{++ Leaves pale or white beneath; fruit mature in autumn.}

6. S. seríssima (Bailey) Fernald. (AUTUMN W.) Leaves elliptic-lanceolate or oblong-lanceolate, short-acuminate, in maturity coriaceous, 4-8 cm. long, 1-3 cm. broad, closely serrulate; staminate aments 1-1.5 cm. long, $1-1.2 \mathrm{~cm}$. thick; the fertile becoming loosely flowered, $2-3.5 \mathrm{~cm}$. long; the olive- or browntinged finally lustrous indurated capsule conicsubulate, 7-10 $\mathrm{mm}$. long, the pedicel twice exceeding the gland; tall shrub. - Mossy swamps, mostly in calcareous regions, e. Qne. to Alb., s. to w. Ct., n. N. J., W. N. Y., and the Great Lakes. Fig. 645.

$$
\text { ** Stamens } 2 .
$$

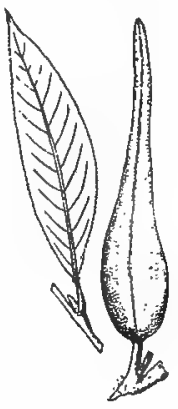

645. 8. serissima.

- Leaves lanceolate or ovate-lanceolate, long-acuminate, closely serrate.

7. S. FRAGILIs L. (CracK W.) Leaves glabrous from the first, green both sides, or only slightly paler beneath, in maturity $1-1.5 \mathrm{dm}$. long, $2.5-4 \mathrm{~cm}$. broad,

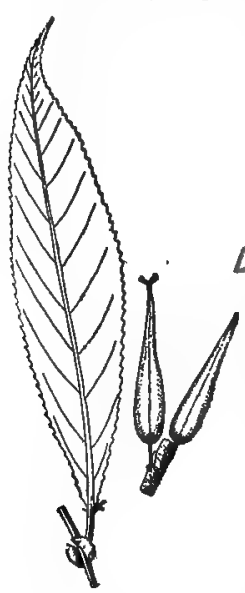

646. S. fragills. rather coarsely undulate-serrate, with about 5 (4-7) teeth to each $\mathrm{cm}$. of the margin; stipules when present halfcordate; aments slender; the staminate 3-5 $\mathrm{cm}$. long; the fertile becoming 5-7 $\mathrm{cm}$. long ; capsule subulate-conical, $5 \mathrm{~mm}$. long, short-pediceled. - A large tree, early planted, and now established, Que. to Ky. - Freely hybridizing with S. alba. (Nat. from Eu.) Fig. 646.

L 8. S. AlaA L. (White W.) Leaves pale with sillky pubescence on both sides, in maturity $5-12 \mathrm{~cm}$. Iong, $1-3 \mathrm{~cm}$. broad, finely serrulate, with about 9 (6-12) teeth to each $\mathrm{cm}$. of margin; stipules ovatelanceolate, deciduous ; capsule ovoid-conical, 3-5 mm. long, sessile or nearly so. The typical tree, with grcenish branch-

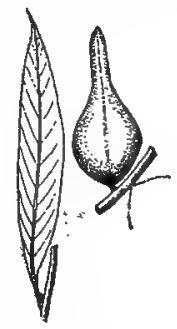

647. S. albe. lets and, leaves permanently silky, is sometimes planted and rarely established in Am. Fig. 647. Var. viTELLINA (L.) Koch, with yellow or reddish branchlets and the old leaves glabrous, white beneath, is a familiar large tree of rapid growth, commonly planted and freely spreading. Var. CAERULEA (Sm.) Koch is similar, but with olive-green branchlets and bluish-green leaves. - Hybridizes with S. fragilis, S. lucida, etc. (Nat. from Eu.)

9. S. BabYlónica L. (WEeping W.) Leaves at first silky, quickly glabrate, pale beneath, in maturity $6-12 \mathrm{~cm}$. long, $0.5-1.5 \mathrm{~cm}$. broad, very slender-atteuuate, sharply toothed; aments $1 . \bar{b}-2 \mathrm{~cm}$. long; the sessile plump capsules 1-1.5 mm. long. - Planted for ornament, and locally spread along river-banks and lake-shores, particularly from Ct. westw. and southw. (Nat, from Eu.) FiG. 648.

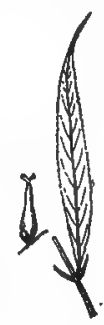

648, 8, baby. loniea. 
- Leaves linear-or oblong-lanceolate, short-acuminate, remotely denticulato with projecting teeth.

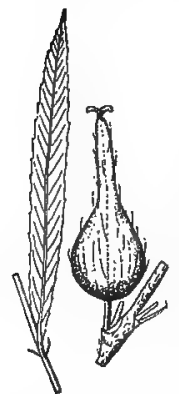

649. S. longifolia.

10. S. longifdlia Muhl. (SANd BAR W.) Leaves $3-15 \mathrm{~cm}$. long, 4-15 $\mathrm{mm}$. broad, tapering at each end, nearly sessite, wore or less silky when young, at length smooth and green both sides, with 2-3 teeth to each cm. of margin; stipules small, lanceolate, deciduous; aments slender-cylindric, often clustered at the ends or the branchlets ; capsule short-pediceled, blunt; stigmas large, sessile. (S. fluviatilis auth., not Nutt.; S. interior Rowlee.) - A shrub or small tree, spreading extensively in alluvial deposits and forming dense clumps, e. Que. to Man., s. to Del. and La.; common and characteristic inland. Fig. 649.

\$2. Aments lateral or terminal, with or without bracts; scales persistent, colored at the tip; stamens 2 (usually 1 in no. 17).

- Filaments glabrous and distinct.

- Capsules glabrous.

- Erect or ascending shrubs or small trees.

$=$ Leaves lanceolate to ovate, acute or acuminate, serrate; sterile aments very silky, with a few bracts at base, becoming $2-4 \mathrm{~cm}$. long, the fertile in fruit 2.5-10 cri. long.

\section{a. Leaves glabrous or quickly glabrate; capsules distinetly pediceled.}

\section{Stipules persistent, usually conspicuous.}

- Leaves dull above, the young pubescent with early-deciduous soft hairs.

+ Fruiting aments 2.5-6 cm. long; mature capsule 4-7 mm. long.

11. S. cordàta Muhl. Twigs glabrous or soon glabrate; leaves oblong-lanceolate or narrower, on the flowering branches often tapering at base, sharply serrulate, green both sides or slightly paler beneath, on vigorous shoots mostly rounded, truncate, or cordate at base, not turning black in drying; stipules reniform or ovate, serrate, usually large;

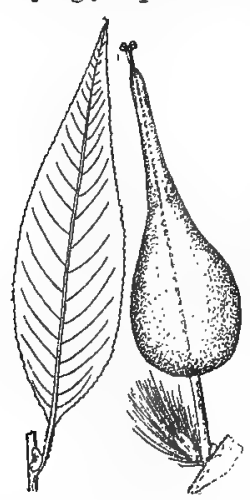

651. S. missouriensis. aments rather slender; capsules greenish or rufescent. - In wet places, along streams, etc.; a "widely distributed shrub, freely hybridizing. Fig. 650. Var, My ricoÌdes (Muhl.) Carey. Twigs cinereous or canescent with permanent pubescence; leaves elongate, even those of the most vigorous shoots tapering and rather acute at base, glaucous or glaucescent beneath and sparsely appressed-hairy; stipules snıall, ovate, pointed; capsules often silky when young, becoming glabrate, short-pediceled; twigs brittle at base. - Mass.

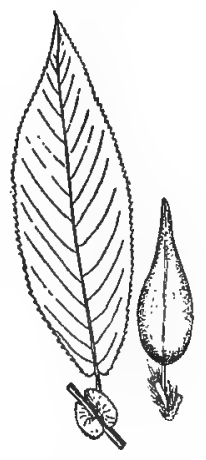

650. S. cordata. to Wisc. and Kan. - Perhaps a hybrid with S. sericea.

++ Fruiting aments 6-10 cm. long; mature capsules 8-10 mm. long.

12. S. missouriensis Bebb. Tree or large shrub (3-10 m. high), with black bark and permanently pubescent twigs; leaves lanceolate to ovate-oblong, rarely obovate, glaucous beneath. Mo. to Neb. and I. T. - A poorly understood tree, said to flower earlier than S. cordata; perhaps a variety (var. vestita Anders.) of that species. Fig. 651.

\section{O O Leaves glossy above, glabrous from the first.}

13. S. glaucophýlla Bebb. Leaves from ovate or obovate to oblong-lanceo- 
vate, with a broadly rounded base, $4.5-12 \mathrm{~cm}$. long, $2-4.5 \mathrm{~cm}$. wide, short-acuminate, glandular-serrate, subcoriaceous, glabrous throughout, dark green and

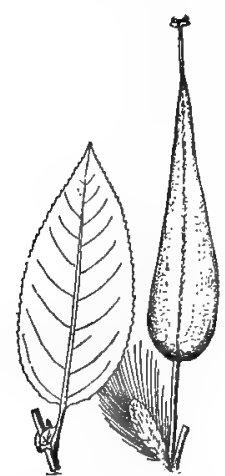

652. S. glaucophylia. shining above, glaucous beneath, the young drying black; stipules large, ear-shaped, dentate; aments dense, thickcylindrical, very silky, the staminate $3.5-5 \mathrm{~cm}$. long, the pistillate becoming 4-7 cm. long ; capsules attenuate-rostrate, 9-11 mm. long, greenish, drying brow1, - Shrub or shrubby tree (1-5 m. high), forming extensive thickets on sandy or alluvial shores of rivers and lakes, e. Que. to Alb., s. to N. B., Me., and the Great Lakes. FIG. 652 . Var. ANgustifólia Bebb. Leaves narrower ( $8 \mathrm{~cm}$. long, $2 \mathrm{~cm}$. wide), pointed at both ends. - Same range. Var. Brevifólia Bebb. Leaves obovate or oblong, $2.5-3.5 \mathrm{~cm}$. long, strongly veimed. - Mich.

\section{Stipules obsolete or minute.}

14. S. balsamifera Barratt. Leaves short-oval to oblong-lanceolate, broadly rounded and usually subcordate at base, at first very thin, subpellucid and of a reddish color, balsamic-fragrant, at length firm but thin, dark green above, paler or glaucous and prominently reticulate-veined beneath, slightly glandular-ser-

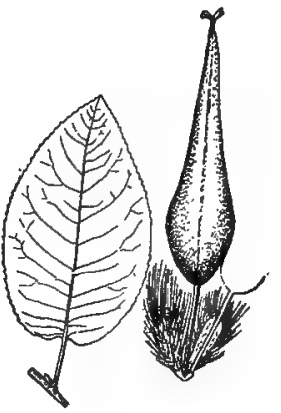

653. S. balsanaifera. rulate; petioles long and slender; fertile aments becoming very lax in fruit, the long slender pedicels $6-8$ times the length of the gland; style short. - Iow woods and thickets, Nfd. and Iab. to Mackenzie and B. C., s, to n. N. E., N. Y., Mich., and Minn. - A much-branched shrub, rarely a tree $7 \mathrm{~m}$. high, with shining reddish-castaneous or olive twigs. Fig. 653.

\section{b. Leaves clothed, even when fully grown, with a long silky tomentum on both} sides, which is finally deciduous; capsule subsessile.

15. S. syrtícola Fernald. Leaves ovate or very broadly lanceolate, cuspidate-acuminate, dull green both sides, very closely serrate with fine projecting gland-tipped teeth; stipules conspicuous, ovate-cordate, glandular-serrate, exceeding the short stout petioles, which are dilated at base and embrace the

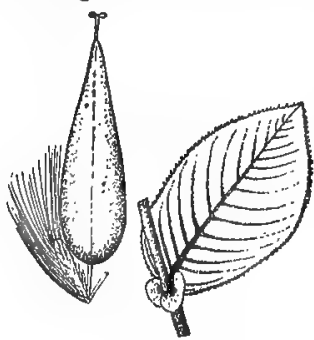

654. S. syrttcola. obtuse silky buds; aments leafy-peduncled, the fertile not rarely becoming $1 \mathrm{dm}$. long, densely flowered. (S. adenophylla Am. auth., not Hook.) - Shores of the Great Lakes. - A large straggling shrub, with stout tomentose twigs and crowded leaves. Fig.654. $==$ Leaves oblong-linear to ellipticobovate, entire; sterile aments sparingly pubescent or glabrate, 1-2 $\mathrm{cm}$. long, the fertile in fruit $1-3 \mathrm{~cm}$. long; stigmas sessile or nearly so.

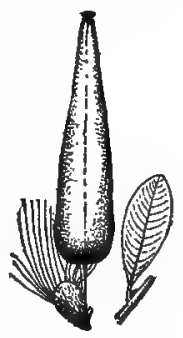

16. S. pedicellàris Pursh. Ieaves 655. S. pedicellut is. $1.5-7 \mathrm{~cm}$. long, obtuse or somewhat pointed, acutish at base, smooth on both sides, somewhat coriaceous when mature, revolute, reticulated, pale or glaucous beneath; fertile aments thick-cylindric, loosely few-flowered, borne on long leafy peduncles; capsules reddish-green; pedicels slender, twice the length of the nearly smonth greenish-yellow scale. ( $S$. myrtilloides Man. ed. 6, nnt L.) - Cold bogs and wet meadows, e. Que. to B. C., N. J., L'a., and n. Ia. Fia. 655. 


\section{- Prostrate or creeping and matted alpine shrubs.}

17. S. Ùva-úrsi Pursh. 'Leaves elliptical and pointed, or obovate and obtuse, 0.5-2.5 $\mathrm{cm}$. long, tapering at base, slightly toothed, strongly veined, smooth and

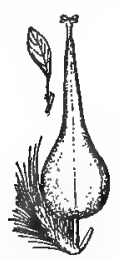

656. S. Uva-ursi. shining above, pale and rather glaucous beneath; aments borne on slender lateral leafy peduncles, thick-cylindric, the fertile lengthening. to 2 or $3 \mathrm{~cm}$. and becoming narrowly cylindric, densely flowered above, of ten loose below ; scales obovate, rosered at the tip, covered with long silky hairs; stamen 1 (rarely 2); capsule ovoid-conical, brownish at maturity; pedicel scarcely exceeding the gland; style distinct. - Lab. to Alaska, s. to alpine summits of n. N. E. and $\mathrm{N} . \mathrm{Y}$. - Closely prostrate, spreading from a stout central root over an area 3-9 din. broad. Fig. 656 .

18. S. herbàcea L. Leaves roundish oval, heart-shaped, obtuse or retuse, $1-3 \mathrm{~cm}$. long, serrate, smooth and shining, reticulately veined; aments terminating 2 -leaved branchlets, small, ovoid, 4-10-flowered; scales concave, obovate, obtuse, glabrous or slightly pubescent; capsule subsessile. - Arctic Am., s, to alpine regions of Mt. Katahdin, Me, and Mt. Washington, N. H. - A very small herb-like species, the half-underground stems creeping and rooting in moss or humus, the branches seldom rising $0.5 \mathrm{dm}$. from the ground.

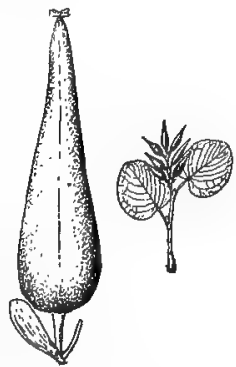

657. S. herbacea.

(Eu.) Fig. 657 . +- + Capsule pubescent.

- Fruiting pedicel 3-6 times the length of the gland; style short or none (elon. gate in no. 25).

= Mature leaves glabrous or glabrate beneath, or at most with a few scattered hairs. (Extreme furms of $\mathrm{S}$, rostrata may be looked for here.)

a. Aments sessile on the old wood, naked at base, appearing before the leaves; scales dark red, brown, or blackish; mature capsule 7-12 mm. long.

19. S. discolor Muhl. (GLa dcous W.) Leaves lanceolate to elliptic, smooth and bright green above, soon smooth and glaucous beneath, irregularly crenate-

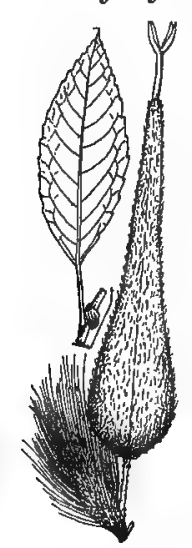

658. S. discolor. sel'rate, the serratures reunote at base, closer, finer and becoming obsolete toward the point; stipules $1 \mathrm{~cm}$. or more long and sharply toothed, or small and nearly entire; aments thick, cylindrical, 2.5-7 cm. long, appearing in earliest spring; scales copiously clothed with long glossy hairs; style short but distinct. Fig. 658. Var. Eriocéphal (Michx.) Anders. Aments more densely flowered and more silvery-silky; leaves sometimes retaining a ferruginous pubescence beneath even when fully grown. (S. eriocephala Michx.) Var. PRinoldes (Pursh) Anders. Aments more loosely flowered, less silky; capsules more thinly tomentose; style longer; stigma-lobes Jaciniate; leaves narrower. ( $S$. prinoides Pursh.) Includes narrow-leaved forms of the type, and others which are probably hybrids with $\$$. cordata. - Large shrub or small tree of low meadows and river-banks, common. - The just, expanding leaves are often overspread with evanescent ferruginous hairs.

b. Aments short-stalked, leafy-bracted at base, appearing with the leaves; scales pale brown or yellowish; mature capsule 4-6 $\mathrm{mm}$. long.

20. S. petiolàris $\mathrm{Sm}$. Leaves narrowly lanceolate, taperpointed, finely and eveniy serrate, slightly silky when young. soon smooth; stipules linear or semicordate, deciduous : fertile

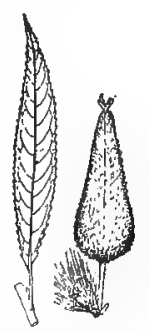

658. 9. petloiarie 
aments ovoid-cylindric, at first 1-2 cm. long, in fruit broad and loose from the lengthening of the pedicels, becoming $2-4 \mathrm{~cm}$. long; capsule rostrate from an ovoid base, blunt. - Low shrub of damp soil, N. B. to the Great Lake region and Man., s. to Tenn. Fig, 659.

\section{$==$ Mature leaves pubescent at least beneath.}

a. Aments sessile on the old wood, naled at base, appearing before the leaves.

1. Leaves dull, grayish-tomentose, undulate-crenate or subentire; capsules slender-beaked.

21. S. hùmilis Marsh. (PraIRIE W.) Leaves oblanceolate or oblong-lancenlate, rarely obovate, $5-15 \mathrm{~cm}$. long, above downy becoming glabrate, beneath

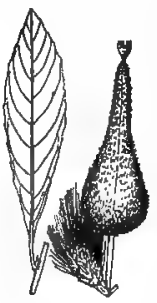
glaucous, rugose-veined and softly tomentose, the margin revolute, undulate-entire; stipules mediun-sized, semi-ovate, entire or oftener toothed; petioles distinct; aments ovoid or ellipsoid, often recurved, $1.5-4 \mathrm{~cm}$. long. - Dry plains and barrens, Nfd. to Minn. and N. C. - A shrub, 1-3 m. high, varying much in the size and shape of the leaves. FIG. 660 .

Var. rigidiúscula Anders. Leaves narrowly oblanceolate to lance-ublong, 0.5-1 dm. long, rigid, strongly ascending, very rugose and glabrescent beneath. - O. to Ga. and Kan. - Shrub or small tree.

660. S. humilis. 22. S. trístis Ait. (Dwarf Gray W.) Leaves similar to those of the last, small (1-5 cm. lonr),

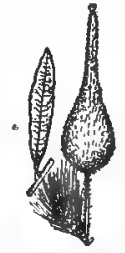
rowded, linear-oblanceolate, tapering to a very short petiole; 661 . s. tristis. stipules minute, deciduous; aments very small, globular or ovoid, $1-1.5 \mathrm{~cm}$. long in fruit. - Sandy plains or on the borders of hillside thickets, N. E. to Minn. and southw., mostly near the coast. - A tufted shrub, $0.5 \mathrm{~m}$. high. Fig. 661 .

2. Leaves lustrous beneath with minute silky pubescence, fine-serrate; capsules blunt.

23. S. sericea Marsh. (Silk W.) Leaves narrowly lanceolate, 0.4-1 dm. long, 1-2.5 cm. broad, finely serrate, at first (principally beneath) very silky,

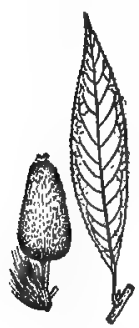

662. S. serlcen, turning black in drying; stipules narrow, deciduous; aments narrowly cylindrical, the fertile densely flowered, in maturity $2-3 \mathrm{~cm}$. long; capsule sericeous, ovoid-oblong, round-tipped, its pedices about equaling the short-bairy scale and twice exceeding the gland, - Large shrub of wet places, N. B. to N. C. and Mich. Fig. 662.

\section{b. Aments leafy-bracted at base, appearing with the leaves.}

1. Leaves strongly rugose in age, grayish-pubescent or glabrate benealh; capsile gray-pubescent, its pedicel several times exceeding the subtending scale.

24. S. rostràta Richards. Leaves obovate to elliptic-lancenlate, $3-10 \mathrm{~cm}$. long, acute or acuminate, dull green and minutely downy above, serrate, crenate, or subentire, thin, becoming rigid; stipules when present semi-cordate, toothed, acule; sterile aments narrowed at base, the fertile loosely flowered, 2-6 cm. long ; capsuies tapering to a very long slender beak; pedicels thread-like, much exceeding the pale rose-tipped linear thinly villous scales; style soarcely any ; stigma lobes entire or deeply parted. (S. Bebbiana Sarg.) - Shrub or small tree of moist or dry ground, Nfd. to Alaska, s. to N. J., Pa., IJl., Ia., etc, Fı, 663 .

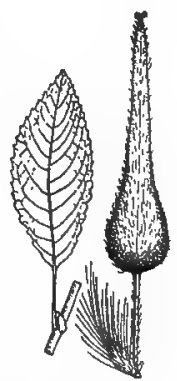

668. S. rostint? 
2. Leaves scarcely rugose, lustrous-white beneath; capsule white-pubescent, its pedicel scarcely exceeding the subtending scive.

25. S. argyrocárpa Anders. Leaves 2.5-5 cm. long, repand-crenate, Japering evenly to both ends, acute, or the earliest obovate and obtuse, at length rigid, the

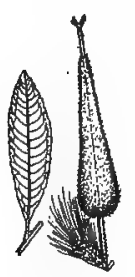

664. S. margin slightly revolute; petiole short; stipules minute, fugaceous; fruiting ament short (1.5-2.5 cm. long), lax; capsule tapering, densely silky-silvery, style elongate; gland of the staminate flower variously doubled. - Moist ravines and alpine slopes, Lab. to the highest mts. of Que., Me, and N. H. - A bushy-branched shrub, erect or depressed at base, rarely $0.5 \mathrm{~m}$. high. FrG. 664. Hyluridizes with $S$, phylicifolia.

26. S. coáctilis Fernald. Leaves oblong or lance-ovate, longacuminate, at first reddish-white beneath with lustrous felt-like pubescence, later velvety with distinct hairs, in maturity 6-18 cm. long, 2-5 $\mathrm{cm}$. broad, remotely and coarsely glandular-dentate; stipules argyrocarpa. semi-ovate, gland-toothed, 4-5 inm. long, persistent; aments in anthesis $2-3.5 \mathrm{~cm}$. long, in fruit 4-5.5 cm. long, $7 \mathrm{~mm}$. thick; scales oblong or obovate, dark brown or black, very long-hairy ; capsule conic-subulate, $5 \mathrm{~mm}$. long, white-villous; the pedicel about five times as long as the gland. Banks of the I'enobscot R., Me. - A large shrub with coarse dark brawchlets, the younger ones puberulent.

+* Fruiting pedicel at most twice the length of the gland. $=$ Leaves distinctly pubescent beneath.

\section{a. Pubescence of the leaves and branchlets a dull white floccu-} lent tomentum.

27. S. cánđida Flügge. (SAGE W., HoAnY W.) Leaves oblong to linear-lanceolate, 4-12 cm. long, rather rigid, downy above, becoming glabrate, beneath covered with a dense white tomentum, the revolute margin subentire; stipules lanceolate, about as long as the petioles; aments cylindrical, densely flowered, $8-5 \mathrm{~cm}$. long in fruit; anthers red; the dark gland elongated; capsule densely white-woolly; style dark red ; stigmas short, spreading, notched. - Cold bogs, Nfd. and Lab. to Athabasca, s. to N. J., Pa., O., Ia., etc. - A hoary shmb, 0.5-2 m. high ; young shoots white-woolly, the older red. Fig. 665. Var. denudAta Anders.

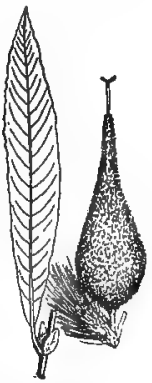

665. S. candida. Leaves dark green and glabrate above, sparingly pubescent or glabrate beneath. - Gaspe Co., Que. to Wisc. and Ct.

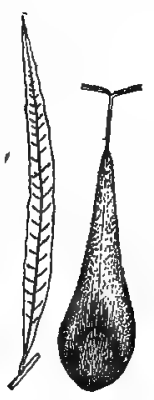

666. S. vim!nalis.

\section{b. Pubescence of the leaves lustrous.}

\section{Leaves pubescent beneath with minute satiny hairs.}

28. S. viminAlis $L$. (Osier.) Large shrub or small tree; branchlets greenish or pale brown; leaves lanceolate or linear-lanceolate, taper-pointed, green and glabrous above, 6-15 cm. long; aments sessile or subsessile on the old wood, the pistillate becoming 5-7 cm. long; capsule subsessile, minutely puberulent, 6-8 mm. long. - Cultivated and occasionally established. (Introd. from Lu.) FiG. 666.

2. Leaves, at least when young, lustrous beneath with velvety pubescence.

29. S. pellita Anders. Large shrub or small tree with dark reddish or olive branchlets; leaves lancelinear to oblanceolate, subentire, green and glabrous above, white-velvety to pale green and glabrate beneath, 4-12 cm. long; aments leafy-bracted at base, the fertile $2-5 \mathrm{~cm}$. long; capsule 4-5 $\mathrm{mm}$. long, densely white-hairy; style yellowish, turning brown. - River banks a:rl swamps, Gulf of St. Lawrence to Lake St, John, Que, and Lake W Wunipeg, s, to Me, and Vt, FıG, 667,

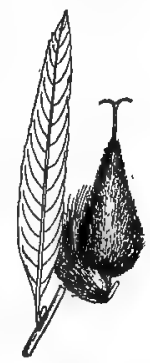

667. S, pellita 
$==$ Leaves glabrous, or the youngest occasionally with arachnoid hairs.

30. S. phylicifolia L. Leaves elliptic-lanceolate to oblong, somewhat equally

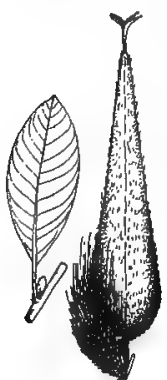

668. B. phylictfolía. Leaf $\times 1 / 3$ Fruit $\times 6$ pointed or obtuse at both ends, remotely and minutely repandtoothed, $2.5-7 \mathrm{~cm}$. long, very smooth on both sides, dark green and shining above, glaucous beneath, at length coriaceous; stipules obsolete; aments sessile with a few small bracts at base, $1.5-3 \mathrm{~cm}$. long, rather densely flowered, short-cylindric, the fertile becoming in fruit somewhat stalked, $3.5-4.5 \mathrm{~cm}$. long; scales dark, silky-villous; capsule conic-rostrate from an ovoid base; stignas bifid or entire, yellow, drying black. (S'. chlorophylla Anders.) - Lab. to Alaska, s. to alpine districts of Que., Me., N. H., and Vt. - A divaricately much branched shrub $0.5-3 \mathrm{~m}$. high ; twigs glabrous, purplish, sometimes covered with a glaucous bloom. (Eu.) Fr. 668.

\section{* Hairy filaments and often the reddish anthers united so as to appear as one.}

31. S. PURPÙReA L. (PurPle W.) Leaves oblanceolate or tongue-shaped, slightly serrulate, very smooth, glaucescent, subopposite; stipules obsolete; aments densely flowered, narrow-cylindrical, the sterile at least closely sessile, with only very small bracts at base; scales small, round, crisp-villous, tipped with dark purple; capsules grayish-tomentose, ovoid-conical, obtuse, sessile, $2-3 \mathrm{~mm}$. long.Low grounds; originally cultivated for basket rods; now established. (Nat. from Eu.) Fig. 669.

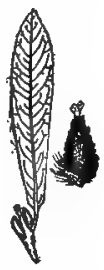

669. $\rightarrow$. purpurea.

\section{PÓPUlus [Tourn.] L. Poplar. Aspen}

Flowers from a cup-shaped disk which is obliquely lengthened in front. Stamens 8-30, or more ; filaments distinct. Stigmas 2-4. Capsules 2-4-valved. Trees, with broad and more or less heart-shaped or ovate toothed leaves, and often angular branches. Buds scaly, covered with resinous varnisb. Catkins long and drooping, appearing before the leaves. (The classical Latin name, of uncertain origin.)

§ 1. Styles 2, with 2-3 narrow or filiform lobes; capsules thin, slender-conical, 2-valved, small, on very short pedicels; scales silky; stamens 6-20; leaves ovate, on laterally flattened petioles; terminal buds small, slightly glutinous.

1. P. Alba L. (White P., Silver-leaved P., Abele.) The younger branches and the under surface of the rhombic-oval sinuate-toothed acute leaves white tomentose; scales crenate, fringed. - Frequently cultivated for shade, spreading widely by the root, and occasionally spontaneous. (Introd. from Eu.)

2. P. tremuloides Michx. (American A.) Tree 6-20 m. high, with smooth greenish-white bark; bud-scales glabrous or merely ciliate; leaves roundishheart-shaped, with a short sharp point, and small somerohat regular teeth, smooth on both silles, with serrulate unargins, downy when young, on long slender petioles; scales cut into 3-4 deep lenear divisions, fringed with long hairs. - Light soils, Lab. to Alaslra, s. to Pa., Mo., etc.

3. P. grandidentata Michx. (LARGE-Toothed A.) Tree often $20 \mathrm{~m}$. high, with swoothish gray bark; bud-scales tomentose; leaves roundish-ovate, with large and irregular sinuate teeth, when young densely covered with white silky wool, at length sinooth both sides; scales cut into 5-6 unequal small divisions, slightly fringed. - Rich woods and borders of streams, N. S. to the mts. of N.C., w. to Ont., Minn., and Ia.

\$2. Styles 2-4, with dilated lobes; capsules large, often thick, subglobose to ellipsoid, 2-4-valved; scales mostly glabrous; terminal buds large and very glutinous. 


\section{* Petioles terete or channeled, but little if at all laterally flattened.}

- Young leaves and petioles white-tomentose; capsule slender-pediceled.

4. P. heterophylla L. (Downy P.) Tree 10-25 m. high; leaves ovate, with a somewhat truncate or cordate base, obtuse, crenate, at length nearly smooth, except on the elevated veins beneath; fertule catkins few-flowered; stamens 12-60; capsules $1-1.3 \mathrm{~cm}$. lung, equaling the pedicels. - Borders of river swamps, Ct. to Ga. ; also from O. to Ark. and La.

\section{+ + Young leaves and petioles not white-tomentose; capsule stout-pediceled.}

5. P. balsamífera L. (Balsam P., Tacamahac.) Tree 6-30 m. high, the large buds varnished with a copious fragrant resin; leaves ovate-lancevlate to cordate-ovate, gradually tapering and pointed, finely crenate, smooth on both sides, silvery and reticulately veined beneath; scales dilated, slightly hairy; stamens 20-30 ; capsule ovoid, 2-valved. - Borders of rivers and swamps, Lab. to Alaska, s. to n. and w. N. E., Mich., Minn., etc.

6. P. cándicans Ait. (Balm of Gillead.) Leaves broader and more or less heart-shaped, petiole and lower surface hairy. ( $P$. balsamifera, var. Gray.) - Common in cultivation and freely escaping; perhaps of Asiatic origin. (Introd.)

$$
\text { ** Petioles laterally flattened. }
$$

V 7. P. deltoìdes Marsh. (CotTon-wood, Neck tace P.). Tree 15-30 m. high; leaves broadly deltoid, with numerous crenate serratures and narrow very acute acumination, sometimes ovate, rarely cordate, on elongated petioles ; scales lacerate-fringed, not hairy ; strmens 60 or more; capsules on slender pedicels, 6-10 $\mathrm{mm}$. long, in long catkins, ellipsoid-ovoid, 3-4-valved. ( $P$. monzlifera Ait.) - Borders of streans, w. Que. and N. H. to Fla., w. to the Rocky Mts.

P. Nìgra L., the Black P. of Fun., a pyramidal tree somewhat resembling the preceding but with the less lustrous rhombic-deltoid smaller leaves broader than long, more finely crenate, and its var. ITÁlica Du Roi, the LombardY P., with strictly ascending branches, are spreading from cultivation. (Introd. from Eu.)

\section{MYRICACEAe (Sweet Gale Family)}

Monoecious or dioecious shrubs, with each kind of flowers in short scaly catkins, and resinous-dotted often fragrant leaves, - differing from the Birches chiefly in the 1-celled ovary with a single ereet orthotropus ovule, and the drupelike nut. Involucre and perianth none.

\section{MYRICA L.}

The only genus. - Flowers solitary under a scale-like bract and with a pair of bractlets, the sterle in ellipsoid or cylindrical, the fertile in ovoid or globular catkins, from axillary scaly buds; stamens $2-8$; filaments somewhat united below ; anthers 2-celled. Fruit small, globular or short-cylindric, dry, coated with resinous grains or wax. (Mvplk $\eta$, the ancient name of the Tamarisk or sume other shrub; perhaps from $\mu \nu \rho(\zeta \in t \nu$, to perfume.)

* Mostly dioecious; fertile catkins ovoid; ovary with 2-4 scales at base; nut globular; leaves entive or somewhat serrate.

1. M. Gale L. (SweEt GaLE.) Shrub 1-1.5 m. high ; leaves wedge-lanceolate, serrate toward the apex, pale, later than the flowers; sterile catcins closely clustered; nuts imbricated in heads, 2-winged by the two thick ovate scales which coalesce with its base. - Borders of ponds, and in swamps, Lab. to N. E., along the Great Lakes to Minn., and northwestw.; s. in the mts. to Va. April, May. (Eurasia.)

$\checkmark 2$. M. cerifera L. (WAX MYrTle.) Leaves ( $1-1.6 \mathrm{~cm}$. broad) lanceolate, narrowed at the base, entire or sharply toothed toward the acute apex, shining and resinous-dotted both sides, somewhat preceding the flowers, fragrant; sterile 
catlins scattered, oblong; scales wedge-shaped at the base; nuts scattered and naked, bony, 2.5-3 mm. in diameter, and incrusted with white wax. - Sandy soil, Md., to Fla., Tex., and Ark. March, Apr.

3. M. carolinénsis Mill. (BAYBERRY.) Shrub 1-2 m. high; leaves oblong, entire or somewlat crenately toothed, thinner and more flaccid than in the preceding, mostly obtuse, $1.5-4 \mathrm{~cm}$. broad, green and resinous-dotted on both sides ; fruit 3.5-4 mm. in diameter. (M. cerifera Man. ed. 6, in great part.) - Sandy or sterile soil, chiefly near the coast, P. E. I. and N.B. to Fla. and La.; also on L. Erie.

* * Frequently monoecious ; fertile catkins globular; ovary surrounded by 8 long narrowly awl-shaped persistent scales; nut ovoid-subcylindric; leaves pinnatifid with many rounded lobes.

4. M. asplenifdia I. (Sweet Fern.) Shrub 3-6 dm. high, with sweetscented fern-like linear-lanceolate leaves; stipules balf heart-shaped; scales of the sterile catkins kidney-heart-shaped, pointed. (Comptonia Ait. ; $C$. peregrina Coult.) - Sterile soil, N. B. and N. S. to N. C., Ind., and the Saskatchewan. Apr., May.

\section{LEITNERIÀCEAE (CORK WOOD FAMILY)}

Dioecious shrubs or snall trees, with each kind of flowers in catkins opening before the leaves; the sterile catkins many-the fertile few-flowered; calyx and corolla none; stamens 3-12, whorled, the filaments shont, distinct, hypogynous; ovary 1-cclled with solitary ascending amphitropous ovule and thickish terminal style with lateral groove. Leaves simple, entire, alternate; stipules obsolete or none. Flowers solitary in the axils of ovate pubescent scales, sessile. Frait an obovoid somewhat compressed leathery drupe.

\section{LEITNËRA Chapm.}

Characters of the family. (Named in menory of Dr. E. T. Leitner, a German naturalist who traveled and was killed in Florida.)

1. I. floridàna Chapm. (CoRK Wood.) Stout arborescent shrub $1-7 \mathrm{~m}$. high; leaves oblong or obovate, somewhat canescent-tomentose on the lower surface; sterile catkins about $3 \mathrm{~cm}$. long, the fertile half as long; drupe 1-2 cm. long. - Swamps, s. Mo. and southwestw. ; also Fla. March.

\section{JUGlandaceae (Walnt Famitu)}

Trees. with alternate pinnate leaves, and no stipules; flowers monoecious, the sterile in catkins (aments) with an irreguiar calyx adnate to the bract; the fertile solitary or in a small cluster or spike, with a regular 3-5-lobed calyx adherent to the incompletely 2-4-celled but only 1-ovuled ovary. Fruit a kind of dry drupe. with a crustaceous or bony nutshell, containing a large 4-lobed orthotropous seed. Albumen none. Cotyledons fleshy and oily, sinuous or corru'. gated. 2-lobed ; radicle short, superior. Petals sometimes present in the fertile flowers. - A small family of important trees, consisting chiefly of the two following genera.

\section{JÙGLANS L. WaLNUT}

Stamens 12-40; filaments free, very short. Fertile flowers solitary or several together on a peduncle at the end of the branch, with a 4-toothed calyx, bearing 4 small petals at the sinuses. Styles 2, very short; stigmas 2, somewhat clubshaped and fringed. Fruit with a fibrous-fleshy indehiscent epicarp, and a mostly rough irregularly furrowed endocarp or autshell. - lrees, with odd- 
pinnate leaves of many serrate leaflets. Pith in plates. (Name contracted from Jovis glans, the nut of Jupiter.)

1. J. cinèrea L. (Butrernut, White W.) Leaflets 7-17, oblong-lanceoaate, pointed, rounded at base, downy especially beneath, the petioles and branchlets downy with clammy hair's; fruit ellipsoid, clammy, pointed, the nut deeply sculptured and rough with ragged ridges, 2-celled at the base. - Rich woods, N. B. to the mts. of Ga., w. to Unt., "Dak.," e. Kan. and Ark. - Trunk 16-30 m. high, with gray bark, widely spreading branches, and lighter brown wood than in the next.

2. J. nigra L. (BLACK W.) Leaflets 11-17 (-“23"), ovate-lanceolate, taperpointed, somewhat heart-shaped or unequal at base, smooth above, the lower surface and the petioles minutely downy; fruit spherical, roughly dotted, the nut corrugated, 4-celled at top and bottom. - Rich wouds, w. Mass. to Fla., w. to Ont., Minn., and Tex. - A large and handsome tree, with rough dark bark and valuable purplish-brown wood.

\section{CÀRYA Nutt. HICKORY}

Stamens 3-10 ; filaments short or none, free. Fertile flowers 2-5 in a cluster or short spike, on a peduncle terminating the shoot of the season; calyx 4-toothed; petals none. Stigmas sessile, 2 or 4, large, papillose, persistent. Fruit with a 4-valved firm and at length dry exocarp (involucre), falling away from the swooth and crustaceous or bony cndocarp or nutshell, which is incompletely 2-celled, and at the base mosily 4-celled. - Fine timber-trees with hard and very tough wood, and scaly buds, from which in spring are put forth usually both kinds of flowers, the sterile below and the fertile above the leaves. Nuts ripen and fall in October. (Kapúa, an ancient name of the Walnut.) ScoriA Raf. (1808); Hicorius Raf. (1817); Hicoris Raf. (1836).

\$1. Sterile catkins fascicled (no common peduncle or sometimes a very short one) from separate lateral scaly buds nerr the summit of shoots of the preceding year; bud-scales few ; fruit elongated; the thin-shelled nut 2-celled below; seeds sweet; leaflets short-stalked, numerous.

1. C. illinoénsis (Wang.) K. Koch. (PeCAN.) Minutely downy, becoming nearly smooth; leaflets $9-17$, oblong-lanceolate, tapering gradually to a slender point, falcate, serrate; nut olive-shaped. (C. olivaeformis Nutt.; Hicoria Pecan Britton.) - River bottoms, s. Ind. to Ia., e. Kan., Tex., and Ala. A large tree (25-50.m. high), with delicious nuts.

\$2. Sterile catkins in threes (rarely more) on a common peduncle from the axil of an inner scale of the common bud, therefore at the base of the shoot of the season, wohich, then bearing 3 or 4 leaves, is terminated by the fertile flowers; fruit globular or ovoid; nut 4-celled at base; leaflets sessile or nearly so.

* Bud-scales numerous, about 10, successively inwrapping, the inner ones accrescent, becoming thin and membranaceous and rather tardily deciduous; husk of the fruit splitting promptly into 4 more or less thick and when dry hard or woody valves; seed sweet and delicious. (The Hickory Nuts of the market.)

2. C. ovata (Mill.) K. Koch. (Shelt-BaRK or Shag-Bark H.) Bark of trunk shaggy, exfoliating in rough strips or plates; inner bud-scales becoming large and conspicuous, persistent till the flowers are fully developed; leaflets 5-7, when young minutely dnwny beneath, finely serrate, the three upper obovatelanceolate, the lover pair much smaller and oblong-lanceolate, all taper-pointed; fruit globular or depressed ; nut white, flattish-globular, barely mucronate, the shell thinnish. (C. alba Nutt.; Hicoria ovata Britton.) - N. E. and w. Que. to north shore of L. Huron, e. Minn., Tex., and Fla. - A large and handsome tree (20-28 m. high, or more), yielding the principal HickorY NuT of the markets. Hicoria carolinae-septentrionalis Ashe appears to be merely a smallfruited extreme of this species. 
3. C. laciniòsa (Michx, f.) Loud. (Big Shell-Bark, King Nut.) Bark, etc., as in no. 2 ; leaflets $7-9$, more downy beneath; fruit ovoid, 4-ribbed above the middle, the husk very thick; nut large (3-5 cm. long) and usually angular, dull white or yellowish, thick-walled, usually strongly pointed at both ends. (C. sulcata Nutt.; Hicoria laciniosa Sarg.) - Centr. N. Y. and Pa. to s. Iud., Ia., e. Kan., and I. T. - Trunk 20-30 m. high, or more, in rich soil of bottom lands.

4. C. álba (L.) K. Koch. (Mocker Not, White-heart H.) Bark close, rough, but not shaggy nor exfoliating on old trunks; catkins, shoots, and lower surface of the leaves tomentose when young, resinous-scented; leaflets 7-9, lance-ol ovate or the lower oblong-linceolate, pointed; fruit globular or ovoid, with a very thick and hard husk; nut globular, not compressed, 4-ridged toveard the slightly pointed summit, brownish, very thick-shelled, $2.5 \mathrm{~cm}$. in diameter or smaller. (C. tomentosa Nutt.; Hicoria alba Britton.) - E. Mass. to 1 . shore of L. Erie, e. Neb., and s. to the Gulf. - Tree 20-30 m. high, usually on rich upland hillsides. A species not to be confused with $C$. alba Nutt., which is now to be called $C$. ovata.

5. C. microcárpa Nutt. With rough close bark, small ovoid buds, and the glabrous foliage, etc., of no. 7 ; fruit small, subglobose, with rather thin husk; nut thin-shelled, not angled. (Hicoria Britton; $H$. glabra, var. odorata Sarg.; H. borealis Ashe?) -_Que." and e. Mass. to Del., Mich., and Mo.

* * Bud-scales numerous or fero; husk of the fruit thin and rather friable at maturity, 4-valved only to the middle or tardily to near the base; seed more or less bitter.

\section{- Bark of trunk exfoliating in long strips.}

6. C. aquática (Michx. f.) Nutt. (Bitter PecAn.) Bud-scales few, subvalvate; leaflets $9-15$, falcate-lanceolate, attenuate; serrate, of firm texture; nut strongly compressed and sharply angled; seed very bitter. (Hicoria Britton.) - River swamps, Ya. to s. Ill., Mo., Tex., and Fla.

\section{+ - Bark not exfoliating.}

7. C. glabra (Mill.) Spæch. (Fignut or Broom H.) Bud-scales nearly as in no. 4 , but smaller, caducous ; shoots, catkins, and leaves glabrous or nearly so; leaflets 5-7, oblong- or obovate-lanceolate and taper-pointed, serrate ; fruit pear-shaped to ovoid; nut (3-5 cm. long) with thick bony shell; the oily seed at first sweet in taste, then bitterish. (C. porcina Nutt.; Hicoria glabra Britton.) - Dry woodlands, s. Me. to Fla., w. to Ont., Minn., e. Teb., and 'Tex. - Tree 20-30 (rarely 37) $\mathrm{m}$. high. Passing to

Var. villosa (Sarg.) Robinson. Petioles, rhachises, and peduncles sordidvillous; the lower surface of the leaflets mostly paler, covered with broader and more numerous peltate scale-like glands. (Hicoria glabra, var. Sarg.; $\boldsymbol{H}$. villosa and $H$. pallida Ashe.) - Va, to Mo. and southw.

8. C. cordiformis (Wang.) K. Koch. (Bitrer Nut or Swamp H.) Scales of the small yellowish bnds about 6 , valvate in pairs, caducous in leafing; catkins and young herbage more or less pubescent, soon becoming almost glabrous; leaflets 7-11, lanceolate or oblong-lanceolate ; fruit turgid-ellipsoid, narrowly 6-ridged; nut turgid, smonthish, shallowly reticulate-sulcate, glohular, shortpointed, white (barely $2.5 \mathrm{~cm}$. lnng), thin-valled, with slender-conical beak and persistent expanded stigma; seed at first sweet-tasted, soon extremely bitter. (C. amara Nutt.; Hicoria minima Britton.) - Rich woods, w. Que. and N. E. to Ela., n. shore of L. Hurnn, Mimn., e. Neb, and Tex. - Tree 15-30 m. high; husk and shell thinner and less hard than in other species. Koch, who first transferred Juglans cordiformis Wang. to Carya, confused other material with it, but the binomial technically rests on the plant of Wangenheim.

\section{BETULÀCEAE (Birch Family)}

Monoecious (rarely dinecious) trees or shrubs, with alternate simple straightveined leaves and leciduous stipules; the sterile flowers in catkins, the fertile 
clustered, spiked, or in scaly catkins; the 1-celled and 1-seeded nut with or without a foliaceous involucre. Ovary 2-celled, with 2 pendulous anatropous ovules in each cell; fruit seemingly 1-celled and 1-oruled; styles 2. Seed with no albumen, filled with the embryo, and with 1 integument.

Tribe I. CORÝlEAE. Sterile catkins pendulous, with no calyx; stamens 8 or more to each bract and more or less adnate to it, the filaments often forked (anthers 1-celled). Fertile flowors in a short ament or hed, 2 to each bract, and each with one or more bractlets which form a follaaceous involucre to the nut.

* Bract of staminate flower furnished with a pair of bractlets inside; fertlle flowers few.

1. Corylus. Involucre leafy-coriaceous, Inclosing the large acorn-like rut.

* Bract of staminate flower simple; fertile fiowere in short catkins; nut small, achene-like.

2. Ostrya. Each ovary and nut included in a bladdery and closed bag.

3. Carpinus. Each nut subtended by an enlarged spreading leafy bractlet.

Tribe II. BETÙLEAE. Flowers in scaly catkins, 2 or 3 to each bract. Sterile catkins pendulous. Stamens 2-4, and calyx usually 2-4-parted. Fertile flowers with no calyx, and no involuere to the small compressed and often winged nut.

4. Betula. Stamens 2, bifid. Fertile scales thin, 3-lobed, deciduous with or soon after the nuts.

5. Alnus. Stamens 4. Fertile scales thick, becoming woody, long-persistent.

\section{CóRylus [Tourn.] L. Hazelnut. Filbert}

Sterile flowers consisting of 8 (half-) stamens with 1-celled anthers, their short filaments and pair of scaly bractlets cohering more or less with the inner face of the scale of the catkin. Fertile flowers several from a scaly bud; ovary tipped with the short limb of the adherent calyx, one of the ovules sterile; style slort; stigmas 2, red, elongated and slender. Nut ovoid or subglobose, inclosed in a leafy or partly coriaceous cup or involucre consisting of the two bractlets enlarged and of ten grown together and lacerated at the border. Cotyledons very thick (raised to the surface in germination), sweet and edible; the short radicle included. - Shrubs or small trees, with thinnish doubly-toothed leaves (folded lengthwise in the bud), flowering in early spring; sterile catkins single or fascicled from scaly buds of the axils of the preceding year, the fertile terminating early leafy shoots. (The classical name, probably from кóvs, a helmet, from the involucre.)

1. C. americàna Walt. (HAzelnut.) Twigs and petioles often glandularbristly; leaves roundish-heart-shaped, pointed; involucre open above down to the globose nut, of 2 broad foliaceous cut-toothed almost distinct bracts, their bases coriaceous and downy or with glandular bristles intermixed; pericarp bony. - Thickets, N. E. to Sask., and southw.

2. C. rostràta Ait. (BEA KED H.) Twigs and petioles not glandular-bristly; leaves ovate or ovate-oblong, somewhat heart-shaped, pointed; involucre of united bracts, much prolonged above the ovoid nut into a narrow tubular beak, densely bristly; pericarp thinnish and membranaceous. - Que. to B. C., s. to Del., Mich., Mo., and westw.; also in the mts. to Ga.

\section{2. ÓSTRYa [Mich.] Scop. Hop Hornbeam. Ironwood.}

Sterile flowers consisting of several stamens in the axil of each bract; filaments short, often forked, bearing 1-celled (half-) anthers; their tips hairy. Fertile flowers a pair to each deciduous bract, each of an incompletely 2-celled 2-ovuled ovary, crowned with the short bearded border of the adherent calyz, tipped with 2 long-linear stigmas, and inclosed in a tubular bractlet, which in fruit becomes a closed bladdery ellipsoid bag, very much larger than the small smooth nut; these inflated involucres loosely imbricated to form a sort of strobile, in appearance like that of the Hop. - Slender trees, with very hard wood, brownish furrowed bark, and foliage resembling that of Birch; leaves open and concave in the bud, more or less plaited on the straight veins. Flowers appear. ing with the leaves; the sterile catkins 1-3 together from scaly buds at the tips 
of the branches of the preceding year; the fertile single, terminating short leafy shoots of the season. (The classical name.)

1. 0. virginiàna (Mill.) K. Koch. (American HoP H., Leverwood.) Leaves oblong-ovate, taper-pointed, very sharply double-serrate, downy beneath, with 11-15 principal veins; buds acute; involucral sacs bristly-hairy at the base. (O. virginica Willd.) - Rich woods, N. S. to Man., Minn., Neb., and southw.

\section{CARPINUS [Tourn.] L. HoRnBeam. IRONWOod}

Sterile flowers similar to those of Ostrya. Fertile flowers several, spiked in a sort of loose terminal catkin, with small deciduous bracts, each subtending a pair of flowers; the single involucre-like bract open, enlarged in fruit and foliaceous, merely subtending the small ovate several-nerved nut. - Trees or tall shrubs, with close gray bark, in this and in the sleuder buds and straight-veined leaves resembling the Beech; leaf-buds and inflorescence as in Ostrya. (The early Latin name.)

1. C. caroliniàna Walt. (American H.; Blue or Water-Beech.) Leaves ovate-oblong, pointed, sharply double-serrate, soon nearly smooth; bractlets 3-lobed, halberd-shaped, sparingly cut-toothed on one side, acute. - Along streams, N. S. to w. Ont., and southw.

\section{BÉTULA [Tourn.] L. Brrch}

Sterile flowers 3 (the bractlets 2) to each shield-shaped scale or bract of the catkins, consisting each of a calyx of one scale bearing 4 short filaments with 1-celled anthers (or strictly of two 2-parted filaments, each division bearing an anthercell). Fertile flowers 2 or 3 to each 3 -lobed bract, without bractlets or calyx, each a naked ovary, becoming a winged and scale-like nutlet (or small samara) crowned with the two spreating stigmas. - Uuter bark often separable in sheets, that of the branchlets dotted. Buds sessile, scaly. Sterile catkins teruninal and lateral, sessile, formed in summer, remaining ' ing in early spring, with or preceding the leaves ; fertile catkins ovoid to cylindrical, usually terminating very short 2-leaved early lateral branches of the season. (The ancient Latin name.)

* Trees or shrubs; the leaves with the 8 or more pairs of nerves impressed above; fruiting cattins thich (1 cm. or more), short-cylindric to ovoid, their scales rather persistent; wing of fruit not broade? than the seed-bearing body.

+ Bark and twigs sweet-aromatic; leaves membranaceous, ovate to oblong-ovate, with rounded or cordate bases, regularly serrate, green both sides; fertile catkins sessile, erect.

1. B. lénta L. (Cherry, Sweet, or Black B.) Bark of trunk dark brozon, close, in age becoming ashy-brown and furrowed, very sweet-aromatic; leaves ovate or ovate-oblong from a more or less heart-shaped base, acuminate, sharply and finely double-serrate, when mature bright green above and glabrous except on the veins beneath; fruiting catkins shurt-cylindric (1.5-2.5 cm. long); the scales firm and smooth, with short and divergent lobes. - Rich woods, Nfd. to Ont., s. to Del., Ind. and centr. Ia.; also along the mits. to Fla. and 'Tenn.

2. B. luttea Michx. f. (YELLow or GRAY B.) Bark of trunk yellowish-or silvery-gray, detaching in very thin filmy layers, less aromatic ; leaves slightly or not at all heart-shaped and often narrowed toward the base, duller green above and usually more downy on the veins beneath; fruiting catkins narrow-ovoid to subglobose, the more foliaceous scales mostly longer, pubescent and with narrower barely spreading ciliate lobes. - Rich moist woods, Nfd. to Man., s. to Del., Ill., and Minn.; also along the mts. to 'Tenn. and N. C. - Trees with characteristics somewhat intermediate between this and $B$. lenta have been called $B$. alleghaniensis Britton.

- + Bark not aromati'; leaves Arm, rhombic-ovate, cuneate to subtruncale at base, irrequarly dentate-serrate, whitish beneath; fertile catkins pe? incled. soft-downy. 
8. B. nigra L. (RIVLR or ReD B.) Tree with greenish-brown somewhat laminate bark and reddish twigs; leaves acutish at both ends, when young downy underneath; petioles, peduncles, and thick-cylindric catkins tomentose; bracts with oblong-linear nearly equal lobes. - Banks of streams and in swamps e. of the Alleghenies from e. Mass. to Fla., thence w. to Tex, ; and through the bottom-lands of the Mississippi R. system.

* Trees or shrubs with slender cylindric fruiting catkins, their scales readily deciduous; leaves (of the fruiting branches) with 7 or less pairs of proninent veins.

+ Wing distinctly broader than the body of the fruit; trees or stout shrubs with white, whitish, or brown papery bark.

+ Bark dull, chalky- or ashy-white, smooth and close, the loyers not readily exfoliating; staminate catkin usually solitary.

4. B. populifolia Marsh. (White, GRaY or OLd Field B.) Trunk usually ascending, rarely $10 \mathrm{~m}$. high ; leaves triangular (deltoid), very taper-pointed (usually abruptly), truncate or nearly so at the broad base, smooth and shiming both sides, except for the resinous glands when young, tremulous on very slender petioles ; fruiting catkins slender-stalked, ascending, $1-3 \mathrm{~cm}$. long, $5-7 \mathrm{~mm}$. thick ; the $d r a b$ or $a s h y$-brown wide-spreading scales $2.5-4 \mathrm{~mm}$, long, their lobes puberulent. - Poor sandy or rocky soil, commonest near the coast, P. E. I. to Del., w. to L. Ont.

Bark lustrous, creamy- or pinkish-white to bronze, freely splitting into paper-like layers; staminate catkins mostly 2 or 3.

$=$ Branchlets and leaves strictly glabrous from the first.

5. B. péndula Roth. (White or CANoe B.) Branches slender and flexuous, often drooping, the branchlets usually verrucose with resiniferous atoms; leaves glutinous when young, tirm, rhombic-ovate to del toid or broad-ovate, subcuneate, truncate, or subcordiate at base, long-acuminate, slender-petioled; fertile catkins pendulous, $1.5-3 \mathrm{~cm}$. long, 6-9 mm. thick ; the ascending brown or straw-colored scales 3-5 mm. long, glabrous except for the ciliate margin. (B. verrucosa Ehrh. - Rocky upland woods and slopes, Que. to Alaska, locally s. to Me., Vt., IIl., Man., etc. (Eurasia.) - A polymorphous boreal species, of which the N. E. phase has recently been designated as $\boldsymbol{B}$. caerulea Blanchard (BLUE B.).

$==$ Branchlets puberulent or pubescent; young leaves (except in var. minor) pubescent beneath.

6. B. álba L. (PAPER, Canoe or White B.) Branches and branchlets ascending; resiniferous atoms, if present, mixed with long hairs; leaves ovate, taperpointed, from rounded to cuneate at base, in maturity 3-6 cm. long, smooth and green above, pale, glandular-dotted, and a little hairy on the veins beneath, sharply and unequally double-serrate; fruiting catkins $1.5-4.5 \mathrm{~cm}$. long, $0.5-1.5 \mathrm{~cm}$. thick, spreading or drooping on slender peduncles; the mostly ciliate-margined ascending scales 3-7 mm. long. (B. pubescens Ehrh.) - Large shrub or medium. sized tree, Nfd. to B. C., s. to N. E., the Great Lake region, etc. (Eurasia.) Passing to the commoner American

Var. papyrifera (Marsh.) Spach. Usually a larger tree, with mature leaves 6-9 cm. long. (B. papyrifera Marsh.) - Nfd. to Alaska, s. to Pa., Ind., n. Ia., Neb., Wyo., and Wash.

Var. glutinòsa (Wallr.) Trautvetter. Branches pendulous; leaves $3-5 \mathrm{~cm}$. long, pilose on the veins beneath ; catkins on straight peduncles. - Wassataquoik Valley, Me. (Eu.)

Var. cordifolia (Regel) Fernald. Leaves broad-ovate, cordate, pilose on the veins beneath. - Cool woods and mts., Lab. and Nfd. to B. C., s. to N. E., L. Superior, Ja., and westw. - Becoming a dwarf shrub on alpine slopes.

Var. minor (Tuckerm.) Fernald. Stout dwarf shrub; leaves elliptic- or truncate-ovate, glutinous, glcbrous, $1.5-4 \mathrm{~cm}$. long; staminate catkin often solitarý ; fruiting catkins mostly ascending, $1.3-3 \mathrm{~cm}$. long, $0.5-1 \mathrm{~cm}$. thick. $(B$. 
papyracea, var. 'Iuckerm.) - Alpine regions and cold bogs, Lab. to Sask., s. to n. N. E. and Minn. (Greenl.)

+ Wings narrower than or varely as broad as the body of the fruit, or wanting; shrubs with dark scarcely papery bark, subsessile or short-petioled thickish or coriaceous small leaves, and narrowly ovoid or cylindric mostly erect sessile or short-peduncled catkins.

+ Young branchlets pubescent with long soft hairs.

7. B. pùmila L. (Low or Swamp B.) Stems $0.5-3 \mathrm{~m}$. high, erect or ascending, not glandular; youns branches and lower face of young leaves mostly softdowny; leaves obovate, orbicular, or reniform, $1-3.5 \mathrm{~cm}$. long, not resiniferous, pale beneath, veinlets on both foces finely reticulated; fruiting catkins $0.7-3 \mathrm{~cm}$. long, 5-9.mm. thick. - Bogs, Lab. and Nfd. to Ont., s. to n. N. J., O., Ind., Iil., and Minn. (Eurasia.)

Var. glandulifera Regel. Foung branchlets and leaves resiniferous or glandular-dotted. - Ont. and Mich. to Minn. and Sask.

+ Young branchlets glabrous or at most minutely puberulent, conspicuously dotted with resinous wart-like glands.

8. B. glandulosa Michx. (DWARF B.) Stems erect or depressed, 0.3-2 m. high, or when alpine procumbent; leaves wedge-obovate, $0.5-3 \mathrm{~cm}$. long, green and glabrous both sides, slightly reticulated ; fruiting catkins $0.5-2.5 \mathrm{~cm}$. long, 3-7 mm. thick. - Arctic barrens, s. to mts. of N. B., Me., and N. H.; L. Superior, Minn., etc. (Asia.) Var. Rotundrớl,i (Spach) Regel. Very dwarf; leaves orbicular or reniform. - Arctic regions to mts. of Me. and N. H. (Alaska; Asia.)

\section{5. Álitus [Tourn.] Hill. Alder}

Sterile catkins with 4 or 5 bractlets and 3 (rarely 6 ) flowers upon each shortstalked shield-shaped scale; each flower usually with a 3-5-parted caly $x$ and as many stamens; filaments short and simple; anthers 2-celled. Fertile catkins ovoid or ellipsoid; the fleshy scales each subtending 2 flowers and a group of 4 little scalelets adherent to the scales or bracts of the catkin, which are woody in fruit, wedge-obovate, truncate, or 3-5-lobed. - Shrubs or small trees with few-scaled leaf-buds and solitary or often racemose-clustered catkins. (The ancient Latin name.)

* Flowers developed with the leaves; the sterile catkins from naked buds formed the preceding season; the fertile from scale-covered buds; fruit with a conspicuous thin wing.

1. A. críspa (Ait.) Pursh. (Grees or Mountain A.) Shrub with young branches and peduncles sparingly puberulent or glabrate; leaves round-oval, ovate or slightly heart-shaped, in maturity 3-6 cm. long, glutinous and smooth, or slightly pubescent on the principal veins beneath, irregularly serrulate or biserrulate with very fine and sharp closely set teeth, the margins often puckered ; fertile catkins slender-stalked, loosely racemose, in maturity $1-1.5 \mathrm{~cm}$. long. ( $A$. viridis Man. ed. 6, in part, not DC.; $A$. Alnobetula Am. auth., in part, not K. Koch.) - Cool shores and mts., Lab. to N. B. ; Mt. Katahdin, Me.; Mt. Washington, N. H.; Whiteface Mt., N. Y.; and on the mts. to N. C.

2. A. mollis Fernald. (Downy GreEN A.) Shrub or small tree; young branches and peduncles permanently soft-pubescent; leaves permanently covered beneath with dense soft hairs, in maturity 4.5-11. $\mathrm{cm}$. long; mature fertile catkins $1.2-2 \mathrm{~cm}$. long. ' (A. viridis Man. ed. 6, in part, not DC.; $A$. Alnobetula Am. auth., in part, not $\mathbf{K}$. Koch.) - Damp thickets and exposed rocky banks, s. Nfd. to I. Winnipeg, s. to s. Me, and N. H., w. Mass., N. Y., and L. Superior. Ordinarily distinct, but possibly an extreme variation of A. crispa.

* Flowers developed in earliest spring before the leaves; the catkins all from naked buds formed the preceding season; fruit wingless or with a narrow coriaceous margin. 
3. A. incàna (L.) Moench. (SPEckled or HoAry A.) Shrub or small tree (rarely $6 \mathrm{~m}$. high); leaves broadly elliptical to ovate, mostly rounded at base, sharply and doubly serrate, the upper surface dark green and with impressed nerves, the lower mostly downy at least on the nerves and ferruginous to glaucous; stipules lanceolate; fruit (samara) orbicular. - swamps and borders of streams, Nfd. to Sask., s. to Ya., n. Ia., and Neb.; the common Alder along our northern borders. (Eurasia.)

4. A. rugosa (Du Roi) Spreng. (Sмоотн A.) Shrub or small tree; leaves obovate, acute at base, sharply and almost regularly serrate with minute teeth, thickish, green both sides, rarely impressed-nerved, smooth or sparingly pubescent beneath; stipules oval; fruit ovate. (A. serrulata Willd.) - Me. to Fla. and Tex., rarely inland to Minn.; mostly on the coastal plain northw., more general southw. - Many shrubs near the $\mathrm{n}$. limits of this range appear intermediate between this and the last species.

5. A. volganis Hill. (Black A. of Europe.) 'Tree with dark green flabellate-obovate or suborbicular coarsely dentate glutinous leaves. - Escaped from cultivation and locally established, Nfd. to N. J. and Pa. (Introd. from Eu.)

* * Flowers in autumn (Sept.) from cattins of the season; the fertile mostly solitary in the axils of the leaves, ripening the frut a year later; fruit wingless.

6. A. marítima (Marsh.) Muhl. (SEA-side A.) Glabrous ; leaves oblong, ovate, or obovate, with a wedge-shaped base, slender-petioled, sharply serrulate, bright green, or rather rusty beneath; fruiting catkins large, ovoid or ellipsoid (1.5-2.5 cm. long). - Del, and Md., near the coast; also I. T. - A small tree.

\section{FAGÀCEAE (BEECh FAMILY)}

Monoecious trees or shrubs, with alternate simple straight-veined leaves, deciduous stipules, the sterile flowers in catlins or capitate clusters, the fertile solitary or slightly clustered, the 1-celled and 1-seeded nut inclosed (or partly inclosed) in a cupule consisting of more or less consolidated bracts, whirh become indurated. Ovary 3-7-celled; ovules 1 or 2 in each cell (only 1 ripening); styles 3 . Seed with no albumen, flled by the embryo, and with 2 integuments.

* Sterile flowers in a small head on drooping peduncles.

1. Fagus. Cupule 2-flowered, 4-valved, containing 2 sharply triangular nuts.

* * Sterile flowers in slender catkins.

2. Castanea. Cupule 2-4-flowered, forming a prickly hard bur, 2-4-valved when ripe.

3. Quercus. Cupule 1-flowered, sealy and without valves; nut terete.

\section{FAgUS [Tourn.] L. BeEcH}

Sterile flowers with deciduous scale-like bracts; calyx bell-shaped, 5-7-cleft; stamens 8-16; filaments slender; anthers 2-celled. Fertile flowers usually in pairs at the apex of a short peduncle, invested by numerous awl-shaped bractlets, the inner coherent at base to form the 4-lobed involucre; calyx-lobes 6 , awl-shaped; ovary 3-celled with two ovules in each cell; styles thread-like, stigmatic along the inner side. Nuts usually 2 in each urn-shaped and softprickly coriaceous involucre, which divides to below the middle into 4 valves. Cotyledons thick, folded and somewhat united, but rising and expanding in germination. - Trees with a close and smooth ash-gray bark, a light horizontal spray, and undivided strongly straight-veined leaves, which are open and convex in the tapering bud and plaited on the veins. Flowers appearing with the leaves, the yellowish staminate flowers from the lower, the pistillate from the upper axils of the leaves of the season. (The classical Latin name, from

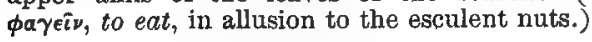


1. F. grandifòlia Ehrrh. Large tree; leaves oblong-ovate, mostly cuneate at base, taper-pointed, distinctly and often coarsely toothed, light green ; petioles and midrib soon nearly naked; prickles of the grayish or yellowish fruit subulate-filiform, elongated, recurved or spreading. (F. ferruginea Ait. ; $F$. americana Sweet.) - Rich uplands, N. B. to w. Ont., g. to Va., Mich. and Minn.

Var. caroliniana (Loud.) Fernald \& Rehder. Leaves ovate to short-obovate, darker green, mostly rounded or subcordate at base and often less coarsely toothed; prickles of the rufescent fruit short, subulate, - Coastal plain, N. J. to Fla. and Miss.; also from O. to Mo. and Tex.

\section{Castanea [Tourn.] Hill. Chestrut}

Sterile flowers interruptedly clustered in long and naked cylindrical catkins ; calyx mostly 6-parted; stamens 8-20; filaments slender; anthers 2-celled. Fertile flowers usually 3 together in an ovoid scaly prickly involucre; calyx with a 6-lobed border crowning the 3-7-celled 6-14-ovuled ovary; abortive stamens 5-12; styles linear, exserted, as many as the cells of the ovary; stigmas small. Nuts coriaceous, inclosed usually $2-3$ together or solitary in the involucre. Cotyledons very thick, somewhat plaited, cohering, remaining underground in germination. - Leaves strongly straight-veined, undivided. Flowers later than the leaves, cream-color; the catkins axillary near the ends of the branches, wholly sterile or the upper androgynous with the fertile flowers at the base. (The classical name, from that of a town in Thessaly.)

1. C. dentàta (Marsh.) Borkh. (Chestnut.) A large tree; leaves oblonglanceolate, pointed, serrate with coarse pointed teeth, acute at base, when mature smooth and green both sides; nuts 2 or 3 (rarely even 7-9) in each involucre, flattened on one or both sides, very sweet. (C. sativa, var. americana Sarg.) Rocky woods and hillsides, s. Me. to Ont., and southw.

$\checkmark$ 2. C. pùmila (L.) Mill. (ChInQUAPIN,) A spreading shrub or small tree; leaves oblong, acute, serrate with pointed teeth, whitish-dorony beneath; involucres small, often spiked; the ovoid pointed $n u t$ scarcely half as large as the common chestnut, very sweet, solitary, not flattened. - Dry woods and thickets, N. J. to Ind., and southw.; introd. northw.

\section{QUERCUS [Tourn.] L. OAK}

Sterile flowers in naked catkins ; bracts caducous ; caly x 2-8-parted or -lobed ; stamens 3-12; anthers 2-celled. Fertile flowers scattered or somewhat clustered, consisting of a nearly 3-celled and 6-ovuled ovary, with a 3-lobed stigma, inclosed by a scaly bud-like involucre which becomes an indurated cup (cupule) around the base of the rounded nut or acorn. Cotyledons remaining underground in germination; radicle very short, included. - Flowers greenish, yellowish, or reddish. Sterile catkins single or often several from the same lateral scaly bud, filiform and banging in all our species. All the species inclined to hybridize freely. (The classica' Latin name.)

51. Bark pale, often scaly; leaves and their lobes or teeth obtuse (rarely with sharp teeth), never bristie-polnted; stamens $6-8$; scales of the cup more or less woody and knobby at base: stigmas sesslle or nearly so; abortive ovules at the base of the perfect sead ; inner sinface of shell of nut glabrous; frult maturing the first year; kernel commonly sweetish. LFPIDOB R LANUB Endl, $a$.

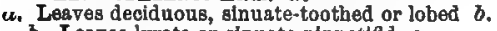

b. Leaves lyrate or sinuate-pinnatild $c$.

c. Mature leaves glabrous benenth ${ }_{\text {c. Mature leaves finely pubescent beneath }}{ }^{2} d$.

a. Seales of the cup naked, not awned.

Frult nearly sesstle; the fine-scaled saucer-shaped oup one third to half as high as the ovold acorn

Fruit peduncled; the coarse-scaled oup nearly oovering the depressed-globose acorn.

d. Upper sales of the cup long-awned

b. Leaves coarsely sinuate-toothed, but not lobed (except "sllghtly in no. 5). -- OhESTN UT OAKs "e.

- Fralting peduncle 2.5-6 $\mathrm{cm}$. long, much exceeding the petioles .

1. Q. alba.

2. Q. stellata.

3. Q. Tyrata.

4. Q. macrocarps.

D. Q. bicotor. 
6. Fruit sessille or on very short peduncles.

Cup $2.5-8 \mathrm{~cm}$. broad; scales free to the base

Cup at most $2.5 \mathrm{~cm}$, broad, only the small tips of the scales distinet.

Leaves with acute or pointed teeth.

Leaves with 8-18 teeth on each margin . . . . 7. Q. Muhlenbergit.

Leaves with 3-7 teeth on each margin : * : 8. 8. prinoides.

Leaves with somewhat rounded teeth . . . . . 9. Q. Prinus.

a. Leaves coriaceous, evergreen, entire or rarely spiny-toothed : : 10 . Q. virginiana.

\$2. Bark dark, furrowed ; leaves deciduous, theil lobes and teeth acute and bristle-pointed (at least in youth); stamens wostly 4-6; cup-scales membranaceous; styles long and spreading; abortive ovules near the top of the perfect seed; Inner surface of shell tomentose; frutt maturing the second year. - ERythrobalanue Spach. (RED or BLACK OAKS.) $f$.

$f$. Leaves pinnatifd or lobed, slender-petioled, not coriaceous, the lobes or teeth couspicuously bristle-pointed $g$.

o. Mature lenves green on both sides; species closely related and freely hybridizing $h$.

h. Longest lobes of the leaf about equaling (rever twice as long as) the breadth of the broadish middle portion of the leaf .

h. Longest lobes of the leaf 2-6 times as long as the breadth of the narrow middle portion of the leaf $i$.

1. Seales of the cup closely apyressed $j$.

3. Expanded saucer-shaped portion of the cup 8-5 mm. high, $1-1.5 \mathrm{~cm}$, broad

1. Cups larger.

Cups brown or castaneous, the scales finally glabrate and lustrous

Cups ashy with persistent duil pubescence.

Gup $2-2.6 \mathrm{~cm}$. broad ; acorn $1.8-2.3 \mathrm{~cm}$. thick .

Cup 1.2-1.8 cm. brosd; acorn 0.8-1.7 cm. thick

6. Upper scales of the cup loosely imbricated

g. Mature leaves whitish or grayish beneath with close down.

Lobes elongate; at least the terminal faleate.

Lobes bruadly triangular. Leaves entire or with fow teath (or somewhat $8-5$-lobed at summit),
f. commonly bristle-pointed; acorns globular, small (rarely over $13 \mathrm{~mm}$. long) $k$.

$k$. Leaves widening or often much dilated upward and more or less sinuate or $8-5$-lobed.

Leaves glabrrus; cup saucer-shaped or hemispherical .

Leaves rusty pubescent beneath ; cup turbinate .

a. Leaves not dilated upward, generally entire.

Leaves permanently stellate-pubescent beneath .

Leaves glabrous or glabrate beneath

11. Q. mona

12. Q. palustris.

18. Q. coccinea.

14. Q. texana.

15. Q. ellipsoidalis.

16. Q. velutina.

17. Q. falcata.

18. Q. tlicifolia.

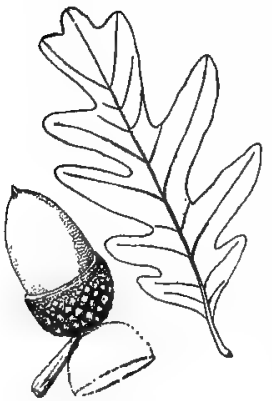

670. Q. alba.

1. Q. álba L. (Whiте O.) Leaves when young white-lanate beneach, when mature pale or glaucous beneath, bright green above, obovate-oblong, obliquely cut into 5-9 oblong or linear and obtuse mostly entire lobes; cup hemispherical-saucer-shaped, rough or tubercled at maturity, puberulent, much shorter than the ovoid or ellipsoid (2-3 cm. long) acorn. - Dryish or upland woods, s. Me. to Ont., Minn., and southw. FIG. 670.

2. Q. stellàta Wang. (Post O., IRoN O.) Leaves grayishor brownish-downy underneath, dark green and rough above, thickish, sinuately cut into 5-7 rounded divergent lobes, the upper ones nuch larger and often 1-3-notched; acorn 1-2 cm. long. (Q. minor Sarg.) - Sandy or sterile soil, Mass. to Ia., Neb., and southw. Fig. 671.

Q. MargarétTa Ashe, with narrower small leaves glabrate and with lobes merely rounded at tip, is possibly a hybrid of $Q$. stellata and $Q$. alba.

3. Q. lyràta Walt. (Over-cur O., Swamp Post O.) Leives crowded at the encl of the branchlets, obovateoblong, acute at base, more or less deeply 7-9-lobed,

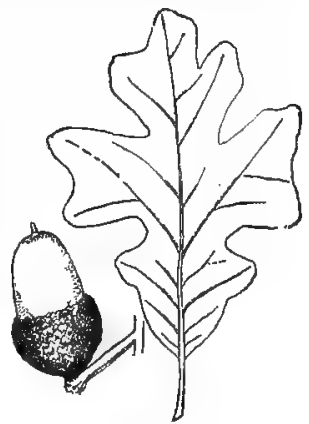

671. Q. stellata 


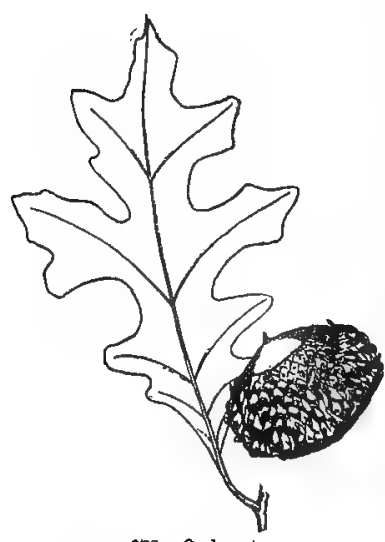

672. Q. lyrata.

white-tomentose beneath or at length smoothish, the lobes triangular to oblong, acute or obtuse, entire or sparingly toothed; cup round-ovoid, thin, with rugged pointed scales; acorn about 2 cm. long. - River swamps, N. J. to Ind., Mo., and southw. FIG. 672.

4. Q. macrocárpa Michx. (Bur O., OrekcuP or MossY-cup O.) Leaves obovate or oblong, lyrately pinnatifid or deeply sinuate-lobed, or nearly parted, sometimes nearly entire, irregular, downy or pale beneath; the lobes sparingly and obtusely toothed, or the smaller ones entire; cup deep, thick and woody (2-5 cm. across), with hard and thick pointed conspicuously imbricated scales, the upper ones aroned, usually making a mossy-fringed border; acorn broadly ovoid, half immersed in or entirely inclosed by the cup. - Rich soil, N. S. to Man., s. to w. Mass., Ky., and Tex. - A large and valuable tree; extremely variable in the size and fringe of the cups. Fig. 673. Var. olivaefórmis (Michx. f.) Gray is a narrower-leaved form with small subcylindric acorns.

5. Q. bicolor Willd. (Swamp White O.) Leaves obovate or oblong-abovate, wedge-shaped at base, coarsely sinuate-crenate and often rather pinnati-

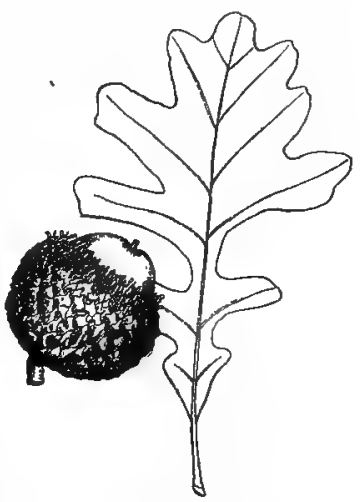

678. Q. macrocarps. fid than toothed, usually soft-dovony and white-hoary beneath, the primary veins lax and little prominent; cup $\frac{1}{3}-\frac{1}{2}$ as long as the acorn, vooody, the upper scales acon-pointed, sometimes forming a mossy-fringed

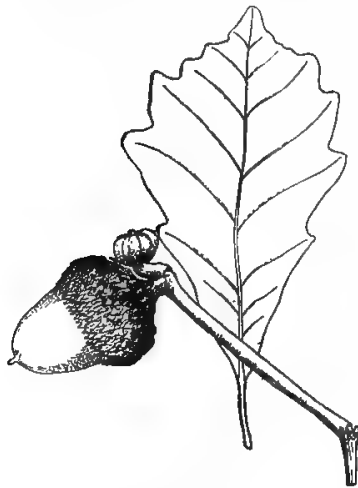

674. Q. bloolor. margin ; acom $2-3$ cn. long. ( $Q$. platanoides Sudworth.) - Borders of streams and swamps, s. Me. to Ont., Minn., and southw. - A large tree, with flaky bark. Fig. 674 .

6. Q. Michaúxii Nutt. (Basket O., Cow O.) Leaves oval or obovate, acute, obtuse, or even cordate at base, regularly dentate (seldom deeply), rather rigid, commonly tomentose beneath; stamens usually 10; fruit short-peduncled; cup shallow, tuberculate with hard and stout acute scales, tips of the innermost often forming a stiff fringe; acorn ovoidsubcylindric, twice as high as the cup, about

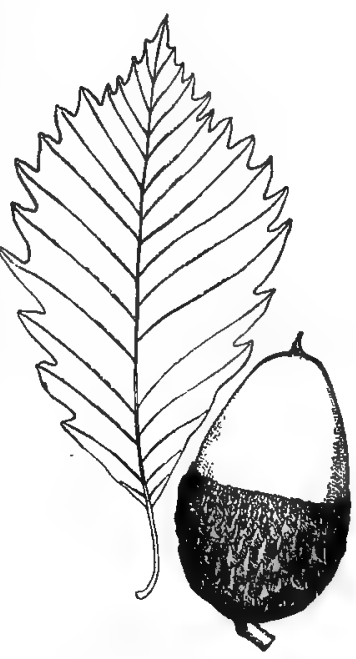

675. Q. Michauxii. 


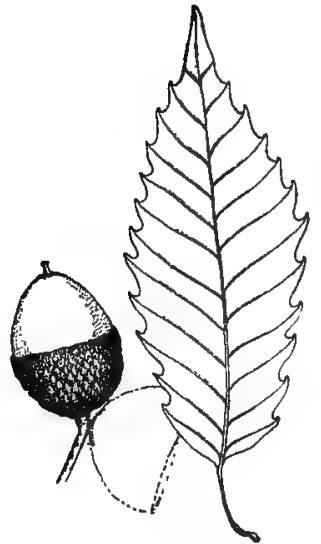

676. Q. Mublenbergii.

$3 \mathrm{~cm}$. long. - Borders of streams and swamps, Del. to Mo., and southw. FiG. 675 .

7. Q. Muhlenbérgii Engelm. (Yellow O., ChestNणn' 0 .) Leaves (1-2 dm. long) slender-petioled, often oblong or even lanceolate, usually acute or pointed, mostly obtuse or rounded at base, almost equally and rather sharply toothed; cup subsessile, shallow, thin, of small appressed scales; acorn globose or obovoid, $1.5-2 \mathrm{~cm}$. long. (Q. acumitrata Houba.) - Dry limestone hillsides and rich bottoms, $V$ t. to Del., along the mts. to n. Ala., w. to Minn., e. Neb., and Tex. - A tall tree, with thin eventually flaky bark. FIG. 676 .

8. Q. prinoides Willd. Like the last, but of low stature (usually 1-3 in. high), with smaller more undulate leaves on shorter petioles (rarely $1 \mathrm{~cm}$. long), and deeper cups with more tumid scales. - Dry soil, N. H. to Minn., and southw. - Branchlets glabrous; leaves covered beneath with a close white tomentum. Fig. 677. Var. RUFfiscens Rehder differs in having the young branchlets pubescent and some tawny wool mixed with the white tomentum on the under surface of the leaves. - Damp woods and pine-barrens, e. Mass. to N. C.

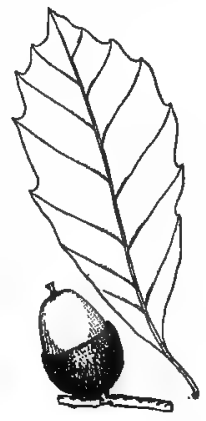

67\%. Q. prinoides.

9. Q. Prìnus L. (Chestnut O.) Leaves thick, obovate or oblong to lanceolate, sometimes acuminate, with an obtusa or acute base, undulately crenate-

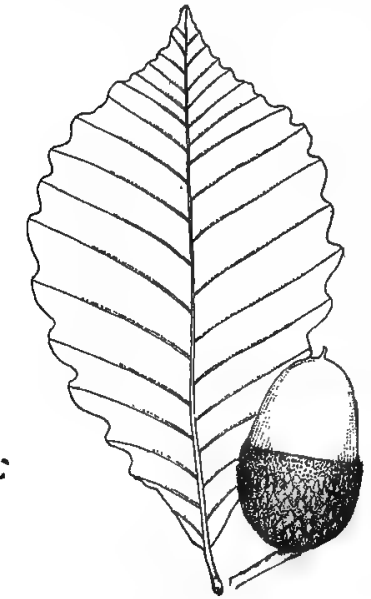

678. Q. Prinus. toothed, pale and minutely downy beneath, the primary ribs 10-16 pairs, straight, prominent beneath; fruiting peduncles shorter than the petioles, of ten very short; cup thick, mostly tuberculate with hard and stout scales. - Rocky banks and hillsides, s. Me. to Ont., and southw. -A large tree, with thick and deeply furrowed bark. FIG. 678 .

10. Q. virginiàna Mill. (Liva O.) Leaves small, oblong or elliptical, hoary beneath (as well as on the branchlets); peduncle usually conspicuous, 1-3-fruited ; cup top-shaped; acorn subcylindric ; cotyledons completely united into one mass. (Q. virens Ait.) - Along the coast from Va. to Fla. and Tex. - Becoming a large tree, or in sterile soil dwarf. Fra. 679.

11. Q. rùbra L. (RED O.) Cup saucer-shaped or flattish, with a narrow raised border, $1.8-2,5 \mathrm{~cm}$. broad, of rather fine closely appressed scales, sessile or on a very

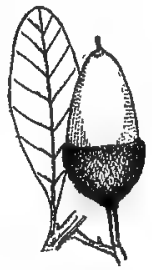

679. Q. virgindana. abrupt narrow stalk or neck, very much shorter than the narrow-ovoid or ellipsoid acorn, which is $2-3 \mathrm{~cm}$. long; leaves rather thin, turning dark red after frost, moderately (rarely very deeply) pinnatifid, the lobes acuminate from a broad base, with a few coarse teeth; lark of trunk dark gray, smoothish. - Common both in rich and poor soil. - Timber coarse and poor. Fig. 680. Along our northern borders passing to Var. ambígua (Michx. f.) Fernald. (GRAY O.) Cups 


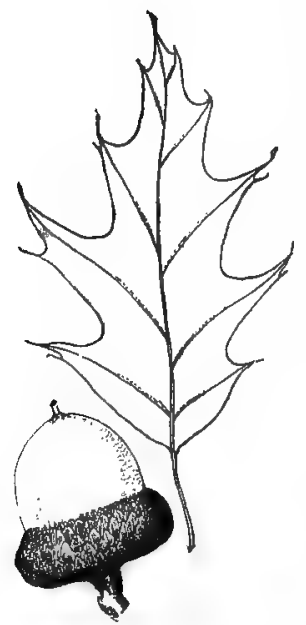

680. Q. rubra.

tending to be deeper and somewhat turbinate ( $Q$. ambigua and borealis Michx. f.; Q. coccinea, var. ambigua Gray.)

12. Q. palústris Muench. (Swamp SPanigh or PIN o.) Cup flat-saucer-shaped, sometimes contracted into a short scaly base or stalk, fine-scaled, very much shorter than the usually globose or depressed acorn, which is $1-1.5 \mathrm{~cm}$. long; leaves deeply pinnatifid with divergent lobes and broad rounded sinuses,-Low grounds, chiefly on the coastal plain and in the Miss, basin ; Mass to Va., w. to Kan. and Ark. Fig. 681.

13. Q. coccínea Muench. (Scarlet O.) Cup topshaped, or hemispherical with a conical base (1.5-2.2 cm. broad), coarsely scaly,

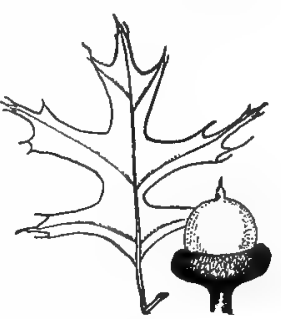

681. Q. palustrik. covering half or more of the subglobose or short ovoid acorn (1.3-2 cm. long), the scales brown, appressed and glabrate; leaves, at least on full-grown trees, bright green, shining above, glabrous beneath, turning red in autumn, deeply pinnatifid, the slender lobes divergent and sparingly cut-toothed; buds small; $b a r k$ of the trunk gray, the

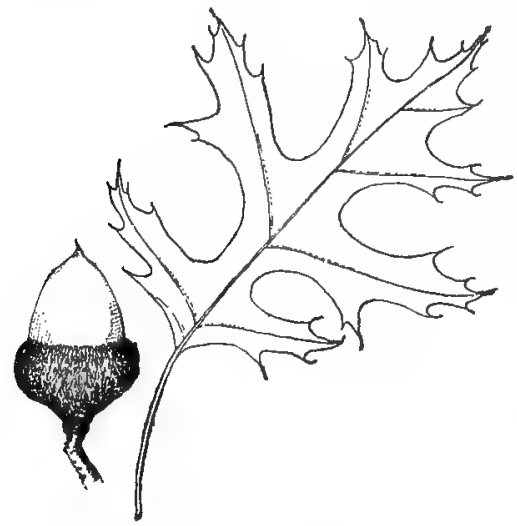

682. Q. coccinea.

slightly broadened upward and toothed at summit; bark gray, becoming in old trees reddish-brown and broken into plates. Bottom-lands and limestone hills, Ind. to Ia., s. to N. C., Fla., and Tex. - A large tree with conspicuously buttressed base.

15. Q. ellipsoidalis E. J. Hill. (YELLow or BLACK 0 .) Cup turbinate or deeply saucer-shaped, $1.2-1.8 \mathrm{~cm}$. broad, the pale brown or ashy scales puberulent, covering from one third to more than one interior reddish.-Dry light soil, s. Me. to Ont., Minn., and Neb., s. to N. C. and Ill., chiefly eastw. FIG. 682.

14. Q. texàna Buckley. (RED O.) Cup deeply sancer-shaped or somevohat turbinate, $2-2.6 \mathrm{~cm}$. broad, the light brown or asliy scales permanently tomentulose, except on the margin, covering one third to one half of the ovoid large (1.5-4 $\mathrm{cm}$. long) acorn; leaves in maturity bright green and glabrous above, paler and with axillary tufts of hairs beneath, turning dark red or brown in autumn, the 5-9 oblong lobes

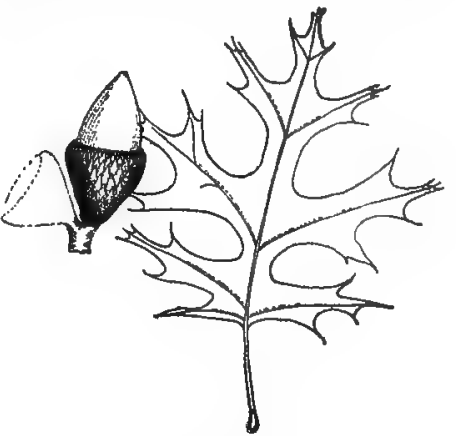

688. Q. ellipsoidalis. 


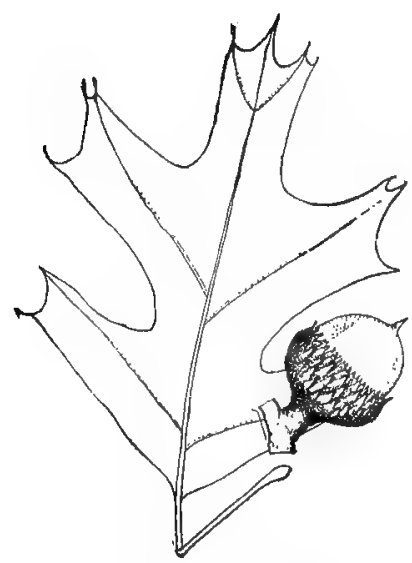

684. Q. velutina.

half of the dark-brown puberulent often striped ellipsoid to subglobose small (1.2-2 $\mathrm{cm}$. long) acorn; leaves smooth and lustrons in age, with axillary tufis beneath, becoming yellow or pale bruwn in autumn, the 5-7 oblung lobes cuarsely toothed at sumuit; bark gray, close and smooth, or in age shallowly fissured, light yellow within. - Clay or gravel, s. Mich. to Man. and Ia. - A medium-sized tree, in habit said to resemble the eastern Q. palustris. FIg. 683.

16. Q. velùtina Lam. (Quencitron, YeLLOW-BARKED Or BLACK O.) Cup turbinate, or hemispherical with a conical base, 1.8 $2.3 \mathrm{~cm}$. broad, its upper pubescent thin lightchestnut scales loosely imbricated or squarrose when dry; acorns ovoid to hemispherical, $1,2-2 \mathrm{~cm}$. long, light-brown, often pubescent ; leaves variously divided, ordinarily with hairy tufts in the axils beneath, turning brownish, orange, or dull red in autumn; bark darkbrown and rough, internally orange. ( $Q$. tinctoria Bartr.; Q. coccinea, var. tinctoria

A. DC.) - Dry or gravelly uplands, s. Me. to w. Ont., and southw. - The bark is largely used in tanning. Fig. 684. Var. Missouritensis Sarg. Leaves with perinanent rusty pubescence beneath, and cup-scales tomentose. - Mo, and A rk.

V 17. Q. falcàta Michx. (SPanish O.) Leaves grayish-downy or fulvous underneath, 3-5-lubed above (sometimes entire); the lobes prolonged, mostly narrow and more or less scythe-shaped, especially the terminal one, entire or sparingly cut-toothed; acorn globose, 8-10 mm. long; cup saucer-shaped with a somewhat top-shaped base and about half the lergth of the acorn. ( $Q$. digitata Sudworth; Q. pagodaefolia Ashe.) - Dry or sandy soil, N. J. to Fla.; and from s. Ind. to Mo. and Tex. - A large or small tree, extremely variable in foliage; bark excellent for tanning. FIG. 685 .

18. Q. ilicifòlia Wang. (Bear or Black Scrub o.) Dwarf (1-3, rarely $6, \mathrm{~m}$. high), straggling; leaves (5-10 cm. long) thickish, obovate, wedgeshaped at base, angularly about 5(3-7)-lobed, white-douny beneath; lobes short and triangular,

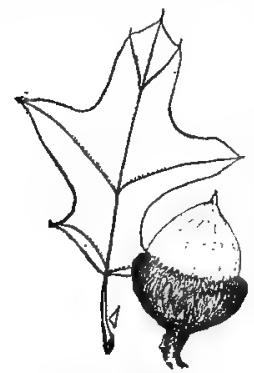

686. Q. Lliolfolia. spreading; acorn 10-12 $\mathrm{mm}$. long. (Q. nana Sarg.) - Sandy barrens and rocky hills, N. E. to $O$, and Ky. Fig 686 .

19. Q. nigra L. (WATER O.) Leaves glabrous and shining, obovate-spatulate or namowly wedge-form, with a long tapering base and an often obscurely 3-lobed summit, varying to oblanceolate. (Q. aquatica Walt.) - Wet ground, around ponds, etc, Del. to the Gulf; and from $\mathrm{Ky}$. and Mo. to Tex. - Tree 8-12 m. high ; running into many varieties, especially southw.; the leaves on seedlings and strong shoots often in-

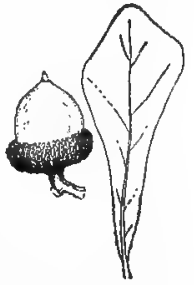

687. Q. nigra. 
cised or sinuate-pinnatifid (then mostly bristle-pointed). FIG. 687.

20. Q. marilándica Muench. (BLAcK JACK or BARREN U.) Leaves broadly wedgeshaped, but sometimes rounded or obscurely cordate at the base, widely dilated and

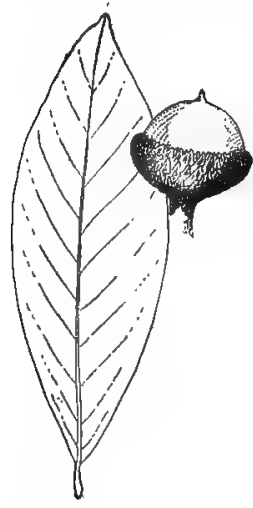

6\$9. Q. imbricaria. somewhat 3 (rarely 5)-lobed at the summit, occasionally with one or two lateral conspicuously bristle-tipped lobes or teeth, rusty-pubescent beneath, shining above, large, $1-2.5 \mathrm{dm}$. long. ( $Q$. nigra Man. ed. 6, not L.) - Dry sandy

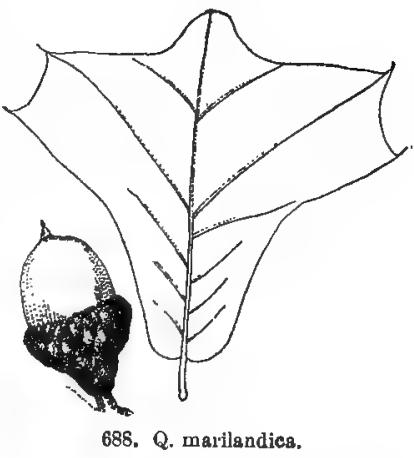

barrens, or heavy clay soil, L. I. to s. Minn., e. Neb., and southw. - A small tree of little value. Fig. 688.

21. Q. imbricària Michx. (Kadrel or SHingle O.) Leaves lanceolate or lance-oblong, thickish, smooth and shining above, downy beneath, the down usually persistent; cup between saucershaped and top-shaped.- Rich woodlands, Pa. to Ga., w. to s. Wisc., e. Neb., and Ark. locally, e. Mass. (Kennedy). - Tree 8-27 m. high. Frg. 689.

22. Q. phéllos L. (WILLow O.) Leaves linear-lanceolate, narrowed to both ends, soon glabrous, light green (about $1 \mathrm{dm}$. long); cup saucer-shaped. - Bottom-lands or rich sandy uplands, Staten I., N. Y. to Fla., w. to Ky., Mo., and Tex. Fig. 690. Val. LAURIFolia (Michx.) Chapm. (Laures O.) Leaves oblong, usually larger. ( $Q$. laurifolia Michx.) - N. J. to Fla. and La.

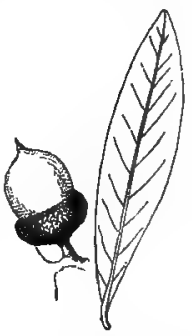

690. Q. phellos.

\section{URTicàceae (Nettre Familx)}

Plants with stipules, and monoecious or dioecious or rarely (in the Elm Tribe) perfect flowers, furnished with a regular calyx free from the 1(ravely 2)-celled otary which forms a 1-seeded fruit; the embryo in the albumen when there is any, its radicle pointing upward; stamens as many as the lobes of the calyx and opposite them, or sometimes fewer. Cotyledons usually broad. Stipules often deciduous. - A large family (far the greater part tropical).

Tribe I. ULMEAE. Flowers mostly polygamous, upon the last year's branches. Anthers erect in the bud, extrorge. Styles or stigtnas 2. Seed suspended. Embryo straight. - Trees, with alternate serrate pinnately veined leares and fugacions stipules.

1. Ulmus. Ovary 1-2-opuled. Fruit winged all around.

2. Planera. Flowers appearing with the leaves. Ovule one. Fruit wingless, nut-like.

Tribe II. CELTfDEAE. As in Tribe I., but the monoeolovis-polygamous flowers upon branches of the same year. Anthers introrse. Frult a drupe. Embryo eurved.

8. Celtis. Ovary 1-ovulot. Flowers appenring with the leaves. Lenves 8-nerved at base.

Tribe III. CANNABINEAE. Flowers dioecions; the sterile racemed or panicled; the fertile in clusters or catkins, the calyx of one sepal embracing the ovary. Filarnents short, erect in the bud. Stigmas 2, elongated. Ovary 1-celled, with a pendulous ovule, forming a small glandular 
achene in fruit. Embryo curved or coiled. - Herbs with watery juice, mostly opposite lobed or divided leaves and persistent stipules.

4. Cannabis. Fertile flowers splked-clustered. Leaves 5-7-divided. Erect.

5. Humulus. Fertile flowers in a short spike forming a membranaceous catkin in fruit. Leaves 8-5-lobed, Climbing.

Tribe IV. MÒREAE. Flowers unisexual; calyx becoming fleshy or juicy in fruit. Anthers inflexed in the bud. Ovule pendulous. Fruit an achene. Embryo curved. - Trees or shrubs, with milky juice, alternate leaves, and fagacious stipnles.

6. Maclura. Sterile flowers in loose racemes; fertile in globose heads. Leaves entire.

7. Broussonetia. Sterile fowers in dense catkins; the fertile in globose heads. Leaves serrate, often lobed.

8. Morus. Fertile and sterile fiowers in separate spikes. Leaves dentate, 8-nerved.

Tribe V. URTfCEAE. Flowers unisexual. Filamente inflexed in the bud. Style or stigma simple. Ovary 1-celied, with an erect ovale, forming an achene in fruit. Embryo straight. Herbs with watery juice.

- Calyx in the fertile flowers of 2-5 separate or nearly separate sepals.

+ Plant beset with stinging bristles.

9. Urtica. Sepals 4 in both fertile and sterile flowers. Achene straight and erect, inclosed by the 2 inner and larger sepals. Stigma eapitate-tufted. Leaves opposite.

10. Laportea. Sepals 5 in the sterile flowers, 4 in the fertile, or apparently only 2 . Stigma longsubulate. Achene very oblique, deflexed, nearly naked. Leaves alternate.

+ + Plant wholly destitute of stinging bristles; leaves opposite.

11. Pilea. Sepals 8 or 4 , those of the fertile flowers anequal, all or all but one small. Achen 6 partly naked, straight and erect. Stigma pencil-tufted. Smooth and ghining.

* * Fertile calyx tubular or cup-shaped, inciosing the achene; unarmed.

12. Boehmeria. Flower-clusters spiked, not involucrate. Style long and thread-shaped, stigmatic down one side. Leaves opposite, serrate.

18. Parietaria. Flowers in involucrate-bracted clusters. Stigma tufted. Leaves alternate, entíre.

\section{1. ÚLMUS [Tourn.] L. Eцm}

Calyx bell-shaped, 4-9-cleft. Stamens 4-9, with long and slender filaments. Ovary 1-2-celled, with a single anatropous ovule suspended from the summit of each cell; styles 2, short, diverging, stigmatic along the inner edge. Fruit a 1-celled and 1-seeded membranaceous samara. Albumen none ; cotyledons large. - Flowers purplish or yellowish, in lateral clusters. Leaves strongly straightveined, short-petioled, and oblique or unequally somewhat heart-shaped at base. Stipules small, caducous. (The classical Latin name.)

* Flowers nearly sessile; fruit orbicular, not ciliate; leaves very rough above.

1, U. fúlva Michx. (Slippery or ReD E.) Buds before expansion softdowny with rusty hairs ; leaves ovate-oblong, taper-pointed, doubly serrate, 1-2 dm. long, sweet-scented in drying, soft-downy beneath or slightly rough downward ; branchlets and pedicels downy; calyx-lobes and stamens 5-9; fruit (1.6$1.8 \mathrm{~cm}$. wide) with the cell pubescent. - Rich soll, w. Que. and N. E. to L. Huron, the Dakotas, and southw. Mar., A pr, - A small or middle-sized tree $(15-20 \mathrm{~m}$. high), with tough reddish wood, and a very mucilaginous inner bark.

2. 'U. Campéstris L. (English E.) A large irregularly branched tree with glabrous pedicels and large suborbicular glabrous fruit. - Commonly planted for shade, and tending to escape. - Variable; some forms with corky-winged branchlets. (Introd. from Eu.)

* Flowers on slender drooping pedicels, which are jointed above the middle; fruit ovate or oval, fringed-ciliate; leaves smooth above or nearly so.

- Flowers vernal, appearing before the leaves.

3. U. americana L. (AMERICAN or White E.) Buds glabrous; branches not corky; leaves obovate-oblong or oval, abruptly pointed, sharply and often 
doubly serrate (5-10 cm. long), soft-pubescent beneath or soon glabrate; flowers in close fascicles; calyx with 7-9 roundish lobes; fruit glabrous except the margins $(1.2 \mathrm{~cm}$. long), its sharp points incurved and closing the notch. - Moist woods, especially along rivers, in rich soil. Apr. - A large and well-known ornamental tree, variable in habit, usually with spreading branches and drooping branchlets.

4. U. racemosa Thouns. (Cовк or Rook E.) Bud-scales downy-ciltate and somewhat pubescent, as are the young branchlets; branches often with corky ridges; leaves nearly as in the last, but with veins more simple and straight; flowers racemed; fruit much as in the last, but rather larger. (U. Thomasi Sarg.) - River-banks and calcareous ridges, w. Que. and w. Vt. to Ont. anc Minn., s. to Mo. and $\mathrm{Ky}$. - A large and very valuable tree.

5. U. alata Michx. (WAHOO or WINGED E.) Bud-scales and branchlets nearly glabrous; branches, at least some of them, corky-winged; leaves downy beneath, ovate-oblong and oblong-lanceolate, acute, thickish, small ( $3-6 \mathrm{~cm}$. long); calyx-lobes obovate; iruit downy on the face when young. - Va. to s. Ind., s. Mo., and southw. Mar. -A sinall tree.

- + Flowers autumnal, appearing long after the leaves.

6. U. serótina Sarg. Tree of moderate size ; leaves narrowly obovate, acuminate, doubly serrate, paler and soft-pubescent beneath ; flowers racemose; calyx cleft nearly to the base, its divisions very narrow; fruit rhombic-ovate, 2-horned, $5 \mathrm{~mm}$. broad. - Limestone hills and bottoms, s. Ky. to n. Ala. and Ga.

\section{Planèra J. F. Gmel. Planer Tree}

Flowers monoeciously polygamous. Calyx 4-5-cleft. Stamens 4-5. Ovary ovoid, 1-celled, 1-ovuled, with 2 spreading styles which are stigmatose down the inner side, in fruit becoming coriaceous. - Trees with small leaves, like those of Elms, the flowers appearing with them in small axillary clusters. (Named for J. J. Planer, 1743-1789, a German botanist and professor at Erfurt.)

1. P. aquática (Walt.) J. F. Gmel. (WATER ELM.) Nearly glabrous; leaves ovate-oblong, small ; fruit stalked in the calyx, beset with irregular rough projections. - Coastal swamps, N. C. to Fla. and Tex, ; inland in the Miss. basin to Mo., s. Ill. and Ky. Apr. - A rather small tree.

\section{Cellis [Tourn.] L. Netthe-tree. Hackberky}

Calyx 5-6-parted, persistent. Stamens 5-6. Ovary 1-celled, with a single suspended ovule; stigmas 2, long and pointed, recurved. Cotyledons folded and crumpled. - Flowers greenish, axillary, the fertile solitary or in pairs, peduncled, appearing with the leaves, the lower usually staminate only, fascicled or racemose along the base of the branches of the season. (A name of Pliny's for an African species of Lotus, transferred to this genus perhaps on account of the sweet berries).

1. C. occidentalís L. (Sugarberry.) Leaves reticulated, ovate, cordateovate ancl ovate-lanceolate, taper-pointed, usually conspicuously and sharply so, more or less oblique at base, sharply serrate, sometimes sparingly so or only toward the apex, scabrous but mostly glabrous above, usually soft-pubescent beneath, at least when young; fruit reddish or yellowish, turning dark purple at maturity, its peduncle once or twice the length of the petiole. (C. canina Raf.) - Woods and river-banles, w. Que. and N. E. to Man., and southw. Apr., May. -A small or sometimes large tree, with the aspect of an EIm, bearing sweet and edible fruits as large as bird-cherries, at first obovoid, ripe in autumn; the flesh thin. Variation as to stature, foliage, form and color of fruit, etc., great in extent but without clear correlation. Var. pumila Muhl. is a dwarf form, being merely a low straggling shrub. Var. crassifolia (Lam.) Gray is a tree and may often be distinguished by its pubescent branchlets and large $(9-13 \mathrm{~cm}$. long) commonly cordate leaves scabrous on the upper surface.

2. C. mississippiensis Bosc. Leaves entive (rarely fow-toothed), very long. 
taper-pointed, rounded at base, mostly oblique, thin, and smooth ; fruit small. - Chiefly in rich bottom-lands, s. Ind. to Mo. (Bush), and s. to Fla. and Tex. - A small tree with warty bark. (Mex., Bermuda.)

\section{CÁNNABIS [Tourn.] L. HeMP}

Flowers green; the sterile in axillary compound racemes or panicles, with 5 sepals and 5 drooping stamens. Achene crustaceous. Embryo simply curved. - A tall roughish annual, with digitate leaves of 5-7 linear-lanceolate coarsely toothed leaflets, the upper alternate; the inner bark of very tough fibers. (The ancient Greek name, of obscure etymology.)

1. C. sativa L. - Waste and cultivated ground. (Adv. from Asia.)

\section{HùMULUS L. HoP}

Flowers dioecious; the sterile in loose axillary panicles, with 5 sepals and 5 erect stamens. Fertile flowers in short axillary and solitary spikes or catkins ; bracts foliaceous, imbricated, each 2 -flowered, in fruit forming a sort of menbranaceous strobile. Achene invested with the enlarged scale-like calyx. Embryo coiled in a flat spiral. - Twining rough perennials, with stems almost prickly downward, and mostly opposite heart-shaped and palmately 3-7-lobed leaves. (A late Latin name, of 'Teutonic origin.)

1. H. Lupulus L. (СоммоN H.) Leaves mostly 3-5-lobed, commonly longer than the petioles; bracts, etc., smoothish; the fruiting calyx, achene, etc., sprinkled with yellow resinous grains, which give the bitterness and aroma to the hop. - Alluvial banks, rubbish heaps, etc., common. July. (Eurasia.)

2. H. JA Pónicus Sieb. \& Zucc., with smaller more deeply 5-lobed leaves and herbaceous bracts without glandular atoms, occasionally escapes from frequent cultivation. (Introd. from Japan.)

\section{MACLÙra Nutt. Osage Orange, Bois d'Arc}

Flowers dioecious; the staminate in loose short racemes, with 4-parted calyx, and 4 stamens inflexed in the bud; the pistillate in a dense globose head, with a 4-cleft calyx inclosing the ovary. Style filiform, long-exserted; ovule pendulous. Fruit an achene, buried in the greatly enlarged fleshy calyx. Albumen none. Embryo recurved. - Trees with entire pinnately veined leaves, axillary peduncles, and stout axillary spines. (Named for the early American geologist, William Maclure.)

1. M. pomifera (Raf.) Schneider. A tree 10-15 m. high; leaves ovate to oblong-lanceolate, pointed, mostly rounded at base, green and shining; syncarp globose, yellowish-green, 7-10 cm. in diameter. (Ioxylon Raf.; Toxylon Sarg.; M. aurantiaca Nutt.) - Rich soil, s. Mo. to n. Tex. ; extensively used for hedges and sometimes spontaneous eastw. - Wood bright orange.

\section{BROUSSONEtTIA L'Hér.}

Flowers dioecious; the sterile in flexuous aments ; calyx 4-parted ; stamens 4 ; flaments inflexed in bud; fertile flowers in dense globular tomentose heads. Leaves alternate, ovate, often irregularly lobed, pubescent and more or less scabrous. (Named for Auguste Broussonet, of Montpellier, physician and naturalist.)

1. B. Papyrffera (L.) Vent. (Paper Mulberrt.) Often cultivated and said to escape in the Middle Atlantic States and southw. (Introd. from Asia.)

\section{MORUS [Tourn.] L. MolberRy}

Flowers monoeclous or dioecious. Calyx 4-parted; lobes ovate. Stamens 4 ; filaments elasticaliy expanding. Ovary 2-celled, one of the cells smaller and disappearing; styles 2, thread-form, stigmatic down the inside. Achene ovate, 
compressed, covered by the succulent berry-like calyx, the whule spike thus becoming a thickened oblong and juicy (edible) aggregate fruit. (The classical Latin naine.)

1. M. rübra L. (RED M.) Leaves heart-ovate, serrate, rough above, dovny beneath, pointed (on young shoots often lobed); flowers frequently dioecious; fruit dark purple, long. - Rich woods, w. N. E. to s. Ont., the 1)akotas, e. Kan., and southw. May. - Large tree, ripening its blackberry-like fruit in July.

2. M. ALBA L. (WhITE M.) Leaves obliquely heart-ovate, acute, serrate, sometimes lobed, smooth and shining; fruit whitish. - Spontaneous near houses. (Introd. from Eu.)

\section{URTICA ['Tourn.] L. Nettle}

Flowers monoecious, or rarely dioecious, clustered, the clusters mostly in racemes, spikes, or loose heads. Ster. Fl. Sepals 4. Stamens 4, inserted around the cup-shaped rudinent of a pistil. Fert. Fl. Sepals 4, in zairs; the 2 outer smaller and spreading; the two inner fiat or concave, in truit membranaceous and inclosing achene. - Stipules in our species distinct. Flowers greenish; in summer. (The classical Latin name; from urere, to burn.)

* Perennials; flower-clusters in branching panicled spikes, often dioecious.

- Petiole more than half as long as the leaf-breadth.

1. U. grácilis Ait. Slender $(0.6-3 \mathrm{~m}$. high), sparingly bristly and often with some short grayish pubescence ; leaves narrowly lance-oblong, $1-5 \mathrm{~cm}$. broad, pointed, serrate, 3-j-nerved from the rounded or scarcely heart-shaped base, almost glabrous, with relatively small teeth (2.)-35 on each side the middle leaves); spikes slender and loosely panicled. - Fence-rows and moist ground, common.

2. U. Lyállii Wats. Sparingly bristly and sometimes grayish pubescent; leaves ovate or ovate-larceolate, mostly $3-7 \mathrm{~cm}$. broad, usually cordate, with fewer and coarser teeth (15-23 on each side); otherwise much like the preceding. - Alluvial thickets and waste places, Nfd. to Ct. and w. N. Y.; also Rocky Mts. and westw.

$$
\text { + - Petioles less than half as long as the leaf-breadth. }
$$

3. U. Drofca L. (Stinging N.) Very bristly and stinging, 6-9 dm. high ; leaves ovate-heart-shaped, pointed, very depply serrate, dorony beneath as well as the upper part of the stem; spikes much branched. - Waste places and roadsides, rather rare. (Nat. from Eu.)

\section{* Annuals; flover-clusters chiefly axillary and shorter than the petiole, androgynous.}

4. U. UेRENg L. Leaves elliptical or ovate, very coarsely and deeply serrate with long spreading teeth, the terminal teeth not longer than the lateral ones; flower-clusters 2 in each axil, small and loose. - Waste grounds, near dwellings, eastw.; scarce. - Plant 1-3 dın, high, with sparse stings. (Nat. from Fu.)

5. U. chamaedryoides Pursh. Leaves ovate and mostly heart-shaped, the upper ovate-lanceolate, coarsely serrate-toothed; flors $r$-clusters globular, $1-2$ in each axil, and spiked at the summit. - Alluvial shaded soil, from $\mathbf{K y}$. to the Gulf States; casual northw. - Slender, 2-7 dm. high, sparsely beset with stings.

\section{LAPórtea Gaud. Wood Nettre}

Flowers monoecious or dioecious, clustered, in loose cymes; the upper widely spreading and chiefly or entirely fertile; the lower mostly sterile. Ster. Fl. Sepals and stamens 5, with a rudiment of an ovary. Fert. Fl. Calyx of 4 sepals, the two outer or one of them usually minute, and the two inner much larger. Stigma hairy down one side, persistent. Achene ovate, flat, reflexed on the winged or margined pedicel, nearly naked. - Perennial herbs with large serrate leaves, and axillary stipules. (Named for Francois $L$. de Laporte, Count of Castelnau, Entomologist of the 19th century) 
1. L. canadénsis (L.) Gaud. Stem 6-9 dm. high; leaves ovate, pointed, strongly feather-veined $(7-15 \mathrm{~cm}$. long), long-petioled; fertile cymes divergent; stipule single, 2-cleft. (Urticastrum divaricatum Ktze.) - Rich woods, N. B. to Ont., Minn., and southw. July-Sept.

\section{Pilea Lindl. Richweed. Clafarweed}

Flowers monoecious or dioecious. Ster. Fl. Sepals and stamens 3-4. Fert. Fl. Sepals 3, more or less unequal, a rudiment of a stamen commonly before each in the form of a hooded scale. - Stingless, mostly glabrous and low herbs, with united stipules; the staminate flowers often mixed with the fertile. (Named from the shape of the larger sepal of the fertile flower in the original species, which partly covers the achene, like the pileus, or felt cap, of the Romans.)

1. P. pùmila (L.) Gray. Low (1-5 dm. high); stems smooth and shining, pellucid; leaves ovate, coarsely toothed, pointed, 3 -ribbed and veiny ; flowerclusters much shorter than the petioles; sepals of the fertile flowers lanceolate, scarcely unequal. (Adicea Raf.) - Cool and moist shaded places. July-Sept.

\section{BOEHMÈria Jacq. False Nettle}

Flowers monoecious or dioecious, clustered; the sterile much as in Urtica; the fertile with a tubular or urn-shaped entire or 2-4-toothed calyx inclosing the ovary. Style elongated-awl-shaped, stigmatic and papillose down one side. Achene elliptical, closely invested by the dry and persistent compressed calyx. - No stings. (Named after $G . R$. Boehmer, professor at Wittenberg in the 18th century.)

1. B. cylindrica (L.) Sw. Perennial, smoothish or somewhat pubescent; stem (3-9 dm. high) simple; leaves chiefly opposite (rarely all alternate), ovate to ovate- or oblong-lanceolate, pointed, serrate, 3-nerved ; stipules distinct ; petioles mostly elongated; flowers dioecious, or the two kinds intermixed, the small clusters densely aggregated in simple and elongated axillary spikes, the sterile interrupted, the fertile often continuous, frequently leaf-bearing at the apex. Moist or shady ground, centr. Me. to Ont., and southw. - Very variable.

Var. scàbra Porter. Leaves oblong-lanceolate, less sharply pointed, smaller, and scabrous-pubescent. - N. J. and Pa., and southw. and westw.

\section{Parietària [Tourn.] L. Pellitory}

Flowers monoeciously polygamous; the staminate, pistillate, and perfect intermixed in the same cymose axillary clusters; the sterile much as in the last ; the fertile with a tubular or bell-shaped 4-lobed and nerved calyx inclosing the ovary and the ovoid achene. - Homely diffuse or tufted herbs, not stinging, with alternate entire 3-ribbed leaves, and no stipules. (The ancient Latin name, because growing on old walls.)

1. P. pennsylvánica Mubl. Low, annual, simple or sparingly branched, minutely downy; leaves oblong-lanceolate, thin, veiny, roughish, with opaque dots; flower's shorter than the involucre; stigma sessile. - Shaded rocky banks, Little Cranberry I., Me. (Redfield); e. Mass. and Vt. to Ont., Minn., and southw. June-Aug.

P. DéBILIs Forst., with small ovate leaves (8-11 mm. long), few-flowered axillary clusters, and short involucres (about equaling the flovers), has been found once on Pautuckaway Mt, s.e. N. H. (Eaton), where probably of casual introduction. (Eurasia, Pacific N. Am., S. Am.)

\section{SANTALÀCEAE (Sandalwood Familx)}

Herbs, shrubs, or trees, with entire leaves; the 4-5-cleft calyx valvate in the bud, its tube coherent with the 1-celled ovary; ovules 2-4, suspended, from the 
apex of a stalk-like free central placenta which rises from the base of the cell, but the (indehiscent) fruit always 1-seeded. - Seed destitute of any proper seed-coat. Stamens equal in number to the lobes of the calyx, and inserted opposite them into the edge of a fleshy disk. Style 1. A small family, chiefly tropical.

1. Comandra. Hlowers perfeot, in umbel-like clusters. Low herbaceous perenniale.

2. Pyrularia. Flowers dioecious or polygamous. Shrub, with alternate leaves,

8. Nestronia. Flowers dioecious, Shrub, with opposite leares.

\section{COMÁNdRa Nutt: Bagtard Toad-rlax}

Flowers perfect. Calyx bell- or urn-shaped, lined above the ovary with an, adherent disk which has a 5-lobed free border. Anthers connecued by a tuft of thread-like hairs to the calyx-lobes. Fruit drupe-like or nut-like, crowned by the persistent calyx-lobes. Smooth (sometimes parasitic) perennials, with herbaceous stems from a rather woody base, alternate and almost sessile leaves,

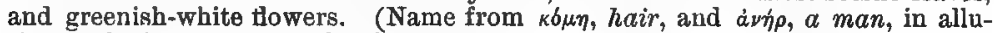
sion to the hairs on the calyx-lobes which are attached to the anthers.)

1. C. umbellata (L.) Nutt. Rootstock underground; flowering stems 1.5-4 dm. high, branched, very leafy; leaves oblong, thin, pale beneath, $1-3.5$ $\mathrm{cm}$. long, the pale midrib prominent beneath; inflorescence an ellipsoid panicle with many cymules of small flowers on divergent branches; calyx-tube conspicuously continued as a neck to the dry globular-urn-shaped fruit; the lobes oblong; style slender. - Dry ground, centr. Me. to Wisc. and Ga. May, June. - Root forming parasitic attachments to the roots of trees and shrubs.

2. C. Richardsiàna Fernald. Rootstock superficial, very elongate and freely branching ; flowering stems $0.5-2.5 \mathrm{dm}$. high, very leafy ; the strongly ascending green leaves lanceolate to ovate, firm, not paler beneath, obscurely veiny; inflorescence corymbose, 1-3 cm. broad, of 1-6 few-flowered cymules on ascending branches. - Dry sandy or gravelly soil, e. Que. to Assina., s. to the Great Lakes, Mo., and Kan. May-Aug.

3. C. pállida A. DC. Leaves narrower, more glaucous and acute, linear to narrovoly lanceolate (or those upon the main stem oblong), all acute or somewhat cuspidate; fruit ovoid, larger (6-10 mm. loug), sessile or on short stout pedicels. - Minn. to N. Mex. and westw.

4. C. livida Richards. Peduncles slender, axillary, 3-5-flowered, shorter than the oval leaves; calyx-tube not continued beyond the ovary, the lobes ovate; style short; fruit pulpy when ripe, red.-Bogs, sterile soil, etc., Lab. to Mackenzie, s. to s. N. B., mts. of n. N. E., Mich., and B. C. June, July.

\section{PYRULARIA Michx. OIL-Nut. Bumralo-nut}

Calyx 4-5-cleft, the lobes recurved, hairy-tufted at base in the male flowers. Stamens 4 or 5 , on very short filaments, alternate with as many rounded glands. Fertile flowers with a pear-shaped ovary invested by the adherent tube of the calyx, naked at the flat summit; style short and thick. Fruit fleshy, pearshaped. - Shrubs or trees, with alternate short-petioled deciduous leaves and small greenish flowers in short and simple spikes or racemes. (Name a diminutive of Pyrus, from the shape of the fruit.)

1. P. pùbera Michx. Shrubby, straggling (1-4 m. high), minutely downy when young; leaves obovate-oblong, acute or pointed at both ends, soft, very veiny, minutely pellucid-punctate; spike few-flowered, terminal ; caly 5 5-cleft ; fruit $2.5 \mathrm{~cm}$. long. - Rich woods, mts. of $\mathrm{Pa}$. to $\mathrm{Ga}$. May. - Whole plant, especially the fruit, imbued with an acrid oil.

\section{NESTRÒNIA Raf.}

Calyx 4-5-lobed. Staminate flowers in 3-8-flowered slender-peduncled umbels; the pistillate solitary, jointed upon short peduncles springing from opposite 
axils. Leaves oval, thin, deciduous, short-petioled. (Name said by its author

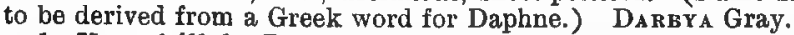

1. N. umbéllula Raf. Low shrub, 3-8.5 dm. high; leaves $3-6 \mathrm{~cm}$. long, mostly acute ; flowers small, greenish; drupes at length globose, $1-1.3 \mathrm{~cm}$. in diameter. (Darbya umbellulata Gray.) - Parasitic on roots of trees, Va. to S.C. and Ala. Apr., May.

\section{LORANTHACEAE (Mistrleton FAMILT)}

Chiefly shrubby plants with coriaceous greenish, yellowish, or olive-brown foliage, parasitic on trees.

1. Phoradendron. Anthers 2-celled. Berry globose, pulpy. Leaves foliaceous,

2. Arceuthobium. Anthers 1-celled. Berry compresed. Leaves seale-like, connate.

\section{PhORADENDRON Nutt. False Mistletoe}

Flowers small, dioecious, in short catkin-like jointed spikes, usually several to each short fleshy bract or scale, and sunk in the joint. Calyx globular. 3 (rarely 2-4)-lobed; in the staminate flowers a sessile anther is borne on the base of each lobe; in the fertile flowers the calyx-tube adheres to the ovary; stigma sessile, obtuse. Berry 1-seeded, pulpy. - Yellowish-green woody parasites on the branches of trees, with jointed much-branched stems and thick firm persistent leaves. (Name composed of $\phi \omega \rho, a$ thief, and $\delta \epsilon \delta \delta \rho \nu$, tree; from the parasitic habit.)

1. P. flavéscens (Pursh) Nutt. (American Mistletoz.) Leaves obovate, glabrous. - On various deciduous trees, chiefly at low altitudes, N. J. and e. Pa. to Fla. and N. Mex., inland in Miss. basin to Mo., s, Ind., and centr. 0 .

\section{ARCEUTHOBBIUM Bieb.}

Caly'x mostly compressed; the staminate usually 8-parted, the pistillate 2-toothed. Anthers a single orbicular cell, opening by a circular slit. Berry compressed, on a short recurved pedicel. - Parasitic on Conifers, glabrous, with rectangular branches and connate scale-like leaves. (From dokevios, the juniper, and $\beta$ los, life.)

1. A. pusillum Peck. (Dwarf Mistretoe.) Very dwarf, the slender scattered or clustered stems 6-20 mm. high, usually simple, olive-green to chestnut; scales obtuse; flowers solitary in most of the axils; fruit narrowly ellipsoid, $2 \mathrm{~mm}$. long. (Razoumofslyya Ktze.) - On Picea and Larix, Nfd. and e. Que. to Pa. and n. Mich. (Wheeler). Apr., May. - Often causing "witch's brooms" on the host-plant.

\section{ARISTOLOCHACEAE (BIRTHWORT FaMiLT)}

Twining shrubs, or low herbs, with perfect flowers, the conspicuous lurid calyx valvate in bud and coherent (at least at base) with the 6-celled ovary, which forms a many-seeded 6-celled capsule or berry in fruit. Stamens 5-12, more or less united with the style; anthers adnate, extrorse. - Leaves petioled, mostly heart-shaped and entire. Seeds anatropous, with a large fleshy rhaphe, and a minute embryo in tleshy albumen. A small family of bitter-tonic or stimulant, sometimes aromatic, plants.

1. Asarum. Stemless herbs. Stamens 12 , with more or less distinct flaments.

2. Aristolochia. Cauiescent herbs or twining shrubs. Stamens 6 , the sessile anthers adnate to the stigma. 


\section{1. Ásarum [Tourn.] L. Agarabacca. Wild Ginger}

Calyz regular; the limb 3 -cleft or -parted. Petals $0-3$, when present rudi. mentary, awl-shaped, alternate with the calyx-lobes. 'Tips of the filaments usually continued beyond the anther into a point. Capsule rather fleshy, globular, bursting irregularly or loculicidal. Seeds large, thick. - Stemless perennial herbs, witlı aromatic-pungent creeping rootstocks bearing 2 or 3 scales, then one or two kidney-shaped or heart-shaped leaves on long petioles, and a shortpeduncled tlower close to the ground in the lower axil ; in spring. (An ancient name, of obscure derivation.)

\$1. Calyx-tube wholly adnate to the ovary, the tips inflexed in bud; fllaments slender, much longer than the short anthers; style barely 6-lobed at the summit, with 6 radiating thick stigmas; leaves a single pair, unspotted.

1. A. canadénse I. Soft-pubescent ; leaves membranaceous, kidney-shaped, more or less pointed (1-1.5 dm. wide when full grown); calyx bell-shaped, the upper part of the short-pointed lobes more or less spreading, brown-purple inside. - Rich woods; common, especially northw. Var. REFLEXUM (Bicknell) Robinson. Calyx-segments short, deltoid, early and rather abruptly refiexed. ( $A$. reflexum Bicknell.) - Ct., southw. and westw. Var. Acuminatum Ashe. Calyx-segments caudate-acuminate. (A. acuminatum Bicknell.) - From Ct. westw. ; the commonest form in the prairie states.

§2. Calyx-tube inflated bell-or flask-shaped, its base adnate to the lower half of the ovary; limb 3-cleft, short; anthers sessile or nearly so, oblong-linear; styles 6 , fleshy, diverging, 2-cleft, bearing a thick extrorse stigma below the cleft; leaves thickish, persistent, usually only one each year, often whitishmottled; peduncle very short; rootstocks clustered, ascending.-HEXastìlis Raf. ( $\$ \$ 1$ and 2 connect in foreign species.)

$\checkmark$ 2. A. virginicum L. Nearly glabrous; leaves round-heart-shaped (about 5 $\mathrm{cm}$. wide); calyx short, campanulate, about $2 \mathrm{~cm}$. long, reticulated within; anthers pointless. (A. minus Ashe; Hexastylis virginica Small.) - W. Va. and Va. to Ga, in the mis.

A. HETERophÝllum Ashe (with "campanulate" calyx and "oval", seed) and A. Memmingèri Ashe (with "urceolate" calyx and "sharply triangular" seed) cannot be satisfactorily distinguished in the material at hand.

3. A. grandiflorum (Michx.) Small. Closely similar in habit and foliage; calyx very large, open-campanulate, 2.5-5 cm. long. (A. macranthum Small; A. Shuttleworthii Britten; Hexastylis Shuttleworthii Small.) - Mts. of Va., Tenn., and N. C.

4. A. arifolium Michx. Leaves halberd-heart-shaped (6-15 cm. long) ; calyx short-tubular, with very short and blunt lobes; anthers obtusely short-pointed. (Hexastylis Small.) - Va. to Fla. and La. A form (not always distinguishable) with a more flask-shaped calyx has been described as $A$. Ruthii Ashe.

\section{ARISTOLÒchia [Tourn.] L. Birthwort}

Calyx tubular; the tube variously inflated above the ovary, mostly contracted ; sessile anthers wholly adnate to the short and fleshy 3-6-lobed or -angled style. Capsule naked, septicidally 6-valved. Seeds very flat. - Twining, climbing, or sometimes upright perennial herbs or shrubs, with alternate leaves and lateral or axillary greenish or lurid-purple flowers. (Named from reputed medicinal properties).

* Calyx-tube bent like the letter $S$, enlarged at the two ends, the small limb obtusely 3-lobed; low herbs.

1. A. Serpentària T. (Virginia SNakeroot.) Stems $1.2-4.5 \mathrm{dm}$. high) branched at base, pubescent; leaves ovate or oblong, from a heart-shaped base or halberd-form, mostly acute or pointed; flowers all next the root, shortpeduncled. - Rich woods, Ct. to Fla., w, to Mich., Mo., and La. July. - The fibrous aromatic-stimulant root is well known in medicine. 
Var. hastàta (Nutt.) Duchartre.

Leaves narrow, lanceolate or linearoblong, sagittate or auriculate-hastate. (A.hastata Nutt. ; A. Nashii Kearney.) - $\mathrm{S}$. C. to Fla. and La. ; said to reach our southern limit in Va.

* Calyx-tube strongly curved like a Dutch pipe, contracted at the mouth, the short limb obscurely 3-lobed; very tall twining shrubs.

2. A. macrophýlla Lam. ( brous; leaves round-kidney-shaped (sometimes $4 \mathrm{dm}$. broad); peduncles with a clasping bract; calyx ( $3 \mathrm{~cm}$. long) with a brown-purple abrupt flat border. ( $A$. Sipho L'Hér.) - Rich woods, Pa. to Ga., w. to Minu. and Kan. May.

3. A. tomentòsa Sims. Downy or soft-hairy; leaves round-heart-shaped, very veiny (8-16 cm. long); calyx yellowish with an oblique dark purple closed orifice and a rugose reflexed limb. - Rich woods, N. C. to Fla., w. to s. Ill. and Mo. June.

*** Calyx-tube straight, open, with ample 6-lobed limb, the lobes appendaged; anthers equidistant; erect herbs; flowers in axillary cymose fascicles.

4. A. CLgmatìns L., with long-petioled cordate leaves, sometimes cultivated, has become locally established in the Atlantic States from N. Y. to Md. (Introd. from Eu.)

\section{POLYGONÀCEAE (BdGkwheat Famil}

Herbs, with alternate entire leaves, and stipules in the form of sheaths (ocreae, these sometimes obsolete) above the swollen joints of the stem; the flowers mastly perfect, with a more or less persistent calyx, a 1-ctlled ovary bearing 2 or 3 styles or stigmas, and a single erect orthotropous seed. Fruit usually an achene, compressed or 3-4-angled or -winged. Stamens 4-12, inserted on the base of the 3-6-cleft calyx.

* Flowers involucrate; stamens 9 ; stipules none.

1. Eriogonum. Involucre several-flowered, with flowers exserted. Calyx 6-cleft.

* Flowers without involucre; stamens 4 to 8.

+ Stipular sheaths manifest; ovule erect from the base of the cell.

\# Sepals 4 or 6 , the outer row reflexed, the inner erect and enlarging in fruit.

2. Oxyria. Sepals 4. Stigmas 2. Achene orbicular-winged. Leaves reniform.

8. Rumex. Sepals 6. Stigmas 8. Achene 3-angled.

\# + Sepals 5 (sometimes 4), equal and erect in fruit; achene triangular or lenticular.

4. Polygonum. Embryo slender, curved around one side of the albumen. Achenes inclosed by the somewhat enlarged fiuiting calyx (or exserted in a few species with lanceulate or linear leaves).

5. Fagopyrum. Eimbryo in the albumen, its very broad cotyledons twisted-plaited. Fruit much exserted from the scarcely enlarged calyx. Leaves deltoid, sagittate or hastate.

6. Polygonella. Eubryo slender, nearly straight. Pedicels solitary. Leaves linear. Plant heath-like.

++ Stipnles obsolete; ovule hanging from the apex of a slender stalk.

7. Brunnichia. Calyx 5-parted, in fruit with a wing decurrent on the pedicel, Tendril-climber

\section{ERIÓGONUM Michx.}

Flowers perfect, involucrate; involucre 4-8-toothed or -lobed, usually manyflowered; the more or less exserted pedicels intermixed with narrow scarious bracts. Calyx 6-parted or -cleft, colored, persistent about the achene. Stamens 9 , upon the base of the calyx. Styles 3 ; stigmas capitate. Achene triangular. Embryo straight and axial, with foliaceous cotyledons. - Leaves entire, without

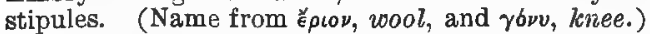

1. E. longifólium Nutt. Perennial, erect; leaves oblanceolate, acute or acutish, canescent beneath, the lower cuneate at base; sepals linear, caudate- 
attenuate, villous-canescenl. - Sandy woods and barrens, "s. Mo." to Fla. and Tex.

2. E. Allèni Wats. Perennial, erect; leaves oblong, canescent-tomentos beneath, flocculent or glabrate above, the lower rather abrupt at base; inflorescence leafy; sepals elliptical, yellow, nearly glabrous. - Dry soil, mts. of W. $\mathrm{Va}$ and $\mathrm{Va}$.

\section{OXÝRIA Hill. Modntain Sorrel}

Outer sepals smaller and spreading, the inner broader and erect (but un. changed) in fruit. Stamens 6. Stigmas 2, sessile, tufted. Achene lenticular, thin, flat, much larger than the calyx, surrounded by a broad veiny wing. Embryo straight, in center of the albumen, slender. - Low alpine perennial, with round-kidney-form and long-petioled leaves chiefly from the rootstock, obliquely trumcate sheaths, and small greenish to crimson flowers clustered in

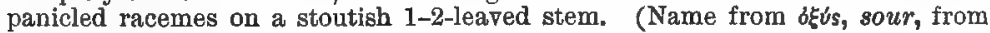
the acid leaves.)

1. O. digyna (L.) Hill. Alpine regions of the White Mts., N. H., and far northw.; Rocky Mts. (Eu.)

\section{RÙMEX L. Dook. SORREL}

Calyx of 6 sepals; the 3 outer herbaceous, sometimes united at base, spreading in fruit; the 3 inner larger, somewhat colored (in fruit called valves) and convergent over the 3-angled achene, veiny, often bearing a grain-like tubercle on the back. Stamens 6. Styles 3 ; stigmas tufted. Embryo slightly curved, lying along one side of the albumen, slender. - Coarse herbs, with small and homely (mostly green) flowers, which are crowded and commonly whorled in panicled racemes; the petioles somewhat sheathing at base. (The ancient Latin nawe; of unknown etymology.)

u. Sone of the leaves halberd-or arrow-shaped $b$.

b. Valpes entire or denticulate, 8-27 mm. broad c.

c. Grains of fruiting calyx 0 , or single and minute, not one thind as long as the valves.

Volves very large, 15-27 $\mathrm{mm}$. broad

Valves 4-7 mm. brosd.

Pedlcels with tumid joints

Pedicels obseurely jointed

c. Grains $1-8$, well developed, wostly one half to three fourths as long as the valves $d$.

a. Pedicels fliform, curved or flexuous o.

c. Lasyes crisped on the margin.

Grains chiefly plump and rounded at both ends

Prineipal grains tapering at summit

6. Leaves tat $f$. greenish, straw-colored, or dull brown calyx. Grains 3,

As broad as or broader than the wings of the valves

Narrower than the wings .

Grain 1

f. Pedicels obscurely jointed, mostly exceeding the membranous finally purpllsh calyx.

Grains 3

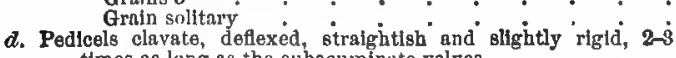
thes as long as the subacuminate valves

b. Valves entire or nearly so, scarcely 2 mm. broad, grain-bear
b. Valves with long sharp salient teeth at least near the base.

b. Valves with long sharp salient teeth at least near the base.
Perennial; pedicels fliform, longer than the subherbaceous valves

Perennial; pedicels flliform, longer than the subherbaceous valves
Perennfal: pedicels thiek, Bhorter than the thickish indurated valves

Anuual; teeth of the valves bristle-form

$u$. Some or all the leaves halberd-or arrow-shaped.

Valves much exceeding the frult; lenves arrow-shaped

Valves much exceeding the frutt; leaves balberd-shaped

Fruit exserted from the minute scarcely changed calyx

\section{1. $\boldsymbol{R}$. venosus.}

2. R. Patientia.

3. R. ocoidentalis.

\section{R. orrispus.}

6. R. olongatus.
7. $\boldsymbol{R}$. pallidus.

8. R. mecicanus.

9. R. altissimus.

4. R, Britannica. 3. $R$. occidentulis.

10. $\boldsymbol{R}$. verticillatus. 11. $R$. conglomeratus 12. R. obtusifolitus.

13. R. pulcher. 14. R. persicarlotdes

16. R. Acbtosa.

16. R. hastatulus.

1'6. R. Acotosella. 
\$1. LAPATHUM [Tourn.] DC. (Dоск.) Flowers perfect or monoeciously polygamous; herbage not sour or scarcely so. (Flowering through the summer.)

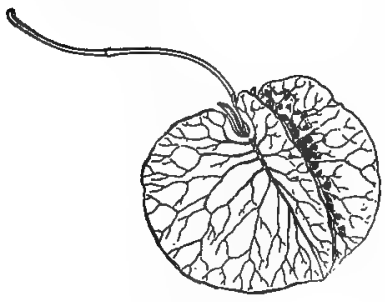

691. 12, vunusus.

Fruiting caly $\times 1$.

1. R. venòsus Pursh. Stems from running rootstocks, erect (2-6 dm. high or less), with conspicuous dilated stipules; leaves on short but rather slender petioles, ovate or oblong to lanceolate, acute or acuminate, only the lowest obtuse at base ; panicle nearly sessile, short, dense in fruit; valves entire, without grains, cordate with a deep sinus, rose-color. - Sask. to centr. Mo., and westw. Fig. 691.

2. R. Patiéntia L. (Patience D.) A very tall species, green and glabrous or nearly so, with ovate-oblong and lanceolate leaves (broadest above the base), those from the root 6-9 dm. long and 1-1.5 dm. broad; pedicels with tumid joints; one of the heart-shaped nearly or quite entire valves ( $6 \mathrm{~mm}$. broad) usually bearing a very small grain, or its midrib merely thickened at base. - Rich open soil, Nfd, to N. Y. and Pa. (Nat. from Eurasia.) Fig. 692. Var. KúRprous Boiss. Grain conspicuous, 2-3 $\mathrm{mm}$. long. - Mich. to Mo., and westw. (Nat. from Eurasia.)

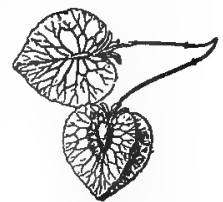

692. R. Patientia. Fruiting calyx $\times 1$.

3. R. occidentalis Wats. Smooth, stout, erect, usually purple-tinged ; leaves - large, flattish; pedicels obscurely jointed; valves broadly ovate or orbicular, somewhat obtusely nointed, often denticulate, 6-9 $\mathrm{mm}$. hroad, all naked or one of them grain-bearing. - Rich (often brackish) soil, Lab. to Alaska, s. to e. Me., Minn., N. Dak., Col, and Cal. Fig. 693. 698. R. oocidentalis. Fruiting ealyx $\times 1$. acute at both ends, transversely veined, and with obscurely erose-crenulate margins (the lowest, including the petiole, 3-6 dm. long, the middle rarely truncate or obscurely cordate at base); racemes upright in a large com-

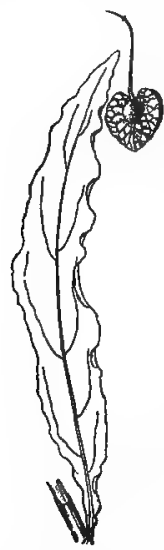

695. R. crispus. Leaf $\times 1 / 8$.

Fruiting calyx $\times 1 \% / 5$.
4. R. Británnica L. (Great Water D.) (1-2 m. high); leaves oblong-lanceolate, rather pound panicle, nearly leafless; . whorls

crowded ; pedicels obscurely jointed; valves orbicular or round-ovate, very obtuse, obscurely heart-shaped at base, finely reticulated, entire or repand-denticulate, all Tall and stout

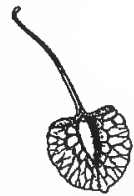

694. R. Britannica. Fruiting calyx $\times 1$. grain-bearing. - Wet places, Nfd. to N. J., w. to Ont., Minn., and Kan. Fig. 694.

5. R. Críspus L. (Yellow D) Smooth, 0.9-1.6 m. high ; leaves with strongly wavy-curled margins, lanceolate, acute, the lower truncate or scarcely heart-shaped at base ; whorls crowded in prolonged wand-like racemes, leafless above; pedicels with tumid joints; valves round-heartshaped, obscurely denticulate or entire, 4-6 mm. broad, mostly all grain-bearing; the grains very plump, subglobose to ellipsoid, with rounded ends. - In culivated and waste ground, very common. (Nat. from Eu.) Fig. 695.

6. R. elongAtus Guss. Resembling $R$. crispus, and perhaps a variety of it; grains lance-ovoid, attenuate. - Widely distr., and becoming common. (Nat. from Eu.)

7. R. pállidus Bigel. (Wнтте D.) Depressed or ascending; root white; leaves glaucous, narrowly lanceolate, or the lowest oblong; the lowest branches of the dense panicle spreading at nearly right angles; pedicels much shorter than the whitish-brown fruiting calyx; valves deltoid-ovate, 3-4 
mm. long, the tips but slightly exceeding the conspicuous whitish ovoid or lance-ellipsoid large grains; achenes 2-3 $\mathrm{mm}$. long. ( $R$. salicifolius Man. ed. 6, in part, not Weinmann.) - Salt marshes, beaches and rocks, coast of N. S., N. B., and N. E. Fig. 696.

8. R. mexicànus Meisn. Upright; leaves linear-lanceolate to narrowly oblong, pale green or glaucous; panicle very clense, its branches strict or strongly ascending; pedicels shorter than or sometimes exceeding the olive- to

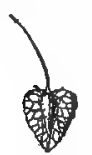

697. R. mexicanus.

Fruiting calyx $\times 12 / 8$. ruddy-brown deltoid-ovoid calyx; valves 3.5-6 $\mathrm{mm}$. long, the tips much exceeding the narrowly ellipsoid to subulate brown grains; achenes 1.7-2.3 mm. long. ( $R$. salicifolius Man. ed. 6, in part, not Weinmann.) - Rich (often brackish) soil, Lab. and Nfd. to Assina. and B. C., locally s. to centr. Me., Mich, and Mo.; and abundant along the Rocky Mts. to centr. Mex. Fig. 697.

9. R. altíssimus Wood. (PALE D.) Rather tall (1-2 m. high); leaves ovate- or oblong-lanceolate, acute,

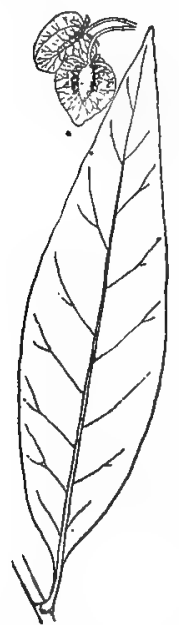

698. L. altissimus.

Leaf $\times 1 / 3$.

Fruiting ealyces $\times 1 \frac{1}{3}$.

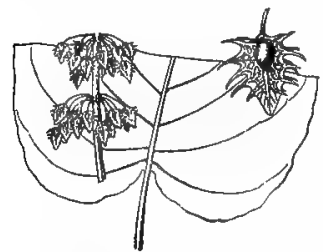

700, R. obtuslfolius.

Base of leaf $\times 1 / 8$.

Two whorls of infloresence $\times 1$. Frutting caly $x \times 2 \%$. 698. 699.

pale, thickish, obscurely veiny (the cauline, $7-15 \mathrm{~cm}$. long, contracted at base into a short petiole); racemes spike-like and panicled, nearly leafless; wholls crowded; pedicels n sdding, shorter than the fruiting calyx; valves broadly ovate or obscurely heart-shaped, obtuse or acut-

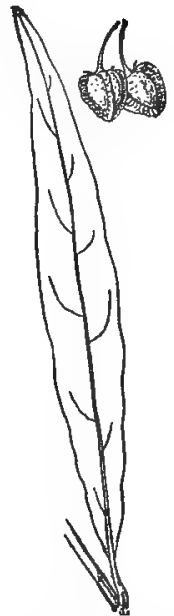

696. P. pallidus,

Lesf $\times$ \%

Fruiting calyces $\times 12 / 3$ ish, entire, loosely reticulated, one with a conspicuous grain, the others with a thickened midrib or naked. - Alluvial soil, Ct. to Neb., and southw. (Mex.) Fro. 10. R. verticillatus L. (SwamP D.) Rather tall (1-1.6 m. high); leaves lanceolate or oblonglanceolate, rather obtuse, thickish, pale green, the lowest often heart-shaped at base; racemes nearly leafless, elongated, loose, the whorls crowded or the lower ones distant ; fruit-bearing pedicels sleniler, club-shaped, abruptly reflexed, 3-4 times longer than the fruiting calyx; valves dilated-rhomboid, obtusely somewhat pointed, strongly rugose-reticulated, each bearing a very large grain. - Wet swamps, w. Que. and Vt. to w. Ont, and southw. FIG.

11. R. Conglomeratus Murr. Smoothish; leaves oblong; panicle leafy; pedicels short; valves obtuse, subentire, all grain-bearing, the callosities relatively large and conspicuous. - Va. (Curtiss according to Trelease) to S. C.; also Cal. (Adv. from Eu.)

12. R. oвtusitolits I. (Bitter D.) Stem roughish; lourest leaves ovate-heart-

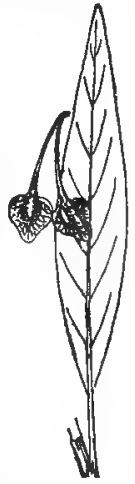

699. R, ver ticillatus.

Leaf $\times 1 /$

Fruiting ca. lyces $\times 1$. shaped, obtuse, ratber downy on the veins beneath, somewhat wavy-margined, the upper oblong-lanceolate, acute; whorls loose and distant; valves ovate. halberd-shaped, with some sharp avol-shaped teeth at base, strongly reticulated. - Fields, roadside ditches, etc., very common. (Nat, from Eu.) Fig 700 


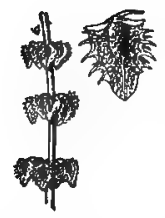

701. R. pulcher.

A. bit of inflores cence $\times 1$.

Frulting caly $x \times 2$.

13. R. PÚLCRER L. Leaves oblong, frequently constricted above the base, mostly acute; valves uvate, many-toothed, suon coriaceous, very strongly reticulated. - Ballast grounds, etc., Va. to La.; Cal. (Adv. from Eu.) FIg. 701.

14. R. persicarioides L. (Golden D.) Minutely pubescent, dittusely branched, 2-6 dm. high; leaves lance-linear, wavy-margined, the lower auricled or heart-shaped at base; whorls excessively crowded in leafy and compact or interrupted spikes; valves rhombic-oblong, lance-pointed, each bearing 2-3 long awn-like bristles on each side, and a large

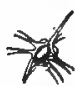

702. 'R. persicarioides.

Fruiting caly $\times 2$. Ont. to Ill., and westw. Fig. 702.

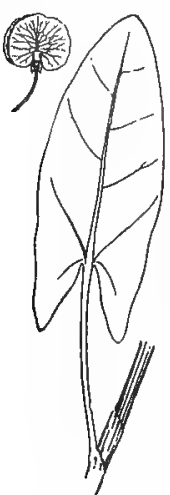

708. 1i. Acetosa. Leaf $\times 1 / 2$. Fruiting calyx $\times 2$.

\section{§ 2. ACETÓSA [Tourn.] DC. (SorReL.) Flowers dioecious, small, in a terminal naked panicle; herbage sour; some leaves arrow- or halberd-shaped; smooth perennials, spreading by running rootstocks, flowering in spring.}

15. R. Agetósa L. (Garden S.) Erect, S-9 dm. high; leaves oblong or broadly lanceolate, arrow-shaped; valves rounded at the apex, $4 \mathrm{~mm}$. broad. - Lab. to $\mathrm{Pa}$., and westw.; frequent near Quebec, comparatively local southw. (Nat. from Eu.) FIg. 703.

16. R. hastátulus Baldw. Stem simple, 3-6 dm. high; leaves linear or lanceolate, some of them hastate with divaricate basal lobes; valves ovate, $2.5 \mathrm{~mm}$. broad. - Sandy soil, near the coast, e. Mass. to Fla. and Tex.; inland in Miss. basin to Ill., Mo., and Kan. Fig. 704.

17. R. Acetosélda L. (Field or Sheep S.) Low (1-3 dm. high); leaves narrowlanceolate or linear, halberd-form, at least the lowermost, the narrow lobes entire, widely spreading; pedicels jointed at the summit; sepals

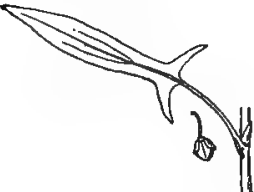

705. R. Acetosells.

Lenf $\times 1$.

Fruiting caly $\times \times 2$ scarcely enlarged in fruit, exceeded by the naked achene. - A common weed. (Nat. from Eu.) Fig. 705.

\section{POLÝGONUM [Tourn.] L. KNOTWEED}

Caly $x$ 4-6 (mostly 5)-parted; the divisions often petallike, all erect in fruit, withering or persistent. Stamens 3-9. Styles or stigmas 2 or 3 ; achene accordingly lenticular or 3-angular. Embryo placed in a groove on the outside of the albumen and curved halfway around it; the radicle and usually the cotyledons slender. Pedicels jointed.-Ours all herbaceous, with fibrous roots (except in $P$. viviparum), flowering through late summer and early

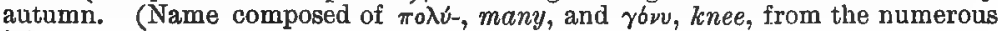
joints.)

\$1. AVICULARIA Meisn. Flowers in axillary fascicles or spicate woith foliaceous bracts; leaves and bracts jointed upon a very short petiole adnate to the short sheath of the 2-lobed or lacerate scarious stipules; stems striate; calyx 5-6-parted, usually more or less herbaceous; stamens 3-8, the 3 inner 
filaments broad at base; styles 3 ; cotyledons incumbent; albumen horny glabrous annuals, except nos. 1 and 2.

Achenes conspicuously exserted.

Prostrate, maritime; achene broadly ovold-pyramidal.

Calyx-lobes petaloid, broadly obovite; foliage nearly white

Calyx-lobes subherbaceons, oblong; foliage pale green.

Erect; achene elongated, Janceolate-pyramidal

Achenes nearly or quite included by the fruiting calyx.

Branehes terete or nearly 50.

Flowers small; sepals (normally 5) white or roseate, 1.8-1.8 mm. long; pedleels tnoluded.

Erect, much branched; leaves linear-oblong, slightly rigld; flowers much surpassed by the bristle-like remnants of the stipules

Prostrate or rarely erect; leaves not frrm, blutsh green; flowers mostly exserted beyond the hyaline flaceid torn stipales".

Flowers larger, the pedicels exserted; sepals (often 6) 2-8 mm. long.

Leaves eliptical, yellowish green, obtuse : : : : : : :
Leaves lanceolate, acute .

Branches rather sharply angled.

Leaves strongly plicate; flowers ereot

Leaves flat with revolute margins; flowers noding

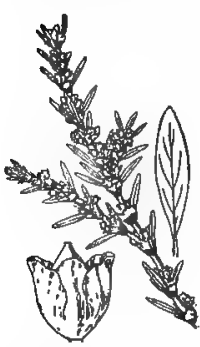

706. P. maritimum.

Flowering branch $\times 2 / 3$. Fruiting calyx $\times 8$.

Stem-leaf $\times 1$.

1. P. marítimum L. Prostrate, very glaucous, nearly white; leaves mostly small, linear-oblong, very thick, usually exceeding the short internodes; stipules silvery; sepals broadly obovate, petaloid, contracted at the base, the bruad roseate tips inclining to spread in fruit. - Sandy sea-coast, Mass. to Fla., local. (Eu.) FIG. 706.

2. P. Fowlèri Robinson. Prostrate, pale green; leaves narrowly elliptic, about equaling the full grovon internodes; sepals oblong, herbacenus with white or roseate margin, not contracted at the base, rather closely ap. pressed to the achene. (P. Rayi Am. auth., not Babington.) - Sea-coast, e. Canada and Me.; also Wash. to Alaska. Fig. 707.

3. P. exsértum Small. Erect much branched annual, 3-8 $\mathrm{dm}$. high ; leaves lanceolate, rather light or pale green, 1-3 $\mathrm{cm}$. long, usually exceeded by the internodes; sepals oblong, green, normally 5 , unequal, closely appressed to the base of the much exserted chestnut-colored ovate-lanceolate achene.

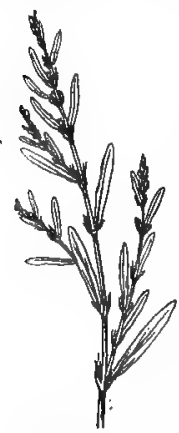

709. P. prolifeum, Flowering branshes $\times 1 /$.
- Brackish meadows, N. B. to N. J.; and on sand-bars and prairies, Ill., Mo., and Neb. to the Saskatchewan. FIG. 708.

4. P. prolíficum (Small) Robinson. Erect or nearly so, much branched, slightly rigid, $3 \mathrm{dm}$. high; leaves linearoblong, obtuse or acute, firm, in a dried state veiny; stipules soon frayed to bristle-like remnants surpassing considerably the small sessile rosente 5-parted flowers. ( $P$. ramosissimum, var. Small.) - Sea-shore, e. Que. to Va.; also Mo., Neb., and Kan. Fig. 709.

5. P. aviculare L. Slender, mostly prostrate or ascending, bluish-green; leaves lanceolate, 6-20 mm. long, usually acute or acutish; sepals hardly $2 \mathrm{~mm}$. long, gxeen with pinkish margins; stamens 8 (rarely 5); achene dull and minutely granular-striate, mostly included.-Common every. where in yards, waste places, etc. (Eurasia.) FIg. $710 a$. 


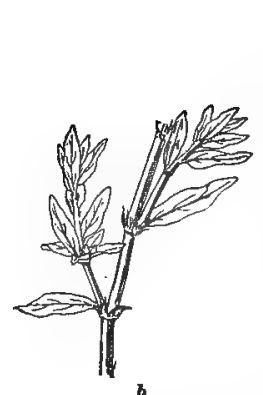

710. P. aviculare.

a. Typleal form $\times 2 / 3$.

b. v. littorale $\times \%$.

c. Stom-leaf of $\nabla$. vegetum $\times 2 / 8$.

d. Stem-leaf of $\nabla$. angust. $\times 2 / 3$.

doubtless elsewhere. (Eu.) FIG. $710 d$.

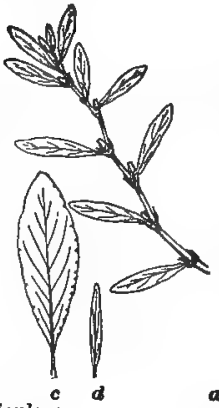

a

Leaves linear, 5-9 times as long as broad. - Summit of Mt. Monadnock, N. H., and

6. P. eréctum L. Stout, erect or ascending, yellowish-

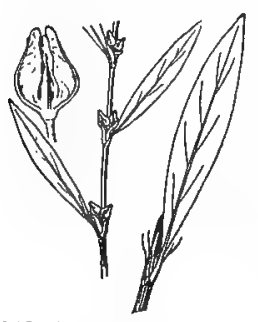

712. P. ramosissimum.

Fruiting calyx $\times 8$.

Bit of flowering branch $\times \%$. Stem-leaf $\times 2 / 8$.
Var. littoraie (Link) Koch. Leaves thick, often obtuse; achenes slightly shining, obscurely punctate or punctatestriate. ( $P$. littorale Link.) - A maritime and littoral form sometimes characteristic, but passing to the typical form and separated by. no constant character. (Eu.) Fig. 710 b.

Var. végetum Ledeb. Larger, erect or nearly so ; the leaves (often $3 \mathrm{~cm}$. long) oblong or narrowly elliptic, thin, the margins crisped. - Rich soil dnd in shade. (Eu.) Fıg. $710 \mathrm{c}$.

Var. angustíssi-

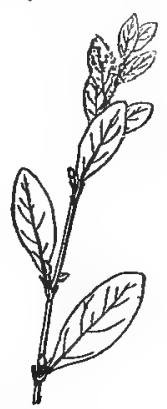

711. P. erectum. green; leaves elliptical, $1.3-6 \mathrm{~cm}$. long, usually obtuse; flowers yellowish-green, about $3 \mathrm{~mm}$. long, on more or less exserted pedicels; stamens 5-6; achene dull, included. - Waysides, waste places, etc. FiG. 711.

7. P. ramosissimum Michx. Flowering branch $\times \%$ Erect or ascending, $0.6-1.9 \mathrm{~m}$. high, yellowish-green; leaves lanceolate $(2-5 \mathrm{~cm}$. long), acute; sepals 6 , the 3 outer $2-3 \mathrm{~mm}$. long, carinate, cucullate at the summit, drying green with yellow margins; the inner sepals smaller, yellow; stamens 3-6; achene smooth, shining, included. ( $P$. camporum of auth. in part, not Meisn.) - Sandy soil, Me. and Mass., local ; w. Pa. ; Ill. to Minn., Tex., and westw. Fig.

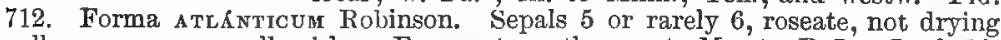
yellow, nor even yellowish. - Frequent on the coast, Me. to R. I. In habit identical with the typical western form.

8. P. ténue Michx. Stem angled, erect (1.5-4 dm. high), glabrous, or slightly scibrous at the nodes; leaves narrowly lanceolate to linear, $2-5 \mathrm{~cm}$. long, acute at each end, strongly plicate; flowers usually solitary, nearly sessile, erect; stamens 8; achene included, dull black.-Dry soil, s. Me. to S. C., w. to Man., Minn., Neb., and Tex. Fig. 713.

9. P. Douglàsii Greene. Stem angted, erect; to shor plicato leaves lanceolate to linear, acute at each end, slightly nature) $\times 2 / 3$. rigid, the margins revolute but the surface not plicate; pedicels 714. P. Doug. short but slender; flowers scon deflexed. - Rocky or sterile soil. Stem-leat $\times 2 \%$. Me. to n. N.
Mts. Fir. 714 .

§2. BISTÓRTA [Tourn.] L. Glabrous alpine perennials, with thict bulb-like caudex and simple stems; flowers in a spike-like raceme; calyx colored, deeply 5-cleft; stamens 8; styles :, 7ong.

10. P. viviparum L. Smooth, dwarf $(4-35 \mathrm{~cm}$. high $)$, learing a linear erect spike of flesh-colored flowers (or uften little red bulblets in their place); leaves 
lanceolate. - Alpine summits of N. E., shores of L. Superior, Col, and Utah to dlaska and Greenl. (Eurasia.)

\$3. PERSICARIA [Tourn.] L. Flowers in dense spikes, with small scarious bracts; leaves not jointed on the petiole; sheaths cylindrical, truncate, entire, naked or ciliate-fringed or margined; calyx colored, 5-parted, appressed to the fruit ;. stamens 4-8; filaments filiform; cotyledons accumbent.

Sheaths nearly or quite free from ciliation.

Annual; achene compressed.

Faces of the achene umbonate; style or stamens exserted

Faces of the achene coneave; style and stamens included. Achene $2.5-2.9 \mathrm{~mm}$. broad.

Leaves glabrous beneath
Leaves more or less flocculent-tomentose beneath, or tardtly

glabrate
Achene $1.5-2 \mathrm{~mm}$. broad $:$ : : : : : : :

Perennial.

Spikes several in pedunculate panicles . . . . . .

Spikes solttary or in pairs.

Leaves elliptical, obtuse or acuts; sulkes 1.2-2.4 cm. long ; pe-

duncios glabrous or nearly so
Leaves lanceolate or ovate, acuminate; spikes $\dot{3}-10 \mathrm{~cm}$. jong; Sheaths bristly-ciliate.

Stem and peduncles glandular-hispid. .

Stem and peduncles not glandular-hispid.

Sepals dotted with dark glands.

Achene dull

A chene shining

Sepals not dark-dotted.

Annual.

Leaves ovate; sheaths often with an herbsceous border

Leaves lanceolate; sheaths without herbaceous border.

Perennial.

Sheaths with a spreading herbaceous border

Sheaths without herbaceous border. Appressed-bristly Finely strigose or smoothish

(14) P. amphibium, v. Harturighti.

17. P. longistyhum.

16. $P$. pennsylvanicum.

12. P. tomentorum.

11. P. lapathifolium.

18. P. densifiorum.

14. P. amplibium.

15. P. Mullenbergid.

18. P. Careyi.

19. P. Hydroptper.

20. P. acre.

21. $P$. orientale.

22. P. Persicaria.

11. P. lapathifolium L. Annual, branching, 0.6-2.4 m. high, glabrous or ihe peduncles obsoletely glandular; leaves lanceolate, attenuate upward from near the cuneate base and acuminate, somewhat scabrous with short appressed hairs on the midrib and margin; sheaths and bracts rarely somewhat ciliolate; spikes slender ( $1-5 \mathrm{~cm}$. long), somewhat panicled, dense, erect or nodding; flowers white or pale rose-color; stamens 6 ; achene ovate, rarely $2 \mathrm{~mm}$. broad. ( $P$. incarnatum of auth. and ? Ell., the latter merely a robust large-leaved form with long drooping spikes.) - Wet places, common and variable. (Eu.) Var. NoDðsum (Pers.) Weinmann is a staut form with strongly nodose stems spotted with red dots.

12. P. tomentdsum Schrank. Annual, simple or moderately branched, 1-5 $\mathrm{dm}$. high ; leaves lanceolate or lance-oblong, acute or barely acuminate, at least the lower retaining more or less flocculent tomentum on the under surface; peduncles distinctly glandular; spikes thickish, the lateral scarcely peduncled; flowers larger and mostly paler than in the last. - Moist ground, Nfd., e. Canada, and N. E. to Cal. and B. C. (Fu.) Passes to the usually dwarf var. INcAnum (Schmidt) Gürke with leaves all permanently white-woolly underneath. ( $P$. lapathifolium, var. Koch.) - Sandy shores, sphagnum bogs and necasionally.on rubbish heaps, N. E. to N. J. and westw., chiefly along the Great Lakes. (Eu.)

13. P. densifldrum Meisn. Perennial, very stout; leaves lanceolate, attenwate at each end, $2-3 \mathrm{dm}$. long, $3-6 \mathrm{~cm}$. broad ; spikes several, slender, densely flowered, rather vigidly erect, paniculate; sheaths turbinate, much exceeded by the slender pedicels; styles 2 ; achene dark brown, strongly biconvex, smooth and shining, $1.5 \mathrm{~mm}$, broad. (P. portoricense Bertero.) - S. Mo. to S. C., La, and Tex. (Trop. Am.)

14. P. amphibium L. Perennial, aquatic or rooting in the mud, glabrous of nearly so, rarely brancling above the rooting base; leaves usually floating, smooth and shining above, mostly long-petioled, elliptical to oblong or some- 
times lanceolate, obtuse or acutish, rounded or rarely subcordate at the base (5-12 cm. lour); peduncles glabrous; spike terminal, dense, ovoid or shortsylindric (1.2-2.t cm. long); Howers bright rose-color, $3-6 \mathrm{~mm}$. long; the 5 stamens and 2-cleft style exserted. - Lakes and pools, e. Que. to N. J., and westw.; widely distributed and rather common. (Eurasia.) Var. 'TERRÉstre Leers is an erect terrestrial state with narrower acutish shortly petioled leaves scabrous on the margin and often strigose-pubescent; sheaths without herbaceous border. - Occasional with the typical form (also Eu.), and passing in Am. to Var. HA RTWRíghtr (Gray) Bissell with spreading foliaceous borders on the stipular sheaths. ( $P$. Hartwrightii Gray.) - An ambiguous plant, sometimes clearly a mere terrestrial and mostly sterile state occurring on the same rootstock as the typical form; but elsewhere seemingly a normal and well marked fertile variety.

15. P. Muhlenbérgii (Meisn.) Wats. Perennial, in muddy or dry places, rarely in shallow water, decumbent or suberect, scabrous with short appressed hairs; leaves lanceolate to ovate, narrowly acuminate (1-2 dm. long); peduncles hispid and often glandular; spikes 3-10 cm. long, often in pairs; flowers and fruit nearly as in the last. ( $P$. emersum Britton.) - Que. and Me. to Fla., and westw. - Exceedingly variable in foliage and pubescence; aquatic states often have essentially glabrous and cordate leaves, while in plants of drier situations these are sometimes narrowly lanceolate, acute at base, and conspicuously appressed-pubescent on both surfaces.

16. P. pennsylvánicum L. Annual; leaves lanceolate; branches above and especially the peduncles beset with stipitate glands; flowers uniform, bright rose-color, in sliort erect spikes, often on exserted pedicels; stamens usually 8; achene nearly orbicular, over $2 \mathrm{~mm}$. broad, at least one surface concave.-Moist soil, in open waste places, centr. Me., westw. and southw. - Neither the stamens nor style conspicuously exserted.

17. P. Iongistỳlum Small. Very like the preceding in habit and foliage; flowers dimorphous, either the stamens or style conspicuously exserted; achenes orbicular, shining, both surfaces convex in the middle. - From s. Ill. and Mo. to w. Kan. (Meehan), and southw.

18. P. Carèyi Olney. Annual, erect, the stem $(0.6-1.6 \mathrm{~m}$. high) and peduncles glandular-bristly; leaves narrowly lanceolate, attenuate to both ends, roughish ; sheaths ciliate or sometimes margined; spikes slender, loose and nodding ; flowers purplish; stamens mostly 5. - Swamps and recent clearings, $\mathrm{Me}$. to N. J., Ont., and Mich.

19. P. Hydrópiper L. (Соmmon Suartweed or Water Pepper.) Aunual, 3-6 dm. high, smooth; leaves narrowly lanceolate, very acrid and peppery; spikes nodding, usually short or interrupted; flowers mostly greenish; stamens 6; style 2-3-parted; achene dull, minutely striate.-Moist or wet grounds; apparently introduced southeast $w_{\text {., }}$ but indigenous northw. and westw. (Eu.)

20. P. àcre HBK. (WATer SMartweed.) Perennial, nearly smooth; stems rooting at the decumbent base, 0.6-1.6 m. high; leaves lanceolate, attennate, $7-12 \mathrm{~cm}$. long, taper-pointed; spikes erect, rather dense, distinrtly peduncled; flowers white or flesh-color; stamens 8; style mostly 3-parted; achene smooth and shining. ( $P$. punctatum Ell., including var. robustius Small.) Wet places; e. Mass., westw. and southw. (Trop. Am.)

Var. leptostàchyum Meisn. Annurl, erect or slightly repent at the base, 3-6 dm. high ; leaves lanceolate, smaller, thinner, and lighter green than in the type; spikes elongated and very loosely flowered, not distinctly peduncled, the widely scattered flowers commonly extending down to the upper leaf-axils. ( $P$. punctatum, var. Small.) - Moist ground, common; sometimes well marked, at other times passing imperceptibly into the typical form.

21. P. orientale L. (Pringe's Feather.) Tall branching annual, softhairy; leaves ovate or oblong, pointed, distinctly petioled; sheaths ciliate or often with an abrupt spreading border; flowers large, bright rose-color, in dense cylindrical nodding spikes; stamens 7 . - Sparingly escaped from gardens into waste grounds. (Introd. from India.)

22. P. Persicaria L. (Ladx's Thumb.) Nearly smooth and glabrous (3-5 dm. high); sheaths more or less bristly-ciliate; leaves lanceolate, pointed, 
roughish, often marked with a dark triangular or lunar spot near the middle; spikes ovoid or short-cylindric, dense, erect, on smooth (or at least not glandular) peduncles; stamens mostly 6 ; styles half 2 -3-cleft; achene gibbous-flattened or sometimes triangular, sinooth and shining. - Waste and damp places, very coumon. (Nit. from Hu.)

23. P. setàceum Baldw. Perennial, stout, erect from a decumbent and somewhat repent base, appressed-hirsute; sheaths fringed with very long coarse bristles; inflorescence and flowers as in the next, the achenes slightly larger, black, shining. - Ho. to S. C., Fla., and Tex. (Asia.)

24. P. hydropiperoides Michx. (Mild W ATER Pepper.) Perennial, not acrid; stem smooth (3-9 dm. high), branching; the narrow sheaths hairy; leaves narrowly lanceolate, sometimes oblong; spikes erect, slender, sometimes filiform, often interrupted at base $(3-6 \mathrm{~cm}$. long); flowers small, flesh-color or nearly white; sepals not dotted; stamens 8; achene sharply triangular, smooth and shining. ( $P$. opelousanum Riddell.) - Wet places and in shallow water, centr. Me., westw. and southw. Var. strigòsum Small (var. Macouni Small) has the stem strigose, and is less frequent throughout our range.

§4. TOVARA (Adans.) Gray. Perennials; flowers in loose naked long and slender spikes; calyx rather herbaceous (greenish), unequally 4-parted, stamens 5; styles 2 , distinct, rigid and persistent on the smooth lenticular achene.

25. $\mathbf{P}$. virginiànum L. Almost smooth; stem terete, upright (6-12 dm. high) ; sheaths cylindrical, hairy and fringed ; leaves ovate, or the upper ovatelanceolate, taper-puinted, rounded at the base, short-petioled, rough-ciliate (7-15 cm. long); flowers 1-3 from each bract, somewhat curved, the styles deflexed in fruit, minutely hooked. - Thickets in rich soil, N. H. to Ont., Minn., and southw. (Asia.)

§5. ECHINOCAÚLON Meisn. Erect or reclining annuals, armed with reflex prickles on the angles of the stem, petioles, etc.; flowers capitate or few in a raceme; leaves arrow- or halberd-shaped.

26. P. arifdlium L. (HaLberd-Leaved Tear-Thumb.) Stem groovedangled; leaves halberd-shaped, taper-pointed, long-petioled; flowers somewhat racemed (few); peduncles glandular-bristly; caly $\mathbf{x}$ often 4-parted; stamens 6 ; styles 2 , very short; achene lenticular (large). - Low grounds, N. B. to Ont., s. to Ga., O., and Mich. (Asia.)

27. P. sagittatum L. (Arrow-Lleaved Tear-Thumb.) Stem 4-angled; leaves arrow-shaped, short-petioled; flowers capitate ; peduncles smooth ; stamens mostly 8 ; styles 3, slender; achene sharply 3-anyled. - Low grounds, common. - Slender, smooth except the angles of the stem and midrib beneath, which are urmed with fine and very sharp saw-toothed prickles. (Asia.)

§. TINIARIA Meisn. Twining (except dwarf var. of no. 29), unarmed; leaves ovate-heart-shaped; flower's in panicled racemes; outer calyx-lobes keeled or winged.

28. P. Convólvulus L. (Black Bindweed.) Annual, twining or procumbent, low, roughish, the joints naked; leaves halberd-heart-shaped, pointed; flowers in small interrupted corymbose racemes; outer calyx-lohes keeled or narrowly winged; achene minutely roughened, dull, black. - Cultivated and waste grounds, common. (Nat. from Eu.)

29. P. cilinode Michx. Perennial, minutely dowm; the sheaths fringed at the base with reflexed bristles; leaves heart-shaped and slightly halberd-shaped, taper-pointed; racemes panicled; calyx-lobes obscurely keeled; achene very smooth and shining. - Copses and rocky hills, e. Que. to mits. of N. C., w. to Minn. and Athabasca. Var. ERkctum Peck (var, breve Peck) is a dwarf erect form with the compound racemes chiefly terminai.

30. P. scándens 1. (Climbing False Blickwhent.) Perennial, smooth; sheaths naked; leaves heart-shaped or slightly halberd-sliaped, pointed; ritcemes interupted, leafy; the 3 outer calyx-lobes strongly kreled and in fruit 
broally winged, 10 15 $\mathrm{mm}$. long; the wings often crisped, subentire; achene smoor h and shining, $4 \mathrm{~mm}$. long. ( $P$.dumetorum, var. Gray.) - Moist thickets, comnion except on our northern borders. - Twining $2-4 \mathrm{~m}$, over bushes. (Japan.)

31. P. dumetorum L. Similar to the preceding; fruiting calyx smaller, 5-7 mm. long; wings subentire; achene black, shining, 2.6-3 mm. long. Woods and rich open places, Mass. to Fla. and 'Tex., near the coast; inland in Miss. basin. (Eu.) Furma crista tum (Engelm. \& Gray) Robinson ( $P$. cristatum Engelm. \& Gray) differs only in having the calyx-wings toothed. - Not rare with and often scarcely distinguishable from the typical form.

§ 7. PLEURÓPTERUS (Turcz.) B. \& H. Erect perennials, unarmed; leaves round-ovate; flowers in panicled racemes.

32. P. Cuspidatum Sieb. \& Zucc. Stout and tall, glabrous except in the loose axillary panicled racemes; leaves round-ovate, shortly acuminate, truncate or cordate at base; outer sepals broadly winged in fruit. (P. Zuccarinii Small.) -Occasionally escaped from gardens. (Introd. from Japan.)

\section{FAGOPỲRUM [Tourn.] L. BUCKWHEAT}

Calyx petal-like, equally 5-parted. Stamens 8. Styles 3 ; stigmas capitate. Achene 3-sided. Embryo large, in the center of the albumen, which it divides into 2 parts, with very broad and foliaceous plaited and twisted cotyledons. Annuals, with triangular-heart-shaped or halberd-shaped leaves, semicylindrical sheaths, and corymbose racemes of white, greenish, or rose-colored flowers. (Name from fagus, the beech, and mupos, wheat, from the resernblance of the grain to the beech-nut; so the English name Buckwheat, from the German Buche, beech.)

1. F. escolentum Moench. (Buckwheat.) Smoothish; flower with 8 honey-bearing yellow-glands interposed between the stamens; achene acute and entire, smooth and shining. (F. Fagopyrum Karst.) - Old fields, remaining as a weed after cultivation, and escaping into copses. June-Sept. (Introd. from Eu.)

2. F. tatáricum (L.) Gaertn. (India-wheat.) Flowers very small, on shorter pedicels ; achene very dull and roughish, the sides sulcate. - An occasional escape from cultivation, especially in n. N. E. and adjacent Canada. (Introd. from Asia.)

\section{POLYGonÉLLA Míchx.}

Calyx 5-parted, petaloid, loosely persistent about the achene, the 3 inner divisions often enlarging in fruit, in which case the outer are usually spreading.

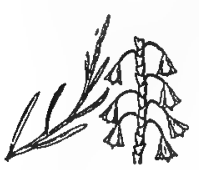

71.5. P, articulata.

Branch $\times 1$.

Bit of fruiting raceme $\times 1$. Stamens 8. Styles 3, and achene 3-angular. Embryo slender, straight or nearly so, toward one side of the albumen. - Slender glabrous annuals or perennials, with aiternate mostly linear leaves jointed at the base, and rather rigid truncate or oblique naked sheaths or bracts. Flowers on solitary pedicels (nodding in fruit) jointed near the base, borne in slender panicled racemes. (Diminutive of Polygonum.)

1. P. articulàta ( $\mathrm{I}_{4}$ ) Meísn. Annual, eroct, branching, glaucous, 1-3 dm. high; leaves linear-filiform, deciduous; flowers rose-color or white, nodding, in very slender racemes, sepals subequal, all erect and connivent about the fruit; achene exserted, smooth. Dry sandy soil, Me. and n. N. H. to N. J. and southw.; also in the interior, chiefly in the region of the Great Lakes. - An enomalous species with the calyx of a Polygonum. FIr. 715.

2. P. americana (Fisch. \& Mey.) Small. Perennial, frutes-

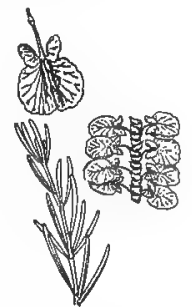

716. P. americana. Branch $\times 1$.

Bit of fruiting raceme $\times 1$.

Fruiting caly $x \times 2$. 
cent; leaves linear, persisting; flowers larger; fruit $4 \mathrm{~mm}$. long; the 2 outer sepals small, at length reflextd. ( $P$. ericoides Engelm. \& Gray.) - S. Mo. (Bush) to Ga. and Tex. Fig. 716.

\section{BRUNNICHIA Banks}

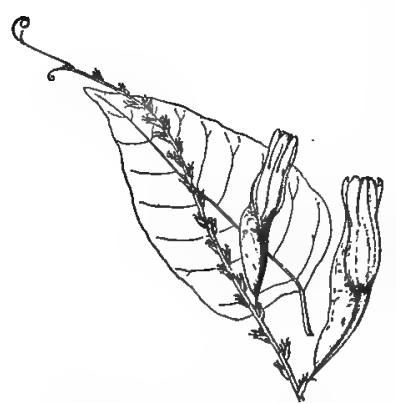

717. B. eirchumal.

Ieaf $\times 1 / 2$.

Bit of fruiting raceme $\times 1$.
Calyx-divisions somewhat petal-like, oblong, connivent and coriaceous in fruit, the base and almost the whole length of the pedicel winged on one side. Stamens 8 ; filaments capillary. Styles 3 , slender ; stiguas depressed-capitate. Ovule pendulous on a slender erect funiculus; seed erect, 6-grooved. Achene obtusely triangular, partly 3 -celled, inclosed in the indurated calyx. - Somewhat shrubby, with grooved stems, climbing by tendrils from the ends of the branches. (Named for $M$. T. Brïnnich, a Norse naturalist of the 18 th century.)

1. B. cirrhosa Gaertn. Leaves ovate, pointed, entire; petioles dilated at base, but with no distinct sheath or stipules; flowers greenish, 2-5 in a fascicle, crowded in axillary and terminal racemes; fruiting caly $\mathrm{x}$ with the wing $2.4-2.7$ sm. long. - 'Thickets, s. Ill. and Mo. to Tex., Fla., and S. C. Fig. 717.

\section{CHENOPODIÀCEAE (GoOsefoot FamiLr)}

Chiefly herbs, of homely aspect, more or less succulent, with mostly alternate leaves and no stipules nor scarious bracts, minute usually greenish flowers, with the free calyx imbricated in the bud, the stamens as many as its lobes, or occasionally fewer, and inserted opposite them or on their base; the 1-celled ovary becoming a 1-seeded thin utricle or rarely an achene. Embryo coiled into a ring around the mealy albumen, when there is any, or else conduplicate, or spiral. Calyx persistent, mostly inclosing the fruit. Styles or stigmas 2, rarely 3-5. - Mostly inert or innocent, weedy plants; several are pot-herbs, such as Spinach and Beet.

* Embryo coiled into a ring about the usually copious central albumen; leavos flat, not spiny; stein not jointed.

+ Flowers perfect (or stamens only occasionally wanting), clustered or panicled ; calyx 3-6-toothed or -parted, obvious, persistent; seed-coat crustaceous.

1. Cycloloma. Oalyx 5-cleft, in fruit surrounded by a horizontal continuous membransceous wing. Seed horizontal, crustaceous. Lenves sinuate-tootlied.

2. Kochia. Like no. 1, but wing 5 -lobed and seed-coat membranaceous. Leaves entire.

3. Roubieva. Calyx 3-5-toothed, becoming saccnte and reticulated. Leaves pinnatifid.

4. Chenopodium. Calyx 3-5-parted, unchanged or becoming tleshy in fruit.

+ + Flowers monoecious or dioecious; the staminate in clustere, mostly spiked, the calyx 3-5 parted; the pistillate without calyx, inclosed between a pair of appressed axillary bracts.

5. Atriplex. Fruiting bracts with margins often dllated and sides often muricate.

+++ Flowers polygamous, olustered in the axils, 1 -sepaled, ebracteolate.

6. Monolepis. Annual herb with lanceolate-hastate leaves; fruit a utricle.

++++ Flowers perfect, naked or 1-sepaled, solitary in the axils of the reduced upper leaves.

7. Corispermum. Pericarp отаl, fnttened, adherent to the vertical seed. Leaves linear.

- * Embryo narrowly horseshue-shaped or conduplieate; no albumen; stem fleshy, jolnted; leaves reduced to opposite fleshy scales or teeth; flowere densely spiked, perfect. 
8. Salicornia. Flowers sunk in hollows of the axis of the fleshy spike. Calyx utricle-like.

*** Embryo coiled into a spiral; albumen mostly none; leavos fleshy, alternate.

9. Suaeda. Embryo flat-spiral. Calyx wingless. Leaves succulent.

10. Salsola. Embryo conical-spiral. Calyx in fruit horizontally winged, Lesves spinescent.

\section{Cycloldma Moq. Winged Pigweed}

Flowers perfect or pistillate, bractless. Calyx with the concave lobes

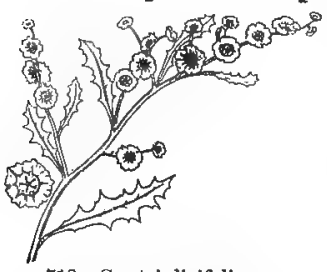

718. C. atriplicifolium.

Flowering branch $\times 2 / 8$. Mature flower from above $\times 11 / 8$.

introd. eastw. Fig. 718. strongly keeled, at length appendaged with a broad and continuous horizontal scarious wing. Stamens 5. Styles 3 (rarely 2). - A much branched coarse annual, with alternate sinuate-toothed petioled leaves, and very small scattered sessile flowers in

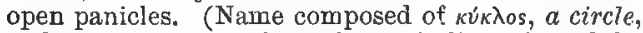
and $\lambda \hat{\omega} \mu a, a$ border, from the encircling wing of the calyx.)

1. C. atriplicifolium (Spreng.) Coult. Diffuse (1.3-5 dm. high), more or less arachnoid-pubescent or glabrate, light green or often deep purple. (C. platyphyllum Moq.) - Sanày soil, Man, to s. Ind., Ark., and westw. across the plains; locally

\section{KOेCHIA Roth.}

Characters nearly as in Cycloloma, but the seed-coat membranaceous andthe albumen wanting. (Named for W. D. J. Koch, a German botanist, 17711849.)

1. K. Scoparia (L.) Schrad. Annual, erect, puberulent or glabrate, branching; leaves narrowly lanceolate to linear; flowers in small axillary clusters, sessile ; each sepal at length developing a narrow thickish dorsal wing or appendage. - Frequently cultivated for its bright autumnal color; locally established as a weed. (Introd. from Eu.)

\section{ROUBIÈVA Moq.}

Flowers minute, perfect or pistillate, solitary or 2-3 together in the axils. Calyx urceolate, 3-5-toothed, contracted at the apex and inclosing the fruit. Stamens 5, included; styles 3, exserted. Fruit membranaceous, compressed. glandular-dotted. Seed vertical. Embryo annular. - Perennial glandular herb. with alternate pinnatifid leaves. (Dedicated to Prof. G.J. Roubieu of Montpellier.)

1. R. Multifida (L.) Moq. Prostrate or ascending, branching and leafy; leaves lanceolate to linear $(1.2-1.8 \mathrm{~cm}$. long), deeply pinnatifid with narrow lobes; fruiting calyx obovate. - Sparingly introduced in the Atlantic States. (Adv. from S. A.)

\section{Chenopódidm [Tourn.] L. Goosefoot. Pigneed}

Flowers all bractless. Calyx 5(rarely 4)-parted or -lobed, more or less enveloping the fruit. Stamens mostly 5; filaments filiform. Styles 2, rarely 3. Seed lenticular, horizontal (i.e. with its greatest diameter at right angles to the (loral axis) or vertical ; embryo coiled partly or fully round the mealy albumen. - Weeds, usually with a white mealiness, or glandular. Flowers sessile in small clusters collected in spiked panicles. (Named from $\chi \eta \nu, a$ goose, and moús, font, in allusion to the shape of the leaves.) - Our species are mostly annuals, flowering through late summer and autumn. 
a. Glandular, more or less aromatic.

Flowers glomerate ; glomerules in bracteate or almost naked spikes

Flowers solitary, sossile in open forking cymes, these in loose spikes. Flowers pubescent; lobes of leaves angled, obtuse

Flowers merely pulverulent-glandular; lobes of leaves not angled. acutish

14. Not glandular or aromatic, often mealy and beary-keented " $b$.

6. Beeds all verticul; styles fliform, one fourth to one half as long as the dianeter" of the utricle.

Flowers in glonerules becoming red and berry like in frult.

b. Seeds veltical and horizontal in the same inforescence; stylebranches short.

Leaves bright green, chiefly acute.

Flowers in leafy spikes; seed $1 \mathrm{~mm}$. broad

Flowers in leafy spikes; seed 1 mm. broad
Flower's in axillary glomerules; seed $0.5 \mathrm{~mm}$. broad:
Leaves pale at least beneath, obtuse

b. Seeds all horizontal; style-branches short $c$.

c. Pericarp coherent to the surface of the seed $\vec{a}$.

d. Leaves Iarge, green, sharply few-toothed, abrupt or usually cordate at base

d. Leaves small, entire, ovite, about $2 s$ broad as long, very fetid "

$d$. Leaves longer than broad, cuneate at the base. Beeds $1.3-1.5 \mathrm{~mm}$. in diameter; flower's glomerate, usually mealy ; leaves rhombic, irregularly few-toothed

Seeds about $1 \mathrm{~mm}$. in diameter ; inflorescence generally loose. Leaves sinall, conspicuously mucronate, all entire or the lower 1-3-toothed on each side; plant flowering at the summit '

Leaves rhombic-ovate with several to many acuminate teeth on each side.

Seeds dull; intlorescences short, spreading, axillary, rather loose

Seeds (not pericarp) shining; Infloreseences suberect,

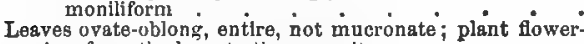
ing from the base to the summit.

c. Pericarp loose, readily detached from the seed.

Leaves thin, entire or somewhat toothed, scarcely at all mealy Leaves entire, linear or nearly 8o, very mealy at least beneath
1. C. ambrostoides.

2. C. Botrye.

3. O. incisum.

4. C. arpitatum.

5. O. Bonus-Eenricus

6. C. rubrum.

7. C. humile.

8. C. glawcum.

9. O. hybredum.

10. O. Vuloarta.

11. C. album.

\section{C. Berlanaieri.}

\section{C. murale.}

14. C. urbicum.

15. C. polyвpermum.

16. $C$. Boscianum.

17. C. Leptophyilum.

1. C. Ambrosioides L. (Mexican TEA.) Annual, smoothish; leaves slightly petioled, oblong or lanceolate, repand-toothed or nearly entire, the upper tapering to both ends; spikes densely flowered, leafy, or intermixed with leaves; fruit perfectly inclosed in the calyx. - Waste places, throughout our range, especially southw. (Nat. from Trop Am.)

Var. Anthelmfnticum (L.) Gray. (Wormseed.) Perennial (at least southward) ; leaves more strongly toothed, the lower sometimes almost laciniatepinnatifid; spikes more or less elongated, mostly leafless. - Same range, sometimes appearing distinct, but all differential characters inconstant. (Nat. from Trop. Am.)

2. C. Inctsum Poir. Annual, glandular-pulverulent and aromatic; leaves sinuate-pinnatifid or -toothed, the lobes ovate-lanceolate, entire or nearly so, acutish; flowers minute, nearly smooth, in open forking cymes borne in elongated mostly leafy inflorescences. - Thoroughly establisbed and abundant in cultivated fields, North Berwick, Me. (Parlin). (Adv. from Trop. Am.)

3. C. Bòtrys L. (Jerusalem Oak, Feather Geranium.) Glandularpubescent and viscid; leaves slender-petioled, oblong, obtuse, sinuate-pinnatifid, the lobes angled and obtuse; racemes cyme-like, spreading, loose, leafless; fruit not perfectly inclosed. - Widely introduced. (Nat. from Eu.)

4. C. capitatum (L.) Asch. (Strawberry Brite.) Stem ascending, branching; leaves triangular and somewhat halberd-shaped, sinuate-toothed; clusters simple (large), intervuptedly spiked, the upper leafless; stamens 1-5; calyx berry-like in fruit; seed ovoid, flattish, smooth, with a very narrow margin. (Blitum L.) - - Light soil and newly cleared land, e. Que. to Alaska, s. to N. J., Pa., Ill., Minn., and in the Rocky Mts. - The calyx becomes pulpy and bright red in fruit, when the large clusters look like strawbervies. (Eu.)

5. C. Buxus-Hexriect L. (Good-King-HFyry.) Stout, prect (0.8-3 m. bigh), mostly simple; leaves broadly triangular-hastate (5-12 cm. long), sub. 
sinuate or entive; flowers somewhat densely paniculate-spiked; seed with obturc edges, - Sparingly in waste places. (Adv. from Eu.)

6. C. rùbrum L. (CoAst Blite.) Stem angled, much branched; leaves thickish, triangular-lanceolate, tapering below into a wedge-shaped base and above into a sleuder point, sparingly and coarsely toothed, the upper linearlanceolate; clusters scattered in axillary leafy spiles; calyx-lobes 2-4, rather fleshy; stamens 1-2; seed shining, $1 \mathrm{~mm}$. broad, the margin acute. - Salt marshes, Nfd. to N. J., and in salime places to Minn. and the Pacific coast. (Lu.)

7. C. hùmile Hook. Similar, dwarf ; leaves lanceolate or spatulate, occasionally hastate ; flowers in axillary glomerules; seed $0.5 \mathrm{~mm}$. broad. - Brackish or saline soil, coast of Me. (Miss Furbish); Man. to the Pacific.

8. C. GLÁ́CUM L. (OAK-LEAVED G.) Lavo, spreading, glaucous-mealy; leaves sinuately pisnatifid-toothed, oblong, pale green above, white beneath; clusiers in axillary spikes, small ; seed sharp-edged. - Waste places. (Nat. from Fu.)

9. C. hybridum L. (MAPLE-LEAVED G.) Bright green throughout; stem widely much branched (6-12 dm. high); leaves thin (5-15 cm. long), somewhat triangular and heart-shaped, taper-pointed, sinuate-angled, the angles extending into a few large and pointed teeth; racemes diffusely and loosely panicled, leafless; calyx not fully covering the fruit, its lobes keeled. - Woods; also frequent in waste places and about cities, centr. Me., westw. and southw.

10. C. Vulvaria L. Low and spreading, branched from the base; leaves entire, broadly ovate, acutish (1 cm. long), on slender petioles nearly their own length, very fetid when rubbed or crushed; inflorescences small, scattered. Waste places, chiefly about cities. (Adv. from Eu.)

11. C. Álum L. (Lamb's Quartirs, Pigween.) Erect, more or less mealy; leaves varying from rhombic-ovate to lanceolate or the uppermost even linear, acute, all or only the lower more or less angulate-toothed; clusters spiked-panicled, mostly dense; calyx (2-2.7 nun. broad) with strongly carinate lobes, nearly or quite covering the seed. - Introduced everywhere. (Nat. from Eu.) Var. vfride (L.) Moq. is less mealy and has a less dense inflorescence. Frequent, especially eastw.

12. C. Berlandièri Moq. Slender, 3-6 dm. tall ; leaves rhombic and somewhat hastately 1-several-toothed upon each side; the upper leaves elliptical, entire, mucronate; inflorescence a loose pyramidal panicle; flowers smaller and less glomerate than in C. album. - Ottawa, Ont. (Macoun) to Fla. and Mex. - A doubtful species, perhaps only a variety of the preceding.

13. C. MCRALE L. Resembles the preceding, but less erect, loosely branched (3-6 dm. high); leaves rhombic-ovate, acute, coarsely, sharply, and unequally toothed, thin, bright green; spikes or racemes diverging, somewhat corymbed; calyz-lobes scarcely keeled; seed sharp-edged. - Waste places. (Adv, from Eu.)

14. C. ÚRBICUM L. Rather pale or dull green, nearly destitute of mealiness, with erect branches (3-9 dm. high); leaves triangular, acute, coarsely and sharply many-toothed; spiles erect, crowded in a long and narrow racemose panicle; calyx-lobes not keeled; sned with rounded margins. - Apparently throughout our range. (Nat. from Eu.)

15. C. POLYSPÉRMM L. Low, often spreading, green and wholly destitute of mealiness; leaves all entire, oblong or ovate and on slender petioles; flowers very small, in slender panicles in all the axils, the thin lobes of the calyx very incompletely inclosing the fruit; seed obtuse-edged. - Sparingly naturalized in the Eastern States. (Adv. from Eu.)

16. C. Bosciànum Moq. Erect, slender (6-9 dm. high), loosely branched, often nearly glabrous; leaves oblong- to linear-lanceolate $(3-5 \mathrm{~cm}$. long), attenuate into a slender petiole, acute, the lower sinuate-dentate or often all entire; flowers small, solitary or in small clusters upon the slender branchlets; calyx not strongly carinate.-Ct. (Bissell) to the Great Lakes, s. to N.C. and Tex.

17. C. leptophýllum Nutt. Densely mealy or sometimes nearly glabrous (2-7 $\mathrm{dm}$. high), simple or branched, often strict; leaves linear $(1.5-2.5 \mathrm{~cm}$. long), entire, rather shortly petioled; flowers closely clustered. in dense or interrupted spikelets; calyx-lobes strongly carinate. (C. album. var. Moq.) - Near' the 
coast, Me. to N.J. and Ya.; n. shore of L. Erie; and from w. Wisc. to Col., N. Mex., and westw. Var, oblongrfollum Wats. is a form with somewhat broader oblong or oblong-lanceolate leaves. - S. Me. (Parlin); Mo. (Bush), and southwestw.

\section{5. ÁTRIPLEX [Tourn.] L. Orach}

Flowers monoecious or dioecious; the staminate like the flowers of Chenopodium, but sterile by the abortion of the pistil; the fertile consisting simply of a naked pistil inclosed between a pair of appressed foliaceous bracts, which are enlarged in fruit, and sometimes united. Seed vertical. Ennbryo coiled into a ring around the albumen. In one section, including the Garden Orach, there are some fertile flowers with a calyx, like the staminate, but without stamens, and with horizontal seeds. - Herbs (ours annuals), usually mealy or scurfy with bran-like scales and with spiked-clustered flowers; in summer and autumn. (The ancient Latin name, a corruption of the Greek, á $\tau \rho \dot{\alpha} \phi a \xi \iota s$.

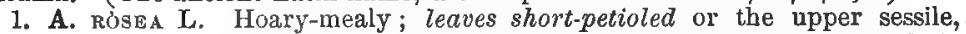
rhombic-ovate or oblong with a wedge-shaped base, coarsely sinuate-toothed; fertile flowers mostly clustered in the axils; fruiting bracts broad, often cuttoothed and warty. - Sparingly introduced at the East. (Adv. from Eu.)

2. A. pátula L. Erect or prostrate (3-12 dm. high), glabrous or somewhat scurfy ; leaves narrowly lanceolate-hastate $(2-10 \mathrm{~cm}$. long), the lower sometimes opposite, entire or sparingly sinuate-dentate, petioled, the upper lanceolate to linear; flowers clustered in rather slender spikes, the two kinds together or separate; fruiting bracts ovate-triangular or rhombic-hastate, entire or toothed, often muricate on the back, united to near the middle. - Nfd, to N. J., Mo., and B. C. (Eu.) Very variable; the marked extremes are: Var. Hastata (L.) Gray. Erect or spreading, stout, at least the lower leaves broadly triangularhastate, often coarsely and irregularly toothed. - Nfd, to $\mathrm{Va}$, , Mo., and northwestw., chiefly in saline places and along the Great Lakes. (Eu.) Var. LiтToRA'tis (L.) Gray. Slender; leaves linear-lanceolate to linear, rarely subhastate or toothed. - P. E. I. to N. J., and westw. along the Great Lakes.

3. A. arenaria Nutt. Silvery-mealy, diffusely spreading; leaves oblong, narrowed at base, nearly sessile; fruiling bracts broadly vedge-shaped, united, 3-nerved, 2-5-toothed at the summit, and usually strongly muricate and reticulate on the sides. - Sandy beaches, along the coast, Mass, to Fla.

4. A. argéntea Nutt. Usualiy low, much branched, gray-scurfy, leafy ; leaves deltoid or subrhombic, often subhastate; staminate flowers in terminal spikes; fruiting bracts round-rhombic, indurated, united, the free margins more or less dilated and deeply toothed, the sides variously appendaged. - Red River Valley, Minn., southw. and westw.

\section{MONÓLEPIS Schrad.}

Flowers small, glomerate in the upper axils. Sepal 1, green, entire, bractlike, fleshy, obtuse. Utricle moderately flattened. Seed vertical, much compressed. Embryo annular about copious albumen. (Name from $\mu b \nu 0 s$, one, and $\lambda e \pi(s$, scale.)

1. M. Nuttalíana (R. \& S.) Wats. Branched from the base, $0.7-3 \mathrm{dm}$. high, somewhat fleshy, rather pale green, scarcely or not at all mealy; leaves narrow, slender-petioled, hastate, passing gradually into foliaceous bracts. Saline and alkaline soil, from the Great Plains westw., extending east to Man., and Minn. ; and introd, in Mo.

\section{CORISPERMUM [A. Juss.] L. Bug-SEed}

Calyx of a single delicate sepal on the inner side. Stamens 1 or 2, rarely 5. Styles 2. Fruit oval, flat, with the outer face rather convex and the inner concave, sharp-margined, seed vertical. Embryo slender, coiled around a central albumen. - Low branching annuals, with narrow linear alternate 1-nerved 


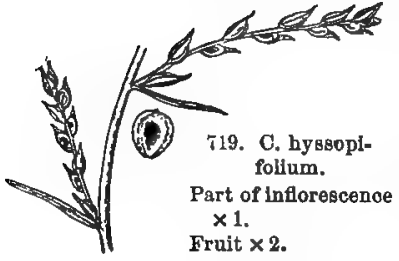

leaves. (Name formed of kópts, a bug, and $\sigma \pi t \rho \mu a$, seed.)

1. C. hyssopifolium L. Somewhat hairy when young, pale; floral leaves or bracts awl-shaped from a dilated base or the upper ovate and pointed, scarinus-margined; fruit wing-margined. - Sandy beaches along the Great Lakes; Mo. to Tex., and nortluwestw. Fig. 719.

\section{Salicórnia [Tourn.] L. Glasswort. Samphire}

Flowers perfect, 3 together immersed in each hollow of the thickened upper joints, forming a spike; the two lateral sometimes sterile. Stamens 1 or 2. Styles 2, united at base. Seed vertical, without albumen. Embryo thick, the cotyledons incumbent upon the radicle.-Low saline plants, with succulent leafless jointed stems, and opposite branches; the flower-bearing branchlets forming the spikes. (Name composed of sal, salt, and cornu, a horn; saline plants with horn-like branches.)

Annuals; middle flower higher than the lateral ones.

Seales mucronate-pointed and conspicuous, especialy when dry $\quad$. . 1. S. mucronuta.

Scales blunt or bluntish, inconspicuous.

Joints much longer than thick, conspicuously exceeding the middle flower 2 . S. europaea.

Joints about as thick as long, scercely exceeding the midule flower $\quad$. 3. S. rubra.

Perennial; flowers nearly equal in beight . . . . . . 4. S. ambigua.

1. S. mucronàta Bigel. Unbranched or with strongly ascending simple or slightly forked branches, rather stout $(0.5-3 \mathrm{dm}$. high), turning red in age; spikes thick, blunt, closely jointed; the joints thicker than long; midale flower half higher than the lateral ones or less, occupying nearly the whole length of the joint; fruit pubescent; seed 1-1.5 mm. long. (S. Bigelowi Torr.) - Salt marshes, N. S. to Fla. and Tex. ; also Cal.

2. S. europaea L. Erect (1-4.5 dm. high), from simple to freely branched, the branches ascending, green, turning red in autumn; scales obscure and very blunt, making a truncate barely emarginate termination of the long joints of the stem or elongated slender (1.5-2.5 mm. thick) tapering spikes; middle flower much higher than the lateral ones, shorter than the joint; fruit pubescent ; seed 1.3-2 mm. long. (S. herbacea L.) - Salt marshes of the coast, N. B. to Ga. ; interior salt springs, N. B. and N. Y.; and on the Pacific coast. (Eurasia.) Var. PACHYstAchya (Koch) Fernald has the spizes much thicker (3-4.5 $\mathrm{mm}$. thick). - Similar range, less common. (Eu.)

Var. prostràta (Pall.) Fernald. Branches horizontally spreading or drooping, very soft and lax, the lowest much elongated and decumbent; or the whole plant depressed and matted. - Brackish or alkaline shores, e. Que. to e. Me.; Sask. (Eurasia.)

3. S. rubra Nelson. Bushy-branched (0.5-2 dm. high), the abundant simple or forking branches ascending, turning red in autumn; scales broadly triangular, blunt or subacute; spikes slender-cylindric (2-3.5 mm. thick), blunt, rather closely jointed; finwers crowded, the middle one higher than the others and usually reaching the tips of the joints; fruit pubescent; seed $1 \mathrm{~mm}$. long. - Low alkaline places, Man. and w. Minn. to centr. Kan., and westw, to the Rocky Mts.

4. S. ambígua Michx. Numerous tufted stems (1-3 dm. long) decumbent or ascending from a hard and rather woody creeping base or rootstock, greenish, turning lead-colored; spikes slender, short-jointed, the scales short, acutish or acute; flowers nearly equal in height and equaling the joint; seed pubescent, $0.7 \mathrm{~mm}$. long. - Sea-coast, Mass. to Fla. ; also Pacitic coast.

\section{SUAÈdA Forskål. SeA Blite}

Flowers sessile in the axils of leafy bracts. Calyx 5-parted, fleshy, inclosing the fruit (utricle) and often carinate or crested. Stamens 5 . Stigmas 2 or 3. 
Seed vertical or horizontal, with a flat-spiral embryo, dividing the scanty albuinen (when there is any) into two portions. - Fleshy saline plants, with alternate nearly terete linear leaves. (An Árabic name.) Dondi Adans.

Leaves linear or slender-cylindric, not broadened at base ; plants of A tlantic coast.

Seed $2 \mathrm{~mm}$. broul

Seed $1,2-1.5 \mathrm{knm}$, broad.

Sepals rounded (not ctrinate) on the back

sepals (ur some of them) carinate on the back.

1 or 2 sepals more cucullate-carinate than the others

Sepals equally carinate

Leaves strongly dilated at base; plants of western plains:

- 1. S. maritima.

2. S. Richii.

8. S. americanif.

4. S. linearis.

5. S. depressa.

1. S. marítima (L.) Dumort. Comparatively low, $0 . \overline{0}-4$ (rarely 5 or 6 ) $\mathrm{dm}$. high, ascending or depressed, subsimple or with spreading-ascending or decumbent subsimple branches, or even forming depressed mats; leaves usually glaucous, acutish, semicylindric (flat above, convex beneath), $5 \mathrm{~cm}$. or less long; those of the flowering branches shorter, and much exceeding the 1-4 axillary flowers; sepals pale green, rounded or obscurely keeled on the back; seed red-brown or black. (Dondia Druce.) - Common on salt marshes, e. Que. to Ct., and occasionally southw. to Ia. Fr., June-Sept. (Eu.)

2. S. Ríchii Fernald. Stems procumbent, forming mats $5 \mathrm{dm}$. or less across (sometimes fruiting when $1 \mathrm{~cm}$. long); leaves dar/l green, not glaucous, subcylindric, dorsally compressed, obtuse, the lower $1.5 \mathrm{~cm}$. or less in length; those of the flowering branches broader and shorter (4-5 $\mathrm{mm}$. long); seed black. Salt marshes and wet sand, coast of N. S. and Me. Fr., July-Sept.

3. S. americàna (Pers.) Fernald. Stens procumbent, the branches 2 or 3 $\mathrm{dm}$. long, only the abundant densely flowered spiciform uitimate branches ascending ; leaves linear, thickish (flat above), acute, the lower about $2 \mathrm{~cm}$. long, those subtending the crowded flowers broader and shorter; sepals very irregular, 1 or 2 strongly keeled. (Salsola salsa, var. Pers.) - Salt marshes, lower St. Lawrence R. to s. Me. Fr., late Sept.-Nov. - Mature plant purplish throughout.

4. S. lineàris (Ell.) Moq. Erect or ascending, 2-9 dm. high, profusely branched; the slender branches ascending or wide-spread, not procumbent; leaves narrowly linear, acute, deep green, not glaucous, the lower $4 \mathrm{~cm}$. or less long, the upper similar but shorter; sepals equally carinate. (Dondia americana Britton, not Salsola salsa, var. americana Pers.) - Sandy coast, Me. to Tex. Fr., Sept. - Nov.

5. S. depréssa (Pursh) Wats. Decumbent or erect, branching from the base; leaves broadest at base, the cauline 1-4 cm. long, the floral lanceolate to ovate; one or more of the calyx-lobes very strongly carinate or crested. (Dondia Britton.) - Saline soil, Man. and $w$. Minn. to Neb., and westw. across the plains.

\section{SÁlSOLA L. SALTWORT}

Flowers perfect, with 2 bractlets. Calyx 5-parted, its divisions at length horizontally winged on the back, the wings forming a broad scarious border. Stamens nostly 5. Styles 2. Seed horizontal, without albumen. - Herbs or slightly shrubby branching plants with fleshy and rather terete or awl-shaped leaves and sessile axillary flowers. (Diminutive of salsus, salty, alluding to the saline habitat of most of the species.)

1. S. Kàli L. (CомmoN S.) Annual, diffusely branching, bushy, pubescent (rarely glabrous) ; leaves all alternate, avol-shaped, stifish, prickly-pointed; flowers single ; calyx with converging lobes forming a sort of beak over the fruit, the yellowish to lead-colored wings nearly orbicular and spreading. - Sandy sea-shore, Nfd, to Ga., and saline places inland. Aug. (Eu.) Var. carolinIANA (Walt.) Nutt. Flabrous throughout (rarely pubescent); the wings larger, roseate. - Similar range. (Eu.)

Var. tenuifolia G. F. W. Mey. (Russian Thistle.) Erect or ascending, very bushy; leaves especially on the young and vegetative stems longer $(3-7 \mathrm{~cm}$. 
in length), more slender, filiform; flowers somewhat variable but apparently showing no constant difference trom those of the typical form. (S. Tragus of auth., but scarcely of $\mathrm{L}_{\text {. }}$ ) - A weed of recent introduction, exceedingly abundant and pernicious in the Northwestern States; also locally established eastw. (Nat. froin Asia.)

\title{
Amaranthàceae (Amaranth Family)
}

Weedy herbs, wilh nearly the characters of the preceding family, but the flowers mostly imbricated with dry and scarious persistent bracts; these often colored, commonly: 3 in number. - The greater part of the family tropical.

\author{
* Anthers 2-celled; leaves alternate. \\ + Ovary 1-ovuled; filaments separate and distinct.
}

1. Amaranthus. Flowers monoecious or polygazoous, all with a caly $x$ of 5 or sometimes 3 distinct erect sepals, not falling off with the fruit.

2. Acnida. Flowers divecious. Calyx none in the fertile flowers.

++ Ovary 2-8-ovuled; filaments united at base.

3. Celosia. Flowers perfect. Calyx 5-parted.

* * Anthers 1-celled; leaves opposite.

4. Iresine. Caly $x$ of 5 sepals. Filaments united below into a eup. Flowers paniculate.

5. Froelichia. Calyx 5-cleft. Filaments united into a tube. Flowers spicate.

6. Gomphrena. Calyx of 5 sepals or 5-cleft. Filaments united into an elongate tube. Flowers capitate.

\section{AMARÁnthus [Tourn.] I. Amaranth}

Flowers 3-bracted. Calyx glabrous. Stamens 5, rarely 2 or 3 , separate; anthers 2-celled. Stigmas 2 or 3. Fruit an ovoid 1-seeded utricle, 2-3-beaked at the apex, mostly longer than the calyx, opening transversely or sometimes bursting irregularly. Embryo coiled into a ring around the albumen. - Coarse annual weeds, with alternate and entire petioled setosely tipped leaves, and small green or purplish flowers in axillary or terminal spiked clusters; in late

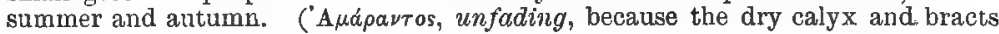
do not wither.)

\section{§ 1. Utricle thin, circumscissile, the top falling away as a lid; flowers polyga- mous.}

* Flowers in terminal and axillary simple or mostly panicled spikes; stem erect (0.3-2 m. high); leaves long-petioled; stamens and sepals 5 .

\section{+ Sepals spatulate.}

1. A. Palmìr Wats. Erect; leaves ovate, long-petioled; spikes, especially the terminal, very long (1-3 dm.) ; sepals somevhat unguiculate; bracts pungent. - By railroads and about towns, Mo. and Kan.; and locally, e. Mass. (Adv. from the S. W.)

\section{+ + Sepals ovate-lanceolate to oblong.}

2. A. Retrofléxus L. (Green A., Pigween.) Roughish and more or less pubescent; leaves dull green, long-petioled, ovate or rhombic-ovate, undulate ; the thick spikes crowded in a stiff glomerate panicle; bracts awn-pointed, rigid, exceeding the acute or obtuse sepals. - Cultivated grounds, common; indigenous southwestw. (Adv. from Trop. Am.)

3. A. HÝbidids L. (Green A., Pigweld.) Similar, but smoother and deeper green, with more slender-cylindric more or less flexuous spikes, the lateral ones spreading; bracts rather long-awned, and sepals acite or acuminate. (A. chlorostachys Willd.)--Cultivated grounds, common. (Nat. from Trop. Am.) Forma nypochondríacus (L.) Robinson. (PRINC's Feather.) Leaves, bracts, and fowers purple-tinged or livid. (A. hy/ochonstiacus L.) Sometimes cultivated, and occasionally found on waste ground. - It is to be 
distinguished from the following species chiefly by its smoother character, thicker spikes, and longer-awned bracts.

4. A. Paniculatus L. (Purple A.) Stem mostly pubescent; leaves oblong-ovate or ovate-lanceolate; spikes long, numerous and slender, panicled, spreading; bracts merely awn-pointed; flowers small, green tinged with red, or sometimes crimson; fruit 2-3-toothed at the apex, longer than the calyx. ( $A$. hybridus, var. Uline \& Bray.) - Roadsides, etc. (Adv. from Trop. Am.)

* Flowers crowoded in close and small axillary clusters; stems low, spreading or ascending; stamens and sepals 3, or the former only 2.

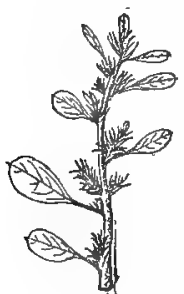

720. A. graecizans $\times 2 / 8$.

5. A. graecizans L. (Tumble WeEd.) Sinooth, pale green; stems whitish, erect or ascending, diffusely branched; leaves small, obovate and spatulate-oblong, very obtuse o: retuse; flowers greenish; sepals acuminate, half the length of the rugose fruit, much shorter than the subulate rigid pungently pointed bracts; seed small, $0.8 \mathrm{~mm}$. broad. (A. albus L.) - Waste grounds, common. Fig. 720.

6. A. blitoides Wats. Like the last, but prostrate or decumbent; spikelets usually contracted; bracts ovate-oblong, shortly acuminate; sepals obtuse or acute; fruit not rugoss; seed about $1.5 \mathrm{~mm}$. broad. - From Minn. to Mo., 'Iex., and westw.; also introduced eastw., chiefly on railroad ballast. Fig. 721 .

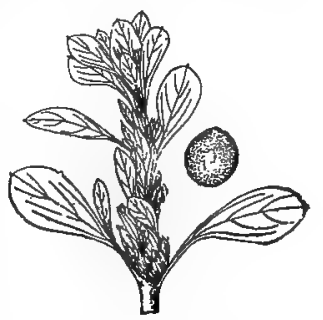

721. A , blitoides.

Tip of branch $\times 2 / 8$. Seed $\times 4$.

§ 2. Utricle thinnish, bursting or imperfectly circumscissile; flowers monoecious.

7. A. spinósus L. (Thorny A.) Smooth, bushy-branched; stem reddish; leaves rhombic-ovate or ovate-lanceolate, dull green, a pair of spines in their axils ; upper clusters sterile, forming long and slender spikes ; the fertile globular and mostly in the axils; flowers yellowish-green, small. - Waste grounds, Me. to Minn., and southw. (Nat. from Trop. Am.)

\$3. EUXXLUS (Raf.) Gray. Utricle remaining closed or bursting irregularly; no spines; bracts inconspicuous.

* Leaves relatively large (2-3 cm. in breadth).

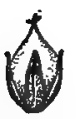

722. A. lividus. Calyx and utriclo $\times 8$.

8. A. Lfvidus L. Stem fleshy, red; leaves emarginate, ovate or obovate, $2-4 \mathrm{~cm}$. long, on petioles two thirds as long; bracts very short; utricle thin, smooth. - About Atlantic ports, not very common. Fig. 722. (Adv. from Trop. Am.)

9. A. viridis $\mathrm{L}$. Similar, but with a warty utricle. - About Atlantic ports ; also reported in O. Fig. 723. (Adv. from Trop. Am.)

$$
\text { * Leaves smaller. }
$$

10. A. pùmilus Raf. Low or prostrate; leaves fleshy and

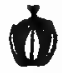

723. A. viridis. Caly $x$ and ntricle $\times 3$. obovate, emarginate, strongly nerved; flower-clusters small and axillary; stamens and sepals 5, the latter half the length of the obscurely 5-ribbed fruit. - Sandy beaches, R. I. to N. C.

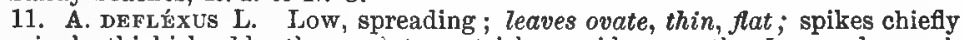
terminal, thickish, bluntly cordate; utricle ovoid, smootb, 5-nerved, much longer than the sepals. - Waste land near the larger Atlantic ports. (Adv. from $\mathrm{Fu}$.)

12. A. críspus (Lesp. \& Thév.) A. Br. Very slender, procumbent, pubescent; leaves small, light green, vhombic-ovate to -lanceolate, acute, the margin crisped and undulate; flowers in small axillary clusters; bracts and sepals scarious, oblanceolate, acute or obtuse ; utricle about as long, roughened, neither 
nerved nor angled. - Streets of Albany, New York City, and Brooklyn; doubtless introduced, but the native habitat unknown.

\section{ACNIDA L. WATER HEMP}

Habit of Amaranthus. Bracts 1-3, unequal. Staminate calyz of 5 thin oblong mucronate-tipped sepals, longer than the bracts; stamens 5 , the anthercells united only at the middle. Stigmas 2-5, often long and plumose-hispid. Fruit somewhat coriaceous and indehiscent, or a thin membranous utricle dehiscing irregularly (rarely circumscissile), usually 3-5-angled. (Name from $\alpha$ - privative, and $\kappa \nu l \delta \eta$, a nettle.)

* Fruit indehiscent, with firm and close pericarp; salt-marsh plants.

1. A. cannabìna $L$. Usually stout, 1-2 m. high or more, glabrous; leaves lanceolate to linear-lanceolate, acuminate, long-petioled; sepals of sterile flowers ovate-oblong, obtuse or acutish ; bracts usually thio, lax, and much shorter than the fruit, sometimes more rigid and longer; fruit about $3 \mathrm{~mm}$. long, obovoid; seed usually less than $3 \mathrm{~mm}$. long, shining. (A. rusocarpa Michx.) - Salt or brackish marshes, coast of N. H. to Fla.

* Fruit dehiscing irregularly, the pericarp thin, loose and usually roughened; not salt-marsh plants.

2. A. tuberculàta Moq. Tall and erect, with flexuous branches; leaves lanceolate to rhombic-ovate, acute or acutish ; sepals of sterile flowers lanceolate, acute or acuminate; pistillate flowers closely clustered in more or less dense naked or leafy axillary and terminal spikes (or the axillary capitate); bracts rather rigid, acuminate, equaling or exceeding the fruit; utricle about $1 \mathrm{~mm}$. long; seed shining, $0.7 \mathrm{~mm}$. in diameter. (A. tamariscina, var. Uline \& Bray.) - Vt. and Mass. (Ammidown) to Dak. and La.

Var. subnùda Wats. Often decumbent; leaves smaller, obtusish ; flowers aggregated into distinct globose glomerules (7-15 mm. in diameter). (A.tamariscina, var. concatenata Uline \& Bray, not $A$. cannabina, var. concatenata Moq.) - Sandy bottom lands, w. Que. to Wisc. and Mo.-Passing into the typical form.

Var. prostràta (Uline \& Bray) Robinson. Prostrate, much branched; leaves (1-2 cm. long, 3-10 $\mathrm{mm}$. broad) and giomerules (4-6 mm. in liameter) small. (A. tamariscina, var. Uline \& Bray.) - Similar situations, w. Que. to Minn., and southw.

$$
\text { *** Fruit regularly circumscissile; western. }
$$

3. A. tamariscina (Nutt.) Wood. With the habit of the preceding species but readily distinguished by the fruit. (Amaranthus Nutt.) - Prairies, etc., " Nak." to Tex. and N. Mex. ; said to occur as far e. as Ill.

\section{CELOSIA L}

Flowers subtended by a bract and two bractlets. Calyx scarious, in fruit erect and (in our species) concealing the utricle. Stamens 5. Fruit a thin membranaceous utricle, circumscissile or dehiscing irregularly, ovoid or subglo-

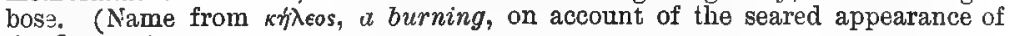
the flower:)

1. C. Angentea L. Erect glabrous herb, 3-12 dm. tall; leaves lanceolate, short-petioled, acute; inflorescence a simple dense cylindrical spike; sepals white or roseate-tinged, much longer than the bracts; style conspicuous, exserted, - Montgomery Co., Pa. (Porter). (Adv. from the Tropics.)

\section{IRESINE $\mathrm{P} . \mathrm{Br}$.}

Flowers mostly polygamous or dioecious, 3-bracted. Calyx of $\mathbf{5}$ sepals. Stamens mostly 5. Fruit a globular utricle, not opening. - Herbs, with opposite petioled leaves, and minute scarious-white flowers crowded into clusters or 
spiked and branching panicles; the calyx, etc., often bearing long wool (whence

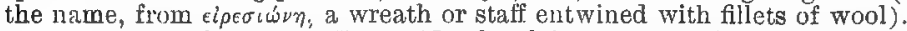

1. I. paniculàta (L.) Ktze. Nearly glabrous, annual, erect, slender (6-12 dm. high); leaves ovate-lanceolate; panicles very slender, often broad and diffuse, naked; bracts and calyx silvery-white, the fertile calyx twice longer than the broad bracts and densely silky-villous at base. (I. celosioides L.) Dry banks, O. to Kan., and far southw. Sept. (Trop. regions.)

\section{FROELÍCHIA Moench,}

Flowers perfect, 3-bracted. Calyx tubular, 5-cleft at the summit, below 2-5crested lengthwise, or tubercled and indurated in fruit, inclosing the indehiscent thin utricle. Filaments united into a tube, bearing 5 oblong 1-celled anthers, and as many sterile strap-shaped appendages. - Hairy or woolly herbs, with opposite sessile leaves, and spiked scarious-bracted flowers. (Named for Joseph Aloys Froelich, a German botanist, 1766-18+1.)

1. F. floridàna (Nutt.) Moq. Root annual; stem leafless above $(0.8-1.5 \mathrm{~m}$. high); leaves lanceolate, silky-downy beneath; spikelets crowded into an interrupted spike: calyx very wolly, becoming brvadly winged, the voings irregularly toothed. (Including $F$. campestris Small.) - Dry sandy places, Del. to Fla.; and from Ill. to Minn., southw. and westw.

2. F. grácilis Moq. More slender, with narrow leaves, the spikelets smaller, and the crests of the matured calyx of nearly distinct rigid processes. - Prairies of Kan. and Neb. to Col. and Tex.

\section{GOMPHRÈNA L.}

Flowers perfect, subtended by a bract and two bractlets. Calyx often lanate at the base, its segments more or less unequal, sessile between the bractlets. Fruit a compressed ovoid 1-ovuled utricle. Seed inverted, suspended by a long funicle from the apex of the utricle. - Erect or prostrate herbs, generally rough-pubescent and with swollen nodes. (Altered from rromphnene, the classical name of some related plant, probably Amaranthus tricolor, from $\gamma \rho a$ a $\phi \epsilon \nu$, to write or to paint, in allusion to the variegated leaves.)

1. G. Globósa L. (Globe Amaranth, Iymortelle.) A low branching pubescent annual with oblong nearly sessile leaves; flowers in dense round heads, crimson, rose-color, or white. - Common in cultivation, and occasionally escaping to roadsides, etc., O. (Gleason). (Introd. from Trop. Asia.)

\section{phytolaccàceat (Poreweed Family)}

Plants with alternnte entive leaves and perfect flowers, having the general characters of Chenopodiaceae, but usually a several-celled ovary composed of as many carpels united in a ring, and forming a berry in fruit.

\section{PHYTOLÁCCA [Tourn.] L. Pokeweed}

Calyx of 5 rounded and petal-like sepals. Stamens 5-30. Ovary of 5-12 carpels united in a ring, with as many short separate styles, in fruit forming a depressedglobose 5-12-celled berry, with a single vertical seed in each cell. Embryo curved in a ring around the albumen. - Tall and stout perennial herbs, with large petioled leaves, and terminal racemes which become lateral and opposite the leaves. (Name compounded of $\phi v \tau b \nu$, plant, and the Frencl lac, lake, in allusion to the crimson coloring matter which the berries yield.)

1. P. decándra $\mathrm{L}$. (Common Poke or Scome, Garaet, Pigeon Berri.) A smonth plant, with a rather unpleasant odor, and a very large poisonots. poot (often $1-1.5 \mathrm{dm}$. in diameter) sending up stout stalks at length $2-3 \mathrm{~m}$. high; caly $\mathrm{x}$ white; stamens and styles 10 ; ovary green; berries in long racemes, 
dark-purple, ripe in autumn. — Low grounds and rich soil, s. Me. to Ont., Minn., and southw. July-Sept.

\section{NYCTAGINÀCEAE (FouR-o'CLOCK FAMILY)}

Herbs (or in the tropics often shrubs or trees), with mostly opposite and entire leaves, stems tumid at the joints, a delicate tubular or funnel-form calyx which is colored like a corolla, its persistent base constricted above the 1-celled 1-seeded ovary and indurated into a sort of nut-lite pericarp; the stamens few, slender, and hypogynous; the embryo coiled around the outside of mealy albumen, with broad foliaceous cotyledons (in Abronia monocotyledonous by abortion). - Represented in our gardens by the Four-o'clock or Marvel of Peru (Mirábilis JALAPA), in which the calyx is commonly mistaken for a corolla, the cup-like involucre of each flower exactly imitating a calyz.

\section{OXÝBAPHUS L'Hẻr.}

Flowers 3-5 in the same 5-lobed membranaceous broad and open involucre, which enlarges and is thin and reticulated in fruit. Calyx with a very short tube and a bell-shaped (rose or purple) deciduous limb, plaited in the bud. Stamens mostly $3(3-5)$, hypogynous. Style filiform; stigma capitate. Fruit achenelike, several-ribbed or angled (pubescent in ours). - Herbs, abounding on the western plains, with very large and thick perennial roots, opposite leaves, and

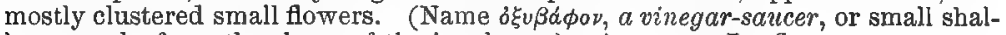
low vessel; from the shape of the involucre.) Allionia Loefl.

* Leaves all petioled except the uppernost reduced ones.

1. 0. nyctagíneus (Michx.) Sweet. Nearly smooth; stem becoming repeatedly forked, $0.3-1.5 \mathrm{~m}$. high; leaves broadly ovate, cordate; inflorescence but slightly pubescent; pedicels slender, becoming $1 \mathrm{~cm}$. in length, the lower axillary, solitary, the upper crowded upon short floral axes; involucres at length very large, $2 \mathrm{~cm}$. in diameter ; fruit cylindric-obovoid, $4 \mathrm{~mm}$. in length, rather acutely angled. - Man., Minn, and Wisc. to Tex. and La. ; also introd. eastw. - The leaves vary to oblong or ovate-lanceolate and abrupt or even cuneate at the base.

2. O. floribúndus Chois. Similar but with mostly narrower ovate to oblong leoves (not cordate); involucres smaller and more numerous, glomerate upou the elongated branches of an open cymose panicle; pedicels short, seldom over $6 \mathrm{~mm}$. in length. (O. nyctagineus, var. oblongifolius Gray; Allionia ovata Pursh, not O. ovatus Vahl.) - "O.g" Mo. (Bush), southwestw. and northwestw.

$$
\text { * * Leaves sessile or nearly so. }
$$

3. 0. hirsùtus (Pursh) Sweet. More or less glandular-hirsute, especially about the nodes and the usually contracted inflorescence, $8-9 \mathrm{dm}$. high ; leaves lanceolate to linear-larceolate, sessile and cuneate at base or narrowed to a short petiole; stamens often 5 ; fruit with thickened obtuse angles. (Allionia Pursh; A. bracteata Rydb.; Calymenia pilosa Nutt.?) - Plains of the Sask. to Tex., Wisc., O. (Louth), and casual eastw. in N. Y. and Ct.

4. 0. álbidus (Walt.) Sweet. Similar but smoother; stem whitish; leaves oblong, elongated, obtuse ; flowers in weak individuals few, axillary, in stronger ones numerous in a terminal panicle. (Allionia Walt.; A. lanceolata Rydb.) Kan. and Mo., S. C. and Tex; occasionally adventive northeastw.

5. 0. linearis (Pursh) Robinson. Often tall, glabrous except the more or less hirsute peduncles and involucres; leaves linear, thick and glaucous, often elongated, 5-15 cm. long. (O. angustifolius Sweet; Allionia linearis Pursh; also A. Bushi Britton, a low form.) - Minn, to Mo., Tex., westw. and not,hwestw. ; established on sandy ground, North Hayen, Cṭ. (Evans). 


\section{ILLECEBRÀCEAE (KNOTWORT FAMILT)}

Herbs, with nostly opposite and entire leaves, scarious stipules (except in Scleranthus), a 4-5-toothed or -parted herbaceous or coriaceous persistent calyx, stamens borne on the calyx, as many as the lobes and oppusite them or fever, styles 2 and often united, and fruit a 1-seeded utricle. Seed upon: a basal funicle, the embryo (in ours) surrounding the mealy albumen. - Small diffuse or tufted herbs, with small greenish or whitish flowers in clusters, or dichotomous cymes, with petals minute or none.

1. Scleranthus. Stamens borne on the throat of the Indurated 5-cleft and pointless calyx. Styles 2. Stipules none.

2. Anychia. Stamens on the base of the 5-parted awnless calyx. Styles hardly any.

8. Paronychia. Stamens on the base of the 5-parted calyx; the sepals hooded at the summit and bristle-pointed. Style 1, 2-cleft at the top.

\section{SCLERÁNTHUS L. KNAWEL}

Sepals 5, united below into an indurated cup, inclosing the utricle. Stamens 10 or 5 . Styles 2, distinct. - Howely little weeds, with awl-shaped leaves, obscure greenish clustered flowers, and no stipules. (Name from $\sigma \kappa \lambda \eta \rho b s, ~ h a r d$, and $\ddot{a} \nu \theta 0 s$, flower, from the hardened calyx-tube.)

${ }^{\prime}$. S. ÁNNUUS L. Much branched, spreading $(7-12 \mathrm{~cm}$. high); flowers sessile in the forks; calyx-lobes scarcely margined. - Waste places and roadsides (Nat. from Eu.)

\section{ANÝCHIA Michx. Forked Chickweed}

Sepals 5, scarcely concave, indistinctly mucronate on the back, greenish. Stamens 2-3, rarely 5. Stigmas 2, sessile. Utricle larger than the calyx. Radicle turned downward. - Small many times forked annuals, with swall stipules; the minute flowers in the forks, produced all summer. (A contracted derivative of Paronychia.)

1. A. polygonoides Raf. More or less pubescent, short-jointed, low and spreading; leaves somewhat petioled, mostly very narrowly lanceolate or oblanceolate; flowers nearly sessile and somewhat clustered. (A.dichotoma Man. ed. 6, not Michx.) - Mostly in open places, N. E. to Fla., w. to Minn. and Ark.

2. A. canadénsis (L.) BSP. Smooth, longer-jointed, slender and erect; leaves thinner, broader and longer (1-3 cm. long); flowers more stalked and inflorescence diffuse. (A. dichotoma Michx.; A. capillacea DC.) - Dry woodlands through nearly the same range; more abundant northw., and extending $w$. to Neb.

\section{PARONÝCHIA [Tourn.] Adans. WhITLOW-Wort}

Sepals 5, linear or oblong, concave, awned at the apex. Petals (or staminodia) bristle-form, or minute teeth, or none. Stamens 5. Style 2-cleft at the apex. Utricle inclosed in the calyx. Radicle ascending. - Tufted herbs (ours peren. nial), with dry and silvery stipules, and clustered flowers. (Greek name for a whitlow, and for a plant thought to cure it.)

1. P. argyrócoma (Michx.) Nutt. Forming broad tufts, freely branched, few of the branches fertile; leaves linear, flat, permanently silky; inflorescence densely cymose, surrounded by conspicuous large silvery bracts; calyz hairy, short-awned, the awns fattish and usually hairy; petals mere teetl between the stamens. - Rncky slopes among the mts., w. Va. to Tenn, and Ga.

Var. albimontàna Fernald. Branches mostly floriferous; leaves glabrate, the margins involute; cymes mostly lax; calyx usually longer, the awons subulate, glabrescent. - Bare mountain slopes, w. Me. and N. H. ; and locally by the Merrimac R., Newburyport, Mass. 
2. P. dichótoma (L.) Nutt, Smooth, tufted; stems (1.5-3 dm. high) ascending from a rather woody base; leaves $(1.2-3.6 \mathrm{~cm}$. long) and bracts narrovoly awl-shaped; cymes open, repeatedly forked; sepals short-pointed; minute bristles in place of petals. - Rocks, Md. to N. C. and Tex. July-Sept.

\section{AIZOÀCEAE}

A miscellaneous group, chiefly of fleshy or succulent plants, with mostly opposite leaves and no stipules. Differing from Caryophyllaceae and Portulacaceae by having the ovary and capsule 2-several-celled, and the stamens and petals sometimes numerous, as in Cactaceae (but the latter wanting in most of the genera). Seeds with the slender embryo curved about mealy albumen. Our genera apetalous and with the calyx free from the ovary.

1. Sesuvium. Calyx-lobes 5, petaloid. Stamens 5-60. Capsule cireumseisile. Succulent.

2. Mollugo. Sepals 5. Stamens 8 or 5. Capsule 8-valved. Not succulent.

\section{Sesùvium L. Sea Purslane}

Calyx 5-parted, purplish inside, persistent, free, Petals none. Stamens 560 , inserted on the calyx. Styles 3-5, separate. Pod 3-5-celled, many-seeded, circumscissile, the upper part falling off as a lid. - Usually prostrate maritime herbs, with succulent stems, opposite leaves, and axillary or terminal flowers. (An unexpiained name.)

1. S. marítimum (Walt.) BSP. Annual, procumbent or sometimes erect; leaves oblong- to obcvate-spatulate, obtuse ; Howers sessile; stamens 5. (S.pentandrum Ell.) - Sea-coast, L. I. to Fla.

\section{MOLlùgo L. Indian Chickweed}

Sepals 5, white inside. Stamens hypogynous, 5 and alternate with the sepals, or 3 and alternate with the 3 cells of the ovary. Stigmas 3 . Capsule 3-celled, 3-valved, loculicidal, the partitions breaking away from the many-seeded axis. - Low homely annuals, much branched; the stipules obsolete. (An old Latin name for some soft plant.)

1. M. verticillata L. (CARPet WeEd.) Prostrate, forming mats ; leaves spatulate, clustered in whorls at the joints, where the 1-flowered pedicels form a sort of sessile umbel; stamens usually 3. - Sandy river-banks, roadsides, and cultivated grounds. June-Sept. (Immigrant from farther south.)

\section{CARYOPHYLLÁELA (PINK FAMILY)}

Herbs, with opposite entire leaves, symmetrical 4-5-merous flovers, with or without petals; the distinct stamens no more than twice, the number of the sepals, either hypogynous or perigynous; styles 2-5 (or rarely united into one); seeds several or usually many, attached to the base or to the central column of the 1-celled (rarely 3-5-celled) pod, with a slender embryo coiled or curved around the outside of mealy albumen, in Dianthus nearly straight. - Bland herbs; the stems usually swollen at the joints; uppermost leaves rarely alternate. Leaves often united at the base. Calyx persistent. Styles stigmatic along the inside. Seeds amphitropous or campylotropous.

Tribe I. ALsfiveaE. Sepals distinct or nearly so, imbricated in tho bud. Petals when present without claws, mostly inbricated, and with the stamens inserted at the base of the sessile ovary, or into a little disk. Styles separate to the base. Stamens opposite the sepale, when not more in number. Low herbs. 
* Stipules present; pod short.

1. Spergularia. Styles 8. Pod 8-valved. Leaves opposite.

2. Spergula. Styles 5. Valves of the pod opposite the sepals. Leaves whorled.

* * Stipules none.

- Styles alternate with the sepals ; stamens as many, or twice as many.

3. Sagina. Petals 4 or 5 , entire, or none. Styles 4 or 5. Pod short, 4-5-valved.

$+\leftarrow$ Styles opposite the sepals, or, when fewer, opposite those which are exterior in the bud.

+* Pod short, splitting into as many valves as styles; valves often bifid or 2-parted.

4. Arenaria. Petals entire. Styles usually 3. Valres of the pod entire, bifid, or 2-parted.

5. Stellaria. Petals 2-cleft or none. Styles usually 3. Valves bifid or 2-parted.

\# + Pod cylindrical, dehiscent by twice as many equal teeth as styles.

6. Cerastium. Petals notched or 2-cleft. Styles 5 or 4. Steds fixed edgewise.

7. Holosteum. Petals denticulate or notched. Styles usually 3. Seeds fixed by the face.

Tribe II. SILÈnEAE. Sepals united into a tube or eup. Petals (mostly convolute in the bud: and stamens (10) borne on the stipe or stalk of the ovary, the former with slender claws, to the base of which the corresponding filaments often adhere. Seeds numerous. Stipules none. Flowers often large and showy.

* Calyx naked; seeds globular or kidney-shaped; embryo curved or colled.

8. Agrostemma. Calyx 5-toothed, 10-nerved. Styles 5, opposite the unappendaged petals.

9. Lychnis. Calyx 5-toothed, 10-nerved. Styles 5, alternate with the often appendaged petals.

10. Silene. Calyx 5-toothed, 10-nerved. Styles 8.

11. Saponaria. Calyx ovoid or sub-cylindrical, obscurely nerved, terete or 5-angled. Pod shortly 4-valved. Styles 2.

12. Gypsophila. Calyx top-Bhaped or eampanulate. Pod deeply 4-valved. Styles 2.

* Calyx with scaly bractlets or small leaves at the base; seeds flattened on the back, attached by the face; embryo nearly straight; styles 2.

13. Tunica. Calyx top-shaped or prismatic, with 5 strong nerves; flowers small.

14. Dianthus. Calyx cylindric or nearly so, with many fine nerves; flowers showy.

\section{SPERgularia J. \& C. Presl. Sand Spurrey}

Sepals 5. Petals 5, entire. Stamens 2-10. Styles and valves of the manyseeded pod 3 , very rarely 5 , when the valves alternate with the sepals! Embryo not coiled into a complete ring. - Low herbs, ours annuals or biennials, mostly on or vear the sea-coast, with filiform or linear opposite leaves, and smaller ones often clustered in the axils; stipules scaly-membanaceous; flowering all summer. (Name a derivative of Spergula.) Tissa \& Boda Adans. LEPIGONuM Wahlb.

\section{* Not Aleshy; stipules lanceolate, attenuate.}

1. S. rubra (L.) J.\& C. Presl. Nearly glabrous below the summit of the prostrate or ascending slender stems, peduncles, and sepals usually glandular-pubescent; leaves linear, flat, scarcely fleshy; stipules lancenlate, entire or cleft; pedicels longer than the bracts; pods and pink-red corolla small (is mm. lonw), about equaling the calyx; seeds rough with projecting points, semi-obovate or gibbous-wedge-shaped, wingless. - Dry sandy soil, e. Que. to Va. and U., chiefly neal' the coast, but rarely maritime. (Eu.)

* Distinctly fleshy, annual; root fibrous; stipules ovate or deltoid, acuminate.

2. S. marina (L.) Griseb. Much branched, procumbent or suberect, pale green, mostly glandular-pubescent; sepals nearly or quite as long as the ovoia acutish pod; seeds pale brown, very minute. (S. salina J. \& C. Presl; Buda marina Man. ed. 6; Tissa marina Britton.) - Brackish sands, etc., N. B. to Fla.; also on the Pacific Slope and in saline regions of the interior. (Eurasia.)

3. S. canadénsis (Pers.) Don. Diffusely branched, greener, smoother and sumewhat more slender than the preceding species; sepals rounded at the apex 
about half as long as the very blunt pod; seeds dark brown, relatively large. (Buda burealis Wats.; Tissa canadensis Britton; S. borealis Robinson.) Coast of Lab. to IR. I. (J. F. Collins).

\section{* * Fleshy biennial with a thick root.}

4. S. mèdia (L.) C. Presl. Stout root perpendicular; stems spreading; flowers large; pods at length $7 \mathrm{~mm}$. long, exceeding the calyx; seeds mostly winged. - Near Salina, N. Y. (Fry); also Cal. (Eu.)

\section{SPÉRgula L. SpUrrey}

Stamens 5 or 10. Styles 5. The 5 valves of the pod opposite the sepals. Embryo spirally annular. Leaves in whorls. Otherwise as Spergularia. (Name from sparyere, to scatter, from the seeds.)

1. S. RVÉssis L. (CORN S.) Annual, bright green, scarcely or not at all viscid; leaves numerous, in whoris, thread-shaped (2-5 cm. long); stipules minute; petals white; seeds roughened with minute whitish papillae. - Grain fields, etc., common. (Nat. from Eu.)

2. S. SATIVA Boenn. Similar but dull green and distinctly viscid ; flowers illscented; seeds margined, obscurely dotted, not papillate. - Sparingly adventive in tields, Ct. (Graves) and Vt. (Jones) to Ont. (Fletcher).

\section{Sagina L. Pearlwort}

Sepals 4 or 5 . Petals 4 or 5 , undivided, or often none. Stamens as many as the sepals, rarely twice as many. Styles as many as the sepals and alternate with thein. Pod many-seeded, 4-5-valved to the base; valves opposite the sepals. - Little inatted herbs, with thread-like or awl-shaped leaves, no stipules, and small flowers terminating the stems or branches; in summer. (Name from sagina, fattening; previously applied to the Spurrey.)

\footnotetext{
$\mathrm{U}$ [per leaves not proliferous; petals not louger than the sepals.

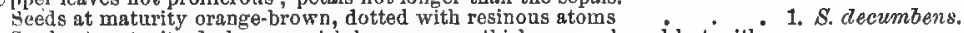

Seeds at maturity dark or grayish brown, smoothish or roughened but with. out atoms
Uper leaves with fascicies of rediced lenves in their axils ; petals decidediy"
longer than the sepals 2. S. procumbens. 3. S. nodos $\alpha$.
}

1. S. decúmbens (Ell.) T. \& G. Annual, ascending; the peduncles and calyx with the margins of the upper leaves at first glandular-pubescent; leaves short, often bristle-tipped; sepals and valves 5 or rarely 4 ; pod oblong-ovoid, nearly twice longer than the calyx. (S. apetala Am. auth., not Ard.) - Mass. to Ill., Mo., and southw. Var. SMímin (Gray) Wats., a slender form, apetalous, at least in the later flowers. - In waste ground near Philadelphia, and in sandy fields at Somers Point, N. J. (C. E. Smith).

2. S. procúmbens L. Annnal or perennial, depressed or spreading on the ground, glabrous; leaves linear-thread-shaped; apex of the peduncle often hooked soon after flowering; petals shorter than the broadly ovate obtuse sepals, sometimes none. - Springy places and damp rocks, chiefly near the coast, Nfd. to $\mathrm{Pa}$. and Del.; also Ont, and Mich. (Eu.)

3. S. noddsa (L.) Fenzl. Tufted perennial, erect, glabrous; upper leaves very short, proliferous in their axils; petals 5 , white, conspicuous. - - Rocky shrres, etc., Cutler, Me. (Kennedy), Isie Royale, L. Superior, and northw. (Eu.) Var, grandorósa (Bess.) Asch. Peduncles, etc., more or less glandulal'puberulent. - Cape Ann, Mass., to Me. (Eu.)

\section{ARENARIA L. SANDWORT}

Sepals 5. Petals 5, entire, sometimes barely notched, rarely wanting. Stamens 10. Styles 3, rarely more or fewer, opposite as many sepals. Pod short, splitting into as many or twice as many valves as there are styles, few-many. 
seeded. - Low usually tufted herbs, with sessile exstipulate leaves and small white flowers. (Name frum arena, sand, in which many of the species grow.) - The following sections are by many botanists taken for genera.

§1. MOEHRíngra (L.) Fries. Ovary at first 3-celled; seeds few, smooth, with a thickish appendage at the hilum; perennials with broadish leaves.

1. A. lateriflora L. Sparingly branched, minutely pubescent; leaves oval or oblóng, obtuse (1-2 cm. long); peduncles 2(rarely 3-4)-flowered, soon becoming lateral; sepals oblong, obtuse. (Moehringia Fenzl.) - Gravelly shores, thickets, etc., Nfd. to Pa., Mo., and northw. May, June. (Eu.)

2. A. macrophýlla Hook. Similar; leaves lance-oblong, acute; sepals lanceolate, acuminate. (Moehringia 'Torr.) - N. Guilford and Durham, Ct. (G. H. Bartlett, Harger), Vt., Lab., L. Superior, and northwestw.

§2. AMMODENIA (Patrin) B. \& H. Styles, cells of the ovary and valves of the fleshy pod 3 , rarely 4 or 5 ; seeds few, smooth, short-beaked at the naked hilum; disk under the ovary more prominent than usual, glandular, 10 lobed; flowers almost sessile in the axils, sometimes dioecious or polygamous; perennial.

3. A. peploides L. Stems (simple or forking from long rootstocks) and ovate partly clasping leaves (1.5-2 cm. long) very fleshy. (Ammodenia Rupr.) - Sea-shore, N. J. to Me. and northw. June. (Eu.)

8 3. ARENARIA proper. Pod splitting wholly or part way down into 3 or at lenglh 6 valves; seeds many, naked at the hilum.

4. A. Serpyllifólia L. (Thyme-Leaved S.) Roughish-pubescent or puberulent, $5-15 \mathrm{~cm}$. high ; leaves ovate, small, acute; cymes leafy ; sepals lanceolate, pointed, 3-5-nerved, about equaling the petals ; capsule flask-shaped, of firm texture. - Sandy or rocky soil, chiefly about towns. June-Aug. (Nat. from Eu.)

5. A. LePTóclados Guss. Similar to the preceding; leaves lanceolate; cymes nearly naked; capsule subcylindric, papery. (A. serpyllifolia, var.'tenuior Koch.) - Locally, Me. to Mich. (Farwell), and westw. (Adv, from Eu.)

§ 4. ALSINE (Gaertn.) B. \& H. Pod splitting to the base into 3 entire valves; seeds many, usually rough, naked at the hilum; flowers terminal or cynose; leaves linear or subulate.

Sepals lanceolate, aeuminate.

Lateral nerves oi the leaves none or much smaller than the midnerve.

Petals retuse

Petals entire.

Capsule longer and petals shorter than the sepals

Capsule shorter and petals much longer than the sepals

Leaves with 3 nearly equal nel'ves

Sepals obtuse or obtusish, inconsplcuodisly velned, not nerved.

Leaves rigid, pungent; petrls entive .

Leaves soft, herbaceous; petals usually retuse

6. A. pátula Michx. Diffusely branched from a slender root; stems 5$30 \mathrm{~cm}$.long; branches of the cyme divergent; peduncles long; sepals $3-5$-nerved. - - Ky. to n. Ill, Minn., and southw. to Tex. and Fla.

7. A. litorea Fernald. Perennial, densely tufted; stems several to many, 6-14 cm. high, leafy chiefly toward the base ; leaves firm, subulate, commonly proliferous in the axils; sepals 3-nerved; capsule $5 \mathrm{~mm}$. long, well exserted at maturity. - Gravelly beaches and calcareous bluffs, e. Que.; and north shore of L. Superior (Loring, G. S. Miller).

8. A. stricta Michx. Erect or diffusely spreading from a small root, smooth ; leaves slender, between awl-shaped and bristle-form, with many others clustered in the axils; cyme diffuse, naked, many-flowered; sepals 3-ribbed, ovate. ( $A$. Michauxii Hook. f.) - Rocks and dry wooded banks, Mt. Washingtun, N. H. (Manning); Vt. to S. C., Minn., Westw, and southwestw. July. 
Var texàna Robinson. More rigid; leaves shorter (6-10 mm. long), chiefly near the base; cymes rather dense; sepals attenuate, rigid. (A. texana Brit. ton.) - Rocky hills, s Mo. to Kan. and 'T'ex.

9. A. vérna L., var. propínqua (Richards.) Fernald. Dwarf, tufted or loosely matted, 2-12 cm. high, glandular-puberulent; leaves awl-shaped, somewhat triquetrous; stems chiefly 2-5-flowered; sepals rather abruptly acuminate, commonly longer than the oblong or spatulate often inconspicuous retals. ( $A$. :propinqua Richards.; $A$. verna, var. hirta auth., in part.) - Limestone or serpentiue rocks and barrens, Lab., e. Que., Smuggler's Notch, Vt. (Pringle, Eggleston), northw. and westw.

10. A. caroliniàna Walt. (Pine-Barren S.) Densely tufted from a deep perpendicular root; leaves closely imbricated, but spreading, awl-shaped, pungent, short, channeled; branches naked and minutely glandular above, severalflowered; sepals abtuse, ovate, shorter than the pod. (A. squarrosa Michx.) - In pure sand, s. New York, N. J., and southw. along the coast. May-July.

11. A. groenlánđica (Retz.) Spreng. (Mountain S.) Densely tulted from slender roots ; stems filiform (5-20 cm. high), erect; leaves linear, obtuse, flaccid; petals obovate, commonly retuse, about twice as long as the oblong nerveless sepals. - Greenl., Lab., mts. of N. E., N. Y., and higher Alleghenies to N. C. ; also coast of N. S. and Me.; Middletown, Ct., etc. June-Sept. - An apetalous form occurs.

\section{STELlÁria L. Chickwed. Starwort}

Sepals 4-5. Petals (white) 4-5, deeply 2-cleft, sometimes none. Stamens 8,10 , or fewer. Styles 3 , rarely 4 or 5, opposite as many sepals. Pod ovoid, 1-celled, opening by twice as many valves as there are styles, several-manyseeded. Seeds naked. - Flowers solitary or cymose, terminal or appearing lateral by the prolongation of the stem from the upper axils. (Name from stella, a star, in allusion to the star-shaped tlowers.) Alsine L. in part, not Wahlenb.

Stems and flower-stalks glabrous.

Petals distinctly shorter than the sepals or none.

Leaves lanceolate.

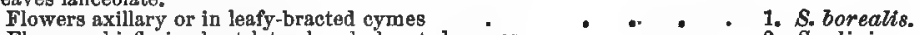

Flowers chiefly in short lateral scaly-bracted cymes . : $\quad: \quad$ : $\quad$ 2. S. uliginosa.

Leaves spatulate
Petals equaling or exceeding the sepals.

Flowers axillary, solitary, or in leafy-bracted cymes.

Leaves lanceolate.

Leaves of soft texture, flat or nearly so.

Mature sepals 3-4 mm. long, two thirds as long as the pod . . 4, S. crassifolia.

Mature sepals less than $3 \mathrm{~mm}$. long, half the length of the pod" : ${ }^{*} \mathbb{B}$. borealis.

Leaves of firm texture, carihate - . . . . . . 7. S. longipes.

Leaves elliptic-ovate - : : : . 5. S. humifusa.

Flowers cymose; bracts smali, scale-like.

Petals 8-12 inm, long; leaves linear, ghucous . . . . . . 6. \$. glauca.

Petals $8-6 \mathrm{~mm}$. long.

Lower pedicels erect, elongated; fruit blackish . . . - . 7. B. longipes.

Lower pedicels deflexed, arcuate; fruit pale.

Leaves linear or nearly 80 ; inflorescence lateral . . . . 8. S. Zongifolia.

Leaves lanceolate; inflorescence terminal - $\quad: \quad: \quad: \quad$ 9. S. graminea.

Stems and flower-stalks pubescent.

Leaves narrowly lanceolate.

Flower $1 \mathrm{~cm}$. in diameter; fruit blackish, on erect pedicels . . - 7. S. Iongipes.

Flower $2 \mathrm{~cm}$. in diameter ; fruit straw-colored, on bodding pedicels . - 10. S. Holostea.

Leaves elliptical, chiefly sessile

Leqves ovate, the lower on petioles of nearly their own length.

Styles 8-4; pods narrowly ovoid, subeylindric

Styles 5 ; pods broadly ovoid

1. S. borealis Bigel. Stems flaccid, many times forked, at length resolved into a leafy cyme; leaves bright green, rather broadly lanceolate; petals 2-5, minute, or none; sepals acute; styles usually 4 ; seeds smoothish. (Alsine Britton.) Shaded or wet places, Nfd. and Lab. to Alaska, s. to N. J., Pa., Mich., Minn., Col., and Cal. (Eu.)

2. S. uliginosa Murr. Stems weak, decumbent or diffuse, at length prolonged, leaving the naked and usually sessile cymes lateral; leaves lanceolate or 
lance-oblong; seeds roughened. (Alsine Britton.) - Swamps and rills, Md. ta P. E. I. and Nfd. ; also Mich., infrequent. (Eu.)

3. S. fontinàlis (Short \& Peter) Robinson. Stems flaccid, regularly dichotomous, hearing flowers in the forks; leaves linear-spatulate, ubtusish; petals none. (Sagina Short \& Peter; Alsine Britton.) - Moist cliffs, ete., Ky. and Tenn.

4. S. crassifdlia Ehrh. Stems diffuse or erect, flaccid; leaves rather fleshy, oblong-lanceolate, acutish ; petals longer than the sepals; seeds rugose-roughened. (Alsine Britton.) - Springy places, Lab. and Gulf of St. Lawrence to Mll., and northwestw. (Eu.)

5. S. humifùsa Rottb. Spreading or creeping; stems and branches $(5 \mathrm{~cm}$. high) 1-3-flowered; leaves fleshy, ovate or elliptical (4-6 mm. long); petals a little longer than the sepals; seeds smooth. (Alsine Britton.) - Salty or brackish marshes, Little Cranberry I., Me. (Redfield) to Lab., Greenl, and Hudson B.; rarely on inland shores, Upper St. John R., Me. (Goodale); also on the Pacific coast. June-Aug. (Eu.)

6. S. GLAÚCA With. Tall (3-5 dm. high) and very slender, pale green; flowers large, on long pedicels (often $6 \mathrm{~cm}$. in length); sepals lance-linear, acute, considerably exceeded by the petals; leaves $(2-4 \mathrm{~cm}$. long) narrow, not at all ciliolate at the base. - Grassy places along the railway, near St. Anne de Beaupre, Que. (Churchill, Murdoch). (Nat. from Eu.)

7. S. 16́ngipes Goldie. Erect or decumbent, $3 \mathrm{dm}$. high, essentially glabrous ; leaves linear-lanceolate, gradually attenuate from near the base, shining or glaucescent, spreading, $2-4.5 \mathrm{~cm}$. long; inflorescence terminal, 'dichotomous; pedicels 2-3.5 cm. long; pod narrowly ovoid, exserted, shining, nearly black. (Alsine Coville.) - Woods, etc., near L. Ontario; and in varying forms from the Sask. far northw. and westw.

Var. Laèta (Richards.) Wats. Usually veŕy glaucous, 1-2 dm. high; leaves shorter and relatively broader, erect and somewhat rigid, 1-2 cm. long ; inflorescence often reduced to 1 or 2 flowers:-The commoner form northeastw.; on sandy or gravelly beaches about the Gulf of St. Lawrence, Hudson B., northw. and westw. June.

8. S. longifolia Muhl. Stem erect, weak, often with rough angles (2-5 dm. high); leaves linear, acutish at both ends, spreading; cymes scaly-bracted, at length lateral, peduncled, many-flowered; the slender pedicels spreading or deflexed ; fruit pale straw-colored; seeds smooth. (Alsine Britton.) - Grassy places, Nfd. to Md., and westw. June, July. (Eu.)

9. S. GRAMfNEA L. Stems weak, ascending or reclining, 3-5 dm. high, rhombic in section; leaves narrovoly lanceolate, broadest a little above the ciliolate base; inflorescence pedunculate, terminal, diffuse, many-flowered; seeds strongly but minutely roughened. (Alsine Britton.) - Grassy places, frequent. (Introd. from Eu.) Var. LATIFòlia Peterm. is a form with somewhat broader ovate- or oblong-lanceolate leaves, the lowest subpetiolate. - In similar situations.

10. S. Holóstea L. Rather tall ; leaves long ( ${ }^{\prime},-8 \mathrm{~cm}$.), sessile, conspicuously attenuate, ciliolate on the margin and midnerve beneath; petals large, obovate, usually cleft only a fourth to half their length. (Alsine Britton.) - Often cultivated, and tending to become established. (Adv. from Eu.)

1- 11. S. pùbera Michx. (GREAT C.) Root perennial; leaves elliptic-oblong, ciliolate, $1.5-5 \mathrm{~cm}$. long, sessile or the lowest somewhat petiolate; petals longer than the calyx; stamens 10. (Alsine Britton.) - Shaded rocks, N. J. and Pa. to Ind. and southw. May. - The petals are cleft sometimes half their length, sometimes nearly to the base. Late shoots produce much larger leaves and often reduced flowers.

12. S. mìdi (L.) Cyrill. (Сомmon C.) Annual or nearly so; stem hairy in lines; leaves ovate to ovate-oblong, the lower on hairy petioles; petals shorter than the calyx, 2-parted; stamens 3-7; seeds scarcely roughened. (Alsine L.) -A common weed. (Nat. from Fu.) Var. Prócera Klett \& Richter ( $S$. neglecta Weihe) with 10 stamens and more or less crested seeds, has been reported by Holm from Washington, D. C.; Sable I., N. S.; Man.; and B. C. (Adv. from Lu.) 
13. S. Aqú́tica (L.) Scop. Perennial, glandular-pubescent; leares large, ovate, acute, cordate, the lower petiolate; petals much exceeding the glandularpuivescent sepals. (Alsine Britton.) - Occasional on waste land, in parks, etc., in the Eastern States, w. Que. and Ont. (Adv. from Eu.)

\section{CERÁstudm L. Mouse-ear Chickweed}

Sepals 5, rarely 4. Petals as many, 2-lobed or -cleft, rarely entire, often wanting in some of the flowers. Stamens 10 or fewer. Styles mostly 5 , rarely 4 or 3, opposite the sepals. Pod 1-celled, usually elongated, often curved, membranaceous, opening at the summit by twice as many teeth as there were styles, many-seeded. Seeds rough. (Name from képas, a horn, alluding to the shape of the pod.)

Perennial.

Petals much longer than the sepals

Petals equaling or shorter than the sepals or wanting . $\quad$ : $\quad$ : 2. C. vulgatum. Annual.

Pedicels 4-10 $\mathrm{mm}$. long.

Sepals lanceolate, attenuate.

Bracts not scarious-margined; petals (if present) cillolate at base . 3. C. viscosum.

Bracts scarlous-Inargined; petals (if present) naked

Sepals oblong, merely acutish; petals (if present) naked

4. C. semidecandrum.

Pedicels, at least the lower ones, $1.5-5 \mathrm{~cm}$. long

5. O. brachypodum.

6. O. nutans.

1. C. arvénise L. (FIELD M.) Stems ascending or erect, tufted, downy or nearly smooth, slender (1-2 dm. high), naked and few-several-flowered at the sumrnit; leaves linear or narrowly lanceolate; petals obcordate, more than twice the length of the calyx; pods (about $1 \mathrm{~cm}$. long) one third to two thirds longer than the calyx. - Dry or rocky places, Lab. to Alaska, s. to Del., Pa., Ind., Mich., Minn., etc., and along the mts. to Ga. May-July. (Eu.)

Var. oblongifolium (Torr.) Hollick \& Britton. Usually taller, pubescent; leaves narrowly to broadly oblong or oblong-lanceolate; pod about twice as long as the calyx. (C. oblongifolium Torr.) - Rocky places, chiefly serpentine, N. Y. to Minn., Col, and southw. Var. villósum Hollick \& Britton. Similar, but densely villous-pubescent, and the leaves lanceolate to ovatelanceolate. (Var. velutinum Britton.) - Serpentine barrens, etc., e. Pa.; also reported at Hamilton, Ont. (Dickson according to J. M. Macoun).

$\sim 2$. C. vulgatum L. (Common M.) Stems clammy-hairy, spreading (1.5-4 $\mathrm{dm}$. long); leaves chiefty oblong (varying to spatulate and ovate-lanceolate); upper bracts nearly herbaceous ; flowers at first clustered; sepals 4-6 mm. long, obtusish; pedicels longer, the fruiting ones much longer than the calyx. ( $\vec{C}$. viscosum of the Linnean herbarium; $C$. triviale Link.) - Fields, dooryards, etc.; common. May-July. (Nat. from Eu.)

$\checkmark 3$. C. viscósom L. Hairy and rather clammy, nearly erect (1-2 dm. high); leaves ovate to obovate or oblong-spatulate; bracts herbaceous; flowers small, at first in close clusters; pedicels even in fruit not longer than the very acute sepals; petals shorter than the calyx. (C.vulgatum of the Linnean herbarium; C. glomeratum 'Thuill.) - Grassy places, chiefly in the middle Atlantic, Gulf, and Pacific States. (Nat. from Eu.)

4. C. SEMIDECANDRUM $\mathbf{L}$. Similar to the preceding but smaller; bracts conspicuously scarious-margined; pedicels in fruit slightly exceeding the sepals. - Dry soil, locally established, Nantucket, (Churchill) and Ct. (Graves) to Va. (Adv. from Eu.)

5. C. brachýpodum (Engelm.) Robinson. Pale green, viscid-pubescent; leaves oblong; flowers in a dense or sometimes open dichotomous cyme; pedicels about equaling the capsules; these usually 2-3 times as long as the sepals. (C. nutans, var. Engelm.) --Near St. Louis, Mo. (Engelmann) to La., westw. and northwestw.

6. C. nuttans Raf. Stems erect, slender, grooved, diffusely branched (1.5-5 dm. high); cyme loose, many-flowered; leaves oblong-lanceolate, acute, the lowest spatulate; peduncles elongated, more or less hooked; petals (sometimes 
ceduced or wanting) a little longer than the calyx ; pods nodding on the stalks, curved upward, nearly or quite thrice the length of the calyx. (C. longe pedunculatum Muhl., as nomen subnudum.) - Moist rich soil, "N. S."; and Vt. to Athabasca, southw. and westw. May-July.

\section{HOLÓSTEUM [Dill.] L. JaGGed Chickweed}

Sepals 5. Petals 5, usually jagged or denticulate at the point. Stamens 3-5, rarely 10. Styles mostly 3 . Pod ovoid, 1-celled, many-seeded, opening at the top by 6 teeth. Seeds rough, flattened on the back, attached by the inner face. - Annuals or biennials, with several (white) flowers in an umbel borne on a long terminal peduncle. (Name from ò $\lambda \sigma \sigma \tau \epsilon o \nu$, a word used by Dioscorides for some unknown plant.)

1. H. UмBELLAtum L. Leaves oblong; peduncle and upper part of the stem glandular-pubescent; pedicels reflexed after flowering. — Roadsides, fields, etc., N.J. and Pa. to Ga. Apr., May. (Nat. from Eu.)

\section{Agrostemma L. Corn Cockle}

Calyx ovoid, with 10 strong ribs; the elongated teeth (in ours $2-3 \mathrm{~cm}$. long) exceeding the 5 large unappendaged petals. Stamens 10. Capsule 1-celled. Leaves linear. - Tall silky annual or biennial. (Name from dópós, field, and

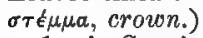

1. A. Githago L. Flowers $2.5-4 \mathrm{~cm}$. in diameter; petals purplish-red, paler toward the claw and spotted with black. (Lychnis Scop.) - Grainfields, and less frequently by roadsides. (Introd. from Eu.) - Seeds poisonous.

\section{LÝChNis [Tourn.] L. Campion}

Styles 5, rarely 4, and pod opening by as many or twice as many teeth; otherwise nearly as in Silene. (Ancient Greek name for a scarlet or flamecolored species, from $\lambda \dot{\chi} \chi v o s$, a light or lamp.)

$$
\text { * Calyx-teeth twisted; petals large; plant white-woolly. }
$$

1. L. coronaria (L.) Desr. (Murcein Pink.) Stem 4-9 dm. high; leaves oval or oblong; petals crimson. - Showy plant, often cultivated and now locally established, Me. to N. Y. and Mich. (Introd. from Eu.)

* Calyx-teeth not twisted; petals shovoy, much exserted; plant green.

$$
+ \text { Flowers perfect. }
$$

2. L. Flos-cưculi L. (RAGged RoBrs.) Perennial, erect, slightly downy below, viscid above; leaves narrowly lanceolate ; flowers in loose panicles; calyx short, glabrous; petals red, 4-lobed, lobes linear. - Moist or marshy places, and in waste land, N. B. to N. J. and Pa.- Often cultivated. (Introd. from Eu.)

3. L. chalcedónica L. (Soarlet Lychis.) Stout erect perennial with ovate leaves and hemispherical clusters of scarlet flowers; petals bifid. - Cultivated, and locally escaped in the Northern States.' (Introd. from Japan.)

$$
++ \text { Flowers dioecious or polygamous. }
$$

4. I. DIofCA L. ( $\operatorname{ReD} C$.) Leaves ovate to lance-oblong; flowers red to rarely white, inodorous, diurnal; calyx-teeth triangular-lanceolate, acute; capsule globose with a wide mouth at dehiscence. (L. diurna Sibth.) - Waste grounds and roadsides, common, especially eastw. (Adv, from Eurasia.)

1. 5. L. Á сы Mill. (Whre C.) Similiar in foliage; flowers white or pink, fragrant, opening in the evening; calyx-teeth longer, attenuate; capsule ovoidconical, narrow-mouthed at dehiscence. (L. vespertina Sibth.) - Same situations, but less common. (Adv. from Old World.)-Resembles Silene noctifiora but has 5 styles. 
** * Calyx-teeth not twisted; petals small, included or scarcely exserted.

6. I. Drummóndii (Hook.) Wats. Cinereous-puberulent; stems erect, almost naked above; leaves narrow; pedicels often long, erect; calyx oroid-cylindric. - Dry plaius, Neb. (Webber) to e. Minn. (Sheidon), Man. and westw.

\section{SilÈne L. Catchally. Campion}

Calyx 5-toothed, 10-many-nerved, naked at the base. Stamens 10. Styles 8, rarely 4. Pod 1-celled, sometimes 3-celled at least at the base, opening by 3 or 6 teeth at the apex. - Flowers solitary or in cymes. Petals mostly crowned with a scale at the base of the blade. (Name from ola cid exudation on the stems and calyx of many species. The English name Catchfly alludes to the same peculiarity.)

\section{* Calyx many-ribbed; annual.}

1. S. cónica L. Puberulent to tomentulose; stems usually several (1.5-5 dm. high), leafy; leaves linear-lanceolate, acute; calyx ovoid, strongly ribbed, $1.5 \mathrm{~cm}$. long, the teeth attenuate; petals small, purple or pink. - Waste places, casual, Dartmouth, Mass. (Hervey); "Clyde, O." (Adv, from Eu.)

* Calyx 5-10-nerved, not inflated except by the enlarging pod; annuals.

- Glabrous, a portion of each joint of the stem glutinous; flowers not racemose.

V2. S. antirrhina L. (Sleepr CAтohfly.) Stem slender (2-9 dm. high); leaves lanceolate or linear; flowers small, paniculate; calyx ovoid; petals obcordate, crowned, opening transiently in sunshine.- Dry soil ; common in waste places and open woods, centr. Me., westw. and southw. June-Sept.

Var. divaricata Robinson. Still more slender, the filıform branches and peduncles usually spreading; petals none. - Dry woods, Mass. to Ill., Mo., and Kan.

3. S. Armerria L. (Sweet William Catchfly.) Glaucous; leaves ovatelanceolate; flowers in flat cymes, open in sunshine; calyx club-shaped; petals rose-colored or white, notched, crowned with awl-shaped scales. - Escaped from gardens. (Adv. from Eu.)

+ + Pubescent and more or less viscid; flowers racemose; pedicels short.

4. S. GALLICA L. Leaves spatulate, obtuse, mucronate $(1.5-3.5 \mathrm{~cm}$. long); racemes simple, terminal, one-sided; calyx ovoid, villous-hirsute; petals small. (S. anglica L.) - Fields and waste places, local. (Adv. from Old World.)

5. S. рiсно́тома Ehrh. Tall, more or less hirsute; leaves lanceolate or oblanceolate; racemes branched; flowers short-pediceled, one in each fork, the others solitary at the nodes of the spreading rhachises; calyz-ribs 5 , birsute, aimple; petals much exserted, white or pink. - Clover fields, etc., N. E. to Tex., and on the Pacific Slope. (Introd. from Eu.)

\section{+++ Pubescent and viscid; flowers cymose.}

6. S. noctiflóra L. (Night-Flowering Catchfly.) Tall (3-9 dm. high); lower leaves large and spatulate, the upper lanceolate; flowers few, large, peduncled, white or nearly so, fragrant, opening at night; calyx-tube $2.5 \mathrm{~cm}$. long, with awl-shaped teeth. - Cultivated grounds.

* * Calyx 5-10-nerved, elongated or cluh-shappd, not inflated except by the enlarging pod; flniners cymose, or clustered; perennial, pubescent with viscid hairs, especially the calyx.

\section{- Petals white or rose-color.}

7. S. Menzièsii Hook. Weak, low, dichotomously branched; flowers small, white, in leafy cymes; calyx obconical ; petals 2-cleft, usually crownless. - $\mathrm{S}$. Mo. (Blankinship) to Neb., Assina., and westw.

8. S. NUtTans L. Leafy chiefly near the base; stems $3-6 \mathrm{dm}$. high, slender, bearing a narrow panicle of nodding pink flowers; petals rather deeply bifid, 
crowned. - Mt. Desert I., Me. (Miss Minot) and Staten I., N. Y. (Kerr); doubtfully established. (Adv. from Eu.)

9. S. pennsylvánica Michx. (WILD PiNk.) Stems low (1-2 dm. high); root-leaves narrowly spatulate, nearly glabrous, tapering into hairy petioles; stem-leaves (2 or 3 pairs) lanceolate; flowers cymosely clustered, short-stalked; calyx club-shaped; petals wedge-form, slightly notched and eroded, pink. ( $S$. carotiniana Walt.?) - Gravelly and rocky places, e. Mass. to N. Y., Ky., and southw. Apr.-June.

+ +- Petals long, deep crimson or scarlet, crovned.

10. S. virgínica L. (Fire Pink, Carchrly.) Stems slender (3-6 dm. high); leaves thin, spatulate, or the upper oblong-lanceolate; flowers few and loosely cymose, peduncled; calyx subcylindrical, soon obconical ; petals oblong, 2-cleft, deep crimson, the limb $2.5 \mathrm{~cm}$. long, - Open woods, s. N. J. to w. N. Y., s. w. Ont., Minn., and southw. June-Aug.

11. S. règia Sims. (Royal CatchflY.) Stem roughish, erect ( $1 \mathrm{~m}$. high); leaves thickish, ovate-lanceolate, acute; flowers numerous, short-stalked, in clusters, forming a strict panicle ; calyx ovoid-club-shaped in fruit; petals spatulate-lanceolate, mostly undivided, deep scarlet. -Prairies, O. to Mo., and southw. July.

12. S. rotundifolia Nutt. (Rodnd-Leaved Catchfly.) Viscid-hairy ; stems weak, branched, decumbent ( $6 \mathrm{dm}$. long); leaves thin, round, abruptly pointed, the lower obovate; flowers few, loosely cymose, stalked; calyx elongated; petals 2-cleft and cut-toothed, deep scarlet. - Shaded banks, s. O., Ky., and southw. June-Aug. - Leaves and flowers large.

**** Calyx bladdery-inflated; perennial; flowers panicled, white, in summer.

13. S. stellàta (L.) Ait. f. (STARrx CAmpion.) Stem 7-10 dm. high, with a large and open pyramidal panicle; leaves in whorls of 4, ovate-lanceolate, taper-pointed; caly x bell-shaped; corolla $2 \mathrm{~cm}$. broad; petals cut into a fringe, crownless. - Wooded banks, Mass. to Minn., Neb., and southw.

14. S. nívea (Nutt.) Otth. Leaves opposite, lanceolate or oblong, taperpointed; calyx subcylindric ; petals wedge-form, 2-cleft, minutely crovoned. ( $S$. alba Muhl., as nomen subnudum.) - Pa, to D.C., w. to Minn. and Neb., rare; also cultivated, and occasionally escaped elsewhere.

15. S. latinòlia (Mill.) Britten \& Rendle. (Bladder Campion.) Glaucous; leaves opposite, ovate-lanceolate; calyx globular, much inflated, elegantly veined; petals 2 -cleft, nearly crownless. (S. inflata Sm. ; S. Cucubalus Wibel; $S$. vulgaris Garcke.) - Fields, roadsides, and alluvial banks, e. Que. to Ont., \&. to N. J., Il., and Ia. - Flowers loosely cymose. (Nat. from Eu.)

***** Dwarf, alpine, tufted, smooth, perennial; flowering shoots 1-flowered.

16. S. acaúlis L. (Moss Campion.) Tufted like a moss; leaves linear, crowded ; flowers almost sessile, or rarely on a naked peduncle; petals purple or rarely white, notched or entire, crowned. - Alpine summits of the White Mountains, N. H., and northw.; also western mountains. July. (Eu.)

\section{SAPONÀRIA L.}

Calyx narrowly ovoid or subcylindric, 5-toothed, obscurely nerved, naked. Stamens 10. Styles 2. Pod 1-celled, or incompletely 2-4-celled at base, 4-toothed at the apex. - Coarse annuals or perennials, with large flowers. (Name from sapo, soap, the mucilaginous juice forming a lather with water.)

1. S. officinalis L. (Sonpwort, Bouncing Bet.) Flowers in corymbed clusters; calyx terete; petals crowned with an appendage at the top of the claw ; leaves oval-lanceolate. - Roadsides, etc. July-Sept. - A stout perennial, with large rose-colored flowers, commonly double. (Adv. from Eu.)

2. S. VACCARIA L. (Cow-herb.) Annual, glabrous; flowers in corymbed cymes; calyx 5-angled, enlarged and wing-angled in fruit; petals pale red, not crowned; leaves ovate-lanceolate. (Vaccaria vulgaris Host; V. Taccaria Britton.) - Occasionally spontaneous, or a weed in grainfields. (Adv. from Eu.) 


\section{GYPSÓPHILA L.}

Calyx narrowly top-shaped or campanulate, 5-nerved, 5-toothed, naked at base. Petals not crowned. Stamens 10. Styles 2. Pod 1-celled, 4-valved at the apex, sessile. - Slender glaucous annuals or perennials, with numerous small

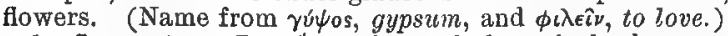

1. G. MURÀlis L. Ánnual, much branched; leaves very narrowly linear: flowers on slender pedicels, solitary in the forks; calyx turbinate, the teeth short. obtuse; petals purplish, crenate or emarginate. - Fields, roadsides, etc., Me. to N. J., Ont., and Mínn. (Nat. from Eu.)

\section{TÙNICA [Rupp.] Scop.}

Calyx 5-ribbed, bluntly toothed. Petals 5. Styles 2. - Slender wiry-stemmed herbs with small terminal flowers and linear leaves. (Name from tunica, a tunic. referring probably to the close-fitting calyx.)

1. T. Saxfrraga (L.) Scop. Low, many-stemmed; leaves less than $1 \mathrm{~mm}$. broad; bractlets 2 pairs, scarious except in the middle; small petals purplish. notched. - Roadsides, etc., Flushing, L. I. (J. Schrenk); London, Ont. (Bur. gess). (Adv. from Eu.)

\section{Diánthos L. Pink. Carnation}

Calyx cylindrical, nerved or striate, 5 -toothed, subtended by 2 or more imbricated bractlets. Stamens 10. Styles 2. Pod 1-celled, 4-valived at the apex. - Seeds flattish on the back; embryo scarcely curved.-Ornamental plants, of well-known aspect and value in cultivation. (Name from $\Delta$ cos, of Jupiter, and

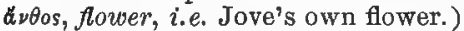

1. D. PRólIfer L. Annual, smooth, slender; flowers clustered; bractlets ovate, dry, concealing the calyx; leaves few, narrow, linear, erect; petals small, pink. - Roadsides and fields, s. e. N. Y. to Del.; also Cleveland, O. (Beardslee). (Nat. from Eu.)

2. D. deltoìdes L. (Matden P.) Perennial; leaves short, narrowly lanceolate, glabrous or roughish; flowers solitary; bracts ovate, half as long as the tube; petals rose-color or white, toothed. - Dry open places, e. N. E. to Mich., becoming more frequent. (Nat. from Eu.)

3. D. Barbatus L. (SWeet William.) Perennial; flowers fascicled; leaves large, lanceolate; bracts filiform-attenuate, equaling the calyx. - Cultivated, and sparingly spontaneous. (Introd. from Eu.)

4. D. Armeria L. (Deptrord P.) Annual; flowers clustered; bractlets of the calyx and bracts lance-cwl-form, herbaceous, downy, as long as the tube; leaves linear, hairy; petals small, rose-color with white dots, crenate. - Fields, etc., Mass. to Va., w. to s. Ont., Mich., and Ia. July. (Adv. from Eu.)

\section{portulacàceae (Purglane Family)}

Herbs, with succulent leaves, and essentially regular but unsymmetricat flowers, viz., sepals fewer than the petals; the stamens opposite the petals when of the same number, but often indefinite; otherwise nearly as Chickweeds. Sepals 2. Petals 5, or sometimes none. Stamens mostly 5-20. Styles 2-8, united below, or distinct, stigmatic along the inside. Pod 1-celled, with few or many campylotropous seeds rising on stalks from the base. Embryo curved around mealy albumen. - Insipid and innocent herbs, with entire leaves. Corolla opening only in sunshine, mostly ephemeral, then shriveling.

* Calyx free, persistent.

1. Montia. Petals $8-5$, usually unequal, sometimes slightly connate at the base. Stamens ar many. Ovules 2 or 3 . Roots fibrous. 
2. Claytonia. Petals and somewhat perigynous stamens 5, equal. Ovales about 6. Peren. nials with corms or thick caudex.

$$
\text { ** Colyx free, deciduous. }
$$

8. Talinum. Stamens hypogynous, usually more numerous than the petals. Pol manyseeđ̊ed.

$$
\text { *** Calyx partly adnate to the ovary. }
$$

4. Portulaca. Stamens 7-20, perigynous. Pod openlng by a lid to which the calyx-lobes are attached.

\section{MÓNTIA [Mich.] L.}

Sepals 2, persistent. Petals 3-5, usually a little unequal and often connate at the base. Stamens as many, adhering to the base of the petals. Stylebranches 3. Ovules few. Seeds 2-3. - Annuals or fibrous-rooted sometimas rhizomatose or stoloniferous perennials, ours with opposite leaves. (Named for Professor Giuseppe Monti of Bologna.)

1. M. fontàna L. (BLINKs.) Small, procumbent, rooting at the nodes; leaves obovate to linear-spatulate, $3-12 \mathrm{~mm}$. long; flowers minute; petals 3 , white, scarcely exceeding the calyx, connate at base, unequal, the tube slit down on one side; few-flowered racemes terminal or axillary. - Wet places, along the coast, islands near Mt. Desert, Me. (Rand, Redfield), to Lab. ; and on the Pacific Slope. (Eurasia.)

2. M. Chamissoi (Ledeb.) Durand \& Jackson. Procumbent or ascending, propagating by slender bulblet-bearing runners; leaves several pairs, oblongspatulate, $2.5-5 \mathrm{~cm}$. long; petals 5 , pale rose-color, much exceeding the calyx. (Claytonia Chamissonis Fsch.) - Moist ground, Minn. ; also Rocky Mts., etc.

3. M. PERFolidta (Donn) Howell, with single pair of cauline leaves connate into a suborbicular disk about the stem, is said to be established near Painesville, O. (Introd. from w. N. A.)

\section{CLAYTdNIA [Gronov.] L. SPRINe BeatTY}

Sepals 2, ovate, free, persistent. Stamens 5, adhering to the short claws of the petals. Style 3-cleft at the apex. Pod 1-celled, 3-valved, 3-6-seeded. Perennials, our two species sending up simple stems in early spring from a smali leep tuber, bearing a pair of opposite leaves, and a loose raceme of pretty flowers. Corolla rose-color with deeper veins, opening for more than one day! (Named in honor of Dr. John Clayton, one of our earliest botanists, who contributed to Gronovius the materials for the Flora Virginica.)

1. C. virgínica L. Leaves linear-lanceolate, elongated (7-15 cm. long).Moist open woods, N. S. to Sask., and southw. ; common, especially westw. and southw.

2. C. caroliniàna Michx. Flowers rather smaller and fewer; leaves spatulate-oblong or oval-lanceolate (2.5-5 cm. long). - N. S. to Sask. and Minn., and southw. along the Alleghenies.

\section{TALìnUM Adans.}

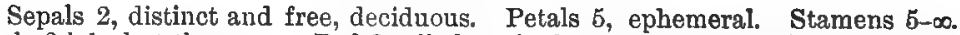
Style 3-lobed at the apex. Pod 3-celled at the base when young, 3-valved, with many seeds on a globular stalked placenta. - Ours perennials, subscapose from a thickish rootstock. Leaves linear, subterete, nuch exceeded by the peduncles. Flowers white or rose-colored, cymose. (Derivation obscure.)

1. T. parviflorum Nutt. Petals 5, pale, $2-3 \mathrm{~mm}$. long; stamens 5 ; capsule ovoid. - Pipestone City, Minn. (Sheldon) to Ark., and southwestw.

2. T. teretifolium Pursh. Petals 5, roseate, $8 \mathrm{~mm}$. long; stamens 15-20; anthers oblong; lobes of the stigma very short; capsule globose. - Serpentine and rarely other rocks, Pa. to Ind., Minn., and southw. June-Aug.

3. T. rugospermum Holzinger. Biennial (?), in appearance closely like the 
preceding; stigma-lobes a fourth to a third as long as the style ; anthers short, almost spherical; seeds roughened. - Prairies, Ind., Wisc., and e. Minn.

4. $\mathbf{T}$. calycinum Engelm. Larger; petals usually $8-10$; stamens 30 or more - Sandy soil or rocks, s. Mo. (Blankinship) to Neb. and southwestw.

\section{PORTulaca [Tourn.] L. Pdrslane}

Calyz 2-cleft; the tube cohering with the ovary below. Petals 5, rarely 6 , inserted on the calyx with the 7-20 stamens, fugacious. Style mostly 3-8parted. Pod 1-celled, globular, many-seeded, opening trausversely, the upper part (with the upper part of the calyx) separating as a lid. - Fleshy annuals, with mostly scattered leaves. (An old Latin name, of unknown meaning.)

1. P. oleracea L. (Common P.) Prostrate, very smooth; leaves obovate or wedge-form ; flowers sessile (opening only in sunny mornings) ; sepals keeled ; petals pale yellow; stamens 7-12; style deeply 5-6-parted; flower-bud flat and acute. - Cultivated and waste grounds; common.--Seemingly indigenous westw. and southwestw. (Nat. from Eu.)

2. P. neglécta Mackenzie \& Bush, known to us from description only, appears to be a more luxuriant plant with ascending stems, larger leaves $(2.5-5 \mathrm{~cm}$. long, 1.2-2.5 cm. broad), and more numerous (15-18) stamens. - Rich bottom lands, Mo. and Kan.

3. P. retùsa Engelm. Leaves often retuse; calyx-lobes obtuse in the bud; petals small or minute; style shorter, 3-4-cleft; seeds larger, sharply tuberculate; otherwise like $P$. oleracea. - Ark. to 'Tex. and westw.; reported from Kan., Ia., and Minn.

4. P. pilosa L. Ascending or spreading, copiously hairy in the axils; leaves linear-subulate, nearly terete, $6-12 \mathrm{~mm}$. long; petals red or purple. - Barrens, Mo. and Kan. to Tex., etc.

\section{CERATOPHYLLÅCEAE (HoRnwort Family)}

Aquatic herbs, with whorled finely dissected leaves, and minute axillary and sessile monoecious flowers without florat envelopes, but with an 8-12-cleft invo, lucre in place of a calyx, the fertile a simple 1-celled ovary, with a suspended orthotropous ovule; seed filled by a highly developed embryo with a very shor radicle, thick oval cotyledons, and a plumule consisting of several nodes and leaves. - Consists only of the genus

\section{CERATOPHÝLLUM L. HoRNwORT}

Sterile flowers of 10-20 stamens, with large sessile anthers. Fruit an achene, beaked with the slender persistent style. - Herbs growing under water; the sessile leaves cut into thrice-forked thread-like rigid divisions (whence the

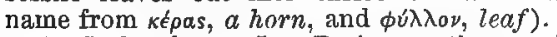

1. C. demérsum $L$. Fruit smooth, marginless, beaked with a long persistent style, and with a short spine or tubercle at the base on each side. - Slow streams and ponds, across the continent. (Eu, etc.) Var. Echindrum Gray bas the fruit mostly larger ( $6 \mathrm{~mm}$. long), rough-pimpled on the sides, the narrowly winged margin spiny-toothed, - Similar range.

\section{NYMPHAEACEAE (WATER LiLx FamiLy)}

Aquatic perennial herbs, with horizontal rootstocks and peitate or sometimes only cordate leaves floating or emersed; the ovules borne on the sides or back (or when solitary hanging from the summit) of the cells, not on the ventral 
suture; the embryo inclosed in a little bag at the end of the albumen next the hilum, except in Nelumbium, which has no albumen. Cotyledons thick and fleshy, inclosing a well-developed plumule. - Flowers axillary, solitary. Vernation involute. Rootstocks apparently endogenous.

\section{SUBFaMILY I. NYMPHAEOfDEAE}

Sepals 4-6, and petals numerous in many rows, persistent or decaying away, either hypogynous or variously adnate to the surface of the compound 8-30celled ovary, which is formed by the union of as many carpels; the numerous ovules inserted over the whole inner face of the cells, except at the ventral suture. Stigmas radiate as in the Poppy. Fruit baccate, with a firm rind. Petioles and peduncles from a (usually thickish) rootstock.

1. Nymphaea. Petals (very small and stamen-like) and stamens inserted under the ovary.

2. Castalia. Petals adnate to the ovary, large; the stamens on its sunamit.

\section{SUbFAMILY II. NELUMBONOf́DEAE}

Sepals and petals numerous in several rows, passing gradually into each other, and with the indefinitely numerous stamens hypogynous and deciduous. Pistils several, 1-ovuled, separately immersed in the obconical receptacle, which is much enlarged and broadly top-shaped at maturity, the imbedded nut-like fruits resembling small acorns. Embryo large; no albumen. - Petioles and peduncles all from the tuberous rootstock, the centrally peltate leaves and the flowers large.

3. Nelumbo. Character of the subfamily.

\section{Sobfamily III. CABOMbofDEAE}

Sepals and petals each 3 or sometimes 4 , hypogynous and persistent. Stamens definite (3-18). Pistils 2-18, free and distinct, coriaceous and indehiscent, 1-3-seeded on the dorsal suture. - Stems slender, leafy, coated with mucilage. Flowers small.

4. Brasenia. Stamens 12-18. Carpels 4-18. Leaves all peltate.

5. Cabomba. Stamens 8-4. Carpels 2-8. Submersed leaves capillary-multifid.

\section{NYMPhak̇a [Tourn.] L. Yellow Pond Lily. Spatter-dock}

Sepals 5, 6, or sometimes more, roundish, concave. Petals numerous, small and thickish, stamen-like or scale-like, inserted with the very numerous shor stamens on the receptacle under the ovary, not surpassing the disk-like 7-24rayed sessile stigma, persistent and at length recurved. Fruit ovoid, naked, usually ripening above the water. Aril none. - Rootstock creeping, cylindrical. Leaves with a deep sinus at the base. Flowers yellow or sometimes tinged with purple, produced all summer. (Name formerly used for the white-flowered water lilies, dedicated by the Greeks to the Water Nymphs.) Nophar Sibth. $\& \mathrm{Sm}$.

V 1. N. ádvena Ait. (Cow Lily). Sepals 6, unequal (yellow, mostly tinged with green or brown); petals shorter than the stamens and resembling them, thick and fleshy, truncate; stigma nearly entive, 12-24-rayed, yellow or pale red; ovary and fruit $(3.5-5 \mathrm{~cm}$. long) scarcely contracted above; thin submersed leaves seldom present; floating or emersed and erect leaves thick (1.5-3 
$\mathrm{dm}$. long), from roundish to ovate or almost oblong, the sinus open, lobes subtriangular. (Nuphar Ait. f.) - Very common in still or stagnant water, especially from N. Y., southw. and westw. Northw. and northeastw. largely replaced by Var. variegata (Engelm.) Fernald, which has flowers partly purple and leaves with a closed sinus and relatively shorter rounder lobes. $(N$. variegata G. S. Miller.)

$\times$ ? N. rubrodísca (Morong) Greene, More slender; leaves somewhat smaller (12 dm. long); flowers usually smaller (sepals $2.5-3 \mathrm{~cm}$. long); stigma 9-13-rayed, crenately toothed, bright red or crimson; fruit (2.5 cm. long) decidedly contracted above. ( $N$. hybrida Peck; Nuphar advena, var. minus Morong.) - N. B. to Mich. and Pa. - Probably a hybrid between $N$. advena, var. variegata and the next species.

2. N. microphýlla Pers. Very slender and with slender rootstock; submersed leaves thin, round-reniform, the floating broadly elliptical, $3.5-10 \mathrm{~cm}$. long, with a deep narrow sinus; sepals usually 5 ; flowers $2.5 \mathrm{~cm}$. or less in diameter; petals spatulate or obovate; stigmas 7-10-2'ayed, dark red; fruit globular (1.2-1.8 cm. in diameter) with a short neck. ( $N$. Kalmiana Sims; Nuphar Ait. f.) - N. B. to Pa. and Minn., and northw. - Doubtfully distinct from $N$. minima Reichenb. of Eu.

3. N. sagittifolia Walt. Rootstock stout; leaves narrowly oblong to oblonglanceolate (1.5-3 dm. long), with short sinus; flowers small, $2.5 \mathrm{~cm}$. broad. (Nuphar Pursh.) - S. Ind. and Ill. (Schneck), and southw.

\section{2. castalia Salisb. Water Nymph. Water Lily}

Sepals 4, green outside, nearly free. Petals numerous, in many rows, the innermost gradually passing into stamens, imbricately inserted all over the ovary. Stamens indefinite, inserted on the ovary, the outer with dilated filaments. Ovary 12-35-celled, the concave summit tipped with a globular projection at the center, around which are the radiate stigmas; these project at the margin, and are extended into linear and incurved sterile appendages. Fruit depressed-globular, covered with the bases of the decayed petals, maturing under water. Seeds enveloped by a sac-like aril. - Flowers white, pink, yellow, or

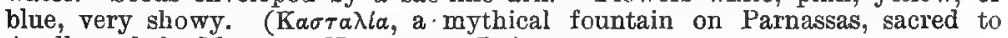
Apollo and the Muses.) Nymphaea L. in part.

1. C. odoràta (Ait.) Woodville \& Wood. (Sweet-scented WAter Lily.) Rootstock with few and persistent branches; leaves orbicular (0.5-2.2 dm. wide), deeply-cordate-cleft at the base, the margin entire, often crimson beneath ; stipules broadly triangular or almost kidney-shaped, notched at the apex, appressed to the rootstock; flower white, very sweet-scented $(0.5-1.3 \mathrm{dml}$. In diameter, when fully expanded, opening early in the morning, closing in the afternoon); petals obtuse; anthers blunt; aril much longer than the distinctly stipitate ellipsoid seeds, these about $3 \mathrm{~mm}$. long. (Nymphaea odorata Ait., including var. minor Sims.) - Ponds and still or slow-flowing water ; common. June-Sept. Passing to the somewhat ill-defined forma Rósea (Pursli) Britton, with pink or bright pink-red flowers. - Shallow ponds, mostly near the coast. Var. GIGANTEA (Tricker) Fernald. Larger; leaves $2-4 \mathrm{dm}$. broad, the margins tumed up; flowers (white or nearly so) $1-1.5 \mathrm{dm}$. in diameter, less fragrant; sepals greenish. (Nymphaea odorata, var. Tricker.) - Del. to Fla. and La. (Mex., W. I., S. A.)

2. C. tuberdsa (Paine) Greene. Leaves reniform-orbicular, mostly larger (2-4 din. wide) and more prominently ribbed than in the last, rarely purplish beneath; rootstock bearing numerous spontaneously detaching often compound tubers; flower scentless (or with a slight odor as of apples), white, never pink, 1-2 dm. in diameter, the petals proportionally broader and blunter than in no.1; the fruit more depressed, and with fewer but much larger (i.e. twice as broad) globular-ovoid seeds, which when mature are barely inclosed by the aril and not stipitate. (Nymphern Paine; $N$. reniformis of auth., not Walt.) Slow rivers, etc., 11. Vt, to Del. (Commons), e, Neb., and Ark. 


\section{NeLÚmbo ['Tourn.] Adans. SACRed Beas}

The only genus of the subfamily. (Name Ceylonese.)

1. N. lùtea (Willd.) Pers. (Yellow Neldmbo, Water Chinquapin.) Leaves usually raised high out of the water, circular, $3-6 \mathrm{dm}$. in diameter, with the center depressed or cupped; fluwer pale yellow, 1.2-2.5 dm. broad; anthers tipped with a slender hooked appendage. (Nelumbium luteum Willd.) - Concord and (Isterville, Mass., s. Ct. (prubably of Indian introduction) to L. Ontario, L. Erie, Mich., Minn., e. Neb., and southw.; rare in the Middle States.-Tubers farinaceous and edible. Seeds also eatable. Embryo like that of Castalia on a large scale; cotyledons thick and fleshy, inclosing a plumule of 1 or 2 wellformed young leaves, inclosed in a delicate stipule-like sheath.

N. NocfFera Gaertn., the oriental Lorus, with pink flowers, has become established about Bordentown, N. J., where artificially introduced.

\section{BRASÈnia Schreb. Water Shield}

Sepals 3 or 4 . Petals 3 or 4 , linear, sessile. Stamens 12-18; filaments filiform ; anthers innate. Pistils 4-18, forming little club-shaped indehiscent pods ; stigmas linear. Seeds $1-2$, pendulous on the dorsal suture!- Rootstock creeping. Leaves alternate, long-petioled, centrally peltate, oval, floating. Flowers axillary, small, dull-purple. (Name of uncertain origin.)

1. B. Schrebèri Grnel. Leaves entire or shallowly crenate, $2-10 \mathrm{~cm}$. across. (B. peltata Pursh.; B. purpurea Casp.) - Ponds and slow streams. June-Aug. (Asia, Afr., Austral.)

\section{5. СABÓMBA Aublet.}

Sepals 3. Petals 3, oval, bi-auriculate above the very sbort claw. Stamens $3-6$; anthers short, extrorse. Pistils 2-4, with small terminal stigmas. Seeds 3 , pendulous. - Slender, mainly submersed, with opposite or verticillate capillary-dissected leaves, a few floating, alternate and centrally peltate. Flowers single on long axillary peduncles. ('Probably an aboriginal name.)

1. C. caroliniàna Gray. Floating leaves linear-oblong or -obovate, often with a basal notch ; flowers $1.2-1.8 \mathrm{~cm}$. broad, white with yellow spots at base; stamens 6. - Ponds, s. Ill. (Schneck) to Fla. and Tex. May-Sept.

\section{RANunculàceae (Crowfoot Family)}

Herbs or sometimes woody plants, with a colorless and usually acrid juice, polypetalous, or apetalous with the calyx often colored like a corolla, hypogynous; the sepals, petals, numerous stamens, and many or few (rarely single) pistils all distinct and unconnected. Flowers regular or irregular. Sepals 3-15. Petals 2-15, or wanting. Stamens indefinite, rarely few. Fruits either dry pods, or seed-like (achenes), or berries. Seeds anatropous (when solitary and suspended the rhaphe dorsal), with hard albumen and a minute embryo. Leaves often dissected, their sta!ks dilated at the base, sometimes with stipule-like appendages. A large family, including some acrid-narcotic poisons.

Tribe I. ANEMÒNEAE. Sepals 8-20, often petal-like, imbricated in the bud. Stamens mostly numerous. Achenes numerous or several, in a head or spike. - Herbs, nerer climbing; leaves alternate or radical, the upper sometimes opposfte or whorled.

* Petals evident; sepals usually 5 ; achenes many.

1. Ranunculus. Petals 5 (or rarely more), yollow or white, with a scale or gland at base Aohezes numeroug, capitato. Seod erect or ascending. 
2. Myosurus. Sepals spurred. Petals 5, white. Achenes in a long spike. Scopes 1-flowered. Seed suspended.

I. Adonis. Sepals and petals (5-16, crimson or scariet) Alat, unappendaged. Seed suspended. * * Petals none; sepals $3-5$, caducous ; seed erect; lenves alternate.

4. Trautvetteria. Achenes numerous, inflated, 4-angled. Flowers corymbose. Filaments white, clnvate.

*** Petals none (rarely some staminodia) ; seed euspended.

+ Leaves alternate, compound; flowers panlcled, often diceclous.

5. Thalictrum. Sepals usually 4 , petal-Hke or greenish. Achenes few.

$++\Delta 11$ but the lower leaves oppusite or whorled; peduncles 1-flowered.

6. Anemonella. Stigma terminal, broad and flat. Radical leaves and involucre compound. Peduncles umbellate. Achenes 4-15, many-ribbed.

7. Hepatica. Involucre close to the flower, of 3 oval bracts, caly $x$-like. Leaves radical, slinple and lobed. Pistils several.

8. Anemone. Involucre leaf-like, remote from the flower. Leaves compound or dissected. Pistils very тљну.

Tribe II. CLEMATIDEAE. Sepals normally 4, petal-like, valvate in the bud, or with the edges bent inward. Petals none, or smail. Achenes numerous, tailed with the feathery or hairy styles. Seed suspended. Leaves all opposite.

9. Clematis. Climbing by the leafstalks, or erect herbs.

Tribe III. HELLEBOREAE. Sepals imbricated in the bud, rarely persistent, petal-like. Petals often nectariferous or reduced to staminodia or none. Pods (follicles) or berries (in nos. 21 and 22) fow, rarely single, few-many-seeded. Leaves alternate.

* Ovules and commonly seeds more than one pair; herbs.

+ Flowers regular, not racemose; petals rednced to inconspleuous nectaries or slender or none; sepais tardily deciduous.

\# Follicles separate.

10. Isopyrum. Petals (in our's) none. Sepals brond, white. Pods few. Leaves compound.

11. Caltha. Petals none. Sepals brond, yellow. Leaves kidney-shaped, undivided.

12. Trollius. Petals 5-20, narrow; pitted above the base. Pods sessile. Leaves palmately lobed,

18. Coptis. Petals 5-6, small, hollowed at apex, white. Pods long-stalked. Leaves radical, trifoliolate.

14. Helleborus. Petals small, tubular, 2-lipped. Sepals 5, broad, persistent and turning green, Pods sessile.

15. Eranthis. Petals merely small 2-lipped nectaries. Sepals 5-8, narrow, deciduous, Flower solitary, involuciate.

+++ Follicles connate.

16. Nigella. Petals small, unguiculate, the blade bifid. Sepals 5 , regúlar, petalold, deciduous. ++ Sepals and large spur-shaped petals regular, each 5 .

17. Aquilegia. Pistils 5, with slender styles. Leaves ternately compound.

+++ Flowers unsymmetrical and irregular; sepals 5.

18. Delphinium. Upper sepal syurred. Petals 4, of two forms; the upper palr with long spurs, inclosed in the spur of the calyx.

19. Aconitum. Upper sepal hooded, covering the two long-clawed small petals.

-+++ Flowers regular, racemose; sepals caducous; petals very small, stamen-like, or none; leaves decompound.

20. Cimicifuga. Flowers in long often paniculate racemes. Pistils 1-8, becoming many-seeded pods.

21. Actaea. Flowers in a single short raceme. Plstll forming a many-seeded berry. ** Ovules a single pair ; flowers regular ; rontstocks yellow and bitter.

22. Hydrastis. Flowors solitary. Sepals 3, petal-like, caducous. Petals none. Stamens numer. ous. Pistils several, becoming 2-seeded berries. Leaves slmple, lobed.

23. Zanthorhiza. Flowers in componnd racemes. Sepals 5. Petals 5, Bmall, 2-lobed, with claws. Stamens 5-10. Pods 1-seeded. Shrub with pinnate leaves, 


\section{RaNúnculus [Tourn.] L. Crowfoot. Butrercte.}

Annuals or perennials; stem-leaves alternate. Flowers solitary or somewhat corymbed, yellow, rarely white. (Sepals and petals rarely oniy 3 , the latter often more than 5. Stamens occasionally few.) - (A Latin name for a little frog: applied by Pliny to these plants, the aquatic species growing where frogs abound.)

§ 1. FICARIA Boiss. Roots tuberous-thickened; sepals 3 ; petals about 8 , yellow, with a free scale aver the honey gland.

1. R. Ficaria L. (Lesser Celandine.) Glabrous and somewhat succu. lent; leaves basal on long stoutish petioles, ovate, rounded, deeply cordate, subcrenate; flowers scapose, $2 \mathrm{~cm}$. in diameter. (Ficaria Karst.) - Wet places, occasional ; Mass. to D. C. Apr., May. (Introd. from Eurasia.)

\$2. BATRACHIUM DC. Petals with a spot or naked pit at base, white, or only the claw yellow; achenes marginless, transverse $y$ wrinkled; aquatic or subaquatic perennials, with the imnersed foliage repeatedly dissected (mostly by threes) into capillary divisions; peduncles 1-flowered, opposite the leaves.

2. R. circinàtus Sibth. (STIFF W sessile, with broad conspicuous stipules, the divisions and subdivisions short, spreading in one roundish plane, rigid, not collapsing when withdrawn from the water. ( $\boldsymbol{R}$. divaricatus auth., not Schrank ace. to Hiern.) - l'onds and slow streams, Vt. to $\mathrm{Pa}$., Ia., northw. and westw., rather rare. (Eu.)

3. R. aquátilis L., var. capillàceus DC. (Сомmon White WATER C.) Leaves all under water and mostly petioled, their capillary divisions and subdivisions rather long and soft, usually collapsing more or less when withdravon from the water; petiole rather narrowly dilated. (R. aquatilis, var. trichophylius Gray; Batrachinm trichophyllum Bosch ; B. flaccidum Rupr.; B. Drouetii Nym. ; and $B$. confervoides auth., not Fries.) - Common, especially in slowflowing waters, the eastern form with more soft and flaccid leaves. JuneAug. (Eu.) Var. CAEsPiTòsus DC. A dwarf terrestrial variety or possibly mere state, rooting at the nodes, the small leaves somewhat fleshy, with broader rigid divisions. - S. Ill. (Schneck), and westw. (Eu.)

* * Receptacle glabrous; no submersed leaves.

4. R. Hederaceus L. Rooting freely in shallow water; leaves all reniform, angulate-lobed. (Batrichium S. F. Gray.) - Fresh-water marshes, Nfd., s. Md. : $\approx$ e. Va. (Nat. from Eu.)

§ 3. HALÒDES Gray. Petrils yellow, with nectariferous pit and scale; carpels thin-2oalled, striate, in a subcylindric head; scapose, spreading by muners:

5. R. C'ymbalària Pursh. (Sea-side C.) Glabrous; scapes 4-22 cm. high, 1-7-flowered; leaves clustered at the root and on the joints of the long rooting runners. roundish-heart-shaped or kidney-shaped, crenate, rather fleshy, longpetioled: petals 5-8. (Oxygraphis Prantl.) - Lab. to N. J., also along the Great Lakes and in alkaline soil of the interior. June-Aug. (Greenl., Eurasia.)

Var. alpinus Hook. Dwarf; leaves 3-toothed, only 3-6 mm. broad. - Cape Breton I., N. S., e. Que., and northw.

\$4. EURANUNCULUS Gray. Petals with a little scale at the base, yellno; achenes nerveless.

* Achenes smooth, or nearly so; mostly perennial.

- Aquatic; inmersed leaves filiformly dissected; as in § Batrachium.

6. R. delphinifolius Torr. (YÉllow WATER C.) Stems floating or immersed, with the leaves all repeatedly 3-forked into long filifol'm divisions, or sometimes creeping in the mud (perennial by rooting from the nodes, if at all); petals 5-8, deep bright yellow, 8-12 mm. long, much larger than the sepals: 
carpels in a round head, pointed with a straight beak, slightly roughened, and margined toward the base with a conspicuous tumid border. ( $R$. multifidus Pursh, not Forskal.) - Quiet water, centr. Me. to Ont., s. to N. C. and Ark. ; also B.C. to Cal. When rooting out of water or left in the mud of drying ponds it becomes the so called var. TERHéstris (Gray) Farwell ( $R$. missouriensis Greene), a mere state, although differing conspicnously in its firmer less finely cut leaves of roundish outline, pubescent petioles, and snaller flowers.

7. R. Púrshii Richards. Wholly immersed and glabrous or creeping upon muddy banks and sparingly to copiously appressed-pubescent; leaves orbicular in outline, $1-2 \mathrm{~cm}$. in diameter (the submersed somewhat larger), radially $3-$ cleft, the segments again cut into $2-5$ rounded lobes; flower about $1 \mathrm{~cm}$. broad; petals bright yellow, not much exceeding the broad similarly colored sepals; carpels small, ovoid, turgid, smooth, without a distinct border; style short, straightish. - Shallow pools and on shores, e, Que, to Alaska, s. to P. E. I., N. S., N. B., Mich., Minn., N. Dak., and in the Rocky Mts. to N. Mex. JuneSept. (Siber.)

+ + Arctic species barely entering our northern limits; leaves all 3(-5)-cleft or 3-parted, glabrous.

8. R. lappónicus L. Creeping; leaves deeply 3-parted, $1.5-4 \mathrm{~cm}$. broad, segments obovate, cuspidately several-toothed; scapes $6-10 \mathrm{~cm}$. high, 1-leaved near the base; flower 7-12 mm. broad; petals oblong, yellow with orange veins ; achenes somewhat fusiform. (Anemone nudicaulis Gray.) - In sphagnum bogs, etc., Greenl. and n. Lab, to the n. shore of L. Superior, n. Minn., and Alaska. (Siber., n. Eu.)

+++ Usually terrestrial but growing in very wet places, glabrous or nearly so; leaves entire or barely toothed, ail or else all but the lowest lanceolate or linear; carpels forming a globular head. (SPEARworT.)

9. R. laxicaúlis (T. \& G.) Darby. (Water Plantain S.) Stems ascend. ing (3-6 dm. long), often rooting from the lower joints ; leaves lanceolate or tht lowest oblong, mostly denticulate (4-10 $\mathrm{cm}$. long), contracted into a margined half-clasping petiole ; petals 5-7, bright yellow, oblong (4-6 mm. long); carpels flattened, large (2 mm. long), pointed with a long narrow-subulate beak. ( $R$. obtusiusculus Raf.?; $\boldsymbol{R}$. ambigens Wats.) - Ditches and muddy places, s. Me to Ga. and Tenn., chiefly at low altitudes; and from W. N.Y. and s. Ont. to Minn. and Ark. June-Aug. - An aquatic state with reduced but undivided leaves occurs.

10. R. Flámmula L. (Smaller S.) Stem reclining or ascending, rooting below; leaves lanceolate or linear, or the lowest ovate-oblong to lanceolate, entire or nearly $\$ 0$, mostly petioled (2-5 cm. long); petals $5-7$, much longer than the calyx, bright yellow; carpels small, flattish but turgid, mucronate with a short abrupt point. - Nfd. ; also Ore. (Eurasia.) Passing by insensible gradations through an undefinable var. INTERMÀIUS Hook, into

Var. réptans (L.) Mey. (CRe eping S.) Small, slender, the filiform creeping stems rooting at all the joints; leaves linear, spatulate, or oblong (6-25 mm. long); flowers small. ( $R$. reptans $L_{\text {. }}$ ) - Gravelly or sandy shores ; Nfd. to Pa., northw. and westw. June-Sept. (Eu.) Passing in its turn into the still more slender var. Filifó nu is (Michx.) Hook., with filiform leaves. - Similar situations.

11. R. oblongifòlius Ell. Usually annual; stem erect or ascending, often pubescent below, slender (3-6 dm. high), diffusely branched above and manyfowered; leaves serrate or denticulate, lower long-petioled, ovate or oblong (1-3.5 cm. long), uppermost linear; flowers $6-10 \mathrm{~mm}$. broad; petals 5 , bright yellow (3-6 mm. long) ; stamens 12-20; carpels minute, almost globular, the small style deciduous. - Swamps and low ground, near the coast, Del. to Fla. and Tex., n. in Miss. basin to Mo. and Ill. Apr.-Sept.

12. R. pusillus Poir. Stem ascending, weak, loosely branching $(\mathbf{1 . 5}-\mathbf{4 . 5} \mathrm{dm}$. long); leaves entire or obscurely denticulate, the lowest round-ovate or heartshaped $(0.7-2 \mathrm{~cm}$. long), long-petioled, the upper oblong or lanceolate $(2-4 \mathrm{~cm}$. long); flowers very small; petals $1-5$, pale yellowish, about $2 \mathrm{~mm}$. long, scarcely 
surpassing the sepals; stamens 3-10 ; carpels very turgid, smooth or slightly papillose, tipped with a minute sessile stigma. - Wet places, near the coast, s. N. Y. to Fla, and 'Tex., n. in the Miss. basin to Mo. and Tenn. Apr.-Sept.

++++ Terrestrial, but often in wet places; leaves mostly cleft or divided.

Root-leaves (or most of them) not divided to the very base; achenes marginless.

= Carpels in a globose head, upon a turgid subglobose receptacle.

13. R. Thomboideus Goldie. (DwarF B.) Low (1-2 dm. high), hairy; rootleaves roundish or rhombic-ovate, rarely subcordate, toothed or crenate; lowest stem-leaves similar or $8-5$-lobed, the upper 3-5-parted, almost sessile, the lobes linear; carpels obovate with a minute beak, in a globose head; petals large, deep yellow. (R. ovalis Raf. ?) - Prairies and dry hills, w. Que. to Mich., Ia., and northw Apr., May.

$==$ Carpels in an ovoid or cylindric head, on an elongated receptacle.

\section{a. Stigma essentially sessile.}

1. Root-leaves all 3-parted or-lobed; the lobes again lobed or toothed.

14. R. sceleràtus L. (CuRsed C.) Annual, glabrous; root-leaves 3-lobed, rounded; lower stem-leaves 3-parted, the lobes obtusely cut and toothed, the uppermost almost sessile, with the lobes oblong-linear and nearly entire; carpels barely mucronulate, very numerous, in ellipsoidal or cylindrical heads; petals scarcely exceeding the calyx. - Wet ditches and bogs; sometimes appearing as if introduced. June-Aug. - Stem thick and hollow; juice acrid and blistering; leaves thickish; Howers small, pale yellow. (Eu.)

\section{Most or all of the root-leaves merely crenate.}

15. R. micránthus Nutt. Villous; roots often fusiform-thickened, fasciculate; root-leaves for the most part broadly obovate, scarcely if at all cordate at the base, some of them 3-parted or pedately 3-divided; the cauline subsessile, divided into $3(-5)$ narrowly oblong leaflets; flowers very small ; petals inconspicuous, light yellow; receptacle glabrous. (R. abortivus, var. Gray.) - Open deciduous woods, s. Me, to the Sask., and southw.

L 16. R. abortivus L. (SMALL-FLowerkd C.) Biennial, slightly succulent; stem 1.5-6 dm. high, covered with a short sparse sometimes fugacious pubescence; primary root-leaves round-heart-shaped with a vide shallow sinus or kidney-form, barely crenate, the succeeding often 3 -lobed or (3) 3-parted; those of the stem and branches 3-5-parted or divided, subsessile, the divisions oblong or narrowly wedge-form, mostly toothed; petals pale yellow, shorter than the small reflexed calyx;

724. R. abortivus.

Carpel $\times 4 \frac{1}{2}$. receptacle villous; carpels minute, merely mucronulate. - Shady hillsides and along brooks, common. Apr.-June. Fig. 724.

Var. eùcyclus Fernald. Stem slender, flexuous, not succulent ; root-leaves larger (often 5-6 cm. broad), orbicular, deeply cordate with a narrow sinus, thin. - Rich low woods, N. B. and Que, to Ct.

\section{b. Stigma borne on a distinct at first straightish at length more or less re- curved style.}

17. R. allegheniénsis Britton. Habit and foliage closely as in $\boldsymbol{R}$. abortivus; stem glaucous; petals minute, pale yellovs; achenes provided with a distinct recurved beak. - Moist places in rich woods, e. Mass. to Vt., e. N. Y., and southw. to N. C., locally abundant. FIA. 725.

18. R. Harvèyi (Gray) Britton. Also with the habit and foliage of $R$. abortivus; root a fascicle of fusiform fibers; petals 5-8, oblong, 5-7 $\mathrm{mm}$. in length, much larger than in

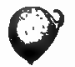

725. R. alleghent: ensis.

Carpel $\times 4 \%$. the related species preceding; achenes tipped with a weak straightish beak (R. abortivus, var. Gray.) - Rocky ground, s. Mo. (Bush) and Ark. 
* Leaves variously cleft or divided; achenes in globular or ovoid heads, com pressed, with an evident firm margin; hirsute or pubescent.

$=$ Achenes with long recurved beak; root-leaves rarely divided.

V 19. R. recurvàtus Poir. (Hooked C.) Hirsute, 3-6 dm. high; leaves of the root and stem nearly alike, long-petioled, deeply 3-cleft, large; the lobes broadly wedge-shaped, 2-3-cleft, cut and toothed toward the apex; petals shorter than the reflexed calyx, pale. - Woods, common. May, June.

$==$ Style long and attenuate, stigmatose at the tip, persistent or the upper part usuclly decidnous; early root-leaves only 3-parted, the later 3-5-foliolate; petals bright yellow.

20. R. fasciculàris Muhl. (EArLY C.) Low, ascending, 1-2.5 dm. high, - pubescent with close-pressed silky hairs ; root a cluster of thickened fleshy fibers;

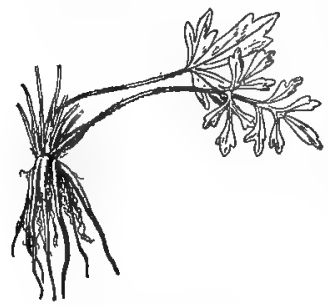

726. R. fascicularis.

Base of plant $\times 1 / 2$. radical leaves appearing pinnate, the long-stalked terminal division remote from the sessile lateral ones, itself 3-5-divided or -parted and 3-5-cleft, the lobes oblong or linear; petals often 6 or 7 , spatulate-oblong, twice the length of the spreading caly $\mathrm{x}$; carpels scarcely margined, tipped with a slerider straight or rather curved beak. - Dry or moist hills, e. Mass, to Ont. and southw. Apr., May. Fig. 726.

21. R. septentrionàlis Poir. (Swamp B.) Usually villous; stems 3-8 dm. long, erect, ascending, or in wet ground some of them procumbent or forming long runners; lower petioles very long; leaves 3 -divided, the divisions all stalked (or at least the terminal one), broadly wedge-shaped or ovate, unequally 3-cleft or parted and variously cut; petals broadly obovate, much
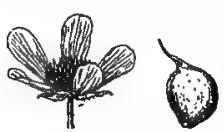

728. R. hispidus.

Flower $\times \frac{5}{7}$.

Carpel $\times 4 \frac{1}{2}$. larger than the spreading calyx; mature carpels $3-3.4 \mathrm{~mm}$. broad, strongly margined, pointed by a stout straightish beak. - Moist or shady places, etc., May-Aug. FIG. 727.

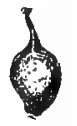

727. R. septentrionalis.

Carpel $\times 41 / 2$.

L 22. R. híspidus Michx. Root a eluster of stout fibers; stem 1.5-4 dm. high, flexuous, not repent, hirsute or smoothish; leaves 3-divided or the basal only 3-lobed; divisions or lobes variously cleft, teeth mostly acutish ; petals oblong, bright yellow, much exceeding the spreading sepals; mature achenes green, obscurely margined, $2-2.6 \mathrm{~mm}$. broad, tipped with a rather slender beak. - Moist places, chiefly in upland woods, Vt., southw, and westw. Fig. 728. - A smoothish form occurs.

$===$ Style short, recurved, stigmatose along the inner nargin, mostly persistent.

23. R. rèpens L. (CReeping B.) Creep$i n g$, in habit and foliage closely similar to the last two species; leaves frequently whitevariegated or spotted; flowers $2-2.6 \mathrm{~cm}$. broad; sepals not reflexed in anthesis. - In low grounds; generally in ditches and along water courses, near the coast and probably introduced from Europe, but indigenous westw. Fig. 729 .

24. R. PARvUlú L. Hirsute, not crecping, similar to but much ismaller than the preceding; leaves rarely over $3 \mathrm{~cm}$. broad;

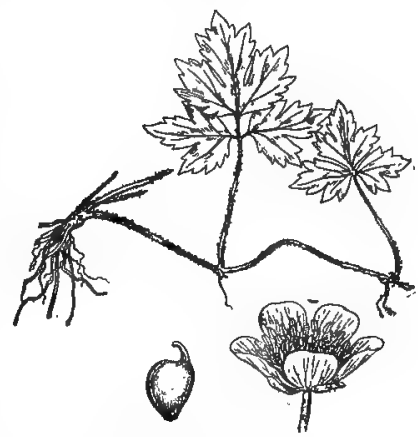

729. R. repens.

Base of plant $\times 1 / 2$. Flower $\times 8 / \%$ Carpel $\times 41 / 2$. 
flowers 1-1.8 cm. in diameter; sepals reflexed in anthesis; head of fruit ovoid; achenes small, flat, strongly margined, the faces sometimes a little warty ; style short, erect. - Waste places, ballast, etc., Philadelphia and southw. (Adv. from Eu.)

25. R. pennsylvánicus L. f. (Bristly C.) Stout and erect from a usually annual root, hirsute with widely spreading bristly hairs, leafy to the top, $4-6 \mathrm{dm}$. high; leaves all ternately divided or compound, the stalked leaflets unequally ;-cleft, sharply cut and toothed, acute; flowers inconspicuous; sepals reflexed; carpels obscurely margined, in a short-cylindric head; receptacle cylindro-conical.

- Wet places. June-Aug. (Asia.)

26. R. Macoúnii Britton. Resembling the last, but the ascending or reclining stems few-leaved, rarely if ever rooting, not always hirsute; petals (about

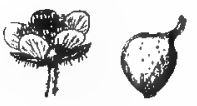

730. 12. Macounii. Flower $\times 5 / 7$. Carpel $\times 4 \frac{1}{2}$.

$6 \mathrm{~mm}$. long) surpassing the hardly reflexed and soon deciduous calyx; achenes with a stout straight beak, in a globose or ovoid head; receptacle thick, obovoid. ( $R$. hispidus Man. ed. 6.) - Que. to L. Superior, "Ia.", and westw. FIG. 730.

c 27. R. Bulbòsus L. (Bulbous C. or B.) Hairy; stem ( $3 \mathrm{dm}$. high) erect from a bulb-like base; radical leaves 3-divided; the lateral divisions sessile, the terminal stalked and 3-parted, all wedge-slıaped, cleft and toothed; peduncles furrowed; petals round, wedge-shaped at base; calyx retlexed; carpels tipped with a very short beak. - Fields; very abundant only in ค. N. E. ; rare westw. May-July. - Leaves appearing as if pinnate. Petals fften 6 or 7, deep glossy yellow, the corolla more than $2.5 \mathrm{~cm}$. broad. (Nat. irom Eu.)

28. R. Acris L. (TALL C. or B.) Hairy ; stem erect (6-9 dm.high); leaves 3-divided; the divisions all sessile and 3-cleft or parted, their segments cut intn anceolate or linear crowded lobes; peduncles not furrowed; petals obovate, nuch longer than the spreading calyx. - Fields; common, especially eastw. June-Aug. - Flowers nearly as large as the last, but not so deep yellow. (Nat. from Eu.) Var. Stevisi (Andrz.) Lange. Leaf-segments broadly oblanceolate or even obovate-cuneate. - Moist meadows, N. E. and northeastw.; not rare. (Nat. from Eu.)

\section{* Achenes beset with rough points or small prickles; annuals.}

29. R. MURICA Tus L. Nearly glabrous; lower leaves roundish or reniform, 3-lobed, coarsely crenate; the upper 3-cleft, wedge-form at the base; petals longer than the calyx; carpels flat, spiny-tuberculate on the sides, strongly beaked, surrounded with a wide and sharp smooth unarmed margin. - Wet places, e. Va. and southw. (Nat. from Furasia.)

30. R. ARvénsis L. Similar to the preceding, but segments of the cauline leaves more narrow and acute; carpels armed on the thick border as well as the surfaces. - Waste places, N. J. to O. (Sparingly adv. from Eu.)

C 31. R. PARVIFLórus L. Hairy, slender and diffuse; lower leaves roundishcordate, 3-cleft, coarsely toothed or cut; the upper 3-5-parted; petals not longer than the calyx; carpels minutely hispid and rough, beaked, narrowly margined. - Waste places, etc., Md. and Va. to Fla. and Tex. (Nat. from Eu.)

\section{MYOSÙRUS [Dill.] L. MOUSE-TAIL}

Sepals 5, spurred at the base. Petals 5, small and narrow, raised on a slender claw, at the summit of which is a nectariferous hollow. Stamens 5-20. Achenes numerous, somewhat 3-sided, crowded on a very long and slender spikeiike receptacle (whence the name, from $\mu \hat{v}$, a mouse, and oujó, $a$ tail), the seed suspended. - Little annuals, with tufted narrowly linear-spatulate root-leaves, and naked 1-flowered scapes. Flowers small, greenish.

1. M. mínimus I. Fruiting spike $2-5 \mathrm{~cm}$. long : achenes quadrate, blunt. Alluvial ground, etc., Ill, to Assina., N. Mex., and Fla.; also at Belleville, Ont. (Macoun); and reported from e. Va. (Eu.) 


\section{ADONIS [Dill.] L.}

Sepals and petals (5-16) flat, unappendaged, deciduous. Achenes numerous, in a head, rugose-reticulated. Seed suspended. - Herbs with finely dissected alternate leaves and showy flowers. ("A $\delta \omega \nu \iota s$, a favorite of Venus, after his death changerl into a flower.)

1. A. a utumalis L. (Pheasant's Eye.) Low leafy annual with scarlet or crimson corolia darker in the center. (A. annua L., in part.) - Occasional in fields. (Sparingly introd. from Eu.)

\section{Trautvettèra Fisch. \& Mey. False Bugbane}

Sepals 3-5, usually 4, concave, petal-like, very caducous. Petals none. Achenes numerous, capitate, membranaceous, compressed, somewhat 4-angled and inflated. Seed erect. - A perennial herb, with alternate palmately-lobed leaves, and corymbose white flowers. (For Prof. E. R. von Trautvetter, an able Russian botanist of the 19th century.)

1. T. carolinénsis (Walt.) Vail. Stems 6-9 dm. high; root-leaves large, 5-11-lobed, the lobes toothed and cut. (T. palmata Fisch. \& Mey.) - Moist ground along streamlets, Md. and s. w. Pa. to Mo. and Ga.

\section{THALÍCtRUM [Tourn.] L. Meadow Rue}

Sepals 4-5, petal-like or greenish, usually caducous. Petals none, Achenes 4-15, grooved or ribbed, or else inflated. Stigma unilateral. Seed suspended. - Perennials, with alternate 2-3-termately compound leaves, the divisions and the leaflets stalked; petioles dilated at base. Flowers in corymbs or panicles, often polygamous or dioecious. (A Greek name of an unknown plant, mentioned by Dioscorides.)

* Flowers perfect; filaments club-shaped, erect or spreading.

1. T. clavàtum DC. Stem slender, glabrous, 3-4 dm. high, 1-3-leaved; radical leaves biternate; leaflets large, thin, glaucous beneath, suborbicular, coarsely and crenately 3-7-toothed; flowers white, few ; achenes 5-10, flat, falcate, tapering into a long and very slender stipe. - By mountain streams, W. Va. and Va. to Ga. and Ala. Maj, June.

\section{* Flowers dioecious or polygamous.}

- Achenes sessile, regularly ribbed, their walls of firm texture.

2. T. confine Fernald. Glabrous and glaucous, $3-10 \mathrm{dm}$. high, from a slender elongate caudex; leaflets often $2-4 \mathrm{~cm}$. broad, suborbicular, veins scarcely prominulous beneath; achenes maturing $2-5$, about $8 \mathrm{~mm}$. long including the beak. - Rocky and gravelly banks of streams, e. N. B., Que., and n. Me. to n. N. Y. and Man. June, July.

- + Achenes broadly spindle-shaped, conspicuously stalked; filaments threadlike; leaves 3-4-ternate.

3. T. coriàceum (Britton) Small. Roots stout, bright yellow; common petioles of the stem-leaves more or less developed, the base much dilated and amplexicaul; leaflets broadly obovate to suborbicular, 3-9-toothed or -lobed, pale and glabrous beneath; style nearly as long as the achene. - Mts. of Pa. to Ky., N. C., and Tenn.

4. T. caulophylloides Small. Similar; roots not yellow; leaflets commoniy large, reniform-suborbicular, broader than long, pale beneath; style thickish, often hooked, about half as long as the achene. - Mcuntain slopes and alluvial banks, Md, to $\mathrm{Ky}$. and 'Tenn. 
+++ Achenes sessile or subsessile, thin-walled, the ribs often connected by transverse reticulntions; leaves $3-4$-ternate.

+ Filaments capillary, soon drooping; petioles of the stem-leaves well deseloped; vernal.

5. T. dioícum L. (EARLY M.) Smooth and pale or glaucous, 3-6 dm. high ; leaves (2-3) all with general petioles; leaflets thin, light green, drooping, suborbicular, 3-7-lobed; flowers dioecious; sepals purplish or greenish white. Rocky woods, etc., centr. Me, westw. and southw., common. Apr., May.

+ ++ Filaments capillary or slightly club-shaped, soon drooping; petioles of the stem-leaves short or none; aestival.

6. T. dasycárpum Fisch. \& Lall. Stem 6-12 dm. high, usually purplish ; leaftets shortly oblong, mostly 3-toothed, more or less veiny, pale and usually covered with a fine non-glandular pubescence beneath; flowers dioecious; sepals and capillary tilaments commonly purplish white. (T. purpurascens Man. ed. 6 , in part.) - Alluvial soil, N. J. to the Saskatchewan, and southwestw.

, 7. T. revolutum DC. Habit and flowers much as in the preceding; leaflet3 thicker, under a lens finely glandular-puberulent, the glands or waxy globules sessile or shortly stipitate. ( $T$. purpurascens Man. ed, 6 , in part, including var. ceriferum Aust.) - Rocky upland woods, etc., also on river banks, e. Mass. to N. J., s. w. Ont., s. Ind., and N. C. - Emitting a heavy odor.

+ + Filaments club-shaped, ascending or spreading until after anthesis.

8. T. polýgamum Mubl. (TALL M.) Glabrous or pubescent but not glandular, 0.5-2.6 m. high; stem-leaves sessile; leaflets rather firm, roundish to oblong, commonly with mucronate lobes or tips, sometimes puberulent beneath ; panicles very compound; flowers white (rarely purplish), the fertile ones with some stamens; anthers not drooping, small, oblong, blunt, the mostly white filaments decidedly thickened upwards; achenes glabrous. ( $T$. Cornuti Man. ed. 5 , not L.) - Wet meadows and along rivulets, Nfd. to $O$. and southw., common. July-Sept. Var. невесÁpum Fernald. Leaflets usually pubescent beneath ; achenes pubescent. - Nfd. to s. Ont. and N. H.

\section{ANEMONÉLLA Spach.}

Involucre compound, at the base of an umbel of flowers. Sepals 5-10, white and conspicuous. Petals none. Achenes 4-15, ovoid, terete, strongly 8-10ribbed, sessile. Stigma terminal, broad and depressed. - Low glabrous perennial ; leaves all radical, compound. (Name a diminutive of Anemone, to which this plant las sometimes been referred.)

1 1. A. thalictroides (L.) Spach. (Rue ANemone.) Stem and slender petiole of radical leaf $(1-3 \mathrm{dm}$. high) rising from a cluster of thickened tuberous roots; leaves 2-3-ternately compound; leaflets roundish, somewhat 3 -lobed at the end, cordate at the base, long-petiolulate, those of the 2-3-leaved 1-2-ternate involucre similar ; flowers several in an umbel; sepals oval $(1.2 \mathrm{~cm}$. long, sometimes pinkish), not early deciduous. (Syndesmon Hoffmannsegg.; Thalictrum anemonoides Michx.) - Woods, common, s. N. H. to Minn., Kan., Tenn., and n. w. Fla. - Rarely the sepals, stamens or involucre are variously modified.

\section{HepAitica [Rupp.] Hill. Liverleaf. Hepatica}

Leaves heart-shaped and 3-lobed, thickish and persistent through the winter, the new ones appearing later than the flowers, which are single, on hairy scapes. (Name from a tancied resemblance to the liver in the shape of the leaves.)

1. H. triloba Chaix. Leaves with 3 ovate obtuse or rounded lobes; those of the involucre also obtuse; sepals $6-12$, blue, purplish, or nearly white; achenes several, in a small loose head, ovate-oblong, pointed, hairy. ( $\boldsymbol{H}$. Hepativa Karst.) - Woods, common from N. S. to Fla., Mo., and Minn.; more abundant eastw. (Alaska, Eu.) 
2. H. acutíloba DC. Leaves with 3 ovate and pointed lobes, or sometimes 5-lobed; those of the involucre acute or acutish. (H. acuta Britton.) - Woods, w. Que., southw. through w. N. H. to Ga., Mo., and Minn., more abundant westw.; York, Mt. (Bicknell). - Passes into the preceding.

\section{ANEMdNE [Tourn.] L. ANEMone}

Sepals few or many, petal-like. Petals none, or in no. 1 resembling abortive stamens. Achenes pointed or tailed, flattened, not ribbed. Seed suspended. - Perennial herbs with radical leaves; those of the stem 2 or 3 together, opposite or whorled, and forming an involucre remote from the flower; peduncles 1-flowered, solitary or umbellate. (The ancient Greek and Latin name, a corruption of $N a^{\prime} m \vec{a} n$, the Semitic name for Adonis, from whose blood the crimsonflowered Anemone of the Orient is said to have sprung.)

\$1. PULSATILLA Pers. Carpels numerous in a head, with long hairy styles which in fruit form feathery tails, as in Clematis; flower large, usually with some minute or indistinct gland-like abortive stamens answering to petals.

1. A. pàtens L., var. Wolfgangiàna (Bess.) Koch. (PAsque Flower.) Silkyvillous; flower erect, solitary ; leaves ternately divided, the lateral divisions 2-parted, the middle one stalked and 3-parted; segments of the leaves and sessile involucre deeply cleft into narrowly linear and acute lobes; sepals 5-7, purplish blue to whitish (15-35 mm. long), spreading when in full anthesis. (Var. Nuttalliana Gray ; Pulsatilla hirsutissima Britton.) - Prairies, Wisc., Ml., 'Tex., northw. and westw. March, Apr. (Eu., Siber.)

§2. ANEMÒNE proper. Styles short, not plumose. Staminodia none.

* Achenes densely long-woolly, compressed; involucre far betow the flower.

- Rootstock tuberous; sepals usually 10-20; style filiform.

2. A. caroliniàna Walt. Stem $7-15 \mathrm{~cm}$. high; root-leaves once or twice 3-parted or cleft; involucre 3-parted, its wedge-shaped divisions 3-cleft; ; sepals 10-20, oblong-linear, purple or whitisn; head of fruit ellipsoid. - Dak. to Ill., Fla., and Tex. May. A. Decapétala Ard., said to reach e. Kan., is doubt. fully distinct, its strongest character being the greater prevalence of simply ter nate basal leaves with crenate uncleft leaflets.

- + Rootstock not tuberous; sepals usually 5-8; styles filiform.

3. A. parvifldra Michx. Stem 1-3 dm. high, from a slender rootstock, 1flowered; root-leaves 3-parted, their broadly wedge-shaped divisions crenateincised or lobed; involucre 2-3-leaved; sepals 5 or 6 , oval, white, with bluish bases; head of fruit globular. - Wet limestone rocks, Lab. to Alaska, s. to e. Que., Ont., Minn., Col., and Ore. May-Sept. (Siber.)

4. A. multifida Poir. Stems from a branching caudex, silky-hairy (1-4 dm. high); principal involucre 2-3-leaved, bearing one naked and one or two 2-leavea peduncles; leaves of the involucre short-petioled, similar to the root-leaves, twice or thrice 3-parted and cleft, their divisions linear; sepals (sometimes numerous) obtuse, red, greenish yellow or whitish; head of fruit spherical or ovoid. (A. Hudsoniana Richards.) - Gravelly and ledgy (calcareous) shores and banks, e. Que. to Alaska, s. to N.B., n. Me., n. Vt., n. N.Y., Mich., S. Dak. ; and in the mts. to Ariz. June. (Extra-trop. S. A.)

+- + + Taller, commonly branching above or producing two or more peduncles; involucral leaves long-petioled; sepals 5-8, silky or downy beneath, oval or oblong; style subulate. (T'HimaleweEDs.)

5. A. cylíndrica Gray. Slender, pubescent; flowers $2-6$, on very long upright nalced peduncles; involucral leaves twice or thrice as many as the pedun. cles, 3-divided; their divisions wedge-lanceolate, the lateral 2-parted, the middin 3 -cleft; lobes cut and toothed at the apex; sepals 5 , rather obtuse, greenisb 
white; head of fruit cylindrical (2-3.5 cm. long). - Rocky woods and dry barrens, W. Me. to Sask., s. to N. J., Pa., Ill., Mo., Kan., N. Mex., and Ariz. May-July.

6. A. ripària Fernald. Less conspicuously pubescent; leaflets thinner, greener, less strongly veined; those of the involucre lanceolate, cuneate at the base; sepals 5, large (1.5 cin. long), obtuse, white or rarely reddish, mostly petaloid; head of fruit subcylindric, the styles suberect. - Calcareous riverbanks, etc., Gaspé Co., Que., to Alberta, s. to Me., w. Ct., e. Pd., and w. N. Y. May, June.

7. A. virginiàna L. Loosely pubescent or glabrate ; involucral leaves 3, 3parted ; their divisions ovate-lanceolate, pointed, cut-serrate, the lateral 2-parted, the middle 3-cleft; peduncles elongated, the earliest naked, the others with a 2leaved involucel at the middle, repeatedly proliferous; sepals 5, acute, greenish (in one variety white and obtuse); head of fruit ovoid or thick-cylindric, the styles diveryent. - Woods and meadows, centr. Me. to Minn., and southw. June-Aug. - Plant 0.6-1 m. high; the upright peduncles 1.5-3 dm. long.

* Achenes naked, orbicular, compressed, wing-margined; sepals 5, obovate; involucre sessile.

8. A. canadénsis L. Hairy, rather low; primary involucre 3-leaved, bearing a naked peduncle, and soon a pair of branches or peduncles with a 2-leaved involucre at the middle, which branch similarly in turn; their leaves broadly wedge-shaped, 3-cleft, cut and toothed; radical leaves 5-7-parted or cleft ; sepals white (1.2-1.8 $\mathrm{cm}$. long); head of fruit spherical. (A. pennsylvanica L.) - River-banks and prairies, e. Que. to Assina., s. to N. S., centr. Me., w. N. E., N. J., Pa., Great Lake region, Mo., Kan., and Col.; escaped from cultivation elsewhere.

* * * Achenes rather few, nearly naked, ovate-oblong; stems slender, 1-flowered; leaves radical.

9. A. quinquefollia L. (Woon A.) Low, smoothish ; stem perfectly simple, from a thick-filiform whitish or brown rootstock ; involucre of 3 long-petioled trifoliolate leaves, their leaflets wedge-shaped or oblong, and laciniately toothed or the lateral ones 2-parted; a similar radical leaf in sterile plants solitary from the rootstock; peduncle not longer than the involucre; sepals $4-7$, oval, white, or tinged with purple outside; carpels only 15-20, oblong, with a hooked beak. (A. nemorosa of Man. ed. 6, not L.) - Margin of woods. Apr., May. - A delicate vernal species; the flower $2 \mathrm{~cm}$. broad.

The European A. Nemoròsa. L., with thicker blackish rootstock, has been found as an escape from cultivation in e. Mass. (Sears).

10. A. trifolia L. Similar in habit, somewhat stouter; the leaflets of the involucre lanceolate to ovate, $2-3 \mathrm{~cm}$. broad, rather regularly serrate, not incised; flower $2.8-3.5 \mathrm{~cm}$. in diameter; sepals oval, white. - Woods, mts. of s. $\mathrm{Pa}$. to Ga. (Eu.)

\section{Clfmatis L. Vizgin's Bower}

Perennial herbs or vines, mostly a little woody, and climbing by the bending or clasping of the leafstalks, rarely low and erect. (K $\lambda \eta \mu a \tau i s$, a name of Dioscorides for a climbing plant with long and lithe branches.)

81. FLAMMULA DC. Flowers cymose-paniculate, rather small, in our species dioecious or the pistillate with some sterile stamens. Sepals petaloid, whitish, spreading, thin. Petals none. Anthers short, blunt.

1. C. virginiàna L. Leaves normally 3-foliolate; leaflets ovate, acute, thin, dark green above, when young silky-villous beneath, in age more or less completely gidbrate, heart-shaped at the base, variously few-toothed. - River-banks, etc., common; climbing over shrubs. July, Aug. A variation, found in the lower Missouri Valley and having more persistent pubescence and " marginless" achenes, has been described as C. missouriensis Rydb. 
2. C. ligusticifolia Nutt. Very similar, but the leaves 5-foliolate or quinateternate; leaflets sınall, $1.5-4 \mathrm{~cm}$. broad, pale green, thickish, of firm texture. Mo. (Bush), Neb., and w. to the Pacific.

\$. VIÓRA Reichenb. Flowers large, solitary on long peduncles, usually lyodaing. Sepals thick, erect and connivent at base, mostly dull purple. Petals none. Anthers linear.

Stems climbing; leaves at least in part pinnate; calyx (and foliage) glabrous or puberulent.

- Tails of fruit plumose.

8. C. Viorna L. (Leather Flower.) Calyx ovoid and at length bellshaped; the purplish sepals (2-3 cm. long) very thick and leathery, wholly connivent or only the tips recurved; long tails of the fruit very plumose; leaflets $3-7$, ovate or oblong, sometimes slightly cordate, 2-3-lobed or entire, not reticulated; uppermost leaves often simple. (C. glaucophylla and C. flaccida Small.) - Rich soil, Pa. to Mo., and southw. May-Aug.

4. C. Addisonii Britton. Suberect, 6-9 dm. high; leaves all or many of them simple, sessile, broadly ovate, deep green above, glaucous beneath, obtuse, the later ones pinnate with prebensile petiolules and elliptic ovate leaflets; flowers and fruit as in C. Viorna. - Alluvial soil, Va. (Addison Brovon), N. C., and Tenn. $\times$ C. vionsrolpes Britton is intermediate between this and $C$. Viorna.

5. C. versícolor Small. Climbing, glabrous or nearly so; leaves pinnate; leaflets oval, veticulated; sepals lanceolate, glabrous on the outer surface, slightly recurved at the tip; achenes with plumose tails. - Dry ledges, Mo. (Bush), and Ark. (according to Small).

\section{+ + Tails of fruit silky or glabrate.}

6. C. Pitchèri T. \& G. Calyx bell-shaped; the dull purplish sepals with narrow and slightly margined recurved points; tails of the fruit filiform and naked or shortly villous; leaflets 3-9, ovate or somewhat cordate, entire or 3lobed, much reticulated; uppermost leaves often simple. (C. Simsii of auth., not Sweet according to Gray.) - S. Ind. to Neb. and Tex. June.

7. C. crispa L. Calyx cylindrical below, the upper half of the bluish-purple sepals (2.5-4 $5 \mathrm{~cm}$. long) dilated and widely spreading, with broad and wavy thin margins; tails of the fruit silky or glabrate; leaflets 5-9, thin, varying from ovate or cordate to lanceolate, entire or 3-5-parted. (C. cylindrica Sims.) - Va. near Norfolk, and southw. May-Aug.

* * Low and erect, mostly simple; flowers solitary, terminal; leaves sessile on nearly so, undivided, strongly reticulated.

8. C. ochroleùca Ait. Leaves broadly ovate, entire or sometimes 3-lobed, silky beneath; sepals yellowish within ; peduncles long; tails of the fruit tawnyplumose, the achenes nearly symmetrical, $3.5 \mathrm{~mm}$. broad. - Copses, s. N. Y. to Ga.; rare. May.

9. C. ovata Pursh. Very similar in habit; leaves narrowly ovate, entire, glabrate; sepals purplish; achenes oblique, 4-5 mm. broad, their silky taits white or nearly so. - Dry slaty hillsides, White Sulphur Springs, W. Va. to S. C.

10. C. Fremóntii Wats. Leaves crowded, thick, often coarsely toothed, sparingly villous-tomentose; peduncles very short; tails villous or glabrate, not plumose. - Mo., Neb., and Kan.

\$3. ATRAGENE DC. Some of the outer filaments enlarged and more or less petaloid; peduncles bearing single large flowers; the thin sepals widely spreading.

11. C. verticillàris DC. Woođy-stemmed climber, almost glabrous; leaves trifoliolate, with slender common and partial petioles; leaflets ovate or slightly heart-shaped, pointed ; flower pinkish-purple, $5-7.5 \mathrm{~cm}$. across; tails of the fruit plumose, $5 \mathrm{~cm}$. long. (Atragene americana Sims.) - Rocky 
woods, chiefly in calcareous districts, e. Que. to Hudson B. and L. Winnipeg locally s. to Del., Va., W. Va., Mich. and Minn. May, June.

\section{ISOPỲRUM L.}

Sepals 5, petal-like, deciduous. Stamens $10-40$. Pistils $3-6$ or more, pointed with the styles. Pods ovate or oblong, 2-several-seeded. - Slender smooth perennial herbs, with 2-3-ternately compound leaves; the leaflets 2-3-lobed. Flowers axillary and terminal, white. (From losivopov, the ancient name of a Fumaria.)

1. I. biternàtum (Raf.) T. \& G. Petals none ; filaments white, club-shaped ; pistils 3-6 (commonly 4), divaricate in fruit, 2-3-seeded; seeds smooth. Moist shady places, s. Ont. (Dearness) to Minn., and southw. May. - Fibers of the root thickened here and there into little tubers.

\section{Cáltha [Rupp.] L. Margh Marigold}

Sepals 5-9, petal-like. Pistils 5-10, with scarcely any styles. Pods (follicles) compressed, spreading, many-seeded. - Glabrous perennials, with round and heart-shaped or kidney-form large leaves. (Ani ancient Latin name for the common Marigold.)

1. 1. c. palústris L. Stem hollow, furrowed, not creeping; leaves round or kidney-shaped, either crunate or dentate or nearly entire; sepals broadly oval, bright yellow. - Swamps and wet meadows, Nfd. to Sask., s. to S. C., Tenn., and Neb. Apr.-June. Often called incorrectly Cowoslips; used as a pot-herb in spring, when coming into flower. (Eu.) Var. Fla Bellifólia (Pursh) T. \& G. is a weak slender form (not creeping), with open reniform leaves and smaller flowers (2 cm. broad or less), occurring in cold mountain springs, $N$. Y. to Md. Var. Radicans (Forst.) Hartm. is a decumbent or procumbent form, creeping at the base, usually more slender and smaller-flowered than the typical form. - Arctic Am, and (according to Rydberg) in swamps near Woodlawn and W. Hampton, N. Y. (Boreal Eurasia.)

2. C. nàtans Pall. Stems commonly floating; leaves ovate-reniform, thin, subentire; flowers small $(1-1.2 \mathrm{~cm}$. broad); sepals white or pinkish; carpels numerous ( $3 \mathrm{~mm}$. long), in a globose head.-In ponds or on muddy shores, n. Minn., and northwestw. June-Sept.

\section{TRÓLliUS L. GLOBeflower}

Sepals 5-15, petal-like. Petals small, 1-lipped, the concavity near the base. Stamens and pistils numerous. Pods 9 or more, many-seeded. - Smooth perennials with palmateiy parted and cut leaves, like Ranunculus, and large solitary terminal flowers. (Name a latinization of Troll from Trollblume, the Germanic vernacular designation.)

1. T. Láxus Salisb. (Spreading G.) Leaves 5-7-parted ; pale greenish-yellow sepals 5-6, spreading; petals $15-25$, inconspicuous, much shorter than the stamens. - Deep swamps, w. Ct. to Del., Pa., and Mich. ; Rocky Mts. May.

\section{CÓPTIS Salisb. Goldthread}

Sepals 5-7, petal-like, deciduous. Petals 5-7, small, club-shaped, hollow at the apex. Stamens 15-25. Pistils 3-7, on slender stalks. Pods divargent, membranaceous, pointed with the style, 4-8-seeded. - Low smooth perennials, with ternately divided root-leaves, and small white flowers on scapes. (Name from $\kappa \delta \pi \tau \epsilon t \nu$, to cut, alluding to the divided leaves.)

1. C. trifolia (L.) Salisb. Rootstocks of long bright yellow bitter fibers; leaves evergreen, shining; leaflets 3 , obovate-wedge-form, sharply toothed, obscurely 3 -lobed ; scape naked, slender, $7-13 \mathrm{~cm}$. high, 1(rarely 2 )-flowered. - 
Mossy woods and swamps, Lab. to Alask, s. to Md., mts. of N. C. and Tenn., Mich., and n. e. Ia. May-July. (Greenl., Eurasia.)

\section{HELLEBORUS [Toum.] L. HELLeBort}

Sepals 5, petal-like or greenish, persistent. Petals 8-10, very small, tubular, 2-lipped. Pistils 3-10, sessile, forming coriaceous many-seeded pods. - Perennial herbs, with ample palmate or pedate leaves and large solitary nodding early vernal flowers. (An ancient name of unknown meaning.)

1. H. vfridis L. (Green H., Christmas Flower.) Root-leaves glabrous, pedate; calyx spreading, greenish. - Has been found wild on L. I., in Pa., N. J., and W. Va. Dec.-Apr. (Nat. from Eu.)

\section{ERÁNTHIS Salisb. WINTERACONITE}

Sepals 5-8, petal-like, deciduous. Petals small 2-lipped nectaries. Carpels few, stipitate, several-seeded. - Perennial herbs, with palmately multifid radical leaves, the scape bearing a single large yellow flower surrounded by an involucre of a single leaf. (Name from $j \rho$, spring, and $k \nu \theta o s$, flower.)

1. E. нтемגers (L.) Salisb. Dwarf ; flowers cup-shaped, shorter than the stamens. (Cammarum Greene.) - Often cultivated; established in e. Pa. Feb., March. (Nat. from Eu.)

\section{Nigella [Tourn.] L. Fennel Flower}

Sepals 5, regular, petaloid. Petals small, ungeniculate, the blade bifid. Pistils 5, partly united into a compound ovary, so as to form a several-celled capsule. - An Old World genus, with blackish aromatic seeds, noteworthy in the family in having a somewhat compound ovary. (Name a diminutive of itiger, black, from the color of the seeds.)

1. N. Damasuina L. (Love-IN-A-MIsT.) Flower bluish, overtopped by a finely divided leafy involucre. - Sometimes cultivated, and occasionally spontaneous around gardens. (Introd. from Eurasia.)

\section{AQUilègia [Tourn.] L. Coldmbine}

Sepals 5, regular, colored like the petals. Petals 5, all alike, with a short spreading lip, produced backward into large hollow spurs, much longer than the calyx. Pistils 5, with slender styles. Pods erect, many-seeded.-Perennials, with 2-3-ternately compound leaves, the leaflets lobed. Flowers large and showy, terminating the branches. (Name of doubtful origin.)

1. A. canadénsis L. (WILD C.) Flowers $5 \mathrm{~cm}$. long, scarlet, yellow inside, nodding, so that the spurs turn upward, but the stalk becoming upright in fruit; spurs nearly straight; stamens and styles longer than the ovate sepals. - Rocks, open woods, etc. A pr.June. Var. Phippenir J. Robinson with salmon-colored flowers, and var. Fuaviflora (Tenney) Britton with yellow flowers, are color forms with paler foliage. A. coccfNeA Small-robust and with acuminate sepals 13-21 $\mathrm{mm}$. long - is a more or less marked and perhaps distinct species of the South and West.

2. A. volgaris L. (Garden C.) Flowers blue, purple, pink, or white; spurs hooked. - Established in many places, especially northw. (Introd. from Eu.)

\section{DELPHífIUM [Tourn.] L. LARKBPUR}

Sepals 5, irregular, petal-like ; the upper one prolonged into a spur at the base. Petals 4 (rarely only 2, united into one), irregular, the upper pair con. tinued backward into long spurs which are inclosed in the spur of the calyx, the lower pair with short claws. Pistils $1-5$, forming many-seeded pods in fruit. - Leaves palmately divided or cut. Flowers in terminal racemes. (Name 
from Delphin, in allusion to the shape of the flower, which is sometimes not unlike the classical figures of the dolphin.)

Introduced snnuals; pistil 1.

Follicle $1 \mathrm{~cm}$. Long, glabrous .

Follicle 1.2-2 om. long, pubescent

Indigenous perennials; pistils 8.

Roots short, tuberous ; pods strongly divergent

Roots elongated, woody; pods nearly or quite ereot.

Flowers purplish blue.

Petals bearded with yellow hairs; inflorescence loose, pyramidal; plant glabrous

Petals bearded with white hairs ; racemes virgate.

Stern glabrous

Stem velvety-pubescent

Flowers sky-blue; raceme lax, few-flowered

Flowers white or nearly so; raceme virgate

1. D. Consolida.

8. D. Afacis.

8. D. trioorne.

1. D. Consólida L. (Findd L.) Leaves dissected into narrow linear lobes ; inflorescence loosely paniculate; pedicels shorter than the bracts ; pod glabrous. - Old grain-fields, and sparingly along roadsides, N. J., southw. and westw., rare. (Nat. from $\mathrm{Eu}$.)

2. D. AJacis L. Flowers more numerous and spicately racemose ; pods pubescent. - Fields, roadsides, and wet places, Vt, to Mo. and N.C. June-Aug. (Nat. from Eu.)

3. D. tricórne Michx. (DWARF L.) Root a tuberous cluster; stem simple, 1.5-9 dm. high; leaves deeply 5-parted, their divisions unequally 3-5-cleft ; the lobes linear, acutish; raceme few-flowered, loose; flowers bright blue, sometimes white, occasionally numerous; spur straightish, ascending; pods strongly diverging. - W. Pa. to Minn., Neb., and southw. Apr., May.

4. D. Treleasei Bush. Essentially glabrous throughout, $7-10 \mathrm{dm}$. high, loosely branching; leaf-segments cleeply cleft, the lobes long, linear, acute ; lower pedicels much elongated, often $10-14 \mathrm{~cm}$. in length; calyx rich bluish purple; the lamina of each sepal more or less distinctly spotted with yellow or brown; petals with a conspicuous yellow beard. - Barrens of s. Mo. (Bush). May, June.

5. D. exaltatum Ait. (Tall L.) Stems slender, 6-15 dm. high; leaves deeply 3-5-cleft, the divisions narrowly wedge-form, diverging, 3-cleft at the apex, acute; racemes wand-like, panicled, many-flowered; flowers purplish blue, downy ; spur straight; pods erect. (1). urceolatum of auth., not Jacq.) - Rich soil, Pa. to Minn., Neb., and southw. July.

6. D. Nortonianum Mackenzie \& Bush. Erect, simple, $8 \mathrm{dm}$. high ; stem leafy, covered with copious spreading yellowish and somewhat viscid pubescence; leaf-segments deeply cleft, the lobes narrowly linear, acutish; raceme single, wand-like, the lower pedicels scarcely longer than the upper; flowers bluish purple; the spur erect or nearly so. - Barrens of the Ozark Mts., s. Mo. (Bush). May, June.

7. D. azùreum Michx. Stem $3-6 \mathrm{dm}$. high, finely cinereous-pubescent; leaves deeply 3-5-parted, the divisions $2-3$ times cleft; the lobes all narrowly linear ; flower's sky-blue; spur ascending or horizontal, usually curved upward; pods erect. ( D D. carolinianum Walt.) - Va., N. C. and Ga. to Ark., Mn., Minn., and Sask. May, June.

8. D. Penárdi Huth. Simple, erect, pubescent and generally glandular; raceme strict, elongated ; flowers numerous, white or nearly so, soft-pubescent; the spur chietly ascending or erect. (D. camporum Greene; $D$. albescens Rydb.) - Prairies and open deciduous woods, Ill. and Wisc. to N. Mex. and the Rocky Mts.

\section{Aconttum [Tourn.] L. Aconime. Monkshood. Wolfsbase}

Sepals 5, petal-like, very irregular; the upper one (belmet) hooded or helmet-shaped, larger than the others. Upper petals 2, consisting of small spurshaped bodies raised on long claws and concealed under the helmet; other petals 6 or fewer, much reduced or wholly wanting. Pistils 3-5. Pods several-seeded. 
Seed-coat usually wrinkled or scaly. - Perennials, with palmately cleft or dissected leaves, and showy flowers in racemes or panicles. (The ancient Greek and Latin name, of uncertain origin.)

1. A. noveboracénse Gray. Ėrect from tuberous-thickened roots, high, leafy, the summit and strict loosely flowered raceme pubescent; leaves rather deeply parted, the broadly cuneate divisions 3-cleft and incised; flowers blue; the helmet gibbous-obovoid with broad rounded summit and short descending benk. Chenango, Orange, and Ulster Cos., N. Y.; also Summit Co., O. ; and reported from Allamakee Co., Ia. (Pammel).

2. A. uncinatum L. (WILD M.) Glabrous; stem slender, from tuberousthickened roots, erect, but weak and disposed to climb; leaves firm, deeply 3-5lobed, petioled, the lobes ovate-lanceolate, coarsely toothed; flowers blue; helmet erect, obtusely conical, compressed, slightly beaked in front. - Rich shady soil along streams, Pa., and southw. in the mts.; Wisc. June-Aug.

3. A. reclinàtum Gray. (TRAILING W.) Glabrous; stems trailing, 1-3 m. long; leaves deeply 3-7-cleft, petioled, the lower orbicular in outlint, 12-15 $\mathrm{cm}$. wide; the divisions wedge-form, incised, often 2-3-lobed; flowers white, $1.8 \mathrm{~cm}$. long, nearly glabrous, in very loose panicles; helmet soon horizontal, elongated-conical, with a straight beak in front. - Cheat Mt., Va., and southw. in the Alleghenies. Aug.

\section{Cimicffuga I. Bugbane}

Sepals 4 or 5, failing off soon after the flower expands. Petals, or rather transformed stamens, 1-8, small, on claws, 2-horned at the apex. Stamens as in Actcea. Pistils 1-8, forming dry dehiscent pods in fruit.-Perennials, with 2-3-ternately divided leaves, the leaflets cut-serrate, and white flowers in elongated wand-like racemes. (Name from cimex, a bug, and fugere, to drive away.)

§ 1. ACTINóSPORA (Turcz.) B. \& H. Pistils 3-8, stipitate; seeds flattened laterally, covered with chaffy scales, in one row in the membranaceous pods; style avol-shaped; stigma minute.

1. C. americàna Michx. (AMEricas B.) Stem 6-12 dm. high ; racemes slender, panicled; ovaries mostly 5, glabrous; pods flattened, veiny, 6-8-seeded. - Watkins, N. Y. (according to Britton); mountaius of s. Pa., and southw. Aug.-Sept.

§2. MACROTRYS (Raf.) T. \& G. (as Macrotys). Pistil solitary or sometimes 2-3, sessile; seeds smooth, flattened and packed horizontally in the pod in two rows, as in Ac aea; stigma broad and flat.

2. C. racemdsa (L.) Nutt. (Black Snakeroot, Black Cohosh.) Stem 1-2.6 m. high, from a thick knotted rootstock; leaves 2-3-ternately and then often quinately compound ; leafiets subcuneate to subcordate at the base ; racemes in fruit becoming 3-9 dm. long; pods ovoid. - Rich woods, s. N. E. to Wisc., and southw.; cultivated and escaped eastw. July. Var. Dissécta Gray. Leaves irregularly pinnately decompound, the rather small leaflets incised. Local, s. w. Ct. (Eames) to Del. (Commons).

Var. cordifdlia (Pursh) Gray. Leaflets few (about 9), very large (1-2.5 dm. long), at least the terminal one deeply cordate. ( $C$. cordifolia Pursh.) - Damp woods, mts. of s. w. Va. to N. C. and Tenn. - Said to flower later than the typical form.

\section{1. aCtata I. Baneberry. Cohosh}

Sepals 4 or 5, falling off when the flower expands. Petals 4-10, small, flat, spatulate, on slender claws. Stamens numerous, with slender white filaments. Pistil single; stigma sessile, depressed, 2-lobed. Seeds smooth, flattened, and packed horizontally in 2 rows. - Perennials, with ample 2-3-ternately compound leaves, the pvate leaflets sharply cleft and toothed, and a short and thiçk ter- 
minal raceme of white flowers. (From d $k r t a$, actaea, ancient names of the Elder, transferred by Linnaeus.)

1. A. rùbra (Ait.) Willd. (RED B.) Racene ovoid; petals rhombic-spatilate, much shorter tban the stamens; pedicels slender; berries cherry-red, poisonous, ovoid-ellipsoid. (A. spicata, var. Ait.) - Rich woods, common, especially northw. Apr., May. A form with decompound leaves and incised leaflets is var. Dissécta Britton. - Lincoln Co., Ont. Forma NEGLÉCTA (Gillman) Robinson has white berries on long slender green pedicels. ( $A$. neglecta Gillman; A. eburnea Rydb.) - Not rare. - Worthy of further study and perhaps distinct.

L. 2. A. álba (L.) Mill. (WHITE B.) Leaflets more incised and sharply toothed; racene ellipsoid; petals slender, mostly truncate at the end, appearing to be transformed stamens; pedicels thickened in fruit, as large as the peduncle and red, the globular-ovoid berries white. - Rich woods, flowering a week or two later than the other, and more common westward and southward.

\section{HYdrástis Ellis. Orange-root. Yellow Pdccoon}

Pistils 12 or more in a head, 2-ovuled; stigma flat, 2-lipped. Ovaries becoming a head of crimson 1-2-seeded berries in fruit. - A low perennial herb, sending up in early spring, from a thick and knotted yellow rootstock, a single radical leaf and a simple hairy stem, which is 2-leaved near the summit and terminated by a single greenish white flower. (Name unmeaning.)

1. H. canadénsis L. (Golden SEAL.) Leaves rounded, heart-shaped at the base, 5-7-lobed, doubly serrate, veiny, when full grown in summer 1-2 dm. wide. - Rich woods, w. N. E. to Minn., and southw. Apr., May.

\section{ZANTHORhiza L'Hér. ShrdB Yellow-root}

Sepals 5, regular, spreading, decidnous. Pistils 5-15, with 2 pendulous ovules. Pods 1-seeded, oblong, the short style becoming dorsal. - A low shrubby plant; the bark and long roots deep yellow and bitter. Flowers polygamous, brownpurple, in compound drooping racemes, appearing along with the 1-2-pinnate leaves from large terminal buds in early spring. (Name compounded of $\xi \alpha \nu \theta \delta s$,

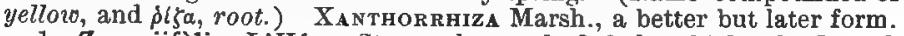

1. Z. apiifolia L'Hér. Stems clustered, 3-6 dm. high; leaflets eleft and toothed. - Shady banks of streams, Pa. and s. w. N. Y. to Ky, and Ga.

\section{MAgNOLIACEAE (Magnolia Familt)}

Trees or shrubs, with the leaf-buds covered by membranous stipules, polypetalous, hypogynous, polyandrous, polygynous; the calyx and corolla colored alike, in three or more roves of three, and imbricated (rarely covolute) in the bud. Sepals and petals deciduous. Anthers adnate. Pistils many, mostly packed together and covering the prolonged receptacle, cohering with each other, and in fruit forming a sort of fleshy or dry cone. Seeds 1 or 2 in each carpel, anatropous ; albumen fleshy; embryo minute. - Leaves alternate, not toothed, marked with minute transparent dots, feather-veined. Flowers single, large. Bark aromatic and bitter.

\section{MAGNÒLIA L.}

Sepals 3. Petals 6-9. Stamens imbricated. with very short filaments, and long anthers opening inward. Pistils coherent, forming a fleshy and rather woody cone-like red fruit; each carpel at maturity opening on the back, from which the 1 or 2 berry-like seeds hang by an extensile thread. (Named for P. Magnol, professor of botany at Montpellier in the 17 th century.) 


\section{* Leaves all scattered along the branches; leaf-buds silky.}

1. M. virginiàna L. (Small or Laurel M., Swete Bay.) Leaves oval to broadly lanceolate, 8-15 cm. long, obtuse, glaucous beneath; flower globular, white, $5 \mathrm{~cm}$. long, very fragrant; petals broad; cone of fruit small, ellipsoid. (M. glauca L.) - Swamps, from near Cape Ann and N. Y. southw., near the

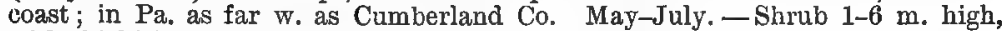
with thickish leaves, which farther south are evergreen.

2. M. acuminata L. (Cucumber Trev.) Leaves thin, oblong, pointed, green and a little pubescent beneath, $13-25 \mathrm{~cm}$. long; flower slender-bell-shaped, glaucous-green tinged with yellow, $5 \mathrm{~cm}$. long; cone of fruit 5-7 cm. long, cylindrical. - Rich woods, w. N. Y. to Ill., Ark, and southw. May, June. - Tree 18-27 m. high ; fruit when young slightly resembling a small cucumber.

3. M. macrophýlla Michx. (GREAT-LEA ved M.) Leaves obovate-oblong, cordate at the narrowed base, pubescent and white beneath; flower open-bellshaped, white, with a purple spot at base; petals ovate, $15 \mathrm{~cm}$. long; cone of fruit ovoid. - Ky., Ark., and southw. May, June. - Tree 6-12 m. high; leaves 3-9 dm. long, somewhat clustered on the flowering branches.

* Leaves crowded on the summit of the flowering branches in an umbrella-like circle; leaf-buds glabrous; flowers white, slightly scented.

$\checkmark$ 4. M. tripetala L. (UMBRELLA TREE.) Leaves obovate-lanceolate, pointed at both ends, soon glabrous, 3-6 dm. long; petals $9-12 \mathrm{~cm}$. long. (M. Umbrella Desr.) - S. Pa. to Ky., Mo., and southw. May. - Small tree.

5. M. Frasèri Walt. (EAR-Leaved Umbrella Tree.) Leaves oblongobovate or spatulate, auriculate at the base, glabrous, $2-5 \mathrm{dm}$. long; petals obovate-spatulate, with narrow claws, $1 \mathrm{dm}$. long. - Swamps and along streams, Va. and $\mathbf{K y}$, along the Alleghenies, and southw. May. - A slender tree 9-15 m. high.

\section{LIRIODÉNDRON L. TULIP TReE}

Sepals 3, reflexed. Petals 6, in two rows, making a bell-shaped corolla. Anthers linear, opening outward. Pistils flat and scale-form, narrow, imbricating and cohering in an elongated cone, dry, falling away whole, like a samara or key, indehiscent, 1-2-seeded in the small cavity at the base. (Name from Xlocov, lily or tulip, and $\delta \epsilon \nu \delta \rho \nu$, tree.)

$\downarrow$ 1. L. Tulipifera L. - Leaves very smooth, with 2 lateral lobes near the base, and 2 at the apex, which appears as if cut off abruptly by a broad shallow notch; petals $5 \mathrm{~cm}$. long, greenish yellow marked with orange; cone of fruit $7.5 \mathrm{~cm}$. long. - Rich soil, Worcester Co., Mass., to Ont., Wisc., and southw. May, June. - A most beautiful tree, sometimes $40 \mathrm{~m}$. high and $2-3 \mathrm{~m}$. in diameter in the Western and Soutbern States, the timber commonly called PoPLAR or White WooD.

\section{Calycanthàceae (Calyoanthus Family)}

Shrubs with opposite entire leaves, no stipules, the sepals and petals similar and indefinite, the anthers adnate and extrorse, and the cotyledons convolute; the fruit like a rose-hip. Chiefly represented by the genus

\section{Calycánthus L. Carolina Allspice}

Calyx of many sepals, united below into a fleshy inversely conical cup (with some leaf-like bractlets growing from it); the lobes lanceolate, mostly colored like the petals, which are similar, in many rows, thickish, inserted on the top of the closed calyx-tube. Stamens numerous, inserted just within the petals, short; some of the inner ones sterile (destitute of anthers). Pistils several or many, inclosed in the caly $x$-tube, inserted on its base and inner face. - Aromatic shrubs with brownish purple flowers verminating leafy shoots. (Name composed of $\kappa \alpha \dot{\lambda} u \xi$, a cup or calyx, and $a \nu \theta \omega$, flower.) Butnerit Duham. 
1. C. flóridus L. Leaves oval, soft-downy underneath; flowers when crushed yielding somewhat the fragrance of strawberries. (Butneria Britton.) - Va. (?) and southw., on hillsides in rich soil; common in gardens. Apr,-Aug.

2. C. fértilis Walt. Leaves oblong or ovate, thin, either blunt or taper-pointed, bright green and glabrous on both sides, or pale beneath; flowers inodorous. (C. glaucus and laevigatus Willd.; Butneria fertilis Britton.) - Franklin Co., Pa. (Porter), and southw, along the Alleghenies. May-Aug.

\section{anonàceae (Cubtard Apple Family)}

Trees or shrubs, with naked buds and no stipules, a calyx of 3 sepals, and $a$ corolla of 6 thickish petals in two rows, valvate in the bud, hypogynous, polyandrous. - Anthers adnate, extrorse; filaments very short. Pistils several or many, separate or cohering in a mass, fleshy or pulpy in fruit. Seeds anatropous, large, with a minute embryo at the base of the miminated albumen. - Leaves alternate, entire, feather-veined. Flowers axillary, solitary. Tropical, excepting

\section{1. asfimina Adans, North American Papaw}

Petals 6 , increasing after the bud opens; the outer set larger than the inner. Stamens numerous in a globular mass. Pistils few, ripening 1-4 large thickcylindric pulpy fruits; seeds several, horizontal, flat, inclosed in a fleshy aril. Shrubs or small trees with unpleasant odor when bruised; the lurid flowers solicary from the axils of last year's leaves. (Name from Asiminier, of the French colonists, from the Indian name assimin)

1. A.tríloba Dunal. (Commos P.) Leaves thin, obovate-lanceolate, pointed ; petals dull purple, veiny, round-ovate, the outer ones 3-4 times as long as the calyx. - Banks of streams in rich soil, N. J. to L. Erie, Mich., n. e. Ia., s. e. Neb., and southw. Apr., May. - Tree 3-12 m. high, the young shoots and jxpanding leaves clothed with a rusty down, soon glabrous. Flowers appearing with the leaves, $3-4 \mathrm{~cm}$. wide. Fruits $7-13 \mathrm{~cm}$. long, green or at length dark brown, the pulp sweet and edible in autumn.

\section{MENispermàceaE (Moonseed Family)}

Woody climbers, with palmate or peltate alternate leaves, no stipules, the sepals and petals similar, in three or more rows, imbricated in the bud; hypogynous, dioecious, 3-6-gynous; fruit a 1-seeded drupe, with a large or long curved embryo in scanty albumen. - Flowers small. Stamens several. Ovaries nearly straight, with the stigma at the apex, but often incurved in fruiting so that the seed and embryo are bent into a crescent or ring. Chiefly a tropical family.

1. Cocculus. Stamens, petals, and sepals each 6 .

* Sepals and petals present; anthers 4-celled; seed incurved.

2. Menispermum. Stamens 12-24, slender. Petals $6-8$.

* * Petals none; anthers 2-celled; seed saucer-shaped.

8. Calycocarpum. Stamens in the sterile flowers 12 ; in the fertile flowers 6, abortive.

\section{CócCuLUs DC.}

Sepals, petals, and stamens 6 , alternating in threes, the two latter short. Anthers 4-celled. Pistils $3-6$ in the fertile flowers; style pointed. Drupe and seed as in Menispermum. - Flowers in axillary racemes or panicles. (An oid name, a diminutive of coccus, кóккos, a berry.)

1. C. carolìnus (L.) DC. Minutely pubescent; leaves downy beneath, ovate ur cordate, entire or sinuately or hastately lobed, variable in shape; flowers 
greenish, the petals in the sterile ones auriculate-inflexed below around the filaments ; drupe red (as large as a small pea). (Cebatha Britton.) - River banks, Va. to s. Ill., Kan., and southw. July, Aug.

\section{MENISPERMUM [Tourn.] L. MoonseEd}

Sepals 4-8. Petals 6-8, short. Stamens 12-24 in the sterile flowers, as long as the sepals; anthers 4-celled. Pistils 2-4 in the fertile flowers, raised on a short common receptacle ; stigma broad and flat. Drupe globular, the mark of the stigma near the base, the ovary in its growth after flowering being strongly incurved so that the (wrinkled and grooved) laterally flattened stone takes the form of a large crescent or ring. The slender embryo therefore is horseshoeshaped ; cotyledons filiform. - Flowers white, in small and loose axillary panicles. (Name from $\mu \eta \eta \eta \eta$, moon, and $\sigma \pi t \rho \mu \alpha$, seed.)

1. M. canadense L. Leaves peltate near the edge, 3-7-angled or -lobed. Banks of streams, w. Que. and w. N. E., westw. and southw. Juue, July. Drupes black with a bloom, ripe in September, looking like frost grapes.

\section{CALYCOCÁRPUM Nutt. CopseEd}

Sepals 6, petaloid. Petals none. Stamens 12 in the sterile flowers, short; anthers 2-celled. Pistils 3, spindle-shaped, tipped with a radiate many-cleft stigma. Drupe globular; thin crustaceous putamen hollowed out like a cup on one side. Embryo foliaceous, heart-shaped. - Flowers greenish white, in long racemose panicles. (Name from $\kappa \dot{\alpha} \lambda \nu \xi, a c u p$, and $\kappa a \rho \pi \delta s$, fruit.)

1. C. Lydni (Pursh) Nutt. Leaves large, thin, deeply 3-5-lobed, cordate at the base ; the lobes acuminate; drupe $2.5 \mathrm{~cm}$. long, black when ripe. - Rich soil, Ky. to s. Ill., Kan., and southw. May. - Climbing to the tops of trees.

\section{BERBERIDÀCEAE (BARBERry FAMILT)}

Shrubs or herbs, with the sepals and petals both imbricated in the bud, usually in two rows of 3 (rarely 2 or 4 ) each; the hypogynous stamens as many as the petals and opposite to them; anthers opening by 2 valves or lids hinged at the top. (Podophyllum is an exception in having more numerous stamens, the anthers opening along the sides; Jeffersonia, in having the sepals in one row.) Pistil single. - Filaments short. Style short or none. Fruit a berry or a pod. Seeds few or several, anatropous, with albumen. Embryo small, except in Berberis. Leaves alternate, with dilated bases or stipulate.

* Petals 6-9; stamens 8-18; fruit many-seeded ; herbs.

1. Podophyllum. Petals 6-9. Stamens 12-18; anthers not opening by uplifted valves. Fruit a large berry.

2 Jeffersonia. Petals and stamens usually 8 ; anthers opening by uplifted valves. Pod opening by $a$ lid.

* * Petals and stamens 6 ; fruit fow-seeded.

3. Diphylleia. Herb with white flowers ; petals much longer than the sepals. Berry 2-4-seeded.

4. Caulophyllum. Herb with greenish flowers; petals thick, much shorter than the sepals. Orary soon bursting; the two seeds left naked.

5. Berberis. Shrubs, with yellow flowers and wood; a pair of glandular spots on the base of each petal. Fruit a berry.

\section{PODOPhÝldum L. May Apple. Mandrate}

Flower-bud with three green bractlets, which early fall away. Sepals 6, fugacious. Petals 6 or 9 , obovate. Stamens twice as many as the petals in our species; anthers linear-oblong, not opening by uplifted valves. Ovary ovoid; 
stigma sessile, large, thick and undulate. Fruit a large fleshy berry. Seeds covering the very large lateral placenta, in many rows, each seed inclosed in a pulpy aril. - Perennial herbs, with creeping rootstocks and thick fibrous roots. Stems 2-leaved, 1-flowered. (Name from moús, $a$ foot, and $\phi v ́ \lambda \lambda o \nu, a$ leaf, probably referring to the stout petioles.)

1. P. peltatum L. Stamens 12-18; leaves 5-9-parted, the lobes oblong, rather wedge-slaped, somewhat lobed and toothed at the apex. - Rich woods, w. Que. and w. N. E. to Minn., and southw. May. - Flowerless stems terminated by a large round 7-9-lobed leaf, peltate in the middle, like an umbrella; flowering stems bearing two one-sided leaves, and a nodding white flower from the fork; fruit ovoid, $2.5-5 \mathrm{~cm}$. long, ripe in July, sweet and slightly acid, edible.

\section{JEFFersonia B. S. Barton. Twinleaf}

Sepals 4, fugacious. Petals 8, oblong, flat. Stamens 8 ; anthers oblonglinear, on slender filaments. Ovary ovoid, soon gibbous, pointed; stigma 2lobed. Pod pear-shaped, opening halfway round horizontally, the upper part making a lid. Seeds many, in severai rows on the lateral placenta, with a fleshy lacerate aril on one side. - A perennial glabrous herb, with matted fibrous roots, long-petioled root-leaves parted into 2 half-ovate leaflets, and simple naked 1flowered scapes. (Named in honor of Thomas Jefferson.)

1. J. diphýlla (L.) Pers. Low ; flower white, $2.5 \mathrm{~cm}$. broad, the parts rarely in tbrees or fives. (J. binata B. S. Barton.) - Woods, n. N. Y. to Wise., n. e. Ia., and southw. Apr., May. - Called Rheumatism Root in some places.

\section{Diphylleita Michx. Umbrella Leaf}

Sepals 6, fugacious. Petals 6, oval, flat. Stamens 6. Ovary ellipsoid ; stigma depressed, subsessile. Ovules 5 or 6 , attached to one side of the cell below the middle. Berry globose, few-seeded. Seeds oblong, with no aril. - Glabrous perennial, with thick horizontal rootstocks, sending up each year either a huge centrally peltate and cut-lobed rounded umbrella-like radical leaf, on a stout stalk, or a flowering stem bearing two similar (but smaller and more 2-cleft) alternate leaves which are peltate near one margin, and terminated by a cyme

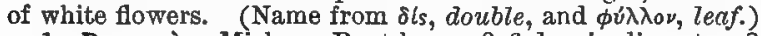

1. D. cymdsa Michx. Root-leaves $3-6 \mathrm{dm}$. in diameter, 2 -cleft, each division 5-7-lobed; lobes toothed; berries blue, - Wet or springy places, mts, of Va. and southw. May.

\section{CAUlophÝllum Michx. Blue Cohosh}

Sepals 6, with 3 or 4 small bractlets at the base, ovate-oblong. Petals 6 thick gland-like somewhat kidney-shaped or hooded bodies, with short claws, much smaller than the sepals, one at the base of each of them. Stamens 6. Pistil gibbous; style short; stigma minute and unilateral; ovary bursting soon after flowering by the pressure of the 2 erect enlarging seeds, and withering away; the spherical seeds naked on their thick seed-stalks, looking like drupes, the fleshy integument turning blue; albumen horny. $-\mathbf{A}$ perennial glabrous herb, with matted knotty rootstocks, sending up in early spring a simple and naked stem, terminated by a small raceme or panicle of yellowish green flowers, and a little below bearing a large triternately compound sessile leaf (whence the name, from $\kappa a u \lambda b s$, stem, and $\phi v \lambda \lambda a \nu$, leaf, the stem seeming to form a stalk for the great leaf.)

1. C. thalictroides (L.) Michx. (Pa proose Roor.) Stems 3-7.5 dm. high ; leaflets obovate-wedge-form, 2-3-lobed, a smaller biternate leaf often at the base of the panicle; flowers appearing while the leaf is yet sniall. - Deep rich woods, N. B. to Man., and southw. Apr., May. - Whole plant glaucous when young, as also the seeds, which are as large as peas. 


\section{BERBERIS [Tourn.] L. BARBERRY}

Sepals 6, roundish, with 2-6 bractlets outside. Petals 6 , obovate, concave, with two glandular spots inside above the short claw. Stamens 6. Stigma circular, depressed. Fruit a 1-few-seeded berry. Seeds erect, with a crustaceous integument. - Shrubs, with yellow wood and inner bark, yellow tlowers in drooping racemes, sour berries, and 1-9-foliolate leaves. Stamens irritable. (Derived from Berberys, the Arabic name of the fruit.)

1. B. canadénsis Mill. (American B.) Leaves repandly toothed, the teeth less bristly-pointed; racemes few-flowered; petals notched at the apex; berries ovoid; otherwise as in the next. - Alleghenies of Va., southw. and westw.; not in Canada. June. - Shrub 3-9 dm. high.

2. B. vulgaris L. (Common B.) Leaves scattered on the fresh shoots of the season, mostly reduced to sharp triple or branched spines, from the axils of which the next season proceed rosettes or fascicles of obovate-oblong closely bristle-toothed leaves (the short petiole jointed !), and drooping many-flowered racemes; petals entire; berries ellipsoid, scarlet. - Thickets and waste grounds in e. and s. N. E., where it has become thoroughly wild; elsewhere occasionally spontaneous. May, June. (Nat. from Eu.)

\section{LAURÀCEAE (LAUReL FaMily)}

Aromatic trees or shrubs, with alternate simple leaves mostly marked with minute pellucid dots, and flowers with a regular calyx of 4 or 6 colored sepals, imbricated in 2 rows in the bud, free from the 1-celled and 1-ovuled ovary, and mostly fewer than the stamens; anthers opening by 2 or 4 uplifted valves. - Flowers clustered. Style single. Fruit a 1-seeded berry or drupe. Seed anatropous, suspended, with no albumen, filled by the large almond-like embryo.

* Flowers perfeet, panicled; stamens 12, three of them sterile, three with extrorse snthers.

1. Persea. Calyx persistent. Anthers 4-celled. Evergreen.

* * Flowers dioecious, or nearly so; stamens in the sterile flowers 9 ; lesves deciduous.

2. Sassafras. Flowers in corymb- or umbel-like racemes. Anthers 4-celled, 4-valved.

3. Litsea. Flowers few in involucrate umbels. Anthers 4-celled, 4-valved.

4. Benzoin. Flowers in umbel-like clusters. Anthers 2-celled, 2-valved.

\section{PÉRSEA [Plum.] Gaertn. f.}

Flowers perfect, with a 6-parted calyx, persistent at the base of the berry-like fruit. Stamens 12 , in four rows, the 3 of the innermost row sterile and glandlike, the rest bearing 4-celled anthers (i.e. with each proper cell divided transversely into two), opening by as many uplifted valves; the anthers of 3 stamens turned outward, the others introse. - Trees, with persistent entire leaves, and small panicled flowers. (An ancient name of some oriental tree.)

1. P. Borbonia (L.) Spreng. (KED BAY.) Tree of medium size ; branchlets early glabrate; leaves oblong, soon shining above, pale and at length glabrate beneath; common peduncle about equaling the petiole; berry dark blue, on a red stalk. ( $\boldsymbol{P}$. carolinensis Nees.) - Swamps, s. Del. to Fla. and Tex.

2. P. pubéscens (Pursh) Sarg. Small tree; branchlets velvety; lower surface of lance-oblong leaves retaining more or less pubescence; peduncles considerably longer than the petioles. - Swamps, Fla. to N. C.; and reported from s. Va.

\section{SẢSSAFRAS Nees}

Flowers dioecious, with a 6-parted spreading calyx; the sterile kind with 8 stamens inserted on the base of the calyx in 3 rows, the 3 inner with a pair of stalked glands at the base of each; anthers 4-celled, 4-valved; fertile flowers 
with 6 short rudiments of stamens and an ovoid ovary. Drupe ovoid (blue), supported on a club-shaped and rather fleshy reddish pedicel. - Trees, with spicy-aromatic bark, and very mucilaginous twigs and foliage; leaves deciduous, often lobed. Flowers greenish yellow, naked, in clustered and peduncled corymbed racemes, appearing with the leaves, involucrate with scaly bracts. (The popular name, applied by the early French settlers in Florida.)

1. S. variffolium (Salisb.) Ktze. Trees 4-38 m. bigh, with yellowisl green twigs; leaves ovate, entire, or some of them 3-lobed, soon glabrous. ( $\boldsymbol{S}$. officinale Nees \& Eberm.; S. Sassafras Karst.) - Rich woods, s. Me. (Deane, Parlin) to s. Unt., Mich., e. Ia., and Kan., and s. to the Gulf. Apr.

\section{LÍTSEA Lam.}

Flowers dioecious, with a 6-parted deciduous calyx; the sterile with 9 stamens in 3 rows; their anthers all introrse, 4-celled, 4-valved; fertile flowers with 12 or more rudiments of stamens and a globular ovary. Drupe globular. - Shrubs or trees, with entire leaves, and small flowers in axillary clustered umbels. (Name of Chinese origin.)

1. L. geniculata (IValt.) Nicholson. (Pond SpIce.) Flowers (yellow) appearing before the deciduous oblong leaves, which are hairy on the midrib beneath; branches forked and divaricate, the branchlets zigzag; involucres 2-4-leaved, 2-4-flowered; fruit red. (Malapoenna Coult.) - Swamps, Va, to Fla. Apr.

\section{BenZòin Fabric. Wild Allspice. Fever Bush}

Flowers polygamous-dioecious, with a 6-parted open caly $\mathrm{x}$; the sterile with 9 stamens in 3 rows, the inner filaments 1-2-lobed and gland-bearing at base; anthers 2-celled and 2-valved; fertile flowers with 15-18 rudiments of stamens in 2 forms, and a globular ovary. Drupe obovoid, red, the stalk not thickened. - Deciduous-leaved shrubs, with honey-yellow flowers in almost sessile lateral umbel-like clusters, appearing before the leaves (in our species); the clusters composed of smaller clusters or umbels, each of $4-6$ flowers and surrounded by an involucre of 4 deciduous scales. Leaf-buds sealy. (So named from its odor, which resembles that of benzoin, an oriental gum.)

1. B. aestivale (L.) Nees. (SPICE Bush, Benjamin Bush.) Nearly smooth (2-5 m. high); leaves oblong-obovate, pale underneath. (Lindera Benzoin Blume ; B. Benzoin Coult.) - Damp woods, s. Me. to Ont., Mich., e. Kan., and southw. March, Apr.

2. B. melissaefdium (Walt.) Nees. Young branches and buds pubescent; leaves oblong, obtuse or heart-shaped at base, downy beneath; umbels few. (Lindera Blume.) - Low grounds, N. C. to Fla,, w. to s. Ill. and Mo. Apr.

\section{PAPAVERÀceaE (Poppy FAMilt)}

Herbs with milly or colored juice, regular flowers with the parts in twos or fours, fugacious sepals, polyandrous, hypogynous, the ovary 1-celled with two or more parietal placentae. - Sepals 2 , rarely 3 , falling when the flower expands. Petals 4-12, spreading, imbricated and often crumpled in the bud, early deciduous. Stamens rarely as few as 16 , distinct. Fruit a dry 1-celled pod (in Papaver imperfectly many-celled, in Glaucium 2-celled). Seeds numerous. anatropous, often crested, with a minute embryo at the base of fleshy and oily albumnn. - Leaves alternate, without stipules. Peduncles mostly 1-flowered. Juice uarcotic or acrid. 
* Petals 8-12, not crumpled in the bad ; pod 1-celled, 2-valved.

1 Sanguinaria. Petals white. Leaves and 1-flowered seape from a short rootstock.

* Petale 4, crumpled in the bud; pod with 2 or more valves.

Pod 2-4-valved, the valves separating to the base from the placentae; leaves plnnately parted; flowers yellow.

2. Stylophorum. Pod bristly; style distinet; stigmas and placentae 8-4.

3. Chelidonium. Pod linear, smooth; style almost none ; stigmas and placentse 2.

4. Glaucium. Pod rough, long-linear, 2-celled by a spongy partition ; style none.

++ Pod 4-20-valved, dehiscent only at the top or to the middle.

5. Papaver. Ovary incompletely many-celled; stigmas united into a radiate sessile orown.

6. Argemone. Stigmas (sessile) and placentae 4-6. Pod and leaves prickly.

\section{SANGUINÅRIA [Dill.] L. BLOODROOT}

Sepals 2. Petals 8-12, spatulate-oblong. Stamens about 24. Style short; stigma 2-grooved. Pod ellipsoid or fusiform, turgid, 1-celled, 2-valved. Seeds with a large crest. - Low perennial ; its thick prostrate rootstocks (surcharged with red-orange acrid juice) sending up in earliest spring a palmate-lobed leaf and 1-flowered scape. Flower white, handsome, the bud erect, the petals not crumpled. (Name from the color of the juice.)

1. S. canadensis L. - Open rich woods; common. Apr., May.

Boccónía cordata Willd, the Plume PopPt, a stout plant with glaucous cordate lobed leaves, and panicles of small greenish apetalous flowers, is frequent in cultivation and has been found as an escape in Madison Co., O. (Mrs. Sharp). (Introd. from China.)

\section{STYLÓPHORUM Nutt, Celandine PopPY}

Sepals 2, hairy. Petals 4. Style distinct, columnar; stigma 2-4-lobed. Pods bristly, 2-4-valved to the base. Seeds conspicuously crested. - Perennial low herbs, with stems naked below and oppositely 2-leaved, or sometimes 1-3leaved, and umbellately 1 -few-flowered at the summit; the flower-buds and the pods nodding. Leaves pinnately parted or divided, Juice yellow. (Fronı $\sigma \tau \hat{v} \lambda_{0 s}$, style, and $\phi \epsilon \in \varepsilon \iota \nu$, to bear, one of the distinctive characters.)

1. S. diphýllum (Michx.) Nutt. Leaves pale beneath, smoothish, déply pinnatifid into 5 or 7 oblong siunate-lobed divisions, and the root-leaves often with a pair of small distinct leaflets; peduncles equaling the petioles; flower deep yellow (5 cm. broad); stigmas 3 or 4 ; pod ovoid. - Damp woods, w. Pa. to Wisc., "Mo.," and Tenn. May. - Foliage and flower resembling Celandine.

\section{Chelidōnium [Tourn.] L. Celakdine}

Sepals 2. Petals 4. Stamens 16-24. Style almost none; stigma 2-lobed, Pod linear-cylindric, smooth, 2-valved, the valves opening from the bottom upward. Seeds crested. - Biennial herb with brittle stems, saffron-colored acrid juice, pinnately divided or 2-pinnatifid and toothed or cut leaves, and small yellow flowers in a pedunculate umbel; buds nodding. (Ancient Greek name, from $\chi^{\epsilon \lambda} \iota \delta \omega \nu$, the swallow, because its flowers appear with the swallows )

1. C. Majos L.- Rich damp soil about towns, centr. Me. to Ont., and southw., coinmon from s. Me. to Pa. May-Aug. (Nat. from Eu.)

\section{GLaÚcium [Tourn.] Hill. Horn Poppy. Sea Poppy}

Sepals 2. Petals 4. Style none; stigma 2-lobed or 2-horned. Pod very long and linear, completely 2-celled by a spongy false partition; seeds crestless. - Annuals or biennials, with saffron-colored juice, clasping leaves, and soljtary yellow flowers. (The Greek name, $\gamma \lambda a \kappa_{\kappa \iota}$, from the glaucous foliage.) 
1. G. Fldvum Crantz. Lower leaves pinnatifid; upper ones sinuate-lobed and toothed, cordate-clasping; pods rough, 1.5-2.5 dm. long. ( $G$. luteum Scop.; G. Glaucium Irarst.) - Waste places, s. e. N. E., Md., and Va.; also about Syracuse, N. Y.; not common. (Adv. from Eu.)

\section{PAPÀver [Tourn.] L. PoPPY}

Sepals mostly 2. Petals mostly 4. Stigmas united in a flat 4-20-rayed crown, resting on the sumnit of the ovary and capsule; the latter short and turgid, with 4-20 many-seeded placentae projecting like imperfect partitions, opening by as many pores or chinks under the edge of the stigma. - Herbs with a white juice; the flower-buds nodding. (Derivation obscure.) - Eour annual species of the Old World are sparingly adventive; viz.:

1. P. somnfferum L. (Common P.) Smooth, glaucous; leaves clasping, wavy, incised and toothed; pod globose; corolla mostly white or purple. - Near dwelliugs in some places. (Introd. from Eu.)

2. P. Rhotes I. (Corn P.) Bristly; leaves pinnatifid; pods obovoid, turbinate; corolla bright scarlet, often dark at center. - Rubbish heaps and rarely fields. (Introd. from Eu.)

3. P. DÜвIом L. Pinnatifid leaves and the long stalks bristly; pods clubshaped, smooth; corolla light scarlet. - Cultivated fields and waste grounds, R. I., and southw., rare. (Adv. from Eu.)

L. P. Argemóne L. Smaller, with finer-cut leaves and paler flowers than the last; pods club-shaped and bristly. - Waste grounds, near Philadelphia. (Adv. from Eu.)

\section{ARgemòne L. Prickly Poppy}

Sepals 2 or 3 , often prickly. Petals $4-6$. Style almost none ; stigmas $3-6$, radiate. Pod ellipsoid, prickly, opening by $3-6$ valves at the top. Seeds crested. - Annuals or biennials, with prickly bristles and yellow juice. Leaves sessile, sinuate-lobed, and with prickly teeth, often blotched with white. Flower-buds erect, short-peduncled. (Name from $a \rho \gamma \epsilon \mu a$, a disease of the eye, for which the juice of a plant so called by the Greeks was a supposed remedy.)

1. A. intermèdia Sweet. Stout, very glaucous; peduncles leafy; corolla white, 8-10 cm. in diameter. (A. platyceras Man. ed. 6, not Link \& Otto.) Meredosia, Ill. (Seymour) to Neb., southw. and westw.

2. A. MExicana L. (Mexicas P.) Less glaucous; flowers smaller, $3-6 \mathrm{~cm}$. broad, yellow or rarely cream-colored (Var. ochroceùca Lindl.). - Waste places and ballast, southw.; casual northw. (Adv. from Mex.)

A. ÁLBA Lestiboudois, a southern species with white flowers on naked peduncles, is said to occur in Mo.

\section{FUMARIÀceaE (Fumitory Familt)}

Delicate smooth herbs, with vatery juice, compound dissected leaves, irregular flowers, with 4 somewhat united petals, 6 diadelphous stamens, and 2-merous pods and seeds like those of the Poppy Family. - Sepals 2, small and scale-like. Corolla flattened, closed; the 4 petals in two pairs; the outer with spreading tips, and one or both of them spurred or saccate at the base; inner pair narrower, and their callous-crested tips united over the stigma. Stamens in two sets of 3 each, placed opposite the larger petals, hypogynous; their filaments often united; middle anther of each set 2-celled, the lateral ones 1-celled. Pod 1-celled, either 1-seeded and indehiscent, or several-seeded with 2 parietal placentae and deciduous valves. - Leaves delicate, usually alternate, without stip. ules. Slightly bitter innocent plants. 
* Corolla bigibbous or 2-spurred, the 2 onter petals alike; pod several-seeded.

1. Adlumia. Petals united in to a spongy persistent subcordate corolla. Seeds crestless.

2. Dicentra. Corolla oordate or 2-spurred at base, less united. Seeds crested. * * Corolla with but one petal spurred at base, deciduoue.

3. Corydalis. Pod with few to many crested or ariled seeds.

4. Fumaria. Fruit a globular 1-seeded nutlet. Seed crestless.

\section{ADlÙmia Raf. Climbing Fumitory}

Petals all permanently united into a cordate-ovate corolla, becoming spongy cellular and persistent, inclosing the small few-seeded pod. Seeds not crested. Stigma 2-crested. Filaments monadelphous below in a tube which is adherent to the corolla, diadelphous at the summit. - A climbing biennial, with thricepinnate leaves, cut-lobed delicate leaflets, and ample panicles of drooping white or purplish flowers. (Dedicated to Major J. Adlum, amateur botanist.)

1. A. fungdsa (Ait.) Greene. - Wet or recently burned woods; e. Que. to Ont., Wisc., and s. in the mts. to N. C. June-Oct. (A. cirrhosa Raf.) Handsome delicate vine climbing by the slender young leaf-stalks over high hushes; often cultivated, and frequently escaping.

\section{DICÉNTRA Bernh.}

Petals slightly cohering into a heart-shaped or 2-spurred corolla, either deciduous or withering gersistent. Stigma 2-crested and sometimes 2-horned. Filaments slightly útitited into two sets. Pod 10-20-seeded. Seeds crested. Low stemless perennials (as to our wild species) with ternately compound and dissected leaves and racemose nodding flowers. Pedicels 2-bracted. (Name

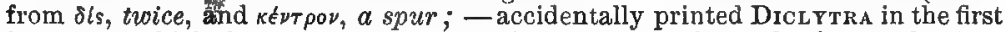
instance, which by an erroneous conjecture was changed afterwards into Dielytra.) Bikukulla Adans. Bicuculla Millsp.

\section{* Raceme simple, few-flowered.}

1. D. Cucullària (L.) Bernh. (Dutchman's Breeches.) Scape and slender-petioled leaves from a sort of granulate bulb; lobes of leaves linear; corolla woith 2 divergent spurs longer than the pedicel; crest of the inner petals minute. (Bicuculla Millsp.) - Rich woods, N. S. to L. Huron and Minn., s. to N. C. and Mo. - A very delicate plant, sending up in early spring, from the cluster of grain-like tubers crowded together in the form of a scaly bulb, the finely cut leaves and the slender scape, bearing 4-10 pretty, but odd, white flowers tipped with cream-color.

2. D. canadénsis (Goldie) Walp. (SquirRex Corv.) Subterranean shoots bearing scattered grain-like tubers (resembling peas or grains of Indian corn, yellow); leaves as in no. 1 ; corolla merely heart-shaped, the spurs very short and rounded ; crest of the inner petals conspicuous, projecting. (Bicuculla Millisp.) - Rich woods, N. S. to Ont. and Minn., s. to Va., Ky., and Mo. Apr., May. Flowers greenish white tinged with rose, with the fragrance of hyacinths.

\section{* Racemes compound, clustered.}

3. D. eximia (Ker) Torr. Subterranean shoots scaly ; divisions and lobes of the leaves broadly oblong; corolla oblong, 2-saccate at the base; crest of the inner petals projecting. (Bicuculla Millsp.) - Rocks, w. N.Y., rare, and southw, along the Alleghenies. May-Aug. - Coarser-leaved than the others: scapes $1.5-2.5 \mathrm{dm}$. high.

\section{CORÝDALIS [Dill.] Medic.}

Corolla 1-spurred at the base (on the upper side), deciduous. Style perzistent. Pod many-seeded. Seeds crested or ariled. Flowers in racemes. our species are biennial, leafy-stemmed, and pale or glaucous. (The ancient Greek name for the crested lark.) CApnoides Adans. Caprodes Ktze. 
* Stem strict; flowers purplish or rose-color with yellow tips.

1. C. sempervirens (L.) Pers. (PALE C.) Plant $1-6 \mathrm{dm}$. high.; racemes panicled; spur of the corolla very short and rounded; pods erect, slender, elongated. (C. glauca Pursh; Capnoides Borkh.) - Rocky places and recent clearings, 七. Que. to Alaska, s. to Ga., Ky., Minn., and Mont. May-Aug.

** Low, ascending; flowers yellow.

+ Outer petals wing-crested on the back.

2. C. flávula (Raf.) DC. Pedicels slender, conspicuously bracted; corolla pale yellow, 6-8 mm. long; spur very short; tips of the outer petals pointed, longer than the inner; crest 3-4-toothed; pods torulose, pendulous or spread$\mathrm{i}$ rg; seeds acutely margined, rugose-reticulated; arils loose. (Capnodes Ktze.)

- N. Y. to Minn., Kan. (according to Britton), and southw.

3. C. micrántha (Engelm.) Gray. Pedicels short and bracts small; corolla pale yellow, $8 \mathrm{~mm}$. long, with short spur and entire crest, or flowers often cleistogamous and much smaller, without spur or crest; pods ascending, torulose; seeds obtuse-margined, smooth and shining. (Capnoides Britton.) -Va. to Minn., Kan. (Shear, Hitcheock), and southw.

4. C. crystállina Engelm. Pedicels short, erect; corolla bright yellow, 1.7 $\mathrm{cm}$. long, the spur nearly as long as the body ; crest very broad, usually toothed; pods terete, erect, densely covered with transparent vesicles; seeds acutely margined, tuberculate. (Capnodes Ktze.) - Prairies and fields, s. w. Mo., Kan. and Ark.

++ Outer petals merely carinate on the back, nt crested.

5. C. aúrea Willd. (Goldes C.) Corolla golden-yellow $1.2 \mathrm{~cm}$. long, the slightly decurved spur about half as long, shorter than the ped, el; pods spread. ing or pendulous, becoming torulose; seeds obtuse-margined. (Capnodes Ktze.) - Rocky (calcareous) banks and recent clearings, e. Que. to sMackenzie, s. to Vt., Pa., Wisc., and Mo.; also in the Rocky Mts. to Ariz.

Var. occidentàlis Engelm. Flowers rather larger, the spur nearly as long as the body ; pods less torulose, on short pedicels ; seeds acutish on the margin. (Capnoides montanum and ? C. campestre Britton.) - Rocky barrens and prairies, Mo., westw. and southw.

\section{FUMÀRIA [Tourn.] L. FUMITORY}

Corolla 1-spurred at the base. Style deciduous. Fruit indehiscent, small, globular, 1-seeded. Seeds crestless. - Branched and leafy-stemmed annuals, with finely dissected compound leaves, and small flowers in dense racemes or spikes. (Name from fumus, smoke, presumably from the nitrous odor of the roots when first pulled from the ground.)

F. officinalis L. (Cомmon F.) Sepals ovate-lanceolate, acute, sharply toothed, narrower and shorter than the corolla (which is flesh-color tipped with crimson); fruit slightly notched. - Waste places, about dwellings. (Adv. from Eu.)

\section{CRUCifferae (Mustard Family)}

Herbs, with a pungent watery juice and cruciform tetradynamous regular flowers; fruit a silique or silicle. Sepals 4, deciduous. Petals 4, hypogynous, their spreading limbs forming a cross. Stamens 6 , two of them inserted lower down and shorter (rarely only 4 or 2). Pod usually 2-celled by a thin partition stretched between the two marginal placentae, from which when ripe the valves separate, either much longer than broad (a silique), or short (a silicle), sometimes indehiscent and nut-like, or separating across into 1-seeded joints. Seeds campylotropous, without albumen, filled by the large embryo, which is curved or folded in various ways : i.e. the cotyledons accumbent, viz., their margins on 
one side applied to the radicle, so that the cross-section of the seed appears thus $\mathrm{O}=$; or else incumbent, viz., the back of one cotyledon applied to the radicle, thus $O \| l$. In these cases the cotyledons are plane; but they may be folded upon themselves and round the radicle, as in Brassica, where they are conduplicate, thus $0 \gg$. In Leavenworthia alone the whole embryo is straight. - Ieaves (except in Lunaria) alternate; stipules none. Fiowers in terminal racemes or corymbs; pedicels rarely bracted. A large and natural family, of pungent or actid, but not poisonous plants. The pods and seeds give the chief characters of the genera.

Tribe 1. ALÝSSEAE. Pubescence, at least in part, branched or stellate. Pods orbicular to (rarely) linear, short, dehiscent, fiattened parallel to a broad partition. Cotyledons mostly accumbent.

* Eruit oval, short-oblong, lanceolate, or rarely linear; seeds wingless.

1. Draba. Petals entire, emarginate or (in $\S$ Erophila) bilid. Seeds numerous, in 2 rows in each cell. Pubescence stellate.

* * Fruit orbicular or broadly elliptical.

2. Berteroa. Petals bitid. Filaments toothed near the base. Pubescence stellate, not appressed. Capsule-valves flat. Seeds few, winged.

3. Lobularia. Petals entire. Filaments toothed near the base. Hair's 2-lobed, attached in the middle, sppressed.

4. Alyssum. Petals entire or retuse. Pubescence stellate. Capsules orbicular; valves con. vex; cells (in our species) 2-seeded.

Tribe II. PHYSARIEAE. Fruit short, very turgid, subglobose or didymous, dehiscent. Cotyledons accumbent. Pubescence stellate.

5. Lesquerella. Pod globose or nearly вo.

Tribe III. LEPIDiEAE. Fruit 2-celled, dehiscent, short, strongly obcompressed (except in the aquatic genus subuzaria). Pubescence of simple hairs or none.

* Pod strongly obcompressed or didyuous, with narrow partition ; flowers white.

+ Seeds several ; cotyledons accumbent.

6. Thlaspi. Pods orbicular, obovate or obcordate, winged.

++ Seeds solitary in the cells.

7. Lepidium. Pods ovate or orbicular, flat, scale-shaped.

8. Coronopus. Pods didymous; valves rugose or tuberculate, separating at maturity from the little partition as 2 closed nutlets. Cotyledons incumbent, narrow.

* * Pod ovoid or globular.

9. Subularia. Dwarf, aquatic. Leaves awl-shaped. Flowers minute, white.

Tribe IV. CAMELineAE. Fruit short, seareely longer than broad. Cotyledons Ineumbent. Some or all of the hairs branched.

$$
\text { * Pod 2-valved, dehiscent. }
$$

10. Capsella. Pod (in ours) obcordate-triangular, wingless. Flowers white.

11. Camélina. Pod somewhat turgid, obovoid. Flowers yellow.

$$
\text { * * Pod indehiscent. }
$$

12. Neslia. Pod compressed-globose.- Flowers yellow.

Tribe V. CAKfLEAE. Fruit transversely 2-jointed; cells unequal, each 1-seeded, the ovule in the upper erect, in the lower pendulous. Cotyledons accumbent.

13. Cakile. Corclia white or purplish. Fleshy herbs.

Tribe VI. BRASsfCEAE. Fruit elongated. Cotyledons conduplicate (folded about the radicle) Hafrs simple or none. 
* Fruit indehlscent, often moniliform, 1-celled or transversely several-celled, the partitions spongy or pithy.

14. Raphanus. Petals laige, pale yeilow or purplish. Fruit stout, beaked.

$$
\text { * Fruit longitudinally 2-celled, dehiscent. }
$$

15. Brassica. Seeds globose, in a single row in each cell.

16. Diplotaxis. Seeds ovold, in 2 rows in each cell.

Iribe VII. SISYMBRteaE. Stigma, when lobed, with lobes over the placentae. Firnit lance oblong to linear, 2-celled, dehiscent. Cotyledons incumbent.

* Cauline hairs simple or stellate, not regularly bifid.

- Petals small (not over $1 \mathrm{~cm}$. long), yellow, white, or pale purple.

17. Conringia. Glabrous. Leaves elliptical, entire, cordate, sessile.

18. Alliaria. Glabrous or pubescent. Leaves orbicular or reniform, broadly cordate, toothed, petiolate.

19. Sisymbrium. Pubescent. Leaves various but not as in either of the two preceding. Parti. tion of fruit 1-yerved or, if not nerved, of thin-walled elongrated cells.

20 Braya, Pubescent. Leaves small, narrowly oblong or spatulate, toothed or subentire, sessile. Partition of the fruit without midnerve, its cells thick-walled.

$$
\text { + + Petals large (1.5-2 cm. long), deep purple. }
$$

21. Hesperis. Tall. Leaves ovate-lazceolate, denticulate, the lower long-petioled. Pods very long and slender.

* *auline hairs 2-branched, the branches vertical and appressed.

22. Erysimum. Petals yellow or orange. Leaves lanceolate to linear, not clasping, entire or toothed.

Tribe VIII. ARaBfDEAE. Fruit 2-celled, dehiscent, globose to long and slender, terete or flattened parallel to a broad partition. Cotyledons aceumbent (in Leavenworthia the embryo sometimes nearly straight).

* Fruit globose to ovoid or oblong and terete ; petals yellow or white.

28. Radicula. Flowers small. Leaves toothed, lobed, or pinnate.

* * Fruit either terete and elongated or elliptic- or linear-oblong and strongly compressed parallel to a broad partition.

- Petals yellow.

24. Barbarea. Pods slender, terete or nearly so, Bienniajs.

25. Selenia. Pods broadly elliptic-oblong, very flat. Low annual.

++ Petals white, pink, or purple, not yellow except sometimes near the brse.

++ Pods long and slender, not at all compressed parallel to the partition.

26. Iodanthus. Lateral sepals somewhat horned on the back near the apex. Petals broadly spatulate, purple.

+++ Pods, elliptic-oblong or lance-elliptio, about $2.5 \mathrm{~cm}$. bread, very flat.

27. Lunaria. Petals purplo. Lerves deltoid-ovate.

$+\#+$ Pods distinctly compressed parallel to the partition, but not over $1 \mathrm{~cm}$. broad.

$=$ Peduncles radical, 1-flowered.

25. Leavenworthia. Pods oblong, sometimes torulose. Flowers purple or white with a yellow eye.

$$
- \text { - Peduncles not radical, several-flowered. }
$$

29. Dentaria. Glabrous or pubescent with simple hairs. Rootstock fleshy, toothed, or montlifurm-tuberous. Stem naked below, bearing nea: the middle $2-8$ verticillate or alternate leaves ; these for the most part palmately 3 -7-folfolate, petiolnte. Seeds wingless.

30. Cardamine. Glabrous or pubescent with simple hairs, fibrous-rooted, rarely tuber-bearing. Stem loafy; leaves alternate, from ovate and crenate-dentate to pinnate. Seeds wingless.

31. Arabis. Usually pubescent, some or all of the halrs being branched. Roots fibrous; no tubers. Seeds usually winged or wing-margined. Leaves alternate simple or pinnatifid 


\section{Artificial, Key to Gienera}

3. Petals present, with yellow blade and yellowish or whitish claw $b$.

b. Fruit shurt, not more than 3 times as long as broad.

Pubescence stellate.

Pods thick.

Pods globose,

Pods dehiscent

Pods indehiscent.

Pods obovoid.

Pods thin.

Pods orhicular

Pods oblong

Pubescence simple or none.

Pods subglobose or cylindrical .

Pods very flat and thin

b. Fruit much more than 3 times as long as broad.

Pods 1 -celled or with spongy cross partitions

Pods longitudinally 2-celled.

Seeds 2-rowed in each cell

Seeds 1-rowed in each cell.

Petals $7-15 \mathrm{~mm}$. long.

Pods thickish, 2-6 mm. in diameter.

Pods linear, about $1 \mathrm{~mm}$. in diameter

Petals smaller.

Stem-hairs vertical, attached by the middle, appressed

Stem-hairs (if present) otherwise.

Stem-leares lanceolate, sessile, subentire; stem villous at

Stem-leaves elliptical, sessile, entire ; stem glabrous

Stem-leaves petiolate, toothed or pinnate.

Leaves bipinnatifid

Leaves simple or pinnatifid.

Pods awl-shaped, tapering, closely appressed

Pods inear, cylindrical or compressed.

Pods (when ripe) 2-5 cm. long

Pods (when ripe) $7-9 \mathrm{~cm}$. long
a. Petals (when present) with blade white or purplish (soinetimes yellow at the base) $c$.

c. Peduncles 1-flowered, radical .

c. Peduncles several-flowered. not radical $\dot{d}$.

d. Dwarf aquatic with awl-shaped entire leaves

$d$. Otherwise $e$.

e. Fruit trausversely 2-celled; plant fleshy .

c. Fruit longitudinally 2-celled $f$.

f. Pods short, rarely 3 times as long as wide $g$.

$g$. Pods compressed contrary to a narrow partition.

Carpels thickish, tuberculate-crested or deeply wrinkled

Carpels compressed, smoothish.

Pods wedge-shaped at the base; some or all of the hairs

Pods not wedge-shaped at the base; hairs simple or none.

Seeds several in each cell .

Seeds solftary in each cell

g. Pods compressed (if at all) parallel to the broadish partition.

Pods $2-3 \mathrm{~cm}$. broad.

Pods narrower.

Hairs none or all simple

Hairs at least in part branched or attached by the middle". Hairs vertically 2 -forked, appressed, apparently attached by the middle

Halrs otherwise.

Seeds 2 in ench cell ; pods orbicular

Seeds several to many in each cell.

Petals deeply bifid.

Scapose, $1 \mathrm{dm}$. or less high Leafy-stemmed, 8-8 dm. high

Petals nearly or quite entire

f. Pods $4-\infty$ times as long as wide $h$.

$\hbar$. Hairs simple or none.

Leaves palmately divided

Leaves otherwise.

Fruit thickish, 4-7 mm, in diameter

Fruit slender, 1-8 mm. in diameter.

Petals purple or rose-colored.

Lateral sepals with a humI (often tufted) just below the summit

Lateral sepnls unappendaged

5. Legquerelia.

12. Neslia.

11. Camelina.

4. Alrosum.

1. Draba.

28. Radicula.

25. Selenia.

14. RAPHaNug.

16. Diplotaxis.

15. Bragsion.

19. Sigymbrium

22. Ertamom.

31. Arabis.

17. Conringia.

19. SIEYMBrLUM.

19. Sisymbrium,

24. BarbarEa.

19. Sigymbric:

28. Leaven worthle

9. Subularia.

18. Cakile.

\section{Coronopus.}

10. Capgella.

6. ThLABPI.

7. LePIDIUM.

27. LUNaRia.

23. Radicula.

3. Lobularia,

4. Alyssum.

1. Draba.

2. Bruteroa.

1. DrabA*

29. Dentaria.

14. Raphando.

26. Iopanthus.

80. CARDAMINE 


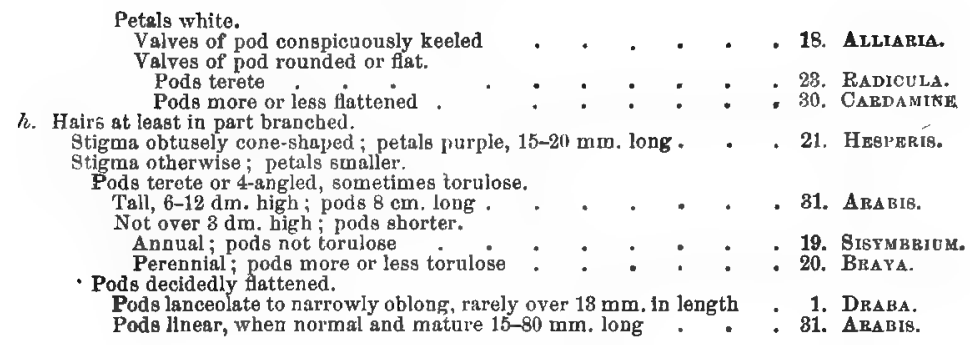

\section{DRÀBA [Dill.] L.}

Pod oval, oblong, or even linear, flat; the valves plane or slightly convex; the partition broad. Seeds several or numerous, in 2 rows in each cell,

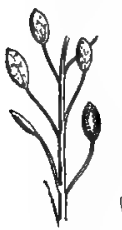

731. D. verna.

Pal't of fruiting raceme $\times \frac{2}{3}$. Potal $\times 11 / \%$.

Eu.) Fig. 731 . marginless. Cotyledons accumbent. Filaments not toothed. Low herbs with entire or toothed leaves, and white or yellow flowers; pubescence often stellate. (Name from $\delta \rho \alpha \beta \eta$, applied by Dioscorides to some cress; meaning unknown.)

§1. ERÓPHILA (DC.) Reichenb. Annual or biennial; flowers white, cleistogamous; petals 2-cleft.

1. D. vérna L. (Whitlow Grass.) Small (scapes $2.5-8 \mathrm{~cm}$. high); leaves all radical, oblong or lanceolate; racemes elongated in fruit; pods varying from round-oval to oblong-lanceolate, smooth, shorter than the pedicels. - Sandy waste places and roadsides, e. Mass, to Minn. and southw. - A species remarkable as an aggregate of many closely related forms which, from their cleistogamy, seldom cross or intergrade. Apr., May. (Nat. from

§2. DRABELLA DC. Winter annuals; leafy stems short; leaves oblang or obovate, hairy, sessile; petals entive or merely emarginate, white (yellow in no. 4); style none.

2. D. caroliniàna Walt. Small (2.5-12 cm. high) ; peduncles scape-like; petals usually twice the length of the calyx; raceme short or corymbose in fruit $(1.2-2.5 \mathrm{~cm}$. long); pods broadly linear, smooth, much longer than the ascending pedicels.--Sandy and waste fields, e. Mass. to Minn., Neb., and southw. March-May. Fig. 732. - Petals often wanting in the later racemes, especially in the var. mior Antha (Nutt.)

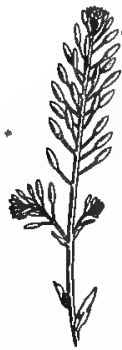

794. D. brachycarpa. Inflorescence $\times 2 / s$. Gray, with minutely rough-hairy pods, which is found with the other, westw.

3. D. cuneifolia Nutt. Leaves obovate, wedge-shaped, or the lowest spatulate, toothed; raceme somewhat elongated in fruit (2.5-7.5 cm.), at length equaling the naked peduncle; petals emarginate, much longer than the calyx ; pods oblong-linear, minutely hairy, longer than the spreading pedicels. - Grassy places, $\mathrm{Ky}$., Ill.? to $\theta$. Kan., southw., and southwestw. March, Apr. Fig. 733.

4. D. brachycárpa Nutt. Low (5-10 cm. high), minutely pubescent; stems leafy to the base of the dense at length elongated raceme; leaves (4-8 ram. long) narrowly oblong or the lowest ovate, few-

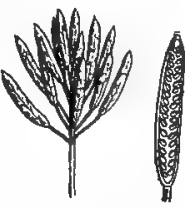

732. D. caroliniana.

Fruiting raceme $\times 2 / s$.

Fruit with valves removed $\times 11 / 8$.

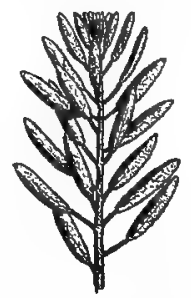

788. D. canelfolia. Fruiting raceme $\times 2 / 8$ 


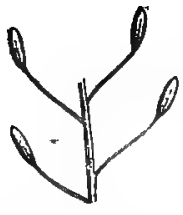

725. D. nemorosa.

Part of fruiting raceme $\times 2 / 3$.

toothed or entire; flowers small; pods smooth, narrowly oblong, acutish ( $4 \mathrm{~mm}$. long), about the length of the ascending or spreading pedicels. - Open ground, Va. to Kan., and southw. Apr. FIG. 734. - Petals sometimes minute, sometimes none.

5. D. nemoròsa L. Leaves oblong or somewbat lanceolate, more or less toothed; racemes elongated (1-2 dm. long in fruit); petals emarginate, small; pods elliptical-oblong, half the length of the horizontal or widely spreading pedicels, pubescent or smooth.-Fort Gratiot, Mich., n. Minn., northw. and westw. (Eu.) Fig, 735.

§3. DRABAEA Lindblom. Petals not notched or cleft; perennial or biennial, leafy-stemmed, leaves finely stellate-pubescent; flowers white; style definite.

Pods pubescent.

Style less than $1 \mathrm{~mm}$. long

Style 2-4 mm. long : "

Pods glabrous

6. D. stylàris J. Gay. Caudex simple or branching; flowering stems simple or slightly branched, pilose, 0.5-3.5 dm. high, remotely leafy ; basal rosettes with oblanceolate entire or remotely dentate canescent leaves (1-4 cm. long), the cauline leaves ovate to oblong, usually dentate; racemes loose; pedicels short, ascending; pods narrowly oblong to lanceolate, sometimes twisted, 7-12 mm. long. (D. incana Man. ed. 6, not L.) - Dry calcareous cliffs and ledges, locally from Lab. to N. B. and $\mathbf{n}$. Vt.; Rocky Mts. May, June. (Furasia.)

7. D. ramosissima Desv. Darker green, less pubescent; leaves laciniatetoothed; racemes corymbosely-branched; pedicels elongate, spreading; pods oval-oblong or lanceolate, strongly twisted, 4-10 mm. long. - Cliffs, Va. to Ky., and southw. Apr.June.

8. D. arábisans Michx. Caudex usually much-branched, the flowering stems simple or slightly branched, $1.5-4.5 \mathrm{dm}$. high, sparingly pubescent; basal leaves oblanceolate or spatulate, entire or somewhat dentate, thin, green, sparingly stellate, 1-7 cm. long, cauline scattered, serrate-dentate; racemes loose; pedicels divergent ; pods elliptic-lanceolate, much twisted, 9-15 mm. loug; style about $1 \mathrm{~mm}$. long. (D. incana, var. arabisans Wats.) - Rocky (usually calcareous) banks, Nfd. to Ont., locally s. to Me., Vt, and n. and w. N. Y. MayJuly. Fig. 736.

Var. orthocárpa Fernald \& Knowlton. Low (1-3 dm. high); pods flat, 5-10 mm. long. - Lab. to N. B. and n. Vt.

Var. canađénsis (Brunet) Fernald \& Knowlton. Low (1-1.5 dm. high); pods elliptic-ovate to suborbicular, 5-7 mm. long. - St. Joachim, Que.

\section{BERTERÒA DC.}

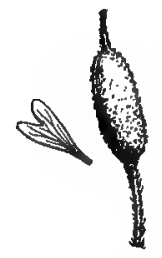

737. B. incena.

Petal $\times 2$.

Pod $\times 2$.

Pod elliptic; seeds several, winged. Petals white, 2-parted. Pubescence stellate. (Carlo Guiseppe Bertero, Piedmontese botanist.)

1. B. Incana (C.) DC. Pale green, 3-6 dm. high, branched; leaves entire, lanceolate; pods canescent-pubescent, plump, 2.5$3.5 \mathrm{~mm}$. thick. (Alyssum L.) - Recently introduced (with clover seed ?), becoming common in N. F. ; occasional in other Atlantic States, and extending inland. (Nat. from Eu.) Frg. 737.

2. B. MUTÁвilis (Vent.) DC. Similar; pods sparingly pubescent or glabrate, flattish, 4.5-6 $\mathrm{mm}$. broad. - Roadsides and cultivated ground, Mass. ; less frequent than the preceding. (Adv, from $\mathbf{E u}$.) 


\section{LOBUlària Desv. Sweet Alyssim}

Pod as in Alyssum. Petals white, entire. Cotyledons accumbent. Hairs of the stem and leaves 2-pointed, appressed, attached in the middle. (Latin lobulus, a little lobe, probably referring to the 2-lobed hairs.)

1. L. Maritrima (L.) Desv. Slightly hoary; leaves linear; flowers small, honey-scented. (Alyssum Lam.; Koniga R. Br.) - Often cultivated, and occasiunally spontaneous. (Introd. from Eu.)

\section{ALÝSSUM [Tourn.] L.}

Pod small, orbicular, with only one or two wingless seeds in a cell; valves nerveless, somewhat convex, the margin flattened. Flowers yellow or white.

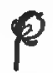

738. A, slyssoides.

Pod with persistent calyx $\times 2 / 8$.

Cotyledons accumbent. Plant stellate-pubescent. (Greek name of a plant reputed to check hydrophobia, as the etymology denotes.)

1. A. ALYssoldes L. Dwarf hoary annual, with linearspatulate leaves, pale yellow or whitish petals little exceeding the persistent calyx, and orbicular sharp-margined 4-seeded pod, the style minute.

grass-land. (Adv. from Eu.) Fig. 738.

(A. calycinum L.) - Occasional in

\section{LESQUERÉLLA Wats.}

Pod mostly globular or inflated, with a broad orbicular to ovate hyaline partition nerved to the middle, the hemispherical or convex thin valves nerveless. Seeds few or several, in 2 rows, flat. Cotyledons accumbent. Filaments toothless. - Low horbs, hoary with stellate hairs or lepidote. Flowers mostly yellow. (Named for Leo Lesquereux, distinguished bryologist and paleobotanist, 18051889.)

1. L. globdsa (Desv.) Wats. Minutely hoary all over stems spreading or decumbent from an annual or biennial root; leaves oblong or lanceolate, with a tapering base, repand-toothed or nearly entire; raceme at length elongated, with filiform diverging pedicels; petals light yellow; style filiform, much longer than the small globose acutish

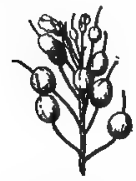

740. L. gracilis. Part of fruiting raceme $\times 2 / 8$. about 4-seeded pod; seeds marginless. (Vesicaria Shortii Torr.) - Rocky banks, Ky. and Tenn. May, June. Fig. 739.

\section{L. argéntea (Pursh) MacM. Bien-}

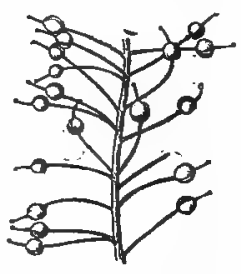

789. L. globosa. Part of Praiting raceme $\times 2 / s$. nial or perennial; pubescence compact; leaves linear-oblanceolate, mostly entire; pods pubescent, pendulous on recurved pedicels; style long. (L. ludoviciana Wats.) - Minn. to Neb. and southwestw.

3. I. grácilis (Hook.) Wats. Annual, slender; pubescence very fine; leaves narrowly oblanceolate; pods glabrous, suberect on ascending or curved pedicels, stipitate; style long. (Vesicaria

Hook.) - Mo. and Kan. to Tex. Fig. 740.

\section{THLÁspi [Tourn.] L. Penny Cress}

Pod orbicular, obovate, or obcordate, flattened contrary to the narrow partition, the midrib or keel of the boat-shaped valves extended into a wing. Seeds $2-8$ in each cell. Cotyledons accumbent. Petals equal. - Low plants, with root-leaves undivided, stemleaves arrow-shaped and clasping, and small white or purplish flowers. (Name from $\theta \lambda d \epsilon \omega$, to crush, from the flattened pod.)

1. T. arvense L. (Field P. ol Mithridate Mustand.) Smooth annual; lower leaves wing-petioled, the upper sagit-

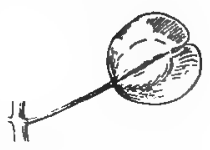

741. T. arrense. $\operatorname{Pod} \times 2 / a$ 
snte-clasping; broadly winged pod $1.2 \mathrm{~cm}$. in diameter, deeply notched at top; style minute. - Wasce places; not common, except along our northern borders, where too abundant and called "FRENCHWEeD." (Nat. from Eu.) FIg. 741 .

2. T. PERFOLIATUM L. Leaves sessile, the upper subperfoliate; pod 3maller (5 mm. broad). - Reported as occurring near Hamilton, Unt. (Adv from $\mathrm{Eu}$.)

\section{LepididM [Tourn.] L. Pepperwort. Peppergrass}

Pod roundish, much flattened contrary to the narrow partition; valves boatshaped. Seeds solitary in each cell, pendulous. Cotyledons incumbent, or in no. 1 accumbent! Flowers small, white or greenish. (Name from $\lambda \epsilon \pi l \delta \iota \nu, a$ little scale, alluding to the fruit.) - Ours are annuals or biennials, except the iast.

* Leaves all with a tapering base, the upper linear or lanceolate and entire, the lower and often the middle ones incised or pinnatifid.

- Stamens 2 ; pods orbicular or oval, slightly notched at top; style minute or none; fruiting pedicels slender, widely spreading; plant green.

1. L. virgínicum L. (WiLd PePPergrass.) Cotyledons accumbent and

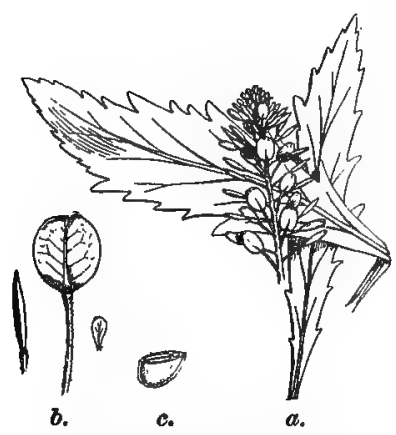

742. L. virginicum.

a. Leaves and tip of raceme $\times 2 / 3$.

b. Septum, pod, and petal $\times 21 / 3$.

c. Cross-section of seed $\times 4$. seed minutely margined; pod marginless or obscurely margined at the top; petals present, except in some of the later flowers. - A common weed of roadsides and waste places, June-Sept. Fig. 742 .

2. L. apétalum Willd. Nearly scentless; leaves toothed or pinnatifid ; cotyledons incumbent as in the following; pod orbicular, minutely wing-margined at the top; petals usually wanting. ( $L$. intermedium Man.

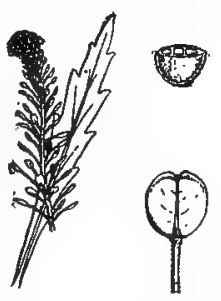

743. L. apetalum. ed. 6.) - Dry places, espe- Leaf and tip of raceme cially roadsides, by rail- $\times 8 / 8$. roads, etc., perhaps native Pod $\times 21 / 3$. in the West, recently introd. Cross-section of seed eastw. (Eurasia.) Fig. $\times 4$.

743.

3. L. RUderale L. Very fetid; lower leaves

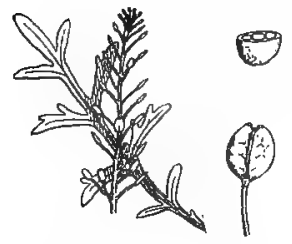

744. L. raderale.

Leaf and thp of raceme $\times 2 / 8$. Pod $\times 2 \frac{1}{3}$.

Cross-section of seed $x 4$. bipinnatifid; the smaller and oval pods and seeds marginless; petals none. - Roadsides and waste places, chiefly near Atlantic ports. (Nat. from Eu.) FIG. 744.

+ - Stamens 6; pods ovate, winged; style more evident in deeper notch; pedicels thickish, compressed, ascending; plant very glaucous.

4. L. sativgm L. (GARDen CRess.) Glabrous annual (3 dm. high); lower leaves bipinnatifid; racemes long and stiff ; petals present. - Common salad plant, tending to escape from cultivation, (Introd from Eu.)

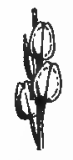

745. L. sativam Part of frult'ng raceme $x ":$, 
* * Stem-leaves with a sagittate partly clasping base, rather crowded.

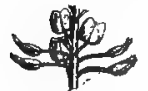

746. I. campestre. Part of fruiting raceme $\times \%$.

5. L. CAMPÉstre (L.) R. Br. Minutely soft downy; leaves arrow-shaped, somewhat toothed; pods ovate, winged, rough, the style longer than the narrow notch. Fields, roadsides, etc., becoming common. (Nat. from Eu.) FIG. 746.

6. I. Dràba L. Perennial, obscurely hoary; leaves oval or oblong, the upper with broad clasping auricles; flowers corymbose; pods heartshaped, wingless, thickish, entire, tipped with a conspicuous style. - Waste places and cultivated grounds; not common. (Nat. from Eu.) FIG. 747.

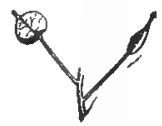

747. L. Draba. Part of fruiting raceme $\times 2 / 8$.

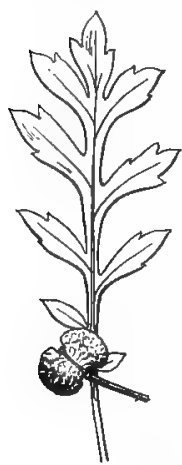

748. C. diaymus.

\section{Corónofus Ludwig. Wart Cress. Swine Cress}

Pod flattened contrary to the narrow partition; the two cells indehiscent, strongly wrinkled or tuberculate, 1-seeded. Cotyledons narrow and incumbently folded transversely. Diffuse or prostrate fetid annuals or biennials, with ininute whitish flowers. Stamens often only 2. (Name from кор crow, and moús, foot, from the deeply cleft leaves.) SEnEBIERA Poir.

$\checkmark$ 1. C. Df́prus (L.) Sm. Leaves 1-2-pinnately parted; pods notched at the apex, rough-wrinkled. (Senebiera Pers.) - Waste places, chiefly near ports. (Adv. from the Old World and now widely distributed as a cosmopolitan weed.) FIG. 748.

2. C. PRocú MBens Gilibert. Leaves less divided, with narrower lobes; pods not notched at the apex, tubercled. (C. Coronopus Karst.; Senebiera Coronopus Poir.) -Ballast, infrequent, Leaf and pod $\times 22 / 3$. from Eu.) Fig. 749 .

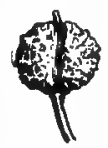
much rarer than the preceding species. (Adv. 749. C. procumb. Pod $\times 2 \% \frac{1}{8}$.

\section{SUBULÀRIA L. AwLworT}

Pod ovoid or globular, with a broad partition; the turgid valves 1-nerved. Seeds several. Cotyledons long and narrow, incumbently folded transversely, i.e., the cleft extending to the radicular side of the curvature. Style none. $A$ dwarf stemless perennial, aquatic; the tufted leaves awl-shaped (whence the name). Scape naked, few-flowered, $2-8 \mathrm{~cm}$. high. Flowers minute, white.

1. S. aquática $\mathrm{L}$. The only species. - Margins of lakes and slow streams, Nfd. to B.C., southw, to centr. N. E., Wyo., and Cal.; local. Aug., Sept. (Eu., Siber.)

\section{Capsélla Medic. Shepherd's Purse}

Pod obcordate-triangular, flattened contrary to the narrow partition; the valves boat-shaped, wingless. Seeds numerous. Cotyledons incumbent. Annuals; petals small, white. (Name a diminutive of capsa, a box.)

1. C. Búrsa-Pastóris (L.) Medic. Stem.leaves arrow-shaped, sessile. (Bursa Britton.) - Common weed; Apr.-Sept. (Nat. from Fu.) - Extremely variable in foliage and outline of pod. Upon these characters Almquist has proposed sixty-three forms or elementary species.

\section{Camelina Crantz. False Flax}

Pod obovoid or pear-shaped, pointed, margined; partition broad; valves 1-nerved. Seeds numerous, oblong. Cotyledons incumbent. Rtyle slender. Flowers small, yellow. (Nane from $\chi_{\alpha} \alpha \alpha$, , dwarf, and $\lambda(\mu 0 \nu, f a x$. ) 


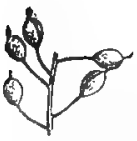

750. O. sativa.

Part of fruiting raceme $\times 1 / 3$.

1. C. satìva (L.) Crantz. Annual; leaves lanceolate and arrow-shaped; pods large (6-7 $m m$. broad), on pedicels $1.2-3 \mathrm{~cm}$. long. - A weed in newly planted fields, etc. (Nat. from Eu.) FIg. 750 .

2. C. Microchrpa Andrz. More slender; racemes long; pedicels 8-18 mm. in length; pods smaller, 4-5 nim. broad. (C. silvestris Wallr.) - Roadsides, newly seeded fields, etc. (Nat. from Eu.) Fig. 751.

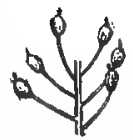

751. O. microcarpa

Part of fruiting raceme $\times 1 / 3$.

\section{NÉslia Desv. Ball Mustard}

Pod subglobose, compressed, beaked, indehiscent, 1-celled or obscurely 2-celled, the surface reticulated. Seed 1 (rarely 2). Cotyledons incumbent.. Style slender. Flowers small, yellow. (Named for $\%$. A. $N$. de Nesle of Poitiers.)

1. N. PANiculata (L.) Desv. Slender annual or biennial, somewhat stellate-pubescent, simple up to the inflorescence; leaves oblong, sagittate-clasping; racemes elongate; pedicels slender, spreading, 5-9 mm. long; capsule 2-3 $\mathrm{mm}$. in diameter. - Grain fields and waste places, e. Que. to B. C., locally s. to Pa. (Nat. from Eu.) FxG. 752.

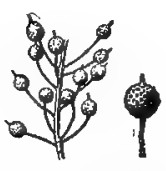

752. N. paniculata.

Part of fruiting raceme $\times 2 / 3$.

$\operatorname{Pod} \times 11 / 8$.

\section{CAKÌle [Tourn.] Ludwig. Sea Rocket}

Pod short, 2-jointed across, fleshy, upper joint separating at maturity ; each joint indehiscent, 1-celled and 1-seeded, or the lower sometimes seedless. Seed erect in the upper, suspended in the lower joint. Cotyledons obliquely accumbent. - Seaside fleshy annuals. Flowers purplish. (An old Arabic name.)

1. C. edéntula (Bigel.) Hook. (American S.) Leaves obovate, sinuate and toothed; lower joint of the fruit obovoid, emarginate; the upper ovate, flattish at the apex. (C. americana Nutt.) - Atlantic coast and shores of the Great Lakes. July-Sept. - Joints nearly even and fleshy when fresh; the upper one 4-angled and appearing more beaked when dry.

\section{RÁPHANUS [Tourn.] L. RADISH}

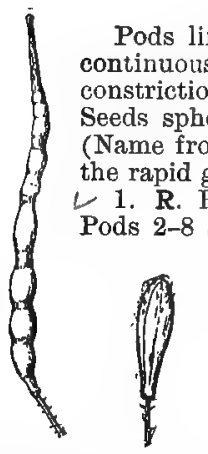

758. R. Raphanistrum.

Pod $\times \%$, Bud $\times 1 \frac{1 / 3}{2} 754$

Pods linear or oblong, tapering upward, indehiscent, several-seeded, continuous and spongy within between the seeds, or necklace-form by constriction between the seeds, with no proper partition. Style long. spherical and cotyledons conduplicate. - Annuals or biennials. (Name from $\dot{\rho} a, q u i c k l y$; and $\phi a i \nu \epsilon \sigma \theta a i$, to appear, alluding to the rapid germination.)

1. R. Raphanístrum L. (Wild R., Jointed Charlock.) eded, necklace-form, slender-beaked; leaves lyreshaped, rough; petals yellow, turning whitish or purplish, veiny. - A troublesome weed in fields, Nfd. to Ont. and Pa. (Nat. from Eu.) Frg. 753.

2. R. satìvug L. (RADish.) Petals pale purple; pods thick, scarcely moniliform, 2-3-seeded, with conical beak. - Persistent about old fields, frequent. (Introd. from Eu.) Fig.
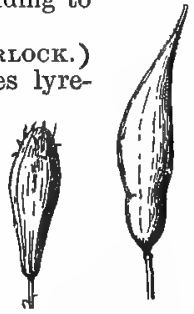

754. R. sativus. Bud $\times 12 / 3$. Pod $\times 2 / 8$.

\section{BRÁssica [Tourn.] L. Mugtard. Turnip}

Pod slender or thickish, nearly terete or 4-sided, with a stout often 1-seeded beak; valves 1-5-nerved. Seeds globose, 1-rowed. Cotyledons conduplicate 
- Annuals or biennials, with yellow flowers. Lower leaves mostly lyrate, inciser, or pinnatifid. (The Latin name of the Cabbage.)

* Beak of the pod large, flat or conspicuousiy anyled, usually containing one seed in an indehiscent cell; leaves not clasping at the base.

1. B. AlbBa ( $\mathrm{I}_{\text {.. }}$ ) Boiss. (Whiтe M.) Pods bristly, ascending on spreading pedicels, mure than half their length occupied by the sword-shaped beat; leaves

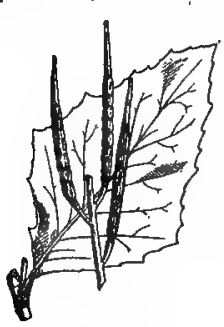

T.j5. B, arvensis.

Steun-leaf and part of fruiting raceme $\times 1 / 3$. all pinnatifid ; seeds pale. (Sinapis L.) - Cultivated, and occasionally spontaneous. (Introd. from Eu.)

2. B. ARVÉnsis (L.) IKtze. (Charlock.) Knotty pods fulty one third occupied by a stout 2-edged beak; upper leaves rhombic, scarcely petioled, merely toothed; fruiting pedicels short, thick; pods smooth or rarely bristly, $4 \mathrm{~cm}$. long. (B. Sinapistrum Boiss. ; Sinapis arvensis $\mathrm{L}_{\text {. }}$ - - Noxious weed in grainfields, etc. (Nat. from Eu.) Fig. 755. * Beak smaller, conical, seedless ; leaves not clasping.

3. B. Júncea (L.) Cosson. Nectrly glabrous, somewliat glaucous; upper leaves oblong, subentire; attenuate at the base; the lower lyrate; pedicels slender, spreading; pod at length $3.5 \mathrm{~cm}$. long. - Roadsides, graill-fields, etc., recently introduced but already conmon. (Nat. from Asia.) Fig. 756.

4. B. JAPónica Siebold. (CURled M.) Leaves crisped and much cleft; ntherwise similar to the last. - Occasionally established after cultivation. (Introd. from Asia.)

อ. B. Nìk A (L.) Koch. (BLACK M.) Hirsute with scattered hairs, green; leaves slender-petioled, the lower with a very large terminal lobe and a few

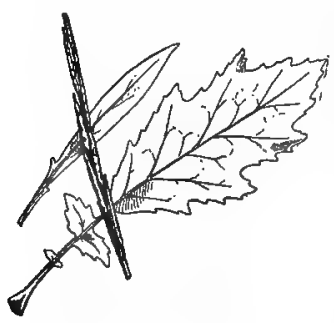

757. B, nigrs.

Leaves and part of fruiting raceme $\times 1 / 2$. small lateral ones; pods short, $1.5-1.8 \mathrm{~cm}$. long, on short erect pedicels, appressed; seeds dark, very pungent. - Roadsides and waste places, common. (Nat, from Eu.) Fig. 757.

** Leaves cordate- or auriculate-clasping at the base.

6. B. Campéstris L. (RutaBAGA.) Glaucous, hispidulous with scattered hairs at least when young; leaves lyrately lobed; flowers rather large, pale yellow (Fig. 758); also B. NAPUs L. (RAPE), which is very similar but entirely glabrous; and B. RAPA L. (TURNIP), which is greener, and has smaller brighter yellow flowers and a thickened ront; all tend to escape from or persist

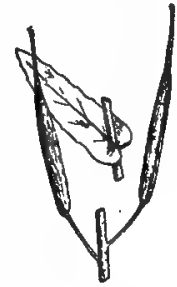

758. B. campestris, Stem-leaf and part of fruiting raceme $\times 1 / 8$. after cultivation, and are often noxious weeds. (Introd. from Fu.) B. ocerdceA L. (CABBagE), with broad fleshy glaucous leaves, is occasionally found in a half-wild state. (Introd, from Eu.)

\section{DIPLOTÁẊIS DC.}

Seerls nvoid, in two rows in each cell ; other characters as in Brassica. Leaves toothed or pinnatifid; flowers yellow. (Name from the Greek, alluding to the biseriate seeds.)

1. D. MURAL1s (L.) DC. Annual or biennial, smooth or sparingly hispid, leafy only near the branching base; leaves oblong, toothed or somewhat pia- 
natifid with short lobes ; flowers small ; fruiting pedicels 8-16 mm. long, spreading; pods linear-terete, erect. - A bout Atlantic ports, and rarely inland. (Adv. from Eu.)

2. D. TENuifólia (L.) DC. Similar but perennial and more caulescent; leaves pinnatifid, and lobes longer; flowers larger, $1 \mathrm{~cm}$. long; pedicels in fruit 2-3 cm. long. - Similar localities. (Adv. from Eu.)

\section{CONRÍngia [Heist.] Link. Hare's-ear Mustard}

Pods long, linear, 4-angled, somewhat rigid. Seeds oblong, one row in each cell. Cotyledons incumbent. - Glabrous annuals with sessile elliptic entire stemclasping leaves. (Named for Prof. Hermann Conving of Helmstadt, 1606-1661.)

1. C. ORIENTÀ LIs (L.) I)umort. Tall, slightly succulent; flowers pale yellow. (C. perfoliata Link.) - Waste places and newly seeded ground, becoming more common. (Adv. from Eu.)

\section{8. alliaria Adans. Garlic Mustard}

Pods long, linear, angled ; valves keeled, 3-nerved; stigma simple, sessile or nearly so. Oval sepals caducous. Pubescence simple or none. - Ours biennial with deltoid-ovate cordate dentate petiolate leaves and small white flowers. (Name from Allium, onion or garlic, referring to the odor.)

1. A. offictiralis Andrz. Tall; pods $2.5-5 \mathrm{~cm}$. long, spreading, borne on short thick pedicels. (A. Alliaria Britton.) - Roadsides and near habitations, eastw., local. (Introd, from Eu.)

\section{SisÝmbridm [Tourn.] L. Hedge Mustard}

Pod terete, flattish or 4-6-sided, the valves 1-3-nerved. Seeds oblong, marginless, in 1 or 2 rows in each cell. Cotyledons incumbent. Calyx open. - Flowers small, white or yellow. Pubescence spreading. (Latinized from an ancient Greek name for some plant of this family.) Ours are mostly annuals or bienuials.

Leafy-stemmed; leaves pinnate or pinnatifld.

Stigraa 2-lobed; pubescence, when present, of simple hairs.

Pods awl-shaped, $1-1.5 \mathrm{~cm}$. long

Pods linear-cylindric, longer.

Pods firm, 6-10 cm. long

Pods delicate, $8-4 \mathrm{~mm}$. long
Stigms simple; pubescence forked or stellate, or reduced to minute granules; pods delicate.

Seeds 2-ranked in each cell

Seeds 1-ranked in each cell.

Leaves pinnatifid or bipinnatifid; pods $6-15 \mathrm{~mm}$. long

Leaves tripinnate; pods about $2 \mathrm{~cm}$. long .

Leaves chiefly basal, entire or barely toothed

1. S. offeinale.

2. S. adtiasimum. 8. S. Irio.

4. S. canescens.

5. S. incisum.

6. S. Sophia.

7. S. Thalianum.

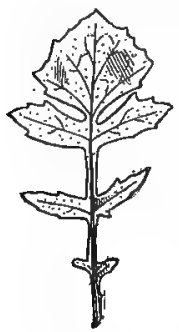

759. S. officinale. Leaf $\times \%$.

1. S. OfFicrinde (L.) Scop. Leaves runcinate; flowers small, yellow; pods thickwalled, at maturity firm in texture, pubescent or tomentulose, close-pressed to the few-branched stem, scarcely. stalked. Waste ground, Me. and Ont.; local; also Cal., ete. (Adv. from Eu.) Fig. 759.

Var. LEIOCÁRPUM 1)C. Pods essentially glabrous. - A common and unsightly weed. (Nat. from $\mathrm{Eu}$.)

2. S. Altfsimum I. (Temble MrgTARD.) Tall ; leaves deeply pinnatifid with narrovo segments ; flowers pale yellow ; pods rigid, very long, divergent, hardly thicker than the short thickish pedicels. - Waste places, roadsides, etc., a recent immigrant, locally abundant as a pernicious weed. (Nat. from Eu.) FIG. 760 .

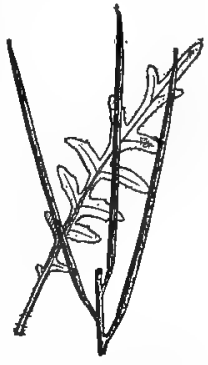

760. S. altissinum. Leaf and part of fruit. ing raceme $\times 1 / 8$. 
3. S. IRIO L. Sinular; leaves runcinate-pinnatifid, the terminal portion large; pods ascending on slender pedicels. - Meadow, Grand Rapids, Mich. (Miss Cole); ballast at Atlantic ports. (Adv. from Eu.)

4. S. canéscens Nutt. Leaves pinnatifid to tripinnatifid, canescent with soft short hairs; flowers yellowish, very small; pods in long racemes, oblongclub-shaped or linear-cylindric, shorter than the horizontal pedicels; seeds 2-ranked in each cell. (Sophia pinnata Howell.) - Pa. to Fla. and westw. Passing by various intermediates to

Var. brachycárpon (Richards.) Wats. Green; stems at most cinereousstellate at base, usually glabrous or glandular-pulverulent. (Sophia Rydb.) Que. to Assina., s. to Ky., Mo., Kan., etc.

5. S. incisum Engelm. Similar; green or greenish; pods more slender, 7-15 mon. long, about equaling the spreading pedicels; seeds mostly 1-ranked. (Sophia Greene.) - A western polymorphous species, extending eastw. to Ont. and Minn.

Var. filipes Gray. Pedicels thread-like, spreading, much exceeding the pods. - Minn., and westw.

Var. Hartwegianum (Fourn.) Wats. The very numerous short pods on still shorter suberect pedicels. - Minn., and westw.

6. S. Sóphia L. A similar hoary species, with decompound leaves; pods slender, about $2 \mathrm{~cm}$. long, ascending; seeds 1-ranked. (Sophia Britton.) Sparingly in waste places. (Nat. from Eu.)

L- 7. S. Thalianum (I.) J. Gay. (Mouse-ear Cress.) Slender, branched, hairy at the base; leaves obovate or oblong, entire or barely toothed; flowers white; pods linear, somewhat 4-sided, longer than the slender spreading pedicels. (Stenophragma Celak.) - Old fields and rocky places, Mass. to "Minn.," Kan. and southw. Apr., May. (Nat. from Eu.)

\section{BRÀYA Sternb. \& Hoppe}

Pods cylindric to linear, often torulose, the septum of peculiar and characteristic structure with its cells elongated transversely or obliquely. Flowers white or purplish, capitate in anthesis. - Arctic perennials with single root and branched hairs. (Named for Contht $F$. G. de Bray of Rouen.)

1. B. hùmilis (C. A. Mey.) Robinson. Sparingly pubescent, 1-2 dm. high or less; leaves narrowly oblanceolate, mostly with coarse and sharp teeth; pods narrow, subcylindrical, 8-18 $\mathrm{mm}$. long, ascending on short pedicels, beaked by a short style; seeds 1-ranked. (Sisymbrium C. A. Mey.) - Limestone cliffs, Willonghby Mt., n. Vt., Isle Royale, Mich., and northw.; and in the Canadian Rocky Mts. (Siber.)

\section{HÉSPERIS [Tourn.] L. ROCKET}

Pod linear, nearly cylindrical ; stigma lobed, erect. Seeds in 1 row in each cell, oblong, marginless. Cotyledons incumbent. - Biennial or perennial, w:th serrate sessile or petiolate leaves, and large purple flowers. (Name from $\dot{\epsilon} \sigma \pi \epsilon \rho$, evening, from the evening fragrance of the flowers.)

1. H. matronalis L. (Dame's Violet.) Tall; leaves lanceolate, acuminate; pods $5-10 \mathrm{~cm}$. long, spreading. - Sometimes cultivated, and spreading to roadsides, etc. (Introd. from Eu.)

\section{ERÝSIMUM [Tourn.] T. Treacle Mustard}

Pud linear', 4-sided, the valves keeled with a strong midrib; stigma broadly lobed. Seeds in 1 row in each cell, oblong, inarginless. Cotyledons in ours (ofterl obliquely) incumbent. - Chiefly biennials, with yellow flowers; the leaves not clasping. Pubescence of appressed 2-i;-parted hairs. (Name from

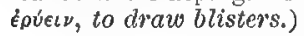




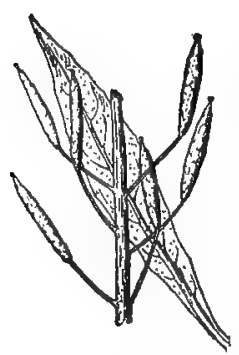

761. E. cheiranthoides.

Leaf and part of fruiting raceme $\times 2 / 3$.

1. E. cheiranthoides L. (Worm-Seed Mustard.) Minutely roughish, branching, slender; leaves lanceolate, scarcely toothed; flowers small; pods small and short (1-2 cm. long), very obtusely angled, ascending on slender divergent pedicels. - Banks of streams or in open sterile soil, July, Aug. (Eu.) Fig. 761.

2. E. parviflòrum Nutt. Perennial; stem erect, often simple; leaves linearoblanceolate, entire or the lowest coarsely toothed; flowers small $6 \mathrm{~mm}$. long); pods narrow, 2.5-6.2 cm. long, ascending on short pedicels. (E. inconspicunm MacM.; E. syrticolum Sheldon). - Ont. and Minn. to Kan. and westw. FIG. 762.

3. E. REPANDUM $\mathrm{L}$. Resembling the last, but annual; leaves repand-denticulate; flowers 7-9 $\mathrm{mm}$. long; pods 4-8 $\mathrm{cm}$. long, slender, divergent, on very short thick pedicels. - Waste places, $O$. to Mo. and Kan.; and about Atlantic ports. (Adv. from Eu.)

4. E. ásperum DC. (WESTERT WALL-FLOWER.) Plant stout, 3-6 dm. high, minutely roughish-hoary ; stem simple ; leaves lanceolate to linear, entire or somewhat toothed; the

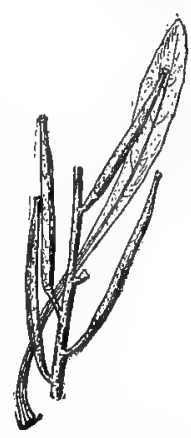

T62. E. parviflorum.

Leaf and part of fruiting raceme $\times \%$. bright orange-yellow flowers crowded; petals $1.5-2.5 \mathrm{~cm}$. long, orbicular, on very slender claws; pods nearly erect or widely spreading on short pedicels, elongated (7-10 cm. long), exactly 4-sided; stigma 2-lobed. - Nfd. (Waghorne); Mingan I., Que. (Macoun); O. (on limestone cliffs) to Ark., S. Dak., and common westw. June, July.

\section{RAdícula [Dill.] Hill. Water Cress}

Pod a short silique or a silicle, varying from slender to globular, terete or nearly so; valves strongly convex, nerveless. Seeds usually numerous, small, turgid, marginless, in 2 irregular rows in each cell (except in $R$, sylvestris). Cotyledons accumbent. - Aquatic or marsh plants, with yellow or white flowers, and commonly pinnate or pinnatifid leaves, usually glabrous. (Name meaning a little radish.) Roripa Scop. Nasturtum R. Br.

§1. Petals white, twice the length of the calyx; pods linear; leaves pinnate.

1. R. Nastú Rtidm-aquáticum (L.) Britten \& Rendle. (True W.) Perennial; stems spreading and rooting; leaflets $3-11$, roundish or oblong, nearly

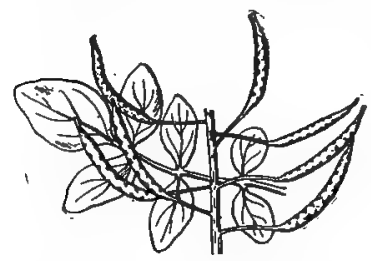

768. R. Nasturtium-aquaticum.

Leaf and part of fruiting raceme $\times 2 / 8$. entire; pods $(1.2-1.6 \mathrm{~cm}$. long) ascending on slender widely spreading pedicels. (Sisymbrium L. ; Nasturtium offcinale R. Br. ; Roripa Nasturtium Rusby.) - Brooks, ditches, etc., originally cultivated. (Nat. from Eu.) FIG. 763.

§2. Petals yellow or yellowish, seldom much exceeding the calyx; pods linear, short-cylindric, or even ovoid or globular; leaves mostly pinnatifid.

* Perennial from creeping or subterranean shoots; flowers rather large, yellow.

2. R. stritéstris (L.) Druce. (Yellow Cress.) Stems ascending; leaves pinnately parted, the divisions toothed or cut, lanceolate or linear; pods (6-12 mm. long) on slender pedicels, linear and narrow, bringing the seeds into one row; style very short. (Nasturtium R. Br.; Roripa Bess.) - Wet meadows. Nfd. to Va., westw. to Ont., Mich., and Ill.; becoming more frequent. (Nat. from Eu.) 
3. R. sinuàta (Nutt.) Greene. Stems low, diffuse; leaves pinnately cleft, the short lobes nearly entire, linear-oblong; pods linear-oblong (6-10 mm. long), on slender pedicels ; style slender. (Nasturtium

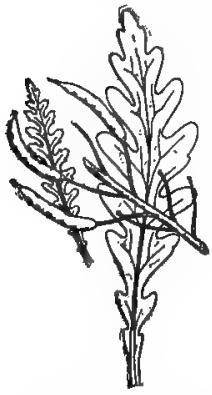

764. R. sinuata,

Leaves and part of irulting raceme $\times 2 / 3$ * Nutt.; Roripa Hitchc.) - Banks of the Miss. and westw. June. Fig. 764.

* Annual or biennial, rarely perennial (?), with simple fibrous roots; flowers small or minute, greenish or yellowish; leaves somerohat lyrate.

4. R. sessiliflora (Nutt.) Greene. Stems erect, rather simple; leaves obtusely incised or toothed, obovate or oblong; fowers minute, nearly sessile; pods elongate-oblong ( $1-1.2 \mathrm{~cm}$. long), thick; style very short. (Nasturtium Nutt.; Roripa Hitchc.) - Richnond, Va. (Churchill) to Neb., e. Kan. and southw. Apr.-June.

5. R. obtìsa (Nutt.) Greene. Stems much branched, diffusely spreading; leaves pinnately parted or dividea, the divisions roundish and obtusely toothed or repand; flowers minute, short-pediceled; pods longer than the pedicels, varying from linear-oblong to short-oval; style short. (Nasturtium Nutt. ; Roripa Britton.) - Low ground, n. Mich. (Farwell) to Tex. and westw.

Var. sphaerocárpa (Gray) Robinson. Pods globular, about equaling the pedicels. (Nasturtium Gray; Roripa Britton.) - Ill., and southwestw.

6. R. palústris (L.) Moench. (Marsin Criss.) Stem erect, 3-8 dm. high, mostly glabrous; leaves pinnately cleft or parted,

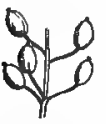

766. R. palustris var. híspida.

Part of frulting raceme $\times \frac{2}{3}$. or the upper laciniate; the lobes oblong, cuttoothed; pedicels about as long as the small flowers and mostly longer than the short-cylind ric ellipsoid or ovoid pods; style short. (Nasturtium DC.; Roripa Bess.) - Wet places or in shallow water ; common. June-Sept. (Eurasia.)

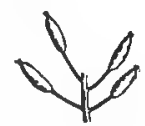

765. R. palustris. Part of fruiting raceme $\times \%$. FIG. 766 .

Var. híspida (Desv.) Robinson. Hirsute; pods globose or nearly so. (Roripa hispida Britton; Nasturtium palustre, var. Gray.) - With the type ; the commoner form eastw. (Eurasia.) Fig.766.

\$3. Petals white, murh longer than the calyx; pods ovoid or globular; leaves undivided, or the lower ones pinnatifid; root perennial.

7. R. aquática (Eat.) Robinson. (LARE CRess.) Aquatic; immersed leaves 1-3-pinnately dissected into numerous capillary divisions ; emersed leaves oblong, entire, serrate, or pinnatifid; pedicels widely spreading; pods ovoid, 1-celled, a little longer than the style. (Roripa americana Britton; Nasturtium lacustre Gray.) - Lakes and rivers, w. Que. and n. Vt. to Minn. and southw. JulyAug.

8. R. Armoracia (L.) Robinson. (Horseradish.) Root-leaves very large, oblong, crenate, rarely pinnatifid, those of the stem lanceolate; fruiting pedicels ascending ; pods globular (seldom formed) ; style very short. (Roripa Hitchc.) - Escaped from cultivation into moist ground. (Introd. from Eu.) - Roots large and long; a well-known condiment.

\section{BARBAREA R. Br. WritrR Cregs}

Pod linear, terete or somewhat 4-sided, the valves being keeled by a midnerve. Seeds in a single row in each cell, marginless. Cotyledons accumbent. - Mostly biennials, resembling Radicula; flowers yellow. (Anciently called the Herb of St. Barbara.)

1. B. vulgàris P. Br. (Common W., Yellow Rocket.) Smooth perennial; lower leaves lyrate, the terminal division round and usually large, the lateral 1-4 pairs or rarely wanting; upper leaves obovate, cut-toothed or pinzatifid at. 
the base; flowers bright yellow, somewhat racemose even in anthesis; pods erect or ascending on spreadin! pedicels. (B. lyrata Asch.; B. Burbarea MacM.)Low grounds and roadsides; apparently introduced in the Eastern and Central States, but indigenous from L. Superior northw. and westw. (Eu.)

2. B. stricta Andrz. Closely similar in foliage; flowers paler, during anthesis corymbosely aggregated at the summit of the raceme; pods alpressed. Shores and meadows, e. Que. to Alaska, s. to Va., Great Lake region, Mo., and westw. (Eu.)

3. B. Vória (Mill.) Asch. (EARLY W.) Leaves with 5-8 pairs of lateral lobes and pods longer, on very thick pedicels. (B. praecox $\mathrm{Sm}$.) - Somewhat rultivated as a winter salad, under the name of Scurvy Grass, and naturalized trom Mass. southw. (Introd. from Eu.)

\section{SELENIA Nutt.}

Pod large, oblong-elliptical, flat; the valves nerveless. Seeds in 2 rows in each cell, rounded, broadly winged; cotyledons accumbent; radicle short. - A low annual, with once or twice pinnatifid leaves and leafy-bracteate racemes of yellow flowers. (Name from $\sigma \epsilon \lambda \eta n \eta$, the moon, with allusion to Lunaria, which this genus somewhat resembles in its pods.)

1. S. aúrea Nutt. Lobes of the simply pinnatifid leaves entire or toothed; pod $1.2 \mathrm{~cm}$. long, on elongated spreading pedicels, beaked by the long slender style. - Sandy soil, Mo. and Kan. to Tex.

\section{IODÁNTHUSS T. \& G.}

Pod long, linear, somewhat flattened; valves 1-nerved; stigma entire but slightly elongated over the placentae. Seeds 1-ranked in each cell, oblong, marginless. Cotyledons essentially accumbent. — Erect perennial with purplish

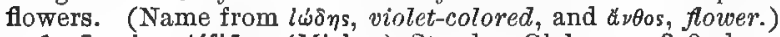

1. I. pinnatffidus (Michx.) Steud. Glabrous, 3-9 dm. high ; root-leaves round or heart-shaped, on slender petioles; stem-leaves auricled, ovate-oblong and ovate-lanceolate, sharply and often doubly toothed, tapering to each end, the lower into a winged petiole, rarely bearing a pair or two of small lateral lobes; pods 1.8-3 cm. long, on short diverging pedicels, pointed by a short style. (Thelypodium Wats.) - Alluvial river-banks, w. Pa. (Porter) to Minn., Mo., and southwestw. Fl. May, June; fr. July, Aug.

\section{LUNARIA L. MOONWORT}

Pods very large and flat. Seeds large, winged. Cotyledons accumbent. Tall herbs with large purple flowers and ovate-deltoid cordate dentate leaves, of which the enrliest are opposite. (Name from luna, the moon, alluding to the persistent silvery septum of the fruit.)

1. L. ANNUA L. (Honestr.) Annual or biennial; pods broadly elliptic, rounded at each end. - Often cultivated, and escaping in s. w. Ct. and e. $\mathrm{Pa}$. (Introd. from Eu.)

2. L. ReDivì A L. Perennial; pods broadly lance-oblong, somewhat pointed at each end. - Also cultivated, and established, it is said, near Niagara. (Introd. from Eu.)

\section{LEAVENWÓRTHIA Torr.}

Pod broadly linear or oblong, flat; the valves nerveless, but minutely reticulate-veined. Seeds in a single row in each cell, flat, surrounded by a thick wing. Embryo straight ! or the short radicle only slightly bent in the direction which if continued would make the orbicular cotyledons accumbent. - Little winter annuals, glabrous and often stemless, with lyrate leaves and short 1-fewflowered scape-like peduncles. (Named for Dr. M. C. Leavenworth, a southern botanist of the last century.) 
1. L. unifldra (Michx.) Britton. Scapes $5-15 \mathrm{~cm}$. high; leaf-lobes usually numerous (7-15); petals purplish or nearly white with a yellowish base, obtuse; pods not torulose, oblong to linear $(1.2-3 \mathrm{~cm}$. long); style short. (L. Michauxii Torr.) - Barrens, s. Ind. to Tenn. and Mo.

2. L. torulòsa Gray. Similar, but pods torulose even when young, linear; style $2-4 \mathrm{~mm}$. long; seeds acutely margined rather than winged; petals emargi. nate. - Barrens of $\mathrm{Ky}$. and Tenn.

\section{Dentaria [Tourn.] L. Toothwort. Pepper-root}

Pod lanceolate, flat. Style elongated, Seeds in one row, wingless, the funiculus broad and flat. Cotyledons petioled, thick, very unequal, their margins somewhat infolding each other. - Perennials, of damp woodlands, with long fleshy sometimes interrupted scaly or toothed rootstocks, of a pleasant pungent taste; stems leafless below, bearing 2 or 3 petioled compound leaves about or above the middle, and terminated by a corymb or short raceme of large white or purple flowers. (Name from dens, a tooth.)

Stem glabrous.

Kootstock continuous, prominently toothed.

Rootstock in terrupted by distinct constrictions.

Rootstock elongate, composed of several fusiform or subcylindre distinctly tootbed segments.

Cauline leaves with ovate or obovate petiolulate leaflets.

Cauline lerves with lanceolate sessile lesflets

Rootstock of readily separable obscurely toothed fusiform tubers Stem pubescent, at least above.

Rontstock of readily separable fusiform tubers; sepals 6-9 mm. long.

Leaves 3-parted, with linear to oblong segments

Basal leaves with ovate or thombic leaflets .

Roots tock elongate, interrupted by constrictions; sepals $3-i \mathrm{~mm}$. long

1. D. diphylla.

1. D. điphýlla Michx. Rootstock long and continuous, often branched, the annual segments slightly or not at all tapering at the ends; stems in anthesis

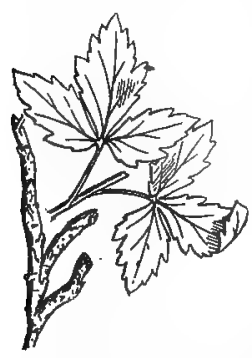

767. D, dlphyila.

Cauline leaves and rootstock $\times 1 / 2$. 1.5-3 dm. high, stoutish; leaves 3-foliolate, the basal and cauline similar, the latter 2 (rarely 3), opposite or subopposite, leaflets 4-10 cm. long, short-petiolulate, rhombic-ovate or oblong-ovate, coarsely crenate, the teeth bluntly mucronate; flowers white; sepals $5-8 \mathrm{~mm}$. long, half the length of the petals; pods rarely maturing. - Rich woods and thickets, e. Que. to s. Ont. and Minn., s. to S.C. and Ky. Apr., May.-Rootstocks 2-3 dm. long, crisp, tasting like Water Cress. FIG. 767.

2. D. măxima Nutt. Rootstock interrupted, consisting of several elongate strongly toothed segments which are constricted at ench end, the older commonly retaining shreds of old stems; cauline leaves $2-3$, alternate, often remote, leaflets $2-5 \mathrm{~cm}$. long, ovate or obovate, petiolulate, more or less ciliolate, sharply and coarsely toothed and somewhat cleft; flowers white or purple-tinged; sepals 5-7 $\mathrm{mm}$. long, half as long as the petals. - By streams in rich woods, local, s. Me. to Mich. and Pa. Apr., May.

3. D. incisifollia Eames. Rootstock much as in the last; cauline leaves 2 and opposite, rarely 3 and alternate, the leaflets $4-9 \mathrm{~cm}$. long, lanceolate, sessile, glabrous throughout, coarsely incised-dentate; basal leaves similar, with broader leaflets; flowers white or somewhat purple-tinged; sepals 6-7 mm. long; petals 1.5-2 cm. long. - Rich hillside woods, Sherman, Ct. (Eames). May.

4. D. heterophýlla Nutt. Tubers near the surface; stems, in anthesis, 1.5-4 $\mathrm{dm}$, high, glabrous or sparingly pubescent above; cauline leaves $2-3$, variontsly disposed, the leaflets 1.5-5.5 $\mathrm{cm}$. long, distinctly petiolulate, oblong-lanceolate to linear, ciliate, entire to deeply crenate, rarely laciniate; basal leaves with ovate to rhombic-obmate usually lobed leaflets ; flowers purplish ; sepals purple-tinged, 
6-9 mm. long; petals $1-1.8 \mathrm{~cm}$. long. $-\mathrm{N}$. J. and $\mathrm{Pa}$. to $\mathrm{Ky}$., and southw. Apr., May.

5. D. Laciniàta Muhl. Tubers deep-seated; stems pubescent above; cauline leaves 3, whorled or nearly so, the lateral leaflets deeply cleft, glabrous or

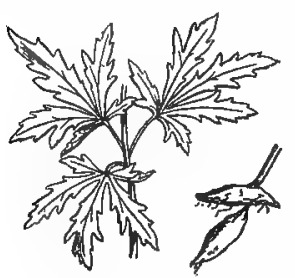

768. D. lociniata. pubescent, the segments linear to narronoly oblong, conspicuously gash-toothed; lasal leaves, when present, similar; flowers white or purplish; calyx 6-9 $\mathrm{mm}$. long; petals $1-2 \mathrm{~cm}$. long. - Rich damp woods, w. Que. and Vt. to Minn., and southw. Apr., early May. Fig. 768. Var. fntegra (Schulz) Fernald. Leaves strictly ternate, the lateral leaflets entire or slightly toothed, not cleft. $-\mathrm{N}$. Y. to Ill.

6. D. anómala Eames. Rootstock with pronounced constrictions between the fusiform tuber-like annual segments, deep-seated; stems somewhat pubescent; leaves 3-foliolate, pubescent on both surfaces; the C:tuline leaves and tubers $\times 1 / 4$. cauline 2 (rarely 3), subopposite, their leaflets 2-5.6 $\mathrm{cm}$. long, short-petiolulate, ovate to rhombic, coarsely and irregularly dentate or even incised or cleft; basal leaves, when present, similar; flowers white, tinged with purplish ; sepals $3-4 \mathrm{~mm}$. long; petals 1-1.2 cm. long. - Rich moist woods, Plainville, Ct. (Bissell). May. - Perhaps a hybrid of nos. 1 and 5 , with which it grows.

\section{Cardámine [Tourn.] L. Bitter Cregs.}

Pod linear, flattened, usually opening elastically from the base; the valves nerveless and veinless, or nearly so; placentae and partition thick. Seeds in a single row in each cell, wingless; the funiculus slender. Cotyledons accumbent, flattened, equal or nearly so, petiolate.-Mostly glabrous perennials, leafy-stemmed, growing along watercourses and in wet places. Flowers white or purple. (A Greek name, used by Dioscorides for some cress, from its cordia] or cardiacal qualities.)

\section{* Simple-leaved perennials with tuberous base.}

1. C. bulbdsa (Schreb.) BSP. (Spring Cress.) Steme upright from a tuberous base and slender rootstock bearing small tubers, simple, or rarely forking, glabrous, in anthesis $1.5-5 \mathrm{dm}$. high; root-leaves oblong to cordateovate, stem-leaves 5-8, scattered, the lower ovate or oblong and somewhat petioled, the upper sessile, almost lanceolate, all often toothed ; sepals greenish, with white margin; petals white, 7-12 $\mathrm{mm}$. long; pods linear-lanceolate, pointed with a slender style tipped by a conspicuous stigma; seeds oval. (C. rhomboidea DC.) - Wet meadows and springs, e. Mass. to Minn., and southw. May, June.

$P$ 2. C. Douglássii (Torr.) Britton. Similar; stem usually somewhat pubescent, in anthesis 1-2.5 dm. high, root-leaves orbicular or suborbicular; stemleaves 2-6, the upper border (ovate to oblong), more or less approximate; sepals purple-tinged; petals rose-purple, 1-1.8 cm. long. (C. rhomboidea, var. purpurea Torr.) - Rich low woods, Ct. to s. Ont. and Wisc., s. to Md. and $\mathbf{K y}$. Apr., early May.

* * Fibrous-rooted perennials with 1-3-foliolate leaves; southern.

3. C. rotundifdlia Michx. (Mountain Water Cress.) Stems branching, weak or decumbent, making long runners; root fibrous; leaves all much alike, roundish, somewhat angled, often heart-shaped at the base, petioled; pods small, linear-awl-shaped, equaled or exceeded by the pedicels; style slender; seeds oval-oblong. - Cool shaded springs, Carrollton, N. Y. (Peck) and Midrile. town, N. J. (Willis) to Ky., and southw. along the wats. May, June.-Flowers white, smaller than in no. 1 .

4. C. Clematitis Shuttlw. Glabrous and lax, with slender rootstock; smal! radical leaves kidney- or heart-shaped, with or without a pair of smaller latera 
leaflets; stem-leaves on sagittately appendaged petioles; terminal leaflet mostly 3-lobed; pods $2.5-3 \mathrm{~cm}$. long, much exceeding the pedicels. - Springy places in the mts., s. Va. and southw.

\section{** * Fibrous-rooted alpine perennial with simple leaves; northern.}

5. C. bellidifòlia L. Dwarf (2-3.5 cm. high), densely tufted; leaves ovate, entire, or sometimes with a blunt lateral tooth, 2-10 $\mathrm{mm}$. long, slender-petioled; flowers $1-5$, white; pods $1.5-2 \mathrm{~cm}$. long, upright, linear ; style extremely short, stout. - Arctic regions and alpine districts of the $\mathrm{n}$. hemisphere. Represented with us by

Var. láxa Lange. Looser and taller (4-11 cm. high); leaves 6-15 mm. long, on very long petioles; pods $2-3 \mathrm{~cm}$. long. - By alpine brooks, and in cold ravines, Lab. to Mt. Katahdin, Me., and Mt. Washington, N. H. ; by a brook, W. Baldwin, Me. (Miss Furbish). June, July. (Greenl.)

$$
\text { **** Root perennial; leaves pinnate; flowers showy. }
$$

6. C. praténsis L. (Cuckoo Flower.) Stem ascending from a short rootstock, simple; leaflets numerons, those of the lower leaves rounded and stalked, of the upper oblong or linear, entire, or slightly angle-toothed; petals (white or rose-color) thrice the length of the calyx; pod 2-3 cm. long, $2 \mathrm{~mm}$. broad; style short. - Wet places and bogs, Lab. to Vt., N.J., Minn, and northw.; rare. May. Also introduced or a local escape in e. and s. N.E. (Eu.)

***** Root mostly biennial or annual; leaves pinnately 5-11-foliolate; flowers small, white.

+ Stamens 4; leaflets strigose-hispid upon the upper surface.

$\checkmark 7$. C. hirsùta L. Leaves chiefly radical, with short and broad leaflets, but those on the erect stem reduced and with narrow leaflets; pods erect, on ascending or appressed pedicels. - Moist places, s. Pa. to N. C., and "Mich." (Eu.) Perhaps introduced. A doubtful specimen from w. Mass. (Miss Vail).

+ - Stamens normally 6; leaflets glabrous; stem leafy.

8. C. parvifiora L. Very slender, subsimple, glabrous or slightly pubescent upon the stem; leaflets of the radical leaves oval or the terminal suborbicular; those of the cauline very narrow, linear, not confluent; pods erect, on ascending pedicels. (C. hirsuta, var. sylvatica of some Am. auth.) - Rocky and barren soil, Me. to Ga. and westw. (Eu.) A form more branched from the base and with leaflets all narrow and often toothed has been described as $C$. arenicola Britton, growing in sandy soil in the Atlantic States but lacking constant characters.

$\checkmark$ 9. C. pennsylvánica Muhl. Larger, nearly or quite glabrous ; leaflets 7-11, the terminal one obovate, ihe lateral oblong, tending to be confluent along the rhachis; pods erect, on ascending pedicels. (C. hirsuta Man. ed, 6, in great part.) - Moist ground, common. Passes imperceptibly into a form (C. flexuosa Britton, perhaps Withering) with fewer more flabelliform leaflets and spreading pods. - Brooks, ete.

\section{1. Árabis L. Rock Cress}

Pod linear, flattened; placentae not thickened ; the valves plane or convex, more or less 1-nerved in the middle, or longitudinally veiny. Seeds marginless or winged. Cotyledons accumbent or a little oblique. - Leaves seldom divided. Flowers white or purple (rarely yellowish). (Name from the country, Arabia.)

\$1. SISYMBRtNA Wats. Seeds oblong or elliptical, very small, wingless, in one row; cotyledons often more or less oblique; biennial or perennial, branching from base.

1. A. 1yràta L. Mostly glabrous, except the lyrate-pinnatifid root-leaves; stem-leaves scattered, spatnlate or linear with a tapering base, sparingly toothed 
or entrre; petals white, much longer than the yellowisb calyx; pods iong and slender, flat, ascending or spreading; style slender, $0.8 \mathrm{~mm}$. long. - On rocks or sandy shores, w. N. E. to Man, and southw. Apr.-July. - Usually biennial, but southw. decidedly perennial. Var. occinentalis Wats. Stigma sessile or on a very short thick style $(0.5 \mathrm{~mm}$. or less in length). - Point Pelce, n. shore of L. Erie ; Rocky Mts. to Alaska. (Kamchatka.)

2. A. dentàta T. \& G. Roughish-pubescent, slender; leaves oblong, very obtuse, unequally and sharply toothed; those of the stem numerous, half-clasping and auricled, of the base broader and tapering into a short petiole; petals (whitish) scarcely exceeding the calyx; pods widely spreading, very slender, short-stalked; style scarcely any. - N. Y. to Minn., Neb., and southw. May, June.

3. A. glàbra (L.) Bernh. (Tower Mustard.) Tall (6-12 dm. high), glaucous; stem-leaves oblong or ovate-lanceolate, entire ; petals yellowish white, little longer than the calyx; pods very narrow ( $8 \mathrm{~cm}$. long) and pedicels strictly erect; seeds marginless; cotyledons often oblique. (A. perfoliatc Lam.) - Rocks and fields, N. B. to B. C., s. to N. J., Pa., Great Lake region, S. Dak., Utah and Cal. May-July. (Eu.)

\$2. 'TURRITIS [Dill.] Gaudin. Seeds not so broad as the partition, in two more or less distinct rows in each cell, at least when young; strict and very leafy-stemmed biennials; cauline leaves partly clasping by a sagittate base.

Calyx essentinlly glabrous; pods erect or loosely spreading.

Pubescence of the basal rosettes none or sparse and of simple or of 2-

pointed hairs attached by the middle
Pubescence of the basal rosettes dense, stellate

Calyx stellate-pubescent ; pods deflexed or pendulous : $: \quad$ : $\quad$ 6. A. Holboellit.

4. A. Drummóndi Gray. Nearly glabrous, somewhat glaucous, 3-9 dm. high ; stem-leaves oblong or narrowly lanceolate, the basal spatulate-lanceolate; pods straightish, $3.5-10 \mathrm{~cm}$. long, $1.3-2.3 \mathrm{~mm}$. broad. (A. confinis Wats., in great part.) - Rocky places, e. Que. to B.C., s. to N. S., s. N. E., N. Y., O., Ill., Utah, and Ore.

Var. connéxa (Greene) Fernald. Stout; pods è-3.3 mm. wide. - Rivière du Loup, Que. ; and mts. of w. N. A.

5. A. brachycárpa (T. \& G.) Britton. Similar in stature and habit; basal leaves densely pubescent with 3-pointed hairs, the cauline glabrous; pedicels widely spreading; pods $1.7-9 \mathrm{~cm}$. long, 1-2 mm. broad, widely spreading. ( $A$. confinis Wats., in part; Turritis brachycarpa T. \& G.) - Sandy woods, rocky banks, etc., e. Que. to Sask, and Assina., s. to N. B., n. Vt., N. Y., Great Lake region, Col., etc.

6. A. Holboellii Hornem. Stems 1-several, 2-9 dm. high, leafy, somewhat closely stellate-pubescent at the base, glabrous or glabrate above; pedicels soon deflexed; petals pink or pinkish, 7-10 mm. long; pods 4-8 cm. long, $1.5-2.5$ $\mathrm{mm}$. broad, blunt, secund and strongly deflexed. - Rocky (calcareous) or sandy places, e. Que.; Thunder Bay, L. Huron (Wheeler) to the mts. of B. C. and Cal. (Greenl.)

§3. ÁRABIS proper. Seeds in one, row in each cell, orbicular or nearly so, more or less wing-margined; cotyledons strictly accumbent.

* Low, chiefly biennials, diffuse or spreading from the base.

\& 7. A. virgínica (L.) Trel. Nearly glabrous, often annual; leaves all pinnately parted into oblong or linear few-toothed or entire divisions, those of the lower leaves numerous; pedicels very short; flowers small, white; pods rather broadly linear, spreading, flat ; seeds winged. (A. ludoviciana Mey.) - Open ground, Va. to Kan., and southw. Mar.-May.

* Erect leafy-stemmed biennials, with simple leaves, white or whitish flowers, narrow but flattened ascending or erect pods, and nearly wingless seeds.

8. A. pàtens Sulliv. Downy with spreading hairs, erect (3-6 dm. high); stem-leaves oblong-ovate, acutish, coarsely toothed or the uppermost entire, 
partly clasping by the heart-shaped base; petals (bright white, $8 \mathrm{~mm}$. long) the length of the caly $\mathrm{x}$; pedicels slender, spreading; pods spreading or ascending, tipped with a distinct style. - Pa. to Minn. and southw. Apr., May.

9. A. hirsuta (L.) Scop. Rough-hairy, sometimes smoothish, strictly erect; stem-leaves oblong or lanceolate, entire or toothed, partly clasping by a somewhat arrow-shaped or heart-shaped base; petals (greenish white) small, but longer than the calyx; pedicels and pods sirictly upright; style scarcely any; immature seeds somewhat 2-rowed. - Gravelly shores and calcareous rocks, especially northw. May, June. (Eu.)

* * Erect leafy-stemmed biennials (3-9 dm. high), with small whitish flowers, recurved-spreading or pendulous flat pods $(7-10 \mathrm{~cm}$. long), and broadly winged seeds, the funiculus adherent to the partition; root-leaves rarely Iyrate.

10. A. laevigàta (Muhl.) Poir. Smooth and glaucous, upright; stem-leaves partly clasping by the arrow-shaped base, lanceolate or linear, mostly toothed, sometimes (var. LAcinid TA T. \& G.) incised; petals scarcely longer than the calyx; pods long and narrow, recurved-spreading on ascending or merely spreading pedicels. - Rocky places, w. Me. to S. Dak. and southw. May.

Var. Búrkii Porter. Leaves narrower, those of the stem essentially entire, not auricled at the base. - Dry hills, Pa. to Va.

11. A. canadénsis L. (SickLE-POD.) Stem upright, smooth above; stemleaves pubescent, pointed at both ends, oblong-lanceolate, sessile, the lower toothed; petals twice the length of the calyx, oblong-linear; pods very flat, scythe-shaped ( $4 \mathrm{~mm}$. wide), hanging on rough-hairy pedicels. - Rocky woods and ravines, e. Mass. and Vt. to Ont., and southw. June-Aug.

\section{CAPPARIDÀCEAE（ (CAPER FAMILY)}

Herbs (when in northern regions) with cruciform flowers, but 6 or more not tetradynamous stamens, a 1-celled pod with 2 parietal placentae, and kidneyshaped seeds. - Pod as in Cruciferce, but with no partition; seeds similar, but the embryo coiled rather than folted. Leaves alternate, mostly palmate. Often with the acrid or pungent qualities of Cruciferae (as in capers, the flower-buds of Capparis spinosa).

* Pod sesslle or short-stiped; stamens $-\infty$.

1. Polanisia. Petals subequal, emarginate.

* * Pod long-stiped; stamens 6.

2. Cleoze. Stamens 6. Pod hnear, many-seeded, long-stlpitate.

\section{POLANISIA Raf.}

Petals with olaws, notched at the apex. Stamens 8-32, unequal. Receptacle not elongated, bearing a gland behind the base of the ovary. Pod linear or oblong, veiny, turgid, many-seeded. - Fetid annuals, with glandular or clammy

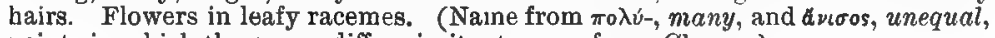
points in which the genus differs in its stamens from Cleome.)

1. P. gravèolens Raf. Leaves with 3 oblong leaflets; stamens about 11 , soarcely exceeding the petals; style short; pod slightly stipitate. - Gravelly shores and banks, w. Que. to Chesapeake Bay, and westw. June-Aug. Flowers small ( $4-6 \mathrm{~mm}$. long); calyx and filaments purplish; petals yellowish white,

2. P. trachysperma T. \& G. Flowers larger $(8-10 \mathrm{~mm}$. long); the stamens $(12-16)$ long-exserted; style 4-6 mm. long; pod sessile; seeds usually rough. fa. to Kan., southw, and westw.; also by a stream, Salisbury, Ct. (Mrs. Phelps, Weatherby), where probablv introduced. 


\section{CLEOMME L.}

Petals entire, with claws. Stamens 6. Receptacle somewhat produced beiween the petals and stamens, and bearing a gland behind the stipitate ovary, Pod linear to oblong, many-seeded. - Our species annuals with bracteate racemes. (Name of uncertain derivation, early applied to some mustard-like plant.)

1. C. serrulàta Pursh. (Stinking Cloverz.) Glabrous; leaves 3-foliolate ; leaflets lance-oblong, mostly entire; petals white or rose-colored, short-clawed; stipe of pod as long as the pedicel. ( $C$. integrifolia T. \& G.) - Dry mostly saline soil, Minn. to $\mathrm{n}$. Ill., Mo., Kan., westw. and northwestw.; rarely eastw. along railroads. - Flowers showy.

2. C. spinòsa L. (SPider-Flower.) Viscid-pubescent; leaflets 5-7, lanceolate, serrulate; petals white or rose-colored. - Cultivated, and occasionally escaping to waste grounds. (Introd. from the troples.)

3. C. lùtea Hook. Lower leaves 5-foliolate; towers yellow. - Western species, reported from Weeping Water, Neb. (Webber).

\section{RESEdàceae (Mignonette Family)}

Herbs, with unsymmetrical 4-7-merous small flower's, a fleshy 1-sided hypogynous disk between the petals and the (3-40) stamens, bearing the latter. Calyx not closed in the bud. Capsule 3-6-lobed, 3-6-horned, 1-celled, with 3-6 parietal placentae, opening at the top before the seeds (which are as in Capparidaceae) are full grown. - Leaves alternate, with only glands for stipules. Flowers in terminal spikes or racemes. A small and unimportant family of the Old World, represented by the Mignonette (Reseda odorata) and the Dyer's Weed.

\section{RESÈdA [Tourn.] L. Mignonetre. Dyer's Rocket}

Petals 4-7, cleft, unequal. Stamens 12-40, on one side of the flower. (Name from resedare, to calm, in allusion to supposed sedative properties.)

1. R. Lutelol L. (DYeR's Wend or WeLD.) Leaves lanceolate; calyx 4-parted; petals 4, greenish yellow; the upper one 3-5-cleft, the two lateral 3-cleft, the lower one linear and entire; capsule depressed. - Roadsides" and ballast, Mass. to Pa., local. - Plant $6 \mathrm{dm}$. high, used for dyeing yellow. (Adv. from Eu.)

2. R. LU̇TEA L. Low, decumbent; leaves irregularly pinnate-parted or bipinnatifid; flowers pale yellow; sepals and petals 6 ; stamens 15-20. Meadows and waste places, Mass. to Pa.; also Mich. (Adv. from Eu.)

3. R. ÁbA I. Tall, erect; leaves pinnately and rather regularly parted; flowers greenish white; stamens 12-15; petals $5 \backsim 6$. - Waste places, becoming more common. (Adv. from Eu.)

\section{SARRACENIACEAE (Pitcher-Plant Family)}

Polyandrous and hypogynous bog-plants, with hollow pitcher-formed or trumpet-shaped leaves, - comprising one plant of Guiana, another (Darling. tonia Torr.) in California, and the following genus.

\section{SARRACENIA [Tourn.] I}

Sepals 5, with 3 bractlets at the base, colored, persistent. Petals 5, oblong or obovate, incurved, deciduous. Stamens numerous, hypogynous. Ovary compound, 5-celled, globose, crowned with a short style, which is expanded at the summit into a very broad and petal-like 5-angled 5-rayed umbrella-shaped 
body, the 5 delicate rays terminating unaer the angles in as many little hooked stigmas. Capsule with a granular surface, 5-celled, with many-seeded placentae in the axis, loculicidally 5 -valved. Seeds anatropous, with a small embryo at the base of tleshy albumen. - Perennials, yellowish green and purplish ; the hollow leaves.all radical, with a wing on one side, and a rounded arching hood at the apex. Scape naked, 1-flowered; flower nodding. (Named for $D r$. Michel Sarrasin, physician at the Court of Quebec early in the 18th century, who sent our northern species to Europe.)

1. S. purpùrea L. (Side-saddle Flower, Pitcher-plant, Hontsman's Cur.) Leaves pitcher-shaped, ascending, curved, broadly winged; the hood erect, open, round heart-shaped, covered within by reflexed bristles; flower globose, scapose, deep purple; the fiddle-shaped petals arched over the greenish yellow style. - Peat-bogs, Lab. to Mackenzie, s. to Fla., Ky., the Great Lake region, and s. $\bullet$. Ia. June. - The curious leaves are usually half filled with water and drowned insects. Var. HETERophŕlua (Eat.) Torr., has greenish Jellow flowers and no purple veins in the foliage. - With the typical form.

2. S. flàva I. (TRUMPETs.) Leaves long (3-10 dm.) and trumpet-shaped, erect, with an open mouth, the erect hood rounded, narrow at the base; wing almost none; flower yellow, the petals becoming long and drooping. $\rightarrow$ Bogs, Va. and southw. Apr.

\section{DROSERÀCEAE (SUNDEW F FMILY)}

Bog-herbs, mostly glandular-haired, with regular hypogynous flowers, pentamerous and withering-persistent calyx, corolla, and stamens, the anthers fixed by the middle and turned outward, and a 1-celled capsule with twice as many styles or stigmas as there are parietal placentae. - Calyx imbricated. Petals convolute. Seeds numerous, anatropous, with a short and minute embryo at the base of the albumen. Leaves, in bud, rolled up from the apex to the base as in Ferns. Small family of insectivorous plants.

\section{DRÓSERA L. SENDEW}

Stamens 5. Styles 3, or sometimes 5, deeply 2-parted so that they are taken for 6 or 10 , slender, stigmatose above on the inmer face. Capsule 3 (rarely 5 )valved; the valves bearing the numerous seeds on their middle for the whole length. - Low perennials or biennials ; the leaves, in our species, all in a tuft at the base (often scattered in submersed plants), clothed with reddish glandbearing bristles; the naked scape bearing the flowers (rarely solitary) in a 1-sided simple (or sometimes forking) raceme-like inflorescence, which nods at the undeveloped apex, so that the fresh-blown flower (which opens only in sunshine) is always highest. The plants yield a purple stain to paper. The glands of the leaves exude drops of a clear glutinous fluid, glittering like dew-drops (whence the name, from $\delta \rho \sigma \sigma e \rho b s$, devoy).

Lenf-blades linear to orbicular, usually distinct from the petioles.

Scapes glabrous.

Leaf-hlades as broad as or brosder than long; seeds spindle-shaped, with a loose testa

Leaf-blades distinctly narrower than long.

Seeds spindle-shaped, the testa loose and produced at the ends; stipules adnate

Seeds ellipsoid or ellipsoid-ovold, with a olose testa.

Leaf-blades spatulate or spatulate-obovate; stipules nearly free.

Leaf-blades linear; stipules adnate to the petioles

Scapes glandular; seeds ellipsoid, with a close testa
Leaves filiform, with no distinction of blade and petiolo :

1. D. rotundifolia.

2. D. anglica.

8. D. longifolia.

- 4. D. linearis.

: 5. D. brevifolia.

1. D. rotundifdlia L. (RouND-LEAVED S.) Leaves suborbicular or transversely broad-elliptic, abruptly narrowed into the spreading hairy petioles; scape 1-3 dm. high, 1-25-flowered; flowers white (rarely pinkish), 4-7 mm. broad, the parts sometimes in sixes; seeds very slender, chaff-like. - Common 
In peat-bogs and moist sandy ground, Lab. to Alaska, s. to Pa., the Great Lake region, Minn., and in the mts. to Ala., Mont., and Cal. June-Aug. (Eurasia.)

Var. comosa Fernald. Dwarf; inflorescence 1-few-flowered, usually capitate; calyx crimson or roseate; petals greenish or crimson, sometimes foliaceous; carpels, and sometimes other parts of the flower, modified to green gland-bearing leaves. - Marly bogs, Gaspé Co., Que. ; and Herkimer and Oneida Cos., N. Y. (Haberer).

2. D. ánglica Huds. Leaves erect, linear- to obovate-spatulate, with smooth or sparsely hairy petioles, the blade $1.5-5 \mathrm{~cm}$. long, 3-7 mm. broad; scapes $0.6-3$ dm. high, 1-8-Howered; corolla white; seeds blackish, loosely faveolate. ( $D$. longifolia L., in part.) - Marly bogs, Nfd. and e. Que. to B. C., s. to Mich., Ida., and n. Cal. June-Aug. (Eurasia, Sandwich I.)

3. D. longifolia L. Leaves spatulate, tapering into the long rather erect naked petioles; scape 0.2-2 dm. high, 1-20-flowered; flowers white; seeds reddish brown, with a close papiliose coat. (D. intermedia Hayne.) - Bogs and sandy shores, Nfd. to Fla. and La. ; and locally inland to the Great L. region. June-Aug. (W. I., Eu.)

4. D. lineàris Goldie. Leaves linear, obtuse, the blade 1-6 cm. long, 1.5-3 mm. wide, on naked erect petioles about the same length; scape $2-10 \mathrm{~cm}$. long, 1-8-flowered ; flowers white or pinkish; seeds black, with a smoothish close coat. - Marly bogs and springy places, e. Que. to Alberta, locally s. to n. Me., Mich., Wisc., and Minn. June, July.

5. D. brevifdlia Pursh, Leaves spreading, very delicate, cuneate-obovate, $0.5-1.5 \mathrm{~cm}$. long (including the smooth dilated petioles); stipules nearly obsolete; scape filiform, glandular, 1-10 cm. high, 1-7-flowered; the white corolla 1-1.5 cm. broad. - Wet banks and ditches, Va. to Fla. and Tex. Apr., May.

6. D. filiformis Raf. Leaves very long (1-3 dm.) and filiform, erect, glandular throughout ; flowers numerous, purplish $(0.7-1.5 \mathrm{~cm}$. broad); seeds spindleshaped. - Wet sand, near the coast, Cape Cod, Mass., to Del. June-Sept.

\section{POdOSTEMÀceAe (River Weed Famitu)}

Aquatics, growing on stones in running water, some with the aspect of Seaweeds, or others of Mosses or Liverworts ; the minute naked flowers bursting from a spathe-like involucre as in Liverworts, producing a 2-3-celled many-seeded ribbed capsule. - Represented in North America by

\section{PODOSTEMUM Michr. RIVER WeED}

Flowers solitary, nearly sessile in a tubular sac-like involucre, destitute of floral envelopes. Stamens 2, borne on one side of the stalk of the ovary, with their long filaments united into one for more than half their length, and 2 short sterile filaments, one on each side; anthers 2-celled. Stigmas 2, awl-shaped. Capsule pedicellate, oval, 8-ribbed, 2-celled, 2-valved. Seeds minute, very numerous, on a thick persistent central placenta, destitute of albumen. - Leaves 2-ranked." (Name from noús, foot, and $\sigma r \eta \mu w \nu$, stamen; the two stamens being apparently raised on a stalk by the side of the ovary.)

1. P. ceratophýllum Michx. Leaves rigid or horny, dilated into a sheathing base, above mostly forked into thread-like or linear lobes. - On rocks in streams, N. B. to Ont., Minn., and southw., local. July-Sept. - A small olive-green plant, of firm texture, resembling a Seaweed, tenaciously attached to loose stones by fleshy disks or processes in place of roots.

\section{CRASSULÀCEAE (Orpine Familt)}

Herbs, succulent (except in 1 genus), with perfectly symmetrical flowers; yiz., the petals and pistils equaling the sepals or calyx-lobes in number (3-20), and the stamens the same or double their number, - technically different from 
Saxifrageae only in this cemplete symmetry, and in the carpels (in most of the genera) being quite distinct from each other. Also, instead of a perigynous disk, there are usually little scales on the receptacle, one behind each carpel. Fruit dry and dehiscent; the pods (follicles) opening down the ventral suture, many (rarely fow)-seeded. Stipules none. Flowers usually cymose, small. Leaves mostly sessile, in Penthorum not at all fleshy

\footnotetext{
* Not succulent; carpels united, forming a 5-celled capsule.
}

1. Penthorum. Calyx-lobes 5. Petals none. Stamens 10. Pod 5-beaked, many-seeded. ** Leaver, etc., thick and succulent; carpels distinct.

2. Tillaea. Calyx-lobes, petals, stauens, and pistils $3-4$. Seeds few-many.

8. Sedum. Calyx-lobes, petals, and plstils 4-5. Stamens 8-10. Seeds many.

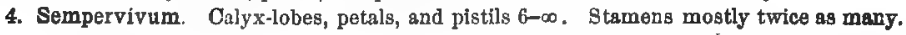

\section{PÉNThORUM [Gronov:] L. Ditch Stonecrop}

Calyx-lobes 5. Petals rare, if any. Stamens 10. Pistils 5, united below, forming a 5-angled 5-lıorned and 5-celled capsule, which opens by the falling off of the beaks, many-seeded. - Upright weed-like perennials (not tleshy like the rest of the family), with 'scattered leaves, and yellowish green flowers loosely spiked along the upper side of the naked branches of the cyme. (Name from $\pi \hat{\varepsilon} \nu \tau \epsilon$, five, and bos, a mark, from the quinary order of the flower.)

1. P. sedoides L. Leaves lanceolate, acute at both ends. - Open wet places, N. B. to Fla., w. to Minn., e. Kan., and Tex. July-Oct. - Parts of the flower rarely in sixes or sevens.

\section{TILLAÈA [Mich.] L.}

Calyx-lobes, petals, stamens, and pistils $3-4$. Pods 2-many-seeded. - Very small tufted annuals, with opposite entire leaves and axillary flowers. (Named in honor of Michael Angelo Tilli, an early Italian botanist.)

1. T. aquática L. Ronting at the base $(1-8 \mathrm{~cm}$. high); leaves linear-oblong; flowers solitary, nearly sessile; calyx half the length of the (greenish white) petals and the narrow 8-10-seeded pods, the latter with a scale at the base of each. (T. simplex Nutt.) - Brackish muddy shores, near the coast, local, Que. to Md., and southw; also on the Pacifie coast. July-Sept. (Eu., n. Afr.)

2. T. Vaillántii Willd. Similar; peduncles slender, about as long as the leaves. - P. E. I. (Churchill); Nantucket, Mass. (Mrs. M. P. Robinson, Floyd). - Perhaps not specifically distinct from the last. (Eu., n. Afr.)

\section{SÈDUM [Tourn.] L. STONecrop. Orpine}

Calyx-lobes and petals 4-5. Stamens 8-10. Follicles many-seeded; a little scale at the base of each. - Chiefly perennial smooth and thick-leaved herbs, with cymose or one-sided inflorescence. Petals almost always narrow and acute or pointed. (Name from sedere, to sit, alluding to the manuer in which these plants fix themselvẹs upon rocks and walls.)

flowers perfect.

Leaves thick (from Ilnear-cylindric to thlek-ovate).

Leaves closely lmbricated, thick-ovate; flowers yellow. . . 1. \$. acre.

Leaves not imbricated, linear-cylindrlo.

Flowers yellow.

Central flower of cyme 5-merons and 10-androns, the others 4-merous and 8-androus

All the flowers 5-merous and 10-indrons :

Flower's white to purplish

Iesves that and broad.

Cauline leaves opposite or whorled

Leaves entire, chietly in whorls of 3 ; flowers white

Lanves crenate, opposite; fower pink of purplish

Caulinn leavos altepnato of spirally artanged.

2. S. Nuttallanum

7. S. reflecum.

8. S. pulchelluin.

4. S. ternatum.

6. S. stolonifertm. 
Low slender plant with basal rosettes; cyme loose, of 8 scorpiold branohes

Cosrse upright plants without rosettes; flowers in a dense corymb.

Follicles long-attenua te

Follicles abruptly pointed a flowers dioecious, inostly 4-merous and 8-androus
Flow

\section{S. Nevii.}

8. S. telephioides.

9. S. purpureum.

10. \$. rosenm.

1. S. ACre L. (Mossy S.) Spreading on the ground, moss-like; leaves very small, alternate, imbricated on the branches, ovate, very thick; petals yellow. Escaped from cultivation to rocky roadsides, etc., e. Que. to Ont., and Va. June, July.' (Nat. from $\mathrm{Eu}$.)

2. S. Nuttalliànum Raf. Annual; stems simple or branched from the base, 5-10 cm. high; leaves flat or teretish, scattered, oblong, 4-6 mm. long; petals rather longer than the ovate sepals; carpels at length widely divergent. ( $S$. Torreyi Don.) - Dry ground, Mo. to Ark. and Tex. May.

3. S. pulchéllum Michx. Stems ascending or trailing, 1-3 dm. high; leaves terete, linear-filiform, much crowded; spikes of the cyme several, densely flowered; petals rose-purple. - On rocks, Va. to Ga., w. to Ind., e. Kan., and Tex.; also cultivated. May, June.

4. S. ternatum Michx. Stems spreading, $7-15 \mathrm{~cm}$. high; leaves flat, the lower whorled in threes, wedge-obovate, the upper scattered, oblong; cyme 3-spiked, leafy ; petals white. - Rocky woods, Ct. to Ga., w. to Mich., Ind., and Tenn. May.

5. S. Nèvii Gray. Stems spreading, simple $(7-13 \mathrm{~cm}$. high); leaves all alternate, those of the sterile shoots wedge-obovate or spatulate, on flowering stems linear-spatulate and flattish; cyme about 3-spiked, densely flowered; petals white, pointed. - Rocks, mts. of Va. to Ala. and Ill. May, June.

6. S. stolonfFerdm Gmel. Low perennial, with stoutish decumbent stems, the flowering branches ascending, 1-2 dm. high; leaves opposite, obovate, crenate above the cuneate base; cyme rather dense, the short branches numerous; flowers about $1 \mathrm{~cm}$. broad; petals pink or purplish. - Roadsides and fields, local, N. S. and Me. June, July. (Introd. from Asia.)

7. S. REFLÉxUM L. Glabrous, erect, $3 \mathrm{dm}$. high ; leaves crowded, cylindric, subulate-tipped, spreading, or reflexed; flowers yellow, pediceled. - Local, e. Mass. and w. N. Y., rare. (Adv. from Eu.)

8. S. telephioìdes Michx. Stems ascending, 1.5-3 dm. high, stout, leafy to the top; leaves oblong or oval, entire or sparingly toothed; cyme small; petals flesh-color, ovate-lanceolate, taper-pointed ; follicles tapering into a slender style. - Sandstone knobs and cliffs, from w. N. Y. to n. Ga. and Ill. Aug., Sept.

9. S. PURPÙREUM Tausch. (GARDEN O., LIVE-FOR-EVER.) Stems erect, 6 dm. high, stout; leaves oval, obtuse, toothed ; cymes compound ; petals purple, oblong-lanceolate; follicles abruptly pointed with a short style. (S. Telephium Man, ed. 6 , not L.; S. Fabaria Koch.) - Rocks and banks, escaped from cultivation in some places. Aug., Sept. (Introd. from Eu.)

10. S. ròseum (L.) Scop. (Roseroot.) Stems erect, 1.2-2.5 dm. high ; leaves oblong or oval, small ; flowers in a close cyme, greenish yellow, or the fertile turning purplish. (S. Rhodiola DC. ; Rhodiola rosea L.) - Greenl, and Lab., along the coast to cliffs of e. Me. ; also locally at Chittenango Falls, N. Y. (House) and on cliffs of Delaware R., Pa. May, June. (Eu.)

\section{SEMPERVIVUM L. HOUGELEEK}

Calyx-lobes, petals, and many-seeded carpels 6-many. Stamens usually twice as numerous. - Succulent perennials with imbricated leaves and cymosepaniculate yellow or purple flowers. (Semper, ever, and vivus, alive, from the tenacious vitality.)

1. S. TECTórUM L. (HeN-AND-CHTCKens.) Leaves of the dense basal and lateral rosettes (on short thick offsets) ovate, acute, ciliate but otherwise gla. brous; those of the stem more oblong, clammy-pubescent; flowers rose-purple - Often planted, and persisting long after or escaping from cultivation. (Introd. from $\mathrm{Eu}$.) 


\section{SAXIFRagÀceae (Saxifragt, Familt)}

Herbs or shrubs, of various aspect, distinguishabie from Rosiceae by having copious albumen in the seeds, opposite as whll as alternate leaves, and usially no stipules, the stamens mostly definite, and the carpels commonly fewer than the sepals, either separate or partly so, or all combined into one compound pistil. Calyx either free or adherent, usually persistent or withering away. Stamens and petals almost always inserted on the calyx. Ovules anatropous.

Tribe I. SAXIIRÀGEAE. Herbs. Leaves alternate (rarely opposite in nos. 4, 7, and 8). Fruit dry, eapsular or follicular, the styles or tips of the carpels distinct.

* Ovary 2(rarely 8)-celled with axile placentae, or of as many nearly distinct carpels.

1. Astilbe. Flowers polygamous, panicled. Stamens ( 8 or 10 ) twice as many as the small petals. Seeds few. Leaves decompound.

2. Sullivantia. Flowers perfect. Stamens 5. Calyx nearly free. Seeds wing-margined.

8. Boykinia. Flowers perfect. Stamens only as many as the petals, which are convolute in the bud and deciduous. Calyx-tube adherent to the ovary. Seed-coat close.

4. Saxifraga. Flowers perfect. Petals 5. Stamens 10. Seeds numerous, with a close coat. * * Ovary 1-celled, with 2 parietal placentae alternate with the stigmas.

5. Tiarella. Caly $x$ nearly free from the slender ovary. Petals entire. Stamens 10. Placentae nearly busal.

6. Heuchera. Calyx bell-shaped, adherent to the ovary below. Petals small, entire. Stamens 5.

7. Mitella. Calyx partly adhering to the depressed ovary. Petals small, pinnatifid, Sta. mens 10.

8. Chrysosplenum. Calyx-tube alherent to the ovary. Petals none. Stamens 10.

*** Ovary 1-celled, with 3-4 parietal placentae opposite the sessile stigmar; glanduliferous scales alternating with the stamens.

9. Parnassia. Sepals, petals, and proper stamens 5. Peduncle scape-like, 1-flowered.

Tribe II. HYDRÁNGEAE. Shrubs. Leaves opposite, simple. Ovary 2-5-celled; the calyx adherent at least to its base. Fruit capsular.

* Stamens 20-40.

10. Philadelphus. Calyx-lobes conspicuous. Petals 4-5, convolute in the bud. Filaments linear. Styles 3-5.

11. Decumaria. Calyx-lobes small. Petals $7-10$, valvate in the bud. Filaments subulate. Style 1.

* * Stamens 8 or 10 .

12. Hydrangea. Calyx-lobes minute in complete flowers. Petals valvate in the bud.

Tribe III. ESCALLONIEAE. Shrubs. Leaves alternate and simple. Ovary 2-5-celled. Fruit capsular.

13. Itea. Calyx 5-cleft, free from the 2-celled ovary, which becomes a septicidal capsnle.

Tribe IV. RIBESIEAE. Shrubs. Leaves alternate and simple, with stipules adnate to the petiole or wanting. Fruit a berry.

14. Ribes. Calyx-tube adnate to the 1-celled ovary. Placentae 2, parietal, many-seeded.

\section{1. astílbe Hamilton. False Goat's Beard}

Flowers dioeciously polygamous, Calyx 4-5-parted, small. Petals 4-5, spatulate, withering-persistent. Ovary almost free, many-ovuled; styles 2, short. Capsule 2-celled, separating into 2 follicles. Seed-coat loose and thin, tapering at each end. - Perennial herbs, with twice or thrice ternately-compound ample leaves, cut-lobed and toothed leaflets, and small white or yellowish flowers in spikes or racemes, which are disposed in a compound panicle. (Name composed of $\alpha$-privative and $\sigma \tau(\lambda \beta \eta$, sheen, because the foliage is not shining.) 
1. A. biternàta (Vent.) Britton. Somewhat pubescent (1-2 m. high); leaf. lets mostly heart-shaped; petals minute or wanting in the fertile flowers; stamens 10. (A. decandra Don.) - Mt. woods, s. e. Ky. (Kearney) and s. w Va. to N. C. and Ga. - Closely imitating Aruncus sylvester, but coarser.

\section{SULLIVÁNTIA T. \& G.}

Calyx bell-shaped, adhering below only to the base of the ovary, 5-cleft. Petals 5, oblanceolate, entire, acutish, withering-persistent. Stamens shorter than the petals. Capsule 2-beaked, many-seeded, opening between the beaks; seeds imbricated upward. - Low and reclined-spreading perennial herbs with rounded and cut-toothed or slightly lobed smooth leaves on slender petioles, and small white flowers in a branched loosely cymose panicle raised on a nearly leafless slender stem (1.5-4 dm. long). Peduncles and calyx glandular; pedicels recurved in fruit. (Dedicated to the distinguished bryologist William Starling Sullivant, who discovered our species.)

1. S. Sullivántii (T. \& G.) Britton. (S. ohionis T. \& G.) - Limestone cliffs, O. and Ind. to Ia. and Minn. June.

\section{BOYKÍNIA Nutt.}

Calyx-tube top-shaped, adherent to the 2-celled and 2-beaked capsule. Sta. mens 5, as many as the deciduous petals, these mostly convolute in the bud. Otherwise as in Saxifraga. - Perennial herbs, with alternate palmately 5-7-lobed or cut petioled leaves, and white flowers in cymes. (Dedicated to the late $D r$. Boykin of Georgia.)

1. B. aconitifdlia Nutt. Stem glandular (2-6 dm. high); leaves deeply 5-7-lobed. (Therofon Millspaugh.) - Rocky banks, W. Va. (acc. to Millspaugh) and mts. of Va. to Ga. and Tenn. July.

\section{SAXIFraga [Tourn.] L. Saxifrage}

Calyx either free from or adhering to the base of the ovary, 5 -cleft or parted. Petals entire, imbricated in the bud, commonly deciduous. Styles 2. Capsule 2-beaked, 2-celled, opening down or between the beaks, or sometimes 2 almost separate follicles. - Chiefly perennial herbs, with the root-leaves clustered, those of the stem mostly alternate. (Name from saxum, a rock, and frangere, to break; many species rooting in the clefts of rocks.)

Acaulescent, the principal leaves in a basal rosette; scapes naked below

the inflorescence.

Flowers nostly replaced by leafy tufts.

Flowers all perfect.

Sepais reflexed.

Leaves conspicnously and coarsely dentrate.

Petals unequal; follicles strongly ribbed

Petals uniform; follicles obscurely or not at all ribbed.

Leaves abruptly contracted to long petioles . .

Leaves gradually narrowed to the base

Leaves finely or shallowly crenate-dentate.

Leaves membranaceous, pilose beneath

Leaves leathery, glabrate beneath

Sepals ascanding.

Petals whito, exceeding the sepals.

Petals green, wuch shorter than the sepals, or wanting ${ }^{*}(7)^{\circ}$ S. virginiensis, v. chlorantha

Caulescent tufted or matted plants, branching at base, the flower-

ing branches mostly leafy below the inflorescence.

Leaves with 3-5 lobes or coarse teeth.

Leaves (basal) rounded, on slender petioles

Leaves gradually narrowed to the base, rigid, with 8 sharp teeth

1. S. stellaris, v. comosa.

Leaves gradually narrowed to the base, rigid, with 8 sharp teeth
Leaves entire or with regularly many-toothed or cilate margins,

Leaves linear-lanceolate, entire (sometimes sparingly ciliate), alternate; Howers yellow

Leaves toothed or ciliate.

Leaves mostly in basal rosettes; scapes upright, bearing numerous

whitish flowers
Leaves crowded and opposite along the matted branches; flowers solitary, purple.

8. S. rivularis.

9. S. triuuspidata.

10. S. aizoides.

11. S. Aizoon.

12. S. oppositfolia. 
1. S. stellàris L., var. comosa Willd. Leaves small, spatulate, wedgeshaped, more or less toothed; scape (7-16 cm. high) bearing a contracted panicle; most of the flowers changed into tufts of green leaves; peials unequal, lanceolate, with a claw. (S. comosa Britton.) - Arctic Am., locally s. to Mt. Katahdin, Me, and mts. of Col. July. (Eurasia.)

2. S. leucanthemifolia Michx. Leaves spatulate-oblong, coarsely toothed or cut, tapering into a petiole; stems (2-5 dm. high) bearing one or more leaves or leafy bracts and a loose spreading corymbose or paniculate cyme; petals white, lanceolate, the 3 larger ones with a heart-shaped base and $\&$ pair of yellow spots, the 2 smaller with a tapering base and no spots. (S. Michauxii Britton.) - Wet cliffs, mts. of Va. to N. C. and Ga.

3. S. caroliniàna Gray. Viscid with glandular hairs; leaves oval or ellipical ( $2-6 \mathrm{~cm}$. broad), coarsely toothed, rather abruptly or somewhat cuneately con. tracted to long hairy petioles; stem $3-4 \mathrm{dm}$. high ; panicle ample; petals ovate. obtuse, white with two purple spots; filaments clavate; follicles united only at the base, widely spreading ( $S$. Grayana Britton.) - Wet limestone rocks, mts. of s. w. Va.

4. S. micranthidifolia (Haw.) Britton. (Letruce S.) Leases oblong or oblanceolate, obtuse, sharply toothed, 6-14 cm. in length, tapering into a margined petiole nearly as long ; scape slender, 3-9 dm. high; panicle elongated, loosely flowered; pedicels slender; calyx reflexed, entirely free, nearly as long as the oval obtuse (white) petals; filaments club-shaped; follicles nearly separate, diverging, narrow, pointed, $4-6 \mathrm{~mm}$. long. (S. erosa Pursh.) - Cold mt. brooks and wet rocks, $\mathrm{Pa}$. to $\mathrm{N}$. C. and Tenn.

5. S. Forbèsii Vasey. Stem stout, 6-12 dm. high ; leaves denticulate, oval to elongated-oblong (1-2 dm. long); sepals oblong; petals pure white, consid erably exceeding the calyx-lobes; filaments filiform; follicles short, ovate.Shaded eliffs, near Makanda, s. Ill. (Forbes); and (?) e. Mo. (Lettermann), where showing some transition to S. pennsylvanica.

- 6. S. pennsylvánica L. (Swamp S.) Iarge (3-6 dm. high); leaves oblanceolate, thickish, obscurely toothed (1-2 dm. long), narrowed at base into a short and broad petiole; cymes in a large oblong panicle, at first clustered; lotes of the nearly free calyx deltoid, about the length of the linear-lanceolate (greenish) small petals; filaments awl-shaped; follicles at length divergent. - Low meadows, N. E. to Ya., W. to Minn. and Mo. - A form with crimson petals occurs in Vt. and N. H. (Miss E. Robinson, Miss Dearborn).

$\checkmark 7$. S. virginiénsis Michx. (EARLY S.) Low (1-3 dm. high); leaves obovate or noal-spatulate, narrowed into a broad petiole, crenate-toothed, thickish; flowers in clustered at length open and loosely panicled cymes; follicles. united merely at the base, divergent, purplish. - Exposed rocks and dry hillsides; N. B. and Que. to Ga., and w. to Minn., Mo., and 'l'enn.; common, especially northw. Apr.-June. Var. Ghlorán'rita Oakes is an anomalous plant of Essex Co., Mass., with tiny green pubescent petals or these modified to stamens.

8. S. rivularis L. (ALPine Broor S.) Small ; stems weak, 3-5-flowered ; lower leaves rounded, 3-5-lobed, slender-petioled, upper lanceolate; petals white, ovate. - Arctic Am., locally s. to Mt. Washington, N. H.; and in the Rocky Mts. to Mont. June, July. (Eu.)

9. S. tricuspidata Rottb. Stems tufted (4-16 cm. high), naked above; flowers corymbose; leaves oblong or spatulate, with 3 rigid sharp teeth at the summit; petals obovate-oblong, yellow. - Rocks, Arctic Am., s. to L. Superior, L. Winnipeg, and mts. of B. C. June-Aug. (Eu.)

10. S. aizoides L. (YrLlow Mountain S.) Low, matted or ascending; branches $0.5-3 \mathrm{dm}$. long, with few or several corymbose flowers ; leaves numer. ous, fleshy, distantly spinulose-ciliate; petals yellow, spotted with orange, oblong. (S. autumnatis I.) - Wet calcareous rocks, Arctic Am., s. to Gulf of St. Lawrence, mts. of n. Vt., w. N. Y., n. Mich., Alb., and B.C. June-Aug. (Eu.)

11. S. Aizdon .Jacq. Scapo 1-5 dm. high; leaves persistent, thick, spatulate, with white cartilaginous toothed margins; calyx partly adherent; petals obovate, cream-color, often spotted. - Calcareous rocks, Greenl. and Iab. to Sask., locally s. to N. S., N. B., mts. of n. Vt. and L. Superior. June, July. (Eurasia.) 
12. S. oppositifolia L. (Mountain S.) Leaves (2-4 mm. long) fleshy, ovate, keeled, ciliate, imbricated on the sterile branches; petals purple, much longeI than the 5-cleft calyx. - Calcareous rocks, Arctic Am., s. to Gulf of St. Law. rence, mts. of $\mathrm{n}$. Vt., Mont. and Ida. May, June, rarely Aug. (Furasia.)

\section{Tiarella L. False Miterwort}

Calyx bell-shuped, 5-parted. Petals 5, with claws. Stamens long and slen. der. Styles 2. Capsule membranaceous, 2 -ralved; the valves unequal. Seeds few, at the base of each parietal placenta, globular, smooth. - Perennials; flowers white. (Name a diminutive from riápa, a tiara, or turban, from the form of the pistil, which is like that of Mitella, to which the name of Miterwor properly belongs.)

1. T. cordifolia L. Leaves from the rootstock or summer runners, heartshaped, sharply lobed and toothed, sparsely hairy above, downy beneath ; stem (1-4 dm. ligh) leafless or rarely with 1 or 2 leaves; raceme simple; petals ob. long, often subserrate. - Rich rocky woods, N. S. and N. B. to Minn., Ind., and southw. in the mts. Apr.-June.

\section{HEUCHÈRA L. ALUm Root}

Calyx 5-cleft. Petals 5, spatulate. Styles 2, slender. Capsule 1-celled, with 2 parietal many-seeded placentae, 2-beaked, opening between the beaks. Seeds oval, with a rough and close seed-coat. - Perennials, with the round heart-shaped leaves principally from the rootstock; those on the stems, if any, alternate. Petioles with dilated margins or adherent stipules at their base. Flowers in small clusters borne in a narrow panicle, greenish or purplish. (Named for $J$. H. Heucher, a German botanist of the 17th and 18th centuries.)

Calyx regular or essentially so.

Calyx in anthesis $1.5-2$ mm. Iong.

Leaves with prominent triangular lobes.

Lower leaf-surfaees glabrous or merely villous along the nerves .

Lower leaf-surfaces villous

Leaves reniform, with obscure rounded lobes :

Caly $x$ in anthesis $8-6 \mathrm{~mm}$. long

Calyx oblique, often very irregular.

Stamens about equaling or slightly exceeding the calyx-lobes.

Petioles hatry

Petioles at most granular- or glandular-puberulent

Stamens about twice as long as the calyx-lobes

1. H. villosa.

2. H. macrorhiaa.

3. H. pasvifiora.

4. H. americana.

5. H. hispida.

6. H. pubescens.

- . H. hirsuticaulis.

1. H. villosa Michx. Rootstock elongate, 0.5-1 cm. in diameter; stems slender (1-3 $\mathrm{mm}$. in diameter at base), 2-9 dm. high, more or less villous with rusty hairs, especially below ; leaves basal, thin, acutely 7-9-lobed, on slender rustyvillous petioles; bracts of the loose panicle linear; calyx and pedicels somewhat glandular-hispid; petals spatulate-linear, about as long as the exserted stamens, soon twisted. ( $H$. crinita Rydb.) - Shallow soil on rocks, Md. to Ill., s, to Ga, and Tenn. June-Aug.

2. H. macrorhiza Small. Similar; rootstock stout, woody, $1.5-2 \mathrm{~cm}$. in diameter; stems stout (4-8 $\mathrm{mm}$. in diameter at base), sometimes leafy, 3-10 dm. high, very densely villous with sordid hairs; basal leaves thick, suborbicular, densely pubescent beneath, sparingly so above, on stout rusty-villous petioles; bracts of the panicle oblong. - Limestone cliffs and river-bluffs, $\mathrm{Ky}$. and Tenn.

3. H. parviflora Bartl. Stems slender, 1.2-6 dm. high, glandular-hirsute (rarely glabrate), as well as the petioles, ete.; leaves round-reniform, with $7-\mathrm{g}$ short and broad rounded lobes; flowers very small (2 $\mathrm{mm}$. long); petals linear. spatulate, twice as long as the calyx-lobes ; fruit narrow. ( $H$. Rugelii Shuttlw.) - Shaded cliffs, Va. to s. Ill., Mo. and Ga.

4. H. americàna L. (Сомmon A.) Stems (6-9 dm. high), etc., glandular and more or less hirsute with short hairs; leaves roundish, with short rounded lobes and crenate teeth; calyx very broad, $4 \mathrm{~mm}$. long, the spatulate petrls equaling or stightly longer than its lobes. (H. lancipetala Ryrb.) - Rocky 
woodlands, Ct. to N. C., w. to Minn., e. Kan., and Miss. Var. GLAúca (Raf.) Rosendahl. Stems, leaves, etc., glabrous or nearly so, often glaucous. ( $H$. glauca Raf.; IT. Curtisii T. \& G. ?) - N. Y. to Tenn. and N. C.

5. H. híspida l'ursh. Stems 5-12 dm. high, hispid or hirsutc with long spreading hairs (occasionally almost glabrous), scarcely glandular; panicle very narrow; calyx 6-8 $\mathrm{mm}$. long; leaves rounded, slightly 5-9-lobed; stamens soon exserted, longer than the spatulate petals. - Mts. of Va. and N. C. to Minn., e. Kan, and northwestw. May, June.

6. H. pubéscens l'ursh. Stem (3-9 dm. high) and petioles granular-pu bescent or glandular above, not hairy, below often glabrous ; leaves round-reniform, with shallow rounded lobes; calyx 6-8 min. long; stamens shorter than or slightly exceeding the lobes of the calyx and the spatulate petals. ( $H$. roseola and $H$. longiflora Rydb.) - Rich woods, in the mts., from $\mathrm{Pa}$. to Ky., and southw. June, July.

7. H. hirsuticaúlis (Wheelock) Rydb. Stems (5-7 dm. high) and petioles hirsute with long whitish hairs; leaves reniform or suborbicular, with 7-11 shallow rounded crenate-toothed lobes, white-hirsute on the veins beneath; inflorescence hirsute and glandular; calyx about $5 \mathrm{~mm}$. long; petals greenish or purplish, usually shorter than the oblong calyx-lobes; stamens long-exserted. - Bluffs and rocky banks, s. Mich. and Ind. to Mo. May.

\section{Mitélla [Tourn.] L. Miterwort. Bishop's CAP}

Calyx short, adherent to the base of the ovary, 5-cleft. Petals 5, slender. Stamens 5 or 10 , included. Styles 2, very short. Capsule short, 2-beaked, 1-celled, with 2 parietal or rather basal several-seeded placentae, 2 -valved at the summit. Seeds smooth and shining. - Low and slender perennials, with round heart-shaped alternate slender-petioled leaves on the rootstock or runners, and naked or 2-few-leaved flowering stems. Flowers small, in a simple slender raceme or spike. Fruit soon widely dehiscent. (Diminutive of mitr $a$, a cap, alluding to the form of the young pod.)

1. M. diphýlla L. Hairy; leaves heart-shaped, acute, somewhat 3-5-lobed, toothed, those on the many-fowered stem 2, opposite, nearly sessile, with interfoliar stipules; flowers white, in a raceme $(1.5-2 \mathrm{dm}$. long); stamens 10.2 Rich woods, Que. and N. E. to N. C., w. to Minn., Ia., and Mo. May.

2. M. prostràta Michx. Similar, but with the elongate flowering stem bearing prominently angulate-lobed alternate leaves quite to the inflorescence. L. Champlain (Michaux); Gaylordsville, Ct. (C. $\mathbb{K}$. Averill).-Very little known and possibly an aberrant plant.

3. I. nùda L. Small and slender; leaves rounded or kidney-form, deeply and doubly crenate; stem usually leafless, few-flowered, very slender (1-1.5 dm. high); flowers greenish; stamens 10.-Deep moist woods, in moss, Lab. to Mackenzie, s. to Ct., Pa., Mićh., Minn., and Mont. May-July.

\section{CHRYSOSPLÈNIUM [Tourn.] L. Golden SAXIFrage}

Calyx-lobes 4-5, blunt, yellow within. Stamens 8-10, very short, inserted on a conspicuous disk. Styles 2. Capsule inversely heart-shaped or 2-lobed, tlattened, very short, 1-celled, with 2 parietal placentae, 2 -valved at the top, manyseeded. - Low and small smooth herbs, with tender succulent leaves, and small solitary or leafy-cymed flowers. (Name compounded of $\chi \rho \nu \sigma 6 s$, gold, and $\sigma \pi \lambda \eta \nu$, the spleen; probably from some reputed medicinal qualities.)

1. C. americànum Schwein. Stems slender, decumbent and forking; leaves principally opposite, roundish or somewhat heart-shaped, obscurely crenatelobed; flowers distant, inconspicuous, nearly sessile, greenish, tinged with yellow or purple. - Cold wet places, e. Que. to n. Ga., w. to Minn. and Ia.

2. C. tetránđrum Fries. Stems erect; leaves alternate, reniform-cordate, doubly crenate or somewhat lobed; flowers corymbose; stamens 4 (rarely 5-8). (C. alternifolium Man. ed. 6 , not L. ; $C$. iowense Rydb.) - In wet moss, Deco. rah, Ia. (Holway), to the Rocky Mts., and northw. (Eurasia.) 


\section{Parnassia [Tourn.] L. Grass of Parnagets}

Sepals 5, imbricated in the bud, slightly united at the base, persistent. Petals $\dot{0}$, spreading, imbricated in the bud; a nore or less cleft gland-bearing scale at the base of each. Stamens 5 , alternate with the petals, persistent. Ovary 1-celled, with 4 projecting parietal placentae; stigmas 4, sessile. Capsule 4-valved, the valves bearing the placentae on their middle. Seeds very numerous, anatiopous. Embryo straight; cotyledons very short. - Perennial smooth herbs, with entire leaves, and solitary flowers on long scape-like stems, which often bear a single sessile leaf. Petals white, with greenish or yellowish veins. (Named from Mount Parnassus.)

Calyx-lobes elongate, herbacenus thronghout, aswending in frult; scales dilated below, $5-\infty$-cleft about to the riddle.

Leaves gradually tapering at base; petals elliptic-oblong . . . . . 1. P. parvifora.

Icaves cordate; petals ovate

Calyx-lobes short-oblong, frm, with scarious maryins, reflexed in fruit; seales 8-cleft to tho base.

Petals sessile.

Bcales shorter than or barely equaling the stamens

Scalos much excecding the stamens

Petals abruptly contracted fnto a claw

1. P. parviflora DC. Scapes $0.5-3 \mathrm{dm}$. high, slightly angled; leaves ovate or oblong, slender-petioled; petals $5-8 \mathrm{~mm}$. long, slightly exceeding the calyxlobes; scrles mostly 5-7-cleft; capsule with thin firm walls. - Meadows, wet rocks, etc., Nfd. to Alaska, s. to Cape Breton I., Mich., Wisc, S. Dak., and Utah. July, Aug.

2. P. palústris $\mathrm{L}$. Scapes subterete, $0.5-4 \mathrm{dm}$. high ; leaves firm, cordateovate, slender-petioled; petals $10-13 \mathrm{~mm}$. long, much exceeding the calyx-lobes; scales mostly ()-15-cleft. - Lab. to Alaska, locally s. to e. Que., Mich., Minn., N. Dak., and Wyo. July, Aug. (Eurasia.)

3. P. caroliniàna Michx. Scapes $1.5-6 \mathrm{dm}$, high; leaves coriaceous, ovate to orbicular, often subcordate; petals ovate-oblong, 10-18 mm. long, manyveined, twice or thrice exceeding the scales. - Swamps or wet mostly calcareous rocks, sonew hat local. Aug., Sept.

4. P. grandifdlia DC. Similar but stnuter, with larger leaves and flowers; gland-tipped cilia filiform, much exceeding the stamens and nearly equaling the petals. - Mts., Va. to Fla. and Mo. (according to Wheelock). Aug., Sept.

5. P. asarifolia Vent. Scapes angled, $2-5 \mathrm{dm}$. high; leaves coriaceous, reniform, the basal slender-petioled; petals oblong-elliptic, 10-18 $\mathrm{mm}$. long, many-veined; scales mostly shorter than the stamens. - Bogs, wet rocks, etc., nuts. from Va. southw. Aug.-Oet.

\section{PHILAdÉlphus L. Mock Orange or Stringa}

Calyx-tube top-shaped ; the limb 4-5-parted, spreading, persistent, valvate in the bud. Petals rounded or obovate, large. Styles united below or nearly to the top; stigmas oblong or linear. Capsule 3-5-celled, splitting at length into as many pieces. Seeds very numerous, with a loose membranaceous coat prolonged at both ends. - Shrubs, with opposite of ten toothed leaves, no stipules, and solitary or cymose-clustered showy white flowers. (An ancient name, applied by Linnaeus to this genus for no obvious reason.)

1. P. inodorus L. Glabrous; leaves ovate or ovate-oblong, pointe', entire or with some spreading teeth; flowers single or few at the ends of the diverging branches, pure white, scentless; calyx-lobes acute, scarcely longer than the tube. - Mts. of Va. to Ga. and Ala.; sometimes established northw.

2. P. grandiflorus Willd. A tall shrub, like the last, but somewhat pubescent, with long and recurved branches, larger flowers, and the calyx-lotes long and taper-pointed. - Along streams, Va. to Fla. - Often cultivated.

P. Corondrius L, the common Mock Orange or Srringa of cultivation, from s. Eu., with racemose cream-colored odorous flowers, sometimes escapes. 


\section{DECUMÁRIA L.}

Flowers all fertile. Calyx-tube turbinate, 7-10-tootbed. Petals oblong Stamens 20-30. Styles united into one, persistent. Stigma thick, 7-10-rayed. Capsule 10-15-ribbed, 7-10-celled, many-seeded, bursting at the sides, the thin partitions at length separating into numerous chaffy scales. - Smooth climbing shrub, with ovate or oblong entire or serrate leaves, no stipules, and nuinerous fragrant white flowers in compound terminal cymes. (Name said to be derived from decumanus, of the tenth part, referring to the often 10-merous flowers.)

i 1. D. bárbara L. Leaves shining, sometimes pubescent; capsule with the persistent style and stigma urn-shaped, pendulous. - Banks of streams, Dismal Swamp, Va., to Fla. and La.

\section{HYDRÁNGEA [Gronov.] L.}

Calyx-tube hemispherical, 8-10-ribbed, adherent to the ovary; the limb 4-5toothed. Petals ovate, valvate in the bud. Stamens 8-10, slender. Capsule 15-ribbed, 2-celled below, nany-seeded, opening by a hole between the 2-4 diverging styles. - Shrubs, with opposite petioled exstipulate leaves. The marginal flowers of the compound cymes usually sterile and radiant, consisting merely of a showy membranaceous and colored flat and dilated calyx. (Nanne

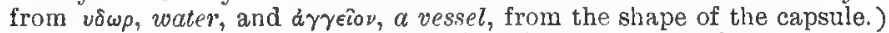

1. H. arboréscens L. (WILD H.) Glabrous or nearly so, 3-25 dm, high; leaves ovate, rarely heart-shaped, pointed, serrate, usually somewhat paler green beneath ; cymes flat ; flowers of ten all fertile, rarely all radiant. - Rocky banks, s. N. Y. to Fla., w. to Ia. and Mo.

2. H. cinèrea Small. Branches cinereous-puberulent; leaves densely tomentose, much paler beneath. (H. radiata Man. ed. 6 , not Walt.) - S. C. and Ga. to Tenn. and Mo.

\section{ITEA [Gronov.] L.}

Calyx 5-cleft, free from the ovary or nearly so. Petals 5, lanceolate, much longer than the calyx, and longer than the 5 stamens. Capsule oblong, 2grooved, 2-celled, tipped with the 2 united styles, 2-parted (septicidal) when mature, several-seeded.-Shrubs, with simple alternate petioled exstipulate leaves, and small white racemose flowers in simple racemes. (Greek name of the Willow.)

$\checkmark$ 1. I. virgínica L. Leaves deciduous, oblong, pointed, minutely errate.Swamps, chiefly on the coastal plain, N.J. and Pa. to Fla. and Tex.; inland in Miss. basin to Ill. and Mo. May, June.

\section{RIbes L. Currant. Gooseberrt}

Calyx 5-lobed, often colored; the tube adherent to the ovary. Petals 5, inserted in the throat of the calyx, small. Stamens 5, alternate with the petals. Ovary 1-celled, with two parietal placentae and 2 distinct or united styles. Berry crowned with the shriveled remains of the caly $x$. - Low sometimes prickly shrubs, with alternate palmately lobed leaves, which are plaited in the bud (except in one species), often fascicled on the branches; the small flowers from the same clusters, or from separate lateral buds. (Ribes, the Arabic name.)

\footnotetext{
* Peduncles 1-4(rarely 5)-flowered, etems mostly bearing spines at the base of the leafstalks or clusters of leaves, and often with scattered bristly prickles. (Our specles are indiscriminstely oblled WILD GoosebrRRY.)

Calyx-lobes decidedly shorter than the tube; berries apt to be prickly.

Calyx-tube campanulate. Leaves densely soft-pubescent Leaves only sparingly ptlose Calyx-tuhe narrowly oylindrio .

: : : : : : : nosbriti, glabratum 2. R. huronense.

(1) $R$ 1. R. Oynosbati.
} 
Calyx-lobes as loug as or exceeding the tube.

stamens at length equaling or exceeding the calyx-lobes; borry smooth.

Calyx $9-12 \mathrm{~mm}$. long

Calyx 5-7 mm, Jong.

Potioles usually bearing only simple elongate glands; brncts of the raceme mostly rounded at tip

Petioles bearing mostly compound elongate trichomes; bracts of the raceme in ostly nointed.

Principal leaves cuneate to truncete at base.

Mature leaves glabrate or slightly pilose beneath Mature leaves densely soft-pubescent

Principal leaves subcordate at base

5. R. oxyacanthoides.

8. $\boldsymbol{R}$. gracile

4. $R$, rotundifolium. 作

* * Flowers several in elongate racemes. (Curkarts.)

Calyx campanulate to saucer-shaped.

Leaves sprinkled, at least benenth, with resinous atoms; calyx cam-

panulate; fruit black.

Calyx-tube equaling the lobes.

Bracts shorter than the pedicels

Bracts longer than the pedicels.

Calyx open-campanulate, the lobes much exceeding the short tube

Leaves with no resinous atoms (except occrsional glands on the pedicels): calyx Hattish.

Stems densely covered with prickles; fruit black

Stems without prickles; fruit red.

Ovary and berries glandular-bristly.

Orary and berries smooth.

Upright shrub; middle lobe of lenf ovate; pedicels without capitate glands; oalyx yellowish

Decumbent shrub; middle lobe of leaf deitoid; pedicels witl capitate glands; calyx purplish

Calyx salver-form, with elongate tube

8. $R$, nigrum.

7. R. floridum.

9. R. hudsonianwm.

10. $R$. lacustore.

11. R. prostratum

12. R. vulgare.

13. R. triste.

14. R. aureum

1. R. Cynósbati L. (Pricksy G., Dogberry.) Infra-axillary spines slender, 0.5-1 cm. long; leaves round-ovate, rounded or subcordate at base, soft-pubescent; racemes loose, $2.5-6 \mathrm{~cm}$. lnng; stamens and undivided style not longer than the bruadly bell-shaped cnlyx; berries large, armed with long vrickles or rarely smooth. - Rocky woods, w. Me. to the mts. of N. C., w. to Man. and Mo. Var. GLABRÁrim Fernald. Leaves glabrate or only sparingly pilose on the nerves beneath. - $\mathrm{O}$. to N. C.

2. R. huronénse Rydb. Said to resemble $R$. Cynosbati, but with shorter racemes, calyx-tube slender, and styles united only below the middle. - L. Huron.

3. R. grácile Michx. (Mrssourr G.) Spines often long (7-17 mm.), stout and red; peduncles long and slender; flower's white or whitish ; filanents capillary, 1-1.5 cm. long, generally connivent or closely parallel, soon conspicuously longer than the oblong-linear calyx-lobes. ( $R$. missouriense Nutt.) - Ct. to $\mathrm{S}$. Dak. and southw.

4. R. rotundifdlium Michx. Spines short (2-5 mm. long); leaves rather firm, sparingly pilose beneath, mostly rounded at base; peduncles short; flowers greenish or the lobes dull purplish; flaments slender, 4-7 $\mathrm{mm}$. long, more or less exceeding the narrovoly oblong-spatulate calyx-lobes. - Rocky banks, w. Mass. and N. Y., s. in the Alleghenies to N. C.

5. R. oxyacanthoides L. ('моотн G.) Spines $3-8 \mathrm{~mm}$. long; leaves thin but leathery, glabrescent, the petioles often with some naled glands among the compound trichomes; peduncles very short; flowers greenish yellow to dull purplish ; stamens usually equaling the rather broadly oblong mostly glabrous calyxlobes. - Nfd. to Pa., w. to N. I)ak. and Man. - The common smooth-fraitec gooseberry of the North, the whitish prickles and spines often numerous. Var CALcfCola Fernald. Leaves densely soft-puhescent; calyx pubescent. - Marly swamps and limestone rocks, e. Que. and n. Mich. Var. saxơsum (Hook.' Coville. Calyx and subcordate teaves essentially glabrous. - Nfd., e. Que., Cap! Breton I., L. Superior, Rocky Mts.

6. $\mathbf{R}$ Grossularia L. (European G.) Spines stout, 1-1.5 cm. long, peduncles very short, 1(rarely 2)-flowered; calyx hirsute, its lobes oblong. ( $R$. Uva-crispa L.) - Escaped from cultivation and locally established in Que., N. E., and the Middle States. (Introd. from Eu.)

7. R. flóridum L'Hér, (WILI) Brack C.) Leaves slightly heart-shaped, 
sharply 3-5-lobed, doubly serrate; racemes drooping, downy, the elongate bracts persistent; flowers large, yellow and whitish; calyx tubular-bell-shaped, smooth, 8-10 mm. long. - Alluvial thickets and rich banks, N. B. to Assina., and southw.

8. R. Nìgum L. (BLACK C. of gardens.) Similar, but the pubescent calyx 5-6 $\mathrm{mm}$. long, the tube broadly campanulate, greenish purple and dull whitish. Cultivated, and occasionally escaping to thickets, etc. (Introd. from. Eu.)

9. R. hudsoniànum Richards. Similar, but the sbort racenes upright or spreading, the short bracts caducous; the white calyx 4-5 $\mathrm{mm}$. long, the tube much shorter than the spreading-ascending lobes. - Swamps, Hudson Bay to Minn., westw. and northwestw.

10. R. lacústre (Pers.) Poir. (Swamp BLack C.) Young stems clothed with bristly prickles and with weak thorns; leaves heart-shaped, 3--5-parted, with the lobes deeply cut; racemes loosely spreading or drooping, the rhachis, pedicels, and ovary glandular-bristly; calyx broad and flat; stamens and style not longer than the petals; fruit bristly, purplish black. - Cold woods and swamps, Nfd. to B. C., s. to n. N. E., Mich., Minn., Col., and n. Cal., and in the mts. to Pa.

11. R. prostràtum L'Hér. (Skunk C.) Stems reclined; leaves deeply heart-shaped, 5-7-lobed, smooth, the lobes ovate, acute, doubly serrate ; racemes erect, slender; calyx flattish; pedicels and red fruit glandular-bristly. - Damp woods and rocks, Lab. to Athabasca, s. to n. N. E., Mich., Minn., and along the pits. to N. C.

12. R. vULGARE Lam. (RED C. of gaïdens.) Suberect; leaves mostly cordate, slightly pubescent beneath or glabrate, the mature blades $3.5-6.5 \mathrm{~cm}$. wide, broadened upward, 3-5-lobed, the lobes mostly short-ovate; racemes borne chiefly among the lecfy shoots, spreading in anthesis, drooping in fruit, 3-5 (becoming 7) $\mathrm{cm}$. long, the rhachis glabrous though often glandular; pedicels mostly glandless; calyx yellow-green, its segments oval and abruptiy narrowed below the middle; petals narrowly cuneate; disks between the stamens and the slightly cleft style a high narrow ring with round-scalloped margin; fruit plump and juicy. ( $R$. rubrum Man. ed.6, not L.) - Commonly cultivated, and frequently escaping to fence-rows, thickets, and open woods. (Nat. from Eu.)

13. R. triste Pall. (Swamp RED C.) Straggling or reclining, the branches often rooting freely; leaves somewhat heart-shaped, the mature blades $5-10 \mathrm{~cm}$. broad, the sides nearly parallel, the lobes mostly broad-deltoid, permanently white-tomentose beneath; racemes borne on the old wond chiefly below the leafy tufts, drooping, $3.5-9 \mathrm{~cm}$. long; pedicels mostly glandular; calyx smoke-color to purplish, the segments broadly cuneate to subrhombie, as broad as or broader than long; petals broadly cuneate; disk a low broad pentagon; style deeply cleft ; fruit mostly small and hard. (R. rubrum, var. subglandulosum Maxim.) Cold woods, swamps, and subalpine regions, Nfd. to Alaska, s. to Me. and Vt. (Asia.) Var. Albinérvium (Míchx.) Fernald. Leaves glabrous or glabrate beneath. - More common, extending s. to N. S., N. H., Vt., Mich., Wisc., etc.

14. R. aúreum Pursh. (Missodri or Bdfralo C.) Tall spineless shrub; leaves 3-5-lobed, rarely at all cordate, convolute in bud; racemes short ; flowers golden-yellow, spicy-fragrant; tube of salver-form calyx 3-4 times longer than the oval lobes; stamens short; berries yellow or black. - Banks of streams; Minn. to Mo., Ark., and westw.; also common in cultivation.

\section{haMAMELId Àceat (Witch-hazel FamiLY)}

Shrubs or trees, with alternate simple leaves and deciduous stimules; flovers in heads or spikes, often polygamous or monoecious; the calyx adhering to the base of the ovary, which consists of 2 pistils united below, and forms a 2-beaked 2-celled woody capsule, opening at the summit, with a single bony seed in each cell, or several, only one or two of them ripening. - l'etals inserted on the calyx, narrow, valvate or involute in the bud, or often none at all. Stamens twice as many as the petals, and half of them sterile and changed into scales, or 
numerous. Seeds anatropous. Embryo large and straight, in scanty albumen; cotyledons broad and flat.

* Flowers with a manifest calyx, or calyx and corolla, and a single ovule suspended from the sumuit of each cell.

1. Hamamelis. Petals 4, strap-shaped. Stamens and scales orch 4, short.

2. Fot hergilla. Petals none. Stamens about 24, long; filaments thickened apward.

* * Flowers naked, with mere rudiments or a calyx and no corolla, crowdeã into catkin-like heads. ovules several or many in each cell.

3. Liquidambar. Monoecious or polygamous. Stamens very numerous. Capsules consolidated by their bases into a dense head.

\section{HAMAMÈLIS L. WITCh-HAzEL}

Flowers in little axillary clusters or heads, usually surrounded by a scale-like 3 -leaved involucre. Calyx 4 -parted, and with 2 or 3 bractlets at its base. Petals 4, strap-shaped, long and llarrow, spirally involute in the bud. Stamens 8, very short; the 4 alternate with the petals anther-bearing; the others imperfect and scale-like. Styles 2, short. Capsule opening loculicidally from the top; the outer coat separating from the inner, which incloses the single large and bony seed in each cell, but soon bursts elastically into two pieces. - Tall shrubs or small trees, with straight-veined leaves, and yellow perfect or polygamous flowers. (Ancient Greek name applied to the Medlar, or some similar tree.)

1. H. virginiàna L. Leaves obovate or oval, wavy-toothed, somewhat downy when young; blossoming late in autumn, when the leaves are falling, and maturing its seeds the next summer. - Damp woods, N. S. to Fla., w. to e. Minn. and "Tex."

\section{FOTHERGÍlLA Murr.}

Flowers in a terminal catkin-like spike, mostly perfect. Calyx bell-shaped, the summit truncate, slightly 5-7-toothed. Petals none. Stamens about 24, borne on the margin of the calyx in one row, all alike; filaments very long, thickened at the top (white). Styles 2, slender. Capsule adhering to the base of the calyx, 2-lobed, 2-celled, with a single bony seed in each cell. - A low shrub; the oval or obovate leaves smooth, or hoary underneath, toothed at the summit; the flowers appearing rather before the leaves, each partly covered by a scale-like bract. (Dedicated to the distinguished Dr. John Fothergill.)

1. F. Gardèni Murr. (F. carolina Britton.) - Low grounds, Va. to Ga. Apr., May.

\section{LiQuidámbar L. Sweet Gum Tree}

Flowers nsually monoecious, in globular heads or catkins; the sterile arranged in a conical cluster, naked; stamens very numerous, intermixed with minute scales; filaments short. Fertile flowers consisting of many 2-celled 2-beaked ovaries, subtended by minute scales in place of a calyx, all more or less cohering together and hardening in fruit, forming a spherical catkin or head; the capsules opening between the 2 awl-shaped beaks. Styles 2 , stigmatic down the inner side. Ovules many, but only one or two perfecting. Seeds with a wingangled seed-coat. - Catkins racemed, nodding, in the bud inclosed by a 4-leaved deciduous involucre. (A mongrel name, from liquidus, fluid, and the Arabic ambar, amber; in allusion to the fragrant terebinthine juice which exudes from the tree.)

1. L. Styraciflua L. (SwEet Gum, Bilsted.) Leaves rounded, deeply 5-7-lobed, smooth and shining, glandular-serrate, the lobes pointed. - Swampy woods, near the coast, s. Ct. to Fla. and 'Tex. ; inland in Miss. basin to Mo. and Ill. Apr., May. (Mex., Centr. Am.) - A large and beautiful tree, with finegrained wood, the gray bark commonly with corky ridges on the branchlets. Leaves fragrant when bruised, turning deep crimson in autumn. The woody pods flled mostly with abortive seeds, which resemble sawdust. 


\section{platanáceae (Plane Tree Family)}

Trees, with watery juice, alternate palmately-lobed leaves, sheathing stipules, and monoecious flowers in separate and naked spherical heads, destitute of calyx or corolla; the fruit merely club-shrped 1-seeded nutlets, furnished with a ring of bristly hairs about the base. Only the following genus (of uncertain relationslip).

\section{Plátands [Tourn.] L. Stcamore. Buttonwood}

Sterile flowers of numerous stamens, with club-shaped little scales intermixed ; filaments very short. Fertile flowers in separate catkins, consisting of inversely pyramidal ovaries mixed with little scales. Style rather lateral, awlshaped or thread-like, simple. Nutlets coriaceous, small, tawny-hairy below, containing a single orthotropous pendulous seed. Embryo in the axis of thin albumen. - Large trees, with the bark deciduous in broad thin brittle plates; dilated base of the petinle inclosing the bud of the next season. (The ancient name, from $\pi \lambda a \tau u ́ s$, broad.)

1. P. occidentalis L. Leaves mostly truncate at base, angularly sinuatelobed or toothed, the short lobes sharp-pointed; fertile heads solitary, hanging on a long peduncle. - Rich soil, s. Me. to n. Vt., Ont., s. e. Minn., e. Kan., and southw. - Our largest tree, of ten $25-40 \mathrm{~m}$. high, with a trunk 2-4.2 m. in diameter.

\section{ROSACEAE (Rose FamiLY)}

Plants with regular flowers, numerous (rarely few) distinct stamens inserted on the calyx, and 1-many pistils, which are quite distinct, or (in the second tribe) united and combined with the calyx-tube. Ovules (anatropous) 1-few in each ovary; sẹeds almost always without albumen. Embryo straight, with large and thick cotyledons. Leaves alternate, with stipules, these sometimes caducous, rarely obsolete or wanting. - Calyx of 5 (3-8) sepals (the odd one superior), united at the base, often appearing double by a row of bractlets outside. Petals as many as the sepals (rarely wanting), mostly imbricated in the bud, and inserted with the stamens on the edge of a disk that lines the caly $x$-tube. Trees, shrubs, or herbs.

Tribe I. SPIRAEEAE. Ovary superior and not inclosed in a calyx-like tube; carpels 1-12, dry at masturity and (in ours) dehiscent, 2-several(rarely 1)-soeded.

* Carpels inflated; leaves simple, often palmstely lobed.

1. Physocarpus. Stamens $\infty$, in several rows. Carpels 2-5, splitting into 2 valpes. Beeds with hard shining cost. Shrubs.

* *arpels not inflated.

+ Carpels alternate with (or of a different number from) the sepals or calyz-lobes.

2. Spiraea. Stamens on the margin of a disk-like expansion of the floral axis. Carpels splitting chiefly nlong the ventral suture. Leaves simple. Shrubs.

3. Aruncus. Dioecious. Stamens borne on the upper (Inner) surface of a disk-like expansion of the floral axis. Leaves compound. Herbs.

++ Carpels (normally 5 ) opposite the 5 sepals or calyx-lobes.

4. Sorbaria, Petals imbricated In bud. Beeds pendulous. Flowers small, corymbose.

5. Gillenia Petals convolute in bud. Seeds ascending. Flowers long-peduncled.

Tribe II. POMEAB. Carpels few, mostly definito (2-5) and usually connate, borne within and adnate to a cup-like or urn-like depression in the enlarged summit of the foral axis (resembling a ealyx-tube), the whole united to form a flosby fruit. Treos and shrubs, with stipules free from the petiole. 
* Mature carpels papery or soft-cartilaginous.

- Cells of the compound ovary as many as the styles, without false or partial partitlone.

6. Pyrus. Fruit depressed-globose to ellipsoidal or obovold; its carpels enveloped in the fleshy receptacle, papery or soft-cartilaglnous, usually 2-ovuled and 2-seeded. Leaves simple or compound.

$\leftarrow+$ Cells of the compound ovary subdifled by partial partitions projecting lnward from the baok.

7. Amelanchier. Carpels usually 5. Leaves simple. Unhrmed.

* * Yature carpels very hard and bony, distinct or firmly coherent in the fleshy frult.

8. Crataegus. Ovules in each cell elther solitary or if 2 unequal, one sessile and fertile, the other stalked and sterle. Shrubs and small trees, usually armed. Leaves simple, mustly serrate or dentate, thin or coriaceous.

9. Cotoneaster. Ovules 2 in ench coll, equal. Armed shrub with coriaceous oval crenuinte evergreen leaves.

Tribe III. POTENTflLeAE. Carpels few-many, 1(-2)-ovuled, becoming dry achenes, not in closed at maturity. Chiefly herbs.

* Styles not elongated after anthesis, mostly deciduous.

- Receptacle pulpy and much enlarged in fruit.

10. Fragaria. Petals white. Leaves 8 -foliate. Bractlets alternating with the calyx-lobes. Lieceptacle juicy.

11. Duchesnea. Petals yellow. Receptacle spongy, not juicy.

+ - Receptacle dry or nearly so, not greatly enlarged in fruit.

+ Stamens 5 .

12. Sibbaldia. Stamens alternate with the petals. Leaflets mostly 3 -toothed at the end.

73. Chamaeshodos. Stamens opposite the petals. Leaflets cleft into linear segments.

$$
\begin{aligned}
& * \text { Stamens numerous. } \\
& \text { - Carpels 1-ovuled. }
\end{aligned}
$$

14. Waldsteinia. Achenes few, 2-6, rarely 10.

15. Fotentilla. Achenes numerous. Petals 5 (rarely 4), consplenons. Calyx-lobes as many, Fith an alternating set of bractlets.

$$
\text { - Carpels 2-ovuled. }
$$

16. Filiperdula. Leaves pinnate; stipules kidney-formed.

* * Styles persistent and elongating after anthesis, often plumose or jointed.

17. Geum. Calyz-lobes nsually with 5 alternating small bractlets. Stamens and carpels numerous; styles becoming plumose or hairy tails, or naked and straight or jointed.

Fribe IV. RÙBEAE. Pistils several or numerous, becoming drupelets in frnit. Ovules 2 and pendulous, but seed solitary. Perennials, herbaceous or with biennial soft-woody stems.

18. Rubus. Pistils mostly numerous, fleshy in fruit, crowded upon a spongy receptacle.

19. Dalibarda. Pistils 5-10, in the bottom of the calyx, nearly dry in fruit.

Tribe V. POTERiEAE. Pistils 1-4, becoming achenes, completely inclosed in the dry and firm cnly $x$-tube, which is constricted or nearly closed at the throat. Herbs with compound or lobed leaves. Petals often none.

20. Alchemilla. Calyx urceolate, bracteolate. Petals none. Stamens 1-4. Flowers minute, clustered.

21. Agrimonia. Calyx top-shaped or bell-shaped, with a margin of hooked prickles. Stamens 5-12. Flowers yellow, in long racemes.

22. Sanguisorba. Calyx-lobes petalotd; tabe 4-angled, naked. Petals none. Flowers densely capitate or spicate.

Tribe VI. RÓSEAE. Pistils many, becoming bony achenes, Inclosed in the globose or urn-shaped fleshy calyx-tube, whlch resembles a pome. Petals conspicuous. Stamens numerous.

23. Rosa. The only genus. Prickly shrubs with pinnate leaves.

Tribe VII. PRÙNEAE. Orary superior and not fuclosed in the calyx-tube at maturity. Calyx deciduous, without bractlets. Pistil, solitary, becoming a stone-fruit. Orules 2, but seec almost alway's solitary. Style terminal. Trees or thrubs, with slmple mostly serrate leaves;

\%. Prunus. Flowels pierfect. Petals and calyx-Inbes 5. Stone of the drupe bony. 


\section{PHYSOCÅRPUS MaXim. NINE-BARK}

Carpels 1-5, inflated, 2-valved; ovules $2-4$. Seeds roundish, with a smooth and shining crustaceous testa and copious albumen. Stamens 30-40. Otherwise as Spiraea. - Shrubs, with simple palmately lobed leaves and umbel-like corymbs of white flowers. (Name from $\phi \hat{v} \sigma \alpha, a$ pair of bellows, and kaprós, fruit.)

1. P. opulifolius (L.) Maxim. Shrub, 1-3 m. high, with long branches, the old bark loose and separating in numerous thin layers; leaves roundish, somewhat $3-l o b e d$ and heart-shaped; the purplish membranaceous pods usually 3 , essentially glabrate, very conspicuous. (Spiraea L. ; Opulaster Ktze.) - Rocky banks of streams, Que. and N. E. to Fla., w. to Ill. - Often cultivated.

Var. intermedius (Rydb.) Robinson. Pods permanently pubescent. (Opulaster intermedius Rydb.) - Similar situations, s. Mich. to S. Dak., Ark., and Ala.

\section{SPIRAÈA [Tourn.] L.}

Calyx 5-cleft, short, persistent. Petals 5, obovate, equal, imbricated in the bud. Stamens 10-50. Pods (follicles) 5-8, not inflated, few-several-seeded. Seeds linear, with a thin or loose coat and no albumen. - Shrubs, with simple leaves, and white or rose-colored flowers in corymbs or panicles. (The Greek name, from $\sigma \pi \varepsilon\llcorner\hat{a} \nu$, to twist, from the twisting of the pods in some of the original species.)

Flowers in compound corymbs.

Calyx-tube top-shaped, pubescent

Calyx-tube bell-shaped, smootbish.

Leaves $2.5-5 \mathrm{~cm}$, broad

Leaves $1-1.6 \mathrm{~cm}$. broad

Flowers racemosely or spicately painicled

Leaves smoothish, scarcely paler beneath.

Pedicels fascicled, $1.5 \mathrm{~cm}$. long; flowers usually double

Flowers densely racemo-paniculate; pedicels 2-6 mm. long.

Inforescence tomentulose

Inflorescence subglabrous or sparingly villous

Leaves green above, densely tomentose and white or tawny beneath

- 1. B. Japonica.

2. 8. corymbosa.

- 8. Sirginiana.

1. S. Japónica L. f. Stems $1 \mathrm{~m}$. or more high; leaves $7-9 \mathrm{~cm}$. long, glaucous beneath; petals pink to deep rose-color. - Frequent in cultivation, and occasionally escaping, s. Ct. (Graves) and e. Pa. (Introd. from Asia.)

2. S. corymbosa Raf. Stems erect, dark purple, simple or nearly so; leaves oval or broadly oblong, smoothish, of firm texture, toothed from near the middle to the rounded or obtuse apex, $2.5-5 \mathrm{~cm}$. broad; flowers white; corymbs 4-10 $\mathrm{cm}$. broad. ( $S$. betulifolia, var. Wats.) - In the Allegheny Mts., N.J. (according to Britton) to W. Va. and Ga.

3. S. virginiàna Britton. Glabrous, much-branched; leaves lance-oblong, $1-1.6 \mathrm{~cm}$. broad, often acute or acutish at the base; flowers white, about $6 \mathrm{~mm}$. broad; pedicels and calyx glaucous. - On rocks; W. Va. (Millspaugh) to N. C. and Tenn.- Not seen; description compiled.

4. S. PRUNIFÓlA Sieb. \& Zucc. Finely pubescent; leaves ovate-oblong, obtuse, cuneate at the base, serrulate; flowers white, often double, $1 \mathrm{~cm}$. in diameter. - Persisting after cultivation, and tending to escape to roadsides, $七$. Mass. and Ct. (Introd. from Japan.)

5. S. salicifólia L. (MEa Dow-Swetr.) Erect shrub, 3-12 dm. high, with tough yellowish-brown stems; leaves finely serrate, lance-oblong, $5-7 \mathrm{~cm}$. long, $1-1.8 \mathrm{~cm}$. broad, rather firm in texture; inflorescence thyrsoid, tomentulose; flowers 6-8 mm. in diameter; petals suborbicular, white. - Chiefly in low ground, N. Y. to N. C., Mo., and northivestw. (Asia.)

6. S. latifdlia Borkh. (MeaDow-sweet.) Stems red or purplish-brown; leaves thin, more coarsely serrate, mostly $1.5-4 \mathrm{~cm}$. broad; influrescence smooth. ish ; petals white or pink. - The common Meadow-sweet in e. N. A.; in rocky pastures, etc., Nfd. to Va.

7. S. tomentosa L, (Hardhack, Stemple Bugh.) Stems and lower sur. 
face of the ovate or oblong serrate leaves very woolly; flowers in short racemes crowded in a dense panicle, rose-color, rarely white; pods woolly.-Low grounds, N. B. and N. S. to the mts. of Ga., w. to Minn. and Kan.

\section{ARÚNCUS [L.] Adans. Goat's Beard}

Dioecious. Carpels 3-4, splitting at the ventral suture. Flowers sessile or nearly so on the long spike-like branches of a large open panicle, the fertile flowers reflexed in fruit. Petals small, narrow, white. - Tall, essentially herbaceous. Leaves 2-3-pinnate, the leaflets rather large, ovate-oblong. (Aruncus, a word used by Pliny to designate the beard of a goat.)

1. A. sylvéster Kosteletzsky. Stem erect, subsimple, bearing a few large compound petiolate leaves and a large pyramidal spicate panicle; leaflets $6-14 \mathrm{~cm}$. long, green on both sides, sharply and somewhat doubly serrate, acuminate, the base mostly abrupt or subcordate, petiolulate. (Spiraea Aruncus L.; Aruncus Aruncus Karst.) - Rich soil, wooded ravines, etc., N. Y. to Ga., I. T., and Alaska. (Eurasia.)

\section{SORBÀRIA A. Br.}

Flowers perfect, paniculate. Carpels mostly 5, opposite the calyz-lobes. Leaves regularly odd-pinnate, the leaflets lance-oblong, sessile, sharply serrate. (Name from Sorbus, the Mountain Ash, from the similar foliage.)

1. S. sorbifólia (L.) A. Br. Suffruticose or nearly herbaceous, erect; leaves 1-4 dm. long, 13-21-foliolate; leaflets caudate-acuminate, with many straightish mostly simple veins springing from the midnerve; panicle ample, pyramidal, terminal ; petals white. (Spiraea L.) - Common in cultivation, and escaping to waste land and copses. (Asia.)

\section{GILlÈnia Moench. Indiay Physic}

Calyx narrow, somewhat constricted at the throat, 5-toothed; teeth erect. Petals 5, rather unequal, linear-lanceolate, inserted in the throat of the calyz, convolute in the bud. Stamens 10-20, included. Pods 5, included, at first lightly cohering with each other, 2-4-seedod. - Perennial herbs, with almost sessile 3-foliolate leaves; the thin leaflets doubly serrate and incised. Flowers loosely paniculate-corymbed, pale rose-color or white. (Dedicated to an obscure German botanist or physician, $\boldsymbol{A}$. Gille, or Gillenius.) Porteranthus Britton. $V$ 1. G. trifoliàta (L.) Moench. (Bowman's Roor.) Leaflets ovate-oblong, pointed, cut-serrate; stipules small, awl-shaped, entire or slightly incised. Rich woods, N. Y. to Ga., Mo., and Mich.

2. G. stipulàta (Muhl.) Trel. (Axericar IpecAc.) Leaflets lanceolate, deeply incised; stipules large and leaf-like, doubly incised. (G. stipulacea Nutt.; Porteranthus stipulatus Britton.) - Moist rich woods, w. N. Y. to Kan., La., and Ala.

\section{PỲRUS [Tourn.] L.}

Calyz-like receptacle urn-shaped, bearing 5 sepals. Petals roundish or obovate. Stamens numerous. Styles 2-5. Fruit a large fleshy pome, or smaller and berry-like, the 2-5 cells imbedded in the flesh, papery or cartilaginous, mostly 2-seeded. - Trees or shrubs, with showy flowers in corymbed or umbellike cymes. (The classical name of the Pear-tree.) A large genus, often subdivided, but with sections less strongly or constantly marked than our few species would suggest.

§ 1. PIRÓPHORUM Focke. (PEAR.) Leaves simple; orifice of concave receptacle partially or almost completely closed by a dish-like cushion; flesh of large obovoid fruit copious, containing sclerotic (gritty) cells.

1. P. commìnss L. 'The common Pear of cultivation. - Stray seedlings with degenerate fruit ocoasionally found in eopses or woods near orchards. (Introd. from Eu.) 
§ 2. MALUS (Hill) S. F. Gray. (APPLE.) Leaves simple; orifice of concave receptacle open; flesh of large subglobular fruit copious, free from sclerotic cells. MaLus ['Tourn.] Hill.

* Leaves and usually the outer surface of the calyx-lobes glabrate. - Calyx-lobes deciduous in fruit.

2. P. baccata L. (Siberian Crab.) Small tree; leaves ovate-oblong, serrate but not lobed, acuminate, at length subcoriaceous; petals narrowly oblong, with cuneate-attenuate base ; pedicels slender, fascicled ; pome $2-3 \mathrm{~cm}$. in diameter, usually yellow with reddish cheek. (Malus Borkh.) - Common in cultivation, and locally established as an escape in borders of woods, etc., Me., Ct., and doubtless elsewhere. (Introd. from Eurasia.)

$\times$ P. PRUNifolia Willd. A highly variable group of hybrids between $P$. baccata and $P$. Malus, combining in differing degrees the characteristics of the two parents. - Cultivated as CRAB APPLES, and not rarely spontaneous by roadsides, in open woods, etc. (Introd. from Eu.)

3. P. angustifolia Ait. Small tree; branchlets often hardened and spinelike; leaves elliptic-oblong to lance-oblong, serrs'e-dentate to nearly entire, those of the sterile shoots often shallowly and sonuewhat pinnately lobed, the midnerve commonly glandular above; flowers in 3-7-flowered umbel-like corymbs; petals oblong to obovate, contracted at the base to a cuneate claw; pome greenish-yellow, hard and sour, $2-2.6 \mathrm{~cm}$. in diameter, depressed-globose. (Malus Michx.) - River thickets, etc., N. J. to Ill., "Kan.," and southw.

\section{++ Calyx-lobes persistent in fruit.}

4. P. coronàia L. (American Crab.) Tree, somewhat armed, 6-10 m. high ; leaves ovate or elliptic, usually rounded or even cordate at the base; those of the sterile shoots somewhat triangular-ovate and lobed, sharply serrate; petals broadly obovate, white or nearly so; fruit much as in the preceding. (Malus Mill.) - Thickets and open woods, N. J. to Ont,, Kan., and southw.

* * Leaves at least on the lower surface and outer surface of the calyx-lobes clothed with a persistent white or gray tomentum.

5. P. ioénsis (Wood) Bailey. Similar in habit to the two preceding; leaves chielly oblong or ovate-oblong, glabrate, dull green, and somewhat rugose above, very pale and densely tomentose beneath, doubly serrate or pinnately several-lobed, usually narrowed at the base; petioles woolly; flowers mostly $2-3$ in a corymb; the pedicels slender, tomentose, becoming 2.5-3.5 $\mathrm{cm}$. long in fruit; calyx-lobes persistent. (Pyrus coronaria, var. Wood; Malus Britton.) Ill. and Wisc. to Minn., Kan., and Okla.

$\times$ P. Soulárdi Bailey. A hybrid between $\boldsymbol{P}$. ioensis and $\boldsymbol{P}$. Maius, and of intermediate character, is said to occur in a wild state from Minn. to Tex. It mav be distinguished from $P$. ioensis by its shorter thicker pedicels, usually about $2 \mathrm{~cm}$. long, and somewhat larger fruit.

6. P. Malus L. (Apple.) Leaves ovate-oblong, rounded or cordate at the base, sub-equally serrate ; pedicels stout, woolly, $2-2.8 \mathrm{~cm}$. long; fruit $4 \mathrm{~cm}$. or nore in diameter. (Malus Britton.) - The coinmonest fruit tree of cultivation, often escaping to woods. (Introd. from Eu.)

§3. ADENóRHACHIS DC. (ChoreberRY.) Leaves simple, the midrib glandular along the upper side; cymes compound; styles united at base, fruit small, berry-like. Aronid Medic.

1) 7. P. arbutifolia (L.) T. f. Shrub, 1-2.6 m. high ; leaves nblong-nblanceolate, mostly acute or acuminate, finely glandular-serrite, green and glabrons or glabrate above, paler and permmnently canescent-tomentose below; perlicels, calyx, and young fruit canewent-tomentose; petals white or redilish ; ripe fruit red, about $7 \mathrm{~mm}$. in diameter; cymes numerously (mostly 9-18-) fruiter. Aronia Ell.) - Swamps and low woods, N. Y. to O., Ark., and Fla. - Appearing to pass without sharp distinction into

Var. atropurpurea (Britton) Robinson. Cymes less numerously (mostly 
3-10-) fruited ; fruit larger, 8-10 $\mathrm{mm}$. in diameter, claret-colored to purplishblack. (Aronia Britton.) - Similar habitats, centr. Me., southw. aud westw. ; common.

V 8. P. melanocárpa (Michx.) Willd. Shrub, similar in habit, generally of lower stature; leaves varying from rather broadly oblong and acuminate to spatulate-oblanceolate and scarcely pointed, glabrous or early glabrate beneath as well as above; pedicels and calyx also nearly or quite smooth; fruit very dark purple or essentially black. (Aronia nigra Britton.) - Moist woods, hut also rocky uplands; common northw. and extending southw. in the Alleghenies at least to $\mathrm{N}$. C.

The members of this section oecasionally form natural hybrids with those of \$4. These may be recognized usually by their imperfectly pinnate or pinnatifid leaves.

\section{§4. SóRBUS (L.) S. F. Gray. (Motnta in Ash.) Leaves odd-pinnate, with rather numerous leaflets; cymes compound; styles distinct; pome berry- like, small. Trees or tall shrubs. Sorbus [Tourn.] L.}

9. P. americàna (Marsh.) DC. (American M.) Nearly glabrous or soon becoming so ; leaflets $13-15$, lanceolate, taper-pointed, sharply serrate with pointed teeth, bright green; cymes large and flat; berries globose, bright red, not larger than peas. (Sorbus Marsh.) - Woods, Lab. to Man., s. to n. and w. N. E., N. Y., the Great L. region, and in the mts. to N. C. ; common.

10. P. sitchensis (Roem.) Piper. Nearly glabrous; leaflets oblong, oval, or lance-ovate, mostly obtuse or abruptly pointed, serrate (often doubly) with more spreading teeth, rather pale beneath, of firmer texture than in the preceding; flowers (earlier) snmewhat larger (8-11 $\mathrm{mm}$. broad); fruit 8-10 mm. in dianneter. ( $P$. sambucifolia Man. ed. 6, not C. \& S.; Sorbus Rnem.) River-banks ard damp rocky uplands, Lab. to centr. Me., westw. and north. westw. to the Pacific.

11. P. Aucuparia (L.) Ehrh. (European M., Rowan Tree.) Leaflets narrowly oblong, mostly obtuse, rather pale beneath, always more or less pubescent or tomentose at least on the lower surface. (Sorbus L.) - Extensively cultivated for ornament, and now tending to become naturalized. (Introd. from $\mathrm{Eu}$.)

\section{AMELÁNCHIER Medic. JUIMeberRt}

Calyx 5-cleft. Petals obovate to oblong, rarely linear. Stamens numerous, short. Styles 5, united below. Ovary 5-celled, each cell 2-ovuled, but with a projection growing from the back of each and forming a false cartilaginous partition, the sweet and edible berry-like pome thus 10-celled, with one seed in each cell (when all ripen). - Small trees or shrubs, with simple leaves, and white racemose flowers. (Name said to be barbaric, the derivation not satisfactorily explained.)

Petals narrowly oblong, 14-25 mm. In length; early flowering; leaves finely and sharply serrate

Petals oblong to obovate, $4-12 \mathrm{~mm}$. in length.

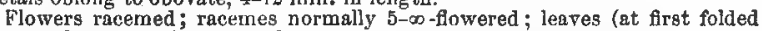
lengthwise) mostly obtuse, sometimes even cordate at base.

Flowering early (mostly $1 \mathrm{Apr} .-15 \mathrm{May}$, frult ripe June-July); leaves

Flowering later (mostly $15 \mathrm{May}-25$ June, fruit ripe A ng.-Sept.); leares

suborbicular-oblong, coarsely dentate
Flowers solitary or $2-4$ in terminal fascicles; lesves (flat even in very early
stages) acutish or subcuneate at base

1. A. canadensis. stages) acutish or subcuneate at base

2. A. oblongifolia.

8. A. spicata.

4. A. oligocarpa.

$\checkmark$ 1. A. canadénsis (L.) Medic. (Shad Bush, Service Berry.) Tree or shrub, 3-12 m. high, nearly or soon glabrous; leaves (when young folderl lengthwise and brownish-purple) ovate to ovate-oblong, usually somewhat cordate at base, pointed, finely and sharply serrate, $4-9 \mathrm{~cm}$. long, $3-6 \mathrm{~cm}$. wide; bracts and stipules very long-silky-ciliate; flowers large, in drooping racemes; 
fruit on elongated pedicels, globose, crimson or purplish. - Dry open woodlands, common. - Dwarf forms with somewhat smaller flowers are found in sterile rocky ground.

Var. Botryàpium (L. f.) T. \& G. Leaves densely tomentose when young, retaining a sparing soft pubescence even in age or tardily glabrate; in other respects like the typical form.-Open ground and wooded hillsides, s. Me. to n. N. H., Mich., and southw.

$\checkmark$ 2. A. oblongifdlia (T. \& G.) Roem. Shrub or small tree, $2-6 \mathrm{~m}$. high ; the young leaves and racemes densely white-tomentose; leaves oblong, usually rounded at each end or mucronate, finely and evenly serrate, at length glabrate, usually pale-green especiałly beneath, $4-6 \mathrm{~cm}$. long, $1.5-2.8 \mathrm{~cm}$. broad ; flowers numerous, smaller, in rather dense racemes; petals obovate or short-oblong; fruit similar, but more juicy and on shorter pedicels. (A. canadensis, var. T. \& G.) - Moist woods and rocky uplands, N. B. to Va., Mo., and Minn. Highly variable, passing into forms with broader elliptical or ovate-lanceolate acutish leaves of deeper green color (being the A. spicata of many auth., not C. Koch). Apparently intergrades with other species. Noteworthy is

Var. micropétala Robinson. Dwarf, 3-9 dm. high; petals $4-7 \mathrm{~mm}$. long, spatulate-oblong to narrowly obovate. - Exposed ledges of rocky hills or dry sandy soil, e. Mass. to $\mathrm{Ct}$., near the coast.

3. A. spicata (Lam.) C. Koch. Shrub, 1-3 m. high; leaves at first covered especially beneath with dense pale yellow tomentum (tardily deciduous as flocculent wool), oval or suborbicular, $3-8 \mathrm{~cm}$. long, $2.3-5.5 \mathrm{~cm}$. wide, coarsely dentate toward the end or more often nearly to the base; veins stronger, straighter, and wore numerous than in the other species; fruit dark purple, autumnal. (Mespilus canadensis, var. rotundifolia Mlichx.; A. rotundifolia Roem.; $A$. alnifolia of some auth., not Nutt.)-Banks of streams, e. Que. to centr. Me., and westw. about the Great Lakes; s. on mts. to w. Mass. (Hofimann).

4. A. oligocárpa (Michx.) Roem. Shrub, 1-3 m. high, early glabrate or nearly so; leaves thin, oblong or oval, finely serrate, $3-5 \mathrm{~cm}$. long, usually acute at the base; flowers few, solitary and terminal or in terminal fascicle-like racemes of 2-4; petals oblong-obovate; fruit often broadly pyriform, at length usually subglobose, dark purple, with dense bloom. (A. arguta Nutt.) - Cold swamps and mt. woods, Lab. to n. N. E., and westw. to L. Superior.

\section{CRatakgus L. Hawthorn. White Thors}

\section{Revised by W. W. Eggleston}

Calyz-tube cup-shaped or campanulate, adnate to the carpels, the limb 5-cleft. Petals 5, white (rarely pink), roundish, inserted on the margin of the disk in the throat of the calyx. Stamens 5-25, inserted in 1-3 rows ; filaments filiform ; anthers oblong, white, yellow, or red. Ovary inferior or its summit free; carpels 1-5; styles 1-5, distinct, persistent, usually surrounded at base by tomentum; stigrmas terminal. Pome small, yellow, red, more rarely blue or black; containing 1-5 bony nutlets, each usually 1-seeded. Seed erect, the testa membranaceous. - Thorny shrubs or small trees, with simple usually lobed leaves (those on vigorous vegetative shoots often of different shape and more deeply cut); stipules linear-lanceolate, very deciduous (those on vegetative shoots much wider and often persistent). Flowers in coryunbs. (Name from kpdros, strength, because of the hardness and toughness of the wood.) A genus of excrptional taxomic difficulty, best developed in the great limestone areas of temperate eastern America, the numerous nearly related species still subject to widely different interpretation by specialists and capable at the present time only of a tentative and provisional treatment. 
N. B. - In this genus, the figures are of the leaves and flowers on a scale of $\frac{2}{3}$, the whole fruit, lateral and terminal views of the fruit with the upper part of the flesh removed, and in some cases ventral vlews of nutlets, all natural size.

\section{Key to Sections, etc.}

a. Introduced species; leaves deeply $3-5$-lobed; fruit red; calyx-lobes entire, short; nutlat solitary .

a. Native species $b$.

b. Nutlets with cavities on their ventral faces. Nutlets with shallow eavities.

Cavities 1 on each ventral face, often faint or wanting; frult red . . . . . \$16

Cavities several on each ventral face, shallow; fruit black : $:$ : : : $:$ : 18

Nutlets with 1 deep cavity on each ventral face . . . . : . : : 17

b. Nutlets without cavities on their ventral faces $c$.

c. Nest of nutlets without sinuses; fruit small.

Nutlets 2 ; leaves deeply lobed or cut . . . . . . . . . . . \$10

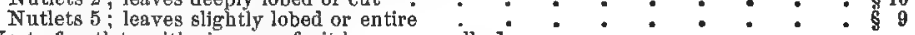

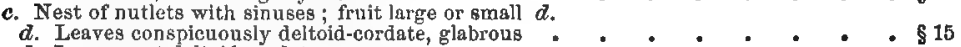

d. Lenves not deltoid-cordate $\theta$.

e. Calyx-lobes foliaceous, persistent on fruit; Howers 1-3(-6) . . . . . 7

6. Calyx-lobes not folinceous, often deciduous $f$.

$f$. Corymbs 8-i-flowered.

Leaves short-obovate to spatulate, very glandular - * . - . - 6

f. Corymbs many-flowered $g$.

g. Leaves obovate or spatulate.

Leaves coriaceous, dark green and shining above . - . - . - \$2

Leaves membianaceous, dull, impressed-veined above.

Fruit glabrous; nutlets acute at both ends; calyx-lobes entire . . . \$ 8

Fruit slightly tomentose; nutlets obtuse at the apex; caly x-lobes serrate no. 49

o. Leaves not obovate or spatulate $h$.

$h$. Leaves 3-lobed toward the apex . . . . . . . . 84

h. Leaves not 3-lobed $i$.

d. Leaves glabrous (when mature) $j$.

4. Leaves broadest at the middle.

Fruit firm when ripe.

Nutlets 2-3 . . . . . . . no. 8

Nutlets 4-5: : : : : : : : : : $:$ no.

Fruit soft when ripe the base. $\quad: \quad-\operatorname{los}_{2} 24,25,26,28$

4. Leaves broadest toward the base.
Fruit firm when ripe . . . . . . . . \$12

Fruit Boft.

Lenves small (3-6 cm. wide); sinuses between the nutlets shallow; nutlets usually $3-4$.

Leaves large (4-10 $\mathrm{cm}$. wide); nutlets $3-5: \quad$ : $\quad$ : $\quad$ nos. 50, 52, 58

t. Leaves pubescent (at least along the veine below).

Leaves broadest at the middle

Leaves broadest toward the base.

Mature leaves usually glabrous above; young foliage bronze-green . \$ 18

Mature leaves tomentose above; young foliage yellow-green . . 14

\section{Adxiliary $\mathrm{KkY}$ (For use in default of mature fruit)}

10. Calyx-lobes entire (sometimes glandular-margined).

Lenves conspicunously deltoid-cordate, glabrous.

Leaves not deltoid-cordate.

Leaves glabrous beneath, pubescent above; region of the apper Great Lakes _ . \$18

Leaves pubescent beneath (at least along the veins).

Leaves deeply lobed; introduced.

Leaves entire or slightly lobed; native.

Leaves broadest toward the apex.

Leaves obovate to oblong.

Leaves coriaceous, dark green and shlning above

Lenves membranaceous, dull, impressed-veined above

Leaves spatulate

Leaves broadest at the middle; apex often 3 -lobed :

u. Calyx-lobes serrate $b$.

Leaves broadest toward the base, membranaceous, glabrous

b. Leaves deeply lobed

b. Leaves entire or slightly lobed c.

c. Corymbs few $(1-7)$-Howered.

Calyx-lobes folinceous, laciniate

Calyx-lobes not foliaceous, glandular-serrate.

Leaves short-obovate, very glandular

Leaves elliptical-ovate, slightly glandular : 
o. Corymbs many-flowered.

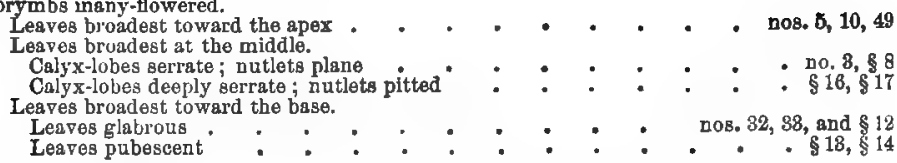

3 1. OXYACANTHAE Loud. Leaves ovate, 3-15-lobed or -cleft, acute at the apex, cuneate to truncate at the base, serrate, $1-4 \mathrm{~cm}$. long, $1-4.5 \mathrm{~cm}$. wide, dark green and glabrous above (when mature), paler and slightly pubescent beneath (especially along the veins); corymbs many-flowered, glabrous; flowers about $1 . \overline{\mathrm{cm}}$. wide; calyx lubes deltoid, entire, vbtuse; stamens about 20 ; anther's pink; styles 1-2; fruit globose or subglobose, red, about $6 \mathrm{~mm}$. thick; calyx-lobes reflexed, persistent; flesh of fruit yellow, mealy; nutlets usually 1 ; shrubs or snall trees, 5-9 m. tall, with strongly ascending branches and dark brown scaly bart; thorns sharp, about $1 \mathrm{~cm}$. long.

1. C. Oxyadentha L. (ENGLish H.) Characters of the section.-Sparingly escaped from cultivation. Fl. May; fr. Sept. (Introd. from Eu.)

§2. CRUS-GALLI Loud. Leaves obovate to elliptical, coriaceous, dark green and shining above, acute or rounded at the apex, cuneate at the base; petiole slightly winged above, glandless, 1-2 cm. long; comymbs manyflowered; calyx-lobes lanceolate-acuminate, usually entire; stamens 10-20; anthers usually pink; fruit subcylindric-ovoid to globose, red, the calyx flattened and the flesh hard, thin, greenish; nutlets $1-3$ (in no. 4 sometimes as many as 5), strongly ridged on the back; trees or shrubs, usually with spreading branches forming a broad crown; bark dark gray, scaly; spines many, strong, straight, chestnut-brown, 3-18 cm. long.

Corymbs and leaves glabrous.

Leaves 2-10 cm. long, 1-4 cm. Wide; nest of 1-2 nutlets longer than thick . 2. C. Crus gatli.

Lenves 2-6 cm. long, 2-5 cm. wide.

Nutlets $2-3$; nest of nutlets about as long as thick

Nutlets $3-5$; nest of nutlets longer than thick

Corymbs and leaves hairy.

Leaves large, 8-9 cm. long, $2-7 \mathrm{~cm}$. wide

Leaves small, 2-6 cm. long, $1-4 \mathrm{~cm}$. wide

2. C. Crus-gálli L. Leaves $2-10 \mathrm{~cm}$. long, 1-4 cm. wide, sharply serrate except toward the base; corymbs glabrous; flowers about $1.5 \mathrm{~cm}$. wide; calyx-lobes glabrous or slightly pubescent; stamens about 10 ; styles $1-3$; fruit ellipsoidalovoid to subglobose, about $1 \mathrm{~cm}$. thick, greenish to dull red; flesh hard and dry;

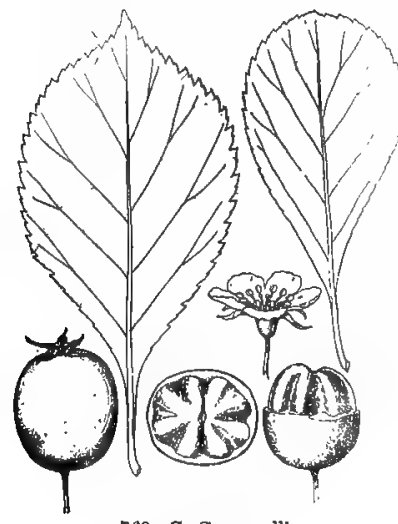

769. O Crus-galli. nutlets usually 2, 8-9 mm. long, 3.5-4.5 mm. thick. - Sandy soil, near Montreal, L. Cbamplain, Nantucket, Hass. (where probably intro. diced), Ct., the lower Hudson Valley to $\mathrm{s}$. ('int., s. Mich., s. e. Kan., and s. to Ga. FIG. 7i9. Var. PYracanthifòlia Ait. has more acute leaves and small bright red fruit. - Occasional, n. Del. to (). Var. oblongata Sarg. liruit ellipsoidal, bright red; nutlets acute. I) thinner; corymbs slightly pubescent; nutlets solitary. - Wilmington, Del. Var. ExfGoA (Sarg.) Fogleston. Fruit ellipsoidal, bright crimson; nutlets solitary. - Ct. Var. PRUNIròr.a (Poir.) T. \& G. Teaves sometimes $7 \mathrm{~cm}$. wide. (C. Bartramiana Sarg.) - Occasional. Fl. May, June; fr. Oct.

C. Crus-gálli $x$ macracántha Eggleston. Broad-leaved forms with foliage as in var. prunifolia, the corymbs pubescent, the calyxlobes scrrate, the nutlets $2-n$, their pits varying 
from shallow to deep, have all the appearan se of natural hybrids between these: two species. (C. persimilis Sarg.; C.prunifolia of European gardens, in part.) - Occasional.

3. C. praténsis Sarg. Leaves ovate-orbicular, $2-6 \mathrm{~cm}$. long, $2-5 \mathrm{~cm}$. wide. coarsely or doubly serrate; flowers about $1 \mathrm{~cm}$. wide; calyx-lobes remotely glandular-serrate, glabrous; stawens about 10 ; anthers yellow or pink; styles $2-3$; fruit short-ovnid to compressed-globose, dull reddish-green ; flesh somewhat succulen', mealy, yellow; nutlets $2-3$, about $5 \mathrm{~mm}$. long; nest of nutlets about 5 Imm. thick. (C. Palmeri Sarg.; C. grandis Ashe.) - Low rich soil, 1ll. and Mo. Fl. May ; fr. Oet.

4. C. Cánbyi Sarg. Leaves oblong-obovate, $2.5-8 \mathrm{~cm}$. long, 2-6 cm. wide, doubly serrate, often lobed toward the apex; corymbs glabrous; flowers about $1.5 \mathrm{~cm}$. wide; styles $3-5$; fruit short-ellipsoidal to globose, $1-1.5 \mathrm{~cm}$. long, dark crimson; flesh bright red, succulent; the $3-5$ nutlets $7-8 \mathrm{~mm}$. long; nest of nutlets 6-7 mm. thick. (C. Pennypackeri Sarg.) - Occasional, e. Pa. and Md. Fl. May ; fr. Oct.

5. C. fecúnda Sarg. Leaves oblong-obovate to oval, $3-9 \mathrm{~cm}$. long, $2-7 \mathrm{~cm}$. wide, doubly serrate, the veins strongly marked; corymbs slightly villous; flowers about $2 \mathrm{~cm}$. wide; calyx-7obes coarsely glandulav-serrate; stamens about 10 ; antlers purple; styles 2-4; fruit short-ellipsoid to subglobose, $2-2.5 \mathrm{~cm}$. long, orange-red, slightly pubescent; calyx-lobes erect; flesh thick; nutlets usually 2-3, 8-10 $\mathrm{mm}$. long; nest of nutlets 8-10 $\mathrm{mm}$. thick. - Rich bottom lands, s. w. Ind. to s. e. Mo. Fl. May; fr. Oct.

6. C. berberifollia T. \& G. Leaves oblong-cuneiform, spatulate, or obovate, 2-6 cm. long, 1-4 cm. wide, rounded or acute and serrate tonard tle apex, rough-pubescent above, white-pubescent or -tomentose beneath; petioles $1 \mathrm{~cm}$. long, densely tomentose ; corymbs densely villous; flowers about $1.5 \mathrm{~cm}$. wide; calyx-lobes slightly villous; stamens about 20; anthers ypllow; styles 2-3; fruit subglobose, about $1 \mathrm{~cm}$. thick, orange or red, slightly pubescent; flesh yellow; nutlets $2-3$, about $6 \mathrm{~mm}$. long; nest of nutlets about $6 \mathrm{~mm}$. thick. Gulf States. - A specimen from Mercersburg, Ya. (Porter) appears intermediate between this and the following.

Var. Engelmánni (Sarg.) Eggleston. Less pubescent; stamens about 10 ; anthers pink. - Va. and Mo. Fl. May; fr. Oct.

§3. PUNCTA TAE Loud. Leaves obovate to oblong, impresspd-veined and usually rather dull above, mustly pulescent l.eneath particularly along the veins, acute or acuminate at the apex, sharply uneate at the borse, serrate, doully serrate, or slightly lobed, but nearly entive toutard the base, subcuriaceous; petioles 1-2 cm. long, stightly winged obove; corymbs many-flowered; calyx-lobes lanceolate-acuminate, entire or sometimes glandular-margined; stamens 10-20; styles 2-5; fruit green, yellow, or red; flesh hard, thich: calyx usnally flattened; nutlets 2-5, ridged on the back; flat-topped trees, 3-10 m. high, with grayish-brown bark; spines straight, 2-7 cm. long.

Fruit ellipsoidal, glabrous; nutlets usually $8-4$.

Yeaves bricht yellow-green above; pest of nutlets longer than thick

Leaves dull gray-green above; nest of nutlets about as long as thick

Frnit globose, glabrous or pubescent; calyx somewhat prominent; nutlets 4-5.

Frult glabrous, green to scarlet; Canadian .

Fruit villous, red; southern .

7. C. pausiaca Ashe, Leaves oblanceolate-obovate, $3-6 \mathrm{~cm}$. long, $1.5-4 \mathrm{~cm}$. wide, dark vivid yellow-green and glabrous above; corymbs pubescent ; flowers $1.2-1.5 \mathrm{~cm}$. wide; calyx glabrous, its lobes slightly pubescent inside; stamens 10-15 ; anthers dark pink; fruit ellipsoidal-pyriform, about $8 \mathrm{~mm}$. thick, dull brick-red; flesh greenish-yellow; nutlets usually 3, 7-10 nim. long; nest of nutlets 6-10 mm. thick. - Abundant in Pa. - Intermediate between C. Crusgalli and $C$. punctata, and to be expected wherever these two species are found. Fl. May; fr. Oct.

8. C. punctàta Jacq. Leaves 2-8 $\mathrm{cm}$. long, 1-5 $\mathrm{cm}$. broad, dull gray-green and strongly impressed-veined above; corymbs tomentose; flowers about $2 \mathrm{~cm}$. 
broad; calyx-tube pubescent, its lobes less so ; stamens usually about 20 ; an. thers white to pink; fruit yellow (var. AúreA Ait.) or red (var. RÙBRA Ait.), $1.2-2.5 \mathrm{~cm}$. thick; nutlets usually $3-4,8-9 \mathrm{~mm}$. long; nest of nutlets $8-10 \mathrm{~mm}$. thick. - Falls of Montmorency, Que., to s. e. Minn., s. (through w. N. E.) to Pa.,

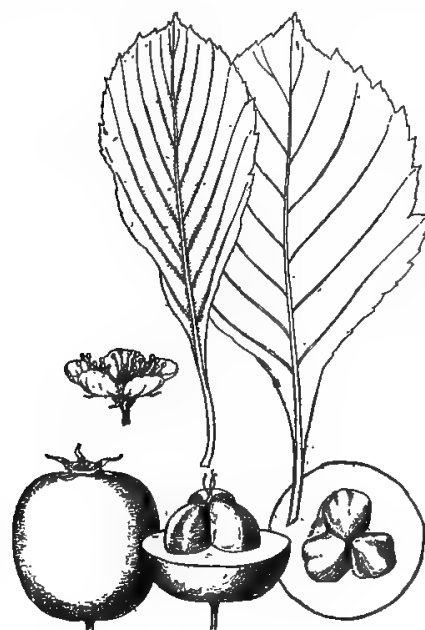

770. C. punctata. n. Ill., and Ia., and along the mots. to n. Ga.; ascending in N. C. to about $1800 \mathrm{~m}$. Fl. May, June; fr. Uct. Fig. 770. Var. OANÉSCENS Britton is a more canescent form occasionally seen.

9. C. suborbiculàta Sarg. Leaves ovateorbicular, 2-7 $\mathrm{cm}$. long, 2-6 $\mathrm{cm}$. wide, membranaceous, dull dark green above, $g l a$ brous; petioles winged above, glandular; coryubs glabrous; flowers about $2 \mathrm{~cm}$. broad; calyx-lobes slightly glandular-margined; stamens about 20 ; anthers rosecolored; styles 4-5; fruit globose or compressed-globose, 1-1.5 cm. thick, dull green to scarlet; calyx somewhat prominent; flesh yellow, containing commonly 5 nutlets (6-7.5 mm. long); nest of nutlets $8-10 \mathrm{~mm}$. thick. - Limestone ridges in the region of Montreal. Fl. May, June; fr. Oct.

10. C. collina Chapm. Leaves obovate to oval, $2-6 \mathrm{~cm}$. long, $1.5-5 \mathrm{~cm}$. wide, yellowgreen, somewhat pubescent when young; petioles slightly pubescent, winged; corymbs and calyx pubescent; flowers $1.5-2 \mathrm{~cm}$. wide; calyx-lobes glabrous or slightly pubescent inside, glandular-ciliate; stamens about 20 ; anthers yellovo; styles 3-5; fruit globose or compressed-globose, dull red, 9-12 mm. thick; calyx somewhat prominent; calyx-lobes persistent; flesh yellow, dry ; nutlets usually 5, 6-7 mm. long; nest of nutlets 8-10 mm. thick. - Common, s. w. Va. to centr. Ga. and n. Miss. Fl. May; fr. Oct.

Var. sórdida (Sarg.) Eggleston. Corymbs rather few-flowered; flowers 2.5-3.5 cm. broad; anthers pink; nutlets 3-4. - Occasional, s. e. Mo. Fl. May; fr. Oct.

Var. Lettermàni (Sarg.) Rggleston. Stamens about 10; fruit subglobose or pyriform, orange-red. - Uccasional, s. e. Mo. Fl, May; fr. Oct.

\$ 4. VfRIDES Beadle. Leaves oblong-ovate to oval, obtuse, acute, or acuminate (often 3-lobed) at the apex, cuneate at the base, serrate or doubly serrate or lobed, dark green, shining, and glabrous above, paler and somevhat pubescent along the veins beneath, usually membranaceous, petioles 1-3 cm. long, slightly winged above; corymbs fev-many-flowered, glabrous; calyxlobes entire or slightly glandular-margined, triangular to lanceolate-acuminate; stamens 10-20; anthers yellow; styles 2-5; fruit glabrous, red, subglobose to ellipsoidal; flesh hard; nutlets 3-5 (2 in no. 11), ridged on the back; trees or large shrubs, 6-11 m. high, with ascending or nearly erect branches, dark brazon bark, and straight spines $2-5 \mathrm{~cm}$. long.

Nutlets 2 ; fruit large, 8-15 mm, thick; lobes of the leaves crenate

Nutlets $8-5$; fruit small, $5-9 \mathrm{~mm}$, thick; lobes dentate.

Fruit bright red, glaucous, 4-6 $\mathrm{mm}$. thick

Fruit dull dark red, $6-9 \mathrm{~mm}$. thick.

11. C. Margarétta Ashe. Leaves 2-6 cm. long, 2-4 cm. wide, obtuse or acute at the apex, crenate-lobed, slightly pubesoent when young, glabrate; corymbs 5-12-flowered, slightly pubescent at first; flowers $1.5-2 \mathrm{~cm}$. wide; calyx-lobes slightly pubescent inside; styles 1-3; fruit dull rusty green to red, 8-15 mm. thick; fiesh yellow, dry and mealy; nutlets usually 2 , about $6 \mathrm{~mm}$. long, about 
2 mm. thick; a tree, with a narrow open crown, 4-8 m. high. (C. Brownii Britton? ?- - Woods and banks of streams, s. Ont. to centr. Ia., s, to centr. Pa., w. Va., and Mo. Fl. May; fr. Oct.

12. C. viridis L. Leaves $2-8 \mathrm{~cm}$. long, $2-5 \mathrm{~cm}$. wide, serrate; flowers 1-1.5 cm. wide; calyx-lobes slightly pubescent inside; styles 4-5; fruit globose or depressed-globose, bright red, glaucous, 4-6 mm. thick; nutlets usually 5, 3.5-5 mm. long; nest of nutlets $3.5-5.5 \mathrm{~mm}$. thick. - Moist soil of the lowlands, Chesapeake City, Md. (Ward), Va. (Clayton) to Mo., s. to Fla. and Tex. Fl, May; fr. Oct.

13. C. nitida (Engeim.) Sarg. Leaves 3-8 cm. long, 2-6 cm. wide, coarsely serrate; corymbs many-flowered, $1.2-2 \mathrm{~cm}$. wide; calyx-lobes lanceolate, acuminate; fruit globose to short-ellipsoidal, dark dull red, 6-9 mm. thick; flesh yellow, mealy; nutlets $3-5,4.5-7$ num. long ; nest of nutlets $5-7 \mathrm{~mm}$. thick; tree sometimes $9 \mathrm{~m}$. high, with a broad crown. - Rare, s. Ill. to s.e. Kan. Fl. May ; fr. Oct. Frg. 771.

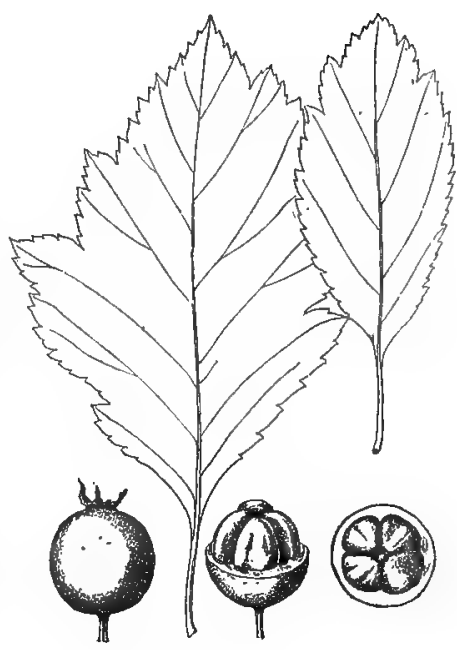

771. C. nitida.

§5. INTRICATAE Sarg. (Borntonianae Beadle; Biltmoreanae Beadle.) Leaves elliptic-ovate, acute and varying from attenuate to truncate, doubly servate or lobed (the teeth gland-tipped), subcoriaceous, yellow-green, bright above; petioles 1-3 cm.long, glandular, slightly winged above; young foliage usually yellow-green; corymbs $3-7$-flowered; bracts very glandular, deciduous; calyx-lobes lanceolate-acuminale or acute, for the most part strongly toothed toward the apex, often entire at the base; stamens about 10 ; anthers usually yellow; styles 2-5; fruit greenish or reddish-yellow to reddish-brown, globose to pyriform, bluntly angular; calyx prominent, its lobes reflexed; flesh of the fivit hard, thick; nutlets usually 3-4, strongly ridged on the back; irregularly topped shrubs or small trees, 1-8 m. high (with occasional spines), preferring rocky woods and cliffs, more common and typical in the southern mountains.

Foliage, corymbs, and fruit glabrous.

Calyx-lobes nearly entire; fruit globose, yellow-green; nutlets 8-5; leaves ovate or oval

Calyx-lobes serrate; intlets usually $8-4$.

Leaves ovate to oval ; fruit globose, red-brown or orange-red . Leaves elliptical-ovate; fruit usually pyriform, yellow-green, tinged with

Foliage and fruit pubescent; corymbs villous.

Fruit globose: anthers yellow.

Matare fruit reddish-brown; nutlets $3-4$.

Mature fruit yellow; nutlets $4-5$.

Fruit pyriform, yellow; nutlets $3-1$; anthers pink

14. C. Boyntòni Beadle. Leaves broadly ovate or oval, glabrous, $2-5 \mathrm{~cm}$. long, $2-5.5 \mathrm{~cm}$. wide; corymbs glabrous; flowers about $2 \mathrm{~cm}$. broad; calyxlobes entire, except near the apex; styles 3-5; fruit globose or depressed-globose, yellow-green, tinged with red, $1-1.5 \mathrm{~cm}$. thick; nutlets $3-5,6-8 \mathrm{~mm}$. long ; nest of nutlets 7-9 mm. thick. - In woods and on banks of streams, between 400 and $900 \mathrm{~m}$. elevation, s. w. Va., N. Car., and Tenn. Fl. May; fr. Oct.

15. C. foetida Ashe. Leaves elliptical-ovate to oval, $4.5-7 \mathrm{~cm}$. long, $4-6 \mathrm{~cm}$. wide, glabrous; corymbs glabrous; flowers about $2 \mathrm{~cm}$. wide ; styles 3-5; fruit subglobose, 1-1.5 cm. thick, orange-red or red-brown; nutlets usually 3-4, 6-8 $\mathrm{mm}$. long ; nest of nutlets 6-9 mm. thick. (C. Baxteri Sarg.)-Conimon, e. Mass. to s. Ont., s, to Va. Fl. May; fr. Oct. 
16. c. appósita Sarg. Leaves elliptical-ovate, $2-7 \mathrm{~cm}$. long, $1.5-5 \mathrm{~cm}$. wide, lobed (the lower pair of lobes often deeply cut), glabrous; corymbs and calyx glabrous ; flowers $1.5-2 \mathrm{~cm}$. wide; fruit pyrifom to ellipsoidal, yellow-green, tinged with red, about $1 \mathrm{~cm}$. thick; the $3-4$ nutlets $5-7 \mathrm{~mm}$. long; nest of nutlets $6-8 \mathrm{~mm}$. thick. (C. coccinea, var. viridis 'T. \& G., in part; $C$. coccinea

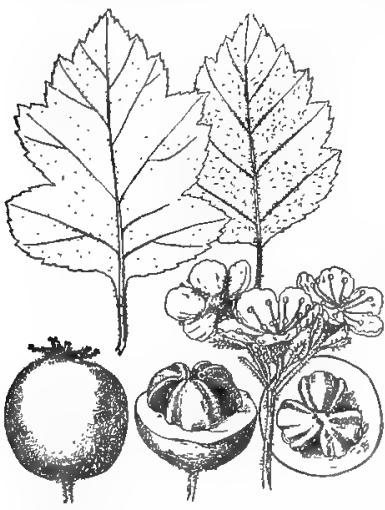

772. C. coccinea. Britton, not L.; C. intricata Sarg., not J. Lange.) - Rocky woods, s. w. Vt. and Mass. to N. Y. and Va. Fl. May, June; fr. Oct.

Var. Bisséllii (Sarg.) Eggleston. Leaves more entire; anthers pink; fruit orange-red - $\mathrm{Ct}$.

17. C. coccínea L. Leaves rough-pubescent, sometimes becoming very scabrous, $2-7 \mathrm{~cm}$. long, 1.5-5 cm. wide; corymbs and calyx villous; flowers about 2.5 cm. wide; stamens about 10 ; anthers light yellow; fruit subglobose to ellipsoidal, pubescent, sometimes becoming nearly glabrous, $8-10 \mathrm{~mm}$. thick, yellow-green, becoming dark reddish-brown when fully ripe; mutlets usually $3-4,5-7 \mathrm{~mm}$. long; nest of nutlets 6-8 mm. thick. (C. coccinea, var. viridis T.\& G., in part ; C. intricata $J$. Lange; C. modesta Sarg.; $C$. premora Ashe.) - Rocky woods, e. Mass. to s. w. Vt., s. e. N. Y., w. Pan, and N. C Fl. May, June; fr. Oct., Nov. Fig. 772 .

18. C. biltmoreàna Beadle. Leaves ovate-elliptical to broadly ovate, $2-9 \mathrm{~cm}$. long, $2-7 \mathrm{~cm}$. wide, pubescent on both sides ; corymbs and calyx villous ; flowers $2-2.5 \mathrm{~cm}$. wide; fruit globose to subglobose, $1.2-1.5 \mathrm{~cm}$. thick, greenish-yellow, yellow, or orange; nutlets usually 4-5,5-7 mm. long; nest of nutlets $7-10 \mathrm{~mm}$. thick, - Mountainous regions, Va. to N. C. and (?) Mo. Fl. May ; fr. Oct.

19. C. Stònei Sarg. Leaves oblong to oblong-ovate, 7-8 cm. long, $4-6 \mathrm{~cm}$. wide, scabrate above, slightly villous along the veins beneath; corymbs villous; flowers $1.5-2 \mathrm{~cm}$. wide; calyx villous; anthers pink; fruit pyriform to shortellipsoidal, 1.2-1.4 cm. thick, light yellow or yellow-green tinged with red, slightly villous; the $3-4$ nutlets $6-8 \mathrm{~mm}$. long; nest of nutlets $6-8 \mathrm{~mm}$. thick. (C. Peckii Sarg.) - Centr. Mass. to Albany, N. Y. Fl. May, June ; fr. Oct.

\$6. FLAVAE Loud. (EuflavaE Beadle.) Leaves short-obovate to spatulate, membranaceous and together woith the petioles and corymbs conspicuously glandular; corymbs few-flowered; calyx-lobes glandular-serrate; fruit usually soft, green, orange, or red, subglobose to ellipsoidal; calyx prominent, its lobes reflexed; nutlets $3-5$, ridged on the back; shrubs or small trees, 1-10 m. high, frequently with undulating or zigzag branches, armed with straight spines $2-6 \mathrm{~cm}$. long. - A group very abundant both in species and individuals south of our range.

20. C. aprìca Beadle. Leaves obovate, rhombic-ovate, or orbicular, $1.5-5 \mathrm{~cm}$. long, $1.5 \mathrm{~cm}$. wide, slightly pubescent, becoming very glabrous, acute at the apex, abruptly cuneate or rounded at the base, dentate, crenate-dentate, or lobed above the middle, dark yellow-green; petioles $7-20 \mathrm{~mm}$. long, wingmargined; corymbs 3-6-flowered, pubescent; stamens 10 ; anthers yellow; frut globose, 0-14 $\mathrm{mm}$. thick, red or orange-red; nutlets about $7 \mathrm{~mm}$. long ; nest of nutlets 6-8 mm. thick. - "Sunny exposures in the mountains," s. Va., W. N. C., e. Tenn., and n. Ga. Fl. May ; fr. Sept., Oct. Fig. 773.

C. JLAva Ait. (described from English botanical gardens) has oval to obovate glabrous leaves,

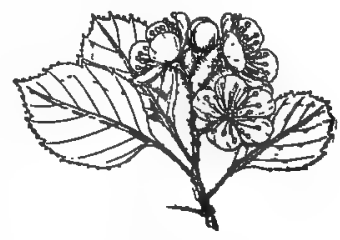

778. C. aprica. 
10 stamens, pink anthers, and pyriform yellow-green fruit. It should be sought ill s. Va.

§ Т. I'ARVIFÓLIAE Loud. (TírloraE Beadle.) Leaves rather small, spatulate, obovate, or oval, obtuse, rounded, or acute at the apex, cuneate at the base, crenate, rrenate-dentate, or serrate, subcoriaceous, shining above, very pubescent when young, becoming scabrate above when mature; petioles very short, pubescent, winged; corymbs tomentose, 1-6-flowered; calyx-lobes long and foliacerus, slightly pubescent, laciniate; stamens about 20 ; anthers white; styles 5-7; fruit pubescent, globose or pyriform, greenishyellow or red; calyx prominent, its lobes reflexed; flesh firm; nutlets usually 5, often more; shrubs, 1-4 m. tall, armed with slender straight often foliaceous spines 1-6 cm. long.

Leaves obovate or spatulate, usually obtuse; corymbs 1-3-flowered .

Leaves ovate, usually acuie; corymbs 3-6-tlowered

-21. C. tomentosa.

22. C. Tailiae.

21. C. tomentosa $\mathrm{L}$. Leaves obovate to spatulate, obtuse or rounded at the apex, $1.5-4 \mathrm{~cm}$. long, 1-3 cm. wide, crenate; corymbs 1-3-flowered, flower's $1-1.5 \mathrm{~cm}$. wide; fruit subglobose, $1-1.5 \mathrm{~cm}$. thick, yellow-green; nutlets 7-9 mm. long, grooved on the back; nest of nutlets $8-10 \mathrm{~mm}$. thick. ( $C$. uniflora

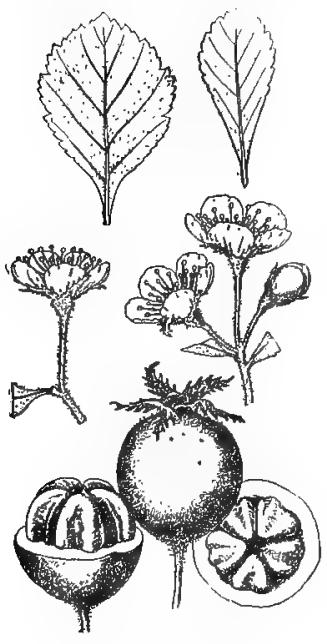

774. C. tomentosa. Muench.; C. parvifolia Ait.) - Sandy soil, L. I. to Fla., w. Ky., Mo., and centr. 'Tex. Fl. May; fr. Oct. Fig. 774. Var. Smíthi (Sarg.) Eggleston. Leaves serrate; fruit red. - Near Philadelphia. Fl. May; fr. Sept.

22. C. Valliae Britton. Leaves $2-5.5 \mathrm{~cm}$. long, $1-4.5 \mathrm{~cm}$. wide, oval or ovate, acute at the apex, cuneate at the base, crenate-serrate, often slightly 3-5-lobed; petioles 4-10 $\mathrm{mm}$. long; corymbs 3-6flowered; flowers $1-1.5 \mathrm{~cm}$. wide; fruit globose. 8-10 mm. thick, reddish-brown; nutlets $5-6 \mathrm{~mm}$. long; nest of nutlets $7-8 \mathrm{~mm}$. thick, - Va. to $\mathrm{n}$. $\mathrm{w}$. Ga.; Greensboro, Ala.

§8. ROTUNDIFOLIAE Eggleston. (Coccineat Sarg.) Leaves elliptical-ovate to orbicular, doubly serrate or lobed, subcoriaceous, darl. yellow-green and shining above; petioles glandular, slightly winged above, 1-5 cm. long; young foliage usually yellow-green; corymbs manyflowered; calyx-lobes glandular-serrate, usually lanceolate-acuminate; stamens 5-20; anther's usually yellow; styles 2-5; fruit depressed-globose to short-ovoid, red; flesh soft; calyx-lobes reflexed; nutlets usually $3-4$, ridged on the back; round-topped shrubs and trees, 3-10 m. high, with numerous curved spines (2-7 cm. long).

Leaves elliptic-ovate, sharply cuneate, deeply-incised

Leaves ovate-orbicular, broadly cuneate or truncate at base.

Calyx prominent; fruit subglobose

Calyx obscure.

Fruit pyriform, yellow-red .

Fruit globose, red.

Fruit angular in cross-section.

Fruit glabrous; flowers $2-2.5 \mathrm{~cm}$. wide; leaves slightly lobed. 26, C. Jackii.

Fruit pubescent; flowers about $1.5 \mathrm{~cm}$. wide; leaves sharply lobed . 27 C. irrasa.

Fruit round in cross-section.

Nest of nutlets shorter than thick; fruit about $1 \mathrm{~cm}$. thick, dark red ; lenves $3-6 \mathrm{~cm}$. wide; anthers yellow

Nest of nutlets longer than thick; fruit about $1.5^{\circ} \mathrm{cm}$, thick, carminered; leaves $1-\xi \mathrm{cm}$. widle; anthers ptnk

24. r. Tonesae.

23. C. columbiant.

24. C. Macauleyate.

25. C. Oakesiana.

24. C. roturudifolia.

23. C. columbiàna Howell. Leaves cunerte-obonate or oblong, 2-6 cm. long, 1-5 cu. wide, incisely 5-9-lobed ahuve the micldle, acute to acuminate, sparingly 
villous ; corymbs slightly villous; flowers about $1.5 \mathrm{~cm}$. broad; calyx glabrous, its lobes triangular-acuminate, slightly villous inside, often red-tipped; stamens about 10 ; styles 2-5; fruit scarlet, short-pyriform, 8-12 mm. long; calyx. lobes persistent; flesh glutinous; nutlets usually 3-4, 6-8 $\mathrm{mm}$. long; nest. of nutlets 6-7 min. thick. - ('olumbia $R$. and tributaries, e. of Cascade Mts. Fl. May; fr. Aug., Sept. Var, P'Pìiı (Britton) Eggleston. Leaves nore pubes. cent; corymbs varying from slightly to densely pubescent; fruit pubescent. With the typical form westward, but extending e. to s. Minn. and L. Superior.

Var. Brunetiàna (Sarg.) Eggleston. Leaves often ovate, $2-9 \mathrm{~cm}$. long, $2-\varepsilon$ sm. wide; corymbs slightly pubescent; calyx-lobes lanceolate-acuminate. Nfd. to L. Superior., s. to N. S. and centr. Me. Fl. June; fr. Sept.

$\times$ ? C. laurentiàna Sarg. Similar to var. Piperi, but usually with 4-5 nutlets with occasional shallow pits on their ventral faces. - A possible hybrid, occurring near Montreal.

24. C. Macaulèyae Sarg. Leaves ovate or oval, $4-6 \mathrm{~cm}$. long, 3.5-5 cm. wide, acute, abruptly cuneate or rounded at the base, membrancceous, glabrons, dull dark green; corymbs glabrous; flowers $1.6-1.8 \mathrm{~cm}$. broad ; caly its lobes pubescent inside ; stamens about 20 ; anthers snall, yellow ; styles 4-5; fruit subglobose to short-ellipsoidal, dark crimson, 1-1.2 cm. thick; calyx prominent; lesh thin, yellow, dry; the $4-5$ nutlets $7-8 \mathrm{~mm}$. long; nest of nutlets $7-8$ mm. thick. - Occasional, w. N. Y. Fl. May; fr. Oct.

25. C. Oakesiàna Eggleston. Leaves ovate to broadly ovate, acute or acuminate, gradually or abruptly cuneate, slightly pubescent above, becoming glabrate, 3-7 cm. long, 3-6 cm. wide, doubly serrate toward the apex; corymbs slightly villous; flowers about $2 \mathrm{~cm}$. wide; calyx villous, its lobes glabrous outside, slightly villous inside; stamens about 20; anthers yellow; styles 3-5; fruit pyriform-ellipsoidal, slightly angular, yellowish-red, about $1 \mathrm{~cm}$. thick; sepals deciduous; flesh soft, mealy, light yellow; the $3-5$ nutlets 6-7 mm. long; nest of nutlets 7-8 mm. thick. - Valley of the Connecticut, n. e. Vt. Fl. May ; fr. Aug., Sept.

26. C. Jáckii Sarg. Leaves ovate-orbicular to obovate, $3-6 \mathrm{~cm}$. long, $2.5-5$ $\mathrm{cm}$. wide, acute, cuneate to rounded at base, dull dark green above, slightly

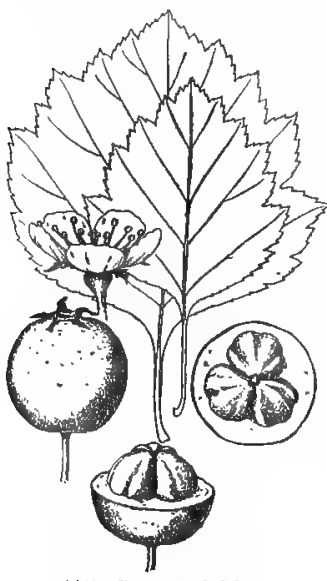

7เ5. C. rotundifolia. pubescent, glabrate ; corymbs slightly villous; flowers $2-2.5 \mathrm{~cm}$. wide; calyx glabrous, its lobes sharply glandular-serrate, slightly pubescent inside; stamens 5-10 ; anthers yellow ; styles 2-3 ; fruit ovoid-ellipsoidal, 1-1.5 cm. thich, dull dark red, prominently angled; flesh thick, reddish ; the $2-3$ nutlets $7-9 \mathrm{~mm}$. long; nest of nutlets $9-10 \mathrm{~mm}$. thick. (C. rotundata Sarg.) - Isle of Montreal to s. Ont. Fl. May; fr. Sept.

27. C. irràsa Sarg. Leaves ovate to elliptical, acute, broadly cuneate, or truncate at base, with 4-6 pairs of acute lobes, $3-6 \mathrm{~cm}$. long, $3-6 \mathrm{~cm}$. wide, membranaceous, slightly pubescent, becoming glabrous above, pubescent beneath, particularly along the veins; corymbs slightly villous; flowers about $1.5 \mathrm{~cm}$. wide; calyx villous, its lobes slightly villous inside; stamens about 20 ; styles $3-5$; fruit sub. globose to short-ellipsoidal, slightly angled, sparingly pubescent, dull red, about $1 \mathrm{~cm}$. thick, with persistent calyx-lobes and reddish flesh; the 3-5 nutlets 6-8 inm. long; nest of nutlets 8-10 num. thick. - Isle of Montreal and Montmorency Falls, Que. Fl. May; fr. Sept.

Var. divérgens Peck. Corymbs more villous; fruit scarlet; nutlets usually 3. - Neal Albany, N. Y.

Var. Blanchárdi (Sarg.) Eggleston. Corymbs and calyx more villous than in the typical form; anthers pink; fruit dark cherry-red. - Deerfield Valley, Vt.

28. C. rotundifolia Moench. Leaves ovate-orbicular or obovate, $3-5 \mathrm{~cm}$. 
long, 2-6 $\mathrm{cm}$. wide, acute, broadly cuneate, doubly serrate with rather cocrse teeth and with 3-4 pairs of acute lobes, glabrous ; corymbs glabrous or slightly pubescent; flowers about $2 \mathrm{~cm}$. wide; calyx-lobes slightly villous inside; stamens $5-10$; styles $2-4$; fruit $1 \mathrm{~cm}$. thick, red ; flesh yeljow, dry, sweet; nutlots usually $2-3,6-7 \mathrm{~mm}$. long ; nest of nutlets $7-9 \mathrm{~mm}$. thick. (C. glandulosa Ait.; C. coccinea, var. rotundifolia Sarg. ; $C$. Dodgei Ashe.) - N. S. to s. Minn., s. to n. Ill., and in the Alleghenies to Va. Fl. May; fr, Sept. F16. 775.

Var. Bicknellii Eggleston. Leaves somewhat sharply lobed toward the apex: calyx-lobes long, laciniate, persistent on the fruit; nutlets usually 4-5. - Nantucket I, Mass. Fl. May; fr. Sept.

Var. Faxòni (Sarg.) Eggleston. Leaves, corymbs, and fruit pubescent. ( $C$. coccinea Linnean herbarium, in part.) - Completely intergrading with the typical form and of the same range. Fr. Aug., Sept.

Var. chrysocárpa (Ashe) Eggleston. Leaves slightly smaller and fruit yellow-red; otherwise like the preceding variety. (C. Sheridana Nelson.) - Cook Co., Minn. (MacMillan), to Col, and Assina.

29. C. Jonèsae Sarg. Leares elliptical-ovate, 4-10 cm. long, 3-8 cm. wide, acute or obtuse, cuneate, glabrous except along the veins beneath, the lobes acute and tips reflexed; petioles slightly pubescent, $3-5 \mathrm{~cm}$. long; corymbs somewhat villous; flowers about $2.5 \mathrm{~cm}$. wide; calyx villous, its lobes linear, acuminate, glabrous outside, slightly pubescent inside; stamens about 10 ; anthers large. pink; styles 2-3; fruit short-ellipsoidal to pyriform, about $1.5 \mathrm{~cm}$. thick, bright carmine-red, slightly pubescent; flesh thick, yellow; calyx-lobes long, appressed; nutlets usually 3 , about $9 \mathrm{~mm}$. long; nest of nntlets about $8 \mathrm{~mm}$. thick. - Mt. Desert I. and adjacent coast to Falmouth, Me. (Chamberlain). Fl. June; fr. Oct.

\$ 9. MICROCÁRPAE Loud. Leaves spatulate to oblanceolate, 8-35. $\mathrm{mm}$. long, 4-20 mm. wide, acute or rounded and sometimes 3-5-lobed at the apex, sharply cuneate into a winged petiole, crenate-serrate, dark green and

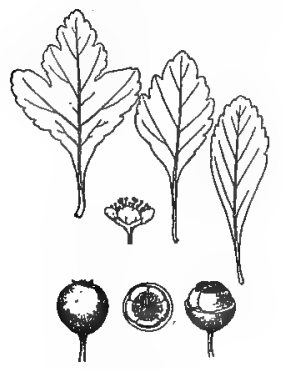

7\%6. C. spathulata. slightly villous along the veins above when young, then glabrate, membranaceous; flowers in manyflowered glabrous corymbs, about $1 \mathrm{~cm}$. wide; calyxlobes deltoid, entire; stamens about 20 ; anthers red; styles 3-5; fruit globose to subglobose, red, 4-6 mm. thick, with reflexed calyx-lobes and dry mealy flesh; nutlets 3-5, slightly ridged on the back, 3-4.5 $\mathrm{mm}$. long, bare at the apex; nest of nutlets $3.5-4.5 \mathrm{~mm}$. thick; shmib or small tree, 6-8 m. high; branches upright and spreading; bark grayish-brown, slightly scaly; twigs reddish-brown, glabrous; thorns sparse, straight, 3-4 cm. long.

30. C. spathulata Michx. The only species of the section. - Moist rich soil of the coastal region, Va. to Fla. and Tex.; also s. Ark. and s. e. Okla. FIG. 776.

\$10. APIIFÒLIAE Loud. Leaves broadly ovate to orbicular, 1-4 cm. long, 1-4 cm. wide, acute, slightly cordnte to cuneate at the base, pinnately 5-7lobed, simply ov doubly servate, pilose above when young, often glabrute, pilose beneath, especially along the veins, membranaceous; petioles 2.5-5 $\mathrm{cm}$. long, tomentose; flowers about $1.5 \mathrm{~cm}$. wide, in 3-12-flowered villous corymbs; calyx-lobes. lanceolate, acuminate, serrate, glabrous outside, slightly pubescent inside; stamens about 20 ; anthers dark red; styles 1-3; fruit ellipsoid or ovoid, 4-7 mm. long, scarlet, slightly pubescent with reflexed calyx-lobes and thin firm flesh; nutlets commonly 2, 5-6.5 mm. long, smooth on the back, bare at the apex; nest $3-3.5$ mm. thick, with no sinus between the nutlets; shrubs or small trees, 2-6 m. high, with nearly horizontal branches and smooth gray bark; twigs light red, long-tomentose but gla. brate; thorns few, chestnut-browu, 2.5-4 cm. long, straight. 


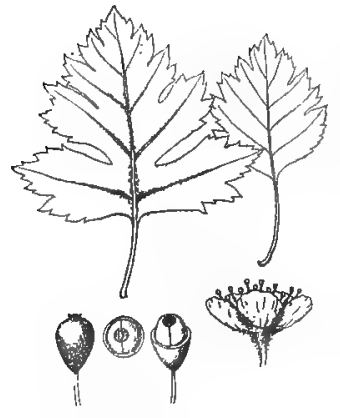

ก7ร. C. Marshallii.

31. C. Marshállii Eggleston. The only species of the section. (Mespilus apiifolia Marsh.; C. apiifolia Michx., not Medic.) - Along streams and about swamps in the lowlands, s. Va. to Fla., w. to Mo. and Tex. Fig. 777.

§ 11. TENUIFÒLIAE Sarg. Leaves ovate, serrate, doubly serrate, or lobed, acute or acuminate, slightly villous but glabrate, dark yellow-green above, paler beneath; petioles slender, $1.5-3 \mathrm{~cm}$. long; young foliage usually bronze-green; corymbs many-flowered; calyx-lobes lanceolateacuminate, usually entive (often glandularmargined), slightly pubescent inside; stamens $5-20$; anthers usually pink; styles 2-5; fruit ellipsoidal, ovoid, or pyriform, red, glabrous, with vather persistent evect or spreading calyxlobes and succulent edible flesh; nutlets usually 3-4, strongly ridged on the back; shrubs or small trees, 2-7 m. high, with ascending branches and strong curved spines 2-7 cm. long. - This section is the most troublesome of any in our range, specific lines being here particularly hard to draw.

Fruit ellipsoidal, ovoid, or pyriform.

Calyx-lubes serrate.

Leaves broadly ovate, flabellate, the lobes reflexed . . - . . 82. C. crudelis.

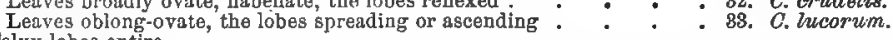

Calyx-lobes entire.

Fruit small, 6-9 mm. thfek, with rather firm flesh ; leaves conspicuously

Frult large, $1-1.5^{\circ} \mathrm{cm}$. thick, with soft flesh; leaves not conspicuously
lobed

Fruit compressed-globose or subglobise.

Lobes of the leaves rehexed ; leaves flabellate

Lobes of the leares sprending or ascending.

Terminal leaves cuneate or rounded at the base

Terminal leaves cordate

84. C. roanentis.

85. C.macrosperma.

86. C. Grayana.

37. C. alnorum.

88. C. populnea.

32. C. crudèlis Sarg. Leaves ovate to broadly ovate, $3-7 \mathrm{~cm}$. Iong, $2.5-6 \mathrm{~cm}$. broad, sharply lobed (the tips of the lobes often recurved), broadly cuneate or truncate, rarely cordate at the base, slightly villous above, becoming scabrate or glabrate; corymbs slightly villous at first; flowers $1.5-2 \mathrm{~cm}$. wide; calyxtube and inside of the lobes slightly villous ; stamens about 10 ; styles $3-5$; fruit ellipsoidal, 8-12 mm. thick, scarlet or crimson; the $3-5$ nutlets $6-8 \mathrm{~mm}$. long; nest of nutlets 6-8 mm. thick. (Mespilus flabellata Bosc, not C. flabellata Heldreich; C. blandita Sarg.) - Caughnawaga Reservation to Falls of Montmorency, Que. Fl. May ; fr. Sept.

33. C. lucòrum Sarg. Leaves oblong-ovate to broadly ovate, 3-6 cm. Iong, $2-5 \mathrm{~cm}$. wide, acute or acuminate at the apex, broadly cuneate or rounded at the base, finely and doubly serrate or lobed; corymbs slightly villous; flowers about $2 \mathrm{~cm}$. broad; calyx glabrous except for a slight pubescence on the inner surface of the lobes; stamens about 20 ; anthers small, deep pink ; styles 4-5; fruit pyriform-ellipsoidal, crimson, $1.5-2 \mathrm{~cm}$. long. - Occasional, n. Ill. and s. e. Wisc. Fl. May ; fr. Sept.

Var. insolens (Sarg.) Eggleston. Styles $3-5$; fruit ellipsoidal, scarlet, glabrous, 1-1.2 cm. long; flesh rather firm; nutlets usually $3-4,6-7 \mathrm{~mm}$. long; nest of nutlets $6-7 \mathrm{~mm}$. thick. - Rare, n. e. Vt.

34. C. roanénsis Ashe. Leaves ovate or oblong-ovate, $2.5-7 \mathrm{~cm}$. long, 2-6 cm. wide, with 3-6 pairs of acute usually straight lobes, the base broadly cuneate to cordate; corymbs glabrous or slightily villous; finwers about $1.5 \mathrm{~cm}$. wide; calyx-lobes slightly villous inside ; stamens $5-20$, usually $5-10$; styles $2-5$; fruit 7-9 mm. thick, 9-13 mm. long, crimson; flesh rather firm; nutlets 6-8, mm. long; nest of nutlets 6-7 mm. thick. (C. fluviatilis Sarg. ; C. ascendens Sarg. i 
C. uber Ashe.) - Montreal to Wisc., s. through w. N. E. to Pa., and in the mts. (ascending to $1800 \mathrm{~m}$.) to N. C. and Tenn. Fl. May ; fr. Sept.

35. C. macrospérma Ashe. Leaves elliptical-ovate to broadly ovate, rounded to truncate or rarely cordate at the base, $2.5-7 \mathrm{~cm}$. long, $2-7 \mathrm{~cm}$. wide, the lobes acute; corymbs glabrous or slightly villous; flowers $1.5-2 \mathrm{~cm}$. wide; stamens

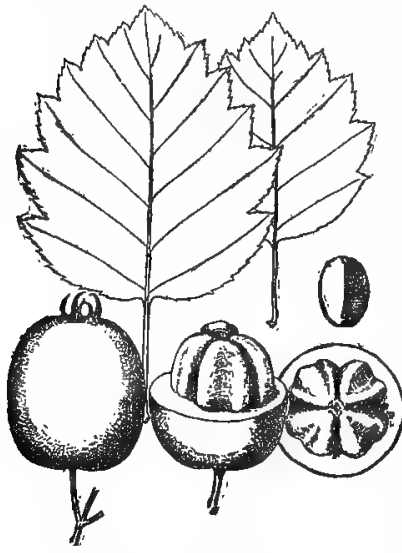

778. C. macrosperma. $5-10(-20)$; styles $2-5$; fruit ellipsoidal or pyriform, 1-1.8 cm. thick, scarlet to crimson, often glaucous; nutlets usually $3-4,6-8 \mathrm{~mm}$. long ; nest of nutlets $6-8 \mathrm{~mm}$. thick.- $N$. S. and $\mathrm{n}$. Me. to n. Mich. and s. e. Minn., s. to Pa., n. Ill., and in the $\mathrm{mts}$. to N. C. and Tenn. Fl. May; fr. Sept. Fig. 778. Var. PENTÁNdRA (Sarg.) Eggleston. Leaves sharply cuneate at the base. - Vt. to Va. Var. Demfssa (Sarg.) Eggleston. Leaves and fruit smaller. - Occasional, w. N. E. to n. Ill. and w. Va.

Var. pastorum (Sarg.) Eggleston. Leaves more nearly entire ; fruit dark crimson. - Low grounds, w. N. E. and N. Y. Var. MatúnA (Sarg.) Eggleston. Lobes of the leaves acuminate, often recurved. - Range of the typical form. Fr. Aug ", Sept. Var. acutíloba (Sarg.) Eggleston. Lobes of leaves acuminate, recurved; leaves of vegetative shoots often cordate. - Coast of N. S. and N. E.

36. C. Grayàna Eggleston. Leaves flabellate, $2.5-8 \mathrm{~cm}$. long, $2-7 \mathrm{~cm}$. wide, acuminate, broadly cuneate to truncate at the base, slightly

pubescent above, glabrate, the lobes 4-6 pairs, often acuminate, their tips recurved; corymbs slightly villous; flowers about $1.5 \mathrm{~cm}$. wide; calyx-tube villous below, the lobes glabrous outside, slightly villous within, somewhat glandular-margined; stamens about 20 ; styles $3-5$; fruit subglobose to shortellipsoidal, angular, dark cherry-red, with reflexed calyx-lobes and thick yellow mealy flesh ; nutlets usually 4-5, 6-7.5 mm. long ; nest of nutlets 6-7 mm. thick, strongly ridged on the back. (C. flabellata Sarg., not Mespilus flabellata Bosc.) - Montmorency Falls to Montreal, Que., w. N. E. and n. e. N. Y. Fl. May; fr. Aug., Sept.

37. C. alnorum Sarg. Leaves ovate, $3-7 \mathrm{~cm}$. long, $2.5-6.5 \mathrm{~cm}$. wide, broadly cuneate to truncate; corymbs glabrous; flowers $1.5-2 \mathrm{~cm}$. Wide; stamens about 20 ; fruit subglobose, $1.2-1.5 \mathrm{~cm}$. thick, slightly angular, dark cherry-red; flesh yellow, acid; the 3-5 nutlets $7-8 \mathrm{~mm}$. long; nest of nutlets $8-9 \mathrm{~mm}$. thick. ( $C$. Edsoni Sarg.) - N. E. to s. Mich. and Pa. Fl. May; fr. Sept.

38. C. popúlnea Ashe. Leaves broadly ovate to elliptic-ovate, $2.5-6.5 \mathrm{~cm}$. long and wide, broadly cuneate to truncate at the base, those on vegetative shoots asually cordate; corymbs glabrous; flowers $1.5-2 \mathrm{~cm}$. wide; stamens 5-10; styles 2-4; fruit globose to short-ellipsoidal, scarlet, 1-1.5 cm. thick, with appressed or spreading deciduous sepals and yellow flesh; nutlets usually $3-4$, 7-8 mm. long; nest of nutlets 7-8 mm. thick. (C. stolonifera Sarg.) - Occasional, s. Ont. to Pa. and Del. Fl. May ; fr. Sept.

\$ 12. PRUINOSAE Sarg. (Silvicolat Beadle.) Leaves ovate, acute or acuninate at the apex, broadly cuneate to truncate (occasionally cordate) at the base, doubly serrate or lobed, membranaceous to subcoriaceous, blue-green, glabrous; petioles slightly glandular, 1-3 cm. long; young foliage usually bronze-green; corymbs many-flowered, glabrous; calyx-lobes deltoid-acuminate, often serrate at the base, glumaceous; stamens 10-20; anthers usually pink; styles 3-5; fruit usually depressed-globose to short-ellipsoidal, strongly angled, red, pruinose, with prominent spreading persistent calyxlobes and hard thick flesh; nutlets usually 4-5, strongly ridged dorsally; nest of nutlets shorter than thick, with deep sinuses between the nutlets; 
shrubs or trees, 3-8 m. high, with irregular ascending branches and numer ous curved chestnut-brown spines $3-6 \mathrm{~cm}$. long. - Rocky woods.

Fruit conspicuously angled, strongly pruinose.

Leaves usually cuneate

Leaves cordate

Fruit without conspicuous angles, slightly pruinose.

Leaves ovate, cuneate or cordate.

Leaves usually cordate

Leaves usually cuneate.

Lotes of leaves shallow, acute

Lobes of leaves deep, acuminate.

Leaves elliptic-ovate, cuneate

39. C. pruinòsa (Wendl.) C. Koch. Leaves elliptic-ovate to broadly ovate, 2.5-6 cm. long. and wide, membranaceous; flowers about $2 \mathrm{~cm}$. wide; stamens

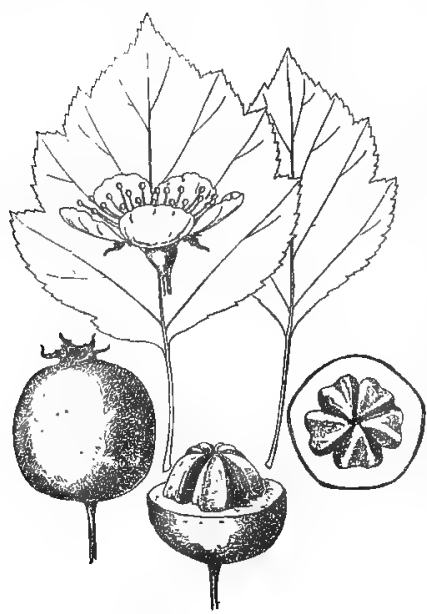

779. C. pruinosa. about 20 ; anthers pink, rarely yellow ; fruit apple-green, becoming scarlet or purple, 1.2$1.5 \mathrm{~cm}$. thick; flesh yellow, sweet; nutlets 6-8 $\mathrm{mm}$. long; nest of nutiets $8-9 \mathrm{~mm}$. thick. -Common, w. N. E. to s. Wise., Mo., Va., and s, in the mts. Fl. May ; fr. Oct., Nov. Fig. 779. Forma dssona (Sarg.) Eggleston. Stamens 10. - With the typical form.

Var. 1atisépala (Ashe) Eggleston. Leaves more nearly entire; fruit reddish-brown. (C. cognata Sarg.) - With the typical form. Var. PHila délPhica (Sarg.) Eggleston. Leaves with more acuminate lobes, those on vegetative shoots usually cordate. ( $C$. fusca Sarg.) - Range of typical form.

Var. conjúncta (Sarg.) Egrgleston. Fruit less angular and not highly colored; anthers light yellow. - Range of typical form.

Var. Portèri (Britton) Eggleston. Fruit pyriform, reddish-brown. - Pocono Mt. and adjacent region, e. Pa.

40. C. deltoìdes Ashe. Leaves broadly ovate, 3-7 $\mathrm{cm}$. long and broad, abruptly acuminate at the apex, cordate or truncate at the base, with 4-6 pairs of broad acuminate lobes; flowers about $2 \mathrm{~cm}$. broad; stamens about 10 ; fruit depressed-globose, bright red, 1-1.5 cm. thick; flesh yellow ; nutlets 6-7 mm. long; nest of nutlets 8-10 mm. thick. - Dutchess Co., N. Y., and e. Pa. Fl. May; fr. Oct.

41. C. silvícola Beadle. Leaves triangular-ovate, $2-7 \mathrm{~cm}$. long, $2-6 \mathrm{~cm}$. wide, rounded, truncate, or on vegetative shoots cordate at the base, incisely lobed; flowers about $1.5 \mathrm{~cm}$. wide; stamens 10 ; fruit globose, 1-1.1 cm. thick, slightly angular, red; the $8-5$ nutlets $6-8 \mathrm{~mm}$. long; nest of nutlets $7-8$ mu. thick. N. Ala. and n. w. Ga.

Var. Beckwithae (Sarg.) Eggleston. Leaves sharply lobed; flowers about 2 cm. wide; fruit subglobose to compressad-globose, cherry red, $1.2-1.5 \mathrm{~cm}$. thick ; nutlets $6-8 \mathrm{~mm}$. long; nest of nutlets $8-10 \mathrm{~mm}$. thick. (C. Robbinsiana Sarg.; C. sequax Ashe.) - Frequent, w. N. E. to s. Mich, and s. to Pa. Fl. May; fr. Oct.

42. C. beàta Sarg. Leaves $3-8 \mathrm{~cm}$. long, $2.5-7 \mathrm{~cm}$. wide, broadly cuneate to truncate at the base, acutely lobed, membranaceous, dull ; flowers about $2 \mathrm{~cm}$. wide; stamens about 20; fruit short-ellipsoidal, slightly angular, crimson, slightly pruinose, $1-1.5 \mathrm{~cm}$. thick ; the $4-5$ nutlets $6-8 \mathrm{~mm}$. long; nest of nutlets 9-11 mm, thick. - Occasional, w. N. Y. and s. Ont. Fl. May ; fr. Oct.

Var. cómpta (Sarg.) Eggleston. Leaves on vegetative sloots sometimes subcordate, subcoriaceous ; Howers about $1.5 \mathrm{~cm}$. wide; stamens $7-10$; nutlets 3-4. - Similar range. Fl. May; fr. Oct. 
43. C. leiophýlla Sarg. Leaves broadly ovate, $3-7 \mathrm{~cm}$. long and wide, broadly cuneate to truncate at the base, subcoriacenss, dull, with $3-5$ pairs of acuminate spreading lobes; flowers about $2 \mathrm{~cm}$. wide; stamens about 20 ; anthers yellow; fruit pyriform-subglobose, 1.2-1.4 $\mathrm{cm}$. thick, slightly angular, dark green, becoming bright red, slightly pruinose; flesh yellow; nutlets usually 4, 7-8 $\mathrm{mm}$. long; nest of nutlets $8-10 \mathrm{~mm}$. thick. - Frequent, w. N. Y. Fl. May ; fr. Oct.

Var. Maineàna (Sarg.) Uggleston. Stamens about 10 ; anthers pink; fruit globose, dark scarlet; nutlets $6-7 \mathrm{~mm}$. long. - Similar range. Fl. May ; fr. Oct.

44. C. Jesùpi Sarg. Leaves elliptic-ovate, $3.5-7 \mathrm{~cm}$. long, $2-5.5 \mathrm{~cm}$. wide, brcadly cuneate to truncate-cordate at the base, yellow-green above, with 4-5 pairs of acute lobes; flowers about $2 \mathrm{~cm}$. wide ; calyx-lobes entive; stamens about 10 ; anthers dark red; fat short-ellipsoidal to pyriform, dark red, about $1 \mathrm{~cm}$. thick, slightly angled, destitute of bloom when mature; calyx-lobes mostly deciduous ; flesh yellow; nutlets usually $3-4,6-8 \mathrm{~mm}$. long; nest of nutlets 7-9 mm. thick. - Twin Mts., W. Rutland, Vt.; e. Pa.; s. Mich.; s. w. Wisc.

\$ 15. COCCINEAE Loud. (FrabellataE Sarg.) Lecues large, ovate (often broadly so), simply or doubly serrate or lobed, membranaceous lo subcoriaceous, when young bronze-green; corymbs many-flowered; calyx-lobes lanceolate, acuminate, glandular-serrate; stamens 5-20; anthers red; styles 3-5; fruit usurrlly red and pubescent, subglobose, ellipsoidal, or pyriform, with soft thick flesh and commonly persistent calyx-lobes; nutlets usually 4-5, slightly ridged on the back; nest of nutlets usually with deep sinuses; round-topped trees or shrubs, $3-10 \mathrm{~m}$. high, with ascending branches and curved spines $2-8 \mathrm{~cm}$. long. - In this section belongs $C$. coccinea Mill. ; 'T. \& G.

Fruit yellow; western

Fruit red.

Lenves oblong-ovate

Leaves sharply lobed ; eastern.

Corymbs nearly glabrous . . . . . . . . 46. O. Folmesiana

Corymbs very pubescent

Leaves subentice; southwestern.

Corymbs and fruit very tomentose . . . . . . . . 48, C. lanuginosa. Corymbs and fruit nearly glabrous : - : : : : : 49. C.pyriformis.

Leaves broadly ovate.

Corymbs and fruit glabrous; stamens abont 20 . . . . . . 50. C. coccinioides.

Leaves on regetative shoots cuneate.

Leaves concave, $3-8 \mathrm{~cm}$. long, $3-7 \mathrm{~cm}$. wide . . . . . 51. O. Pringlei

Leaves plane, $3-10 \mathrm{~cm}$. long, 3-9 $\mathrm{cm}$. wide . : : : : : 52. C. pedicellata.

Leaves on vegetative shoots cordate

- 53. C. polita.

45. C. Kelloggii Sarg. Leaves broadly ovate to suborbicular, $3-7 \mathrm{~cm}$. long, 2.5-7 cm. wide, rounded at the apex, broadly cuneate or truncate at the base, lobed above the middle, dark yellow-green, slightly pubescent but glabrate above, pubescent along the veins beneath; petioles $2-3 \mathrm{~cm}$. long, slender, villous when young; corymbs pubescent; flowers about $1.5 \mathrm{~cm}$. vide; calyx slightly pubescent, its lobes glabrous on the outer surface, slightly villous within; stamens about 20 ; styles 5 ; fruit subglobose to short-ovoid, bright yellow, $2-2.5 \mathrm{~cm}$. thick, with spreading calyx-lobes and yellow mealy flesh; nutlets 5 , slightly grooved on the back, about $8 \mathrm{~mm}$. long; nest of nutlets $9-10 \mathrm{~mm}$. thick; tree 6-8 m. high, with nearly erect branches, dark furrowed bark, and occavionally straight chestnut-brown spines about $3 \mathrm{~cm}$. long. - St. Louis, Mo., uncommon. Fl. A pr.; fr. Sept.

46. C. Holmesiàna Ashe. Leaves elliptic-ovate, $2.5-9 \mathrm{~cm}$. long, 2-6 cm. wide, membranaceous, acute or acuminate at the apex, cuneate at the base, pubescent at length scabrous above, pubescent along the reins beneath, the 4-6 pairs of acute or acuminate lobes often with reflexed tips; petioles $2-3 \mathrm{~cm}$. long, slightly pubescent; corymbs /flabrous or slightly pubescent ; flowers about 1.5 cm. wide; stamens 5-10; styles 3-5 ; fruit pyviform to ellipsoidal, crimson, about $1.2 \mathrm{~cm}$. thick, with enlarged erect persistent calyx-lobes and yellow mealy acid flesh; nutlets usually 3-4,7-9 mm. long; nest of nutlets $6-8 \mathrm{~mm}$. thick; 
sinuses shallow; tree sometimes $9 \mathrm{~m}$. high, with ascending branches, gray-brown scaly bark, and occasional spines $4-6 \mathrm{~cm}$. long. - Moist hillsides, Montreal, centr. Me., R. I., Pa., s. Mich., and s. in the mts. to s. N. C. Fl. May ; fr. Aug., Sept. 'The form occurring from Pa. southw., var, vfllipes Ashe (C. tenuifolia Britton), has the corymbs more pubescent.

47. C. anómala Sarg. Leaves oblong to ovate, $3-9 \mathrm{~cm}$. long, $2-8 \mathrm{~cm}$. wide, acute at the apex, broadly cuneate to truncate at base, acutely lobed, slightly pubescent becoming scabrous above, densely villous along the veins beneath, yellow-green; petioles pubescent, $1-2 \mathrm{~cm}$. long; corymbs and calyx villous, the inside of the calyx-lobes but slightly so; flowers about $1.5 \mathrm{~cm}$. wide; stamens about 10 ; styles 4-5; firuit pyriform-ellipsoidal, 1.5-2 $\mathrm{cm}$. thick, crimson, with prominent calyx, persistent spreading slightly pubescent calyx-lobes and light yellow juicy flesh; nutlets $7-9.5 \mathrm{~mm}$. long; nest of nutlets $8-9 \mathrm{~mm}$. thick. (C. oblongifolia Sarg.) - Montreal I. to centr. Me., North Adams, Mass., and Albany, N. Y. Fl. May ; fr. Oct.

48. C. lanugindsa Sarg. Leaves ovate to suborbicular, $2.5-7 \mathrm{~cm}$. long, 2-6 cm. wide, acute at the apex, broadly cuneate to truncate at the base, coarsely and doubly serrate, appressed-pubescent becoming scabrous above, densely white-tomentose beneath; petioles $5-25 \mathrm{~mm}$. long, tomentose; corymbs whitetomentose; flowers about $2 \mathrm{~cm}$. wide; calyx densely white-tomentose, its lobes ovate-lanceolate, acute; stamens about 20 ; styles 5 ; fruit subglobose to shortellipsoidal, about $1.5 \mathrm{~cm}$. thick, bright cherry-red, tomentose, with prominent caly $x$, spreading calyx-lobes, and orange dry and mealy flesh ; nutlets 5, $6-8 \mathrm{~mm}$. long; nest of nutlets $8-11 \mathrm{~mm}$. thick; tree with spreading and erect branches, armed with many straight thorns $3-9 \mathrm{~cm}$. long, the young thorns often bearing undeveloped leaves. - Common near Webb City, s. W. Mo. Fl. May; fi. Sept.

49. C. pyriformis Britton. Leaves broadly oval to obovate-oval, $3-7 \mathrm{~cm}$. long, $2-6 \mathrm{~cm}$. broad, obtuse at the apex, cuneate at the $b a s e$, sharply and some-

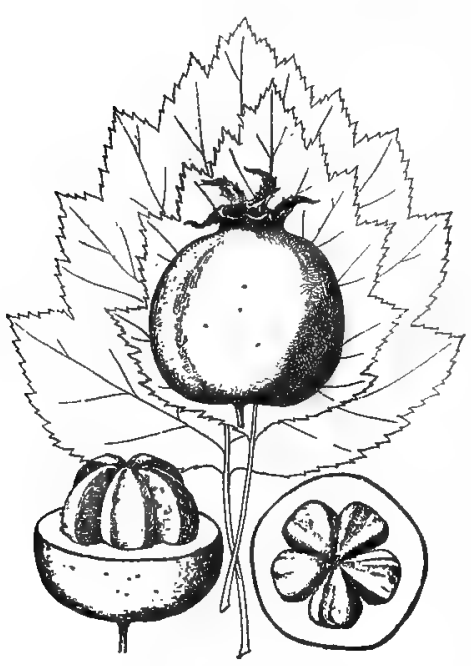

780. C. coccinloides.

times doubly serrate, slightly pubescent but glabrate above, pubescent especially along the veins beneath, yellow-green, membranaceous; petioles $1-3 \mathrm{~cm}$. long, winged above, tomentose to scabrous; corymbs villous; flowers about $2.5 \mathrm{~cm}$. broad; calyx villous, the lobes slightly pubescent ; stamens about 20 ; styles $4-5$; fruit ellipsoidal-pyriform, about $1.2 \mathrm{~cm}$. thick, bright cherry-red, with refexed calyx-lobes and light yellow juicy flesh; nutlets ear-shaped, about $8 \mathrm{~mm}$. long; nest of nutlets about $1 \mathrm{~cm}$. thick. ( $C$. dispessa Ashe.) - Rich bottom lands, s. e. Mo. Fl. May ; fr. Sept.

50. C. coccinioides Ashe. Leaves broadly ovate, acute at the apex, rounded or truncate at the base, doubly serrate and with several pairs of broad acute lobes, 4-9 cm. long, $3.5-8 \mathrm{~cm}$, wide, dark green above, paler and slightly tomentose along the veins beneath, membranaceous; petioles glandular, $2-3 \mathrm{~cm}$. long ; corymibs 5-7-flowered, glabrous; flowers about $2 \mathrm{~cm}$. wide; calyx-lobes ovate, acute, glandular-serrate; stamens about 20 ; styles 3-5; fruit subglobose, obtusely

angled, 1.5-2 cm. thick, dark crimson, with prominent caly $x$, spreading sepals. and subacid red-tinged flesh; nutlets usually 4-5, $7-9 \mathrm{~mm}$. long, 4.5-5.5 mm. thick, grooved on the back. (C. Eggertii Britton.) - Occasional, s. w. Ind. to e. Kan. Fig. 780, 
Var. dilatàta (Sarg.) Eggleston. Corymbs 7-12-flowered; flowers about $2.5 \mathrm{~cm}$. broad; fruit with less prominent calyx, the calyx-lobes more deciduous. (C. speciosa Sarg.) - Montreal I. to R. I., and w. to Mo. Fl. May ; fr. Sept.

51. C. Prínglei Sarg. Leaves concave, ovate to oval, $3-8 \mathrm{~cm}$. long, $2.5-7 \mathrm{~cm}$. wide, obtuse at the apex, rounded or abruptly cuneate at the base, very shallowly iobed, pubescent but glabrate above, pubescent along the veins beneath, bright yellow-green; petioles $1-3 \mathrm{~cm}$. long, pubescent; corymbs pubescent ; flowers about $2 \mathrm{~cm}$. Wide ; stamens about 10 ; styles $3-5$; fruit short-ellipsoidal to pyriform, red, pubescent, about $1.5 \mathrm{~cm}$. thick, with persistent spreading calyx-lobes and yellow acid edible flesh; nutlets $7-9 \mathrm{~mm}$. long; nest of nutlets $7-9 \mathrm{~mm}$. thick, - Common, w. N. E. to n. Ill., s. to Pa. F]. May; fr. Sept. Var. ExcLưsa (Sarg.) Eggleston. Leaves less concave; corymbs deusely pubescent. Vt. and n. e. N. Y. Var. LoBulArA (Sarg.) Eggleston. Leaves more deeply cut. (C. cristata Ashe.) - With the typical form.

52. C. pedicellàta Sarg. Leaves broadly ovate, $3-10 \mathrm{~cm}$. long, $3-9 \mathrm{~cm}$. wide, acute or acuminate at the apex, broadly cuneate to truncate at base, slightly pubescent becoming scabrous above, nearly glabrous beneath, membranaceous; corymbs glabrous or slightly villous; flowers $1.5-2 \mathrm{~cm}$. wide ; calyx glabrous, its lobes slightly villous on the upper side; stamens $10-20$; styles $3-5$; fruit pyriform to short-ellipsoidal, scarlet, glabrous, $1.5-2 \mathrm{~cm}$. thick, with rather persistent erect or spreadiug calyx-lobes and dry mealy flesh; nutlets usually $4-5$, $7-8 \mathrm{~mm}$. long; nest of nutlets $8-10 \mathrm{~mm}$, thick. - Frequent, s. Ct. to s. Ont. and n. Ill., s. to Pa. and Del. Fl. May; fr. Sept. Var. Ellwangeriana (Sarg.) Eggleston has densely villous corymbs, fruits slightly villous, and nutlets $3-5 .-$ Similar range.

53. C. polita Sarg. Leaves broadly ovate to oblong-ovate, cordate, truncate, or broadly cuneate at the base, 3-9 $\mathrm{cm}$. long and wide, membranaceons, glabrous when mature, yellow-green; corymbs glabrous; flowers $1.5-2 \mathrm{~cm}$. wide, calyx glabrous, its lobes slightly pubescent above; stamens $5-10$; styles $3-4$; fruit subglobose to short-ellipsoidal-pyriform, glabrous, cherry-red, $1-1.5 \mathrm{~cm}$. thick, with deciduous calyx-lobes; nutlets sharply ridged on the back, 6-8 mm. long; nest of nutlets $6-8 \mathrm{~mm}$. thick. - Occasional, w. N. E. to s. Mich., s. to Del. Fl. May ; fr. Sept. Var. Tatnalliàna (Sarg.) Eggleston. Leaves slightly pubescent; corymbs, calyx, and fruit villous; nutlets $3-5 .-$ With the typical form.

$\S 14$. MÓLLES Sarg. Leaves large, ovate, pubescent or tomentose becoming scabrate above, acute at the apex, broadly cuneate to cordate at base, doubly serrate or lobed, yellow-green, subcoriaceous or membranaceous; petioles 2-4 cm. long, pubescent or tomentose; young foliage yellow-green; corymbs many-flowered, densely tomentose; calyx-lobes glandular-serrate, someuhat tomentose; stamens 10-20; anthers yellow; styles 3-5; fruit large, red, pubescent, globose, ellipsoidal, or pyriform, with swollen erect or spreading calyx-lobes and thick soft edible flesh; nutlets usually 4-5, slightly ridged on the back; nest of nutlets with deep sinuses; round-topped trees, sometimes $13 \mathrm{~m}$. high, with curved spines $3-5 \mathrm{~cm}$. long.

Leaves on regetative shoots cuneate at the base.

Lobes of the leaves shallow, broad, acuminate; Mass. and Ct. . . 64. C. Amolaiana

Loues deep, narrow, acute.

Frult globose or nearly so ; calyx rather prominent; leaves subcor-

Fruit ellipsoldal-pyriform; calyx obscure; leaves membranaceous Leaves on the vegetative shoots cordate.

Leaves 4-18 $\mathrm{cm}$. long, 4-10 cm. wide, rugose, membranacenus; western

Leaves 8-11 cm. long, 8-9 cm. wide, plane, subcoriaceous ; Champlain Valley.

54. C. Arnoldiàna Sarg. Leaves broadly ovate to oval, 3-10 $\mathrm{cm}$, long, $2.5-$ $8.5 \mathrm{~cm}$. wide, broadly cuneate to truncate at the base, with broad shallow acuminate lobes; flowers about $2 \mathrm{~cm}$. wide; stamens about 10 ; fruit globose or subglobose, 1.5-2 cm. thick, bright crimson, with scarcely enlarged spreading 


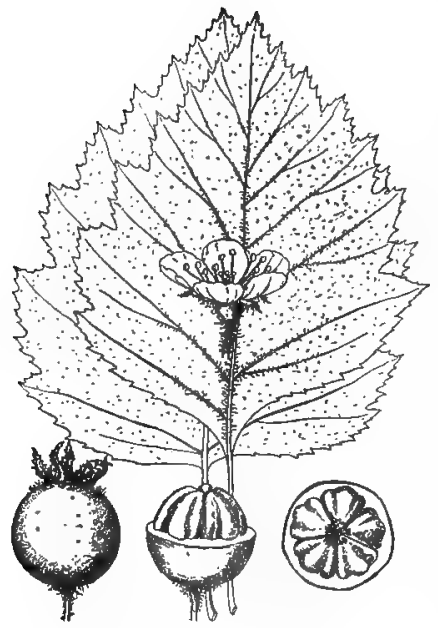

781. C. Arnoldiana.

calyx-lobes; flesh yellow, acid : nutlets 8-9 $\mathrm{cm}$. long ; nest of nutlets 9-10 $\mathrm{mm}$. thick. Rare, e. Mass. and w. Ct. Fl. May; fr. Aug. FIG. 781.

55. C. canadensis Sarg. Leaves ovate, broadly cuneate to truncate at the base, aculely lobed toward the apex, $3-8 \mathrm{~cm}$. long, $2.5-7.5 \mathrm{~cm}$. wide, subcoriaceuus ; flowers about $2 \mathrm{~cm}$. wide; stamens about 20 ; fruit short-ellipsoidal to subglobose, crimson, $1-1.5 \mathrm{~cm}$. thick, with rather mominent calyx, spreading persistent calyx-lobes and yellow mealy flesh; nutlets usually 5, about $7 \mathrm{~mm}$. long; nest of nutlets $9-10 \mathrm{~mm}$. thick. Region of Montreal. Fl. May ; fr. Sept., Oct. 56. C. submollis Sarg. Leaves ovate, broadly cuneate, acutely lobed, 4-11 $\mathrm{cm}$. long, 3-9 cm. wide, membranaceous, yellowgreen; flowers about $2.5 \mathrm{~cm}$. wide ; stamens about 10 ; fruit short-ellipsoidal to pyriform, orange-red, $1.5-2 \mathrm{~cm}$. thick, with persistent calyx and yellow subacid flesh; nutlets strongly ridged on the back, 6-8 mm. long; nest of nutlets $7.9 \mathrm{~mm}$. thick. - Falls of Montmorency, Que., to s. Ont., s. to Me., Mass., and Albany, N. Y. Fl. May; fr. Sept.

57. C. móllis (T. \& G.) Scheele. Leaves broadly ovate, $4-13 \mathrm{~cm}$. long, 4-10 cm. wide, cordate to truncate at the base, slightly rugose, membranaceous, densely tomentose below, with narrow acute lobes; flowers about $2.5 \mathrm{~cm}$. wide; stamens about 20; fruit short-ellipsoidal to subglobose, scarlet, $1.5-2.5 \mathrm{~cm}$. thick, with deciduous calyx-lobes and yellow flesh; nutlets usually 5, 7-8 mm. long; nest of nutlets $9-10 \mathrm{~mm}$. thick. ( $C$. coccinea, var. T. \& G.) - Common, s. Ont. to e. S. Dak., e. Kan., and s. to Ky. Fl. May; fr. Aug., Sept.

Var. sèra (Sarg.) Eggleston. Teaves oblong-ovate; fruit pyriform-ellipsoidal, dull dark red. - Occasional, s. Ont., s. Mich., and 11. Ill. Fl. May; fr. Oct.

58. C. champlainénsis Sarg. Leaves 3-11 cm. long, 3-9 cm. wide, subcoriaceous; stamens about 10 ; fruit short-ellipsoidal to pyriform, bright scarlet; calyx rather prominent, its lobes spreading, per'sistent; nutlets strongly ridged on the back, 7-8 $\mathrm{mm}$. long; nest of nutlets 8-10 mm. thick. - Montreal I., s. through the Champlain Valley. Fl. May; fr. Sept., Oct.

$\S 15$. CORDATAF Beadle. Leaves ovatetriangular, simply or doubly serrate (often conspicuously 3-5-lobed), acuminate at the apex, rounded to cordate at the base. 2-8 cm. long and wide, bright green above, paler beneath, glabrous; petioles 1.5-5 cm. Iong, slender; corymbs many-flowered, glabrous; flowers about $1 \mathrm{~cm}$. wide; calyx-lobes deltoid, entire, pubescent on the margin; stamens about 20; anthers pink; styles 1-5; fruit depressed-globose, 4-6 mm. thick, scarlet, with deciduous calyx-lobes and thin firm flesh; nutlets 5, 3-4 mm. long, 2-2.5 $\mathrm{mm}$. thick, smeoth on the back; apex bare; si-

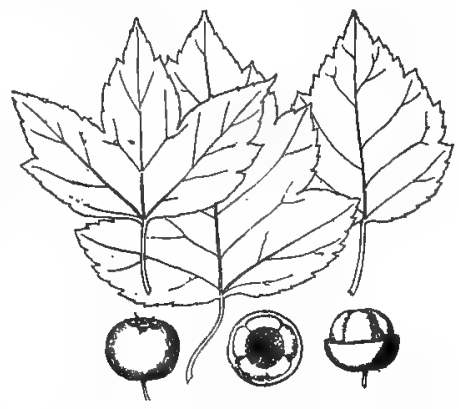

782. C. phaenopyram. nuses between the nutlets shaliow; shrubs or small trees, 5-9 m. tall, with nearly erect branches and grayish-brown scaly bark; twigs chestnut-brown; thorns 2-5 cm. long. 
59. C. phaenopyrum (L. f.) Medic. Only species of the section. (Mespilus L. f.; C. cordata Ait, not Mespilus cordata Mill.) - Along streams in the Appalachian Mts., Va. to n. Ga. and n. Ala.; s. Ill., s. Mo., and n. w. Ark.; naturalized northw. to e. Pa. and s. N. J. Fl. June; fr. Oct. Fig. 782.

§16. ANÓMALAE Sarg. Leaves elliptical to ovate, finely and doubly serrate or lobed, acute at the apex, abruptly cuneate to rounded at the base, subcoriaceous or membranaceous, bright green above, pubescent (particularly alony the veins beneath); petioles slightly winged above, 1-4 cm. long; corymlis many-flowered; calyx-lobes lanceolate, curninate, glabrous outside, slightly pubescent within, glandular-serrate; stamens 5-20; anthers pink; styles 2-5; fruit subglobose to short-ellipsoidal, red, with reflexed calyx-lobes and thin succulent or glutinous flesh; nutlets usually 24, commonly having a shallow pit on the ventral face (a feature often lacking in individual nutlets). - Species appearing as if natural hybrids between the Macracanthae and Tenuifoliae, but seeming now to be thoroughly established as species. Many of the group are still in need of careful study.

Fruit and corymbs pubescent; calyx-lobes sharply glandular-serrate . . 60. C. pertomentosa. Fruit and corymbs glabrous; calyx-lobes remotely glandular-serrate : : 61. C. Brainerdi.

60. C. pertomentòsa Ashe. Leaves oblong to ovate, $3-7 \mathrm{~cm}$. long, $2-6 \mathrm{~cm}$. wide, slightly villous but glabrate above, villous beneath particularly along the veins, vivid dark green, subcoriaceous; petioles about $1 \mathrm{~cm}$. long, villous; corymbs and calyx densely villous; flowers about $2 \mathrm{~cm}$. wide; calyx-lobes deeply serrate; stamens $10-15$; styles $2-3$; fruit globular or nearly so, cherry-red, 8-13 mm. thick, villous when young; flesh yellow, succulent, mealy; nutlets 2-3, 5-6.5 mm. long, 2.5-3 mm. thick. (C. campestris Britton.) - Rocky barrens in the prairies, centr. Ia., w. Mo., and e. Kan. Fl. May; fr. Sept.

61. C. Brainérdi Sarg. Leaves ovate, acute or acuminate, $3-9 \mathrm{~cm}$. long, 2-6 cm. wide, membra ıacenus, glabrate; corymbs glabrous; flowers about 2 cm. wide; calyx-lobes remotely glandular-serrate; stamens about 20 ; styles $2-4$; fruit short-ellipsoidal to subglobose, about $1 \mathrm{~cm}$. thick, cherry-red; fiesh yellow, mealy, succulent, acid ; nutlets usually 3-4, 5-7 $\mathrm{mm}$. long, 2.5-3.5 mm. thick. (C. Sohuettei Ashe.) - N. E. to s. Wisc., s. to Pa. and Ia. Var. scà Brida (Sarg.) Eggleston. Leaves oval to obovate, sharply cuneate, scabrate on the upper surface, pale yellow-green; stamens 5-20. - Range of typical form.

Var. Egglestòni (Sarg.) Robinson. Leaves oval to orbicular, dark green and shining above, subcoriaceous; flesh of the fruit rather glutinous; nutlets usually 2-3.- N. S. and N. E. to Wisc. and Pa. Var. Asperifólia (Sarg.) Eggleston. Leaves oval, acute or acuminate, subcoriaceous, scabrate ; stamens 10 ; fruit bright scarlet; flesh of the fruit rather firm. - Range of typical form.

\$17. MACRACANTHAE Loud. (Tomentosae Sarg.) Leaves rhombic-elliptical, acuite at the apex, cuneate at the base, doubly serrate with fine sharp teeth, subcoriaceous to coriaceous, pubescent when young and at least along the veins beneath at maturity; petioles slightly winged above, 1-2 cm. long; corymbs many-flouered, pubescent; calyx-lobes lanceolate, acuminate. glandular-laciniate, villous; stamens 10-20; anthers pink; styles 2-4 ; fruil globose, short-ellipsoidal, or pyriform, red, with reflexed calyx-lobes and thin glutinous mealy flesh; nutlets usually 2-3, dorsally ridged and with a deep pit on the ventral face; trees or shrubs, with ascending branches and numerous curved spines $3-10 \mathrm{~cm}$. long.

Leaves coriaceons, dark green and shining above .

Leaves thin, dull green, pubescent, and with impressed veins above.

Leaves 4-11 em. long, 8-8 cm. wide; fruit and pits small ; corymbs

many-flowered.
Leaves $2-7 \mathrm{~cm}$. long, $1.5-5 \mathrm{~cm}$. wide; fruit and pits large; corymbs $8-8-$ flowered.

62. C. macracantha.

63. C. Chapmani.

64. C. miesouriensis

62. C. macracúntha Lodd. Leaves rhombic-ovate to obovate, $8-8 \mathrm{~cm}$, long, $2.5-6 \mathrm{~cm}$. wide, coriaceous, dark green and shining above; corymbs slightly villous; flowers about $2 \mathrm{~cm}$. wide; stamens about 10 ; anther's large; styles $2-4$; 
fruit subglobose, about $8 \mathrm{~mm}$. thick, dark cherry-red, shining, villous; nutlets usually 2-3, 5-7 mm. long, 2. 5-3.5 mm. thick. (C. coccinea, var. Dudley.) -

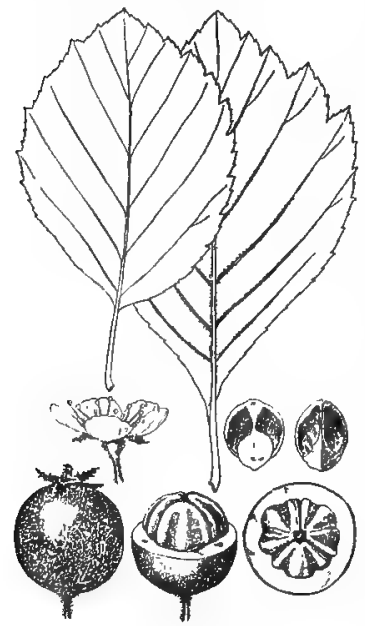

783. C. maicracantha, N. S. (C. B. Robinson) to Minn., s. in the mits. to Va. Fl. May ; fr. Sept. FIg. 783. Var. RHoмBIFóla (Sarg.) Eggleston is a form with more villous corymbs and smaller fruit. - With the typical form. Var. occIDENTA LIs (Britton) Eggleston. Leaves ovate to broadly oval, sometimes $8 \mathrm{~cm}$. wide. (C. colorado Ashe; C. coloradensis Nelson.) - Frequent, s. Man. to e. Kan., Col., and Ida.

Var. succulenta (Schrad.) Eggleston. Stamens about 20 ; fruit larger than in the typical form. - Occasional, with the typical form.

Var. neofluviàlis (Ashe) Eggleston. Stamens 10-20; anthers small ; fruit small._Occasional, w. N. E. to Wisc. and $\mathrm{Pa}_{\text {. }}$, and $\mathrm{s}$, in the mts.

63. C. Chapmani (Beadle) Ashe. Leaves rhombic-ovate, 4-11 cm. long, $3-8 \mathrm{~cm}$. wide, acute or acuminate, those on vegetative shoots ohtuse and more entire than the others, pubescent on both sides, becoming scabrate above, subcoriaceous, dull green ; petioles pubescent ; corymbs white-tomentose; flowers about $1.5 \mathrm{~cm}$. wide; stamens 10-20, usually about 20 ; anthers small; styles $2-4$; fruit globose or subglobose, 8-10 mm. long, bright red; fiesh yellow; nutlets usually 2-3, about $5 \mathrm{~mm}$. long, $2.5 \mathrm{~mm}$. thick, slightly ridged on the back. (C. tomentosa, var. microcarpa Chapm.; C. tomeniosa, var. Chapmani Beadle.) - Frequent, s. Ky. (C. L. Boynton) and Va. to n. Ga. Fl. May; fr. Sept.

Var. Plukenètii Eggleston. Fruit pyriform to ellipsoidal, 1-1.5 cm. long, orange-red, villous; flesh yellow; nutlets usually $2-3$, more strongly ridged on the back, 5-7 mm. long, $2.5-3 \mathrm{~mm}$. thick. (C. leucophleos Moench? C. tomentosa of the Linnean herbarium and auth., not of the Lin. nean description.) - Common, s. Ont. to w. N. J., w. to s. Minn. and e. Kan.; and in the mts. to Ga. Fl. June ; fr. Sept.

64. C. missouriensis Ashe. Leaves elliptical-ovate, 2-7 cm. long, $1.5-5 \mathrm{~cm}$. wide, subcoriaceous, simply or doubly serrate, rough pubescent and shining above, pale-tomentose beneath; petioles 5 mm. long; corymbs 3-8flowered, densely white-tomentose; flowers 1.2-1.5 cm. wille; stamens about 20 ; inthers pink ; styles $3-5$; fruit subglobose or pyriform, about $1 \mathrm{~cm}$. thick, bright red, slightly villous; flesh sweet; nutlets $5.5-6.5 \mathrm{~mm}$. long, with large deep pits on the ventral faces; nest of nutlets 6-7 min. thick ; thorns straight, slender, 1-7 cm. long. - Rocky bluffs, s. Mo.; Tenn. (Ashe). Fl. May; fr. Sept.

§18. DOUGLASIÀNAE [Loud.] Sarg. Leaves owate to obovate, acute or obtuse at the apex, cunerte at the base, doubly serrate and lobed except newr the base, dark green and pubescent above (particularly along

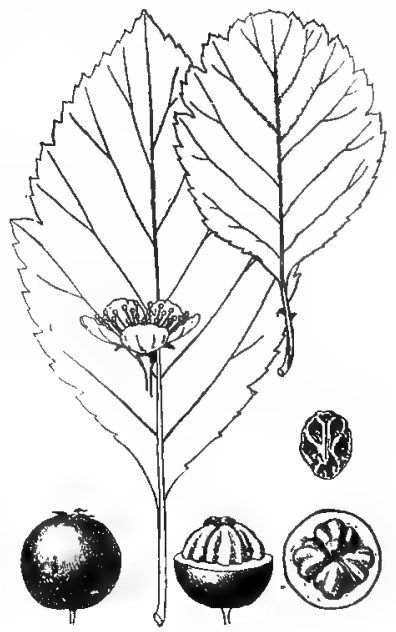

784. C. Douglasil. the veins), glabrous below, subcoriaceons; petioles slightly winged, pubescent and glandular; carymbs glabrous or nearly so; flowers about $1.5 \mathrm{~cm}$. wide; 
calyx-lobes acute or acuminate, entire, villous above, tinged with red; stamens 10-20; anthers light yellow; styles $3-5$; fruit short-ellipsoidal, black, 8-10 mm. thick; flesh yellow, 'sweet; nutlets 3-5, 5-6 mm. long, 2.5-3.5 mm. thick, ear-shaped, ridged on the dorsal and roughly pitted on the ventral face; trees or shrubs, 3-13 m. high, with ascending branches and dark brown scaly bark; twigs reddish; thorns usually 1-2 cm. long.

65. C. Douglàsii Lindl. The only species of this section within our range. ( $C$. glandulosa, var. $\beta$ brevispina Nutt.) - Common on Keweenaw Peninsula, Mich. ; Michipicoten I., L. Superior; Thunder Bay I., L. Huron; and far northwestw. Fl. May; fr. Aug., Sept. Fig. 784.

\section{COTONEÁSTER [Rupp.] Medic.}

Calyx small, adherent to the 2--5 carpels, the 5 lobes short, persistent as teeth. Styles free, stigmatic at the slightly enlarged summit. Carpels at maturity bony, 1-seeded. Fruit small, berry-like, mealy. - Much branched shrubs with small alternate usually coriaceous and often evergreen leaves, and small white eymose flowers. (Name New Latin implying resemblance to the quince.)

1. C. Prracantha (L.) Spach. (Frre Thorn.) Shrub, armed with slender spreading purple spines ; leaves elliptic-oblanceolate, crenate-serrate, coriaceous, 3-6 cm. long; fruit globose, scarlet. (Pyracantha coccinea Roem.) - Attractive shrub, used for formal hedges, etc., said to have escaped from cultivation and become established in thickets, s. Pa., and southw. (Introd, from Eu.)

\section{FRAGÅria [Tourn.] L. Strawberky}

Flowers nearly as in Potentilla, but in varying degrees polygamo-dioecious. Styles deeply lateral, Receptacle in fruit much enlarged and conical, becoming pulpy and scarlet, bearing the minute dry achenes scattered over its surface. Stemless perennials, with runners, and with white cynıse flowers on scapes. Leaves radical ; leaflets 3 , obovate-wedge-form, coarsely serrate ; stipules cohering with the base of the petioles, which with the scapes are usually hairy. Flowering in spring and early summer. (Name from the fragrance of the fruit.)

* Inflorescence umbelliform or a flattish-topped cyme with subequal primary branches; calyx-lobes lanceolate, tending to be appressed or connivent about the young fruit; achenes in pits of the pulpy receptacle.

1. F. virginiàna Duchesne. Leaves, peduncles, and runners from a subsimple caudex at the end of a simple thickish rhizome; leaflets of a firm slightly coriaceous texture; the hairs of the villous (rarely glabrate) scapes subappressed or widely spreadiug; pedicels silky. - Moist rich woodlands, fields, etc.; common. The typical form is a rather slender plant with the hairs of the scape loosely appressed or more or less spreading. A form with the pubescence generally more sparing, the bairs on the scapes being subappressed, is sometimes distinguished. ( $F$. canadensis Michx., in part.) - Common northw. Another scarcely separable form has the hairs on both scapes and petioles sparse and subappressed. (F. terrac-novae Rydb.) - Northeastw. and less frequent.

Var. illinoénsis (Prince) Gray. Coarser and larger; scapes and pedicels tomentose with somewhat spreading to divaricate hairs. ( $F$, illinoensis Prince; F. virginiana, var. Grayana Rydb.) - Rich soil, w. N. Y. to Minn., and southwestw.

* Inflorescence soon irregular and somewhat raceme-like, the primary branches of the cyme distinctly unequal; calyx-lobes lanceolate to ovate-lanceolate, loosely spreading or reflexed, much shorter thon the exrly exposed fruit; achenes superficial or nearly so, slightly smaller than in the preceding.

2. F. vésca L. Usually stoutish; leaflets rather deeply toothed, strongly zeined above: pubescence of the petioles and stipe mostly wide-spreading, that 
of the pedicels appressed; receptacle broadly ovoid-conic or subglobose. Dooryards, old fields, dry open woods, etc.; chiefly from N. E. to Pa., often appearing as if introduced, but apparently passing without sharp limit into the following clearly indigenous var. americana. (Introd. from Eurasia?) Var. Á LBA (Ehrh.) Rydb. Receptacle white. - N. E., N. Y., and Pa.

Var. americàna Porter. Slender, thin-leaved; pubescence of the scapes as well as of the pedicels and sometimes also of the petioles more or less closely appressed, often sparse ; receptacle more narrowly conical or subcylindric-ovoid. ( $F$. americana Britton.) - Common, chiefly in open rocky woods.

\section{DUCHÉSNEA Sm. Indian Strawberry}

Caly $x$ 5-parted, the lobes alternating with much larger foliaceous spreading 3-toothed appendages. Petals 5, yellow. Receptacle in fruit spongy but not juicy. Flowers otherwise as in Fragaria. - Perennial herb with leafy runners and 3-foliolate leaves similar to those of the true strawberries. (Dedicated to Antoine Nicolas Duchesne, an early monographer of Fragaria.)

1. D. fNDICA (Andr.) Focke. Fruit red, insipid. (Fragaria Andr.) - Waste ground, grassy places, etc., s. N. Y. and e. Pa. to Fla., Ark., and Mo. (Introd. from Eurasia.)

\section{SIBBÁLDIA L.}

Calyx flattish, 5-cleft, with 5 bractlets. Petals 5 , linear-oblong, minute. Stamens 5, alternate with the petals, inserted into the margin of the woolly disk which lines the base of the calyx. Achenes 5-10; styles lateral. — Low and depressed perennials. (Dedicated to Dr. Robert Sibbald, professor at Edin. burgh at the close of the 17 th century.)

1. S. procúmbens L. Leaflets 3 , wedge-shaped, 3-toothed at the apex; petals yellow. - Arctic Am., s, to mts, of e. Que., White Mts., N. H. ; and in the Rocky Mts. to Utah. (Eurasia.)

\section{CHAMAÉRHODOS Bunge.}

Calyx top-shaped, 5-cleft, without bractlets. Petals 5, obovate, white or purplish, about as long as the calyx-lobes. Stamens 5, opposite the petals. Carpels 5-20; styles decidedly lateral or basilar, articulated near the base. Ovule solitary, ascending. - Erect pubescent essentially herbaceous plants with 3 -foliolate leaves; the leaflets cleft into linear segments. (Name from $x^{a \mu a l, ~ o n ~}$ the ground, low, dwarf, and $\rho 6 \delta \circ v$, a rose.)

1. C. erécta (L.) Bunge. Glandular-pubescent; root woody ; stem erect, 1-3 dm. high, of 3 with ascending branches, leafy; flowers small, crowded in small rounded cymes. - Sandy soil, arid prairies, etc, n. w. Minn. to Col., Mont., and Assina. (Siber.)

\section{WALDSTEINIA Willd.}

Calyx-tube inversely conical ; the limb 5-cleft, with 5 often minute and desiduous bractlets. Petals 5. Stamens many, inserted. into the throat of the calyx. Achenes 2-6, minutely hairy; the terminal slender styles deciduous from the base by a joint. Seed erect; radicle inferior. - Low perennial herbs, with chiefly radical $3-5$-lobed or divided leaves, and small yellow flowers on bracted scapes. (Named in honor of Francis Adam, Count of Waidstein-Wartenburg, a Gernan botanist.)

1. W. fragarioides (Michx.) Trattinick. (Barren Strawberry.) Low; leaflets 3 , broadly wedge-form, cut-toothed; scapes several-flowered; petals mostly longer than the calyx-lobes. - Wooded hillsides, Carlton Co., N. B. ( (ay) ; w. N. E. to Ga., Ind., and Minn. A form with narrow petals about equaling the calyx-lobes has been distinguished as $W$. parviftora Small. 


\section{Potentílla L. Cinguefroll. Five-finger}

Calyx flat, deeply 5-cleft, with as many bractlets at the sinuses, thus appearing 10-cleft. Petals 5, usually roundish. Stamens many. Achenes many, collected in a head on the dry mostly pubescent or hairy receptacle; styles lateral or terminal, deciduous. Radicle superior. - Herbs, or rarely shrubs, with compound leaves, and solitary or cymose flowers; their parts rarely in fours. (Name a diminutive from potens, powerful, originally applied to $P$. Anserina, from its once reputed medicinal powers.)

r. Petals reddish-purple

$a$. Petals yellow or white $b$.

b. Stems shrubby

$b$. Stems herbaceons $c$.

c. Flowers solitary, on naked peduncles from the axils of the foliagelegves or on the stolons.

Leaves pinnate, of numerous leaflets

Leaves palmate, of $8-5$ leaflets.

Tufted alpine plant
Plants with elongate slender stems.

Earliest flower from the node above the first well-developed internode. . . . . . . . .

Earliest fluwer from the node above the second or third welldeveloped internode.

Stems ascending or procumbent, not repent

Stems repent.

Leaflets mostly 5, spatulate-oblong, finely crenate-dentate nearly to the base

Leaflets mostly 3 , cuneate-obovate, coarsely incised chlefly above the middle.

c. Flowers cymose, or if solitary in the axils of reduced upper leaves $d$.

d. Leaves pinnate.

Inflorescence glandular-viscid

Inflorescence not glandular.

Leaves white-pubescent above.

Pubescence of the leaves lustrous and silky

Pubescence a dull tomentum

Leaves green or greenish above,

Leaves definitely pinnate, the leaflets essentially uniform ;

cyme very leafy
Leaves seemingly palmate, the leaflets crowded and the lower ones much smaller than the others.

Cyme very leafy; petals minute

Cyme scarcely leafy ; petals showy ${ }^{\circ}:$ : $^{\prime}:$ :

a. Leaves palmate $e$.
e. Petals white; leaflets toothed only at tip

e. Petals white; leafiets toothed only at tip

f. Tufted alpine plant with 1-2-flowered short branches .

$f$. Leafy-stemmed plants with cymose flowers $g$.

g. Petioles and lower part of stem hirsute.

Leaflets 3 ; petals about as long as the calyx-lobes

Leaflets 5-7; petals much exceeding the calyx-lobes

g. Petioles and stems woolly or tomentulose $h$.

$h$. Leaves silvery-white beneath .

$h$. Leaves green or at most slightly grayish beneath $i$.

i. Plants loosely branched, with very leafy diffuse cymes. Perennial ; petals obcordate - owly cuneate.

Achenes strongly gibbous on the ventral side

A chenes not gibbous on the ventral side

d. Plants with simple stems and scarcely leafy corymbiform cymes
14. $P$, palustris.

15. P. fruticosa.

17. P. Anserina.

11. P. Robbinsiana

18. P. pumila.

19. P. cunadenst8.

20. P. repians.

21. P. procumbens.

1. P. arguta.

12. P. Hippiana.

18. P. อf $u$ a.

4. P. paradoxa.

3. P. rivalie.

6. $P$. pennsyloanica

16. P. tridentata.

11. P. Robbinsiana.

2. P. monspeliensis. 10. P. recta.

7. P.argentea.

8. P. intermedia.

5. P. Nicolletii.

3. P. rivalie.

9. P. Nuttallii.

\$1. Styles thickened and glandular tovard the base; achenes glabrous, numerous; inflorescence cymose.

* Style nearly basal; stamens $25-30$; perennial glandular-villous herbs, with pinnate leaves, and rather large white or yellow petals.

1. P. argùta Pursh. Sterns erect, usually stout, 3-10 din. high, brownishhairy, clainmy above ; leaflets 7-11, oval or ovate, cut-serrate, downy beneath; cyme strict and rather close; stamens mostly 30 , on a thick glandular disk. (Drymocallis Rydb.) - Rocky, gravelly, or alluvial soils, e. Que. to D. C., and westw. June, July. 
* Style terminal; flowers small; petals yellow.

+ Annual or biennial; leaflets incisely serrate, not white-tomentose; ;tamens 5-20.

2. P. monspeliénsis L. Stout, erect, hirsute, $2-9 \mathrm{dm}$. high; leaves 3-foliolate; leaflets obovate to oblanceolate, those of the uppermost leaves toothed nearly the whole length; cyme rather close, leafy; calyx large; stamens 15-20. -Open soil, Nfd. to Alaska, s. to D. C., Mo., Kan, and N. Mex. May-Aug. (E. Asia.)

Var. norvégica (L.) Rydb. Less hirsute; leaflets more narrowly oblong, those of the uppermost leaves mostly 3-5-toothed near the end; inflorescence looser. ( $\boldsymbol{P}$. norvegica L.) - Similar situations, e. Que. to n. N. E., L. Superior, and northwestw.; occasional on ballast southw. (Eurasia.)

Var. labradorica (Lehm.) Fernald. Low (1-3 dm. high, in exposed situations acaulescent); stem glabrous or sparingly silky-villous; leaves smoothish. - Lab. to the alpine regions of the White Mts., N. H.

3. P. rivalis Nutt. More slender and branched, softly villous; leaves pinnate, with two pairs of closely approximate leaflets, or a single pair and the terminal leaflet 3-parted; leaflets cuneate-obovate or -oblong; cyme loose, often diffuse, less leafy; calyx small; petals minute; stamens 10-20 (rarely 5). Neb. to Mo., N. Mex., and westw. May-Aug.

Var. millegràna (Engelm.) Wats. Leaves all 3-foliolate; lateral leaflets not divided; stems erect, or weak and ascending; achenes often small and lightcolored. ( $P$. leucocarpa Rydb.) - Minn. to Mo., westw. and southwestw.

Var. pentándra (Engelm.) Wats. Leaves digitately 3 -foliolate, the lateral leaflets of the lower leaves parted nearly to the base; stamens 5 , opposite the sepals. (P. pentandra Engelm.) - Minn. to Mo. and Ark.

4. P. paradóxa Nutt. Stems decumbent at base or erect, often stout, leafy, subvillous; leaflets pinnately 5-11, obovate or oblong ; cyme loose, leafy; stamens 20 ; achenes strongly gibbous on the ventral side. ( $P$. supina of auth., not L.) - Prairies and river banks, w. N. Y. and Ont. to Ml., Mo., N. Mex., and B. C. June-Aug. (Asia.)

5. P. Nicollètii (Wats.) Sheldon. Slender; leaflets mostly 3 ; inflorescence much elongated, leafy, falsely racemose. ( $P$. supina, var. Wats.) - Sandy soil, Mo. (Bush) to N. Dak.

+ + Herbaceous perennials, more or less white-tomentose; leaflets incisely pinnatifid; bractlets and sepals nearly equal; stamens 20-25.

6. P. pennsylvánica L. Stems erect or decumbent at base, $2-6 \mathrm{dm}$. high ; leaflets $5-9$, white-tomentose beneath, short-pubescent and greener above, oblong, obtuse, the linear segments slightly or not at all revolute; cyme fastigiate but rather open. ( $P$. litoralis Rydb.) - Coast of N. H., Me., and the lower St. Lawrence, L. Superior, and westw. June-Aug.

\section{\$2. Styles fliform, not glandular at base; inflorescence cymose.}

* Style terminal; achenes glabrous; stamens 20 ; herbaceous perennials, with rather large yellow petals.

\section{- Leaves palmaie.}

\section{+ Flowers in loose leafy cymes.}

7. P. argéntea L. (Silvery C.) Stems ascending or depressed, 1-5 dm. long, paniculately branched at the summit, many-flowered, white-woolly; leaflets 5 , wedge-oblong, almost pinnatifid, entire toward the base, with revolute margins, green above, white with silvery wool beneath; calyx white-tomentose. - Dry barren fields, eto., N. S. to Dak, and southw. to D. C. JuneSept. (Eu.)

8. P. intermetia L. Coarser; the stout upright grayish-tomentulose stems $3-7 \mathrm{dm}$, high; leaflets $3-5$, the lateral and often the terminal deeply cleft, oblanceolate to narrowly obovate, coarsely dentate, green above, grayish-villous and tomentulnse beneath; cyme somewhat leafy and diffuse; calyx villous. 
hirsute.--Roadsides and waste places. local, Mass. to N.J. and Mich. (Adv. from Eu.)

+ Flowers in rather compact scarcely leafy oymes (stems only 1-L-flowered in n. 11).

\section{$=$ Leaves 5-9-foliolate; flowers numerous.}

9. P. Nuttállii Lehm. Stems several, ascending from a stoutish base, 2-? dm. high, somewhat villous or glabrate; leaflets oblanceolate or spatulate, the narrow divergent teeth extending halfway to the midrib, green above, glabrous or glabrate and scarcely paler beneath; cyme with few upright branches. Meadows and banks of streams, Minn, Man., and westw. June-Aug.

10. P. Récta L. Stems upright, very leafy, 3-7 dm. high, loosely hirsute; leaflets oblanceolate, with narrowly deltoid divergent teeth, more or less hirsute on both surfaces, paler beneath; calyx hirsute; the showy yellow corolla $2 \mathrm{~cm}$. broad. ( $P$. sulphurea Lam.) - Fields and roadsides, Me. to Ont., Ill., and D. C. June-Aug. (Nat. from Eu.)

\section{$==$ Leaves 3 -folivlate; flowers 1 or 2.}

11. P. Robbinsiàna Oakes. Dwarf, tufted, villous when young; leaflets broadly cuneate-obovate, deeply 3-5-toothed at summit, nearly glabrous above : flowers mostly solitary, small, on very slender stems ; bractlets and sepals subequal. ( $P$. frigida Man. ed.6, not Vill.) - Alpine summits of the White Mts., N. H. June, early July.

$$
++ \text { Leaves pinnate. }
$$

12. P. Hippiàna Lehm. Densely white-tomentose and silvery-silky throughout, the upper surfaces of the leaves a little darker; stems ascending, $1.5-6 \mathrm{dm}$. high, slender, branching above into a diffuse cyme; leaflets 5-11, cuneateoblong, incisely toothed at least toward the apex, diminishing uniformly down the rhachis; carpels 10-30. - Prairies and banks of streams, w. Minn. to Sask. and $\mathrm{N}$. Mex. June-Aug.

13. P. effùsa Dougl. Tomentose throughout and with scattered villous pubescence; stems ascending, 1-3 dm. high, diffusely branched above; leaves interruptedly pinnate, the leaflets 5-11, the alternate ones smaller, cuneateoblong, coarsely incised-serrate or dentate; carpels 10. - Dry plains, w. Minn. to Assina, and N. Mex.

* * Style lateral; purple petals (shorter than the broad calyx) somewhat per-
sistent; disk thick and hairy; achenes glabrous; hairy receptacle becoming
large and spongy.

14. P. palústris (L.) Scop. (Marsh F.) Stems stout, ascending from a decumbent rooting perennial base, 1-6 dm. long, glabrous below ; leaves pinnate ; leaflets 5-7, oblong, serrate, lighter colored and more or less pubescent beneath; flowers few in an open cyme; calyx $2-2.5 \mathrm{~cm}$. broad, dark purple inside. (Comarum L.) - Cool bogs, Lab. to Alaska, s. to N. J., Pa., Great L. region, is. Ia., Wyo, and Cal. June-Aug. (Eurasia.)

*** Style attached below the middle; achenes and receptacle densely villous; woody perennials.

15. P. fruticòsa L. (Shrubiry C.) Stem erect, shrubby, 1-8 dm. high, much branched ; leaves pinnate; leaflets $5-7$, crowded, oblong-lanceolate, entive, silky, usually whiter beneath and the margins revolute; petals yellow, orbicular. (Dasiphora Rydb.) - Wet or dry open ground, Lab. to Alaska, s. to N. J., Pa., Great L. region, n. Ia., Ariz., and Cal. June-Sept. (Eurasia.)

16. P. tridentata Ait. ('Threv-toormen C.) Stems low $(3-22 \mathrm{~cm}$. high), rather woody at base, tufted, ascending, cynosely several-flowered; leaves palmate; leaflets 3, wedge-oblong, nearly smooth, thick, coarsely 3-toothed at the end; petals white; achenes and receptacle very hairy. (Sibbaldiopsis Rydb.) - Lab. to e. N. T., where common in exposed rocky or gravelly situations, N. J., and southw. on the upper Alleghenies; also westw, chiefly along the Great Lakes. June-Aug. 
§ 3. Styles fliform, lateral; peduncles axillary, solitary, 1-flowered; achenes glabrous; receptacle very villous; herbaceous perennials, with yellow petals.

17. P. Anserìna L. (SILver WEeD.) Spreading by slender many-jointed runners, white-tomentose and silky-villous; leaves all radical, pinnate; leaflets 7-21, with smaller ones interposed, oblong, sharply serrate, silky-tomentose at least beneath; bractlets and stipules often incisely cleft; peduncles elongated. (Argentina Rydb.) - Brackish marshes, river-banks, etc., Arctic Am., s. to. N. J., Great L. region, Ia., N. Dak., N. Mex., and Cal. June-Aug. (Eurasia.) $P$. Egedii Wormsk., at least as to forms in our range, appears to be a dwarf state common on exposed rocks. Var. grandis T. \& G., is merely a luxuriant state in rich meadows.

Var. cóncolor Ser. Leaflets silky-canescent above as well as beneath. Common in the Rocky Mts., and in less pronounced form from $n$. N. Y. to $n$. Me. and e. Que.

if 18. P. pùmila Poir. Stems very slender, soon prostrate and repent, appressedvillous, flowering from the node above the first well-developed internode; leaves 3-foliolate but apparently 5-foliolate by the parting of the lateral leaflets; leaflets cuneate-obovate, incisely dentate, obscurely appressed-villous above, silkycanescent beneath. - Dry soil, common, coast of Me. to Md. Apr.-early June. - A loosely spreading-villous doubtfully distinct plant from Mo. and southeastw. may well be P. Caroliniana Poir.

19. P. canadénsis L. Suberect (2-7 dm. high) or procumbent, at length often rooting at the tip; stem sprending-hirsute, flowering from the node above the second well-developed internode, leaves divided as in the preceding ; leaflets commonly more oblong, serrate rather than dentate, obscurely villous or entirely glabrate above, canescent-silky to green and merely appressed-villous on the veins beneatl. - Dry sandy soil, s. Me. to Vt., along the Great Lakes to Minn., Kan., and southw. May-July.

Var. simplex (Michx.) T. \& G. Stem covered with shorter appressed or subappressed hairs or glabrate; leaflets (apt to be oblanceolate) rather shortly appressed-villous on the veins beneath. ( $P$. simplex Michx.) - Chieffy in dry sandy soil, very common; N. S., southw. and westw.

20. P. RÉptaxs L. Stems almost filiform, sparingly pubescent or glabrate, prostrate and usually repent; leaves much as in $P$. pumila; the leaflets green on both faces, sparingly strigose-pubescent or glabrate, cuneate-oblanceolate, crenate-dentate nearly or quite to the base; stipules usually small and inconspicuous; bractlets ovate-lanceolate, about equaling the calyx-lobes; petals broadly obcordate, half longer than the calyx-lobes. - Grass-land and waste places, local, Mass. to N. J. and O. June. (Adv. from Eu.)

21. P. Procúmbens Sibth. Similar, strigose-pubescent; leafets 3 (rarely 5), cuneate-obovate, coarsely incised chiefly above the middie; stipules conspicuous; bractlets linear-lanceolate. ( $P$. nemoralis Nestler.) - Grassy and waste places, Cape Breton I., N. S. (Nat. froin Eu.)

\section{FILIPÉNDULA [Tourn.] Hill.}

Flowers perfect or polygamous. Calyx (4-)5-parted. Petals (4-)5, shortclawed. Stamens 20 or more, almost hypogynous, the disk obscure. Carpels 5-15, free, 2-ovuled, mostly 1-seeded, indehiscent, compressed, sometimes twisted. - Perennial herbs, with pinnate leaves and panicled cymose flowers. Stipules kidney-shaped. (Name from filum, a thread, and pendulus, hanging, in allusion, it is said, to the roots.)

1. F. rubra (Hill) Robinson. (Queen of The PRairie.) Glabrous, 6-25 dm. high; leaves interruptedly pinnate, green and scarcely paler beneath; terminal leaflet large, 7-9-parted, the lobes lance-oblong, incised and toothed; lateral leaflets also cut; petals deep peach-blossom-color. (Spiraea lobata Gronov ; Ulmaria rubra Hill.) - Meadows and prairies, Pa. to Mich., Ia., $\mathbf{K y . ,}$ and $\mathrm{Ga}$. also locally established northeastw. Jume, July. 
2. F. Ulmaria (L.) Maxim. (Quenn of the Meadow.) Leaves canescenttomentose beneath; terminal leaflet 3-5-lobed, lobes ovate, doubly serrate ; the lateral leaflets mostly unlobed; petals white. (Spiruea L. ; Ulmaria Barnhart.) - Commonly cultivated ; established at several places in N. E. and Que. July. (Introd. from Eurasia.)

\section{GÈUM L. AVENS}

Calyx bell-shaped or flattish, deeply 5-cleft, usually with 5 small bractlets at the sinuses. I'etals 5. Stamens many. Achenes numerous, heaped on a conical or cylindrical dry receptacle, the long persistent styles forming hairy or naked and straight or jointed tails. Seed erect; radicle inferior. - Perennial herbs, with pinnate or lyrate leaves. (A plant name used by Pliny.)

§ 1. EUGEUM T. \& G. Styles jointed and bent near the middle, the upper part deciduous and mostly hairy, the lower naked and hooked, becoming elongated; head of fruit sessile in the calyx; calyx-lobes reflexed.

* Petals white or pale greenish-yellow, small, spatulate or oblong; stipules small. - Receptacle of the fruit densely hairy.

1. G. canadénse Jacq. Stem (0.6-1.1 m. high) and petioles sparingly hairy; leaves soft-pubescent beneath or glabrate, the basal of 3-5 leaflets or undivided. those of the stem mostly 3-divided or -lobed, rather sharply toothed; stipules ovate-oblong, 1-1.5 cm. long, subentire; petals white. (G. album J. F. Gmel.) - Borders of woods, etc., widely distributed.

2. G. flàvum (Porter) Bicknell. Stem and petioles hirsute; leaves much as in the preceding but inore bluntly toothed; stipules ovate or obovate, usually about $2 \mathrm{cmz}$. long, conspicuously cleft; petals greenish-yellow. - Dry woods, Ct. to 0 . and Va.

+ + Receptacle of the fruit glabrous or nearly so.

3. G. virginiànum L. Bristly-hairy, especially the stout stem; lower and root-leaves pimnate, very various, the upper mostly 3 -parted or divided. incised; petals inconspicuous, shorter than the calyx; heads of fruit larger, the short stout peduncles hirsute with reflexed hairs; receptacle glabrous or nearly so. Borders of woods and low grounds; common. June-Aug.

* Petals golden-yellow, conspicuous, broadly obovate, exceeding the calyx; stipules larger and all deeply cut.

- Terminal segment of leaves suborbicular, fnely crenate-dentate.

4. G. macrophýllum Willd. Bristly-hairy, stout, 3-9 dm. high ; root-leaves lyrately and interruptedly pinnate, with the terminal leaflet very large and round heart-shaped; lateral leaflets of the stem-leaves 2-4, minute, the terminal round ish, 3-cleft, the lobes wedge-form and rounded; receptacle nearly naked. - Rich soil, Nfd. to Alaska, s. to mts. of n. N. E. and N. Y., Mich., n. Wisc., Minn., Col., and Cal. (N. E. Asia.)

\section{+ + Terminal segment of leaves cuneate-obovate or oblanceolate.}

- Leaves incisely toothed; body of ripe achene 1-2 mm. long.

5. G. stríctum Ait. Somewhat hairy, 9-15 dm. high; root-leaves interruptedly pinnate, the leaflets wedge-obovate; leaflets of the stem-leaves 3-5, rhombic-ovate or oblong, acute; receptacle downy. - Moist meadows, thickets, eto., Nfd. to B. C., s. to N. J., 1’a., Ill., Mo., and N. Mex. July, Aug. (Asia.)

+ + Leaves bluntly toothed; body of ripe achene 4-5 mm. long.

6. G. URBANUM L. Smoothish, loosely brancined; segments of stem-leaves mostly rhombic-obovate; petals yellow, about equaling the calyx. - Established in Cambridge, Mass. (Adv. from Eu.) 


\section{\$2. STÝLIPUS (Raf.) T. \& G. Styles smooth; head of fruit conspicuously stalked in the calyx; bractlets of the calyx none; otherwise nearly as $\$ 1$.}

7. G. Yérnum (Raf.) T. \& G. Somewhat pubescent; stems ascending, fewleaved, slender; root-leaves roundish-heart-shaped, 3-5-lobed, or some of them pinnate, with the lobes cut; petals yellow, about the length of the calyx; receptacle sinooth. - Thickets, Ont. to Tenn., Tex., and Kan.

§3. CARYOPHYLLATA [Tourn.] Ser. Style jointed and bent in the middle, the upper joint plumose; flowers large; calyx erect or spreading; petals erect.

8. G. rivàle L. (Water or Purple A.) Stems nearly simple, several-flowered, $6 \mathrm{dm}$. high ; root-leaves lyrate and interruptedly pinnate, those of the stem few, 3-foliolate or 3-lobed; flowers nodding; calyx purplish, campanulate, the lobes in anthesis $6-10 \mathrm{~mm}$. 1ong ; petals dilated-obovate, retuse, contracted into a claw, purplish-orange; head of fruit stalked, its pedicel erect. - Bogs and wet meadows, Nfd. to Sask., s. to N. J., Pa., Mich., and Col. (Eu.)

$\times$ G. púlchrum Fernald. Hirsute, 6-8 dm, high ; in habit and foliage similar to the preceding; flowers smaller; lobes of the purple calyx 4-5 $\mathrm{mm}$. long, widely spreading; petals clear golden yellow, obovate, less contracted at base; styles rich carmine. - Boggy meadows, Bic, Rimouski Co., Que. ; also Mendon, Vt. (Éggleston); Alberta. - Apparently a hybrid of $G$. macrophyllum and G. rivale.

\$4. SIEVERSIA (Willd.) T. \& G. Style not jointed, wholly persistent and straight; head of fruit sessile; flowers large; calyx erect or spreading. (Flowering stems simple, and bearing only bracts or small leaves.)

9. G. trifldrum Pursh, Low, softly hairy ; root-leaves interruptedly pinnate : leaflets numerous and crowded, oblong-wedge-form, deeply cut-toothed ; flowers 3 or more on long peduncles; bractlets linear, longer than the purple calyx, as long as the oblong purplish erect petals; styles very long (5 cm.) strongiy plumose in fruit. (G. ciliatum Pursh; Sieversia ciliata G. Don.) - Calcareous soil, Lab., Yfd., Watertown, N. Y. (Crawe), Ont., Wisc., Mll., and westw.

10. G. Péckii Pursh. Smoothish ; root-leaves rounded-kidney-shaped, radiateveined, $5-12 \mathrm{~cm}$. broad, doubly or irregularly cut-toothed and obscurely 5-7lobed, with a set of minute leaflets down the long petiole; stems $1.5-4 \mathrm{dm}$. high, 1-5-flowered; bractlets minute; petals yellono, round-obovate and more or less obcordate, exceeding the calyx ( $1 \mathrm{~cm}$. long), spreading; styles naked except at the base. (G. radiatum, var. Gray; Sieversia R. Br.) - Exposed slopes, Me., and alpine summits of White Mts., N. H.

\section{RÙBUS [Tourn.] L. BRAMBLE}

Calyx 5(3-7)-parted, without bractlets. Petals 5, deciduous. Stamens numerous. Achenes usually many, collected on a spongy or succulent receptacle, becoming small drupes; styles nearly terminal. - Perennial herbs, or somewhat shrubby plants, with white (rarely reddish) flowers, and usually edible fruit. (The Roman name, kindred with ruber, red.)

§1. IDAEÓBATUS Focke. Prickly-stemmed shrubs; fruit falling off whole from a dryish receptacle when ripe; leaves pinnately 3-7-foliolate. RAsPBERR $\mathbf{r}$.

1. R. idaèus L. Stems upright, and with the stalks, etc., beset with stiff straight bristles (or a few becoming weak hooked prickles), glandular when young, somewhat glaucous ; leaflets $3-5$, oblong-ovate, pointed, cut-serrate, whitish-downy underneath, the lateral ones sessile; petals as long as the sepals; the latter velvety, with or without a few scattered setiform prickles; fruit light red. - Thickets, e. Qne., L. Superior region, and Rocky Mts. (Eurasia.)

Var, aculeatíssimus [C. A. Mey.] Regel \& Tiling. (WILn Red R.) Calyx bristly-hispid with setiform prickles. ( $\boldsymbol{R}$. strigosus Michx.) - Thickets and

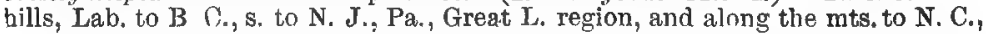


N. Mex., and Ariz. Forma ÁcBus (Fuller) Fernald has white or amber-colored fruit.

Var. anómalus Arrhenius.' Dwarf (1-3 dm. high), scarcely or not at all armed; leaves simple, broadly ovate and shallowly 3-lobed, or 3-foliolate with rounded ovate obtuse leaflets; calyx somewhat hispid. - Limestone ledges, Cavendish, Vt. (Eggleston); and (?) woods, Clarke, Ind. (Umbach), the latter recently described as Batidaea heterodoxa Greene.

$\times$ ? R. neglectus Peck. Habit and glaucous canes of no. 3 , the stems and branches often rooting at the tip, but with slender straightish prickles of the pre. ceding species; calyx somewhat setose; fruit purplish-red. - Rocky woods, gravelly banks, etc., N. E. to Ont., Pa., and O. - Probably a self-perpetuating hybrid between $R$. occidentalis and $R$. idaeus, var. aculeatissimus.

2. R. PHoEnicorAsius Maxim. (WinenerRy.) Leaflets 3, broadly ovate, obtusish ; inflorescence crowded and with the petioles, branches, and even the main stems covered with long soft densely crowded reddish or purple gland. tipped hairs; prickles scattered, slender; fruit broadly ovoid, cherry-red. Sometimes cultivated, and now established at Fairfield, Ct. (Eames) ; Painesville, O. (Hacker), etc. (Introd. from Japan.)

3. R. occidentàlis L. (B $\mathrm{LACK}$ R., ThimbleberRy.) Glaucous all over; stems recurved, rooting at tips, ar'med like the stalks, etc., with hooked prickles, not bristly; leaflets 3 (rarely 5), ovate, pointed, coarsely double-serrate, whitened-downy underneath, the lateral ones somewhat stalked; petals shorter than the sepals; fruit purple-black, ripe early in July. - Copses, fence rows, etc., N. B. and s. w. Que., southw. and westw. Forma PÁlious (Bailey) Robinson has yellow or amber fruit.

§2. ANAPLÓBATUS Focke. Unarmed shrubs; leaves simple, 3-5-lobed or angled; flowers large and showy; fruit large, hemispherical, red. $\mathrm{Ru}$ BaCer Rydb.

4. R. odoràtus L. (Purple Flowering R.) Shrubby, 1-1.6 m. high; branches, stalks, and calyx bristly with glandular-clammy hairs; leaves 3-5lobed, the lobes pointed and minutely toothed, the middle one prolonged; peduncles many-flowered; flowers showy (3-6 cm. broad); calyx-lobes tipped with a long narrow appendage; petals rounded, purple rose-color; fruit scarcely edible. - N. S. to Ga., w. to Mich. Var. CoLUn BIANus Millspaugh has been distinguished by the narrower more lanceolate doubly serrate lobes of the leaves, smaller flowers $(2-3 \mathrm{~cm}$. in diameter) and musky fruit. ( $R$. columbianus Rydb.) - W. Va.

5. R. parviflorus Nutt. (SALMoN BERRY.) Glandular, scarcely bristly; leaves almost equally 5-lobed, coarsely toothed; peduncles few-flowered; petals oval, white. (R. nutkanus Mociño.) - Rocky woods, shores, etc., w. Ont., n. Mich., Minn., and westw.

\$ 3. CHAMEMÒRUS (Ehrh.) Focke. Unarmed creeping herbs, with upright branches, few orbicular simple leaves, and solitary terminal nonoecious or dioecious flowers; fruit amber-colored, becoming yellow and separating from the dryish receptacle.

6. R. Chamaemorus I. (Cloldberri, Baked-Apple Berry.) Low (1-3) dn. high); lranches simple, 2-3-leaved; leaves roundish-kidney-form, somewhat 5-lobed, serrate, wrinkled; calyx-lobes pointless; petals obovate, white; fruit about $2 \mathrm{~cm}$. in diameter, very juicy when ripe. - In sphagnous bogs, Arctic Am., southw. in the coastal region to e. Me.; also on mountain tops, w. Me. and 1. N. H. (Eurasia.)

\$4. CYLÁCTIS (Raf.) Focke. Low, essentially herbaceous (soft-woody at base); leaves $3(-5)$-foliolate; fruit red, not separating easily from the receptacle.

7. R. trifldrus Richards. (DwarF R.) Stems ascending, 1-4 dm. high. or trailing and more elongated ; leaves 3 (or pedately 5)-foliolate; leaflets rhombicovate or ovate-lanceolate, acute at both ends, coarsely and doubly serrate, thin, 
smooth; peduncles 1-3-flowered; petals small, erect, white or pink; fruit of rather large juicy but acid drupelets. ( $R$. americanus Britton.) - Wet woods, etc., Lab. to Alaska, southw. to N. J., the Great L. region, n. Ia., and Neb. Sepals and petals often 6-7.

8. R. árcticus L, Stems suberect, $5-20 \mathrm{~cm}$. high, filiform; leaflets $3(-5)$, cuneate-obovate, rounded at the tip, somewhat firm, glossy above, coarsely serrate-dentate; petals rather large, spreading, rose-colored (rarely white); fruit as in the preceding. - Boggy places, Arctic Am., southw. to e. Que. and $\mathbf{n}$. Minn. (Boreal and Arctic Eurasia.)

§5. EÜBATUS Focke. Armed (rarely unarmed) shrubs; stems biennial; leaves on the first year's yrowth mostly 5-foliolate (pedate), on the flowering canes chiefly 3 -foliolate; fruit not separating from the juicy receptacle, blackish vohen ripe (reddish in no. 34). BLACKBER Y. - A group of great taxonomic difficulty, in which many species have been recently proposed. Of these, the better marked have been here freely included, but without entire confidence that future intensive study may not show them to he intergradient and perhaps in some cases hybrid forms.

u. Canes erect or arched-ascending $b$.

b. Pedicels habitually unarmed, often pubescent or glandular-hispid, rarely with a few weak bristles $c$.

c. Pedicels copiously glandular-hispid.

Leaflets appressed-villous above; prickles of the stem stoutish

Leaflets glabrous above; prickles of the stem setiform rather than thorv-like.

Petioles of the 5-foliolate leaves scarcely or not at all glandular, copiously armed with hooked prickles; leaflets rhomblc-lanceolate or narrowly ovate.

Lower surface of the leaflets velvety to the touch

Lower surface of the leatlets essentially flabrous.

Petioles of the 5-foliolate leaves copionsly g-landular-pubescent, weakly armed.

Fruit of 30-60 small drupelets

Frult of few large drupelets
c. Pedicels glandless or with only occasional gland-tipped hairs $d$.

$d$. Lower surface of leaflets even at maturity downy to the touch $e$.

o. Inflorescence numerously flowered, at lengch elongated and more or less cylindrical.

Inflorescence provided with 4-6 unifoliolate petioled bracts Inflorescence with 1-2 nnifoliolate petioled bracts

c. Inflorescence mostly fewer-flowered, corymbiform.

Canes ereet or nearly so ; teeth of the leaflets deltold-ovate, mucronulate-acuminate; prickles of stem few, weak, 1-2 mm. long

Canes commonly recurved and often rooting at tip; teeth of leaflets lanceolate, narrowly acuminate; prickles of stem mostly $3-5 \mathrm{~mm}$. long

d. Lower surface of lentlets glabrous, glabrate, or nearly so.

Internodes of main stem and petioles of 5 -foliolate leaves armed with numerous slender or bristle-formed prickles.

Prickles chietly or exclusively on the angles; leaflets of the mature 3-foliolate leaves suall, rarely over $5 \mathrm{~cm}$. long.

Prickles on the faces as well as the angles of the stem; leaflots of the 3-foliolate leaves larger, often $6-8 \mathrm{~cm}$, long .

Internodes and petioles with fow prickles or unarmed.

Inflorescence corymbiform

Inflorescence racemiform, subcylisidric :

b. Pedicels armed with stoutish or slender but pungent bristle-formed prickles $f$.

f. Leaflets laciniate-cleft; introduced .

$f$. Leaflets not laciniate-cleft $g$.

g. Lower surfaces of the lentlets velvety to the touch.

Leaflets white-tomentose beneath

Leaflets green or merely graylsh benenth.

Prickles of the first year's growth rigid.

Pedicels copiously glandular-pubescent

Pedicels tomentulose but not glandular.

Stems rigid, not rooting at the tip; prickles on the

first year's growth $5-7 \mathrm{~mm}$. long
Stems texuous, often rooting at the tip; prickles on the first yesr's growth $2-5 \mathrm{~mm}$. long

Prlokles on the first year's growth numerous, weak, bristlefrrmed, on the sulfaces as well as the angles of the stem.

9. R. allegheniensis.

10. R. flarinanus.

11. R. junceus.

12. R. glandicaulis.

13. R. frondisentis.

14. R. frondosus.

15. R. pergratus.

16. R. sativets.

17. $R$. recurvans.

18. R. elegantulus.

19. R. peculianis.

20. R. Randii.

21. R. canadensis.

22. R. laciniatus.

23. R. cuneifolius.

24. R. Andrenosianus

25. R. floricomus.

26. Ir. Jeckylanue

27. R. abbrevians. 
g. Lower surface of the leaflets green and essentially glabrous.

Canes armed with few flrm prickles mixed with numerous setue; pedicels with gland-tipped setre

Canes armed with nearly uniform and vely numerous setae.

Pedicels and sepals with numerous and conspicuous glandtipped setae

Pedicels and sepals" minutely" and obscurely glandular-pubescent or glandless, their bristles free from glandularity

w. Canes trailing or at least with a decided tendency to be prostrate toward the end $h$.

$h$. Pedicels covered with copions gland-tipped setae.

Sepals dorsally glandular-hispid.

Stem and petioles of the first year's growth with numerous glandular bristles among the abundant prickles

Stem and petioles of the furst year's growth less coptoisly armed and without glandular bristles

Sepals not dorsally glandular-hispid.

h. Pedicels not glandular or at most finely and obscurely glandulartomentulose.

Fruit red or reddish, small ; leaflets subcoriaceous, shining ; flowers several, in corymbiform racemos.

Fruit black.

Prickles much broadened at base; those of the pedicels numerous, strong.

Petioles, pedicels, etc., scarcely or not at all glandular; peduncles 1-3-tlowered.

Petioles, pedicels, etc., covered with reddish gland-tipped

hairs; peduncles 3 -several-flowered
Prackles merely acicular; those of the pedicols fow and weak, or none.

Leatlets of first year's growth finely and doubly serrate.

Leaflets of first year's growth coarsely and simply serrate

28. R. biformiapinus.

29. R. setosus.

80. R. nigricans.
81. R. pormiatus.

32. $R$, turdatus.

83. R. jacens.

84. R. hispidas8.
35. R. trivialis.

86. R. rubrisetus.

87. R. villosus.

88. R. invisus.

9. R. allegheniénsis Porter. Shrubby, 1-2 m. tall; old canes purplish, armed with stout straightish prickles; leaflets appressed-villous above, velvety beneath; branchlets, pedicels (unarmed), etc., glandular-pubescent; flowers $2.5-3: 5 \mathrm{~cm}$. broad, racemose, only the lower leafy-bracted ; petals narrowly obovate; fruit (rarely pale) generally subcylinaric, of many rather small drupelets, of good flavor. ( $\boldsymbol{R}$. villosus Man. ed. 6, in large part, not Ait.; $\boldsymbol{R}$. nigrobaccus Bailey.) - Dry open thickets and recent clearings, N. S. to Ont. and N. C., common. Forma albinug (Bailey) Fernald (White BlackBerry) has amber-colored fruit. Var. ca Lycosos Fernald. Sepals elongated and leaf-like; fruit dry, abortive. - A local sport, N. H. to Va.

Var. Gravèsii Fernald. Unarned; canes paler, mostly greenish; inflorescence much elongated $(2-3 \mathrm{dm}$.) - Ct. (Graves).

10. R. flavinànus Blanchard. Erect, 5-10 dm. high; old canes reddish, abundantly armed with slender curved prickles; leaflets glabrous above, velvety beneath; pedicels (unarmed) glandular-pubescent; flowers $2-2.5 \mathrm{~cm}$. broad; petals oblong-spatulate; fruit poor, with few drupelets. - Stratton, Vt.

11. R. junceus Blanchard. Erect or at length reclining; canes slender, weak, 6-9 dm. high, with weak recurved prickles; leaflets incisely toothed, glabrous above, essentinlly glabrous beneath; racemes short, becoming $6-8 \mathrm{~cm}$. long; pedicels (unarmed) glandular-hispid; flowers $2-2.5 \mathrm{~cm}$. broad; petals oblong-spatulate; fruit globose, of few drupelets. - Dry open places, York Co., Me.

12. R. glandicaúlis Blanchard. Strict; canes (purplish in age) 1-2 m. high, glandular-hispid and with numerous stout straightish prickies; leaflets glabrous above, velvety beneath ; racemes rather short; rhachis and pedicels glandularhispid; flnwers $2.5-3 \mathrm{~cm}$. broad; petals narrowly obovate ; fruit cylindrical, of 30-60 small drupelets, of good quality. - Dry open places, N. S. to s. Me., near the coast.

13. R. frondiséntis Blanchard. Erect; old canes (purplish) slender, 9-15 $\mathrm{dm}$. high, closely covered with fine prickles and stalked glands; leaflets mostly large, glabrous above, velvety beneath ; racemes short, somewhat corymbiform; rhachis and pedicels very glandular-hispid; flowers $2-3 \mathrm{~cm}$. broad; petals narrowly obovate ; fruit small, short-cylindric, of fero rather large drupelets.-Dry open soil, s. w. N. H. and s. e. Vt.

14. R. fronddsus Bigel. Clanes arched-recurving, with stout straightish 
prickles; leaflets subglabrous above, velvety beneath; racemes cylindrical, somewhat elongated, provided for more than half their length with nearly uniform unifoliolate ovate-oblong petiolate very persistent bracts; pedicels scarcely or not at all glandular; flowers $2.5-3 \mathrm{~cm}$. broad; petals broadly obovate; fruit subglobose, falling before the bracts; drupelets rather few. ( $R$. villosus, var. Torr.; $R$. philadelphicus Blanchard.) - Dry rocky billsides, e. Mass. to D. C.

15. R. pergràtus Blanchard. Erect, 1-2 m. high; old canes strongly furrowed, purplish, with stout broad-based straightish subremote prickles; leaflets sparingly villous (at length for the most part glabrate) above, velvety beneath; racemes short-cylindric; rhachis and pedicels villous, essentially glandless; flowers $2.5-3.5 \mathrm{~cm}$. broad; petals broadly obovate; frut short-cylindric, with numerous juicy drupelets. ( $R$. orarius and $R$. amnicolus Blanchard.) -Open ground, N. B. to Vt. and Mass., common.

16. R. sativus (Bailey) Brainerd. Erect or nearly so, 3-7 dm. high; canes rather weal, greenish, unarmed or with few small prickles; leaves even on the first year's shoots chiefly 3-foliolate; leaflets short, broadly ovate, glabrous or nearly so above, velvety beneath, with deltoid teeth; inflorescence a fero-flowered small corymb, leafy at base ; flowers $1.5-2 \mathrm{~cm}$. broad; petals narrowly obovate; fruit subglobose, of few large juicy drupelets. ( $R$. villosus, var. Bailey? $\boldsymbol{R}$. nigrobaccus, var. Bailey?) - Alluvial soil, w. Vt. (Brainerd, Eggleston), and presumably westw.

R. ARGUTrs Link, of this group, an American species, described from specimens cultivated in Berlin, has been variously interpreted, but cannot now be certainly identified from the flowering material preserved.

17. R. recúrvans Blanchard. Erect or recurving, often rooting at the tip; canes firm, obtusely 5-angled, often much elongated (2-4 B. long), purplish, remotely armed along the angles with strong straightish prickles; leaflets smoothish above, velvety beneath, sharply and irregularly toothed; racemes short, leafy toward the base, corymbiform; flowers $2-2.5 \mathrm{~cm}$. broad; petals obovate; fruit short-cylindric, with ratber numerous large juicy drupelets. ( $R$. arundelanus Blanchard.) - Open soil, in thickets, etc., N. E., common.

18. R. elegántulus Blanchard. Erect, 6-12 dm. high; canes slender, glabrous, armed chiefly on the angles with slender straightish prickles; leaflets of the mature 3-foliolate leaves small, glabrous on both surfaces, rather firm, sharply toothed; inflorescence of slender sometimes compound leafy-bracted racemes; pedicels filiform, sometimes bearing scattered setae, obscurely tomentulose; flowers $2.5-3 \mathrm{~cm}$. broad; petals oblong-spatulate; fruit globose, with few large drupelets.-Uplands, s. W. N. H. and s. e. Vt.

19.' R. peculiàris Blanchard. Erect or slightly recurving; old canes purple, 5-angled, armed on the faces as well as the angles with numerous setiform prickles; leaflets of the mature 3-foliolate leaves large, glabrous on both surfaces, rather coarsely serrate-dentate; inflorescence a short raceme, leafy-bracted at base; flowers $2.8-9 \mathrm{~cm}$. broad; petals oblong-obovate ; fruit subglobose, of few rather large drupelets. - Dry ground, York Co., Me.

20. R. Rándii (Bailey) Rydb. Slender weakly armed reddish or greenish culps suberect or recurved, sometimes elongated and rooting at the tip, subterete; leaflets thin, glabrous on both surfaces, sharply and irregularly toothed; inflorescence a few-florvered corymbiform raceme, leafy-bracted at base; pedicrls fliform, nearly unarmed, often glabrate, flexuous; flowers $2-3 \mathrm{~cm}$. broad; petals narrowly obovate; fruit subglobose, of few drupelets. ( $R$. argutus, var. Bailey; $R$. recurvicaulis Blanchard.) - River banks, alluvial soil, etc., Nfd. to $\mathrm{Vt}$, and $\mathrm{Ct}$.

21. R. canadénsis I. Erect or recurving, often stout; old canes glabrous, unarmed or with rar'e prickles; leaflets glabrous on both surfaces, finely, evenly, and sharply toothed, those of the 5-foliolate leaves caudate-acuminate; racemes cylindric, rather long, leafy-bracted at base; pedicels filiform, tomentulose, not glandular; flowers $2.5-4 \mathrm{~cm}$. broad; petals obovate; frut subglobose to short-cylindric, of large and juicy but somewhat acid drupelets. ( $\boldsymbol{R}$. amabilis Blanchard.) - Rocky soil, in thickets, etc., Nfd. to L. superior, s. chiefly in the uplands to $\mathrm{N}, \mathrm{C}$, 
R. MillsPaÚghi Britton, a robust plant of W. Va., is but little known. In technical characters it scarcely differs from the preceding species, of which it may well prove a luxuriant form.

22. R. LACINì̃us Willd. Readily recognized by its laciniate-cleft leaflets, prickly calyx, and broad-based pale prickles. - Sometimes cultivated and now locally established, s. N. Y., e. Pa., and Del. - A plant of unknown origin, perhaps only a cut-leaved form of the European $R$. fruticosus L.

23. R. cuneifolius Pursh. (SAND B.) Shrubby, 3-12 dm. high, upright or ascending, armed with stout recurved prickles; branchlets and lower surface of leaves white-tomentose; leaflets wedge-obovate, thickish, srrate above the middle; peduncles 1-4-flowered; corolla 2-3 $\mathrm{cm}$. broad. - Rocky or sandy soil, Ct. to Fla., La., and Mo.

24. R. Andrewsiànus Blanohard. Erect or arched-ascending, not rooting at the tip, 9-15 dm. high; old canes stout and stiff, prominently angled and furrowed, purplish, strongly armed with broad-based straight prickles; leaflets sparingly pubescent above, velvety beneath, rather finely and sharply serrate; racemes short; rhachis and pedicels tomentose and glandular-hispid, the latter bearing slender hooked prickles; calyx somewhat glandular; flowers $2.5-3 \mathrm{~cm}$. broad ; petals obovate, abruptly narrowed at base to a long claw; fruit shortcylindric, large, of about 30 juicy drupelets. - Sandy plains near the coast, Mass. to Va.

25. R. florícomus Blanchard. Erect and somewhat rigid, 8-14 dm. high; canes strongly angled and grooved, greenish or purplish, stoutly armed with long firm straightish needle-pointed prickles; branchlets somewhat tomentose, and as well as the pedicels, petioles, and often midnerves beset with stout hooked prickles; leaves firm, glabrate above, rusty-velvety beneath; leaflets coarsely and sharply toothed; raceme 7-12-flowered, corymbiform; pedicels widely spreading; rhachis, pedicels, and calyx softly villous-tomentose; fruit subglobose, with fero rather large drupelets. - Southington, Ct.; (?) Jaffrey, N. H., and (?) Weybridge, Vt. (Brainerd).

26. R. Jeckylànus Blanchard. Recurved-ascending, the branches often rooting at the tip; canes subterete, sparingly arned with short slender prickles; leaves glabrate above, velvety beneath, those of the flowering uranches overtopping the corymbiform few-flowered inflorescence; thachis and pedicels softly tomentose, not glandular, the latter sparingly beset with very fine straight prickles; leaflets sharply and unequally dentate; flowers about $3 \mathrm{~cm}$. broad; petals elliptical ; fruit globose, of few large drupelets. - Open places, York Co., Me.

27. R. abbrèvians Blanchard. Erect, 3-6 dm. high; the slender terete canes firm, reddish brown, closely beset with fine straight prickles and gland-tipped bristles; leaves rather small, smoothish above, velvety beneath; leaflets on the fruiting canes broadly obovate, coarsely dentate; racemes short, subcorymbiform, leafy-bracted at base; rhachis and pedicels glandular-hisyid and setulose; flowers $2.5 \mathrm{~cm}$. broad; petals narrowly obovate; fruit short-cylindric, of few large finally sweet drupelets. - Uplands of Windham Co., Vt.

28. R. biformispinus Blanchard. Reclining; the elongate terete purplish flexuous canes armed with scattered straightish prickles and numerous smaller in part gland-tipped bristles; leaves glabrous on both surfaces; racemes short, leafy-bracted at base; rhachis and pedicels glandular-hispid and with scattered hooked prickles; flowers $2-2.5 \mathrm{~cm}$. broad; fruit globose, of few drupelets. Dry open ground, York Co., Me.

29. R. setdsus Bigel. Ascending; the terete canes (in age purplish) densely covered with retrorse bristles and shorter gland-tipped hairs; leaves rather large, glabrous on both surfaces, usually equaling or surpassing the corymbiform several-flowered racemes; petioles often setulose; rhachis and pedicels densely glandular-hispid and nostly setose; flowers 1.5-2.5 cm. broad ; petals oblong-spatulate; fruit subglobose. ( $\boldsymbol{R}$. nigricans Rydb., in part.) - Meadows and swamps, I'. E. I. to $V^{2}$. and Ct.

30. R. nigricans Rydb. Similar, more upright, 6-12 dm. high; canes armed with numerous fine prickles, but without glands; leatlets glabrous on both 
surfaces; pedicels and sepals obscurely or not at all glandular. (R. hispidus, var. suberectus Peck; $R$. setosus of auth., in part, not Bigel.; $R$. vermontanus Blanchard; $R$. semisetosus Blanchard?)-Open places, e. Que. to N. Y. and Micr.

31. R. permixtus Blanchard. Recurving and soon prostrate; stems (as vell as petioles, rhachis, pedicels, etc.) densely glandular-hispid and armed with scattered stronger straightish or more often curved prickles; leaflets glabrous above, velvety beneath, rather small, those of the flowering canes $2-6 \mathrm{~cm}$. long; racemes few-flowered, short; flowers $1.5-2 \mathrm{~cm}$. broad; calyx glandular-hispid; petals oblong-spatulate; fruit short-cylindric, with few large drupelets, sweet. Dry soil in open places, s. e. Vt.

32. R. tardàtus Blanchard. Decumbent, becoming prostrate; the subterete slender stems with numerous straightish prickles, but with few or no glands; petioles smooth or sparingly prickly ; leaflets smooth on both surfaces, those of the flowering stems 4-10 cm. long; racemes somewhat compound, corymbiform; pedicels glandular-hispid, occasionally setulose; flowers $2 \mathrm{~cm}$. broad; petals narrowly obovate; fruit globose, of few large sour drupelets. - Sandy soil, York Co., Me. - Perhaps merely a form of the next.

33. R. jacens Blanchard. Similar, but the stem more glandular; leaflets of the towering stems $2-5 \mathrm{~cm}$. long ; sepals dorsally free from glands; fruit globose, of a few sweet drupelets. - Dry open places, s. w. N. H.

34. R. hispidus L. Prostrate or nearly so; the slender terete often elongated stems more or less beset with retrorse prickles; the branches suberect, $5-30 \mathrm{~cm}$. high ; leaflets glabrous on both surfaces, of firm texture, subcoriaceous, rather dark green and somevhat shining above; racenes few-flowered, corymbiform; rhachis and pedicels occasionally setulose; flowers $1.5-2 \mathrm{~cm}$. brond; fruit small, reddish-purple, of few small sour drupelets. - Low woods and swampy meadows, N. S. to s. w. Ont. and N. C., common.

35. R. trivialis Michx. Prostrate; stems terete, elongated, slender, armed (as are also the petioles and often the peduncles) with broad-based flattish short hooked retrorse prickles, not conspicuously glandular ; leaflets coriaceous, evergreen, elliptical, rather sharply serrate; peduncles 1-3-flowered, flowers 3-4 cm. broad; petals broadly obovate; fruit cylindrical, of many drupelets. - Dry soil, Va. to Fla. and Tex., near the coast.

36. R. rubrisetus Rydb. Similar; the stems, petioles, and especially the pedicels glandular-hispid with reddish or purplish hairs ; corymbs 3-9-flowered; thowers 1.5-2.5 cm. broad; petals oblong-spatulate. - Sandy soil, Mo. to La. and Fla.

37. R. villdsus Ait. (DEwBERRY.) Becoming prostrate; stems elongate, subterete, rather woody, armed with stout slender retrorse straightish prickles; fruiting branches upright, 1-3 dm. high, (1-)3-15-flowered; leaflets rhombicobovate, doubly and vather finely serrate, acutish, membranaceous, smooth or sparingly villous beneath; fowers in leafy corymbiform racemes, 2-3 cm. broad; sepals not foliaceous; fruit subglobose to short-cylindric, with few-many large juicy drupelets. (R. canadensis of auth., not L.; $R$. procumbens Muhl.)-Dry open places, s. Me., westw. and southw., common. Var. Roribáccos Bailey. (IJUCRETIA D.) A large-flowered extreme, with elongated pedicels; the flozers $4 \mathrm{~cm}$. broad; sepals often foliaceous. - W. Va., where doubtfully native; and in cultivation.

Var. humifúsus T. \& G. Stems slender, less woody; flowering branches chiefly 1-flowered; flowers large, 3-4 cm. broad. ( $R$. Enslenii Trattinick; $R$. Baileyanus Britton; R. subuniflorus Rydb.) - Chiefly near the coast, froin e. Mass. southw.

(Several recently proposed species are obviously related to and not very clearly distinct from $R$. villosus and await further study.)

38. R. invisus (Bailey) Britton. Similar, but stouter; the canes less procumbent; leaflets, especially those of the vegetative shoots, simply and rather coarsely toothed; pedicels long (becoming $1.5 \mathrm{dm}$. in length); sepals large, foliaceous. - N. Y. to Kan. and southw. - The original of several cultivated Dewberries. 


\section{DALIBÁRDA Kalm.}

Calyx deeply 5-6-parted, 3 of the divisions larger and toothed. Petals 5, ses. sile, deciduous. Stamens many. Ovaries $5-10$, becoming nearly dry seed-like drupes; styles terminal, deciduous. - Low unarmed perennials, with creeping and densely tufted stems or rootstocks, and roundish-heart-shaped crenate leaves on slender petioles. Flowers of 2 kinds, a few upright long-peduncied usually sterile ones with white petals, and numerous fertile apetalous ones on short curved peduncles. (Named for Thomas François Dalibard, a French botanist of the time of Linnaeus.)

1. D. rèpens L. Downy; sepals of the petaliferous flowers spreading, of the cleistogamous ones converging and inclosing the fruit. - Woods, N. B. to Ont., s. to N. J., Pa., O., Mich., and Minn. June-Aug.

\section{0. alchemílla L. Ladx's Mantle}

Calyx-tube inversely conical, contracted at the throat; limb 4-parted with as many alternate accessory lobes. Petals none. Stamens 1-4. Pistils 1-4; the slender style arising from near the base; achenes included in the tube of the persistent calyx. - Low herbs, with palmately lobed or compound leaves, and small corymbed greenish flowers. (From Alkemelyeh, the Arabic name, having reference to the silky pubescence of some species.)

1. A. ARÝénsis Scop. (Parsley PierT.) Small annual, 4-20 cm. high; leaves 3-parted, with the wedge-shaped lobes 2-3-cleft, pubescent ; flowers fascicled opposite the axils. - N. S. (according to Lawson); D. C. (where said to be extinct); Va. to Tenn. and Ga. (Adv. from Eurasia.)

2. A. Pratrinsis F. W. Schmidt. Perennial, 1-3 dm. high, from a stout candex; leaves orbicular, 2-10 cm. in diameter, deeply cordate, finely serrate, shallowly 5-9-lobed; inflorescence paniculate; pedicels filiform. - Dry roadsides, etc., N. S., where locally abundant near coast; also casual at Westford, Mass. (Miss Fletcher). (Nat. from Eu.)

\section{AGRIMONIA [Tourn.] L. AGRIMONY}

Calyx-tube top-shaped or hemispherical, the throat beset with hooked bristles, indurated in fruit and inclosing 2 achenes; the limb 5-cleft, closed after flowering. Petals 5, yellow. Stamens 5-15. Styles terminal. - Perennial herbs, with interruptedly pinnate leaves, crenate-serrate leaflets, and small spicateracemose flowers. - Bracts 3-cleft. (Name a corruption of Argenone.)

$\boldsymbol{u}$. Fruiting calyx more or less top-shaped, deeply furrower $b$.

b. Leaflets (exclusive of the little intermediate ones) chiefly 5-9, ovate to obovate or elliptic-oblong.

Rhachis of inflorescence covered with minute glandular puberulence interspersed with long widely spreading hairs; leaves spuringly pubescent beneath; roots not thickened

Rhrchis appressed-villous or glandular-puberulent, without "long widely spreading bairs.

Roots not thickened; lower surface of leaflets conspicuously resizous-dotted, only the veins villous

Roots fusiform-thickened toward the end; lower surface of leaflets velvety-tomentose, scarcely or not at all resinous-dotted.

Larger Jeaflets 5-9, oblong or elliptical; fruiting calyx 4-5 mm. wide (exelusive of spreading hooks) :

Larger leaflets $8-5$, obovate; fruiting calyx about 3 inm. wide (exclusive of hooks).

b. Leaflets (exclusive of little inteimediate ones) 11-18, lanceolate to nar rowly lance-oblong

$u$. Fruiting calyx hernispherical, striped but acarcely furrowed

1. A. gryposepala.

2. A. striata.

8. A. mollis.

4. A. microcarpa.

Б. A. parvifiora.

6. A. rostellata.

1. A. gryposépala Wallr. Tall (7-12 dm.); stem hirsute; leaflets large, thin, smoothish, scarcely paler beneath; fruiting calyx nearly $1 \mathrm{~cm}$. long; hooks long, widely spreading, the outer deflexed. (A. Eupatoria Man. ed. 6, in part, not L.; A. hirsuta Bicknell.) - Thickets, ravines, etc., s. N. S. and centr. Me. to Va., and westw.; frequent. 
2. A. striàta Michx. Erect, subsimple up to the inflorescence, 3-15 dm. high, softly pubescent, the hairs inclining to be appressed; leaflets mostly narrowed to a point, somewhat costate ; fruiting-calyx strongly deflexed; the hooks relatively short and connivent or scarcely spreading. (A. Eupatoria Mall. ed. 6, in part, not L.; A. Brittoniana Bicknell.) - Damp woods, alluvial soil, etc., Nfd. to Sask., s. to W. Va., Ill., Neb., S. Dak., and N. Mex. (Eurasia.)

3. A. móllis (T, \& G.) Britton. Grayish-pubescent, 6-15 dm. high ; leaflets oblong, mostly obtuse, soft to the touch on both surfaces; fruit broadly topshaped, the hooks borne on a broad disk, the outer widely spreading. ( $A$. rubescens Wallr. ?) - Open woods, dry ground, etc., Mass. to N. C., and westw.

4. A. microcárpa Wallr. Small, subsimple, mostly 3-5 dm. high; leaflets obovate, soft-tomentose beneath, sparingly appressed-pubescent or subglabrous above; fruiting calyx much as in the last but smaller. (A. pumila Muhl, inadequately characterized.) - Woods, etc., Pa. to Fla. and Tex.

5. A. parviflòra Ait. Stem hirsute, 7-12 dm. high, leafy ; leaflets numerous, narrow, with many smaller intermediate ones of 2 or 3 different sizes; fruiting calyx small (4-5 mm. long), abruptly deflexed at maturity from an ascending pedicel; outer hooks widely spreading. - Chiefly in sandy and alluvial soil, Ct. to Ga., westw. to Ont., Kan., and La.

6. A. rostellà ta Wallr. Slender, $4-8 \mathrm{dm}$. high ; stem nearly glabrous, roughish ; leaflets few, obovate ; fruiting calyx small, almost hemispherical, not deeply furrowed, the hooks small, the longest shorter than the connivent calyx-lobes. (A. striata Bicknell, not Michx.) - Rocky woods, alluvium, etc., Ct. to Ga., and westw.

\section{SANGUISÓRBA [Rupp.] L. BURNet}

Calyx with a top-shaped tube, constricted at the throat, persistent; the 4 broad petal-like spreading lobes imbricated in the bud, deciduous. Petals none. otamens 4-12 or more, with flaccid filaments and short anthers. Pistils 1-3; the slender terminal style tipped with a tufted or brush-like stigma. Achene (commonly solitary) inclosed in the 4-angled dry and thickish calyx-tube. Seed suspended. - Chiefly perennial herbs, with unequally pinnate leaves, stipules adherent to the petiole, and small often polygamous or dioecious flowers srowded in a dense head or spike at the summit of a long and naked peduncle, each bracteate and 2-bracteolate. (Name from sanguis, blood, and sorbere, to drink up, to absorb, from reputed styptic properties in folk-medicine.) НотERIUM L., in part.

\section{* Stamens 4 ; leaflets 2-5 cm. long.}

1. S. canadénsis L. (CANadian B.) Stamens long-exsërted, club-shaped, white, as is the whole of the elongated and cylindrical spike; stem 3-16 dm. high ; leaflets numerous, ovate or oblong-lanceolate, coarsely serrate, obtuse, heart-shaped at base, as if stipellate; stipules serrate. (Poterium Gray.) Bogs and wet meadows, Lab. to mts. of Ga., w. to Mich.

2. S. officinalis L. In habit similar to the preceding; spites dense, ovoid, brownish-or purplish-red. - Established in low fields near coast of Me.; also reported from Minn. (Adv. from Eurasia.)

* Stamens numerous; leaflets 8-15 mm. long.

3. S. Mìnor Scop. (GARDEN B.) Stamens 12 or more in the lower fiowers of the globular greenish head, with drooping capillary filaments, the upper flowers pistillate only; stems $3-5 \mathrm{dm}$. high; leaflets small, ovate, deeply cut. ( $P$ oterium Sanguisorba L.) - Locally established in grassy places, cultivated grounds, etc., Me. to Md. and W. N. Y. (Adv. from Eurasia.)

\section{ROSA [Tourn.] L. Rosk}

Calyx-tube urn-shaped, contracted at the mouth, becoming fleshy in fruit. Petals 5, obovate or obcordate, inserted with the many stamens into the edga of the hollow thin disk that lines the calyx-tube and within bears the numerous 
pistils below. Ovaries hairy, becoming bony achenes in fruit. - Shrubs, usually prickly, with odd-pinnate leaves, and stjpules adnate to the petiole; stalks, foliage, etc., often bearing aromatic glands. Many of the species highly variabie and often indeterminable from imperfoct specimens. (The ancient Latin name.)

". Styles coberent in a protruding column, as long as the stameris

1. R. sotigera.

u. Styles distinct $b$.

b. Sepals connivent after flowering, persistont; pedicels and receptacle naked $c$.

$\therefore$ Prickles scattered or none, the infra-stipular when present not enlarged.

Leaf-rhachis glandular-puberulent or -bristly.

Fruit pyriform, obovoid or oblong, toly-shaped at base

Fruit subglobose, obtane or ronnded at base (2) R. acicule
Leaf-rhachis softly and finely villous or tomentulobe; glandular

2. R. acicularis. hairs inerely occasional or none.

Prickles numerous, seattered; leaflets 7-11.

Prickles occasionally present on main stem but mostly few or

none; leaflets $5-7$
c. Prickles not wholly uniform, the infra-stipular somewhat stouter.

Calyx-lobes essentinlly entjre.

Calyx-lobes $1-1.5 \mathrm{~cm}$. long.

Leaves $6-10 \mathrm{~cm}$. long; Jeatlets pubescent beneath ; stem armed chiefly near the nodes.

Leaves $2-4 \mathrm{~cm}$. long; leaflets essentially glabrous; stem excessively spiny throughout

Calyx-lobes $2-2.5 \mathrm{~cm}$. long

Onter calyx-lobes conspicuously pinnatific

b. Sepals spreading after Howering, deciduous from the mature frut : recoptacle and pedicels more or less hispid or tomentose.

Leallets thick, evergreen or nearly so; leceptacle tomentose

Leaflets membranaceous; receptacle not tomentose.

Leaf-rhachis very glandular.

Prickles strong, hooked; leaflets rarely $2 \mathrm{~cm}$. long

Prickles weak, acicular, often gland-tipped; leaflets $8-6 \mathrm{~cm}$. long:

Leaf-rhachis puberulent or glabrous, scarcely if at all glandular.

Young growth densely covered, even into the inflorescence, with needle-like prickles

Young grow th armed at the nodes or not at all.

Stipules narrowly linerr, their free auricles merely shortlancenlate teeth; leaflets serrulate; infri-stipular prickles short, 2-4 (rarely 6) mm. long, broad-bosed and decidedly curved

Stipules more dilated, oblanceolate, their auricles somewhit deltoid; serratures of the leaflets coarser and deeper; infra-stipular prickles longer.

Prickles decidedly curved; leaflets somewhat shining above Prickles straight or nearly so; leaflets dull above

3. R. pratincola.

4. R. blanda.

\section{R. Woodsid.}

6. R. spinosissima.

7. R. cinnamomea.

8. R. canina.

9. R. bracteata.

10. R. rubiginosa.

11. R. galliaa.

12. R. nitida

13. R. caroldna.

14. $R$ virginiana.

15. R. humilis.

1. R. setigera Michx. (Climbing or Prarrie R.) Stems climbing, armed with stout nearly straight scattered prickles, not bristly; leaflets $3-5$, ovate, acute, sharply serrate, smooth or downy beneath; stalks and calyx glandular; flowers corymbed; sepals pointed; petals deep rose-color changing to white; fruit globular. - Borders of prairies and thickets, Ont. to Fla., w. to Wisc., Neb., and Tex.; also an escape from cultivation in Ct. July. - Strong shoots growing 3-6 $\mathrm{m}$. in a season.

2. R. aciculàris Lindl. Stems $3-12 \mathrm{dm}$. high, very prickly; stipules usually dilated, glandular-ciliate and resinous ; leaflets $3-7$, broadly elliptical to oblonglanceolate, sessile and obtuse or suhcordate at base, usually pale and somewhat resinous-puberulent beneath, the teeth serrulate; fowers large, solitary (very rarely $2-3$ ) ; onter sepals usually with 1-2 narrow lateral lobes, not hispid ; fruit obovoid or ellipsoid, top-shaped at base. ( $R$. Engelmanni Wats.) - Sandy thickets. L. Huron to Minn., Col., and Ida. (Siber.)

Var. Bourgeauiàna Crépin. Fruit globose, rounded at base; leaves sometimes smoothish but more often soft-pubescent and resinous-pulverulent beneath. - Ledges, rocky woods, etc., Anticosti to s. Vt., n. Mich., centr Ill., Col., and nortbw.

3. R. pratíncola Greene. Stems low, very prickly; stipules narrow, more or less glandular-toothed above (or even glandular-ciliate); leaflets 7-11, broadly elliptical to oblong-oblanceolate, subcuneate at base, somewhat firm and strongly 
vemed, simply toothed, nol resinous; flowers corymbose; sepals rarely hispid, the outer lobed. (R. arkansana of auth., not Porter.) - Prairies, etc., Man. to Mont., s. to Mo. and Tex.

4. R. blánda Ait. Stems 3-15 dm. high, wholly unarmed or occasionally covered with numerous prickles; stipules dilated, naked and entire or slightly glandular-toothed; leaflets 5-7, usually oblong-lanceolate, thinner and less strongly veined than in the preceding, cuneate at base and petiolulate, simply serrnte, not resinous; flowers usually large, corymbose or solitary; sepals hispid, entire. - On rocks and shores, Nfd. to N. E., and westw. chiefly in the region of the Great Lakes to Mo. and Assina.

5. R. Woódsii Lindl. Stems usually low (1-9 dm. high), with slender straight or recurved prickles, or wholly unarmed above; leafiets $5-7$, obovate to oblong or lanceolate, more or less toothed; flowers corymbose or solitary ; sepals naked or hispid, the outer usually lobed; fruit globose, with a short neck. - Minn. to Mo., westw. and northwestw.

6. R. spinosfssima L. (Śотсн R.) Low spreading shrub; stems densely covered with long straightish prickles and innumerable shorter ones; leaflets 7-13, small, broadly elliptic to suborbicular, glabrous or nearly so ; stipules very small ; fruit globular, black. - Often cultivated, and inclined to spread from old gardens, N. E.., Ont., etc. (Introd. from Eurasia.)

7. R. cinnamóma L. (Cinnamon R.) Stems flexuous, reddish brown, armed with pairs of light-colored broad-based slightly recurved infra-stipular prickles ; leaflets rather narrowly eltiptical, $2-3 \mathrm{~cm}$. long, paler beneath, sharply and finely serrate; flowers commonly double.-Once much cultivated, and now established in hedgerows, etc. (Introd. from Eurasia.)

8. R. Cavint I. (Dog R.) Stems armed with stout recurved prickles, the branches sometimes unarmed; leaflets 5-7, elliptical or oblong-ovate, glabrous or somewhat pubescent, simply toothed, not resinous-puberulent; flowers solitary (or 2-4) on usually naked pedicels ; sepals pinnatifid; fruit ovoid or nearly globular. - A casual escape from cultivation, Mass. to Tenn.; thoroughly naturalized on river-banks in Pa. (Porter). (Introd. from Eurasia.)

9. R. BRactedta Wendl. (MacarTnY R.) Leaflets mostly 7, narroviy obovate, rounded at the apex, thick, shining, evergreen, glabrous ; flowers large; calyx densely villons-tomentose; petals mostly white. - Cultivated from China, extensively naturalized in parts of the Southern States, extending to Va. (Introd. from Asia.)

10. R. Rubiginósa L. (Sweetbrier, Eglantine.) Armed with strong hooked mostly infra-stipular prickles (with or without scattered smaller ones); leaflets densely resinous beneath and aromatic, doubly serrate; the short pedicels and pinnatifid sepals hispid ; flowers pink, mostly 3-4 cm. in diameter ; fruit obovate. - Rocky pastures, etc., common. (Introd. from Eu.)

Var. m icrántha (Sm.) Lindl. Leaves less glandular, nearly scentless, flowers smaller (about $2-2.5 \mathrm{~cm}$. in diameter) and paler; fruit somewhat flaskshaped. - Along roadsides, etc., e. Mass. (Introd. from Eng.) - Inconstant and suggesting relationship to no. 8 .

11. R. GĹLIICA L. Erect, 1-1.6 m. high ; stem glandular-hispid and armed with straightish slender prickles; leaflets $3-5$, broadly elliptic, cordate at base, rounded or obtusish at apex, doubly glandular-serrate; flowers large, mostly - deep red and double. - Often cultivated, and now well established in roadside thickets, N. E., O., and probably elsewhere. (Introd. from Eu.)

12. R. nitida Willd. Low, nearly or quite glabrous throughout, the straight slender infra-stipular prickles scarcely stouter than those which usually thickly cover the stem and branches; stipules mostly dilated; leaflets bright green and shining, usually narrow-oblong and acute at each end; flowers solitary (rarely 2-3); sepals entire. - Margins of swamps, Nfd. to N. E.

13. R. carolina L. Stems usually tall (3-25 dm. high), with stout straight or usually more or less curved prickles; stipules long and very narrow; leaflets 5-9 (mostly 7), finely serrate, dull green, usually narrow-oblong and acute ab each end and petiolulate, but often broader, usually pubescent beneath. - Borders of swamps and streams, N. S. to Fla., w. to Minn. and Miss. 
$\checkmark$ 14. R. virginiàna Mill. Stems often tall and stout (2-20 (lm. high), with at length stont and usually more or less hooked prickles; stipules usually naked. more or less dilated; leaflets (mostly 7) dark green, rather thick, smooth and often shining above; flowers corymbose or solitary; outer sepals frequently with 1 or 2 small lobes. (R. lucida Ehrh.) - Margins of swamps and rocky shores, Nfd. and e. Que. to N. Y. and e. Pa.

15. R. hùmilis Marsh. Stems usually low (3-9 dm. high), slender, with straight slender prickles (spreading or sometimes reflexed); stipules narrow, rarely somewhat dilated; leaflets as in the last, but usually thimner and duller; flowers very often solitary; outer sepals always more or less lobed. - Mostly in dry soil or on rocky slopes, N. S. to Fla., w, to Minn., Mo., Okla., and La.

\section{PRÙnUS [Tourn.] L. Plum, Cherry, etc.}

Calyx 5-cleft ; the tube bell-shaped, urn-shaped, or tubular-obconical, deciduous after flowering. Petals 5, spreading. Stamens 15-20. Pistil solitary, with 2 pendulous ovules. Drupe fleshy, with a bony stone. - Small trees or shrubs, with mostly edible iruit. (The ancient Latin name.) Curasus B. Juss. AMYGDALS L.

$u$. Ovary glabrous; stone smoothish or shallowly sculptured $b$.

b. Flowers racemnse; pedicels much shorter than the floriferous part of the rhachis.

Leaves oblong, thickish, crenatemserrulate, the teeth incurved

Leaves mostly obovate, thin, sharply serrate; teeth somewhat

b. Flowers unbellate or, if racemose, with pedicols excoeding the floriferous part of the rhachis $c$.

c. Flowars small; petals mostly $4-6 \mathrm{~mm}$. long $d$.

$d$. Leuves broad or, if narrow, serrulate practically to the base $e$.

e. Eeaves lanceriate to oblong, ovate, or obovate $f$.

$f$. Petioles tomentose at least on the npper side.

Leaves lanceolate, attenuate.

Petioles 15-9s mm. long

Petioles 5-8 mm. long

Leaves ovate- or obovate-oblong to elliptical.

Leaves obovate, thinuish, mostly cuneate at base, 1-2.5 cm. wide, somewhat doubly serrate; pedicels 1-3 in a fascicle

Leaves ovate- or obovate-oblong, thickish, rugose, mostly obtuse at base, usually $3-4 \mathrm{~cm}$. broad, simply seriate; pedicels $2-6$ in a fasciclo

f. Petioles essen tially glabrous.

Teeth of the ovate-lanceolate mostly falcate-acuminate leaves unequal

Teeth of the lance-elliptical acute or obtusish leares equal

e. Leaves suborbicular, rounded or subcordate at base.

Teeth of lesves fine, obtuse; the siuuses glandular . .

Teeth of leaves coarser, bristle-tipped; the sinuses nut

d. Leaves relatively narrow, spatulate-linear or -oblong, subéntire at the cuneate base.

Erect shrub; leaves spatulate-oblong

Prostrate; leaves lineur- or oblanceolate-spatulate : $\quad$ - $\quad$ 11. P. púnila.

c. Flowers large; petals 8-16 mm. long.

Teeth of leaves obtusish, some or all glandular.

Caly $x$-lobes entire or nearly so.

Inner scales of the tlowering buds subherbaceous, ligulate, spreading.

Inner scales not very unliks the outer, subappressed :

Calyx-lobes conspicuously glandular-serrulate.

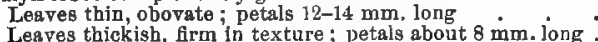

Teeth of leaves acute or acuminate, bristle-tipped, not glandular

a. Ovary and fruit velvety-tomentose; stone deeply sculptured and jitted

1. $P$. serotina.

2. P. virginianu.
15. P. hortulama.

4. P. alleghaniensis.

5. P. instititia.

6. P. maritima.

3. P. pennsylvanica

7. P. angustifolit.

8. P. Mahaleb.

9. P. Gravesii.

\section{P. cuneata.}

\$1. PADUS [L.] Reichenb. Drupe small, globose, without bloom; the stone turgid-ovate, marginless; flowers in racemes terminating leafy branches, therefore appearing after the leaves, late in'spring. Padus Moench.

1. P. serótina Ehrh. (WiLn BLACK or Rom C.) A large tree, with reddishbrown branches, the inner barlc aromatic; leaves oblong or lanceolate-oblong. 
taper-pointed, serrate, with incurved short and callous teeth, thickish, shining above; racemes elongated ; petals obovate ; fruit purplish-black. - Woods, N. S. to Fla., w. to Dak, and A riz. - Fruit slightly bitter, but with a pleasant vinous flavor.

2. P. virginiàna L. (Сноке C.) A tall shrub or small tree, with grayish bark, the inner layers with a rank disagreeable odor; leaves oval, oblong, or obovate, abruptly pointed, very shamply (often douhly) serrate with slender teeth, thin; petals roundish; fruit red turning to dark crimson, austere and astringent; stone smooth. - Nfd. to Ga., and westw. Var. LEuCoCARPA Wats., with short dense racemes and sweeter yellowish fruit, has been found at Dedham, Mass.

§ 2. PRUNÓPHORA (Neck.) Endl. Drupe smooth; the stone smooth or somewhat rugged; flowers (usually white) from separate lateral scaly buds in early spring, preceding or developing with the leaves; pedicels few or several in simple umbel-like clusters.

3. P. pennsylvánica L. f. (WILD Red, BIRD, Fire or PIN C.) Tree, 6-10 $\mathrm{m}$. high, with light red-brown bark; leaves oblong-lanceolate, pointed, finely and sharply serrate, shining, green and smooth both sides; flowers many in a cluster, on long pedicels; fruit globose, light red, very small, with thin and sour flesh; stone globular. - Rocky woods and recent clearings, Lab. to B. C., s. to Pa., Great L. region, centr. Ia, and along the mts, to N. C., Tenn., and Col.

4. P. alleghaniénsis Porter. (SLOe.) A low straggling shrub or small tree (1-5 m. high), selilom thorny; leaves lanceolate to oblong-rvate, often longacuminate, finely and shaiply serrate, softly pubescent when young, glabrate with age; fruit globose-ovoid, very dark purple, with a bloom, less than $12 \mathrm{~mm}$. in diameter; stone turgid, a shallow groove on one side and a broad flat ridge on the other. - Thickets, s. Ct. (Eames, Graves) to the Allegheny M ts. of P'a.

5. P. rinstitítia L. (Bullace P.) Somewhat thorny; leaves obovate, mostly obtusish at the apex and narrowed at base, sharply and somewhat doubly serrate, soft-pubescent beneath; fruit small, globular, black, with a bloom. ( $P$, spinosa, var. Gray.) - lioadsides and waste places, N. E. and perhaps occasionally in the Middle States. (Adv. from Eurasia.)

6. P. marítima Wang. (BeACH P.) Low and straggling (3-15 dm. high); leaves ovate or oval, finely serrate, softly pubescent underneath; pedicels short, pubescent ; fruit globular, purple or crimson (rarely paler), with a bloom, 13-25 $\mathrm{mm}$. in diameter; the stone very turgid, acute on one edge, rounded and minutely grooved on the other. - Sea-beaches, dunes, etc., s. Me. to Va.

7. P. angustifolia Marsh. (Chickasaw P.) Scarcely thorny, 2-5 m high; leaves membranaceous, elliptic-lanceolate, finely serrulate, glabrous ; fruit glubular, red, nearly destitute of bloom, thin-skinned, $12-16 \mathrm{~mm}$. in diameter: the ovoid stone almost as thick as wide, rounded at both sutures, one of them minutely grooved. ( $P$. Chicasa Michx.)-Del. to Fla., and westw. to Tex. and Kan.

Var. Watsóni (Sarg.) Waugh. (SAND P.) Dwarf (1-1.3 m. high); stems much branched and somewhat rigid; leaves smaller and rather firm in texture; fruit small, red, thick-skinned. (P. Watsoni Sarg.) - Kan. and Neb.

8. P. Mahaleb L. (Perfumed C.) Shrub or small tree (7 m. high), glabrous or nearly so; leaves ovate-orbicular, short-pointed or obtuse, slenderpetioled, crenulate-denticulate, glandular between the teeth; flowers corymbose; fruit ovoid to subglobose, black or nearly so, 7-10 $\mathrm{mm}$. long. - Koadsides, riverbanks, open woods, etc., spreading from cultivation, Ct. to Del, and westw. (Introd. from s. Eu )

9. P. Gravèsił Small. Unarmed shrub, 1-1.3 m. high; leaves obovateorbicular, finely pubescent on both surfaces, serrate-dentate, rounded or even retuse at the apex, $2-3 \mathrm{~cm}$. in diameter; flowers $1-3$ in a fascicle, the pedicels pubescent; fruit globose, bluish-black, $12-15 \mathrm{~mm}$. in diameter; stone about 9 $\mathrm{mm}$. long, subglobose but with one sharp edge. - Gravelly ridge, Groton, Ct. (Graves.)

10. P. cuneata Raf. Low erect shrub, obscurely puberulent to entirely 
glabrous; leaves spatulate-oblong or more rarely lance-oblong, obtuse or acute, serrate above the middle, entire toward the cuneate base, pale beneath ; flowers $2-t$ in a fascicle; fruit globose, without bloom, nearly black, about $1 \mathrm{~cm}$. ill diameter. ( $P$. pumila, var. Bailey.) - 'Thickets, sandy soil, s. Me. to N. C. and Minn.

11. P. pùmila L. (SAND C.) Prostrate, spreading and creeping; leaves linear-spatulate to oblanceolate, usually acute or acutish, pale beneath, subentire or toothed above the middle; flowers as in the preceding; fruit globose, pendulous, dark claret-color, without bloom, about $1 \mathrm{~cm}$. in dianeter. Sandy and rocky shores, e. Que. to Pa., n. Ind., Wisc., and Man.

12. P. Avium L. (Sweet C., Mazzalid.) Tree of pyramidal form and reddish-brown bark; flowers large; petals mostly 12-15 m m. long; inner budscales at the base of the pedicels greenish, large, widely spreauling, very hairy on the inner surface and conspicuously glandular-serrate; fruit depressed-globose, yellow or red, sweet and juicy.-Often escaping from cultivation and forming thickets in hedgerows, etc. (Introd. from Eurasia.)

13. P. Cerasus L. (Sour or Morello C.) Tree of lower growth and rounder head than the preceding; bark gray; flowers as in the preceding but inner bud-scales small, not conspicuously spreading; fruit depressed-globose, red, acid. - Commonly cultivated, and occasionally escaping to hedgerows, woods, etc. (Introd. from s. Eu.)

14. P. nigra Ait. (Wild or Canada P.) Shrub or small tree (2-8 m. high), armed ; leaves thin, broadly obovate, subcaudately acuminate, doubly crenciteserrate, the teeth usually gland-tipped; petioles mostly with 2 glands at the summit ; calyx-lobes glandular-serrate, glabrous within; petals white, broadly obovate, 12-14 mm. long; fruit orange-red or yellow, $2.5 \mathrm{~cm}$. long, compressedoroid to subglobose, almost without bloom. - River-banks and roadside thickets, Nfd. to s. N. E. and westw. along the Great Lakes.

15. P. hortulana Bailey. (WILD Goose P.) Small unarmed tree; leaves ovate- or lance-oblong, caudate-acuminate, glabrous on both surfaces, at maturity 9-15 cm. long, rounded at base, finely and somewhat unevenly crenateserrate; the teeth mostly gland-tipped; flowers $2-4$ in a fascicle; pedicels glabrous; calyx-lobes glandular-serrate; petals obovate, about $8 \mathrm{~mm}$. long; fruit globular, thin-skinned, light yellow to red. - Rich bottom lands, Ill. and Mo.

16. P. americàna Marsh. (WILD P.) Tree, 3-10 m. high, armed; leaves rather narrowly obovate, long-acuminate, sharply and doubly serrate, the teeth not glandular; petioles with or without glands; petals narrowly obovate, about $1 \mathrm{~cm}$. long; calyx-lobes entire, hairy on the inner surface; fruit subglobose, becoming red at full maturity, about $2 \mathrm{~cm}$. in diameter. - River-banks and borders of woods, Ct. to Fla., and westw. to Col.

Var. móllis ' $\Gamma$. \& $G$. Leaves permanently soft-pubescent or tomentose beneath. - Ia. to La. and Tex.

§3. AMÝGDALUS (L.) B. \& H. Drupe velvety-tomentose; the stone deeply sculptured and pitted; flowers subsessile, from a scaly bud, opening before the leaves appear; the latter conduplicate in bud. AMYGDALUs [Tourn.] L. Persica [Tourn.] Borkh.

V17. P. Pérstca (I.) Stokes. (Peach.) Small tree; leaves lance-oblong, attenuate, serrate; flowers pink; fruit subglobnse. (Amygrlalus L.) - Abundantly cultivated, and tending to become established in thickets, etc., N. Y., and southw. (Introd. from Asia.)

\section{LEguminòsae (Pulse Family)}

Plants with papilionaceous or sometimes regular flowers, 10 (rarely 5 and sometimes many) monadelphous, diadelphous, or rarely distinct stamens, and a single simple free pistil becoming a legume in fruit. Seeds mostly without albumen. Leaves atternate, with stipules, usually compound. One of the 
sepals inferior (i.e. next the bract); one of the petals superior (i.e. next the axis of the inflorescence). - A very large family.

\section{SURFamily I. MimosofDeAE}

Flowers regular, small. Corolla valvate in aestivation, often united into a 4-5-lobed cup, hypogynous, as are the (often very numerous) exserted stamens. Embryo straight. Leaves twice pinnate.

\section{* Stamens numerous.}

1. Acacia, Filaments distínct. Pod and stem (in ours) unarmed.

2. Abizzia. Filaments united into a tube at base. Unarmed shrubs or treses.

$$
\text { * * Stamens 5-10. }
$$

8. Desmanthus. Petals distinct. Stamens 5 or 10. Pods smooth, flat. Herbaceous or nearly so.

4. Schrankia. Petals united below into a cup. Stamens 8 or 10. Pod covered with small prickles or rough projections.

\section{Subfamily II. CAESALPINIOfDEAE}

Corolla imperfectly or not at all papilionaceous, sometimes nearly regular, imbricated in the bud, the upper or odd petal inside and inclosed by the others. Stamens 10 or fewer, commonly distinct, inserted on the calyx. Seeds anatropous, often with albumen. Embryo straight.

* Flowers not at all papilionaceous, polygamous or dioecious; trees.

5. Gymnocladus. Unarmed. Teaves doubly pinnate. Calyx-tube elongated, at 1ts summit bearing 5 petals resembling the calyx-lobes. Stamens 10 .

6. Gleditsia. Thorny. Leaves simply and doubly pinnate. Calyx-tube short; its lobes, as well as the petals and stamens, 8-5.

* * Flowers not at all papilionaceous, perfect; calyx 5-parted; herbs.

7. Cassia. Leaves simply and pobruptly pinnate.

** * Flowers inperfectly papilionaceous, perfect; trees.

8. Corcis. Calyx campanulate, 5-toothed. Pod flat, wing-margined. Leaves simple.

\section{Subfamily III. PAPILIONOfDEAE}

Calyx of 5 sepals, more or less united, often unequally so. Corolla inserted into the base of the calyx, of 5 irregular petals (or very rarely fewer), more or less distinctly papilionaceous, i.e. with the upper or odd petal (vexillum or standard) larger than the others and inclosing them in the bud, usually turned backward or spreading; the two lateral ones (wings) oblique and exterior to the two lower, which last are connivent and commonly more or less coherent by their anterior edges, forming the carina or keel, which usually incloses the stamens and pistil. Stamens 10 , very rarely 5 , inserted with the corolla, monadelphous, diadelphous (mostly with 9 united into a tube which is cleft on the upper side, and the tenth or upper one separate), or occasionally distinct. Ovary 1-celled, sometimes 2-celled by an intrusion of one of the sutures, or transversely 2-many-celled by cross-division into joints; style simple; ovules amphitropous, rarely anatropous. Cotyledons large, thick or thickish; radicle incurved. - Leaves simple or simply compound, the earliest ones in germina. tion usually opposite, the rest alternate; leaflets almost always quite entire. Flowers perfect. 


\section{Stamens (10) distinct.}

* Leaves palmately 3-foliolate or simple; caly x 4-5-lobed; herbs.

9. Baptisia. Pod 1nflated.

10. Thermopsis. Pod flat, linear,

$$
\text { * Leaves pinnate; calyx-teeth short. }
$$

1.1. Cladrastis. Flowers panicled, white. Pod fat. A tree.

12. Sophora. Flowers racemose, white. Pod terete, moniliform. Herbaceous.

II. Stamens monadelphous, or diadelphous (9 and 1, rarely 5 and 5), nearly distinet in no. 25.

* Anthers of two forms ; stamens monadelphous; leaves digitate, sinple, or rarely phyllodial. + Calyx 5-lobed; pod inflated.

18. Crotalaria. Herbs with stmple leaves.

$$
\text { + + Calyx 2-lipped; pod flat. }
$$

14. Genista. Seeds estrophiolate, Corolla yellow.

$$
\text { \#+Shrubs with 1-8-foliate leaves. }
$$

15. Cytisus. Seeds strophiolate. Corolla yellow.

$$
++4 \text { Shrubs; leaves reduced to pungent petioles. }
$$

16. Ulez Seeds strophiolate. Corolla yellow.

$$
+++++ \text { Herbs; leaves (in ours) } \eta-11 \text {-foliolate. }
$$

17. Lupinus. Seeds estrophiolate. Corolla (in ours) blue, roseate, or rarely white.

$$
\text { ** Anthers uniform (except in nos, } 24 \text { and } 40 \text { ). }
$$

4- Leaves digitately (rarely pinnately) 8-foliolate; leafets dentienlate or serrulate; stamens diadelphous; pods small, 1-few-seeded, often inclosed in the calyx or curved or coiled.

18. Trifolium. Flowers capitate. Pods membranaceous, 1-6-seeded. Petals adhereat to the stamen-tube.

19. Melilotus. Flowers racemed. Pod coriaceous, wrinkled, 1-2-secded.

20. Medicago. Flowers racemed or spiked. Poda curved or coiled, 1-few-seeded.

+ + Leaves unequally pinnate (or digitate in no. 24); leaflets entire; pod not jointed; neither twining nor climbing (except in no. 31).

$\leftarrow$ Herbage not resinous-dotted; flowers umbellate, loosely capitate or solitary and axillary; her'bs.

$$
- \text { Filaments all connate. }
$$

21. Anthyllis. Leaves odd-pinnate (the basal sometimes 1-foliolate). Flowers loosely capitate. Pod subindehiscent, included in the calyx.

$m=$ One filament free, the others connate.

22. Hosackia. Leaflets (in ours) 1-3. Flowers (in ours) solitary on leafy-bracted peduncles.

23. Lotus. Leaflets (in ours) 5 , the lower pair simulating folisceous stifules. Flowers (in ours) umbellate.

+ \# Herbage glandular-dotted; stamens mostly monadelphous; pod small, indehiscent, mostly 1-seeded; leaves pinnate (except in no. 24).

24. Psoralea. Corolla truly papilionaceous. Stamens 10, half of the anthers often smaller or less perfect. Leaves mostly palmate, 3-5-folioiate.

25. Amorpha. Corolla of one petal! Stanens 10, monadelphous at base.

26. Dalea. Corolla imperfectly papilionaceous. Stamens 9 or 10 ; the cleft tube of flaments bearing 4 of the petals about its middle.

27. Petalostemum. Corolla ecarcely at all paptlionaceous. Stamens 5 ; the cleft tabe of fila. ments bearing 4 of the petals on its sumuit.

4* Herbage not glondular-dotted (except in no. 84); stamen s mostly diadelphous; pod 2 valved, several-seeded; leaves pinnately severnl-foliolate; Howers racemose.

- Wings cohering with the keel; pod flat or 4-angled; hoary perennial horbs.

28 Tephrosia. Standard broad. Pod tat. Lestlets oinnately veined. 


\section{$=-$ Flowers large and showy; standard broad; wings free.}

20. Sesbania. Leaves even-pinnate. Ours herbs.

80. Robinia. Pod Hat, thin, margined on one edge. Trees or shrubs.

81. Wisteria. Pud tumid, marginless. Wuody twiners. Leatlets obscurely stipellate. $=x=$ Standard narrow, erect; pod turgid or inflated ; perennial herbs.

32. Astragalus. Keel not tipped with a point or sharp appendage. Pod with one or both the sutures turned in, sometimes dividing the cell lengthwise into two.

83. Oxytropis. Keel tipped with an erect point; otherwise as Astragalus.

34. Glycyrrhiza. Flowers, etc., of Astragulus. Anther-cells contluent. Pod prickly or muricate, short, nearly indehiscent.

+++ Herbs; no tendrils; pod transversely 2-8everal-jointed, the reticulated 1-seeded joints Indehiscent, or sometimes reduced to one such joint.

t+ Leaves pingate, with several leaflets, not stipellate.

35. Aeschynomene. Stamens equally diadelphous (5 and 5). Calyx 2-lipped. Pod severaljuinted ; joints square.

86. Coronilla. Stamens linequally diadelphous (9 and 1). Calyx 5-toothed. Jolnts suboylindric, 4-angled. Flowers umbellate.

37. Hedysarum. Stamens unequally diadelphous (9 and 1). Calyx 5-cleft. Pod several-jointed; joints roundish.

+ ++ Leaves pinnately 8-follolste, rarely 1-foliolate.

38. Desmodium. Stamens diadelphous (9 and 1) or monadelphous below. Calyx 2-lipped. Pod several jointed. Flowers all of one sort and complete. Leaflets stipellate.

39. Lespedeza. Stamens diadelphous (9 and 1); anthers uniform. Pod 1-2-jointed. Flowers often of 2 sorts, the more fertile ones apetalous. Leaflets not stipellate.

40. Stylosanthes. Stamens monodelphous; anthers of 2 sorts. Poo 1-2-jointed. Calyx deciduous, the tube narrow and stalk-like. Leaflets not stipellate.

$4+4$ Leaves alghtately 2 - or 4 -foliolate.

41. Zomia. Flowers spicate, each enveloped by 2 velny leaf-like biacts.

++++ Herbs with abruptly pinnate leaves, terminated by a tendill or bristle; stamens diadelphous; pod continuous, 2-valved, few-several-seeded.

42. Vicia. Wings coherent with the keel. Style fliform, bearded with a tuft or ring of hairs at the aprex.

49. Lathyrus. Nings nearly free. Style somewhat dilated and flattened upwards, bearded down the inner fuce.

+++++ Twining (sometimes only trailing) herbs; leaves pinnately 8 (rarely 1 or 5-7)-foliolate; no tendrils; peduncles or flowers axillary; pod not jointed, 2-valved.

4 Leaves pinnately 5-many-foliolate.

44. Apios. Herbsceous twiners; leaflete 5-9. Keel slender and much incurved or colled.

++ Leaves 3 -foliolate; orules and seeds several.

- Style bearded lengthwise on the upper surface.

45. Phaseolus. Keel sptrally coiled; standard recurved-spreading. Flowers racemose. Corolla (in ours) purple. Seeds round-reniform.

46. Vigna. Keel strongly curved but not forming a spiral. Flowers fow in pedunculate heads or very short 1'acemes. Corolla (in ours) pale yellow.

47. Strophostyles. Keel long, strongly incurved but not forming a opiral. Flowers few in pedunculato heads. Corolla purple. Seeds oblong, mostly pubescent.

48." Clitoria. Keel scythe-shaped; stardard spurred at the base, large and showy, pale blue.

$=$ Style bearded at the summit about the stigma.

49. Centrosema. Standard much longer than the other petals. Pod linear, narrow; the valves spirally twisted after dehiscence.

50. Dolichos. Standard little exceeding the other petals in length. Pod Iunate-oblong; the valves brood, not spirally colled in deblscence.

$$
=-\infty \text { style beardless. }
$$

61. Amphicarpa. Calyx tubuln', 4-5-toothed. Standard erect; keel almost straight. Some apetalous especially fertile fluwers at the base of the plant. Bracts persistent. 
52. Galactia. Calyx deeply 4-cleft; the upper lobe broadest and entire. Bract and bractlets mostly minute and deolduous.

+t +t + Leaves 1-8-follolate; ovules and seeds 1-2; flowers yellow.

58. Rhynchosia. Keel scythe-shaped. Calyx 4-5-parted. Pod short.

\section{ACẢCIA [Tourn.] Mill.}

Flowers perfect or polygamous, regular, small, capitate or spicate. Sepals 4-5, nearly distinct or united into a 4-5-toothed campanulate cup. Petals as many, narrow. Stamens $\infty$, exserted. Pod oblong to linear, compressed or turgid. - Shrubs or trees (mostly armed), with bipinnate or (in certain Australian species) vertically expanded phyllodial leaves. (Ancient Greek name of an Egyptian species.)

1. A. angustíssima (Mill.) Ktze., var. hirta (Nutt.) Robinson. Unarmed hirsute undershrub; pinnae 8-14 pairs and leaflets mostly 18-40 pairs (both less numerous in young shoots) ; flowers in yellow or salmon-colored paniculate globose heads. (A. hirta Nutt.; A. filicioides 'Trel.) - Dry bluffs, McDonald Co., Mo. (Bush), Kan. (Hitchcock), and southw. - The typical form (Mimosa angustissina Mill.) of Mex. has fewer pinnae and more numerous leaflets.

\section{ALbízziA Durazzini.}

Flowers perfect or polygamous. Calyx tubular, 5-dentate. Petals united for more than half their length into a tubular somewhat salver-formed corolla. Stamens numerous; the filaments much elongated. Pod narrowly oblong, the valves neither twisted nor elastically spreading. - Unarmed trees with bipinnate leaves. (Dedicated to the Albizzi, a noble Italian family, one of whom is said to have introduced this genus into European cultivation.)

1. A. JULrbrfssin Durazzini. Flowers in tassel-like clusters at the end of slender naked peduncles. - Frequently cultivated in the Southern States, and locally established as far $\mathrm{n}$. (according to Small) as Va. (Introd. from Asia and Afr.)

\section{DESMÁNTHUS Willd.}

Flowers perfect or polygamous, regular. Calyx campanulate, 5-toothed. Petals 5, distinct. Stamens 5 or 10 . Pod flat, membranaceous or somewhat coriaceous, several-seeded, 2-valved, smooth. - Herbs, with twice-pinnate leaves of numerous small leaflets, and with one or more glands on the petiole, setaceous stipules, and axillary peduncles bearing a head of small greenish-white flowers.

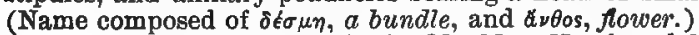

1. D. illinoénsis (Michx.) MacM. Nearly glabrous perennial, erect, 3-24 dm. high; pinnae $6-15$ pairs; leaflets $20-30$ pairs; peduncles $2.5-7.5$ $\mathrm{cm}$. long; stamens 5 ; pods numerous in dense globose heads, oblong or lanceolate, curved, scarcely $2.5 \mathrm{~cm}$. long, 2-6-seeded. (Mimosa Michx.; Acuan Ktze.; D. brachylobus Benth.) - Prairies and alluvial banks, O. and Ky. to S. Dak, Mo., Tex., and Fla.

\section{SCHRÁNkia Willd, Sengitive Brier}

Flowers polygamous, regular. Calyx minute, 5-toothed. Petals united into a funnel-form 5-cleft corolla. Stamens 10-12, distinct, or the filaments united at base. Pods long and narrow, rough-prickly, several-seeded, 4-valved, i.e. the two narrow valves separating on each side from a thickened margin. - Perennial herbs, nearly related to the true Sensitive Plants (Mimosa); the procumbent stems and petioles recurved-prick, $J$, with twice pinnate sensitive leaves of many small leaflets, and axillary peduncles bearing round heads of small rosecolored flowers. (Named for Franz von Paula, von Schrante, a German botanist, 1747-1835.) Morongia Britton. 
1. S. uncinàta Willd. Prickles hooked; pinnae 4-6 pairs; leaflets elliptical, reticulated with strong veins beneath; pods oblong-linear, nearly terete, short pointed, densely prickly, $5 \mathrm{~cm}$. long. (Morongia Britton.) - Dry prairies and open woods, Va. to Fla. and Tex.; northw. in Miss. basin to Ia. and Ill. June, July.

2. S. angustàta 'I'. \& G. Leaflets oblong-linear, scarcely veined; pods slender, taper-pointed, sparingly prickly, $1 \mathrm{dm}$. long. (Morongia Britton.) - Dry sandy soil, s. Va. to Fla., Tenn., and Tex. June-Aug.

\section{GYMNÓCLAdUS Lam. Kentucky Coffen-trex}

Flowers dioecious or polygamous, regular. Calyx elongated-tubular below, 5-cleft. Petals 5, oblong, equal, inserted on the summit of the calyx-tube. Stamens 10, distinct, short, inserted with the petals. Pod oblong, flattened, hard, pulpy inside, several-seeded. Seeds flattish. - A tall unarmed tree, with rough bark, stout branchlets, and large unequally twice-pinnate leaves. Flowers whitish, in terminal racemes. (Name from $\gamma v \mu \nu \delta s, n a k e d$, and $\kappa \lambda \alpha \delta \delta$, a branch, alluding to the stout branches for many months destitute of spray.)

1. G. dioíca (I.) Koch. Leaves 6-9 dm. long, with several large partial leafstalks bearing 7-13 ovate stalked leaflets, the lowest pair with single leaflets; stipules wanting; pod 1.5-2.5 dm. long, $3-4 \mathrm{~cm}$. broad; seeds over $1.3 \mathrm{~cm}$. across. (G. canadensis Lam.) - Rich woods, centr. N. Y. and Pa. to Minn., t. Neb., Okla., and 'Tenn. May, June.

\section{GLEDITSIA L. Honey Locdst}

Flowers polygamous. Calyx short, 3-5-cleft, the lobes spreading. Petals as many as the sepals and equaling them, the two lower sometimes united. Stamens 3-10, distinct, inserted with the petals on the base of the calyx. Pod flat, 1-many-seeded. Seeds flat. - Thorny trees, with abruptly once or twice pinnate leaves, and inconspicuous greenish flowers in small spikes. Thorns above the axils. (Simplified and Latinized name of $J$. G. Gleditsch, a botanist contemporary with Linnaeus.)

1. G. triacánthos L. (Hovey Locust.) Thorns stout, often triple or compound; leaflets lanceolate-oblong, somewnat serrate; pods linear, elongated (2-4.5 dm. long), often twisted, filled with sweet pulp between the seeds. - Rich woods, w. N. Y. and Pa. to Ga., w. to e. Neb., Kan., and Tex.; common in cultivation, and establishing itself northeastw. May, June.

2. G. aquática Marsh. (W T TER Locusr.) 'Thorns slender, mostly simple; leaftets ovate or oblong; pods oval, 1-seeded, pulpless. - Deep swamps, S. C. to Fla. and Tex.; northw. in Miss. basin to Ky., Ind., Ill., and Mo. $-\mathbf{A}$ smaller tree, 8-12 m. high

\section{CÁSSIA [Tourn.] L. SENNA}

Sepals 5, scarcely united at base. Petals 5, little unequal, spreading. Stamens $5-10$, unequal, and some of them often imperfect, spreading; anthers opening by 2 pores or chinks at the apex. Pod many-seeded, often with cross partitions. - Herbs (in the United States), with simply and abruptly pinnate leaves, and mostly yellow flowers. (An ancient name of obscure derivation.)

\section{* Leaflets large;-stipules deciduous; the three upper anthers deformed and imperfect; flowers in short axillary racemes, the upper ones panicled; herbage glabrous.}

1. C. marilándica L. (WILD S.) Root perennial; stem 9-12 dm. high; stipules linear-setaceous, caducous ; leaflets 5-9 pairs, lanceolate-oblong, obtuse; petiole with a slender club-shaped gland near the base; pods linear, slightly curved, flat, at first hairy, 6.5-11 cm. long, their segments as long as broad; seed flat, quadrate-orbicular, - Alluvial soil, N. E. to O., Tenn., and N. C. July, Aug. 
2. C. Medsgèri Shafer. (WILn S.) Similar; root biennial (?); stipules linear-lanceolate; petiolar gland short-cylindric to conic-ovoid; leaflets 7-10 pairs; pods thickish, 5-9 cu. long, their segments much shorter than broad; seed plump, oblong-obovoid, twice as long as thick. (C. marilandica Man. ed. 6, in part; C. acuminata Moench ?) - Dry gravelly soil, Pa. to la. and Kan., s. to Ga. and rex. Aug.

3. C. Tòra L. Annual; leaflets 3 or rarely 2 pairs, obovate, obtuse, with an elongated gland between those of the lower pairs or lowest pair; pods slender, $1.5 \mathrm{dm}$. long, curved. (C. obtusifolia L.) - River-banks, etc., s. Va. to Fla. and Tex.; northw. in Miss. basin to Kan., Mo., and Ind. July-Sept. (Trop. regions.)

4. C. occidentalis L. Annual; leaflets $4-6$ pairs, ovate-lanceolate, acute; an ovoid gland at the base of the petiole; pods long-linear (12 cm. long), with a tumid burder, glabrous. - Waste places and shores, Va. to Fla. and Tex.; northw. in Miss. basin to Mo, and Ind. Aug., Sept. (Nat. from the tropics.)

* Leaflets small, somewhat sensitive to the touch; stipules striate, persistent; a cup-shaped gland beneath the lowest pair of leaflets; anthers all perfect; flowers in small clusters above the axils; pods flat.

5. C. Chamaecrista L. (Partridge Pea.) Annual, subercet; branches usually simple, ascending; pubescence subappressed, usually scanty; leaflets 10-15 pairs, linear-oblong, oblique at the base; flowers (large) on slender pedicels, 2 or 3 of the showy yellow petals often with a purple spot at base; anthers 10 , elongated, unequal (4 of them yellow, the others purple); style slender. Sandy fields, Mass. to Minn., and southw., except in the upland regions. July-Sept.

Var. robusta Pollard. Stouter, hirsute with spreading hairs. - Ky. (Short), Ill. (McDonald), and southw.

6. C. depréssa l'ollard. Slender procumbent perennial (?) ; branches starting from near the base, usually again branched; leaflets (4-10 pairs) smaller and less numerous and flowers larger and later than in the otherwise similar $C$. Chamaecrista. - Potosi, Mo. (Pech) to Miss. and Fla. July-Sept.

7. C. níctitans $\mathrm{C}$. (Wild Sensitive Plant.) Leaflets 10-20 pairs, oblonglinear; flowers very small, on very short pedicels; anthers 5 , nearly equal; style short. - Sandy fields, N. E. to Fla., w. to Kan. and Ariz. July-Sept.

\section{Cercis L. Redrud. Judas Tree}

Calyx 5-toothed. Corolla imperfectly papilionaceous; standard smaller than the wings, and inclosed by them in the bud; the keel-petals larger and not united. Stamens 10, distinct, declined. Pod oblong, flat, many-seeded, the upper suture with a winged margin. Embryo straight.- Trees, with rounded heart-shaped simple leaves, caducous stipules, and red-purple flowers in umbellike clusters along the branches of the last or preceding years, appearing before the leaves, acid to the taste. (The ancient name of the oriental Judas Tree.)

$\checkmark$ 1. C. canadénsis L. (REDBDD.) Leaves pointed; pods nearly sessile above the calyx. - Rich soil, N. Y. and N. J. to Fla., w. to s. Ont., t. Neb., and Tex. A small ornamental tree, often cultivated.

\section{Baptísia Vent. Falge Indigo}

Caly $x$ 4-5-toothed. Standard not longer than the wings, its sides reflexed; keel-petals nearly separate, and, iike the wings, straight. Stamens 10, distinct. Pods stalked in the persistent calyx, roundish or subcylindric, inflated, pointed, many-seeded. - Perennial herbs, with palmately 8-foliolate (rarely simple) leaves, which generally blacken in drying, and racemed flowers. (Name from $\beta a \pi \tau l \zeta \epsilon \iota$, to $d y e$, from the economical use of some species, which yieid a poor indigo.) 
* Racemes many, short and loose, terminal, often leafy at base; flowers yellow.

1. B. tinctoria (L.) R. Br. (WILd INDigo.) Smooth and slender, 3-9 dm. high, rather glaucous; leaves almost sessile; leaflets wedge-obovate, 1.5-2.5 $\mathrm{cm}$. long; stipules and bracts minute and deciduous; pods ovoid-globose, on a stalk longer than the calyx. - Dry woods and plains, s. N. H. to Fla., locally westw. to Ky. and Minn. June-Sept.

\section{** Racemes fever, opposite the leaves. - Flowers yellow.}

2. B. villdsa (Walt.) Ell. Sometimes soft-hairy, usually minutely pubescent when young, erect, 6-9 dm. high, with divergent branches; leaves almost sessile; leaflets wedge-lanceolate or obovate; lower stipules lanceolate and persistent, on the branchlets often small and subulate; racemes many-flowered, pedicels short; bracts subulate, mostly deciduous ; pods ovoid-ellipsoid, taperpointed, minutely pubescent. - Va. to N. C. and Ark. May, June.

\section{+ + Flowers white or cream-color.}

3. B. bracteàta (Muhl.) Ell. Hairy, low (3 dm. high), with divergent branches; leaves almost sessile; leaflets narrowly oblong-obovate or spatulate; stipules and bracts large and leafy, persistent; racemes long (often $3 \mathrm{dm}$.), reclined; Alwers on elongated pedicels, cream-color"; pods pointed at both ends, hoary. (B. leucophaea Nutt.) - Prairies, Mich. to Minn., s. to Tex. May.

4. B. leucántha T. \& G. Smooth, tall, and stout; leaflets oblong-wedgeform, obtuse; stipules early deciduons; flowers white; pods ovoid-ellipsoid, on a stalk fully twice the length of the calyx. - Alluvial soil, Ont. and 0 . to Minn., s. to Fla. and La. June, July.

5. B. álba (L.) R. Br. Smooth, 3-9 dm. high, the branches slender and widely spreading; petioles slender; stipules and bracts minute and deciduous; leaflets oblong or oblancenlate; racemes slender, on a long naked peduncle; pods linear-oblong, $2.5-4 \mathrm{~cm}$. long, short-stalked. - Dry soil, N. C. to Fla. and Ala.; and reported from Ind., Mo., etc. May.

\section{++ Flowers indigo-blue.}

6. B. austràlis (L.) R. Br. (Burve F.) - Smonth, tall and stout (1.2-1.6 m. high); leaflets oblong-wedge-form, obtuse; stipules lanceolate, as long as the petioles, rather persistent ; raceme elongated (3-6 dm.) and many-flowered, erect; bracts decidunus; stalk of the ovoid-ellipsoid pods about the length of the calyx. - Alluvial soil, Pa. to Ga., w. to s. Ind., Kan. and Ark.; cultivated eastw., and established on alluvium of $\mathrm{Ct}$. R. and tributaries, Vt. May, June.Hybridizes with B. bracteata, according to Hitchcock.

\section{THERMÓPSIS R. Br.}

Pod sessile or shortly stipitate in the calyx, flat, linear, straight or curved, Otherwise nearly as Baptisia. - Perennial herbs, with palmately 3-foliolate leaves and foliaceous stipules, not blackening in drying, and yellow flowers in terminal racemes. (Name from $\theta \epsilon \epsilon_{\mu o s}$, the lupine, and $\delta \psi(s$, appearance.)

1. T. móllis (Miclıx.) M. A. Curtis. Finely appressed-pubescent, 4-6 dm. high ; leaflets rhombic-lanceolate, $2.5-7.5 \mathrm{~cm}$. long; stipules narrow, mostly shorter than the petiole ; raceme elongated; pods narrow, short-stipitate, somewhat curved, 5-10 cm. long. - Mts. of s.Va., N. C., and Tenn. May.

\section{CLADRÁSTIS Raf. Yellow Wood. Virgilia}

Calyz 5-toothed. Standard large, roundish, reflexed ; the distinct keel-petals and wings straight, oblong. Stamens 10 , distinct; filaments slender, incurved above. Pod short-stalked above the calyx, linear, flat, thin, marginless, 4-6seeded, at length 2-valved. - A handsome tree, with yellow wood (yielding a dye), smooth bark, nearly smooth pinnate leaves of 7-11 oval or ovate leaflets, and ample panicled racemes (2.5-5 dm, long) of showy white flowers drooping 
from the ends of the branches. Stipules obsolete. Base of the petioles hullow, inclosing the leaf-buds of the next year. Bracts minute and fugacious. (Name from $k \lambda a \dot{\delta} \delta s, a$ branch, and $\theta \rho a v \sigma \mathrm{T} b s$, brittle.)

1. C. lùtea (Michx. f.) Koch. Sometimes $15 \mathrm{~m}$. high ; pods $7.6-10 \mathrm{~cm}$. long. (C. tinctoria Raf.) - Rich woods and calcareous bluffs, Ky. to N. C., n. Ala, and Mo.; also in cultivation. May.

\section{SOPHÒRA L.}

Calyx bell-shaped, shortly 5-toothed. Standard rounded; keel nearly straight. Stamens distinct or nearly so. Pod coriaceous, stipitate, terete, more or less constricted between the seeds, indehiscent. Seeds subglobose. Shrubby or ours an herbaceous perennial, the leaves pinnate with numerous leaflets, and flowers white or yellow in terminal racemes. (Said by Linnaeus to be the ancient name of an allied plant.)

1. S. sericea Nutt. Silky-canescent, erect, $3 \mathrm{dm}$. high or less; leaflets oblong-obovate, 6-12 mm. long; flowers white; pods few-seeded. - Prairies, Neb. and Kan. to Col, Tex., and Ariz. Apr., May. (Mex.)

\section{CROTALARIA [Dill.] L. RAtTLe-box}

Calyx 5-cleft, scarcely 2-lipped. Standard large, heart-shaped; keel scytheshaped. Sheath of the monadelphous stamens cleft on the upper side; 5 of the anthers smaller and roundish. Pod inflated, subcylindric, many-seeded. -

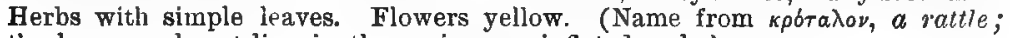
the loose seeds rattling in the coriaceous inflated pods.)

\section{* Pubescence spreading-ascending, prominent.}

1. C. sagittàlis L. Annual, hairy, suberect, $7.5-25 \mathrm{~cm}$. high; leaves oval or oblong-lanceolate, scarcely petioled, nurrowed to each end; stipules often conspicuous, united and decurrent on the stem, so as to be inversely arrowshaped; peduncles few-flowered; corolla not longer than the calyx; pod blackish. - Sandy soil, e. Mass. and s. Vt. to Fla. and Tex., chitfly coastal; and northw. in Miss. basin to Ind. and S. Dak. June-Sept. (Mex.)

2. C. rotundifdia (Walt.) Poir. Thick-rooted perennial; stems several, prostrate or nearly so; leaves suborbicular or oval, rounded at each end; stipules few or wanting. (C. ovalis Pursh.) - Sandy soil, s. Va. to Fla. and La. May-July.

\section{* Pubescence appressed and inconspicuous.}

3. C. Púrshii DC. Perennial; stems several, erect or ascending; leaves linear to oblong; stipules usually large and conspicuous. - Sandy soil, s. Va. to Fla. and Tex. May-July.

\section{GENfSTa L. Woad-waxen. Wern}

Calyx 2-lipped. Standard oblong-oval, spreading; keel oblong, straight, deflexed. Stamens monadelphous, the sheath entire; 5 alternate anthers shorter. Pod mostly flat and several-seeded. - Shrubby plants, with simple leaves, and yellow flowers. (Name from the Celtic gen, a bush.)

1. G. Tinctoria L. (Drer's Greenween.) Low, not thorny, with striateangled erect branches; leaves lanceolate; flowers in spiked racemes. - Established on sterile hills and roadsides, s. Me. to Mass. and e. N. Y. June, July. (Nat. from Eu.)

\section{Cytisus [Tourn.] L. Broom}

Calyx campanulate, with 2 short broad lips. Petals broad, the keel obtuse and slightly incurved. Stamens monadelphous. Pod flat, much longer than the calyx. Seeds several, with a strophiole at the hilum. - Shrubs, with stiff 
green branches, leaves mostly digitately 3-foliolate, and large bright yellow flowers. (The ancient Roman name of a plant, probably a Medicago.)

1. C. scoparius (L.) Link. (Scotcr B.) Glabrous or nearly so, about 1 m. high; leaflets small, obovate, often reduced to a single one ; flowers solitary or in pairs, on slender pedicels, in the axils of the old leaves, forming leafy racemes along the upper branches; style very long and spirally incurved. (Sarothannus Wimmer.) - Sandy barrens, etc., N. S.; s. e. Mass, to Va., and southw. May, June. (Nat. from Eu.)

\section{6. ÙleX L. Furze, Gorse}

Calyx deeply 2-lipped. Standard ovate; wings and keel oblong, of abont equal length. Stamens monadelphous. Pod short-oblong. - Low densely branched shrubs with spine-like phyllodial leaves. (An ancient name, used by Pliny for some not certainly identified plant.)

1. U. ECropatios L. Calyx large, yellow, tomentulose.-Sometimes cultivated as a sand-binder and now somewhat extensively established locally near the coast from Nantucket to Va. (Introd. from Eu.)

\section{LUPINUS [Tourn.] L. LUPine}

Calyx very deeply 2-lipped. Sides of the standard reflexed; keel scytheshaped, pointed. Sheath of the monadelphous stamens entire; anthers alternately oblong and roundish. Pod oblong, flattened, often knotty by constrictions between the seeds. Cotyledons thick and fleshy. - Herbs, with palinately 1-15-foliolate leaves, stipules adnate to base of the petiole, and showy flowers in terminal racemes or spikes. (Name from lupus, a wolf, because these plants were thought to devour the fertility of the soil.)

$\checkmark$ 1.' $\mathbf{L}$. perénnis L. (WILD L.) Perennial, somewhat hairy; stem erect, 3-6 dm. high; leaflets 7-11, cblanceolate; flowers in a long raceme, showy, purplish-blue (rarely pale); pods broad, very hairy, 5-6-seeded. - Sandy soil, s. w. Me. to Minn., and s. to the Gulf. May, June. Var. occioentalis Wats. has stems and petioles more villous. - Mich., n. Ind. (C. P. Smith), and Wisc.

\section{TRIFÒliUM [Tourn.] L. Clover:' Treforl}

Calyx persistent, 5-cleft, the teeth usually bristle-form. Corolla mostly withering or persistent; the claws of all the petals, or of all except the oblong or ovate standard, more or less united below with the stamen-tube; keel short and obtuse. Tenth stamen more or less separate. Pods small and membranous, often included in the calyx, 1-6-seeded, indehiscent, or opening by one of the sutures. - Tufted or diffuse herbs. Leaves mostly palmately (sometimes pinnately) 3-foliolate; leaflets usually toothed. Stipules united with the petiole. Flowers in heads or spikes. (Name from tres, three, and folium, a leaf.)

a. Flowers sessile in dense beads.

Calyx-teeth silky-plumose, aurpassing the corolla

Calyx-teeth ciliate, villous, or glabrous, surpassed by the corolla.

Heads cylindrical; corolle scarlet to deep red .

Heads globose or ovoid ; corolla magenta or purple (rarely white). Caly x soft-hairy

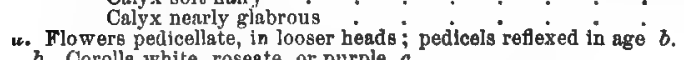

b. Corolla white, rosente, or purple $c$.

c. Calyx-teetii bristle-tipped.

Calyx villous or hispld.

Lenflets narrowly oblong

Leatlets ubnvate

Calyx essentially glabrou:.

Stoloniferous.

Flowers $1-1.8 \mathrm{~cm}$. long: corolla red; peduncles rarely more than twice the length of the bead

1. T. arvense.

2. T. incairnatum.

8. T. pratense.

4. T. medium.
5. T. virginicum

6. T. refiecum.

7. T. stoloniforum. 
Flowers 6-9 mm. long; corolla white or pink; peduncles mostly 3 -many times the length of the heads.

Not stoloniferous.

c. Calyx-teeth deltoid-lanceolate, herbaceous
Corolla yellow.

Corolla conspicuously striate-sulcate in age.

Ieaflets all sessile

Terminal leatlet stalked

Corolla not striate-sulcate:

V 1. T. ARvénse L. (Rabit-Foot or Stone C.) Silky branching annual, 1-4 dm. high ; leaflets oblanceolate; heads becoming very soft-sillky and grayish, ovoid-cylindrical. - Dry sandy or gravelly soil, roadsides, ete. (Nat. from Isu.)

2. T. INCARNATUM L. (Crimson or Italian C.) Suberect soft-pubescent anuual, $3-5 \mathrm{dm}$. high; heads cylindrical, often $5 \mathrm{~cm}$. long; leaflets obovate. Often cultivated, and sparingly escaping. (Introd. from Eu.)

3. T. PRATínse L. (RED C.) Perennial ; stems ascending, somewhat hairy: leaflets oval or obovate, often notched at the end and marked on the upper side with a pale spot; stipules broad, bristle-pointed; heads ovoid, sessile or not rarely pedunculate; corolla magenta to whitish ; calyx soft-hairy. - Fields and meadows ; extensively cultivated. (Introd. from Eu.)

4. T. MÈDIUM L. (ZIGZAG C.) Stems zigzag, smoothish; leaflets oblong, entire, and spotless; heads mostly stalked; flowers deeper purple; calyx-tube nearly or quite glabrous; teeth slightly rigid, scarcely ciliate. - Dry hills, e. Mass.; several reports from other Am. localities appear to refer to the preceding species. (Nat. from Eu.)

5. T. virgínicum Small. Low villous perennial, not stoloniferous; leaflets narrowly oblong, denticulate; flowers nearly white, in large heads; short calyx canescent-pubescent. - Rocky slopes, Kate's Mt., W. Va.

6. T. reflexum L. (BuFfalo C.) Annual or biennial; stems ascending, downy; leaflets obovate-oblong, finely toothed; stipules thin, ovate; standard rose-red; wings and keel whitish; calyx-teeth hairy; pods 3-5-seeded. Borders of fields and woods, w. N. Y. and Ont. to Ia., "Neb.," Kan, and southw.

7. T. stoloniferum Muhl, Smooth perennial; stems with long runners from the base; leaflets broadly obovate or obcordate, minutely toothed; heads loose; flowers white, tinged with purple; pods 2-seeded. - Open woodlands and prairies, O. and Ky., w. to Ia., "Neb.," and Kan.

8. T. rèpens L. (White C.) Smooth perennial; the slender stems spreading and creeping; leaflets inversely heart-shaped or merely notched, obscurely toothed; stipules scale-like, narrow; petioles and especially the peduncles very long; heads small and loose; calyx much shorter than the white corolla; pods about 4-seeded. - Fields and copses, every where; indigenous only in the northern part of our range, if at all. (Eurasia.).

9. T. HÝBRIDUM L. (Alsike C.) Rezembling $T$. repens, but the stems erect or ascending, not rooting at the nodes; leaflets ovate, rounded at apex; flowers rose-tinted. - Generally common. (Introd. from Eu.)

10. T. caroliniànum Michx. Somewhat pubescent small perennial, prouumbent, in tufts; leaflets wedge-obovate and slightly notched; stipules ovate, foliaceous; heads small, on slender peduncles; calyx-teeth lanceolate, nearly equaling the purplish corolla; standard pointed; pods 4-seeded. - Rocky places, Va. to Fla., 'Tex., and Kan.; introd. on waste ground near Philadelphia.

$\checkmark$ 11. T. AGRARIUM L. (YELLOW or HoP C.) Smoothish annual, somewhat upright, 1-3 dm. high; leaflets obovate-oblong, all three from the same point (palmate) and nearly sessile; stipules narrow, cohering with the petiole for more than half its length; corolla.yellow, persistent, becoming dry and brown in age. ( $T$. aureum at least of $\mathrm{Am}$. auth.) - Sandy fields and roadsides; N. S. to 7 . ; also in w. N. Y., Ont., and Ia. (Nat. from Eu.)

12. T. Procúmbens L. (Low Hop C.) Similar ; stems spreading or ascending, pubescent, 1-1.5 din. high; leaflets wedge-obovate, notched at the end, the 7ateral at a small distance from the other (pinnately 3 -foliolate); stipules ovate, short. - Sandy fields and roadsides, common. (Nat. from Eu.) 
13. T. DÙвом Sibth. Similar to the preceding but smaller throughout, heads loosely few-flowered; standard $4 \mathrm{~mm}$. long, about 11-nerved, scarcely or not at all striate in age. (T. procumbens, var. minus Man. ed. 6.) - Similar situations, Mass. to Va. and Tenn.; also locally established westw. (Nat. from Eu.)

\section{Melilòtus [Tourn.] Hill. Melilot. Sweet Clover}

Flowers much as in Trifolium, but in spike-like racemes, small. Corolla de. ciduous, free from the stamen-tube. Pod ovoid, coriaceous, wrinkled, longer than the calyz, scarcely dehiscent, 1-2-seeded. - Annual or biennial herbs, fragrant in drying, with pinnately 3 -foliolate leaves. (Name from $\mu \epsilon \lambda$, honey, and

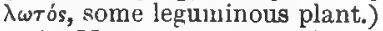

1. M. OFFICINALIS (L.) Lam. (YELLow M ) Upright, usually tall; leaflets obsvate-oblong, obtuse, closely serrate; petals yellow, of nearly equal length, 6-9 mm. long; pod 2.5-3.5 mm. long, glabrous or glabrate, prominently cross-ribbed. - Waste or cultivated ground, common. (Nat. from Eu.)

2. M. A LTf́ssima Thuill. Similar; leaftets linear-to lance-oblong, subentive or remotely toothed; pod gibbous, 4.5-6 $\mathrm{mm}$. long, pubescent, obscurely reticulate. - Ballast about Atlantic ports. (Adv. from Eu.)

3. M. INDica (L.) All. Low; leaflets cuneate-oblanceolate or -obovate, truncate or emarginate, tnothed above the middle; corolla yellow, 2-2.5 $\mathrm{mm}$. long; pod gibbous, about $2 \mathrm{~nm}$. long, alveolate. - Ballast and waste places abont Atlantic ports. (Adv. from Turasia.)

4. M. ÁlBa Desr. (White M.) Tall; leaflets narrowly obovate to oblong, serrate, truncrte or emarginate; cornlla vohite, $4-5 \mathrm{~mm}$. loner, the standard longer than the other petals; pod 3-4 mm. long, somewhat reticulate. - Rich soil, roadsides, etc., common. (Nat. from Eu.)

\section{MEDICÀGO [Tourn.] L. Medick}

Flowers nearly as in Melitotus. Pod 1-several-seeded, scythe-shaped, incurved, or variously coiled. - Leaves pinnately 3-foliolate; leaflets toothed; stipules often cut. ( $M \eta \delta \iota \gamma$, the name of the Alfalfa, because it came to the Greeks from Media.)

\section{* Perennials; pods straighwish or loosely coiled, unarmed.}

1. M. sativa L. (Lucerne, Alfalfa.) Upright, smooth, perennial ; leaflets obovate-oblong, toothed; flowers bluish-purple, racemed; pods twisted. Cultivated for green fodder and often spontaneous. (Introd. from Eu.)

2. M. FALCATA L. Similar; leaflets linear; flowers yellow; pod straightish or scarcely coiled. - Waste ground, eastw., rare and casual; perhaps not persisting, (Adv. from Eu.)

$$
\text { * * Annuals; pods (often armed) reniform or tightly coiled. }
$$

3. M. Lupulina L. (Black M., Nonesuch.) Procumbent, pubescent, annual; leaflets wedge-obovate, toothed at the apex; flowers yellow, in short spikes; pods .lidney-form, 1-seeded. - Waste places, common. (Adv. from Eu.)

4. M. arfíica Huds. (Spotted M.) Spreading or procumbent annual, somewhat pubescent; leaflets obcordate, with a purple spot, minutely tonthed; peduncles 3-5-flowered; flowers yellow; pods compactly spiral, of 2 or 3 turns, compressed, furrowed on the thick edge, and fringed with a double row of curved prickles. ( $\boldsymbol{M}$. maculata Sibth.) - Middle Atlantic States to N. B., on waste ground, not common. (Adv. from Eu.)

5. M. hispida Gaertn. (Bतr Clover.) Nearly glabrous; pods deeply reticulated, and with a thin keeled edge; otherwise as the last. (M. denticulata IVill,.) - Waste places, frequent; a fodder plant westw. (Introd. from Eu.) 


\section{ANTHÝlLIS [Rivinius] L.}

Calyx 5-toothed, loose, persistent and somewhat vesicular in age. Corolla yellow to crimson. Keel blunt or short-pointed. Pod mostly stalked, included in the calyx, nearly or quite indehiscent, 2-several-seeded. - Herbs, with pinnate leaves and large loose clover-like heads. (An ancient plant-name employed by Dioscorides.)

1. A. Vulneraria L. Pubescent, $2-3 \mathrm{dm}$. high; leaflets mostly b-13 (on the baval leaves often fewer and sometimes reduced to a solitary enlarged terminal leaflet); heads ovoid or subglobose, involucrate. - In clover felds, Oxford Co., Ont. (Burgess); also occasicnal as a ballast plant about Atlantic ports. (Adv, from Eu.)

\section{HOSÁCKIA Dougl.}

Calyx-teeth nearly equal. Petals free from the diade)phous stamens; standard ovate or roundish, its claw often remote from the others; wings obovate or oblong; keel incurved. . Pod linear, compressed or somewhat terete, sessile, several-seeded. - Herbs, with pinnate leaves (in ours 1-3-foliolate, with glandlike stipules), and small yellow or reddish flowers in umbels (uurs solitary) upon axillary leafy-bracteate peduncles. (Named for Dr. David Hosack, $1769-$ 1835 , professor of botany and materia medica in Columbia College.)

1. H. americàna (Nutt.) Piper. Annual, more or less silky-villous or subglabrous, often $3 \mathrm{dm}$. high or more; leaves nearly sessile, the 1-3 leaflets ovate to lanceolate $(0.6-1.8 \mathrm{~cm}$. long); peduncles often short, bracteate with a single leaflet. (Lotus Bischoff; $\boldsymbol{H}$. Purshiana Benth.) - Dry soil, w. Minn. to Ark., and westw.; also introduced in Greene Co., Ill. (according to McDonald).

\section{Lòtus [Tourn.] L. Bird's-foot Treforl}

Similar to the preceding genus but with pinnately 5-foliolate leaves, the basal pair of leaflets simulating stipules. (Ancient Greek plant-name.)

L. CoRNicolatus L. Diffuse many-stemmed perennial; flowers yellow in slender-peduncled capitate umbels. - Dry meadows, Washington, D. C. (Pech), and on ballast, etc., to N. S. (Adv. froin Old World.)

\section{PSORALEA I.}

Calyx 5-cleft, persistent, the lower lobe longest. Stamens diadelphous or sometimes monadelphous. Pod seldom longer than the calyx, thick, often wrinkled, indehiscent, 1-seeded. - Perennial herbs, usually sprinkled all over or roughened (especially the calyx, pods, etc.) with glandular dots or points. Leaves mostly 3-5-foliolate. Flowers spiked or racemed, white or mostly blue-purplish, Root sometimes tuberous and farinaceous. (Name, $\psi w p a \lambda t a s$, scurfy, from the glands or dots.)

\section{* Leaves pinnately 3-foliolate.}

1. P. Onóbrychis Nutt Nearly smooth and free from glands, erect, 1-2 m. high; leaflets lanceolate-ovate, taper-pointed, 7-8 $\mathrm{mm}$. long; stipules and bracts acol-shaped; racemes elongated; peduncles shorter than the leaves; pods roughened and wrinkled. - River-banks and deciduous woods, 0 . to Ill. and Mo.; also s. and e. to S. C.

2. P. stipulàta T. \& G. Nearly smnoth and glandless; stems diffuse; leaflets orate-elliptical., reticulated; stipules ovate; flowers in heads on rather slort peduncles; bracts broadly ovate, sharp-pointed. - Limestone ledges, Ohio R. above Louisville, Ky., and New Albany, Ind.; very local. June.

3. P. pedunculata (Mill.) Vail. Somewhat pubescent, more or less glandular; stems erect, 3-6 dm. high, slender; leaflets lanceolate or narrowly wblong; spike cylindrical, long-peduncled; stipules awl-shaped; bracts ovate or lanceolate, taper-pointed; pods strongly wrinkled transversely. ( $P$. melilotoides 
Michx.) - Dry soil, Fla. to Tenn., Sandusky, O. (Moseley), s. Ind, and Kar. June.

* Leaves palmately 3-5-foliolate; roots not tuberous.

+ Fruit more or less compressed, ovate.

4. P. tenuiflora Pursh. Slender, erect, much branched and bushy, 6-1.6 dm. high, minutely hoary.pubescent when young; leaflets varying from lineat to obovate-oblong, 1.2-3.6 cm. long, glandular-dotted; flowers (4-6 mm. long) in loose racemes; lobes of the caly $x$ and bracts ovate, acute; pod glandular. Prairies, Ill. to Minn., Tex., and westw, June-Sept.

Var. floribúnda (Nutt.) Rydb. Flowers more numerous, slightly larger and in denser racemes. ( $P$. floribunda Nutt.) - Same range.

5. P. argophýlla Pursh. Silvery sillwy-white all over, erect, divergently branched, $3-9 \mathrm{dm}$. high ; leaflets elliptical-lanceolate; spikes interrupted; flower 8-10 $\mathrm{mm}$. long; lobes of the calyx and bracts lanceolate. - High plains, $\mathrm{n}$. Wisc. to Ia., Mo., and westw. June.

6. P. digitàta Nutt. More slender and less hoary, 3-6 dm. high; leaflets linear-oblanceolate; bracts of the interrupted spike obcordate; calyx-lobes oblong, acute. - Sandy soil, Kan. to Col, and Tex. 'June, July.

\section{+ + Fruit globose.}

7. P. lanceolàta Pursh. Glabrous or nearly so, yellowish-green, densely punctate ; leaflets 3 , linear to oblanceolate ; flowers small, in very short spikes; calyx $2 \mathrm{~mm}$. long, with short broad teeth. ( $P$. micrantha Gray.) - Ia. and Kan. to the Sask, and westw.

* * Leaves palmately 5-foliolate; root tuberous; spike-like racemes dense.

8. P. esculénta Pursh. Roughish hairy all over; stem stout, $1-4 \mathrm{dm}$. high, erect, from a tuberous or turnip-shaped farinaceous root; leaflets obovate- or Ianceolate-oblong; spikes ellipsoid, long-peduncled; lobes of the calyx and bracts lanceolate, nearly equaling the corolla $(1.2 \mathrm{~cm}$. long). - High plains, Wisc. to Tex., and northwestw. May-July. - The Pomme BLaxche, or Ponme De Prairie, of the voyageurs.

\section{AMÓRPHA L.}

Calyx inversely conical, 5-toothed, persistent. Standard (the other petals entirely wanting 1) wrapped around the stamens and style. Stamens 10, inonadelphous at the very base, otherwise distinct. Pod oblong, longer than the calyx, 1-2-seeded, roughened, tardily dehiscent. - Shrubs, with odd-pinuate leaves; the leaflets marked with minute dots, usually stipellate, the midvein excurrent. Flowers violet or purple, crowded in clustered terminal spikes. (Name, duopфos, deformed, from the absence of four of the petals.)

$$
\text { * Leaflets small (1.2 cm. long or less), crowded. }
$$

1. A. canéscens Pursh. (LEAD PLANT.) Whitened with hoary dovn, 3-14 dm. high; leaflets 31-51, oblong-elliptical, becoming smoothish above; spikes usually clustered at the summit. - Hills and prairies, Ind. to Man:, and southw. June-Aug.

2. A. microphylla Pursh. Nearly glabrous throughout, $3 \mathrm{dm}$. high or less; leaflets rather rigid; spikes usually solitary. - Prairies, Minn. and Man. to Kan. June, July.

\section{* Leafiets larger, scattered.}

3. A. fruticosa L. (FALSE Indigo.) A tall shrub, rather pubescent or smoothish; leaflets 9-25, oblong to broadly elliptical. — River-banks, s. Pa. to Fla., w. to Sask., Tex., and the Rocky Mts; often cultivated, and escaping eastw. May, June. (Mex.) - Very variable.

Var. angustifolia Pursh. Leaflets narrower, lance-oblong or lance-elliptic, of firmer texture; fruit somewhat smaller, 6-8 mm. long. (A. angustifolia Boynton.) - Banks of streams, Ia., westw. and southwestw. 


\section{DẢLEA Juss}

Calyx 5-cleft or -toothed. Corolla imperfectly papilionaceous; petals all on claws; the standord heart-shaped inserted in the bottom of the calyx; the keel and wings vorne on the middle of the monadelphous sheath of filaments, which is cleft down one side. Stamens 10, rarely 9. Pod membranaceous, 1-seeded, indehiscent, inclosed in ths persistent calyx. - Mostly herbs, more or less glandulis-dotted, with minute stipules; the small flowers in terminal spikes or heads. (Named for Samuel Dale, 1659-1739, an English botanist.) Parosela Cav.

1. D. alopecuroides $W$ illd. Erect annual, 3-6 dm. high; leaflets 19-35, glabrous, linear-nb.ong; flowers light rose-color or whitish, in cylindrical spikes; bracts ovate-1mnceolate, acuminate, deciduous; calyx very villous, with long slender teeth. (Parosela Dalea Britton.) - Alluvial soil, Ill. to Minn. and Ala., w. to the Rocky Mts. Aug., Sept. (Mex.)

2. D. enneándra Nutt. Erect perennial, 3-12 dm. high, branching; leaflets 5-13, linear, 4-6 mm. long; spikes loosely flowered ; bracts conspicuous, persistent, alnost orbicular and very obtuse; petals white; calyx densely villous, the long teeth beautifully plumose. (D. laxiflora Pursh.) - Dry soil, Ia. and Mo, to Tex. and Col. May-Aug.

\section{Petalostèmum Michx. Prairie Clover}

Calyx 5-toothed. Corolla indistinctly papilionaceous; petals all on threadshaped claws, 1 of them nearly alike and spreading, borne on the top of the monadelphous and cleft sheath of filaments, alternate with the 5 anthers; the fifth (standard) inserted in the bottom of the calyx, heart-shaped or oblong. Pod membranaceous, inclosed in the calyx, indeliscent, 1-2-seeded. - Chiefly perennial herbs, upright, glandular-dotted, with crowded odd-pinnate leaves, minute stipules, and small flowers in very dense terminal and peduncled heads or spikes. (Name, often but not originally spelled Petalostemon, combined of the two Greek words for petal and stamen, alluding to the peculiar union of these organs in this genus.) KuHnisterA Lam.

\section{* Corolla rose-colored.}

1. P. purpùreum (Vent.) Rydb. Smoothish; leaflets 5 , narrovoly linear; heads glohose-ovoid or short-cylindrical when old; bracts pointed, not longer than the silky-hoary calyx. (P. violaceum Michx.; Kuhnister $\alpha$ MacM.) - Dry prairies, Ind. to Man. and La., w. to the Rocky Mts. June-Aug.

2. P. villòsum Nutt. Soft-downy or silly all over; leaflets 13-17, linear or oblong, smali (8-10 mm. long); spikes cylindrical, $2.5-12 \mathrm{~cm}$. long, shortpeduncled, soft-villous. (Kuhniastera Ktze.) - Sandy soil, W1sc. to Sask. and Tex., w. to Rocky Mts. July.

3. P. foliosum Gray. Smooth, very leafy; leaflets 15-29, linear-oblong; spikes cylindrical, short-peduncled; bracts slender-awned from a lanceolate base, exceeding the glabrous calyx. (Kuhniastera Ktze.) - River-banks and rocky hills, Ill. and Tenn. July-Sept.

\section{* * Corolla white.}

4. P. multiflorum Nutt, Glabrous throughout, erect, branching; leaflets 3-9, linear to oblong; heads globose, the subulate-setaceous bracts much shorter than the acutely toothed calyx. (Kuhnistera Heller.)-Prairies, w. Ia. (Pammel) to Ark. and Tex. Aug.

5. P. cándidum Michx. Smooth; leaflets 7-9, lanceolate or linear-oblong; heads short-cylindrical; bracts awned, longer than the nearly glabrous calyx. (Kuhniastera Ktze.) - Dry prairies, Ind. to Man., La., and w. to the Rocky Mts. June, July.

$$
\text { GRAY'S MANUAL - } 33
$$




\section{Tephrósia Pers. Hoarx Pea}

Caly $x$ about equally 5-clett. Standard roundish, usually silky outside, turned back, scarcely longer than the coherent wings and keel. Stamens monadelphous or diadelphous. Pod linear, flat, several-seeded, 2-valved.-Hoary perennial herbs, with odd-pinnate leaves, and white or purplish racemed flowers. Leaflets mucronate, veiny. (Name from $\tau \varepsilon \phi \rho \delta s, ~ a s h$-colored or hoary.) Cracca L.

1. T. virginiana (L.) Pers. (Goat's Rue, Catgut.) Silky-villons with whitish hairs when young; stem erect and simple, 3-6 dm. high, leafy to the top; leaflets 17-29, linear-oblong; flowers large and numerous, clusiered in a terminal ellipsoid dense raceme or panicle, yellowish-white marked with purple. (Cracca I.) - Dry sandy soil, s. N. H. to Minn., and southw., chiefly at low altitudes. June, July. - Roots long and slender, very tough. Var. holoserícea (Nutt.) 'T. \& G. has more copious or even woolly pubescence and usually narrower leaflets. - With the typical form, westw.

2. T. spicàta (Walt.) T. \& G. Villous with rusty hairs; stems branched below, 'straggling or ascending, $6 \mathrm{dm}$. long, few-leaved; leaflets 9-15, obovate or oblong-wedge-shaped, often notched; flovers few, in a loose and interrupted very long-peduncled spike, reddish. (Cracca Ktze.) - Dry soil, Del. and Va. to Fla. and La. May-July.

3. T. hispidula (Michx.) Pers. Hairy with some long and rusty or only minute and appressed pubescence; stems slender, $2-6 \mathrm{dm}$. long, divergently branched, straggling; leaflets 5-17, oblong, varying to obovate-wedge-shaped and oblanceolate; peduncles longer than the leaves, "2-4-flowered; flowers reddish-purple. (Cracca Ktze.) - Dry sandy soil, Va. to Fla. and La. May-July.

\section{SESBÀNIA Scop.}

Calyx campanulate, equally toothed. Standard large, round. Stamens diadelphous. Ovary many-ovuled; pod long. - Herbs or shrubs with long evenpinnate leaves. Flowers on axillary peduncles or lateral racemes. (Name latinized from the earlier Sesban Adans., said to be of Arabic origin.)

1. S. macrocárpa Mubl. Erect annual, $0.7-3 \mathrm{~m}$, high; leaflets $12-25$ pairs, narrowly oblong; corolla pale yellow, often spotted; pods $2 \mathrm{dm}$. in length, narrow, with thickened margins. - Mo. to Fla. and 'Tex. ; introd. in s. Pa.

\section{ROBÍNIA L. Locust}

Calyx short, 5-toothed, slightly 2-lipped. Standard large and rounded, turn $\epsilon$ ? back, scarcely longer than the wings and keel. Stamens diadelphous. Pod linear, flat, several-seeded, at length 2-valved.-- Trees or shrubs, often with spines for stipules. Leaves odd-pinnate, the ovate or oblong leaflets stipellate. Flowers showy, in hanging axillary racemes. (Named for John Robin, herbalist to Henry IV. of France, and his son Vespasian Robin, who first cultivated the Locust-tree in Europe.)

1. R. Pseùdo-Acàcia I. (Common L., False Acacia.) Branches glabrous or glabrate; racemes slender, loose; Howers white, fragrant; pod smuoth. Along the mts., Pa. to Ga., and in the Ozark Mts. of Mo., Ark., and Okla.; commonly cultivated as an ornamental tree, and for its valuable timber, and naturalized in many places. May, June.

2. R. Viscosa Vent. (C, мm I.) Branchlets and leaf-stalks clammy; flowers crowded in short racemes, tinged with rose-color, nearly inodorous; pod glandular-hispid. - Va. to Gra., in the mts.; cultivated, like the last, and often escaping. May, June.

3. R. híspida L. (Bristly L., Rose Acacia.) Shrub, 1 to $3 \mathrm{~m}$. high; branchlets and stalks bristly; flowers large and deep rose-color, inodorous; pode glandular-hispid. - Mts. of Va. to Ga. ; cultivated and established northw. May, June. 


\section{WISTERIA Nutt.}

Calyx campanulate, somewhat 2-lipped; upper lip of 2 short teeth, the lower of 3 longer ones. Standard roundish, larye, turned baek, with 2 callosities at its base; keel scythe-shapea ; wings doubly aurıcled at the base. Stamens diadelphous. Yods elongated, thickish, knobby, stipitate, many-seeded, at length 2 -valved. Seeds large. - Uvate-lancenlate leaflets $9-13$; racemes of large and showy lilac-purple flowers. (1)edicated to Professor Cnspar Wistar, distinguished anatumist of Philadelphia.) Kraunhis Kaf. Wistaria Spreag. (a later spelling).

1. W. frutéscens (L.) Poir. Downy or smoothish when old, without clubshaped hairs; racemes short and dense; calyx-teeth very short. (Kraunhia Raf.; Bradleya Britton.) - Alluvial grounds, Va. to Fla. May. - Sometimes cultivated for ornament as is the still handsomer and more showy Chinese species, $W$. chinensis 1) C.

2. W. macrostàchya Nutt. Racemes $1.5-2 \mathrm{dm}$. long; pubescence of the pedicels and calyx mixed, including club-shaped hairs; calyx-teeth half to thret fourths the length of the tube; standard less strongly auricled than in the preceding. (Kraunhia macrostachys Small ; Bradleya Small.) - Rich soil, swamps, etc., Ind. (?) to Mo., Kan. (?), and La. May.

\section{ASTRÁGaluS [Tourn.] I̦. MiLk Vetch}

Calyx 5-toothed. Corolla usually long and narrow; standard narrow, equaling or exceeding the wings and blunt keel, its sides reflexed or spreading. Stamens diadelphous. Pod several-many-seeded, various, mostly turgid, one or both sutures usually projecting into the cell, either slightly or so as to divide the cavity lengtlıwise into two. - Chiefly herbs (ours perennials), with odd-pinnate leaves and spiked or racemed flowers. Mature pods are usually necessary for certain identitication of the species. (The ancient Greek name of a leguminous plant, as also of the ankle-bone.)

\$1. Pod turgid, completely or imperfectly 2-celled by the intrusion of the dorsal suture, the ventral suture being not at all or less deeply inflexed.

* Pod plum-shaped, succulent, becoming thick and fleshy, indehiscent, not stipitate, completely 2-celled.

1. A. caryocárpus Ker. (Grodwd Plum.) Pale and minutely appresisedpubescent; leaflets narrowly oblong; flowers in a short spike-like raceme; corolla violet-purple; fruit glabrous, ovoid-globular, more or less pointed, about $1.6 \mathrm{~cm}$. in diameter, very thick-walled, cellular or corky when dry. (A. crassicarpus Nutt.) - Prairies, Sask. and Minn. to Mo., s. w. and w. to Tex. and Col. Apr., May.

2. A. mexicànus A. DC. (Ground Plum.) Smoother, or pubescent with looser hairs, larger; leaflets roundish, obovate, or oblong; flowers larger (2-2.5 $\mathrm{cm}$. long); caly x softly hairy ; corolla cream-color, bluish only at the tip; fruit globular, very obtuse and pointless, $2.5 \mathrm{~cm}$. or more in diameter; otlerwise like the last. - Prairies and open plains, Ill. to Kan., s. to La. and 'Tex. Apr., May. -The unripe fruits of this and the preceding species resemble green plums (whence the popular name) and are eaten raw or cooked.

3. A. platténsis Nutt. Loosely villous; leaflets oblong, often glabrous above; flowers crowded in a short spike or head, cream-color, often tinged or tipped with purple; fruit ovoid, pointed, $1.2-1.6 \mathrm{~cm}$. long, with surface even; calyx villous. - Gravelly or sandy banks, Minn. to Col. and Tex. Apr.-June.

4. A. tennesseénsis Gray. Hirsute; stipules large; leaves and flowers as in the last; fruit 2.4-2.8 cm. long, pointed, strongly wrinkled. (A. plattensis, var. Gray.) - Ill, Morris (Vasey), Ogle Co. (Bebb); Tenn. and Ala.; reported alse from Mo. Apr., May. 
* Pod dry, coriaceous, cartilaginous or membranous, dehiscent. - Pud completely 2-celled, sessite.

5. A. canadénsis L. Tall and erect, $3-16 \mathrm{dm}$, high, somewhat pubescent or glabrate; leaflets 21-27, oblong; flowers greenish cream-color, very numerous, in long dense spikes; pods crowded, oblong (1.2 cm. long), glabrous, terete, scarcely sulcate and only on the back, nearly straight. (A. carolinianus L.) Dry or gravelly soil, w. Que., shores of L. Champlain, Vt. (Brainerd), N. Y. to n. Ga., and far westw. July, Aug.

6. A. adsúrgens Pall. Ascending or decumbent, $1-4.5 \mathrm{dm}$. high, cinereous with minute appressed pubescence or glabrate; leaflets about 21 , narrowly oblong; spike dense, with medium-sized pale or purplish flowers; pubescence of calyx appressed; pod oblong, 8-10 mm. loug, finely pubescent, triangular-compressed, with a deep dorsal furrovo, straight. - Keewatin to Minn., w. Kan., and westw. (Asia.)

7. A. hypoglottis L. Slender; stems $1.5-6 \mathrm{dm}$. long, diffusely procumbent or ascending, with a rather loose pubescence or nearly glabrous; leaflets 15-21, oblong, obtuse or retuse; flowers violet, capitate; calyx loosely pubescent; pod as in the last, but ovate and silky-villous. - Minn. to centr. Kan., and worthwestw. May-July. (Eurasia.)

\section{- + Pod not conpletely 2-celled. \\ + Pod stipitate, pendent.}

8. A. alpinus L. Diffuse, from a very loosely forking base, the prostrate or decumbent branches $0.5-1.5 \mathrm{dm}$. long, smooth or slightly hairy; leaflets 11-23; flowers violet-purple, or at least the keel tipped with violet or blue; calyx campanulate; pod narrowly oblong, short-acuminate, intensely black-pubescent with long slightly spreading hairs, triangular-turgid, deeply grooved on the back, straight or curved, its stipe usually rather exceeding the calyx. - Rocky banks and gravelly shores, Arctic Am., s. to Nfd., e. Que., and Col. (Eurasia.)

Var. Brunetiànus Fernald. Commonly larger, the branches mostly 2-6 dm. long; leaflets usually $15-29$; mature pods greenish or pale brown, strigose with shorter black or even whitish hairs. - Limestone ledges and gravelly shores, e. Que. to Hudson B., s. to s. N. B., centr. Me., and Vt.; also in the Rocky Mts. May-Sept.

9. A. Robbínsii (Oakes) Gray. Nearly smooth and erect, $3 \mathrm{dm}$, high, slender; leaflets $7-11$; calyx more oblong; flowers white; pod oblong ( $1.2 \mathrm{~cm}$. long), obtuse or acutish, minutely darkish-pubescent, somewhat laterally compressed, not dorsally sulcate or obsoletely so, straight or somewhat incurved, rather abruptly narrowed at base into the often included stipe. - Rocky ledges of the Winooski R., Vt. (station now extinct).

10. A. Blakkei Eggleston. Habit and foliage nearly as in the preceding, more robust; corolla larger, bluish-purple; pod triangular in section, sulcate dorsally. (A. Robbinsii, var. occidentalis Wats., var. Jesupi Fggleston \& Sheldon; A. Jesupi Britton; $A$. occidentalis Jones.) - Rocky banks, $\mathrm{n}$. Me. to Vt.; also in Rocky Mts.

11. A. racemosus Pursh. Stout, 3-6 dm. high, erect or ascending, appressedpubescent or glabrate; leaflets $13-25$; flowers numerous, vohite, pendent; calyx campanulate, gibbous, white-pubescent; $p \circ d$ straight, jarrow, $2.5 \mathrm{~cm}$. long, acute at both ends, triangular-compressed, deeply grooved on the back, the ventral edge acute. - Neb. to Mo., westw. and northwestw.

\section{++ Pod sessile.}

12. A. parviflorus (Pursh) MacM. Subcinereous, slender, $3 \mathrm{dm}$. or more high; leaflets 11-17, linear-filiform, 1.4-2 $\mathrm{cm}$. long, obtuse or returs; racemes loose; flowers small ( $6 \mathrm{~mm}$. long); pod pendent, 4-6 $\mathrm{mm}$. long, coriaceous, elliptic-ovate, concave on the back, the ventral suture prominent, white-hairy, at length glabrous, transversely veined. (A. gracilis Nutt.) - Minn. to Mo,, and westw. A. microlobus Gray, with lrakets linear-oblong, retuse, $1-1.2 \mathrm{~cm}$. long, said to have been collected in Mo., is scarcely more than a variety of this. 
13. A. distórtus T. \& G. Low, diffuse, many-stemmed, subglabrous ; leaflets 17-25, oblong, einarginate; flowers in a short spike, pale purple; pod ovate- or lance-oblong, curved, $1.2-1.8 \mathrm{~cm}$. long, glabrous, thick-coriaceous, somewhat grooved on the back, the ventral suture nearly flat.- "W. Va." and Miss. to Ill., Ia., and 'Tex.

14. A. lotifldrus Hook. Hoary or cinereous with appressed hairs; stems very short; leaflets 7-13, lance-oblong; flowers yellowish, in few-flowered heads, with peduncles exceeding the leaves or very short; calyx campanulate, the subulate teeth exceeding the tube; pod oblong-ovate, 1.8-2.4 cm. long, acuminate, acute at base, canescent, the back more or less impressed, the acute veritral suture nearly straight. - Man. to Mo. (Bush), Tex., and B. C.

\$2. Pod 1-celled, neither suture being inflexed or the ventral more intruded than the dorsal.

* Pod sessile in the calyx; valves strongly convex.

15. A. negléctus (T. \& G.) Sheldon. Nearly smooth, erect, 3-6 dm. high ; leaflets 11-21, elliptical or oblong, somewhat retuse, minutely hoary beneath ; flowers white, rather numerous, in a short spike; calyx dark-pubescent; pod coriaceous, inflated, ovoid-globose, $1.2-1.8 \mathrm{~cm}$. long, acute, glabrous, slightly sulcate on both sides, cavity webby. (A. Cooperi Gray.) - Cliffs and clayey banks, e. Que. (according to Macoun); Ont., and w. N. Y. to Minn. and Ia.

16. A. flexudsus Dougl. Ashy-puberulent, ascending, 3 to $6 \mathrm{dm}$. high ; leaflets 11-21, mostly narrow; flowers small, in loose racemes; pod thin-coriaceous, cylindric, $1.6-2.2 \mathrm{~cm}$. long, $4 \mathrm{~mm}$. broad, pointed, straight or curved, puberulent, very shortly stipitate. - Minn. to Col., and northw.

17. A. eucósmus Robinson. Decumbent, ashy-puberulent, 3-6 dm. high ; leaflets 1:3-15, oblong, 1.2-2.8 cm. long, glabrous above; long-peduncled racemes at length loose; flowers small, pale blue or purple; pod sessile, ovate-oblong, strongly compressed. (A. oroboides, var. americanus Gray; A. elegans Britton, not Bunge.) - Gravelly banks, Lab. to n. Me.; Rocky Mts.

$$
\text { * Pod slender-stiped; valves flattish. }
$$

18. A. tenéllus Pursh. Slender, decumbent, branched from the base, $2-4 \mathrm{dm}$. high; leaflets 11-15, carrowly oblong to linear, obtuse, pale green; racenies axillary, short-peduncled; flowers small, $7-9 \mathrm{~mm}$. long; petals ochroleucous, sometimes pink-tinged; pod lance-oblong, 1-1.2 cm.long, thin. (A. muttiflorus Gray; Homalobus tenellus Britton.) - Dry sandy plains, w. Minn. to N. Mex. and B. C.

\section{OXÝTROPIS DC.}

Keel tipped with a sharp projecting point or appendage; otherwise as in Astragalus. Pod often more or less 2-celled by the intrusion of the ventral suture. - Our species low nearly acaulescent perennials, with tufts of numerous very short stems from a hard and thick root or rootstock, covered with scaly adnate stipules ; pinnate leaves of many leaflets ; peduncles scape-like, bearing a head or short spike of flowers. (Name from ozus, sharp, and $\tau \rho \dot{d} \pi \iota s, k e e l$.

Spiesia Neck. ARagaluus Neck.

\section{* Leaves simply pinnate.}

1. 0. campéstris DC., var. johannénsis Fernald. Villous, $3-5 \mathrm{dm}$. high ; leaflets lanceolate or oblong ; flower's showy, rose-colored, drying purplish-blue ; pods $2-2.5 \mathrm{~cm}$. long, ovate- or oblong-lanceolate, thin and papery. (Var. caerulea Man. ed. 6, not Koch; Spiesia campestris Britton, in part; Aragallus johannensis Rydb.) - Gravelly shores, Gaspé Co. to Isle of Orleans, Que., s. to the Restigouche R., N. B., and the Aroostook R., Me.

2. 0. Lambérti Pursh. Silty with fine appressed hairs; leaflets mostly linear; flowers larger, purple, vinlet, or sometimes white; pods cartilaginous or firm-coriaceous in texture, silky-pubescent, strictly erect, cylindraceouslanceolate and long-pointed, almost 2-celled by intrusion of the ventral suture 
(Spiesia Ktze, ; Aragallus Greene.) - Dry plains, Sask. and Minn. to Mo. and Tex., w. to the mts.

* * Leaflets numerous, mostly in fascicles of 3-4 along the rhachis.

3. 0. spléndens Dougl. Silky-villous, 1.5-3 dm. high ; scape spicately severalmany-flowered; flowers erect-spreading; pod ovate, erect, 2-celled, hardly surpassing the very villous calyx. (Spiesia Ktze. ; Aragallus Greene.) - Plains of Sask. and w. Minn. to N. Mex, and the Rocky Mts.

\section{GLYCYRRHIZA [Tourn.] L. LiquORICE}

Calyx with the two upper lobes shorter or partly united. Anther-cells confluent at the apex, the alternate ones smaller. Pod ovate or oblong-linear, compressed, scarcely dehiscent, few-seeded. The flower, etc., otherwise as in Astragalus. - Long perennial root sweet (whence the name, from $\gamma \lambda u \kappa v$ s, swoeet, and $\dot{\rho}(\zeta a, r \circ o t)$; herbage glandular-viscid; leaves odd-pinnate, with minute stipules; flowers in axillary spikes, white or bluish.

1. G. lepiddta (Nutt.) Pursh. (W ILD L.) Tall (6-9 dm. high); leaflets 15-19, oblong-lanceolate, mucronate-pointed, sprinkled with little scales when young, and with corresponding dots when old; spikes peduncled, short ; flowers whitish; pods oblong, beset with hooked prickles. - Hudson B. and Minn. to Mo., N. Mex., and westw.; also sporadically on waste land, etc., eastw.

\section{AEschynómene L. Sensitive Joint Vetch}

Calyx 2-lipped; the upper lip 2-, the lower 3-cleft. Standard roundish; keel boat-shaped. Stamens diadelphous in two sets of 5 each. Pod flattened, composed of several easily separable joints. - Leaves odd-pinnate, with several pairs of leaflets, sometimes sensitive, as if shrinking from the touch (whence the name,

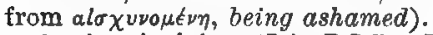

1. A. virgínica (L.) BS P. Erect bristly annual; leaflets $37-51$, linear; racemes few-flowered ; flowers yellow, reddish exterually; pod stalked, 6-10jointed. (A. hispida Willd.) - Along rivers, N. J. and s. Pa. to Fla. and La.

\section{CORONÍLA $\mathrm{L}$.}

Caly $x$ 5-toothed. Standard orbicular ; keel incurved. Stamens diadelphous, 9 and 1. Pod terete or 4-angled, fointed; the joints subcylindric. - Glabrous herbs or shrubs, with pinnate leaves, and the flowers in umbels terminating axillary peduncles. (Diminutive of corona, a crown, alluding to the inflorescence.)

1. C, varia L. A perennial herb with ascending stems; leaves sessile ; leaflets 15-25, oblong; flowers rose-color; pods coriaceous, 3-7-jointed, the 4-angled joints 6-8 mm. long. - Roadsides and waste places, N. E. to N. J. (Nat. from Eu.)

\section{HEDÝSARUM [Tourn.] L.}

Calyx 5-cleft, the lobes awl-shaped and nearly equal. Keel nearly straight, obliquely truncate, not appendaged, longer than the wings. Stamens diardelphous, 9 and 1. Pod flattened. composed ot several equal-sided separable roundish joints connected in the middle. - Perennial herbs'; leaves odd-pinnate.

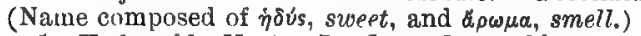

1. H boreàle Nutt. Lueaflets $13-21$, oblong or lancenlate, nearly glabrous; stipules scaly, united opposite the petiole; raceme of many defexed magenta to white flowers; standard shorter than the keel; joints of the pod 3-4, smooth, reticulated. ( $\boldsymbol{H}$. americanum Britton.) - Rocky or gravelly banks, Nfd. and Lab. to Alaska, s, to St. John Valley, N. B. and Me., mts. of n. Vt., n. shore of L. Superior, S. Dak, and Rocky Mts. to Col. June-Aug. 


\section{DESMÒdIUM Desv. Tick TreFoll}

Calyx usually 2-lipped. Standard obovate; wings adherent to the straight or straightish and usually truncate keel, by means of a little transverse appendage on each side of the latter. Stamens diadelphous, 9 and 1 , or munadelphous below. Pod flat, deeply lobed on the lower margit, separating intu flat reticu. lated joints (mostly roughened with minute houlced hairs). - Perennial herbs: with pinnately 3 -foliolate (rarely 1-foliolate) leaves, stipellate. Fluwtrs in axil. lary or terminal racemes, often panicled, and 2 or 3 from each bract, puiple (us purplish, often turning green in withering. Stipules and bracts scale-like, often striate. (Name from $\delta \epsilon \sigma \mu b s$, $a$ bond or chain, from the connected joints of the pods.) Meibomia Adans.

N.B. - In this genus the figures of the loments are on a scale of $1 \frac{1}{2}$.

\$1. Fod raised on a stalk (stipe) many times longer than the slightly toothed calyx and nearly as lon! as the pedicel, straightish on the upper margin, deeply

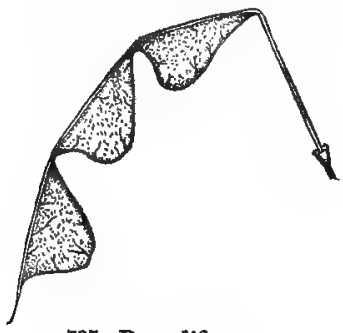

785. D. nuđiflorum. sinuate on the lower; the $1-4$ joints mostly half-obovate and concave on the back; stamens monadelphous below; plants nearly glabrous; stems erect or ascending; raceme terminal, panicled; stipules bristle-form, deciduous.

1. D. nudiflorum (L.) DC. Leaves all crowded at the summit of sterile stems; leaflets broadly ovate, bluntish, whitish beneath; raceme elongated on an ascending mostly leafless stalk ur scape 6-10 dm. high. (Meibomia Kize.) - Dry woods, s. Me. to w. Que., Ont., Minn. and southw. Fig. 785.

2. D. grandiflorum (Walt.) DC. Leaves all crovoded at the summit of the stem from which arises the elongated nalied raceme or panicle; leatlets roundovate, taper-pointed, green both sides, the end one round $(1-1.3 \mathrm{dm}$. long). (D. acuminatum DC. ; Meibomia grandiflora Ktze.) - Rich woods, centr. Me. to Unt., S. Dak., and southw. Fig. 786.

3. D. pauciflorum (Nutt.) DC. Leaves scattered along the low (2-4 dm. high) ascending stems; leaflets rhombic-ovate, bluntish, pale beneath ; raceme few-flowered,

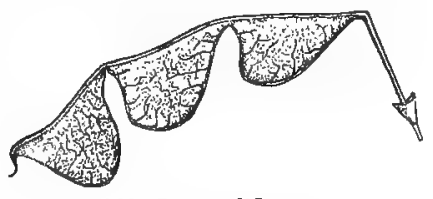

786. D. grandiflorum. terminal. (Meibomia Ktze.) - Woods, Ont. to Pa., Mich., Kan., and southw.

$\$ 2$. Pod raised on a stall (stipe) little if at all surpassing the de eply cleft calyx; stems long and prostrate or decumbent; racemes axillary and terminal.

* Stipules conspicuous, ovate, attenuate, striate, persistent; racemes mostly simple.

4. D. rotundifolium (Michx.) DC. Soft-hairy all over, truly prostrate ; leaflets orbicular, or the odd one slightly rhumboid; flowers purple; pods almnst

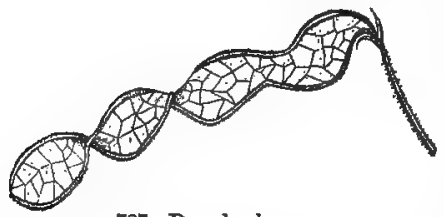

787. D. ochroleucum. equally sinuate on both edges, 3-5-jointed; the joints rhomboid-oval. (Meibumia Michauxii Vail.) - Dry woods, e. Mass. to Fla., w. to Minn., Mo., and La. - A form with ovate leaflets nccurs in Va. (Curtiss).

5. D. ochroleùcum M. A. Curtis. Stems sparsely hairy, decumbent; leaflets nearly glabrous, ovate, acute or obtuse, transversely reticulated beneath, the lateral ones smaller or sometimes wanting; racemes much elongated ; corolla whitish; pods twisted, 2-4-jointed, the large rhomboid joints smooth and reticulated but the margins downy. (Meibomia Ktze.) - Woodlands, N. J. and Del. to Ga. and Mo. FIG, 787. 
* * Stipules smaller, lanceolate and awl-shaped, less persistent; racemes panicled,

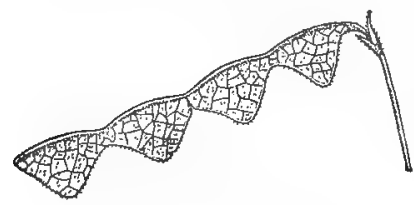

788. D. glabellum.

6. D. glabéllum (Michx.) DC. Glabrous or nearly so, procumbent; leaflets ovate or ovate-oblong, rather obtuse, much smaller than in the two preceding $(3-6 \mathrm{~cm}$. long); corolla purple; pods 2-4-jointed, flat, the ovalrhomboid joints minutely scabrous throughout. (D. humifusum Beck; Meibomia glabella Ktze.) - Dry sandy soil, Mass. to s. Pa., Md., and southw. Frg. 788 .

\$3. Pod slightly if at all stalked in the calyx; racemes panicled.

* Stems tall (1-2 m. high) and erect; the persistent stipules and deciduous bracts large and conspicuous, ovate or ovate-lanceolate, taper-pointed; flowers rather large.

- Pods of 4-7 unequal-sided rhombic joints, which are considerably longer than broad (about $1.2 \mathrm{~cm}$. long).

7. D. canéscens (L.) DC. Stem loosely branched, hairy, branches clothed with both minute and hooked as well as longer spreading rather glutinous hairs; leaflets ovate, bluntish, about the length of the petioles, whitish and

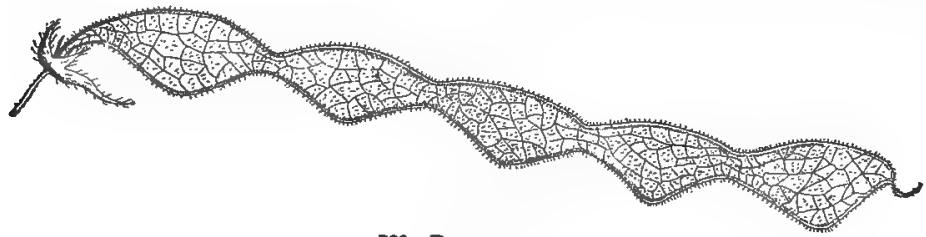

789. D. canescens.

reticulated beneath, bath sides roughish with a close fine pubescence; joints of the pod very adhesive. (Meibomia Ktze.) - Dry chiefly sandy soil, Mass. to Minn. and southw. FIg. 789. Var. Hirsútum (Hook.) Robinson. Panicle and upper part of the stem very villous; leaflets oblong-ovate. (D. canadense, var. Hook. ; $D$. canescens, var. villosissimum ' $\mathrm{.} \mathrm{\&} \mathrm{G.;} \mathrm{Meibomia} \mathrm{canescens,}$ var. hirsuta Vail.) - Ill, and Mo. to Tenn.

8. D. bracteosum (Michx.) DC. Very smooth except the panicle; stem straight ; leaflets lanceolate-ovate and taper-pointed, green and glabrous on both sides, longer than the petiole; the conspicuous bracts and stipules $1-1.5$ cm. long ; joints of the pod rhomboidoblong, smoothish. (D. cuspidatum Hook, ; Meibomia bracteosa Ktze.) Thickets, s. N. H. to Minn., and southw. Frg. 790.

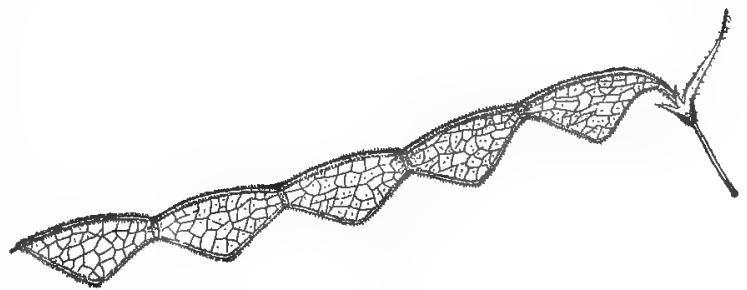

790. D. bracteosum.

Var. longifolium (T. \& G.) Robinson. Stem with some persisting pubescence; leaflets scabrous above, villous beneath. (D. canadense, var. T. \& G.; Meibomia longifolia Vail.) - Mich. to Kan. and Ark.

$$
\text { + + Pods of 3-5 oval joints (not over } 6 \mathrm{~mm} \text {. long). }
$$

9. D. illinoénse Gray. Erect, 1-2 m. high; stem and leaves with short rough pubescence; leaflets ovate-oblong or -lanceolate, $5-10 \mathrm{~cm}$. long, obtuse, 


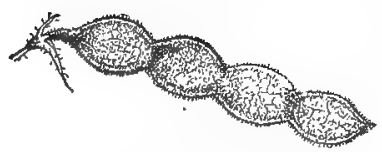

791. D. illinoense.

subcoriaceous, cinereous beneath, veins and vein. lets prominent, strongly reticulated, the lower leaflets nearly equaling the petiole; pods scarcely over $2.5 \mathrm{~cm}$. long, sinuate on both wargins (more deeply below). (Meibomia Ktze.) - Iry ground, Lakeside, O. (Moseley) ; Jackson Co., Mich. (Wheeler); Ill. to Neb., Kan., and Okla. Fig. 791.

* * Stem 6-15 dm. high, erect; stipules and bracts mostly deciduous, small and inconspicuous; joints of the pod 3-5, triangular or half-rhombic or very unequal-sided alid rhomboidal, longer than broad, $6 \mathrm{~mm}$. or less in length; flovers middle-sized.

10. D. laevigàtum (Nutt.) DC. Smooth or nearly so throughout; stem straight; leaflets ovate, bluntish, pale beneath, $5-7.5 \mathrm{~cm}$. long, thin and without prominulous reticulation; panicles minutely rough-pubescent. (Meibomia Ktze.)-Pine woods, s. N. Y. and N. J. to Fla., Mo., and Tex. Fig. 792. From Va. southw. passing to D. RHOMBIFóluM (Ell.) DC., a more pubescent plant,

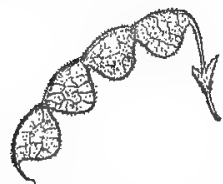

798. D. viridiflorum. with thickish leaves, the veins prominulous beneatly. ( $\mathrm{Mei}$ bomia Vail.)

11. D. viridiflorum (L.) Beck. Stem very downy, rough

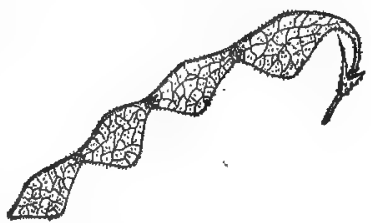

792. D. kevigatum. at the summit; leaflets broadly ovate, very obtuse, rough above, whitened with a soft velvety down underneath, 5-7.5 cm. long. (Meibomia Ktze.) - Dry open woods, common, s. N. Y. to Fla., Mich., Mo., and Tex. Fig. 793.

12. D. Dillènii Darl. Stem pubescent; leaflets oblong or oblong-ovate, commonly bluntish, pale beneath, softly and finely pubescent, mostly thin, 5-7.5 cm. long. (Meibomia Ktze.) - Upen woodlands, centr. Me. to Ont., Minn., and southw. Fig. 794.

13. D. paniculàtum (L.) DC. Essentially smooth throughcut; stem slender, tall; leaflets oblong-lanceolate,

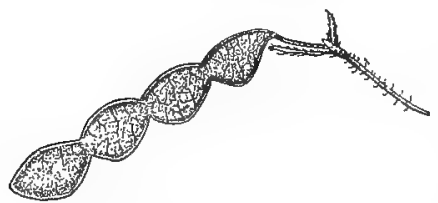

795. D. panjeulatum. tapering to a blunt point, thin, 7.5-12.5 cm. long; racemes much panicled. ( $\mathrm{Mei}$ bomia Ktze.) - Copses, s. w. Me. to Ont., Minn., and southw. EIG. 795.

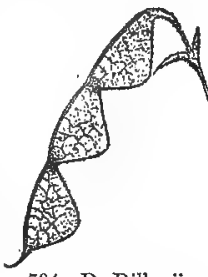

794. D. Dillenii.

Var. angustifolium T. \& G. Leaflets narrower, lance-linear. (Meibomia paniculata, var. Chapmani Britton.) - Va., Ky., and southw.

Var. pùbens T. \& G. Stem puberulent; leaves sparingly pubescent beneath. (Meibomia paniculata, var. Vaill.) - N. J. to Kan., and southw.

14. D. strictum (Pursh) DC. Stem very straight and slender, simple, 6-9 $\mathrm{dm}$. high, the upper part and narrow panicle roughglandular; leaflets linerr, blunt, strongly reticulated, thickish, very smooth, 2.5-5 cm. long, $6 \mathrm{~mm}$. wide; joints of the pod 1-3, semi-obovate or very gibbous, only $4 \mathrm{~mm}$. long. (Meibomia Ktze.) - Pine woods, N. J. to Fla. and La. FIG. 796 .

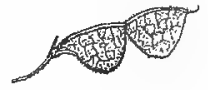

796. D. strictum.

* * Stipules small and inconspicuous, mostly deciduous; pods of few roundisl or obliquely oval or sometimes roundish-rhomboidal joints 3-5 $\mathrm{mm}$. long.

- Stems ercct; bracts before flnwering conspicuous; racemes densely flowered.

15. D. canadénse (L.) DC. Stem hairy, 5-15 dm. high; leaflets oblon! 


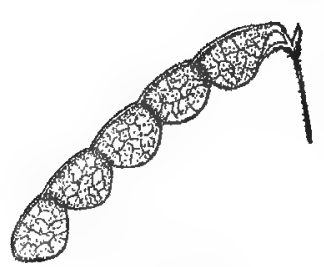

747. D. canadense.

lanceolate or ovate-lanceolate, obtuse, with numer. ous straightish veins, much longer than the petiole, 3.7-7.5 cin. long; flowers showy, larger than in any of our other species, 8-12 min. long. (Meibomia Ktze.) - Open woods and banks of streaws, N. B. to N. C., L. Winnipeg, Kan., and Ukla. Fis. 797.

16. D. sessilifolium (Torr.) $\mathrm{T}$. \& G. Stem pubescent, 6-12 dm. high; leaves nearly sessile; leaflets linear or linear-oblong, blunt, thickish, reticulated, rough above, downy beneath; branches of the panicle long; flowers small. (Meibomia Ktze.)-Sandy soil, s. e. Mass. to Pa.; and from $\mathrm{O}$. and Mich. to Ill., s. to Miss. and Tex.

- - Sterns ascending, 3-9 dm. high; bracts small; racemes or panicles elongated and loosely flovered; flowers small.

17. D. rigidum (Ell.) DC. Stem branching, somewhat hoary, like the lower surface of the leaves, with a close roughish pubescence; leaflets ovate-oblong, blunt, thickish, reticulated-veiny, rather rough above, the lateral ones longer than the petiole. (Meibomia Ktze.) - Dry hillsides, s. N. H. and e. Mass. to Fla., Mich., Neb., and La. Fig. 798.

18. D. obtùsum (Mubl.) DC. Stem slender, hciry or roughpubescent; leaves crowded, on very short hairy petioles; leaflets round-ovate or oval, thickish, more or less hairy on the margins and underneath, $1.2-2.5 \mathrm{~cm}$. long. (D. ciliare DC.; Meibomia obtusa Vail.) -Dry hills and sandy fields, Mass. to Fla., w. to 798. D. rigidum. ()nt, Mich., Mo., and Tex.

19. D. marilándicum (L.) DC. Nearly smooth throughout, slender; leaflets ovate or roundish, very obtuse, thin, the lateral ones about the length of the slender petiole; otherwise resembling the preceding. (Meibomia Ktze.) - Copses, Mass. to Fla., w. to Minn., Mo., and La.

\section{+ + + Stems reclining or prostrate; racemes loosely flowered.}

20. D. lineàtum (Michx.) DC. Stem minutely pubescent, striate-angled; leaflets orbicular, smonthish, 1-2.5 cm. long, much longer than the petiole; pod scarcely stalked in the caiyx.

799. D, linestum.

(Meibomia arenicola Vail.) - Dry soil, Md. and Va to Fla and La. : also (?) Erie Co., O. (Moseley). Frg. 799.

\section{LESPEdEza Michx. Bush Clover}

Calyx b-cleft; the lobes nearly equal, slender. Stamens diadelphous ( 9 and 1 ) ; anthers all alike. Pods of a single 1-seeded joint (sometimes 2-jointed, with the lower joint empty and stalk-like), oval or roundish, flat, reticulated. Herlos with pinnately 3 -foliolate leaves, not stipellate. Flowers often polygamous. in summer and autumn. (Dedicated to Lespedez, the Spanish governor of Florida in the time of Michaux.)

u. Stivules subulate-setaceous; bracts minute; calyx-lobes attenarto: perennials $b$.

b. Flowers of 2 kinds; the larger (violet-purple) perfect but seldom fruitful, racemose or pavicled; the smaller pistillate and fertile but mostly apetalous, in small sessile clusters or intermixed with the others $c$.

c. Petaliferous flowers 1-6, on elongate filiform peduncles, whioh are mostly 2-4 times as long as their subtending leaves.

Stems soft-downy with short spreading liairs .

Btems glubrate or sparingly appressed-pubescent.

Stems prostrate or tratling ; stipules mostly $2-4.5 \mathrm{mn}$. long Stems upright; stipiles inostly 5-8 min. long

c. Petallferons flowers few-many; peduncles stouter," some or all of

1. L. procumbens

2. L. repens.

8. L. wiolacea.

d. Mary of the pedunoles elongate and excesding thelr subtending leuves. 
Calyx 4-5 mm. long, much shortar than the pod.

Leaflets densely velvety beneath

Leaflets appressed-pubescent or sparingly villous beneath

Calyx $6-9 \mathrm{~mm}$. long, about equaling the pod

4. L. Brittonit.

5. L. Nuttallii.

b. L. Manniana.

$a$. Few if any of the peduncles exceeding the leares $\dot{e}$.

c. Calyx of the petaliferous tlowers $8-5 \mathrm{~mm}$, long, rarely half as long as the pod.

Leatlets densely woolly or velvety beneath

Losflets glabrate or appressed-pubescent beneath.

Leaflets linear to linear-oblong; petaliferous inflorescences mostly sessile or subsessile

Leeflets vval to oblong; petaliferous inflorescences often short-peduncled .

6. Calyx of the petaliferous flowers $6-8 \mathrm{~mm}$. long, two thirds as long as the pod.

b. Flower's all alike and perfect, in close splkes or heads; corolla whitish or cream-color, with a purple spot on the standard, about the length of the ealyx $f$.

f. Peduncles mostly shorter than the dense subglobose heads; Howers closely appressed-ascending.

Stem pubescent with long spreading or loosely ascending hairs, rarely glabirate; caly 8 8-12 min. long

Stem short-mbescent with chietly approssed hairs or glabrate; calyx $5-T$ min. long elongate, chietly equaling the cylindric or subcylindric

f. Poduncles

Spikes thick-cylindric, $1-1.5 \mathrm{~cm}$. thick.

Sterns with long epreading or loosely ascending pubescence: leaflets oblong to orbicular; flowers spreading or loosely ascending

Stems chiefly appressed-jubescent or glabrate; leaflets linear to linear-oblong; flowers appressed-ascending .

Bpikes slender-cylindric, 5-s mm. thick

v. Stipules and bracts broad and scarious; calyx-lobes broad; annual

12. L. eapitatn.

18. L. angustifolia.

11. L. horta.

18. I. angustifolia.

14. L. Leptostachya.

15. L. stricuta.

1. I. procúmbens Michx. Stem trailing, prostrate or nearly so, soft-downy with short spreading hairs; leaflets downy, oval or obovate-elliptical, 6-18 mm. tong; peduncles very slender, few-tlowered; keel equaling the wings ; pod small, roundish. - Dry sandy soil, chiefly near the coast, s. N. H. to Fla. and Tex.; inland in Miss. basin to Mo., Ill., and Ind. Fl. late Aug., Sept.

2. I. rèpens (L.) Bart. Like the preceding but more slender and glabrous or finely appressed-pubescent; stipules subrigid, mostly $2-4.5 \mathrm{~mm}$. long. Sandy or rocky soil, chiefly near the coast, Ct. to Fla, and 'Tex., inland' in

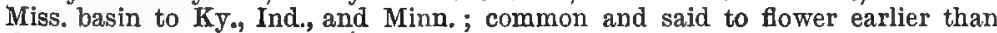
the preceding.

3. L. violàcea (L.) Pers. Stems upright or spreading, slender, branched, 2-7 dm. high, rather sparsely leafy and sparingly pubescent; stipules setaceous, mostly 5-8 mm. long; leaflets thin, broadly oval or oblong, finely appressedpubescent beneath, those of the stem-leaves mostly $2-5 \mathrm{~cm}$. long, $1.2-2.2 \mathrm{~cm}$. broud; peduncles very slender, loosely few-flowered, mostly longer than the leaves; petals 6-8 mm. long, the keel often the longest; pod, ovate, 4-6 mm. long, minutely strigose. - Dry copses, s. N. H. and Vt. to Minn., e. Kan., La., and Fla., chiefly at low altitudes. July-Sept. Var. PRAfrea Mackenzie \& Bush. Principal leaflets 1-2 cm. long, 0.5-1 cm. braad. (L. prairea Britton.) - Lry prairies, Mo. and Kan., southw.

4. L. Brittonii Bicknell. Densely cinereous-velvety or -tomentose; stems loosely ascending or arrhing, 6-13 dm. long; leaves mostly short-petioled, the thick oblong or lance-elliptic leaflets velvety beneath, cinereous-pilose or glabrate above, the principal ones $1.5-4 \mathrm{~cm}$. lnng; inflorescences numerous along the upper half of the stem or on short lateral branches; peduncles rarious, some shorter than the leaves, others elnngate; caly $4-5 \mathrm{~mm}$. long; corolla $6-8 \mathrm{~mm}$. Inng, pink and purple, the standard deeper purple at base; pod tomentose, sharply acnte or acuminate. - Dry soil, near the coast, e. Mass. to Md.; local and little known.

5. L. Nuttállii Dä̀l. Stems erect, stoutish, 6-12 dm. high, villous; leaves mostly long(1-3 cm.)-petioled, the oval leaflets glabrou's or glabrate abore, appressed-pubescent or sparingly villous beneath, the principal ones $2.5-4 \mathrm{~cm}$. long; peduncles of various lengths; calyx 4-5 mm. long, much shorter than the 
narrowly oval strigose pod.-Dry rocky woods, s. N. H. to Mich., s to N. C. and $\mathrm{Ky}$.

6. L. Manniàna Mackenzie \& Bush. Erect or ascending, rather slender stems appressed-pubescent or slightly pilose; leaves mostly sliort (0.5-1.5 cm.)-petioled, the linear-oblong to narrowly elliptic thick leaflets strigose-pubescent beneath; peduncles various, many of them elongate; calyx 6-9 mm. long, about equaling the corolla and the strigose pod. - Barrens and dry open woods, Mich. to Kan. and Ark.

7. I. Stùvei Nutt. Stem upright-spreading, 3-12 dm. high, very leafy, downy with spreading pubescence, simple or with few densely flowered wandlike branches; leaves crowded, short-petioled; the elliptical firm leaflets woolly or velvety beneath and sometimes above, mostly $1-2.5 \mathrm{~cm}$. long; pedancles all short, the crowded racemes appearing sessile or subsessile; calyx $3-5 \mathrm{~mm}$. long, much shorter than the villous-canescent pod. - Dry soil, e. Mass. and s. Vt. to Mich., and southw. Var. Neglécta Britton. Leaflets linear or linear-oblong. - N. J. to $\mathrm{M}$., and southw.

8. L. virgínica (L.) Britton. Stems upright, 3-11 dm. high, wand-like or with few erect branches, minutely appressed-pubescent or glabrate; leaves very crowded; the principal cauline ones with slender rather long petioles, their thickish linear or linear-oblong leafiets 1.5-4 cm. long, 3-7 mm. broad, finely appressed-pubescent; flowers on very crowded short peduncles; keel shorter than the standard; calyx $3-5 \mathrm{~mm}$. long, shorter than the strigose pod. ( $L$. reticulata Pers.) - Barrens and dry open woods, s. N. H. to Fla.; and from s. Ont. to Kan., La., and Tex.

9. L. frutéscens (L.) Britton. Stems erect, slender, 1.5-7 dm. high, slightly appressed-pubescent or glabrrte; leaves mostly with slender long (1.5-3 cm.) petioles; the oval to oblong firm leaflets finely appressed-pubescent or glabrate, those of the cauline leaves $1.5-4 \mathrm{~cm}$. long; peduncles of various lengths, mostly very short, a few sometimes nearly equaling the leaves; calyx $3-5 \mathrm{~mm}$. long, much shorter than the strigillose pod. (L. Stuvei, var. intermedia Wats.) Open rocky woods, etc., s. Me. to Minn., and southw.

I. ACUTICA RPA Mackenzie.\& Bush, described from Mo. and Ark., but unknown to us, seems from its description to resemble no. 9, but to have more elongate peduncles.

10. L. simulàta Mackenzie \& Bush. Stems erect, with few upright branches, rather stout, 3-9 dm. high, short-pubescent or glabrate; leaves short-petioled, the linear-oblong to elliptic firm leaflets appressed-pübescent, often silvery, those of the cauline leaves $1.5-4 \mathrm{~cm}$. long; petaliferous flowers in subcapitate sessile. or short-peduncled clusters; calyx 6-8 $\mathrm{mm}$. long, nearly equaling the corolla and the strongly pubescent pod. - Dry open woods and plains, Ct. to O., Mo., and southw. - Resembling no. 12.

11. L. hírta (L.) Hornem. Stem with mostly spreading pubescence; petioles 4-12 mm. long; leaflets from orbicular to oblong-ovate, hairy; spikes thickcylindric, on elongated peduncles; pod (at maturity) oblong-ovate, pubescent, nearly $6 \mathrm{~mm}$. long, hardly shorter than the calyx. (L. polystachya Michx.) Dry hills and plains, s. Me. to Ont., Minn., and southw. Var. oblongifólia Britton. Leaflets narrowly obiong.--Pine barrens, N. J. to Fla.

12. L. capitàta Michx. Stems rigid, tomentose (rarely glabrous or glabrate), 0.6-1.2 m. high ; petioles very short; leaflets oblong to narrowly elliptical, thickish, reticulated and smooth or silky above, silky beneath; heads of flowers globular, on peduncles shorter than the leaves; pod oblony-ovate, pubescent, much shorter than the calyx. - Dry and sandy soil, N. E. to Fla., w. to Minn., Neb., and La. l'assing gradually to

Var. velùtina (Bicknell) Fernald. Stems and both faces of the leaves velvety. with short dull ashy tomentum. (L. velutina Bicknell ; L. Bicknellii House.)N. H. to N. J.

Var. longifolia (DC.) T. \& G. Leaflets narrower, lance-oblong to linear, acute, glabrous above. - Ill. and Mo. to Ky. and La.

13. L. angustifdlia (Pursh) Ell. Like the last, but mostly appressed-bilky , leaflets linear; the snaller often short-cylindric heads on distinct and sometimes 
slender peduncles; the pod round-ovate, acutish, $3-1 \mathrm{~mm}$. long, hardly shorter than the calyx. - Sandy barrens, e. Mass. to Fla. and La.

14. L. leptostàchya Engelm. Clothed with appressed silky pubescence; stems often branched, slender; leaflets linear to narrowly oblong; spikes slender, somewhat loosely flowered, on peduncles as long as the leaves; pod ovate, swall (3 mm. long), about equaling the calyx, densely pubescent. - Ill., Wisc., Minn., and Ia.

15. L. striata (Thunb.) H. \& A. Diffuscty branched decumbent subpubescent annual; petioles very short; leaflets oblong-obovate, $1.2 \mathrm{~cm}$. long or less ; peduncles very short, 1-b-flowered; pod small, little exceeding the calyx. Roadsides and open soil, D. C. to Mo., and southw. (Nat. from e. Asia.)

\section{STYLOSÁNTHES Sw.}

Calyx early deciduous ; tube slender and stalk-like ; limb unequally 4-5-cleft, the lower love more distinct. Corulla and monadelphous stamens inserted at the summit of the calyx-tube; standard orbicular; keel incurved. Anthers 10, in two series. Style filiform, its upper part deciduous, the lower incurved or hooked, persistent on the 1-2-jointed short reticulated pod; the lower joint when present empty and stalk-like. - Low perennials, branched from the base, with wiry stems, pinnately 3-foliolate leaves, and small yellow flowers in terminal heads or short spikes. (Name composed of $\sigma \tau \bar{v} \lambda$ os, a column, aud ${ }^{2} \nu \theta 0$, a flower, from the stalk-like calyx-tube.)

1. S. biflora (L.) B S P. Erect or spreading, pubescent and tawny-setose about the few-flowered heads; leaflets narrovoly lanceolate, mostly acute at hoth ends; uppermost floral bracts entire; style not quite apical on the fruit. (S. elation $\mathrm{SW}$. ) - Pine barrens and dry soil, near the coast, L. I. and N. J. to Fla. and Tex. ; northw. in Miss. basin to Kan., Mo., Ill., and Ind. June-Aug.

Var. hispidíssima (Michx.) Pollard \& Ball. Stems covered with tawny tetose pubescence. (S. elatior, var. T. \& G.) - Va., Okla., and southw.

2. S. riparia Kearney. More slender and decumbent, scarcely setose; stems tomentulose in lines; leaflets oval or elliptical, obtuse, mucronulate; uppermost bracts cleft; terminal joint of the loment symmetrical. - Del. to Ala. July, Aug.

\section{ZÓRNIA Gmel.}

Calyx bilabiate, 5-toothed, the tube not elongated. Corolla yellow. Stamens monadelphous. Ovary sessile. - Prostrate wiry-stemmed.perennials with long tough root. (Named presumably for Johann Zorn, a German apothecary of the 18 th century.)

1. Z. bracteàta (Walt.) Gmel. Leaves 4-foliolate. 一 Sandy fields, s. e. Va. (Heller), and southw. (Mex.)

\section{Vifcla [Tourn.] L. Vetch. Tare}

Calyx 5-cleft or 5-toothed, the 2 upper teeth often shorter, or the lowest longer. Wings of the corolla adhering to the middle of the keel. Stamens more or less diadelphous ( 9 and 1 ) ; the orifice of the tube oblique. Style filiform, hairy all round or only on the back at the apex. Pod flat, 2-valved, 2-severalseeded. Seeds globular. Cotyledons very thick, remaining under ground in germination. - Herbs, mostly climbing more or less by the tendril at the end of the pinnate leaves. Stipules half-sagittate. Flowers or peduncles axillary. (The classical Latin name.)

Peduncle very short or wanting ; flowers few, 1-3 cm. long.

Annuals; calyx-teeth neerly equaling the tube.

Flower $2-3 \mathrm{~cm}$. long .

Flower $1-1.8 \mathrm{~cm}$. long.

Perennial; calyx-teeth much shorter than the tube

1. T. sativa.

2. V. angustifolia.

3. V. sepium. 
Peduncle well developed. Flowers 1-6, tiny (2-4 mm. long); seeds $2-4$; snnuals.
Pods glabrous, 4-seeded

Pods hairy, 2-seeded
Flowers ustally more numerous, larger; perennlals except no. 10. Smooth or merely appressed-pubescent perennials.

Flowers b-12 un. long.

Flower's $2-8$; seeds $4-6$

Flowers more numerous; seeds 6-12.

Flowers 1-1.2 cm. Jong, blue and purple.

Flowers barely $1 \mathrm{~cm}$. long, white, the keel tipped with blne :

Flower's 1.5-1.8 oin. long .

Villous annual or biennial

1. V. sativa L. (Spring V.) Annual (or winter-annual), pubescent, becoming glabrate; the stein simple or branched at base; leaves essentially uniform; leatlets 4- 8 pairs, oblong to oblong-obovate, truncate to emarginate and mucronate at apex, 1.5-3 cm. long, 5-13 mm. bruad; flowers chietly in twos in the upper axils, 2-3 cm. long, showy, purple and rose-color; calyx $1-1.5 \mathrm{~cm}$. long; pod pubescent when young, torulose, $4-8 \mathrm{~cm}$. long, 7-8 mm. wide. - Cultivated for forage in eastern Canada and occasionally elsewhere, and sometimes persisting or spreading to waste ground. July, Aug. (Introd. from Eurasia.)

2. V. ANGUSTIFolia (L.) Reichard. (Common V.) Similar, glabrous or glabrate; leaflets 2-5 (rarely 6) pairs, those of the lower leaves oblong and truncate, of the upper linear-to lance-attenuate, inucronate, $1.5-3 \mathrm{~cm}$. long, $1-4 \mathrm{~mm}$. broad; flowers smaller (1-1.8 cm. long); calyx 7-11 mn. long; pol 4-5.5 cm. long, 5-7 in m. wide, less tormlose. - Gravelly waste places, chiefly eastw. MaySept. (Nat. from Eu.) Var. sEGETALIs (Thuillier) Koch. Leaflets of the upper leaves truncate or emarginate and wucronate at apex, oblong to oblong-obovate, 2-8 mm. bruad. (V. sativa Man. ed. 6, not L.) - Roadsides, waste places, etc., cominon. (Nat. from Eu.)

3. V. sì PIUM L. Perennial; leaflets 5-8 pairs, elliptic-ovate ; flowers 3-4, in subsessile racemes; pod oblong, obliquely acuminate, many-seeded. - Locally in fielus and waste places, Me. to Ont. June, July. (Nat. from Eu.)

4. V. Tetraspérma (L.) Moench. Peduncles 1-2-fowered; leaflets 4-6 pairs, linear-oblong, obtuse; caly $x$-teeth unequal ; corolla bluish ; pods narrov, 4-seeded, smooth. - Waste places, 七. Que, to Unt., Fla., and Miss. May-Sept. (Nat. from Eu.)

5. V. HIRsúta (L.) S. F. Gray. Peduncles 3-6-flowered; leaflets 6-8 pairs, truncate; caly x-teeth equal ; corclla whitish; pods oblong, 2-seeded, hairy. Waste places, e. Que. to Ont. and Ga. May-Aug. (Nat. from Eu.)

6. V. ludoviciana Nutt. Peduncles $\frac{2}{3}-1 \frac{1}{2}$ times as long as the leaves, 2-8flowered; leaflets 7-11, elliptical to oblong; flowers 6-8 $\mathrm{mm}$. long, blue or purple. -Greene Co., Mo. (Blankinship), and southw. Apr., May.

V7. V. Crácca L. Appressed-pubescent; leafiets 8-24, obiong-lanceolate, strongly mucronate; racemes densely many-flowered, 1-sided; flowers blue, turning purple (rarely white), 1-1.2 cm. long, reflexed; caly x-teeth shorter than the tube. - Borders of thickets or in fields, Nfd, to N. J., w. to Ky., Ia., and Minn. June-Aug. (Eu.)

8. V. caroliniana Walt. Tearly smooth; leaflets 8-24, oblong, obtuse, scarcely mucronate; peduncles hosely flowered; flowers small, more scattered than in the preceding, whitish, the keel tipped with blue; calyz-teeth very short. - River-banks, Ont, to Ga., Minn., and Kan. Apr.-June.

9. V. americàna Muhl. Glabrous; leafets 10-14, elliptical or ovate-oblong, very obtuse, many-veined; peduncles 4-8-fovered; fowers purplish $(1.5-1.8 \mathrm{~cm}$. long). - Moist soil, N. Y. to Va., Minn., Kan., and westw. May, June. Var. Truncata (Nutt.) Brewer. Leaflets conspicuously truncate. - Reported from e. K’ın. Var. Angustifóla Nees. Leaflets linear. (Var. linearis Wats.) Minu., westw, and southw.

10. V. villósa Roth. (Hairy or Winter V.) Resembling $\boldsymbol{V}$. Cracca, but "nnual or biennial; the stems, peduncles, and leaves villous; the violet and white flowers larger. - Frequentily planted for fodder, and inclined to persist or uscape into dry open soil. May-Sopt. (Introd. from Eurasia.) 


\section{4s. IAthyrus [Tourn.] L. Vetchling. Everlasting Pea}

Style dilated and flattish (not grooved) above, hairy along the inner side (next the free stamen). Sheath of the filaments scarcely oblique at the apex. Otherwise nearly as in Vicia. - Our species perennial and mostly smooth plants ( $\Lambda$ átupos, a leguminuus plant of 'l'heophrastus.)

Stipules broadly ovate, regularly balberd-shaped .

Btipules semi-cordate, semi-sagiltate, or with unequal sides.

Flowers purple or purplish to pink or white.

Leatets $4-12$

Principal leaves with 4-8 leaflets; flowers 2-8 . . . . . . 2. L. palustris

Principal leaves with -12 leaflets ; flowers $10-25$ (rarely as few as 6 ) * 3. L. venosus.

Leaftets 2

Stems and petioles winged.

Stems and petioles slender and wingless - . - . . 5. L. latifolius.

Flowers yellow or yellowish.

Leatlets 4-6; flowers yellowish-white - . . . . . . . 4. L. ochroleucus.

Leatlets 2 ; flowers bright yellow

1. L. maritimus (L.) Bigel. (Веach Pea.) Stout, trailing or climbing, 0.3$1 \mathrm{~m}$. high; stipules nearly as large as the leaflets, the lower lobe larger and usually coarsely toothed; leaflets mostly $6-10$, thick, ovate-oblong, $2-6 \mathrm{~cm}$. long; peduncles a little shorter than the leaves, 6-10-flowered f flowers large (1.8-2.5 em. long), purple. - Seashores from N.J. and Ure. to the Aretic Sea; also on Oneida L., N. Y., and the Great Lakes. June-Sept. (Lurasia.)

2. L. painstris L. Slender, glabrous, the usually winged stems $0.5-1 \mathrm{~m}$. high ; stipules obliquely lanceolate to ovate, sharp-pointed at both ends; leaflets 3-4 (rarely 5) pairs, mostly 3.5-7 cm. long, lanceolate to elliptic, rather firm ; peduncles 3-5(rorely 8)-Howered; flowers purple, 1.6-2.5 cm. long. - Banks of rivers and lakes, Que. to Alaska, s. to Me., Vt., w. N. Y., and the Great L. region. June-Aug. (Eurasia.) Var. PILosus (Cham.) Ledeb. Lower surface of leaves, peduncles, calyces, etc., pubescent. (L. myrtifolius, var. macranthus T. G. White.) - Nfd. and e. Que. to e. Me. (E. Asia.)

Var. linearifòlius Ser. Stems winged, 2-7 cm. high; leaflets $2-3$ (rarely 4) pairs, linear to lanceolate, firm; peduncles 2-5-flowered; flowers 1.4-1.7 cm. long. - Meadows (often brackish), shores, and open woods, Nfd. to Alaska, s. to R. I., w. N. Y., and Minn.

Var. myrtifolius (Muhl.) Gray. Stems very slender, wingless, $0.3-1 \mathrm{~m}$. high ; stipules sometimes broader; leaflets 2-3 pairs, elliptical, thinner, mostly 2$4 \mathrm{~cm}$. long; peduncles 3-9-flowered; flowers 1-1.5 cm. long. (L. myrtifolius Muhl.) - By lakes and streams, w. Que. to Man., s. to N. C. and Tenn.

3. L. venosus Muhl. Stout, climbing, usually somewhat downy ; stipules very small and mostly slender; leaflets 4-6 pairs, oblong-ovate, mostly obtuse, about $5 \mathrm{~cm}$. long; peduncles many-flowered; flowers $1.2-1.6 \mathrm{~cm}$. long. - Shady banks, N. J. and Pa. to the Sask., and southw. May-July.

4. L. ochroleùcus Hook. Stem slender, $3-9 \mathrm{dm}$. high; stipules semicordate, half as large as the thin ovate leaflets; peduncles 7-10-flowered; flowers 1.5-1.8 $\mathrm{cm}$. long, yellowish-white. - Hillsides, w. Que. to Sask., s. to N. J., Pa., Great L. region, Ia., S. Dak., and Wyo. May-July.

5. L. iatifolius L. (Everlasting or Perennial Pea.) Tall perennial with broally winged stems; leaves and stipules coriaceous and veiny; petioles mostly winged; the 2 elliptic to lanceolate leaflets $0.5-1 \mathrm{dm}$. long; peduncles stiff, many-fliwered; flowers showy, pink, purple, or white. - Frequently cultivated, and escaping to roadsides and thickets, Ct. to D. C. (Iutrod. from Eu.)

6. L. TUBERosus L. Slender perennial; the rootstncks bearing ntumerous tubers; stems glabrous; leaves and stipules thin; petioles and tendrils filform; the 2 oblong leaflets $2-3.5 \mathrm{~cm}$. long; peduncles filiform, 3-6-flowered; the fragrant violet flowers about $1.5 \mathrm{~cm}$. long. - Fields and meadows, locally established in Vt. and Ont. June-Aug. (Introd. from Eurasia.)

7. L. PRATÉssis L. Low and straggling; the 2 bright green leaflets narrowly 
laneeoiate to linear, acute; peduncles 4-8-flowered; the yellow flowers 1.5-2 cm. long. - Fields and waste places, local, N. B. to N. Y. and Unt. June-Aug. (Nat. from Eu.)

\section{4. Ápios [Boerh.] Ludwig. Groundnut. Wild Bean}

Calyx somewhat 2-lipped, the 2 lateral teeth being nearly obsolete, the upper very short, the lower one longest. Standard very broad, retlexed; the long scythe-shaped keel strongly incurved, at length coiled. Stamens diadelphous. Pod straight or slightly curved, linear, elongated, thickish, roany-seeded. Perennials, twining and climbing over bushes; the rootstocks with tuberous enlargements. Leaflets 3-9, ovate-lanceolate, obscurely stipellate. Flowers in dense and short often branching racemes. (Name from $\alpha \pi \omega v$, a pair, from the shape of the tubers.)

1. A. tuberdsa Moench. Rootstocks moniliform, the tuberous enlargements numerous; flowers brown-purple, violet-scented; standard unappendaged at the summit. (A. Apios MroM.) - Thickets, N. B. to Fla., Minn., Kan., and La. July-Sept.

2. A. Priceàna Robinson. Tuber solitary, very large; flowers pale rosecolor; standard bearing a fleshy knob at the apex. - Woods and thickets, Warren Co., Ky. (Miss S. F. Price). July-Sept.

\section{PHasèolus [Tourn.] L. KIDney Bean}

Calyx 5-toothed or 5-cleft, the two upper teeth often shallower. Stameds diadelphous. Stigma oblique or lateral. Pod scythe-shaped, several-many, seeded, tipped with the hardened base of the style. Cotyledons thick and fleshy, rising out of the ground nearly unchanged in germination. - Twining herbs, with pinnately 3 -foliolate stipellate leaves. Flowers racemose, produced in summer and autumn. (The ancient name of the Kidney Bean.)

1. P. polystàchyus (L.) BSP. (WILD BEAN.) Perennial; leaflets roundish-ovate, short-pointed ; flowers purple, handsome, but small ; pods drooping, 4-5-seeded. ( $P$. perennis Walt.) - Copses, chiefly near the coast, Ct. to Fla. and La.; northw. in Miss. basin to Mo., Ill, and Ind.; reported northw. to Minn. and Neb. July-Sept.

\section{VIGNA Savi}

Habit and floral characters nearly as in Phaseolus, but the keel merely arcuate not spirally colled at the tip. - Twining herbs, with pinnately 3 -foliolate leaves. (Dedicated to Dominico Vigna, Italian scientist of the 17th century.)

1. V. sinḱnsis (L.) Endl. (Cow PEA.) Anıhual; leaflets broadly ovate. often very oblique or sometimes slightly contracted above an obtusely hastate base ; flowers few, loosely subcapitate at the end of the long stiffish peduncle; pods 1-2 dm. long. ( $V$. Catjang Valp.) - Cultivated, and tending to escape, Mo. (Bush), s. to the Gulf. (Introd. from Asia.)

\section{STROPHOSTỲLES Ell.}

Keel of the corolla with the included stamens and style elongated, strongly incurved, not spirally coiled. Pod linear, terete or flattish, straight or nearly so. Seeds quadrate or oblong with truncate ends, mealy-pubescent or glabrate; hilum linear. Otherwise as Phaseolus. - Stems prostrate or climhing, more or less retrorsely hairy. Stipules and bracts striate. (Name from $\sigma \tau \rho \circ \phi \eta$, a turning, and orv̂̀os, a style.)

1. S. hélvola (L.) Britton. Annual; stems branched, 0.3-2 m. long; leaflets ovate to oblong-ovate (rarely linear-oblong), with a more or less prominent rounded lobe toward the base (the terminal 2-lobed), or some or all often entire, 
$1.2-4 \mathrm{~cm}$. long; corolla greenish-white and purplish; pod terete, $5-7.5 \mathrm{~cm}$. wide, 4-8-seeded, nearly glabrous; seeds oblong, about $6 \mathrm{~mm}$. long, usually very pubescent. (S. angulosa Ell.) - Sandy shores and river-banks, coast of Mass. and sonthw, along the Great Lakes to Minn., and s. to Kan. and 'Tex. June-Sept.

Var. missouriénsis (Wats.) Britton. Climbing high (3-10 m.) ; leaflets ofter $8 \mathrm{~cm}$. long, rhombic-ovate, rarely at all lobed; seeds $6-8 \mathrm{~mm}$. long. - River bottoms, D. C., Ill., Mo., and Kan. Flowering somewhat later.

2. S. umbellàta (Muhl.) Britton. Stems more slender, 6-12 dm. long, from a perennial rootstock; leatlets ovate to oblong-linear, rarely at all lobed, 2.5 cm. long or less; pod $3.5-5 \mathrm{~cm}$. long, scarcely $4 \mathrm{~mm}$. wide; seeds much smaller, short-oblong to quadrate. ( $S$. peduncularis Ell.) - Damp sandy ground, L. I. to Fla. and Tex.; northw. in Miss. basin to s. Ind. Sept., Oct.

3. S. pauciflora (Benth.) Wats. Annual, slender, low-climbing, pubescent; leaflets oblong-lanceolate or ovate-oblong to linear, not I $8 \mathrm{bed}, 2.5 \mathrm{~cm}$. long; pod pubescent, 2-3 cin. long, flattish; seeds as in the last, very finely mealy, soon glabrate. - River-banks, Ind. to Minn., Kan., Tex, and Miss. July, Aug.

\section{Clitdria L. Butterfly Pea}

Standard much larger than the rest of the flower, erect, rounded, notched at the top, not spurred on the back; keel small, shorter than the wings, incurved, acute. Stamens monadelphous below. Pod linear-oblong, fiattish, knotty, several-seeded, pointed with the base of the style. - Erect or twining perennials, with mostly pinnate 3 -foliolate stipellate leaves, and very large flowers. Peduncles 1-3-flowered; bractlets opposite, striate. (Derivation recondite.)

1. C. mariàna L. Low, ascending or twining, smooth; leaflets oblong-ovate or ovate-lanceolate; stipules and bracts awl-shaped ; peduncles short ; the showy pale blue flowers $5 \mathrm{~cm}$. long. - Dry banks, N. J. to Fla. and Tex., northw. in Miss. basin to Ill. and Mo. June-Aug.

\section{Centrosèma (DC.) Benth.}

Corolla, etc., much as in Clitoria, but the spreading standard with a spurshaped projection on the back near the base; keel broad. Pod long and linear, flat, pointed with the awl-shaped style, many-seeded, thickened at the edges, the valves marked with a raised line on each side next the margin. - Iwining perennials, with 3-foliolate stipellate leaves, and large showy flowers. (Name

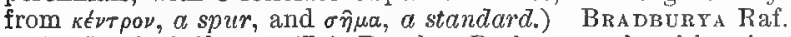

1. C. virginiànum (L.) Benth. Rather rough with minute hairs: leaflets varying from oblong-ovate to lanceolate and linear, very veiny, shining; peduncles 1-4-flowered; calyx-teeth linear-awl-shaped; corolla riolet, $2.5 \mathrm{~cm}$. long; pods straight, 1-1.2 dm. long. - Sandy woods, "N. J." and Md. to Fla., Ark., and Tex. July, Aug.

\section{Dólichos L.}

Calyx bell-shaped, with deltoid teeth, the upper pair united nearly or quite to the apex. Standard orbicular, with incurved auricles at base. Flowers fasciculate-racemose. Pods linear and falcate, or oblong-lunate, compressed ; seeds several. (The Greek $\delta \circ \lambda_{\iota} \chi \delta s$, long, a word also employed by Theophrastus as the name of some kind of pulse.)

1. D. LABlab L. (Hyacinte BeAx.) Stoutish twining annual, 3-6 m. in length; leaflets large, deltoid-ovate; flowers purple; pods $2 \mathrm{~cm}$. broad. - Often cultivated for ornament and in tropical countries for its seeds ; tending to escape, D. C. to $O$. (Introd. from India.)

\section{1. amphicárpa Ell. Hog Peantt}

Flowers of 2 (or 3 ) kinds; those of the racemes from the upper branches perfect; those near the base and on fliform creeping branches with the corolla 
none or rudimentary, and few free stamens, but fruitful ; reduced flowers of slightly different form sometimes also on aërial racemes. Caly $\mathrm{x}$ about equally 4 (rarely 5)-toothed. Stamens diadelphous. Pods of the upper flowers, when formed, sormewhat scimiter-shaped, stipitate, 3-4-seeded; of the lower ones commonly subterranean and fleshy, obovate or pear-shaped, ripening usually but one large seed. - Low and slender perennials; the twining stems clothed with brownish hairs. Leaves pinnately 3 -foliolate; leaflets rhombic-ovate, stipellate. Petals purplish. Bracts persistent, round, partly clasping, striate, as well as the stipules. (Name from $\dot{a} \mu \phi l, b o t h$, and $k a \rho \pi \delta s$, fruit, in allusion to the two kinds of pods.) Falcata Gmel.

1. A. monoica (L.) Ell. Leaflets thin, $1.3-5 \mathrm{~cm}$. long; racemes nodding; calyx of the upper flowers $4 \mathrm{~mm}$. long; the ovary glabrous except the mostly appressed hairy margin, pod $2.5 \mathrm{~cm}$. Iong; ovary and pod of the rudimentary flowers hairy. (Falcata comosa Am. auth.; Glycine comosa L. ?) - Rich damp woodlands, common. Aug., Sept.

2. A. Pitchèri T. \& G. Leaflets usually $5-10 \mathrm{~cm}$. long; rhachis of the racemes usually villous; caly $x$ mm. long, the teeth acuminate; pod sometimes hairy on the valves, the margins retrorse-hispid. (Falcata Ktze.) - Rich woods and thickets, near the coast, Mass. to D. C. ; and from w. N. Y. to S. Dak., s. to La. and Tex. July-Sept.

\section{Galáctia P. Br. Milk Pea}

Keel scarcely incurved. Stamens diadelphous or nearly so. Pods linear, flat, several-seeded (a few of them rarely subterranean and fleshy or deformed). Low mostly prostrate or twining perennial herbs. Leaflets usually 3 , stipellate. Flowers in somewhat interrupted or knotty racemes, purplish; in summer.

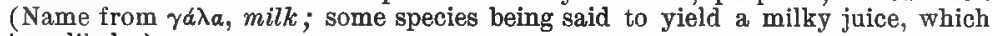
is unlikely.)

1. G. regulàris (L.) BSP. Stems nearty smooth, prostrate; leaflets elliptical or ovate-oblong, sometimes slightly hairy beneath ; racemes short, 4-8-flowered; pods somewhat hairy. (G. glabella Michx.) - Sandy woods, near the coast, s. N. Y. to Fla. and Miss.; locally northw. in Miss. basin to Kan. July, Aug.

2. G. volùbilis (L.) Britton. Stems decumbent and somewhat twining, hoary-pubescent; leaves glabrous above, soft-downy and hoary beneath; leaflets oval; racemes many-flowered; pods very downy. (G. pilosa Ell.) - Dry soil, near the coast, L. I. to Fla. and Tex. Var. Mississippiensis Vail. Leaves pubescent above. - Miss. basin, from Mo. southw.

\section{RHYNCHÓSIA Lour.}

Stamens diadelphous. Ovules only 2. Pod 1-2-seeded, flat, 2-valved.Perennial herbs, with leaves pinnately 3 -foliolate, or with a single leaflet, nor stipellate. Flowers yellow, racemose or clustered. (Name from $\dot{\rho} v$ ' $\chi \circ s, a$ beak, from the shape of the keel.)

\section{* Stem elongated, trailing or twining; leaflets 3 .}

1. R. tomentosa (L.) H. \& A. Trailing and twining; the stem and leaves more or less pubescent with spreading hairs, leaflets 3 , roundish or round-rhombic, acute or acutish ; racemes short, few-flowered, almost sessile; calyx 8-10 mm. long, about equaling the corolla, 4-parted, the upper lobe 2-cleft; pod oblong. - Dry soil, Va. to Fla. and Tex.

2. R. latifdlia Nutt. Soft-pubescent; leaflets large, ovate, rounded at the base; racemes long, many-flowered, equaling or usually exceeding the leaves; calyx-lobes lance-linear, 1.1 -1.3 cm. long, equaling the corolla. - Mo. (Bush) to La. and Tex.

$$
\text { * Erect; stem shorter. }
$$

3. R. erécta (Walt.) DC. Stem (3-6 dm. high) and leaves more or less $t$ mentose; leaflets 3 , oval to oblong, obtuse or acutish; racemes short and shortly pedunculate. - Dry soil, Del. to Fla. and Miss. 
4. R. simplicifdlia (Walt.) Wood. Dwavf (1-2 dm. hig ${ }_{\nu}$; pubescence spreading; leaflets solitary (rarely 3), round-reniform, very obtuse or apiculate ; racemes few-flowered, sessile in the axils. (R. veniformis DC.) - Va. to Fla. and Miss.

\section{LINACEAE (Flax Family)}

Herbs (rarely shrubs) with the regular and symmetrical hypogynous flowers 4-6-merous throughout, strongly imbricated calyx and convolute petals, 5 stc-. mens monadelphous at base, and an 8-10-seeded pod having twice as many cells as there are styles.

1. Linum. Flowers 5-merous,

2. Millegrana. Flowers 4-merous.

\section{LiNum [Tourn.] L. Flax}

Sepals (persistent), petals, stamens, and styles 5 , regularly alternate with each other. Pod of 5 united carpels (into which it splits in dehiscence), 5-celled, with 2 seeds hanging from the summit of each cell, which is partly or completely divided into two by a false partition projecting from the back of the carpel, the pod thus becoming 10-celled. Seeds anatropous, mucilaginous, flat,tened, containing a large embryo with plano-convex cotyledons. - Herbs, with tough fibrous cortex, simple and sessile entire leaves, without stipules, but often with glands in their place, and with corymbose or panicled flowers. Corolla usually ephemeral. (The classical name of the Flax.)

Petals blue, large ( $1 \mathrm{~cm}$. or more in length); capsule 10-12 $\mathrm{mm}$. in diameter.

Annuals; stigmas elongated.

False septa of the eapsule not ciliate . . . . . . 1. L, usitatissimum.

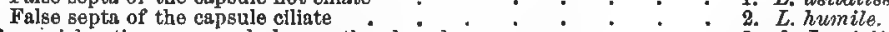

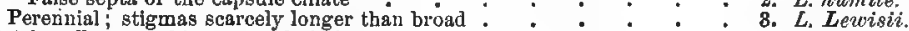

Petals yellow or white; capsule $8-6 \mathrm{~mm}$. in diameter.

Petals more than $1 \mathrm{~cm}$. long; western

Petals 4-8 $\mathrm{mm}$. Iong.

False septa very incomplete, conspicuously ciliate.

Petals white; leares chiefly opposite; fruiting pedicels $4-10 \mathrm{~mm}$.

long Petals yellow ; leaves chiefly alterinate; pedicels $1-3 \mathrm{~mm}$ iong : :

False septs nearly complete, not ciliate.

Stem-leaves chietly opposite; branches striate-angulate

Stem-leaves chlefly alternate; branches subterete.

Capsule depressed-globose.

Lespes oblong or lance-oblong, deep green: flowering branches

flilform, floxuous, ascending-spreading
Leaves narrowly lanceolate, dull or pale green; flowering branches slightly rigid and fastigiate

Capsule globose-ovoid

4. L. rigidum.

5. L. catharticum.

6. L. sulcatum.

7. L. striatum.

8. L. virginianum.

9. L. medium.

10. L. flovidanum.

1. L. usitatissimom L. (Common F.) Erect annual; stem 3-5 dm. high, corymbosely branched at top; sepals acute, ciliate; fruit nearly indehiscent, its septa not ciliate. - Occasionally spontaneous in fields and on roadsides. (Introd. from Eu.)

2. L. HƯmiLe Mill. Similar but of lower growth; capsule dehiscent, its septa ciliate. - Similar situations. (Introd. from Eu.)

3. L. Lewisii Pursh. Perennial, glabrous and glaucous, 3-9 dm. high; leaves liciear, acute; flowers rather few on long pedunoles; sepals obtuse or acutish, not glandular-serrulate; styles distinct; pod ovoid. - Plains, Wisc. to Tex. and Alaska.

4. L. rígidum Pursh. Glaucous, sometimes slightly puberulent, often low and cespitose, the rigid branches angled; leaves narrow, erect, usually with stipular glands; flowers large; sepals lanceolate, glandular-serrulate; styles united; capsule ovoid, 5-valved. - Dry soil, Sask. and Minn. to Kan., and southwestw. (Mex.) 
5. L. СатнА́ втісом L. Delicate annual, 1-2 dm. high, corymbosely branched ; ieaves small (3-8) mm. long), elliptic-oblanceolate, obtuse. — Old fields, etc., N. S. and Ont. (Adv. from Eu.)

6. L. sulcàtum Middell. Annual; branchlets grooved; leaves linear or subulate, commonly with dark glands in the place of stipules; sepals ovatelanceolate, conspicuonsly pointed, glandular-ciliate. - Dry or sandy soil, e. Mass, and Vt. to Man., and southwestw.

7. L. striàtum Walt. Erect from a slightly decumbent base; flowers small, somewhat crowded on the stiffish spreading-ascending angulate branches. - Wet woods, sandy shores, etc., Mass. to Ga., Mo., and Tex. - The fruiting plant has much the habit of Lechea.

8. L. virginiànum L. Tall, 3-5 dm. high; stem and branches subterete; lerves thin, deep green, elliptic-lanceolate or narrowly oblong, the lower spatu. late and often opposite, chiefly spreading-ascending; fiowers scattered on a few often sulusimple brauches; sepals ovate, short-pointed, nearly or quite entire; capsule depressed-globose. - Dry woods and barrens, s. Me. to Ga., Ky., and s. Ont.

9. L. mèdium (Planch.) Britton. Leaves of firm texture, acute, erect or ascending; pedicels short (1-7 $\mathrm{mm}$. long); the inner sepals commonly erose or somewhat glandular-ciliolate; capsule depressed-globose. - Dry or sandy soil, Vt. to Ont, and Mich., southw. and southwestw.

10. L. floridànum (Planch.) Trel. Similar to the preceding, perennial; leaves firm, erect, pale, narrowly lanceolate to oblong, acute; branches few, slender, arched-ascending; sepals glandular-ciliate on the covered margins; capsule ovoid, pointed. - Bogs and sterile soil, e. Mass. to Fla.

\section{MILLEGRÀNA Adans. AlL-SEed}

Sepals (toothed), petals, stamens, and styles 4. Pod of 4 almost 2-celled carpels, each carpel 4-seeded. Seeds without albumen.-A minute annual with filiform sirnple stems or forking branches, opposite leaves, and tiny corymbiform cymes. Corolla fugacious. (Name from mille, thousand, and granum, seed.) Radiola Roth.

1. M. Radiola (L.) Druce. The only species. (Radiola Linoides Roth.) - Ditches, Louisburg, Cape Breton (Macoun). (Nat. from Eu.)

\section{OXALIdàceAe (WoOd Sorrel Famiy)}

Plants with regular 5-merous 10-15-androus flowers. Ovary superior,

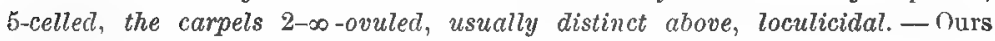
low herbs with sour watery juice and delicate impunctate palmate alternate or radical leaves with 3 obcordate leaflets.

\section{Oxalis L. Wood Sorrel}

Sepals 5, persistent. Petals 5, sometimes united at base, withering after expansion. Stamens 10 , usually monadelphous at base, alternately shorter. Styles 5, distinct. Pod prismatic, cylindric, or awl-shaped, membranaceous; valves persistent, being fixed to the axis by the partitions. Seeds pendulous from the axis, anatropous, their outcr coat loose and separating. Embryo large and straight in fleslyy albumen; cotyledons flat. - Soveral species produce small peculiar Howers, precociously fertilized in the bud and particularly fruitful; and the ordinary flowers are often dimorphous or even trimorphous in the relative length of the stamens and styles. (Name from b̌us, sour.)

$N$. B. - In this genus the figrues are on the scale of $\frac{2}{3}$. 
Stemless; retals white or purple.

Rootstock creeping; scapes 1-flowered . . . . . . . . 1. 0. Acetosella.

Bulbose; scapes umbellately several-flowered : $: \vdots \vdots: \vdots ; 2$ o. violacea.

Caulescent; petals yellow.

Flowers large; petals $1.4-2 \mathrm{~cm}$. long; $\mathrm{Pa}$, and southward.

Petals hairy on the margin; leaflets 8-15 mm. broad. . . . . 3. O. Priceae.

Petals essentially glabrous; lealets 2-4 cm. broad : : : $\quad$ 4. O. grandis.

Flowers smaller; petals 8-12 mm. long.

Stems erect or decumbent but not extensively cresping.

Peduncles mostly 2 -flowered; pedicels appressed-pubescent or strigillose, deflexed in fruit.

Stem covered with closely appressed short hairs

5. O. stricta.

Stera covered with loose spleading woolly pubescence

Peduncles mostly several-tlowered; pedjcels ascending or widely dive. . gent, their pubescence sparse, spreading

Stems prostrate, elongated, rooting at the nodes.

6. O. filipes.

7. O. comniculata.

1. 0. Acetosélla L. (Common W.) Creeping; leaves radical; scapes 1-flowered, 5-15 cm. high; petals white, with rose-colored or purple veins. Deep woods, N. S. and e. Que. to Sask., s. to N. E., N. Y., and in the mts. to N. C. (Eu.) Var. subPURPURÁscens DC., with petals rose-colored or purple, has been found at Chesterville, Me. (Miss Eaton), and at Manchester, Vt. (Grout). (Eu.)

$\checkmark$ 2. 0. violàcea L. (Viouet W.) Nearly glabrous; base bulbous, scaly; leaves radical; scapes umbellately several-flowered, 1.2-2.5 dm. high, exceeding the leaves; petals violet. - Rocky places and open woods, e. Mass to Minn. and southw.

3. 0. Príceae Small. Caulescent; stems erect, soft-villous, from a long slender dark-colored rootstock; leaflets 8-12 $\mathrm{mm}$. broad; pedicels in 2's or 3's at the ends of long slender peduncles, deflexed in fruit; petals yellow, ciliats. Bowling Green, Ky. (Miss Price); and Ala.

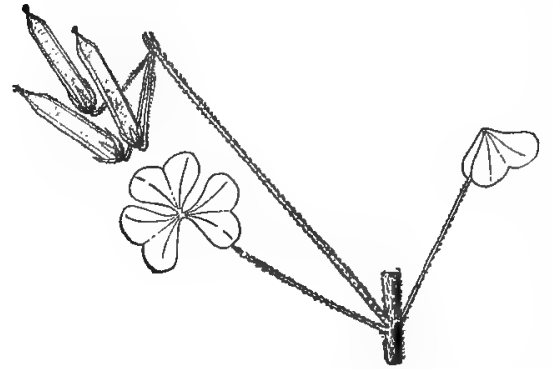

800. 0. stricts.

4. 0 . grándis Small. Tall (3-4.6 dm. bigh), smoothish or covered with soft spreading pubescence; leaflets large (often $3.5-4.1 \mathrm{~cm}$. broad), frequendy brownish-purple at the margin; long-peduncled inflorescences 3several-flowered; petals yellow, 1.4-1.8 cm. long, not ciliate. Sandy woods and alluvial soil, $\mathbf{P a}$. to Ill. and southw. May-Aug.

5. 0. strícta L. Pale green, appressed-pubescent or strigose; stems usually several, decumbent, stoutish; stipules evident; pedicels 1-4 (mostly 2), subumbellate at the end of the peduncle, at length deflexed; the fruit large, columnar, short-pointed, $15-23 \mathrm{~mm}$. long. - Dry or sandy soil, s. Me. to Dak. and southw., common. - The petals pale yellow, often with a reddish spot near the base. Fig. 800 .

6. O. filipes Small. Very slender, pubescence of the stem loose and spreading; petioles and peduncles filiform, elongated; umbels chiefly 2-flowered; petals yellow. (O.Brittonae Small.) -Sandy soil, s. Me. (Chamberlain \& Collins) to n. N. Y., Ct., Fla., and Tex. Fig. 803 .

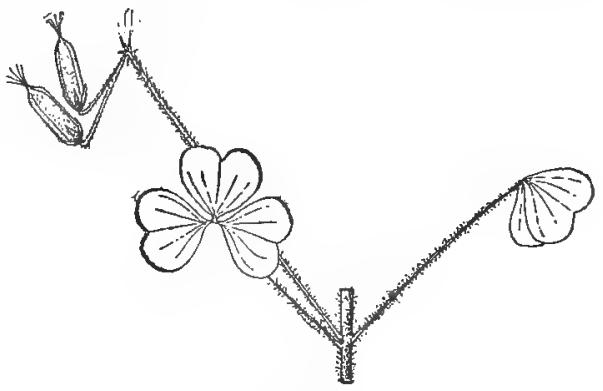

801. O. filipes. 
7. 0. corniculàta L. (LAdY's Sorrel.) Ereet or decumbent, apparently flowering the first year but perennial by numerous siender pale runners; leaflets

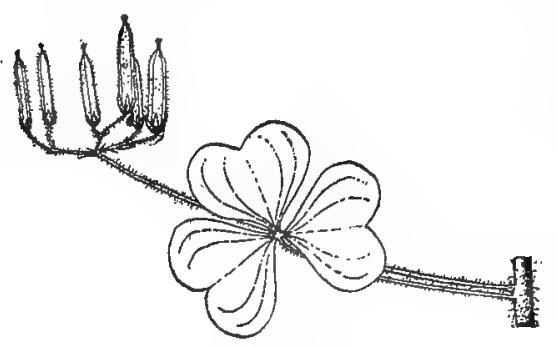

802. O. corniculata.

auth., not L.) - Dry or moist open soil, a very common weed. (Fu.) FIG. 802.

8. 0. rèpens Thunb. Stems several, prostrate and creeping, the numerous erect branches low, seldom $1 \mathrm{dm}$. high; leaflets green or often purplish; pedicels subumbellately or at length cymosely arranged at the summit of the peduncle, ascending, sparingly pubescent, the hairs spreading; petals yellow. (O. cymosa, Bushii, \& rufa Small; 0 . stricta of many

small ; flowers small, 2-5 on very short at length deflexed pelicels. (O. corniculata of L., in part, and of many later authors.) - A weed, chiefly in and about greenhouses. (Cosmopolitan.) Fug. 808.

\section{Geramiaceae (Geranium Family)}

Plants with perfect regular 5-merous hypogynous flowers, Sepals imbricated in the bud, persistent. Glands of the disk 5, alternate with the petals. Stamens, counting the sterile filaments, as many or commonly twice as many as the sepals. Ovary deeply lobed; carpels 2-ovuled, 1-seeded, separating elastically with their long styles, when mature, from the elongated axis. Cotyledons plicate, incumbent on the radical. - Our species herbs with lobed or divided stipulate leaves, and astringent roots.

1. Geranium. Stamens with anthers 10 , rarely 5. The recurving bases of the styles or tails of the carpels in fruit naked inside.

2. Erodium. Stamens with anthers only 5. Tails of the carpels in fruit bearded inside, often spirally twisted.

\section{GERANIUM [Toum.] L. Cranesbillt}

Stamens 10 (rarely 5), all with perfect anthers, the 5 longer with glands at their base (alternate with the petals). Styles smooth inside in fruit when they separate from the axis. - Stems forking. Peduncles 1-3-flowered. (An old Greek name, from repavos, a crane; the long fruit-bearing beak thought to resemble the bill of that bird.)

Perennials with stoutisb caudex and tough fibrous roots.

Petals more than $1 \mathrm{~cm}$. long.

Pedicels puberulent but not glandular; petals light purple . . . 1. G. maculaku.

Pedicels glandular'puberulent; petals deep purple : : : 2. G. pratenso.

Petals lese than $1 \mathrm{~cm}$. long.

Sepals strongly awned; flowers mostly solltary . . . . 8, G. sibiricum.

Sepals merely pointed ; thowers in palrs. :

Annuals or blennials; flowers small ; petals not over $1 \mathrm{~cm}$. long.

Petals about $1 \mathrm{~cm}$. long, twice the length of the sepals.

Potals entire; leaves ternately dissected .

Petals deoply retuse; leaves nalmately lobed

Petals less thrn $1 \mathrm{~cm}$. Jong, $1-1 \frac{1}{2}$ times the length of the sepals.

Fertile part of the carpel pubescent. 
Frult 1.7-2.4 cm. long; soeds pltted. Flowers crowded Inflorescence lax

Frult $1-1.5 \mathrm{~cm}$. long.

Seeds pitted; sepals short-awned.

Beeds smooth; sepals awnless.

Fertlle part of the carpel esentially glabrons.

Pedicels 8-15 ram. long

Pedicels 8-6 cm. long.

1. G. maculatum L. (WILD C.) Erect, hairy; leaves about 5-parted, the wedge-shaped divisions lobed and cut at the end; sepals slender-pointed ; pedicels and beak of fruit hairy but not glandular; petals entire, light purple, bearded on the claw. - Open woods and fields, centr. Me. to Man., and southw. Apr.-July.

2. G. Pratére I. Tall (7 dm. high); leaves mostly 7-parted, the narrow lobes incised; pedicels and beak glandular-pubescent; petals deep purple. Fields and meadows, n. e. Me., N. B., and Que.; also locally, e. Mass. (Introd. from Eu.)

3. G. sibfricum L. Weak, diffusely branched; stem leafy; leaves. 3(-5)parted, the segments broadly lanceolate or rhombic, sharply cut-toothed, acute; carpels finely pubescent; seeds lineolate. - Said to be established on Manhattan I. (Adv. from Eurasia.)

4. G. Robertiànum L. (Herв Roвert.) Sparsely hairy, diffuse, strongscented; leaves 3-divided or pedately 5-divided, the divisions twice pinnatifid; sepals awned; petals red-purple, long-clawed; carpels wrinkled; seeds smooth. - Moist woods and shaded ravines, e. Que. to Minn., s. to N. J., Pa., and Mo. June-Oct. (Eu.)

5. G. Pyrena icum Burm. f. Soft-pubescent and somewhat glandular, $2-6 \mathrm{dm}$. high; leaves orbicular, 5-7-cleft two thirds of the way to the base, the lobes

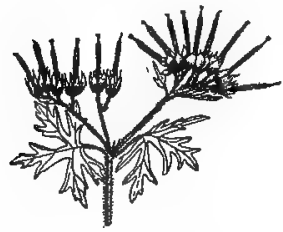

804. G. carolinianum. $\times 1 / 2$. obovate-oblong, again toothed; sepals puberulent, merely pointed, not awned ; petals rose-colored, deeply notched; carpels puberulent; seeds smooth. - Roadsides and waste places, about Quebec ; also at Bethlehem, Pa. (Adv. from Eu.)

6. G. caroliniànum L. Diffusely branched, hairy ; leaves about 5-parted, the divisions cut and cleft into many oblong-linear segments; flovers glomeratecymose; sepals ovate, about as long as the whitish or very pale pink petals; beak of fruit tipped with a short filiform style; seeds ovoid, minutely reticulated. - Rocky places, etc., mostly in poor soil, e. Mass., southw. and westw., common; May-June. Fig. 804.

7. G. Bicknéllii Britton. Diffusely branched; leaves somewhat angular in contour, deeply cleft into narrow segments and lobes; flowers in pairs, the peduncles scattered; petals rosecolored, somewhat exceeding the sepals; beak of fruit tipped with a prolonged filiform style (4-6 mm. in length); seeds nearly black, finely reticulated. - Open woods, clearings, etc., Nfd. to B. C., s. to N. E., N. Y., Mich., Utah, etc. FIG. 805.

8. G. RоTUNDIFòıIdM L. Weak, diffusely branched, villous with gland-tipped hairs; leaves orbicular in outline, cleft half to two thirds the way to the base, the broadislı segments crenate-toothed or lobed; petals rose-color, entire; seeds finely reticulated. - Waste places about New York City, Philadelphia, etc., rare. (Adv. from Eu.)

9. G. Pusfllum Burm. f. Similar to the preceding in habit and foliage; flowers very small; petals purplish, about equaling or little exceeding the awnless sepals; sta-

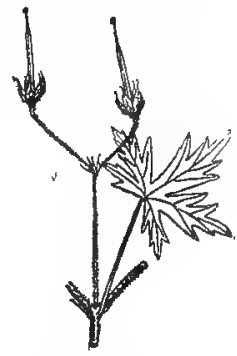

805. G. Bicknellii. $\times 3 / p$ mens 5 ; fruit pubescent; seed smooth. - Waste places and cultịated ground, Mass., southw. and wesțw., casual. (Adv. from Eu. 
10. G. MólLe L. Weak, spreading, soft-pubescent; leaves orbicular, cleft to the middle, the segments crenate or incised; sepals ovate-oblong, not awoned, villous; petals rose-colored, notched; stamens 10 ; carpels transversely urinkled, glabrous. - Recently seeded lawns, etc., casual but not rare. (Adv. from Eu.)

11. G. columbìnum L. (Long-stalike C.) Minutely hairy, with slender decumbent stems; leaves 5-7-parter, and cut into narrow linear lobes; peduncles and pedicels fliform, much elongated; sepals awoned, about equaling the retuse purple petals; carpels subglabrous ; seeds minutely reticulated. - Borders of fields, etc., N. J. and Pa. to Va. ; also Dak. (Nat. from Eu.)

\section{ERÒDIUM L'Hér. STORKSBILL}

The 5 shorter stamens sterile or wanting. Styles in fruit twisting spirally, bearded inside. Otherwise as Geranium. (Name from épwotós, a heron.)

$\checkmark$ 1. E. CICUTA RIOM (L.) L'Hér. Annual, hairy ; stems low, spreading; stipules acute; leaves pinnate, the leaflets sessile, 1-2-pinnatifid; sepals bristletipped; filaments not toothed. - About cities, not rare. (Adv. from Eu.)

2. E. moschà тum (L.) L'Hér'. Similar, but stouter; leaflets less divided; sepals not bristle-tipped; antheriferous filaments 2-toothed. - Waste ground, etc., eastw., infrequent. (Adv. from Eu.)

\section{ZYGOPHYLLÀceAE (Caltrop FamLY)}

Herbs (or southward wondy plants), with opposite (or alternate) in our species abruptly pinnate undotted leaves, and perfect regular mostly 5-merous flower's. Stamens free, essentially hypogynous, in ours twice as many as the petals. Pistil of several united 1-few-rvuled carpels. Ovules anatropous with superior micropyle and large straightish embryo. - Chiefly tropical.

1. Tribulus. Cirpels 5, several-nvuled, prickly.

2. Kallstroemia. Carpels 10, one-ovuled, tuberculate.

\section{TRÍBULUS [Tourn.] L.}

Sepals and petals (4-)5. Filaments slender, unappendaged; those before the petals sometines slightly united with them, the alternate ones subtended by glands. Cells of ovary as many as the petals, 3-5-ovnled. - Ours spreading annuals. (The Latin name of the caltrop, which in form its prickly fruit suggests.)

1. T. TERRÉstris L. (CA LTROP.) Branched îrom the base; leaflets 5-7 pairs; flowers simall, short-peduncled; petals pale yellow; mature carpels crested and armed with 2-4 spreading prickles. - Occasional in Atlantic States; also Ill., Neb., and Kan. ; chiefly on dumps. (Adv. from Old World.)

\section{KALLSTROEMIA Scop.}

Sepals, petals, and stamens as in Tribulus. Cells of the ovary twice as many as the petals, each 1-ovuled, becoming 1-seeded nutlets, dorsally rounded, smooth or tuberculate but not prickly, at maturity falling away from the persistent stylar axis.-- Diffuse annuals. (Name unexplained, given presumably in honor of some obscure botanist.)

1. K. Ḿxima (L.) T. \& G. Prostrate, grayish-hirsute; leaflets 4-6 pairs, oblong, olstuse, about $1 \mathrm{~cm}$. long; flowers $9-15 \mathrm{~cm}$. in diameter; petals yellow; fruit depressed-ovoid, beaked with a stoutish columnar style. - Railroad yards, etc., w. Mo, and e. Irian., where presumably adventive from the Soutliwest. (Trop. Am.) 


\section{RUTÀCEAE (RUe FAMILY)}

Plants with simple or compound leaves, dotted with pellucid glands and abounding with a pungent or bitter-aromatic acrid volatile oil, producing hypogynous almost always regular 3-5-merous flowers, the stamens as many or twice as many as the sepals (rarely more numerous); the 2-5 pistils separate or combined into a compound ovary of as many cells, raised on a prolongation of the receptacle (gynophore) or glandular disk. Embryo large, usually in fleshy albumen. Styles commonly united or cohering. Fruit usually capsular. Leaves in ours alternate. Stipules none. - A large family, chiefly of the old World and the southern hemisphere.

1. Zanthoxylum. Flowers dioecious; ovaries $3-5$, separate, forming floshy pods.

2. Ptelea. Flowers polygamous; ovary 2-celled, forming a samara, like that of Elm.

3. Ruta. Flower's perfect; opary 4-5-lobed, forming a several-seeded capsule.

\section{ZanthóXYlum L. Prickly Ash}

Flowers dioecious. Sepals 4 or 5, obsolete in one species. Petals 4 or 5 , imbricated in the bud. Stamens 4 or 5 in the sterile flowers, alternate with the petals. Pistils 2-5, separate, but their styles conniving or slightly united. Pods thick and fleshy, 2-valved, 1-2-seeded. Seed-coat crustaceous, black, smooth and shining. Embryo straight, with broad cotyledons. - Shrubs or trees, with mostly pinnate leaves, the stems and often the leafstalks prickly. Flowers small, greenish or whitish. (From $\xi a \nu \theta b s$, yellow, and $\xi u ́ \lambda o v$, wood.)

1. Z. americànum Mill. (NORTHERN P., TOOTHACHE-TREe.) Leaves and flowers in sessile axillary umbellate clusters; leaflets 2-4 pairs and an odd one, ovate-oblong, downy when young; calyx none; petals $4-5$; pistils $3-5$, with slender styles; pods short-stalked. (Xanthoxylum of auth.). - - Rocky woods and river-banks, w. Que. to Minn., s. to Va., Ky., Mo., and e. Kan. Apr, May. - An aromatic shrub, with yellowish-green flowers appearing before the leaves.

2. Z. Clàva-Hérculis L. (Southern P.) Glabrous; leaflets 3-8 pairs and an odd one, ovate or ovate-lanceolate, oblique, shining above; flowers in an ample terminal cyme; sepals and petals 5 ; pistils $2-3$, with short styles; pods sessile. (Z. carolinianum Lam.) - Sandy coast of Va., and southw. June. A small tree with very sharp prickles.

\section{PtÈleA L. Shrdbey Trefoll. Hop Tree}

Flowers polygamous. Sepals 3-5. Petals 3-5, imbricated in the bud. Stamens as many. Ovary 2-celled; style short; stigmas 2. Fruit a 2-celled and 2-seeded samara, winged all round, nearly orbicular. - Shrubs, with 3-foliolate leaves, and greenish-white small flowers in compound terminal cymes. (The Greek name of the Elm, here applied to a genus with similar fruit.)

1. P. trifoliàta $\mathrm{L}$. Leaflets ovate, pointed, downy when young. - Rocky places, L. I. to Ont., Minn., and southw. ; cultivated and often established elsewhere. June. - A tall shrub. Fruit bitter, used as a substitute for hops. Odor of the flowers disagreeable.

Var. mbllis T. \& G. Branchlets, petioles, and both surfaces of the somewhat thickish leaflets densely and permanently velvety. - Shore of L. Mich., Saugatuck, Mich. (Wheeler); also Tex., etc.

\section{RÙTA [Tourn.] L. RסE}

Flowers perfect, 4-5-merous. Calyx persistent. Petals yellow, the sidès and apex strongly inrolled, the margin denticulate or ciliate-dentate. Stamens 8-10, inserted about the base of the torus, the alternate ones smaller. Capsule 4-5-lobed, dehiscent at the summit, many-seeded. - Heavy-scented herbs of 
undershrubs with alternate simple or variously compound leaves. (The ancient name.)

1. R. gravielons L. (Сommon R.) Suffruticose, glaucous, 3-6 dm. high; leaves thickish, 2-3-pinnatifid, ultimate lobes or divisions obovate-cuneate; petals denticulate. - Formerly much cultivated for aromatic qualities and supposed medicinal value; now locally established in pastures, Weybridge, Vt. (Brainerd), Peaks of Otter, Va. (Curtiss), and very likely elsewhere. (Introd. from $\mathrm{Eu}$.)

\section{SIMARUBACEAE (QUASBIA FAMILT)}

Trees and shrubs with foral structure much as in the Rutaceae but the foliage destitute of pellucid dots. - Chiefly tropical.

\section{1. ailánthus Desf. Tree of Heaven}

Flowers polygamous. Calyx regular, 5-parted, the lobes imbricaled. Petals 5 , infolded-valvate. Stamens in staminate flowers 10 , in perfect flowers $2-3$, in pistillate flowers none. Disk lobed. Ovary 2-5-parted, becoming in fruit 1-5 narrowly oblong membranaceous samaras (1-seeded in the middle). - Handsome trees of rapid growth. Leaves odd-pinnate. Flowers small, green or yellowish, in ample terminal panicles, especially the staminate of unpleasant odor. (Name said to be from a vernacular Moluccan designation, meaning tree of heaven, in allusion to the height in the native habitat.)

1. A. GLandulosa Desf. Leaves 3-6 dm. long, 11-23-foliolate; leaflets ovate, acuminate, entire or sparingly toothed toward the base. - Extensively cultivated as a shade tree, freely spreading by suckers, and locally self-sown. (Introd. from Asia.)

\section{POLYGalàCEAE (Milkwort Familu)}

Plants with irregular hypogynous flowers, 4-8 diadelphous or monadelphous stamens, their 1-celled anthers opening at the top by a pore or chink; the fruit a 2-celled and 2-seeded pod.

\section{POLÝGALA [Tourn.] L. MiLkwort}

Flower very irregular. Calyx persistent, of $\mathbf{5}$ sepals, of which 3 (the uppermost and the 2 lowest) are small and often greenish, while the two lateral or inner (called wings) are much larger and colored like the petals. Petals 3 , hypogynous, connected with each other and with the stamen-tube, the middle (lower) one keel-shaped and often crested on the back. Stamens 6 or 8 ; their filaments united below into a split sheath, or into 2 sets, cohering more or less with the petals, free above; anthers 1-celled. Ovary 2-celled, with an anatropous ovule pendulous in each cell; style prolonged and curved; stigna various. Fruit a small loculicidal 2-seeded pod, usually rounded and notched at the apex, much flattened contrary to the very narrow partition. Seeds carunculate. Eimbryo large, straight, with flat and broad cotyledons, in scanty albumen. Bitter plants (low herbs in temperate regions), with simple entire often dotted

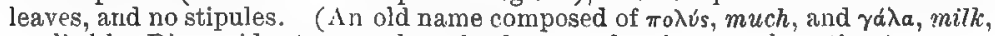
applied by Dioscorides to some low shrub reputed to increase lactation.)

* Perennial or biennial; flowers purple or white; leaves altcrnate.

- Hlowers showy, commonly rose-purple, conspicuously crosted; also some inconspicuous colorless cleistogamous flowers on subterranean branches.

1. P. paucifolia Willd. (Fringed Polycala, Flowering Wintergreen.) I'erennial; flowering stems short (7-10 cm. high); lower leaves small and scale-7ike, scattered, the appper ovate, petioled, crowded at the summit ; flowers 1-;, large, peduncled; wings obovate, rather shorter than the fringe-crested kent : stamens 6; caruncle of 2 or 3 awl-shaped lobes longer than the seed. - 
Woods, in light soil, e. Que. to Man., s. to Ga., Ill, and Minn. May, June. A delicate plant, its handsome flowers $1.8 \mathrm{~cm}$. long, rarely white.

2. P. polýgama Walt. Stems numerous from the biennial root, mostly simple, ascending, very leafy, 1.5-2.5 dm. high; leaves oblanceolate or oblong; terminal raceme loosely many-flowered, the broadly obovate wings longer than the keel ; stamens 8 ; radical flowers racemed on short subterrauean runners; lobes of the caruncle 2, scale-like, shorter than the seed. - Dry sandy soil, N. S., westw. and southw. July.

- Flowens white, in a solitary close spike; none cleistogamous.

3. P. Sénega L. (Seneca SNakeroot.) Stems several from thick and hard knotty rootstocks, simple, $1.5-3 \mathrm{dm}$. high ; leaves lanceolate or oblonglanceolate, with rough margins; wings round-obovate, concave; crest short; caruncle nearly as long as the seed. - Rocky soil, N. B. to Hudson Bay, Alberta, and southw. May--July.

Var. latifdlia T. \& G. 'Taller, sometimes branched; leaves ovate or lanceolate, 5-10 cm. Iong, tapering to each end, - Md. to L. Huron, Dak., and Tenn. * *nuls, with all the leaves alternate; flowers in terminal spiles, heads, or racemes, chiefly purple or rose-color, in summer; none subterranean.

+ Keel conspicuously crested; claws of the true petals united into a long and slender cleft tube much surpassing the wings.

4. P. incarnàta L. Glaucous; stem slender, sparingly branched; leaves minute and linear-awl-shaped; spike cylindrical; fiowers flesh-color; caruncle longer than the narrow stalk of the hairy seed. - Dry soil, N. J. to s. Ont., Wisc., Neb., and southw., rather rare.

- + Keel minutely or inconspicuously crested; the true petals not longer but mostly shorter than the wings; seed pear-shaped.

5. P. sanguinea L. Stem sparingly branched above, leafy to the top; leaves oblong-linear; heads globular, at length oblong, very dense (8-10 mm. thick), bright red-purple (rarely paler or even white); pedicels scarcely any; wings broadly ovate, closely sessite, longer than the pod; the 2-parted caruncle almost equaling the seed. ( $P$. viridescens L.) - Sandy and moist ground; common, N. E., westw. and southw.

6. P. mariana Mill. Stem slender, at length corymbosely branched; leaves narrowly linear, acute, 6-16 $\mathrm{mm}$. long; spikes short and dense $(6 \mathrm{~mm}$. in diameter); the small rose-purple flowers on pedicels of about the length of the pod; wings obovate- or oval-oblong, narrowed at the base, scarcely exceeding the pod; bracts deciducous with the flowers or fruits; caruncle as long as and nearly enveloping the stalk-like base of the minutely hairy seed. ( $P$. fastigiata Nutt.) - Pine barrens of N. J. to Ky., Fla., and Tex.

7. P. Nuttállii 'T. \& G. Resembling the last, but usuaily lower; spikes cylindrical, slender; flowers duller or greenish-purple, on very short pedicels; the awl-shaped scaly bracts persistent on the axis after the flowers or fruits fall; seed very hairy, the caruncle smaller. - Dry sandy soil, coast of Mass. to Del., Md., and southw. - Spike sometimes rather loose.

8. P. Curtissii Gray. Slender, $2.5 \mathrm{dm}$. high; leaves, etc., as in the two preceding; flowers rose-purple, in usnally short racemes; pedicels about equaling or exceeding the persistent bracts ; the narrow oblong erect wings fully twice the length of the pod; caruncle small, on one side of the stalk-like base of the very hairy seed, which is conspicuously apiculate at the broader end. - Md. to Ky., Ga., and Ala. - Founded upon an abnornal form with elongated racemes and pedicels.

** Annuals with at lecust the lower stem-leaves vhorled in fours or fives; spikes terminating the stem and branches; flowering summer and autumn. - Spikes short and thick (8-18 $\mathrm{mm}$. in diameter); bracts persisting after the fall of the middle-sized rose- or greenish-purple flowers; crest small.

9. P. cruciata I. Stems 1-2.5 dm. high, almost winged at the angles, with spreading opposite branches; leaves nearly all in fours, linear and some- 
what spatulate or oblanceolate; spikes sessile or mearly so; wings broadly deltoid-ovate, slightly heart-shaped, tapering to a bristly point or rarely pointless; caruncle nearly as long as the seed. - Margins of swamps, and occasionally in drier places, s. Me, to S. C., mostly near the coast; and from Mich. to Minn. and Neb.

10. P. brevifblia Nutt. Rather slender, branched above; leaves scattered on the branches, narrower; spikes peduncled; wings lanceolate-ovate, pointless or barely mucronate. - Margins of sandy bogs, R. I., N. J., and southw.

- + Spites slender (about $4 \mathrm{~mm}$. thick), the bracts falling with the flowers, which are small, greenish-white or barely tinged with purple, the crest of the keel larger.

$\checkmark$ 11. P. verticillàta L. Slender, $8-25 \mathrm{~cm}$, high, much branched; stem-leaves all whorled, those of the mostly opposite branches scattered, linear, acute; spikes peduncled, usually short and dense, acute; wings round, clawed; the 2-lobed caruncle half the length of the seed. - Dry soil, N. E., westw. and southw.

Var. ambígua (Nutt.) Wood. Usually taller (2-3.5 dm. high) ; leaves (and branches) all scattered or the lowest in fours; spikes long-peduncled, more slender, the flowers often purplish and scattered. ( $P$. ambigua Nutt.) $-\mathrm{Me}$. to Mich., and southw.

* * * Biennials or annuals, with alternate leaves, and yellow flowers, which are disposed to turn greenish in drying; crest small; flowering all summer.

12. P. lutea I. Low; flowers bright orange-yellow, in solitary ovoid oy subcylindric heads (1.8 cm. thick) terminating the stem or simple branches; leaves 2-5 cm. long, obovate or spatulate; lobes of the caruncle nearly as long as the seed. - Sandy swamps, L. I. to s. e. Pa., and southw. near the coast.

13. P. ramosa Ell. Flowers lemon-yellow, in numerous short and dense spike-like racenes collected in a flat-topped compound cyme; leares oblonglinear, the lowest spatulate or obovate; seeds ovoid, minutely hairy, twice the length of the caruncle. - Damp pine barrens, Del, and southw. June-Sept.

14. P. cymosa Walt. Stem short, naked above, the numerous racemes in a usually almost simple cyme; leaves narrow, acuminate; seeds globose, without caruncle. - Del., and southw. ; fl. midsummer.

\section{EUPHORBIÀceAe (Spurge FamiLt)}

Plants usually with a milky acrid juice, and monoecious or dioecious flowers, mostly apetalous, sometimes achlamydeous (occasionally polypetalous or gamopetalous); the ovary free and usually 3-celled, with one or sometimes two ovules hanging from the sunmit of pach cell; stigmas or branches of the style as many or twice as many as the cells; fruit commonly a 3-lobed capsule, the lobes or carpels separating elastically from a persistent axis and elastically 2-valved; seed anatropous; embryo straight, almost as long as and the flat cotyledons mostly as wide as the fleshy or oily albumen. .Stipules often present. - A vast family in the warmer parts of the world; most numerously represented in northern countries by the genus Euphorbia, which has very reduced flowers within a calyx-like involucre.

* Flower's with a calyx, without involuere.

+ Seeds and ovules 1 in erch cell.

\# Flowers apetalous, in cymose panioles (2-8-chotomous); stamens 10, erect in the bud.

1. Jatropha. Calyx corolla-like, the staminate salver-form. Armed with stinging hairs. \# H Flowers in terminal racemes or spikes; stamens inflexed in the bud; stellate-downy or scurfy: or hairy and glandular; leaves mostly entire.

2. Croton. Flowers spiked or glomerate. Opary and fruit B(rarely 2-4)-celled.

3. Crotonopsis. Flowers acattered on the branchlets. Ovary and fruit 1-celled. 
$\because+$ Flowers in axillary spikes or racemes (except no. 7), apetalous (except no, 4); stamens 8 or more; anthers erect in the bud.

4. Argythamnia. Petals and sepals 5. Stamens 10-15, united. Styles bifid, linear.

5. Mercurialis. Sepals 3 or calyx 3-parted. Stamens $8-20$; anther-cells attached at tip, pendulous. Styles (slightly united at the base) strongly papillose, undivided.

6. Acalypha. Calyx 4(3-5)-parted. Stamens mostly 8. Fertile flower in the axils of leafy bracts. Stigmas finely dissected.

7. Ricinus. Racemes terminal, subpanicled. Calyx 3-5-parted. Stamens very numerous; the filaments repeatedly branched. Styles 2-parted.

++++ Flowers apatalous, in racomes or spikes pistillate at base ; stamens 2 or 3 ; styles simple.

8. Tragia. Flowers rícemose. Calyx-lobes valvate in bud. Hirsute or pubescent.

9. Stillingia. Flower's spicate. Calyx-lober imbricate in bud. Fertile bracts glanduliferous. Glabrous.

++ Seeds and ovules 2 in 3 soh cell ; flowers monoecious.

10. Phyllanthus. Flowers axillary. Stazens 3 , ur 'ed.

11. Andrachne. Stamens 5 or 6 . Flowers axillary, the staminate petaliferous.

* Flowers all without calyx, included in a cup-shaped calyx-like involucre, - the whole liable to be mistaken for a single flower.

12. Euphorbia. Involucre surrounding many staminate flowers (ench of a single naked stamen) and one pistillate flower (a 3-lobed pistil).

\section{JÁTROPHA L.}

Flowers monoecious, rarely dioecious, in a terminal open forking cyme; the iertile ones usually in the lower forks. Calyx corolla-like, in the staminate flowers often salver-shaped, 5-lobed; in the pistillate 5-parted, imbricated or convolute in the bud. Glands of the disk opposite the calyx-lobes. Stamens 10-30, monadelphous at base. Ovary mostly 3-celled; styles 3 , united below cheir summits once or twice forked. Capsule separating into 3 two-valved carpels. Seed carunculate. - Perennial herbaceous or shrubby plants, chiefly tropical, with alternate mostly long-petioled palmately-veined leaves, and stipules. Our species has apetalous flowers, the staminate corolla salver-form, and is armed with stinging bristles. (Name said by Linnaeus, without entire clearness or classical accuracy, to be formed of larpò, a remedy, and $\phi d \gamma \omega, I$ eat.)

1. J. stimulosa Michx. ('I'Read-Softly, SPuRge Nettre.) Herbaceous, from a long perennial root, branching, 1.5-6 dm. high; leaves roundish-heartshaped, 3-5-lobed nearly to the base, on long petioles; the divisions entire or acutely toothed, cut, or even pinnatifid, often discolored; flowers white, fragrant, $1.8 \mathrm{~cm}$. long or more; filaments 10 , monadelphous only at the woolly base, the outer sot almost distinct. - Dry sandy soi], Va. to Fla. and La. June-Sept.

\section{CRÒTON L.}

Flowers monoecious, rarely dioecious, mostly in terminal spike-like racemes or spikes. Ster. Fl. Calyx 5(rarely 4-6)-parted; the divisions lightly imbricated or nearly valvate in the bud. Petals usually present, as many, but mostly small or rudimentary, hypogynous. Glands or lobes of the disk as many as and alternate with the petals. Receptacle usually hairy. Stamens 5 or more; filaments with the anthers inflexed in the bud. Fert. Fl. Calyx 5-10-cleft or -parted, nearly as in the staminate flowers; but petals none or minute rudiments. Ovary 3(rarely 2-4)-celled, with a single ovule in each cell; styles as many, from once to thrice 2-cleft. Capsule separating into as many 2-valved 1-seeded carpels. Seeds carunculate. - Stellate-downy, scurfy, or hairy and glandular plants, mostly strong-scented; the fertile flowers usually at the base of the sterile spike or cluster. Leaves alternate, or sometimes imperfectly opposite, with or without obvious stipules. (Koorw'v, the Greek name of the Castor-oil Plant, of this family.) 
* Sterile flovers with 4-parted calyx, as many petals, a 4-rayed disk, and 8 strmens; fertile flowers with 5-parted calyx, very minute rudimentary petals, and the 3 styles 2-cleft.

1. C. glandulòsus L., var. septentrionàlis Muell. Arg. Annual, roughhairy and glandular, 3-6 dm. high, somewhat umbellately branched; leaves oblong or linear-oblong, obtusely toothed, the base with a saucer-shaped gland on each side; fertile flowers captitate-clustered at the base of the sterile spike, sessile in the forks and terminal. - Open waste places and sandy barrens, Va. to Fla., and Tex.; northw. in Miss. basin to Kan., Ia., Ill., and Ind. ; rarely on ballast northeastw.

演 * Sterile flowers with 5-parted calyx, as many glands alternating with the petals, and 10-14 stamens; fertile fowers with 7-12-parted calyx, no petals, and the 3 styles twice or thrice 2-parted.

2. C. capitàtus Michx. Annual, densely soft-woolly and somewhat glandular, 2-6 or more din. high, branched; leaves long-petioled, lance-oblong or elongated-oblong, rounded at base, entíre; petals obovate-lanceolate, densely fimbriate; fertile flowers several, capitate-crowded at the base of the short terminal sterile spike. - Barrens, N. J. to Fla. and Tex. ; northw. in Miss. basin to Ind., Ill., Mo., and Kan. July-Sept.

* * Sterile flowers with unequally 3-5-parted calyx, as many petals and scalelike glands, and 3-8 stamens; fertile flowers with equally 5-parted calyx, no pelals, 5 glands, and 2 sessile 2-parted stigmas.

3. C. monanthógynus Michx. Annual, whitish-stellate-pubescent and rustyglandular; stems 1.4-6 dm. high, slender, erect, below often umbellately 3-4forked, then repeatedly 2-3-forked or alternately branched; leaves oblong-ovate or narrowly oblong, entire, often acutish, 1.5-3 dm. long, about twice the length of the petioles; flowers in the forks, the sterile few on the summit of a short and erect peduncle, the fertile few and clustered or mostly solitary on short recurved peduncles; ovary 2 -celled; fruit often by abortion 1-celled and 1 seeded; the seed broadly oval. - Barren and dry prairies, s. Ind. to N. C. and Fla., w. to Ia., e. Kan., and Tex, ; occasionally adv. northeastw. June-Sept.

**** Dioecious; calyx equally 5-parted; petals none; stamens 10 or more; styles twice or thrice dichotomously 2-parted.

4. C. texénsis (Klotzsch) Muell. Arg. Annual, covered with a close canescent stellate pubescence, dichotomously branched or spreading, $3-6 \mathrm{dm}$. high ; leaves narrowly oblong-lanceolate to linear; staminate spikes or racemes very short, often sessile ; crpsule stellate-tomentose and somewhat muricate. - Sandy soil, Del. (Commons); and from Ala. to Wyo., Col., Ariz., and Mex. ; rarely on ballast northw.

\section{CROTONÓPSIS Michx.}

Flowers monoecious, in very small terminal or lateral spikes or clusters, the lower fertile. Ster. Fl. Calyx equally 5-parted. Petals 5, spatulate. Stamens 5, opposite the petals; filaments distinct, inflexed in the bud, enlarged at the apex. Fert. Fl. Calyz unequally 3-5-parted. Petals none. Glands (petal-like scales) 5, opposite the sepals. Ovary 1-celled, simple, 1-ovuled, bearing a twice or thrice forked style. Fruit dry and indehiscent, 1-seeded. Seed without caruncle. - A slender low annual, with short-petioled linear or elliptical-lanceolate leaves, which are green and smoothish above, but silveryhoary with stellate hairs and scurfy with brownish scales underneath. (Croton and $\delta \psi(s$, apperarance, from likeness to Croton.)

1. C. lineàris Michx. Fruit about $2 \mathrm{~mm}$. long. - Dry sandy soil, s. Ct. (Eames) to Pil., southw. near the const to Fla. and Tex.; inland in Miss. basilu to Ill., Mo,, and Kan. July-Sept. 


\section{ARGYTHÁMNiA P. Br.}

Flowers monoecious. Calyx 5-parted, valvate in the staminate flowers, imbricate in the pistillate. Petals alternate with the calyx-Iobes and with the prominent lobes of the glandular disk. Stamens 5-15, united into a central column in 1-3 whorls. Styles 1-3-cleft. Capsule depressed, 3-lobed. Seeds subglobose, roughened or reticulated, not carunculate. - Erect herbs or undershrubs, with purplish juice, and alternate usually stipulate leaves. (Name from dorvpos, silver, and $\theta a \mu_{\mu \nu o s,}$ bush, from the hoariness of the original species.)

1. A. mercurialina Muell. Arg. Stem erect, nearly simple, 3-6 dm. high, sericeous; leaves sessile, oblong-ovate to lanceolate, entire, pubescent with appressed hairs or glabrate, somewhat rigid; raceme many-flowered, exceeding the leaves; spatulate petals of the sterile flowers as long as the calyx-lobes; ovary sericeous; capsule appressed-pubescent, 8-10 mm. in diameter. (Ditaxis Coult.) - Kan, to Ark. and Tex.

\section{MERCURIÀLIS [Tourn.] L. MERCURY}

Dioecious or monoecious. Flowers apetalous, in interrupted axillary spikes. Stamens 8-20, distinct. Calyx small, green, globose in bud, 3-parted. Carpels $2(-3)$. - Herbs, with opposite pinnately veined leaves. (A plant-name used by Pliny and meaning belonging to the god Mercury.)

1. M. ÁNuA L. Weak erect leafy-stemmed annual; leaves lanceolate or ovate-lanceolate, crenate-serrate; carpels hispid. - Waste places and ballast ground, N. S. to S. C. and O. (Adv. from Eu.)

\section{Acaltypha L. Three-seeded Mercury}

Flowers monoecious; the sterile very small, clustered in spikes; the few or solitary fertile flowers at the base of the same spikes, or sometimes in separate ones. Calyx of the sterile flowers 4-parted and valvate in bud; of the fertile, 3-5-parted. Corolla none. Stamens 8-16; filament short, monadelphous at base; anther-cells separate, long, often worm-shaped, hanging from the apex of the filament. Styles 3, the upper face or stigmas cut-fringed (usually red). Capsule separating into 3 globular 2-valved carpels, rarely of only one carpel. Herbs (ours annuals), or in the tropics often shrubs, resembling Nettles or Amaranths; the leaves alternate, petioled, with stipules. Clusters of sterile flowers with a minute bract; the fertile surrounded by a large and leaf-like

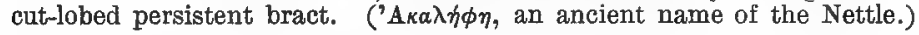

\section{* Fruit smooth or merely pubescent; seeds nearly smooth.}

1. A. virginica L. Smoothish or hairy, 8-6 dm. high, often turning purple ; leaves ovate or oblong-ovate, obtusely and sparsely serrate, long-petioled; sterile spike rather few-flowered, mostly shorter than the large leaf-like palmately 5-9-cleft fruiting bracts; fertile flowers 1-3 in each axil. - Fields and open places, N. S. to Ont. and Minn., s. to the Gulf. July-Sept.

2. A. grácilens Gray. Finely pubescent and often villous; leaves lanceolate or even linear, less toothed and shorter-petioled; the slender sterile spike often $2 \mathrm{~cm}$. long, and much surpassing the less cleft or few-toothed fruiting bracts. (A. virginica, var. Muell. Arg.) - Sandy or dry soil, s. N. H. to Fla., w. to e. Kan. and Tex. - Carpels by abortion sometimes reduced to one $(A$. monococca Engelm.).

* * Fruit echinate with soft bristly green projections; seeds rough-wrinkled.

3. A. ostryaefolia Riddell. Leaves thin, ovate-cordate, sharply and closely serrate-toothed, abruptly acuminate, long-petioled ; sterile spikes short, axillary ; the fertile ones mostly terminal and elongated, their bracts deeply cut into Inany linear lobes. ' ( $A$. caroliniana Ell., not Walt. - N. J. to Fla., w. to O.. Kan.. and Tex. 


\section{Rícinus [Tourn.] L. Cabtor-oir Plant}

Flowers in racemose or panicled clusters, the fertile above, the staminate below. Calyx 5-parted. Stamens very numerous, with repeatedly branching filaments. Styles 3, united at base, each bifid, red. Capsule large, 3-lobed, with 3 large seeds. - A tall stately annual, with very large alternate peltate and palmately 7-11-cleft leaves often 3-6 dm. broad. (Ancient Roman name.)

1. R. COMMUNis L. - Cultivated for ornament, and sometimes spreading to waste ground. (Introd. from the tropics.)

\section{TRÀGIA [Plumier] L.}

Flowers monoecious, in racemes, apetalous. Ster. Fl. Calyx 3-5(chiefly 3)-parted, valvate in the bud. Stamens 2 or 3 ; filaments short; anther-cells united. Fert. Fl. Calyx 3-8-parted, persistent. Style 3-cleft or 3-parted; the branches 3 , simple. Capsule 3-celled, 3-lobed, bristly, separating into three 2-valved 1-seeded carpels. Seeds not carunculate. - Erect or climbing plants (ours perennial herbs), pubescent or hispid, sometimes stinging, with mostly alternate stipulate leaves; the small-flowered racemes terminal or opposite the leaves; the sterile flowers above, the few fertile at the base, all with small bracts. (Named for the early herbalist Bock, latinized Tragus.)

1. T. ùrens L. Erect, paniculate-branched, softly hairy, 1.5-3 dm. high; leaves varying from obovate-oblong to narrowly linear, acute at base, obtusely or sinuately few-tonthed or lobed, sometimes entire, short-petioled or sessile, paler beneath; sterile calyx usually 4-parted ; stamens 2. (T. innocua Walt.) Dry sandy soil, e. Va. to Fla. and La. May-Ang. - Not stinging.

2. T. nepetaefolia Cav. Erect or reclining or slightly twining, hirsute with stinging hairs; leaves ovate-lanceolate or triangular-lanceolate, or the lower ovate, all somewhat cordate or truncate at base, coarsely cut-toothed, short-petioled; sterile calyx usually 3-parted and stamens 3. (T. urticaefolia Michx.) - Va. (Pursh), and common southw. to Fla. and Tex.; Mo., Kan., and westw. T. RAMòs A Torr. ( $T$. stylaris Muell. Arg.), with 4-6-parted sterile calyx, 4-6 stamens, and elongated styles, is probably only a variety. - Mo. to Kan. and southwestw.

3. T. macrocárpa Willd. Twining, somewhat hirsute; leaves deeply cordate, ovate, mostly narrowly acuminate, sharply serrate, 6-11 $\mathrm{cm}$. long, all but the uppermost iong-petioled; pod $1.3 \mathrm{~cm}$. broad. (T. cordata Michx.) - Ky. and Mo. to Ga., Fla., and Tex.

\section{STILLfNGIA Garden.}

Flowers monoecious, aggregated in a terminal spike. Petals and glands of the disk none. Caly $\times 2-3$-cieft or -parted; the divisions imbricated in the bud. Stamens 2 or 3 ; anthers adnate, turned outward. Style thick; stigmas 3 , diverging, simple. Capsule 3-celled, 3-lobed, 3-seeded. Seed carunculate. Smooth upright plants, with the alternate leaves mostly 2-glandular at base; the fertile flowers few at the base of the dense sterile spike (rarely separated); the bract for each cluster with a large gland on each side. (Named for $D r$. $B$. Stillingfleet, English naturalist of the 18th century.)

1. S. sylvática L. Herbaceous, 3-9 dm. high; leaves almost sessile, oblonglanceolate, serrulate; glands of the spike saucer-shaped. - Sandy and dry soil, Va. to Fla., w. to Kan. and 'Tex. May-Oct. - Sometimes called Queen's-RuoT or QUEEN'S-DELIGHT.

\section{PHYLLÁNTHUS L.}

Flowers monoecious, axillary. Calyz usually 5-6-parted, imbricated in the bud. Petals none. Stamens mostly 3 , erect in the bud, often united. Ovules 2 in each oell of the ovary. Capsule depressed; each carpel 2-valved, 2-reeded. seedis nat car!nc ulate. - Leaves alternate, 2 ranked with small stipules, i Namo 


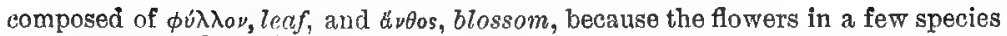
are borne upon leaf-like dilated branches.)

1. P. caroliniensis Walt. Annual, low and slender, branched; leaves obovate or oval, short-petioled; flowers commonly 2 in each axil, almost sessile, one staminate, the other fertile ; calyx 6-parted; stamens 3 ; styles 3 , each 2 -cleft ; glands of the disk in the fertile flowers united into a cup. - Gravelly banks, ө. Ya. to centr. Ill., s. e. Mo., and southw.

\section{ANDRÁCHNE L.}

Flowers monoecious, pedicellate, the sterile petaliferous, fasciculate, the fertile often petaliferous, usually solitary in the axils. Stamens and calyxsegments 5-6. Pod dry, splitting into three 2-valved carpels. - Shrubs and undershrubs, with many ascending leafy branches. Leaves oval or obovate, entire. (From á $\delta \rho a ́ \chi \nu \eta$, classic Greek for the purslane.)

1. A. phyllanthoides (Nutt.) Muell. Arg. Nearly glabrous shrub ; stems and ascending simple branches lithe; leaves broadly obovate, membranaceous, 1.5 $\mathrm{cm}$. long, shortly petiolate; pedicels capillary, 7-14 cm. long; petals in the sterile flowers about as long as the obovate calyx-segments, in the fertile obsolescent. - Rocky and gravelly places, s. Mo. to Tex.

\section{EUPHóRBia L. SPURge}

Flowers monoecious, included in a cup-shaped 4-5-lobed involucre (flower of older authors) resembling a calyx or corolla, and usually bearing large thick glands (with or without petal-like margins) at its sinuses. Sterile flowers nuInerous and lining the base of the involucre, each from the axil of a little bract, and consisting mereiy of a single stamen jointed on a pedicel like the filament; anther-cells globular, separate. Fertile flower solitary in the middle of the involucre, soon protruded on a long pedicel, consisting of a 3-lobed and 3-celled ovary with no calyx (or a mere vestige). Styles 3, each 2 -cleft; the stigmas therefore 6. Pod separating into three I-seeded carpels, which split elastically into 2 valves. Seed often caruncled (ours only in $\$ \$ 5$ and 6 ). - Plants (ours essentially herbaceous) with a milky acrid juice. Peduncles terminal, often umbeilate-clustered; in the first section mostly appearing lateral, but not really axillary. (Named for Euphorbus, physician to King Juba.)

A. Glands of the involucre with petal-like usually white or rose-colored margins or appendages; these almost obsolete in no. 1.

§ 1. ANISOPHÝLLUM Röper. Leaves all opposite, short-petioled, small, oblique at base; stipules awl-shaped or scaly and often fringed, persistent; stems much branched, spreading or usually procumbent; involucres solitary in the forks or in terminal or pseudo-lateral clusters, small, with 4 glands; annuals.

* Seeds smooth and even; leaves entire; whole plant glabrous.

- Leuves oblong to linear, 6-20 mm. long; pod 2-3 mm. in length.

+ Appendages of the involucral glands minute or none.

1. E. polygonifdilia L. (SEAside S.) Prostrate-spreading; leaves oblonglinear, obtuse, mucronate, slightly cordate or obtuse at base, 8-16 mm. long; stipules setaceously divided; peduncles in the forks, as long as the petioles: lobes of the involucre longer than the minute not appendaged glands; pods obtusely angled; seeds ovate, over $2 \mathrm{~mm}$. long, the largest of this section.Sandy shores of the Atlantic (from N. S. southw.) and of the Great Lakes; also reported from centr. Ia. and westw.

2. E. Geyèri Engelm. Procumbent; leaves oblong-ovate, obtuse, slightly mucronate, mostly acutish at base, lowermost cordate, $6-12 \mathrm{~mm}$. long; stipules setaceously divided; peduncles as long as the petioles, at length in lonse foliaceous lateral clusters; glands with narrow white or red appendages; pods 
acutely angled; seeds ovate, acute at one end, $1 \mathrm{~mm}$. long. - Sandy soil, Inl. to Wisc., Minn., and Kan. June-Sept.

\section{- Appendages of the involucral glands broad and conspicuous, white and petaloid.}

3. E. petaloidea Engelm. Half-erect and spreading; leaves narrowty oblong, rotuse or emarginate; peduncles $2 \mathrm{~mm}$. in length, longer than the petioles; pod obtusely angled; seeds nearly $2 \mathrm{~mm}$. long. - Ia. and Mo., westw. and southwestw. June-Sept.

4. E. zygophylloides Boiss. Habit of the preceding but taller and more slender; leaves linear; peduncles capillary, 5 mm. long; capsule deeply 3-sulcate, the lobes carinate; seeds obscurely 4-angled. ( $\boldsymbol{E}$. Nuttallii Small.) Limestone barrens, Greene Co., Mo. (Blankinship) to Kan., and southwestw.

$$
\text { + + Leaves suborbicular, 1-3 mm. long; pod 1-1.5 mm. long. }
$$

5. E. sérpens HBK. Stems filiform, prostrate, and often rooting; leaves round-ovate, obtuse or cordate at base, only 1-3 $\mathrm{mm}$. long; stipules membranaceous, triangular; peduncles much longer than the petioles, at length in loose foliaceous lateral clusters; glands of the very small involucre with minute crenulate appendages; pods acutely angled; seeds obtusely angled, 1 mut. long or less. - Rich soil, s. w. Ont., Ill., and Ia. to Kan., and southw.; rarely adr. eastw. * Seeds minutely roughened or transversely wrinkled; leaves more or less

\section{- Glabrous or nearly so.}

$\leftarrow$ Seeds acutely angled; leaves 4-12 mm. long.

6. E. serpyllifòlia Pers. Glabrous, prostrate-spreading; leaves obovate-oblong, narrowed at the very oblique base, sharply serrulate toward the obtuse apex, $6-12 \mathrm{~mm}$. long, often with a red spot; stipules lanceolate, fimbriate; peduncles as long as or longer than the petioles, at length in loose foliaceous lateral clusters; glands of the small involucre with narrow somewhat toothed appendages; pods sharply angled; seeds acutely quadrangular, slightly cross-2orinkled, often pitted, nearly $1.5 \mathrm{~mm}$. Iong. - Sandy and alluvial soil, n. Mich. (Farwell) to Mo., Tex., and westw.

7. E. glyptospérma Engelm. Glabrous (or very rarely puberulent), erectspreading; leaves linear-oblong, mostly falcate, very unequal at base, slightly serrulate toward the obtuse apex, 4-10 mm. long; stipules lanceolate, setaceously divided; peduncles as long as the petioles, in dense foliaceous lateral clusters; glands of the very small involucre with narrow crenulate appendages; pods sharply angled; seeds'sharply 4-angled and with 5 or 6 sharp transverse wrinkles, 1 mm. long.-Oxford Co., Me. (Parlin, Miss Furbish); Fisher's I.s N. Y.; Ont. to Wisc., Mo., and westw.

$$
\text { ++ ++ Seeds obtusely angled; leaves 1-3 cm. long. }
$$

8. E. Préslii Guss. Stem often subsimple below, erect or obliquely ascend. ing, 2-10 dm. high ; leaves oblique at the obtuse or slightly cordate base, ovateoblong or oblong-iinear, sometimes falcate, serrate, $1-3 \mathrm{~cm}$. long, usually with a red spot or red margins; stipules triangular; peduncles longer than the petioles, collected in loose leafy terminal cymes; appendages entire, larger and white, or smaller and sometimes red; pod glabrous; seeds ovate, obtusely angled, corinkled and tubercled, 1 mm. long, blackish. ( $E$. hypericifolia Man. ed. 5, not L.? $\boldsymbol{E}$. nutans Lag.) - Dry open soil, Mass. to Ont., Wisc., Neb., and southw.

$$
\text { + + Puberulent to hirsute. }
$$

9. E. hirsùta (Torr.) Wiegand. Of lower statuxe and more procumbent than the preceding; stems hirsute, copiously branched from near the base; leaves smaller, 8-14 mm. long, oblong to ovate; seeds black with pale semi-transparent envelope, sharply 4-angled, the flattish or concave sides obscurely wrinkled. (E. hypericifolia, var. Torr.) - Dry sandy soil, e. Que. to w. Ont., s. to N. J.। Pa.. O.. and Ill.. common. 
10. E maculata L. (Mrrk Porslane.) Prostrate; stems puberulent or hairy ; leaves oblong-linear, very oblique at base, serrulate upward, more or less pubescent or sometimes smoothish, 8-12 $\mathrm{mm}$. long, usually with a brown-red spot in the center; stipules lanceolate, fimbriate; peduncles as long as the petioles, in dense foliaceous lateral clusters; glands of the small involucre minute, with narrow slightly crenate usually red appendages; pods acutely angled, puberulent; seeds $0.4 \mathrm{~mm}$. long, red, with pale envelope, sharply 4-angled and with about 4 shallow grooves across the concave sides. - Open places, roadsides, etc., common.

11. E. humistràta Engelm. Procumbent, puberulent or hairy; leaves elliptical or obovate, very oblique at base, serrulate toward the apex, sparsely hairy underneath, $8-18 \mathrm{~mm}$. long, sometimes with a brown spot above; stipules lanceolate, fimbriate; peduncles rather shorter than the petioles, in dense scarcely foliaceous lateral clusters; involucre cleft on the back, its red or white appendages truncate or crenate; pods sharply angled, puberulent; seeds ovate, red, with pale envelope, obtusely angled, minutely roughened, 1 mm. long. Rich soil, Ont. to Minn., and southw.

12. E. stictóspora Fngelın. Similar in habit and pubescence; leaves mostly shorter, oval or suborbicular, not spottcd; seeds at maturity reddish-gray, finely and distinctly pitted. - Kan., westw. and southwestw.

§ 2. ZYGOPHYLLfDIUM Boiss. Leaves opposite, on short petioles, not oblique, with stipular glands; stems dichotomously branched, erect; cymes terminal; involucres with 5 glands; seeds tuberculate.

13. E. hexágona Nutt. Somewhat hairy, 3-15 dm. high ; branches striateangled; leaves linear-lanceolate, entire ; involucre hairy without and within; glands with green ovate-triangular appendages twice their length ; capsule smooth; seeds ovate. - Ia. to 'Tex., w. to Col. and Mont.; also on waste ground, Wilmington, Del. (Commons).

§ 3. PETALOMA Boiss. Uppermost leaves with conspicuous white petal-like margins, whorled or opposite, the others scattered; erect annuals, with leaves equal at base and entire, and with lanceolate deciduous stipules; involucres 5-lobed, in an umb̈l-like inflorescence.

14. E. marginata Pursh. (Snow-on-The-Mountain.) Stem stout, 3-9 dm. high, erect, hairy; leaves sessile, orate or oblong, acute; umbel with three dichotomous rays; glands of the involucre with broad white appendages. Minn. to Mo., Col, , Tex, and S. C.; spreading eastw. to O., and frequently escaping from flower-gardens.

\section{§4. 'TITHYMALÓPSIS (Klotzsch \& Garcke) Boiss. Only the uppermost leaves whorled or opposite; erect perennials, with entire leaves equal at base; stipules none; involucres mostly 5-lobed, in the forks of the branches and terminal; inflorescence umbelliform.}

b 15. E. corollàta L. (FLowering S.) Glabrous or sometimes sparingly hairy, 4-10 dm. high; root deep; stem usually simple for more than half its length; leaves ovate, lanceolate, or linear, entire, obtuse; umbel $5(3-7)$-forked, and the forks again 2-3(or rarely 5)-forled; involucres long-peduncled, with showy white appendages (appearing like petals), the lobes minute and incurved; pod slender-pediceled, smooth ; seeds thick, $2 \mathrm{~mm}$. long or more, ash-colored, slightly uneven. - Rich or sandy soil, N. Y. to Fla., w. to Minn. and La.; also locaily naturalized in N. E. July-Oct.

16. E. marilándica Greene. Pale green; root or rootstock horizontal, near the sunface; stem $3 \mathrm{dm}$. high, trichotomous from near the base; leaves lancelinear, whorled below, the upper opposite, and floral reduced to subulate bracts. - Sand hills, Anne Arundel Co., Md. (Greene). - Not seen; description compiled. 


\section{AA. Olands of the involucre without petaloid appendages.}

§5. POINSETTIA (Graham) Baill. Involucres in terminal clusters, 4-5-lobed, with few (or often solitary) cup-shaped glands; ereot annuals, with entire, dentate, or sinuate leaves, all or only the upper anes opposite, the uppermost often colored, especially at base; stipules reduced to small glands.

17. E. dentàta Michx. Erect or ascending, hairy, 2.5-12 dm. high; leaves ovate, lanceolate, or linear, petioled, coarsely toothed, 4-8 cm. long, only the lowest alternate, the upper often paler at base ; involucres almost sessile, with 5 oblong dentate lobes, and one or sometimes more short-stalked glands; seeds ovoid-globular, slightly tubercled. - Rich soil, Pa. to Wyo. and Tex. July-Sept.

18. E. heterophýlla L. (Painted Lear.) Erect, 3-9 dm. high, glabrous; leaves alternate, petioled, ovate-fiddle-shaped and sinuate-toothed, or lanceolate or linear and entire, often only those of the branches linear; the upper usually with a red base; involucres about the length of the peduncle, with 5 ovate incised lobes and one or few almost sessile glands; seeds nearly globular, tubercled. Slopes and rocky soil, Minn. to w. Ill., Kan., Tex., and Fla.

§6. TITHÝMALUS [Tourn.] Pers. Involucres in a terminal dichotomous or commonly umbelliform inflorescence, 5- or usually 4-lobed, with as many flat or convex entire or crescent-shaped glands; seeds carunculat - (except in no. 19); ours ascenaing or erect, and mostly glabrous, without stipules.

* Perennials with entire leaves, all or only the upper opposite; involucres longpeduncled in a dichotomous inflorescence, mostly with 5 transversely oblong glands; seeds without caruncle.

19. E. Ipecacuánhae L. Stems many from a very long perpendicular root, erect or diffusely spreading, $1-2.5 \mathrm{dm}$. long, forking from near the base; leaves varying from obovate or oblong to narrowly linear, almost sessile, glabrous ; peduncles elongated (1.3-2.5 cm. long) ; pod long-pediceled, obtusely angled, nearly smooth ; seed ovoid, white, sparsely marked with impressed dots. - Sandy soil, near the coast, Ct. to Fla.; also barrens of s. Ind.

* Leaves scattered, only the floral in the umbelliform inflorescence whorted or opposite and of a different shape; glands mostly 4.

- Leaves serrulate or rarely entire; glands transversely oval, obtuse. - Seeds smooth and even; pod warty or rough.

20. E. Darlingtonii Gray. Tall perennial, 6-12 dm. high; leaves entire, minutely downy beneath; those of the stem lanceolate-oblong from a narrow base; the floral oval, very obtuse; the upper roundish-dilated with a truncate base; umbel 5-8-rayed, then simply forked; pod minutely warty; large globular seed with a small caruncle. - Copses, Pa. to the mts. of N. C. July-Sept.

21. E. obtusatta Pursh. Erect annual, 3-6 dm. high; leaves oblong-spatulate, minutely serrulate, smooth, all obtuse; upper ones cordate at base; floral ones ovate, dilated, barely mucronate; umbel once or twice divided into 3 ravs, then into 2 ; involucre with naked lobes and small stipitate glands; styles distinct, longer than the ovary, erect, 2-cleft to the middle; pod beset with long warts. Damp woods, Pa. to S. C., w. to Ia., Kan., and (?) Tex.

22. E. PLATYPHÝLLA L. Erect annual, $2-4.5 \mathrm{dm}$. high; upper stem-leaves lanceolate-oblong, acute, cordate at base, minutely serrulate, mostly with scattrred hairs beneath; floral ones triangular-ovate, subcordate; umbel 5-rayed ; involucre with ciliate lobes and large sessile glands; styles longer than the ovary, united at base, slightly 2-cleft; pod covered with depressed warts. I. Champlain to $\mathrm{W} . \mathrm{Pa}$. and Man. June-Aug. (Nat. from Eu.)

++ t+ Seeds rugose or reticulated; leaves serrulate; annuals.

23. E. dictyospérma Fisch. \& Mey. Stem erect, $2-4.5 \mathrm{dm}$. high; leaves oblong- or obovate-spatulate, smooth, all obtuse and obtusely serrate; upper ones cordate at base; floral ones roundish-ovate or obscurely heart-shaped, slightly mucronate; umbels once or twice 3-forked, then 2-forked; involucre 
with nearly naked lobes and small almost sassile glands; styles shorter than the ovary, spreading or recurved; pod warty; seeds deticately reticulated (E. arkansanre and var. missouriensis Norton.) - Prairies and roadsides, Mo to Ala., and westw. May-July.

24. E. Helioscópia L. (Wartweed.) Stems ascending, 1.5-3.5 dm. high, stout; leaves all obovate and very rounded or retuse at the end, finely serrate, smooth or a little hairy, those of the stem wedge-shaped; umbel divided into $\hbar$ rays, then into 3 , or at length simply forked; glands orbicular, stalked; podo smooth and even; seeds with coarse honeycomb-like reticulations. - Waste places. and dry open soil, e. Que. to Ont., abundant; locally s. to Pa., O., and Ill. (Nai, from Eu.)

+ + Leaves entire; glands crescent-shaped or 2-horned.

- Seeds smooth and dark-colored; perennials, with running rootstocks.

25. E. Ésuta L. Stems clustered, 3-4 dm. high ; leaves lanceolate to linear, the floral (yellowish) broadly heart-shaped, inucronate; umbel divided into many rays, then forking; glands short-horned (brown); pods smoothish and granular. - Sandy banks, s. Me. (Parlin) to N. J., Pa., and Mich. (Nat. from Eu.)

26. E. Cyparíssias L. (Cypress .S.) Stems densely clustered, $1.2-3 \mathrm{dm}$. high ; stem-leaves linear, crowoded, the floral heart-shaped; umbel many-rayed; glands crescent-shaped; pods granular. - Escaped from gardens, common. (Introd. from Eu.)

27. E. LƯcidA Waldst. \& Kit. Stout and tall glabrous perennial; leaves oblong or ablong-lanceolate, the floral broadly heart-shaped, mucronate; terminal umbel many-rayed, the rays forking; glands short-horned; pods finely wrinkled. (E. nicaeensis Man. ed. 6, not All.) - Field and roadsides, Susquehanna Valley, N. Y. and Pa. (Nat. from Eu.)

+ + Seeds sculptured, ash-colored; pod smooth; annuals or biennials.

28. E. Piplus L. (Petry S.) Erect or ascending, 1.5-3 dm. high; leaves round-obovate, the upper floral ones ovate; umbel 3 -rayed, then forking; glands long-horned; lobes of the pod 2-wing-crested on the back; seeds 2-grooved on the inner face, pitted on the back, scarcely over $1 \mathrm{~mm}$. long. - Waste places and cultivated ground, N. B. to N. J., Pa., and Ia. (Adv. from Eu.)

29. E. commutàta Fngelm. Stems branched from a commonly decumbent, base, 1.5-3 dm. high; leaves obovate, obtuse, the upper all sessile, the upper floral ones roundish-dilated, broader than long; umbel 3-forked; glands with slender horns; capsule obtusely angled; seeds ovoid, pitted all over, $2 \mathrm{~mm}$. long. - Along streams and shady slopes, Pa. to Fla., Mo., and Minn.

* * Glabrous annual or biennial with entire opposite and decussate leaves, an unbelliform inflorescence, and short-horned glands.

30. E. Láthyrdo L. (Caper S., Mole Plant.) Stem stout, 3-9 dm. high; leaves thick, linear or oblong, the floral oblong-ovate and heart-shaped ; umbel 4-rayed, then forking. - Sparingly escaped from gardens, Ct. and N. Y. to N. C. (Introd. from $\mathrm{Fu}$. .)

\section{CALLITRICHÀCEAE (WAter Starwort FAMILY)}

Low slender and usually tufted chiefly aquatic herbs (glabrous or beset vith microscopic stellate scales), with entire spatulate or linear leaves, monoecious flowers (solitary or 2 or 3 together in the axil of the same leaf) wholly nalied or inclosed by a pair of membranaceous bracts. Sterile flower a single stamen, the filament bearing a heart-shaped 4-celled anther, which by confluence becomes 1-celled, and opens by a single slit. Fertile flower a single 4-celled ovary, bearing 2 distinct filiform stigmas. Fruit nut-like, compressed, 4-lobed, 4-celled, separating at maturity into as many closed 1-seeded pnrtions. Seeds pendulous : embryo slender, straight or slightly curved, nearly the length of the oily albumen 


\section{Callítriche L. Water Starwort}

The only genus. (Name from $k a \lambda b s$, beautiful, and $\theta \rho l \xi$, hair, from the slender stems.)

- Small annuals, forming tufts on moist soil, destitute of stellate scales; leaves uniform, very small, obovate or oblanceolate, 3-nerved, crowded; bracts none.

1. C. deflexa A. Br., var. Austini (Engelm.) Hegelm. Stems $1-2.5 \mathrm{~cm}$. high ; fruit $0.7 \mathrm{~mm}$. wide, broader than high, deeply notched above and below, on a pedicel often nearly of its own length or almost sessile ; lobes of the fruit narrowly winged and with a deep groove between them; persistent stigmas shorter than the fruit, spreading or reflexed ; leaves $2-4 \mathrm{~mm}$. long. (C.Austini Engelm.) - Damp soil, Ct. to Del.; also from Tenn. to Mo. and Tex. (Mex., S. A.)

* Amphibious perennials; leaves with stellate scales, the floating ones obovate and 3-nerved, the submersed linear (all uniform and narrowly oblong in terrestrial forms); flowers usually between a pair of bracts.

2. C. palústris L. Fruit $1 \mathrm{~mm}$. long, higher than broad, obovate, slightly obcordate, usually thickest at the base, sessile, its lobes sharply keeled or very narrovoly winged above, and with a wide groove between them; stigmas shorter than the fruit, almost erect, usually deciduous; floating leaves crowded in a tuft, obovate, narrowed into a petiole. (C.verna $\mathrm{L}$., in part.) - Common in quiet waters. (Eu.)

3. C. heterophýlla Pursh. Fruit smaller, as broad as or broades than high, deeply emarginate, thick, almost ventricose, sessile or nearly so, its iobes obtusely angled, with a small groove between them; stigmas as long as the fruit, erect, persistent; floating leaves crowded in a tuft, broadly spatulate, often retuse, abruptly narrowed into a long petiole. - Quiet water, Nfd. to Md., La., and westw.

* * * Submersed perennial, with numerous uniform linear 1-nerved leaves; flowers without bracts; carpels separate nearly to the axis.

4. C. autumnalis L. Stems $7-15 \mathrm{~cm}$. high; fruit large $(2 \mathrm{~mm}$. wide or more), flattened, circular, deeply and narrowly notched, sessile or nearly so, its lobes broadly winged, and with a very deep and narrow groove between them; stigmas very long, reflexed, deciduous; leaves all linear from a broader base, retuse or notched at the tip, 4-12 $\mathrm{mm}$. long. (C. bifida Morong.) - Lakes and cold streams, w. Mass., L. Champlain, and w. Que. to L. Superior, and westw. (Eu.)

\section{BUXÀCEAE (BOX FAMILY)}

Perennial herbs or more often trees or shrubs, with simple opposite or alternate usually evergreen leaves, watery juice and snall greenish monoecious or dioecious apetalous flowers; sepals imbricated or none; stamens opposite the sepals or indefinite; carpels 3; ovary 3-celled; styles 3, simple; ovules (in ours) geminate in the cells, suspended, the rhaphe dorsal. - A small family, often! united with the Euphorbiaceae.

\section{PACHYSÁNDRA Michx.}

Flowers monoecious, in naked spikes. Calyx 4-5-parted. Petals none. Ster. $F l$. Stamens 4, separate; filaments long-exserted, thick and flat; anthers oblong-linear. Fert. Fl. Styles thick, awl-shaped, recurved, stigmatic down their whole length inside. Capsule deeply 3-horned, 3-celled, splitting into 3 at length 2 -valved 2-seeded carpels. - Nearly glabrous low and procumbent perennial herbs, with matted creeping rootstocks, and alternate ovate or obovate coarsely toothed leaves narrowed at base into a petiole. Flowers each 1-3bracten, the upper staminate, a few fertile ones at base, unpleasantly scented; 
sepals greenish or purplish ; filaments white (their size and thickness giving the

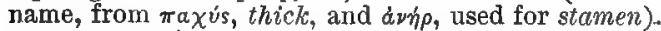

1. P. procúmbens Michx. Stems $1.5-2.3 \mathrm{dm}$. long, bearing several approximate leaves at the summit on slender petioles, and a few many-flowered spikes along the base; the intervening portion naked, or with a few small scales. Woods, mts. of Ky., W. Va., and southw.; adv. northw. March-May.

\section{EMPETRÅCEAE (Crowberry FaMiLy)}

Low shrubby evergreens, with the foliage, aspect, and compound pollen of Heaths, and the drupaceous fruit of Arctostaphylos, but the divided or lcciniate stigmas, etc., of some Euphorbiaceae. - Probably only an apetalous and degenerate form of Ericaceae, and comprising three genera, two within the limits of this work, the third farther south.

1. Empetrum. Flowers scattered and solitary in the axils. Sepals 8, petalold.

2. Corema. Flowers collected in terminal heads. Calyx none.

\section{1. ÉMPETRUM [Tourn.] L. CROWBerRT}

Flowers polygamous, scattered and solitary in the axils of the leaves, inconspicuous, scaly-bracted. Calyx of 3 spreading and somewhat petal-like sepals. Stamens 3. Style very short; stigma 6-9-rayed. Fruit a berry-like drupe, with 6-9 seed-like nutlets, each containing an erect anatropous seed. (An ancient name, from $\epsilon$, upon, and $\pi \epsilon \tau \rho o s, \alpha$ rock.)

1. E. nigrum L. (BLACK C.) Procumbent and spreading; branchlets and scattered linear-oblong leaves glabrous or merely pulverulent; fruit black. Arctic Am., s. to the coast of e. Me., mis. of n. N. E. and N. Y., n. Mich., and coast of Ore. (Eurasia.) Var. Purpureum (Raf.) DC. Fruit red or purple. Less common.

Var. andinum (Philippi) DC. Branchlets and young leaves tomentose; berries reddish or plum-colored, larger and more juicy. - Nfd., and mts. of $\mathbf{M e}_{\text {. and }}$ N. H. (Chili.)

\section{CORÈma D. Don. Broom Crowberry}

Flowers dioecious or polygamous, in terminal heads, each in the axil of a scaly bract, and with 5 or 6 scarious imbricated bractlets, but no proper calyx. Stamens 3, rarely 4. Style slender, 3(or rarely 4-5)-cleft; stigmas narrow, ofteı toothed. Drupe small, with 3 (rarely 4-5) nutlets. - Diffusely branched little shrubs, with subverticillate narrowly linear heath-like leaves. (Name $\kappa \delta p \eta \mu \alpha, a$ broon, from the bushy aspect.)

1. C. Conràdii Torr. Shrub, 1.5-6 dm. high, diffusely branched, nearly smooth; drupe very small, dry and juiceless when ripe. - Sandy pine-barrens and dry rocky places, N. J. and L. I. (P), Shawangunk Mts., N. Y., coast of s. e. Mass, and Me. to Nfd. - The sterile plant is handsome in flower, on account of the tufted purple filaments and brown-purple anthers.

\section{Limnanthäceae (False Mermaid Family)}

Herbaceous plants with perfect regular 3-6-merous slightly perigynous symmetrical flowers, the persistent sepals valvate. Glands alternate with the petals. Stamens distinct. Carpels nearly distinct, with a common style, 1-ovuled, at length fleshy and indehiscent, not beaked, separating from a very short axis. Embryo straight; cotyledons very thick; radicle very short.-Low tender anuuals, with alternate pinuate exstipulate leaves. 


\section{FloÉrkeA Willd. False Mermaid}

Sepals 3. Petals 3, shorter than the calyx, oblong. Stamens 6. Ovaries 3, opposite the sepals, united only at the base; the style rising in the center; stigmas :3. Fruit of 3 (or 1-2) roughish fleshy achenes. Seed anatropous, erect. Small and inconspicuous berbs, with minute solitary flowers on axillary pedun. cles. (Named for Gustav Heinrich Flörke, a German botanist.)

1. F. proserpinacoides Willd. Leafiets 3-5, lanceolate, sometimes 2-3-cleft. - Marshes and river-banks, w. Que. to Del., Ky., and westw. Apr.-June.Taste slightly pungent.

\section{ANACARDiàceaE (Cashew Family)}

Trees or shrubs, with resinous' or milky acrid juice, dotless alternate leaves, and small often polygamous regular 5-merous flowers, but the ovary 1-celled and 1-ovuled, with 3 styles or stigmas. - Petals imbricated in the bud. Fruit mostly drupaceous. Seed without albumen, borne on a curved stalk that rises from the base of the cell. Stipules none. Some species pervaded by an exceedingly active poisonous principle.

\section{RHÚS L. SUMACH}

Calyx small, 5-parted. Petals 5. Stamens 5, inserted under the edge or between the lobes of a flattened disk in the bottom of the calyx. Fruit small and indehiscent, a sort of dry drupe. - Leaves usually compound. Flowers green. ish-white or yellowish. (The old Greek and Latin name.)

\$ 1. SLMAC DC. (in part). Flowers polygamous, in a terminal thyrsoid panicle; fruit globular, symmetrical, clothed with acid crimson hairs; stone snooth; leaves udd-pinnate. (Not poisonous.)

1. R. typhina L. (Stragionn S.) Shrub or tree, 1-10 m. high, with orangecolored wood; branches and stalks densely velvety-hairy; leaflets $11-31$, pale beneath, oblong-lanceolate, pointed, serrate. ( $R$. hirta Sudworth.) - Dry or gravelly soil, e. Que. to Ont., s. to Ga., Ind., and Ia. June, July. - Apparently hybridizes with the next species. Forma laciniata (Wood) Rehder. Leaflets and bracts more or less deeply and laciniately toothed. - A frequent form, at least in some cases pathological and with inflorescence transformed in part into contorted bracts (the Datisca hirta of L.). Forma Disścta Rehder. Leaves bipinnatifid to bipinnate. - An occasional form, now in cultivation.

2. R. glàbra L. (Sмоотн S.) Smooth glancous shrub, 6-30 dm. high; leaflets 11-31, whitened beneath, lanceolate-oblong, pointed, serrate. - Common in dry soil, centr. Me., westw. and southw. June, July. Forma LAciniàta (Carr.) Robinson. Leaves laciniately bipinnatifid to bipinnate. - Pa. and Del.

3. R. copallina L. (I) WARF S.) Shrub, 0.3-2 or (especially southward) even $10 \mathrm{~m}$. high; branches and stalks downy; petioles wing-margined between the 9-21 oblong or ovate-lanceolate often entire leaflets, which are oblique or unequal at the base, smooth and shining above. - Rocky hills, s. Me., southw. and westw. July.

§2. VENENATAE Engl. Flowers polygamous, in loose and slender axillary panicles; fruit symmetrical, globular, glabrous or pubescent, whitish or dun-colored; the style terminal; stone striate; leaves odd-pinnate or B-foliolate, thin. (Poisonous.) Toxiconendron Mill.

4. R. Vérnix I. (l'orson S. or Dogwood,) Shrub, 2-5 m. high, smooth or nearly so; leaflets $7-1.3$, obovate-oblong, entire. ( $R$. venenata DC.) - Swamps. w. Me. to w. Mnt.. and southw. June. Cour most poisonous species; also called Porson Eismel.

5. R. Toxicodéndron L. (Poisox Irr, Porson Onk.) Sulerect and bushy, 
scrambling over fences, walls, etc., or in woods climbing by rootlets to considerable heights (var. RADIcaNs (L.) Torr.), sparingly pubescent or glablate; leaves pinnately 3-foliolate, leaflets ovate to rhombic, mostly acuminate, entire, crenulate, or irregularly and coarsely few-toothed, paler and with some persistent or tardily deciduous pubescence beneath ; berries whitish or cream-colored, subglobose, glabrous or nearly so, 5-6 mm. in diameter, in age sulcate. $\Lambda$ bundant in hedgerows, thickets, and woods. June, July. - To many persons poisonous to the touch. Passing on our western limits to a thicker-leaved smoother form ( $\boldsymbol{R}$. Rydbergi Small).

Var. microcárpa Michx. Similar ; fruit 3-4 $\mathrm{mm}$. in dianeter. ( $\boldsymbol{R}$. microcarpa Steud.) - Apparently local, w. Que. to Fla., and westw.

$\checkmark 6$. R. quercifdlia (Michx.) Steud. (Porson OAK.) Erect, 3-5 dm. high; leaflets broadly rhombic-ovate, conspicuously 3-7-lobed, permanently and somewhat copiously pubescent beneath, rather firm in lexture and somewhat veiny; fruit $4-5 \mathrm{~mm}$. in diameter, at first pubescent, in maturity glabrate but papillose. - Woods and barrens, Va., southw. and southwestw.

§3. LOBADIUM (Raf.) DC. Flowers polygamo-dioecious, in small solitary or clustered spikes or heads which develop in spring before the leaves; leaves 3-foliolate; fruit as in the first group. Schmaltzia Desv.

7. R. canadénsis Marsh. Leaves soft-pubescent when young, becoming glabrate; leaflets rhombic-obovate or ovate, unequally cut-toothed, $2.5-7.5 \mathrm{~cm}$. long, the terminal one cuneate at base and sometimes 3-cleft; flowers pale yellow. ( $R$. aromatica Ait.) - Dry rocky banks, w. Vt. to Minn,, and southw. A straggling bush, 1-2 m. high ; the crushed leaves not unpleasantly scented.

Var. illinoénsis (Greene) Fernald. Branchlets and petioles tomentulose; ieaves permanently appressed-pubescent above, velvety beneath. (Schmaltzia illinoensis Greene.) -Dry sandy banks, centr. Ill.

Var. trilobàta (Nutt.) Gray. With smaller somewhat flabelliform and obtusish leaflets, $1.5-2.5 \mathrm{~cm}$. long, crenately few-lobed or incised toward the summit. - Ill. ( $H a l l$ ), and common westw. - Unpleasantly scented.

\$4. CóTINUS (Adans.) DC. Ovary becoming very gibbous in fruit, with the remains of the styles lateral; flowers in loose ample panicles, the pedicels elongating and becoming plumose; leaves simple, entire.

8. R. cotinoides Nutt. A tree, 8-12 m. high, glabrous or nearly so ; leaves thin, oval, 7-15 cm. long. (Cotinus Britton.) - Wooded calcareous banks, s. e. Mo. to Tenn., and southw., rare and local. - Flowers and fruit much as in the cultivated SMOKE-TREe ( $R$. Cotinus L.), which is an occasional escape within our range.

\section{CYRILlàceAe (Crrilla Family)}

Shrubs or small trees with alternate entire thickish leaves, no stipules, and (4-)5-parted small regular and perfect flowers. Stamens hypogynous, 5 or 10 , when 5 alternate with the petals. Ovary 2-5-celled; cells 1-4-ovuled. Petals (white or roseate) imbricated or convolute in bud, sessile or unguiculate. Fruit a small corky drupe or tardily dehiscent pod. Flowers racemose-spicate.

\section{Cyrilla Garden. Leatherwood. Black Ti-ti}

Petals sessile. Stamens 5, attached with the petals under a disk; anthers somewhat sagittate. Ovary 2-3-celled; ovules anatropous or half-anatropous ; cotyledons terete; small; radicle superior. - Leaves oblanceolate, coriaceous, evergreen or nearly so. (Named in honor of Dominiro Cyrillo, protessor of medicine at Naples.)

1. C. racemiflora L. Glabrous shrub, with shining somewhat veiny leaves and innumerable small flowers in clustered racemes. - Edges of swamps, s. e. Va., and southw. (W. I.; S, A.) 


\section{AQUIFOLIÀCEAE (HoLly FAMILY)}

Trees or shrubs, with small axillary 4-8-merous flowers, a minute calyx fres from the 4-8-celled ovary and the 4-8-seeded berry-like drupe; the stamens as many as the divisions of the almost or quite 4-8-petaled corolla and alternate with them, attached to their very base. Corolla imbricated in the bud. Anthers opening lengthwise. Stigmas 4-8, or united into one, nearly sessile. Seeds suspended and solitary in each cell, anatropcus, with a minute embryo in fleshy albumen. Leaves simple, mostly alternate. Flowers white or greenish, mostly polygamo-dioecious. - Small family, related to the Ebenaceae.

1. Ilex. Petals or corolla-lobes oval or obovate. Stamens adnate to the base of the corolls.

2. Nemopanthus. Petals linear, free from each other and from the stamens.

\section{1. İLEX L. HOLLY}

Calyx 4-6-toothed. Petals 4-6, separate or united only at the base, oval or obovate, obtuse, spreading. Stamens 4-6. The berry-like drupe containing 4-6 little nutlets. - Leaves alternate. Fertile flowers inclined to be solitary, and the sterile or partly sterile flowers to be clustered in the axils. (The ancient Latin name of the Holly Oak, rather than of the Holly.)

§1. AQUIFOLIUM [Tourn.] Gray. Parts of the flower commonly in 4's, sonetimes in 5's or 6's; drupe red or yellow, its nutlets ribbed, veiny, or 1-grooved on the back; leaves mostly smooth, coriaceous and evergreen.

* Leaves armed with spiny teeth; trees.

1. I. opàca Ait. (AMERICAN H.) Leaves oval, flat, the wavy margins with scattered spiny teeth; flowers in loose clusters along the base of the young branches and in the axils; calyx-teeth acute; fruit red. - Moist woodlands, Mass. to N. J., near the coast, w. to s. Mo., and southw. June, - Tree, 6-12 m. high; the deep green foliage less glossy than in the European Holly. Forma zanthocarpa Rehder. Fruit bright yellow. - New Bedford, Mass. (Hervey).

$$
\text { * Leaves serrate or entire, not spiny; shrubs. }
$$

2. I. vomitoria Ait. (CAssena, YaUPON.) Leaves lance-ovate or elliptical, cronate, $2.5-3.8 \mathrm{~cm}$. long; flower-clusters nearly sessile, smooth; calyx-teeth ohtuse. (I. Cassine Man. ed. 6, not I.) -Va. to Fla., Ark., and Tex. May. - Leaves used for tea by the people along the coast, as they were also to make the celebrated black drint of the North Carolina Indians. (W. I.)

3. I. Cassine L. (Dahoon H.) Leaves oblanceolate or oblong, entire, or sharply serrate toward the apex, with revolute margins, 5-7.5 cr. long, the midrib and peduncles pubescent; calyx-teeth acute. (I. Dahoon Walt.) Swamps, s. Va., and southw. May, June.

Var. myrtifdila (Walt.) Sarg. Leaves smaller $(2.5 \mathrm{~cm}$. long or less) and narrower. (I. myrtifolia Walt.) - Same range. May.

§2. PRINOIDES Gray. Parts of the polygamous or dioecious flowers in 4's or 5's (rarely 6's); drupe red or purple; nutlets striate-many-ribbed on the back; leaves deciduous; shrubs.

4. I. decidua Walt. Leaves wedge-oblong or lance-obovate, obtusely serrate, downy on the midrib beneath, shining above, becoming thickish; peduncles of the sterile flowers longer than the petioles, of the fertile short; calyz-teeth smooth, acute. - Wet grounds, Va. to Mo., Kan., and southw. May.

5. I. montícola Gray. Leaves ovate or lance-oblong, ample (6-12 cm. long), taper-pointed, thin-membranaceous, smooth, sharply serrate; fertile flowers very short-peduncled; caly $x$ ciliate. - Damp woods, Taconic and Catskill Mts., and Cattaraugus Co., N. Y., and southw. along the Alleghenies. May. 
Var. mollis (Gray) Britton. Ieaves soft-downy beneath. (I. mollis Gray.) -Taconic Mts., Mass. (Hoffmann) to N. C. At the South appearing to pass without clear limits into a form with shorter rounder leaves and tomentose calyx (I. Beadlei Ashe).

§ 3. PRINOS Gray. Parts of the sterile flowers commonly in 4's, 5's, or 6's, those of the fertile flowers commonly in 6's (rarely in 5's, 7's, or 8's); nutlets smooth and even; shrubs.

* Leaves deciduous; fiuit red or yellow.

6. I. verticillata (L.) Gray. (Black Alder, Winterberry.) Leaves 3-7 $\mathrm{cm}$. long, oval; obovate, or wedge-lanceolate, pointed, acute at base, serrate, downy chiefly on the veins beneath; flowers all very short-peduncled; calyxlobes ciliate on the margins; fruit red. - Low grounds, common. May, June. Forma CHRYsocḱrpA Robinson. Fruit yellow, - Georgetown, Mass. (Mrs. Horner).

Var. tenuifolia (Torr.) Wats. Leaves thinner, smoother, pellucid-puncticulate under a lens; fertile flowers more inclined to be solitary. ( 1 . bronxensis Britton.) - A northeastern woodland form, N. S. to Ont., Mich., and N. J.

Var. cyclophýlla Robiuson. Leaves small, suborbicular, finely pubescent upon the veins beneath, teriding to be clustered at the ends of the branchlets. (Var. padifolia Britton, not T. \& G.) - Shores of L. Erie; a similar form with small and clustered but narrower leaves on Mt. Desert I., Me. (Rand).

Var. padifolia (Willd.) 'T. \& G. Leaves $5-12 \mathrm{~cm}$. long, as in the typical form, but tomentulose on the surface (as well as the veins) beneath. - Mass. to Minn. and southw.

7. I. laevigata (Pursh) Gray. (Smooth WrnterberRy.) Leaves lanceolate or oblong-lanceolate, appressed-serrulate, shining above, mostly glabrous beneath; sierile flowers long-peduncled; calyx-lobes not ciliate. - Wet grounds, N. H. to the mts. of N. C. June.-Fruit larger than in the last, ripening earher. Forma Hervixi Robinson. Fruit bright yellow. - New Bedford, Mass. (Hervey).

* Leaves coriaceous, evergreen, shining, often dotted beneath; fruit black.

$V$ 8. I. glabra (L.) Gray. (INkBenRY.) Shrub, 6-9 dm. high, the twigs ashypuberulent; leaves wedge-lanceolate or oblong, sparingly toothed toward the apex, smooth, 1.4-4.8 cm. long, 8-15 mm. wide; peduncles (1.2 cm. long) of the sterile flowers $3+6$-flowered, of the fertile 1 -flowered; calyx-teeth rather blunt. - Low sandy grounds, s. w. N. S.; and from Cape Amn, Mass., to Fla. and La., near the coast. June.

9. I. lùcida (Ait.) T. \& G. Largex shrub, with glabrous or viscid-puberulent branchlets; leaves obovate to oblanceolate, coriaceous, entive or remotely toothed, short-acuminate, mostly $3-7.5 \mathrm{~cm}$. long, $1.6-2.8 \mathrm{~cm}$. wide, on thickish petioles 6-10 $\mathrm{mm}$. in length. - Swamps, Va. to Fla. and La.

\section{NEMOPÁNTHUS Raf. MOUNTAIN HoLly}

Flowers polygamo-dioecious. Calyx in the sterile flowers of 4-5 minute deciduous teeth, in the fertile ones obsolete. Petals 4-5, oblong-linear, spreading, distinct. Stamens 4-5; filaments slender. Drupe with 4-5 bony nutlets, light red. - A much branched shrub, with ash-gray bark, alternate deciduous entire or slightly toothed smooth leaves on slender petioles. Flowers on lons slender axillary peduncles, solitary or sparingly clustered. (Name said by the author to mean "flower with a filiform peduncle," presumably from

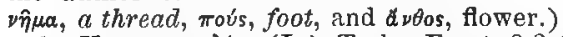

1. N. mucronata (L.) Trel. Erect, $0.3-3 \mathrm{~m}$. high ; bark gray ; leaves elliptic-oblong, thin, slightly paler beneath. - (Nemopanthes fiscicularis Raf., Ilicioides mucronata Britton.) - Damp cool woods, from the mts. of Va. to Nfd., Ind., Wisc, and northw. 


\section{Celastraceate (Staff Tree Family)}

Shrubs with simple leaves, and small regular florers, the sepals and the petals both imbricated in the bud, the 4 or 5 perigynous stamens as many as the petals and alternate with them, inserted on a disl which fills the buttom of the calyx and sometimes covers the ovary. Seeds arilled. Ovule anatropous; styles united into one. Fruit 2-5-celled, free from the calyx. Embryo large, in fleshy albumen; cotyledons broad and thin. Stipules minute and fugacious. Pedicels jointed.

* Leaves opposite ; flowers in axillary cymes or solitary.

1. Evonymus. Erect shrobs, Leaves deciduous, Fruit 3-5-lobed, 8-5-valved. A ril red.

2. Pachistima. Dwarf evergreen shrub. Flowers very small. Fruit oblong, 2-valped. Aril white.

* Leaves alternate; flowers in terminal racemes.

3. Celastrus. A shrubby climber. Fruit globose, orange, 3-valved. Aril searlet.

\section{EVÓNYMos [Tourn.] L. SPINdLe Tree}

Flowers perfect. Sepals 4 or 5 , united at the base, forming a short and flat calyx. Petals 4-5, rounded, spreading. Stamens short, borne on the edge or face of a broad and flat 4-i-angled disk, which coheres with the calyx and is stretched over the ovary, adhering to it more or less. Style short or none. Pod 3-5-lobed, 3-5-valved, loculicidal. Seeds 1-4 in each cell, inclosed in a red aril. - Shrubs, with 4-sided branchlets, opposite serrate leaves, and loose pedúnculate cymes of small flowers on axillary peduncles. (Name from $\varepsilon \hat{v}$, good, and byora, name, but nsed ironically, the plants having had the bad reputation of poisoning cattle.)

1. E. atropurpùreus Jacq. (Burning Bush, WaAhoo.) Tree-like shrub, 2-4 m. high; leaves petioled, oval-oblong, pointed; parts of the dark-purple flower commonly in fours; pods smooth, deeply lobed. - N. Y. to Wisc., Neb.; southw. and westw.; also cultivated, and locally establishing itself northeastw. June. - Ornamental in autumn, its copious crimson fruit drooping on long peduncles.

2. E. edropatus L., the European Spixde Tree, with similar foliage but less numerous greenish or yellowish-white flowers, occasionally escapes from cultivation in the Atlantic States, (Introd. from Eu.)

3. E. americànus L. (STrawberRY Bush.) Shrub, low, upright or straggling, 1-2 m. high ; leaves almost sessile, thickish, bright green, ovate to oblonglanceolate, acute or pointed; parts of the greenish-purple flowers mostly in 5's ; petals distinctly clawed; pods rough-warty, depressed, crimson when ripe; the aril and dissepiments scarlet. - Wooded river-banks, N. Y. to Ill., Fla. and I'ex. June.

4. E. obovàtus Nutt. Trailing, with rooting branches; flowering stems 3-6 $\mathrm{dm}$. high; leaves thin and dull, obovate or oblong, obtuse; petals without distinct clazo. (E. americanus, var. T. \& G.) - Low or wet places, w. Ont. to Pa., Ky, and Ill.; commoner than the preceding.

\section{PACHISTIMA Raf.}

Flowers perfect. Sepals and petals 4. Stamens 4, on the edge of the broad disk lining the calyx-tube. Ovary free; style very short. Pod small, oblong, 2-celled, loculicidally 2 -valved. Seeds 1 or 2 , inclosed in a white membranaceous many-cleft aril. - Low evergreen shrubs, with smooth serrulate coriaceous opposite leaves and very small green flowers solitary or fascicled in the axils. (Name from $\pi \alpha \chi u ́ s$, thick, and $\sigma r(\gamma \mu a$, stigma.) 
1. P. Cánbyi Gray. Leaves linear to linear-oblong or oblong-obovate, obtuse, 6-25 inun. long; pedicels very slender, often solitary, shorter than the leaves; fruit $4 \mathrm{~mm}$. long. - Steep rocky siopes, mts. of s. Va. and W. Va.

\section{Celástrus L. Staff Tree. Shrubiy Bitter-sweet}

Flowers polygamo-dioecious. Petals (crenulate) and stamens 5, inserted on the margin of a cup-shaped disk which lines the base of the calyx. Pod globose, orange-color and berry-like, 3-celled, 3-valved, loculicidal. Seeds i or 2 in each cell, erect, inclosed in a pulpy scarlet aril.-Leaves aiternate. Flowers small, greenish, in raceme-like clusters terminating the branches. (An ancient Greek name for some evergreen.)

1. C. scándens L. (Waxwork, Climbing Bitter-sweet.) Twining shrub; leaves ovate-oblong, finely serrate, pointed.-Along streams and in thickets, Me. to Man., and southw. June.-The opening orange-colored pods, displaying the scarlet covering of the seeds, are very ornamental in autumn.

\section{STAPHYLEACEAE (Bladder Nut FaMily)}

Shrubs or small trees with opposite chiefly pinnate stipulate leaves and perfech flowers. Stamens as many as and alternate with the petals, borne outside a large disk. Fruit (in ours) a bladdery inflated 2-3-horned capsule. Seeds (in ours) with scanty albumen and straight embryo. - Chiefly Asiatic.

\section{STAPHYLEA L. BLADDER NuT}

Calyx deeply 5-parted, the lobes erect, whitish. Petals 5, erect, spatulate. Pistil of 3 several-ovuled carpels, united in the axis, their long styles lightly cohering. Pod large, inflated, 3-celled, at length bursting at the summit; the cells containing $1-4$ bony anatropous seeds. Cotyledons broad and thin. -Upright shrubs, with opposite piunate leaves of 3 or 5 serrate leaflets, and white flowers in drooping raceme-like clusters terminating the branchlets. Stipules and stipels deciduous. (Name from $\sigma \tau a \phi v \lambda \dot{\eta}$, a cluster.)

1. S. trifòlia L. (A MEncAN B.) Leaflets 3, ovate, pointed. -Thickets, in moist soil, w. Que. and w. N. E. to Minn., and southw. May. - Shrub, 3 m. high, with greenish striped branches.

\section{aceràceae (Maple Familir)}

Trees and shrubs with watery saccharine sap, opposite simple and palmately iobed or more rarely palmately or pinnately divided leaves, small regular mostly polygamous or dioecious sometimes apetalous flowers. Ovary 2-celled, 2-lobed; ovules 2 in each cell. Embryo coiled or folded; cotyledons long and thin. Chiefly trees of temperate regions.

\section{1. ÀCER [Tourn.] L. MAPLE}

Flowers polygamo-dioecious. Calyx colored, 5(rarely 4-12)-lobed or -parted. Petals either none or as many as the lobes of the calyx, equal, with short claws if any, inserted on the Inargin of a perigynous or hypogynous disk. Stamens 312. Ovary 2-celled, with a pair of ovules in each cell; styles 2, long and slender, united only below, stigmatic down the inside. From the back of each carpel grows a wing, converting the fruit into two 1-seeded at length separable samaras or keys. - Trees or sometimes shrubs, with opposite palmately lobed leaves, and small flowers. Pedicels not jointed. (The classical name, from the Celtic ac, hard.) 


\section{\$1. ACER proper. Disk usually present. Leaves in ours simple, palmately lobed or cleft.}

* Flowers in terminal racemes, greenish, appearing after the leaves; stamens $6-8$.

1. A. pennsylvánicum L. (Striped M., Moosewood.) Leaves 3-lobed at the apex, finely and sharply double-serrate, the short lobes taper-pointed and also serrate; racemes drooping, loose; petals obovate; fruit with large diverging wings. - Rich woods, e. Que. to w. Ont., s. to N. E., N. Y., Great L. region, and in the mts. to Ga. June.-A small and slender tree, with light green bark striped with dark lines, and greenish flowers and fruit.

2. A. spicatum Lam. (Modntain M.) Leaves downy beneath, 3(or slightly 5)-lobed, coarsely serrate, the lobes taper-pointed; racemes upright, dense, somewhat compound; petals linear-spatulate; fruit with small erect or divergent wings. - Moist woods, Nfd. and Lab. to Hudson B. and Man., s. to N. E., N. Y., Great L. region, e. Ia., and in the mts. to Ga. June. - A tall shrub or small tree, with reddish fruit.

** Flowers in nearly sessile terminal and lateral umbellate-corymbs, greenishyellow, appearing with the leaves.

3. A. sáccharum Marsh. (SṫGAR or Rock M.) Leaves 3-5-lobed, with rounded sinuses and pointed sparingly sinuate-toothed lobes, either heartshaped or nearly truncate at the base, whitish and smooth or a little downy on the veins beneath ; flowers from terininal leaf-bearing and lateral leafless buds, drooping on very slender hairy pedicels ; calyx hairy at the apex; petals none; wings of the fruit broad, usually slightly diverging. (A. saccharinum Wang., not L.) - Rich woods, especially northw. and along the mts. southw. Apr., May. - A large and handsome tree.

Var. nigrum (Michx. f.) Britton. (Black Sugar M.) Leaves green and scarcely paler but usually downy benecth, the lobes wider, often shorter and entire, the sinus at the base commonly closed; stipules often conspicuous. - Rich soil, w. Que. and w. N. H., southw. and westw.; sometimes appearing distinct.

** * Flowers in umbel-like clusters arising from separate lateral buds, and much preceding the leaves; stamens 3-6.

4. A. saccharìnum L. (White or SiLver M.) Leaves very deeply 5-lobed, with the sinuses rather acute, silvery-white (and when young downy) underneath, the divisions narrow, cut-lobed and toothed ; flowers on short pedicels; petals none; fruit woolly when young, with large divergent wings. (A. dasycarpum Ehrh.) - River-banks. March, Apr. - A fine ormamental tree.

$\checkmark$ 5. A. rùbrum L. (RED or Swarp M.) Leaves broadly ovate to suborbicular, truncate or cordate at base, tomentose when young, soon glabrate, whitened beneath, $8-15 \mathrm{~cm}$. long; the 3-5 acuminate lobes irregularly serrate and notched, the middle one oblong at base ; petals linear-oblong; flowers (scarlet, crimson, or sometimes yellowish) on very short pedicels; but the smooth fruit on prolonged drooping pedicels. - Swamps and wet woods, e. Que. to w. Ont., and southw. Apr. - A medium-sized tree, with reddish twigs; the leaves varying greatly in shape, turning bright crimson in early autumn.

Var. Drummóndii (H. \& A.) T. \& G. Leaves large and firm, permanently tomentose beneath. (A. Drummondii H. \& A.) - Mo, and southw.

Var. tridens Wood. Leaves small (5-10 $\mathrm{cm}$. long), obovate, narrowed or rounded and subentire or sparingly toothed below the 3 short lobes; the middle lobe broadly triangular. (A. carolinianum Britton, perhaps Walt.) - Local, Mass. to Fla., Mo., and Tex.

§2. NEGÚNDO (Moench) Koehne. Flower's strictly dioecious. Disk none. Leaves pinnate. NEGINDO Moench.

6. A. Negúndo L. (Box ELDLr.) Leaflets 3-5 (-9), smoothish when old, very veiny, ovate, liointed, toothed; petals none; fruit smooth, with large 
cather incurved wings. (Negundo aceroides Moench.) - River-banks, w. N. E. to Man., southw. and westw, ; extensively cultivated and frequently seeding itself eastw. Apr. - A small but handsome tree, with light-green twigs, and very delicate drooping clusters of small greenish flowers rather earlier than the leaves.

\section{SAPINDACEAE (SOAPBERRY FAMILT)}

Trees, shrubs, rarely herbaceous climbers, with exstipulate chiefly alternate and compound leaves. Flowers often polygamous, mostly unsymmetrical. Stamens commonly more numerous than the petals, rarely twice as many. Embryo curved or convolute, rarely straight; cotyledons thick and fleshy. - Large family, chiefly woody climbers in the tropics.

1. Sapindus. Flowers subregular. Leaves alternate, pinnate.

2. Aesculus. Flowers irregular. Leaves opposite, palmate.

\section{SAPINDUS ['Tourn.] L. SoapberRY}

Flowers regular, polygamous. Sepals $4-5$, imbricated in 2 rows. Petals 4-5, with a scale at the base. Stamens 8-10, upon the hypogynous disk. Ovary 3-celled, with an ascending ovule in each cell. Fruit a globose or 2-3-lobed berry, 1-3-seeded. Seed crustaceous, globose. - Trees or shrubs, with alternate abruptly pinnate leaves, and small flowers in terminal or axillary racemes or panicles. (Name a contraction of sapo indicus, Indian soap, having reference to the saponaceous character of the berries.)

1. S. Drummóndi H. \& A. 'Tree, 6-18 m. high; leaflets $4-9$ pairs, obliquely lanceolate, sharply acuminate, entire, $3.7-7.5 \mathrm{~cm}$. long; the rbachis of the leaf not winged; flowers white, in a large panicle; fruit mostly globose, $1.2 \mathrm{~cm}$. in diameter. (S. acuminatus Man. ed 6, not Raf.) - Kan. to La. and Mex.

Cardospérmum Halichcabum L., the Balloon Vine of cultivation, an herbaceous climber with bi-ternate leaves and bladdery pods, is occasionally spontaneous. (Introd. from Tropics.)

\section{Aésculus L. Horse-chestndt. Buckeye}

Calyx tubular, 5-lobed, often oblique or gibbous at base. Petals 4-5, more or less unequal, with claws, nearly hypogynous. Stamens 7 (rarely 6 or 8) ; filaments long, slender, often unequal. Style 1; ovary 3-celled, with 2 ovules in each cell. Fruit a leathery pod, 3-celled and 3-seeded, or usually by abortion 1-celled and 1-seeded, loculicidally 3-valved. Seed very large, with thick shining coat, and a large round pale scar. Cotyledons very thick and fleshy, their contiguous faces coherent, remaining under ground in germination; plumule 2-leaved; radicle curved. - Trees or slurubs. Leaves opposite, digitate ; leaflets serrate, straight-veined, like a Chestnut leaf. Flowers in a terminal thyrse or dense panicle, often polygamous, most of them with imperfect pistils and sterile; pedicels jointed. Seeds farinaceous, but imbued with a bitter and narcotic principle. (The ancient name of some Oak or other mast-bearing tree.)

\section{§1. EUAÉSCULUS Pax. Fruit covered with prickles when young.}

1. A. Hippocastanum L. (Common H.) Corolla spreading, white, spotted with purple and yellow, of 5 petals; stamens declined; leaflets 7. - Commonly planted and occasionally self-sown. (Introd. from Asia via Eu.)

2. A. glàbra Willd. (FETid or Oнıо B.) Stamens curved, longer than the pale yellow corolla of 4 upright petals; leaflets usually 5. - River-banks, w. Pa. to Mich., Mo., Kan., and southw. June. - A large tree; the bark exhaling an unpleasant odor, as in the rest of the genus. Flowers small, not showy. 
Var, argùta (Buckley) Robinson. Leaflets mostly 6 or 7 , lanceolate, attent. ate, sharply serrate. (A. arguta Buckley.) - Ia, (Mills), Mo. (Bush), to Kan. and Tex.

\section{§ 2. PAVIA [Boerh.] Pers. Fruit smooth; petals 4, conniving; the 2 upper smaller and longer than the others, with a small rounded blade on a very long claw.}

3. A. octándra Marsh. (SweEt B.) Stamens included in the yellow corolla: calyx oblong-campanulate; leaflets 5 , sometimes 7 , glabrous, or often ininutely downy underneath. (A. flava Ait.) - Rich woods, Pa. to Wisc., Ia., and southw. May, - A large tree or a shrub.

Var. hýbrida (DC.) Sarg. Calyx and corolla tinged with flesh-color or dull purple; leaflets commonly downy beneath. (A. flava, var. purpurascens Gray.) -W. Va., southw. and westw.

4. A. Pavia L. (BED B.) Stamens not longer than the corolla, which is bright red, as well as the tubular calyx; leaflets glabrous or soft-downy beneath - Fertile valleys, Va., Ky., Mo., and southw. May. - A shrub or small tree.

\section{BALSAMINACEAE. (TOUCh-ME-NoT FAMILT)}

Herbs or undershrubs with bland watery juice, alternate simple exstipulate lexves, irregular flowers, and petaloid imbricated spurred calyx. Stanens 5, with short flat filaments and introrse more or less connivent anthers. Ovary 5-celled. Seeds without albumen; embryo straight. - Ours glaucous succulent annuals.

\section{IMPÀTIENS [Rivinius] L. BaLGAM. JEWELWEed}

Sepals apparently only 4 ; the anterior one notched at the apex (probably two combined); the posterior one (appearing anterior as the flower hangs on its stalk) largest, and forming a usually spurred sac. Petals 2, 2-lobed (each a pair united). Filaments appendaged with a scale on the inner side, the 5 scales connivent over the stigma; anthers introrse. Pod with evanescent partitions, and a thick axis bearing several anatropous seeds; valves 5, coiling elastically and projecting the seeds in dehiscence. - Leaves in ours ovate or oval, coarsely coothed, petioled. Flowers axillary or panicled, often of two sorts, viz., the larger ones which seldom ripen seeds; and very small ones which are fertilized early in the bud, their floral envelopes never expanding but forced off by the growing pod and carried upward on its apex. (Name from the sudden bursting of the pods when touched, whence also the popular appellation.)

1. I. pállida Nutt. (PALE Touch-ME-Not.) Flovers pale-yellovo, sparingly dotted with brownish-red ; sac dilated and very obtuse, broader than long, tipped with a short incurved spur. (I. aurea Muhl. ?) - Moist shady places and along rills, in tich soil, n. Me. and w. N. E., westw. and southw. July-Sept. - Larger and greener than the iext, with larger flowers. A form with unspotted flowers occurs.

2. I. biflora Walt. (SPOTTed Touch-ME-Not.) F'lovers orange-color, thickly spotted with reddish brown; sac longer than broad, acutely conical, tapering into a strongly inflexed spur half as long as the sac. (I. fulva Nutt.) - Rills and shady moist places. June-Sept. - Plant 6-8 dm. high. Forms with spotless, whitish, or roseate flowers have been found.

I. Nóli-TANGERE L., of Eurasia and $n$. w. Am., with pale yellow flowers and the sac much longer than broad, is reported from Ottawa, Ont. (Macoun).

\section{RHAMNÀCEAE (BtCKTHORN FAMILx)}

Shrubs or small trees, with simple leaves, small and regular flowers (sometimes apetalous), woith the 4 or 5 perigynous stamens as many as the valvate sepals and alternate with them, accordingly opposite the petals! Drupe or pod 
with only ons erect seed in each cell, not arilled. Petals folded inwards in the bud, hooded or concave, inserted with the stamens into the edge of the fleshy disk which lines the short tube of the calyx and sometimes unites it to the lower part of the 2-5-celled ovary. Ovules solitary, anatropous. Stigmas 2-5. Fmbryo large, with broad cotyledons, in sparse fleshy albumen. Flowers often polygamous, sometimes dioecious. Leaves mostly alternate; stippules small or obsolete. Branches often thorny. - Slightly bitter and astringegs ; the fruit often mucilaginous, commonly rather nauseous or drastic.

* Caly $x$ and disk free from the ovary.

1. Berchemia. Petals sessile, entire, as long as the calyx. Drupe with thin flesh and a 2-celled bony putamen.

2. Rhamnus. Petals small, short-clawed, notched, or none. Drupe berry-11:4, with 2-4 separate seed-like nutlets.

* *alyx with the disk adherent to the base of the ovary.

8. Ceanothus. Petals long-clawed, hooded. Fruit dry, at length dehiscent.

\section{BERCHÈMIA Neck. SUPPLE-JACK}

Caly $\mathrm{x}$ with a very short and roundish tube; its lobes equaling the 5'oblong sessile acute petals, longer than the stamens. Disk very thick and flat, filling the calyx-tube and covering the ovary. 1)rupe ellipsoid, with thin flesh and a bony 2-celled putamen. - Woody high-climbing twiners, with the pirnate veins of the leaves straight and parallel, the small greenish-white flowers in small panicles. (Name unexplained, probably personal.)

1. B. scándens (Hill) Trel. Glabrous; leaves oblong-ovate, acute, scarcely serrulate; style short. (B. volubilis DC.) - Damp soils, Va. to Mo., and southw. June. - Stems tough and very lithe, whence the popular name.

\section{RHÁMNUS [Tourn.] L. BUCKTHORN}

Calyx 4-5-cleft; the tube campanulate, lined with the disk. Petals small, short-clawed, notched at the end, wrapped around the short stamens, or sometimes none. Ovary free, 2-4-celled. Drupe berry-like (black), containing 2-4 separate seed-like nutlets, of cartilaginous texture. - Shrubs or small trees, with loosely pinnate-veined leaves, and greenish perfect, polygamous, or dioecious flowers, in axillary clusters. (The ancient Greek name.)

§1. EURHAMNUS Griseb. Flowers usually dioecious; nutlets and seeds deeply grooved on the back; rhaphe dorsal; cotyledons foliaceous, the margins revolute.

* Calyx-lobes and stamens 5 ; petals wanting.

1. R. alnifolia L'Hér. A low shrub; leaves oval, acute, serrate, nearly straight-veined ; fruit 3-seeded. - Swamps, Nfd. to B. C., s. to N. J., Pa., Ili., Neb., Wyo., ete. June.

\section{** Calyx-lobes, petals, and stamens 4.}

2. R. CATHÁRICA L. (CoMmon B.) Leaves ovate, minutely serrate; fruit 3-4-seeded; branchlets rigid, often spine-like. - Cultivated for hedges; locally naturalized eastw. May, June. (Introd. from Eu.)

3. R. lanceolàta Pursh. Tall unarmed shrub; leaves oblong-lanceolate and acute, or on flowering shoots oblong and obtuse, finely serrulate, smooth or minutely downy beneath; the yellowish-green flowers of two forms on distinct plants, both perfect; one with short pedicels clustered and with a short included style; the other with pedicels oftener solitary, style exserted; petals deeply notehed; fruit 2-seeded. - Hills and river-banks, Pa. to Neb., southw. and westw. May. 


\section{§ 2. FRÁNGULA S. T. Gray. Flowers perfect; nutlets and seeds not furrowed;} cobyledons flat, thich; rhaphe lateral.

4. R. caroliniàna Walt. Thornless shrub or small tree; leaves $7-13 \mathrm{~cm}$. long, oblong, obscurely serrulate, nearly glabrous, deciduous ; fowers 5 -merous, in one form solitary in the axils, in another in short-peduncled umbels; drupe globose, 3-seeded. - Niwamps and river-banks, rarely on dry rocky hills, N. e. to Kan., and southw. Iume.

5. R. FRANGULA L., with sessile umbels, is established in Ont., on L. I., and in n. N. J. (Introd, from Eu.)

\section{CEANOTHUS L. RED-ROOT}

Calyx 5-lobed, incurved; the lower part cohering with the thick disk to the ovary, the upper separating across in fruit. Petals hooded, spreading, on slender claws longer than the calyx. Filaments elongated. Fruit 3 -lobed, dry and splitting into its 3 carpels when ripe. - Shrubby plants; flowers in little umbel-like clusters, forming dense panicles or corymbs at the summit of naked flowerbranches; calyx and pedicels colored like the petals. (An obscure name used by Theophrastus, probably nisspelled.)

V' 1. C. americanus L. (NEW JeRsey TEA.) Leaves ovate or oblong-ovate, 2.4-5.5 cm. broad, acutish to acuminate, 3-ribbed, serrate, more or less pubescent, often slightly heart-shaped at base; common peduncles elongated. - Dry woodlands and gravelly shores, centr. Me. to w. Ont., and southw. July. Stems 3-9 dm. high from a dark red root; branches downy. Flowers in pretty white clusters, on leafy shoots of the same year. The leaves were used for tea during the American Revolution.

2. C. ovatus Desf. Leaves narrowly oval or elliptical-lanceolate, 7-22(-26) $m m$. broad, obtuse or rounded at the apex, finely glandular-serrate, glabrous or nearly so, as well as the short common peduncles. - Dry rocky or sandy soil, w. Vt. and e. Mass. to Man., Minn., Ill., and southwestw.; rare eastw. May. Var. PUBéscens 'T. \& G. has leaves permanently sordid-tomentose. - Ia. and southwestw.

\section{VITACEAE (VINE Family)}

Shrubs with watery acid juice, usually climbing by tendrils, with small regular greenish commonly polygamous flowers, a minute or truncated calyx, its limb mostly obsolete, and the stamens as many as the valvate petals and opposite them! Berry 2-celled, usually 4-seeded. Petals 4-5, very deciduous, hypogynous or perigynous. Filaments slender ; anthers introrse. Style short or none ; stigma slightly 2-lobed; ovary 2-celled, with 2 erect anatropous ovules from the base of each cell. Seeds bony, with a minute embryo at the base of the hara albumen. Stipules deciduous. Leaves alternate, palmately veined or compound; tendrils and flower-clusters opposite the leaves.

* No distinct hypogynous disk; some or all the tendril-branches with dilated adhesive tips.

1. Psedera. Corolla expanding. Jueaves digitate.

* * Ovary surrounded by a nectariferous or glanduliferous disk ; tendrils coiling, naked-tipped.

2. Cissus. Corolla expanding. Disk oupular, Rerry with scanty pulp, inedible. Leaves simple or pinnately compound.

3. Vitis. Corolla esducous without expanding. Hypogynous glands 5, alternate with the stamens. Fruit pulpy. Leaves simple.

\section{PSEDera Neck. Virginia Creeper. Woodbine}

Calyx slightly 5-toothed. Petals concave, thick, expanding before they fall. Disk none. - Woody climbers, with digitate leaves; leaflets $5(3-7)$, oblong- 
?anceolate, rather coarsely serrate. Flower-clusters cymosely compound. Tendrils branched, their tips twining or affixing themselves by enlarged terninal adhesive disks. (Name supposedly intended as a contraction of $\psi \epsilon \hat{v} \delta o s$, false, and Hedera, the Ivy.) Ampelopsis Michx., in part. Parthenocissus Planch.

1. P. quinquefolia (L.) Greene. Glabrous even upon the young shoots; leaflets dull green, decidedly paler beneath, distinctly petiolulate; tendrils with $5-12$ rather long branches mostly ending in adhesive disks; peduncles $1-4 \mathrm{~cm}$. long; inflorescence paniculate, its main branches unequal; fruit subglobose, scarcely fleshy, about 6-7 mm. in diameter. (Ampelopsis Michx.; Parthenocissus Planch.) - Copses, etc., s. N. H., westw, and southw., common. (Mex., W. I.)

Var. hirsùta (Donn) Rehder. Branchlets, tendrils, petioles, and to some extent the leaflets pubescent at least when young; aërial rootlets often present ; otherwise like the typical form. (Ampelopsis quinquefolia, var. pubescens Bailey.) - Vt. to Ia., southw. and souchwestw.

Var. Saint-Paúlii (Koehne \& Graebner) Rehder. Somewhai pubescent upon the younger parts; aërial rootlets more prevalent than in the other forms of the species; leaflets cuneate to a sessile or scarcely petiolulate base; cymules somewhat racemosely arranged, rendering the elongated main branches of the inflorescence subcylindric. - Ia., Ill., and southwestw.

2. P. vitàcea (Knerr) Greene. Glabrous or sparingly pubescent; leaflets deep green, thin, somewhat shining above, scarcely paler beneath; tendrils with 2-5 long twining branches, these only exceptionally ending in adhesive disks; aërial rootlets none; peduncles mostly $48 \mathrm{~cm}$. long; inflorescence regularly dichotomous, the primary branches nearly equal; fruit somewhat obovoid, 6-10 $\mathrm{mm}$. in diameter, more fleshy than in the preceding species. (Ampelopsis quinquefolia of auth., in part, not Michx.; Parthenocissus vitaced Hitchc.) Moist woods, alluvial thickets, etc., centr. Me. to Assina. and Tex., common.

\section{2. císsus L.}

Flowers perfect or sometimes polygamous, 4-merous or (in ours) 5-merous. Petals expanding. Disk cup-shaped, surrounding the base of the ovary. Berry inedible, with scanty pulp. Seeds usually triangular-obovate. Tendrils in our species few and mostly in the inflorescence. - A vast genus, mainly tropical. (Greek name of the Ivy.) Ampelopsis Michx., in part.

1. C. Ampelopsis Pers. Nearly glabrous; leaves heart-shaped or truncate at the base; coarsely and sharply toothed, acuminate, not lobed; panicle small and loose; style slender; berries of the size of a pea, 1-3-seeded, bluish or greenish. (Ampelopsis cordata Michx., not C. cordata Roxb.) - River-banks, Va. to Neb., Tex, and Fla. June.

2. C. arbòrea (L.) Des Moulins. (PepPer-vine.) Nearly glabrous, bushy and rather upright; leaves twice pinnate or ternate, the leaflets cut-toothed ; flowers cymose ; calyx 5-toothed; disk very thick, adherent to the ovary ; berries black, obovoid. (C. stans Pers.; Ampelopsis arborea Rusby.) - Rich soils, Va. to Mo., arid southw.

3. C. incisa (Nutt.) Des Moulins. A stout vine, with somewhat succulent deeply 3-parted or pinnately 3-foliolate leaves, the leaflets ovate or obovate, cuneate, coarsely and irregularly toothed; inflorescence suggesting a compound umbel. - Open sandy or rocky woods, "Mo." and Kan. to Tex. and Fla.

\section{Vitis [Tourn.] L. Grape}

Flowers polygamo-dioecious (some plants with perfect flowers, others staminate with at most a rudimentary ovary), 5-merous. Calyx very short, usually with a nearly entire border or none at all. Petals separating only at base and falling off without expanding. Hypogynous disk of :, nectariferous glands altrmate with the stamens. Berry pulpy. Seeds pyriform, with beak-like base. - Plants climbing by the coiling of naked-tipped tendrils. Flowers in a 
compound thyrse, very fragrant; pedicels mostly umbellate-clustered. Leaves simple, rounded and heart-shaped. (The classical Latin name.)

Lower surface of leaves velvety-tomentose or covered with floceulent wool.

Berries large, 14-18 min. In diameter

Berrics smaller, rarely over $12 \mathrm{~mm}$. in diameter.

Branchlets telete or nearly so, glabrous, glabrate, or retaining only floceulent remnants of wool.

Branchlets, petioles, and lower surface of leaves covered with somewhat

persistent reddish flocculent wool
Branchlets even when young glabrous or nearly so; lower surface of leaves very pale and glaucous, at length nearly smooth.
chlets distinctly angled, covered with a fine dense and persistent

Branchlets distinctly angled, covered with a fine dense and persistent

Fower surface of the leaves merely pubescent (chiefiy along or in the axils of the nerves) or clabrous.

Leaves very glaucous or even whitened beneath . . . . . . 3. F. bicolor.
Leaves green beneath.

Bark of stem loose and shredding; berries $7-10$ um. in diameter.

Leaves ovate to suborbicular ; berries mostly acid ; tall climbers.

Teeth of leaves narrowly deltoid or even lonceolate, sharply acuminate, and often slightly falcrte; berries blue, with copious bloom

Teeth of leaves broadly deltoid, cuspidate; belries black or dark purple, with little or no bloom.

Leaves scarcely or not at all 3 -lobed; the basal sinus mostly rather

Leaves habitually and rather incisely $3(-5)$-lobed ; the basal sinus

mostly wide, shallow, and rounded
Leaves reniform or depressed-ovate, broader than long; berries sweet;
bushy or sprawling.

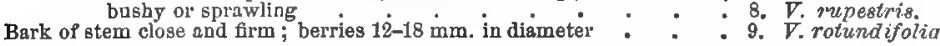
2. T. aestivalis.
3. F. bicolor.
4. $V$. cinerea.

6. V. vulpina.

5. V. cordifolia.

7. T. palmata.

1. EUVITIS Planch. Bark loose and shreddy; tendrits forked; nodes solid.

* A tendrit (or inflorescence) opposite each of several successive leaves.

1. V. labrúsca L. (Northers Fox G.) Branchlets and young leaves very woolly ; leaves large, entire or deeply lobed, slightly dentate, continuing rustywoolly beneath ; fertile panicles compact ; berries large. - Moist or dry thickets, N. E. to the Allegheny Mts., and s. to Ga.; also n. w. Ind. - Fruit ripe in Sept. or Oct., dark purple or amber-color, with a tough musky pulp. Improved by (ultivation, it has given rise to the Isabella, Catawba, Concord, and other ' 7 arieties.

** Tendrils intermittent (none opposite each third leaf).

- Leaves pubescent and floccose, especially beneath and when young.

$\checkmark$ 2. V. aestivalis Michx. (Summer or PIGeON G.) Branchlets terete, loosely pubescent; leaves large, unlobed or more or less deeply and obtusely 3-5-lobed, with short brond teeth, very woolly and mostly red or rusty when young, tawnyflocculent even in age; petioles rather short, pubescent ; berries middle-sized, black, with a bloom, in compact bunches. - Thickets, s. N. H. to Fla., w. to Kan. and Tex. May, June. - Berries pleasant, ripe in Sept.

3. V. bícolor Le Conte. (Summe G.) Branchlets terete, glabrous or nearly so; petioles long, glabrous; leaves thickish, very glaucous and early glabrate beneath; teeth less salient; otherwise resembling the preceding. $-N$. $H$. to N. C., and westw.

4. V. cinèrea Engelm. (SWEet Winter G.) Branchlets angular; pubescence whitish or grayish, persistent; leaves entire or slightly 3-lobed ; inflorescence large and loose; berries small, black, without bloom. - Centr. Ill. to Kan. and Tex.

+ + Leaves glabrous and mostly shining, or short-hairy especially on the ribs beneath, incisely lobed or undivided.

5. V. cordifolia Michx. (Frost or Chickes G.) Leaves $7.5-10 \mathrm{~cm}$. wide, unlobed or slightly 3 -lobed, cordate with a deep acute sinus, acuminate, coarsely and sharply toothed ; stipules small; inflorescence ample, loose; berries sinali, 3lack and shining, very acerb, ripening after frosts; seeds 1 or 2 , with promi. scent rhaphe. ( $\boldsymbol{V}$. Baileyana Munson.) - 'l'hickets and stream-bauks, Pa., "s 
N. Y.? to centr. M1., Mo., Neb., and southw. May, June. Var. Fótidi Engelm., of the Mississippi Valley, has unpleasantly aromatic fruit.

6. V. vulpina L. (RIVER-BANK or Frost G.) Differing from the last in the larger and more persistent stipules (4-6 $\mathrm{mm}$. long), more shining and usually 3-lobed leaves with a broad rounded or truncate sinus and large acute or acuminate teeth ; smaller compact inflorescence; berries $8-10 \mathrm{~mm}$. in diameter, blue, with a bloom, acid and very juicy, ripening from Sept. to Nov.; rhaphe indistinct. (V. riparia Michx.) - Stream-banks or near water, N. B. to W. Va., N. Dak., and Kan. Var. PrAècox Bailey has small sweet early fruit. - Mo.

7. V. palmàta Vahl. (RED or CAT G.) Branches bright red; leaves dark green and dull, 3-5-lobed, with a broad sinus, the lobes usually long-acuminate; inflorescence large and loose; berries black, without bloom, ripening late ; seeds very large and rounded; otherwise-like no.6. (V. vubra Michx.) - Ill., Mo., and southw.

8. V. rupéstris Scheele. (SAND or Sugar G.) Usually low and bushy, often without tendrils; leaves rather small, shining, broadly cordate, abruptly pointed, with broad coarse teeth, rarely a little lobed; berries rather small, swoeet, in very small close bunches, ripe in Aug. - Sandy banks, hills, etc., s. Pa. (Porter) to Mo., and southw. Var. DIssecta Eggert has more ovate and somewhat laciniately toothed leaves. - Mo.

§2. MUSCADINIA Planch. Bark closely adherent on the branches; pith continuous through the nodes; tendrils simple, intermittent; seeds with transverse wrinkles on both sides.

ᄂ9. V. rotundifolia Michx. (Muscadine, Bullace, or Southern Fox G.) Leaves shining both sides, small, rounded, heart-shaped at the base, with broad and bluntish teeth, seldom lobed; panicles small, densely flowered; berries large (1.2-1.8 cm. in diameter), musky, purplish, without a bloom, with a thick and tough skin, ripe early in autumn. (V. vulpina Man. ed. 5, not L.) River-banks, Del. (Commons) to Ky., Mo,, Kan., and southw. May. - Branchlets minutely warty. This is the original of the Scuppernong Grape, etc.

\section{TILIACEAE (Linden Familt)}

Trees (rarely herbs), with the mucilaginous properties, fibrous bark, valvate calyx, etc., of the Mallow Family; but the sepals deciduous, petals imbricated in the bud, the stamens usually polyadelphous, and the anthers 2-celled. - Represented in northern regions by the single genus

\section{1. tília [Tourn.] L. Linden. Basswood}

Sepals 5. Petals 5, spatulate-oblong. Stamens numerous; filaments cohering in 5 clusters with each other (in European specits), or with the base of a spatulate petal-like body placed opposite each of the real petals. Pistil with a 5-celled ovary, and 2 half-anatropous ovules in each cell, a single style, and a 5-toothed stigma. Fruit dry and woody, indehiscent, globular, becoming 1-celled and 1-2-seeded. Embryo in hard albumen; cotyledons broad and thin, 5-lobed, crumpled. - Fine trees, with soft and white wood, very fibrous and tough inner bark, more or less heart-shaped and serrate alternate leaves (oblique and often truncate at the base), deciduous stipules, and small cymes of flowers hanging on an axillary peduncle which is united to a ligulate membranaceous bract. Flowers cream-color, honey-bearing, fragrant. (The classical Latin name.)

1. T. americàna L. (BAsswooD.) Leaves large, green and glabrous or nearly so ; floral bract usually tapering or stalked at base ; fruit ovoid, obscurely ribbed. - Rich woods. May, June. - Here rarely called LIME-TREE, oftener Wirtewoon, commonly Basswoov; the last name now obsolete in England.

2. T. Michaúxii Nutt. Lerves smaller $(5-7.5 \mathrm{~cm}$. long), rather densely pubescent and grayish-green beneath; floral bract usually rounded at base; fruit 
globose, smaller, $6 \mathrm{~mm}$. thick. (T. pubescens Man. ed. 6, not Ait.) - Ct. to Fla., and westw.

3. T. heterophÿlla Vent. (White B.) Leaves larger, smooth and bright green above, silvery-whitened with a fine down underneath; bract usually tapering at base. - Chiefly on limestone, s. N. Y. and mts. of Pa. to s. Ill., and southw.

\section{MALVÀCEAE (MaLLow FamiLy)}

Herbs or shrubs, with alternate stipulate leaves and regular flowers, the calyx valvate and the corolla convolute in the bud, numerous stamens monadelphous in a column and united at base with the short claws of the petals, 1-celled anthers, and kidney-shaped seeds. Sepals 5, united at base, persistent, often involucellate with a whorl of bractlets forming a sort of exterior calyx. Petals 5. Anthers kidney-shaped, opening along the top. Pistils several, the ovaries united in a ring or forming a several-celled pod. Seeds with little albumen; embryo curved, the leafy cotyledons variously doubled up. - Mucilaginous innocent plants, with tough bark and palmately-veined leaves. Flower-stalks with a joint, axillary.

Tribe I. MÁLVEAE. Column of stamens anther-bearing at the top. Oparies and carpels 5-20 or more, closely united in a ring around a central axis, from which they separate after ripening.

* Stigmas terminal, capitate ; carpels 1-few-seeded, usually dehiscent.

1. Abutilon. Involucel none. Seeds $8-9$ in each cell.

2. Sphaeraicea. Bractlets 8 . Seeds 2 or 3 in each cell.

8. Modiola. Bractlets 8 . Seeds 2 in each cell, with a transverse partition between them.

4. Malvastrum. Involucel of 3 bractlets or none. Seed solitary, filling the cell, ascending.

5. Sida. In volucel none. Seed solitary in each cell, pendulous.

* * Stigmas occupying the inner face of the styles; carpels 1-seeded, falling atrny separately.

0. Althaea. Involucel of 6-9 bractlets.

7. Malva. Involucel of 3 bractlets. Petals obcordate. Carpels rounded, beakless.

8. Callirhoë. Involucel of 1-3 bractlets or none. Petals truncate. Carpels beaked.

9. Napaea. Involucel none. Flowers dioecious. Stamens few (15-20). Carpels beakless.

Tribe II. HIBÍsceAE. Column of stamens anther-bearing for a considerable part of its length, naked and 5-toothed at the very apex. Pod mostly 5-celled, loculicidal, leaving scarcely any axts in the center after opening.

10. Kosteletzkya. Involucel of several bractlets. Pod 5-celled, 5-seeded.

11. Hibiscus. Involucel of many bractlets. Pod 5-celled, many-seeded.

\section{ABÙtilon [Tourn.] Mill. Indian MaLlow}

Carpels 2-9-seeded, at length 2-valved. Radicle ascending or pointing inward. Otherwise as in Sida. (Name of unknown origin.)

1. A. Theophrásti Medic. (Velvet Leaf.) Tall annual, 6-12 dm. high ; leaves roundish-heart-shaped, taper-pointed, velvety; peduncles slorter than the leaf-stalks; corolla yellow; carpels 12-15, hairy, beaked. (A. Avicennae Gaertn.; A. Abutilon Rusby.) - Waste places, vacant lots in cities, etc. (Nat. from India.)

\section{SPHAERÁLCEA St. Hil.}

Ovules and seeds usually 2 or 3 in each cell. Characters otherwise as in

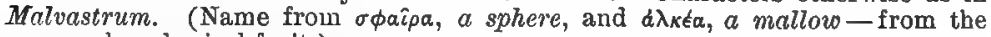
commonly spherical fruit.)

1. S. remota (Greene) Fernald. Perennial, erect, bushy-branched, 1-2 m. high, densely and stellately pubescent; leaves maple-shaped, 5-7-cleft; flowers clustered in the upper axils and subspicate; calyx densely pubescent, its caudate-acuminate lobes $1-1.5 \mathrm{~cm}$. long; petals rose-color. (S. acerifolia Man, ed. $\mathbf{6}$, not Nutt.) - Known only from a gravelly island in the Kankakee R., Ill. 


\section{MOdIOLA Moench.}

Calyx with a 3-leaved involucel. Petals obovate. Stamens 10-20. Stigmas capitate. Carpels 14-20, kidney-shaped, pointed, and at length 2-valved at the top ; the cavity divided into two by a cross partition, with a single seed in each cell. - Humble procumbent or creeping annuals or biennials, with cut leaves and small purplish flowers solitary. in the axils. (Name from modiolus, the broad and depressed fruit resembling in shape the Roman measure of that name.)

1. M. caroliniàna (L.) G. Don. Hairy ; leaves 3-5-cleft and incised ; fruit hispid at the top. (M. multifida Moench.) - Low grounds, Va. and southw. (Trop. Am.)

\section{4. malvástrom Gray. False Mallow}

Calyx with an involucel of 2 or 3 bractlets, or none. Petals notched at the end or entire. Styles 5 or more; stigmas capitate. Carpels as in Malva, or else as in Sida, but the solitary kidney-shaped seed ascending and the radicle pointjng downwarr. as in the former. (Name altered from Malva.)

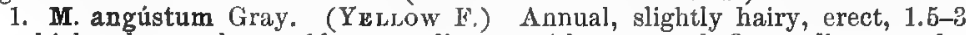
$\mathrm{dm}$. high; leaves lance-oblong or linear, with scattered fine callous teeth; flowers in the upper axils, on short peduncles; bractlets and stipules setaceous; petals yellow, scarcely exceeding the calyx; carpels 5, kidney-shaped, smooth, at length 2-valved. - Fravelly and rocky hills, centr. Tenn. to Ia. and Kan. Aug.

2. M. coccíneum (Pursh) Gray. (RED F.) Perennial, low and hoary; leaves 5-parted or pedate; flowers in short spikes or racemes, the pink-red petals very much longer than the calyx; carpels 10 or more, reticulated on the sides and indehiscent. - Man. and w. Ia. to 'Tex., and westw.

\section{SÌDA L.}

Calyx naked at the base, 5-cleft. Petals entire, usually oblique. Styles 5 or more, tipped with capitate stigmas; the ripe fruit separating into as many 1-seeded carpels, which are closed, $n:$ commonly 2-valved at the top, and tardily separate from the axis. Seed pendulous. Embryo abruptly bent; the radicle pointing upward. (A name used by 'Theophrastus.)

1. S. hermaphrodita (L.) Rusby. A smooth tall (1.2-3 m. high) perennial ; leaves 3-7-cleft, the lobes oblong and pointed, toothed; flowers white, umbellatecorymbed, $2.51 \mathrm{~cm}$. wide; carpels 10 , pointed. (\$. Napaea Cav.) - Glades and river-banks, Pa. to Tenn., rare; cultivated in old gardens.

2. S. Ellióttii T. \& G. A smooth erect perennial, 3-12 dm. high; leaves linear, serrate, short-petioled; peduncles axillary, 1-flowered, short; flowers yellow, rather large; carpels 9-10, slightly and abruptly pointed, forming a depressed fruit. - Sandy soil, s. Va. to s. Mo., and southw. May-Aug.

3. S. spivoss L. Annual weed, minutely and softly pubescent, low $(2,5-5)$ din. high), much branched; leaves ovate-lanceolate or oblong, serrate, rather lons-petioled; peduncles axillary, 1-flowered, shorter than the petiole; flowers yellow, small; carpels 5, combined into an ovoid fruit, each splitting at the top into 2 bealcs. - Waste places, Mass. to Mich., Kan., and southw., where comnon. - A little tubercle at the base of the leaves on the stronger plants gives the specific name, but it cannot be called a spine. (Nat. from the Tropics.)

\section{6. althata I. Margh Mallow}

Calyx surrounded by a 6-9-cleft involucel. Otherwise as in Malva. (Old Greek and I,atin name, from a $\lambda A \epsilon \iota$, to cuve, in allusion to its healing properties.)

1. A. officinalis L. (Marsh Mallow.) Stem erect, 6-12 cm. high; leaves ovate or slightly heart-shaped, toothed, sometimes 3-lobed, velvety-downy; peduncles axillary, many-flowered; flowers pale rose-color, - Salt marshes, 
coast of N. E. and N. Y., also locally westw. to Mich. and Ark. Aug., Sept. Perennial root thick, abounding in mucilage. (Nat. from Eu.)

A. OANNABìA L., with digitately 5-parted leaves, is said to be somewhat established at Washiugton, D. C. (Adv. from Eu.)

A. Rosea Cav, the Holly Hock of gardens, sometimes persists after cultivation.

\section{MÁlva [Tourn.] L. Mallow}

Calyz with a 3-leaved involucel at the base, like an outer calyx. Petals obcordate. Styles numerous, stigmatic down the inner side. Fruit depressed, separating at maturity into as many 1-seeded and indehiscent round kidneyshaped blunt carpels as there are styles. Radicle pointing downward. (An old Latin name, from the Greek name, $\mu a \lambda \alpha_{\chi} \eta$, having allusion to the emollient leaves.)

\section{* Flowers fascicled in the axils.}

1. M. rotundfòdia L. (Common M., Cheeses.) Stems procumbent from a deep biennial root; leaves round-heart-shaped, on very long petioles, crenate, obscurely lobed; petals twice the length of the calyx, whitish; carpels pubescent, even. - Waysides and cultivated grounds, common. (Nat. from Fu.)

2. M. VERTIC ILIÀtA L. Erect annual, with round crenately 5-7-lubed leaves; flowers small, pale, sessile, crowded in the axils; carpels slightly reticulated. Roadsides, waste places, etc., N. S., Que., and w. Vt. ; Pa. (Nat. from Asia.) M. crfsPA L. (the Curled M.), which scarcely differs sa:e in its crisped leaves, is occasionally spontaneous about gardens, etc. (Adv. from Eu.)

3. II. SYLÝSTRIS L. (HIGH M.) Biennial; stem erect, branched, 6-9 dm. high; leaves sharply 5-7-lobed; petals thrice the length of the calyx, large, purple and rose-color; carpels wrinkled-veiny. - Waysides and about gardens, rarely escaped from cultivation. (Introd. from Eu.)

* * Flowers only in the upper axils, somewhat racemose or paniculate.

4. M. Moschàta L. (Musk M.) A low perennial, with mostly simple pubescence; stem-leaves 5-parted, and the divisions once or twice parted or cleft into linear lobes, faintly musky-scented; flowers rose-color or white, large, on short peduncles crowded on the stem and branches; fruit downy. - Fieids and roadsides, abundant in e. Canada and n. N. E., occasional elsewhere. (Nat. from Eu.)

5. M. ÁceA L. Similar, with short stellate pubescence; stem-leaves only once 5-parted or -cleft, the lobes incised; large flowers as in the last; fruit sinooth; bractlets of the involucel ovate. - Escaped from gardens in N. E., Pa., and Mich. (Introd. from Eu.)

\section{Callírhö̈ Nutt. Poppy Mallow}

Calyx either naked or with a 3-leaved involucel at its base. Petals wedgeshaped and truncate (usually red-purple). Styles, etc., as in Malva. Carpels 10-20, straightish, with a short empty beak, separated within from the 1-seeded cell by a narrow projection, indehiscent or partly 2-valved. Radicle pointing downward. (Name drawn from Greek mythology.)

\section{* Involucel 3-leaved.}

1. C. triangulata (Leavenw.) Gray. Stellate-pubescent; stems nearly erect, t $\mathrm{dm}$. high, from a fusiform root; leaves triangular or halberd-shaped, or the lowest rather heart-shaped, coarsely crenate; the upper incised or 3-5-cleft; tlowers panicled, short-pediceled, purple ; involucel as long as the 5-cleft 5-nerved calyx; carpels not rugose. - Dry prairies, Ind. to Minn., and southw.

2. C. involucràta (T. \& G.) Gray. Hirsute or hispid, procambent; leaves rounded, 5-7-parted or -cleft, the segments incisely lobed; peduncles elongated, 1-flowered; calyx 5-parted, the lanceolate 3-5-nerved sepals twice as long as the involucel; petals red or purplish ; carpels indehiscent, rugose-reticulated Minn. to Tex., and westw, 
* Involucel none; calyx 5-parted; carpels strongly rugose.

3. C. alcaeoides (Michx.) Gray. Strigose-pubescent; stems slender, $3 \mathrm{dm}$. high, erect from a perennial root; lower leaves triangular-heart-shaped, incised, the upper 5-7-parted, laciniate, the uppermost divided into linear segments; flowers rose-color or white, corymbose, on slender peduncles. - Barren oak lands, s. Ky. to Neb. and Tex.

4. C. digitàta Nutt. Sparsely hirsute or glabrous, erect; leaves few, roundcordate, 5-7-parted, the cauline commonly with linear divisions ; peduncles subracemose, long, filiform; flowers red-purple to white. - Ill. to Kan. and Tex.

\section{Napatia [Clayt.] L. Glade Mallow}

Calyz naked at the base, 5-toothed. Petals entire. Flowers dioecious ; the staminate destitute of pistils, with 15-20 anthers; the fertile with a short column of usually antherless filaments. Styles 8-10, stigmatic along the inside. Fruit depressed-globular, separating into as many kidney-shaped 1-seeded beakless scarcely dehiscent carpels as styles. Radicle pointing downward. - Tall roughish perennial herb, with very large 9-11-parted lower leaves, the pointed lobes pinnatifid-cut, and small white panicled flowers. (Named from vór $\eta, \mathrm{a}$ glade, or, poetically, a nymph of the glades.)

1. N. dioica L. Stems nearly simple, 1.5-3 m. high. - Pa, to Va, w. to Ia. and Minn., rare. July.

\section{KOStelétzkya Presl.}

Pod depressed, with a single seed in each cell. Otherwise as Hibiscus. Shrubs or, as in the case of our single species, perennial herbs, chiefly of tropical America. (Named for $V . F$. Kosteletzky, a Bohemian botanist.)

1. K. virgínica (L.) Presl, Roughish-hairy perennial, $6-12 \mathrm{dm}$, high; leaves halberd-shaped and heart-shaped, the lower 3 -lobed; corolla $5 \mathrm{~cm}$. wide, rosecolor ; column slender. - Marshes on the coast, N. Y., and southw. Aug.

\section{1. hibíscus L. Rose Mallow}

Calyx involucellate at the base by a row of numerous bractlets, 5-cleft. Col umn of stamens long, bearing anthers for much of its length. Styles united, stigmas 5, capitate. Fruit a 5-celled loculicidal pod. Seeds several or many in each cell. - Herbs or shrubs, usually with large and showy flowers. (An old Greek and Latin name of unknown meaning.)

a. Calyx herbaceous, not inflated about the capsule; perennials $b$.

b. Shrub, with rhombic-ovate glabrous leaves.

b. Herbs $c$.

S. Stems and lower surfaces of leaves pubescent.

Capsule smooth; leaves glabrous or glabrate above.

Corolla rose-color; capsule depressed-globose, abruptly beaked

Corolla white, with crimson center; capsule ovold, gradually pointed.

Capsule hirsute; leäres pubescent above.

Leaves minutely stellate-canescent; capsule beaked

Leaves loosely and coarsely stellate-tomentose; capsule rounded or truncate at tip.

c. Stems and lenves glabrous

a. Calyx bladdery-inflated, soon becoming Bcarious; innual

1. H. syriacus.

2. H. Moschertos.

3. $\boldsymbol{H}$. oculiroseus.

4. H. incanus.

5. H. lasiocampos.

6. H. militaris.

7. $\boldsymbol{H}$. Trionum.

1. H. strìcus L. (Shrubby Althata of gardens.) Tall shrub, smooth; leaves rhombic- or wedge-ovate, pointed, cut-toothed or lobed; corolla usually rose-color. - Established in thickets and by roadsides, N. J., Pa., and southw. July-Sept. (Introd. from Asia.)

2. H. Moscheùtos L. (Swamp R.) Tall perennial $(1-2.5 \mathrm{~m}$. high); the stem puberulent above; leaves ovate, pointed. toothed, the lower and sometimes 
the upper 3-lobed, downy-whitened underneath, glabrous or slightly down above; calyx and bracts densely stellate-puberalent; calyx in anthesis $2-3 \mathrm{~cm}$. long, its lobes ovate or ovate-oblong; petals $6-12 \mathrm{~cm}$. long, rose-color; capsule glabrous, subglobose, abruptly beaked.--River-banks and fresh or brackish marshes, near the coast, e. Mass., southw.; also lake-shores and swamps (especially near salt springs) westw, to Ont. and Mo. July-Sept.

3. H. oculirdseus Britton. (CRIMSon-EYED or White Hibiscus.) Similar; calyx in anthesis $3-4 \mathrm{~cm}$. long, its lobes ovate-lanceolate; petals white, with a crimson blotch at base; capsule ovoid, gradually pointed. - Marshes near the coast, N. J., and southw. July-Sept.

4. H. incànus Wendland. Resembling the preceding; leaves ovate to lanceolate, toothed, rarely lobed; calyx in anthesis $2.5-3 \mathrm{~cm}$. long; petals white, yellowish, or pink, crimson-blotched at base; capsule ovoid, beaked, closely stellate-tomentose and loosely hirsute. - Swamps, Md, and southw.

5. H. lasiocárpos Cav. Leaves broadly to narrowly ovate, soft-pubescent upon both surfaces, the upper surface bearing many simple or subsimple hairs; bractlets ciliate; petals white or rose-color, crimson-blotched at base; capsule short-cylindric, subtruncate, densely villous-hirsute. - Marshes, Ga. to Tex., northw. in Miss. basin to Ky., Ind., Ill., and Mo. July-Sept.

6. H. militàris Cav. (Halberd-LeAved R.) Smooth throughout; lower leaves ovate-heart-shaped, toothed, 3-lobed; upper leaves commonly halberdform; peduncles slender; corolla $5-7.5 \mathrm{~cm}$. long, flesh-color, with purple base ; fruting calyx inflated; seeds hairy. - River-banks, $\mathrm{Pa}$. to Minn., and southw.

7. H. Trionum L. (Flower-of-An-hour.) A low rather hrity annual; upper leaves 3-parted, with lanceolate divisions, the middle one much the longest; fruiting calyx inflated, membranaceous, 5-winged, with numerous dark ciliate nerves; corolla sulphur-yellow, with a blackish eye, ephemeral. - Cultivated and waste ground, rather local. (Nat, from Eu.)

\section{TERnstroemiàceae (Tea or Camelia Family)}

Trees or shrubs, with alternate simple feather-veined leaves and no stipules, the regular flowers hypogynous and polyandrous, the sepals and petals both imbricated in aestivation, the stamens more or less mited at the base with each other (monadelphous or 3-5-adelphous) and with the base of the petals. Anthers 2-celled, introrse. Fruit a woody 3-5-celled loculicidal pod. Seeds few, with little or no albumen. Embryo large, with broad cotyledons. -1 family with showy flowers, the types of which are the well-known CAmellia and the more important Tea Plant.

1. Stewartia. Stamens monadelphous. Ovules 2 in each cell, ascending.

2. Gordonia. Stamens 5-adelphous. Ovules 4-8 in each cell, pendulous.

\section{STEWARTIA L.}

Sepals 4, rarely 6, ovate or lanceolate. Petals 5, rarely 6, obovate, crenulate. Stamens monadelphous below. Pod 5-celled. Seeds 1 or 2 in each cell, crustaceous, anatropous, ascending. Radicle longer than the cotyledons. - Shrubs with membranaceous deciduous oblong-ovate serrulate leaves, soft-downy beneath, and large short-peduncled flowers solitary in their axils. (Named for John Stuart, - or as formerly often written Stewart, - Marquis of Bute.)

1. S. Malachodendron L. Petals 5 , white, $2.5 \mathrm{~cm}$. long; sepals ovate; style 1 ; stigma 5-toothed; pod globular, blunt; seeds not margined. (S. virginict Cav.) - Woods, Va., and southw.

2. S. pentágyna L'Hér. Leaves larger, 1.3-1.5 dm. long; sepals acute; petals often 6 ; styles 5 , distinct; pod angled, pointed; seeds wing-margined... itts. of $\mathrm{Ky}$, and N. Car, to Ga. 


\section{GORDONIA Ellis. LoBLoLty BAY}

Sepals 5, rounded, concave. Petals 5, obovate. Stamens 5-adeljuhous, one cluster adhering to the base of each petal. Style 1 . Pod ovoid, 5-ralved; the valves separating from the persistent axis; cells 2-8-seeded. Seeds pendulous; radicle short; cotyledons thin, longitudinally plaited. - Shrubs or small trees, with large and showy white flowers on axillary peduncles. (Dedicated by Dr. Garden to bis "old master, Dr. James Gordon of Aberdeen," and by Fllis to a London nurseryman of the same name.)

1. G. Lasiánthus L. (TAN $B_{A Y}$.) Leaves coriaceous and persistent, lanceolate-oblong, narrowed at the base, minutely serrate, smootl and shining; petals 3-4 cm. long; pod pointed; seeds winged above.-Swamps near the coast, Va., and southw. May-July.

\section{HYPERICÀCEAE (ST. JoHN's-WORT FAMILY)}

Herbs or shrubs, with opposite entive dotted mostly sessile leaves and no stipules, regular hypogynous flowers, the petals mostly oblique and convolute in the bud, and many or few stamens sometimes collected in 3 or mor'e clusters or bundles. Pod 1-celled with 2-5 parietal placentae, and as many styles, or 3-7celled by the union of the placentae in the center; dehiscence mostly septicidal. Sepals 4 or 5 , imbricated in the bud, herbaceous, persistent. I'etals 4 or 5 , mostly deciduous. Styles persistent, at first sometimes united. Seeds numerous, small, anatropous, with no albumen. - Plants usually smooth. Flowers solitary or cymose.

1. Ascyrum. Sepals 4, in 2 very unegual $\Gamma$ airs. Petals 4, Stamens many, distinct.

2. Hypericum. Sepals 5. Petals 5. Stamens usually many and often in 3 or 5 clusters.

\section{1. ÁSCYRUM L. ST. PETER'S-TYORT}

Sepals 4 ; the two outer very broad and leaf-like; the inner much smaller. Petals 4, oblique, very deciduous, convolute in the bud. Stamens numerous; the filaments distinct and scarcely in clusters. Pod strictly 1-celled, 2-4valved. - Low rather shrubby smooth pale green plants, with nearly solitary light yellow flowers. (Ancient Greek name for some plant probably of this family.)

1. A. stáns Michx. (Sr. Peter's-wort.) Stem suberect, 2-edged, 3-6 dm. high, stout; leaves oval or oblong, somewhat clasping, thickish ; flowers showy ; outer sepals round-cordate, inner lanceolate; petals obovate; styles 3 or 4. Pine barrens, L. I. to Pa., and southwestw. July, Aug.

2. A. hypericoìdes L. (ST. ANDREw's CRoss.) Low, much branched and decumbent; leaves narrowly obovate-oblong, contracted at the base, thin; petals linear-oblong; styles 2, very short; pod flat. (A. Crux-Andreae L. 1763, not 1753.) - Wet sand or rocky barrens, Nantucket I., Mass., to s. Ill., Neb., and southw. July-Sept. - Petals scarcely exceeding the outer sepals, approaching each other in pairs over them, in the form of a St. Andrew's 'cross.

\section{HYPERICUM [Tourn.] L. ST. Johs's-WORT}

Sepals 5, usually subequal. Petals 5, oblique, convolute in the bud (except in $\$ 6$ ). Stamens frequently united or clustered in 3-5 parcels; no interposed glands. Pod 1-celled or :3-5-celled. Seeds usually cylindrical. - Herbs or shrubs, with cymose yellow, flesll-colored, or purplish flowers. (An ancient Greek name of obscure meaning.) 
a. Petals yellow (at most mottled or striped with red, purple, or black) $b$.

b. Styles 5 ; pods 5 -celled.

Tall horb; flowers 4-6 cm. broad; pods $2-3 \mathrm{~cm}$. long

Slender shrub; flowers.1.5-3 cm. broad; pods 5-10 mm. long

1. H. Ascyron.

8. H. Kalmianum

b. Styles 8 , rarely $4 ;$ pods 8 (rarely 4 ).celled $c$.

c. Stamens very numerous (more than 12) $d$.

d. Shrubs, 0.5-2 m. high.

Pods $1-1.5 \mathrm{~cm}$. long

Pods 5-8 mm. long

d. Herbs, at most slightly woody at base $e$.

e. Stamens in $3-5$ clusters; petals marked with black dots or lines $f$.

$f$. Petals bearing black dots only on the margin.

Flowers and jeaves few, the latter $1.5-3 \mathrm{~cm}$. broad

Flowers and leaves very numerous, the latter rarely $1 \mathrm{~cm}$. broad

f. Petals bearing several rows of black dots or lines.

Leaves rounded at tip; sepals blunt or acutish; pods 4-6 mm. long. . . . . .

Leaves (at least the upper) narrowed to the tip; sepals acuminate; pods $6-8 \mathrm{~mm}$. long c. Stamens obscurely if at all clustered; petals without black
dots $g$.

g. Stems herbaceous, from slender creeping freely stoloniferous bases.

Leaves and linear-lanceolate acute firm sepals with revolute margins . . . .

Leaves and oblancelate or obovate thin folisceous sepals plane

a. Stems woody at base, or if herbaceous without slender
stolons $h$.

r. Btems freely branching, woody at base ; cymes loafybracted; styles united below; stigmas elongate $i$.

i. Capsule thick-ovoid to subglobose, somewhat 3angled, esseutially 1-celled.

Sepals 6-18 mm. long; corolla $1.5-2 \mathrm{~cm}$, broad.

Sepals 6-10 mm. long, 2-5 mm. broad

Sepals pariable, the larger $1-1.3 \mathrm{~cm}$. long, $6-\dot{8}$ mm. wide

Sepals 3-5 mm. long; corolla $1-1.5 \mathrm{~cm}$. broad

i. Capsule conic-subulate, distinctly 8-celled

$h$. Stems simple below the loosely forking essentially naked inflorescence, herbaceous; styles distinet;

c. Stamens 5-12 j. mitate, herbaceous; styles distinet;

j. Stem simple or loosely branched; leaves linear to ovate, spreading $k$ :

k. Bracts of the inflorescence foliaceous, resembling reduced Btem-leaves of

$k$. Ultimate bracts of the Inflorescence setaceous to linearsubulate.

Leaves orbicular, ovate-deltoid, or rounded-oblong, clasping.

Lenves ovate-oblong or short-elliptic, rounded at tip; pod short-ellipsoid.

Leaves ovate-deltoid, acutish" or blunt; pod slenderconical

Leaves lanceolate to "In ${ }^{\circ}$ ar, merely sessile (if clasping with lance-attenuate outline).

Leaves lancoolate, chiefly $5-T$-nerved at base

j. Stems Pastigiately branched; leaves seale-like or linearsubulate, strongly ascending.

Leaves 6-20 mm, long; pods ovoid, slightly exceeding the

calyx shorter, seale-ilks; pods lince-subulate, much excesding the caly $x$

a. Petals flesh-color or purplish.

Leaves sessile or clasping
Leaves narrowed to distinct petioles

10. H. adpressum.

14. H. ellipticum.

11. $H$. dolabriforme.

12. H. Bissellizi.

13. H. cistifolium.

9. H. galioides.

15. H. virgatum.
17. H. mutilum.

18. H. gymnanthum.

19. H. majus.

20. H. canadense.
21. H. Drummondiz.

22. H. gentianoides.

28. H. virginicum.

24. H. petrolatum.

§1. RÓSCYNA (Spach) Endl. Stamens very numerous, 5-adelphous; styles 5, united below, the stigmas capitate; pod 5-celled, the placentae turned far back into the cells; perennial herb; flowers very large.

1. H. Áscyron L. (Great S.) Stems 5-15 dm. high; branches 2-4-angled; leaves $4-9 \mathrm{~cm}$. long, ovate-oblong, partly clasping ; petals narrowly obovate, 2. a 
$\mathrm{cm}$. long, not deciduous until after they wither; pod $2-3 \mathrm{~cm}$. long, conical. Banks of rivers, w. Que. to Man., s. to Pa., Ill., Mo., and Kan. July, Aug.

§ 2. EUHYIERICUM Boiss. Stamens very many, in 3 or 5 clusters; styles 3 , separate and usually diverging; pod 3-celled; calyx erect; petals and anthers with black dots; perennials.

2. H. gravèolens Buckley. (Modntain S.) Leaves elliptic-oblong, $5-7 \mathrm{~cm}$. long; flowers large, $2-5 \mathrm{~cm}$. broad; petals sparingly dotted on the margin; pod rather large, $7-10 \mathrm{~mm}$. long. - Summits of the higher mts. of s. w. Va. and N. C.

3. H. Plerforatum L. (Cомmon S.) Stem much branched and corymbed, somewhat 2-edged, producing runners from the base; leaves elliptic- or linearoblong, with pellucid dots; petals deep yellow, black-dutted along the margin. twice the length of the lanceolate acute sepals; flowers numerous, in open leafy cymes. - Fields, etc. June-Sept. - A pernicious weed, difficult to extirpate; juice very acrid. (Nat. from Eu.)

4. H. punctàtum Lam. Conspicuously marked with both black and pellucid dots; stem terete, sparingly branched; leaves oblong, rounded at tip, the base either subclasping, sessile, or subpetiolate; flowers crovoded; petals pale yellow, marked with dark lines and dots, about twice as long as the oblong bluntish or acute sepals; pods 4-6 mm. long. (H. maculatum Walt., not Crantz; II. corymbosum Muhl.) - Damp places, e. Que. to Ont., and southw. July-Sept.

5. H. pseudomaculàtum Bush. Similar; leaves oblong-lanceolate to ovate, at least the upper narrowed to the tip; petals three or four times as long as the acuminate sepals; pods 6-8 mm. long. - Woods and prairies, Ill. and Mo. to Tex. and Ga.

§ 3. MYRIÁNDRA (Spach) Endl. Stamens very numerous, obscurely if at all clustered; styles more or less united, the stigmas elongate; pod more or less 3-5-celled; placentae central or parietal.

* Bushy shrubs, 5-20 dm. high, leafy to the top.

+ Styles 3 ; pod completely 3-celled.

6. H. prolíficum L. (ShrubBY S.) Branchlets 2-edged; leaves narrowly oblong, 3-7 cm. long, mostly obtuse, narrowed at the base; flowers numerous, in simple or compound clusters; pods subulate to ovoid, 1-1.5 cm. long. - N. J', to s. Ont., Minn., and southw. July-Sept. - Varies greatly in size, etc.

7. H. densiflorum Pursh. Exceedingly branched above, $0.5-2 \mathrm{~m}$. high, the branches slender and crowded with smaller leaves ; flowers smaller $(1.2-1.7 \mathrm{~cm}$. in diameter) and more numerous, in crowded compound cymes; pod 5-8 $\mathrm{mm}$. long. - Pine barrens of N. J. to glades of Ky., Ark., and southw.

+- +- Styles 5; pod completely 5-celled.

8. H. Kalmiànum L. (KALM's S.) Branches 4-angled; branchlets 2-edged ; leaves crowded, glaucous, linear to oblanceolate, $3-4.5 \mathrm{~cm}$. long; Hlowers few in a cluster, 3-5 cm. wide; pods ovoid. - Rocky or sandy soil, Pontiac Co., Que., to Niagara Falls, and along the Great Lakes to w. Ont., Mich., and Ill.

* Perennials, herbaceous or a little woody at base; pod incompletely 3-4-celled.

9. H. galioìdes Lam. Slender, branching, woody below; leaves linear-oblanceolate, narrowed downward, $1.5-7 \mathrm{~cm}$. long, mostly acute ; flowers small in terminal and axillary cymes; sepals very narrow, $3-5 \mathrm{~mm}$. long; pod 5-6 $\mathrm{mm}$. long, ovoid. - Del. to Ga. and e. Tenn.

10. H. adpréssum Bart. Stem simple, 3-6 dm. high, herbaceous, from a siender creeping freely stoloniferous base, obscurely 4-angled below and 2-edged above; leaves ascending, lanceolate or linear-oblong, often acute, thin, $4-5 \mathrm{~cm}$. long; cyme terminal, leafy at the base, few-Howered; sepals linear-lanceolate; petals bright yellow, $7-10 \mathrm{~mm}$. long; pods ovoid. - Moist sandy shores, e. Mass. to Pa., and southw., chiefly near the coast. July, Aug. Var. spongiossum Robinson. Taller ( $7 \mathrm{dm}$. or more high), the stem spongy-thickened at base; leaves oblong. - Marshy borders of ponds, s. e, Mass. 
§ 4. BRATHÝDIUM (Spach) Endl. Similar to $\S 3$; pod 1-celled, with 3 parietal placentae.

11. H. dolabriforme Vent. Stems branched from the decumbent base, woody below, 1.5-5 dm. high, terete; leaves linear-lanceolate, widely spreading, veinless ; cyme leafy, few-flowered; sepals oblong or ovate-lanceolate, about the length of the very oblique petals (1-1.2 cm. long); pods ovoid-conical, the walls very thick and bard. - Dry hills and rocks, barrens of $\mathrm{Ky}$. and Tenn. JuneAug.

12. H. Bisséllii Robinson. Stems subsimple or with short ascending branches, somewhat woody below, 4-5 dm. high; leaves narrowly oblong, obtusish, ascending, 2.5-3.5 cm. long, 3-5 mm. wide, 1-nerved, deep green above, pale beneath; cyme about 20 -flowered, leafy-bracted, the bracts ovate; flowers 1.5 $\mathrm{cm}$. broad; sepals very unequal, the largest broad-ovate, $1.3 \mathrm{~cm}$. long, $8 \mathrm{~mm}$. wide, subcordate, acuminate; petals oblong-obovate, oblique, with a mucro on one side near the tip. - Southington, Ct. (Bissell).

13. H. cistifolium Lan. Stems mostly simple, herbaceous, 3-5 dm. high, with a somewhat woody base, angled with 4 very narrow salient lines; leaves narrowly oblong to nearly linear, $3-7 \mathrm{~cm}$. long, sessile with a somewhat clasping base; the cyme naked, compound, usually many-flowered; sepals ovate; pods depressed-globular or ovoid-conical; seeds large, oblong, very rough-pitted. (H. sphaerocarpum Michx.) - Rocky river-banks, s. w. O. to Ia., and southw. July-Sept. - Flowers small.

14. H. ellípticum Hook. Stem simple, herbaceous, 2-5 dm. high, obscurely 4-angled, from a slender creeping stoloniferous bas?; leaves spreading, ellipticalblong, obtuse, usually narrower toward the subclasping base, thin; eyme nearly naked, lather few-flowered; petals bright yellow, 6-10 mm. long ; sepals oblong; pods ovoid, very obtuse; seeds minutely striate. - Wet places, N. B. to Man., $\mathrm{s}$. to $\mathrm{Pa}$., Mich., Wisc., and Minn. July, Aug. - Aberrant plants often have small red or purplish petals.

§5. BRATHYS (Mutis) Choisy. Stamens distinct or in 3 clusters; pod 1-celled, with 3 strictly parietal placentae; styles short, distinct, with capitate stigmas; petals small, oblong or linear; sepals narrow; erect; slender plants, with 4-angular branches, flowering all summer.

\section{* Stamens $\infty$.}

15. H. virgàtum Lam. Stem slender, strict, simple, sharply 4-angled, herbaceous, 3-6 dm. high ; leaves ascending, opaque, ovate or oblong-lanceolate, acute, $1.5-2.7 \mathrm{~cm}$. long, closely sessile by a broad base; inflorescence compound, naked, the scattered flowers racemose on its ascending branches; petals copperyellow, 8-10 mm. long; sepals herbaceous, erect, inclosing the ovoid pod. ( $H$. angulosun Michx.) - Wet pine barrens, $\mathbf{P a}$. to Ga., westw. to $\mathrm{O}$., $\mathbf{K y}$., and (?) Ill. July-Sept.

Var. ovalifolium Britton. Leaves oval, erect, 1-1.8 cm. long, more than half as broad. - Pine barrens, N. J. and southw.

\section{* Stamens 5-12.}

- Stem simple or loosely branched; leaves linear to ovate, spreading.

16. $\mathrm{H}$. boreàle (Britton) Bicknell. Perennial ; the stems decumbent and leafy-bracted at base, slender, 5-30 cm. high (rarely submersed and very elongate); leaves elliptic, rounded at tip, sessile, 3-20 mm. long, 3-5-nerved; cymes leafy-bracted, all the bracts foliaceous and broad; pedicels short; sepals linear, bluut, shorter than the rounded short-ellipsoid pod (3-5 mm. long). (H. canadense, var. minimum Man. ed. 6.) - Bogs, margins of ponds, etc., Nfd. to W. Ont., s. to N. J., Pa., O., and Ind. July, Aug:

17. H. mùtilum L. Stem flaccid, widely branching, annual, or perennial with leafy-bracted decumbent bases; leaves ovate to narrowly oblong, obtuse, partly clasping, 5-nerved; cyme (in well developed plants) diffuse, somewhat leafy bracted, the uttimate bracts setaceous; flower $4 \mathrm{ma}$. broad; sepals linear. 
lanceolate, acute; pods $2.5-3.5 \mathrm{~mm}$. long, short-ellipsoid, rounded at apex. Low grounds, common. July, Aug.

18. H. gymnánthum Engelm. \& Gray. Almost simple, with strict stem and branches, 3-9 dm. high; leaves clasping, heart-shaped, acute or obtuse; cyme naked, the floral leaves reduced to small awl-shaped bracts; pods slender-conical, pointed, 4-5 $\mathrm{mm}$. long, sliglitly exceeding the lance-acuminate sepals. Wet sandy barrens, N. J. and e. Pa. to Fla. and Tex.; northw. in Miss. basin to Mo.. Iil., Ind., and $O$.; reported also from Minn.

19. H. màjus (Gray) Britton. Annual, or perennial by short leafy offshoots ; stems solitary or tufted, erect, rather stout, 1-7 dm. high ; leaves chiefly 5-7nerved at the rounded or subcordate sessile or clasping base, lanceolate, the upper acute or bluntish, $1.5-4.5 \mathrm{~cm}$. long, $3.5-13 \mathrm{~mm}$. broad ; cymes essentially naked, the bracts slender; sepals lance-atlenuate, 5-7 $\mathrm{mm}$. long, nearly equaling the conic-ellipsoid bluntish pod. (H. canadense, var. Gray.) - TVet or dry open soil, e. Que. to Man., s. to L. I., N. J., Pa., Ill., Ia., and S. Dak.; also e. Wash. July, Aug.

20. H. canadénse L. Annual, or perennial by short leafy offshoots; stems slender, 1-4 dm. high; leaves 1-3-nerved, linear to linear-oblanceolate, rounded at tip, narrowed to the sessile or subpetiolar base, 1-4 cm. long, 1-6 mm. broad; cymes naked except for the linear-setaceous bracts; sepals linear-lanceolate, blunt or acutish, 2.5-5 $\mathrm{mm}$. long, much shorter than the slender-conical red or purplish pod. - Wet or dry, chiefly exsiccated places, Nfd. to Man., s. to Ga., Ky., Wisc., and Minn. July-Sept.

- + Stems fastigiately branched; leaves linear or bract-like, ascending or appressed.

21. H. Drummóndii (Grev. \& Hook.) T. \& G. Stem and the mostly alternate bushy branches rigid, erect, $1.5-8 \mathrm{dm}$. high ; lecves linear-subulate, nearly erect, 1-nerved, 6-20 $\mathrm{mm}$. long; flowers scattered along the upper part of the leafy branches, short-pediceled; pods ovoid, not longer than the calyx. - Dry soil, Ashtabula Co., O. (Louth), Ill., Ia., Kan., and southw.

22. H. gentianoìdes (L.) B S P. (Orange Grass, Pineweed.) Stem and bushy branches thread-like, wiry, 1-3 dm. high ; leaves minute awl-shaped scales, appressed; flowers minute, mostly sessile and scattered along the erect branches; pods ovoid-lanceolate, acute, much longer than the calyx. (Sarothra L.; $H$. nudicaule Walt.) - Sandy or rocky soil, Me. to Fla. and Tex., chiefly e. of the Alleghenies; and from s. w. Ont. to Ill., and southw.

§6. ELODEA (Juss.) Choisy. Petals imbricated in bud, flesh-colored or purplish. Stamens mostly 9, in 3 bundles. Styles 3, distinct. - Elodwa Juss.; Elodes Man. ed. 6, not Adans.

23. H. virgínicum L. (Marsh S.) Stoloniferous; leaves closely sessile or clasping by a broad base, oblong or ovate, very obtuse ; filaments united below the iniddle. (Triadenum Raf.; Elodea campanulata Pursh.) - Common in swamps. July, Aug. - The entire plant frequently has a pink or crimson tone.

24. H. petiolàtum Walt. (MARSH S.) Taller, more branching; leaves tapering into a short petiole, oblong; filaments united beyond the middle. (Triadenum Britton.) - Cypress swamps, ete., N. J. to Mo., and southw.

\section{ELATINACEAE. (WATERWoRt FAMtLY)}

Little marsh annuals, with membranaceous stipules between the opposite dot. less leaves, minute axillary flowers like those of the Chickweeds, but the pod 2-5-celled, and the seeds as in St. John's-wort.

1. Elatine. Flowers 2-4-merous. Capsule globose. Glabrous, growing in or near water.

2. Bergia. Flowers 5-merous, Capsule ovold. Plant pubescent, terrestrial. 


\section{ELATİNE L. WATERWorT}

Sepals 2-4, obtuse. Petals 2-4, hypogynous. Stamens as many, rarely twice as many. Styles, or sessile capitate stigmas, 2-4. Pod inembranaceous, 2-4celled, several-many-seeded, 2-4-valved; the partitions left attached to the axis, or evanescent. - Dwarf plants, often rooting at the nodes. (A Greek name for an obscure herb.)

1. E. americàna (Pursh) Arn. 'Tufted, 1-2.5 cm. high, creeping; leaves obovate, obtuse, $2-6 \mathrm{~mm}$. long; flowers sessile, rarely opening in the aquatic form ; sepals, petals, stamens, and stigmas 2 , rarely 3 ; seeds 5 or 6 in each cell, rising from the base, relatively large, marked by 9 or 10 longitudinal lines ane? 20-30 crossbars. - Margiu of ponds, etc., e. Que. to B. C., s. to Va., Mo., and in the Rocky Mts. to Mex.

2. E. triándra Schkuhr. Leaves oblanceolate or nearly lanceolate; petals and stamens commonly 3 ; seeds more slender, covering the axis. - Ponds, IIl. to Neb., and westw. (Eu.)

3. E. brachyspérma Gray. Leaves oblong or oval, with narrowed base; flowers mostly dimerous; seeds short-oblong, with 6 or 7 longitudinal lines and 10-12 crossbars. - Ill. and southwestw.

\section{BERGIA L.}

Sepals 5, acuminate, with thickened midnerve and scarious margins. Petals 5. Stamens 5 or 10 . Pod of firm texture. - Diffuse or ascending plants, chiefly tropical. (Named for $P$. J. Bergius, a Swedish botanist of the 18th century.)

1. B. texàna (Hook.) Seubert. Branched from the base ; branches 1-4 dim. long; flowers scarcely peduncled in the axils of the lance-oblong serrulate leaves. - Swamps and wet banks, s. Ill. to Kan., southw. and westw.

\section{CISTÀCEAE (Rockrose FAMILY)}

Low shrubs or herbs, with regular flowers, distinct and hypogynous mostly indefinite stamens, a persistent calyx, a 1-celled 3-5-valved capsule with as many parietal placentae borne on the middle of the valves, and orthotropous albuminous seeds. Sepals 5 ; the two external much smaller, bract-like, or sometimes wanting; the 3 otlers a little twisted in the bud. Petals 3 or 5 , convolute in the opposite direction from the calyx in the bud. Anthers short, innate, on slender filaments. Style single or none. Ovules few or many, on slender stalks, with the orifice at the apex. Embryo long and slender, straightish or curved, in mealy albumen; cotyledons narrow. Leaves simple and mostly entire, the lower usually opposite, and the upper alternate. - Inert plants.

1. Helianthemum. Petals 5 , crumpled in the bud, fugacious (or none). Stigma nearly sessile. Stamens and ovules numerous in the petal-bearing flowers.

2. Hudsonia. Petals 5, fugacious. Stamens 9-30. Style long and slender. Pod strictly 1-celled, 2-6-seeded. Heath-like.

8. Lechea. Petals $B$, flat in the bud, withering-persistent. Stamens 8-12. Style none. Pod partly 8-celled, the imperfect partitions bearing brosd 2-seeded placentae.

\section{HELIÂNTHEMUM [Tourn.] Mill. Rocisrose}

Capsule strictly 1-celled. Embryo curved in the form of a hook or ring. Flowers in most $\mathrm{N}$. A merican species of two sorts, viz., primary or earlier ones, with large yellow petals, indefinitely numerous stamens, and many-seeded pods; and secondary, or later ones, which are much smaller and in clusters, with small petals or none, 3-10 stamens, and much smaller 3-few-seeded pods, 
- The large flowers open only once, in sunshine, and cast their petals by the nex lay. (Name from भुर $\lambda_{\text {Los, }}$ the sun, and $t \nu \theta \epsilon \mu \nu \nu$, flower.)

1. H. canadénse (L. ?) Michx. (Frostween.) Erect, hoary-pubescent, 3-l. dm. high, at first simple; leaves lance-oblong, pale beneath; large flowers solitary, $2.5 \mathrm{~cm}$. broad, soon surpassed by lateral branches, their pods $6 \mathrm{~mm}$. iong; the small flowers clustered on short 1-4-flowered branchlets, their pods light brown, unequal, those of the terminal flowers commonly larger, $3-4 \mathrm{~mm}$. in diameter. - Sandy or gravelly dry soil, Me. to Mich., N. C., and Miss. JuneAug. - Late in antumn crystals of ice shoot from the cracked bark at the base of this and the next species, whence the popular name. A dwarf and rather more cespitose plant with crowded stems only 1-2 dm. bigh, common on sterile shores and sandy hilis near the sea, from e. Mass. southw. (H. propinquum Bicknell) appears to be only a stunted form of this species.

2. H. màjus BSP. (FrostwEen.) Similar in habit and more canescent; primary flowers clustered at the summit of the stem, not surpassed by branches; petals slightly paler yellow than in the preceding; secondary flower's very small, numerous, closely clustered along slender branches, their pods dark brown, 2 mm. in diameter. - Similar situations, N. S. to Minn., Col., and southw. - This is $\boldsymbol{H}$. majus B S P., at least in part, and of recent auth. It seems probable, however, that Lechea major L. represented rather the preceding species. Until the Linnean types both of Cistus canadensis and of Lechea major can be definitely identified, it seems best to allow the current interpretation of the names under Helianthemum to stand as above.

3. H. corymbòsum Michx. Flowers all corymbosely clustered at the summit of the stem or branches, the petal-bearing ones at length on slender stalks; calyx woolly. - Pine barrens, N. J., and southw. along the coast.

\section{HUDSONNIA L.}

Petals much larger than the calyx. Style long and slender; stigma minute. Pod terete, inclosed in the calyx, strictly 1-celled, with 1 or 2 seeds attached near the base of each nerve-like placenta. Embryo coiled into the form of a closed hook. - Bushy heath-like little shrubs, covered with the sınall awl-shaped or scale-like alternate persistent downy leaves, producing numerous small but showy bright yellow flowers crowded along the upper part of the branches. (Named in honor of William Hudson, an early English botanist.)

1. H. ericoìdes L. Downy but greenish; leaves slender, awl-shaped, loose; flowers on slender naked stalks; ovary hairy. - Dry sandy soil near the coast, Nfd. to Va. May.

2. H. tomentosa Nutt. Hoary with down; lenves oval or narrowly oblong, $2 \mathrm{~mm}$. long, close-pressed and imbricated; flower's sessile or nearly so. - Sandy shores, dunes, etc., N. B. to Va., and along the Great Lakes to Minn. ; rarely on banks of streams inland. May, June. Passing into var. INTERMÈdra Peck. Leaves tending to be more awl-shaped; flowers obviously peduncled. - Sand hills, etc., e. Que. to Mackenzie, s. to e. N. B., Saco Valley, Me. and N. H., shores of L. Champlain, Vt., and the Great L. region.

\section{LÈCHEA [Kalm] L. Pinweed}

Stigmas 3, plumose. Pod globular or obovoid. Embryo straightish. - Slender erect paniculately branched perennial herbs, developing leafy shoots from the base. Flowers very small, greenish or purplish, in summer. (Named in honor of Johan Leche, a Swedish botanist.)

Leaves of the brsal shoots elliptical or oblong.

Pubescence of the stem spreading; panicle of small dense corymbose clusters.

Pubescence of the stem appressed; paniele more opèn.

Outer sepals exceeding the inner.

Onter sepals shorter than the others.

1. L. villosa.

GR+Y'S MANUAL -37 
Fruiting celyx narrow, obovold or pyriform; leaves of the basal shoots

Fruiting calyx subglobose; leaves of the basal shooti hoary-pubescent Leaves of the basal shoots narrowly lanceolate to linear.

Inner sepals l-nerved, usually exceeded by the narrow outer ones. . . 6. L. tenuifolia.

Inner sepals 3-nerved, oqualing or longer than the outer.

Canescent-pubescent.

Panicle strict, fastigiate, spire-like

Panicle broadly pyramidal .

Green, more sparingly pubescent.

Fuluiting caly $x$ depressed-globose, $2.5-3 \mathrm{~mm}$. broad.

l'ruiting calyx obovoid, 1.5-2 mm. broad

8. L. racemulosa

5. L. maritima.

4. L. stricta.

5. L. inaritima.

3. L. intermedia.

7. L. Leggettit.

* Pubescence villous, spreading; leaves oblong; flowers very short-pediceled, in cymulose clusters.

1. L. villòsa Ell. Stem upright, $3-\overline{7}$ dn. high, stout, simple, very leafy, producing slender prostrate branches from the base; leaves elliptical, mucronate-pointed, alternate and opposite or sometimes whorled; flowers densely crowded; pedicels shorter than the very small depressed-globose pod; sepals narrower than the valves of the capsule. (L. major Michx., not L.) - Sterile grounds, s. N. H. and s. Vt. to Fla.; also from s. Ont. and O. to Neb., and southw., common.

\section{* Pubescence appressed; flowers open-paniculate. \\ - Leaves comparatively short, broad, and thin.}

2. L. minor L. Erect, about 3-6 dm. high; stem-leaves oval or oblong, 6-12 mm. long, commonly somewhat hairy, some whorled or opposite, those of the rather crowded panicles more linear; pod obovoid-globose. ( $L$. thymifolia Michx.) - Dry soil, s. N. H. and s. Vt. to Fla. and Miss.; also s. Ont. and Mich.

\section{+ Leaves firmer, narrow, the cauline linear to slender-subulate; panicles more naked and racemiform.}

+ Fruiting calyx globular or broadly ovoid; pod nearly globose.

3. L. intermèdia Leggett. Rather strict, $3 \mathrm{dm}$. higl or more, usually glabrate in age; leaves of the basal shoots lanceolate, $3-6 \mathrm{~mm}$. long, the cauline linear-lanceolate, 1-2.5 cm. long; panicle elongated, subcylindrical ; pod large for the genus, depressed-globose, $2-3 \mathrm{~mm}$. in diameter. (L. minor Man. ed. 6, in part.) - Dry soil, N. B. to e. N. Y. and Pa.; also s. Ont., Mich., and Wisc. Passing to

Var. juniperina (Bicknell) Robinson. Branches short, fastigiately appressed; leaves erect, mostly appressed; pedicels short; leafy panicle spire-like. ( $L$. juniperina Bicknell.) - Sandy soil, coast of $\mathrm{s}$. Me., extending inland in the Androscoggin and Saco valleys to n. N. H.

4. L. stricta Leggett. Virgate, fastigiately branched, very pale with fine appressed pnbescence; inflorescence close, spire-like; pod 1.7-2 $\mathrm{mm}$. in diameter. - Borders of woods, etc., w. N. Y. to Ill. and Minn.

5. L. maritima Leggett. Stout and rigid for the genus, $3-5 \mathrm{dm}$. high, pale ; leaves of the basal shoots lance-oblong, hoary-pubescent, thickish, those of the stem and inflorescence linear or nearly so; panicle broadly pyramidal; calyx canescent-pubescent, globular in fruit; pedicels $0.5-1.5 \mathrm{~mm}$. long. ( $L$. minur, var. Gray.) - Sandy soil near the coast, from the mouth of the Kennebec., Me., to Ga. Passing inland to

Var. intèrior Robinson. Lower (2-3 dm. high), more slender, thinner-leaved and greener; pedicels filiform, 2-3 mm. long. - Open sandy places, s. N. H. to w. Mass. - Distinguished from $L$. intermedia by its pyramida! inflorescence and slightly smaller pods.

6. L. tenuifolia Michx. Low, slender and diffise, minutely pubescent or glabrous; leaves all small and very narrow; flowers mostly on very short pedicels, diffusely racemose-paniculate; one or both the narrow outer sepals exceeding the inner ones, the latter strictly 1-nerved; pod subglobose. - Dry sterile soil, s. N. H. to Wis., Neb., and southw. 
++ Smaller-fowerer ; fruiting calyx narrower, ellipsoidal or pyriform.

7. L. Leggéttii Brition \& Hollick. Slender, 3-5 dm. high, glabrate; all leaves lance-linear to narrowly linear, green; panicle open, diffuse, ovoidpylamidal, the flowers often inclining to be secund-racemose; fruiting calyx obovoid or pyriform. (L. moniliformis Bicknell.) - Nantucket to Ind. and suuthw.

8. L. racemulosa Lam. Erect, soft-pubescent when young, soon nearly glabrous; leaves of radical shoots oblong, the cauline oblong-linear, $1-2 \mathrm{~cm}$. long; inflorescence loose and diffuse; fruiting calyx glabrous, ellipsoidal.Dry and rocky soil, L. I. to IKy. and southw.

\section{VIOLÀCEAE (VIOLET FAMILY)}

Herbs, with a somewhat irregular 1-spurred or gibbous corolla of 5 petals, 5 hypugynous stamens with adnate introrse anthers conniving over the pistil, and a 1-celled 3-valved pod with 3 parietal placentae. Sepals 5, persistent. Petals imbricated in the bud. Stamens with their short and broad filaments continuerl beyond the anther-cells, and often coherent with each other. Style usually club-shaped, with the simple stigma turned to one side. Valves of the capsule bearing the several-seeded placentae on their middle; after opening, each valve as it dries folding together lengthwise firmly, projecting the seeds. Seeds anatropous, with a hard seed-coat, and a large straight embryo nearly as long as the albumen; cotyledons flat. - Leaves alternate, with stipules. Flowers axillary, nodding.

1. Hybanthus. Sepals not auricled. Petals (in ours) equal in length. Stamens united into a sheath.

2. Viola. Sepals auricled. Lower petal spurred. Stamens distinct, the two lower spurred.

\section{1. hybánthus Jacq. Green Violet}

Petals nearly equal (or in extralimital species very unequal) in length, but the lower one larger and gibbous or saccate at the base, more notched than the others at the apex. Stamens (in ours) completely united into a sheath inclosing the ovary, and bearing a broad gland on the lower side. Style hooked at the summit. - Perennials, with stems leafy to the top, and 1-3 small greenishwhite flowers on short recurved axillary pedicels. (Name from ißss, humpbacked, and aptos, flower, from the dorsal gibbosity.) Canceocania Loef. Solea Spreng. Ionidum Vent. Cubelium Raf.

1. H. cóncolor (Forster) Spreng. Plant 4-8 dm. high; leaves oblong, pointed at both ends, entire ; pod $2 \mathrm{~cm}$. long. (Solea Gingins ; Cubelium Raf.) Rich woods, moist ravines, etc., N. Y. to Mich., Kan., and southw. Fl. A pr.June; fr. July.

\section{2. viola [Toum.] L. Violet. Heart's-tease}

\section{Revised by E, Brainerd}

Petals somewhat unequal, the lower one spurred at the base. Stamens closely surrounding the ovary, often slightly cohering with each other; the two lower bearing spurs which project into the spur of the corolla. Besides these conspicuous blossoms, which appear in spring, others are produced later, on shorter peduncles or on runners, often concealed under the leaves; these never open nor develop petals, but are fertilized in the bnd and are far more fruitful than the ordinary blossoms. - The closely allied species of the same section, when growing together, often hybridize with each other, producing forms that are confusing to the student not familiar with the specific types. The hybrids 
commonly display characters more or less intermediate between those of the parents, and show marked vegetative vigor but greatly impaired fertility. (The ancient Latin name of the genus.)

$N . B .-$ In this genus the figures are of the stigmas, styles, and upper part of the ovary, and are on a scale of 5 .

I. Plants stemless, the leaves and scapes directly from a rootstock or from runners. (For Group II. see p. 585.)

§1. Style club-shaped, beakless, obliquely concave at the summit; stigma within a small protuberance near the center of the cavity (Fig. 806).

1. V. peđàta I. (Brro-Foor V.) Nearly glabrous; rootstock short, erect, not scaly ; leaves 3 -divided, the lateral divisions 3-5-parted or -cleft, the segments

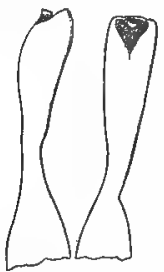

806. $\nabla$. pedata $\mathrm{v}$, linearilobr. all linear or narrowly spatulate, often 2-3-toothed or cut near the apex; the leaves of early spring or of autumn often less dissected; flowers $2-3 \mathrm{~cm}$. broad; the upper petals dark violet, the others pale to deep lilac-purple, all beardless; the orange tips of the stamens large and conspicuous at the center of the flower; capsules green, glabrous; seeds copper-colored; apetalons flowers wanting, but petaliferous flowers often produced in late summer and autumn. (Var. bicolor Pursh.) - Open sunny slopes in sandy soil, s. N. E. (where rare) to Md. Tar. Linearfloba DC. All the petals of the same lilac-parple color. ( $V$. pedata Man. ed. 6, not L.) - Locally abundant, e. Mass. to Minn., and southw. Fig. 806.

\section{\$2. Style dilated upward in a vertical plane, capitate, with a conical beak on} the lower side; stigma within the tip of the beak (Fig. 807).

a. Rootstock fleshy and thickened, without runners; petals violet-blue to purple, the lateral bearded (Buve Violets) $b$.

b. Leaves heart-shaped, the margins merely crenate-serrate, or in nos. 8-10 some lenves lobed but the cleistogamous flowers on prostrate peduncles c.

c. Plants essentially glabrous.

Beard of lateral petals strongly knobbed; cleistogamous flowers long and slender

Beard of lateral petals not strongly knobbed; cleistogamous flowers ovoid or ovoid-acuminate.

Cleistogamous flowers mostly on ascending peduncles; capsules 5-10 mm. loag.

Leaves and sepals obtuse; capsules green

Leaves and sepals acute; cleistogamous capsules usually purplish

Clelstogamous flowers mostly on short prostrate peduncles; cepsules 10-15 mm. long.

Lenves all undivided.

Yernal leaves purplish beneath ; plants of sandy or dry soil Vernal leaves green beneath ; plants of moist soil.

Leaves narrow, gradually attenuated; flowers pale violet

Leaves broad, "merely acute or abruptly" pointed; flowers deep violet

Leaves palmately lobed or parted

c. Plants more or less pubescent $a$.

a. Leaves for the most part palmately 5-9-lobed

2. V. cucullata.

d. Some leaves hastately $3-5$-lobed

$d$. Leaves all undivided $e$.

6. Spurred petal glabrous or bearing only seattered hairs; capsules 8-12 mm. long.

e. Spurred petal villous; capsules $5-8$ inm. Inng.

Pubescent only on upper surface of leaves

Pubescent on petioles and lower surfice of lerves.

Bepals and their aurieles olliolate

Sepals and their auricles not ciljolate

b. Leavos not heart-shaped, usually sharply dentate toward the base or lobed; clolstogamous flowers sagittate, on erect peduncles; capsules green $f$.

$f$. Spurred petal villous $g$.

a. Leaves ovate-oblong, pubescent, short-petioled .

o. Leaves lancoolate, usually glabrous, long-petioled; basal lobes often dileted and incised

\section{V. nephrophylla.}

4. V. affinis.

5. T. Latiuseula.

6. V. missourisnsis.

7. V. papilionacea.

8. V. Stoneana.

9. $\quad$. palmata.

10. V. triloba.

11. $\nabla$, sororia.

12. Г. hirsubula

13. $V$. septentrionalas

14. V. novae-angliae.

15. F. fmbriatula.

16. V. sagittata. 
g. Leaves deltoid, glabrous, sharply dentate below the middle

0. Leaves parted into narrow lobes; specios of the Atlantic coast

$g$. Leaves ovate-deltoid, the margins closely pectlnate or sharply dentate

a. Toaves parted into many linear segments, or sometimes only" cleft ; species of the Middle West.

$f$. Spurred petal glabrous, nariow

a. Rootstock long and fliform, producing slender runners except in no. $29 h$.

h. Petais lilac or pale violet.

Leaves minutely hairy on the upper surface; spur large

h. Petals white, with purple lines on the three lower (Wirite $\dot{V}_{\text {Iousts }}$ i.

$i$. Leaves glabrous on both sides, rarely pubescent in no. $25 ;$ cleistogamous capsules ellipsoid, green, on erect peduncles.

Leaves lanceolate or linear-lanceolate.

Leaves ovate, ncute, base subcordate or tapering

Leaves heart-shaped, usually obtuse

i. Leaves pubescent on one or both sides; cleistoganous capsule ovoid, usually purplish, on erect peduncles only when ripe ; seeds brown, 1.5-2 $\mathrm{mm}$. long.

Leaves heart-shaped, minutely hairy above; plant elsewhere glabrous; lateral petals beardless

Leaves broadly heart-shaped; plant more or less pubescent; lateral petals bearded

Leaves reniform, pubescent; lateral pétals beardiess
17. T. emarginata.

18. F. Brittoniana.

19. T. pectinata.

20. V. pedatifida.

21. V. viarum.

23. V. palustris.

24. V. lanceolata.
25. V. primulifotia
26. V. pallens.

\section{V. blanda.}

28. $T$, incognita.

29. V. renifolia.

2. V. cucullata Ait. Leazes except the earliest acute or pointed; petaliferous flowers violet-blue becoming darker toward the throat, commonly on peduncles much taller than the leaves; spurred petal glabrous, generally somewhat shorter than the lateral; sepals narrowly lanceolate ; cleistogamous flowers on erect or ascending often elongated peduncles; capsules opoid-cylindric, green, 10-15 $\mathrm{mm}$. long, but little exceeding the long-auricled sepals ; seeds dark brown, $1.5 \mathrm{~mm}$. long. (V. palmata, var. Gray, in part.) - Wet places, common. Forms with flowers white or pale lavender are not infrequent.

3. V. nephrophýlla Greene. Nearly or quite glabrous; earliest leaves orbicular or slightly reniform, later leaves broadly heart-shaped, obtuse, obscurely crenate, 3-6 cm. wide; flowers large, violet, on peduncles generally exceeding the leaves; spurred petal villous, the upper pair often with scattered hairs; sepals ovate to lanceolate, obtuse and often rounded; cleistogamous flowers on erect or recurved peduncles; capsules green, glabrous, short-ellipsoid ; seeds olive-brown. ( $V$. vagula Greene.) - Cold mossy bogs, and borders of streams and lakes, e. Que. to B. C., s. to centr. Me., n. w. Ct., s. Ont., Wisc., Col., and Wash.

4. V. affinis Le Conte. Leaves that unfold at flowering time narrowly heartshaped and commonly attenuate toward the apex, becoming $4-6 \mathrm{~cm}$. broad in summer, the margins noticeably crenate-serrate or sometimes irregularly sinuate; petioles slender; petals violet, with the white base conspicuous, spurred petal more or less villous; cleistogamous flowers small, ovoid, on rather long ascending peduncles ; capsules ellipsoid, usually purple-dotted, sometimes green, either glabrous or clothed with minute dense pubescence; sepals acuminate, half the length of the capsule, with small appressed auricles; seeds buff-colored. ( $V$. venustula Greene.) - Moist thickets and boggy meadows, w. N. E. to Wisc., and southw.

5. V. latiúscula Greene. Earliest leaves round-cordate, $2-3 \mathrm{~cm}$. wide, obtuse; mature leaves 4-10 cm. wide, often dilated and abruptly pointed, glabrous except for occasional puberulence or granular roughness on the edges of the petiole near the blade; flowers large, rich violet; spurred petal somewhat villous; outer sepals lanceolate, glabrous, with short rounded auricles ; cleistogamous capsules ovoid or ellipsoid, fecked with purple, 8-12 $\mathrm{mm}$. long, the persistent sepals one third as long; seeds brown. - Dry open woods, in light soil, Vt. to N. J.

6. V. missouriénsis Greene. Aestival leaves narrowly deltoid with a cordate base, or sometimes broader with rounded basal lobes and pointed apex, rather coarsely crenate-serrate ; flowers pale violet, with a darker band above the white center; spurred petal glabrous; sepals ovate-oblong to lanceolate, narrowly 
white-margined, slightly ciliolate ; capsules from apetalous flowers broadly ellip. soid, finely dotted with purple; seeds buff-colored. - River bottoms and low woods, Mo. and southw.

T. V. papilionàcea Pursh. Plants commonly robust from a stout horizontal branching rootstock; leaves often $12 \mathrm{~cm}$. broad, sometimes deltoid in outline above the cordate base, sometimes rounded and abruptly

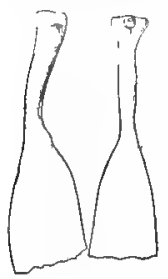

807. V. papilionacea. pointed; petioles often sparingly pubescent; petals deep violet, white or greenish-yellow at the base, sometimes wholly white; the spurred petal often narrow and boat-shaped, usually glabrous; outer sepals ovate-lanceolate, rarely ciliolate; cleistogamous flowers ovoid, on borizontal peduncles usually underground but lengthened and erect when the capsules ripen; capsules ellipsoid to cylindric, green or dark purple, 10-15 mm. long; seeds $2 \mathrm{~mm}$. long, dark brown. (V. pal. mata, var. cucullata Gray, in part.) - Moist meadows and groves, frequently about dwellings, Mass. to Minn., and southw. Fig. 807.

8. V. Stoneàna House. Leaves variously 3-9-lobed or parted, the outer segments broadly lunate, all somewhat dentate or incised, narrowed toward the base; the vernal and late summer leaves less deeply cut or not at all, glabrous except for minute hairs on the margin and sometimes on the veins; flowers large, violet, darker towards the throat; spurred petal glabrous ; capsules from the cleistogamous flowers ovoid, blotched with purple ; seeds buff-colored. - Moist woodlands, N. J., e. Pa., and Md.

9. V. palmata L. Leaves of early summer palmately 5-9-lobed or -parted, the segments variously toothed or cleft, the niddle segment usually widest; the first leaves of spring sometimes undivided; petioles and veins of the lower surface densely villous, upper surface often glabrous ; flowers violet-purple, $2-3 \mathrm{~cm}$. broad; sepals ovate-lanceolate, rather blunt; cleistogamous flowers on prostrate peduncles, their capsules ovoid, purple-dotted, 8-12 $\mathrm{mm}$. long; seeds brown. Dry rich woodlands, Mass. to Minn., and southw.

L 10. V. triloba Schwein. Early foliage purplish, turning yellowish-green at flowering time; some leaves broadly heart-shaped, others 3-5-lobed, the middle segment always broad, the basal segments lunate, the lateral if present narrow, the blade $10-15 \mathrm{~cm}$. wide when mature; petioles densely villous; peduncles mostly glabrous, shorter than the leaves; petals deep violet within, paler with. out; outer sepals ovate-lanceolate, somewhat obtuse, slightly ciliolate; cleistogamous capsules ovoid, purplish; seeds buff or pale brown. ( $V$. congener Le Conte; V. palmata, var. dilatata Pollard, not Ell.) - Dry woodlands, s. N. F., s. N. Y., and southw, - Freely intergrades with the following.

- $L$ 11. V. soròria Willd. In size and habit like no. 7 , into which it passes ; leaves villous-pubescent especially on the petioles and under surface when young ; verual flowers on peduncles about the length of the leaves, violet to lavender and occasionally white; outer sepals ovate-oblong, commonly obtuse, ciliolate below the middle and on the short rounded anricles; cleistogamous flowers ovoid, on short prostrate peduncles; capsules of these usually purple; seeds dark brown. (V. palmata, var. Pollard.)-Moist meadows, alluvial woods, shady ledges and dooryards, w. Que. to Minn., and southw.

$V$ 12. V. hirsutula Brainerd, The smallest species of the group; leaves commonly appressed to the ground, $2-4 \mathrm{~cm}$. wide, broadly cordate, obtuse, purplish and glabrous beneath, silvery-pubescent above and marked with varying shades of green; petaliferous flowers violet-purple, on peduncles taller than the leaves; apetalous flowers sulall, ovoid, on short prostrate peduncles; their capsules ovoid, 6-8 $\mathrm{mm}$. long, purple, when ripe raised $3-4 \mathrm{~cm}$. above the leaves; seeds yellow-brown, 20-30 in a capsule. ( $V$. villosa of recent allt., not Walt.) Dry rich woods, s. N. Y. to $\mathrm{Ky}$. and Ga. - V. villosa, var. cordifolia Nutt., with broader acute leaves less pubescent above, and with infertile capsules and darker seeds, seems to be a cross between $V$. hirsutula and $V$. papilionacea.

13. V. septentrionàlis Greene. Leares $3-7 \mathrm{~cm}$. wide, hirsutulous especially on the margins, veins, and petioles, somewhat pointed but the apex blunt 
petioles slender, wiry, often purplish at base; petals variable, 4-12 nm. wide, deep violet to pale lilac, rarely pure white or white suffused with violet, all occasionally bearing scattered hairs; sepals ovate, usually obtuse, closely ciliolate nearly to the tip; cleistogamous flowers sagittate, on horizontal or recurved peduncles; their mature capsules purple (sometimes green), subglobose, 5-8 $\mathrm{mm}$. long, subtended by the spreading ciliolate auricles of the sepals; seeds brown. - Moist open woodlands, especially under conifers, P. E. I., Que., and Ont. to Ct. and w. N. Y.

14. V. novae-angliae House. Differs from the last in its narrow cordatetriangular leaves, 2-4 cm. wide at time of petaliferous flowering, in not having ciliolate sepals and auricles, and in flowering a week or two later ; in late summer the breadth of leaf often equals its length. - Gravelly beaches of the St. John R., n. Me. (Fernald); rocky banks of the Penobscot R., Me. (Knight).

$\checkmark$ 15. V. fimbriátula Sm. Rootstock becoming long and stont in age, usually erect; the earliest leaves ovate, obtuse, the later ones ovate-oblong, acute, finely pubescent, obscurely crenulate toward the apex, the basal lobes sometimes sharply toothed or incised; flowers violet-purple, on peduncles commonly longer than the leaves; cleistogamous capsules green, ovoid, 6-10 mm. long; auricles of the sepals spreading and ciliate; seeds brown. (V. ovala Nutt.; V. sagittata Man. ed. 6, in part.) - Sandy fields and dry hillsides, N. S. to Wisc., and southw. 16. V. sagittàta Ait. Mature leaves lanceolate or oblong-lanceolate, the blades 4-8 cm. long, hastately or sagittately incised or toothed at the base; the earliest and those produced in late summer often nearly deltoid, obtuse, merely crenate at the base; petals violet-purple; sepals narrowly lanceolate, acute, glabrous ; capsules 8-14 mm. long, containing 50-70 brown seeds. - Moist banks and fields, Mass. to Minn., and southw., especially near the coast. - In O. and westw. a pubescent form of the species is prevalent ( $V$. subsagittata Greene).

$\checkmark$ 17. V. emarginàta Le Conte. Mature leaves approximately triangular, the base trumcate or slightly cordate, often decurrent, obscurely crenate-serrate above the middle, coarsely toothed or incised below; petals violet-blue, frequently emarginate ; cleistogamous capsules narrowly ovoid, 8-14 mm. long, on peduncles somewhat shorter than the leaves; seeds brown. - Dry woods and hillsides, N. J. and southw.

18. V. Brittoniàna Pollard. First leaves reddish beneath, merely dentate: later leaves reniform to ovate in outline, 5-9-lobed or -parted, the lateral segments narrow, the middle segment often much the widest, glabrous except for minute pubescence on the upper surface and margin; flowers large, rich violet, with the white throat conspicuous; sepals linear-lanceolate, acuminate; capsules ovoid-cylindric, 10-18 mm. long, on peduncles about the length of the petioles; seeds about $1.6 \mathrm{~mm}$. long, buff-colored. (V. septemloba of auth., not Le Conte; $V$. atlantica Britton, not Pomel.) - In moist sandy or peaty soil near the coast, s. Me., and southw.

19. V. pectinàta Bicknell. Leaves ovate-deltoid in general outline, sometimes narrower but often much wider than long, the base truncate, subcordate, or somewhat decurrent on the petiole, the apex acute to acuminate or occasionally blunt, the margin sharply dentate or below the middle closely pectinate; in pubescence, flower, fruit, and seed quite the same as $\boldsymbol{V}$. Brittoniana, with which it is associated in all the known stations. - Damp meadows, Dedham, Mass. ; Stratford, Ct. ; Woodmere, N. Y. ; Dayton, N. J.

20. V. pedatífida G. Don. Rootstock short, vertical ; leaves palmately parted, the divisions variously cleft and incised into linear lobes; leaves usually cumeate at the base, with prominent flabelliform veins, minutely pubescent on the margin; scapes exceeding the leaves, bearing showy violet flowers; cleistoga. mous capsules light gray when ripe, $10-15 \mathrm{~mm}$. long, on peduncles commonly shorter than the petioles; seeds $2 \mathrm{~mm}$. long, light brown. - Prairies, $\mathbf{n}$. $\mathrm{O}$. to Sask., southwestw. to N. Mex. - Varies much in leaf-pattern, passing through forms less deeply dissected and with wider oblong lobes ( $V$. Bernardi Greene) to forms with leaves somewhat rhomboidal in nutline, the base broarly cuneare and entire, the upper contour rounded, sharply cleft aud toothed ( $V$. indivisa Greene). 
21. V. viàrum Pollard. Leaves broadly deltoid, with the basal anglen rounded, some undivided, merely crenate-serrate or with a few slight incisions, others hastately 3-7-lobed or -parted, the middle segment broad, acute, serrate ; petals rich violet, spurred petal glabrous, narrow, emarginate, nearly tubular from the inrolling of the margins, lateral pair narrow, convergent about the spurred petal, bearing a sparse short clavate beard, upper pair broader, divergent, emarginate; sepals narrowly lanceolate, with rather short entire auricles ; cleistogamous fruit on peduncles somewhat shorter than the petioles, pale green when ripe, cylindric-ovoid; seeds olive-brown. - Open ground, waysides and river-banks, Mo. to Kan, and Okla.

22. V. Selkírkii Pursh. (Great-SPurred V.) Small and delicate; runners all underground; leaves round-cordate, the basal Iobes converging or overlapping, crenate, at vernal flowering about $2 \mathrm{~cm}$. wide, when mature $3-4 \mathrm{~cm}$. wide, the upper surface bearing minute spreading hairs, plant otherwise glabrous; scapes about as tall as the leaves; petals all beardless; peduncles of cleistogamous flowers erect or ascending, the capsules subglobose, dotted with purple ; seeds small, straw-colored, - Shaded ravines and cold woods, N. B. to w. Mass., n. Pa., L. Superior, and northw., rare. (Greenl.)

23. V. palústris L. Smooth; leaves round-cordate and reniform, slightly crenate; flowers small; petals pale lilac, with purple lines, the lateral pair somewhat bearded, spur very short and obtuse. - Alpine region of the White Mts., N. H., and far northw. (Eu.)

24. V. lanceolata L. (LANCE-LEAved V.) Stolons leafy, often bearing apetalous flowers; leaves and scapes glabrous, $5-8 \mathrm{~cm}$. high at time of vernal flowering ; later leaves $20-30 \mathrm{~cm}$. high, the blades obscurely crenulate, gradually tapering into a long margined often reddish petiole; lateral petals usually beardless ; sepals lanceolate, acute ; cleistogamous capsules 6-12 $\mathrm{mm}$. long, on erect peduncles that are usually shorter than the leaves; seeds dark brown. Open bogs, moist meadows, and shores, N. S. to Minn., and southw.

25. V. primulifolia L. (Primrose-Leaved V.) Leaves oblong or ovate, with either subcordate, obtuse, or tapering base, obscurely creoate-serrate, commonly glabrous; stolons, flowers, and fruit as in the preceding; seeds reddish-brown, about $1.5 \mathrm{~mm}$. long. - Moist or almost dry soil, N. B., southw. along the coast.

26. V. pállens (Banks) Brainerd. Leaves heart-shaped, obtuse or rarely acute; petioles and scapes often with scattered hairs, sometimes dotted with red; lateral petals usually bearing a small tuft of hairs, upper petals broadly obovate; seeds small, $1 \mathrm{~mm}$. long, almost black. ( $\boldsymbol{V}$. blanda of recent Am. auth., not Willd.) - Springy land and along brooks, Lab. to B. C., s. to the mts. of S.C. and Tenn., Mich., and Wyo. - This and the two species following are commonly known as SWEET WHITE V.

27. V. blanda Willd. Glabrous except for minute white hairs on the upper surface of the leaves especially on the basal lobes; leaves commonly acute, often pointed; midribs, petioles, and scapes usually tinged with red ; lateral petals beardless, the upper pair often long, narrow, and strongly reflexed, sometimes twisted; in flower 10-15 days later than the two following; freely producing in summer slender leafy runners. ( $V$. amoena Le Conte; $\cdot V$. blanda, var. palustriformis Gray.) - Moist rich woodlands, w. Que, to Minn,, and southw, to Ga. and La.

28. V. incógnita Brainerd. Peduncles, petioles, and lower surface of leaves more or less pubescent with soft white hairs especially when young, the upper leaf-surface often glabrous; aestival leaves large, rugose, broadly heart-shaped, acute; lateral petals bearded, upper pair obovate ; flowering early ; in summer producing numerous filiform runners. - Mountain slopes and low moist woodlands, Nfd. and e. Que. southw. to Pa., and westw.

29. V. renifolia Gray. Leaves reniform, often abruptly pointed, more or less pubescent, but upper surface often quite glabrous; petals all beardless, the upper pair oflbicular; flowering early; runners rarely present, very short, raceme-like, bearing cleistogamous flowers. - Arbor Vitae swamps and cold woods, Nfd. to the Mackenzie R., so to N. F., Pa., Mich., and Minn. 
$\$ 3$ Style enlarged upward, abruptly capitate, beakless; stigma within a small orifice on the lower side of the summit (Fig. 808); petals yellow.

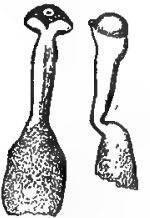

808. $\nabla$. rotundifolia.

30. V. rotundifolìa Michx. (Round-LEAved or EARLT YELLOW V.) Rootstock stout, jagged with the persistent bases of former leaves; runners short, usually without roots or leaves, bearing 1-5 cleistogamous flowers, thus simulating racemes; leaves oval or round-cordate, obtuse, repand-crenulate, with short and narrow basal sinus, at flowering time minutely pubescent, $2-3 \mathrm{~cm}$. wide, in midsummer mostly glabrous, $6-10 \mathrm{~cm}$. wide, prostrate; petals bright yellow, the three lower with brown veins, the lateral bearded; capsules ovoid, 6-8 $\mathrm{mm}$. long, closely dotted with purple; seeds nearly white. - Cold woods, centr. Me. to s. W. Ont., O., Pa., Del., and along the Alleghenies to n. Ga. FIG. 808.

\$4. Style not club-shaped nor capitate, ending in a small hook pointing downward (Fig. 809); petals violet or sometimes white.

31. V. odorata L. (English or Sweet V.) Producing above ground leafy stolons; leaves broadly cordate, finely pubescent; flowers very fragrant; summer-capsules broadly ovoid, angled, pubescent, purple; seeds relatively large, cream-colored. - Often cultivated, and occasionally spontaneous. (Introd. from Eu.) Fig. 809.

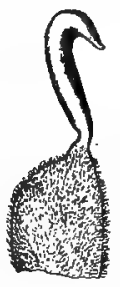

809. V. odorata.

\section{Plants with teaffy gtems}

\section{Style capitate, beakless, bearded at the summit (Fig. 810); spur short; stip- ules entire, the lower more or less scarious.}

Stems numerous, ascending, bearing leaves and flowers from near the

Stems few, mostiy erect, not leafy below.

Petals yellow.

Nearly glabrous; stem-leaves halberd-shaped or narrowly heart-shaped

Softly pubescent; root-leaves often wanting; stem-leaves broad, often

over $7 \mathrm{~cm}$. wide
Sparingly pubescent; root-leaves usually $1-2$; stem-leaves rarely over $i$
cm. wide

Petals white inside, outside tinged with violet

32. V. Nuttallii.

39. V. hastata.

34. F. pubescens.

35. F. scabriuscula. 36. F. canadensis.

32. V. Iruttállii Pursh. Pubescent or nearly glabrous; leaves ovate to oblong-lanceolate, obtuse, entire or slightly crenate, tapering into margined petioles; petals yellow, sometimes violet on the outside. - Prairies, Mo., N. Dak., and westw.

33. V. hastàta Michx. (HaLberd-Leaved V.) Stem slender, 1-2.5 ảm. high, from a horizontal fleshy rootstock; stem-leaves 2-4 near the summit, halberd-shaped or oblong-heart-shaped, slightly serrate, acute; stipules ovate, small. - Woods, n. O., mts. of Pa., and southw.

34. V. pubéscens Ait. (DownY Yollow V.) Softly pubescent, 2-3.5 dm. high; stems often solitary; leaves 2-4 near the summit (or occasionally a longpetioled root-leaf), broadly ovate with cordate or truncate-decurrent base, crenate-dentate, somewhat pointed ; stipules large, ovate-oblong; petals purpleveined, the lateral bearded; sepals narrowly lanceolate, acute; apetalous flowers abundant in summer on short peduncles; capsules ovoid, glabrous or woolly ; seeds light brown, large, nearly $3 \mathrm{~mm}$. long. - Dry rich woods, s. Me. to Ont., Kan., and Md.

35. V. scabriúscula Schwein. (Sмоoтн Yellow V.) Similar to the preced. ing, with which it intergrades; the more pronounced forms have commonly $2-4$ stems and 1-3 radical leaves from one roptstock, the stems shorter and more leafy, the Ieaves smaller and sparingiy pubescent to glabrate, the time of flower- 


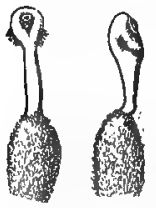

ing earlier ; flowers, capsules, and seeds as in the preceding. Moist thickets, often in heavy soil, $t$. Que. to L. Winnipeg, and southw.

36. V. canadénsis I. (CANADA V.) Usually $3-4 \mathrm{dm}$. high, minutely pubescent, glabrate; leaves heart-shaped, pointed, serrate; stipules sharply lanceolate; petaliferous flowers often borne throughout the summer, lateral petals bearded, spurred petal yellow at the base and striped with fine dark lines; 810. V. canadensis. sepals slender, acuminate ; capsules subglobose, $6-10 \mathrm{~mm}$. long, often downy or puberulent; seeds brown. - Woods, Nfd. to n. Vt., thence southw. and westw. FIG. 810 .

\section{\$6. Style not capitate, slender (Fig. 811); length of spur at least twice its width; stipules fringed-toothed, somewhat herbaceous.}

Tip of the style bent downward, slightly pubescent near the summit; lateral petals bearded; spur less than $8 \mathrm{~mm}$. long.

Petals white or cream-colored.

Petals pale violet or violet-purple.

Stems ascending.

Plants glabrous or nearly so.

Stipules ovate-lanceolate; later leaves subacuminate and northern.

Plants densely puberulent.

Stems prostrate; leaves suborbicular

Style straight and glabrous; lateral petals beardless, spur slender, 10-12

mm. long

87. V. striata.

38. V. conspersa.

39. V. labradorica.

40. V. arenaria.

41, V. Waltbri.

42. V. rostrata.

37. V. striàta Ait. Usually $15-30 \mathrm{~cm}$. high when in flower, often in late summer $6 \mathrm{dm}$. high, glabrous or nearly so; leaves heart-shaped, finely crenateserrate, often acute; stipules large, oblong-lanceolate; spur rather thick, shorter than the petals ; sepals ciliate, narrow, attenuate ; capsules ovoid, glabrous, 4-6 mm. long; seeds light brown. - Low or shady ground, Ct. to Minn., and southw.

38. V. conspérsa Reichenb. Rootstock oblique, often much branched; at time of vernal flowering stems $8-16 \mathrm{~cm}$. high; lower leaves round-reniform, upper round-cordate, crenate, $1,5-3 \mathrm{~cm}$. wide; flowers numerous, usually pale, sometimes white, raised above the leaves on axillary peduncles $5-8 \mathrm{~cm}$. long; in summer the leaves becoming wider, the stems elongating and bearing cleistogamous flowers on short peduncles from the same axils that bore vernal flowers or from the axils of later leaves; seeds straw-colored. ( V. Muhlenbergii Torr. ; V. labradorica of recent Am. auth., not Schrank.) - Common in low or shaded ground, e. Que. to Minn., and soutliw. Fig. 811.

39. V. labradorica Schrank. Habit of the preceding but more (lwarf; stems and petioles nearly or quite glabrous; stipules narrow, lance-linear ; leaf-blades unore or less hispidulous above, the later ones rounded to an obtuse (not in the least acuminate) apex; petals commonly deep violet, more rarely paler; seeds light brown. ( $V$. Muhlenbergiana, var. minor Hook.) - Greenl, and Lab., s. to cool or alpine situations of Me.. N. H., and n. N. Y.

40. V. arenaria DC. Low, tufted; stems several or many; leaves 1-2 cm. broad, thickish, densely puberulent on both surfaces, ovate, often subcordate, narrowed above to an obtuse apex; spur usually straight and blunt, but sometimes with a sharp point abruptly bent inward; cleistogamous flowers and

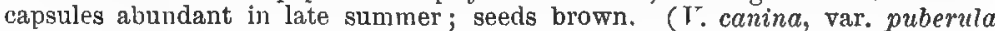
Wats.) - Sandy and sterile soil, e. Que. to n. e. Mass., westw. to Minn. and Sask. (Eu.)

41. V. Waltèri House. Blossoming first from rosettes of radical leaves, afterwards producing prostrate leafy stems that bear cleistogamous flowers; leaves orbicular to reniform, with cordate base, $1-4 \mathrm{~cm}$. wide, crenulate, often dark-colored along the veins; flowers and fruit much as in $V$. conspersa. ( $\nabla$. multicaulis Britton, not Jord.) - Rocky or sandy ground, Ky. to Fla. and Tex. 
42. V. rostràta Pursh. (Long-spurred V.) Stems often nunderous, commonly 1-1.2 dm. high; leaves round-heart-shaped, nearly or quite glabrous, serrate, the upper acute or pointed; petals lilac-colored with a violet spot near the center, borne on long peduncles above the leaves; cleistogamous flowers with minute or abortive petals appearing later on short peduncles from the axils of the upper leaves ; capsules ovoid, 3-5 mm. long, glabrous ; seeds yellowish-brown. Shaded hillsides, w. Que. to Mich., and southw. in the Alleghenies to Ga.

\$ 7. Style much enlarged upward into a globose hollow summit with a wide orifice on the lower side (Fig. 812); stipules large, leaf-like, lyrate-pinnatifid.

Stipules pinnatisect at the base; upper leaves crenately serrate; introduced species.

Petals $2-3$ times as long as the sepals

Petals seldom longer than the sepals
Stipules paimately pectinate at the base; upper leaves entire or nearly so ; indigenous

48. $V$. inicolor.

44. T. anvensis.

45. V. Rafinesquiz

43. V. Trfcolor L. (Pansy, Heart's-ease.) Stems angled, $1.5-3 \mathrm{dm}$. high; lower leaves roundish or cordate, upper oblong, crenate; flowers large

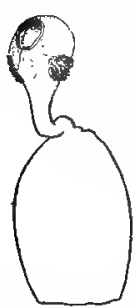
and widely spreading, variously marked with yellow, white, and purple; capsules ovoid; seeds brown. - An escape from cultiva tion, rarely persisting. (Introd. from Eu.) FIG. 812.

1. 44. V. arvínsis Murr. (Wild Pansy.) Similar to the pre. ceding, but smaller; petals all pale yellow, usually shorter than the rather long lanceolate acute sepals; capsules globose. - Old fields, frequent, Nfd. to N. E. and Ont. (Nat. from Eu.)

45. V. Rafinésquii Greene. (Wuld Passy.) Very slender, often branched from the base; root annual; leaves small, the earliest suborbioular, on slender petioles, the later obovate to linear-oblanceolate, attenuate at the base; internodes usually exceeding the leaves; flowers small, 7-10 mm. long, the obovate 812. V.tricolor. bluish-white to cream-colored petals nearly twice the length of the sepals. ( $V$. tenella Raf., not Poir.; $V$. tricolor, var. arvensil Man. ed. 6, not DC.) - Woods and open places, N. Y. to Mich., Tex., and Ga.

\section{PASSIFLORÀceat (Passion Flower family)}

Herbs or woody plants, climbing by tendrils, with perfect flowers, 5 monadelphous stamens, and a stalked 1-celled ovary free from the calyx, with 3 or 4 - parietal placentae, and as many club-shaped styles.

\section{PASSiflóra L. Pagsion Flower}

Calyx of 5 sepals shortly united at the base; the throat crowned with a double or triple fringe. Petals 5, on the throat of the calyx. Filaments united into a tube which sheathes the long stalk of the ovary, separate above; anthers large, fixed by the middle. Berry (often edible) many-seeded. Leaves alternate, generally palmately lobed, with stipules. Peduncles axillary, jointed. - Ours are perennial herbs. (An adaptation of flos passionis, a translation of fior della passione, the popular Italian name early applied to the flower from a fancied resemblance of its parts to the implements of the crucifixion.)

1. P. lùtea L. Srrooth, slender; leaves obtusely 3-lobed at the summit, the lobes entire; petioles glandless; flowers greenish-yellow, $2.5 \mathrm{~cm}$. broad; fruit $1.2 \mathrm{~cm}$. in diameter. - Damp thickets, s. Pa. to Mo., Tex., and Fla.

2. P. incarnata L. Pubescent; leaves 3-5-cleft, the lobes serrate, the base bearing 2 glands; flower large $(5 \mathrm{~cm}$. broad), nearly white, with a triple purple and flesh-colored crown ; involucre 3-leaved; fruit as large as a ben's egg. Dry soll, Va. to Fla., w. to Mo. and Tex. - Fruit called MaYpops. 


\section{LOASACEAE (LOAsa FAMily)}

Herbs, with a rough or stinging pubescence, no stipules, the calyx-tube adherent to a 1-celled ovary with 2 or 3 parietal placentae;-represented here only by the genus

\section{MENTZELIA [Plumier] L.}

Calyx-tube cylindrical or club-shaped; the limb 5-parted, persistent. Petals 5 or 10 , regular, spreading, flat, convolute in the bud, deciduous. Stamens inserted with the petals on the throat of the calyx. Styles 3, more or less united into 1 ; stigmas terminal, minute. Capsule at length dry and opening at the summit. Seeds flat, anatropous. - Stems erect. Leaves alternate, very adhesive by the barbed pubescence. (Dedicated to $C$. Mentzel, an early German botanist.)

1. M. oligospérma Nutt. (Stick IenF.) Much branched, 3-9 dm. high; leaves ovate and oblong, cut-toothed or angled, often petioled; floroers yellow, $1.5-2 \mathrm{~cm}$. broad, opening in sunshine; petals 5, wedge-oblong, pointed ; stamens 20 or more; capsule small, about 9-seeded. - Limestone hills and banks, Ill. to Kan. and Col., s. to Tex. May-Aug.

2. M. decapétala (Pursh) Urban \& Gilg. Larger in all its parts; leaves elongate-lanceolate, sharply and coarsely dentate; flowers white or pale yellow, $7-12 \mathrm{~cm}$. broad, opening in the evening; petals 10 , lanceolate; stamens abundant; seeds numerous. - Rocky hillsides and dry prairies, n. w Ia. to Sask., Tex., and westw. July-Sept.

\section{CaCtaceae (Cactus Famity)}

Fleshy and thickened mostly leafless plants, globular or columnar and manyangled, or flattened and jointed, usually with prickles. Flowers solitary, sessile; the sepals and petals numerous, imbricated in several rows, the bases adherent to the 1-celled ovary. Stamens numerous, inserted on the inside of the tube or cup formed by the union of the sepals and petals. Style 1 ; stigmas numerous.

1. Mamillaria. Globose or ovoid plønts, covered with spine-bearing tubercles. Flowers from between the tubercles. Ovary naked; berry succulent.

2. Opuntia. Branching or jointed plants; the joints flattened or cylindrical.

\section{MAMILLARIA Haw.}

Flowers about as long as wide, the tube campanulate or funnel-shaped. Ovary often hidden between the bases of the tubercles, naked, the succulent berry exserted. Seeds yellowish-brown to black, crustaceous. - Globose or ovoid plants, covered with spine-bearing cylindrical, ovoid, or conical tubercles, the flowers from distinct woolly or bristly areoles at their base. (Name from mamilla, a nipple, referring to the tubercles.)

1. M. vivipara (Nutt.) Haw. Single or tufted, 2.5-12 cm. high, the almost terete tubercles bearing bundles of 5-8 reddish-brown spines ( $2 \mathrm{~cm}$. long or less) surrounded by $15-20$ grayish ones in a single series, all straight and rigid ; flowers red or purple, with fringed sepals and lance-subulate petals ; berries ovoid, green; seeds pitted, light brown. (Cactus Nutt.) - Granite ledges, w. Minn. (Moyer); and on prairies and dry plains to Alb. and Cal.

2. M. missouriénsis Sweet, var. caespitosa (Engelm.) Wats.' Smaller, stems globose, clustered, the tubercles with fewer (10-20) weaker ash-colored spines; flowers yellow, 2.5-5 cm. broad; berry subglobose, scarlet; seeds few, pitted, black. (Cactus missouriensis, var, similis Coult.) - Dry prairies, e. Kan. to Tex.. and westw. 


\section{OPÚntia [Tourn.] Mill. Pricinly Pear. Indian Fig}

Sepals and petals not united into a prolonged tube, spreading, reguiar, the inner roundish. - Stem composed of joints (flattened in ours), bearing very small awl-shaped and usually deciduous leaves arranged in a spiral order, with clusters of barbed bristles and often spines in their axils. Flowers in our species yellow, opening in sunshine for more than one day. (A name of Theophrastus, originally belonging to some different plant.)

\section{* Spines small or none; fruit pulpy.}

1. 0. vulgàris Mill. Prostrate or spreading, light green; joints broadly ob. ovate, $5-10 \mathrm{~cm}$. long; leaves minute (4-5 mm. long), ovate-subulate, generally appressed; bristles short, greenish-yellow; spines solitary or more often none; flowers pale yellow, about $5 \mathrm{~cm}$. broad, with about 8 petals; fruit $2.5 \mathrm{~cm}$. long. - Sandy fields and dry rocks, Nantucket to S. C., near the coast; Falls of the Potomac.

2. O. Rafinésquii Engelm. Prostrate, deep green; joints broadly obovate ol orbicular, 7-12 cm. long; leaves 6-8 mm. long, spreading; bristles bright red. brown, with a few small spines and a single strong one (1.8-2.4 cm. long) or none; flowers yellow, 6-9 cm. broad, sometimes with a reddish center; petals 10-12 ; fruit $3.6 \mathrm{~cm}$. long, with an attenuated base. (Probably 0 . cespitosa, mesacantha, and humifusa Raf., in part.) - Sandy soil, limestone bluffs, etc., n. O. and Mich, to Minn, and s. to Ky. and Tex.

Var. minor Engelm. Dwarf; joints orbicular, $5 \mathrm{~cm}$. in diameter, nearly spineless. - Sandstone rock, s. Mo. (Engelmann according to Coulter.)

$$
\text { * Very spiny; fruit dry and prickly. }
$$

3. O. polyacántha Haw. Prostrate, joints light green, broadly obovate, fla and tuberculate, 5-15 $\mathrm{cm}$. long; leaves small (3-4 mm. long), their axils armed with a tuft of straw-colored bristles and 5-10 slender radiating spines $(2.5-5 \mathrm{~cm}$. long) ; flowers light yellow, $5-7.5 \mathrm{~cm}$. broad ; fruit with spines of variable length, (O. missouriensis DC.) - Wisc. to Mo., and westw. across the plains; very variable.

4. O. frágilis (Nutt.) Haw. Subdecumbent; joints small (2.5-5 cm. long os less), ovate, compressed or tumid, or even terete; leaves hardly $2 \mathrm{~mm}$. long, red; bristles few, larger spines 1-4, cruciate, with 4-6 smaller white radiating ones below; flowers yellow. - Minn., Ia., Kan., and westw.

\section{ThYMeLAEÀCeAe (Mezhreum Family)}

Shrubs, with acrid and very tough (not aromatic) bark, entire leaves, and perfect flowers with a regular and simple colored calyx, bearing usually twice as many stamens as its lobes, free from the 1-celled and 1-ovuled ovary, which forms a berry-like drupe in fruit, with a single suspended anatropous seed. Embryo large; albumen little or none.

1. Dirca. Calyx tubular, without spreading lobes. Stamens (8) and style exserted.

2. Daphne. Calyx-lobes (4) spreading. Stamens (8) included. Style short or none.

\section{Dírca L. Leatherwood. Moosewood}

Calyx petal-like, tubular-funnel-shaped, truncate, the border wavy or obscurely about 4-toothed. Stamens inserted on the calyx above the middle, the alternate ones longer. Style thread-form. Drupe ovoid, reddish. - A much branched bush, with jointed branchlets, oval-obovate alternate leaves on very short petioles, the bases of which conceal the buds of the next season. Flowers light yellow, preceding the leaves, 3 or 4 in a cluster from a bud of as many dark-hairy scales, these forming an involucre, from which soon after proceeds a leafy branch. (Name of uncertain derivation.) 
1. D. palístris L. (WICOPY.) Shrub, 1-2 m. high; the wood white, soft, and very brittle; but the fibrous bark remarkably tough (used by the Indians for thongs, whence the popular names). -- Damp rich woods, N. B. to Ont., and southw. Apr.

\section{DÁPHNE I. Mezereum}

Calyx salver-shaped or somewhat funnel-shaped. Anthers nearly sessile on the calyx-tube. Stigma capitate. Drupe red.- Hardy low shrub. (Mythological name of the nymph transformed by A pollo into a Laurel.)

1. D. Mezéreum L. Shrub, 3-9 dm. high, with purple-rose-colored (rarely white) flowers, in lateral clusters on shoots of the preceding year, before the lanceolate smootb leaves. - Escaped from cultivation, and locally established, w. Que. and Ont. to Mass. and N. Y. Early spring. (Introd. from Eu.)

\section{elaeagnàceae (Oleaster Family)}

Shrubs or small trees, with silvery-scurfy leaves and perfect or dioecious flowers; further distinguished from the Mezereum Family by the erect or ascending albuminous seed, and the calyx-tube which becomes pulpy and berryjike in fruit, strictly inclosing the achene.

1. Elaeagnus. Flowers perfect. Stamens 4. Leaves siternate.

2. Shepherdia. Flowers diosclous. Stamens 8. Leaves opposite.

\section{ELAEÁGNUS [Tourn.] L.}

Calyx eylindric-campanulate above the persistent cylindrical or globose base, che limb valvately 4-ceft, deciduous. Stamens 4, in the tbroat. Style linear, stigmatic on one side. Fruit drupe-like, with an ellipsoid 8-striate stone.Leaves alternate, entire and petioled, and flowers axillary and pedicellate. (From eliala, the olive, and a joos, the Greek name of the Chaste-tree, Vitex Agnus-castus.)

1. E. argentea Pursh. (Silverberry.) A stoloniferous unarmed shrub, 2-4 $\mathrm{m}$. high, the younger branches covered with ferruginous scales ; leaves elliptic to lanceolate, undulate, silvery-scurfy and more or less ferruginous; flowers numerous, deflexed, silvery without, pale yellow within, fragrant; fruit foundovoid, dry and mealy, edible, 8-10 mm. long. - Bonaventure R., Que. (Post); and from Isle of Orleans, Que., to Hudson Bay and B. C., s to Minn., S. Dak., and Utah.

\section{SHEPHERDIA Nutt.}

Flowers dioecious; the sterile with a 4-parted calyx (valvate in the bud) and 8 stamens, alternating with as many processes of the thick disk; the fertile with an urn-shaped 4-cleft calyx, inclosing the ovary (the orifice closed by the teeth of the disk) and becoming berry-like in fruit. Style slender; stigma 1-sided. - Leaves opposite, entire, deciduous; the small flowers nearly sessile in their axils on the branches, clustered, or the fertile solitary. (Named for John Shepherd, once curator of the Liverpool Botanic Garden.) LEPARGYica Raf.

1. S. canadénsis (L.) Nutt. Shrub, 1-2 m. high ; leaves elliptical or ovate, nearly naked and green above, silvery-downy and scurfy with rusty scales beneath; fruit yellowish-red, nauseous. (Lepargyrea Greene.)-Calcareous rocks and banks, Nfd. to Alaska, s. to N. S., Me., Vt., n. and w. N. Y., Mich. Wisc., and along the Rocky Mts. to N. Mex. May.

2. S. argéntea Nutt. (Buffalo Berry.) Somewhat thorny, 1-6 m. high; teaves cuneate-oblong, silvery on both sides; fruit ovoid, scarlet, acid and edibie (Lepargyrea Grene.) - Man. and n. Minn. to Kan., and westw 


\section{LYTHRÀCEAE (LOOSESTRIFE FAMILY)}

Herbs, with mostly opposite entire leaves, no stipules, the calyx inclosing but free from the 1-4-celled many-seeded ovary and membranous capsule, and bearing the 4-7 deciduous petals and 4-14 stamens on its throat, the latter lower down. Style 1 ; stigma capitate, or rarely 2 -lobed. Flowers axillary or whorled, rarely irregular, perfect, sometimes dimorphous or even trimorphous, those on different plants with filaments and style reciprocally longer and shorter. Petals sometimes wanting. Capsule often 1-celled by the early breaking away of the thin partitions; placentae in the axis. Seeds anatropous, without alburnen. - Branches usually 4-sided.

\section{* Flowers regular or nearly so. \\ + Calyx short, campanulate or globular.}

1. Didiplis. Calyx without appendages. Petals none. Stamens 4. Capsule globular, indehis. cent, 2-celled. Small aquatie.

2. Rotala. Calyx with the sinuses appendaged. Petals and stamens 4. Capsules 4-celled, septicidal, with $8-4$ valves.

8. Ammannia. Flowers not trimorphous. Petals generally 4 or none. Stamens 4-8. Capsula glsbular, 2-4-celled, bursting irregulariy.

4. Detodon. Flowers trimorphous. Petals 5 (rarely 4). Stamens 8-10. Capsules 8-4-valved, loculicidal. Leaves often whorled.

$$
++ \text { Calyx tubular, cylindrical. }
$$

5. Lythrum. Petals usually 6 . Stamens mostly 6 or 12 .

. * * Flowers irregular and unsymmetrical, with 6 petals and 11-12 stamens in 2 sets.

6. Cuphea. Calyx sparred or enlarged on one slde at base. Petals unequal.

\section{DIDIPLIS Raf. Water Pursuane}

Submersed aquatic (sometimes terrestrial), rooting in the mud, with opposite linear leaves, and very small greenish flowers solitary in their axils. (In the words of Rafinesque "Didiplis means two doubling;" from $\delta t_{s}$, twice, and $\delta เ \pi \lambda$ áos, double, in reference presumably to the stamens.)

1. D. diándra (Nutt.) Wood. Leaves when submersed elongated, thin, closely sessile by a broad base, when emersed shorter and contracted at base; calyx with broad triangular lobes; style very short; capsules very small. ( $D$. linearis Raf.) - Minn. and Wise. to Tex., e. to N. C. and Fla.

\section{ROTÀLA L.}

Petals 4 (in ours). Capsule-valves (under a strong lens) transversely and closely striate. (Name a diminutive of rota, a wheel, from the whorled leaves of the original species.)

1. R. ramosior (L.) Koehne. Leaves tapering at base or into a short petiole, linear-oblanceolate or somewhat spatulate; flowers solitary (rarely 3) in the axils, sessiie; accessory teeth of calyx as long as the lobes or shorter. ( $A m$ mannia humilis Michx.) - Low or wet ground, Mass. to Fla. and Tex., and in the interior from 0 . to Minn., and southw. (Trop. Am.)

\section{8. aMmánNita [Houston] L.}

Flowers small, in 3-many-flowered axillary cymes. Calyx globular or bellshaped, 4-angled, 4-toothed, usually with a little horn-shaped appendage at each sinus. Petals 4 (purplish), small and deciduous, sometimes wanting. - Low and inconspicuous smooth herbs, with opposite narrow leaves. (Named fo] Paul Ammann, a German botanist prior to Linnaeus.) 
1. A. coccinea Rottb. Leaves linear-lanceolate, $5-7 \mathrm{~cm}$. long, with a broad auricled sessile base; cymes subsessile, dense; petals purplish; stamens more or less exserted; style long and slender. - Muddy banks and wet sandy shores, N. J. to Fla.; and from $O$. to Dak. and southw.

2. A. Koèhnei Britton. Leaves oblong to oblanceolate, the lowest contracted, the others broadiy auricled at the base; cymes sessite or nearly so; style very short; petals minute, pink, fugacious.-Swamps, N. J. (according to Britton) to Fla. - Differs from the tropical $\boldsymbol{A}$. latifolia $\mathrm{L}$. only in having petals.

3. A. auriculata Willd. Erect, few-branched; leaves lanceolate to narrowly oblong, acute; cymes on slender peduncles (4-6 mm. long); fruit small ; style relatively long. - Borders of ponds, etc., w. Mo. and Neb. to Tex., and southwestw.

\section{DÉCOdon J. F. Gmel. Swamp Loosestrife}

Calyx with 5-7 erect teeth, and as many longer and spreading horn-like processes at the sinuses. Stamens exserted, of two lengths. Capsule globose, 3-5-celled, loculicidal. - Perennial herbs or slightly shrubby plants, with opposite or whorled leaves, and axillary clusters of trimorphous flowers. (Name from $\delta \epsilon \kappa a$, ten, and boov's, tooth.)

1. D. verticillàtus (L.) Ell. (WATER WILlow.) Smooth or downy; stems recurved, 6-25 dm. long, 4-6-sided; leaves lanceolate, nearly sessile, opposite or whorled, the upper with clustered short-pediceled flowers in their axils; petals 5, wedge-lanceolate, magenta, $1.2 \mathrm{~cm}$. long; stamens 10 , half of them shorter. - Swampy grounds, Me. to Fla., La., and Minn. - Bark of submersed parts of the stem often spongy-thickened.

\section{LÝTHRUM L. LOOSESTRIFE}

Calyx cylindrical, striate, 5-7-toothed, with as many little processes in the sinuses. Petals 5-7. Stamens as many as the petals or twice the number: inserted low down on the calyx. Capsule subcylindrical, 2-celled. - Slender herbs, with pink or magenta (rarely white) flowers in summer. (From kúlgov, blood; perhaps from the styptic properties.)

* Stamens and petals 5-7; flowers small, solitary and nearly sessile in the axils of the mostly scattered upper leaves; proper calyx-teeth often shorter than the intermediate processes; plants smooth.

1. L. Hyssopifolia L. Annual, 1-6 dm. high, pale; leaves oblong-linear, obtuse, longer than the inconspicuous flowers; petails pale-purple; stamens usually 4-6, included. - Marshes and sterile soil, near the coast, Me. to N.J.; also on the Pacific coast. (Eu.)

2. L. lineare L. Stem slender and tall (1-1.3 m. high), bushy at top, with 2 margined angles; leaves linear, chiefly opposite; petals whitish ; flowers with 6 included stamens and a long style, or the stamens exserted and style short; ovary on a thick short stalk; no fleshy hypogynous ring. - Brackish marshes, N. J. to Fla. and Tex.

3. L. alàtum Pursh. Tall and wand-like perennial; branches with margined angles; leaves oblong-ovate to linear-lanceolate, acute, with a cordate or rounded base, the upper mostly alternate; calyx about $4-6 \mathrm{~mm}$. long; petals rather large, deep purple; stamens of the short-styled flowers exserted; fleshy hypogynous ring prominent. - Swamps and meadows, Ont. to Minn., s. to Ga., La., and Col. ; also locally in $\Theta$. Mass. and Ct.

The allied Mexican L. Vulneraria Ait., with calyx 9-12 mm. long, has been reported from the vicinity of St. Louis, Mo.

* Stamens 12 (rarely 8 or 10), twice the number of the petals, 6 longer and 6 shorter; flowers large, crowded and whorled in an interrupted spike.

4. I. Salicaria L. (Spiked L.) More less dorony and tall; lecues lanceolate, heart-shaped at base, sometimes whorled in threes; flowers magenta, 
trimorphous in the relative lengths of the stamens and style; calyx and bracts greenish, somewhat pubescent, the calyx-lobes much shorter than the subulate appendages, - Wet meadows, local, N. E. to Del. and D. C. (Introd. from Eu.) June-Sept. Var. томentósum (Mill.) DC. Calyx and bracts white-tomentose. - Wet meadows and shores, e. Que. to Vt. and s. Ont. (Nat. from Eurasia.)

5. L. VIRGATUM L. Similar, glabrous throughout; leaves narrowed to the sessile or short-petioled base; the calyx-lobes shorter than or equaling the appendages, - Locally established, e. Mass. (S. F. Poole). (Introd, from Eurasia.)

\section{CÙPHEA P. Br.}

Calyx tubular, 12-ribbed, gibbous or spurred at the base on the upper side, 6-toothed at the apex, and usually with as many little processes in the sinuses. Ovary with a curved gland at the base next the spur of the calyx, 1-2-celled; style slender; stigma 2-lobed. Capsule oblong, few-seeded, early ruptured through one side. - Flowers solitary or racemose, stalked. (Name from $\kappa v \phi b s$, gibbous, from the shape of the calyx.)

1. C. petiolata (L.) Koehne. (Ссамm C.) Annual, very viscid-hairy, branching; leaves ovate-lanceolate; petals ovate, short-clawed, purple; seeds flat. (C. viscossima Jacq.; Parsonsio Rusby.) - Dry fields, N. H. (Miss Scorgie) to Ga, w. to Kan. and La.

\section{MELA̧STOMÀCEAE (MeLagtoma FAMILY)}

Plants with opposite 3-7-ribbed leaves, and definite stamens, the anthers opening by pores at the apex; otherwise much as in the Onagraceae. - All tropical, except the genus

\section{RHéxia L. Deergrass. Meadow Beadty}

Calyx-tube urn-shaped, adherent to the ovary below, and continued above it, persistent, 4-cleft at the apex. Petals 4, convolute in the bud, oblique, inserted with the 8 stamens on the summit of the calyx-tube. Anthers long, 1-celled, inverted in the bud. Style 1; stigma 1. Capsule 4-celled, with 4 many-seeded placentae projecting from the central axis. Seeds coiled like a snail-shell, without albumen.-Low perennial often bristly herbs with showy cymose flowers in summer; the petals falling early. (A name used by Pliny for some unknown plant.)

* Anthers linear, curvsd, with a minute spur on the back at the attachment of the filament above its base; flowers cymose, peduncled.

1. R. virginica L. Stem square, with wing-like angles; leaves oval-lanceolate, sessile, acute; calyx-tube and pedicels more or less hispid with gland-tipped hairs ; petals magenta. - Sandy swamps and shores, Me. to Fla. ; also from s. w. Ont. to s. e. Ia., and southw. July-Sept. — Slender rootstocks tuberiferous.

2. R. aristosa Britton. Branches somewhat wing-angled; leaves linearoblong, sessile, not narrowed at base, naked or very sparsely hairy ; hairs of the calyx mostly below the throat, not gland-tipped; petals sparsely villous, pink or purplish. - Wet pine barrens, Egg Harbor City, N. J. (J. E. Peters) to Ga. July, Aug.

3. R. mariàna L. Stems cylindrical; leaves linear-oblong, narrowed below, mostly petiolate; petals paler. - Sandy swamps, L. I. to Fla., w. to Mo. and Tex.

* Anthers oblong, straight, without any spur; flowers few, sessile.

4. R. ciliòsa Michx. Stem square, glabrous; leaves broadly ovate, ciliate with long bristles; calyx glabrous. - Md. to Fia. and La. 


\section{onagràceate (Eventing Primroge family)}

Herbs, with 4-merous (sometimes 2-;) or 5-6-merous) perfect and symmetrical flowers; the tube of the calyx adhering to the 2-4-celled ovary, its lobes valvate in the bud or obsolete; the petals cunvolute in the bud, sometimes wanting; and. the stamens as many or twice as many as the petals or calyx-lobes, inserted on the summit of the ralyx-tube. Style single, slender; stigma 2-4-lobed or cajitate. Pollen-grains often connerted by cobwebby threads. Seeds anatropous, small, without albunen. - Mostly herbs, with opposite or alternate leaves. Stipules none or glandular.

* Parts of the flower in fours or more numerous.

- Fruit a many-seeded pod, usually loculicidal.

+ Calyx-limb (divider to the summit of the ovary) persistent.

1. Jussiaea. Petals 4-6. Stamens twice as many. Capsule elongated, 4-6-celled.

2. Ludvigia. Petals 4 or none. Stamens 4. Capsule short.

\# Calyx-tube or deeply cloft limb deciduous from the summit of the eapsule; petals 4; stamens 8.

8. Epilobium. Seeds sllky-tufted. Flowers (in ours) not yellow. Lower loaves often opposite.

4. Oenothera. Seeds not tufted. Flowers mostly yellow. Leaves alternate.

++ Frult dry and indehiscent, 1-4-seeded.

* Terrestrial; leaves alternate; stamens 6-8.

5. Gaura. Calyx-tube obconical. Filaments appendaged at base.

6. Stenosipion. Calyx-tube fllform. Filanents (8) not appendaged. H H Aquatic; leaves opposite or whorled; stamens 4.

7. Trapa. Calyx-tube short. Filaments unappendaged. Fruit large, coriaceous, tarbinate. * * Parts of the flower in twos; leaves opposite.

8. Circaea. Petals 2, obcordate or 2-lobed. Stamens 2. Fruit 1-2-seeded, bristly.

\section{JUSsiaka L. Primrose-willow}

Caly $x$-tube elongated, not at all prolonged beyond the ovary ; the lobes 4-6, herbaceous and persistent. - Herbs (ours glabrous perennials), with mostly entire and alternate leaves, and axillary yellow flowers in summer. (Dedicated to Bernard de Jussieu, the founder of the Natural System of Botany.)

1. J. decúrrens (Walt.) DC. Stem erect, 3-6 dm. high, winged by the decurrent lanceolate leaves; calyx-lobes 4 , as long as the petals; capsule cylindric club-shaped, wing-angled; seeds in several rows in each cell. - Wet places, "Md." and Va. to Fla.; s. Ill. and Mo. to La. and Tex.

2. J. diffùsa Forsk. Stem creeping, or floating and rooting; leaves oblong, tapering into a slender petiole; flowers large, long-peduncled; calyx-lobes and obovate petals 5; pod woody, cylindrical, with a tapering base; seeds quadrate, in 1 row in each cell, adherent to the spongy endocarp. ( $T$. repens of auth., probably not of L.) - In water or on muddy banks, Ky. and Ill. to e. Kan., and southw.

\section{LUdVfGia L. False Loosestrife}

Calyx-tube not at all prolonged beyond the ovary; the lobes 4, usually persistent. Capsule short or cylindrical, many-seeded.-Perennial herbs, with axillary (rarely capitate) flowers through summer and autumn. (Named for C. G. Ludwig, Professor of Botany at Leipsic, contemporary with Linnaeus.) 


\section{* Leaves all alternate, sessile or nearly so.}

- Flowers peduncled in the upper axils, with conspicuous yellow petals (8-16 mm. long), equaling the ovate or lanceolate foliaceous lobes of the calyx.

1. L. alternifòlia L. (Skediox.) Smooth or nearly so, branched, $1 \mathrm{~m}$. nigh ; roots fascicled, fusiform; leaves lanceolate to linear-lanceolate, acute or pointed at both ends; capsules cubical, roumded at base, wing-angled. - Shady banks, low wet woods, and swamps, e. Mass. to Fla. and Tex.; and in the interior from s. w. Ont. to Kan, and southw.

Var. linearifolia Britton. Leaves linear; calyx-lobes linear-lanceolate. W. Va.

2. L. hirtélla Raf. Hairy; roots clustered, fusiform-thickened; stems nearly simple, 3-8 dm. high; leaves oblong, or the upper lanceolate, blunt at

- both ends; capsules nearly as in the last; but scarcely wing-angled. - Moist pine barrens, N. J. to Fla, and Tex.

+ + Flowers small, sessile (solitary or sometimes clustered) in the axils; petals small and greenish or none; leaves mostly lanceolute or linear on the evect stems (3-9 dm. high) and numerous branches; but prostrate or creeping sterile shoots often produced from the base, thiclly beset with shorter obovate or spatulate leaves. (Our species glabrous, except no. 3.)

\section{+ Capsule about as broad as long.}

3. L. sphaerocárpa Ell. Minutely pulescent, especially the calyx, or nearly glabrous; leaves lanceolate or linear, acute, tapering at base, those of the runners obovate with a wedge-shaped base, glandular-denticulate; bractlets minute, obsolete, or none; capsules globular or depressed (sometimes acute at base), not longer than the calyx-lobes (less than $4 \mathrm{~mm}$. long). - Water or wet swamps, e. Mass. to Fla. and La. - Bark below often spongy-thickened.

4. L. polycárpa Short \& Peter. Stoutish; leaves narrowly lanceolate, acute at both ends, those of the runners oblong-spatulate, acute, entire; bractlets linear-awl-shaped and conspicuous on the base of the 4-sided somewhat top-shaped capsule, which is longer than the lanceolate calyx-lobes. - Wet places, e. Mass. to $\mathrm{Ct}$. ; s. w. Ont. and O. to Neb., s. to 'renm. and Kan.

5. L. alata Ell. Very similar to the preceding but more slender; calyx-lobes short, broadly deltoid. - Jackson, Mo. (Bush according to Tracy); N. C. to Fla and "La."

$$
\text { * Capsule decidedly longer than broad. }
$$

6. I. lineàris Walt. Slender, mostly low; leaves narrowly linear, those of the short runners obovate; minute petals usually present; bractlets minute, at the base of the elongated top-shaped 4-sided capsule, which is $6 \mathrm{~mm}$. long and much longer than the calyx-lobes. - Bogs, pine barrens of "N. Y.," N. J., and southw.

7. L. glanäulosa Walt. Much branched; leaves oblong-or spatulate-lanceolate, tapering at the base or even petioled ; bractlets very minute at the base of the cylindrical capsule, which is $6 \mathrm{~mm}$. long, and several times exceeds the calyxlobes. (L. cylindrica ElI.) - Low shady woods, about ponds, and in swamps, s. Ill. to Fla. and 'Tex.

\section{* Leaves all opposite; stems creeping or floating.}

8. I. palústris (L.) Ell. (Water Purstane.) Smooth; leaves ovate or oval, tapering into a slender petiole; petals none, or small and reddish when the plant grows out of water ; calyx-lobes very short; capsules 4-sided, not tapering at base, sessile in the axils, $4 \mathrm{~mm}$. long. (Isnardia $\mathrm{I}_{\text {. }}$ ) - Ditches and wet shores, common. (Eu.)

9. L. arcuàta Walt. Smooth, small and creeping ; leaves oblanceolate, nearly sessile; flowers solitary, long-peduncled; petals yellow, exceeding the caly 8 (6 mm. long); capsules club-shaped, somewhat curved, $8 \mathrm{~mm}$. long. (Ludwigi antha Small.) - Swamps, Va. to Fla. 


\section{EPILÒBIUM L. WILLOW-HERB}

Calyx-tube scarcely or not at all prolonged beyond the ovary; limb 4-cleft or -divided. Petals 4, violet, magenta, pink, or white. Capsule slender, manyseeded. Seeds with a tuft of long hairs at the end. - Mostly perennial herbs with nearly sessile leaves. (Name from $\epsilon \pi t$, on, and $\lambda \delta \beta \iota \nu, a$ little pod.)

§ 1. CHAMAENERION [Tourn.] Tausch. Petals entire, large, magenta (rarely white); calyx-limb divided essentially to the simmit of the ovary; stamens and style successively deflexed; stigma of 4 long lobes; flowers racemed.

1. E. angustifolium L. (Great W., Fireweed.) Tall (0.3-2 m. high), simple; leaves scattered, long, lanceolate, subentire, pinnately veined. ( $E$. spicatum Lam.; Chamaenerion angustifolium Scop.) - Low ground, especially in clearings and newly burned lands, common. July, Aug. (Eurasia.)

\$2. LYSIMACHION Tausch. Petals notched at the summit; calyx-tube prolonged a little beyond the ovary; stamens and style erect; flowers corymbed or panicled or few in the upper axils.

- a. Stigma 4-parted; petals 1-2 cm. long .

2. E. hirsutum

$a$. Stigma entire; petals smaller $b$.

b. Stems terete, no decurrent lines running down from the bases of the leaves ; lenves entire or subentire, with revolute margins.

Stem and pods densely covered with fine short straight spreading hairs .

Stems and pods cinereous with appressed or incurved hairs, of

Leaves closely and evenly pubescent above; well developed

plant freely branching
Leaves glabrous above, or with scattered hairs; plant simple or subsinple

b. Stems subterete, with decurrent lives running down" from the

bases of the leaves; leaves toothed (rarely entire), fat, the margins not revolute.

Stems solitary; the basal shoots (developing in late autumn) in the form of sessile or short stalked rosettes.

Eeed sbruptly contracted above; mature coma cinnamon-

color ; leaves elongate-laceolate

leaves oblong-lanceolate to narrowly ovate
Stems tufted; the basal shoots quickly developing into elongate branches.

Beed (under a microscope) smooth.

Stems ereet; flowers ehiefly $3-6$, the lowest in the axils of the foliage-leaves * * * *

Stems strongly deenmbent; flowers $i$ or 2 (rarely 8), es-
sentially terminal.

Beed (under a microscope) papillose

6. E. coloratum.

7. E. adenocaulon.

\section{E. alpinum.}

9. E. anagallidifolium. 10. $E$. Hornemanni.

2. E. hirsitưm L. Tall (1-2 m. high), the much branched stem densely covered by rather long fine straight spreading hairs; leaves oblong, sermlate, sessile and clasping; petals magenta, showy. - In waste places and about dwellings, local, s. Me. to Ont, and s. N. Y. July-Sept. (Nat. from Eu.)

3. E. mólle Torr. Erect, 2-15 dm. high, simple or with few upright branches toward the. summit, stems, leaves, and pods grayish-velvety; leaves narrowly lanceolate to linear, entire or undulate, the margins revolute; petals pink, 7-8 mm. long; seed nearly $2 \mathrm{~mm}$. long, minutely papillate, coma dingy. (E. strictum Muhl.? as nomen subnudum.) - Bogs and mossy meadows, rather local, e. Que. to Athabasca, s. to Va., Ill, and Minn. July-Sept.

4. E. densum Raf. Minutely hoary-pubescent, 3-10 dm. high, usually much branched and very leafy, rarely stoloniferous; leaves linear or nearly so, revolute, acute, canescent above (the lateral veins inconspicuous), erect, usually much exceeding the internodes, commonly proliferous in the axils; pedicels $\frac{1}{2}$ as long as the canescent pods; petals $3-5 \mathrm{~mm}$. long, pink or white; seed $1.5 \mathrm{~mm}$. long. (E. iineare Muhl.? as nomen subnudum.) - Open low grounds, e. Que. to Alb., s. to Del., W. Va, Kan, and Col. July-Sept. 
5. E. palústre L. Decumbent, stoloniferous, 1-6 dm. high, the simple on sparingly branched stem minutely pubescent above or glabrate; leaves thin, green, linear- to oblong-lanceolate, subacute, spreading-ascending, rather remote, the middle ones 3-6 cm. long, $4-10 \mathrm{~mm}$. broad; flowers few; redicels much shorter than the slightly pubescent or glabrate pods; petals pink or white, 5-7 mm. long. - Bogs and wet banks, Nfd. and Lab. to Alaska, s. to n. N. E. and L. Superior. July, Aug. (Eurasia.)

Var. labradoricum Haussk. Dwarf, 6-15 cm. high, often freely branched; leaves elongate-oblanceolate to linear, approximate, with rounded lips and definite petioles, $1.0-3 \mathrm{~cm}$. long, 1-4 $\mathrm{mm}$. wide ; pedicels mostly as long as the pods. Lab. to the alpine regions of the White Mts., N. H. (Greenl.)

Var. montícola Haussk. Mostly simple, 1-5.5 dim. high ; leaves thich, mostly linear-oblanceolate, obtuse, strongly ascending, remote, the middle ones 1-3 cm. long, 1.5-4 mm. wide; pedicels various. ( $E$. oliganthum Michx.; $E$. lineare, var. oliganthum Trel.) - Bogs and wet meadows, Nfd. and Lab. to Man., s. to Mass., Pa., and the Great L. region. (Eu.)

6. E. coloràtum Muhl. Stem erect, not stoloniferous (often developing in late autumn sessile or subsessile basal rosettes), 3-9 dm. high, usually muchbranched, glabrous below, canescent at least in lines above with incurved hairs; leaves elongate-lanceolate, 5-15 cm. long, 1-2 cm. broad, distinctly shortpetioled, closely and irregularly serrulate; flowers abundant on the divergent branches; petals pink, $\mathrm{b}-5 \mathrm{~mm}$. long; pedicels short; seed $1.5 \mathrm{~mm}$. long, abruptly rounded at tip, minutely papillate; mature coma cinnamon-colored.Low ground, Me. to Neb., and southw. July-Sept.

7. E. adenocaúlon Haussk. Similar in habit, 1-10 dm. high; stem glabrous below, minutely pubescent above with more or less incurved pale hairs, sometimes glandular or viscid; leaves oblong-lanceolate to narrowly ovate, short-petioled or subsessile, rounded or cordate at base, less toothed than in the preceding, the middle ones $2-8 \mathrm{~cm}$. long, $7-30 \mathrm{~mm}$. broad; seed about $1 \mathrm{~mm}$. long, shortbeaked, papillate; coma whitish. - Rich damp soil, Nfd. to B. C., s. to Del., W. Va., Great L. region, Neb., Col., and Cal. July-Sept. Var. Perpléxans Trel. Glabrous or very sparingly pubescent above; leaves flaccid, gradually narrowed to the distinct petiole. - A somewhat local extreme, e. Que. to B. C., s. to N. E., N. Y., Wisc., N. Mex., and Cal.

8. E. alpinum L. Glabrous or essentially so, tufted, the erect stems 1.5-3.5 dm. high, with elongated internodes; leaves elliptical or the lowest obovatespatulate, distinctly petioled, slightly repand-denticulate, obtuse, $1.5-4 \mathrm{~cm}$. long, 7-17 $\mathrm{mm}$. broad; flowers mostly 3-6 (rarely 12), terminal and in the upper axils; petals white or pinkish, 3-6 mm. long; pedicels mostly shorter than the green or red-tinged pod; seed 1.2-1.5 min. long, smooth. (E. lactiflorum Haussk.) - Arctic Am., s. to alpine slopes and cliffs of the White Mts., N. H., Col., and Ore. June-Aug. (Eurasia.)

9. E. anagalliaifolium Lam. Dwarf, the fruiting stems decumbent, finally $5-20 \mathrm{~cm}$. high, the basal shoots wide-spreading and leafy; leaves narrowly elliptic to oblong, obscurely petioled, subentire or remotely denticulate, obtuse, $1-1.7 \mathrm{~cm}$. long, $2.5-8 \mathrm{~mm}$. broad; flowers 1 or 2 (rarely 3 ), terminal, often nodding; petals pink, 4-6 mm. long; pedicels upright in fruit, mostly equaling or exceeding the purplish pod; seed 1.5 mm. long, smooth.-Arctic Am., s. in alpine districts to e. Que., Me.?, Col., and Cal. - Immature specimens from Mt. Katahdin, Me., are apparently of this species, although Haussknecht's records of its occurrence in the White Mts. and the Adirondacks have not been confirmed. July, Aug. (Eurasia.)

10. E. Hornemánni Reichenb. Resembling no. 8 ; the upper leaves usually exceeding the internodes, ovate and mostly acutish, pellucid, $2-4.5 \mathrm{~cm}$. long, $7-23 \mathrm{~mm}$. broad; flowers 2-several, in the upper axils; petals pink to crimson, 6-7 $\mathrm{mm}$. long; pedicels mostly shorter than the pod; seed $1 \mathrm{~mm}$. long, papillate. (E. alpinum, var. fontanum Wahlenb.) - Arctic Am., s. in cold and alpine situations to N. S., Me., N. H., Col., and Cal. July, Aug. - The plant from the Dells of the Wisconsin $\mathrm{R}$. formerly reported as $E$. Hornemanni is apparently E. adenocaulon, var. perplexans. (Eurasia.) 


\section{Oenothìra I. Evening Primose}

Calyx-tube prolonged beyond the ovary, deciduous; the lobes 4, reflexed. Petals 4. Stamens 8; anthers mostly linear and versatile. Capsule 4-valved, many-seeded. Seeds naked or with an obscure membranaceous crest. - Leaves alternate or rarely all basal. Flowers yellow, white, or rose-color. (An old name of unknown origin, for a species of Epilobium.)

§ 1. ONAGRA (Adans.) Ser. Stigma-lobes linear, elongated; flower-buds upright; petals yellow; fruit subcylindrical, elongated; seeds in 2 rows in each cell; caulescent annuals or bienuials. ONAgRA Adans.

a. Pods lance-cylindric or -prismatic, i.e, tapeling from a thickish base $b$.

b. Petals linear

i. Petals obovate $c$.

c. Pods glabrous even when young

c. Pods more or less pubescent at least when young.

Bracts decidedly leaf-like. $i$.. at least the lower flowers in the axils of foliage leaves, even the upper bracts exceeding the pods.

Sepals appendaged on the back somewhat below the tip; pubescence of the stem altogether fine and appressed

Sepals appendaged essentially at the tip; pubescence of the stem usually including long spreading hairs with reddish or purplish enlarged bases

Bracts reduced and somewhat deciduous, the flowers and "especially the pods in elongated exposed spikes, the npper bracts usually shorter than the pods

a. Pods more slender and of essentially uniform diameter.

Flowers in a distinct terminal spike

Flowers in the axils of foliage leaves,

Grayish-pubescent and somewhat silky; floral leaves mostly entire or nearly so: seed smootbish.

Green, more loosely and sparingly pubescent; floral leaves mostly plnnatifid toward the base; seed distinctly pitted

1. o. cruciata.

2. O. argillecola.

8. U. Oakestana.

4. o. muricata.

5. 0. biennis.

6. o. rhombipetala

7. O. humifusa.

8. O. Laciniata.

1. 0. cruciàta Nutt. Simple or sparingly branched, 3-8 dm. high ; stem commonly reddisl, smooth or somewhat strigose ; stem-leaves lanceolate, remotely and shallowly dentate; sepals appendaged somewhat below the tip; petals very narrow, linear, 5-12 mu. long, 1-3 mm. wide, light jellow. (O. biennis, var. T. \& (. ; Onagra cruciata Small.) - Sandy or gravelly soil, centr. Me. to w. Mass. and n. N. Y.

2. 0. argillícola Mackenzie. Glabrous, 5-15 dm. high; stem stoutish, very leafy; leaves linear-lanceolate, only 5-8 $\mathrm{mm}$. wide, subentire or remotely and obscurely few-toothed; flowers large; calyx glabrous; petals bright yellow, broadly obovate, $3-4 \mathrm{~cm}$. long ; capsules crowded, mostly curved, $2-3 \mathrm{~cm}$. long, glabrous, tapering to a slender summit. (Onagra Mackenzie.) - Mts. of Va. and W. Va.

3. 0. Oakesiana Robbins. Finely puberulent, the hairs mainly appressed; stem-leaves lanceolate, shallowly denticulate, $8-15 \mathrm{rmm}$. broad; sepals appendaged considerably below the tip; petals obovate, $1.5-2 \mathrm{~cm}$. long; pods rather large, slightly spindle-form, $3 . \overline{-}-4 \mathrm{~cm}$. long, appressed-puberulent. (O. biennis, var. Gray ; Onagra Britton, in part.) - Sandy fields, etc., e. Mass. to Ct.

4. 0. muricàta $\mathrm{L}$. Simple or nearly so, 2-8 dm. high, very leafy; stem puberulent and usually beset at least above with longer spreading hairs on enlarged reldish tuberculate bases; leaves lanceolate, ascending, entire or sparingly and very shallowly denticulate, passing without marked transition into the foliaceous bracts; flowers axillary, the lower inuch exceeded by the bracts; sepals not prominently appendaged; petals obovate, light yellow, 1.2-2 cm. long; capsule more or less hirsute, subfusiform-cylindric, $2.5-3 \mathrm{~cm}$. long. - Siandy or gravelly shores, Nfd, and e. Que. to N. Y. Var. cantescens (T. \& G.) Robinson. Hoarypubescent or somewhat silky throughout, the tuberculate-based hairs few or none. ( $O$. biennis, var. $\mathrm{T}$. \& $\mathrm{G}$. ; Onagra strigosa Rydb.) - From the Great Lakes to Mo., Col., and northwestw.

5. O. biénnis L. (Соммом E.) Rather stout, erect, 3-15 dm. high, usually simple, more or less spreading-pubescent to hirsute; leaves lanctolate to oblongor rarely orate-lanceolate, repandly denticulate, acute or acuminate; bracts 
lanceolate, shorter than or scarcely exceeding the capsules; calyx-tube 2.5-3.5 cm. long; petals yellow, obovate, $1.5-2.5 \mathrm{~cm}$. long; pods more or less hirsute, narrowed almost from the base, $2-3.5 \mathrm{~cm}$. long. (Onagra Scop.) - Open places, common.

O. GRANDIFLóra Ait. (O. biennis, var. Lindl.; Onagra Cockerell), a related species of Alabama, with much larger flowers, the petals $4-6 \mathrm{~cm}$. long, was formerly cultivated and has on rare occasions been found, presumably as an escape, uithin our range.

6. 0. rhombipétala Nutt. Rarely branching, appressed-puberulent and subcanescent; leaves narrowly lanceolate, acuminate, denticulate or subentire, the lowest attenuate to a petiole and rarely pinnatifi, diminishing upward into the close elongated conspicuously bracted spike; calyx silky-canescent, the tube 2-3.5 cm. long; petals rhombic-ovate, $1.2-2.5 \mathrm{~cm}$. long. - Ind. to Minn., Neb., and Tex.

7. 0. humifùsa Nutt. Hoary with short dense appressed hairs; stems decumbent or ascending, 1.5-6 dm. long; stem-leaves narrowly lanceolate or oblanceolate, 1-4 cm. long, sparingly repand-dentate or entive, the radical leaves pinnatifid, the floral not reduced; petals $1.2-2.5 \mathrm{~cm}$. long; capsule 2-3.5 cm. long, silky ; seeds smoothish. - Sandy coast, N. J. to Fla.

$\checkmark$ 8. 0 . laciniàta Hill. Stems ascending or decumbent, simple or branched, 1-7 dm. high, more or less strigose-pubescent and puberulent; leaves oblong or lanceolate, $2-10 \mathrm{~cm}$. long, sinuately toothed or often pinnatifid, the floral similar; petals 5-12 m. long; capsules $2-3 \mathrm{~cm}$. long; seeds strongly pitted. ( $O$. sinuata L.) - Dry open mostly sandy places, N. J. to Fla., 'Tex., and S. Dak. also adventive northeastw.

Var. grandiflòrd (Wats.) Robinson. Flowers larger; the petals $2.5-4 \mathrm{~cm}$. long. (O. sinuatc, var. Wats.; O. laciniata, var. grandis Britton.) - Common in sandy fields, etc., Mo. and Kan. to Tex.

\$2. ANOGRA (Spach) Endl. Stigma-lobes linear, elongated; flowers nodding
in the bud; seeds in a single row in each cell; fruit subcylindric or pris-
matic, elongated; caulescent perennials. A NoGR Spach.

9. 0. pállida Lindl. Stems erect, 1.5-12 dm. high, commonly branched, white and often shreddy, glabrous or puberulent; leaves linear to oblong-oblanceolate, $2.5-8 \mathrm{~cm}$. long, entire or repand-denticulate, or sinuate-pinnatifid toward the base; calyx-tips free in bud, throat naked ; fowers axillary ; petals white, turning rose-color, suborbicular, obcordate, $1.5-3 \mathrm{~cm}$. long; pods $2-5 \mathrm{~cm}$. long, often curved or twisted; seeds lance-linear, smooth. (O. albicaulis Man. ed.6, not Nutt.; Anogra pallida Britton.) - Dry plains and prairies, Sask. to w. Minn., westw. and southwestw. (Mex.)

\$3. KNEfFFIA (Spach) Endl. Stigma-lobes linear, elongated; flowers yellow, erect in the bud (the whole floral axis recurved in no. 11); fruit short, obovoid, tetragonal; seeds clustered in each cell, not in distinct rows, not crested; caulescent. KNELFFiA Spach.

a. Pods 4-6 mm. long; calyx-tube about $2 \mathrm{~mm}$. long; stem-leares al-

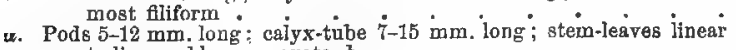
to linear-oblong or ovate $b$.

b. Pods smooth to sparingly puberulent with spreading gland-tipped hairs.

Petals 5-10 mm. long

Potals 1.4-3 cm. long.

Leaves ovate, glancons, entirely glabrous; capsule more than

$9 \mathrm{~mm}$. long
Leaves lance- to linear-oblong, pubescent or at least ciliolate; capsule usually less than $9 \mathrm{~mm}$. long . .

b. Pods grayish-pubescent with fne incurved glandless hails :

$b$. Pods covered with copious widely spreading straight glandless hairs
Stem, pedicels, calyx, etc., finely and softly puberulent; sepals

Stem, pedicels, caly $x$, etc., finely and softly puberulent; sepals
wholly consivent or their free tips very short $(1 \mathrm{~mm}$, long

or less)
stem, pedicels, calyx, cte.., coarsely hirsute; tips of sepals free in bud, qsually spreading, $2 \mathrm{~mm}$. long.

10. O. linifolia.

11. O. pumila.

12. o. glauca.

13. o. fruticosa.

14. O. linearis.

15. O. Zongipedicellata.

16. O. pratengis. 
10. 0. linifolia Nutt. Annual or biennial, erect, very slender, simple or diffuse, $1-4$ du. high, glabrous, the brauchlets and capsules puberulent; cauline leaves linear-filiform, $1.5-4 \mathrm{~cm}$. long, the radical oblanceolate; spikes loosely flowered, the bracts inconspicuous; corolla $4-6 \mathrm{~mm}$. long; stigma-lobes short; pods obovoid to short-clavate, glandular-puberulent, $4-6 \mathrm{~mm}$. long, not winged, nearly sessile. (Kneifia Spach.) - Prairies and rocky hills, Ill. to e. Kan., Tex., and Ga.

11. 0. pùmila L. Perennial, puberulent, 1-6 dm. high; leaves mostly glabrous, entire, obtuse or obtusish, the basal spatulate, the cauline narrowly oblanceolate to lanceolate; spikes loose, at first nodding; petals $5-10 \mathrm{~mm}$. long; pods obscurely glandular-puberulent, clavate, 6-12 mm. long, sessile or shortly pediceled, slightly winged. (Kneifia Spach.) - Open places, e. Que to Man., s. to Wisc., O., and in the mts. to Ga. ; common.

12. 0. glaúca Michx. Perennial, erect, 5-9 dm. high, glabrous and glaucous; leaves ovate to ovate-oblong, 5-10 cm. long, repand-denticulate ; flowers in short leafy corymbs; petals $2.5-3.5 \mathrm{~cm}$. long; capsule glabrous, glaucous, ovoid-ellipsoid, broadly winged, rather abruptly contracted at base. (Kneiffia Spach.) - Mts., Va., Ky., and southw.

13. O. fruticdsa L. (Sundrops.) Perennial, erect, 3-9 dm. high, puberulent or nearly glabrous; leaves oblong-to linear-lanceolate, mostly denticulate, ciliolate; spikes short narrow-bracted, usually on naked peduncles; petals $1.4-2.6 \mathrm{~cm}$. long; capsule glabrous or sparingly glandular-puberulent, ellipsoid to slightly clavate, winged. (Kneiffia Raimann.) -Dry sandy soil, s. N. F. to S. C. ; also O., Mich., and Ind. Var. HIRsưt A Nutt. Stem spreading-pilose; the leaves also with more copious and looser pubescence. (Rneiffia fruticosa, var. pilosella Britton.) - In similar situations and extending northeastw, to centr. Me.

14. 0. lineàris Michx. Erect, puberulent, 2-9 dm. high; leaves linear to narrowly oblanceolate, entire or nearly so, minutely puberulent; petals $1.2-3$ $\mathrm{cm}$. long ; capsule clavate, 6-10 $\mathrm{mm}$. long, canescent with fine incurved glandless hairs, on a pedicel usually as long as itself. (Kneiffi Spach; $O$. fruticosa, var. Wats.) - Meadows and open woods, along the coast, e. Mass. to Fla. and Ala.; also Ark. and Mo. O. fruticosa, var. humifusa Allen (Kneiffia Alleni Small) appears to be merely a stunted decumbent or sprawling form growing in sterile sands (L. I., etc.) and smaller in all its parts. Var. EAmisir Robinson. Decumbent; leaves elliptical, the larger ones $2.7 \mathrm{~cm}$. long, $11 \mathrm{~mm}$. wide. Sandy shore of a salt pond, Stratford, Ct. (Eames).

15. 0. longipedicellata (Small) Robinson. l'erennial, erect and subsimple, 2-6 dm. high (rarely bushy-branched and sprawling), short-hirsute; capsule as in the preceding, but spreading-hirsute; the pedicels of variable length, the lowest often exceeding the fruit. ( $\boldsymbol{K}$ neiffia Small.) - Low ground, near the coast, Ct. to Fla.

16. 0. praténsis (Small) Robinson. Perennial, erect or nearly so, 3-6 dm. high; stems covered with soft long widely spreading hairs; leaves oblonglanceolate, 1-2 cm. broad, somewhat hirsute on both faces; lower flowers in the axils of decidedly foliaceous bracts; calyx with conspicuous caudiform free green densely hispid tips, the limb considerably shorter than the tube; petals $1.5-2.5 \mathrm{~cm}$. long; capsule clavate, sessile, hispid-pilose. (Kneiffa Small.) - Low grounds, s. Me. to Ct. ; n. w. Pa. to Ia. and Ark.

§4. HARTMANNIA (Spach) Endl: Stigma-lobes linear; fowers white or rose-colored, nodding in bud; fruit short, obovoid to ellipsoid, 4-angled and strongly ribbed; caulescent.

17. O. speciosa Nutt. (Whiте E.) Perennial, erect or subdecumbent, puberulent; leaves oblong-lanceolate to linear, repand-denticulate or more or less deeply sinuate-pinnatifid ; petals $2.5-4 \mathrm{~cm}$. long; capsule clavate-obovoid, strongly 8-ribbed, rigid, acute, stoutly pediceled. (Hartmannia Small.) Prairies and plains, Mo. and Kan. to Tex., spreading eastw, into Ill., S. C., and Fa. 


\section{§ 5. LAVAƯIA (Spach) Lndl. Stigma-lobes linear; flowers white or rose- colored; fruit ovoid, 4-winged; acaulescent.}

18. 0. trilloba Nutt. Biennial or perennial, nearly glabrous; leaves $1-3 \mathrm{dm}$. long, somewhat ciliate, long-petioled, runcinate-pinnatifid or oblanceolate and only sinuate-toothed; calyx-tips free, the tube slender, 6-20 cm. long; petals $1.2-4 \mathrm{~cm}$. long; capsule ovoid to ellipsoid, $2-3.5 \mathrm{~cm}$. long, strongly winged, net-veined. (Lavauxia Spach.) - Shaly limestone crevices, etc., Ky. and 'Tenn.; Assina. to Kan., Tex., and westw. (Mex.)

Var. (?) parviflora Wats. Seemingly annual; flowers very small, $2.5-5 \mathrm{~cm}$. long, fertilized in the bud and rarely opening fully; fruit abundant, forming at length a densely crowded hemispherical or cylindrical mass nearly $5 \mathrm{~cm}$. in diameter and often 5-7 cm. high. (Lavauxia triloba, var. Watsoni Britton.) - ilains, Kan. and Neb. - Little known.

§6. MEGAPTĖRIUM (Spach) Endl. Stigma-lobes linear; flowers yellow; fruit ellipsoidal to suborbicular, broadly 4-winged; seeds in a double row in each cell, crested; caulescent.

19. 0. missouriénsis Sins. Decumbent, canescent-puberulent or glabrate; leaves thick, lanceolate to lance-elliptic, 5-12 cm. long, acute or acuminate, entire or repand-denticulate ; calyx-tube 5-14 cm. long; petals broad, 3-6 cm. long; capsule 5-8 cm. long. (Megapterium Spach.) - Limestone cliffs and barrens, Mo. to Neb., Col., and sonthwestw.

§ 7. CALÝLOPHIS [Spach] T. \& G. Stigna disk-like, scarcely lobed; calyxtube funnel-form with broadly dilated throat; flowers yellow; capsule linear-cylindric, elongated; suffrutescent.

20. O. serrulàta Nutt. Slender, 1-5 dm. high, simple or branched, canescent on the younger parts; leaves linear to linear-lanceolate, $2-6 \mathrm{~cm}$. long, subentire or shallowly denticulate; calyx-tube $6-13 \mathrm{~mm}$. long, the flaring throat strongly nerved; petals broadly obovate, 8-17 mm. long, crenulate; capsule 1.8-3 cm. long. (Meriolix Walp. ; M. intermedia Rydb.?) - Sandy and rocky places, Man. and W. Wisc. to Mo., and southwestw.

\section{GAƯRA L.}

Calyx-tube much prolonged beyond the ovary, deciduous; the lobes 4 (rarely 3), reflexed. Petals clawed, unequal or turned to the upper side. Stamens mostly 8, often turned down, as is also the long style. A simall scale-like appendage before the base of each filament. Stigma 4-lobed, surrounded by a ring or cup-like border. Fruit hard and nut-like, 3-4-ribbed or -angled, indehiscent or nearly so, usually becoming 1-celled and 1-4-seeded. Seeds naked. Leaves alternate, sessile. Flowers rose-color or white, changing to reddish in fading, in spikes or racemes, in our species quite small (so that the name, from yavipos, superb, does not seem appropriate).

\section{* Fruit sessile or nearly so.}

1. G. biénnis L. Soft-hairy or downy, 1-3.2 m. high ; leaves oblong-lanceolate, denticulate; spikes wand-like; fruit ovoid-fusiform, 4-angled, acute at both ends, 4-6 mm. long, ribbed, downy. - Dry bauks, w. Que. to Ct. (Bishop), Minn., Neb., and southw.; casual in e. N. E.

2. G. parviflora Dougl. Soft-villous and puberulent, $1-3.6 \mathrm{~m}$. high ; leaves ovate-lanceolate, repand-denticulate, soft-pubescent; spikes dense; fruit fusiform or clovate, narrowed to both ends, 4-nerved, obtusely angled above, 6-8 mm. long. - Ia. and Neb. to Mo., La., and westw.

3. G. coccínea Pursh. Canescent, puberulent or glabrate, 1.5-4 dm. high, very leafy; leaves lanceolate, linear-oblong or linear, repand-denticulate or entire; flowers in simple spikes, rose-color turning to scarlet ; fruit terete below, 4-sided and broader above, 4-6 mm. long. - Man. to Mo. (Bush), N. Mex., and pestw.; introduced about Rochester, N. Y. (M. S. Baxter, V. Dewing). 


\section{* Fruit slender-pediceled.}

4. G. filipes Spach. Nearly smooth; stem slender, 6-12 dm. high; leaves linear, mostly toothed, tapering at base; branches of the panicle very slender, naked; fruit obovoid-club-shaped, 4-angled at the summit. (G. Michauxii Spach.) - Open places, S. C. and Fla. to Tenu. and Okla.; also said to occur from $V a$, to $O$. and Kan., - a range in need of further confirmation.

\section{STENOSIPHON Spach.}

Calyx prolonged beyond the ovary into a fliform tube. Fruit 1-celled, 1-seeded. Habit of Gaura. (From $\sigma \tau \epsilon \nu b s$, narrovo, and $\sigma i \phi \omega \nu, a$ tube.)

1. S. linifolius (Nutt.) Britton. Slender, 6-12 dm. high, glabrous, leafy ; leaves narrowly lanceolate to linear, pointed, entire, wuch reduced above; flowers numerous in an elongated spike, white, $1.2 \mathrm{~cm}$. long; fruit pubescent; ovoid, 8-ribbed, 2.5-3 mm. long. (S. virgatus Spach.) - Gravelly hills and dry prairies, e. Kan. to Col, and Tex.

\section{TRÁpa L. Water Nut. Water Caltrop}

Calyx-tube short, inclosing the base of the ovary; limb 4-parted, the segments persistent and becoming spinescent. Fruit indehiscent, large, with 2-4 strong spines, 1-celled, 1-seeded. - Aquatic plants, with opposite or whorled leaves, the upper crowded, with inflated petioles, rhombic, coarsely toothed, the submersed remote, witl capillary segments; flowers borne among the floating leaves. (Name abridged from calcitrapa, a caltrop, in allusion to the spreading points of the fruit.)

1. T. Natans L. (Water Chestnut.) Fruit 4-horned; seed edible. - Quiet streams and ponds, Middlesex Co., Mass.; Schenectady Co., N. Y. (Introd. from Eurasia.)

\section{Circat̀a [Tourn.] L. Enchanter's Nightshade}

Calyx-tube slightly prolonged, the end filled by a cup-shaped disk, deciduous; lobes 2, reflexed. Fruit indehiscent, small and bur-like, bristly with hooked hairs, 1-2-celled; cells 1-seeded. - Low perennials, with opposite leaves or. slender petioles, and small whitish flowers in racemes, produced in summer. (Named for Circe, the enchantress.)

1. C. lutetiàna L. Tall (3-9 dm. high); leaves ovate, tending to orateoblong, mostly rounded at the base, of rather firm texture, slightly toothed; bracts none; hairs of the roundish pyriform 2-celled fruit bristle-like (rarely wanting). - Common in dry open woods, N. S. to Ont., and southw. (Eu.)

2. C. intermèdia Ehrlh. Lower, '2-4 dm. high; leaves thin, ovate, the middle and upper more or less cordate, the teeth salient; minute bracts usually present; petals as long as the calyx; fruit nearly as in the preceding. Deep shade, e. Que. to Ont., Ia., and Tenn. (Eu.) - Not always well marked.

3. C. alpina L. Low (7-20 cm. high), smooth, weak; leaves heart-shaped, thin, shining, coarsely toothed; bracts minute; petals usually shorter than the calyx; hairs of the obovoid 1-celled fiuit soft and slender. - Deep woods, Lab. to Alaska, s. to Ga., Ind., Mich., n. e. Ia., and S. Dak. (Eu.)

\section{haLORAGidàceAE (WATgr Milfoil Family)}

Aquatic or marsh plants (at least in northern countries), with the inconspicuous symmetrical (perfect or unisexual) flowers sessile in the axils of leaves or bracts, calyx-fulp adherent to the ovary, which comvists of 2-4 more or less united carpels (or in Hippuris of only one carpel), the styles or sessite stipmas distinct. Linb of the calyx obsolete or very shurt in fertile flowers 
I'etals sinall or none. Stamens 1-8. Fruit indehiscent, 1-4-celled, with a single anatropous seed suspended from the summit of each cell. Embryo in the axis of flesliy albımen; cotyledons minute.

1. Myriophyllum. Flowers monnecious or polygamons, the parts in fours, with or without petrls. Stamens 4 or 8 . L Leaves often whorled, the immerserl commonly pinnately rlismerter.

«. Proserpinaca. Hlowers perfect, the parts in threes, Petals none. Leaves alternate, the inuluersed pinnately dissected.

8. Hippuris. Flowers apetalous. Stamen and style only one. Leaves entire, whorled.

\section{MYRIOPHÝlLUM [Vaill.] L. Water Milforl}

Flowers monoecious or polygamous. Calyx of the sterile flowers 4-parted, of the fertile 4-tootled. Petals 4, or none. Stamens 4-8. Fruit nut-like, 4-celled, deeply 4-lobed; stigmas 4, recurved. - Perennial aquatics. Leaves crowded, often whorled; those under water pinuately parted into capillary divisions. Flowers sessile in the axils of the upper leaves, usually above water, in summer; the uppermost staminate. (Name from $\mu$ ópıo, numberless, and $\phi v \lambda^{\prime} \lambda_{o v}$, a leaf, alluding, like Milfoil, to the innumerable divisions of the leaves.)

$u$. Flowering stems leafy; foliage leaves pectinate $b$.

b. Flowers in terminal naked spikes or in the axils of greatly reduced or modified leaves $c$.

c. Leaves in definite whorls $d$.

a. Leaves 5-12 mu. Iong; flowers chlefly 1 or 2 at each node of the spike

d. Leares chiefly longer; flowers numerous, in remote verticels $b$.

t. Verticels apparently naked, the floral leaves shorter than or only slightly exceeding the flowers.

Rhachis and segments of the foliage leaves capillary and of uniform diameter; floral leaves entire or merely dentate.

Rhachis flattish and somewhat broadel than the segments of

\section{M. alterniflorum.} the foliare leqves; floral leaves pectinate (3) $M$. verticillatum, v. peotinutum.

e. Verticels subtended by elongate floral leaves $f$.

$f$. Petals quickly deciduous; stamens 8 ; carpels plump and

f. Petals tardily deciduons; stamens 4 ; carpels 1-2-ridged or -angled on the back.

Floral leaves opate to oblanceolate; carpels papilloseroughened

Floral leaves linear or linear-lanceolate; carpels smooth

c. Leaves variously arranged (vertieillate, falsely verticillate, opposite, or alternate) on the same plant.

Carpels with flat sides and tuberculate-ridged back . . . 6. MC. scabrattum.

Carpels plump, smooth or minutely papillose.$\quad$ : $_{\text {. }}$. 8. M. humile.

b. Flowers in the axils of nnmodified foliage leaves.

Carpels smooth or barely papillose, plump, not ridged on the back . 8. M. humile.

Carpels with flat sides and prominent tuberculate dorsal ridges.

Fruit $2-2.5 \mathrm{~mm}$. long

Fruit 1-1.5 mm. long

a. Flowering stems vaked ol with few scattered fillorm uncleft leaves

8. M. rerticillatum,

4. M. heterophyllum. 5. M. hippuroides.

7. M. Farwellit. 6. II. scabratum.

9. $M$. tenellum.

\section{§1. PENTÁPTERIS DC. Stamens 8; petals early deciduous; leaves whorled. \\ * Floral leaves (bracts) scattered; flowers rarely in verticels.}

1. M. alterniflòrum DC. Very slender; leaves $5-12 \mathrm{~mm}$. long, the rhachis and segments capillary; flowers solitary or in pairs, in simple or branched nearly naked spikes; lowermost bracts pectinate, the others entire or nearly so, shorter than the flowers. - Ponds and slow streams, Nfd. to Ont., s. to Middlesex Co., Mass., and L. Champlain, Vt. (Greenl., Eu.)

$$
\text { * * Florrl leaves and flowers in verticels. }
$$

2. M. spicàtum L. Leaves somewhat rigid, 1-3 cm. long, the rhachis and capillary segments of uniform diameter; flowers verticillate, in an interrupted apparently naked spike; the bracts shorter than or slightly exceeding the flowers, entire or merely dentate; stigmas roundish, closely sessite, not elongated; sepals 
of the staminate flowers deep purplish ; fruit globose, 4-furrowed, 2-3 mm. long، - Brackish or fresh pools or slow streams, Nfd. to Alaska, s. to Ct., Great L. region, Kan., N. Mex., Ariz., and s. Cal. (Eurasia.)

3. iL. verticillatum L. Leaves flaccid, $1.5-4 \mathrm{~cm}$. long, the flattish rhachis somerohat broader than the linear-filiform segments; floral leaves or bracts similar but firmer, 6-20 mm. long, uniform or nearly so, all much exceeding the flowers; stigmas somewhat elongate, recurved; sepals of the staminate flowers pale green to pinkish; fruit subglobose, the 4 carpels plump, $2.5-3 \mathrm{~mm}$. long. The typical European plant, rare or local with us; examined only from w. N. Y. and Ill. Represented in America chiefly by

Var. pectinatum Wallr. Spike appearing naked or nearly so, much as in $M$. spicatum, all or most of the pectinate bracts shorter than or only slightly exceeding the flowers. - Fresh or brackish pools, Gaspé Co., Que, to Sask. and B. C., s. to n. Me., L. Memphremagog, Que., centr. and W. N. Y., Great L. region, Minn., and Utah. (Eurasia.)

\section{§2. TESSARÓNIA Schindler. Stamens 4 ; petals rather persistent. \\ * Carpels 1-2-ridged on the back.}

- Flowers on emersed spikes, the floral leoves chiefly modified.

4. M. heterophyllum Michx. Stem stout (the base of the spike 2-5 mm thick); leaves whorled in 4 's, 5 's; or 6 's, the submersed $1.5-5 \mathrm{~cm}$. long, the flattened rhachis slightly broader than the linear-filiform segments; spikes 1-3 $\mathrm{dm}$. long; floral leaves whorled, crowded, ovate to oblanceolate, entire or denticulate, thickish, 4-16 mm. long; fruit 1-1.5 mm. long, about as thick, papillose-roughened, the carpels 2-ridged on the back, convex on the sides, their styles prominent. - Ponds and slow streams, near the coast, Va. to Fla.; also from W. N. Y. and Ont. to Minn., s. to Mo. and Tex.

5. M. hippuroides Nutt. Similar, more slender; floral leaves linear to linearlanceolate, entire to pectinate; fruit $2 \mathrm{~mm}$. long, about $1 \mathrm{~mm}$. thick, the smoothish carpels flattish on the sides, their styles very short. - Apparently local, s. Ont.; also from Wash. to Cal.

6. M. scabràtum Michx. Slender; leaves variously arranged, verticillate, subverticillate, or scattered, on the same plant, the subuersed with linear-capillary segments; the emersed and the floral leaves linear, pectinate-toothed or cutserrate; fruit 1-1.5 mm. long, about as broad, the carpels with flat sides and 2 tuberculate ridges on the brck. ( $\boldsymbol{M}$. pinnatum BSP., at least in part; possibly Potamogeton pinnatum Walt.) - Shallow ponds and muddy shores, e. Mass. to S. C., near the coast; also from w. Ky. and w. Tenn. to Ia. and Tex.

\section{+ + Flowers in the axils of unmodified submersed leaves.}

7. M. Farwéllii Morong. Slender, flowering below the surface of the water ; leaves all divided into filiform segments, subverticillate or scattered; flowers solitary in the middle axils ; fruit $2-2.5 \mathrm{~mm}$. long, somewhat narrower, the flatsided carpels with prominently tuberculate dorsal ridges. - Ponds and slow streams, Gaspé Co., Que., to n. Mich., s. to s.'Me., s. N. H., s. Vt., and centr. N. $\mathrm{Y}$.

\section{* * Carpels rounded and even on the back; leaves chiefly scattered, or wanting on the flowering stems.}

8. M. hùmile (Raf.) Morong. Stems slender, $5-15 \mathrm{~cm}$. high, erect or decumbent, rooting in the mud; leaves subopposite or alternate, the lower 4-8 $\mathrm{mm}$. long, pinnately divided; floral leaves similar or linear and serrate or entire; flowers mostly perfect; fruit $0.7 \mathrm{~mm}$. long, the subcylindric carpels smooth or minutely papillose. ( $\boldsymbol{M}$. ambiguum, var. limosum Nutt.) - Muddy shores and shallow pools, centr. Me. to $\mathrm{Vt}_{\mathrm{t}}$, s. to Md.; reported from Ind. and Ill. to Tenn. and Mo. Forma MAтA s (DC.) Fernald. Stems elongate and partly submersed; foliage leaves crowded, sometimes verticillate, larger, with long capillary divisions; spikes emersed; floral leaves as in the typical form. (M. ambigu Nutt.) - Shallow ponds ad slow streams. Forma capiltaceum (Torr.) Fer- 
nald. Stems elongate, completely submersed ; flowers in the axils of elongate capillary-divided leaves, ( $\boldsymbol{M}$. ambiguum, var. capillaceum T, \& G.) - Ponds and streams.

9. M. tenéllum Bigel. Flowering stems nearly leafless and scape-like, 7-35 cm. high, erect, simple ; the sterile shoots creeping and tufted; leaves filiform, undivided; bracts small, entire; flower's alternate, monoecious ; fruit smooth. Borders of ponds and streams, Nfd. to Ont., s. to N. J., Pa., and Mich.

\section{PROSERPINÀCA L. MERMAID-WEED}

Flowers perfect. Calyx-tube 3-sided, the limb 3-parted. Petals none. Stamens 3. Stigmas 3, cylindrical. Fruit bony, 3-angled, 3-celled, 3-seeded, nut-

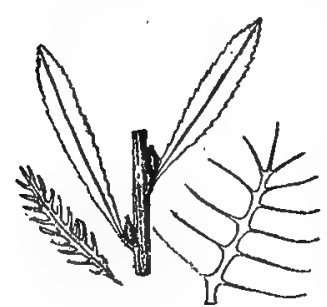

818. P. palustris $\times \%$.

like. - Low perennial herbs, with the stems creeping at base, alternate leaves, and small flowers sessile in the axils, solitary or 3-4 together, in summer. (Name applied by Pliny to a Polygonum, meaning pertaining to Proserpine.)

1. P. palústris L. Fertile leaves (those with flowers or fruit in their axils) lanceolate, sharply serrate, the sterile (often occurring above as well as below the fertile) usually pectinate. - Muddy borders of ponds or in shallow water, N. B. to Fla., Tex., and Minn. FIG. 813.

2. P. pectinàta Lam. Leaves uniform, both fertile and sterile divided to the rhachis; the divisions slightly rigid, linearawl-shaped. - Sandy swamps, near the coast, s. Me. to Fla. and La., local. FIG. 814.

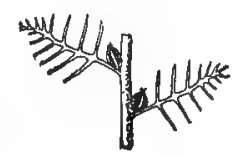

814. P. pectinata $\times 2 / 3$,

\section{HIPPÙRIS L. MARE'G-TAIL}

Flowers perfect or polygamous. Calyx entire. Style thread-shaped, stigmatic down one side, received in the groove between the lobes of the large anther. Fruit nut-like, 1-celled, 1-seeded.-Perennial aquatics, with simple entire leaves in whorls, and minute flowers sessile in the axils, in summer. (Name from i $i \pi \pi$ s, a horse, and oủoá, a tail.)

1. H. vulgàris L. Stems simple, $1.5-6 \mathrm{dm}$. high ; leaves in whorls of 6-12, linear, acute ; fruit nearly $2 \mathrm{~mm}$. long. - Ponds and streams, Lab. to Alaska, s. to N. S., Me., Vt., N. Y., Ind., Ill., Minn., Neb., and N. Mex. (Eu.)

\section{araliàceae (Ginseng Family)}

Herbs, shrubs, or trees with much the same charcters as Umbelliferae, but with usually more than 2 styles, and the fruit a fero-several-celled drape. Albumen mostly fleshy. Petals 5, epigynous, not inflexed. Stamens 5, epigynous, alternate with the petals.

\footnotetext{
* Leaves compound.
}

1. Aralia. Lesves alternate, compound, the ultimate divisions pinnate. Carpels 5; fruit black.

2. Panax. Leaves whorled, palmately $3-7$-foliolate. Carpels 2-8; fruit red or yellow.

$$
\text { * Leaves simple but palmately lobed. }
$$

8. Fatsia. Leaves orbicular, cordate, palmately lobed, scattered. Carpels 2; fruit red, 2-seeded.

\section{ARALIA [Tourn.] L.}

Flowers polygamous. Petals slightly imbricated in the bud. Ovary 5-celled; ovules solitary, anatropous, suspended in the cells. - Leaves compound or deeompound. Flowers white or green, in umbels or panicles. Qualities aromatic. (Derivation obscure.) 
* Umbels numerous in a large compound panicle; leaves very large, decompound.

1. A. spindsa L. (ANgelica-tree, Herculies' Club.) Shrub, or a low tree; the stout sten and stalks prickly; leaflets ovate, pointed, serrate, pale beneath. - River-banks, s. N. Y. to Mo., and southw. July, Aug.

2. A. racemosa L. (SPIKEnARD.) Herbaceous; stem widely branched; leaflets heart-ovate, pointed, doubly serrate, slightly downy; umbels racemose; styles united. - Rich woodlands. July. - Well known for its spicy-aromatic large roots.

\section{* Umbels mostly 2-7, corymbed; stem short, somewhat woody.}

3. A. híspida Vent. (Bristly Sarsaparilla, Wild Elder.) Stem 4-9 dm. high, bristly, leafy, terminating in a peduncle bearing several umbels; leaves twice pinnate; leaflets oblong-ovate, acute, cut-serrate.-Rocky and sandy places, Nfd. to Hudson Bay, s. to N. C., W. Va., Ind., Mich., and Minn. June, July.

4. A. nudicaúlis L. (WILd SARSAPARILla.) Stem scarcely rising out of the ground, smooth, beasing a single long-stalked leaf (2-4 dm. high) and a shorter naked scape, with 2-7 umbels; leaflets oblong-ovate or oval, pointed, serrate, 5 on each of the :3 divisions. - Moist woodlands; Nfd. to Ga., Col., and Ida. May, June. - The long horizontal aromatic roots a substitute for officinal S. RsAparilla. Var. elongata Nash, from the Catskill Mts., has been distinguished because of its somewhat longer narrower leaflets $(13-15 \mathrm{~cm}$. long, $4 \mathrm{~cm}$. widt), which are paler beneath. Var. Protffera Apgar, of w. N. J., has more divided leaves with 25-40 leaflets and proliferous inflorescence with 5-70 umbellets.

\section{PÀnax L. Ginseng}

Flowers dioeciously polygamous. Unbel solitary, simple, terminal. Carpels 2-3. - Herbaceous perennials, springing from thickish roots or tubers, the erect simple stems bearing a solitary whorl of 3 palmate leaves. (Name from " $r \hat{s} s$, all, and axos, cure, that is, all-healing, a panacea.) Often included in Aralia.

1. P. quinquefolium L. (GINSENG.) Root large and spindle-shaped, often forked, 1-2 dm. long, aromatic ; stem $3 \mathrm{dm}$. high; leaflets long-stalked, mostly 5 , large and thin, obovate-oblong, pointed; styles mostly 2 ; fruit bright red. (Aralia Done. \& Planch.) - Rich and cool woods, Que. and Ont., s. to N. E., N. Y., Great L. region, e. Ia., Mo., and along the mts. to Ga. July. - Much sought for the root, which is purchased by the Chinese and extensively employed by them in their medicine, as is also the even more highly prized Asiatic $P$. ginseng C. A. Mey.

2. P. trifolium L. (DWARF G., Ground-nut.) Ront ov tuber globular, deep in the ground; stem 1-2 dm. high; leaflets $3-5$, sassile at the summit of the leafstalk, narrowly oblong, obtuse; styles usually 3 ; fruit yelloroish. (Aralia Dcne. \& Planch.) - Rich woods, N. S. to w. Ont., s. to Del., Md., Ill., Ia., and along the mts. to Ga. Apr., May.

\section{FÅTSIA Dene. \& Planch.}

Flowers perfect or polygamous. Unbels numerous in simple or compound racemes or paniculately disposed. Calyx-margin narrow or obsolete, obscurely crenate-lobed. Carpels (in ours) 2. - Stout sometimes arborescent shrubs, ours very prickly. Leaves simple, long-petioled, the limb suborbicular, palmately lobed. (Name from the Japanese vernacular designation of one of the species.) Echisopinax Dene. \& Planch. Oplopanax Miquel.

1. F, hórida (Sm.) B. \& H. (DEvIt;'s CrrB.) Coarse shrub, thickly beset with stramineous prickles; leaves $1-3 \mathrm{dm}$. in dirmeter, with $5-13$ deltoid acute lubes, the margin sharply and unevenly serrate, the ribs prickly beneatl. (Echinopanax Done. \& Planch.) - Rocky cliffs, etc., Isle Royale, L. Superion (W. A. Wheeler); and from the Rocky Mits. to Cal. and s. Alaska. (Japan.) 


\section{UMBelífferae (ParsLet Family)}

Herbs, with small fluwers in umbels (or rarely heads), the calyx entive or 5-toothed, the tube wholly adhering to the 2-celled and 2-ovuled ovary, the 5 petals and 5 stamens inserted on the disk that crowns the ovary and surrounds the base of the 2 styles. Fruit of" sped-like dry carpels (called mericarps) cohering by their inner face (the commissure), when ripe separating from each other and usually suspended from the summit of a slender prolongation of the axis (crrpophore); each carpel marked lengthwise with 5 primary ribs, and often with 4 intermediate (secondary) ones; in the interstices or intervals are commonly oil-tubes (vittae), longitudinal canals containing aromatic oil. (These are best seen in slices made across the fruit.) Seed suspended from the summit of the cell, anatropous. Stems usually hollow. Leaves alternate, mostly compound, the petioles expanded or sheathing at base. Umbels usually compound, the secondary ones being termed umbellets; the bracts which often subtend the general umbel form the involucre, and those of the umbellets the involucels. The frequently thickened base of the styles is called the stylopodium. - A large and difficult family, some of the species innocent and aromatic, others with very poisonous properties.

N. B. - In this family the figures represent the mature fruit entire and in cross section.

1. Fruit with primary ribs only, hence 8 dorsal ones on each carpel (these sometimes obscure or obsolete in the first group.)

* Frait ovoid, obovoid, or globose, not ribbed, scaly or densely covered with hooked prickles.

1. Eryagium. Flowers sessile in dense bracteate heads, white or blue. Leaves mostly rigid. more or less spinose.

2 Sanicula. Flowers in irregular compound few-rayed umbels, yellow or green. Leaves paimate.

[Spermolepis may be sought here.]

* * Fruit flattened laterally.

+ Carpels also strongly flattened laterally.

++ Seed straight, not sulcate; umbels simple (often proliferous.)

3. Hydrocotyle. Fruit suborbicular; carpels with 8 dorsal ribs, not reticulated. Petals small, somewhat tubular. Low perennials in or near water. Leaves simple, roundisl.

4. Centella. Fruit orbicular; carpels with 5 dorsal ribs, and somewhat reticulated. Petals flat. Leaves ovate.

\#+ Seed lunate, deeply sulcate on the face; umbels compound, leafy-bracter.

5. Erigenia. Fruit nearly orbicular, with numerous ail-tubes. Low, nearly acaulescent from a deep-seated tuber. Leares ternately decompound.

$+\div$ - Carpels terete or slightly flattened laterally; petals white (greenish-yellow in Petroselinum)

$\rightarrow$ Seed-face concate; Pruit linear-oblong (rarely broader), with usually conical stylopodium.

6. Chaerophyllum. Fruit glabrons, with small mostly solitary oll-tubes.

7. Osmorhiza, Fruit bristly, the oil-tubes obsolete. +++ Seed-face concave; fruit ovate; leaves finely divided.

8. Spermolepis. Fruit warty or bristly, the ribs oosolete. Slender annuals.

9. Conium. Fruit smooth, with conspicuous often undulate ribs. Ours blennia] ++++ Seed-face flat.

$=$ Leaves finely dissected; oil-tubes solitary; very slender annuals

10. Ptitimnium. Darsul ribs filiform, ise lateral very thick and corkv. 
$=-$ Leaves decompound; oil-tubes solitary or none; perennials.

11. Aegopodium, Ribs equal, filiform. Oil-tubes none; stylopodiun conical. Leaves biternate.

12. Cicuta. Ribs fluttish, corky, the lateral largest. Marsh plants.

18. Carum. libs fillorm, inconspicuous; stylopodium short-conical, Leaf-segments fliform. Petals waitc or roseate.

14. Petroselinum. Ribs filiform, inconspicuous; stylopodium short-conical. Leaf-segments incised. Petals greenish-yellow.

$=-=$ Leaves once pinnate; oll-tubes 6-many ; stylopodium depressed ; aquatic perennials.

15. Berula. Fruit nearly globose; ribs inconspicuous; pericarp thick and corky.

16. Sium. Fruit ovate to oblong; ribs prominent, corky, nearly equal.

$-\ldots=$ Leaves 3-foliolate; stylopodium conical; oil-tubes solitary, beneath and between tho ribs.

17. Cryptotaenia. Ribs obtuse, equal; fruit linear-oblong, glabrous.

+++ Carpels terete or slightly flattened laterally; petals golden yellow.

1S. Zizia. Fruit ovate to oblong; ribs fliform; stylopodium none; seed terete.

++++ Carpels depressed dorsally ; fruit short.

+ Seed-face flat or nearly so; petals mostly yellow.

19. Foeniculum. Ribs prominent; oil-tubes solitary. Leaves filiform-dissected.

20. Pimpinella. Ribs filiform; oll-tubes numerous; stylopodium depressed-conical. Leaves pinnate. Petals whito.

21. Taenidia. Ribs filiform; oil-tubes numerous; stylopodium none. Leaves palmately com. pound. Petals yellow.

+ + Seed-face decidedly concave; petals white (except in Bupleurum).

$=$ Leaves compound.

a. Fruit beakless; oil-tubes numerous.

22. Eulophus. Stylopodium conieal. Glabrous peronnials from fascicled tubers. Leaves pin. zately compound.

b. Fruit (in ours) conspicuously beaked; oil-tubes solicary in the intervals or none; leaves $2-8$ ternately or -pinnately divided.

23. Anthriscus. Beak not more than one third to one half as long as the body of the fruit, smuoth.

21. Scandix. Beak much exceeding the body of the fruit, its margins upwardly hispid. $-=$ Leaves entire.

25. Bupleurum. Fruit oblong, with slender ribs, no oll-tubes, and prominent flat atylopodium. Leaves simple, perfoliate.

*** Fruit not flatteued olther way or but slightly, neither prickly nor scaly.

- Dorsal ribs fliform, the lateral very thick and corky; oil-tubes solitary.

86. Lilaeopsis. Small glabrous creeping peronnials, rooting in the mud, with small simpie umbels and leaves reduced to hollow cylindrical jointed petioles.

27. Cynosciadium. Annuals with compound leaves and compound umbels.

++ Libs all prominent and equal but not winged; flowers white or roseate.

+ Ribs acutish or rounded, narrower than the intervals between them.

23. Ligusticum. Stoutish perenntals. Leaves 2-4-ternate; leafets ovate, obovate, or oblong.

29. Coriandrum Slender annuals. Ouxline leaves cleft or dissected into linear segments.

+ + Ribs thickish and corky, broader than the intervals.

30. Aethusa. Slender annual with finely divlded leaves. Onl-tubes solitary in the intervals. 2 on the commissure.

81. Coelopleurum. Stout maritime perennial. Ofl-tubes under the ribs as well as in the intervals, 2-4 on the commissure.

+++ Ribs all conspleuously winged; stylopodiom depressed or wanting ; perennials.

82. Cymopterus. Low and glabrous, mostly cespitose, with plnnately compound leaves and white flowers. Oil-tubes 1-several. Western.

88. Thaspium. Tall, with ternately divided or simple leaves, and yellow flowers (rarely purple). Oll-tubes solitary in the in tervals, 2 on the commisare. 
**** Fruit struugly fiattened dorsally, the Interal ribs prominently winged.

- Acaulescent or nearly 80, with fliform dorsal ribs, thin coherent wings, and no stylopodium.

84. Lomatium. Fruit orbicular to oblong, oil-tubes $1-4$ in the intervals, 2-6 on the commissure, -+ Canlescent branching plants, with depressed stylopodium and yellow petals (these unknown in $\mathrm{no.}$. 35).

+ Leaflets entire.

85. Pseudotaenidia. Fruit lance-oblong; lateral wings connivent, somewhat corky; stylopo. dium obscure; oil-tubes solitary in the iutervals or double in the lateral intervals.

++ Leaflets scrrate or incised.

- Involucre none.

36. Polytaenia. Firuit with thick corky margin, obscure ribs, and very numerous oll-tubes.

37. Pastinaca. Fruit with filiform dorsal ribs, thin wings, and solitary oil-tubes. = - Involucre conspicuous, of several lanceolate deflexed bracts.

38. Levisticum. Fruit strongly ribbed; oil-tubes solitary.

++++ Leaves decompound, their divisions dissected into linear-filiform segments.

89. Anethum Fruit elliptical, rounded at each end; dorsal ribs thin and sharp, the lateral witl distinct narrow wings.

+++ Caulescent branching plants, with petals white or nearly so.

+ Lateral wings closely contiguous; oil-tubes solitary; stylopodium thick-conical.

- Oil-tubes conspicuous, obclavate, extending only one half or two thirds the way to the base of the fruit.

40. Heracleum. Dorsal ribs fliform, the broad wings with a marginal nerve. Petals con. spicuous. Tall stout pubescent perennials, with ternate or pinnate leaves and large incised and toothed leaflets.

$=-$ Oil-tubes of more uniform diameter, extending essentially to the base of the fruit.

4. Imperatoria. Leaves ternately compound; leaflets broad, ovate to obovate, serrate and incised. stout, terrestrial.

42. 0xypolis. Dursal ribs apparently 5, filiform. Leaves pinnate or reduced to hollow cylin. drical petioles. Glabrous swamp plants.

+ ++ Lateral wings distinct; oil-tubes usually more than one in each interval.

43. Conioselinum. Stylopodium slightly conical. Dorsal ribs prominent. Tall slender glabrous perennial, with thin finely and pinately rompound leaves.

44. Angelica. Stylopodium mostly depressed, but the disk prominent and crenulate. Dorsal ribs strong. Stout perennials, with coarse 2-3-ternately or -pinnately divided leaves.

II. Fruit with secondary ribs the most prominent, winged and armed with barbed or hooked prickles, the primary ribs filiform and bristly.

45. Torilis. Calyx-teeth prominent. Fruit flattened laterally. Beed-face deeply sulcato.

46. Daucus. Calyx-teeth obsolete. Fruit flattened dorsally. Seed-face flat.

\section{ERÝNGIUM [Tourn.] L. ERYngo}

Calyx-teeth prominent, rigid and persistent. Styles slender. Fruit ovate or obovate, covered with little hyaline scales or tubercles, with no ribs, and usually 5 slender oil-tubes on each carpel. - Chiefly perennials, with coriaceous, toothed, cut, or prickly leaves, and blue or white bracted flowers closely sessile in dense heads. (A name used by Dioscorides, of uncertain origin.)

* Stout, with parallel-veined elongated linear thick leaves.

1. E. yuccifolium Michx. (Rattlesiake Master, Button Snakeroot.) Branching above, $0.5-1.7 \mathrm{~m}$. high ; leaves rigid, tapering to a point, the lower 4-9 dm. long, the margins remotely bristly; heads ovoid-globose, $1.8 \mathrm{~cm}$. long, with ovate-lanceolate mostly entire cuspidate-tipped hracts shorter than the 
head, and similar bractlets. (E. aquaticum L. 1762, in part, not L. 1753.) Ct. to Minn., Kan., Tex, and Fla. July-Sept.

* Tall and often stout; leaves thick, not parallel-veined.

2. E. aquáticum L. Slender, 3-9 dm. high; radical and lover stem-leaves linear-to oblong-lanceolate, on long (sometimes $3 \mathrm{dm}$.) fistulous petioles, entire or with small hooked teeth; upper leaves sessile, spiny-toothed or laciniate;

- heads ovoid-ellipsoid, $1.2 \mathrm{~cm}$. long, with reflexed bracts, and bractlets with spiny cusps (the middle one largest). (E. virginianum Lam.) - By ponds and streams, N. J. to Fla. and Tex., near the coast. Ang., Sept.

3. E. Leavenwórthii T. \& G. Stout, 4-9 dm. high; lowest stem-leaves brocdly oblanceolate, spinosely toothed, the rest sessile and deeply and palnately parted into narrow incisely pinnatifid spreading pungent segments; heads ovoid-ellipsoid, $2.5-4 \mathrm{~cm}$. long, with pinnatifid spinose bracts and 3-7-cuspidate bractlets, the terminal ones very prominent and resembling the bracts. - Dry soil, e. Kan., Ark., and Tex.

* * Prostrate and slender, rooting at the joints, diffusely branched, with small thin unarmed leaves and very small heads.

4. E. prostràtum Nutt. Lower leaves oblong, entire, few-toothed, or lobed at base; upper leaves smaller, clustered at the rooting joints, ovate, few-toothed or entire (occasionally some additional trifid ones); reflexed bracts longer than the ellipsoid heads $(4-7 \mathrm{~mm}$. long). - Wet places, s. Mo. to Fla. and 'Tex.

\section{SANfCULA [Tourn.] L. SANicí. Black SNakeroot}

Calyz-teeth manifest, persistent. Fruit globular; the carpels not separating spontaneously, ribless, thickly clothed with hooked prickles. - Perennial rather tall glabrous herbs, with few palmately lobed or parted leaves,
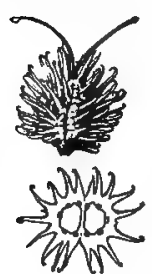

315. S. marilandica $\times 2$. those from the base long-petioled. Umbels irregular or compound, the flowers (greenish or yellowish) capitate in the umbellets, perfect, and with staminate ones intermixed. Involucre and involucels few-leaved. (Name said to be from sanare, to heal; or perhaps from San Nicolas.)

* Styles much exceeding the bristles of the fruit, recurved.

1. S. marilándica L. Stem erect, 3-10 dm. high; leaves 6-7-parted, the divisions sharply serrate, acute; sterile flowers pedicellate, often in separate umbels; fruit 6-7 $\mathrm{mm}$. long, sessile. - Nfd. to Ga. and w. to the Rocky Mts., common. FIG. 815 .

2. S. gregària Bickrrell. Stem slender, $6 \mathrm{dm}$. high ;
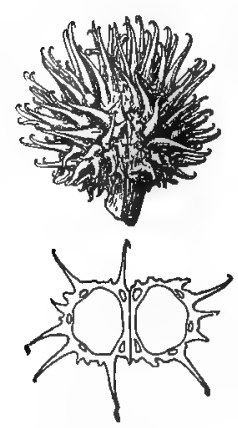

R17, s. camadensis $\times 4$. leaves 5-foliolate; leaflets obovate, cleft and serrate; fruit only $3-4(-5)$ $\mathrm{mm}$. long, somewhat stipitate. Rich woods, St. John Valley, N. B.; s. N. H. to Minn., Ark., and Ga. FIG. 816.

\section{* Styles shorter than the bristles.}

3. S. canadénsis $\mathrm{L}$. Simple, erect, 5-8 dm. high; leaves 3-5foliolate, leaflets narrowly obovate, sharply serrate; sterile flowers few, short-pediceled; fruit nearly sessile, subglobose, $3-6 \mathrm{~mm}$. long.

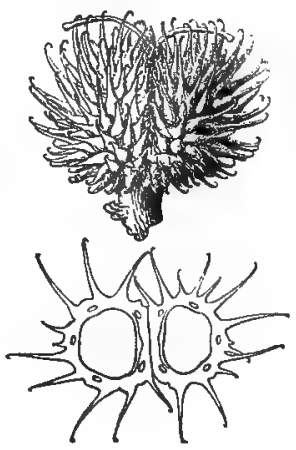

816. S. gregaria $\times 4$.

-N. H. to Fla., Minn., Neb., and Tex., common. Fig. 817.

4 S. trifoliàta Bicknell. Similar in habit, the leaflets 


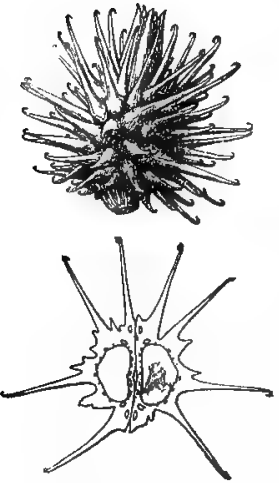

818. S. trifoliata $\times 2 \% / 3$.

broader; sterile flowers on long slender pedicels; fruit ovoid or at inaturity somewhat fusiform, tipped with the conspicuous beak-like calyx. - Rich soil, Kennebee Valley, Me. (Scribner); and from the Cs. Valley to Ont., Minn., and W. Vq. FIG. 818.

\section{HYDROCÓTYLE [Toum.] L. WAter PenNywort}

Calyx-teeth obsolete. Carpels with 2 of the ribs enlarged and often forming a thickened margin; oiltubes none, but usually a conspicuous oil-bearing layer beneath the epidermis. - Tow mostly smooth marsh or aquatic perennials, with slender creeping stems, round shield-shaped or kiduey-form leaves, and scale-like stipules. Flowers small, wbite, in simple umbels or clusters, which are either single or proliferous (one above another), appearing all summer. (Name from water, and кorú $\lambda$, a flat cup, the peltate leaves of several species being somewhat cup-shaped.)

* Pericarp thin except at the broad corky dorsal and lateral ribs; leaves round, peltate, crenate; peduncles as long as the petioles, from creeping rootstocks.

$$
\text { - Fruit notched at base and apex; intermediate ribs corky. }
$$

1. H. umbellàta L. Umbels many-flowered, simple (sometimes proliferous) pedicels 4-12 mm. long; fruit about $3 \mathrm{~mm}$. broad, strongly notched, the dors; , ribs prominent but obtuse. - Mass. to Fla. and Tex., chiefly on the coastil plain ; also Mich. and Ind., and reported from Minn.

2. H. Cánbyi Coult. \& Rose. Umbels 3-9-flowered, generally proliferous; pedicels very short, but distinct; fruit $3-3.5 \mathrm{~mm}$. broad; carpels broader and more flattened than in the preceding, sharper-margined, the dorsal and lateral ribs much more prominent; seed-section much narrower. - N. J. to Md.

$$
\text { +- + Fruit not notched; intermedicate ribs not corky. }
$$

3. H. verticillàta Thunb. Umbels few-flowered; proliferous, forming an interrupted spike; pedicels very short or none ; fruit $3-4$ min. broad, subsessile; dorsal and lateral ribs very prominent. - Mass, to Fla., Ark., and Tex.

4. H. austràlis Coult. \& Rose. Very like the preceding ; flowers pediceled.Dismal Swamp, Va. (Pollard according to Coult. \& Rose), and sonthw.

* * Pericarp uniformly corky-thickened, and ribs all filiform; leaves not peltate; peduncles much shorter than the petioles.

5. H. americàna L. Propagating by slender tuberiferous stolons; stems filiform, branching and creeping; leaves thin, lound-reniform, crenate-lobed and the lobus crenulate, shining; few-flowered umbels axillary and almost sessile; fruit less than $2 \mathrm{~mm}$. broad; intermediate ribs prominent; no oil-bearing layer; seed-section broadly oval. Common. Fig. 819.

6. H. ranunculoides L. f. Usually floating; leaves thicker, round-reniform, 3-7-cleft, the lobes crenate; peduncles $2.5-7.5$ cni. long, reflexed in fruit; capitate umbel 5-10-flowered; fruit 2-3 $\mathrm{mm}$. broad; ribs rather obscure; seed-section oblong. Muddy shores, e. Pa. to Ela., thence westw. (Trop. regions.)

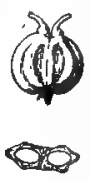

819. H. americana $\times 4$.

\section{CENTÉLLA L.}

Calyx-teeth obsolete. Petals white, imbricated in bud. Carpels 7-9-ribbed and somewhat reticulated. - Creeping perennials with simple ovate leaves. Umbels subtended by 2 conspicuous bracts. (Name of obscure origin.)

1. C. asiática ( $\mathrm{T}$.) Urban. Leaves repand-toothed, thickish; umbel 2-4flowered; pedicels very short. (C. repanda Small; Hydrocotyle asiatica L.) Md to Fla. ('Tropics.) 


\section{ERIGENİA Nutt. Harbinger-OF-SPRING}

Calyz-teeth obsolete. Petals obovate or spatulate, flat, entire, white. Fruit didymous, laterally flattened, the carpeis incurved at top and bottom, nearly kidney-form, with 5 very slender ribs, and several (1-3) small oil-tubes in the intervals. - A small glabrous verual plant, with a simple stem, bearing one or two 2-3-ternately divided leaves, and a few-flowered leafy-bracted umbel. (Name from hoı réveta, born in the spring.)

1. E. bulbdsa (Michx.) Nutt. Stern 1-2.3 dm. high; leaf-segments linearoblong; fruit $2 \mathrm{~mm}$. long, $3 \mathrm{~mm}$. broad, - Deciduous woods, etc., s. Ont. and w. N. Y. to Minn., and southw.

\section{CHAEROPHÝLLUM [Tourn.] L.}

Calyx-teeth obsolete. Fruit narrowly oblong to linear, notched at base, with short beak or none, and equal ribs, oil-tubes solitary in the intervals; seed-face

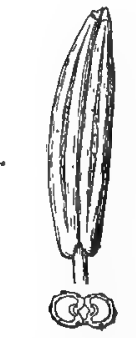

820. C. procumbens $\times 8$ more or less deeply grooved. - Annuals, with ternately decompound leaves, pinnatifid leaflets with oblong obtuse lobes, mostly no involucre, involucels of many bractlets, and white flowers. (Name from $\chi a i \rho \epsilon t$, to gladden, and $\phi \dot{v} \lambda \lambda \circ \nu$, a leaf, alluding to the agreeable odor of the foliage.)

1. C. procúmbens (L.) Crantz. More or less hairy; stems slender, spreading, $1.5-5 \mathrm{dm}$. high; umbels few-rayed ; fruit narrowly oblong, 5-10 mu. long, glabrous, contracted but not tapering at the summit, the intervals broader than the ribs. - Moist ground, N. Y. to N. C., w. to Mich., Ir., Ark, and Miss. Fig. 820.

Var. Shórtii T. \& G. Fruit more broadly oblong to ovate (often somewhat pubescent), not at all contracted at the summit. - Pa. to Va., Ky., and $O$.

2. C. Tainturièri Hook., var. floridànum Coult. \& Rose. Stoüter and more pubescent than the preceding species; fruits $7-8$ in each umbel, sessile or pediceled, glabrous, the ribs narrower than the intervals, - Barrens, Eagle Rock, Mo. (Bush); S. C. to Fla.

\section{OSMORHİZA Raf. SWEET CICELY}

Calyx-teeth obsolete. Fruit with prominent caudate attenuation at base, and equal ribs. - Glabrous to hirsute perennials with thick aromatic roots, ternately compound leaves, ovate variously toothed leaflets, few-leaved involucres, and white flowers in few-rayed and few-fruited umbels. (Name from $\delta \sigma \mu \eta$, , a scent, and $\dot{\rho} l \xi a, a$ root.) WAsHingtonia Raf.

\section{* Rays of the umbel mostly bearing involucels.}

1. 0. Claytoni (Michx.) Clarke. Stems rather slender, 3-9 din. ligh, villous-pubescent; leaves $2-3$-ternate, crisp-hairy ; leaflets mostly $4-7 \mathrm{~cm}$. lnng, acuminate, crenate-dentate and somewhat cleft; stipules ciliate-hispid; fruit (not including the attenuate base) 1-1.3 cm. long; stylopodium and style 0.7-1 mm. long. (O. brevistylis DC.; Washingtonia Claytoni Britton.) - Open woods, e. Que. to w. Ont., s. to N. C., Ala., Mo., and Kan.

2. 0. longistylis (Torr.) DC. Coarser; stems 4-12 dm. high, glabrous or essentially so except at the nodes; leaflets mostly longer, less cleft; stipules densely pilose on the maryin; fruit (excluding the attenuate base) $1.2-1.5 \mathrm{~cm}$. long; the seed-fice more deeply and broadly concave than in the preceding; stylopodium and style 2-4 mm. long. (Washingtonia Britton.) -

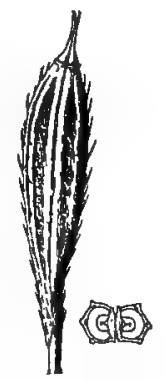

821. 0 . longistylis $\times 2$. Rich woods, e. Que. to Assima., s. to N. C.. Ill., Ia., S. Dak., and Col. Fig. 821. Var, villicaúlis Fernald. stems white-villous, - Pa. to 1ll. and Kan. 
* * Rays of the umbel without involucels.

3. 0. obtùsa (Coult. \& Rose) Fernald. Stems glabrous or sparingly pubeszent, 1.5-7 dm. high; leaves 2-3-ternate, more or less crisp-pubescent ; leaflets $1.5-6 \mathrm{~cm}$. long, acuminate, the teeth mucronate; umbels naked or obsoletely involucrate, with 3-5 naked finally very divergent rays; fruit on divergent long pedicels, the enlarged portion 8-12 $\mathrm{mm}$. long, rounded or short-beaked at tip; stylopodium depressed, bröaler than high, with the style 0.3-0.5 mm. long. (Washingtonia Coult. \& Rose.) - Rich chiefly coniferous wools, Nfd. and s. Lab. to the upper St. John Valley, N. B.; and from Assina. and B. C. to N. Mex. and Ariz.

4. 0. divaricàta Nutt. Similar, usually taller (4-10 dno, high); umbels with 3-7 ascending-sprending rays; fruit on ascending pedicels, 11-17 mm. long, with a conical beat $2 \mathrm{~mm}$. Iong; stylopodium conical, with the style about $1 \mathrm{~mm}$. long. (Washingtonia Britton.) - Rich chiefly coniferous woods, Gaspé Co., Que., to the White Mts., N. H.; also B. C. to Cal., Nev., etc.

\section{SPERMÓLEPIS Raf.}

Involucre none but involucels present. Flowers small in pedunculate compound irregular umbels. Stylopodium small, conical. Fruit thin-walled; oiltubes present. - Slender snooth bramching plants. (Name from $\sigma \pi \epsilon \rho \mu a$, seed, and $\lambda \epsilon \pi\left(s\right.$, scale, alluding $t_{1}$ ) the scurfy or bristly fruit.) LEPToca ULIS Nutt.

1. S. pàtens (Nutt.) Robinson. Stem geniculate, 3-5 dm. high; leaf-segments linear-filiform; fruit merely warty; oill-tubes many. (Leptocaulis Nutt.; Apiastrum Coult. \& Rose.) - Sandy soil and barrens, n. e. Ind. to Neb., and snuthwe'stw.

2. S. echinàta (Nutt.) Heller. Similar in habit; fruit bristly ; oil-tubes 6 . (Leptocaulis Nutt.) - Scott Co., Mo. (Eggert), and" southw.

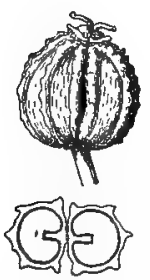

822. C. maculatum $\times 4$.

\section{Conidum L. Poison Hemlock}

Fruit somewhat flattened at the sides, glabrous, with prominent wavy ribs; oil-tubes none, but a layer of secreting cells next the seed, the face of which is deeply and narrowly concave. - Poisonous biennial, with spotted stems, large decompound leaves with lanceolate pinnatifid leaflets, involucre and involucels of narrow bracts, and white flowers. (Kúvecov, the Greek name of the Hemlock, by which criminals and philosophers were put to death at Athens.)

1. C. MACOLATUM L. A large branching herb, in waste places, Que. to Del, Pa., and westw. (Nat, from Eu.) Fig. 822 .

\section{PTILIMNIUM Raf. Mook Bishop's-weed}

Fruit ovate, glabrous ; carpel with dorsal ribs filiform to broad and obtuse, the lateral very thick and corky, those of the two carpels closely contiguous and forming a dilated obtuse or acute corky band; oil-tubes solitary; stylopodium conical; seed nearly terete. - Smooth annuals, with involucre of foliaceous bracts, involucels of prominent or minute bractlets, and white flowers. (Name unexplained by Rafinesque, presumably from $\pi \tau$ liov, a feather, or down, in allusion to the finely divided leaves.) Discopritira I)C.

1. P. capillàceum (Michx.) Raf. Plant 3-6(-18) dm. high; leaf-divisions filiform; umbel 5-20-rayed; involucre of filiform bracts usually cleft or parted, and involucels more or less prominent; fruit 2-3 mm. long, acute. (Discoplura DC.) - Brackish (rarely fresh) marshes, along the coast, Mass. to Fla. and Tex.; ]ncally n, in Miss. basin to Mo. and Kan. June-Uct. Fig. 823.
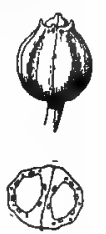

823. P. capti laceum $\times 4$ 
2. P Nuttállii (DC.) Britton. Similar in habit; involucral bracts short and entire; fruit ouly $1 \mathrm{~mm}$. long, as broad as high, blunt. (Discopleura DC.) Il. to e. Kan., La., and Tex.

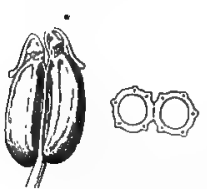

824. A. Podagraria $\times 4$.

\section{AEGOPODIUM L. GOUTWEED}

Fruit ovate, glabrous, with equal filiform ribs, and no oil-tubes; stylopodium conical and prominent; seed neariy terete. - A coarse glabrous perennial, with creeping rootstock, sharply toothed ovate leaflets, and rather large naked umbels of white flowers. (Name from alk, goat, and $\pi 6 \delta i o \nu$, a little foot, probably from the shape of the leaflets.)

1. A. Podagraria L. - Waste-heaps, etc., e. Mass. to Del. (Adv, from Eu.) Fig. 824.

\section{CICÙta L. WATER HEMLOCK}

Calyx-teeth prominent. Fruit ovoid to nearly orbicular, glabrous, with strong flattish corky ribs (the lateral largest); oil-tubes conspicuous, solitary; stylopodium depressed; seed nearly terete. - Very poisonous plants, with pinnately compound leaves and serrate leaflets, involucre usually none, involucels of several slender bractlets, and white flowers. (The ancient Latin name of the Hemlock.)

1. C. maculata L. (Spotted Cowbane, Musquash Root, Beaver Poison.) Stem stout, 1-2.2 m. high, streaked with purple; leaves 2-3-pinnate, the lower on long petioles; leaflets lanceolate to oblong-lanceolate, $3-12 \mathrm{~cm}$. long, acuminate; pedicels in the umbellets numerous, "very unequal; fruit broadly ovate to oval, 3-i3.5 mm. long, shallowly or not at all grooved at the commissure. - N. B. to Va., and westw., common. Fig. 825 .

2. C. Curtissii Coult. \& Rose. Coarser; fruit $2-3 \mathrm{~mm}$. long, subglobose, grooved at the junction of the carpels. - Va. to $\mathrm{Ky}$., and southw. - Perhaps only a variety of the preceding.

\section{C. bulbifera L, Rather slender, 3-10 dm.}
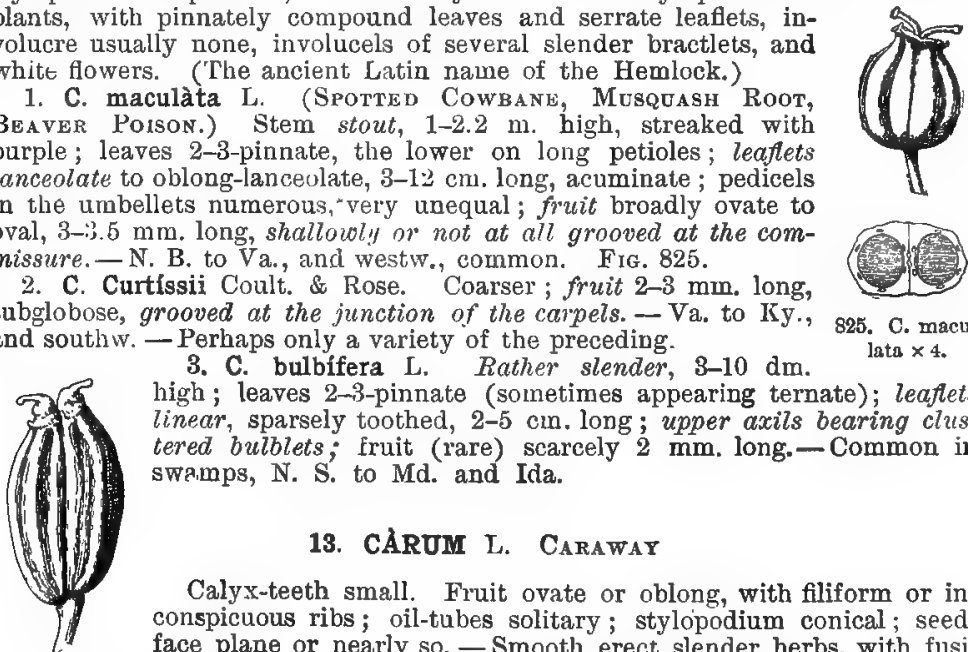
high; leaves 2-3-pinnate (sometimes appearing ternate); leaflets linear, sparsely toothed, 2-5 cu. long; upper axils bearing clustered bulblets; fruit (rare) scarcely $2 \mathrm{~mm}$. long.-Common in swamps, N. S. to Md. and Ida.

\section{CARUM L. CARAWAT}

Calyx-teeth small. Fruit ovate or oblong, with filiform or inconspicuous ribs; oil-tubes solitary; stylopodium conical ; seedface plane or nearly so. - Smooth erect slender herbs, with fusiform or tuberous roots, pinnate leaves, involucre and involucels of few to many bracts, and white (rarely pink) flowers. (Name perhaps from the country, Caria.)

1. C. CARvi L. (CARAway.) Leaves with filiform divisions. 826. C. Oarvi - Naturalized in many places, especially northward. (Nat. from r. Eu.) Fig. 828.

\section{PETroselinUm Hoffm. Parslet}

Calyx-teeth obsolete. Petals greenish-yellow, with attenuate incurved points. Fruit orate, glabrous, laterally compressed; carpels pentagonal, the primary ribs filiform, subequal; oil-tubes solitary in the intervals; stylopodium cushionlike. - Chiefly biennials, with ternately pinnate decompound leaves, toothed leaf-segments, compound umbels, few-parted involucres, and several-many-

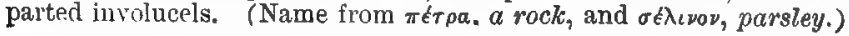


1. P. horténse Hoffm. (Common P.) Leaflets small, ovate, 3-cleft or -toothed. (P. sativum Hoffm.; Carum Petroselinum B. \& H.) - Commonly cultivated in market gardens, and occasionally found as an escape. (Introd. from the Mediterranean region.)

\section{BERULA Hoffm.}

Calyx-teeth minute. Fruit emarginate at base, glabrous; carpels nearly globose, with very slender inconspicuous ribs and thick corky pericarp; oil-tubes

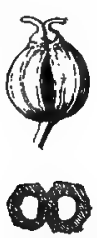

numerous and contiguous about the seed-cavity; seed terete. Smooth aquatic perennial, with simply pinnate leaves and vari. ously cut leafiets, usually conspicuous involucre and involucels of narrow bracts, and white flowers. (The Latin name of the Water Cress, of Celtic origin.)

1. B. erécta (Huds.) Coville. Erect, $2-9 \mathrm{dm}$. high ; leaflets 5-9 pairs, linear to oblong or ovate, serrate to cut-toothed, often laciniately lobed, sometimes crenate, $2-8 \mathrm{~cm}$. long ; fruit scarcely $2 \mathrm{~mm}$. long. (B. angustifolia Mertens \& Koch ; Sium angustifolium L.) - Swamps and streams, s. Ont. and Mich. to Minn., 827. B. erecta $\times 8$. southw. and westw. July, Aug. Fig. 827.

\section{SİUM [Tourn.j L. Water Pargnip}

Calyx-teeth minute. Fruit ovate to oblong, glabrous, with prominent corky nearly equal ribs; oil-tubes $1-3$ in the intervals ; stylopodium depressed ; seedface plane. - Smooth perennials, with pinnate leaves and serrate or pinnatifid leaflets, involucre and involucels of numerous narrow bracts, and white flowers. (From olov, the Greek name of some marsh plant.)

1. $\mathrm{S}$. cicutaefolium Schrank. Stout, $0.8-2 \mathrm{~m}$. high ; leaflets 3-8 pairs, linear to lanceolate, sharply serrate and mostly acuminate, $5-12 \mathrm{~cm}$. long, the lower leaves sometimes submersed and. finely dissected; fruit $2.5-3 \mathrm{~mm}$. long, with prominent ribs. ( $S$. lineare Michx.) - Muddy banks, common. FIG. 828. S. Carsonii Durand appear's to be merely a weak aquatic state or perhaps
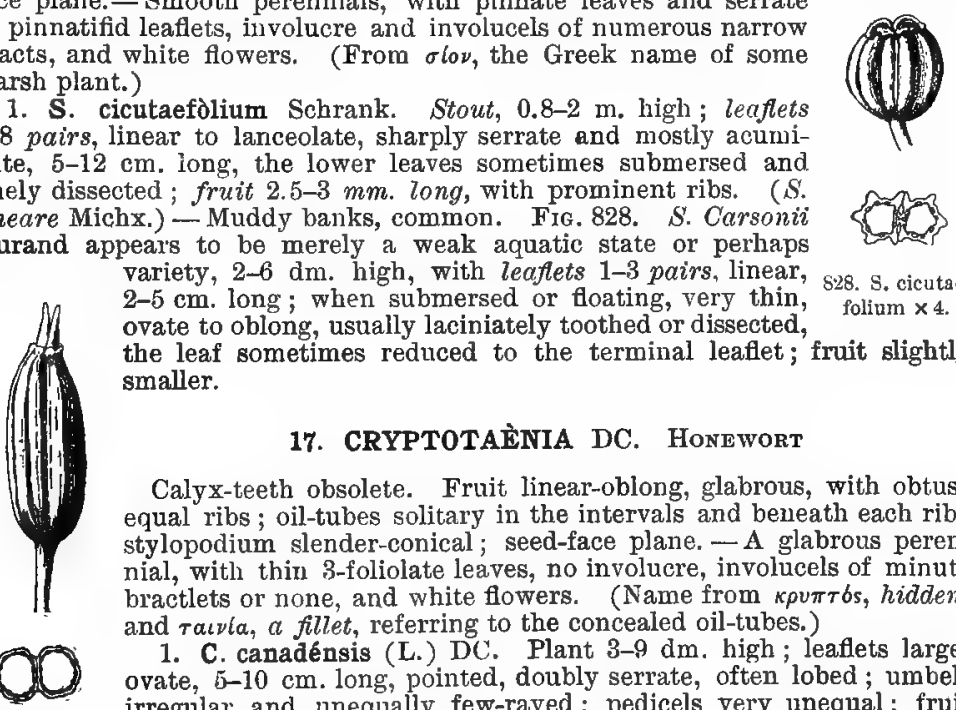
variety, 2-6 dm. high, with leaflets 1-3 pairs, linear, $2-5 \mathrm{~cm}$. long; when submersed or floating, very thin, ovate to oblong, usually laciniately toothed or dissected, the leaf sometimes reduced to the terminal leaflet; fruit slightly smaller.

\section{CRYPTOTAENIA DC. Honewort}

Calyx-teeth obsolete. Fruit linear-oblong, glabrous, with obtuse equal ribs; oil-tubes solitary in the intervals and beneath each rib; stylopodium slender-conical; seed-face plane. - A glabrous perennial, with thin 3-foliolate leaves, no involucre, involucels of minute

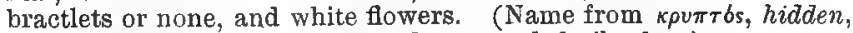
and $\tau a \iota v(a, a$ fillet, referring to the concealed oil-tubes.)

1. C. canadénsis (L.) DC. Plant 3-9 dm. high; leaflets large, ovate, $b-10 \mathrm{~cm}$. long, pointed, doubly serrate, often lobed; umbels irregular and unequally few-rayed; pedicels very unequal; fruit 829. C. cana- 4-6 mm. long; often curved. (Deringa Ktze.) - N. B. to Ga., densts $\times 4$. w. to Tex. and w. Ont. June-Sept. FiG. 829.

\section{ZÍZIA Koch.}

Calyx-teeth prominent. Fruit ovate to oblong, glabrous, with filiform ribs. Qil-tubes large and solitary in the broad intervals, and a small one in each rib; 
stylopodium wanting; seed terete. - Smooth perennials, with mostly Thaspium. like leaves, no involucre, involucels of small bractlets, yellow flowers, and the central fruit of each umbellet sessile. Flowering in spring. (Named for $1 . B$. Ziz, a Rhenish botanist.)

1. Z. aúrea (L.) Koch. (Goldex Alexanders.) Leaves (except the uppermost) 2-3-ternate, the radical very long-petioled ; leaflets ovate to lanceolate, sharply serrate, acuminate; rays 15-25, stout, $2-5 \mathrm{~cm}$. long; fruit oblong, about $4 \mathrm{~mm}$. long. - River-banks, meadows, and rich woods, e. Que. to Sask., s. to Va., Ark., and Tex. Fig. 830. Var. obtusifólia Bissell. Leaflets broader̃, rounded at tip. - Local, w. Ct.

2. Z. Bébbii (Coult. \& Rose) Britton. Slender ; leaflets somewhat coarsely serrate, the lower leaves small, inclined to be simple; rays $2-8$, slender, $5-7 \mathrm{~cm}$. long; fruit oval, $2-3 \mathrm{~mm}$. long. (Z. aurea, var. Coult. \& Rose.) - Mts., W. Va. to Ga. and Tenn.

3. Z. cordàta (Walt.) DC. Radical leaves mostly long-petioled,

B30. Z. aurea $\times 4$.

cordate or even rounder, crenately toothed, very rarely lobed or divided; stem-leaves simply ternate or quinate, with the ovate or lanceolate leaflets serrate, incised, or sometimes parted; fruit ovate, $3 \mathrm{~mm}$. long. - Ct. (Eames) to N. C., w. to Alb., Col., and westw.

\section{FOENICULUM [Tourn.] Hill. FENNEL}

Fruit oblong, glabrous, with prominent ribs and solitary oil-tubes. - Stout giabrous aromatic herb, with leaves dissected into numerous filiform segments, no involucre nor involucels, and large umbels of yellow flowers. (The Latin name, from foenum, hay.)

1. F. vUlgAre Hill. (F. officinale All.; F. Foeniculum Karst.), the cultivated FenNel from Europe, is a common escape, and somewhat naturalized in Md. and $\mathrm{Va}$.

\section{PIMTINÉLLA L.}

Fruit oblong to ovate, glabrous, with slender equal ribs, numerous oil-tubes, and depressed or cusbion-like stylopodium. - Smooth perennials, with involucre and involucels scanty or none; ours with white flowers. (Name said to be formed from bipinnula, referring to the bipinnate leaves.)

1. P. Saxffragra L. Leaves simply pinnate, with sharply toothed leaflets; fruit oblong, 2 mm. long; stylopodium cushionlike. - Roadsides and waste places, local, N. B. to Del., Pa., and O. (Nat. from Nu.)

\section{TAENIDIA Drude.}

Fruit short-oblong, flattened laterally, wingless, glabrous; oil-tubes mostly 3 in the intervals; seed subterete but the face slightly concave. Involucre and involucels mostly wanting. Flowers yellow. - Glabrous glaucous perennial, with ternate leaves. (Name from $\tau a \iota \nu l \delta i o \nu, ~ a ~ l i t t l e ~ b a n d$, in reference to the small scarcely prominent ribs.)

1. T. integérrima (L.) Drude. Slender, 5-10 dm. high;
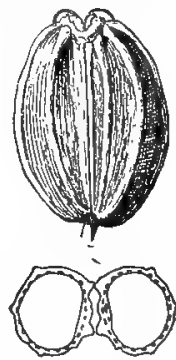

831. T. integerrima $\times 6$. leaves 2-3-ternate; leaflets lanceolate to ovate, entire; fruit oblong, $4 \mathrm{~mm}$. long. (Pimpinella Gray.) - Dry gravelly woods and thickets, w. Que. and w. N. E. to N. C., Ark., and Minn. Fig. 831.

\section{EÙLOPHUS Nutt.}

Calyx-teeth prominent. Fruit ovate or oblong, glabrous, with equal filiform ribs; eil-tubes 1-5 in the intervals; stylopodium conical, with long recurved styles; seed-face broadly concave, with a central longitudinal ridge. - Ours 


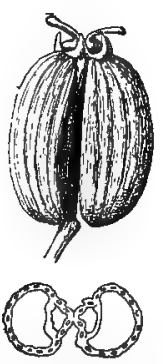

832. E. americanus $\times 4$.

with pinnately compound leaves, involucels or numerous narrowly lanceolate acuminate bractlets, and long-peduncled umbels of white flowers. (Name from $\epsilon \hat{U}$, well, and $\lambda \delta \phi \circ s, a$ crest, alluding to the calyx or perbaps to the plume-like leaves.)

1. E. americanus Nutt. Radical and lower stem-leaves large, 1-2-pinnately compound, with leaflets cut into short narrow segments; upper stem-leaves ternate, with narrowly linear elongated leaflets; fruit $4-6 \mathrm{~mm}$. long. -0 . to Mo., Tenn., and Ark. July. Frg. 832.

\section{ANTHRÍSCUS Bernh. CherviL}

Fruit linear, notched at base, beaked, glabrous, without ribs (but beak ribbed); oil-tubes none, stylopodium conical, seed-face sulcate. - Resembling Chaerophyllum in vegetative characters. (The ancient Roman name.)

1. A. Cerefólium (L.) Hoffm. Mature fruit smooth and shining. - Waste places, fields, etc., Que. and e. Pa. (Introd, from $\mathrm{Eu}_{\text {. }}$ )

\section{SCANDIX [Tourn.] L. Venus' Comb}

Fruit narrowly oblong, terminating in a long linear beak. Oil-tubes solitary at the intervals or none. Carpels subterete. Seed concave on the inner face. Slender annuals with pinnately much divided leaves and white flowers. (Ancient Greek name of the Chervil.)

1. S. Pécten-Véneris L. Sparingly pubescent, $2-5 \mathrm{dm}$. high, commonly branched from the base ; flowers nearly sessile ; the beak of the fruit $4-6 \mathrm{~cm}$. long, densely ciliate on the edges. - Waste places, especially near Atlantic ports, more sparingly westw. (Adv. from Eurasia.)

\section{BUPLEƯRUM [Tourn.] I. ThOROUGH-WAX}

Calyx-teeth obsolete. Fruit oblong, with very slender ribs, no onl-tubes, depressed stylopodium, and seed-face somewhat concave. - Smooth annual, with ovate perfoliate entire leaves, no involucre, involucels of 5 very conspicuous ovate mucronate bractlets, and yellow flowers. (Name from Bov̂s, an $o x$, and $\pi \lambda \epsilon u p b \nu, a r i b$.)

1. B. notundifótrum L. - Frequent in fields, etc., N. H. to N. C., S. Dak., and Ariz. (Nat from Eu.)

\section{LILAEÓPSIS Greene.}

Calyx-teeth small. Fruit globose or slighfly flattened laterally; dorsal ribs filiform, the lateral thick and corky; oil-tubes solitary in the intervals, 2 on the commissure. - Dwarf creeper with hollow cylindrical or awl-shaped nodose petioles in place of leaves, simple few-flowered umbels, and white flowers. (Named from its resemblance to Lilaea.) Crantzia Nutt., not Scop.

1. L. lineàta (Michx.) Greene. Leaves very obtuse, $2-8 \mathrm{~cm}$. long, $2-4 \mathrm{~mm}$. broad; fruit $2 \mathrm{~mm}$. long, the thick lateral wings forming a corky margin. (Crantzia Nutt.) - In mud of brackish marshes along the coast, N. E. to Miss. July. (Widely distributed.)

\section{CXNOSCIÁDIUM DC.}

Calyx-teeth distinct. Fruit short, glabrous, scarcely flattened; lateral ribs forming a corky margin; stylopodium conical. - Slender annuals, with pinnately divided leaves. Involucre and involucels present. Petals white. (Name from $\kappa \dot{v} \omega \nu, d o g$, and $\sigma \kappa \iota^{\prime} \delta \omega_{0},, a$ sunshade, a fanciful designation referring to the umbels, ) 
1. C. pinnatum DC. Segments of the leaves $2-3$ pairs, narrow, distant, the terminal one the longest. - MeDonald Co., Mo. (Bush) to Kan. and Tex.

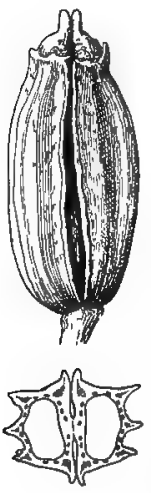

833. L. ecothieum $\times 4$.

\section{LIGÚSTICUM L. LovagE}

Fruit oblong or ovate, flattened laterally if at all, glabrous : carpels with prominent equal acute ribs and broad intervals. oil-tubes 2-6 in the intervals, 6-10 on the commissure. Stylopodium conical. - Smooth perennials, from large aromatic roots, with large ternately compound leaves, mostly no involncre, involucels of narrow bractlets, and white flowers in large manyrayed umbels. (Named from the country Liguria, where the officinal Lovage of the gardens abounds.)

1. L. canadénse (L.) Britton. (Nondo, Axgelico.) Stem stout, branched, 1-2 m. high; leaves very large, 3-4ternate; leaflets broadly oblong, 5-12 cm. long, coarsely serrate; fruit ovate, 4-6 $\mathrm{mm}$. long; seed with angled back. (L. actaeifolium of auth., not Michx.) - Rich ground, s. Pa. to Mo., and southw.

2. L. sçóthicum I. (Sсотсн L.) Stem simple, 3-6 dm. high ; leaves biternate; leaflets ovate, $2.5-5 \mathrm{~cm}$. long, coarsely toothed; fruit narrowly oblong, 8-10 $\mathrm{mm}$. long; seed with round back. - Salt marshes and rocks, along the coast from N. Y. northw. Aug. (Eu.) Fig. 833 .

\section{CORIÁNDRUM [Toum.] L. CoRIANder}

Fruit nearly globose, not at all narrowed at the commissure; ribs filiform or acutish. Seed dorsally compressed, somewhat concave on the inner face.Slender glabrous herbs, with pimately dissected leaves, compound umbels, no involucre, few-parted involucels, and white or roseate unequal petals. ('The ancient Latin name.)

1. C. SATìvom $\mathrm{L}$. Lower leaves pinnate, the leaflets flabelliform, many-cleft, cuneate at the base, upper leaves deeply cut into linear segments. - Waste places, becoming frequent. ( $\mathrm{Adv}$. from Eurasia.)

\section{Aethùsa L. Fool's Parslet}

Calyx-teeth obsolete. Fruit ovoid-globose, slightly flattened dorsally; carpel with 5 thick sharp ribs; oil-tubes solitary in the intervals, 2 on the commissure. - Poisonous annuals, with 2-3-ternately compound leaves, divisions pinnate, ultimate segments small and many-cleft, no involucre, long narrow involucels, and white flowers. (Attovoa, burning, in aliusion to the

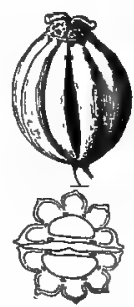

831. 1. Cynapùum $\times 4$.

bright or shining foliage, probably in transtation of the Swedish vernacular name glis.)

1. A. CYnapiom L. A fetid poisonous herb, in waste or cultivated grounds, from N. S. to Pa., Minn, and Ont. June-Aug. (Nat. from Eu.) Fig. 834.

\section{COELOPLEURUM Ledeb.}

Fruit globose to ellipsoid, with prominent nearly equal thick corky ribs (none of them winged); oil-tubes solitary in the intervals and under the ribs, 2-4 on the commissure. Seed loose in the pericarp. - Stout glabrous (or inflorescence puberulent) maritime perennials, with 2-3-ternate leaves on very large inflated petioles, few-leaved deciduous involucre, involncels of numerous small linear-lanceolate bractlets (often conspicuous or even leaf-like), and greenislwhite flowers in many-rayed umbels. (From koînos, hollow, and $\pi \lambda \epsilon u \rho b \nu, a$ rib.) 


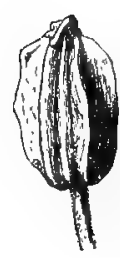

3. C. actaeifolium (Michx.) Coult. \& Rose. Stem 3-12 dm. high ; leatlets ovate, irregularly cut-serrate, $5-7 \mathrm{~cm}$. long; fruit 4-7 11m. lomg. (C. Gmelini of auth., not Ledeb.) - Rocky coasts, Mass. to Greeni. Fig. 835 .

\section{CYMÓPTERUS Raf.}

Calyz-teeth more or less prominent. Fruit usually globose, with all the ribs conspicuously winged; oil-tubes 1-several in the intervals, 2-8 on the commissure. Stylopodium depressed. Seed-face slightly concave. - Mostly low (often cespitose) glabrous perennials, from a thick elongated root, with more or less pinnately compound leaves, with or without an involucre, prominent involucels, and white flowers (in ours). (From kî́na, a wave, and $\pi \tau \epsilon \rho \delta \nu, ~ a$ wing, referring to the often undulate wings.)

1. C. acaúlis (Pursh) Rydb. Iow (1-2 dm. high), with a short

erect caudex bearing leaves and peduncles at the summit, glabrous;

885. C. actaei. folium $x$ : rays and pedicels very short, making a compact cluster; involucre none; involucel of a single palniately 5-7-parted bractlet; fruit globose, 6-8 mm. in diameter; wings rather corky; oil-tubes $4-5$ in the intervals. ( $C$. glomeratus Raf.) Minn. to Ia., Ark., and westw.

\section{THÁspiUm Nutt. Meadow Parsnip}

Calyx-teeth conspicuous. Fruit ovoid to oblong, sligintly flattened dorsally; carpel with 3 or 4 or all the ribs strongly winged; vil-tubes solitary in the intervals, 2 on the commissure. Stylopodium wanting; styles long.- P'erennials, with ternately divided leaves (or the lower simple) and broad serrate or toothed leaflets, mostly yellow flowers, and all the fruit pediceled. (Name a play upon Thapsia, so called from the island of 'Thapsus.)

1. T. aúreum Nutt. Glabrous; root-leaves mostly corlate, serrate; stem-leaves simply ternate (rarelv biternate); leaflets ovate to lanceolate, round or tapering at base, serrate; flower's deep yellow; fruit globose-ovoid, about $4 \mathrm{mmn}$. long, all the ribs equally winged. - Thickets and woodlands, n. O. to Md., Ga., Ark., and Wyo. - Fl. summer. Fra. 836.

Var. atropurpùreum (Desr.) Coult. \& Rose. Petals darkpurple. - N. J. to Ga. and Ill.

2. T. barbinòde (Michx.) Nutt. Loosely branched, pubescent on the joints, sometimes puberulent in the umbels; leaves 1-3-ternate; leaflets ovate to lanceolate, acute, with cuneate base, coarsely cut-serrate, often ternately cleft or parted; flowers light yellow; fruit broadly oblong, about $6 \mathrm{~mm}$. long and $4 \mathrm{~mm}$. broad, with mostly 7 prominent wings. - Banks of streams, N. Y. to Minn., and southw. May-June. Var. ANGUSTIFólium Coult. \& Rose, has narrower more sharply cut leâflets, and fruit more or less puberulent. - Pa. to Pt. Pelee, Ont., and IIl.

3. T. pinnatifidum (Buckley) Gray. Resembling the last, but puberulent on the branchlets, umbels, and fruit, with fewer leaves; leaflets 1-2-pinnatifid, the lobes linear or oblong; one or two leaves near the base often very large and longpetioled ; flowers ligit yellow; fruit oblong, $3-5 \mathrm{~mm}$. long and 2-3 $\mathrm{mm}$. broad, all the ribs winged, generally three of them uarrowly so. - Barrens and mts., Ky. to Tenn. and N. C.

\section{LOMÀTIUM 'Raf.}

Fruit flattened dorsally, oblong to nearly orbicular, laterally winged; oiltubes usually many. Roots fusiform. Leaves dissected. Involucre none.- 
Perennials of dry ground, nearly or quite acaulescent. Petals yellow or white. (Name from $\lambda$ Qua, $a$ border, referring to the winged fruit.) Peuchdancm of Am. auth., but scarcely of L.

1. L. orientàle Coult. \& Rose. Pubescent, 1-2 dm. high ; leaves bipinnate; petnls white or pinkish; fruit nearly round; dorsal ribs indistinct. (Peucedauum nuclicaule Nutt., in part.) - Gravelly soil, Minn. to Ia., Kan., and westw.

2. L. daucifolium (Nutt.) Coult. \& Rose. Leaves finely dissected; petals yellow; fruit oval; dorsal ribs prominent. (Peucedanum villosum Niutt., in part.) - Barrens, w. Mo. to Neb. and 'lex.

\section{PSEUdOTAENÍdia Mackenzie.}

Calyx-teeth short, thickish. Petals inferentially yellow. Fruit thickish, strongly compressed dorsally, oblong-lanceolate; carpels obcompressed, with slender dorsal ribs and broad somewhat corky lateral wings. Oil-tubes mostly solitary in the intervals. - Glabrous erect perennial, with 2-3-ternate leaves, entire leaflets and exinvolncrate compound umbels. (Name from $\psi$ evóos, false, and Taenidia, to which this recently discovered genus possesses a marked habital resemblance.)

1. P. montàna Mackenzie. Slender, erect, 5-8 dm. high; root slightly thickened; petioles broad and clasping; leaflets elliptical to lance-ovate or -oblong, entire, thin; umbels 6-12-rayed; involucels none or inconspicuous;

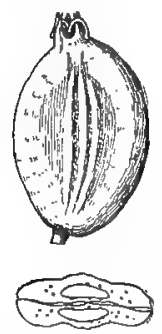

897. P. Nuttalli $\times 3$. fruit $6 \mathrm{~mm}$. long, - Clayey and rocky mountain slopes, Kate's Mt., W. Va. (Mackenzie) and Luray Cavern, Va. (Steele).

\section{POLYTAÈNIA DC.}

Calyx-teeth conspicuous. Fruit obovate to oval, much flattened dorsally ; dorsal ribs small or obscure in the depressed back, the lateral with broad thick corky closely contiguous wings forming the margin of the fruit; oil-tubes 12-18 about the seed and many scattered through the thick corky pericarp. - A perennial mostly glabrous herb, with 2-pinnate leaves (upper opposite and 3-cleft), the segments cuneate and incised, no involucre, narrow involucels, and bright yellow flowers in May. (Named from $\pi \circ \lambda \dot{v}$, many, and raıvia, a fillet, alluding to the numerous oil-tubes.)

1. P. Nuttálliii DC. Plant 5-10 dm. high ; pedicels and involucels pubescent. -- Barrens, Mich. to n. Ala., Tex., Okla., Ia., and Wisc. Fig. 837.

\section{PASTINÀCA L. PARsNiP}

Calyx-teeth obsolete. Fruit oval, very much flattened dorsally ; dorsal ribs filiform, the lateral extended into broad wings, which are strongly nerved toward the outer margin; oil-tubes small, solitary in the intervals, $2-4$ on the commissure; stylopodium depressed. - Tall stout glabrous biennial, with pinnately compound leaves, mostly no involucre or involucels, and yellow flowers. (The Latin name, from pastus, food.)

1. P. sativa L. Stem grooved; leaflets ovate to oblong. cut-toothed. - Waste places, open rich soil, etc. (Nat. from Eu.j Fig. 838 .

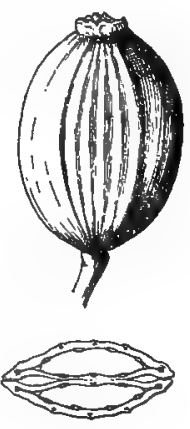

838. P. sativa $\times 8$.

\section{LEVí́sticuM [Rivinius] Hill. LovaGE}

Calyx-teeth obscure. Petals greenish-yellow, Fruit oblong, rounded at each ond, strongly ribbed, the laternl ribs moderately winged; oil-tubes solitary in the intervals, 2 on the commissure; seed flattish on the inner face. - Stont 
perennial herb, with branched stems, large bipinnate leaves with rhombicobovate and compound conspicuously involucrate umbels. (Name said to be a corruption of Ligusticum.)

1. L. OFFICisaLE (L.) Koch. Essentially glabrous; leaflets coarsely toothed toward the apex, entire at the cuneate base. (L. Levisticum Karst.) - Cultivated for the aromatic qualities especially of its seeds, and now occrsionally found as a local escape. (Introd. from s. Eu.)

\section{ANETHUM [Tourn.] L. Dill}

Petals yellow. Fruit elliptical, flattened dorsally, the lateral ribs winged. Involucre and involucels none. - Slender caulescent annuals with tinely divided leaves, and compound umbels. ("A to come from $d \theta \epsilon \iota \nu$, to burn, in allusion to the pungent seeds.)

1. A. graviolens L. Erect, glabrous, usually branched, $3-10 \mathrm{dm}$. high : leaves finely dissected, fennel-like. - Thoroughly established at Bridgeport, Ct. (Eanes), and casual on waste ground, etc., elsewhere. (Introd. from Eu.)

\section{HERACLÈUM L. Cow Parswip}

Fruit obovate, as in Pastinack, but with a thick conical stylopodium, and the conspicuous obclavate oil-tubes extending scarcely below

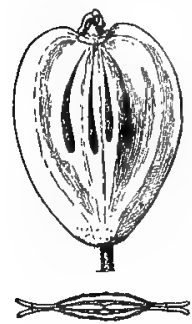
the middle. - Tall stout perennials, with large compound leaves, broad umbels, deciduous involucre, and many-leaved involucels, white or purplish flowers, and obcordate petals, the outer ones commonly larger and 2-cleft. (Dedicated to Hercules.)

1. H. lanàtum Michx. Woolly; stem grooved, $1-2.8 \mathrm{~m}$. high; ieaves ternate; leaflets broad, irregularly cut-toothed. - Wet ground, Nfd. to the Pacific, and southw. to N. C., Ky. and Kan. June. Fig. 839.

2. H. Sphondúltum L. Spreading-pubescent and somewhat scabrous; leaves pinnate; leaflets $3-7$, coarsely and rather bluntly toothed. - Casual on waste land, etc., chiefly 889. H. lanatum $\times 2$. about Atlantic ports. (Adv. from Eu.)

\section{IMPERATỎRIA [Tourn.] L.}

Calyx-teeth obsolete. Petals small, white. Fruit suborbicular or broadly elliptical, distinctly cordate at base and apex, smooth, the ribs filiform except the lateral, which are developed into a broad thin wing ; stylopodium conical; oil-tubes solitary in the intervals and as long or nearly as long as the fruit. Stately smoothish perennials, with ternately compound leaves. (From imperator, master, emperor, in allusion, it is said, to its powerful medicinal qualities.)

1. I. Ostrutthiom L. (Masterwort.) Stem hollow, 8-15 dm, high; leaflets large, ovate or obovate, serrate and commonly incised, nearly or quite glabrous ; umbels with very numerous rays exinvolucrate or nearly so; bracts of the involucels few, narrow, inconspicuous. - Formerly cultivated, now locally established in e. Pa., Mich., and perhaps elsewhere. (Introd. from Eu.)

\section{OXÝPOLIS Raf.}

Calyx-teeth evident. Fruit ovate to obovate, flattened dorsally ; dorsal ribs fliform, the lateral broadly winged, closely contiguous and strongly nerved next to the body (giving the appearance of 5 dorsal ribs); oil-tubes solitary in the intervals, 2-6 on the commissure; stylopodium short, thick-conical. - Glahro' 1 s erect aquatic herbs; involucre and involucels present, and flowers white. (Derivacion unexplained.) Tredemannia DC. 


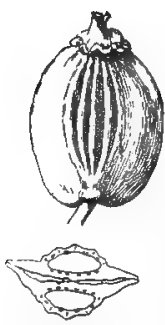

840. 0. rigidior $\times 4$.

1. 0. filifórmis (Walt.) Britton. Stem hollow, 4-20 dm. high; leaves reduced to cylindrical hollow pointed nodose petioles; fruit obovate, rounded or truncate at the ends (Tiedemannia teretifolia DC.) - Ponds, Va. to Fla. and La. Aug., Sept.

Var. Cánbyi Coult. \& Rose. Fruit short, suborbicular, retuse at both ends. - Ellendale, Del. (Canby, Commons).

2. 0. rigidior (L.) Coult. \& Rose. (Cowbaxt.) Stem 6-15 $\mathrm{dm}$. high; leaves simply pinnate, with $3-9$ linear to lanceolate remotely toothed leaflets; oil-tubes mostly small. (Tiedemannia rigida Coult. \& Rose.) - Swamps, N. Y. to Minn., s. to the Gulf. Aug. - Poisonous; roots tuberiferous. Var. AMBigua (Nutt.) Robinson (Var. longifolia Britton) with entire leaflets, occurs in N. J., and soutliw. FiG. 840.

\section{ConioselìnUm Fisch. Hemlock Parslet}

Fruit oval, flattened dorsally, glabrous, the lateral ribs extended into broad wings ; seed slightly concave on the inner face. - Tall slender glabrous рөгеnnials, with finely 2-3-pinnately compound leaves, few-leaved involucre or none, involucels of elongated (in ours) linear-setaceous bractlets, and white flowers. (Compound of Conium and Selinum, from its resemblance to these genera.)

1. C. chinénse (L.) BSP. Teaflets pinnatifid; wings nearly as broad as the seed; oil-tubes $2-3$ in the intervals, sometimes 1 or 4. (C. canadense T. \& G.) - Swamps and cold cliffs, Nfd. to Ont., s. to N. E., N. Y., Ind., Minn, and in the mts. to N. C. Aug.-Oct. FIG. 841 .

\section{ANGELICA L. Angelica}

Fruit strongly flattened dorsally ; primary ribs very prominent, the lateral extended into broad distinct wings, forming a doublewinged margin to the fruit; oil-tubes 1-several in the intervals or indefinite, 2-10 on the commissure. - Stout perennials, with ternately or pinnately compound leaves, large terminal umbels,

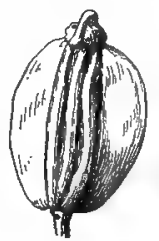
scanty or no involucres, small many-leaved involucels, and white or greenish flowers. (Named angelic from its cordial and medicinal properties.)

* Seed adherent to the pericarp; oil-tubes 1-several in the intervals; uppermost leaves mostly reduced to large inflated petioles.

1. A. Curtísii Buckley. Glabrous; leaves twice ternate or the divisions quinate; leaflets thin, ovate-lanceolate, sharply and ivregularly
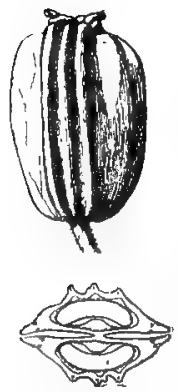

842. A. rotopurpureal $\times 3$. toothed, $2.5-8 \mathrm{~cm}$. broad; fruit glabrous, ; $-9 \mathrm{~mm}$. broad; oiltubes mostly solitary (rarely 2-3) in the intervals. - Along the Alleghenies from I'a. to N. C. A ug.

2. A. villosa (Walt.) BSP. Pubescent above; leaves twice pinnately or ternately divided; leuflets thickish, lanceolate to oblong, 1-2 cm. broad, serrate; fivit pubescent, $4 \mathrm{~mm}$. broad; oil-tubes $3-6$ in the intervals. (A. hirsuta Muhl.) - Rocky woods, w. Mass, to Minn., Tenn., and Fla. July.

3. A. srlvestris L. Puberulent above; leaves ternately bipinnate; leaflets thin, ovate to lancolate, finely serrate; fruit glabrous, $5-6 \mathrm{~mm}$. long, $3 \mathrm{~mm}$. broad; oil-tubes mostly 1 in each interval. - Old fields, Louisburg, Cape Breton I. (Macoun). (Nat. from Eu.)

* Seed loose; oil-tubes indefinite (2;-;0); upper petioles not so promimnt.

8. A. atropurpùrea L. Very stout, glabrous throughout, 
With dark purple stem; leaves 2-3-ternately divided, the pinnate segments of 5-7 lanceolate to ovate leaflets, $2-4 \mathrm{~cm}$. broad, sharply mucronate-serrate. (Archangelica Hoffm.) - Alluvial soils, Nfd. to Del., Ill., Ia., Minn., and w. ()nt. Frg. 842.

\section{TÓRILIS Adans.}

Calyx-teeth short, triangular, persistent. Fruit bristly with hooked prickles or warty, the primary ribs not so prominent as the secondary. - Erect slender caulescent annuals with bipinnate leaves, compound umbels, and dense heads of white flowers, the involucres and involucels of linear bracts. (Etymology unknown.) CAUCALIS of auth., in part.

1. T. Anrhriscus (L.) Bernh. Umbels open, lonse, long-peduncled, raised above the leaves; priclcles evenly distributed on the frutt. (Caucalis Huds.) Open woods and waste places, N. Y. to D. C., Ky., and O. (Nat. from Eu.)

2. T. NodósA (L.) Gaertn. Umbels dense, subcapitate; peduncles much shorter than the leaves; prickles often confined to one side of the elsewhere warty carpels. (Caucalis Scop.) - Similar situations, from the Middle Atlantic States westw. (Adv. from Eu.)

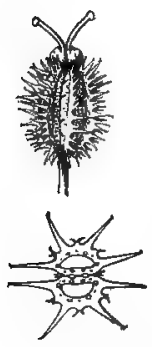

848. D. Carota $\times 31 / 3$.

\section{DaÚcús [Tourn.] L. Carrot}

Fruit oblong, flattened dorsally; stylopodium depressed; carpel with 5 slender bristly primary ribs and 4 winged secondary ones, each of the latter bearing a single row of barbed prickles; oil-tubes solitary under the secondary ribs, two on the commissural side. - Bristly anmuals or biemnials, with pinnately deconnpound leaves, foliaceous and cleft involucral bracts, and compound umbels which become strongly concave. (The ancient Greek name.)

1. D. Caróxa I. Bienuial; steun bristly; ultimate leaf-segments lanceolate and cuspidate; rays numerous. - Fields and waste places; a pernicious weed. - I'he flowers vary from white to roseate or pale yellow, the central one in each umbel usually dark purple. (Nat. from Eu.) FIG. 843.

\section{CORNÀCEAE (Dogwood FAMILY)}

Shrubs or trees (rarely herbaceous), with opposite or alternate simple leaves, the calyx-tube adherent to the 1-2-celled ovary, its limb minute, the petals (valvate in the bud) and as many stamens borne on the margin of an epigynous disk in the perfect flowers; style one; a single anatropous ovule hanging from the top of the cell; the fruit a 1-2-seeded drupe; embryo nearly as long as the albumen, with large foliaceous cotyledons. - Including two genera with us, of which Nyssa is partly apetalous. Bark bitter and tonic.

1. Cornus. Flowers perfect, 4-merous. Leaves mostly opposite.

2. Nyssa. Flowers dioeciously polygamous, 5-merous. Leaves alternate.

\section{CORNuS [Tourn.] L. CoRnel. DoGwOod}

Flowers perfect (or in some foreign species dioecions). Calyx minutely 4-toothed. Petals 4, oblong, spreading. Stamens 4 ; filaments slender. Style slender; stigma terminal, flat or capitate. Drupe small, with a 2-celled and 2-seeded stone. - Leaves opposite (except in one species), entire. Flowers small, in open naked cymes, or in close heads surrounded by a corolla-like 5nvolucre. (Name from cornu, a horn; alluding to the hardness of the wood.) 
\$1. Flowers greenish or purple in a close cluster, surrounded by a showy usually 4-bricted corolla-like white or pinkish involucre; fruit bright red.

1. C. canadénsis L. (DWarf C., Bunchberry.) Stems low and simple, 9-2: $\mathrm{cm}$. hinh, from a slender creeping and subterranean rootstock; leaves scarcely petioled, the lower scale-like, the upper crowded into an apparent whorl in sixes or fours (rarely opposite), ovate or oval, pointed; bracts of the involucre ovate, short-acuminate; flowers greenish-white or the petals purple-tipped ; fruit globular. - Damp cold woods, Lab. to Alaska, s. to N. J., W. Va., Ind., Minn., etc. June, July. (E. Asia.) - Leaves and involucres (rarely 3) often modified and variously colored.

2. C. suécica I. Similar but more slender; leaves short-oval, in 3-several pairs, not verticillate; flowers deep violet; involucral bracts ovate, obtusish, usually smaller than in the preceding. - Wooded crests of headlands and cliffs, Riviere du Loup, Que., and Nfd. to Greenl, and Alaska. July. (Borea! Eurasia.)

13. C. florida L. (Flowering D.) Tree, 4-12 m. high; leaves ovate, pointed, acutish at the base ; bracts of the involucre obcordate, $, 0,6 \mathrm{~cm}$. long; fruit ovoid. - Dry woods, from s. Me. to Ont. and s. Minn,, s. to Fla. and Tex. May, June. - Very showy in flower, scarcely less so in fruit.

§ 2. Flowers white, in open flat spreading cymes; involucre none; fruit spherical; leaves all opposite (except in mo. 11.)

* Pubescence woolly and more or less spreading.

- Eruit light blue.

4. C. circinata L'Her. (Round-Leaved C. or D.) Shrub, 2-3 m. high; branches greenish, warty-dotted; leaves round-oval, abruptly pointed, woolly beneath, 5-12 cm. broad; cymes flat; fruit light blue. - Copses, in rich or sandy soil, or on rocks, e. Que. to Man., s. to Va., Ind., Ill., Ia., and N. Dak. June, July.

5. C. Amòmum Mill. (Silky C., Kinnikinsik.) Shrub, 1-3 m. high; branches purplish; the branchlets, stalks, and lover surface of the ovate or elliptical pointed leaves silky-downy (often rusty), pale and dull, not microscopically papiliose; cymes flat, close ; calyx-teeth lanceolate ; fruit pale blue. (C. sericea L.) - Wet places, Nfd. to N. D., s. to Fla. and La. June. - C. Purpusi Koehne, with slightly narrower leaves microscopically papillose but not rusty-pubescent beneath, appears to be an inconstant form rather than a distinct species.

\section{+ + Fruit white.}

6. C. asperifdlia Michx. Branches brownish; the branchlets, etc, roughpubescent; leaves oblong or ovate, on short petioles, pointed, rough with a harsh pubescence above, and downy beneath; corolla subcylindric in bud, petals rather long; calyx-teeth minute ; fruit white, 5-6 $\mathrm{mm}$. in dianeter. - Dry or sandy soil, n. shore of L. Erie to Minn., Kan., and southw. May, June. - A rather tall shrub. C. Prfoe a Small, of $\mathbf{K} y$. and Tenn., is said to have sinaller fruit (about $3 \mathrm{~mm}$. in diameter).

7. C. Bailèyi Coult. \& Evans. Branchlets brownish, spreading-pubescent, not scabrous; leaves ovate to ovate-lanceolate, not scabrous, appressed-pubescent above, covered beneath with spreading and subappressed pubescence; corolla ovoid in bud; petals short; fruit pure wlite. - Sandy shores, etc., w. Pa. and s. Ont. to Minn. and Man.

\section{* Pubescence closely appressed, straight and silky, or none.}

8. C. stolonifera Michx. (RED-osier D.) Branches, especially the osierlitce shoots of the season, bright red-purple, smooth; leaves ovate, rounded at base, abruptly short-pointed, roughish with a minute close pubescence on both sides, whitish underneath; cymes small and tat, rather few-flowered, smooth; fruit white or lead-color (rarely blue). - Wet places, Nfd. to Mackenzie, s. to D. C., Great L, region, Ia., Neb., N. Mex., etc.; common, especially northw. - 
Multiplies freely by prostrate or subterranean suckers, and forms broad clumps 1-2 m. high. June-Aug.

9. C. strícta Lam. (STiFr C.) A shrub 2-5 m. high ; branches brownish or reddish, smooth; leaves ovate or ovate-lanceolate, taper-pointed, acutish at base, glabrous, of nearly the same hue both sides; cymes loose, flattish; anthers and fruit pale blue. - Swamps, Va. and Mo., southw. Apr., May.

10. C. paniculáta L'Hér. Shrub 1-2.5 m. high, much branched; branches gray, smooth; leaves ovate-lanceolate, taper-pointed, acute at base, whitish beneath but not downy; cymes convex, loose, often panicled: fruit white, depressed-globose, on bright red pedicels. (C. candidissima Marst. ?, not Mill.) Thickets and river-banks, centr. Me. to Ont., Minn., and southw. June, July.

$\checkmark$ 11. C. alternifòlia T. f. Shrub or tree $2-6 \mathrm{~m}$. high; branches greenish, streaked with white, the alternate leaves clustered at the ends, ovate or oval, long-pointed, acute at base, whitish and minutely pubescent beneath; cymes very broad and open; fruit deep blue, on reddish stalks. - Copses, e. Que. to w. Ont., Minn., and Ia., s. to Ga. and Ala. May, June.

\section{NÝssa L. Tupelo. Pepperidge. Sour Gum}

Flowers borne at the summit of axillary peduncles. Stam. Fl. numerous. Calyx small, 5-parted. Petals as in fertile flower or none. Stamens 5-12, oftener 10, inserted on the outside of a convex disk. No pistil. Pist. Fl. solitary, or $2-8$, sessile in a bracted cluster, much larger than the staminate flowers. Petals very small and fleshy, deciduous, or often wanting. Stamens $5-10$, with perfect or imperfect anthers. Style elongated. Drupe ovoid or ellipsoid. -Trees with entire or sometimes angulate-toothed alternate leaves and greenish flowers. (The name of a Nymph: "so called because it [the original species] grows in the water.")

V 1. N. sylvática Marsh. (BLAcK Gum.) Middle-sized tree, with horizontal branches; leaves oval or obovate, commonly acuminate, glabrous or villouspubescent when young, at least on the margins and midrib, shining above when old ; fertile flower's 3-8, at the summit of a slender peduncle; fruit ovoid, acid, bluish-black, about $1.2 \mathrm{~cm}$. long. ( $N$. multiflora Wang.) - Rich soil, either moist or nearly dry, s. Me. and n. Vt. to Mich., s. to Fla. and Tex. Apr., May. - Leaves turning bright crimson in autumn. Wood firm, close-grained.

Var. bifldra (Walt.) Sarg. Leaves narrower, subcoriaceous, more obtuse; stone decidedly furrowed. ( $N$. biflora Walt.) - Marshes, southw.; sometimes well marked.

2. N. aquática L. A large tree; leaves oblong or ovate, sometimes slightly cordate at base, long-petioled, entire or angulate-toothed, pale and downy-pubescent beneath, at least when young, 1-3 dm. long ; fertile flower solitary on a slender peduncle; fruit ellipsoid, blue, $2.5 \mathrm{~cm}$. or more in length. (N. uniflora Wang. - Deep swamps, s. Va. to s. IIl. and Mo., s. to Fla. and Tex. Apr. Wood soft; that of the roots very light and spongy.

\section{ERICACEAE (Heath Family)}

Shrubs, sometimes herbs, with the flowers regular or nearly so; stamens as many or twice as many as the 4-5-lobed or 4-5-petaled corolla, free from but inserted with it; anthers 2-celled, commonly appendaged, or opening by terminal chinks or pores, introrse (except in Subfamily I); style 1; ovary 3-10-celled. Pollen compound, of 4 united grains (except in Subfamily II). Seeds small, anatropous. Embryo small, or sometimes minute, in fleshy albumen.-A large family, very various in many of the characters, ours comprising four well-marked subfamilies. 


\section{Subamily I. PYrolofdeat (Pyrola Subeamly)}

Calyx free from the ovary. Corolla polypetalous. Anthers extrorse in the bud, opening by pores at the base (inverted in the flower). Seeds with a loose and translucent cellular coat, much larger than the nucleus.

Tribe I. CLetrhreaE. Shrubs or trees, with deciduoitr foliage (in ours). Pollen-gralns simple.

Capsule 3-celled.

1. Clethra. Sepals and petals 5. Stamens 10. Style 3-cleft at the apex.

Tribe II. PYRdLEAE. Herbaceous or nearly so, with evergreen foliage. Pollen-grains compound. Capsule 5(rarely 4)-celled.

2. Chimaphila. Stems leafy. Flowers corymbed or umbeled. Petals widely spreading. Style very short and top-shaped. Falves of the capsule smooth on the edges.

8. Moneses. Scapo 1-flowered. Petals widely spreading. Style straight, exserted; stjgma 5-rayed. Valves of the capsule smooth on the edges.

4. Pyrola. Acaulescent. Flowers in a raceme. Petals not widely spreading. Filaments awlshaped. Style long. Valves of the capsule cobwebby on the edges.

\section{Subfamily II. MONOtropoldeat (Indian Pipe Subfamily)}

Flowers nearly as in Subfamily I or III, but the plants herbaceous, root-parasitic or saprophytic, entirely destitute of green foliage, and with the aspect of Beech Drops. Seeds as in Subfamily $\mathrm{I}$.

* Corolla of 4 or 5 separate petals; calyx imperfect or bract-like.

5. Monotropa. Petals narrow. Anthers kidney-shaped, opening across the top.

* * Corolla gamopetalous; anthers 2-celled.

6. Pterospora. Corolla ovold, 5-toothed. Anthers 2-8wned on the back, opening lengthwise.

7. Monotropsis. Corolla broadly bell-shaped, 5-lobed. Anthers opening at the top.

\section{Subfamily III. ERICofdeae (Heate Subfamily)}

Calyx free from the ovary. Corolla gamopetalous, rarely polypetalous, hypogynous. - Shrubs or swall trees.

Tribe I. RHODODENDREAE. Fruit a septicides capsule. Corolla deciduons.

* Flowers developed from scaly buds.

+ Scales or bracts cadtucous; anther-celis opening by a hole or chink at the top.

8. Ledum. Corolls regular, all 5 petals nearly separate. Stamens 5-10. Leaves evergreen.

9. Rhododendron. Flowers usually 5-merons. Corolla bell-shaped or funnel-form, lobed or parted, often somewhat irregular. Leaves decfduous or evergreen.

10. Menziesia. Corolla globular-bell-shaped, 4-toothed. Stamens 8. Leaves deciduous.

++ Bud-seales firm and persistent; anther-cells opening lengthwise; lesves evergresa.

11. Leiophyllum. Corolia of 5 separate petals, Stamens 10 , exserted.

12. Loiselouria. Corolla deeply 5-cleft. Stamens 5, included.

* * Flowers not from scaly buds; the bracts leaf-like or coriaceons.

18. Kalmia. Corolla broadly bell-shaped or wheel-shaped, with 10 pouches receiving as many anthers. Leaves oblong or linear.

14. Phyllodoce. Corolla ovoid or urn-shaped, Leaves narrow and heath-like.

Tribe II. ANDROMEDEAE. Fruit a loculicidal capsule (berry-like in no. 22). Corolla decidaous.

* Calyx dry, not becoming fleshy after flowering.

+ Anther-cells opening only at the top; corolls not salver-shaped.

+ Corolla campanulate, 4-5-lobed or -parted; heath-like, with acerose imbricated leaves.

15. Cassiope. Calyz of ovate imbricated sepals. Capsule globular-ovoid, 4-5-valved, the valves s-eleft. 
$++*+$ Corolla ureeolate to oylindrical, 5-toothed; not heath-like.

16. Leucothoë. Calyx slightly or much inbrioated, naked or bibracteato. Corolla ovoid or rylindraceous. Capsule depressed, 5-lobed, the valves entire.

17. Andromeda. Calyx ralvate and very early open, nakerl. Anthers 2-4-awned. Capsule defrressud-globose to olmovold, not thickened at the sutures. Seeds mostly banging on the central placenta.

18. Lyonia. Calyx, "te, much as in Andromeda. Anthers awnless. Cupsule 5-angled, the sutures with corky or spongy thickenings.

19. Chamaedaphne. Calyx of rigid imbrịcated ovate sepals, bibracteate. Corolla cylindraceous. Capsule splitting when ripe into an outer and inner layer, the inner of 10 valves.

20. Oxydendrum. Calyx short, early open, naked. Capsulo slender-pyramidal. Seels all ascenting. A snuall tree.

+ + Anther-cells opening through their whole length, not appendaged.

21. Epigaea. Corolla salver-shaped. Calyx of 5 separate dry and pointed sepals. * * Caly $\mathrm{x}$ becoming enlarged and berry-like in fruit.

22. Gaultheria. Calyx 5-cleft, in fruit inclosing the capsule. Anthers 4-awned at top.

Tribe 1II. ARBÙTEAE. Fruit indehiscent, a berry or drupe. Corolla deciduous.

28. Arctostaphylos. Corolla ura-shapel. Drupe berry-like, 5-10-seeded.

Tribe IV. ERICEAE. Corolla persistent, becoming scarious. Capsule septicidal.

24. Calluna. Corolla bell-shaped, 4-jarted. Leaves minute, opposite, imbricate.

\section{Subramily IV. VACCINOfDEAE (Whortemberie Subamly)}

Calyx-tube adherent to the ovary, which forms an edible berry or berry-like fruit, crowned with the short calyz-teeth. Anther-cells opening at the apex.Shrubs or' somewhat woody plants, with scaly buds.

25. Chiogenes. Berry t-celled, many seeded, its snmmit free. Anther-cells not prolonged into a tube, but each 2-pointed, Slender trailing evergreen.

26. Gaylussacia. Ovary 10-celled, with a single ovule in each cell. Fruit a berry-like drupe with 10 small seed-like nutlets.

27. Vaccinium. Berry 4-5-celled (or imperfectly $8-10$-celled by false partitions), many-seeded. Anther-cells tapering upward into a tube.

\section{Clèthra [Grohov.] L. White Alder}

Sepals imbricated in the bud. Petals obovate-oblong. Anthers arrow-shaped, erect in the bud, becoming inverted. Style slender. Capsule "s-valved, inanyseeded, inclosed in the caly $x$. - Shrubs or trees, with alternate serrate deciduous leaves, and white flowers in terminal hoary racemes. Bracts deciduous. (K $\lambda \eta \theta \rho a$, the ancient Greels name of the Alder, which this genus somewhat resembles in foliage.)

1. C. alnifolia L. (SweEt Pepperausi.) Shrub 1-3 w. high ; leaves 3.5-7 $\mathrm{cm}$. long, wedge-obovate, sharply serrate, entire toward the base, prominently struight-veined, smooth, green both sides; racemes upright, usually panicled; petals white, rarely pink; bracts shorter than the flowers; filaments smooth. Wet copses, Me. to Fla., mostly near the coast. July-Sept.

2. C. acuminàta Michx. A tall shrub or small tree; leaves oval or oblong, pointed, thin, finely serrate, $7-15 \mathrm{~cm}$. long, pale beneath; racemes solitary, flexuous or drooping; bracts longer than the flowers; filaments and pods hairy. - Woods in the Alleghenies, Va. to Ga. July, Aug.

\section{Chimáphila Pursh. Pipsissewa}

Petals 5, concave, orbicular. Stamens 10 ; filaments enlarged and hairy in the middle; anthers as in Pyrola, but more or less conspicuously 2-horned. Style nearly immersed in the depressed summit of the globular ovary; stigma 
broad and orbicular, disk-shaped, the border 5-crenate. Capsule, etc., as in Pyrola, but splitting from the apex downward. - Low nearly herbaceous plants, with long running underoround shoots, and thick shining leaves, somewhat whorled or scattered along the short ascending stems; the flowers pink or roseate, on a terminal peduncle. (Name from $\chi \in \hat{\imath} \mu \alpha$, winter, and $\phi \iota \lambda \epsilon i ̂ \nu$, to love, in allusion to one of the popular names, viz. Wintergrem.)

1. C. umbellàta (L.) Nutt. (Prince's Pine, Pipsissewa.) Leafy, 1-4 dm. high; leaves wedge-lanceolate, sharply serrate, not spotted; peduncles 2-8flowered; petals flesh-color; anthers violet. - Dry woods, N. S. to Ga., w. to the Pacific. July, Aug, (Mex., Eurasia.)

2. C. maculàta (L.) Pursh. (Spotté Wintergreen.) Stem 1-2.5 dm. high ; leaves lanceolate or ovate-lanceolate, obluse at the base, remotely toothed, the upper surface variegated with white; peduncles 1-5-flowered. - Dry woods, Mass, to Ont., Minn., and southw. June, July.

\section{MONEses Salisb. One-frowered Prrola}

Petals 5, orbicular. Filaments awl-shaped, naked; anthers as in Pyrola, but conspicuously 2-horned. Stigma large, peltate, with 5 narrow and conspicuous radiating lobes. (Flowers occasionally tetramerous.) - Intermediate between Pyrola and Chimaphila. (Name formed of $\mu$ ovos, single, and $\bar{j} \sigma \iota s$, delight, from the pretty solitary flower.)

1. M. uniflora (L.) Gray. A small perennial; the rounded and veiny serrate thin leaves, $1-3 \mathrm{~cm}$. long, clustered at the ascending apex of creeping subterranean shoots; the 1-2-bracted scape, $3-13 \mathrm{~cm}$. high, bearing a fragrant waxy-white or rose-colored terminal flower $1-2 \mathrm{~cm}$. wide. (M. grandiflora S. F. Gray.) - Deep cold woods, Lab. to Alaska, s. to Pa., Mich., Minn., and in the Rocky Mts. June, July. (Eurasia.)

\section{PÝrola [Tourn.] L. Wintergreen. Shim Leaf}

Calyz 5-parted, persistent. Petals 5, concave and more or less converging, deciduous. Stamens 10 ; filaments naked; anthers extrorse in the bud, but in the flower inverted by the inflexion of the apex of the filament, more or less 4-celled, opening by a pair of pores at the blunt or somewhat 2-horned base (by inversion the apparent apex). Stigma 5-lobed or 5-rayed. Capsule depressed-globose, 5-lobed, 5-valved from the base upward (loculicidal). Seeds minute, innumerable, resembling sawdust, with a very loose cellular-reticulated coat. - Low and smooth perennial herbs, with running subterranean shoots, bearing a cluster of roundish petioled evergreen basal leaves, and a simple raceme of nodding flowers, on an upright more or less scaly-bracted scape. (Name a diminutive of Pyrus, the Pear-tree, from some fancied resemblance in the foliage.)

* Style straight, much narrower than the peltate 5-rayed stigma; pelals and stamens erect and connivent; anthers not narrowed below the openings.

1. P. minor L. Scape $0.5-2 \mathrm{dm}$. high ; leaves roundish, slightly crenulate, thickish, mostly longer than the margined petiole; flowers small, crowded, white or rose-color; calyx-lobes triangular-ovate, very much shorter than the nearly globose corolla; style short and included. - Cold woods, Lab. to Alaska, s, to N. S., N. B., n. N. E., Mich., Minn., etc. (Eurasia.)

2. P. secúnda L. Subcaulescent, 1-2.5 dm. high ; leaves ovate, mucronate, longer than the petiole, scattered, crenate-serrate; racemes dense and spike-like, the numerous small greenish-white flowers all turned to one side, scarcely nodding; calyx-lobes ovate, very much shorter than the oblong-oval petals; style long, exserted. - Rich woods, Lab. to Alaska, s. to Md., Mich., Neb., etc. June-Aug. (Eurasia.)

Var. obtusàta Turcz. is a smaller plant, with thin pale rounded leaves more crenulate, and a 3-8-flowered scape of whiter flowers. (Var. pumila Gray.) -- 
Peat-bogs and cold mossy woods, s, to N. S., n. and w. N. E., mts. of Pa., Mich. etc. (Asia.)

* * Style strongly declined, the apex curved upward, longer than the conniven, or spreading petals; stigma much narrower than the truncate excavatec ring-like apex of the style; anthers contracted below the openings, forming a short neck; leaves denticulate or entire.

\section{- Petals white or greenish-white.}

3. P. chlorántha sw. Leaves small (rarely 3 or $4 \mathrm{~cm}$. long), roundish, thick dull, shorter than the petiole, or even wanting; scape few-flowered, naktd ol with a single small bract, $0.5-3 \mathrm{dm}$. high; calyx-lobes roundish-otate, very shor, the elliptical obtuse petals converging, greenish-white; anther-cells contractec into a distinct neck; style little exserted. - Open woods, Lab. to B. C., s. to D. C. Ill., Mich., Wisc., etc. June, July. (Fu.)

P. oxypétala Aust., described in 1867 from a wooded hill near Deposit, Delaware Co., N. Y., has not since been collected. It was probably an anomalous development of no. 3 , in which the leaves and petals were acute or even subacuminate.

4. P. ellíptica Nutt, (Shin Lesw.) Leaves thin and dull, elliptical or obo. vate-oval, longer than the margined petiole; raceme many-flowered; calyx-lobes ovate, acute, not one fourth the length of the obovate rather spreading whitisk. petals; anther-cells blunt. - Dry woods and thickets, e. Que. to B. C., s. tc I). C., Ill., Mich., Wisc., Ia., etc. June, July.

5. P. americàna Sweet. Leaves orbicular to broadly elliptic, thick, shining usually as short as the petiole; scape bracted, 1-3.5 dm. high; raceme elon. gated, many-flowered; calyx-lobes lanceolate or oblong-lanceolate, acutish, with somewhat spreading tips, one half or one third the length of the roundish. obovate rather spreading thick white petals; corolla $1.5-2 \mathrm{~cm}$. broad; anther. cells mucronate. ( $P$. rotundifolia Man. ed. 6, not L.) - Open or sandy woods. P. E. I. and N. S. to S. Dak. and Ga. June-Aug.

$$
++ \text { Petals pink or rose-purple. }
$$

6. P. asarifolia Michx. Leaves transversely broad-elliptic or round-reniform, cordate, coriaceous, glossy; scapes 1-3 dm. high, bracted; raceme loose, elongated, the flowers $1-1.5 \mathrm{~cm}$. broad; calyx-lobes ovate or ovate-triangular. ( $P$. rotundifolia, var. Hook.) - Alluvial woods and swamps, e. Que. to Yukon. s. to N. S., n. N. E., n. N. Y., n. Mich., and Col. June-Aug. (Asia.) Passing tc

Var. incarnàta (Fisch.) Fernald. Leaves obovate to suborbicular, roundea at base, rather dull; scapes 1-5 dm. high. ( $P$. uliginosa Torr.) - Bogs and mossy woods, Nfd. to Alaska, s. to n. N. E., centr. N. Y., Mich., Wisc., Col., and Cal. (Asia.)

\section{5. monotropa L. Indian Pipe. Pinegap}

Calyx of 2-5 lanceolate bract-like scales, deciduous. Corolla of erect spatulate or wedge-shaped scale-like petals, which are gibbous or saccate at the base. and tardily deciduous. Stamens 8 or 10 ; filaments awl-shaped; anthers becoming 1-celled. Style columnar; stigma disk-like, 4-5-rayed. Capsule ovoid, 8-10-grooved, 4-5-celled, loculicidal; the very thick placentae covered with innumerable mainute seeds, which have a very loose coat. - Low and fleshy herbs, tawny, reddish, or white, parasitic on roots, or growing on decomposing vegetable matter; the clustered stems springing from a ball of matted fibrous rootlets, furnished with scales or bracts in place of leaves, 1-several-flowered; the summit at first nodding, in fruit erect. (Name composed of $\mu$ óvos, one, and

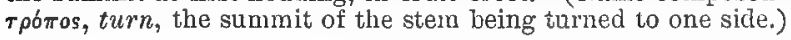

\$1. EUMONÓTROPA Gray. Plant inodorous, 1-flowered; calyx of 2-4 irregular scales or bracts; anthers transverse, opening equally by 2 chinks; style short and thick.

1. M. uniflora L. (Indian Pipe, Corpse Plant.) Smooth, waxy-white, - Alesh-color, or rarely deep red, turning blackish in drying, 0.5-3 dm. high; 
stigma naked. - Dark and rick woods, nearly throughout the continent. JuneAug. (Mex., Asia.)

§2. HYPÓPITYS [11ll.] Gray. Plant commonly fragrant; flowers several in a scaly raceme, the terminal one usually 5-merous, the rest 3-4-merous; bract-like sepals mostly as many as the petuls; anther's opening by a continuous line into 2 very unequal valves; style longer than the ovary, hollow.

2. M. Hypópitys L. (Pinesap, False Beech Drops.) Somewhat pubescent or downy, tawny, whitish, or red, 1-4 dm. high; pod globular or ovoid; stigma ciliate. (Hypopitys Small ; H. lanuginosa Nutt.; $H$. americana Small.) - Rich woods. June-Oct. (Mex., Eurasia.)

\section{PTERÓSPORA Nutt. Pine Drops}

Calyx 5-parted. Corolla ovate, urn-shaped, persistent. Stamens 10. Style short; stigma 5-lobed. Capsule globose, depressed, 5-lobed, 5-celled, loculici, dal, but the valves coliering with the columella. Seeds very numerous, ovoid, tapering to each end, the apex expanded into a broad reticulated wing many times larger than the body of the seed. - A stout and simple purplish-brown clammy-pubescent ront-parasitic herb, 3-9 dm. high; the wand-like stem furnished towards the base with scattered lanceolate scales in place of leaves, above bearing many nodding white flowers, in a long bracted raceme. (Name from $\pi \tau \epsilon \rho \delta \nu, a$ wing, and $\sigma \pi o \rho a ́$, seed, alluding to the singular wing borne by the seeds.)

1. P. andromedèa Nutt. - Hard clay soil, parasitic apparently on the roots of pines, P. E. I. to B. C., s. to Pa., Mich., and in the mts. to Mex.; rare. June-Aug.

\section{MONOTRÓPSIS Schwein. Sweet Pinesap}

Calyx of 5 oblong-lanceolate acute scale-like sepals, erect, persistent. Corolla persistent, rather fleshy, slightly 5-gibbous at the base. Stamens 10 ; anthers much shorter than the filaments, fixed near the summit, awnless, with two sacshaped cells. Capsule ovoid, 5-celled, with a short and thick style, and a large 5-angular stigma. Seeds inuumerable. - A low and smooth brownish plant, 0.5-1 dm. high, with the aspect of Monotropa, scaly-bracted, the flowers several in a terminal spike, at first nodding, flesh-color, with the fragrance of violets. (Name from Monotiopa and bíts, appearance, from resemblance to that genus.) Sohweinitzia Ell.

1. M. odoràta Ell. - In woods, Md. to N. C. Apr., May.

\section{LẼDUM L. LABrador Tea}

Calyx 5-toothed, very small. Corolla of 5 obovate and spreading petals. Capsule 5-celled, splitting from the base upward, many-seeded; placentae borne on the summit of the columella. - Low shrubs, with the alternate entire leaves clothed with rusty wool underneath, persistent, the margins revolute; herbage fragrant when bruised. Flowers white, small, in terminal umbel-like clusters. ( $\Lambda$ joov, the amcient Greek name of the Cistus.)

1. L. groenlándicum Oeder. Erect, $1 \mathrm{~m}$. or less high; leaves oblong or linear-oblong, $2-5 \mathrm{~cm}$. long, very obtuse; stamens $5-7$; capsule slender, subcylindric, acutish. (L. latifolium Ait.) - Bogs, damp thickets, and mountainslopes, common northw., s. to Ct., N. J., Pa., Mich., Wisc., Minn., etc. May. June, rarely to Aug. (Greenl.)

2. L. palústre L. Lower, at most $6 \mathrm{dm}$. high ; lours narrovoly linear, 1-3 cm, long; stamens mostl! $7-11$; capsule ellipsoid-ovoid. - Arctic regions, s. to Nfd. 
Var. dilatàtum Wahlenb. Leaves broader, linear-oblong, 1-4 cm. long. -Nfd., e. Que., Mt. Katahdin, Me., and apparently on the Great Lakes, and northw. (Eurasia.)

\section{RHODODÉNDRON L.}

Calyx mostly small or minute. Stamens sometimes as few as the corollalobes, more commonly twice as many, usually declined; anther-cells opening by a round terminal pore. Capsule 5-celled, 5-valved, many-seeded. Seeds scalelike. - Shrubs or small trees, of diverse habit and character, with chiefly alternate entire leaves, and large and showy flowers in umbeled clusters from

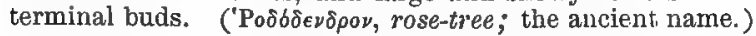

§1. AZALEA (L.) Planch. Leaves deciduous, glandular-mucronate; stamens (5-10) and style more or less exserted and declined.

* Flower-buds of numerous much imbricated scales; corolla with conspicuous funnel-form tube; stamens (chiefly 5) and style long-exserted; $0.6-6 \mathrm{~m}$. high, with leaves obovate to oblong-oblanceolate.

\section{- Flowers appearing after the leaves.}

1. R. arboréscens (Pursh) Torr. (Sмоотн Azalea.) Branchlets smooth; leaves obovate, obtuse, very smooth both sides, shining above, glaucous beneath, the margins bristly-ciliate; calyx-lobes long and conspicuous; corolla slightly clammy, rose-colored, fragrant. (Azalea Pursh.) - Mts. of Pa., southw. June. $\checkmark$ 2. R. viscosum (L.) Torr. (Clammy Azalea, White Swamp HonexsuckLe.) Branchlets bristly, as well as the margins and midrib of the oblong-obovate otherwise smooth leaves; calyx-lobes minute; corolla clammy, the tube much longer than the lobes. (Azalea L.) - Swamps, mostly near the coast, Me. to O., Ark., and soutlww. June, July. Var GLAúcuM (Michx.) Gray. Jeaves paler, often white-glaucous underneath or on both sides, sometimes rough-hairy. - N. E. to Va. Var. Níridum (Pursh) Gray. Dwarf, with oblanceolate leaves green both sides. - N. E. to Va.

\section{+- + Flowers appearing before or with the leaves.}

3. R. nudiflorum (L.) Tolr. (Purpe A., Pinxtir Flower.) Leaves oblanceolate to obovate, sparingly pubescent, or glabrate except on the ciliolate margins and strigose midrib (beneath); pedicels strigose-hairy; corolla fleshcolor, pink or purple, the tube strigose or slightly glandular, scarcely longer than the ample lobes; capsule strigose, 1.5-3 cm.long. (Azalea L.) -Open woods and swamps, Mass. to Fla. and Tex.; locally n. in Miss. basin to Union Co., Ill. (Gleason.) May, June.

t. R. canéscens (Michx.) G. Don. Similar; leaves ovate, obovate, or elliptic, softly pubescent beneath, especially when young; pedicels, corolla-tube, and capsule (1.2-1.8 cm. long) glandular. (Azalea Michx.) - Woods and gravelly shores, N. H. to N. Y., and southw. May, June. - Sometimes too near the preceding species.

5. R. calendulàceum (Michx.) 'Torr. (Flame-colored A.) Leaves hairy ; tube of the corolla shorter than the lobes, hairy. (Azalea Michx.; A. lutea L., not $R$. luteum 'Sweet.) - Woods, s. N. Y. and mts. of Pa. to Ga. May. - Cov- ered as the leaves appear with large orange blossoms, usually turning to flamecolor, not fragrant.

* * Flonoer-buds of fewer and early caducous scales; corolla irregular (asually earlier than the leaves), with short or hardly any tube, anterionly divided to the base; the limb equaling the 10 stamens and style.

6. R. canadénse (L.) BSP. (Rhodora.) Shrub, $1 \mathrm{~m}$. or less high; young parts sparingly strigose-hairy; leaves oblong, pale, more or less pubescent; corolla rarely 2 crn. long, purplish-rose-color (rarely white), bilabiate, with the posterior lip 3-lobed, the anterior of 2 oblong-linear and recurving nearly or quite distinct petals. (Rhodora L. ; Rhododendron Rhodora Gmel.) - Swamps and damp slopes, Nfd. to w. Que., Pa. and N. J. May, June (rarely July). 
§2. EURHODODENDRON DC. Leaves coriaceous and persistent; stamens (comnonly 10) and style rarely exserted, somewhat declined, or sometimes equally spreading.

7. R. máximum L. (Great Lavrez.) Shrub or tree, 2-10 m. high ; leaves 0.8-2 dm. long, very thick, elliptical-oblong, or lance-oblong, acute, narroved toward the base, very smooth, with somewhat revolute margins; pedicels viscid; corolla bell-shaped, $3.5-5 \mathrm{~cm}$. broad, pale rose-color or nearly white, greenish in the throat on the upper side, and spotted with yellow or reddish. - Damp deep woods, rare from N. S., Me., and Que. to Ont. and O., but very common through the Alleghenies from N. Y. to Ga. June, July.

8. R. catawbiénse Michx. (Mountain Rose BAy.) Leaves oval or oblong, rounded at both ends, smooth, pale beneath, $0.5-1.5 \mathrm{~cm}$. long; corolla broadly bell-shaped, lilac-purple; pedicels rusty-downy. - High Alleghenies, Va. to Ga. June.

9. R. lappónicum (L.) Wahlenb. (LuAPLAXD Rose BAYY.) Dwarf, prostrate in broad tufts; leaves $0.5-1.5 \mathrm{~cm}$. long, elliptical, obtuse, dotted (like the branches) with rusty scales; umbels few-flowered; corolla open bell-shaped, dotted, violet-purple; stamens 5-10. - Alpine summits, N. Y., N. H., and Me. to the Arctic regions. June, July. (Arctic Eurasia.)

\section{MENZIÈSIA Sm.}

Calyx small and flattish, 4-toothed or 4-lobed. Corolla cylindraceous-urnshaped, soon beli-shaped. Stamens included; anther-cells opening by an oblique pore. Capsule ovoid, woody, 4-celled, 4-valved, many-seeded. Seeds narrow, with a loose coat. - Low shrubs, the straggling branches and the alternate leaves usually hairy and ciliate with rusty rather chaff-like bristles. Flowers small, developed with the leaves, in terminal clusters, greenish-white and purplish, nodding. (Named for Archibald Menzies, who in Vancouver's voyage brought the original species from the Northwest Coast.)

1. M. glabélla Gray. Strigose-chaffy scales mostly wanting ; leaves obovate, barely mucronate-tipped, glabrous or nearly so ; filaments ciliate below; capsule glabrous or nearly so ; seeds long-caudate at each end. - Minnesota Point, L. Superior, and northwestw. June, July.

2. M. pildsa (Michx.) Pers. More or less chaffy; leaves obovate-oblong, prominently glandular-mucronate, strigose-hirsute especially above; filaments glahrous; capsule beset with short gland-tipped bristles; seeds merely apiculate. (M. globularis Salisb.) - In the Alleghenies from Pa. to Ga. May-July.

\section{Leiophýllom Pers. Sand Mrrtle}

Calyx 5-parted. Corolla of obovate-oblong petals, spreading. Style filiform. Capsule 2-3-celled, splitting from the apex downward, many-seeded. - A low much branched evergreen, with the aspect, foliage, etc., of Ledum, but the crowded leaves sometimes opposite, scarcely petioled. Flowers small, white, in terminal umbel-clusters. (Name formed of $\lambda \epsilon \hat{i} o s$, smooth, and $\phi \hat{u} \lambda \lambda_{o \nu}$, leaf.) Dendriug Dest.

1. L. buxifolium (Berg.) Ell. Shrub, 1-9 dm. high ; leaves oval or oblong, smooth and shining, 8-13 mm. long. - Sandy pine barrens, N. J. to Fla. May, June.

\section{LOISEleUtria Desv. Alpine Azalea}

Calyx 5-parted, nearly as long as the bell-shaped regular corolla. Stamens not declined. Style short. Capsule ovoid, 2-3-celled, many-seeded, 2-3-valved ; valves 2 -cleft from the apex; placentre borne on the middle of the columella. A small depressed shrubby evergreen, much branched and tufted, smooth, with coriaceous opposite elliptical leaves, on short petioles, with revolute margins. Flowers small, white or rose-color, $2-5$ in a cluster. (Named for $J . L . A$. Loiseleur-Delongchamps, a French botanist.) ChamaEcistus Oeder. 
1. L. procúmbens (L.) Desv. - Alpine summits, N. H., Me., and Que. ; and in humus, Bay of Fundy, N. S., Nfd., and northw. June, July. (Eurasia.)

\section{KÁlmia L. Lauré (of America)}

Calyx 5-parted. Corolla 5-lobed. Filaments long and thread-form. Capsule globose, 5-celled, many-seeded. - Evergreen mostly swooth shrubs, with alternate or opposite entire coriaceous leaves, naked buds, and showy flowers. (Dedicated to Peter $K a l m$, a pupil of Linnaeus, who traveled in America.)

\$1. Flowers in simple or clustered naked umbel-like corymbs; pedicels from the axils of small and firm foliaceous persistent bracts; calyx smaller than the pod, persistent; leaves and branches glabrous, or nearly so.

1. K. latifolia L. (Mountain L., Calico Bush, Spoon-wood.) Leaves mostly alternate, bright green both sides, ovate-lanceolate or oblong, acute at each end, petioled; corymbs terminal, many-flowered, clammy-pubescent; flowers 1.5-2.5 cm. broad, pink or white; pod depressed, glandular. - Rocky hills and damp soil, N. B. to Ont., and southw. Usually a shrub, but in the ints. from Pa. southw., often tree-like. May-July.

2. K. angustifolia L. (Sheep L, Lambir, W W high; leaves commonly opposite or in threes, pale and glabrate underneath, bright green above, narrowly oblong, obtuse, petioled ; corymbs lateral (appearing later than the shoots of the season), slightly glandular, many-flowered; flowers rarely $1 \mathrm{~cm}$. broad, crimson; calyx glandular; pod depressed, nearly smooth ; pedicels recurved in fruit. - Hillsides, pastures, and bogs, Lab. to Ont., and southw. June, July.

3. K. carolina Small. Similar; leaves permanently pale-puberulent beneath ; calyx puberulent, not glandular. - Swamps and woods, Va. to S. C. May, June.

4. K. polifolia Wang. (PALE L.) Straggling, 1-6 dm. high ; branchlets 2edged; leaves opposite, nearly sessile, oblong, white-glaucous beneath, with revoIute margins; corymbs terminal, few-flowered, smooth; bracts large ; flowers 1-2 cm. broad, rose-purple; pod ovoid, smooth. ( $K$. glauca Ait.) - Cold bogs and ints., Lab. to Alaska, s. to N. J., Pa., Mich., Minn., and Cal. MayJuly.

§ 2. Flowers scattered, solitary in the axils; calyx leafy, larger than the pod, nearly equaling the corolla, deciduous; leaves and branches bristly-hairy.

5. K. hirsùta Walt. Shrub 2-6 dm. high; branches terete; leaves oblong or lanceolate, $0.5-1 \mathrm{~cm}$. long, becoming glabrous; corolla rose-color. - Sandy pine barren swamps, Va. to Fla. May-Aug.

\section{PHYLLÓDOCE Salisb.}

Corolla 5-toothed. Stamens 10, anthers pointless, shorter than the filaments. Capsule 5-celled, 5-valved, many-seeded. - Low alpine heath-like evergreen undershrubs, clothed with crowded linear and obtuse rough-margined leaves. Flowers nodding on solitary or umbeled peduncles at the summit of the branches. - Sometimes united with Bryanthus, a Siberian genus with 4-parted umbeled flowers. (Phyllodoce, a sea-nymph mentioned by Virgil.)

1. P. coerùlea (L.) Bab. Calyx pubescent; corolla cylindric-urn-shaped, 5-toothed, purplish, smooth; style included. (Bryanthus taxifolius Gray.) Arctic Am., s. to alpine summits of Me, and N. H. June-Aug. (Eurasia.) Corolla turning bluish in drying.

\section{CASsiope D. Don.}

Calyx without bractlets, of 4 or 5 nearly distinct ovate sepals, imbricated in the bud. Corolla open-campanulate, 4-5-lobed or -cleft. Stamens 8 or 10; anthers fixed by the apex ; the ovoid cells each opening by a large terminal pore, 
and bearing a long recurved awn behind. Capsule 4-5-celled; placentae many. seeded, pendulous from the summit of the columella. Seeds smooth and wingless. - Small arctic or alpine evergreen plants, with scale-like or needle-like leaves, and solitary white or rose-colored flowers nodding on slender erect peduncles. (Named for Cassiope, mother of Andromeda.)

1. C. hypnoides (L.) D. Don. Tufted and procumbent, moss-like, 1-12 cm. high ; leaves needle-shaped, loosely imbricated; corolla 5-cleft; style short and conical. - Alpine summits, Me., N. H., and N. Y., cliffs of L. Superior, and high northw. June, July. (Eurasia.)

\section{LEUCÓTHÖ̈ D. Don. FetTer BUSH}

Calyx of 5 nearly distinct sepals, imbricated in the bud. Stamens 10 ; anthers naked, or the cells with 1 or 2 erect awns at the apex, opening by a pore. Capsule depressed, more or less 5-lobed, 5-celled, 5-valved, the sutures not thickened; the many-seeded placentae borne on the summit of the short columella. Seeds mostly pendulous. - Shrubs with petioled and serrulate leaves, and white scaly-bracted flowers in dense axillary or terninal spiked racemes. (Leucothoë, daughter of Orchamus, King of Babylonia, referred to by Ovid.)

* Anthers aunless; stigma 5-rayed ; racemes sessile, dense, with persistent bracts, in the axils of thick and shining evergreen leaves; calyx not bracteolate.

1. L. axillàris (Lam.) D. Don. Leaves lanceolate-oblong or oval, abruptly pointed or acute, somewhat spinulose-serrulate, on very short petioles; sepals broadly ovate. - Low grounds, Va. to Fla. and Ala. Feb.-Apr.

2. L. Catesbaèi (Walt.) Gray. Leaves ovate-lanceolate, taper-pointed, serrulate with ciliate-spinulose appressed teeth, conspicuously petioled, $7-15 \mathrm{~cm}$. long; sepals ovate-oblong, often acute.-Moist banks of streams, Va. to Ga. along the ints. May. - Shrub $1 \mathrm{~m}$. high, with long spreading or recurved branches. Flowers exhaling the unpleasant scent of Chestnut-blossoms.

* * Anthers awned; stigma simple; flowers very short-pediceled, in long onesided racemes mostly terminating the branches; bracts deciduous; leaves membranaceous and deciduous, serrulate; calyx bibracteolate.

3. L. recúrva (Buckley) Gray. Branches and racemes recurved-spreading; leaves lanceolate or ovate, taper-pointed; sepals ovate; anther-cells 1-awned; pod 5-lobed; seeds flat and cellular-winged. - Dry hills, Alleghenies of Va. to Ala. Apr. - Lower and more straggling than the next.

4. L. racemosa (L.) Gray. Branches and racemes mostly erect; leaves oblong or oval-lanceolate, acute; sepals ovate-lanceolate; anther-cells each 2-anoned; pod not lobed; seeds angled and wingless. - Moist thickets, Mass, to Fla. and La., near the coast. May, June. - Shrub 1-3 m. high. Corolla cylindrical.

\section{ANDRÓMEDA L.}

Calyx of 5 nearly or partly distinct sepals, valvate in the bud, but very soon separate or open. Corolla urceolate. Stamens 10 ; filaments unappendaged; anthers fixed near the middle, each cell bearing $1-2$ awns. Capsule subglobose, 5-celled, 5-valved, the sutures not thickened; the many-seeded placentae borne on the summit or middle of the columella. - Evergreen shrubs, with umbeled, clistered, or panicled and racemed pink or white flowers. (Fancifully named by Linnaeus for Andromeda of Greek mythology.)

* Anthers awned; capsule more or less globose; leaves thick and evergreen.

\$1. EUANDRÓMEDA Gray. Corolla globose-urceolate; cach anther-cell bearing a slender ascending awn; seeds oval, with a smooth and shining crustaceous coat.

1. A. Polifolia L. Low shrub, with elongate creeping base; stem simple or with ascending branches, 5-30 $\mathrm{cm}$, high; leaves linear to narrowoty obiong, 
either flat or revolute, glabrous, generally whitened beneath with a varnish-like coat, later often green; bud-scales scarcely glaucous; pedicels in terminal umbels,

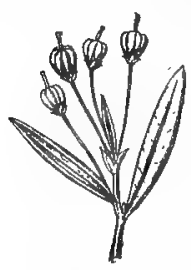

844. A. Polifolia. End of fruiting branch $\times 2 / 3$.

filiform, straightish, 2-4 times exceeding the nodding flower and erect fruit; corolla pink or white; calyx with pale or usually reddish slightly ascending lobes; capsule brown or reddish, obovoid or subglobose, as high as broad. - Arctic regions, extending very locally s. to the Adirondack $\mathrm{Mts}_{\text {. }}$ N. Y.(?), L. Huron, etc. May-July. (Eurasia.) FIG. 844.

2. A. glaucophýlla Link. (Bog Rosemary.) Similar in habit ; leaves white beneath with close fine pubescence; branchlets and bud-scales glaucous; flowers on thickish curved pedicels rarely twice their length; calyx-lobes whitish, usually spreading; capsule depressed, turban-shaped, glaucous. (A. Polifolia mostly of Am. auth., not L.) - Bogs and wet shores, Lab. to Man., s. to N. J., Pa., and Minn. May-July; rarely Sept., Oct. Fig. 845 .

§2. PORTÙNA (Nutt.) Gray. Corolla ovoid-urceolate; each anther-cell bearing a deflexed awn; seeds scobiform.

3. A. floribúnda Pursh. Very leafy, 5-15 dm. high; young branchlets, etc., strigose-hairy; leaves lanceolateoblong, acute or acuminate, ciliate-serrulate, glandular-dotted

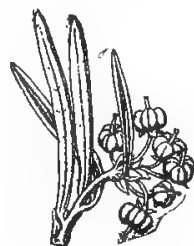

845. A. glaucophylla. End of fruiting branch $\times \frac{2 \%}{2}$. beneath, 4-6 cm. long; racemes crowded in short terminal panicles, densely flowered. (Pieris B. \& H.) - Moist hillsides, in the Alleghenies from Va. to Ga. May.

\section{LYÒNIA Nutt.}

Similar to Andromeda. Filaments hairy and often toothed or appendaged; anthers oblong, unappendaged. Capsule 5-angled, the dorsal sutures with a thickened ridge, which usually divides in dehiscence of the capsule; the placentae borne both upon the colnmella and the walls of the cells. Seeds scobiform, with a loose thin testa. - Shrubs with fascicled, racemose, or panicled white flowers. (Named for John Lyon, early American botanist and explorer of the southern Alleghenies.)

\section{* Leaves coriaceous and evergreen.}

1. L. nítida (Bartr.) Fernald. (Fetтer Bush.) Glabrous shrub, 0.5-1.5 m. high; branches sharply triangular; leaves glossy, oblong-ovate to lanceolate, acuminate, entire, with a conspicuous nerve next the revolute margin; flowers in axillary umbels; filaments appendaged at summit; capsule subglobose. (Andromeda Bartr.; Pieris B. \& H.) - Low woods and barrens, Va. to Fla. and La. May.

\section{* * Leaves thinnish and deciduous.}

2. L. mariàna (L.) D. Don. (Stagger-bush.) Mostly glabrous, 5-10 dm. high; leaves oblong or oval, 3.5-8 cm. long; fascicles of nodding flowers racemose on leafless shoots; filaments 2-toolhed near the apex; capsule ovoidpyramilal, truncate at the contracted apex. (Andromeda L.; Pieris B. \& H.) - Low grounds, R. I. to Fla., Tenn., and Ark. - Foliage said to poison lambs and calves.

I 3. L. ligustrina (L.) DC. (MALE BerRY.) Minutely pubescent, 0.5-3 m. high; leaves obovate to lanceolate-oblong, $2.5-8.5 \mathrm{~cm}$. long, serrulate or entire; racemes crowded in chiefly naled panicles; filaments flat, not appendaged; capsule globular. (Andromeda Muhl.; Xolisma Britton.) - Moist thickets, centr. Me, to centr. N. Y., and southw. June, July.

Var. foliosifldra (Michx.) Fernald. Racemes less crowded, often more elongate, conspicuously leafy-bracted. (Xolisma foliosiflora Small.) - Common southw., local and less cliaracteristic northw. 


\section{Chamaedáphive Moench. Leather Leaf, Cassandra}

Calyx of 5 distinct acute sepals. Stamens 10 ; anther-celis tapering into a tubular beak, awnless. Capsule depressed, 5-celled, many-seeded. Seeds flattened, wingless. - I ow and much branched shrubs, with nearly evergreen and coriaceous leaves, which are scurfy, especially underneath. Flowers white, in the axils of the upper small leaves, forming small 1-sided leafy racemes. (From

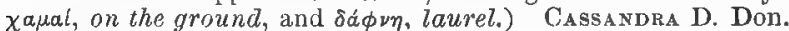

1. C. calyculàta (L.) Moench. Leaves oblong, obtuse, flat. (Cassandra D. Don.) - Bogs, Lab. to B. C., s. to Minn., Wisc., Ill., and Ga. Apr., May. (Eurasia.)

\section{OXYDÉNDRUM DC. SORREL-TREE. SOUR-WOOD}

Calyx of 5 almost distinct sepals, valvate in the bud. Corolla ovate, puberu. lent. Stamens 10 ; anthers fixed near the base, linear, awnless, the cells tapering upward. Capsule 5-celled, 5-valved; the many-seeded placentae at the base of the cells. Seeds slender, the thin and loose reticulated coat extended at both ends into awl-shaped appendages. - A tree with deciduous oblong-lanceolate pointed soon smooth serrulate leaves on slender petioles, and white flowers in long one-sided racemes clustered in an open panicle, terminating the branches of the season. Bracts and bractlets minute, deciduous. Foliage acid (whence the name, from $\delta \xi u s$, sour, and $\delta \epsilon \nu \delta \rho \nu, t r e e)$.

1. 0. arboreum (C.) DC. - Rich woods, from Pa. to Ind., and southw., mostly along the Alleghenies, to Fla. and La. June, July.

\section{1. epigata L. Ground Laurel. Trailing Arbutus}

Corolla-tube hairy inside, as long as the ovate-lanceolate scale-like nearly distinct sepals. Stameus 10 , with slender filaments; anthers oblong. Style slender, its apex (as in Pyrola) forming a sort of ring or collar around and partly adnate to the 5 little lobes of the stigma. Capsule depressed-globular, 5-lobed, 5-celled, many-seeded. - A prostrate or trailing scarcely shrubby plant, bristly with rusty hairs, with evergreen and reticulated rounded and heartshaped alternate leaves on slender petioles, and with rose-colored flowers in small axillary clusters, from scaly bracts. (Name composed of $\dot{\epsilon} \pi i$, upon, and $\gamma \hat{\eta}$, the earth, from the trailing growth.)

1. E. rèpens L. (MAYFLower.) - Sandy woods, or in rocky soil, especially in the shade of pines, Nfd. to Sask., Wisc., Mich., Ky., and Fla. - Flowers appearing in early spring, exhaling a rich spicy fragrance, dimorphous as to style and stamens, and subdioecious.

\section{GaULthèria [Kalm] L. Aromatic Wintergreen}

Corolla cylindrical-ovoid or a little urn-shaped, 5-toothed. Stamens 10, included. Capsule ciepressed, 5-lobed, 5-celled, 5-valved, many-seeded, inclosed when ripe by the calyx, which thickens and turns fleshy, so as to appear as a globular red berry ! - Slırubs, or almost herbaceous plants, with alternate evergreen leaves and axillary nearly white flowers; pedicels with 2 bractlets. (Dedicated to Hugues (Aaultier - also spelled Gaulthier, Gunthier, and Gautiernaturalist and court-physician at Quebee, in the mildle of the 18th century.)

1. G. procúmbens L. (Teaberry, Checkerberry.) Stems slender and extensively creeping on or below the surface; the flowering branches ascending, leafy at the summit, $5-15 \mathrm{~cm}$. high ; leaves obovate or oval, obscurely serrate : Howers fow, mostly single in the axils, nodding. - Woods and clearings, Nfd. to Man., and southw. July, Aug. - The bright red berries (formed of the calyx) and the foliage have the well known spicy-aromatio flavor of the Sweet Bireh. 


\section{ARCTOSTÁPHYLOS Adans. BeARberry}

Corolla with a short revolute 5-toothed limb. Stamens 10 , included; anthere with 2 reflexed awns on the back near the apex, opening by terminal pores. Shrubs, with alternate leaves, and scaly-bracted nearly white fow' rs in termina!

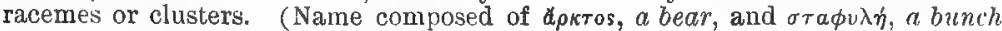
of grapes, the Greek of the popular name.)

1. A. Ùva-úrsi (L.) Spreng. (Bearberry.) Trailing; leaves thich and evergreen, obovate or spatulate, entire, smooth; fruit red, inedible. - Rocks and. bare hills, N. J, and Pa. to Mo., and far northw. and westw. May. (Eurasia.)

2. A. alpina (L.) Spreng. (Alpine B.) Depressed; leaves deciduous, serrate, wrinkled, with strong netted veins, obovate; fruit black, juicy and edible. (Mairania Desv.) - Arctic Am., s. to alpine summits of Me. and N. H. (Arcticalpine Eurasia.)

\section{Callùna Saligb. Heather. Ling}

Calyx of 4 colored sepals. Corolla much shorter and less conspicuous than the calyx, both becoming scarious and persistent. Stamens 8 , distinct; anthers with a pair of deflexed appendages on the back, the cells opening each by a long chink. Capsule 4-celled, 4-valved. - Evergreen undershrub, with no scaly buds, opposite and minute leaves (mostly extended at base into 2 sharp auricles), crowded and imbricated on the branches. Flowers axillary, or terminating very short shoots and crowded on the branches, forming close mostly one-sided spikes or spike-like racemes, rose-colored or sometimes white, small, bracted by 2 or 3 pairs of leaves, the innermost of which are more or less scarious. (Named from $\kappa a \lambda \lambda u ́ v e t \nu$, to brush or sweep, brooms being made of its twigs.)

1. C. vULGA Ris (L.) Hull. - Low grounds, in the coastal region, very locally from R. I. to Nfd.; probably introduced from Eu.

Two European heaths, Erìca cinèrea L. and E. Tétratix L., have been found slightly established in small patches on Nantucket I., Mass.

\section{Chiógenes Salisb. Crejping Showberry}

Calyx-limb 4-parted, persistent. Corolla bell-shaped, deeply 4-cleft. Stamens 8 , included, inserted on an 8-toothed disk, filaments very short and broad; anther-cells ovate-oblong, separate, not awned on the back, but each minutely 2-pointed at the apex, and opening by a large chink down to the middle. Berry white, globular. - A trailing and creeping evergreen, with very slender and scarcely woody stems, and small Thyme-like ovate and pointed leaves on short petioles, with revolute margins, smooth above, the lower surface and the branches beset with rigid rusty bristles. Flowers very small, solitary in the nxils, on short nodding peduncles, with 2 large bractlets under the calyx. (Name from $\chi \iota \omega \nu$, snow, and yévos, offspring, in allusion to the snow-white berries.)

1. C. hispídula (L.) T. \& G. (Moxie Plum, Capillaire.) Leaves 0.5-1 cm. long; berries $5-7 \mathrm{~mm}$. thick, bright white, delicately acid and aromatic. (C. serpyllifolia Salisb.) - Peat-bogs and mossy woods, Lab. to B. C., s. to Minn. Mich., and N. C. May. - Plant with the aromatic flavor of Gaultheria or of Sweet Birch.

\section{GAYLUSSACIA HBK. HUCKLEBERRY}

Corolla tubular, ovoid, or bell-shaped; the border 5-cleft. Stamens 10 ; anthers awnless; cells tapering upward into more or less of a tube, opening by a chink at the end. Fruit a berry-like drupe, containing 10 seed-like nutlets. - Branching shrubs, with the aspect of I'accinium, commonly sprinkled with resinous dots; the flowers (pale, tinged with purple or red) in lateral and bracted racemes. (Named for the chemist, Gay-Lussac.) 
* Lecues thick and evergreen, somewhat serrate, not vesinous-dotted.

1. G. brachýcera (Michx.) Gray. (Box, 11.) Very smooth, 2-1 dm. high; leaves oval, finely crenate-toothed; racemes short and nearly sessile; pedicels very short; corolla cylindrical-bell-shaped. - Wooded hills, Perry Co., Pa., to Del. and Va. May. - Leaves resembling those of the Box.

* Leaves deriduous, entire, sprinkled more or less with resinous or maxy atoms.

- 2. G. dumosa (Andr.) 'T. \& G. (DwarF H.) Somewhat hairy and glan. dular, low, 2-1,i dm. high, from a creeping base, tushy; leaves obovate-oblong, mucronate, green both sudes, rather thick and shining when old; racemes elongated; bracts leaf-like, werl, persistent, as long as the pedicels; ovary bristly or glandular; corolla bell-sinaped; fruit black. - Sandy swamps, Nfd. to Fla. and La., mostly on the coastal plain. June.

Var, hirtélla (Ait. f.) Gray. Young branchlets, racenıes, and often the leaves bristly-hairy. 一 Va. to Fla., etc.

$\checkmark$ 3. G. frondosa (L.) T. \& G. (Blee ThNgle, Dangleberry.) Slender, 5-1.5 dm. high; branches smooth, divergent; leaves obovate-oblong, biunt, pale; finely pubescent and glaucous beneath, in maturity $2.5-6.5 \mathrm{~cm}$. long, $1.5-3 \mathrm{~cm}$. broad; racemes slender, loose; bracts oblong or linear, deciduous, shorter than the slender drooping pedicels; corolla globular-bell-shaped ; fruit dark blue with a white bloom, sweet and edible. - Low copses, coast of $\mathrm{N}$. H. to O. and La. May, June.

4. G. ursina (M. A. Curtis) T. \& G. (BEAR H.) Sinilar; branehes smooth or slightly hairy; leaves green both sides, thin, oblong to lance-obovate, acuminate, in maturity $5-12 \mathrm{~cm}$. long, $2-4.5 \mathrm{~cm}$. broad; fruit reddish, becoming black, insipid. - Woods, Ky. to N. C. and Ga. May, June,

5. G. baccàta (Wang.) C. Koch. (BLACK H.) Much branched, rigid, stightly pubescent when young, $0.3-1 \mathrm{~m}$. high; leaves oval, oblong-ovate, or oblong, thickly clothed and at first clammy, as well as the flowers, with shining resinous globules; racemes short, clustered, one-sided; pedicels about the length of the flowers; bracts and bractlets reddish; corolla ovoid-conical, or at length cylindrical with an open mouth; fruit black, without bloom, pleasant. ( $G$. resinosa T. \& G.) - Rocky woodlands and swamps, Nfd. to Man., s. to e. Ia., Wisc., Mich., Ill., and Ga. May, June. Forma Gla ucockrpa (Robinson) Mackenzie. (BLUE H.) Fruit blue, with a bloom, generally larger and juicier. Me. to N. C. Forma leucockrpa (Porter) Fernald. (White H.) Berries white to pinkish, somewhat translucent. - Local, but occasionally abundant and fruitful.

\section{Vaccinium L. Blueberry. Cranberry}

Corolla various in shape; the limb 4-5-cleft, revolute. Stamens 8 or 10 ; anthers sometimes 2-awned on the back; the cells opening br a hole at 1 he apex. Berry 4-5-celled, many-seeded, or sometimes 8-10-celled by a false partition stretching from the back of each coll to the placenta. - Shrubs witl solitary, clustered, or racemed flowers, in spring or early summer; the corolla white or reddish. (Ancient Latin name, of obscure derivation.)

\$1. BATODÉNDRON (Nutt.) Gray. Corolla open-campanulate, 5-lobed; anthers with 7 nug tubes, and 2-awned on the back; berry spurionsly 10-celled; leaves decillous but firm; flowers solitary or in leafy-bracted racemes, slender-pediceled.

\section{* Flowers articulated with the pedicel; anthers included.}

1. V. arboreum Marsh. (FARKLEBRRY.) Tall (2-9 m, high), smoothish ; leaves obovate to oblong, entire or denticulate, mucronate, bright green, shining above, at the South evergreen; coroila white; berries black, globose, small, many-seeded. (Batodendron Nutt.; B. andrachneforme Small.) - Sandy soil, s. Ill. to Tex, Ela. and N, C. 
* Flowers not articulated with the pedicel; anther's exserted.

- Leaves and branchlets pubescent.

F 2. V. stamíneum L. (Deerberry, Squaw Hucklemerry.) Diffusely branched, 3-9 dm. high, somewhat pubescent; leaves ovate or oval, pale, glaucous or whitish underneath; calyx glabrous or essentially so; corolla greenish-white or purplish; anthers much exserted; bervies greenish or yellowish, globular or pear-shaped, large, few-seeded, tart. (Polycodium Greene; $P$. candicans Small.) - Dry woods and plains, Mass. to Ont, and southw.

3. V. melanocárpum Mohr. (Sovrurern Gooseberry.) Similar, the young parts minutely white-pubescent; calyx white-tomentose; fruit dark purple, lustrous, palatable. (Polycodium Small.) - Upland woods, N. C. to Mo., and southw.

$$
\text { + + Leaves and branchlets glabrous. }
$$

V4. V. negléctum (Small) Fernald. Glabrous essentially throughout; leaves thin, at most ciliolate, becoming slightly coriaceous, oblong-lanceolate to narrowly obovate, short-acuminate, green to slightly glaucous beneath; calyx glabrous; corolla white or pink ; fruit greenish or yellowish, hardly edible. (Polycodium Small.) - Dry woods, Va. to Kan., and southw.

§2. CYANOCÓCCUS Gray. (BuuEBERRIEs.) Corolla cylindraceous to campanulate, 5-toothed; filaments hairy; anthers included, awnless; berry edible, mostly blue or black, completely or incompletely 10-celled; flowers in fascicles or short racemes, shart-pediceled, appearing from large scaly buds with or before the leaves.

* Leaves coriaceous, evergreen; bracts firm, tardily deciduous.

5. V. Myrsinites Lam. (Evergreer B.) Low (2-6 dm. high), with branches puberulent when young; leaves from obovate to oblong-lanceolate or spatulate, 1-3 cm. long, smooth and shining above, puberulent or glabrate and strongly veiny beneath, entire or denticulate; calyx with acute teeth; corolla cylindraceous, 6-8 mm. long; fruit globose, blue-black. — Sandy parrens, Va. to Fla. and La.

* Leaves deciduous ; bracts scaly, early deciduous. - Corolla cylinaraceous when developed.

6. V. virgàtum Ait. Low, more or less pubescent; leaves ovate-oliong to cuneate-lanceolate, usually acute and minutely serrulate, thinnish, shining at least above, in maturity $2.5-5 \mathrm{~cm}$. long; flower-clusters sometimes virgate on naked branches; corolla rose-color, 7-10 mm. long; berry black. - In swamps and pine barrens, Staten I. and N. J. (according to Mackenzie) to Fla., etc.

Var. tenéllum (Ait.) Gray. Lower; the mostly small (1-3 cm. long) leaves and smaller (6-8 mm. long) nearly white flowers in shorter or closer clusters. Va. to Ill., Mo., and southw.

+ +Corolla globose-urceolate to ellipsoid.

+ Low shrubs, mostly less than 1 m. high.

7. V. pennsylvánicum Lam. (Low Sweex B., EARLy Sweet B.) Dwarf (2-6 dm. high); the green warty stems and branches glabrous (or pubescent northward); leaves lanceolate or oblong, distinctly servulate with bristle-pointed teeth (rarely entire), bright green, smooth and shining both sides (or sometimes hairy on the midrib beneath), in maturity $2-3.5 \mathrm{~cm}$. long, $8-15 \mathrm{~mm}$. broad; corolla short (6-7 mm. long), cylindric-bell-shaped; berries bluishblack and glaucous, varying to black or red, either with or without a bloom, and rarely dull white (forma LeUCOCARPOM Deane). - Dry hills, barrens, etc., Nfd., to Sask., s. to Va., Ill., and Wisc. - The lowest and earliest ripened of the blueberries. Var. ANGustifóciom (Ait.) Gray. A dwarfer high-mountain or northern form, with narrower lanceolate leaves, 7-20 $\mathrm{mm}$. long, 3-7 $\mathrm{mm}$. broad. - Ct. (Graves) ; mts. of N. Y. and N. E. to Nfd., and far northw.

Var. nigrum Wood. (Low BLACK B.) Leaves firmer, blue-green, glaucous 
beneath; berries black, usually without bloom. ( $V$. nigrum Britton.) - Often hssociated with the species, or by itself, N. B. to N. J., Pa., and Mich.

8. V. canadénse Kalm. (Sovr-top or Velvet-Leaf B.) Low (2-6 dm. high) ; leaves oblong-lanceolate or elliptical, entive, dorony both sides, as well as the crowded branchlets, in maturity $2-4 \mathrm{~cm}$. long, 5-15 $\mathrm{mm}$. broad; corolla shorter (4-6 mm. long); berries blue with much bloom (rarely black), ripening later than those of no. 7. - Dry plains, swamps or moist woods, Lab. to Man., s. to N. E., Ill., Minn., and along the mts. to Va. Forma chrococoum Deane is a rare form with white fruit.

$\checkmark$ 9. V. vacíllans Kalm. (LATE Low B.) Low (3-9 dm. high), glabrous, with yellowish-green branchlets ; leaves obovate or, oval, in maturity $2.5-4.5 \mathrm{~cm}$. long, $1.5-2.5 \mathrm{~cm}$. broad, very pale or dull, glaucous, at least underneath, entire or minutely ciliolate-serrulate; calyx usually reddish; corolla $5-8 \mathrm{~mm}$. long, greenish-yellow, often tinged with red; berries blue, with a bloom, ripening later than those of no. 7. - Dry places, especially in sandy soil, N. E. to Mich., and southw.

\section{$\rightarrow+S h r u b s$ 1-4 m. high.}

10. V. corymbòsum L. (High or Swamp B.) Tall (1-4 m.) ; leaves ovate to elliptic-lanceolate, smooth or slightly pubescent beneath, half-grown at flowering time, in maturity $4-8 \mathrm{~cm}$. long, $2-4 \mathrm{~cm}$. broad, the margins entire; calyx usually glaucous, the lobes acutish or blunt; corolla white or pinkish, 6-10 $\mathrm{mm}$. long, varying from ovoid to cylindric-urn-shaped; berries blue-black, with a bloom, 7-10 inın. in diameter. - Swamps, low woods, or even dry pastures, Me. to Minn., and southw.; chiefly eastw.

Var. amoènum (Ait.) Gray. Similar ; leaves bright green both sides, ciliateserrulate or bristly-ciliate. - Similar range, less abundant.

Var. pállidum (Ait.) Gray. Glaucous; leaves ciliate-serrulate, whitened beneath. (V. pallidum Ait.) - Throughout the range.

L 11. V. atrocóccum (Gray) Heller. (BLAck High B.) Resembling the preceding; leaves entire, downy or woolly underneath even when old, unexpanded at flowering time; calyx not glaucous, the lobes obtuse or rounded; corolla turgid-ovoid to ellipsoid, yellowish- or greenish-white, tinged with rerl, $5-8 \mathrm{~mm}$. long; berries polished black, without bloom, $5-8 \mathrm{~mm}$. in diameter. (V. corymbosum, var. Gray.) - Swamps, low woods and barrens, s. Me. to N. C. and Ont. - Flowering and fruiting a week or ten days earlier than no. 10, with which it is often associated.

§3. EUVACCINIUM Gray. (BirberRIEs.) Corolla ellipsoid to globular, 4-5-toothed; filaments glabrous; anthers 2-awned on the back, included; berry 4-5-celled; leaves deciduous; flowers on drooping pedicels, solitary or few together, appearing with or after the leaves; mostly glabrous.

\section{* Parts of the flower mostly in fours; stamens 8.}

12. V. uligindsum L. (Bog Bilberer.) Low and spreading stout shruk $2-60 \mathrm{~cm}$. high; leaves entire, dull, obovate or oblong, in maturity $5-20 \mathrm{~mm}$. long, 3-15 mm. wide, pale and slightly pubescent underneath; flowers single or 2-3 together from a scaly bud, almost sessile; corolla short, urn-shaped; berries black, with a bloom, sweet. - A retic Am., s. to the barrens of W ashington Co., Me., mts. of n. N. E. and n. N. Y., and n. Mich.

* * Parts of the flower in fives; stamens 10 ; leaves membranaceous; flowers solitary on short axillary peduncles, nodding.

13. V. caespitosum Michx. (DWarf Bilberry.) Draff tufted slender shrub (5-30 cm. high), with rounded branches; leaves obovate, cuneate-lanceolate or cuneate-spatulate, narrowed at base, smooth and shining, serrate, in maturity 1-4 cm. long, 4-20 mm. broad; corolla ellipsoid, slightly urn-shaped, usually pink or coral-red; berries blue, sweet.-Gravelly or rocky woods and shores, Lab. to Alaska, s. to s. Me., s. Vt., n. Mich., n. Wisc., Col., and Cal, ; alpine summits, N. F. and N. Y.

14. V. membrand ceum Dougl. More erect, 8-15 dm. high ; branchlets somewhat anoled: leaves mostly ovate and acute or pointed, in maturity 2-7 cm. long, 
1.5-3 cm. broad, sharply and closely serrulate, bright green, nearly smooth ; border of the calyx almost entire; corolla depressed-globular, rather large ; berries large, black, rather acid. (V. myrtilloides Man. ed. 6, not Michx.) Damp woods, L. Superior, and northwestw. - Pedicels 5-15 mm. long, drooping in flower, erect in fruit.

15. V. ovalifòlium Sm. Similar, straggling, 5-15 dm. high; leaves elliptical, obtuse, nearly entire, pale, mostly glaucous beneath, smooth ; corolla ovoid; berries blue. - Low woods and mountain slopes, Lab. to Alaska, s. to Nfd., e. Que., n. Mich., and Ore.

§4. VITIS-DDAEA [Tourn.] Koch. Corolla, berry, etc., as in $\S 3$; filaments hairy; anthers awnless; leaves coriaceous and persistent; flowers in clusters from separate buds, 4-merous (in our species); mostly glabrous.

16. V. Vitis-Iđaèa L. (Cowberry, Foxberry.) Low (1-2.5 dm. high); branches erect from tufted creeping stems; leaves obovate with revolute margins, dark green, smooth and shining above, dotted with blackish bristly points underneath, 1.5-3 cm. long, 7-16 mm. broad ; corolla bell-shaped, 4-cleft, white or pink ; berries dark red, acid and rather bitter, edible when cooked. (VitisIdaea Britton.) - Eu. Represented with us by

Var. minus Lodd. (Mountain or Rock CranberRT.) Dwari, forming close or loose mats $2-10$ (rarely even 20 ) $\mathrm{cm}$. high ; leaves very thick and coriaceous, 5-18 mm. long, 4-9 mm. broad; corolla rose-pink or red. - Dry or rocky banks, rarely wet moss, Aretic Am., s. to the mis. of Me., N. H., and Vt., J. Superior, etc.; and along the coast to Cape Ann, Mass. (Greenl., e. Asia.)

\$ 5. OXYCóCCOS [Tourn.] Hook. Corolla deeply 4-parted or-cleft, with linear reflexed lobes; anthers exserted, awnless, with very long terminal tubes; berry 4-celled; flowers axillary or terminal, nodding on long filform pedicels.

* Stem uprighi and leaves deciduous, as in common Blueberries; flovers axillary and solitary; corolla deeply 4-cleft; berries light red, turning purple, insipid.

17. V. erythrocárpum Michx. Smooth, divergently branched, 3-18 dm. high ; leaves oblong-lanceolate, taper-pointed, bristly-serrate, thin. (Oxycoccus Pers.) - Damp woods, higher Alleghenies, Va. to Ga. July.

* * Stems very slender, creeping or trailing; leaves small, entire, whitened beneath, evergreen; pedicels erect, the pale rose-colored flower nodding; corolla 4-parted; berries red, acid. - CRANBERRIEs.

18. V. Oxycóccos I. (Smald Cranberrt.) Stems very slender, the branches almost capillary, erect or ascending; leaves oblong or ovate, $3-8 \mathrm{~mm}$. long, 1-3 mm. broad, strongly revolute, becoming narrowly triangular in outline, conspicuously whitened beneath; pedicels 1-4, springing from a terminal (rarely proliferating) short rhachis (at most 3 or $4 \mathrm{~mm}$. long), and bearing near or below the middle 2 lanceolate or lance-ovate often involute colored bractlets (1-2.5 mm. long); corolla-segments $5-6 \mathrm{~mm}$. long; filaments $\frac{1}{2}$ as long as the anthers; berry 6-8 mm. in diameter. (Oxycoccus MacM; O. palustris Pers.) In sphagnum and wet humus, Arctic Am., s. to Pa., Mich., and Wisc. (Eurasia.) Var. intermedicm Gray. Coarsei ; leaves 6.5-15 mm. long, 3-6.5 mm. broad, acute or obtuse, only slightly revolute; pedicels 2-10, from a longer (often 5-10 $\mathrm{mm}$. long) rhachis; corolla-segments 6-8 mm. long; berry 8-10 mm. in diameter. - Nfd. to B. C., s. to Mich., and in the mts. to N. C. (Asia.)

19. V. macrocárpon Ait. (LaRge or American Cranberrr.) Stems comparatively stout, elongated, the flowering branches ascending; leaves oblongelliptic, blunt or rounded at tip, 6-17 $\mathrm{mm}$. long, $2-8 \mathrm{~mm}$. broad, pale or slightly whitened beneath, flat or slightly revolute; pedicels $1-10$, springing from an elongated (1-3 cm. long) rhachis which is terminated by a long leafy shoot, and bearing toward the tip 2 flat leaf-like bractlets (4-10 mm. long); corolla-segments 6-10 mm. long; filaments scarcely $\frac{1}{8}$ the length of the anthers; berry $1-2 \mathrm{~cm}$. in diameter. (Oxycoccus Pers.) - Open bogs, swamps, and wet shores, Nfd, to I. Erie, w. Wisc., and southw. to W. Va. and Ark., mostly northeastw. 


\section{diapensiaceae (Dia pensia Family)}

Low perennial herbs or suffruticulose tufted plants, glabrous or nearly so, with simple leaves, no stipulcs, regular 5-merous flowers (except the 3-celled ovary), stamens adnate to the corolla and sometimes monadelphous (those opposite its lobes when present reduced to staminodia); pollen simple; loculicidal capsule and seeds of Ericaceae. Flowers solitary or racemose. Style 1, with 3-lobed stigma. - Distinguished from the Ericaceae chiefly by the insertion of the stamens upon the corolla.

Tribe I. DIAPENStEAE. Dwarf woody evergreens, with small entire crowded coriaceous leaves. Staminodia none; filaments adnate to the campanulate corolla up to the sinuses; anthers 2 celled. Calyx conspicuously bracteolate. Flowers solitary.

1. Diapensia. Flower (or at least fruit) on a scape-like peảuncle. Anther-cells blunt, obliquely dehiscent. Sopals concave, coriaceous.

2. Pyxidanthera. Flowers sessile on short leafy branchlets. Anther-cells awn-pointed at base, opening transversely. Sepals thin.

Tribe II. GALACfNEAE. Acaulescent, with creeping rootstocks sending up long-petioled evergreen leaves, and a 1-several-flowered scape. Staminodia present.

3. Galax. Colyx minutely 2-bracteolate. Stamens monadelphous; anthers 1-celled.

\section{DIAPÉNSIA L.}

Corolla bell-shaped, 5-lobed; lobes rounded. Filaments, broad and flat, adherent to the corolla up to the sinuses, short; anthers adnate, of 2 ovoid cells, diverging below. Capsule, inclosed in the calyx, cartilaginous; cells few-seeded. - Alpine, growing in very dense convex tufts, the stems covered below by imbricated cartilaginous narrowly spatulate mostly opposite leaves, and terminated by a 1-flowered peduncle, 3-bracted under the caly . Corolla white, $1.5-2 \mathrm{~cm}$. wide. (Said to be an ancient Greek name of the Sanicle, of obscure meaning, strangely applied by Linnaeus to this plant.)

1. D. lappónica L. Leaves 5-15 mm. long; peduncle at length $1.5-3 \mathrm{~cm}$. long. - Alpine summits, N. E., N. Y., and northw. June, July. (Eurasia.)

\section{PYXIDANTHÈRA MichX.}

Prostrate and creeping, with narrowly oblanceolate and awl-pointed leaves, mostly alternate on the sterile branches and somewhat hairy near the base. Flowers solitary and sessile, very numerous, white or rose-color. (Name from $\pi v \xi i s$, a small box, and anthera, new Latin for anther, the anther opening as if by a lid.)

1. P. barbulata Michx. (Flowering Moss, Prxie.) Leaves 3-8 mm. long. - Sandy pine berrens of N. J. to N. C. Apr., May.

\section{GALAX L.}

Calyx imbricate, persistent. Petals hypogynous, obovate-spatulate, rathe1 erect, deciduous. Filaments united into a 10-toothed tube, slightly adhering to the base of the petals, the 5 teeth opposite the petals naked, the alternate ones shorter and bearing roundish anthers, which open across the top. Style short. Capsule ovoid, 3-celled; columella none. Seeds numerous, the cellular loose coat tapering to each end. - Evergreen herb, with a thick matted tuft of scaly creeping rootstocks, beset with fibrous red roots, sending up round-heart-shaped crenate-toothed and veiny shining leaves (3-16 cm. wide), and a slender naked scape, 3-8 dm. high, bearing a wand-like spike or raceme of small and minutely bracted white flowers. (Name from rá $\lambda a$, millk, - of no conceivable application to this plant.)

I. G. aphŷlla L. - Open woods, Va. to Ga. June. 


\section{PLUMbaginàceate (Leadwort Family)}

Herbs, with regular 5-merous flowers, a plaited calyx, the 5 stamenc opposite the separate petals or the lobes of the corolld, and the firee ovary 1-celled, with a solitary ovule hanging from a long cord which rises from the base of the cell. Represented in our flora by the single genus

\section{Limonium [Tourn.] Hill, Sea Lavender. Margh Rosemary}

Flowers scattered or loosely spiked and 1-sided on the brancbes, 2-3-bracted. Calyx funnel-form, dry and membranaceous, persistent. Corolla of 5 nearly or quite distinct petals, with long claws, the 5 stamens severally attached to their. bases. Styles 5, rarely 3, separate. Fruit membranous and indehiscent, in the bottom of the calyx. Embryo straight, in mealy albumen. - Sea-side perennials, with thick and stalked radical leaves; the naked flowering stems or scapes branched into panicles. ( $\Lambda \epsilon \iota \omega \dot{\omega} \nu \circ \nu$, the ancient Greek name, presumably from

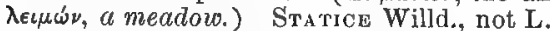

1. L. caroliniànum (Walt.) Britton. Root thick and woody, very astringent; leaves oblong, spatulate, or obovate-lanceolate, 1-ribbed, tipped with a decidunus bristly point, petioled; scape much-branched, panicled, 1.5-6 dm. high ; spikelets 1-3-flowered; flowers lavender-color; calyx-tube hairy on the angles, the lobes acute or acuminate, with as many teeth in the sinuses. (Statice Limonium, var. Gray.) - Salt marshes, Lab. to Tex. July-Sept.

\section{PRIMULÀCEAE (Primrose Familu)}

Herbs, with simple leaves, and regular perfect flowers, the stamens as many as the lobes of the gamopetalous (rarely polypetalous) corolla (none in Glaux) and inserted opposite them (on the tube or base), and a 1-celled ovary with a central free placenta rising from the base, bearing several or many seeds. Calyx free from the ovary, or in Samolus partly adherent. Stamens 4 or 5 , rarely 6 or 8 . Style and stigma one. Seeds with a small embryo in fleshy albumen. Ovules amphitropous, except in Hottonia.

* Corolla or petaloid calyx with crect or spreading segments.

- Stemless; leaves all in a cluster from the root; capsule dehiscent by valves or teeth.

1. Primula. Corolla funnel-form or salver-shaped, open at the throat. Stamens included.

2. Androsace. Corolla short, very small, constricted at the throat. Stamens included. $+\div$ Stems leafy.

* Aquatic; immersed leaves pectinate.

8. Hottonia. Corolla short-salver-form. Flowers verticillate and racemose: + + Terrestrial or marsh plants; leaves entire.

- Ovary adnate at base to the base of the calyx.

4. Samolus. Corolla bell-shaped, with 5 staninodia in the sinuses. Flowers racemose. $=-$ Ovary wholly free.

a. Capsule dehiscent vertically by valves or irregularly, mostly globose.

5. Lysimachia. Corolla 5-6-parted or 5-6-petaled. Staminodia none. Leaves dotted.

6. Steironema. Corolla and ealyx 5-parted. Five slender staminodis between the fertile stamens.

7. Trientalis. Corolla and calyx mostly 7-parted. Btem leafy only at the summit.

8. Glaux. Corolla none; the calyx petal-like. Flowers axillary.

b. Globose capsule circumscissile, the top falling off as a lld ; flowers axillary.

9. Anagallis. Corolla longer than the calyx, 5-parted. Leaves opposite.

10. Centunculus. Corolla shorter than the calyx, 4-5-cleft. Leaves alternate. * * Corolla and ealyx with reflexed segments.

11. Dodecatheon. Corolla 5-parted. Stamens exserted, connivent in a cone. 


\section{Primola L. Primrose. Cowslip}

Calyx tubular, angled, 5-cleft. Corolla enlarging above the insertion of the stamens; the 5 lobes often notched or inversely heart-shaped. Capsule manyseeded, splitting at the top into 5 valves or 10 teeth. - Low perenuial herbs, with tufted and simple scapes, the flowers in an umbel. (Name a diminutive of primus, from the flowering of the true primrose in early spring.)

1. P. farindsa I. (BIRD's-EYE P.) Scape 0.5-3 dm. high; leaves oblanceolate to narrowly obovate, denticulate, $1.5-6 \mathrm{~cm}$. long, the lower side and the 1-20-flowered involucre, etc., covered with a white mealiness, at least when young; involucral bracts lance-attenuate, $3.5-15 \mathrm{~mm}$. long; pedicels in anthesis mostly shorter than the calyx, in fruit becoming slightly longer; calyx 3-5 mm. long; corolla pale lilac, with a yellow eye, its tube barely exserted; capsule 6-8 $\mathrm{mm}$. long, slightly exserted. - Nfd. and Lab. to $\mathrm{n}$. Mich. (Eurasia.) Var. Ambricáa Torr. Similar; leaves narrow, stiff, $2-6 \mathrm{~cm}$. long, sulphur-yellow beneath; pedicels elongate, often $2-5$ times as long as the calyx; capsule much exserted. - Shores of L. Huron and L. Michigan.

Var. macrópoda Fernald. Scape 1-4.5 dm. high; leaves spatulate to rhombic-ovate, long-petioled, $2.5-10 \mathrm{~cm}$. long, usually whitened beneath; bracts involute in drying, 6-11 $\mathrm{mm}$. long; pedicels usually elongate, 1-5 cm. long; calyx in anthesis 6-8 mm. long; capsule 9-12 mm. long, exserted. - Calcareous cliffs and shores, Lab. to Mackenzie, s. to N. S., Me., and Sask.

2. P. mistassínica Michx. Scape 0.5-2 dm. high; leaves spatulate or wedgeoblong, thin and veiny, scarcely or not at all mealy, 1-4 cm. long; involucre 1-8-flowered, the lance-subulate bracts 2-4 $\mathrm{mm}$. long; pedicels filiform, in anthesis mostly exceeding the calyx, loosely ascending, in fruit much elongate; calyx 3-5 mu. long; corolla flesh-color (rarely white), its tube conspicuously exserted; capsule 5-8 mm. long. - Wet calcareous banks and shores, Nfd. to Sask., s, to N. B., Me., Vt., N. Y., Mich., Wisc., and Minn. May-July.

\section{ANDRÓSACE [Tourn.] L.}

Calyx 5-cleft; tube short. Corolla salver-shaped or funnel-form; the tube shorter than the calyx; limb 5-parted. Capsule 5-valved. - Small herbs, with clustered root-leaves, and very small solitary or umbeled flowers. (An ancient Greek name of a polyp, formerly believed to be a plant.)

1. A. occidentalis Pursh. Smoothish annual; scapes diffuse, $2-8 \mathrm{~cm}$. high, several-flowered; leaves and bracts of the involucre oblong-ovate, entire, sessile; calyx-lobes leafy, triangular-lanceolate, longer than the white corolla. Bare hills and barrens, Ill, to Man., and westw. Apr., May.

\section{3. hottònia [Boerh.] L. Featherfoll. Water Violet}

Calyx 5-parted, the divisions linear. Corolla with a short tube ; limb 5-parted. Stamens 5, included. Capsule many-seeded, 5-valved; the valves cohering at the base and summit. Seeds anatropous. - Perennials, with the erect hollow flower-stems almost leafless. Flowers white or whitish, whorled at the joints, forming an interrupted raceme. (Named for Peter Hotton, early. Dutch botanist.)

1. H. inflàta Ell. Leaves dissected into thread-like divisions, scattered on the floating and rooting stems, and crowded at the base of the cluster of peduncles, which are strongly inflated between the joints; pedicels short. Pools and ditches, s. Me. to Fla, and La., near the coast; inland in the Miss. basin to Mo. and Ind. May-Aug.

\section{Sámolus [Tourn.] I. Water Pimpernel. Brook-weed}

Calyx 5-cleft. Corolla somewhat bell-shaped, 5-cleft. True stamens 5, on the corolla-tube, included. Capsule globose, 5-valved at the summit, manyseeded. - Smooth herbs, with alternate entire leaves, and small white flowers 
(Ancient name of Celtic origin, said to refer to curative properties of this genus in diseases of cattle and swine, )

1. S. VALERÁnd L. Stem erect, $0.5-8 \mathrm{dm}$. high, leafy; leaves obovate or spatulate, the basal rosulate; bracts none; slender pedicels ascending, bracteolate in the middle, in maturity 6-11 mm. long; capsule 3-4 mm. long. - Ballast, Philadelphia, etc. (Adv. from Eu.)

2. S. floribúndus H B K. More slender, becoming diffuse; racemes often panicled, the pedicels longer (11-18 $\mathrm{mm}$. long) and spreading; capsule 2 - $3 \mathrm{~mm}$. long. ( $S$. Valerandi, var. americanus Gray.) - Wet places, chiefly near the coast, and at low altitudes inland. June-Sept.

\section{LYSIMÀCHIA [Tourn.] L. LoosESTRIFE}

Calyx 5-6-parted. Corolla rotate, the divisions entire, convolute in bud. Filaments commonly monadelphous at base; anthers oblong or oval. Capsule few-several-seeded. - Leafy-stemmed perennials, with herbage commonly glan-

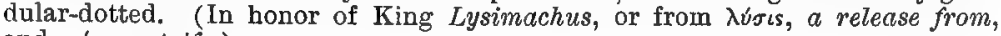
and $\mu \alpha \chi \eta$, strife.)

§ 1. LYSIMÁSTRUM Duby. Corolla yellow, rotate, very deeply parted, and with no teeth between the lobes; stamens more or less monadelphous, often unequal; leaves opposite or whorled, or some abnormally alternate.

* Corolla plain yellow, without dark markings.

1. I. VDLGARis L. Coarse and tall, softly often viscidly pubescent, branching above; leaves lanceolate to ovate-lanceolate, distinctly short-petioled; flowers $1.5-2 \mathrm{~cm}$. broad, in terminal leafy panicles; calyx 4-5 mm. long, with dark margin; glandular filaments united to near the middle. - Roadsides and thickets near towns, Me. to Ont. and O. July-Sept. (Nat. from Eu.)

2. L. PONCTATA L. Similar, but with flowers often merely whorled in the upper axils; calyx 7-10 $\mathrm{mm}$. long, green throughout; corolla-lobes with glandular-ciliolate margins. - Roadsides, etc., N. S. to N.J. and $\mathrm{Pa}$. June-July. (Nat. from $\mathrm{Eu}$. )

* Corolla dark-dotted or streaked; filaments conspicuously monadelphous, unequal.

1/. L. quadrifolia L. Somewhat loosely hairy, or smooth ; stem simple, 3-9 dm. high ; leaves whorled in fours or fives (sometimes in twos, threes, or sixes, rarely only opposite or partiy alternate), lanceolate to lance-ovate; flowers on long capillary peduncles from the axils of the leaves; corolla $1-1.5 \mathrm{~cm}$. broad, its lobes ovate-oblong. - Moist or sandy soil, N. B. to Ont., Minn., Mich., and Ga. June, July.

$\times$ L. prodúcta (Gray) Fernald. Stem smooth, 0.5-1 m. high, simple or slightly branched; leaves opposite or in whorls of 3-5, lanceolate to ovatelanceolate; flowers in terminal bracted racemes $(0.5-5 \mathrm{dm}$. long), the lower from the axils of the upper foliage leaves; corolla 1-2 cm. broad, the lobes ovate-oblong to oblong-lanceolate. (L. foliosa Small.) - Damp thickets and shores, Me. to N. C. and Mich. July, Aug. - Apparently a widely distributed and fertile hybrid of nos. 3 and 4.

4. L. terréstris (L.) BSP. Stems 2-8 dm. high, often bearing oblong or moniliform bulblets in the axils, smooth, at length branched, very leafy; leaves opposite or rarely alternate, lanceolate, acute at each end; flowers on slender pedicels, in a bracted raceme $(0.5-2.5 \mathrm{dm}$. long); lobes of the corolla lance-oblong. (L. stricta Ait.) - Low grounds, Nfd. to Hudson Bay, and southw. June-Aug. * * * Flowers 2-3 cm. broad, solitary in the axils of ordinary leaves; corolla not dark-dotted nor streaked; filaments slightly monadelphous.

5. L. Nummularia L. (Moneywort.) Smooth ; stems trailing and creeping; leaves roundish, small, short-petioled; divisions of the corolla broadly ovate, obtise, longer than the lance-ovate calyx-lobes and stamens. - Escaped from gardens into damp ground in some places. June-Aug. (Introd, from Eu.) 
8. NAUMBÚRGIA (Moench) Koch. Corolla very deeply i(or 6-7)-parted into linear somewhat purplish-dotted divisions, with w without a small tooth in each sinus; flaments distinct, equal; leaves opposite (rarely whorled), the lowest scale-like.

6. L. thyrsiflora Is. (TuFtev L.) Smooth (or with loose scurfy pubescence above when young); stem simple, $2.5-8 \mathrm{dm}$. high ; all but the lower leaves lanceolate, the axils of $1-4$ middle pairs bearing short-peduncled head-like or spikelike clusters of small light yellow flowers. - Cold swamps, Que. to Sask., s. to Pa., Ill., Mo., etc. May-July. (Eu.)

\section{STEIRONEMA Raf.}

Corolla rotate, with no proper tube ; divisions ovate, cuspidate-pointed, erosedenticulate above, each separately involute around its stamen. Filaments distinct or nearly so on the ring at base of corolla; anthers linear. Capsule 10-20-seeded. - Leafy-stemmed perennials, glabrous except the ciliate petioles, not punctate, the leaves all opposite, but mostly in seeming whorls on the flowering branches. Peduncles slender, axillary, bearing yellow flowers. (From $\sigma \tau \epsilon \hat{i} o_{s}$, sterile, and $\nu \hat{\eta} \mu \alpha$, thread, referring to the staminodia.)

† 1. S. ciliàtum (L.) Raf. Sten erect, 3-12 dm. high; leaves ovate-lanceolate to broadly ovate, $5-13 \mathrm{~cm}$. long, tapering to an acute point, rounded or heart-shaped at base, all on long ciliate-fringed petioles; corolla longer than the calyx; fruiting calyx 6-10 $\mathrm{mm}$. long, commonly exceeded by the capsule. - Low grounds and thickets. June-Aug.

2. S. intermedium Kearney. Comparatively low, $2-7 \mathrm{dm}$. high ; leaves $3-8$ $\mathrm{cm}$. long, the petioles naked except at base; caly x-lobes commonly exceeding the capsule. ( $S$. tonsum Bicknell.) - Usually in drier rocky soi], Va., Ky., and southw.

3. S. radicans (Hook.) Gray. Stem slender, soon reclined, the elongated branches often rooting in the mud; leaves lanceolate to ovate-lanceolate, mostly rounded at base, $2.5-9 \mathrm{~cm}$. long, on slender petioles; corolla about the length of the calyx; fruiting calyx 3-5 mm. long. - Swampy river-banks, Va. to Mo. and I'ex. June-Aug.

4. S. lanceolàtum (Walt.) Gray. Stem erect (or rarely reclined and rooting at the joints) ; leaves lanceolate, 4-10 $\mathrm{cm}$. long, narrowed into a short margined petiole or tapering base, or the lowest short and broad on long petioles ; corolla longer than the caly $\mathrm{x}$; fruiting calyx 5-8 $\mathrm{mm}$. long. - Low grounds and thickets, Me. to N. Dak., and southw. Var. HYвRIDUm (Michx.) Gray, with cauline leaves oblong, is less frequent.

5. S. quadriflorum (Sims) Hitchc. Stem erect, 4-angled, slender, 2-9 dm. high, often branched below; stem-leaves sessile, narrowly linear, elongated, 3-9 $\mathrm{cm}$. long, smooth and shining, rather rigid, obtuse, the margins often a little revolute, the veins obscure ; the lowest leaves oblong or spatulate; corolla longer than the calyx, the lobes conspicuously pointed; fruiting calyx $5-7 \mathrm{~mm}$. long. (S. longifolium Gray.) - Banks of streams, N. Y. to Man., s. to Va. and Mo. June-Sept.

\section{TrIentAllis L. Chickweed Wintergreen}

Corolla spreading, flat, without tube. Filaments slender, united in a ring at the base ; anthers oblong, revolute after flowering. Capsule few-seeded. - Low and smooth perennials, with simple erect stems, bearing a few alternate usually minute and scale-like leaves below, and a whorl of thin veiny leaves at the summil. Peduncles one or more, very slender, bearing a delicate white and starshaped Hower. (A Latin name, meaning the third part of a foot, alluding to the height of the plant.)

1. T. americana (Pers.) Pursh. (Star Flower.) Spreading by very slender elongated rootstocks, rarely producing long stolons fiom the upper axils; leaves elongated-lanceolate, tapering to both ends; petals finely pointed. Woods, Lab. to Man., Minn., Ill., and Va. May-July. 


\section{GLAÚX [Tourn.] L. Sea Milkwort}

Calyx bell-shaped, 5-cleft; lobes ovate or oblong, petal-like. Corolla wanting. Stamens 5, on the base of the calyx, alternate with its lobes. Capsule 5-valved, few-seeded. - A low and leafy fleshy perennial, with opposite entire sessile leaves, and solitary nearly sessile (white, pink, or lavender and crimson) flowers in their axils. (An ancient Greek name, from $\gamma \lambda a v \kappa b s$, sea-green.)

1. G. maritima L. Diffusely branched (rarely simple), the branches prostrate, loosely ascending or sometimes erect, $3-15 \mathrm{~cm}$. liigh; leaves linear to oblong, the larger 3-12 mm. long, I.5-6 mm. broad, bluntly pointed; flowers :-5 $\mathrm{mm}$. long ; mature capsule 2-3 $\mathrm{mm}$. long, 2-2.5 min. broad. - Seashores from Cape Cod northw.; also in subsaline soil, Minn. to Sask., and westw. June, July. (Eurasia ) Passing to the commoner

Var. obtusifòlia Fernald. Erect, $0.5-3 \mathrm{dm}$. high, simple or with few erect branches; leaves oval or broadly oblong, the principal ones 8-15 mm. long, 4-8 mm. broad, with rounded tips; mature capsule $2.5-4 \mathrm{~mm}$. broad. - N. J., northw.; also Pacific coast. (Japan, etc.)

\section{ANagállis [Tourn.] L. Pimpernel}

Corolla wheel-shaped, with almost no tube; the divisions broad. Stamens 5 ; filaments bearded. Capsule membranaceous, many-seeded. - Low spreading or procumbent herbs, mostly annuals, with opposite or whorled entire leaves, and solitary flowers on axillary peduncles. (The aneient Greek name, probably

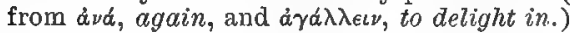

$\checkmark$ 1. A. arvínsis L. (Common P.) Leaves ovate, sessile, shorter than the peduncles; petals obovate, obtuse, fringed with minute teeth and stalked glands. -Waste sandy fields. June-Ang. - Flowers variable in size, scarlet or white, quickly closing at the approach of bad weather; whence the English popular name of "Poor Man's Weatherglass." (Nat. from Fu.) Var. CAERÚleA (Schreb.) Ledeb. Petals blue, often nearly or quite destitute of glandular ciliation. - Cultivated ground, etc., rather rare. (Adv. from Eurasia.)

\section{Centúnculus [Dill.] L. Chaffweed}

Corolla wheel-shaped, with an urn-shaped short tube, usually withering on the summit of the pod (which is like that of Anagallis). Stamens 4 or 5 ; filaments beardless. - Small annuals, with entire leaves, znd solitary inconspicuous flowers in their axils. (Derivation obscure.)

1. C. mfnimus L. Stems ascending, $3-8 \mathrm{~cm}$. long; leaves ovate, obovate, or spatulate-oblong; flowers nearly sessile, the parts mostly in fours. - Low grounds, P. E. I. (according to Macoun); and from Ill. and Minn. to Fla., Tex., and westw. (Eu.)

\section{DODECÀTHEON L. American Cowslip}

Calyx deeply 5-cleft, the divisions lanceolate. Corolla with a very short tube and thickened throat; the divisions long and narrow. Filaments short, monadelphous at base; anthers long and linear, approximate in a slender cone. Perennial smooth herb, with fibrous roots, a cluster of basal leaves, and a simple naked scape, involucrate with small bracts at the summit, bearing an ample umbel of showy flowers, nodding on slender pedicels. Corolla rose-color, or sometimes white. (Name from $\delta \omega \delta \epsilon \kappa a$, twelve, and $\theta \epsilon o l$, gods, given by Pliny to the primrose, which was believed to be under the care of the superior gods.)

1. D. Meadia L. (Shooting Star.) Leaves oblong or spatulate, gradually narrowed at base. - Woods, prairies, and moist cliffs, P'a. and Md. to Man., and southw. May, June.

Var. Frénchii Vasey. Lęaves ovate of elliptic, abruptly narrowed at base.. Pa. to Ill. and Ark. 


\section{SAP0TÀCEAE (SAPOdilla Family)}

Trees or shrubs, mostly with a milky juice, simple and entire alternate leaves (often rusty-downy beneath), snall and perfect regular flowers usually in axillary clusters; the calyx free and persistent; the fertile stamens commonly as many as the lobes of the hypogynous short corolla and opposite them, inserted on its tube, along with one or more rows of appendages and scales (or sterile stamens); anthers turned outward; ovary 4-12-celled, with a single anatropous ovule in each cell; seeds large. Albumen mostly none; but the large embryo with thickened cotyledons. Style single, pointed. - A small mostly tropical family.

\section{BUMÈLIA Sw.}

Calyx 5-parted. Corolla 5-cleft, with d pair of internal appendages at each sinus. Fertile stamens 5 ; anthers arrow-shaped. Sterile stamens 5, petal-like, alternate with the lobes of the corolla. Ovary 5-celled. Fruit small, resembling a cherry, black, containing a large ovoid and erect seed, with a roundish scar at its base. - Flowers small, white, in fascicles from the axils of the leaves. Branches sometimes spiny. Leaves often fascicled on short spurs. Wood very hard. (The ancient name of a kind of Ash.)

1. B. lycioides (L.) Pers. (Suuthern Buckthorn.) Spiny, 3-9 dm. high ; leaves wedge-oblong varying to oval-lanceolate, with a tapering base, often acute, reticulated, nearly glabrous, 3-12 cm. long; clusters densely many-flowered, glabrous; fruit ovoid. - Moist ground, Va. to s. Ill., Fla., and Tex. June, July.

2. B. lanugindsa (Michx.) Pers. (False Buckthorn.) Spiny, 3-18 m. high; leaves oblong-obovate or wedge-obovate, rusty-woolly beneath, obtuse, $2.5-9 \mathrm{~cm}$. long; clusters 6-12-flowered, pubescent; fruit globular. - Woods, s. Ill. to Kan., southw. to Fla. and 'Tex. July.

\section{EBENÅCEAE (EBont FaMiLT)}

Trees or shrubs, with alternate entire leaves, and polygamous regular flowers which have a calyx free from the 3-12-celled ovary; the stamens 2-4 times as many as the lobes of the corolla, often in pairs before them, their anthers turned inward, and the fruit a several-celled berry; ovules 1 or 2 , suspended from the summit of each cell. Seeds anatropous, mostly single in each cell, large and liat, with a amooth coriaceous integument; the embryo shorter than the hard albumen, with a long radicle and flat cotyledons. Styles wholly or partly separate. Wood hard and dark-colored. No milky juice.-A small family, chiefly tropical.

\section{DIOSPỲROS L. PERSIMMON}

Calyx 4-6-lobed. Corolla 4-6-lobed, convolute in the bud. Stamens commonly 16 in the sterile flowers, and 8 in the fertile, in the latter imperfect. Berry large, glohular, surrounded at base by the thickish calyx, 4-8-celled, 4-8-seeded. - Flowers dioeciously polygamous, the fertile axillary and solitary, the sterile smaller and often clustered. (Nane from $\Delta \iota \delta s$, of Jove, and $\pi v \rho \delta s$, grain.)

L 1. D. virginiana L. (Common P.) Leaves thickish, ovate-oblong, smooth or nearly so; peduncles very short; calyx 4-parted; corolla pale yellow, thickish, between bell-shaped and urn-shaped, $1-1.5 \mathrm{~cm}$. long in the fertile flowers, much smaller in the sterile; styles 4, two-lobed at the apex; ovary 8-celler. - Woods and old fields, Ct. to s. e. Ia., and southw. Jume. - Tree, 6-30 m. high, with very hard blackish wood; the plum-like fruit $2-4 \mathrm{~cm}$. in diameter, exceedingly astringent when green, yellow when ripe, and sweet and sometimes edible after exposure to frost. 


\section{STYRACACEAE (Storax FAMILY)}

Shrubs or trees, with alternate simple leaves destitute of stipules, and perfect regular flowers; the calyx either free or allherent to the 2-5-celled ovary; the corolla of 4-8 petals, commonly more or less united at base; the stamens twice as many as the petals or more numerous, monadelphous or polyatlelphous at base; style 1; fruit dry or drupe-like, 1-5-celled, the cells commonly 1-seeded. Seeds anatropous. Embryo nearly the length of the albumen; radicle slender, as long as or longer than the flat cotyledons. Corolla hypogynous when the calyx is free; the stamens adherent to its base. Ovules 2 or more in each cell. - A small family, mostly of warm countries.

\footnotetext{
* Calyx 5-cleft, imbricate; stamens in several series ; anthers short, innate; embryo terete ; flowers yellow; pubescence simple.
}

1. Symplocos. Calyx adherent to the lower part of the 3-celled ovary. Petals 5, united merely at the base.

* * Calyx 4-8-toothed or entire; stamens 2-4 times as many as the petals, in one series; anthers linear or oblong, adnate, introrse ; cotyledons flat; flowers white; pubescence soft and mostly stellate.

2. Halesia. Calyx adherent to the whole surface of the 2-4-celled ovary, which is 2-4-winged and 1-4-celled in fruit. Corolla 4-lobed.

3. Styrax. Calyx adherent only to the base of the 3-celled ovary. Corolla mostly 5-parted. Fruit 1-celled, mostly 1-seeded.

\section{SÝMPLOCOS Jacq. SWEET LEAF}

Petals imbricated in the bud. Stamens in 5 clusters, one adhering to the base of each petal ; filaments slender. Fruit drupe-like or dry, mostly 1-celled and 1-seeded. - Shrubs or sinall trees, the leaves commonly turning yellowish in drying, and furnishing a yellow dye. Flowers in axillary clusters or racemes, yellow. (Name $\sigma \dot{u} \mu \pi \lambda$ oкos, connected, from the union of the stamens.)

1. S. tinctòria (L.) L'Hér. (Horse Sugar.) Leaves elongated-oblong, acute, obscurely toothed, thickish, almost persistent, minutely pubescent and pale beneath, 7-15 cm. long; flowers $6-14$, in close and bracted clusters, odorous. - Rich ground, Del. to Fla. and La. Apr. - Leaves sweet, greedily eaten by cattle.

\section{HALÈsia Ellis. SNowdrop or Silver-Bell Tree}

Calyx inversely conical, 4-toothed; the tube 4-ribbed. Petals 4, united at base, or oftener to the middle, into an open bell-shaped corolla, convolute or imbricated in the bud. Stamens 8-16; filaments united into at ring at base, and usually a little adherent to the base of the corolla ; anthers linear-oblong, Ovules 4 in each cell. Fruit large and dry, bony within. Seeds single, cylindrical. - Shrubs or small trees, with large and veiny pointed deciduous leaves; the snowy white flowers drooping on slender pedicels, in clusters or short racemes, from axillary buds of the preceding year. Pubescence partly stellate. (Named for Stephen Hales, author of Vegetable Statics, etc.) MoHrodenidron Britton.

1. H. carolìna L. (Opossum Wood.) Leaves oblong-ovate; fruit 4-winged, 3-4 cm. long. ( $H$. tetraptera L. ; Mohrodendron carolinum Britton.) - Banks of streams, Va. to Ill., s. to Flu. - Flowers opening while still small and green (according to Harper). 


\section{STỲraX [Tourn.] L. STORaX}

Calyx truncate, somewhat 5-toothed. Corolla 5(rarely 4-8)-parted, large ; the lobes mostly soft-downy. Stamens twice as many as the lobes of the corolla; flaments flat, united at the base into a short tube; anthers linear. Fruit globular, its base surrounded by the persistent caly $x$, dry, often 3-valved. Seed globular, erect, with a hard coat. - Shrubs or small trees, with commonly deciduous leaves, and axillary or leafy-racemed white and showy flowers on drooping peduncles, produced in spring. (The ancient Greek name of the tree which produces storax.)

1. S. grandifolia Ait. Shrub, 1-3.5 m. high; leaves obovate, acute or short-acuminate, white-tomentose beneath, 0.5-1.5 dm. long; flowers mostly in elongated racemes; corolla $1.5 \mathrm{~cm}$. long, convolute-imbricated in bud. - Woods, s. Va. to Fla.

2. S. pulverulénta Michx. Shrub, $0.3-1.2 \mathrm{~m}$. high; leaves oval or obovate, 3-6 cm. long, sparingly puberulent above, and scurfy-tomentose beneath; flowers $1-1.5 \mathrm{~cm}$. long, $1-3$ together in the axils and at the tips of the branches, fragrant. - Low pine barrens, s. Va, to Fla. and Tex.

3. S. americàna Lam. Shrub, 1-2.5 m. high; leaves oblong, acute at both ends, 2.5-9 cm. long, smooth, or barely pulverulent beneath; flovers axillary or in 3-4-flonoered racemes; corolla valvate in the bud. - Along streams, in cypress swamps, etc., Va. to Fla., La., and northw。 in the Miss. Valley to Mo. and Ill.

\section{OLEÀCeAe (Olive Familu)}

Trees or shrubs, with opposite and pinnate or simple leaves, a 4-cleft (or sometimes obsolete) calyx, a regular 4-cleft or nearly or quite 4-petalous corolla, sometimes apetalous; the stamens only 2 (rarely 3 or 4 ); the ovary 2-celled, with 2 (rarely more) ovules in each cell. Seeds anatropous, with a large straight embryo in hard fleshy albumen, or without albumen.

Tribe I. FRaxfineaE. Fruit dry, indehlscent, winged, a agmara. Leaves pinnste.

1. Fraxinus. Flowers mostly apetalous, sometimes also without calyx.

Tribe II. SYRfNGEAE. Fruit a loculicidal capsule. Leaves simple.

2. Syringa. Corolla salver-form, the lobes mostly 4, valvate in bud.

Tribe III. OLEINEAE. Frult a drupe, or rarely a berry. Leaves simple.

8. Adelia. Flowers apetalous, dioecious or polygamous, from a scaly catkin-like bad. Sta. erens 2-4.

4. Chionanthus. Flowers complete, sometimes polygamous. Calyx and corolla 4-merous, the latter with long and linear divisions.

5. Iirustrum. Oorolla nunnel-form, 4-cleft, the tube longer than the calyx.

\section{FRÁXINUS [Tourn.] L. AsH}

Flowers dioecious, polygamous, or monoecious. Calyx small and 4-cleft, toothed. or entire, or obsolete. Petals 4, or altogether wanting in our species. Stamens \%, sometimes 3 or 4 ; anthers linear or oblong, large. Style single; stigma "2-cleft. Fruit 1-2-celled, flattened, 1-2-seeded. Cotyledons elliptical ; radicle slender. - Timber-trees, with petioled pinnate leaves; the small flowers in crowded panicles or racemes from the axils of last year's leaves. (The classical Latin name.)

\section{* Leaflets petiolulate; anthers linear-oblong. \\ - Calyx small, persistent in firuit. \\ * Fruit with a terete or nearly terete body.}

1. F. americàna L. (White A.) Branchlets and petioles glabrous; leaflete 5-9, ovate- or lance oblong, pointed, pale and either smooth or pubescent under. 
neath, entire or sparingly serrate or denticulate ; fruit $2.5-5 \mathrm{~cm}$. long, marginless below, abruptly dilated into a lanceolate, oblanceolate, or wedge-linear wing $2-3$ times as long as the cylindraceous body $(1.3-2 \mathrm{~cm}$. long.

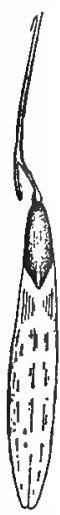
3-4 $\mathrm{mm}$. thick). - Rich or moist woods, N. S. to Ont., and southw. Apr., May. - A large and very valuable forest tree, with gray furrowed bark, smooth gray branchlets, and rustcolored buds. Monoecious flowers rarely occur. Fig. 846.

2. F. biltmoreàna Beadle. Branchlets, petioles, etc., pubescent or tomentose; leaflets 7-9, lanceolate, acuminate, decidedly paler and sparingly pubescent beneath; fruit linear-oblong, scarcely narrowed to the rounded apex, the body short and stout (1-1.4 cm. long, 4-5 mm. thick). - Pa. to Ga.

3. F. pennsylvánica Marsh. (REv A.) Branchlets and petioles velvety-pubescent; leaflets 5-9, ovate or oblong-lanceolate, taperpointed, almost entire, pale or more or less pubescent beneath; fruit $2.5-7 \mathrm{~cm}$. long, the edges gradually dilated into the linear or spatulate wing, the body $1.4-2 \mathrm{~cm}$. long, $2-3 \mathrm{~mm}$. thick. ( $\boldsymbol{F}$. pubescens Lam., including the narrowest-fruited form, $F$. Darlingtonii Britton.) - Low ground, Me. to 846. F. americana. Dak, and southw, - Tree of middle or
Fruit $\times \%$. large size; inner face of outer bark of the Fruit $\times \%$.

Fig. 847. Passing to branches red or cinnamon-color when fresh.

Var. lanceolàta (Borkh.) Sarg. (GREen A.) Glabrous

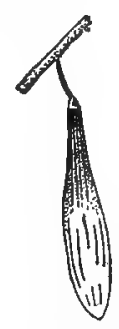

847. F. pennsylvanica. Fruit $\times \frac{2 / 3}{3}$. throughout; leaflets often wedge-shaped at the base and serrate above, bright green both sides. ( $F$. viridis Michx. f.)-Along streams, Me. to Sask., and southw.

\section{* Fruit with a flattish body passing insensibly into the wing.}

4. F. profúnda Bush. (Ромгкin A.) Terete branchlets velvety-pubescent, as are the petioles, rhachises, etc.; leaflets $7-9$, ovate-lanceolate, long-petiolulate,

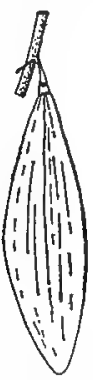

848. F. carollniana. Fruit $\times \frac{2}{3}$. subentire; fruit linear-oblong, rounded or retuse at the apex, somewhat narrowed to the thickish base but without distinctly limited body.-River-swamps, etc., w. N. Y. to Mo., and southw.

5. F. caroliniàna Mill. (WATER A.) Branchlets terete, glabrous or pubescent; leaflets $5-7$, ovate or oblong, acute at both ends, short-stalked; fruit broadly winged (not rarely 3-winged), elliptic or oblanceolate, acutish at apex, with a tapering base. ( $F$. platycarpa Michx.) - River-swamps, Va. to Fla., La., and Mo. March. - Tree of middle size. FIG. 848.

$$
\text { + + Calyx wanting or a mere disk-like ring. }
$$

6. F. quadrangulàta Michx. (BLDE A.) Branchlets square (at least on vigorous shoots), glabrous; leaflets 7-11, shortstalked, oblong-ovate or lanceolate, pointed, sharply serrate, green both sides; fruit oblong, blunt, and of the same width at both ends, or slightly narrowed at the base, often notched at the apex, 2.5-5 cm. long, 6-15 mm. wide.-Dry or moist rich woods, O. to Mich. and Minn., Ala., Ark., etc. - Large timber-tree, the inner bark yielding a blue color to water.

* Lateral leaflets sessile; anthers short-oblong; flowers wholly naked.

7. F. nigra Marsh. (Black A.) Branchlets and petioles glabrous; leaflets $7-11$, oblong-lanceolate, tapering to a point, serrate, obtuse or rounded at the base, green and smooth both sides, when young with some rusty hairs along the midrib; fruit linear-oblong or narrowly elliptical, blunt at both ends. ( $F$. sambucifolia Lam.) - Swamps and wet banks, Nfd. to Man., Del., Va., and 
Ark. - Small or middle-sized tree, with very tough and fissile wood Bruised foliage exhales the odor of Elder.

\section{SYRINGA L. ILILAC}

Corolla salver-formed, much exceeding the 4-toothed calyx, pale violet to roseate or white. Ovary 2-celled; ovules 2 in each cell, pendulous. - Upright shrubs with simple opposite ovate or lanceolate leaves and numerous flowers in thyrsoid or pyramidal panicles. (Name from $\sigma \hat{v} \rho \imath \xi$, a pipe or tube, perhaps in reference to the tubular corolla, perhaps to the use of the wood for pipe-stems or whistles.)

1. S. VULGARIS L. (Common L.) Leaves ovate, acuminate, entire, truncate or subcordate at base, slender-petioled; corolla lilac-purple, rarely white. Long popular in cultivation and not rarely found in a wild state. (Introd. from Eu.)

\section{ADÈLIA P. Br.}

Calyx of 4 minute sepals. Anthers oblong. Ovary ovoid, 2-celled, with 2 pendulous ovules in each cell; style slender ; stigma somewhat 2-lobed. Drupe small, ovoid, 1-celled, 1-seeded. - Shrubs, with opposite and often fascicled deciduous leaves, and small flowers from the axils of the preceding year. Fertile peduncles short, 1-3-flowered. (Name from $a \delta \eta \lambda o s$, obscure, from the minute flowers.) Forestiera Poir.

1. A. acuminàta Michx. (Swamp Priver.) Glabrous, somewhat spinescent, $1.5-3 \mathrm{~m}$. high ; leaves thin, oblong-ovate or ovate-lanceolate, acuminate at both ends, often serrulate; drupe elongated-ellipsoid, usually pointed. (Forestiera Poir.) - Wet river-banks and swamps, s. W. Ind. to Mo., s. to Tex.

\section{CHIONÁNTHUS L. Fringe-TREE}

Calyx 4-parted, very small, persistent. Petals barely united at base. Stamens 2 (rarely 3 or 4 ), on the very base of the corolla, very short. Stigma notched. Drupe fleshy, globular, becoming 1-celled, 1-3-seeded.-Low trees or shrubs, with deciduous and entire petioled leaves, and delicate flowers in loose and drooping graceful panicles, from lateral buds. (Name from $\chi \iota \dot{\omega}$, snow, and avoos, blossom, alluding to the light and snow-white clusters of flowers.)

1. C. virgínica L. (Old MAN's BEARD.) Leaves oval, oblong, or obovatelanceolate; flowers on slender pedicels; petals $2-2.5 \mathrm{~cm}$. long, narrowly linear, acute, varying to 5 or 6 in number; drupe purple, with a bloom, ovoid, $1-1.8 \mathrm{~cm}$. long. - River-banks, N. J. and Pa. to Fla., Tex, and Mo. - Very ornamental in cultivation. May, June.

\section{Ligústrum [Tourn.] L. Privet}

Calyx short-tubular, 4-toothed, deciduous. Stamens 2, on the tube of the corolla, included. Berry 2-celled, 1-2-seeded. - Shrubs with entire leaves and small white flowers in terminal panicles. (The classical name.)

1. L. vulgare L. (Privet or Prim.) Leaves very smooth ; berries black. - Used for low hedges, and naturalized from Me. to Ont. and N. C. June, July. (Introd. from Eu.)

\section{LOGANiÀceae (Logania Family)}

Herbs, shrubs, or trees, with opposite and entire leaves, and síipules or a stipular membrane or line between them, and with regular 4-5-merous 4-5androus perfect flowers, the ovary free from the calyx; a connecting group between Gentianaceae. Apocynacene, Scrophulariaceae (from all which they are known by their stipules) and Rubiaceae, from which they differ in their 
free ovary; our representatives of the family are related most nearly to the Rubiaceae, to which, indeed, they have been appended.

* Woody twiners; leaves evergreen; stigmas 2, each 2-parted.

1. Gelsemium. Corolla large, the 5 lobes imbricated in the bud. Style slender.

** Herbs; stigmas single, entire or 2-lobed.

2. Spigelia. Corolla 5-lobed, valvate in the bud. Style single, jointed in the midale.

8. Cynoctonum. Corolla 5-lobed, valvate in the bud. Styles 2, short, converging, united at the summit, and with a common stigma.

4. Polypremum. Corolla 4-lobed, not longer than the calyx, imbricated in the bud.

\section{Gelsk̀miuM Juss. Yellow (Falge) Jessamine}

Corolla open-funnel-form. Stamens 5, with oblong sagittate anthers. Divisions of stigma linear. Capsule elliptical, flattened contrary to the narrow partition, 2-celled, septicidally 2-valved. Seeds many or several, winged. Embryo straight, in fleshy albumen; the ovate flat cotyledons much shorter than the slender radicle, - Smooth twining shrubby plants with ovate or lanceolate leaves, minute deciduous stipules, and showy yellow dimorphous flowers. (Gelsomino, the Italian name of the Jessamine.)

1. G. sempérvirens (L.) Ait. f. Stem climbing high; leaves short-petioled, shining, nearly persistent; flowers in short axillary clusters; pedicels scaly bracted; flowers very fragrant; corolla $2.5-4 \mathrm{~cm}$. long; capsule flat, pointed. Low grounds, e. Va. to Fla. and Tex. Mar., Apr.

\section{SPIgÈLIA L. Pink-root. Worm-Grass}

Corolla tubular-funnel-form, 5-lobed at the summit. Stamens 5; anthers linear. Style slender, hairy above. Capsule short, 2-celled, twin, laterally flattened, separating at maturity from a persistent base into 2 carpels, which open loculicidally, few-seeded. - Chiefly herbs, with opposite leaves united by stipules, and the flowers spiked in one-sided cymes. (Named for Adrian Spiegel, latinized Spigelius, who wrote on botany early in the 17th century, and was perhaps the first to give directions for preparing an herbarium.) -

1. S. marilándica L. (INDiAn PinK.) Stems simple and erect, 3-6 dm. high, from a perennial root; leaves sessile, ovate-lanceolate, acute; spike simple or forked, short; corolla $3-5 \mathrm{~cm}$. long, red outside, yellow within ; tube 4 times the length of the calyx, the lobes lanceolate; anthers and style exserted. Rich woods, O. and Ky. tc Fla., Mo, and Tex. May, June.

\section{CYNóctondm J. F. Gmel. Miterwort}

Corolla little longer than the calyx, somewhat funnel-form. Stamens 5 , included. Ovary at the base slightly adnate to the bottom of the calyx, 2-celled. Capsule exserted, strongly 2-horned or miter-shaped, opening down the inner side of each horn, many-seeded. - Annual smooth herbs, 1-7 dm. high, with small stipules between the leaves, and small white flower's spiked along one side

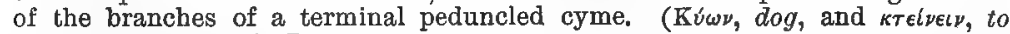
kill.) Mitriela R. Br.

1. C. Mitréola (L.) Britton. Leaves thin, oblong-lanceolate, petioled. ( $\boldsymbol{M}$. petiolata T. \& G.) - Damp soil, from e. Va. to Tex. June-Nov.

\section{POLYPRÈMUM L.}

Calyx 4-parted; the divisions awl-shaped from a broad scarious-margined base. Corolla almost wheel-shaped, bearded in the throat. Stamens 4 , very short; anthers globular. Style very short; stigma ovoid, entire. Capsule ovoid, a little flattened, notched at the apex, 2-celled, loculicidally 2-valved, 
many-seeded. - A smooth diffuse much branched small annual, with narrowly linear or awl-shaped leaves connected at base by a slight stipular line; the small flowers solitary and sessile in the forks and at the ends of the branches ; corolla inconspicuous, white. (Name altered from $\pi \circ \lambda$ iv $\pi \rho \mu \nu$ s, many-stemmed.)

1. P. procúmbens L. - Dry fields, mostly in sandy soil, Md. to Fla., Tex., and Mo. ; also adventive in N. J. and Pa. June-Oct.

\section{gentianaceat (Gentian Family)}

Smooth herbs, with a colorless bitter juice, opposite and sessile entive and simple leaves (except in no. 9) without stipules, regular flowers with the stamens as many as the lobes of the sorolla, which are convolute (rarely imbricated and sometimes valvate) in the bud, a 1-celled ovary with? parietal placentae, or nearly the whole inner face of the ovary ovuliferous; the fruit usually a 2-valved and septicidal many-seeded capsule. Calyx persistent. Corolla mostly with. ering-persistent; the slamens inserted on its tube. Seeds anatropous, with ? minute embryo in fleshy albumen. - Bitter-tonic plants.

\section{Subfamit I. GENTIANofDeaE}

Leaves always simple and entire, sessile, never alternate. Aestivation of corolla never valvate.

* Lobes of corolla convolute in the bud.

+ Style filform, usually declduous; anthers oblong to linesr, mostly twisting or eurving in age.

1. Sabatia. Parts of flower 5-12. Corolla rotate. Anthers recurved or revolute.

2. Centaurium. Parts of flower 5 or 4 . Corolla salver-form. Anthers twisting spirally ++ Style stout and persistent or none; anthers remaining straight.

+ Corolla with scale-like appendages but no large pits or glands at base.

8. Gentiana. Corolln funnel-form or bell-shaped, mostly plaited in the sinuses. Calyx 4-5-cleft.

4. Pleurogyae. Corolla rotate. Calyx 4-5-parted. \#+ Corolls with a large pit or gland at the base of each lobe.

5. Frasera. Corolla 4-parted, rotate; a fringed glandular spot on each lobe.

6. Halenia. Gorolla 4-5-cleft, campanulate, and usually 4-5-8purred at the base. ** Lobes of corolla imbricate in the bud; no appendages nor glands.

7. Bartonia. Calyx 4-parted, Corolla deeply 4-cleft, somewhat campanulate.

8. Obolaria. Calyx of 2 folisceous sepals. Corolla 4-lobed, oblong-campanulate.

\section{SUbFamily II. MENYANTHOfDEAE}

Leaves all alternate and mostly petioled, sometimes trifoliolate or crenate Aestivation of corolla induplicate-valvate. Marsh or aquatic perennials.

9. Menyanthes. Corolla bearded inside. Leavas 8-foliolate.

10. Nymphoides. Corolla naked, or bearded on tha margins only. Leaves simple, rounded

\section{SABATIA Adans.}

Calyx 5-12-parted, the lobes slender. Corolla 5-12-parted, wheel-shaped. Stamens 5-12; anthers soon recurved. Style 2-cleft or -parted, slender. Blennials or annuals (rarely perennial by stolons), with slender stems, and cymose-panicled handsome (white or rose-purple) flowers in summer. (Dedicated, it is said, to $L$. Srbbati, an early Italian botanist.) SABBatia Salisb. 
* Corolla 5-parted, or rarely 6-7-parted.

- Branches all opposite and stems more or less 4-angled; flowers cymose; calyx with long and slender lobes.

+ Corolla white, often turning yellowish in drying.

1. S. paniculàta (Michx.) Pursh. Stem much branched, 2-7 dm. high; leaves linear or the lower oblong, obtuse, 1-nerved, nearly equaling the internodes; calyx-lobes much shorter than the corolla. - Low grounds, Va. to Fla.

2. S. lanceolàta (Walt.) T. \& G. Stem simple, 4-9 dm. high, bearing a flattopped cyme; leaves ovate-lanceolate or ovate, 3-nerved, the upper acute, much shorter than the internodes; calyx-lobes longer and flowers larger than in no. 1. - Wet pine barrens, N. J. to Fla.

+ Corolla rose-pink, rarely white, with a yellowish or greenish eye.

3. S. brachiàta Ell. Stem slightly angled, simple below, 3-6 dm. high; leaves linear and linear-oblong, obtuse, or the upper acute; branches rather few-flowered, forming a panicle; calyz-lobes nearly half shorter than the corvlla. (S. angustifolia Britton.) - Dry or low places; Ind. and N. C. to La. and Fla.

4. S. angulàris (L.) Pursh. Stem somewhat 4-wing-angled, much branched above, 3-9 dm. high, many-flowered; leaves ovate, acutish, 5-nerved, with a somewhat heart-shaped clasping base; calyx-lobes one third or half the length of the corolla. - Rich soil, N. Y. to Ont. and Mich., s. to Fla. and La.

+ - Branches alternate (or the lower opposite in no. 5); peduncles 1-flowered. +r. Calyx-lobes foliaceous.

5. S. calycina (I.am.) Heller. Diffusely forking, pale, 1-5 dm. high ; leaves oblong or lance-oblong, narrowed at base; calyx-lobes spatulate-lanceolate, 1-2 $\mathbf{c m}$. long, exceeding the rose-colored or almost white corolla. (S. calycosa Pursh.) - Sea-coast and near it, Va. to Tex.

+ Calyx-lobes slender and tube very short (prominently costate in no. 6, and longer, nearly or quite inclosing the retuse capsule).

6. S. campéstris Nutt. Stem $0.5-4 \mathrm{dm}$. high, divergently branched above; leaves ovate with subcordate clasping base, 1-3 cm. long, on the branches lanceolate; calyx equaling the lilac corolla $(3-4.5 \mathrm{~cm}$. broad). - Prairies, Mo. to Tex.

7. S. stellàris Pursh. Loosely branched and forking; leaves oblong to lanceolate, the upper narrowly linear; calyx-lobes awl-shaped-linear, varying from half to nearly the length of the bright rose-purple corolla; style nearly 2-parted. - Salt marshes, Mass. to Fla. - Appears to pass into the next; corolla in both at times pink or white.

8. S. grácilis (Michx.) Salisb. Stem very slender, at leugth diffusely branched; branches and long peduncles filiform; leaves linear, or the lower lance-linear, the uppermost similar to the setaceous calyx-lobes, which equal the rose-purple corolla; style cleft to the middle. (S. campanulata Torr.?) Brackish marshes, s. e. Mass. and N. J. to Fla. and La.

$$
\text { * *orolla 8-12-parted, large (3-5.5 cm. broad). }
$$

9. S. dodecándra (L.) BSP. Stem 1-6 dm. high, loosely panicled above; peduncles slender, 1-flowered; leaves oblong-lanceolate; calyx-lobes linear, half the length of the deep rose-colored (rarely white) corolla. (S. chloroides Pursh.) - Borders of brackish ponds, Mass. to N. C.

\section{Centafrium Hill. Centaury}

Caly x 4-5-parted, the divisions slender. Corolla funnel-form or salver-form, with slender tube and 4-5-parted limb. Anthers exserted, erect, twisting spirally. Style slender, single; stigma capitate or 2-lipped. - Low and small branching annuals, chiefly with rose-purple or reddish flowers in summer. (An 
old name, variously applied by the herbalists, from centum, hundred, and aurum, gold or gold-piece, alluding, it is said, to the priceless medicinal value; com. pare the German vernacular name Tausendgïldenkraut.) ERithreA Neck. Erythraea Borkh.

$$
\text { * Elowers in spikes. }
$$

1. C. spicatum (L.) Fernald. Stem strictly upright, 1-4 dm. high ; the flowers sessile and spiked along one side of the simple or rarely forked branches; leaves oval and oblong, rounded at base, acutish; tube of the rose-colored or whitish corolla scarcely longer than the calyx, the lobes oblong. (Erythraea Pers.) - Sandy coast, Nantucket, Mass., and Portsmouth, Va. (Nat. from Eu.)

* Flowers in cymes or panicles.

- Flowers in definite terninal cymes, at least the central flower sessile.

2. C. ombellàtom Gilib. (Centaurx.) Stem upright, 1-5 dm. high, corymbosely branched above; leaves oblong or elliptical, acutish, the basal rosulate, the uppermost linear; cymes clustered, flat-topped, the flowers all nearly sessile; tube of the purple-rose-colored corolla not twice the length of the oval lobes. (Erythraea Centaurium Pers.) - Waste grounds, N. S.; Mass. to Ind. and Mich. (Nat. from Eu.)

\section{- Flowers loosely paniculate or paniculate-cymose, all pediceled. +- Corolla-lobes 3-5 mm. long; anthers oblong.}

3. C. PUlснецды (Sw.) Druce. Low $(0.5-3 \mathrm{dm}$. high); stem. many times forked above and forming a diffuse cyme; leaves ovate-oblon, or oval, not rosulate below; pedicels shorter than the calyx; tube of the pink-purple corolla thrice the length of the elliptical-oblong lobes. (Erythraea ramosissima Pers.) - Wet or shady places, N. Y. to Ill., and southw. (Nat. from Eu.)

4. C. texénse (Griseb.) Fernald. Similar to the preceding, but more diffusely forked; cauline leaves linear or linear-lanceolate, the upper reduced to subulate bracts; pedicels equaling or axceeding the calyx; corolla-tube twice the length of the lance-oblong lobes. (Erythraea Griseb.) - Dry soil, Mo. to Tex.

\section{+ Corolla-lobes 7-10 mm. long; anthers linear.}

5. C. calycosum (Buckley) Fernald. Simple or corymbose-branched, 1-6 dm. high; leaves oblong to lance-linear; pedicels equaling or exceeding the calyx; corolla-tube nearly equaled by the oblong or oval lobes. (Erythraea Buckley.) - Damp soil, Mo. to Tex.

\section{Gentiàna [Tourn.] L. Gentian}

Corolla 4-5-lobed, usually with intermediate plaited folds, which bear appendages or teeth at the sinuses. Stamens inserted on the tube of the corolia. Style short or none; stigmas 2, persistent. Capsule ellipsoid, 2-valved, the innumerable seeds either borne on placentae at or near the sutures, or in most of our species covering nearly the whole inner face of the pod. - Flowers solitary or cymose, showy, in late summer and autumn. (Name from Gentius, king of Illyria, who according to Pliny discovered the plant, i.e. its medicinal virtue.)

\$1. GENTIANELLA [Rupp.] Reichenb. Corolla (not rotate) destitute of extended plaits or lobes or teeth at the sinuses; root annual or biennial.

* Flowers large, solitary on long terminal peduncles, mostly 4-merous; corolla campanulute-funnel-form, its lobes usually fimbriate or erose, not crowned; a row of glands between the bases of the filaments.

1. G. crinita Froel. (Fringed G.) Stem 1-9 dm. high; leaves lanceolate or ovate-lanceolate from a partly heart-shaped or rounded base; lobes of the 4-cleft calyx unequal, ovate and lanceolate, as long as the bell-shaped tube of the blue (rarely white) corolla $(2.5-6 \mathrm{~cm}$. long), the lobes of which are voedgeobovate, and strongly fringed around the summit; ovary lanceolate. - Low grounds, centr. Me. and w. Que. to Dak., Ia., O., and Ga. 
2. G. prócera Holm. Stem 1.5-5 dm. high; leaves linear or lance-linear, ncute, the basal spatulate; lobes of the 4-cleft calyx unequal, alternately lancetriangular and linear-lanceolate, all pointed and keeled and scabrous on the back; lobes of the sky-blue corolla roundish, with ciliate-fringed margins and merely dentate summit; ovary elliptical. (G. serrata Man. ed. 6 , not Gunner; $G$. retonsa Am. auth., not Rottb.) - Moist grounds, N. Y. and Ont. to Man. and Ia.

* Flowers smaller, 4-5-merous; corolla somewhat funnel-form or salver-form,

its lobes entire; peduncles short or none, terminal and lateral on the acuceangled stem.

3. G. Amarélla L. Stems $0.5-6 \mathrm{dm}$. high; leaves lanceolate to narrowly oblong, or the lowest obovate-spatulate, the margins minutely scabrous; calyxlobes (4-5) foliaceous, lanceolate or linear; corolla blue, lavender, or white, 8-15 mm. long, with a fimbriate crown at the base of the oblong acute lobes; capsule sessile. Eurasia.

Var. acuta (Michx.) Herder. Calyx almost 5-parted ; crown usually of fewer and sometimes very few setae. (G. acuta Michx.)-Barrens, meadows, and rocky banks, Lab. to Alaska, s. to n. N. B., n. Me., n. Vt., Minn., N. Dak., N. Mex., and Cal. (Asia.)

4. G. quinquefolia L. Slender, simple or branching, $0.5-6 \mathrm{dm}$. high ; leaves ovate-lanceolate from a partly clasping and heart-shaped base, 3-7-nerved, tipped with a minute point; branches racemed or panicled, about 5-flowered at the summit; lobes of the small 5-cleft calyx awl-shaped-linear; corolla pale blue or ochroleucous, 1-2 cm. long, its lobes triangular-ovate, bristle-pointed, without crown, but the glands at the base of the slender obconical tube manifest; capsule stipitate. (G. quinqueflor'a Hill, a more appropriate but later name.) Moist hills, s. Me. to Ont, Ill., and Fla. Var. occidentA LIs (Gray) Hitehc. Often taller and paniculately much branched; calyx-lobes more leaf-like, linearlanceolate to oblong-lanceolate, reaching to the middle of the broader funnelform corolla. - O. to Minn., and southw.

\$2. PNEUMONANTHE [Gleditsch] Link. Corolla (funnel-form or salverform) with thin-membranaceous toothed or lobed plaits in the sinuses; no crown nor glands; capsule stipitate; autumn-flowering perennials, the flowers large, sessile or short-pedunculate and bibracteate (except in no. 12).

- Anthers unconnected or soon separate; leaves rough-margined; seeds winged.

5. G. affinis Griseb. Stems clustered, 1-4.5 dm. high; leaves oblong or lanceolate to linear; flowers numerous and thyrsoid-racemose or few or rarely almost solitary; calyx-labes unequal, the longest rarely equaling the tube, the shortest sometimes minute; corolla blue or bluish, $2-3 \mathrm{~cm}$. long, rather narrowly funnel-form, with ovate spreading lobes, the plaits with conspicuous laciniate appendages sometimes equaling the lobes. - Damp soil, Minn. and westw.

6. G. puberula Michx. Stems mostly solitary, erect or ascending, 1.5-5 dm. high, mostly rough and minutely pubescent above; leaves rigid, linear-lanceolate to oblong-lanceolate, $2-7 \mathrm{~cm}$. long; flowers clustered, rarely solitary; calyxlobes lanceolate, much shorter than the bell-funnel-form open bright blue corolla, the spreading ovate lobes of which are twice or thrice the length of the cuttocthed appendages. - Dry prairies and barrens, Md. to Ga., Kan., and Minn. Oct.

\section{* Anthers cohering in a ring or short tube; Hovers in terminal and often axillary clusters.}

- Calyx-iobes and bracts ciliolate-scabrous; seeds conspicuously vinged; leaves somewhat rough-margined.

7. G. Saponària I. (SoAPWORT G.) Stem erect or ascending, smooth; leaves ovate-lanceolate, oblong, or lanceolate-obovate, narrowed at the base: calyx-lobes linear or spatulate, acute, equaling or exceeding the tube, half the length of the corolla; lobes of the club-bell-shaped light blue corolla obtuse, 
erect or converging, short and broad, but distinct, and more or less longer than the conspicuous 2-cleft and minutely tootbed appendages. - Moist woods, Ct. to Ont, and southw.

8. G. Andréwsii Griseb. (CLosev G.) Stems upright, smooth; leaves ovate-lanceolate and lanceolate from a narrower base, gradually pointed; calyxtobes lanceolate to obovate, recurved, shorter than the top-shaped tube, and nuch shorter than the more cylindric and truncate mostly blue corolla, which is closed at the mouth, the proper lobes equaled by the broad notched appendages. Moist ground, s. Me. to Man., and southw. - Corolla blue with white plaits, or sometimes all white.

+ + Margins of leaves, bracts, etc., smooth and naked; terminal flower-cluster leafy-involucrate; seeds winged.

9. G. flávida Gray. Stems upright, stout; flowers sessile and crowded in a dense terminal cluster; leaves ovate-lanceolate from a heart-shaped closely clasping base, gradually tapering; calyx-lobes ovate or subcordate, wany times shorter than the tube of tho corolla, veflexed-spreading; corolla white, more or less tinged with greenish or yellowish, inflated-club-shaped, at length open, its short and broad ovate lobes twice the length of the broad toothed appendages. (G. alba Man. ed. 6, not Muhl.) - Sandy woods and meadows, Ont. to Mo., $\mathrm{Ky}$, and Va.

10. G. linedris Froel. Stems slender and strict, $2.5-7 \mathrm{dm}$. high ; flowers 1-5 in the terminal cluster; leaves linear or lanceolate, with somewhat narrowed base; bracts sometimes very finely scabrous; calyx-lobes appressed-ascending, linear or lanceolate, mostly subequal; corolla blue or white, slender-funnel-form, its erect roundish-ovate lobes a little longer than the triangular appendages. (G. rubricaulis Schwein.) - Bogs and wet rocks, N. B. to Ont., Minn., N. Y., and $M d$.

Var. latifolia Gray. Stout; leaves closely sessile, not contracted at base, the lowest oblong-linear, the upper ovate-lanceolate; calyx-lobes unequal; appendages broad, acute or subtruncate, mostly thrice exceeded by the corollalobes. - L. Superior; N. B.

+++ Calyx-lobes and bracts with the margins smooth or nearly so; seeds completely marginless.

11. G. villosa L. (Sampson's SNakeroot.) Stems ascending, smooth ; leaves from broadly obovate and obtuse to somewhat lanceolate, all narrowed at base; calyx-lobes linear, unequal, much longer than the tube, rather shorter than the greenish-white open corolla, which is painted inside with green veins and lilac-purple stripes; corolla-lobes ovate, much exceeding the small sparingly toothed oblique appendages. (G. ochroleuca Froel.) - Dry or damp grounds, N. J. and Pa. to Fla, and La.

* * Anthers not connected; flowers terminal, solitary, commonly peduncled and naked; seeds wingless.

12. G. Porphyrio J. F. Gmel. Stems slender and ascending, 1-4.5 dm. high, mostly simple; leaves linear or the lower oblanceolate, rigid; corolla openfunnel-form, 4-6 crm. long, azure-blue, rarely greenish or white, about twice the length of the thread-like calyx-lobes, its ovate spreading lobes twice as long as the cut-toothed appendages. (G. angustifolia Michx.) - Moist pine barrens, N. J. to Fla.

\section{PLEURÓgYNe Esch.}

Acute divisions of the showy corolla with a pair of scale-like appendages at base. Stamens inserted at base of corolla. Style none; stigmas decurrent. Small annuals of cold regions. (Name from $\pi \lambda \epsilon u \rho b \nu$, rib or side, and $j u v \gamma$, female; referring to the decurrent latera!, not terminai, stiguas.)

1. P. rotata (L.) Griseb. (MARSh FELwort.) Stem $0.5-3 \mathrm{dm}$. high, from simple and 1-flowered to fastigiate-branched and many-flowered; leaves linear or lanceolate, or the lowest spatulate; sepals linear to lanceulate, resembling the upper leaves, and often much elongated; corolla blue or white. the 3-5 ovate. 
oblong or lanceolate lobes (5-15 $\mathrm{mm}$. long) shorter than or exceeding the calyxjobes. (Including $P$. carinthiaca, var. pusilla Gray.) - Brackish shores and marshes, e. Que., Nfd., Lab., and northw.; Rocky Mts. - Pursh's report of the plant from the White Mts., N. H., was probably erroneous. Aug., Sept. (Greenl., 1.. Eurasia.)

\section{FRASERA Walt. American Columbo}

Calyx deeply 4-parted. Filaments awl-shaped, usually monadelphous at base; anthers oblong, versatile. Style persistent; stigma 2-lobed. Capsule oval, flattened, 4-14-seeded. Seeds large and flat, wing-margined. - Tall and showy herbs, with thick root, upright mostly simple stems, whorled leaves, and numerous peduncled flowers in open cymies, disposed in an ample elongated panicle. (Named for John Fraser, an 18th century collector.)

1. F. caroliniénsis Walt. Smooth biennial or triennial, 1-2.5 m. high ; leaves mostly in fours, lance-oblong, the lowest spatulate, veiny ; panicle pyramidal, loosely flowered; corolla 2-3 cm. broad, light greenish-yellow, marked with small brown-purple dots, its divisions oblong, mucronate, longer than the narrowly lanceolate calyx-lobes, each with a large round gland below the middle; capsule much flattened parallel with the flat valves. - Rich dry soil, N. Y. and Ont. to Wisc., and southw. May, June.

\section{Halènia Borkh. Spurred Gentian}

Calyx 4-5 parted. Corolla without folds or fringe, usually prolonged at the base underneath the erect lobes into spurs, which are glandular in the bottom. Stigmas 2, sessile, persistent on the oblong flattish capsule. Seeds rather numerous, oblong. - Small and upright herbs, with yellowish or purplish panicled-cymose flowers. (Named for Johann Halen, a German botanist.) 'Tetragonanthos Ginel.

1. H. deflexa (Sm.) Griseb. Leafy annual or biennial, 1-9 dm. high, simple or branched above; leaves 3-5-nerved, the lowest oblong-spatulate and petioled, the others oblong-lanceolate to ovate, acuminate, the nodes mostly remote; spurs cylindrical, obtuse, curved, descending, half the length of the acutely 4-lobed corolla. (Tetragonanthus Ktze.) - Damp and cool woods, Nfd. and Lab. to Sask., s. to centr. Me., w. Mass., centr. N. Y., Mich., and Minn. July-Sept. Var. heterátha (Griseb.) Fernald. Lower or sometimes all the flowers without spurs. - Nfd. and Lab. to Me. and Mich.

\section{BARTónia Muhl.}

Stamens short. Capsule oblong, flattened, pointed with a large persistent at length 2-lobed stigma. Seeds minute, innumerable, covering the whole inner surface of the pod. - Small annuals or biennials with tbread-like stems, and little awl-shaped scales in place of leaves. Flowers small, peduncled. (Dedicated to Prof. Benjamin Smith Barton, of Philadelphia.)

* Corolla-lobes oblong to spatulate, obtuse, usually denticulate.

- Flowers 7-9 mm. long; corolla-lobes spatulate, more than twice as long as the calyx-lobes.

1. B. vérna (Michx.) Muhl. Stem 1-few-flowered, 4-25 cm. high, nearly naked; leaf-scales inconspicuous, remote, mostly opposite or nearly so ; corollalobes narrowly spatulate to spatulate-obovate, obtuse, denticulate or subentire, 2-3 times as long as the calyx-lobes. - Bogs near the coast, s. Va. to Fla. and La. Mar.-May.

- + Flower*s 3-4 mm. long; corolla-lobes one third to one half longer than the . calyx-lobes or rarely twice their length.

2. B. virgínica (L.) BSP. Stems yellowish, $5-30 \mathrm{~cm}$. high, erect and straight or irregularly flexuous, mostly sharp-angled, simple or forked at the hard sub- 
ligneous base, with numerous mostly opposite or'subopposite subulate scales below; the branches or peduncles chiefly opposite, 1-few-Howered; flowers yellowish-white; corolla-lobes oblong, commonly denticulate, obtusish to rounded at the apex ; stigma columnar, about $1 \mathrm{~mm}$. long. (B. tenella Muhl.) - Sandy or boggy places, N. S. to Minn., and southw. July-Sept.

* Corolla-lobes lanceolate or ovate-lanceolate, acute or acutish, essentially entive.

3. B. paniculata (Michx.) Robinson. Tall and very slender, $2-4 \mathrm{dm}$. high, more apt to be irregularly and paniculately branched above, but mostly simple at the base; branches and leaf-scales often alternate; the peduncles curvedascending; flowers 2-4(-5) mm. long; corolla-lobes lanceolate, acute, yellowish- or greenish-white, about twice as-long as the narrowly lanceolate caly $x$-lobes; stigma short, scarcely columnar, $0.5 \mathrm{~mm}$. in length; anthers yellow. (B. lanceolata Small ; Centaurella paniculata Michx. ; C. Moseri Steud. \& Hochstetter.) - Wet sandy woods, swamps, etc., e. Mass. to Fla. and La. Aug.-Oct.

4. B. iodándra Robinson. Dwarf and subsimple, 1-2 dm. high; scales few and often alternate as are the rather long curved-ascending peduncles; flowers for the most part nearly twice as large as in the preceding, purplish-tinged, 6 $m m$. long; corolla-lobes ovate-lanceolate, acutish, about twice the length of the lance-oblong calyz-lobes; anthers chiefy brownish-purple; stigma short. Sphagnous bogs, Nfd. and N. S. Aug., Sept.

\section{OBOLARIA L. PENNYWORT}

Calyx of 2 spatulate spreading sepals, resembling the leaves. Corolla withering-persistent; the lobes oval-oblong, or with age spatulate, imbricated in the bud! Stamens inserted at the sinuses of the corolla, short. Style short, persistent ; stigma 2-lipped. Capsule ovoid, 1-celled, the cell cruciform; the seeds covering the whole face of the walls. - A low and very smooth purplish-green perennial 6-15 $\mathrm{cm}$. high, with a simple or sparingly branched stem, opposite wedge-obovate leaves; the dull white or purphsh flowers solitary or in clusters of three, terminal and axillary, nearly sessile, in spring. (Name from $b \beta 0 \lambda \delta s$, a small Greek coin, from the thick rounded leaves.)

V. 1. 0. virgínica $L$. Herbaceous and rather fleshy, the lower leaves scale-like; flowers $1 \mathrm{~cm}$. long. - Moist woods, N. J. to Ill., s. to Ga. and Tex. Mar.-May.

\section{MENYÁNTHES [Tourn.] L. Buckbean}

Calyx 5-parted. Corolla short funnel-form, 5-cleft, deciduous, the whole upper surface white-bearded. Style slender, persistent; stigma 2-lobed. Capsule bursting somewhat irregulariy, many-seeded. Seed-coat hard, smooth and shining. - A perenuial herb, with a thickish creeping rootstock, sheathed by the membranous bases of the long petioles, which bear 3 oval or oblong leaflets; the flowers racemed on the naked scape (1-3 dm. high), white or slightly reddish. (The ancient Theophrastian name, probably from $\mu \eta \nu$, month, and a $\theta_{00 s}$, a former, some say from its flowering for about that time.)

1. M. trifoliàta L. - Bogs and shallow water, Lab. to Alaska, s. to N. J., Pa., Great L. region, Ia., etc. Apr.-June. (Eurasia.)

\section{NYMPhoÌdes [Tourn.] Hill. Floating Heart}

Calyx 5-parted. Corolla almost wheel-shaped, 5-parted, the divisions bearing a glandular appendage near the base. Style short or none; stigma 2-lobed, persistent. Capsule few-many-seeded, at length bursting irregularly. Seed-coat hard. - Perennial aquatics, with floating leaves on very long petioles, which, in most species, bear near the summit the umbel of polygamous flowers, often along with a cluster of short and spur-like roots ; flowering all summer. (Name

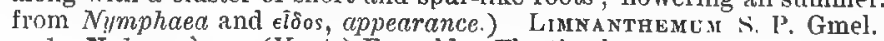

1. N. Jacundsum (Vent.) Fernald. Floating leaves round-heart-shaped, 1.5-6 
cm. broad, thickish; petioles filiform; lobes of the white corolla broadly oval, about $1 \mathrm{~cm}$. long, naked, except the crest-like yellowish gland at the base, twice the length of the lanceolate calyx-lobes; style none; seeds smooth and even. (Limnanthemum Griseb.) - Shallow water, N. S. to Fla., and locally westw. Jaly-Sept.

2. N. aquáticum (Walt.) Fernald. Leaves larger (0.5-1.5 dm. broad) and rounder, thicker, often wavy-margined or crenate, roughish and dark-punctate or pitted beneath; petioles stouter; flower 1-2 cm. broad; seeds glandularroughened. (Limnanthemum Britton; L. trachyspermum Gray.) - Ponds and streams, N.J. to Fla. and Tex.

3. N. Peltatum (S. P. Gmel.) Britten \& Rendle. Stout and branching; petioles bearing no spur-like roots; corolla large (2-3 cm. broad), bright yellow, the segments somewhat fringed; seeds with fringe-like margin. (Limnanthemum nymphoides Hoffmannsegg \& Link.) -- Ponds about Washington, D. C.; often cultivated. (Introd. from Eu.)

\section{APOCYNàceae (Dogbane Family)}

Plants almost all with milky acrid juice, entire chiefly opposite leaves without stipules, regular 5-merous and 5-androus flowers; the 5 lobes of the corolla convolute and twisted in the bud; the filaments distinct, inserted on the corolla, and the pollen glandular; calyx free from the two ovaries, which (in our genera) are distinct (forming follicles), though their styles or stigmas are united into one. Seeds amphitropous or anatropous, with a large straight embryo in sparing albumen, often bearing a tuft of down (comose). - Chiefly tropical acridpoisonous plants.

\footnotetext{
* Leaves alternate.
}

1. Amsonia. Seeds naked. Corolla-tube bearded inside. Anthers longer than the filaments. Plant upright.

** Leaves opposite.

2. Vinca. Seeds naked. Corolla-tube naked. Plant creeplng or trailing.

3. Trachelospermum. Seeds comose. Corolla funnel-form, not appendaged. Flaments slender. Calyx glandular inside.

4. Apocynum. Seeds comose. Corolla bell-shaped, appendaged within. Filaments short, broad and fat. Calyz not glandula:.

\section{AMSONIA Walt.}

Calyx small. Corolla with a narrow funnel-form tube; the limb divided into long linear lobes. Stamens inserted on the tube, included; anthers obtuse at both ends. Ovaries 2; style 1; stigma rounded, surrounded with a cup-like membrane. Pods (follicles) 2, long and slender, many-seeded. Seeds cylindrical, abrupt at both ends, packed in one row. - Perennial herbs, with alternate leaves, and pale blue flowers in terminal panicled cymes. (Naned for Dr. Amson, physician of Gloncester, Virginia, in 1760, and friend of John Clayton.)

1. A. Tabernaemontàna Walt. Loosely pubescent or hairy when young, soon glabrous; leaves from ovate-lanceolate to linear-lanceolate, taper-pointed; calyz-lobes short, awl-shaped; tube of the bluish corolla little longer than the lobes, the upper part either hairy when young or glabrous. (A. salicifolia Pursh; A. Amsonia Britton.) - Low grounds, Pa. to Mo., and southw.; introd. in N. J. May, June.

\section{VíNCA L. PERIWINKLE}

Calyx-lobes acuminate. Corolla-tube funnel-form; the limb salver-form. Stamens inserted below the throat; filaments short. Style slender. Pods short-cylindric. Seeds rough. - Smooth trailing hardy plants (or in the Tropies 
tender annuals) with evergreen firm leaves and axillary flowers. (Ancient Latin name of uncertain derivation.)

1. V. Mìnor L. (Commun P., "MYrTLE.") Spreading by creeping stems ; leaves glossy, ovate to oblong, $1.5-3 \mathrm{~cm}$. long; flowers peduncled; corolla blue, with truncate lobes. - Roadsides, etc.; escaped from cultivation. Apr.-June. (Introd. from Eu.)

\section{TRAChelospermum Lemaire. Climbing Dogbane}

Calyx with $3-5$ glands at its base inside. Stamens included; anthers arrow-shaped, with an inflexed tip. Pods (follicles) 2, slender, many-seeded. Seeds oblong. - T'wining plants, more or less woody, with small flowers in cymes. (Name from $\tau \rho \dot{\alpha} \chi \eta \lambda$ os, $a$ neck, and $\sigma \pi \epsilon \rho \mu a$, seed, upon the supposition that the seed was beaked.)

1. T. diffórme (Walt.) Gray. Nearly herbaceous and glabrous ; leaves ovallanceolate, pointed, thin; calyx-lobes taper-pointed; corolla pale yellow. Damp grounds, Del. to Flá. and Tex. June, July.

\section{Apócynum [Tourn.] L. Dogbane. Indian Hemp}

Calyx-lobes acute. Corolla bell-shaped, bearing 5 triangular appendages below the throat opposite the lobes. Stamens on the very base of the corolla; filaments shorter than the arrow-shaped convergent anthers, which slightly adhere to the stigma. Style none; stigma large, ovoid, slightly 2-lobed. Fruit of 2 long and slender follicles. Seeds with a tuft of long silky down at the apex. - Perennial herbs, with upright branching stems, opposite mucronatepointed leaves, a tough fibrous bark, and small and pale cymose flowers on short pedicels. (Ancient name of the Dogbane, composed of $\alpha \pi \delta$, from, and $\kappa u ́ \omega \nu, a$ dog.)

* Corolla pink or pink-striped or white, $4-9 \mathrm{~mm}$. long, the lobes more or less
spreading.

- Inflorescences both terminal and axillary cymes of nodding flowers 6-9 $\mathrm{mm}$. long; corolla campanulate, the lobes prominently flaring.

1. A. androsaemifdlium L. (Spreadrvg D.) Stems smooth, 3-5 dm, high, lonsely wide-branched above with ascending often dichotomous branches; leaves ovate to ovate-oblong, mucronate-tipped, slender-petioled, loosely spreading or drooping, dull dark green and smooth above, pale and usually somewhat pubescent beneath; cymes flowering simultaneously, the terminal usually largest; flowers fragrant, mostly nodding; calyx rarely balf as long as the corolla-tube ; corolla pink, with deeper stripes in the tube, the finally recurved lobes blunt. Dry thickets, open woods, etc. June-Aug.

+ + Inflorescences terminal or at the tips of leafy branches, of spreading or slightly nodding flowers 4-7 $\mathrm{mm}$. long; corolla from urceolate to shorttubular, the tube somewhat pentagonal, the lobes slightly spreading.

2. A. mèdium Greene. Similar to no, 1 ; the branches ascending or sprearing ; leaves firm, ovate-oblong to elliptic, glabrous or slightly pubescent beneath ; central cyme flowering earlier than those at the tips of the elongate branches; corolla white or pink-tinged, the blunt lobes slightly spreading but not recured. (Intermediate between the preceding and the following, including $A$. speciosum and $\boldsymbol{A}$. urceolifer G. S. Miller, A. Milleri Britton, and some other recently proposed species.) - Open dry or moist ground, rocky shores, etc., e. Que. to Md., w. to Col. June-Aug.

* Corolla greenish to greenish-white, tubular, pentagonal, 3-4.5 mm. long, the lobes ascending; cymes terminal, of mostly ascending floners.

3. A. cannabinum L. (Indian Hemp.) Glabrous, $2-24 \mathrm{dm}$. high, the stems and branches ascending (but on gravel beaches, etc., depressed and wide-spreading); leaves mostly ascending, usually pale green, ovate-oblong to lanceolate, glabrous 
or sparingly pubescent beneath, those of the chief axis narrowed at base to distinct petioles (2-7 mm. long), those of the branches often subsessile; central cyme flowerung first; flowers erect; calyx glabrous, its lobes about equaling the corvllatube. - Gravelly or sidndy soil, mustly near streams; on beaches becoming dwarfed and diffuse, with smaller and narrower leaves ( $A$. album Greene). June-Aug. Varying greatly, the most recognizable extremes being

Var. pubéscens ( $K . \mathrm{Br}_{\text {. }}$ ) DC. Calyx and pedicels pubescent; leaves white. pubescent beneath. (A. pubescens R. Br.) - R. I. to Ont., Ia., and southw.

Var, nemoràle (G.s. Miller) Fernald. Leaves mostly spreading or drooping on elongate ( $1-1.5 \mathrm{~cm}$. long) slender petioles. (A. nemorale G. S. Miller.) Open woods, Fairfax Co., Va.

Var. hypericifolium (Ait.) Gray. Principal leaves sessile or subsessile, rounded or subcordate at base. (A. hypericifolium Ait.) - Que. to Sask. and B. C., s. to w. Me., centr. N. Y., O., Kan., Col., and Cal. ; chiefly westw.

\section{ASClepiadàceat (Milkweed Family)}

Plants with milky juice, and opposite or whorled (rarely scattered) entive leaves; the follicular pods, seeds, anthers (connected with the stigma), sensible properties, etc., as in the preceding family, from which they differ in the commonly valvate corolla, and in the singular connection of the anthers with the stigma, the cohesion of the pollen into wax-like or granular masses (pollinia), etc., as explained under the typical genus Asclepias.

Tribe I. CYNANCHEAE. Anthers tipped with an inflexed or sometimes erect scarious membrane, the cells lower than the top of the stigma; pollinia suspended.

* Stems erect or merely decumbent.

1. Asclepiodora. Corolla rotate, merely spreading. Crown of 5 hooded fleshy bodies, with a salient crest in each. Leaves alternate.

2. Asclepias. Corolla reflexed, deeply 5-parted. Crown as in no. 1, but with an incurved horn rising from the cavity of each bood. Lenves usually opposite.

8. Acerates. Corolla reflexed or merely spreading. Crown as in no. 1, but with neither crest nor horn inside. Leaves mainly alternate.

* Stems twining; leaves mostly opposite.

4. Gonolobus. Corolla erect. Crown of 5 membranaceous flat bodies, terminated by a 2-cleft tail or awn.

5. Cynanchum. Corolla rotate, spreading. Crown a fleshy 5-10-lobed ring or disk.

Tribe II. VINCETOXfCEAE. Anthers with short if any scarious tip, borne on the margin of or close under the disk of the stigma; pollinia horizontal.

6. Vincetoxicum. Corolla rotate. Crown a wavy-lobed fleshy ring. Stems twining.

\section{ASCLEPIODORA Gray}

Resembling Asclepias; but the corolla-lobes ascending or spreading, and the hoods destitute of a horn, widely spreading and somewhat incurved, slippershiped and laterally compressed, the cavity divided at the apex by a crest-like partition. - Umbels solitary and terminal or cory mbed, loosely-flowered. Iollicles ovoid, often somewhat muricate with soft spinous projections. ("A $A \kappa \lambda \eta \pi t b s$,

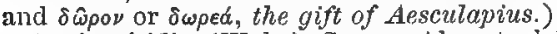

1. A. víridis (Walt.) Gray. Almost glabrous; stems 3-7 dm. high; leavew alternate, short-petioled, ovate-oblong to lanceolate, $3-13 \mathrm{~cm}$. wide; urvbels several in a cluster, short-peduncled ; flowers large $(2-3 \mathrm{~cm}$. broad), green, with a purplish crown. - Prairies, Ill, to Tex. and S. C. May, June.

\section{ASCletpias [Tourn.] L. Milimeed. Silkweted}

Calyx persistent; divisions small, reflexed. Corolla deeply 5-parted; divisione ralvale in bul, dccianous, Crown of 5 hooded hodies seated on the tube nf 
stamens, each containing an incurved horn. Stamens 5, inserted on the base of the corolla; filaments united into a tube which incloses the pistil; anthers adkerent to the stigma, each with 2 vertical cells, tipped with a membranaceous appendage, each cell containing a flattened pear-shaped and waxy pollen-mass; the two contiguous pollen-masses of adjacent anthers, forming pairs which hang by a slender prolongation of their summits from 5 cloven glands that grow on the angles of the stigma (extricated from the cells by insects, and directing copious pollen-tubes into the point where the stigma joins the apex of the style). Ovaries "2, tapering into very short styles; the large depressed 5-angled fleshy stigmatic disk common to the two. Follicles 2, one of them often abortive, soft, ovoid or lanceolate. Seeds anatropous, flat, margined, bearing a tuft of long silky hairs (coma) at the hilum, downwardly imbricated all over the large placenta, which separates from the suture at maturity. Embryo large, with broad foliaceous cotyledons in thin albumen. - Perennial herbs; peduncles terminal or lateral and between the usually opposite petioles, bearing simple many-flowered umbels, in summer. (The Greek name of Aesculapius, to whom the genus is dedicated.)

\$1. Anther-wings broadest and usually angulate-truncate and salient at base; hor'n conspicuous.

* Flowers orange-color; leaves mostly scattered; juice not milky.

1. A. tuberòsa L. (Butterfly-weed, Pleurisy-root.) Roughish-hairy, $3-9 \mathrm{dm}$. high; stems ascending or decumbent, very leafy, branching at the surmit, and bearing umbels in a terminal corymb, or scattered in racemes along the branches; leaves from linear to oblong-ovate, sessile or slightly petioled; divisions of the corolla oblong, greenish-orange; hoods narrowly oblong, bright orange, scarcely longer than the nearly erect and slender awl-shaped horns; pods hoary, erect; on deflexed pedicels, (Including $A$. decumbens L.) - Dry fields and banks, N. H. to Ont., Minn., southw. and southwestw. June-Aug.

* * Corolla bright red or purple; follicles naked, fusiform, erect on the deflexed pedicels (except in no. 5); leaves opposite, mostly broad.

- Flowers rather large; hoods about $6 \mathrm{~mm}$. long and exceeding the anthers; leaves transversely veined.

2. A. lanceolàta Walt. Glabrous; stem slender, 6-15 dm. high; leaves elongated-lanceolate or linear, 1-2 dm. long, tapering to both ends, slightly petioled; umbels 5-12-flowered; divisions of the red corolla narrowly oblong; the bright orange hoods broadly oblong, obtuse, much exceeding the incurved horn. (A. paupercula Michx.) - Wet pine barrens on the coast, N. J. to Fla. and Tex. July.

3. A. rùbra L. Glabrons; leaves ovate or lanceolate and tapering from a rounded or heart-shaped base to a very acute point, sessile or nearly so, $0.5-1.8$ dm. long, 1-6.5 cm. wide, bright green; umbels many-flowered; dirisions of the corolla and hoods oblong-lanceolate, purple-red; the horn long and slender, straightish.-- Wet pine barrens, etc., N. J. and Pa. to Fla., La., and Mo. July.

4. A. purpuráscens L. (Purple M.) Stem rather slender, $1 \mathrm{~m}$. or less high ; leaves elliptical or ovate-oblong, the upper taper-pointed, minutely velvetydowny underneath, smooth above, contracted at base into a short petiole; pedicels shorter than the peduncle, 3-4 times the length of the dark purple lanceolateovate divisions of the corolla; hoods oblnng, abruptly narrowed above; the horn broadly scythe-shaped, with a narrow and abruptly inflexed horizontal point. Dry ground, N. H. to Ont., Minn., Kan., and southw. - Flowers 1.5 cin. long. June, July.

+ + Flowers small; hoods 2-3 mm. long, equaling the anthers; veins ascending.

5. A incarnata L. (Swamp M.) Smooth or nearly so; the stem 5-10 dm. high, very leafy, with two downy lines above and on the branches of the pedun. cles; leaves oblong-lanceolate, acute or pointed, obtuse, obscurely heart-shaped or narrowed at base; flowers rose-purple (rarely whitish); hoods scarcely equaling 
the slender needle-pointed horn. - Swamps, N. B., westw. and southw. July, Aug.

Var. púlchra (Ehrh.) Pers. Leaves broader and shorter-petioled, more or less hairy, as well as the stem; flowers paler. (A. pulchra Ehrh.) - N. S. to $\mathrm{N}$. C. and Ga., rarely w. to Minn.

* * Flowers greenish, yellowish, white, or merely purptish-tinged; leaves opposite or whorled, or the upper rarely scattered.

- Follicles echinate with soft spinous processes, densely tomentose (smooth, and only minutely echinate at the apex in no. 8 ), large (8-18 $\mathrm{cm}$. long), ovoid and acuminate, erect on deflexed pedicels; leaves large and broad, shortpetioled; umbels terminal and lateral.

6. A. speciosa Torr. Finely canescent-tomentose or glabrate, the manyflowered umbel and calyx densely tomentose; leaves subcordate-oval to oblong; corolla-lobes purplish, ovate-oblong, $1 \mathrm{~cm}$. long; hoods slightly longer, with a short inflexed horn, the truncate summit abruptly produced into a very long lanceolate-ligulate appendage. - Along streams, Minn. to Ark., and westw. Iune-Aug.

T. A. syriaca L. (Common M. or Silkwerd.) Stem tall and stout, finely soft-pubescent; leaves lance-oblong to broadly oval, 1-2 dm. long, pale, minutely downy beneath, as well as the peduncles, etc.; corolla-lobes dull purple to white, 6-9 mm. long; hoods rather longer than the anthers, ovate, obtuse, with a tooth each side of the short stout claw-like horn. (A. Cornuti Dene.)-Rich ground, N. B. to Sask., and southw. June-Aug. - Intermediates, perhaps of hybrid origin, occur between this and some of the related species.

8. A. Sullivántii Engelm. Very smooth throughout, tall; leaves ovateoblong with a somewhat heart-shaped base, nearly sessile; hoods obovate, entire, obtusely 2-eared at the base outside; flowers larger $(1.5-2 \mathrm{~cm}$. long) and more purple than in the preceding; anther-wings 2-toothed at base; pod nearly glabrous, obscurely spiny chiefly on the beak. - Rich ground, s. Ont. and O. to Kan., Neb., and Minn. June, July.

+ + Follicles wholly unarmed, either glabrous or tomentulose-pubescent.

Follicles erect or ascending on the deflexed or decurved fruiting pedicels.

= Umbel solitary, on a nakeã terminal peduncle; leaves sessile, broad, transversely veined, wavy; glabrous and pale or glaucous.

9. A. amplexicaúlis Sm. Stem $3-8 \mathrm{dm}$. high; leaves oblong, with a heartshaped clasping base, very obtuse or retuse, 4-12 cm. long; peduncle $3-20 \mathrm{~cm}$. long; corolla pale greenish-purple; hoods truncate, somewhat toothed at the summit, shorter than the slender awl-pointed horn. (A. obtusifolia Michx.) Sandy woods and fields, N. H. to Neb., and southw. June, July. - A second umbel at the base of the peduncle occasionally occurs.

10. A. Meàdii Torr. Stem slender, 4-6 dm. high ; leaves ovate or oblongovate, obtuse or acutish, $3-7 \mathrm{~cm}$. long; peduncle only twice the length of the upper leaves; pedicels rather short; corolla greenish-white; hoods roundedtruncate at summit, and with a sharp tooth at each margin, somewhat exceeding the stouter horn. - Dry ground, Wisc., Ill., and Ia. June.

$==$ Umbels mostly more than one; peduncle not overtopping the leaves.

a. Leaves large, orbicular to oblong-lanceolate; hoods broad, little if at all exceeding the anthers; glctbrous or with some minute pubescence on young parts.

11. A. phytolaccoides Pursh. (Poke M.) Stem 5-15 dm. high; leaves broadly ovate, or the upper oval-lanceolate and pointed at both ends, shortpetioled, smooth or slightly downy underneath, 1-3 dm. long; lateral umbels several; pedicels loose and nodding, numerous, slender, $2-5 \mathrm{~cm}$. long, equaling the peduncle; corolla-lobes ovate-oblong, greenish; hoods (white) truncate, the margins 2-toothed at the summit, the horn with a long projecting awl-shcrped point. (A. exaltata Muh1. ? nomen subnudum.) - Moist copses, N. E. to Mins . g. to Ga. and Ark, June-Aug. 
12. A. variegàta L. Stem 3-9 dm. high ; leaves (4-5 pairs) ovate, oval, or obovate, somewhat wavy, contracted into short petioles, middle ones sometimes whorled; pedicels (numerous and crowded) and peduncle short, dovny; divisions of the corolla ovate, white; hoods urbicular, entire, purplish or reddish, the horn semilunar with a horizontal point. - Dry wosds, L. I. to Ind., s. to Fla., and w. La. May, June. - Remarkable for its compact umbels of nearly white flowers.

b. Leaves mostly pubescent or puberulent; hoods obtuse, entire, twice or thrice the length of the anthers.

13. A. ovalifdia Done. Low, 1.5-6 dm. high, soft-downy especially the lower surface of the ovate or lanceolate-oblong acute short-petioled leaves (3.5-8 cm. long); umbels loosely 10-18-flowered, sessile or peduncled; pedicels slender; hoods oblong, yellowish, with a small horn, about the length of the oval greenish-white corolla-lobes (tinged with purple outside). - Prairies and oak openings, Ill. and Wisc. to S. Dak, and Man. June, July.

+ Follicles and pedicels erect; leaves often whorled; glabrous or nearly so. = Leaves ovate to broadly lanceolate, thin, rather slender-petioled.

14. A. quadrifolia Jacq. Stem slender, $3-8 \mathrm{dm}$. high, mostly leafless below, bearing usually one or two whorls of four in the middle and one or two pairs of ovate or ovate-lanceolate taper-pointed petioled leaves $(0.5-1 \mathrm{dm}$. long); pedicels slender; corolla-lobes pale pink, oblong; hoods white, elliptical-ovate, the incurved horn short and thick. - Dry woods and hills, N. H. to Ont. and Minn., s. to N. C. and Ark. May-July.

15. A. perénnis Walt, Stems 3-7 dm. high, persistent or somewhat woody at the base; leaves lanceolate or lanceolate-ovate, tapering to both ends, thin, rather slender-petioled; flowers white, small; the small hoods of the crown shorter than the needle-shaped horn; seeds sometimes destitute of a coma ! Low grounds, Ind. to Mo., Fla., and Tex. May-Aug.

\section{$==$ Leaves narrowly linear to filiform; horn subulate, exserted; column conspicuous.}

16. A. verticillata L. Stems slender, simple or sparingly branched, 3-9 $\mathrm{dm}$. high, from a fibrous root, very leafy to the summit; leaves linear, with revolute margins, 3-6 in a whorl; umbels small, lateral and terminal; divisions of the corolla ovate, greenish-white; hoods roundish-oval, about half the length of the incurved claw-shaped horns. - Prairies and open woods, Mass. to Sask., and southw.

17. A. pùmila (Gray) Vail. Similar; low (1-1.5 dm. high) and manystemmed from a woody caudex; leaves much crowded, spirally arranged, filiform or filiform-linear. (A. verticillata, var. Gray.)-Dry plains, w. Ia. and Neb. to Col. and N. Mex.

\section{$\$ 2$. Anther-wings broadly rounded at base and conspicuously auriculate-notched} just above it; hoods with a minute horn exserted from the 2-lobed apex.

18. A. stenophýlla Gray. Puberulent, but foliage glabrous; stems slender, $0.3-1 \mathrm{~m}$. high; leaves narrowly linear, the upper alternate, lower opposite; umbels several, short-peduncled, 10-15-flowered ; corolla-lobes oblong, greenish; hoods whitish, equaling the anthers, conduplicate-concave; follicles erect or ascending pedicels. (Acerates anğustifolia Dene.) - Dry prairies, Neb. to Mo., southw. and westw. June-Aug.

\section{ACerAtes ell. Green Milkweed}

Nearly like Asclepias; but the hoods destitute of crest or horn (whence the name, from a-privative, and képas, a horn). - Flowers greenish, in compact many-flowered umbels. Jueaves opposite or irregularly alternate, short-petioled or sessile. Pollen-masses slender-stalked. Follicles not tuberculate. 


\section{* Crown upon a column shorter than the globular mass of anthers and stigmas;} leaves mainly alternate-scattered.

1. A. auriculata Engelm. Glabrous, or puberulent above, $1 \mathrm{~m}$. or less high ; leaves narrowly linear or filiform, 1 or $2 \mathrm{dm}$. long; umbels numerous, lateral, on peduncles about as long as the slender pubescent pedicels; column very short and inconspicuous; hoods emarginate, appendaged below with a pair of broad auricles. - Dry ground, Neb. and Kan., westw. and southw. June-Aug.

2. A. floridàna (Lam.) Hitchc. Minutely roughish-hairy or smoothish; leaves linear to lanceolate; umbels fow, terminal or lateral, on peduncles of about the length of the slender pedicels; column about $1 \mathrm{~mm}$. long; hoods entire, not auricled. (A. longifolia Ell.) - Prairies and pine barrens, $\mathrm{O}$. to Ont., Mimn., Tex., and Fla. June-Sept.

*** Crown sessile, the oblong hoods nearly equaling the anthers; leaves often opposite and broader.

3. A. viridiflora Ell. Minutely soft-dowony, becoming smoothish; stems ascending, 3-8 dm. high; leaves oval to oblong, thick, 4-10 cm. long; umbels nearly sessile, lateral, dense and globose ; flower (when the corolla is reflexed) $1 \mathrm{~cm}$. long, short-pediceled. - Dry soil, Mass. to Sask., and southw. June-Sept. Var. la NCEOLA ta (Ives) Gray. Leaves lanceolate, 6-10 cm. long. (Var. Ivesii Britton.) - Range of the typical form. Var. LINEARIs Gray. Leaves elongated, linear ; stems low; umbels often solitary. - Man., N. Dak., and southw.

4. A. lanuginòsa (Nutt.) Dene. Hairy, low (1-2.5 dm. high); leaves lanceolate or ovate-lanceolate; umbel solitary and terminal, peduncled; flowers smaller; pedicels slender. - Prairies, Ill. to Minn., and westw. July.

\section{GONÓLOBUS Michx. ANGLE-POD}

Crown of free leaflets, which are truncate or obscurely lobed at the apex, where they bear a pair of flexuous awns united at base. Anthers nearly as in Asclepias; pollen-masses oblong, obtuse at both ends, fixed below the summit of the stigma to the descending glands. Follicles elongate-ovoid to lanceolate, smooth. Seeds with a tuft, as in Asclepias. - A perennial twining herb, smooth, with opposite heart-ovate and pointed long-petioled leaves, and small whitish flowers in raceme-like clusters on slender axillary peduncles. (Name from rwpla, an angle, and $\lambda_{o} \beta \delta s$, a pod, from the angled fruit.) Enslenia Nutt.

1. G. laèvis Michx. Climbing, $3-4 \mathrm{~m}$. high ; leaves $3.5-12 \mathrm{~cm}$. wide. (Enslenia albida Nutt.; Ampelanus albidus Britton.) - River-banks and thickets, Pa. to Ill., Kan., and southw. July-Sept.

\section{CYNÁNCHUM L.}

Crown flat, simple. Anthers, smooth follicies, and seeds much as in Asclepias. - Herbs, often twining. (An ancient name for some plant supposed to be poisonous to dogs, from $\kappa \dot{w} \omega \nu, d o g$, and $a \gamma \gamma \epsilon \iota \nu$, to strangle.) VINCETOXicum Medic., Moench, etc., not Walt.

1. C. Nìgrom (L.) Pers. Twining, nearly smooth ; leaves ovate or lanceovate; flowers small, dark purple, in an axillary cluster, on a peduncle shorter than the leaves; corolla pubescent within. - Waste places and old fields, e. Mass. and Vt. to Pa. and O. June-Sept. (Introd, from Eu.)

2. C. Vincetóxicum (L.) Pers. Suberect, $3-6 \mathrm{dm}$. high ; leaves ovatelanceolate ; flowers greenish-zohite; corolla glabrous. - Escaped from cultivation in s. Ont., near Niagara Falls (according to J. M. Macoun). (Introd. from Eu.)

\section{VINCETÓXICUM Walt. ANGLe-PoD}

Corolla wheel-shaped, sometimes reflexed-spreading; the lobes convolute in the bud. Crown small, annular or cup-shaped, in the throat of the corolla. Anthers partly hidden under the fiattened stigma, opening transversely. Pollen 
masses 5 pairs, horizontal. Follicles turgid, mostly muricate with soft warty projections, sometimes ribbed. Seed with a coma. - Herbs or shrubs with opposite heart-shaped leaves and corymbose-umbeled greenish or dark purple flowers on peduncles rising from between the petioles. Our species belong to the typical section, with the crown simple and unappendaged, and the corolla nearly veinless. (Name from vincere, to conquer, and toxicum, poison, applied originally to species of the preceding genus in allusion to supposed curative properties.) Gonolobus Michx., in part.

* Crovon a low undulately 10-lobed fleshy disk ; follicles unarmed, glabrous, 3-5costate or -angled.

1. V. suberdsum (L.) Britton. Leaves cordate with an open shallow or sometimes deeper and narrow sinus, pointed, glabrate or hairy, 6-14 cm. long ; umbels 3-9-flowered, much shorter than the petiole; corolla broadly conical in bud, abruptly pointed, twisted; lobes ovate or triangular-lanceolate, acute, pubescent inside; calyx half as long. (Gonolobus R. Br.) - Near the coast, Va. to Fla. June-Aug.

2. V. gonocárpos Walt. Leaves cordate with a deep and narrow often closed sinus, conspicuously acuminate, $0.5-1.5 \mathrm{dm}$. long, finely pubescent beneath; umbels 5-10-flowered, barely equaling the petiole; corolla elongated-conical in bud, not twisted; lobes narrowly lanceolate, obtuse, glabrous inside, 3-4 times as long as the calyx. (Gonolobus laevis Man. ed. 6, not Michx.) - River-banks, Va. to s. Ind., Mo., S. C., and Tex. June, July.

* Crown cup-shaped, as high as the anthers; follicles muricate, not costate.

- Crown fleshy, merely 10-crenate, or the crenatures bidentate.

3. V. oblìquum (Jacq.) Britton. Leaves rounded- to ovate-cordate with $a$ narrow sinus, abruptly acuminate, 0.7-2.5 dm. long; umbel many-flowered; corolla in bud conical, its lobes linear-ligulate, $1-1.5 \mathrm{~cm}$. long, $2 \mathrm{~mm}$. wide, crimson-purple inside, dull or greenish and minutely pubescent outside. (Gonolobus R. Br.) - River-banks, Pa. and Va. to O. and Mo. June, July.

4. V. hirsuttum (Michx.) Britton. Commonly more hairy; leaves with the basal lobes sometimes overlapping; peduncles fewer-flowered; corolla in bud ovoid, its lobes elliptical-oblong, rarely $1 \mathrm{~cm}$. long, barely puberulent outside, brownish-purple to yellowish. (Gonolobus Michx.) - Md. and Va. to Tenn. and Fla. May-Aug.

\section{++ Crown thinner, the border lobed or toothed; leaves as in the preceding.}

5. V. Shórtii (Gray) Britton. Resembles no. 3, but larger-leaved; corolla conical in bud, dark crimson-purple, its lobes ligulate, $1.5 \mathrm{~cm}$. long; crown about 10-toothed, the alternate teeth thinner, narrower and longer, either emarginate or 2-parted. (Gonolobus Gray.) - Ky., and southw.

$\checkmark$ 6. V. carolinénse (Jacq.) Britton. Flower-bud elongate-ovoid; corolla brownish-purple, its lobes oblong or linear-oblong, rarely $1 \mathrm{~cm}$. long; crovon undulately and very obtusely 5-lobed, with a longer bifid subulate process in each sinus. (Gronolobus R. Br.) - Va. to Mo., and southw. May-July.

7. V. Baldwiniànum (Sweet) Britton. Corolla whitish, with spreading oblong or spatulate lobes (at most $1 \mathrm{~cm}$. long) ; crown deeply cleft into 5 usually emarginate lobes half as long as the pair of subulate processes in each sinus. (Gonolobus Sweet.) - Ga. to Mo. and Ark. May, June.

\section{CONVOLvUläceae (Convolvolus Famitu)}

Chiefly twining or trailing herbs, often with some milky juice, with alternat leaves (or scales) andregular 5-androus flowers ; a calyx of 5 imbricated sepals; a 5-plaited or 5-lobed corolla convolute or twisted in the bud (imbricate in no. 6); a 2(rarely 3)-celled ovary ( $m$ in one tribe 2 separate pistils), with a pair of erect ovules in each cell, the cells sometimes doubled by a false partition between the seeds, so becoming 4-celled; the enbryo large, curved or coiled in mucilagi. 
nous albumen. Fruit a globular 2-6-seeded capsule. Flowers mostly showy, on axillary peduncles; pedicels articulated, often 2-bracted. - Many are cultivated for ornament, and one, the Sweet Potato, for its edible farinaceous roots; those of several species are carthartic, e.g. Jalap.

Tribe I. DICHÓNDREAE. Carpels 2 or 4 , distinct or nearly so; styles 2, basilar. Oreeping herbs.

1. Dichondra. Corolla deeply 5-cleft. Pistils 2, one-seeded.

Tribe II. CONvOLvÙLEAE. Ovary entire. Leafy plants, mostly twiners.

2. Breweria. Style 2-cleft or 2-divided; the divisions simple; stigmas capitate.

3. Evolvulus. Styles 2, each 2-cleft; atigmas linear-filiform. Not twining.

4. Ipomoea. Style undivided, with stigma capitate or 2-3-globose.

5. Convolvulus. Style undivided or 2-cleft only at apex; stigmas 2, linear-fillorm to subulate or ovate.

Tribe III. CUscùteaE. Ovary entire. Leafless parasitic twining herbs, never green. Embryo filiform, coiled, without cotyledons.

6. Cuscuta. The only genus of the group.

\section{DICHÓNDRA Forst.}

Calyx 5-parted. Corolla broadly bell-shaped. Stamens included. Styles, vvaries, and utricular 1-2-seeded capsules 2, distinct. Stigmas thick. - Small and creeping perennial herbs, soft-pubescent, with kidney-shaped entire leaves, and axillary 1 -flowered bractless peduncles. Corolla small, yellowish or white. (Name from $\delta i s$, double, and $\chi b v \delta \rho o s, a$ grain, from the fruit.)

1. D. rèpens Forst. Leaves round-kidney-shaped, pubescent, green both sides; corolla not exceeding the calyx. (D. evolvulacea Britton.) - Wet ground, Va. to Tex., near the coast.

\section{BREWERIA R. Br.}

Styles 2, or rarely 3, simple and distinct, or else united into one below; stigmas depressed-capitate. Otherwise as Convolvulus and Evolvulus. - Perennial prostrate or diffusely spreading herbs; flowers small, in summer; corolla more or less hairy or silky outside. (Named for Samuel Brewer, an English botanist or amateur of the 18th century.)

1. B. humistràta (Walt.) Gray. Sparsely hairy or nearly smooth; leaves varying from oblong with a somewhat heart-shaped base to linear, mucronate or emarginate; peduncles 1-7-flowered; bracts shorter than the pedicels; sepals painted, glabrous or nearly so; corolla white; filaments hairy; styles united at base. - Dry pine barrens, Va. to La.

2. B. aquática (Walt.) Gray. Minutely soft-downy and somewhat hoary; peduncles 1-3-flowered ; sepals silky; corolla pink or purple; filaments smooth; styles almost distinct; otherwise nearly as no. 1. - Wet pine barrens and margins of ponds, N. C. to Tex., extending into Mo.

3. B. Pickeríngii (M. A. Curtis) Gray. Soft-pubescent or smoothish ; leaves very narrowly linear or the lowest linear-spatulate, tapering to the base, nearly sessile; peduncles 1-3-flowered; bracts resernbling the leaves, mostly exceeding the flowers; sepals hairy; filaments (scarcely hairy) and styles (united far above the middle) exserted from the open white corolla. - Dry pine barrens and prairies, N. J., and southw.; also Ill., Ia., and southw.

\section{EVÓLVULUS L.}

Calyx of 5 sepals, naked at base. Corolla open-funnel-form or almost rotate. Styles 2, each 2-cleft ; stigmas obtuse. Capsule 2-celled the cells 2-seeded. Low and small herbs or suffrutescent plants, mostly diffuse, never twining (hence the name, from evolvere, to unroll, in contrast with Convolvulus).

1. E. argénteus Pursh. Many-stemmed from a somewhat woody base, dwarf, silky-villous all over; leaves crowded, broadly lanceolate, sessile, or the lowe 
oblong-spatulate and short-petioled; flowers almost sessile in the axils ; corolla purple, about $1 \mathrm{~cm}$. broad. ( $\boldsymbol{E}$. pilosus Nutt.) - Sterile plains and prairies, N. Dak. and Neb. to Mo. and Tex. May-July.

\section{IPOMOÈA L. Morning Glory}

Calyx not bracteate at base, but the outer sepals commonly larger. Corolla salver-form or funnel-form to nearly campanulate; the limb entire or slightly lobed. Capsule globular, 4-6 (by abortion fewer)-seeded, 2-4-valved. (Name, according to Linnaeus, from $t \psi, a$ Bindweed, and orocos, like; but $\psi_{\psi}$ is a worm.)

§ 1. QUAMOCLIT [Tourn.] Gray. Corolla salver-form, or with somewhat funnel-form but slender tube; stamens and style exserted; flowers red; annual twiners.

1. I. QuÁmoclit L. (Crpress Vine.) Leaves pinnately parted into linearthread-shaped parallel lobes; peduucles 1-2-flowered ; corolla slender, $3.6-4 \mathrm{~cm}$. long, scarlet-red, or sometimes white. (Quamoclit Britton.) - Sparingly spontaneous, especially southw. July-Oct. (Introd. from Trop. Am.)

2. I. coccfNeA L. Leaves heart-shaped, acuminate, entire or angled ; peduncles 2-several-flowered; sepals awn-pointed; corolla light scarlet, 2-3 cm. long. (Quamoclit Moench.) - River-banks and waste places, N. Y. to Mo., and southw. July-Oct. (Indigenous southwestw.) Var. HederifòliA (L.) Gray. Leaves deeply palmate-lobed. - River-flats, waste land, etc., from Mass. westw. and southw. (Adv. from Trop. Am.)

§ 2. EUIPOMOkA Gray. Corolla funnel-form or nearly campanulate, contorted in the bud; stamens and style not exserted.

* Lobes of stigma and cells 3, sepals long and narrow, attenuate upward, mostly hirsute below; corolla purple, blue, or white. (MORNING GLORY.)

3. I. HEDERACEA Jacq. Stems retrorsely hairy ; leaves heart-shaped, 3-lobed, the lobes acute or acuminate; peduncles short or rather long, 1-3-flowered; calyx densely hairy below; corolla white and purple or pale blue, $3-4.5 \mathrm{~cm}$. long. - Waste and cultivated ground, from s. Me. westw, and southw. JulySept. (Introd. from Trop. Am.)

4. I. PURPỨReA (L.) Roth. (Common M.) Annual ; stems retrorsely hairy; leaves heart-shaped, acuminate, entire; peduncles long, umbellately 3-5-flowered; calyx bristly-hairy below; corolla funnel-form, 4.5-7 cm. long, purple, varying to white. - Escaped in cultivated grounds. (Introd. from Trop. Am.)

* Stigma 2-lobed or entire; cells 2, each 2-seeded; sepals broader, imbricated; leaves cordate, acuminate.

5. I. pandurata (L.) G. F. W. Mey. (Wild Potato-vine, Man-of-theEarti.) Perennial, smooth or nearly so when old, trailing or sometimes twining; leaves occasionally ccntracted at the sides so as to be fiddle-shaped; peduncles longer than the petioles, 1-5-flowered; sepals smooth, ovate-oblong, very obtuse; corolla open-funnel-form, $4.5-8 \mathrm{~cm}$. long, white, with purple in the tube. - Dry ground, Ct. to Ont., southw. and southwestw. June-Sept. Stems long and stout, from a huge root, which often weighs $4-8(-11) \mathrm{kg}$.

6. I. lacundsa L. Annual ; rather smooth; stem twining and creeping, slender; leaves entire or angle-lobed; peduncles short, 1-3-flowered; sepals ianceoblong, pointed, bristly-citiate or hairy, half the length of the sharply 5-lobed (white, 1-2 cm. long) corolla. - River-banks and low grounds, Pa. to Mll., Kan., and southw.; adv. on ballast northw.

\section{Convólvulus [Tourn.] L. Bindwed}

Corolla funnel-form to campanulate. Stamens included. Capsule globose, 2-(Nlled, or imperfectly 4-celled by spurious partitions between the 2 seeds, or by aborítion 1-celled, mostly 2-4-valved. - Herbs or somewhat shrubby plants, twining, erect, or prostrate. (Name from convolvere, to entwine.) 
\$1. CALYSTEGIA (R. Br.) Gray. Stigmas oval to oblong; calyx inclosed in 2 broad leafy bracts.

* Erect; petioles at most one fourth as long as the leaf-blades.

1. C. spithamaèus L. Downy; stem low and mostly simple, upright or ascending, 1.5-3 dm. long; leaves broadly oblong, with cr without a heart-shaped or auricled base; corolla white, 4-5 cm. long; stigmas oval. - Dry and sandy or rocky soil, local. May-Aug.

** Twining or trailing; petioles longer.

- Flowers double.

2. C. JaPónicus Thunb. Pubescent; leaves narrowly hastate; fovers usually double, pink. - Waste places, etc., escaped from cultivation. (Introd. from Asia.)

- + Flowers single.

3. C. sèpium L. (HeDGe B.) Glabrows or essentially so; stem high-twining or sometimes trailing extensively; leaves triangular-halberd-shaped, acute or pointed, the basal lobes obliquely truncate and often somewhat toothed or sinu. ate-lobed or merely rounded; peduncles chiefly elongated, 4-angled; bract? rounded to sharp-acuminate at tip ; corolla white or rose-color, $3-5 \mathrm{~cm}$. long. (Including var. americanus Sims.) - Moist alluvial soil or along streauns. JuneSept. (Eurasia.) Passing freely to

Var. pubéscens (Gray) Fernald. More or less pubescent; stems traiting or sprawling, 3-7 dm. long; leaves oblong-ovate, cordate, the basal lobes obtuse or rounded and entire. (Var. repens Gray ; C. repens L.) - Gravelly or marshy sea-coast, e. Que. to Fla.; rare about the Great Lakes.

Var. fraterniflorus Mackenzie \& Bush. More or less pubescent; leaves hastate; flowers 1 or 2 in the axils, their peduncles mostly short and wing-angled. -D. C. to Mo., and southw.

\section{§2. STROPHOCAƯLOS G.Don. Stigmas filiform; no bracts at or near the base of the calyx.}

4. C. ARvénsis L. (Field B.) Perennial; stem procumbent or twining, and low ; leaves ovate-oblong, arrow- or halberd-shaped, with the lobes at the base acnte ; peduncles mostly 1-flowered ; bracts minute, remote; corolla 1.5-2 $\mathrm{cm}$. long, white or tinged with red. - Old flelds and in waste places. June-Aug. (Nat. from Eu.) Var. oBtusifólus Choisy. Basal lobes of the leaves rounded. - Less common. (Adv. from Eu.)

\section{6. cúscuta [Tourn.] L. Dodder. Love Vine}

Calyx 5(rarely 4)-cleft, or of 5 sepals. Corolla globular-urn-shaped, bellshaped, or short-tubular, the spreading border 5(rarely 4)-cleft, imbricate. Stamens with a seale-like often fringed appendage at base. Ovary 2-celled, 4-ovuled; styles distinct, or rarely united. Capsule mostly 4-seeded. Embryo spirally coiled in the rather fleshy albumen, sometimes with a few alternate scales (belonging to the plumule); germination occurring in the soil. - Leafless annual herbs, with thread-like yellowish or reddish stems, bearing a few minute scales in place of leaves; on rising from the ground becoming entirely parasitic on the bark of herbs and shrubs on whjch they twine, and to which they adhere by means of suckers developed on the surface in contact. Flowers small, cymose-clustered, mostly white, usually produced in summer and autumn. (Name supposed to be of Arabic derivation.)

\section{§1. Stignas elongated; capsule circumscissile. \\ * Styles longer than the ovary and capsule.}

1. C. Epfrindu Weihe. (Flax D.) Stems very slender, low; flowers yellowish, globular, sessile in dense scattered heads; corolla 5-parted, short-cylindrical, scarcely exceeding the broadly ovate acute divisions of the ealyx, 
persistent around the capsule; stamens included; scales short, broad, crenu. late, shorter than the globose ovary. - Flax-fields; in Europe very injurious; sparingly introduced with flax-seed into the Northern States. June-Aug. (Introd. from Eu.)

2. C. Ерfтнмим Murr. Stems very slender ; flowers whitish or pinkish. capitate; corolla-lobes spreading, the cylindrical tube lorger than the suberect acute sepals; scales large, contiguous, toothed; stamens exserted. ( $C$. Trifoliz Bab.) - Occasionally found on clover, etc. July, Aug. (Introd. from Eu.)

* Styles shorter than the ovary and capsule.

3. C. EUROPAìa L. Slender; flowers subglobose, in dense globular clusters ; corolla 4-5-parted, the lobes obtuse; scales truncate or bifid, very small and thin or seemingly obsolete; calyx with obtuse lobes; capsule comparatively large, often loosely capped by the old corolla. - On Solidago, Viburnum, etc.s in a hedge-row, Gilead, Me. (Miss Furbish). July, Aug. (Adv. from Eu.)

\section{\$2. Stigmas capitate; capsule indehiscent.}

* Calyx gamosepalous; ovary and capsule depressed-globose.

- Flowers in dense or globular clusters; corolla with short and wide tube, persistent at the base of the capsule; styles mostly shorter than the ovary.

4. C. obtusifldra HBK. Stems coarse, orange-colored; flowers white, $2-3 \mathrm{~mm}$. long; lobes of calyx oblong, obtuse, of corolla obtuse or acutish, often longer than the tube; scales small, 2-cleft, often reduced to a few teeth; the thin capsule pale greenish-yellow. (C. chlorocarpa and C. Polygonorum Engelm.) - Wet places, Del. and Ya. to Minn., and southw.; often on Polygonum. July-Sept. (Trop. Am., Eurasia.)

5. C. arvénsis Beyrich. Stems pale and slender, low ; flowers smaller (1.5-2 mm. long) ; calyx-lobes (5) obtuse, mostly very broad; lobes of the corolla acuminate, longer than the tube, with inflexed points; scales large, deeply fringed. - Rather dry soil, on various low plants, Mass., westw. and southw. July-Oct.

+ + Flowers in panicled often densely compound cymes; styles slender, mostly longer than the ovary; corolla withering on the summit of the large capsule.

6. C. Cephalanthi Engeln. Stem coarse and yellow, usually rather highclimbing ; flowers $2 \mathrm{~mm}$. long, on short thick pedicels, often 4-merous; lobes of calyx and corolla oblong, obtuse, the latter mostly shorter than the slender deeply campanulate tube; scales shorter than the tube, fringed. (C. tenuiflora Engelm.) - On tall herbs and shrubs, Pa. to Minn., and southw. July, Aug.

* Calyx gamosepalous; ovary and capsule pointed, the latter enveloped or capped by the marcescent corolla; flowers in loose panicled cymes.

\section{- Acute tips of the corolla-lobes inflexed.}

7. C. indecora Chois. Stems coarse ; flowers fleshy and more or less papillose, 3-6 mm. long; calyx-lobes triangular, acute or acutish; lobes of the broadly campanulate corolla ovate-lanceolate, minutely crenulate, spreading; scales large, deeply fringed; capsule enveloped by remains of corolla; anthers and stigmas yellow or deep purple. (C. decora Engelm.) - Wet prairies, on herbs and low shrubs (principally Leguminosae and Compositae), from Ill. to Fla., 'Tex., and westw. June-Sept. (Trop. Am.)

8. C. Coryli Engelm. Similar to the preceding; flowers of the same structure, but smaller ( $2 \mathrm{~mm}$. long), generally 4-merous; corolla deeper, with erect lobes, finally capping the capsule; scales reduced to a few teeth. (C. inflexa Engelın.) - Open woods and dry prairies, on shrubs (hazels, etc.) or coarse herbs, Ct. (according to Britton); Va. to Minn., Neb., and southw.

\section{+ + Corolla-lobes obtuse, spreading.}

9. C. Gronòvii Willd. Stems coarse, often climbing high; corolla-lobes shorter than or equaling the deeply campanulate tube; scales copiously fringed; capsule globose, umbonate.-Wet shady places, N. S. to Man., and southw.- 
The commonest of our species. Very variable in size and compactness of clusters.

10. C. rostràta Shuttlw. Similar to the preceding; flowers larger (4-6 mm. long), more delicate and whiter; lobes of corolla and calyx shorter than the tubes; slender styles longer ; ovary bottle-shaped; capsule long-pointed. - Shady valleys in the mts., Md. and Va., southw.; on tall herbs, rarely shrubs.

*** Sepals 5, distinct, surrounded by 2 or more similar bracts; styles capillary; scales large, deeply fringed; capsule capped by the marcescent corolla.

11. C. cuspidàta Engelm. Stems slender; flowers $3-5 \mathrm{~mm}$. long, thin, on tracteolate pedicels in loose panicles; the ovate-orbicular bracts and sepals and the oblong corolla-lobes euspidate or mucronate, rarely obtuse, shorter than the cylindrical tulue; styles many times longer than the ovary, at length exserted.Wet or dry prairies, on Ambrosia, Iva, some Leguminosae, etc., Neb. to Mo. and Tex.

12. C. compácta Juss. Stems coarse ; flowers closely sessile in densely compact clustors; bracts (3-5) and sepals orbicular, concave, slightly crenate, appressed, nearly equaling or much shorter than the cylindrical tube of the corolla; stamens shorter than the oblong obtuse spreading lobes of the latter. - In damp woods, almost always on shrubs, Mass. to Ont, and southw.

13. C. glomeràta Chois. Flovers very densely clustered, forming knotty masses closely encircling the stem of the foster plant, much imbricated with scarious oblong bracts, their tips recurved-spreading; sepals nearly similar, shorter than the short-cylindrical tube of the corolla; stamens nearly as long as the oblong-lanceolate obtuse spreading or reflexed corolla-lobes; style several times longer than the ovary. (C. parados:a Raf.?) - Wet prairies, o. to Minn., Kan., and Tex., mostly on tall Compositae. - The rope-like twists (1-3 cm. thick) of white flowers, with golden yellow anthers imbedded in a mass of curly bracts, have a singular appearance.

\section{POLEmoniÀceae (Polemonidm Familx)}

Herbs, with alternate or opposite leaves, regular 5-merous and 5-androus flowers, the lobes of the corolla convolute in the bud, a 3-celled ovary and 3-lobed style; capsule 3-celled, 3-valved, loculicidal, few-many-seeded; the valves usually breaking avory from the triangular central column. Seeds amphitropous, the coat frequently nucilaginous when moistened and emitting spiral threads. Embryo straight, in the axis of copious albumen. Calyx persistent, imbricated. Corolla with a 5-parted border. Anthers introrse. - Insipid and innocent plants, many ornamental and in cultivation.

1. Phlox. Corolla salver-form. Calyx slender. Leaves opposite, entire.

2. Gilia. Corolla tubular-funnel-form or salver-form. Calyx slender, partly scarione. Leaves mostly alternate.

3. Polemonium. Corolla open-bell-shaped. Calyx herbaceous, bell-shaped. Filaments slender, equal. Leaves alternate, pinnate or pinaately parted.

\section{PHLÓX L.}

Calyx somewhat prismatic, or plaited and angled. Corolla with a long tube. Stamens very unequally inserted in the tube of the corolla, included. Capsule ovoid, with sometimes 2 ovules but ripening only a single seed in each cell. Perennials (except a few southern species), with opposite and sessule perfectly entire leaves, the floral often alternate. Flowers cymose, mostly bracted ; the open clusters terminal or crowded in the upper axils. ( $\Phi \lambda \hat{\lambda} \xi$, flame, an ancient name of Lychnis, transferred to this North American genus.) Most of our species are cultivated in gardens. 


\section{\$1. Herbaceous, with flat (broad or narrow) leaves.}

* Stem strictly erect; panicle pyramidal or ellipsoid, many-flowered; peduncles and pedicels very short; corolla-lobes entire.

1. P. paniculàta L. Stem stout, $0.5-1.5 \mathrm{~m}$. high, smooth, or puberulent or villous above; leaves oblong-lanceolate and ovate-lanceolate, pointed, large, tapering or rounded, the upper often heart-shaped at the base; panicle ample, pyramidal-corymbed; calyx smooth or glandular-hispid, the teeth awn-pointed; corolla pink-purple varying to white. (Including $P$. acuminata Pursh, $P$. glanduTosa shuttlw., and $P$. amplifolia Britton.) - Open woods, Pa. to Ill., Kan., and southw.; escaped from cultivation northw. July-Sept. - Highly variable in outline of leaf, pubescence of leaves, stems, calyx, and corolla, but without concomitant characters.

2. P. maculàta L. (WILd Sweet Wilciam.) Smooth, or barely roughish; stem spotted with purple, rather slender, 3-9 dm. high ; lower leaves lanceolate, the upper nearly ovate-lanceolate, tapering to the apex from the broad and rounded or somewhat heart-shaped base; panicle narrow, ellipsoid, leafy below; calyx-teeth triangular-lanceolate, short, scarcely pointed; corolla pink-purple.Rich woodlands and along streams, Ct. to Minn., and southw. June-Sept. Var. cÁNDidA Michx. Whịte-flowered; commonly with spotless stem.-With the ordinary form.

* Stems, at least the flowering ones, ascending or erect; flowers in corymbed or simple cymes; corolla-lobes obovate or obcordate.

+ Calyx-teeth triangular-subulate; corolla-lobes rounded, entire; glabrous or nearly so.

3. P. ovàta L. Stems ascending, $2.5-6 \mathrm{dm}$. high, often from a prostrate base ; leaves oblong-lanceolate, or the upper ovate-lanceolate, and sometimes heartshaped at the base, acute or pointed; flowers pink or rose-red, crowded, shortpeduncled. ; calyx-teeth short and broad, acute. - Woods, Pa. to Ala. MayJuly.

4. P. glabérrima L. Stems slender, erect, 0.3-1 m. high; leaves linear-lanceolate or rarely oblong-lanceolate, very smooth (except the rough and sometimes revolute margins), 5-12 $\mathrm{cm}$. long, tapering gradually to a point; cymes few-flowered and loosely corymbed; flowers peduncled, pink or whitish; calyxteeth narrower and very sharp-pointed. - Prairies and open woods, n. Va. to 0 . and Minn., s. to Fla. and Mo. June, July.

\section{+ + Calyx-teeth long and slender; more or less hairy or glandular-pubescent.}

\section{+ No runners or prostrate leafy shoots.}

5. P. pildsa L. Stems slender, nearly erect, 2-5 dm. high, usually hairy, as are the lanceolate or linear leaves (2.5-10 dm. long), which commonly taper to a sharp point; cymes at length open; calyx-teeth slender, avol-shaped and acon-like, longer than the tube, loose or spreading; lobes of the pink-purple or rose-red (rarely white) corolla obovate, entire. - Dry or sandy woods, prairies, etc., Ct. to Ont., Man., and southw. May, June.

6. P. amoèna Sims. Stems ascending, $1.5-5 \mathrm{dm}$. high, mostly simple; leaves broacily linear, lanceolate, or ovate-oblong, abruptly acute or blunt, $2-5 \mathrm{~cm}$. long, on sterile shoots often ovate; cyme mostly compact and sessile, leafy-bracted; calyx-teeth awl-shaped or iinear, sharp-pointed, but seldom awned, rather longer than the tube, straight; lobes of the corolla obovate and entire (or rarely notched), purple, pink, or sometimes white. - Dry hills and barrens, Va. to Ky., s. to Fla. May, June.

+ + Leafy shoots from the base creeping or decumbent; leaves rather broad.

7. P. stolonifera Sims. Runners creeping, bearing roundish-obovate smoothish and thickish leaves; flowering stems (1-2.5 dm. high) and their oblong or ovate obtuse leaves (1-2.5 cm. long) pubescent, often clammy ; cyme close, fewflowered; calyz-teeth linear-awl-shaped, about the length of the tube; lobes of the reddish-purple corolla round-obovate, mostly entire.

( $P$. reptans Michx.) - 
Namp woods, in the Allegheny region, $\mathrm{Pa}$. to $\mathrm{Ky}$. and Ga.; locally introd. northw. May, June.

8. P. divaricata L. (Bude Phlox.) Stems spreading or ascending from a decumbent base, $2-5 \mathrm{dm}$. high ; leaves oblong-or lance-ovate or the lower oblonglanceolate, 2-5 cm. long, acutish ; cyme corymbose-panicled, spreading, loosely flowered; calyx-teeth slender awl-shaped, longer than the tube; lobes of the pale lilac or bluish corolla obcordate or wedge-obovate and notched at the end, or often entire, equaling or longer than the tube, with rather wide sinuses between them. - Rocky damp woods, w. Que. to Minn., and southw. May, June - A form occurs near Crawfordsville, Ind., with reduced flowers, the narrow entire acuminate corolla-lobes scarcely half as long as the tube.

* * Stems low, diffuse and branching; flowers scattered or barely cymulose; corolla-lobes narrowly cuneate, bifid; calyx-lobes subulate-lanceolate.

9. P. bifida Beck. Minutely pubescent; stems ascending, branched, 1-2 dm. high; leaves linear, becoming nearly glabrous, $1-4.5 \mathrm{~cm}$. long, $2-3 \mathrm{~mm}$. wide; flowers few, on slender peduncles; calyx-teeth awl-shaped, about as long as the tube; lobes of the pale purple corolla 2-cleft to or below the middle, equaling the tube, the divisions linear-oblong. - Sandy soil, Ind. to Mich., Ia., and Mo May, June.

10. P. Stellària Gray. Very glabrous; leaves barely somewhat ciliate at base, linear, $1.5-5.5 \mathrm{~cm}$. long, 1-3.5 mm. wide, acute, rather rigid; flowers mostly long-peduncled; lobes of the pale blue or almost white corolla bifid at the apex into barely oblong lobes. - Limestone cliffs of Ky. R., s. Ill., and barrens of Tenn. Apr., May.

\section{\$2. Suffruticulose and creeping-cespitose, evergreen, with mostly crowded and fascicled subulate and rigid leaves.}

11. P. subulàta L. (Ground or Moss Pink.) Depressed, in broad mats; stems villous above, or somewhat glandular; leaves awl-sbaped, lanceolate, or narrowly linear, $0.5-1.5 \mathrm{~cm}$. long; cymes few-flowered; calyx-teeth awl-shaped, rigid; corolla pink-purple or rose-color with a darker centex, sometimes white; lobes wedge-shaped, notched, or entire. ( $P$. Hentzii Nutt. =P. Brittonii Small, the most glandular state.) - Dry rocky hills and sandy banks, N. Y. to Mich., Ky., and Fla.; naturalized in N. E. Apr.-June.

\section{GILIA R. \& P.}

Calyx-lobes narrow and acute, the tube scarious below the sinuses. Stamens equally or unequally inserted. Capsule with solitary to numerous seeds. Mostly herbs with alternate leaves. (Dedicated to Felipe Gil, a Spanish botanist.)

§ 1. COLLÒMIA (Nutt.) Gray. Flowers capitate-glomerate and foliosebracted; stamens unequally inserted in the narrow tube of the salver-form corolla; ovules solitary; leaves sessile and entire; annuals.

1. G. lineàris (Nutt.) Gray. Branching and in age spreading, $1.5-5 \mathrm{dm}$. high; leaves linear- or oblong-lanceolate; calyx-lobes triangular-lanceolate, acute; corolia $1 \mathrm{~cm}$. long, from lilac-purple to nearly white, very slender, with small limb. (Collomia Nutt.) - Dry open soil, n. e. N. B. and adjacent Que.; Minn. and Man. to B. C., s. to Ariz. and Cal, ; slightly adv, eastw.

§ 2. IPOMÓPSIS (Michx.) Benth. Flowers in long thyrsoid panicles; stamens equally inserted at or below the throat of the narrow funnel-form corolla; ovules many; leaves mostly divided; biennials.

2. G. Rưbra (L.) Heller. (Standing Cypress.) Simple, 0.5-1 m. high; leaves crowded, divided into filiform segments; thyrse $2-4 \mathrm{dm}$. long; calyx with long sctaceous lobes; corolla red, pink, or white, $2.5-3.5 \mathrm{~cm}$. long; stamens inclurted or barely exserted. (G. coronopifolia Pers.) - Pastures and roadsides, locil, Franklin Co., Mass, and O. June-Aug. (Nat. from the Southwest.) 


\section{POLEMònIUM [Tourn.] L. Greek Valerian}

Stamens equally inserted at the summit of the very short tube of the openbell-shaped or short funnel-form corolla; filaments declined, hairy-appendaged at the base. Capsule few-several-seeded. - Perennials, with alternate pinnate leaves, the upper leaflets sometimes confluent; the corymbose flowers nearly bractless. (An ancient name, from $\pi 6 \lambda \epsilon \mu o s$, war, of doubtful application.) W 1. P. réptans L. Smooth throughout or slightly pubescent; stems weak and spreading, 2-4 dm. high, never creeping as the name denotes; leaflets 5-1.5, ovate-lanceolate or oblong ; corymbs few-flowered ; flowers nodding ; calyx-lobes ovate, shorter than the tube; stamens and style included; corolla light blue, about 1-1.5 cm. wide; capsules about 3-seeded. - Woods, N. Y. to Minn., and southw. Apr.-June.

2. P. Van-Brúntiae Britton. Stem erect, $1 \mathrm{~m}$. or less high, nearly or quite glabrous; leaflets $9-21$, ovate to lanceolate, or the upper leaves rarely simple; flowers in close cymes forming a thyrse or contracted panicle; caly $x$ enlarged in fruit, becoming $1 \mathrm{~cm}$. or more long, the acutish lobes about equaling the tube; stamens and style exserted; corolla blue, $1.5-2 \mathrm{~cm}$. broad; capsule several-seeded. ( $P$. coeruleum Man. ed. 6, not L.) - Mountain swamps, Vt., n. W. Ct., and N. Y. to Md. May-July.

\section{HYDROPHYLLÀCEAE (WATERLEAF FamiLY)}

Herbs, commonly hairy, with mostly alternate leaves; regular 5-merous and 5-androus flowers, in aspect between the foregoing and the next family; but the ovary entire and 1-celled with 2 parietal 4-many-ovuled placentae, or rarely 2-celled by the union of the placentae in the axis; style 2-cleft, or 2 separate styles; fruit a 2-valved 4-many-seeded capsule. Seeds mostly reticulated or pitted. Embryo small, in copious albumen. Flowers chiefly blue or white, in 1-sided cymes or false racemes, which are mostly bractless and coiled from the apex when young, as in the Borage Family. - A small family of plants of no marked properties; some cultivated for ornament.

Tribe I. HYDROPHÝLLEAE. Orary and capsule 1-celled. Seeds pitted or reticulated; albumen cartilaginous. Leaves cut-toothed, lobed, or pinnate. Style 2-cleft.

* Ovary lined with the dilated and Heshy placentae, which inclose the ovules and seeds (in our plants only 4) liko an inner pericarp.

1. Hydrophyllum. Stamens exserted; anthers linear. Calyx unchanged in fruit.

2. Nemophila. Stamens included; anthers ovoid or cordate. Calyx with reflexed appendages at the sinuses, enlarged in fruit.

3. Ellisia. Stamens included, Calyx destitute of appendages, enlarged in fruit.

** Ovary with narrow parietal placentae, in fruit projecting inward more or less.

4. Phacelia. Corolla-lobes imbricated in the bud. Calyx destitute of appendagres.

Tribe II. HYDRÓLEAE. Ovary and capsule 2-celled, the placentae often projecting from the axis far into the cells. Albumen fleshy. Leaves entiro. Styles 2.

5. Hydrolea. Corolla between wheel-shaped and bell-shaped.

\section{HYDROPHÝLLUM [Tourn.] L. WATERLEAF}

Calyx 5-parted, sometimes with a small appendage in each sinus, early open in the bud. Corolla bell-shaped, 5-cleft; the lobes convolute in the bud; the tube furnished with 5 longitudinal linear appendages opposite the lobes, forming a nectariferous groove. Stamens and style mostly exserted; filaments more or less bearcled. Ovary bristly-hairy (as is usual in the family); the placentae soon free from the walls except at the top and bottom. Capsule ripening $1-4$ seeds, spherical. - Perennials, with petioled ample leaves, and white or bluish-purple 
cymose-clustered flowers. (Name formed of $\ddot{\nu} \delta \omega \rho$, water, and $\phi \dot{\lambda} \lambda \dot{\lambda}_{0}$, leaf; of no obvious application.)

* Calyx with minute if any appendages; rootstocks creeping, scaly-toothed.

1. H. macrophÿllum Nutt. Rough-hairy; leaves oblong, pinnate and pinnatifid; the divisions :-13, ovate, obtuse, coarsely cut-toothed; basal leaves $2-3.5 \mathrm{dm}$. long; peduncle shorter than the petiole; calyx-lobes lanceolate-pointed from a broad base, very hairy; flowers $1 \mathrm{~cm}$. or so long, crowded in a globular cluster; anthers short-oblong. - Rich woods, Va. to O., Ill., and southw. May, June.

2. H. virginiànum L. Smoothish, 2-7 dul. hich ; leaves pinnately divided; the divisions 5-7, ovate-lanceolate or oblong, pointed, sliarly cut-toothed, the lowest mostly 2-parted, the uppermost confinent; peduncles longer than the petioles of the upper leaves, forked; calyx-lobes narrowly linear, bristly-ciliate ; Howers $1 \mathrm{~cm}$. or less long; anthers oblong-linear. - Rich woods, N. H. and w. Que., westw. and southw. May-Aug. - H. patens Britton, indistinguishable as to foliage, is said to differ in its somewhat more ciliate petioles, appressed caly $\mathrm{x}$-lobes, and more spreading corolla-lobes.

3. H. canadénse L. Nearly smooth, 2-7 dm. high ; leaves $0.5-2.5 \mathrm{dm}$. broad, palmately 5-7-lobed, rounded, heart-shaped at base, mnequally toothed, those from the base sometimes with 2-3 small and scattered lateral leaflets; peduncles mostly shorter than the petioles, forked, the nearly white flowers on very short pedicels; calyx-lobes linear-awl-shaped, nearly smooth, often with minute teeth in the sinuses. - Damp rich woods, s. w. Vt. and w. Mass. to Ont., Ill., Ky., and N. C. June-Aug.

* *alyx with a small reflexed lobe in each sinus; stamens little exserted.

4. H. appendiculàtum Michx. Hairy; stem-leaves palmately 5-lobed, rounded, the lobes toothed and pointed, the lowest pinnately divided; cymes rather loosely flowered; filiform pedicels and calyx bristly-hairy. - Damp woods, N. Y. and Ont. to Minn., and southw. May, June.

\section{NEMÓPHILA Nutt.}

Corolla bell-shaped or almost wheel-shaped; lobes convolute in the bud: tube mostly with 10 small folds or scales inside. Placentae (bearing each 2-12 ovules), capsule, and seeds as in Hydrophyllum. - Diffuse fragile annuals, with opposite or partly alternate pinnatifid or lobed leaves, and 1-flowered peduncles. (Name from $\nu \epsilon \mu o s$, a grove, and $\phi i \lambda \in \hat{\imath} \nu$, to love.)

1. N. micrócalyx (Nutt.) Fisch. \& Mey. Sinall, roughish-pubescent; stems diffusely spreading, $0.5-4 \mathrm{dm}$. long; leaves parted or deeply cleft into $3-5$ roundish or wedge-obovate sparingly cut-lobed divisions, the upper all alternate; peduncles opposite the leaves, shorter than the long petioles; flowers minute; corolla white, longer than the calyx; placentae each 2-ovuled; capsule 1-2seeded. - Moist woods, Va. to Fla., w. to Ark. and Tex. Apr.-June.

\section{ELLÍSIA L.}

Corolla bell-shaped or cylindraceous, not longer than the calyx, 5-lobed above, the lobes inubricated or convolute in the bud, the tube with 5 minute appendages within. Placentae (each 2-ovuled), fruit, and seeds much as in Hydrophyllum. - Delicate and branching annuals, with lobed or divided leaves, the lower opposite, and small whitish flowers. (Named for John Ellis, distinguished naturalist and correspondent of Linnaeus.) Microcalyx Trew.

1. E. Nyctèlea I. Minutely or sparingly roughish-hairy, divergently branched, 1-4 dm. ligh; leaves pinnately parted into $7-13$ lanceolate or linear-oblong sparingly cut-toothed divisions; peduncles solitary iu the forks or opposite the leaves, 1-flowered; calyx-lobes lanceolate, pointed, about the length of the cylindraceous corolla, in fruit ovate-lanceolate, $1 \mathrm{~cm}$. long; capsule penduluus. - Shady damp places, N. J. to Sask., and southw.; casual nortleastw. Apr.-July. 


\section{PHACELIA Juss.}

Corolla open-bell-shaped, 5-lobed. Filaments slender, often (with the 2-elef $t$ style) exserted ; anthers ovoid or oblong. Ovary with 2 linear placentae adherent to the walls, the two often forming an imperfect partition in the ovoid t-many-seeded capsule. Ovules 2-30 on each placenta. - Perennial or mostly annual herbs, with simple, lobed, or divided leaves, and often bandsome (blue, purple, or white) fluwers in scorpioid raceme-like cymes (to which the name, from фáкєોos, a fascicle, doubtless alludes).

§1. EUPHACELIA Gray. Seeds and ovules only 4 (two on each placenta); coroila campanulate, with narrow folds or appendages within, the lobes entire.

1. P. bipinnatifida Michx. Biennial ; stem upright, hairy, 2.5-6 dm. high ; leaves long-petioled, pinnately 3-5-divided, the divisions ovate or oblong-ovate, acute, coarsely and often sparingly cut-lobed or pinnatifid; racemes elongated, loosely many-flowered, glandular-pubescent; pedicels about the length of the calyx, spreading or recurved; corolla bright blue, $1-1.5 \mathrm{~cm}$. broad, with 5 pairs of longitudinal ciliate folds; stamens bearded below and with the style exserted. - Rich shaded banks, O. to Mo., and southw. May, June.

§2. COSMÁNTHUS (Nolte) Gray. Ovules and seeds as in \$ 1 ; corolla almost rotate, with fimbriate lobes, and no appendages within; filaments villousbearded, rarely exserted; leaves pinnatifid, the upper clasping.

2. P. Púrshii Buckley. Sparsely hairy; stem erect or ascending, branched, 1.5-5 dm. high; lobes of the stem-leaves 5-9, oblong or lanceolate, acule; raceme many-flowered; calyx-lobes lance-linear; corolla light blue, varying to white, $1 \mathrm{~cm}$. or so broad. - Moist woods, etc., Pa. to Minn., and southw.; locally introd. in e. Ont. and Ct. Apr.-June.

3. P. fimbriata Michx. Slightly hairy, slender; stems spreading or ascending, 1-3 dm. long, few-leaved; lowest leaves divided into $3-5$ roundish leaflets ; the upper 5-7-cleft or cut-toothed, the lobes obtuse; raceme 3-10-flowered; calyx-lobes linear-oblong, obtuse, becoming spatulate; corolla white, barely 1 cm. broad. - Woods, high mts., Va. to Ala. May, June.

§3. COSMANTHOIDES Gray. Ovules and seeãs 2-8 on each placenta; corolla rotate or campanulate, with entire lobes and no appendages.

4. P. dùbia (L.) Small. Somewhat hairy, slender, diffusely spreading, 1-3 $\mathrm{dm}$. high; leaves pinnately cleft or the lower divided into 3-5 short lobes; racemes solitary, loosely 5-15-flowered; pedicels fliform, mostly longer than the oblong calyx-lobes; corolla open-campanulate, bluish-white, 8-14 $\mathrm{mm}$. broad; filaments hairy; capsule globular, 6-12-seeded, one half shorter than the calyx. " $P$. parviftora Pursh.) - Shaded banks, N. Y. to Kan., and southw. Apr.-June.

5. P. hirsùta Nutt. More hirsute and less slender ; corolla larger, 13-15 mm. in diameter; seeds 4-8. - Prairies and barrens, Va. to Kan., and southw.

6. P. Covillei Watson. Iike the preceding; racemes 2-5-flowered; calyxlobes linear, in fruit $6 \mathrm{~mm}$. long or more; corolla tubular-campanulate, with erect limb; fllaments glabrous; capsule depressed-globose; seeds 4 , large. Alluvial soil, D. C. ; "Ill."' Apr., May.

§4. EÙTOCA (R. Br.) Gray. Ovules and seeds numerous on each placenta; corolla rotate-campanulate, with 10 vertical lamellae within.

7. P. Franklínii (R. Br.) Gray. Soft-hairy; stem 3rect, 2-6 dm. high, rather stout; leaves pinnately parted into many lanceolate or oblong-linear lobes, which are crowded and often cut-toothed or pinnatifid; racemes short, dense, crowded into an oblong spike; calyx-lobes linear; corolla blue. - Dry soil and recent clearings, Ont, and Mich. to the Rocky Mts., and far northw. June-A'ug. 


\section{HYDROLEA L.}

Corolla 5-cleft. Filaments dilated at base. Capsule globular, with very large and fleshy inany-seeded placentae, thin-walled, 2-1-valved or bursting irregularly. Seeds minute, striate-ribbed. - Herbaceous or scarcely shrubby, growing in water or wet places, often having spines in the leaf-axils, and clustered blue flowers. (Name unexplained, doubtless in part from iswo, water, in allusion to the aquatic habitat.) NAMA L., in part.

1. H. affiinis Gray. Glabrous throughout; stem ascending from a creeping base; leaves lanceolate, tapering to a very short petiole; flowers in small axillary leafy-bracted clusters; divisions of calyx lance-ovate, equaling the corrolla and the irregularly bursting globose capsule. - Banks of streams, etc., Ill. to 'T'enn. and Tex. June-Aug.

2. H. quadriválvis Walt. Similar, but villous-hispid above; divisions of calyx linear or linear-lanceolate. - Wet ground, Va., and southw. July-Sept.

3. H. ovàta Nutt. Hirsute or puberulent; leaves ovate; flowers in terminal leafy panicles; calyx hirsute, with lanceolate divisions shorter than the corolla. -Mo. to La. and Tex. June-Aug.

\section{BORAGINÅCEAE (Borage FAMLL)}

Chiefly rough-hairy herbs, with alternate entive leaves, and symmetrical Alowers with a 5-parted calyx, a regular b-lobed corolla (except in Echium), 5 stamens inserted on its tube, a single style and a usually deeply 4-lobed ovary (as in Labiatae), forming in fruit 4 seed-like 1-seeded nutlets, or separnting into two 2-seeded or four 1-seeded nutlets. Albumen none. Cotyledons planoconvex; radicle pointing to the apex of the fruit. Stigmas 1 or 2. Calyx valvate, the corolla imbricated (in Myosotis convolute) in the bud. Flowers mostly on one side of the branches of a reduced cyme, imitating a spike or raceme, which is rolled up from the end, and straightens as the blossoms expand (circinate or scorpioid), often bractless. - A rather large family of innocent mucilaginous and slightly bitter plants; the roots of some species yielding a red dye.

N.B. - In this family the figures represent the inflorescence (or a portion of it) $\times \frac{2}{3}$ and details (flower, fruiting calyx, or nutlet) $\times 2$.

Tribe I HELIOTROPIEAE, Ovary not lobed; fruit separating into $2-4$ nutlets.

1. Heliotropium. Corolla salver-form. Stamens included. Nutiets 1-2-celled.

Tribe II. BORAGinEAE. Ovary deeply 4-parted, forming as many separate 1-seeded nutlets in fruit; style rising from the center between them.

* Nutlets attached laterally.

+ Nutlets armed with prickles ; throat of corolla closed by 5 scales.

2. Cynoglossum. Nutlets horizontally radiate, much produced downward, covered with barbed prickles.

3. Lappula. Nutlets erect or ascending, the unargin or bock arned with barbed prickles. ++ Nutlets at roost granular'-roughened.

4. Amsinckia. Calyx slmply but deeply b-eleft. Corolla yellow, with slender tube and oper throat.

5. Asperugo. Calyx with 5 broad flat velny lobes and 5 smaller alternating ones. Corolla blue.

* Nutlets attached at or near the base, smooth or merely wrinkled, not prickly.

+ Throat of corolla closed by 5 scules.

* Cornlla and stamens regular; achene with large excavated scar.

6. Symphytum. Corolla short-tubular, enlarged abovo, closed by 5 linear-subulate scales 
\# +Corolla irregular, limb and throat oblique, and lobes unequal.

7. Lycopsis. Corolla-tube curved. Stamens included.

+ + Throat of corolla open or merely with folds or crests (not seales).

++ Corolla and stamens regular.

8. Myosotis. Corolla short salver-form, its lobes rounded, and throat crested. Racemes not leufy-bracted (or only exceptionally so at base).

9. Mertensia. Corolla trumpet- or funnel-shaped, with open or crested throat, asually blue. Nutlets fleshy or becoming dry, attached just above the base.

10. Lithospermum. Corolla salver-form to funnel-form, its rounded lobes spreading; tho throat either naked or with low crests. Racemes leafy-bracted.

11. Onosmodium. Corolla tubular, unappendaged, its erect lobes acute. Racemes leafy-bracted. ++ + Corolla irregular, limb and throat oblique, and lobes unequal.

12. Echium. Dilated throat of corolla unappendaged. Stamens unegual, exserted.

\section{Heliotròpium [Tourn.] L. Turnsole. Helrotrope}

Corolla salver-form or funnel-form, unappendaged, more or less plaited in the bud. Anthers nearly sessile. Style short; stigma conical or capitate. Fruit separating into 2 indurated 2-celled and 2-seeded closed carpels, or more commonly into 4 one-seeded nutlets. - Herbs or low shrubby plants ; leaves entire; fi. in summer. (The ancient name, from $\eta \lambda \iota s$, the sun, and $\tau$ por $\eta^{\prime}, a$ turn, with reference to its flowering at the summer solstice.)

§ 1. EUHELIOTRÒPIUM Griseb. Fruit 4-lobed, separating into four 1-celled 1-seeded nutlets; style short.

* Flowers in bractless one-sided scorpioid spikes.

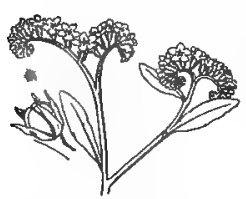

849. II. curassavicum.

1. H. EUROPAìu L. Erect annual, 1.5-8 dm. bigh, hoary-pubescent; leaves ovat, long-petioled ; lateral spikes single, the terminal in pairs; calyx spreading in fruit, hairy; corolla white, rarely $4 \mathrm{~mm}$. broad. - Waste and ballast ground, Mass. to D. C. and Fla. (Adv. from Eu.)

2. H. curassávicum L. (Seaside H.) Apparently annual, glabrous; stems ascending; leaves lance-linear or spatulate, thickish, pale, almost veinless; spikes in pairs ; flowers white or bluish. - Sandy seashores and salt marshes, from Del. southw.; saline soils, S. Ill., southw. and westw.; ballast and waste places near the coast, locally northw. to Me. Fig. 849.

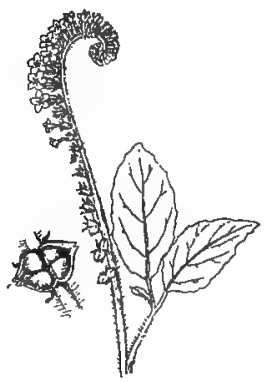

851. H. Indicum.

\section{* * Inflorescence not at all scorpi- oid; flowers scattered.}

3. H. tenéllum (Nutt.) Torr. Stem 1.5-4 dm. high, paniculately branched, slender, strigose-canescent; leaves narrowly linear, with revolute margins; flowers white, often bractless. - Open dry ground, Ky. to Kan., and southw. Fig. 850.

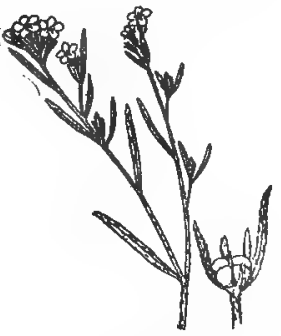

850. H. tenellam.

§2. TIARIDIUM (Lehm.) Gray. Fruit 2-lobed, separating into two 2-celled 2-seeded carpels, with sometimes a pair of empty false cells; style very short; flowers in bractless scorpioid spities.

4. H. INDICUM L. Erect and hairy annual ; leaves petioled, ovate or oval and somewhat heart-shaped; spikes single ; corolla blue ; fruit 2-cleft, miter-shaped, with an empty false cell before each seed-bearing cell. - Waste places, $\mathrm{K} y$. to Ind., Mo, and southw.; also on ballast northw. (Adv. from India.) Frg. 851. 


\section{CYNOGLÓSSUM ['Tourn.] L. Hound's Tongde}

Corolla funnel-form, the tube about equaling the 5-parted calyx; lobes rounded. Stamens included. Nutlets depressed or convex, oblique, fixed near the apex to the base of the style, roughened all over with short barbed or hooked prickles. - Coarse herbs, with petioled lower leaves ; the mostly panicled (socalled) racemes naked above, usually bracted at base. (Name from $\kappa u ́ \omega v, a d o g$, and $\gamma \lambda \hat{\omega} \sigma \sigma a$, tongue; from the shape and texture of the leaves.)

1. C. OfFICINALE L. (Cомmon H.) Biennial, clothed with short soft hairs, leafy, panicled above; upper leaves lanceolate, closely sessile by a rounded

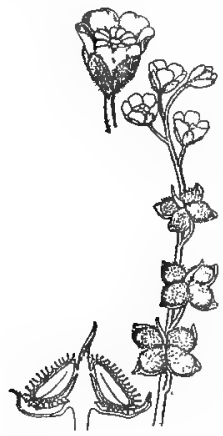

852. C. officinale. or slightly heart-shaped base; racemes nearly bractless; corolla reddish-purple (rarely white); nutlets flat on the broad upper face, somewhat margined, - Waste ground and pastures, locally abundant, the large nutlets adhering to the fleece of sheep, etc. (Nat. from Eu.) - Strong-scented. Fig. 852 .

2. C. virginiànum L. (Wild Comfrey.) Perennial, roughish with spreading bristly hairs; stem simple, fewleaved, 3-8 dm. high; stem-leaves lanceolate-oblong, clasping by a deep heart-shaped base; racemes few and corymbed, raised on long nalced peduncles, bractless; calyx in anthesis $3.5-4.5 \mathrm{~mm}$. long; corolla pale blue, 1-1.2 cm. broad, with suborbicular lobes and closed sinuses; nutlets strongly echinate, compressed-orbicular-obovoid, cuneate at base, 7-9 mm. long. - Open deciduous woods, N. J. to Mo., southw. and southwestw. May.

3. C. boreale Fernald. Similar, but more slender; stems vilious-hispid at base, appressed-pubescent above; only the upper stem-leaves clasping; calyx in anthesis $2-2.5 \mathrm{~mm}$.

long; corolla 6-8 mm. broad, the lobes oblong-ovate, the sinuses open; nutlets compressed-pyriform-obovoid, 4-5 mm. long. (C. virginicum Man. ed. 6, in part.) - Open woods and alluvial banks, e. Que. to B. C., s. to Ct., N. Y., Mich., and Minn. May, June.

\section{LÁPPUla [Rivinius] Moench. Stickseed}

Corolla salver-form, short, imbricated in the bud. Stamens included. Nutlets fixed to the base of the style or central column, triangular or compressed, the back armed with prickles which are barbed at the apex, otherwise naked. Rough-hairy and grayish herbs, with small blue to whitish flowers in racemes or spikes; flowering all summer. (Name a diminutive of lappa, a bur.) Echinospermum $\mathrm{Sw}$.

* Slender pedicels recurved or deflexed in fruit; calyx-lobes short, at length reflexed; biennial or perennial, not hispid.

1. L. virginiàna (L.) Greene. (Beggar's Itoe.) Stem $3-12$ dm. high; radical leaves round-ovate or cordate, slender-petioled; cauline 0.5-2.5 dm. loug, ovate-oblong to oblong-lanceolate, acuminate at both ends; loosely paniculate racemes divaricate; pedicel and flower each about $2 \mathrm{~mm}$. long; nutlets of the globose fruit equally short-glochidiate over the whole back. (Echinospermum virginicum Lehm.) - Woods, thickets, and waysides, Me. and w. Que., westw. and southw. FJg. 853.

2. L. defléxa (Wahlenb.) Garcke. Diffusely

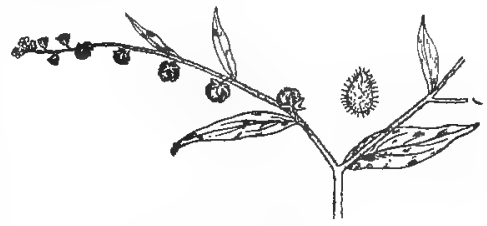

868. L. virginiana.

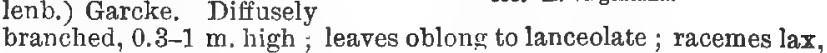
854. L. deflexa. loosely paniculate; flowers small; the globular-pyramidal fruit 
3-4 $\mathrm{mm}$. long, the nutlets only marginally glochidiate. (Echinospermum Lehm.) - Calcareous mountains and cliffs, e. Que.; roadsides and waste places, N. B. to Minn., local. (Eurasia.) Frg. 854.

Var. americàna (Gray) Greene. Nutlets with a few prickles

\$55. L. defl., v. amer.

along the middle. - Thickets and open woods, Ia. to Man., westw. and northw. Fig. 855 .

3. L. floribúnda (Lehm.) Greene. Rather strict, $0.3-1.5 \mathrm{~m}$. high; leaves oblong- to linear-lanceolate, the lowest tapering into margined petioles; racemes numerous, commonly geminate and in fruit rather strict; corolla iarger, blue, sometimes white, $0.5-1 \mathrm{~cm}$. in diameter; nutlets 4-6 $\mathrm{mm}$. long, scabrous and margined with a close row of flat-subulate prickles. (Echinospermum Lehrn.) -Ont. and Minn. to Sask., and westw. Frg. 856.

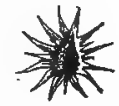

856. L. florbunda.

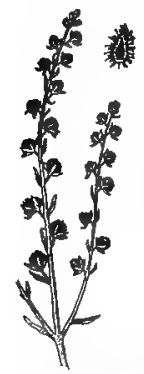

* * Stout pedicels not deflexed; calyx becoming foliaceous ; leaves linear, lanceolate, or the lower spatulate; hispid annuals.

4. L. вснілатA Gilibert. Erect, 1.5-6 dm. high ; nutlets rough-granulate or tuberculate on the back, the margins with $a$ double rov of slender distinct prickles, or these irregularly distributed over most of the back. (Echinospermum Lappula Lehm.) - Waste and cultivated grounds, local. (Nat. from Eu.) Fig. 857.

5. L. Redówskii (Hornem.) Greene, var. occidentàlis (Wats.) Rydb. Erect, 1.5-6 dm. high, at length diffuse; nutlets irregularly and minutely sharp-tuberculate, the margins armed with a single row of stout flattened prickles sometimes confluent at base. ( $L$. texana Britton.) - Ont. to Sask. and Tex., and

857. L. echlnata. 858 . westw.; ballast and waste places, eastw. FIG. 858. L. Redowskil,

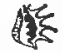
858.

\section{AMSÍNCKIA Lehm.}

Corolla salver-form or tubular-funnel-form. Style filiform. Nutlets rough, dull, ovoid-trigonous, attached below the middle. - Rough-hairy annuals, with

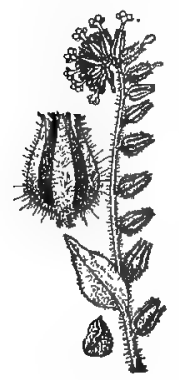

859. A. lycopsoldes. oblong or narrower leaves and scorpioid-spicate yellow flowers, at least the lowest leafy-bracted. (Dedicated to the memory of Wilhelm Amsinck, a burgomaster of Hamburg, who gave important support to the, botanical garden of that city.)

1. A. Lycopsoìdes Lehm. Decumbent, loosely branched, 3-6 dm. high; leaves lanceolate or ovate-lanceolate, the lower $0.5-1 \mathrm{dm}$. long, the upper shorter; flowers mostly bractless; corolla pale yellow, 7-10 mm. long, the slender tube exceeding the calyx. - Waste places, etc., locally established, e. Mass. to Ct. May-July. (Adv. from Cal.) Fig. 859.

\section{ASPERUัGO [Tourn.] L. MADWORT}

Corolla with short tube slightly enlarged above, and with spreading limb, smaller than the conspicuous calyx. Stamens included. Nutlets granulated. - Low annual with harsh slender stems, oblong or spatulate leaves, and few axillary flowers on short recurved pedicels, (Name from asper, rough.)

1. A. Procitmbens L. - Ballast and made land,

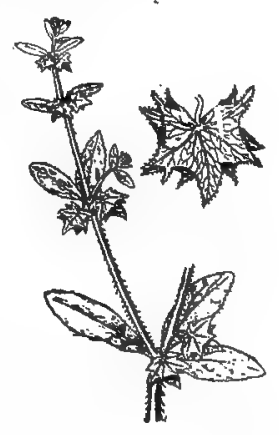

860. A. procumbens. Mass, to D. C. and Minn. May-July. (Ady, from Eụ.) Fị, 860. 


\section{SÝMPHYTUM [Tourn.] L. ComfreY}

Corvlla 5-toothed, the short teeth spreading. Stamens included; anthers elongated. Style thread-form. Nutlets erect, fixed by the large hollowed base,

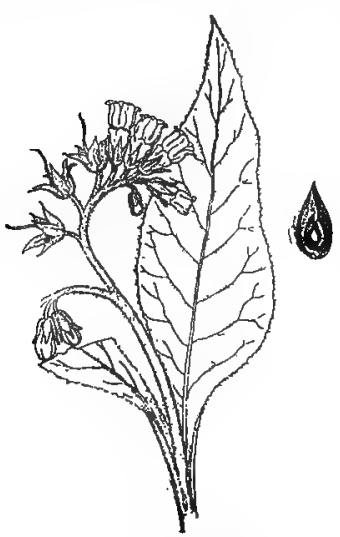

861. S. offirinale. which is finely toothed on its margin. - Coarse perennial herbs, with thickened bitterish mucilaginous roots ; the nodding raceme-like clusters either single or in pairs. (Ancient Greek name from

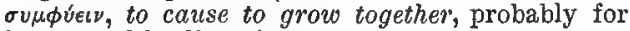
its reputed healing virtues.)

1. S. officinale L. (Common C.) Hairy, branched; upper leaves decurrent upon the stem in broad cuneate wings, the lower large, ovate or ovate-lanceolate; calyx-segments lance-linear; corolla yellowish- or pinkish-white to bluish- or roseate-purple; nutlets nearly smooth, somerohat shining. - Moist places, escaped from gardens. June, July. (Introd. from Eu.) Frg. 861.

2. S. TUвERósum $\mathrm{L}$. Frect and rather slender from a knotted tuberous base, pubescent; leaves mostly elliptic-ovate or -lanceolate, petiolate, the petioles decurrent as very narrow wings upon the stem ; calyx-segments lanceolate, finely appressedpubescent and somewhat hirsute ; corolla yellowishwhite; nutlets granulate-tuberculate, dull. -Low sandy meadows, Southington, Ct. (Andrews), and

very likely elsewhere.

(Adv. from Eu.)

3. S. ASPÉRRIMOM Donn. Harsh with short recurved priclele-like hairs; leaves not decurrent; calyx very small, in anthesis 2-4 mm. long, prickly-hispid all over ; corolla chiefly purple. - Low ground, not rare. (Introd. from Eu.)

\section{LYCÓPSIS L. Bugloss}

Corolla funmel-shaped, with curved tube and slightly unequal limb; the throat closed with 5 convex obtuse bristly scales opposite the lobes. Stamens and style included. Nutlets rough-wrinkled, erect, fixed by a hollowedout base. - Annuals. (Name from גúkos, $a$ wolf, and $b \psi i s$, appearance.)

1. L. aRVénsis L. (SMall B.) Very rough-bristly, 1-6 dm. high ; leaves lanceolate; flowers in leafy racemelike clusters; calyx as long as the tube of the small blue corolla. - Dry or sandy fields and waste places, Que. to Va., Minn., and Ont., scarce. (Adv. from Eu.) Fig. 862.

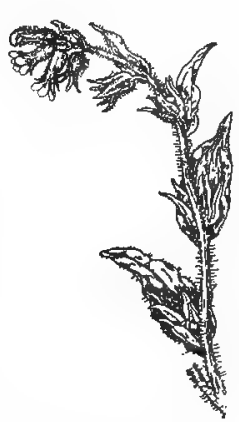

862. L. arvensis.

\section{MYOSÒtis [Rupp.] L. Scorpion-graes. Foreet-Me-Not}

Corolla-tube about the length of the 5-toothed or 5-cleft calyx, the throat with 5 small and blunt arching appendages opposite the rounded lobes; the latter convolute in the bud! Stamens included, on very short filaments. Nutlets compressed. - Low and mostly soft-hairy herbs, with entire leaves, those of the stem sessile, and with small flowers in naked racemes, which are entirely bractless, or occasionally with small leaves next the base, prolonged and straightened in fruit. (Name composed of $\mu \hat{v}$, mouse, and ovs, ear, from the short and soft leaves in some species.)

* Calyx open in fruit, its hairs appressed, none of them hooked or glandular.

1. M. scorpioìdes L. (True F.) Perennial; stems ascending from an oblique creeping base. 3-7 dm. high, loosely branched, smoothish; leaves 


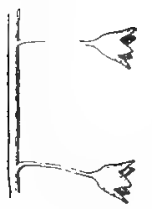

863. M. scolpioilles.

rough-pubescent, oblong-lanceolate or linear-oblong; calyxlobes much shorter than its tube; liml) of corolla 5-8 mm. broad, sky-blue, with a yellow eye. (M. palustris Hill.) - In wet ground, Nfd. to w. N. Y., and southw. May-Sept. (Nat. from Eu.) F1G.863. V2. M. láxa Lehm. Perennial from filiform subterranean shoots; stems very slender, decumbent; pubescence all appressed; leaves lanceolate-oblong or somewhat spatulate; calyx-lobes as long as the tube; limb of corolla rarely $5 \mathrm{~mm}$. broad, paler blue. - In water and wet ground, Nfd. to Ont., and southw. May-Aug. (Eu.) Fig. 864.

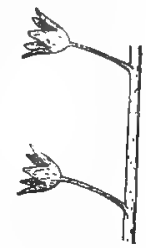

864. M. laxi.

* * Calyx closing or the lobes erect in fruit, clothed with spreading hairs, some minutely hooked or gland-tipped; corolla small; annual or biennial.

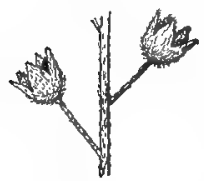

+ Calyx about equally 5-cleft. + Pedicels in fruit longer than the calyx.

3. M. arvénsis (L.) Hill. Hirsute with spreading hairs, erect or ascending, $1-4.5 \mathrm{~km}$. high; leaves oblong-lanceolate, acutish ; racemes naksd at the base and stalked; corolla blue, rarely white, - Fields, etc., Nfd. to Minn. and W. Ta. June865. M. arvensis. Aug. (Eu.) Fig. 865.

++ Pedicels shorter than the calyx, the latter about $4 \mathrm{~mm}$. long.

4. M. versfcolor (Pers.) Sm. Siender, 1-3 dm. high, mostly simple at base, often branched above; stems and leaves

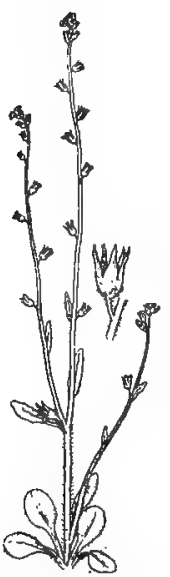

86\%. M. micrantha, uniformly pubescent with ascending straightish hairs; upper leaves somewhat pointed; racemes loose, mostly naked at base; pedicels appressedpubescent; corolla pale yellow, changing to blue, then to violet, the tube exceeding the calyx ; style distinctly longer than the nutlets. Fields, "N. Y.," and Del. May-July. (Nat. from Eu.) Fra. 866.

5. M. micrátih Pallas. Stems $0.5-2 \mathrm{dm}$. high, branching from the base, with the oblong or lanceolate blunt leaves pubescent with mixed straight and livergent hooked hairs; scattered flowers produced from the lower axils; pedicels very short, mostly with some divergent hooked hairs; corolla blue, the tube barely equaling the calyx; style rarely equaling the nutlets. (M. collina Am. auth., not Hoffm.) - Roadsides, old fields, etc., Mass. to Ont. and $O$. May-Aug. (Nat. from Fu.) Frg. 86i.

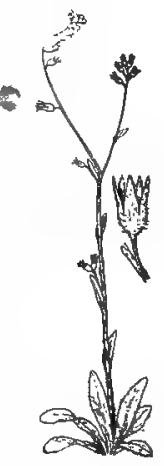

866. M. versientor. + + Calyx somerohat 2-lipped, unequally and deeply 5-cleft.

6. M. virgínica (L.) BSP. Bristly-hirsute, branched from the base, erect, $0.5-4 \mathrm{dm}$. high; leaves obtuse, linear-oblong, or the lower spatulate-oblong; racemes leafy at the base; corolla very small, white, with a short limb; pedicels in fruit erect and appressed at the base, usually abruptly bent ontward near the apex; calyx very hispid, $3-5 \mathrm{~mm}$. long. ( $\boldsymbol{H}$. verna Nutt.) - Dry banks and rocky woods, Me. to Ont. and Minn., westw. and southw. Apr.-July. Frg. 868. Passing westw. and southw, to the larger formal var. macrosperma (Engelm.)

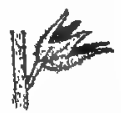

SRs M. virginica.

Fernald ( $M$. macrosperma Engelm.), with looser inflorescence and larger calyx and nutlets. 


\section{MERTÉNSIA Roth. LUNGWORT}

Corolla longer than the deeply 5-cleft or 5-parted calyx, naked, or with $\mathbf{5}$ small glandular folds or appendages in the open throat. Anthers oblong or arrow-shaped. Style long and thread-form. Nutlets ovoid, fleshy when fresh,

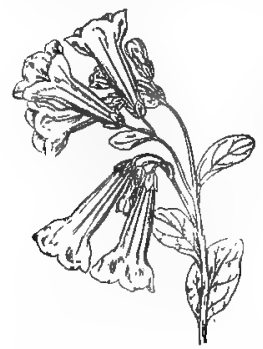

S69. M. virginica. smooth or wrinkled, obliquely attached by a prominent internal angle; the scar small. - Smooth or soft-hairy perennial herbs, with pale and entire leaves, and handsome purplish-blue (rarely white) flowers, in loose and short panicled or corymbed raceme-like clusters, only the lower one leafy-bracted; pedicels slender. (Named for Franz Iarl Mertens, a German botanist.)

* Corolla trumpet-shaped, with spreading nearly entire limb and naked throat; filaments slender, exserted; hypogynous disle 2-lobed.

1. M. virgínica (L.) Link. (Vurginian Cowslip, Blueber.s.) Very smooth, pale, erect, 2-6 dm. high; leaves obovate, veiny, those at the root 1-1.5 dm. long, petioled; corolla trumpet-shaped, $2-2.5 \mathrm{~cm}$. long, many times exceeding the calyx, light blue (pinkish in bud), rarely white; nutlets dull and roughish. - Alluvial banks, N. Y. and Ont. to Neb., and southw. Apr., May. Fis. 869.

\section{* Corolla with conspicuously 5-lobed limb and crested throat.}

+ Filaments broad and short; nutlets dull, wrinkled or roughish when dry.

2. M. paniculàta (Ait.) G. Don. Roughish and more or less hairy, erect, $0.3-1 \mathrm{~m}$. high, loosely branched; leaves ovate and ovate-lanceolate, taper-pointed, ribbed, thin; corolla 1-1.5 $\mathrm{cm}$. long, somewhat funnel-form, 3-4 times the length of the lance-linear acute divisions of the calyx; filaments broader and shorter than the anthers. - Shore of L. Superior, northw. and westw. July, Aug.

\section{+ + Filaments longer and narrower than the anthers; nutlets shining, utricular.}

3. M. marítima (L.) S. F. Gray. (Sea L.) Spreading or decumbent, smooth, glaucous; leaves ovate, obovate, or spatulate, fleshy, the upper surface becoming papillose; corolla white, rose-pink, or blue, bell-funnel-form, 5-7 $\mathrm{mm}$. long, twice the length of the calyx. (Pneunaria Hill.) - Sea-coast, on rocks and sand, Nantucket, Mass., and northw. June-Sept. (Eurasia.) Fig. 870 .

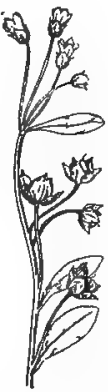

870. M. maritim I.

\section{Lithospérmum [Tourn.] L. Gromwerc. Puccoon}

Throat of corolla naked, or with a more or less evident transverse fold or scale-like appendage opposite each lobe; the limb 5-cleft. Anthers oblong, almost sessile, included. Nutlets smooth or roughened, mostly bony or stony; scar nearly flat. - Herbs, with thickish and commonly red roots and sessile leaves; flowers solitary and as if axillary, or spiked and leafy-bracted, sometimes dimorphous as to insertion of stamens and length of style. (Name formed of $\lambda\left(\theta 0 s\right.$, stone, and $\sigma \pi \epsilon \rho_{\mu a}$, seed, from the hard nutlets.)

§ 1. RHYTISPERMUM (Link) Reichenb. Nutlets tubercled or roughwrinkled and pitted, gray and dull; throat of the (nectrly white) corolla destitute of any evident folds or appendages.

1. L. ARvénse L. (Corn G.) Minutely roughened and hoary, annual or biennial; stems erect, $2-7 \mathrm{dm}$. high; leaves lanceolate or linear, veinless; 


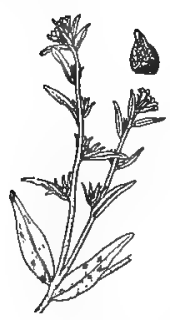

871. L. arvense.

corolla scarcely longer than the calyx. - Sandy fields and road. sides, Me. to Unt., Kan., and southw. May-Aug. (Nat. from Eu.) Fig. 871.

8. EULITHOSPERMUM DC. Nutlets smooth and shining, white like ivory; corolla greenish-white or pale yellow, small, with 5 distinct pubescent crests in the throat; perennial.

2. I. OFFICINALE L. (Соmmon G.) Much branched above, erect, $0.3-1 \mathrm{~m}$. high ; leaves thinnish, broadly lanceolate, acute, with a few distinct veins, rough above, soft-pubescent beneath; corolla exceeding the calyx. $\rightarrow$ Roadsides and pastures, e. Que. to Minn. and N. J. (Nat. from Eu.) Fig. 872.

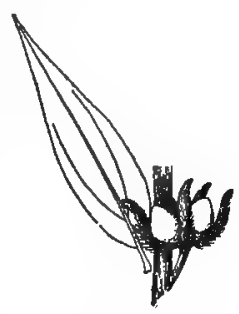

872. L. officinale.

3. L. latifolium Michx. Stem loosely branched, erect, 5-9

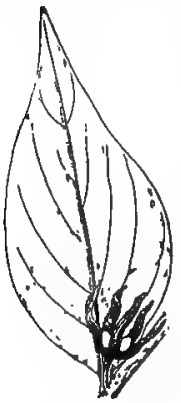
$\mathrm{dm}$. high, rough; leaves ovate and ovate-lanceolate, mostly taper-pointed (even the floral ones $3-9 \mathrm{~cm}$. long), ribbed-veined, roughish above, finely soft-pubescent beneath, the basal leaves large and rounded; corolla shorter than the calyx. - Open ground and borders of woods, w. Que, and N. Y. to Minn., s. to Va. and Ark. Fig. 873.

§3. BÁTSCHIA (G. F. Gmel.) Endl. Nutlets white, smooth and shining; corolla large, salver-form or nearly so, deep orange-yellow, somewhat pubescent, the tube much exceed ing the calyx, and the throat appendaged; roots perennial, long and deep, yielding a red dye.

* Corolla-tube one half to twice longer than the calyx, not much longer than the ample limb, the lobes entire; appendages little if at all projecting.

378. L. Latifollum.

4. L. Gmelini (Michx.) Hitchc. Hispid with bristly hairs, $2-8 \mathrm{dm}$. high; stem-leaves lanceolate or linear, those of the flowering branches ovate-oblong, bristly-ciliate; corolla woolly-bearded at the base inside, the limb $1.5-2.5 \mathrm{~cm}$. broad; flowers distinctly peduncled, crowded, showy ; fruiting calyx $1 \mathrm{~cm}$. or more long, 3-4 times longer than the nutlets. (L. hirtum Lehm.)-Pine barrens, ete., N. Y. to Minn., southw. and westw. Apr.-June.

5. L. canéscens (Michx.) Lehm. (PJccoon.) Softty hairy and more or less hoary, 2-5 dm. high ; leaves obtuse, linear-oblong, or the upper ovate-oblong, more or less downy beneath and roughish with close appressed hairs above; flowers sessile; corolla naked at the base within; fruiting calyx 6-8 mm. long, barely twice the length of the nutlets. - Plains and open woods, in sandy soil, Ont. to N. J., Va., Ala., and westw. Apr., May. Fig. 874.

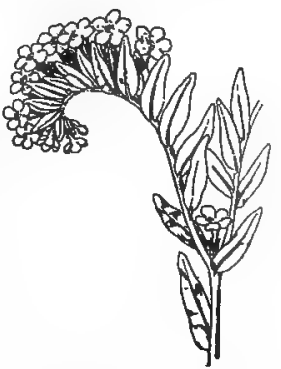

874. L. canescens.

* * Corolla-tube in well developed flowers 2-4 times the length of the calyx and of its erose-toothed lobes, and the appendages conspicuous and arching; later flowers small, cleistogamous.

6. L. angustifolium Michx. Erect or diffusely branched from the base, 1-5 dm. high, minutely rough-strigose and hoary; leaves linear; flowers pediceled, leafy-bracted, of two sorts; the earlier large and showy (corolla-tube 1.5-3.5 $\mathrm{cm}$. long), the later and those of more diffusely branching plants with inconspicuous or small and pale corollas, without crests, and the pedicels commonly recurved in fruit: nutlets usually punctate, ( $L$. linearifolium Goldie.) - Dry 
and sterile or sandy soil, s. Ont., Ind., and Mich. to N. Dak., Tex., and westw. Apr.-July.

\section{ONosmòdidm Michx. False Gromwell}

Divisions of calyx linear and erect. Corolla tubular, or tubular-funnel-form (the sinuses minutely hooded-inflexed), the 5 acute lobes converging or barely

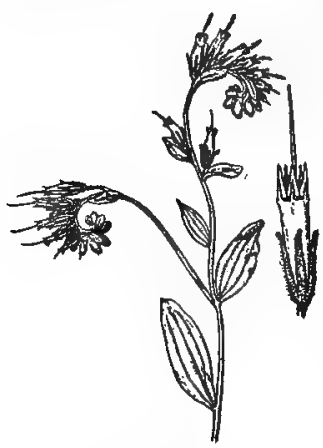

875. O. virginianum. spreading. Anthers oblong-linear or arrow-shaped. mucronate, inserted in the throat. Style thread. form, much exserted. Nutlets bony, ovoid, erect; the scar not hollowed out. - Chiefly perennial herbs, coarse and hispid, with oblong and sessile rib-veined leaves, and white, greenish, or yellowish flowers in at length elongated and erect leafy raceme-like clusters ; $f$. in summer. (Named from a likeness to the genus Onosma, meaning ass-smell.)

* Corolla-lobes lance-subulate, 2-3 times as long as wide.

1. O. virginiànum (L.) A. DC. Clothed with harsh and rigid appressed short bristles; stems rather slender, 3-8 dm. high; leaves narrowly oblong or oblong-lanceolate, $3-9 \mathrm{~cm}$. long, the lower narrowed at base; nutlets $2-2.8 \mathrm{~mm}$. long, irregularly pitted, not conspicuously constricted at base. - Dry banks, sandy hillsides, etc., Mass. to Fla. and La. FIG. 875.

* Corolla-lobes deltoid, scarcely longer than broad.

- Stem hispid, villous, or hirsute to the base.

* Silky-pubescent; nutlets conspicuously pitted.

2. O. mblle Michx. Finely grayish-pubescent; the lowest leaves oblanceolate, the others ovate to ovate-lanceolate, conspicuously veined, acutish ; calyx silky as well as sparingly hirsute; nutlets $3 \mathrm{~mm}$. long, pitted, sometimes slightly constricted at the base. (O. carolinianum, var. Gray, in part.) - Old fields and cedar barrens, Ky. and Tenn.

\section{+ + Strigose to hirsute; nutlets scarcely or not at all pitted.}

3. 0. occidentàle Mackenzie. Stoutish and somewhat rigid, 4-6 dm. high, rather finely but copiously grayish-pubescent; leaves lanceolate to narrowly lance-ovate, strongly rib-veined, 4-8 cm. long, 1-1.8 cm. wide, with pubescence mostly appressed or subappressed; nutlets rounded and not at all constricted at the base. ( $O$. carolinianum, var. molle Gray, in part.) - Alluvial soil, sandy or gravelly banks, etc., Ill. to Sask., Col., and N. Mex. Var. syl véstre Mackenzie. Taller, $1 \mathrm{~m}$. or more high, less canescent and more shaggy-hirsute in the manner of the next species, but with nutlets unconstricted at the base. Ill. and Mo.

4. 0. hispidíssimum Mackenzie. Stout, erect, 10-12 dm. high, green, coarsely hirsute throughout ; stem-leaves ovate, 8-10 cm. long, 1.8-4 cm. wide, the pubescence mostly spreading; nutlets about $3 \mathrm{~mm}$. long, with a very short neck or constriction at the base, brownish tinged. (O. carolinianum Man. ed. 6, not DC.) - River-banks, rich bottoms, etc.,

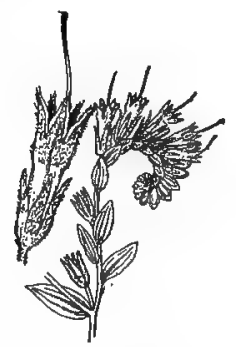

876. O. hispldissimum. N. Y. and s. Ont. to Neb., and southw. Fig. 876 . Var. Macrospérmum Mac. kenzie \& Bush, with larger and more shining white nutlets nearly $4 \mathrm{~mm}$. long, is distinguishable in Ill. and Mo.

\section{+ + Stem essentially smooth and glabrous belou.}

5. 0. subsetdsum Mackenzie \& Bush. Stem erect, nearly or quite glabrous to the middle, $6 \mathrm{dm}$. or more in height; leaves narrowly lanceolate, finelv 
appressed-pubescent upon both surfaces, $6-8 \mathrm{~cm}$. long, 1-1.5 cm. wide ; nutlets brownish-white, not constricted at the base, usually pitted, $2-3 \mathrm{~mm}$. long. Rocky hills and barrens of the Ozark region, Mo. and Ärk.

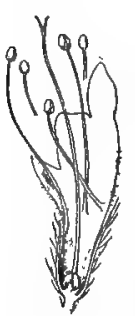

877. E. vulgare.

\section{ECHIUM [Tourn.] L. VIPER's Bugloss}

Corolla with a cylindraceous or funnel-form tube; lobes rounded, spreading. Stamens mostly exserted, unequal. Sty!e thread-form. Nutlets roughened or wrinkled, fixed by a flat base. (A plant name used by Dioscorides from ě $\chi$ cs, $a$ viper.)

1. E. vulgare L. (Blue-weed, Bude Devil.) Rough. bristly biennial; stem erect, $3-9 \mathrm{dm}$. high ; stem-leaves linearlanceolate, sessile; flowers showy, in short lateral clusters, disposed in a long and narrow thyrse or in an open panicle; buds pink; corolla brilliant blue (rarely pale or roseate). - Roadsides and meadows, locally abundant. June-Sept. (Nat. from Eu.) FIG. 877.

\section{VERBENACEAE (Vervain Familu)}

Herbs or shrubs, with opposite leaves, more or less 2-lipped or irregular corolla, and didynamous stamens, the 2-4-celled fruit dry or drupaceous, usually splitting when ripe into as many 1-seeded indehiscent nutlets; resembling tho following family, but the ovary not 4-lobed, the style therefore terminal, and the plants seldom aromatic or furnishing a volatile oil. . Seeds with straight embryo and little or no albumen. - A large family in the Tropics, sparingly represented in cool regions.

1. Verbena. Flowers in splkes or heads. Calyx tubular. Fruit splitting into 4 nutlets.

2. Lippia. Flowers in spikes or heaàs. Oalyx short, 2-cleft. Fruit splitting into 2 nutlets.

8. Callicarpa. Flowers in axlllary cymes. Calyx short. Fruit berry-like, with 4 nutlete.

\section{VERBENA [Tourn.] I. VERVAIN}

Calyx E-toothed, one of the teeth often shciter than the otbers. Corolla tubular, often curved, salver-form; the border somewhat unequally 5-cleft. Stamens included; the upper pair occasionally without anthers. Style slender ; stigma mostly 2-lobed. - Flowers sessile, in single or often panicled spikes, bracted, produced all summer. (The Latin name for any sacred herb; derivation obscure.) - The species present numerous spontaneous bybrids.

§1. Anthers not appendaged; flowers small, in slender spikes.

* Spikes filiform, with flowers or at least fruit scattered, naked, the inconspicuous bracts shorter than the calyx.

1. V. officinalis L. (European V.) Annual, glabrous or nearly so, loosely branched, 3-9 $\mathrm{dm}$. high; leaves pinnatifid or 3-cleft, oblong-lanceolate, sessile, smooth above, the lobes cut and toothed; spikes panicled; flover's purplish, very small.-Roadsides, waste places, and old fields, especially from the Middle States westw. and southw. (Nat. from Eu.) Fig. 878.

2. V. urticaefolia L. (Whrte V.) Perennial, from minutely pubescent to almost glabrous, rather tall $(0.5-1.5 \mathrm{~m}$. high); leaves

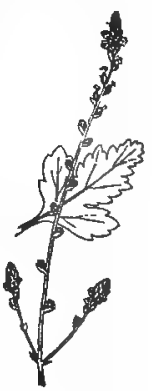

878. V. oflicinalis $\times 1 / 8$. oval or oblong-ovate, acute, coarsely serrate, petioled; spikes at length much elongated, loosely panicled; flowers very small, white. - Thickets, roadsides, and waste ground. (Trop. Am.)

Var. riparia (Raf.) Britton. Leaves deeply cleft or incised ; flowers blue.N. J. to Va. and N. C. 
* * Spikes thicker or densely flowered; the fruits crowded, mostly overlapping one another; lracts inconspicuous, not exceeding the flowers; perennial.

3. V. angustifolia Michx. Low, 2-6 dm. high, often simple; leaves narrowly lanceolate, tapering to the base, sessile, roughish, slightly toothed; spikes

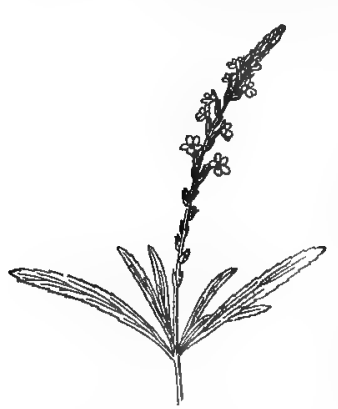

879. V. angustlfolia $\times 1 / 8$. few or single; the purple flowers crowded, larger than in the next. - Dry or sandy ground, Mass. and s. Vt. to Minn., and southw.; rarely adventive further northeastw. FIG. 879 .

4. V. hastàta L. (BLUE V.) Tall (0.5-2 m. high); leaves lanceolate or oblong-lanceolate, taperpointed, cut-serrate, petioled, the lower often lobed and sometimes halberd-shaped at base; spikes linear, erect, corymbed or panicled; flowers violet-blue (rarely pink or white). - Damp grounds, etc.

5. V. stricta Vent. (HoARY V.) Downy with soft whitish hairs, erect, simple or branched, 3-9 $\mathrm{dm}$. high ; leaves sessile, obovate or oblong, serrate; spikes thick, somewhat clustered, hairy ; floweri rather large, purple. - Barrens and prairies, Ont, and 0. , westw. and southw.; rarely nat. eastw.

*** Spikes thick, sessile and leafy-bracted; annual

6. V. bractedsa Michx. Widely spreading or procumbent, hairy; leave, wedge-lanceolate, cut-pinnatifid or 3-cleft, short-petioled; spikes single, ri motely flowered; bracts large, the lower pinnatifid, longer than the small purple flowers. - Prairies and waste grounds, Va. to o., westw. and soutbw.; on ballast and in waste places northeastw.

§2. Anthers of the longer stamens glandulartipped; flowers showy, from depressedcapitate becoming spicate.

7. V. bipinnatffida Nutt. Hispid-hirsute, 1-4 dm. high; leaves bipinnately parted, or 3-parted into more or less bipinnatifid divisions, the lobes commonly linear or broader; bracts mostly surpassing the calyx; limb of bluish-purple or lilac corolla 1-1.5 cm. broad.

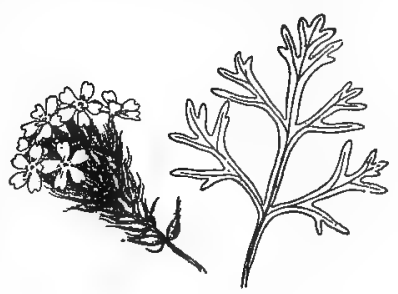

880. $\nabla$. blpinnatifida $\times 1 / 8$. - Plains and prairies, Mo. to S. Dak. and Mex. Fig. 880.

8. V. canadénsis (L.) Britton. Slender, $5 \mathrm{dm}$. high or less, soft-pubescent or glabrate; leaves ovate or ovate-oblong in outline, with a wedye-shaped buse, incisely lobed and toothed, often more deeply 3-cleft ; bracts shorter than or equating the calyx; limb of reddish-purple or lilac (rarely white) corolla $1.5-2.5 \mathrm{~cm}$. broad. (V. Aubletia Jacq.; $\nabla$. Drummondi of auth.) - Open woods and prairies, Va. to Fla.; also Ind. to Kan., and southw.

\section{IfPPIA [Houston] L.}

Calyx often flattened, 2-4-toothed, or 2-lipped. Corolla 2-lipped, upper lip notched, lower much larger, 3-lobed. Stamens included. Style slender ; stigma obliquely capitate. (Dedicated to Agostino Lippi, Ittalian naturalist.)

1. I. lanceolata Michx. (Fog-Fruit.) Decumbent or procumbent, green; lecuves oblanceolate to lanceolate, serrate above; peduncles axil881. L. lanceolata $\times 1 / 8$. lary, slender, exceeding the leaves, bearing solitary 


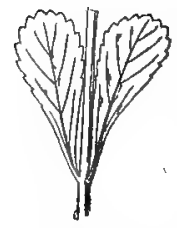

882. L. nodiflora $\times 1 / 8$.

closely bracted heads of bluish-white flowers; bracts mucronate or pointless. - River-banks, N. J. to s. Ont. and Minn., s, to Fla. and Tex. May-Sept. Fig. 881.

2. I. nodiflora (L.) Michx. Similar, but more depressed, cinereous or greenish; leaves blunter and more spatulate; corolla rose-purple or white. - Mo. to N. C. and Tex. May-Sept. Fig. 882.

3. L. cuneifolia (Torr.) Steud, Diffusely branched from a woody base, procumbent (not creeping), minutely canescent throughout; leaves rigid, cuneate-linear, incisely 2-6-toothed above the middle; peduncles axillary, often shorter than the leaves; bracts rigid, broadly cuneate, abruptly acuminate; corolla pale. Plains, Neb., Kan., and westw. May-Sept.

\section{CALLICÁRPA L.}

Calyx 4-5-toothed. Corolla tubular-belishaped, 4-5-lobed, nearly regulax. Stamens 4, nearly equal, exserted; anthers opening at the apex. Style slender, thickened upward. Shrubs, with scurfy pubescence, and small

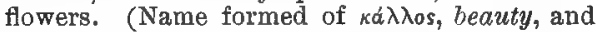
карлбs, fruit.)

1. C. americàna L. (French Mulberry.) Leaves ovate-oblong with a tapering base, acuninate, toothed, whitish-tomentose beneath; cymes many-flowered; caly x obscurely 4-toothed; corolla bluish; fruit violet-color. - Rich soil, Va. to Mo. and Tex. May-July. Fig. 883.

2. C. PURPÚREA Juss. Leaves elliptic, glabrous beneath, glandular-dotted; corolla pink. - Swamp, Wilmington, Del. (Tatnall). Aug. (Introd. from Asia.)

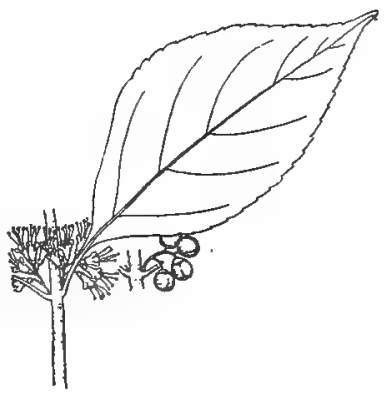

888. C. amerieana $\times 1$ '.

\section{LABIATAE (Mint Family)}

Chiefly herbs, ordinarily with square stems, opposite aromatic leaves, more on less 2-lipped corolla, didynamous stamens or these only two, and a deeply 4-lobea ovary, which forms in fruit 4 little seed-like nutlets or achenes, surrounding the base of the single style in the bottom of the persistent calyx, each filled with a single erect seed. Nutlets smooth or barely roughish and fixed by their base, except in the first tribe. Albumen mostly none. Embryo straight (except in Scutellaria); radicle at the hase of the fruit. Upper lip of the corolla 2-lobed or sometimes entire; the lower 3-lobed. Stamens inserted on the tube of the corolla. Style 2-lobed at the apex. Flowers axillary, chiefly in cymose clusters, these often aggregated in terminal spikes or racemes. - Foliage mostly dotted with small glands containing a volatile oil, upon which depends the warmth and aroma of the plants of this large and well known family.

I. Nutlets rugose-reticulated, attached obliquely or ventrally; ovary merely 4-lobed.

Tribe I. AJưgeaE. Stamens 4, ascending and parallel, mostly exserted from the upper slde of the corolla. Calyx 5-10-nerved.

* Limb of corolla irregular, вeemingly unilablate, the upper lip belng elther split down or very short; stamens exserted from the cleft.

1. Ajuga. Corolla with a very short and as if trunoste upper lip.

2. Teucrium. Corolla deeply cleft between the 2 amall lobes of the upper lp. 
* * Limb of corolla merely oblique, of 5 nearly equal and similar lobes.

8. Isanthus. Calyx bell-shaped. Corolla small, the lobes spreading. Stamens included.

4. Trichostema. Corolla-lober all declined. Calyx oblique. Stamens much exserted.

\section{Nutlets smooth or granulate; scar basal, small; ovary deeply 4-parted.}

Iribe II. SCUTELLARIEAE. Stamens 4, ascending and parallel. Calyx bllabiate, closed in fruit: the rounded lips entire. Corolla bilabiate, the upper lip arched.

5. Scutellaria. Calyx with a helmot-like projection on the upper side.

Tribe III. STACHY̌EAE. Stamens ascending or spreading, extended straight forward. Calyx usually open in frait, without a projection on the upper side.

* Stamens and style included in the corolla-tube.

6. Marrabium. Calyx tubular, 5-10-nerved, and with 5 or 10 aw]-shaped teeth.

** Stamens exserted beyond the corolla-tube.

+ Btamens 4, the upper (inner) pair longer than the lower, ascending or diverging ; corolla 2-lipped ; the upper lip concave or arched, the lower eprending; calyx mostly 15-nerved.

$\rightarrow$ Anthers not approximate in pairs; their cells parallel or nearly so.

7. Agastache, Stamens divergent, exserted; upper pair declined, lower ascending.

8. Meehania. Stamens all ascending, not exceeding the lip of the corolla.

\# + Anthers more or less approximate in pairs; their cells divaricate or divergent; fllaments ascending, not exserted.

9. Nepeta. Calyx more or less curked, equally 5-toothed.

10. Dracocephalum. Caly $x$ straight, the uppermost tooth much the largest.

$4+$ Stamens 4, parallel and ascending under the galeste or concave upper lip, the lower (outer) pair longer (except in nos. 14 and 17); calyx 5-10-nerved, not 2-lipped (except in no. 11).

+ Calyx reticulate-veiny, deeply bilabiate, closed in fruit.

11. Prunella. Calyx nerved and veiny; upper lip flat, 3-toothed, the lower 2-cleft. it + Calyx thin, inflated in fruit, obscurely nerred, 8-5-lobed, open.

12. Physostegia. Calyx 5-toothed or 5-lobed. Anther-cells parallel.

18. Synandra. Caly $x$ almost equally 4-lobed ! Anther-cells svidely divergent.

$+\#$ Calyx of firmer texture, distinctly 5-10-nerved or -strinte, 5-10-toothed.

- Stamens not deflexed after anthesis; naturalized from the old World.

14. Phlomis. Calyx tubular, the 5 teeth abruptly awned. Upper lip of the corolla arched.

15. Galeopsis. Calyx tubular-bell-shaped, the 5 teeth spiny-pointed. Anthers transversely 2-valved, the smaller valve ciliate.

16. Lamium. Galyx-teeth not spiny-pointed. Nutlets sharply 8-angled, truncate.

17. Leonurus. Caly $x$ top-shaped, the rigid spiny-pointed teeth soon spreading. Nutlets truncate and acutely s-angled at top. Leaves cleft or incised.

18. Ballota. Calyx somewhat funnel-form, expanding above into a spreading 5-toothed border. Nutlets roundish at top. Upper lip of the corolla erect.

$$
=- \text { Stamens often deflexed or contorted after anthesis. }
$$

19. Stachys. Calyx tubular-bell-shaped, equally 5-toothed or the 2 upper teeth united into 1. Nutlets rounded at top.

+++ Stamens 2 , ascending and parallel ; anthers apparently or really 1-celled; corolla strongly 2-lipped.

20. Salvia. Calyx 2-lipped. Anthers with a long connective astride the filament, bearing a linear cell at the upper end, and none or an imperfect cell on the lower.

21. Monarda. Calyx tubular and elongated, equally 5-toothed. Anthers of 2 cells confluent into 1 , the connective inconspicuous.

22. Blephilia. Calyx ovoid-tubular, 2-lipped. Anthers as in the preceding. 
++++ Upper pair of stamens shorter or wanting; anthers 2-celled; upper lip of corolla nelther galeate nor concave.

\# Flowers in more or less crowded clusters or whorle, exillary or spicate.

- Corolla more or less 2-lipped.

w. Stamens (often only 2 in no. 23) ascending or arcuate, often more or less converging (or ascending paraliel under the erect upper lip in no. 25).

28. Hedeoma. Calyx gibbous on the lower side, hairy in the throat. Flowers loose.

24. Melissa. Calyx tubular-bell-shaped, finttish on the upper side. Corolla curved upward.

25. Satureja. Calyx bell-shaped or tubular, 10-13-nerved. Tnbe of corolla straight.

b. Stamens distant and straight, often divergent, never convergent nor curved.

1. Stamens 4; calyx 10-15-nerved, bairy in the throat (except no. 26).

26. Hyssopus. Calyx tubular, 15-nerved, equally 5-toothed. Stamens exserted.

27. Origanum. Calyx oroid-bell-shaped, 5 -toothed. Spikes with large colored bracts.

28. Pycnanthemum. Calyx ovoid or short-tubular, equally 5-toothed or somewhat 2-lipped. Flowers in dense heads or clusters.

29. Thymus. Calyx ovold, nodding in fruit, 2-lipped. Bracts minute. Leaves very small.

2. Stamens 2, with or without rudiments of the upper pair.

30. Cunila. Calyx very hairy in toe throat, equally 5-toothed. Corolla small.

- - Corolla not evidently 2-lipped, but almost equally 4-lobed, small ; stamens erect, distant.

81. Lycopus. Fertile stamens 2 ; often also 2 sterile filaments without anthers.

32. Mentha. Fertile stamens 4, nearly equal.

\#+ Flowers in loose terminal panicled racemes; calyx 2-lipped, enlarged and declined in fruit.

83. Collinsonia. Lower lobe of corolla fimbriate, mueh the larger. Stamens 2.

34. Perilla. Corolla short, the lower lobe little larger. Stamens 4 , incladed. ++ ++ + Flowers In dense spikes; calyx hardly 2-lipped, the teeth equal.

85. Elsholtzia. Corolla slightly 2-lipped. Stamens 4, exsorted.

\section{1. ÁJUGA L. Bdgle Weed}

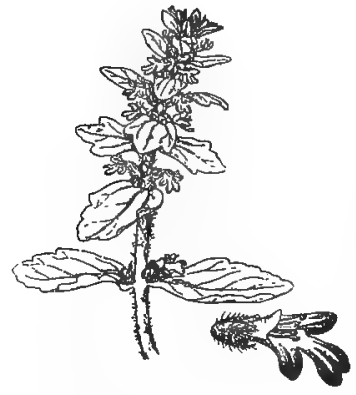

884. A. generensis.

Calvx 5-toothed. The large and spreading lower lip of the corolla with the middle lobe emarginate or 2-cleft. Stamens as in Teucrium, but anthercells less confluent. (From $\alpha$ - privative, and $\zeta v \gamma b \nu$, - Latin jugum, - yoke, from the seeming absence of a yoke-fellow to the lower lip of the corolla.)

1. A. réptans L. Perennial, 1-2.5 dm. high, smooth or but slightly pubescent, with copious creeping stolons; leaves obovate or spatulate, sometimes sinuate, the cauline sessile, the floral approximate, subtending several sessile blue flowers. - Locally in fields, Me, and Que. to s. N. Y. May-July. (Nat. from Eu.)

2. A. GENEVENSIS L. Similar; the stems copiously soft-pubescent, tufted, not stoloniferous; leaves somewhat pubescent; flowers larger. . Inflorescence $\times 1 / 2$. Flower $\times 1 \frac{1}{2}$. and $\mathrm{Pa}$. (Introd. from Eu.) FIG. 884.

\section{TEÙCRIUM [Tourn.] L. Germander}

Calyx 5-toothed. Corolla with the 4 upper lobes nearly equal, oblong, turned forward, so that there seems to be no upper lip; the lower lobe much larger. Stamens 4, exserted from the deep cleft between the 2 upper lobes of the corolla anther-cells confluent. (Named for Teucer, king of Troy.) 
- Perennials ; leaves merely dentate or serrate; inflórescences terninal, spictform.

+ Inflorescence cylindric; calyx densely pubescent.

1. T. canadense L. (American G., Woon Sage.) Stems $1 \mathrm{~m}$. or less high, appressed-pubescent, simple or branched; leaves lanceolate to ovate, serrate, $2.5-5 \mathrm{~cm}$. broad, rounded or narrowed at base, short-petioled, hoary beneath, green and glabrous or sparingly appressed-pubescent but scarcely papillose above; whorls about 6 -flowered, crowded in long and simple wand-like racemes ; caly canescent-pannose, the 3 upper lobes very obtuse, or the middle one acutish; corolla $1.5-2 \mathrm{~cm}$. long, purplish, pink, or sometimes cream-color.-Rich low ground, N. E. to Neb., and southw. July-Sept.

Var. littorale (Bicknell) Fernald. Stiff, usually simple, $2-7 \mathrm{dm}$. high ; leaves lanceolate to lance-ovate, $1.5-3 \mathrm{~cm}$. broad, mostly tapering at base, thick and somewhat rugose, the upper surface papillose beneath the dense appressed pubescence; flowers slightly smaller. ( $T$. littorale Bicknell.) - Near the coast, Me. to Fla. and Tex, and northw, in the Miss. basin to Okla.

2. 1. occidentàle Gray. Stem villous, 3-9 dm. high ; leaves lance- to ovateoblong, white-villous beneath; calyx and bracts vilious with viscid hairs and with shorter capitate or stipitate glands; the upper calyx-lobes acute or the middle one acuminate; corolla 8-12 mm. long. - Alluvial soil, Me. to B. C., s. to Pa., O., Mo., N. Mex., and Cal.

Var. boreàle (Bicknell) Fernald. Stem more closely pubescent; calyx and bracts with few or no capitate glands amongst the often viscid bairs; corolla slightly longer. ( $T$. boreale Bicknell.) - Similar situations, n. N. H. to Wash., s. to w. N. Y., Ml., and Tex.

\section{+ + Inflorescence secund; calyx glabrous or glabrate.}

3. T. Scorodònia L. (Wood Sagf, Germander Sage.) Stems ascending from a freely creeping rootstock, villous, $2-5 \mathrm{dm}$. high, simple or with few erect branches ; leaves deltoid-lanceolate to -ovate, crenate, rugose, cordate or truncate at base, short-petioled; flowers pale yellow, paired in slender 1-sided racemes; upper tooth of the calyx large and recurved. - Said to be established in Ont. and $\mathrm{O}$. (Adv. from Eu.)

$$
\text { * Annual; leaves pinnatifld; flowers in axillary verticels. }
$$

4. T. Bótrys L. (Cut-leaf G.) Erect or decumbent, 1-3 dru. high; leaves long-petioled, rhombic-ovate, 1-2 cm. long, divided into few linear or oblong segments; flowers slender-pediceled; corolla reddish-purple; calyx gibbouscampanulate, the lower side saccate, the subequal deltoid teeth short. - Dry pastures, waste places, etc., local, w. Mass. to Ont. and O. (Nat. from Eu.)

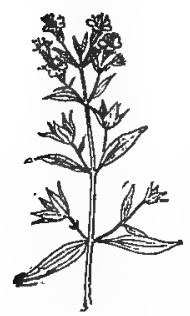

885. I. brachiatus $\times 1 / 2$.

\section{IsÁnthus Michx. False Pennyrotal}

Calyx equally 5-lobed, enlarged in fruit. Corolla little longer than the calyx; the border bell-shaped, with obovate lobes. Stamens slightly didynamous, incurved-ascending, scarcely ex. ceeding the corolla. - A low much branched annual, clammy pubescent, with nearly entire lance-oblong 3-nerved leaves, and small pale blue flowers on axillary 1-3-flowered peduncles. (Name from toos, equal, and avoos, flower, referring to the almost regular corolla.)

1. I. brachiàtus (L.) BSP. Corolla $5 \mathrm{~mm}$. long, little exceeding the calyx. (I. caeruleus Michx.) - I)ry or sterile ground, Vt. and w. Que. to Minn., and southw. July, Aug. FIG. 885 .

\section{4. trichostèma L. Blde Curls}

Calyx bell-shaped, deeply 5-cleft; the 3 upper teeth elongated and partly anited, the 2 lower very short. Stamens with very long curved capillary fila 
ments; anther-cells divergent and at length confluent.-Low annuals, some. what clammy-glandular and balsamic, branched, with entire leaves, and mostly solitary 1-flowered pedicels terminating the branches,

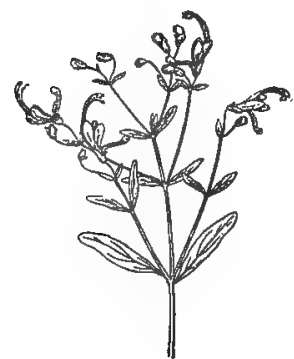

886. T. dichotomum $\times 1 / 2$. becoming lateral by the production of axillary branchlets, and the flower appearing to be reversed, namely, the short teeth of the calyx upward, etc. Corolla blue, varying to pink, rarely white, small; $t$. in summer and autumn. (Name conposed of $\theta p l \xi$, hair, and $\sigma \tau \hat{\eta} \mu \alpha$, stamen, from the capillary filaments.)

1. T. dichótomum L. (Bastard Pennyroyal.) Viscid with rather minute pubescence; leaves lanceoblong or thombic-lanceolate, rarely lance-linear, shortpetioled; lower lobe of the corolla oblong, longer than the remaining broader ones. - Sandy fields, Me. and Vt. to Ky., Mo., and Tex. Fig. 886.

2. $\mathbf{T}$. lineàre Walt. Puberulent, more slender and less forked; leaves linear, nearly smooth. - In sandy ground near the coast, Ct. to La.

\section{SCUTELLÀRIA L. SkULlcap}

Calyx bell-shaped in flower, splitting to the base at maturity, the lips entire, the upper usually falling away. Corolla with an elongated curved ascending tube, dilated at the throat; the upper lip entire or barely notched, the lateral lobes mostly connected with the upper rather than the lower lip; the lower lobe or lip spreading and convex, notehed at the apex. Stamens ascending under the upper lip; anthers approximate in pairs, ciliate or bearded, those of the lower stamens 1-celled (halved), of the upper 2-celled and heart-shaped. - Bitter perennial herbs, not aromatic, the short peduncles or pedicels chiefly opposite, 1-flowered, often 1-sided, axillary or spiked or racemed; $\mathrm{fl}$. in summer. (Name from scutella, a dish, in allusion to the appendage of the fruiting calyx.)

\section{\$1. Nutlets wingless, mostly marginless, on a low gynobase.}

* Flowers small (5-8 mm. long), in axillary and sometimes terminal 1-sided racemes.

1. S. lateriflòra L. (MAD-DoG S.) Smooth; stem upright, much bramcbed, 1-8 din. high ; leaves lanceolate-ovate or ovate-oblong, pointed, coarsely serrate, rounded at base, petioled, $3-9 \mathrm{~cm}$. long, the lower floral ones similar; flowers blue, rarely pink or white. - Wet shaded places, common. July-Sept.

* Flowers solitary in the axils of the upper leaves or in terminal single or panicled racemes; the floral leaves mostly smaller than the cauline.

- Flowers 1-3 cm. long; principal stem-leaves more than $2 \mathrm{~cm}$. long.

- Stem-leaves all cordate, crenate-toothed, slender-petioled; lateral lobes of the corolla almost equaling the short upper lip.

2. S. versicolor Nutt. Soft-hairy, the hairs of the inflorescence, etc., partly viscid-glandular; stem mostly erect, 3-9 dm. high; leaves ovate or round-ovate, very veiny, rugose, the floral reduced to broadly ovate subentire bracts about equaling the glandular-hairy calyx ; racemes mostly simple; corolla bright blue, with lower side and lip whitish. (S. cordifolia Muhl.?, nomen subnudum.) Banks of streams, Pa. to Wisc., Minn., and southw. June, July. Fig. 887 .

3. S. saxátilis Riddell. Glabrous or slightly hairy; stem weak, ascending, 1-5 dm. long, often producing runners, branched; leaves ovate or ovate-oblong, $1.5-5 \mathrm{~cm}$. long, thin, obtuse; upper bracts oblong or ovate, small,

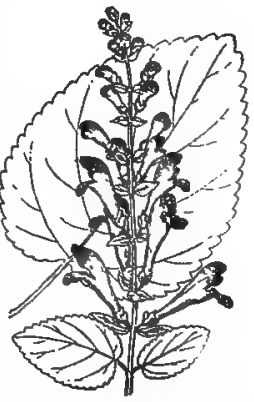

857. S. versicolor $\times 1 / 8$ 
entire ; raceme simple, loose. - Moist shaded banks, Del. to O., s. in the mts. to Va. and Tenn. June, July.

+ Stem-leaves if slender-petioled not cordate (or only the very lowest sometimes so); lateral lobes of the usually violet-blue corolla shorter than the galeate upper lip.

\section{$=$ Stem-leaves crenate-dentate or serrate. \\ a. Stem-leaves on distinct petioles ( $8 \mathrm{~mm}$. or more long).}

1. Flowers in terminal single or panicled racemes; the floral leaves gradually reduced to entire inconspicuous bracts.

4. S. serràta Andr. Green and nearly glabrous; stem rather simple, 2.5-7 $\mathrm{dm}$. high, with single loosely flowered racemes; leaves serrate, acuminate at both ends, ovate or ovate-oblong; calyx, etc., somewhat hairy ; corolla $2-2.5 \mathrm{~cm}$. long, slender, its lips equal in length. - Woods, N. Y. and Pa. to Ill. and N. C. May, June.

5. S. canéscens Nutt. Stem branched above, 0.5-1.2 m. high, with the panicled many-flowered racemes, flowers, and the lower surface of the ovate or lance-ovate acute (at the base acute, obtuse, or cordate) crenate leaves whitish with fine soft down, often becoming rather glabrous; bracts oblong or lanceolate; corolla $2 \mathrm{~cm}$. long. (S. incana Muhl.?, nomen subnuàum.) - Woods and river-banks, Pa. to s. Ont., Mich., and southw. July-Aug.

V6. S. pilosa Michx. Pubescent with spreading hairs; stem nearly simple, 2-7 dm. high; leaves rather distant, crenate, oblong-ovate, obtuse, varying to roundish-ovate, $2-5 \mathrm{~cm}$. long, the lower abrupt or heart-shaped at base and longpetioled, the upper on short margined petioles, veiny; bracts oblong-spatulate; racemes short, often branched; corolla 1.2-1.7 cm. long, rather slender, the lower lip a little shortex, - Dry or sterile ground, s. N. Y. to Mich., s. to Fla. and 'Tex. May, June.

Var. hirsùta (Short) Gray. A large form (8-9 dm. high), more hirsute, with larger very coarsely crenate leaves. - Richer soil, Ky. and Va.

2. Flowers mostly borne on elongate branches even from the base of the plant, solitary in the axils of mostly dentate leaves.

7. S. Churchilliàna Fernald. Stems ascending from a slender rootstock, 3.5-6 dm. high, minutely pilose, freely branching; the branches simple or forked, flexuous, mostly $1.5-3 \mathrm{dm}$. long; leaves ovate-acuminate, thin, glabrous above, minutely pilose on the nerves beneath, those of the primary stem 4-6 $\mathrm{cm}$. long, crenate-dentate, those of the branchlets smaller (1.5-3.5 cm. long); corolla 1-1.5 cm. long, slender-funnel-form, gradually enlarged upward.Alluvial soil, N. B. and Me. July-Sept.

b. Stem-leaves subsessile or on short petioles (1-4 mm. long).

8. S. galericulata L. Herbaceous; subterranean stolons not tuberiferous; smooth or a little downy, erect, 1-9 dm. high; leaves ovate-lanceolate or oblong, acute, serrate, roundish and slightly beart-shaped at base, $1.5-6 \mathrm{~cm}$. long; flowers solitary in the axils of the upper leaves; corolla violet-blue, 1.7-2.2 cm. long, with slender tube, the large lower lip nearly erect. - Wet places, Nfd. to B. C., s. to N. C., O., and Neb. June-Aug.

$$
=\text { - Stem-leaves (or all but the lovest) entire. }
$$

V9. S. integrifolia L. Downy all over with a minute hoariness; stems solitary and commonly simple, 3-8 dm. high, from a slender base; upper leaves oblong-lanceolate, mostly entire, obtuse, very short-petioled, the lowest longpetioled, ovate, dentate; flowers in the axils of the upper more or less reduced leaves or in terminal single or panicled racemes; corolla $2-2.5 \mathrm{~cm}$. long, much enlarged above, the ample lips subequal in length. - Moist ground, e. Mass. to Fla. and Tex., chiefly near the coast. May-July.

10 . S. Búshii Britton. Stems numerous, from $\alpha$ short ligneous caudex, $1.5-3 \mathrm{dm}$. high, closely puberulent; leaves uniform, oblanceolate, obtuse, all entire; flowers axillary, along the upper two thirds of the stem; corolla 2-2.5 cm. long. - Barrens, s. Mo. May, June, 


\section{+ - Flovers 5-10 mm. long; leaves at most $2 \mathrm{~cm}$. long.}

11. S. párvula Michx. Herbaceous; subterranean stolons moniliforis-tuber. iferous; pubescent throughout with spreading often viscid hairs, dwarf $(0.8-3$ dm. high), branched and spreading; all but the lower leaves sessile and entire or sparingly toothed, the lowest round-ovate, the others ovate or lance-ovate,

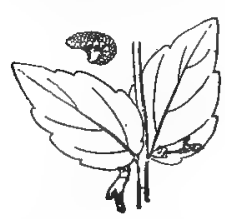

888. B. nervosa.

An upper node $\times 1 / 2$ Nutlet $\times 5$. slightly heart-shaped ; flowers axillary. (Including var, mollis Gray; $S$. campestris Britton.) - Sandy banks, Vt. and w. Que. to Mich., s. to Tenn. and Tex. Apr.-July.

Var. ambígua (Nutt.) Fernald. Minutely puberulent or glabrate. (S. parvula Britton, not Mich $x_{\text {. }}$ - Me. to Wisc., $\mathrm{Ky}$, and Tex.

\section{§ 2. Nutlets conspicuously winged, each raised on a slender base.}

12. S. nervosa Pursh. Smooth, simple or branched, slender, 1.5-5 dm. high; lower leaves roundish, the middle ovate, toothed, somewhat heart-shaped, $2-4.5 \mathrm{~cm}$. long, the floral ovate-lanceolate, entire ; nerve-like veins prominent beneath ; corolla bluish, $1 \mathrm{~cm}$. long, the lower lip exceeding the concave upper one. - Moist thickets and rich woods, s. Ont. and N. Y. to Mo. and N. C. Fig. 888.

\section{MARRÙBIUM [Tourn.] L. Horehound}

Calyx-teeth more or less spiny-pointed and spreading at maturity. Upper lip of the corolla erect, notched, the lower spreading, 3-cleft, its middle lobe broadest. Stamens 4. - Whitish-woolly bitter-aromatic perennials, branched at the base, with rugose and crenate or cut leaves, and many-flowered axillary whorls. (A name used by Pliny, from the Hebrew marrob, a bitter juice.)

1. M. vuladre L. (Common H.) Stems ascending; leaves round-ovate, petioled, crenate-toothed; whorls capitate; calyx with 10 recurved teeth, the alternate ones shorter; corolla small, white. - Waste places, Me. to Ont., westw. and southw. June-Aug. (Nat. from Eu.) Fig. 889.

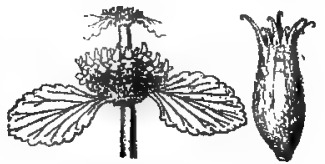

889. M. vulgare.

Node $\times$ 16. Fruiting calyx $\times 2$.

\section{AGÁstache Clayt. Giant Hrssop}

Calyx tubular-bell-shaped, 15-nerved, oblique, 5-toothed, the upper teeth rather longer than the others. Upper lip of corolla nearly erect, 2-lobed, the lower 3-cleft, with the middle lobe crenate. Stamens 4, exserted; the upper

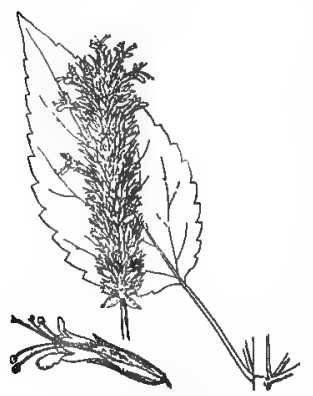

890. A. scrophularinefolin. Node and spike $\times 1 / 2$. Flower $\times 2$. pair declined, the lower and shorter pair ascending, so that the pairs cross; anther-cells nearly parallel. Perennial tall herbs, with petioled serrate leaves, and small flowers crowded ir, interrupted terminal spikes

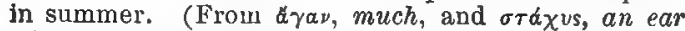
of corn, in reference to the numerous spikes.) LoPhanthics Benth., in part.

1. A. nepetoides (L.) Ktze. Stem stout, 0.7-1.5 m. high, sharply 4-angled, smooth or nearly so; leaves ovate, somewhat pointed, coarsely crenate-toothed, 5-12 cm. long; spikes $3-12 \mathrm{~cm}$. long, crowded with the ovate pointed bracts; calyx-teeth ovate, rather obtuse, little shorter than the pale gremish-yellow corolla. (Lophanthus Benth.) - Borders of woods, セ. Mass., Vt., and w. Que. to Minn., and southw.

2. A. scrophulariaefolia (Willd.) Ktze. Stem (obtusely 4-angled) and lower surface of the ovate or somewhat heart-shaped acute leaves slightly pubescent; 
spikes 0.5-5 dm. long; calyx-teeth lanceolate, acute, shorter than the purplish corolla; otherwise like the preceding. (Lophanthus Benth.) - N. H. to Ont., Mo., Ky., and Va. Fig. 890. Var. Mólis (Fernald) Heller. Stems and lower surfaces of leaves densely villous. - Vt. and Ct. to Ill.

3. A. Foenículum (Yursh) Ktze. Smooth, but the ovate acute leaves glaucouswhite underneath with minute down; calyx-teeth lanceolate, acute. (Lophanthus anisatus Benth.; A. anethiodora Britton.) - Plains, L. Superior and Man. to Neb., and westw. - Foliage with the scent of anise.

\section{MEEHANIA Britton.}

Calyx rather obliquely 5-toothed, 15-nerved. Corolla ample, expanded at the throat; the upper lip flattish or concave, 2-lobed, the lower 3-cleft, the middle lobe largest. Stamens 4, ascending, the lower pair shorter; anthercells parallel. - Low stoloniferous herb, with pale purplish flowers. (Named for the late Thomas Meehan, Philadelphian botanist.)

1. M. cordata (Nutt.) Britton. Low, with slender runners, hairy; leaves broadly heart-shaped, crenate, petioled, the floral shorter than the calyx; whorls few-flowered, at the summit of short ascending stems; corolla hairy inside, 2-3.5 cm. long; stainens shorter than the upper lip. (Cedronella Benth.) - Moist shady banks, w. Pa. to Ill., Tenn., and N. C. June.

\section{9. népeta L. Cat Mint}

Calyx tubular, often incurved. Corolla dilated in the throat; the upper lip erect, rather concave, notched or 2-cleft; the lower 3-cleft, the middle lobe largest, either 2-lobed or entire. - Perennial herbs. (The Latin name, thought to be derived from Nepete, an Etruscan city.)

\$1. CA'TÀRIA [Tourn.] Reichenb. Cymose clusters rather dense and manyflowered, forming interrupted spikes or racemes; upper floral leaves small and bract-like.

1. N. CatAria L. (Catnip.) Downy, erect, branched; leaves heart-shaped, oblong, deeply crenate, whitish-downy underneath ; corolla whitish, dotted with purple. - Near dwellings; a common weed. July-Sept. (Nat. from Eu.)

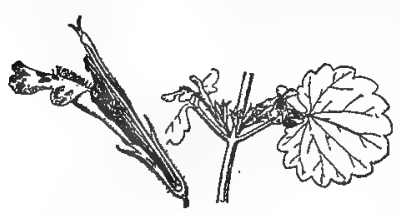

891. N. hederacea.

Node $\times 1 / 2$.

Longitudinal section of flower $\times 2$.
§2. GLECHÒMA (L.) Benth. Leaves all alitee; the axitlary clusters loosely few-flowered.

2. N. hederacea (L.) Trevisan. (Ground Ivy, GILl-over-THE-Groond.) Creepirg and trailing; leaves petioled, round-kidney-shaped, crenate, green both sides; corolla thrise the length of the calyx, light blue. (Glecrma L. ; $N$. Glechoma Benth.) -Damp or shady places, near towns. May-July. (Nat. irom Eu.) Fig. 891.

\section{DRACOcÉphalum [Tourn.] L. Dragon head}

Calyx tubular, 13-15-nerved, 5-toothed. Upper lip of the corolla slightly arched and notched; the lower 3-cleft, with its middle lobe largest and 2-cleft or notched at the end. - Whorls many-flowered, mostly spiked or capitate, and with awn-toothed or fringed leafy bracts. (Name from $\delta \rho \alpha \kappa \omega \nu, a$ dragon, and $\kappa \in \phi a \lambda \eta$, head, alluding to the form of the corolla in the original species.)

1. D. parviflorum Nutt. Annual or biennial ; stem erect, leafy, $1.5-8 \mathrm{dm}$. bigh; leaves ovate-lanceolate, sharply cut-toothed, petioled; whorls crowded in a terminal head or spike; upper tooth of the calyx ovate, nearly equaling 


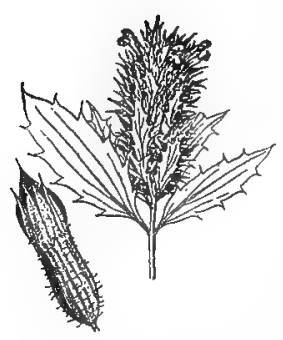

892. D. parviflorum. Inflorescence $\times 2 / 2$. Frufting calyx $\times 2$.

the small slender bluish corolla. - Rocky or gravelly calcareous soil, chiefly in recent clearings, e. Que. to Yukon, southw. to n. and w. N. Y., Mich., Wisc., Ia., N. Mex., and Ariz.; occasionally adventive in N. E. June-Aug. Fig. 892.

\section{PRUNflla L. Self-aeat}

Calyx tubular-bell-shaped, somewhat 10-nerved, naked in the throat, closed in fruit; upper lip broad, truncate. Corolla ascending, slightly contracted at the throat and dilated at the lower side just beneath it, 2-lipped; upper lip erect, arched, entire; the lower reflexed-spreading, 3-cleft, its lateral lobes oblong, the middle one rounded, concave, denticulate. Filaments 2-toothed at the apex, the lower tooth bearing the anther; anthers approximate in pairs, their cells diverging. - Low perennials, with nearly simple stems, and 3 -flowered clusters of flowers sessile in the axils of round and bract-like membranaceous floral leaves, imbricated in a close spike or head. (Name said to be from the German Bräune, a disease of the throat, for which this plant was a reputed remedy. Often written Brunella, which was a pre-Linnean form.)

V 1. P. vulgàris L. (Heal-All, Carpenter-Weed.) Leaves ovate-oblong, entire or toothed, petioled, hairy or smoothish; corolla violet or flesh-color, larely white, not twice the length of the purplish calyx. - Woods and fields, Nfd. to Fla., westw. across the continent. June-Sept. (Eu.) Var. cacinidta L. Some upper leaves tending to be pinnatifid. ( $P$. laciniata $\left.L_{\text {. }}\right)$ - Said to be introd. near Washington, D. C. (Adv. from Eu.)

\section{Physostegia Benth. False Dragon Head}

Calyx obsourely 10-nerved, short-tubular or bell-shaped, more or less enlarged and slightly inflated in fruit. Corolla funnel-form, with a much inflated throat, 2-lipped ; upper lip erect, nearly entire ; the lower 3-parted, spreading, small, its middle lobe larger, broad and rounded, notched. Smooth perennials, with upright wand-like stems, and sessile lanceolate or oblong mostly serrate leaves. Flowers large and showy, rose or flesh-color variegated with purple, opposite, crowded in simple or panicled terminal leafless spikes. (Name from $\phi \hat{v} \sigma \alpha$, a bladder, and $\sigma \tau \dot{t} \gamma \eta$, a covering, in allusion to the calyx, which is at length somewhat inflated.)

* Stem conspicuously leafy up to the inflorescence.

1. P. virginiàna (L.) Benth. Stem 0.5-1.3 m. high, terminated by a simple virgate spike or several panicled spikes; leaves thickish, mostly sharply serrate; calyx tubular-campanulate, its teeth half the length of the tube, acuminate, at length acerosetipped; corolla 1.8-2.3 cm. long. - Wet grounds, from W. Que. westw. and southw.; frequently escaped from cultivation in e. N. E. June-Sept. Fig. 893.

P. parviflòra Nutt: Stem 2-8 dm. high, simple to the inflorescence; leaves thin, lanceolate, denticulate to serrate; spikes short and dense; calyxteeth short and biunt; corolla 1-1.5 cm. long. Wet banks, Wisc. to Sask., N. Dak, and westw. July-Septo

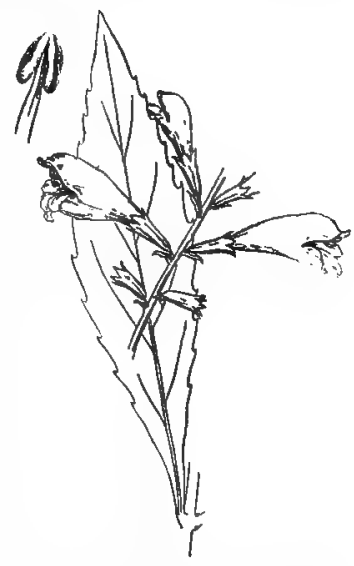

\$98, P. Nrginiana,

Leaf and bit of splke $\times \%$ Anther $\times 8$. 
* Stem-leaves greatly reduced upward, the inflorescences long-pedunculate.

2. P. denticulata (Ait.) Britton, Slender, simple, or the inflorescence branched, 0.6-1.2 dm. high; leaves thick, pale green, from crenate-dentate tn serrate; spikes solitary or in large plants several and paniculately disposed, rather loose ; corolla $2.5-3.5 \mathrm{~cm}$. long. ( $P$. virginiana, var. Gray.) - Prairies, river-banks, etc., Va. to Ill., Kan., and southw. June-Aug.

4. P. intermèdia (Nutt.) Engelm. \& Gray. Slender, 3-15 dm. high, remotely leaved; leaves linear-lanceolate, repand-denticulate; rhachis filform, rather remotely flowered; calyx short and broadly campanulate; corolla 1-1.5 cm. long, much dilated upward. - Barrens, w. Ky. and Ark, to La. and Tex.

\section{SYNÁNDRA Nutt.}

Calyx bell-shaped, inflated, membranaceous, irregularly veiny. Corolla with a long tube, much expanded above and at the throat; the upper lip slightly arched, entire, the lower spreading and 3-cleft, with ovate lobes, the middle one broadest and notched at the end. Filaments hairy; anthers approximate in pairs under the upper lip; the two upper each with one fertile and one smaller sterile cell, the latter cells cohering together (whence the name; from ouv, together, and àno, for anther).

1. S. hispidula (Michx.) Britton. Hairy biennial, 3-6 dm. high; lower leaves long-petioled, broadly ovate, heart-shaped, crenate, thin, the floral sessile, gradually reduced to bracts, each with a single sessile flower; corolla $3-4 \mathrm{~cm}$. long, yellowish-white. (S. grandiflora Nutt.) - Shady banks of streams, O. to Ill., Tenn., and Va. June.

\section{PHLòmis [Tourn.] L. Jerusalem Sage}

Upper lip of the corolla arched; the lower spreading, 3-cleft. Stamens ascending under the upper lip; the filaments of the upper pair longer than the others in $\boldsymbol{P}$. tuberosa, with an awl-shaped appendage at base; anther-cells divergent and confluent. - Leaves rugose. Whorls dense and many-flowered, axillary, remote, bracted. (An old Greek name of a woolly plant.)

1. P. TUBERósA L. Tall perennial, nearly smooth ; leaves ovate-heart-shaped, crenate, petioled, the floral oblong-lanceolate; bracts awl-shaped, hairy; upper lip of the purple corolla densely bearded with white hairs on the inside. - Shore of L. Ontario, N. Y., local. June, July. (Nat. from Eu.)

\section{GALEópsis L. Hemp Nettle}

Calyx about 5-nerved, with 5 somewhat equal teeth. Corolla dilated at the throat; upper lip ovate, arched, entire ; the lower 3-cleft, spreading, the lateral lobes ovate, the middle one inversely heart-shaped; palate with 2 teeth at the sinuses. - Annuals, with spreading branches, and several-many-flowered whorls in the axils of floral leaves which are nearly like the lower ones. (Name com-

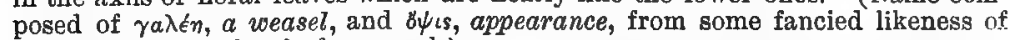
the corolla to the head of a weasel.)

1. G. TетRAнit L. (Соммом H.) Stem swollen below the joints, bristlyhairy; leaves ovate, coarsely serrate; corolla purplish, white, or variegated, about twice the length of the calyx. - Waste places and fields, common. JuueSept. (Nat. from Eu.)

2. G. LÁDANu L. (Red H.) Stem canescent with appressed pubescence; leaves linear or lanceolate, more or less downy, entire or obscurely serrate; corolla red or rose-color (often spotted with yellow), much exceeding the calyx. - Ballast and waste places, N. B. to Mich. and N. J., local. (Adv. from Eu.) Var. LATIFólia Wallr. Leaves ovate-oblong, sharply toothed; upper parts of the plant copiously glandular. - Similar places, casual. (Adv. from Eu.) 


\section{LAmium L. Dead Netrte}

Calyx tubular-bell-shaped, about 5-nerved, with 5 nearly equal awl-pointed ceeth. Corolla dilated at the throat; upper lip ovate or oblong, arched, narrowed at the base; the middle lobe of the spreading lower lip broad, notched at the apex, contracted as if stalked at the base; the lateral ones small, at the margin of the throat. - Decumbent herbs, the lowest leaves small and longpetioled, the middle heart-shaped and doubly toothed, the floral subtending the

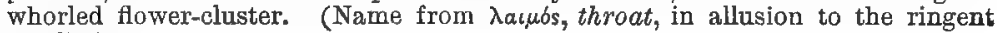
corolla.)

* Annuals or biennials, low; flowers small, purplish, at most $1.5 \mathrm{~cm}$. long.

1. L. AMPlexicaúle L. (Henbit.) Leaves rounded, deeply crenate-toothed or cut, the upper ones clasping; corolla elongated, upper lip bearded, the lower spotted, lateral lobes truncate. - Waste and cultivated places, Apr.-Oct. (Nat. from Eu.)

2. L. PURPƯRUM L. Leaves roundish or oblong, heart-shaped, crenatetoothed, all petioled. - N. E. to N. C. Apr., May. (Nat. from Eu.)

\section{* Perennial, taller; flowers larger.}

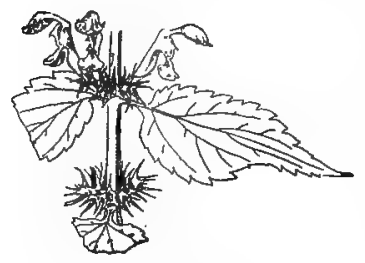

894. L. album $\times 16$.

3. L. Áвuм L. Hairy ; leaves ovate, heartshaped, petioled; calyx-teeth very slender, spreading; corolla white, the tube curved upward, obliquely contracted near the base, where there is a ring of hairs inside; lateral lobes of lower lip bearing a long slender tooth, - Roadsides and waste places, mostly escaped from cultivation. May-July. (Introd. from Eu.) Fig. 894.

4. L. Maculatum L. Like the last, but leaves more frequently marked with a white spot on the upper face, and flowers purplish or white, with the ring of hairs transverse instead of oblique. Sparingly escaped to roadsides and thickets. May-July. (Introd. from Eu.)

\section{LEONÙRUS L, MOTHERWORT}

Calyx 5-nerved, with 5 nearly equal teeth. Upper lip of the corolla oblong and entire, somewhat arched; the lower spreading, 3-lobed, its middle lobe larger, narrowly oblong-obovate, entire, the lateral ones oblong. - Upright herbs, with cut-lobed leaves, and close whorls of flowers in their axils; in summer. (Name from $\lambda \epsilon \omega v$, a lion, and ovod, tail, i.e. Lion's-tail.)

1. L. CARDìacA L. (Common M.) Tall perennial; leaves long-petioled, the lower rounded, palmately lobed, the floral wedge-shaped at base, subentive or 3-cleft, the lobes lanceolate; upper lip of the pale purple corolla bearded. Waste places, around dwellings. (Nat. from Eu.)

2. L. Marrubiástrum L. Tall biennial, with elongated branches; stemleaves oblong-ovate, coarsely toothed; corolla whitish, shorter than the calyxteeth, the tube naked within; lower lip rather erect. - Waste places, etc., Pa. and Del. (Adv. from Eu.)

3. L. sibfricus L. Tall biennial; leaves 3-parted, the divisions 2-5-cleft, or deeply 3-7-cleft and incised; corolla purplish, twice as long as the calyx, the upper lip fornicate, the lower little spreading. - Waste grounds, $\mathrm{Pa}$, and Del. (Adv. from Eurasia.)

\section{BALLÒTA L. FETID HOREHOUND}

Calyx nearly funnel-form; the 10-ribbed tube expanded above into a spread. ing regular border, with 5-10 teeth. Anthers exserted beyond the tube of the corolla, approximate in pairs. Otherwise much as in Marrubium. (The Greek name, of uncertain origin.) 
1. B. Nigra L. (Bla ok Horenovnd.) More or less hairy, but green, erect; the root perennial ; leaves ovate, toothed ; whorls many-flowered, dense ; calyx. teeth 5 , longer than the tube of the purplish corolla. - Waste places, N. E., Yam etc., rare. (Nat. from $\mathrm{Eu}$. )

\section{STACHYS [Tourn.] L. Hedge Nettle}

Corolla not dilated at the throat; upper lip erect or rather spreading, often arched, entire or nearly so; the lower usually longer and spreading, 3-lobed, with the middle lobe largest and nearly entire. Stamens 4, ascending under the apper lip (often reflexed on the throat after flowering); anthers approximate in pairs. Nutlets obtuse, not truncate. - Whorls 2-many-flowered, approximate in a terminal raceme or spike (whence the name, from orá $\chi v s, a$ spike).

a. Annuals.

Stem sunoothish; corolla yellow, much exceeding the calyx .

1. S. annua.

Stem hirsute; corolia purplish, about equaling the calyx .

2. S. arvensis.

a. Perennials $b$.

$b$. Stems glabrous on the sides, smooth or bristly on the angles $e$.

a. Calyx-teeth triangular-lanceolate, abont equaling the tube.

Leaves entire or obscurely toothed, linear or linear-oblong

Lesves regularly serrate or serrulate.

Leaves 5-13 mm. broad, their petioles $1-8 \mathrm{~mm}$. long

Leaves broader, their petioles $5-15(-20) \mathrm{mm}$. long.

Leaves rounded-truncate to cuneate at base, acute or merely

acuminate at tip
Leaves beart-shaped at base, candate-acuminate at tip

c. Calyx-teeth broadly deltoid, much shorter than the tubs

b. Stems pubescent (or puberulent) on the sides as well as on the angles.

Leaves liuen to linear-ianceolate, 10-12 times as long as broad ."

Leaves broader, oblong to cordate-ovate.

Leaves subsessile or very short-petioled, the lower petioles not conspicuously longer than the upper.

Lower leaves on elongate petioles, the upper on shorter petioles or subsessile.

Calyx-teeth broad-deltoid, much shorter than the tube

Calyx-teeth lance-deltoid, nearly equaling the tube

8. S. hysoopifolia,

4. S. ambigua.

5. S. tenuifoulu.

6. S. Nuttallit.

7. S. latidens.

8. S. arenicola.

9. S. palustrits.

10. S. cordata.

11. S. salzioiáes.

1. S. ANNOA L. Erect smoothish annual; leaves oblong to oblanceolate, the lower crenate, the upper subentire ; calyx pilose and glandular-puberulent, 6-8 $\mathrm{mm}$. long, the subequal lanceolate lobes about equaling the tube ; corolla yellow, $1.5 \mathrm{~cm}$. long. - Waste places and ballast, chiefly about Atlantic ports. July, Aug. (Adv. from Eu.)

2. S. ARvinsis L. Low decumbent annual; stems hirsute; leaves ovate, crenate, subcordate, hirsute, the lower long-petioled; calyx $4.5-6 \mathrm{~mm}$. long, hirsute, about equaling the purplish corolla. - Waste places and ballast, chiefly near Atlantic ports. ( $\mathrm{Adv}$. from Eu.)

3. S. hyssopifdilia Michx. Smooth and glabrous, or the nodes hirsute; stems siender, 2-5 dm. high ; leaves linear-oblong or narrowly linear, sessile, entire or obscurely toothed tovard the apex, 2-5 cm. long, 3-10 mm. wide; whorls 4-6flowered, rather distant; corolla twice or thrice the length of the triangularawl-shaped spreading calyx-teeth. - Wet sandy places, Mass. to Fla.; 8. Mich. July-Sept.

4. S. ambigua (Gray) Britton. Resembling the precedung, but stouter, with scattered retrorse bristles on the angles of the stem, and with serrulate leaves about $1 \mathrm{~cm}$. broad. (S. hyssopifolia, var. Gray.) - Pa. to Wisc., and southw June-Aug.

5. S. tenuifdlia Willd. Rootstock slender; stem slender, smooth and glabrous throughout, or with few minute bristles on the angles; leaves lanceolate to oblong, taper-pointed, sharply toothed, mostly 5-10 cm. long, short-petioled, only the lower floral longer than the flowers; spike slender and interrupted; calyx glabrous, the tube rather slender, the lance-subulate teeth somewhat spreading. (S. aspera, var. glabra Gray.) - Wet ground, N. Y. to Ia., and southw.

Var. Aspera (Michx.) Fernald. Angles of the stem beset with long reflexed bristles; leaves oblong- to ovate-lanceolate, short-petioled, more or less hairy; 
calyx slightly larger, the teeth often less spreading. (S. aspera Michx.) $-\mathrm{Vt}$. and e. Mass. to Ont., and.southw. July, Aug.

6. S. Nuttállii Shuttlw. Tall, very hirsute on the angles; leaves cordateovate to -oblang, hirsute on the veins, serrate-dentate, caudate-acuminate; spike very interrupted, the lower verticels borne in the axils of the short-petioled foli. age leaves; calyx hirsute, the spiny teeth nearly equaling the corolla-tube. U. and Va. to 'Ienn.

7. S. látidens Small. Stem stout, 6-7 dm. high, smooth, or finely setose on the anyles; leaves ovate-oblong, subcordate, glabrous or sparingly setulose, short-petioled, mostly $1-1.3 \mathrm{dm}$. long, 3-5 cm. broad, coarsely crenate-dentate ; spike slender and interrupted, the lowest floral leaves large; calyx pubescent, short-campanulate, with short deltoid firm teeth. - Mts. of Va., N. C., and Tenn.

8. S. arenicola Britton. Stem 3-6 dm. high, copiously retrorse-hispid on the sides and angles; leaves linear to linear-lanceolate, $6-10 \mathrm{~cm}$. long, 5-10 $\mathrm{mm}$. wide, densely pubescent on both faces, crenate-serrate; spike dense, slightly interrupted; the lower bracts much exceeding the flowers, the upper short, all densely hispid ; calyx hispid, the lobes acicular; corolla inconspicuous, the upper lip hispid. - Sandy soil, N. Y. to Ill. and Mich.

9. S. palústris L. (Woundwort.) Rootstock tuberous-thickened, freely stoloniferous; stem 3-10 dm. high, leafy, hirsute on the angles with spreading or reflexed hairs, the sides more finely appressed-pubescent; leaves sessile, or the lower short-petioled, lanceolate to ovate-oblong, crenate-serrate, rounded at base, downy or hairy, obtusish, 4-10 $\mathrm{cm}$. long, only the uppermost floral ones shorter than the nearly sessile calyx; whorls 6 -10-flowered, the upper crowded into an interrupted spike; calyx hispid, the lance-subulate teeth somewhat spiny, half the length of the corolla, diverging in fruit. - Wet ground, Nfd. to the Mackenzie, s. to N. C., O., Ill., Minn., Col., etc. (Eurasia.) Var. номótricha Fernald. Sides of the stems and the angles almost uniformly hirsute with long retrorse hairs. - N. B. to Ct., centr. N. Y., and westw.

10. S. cordata Riddell. Stem rather weak, long-hirsute on the angles, 6-8 $\mathrm{dm}$. high ; leaves long-petioled, all ovate- or oblong-cordate, acuminate, crenate, $7-15 \mathrm{~cm}$. long, the floral mostly minute; spikes slender, of numerous fewflowered clusters ; calyx small, with very short teeth; corolla about $1 \mathrm{~cm}$. long. Thickets, s. O. to Va. and Tenn.

11. S. salvioides Small. Stems closely glandular-puberulent to short-hirsute, 3-9 dm. high ; leaves petioled, the petioles glandular-short-hirsute, the closely pubescent cordate-ovate dentate acuminate blade 6-12 cm. long; spike slender, few-flowered; the bracts ovate, about equaling the calyx; calyjx-lobes lancedeltoid, about equaling the tube; corolla about $1 \mathrm{~cm}$. long. - Stony soil, Va. and W. Va. to Tenn.

\section{SÁlviA [Tourn.] L. SAGE}

Upper lip of calyx 3-toothed or entire, the lower 2-cleft. Corolla deeply 2-lipped, ringent; upper lip straight or scythe-shaped, entire or barely notched, the lower spreading or pendent, 3-lobed, its iniddle lobe larger. Stamens on short filaments, jointed with the elongated transverse connective, one end of which, ascending under the upper lip, bears a linear 1-celled (half-) antber, the other, usually descending, bears an imperfect or deformed (half-) anther or none at all. - Flowers mostly large and showy, in spiked, racemed, or panicled whorls. (Name from salvare, to save, in allusion to the reputed healing qualities of Sage.)

\section{* Both anther-cells polliniferous; leaves mostly lyrately lobed or pinnatifid.}

1. S. lyràta L. (LYRE-LEaved S.) Low perennial, 2-6 dm. high, somewhat hairy; stem nearly simple and naked; root-leaves lyre-shaped or sinuatepinnatifid, sometimes almost entire; those of the stem mostly a single pair, smaller and narrower; bracts oblong-linear, not longer than the calyx; whorls loose and distant, forming an interrupted raceme; upper lip of the blue-purple pubescent corolla $(2-3 \mathrm{~cm}$. long) short, straight, not vaulted. - Sandy woods and barrons, Ct. to Ill., s. to Fla. and Tex. May, June. 
* Lower anther-cell wanting; the sterile ends of the connectives mostly united.

+ Calyx obscurely bilabiate; corolla 1.5-2.5 cm. lang, with prominently exserted tube.

2. S. azùrea Lam., var. grandiflora Benth. Cinereous-puberulent, 0.5-1.5 m. high; lower leaves lanceolate or oblong, obtuse, denticulate or serrate; tapering to a short petiole; upper narrower, often linear, entire; inflorescence spike-like, tomentulose-sericeous ; calyz-teeth short, the broad upper lip entire; corolla blue or white. (S. Pitcheri 'Torr.) - Minn, to Mo., westw. and southw. July-Sept.

\section{+ + Calyx deeply bilabiate; corolla-tube hardly at all exserted.}

\section{+ Annual.}

3. S. lanceaefolia Poir. Puberulent or nearly glabrous, 1-12 dm. high ; leaves lanceolate or linear-oblong, irregularly serrate or nearly entire, tapering to a slender petiole; inflorescence virgate-spiciform, interrupted; upper lip of calyx entire, lower 2-cleft; corolla blue, $1 \mathrm{~cm}$. long, little exserted; style glabrous or nearly so. (S. lanceolata Broussonet, not Lam.) - Plains and open soil, Ind. (C. P. Smith) to Neb., Tex., and Ariz.; introd. at Columbus, 0. (Kellerman). May-Oct.

\section{+ + Perennials.}

\section{$=$ Pedicels about equaling the fruiting calyx.}

4. S. urticifdlia L. Villous-pubescent and somewhat viscid, or glabrate, 3-6 $\mathrm{dm}$. high ; leaves coarsely serrate, ovate, with truncate or cuneate base decurrent into a winged petiole; inflorescence racemose-spicate, of numerous distant clusters; calyx-lips divergent, the upper 3-toothed, lower 2-cleft; corolla blue and white, 1-1.5 cm. long, twice the length of the calyx; style strongly bearded. Woodlands, Pa. to Ky., s. to Ga. and La. May-July.

\section{$==$ Pedicels much shorter than the fruiting calyx.}

5. S. Sclarea L. (Clary.) Villous-pubescent, viscid, stout, $1 \mathrm{~m}$. or less high ; leaves ample, long-petioled, ovate and cordate, crenate, rugose, the floral forming large bracts of the spike, tinged with white and rose-color; corolla white and bluish, rather large, the long upper lip falcate and compressed. Escaped from gardens, from Pa. southw. (Introd. from Eu.)

6. S. Verbenaca L. Puberulent to villous, 3-6 $\mathrm{dm}$. high; leaves ovate or oblong, mostly sinuate-incised or moderately pinnatifid, the lobes crenatetoothed, rugose, the few cauline mostly sessile, the floral inconspicuous; spike interrupted; calyx reflexed after flowering; corolla bluish, small, the upper lip nearly straight. - Sparingly in waste places, Middle and Southern States. (Nat. from liv.)

\section{MONÁRdA L. Horge MINT}

Calyx 15-nerved, usually hairy in the throat. Corolla elongated, with a slightly expanded throat; lips linear or oblong, somewhat equal, the npper erect, entire or slightly notched, the lower spreading, 3-lobed at the apex, its lateral lobes ovate and obtuse, the middle one narrower and slightly notcher. Stamens elongated, ascending, inserted in the throat of the corolla. - Odorous erect herbs, with entire or toothed leaves, and large attractive flowers in a few verticels closely surrounded by bracts. (Dedicated to Nicolás Monardes, author of many tracts upon medicinal and other useful plants, especially those of the New World, in the latter half of the 16th century.)

* Stamens and style exserted beyond the linear straight acute upper lip of the corolla; heads solitary and terminal or sometimes 2 or 3 ; leaves acutely more or less serrate; perennials.

- Leaves petioled; calyx-teeth scarcely longer than the width of the tube.

* Glabrous or villous.

工 Calyx smooth or smoothish in the throat.

1. I didyma L. (Oswego Tea, Bee Balm.) Stem somewhat hairy, $1 \mathrm{~m}$. or less high, acutely 4-angled; leaves ovate-lanceolate, acuminate, the floral 
Ines and the large outer bracts tinged with red; calyx smoothish, nearly naked in the throat; corolla smooth or minutely pubescent, 4-5 cm. long, bright rod, showy. - Moist woods, by streams, w. Que., Ont., and sonthw. July, Aug.

$$
==\text { Calyx hairy in the throat. }
$$

2. M. clinopodìa $I$. Nearly glabrous to villous-pubescent; leaves ovatelanceolate and ovate; bracts whitish; calyx moderately hirsute in the throat; corolla slightly pubescent, 2-2.5 cm. long, dull white or flesh-colored. - Shady places, ravines, etc., N. Y. to Ill. and Ga. July.

3. M. fistulosa I. (Wild Bergamot.) Branches more or less villous or hirsute, $0.5-1.5 \mathrm{~m}$. high ; leaves ovate-lanceolate, pubescent especially beneath, the uppermost and outer bracts somewhat colored (whitish or purplish); calyx slightly curved, very hairy in the throat; corolla $2.5-4 \mathrm{~cm}$. long, litac or pink, the upper lip very hairy.-Dry soil, N. E. to Col. and Tex.; often cultivated and mostly introd, northeastw. Var. RÙBRA Gray. Stem smooth; corolla bright crimson or rose-red; habit of no. 1, but upper lip of corolla villous-bearded on the back at tip; throat of calyx with the outer bristly hairs widely spreading. (M. media Willd.) - Me. to Ont. and Tenn.; mostly introd. northw. July, Aug.

* Leaves canescent (especially beneath) with minute appressed puberulence.

4. M. móllis L. Tall and branching; leaves firm, oblong-or deltoid-ovate, long-acuminate; throa; of calyx mostly filled with dense beard, with sometimes an outer row of bristles; corolla flesh-color to lilac, glandular, its upper lip hairy outside or more bearded at the tip. (M. scabra Beck; $M$. fistulosa, var. mollis Benth.) - Dry plains, Me. to Man., and southw. July, Aug.

++ Leaves nearly sessile; calyx-teeth elongated, lax; head solitary.

5. II. Bradburiana Beck. Leaves clothed with long soft hairs, especially underneath; the floral and the outer bracts somewhat heart-shaped, purplish; calyx smoothish, contracted above, very hairy in the tliroat, with awl-shaped awned teeth; corolla smoothish, bearded at the tip of the upper lip, scarcely twice the length of the calyx, pale-purplish or white, the lower lip dotted with purple. - Thickets and woods, Ind. to Tenn. and Mo. May-July.

* Stamens not exceeding the falcate upper lip of the short corolla; heads axillary or interrupted-spicate; leaves lanceolate or oblong, sparsely serrate, tapering into the petiole.

6. M. punctàta L. (Horse Mirr.) Perennial, minutely downy, 3-9 dm. high ; leaves petioled, lanceolate, narrowed at base; bracts lanceolate, blunt, obtuse at base, sessile, yellowish and purple; teeth of the downy calyx short and aconless, rigid, soon spreading; corolla nearly smooth, yellowish, the upper lip spotted with purple, notched at the apex, the tube scarcely exceeding the calyx. - Sandy ground, N. Y. to Minn., s. to Fla. and Tex.; adv. in N. E. July-Sept.

7. M. citrioddra Cerv. (Lemon Mint.) Annuai, 3-8 dm. high; bracts narlowly oblong, their slender awned tips spreading or recurving; calyx-teeth slender, at length usually spreading; corolla white or pinkish, not spotted. - Ill. to Neb. and Tex. June-Sept.

\section{BLEPHILIA Raf.}

Calyx 13-nerved, naked in the throat; upper lip with 3 awned teeth, the lower with 2 nearly awnless teeth. Corolla inflated in the throat, nearly equally 2-lipped; upper lip erect, entire, the lower spreading, 3-cleft, its lateral lobes ovate and rounded, larger than the oblong and notched middle one. Stamens sxserted (the upper pair minute or none). - Perennial herbs, with nearly the loliage, etc., of Monarda; the small pale bluish-purple flowers crowded in

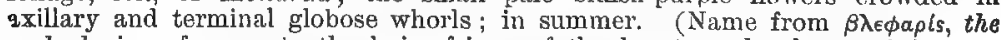
eyelash, in reference to the hairy fringe of the bracts and calyx-teeth.)

1. B. ciliata (I.) Raf. Somewhat downy, 3-9 dm. high; leaves almcst sessile, oblong-ovate, narrowed at base, whitish-downy underneath; outer-bracts 
ovate, acute, colored, ciliate, as long as the calyx; corolla hairy. - Dry open places, Vt. to Minn., s. to Ga. and Mo.

2. B. hirsita (Pursh) Bentl, (Woon MiNT.) Taller, hairy throughout; leaves long-petioled, ovate, pointed, rounded or heart-shaped at base; the lower floral ones similar, the uppermost and the bracts linear-awl-shaped, shorter than the long-haired calyx ; corolla pale, with darker purple spots. - Moist shady places, w. Que. and Vt. to Minn., s. to Ga. and e. Tex. Var. glabrata Fernald. Stem and leaves glabrous. - Local, s. Vt. (Miss Day).

\section{3. hededma Pers. Mock Penntrotal}

Calyx ovoid or tubular, gibbous on the lower side near the base, 13-nerved, hearded in the throat, 2-lipped; upper lip 3-toothed, the lower 2-cleft. Upper lip of corolla flat, notched at the apex, the lower spreading, 3-cleft. - Low odorous annuals, with small leaves and loose axillary clusters of flowers (in summer) often forming terminal leafy racemes. (Altered from i் $\delta$ ó $\mu_{0} \nu$, an ancient name of Mint, from $\dot{\eta} \partial \hat{u}$ s, sweet, and $\delta \sigma \mu \dot{\eta}$, scent.)

* Sterile filaments manifest; leaves oblong-ovate, petioled, somewhat serrate.

1. H. pulegioìdes (L.) Pers. (American Pennyroyal.) Erect, branching, hairy; whorls few-flowered ; upper calyx-teeth triangular, the lower setaceoussubulate; corolla bluish, pubescent, scarcely exserted, 3-5 mm. long; taste and odor nearly of the true Pennyroyal (Mentha Pulegium) of Europe. - Dry soil, N. S. and Que. to Dak., and southw.

* Sterile filaments minute or obsolete; leaves narrow, entire, sessile or nearly so.

2. H. híspida Pursh. Mostly low; leaves linear, crovoded, almost glabrous, somewhat hispid-ciliate; bracts spreading or reflexed; upper flowers rather crowded; calyx-teeth all subulate, equaling the bluish corolla. - Plains and rocky banks, N. Y. (Haberer) and Ont. to Sask. and La.; locally introd is Vt.

\section{MELísSA [Tourn.] L. BaLM}

Calyx with the upper lip flattened and 3-toothed, the lower 2-cleft. Corolla with a recurved-ascending tube. Stamens 4 , curved and conniving under the upper lip. Otherwise nearly as Satureja. - Clusters few-flowered, loose, onesided, with few and mostly ovate bracts resembling the leaves. (Name from $\mu \epsilon \lambda \iota \sigma \sigma \alpha, a$ bee; the flowers yielding abundance of honey.)

1. M. OFFICINA tis L. (Common B.) Upright, branching, perennial, pubescent; leaves broadly ovate, crenate-toothed, lemon-scented; corolia nearly white. - Sparingly escaped from gardens. (Introd. from Eu.)

\section{Saturèja [Tourn.] L. Savory. Calamint}

Calyx tubular to bell-shaped, 10-13-nerved, naked or hairy in the throat. Corolla with a straight tube and an inflated throat, distinctly 2-lipped; the upper lip erect, flattish, entire or notched; the lower spreading, 3-parted, the middle lobe usually largest. Stamens 4, somewhat ascending. - Herbs or shrubs, with mostly purplish or whitish flowers produced all summer; inflorescence various. (The ancient Latin name.) Including Clinopodiom L. Ca lamintha Lam.

\section{\$1. Loosely flowered, without long-subulate bracts.}

* Calyx bell-shaped, nalked in the throat.

1. S. Hortensis L. (Summer S.) Pubescent annual ; leaves linear, entire ; clusters few-flowered, in dense interrupted spikes; bracts small or none.Escaped from gardens and sparingly wild, N. B. to Mich. and Ky. (Introd. from Eu.) 
- Calyx cylindric or tubular, hairy in the throat.

- Pubescent; bracts minute.

- Common peduncle short but distinct.

2. S. Nefeta (L.) Scheele. (Basil Thyme.) Softhairy; stem ascending, $1 \mathrm{~m}$. or less high; leaves petioled, broadly ovate, obtuse, crenate; corolla 7-8 $\mathrm{mm}$. long, twice the length of the calyx. (Calamintha Savi; Clinopodium Ktze.) - Dry waste grounds, Md. to Ind., Ark., and southw. (Nat. from Eu.)

* Common peduncle none.

3. S. Ácinos (L.) Scheele. Mostly branching and decumbent at base, $1.5-2.5 \mathrm{dm}$. high ; leaves elliptic-ovate to -oblong, acute, about $1 \mathrm{~cm}$. long, petioled; calyx constricted at the throat. (Clinopodium Ktze.) - Roadsides and waste places, Mass. to Ont. and N. J. (Nat. from. Eu.)

+ + Glabrous or nearly so; common peduncles hardly any; pedicels 1-5, slender, the conspicuous bracts subulate-acuminate.

4. S. glabélla (Michx.) Briquet. Smooth; stems diffuse or spreading, 2-5 $\mathrm{dm}$. long; leaves slightly petioled, oblong or oblong-linear, narrowed at base, 2-5 cm. long, sparingly toothed or nearly entire; clusters 3-5-flowered; corolla purplish, ahout $1 \mathrm{~cm}$. long, fully twice the length of the calyx. (Calamintha Benth.; Clinopodium Ktze.) - Damp (generally calcareous) soil, s. Ind., Ky., Tenn., and Ark.

5. S. glàbra (Nutt.) Fernald. Smaller; the flowering stems more upright, 1.5-4 dm. high, with narrower mostly entire leaves and fevor-flowered clusters, while sterile runners from the base bear ovate thickish leaves $0.5-1 \mathrm{~cm}$. long. (Clinopodium Ktze.; Calamintiha .Nuttallii Benth.) - Rocky banks, N. Y. and e. Ont. to Minn. and Tex.

$\$ 2$. Flowers in sessize dense many-flowered clusters, and involucrate with conspicuous setaceous-subulate bracts; calyx nearly naked in the throat.

6. S. vulgàris (L.) Fritsch. (BasIL.) Hairy, erect, 2-6 dm. high; leaves ovate, petioled, nearly entire; flowers lavender to pink, in globular clusters; hairy bracts as long as the calyx. (Clinopodium L.; Calamintha Clinopodium Benth.) - Woods, thickets, and alluvial banks, Nfd. to Va., O., Ind., and Man. (Eurasia.)

\section{HYSSOPUS [Tourn.] L. HYssoP}

Calyx tubular, 15-nerved, equally 5-toothed, naked in the throat. Corolla short, 2-lipped; upper lip erect, flat, obscurely notched, the lower 3-cleft, with the middle lobe larger and 2-cleft. - Perennial herb, with wand-like simple branches, lanceolate or linear entire leaves, and blue-purple flowers ir small clusters, crowded in a spike. (The ancient name.)

1. H. officinalis L. - Roadsides, etc., snaringly escaped from gardens. (Introd. from Eu.)

\section{ORfGandm [Tourn.] L. Wild Marjoram}

Calyx hairy in the throat, striate, 5-toothed. Tube of the corolla about the length of the calyx ; the upper lip rather erect and slightly notched, the lower longer, of :3 nearly equal spreading lobes. Stamens exserted, diverging. Perennials, with nearly entire leaves, and purplish flowers crowded in cylindrical or ellipsoid spikes, inbricated with colored bracts. (An ancient Greek name, composed of boos, a mountain, and yóvos, ornament.)

1. 0. VULGARr L. Upright, hairy, corymbose at the summit; leaves petioled, round-ovate ; bracts ovate, obtuse, purplish. - Roadsides and fields, Mass. to Ont. and $\mathrm{Pa}$. June-Oct. (Nat. from $\mathrm{Eu}$.) 


\section{Pychanthemum Michx. Mountain Mint. Basil}

Calyx about 13-nerved, naked in the throat. Corolla short, more or less 2-lipped; the upper lip straight, nearly flat, entire or slightly notched; the lower 3-cleft, its lobes all ovate and obtuse. Lower pair of stamens rather longer than the upper; anther-cells parallel. - Perenoial upright herbs, with a pngent mint-like tlavor, corymbosely branched above, the floral leaves often whitened; the many-flowered whorls dense, crowded with bracts, and usually forming terminal heads or close cymes. Corolla whitish or purplish, the lips mostly dotted with purple. Fl. summer and early autumn. Varies, like the Mints, with the stamens exserted or included in different flowers. (Name composed of $\pi u \kappa \nu b s$, dense, and $\measuredangle \nu \theta \epsilon \mu \nu \nu, a$ blossom, from the compact inforescence.) Íoellia Moench.

* Calyx-teeth long, bristly-ciliate, or at least bearing long terminal bristles. - Glomerules terminating the upper branches, rather densely clustered and forming a corymb.

1. P. Iéptodon Gray. Soft-pubescent, or glabrate below, loosely branched; leaves membranaceous, green, 3-6 cm. long, lanceolate or oblong-lanceolate, entire or subentire, subsessile; infloresence canescent-hirsute; long-acuminate bracts and calyx-teeth slender-subulate, villous-hirsute. - O. to Mo. and N. C.

+ + Glomerules verticillastrate or terminating short paniculately disposed branches.

2. P. clinopodioides T. \& G. Pubescent; leaves short-petioled, broad-or oblong-lanceolate, sharply denticulate or entire, all pale green, the upper not whitened; bracts loose, slightly ciliate; calyx-teeth one third or one half as long as the tube, sparingly bristle-tipped. (Koellia Ktze.) - Dry soil, Ct. to Pa. and Va.

3. P. pycnanthemoides (Leavenw.) Fernald. I'ubescent; leaves ovateoblong, remotely toothed, the lower dark green and loosely soft-downy, the floral ones whitened; cymes dense; bracts much surpassing the flowers, their long awn-like points and the awn-pninted calyx-teeth (equaling the tube) bearded with long loose hairs. (Koellia Ktze.; P. Tullia Benth.) - Va. to Ky., and southw. - Sometimes too near no. 10.

* * Calyx-teeth without long bristles (except in dubious forms of no. 10).

- Bracts and equal calyx-teeth awn-tipped, rigid, naked, as long as the corolla; flowers in dense heads mostly terminating the branchlets; leaves slightly petioled.

4. P. aristàtum Michx. Minutely hoary-puberulent, 4-8 dm. high; leaves ovate-oblong and oblong-lanceolate, acute, sparingly denticulate-serrate, 2-6 $\mathrm{cm}$. long, roundish at the base. (Koellia Ktze.) - Pine barrens, N. J. to Fla. and La.

Var. hyssopifolium (Benth.) Gray. Leaves narrowly oblong or broadly linear, nearly entire and obtuse. (Koellia hyssopifolia Britton.) - Va. to Fla. + + Bracts and equal and similar calyx-teeth not long-awned.

+ Leaves lanceolate or linear; heads mostly terminating the branches, subcorymbosely disposed.

\section{$=$ Leaves linear.}

5. P. flexuosum (Walt.) BSP. Smooth, freely branching; leaves firm; heads $5 \mathrm{~mm}$. or less high, somewhat downy, densely corymbose; appressed rigid bracts and lance-subulate calyx-teeth with short firm points. (Koellia MacM.; P. linifolium Pursh.) - Dry ground, centr. Me. to Minn, and southw.

$$
==\text { Leaves lanceolate. }
$$

a. Leaves all glabrous or merely pubescent on the nerves beneath.

6. P. virginiànum (L.) Durand \& Jackson. Smoothish or minutely pubescent, 2-10 dm. high; leaves lanceolate or lance-linear, nearly sessile, entire, 
very numerous, obtuse at base; capitate glomerules small and numerous, densely corymbose, imbricated with many short appressed downy rigid ovate or lanceolate bracts; calyx-teeth short and triangular. (Koellia MacM.; P. lanceolatum Pursh.) - Dry banks, centr. Me. to Dak., and southw.

7. P. Torrèi Benth. Puberulent; stem strict and nearly simple, 5-9 dm. high ; leaves thin, lanceolate or linear-lanceolate, tapering to both ends, petioled, nearly entire; flowers in mostly terminal dense capitate clusters; awl-shaped calyx-teeth and mostly appressed bracts canescent. (Koellia verticillata Am. euth., in part, not Ktze.) - Dry soil, N. Y. and Pa. to Ga.

\section{b. At least the uppermost leaves closely puberulent above.}

8. P. pilosum Nutt. Hoary with loose pubescence ; leaves thick, pubescent and dull, oblong-lanceolate, entire, mostly acute or acutish at base, the upper green; bracts and especially the narrow (often somewhat unequal) calyx-teeth villous-pubescent, canescent; stamens exserted. (Foellia Britton ; P. muticum, var. Gray.) - Prairies and dry woods, Pa. to Ia., Kan., and Ark.

9. P. verticillàtum (Michx.) Pers. Stem closely pubescent, especially above; leaves lanceolate, entire or subentire, subsessile, mostly glabrous, only the upper closely puberulent and paler ; bracts of the glomerules ovate-lanceolate, ciliate, with subulate tips; stamens included. (Koellia Ktze.) - Moist fields and open woods, w. Que., Vt., and e. Mass. to N. C.

\section{$\rightarrow+$ Leaves ovate or ovate-oblong.}

\section{$=$ Calyx and bracts densely invested with close minute appressed pubescence.}

10. P. incànum (L.) Michx. Leaves ovate-oblong, acute, remotely toothed, downy above and mostly hoary with whitish wool underneath, the uppermost whitened both sides; cymes large, open, mostly verticillastrate or terminal, few; bracts linear or lanceolate, more or less bristly-ciliate ; calyx-teeth deltoid, short, herbaceous, rarely a little bristly-ciliate. (Koellia Ktze.) - Open woods, Vt. and Mass, to Ont., Mo., and southw.

11. P. albéscens T. \& G. Closely resembling the preceding, but with no villous pubescence, the leaves closely cinereous-puberulent beneath. (Koellia Ktze.) - Low sandy ground, Va. and Ky. to Fla. and Tex.

$$
==\text { Calyx and bracts pilose or hispid with distinet spreading hairs. }
$$

12. P. mùticum (Michx.) Pers. Minutely hoary throughout, or becoming almost smooth, corymbosely much branched, 3-9 $\mathrm{dm}$. high; leaves ovate or broadly ovate-lanceolate, rather rigid, acute, rounded or stightiy heart-shaped at base, mostly sessile and minutely sharp-toothed, prominently veined, green and glabrate when old; the floral ones and the subulate-tipped lance-attenuate or linear bracts and the calyx-teeth hoary; flower-clusters very dense, corymbose; stamens exserted. (Koellia Britton.) -N. H. to Mo., and southw.

13. P. montànum Michx. Glabrous or essentially so, tall (6-10 dm. high), simple or sparingly branched above; leaves lance-ovate or -oblong, thin, sharply serrate, acuminate; heads chiefly in the upper axils, or solitary at the tips of the elongate branches; the long thin bracts long-acuminate, ciliate-hispid; calyxteeth deltoid-subulate, smoothish. (Koellia Ktze.) - Mountain woods, Va. to 'Tenn., and southw.

\section{THYेMUS [Tourn.] L. ThYME}

Calyx 13-nerved, hairy in the throat; the upper lip 3-toothed, spreading; the lower 2-cleft, with the awl-shaped divisions ciliate. Corolla short; the upper lip straight and flattish, notched at the apex, the lower 3-cleft. Stamens 4, straight and distant, usually exserted.-Low perennials, with small and entire strongly veined leaves, and purplish or whitish flowers. (The ancient Greek name of the Thyme, probably from $\theta \dot{\epsilon} \epsilon \nu$, to burn perfume, because it was used for incense.)

1. T. Serpýlum L. (Crefping T.) Prostrate ; leaves green, flat, ovate, entire, short-petioled; flowers crowded at the ends of the $b$ "anches. - Old fields, p.tc., N. S. to N. Y. and Pa. July, Aug. (Nat. from Eu.) 


\section{Cuntla L. Dittant}

Calyx oroid-tubular, equally 5-toothed, very hairy in the throat. Upper lip of corolla erect, tlattish, mostly notched; the lower spreading, 3-cleft. Stamens 2, erect, exserted ; sterile filaments short, minute. - Perennials, with small white or purplish flowers, in corymbed cymes or clusters. (An ancient Latin name, of unknown origin.)

1. C. origanoides (L.) Britton. (Common D.) Stems tufted, corymbosely much branched, $2-4 \mathrm{dm}$. high ; leaves smooth, ovate, serrate, rounded or heartshaped at base, nearly sessile, dotted, $1.5-4 \mathrm{~cm}$. long; cymes peduncled; calyx striate. (C. Mariana L.) - Dry hills, N. Y. to Ill., Ark., and Ga.

\section{LÝCOPUS [Tourn.] L. WATER HOREHOUND}

Calyx bell-shaped, 4-5-toothed, naked in the throat. Corolla bell-shaped. Stamens 2, distant, the upper pair either sterile rudiments or wanting. Nutlets with thickened margins. - Perennial mostly stoloniferous herbs, glabrous or puberulent, resembling Mints, with sharply toothed or pinnatifid leaves, the floral ones similar and much longer than the dense axillary whorls of small mostly white flowers; in summer. (Name compounded of Xúkos, a wolf, and moís, foot, from some fancied likeness in the leaves.)

\section{* Leaves merely serrate.}

\section{- Calyx-teeth lanceolate or deltoid, barely acutish, shorter than the mature nutlets.}

1. L. virglnicus L. (BUGLe WEED.) Stem obtusely angled, usually puberulent, 2-8 dm. high, rising from a slender (not tuberous-thickened) base; stolons filiform, not tuberiferous; leaves dark green (or purple-tinged), ovate or ovateoblong, firm, rather abruptly acuminate at both ends, coarsely toothed, 6-15 cm. long, $2-5 \mathrm{~cm}$. broad; glomerules dense, often seemingly compound, in maturity 8-15 mm. broad; calyx ovoid-cylindric; corolla tubular, with erect lobes; stamens mostly included. - Rich moist soil, N. H. to Neb., and southw. (Asia.)

2. L. uniflorus Michx. (BugLE WEED.) Similar, but usually more slender and glabrate, from a tuberous base; stolons finally tuberiferous; leaves light green (rarely purple-tinged), thinner, lanceolate to lance-oblong, gradually narrowed at both ends, $2-11 \mathrm{~cm}$. long, $0.5-3.5 \mathrm{~cm}$. broad; glomerules smaller and less dense, in maturity $4-9 \mathrm{~mm}$. broad; calyx campamulate; corolla with flaring lobes; stamens mostly exserted. ( $L$. communis and $L$. membranaceus Bicknell.) - Low ground, Nfd. and Lab. to B. C., s. to mts. of Va., Mich., Minn., Neb., Wyo., and Ore. (Asia.)

\section{+ + Calyx-teeth narrow, very acute, longer than the nutlets.}

- Bracts minute; corolla twice as long as the catyx.

3. L. sessilifolius Gray. Tuberiferous; stem rather acutely 4-angled, puberulent; leaves closely sessize, ovate to lanceolate, $3-10 \mathrm{~cm}$. long, sparsely sharpserrate; calyx-teeth subulate, rigid. - Low grounds, Mass. to Fla. and Miss., near the coast.

4. L. rubéllus Moench. Stem rather obtusely 4-angled; leaves petioled, ovate-oblong or oblong-lanceolate, sharply serrate in the middle, attenuate-acuminate at both ends, 4-12 cm. long; calyx-teeth triangular-subulate, not rigidpointed. - Vt. and Mass. to Minn., and southw. - Resembles no. 1, but has long slender calyx-teeth.

\section{+ + Outer bracts conspicuous; corolla hardly exceeding the calyx.}

5. L. lùcidus Turez., var. americànus Gray. Stem strict, stout, 2-9 dm. high; leaves lanceolate and oblong-lanceolate, 5-10 cm. long, acute or acuminate, very sharply and coarsely serrate, sessile or nearly so; calyz-teeth lanceovate, acuminate. ( $L$. asper Greene.) - Mich. to Man., Kan., and westw. Typical $L$. lncidus of Asia and n. w. Am., with elongate subpetiolate leaves and lance-subulate caly $\mathrm{x}$-teeth, approaches our $\mathrm{n}$. w. borders. 
* Leaves incised or pinnatifid at least at base.

o. I. EUROPAÉUS L. Rarely stoloniferous, not tuberiferous; stem coarse, more or less villous, $1 \mathrm{~m}$. or less high; leuves petioled, ovate, pubescent, coarsely toothed, sinuate or pinnatifid at base; calyx-teeth subulate-tipped. - Damp or waste ground, Mass to Va. (Nat. from Eu.)

7. L. americànus Muhl. Stem erect, slender, 2-9 dm. high, acutely 4-angled, glabrate, freely stoloniferous; leaves oblong or lanceolate, acuminate, irregularly incised or laciniate-pinnatifi, the upper narrow and merely sinuate, all tapering to slender petioles; calyx-teeth short-cuspidate; sterile filaments slender, conspicuous, with globular or spatulate tips. (L. sinuatus Ell.) - Damp soil, Nfd. to B. C., and southw.

\section{MENTHA [Tourn.] L. Murt}

Caly $\mathrm{x}$ bell-shaped or tubular, the 5 teeth equal or nearly so. Corolla with a short included tube, the upper lobe slightly broader, entire or notehed. Stamens 4, equal, erect, distant. - Odorous perennial berbs; the small flowers mostly in close clusters, forming axillary capitate whorls, sometimes approximated in interrupted spikes, produced in summer, of two sorts as to the fertility of the stamens in most species. Corolla pale purple or whitish. Species mostly adventive or naturalized from Europe, with many hybrids. ( $M l v \theta \eta$ of Theophrastus, from a Nymph of that name, fabled to have been changed into Mint by Proserpine.)

* Spitces narrow and leafless, densely crovdled; leaves sessile or nearly so.

\section{- Spikes canescent.}

1. M. Longifolia (L.) Huds. (Horse M. of Eu.) Finely pubescent or canescent; 7eaves ovate-oblong to oblong-lanceolate, acute, sharply serrate, of ten glabrous above; spikes rather slender, canescently pubescent. (M. sylvestris L.) - Roadsides, etc., Ct. to Del., Pa., and O. (Nat. from Eu.)

2. M. A LOPECurotoes Hull. Downy; leaves larger, more nearly sessile, broadly oval and obtuse, often subcordate, coarsely open-dentate, more veiny, but not rugose above; spikes coarser, canescent; approaching the next. - Damp roadsides, etc., Ct. to N. J., Mo., and Wisc. (Nat. from Eu.)

$$
+ \text { - Spikes not canescent. }
$$

3. M. rotundifólia (L.) Huds. Soft-hairy or downy ; leaves broadly elliptical to round-ovate and somewhat heart-shaped, rugose, coarsely crenate-toothed; spikes slender. - At a few stations, Me. to O., Fla., and Tex. (Nat. from Eu.)

4. M. spicata I. (SPEARMiNT.) Nearly smooth; leaves oblong-or ovatelanceolate, unequally serrate, sometimes short-petioled; bracts linear-lanceolate and subulate, conspicuous. ( $M$. viridis L.) - Wet places, common. (Nat. from Eu.)

* Flowers pedicellate, less crowded in interrupted leafless spiciform clusters or terminal heads, or some in the upper axils; leaves petioled.

- Calyx (at least the leeth) more or less hirsute.

5. M. PiPerita L. (PepPermint.) Glabrous, very pungent-tasted; leaves ovate-oblong to oblong-lanceolate, acute, sharply serrate; spikes becoming loose; calyx glabrous below, the teeth hirsute. - Along brooks, frequent. (Nat. from Eu.)

6. M. AQdÁtica L. (W ATER M.) Pubescent voith recurved hairs; leaves ovate or round-ovate; flowers in a terminal globular or interrupted and ellipsoid head, often with one or more clusters in the axils of the upper leaves; calyx and pedicels hairy. - Wet places, N. S. to Del., rare. (Nat. from Eu.)

7. M. crfspa L. Glabrous or slightly pubescent; leaves short-petioled, ovate to orbicular, lacerate-dentate and crisped; spikes narrow; calyx slightly pubes. cent or glabrate below, - Wet ditches, etc., Ct. to Pa. (Nat. from Eu.) 


\section{++ Calyx giabrous.}

8. M. citrdta Ehrh. Glabrous or glabrate; leaves slender-petioled, ovate, soarsely appressed-serrate; flowers in small roundish heads, terminal and in the upper axils. - Damp soil, Ct. and N. Y, to O. and Mich. (Nat. from Eu.)

* * Flowers in globular whorls or clusters, all in the axils of the leaves, the uppermost axils rarely flower-bearing; leaves more or less petioled, toothed.

- Upper leaves conspicuously reduced, 2 or 3 times exceeding the glomeriles.

9. IM. CARDíaca Gerarie. Tall and erect, with ascending branches toward the top; stem more or less pubescent; leaves lanceolate to oblong-lanceolate, acuminate, sharply serrate, slightly pubescent. (M. sativa of many Am. auth., not L.) - Wet meadows and shores, N. S. to Pa. (Nat. from Eu.) - Resembling M. spicata, but with more interrupted leafy inflorescence.

+ + Opper leaves scarcely reduced, much exceeding the glomerules.

+ Stem glabrous or rarely with a few scattered hairs.

10. M. GENThLIS L. Stems freely branching from below, often reddish, $1 \mathrm{~m}$. or less high; leaves ovate to obovate, coarsely and sharply serrate, especially above, slightly pubescent or glabrate, frequently white-mottled. ( $\boldsymbol{M}$. sativa $\mathbf{L}$.) - Rich damp soil, P. E. I. to Ia. and N. C. (Nat. from Eu.)

* Stems retrorse-pubescent at least on the angles with fine hairs.

11. M. arvénsis L. Stems freely branching, especially below, or subsimple, 1-8 dm. high, more or less retrorse-pubescent; leaves oblong to ovate, rounded at base, ninutely pubescent or villous, closely serrate, the primary ones distinctly petioled; calyx pubescent, the teeth from deltoid to subulate; corolla white, pink, or violet. - A bundant in damp rich soil, Nfd. to Neb. and Ky.; also in Cal., etc. (Eurasia.)

Var. canadénsis (I.) Briquet. Leaves pubescent, lanceolate to oblong-lanceolate, cuneate-narroved at base. (M. canadensis L.) -N. B. to B. C., and southw. Var. LANATA Piper. Stems and lower surfaces of leaves densely tonentose or lanate. - Me. to B. C. and Cal.

Var. glabràta (Benth.) Fernald. Less branched; stems glabrous on the sides, minutely pubescent on the angles; leaves oblong to ovate, glabrous, short-petioled. ( $\boldsymbol{M}$. canadensis, var. Benth.; $\boldsymbol{M}$. arvensis, var. Penardi Briquet.) Gaspé Co., Que., to B. C., s. to n. N. E., n. Pa., Mo., N. Mex., and Cal.

\section{COLLINSÒNIA L. Horse BaLm}

Calyz ovoid, enlarged and declined in fruit, 2-lipped; upper lip truncate and flattened, 3-toothed, the lower 2-cleft. Corolla elongated, expanded at the throat, somewhat 2 -lipped, the tube with a bearded ring within; the 4 upper lobes nearly equal, but the lower much larger and longer, pendent, toothed or lacerate-fringed. Stamens 2 (sometimes 4, the upper pair shorter), much exserted, diverging ; anther-cells divergent. - Strong-scented perennials, with large ovate leaves, and yellowish flowers on slender pedicels. (Named in honor of Peter Collinson, early English botanist.)

1. C. canadénsis L. (RICH-weed. Stone-Root) Nearly smooth, 5-10 dm. higl ; leaves serrate, pointed, petioled, 1-2 dm. long; panicle loose; corolla $1.5 \mathrm{~cm}$. long, lemon-scented; stamens 2. - Rich moist woods, w. Que. to Wisc. s. to Fla. and Mo. July-Sept.

\section{PERflla L.}

Calyx as in Collinsonia. Corolla-tube included, the limb 5 cleft ; lower lobe a little larger. Stamens 4, included, erect, distinct. - Coarse aromatic annual, with small flowers. (A Greek and Latin proper name.)

1. P. Frotéscens (L.) Britton. Erect, branching, 0.3-1 m. high; leaves ovate, coarsely toothed; flowers white. ( $P$. ocymoides L.) - About dwellings and roadsides, Ct. to Mo. and N, C (Nat. from e. Asia.) 


\section{ELSHOLTZIA Willd.}

Calyx with equal teeth. Corolla 4-lobed, slightly 2-lipped. Stamens 4, ascending, exserted, didynamous; anther-celis divergent. - Herbs, with ovate or oblong petioled leaves and spicate small flowers. (Named for J. S. Elsholtz, German plysician and botanist of the 17th century.)

1. E. I'A Trist (Lepechin) Garcke. Smooth annual, 3-7 dm. high ; bracts of the spike ovate, veiny, mucronate; calyx hirsute; corolla purplish, 2-3 mm. long. - Clearings and shores, L. Temiscouata, Que. (Northrop). (Nat. from Asia.)

\section{SOLANÅCEAE (Nightshade FAMrLT)}

Herbs (or rarely shrubs), with colorless juice and alternate leaves, regular 5-merous and 5-androus flowers, on bractless pedicels; the corolla imbricate or valvate in the bud, and mostly plaited; the fruit a 2-celled (rarely 3-5-celled) many-seeded capsule or berry. Seeds campylotropous or amphitropous. Embryo mostly slender and curved in fleshy albumen. Calyx usually persistent. Stamens mostly equal, iuserted on the corolla. Style and stigma single. Placentae in the axis, often projecting far into the cells. (Foliage rank-scented, and with the fruits mostly narcotic, often very poisonous, though some are edible.) - A large family in the tropics, but sparingly indigenous in our district, shading off into Scrophulariaceae, from which the plaited regular corolla and 5 equal stamens generally distinguish it.

(Various cultivated species, as the Tumato, Lycopérsicon esculéntum Mill., the Potato, Soldnom tuberósom L., the Egg-plant, S. Melongiesa L., and Petunias, Petúnia axillaris (Lam.) BSP. and P. vroldicea Lindl., stray from zultivation but seldom persist.)

"Corolla wheel-shaped, 5-parted or 5-lobed; the lobes valvate and their margins usually tarned Inward in the bud; anthers connivent; fruit a berry.

1. Solanum. Anthers opening by pores or chinks at the tip.

* Corolla various, not wheel-shaped, nor valvate in the bud; anthers separate.

+ Fruit a berry, closely invested by an herbaceous (not angled) calyx.

2. Chamaesaracha. Corolla plicate, 5-angulate. Pedicels solitary, recurved in fruit.

+ + Fruit a berry, inclosed in the bladdery-intlated calyx ; corolla widely expanding.

8. Physalis. Calyx 5-eleft. Corolla 5-lobed or nearly entire. Berry julcy, 2-celled.

4. Nicandra. Calyx 5-parted. Corolla nearly entire. Berry dry, 3-5-eelled. +++ Fruit a berry, with th $\theta$ ualtered calyx persistent at its base.

5. Lycium. Corolla funnel-form or tubular, not plaited. Berry small, 2-celled. +++ Fruit a capsule.

6. Hyoscyamus. Calyx urn-sbaped, Inelosing the smooth 2-celled capsule, the top of which falls off as a lid. Corolla and stamens somewhat Irregular.

7. Datura. Calyx prismatic, 5-toothed. Capsule prickly, naked, more or less 4-celled, 4-valved. Corolla funnel-form.

8. Nicotiana. Calyx tubular-bell-shaped, b-cleft. Capsale Inclosed to the alyx, 2allyx.

\section{SOLANUM [Tourn.] L. Nightbhade}

Calyx and wheel-shaped corolla 5-parted or 5-cleft (rarely 4-10-parted), the atter plaited in the bud, and valvate or induplicate. Stamens exserted; filanents very short; anthers converging around the style, opening at the tip y two pores or chinks. Berry usually 2-celled. Herbs, or shrubs in warm cliates, the larger leaves often accompanied by a smaller lateral (ra-meal) one; 
she peduncles also mostly lateral and extra-axillary. - A vast genus, chiefly in warmer regions. (Name of unknown derivation.)

* Not prickly; anthers blunt; flowers and globose naked berries small. - Perennial, climbing or twining.

1. S. Dulcamara L. (Birtersweet.) More or less pubescent; leaves svate-heart-shaped, the upper halberd-shaped, or with 2 ear-like lobes or leaflet: at base; flowers (purple or blue) in small cymes; berries ovoid, red. - Moist banks and around dwellings. June-Sept. (Nat. from Eu.)

\section{++ Simple-leaved annuals.}

2. S. trifldrum Nutt. Low, spreading, slightly hairy or nearly glabrous; leaves oblong, pinnatifid (7-9-lobed), with rounded sinuses; peduncles 1-3flowered; corolla white; berries green, as large as a small cherry. - Ont. to Man., Kan., and westw.; chiefly a weed near dwellings.

3. S. nigrum L. (Соммом N.) Low, much branched and often spreading, nearly glabrous; the stem rough on the angles; leaves ovate, wavy-toothed; fowers white, in small umlel-like lateral clusters, drooping; calyx spreading; filaments hairy; berries globular, black. - Shaded and rich open grounds; appearing as if introduced, but a cosmopolite. July-Sept.

Var. villósum L. Low, somewhat viscid-pubescent or villous ; leaves small, conspicuously angular-dentate; filaments glabrous; berries yellow. - Established near Philadelphia, from ballast. (Adv. from Eu.)

* More or less prickly; anthers tapering upward; pubescence stellate.

- Perennial; fruit naked; anthers equal; corolla violet, ravely white.

4. S. carolinénse L. (Hokse NetTLE.) Hirsute or roughish-pubescent with 4-8-rayed hairs; prickles stout, yellowish, copious (rarely scanty); leaves oblong or ovate, obtusely sinuate-toothed or lobed or sinuate-pinnatifid; racemes simple, soon lateral; calyx-lobes acuminate; berry 1-1.5 cm. broad. - Sandy soil and waste grounds, N. E. to Ont., westw. and southw.; adventive eastw.

5. S. elaeagnifolium Cav. (White Horse Netrte.) Silvery-canescent with dense scurt-like pubescence of many-rayed hairs; prickles small,.slender: more or less copious or wanting; leaves lanceolate to oblong and linear, sinuaterepand or entire; calyx-lobes slender; berry $1-1.5 \mathrm{~cm}$. in diameter. - Prairies and plains, Mo. to Tex., and westw.

+ - Annual; fruit partly covered by the spiny calyx; anthers equal; corolla blue or white.

6. S. SISTMBRIfòlidm Lam. Villous with viscid hairs; strongly armed throughout with stout golden prickles; leaves deeply pinnatifid, the oblong lobes sinuate or deeply cut; calyx-lobes becoming ovate-lanceolate and loosely covering the berry. - Ballast and waste places near the coast. (Adv. from 'Trop. Am.)

+++ Annual ; fruit closely covered; lowest anther much the longest.

7. S. Rostratum Dunal. (Buffalo Bur.) Very prickly, somewhat hoary or yellowish with a copious wholly stellate pubescence; leaves 1-2-pinnatifid; calyx densely prickly; corolla yellow; stamens and style much declined. Plains of Neb. to Tex.; recently spread eastw. to the coast as a weed.

8. S. citrullifolium A. Br. Similar, but less glandular-pubescent; corolla violet, $4 \mathrm{~cm}$. broad. (S. heterodoxum Britton, not Dunal.) - Ia. and Kan., southwestw.

\section{CHAMAESARÅCHA Gray.}

Calyx herbacecus, closely investing the globose berry (or most of it), obscurely if at all veiny. Corolla rotate, 5-angulate, plicate in the bud. Filaments filiform; anthers separate, oblong. - Perennials, with mostly narrow entire or pinnatifid leaves tapering into margined petioles, and filiform naked pedicels solitary in the axils, refracted or recurved in fruit. (Saracha is a tropical 
American genus dedicated to Isidoro Saracha, a Spanish Benedictine; the prefix xasal, on the grourd, i.e. dwaif:)

1. C. sordida (Dunal) Gray. Much branched from root or base, somewhat cinereous with sliort viscid pubescence; leaves obovate-spatulate or cuneateoblong to oblanceolate, repand to incisely pinnatifid; calyx when young villousviscid; corolla pale yellow or violet-purple, $1-1.5 \mathrm{~cm}$. broad; berry as large as, a pea. (C. conioides Britton.) - Dry or clayey soil, Kan. to Tex. and Ariz.

\section{3. phírsalis L. Ground Cherry}

Calyx 5-cleft, reticulated and enlarging after flowering, at length much inflated and inclosing the 2-celled globular (edible) berry. Corolla between wheel-shaped and funnel-form, the very short tube marked with 5 concave spots at the base; the plaited border somewhat 5-lobed or barely 5-10-toothed. Stamens 5, erect; anthers separate, opening lengthwise. - Ours herbs with extra-axillary pedun-

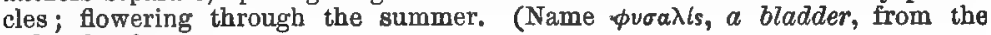
inflated calyx.)

a. Corolla large, white with pale yellow center; ealyx neither angled nor

a. Corolle lurid, greenish or yellowish-white to deep yellow with dark

\section{P. grandiflora.}

b. Annual $c$.

c. Glabious or merely puberalent.

Corolla $1-2.5 \mathrm{~cm}$. broad

Corolla 4-10 $\mathrm{mm}$. in diameter.

Teeth of leaves acuminate

Teeth of leaves obtusish

c. Villous or pubescent, hairs simple, viscid or glandular.

Fruiting calyx carinately 5-angled, its teeth during anthesis lanceolate.

Fruiting calyx subglobose-ovoid, rather abruptly pyramidal at summit.

Plant green
Plant somewhat hoary

Fruiting caly $x$ flask-shaped, gradually conic-pyramidal at summit
Frulting caly $x$ not sharply angled, its teoth deltoid during anthesis

b. Perennial $\tilde{d}$.

$d$. Canescent, covered with short dense stellate tomentum .

d. Pubescence loose ; hairs once or twice branched

d. Hairs simple or none.

Fruiting caly $x$ scarlet

Eruiting calyx greenish.

Leaves broadly ovate, rounded or cordate at base; viscidpubescent

feaves narrowly ovate to oblong or lanceolate, cuneste at base. Nearly glabrous; leaves 4-5 times as long as broad . Btrigillose to villous-pubescent; leaves $1 \frac{1}{2}-8$ times as long as broad.

Btem and branches striglliose

Stem and branches spreading-villous, retrorsely juberulent or glandular-pulverulent

Btem and branches hirsutulous

4. P. pubescens.

5. $P$. pruinosa.

6. P. barbadensis

7. P. missouriensis

8. P. viscosa.

9. P.pumila.

10. P. Alzekengi.

\section{P. Reterophylla}

12. $P$. longifolia.

18. P. subglabrata.

14. $P$. virginiana.

15. P. lanceolata.

1. P. grandifldra Hook. Clammy-pubescent, erect; leaves lance-ovate, pointed. entire or nearly so; corolla $2.5-5 \mathrm{~cm}$. voide, white, vith a pale yellow $c^{2}$ ter. woolly in the throat; fruiting calyx globular. (Leucophysalis Ryd b.) Recent clearings and sandy shores., e. Que, to the Saskatchewan, s. to L. Chamblain, Mich., Wisc., and Minn.

2. P. Ixockrpa Brotero. (Tomatillo.) Erect branching annual, 2-9 dm. high, glabrous or merely puberulent; leaves entire to sharply sinuate-dentate; peduncles 3-6 mm. long, distinctly shorter than the flowers; calyx-teeth deltoid; corolla 1-2.5 cm. wide, lurid, yellowish or greenish, with dark center. (P. aequata Jacq. f.) - Often cultivated and frequently spontaneous. (Introd. from the Southwest.) - The large purple fruit often bursts the calyx. $P$. pendula Rydb. appears to be a smaller-flowered long-peduncled extreme found from Ill. (Vasey) southw. and westw.

3. P. angulàta L. Much branched; leaves ovate or ovate-oblong, sharply and irregnlarly laciniate-toothed; peduncles fliform; corolla unspotted, very 
small (6-10 $\mathrm{mm}$. broad when expanded); fruiting calyx conical-ovoid with a truncate or sunken base, 10-angled, loosely inflated, at length well filled by the greenish-yellow berry. - Open rich grounds, Pa. to Minn., and southw.

4. P. pubéscens L. Pubescent but not hoary; leaves thin, entire at least near the oblique but rarely cordate base; stem slender, geniculate, diffusely branched; fruiting calyx subglobose, shortly acuminate, carinately 5-angled. Pa. to Va., and westw.

5. P. pruindsa L. (STrawberRy Tomato.) Hoary-pubescent; stem stouter; leaves thicker, sinuate-deniate even to the oblique and distinctly cordate base; fruiting calyx subglobose, rather abruptly acuminate, carinately 5-angled. - Sandy soil, Mass. to Ont., Ia., Kan., and southw.

6. P. barbadénsis Jacq. Pubescent or somewhat hoary, near the two preceding but with $\mathrm{m}$ )re elongated ovoid and gradually attenuate fruiting calyx of somewhat firmer texture ; leaves toothed or entire, rounded or subcordate at the scarcely oblique base. - Pa. (Knipe) to Mo. (Bush), and southw. Var. obscùra (Michx.) Rydb. Nearly glabrous. ( $P$. obscura Michx.) - Mo. (Bush, Eggert), and southw.

7. P. missouriénsis Maskenzie \& Bush. Leaves repand, oblique but not cordate at base, thin ; flowers $4-8 \mathrm{~mm}$. in diameter; fruiting calyx subglobose, not sharply angled, $2 \mathrm{~cm}$. or less in length. - Mo. and Kan.

8. P. viscossa L. Cinereous or when young almost canescent with short stellate or 2-3-forked pubescence; stems ascending or spreading from slender ereeping subterranean shoots; leaves ovate or oval, varying to oblong and obovate, entire or undulate; corolla greenish-yellow, with a more or less dark eye; fruiting calyx globose-ovoid; berry yellow or orange. - In sands on and near the coast, Va. to N. C. and Fla.

9. P. pùmila Nutt. Dichotomously branched, $3 \mathrm{dm}$. high ; stems geniculate, shortly hirsute with spreading once or twice branched sordid hairs; leaves ovate-oblong, mostly entive, acute or acutish at each end; fruiting calyx yellowi.h-green, ovoid-pyramidal, $2.5-3 \mathrm{~cm}$. in diameter, searcely umbonate at base. (P. lanceolata, var. hirta Gray.) - Dry ground, w. Mo. (Bush), and southwestw.

10. P. Alkekéngi L. (Winter Cherry.) Stems subsimple, erect from a creeping perennial rootstock; leaves thin, green, broadly ovate, entire or angled ; flowers $2.5 \mathrm{~cm}$. in diameter; fruiting calyces firm, veiny, scarlet or crimson. - Frequently cultivated for its decorative fruit; said to be escaping localiy, as also the doubtfully distinct P. Franchìti Masters (Chinese LanTERN PLANT), which is annual and has even larger and more showy scarlet or crimson fruiting calyces $(5 \mathrm{~cm}$, in diameter). (Introd. from e. Asia.)

11. P. heterophȳlla Nees. Perennial, diffusely much branched and widely spreading or at tirst erect, puberulent or tomentose, usually viscid; leaves sometimes oblong, repand or obtusely toothed, acute or obtuse; corolla 1.5-2.2 cm. broad, 5-angled or 5-10-toothed; anthers chiefly yellow. ( $P$. virginiana Man. ed. 6, not Mill.) - Chiefly in sandy or alluvial soil, N. B., southw. and westw. Var. AMBfGuA (Gray) Rydb. Spreading-villous; anthers chiefly purplish. - N. H., southw. and westw. Var. NrctagfNea (Dunal) Rydb. Leaves thinner, mostly subentire and acuminate, pubescent chiefly on the veins. - R. I., southw, and westw.

12. P. Longifolia Nutt. Essentially smooth and green, 4-6 dm. high, much branched above; leaves narrooly lanceolate, attentuate at each end, entire or undulate-dentate; caly $\mathbf{x}$ and peduncles more or less strigillose; corolla 1-1.5 cm. wide. - Bottom lands, etc., Ia. to S. Dak., and southwestw.

13. P. subglabrata Mackenzie \& Bush. Leaves ovate or ovate-oblong, oblique at base, entire, repand, or sparingly angulate-toothed; peduncles 1-3 cm. long; calyx-teeth ovate-lanceolate; corolla brozonish- or violet-spotted in the center; calyx at maturity globose and completely filled by the large reddish or purple berry and open at the mouth. ( $P$. philadelphica Man. ed. 6, but perhaps noi of Lam. ) - Fertile soil, R. I. to Minn., and southw.

14. P. virginiàna Mill. Erect perennial ; stem 1.5-3 dm. high, villous; leaves rather narrowly ovate, mostly acutish at each end, subentire or more often witt 1-5 acutish or rounded teeth on each side, thinner than in the next species: 
calyx-lobes lanceolate, in anthesis about equaling the tube; fruiting calyx 2.5 $\mathrm{cm}$. long, deeply umbonate at base; corolla pale yellow, $1.8-2.3 \mathrm{~cm}$. in diameter. (P. lanceolata Man. ed. 6, in part, not Michx.) - Dry hills, gravelly soil, etc., Ct. to Ia., and southw. The typical form with villous spreading pubescence seems relatively infrequent. The more common form has the pubescence on stem and branches very short, the hairs retrorse or recurved, not viscid. Occasional specimens are inerely glandular-pulverulent. Var. INTERMÈvia Rydb. Leaves larger, thinner, more entire; pubescence somewhat glandular when young. - Ind. (according to Britton), and southw.

15. P. lanceolàta Michx. More or less hirsute-pubescent with short stiff hairs, varying to nearly glabrous; stems from rather stout subterranean shoots, angled, somewhat rigid ; leaves oblong-ovate to lanceolate, sparingly angulatetoothed or more often entire ; corolla ochroleucous, with a more or less dark eye; calyx commonly hirsute, in fruit pyramidal-ovoid, $2.5-3.6 \mathrm{~cm}$. long ; berry reddish. - Dry prairies and on sandy or clayey bluffs, Ill. to Wyo. and $\mathrm{N}$. Mex.; also southeastw. to $\mathrm{S}$. C.

\section{NICÁNdRa Adans. Apple of Perd}

Calyx 5-parted, 5-angled, the divisions rather arrow-shaped, enlarged and bladder-like in fruit, inclosing the 3-5-celled globular dry berry. Corolla with border nearly entire. Otherwise much like Physalis. - Coarse smooth annual, with ovate sinuate-toothed or angled leaves, and solitary pale blue flowers on axillary and terminal peduncles. (Named for the poet Nicander of Colophon.) Physalodeg Boehmer.

1. N. Prysalónes (L.) Pers. (Physalodes Britton.) - Waste grounds, near dwellings and old gardens. July-Sept. (Introd. from Peru.)

\section{LFCiUM L. Matrimont Vine}

Calyx 3-5-toothed or -cleft, not enlarging, persistent at the base of the berry. Corolla funnel-form or salvэr-shaped, 5 -lobed, the lobes imbricated and not plaited in the bud. Stamens 5; anthers opening lengthwise. Style slender; stigma capitate. Berry small, 2-celled. - Shrubby often spiny plants, with alternate and entire small leaves, and mostly axillary small flowers. (Named from the country, Lycia.)

1. L. Halimifoliom Mill. (Сомmon M.) Shrub with long sarmentose recurved-drooping branches, smooth, sparingly if at all spiny; leaves oblongor spatulate-lanceolate, often fascicled, narrowed into a short petiole; flowers on slender peduncles fascicled in the axils; corolla short funnel-form, greenishpurple; style and slender filaments equaling the corolla-lobes; berry ovoid, orange-red. ( $L$. vulgare Dunal.) - About dwellings, and sometimes escaped Into waste grounds. (Introd. from Eu.)

\section{HYOSCỲAMUS [Tourn.] L. Henbane}

Caly $\mathrm{x}$ bell-shaped or urn-shaped, 5-lobed. Corolla funnel-form, oblique, with a 5-lobed more or less unequal plaited border. Stamens declined. Capsule inclosed in the persistent calyz, 2-celled, opening transversely all round near the apex, which falls off like a lid. - Clammy-pubescent fetid narcotic herbs, with lurid flowers in the axils of angled or toothed leaves. (Name composed of us, a hog, and kvaros, a bean; said to be poisonous to swine.)

1. H. Nhar L. (BLACK H.) Biennial or annual ; leaves clasping, sinuatetoothed and angled; flowers sessile, in one-sided leafy spikes; corolla dull yellowish, strongly reticulated with purple veins. - Open sandy soil and waste places, e. Que. to Ont. and Mich.; also rarely about ports southw. June, July. (Nat, from Eu.) 


\section{DATƯRA L. JaMestown or Jimson WeEd, Thorn APPLE}

Calyx prismatic or cylindrical, 5-toothed, separating transversely above the base in fruit, the upper part falling away. Corolla funnel-form, with a large and spreading 5-10-toothed plaited border. Stigma 2-lipped. Capsule globular, prickly, 4-valved, 4-celled except near the 2-celled top. Seeds rather large, flat. - Rank weeds, narcotic-poisonous, with ovate leaves, and large showy flowers produced all summer and autumn on short peduncles in the forks of the branching stem. (Altered from the Arabic name, Tatorah.)

1. D. Stramónium L. (Stramonium.) Annual, glabrous; leaves ovate, sinuate-toothed or angled; stem green; calyx prismatic; corolla white, 7-9 cm. long, the border with 5 teeth; lower prickles of the capsule mostly shorter. Waste grounds; a well-known ill-scented weed. (Nat. from Asia?)

2. D. TÁtula L. (Purple T.) Mostly taller; stem purple; corolla pale violet-purple; prickles of the capsule nearly equal. - Waste grounds, Atlantic States to Ont., Minn., and southwestw. (Nat. from Trop. Am.)

3. D. M̀̀тL L. Pubescent ; leaves entire or slightly toothed ; calyx tubular ; corolla $1.5-2 \mathrm{~cm}$. long ; capsule evenly prickly. - Waste ground, etc., becoming frequent. (Adv. from Trop. Am.)

\section{NICOTIANA [Tourn. $]$ L. Tobacco}

Calyx tubular-bell-shaped, 5-cleft. Corolla funnel-form or salver-form, usually with a long tube; the plaited border 5-lobed. Stigma capitate. Capsule 2-celled, 2-4-valved from the apex. Seeds minute. - Rank acrid-narcotic herbs, mostly clammy-pubescent, with ample entire leaves, and racemed or panicled flowers. (Named after Jean Nicot, who was thought to have introduced Tobacco, N. Tabacum L., into Europe.)

1. N. Rústica L. (WIID ToBacco.) Annual; leaves ovate, petioled; tube of the dull greenish-yellow corolla cylindrical, two thirds longer than the salyx, the lobes rounded. - Old fields, N. Y. and Ont., westw. and southw.; a relic of cultivation by the Indians. (Of unknown nativity.)

N. LONGIFLORA Cav., with long slender tubular corolla, is said to escape from cultivation.

\section{SCROPHULARIÀCEAE (FIGWORT FAMILY)}

Chiefly herbs (rarely trees), with didynamous stamens (or perfect stamens often only 2, rarely 5) inserted on the tube of the 2-lipped or more or less irregular corolla, the lobes of which are imbricated in the bud; fruit a 2-celted and usually many-seeded capsule, with the placentae in the axis; seeds anatropous or amphitropous, with a small embryo in copious albumen. Style single; stigma entire or 2-lobed. Leaves and inflorescence various, but the flowers not terminal in any genuine representatives of the family. - A large family of bitterish plants, some of them narcotic-poisonous.

\section{Subfamily I. ANTIRRHINOfDEAE}

Upper lip or lobes of the corolla covering the lower in the bud (with occasional exceptions in Mimulus, etc.). Capsule usually septicidal.

Tribe I. VERBASCEAE. Corolla rotate. Flowers racemose. Leaves alternate.

1. Verbascum. Stamens 5 , all with anthers, and 3 or all with bearded fliaments.

Tribe II. ANTIRRHfNEAE. Corolla tubular, with a spur or aac at the base below, the throat usually with a palate. Capsule opening by chinks or holes. Flowers in simple racemes or axtliary. Lowor leaves usually opposite or whorled. Stamens 4.

2. Linaria. Corolla spurred at base; the palate seldom closing the throst.

8. Antirrhinum. Corolla merely saccato or gibbous at the base; the throat nearly or quite alneed by a conspicuous palate. 
Tribe U. CHELÒNEAE. Corolla tubular or 2-lipped, neither spurred nor saceate below. Capsule 2-4-valved. Leaves opposite. Inflorescence usually compound, of small axillary spiked or racemed or uwbel-like clusters or cymes, or when reduced to a single flower the peduncle mostly 2-bracteate. Stamens 4 , and usually a rudiment of the fifth.

4. Collinsia. Corolla 2-oleft, the short tabe saceate on the upper side; the middle lobe of the lower lip sac-like and inclosing the declined stamens.

5. Scrophularia. Corolla inflated, globular or subcylindric, with four ereot lobes and one spreading one. Rudiment of the sterile stamen a scale on the upper lip.

6. Pentstemon Corolis tubular. Sterile stamen about as long as the rest. Beeds wingless or but narrowly margined.

7. Chelone. Oorolla tubular, Inflated above. Sterlle stamen shorter than the others. Anthers very woolly. Seeds winged.

8. Paulownia. Tree. Corolle tubular, Inflated above, the lobes spreading. Sterle stamen none.

Tribo IV. GRATIOLEAE, Corolla tubalar, not anccate nor spurred. Capsule 2-valved. Flowers solitary in the axils of bracts or leaves; peduncles naked (or 2-bracteolate In no. 15). Leaves all or the lower ones opposite. No trace of a fifth stamen.

* Btamens 4, all anther-bearing and similar.

9. Mimulus. Calyx prismatic, 5-angled, 5-toothed, Corolla elongated.

10. Conobea. Calyx 5-parted, the divislons equal. Corolls short.

11. Bacopa. Calyx 5-parted, unequal, the upper division largest. Corolla short.

12. Limosella. Calyx 5-toothed. Corolla open-bell-shaped, 5-cleft, nearly regular. Leavea alternate or fnscicled, fleshy. Dwarf aquatic or marsh plant.

* Anther-bearing stemens 2 ; usually also a pair of sterile fllaments.

13. Micranthemum. Flowers minute. Calyx 4-toothed or eleft. Upper Hp of corolla short or rone. Filaments with an appendage; sterile pair none. Dwarf aquatic.

14. Jysanthes. Calyx 5-parted. Stamens included, the sterlle flaments protruded.

15. Gratiola. Caly x 5-parted. Stamens included, the sterile pair short or none.

\section{Sobfamily II. Rhinanthofdeat}

Under lip of the lateral lobes of the corolla covering the upper in the bud. Capsule commonly loculicidal.

Tribe V. DIGITALEAB. Corolla wheel-shaped, salver-shaped, or bell-shaped. Stamens 8 or 4, not approaching in pairs nor strongly didynamous; anthers 2-celled.

16. Digitalis. Calyx 5-parted. Corolla tubular or elongate-bell-shaped, declined. Stamens 4.

17. Veronica. Calyx 4(rarely 8-5)-parted. Corolla wheel-shaped or salver-shsped, almost regular. Stamens 2. Leaves chlefly opposite or whorled. Flowers racemed or axillary.

18. Synthyris. Oalyx 4-parted. Corolla bell-shaped, 2-4-lobed, Irregular. Stamens 2 or 4. Leaves alteruate. Flowers racemed or spiked.

Tribe V. GERARDIEAR. Corolla with a spreading and slightly unequal 5-lobed limb. Stamens 4, approximate in pairs. Leaves opposite, or the appermost alternate.

* Corolla bell-shaped to funnel-form; anthers 2-celled.

19. Seymeria. Stamens nearly equal. Tube of the corolls broad, not longer than the lobes.

20. Gerardia. Stamens strongly nnequal, incladed. * * Corolla salver-ghaped; anthers 1-celled; flowers in a eplke.

21. Buchnera. Calyx tubular, 5-toothed. Limb of the elongated corolla 5-eleft.

Trbe VI. EUPHRAStEAE. Corolla tubular, obvlously 8-lipped ; the upper lp narrow, oreat o arched, Inclosing the 4 usually strongly didynamous stamens.

* Anther-eells unequal and separated; capsule many-seeded.

22. Castilleja. Calyx tubular, cleft down the lower, and often also on the upper, slde Upper lip of corolls alongated; the lower short, often very small.

28. Othocarpus. Calyx tubulni-enmpanulate, 4-cleft. Upper lip of corolla rittle longer ant usually much naituwer than the Inflated lower one. 
* * Anther-cells equal ; capsule 1-4-seeded.

24 Melampyrum. Calyx 4-cleft. Ovary 2-celled, 4-ovuled. Capsule flat, oblique.

*** Anther-eells equal; capsule uany-several-seeded.

25. Euphrasia. Calyx 4-cleft. Upper lip of the corolls 2-lobed, and stdes folded back. Capsule oblong.

26. Odontites. Calyx 4-cleft. Upper lip of corolla entire, and stdes not folded back.

27. Pedicularis. Calyx not inflated. Capsule ovate or sword-shaped; seeds wingless.

28. Rhinanthus. Calyx inflated, nvate. Capsule orbicular; seeds winged.

29. Schwalbea. Calyx 6-toothed, very oblique, the uppermost tooth much the smallest.

\section{VERBÁSCUM [Tourn.] L. MULLEIN}

Calyx 5-parted. Corolla 5-lobed, open or concave; the lobes broad and rounded, a little unequal. Style flattened at the apex. Capsule globular, manyseeded. - Tall and usually woolly biennial herbs; the leaves of the stem sessile, often decurrent. Flowers in large terminal spikes or racemes, ephemeral, in summer. (The ancient Latin name, altered from Barbascum.)

1. V. Th⿱亠䒑十sus L. (Сомmon M.) Densely woolly throughout; stem tall and stout, simple, winged by the decurrent bases of the oblong acute leaves; flower's yellow, very rarely white, in a prolonged and very dense cylindrical spike; lower stamens usually beardless. - Fields, rocky or gravelly banks, etc., a common weed. (Nat. from Eu.)

2. V. PHLomoides L. Similar, but the sessile leaves not at all or only slightly decurrent. - Locally from N. E. to Ky. (Nat. from Eu.)

3. V. Blattaria L. (Motr M.) Green and smoothish, or somewhat glandular-pubescent above, slender; lower leaves petioled, oblong, doubly serrate, sometimes lyre-shaped, the upper partly clasping; raceme loose, the pedicels longer than the fruit; filaments all bearded with violet wool. - Roadsides and waste places, w. Me. to Ont., and southw., local. - Corolla either yellow, or (in var. AlBIfLórum Ktze.) white with a tinge of purple. (Nat. from Eu.)

4. V. virgatum Stokes. Similar to the preceding species, but somewhat more pubescent and glandular; pedicels shorter than the fruit. - Roadsides, Cape Breton I. (Macoun) and Cal. (Adv, from Eu.)

5. V. Lxchnits L. (White M.) Clothed with thin powdery woolliness; stem and branches angled above; leaves ovate, acute, not decurrent, greenish above; flowers yellow, rarely white, in a pyramidal panicle; filaments with whitish wool. - Fields, etc., Mass. to N. J., Pa., and Ont., rather rare. (Adv. from Eu.)

\section{LINÅria [Tourn.] Hill. Toadflax}

Calyx 5-parted. Corolla spurred at base on the lower side (in abnormal specimens sometimes regularly 5-spurred). Capsule thin, opening below the summit by 1 or more pores or chinks. Seeds many. - Herbs, with at least all the upper leaves alternate (in ours), flowering in summer. (Name from Linum, the Flax, which some species resemble in their foliage.)

\section{* Erect or ascending, with narrow entire leaves.}

\section{- Fiowers yellow.}

1. L. vulgaris Hill. (Ramsted, Butter and Eggs.) Glabrous, erect, 1.3 m. or less high; leaves pale, linear or nearly so, extremely numerous, subalternate; raceme dense; corolla $2-3 \mathrm{~cm}$. long or more, including the slender subulate spur; seeds winged. - Fields and roadsides, throughout our range. (Nat. from Eu.)

2. L. SuPtwa Desf. Diffusely branched at base, 1-2.5 dm. high; leaves linear, the lower whorled; racemes short, few-flovered; corolla ratier smaller than in the preceding. - Ballast and waste land along the coast. (Adv. from Eu.) 
++ Flowers blue or purple.

- Corolla equaling or longer than the pedicels.

ᄂ 3. L. canad6nsis (L.) Dumont. Slender, glabrous; flowering stems nearly simple, 2-8 dm. high; leaves flat, 2-4 mm. wide; racemes slender, naked, loose; corolla $1 \mathrm{~cm}$. or less long, sometimes wanting (in reduced and cleistogamous flowers). - Sandy soil, N. B. and centr. Me., westw. and southw.

++ Corolla much shorter than the slender axillary pedicels.

4. I. Mìor (L.) Desf. Low branched glandular annual, 1-3 dm.. high; leaves spatulate-linear ; corolla 5-8 mm. long. - Ballast and made land, Atlantic coast to Ont. and Mich. (Adv. from Eu.)

* Annual, procumbent, much brrnched, with broad petioled veiny alternate leaves, and small purplish and yeliow flowers from their axils."

$$
\text { + Pubescent. }
$$

5. L. Elatine (L.) Mill. Leaves hastate or the lower ovate, much surpassed by the filiform peduncles; calyx-lobes lanceolate, acute ; corolla $0.5-1 \mathrm{~cm}$. long, including the subulate spur. (Elatinoides Wettst.) - Sandy banks, shores and waste places, Mass. to N. C. and Mo., rather rare. (Nat. from Eu.)

6. L. SPÙRIA (L.) Mill. Like the preceding, but with roundish or cordate leaves and ovate or cordate calyx-lobes. (Elatinoides Wettst.) - Occasional on ballast or waste grounds. (Adv. from Eu.)

$$
++ \text { Glabrous. }
$$

7. L. Cymbalaria (L.) Mill. (Kenilworth or Colisedm Ivy.) Leaves reniform-orbicular, 5-9-lobed; peduncles slender, becoming recurved in fruit; calyx-lobes lanceolate. (Cymbalaria Wettst.) - Waste places and ballast; also cultivated. (Adv. from Eu.)

\section{ANTIRRHINUM [Tourn.] L. ShapdragoN}

Calyx 5-parted. Corolla-tube saccate or gibbous in front, not spurred; the lower lip 3-lobed, spreading, developed at the base into $\mathbf{a}$ prominent palate, which nearly or quite closes the throat; upper lip erect, shortly 2-lobed. Stamens 4, didynamous, included; anther-cells distinct and parallel. - Ours herbaceous plants with lance-oblong to linear entire leaves and axillary or racemose flowers. (Name from $a v i l$, in the sense of like, and $\dot{\rho} l s, a$ snout, in reference doubtless to the peculiar form of the corolla.)

1. A. Orónticm L. Slender usually branched annual, pubescent or smoothish; leaves linear; calyx-lobes linear, exceeding the capsule ; corolla purple or white, 1-1.6 cm. long. - Casual in fields, about dumping grounds, etc., rather rare. (Adv. from Eu.)

2. A. MAJUs L. Perennial, glandular-pubescent and somewhat viscid; leaves lance-oblong; calyx-lobes ovate or oblong, short; corolla crimson, white, or variegated, $2-3 \mathrm{~cm}$. long. - Commonly cultivated, and occasionally found as an acape. (Introd. from Eu.)

\section{COLIfNSIA Nutt.}

Calyx deeply 5-cleft. Corolla declined; upper lip 2-cleft, its lobes partly turned backward. Fifth stamen gland-like. Capsule 4-many-seeded. - Slender annuals or biennials, with party-colored flowers in umbel-like clusters, appearing whorled in the axils of the upper leaves. (Dedicated to Zaccheus Collins, Philadelphian botanist, 1764-1831.)

1. C. vérna Nutt. (Bloe-eyed MARY.) Slender, $1.5-6 \mathrm{dm}$. high; lower leaves ovate, the upper ovate-lanceolate, clasping by the heart-shaped base, toothed; whorls about 6-flowered; flowers long-peduncled; corolla blue and white, 1-1.5 cm. long, more than twice exceeding the calyx. - Moist soil, Ont. and N. Y. to Ia., and southw. Apr.June. 
C. BfColor Benth, of Cal., differing in its very short-peduncled flowers, lias been found "introduced" in a wooded ravine at Galesburg, Ill. (C. Z. Nelson).

2. C. violàcea Nutt. Similar to no. 1 ; upper leaves lanceolate; corolla violet. - Rich scil, w. Mo. and e. Kan. to Tex, Apr., May.

3. C. parviflora Lindl. Small; lower leaves ovate or rounded, the upper oblong-lanceolate, mostly entire; whorls 2-6-flowered; flowers short-peduncled; the small blue and white corolla 5-8 mm. long, slightly exceeding the calyx. Rich soil and linı gravel, Unt., n. Mich., and westw. May, June.

\section{SCROPHULÀRIA [Tourn.] L. FIGWORT}

Calyx deeply 5-cleft. Stamens declined, with the anther-oclls transverse and confiuent into 1. Capsule many-seeded. - Rank herbs, with mostly opposite leaves, and small greenish-purple or lurid flowers in loose cymes, forming a terminal slender panicle. (So called because a reputed remedy for scrofula.)

1. S. marilándica L. Perennial, 1-1.7 m. high, with lisotted root and square stem, glandular-puberulent in the open pyramidal inflorescence, otherwise glabrous; leaves ovate to ovate-lanceolate, mostly acuminate, serrate or somewhat incised; dorsal lobes of the corolla suborbicular, little longer than the others; rudimentary stamen brononish-purple; capsule thin, subglobose, with short conical summit. (S. nodosa, var. Gray.) - Rich open woods, e. Mass. to S. C., Kan., and La. July-Sept.

2. S. leporélla Biclmell. Of similar liabit, foliage, and pubescence; root more simple ; inforescence slender, elongated; dorsal lobes of the corolla broadly oblong, erect, considerably longer than the others; rudimentary stamen yellowish-green; capsule ovoid-conical, of firmer texture. - Rich open woods, N. B. and Que. to Minn., Mo., and Va. May-Sept.

S. AQUÁTICA L., with crenate oblong very obtuse leaves (often biauriculate at the base) and calyx-lobes with broad scarious margin, has been found upon ballast in N. Y., N. J., and Pa. (Adv, from Eurasia.)

\section{PENTSTÈmon [Mitchell] Ait. Beard-Tongue}

Calyx 5-parted. Corolla tubular, gradually or abruptly dilated in the throat, more or less 2-lipped; upper lip 2-lobed, the lower 3-cleft. Fertile stamens 4, declined at base, ascending above, the fifth sterile flament either naked or bearded. Seeds numerous. - Perennials, with opposite entire or toothed leaves, the upper sessile and mostly clasping. Flowers mostly showy, thyrsoid or in open racemose panicles. (Name from $\pi \dot{t} \nu \tau \epsilon$, five, and $\sigma \tau \eta \mu \omega \nu$, in the sense of stamen; the fifth stamen being present and conspicuous, although sterile.)

a. Inflorescence viscid or glandular, at least minutely s0; leaves toothed or entise $b$

- Middle and lower internodes pubescent or at least finely puberulent $c$.

c. Corolla slender, tubular or trumpet-shaped, without marked inflation of the tliroat.

Middle and lower internodes somewhat loosely pubescent; panicle mostly loose and open; corolla-limb suberect, not widely ex-

Middle and lower internodes minutely granular-puberulent ; paricle mostly strict and racemiform; corolla-limb ringent or flaring .

1. P. Mirsutus.

2. P. graoilis.

c. Corolla with a decidedly dilated ven tricose or eampanulate open throat.

Corolla $3.5-5 \mathrm{~cm}$. long; throat $2 \mathrm{~cm}$. in diameter
Corolla $2-3 \mathrm{~cm}$, long: throat about $1 \mathrm{~cm}$. in diameter.

Intlorescence loosely paniculate; capsules $6-8 \mathrm{~mm}$. long

Inflorescence a strict dense racemiform panicle; capsules $10-1 \dot{2}$ mm. long.

b. Middle and lower internodes entirely smooth and glabrous.

Corolla-limb subrotate, the lobes widely spreading

Corolla-limb erect or but slightly spreading

a. Inflorescence glabrous; leaves entire.

Corolla with a distinct ventricose throat.

Corolla $4-5 \mathrm{~cm}$. long; stem-leaves oval to suborbicular

Corolla 2.8-3.7 cm. long; stem-leaves ovatc-lanceolate to narrowly oblong

Corolla trumpet-shaped, about $2 \mathrm{~cm}$. long; throat gradiully dilated :

3. P. Cobaea.

4. P. canescens.

5. P. albiaus.

6. $P$. tubifioms.

7. P. laevigatus.

8. P. grandifiorus

9. P. glaber.

10. P. acuminatus. 
1. P. hirsùtus (L.) Willd. Stem 2-9 dm. high, covered with fine and often crowded spreading whitish mostly gland-tipped hairs; leaves oblong to lanceolate, 5-10 cm. long, the lowest and radical ovate or oblong, usually denticulate; thyrse rather slender; corolla dull violet or purple (or partly whitish), scarcely enlarged upward, the throat nedrly closed by a villous palate; sterile filament tensely bearded. ( $P$. pubescens Ait.) -Dry or rocky grounds, centr. Me. to Ga, westw. to Wisc. and Mo. May-July.

2. P. grácilis Nutt. Stem 2-4 dm. high, minutely granular-pubescent; stem-leaves mostly linear-lanceolate, the radical spatulate or oblong; inflorescence glandular-puluerulent; corolla tubular-funnel-form or nearly cylindrical with open throat, lilac-purple or whitish. - Man. and Minn. to Mo., Okla., alr! westw. May-July.

3. P. Cobaèa Nutt. Soft-puberulent, 3-6 dm. high; leaves ovate or oblong, or the lower broadly lanceolate and the upper cordate-clasping, mostly sharptoothed; thyrse short; corolla large $(3.5-5 \mathrm{~cm}$. long), strongly ventricose, ảull purple or whitish. - Prairies, Mo. and Kan. to Tex.; reported from n. 0 . (Hacker). May, June.

1. 4. P. canéscens Britton. Stem erect or somewhat decumbent, 3-7 dm. high, mostly simple to the inflorescence, minutely granular-puberulent; leaves oblong to lance-linear, the upper cordate-clasping, sometimes a little panduriform; inflorescence loosely paniculate, glandular-puberulent; corolla about $2.5 \mathrm{~cm}$. long, pale purplish or nearly white, with distinct proper iube, dilated somevhat ventricose throat, and ringent limb. (Including $P$. pailidus Small, at least in part.) - Rocky banks, w. Va. to Mo. and Ga. May, June.

5. P. álbidus Nutt. Stems several from a branched caudex, erect or nearly so, 2-4 dm. high, closely puberuleat; leaves lance-oblong to linear; thyrse strict, raceme-like; calyx densely viscid-pubescent; corolla $2-2.5 \mathrm{~cm}$. loug, white or purplish-tinged, perceptibly dilated in the throat, the limb of ample roundish widely spreading lobes. - Prairies, etc., W. Minn. to Assina., southw. to Col. and Tex.

6. P. tubiflorus Nutt. Wholly glabrous up to the glandular-puberulent inforescence; stem 5-10 dm. high; leaves oblong or ovate-lanceolate, entire or sparingly toothed, the floral shorter than the remote dense clusters of the virgate thyrse; corolla $1.5-2 \mathrm{~cm}$. long, trumpet-shaped, with gradually dilated throat and widely spreading limb, white or whitish. - Low prairies, barrens, etc., Mo, Kan., and Ark.; also locally established in the Eastern States. May-July.

7. P. laevigatus Ait. Stem 5-15 dm. high, glabrous to the inflorescence; leaves rather firm, somewhat glossy, the cauline ovate-oblong or lanceolate, $5-15 \mathrm{~cm}$. long, with subcordate clasping base; thyrse rather open; calyx-lobes 3-7 mm. long; corolla $1.5-2.5 \mathrm{~cm}$. long, white or tinged with purple, gradually enlarged upward, the throat somewhat widely open but the limb scarcely spreading; sterile filament thinly bearded above. (P. Pentstemon Britton.) Moist or rich soil, Pa. to Fla., and westw.; also established in fields northw. June, July.

Var. Digitàlis (Sweet) Gray. Calyx-lobes 6-10 $\mathrm{mm}$. long; corolla larger, $2-3$ cm. long, more abruptly inflated. ( $P$. Digitalis Nutt.; $P$. calycosus Small.) - Pa. to Ia., Mo., Ark., etc.; locally established northeastw.

8. P. grandiflorus Nutt. Glabrous and somewhat glaucous; stem 5-10 dm. high ; leaves thickish, the upper and floral roundish, all but the obovate radical ones clasping or perfoliate; pedicels short; corolla large (4-5 cm. long). ventricose-campanulate, lilac or lavender-blue; sterile filament hooked and minutely bearded at the apex. - Prairies, Ill. and Wisc. to Wyo. and Kan.; established locally in the Eastern States. May, June.

9. P. glaber Pursh. Glabrous; stems $3-8 \mathrm{dm}$. high; leaves mostly oblonglanceolate or the upper ovate-lanceolate; thyrse elongated, the peduncles and pedicels very, short; corolla $2.4-3.7 \mathrm{~cm}$. long, bright blue to violet-purple, dilated above; anthers and apex of the sterile filament glabrous or sparsely iirsute. - Plains of e. Neb. and s. Dak. to Wash. and N. Mex. June-Aug.

10. P. acuminatus Dougl. Glabrous, erect or ascending, $3 \mathrm{dm}$. high; leaves thickish, firm, very smooth and somewhat glaucous, svate-lanceolate to narrowly 
oblong; thyrse elongated, slender; corolla about $2 \mathrm{~cm}$. long, trumpet-shaped, with slender gradually expanded tube, blue. - Sandy and rocky soil, Minn. to 'Tex., and westw. May-July.

\section{Chelòne [Tourn.] L. Turtlehead. Sakemead}

Calyx of 5 distinct imbricated sepals. The mouth of the corolla a little open ; upper lip broad and arched, keeled in the middle, notched at the apex; lower woolly-bearded in the throat, 3-lobed at the apex, middle lobe smallest. Seeds many. - Smooth perennials, with upright branching stems, serrate leaves, and large white or purple flowers, which are nearly sessile in spikes or clusters, and closely imbricated with round-uvate concave bracts and bractlets. (Name from $\chi \epsilon \lambda \omega \nu_{\eta}, a$ tortoise, the corolla resembling in shape the head of a reptile.)

1. C. glabra L. (Ba Lmonr.) Stem 0.5-2 m. high: leaves narrowly to broadly lanceolate, $0.5-2 \mathrm{dm}$. long, 1-4 cm. wide, gradually acuminate, serrate with sharp appressed teeth, narrowed at base usually into id very short petiole; uracts not ciliate; corolla white, or tinged with rose. - Wet places, Nfd, to Man., and southw. July-Sept.

2. C. obliqua L. Less strict or with spreading branches, $5-8 \mathrm{dm}$. high ; leaves broadly lanceolate to oblong, $0.5-2 \mathrm{dm}$. long, sometimes laciniately serrate, more veiny and duller, acute or obtuse at base, mostly short-petioled; bracts ciliolate; corolla deep and bright rose-color. - Rich damp woods, etc., s. Ill. to Va. and Fla.

3. C. Lyòni Pursh. Leaves elliptic to broadly ovate, abruptly acuminate, sharply serrate, long-petioled; bracts eiliolate; corolla rose-purple. - Mts. from Va. southw.

\section{PAULÓWNIA Sieb. \& Zuce.}

Calyx 5-cleft. Corolla-tube enlarged upward, the 5 unequal lobes spreading. Stamens didynamous; sterile filament none. Seeds numerous, winged. - Tree, with large cordate pubescent petioled leaves and terminal panicles of large violet flowers. (Named for Anno Paulowna, a Russian princess.)

$\sim$ 1. P. тomentósa (Thunb.) Steud. ( $P$. imperialis Sieb. \& Zucc.) - Escaped from cultivation and established from N. $\dot{Y}$. southw. (Introd. from Japan.)

\section{MimUlus L. Monkex Flower}

Calyx prismatic, 5-angled, 5-toothed, the uppermost tooth largest. Upper lip of corolla erect or reflexed-spreading, 2-lobed; lower spreading, 3-lobed. Stigma 2-lobed; lobes ovate. Seeds numerous. -- Herbs, with opposite (rarely whorled) leaves, and mostly handsome flowers. (Diminutive of mimus, a buffoon, from the grinning corolla.)

* Corolla violet-purple (rarely white); erect glabrous perennials; leaves feather-veined.

1. M. ríngens L. Stem square, $1 \mathrm{~m}$. or less high ; leaves oblong or lanceolate, pointed, clasping by a heart-shaped base, serrate; peduncles longer than the flower; calyx-teeth taper-pointed, nearly equal; corolla personate, $2-4 \mathrm{~cm}$. long. - Wet places, N. B. to Man., and southw. June-Sept.

2. M. alatus Ait. Stem winged at the angles; leaves oblong-ovate, tapering into a petiole; peduncles shorter than the very short-toothed calyx; otherwise like the preceding. - Wet places, Ct. to s. Ont., Kan., and sonthw.

$$
\text { * Corolla yellow. }
$$

- Leaves several-nerved and veiny, the upper sessile or "laspin!; calyx obliqup. the uppermost torth longest.

3. M. glabràtus IIBK., var. Jamèsii (T. \& G.) Gray. Diffusely spreading, sminth or smoothish; stems creeping at base; stem-leaves roundish or kidney- 
shaped, nearly sessile, equaling the peduncles; calyx ovoid, inflated in fruit and 7-10 mm. long; throat of corolla 1-2 cm. long, broad and open. (M. Jamesii T. \& G.) - In water or wet places, usually in springs, Ont. to Ill., Wisc., Mo., and westw.

4. M. LAngsdórfir Donn. Smooth, suberect or decumbent; stem-leaves oval, the lowermost long-petioled, the upper much exceeded by the peduncles; fruiting calyx $1.5-2 \mathrm{~cm}$. long; corolla $2.5-4 \mathrm{~cm}$. long. (M. guttatus DC.) Locally naturalized in brooks and meadows, Ct. and N. Y. (Introd. from the Pacific slope.)

+ - Leaves feather-veined, none clasping; calyx-teeth nearly equal.

5. M. moschàtus Dougl, (Musk Flower.) Villous and viscid, muskscented; stems spreading or ascending; leaves oblong-ovate, short-petioled; corolla pale yellow. - Damp soil, especially by cold streams, Nfd. to N. Y., e. Pa., Ont., and Mich.; abundant in the Rocky Mts., whence perhaps introd. June-Sept.

\section{CONOBEA Aublet.}

Upper lip of corolla 2-lobed, the lower 3-parted. Anthers approximate. Stigma 2-lobed, the lobes wedge-form. Seeds numerous. - Low branching herbs, with small solitary flowers. (Name unexplained.)

1. C. multifida (Michx.) Benth. Annual, diffosely spreading, much branched, minutely pubescent; leaves petioled, pinnately parted, divisions linear-ivedgeshaped; peduncles naked; corolla greenish-white, scarcely longer than the calyx. - Along streams and shores, Ont. to Kan., and southw.; also adv. below Philadelphia. July-Sept.

\section{BACOPA Aublet. Water Hrssop}

Calyx 5-parted; the uppermost division broadest, the innermost often very narrow. Upper lip of the corolla entire, notched or 2-cleft, and the lower 3 -lobed, or the limb almost equally 5-lobed. Style dilated or 2-lobed at the apex. Seeds numerous. - Low herbs, flowering in summer; ours rather succulent perennials. (Said to be an aboriginal South American name.) Herpestis Gaertn. f. Moniera B. Juss. ex I'. Br. Monniera B. Juss.

* Corolla plainly bilabiate, the 2 upper lobes united to form the upper lip; leaves many-neved.

1. B. acuminàta (Walt.) Robinson. Erect or ascending, very leafy, glabrous; leaves pinnately veined, oblong to cuneate-lanceolate, $2-5 \mathrm{~cm}$. long, serrate; pedicels equaling and the upper surpassing the leares; corolla whitish or purplish. (Gratiola Walt.; Monniera Ktze.; Herpestis nigrescens Benth.) Wet places, Md. to Fla. and Tex., chiefly near the coast, inland to s. Mo.

2. B. rotundifòlia (Michx.) Wettst. Nearly smooth, creeping; leaves roun obovate, half-clasping, 1-2.5 cm. long, entire, basally nerved; peduncles twice or thrice the length of the calyx; upper sepal ovate; corolla white or pale blue. (Monniera Michx.; Herpestis Pursh.) - Margins of ponds, Ill. to Minn., Neb., and southw.

3. B. caroliniàna (Walt.) Robinson. Stems hairy, creeping at base; leowes ovate, clasping, entire, basally nerved; peduncles shorter than the calyx; upper sepal heart-shaped; corolla blue. (Obolaria Walt.; Monniera Ktze.; Herpestis amplexicaulis Pursh.) - Margin of ponds, pine barrens, N. J. and Md. to La. Aromatic when bruised.

* Corolla obscurely bilabiate, the limb subequally 5-7obed; stamens almost equal.

4. B. Monniè ia (L.) Wettst. Glabrous, prostrate and creeping; leaves spatulate to obovate-cuneate, entire or sumewhat toothed, nearly nerveless, sessile; corolla pale blue. (Herpestis HBLi,; Monniera Monniera Britton.) River-banks and shores near the sea, Md. to Tex. 


\section{LIMOSÉLLA L. MUDWORT}

Calyx bell-shaped. Anthers confluently 1-celled. Style short, club-shaped. Capsule globular, many-seeded; the partition thin and vanishing. - Small annuals, growing in mud, usually near the seashore, creeping by slender runners, without ascending stems; the entire fleshy leaves in dense clusters around the simple 1-flowered naked peduncles. Flowers small, white or purplish. (Name from limus, mud, and sella, seat.)

1. L. aquática L., var. tenuifólia (Wolf) Pers. Leaves with no blade distinct from the petiole, awl-shaped or thread-form. (L. tenuifolia Wolf.) - Brackish river-banks and shores, Lab. to N. J., and far n. and w., local. (Eurasia, etc.)

\section{MICRÁNTHEMUUM MichX.}

Stamens anterior, the short filaments with a glandular (mostly basal) appendage; anthers 2-celfed, didymous. Style short; the stigma 2-lobed. Capsule globular, thin, with an evanescent partition, several-many-seeded. - Small smooth depressed and tufted or creeping annuals, in mud or shallow water, wikh opposite and entire rounded or spatulate sessile leaves, and minute white or purplish flowers solitary in the axils of some of the middle leaves (usually one axil floriferous, that of the other leaf sterile). (Name formed of $\mu \iota \kappa \rho \delta s$, small, and $\& \nu \theta \in \mu \nu \nu$, flower.)

1. M. micranthemoides (Nutt.) Wettst. Branches ascending, 1-6 cm. high ; leaves obovate-spatulate or oval; peduncles at length recurved, about the length of the calyx which is bell-shaped, 4-toothed, and usually split down on one side, in fruit becoming pear-shaped; middle lobe of the corolla linear-oblong, nearly twice the length of the lateral ones; appendage of the stamen nearly as long as the filament itself; stigmas subulate. ( $M$. Nuttallii Gray.) - Tidal mud of rivers, N. J. to Fla. Aug.-Oct.

\section{ILYsánthes Raf. False Pimperned}

Upper lip of corolla short, erect, 2-lobed; lower larger and spreading, 3-cleft. Fertile stamens 2, included, posterior; anterior pair sterile, inserted in the throat, 2-lobed; one of the lobes glandular, the other smooth, usually short and tooth-like. Stigma 2-lobed. Capsule ovoid or ellipsoid, many-seeded. - Small and smooth annuals; the purplish flowers on filiform peduncles, or the upper

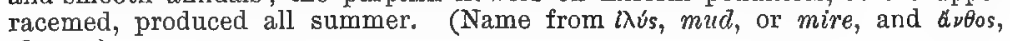
flower.)

1. I. dùbia (L.) Barnhart. Much branched, spreading; stems $1-3 \mathrm{dm}$. long, at first simple, erect, leafy; leaves ovate, rounded, or oblong, usually crenatetoothed, mostly 1.8-3 cm. long, the upper partly clasping, the lower more or less narrowed at the base; lower peduncles about as long as the subtending leaves or shorter; calyx-lobes linear, about equaling or slightly exceeding the ellipsoidal pod; corolla 5-10 $\mathrm{mm}$. long. ( $I$. viparia Man. ed. 6, in part, and perhaps of Raf.; I. attenuata Small.) - Wet places, N. B., westw. and southw., common. (Adv. in France.)

2. I. anagallídea (Michx.) Robinson. More slender, diffuse, and usually smaller-leaved; leaves elliptic to ovate, commonly entire or nearly so, 3-20 (mostly about 10) mm. long; peduncles long and filiform, spreading-ascending, even the lower ones much exceeding the subtending leaves; calyx-lobes somewhat shorter than the pod; corolla as in the preceding. (Gratiola Michx.; I. dubia of Am. auth., not Fratiola dubia L.; I. riparia Raf.?) - Wet places, e. Mass., southw. and westw., frequent.

\section{GRATíla L. Hedge Hrssop}

Narrow divisions of calyx nearly equal. Upper lip of corolla entire or 2-cleft, lower 3-cleft. Style dilated or 2-lipped at apex. Capsule 4-valved, many-seedéd. - Low herbs, mostly perennials, some apparently annuals, with sessile leaves, 
and usually with 2 bractlets at the base of the calyx. Flowering all summer; in wet or damp places. (Name from gratia, grace or favor, from supposed medicinal properties.)

\$1. Anthers with a broad connective, the cells transverse; stems mostly diffusely branched, or creeping at base, soft viscid-pubescent or smooth; corollas $0.8-1.5 \mathrm{~cm}$. long; bractlets foliaceous, equaling the calyx.

* Sterile filaments minute or none; corolla whitish, with the tube yellowish.

1. G. virginiana L. Stem clammy-puberulent above, 1-3 dm. high; leaves lanceolate, with narrow base, acute, entire or sparingly toothed; peduncles almost equaling the leaves (1-2.5 $\mathrm{cm}$. long); pod ovoid, 4-5 mm. long. - Wet or muddy places, local, centr. Me. and w. Que., westw. and southw. June-Aug.

2. G. sphaerocárpa Ell. Smooth, rather stout, 1.5-4 dm. high ; leaves lanceovate or oblong to oval-obovate, $2-5 \mathrm{~cm}$. long, toothed; peduncles scarcely longer than the calyx and the large globular pod $(6 \mathrm{~mm}$. in diameter). - Wet places, N. J. to Mo., and southw. Apr.-June.

* Sterile filaments slender, tipped with a little head; leaves short (1-2.5 cm. long).

3. G. viscdsa Schwein. Clammy-pubescent or glandular; leaves ovate-lanceolate or oblong, acute, toothed, mostly shorter than the peduncles; corolla whitish, yellow within. - Del. (Commons) to Ky., and southw.

4. G. aúrea Muhl. Nearly glabrous; leaves lanceolate or oblong-linear, entire, equaling the peduncles; corolla golden-yellow (rarely pale yellow or white), 1.2-1.8 cm. long. - Wet sandy shores, Me., w. Que., and Ont. to Va.

\$2. Anthers with no broad connective, the cells vertical; sterile filaments tipped with a head; hairy apparently annual plants, vith erect rigid and more simple stems.

5. G. pildsa Michx. Leaves ovate or oblong, sparingly toothed, sessile, 1-2 $\mathrm{cm}$. long ; flowers nearly sessile ; corolla white, 6-9 $\mathrm{mm}$. long, scarcely exceeding the calyx. - Low ground, N. J. to Fla. and Tex.

\section{DIGITÀLIS [Tourn.] L. FoxGLOVE}

Calyx 5-parted; the lobes often foliaceous. Corolla with a somewhat inflated tube and short scarcely spreading limb, declined. Stamens 4, didynamous, included in the corolla. - Tall herbs, with alternate or scattered entire or toothed leaves and showy racemose flowers. (Digitalis, of or belonging to the finger, as the fingers of a glove, which the tubular corollas have been thought to resemble.)

1. D. PURPÚReA L. Stoutish pubescent biennial ; corolla purple to white, spotted, 4-5 cm. long. - Meadows and pastures, Cape Breton I.; also N. Y.; rather. rare and local, a casual escape from gardens. (Introd. from Eu.)

\section{VERONICA [Tourn.] L. SPEEDWELI}

The latera] lobes of the corolla or the lowest one commonly narrower than the others. Stamens 2, one each side of the upper lobe of the corolla, exserted ; anther-cells confluent at the apex. Style entire; stigma single. Capsule flattened, obtuse or notched at the apex, 2-celled, few-many-seeded. - Chiefly herbs; flowers blue, flesh-color, or white. (Derivation doubtful; perhaps the flower of St. Veronica.)

* Tall perennials, with "elongate leaves; racemes terminal, dense, spiked; bracts very small; tube of the salverform corolla equaling or exceeding the calyx; both sometimes 5-cleft.

1. V. virgínica I. (Culver's-root, Culver's Physic.) Smooth or rather downy; stem simple, straight, $0.5-2 \mathrm{~m}$. high ; leaves whorled in 4's to 7's, short- 
petioled, lanceolate, pointed, finely serrate; spikes panicled; corolla small, nearly white, the tube much longer than the calyx and short limb; stamens much exserted; capsule oblong ovate, not notched, opening by 4 teeth at the apex, many-seeded. (Leptandra Nutt.) - Rich soil, w. Mass. and Ct. to Man., and southw. July, Aug.

2. V. LONGIFólia L. Similar; stem puberulent; leaves opposite or in 3's, slender-petioled, narrowly lanceolate, coarsely and doubly serrate; spikes solitary or few; corolla blue, the tube about equaling the calyx and linb; capsule suborbicular, flat, rounded or emarginate at apex. - Cultivated, and sometimes found by roadsides, in thickets, and about old house-sites, N. S. to W. Que. and N. Y. (Introd. from Eu.)

3. V. Bachогі⿰II Heuffel. Like the preceding, but the leaves triangularovate, cordate. - Vicinity of Quebec. (Introd. from Eu.)

* * Corolla wheel-shaped, the tube short; capsule more or less notched, strongly flattened except in nos. 4 and 5 ; low or decumbent herbs.

- Perennials, stoloniferous or rooting at base, with opposite usually serrate leaves; racemes axillary, mostly opposite; corolla pale blue.

\section{+ Capsule turgid, orbicular, many-seeded.}

4. V. Anagállis-aquática L. (W base, then erect, 1-10 dm. high ; leaves sessile, most of them clasping by a heart shaped base, ovate-lanceolate, acute, serrate or entire, $1 \mathrm{dm}$. or less long; pedi cels spreading; corolla pale blue, with purple stripes; capsule slightly notched. - Brooks and ditches, Essex Co., Mass. (Oakes); w. N. E. to B. C., and southw. June-Aug. (Eurasia.)

5. V. americàna Schwein. (American Broorlime.) Similar; leaves ianceolate to elongate-ovate, acule or acutish, serrate, short-petioled; mature fruiting pedicels very slender, 6-11 mm. long.-Brooks, ditches, etc., Nfd. to Alaska, s. to Va., W. Va., Great L. region, Neb., and in the Rocky Mts. June-Aug.

6. V. Beccabứag L, (EURopean Brooklme.) Almost fleshy, prostrate and strongly repent; leaves oval or short-oblong, rounded at tip, crenate, shortpetioled ; mature fruiting pedicels thickish, 4-5 mm. long. - Brooks and ditches about Quebec and near New York City. "(Nat. from Eu.)

\section{+ Capsule strongly flattened, several-seeded.}

7. V. scutellàta L. (Marsh S.) Smooth, slender and weak, 1-5 dm. high ; leaves sessile, linear or linear-lanceolate, acute, remotely denticulate; racemes several, very slender and zizag; flowers few and scattered, on elongated spreading or reflexed pedicels; capsule very flat, much broader than long, notcled at both ends or didymous. - Swamps and wet places, Nfd. to B. C., s. to N. Y., Wisc., and Cal. May-Aug. (Eurasia.) Var. villós. Schumacher. Stems villous. - Ont. and w. N. Y. to Wash.

3. V. officinàlis L. (Соммом S.) Pubescent; stem prostrate, rooting at base; leaves short-petioled, obovate-elliptical or vedge-oblong, obtuse, serrate; racemes densely many-flowered; pedicels shorter than the calyx; capsule obovaterriangular, broadly notched. - Dry hills and open woods, Nfd. to Ont., Mich., and southw. May-Aug. (Eurasia.)

9. V. ChamaEdRys L. (BIRD'S-EYE.) Stem very slender, pubescent (at least in two lines), ascending from a creeping base; leaves subsessite, ovate or cordate, incisely crenate; racemes loosely flowered, flexuous; pedicels little longer than the 4-parted calyx ; capsule triangular-obcordate. - Pastures, open woods, etc., N. S. to Ont. and O., local. May, June. (Nat. from Eu.)

10. V. Teúcrium L. Stems pubescent, stiff and upright, 3-7 dm. high, leaves subsessile, oblong, coarsely toothed, pubescent; racemes more densely' flowered, strictly ascending; calyx unequally 5-parted; corolla $1 \mathrm{~cm}$. broad. bluish ; capsules orbicular or oval. - Escaped from cultivation to roadsides, etc., N. E. (Intiod. from Eu.) 
+ Leaves opposite; flowers in a terminal raceme; the lower bracts leaf-like, capsules flat, several-seeded; perennials, mostly turning blackish in drying.

11. V. alpìna L., var. unalaschcénsis C. \& S. Stems tufted, erect, simple, 1-3 dm. high; leaves elliptical, or the lowest rounded, entire or toothed, nearly sessile; raceme hairy, few-flowered, crowded; capsule obovate, notched. ( $V$. Wormskjoldi R. \& S.) - By alpine brooks, Que., Me., N. H., and northw. July, Aug. (Eurasia.)

12. V. serpyllifolia L. (Thrme-Leaved S.) Much branched at the creeping base, nearly smooth; branches ascending and simple, $0.5-2 \mathrm{dm}$. high; leaves ovate or obtong, obscurely crenate, $1.5 \mathrm{~cm}$. or less long, the lowest petioled and rounded, the upper passing into lanceolate bracts; raceme loose, the rhachis and pedicels appressed-puberulent; corolla $3-4 \mathrm{~mm}$. broad, whitish or pale blue, with deeper stripes; capsule rounded, broader than long, obtusely notched, 3-4 mm. broad. - Damp grassy ground, Nfd. to Ont., and southw'.; both indigenous and introduced. May-July. (Eurasia.)

13. V. humifùsa Dickson. Stouter, 2-4 dm. high; leaves 1-2.5 cm. long; rhachis and pedicels pubescent with spreading viscid or gland-tipped hairs; corolla 0.5-1 cm. broad, deep blue; capsule 4-6 mm. broad. ( $V$. serpyllifolia, var. borealis Laestad.) - Springy places, Lab. and Nfd. to N. B., n. N. E., and N. Y.; Rocky Mts., etc. (Eu.)

+++ Annuals; floral leaves like those of the stem (or somewhat reduced), the flowers appearing to be axillary and solitary, mostly alternate; corolla shorter than the calyx (except in no. 17).

\section{+r Flowers short-pediceled; floral leaves reduced.}

v'14. V. peregrìna L. (Neckweed, Purslane S.) Glandular-puberulent or nearly smooth, erect, 1-3 dm. high, branched; lovoest leaves petioled, ovaloblong, toothed, thickish, the others sessile, obtuse; the upper oblong-linear and entire, longer than the almost sessile whitish flowers; capsule orbicular, slightly notched, many-seeded.-Waste and cultivated grounds, in damp soil, N. B. to Fla., and across the continent. Apr.-Oct. (Eu.)

15. V. ARvénsis L. (CorN S.) Simple or diffusely branched, $0.5-4 \mathrm{dm}$. higb, hairy; lower leaves petioled, ovate, crenate; the uppermost sessile, lanceolate, entire; capsule inversely heart-shaped, the lobes rounded. - Cultivated grounds, N. S. to B. C., and southw.; in N. E. and Pa. often in rocky woods as if indigenous; rather rare. (Nat. from $\mathrm{Eu}_{\text {. }}$ )

++ Flowers long-pediceled in axils of ordinary leaves; seeds cup-shaped.

16. V. AGRÉSTIS L. (FIELD S.) Leaves round or ovate, crenate-toothed, the floral somewhat similar; calyx-lobes oblong; flowers small; ovary many-ovuled, but the nearly orbicular and sharply notched capsule 1-2-seeded. - Sandy fields, in the Maritime Provinces of Canada, and from the Middle States southw., chiefly near the coast, local. (Adv. from Eu.)

17. V. Tournefórti C. C. Gmel. Leaves round or heart-ovate, crenately cuttoothed, 1-2.5 cm. long; flowers large, $1 \mathrm{~cm}$. wide, blue; calyx-lobes Ianceolate, widely spreading in fruit; capsule obcordate-triangular, broadly notched, 16-24seeded. (V. Buxbaumii Tenore; $V$. byzantina BSP.) - Waste grounds, e. Que. to Ont., O., and N. Y. (Adv. from Eu.)

18. V. HEDERAEFóIA L. (IVy-LEAVED S.) Leaves rounded or heart-shaped, 3-7-toothed or -lobed, calyx-lobes somewhat heart-shaped; flower's small ; capsule turgid, 2-lobed, 2-4-seeded. - Shaded places, N. Y. to N. C. Apr.-June. (Adv. from Eu.)

\section{SÝNTHYRIS Bentl.}

Stamens inserted just below the upper sinuses, occasionally with another pair from the other sinuses, exserted; anther-cells not confluent. Style slender; stigma simple. Capsule flattened, rounded, obtuse or notehed, 2-celled (rarely 3-lobed and 3-celled), many-seeded, loculicidal; the valves cohering below with the axis. - Perennial herbs, with the simple stems beset with partly clasping 
bract-like alternate leaves, the root-leaves rounded and petioled, crenate. (Name from $\sigma u v$, together, and $\theta u \rho l s, a$ little door; in allusion to the closed valves of the pod.)

1. S. Búllii (Eaton) Heller. Hairy ; root-leaves ovate, heart-shaped; spike dense, 1-3 dm. long; corolla greenish-white or yellowish, not longer than the calyx, usually 2-3-parted. (S. Houghtoniana Benth.; Wulfenia Houghtoniana Greene.) - Oak barrens and prairies, Mich. to Minn., s. to O., Ind., Ill., and Ia. May, June.

\section{SEYMÈRIA Pursh.}

Calyx bell-shaped, deeply 5-cleft. Corolla with a short and broad tube, not longer than the 5 ovate or oblong nearly equal and spreading lobes. Anthers approximate by pairs, oblong, 2-celled; the cells equal and pointless. Capsule many-seeded. - Ereet branching herbs, with the aspect of Gerardia; leaves mostly dissected or pinnatifid, the uppermost alternate and bract-like. Flowers yellow, interruptedly racemed or spiked. (Named for Henry Seymer, an English naturalist.) AFZELiA J. G. Gmel.

1. S. macrophýlla Nutt. (MuLlein Foxglove.) Rather pubescent, 1-1.5 m. high; leaves large, the lower pinnately divided, with the broadly lanceolate divisions pinnatifid and incised, the upper lanceolate; tube of the corolla incurved, very woolly inside, as are the filaments except at the apex; style short, dilated and notched at the point; capsule ovoid, pointed. (Afzelia Kzte.) Shady river-banks, O. to Neb., s. to Tex. July, Aug.

\section{GeráRdia [Plumier] L, Gerardia}

Calyx bell-shaped, 5-toothed or 5-cleft. Corolla swelling above, with more or less unequal lobes, the 2 upper usually rather smaller and more united. Stamens hairy; anthers approaching by pairs, 2-celled, the cells parallel, often pointed at base. Style elongated, mostly enlarged and flattened at the apex. Capsule globular or ovoid, pointed, many-seeded. - Erect branching herbs (more or less root-parasitic); stem-leaves opposite, or the upper alternate, the uppermost, reduced to bracts and subtending 1-flowered peduncles, which often form a raceme or spike. Flowers showy, pink, purple, or yellow, in late summer and autumn. (Dedicated to the celebrated herbalist, John Gerarde.)

§ 1. DASÝSTOMA [Raf.] Gray. Corolla yellow, the tube woolly inside, as well as the anthers and filaments; anthers alike, awn-pointed at base; leaves rather large, more or less incised or pinnatifid.

* Pubescence partly glandular and, viscid; corolla pubescent outside.

1. G. pediculària L. Annual or biennial, much branched, $1 \mathrm{~m}$. or less high, very leafy, villous at base, puberulent above; leaves ovate-lanceolate, pinnatifid, and the lobes cut and toothed; pedicels glandular, about equaling the mostly serrate slightly glandular or glabrate calyx-lobes. (Dasystoma Benth.) - 1)ry copses, Me. to Ont., Minn., and W. Va.

Var. ámbigens Fernald. Stems glandular-villous above; pedicels and calyx usually villous. - Wise. to N.C. and Mo. Passing to the more southern var. PECTINAta Nutt., with densely villous stems and leaves, and glandular-hispid calyx.

* No glandular pubescence; corolla glabrous outside; perennial. - Stems finely and closely pubescent.

2. G. grandifldra Benth. Minutely downy; stem much branched, $0.5-1 \mathrm{~m}$. high; leaves ovale-lanceolate, even the upper ones more or less cut or pinnatifi, the lower pinnatifid; pedicels rather shorter than the calyx; corolla $4-5 \mathrm{~cm}$. long, 4 times the length of the broadly lanceolate entire or toothed calyx-lobes; capsule glabrous. (Dasystoma Wood.) - Oak openings, Wisc. and Minn. to Tenn. and Tex. 
Var. serràta (Torr.) Robinson. The upper leaves oblong, merely serrate or even quite entire. (Var. integriuscula Gray ; Dasystoma serrata Small.) - Mo. and Kan. to La. and Tex. - Sometimes well marked, but not always so.

3. G. flava L. (Dowxy KA Lse Foxglove.) Pubescent with a fine close down; stem $0.5-1 \mathrm{~m}$. high, mostly simple; leaves avate-lanceolate or oblong, obtuse, entire, or the lower usually sinuate-toothed or pinnatifi, pedicels very short; calyx-lobes oblong, obtuse, rather shorter than the tube ; corolla 4-5cm. long; capsule pubescent. (Dasystoma Wood.) - Open woods, s. Me. to unt., Ia., and southw.

$$
++ \text { Stem glabrous. }
$$

4. G. virgínica (L.) BSP. (Sмоoth False Foxglove.) Glaucous, 1-2 m. high, usually branching; lovoer leaves commonly twice pinnatifid; the upper oblong-lanceolate, pinnatifid or entire; pedicels nearly as long as the calyx; calyx-lobes lance-linear, acute, as long as the at length inflated tube; corolla 4-5 cm. long. (Dasystoma Britton; G.quercifolia Pursh.) -Dry woods, s. Me. to Minn., and southw.

5. G. laevigàta Raf. Not glaucous; stem 3-8 dm. high, mostly simple; leaves lanceolate, acute, entire, or the lowest obscurely toothed; pedicels shorter than the calyx-tube; corolla 2-3 $\mathrm{cm}$. long. (Dasystoma Chapm.) - Oak barrens, etc., Pa. to Mich. and Mo., s. in the mts. to Ga.

\$2. O'TOPHÝlLA Benth. Corolla purple (rarely white), naked within, as well as the very unequal flaments; anthers dissimilar, pointless. glabrous or sparingly hairy.

6. G. auriculàta Michx. Rough-hairy ; stem erect, nearly simple, $2-6 \mathrm{dm}$. high; leaves lanceolate or ovate-lanceolate, sessile, the lower entire, the others with an oblong-lanceolate lobe on each side at the base; flowers nearly sessile in the cxils, $1.5-2 \mathrm{~cm}$. long. - Low grounds and prairies, Pa. to Minn., s. to N.C. and Kan.

7. G. densiflora Benth. More hispid and rough, very leafy; leaves rigid, pinnately parted into 3-7 narrowiy linear acute divisions, those subtending the densely spicate flowers similar and crowded; corolla $2-3 \mathrm{~cm}$. long. - Prairies, e. Kan. to Tex.

§ 3. EUGERÁRDIA Benth. Corolla purple or rose-color (rarely white); calyx-teeth short; anthers alike, nearly pointless, pubescent; cauline leaves linear or narrower, entire.

* Perennial; leaves erect, very narrow; pedicels erect, as long as floral leaves.

8. G. linifolia Nutt. Glabrous, $6-9 \mathrm{dm}$. high, sparingly or paniculately branched; leaves flat, thickish, 2-3 $\mathrm{mm}$, wide; calyx-teeth minute; corolla $2.5 \mathrm{~cm}$. long, minutely pubescent outside, villous within and the lobes ciliate; anthers and filaments very villous. - Low pine barrens, Del. to Fla.

$$
\begin{aligned}
& \text { * Annuals; herbage blackish in drying (except in nos. } 15 \text { and 17). } \\
& + \text { Pedicels little ff at all longer than the calyx and capsule. } \\
& + \text { - Capsule ellipsoid, distinctly longer than thick. }
\end{aligned}
$$

9. G. áspera Doug]. Sparingly or somewhat fastigiately branched, 3-6 dm. high; leaves linear, rough; pedicels often alternate, equaling or moderately exceeding the calyx; calyx-teeth triangular-lanceolate, about half as long as the tube; corolla 1.8-2.6 cm. long. - Plains and prairies, Mich. and w. Ind. to N. Dak., Col., and Ark.

$$
\text { + + Capsule subglobose. }
$$

\section{$=$ Flowers large; corolla $2.3-3.1 \mathrm{~cm}$. long.}

10. G. fasciculata Ell. Tall, 6-12 dm. high ; stem subterete, scabrous-puberulent; branches virgate, elongawd, iscending, subfostigiate, mostly 10-16-flowered; leaves narrowly linear, with smaller ones fasicled in theiv axils; pedicels shorter than the calyx; corolla about $2.5 \mathrm{~cm}$. long, purple. - Sandy fields, low meadows and shores, Va. to Fla. and Tex. 
11. G. purpùrea L. (PuRPLF G.) Stem 3-8 dm. high, somewhat angled, nearly or quite smooth; branches long, widely spreading, usually flexuous, mostly 3-8-flowered; leaves linear, acute, rough-margined; calyx commonly exceeding the pedicel, its teeth sharp-pointed, from very short to half the length of the tube; corolla usually $2.6-3 \mathrm{~cm}$. long, bright purple, very pubescent. Low mostly sandy ground, e. Mass. to Fla. and Tex., near the coast; alsc westw. along the Great Lakes to Wisc.

$$
=- \text { Flowers smaller; corolla 1.4-1.8 cm. long. }
$$

12. G. paupércula (Gray) Britton. Slender erect annual, 1-6 dm. high: stem angled, glabrous or nearly so, subsimple or more often branched above; leaves narrowly linear, acute, scabrous, often with smaller ones fascicled in their axils; pedicels usually about equaling the globose capsules; calyx-teeth deltoid-lanceolate, sharp-pointed; corolla decidedly smaller than in the preceding species, 1.4-1.8 cm. long, lighter rose-purple, merely puberulent except at the hairy margin. (G. purpurea, var. Gray.) - Sterile soil, bogs, sandy shores, etc., N. S. to Man., and southw.

13. G. marítima Raf. (SeA-Side G.) Similar to the preceding, but somewhat fleshy; leaves linear, obtuse or rounded at the ends; calyx-teeth very short and obtuse or rounded; corolla $1-1.5 \mathrm{~cm}$. long. - Salt marshes along the coast, s. Me. to Fla.

\section{- + Pedicels usually exceeding the corolla; woolly anthers cuspidate at base.}

+ Corolla-lobes rounded or merely emarginate; capsule subglobose.

$$
\text { = Corolla glabrous within. }
$$

\section{a. Leaves flat, linear to lanceolate, much blackened in drying.}

14. G. tenuifolia Vahl. (Shender G.) Leaves narrowly linear, acute, the floral ones mostly like the others; calyx-teeth very short, acute; capsule globular; corolla 1-1.5 cm. long, rose-purple, the upper lip somewhat arched. (G. Gattingeri Small.) - Low or dry ground, w. Me. and w. Que. to Neb., Fla., and Tex. Var, macrophŕlua Benth. Stouter; larger leaves $3-5 \mathrm{~cm}$. long, and 4-5 mm. wide, scabrous; pedicels ascending; calyx-teeth larger. ( $G$. Besseyana Britton.) - Ct. to Ont., N. Mex., and the Rocky Mts.

b. Leaves filiform or with revolute margins, slightly blackened in drying.

15. G. Skinneriàna Wood. Slender, 2-5 dm. high, with ascending branches, the slightly margined angles roughish; leaves hispidulous-scabrous; pedicels rather stiffy ascending, $1-4 \mathrm{~cm}$. long; calyx greenish, the lance-deltoid lobes nearly one third as long as the tube ; corolla $10-13 \mathrm{~mm}$. long, rose-color; capsule globose-ovoid. (G. tenuifolia, var. asperula Gray.) - Dry woods and hills, Ont. to Minn., Tenn., and Mo.

\section{$==$ Corolla villous in the throat.}

16. G. setàcea Walt. Slender, 3-6 dm. high, with strongly ascending branches ; leaves setaceous-linear, often revolute, somewhat darkened in drying; pedicels capillary, 1-2 cm. long; calyx green, with minute subulate teeth; corolla rose-purple, $2 \mathrm{~cm}$. long, ventricose above the slender exserted tube, the lobes wide-spreading. (G. Holmiana Greene.) - Sandy barrens, D. C. to Fla. and Tex., mostly near the coast.

\section{$4+$ Corolla-lobes obcordate; capsule ellipsoid-ovoid.}

17. G. parvifolia Chapm. Rigid, $0.5-5 \mathrm{dm}$. high, witl stiff upright angled branches; leaves linear-subulate, rather rigid, not darkened in drying; inflorescence subracemose, the floral leaves greatly reduced; calyx whitish-green. nervose, with short subulate teeth; corolla about $1 \mathrm{~cm}$. long, bright pink, the lobes all spreading; capsule much exceeding the calyx. (G. Skinneriara Man. ed. 6, not Wood; $G$. decemloba Greene.) - Sandy soil, near the coast, Mass. to Fla. and La.; and apparently in the Miss. basin 


\section{BUChNERA L. Blue Hearts}

Calyx obscurely nerved. Corolla with a straight or curved tube and an almost equally 5-cleft limb, the lobes oblong or wedge-obovate, flat. Stamens included; anthers one-celled (the other cell wanting). Style club-shaped and entire. Capsule 2-valved, many-seeded. - Perennial rough-hairy herbs (doubtless root-parasitic), turning blackish in drying, with opposite leaves, or the uppermost alternate; the flowers opposite in a terminal spike, bracted and with 2 bractlets. (Named in honor of $J$. $G$. Buchner, an early German botanist.)

1. B. americana L. Rough-hairy; stem wand-like, 3-8 dm. high; lower leaves obovate-oblong, the others ovate-oblong to linear-lanceolate, sparingly and coarsely toothed, veiny ; spike interrupted; calyx longer than the bracts, one third the length of the deep-purple corolla ( $2 \mathrm{~cm}$. long). - Moist sandy ground, N. J. to w. N. Y., s. Ont., Minn., and southw. June-Aug.

\section{Castillèta Mutis. Painted Cup}

Divisions of the calyx entire or 2-lobed. Tube of the corolla included in the calyx; its upper lip (galea) keeled, flattened laterally. Anther-cells oblonglinear, the outer fixed by the middle, the inner pendulous. Capsule manyseeded. - Herbs (root-parasitic), with alternate entire or cut-lobed leaves; the floral ones usually dilated, colored, and more showy than the yellow or reddish spiked flowers. (Dedicated to Doningo Castillejo, a Spanish botanist.)

1. C. coccinea (L.) Spreng. (Scarlet P.) Hairy biennial or annual; stem simple; root-leaves clustered, mostly entire, obovate or oblong; those of the stem incised; the floral 3-5-cleft, brimht scarlet toward the summit (rarely yellow); calyx about the length of the pale yellow corolla, equally cleft both sides, the lobes quadrate-oblong, entire or retuse. - Low sandy ground, Mass. to Man., s. to Va., Tenn, and Tex.

2. C. pálliđa (L.) Spreng., var. septentrionàlis (Lindl.) Gray. Perennial, smooth or sparingly hairy, at the summit woolly; leaves mainly entire, the lower linear, upper broader; the floral oblong or obovate, greenish-white, varying to yellowish, purple, or red; calyx equally cleft, the lobes oblong or lanceolate, 2-cleft; corolla 1.5-2.5 cm. long, the yalea decidedly shorter than the tube, not over 2 or 3 times as long as the lip. (C. acuminata Spreng.) - Damp gravelly or rocky banks, Iab., Nfd;, and westw., s. to the St. John R., the mts. of n. N. E., the Great Lakes, Minr., and the Black IIills. June-Aug.

3. C. sessiliflora Pursh. Perennial, 1.5-3 dm. high, very leafy, cinereouspubescent; leaves mostly 3-5-cleft, with narrow diverging sometimes cleft lobes ; the floral similar or broader, not at all colored; calyx deeper cleft in front, the narrow lobes deeply 2-cleft; corolla 3-4 cw. long, the short galea but troice as long as the slender-lobed lip.-Prairies, Man. to Ill., Mo., Tex., and the Rocky Mts. May-July.

\section{ORTHOCÁRPUS Nutt.}

Corolla with the upper lip (galea) little longer and usually much narrower than the inflated 1-3-saccate lower one. Otherwise nearly as Castilleja. (Nawe

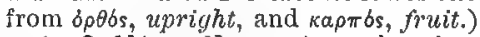

1. 0 . lùteus Nutt. Annual, pubescent and hirsute, sometimes viscid, erect, 1.5-4 dm. high; leaves linear to lanceolate, occasionally 3-cleft ; spike dense; bracts broader, mostly 3-cleft, about equaling the flowers, not colored; corolla golden-yellow, $1 \mathrm{~cm}$. long, 2-3 times as long as the calyx. - Plains, n. Minn., Man, and westw.

\section{MELAMPỲRUM [Tourn.] L. Cow WITEAT}

Calyx bell-shaped, sharply cleft. Tube of corolla cylindrical, enlarging above ; upper lip compressed, straight in front; lower erect-spreading, biconvex, 3-lobed at apex, Anthers approximate, oblong, nearly vertical, hairy; the cells minutely 
pointed at base. Capsule 1-4-seeded. - Erect branching annuals, with opposite leaves, the lower entire, the upper mostly toothed at base. Flowers solitary in

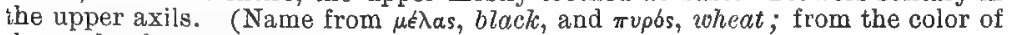
the seeds of some species.)

1. M. lineàre Lam, Leaves linear-lanceolate to narrow-ovate, short-petioled, the floral ones like the lower, or truncate at base and beset with a few bristly teeth ; calyx-teeth not half the length of the slender tube of the pale greenishyellow or purplish corolla $(1 \mathrm{~cm}$. long); seeds white. (M. americanum Michx.; M. latifolium Muhl.) - Open woods, N. S. and Que. to B. C., s. to Ga., Tenn., and Ia. June-Sept.

\section{EUPHRÀSIA [Tourn.] L. EYEBRIGHT}

Calyx tubular or bell-shaped, 4-cleft. Upper lip of the corolla erect, scarcely arched, 2-lobed, and the sides folded back; lower lip spreading, 3-cleft, the lobes obtuse or notched. Anther-cells pointed at the base. Capsule flattened. Herbs, with opposite toothed or cut leaves. Flowers small, spiked. (Name $\epsilon \dot{\phi} \phi \alpha \sigma(a, c h e e r f u l n e s s$, in allusion to its reputed medicinal properties.)

* Flowers very small, borne in a compact leafy head or very short subcapitate raceme; stems filiform, normally simple; corolla dorsally 3-4 mm. long; dwarf arctic-alpine species.

1. E. Oakèsii Wettst. Leaves ovate-orbicular, bluntly sinuate-toothed, grayish-pubescent beneath; corolla white or nearly so, with purple or violet veins and yellow eye. - Open stony ground, White Mts. of N. H, near Mt. Monroe and at the head of Oakes Gulf ; Mt. Katahdin, Me.

2. E. Williámsii Robinson. Leaves much as in the preceding but green and glabrous except near the margin; corolla brownish-purple, with deeper colored veins and yellow eye. - Slopes of Mt. Washington, N. H., from the "Alpine Garden" to "Cape Horn."

\section{* Flowers small (corolla 3-4 mm. long dorsally), borne in open racemes; stems usually branched.}

3. E. Rándii Robinson. Leaves ovate to flabelliform, bluntly 9-11-toothed, finely pubescent upon both surfaces; corolla varying from deep violet to roseate or cream-colored, with violet veins and yellow eye. - In humus and damp spots, along the coast, Nfd. and e. Que. to Kriox Co., Me. (S. Plaisted).

Var. Farlowii Robinson has smaller grayish-pubescent 5-7-toothed leaves (only 2-4 mm. long), - Dry crests of sea-cliff, Nfd.; Dog I., Eastport, Me.

* ** Flowers larger; corolla dorsally 5-7 mm. long, white, with lavender or purple veins and yellow eye.

4. E. árctica Lange. Simple or branched, $4-12 \mathrm{~cm}$. or more in height; leaves conspicuously pubescent upon both surfaces, the cauline ovate, rather bluntly toothed, the floral flabelliform, more sharply toothed; corolla with pale lavender veins, the lobes of the lower lip nearly parallel. ( $E$. latifolia Pursh, as to plant, but not as to name-bringing synonym ; $E$. hirtella Robinson, not Jord.) - Calcareous soil, Lab. to n. Me., L. Superior, and Arctic Am.

5. E. americana Wettst. Simple or more often with elongated strongly ascending branches, 1-3 dm. tall, flowering for the most part above the middle; leaves essentially glabrous, the larger 8-14 $\mathrm{mm}$. long, the lateral teeth awn. pointed; bracts about 7-toothed ; calyx usually purple-nerved ; corolla relatively large and showy, $8 \mathrm{~mm}$. long, somewhat suffused with purple or crimson and marked with deep purple lines, the lateral lobes of the lower lip strongly divergent. - Damp open places, Nfd. and e. Que., along the coast to Lincoln Co., Me.

6. E. canadénsis 'Townsend. Similar, usually smaller and more diffuse, mostly flowering from below the middle, the elongated spikes dense; larger leaves 4-9 $\mathrm{mm}$. long; bracts $9-11$-toothed, the teeth setose-tipped ; caly $\mathrm{x}$ green, the teeth aristate; corolla 6-7 $\mathrm{mm}$. long, white, with bluish or lavender veins and yellow eye. ( $E$. americana, var. Robinson.) - Dry grassy or rocky places, from the lower St. Lawrence to N. S., e. Me., and n. N. H. 


\section{ODONTİTES [Rivinius] Ludwig.}

Calyx equally cleft. Corolla with upper lip entire and sides not folded back. Otherwise nuch as Euphrasia. - Herbs, with opposite sessile leaves, and subsessile flowers in the upper axils and in a terminal leafy spike. (Odontitis, an ancient plant-name from $\delta \delta o v$ s, tooth, applied to some herb used for tooth-ache.)

1. O. RỦBRA Gilib. Stem 1-4 dm. high, from an annual root, branching, scabrous-pubescent; leaves oblong-lanceolate, coarsely and remotely serrate; spikes elongated, loosely-flowered; corolla small, rose-red. (Bartsia Odontites Ifuds.; Odontites Odontites Wettst.) - Fields, roadsides, etc.; coast of Me., N. B., and N. S.; rarely in the interior. (Nat. from Eu.)

\section{PEDICULÀRIS [Tourn.] L. LouseworT}

Calyx various. Corolla strongly 2-lipped; the upper lip flattened, often beaked at the apex; the lower erect at base, 2-crested above, 3-lobed; lobes commonly spreading, the lateral ones rounded and larger. Anthers transverse; the cells pointless. Capsule mostly oblique, several-seeded. - Perennial herbs, with chiefly pinnatifid leaves (the floral bract-like) and rather large flowers in a spike. (Name from pediculus, a louse ; of no obvious application.)

* Small-leaved annual or biennial, mostly branched, bearing axillary and terminal flowers.

1. P. palústris L. Essentially glabrous, $2-6 \mathrm{dm}$. high ; leaves lanceolate, 2-5 cm. long, pinnately parted, with small crenate oblong segments ; calyx-lobes cristate ; corolla 1-1.5 cin. long, purplish and rose-color (rarely white), the tube longer than the lips. (P. parviflora Britton, not Sm.) - Marshes and wet places, Temiscouata Co. to Gaspé Co., Que., Nfd., and northw. (Eu.)

* Large-leaved perennials; simple or somerohat branched, with terminal spikes.

1. P. canadénsis L. (Соммом L., Wood Beтonr.) Hairy; stems simple, clustered, 1.5-4 dm. high; leaves scattered, the lowest pinnalely parted, the others half-pinnatifid; spike short and dense; calyx split in front, otherwise almost entire, oblique; upper lip of the dull greenish-yellow and crimson corolla hooded, incurved, 2-toothed under the apex; capsule flat, somewhat swordshaped. - Copses and banks, N. S., centr. Me., and W. Que. to Man., and southw. May, June.

3. P. lanceolàta Michx. Stem uprigbt, 3-9 dm. high, nearly simple, mostly smooth; leaves partly opposite, oblong-lanceolate, doubly cut-toothed; spike crowded; calyx 2-lobed, leafy-crested; upper lip of the pale yellow corolla incurved and bearing a short truncate beak at tlue apex, the lower erect, so as nearly to close the throat; capsule ovate, scarcely longer than the calyx. Swamps, Mass. to Ont. and Man., s, to Va., O., and Neb. Aug., Sept.

4. P. Furbíshiae Wats. Tall ( $5-9 \mathrm{dm}$. high), pubescent or glabrate; leares lanceolate, pinnately parted and the short oblong divisions pinnatifid-incised, or the upper simply pinnatifid and the lobes serrate, silvery-margined; bracts ovate, laciniate-dentate; calyx 5-lobed, the lobes rather unequal, linear-lanceolate, entire or toothed; upper lip of corolla straight and bealkless, the truncate apex bicuspidate, the lower erect, truncately 3-lobed; capsule broadly ovate. Banks of the St. John, Me. and N. B. July, Aug.

\section{RHINÅNTHUS L. YelLow RATTLE}

Calyx membranaceous, flattened, much inflated in fruit, 4-toothed. Upper lip of corolla arched, ovate, obtuse, flattened, entire at the summit, but with a dark tooth on each side below the apex ; lower lip 3-lobed. Anthers approximate, hairy, transverse ; the cells pointless. Causule orbicular, flattened. Seeds orbicular, winged. - Anumal tupright herbs, with opposite leaves; the yellow or yellowish flowers crowded in a one-sided leafy-bracted spike. (Name composed 
of $\dot{p} i \nu, a$ snout, and $a \nu \theta o s, a$ flower, from the beaked upper lip of species once united with this genus.)

Teeth of the upper lip of the corolla elongate, $1.5-2 \mathrm{~mm}$. long .

Teeth of the upper lip broad and low, less than $1 \mathrm{~mm}$. long.

Branches of the stem, when present, short and scarcely developed at flowering season, later if elongating bearing only reduced flowers.

Upper part of the stem marked with fine black lines; upper lip of corolla with purplish teeth, lateral lobes of the lower lip with a black spot at base

Stem green, without blnck lines; corolla yellow throughout . .

Branches of the stem in well developed plants elongate at flowering season, their flower's like those of the primary inflorescence.

Upper part of the stem marked with fine black lines; upper lip of corolla with bluish teeth, lower lip with brown markings

Stem green, without black lines; corolla yellow throughout, the teeth of the upper lip whitish-yellow .

1. R. major.

2. R. Crista-galli.

3. R. oblongifolizts.

4. R. stenophyllus:

5. R. Kyrollas.

1. R. MÀJor Ehrh. Simple or with numerous long branches, $2-8 \mathrm{dm}$. high ; stern with conspicuous black lines above, essentially glabrous, the branches mostly without axillary fascicles; leaves lanceolate, the teeth subappressed ; bracts glibrous, all but the lowest pale, broadly triangular, the tip prolonged, their low st lance-attenuate teeth $5 \mathrm{~mm}$. long; calyx glabrous except for the slightly scabrous margin; corolla $2 \mathrm{~cm}$. long, the tube slightly curved, the purple teeth of the upper lip horizontal. - Damp fields, Plymouth, Mass. (Oakes). (Adv. or nat. from Eu.)

2. R. Crísta-gálli L. Stems 1-6 dm. high, black-lineolate, at flowering season usually bearing short branches in all but the lower axils; these branches remaining conspicuously shorter than the primary stem, sometimes slightly elongating and beroring reduced flowers; leaves lanceolate or lance-attenuate, crenatedentate, the teeth subappressed; bracts glabrous, dark green, the lower lance-attenuate, the otbers elongate-deltoid, their lower lance-attenuate spreading-ascending crowded teeth ( $5 \mathrm{~mm}$. long) much exceeding the appressed upper ones; calyx glabrous, green, often black-striate; corolla, yellow, about $1.5 \mathrm{~cm}$. long, its tube straight, the teeth of the upper lip depressed, rounded, violet, the lateral lobes of the lower lip with a black spot at base. (R. minor Ehrh.) Dry gravelly thickets and sterile fields, near the coast, $\mathrm{Nfd}$. and e. Que. to Ct.; indigenous northw., perhaps naturalized southw. (Eu.) - Plant strongly blackened in drying.

3. R. oblongifdlius Fernald. Stems $6-40 \mathrm{~cm}$. high, simple or with few very short branches, green; leaves oblong or linear-oblong, obtuse, crenate-dentate, scabrous above, minutely pilose beneath ; racts scabrous, mostly shorter than the mature calyces, deltoid-ovate, laciniate-dentate, the lower deltoid-lanceolate teeth 3-4 mm. long; calyx glabrescent, the margins ciliate, in fruit $1.3-1.9 \mathrm{~cm}$. long, greenish-yellow, often tinged with bronze; corolla yellow, 1-1.2 cm. long. - Lab. to alpine regions of Me., N. H., and n. N. Y. - Plant but slightly blackened in drying.

4. R. stenophýlius (Schur) Schinz \& Thellung. Stems $2-6 \mathrm{dm}$, bigh, blacklineolate, commonly with long arcuate-ascending branches with axillary fascicles; leaves linear- to oblong-lanceolate, crenate-dentate, the teeth subappressed; bracts glabrous, purple-tinged, the lower like the foliage leaves and subtending the remote flowers; upper bracts subapproximate, triangular, equaling the calyx, their teeth lance-deltoid; calyx purple-tinged, glabrous, in fruit $1.5 \mathrm{~cm}$. long; corolla $1.5 \mathrm{~cm}$. long, canary-yellow, turning brownish, the teeth of the upper lip blue-gray, the lower lip with brown markings. - Boggy meadows and shores near the Gulf of St. Lawrence, Gaspé Co., Que., to N. S. (Eu.)

5. R. Kyrollae Chabert. Stems 3-7 dm. high, green, not blacli-lineolate, simple, or commonly with long ascending branches without axillary fascicles; leaves oblong-lanceolate, scabridulous, the teeth subappressed or slightly spreading; bracts pale green, lance-deltoid, with lance-acuminate spreading-ascending teeth; calyx yellow-green, in maturity $1.5 \mathrm{~cm}$. long; corolla 8-12 $\mathrm{mm}$. long, light yellow, the teeth of the upper lip whitish-yellow. - Gravelly thickets and neadows in calcareous districts, e. Que. to N. S. and n. Me.; Wash. 


\section{SCHWÁlbea [Gronov.] I. ChafF-SeEd}

Calyx tubular, 10-12-ribbed, 5-toothed; the posterior tooth much the small. est, the 2 anterior united higher than the others. Upper lip of the corolla oblong, entire; the lower little shorter, erect, 2-plaited, with 3 very short and broad obtuse lobes. Anther-cells parallel. Capsule ovate. Seeds linear, with a loose chaff-like coat. - A perennial minutely pubescent upright herb, 3-6 dm. high, with leafy simple stems terminated by a loose spike of rather large dull purplish-yellow flowers ; leaves alternate, sessile, 3-nerved, entire, ovate or oblong, the upper gradually reduced to narrow bracts; pedicels very short, with 2 bractlets under the calyx. (Dedicated to $C$. G. Schwalbe, an obscure German botanist.) July.

1. S. americàna L. - Wet sandy soll, Mass, to La., near the coast. May-

\section{LENTIBULARIÀCEAE (BladDERWORT FAMiLY)}

Small herbs (growing in vater or wet places), with a 2-lipped calyx, and a 2 lipped personate corolla, 2 stamens with (confluently) 1-celled anthers, and a 1-celled ovary with a free central placenta, bearing several anatropous seeds, with a thick straight embryo, and no albumen. Corolla deeply 2-lipped; the lower lip larger, 3-lobed and with a prominent palate, spurred at the base in front; the palate usually bearded. Ovary free; style very short or none ; stigma 1-2-lipped. Capsule often bursting irregularly. Scapes 1-few-flowered. - The following are the two principal genera.

1. Utricularia. Calyx-lobés mostly entire. Upper lip of corolla erect. Filaments strongly incurved. Foliage usually dissected, bladder-bearing.

2. Pinguicula. ('ulyx with upper lip deeply 3 -and lower 2-cleft. Corolla-lobes spreading. Filaments straighter. Terrestrial, with entire rosulate leaves next the ground.

\section{UTRICULÀRIA L. BLADDERWORT}

Corolla personate, the palate on the lower lip projecting, often closing the throat. Anthers convergent. - Aquatic and immersed, with capillary dissected leaves bearing little bladders, which float the plant at the time of flowering; or rooting in the mud, and sometimes with few or no leaves or bladders. Scapes 1-few-flowered. Bladders furnished with a valvular lid and usually with a few bristles at the orifice. (Name from utriculus, a little bladder.)

$N . B .-$ In this genus the figures of the leaves and flowers are on a scale of $\frac{2}{3}$.

* Upper leaves in a whorl on the otherwise naked scape, floating by means of large bladders formed of the inflated petioles; the lower leaves dissected and capillary, bearing small bladders; rootlets few or none.

1. U. inflàta Walt. Swimming free; bladder-like petioles oblong, pointer at ends and branched near apex, bearing fine thread-like divisions; flowers 3-10, large, yellow; appressed spur half the length of the corolla; style distinct. In still water, Me. to Tex., mostly near the coast. July-Sept.

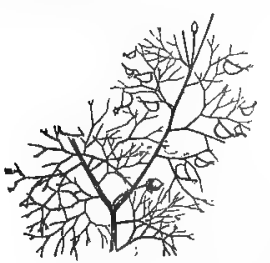

895. U. clendestina.

* Scapes naked (except some small scaly bracts), from immersed branching stems, which commonly swim free, bearing capillary dissected leaves with small bladders on their lobes; roots few and not affixed, or none; mostly perennial, propagated from year to year by tuber-like buls.

- Cleistogamous flowers along the submersed copiousl' bladder-bearing stemis.

2. U. clandestina Nutt. Leaves numerous on the slender immersed stems, several times fork6, capillary; 
scapes slender, $1 \mathrm{dm}$. high; lips of the yellow corolla nearly equal in length, the lower broader and 3-lobed, somewhat longer than the approximate thick and blunt spur.-Ponds, N. B. to Del. and Pa., chiefly near the coast. July, Aug. Fig. 895 .

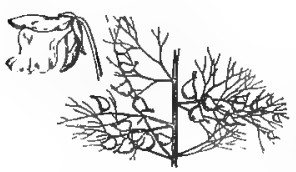

896. U. จulg. ₹. amer.

$\leftarrow$ No cleistogamous flowers.

+ Pedicels recurved in fruit; corolla yellow.

3. U. vulgàris L. (Gre.ATER B.) Immersed stems 3-10 dm. long, crowded with 2-3-pinnately many-partert capillary leaves bearing many bladder'; scapes 5-12flowered, 1-3 dm. long; corolla closed, 1-2 cm. broad, the sides reflexed; spur conical, rather shorter than the lower lip, thick and blunt.-Eurasia; n. w. Am

Represented with us by

Var. americàna Gray. Spur more slender and rather acute.-Common ir ponds and slow streams, Nfd. to Minn., s. to Va. and Tex., and westw. June-Aug. Frg. 896.

4. U. mìnor L. (SMaller B.) Leaves scattered.on the threadlike immersed stems, 2-4 times forked, short; scapes weak, 2-8flowered, 0.5-2 din. high ; upper lip of the gaping corolla not longer than the depressed palate; spur very short and blunt, or almost none. - Shallow water, e. Que. to B. C., s. to N. J., w. N. Y., Great L. region, Utah, and Cal, May-July. (Eu.) FiG. 897.

++ ++ Pedicels erect in fruit, few and slender; corolla yellow.

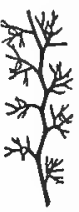

897. U. minor.

5. U. gibba L. Scape $2.5-10 \mathrm{~cm}$. high, 1-2-flowered, at base furnished with very slender short branches, bearing sparingly dissected capillary root-like leaves and scattered bladders; corolla 6-8 mm. broad, the lips broad and rounded, nearly equal; the lower lip with the sides reflexed, exceeding and approximate to the very thick and blunt conical gibbous spur. - Shallow water, Me. to Fla. and Ala., near the coast ; and from w. Vt. to Ont., Ill., and "Minn." July-Sept. Fig. 898.

898. U.

6. U. bifldra Lam. Scape $0.5-1.3 \mathrm{dm}$. high, 1-3-flowered, at the base bearing somewhat elongated submersed branches with capillary root-like leaves and numerous bladders; corolla 8-13 $\mathrm{mm}$. broad, the spur oblong, equaling the lower lip; seeds scale-shaped. Ponds and shallow waters, Mass. to Fla.; and from Wisc. and Minn. to Ala. and Tex. Aug., Sept. Fig. 899.

7. U. fibrosa Walt. Leaves crowded or whorled on the small immersed stems, several times forked, capillary; the bladders borne mainly along the stems; flowers $2-6,1-1.3 \mathrm{~cm}$. broad; lips nearly equal, broad and expanded, the upper undulate, concave, plaited-striate in the middle; spur nearly linear, obtuse, approaching and almost equaling the lower lip. - Shallow pools in pine barrens, L. I. and N. J. to Fla. and Ala. May-July.

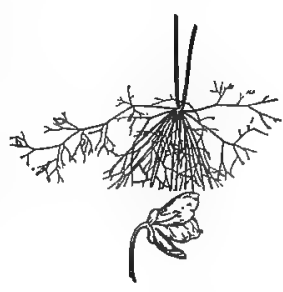

899. U. biffora.

8. U. intermèdia Hayne. Leaves crowded on the im.

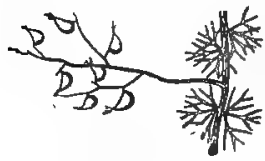
mersed stems, 2-ranked, 4-5 times forked, rigid, the divi. sions linear-awl-shaped, minutely bristle-toothed along the margins; the bladder's borne on separate leafless branches; upper lip of corolla much longer than the palate; spur conical-subulate, acute, appressed to and nearly as long as the very broad (1-1.5 cm.) lower lip. - Shallow pools and streams, Nfd. to B. C., s. to N. J., Pa., Great L. region,

900. U. intermedir. Ia., and Cal. May-July. (Eurasia.) Fıg. 900. - + Pedicels erect in fruit, rather long; corolla violet-purple.

7. U. purpùrea Walt. Leaves whorled along the long immersed free-floating GRAY'S MANLAW -47 
stems, petioled, decompound, capillary, bearing many bladders ; flowers 2-4. $1-1.3 \mathrm{~cm}$. wide; spur appressed to the 3 -lobed 2 -saccate lower lip of the coroila

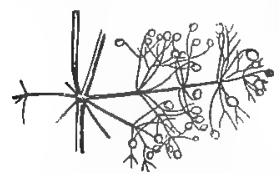

901. U. purpurea. and about half its length. - Ponds, N. B. to Fla.; also 11. Ind. and Mich. to Mini. July-Sept. Fig. 901.

* Scape solitary, slender and naked, or with a few small scales, the base rooting in the mud, or soil; leaves small, awol-shaped or grass-like, oflen raised out of the water, commonly few or fugacious; airbladders few on the leaves or rootlets, or commonly none.

+ Flower showy, purple, solitary; leaves bearing a few delicate lobes.

10. U. resupinàta B. D. Greene. Scape 0.5-2 dm. high, 2-bracted above ; leaves thread-like, on delicate creeping branches; corolla $1 \mathrm{~cm}$. long, deeply 2-parted; spur slender-conical, very obtuse, shorter than the dilated lower lip and remote from it, both ascending, the flower resting transversely on the summit of the scape. - Sandy margins of ponds, N. B. to w. Ont., s. to Fla., and the Great L. region. Aug.

++ Flowers minute, purplish or whitish, solitary or few; leaves entire.

11. U. cleistógama (Gray) Britton. Only $2-5 \mathrm{~cm}$. high, bearing 1 or 2 evidently cleistogamous flowers (not larger than a pinhead); capsule becoming 2 mm. long. (U. subulata, var. Gray.) - Sandy and muddy shores, Cape Cod, and southw. Aug., Sept.

$$
\begin{gathered}
+++ \text { Flowers } 2-10 \text {, yellow; leaves entire, rarely seen. } \\
++ \text { Stem flexuous; flowers long-pediceled. }
\end{gathered}
$$

12. U. subulàta L. Stem capillary, 2-20 cm. litgh; the raceme zigzag ; pedicels capillary; lower lip of the corolla flat or with its margins recurved, equally 3-lobed, much larger than the ovate upper one; spur oblong, acute, straight, appressed to the lower lip, which it nearly equals in length. - Sandy swamps and pine barrens, Nantucket, Mass., to N. J., Fla., and Tex., near the coast. May-Sept.

$$
\begin{aligned}
& \text { - Stem strict; flowers sessile or short-pediceled. } \\
& \text { = Corolla conspicuously exceeding the calyx. }
\end{aligned}
$$

13. U. cornùta Michx. Stem 0.5-3 dm. high, 1-5-flowered; corolla 1.5-2 $\mathrm{cm}$. broad, the lower lip large and helmet-shaped, its center very convex and projecting, while the sides are strongly reflexed; upper lip obovate and much smaller; spur awl-shaped, turned downward and outward, 10-12 $\mathrm{mm}$. long. - Peat-bogs or sandy shores, Nfd. to Ont. and Minn., s. to Fla. and Tex. Jume-Aug.

14. U. júncea Vahl. Stem 1-4 dm. high, 4-10-flowered; pedicels short; corolla barely $1 \mathrm{~cm}$. broad, lower lip obovate, consisting principally of the higharched palate; spur awl-shaped, about $6 \mathrm{~mm}$. long. - Bogs and wet shores, Va., and southw. June-Sept.

$$
==\text { Corolla barely if at all exceeding the calyx. }
$$

15. U. virgátula Barnhart. Very slender and strict, $2.5-25 \mathrm{~cm}$. high; flowers 2-6, remotely spicate, rarely solitary; corolla usually shorter than the purplish calyx; the upper lip spatulate, emarginate; the lower laterally compressed, apiculate, hairy at throat; the conical spur 2-3 mm. long; capsule subglobose, 1.5-2 mim. in diameter, seemingly beaked by the persistent acuminate upper calyx-lobe. ( $U$. simplex C. Wright, not R. Br.) - Shores of ponds, pine barrens of L. I. and N. J.; also Fla. to Miss. Aug., Sept. (Cuba.)

\section{PINGUícula [Tourn.] L. Butterwort}

Upper lip of the calyx 3-cleft, the lower 2-cleft. Corolla with an open hairy or spotted palate, the lobes spreading. - Small and stemless perennials, growing 
on damp rocks, with 1-flowered scapes; the broad and entire leaves soft-fleshy, mostly greasy to the touch (whence the name, from pinguis, fat).

1. P. vulgàris $\mathrm{L}$. Leaves spatulate or elliptical; scape and calyx a little pubescent; lips of the violet corolla very unequal, the tube funnel-form; spur straightish. - Wet calcareous rocks, N. B. and Que. to n. N. Y., Mich., Minn., and far northw.; very local southw. June-Aug. (Eurasia.)

\section{OROBANCHÀceae (Broom-rape Family)}

Herbs (root-parasites) destitute of green foliage, gamopetalous, the ovary one-celled with 2 or 4 parietal placentae; pod very many-seeded; seeds minute, with albumen and a very minute embryo. Calyx persistent, 4-5-toothed or -parted. Corolla tubular, more or less 2-lipped, ringent, persistent and withering; upper lip entire or 2-lobed, the lower 3-lobed. Stamens 4, didynamous, inserted on the tube of the corolla; anthers 2-celled, persistent. Ovary free, ovoid, pointed with a long style; stigma large. Capsule 1-celled, 2-valved; each valve bearing on its face one placenta or a pair. Seeds very numerous, minute. - Low thick or fleshy herbs, bearing scales in place of leaves, lurid yellowish or brownish throughout. Flowers solitary or spiked.

* Flowers of two sorts, scattered along slender panicled branches.

1. Epifagus. Upper flowers sterile, with a tubular corolla; the lower fertile, with the corolla minute and not expanding. Bracts inconspicuous.

* Flowers all alike and perfect; stems mostly siuple.

2. Conopholis. Flowers in a thick scaly spike. Calyx deeply cleft in front. Corolla 2-lipped. Stamens exserted.

8. Orobanche. Flowers sessile, spicate, thyrsoid-spicate, or pedicellate. Calyx 5-cleft. Corolla 2-lipped. Stamens included.

\section{EPIFÄGUS Nutt, Beech-Drops, Cancer-root}

Flowers racemose or spiked; the upper sterile, with long flaments and style; the lower fertile, with a very short corolla which is forced off from the base by the growth of the pod; stamens and style very short. Calyx 5-toothed. Stigma capitate, a little 2-lobed. Capsule 2-valved at the apex, with 2 approximate placentae on each valve. - Herbs, slender, purplish or yellowish-brown, much branched, with small scattered scales, $1-6 \mathrm{dm}$. high. (Name from $k \pi l$, upon, and $\phi \eta \gamma \delta s$, the Beech, because it grows on the roots of that tree.) LEPtamium Raf. EPIPhegds Spreng.

1. E. virginiana (L.) Bart. Corolla of the upper (sterile) flowers whitish and purple, $1 \mathrm{~cm}$. long, curved, 4-toothed. - Common under Beech-trees, parasitic on their roots; N. B. to Ont., Wisc., and southw. Aug.-Oct.

\section{CONÓPHOLIS Wallr. Squaw-RooT. Cancer-root}

Flowers with 2 bractlets at the base of the irregularly 4-5-toothed calyx, its tube split down on the lower side. Corolla tubular, swollen at base; upper lip arched, notched at the summit, the lower shorter, 3-parted, spreading. Stigma depressed. Capsule with 4 placentae, a pair on the middle of each valve. Upper scales forming bracts to the flowers, regularly imbricate, not unlike those of a fir-cone (whence the name, from $\kappa \hat{\omega}$ vos, a cone, and $\phi \circ \lambda l s, a$ scale).

1. C. americàna (L. f.) Wallr. - In woods, mostly under oaks, in clusters among fallen leaves; s. Me. to Mich., s. to Fla. and Tenn. May, June. - A singular plant, chestnut-colored or yellowish throughout, as thick' as a man's thumb, 1-2.5 dm. high, covered with fleshy scales, which become dry and hard. 


\section{OROBÁNCHe [Tourn.] L. Broom-RAPE}

Upper lip of corolla more or less spreading and 2-lobed, emarginate, or entire the lower spreading, 3-lobed. Stigma broadly 2-lipped or crateriform. Capsule with 4 placentae, equidistant or contiguous in pairs. - Plants brownish, purplish, or whitish. Flowers (blue, purple, or yellowish) and raked or bracted stems

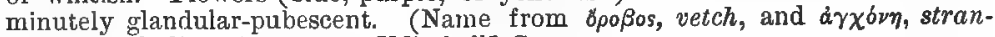
gler.) Including ApHyLLon [Mitchell] Gray.

* Flowers spicate or thyrsoid-spicate, with 1-3 bracts at base of calyx; corolla 2-lipped, the upper lip generally 2-cleft.

- Each flower with 3 bracts (1 large and 2 small) at base of calyx.

1. 0. PUFPƯREA Jacq. Stem simple, 1-2 dm. high, bluish-or purplish. tinged; flovers deep violet; calyx 5-lobed; corolla $2 \mathrm{~cm}$. long, slightly bilabiate. - In lawns, on Achillea, Wingham, Ont. (J. A. Morton). (Adv. from Eu.)

2. 0. RAMOSA L. Much more slender and usually freely branched, straucolored; flowers yellow and pale blue; calyx 4-lobed; corolla 1-1.5 cm. long. Parasitic on tomato, New Brunswick, N. J. (Halsted); on hernp and tobacco, Ill. and Ky. (Adv. from Eu.)

- + Each flower with 1 or 2 bracts at base of calyx.

3. 0. Mìnor Sm. Stem 1-3 dm. high, pubescent, pale yellowish-brown, or with purplish-tinged flowers in a rather loose spike; calyx cleft before and behind almost or quite to the base, the divisions usually 2-cleft ; corolla 1-1.5 $\mathrm{cm}$. long, the limb bluish, with rounded lobes, the upper lip emarginate. Parasitic on clover, N. J. to Va. (Nat. from Eu.)

4. 0. ludoviciàna Nutt. Simple or clustered, 1-3 dm. high; flowers densely spicate or thy rsoid, purplish, bracts 1 or 2 ; calyx 5-cleft, nearly regular; corollalobes acutish. (Aphyllon Gray.) - Sandy soil, Minn. to Ill., Tex., and westw.

* * Flowers solitary on long naked scapes or peduncles, without bracts ; corolla wilh a long curved tube and spreading 5-lobed limb.

5. 0. unifldra L. (ONE-FLOWERED CANCER-ROOT.) Stem subterranean or nearly so, very short, scaly, often branched, each branch sending up 1-4 slender 1-flowered scapes $0.5-2 \mathrm{dm}$. high; divisions of the calyx lance-avol-shaped, half the length of the corolla, which is $1.5-2.5 \mathrm{~cm}$. long, with 2 yellow bearded folds in the throat, and obovate lobes. (Aphyllon Gray; Thalesia Britton.) Damp woodlands, Nfd. to Va. and Tex., and westw. to the Pacific. Apr.July.

6. 0 . fasciculata Nutt. Scaly stem erect and rising 0.5-1 dm. out of the ground, mostly longer than the crowded peduncles; divisions of the calyx triangular, very much shorter than the corolla, which has rounded short lobes. (Aphyllon Gray; Thalesia Britton.) - On Artemisia, Eriogonum, etc., sandy ground, L. Michigan; Minn., southw. and westw. Apr.-Aug. (Mex.)

\section{BIgNONIÀceAE (Bignonia Family)}

Woody plants, gamopetalous, didynamous or diandrous, with the ovary commonly 2-celled by the meeting of the two parietal placentae or of a projection from them, many-ovuled; fruit a dry capsule, the large flat winged seeds with a flat embryo and no albumen, the broad and leaf-like cotyledous notched at both ends. Calyx 2-lipped, 5-cleft, or entire. Corolla tubular or bell-shaped, 5-lobed, somewhat irregular or 2-lipped, deciduous; the lower lobe largest. Stamens inserted on the corolla; the fifth or posterior one, and sometimes the shorter pair also, sterile or rudimentary; anthers of 2 diverging celis. Ovary free, bearing a long style, with a 2-lipped stigma. Leaves compound or simple, opposite, rarely alternate. Flowers large and showy.-Chiefly a tropical family. 
1. Tecoma. Pod flattish contrary to the partition. Leaves compound, without tendrils.

2. Catalpa. Pod terete. Fertile stamens only 2. Trees; lesves simple.

3. Bignomia. Pod flattened parallel with the partition. Leaves compound, tendril-bearing.

\section{TÉCOMA Juss, TRUMPet-FLOWER}

Calyx bell-shaped, 5-toothed. Corolla funnel-form, 5-lobed, a little irregular. Stamens 4. Capsule 2-celled, with the partition at right angles to the convex valves. Seeds transversely winged. - Woody, with compound leaves, climbing by aërial rootlets. (Abridged from the Mexican name tecomaxochitl.)

1. T. radicans (L.) Juss. (Trumpet Cresper.) Leaves pinnate; leaflets 9-11, ovate, pointed, toothed; flowers corymbed; stamens not protruded beyond the tubular-funnel-form orange and scarlet corolla (6-8 cm. long); pod oblanceolate, 1-1.5 dm. long. - Moist soil, N. J. to s. e. Ia., s. to Fla. and Tex.; common in cultivation farther northw. Aug., Sept.

\section{Catálpa scop. Catalpa. Indian Bean}

Calyx deeply 2-lipped. Corolla bell-shaped, swelling; the undulate 5-lobed spreading border irregular and 2-lipped. Fertile stamens 2, or sometimes 4 the 1 or 3 others sterile and rudimentary. Capsule very long and slender, nearly cylindrical, 2-celled, the partition at right angles to the valves. Seeds winged on each side, the wings cut into a fringe. - Trees, with ovate or cordate and mainly opposite leaves. (The aboriginal name.)

1. C. speciósa Warder. (Catawia Tree, Cigar Tree.) A large and tall tree, with thick bark; leaves ample, heart-shaped, long-acuminate; corolla 3.6-5 cm. long, nearly white, inconspicuously spotted, with obconical tube and slightly oblique limb, the lower lobe emarginate; capsule thick. - Low rich woodlands, s. Ind. to Tenn., Mo., and Ark. May, June.

2. C. BIGNONioìes Walt. A low much branched tree, with thin bark; corolla smaller (2.5-4 cm. long), thickly spotted, with oblique limb and entire lower lobe; capsule much thinner. (C. Cotalpa Karst.) - Naturalized from N. Y. southw.; indigenous on the Gulf coast.

\section{BIGNONIA [Tourn.] L.}

Calyx truncate, or slightly 5-toothed. Corolla somewhat bell-shaped, 5-lobed and rather 2 -lipped. Stamens 4 , often with a rudiment of the fifth. Capsule linear, 2-celled. Seeds transversely winged. - Woody climbers. (Named for the Abbé Jean-Paul Bignon, court-librarian at Paris and friend of Tournefort.) $\checkmark$ 1. B. capreolàta L. (Cross-VINE.) Sinooth; leaves of 2 ovate or oblong leaflets and a branched tendril, often with a pair of accessory leaves in the axil resembling stipules; peduncles few and clustered, 1-flowered; corolla orange, $5 \mathrm{~cm}$. long; pod $1.5 \mathrm{dm}$. long; seeds with the wing $4 \mathrm{~cm}$. long. (B. crucigera L., in part.) - Rich soil, Va. to O. and Ill., s. to Fla. and La. Apr.-June. Climbing tall trees; a transverse section of the wood showing a cross.

\section{MARTYNiÀceae (Martinia Familt)}

Herbs, with chiefly opposite simple leaves, and flowers as of the Lentibulariaceae, except in structure of ovary and fruit, the former being 1-celled, the latter fleshy-drupaceous, with wingless seeds and thick entire cotyledons. Ovary (in ours) 1-celled, with 2 parietal intruded placentae expanded into 2 broad lamellae or united into a central columella. - Chiefly tropical.

\section{MARTÝNIA L. UNICORN-PLANT}

Calyx 5-cleft, mostly unequal. Corolla gibbous, bell-shaped, 5-lobed and somewhat 2-lipped. Fertile stamens 4, or only 2. Flesh of fruit at length falling away in 2 valves; inner part woody, terminated by a 2-horned beak. 
imperfectly 5-celled. Seeds several, with a thick roughened coat. - Low branching annuals, clammy-pubescent, exhaling a heavy odor; stems thickish; leaves simple, rounded; flowers racemed, large. (Dedicated to Prof. John Martyn, of Cambridge, England.)

1. M. louisiana Mill. Leaves heart-shaped, oblique, entire or undulate, the upper alternate; corolla dull white or purplish, or spotted with yellow and purple; endocarp of the fruit crested on one side, long-beaked. ( $\boldsymbol{M}$. proboscidea Gloxin.) - River-banks and waste places, s. Ind., Ill., and Ia. to n. Mex.; also cultivated and naturalized northw.

\section{aCANThàceae (Acanthus Family)}

Chiefly herbs, with opposite simple leaves, didynamous or diandrous stamens inserted on the tube of the more or less 2-lipped corolla, the lobes of which are convolute or imbricated in the bud; fruit a 2-celled and few(4-12)-seeded capsule; seeds anatropous, without albumen, usually flat and supported by hooked projections of the placentae (retinacula). Flowers commonly much bracted. Calyx 5-cleft. Style thread-form; stigna simple or 2-cleft. Pod loculicidal, usually flattened contrary to the valves and partition. Cotyledons broad and flat. - Mucilagino's and slightly bitter, not noxious. A large family in the warmer parts of the world; represented in gardens by Thunbergia, which differs from the rest by the globular pod and seeds, the latter not on hooks.

* Corolla bilabjate, upper líp erect and concave, lower spreading ; stamens 2.

1. Dianthera. Capsule obovate, flattened, 4-seeded.

* * Corolla not obviously błlabiate, the 5 lobes broad and roundish, spreading; stamens 4.

E. Ruellia. Calyx-lobes mostly linear or lanceolate. Capsule 6-20-seeded.

3. Dyschoriste. Calyx-lobes long-filiform. Capsule 2-4-seeded.

\section{DIANTHÈRA [Gronov.] L. WATER WILlOW}

Calyx 5-parted. Upper lip of corolla notched ; the lower spreading, 3-parted, external in the bud. Anthers 2-celled, the cells separated and somewhat unequal. Capsule contracted at base into a short stalk. - Perennial herbs, growing in water or wet places, with entire leaves, and purplish flowers in axillary peduncled

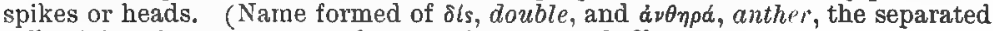
cells giving the appearance of two anthers on each filament.)

1. D. americàna L. Stem 3-9 dm. high ; leaves linear-lanceolate, elongated; spikes cylindric, dense, long-peduncled; corolla $1 \mathrm{~cm}$. long, the lower lip rugose. - In water, w. Que. and Vt. to Wisc., s. to Ga. and Tex. July-Sept.

2. D. ovàta Walt. Slender, 1.5-4 dm. high; leaves oblong or ovate-oblong; peduncles mostly shorter than the leaves. - Swamps, etc., Va. to Fla. and Tex., inland to Mo.

\section{RUÉLlia [Plumier] L.}

Calyx 5-parted. Corolla funnel-form, with spreading ample border, convolute in bud. Cells of the somewhat arrow-shaped anthers parallel and nearly equal. Capsule narrow, in ours somewhat flattened, contracted and seedless at base. Seeds with a mucilaginous coat, when wet exhibiting under the microscope innumerable tapering short bristles, their walls marked with rings or spirals. - Perennials, with large showy blue or purple flowers, sometimes also with small flowers precociously close-fertilized in the bud. Calyx often 2-bracteolate. (Named for the early French herbalist, tean Ruelle.)

I R. ciliosa Pursh. Hirsute with soft whitish hairs, 3-9 dm. high ; leaves $n s a .7 \mathrm{~g}$ sessile, oval or ovate-oblong, $2.5-7 \mathrm{~cm}$. long; flowers $1-3$ and almost sessile in the axils; tube of the corolla $: .5-4 \mathrm{~cm}$. long, fully twice the length of 
the setaceous calyx-tobes; the throat short. - Dry ground, N. J. to Fla., w. to Mich., Neb., and Tex. June-Sept. Var. Parvifuora (Nees) Britton. Sparingly hirsute-pubescent or glabrate; leaves ovate-oblong, usually snort-petioled, larger; tube of corolla little exceeding the hardly hirsute calyx. (Var. ambigua Gray.) - Va. and Ky. to Ala. - Appearing as if a hybrid with the next.

2. R. strềpens L. Glabrous or sparingly pubescent, $3-10 \mathrm{dm}$. high; lecoves narrowed at base into a petiole, ovate, obovate, or mostly oblong, $0.7-1.5 \mathrm{dm}$. long; tube of the corolla (3-5 $\mathrm{cm}$. long) little longer than the dilated portion, slightly exceeding the lanceolate or linear calyx-lobes. - Rich soil, Pa. to Wisc., s. to Fla, and Tex. July-Sept. Var. cheistántria Gray. Leaves commonly narrower and oblong; flowers for most of the season cleistogamous. (Var. micrantha Britton.) - Common with the ordinary form.

3. R. pedunculàta Torr. "Puberulent, slender, $3-8 \mathrm{dm}$. high, the branches spreading; leaves ovate-oblong, 4-7 dm. long, short-petioled; flowers solitary or 3 , on slender peduncles $(1.5-5 \mathrm{~cm}$. long) with 2 leaf-like bracts at the tip ; corolla $3-5 \mathrm{~cm}$. long, the tube slightly exceeding the subulate-filiform calyxlobes. - Dry woods, Mo., and southw.

\section{DYSCHORÍSTE Nees.}

Calyx deeply 5-cleft or -parted. Corolla funnel-form, with ample limb, con volute in bud. Anthers mucronate or sometimes aristate at base. Ovules a single pair in each cell. Capsule oblong-linear. - Iow branching perennials, pubescent or hirsute, with few proportionally large axillary nearly sessile flowers

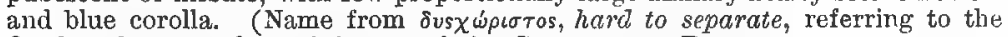
firmly coherent valves of the capsule.) Calophanes Don.

1. D. oblongifolia (Michx.) Ktze. Stems usually erect and simple, 1.5-t dm. high; leaves from narrowly oblong to oval, very obtuse, sessile, $1.5-3 \mathrm{~cm}$. Long; corolla blue, sometimes purple-dotted or mottled, seldom $2.5 \mathrm{~cm}$. long; calyx-lobes nearly distinct, filiform-setaceous, hirsute. (Calophanes Don.) Pine barrens, s. Va. to Fla.

\section{PHRYMÀceae (LOPSEed Family)}

$A$ perennial herb, with slender branching stems, and coarsely toothed ovate leaves, the lower long-petioled; the small opposite flowers in elongated and slender terminal spikes, strictly reflexed in fruit. Corolla purplish or rose-colon. Calyx cylindrical, 2-lipped; the upper lip of 3 bristle-awl-shaped teeth; the lower shorter, 2-toothed. Corolla 2-lipped; upper lip notched; the lower much larger, 3-lobed. Stamens included. Style slender ; stigma 2-lobed. Fruit dry, in the bottom of the calyx, oblong, 1-celled and 1-seeded. Seed orthotropous. Cotyledons convolute round their axis.

\section{PHRYMMA L. LOPSEED}

A single species, with characters of the family. (Derivation of the name unknown.)

1. P. Leptostàchya L. Plant $3-9 \mathrm{dm}$. high ; leaves $0.5-1.5 \mathrm{dm}$. long, thin ; calyx strongly ribbed and closed in fruit, the long slender teeth hooked at the tip. - Moist and open woods, N. B. and Que. to Man., and southw. July, Aug. (E. Asia.)

\section{Plantaginàceae (Plantain Familt)}

Chiefly stemless herbs, with regular 4-merous spiked flowers, the stamens inserted on the tube of the dry and membranaceous veinless gamopetalous corolla, altemate with its lobes, - Chiefly represented by tho two following genera, 
1. Littorella. Scape 1-2-flowered. Ovary 1-celled, 1-seeded. Aquatic.

2. Plantago. Scape several-many-flowered. Ovary 2-celled, 2-co-Beeded. Terrestrial.

\section{LITTORÉLIA Bergius.}

Flowers monoecious. The staminate solitary, on a mostly simple naked scape ; caly $x$ 4-parted, longer than the cylindraceous 4-cleft corolla ; anthers exserted, on very long capillary filaments. Pistillate flowers usually 2, sessile at the base of the scape; calyz of 3 or 4 unequal sepals; corolla urn-shaped, with a 3-4-toothed orifice. Ovary with a single cell and ovule, tipped with a long laterally stigmatic style, maturing as an achene. (Name from litus or littus, shore, from the place of growth.)

1. L. unifldra (L.) Asch. Stoloniferous but otherwise stemless; leaves terete, linear-subulate, $2-7 \mathrm{~cm}$. long. ( $L$. lacustris L.) - In water or on gravelly shores, Nfd. to Me., Vt., Ont., and Minn.; very rare. (Eu.)

\section{Plantàgo [Tourn.] L. Plantain. Ribwort}

Calyx of 4 imbricated persistent sepals, mostly with dry membranaceous margins. Corolla salver-form or rotate, withering on the pod, the border 4parted. Stamens 4, or rarely 2 , in all or some flowers with long and weak exserted filaments, and fugacious 2-celled anthers. Ovary 2(or in no. 6 falsely $3-4)$-celled, with 1-several ovules in each cell. Style and long hairy stigma single, filiform. Capsule 2-celled, 2-several-seeded, opening transversely, so that the top falls off like $a$ lid and the loose partition (which bears the peltate seeds) falls away. Embryo straight, in fleshy albumen. - Leaves ribbed. Flowers whitish, small, in a bracted spike or head, raised on a naked scape. (The Latin name.)

a. Corolla not closed over the fruit $b$.

$b$. Seeds plump, not hollowed on the face $c$.

c. Leaves with more or less dilated strongily ribbed blade.

Ribs of the broad leaves rising from the midrib . . . . 1. P. cordata.

Ribs of the leaf freo to the contracted base.

Pod circumscissile near the middle

Sepals sharply carinate on the back.

Spike densely flowered; crpsule 4-9-seeded

Spike remotely flowered; cnpsule 2 -seeded.

Sepals rounded, not sharply carinate on the back

c. Lesves linear to subterete, fleshy, obscurely ribbed

$b$. Seeds fattened, or bollowed on the face, or bost-shaped $a$.

$d$. Leaves lanceolate to ovate, strongly ribbed.

Leares lancelate to lance-oblong . . . . . . 7. P. lanceolata

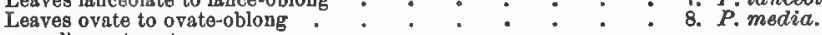

d. Leaves linear to setaceous.

White, silky-lanate; bracts not exceeding the calyx . . . 9. P. Purshit,

Green, loosely pubescent; lower bracts much exceeding the ealyx 10 . $P$. aristata.

a. Corolla (of fertile flowers) closed over the fruit.

Leaves spatulate-lanceolate to obovate; stamens 4.

Frulting calyx 1.5-2.5 mm. long; beed 0.8-1.5 mm. long . . . 11. P. virginica.

Fruiting calyx $3-4 \mathrm{~mm}$. long ; seed $2.5-8 \mathrm{~mm}$. long . . . . 12. P. rhodosperma.

Leaves linear to filiform; stamens 2.

Capsule 4-seeded

Capsule 10-28-seeded

\$1. Stamens 4 ; flowers all perfect; corolla not closed over the fruit.

* Flovers proterogynous, the style first projecting from the unopened corolla, the anthers long-exserted after the corolla has opened; seeds not hollowed on the face (except in nos. 7 and 8).

1. P. cordata Lam. Tall, glabrous; leaves fleshy, heart-shaped or roundovate, 1-2.5 dm. long, long-petioled, the ribs arising from the midvib; spike at length loosely flowered; bracts round-ovate, fleshy; capsule 2-4-seeded. Along streams, in wooded swamps, etc., N. Y. and Ont, tọ Mind., and southw. 
2. P. mà jor L. (Commor P.) Smooth or rather hairy, sometimes roughish ; leaves thick and leathery, 0.5-3 dm. long, the blade from broad-elliptic to cordateovate, undulate or more or less tootbed, the broad petiole channeled; scapes

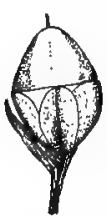

002. P. major. Fruit $\times 81 / 3$. $1.5-9 \mathrm{dm}$. high, commonly curved-ascending; spike dense, obtuse, becoming $1-4 \mathrm{dm}$. long; sepals round-ovate or obovate; capsule ovoid, circumscissile near the middle, 8-18-seeded; seeds angled, reticulated. - Waysides and near dwellings, exceedingly common. FIG. 902. - Sometimes with leafy-bracted scapes or with paniculate-branched inflorescences. (Cosmopolitan.) Var. INTERMìdiA (Gilibert) Dcne. Leaves lance-ovate to narvowly elliptic, coarsely sinuate-dentate, sometimes densely pubescent, closely rosulate. (P. halophila Bicknell.) - Salt marshes and coastal rocks, Me. to N. J. (Eurasia.)

Var. asiatica (L.) Done. Leaves upright, the thin smooth blades tapering to slender petioles; scapes erect. - River-banks, etc., e. Que. to B. C., s. to n. N. E., L. Superior, N. Dak., Col., etc. (Asia.)

3. P. Rugelii Dene, Leaves as in no. 2, but paler and thinner, the rather slender petioles crimson at base; spikes long and thin, attenuate at the apex; sepals oblong, acutely carinate; capsules cylindraceous, circumscissile much below the middle, 4-9-seeded; seeds oval, not reticulated. $\rightarrow$ N. B. to Ont. and Minn., s. to Ga. and 'lex. Fig. 903.

4. P. sparsiflora Michx. Leaves oblong-lanceolate, often very long (3-4 dm.), villous to glabrous; scape elongate, terminated by a long loosely flowered spike; sepals oval, rigid ; capsules ellipsoid, about twice as long as the calyx, circumscissile toward the base, 2-seeded. - Pine barrens and damp sands, S. C. to Fla.; reported from s. Ill.

5. P. eriópoda Torr. Usually with a mass of yellowish wool at the base; leaves thickish, oblanceolate to obovate, with short stout petioles; spike dense or loose; sepals and bract more or less scarious but not cavinate; capsule ovoid, never over 4-seeded. -

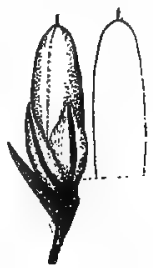
908. P. Rugelii. Fruit $\times 31 / 3$. Salt marshes, e. Que. to N. S.; saline soil, Red River valley, Minn., to n. Cal. and the Arctic region.

6. P. decípiens Barneoud. (SEAside P.) Leaves linear to nearly filiform, 1-10 mm. broad, entire or remotely serrate, fleshy, indistinctly ribbed; scapes slightly pubescent below, densely so at tip, 2-30 cm. high, from erect to strongly arcuate; spikes slender-cylindric, $0.5-12 \mathrm{~cm}$. long, dense or loose; scales and sepals from drab to purplish-brown; corolla-tube often pubescent; seeds 2-4. ( $P$. maritima Man. ed. 6, not L.) - Salt marshes and maritime rocks, Greenl. and Lab. to N.J.- Very variable in size and habit, the most dwarf extreme sometimes separated as $\boldsymbol{P}$. borealis Lange.

7. P. Lanceolata, L. (Rib Grass, Ripple Grass, English P.) Mostly hairy; scape grooved-angled, at length much longer than the lanceolate or lance-oblong leaves, slender, $2-7 \mathrm{dm}$. high ; spike dense, at first capitate, in age cylindrical; bracts and sepals scarious, brownish; seeds 2, hollowed on the face. - Very common in grass land. (Nat. from Eu.)

8. P. MEdia L. (HOARY P.) Resembling the preceding, but with shorter ovate or broad-oblong finely canescent leaves; the cylindric spike $2.5-8 \mathrm{~cm}$. long; seeds slightly concave or flat on the face; flowers fragrant. - Sparingly in fields, etc., Me. to Ont. and N.Y. (Adv. from Eu.)

* Flowers of 2 sorts (as respects length of anthers and flaments) on different plants, mostly cleistogamous; corolla-lobes broad, rounded, persistently spreading; seeds 2, boat-shaped; inflorescence and narrow leaves silkypubescent or woolly; annual.

9. P. Púrshii R. \& S. White with silky wool; leaves 1-3-nerved, varying from oblong-linear to filiform; spike slender-cylindsic, very dense, $0.5-15 \mathrm{~cm}$. long, woolly ; bracts not exceeding the calyx; sepals very obtuse, scarious, with a thlck center. ( $P$. patagonica Jacq., var. gnaphalioides Gray.) - Prairies and dry plains, Minn. to Ind., $\mathbf{K y}$, Tex, and westw, to the Pacific; adventive eastw, to N. E. 
10. P. aristàta Michx. Similar; loosely hairy and green, or becoming gla. brous ; the narrowly linear bracts $2-6$ times as long as the flowers. ( $P$. patagonica, var. Gray.) - I)ry plains and prairies, 1ll. to La., and westw.; naturalized in sterile soil eastw. to the Atlantic.

\$2. Flowers subdioecious or polygamo-cleistogamous; the corolla in the fertile (or mainly fertile) plant closed over the maturing capsule and forming a kind of beak, and anthers not exserted; sterile flowers with spreading corolla and long-exserted filaments; seeds mostly flat; small annuals or biennials.

11. P. virginica L. Hairy or hoary-pubescent, 0.5-4 dm. high; leaves oblong, varying to obovate and spatulate-lanceolate, :3-5-nerved, slightly or coarsely and sparingly toothed; spikes mostly dense, 1-1 $\mathrm{cm}$. long; fruiting calyx 1.5-2.5 mm. long; mature corolla slender-cylindric; seeds usually 2 , brown or yellowis b, 0.8-1.5 mm. long. - Sandy grounds, chiefly near the coast, R. I. to Fla. and Tex.; inland in Miss. basin to s. Mich., Ill., Mo., and Kan.; also on the Pacific slope. (Mex.)

12. P. rнodospérma Dene. Similar to the preceding; fruiting calyx 3-4 mm. long; mature corolla slender-conical; seeds reddish, 2.5-3 mm. long. Dry prairies and open woods, La. to Ariz. and n. Mex.; adventive in Mo.

13. P. elongàta Pursh. Minutely pubescent, $3-16 \mathrm{~cm}$. high; leaves linear to filiform, entire; capsule short-ovoid, 4-seeded, little exceeding the calyx and bract. (P. pusilla Nutt.) - Sandy soil, s. Mass. to Ga.; and from Ill. to Assina., La., and westw. Apr.-Aug.

14. P. heterophýlla Nutt. Leaves rather fleshy, acute, entire, or some of them 2-4-lobed or toothed below; capsule slender-conoidal, 10-28-seeded, nearly twice the length of the calyx and bract. - Low sandy ground, N. J. to Fla,, 'Tex, and Ark. Apr.-June.

\section{RUBiàceae (Madder Family)}

Woody or herbaceous plants, with opposite entire leaves connected by interposed stipules, or in whorls without apparent stipules, the calyx adherent to the -4-celled ovary, the stamens as many as the lobes of the regular corolla (4-5), and inserted on its tube. Flowers perfect, but often dimorphous (as in Mitchella and Houstonia). Fruit various. Seeds anatropous or amphitropous. Embryo commonly rather large, in copious hard albumen. - A very large family, the greater part, and all its most important plants (such as the Coffee and Peruvianbark trees), tropical.

$N$. $B$. The figures in this family are on a scale of $\frac{2}{3}$.

SubFaml I. COFFEOfDEAE. Ovules solitary in the cells

* Herbs.

+ Leaves in whorls.

1. Sherardia. Corolla funnel-form, Calyx-lubes lanceolate. Flowers subsessile, involucrate.

2. Asperula. Corolla tubular-campanulate below. Calyx-lobes obsolete. Fruit as in Galium.

8. Galium. Corolla wheel-shnped, 4 (or rarely 8)-parted. Calyx-teeth obsolete. Fruit twin, separating into 2 indehiscent 1 -seeded carpels.

++ Leares opposite.

* Flowers nxillary, separate; fruit dry when ripe.

4. Spermacoce. Corolla funnel-form or salver-form; lobes 4. Fruit separating when ripe into 2 carpels, one or both of them opening.

5. Diodia. Fruit separating Into 2 or 3 closed and indeliscent carpels; otherwise as no, 4. ++++ Flowers twin; their ovaries united into 1 ; fruit a 2 -eyed berry.

b. Mitchella. Corolla funnel-form; its lohes 4. A creeping Lerb. * * Shrubs or trees.

7. Cephalanthus. (orolla tubular; lobos 4. Fruit inversely pyramidal, $:-4$-sueded. 
Subfamlit II. CINCHONofDeAE. Ovules numerous in each cell; leaves opposite.

? Houstonia, Corolla salver-form or funnel-form, 4-lobed. Seeds rather few, thirable-shaped "1' silurer-shaped. Low herbs.

9. Oldenlandia. Corolla wheel-shaped in our species, 4-lobed. Beeds very numerons and minute, angula1: Low herbs.

\section{SHERÁRdia [Dill.] I. Field Madder}

Calyx-lobes lanceolate, persistent. Corolla funnel-form, the limb 4-5-lobed. Style filiform, 2-cleft; stigmas capitate. Fruit dry, twin, of 2 indehiscent 1-seeded carpels. - A slender procumbent herb, with square stems, lanceolate pungent leaves in whorls of $4-6$, and small blue or pinkish flowers surrounded by a gamophyllous involucre. (Named for $D r$. William Sherard, patron if Dillenius.)

1. S. Arvérars L. The only species.-Waste places and fields, N. S. to Ont., O., and N. J., local. (Nat. from Eu.)

\section{ASPÉRULA L.}

Similar to Galium, but with tubular or tubular-campanulate corolla. - An old World genus. (Name from asper, rough, in reference to some scabrous species.)

1. A. Galioines Bieb. Smooth and glaucous, $3-8 \mathrm{dm}$. high; leaves 5-10 in a whorl, linear, subulate-tipped ; flowers white, short-pediceled in cy wules forming a handsome panicle. - Fields, local, Ct. to Mich. (Adv. from Eu.)

\section{Gàlium L. Bedstraw. Cleaters}

Calyx-teeth obsolete. Corolla wheel-shaped, valvate in the bud. Stamens 4, rarely 3 , short. Styles 2. Fruit dry or fleshy, globular, twin, separating when ripe into the 2 seed-like indebiscent 1-seeded carpels. - Slender berbs, with small cymose flowers (produced in summer), square stems, and whorled leaves, the roots often containing a red coloring matter. (Name from $\gamma d \dot{\lambda} a$, milk, which some species are used to curdle.)

w. Fruit dry $b$.

b. Annuals.

Fruit bristly.

Flowers sessile or subsessile ; leaves $4-7 \mathrm{~mm}$. long . . . 1. G. virgatum.

Flowers on long ascending axillary peduncles . - . . 2. G. Aparine.

Fruit smooth or merely granulate-roughened.

Flowers 1-few on axillary peduncles; fruit 3-4 mm. thick . 3. G. tricorne.

Flowerstiny, in terminal small cymes; fruit barely 1 mm. thick ${ }^{*}$. $G$, parisiense.

b. Perennials $c$

c. Flowers yellow.

Panicle rather dense, its lower branches much exceeding the

internodes
Tanicle loose, slender, interrupted, its lower branches shorter than the internodes

c. Flowers white, greenish-white, or purplish $\dot{d}$.

d. Erect plants, neither the stems nor leaves retrorsely seabrous $e$.

e. Leaves mostly in $4^{\prime} s f^{\prime}$.

$f$. Peduncles loosely 8 -several-flowered ; flowers dull purple to greenish-white $g$.

g. Fruit uncinate-hispid.

Mature flowers and fruits on distinct pedicels.

Leaves firm aud dull, the whorls uniform.

Leaves filmy and lucid; the npper whorl jargest

Flowers and fruits mostly sessile or subsessile along the loosely divergent branches of the peduncles.

Leaves oval or oblong, obtuse; tlowers commonly pubescent

Leaves lance-acuminate; flowers glabrous " : .

g. Fruit smooth.

Leaves ovate-lanceolate, 3-nerved .

Leaves linear or lanceolate, 1-norved

5. G. verum.

6. G. Wirtgenti.
7. G. pilosum.

8. G. Kamtschaticum
9. G. circaezans.

10. G. lanceolatum.

11. G. latifolium.

12. G. arkansanum. 
f. Flowers bright white, numerous, in a compact panicle; leaves linear-lanceolate flowers white, numerous, in leafy

13. G. boreale.

6. Lesves mostly in 6's or 8's ; flowers white, numerous, in
panicles.

Leaves firm, linear or oblanceolate, rarely $2 \mathrm{~cm}$. long.
Flowering branches and pedicels strongly divaricate Flowering branches and pedicels mostly ascending .

Leaves thin, lanceolate, mostly $8-5 \mathrm{~cm}$. long

a. Matted, reclining, or ascending plants. usually with more or less retrorsely scabrous stems or leaves $h$.

$h$. Fruit smooth or merely granulate-roughened $i$.

$i$ Leaves obtuse.

Flowers several in a small dichotomous cyme; the pedicels horizontally spreading.

Flowers solitary or in mastly simple cymes of $2-5$ tiowers.
Corollas greenish-white, small ( $1.5 \mathrm{~mm}$. or less broad), commonly with 3 obtuse lobes; stems retrorsescabrous.

Flowers mostly solitary, on capillary arcuate scabrous pedicels

Flowers in 2 's and 8 's ; pedicels straight, smooth: Corollas white, $2-2,5$ mm. broad, com
lobes; stems mostly smooth.

Leaves chielly ascending ; fruit $2.5-3.5 \mathrm{~mm}$, in diameter.

Leaves chiefly reflexed; fruit $1-\dot{1}, 5$ mm. in diameter

d. Leaves acute or cuspidate.

Leaves linear, slightly upward-scabrous on the margins .

h. Fruft bristly

$a$. Fruit a berry; lenves in 4's, 1-nerved

14. G. Mollugo.

15. $G$. erectum.

16. G. syloaticum

17. O. palustre.

18. G. trifidum.

19. G. Olaytoni.

20. G. tinctorium.

21. G. labradoricum.

22. G. concinnum.

23. G. asprellum.

24. G. trifiorum.

25. G. hispidulum.

1. G. virgàtum Nutt. . Slender and erect; stem 1-3 dm. high, simple or branching from the base; leaves mostly in 4's, thick, oblong or linear, 4-7 mm. long; flowers solitary, sessile, subtended by a pair of small bracteal leaves; fruit uncinate-hispid. - Dry soil, Mo. to Tenn. and Tex.

レ'2. G. Aparìne L. (Cleavers, Goose Grass.) Stem weak and reclining, bristle-prickly backward, hairy at the joints; leaves about 8 in a whorl, lanceolate, tapering to the base, short-pointed, rough on the margins and midrib, $2.5-7 \mathrm{~cm}$. long ; peduncles 1-3-flowered; flowers white ; fruit bristly, $3-4 \mathrm{~mm}$. in diameter. - Seashores, Que. to Fla., and in rich or shaded ground inland; perhaps sometimea introd. (Eurasia.)

Var. Vaillántii (DC.) Koch. Smaller; the leaves less than $2.5 \mathrm{~cm}$. long; hispidulous fruit smaller, $1.5-2 \mathrm{~mm}$. in diameter. (G. spurium L.) - Ont., westw. and southwestw.

3. G. TRICóRNe Stokes. Resembling no. 2, rather stout, with simple branches; leaves 6 or 8 , oblanceolate, cuspidate-mucronate, the margins and stem retrorsely prickly-hispid; flowers mostly in clusters of 3, dull white; fruits rather large, tuberculate-granulate, not hairy, pendulous. - Ballast, local. (Adv. from Eu.)

4. G. PARIsí́nse L. Slender, diffuse, 1-3 dm. high, glabrous; leaves 5-7, oblanceolate to nearly linear, 5-10 $\mathrm{mm}$. long, their margins and the angles of the stem spinulose-scabrous; flowers rather few, cymulose on leafy branches, greenish-white, very small; fruit glabrous, more or less tuberculate. (G.anglicum Huds.) - Roadsides, Va. (Nat. from Eu.)

5. G. vìruM L. (Yellow B.) Stems smooth, erect; leaves 8 or sometimes 6 in the whorls, linear, roughish, soon deflexed; flowers yellow, very numerous, densely paniculate, the lower branches of the panicle at anthesis much exceeding the subtending leaves; fruit usually smooth. - Dry fields, Me. to N. J., Pa., and Ont., local. (Nat. from Eu.)

6. G. Wirtainı F. Schultz. Similar to the preceding; flowers yellow, slightly larger, $3 \mathrm{~mm}$. in diameter; the panicle long and interrupted, the lower branches at anthesis shorter than or scarcely surpassing the subtending leaves. - Established in meadows, Norfolk, Ct. (Miss Seymour). (Adv. from Fu.)

7. G. pildsum Ait. Hairy; leaves oval, dotted, hairy, $2-2.5 \mathrm{~cm}$. long, the lateral nerves obscure; peduncles 2-3-forked, the flowers all pediceled. - Dry copses, N. H. to Ont., Mich., Ill., Kan., and southw.

Var. puncticuldsum (Michx.) T. \& G. Almost glabrous; leaves varying to elliptical-oblong, hispidulous-ciliate. - N. J. to Va. and Tex. 
8. G. kamtscháticum Steller. Stems weak, mainly glabrous, 1-3 dm. long; leaves orbicular to oblong-ovate, thin, 1-3 cm. long, slightiy pilose; flowers slender-pediceled; corolla glabrous, yellowish-white, not turning dark, its lobes merely acute. - Mts. of Cape Breton I., Que., N. I., and N. Y. (E. Asia.)

v. G. circaèzans Michx. (WiLD Liquorice.) More or less pubescent, $3 \mathrm{dm}$. high ; leaves oval, varying to ovate-oblong, mostly obtuse, ciliate, 1.5-4.5 $\mathrm{cm}$. long; peduncles usually once forked, the branches elongated and widely diverging in fruit, bearing several remote flowers on very short lateral pedicels, reflexed in fruit; lobes of the greenish corolla hairy outside, acute or acuminate. - Rich woods, s. Me. and w. Que. to Minn., s. to Fla. and Tex. Var. g LA Brum Britton. Smoothish, leaves sparingly pubescent on the upper surface or merely ciliate; corolla glabrous. (Var. glabellum Bvitton.) - Rensselaer, Albany, and Washington Cos., N. Y. (according to Peck).

10. G. lanceolatum Torr. (WILD LrquonICE.) Nearly glabrous; leaves (except the lowest) lanceolate or ovate-lanceolate, tapering to the apex, 3-7.5 $\mathrm{cm}$. long; corolla glabrous, yellowish, turning dull purple, its lobes more acuminate; otherwise like the preceding. - Dry woods, s. Me. and w. Que. to Minn., s. to $\mathrm{O}_{\text {., }} \mathrm{Ky}$, and $\mathrm{Va}$.

11. G. latifolium Michx. Smooth, $3-6 \mathrm{dm}$. high ; leaves lanceolate or ovatelanceolate, acute, $3-6 \mathrm{~cm}$. long, the midrib and margins rough, the lateral nerves prominent; cymes panicled, loosely many-flowered, the purple flowers on slender. spreading pedicels; fruit rather fleshy. - Dry woods, mts. of Pa. to N. C. and Tenn. Var. Híspioum Small. Stems and leaves hispid. - Iron Mts., Va.

12. G. arkansànum Gray. Similar; leaves lanceolate to linear, $2-3.5 \mathrm{~cm}$. long, the lateral nerves obscure or none. - Rocky woods, s. Mo., Ark., and Okla.

13. G. boreale L. (NortherN B.) Smooth, 8-9 dm. high; leaves in 4's,

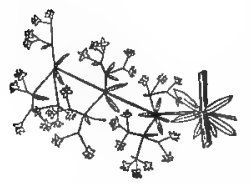

904. G. Mollugo, linear-lanceolate; flowers bright white, in compact panicles; fruit minutely bristly, sometimes smooth. - Rocky banks, shores, etc., Que. to Alaska, s. to N. J., Pa., Mich., Mo., S. Dak., Col., etc.; rare eastw.

14. G. Mollúgo L. Perennial, smooth throughout or pubescent below; stems erect or diffuse, usually numerous, 3-9 dm. long; leaves in 8's or on the branchlets in 6's, oblanceolate to nearly linear; flowers white, very numerous in loose ample almost leafless panicles; branches and pedicels mostly wide-spreading; fruit smooth. - Roadsides and fields, Nfd. to Del. and O. (Nat. from Eu.) Fig. 904.

15. G. ERÉCTUM Huds. Sinilar; stems mostly erect; flowers fewer and slightly larger; the branches and pedicels mostly ascending. - Fields, etc., e. Que. to Vt. and Ct. (Nat. from Eu.) Fig. 905.

16. G. sylquticum L. (Scotch Mist, BabY's Breath.) Stems very many, tall, suberect, shining, somewhat geniculate at base; lower leaves 8 , upper 4 or 6 in a whorl, acuminate, smooth, entire, glaucous beneath ; pedicels capillary, very ascending, in loose terminal panicles; fruit smooth. - Fields and

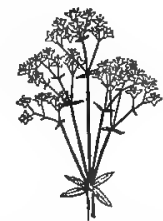

905. G. erectum.

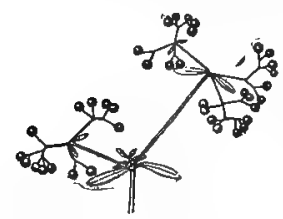

906. A. palustre. thickets, N. E., escaped from cultivation.

(Introd. from Eu.)

17. G. palístre L. Slender, 2-5 dm. high, slightly branched, branches solitary or opposite; leaves linearelliptic or spatulate, thin, dull, barely $1 \mathrm{~cm}$. long; flowers numerous in terminal cymes; pedicels becoming strongly divaricate; corolla 4-parted, white or rosetinged, 2.5-3.3 mn. broad; fruit glabrous, lunate in cross-section. - Wet meadows and banks, Nfd. and Que. to Ct., N. Y., and Mich. June, July. (Eu.) Fig. 906.

18. G. trifidum L. Slender and weak, very freely branched, forming dense mats; primary leaves oftenest in 4 's, linear-spatulate, $0.5-1.3 \mathrm{~cm}$. long ; flowers solitary, or when terminal in 3's, on capillary scabrous arcuate pedicels; corolla whitish, 0.5 mm. long; fruit annular in cross-section. (G. trifidum. 


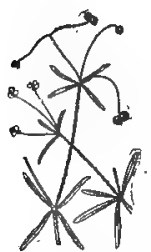

907. G. trifidum.

var. pusillum Gray.) - Bogs, mossy woods, and wet shores, Nfd, and Lab. to B. C., s. to n. and W. N. E., centr. N. Y., O., Mich., Neb., etc. July-Sept. (Eurasia.) Fig. 907. $\checkmark$ 19. G. Claytoni Michx. Stouter, ascending or reclining; primary leaves in 4's and 6's ; flowers in terminal clusters of '2's and 3's ; pedicels stout, straight, and glabrous. ( $Q$. trifiam Man ed. 6, in part.) - Swamps and damp places, e. Que. to N. C., Neb., and Tex. July-Sept. Fig. 908.

20. G. tinctòrium $\mathbf{L}$. Erect; stem smooth, stiffish, 1.5-8 dm. high, freely branched from near the base; leaves mostly in $4^{\prime} \mathrm{s}$, linear or lanceolate, 1.5-2.5 cm. long, cuneate at base, dull green, slightly scabrous on margin and midrib; flowers 2 or 3 in terminal clusters, the pedicels scarcely divaricate even in fruit; fruit $25-3.6 \mathrm{~mm}$. in diameter. (G. trifidum, var. latifolium Torr.)

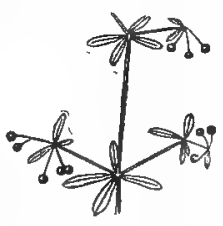

908. G. Claytoni.

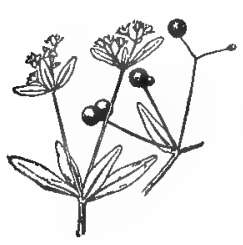

909. G. tinctorium. - Damp shady places, w. Que. to Neb. Ariz. May-July. Fig. 909.

Var. filifolium Wiegand. More slender; leaves nearly filiform ; inflorescence more open ; corolla broader. - Va., and southw. near the cosst.

21. G. labradóricum Wiegand. Low; stem smooth, slender, 0.5-3 dm. high, from capillary rootstocks; leaves small, 0.5-1.5 cm. long, soon reflexed, scabrous beneath on the margin and nerve; flowers as in the preceding but smaller; fruit much smaller. ( $G$. tinctorium, var. Wiegand.) - In moss, mostly beneath Larch or Arbor Vitae, Nfd. to Wisc., N. Y., and n. Ct. FIg. 910.

22. G. concínnum T. \& G. Stems low and slender, 1.5-3 $\mathrm{dm}$. high, with minutely roughened angles; leaves all in 6's, linear, slightly pointed, veinless, the margins upwardly roughened; peduncles $2-3$ times forked, diffusely panicled; pedicels short. $\longrightarrow$ Dry hills, N. J. and Pa. to Va., w. to Minu., Ia., and Ark.

23. G. aspréllum Michx. (Rovgr B.) Stem $0.5-1.8 \mathrm{~m}$. high, much branched, rough backwards with hooked prickles, leaning on bushes; leaves in whorls of 6 , or $4-5$ on the branchlets, oval-lanceolate, with almost prickly margins and midrib; peduncles short, 2-3 times forked. - Alluvial ground, Nfd, to N. C., w. to Ont, Minn., Neb., and Mo.

24. G. triflorum Michx. (Sweet-scented B.) Stem 3-10 dm. long, bristlyroughened backward on the angles; leaves elliptical-lanceolate, bristle-pointed, with slightly roughened margins, $2-8.5 \mathrm{~cm}$. long; peduncles 3-flovered, the flowers all pediceled, greenish; fruit beset with hooked bristles. - Rich woodlands, Nfd. to B. C., and southw. - Sweet-scented in drying. (Greenl., Eu.)

25. G. hispidulum Michx. Hirsute-pubescent, scabrous, or sometimes nearly smooth, 3-6 dm. high, diffusely branched; leaves oblong or oval, mucronate, $05-2 \mathrm{~cm}$. long; pedicels solitary or commonly 2 or 3 from the small involucral whorl, all naked, or one of them bracteolate; flowers white; berry purple, glabrate. - Dry or sandy soil, s. N. J. to Fla., along the coast.

\section{SPERMACOCE [Dill.] L. BUTTONWEED}

Calyz-tube short; the limb parted into 4 teeth. Corolla funnel-form or salver-form, valvate in the bud. Stigma or style 2-cleft. Fruit small and dry, 2 -celled, splitting when ripe into 2 carpels, one of them usually carrying with it the partition, and therefore closed, the other open on the inner face. - Small herbs, the bases of the leaves or petioles connected by a bristle-bearing stipular membrane. Flowers small, whitish, crowded into sessile axillary whorled clus- 


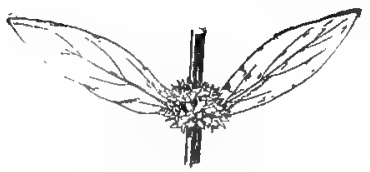

911. S. glabra.

ters or heads. (Name compounded of $\sigma \pi \varepsilon \rho \mu \alpha$, seed, and $\alpha \kappa \omega \kappa$, a point, probably from the pointed caly $x$-teeth on the fruit.)

1. S. glàbra Michx. Glabrous perennial; stems spreading, 2-5 dm. lougr; leaves oblonglanceolate; heads many-flowered; corolla little exceeding the calyx, bearded in the throat, bearing the anthers at its base; filaments and style hardly any. - River-banks, s. O. to Ill., Ark., Tex., and Fla. Aug. Fig. 911.

\section{DIODIA [Gronov.] L. BUTTONWEED}

Calyx-teeth 2 5 , often unequal. Fruit 2(rarely 3)-celled, the crustaceous carpels into which it splits all closed and indehiscent. Flowers 1-3 in each axil. - Resembling Spermacoce. Flowering all summer. (Name from olosos, a thoroughfare; the species often growing by the wayside.)

1. D. virginiàna $L$. Smooth or hairy perennial ; stems spreading, $3-6 \mathrm{dm}$. long; leaves lanceolate or oblong-lanceolate, sessile; corolla white, $1 \mathrm{~cm}$. long, the slender tube abruptly expanded into the large limb; style 2-parted; fruit ellipsoid, strongly furrowed, crowned mostly with 2 slender calyx-teeth. - Low grounds along streams, s. N. J. to Fla., w. to Mo., Ark., and 'Tex. Fig. 912.

2. D. tères Walt. Hairy or minutely pubescent annual ; stem spreading, 1-8 dm. long, nearly terete; leaves linear-lanceolate, closely sessile, rigid; corolla funnel-

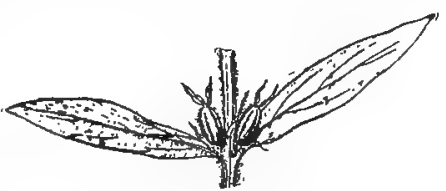

912. D. virginiana. form, 4-6 mm. long, whitish, with short lobes, not exceeding the long bristles of the stipules; style undivided; fruit obovoid-turbinate, not furrowed, crowned with 4 short calyx-teeth. - Sandy shores and barrens, Ct. to Fla.; and from 0 . to Kan., and southw. (Mex, W. I.)

\section{6. mitchélla L. Partridge Berry}

Flowers in pairs, with their ovaries united. Calyx 4-toothed. Corolla-lobes spreading, densely bearded inside, valvate in the bud. Style 1 ; stigmas 4 , linear. Fruit a berry-like double drupe, crowned with the caly $x$-teeth of the two flowers, with 4 small seed-like bony nutlets to each flower. - A smooth and trailing small evergreen herb, with round-ovate and shining petioled leaves, minute stipules, white fragrant flowers often tinged with purple, and scarlet (rarely whitish) edible (but nearly tasteless) berries, which remain over winter. Flowers occasionally 3-6-merous, always dimorphous; all those of some individuals having exserted stamens and included stigmas; of others, included stamens and exserted style. (This very pretty plant commemorates $D r$. John Mitchell, an early correspondent of Linnaeus, and an excellent botanist, who resided in Virginia.)

1. M. ràpens L. - Dry woods, creeping abont the bases of trees, especially Coniferae, throughout our range, and southw. June, July. - Leaves often variegated with whitish lines. Rarely the two flowers completely confluent into one, with a 10-lobed corolla.

\section{CEPHALÁNThus L. Buttonbush}

Calyx-tube inversely pyramidal, the limb 4-toothed. Corolla-teeth imbricated in the bud. Style thread-form, much protruded. Stigma capitate. Fruit small, at length splitting from the base upward into 2-4 closed 1-seeded portions. Shrubs or small trees, with the white flowers densely aggregated in spherical

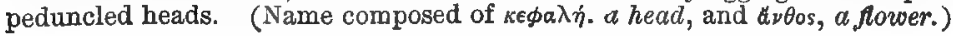


1. C. occidentàlis L. Smooth; leaves petioled, essentially glabrous, ovate, or lanceolate-oblong, pointed, opposite or whorled in threes, with short intervening stipules. - Swamps and along streams, s. w. N. B. to w. Ont., and southw. July, Aug. - Usually a shrub with us, rarely arborescent and 5 or $6 \mathrm{~m}$. high. (Mex., W. I.)

-Var. pubéscens Raf. Branchlets and at least the lower surfaces of the leaves soft-pubescent. - Ill. to Ga., La., and Tex.

\section{HOUSTÒNIA L.}

Calyx 4-lobed, persistent; the lobes in fruit distant. Corolla usually much longer than the calyx-lobes, the lobes valvate in the bud. Anthers linear or oblong. Style 1; stigmas 2. Ovary 2-celled, Pod top-shaped, globular, or didymous, thin, its summit or upper half free from and projecting beyond the tube of the calyx, loculicidal across the top. Seeds 4-20 in each cell, pitted. Sinall herbs, with short entire stipules connecting the petioles or narrowed bases of the leaves, and cymose or solitary and peduncled flowers ; these dimorphous, in some individuals with exserted anthers and short included style; in others the anthers included and the style long, the stigmas therefore protruding. (Named for Dr. William Houston, an English botanist, who collected in tropical America.)

* Snall and delicate, vernal-flowering; peduncles 1-flowered; corolla salverform; upper half of the broad and somewhat 2-lobed pod free; seeds globular, with a very deep round cavity occupyiny the inner face.

- Perennial by delicate filform creeping rootstocks or creeping stems; peduncles filiform, 2-5 cm. long.

1. H. caerùlea L. (Bluets, InNocence.) Glabrous; stems erect, slender, sparingly branched from the base, $0.5-2 \mathrm{dm}$. high ; leaves oblong. spatulate, 6-9 num. long; peduncle filiform, erect; corolla light blue, pale lilac or nearly white, with a yellowish eye, the straight slender long-exserted tube much longer than its lobes or than those of the calyx. - Moist and grassy places, N. S. to Ga., w. to Ont., Wisc., and Ala.; producing from early spring to midsummer its delicate little flowers.

Var. Faxondrum Pease \& Moore. Corolla white, with a prominent yellow eye, the tube shorter, gradually expanding to the limb. - Alpine regions, White Mts., N. H.

2. H. serpyllifolia Michx. Like the preceding species, but the filiform stems prostrate, extensively creeping and rooting; leaves orbicular to ovate, 4-9 mm.

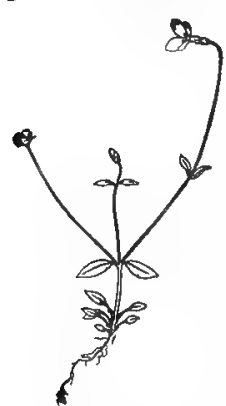

919. H. patens. long; corolla rather larger, and deep violet-blue.-Along streamlets and on mts., Pa. to Tenn. and S. C.

+ + Winter-annuals, branching chiefly from the base; root simple; peduncles much shorter.

3. H. pàtens Ell. Stems $2 \mathrm{~cm}$. to at length $1 \mathrm{dm}$. high, with ascending branches and erect peduncles; leaves spatulate to ovate; corolla much smaller than that of no. 1, violet-blue or purplish without yellowish eye, the tube longer than its lobes, twice the length of the calyx-lobes. (H. minor Britton.) - Dry or sandy soil, Va. to Ill. and Mo., s. to Ga. and Tex. Fig. 913.

4. H. minima Beck. More diffuse, commonly scabrous; stems at length much branched and spreading, 2-10 cm. high; lowest leaves ovate or spatulate, the upper oblong or nearly linear; earlier peduncles elongated and spreading in fruit, the later ones short; tube of the purplish corolla not longer than its lobes or the ample calyx-lobes (3 mm. long). - Dry hills, s. e. Ia. to Tex. Mar.-May. 
** Erect, mostly perennial herbs, 1-5 dm. high, with stem-leaves sessile, ahd flowers in small terminal cymes or clusters; corolla funnel-form, white to purplish, often hairy inside; seeds meniscoidal, with a ridge across the hollowed inner face.

- Pod free above the middle.

+ Pod distinctly broader than high.

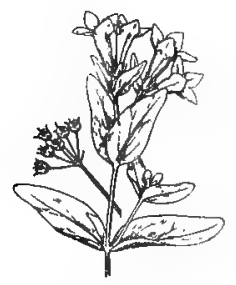

914. H. purpureq.

5. H. purpùrea L. Smooth or slightly pubescent, 1-5 dm. high ; leaves varying from roundish-ovate to lanceolate, 3-5ribbed; calyx-lobes longer than the half-free globular pod. - Woodlands, Md. to s. Ia., and southw. May-Sept. Fig. 914. Var. pubśscexs Britton. Stems and leaves densely pubescent. - Range of the typical form.

6. H. tenuifdlia Nutt. Slender, lax, diffuse, 1.5-3 dm. high, with loose inflorescence, and almost filiform branches and peduncles; cauline leaves all linear, hardly over $2 \mathrm{~mm}$. wide. ( $H$. purpurea, var. Gray.) - Dry rocks, e. O. to Va., N. C., and 'l'enn.

$$
\begin{gathered}
++ \text { Pod as high as broad. } \\
=\text { Leaves smooth. }
\end{gathered}
$$

7. H. longifolia Gaertn. Similar to no. 5; stem 1-2.5 dm. high, mostly glabrous; leaves oblong-lanceolate to linear, $1.5-2.5 \mathrm{~cm}$. long; radical oval or oblong, less rosulate, not ciliate ; calyx-lobes subulate, 1.5-2.5 mm. long. ( $\boldsymbol{H}$. purpurea, var. Gray.) - Rocky or gravelly ground, centr. Me. to Man., s. to Ga. and Mo. FrG. 915.

8. H. lanceolàta (Poir.) Britton. Stoutish, 1.5-4 dm. bigh; leaves broadly lanceolate, thickish; inflorescences very leafy; calyx-lobes lanceolate, herbaceous, 5-9 mm. long, much exceed-

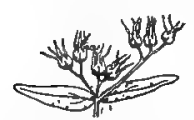

916. H. lanceolata. ing the globose-ovoid capsule. (H. purpurea, var. calycosa Gray.) - Dry soil, s. Me. to Ill., Okla., and Ala. Fig. 916.

$$
==\text { Lewes (at least the basal) ciliate. }
$$

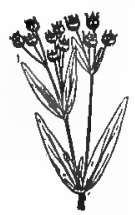

915. H. longifolia.

9. H. ciliolata Torr. Stems 1-2 dm. high, leaves $1-2 \mathrm{~cm}$. long. thickish ; cauline oblong-spatulate ; radical oval or oblong, rosulate, hirsuteciliate; calyx-lobes a little longer than the pod. (H. purpurea, var. Gray.) Rocky banks and shores, w. N. Y. and s. Ont. to Minn., Ill., and Ky.

\section{+ + Pod free only at summit.}

10. H. angustifòlia Michx. Stems tufted, from a hard or woody root; leaves narrowly linear, acute, 1-ribbed, many of them fascicled; flowers crowded, short-pediceled; lobes of the corolla densely bearded inside ; pod obovoid, acute at base, only its summit free, opening first across the top, at length through the partition. - Barrens, Ill. to Kan., s. to Tex. and Fla. (Mex.)

\section{OLDENLÁNDIA [Plumier] L.}

Calyx 4-lobed, persistent. Corolla short, the limb valvate in the bud. Anthers snort. Style 1 or none; stigmas 2. Pod thin, 2-celled, opening loculicidally across the summit. - Low herbs, with swall stipules united to the petioles. (Dedicated to the memory of $\boldsymbol{H}$. $B$. Oldenland, a Danish physician and botanist, who died about the end of the 17th century at the Cape of Good Hope.)

1. 0. unifldra L. An inconspicuous pubescent or smoothish branched and spreading annual, 0.2-4 dm. high; leaves ovate to oblong; flowers in sessile axillary clusters; corolla nearly wheel-shaped, white, much shorter than the calyx. (O. glomerata Michx.) - Wet places, near the coast, N. Y. to Fla. and Tex. FIG. $\Omega 17$.

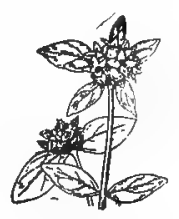

917. O. unitiora 


\section{CAPRIFOLIÀCEAE (Honetsuokle Family)}

Shrubs, or rarely herbs, with opposite leaves, the calyx-tube adherent to the 2-5-celled ovary, the stamens as many as (1 fewer in Linnaea, doubled in Adoxa) the lobes of the tubular or rotate corolla, and inserted on its tube. liruit a berry, drupe, or pod, 1-several-seeded. Seeds anatropous, with small embryo in fleshy albumen.

Tribe I. LONICEREAE. Corolla tubular, often irregular, sometimes 2-lipped. Style slender; stigma capitate.

\footnotetext{
* Erect or climbing shrubs, with scaly winter-buds.
}

1. Diervilla. Stamens 5. Corolla funnel-form, nearly regular. Pod 2-celled, 2-valved, manyseeded, slender.

2. Lonicera. Stamens 5, as many as the lobes of the tubular and more or less irregular corolla. Berry severai-seeded; all the 2 or 8 cells fertile.

3. Symphoricarpos. Stamens 4 or 5 , as many as the lobes of the bell-shaped regular corolls. Berry 4-celled, but only 2-seeded; two of the cells sterile.

* * Herbs, with axillary flowers.

4. Linnaea. Stamens 4, one fewer than the lobes of the corolla. Fruit dry, 8-celled, but only 1-seeded. Creeping, with long-pedunculate twin flowers,

5. Triosteum. Stamens 5. Corolla gibbous at the base. Fruit a 8-celled drupe. Erect; flowers sessile.

Tribe II. SAMBÙCEAE. Corolla wheel-shaped or urn-8haped, regular, deeply 5-lobed. Stigmas 1-5, sessile or nearly so. Inflorescence terminal and cymose.

* Shrubs, with stamens as many as corolla-lobes, the flowers in broad compound cymes.

6. Viburnum. Fruit a 1-celled 1-seeded drupe, with a compressed stone. Leaves simple.

7. Sambucus. Fruit berry-like, containing 8 small seed-like nutlets. Leaves pinnate-

* * Dwarf herb, with stamens doubled and flowers in a capitate eluster.

8. Adoxa. Fruit a dry greenish drupe, with $8-5$ cartilaginous nutlets. Canline leaves a single pair and ternate.

\section{Diervillla [Tourn.] Mill. Bush Hone ysuckle}

Calyz-tube tapering at the summit; the lobes slender, awl-shaped, persistent. Corolla 5-lobed. Pod slender, pointed, septicidal. - Low upright shrubs, with ovate or oblong pointed serrate leaves, and cymosely 3-several-flowered pedunales, from the upper axils or terminal. (Named in compliment to $D r . N$. Diéreville, who carried it from Canada to Tournefort.) Several early-flowering $A$ siatic shrubs of this genus are frequent in cultivation under the name WEIGELA, and may in some instances persist or spread.

1. D. Lonicèra Mill. Leaves oblong-ovate, taper-pointed, petioled; peduncles mostly 3-flowered; pod long-beaked. (D. trifida Moench; $D$. Diervilla MacM.) - Dry woods and rocky places, Nfd. to Man., s. to N. C. and the Great L. region. June-Aug. - Flowers at first pale yellow, turning to deep yellow, scarlet, crimson, or even maroon.

\section{LONICÈRA L. HONEYSUCKLE}

Calyx-teeth very short. Corolla tubular or funnel-form, often gibbous at the base, irregularly or almost regularly 5-lobed. Berry several-seeded. - Erect or climbing shrubs. Leaves entire. Flowers often showy and fragrant. (Named in honor of Adam Lonitzer, latinized Lonicerus, a German herbalist of the 16th century.) A large boreal genus most abundant in Asia and long popular in cultivation. 
§ 1. XYLÓSTEON [Tourn.] Pers. Leaves all distinct; peduncles axillary, single, 2-flowered at the summit; the two berries sometimes united into one; calyx-teeth not persistent.

* Upright bushy shrubs.

+ Bracts (2 or sometimes 4) at the base of the ovaries small, lance-oblong to linear.

+ Corolla-lobes subequal.

= Peduncles short (3-7 mm. in length).

1. L. caerulea L., var. villosa (Michx.) T. \& G. (Mountain Fly H.) Low (3-9 dm. high); branches upright; leaves oval, downy when young; bracts awl-shaped, longer than the ovaries which are united into one blue edible berry; calyx-lobes glabrous; corolla yellowish. - Low woods and bogs, Lab. to Alaska, s. to Pa., Mich., Wisc., Minn., etc. May, June.

2. L. Monkòwi Gray. Shrub, 1.5-2 m. high, soft-downy ; branches spreading; leaves oblong, rounded or subcordate at base, dark green and somewbat rugose above, much paler and grayish-tomentose beneath, obtuse or barely acutish ; calyx-teeth hirsute or ciliate; corolla-lobes subequal, nearly as long as the tube, widely spreading, white or cream-colored; berries bright red. - Frequently cultivated, and now locally established in e. Mass. (Introd. from Japan.)

$$
==\text { Peduncles long and slender (1.4-3 cm. in length). }
$$

3. L. Tatárica L. (Tartarian H.) Smooth shrub, 1.5-3 m. high; leaves thin, glabrous, entire, cordate-oval, on short petioles; corolla showy, white or rose-colored; the lobes subequal, widely spreading, nearly as long as the tube; berries united at the base, red or orange. - Escaped from cultivation and established on rocky shores and sheltered banks, Me. to Ont, N. J., and Ky. May, June. (Introd, from Asia.)

4. L. canadénsis Marsh. (American Fly H.) Branches straggling, 1-1.5 m. high; leaves ovate-oblong, often heart-shaped, petioled, thin, downy beneath when young, ciliate; corolla funnel-form, $2 \mathrm{~cm}$. long, greenish-yellow, the labes much shorter than the tube; berries separate, red. (L. ciliata Muhl.) - Woods, e. Que. to Sask., s. to Pa., Mich., Wisc., and Minn. Apr.-June.

+ Corolla strongly bilabiate, the lips of very unequal breadth, the upper shallowly 4-lobed, the lower of a single entire lobe.

5. L. Xxцóstedm L. (European Fly H.) Erect shrub, 1-2 m. high; leaves broadly oval, thin, very pubescent beneath, especially when joung; peduncles rather short (8-12 mm. in length), thickish; bracts and calyx pubescent; corolla yellowish; berries separate, red. - Escaping from cultivation and becoming locally established in s. N. E., N. Y., and N. J. (Introd. from Eu.)

6. L. oblongifdlia (Goldie) Hook. (Swame FLY H.) Shrub, 5-15 dm. high; branches upright; leaves 2-7 cm. long, oblong, downy when young, smooth when old; peduncles slender, 1.5-4 cm. long; bracts minute or deciduous; corolla deeply 2-lipped, 1-1.5 cm. long, yellowish-white; berries red or purplish, united or nearly distimet. - Larch and Arbor Vitae swamps, n. N. B. to Man., s. to Me., Vt., N. Y., w. Pa., Mich., and Minn. May-July.

+- + The two flowers involucrate by 4 conspicuous and broad foliaceous bracts.

7. L. involucràta (Richards.) Banks. Pubescent, or becoming glabrous ; branches 4-angular; leaves $0.5-1.5 \mathrm{dm}$. long, exceeding the peduncle, ovateoblong, mostly pointed, petioled, and with a strong midrib ; corolla yellowish, viscid-pubescent, cylindraceous, $1-1.5 \mathrm{~cm}$. long ; ovaries and globose dark purple berries distinct. - Woods and banks of streams, n. N. B. and e. Que, shores of L. Superior, northw, and westw. June, July.

\section{* * Twining or trailing shrub.}

8. L. JaPósica Thunb. (JaPanese H.) Pubescent; leaves ovate or oblong, thickish, entire, short-petioled; peduncles rather short; bracts leaf-like, con- 
spicuous; corolla white, pink, or yellow, the slender pubescent tube $2.5 \mathrm{~cm}$. long; berries black. - Escaped from cultivation and established in woods and thickets, Ct. to Fla. May-July. (Introd. from Asia.)

§ 2. CAPRIFOLIUM [Tourn.] Pers. Twining shrubs, with the flowers in sessile whorlea clusters from the axils of the often connate upper leaves, forming interrupted terminal spikes; calyx-teeth persistent on the red or orange berry.

* Corolla trumpet-shaped, almost regular; stamens and style little exserted.

9. L. sempervirens L. (Trumpet H.) Branches and upper surface of the leaves glabrous or nearly so; flowers in somewhat distant whorls, scentless, nearly $5 \mathrm{~cm}$. long, deep red outside, yellowish within or rarely throughout, glabrous; leaves oblong, smooth, the lower petioled, the uppermost pairs connate. - Copses, Me. to Neb., and southw.; common in cultivation. May-Oct. Leaves deciduous at the north. Var. HIRstitula Rehder. Branchlets villous or glandular-pubescent ; upper surface of leaves appressed-villous ; corolla externally pubescent. - Va. and N. C.

* Corolla ringent; the lower lip narrow, the upper broad and 4-lobed; stamens and style conspicuously exserted.

- Corolla-tube $2-2.5 \mathrm{~cm}$. long, glabrous inside; stamens and style glabrous.

10. L. Caprifólium L. "American" or Italian Woodbine.) Leaves smooth, glaucous beneath, obovate, the 2 or 3 upper pairs united; flowers whorled in the uppermost axils; corolla whitish, with a purple tube, fadingr yellowish, not gibbous at base, fragrant. (L. grata Ait.) - Rocky woodlands, N. Y., N. J., and Pa. to Mich., Mo., and southw.; escaped from cultivation. May, June. (Introd. from Fu.)

$$
+4 \text { Corolla hairy within, the tube } 1.3 \mathrm{~cm} \text {. long or less. }
$$

11. L. hirsùta Eat. (HAIRY H.) Twining and rather high-climbing; leaves ciliate, deep green and more or less appressed-setulose above, downy-hairy beneath, as well as the branches, veiny, dull, broadly oval, the uppermost united, the lower short-petioled ; flowers in approximate whorls; corolla $2-2.5 \mathrm{~cm}$. long, orange-yellow, clammy-pubescent; the tube slightly gibbous at base, slender.Damp copses and rocks, w. N. E. to Pa., Mich., and Man. July. - A coarse large-leaved species.

\section{+ Branches glabrous; leaves glabrous above. $=$ Corolla mostly 1.2-2.4 cm. long.}

12. L. Sullivántii Gray. Much whitened with glaucous bloom, 1-2 m. high, glabrous excent for a slight mberulence on the lower surface of the leaves; disk of the uppermost connate leaves orbicular or nearly so, its ends rounded or often retuse, sometimes slightly mucronate; inflorescence tending to elongate : corolla pale yellow; the tube $1-1.5 \mathrm{~cm}$. long, slightly gibbous at the base; filaments nearly glabrous. - Rocky woods or banks, Tenn. to O., centr. Ia, and Minn.

13. L. glaucéscens Rydb. Less glaucous; leaves glabrous above but decidedly pubescent beneath, the uppermost connate ones forming a somewhat oblong or rhombic disk, usually pointed acutely or obtusely at the ends, the margin cartilaginous, not ciliate; corolla pale yellow, $1.2-2 \mathrm{~cm}$. long, the pubescent tube gibbous at the base; ovary glabrous or nearly so. - Ont. and Man., s. to Va., $O$, and Neb. Var. DAsÝgYna Rehder. Ovary densely hirsute and some-what glandular. - 0 .

14. L. dioíca L. Glabrous, 1-9 $\mathrm{m}$ high; leaves oblong, 5-10 $\mathrm{cm}$ long, glaucous and glabrous beneath, the upper 1-4 pairs connate into disks; even the uppermost disks somewhat oblong or rhombic, more or less pointed (at least obtusely) at each end; corolla greenish-yellow or purplish, the tube barely $1 \mathrm{~cm}$. 
long, hirsute within; style and stamens also hairy. (L. glauca Hill.) - Rocky grounds, s. Me. to Man,, s. to N. C., O., and Mo. May, June.

\section{$==$ Corolla about $3 \mathrm{~cm}$. long.}

15. L. flàva Sims. (Yellow H.) Leaves oblong to oval, the upuermost united into oval disks, dark green, not glaucous above, but pale or glaucous beneath; inflorescence short, capitate; corolla orange-yellow, the tube not gibbous at base, only slightly hairy within. - Mts. of N. C. to Ky., Mo., and southw. Apr., May.

\section{SYMPHORICÁRPOS [Dill.] Ludwig. SNOWBERRY}

Calyx-teeth short, persistent. Corolla bell-shaped, regularly 4-5-lobed, with as many short stamens inserted into the throat. Berry 4-celled, 2-seeded. Seeds bony. - Low and branching upright shrubs, with oval short-petioled leaves, which are usually downy underneath and entire, or wavy-toothed or lobed on the young shoots. Flowers white, tinged with rose-color, in close short spikes or clusters. (Name composed of $\sigma \nu \mu \phi o \rho \epsilon i \nu$, to bear together, and

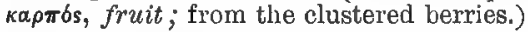

* Style bearded; fruit red; flowers all in short dense axillary clusters.

1. S. orbiculàtus Moench. (Indian Currant, Coral-Berry.) Flowers in the axils of nearly all the leaves; corolla sparingly bearded; berries small. (S. vulgaris Michx.; S. Symphoricarpos MacM.) - Rocky banks, N. Y, to Dak., s. to Ga. and Tex.; escaping from cultivation eastw. July.

\section{* Style glabrous; fruit white; flowers in clusters or sometimes solitary.}

2. S. occidentàlis Hook. (WolfBerRy.) Flowers in dense terminal and axillary spikes; corolla funnel-form, much bearded within; stamens and style protruded. - Rocky ground, n. Mich. and Ill. to Kan., w. to the Rocky Mts.

3. S. racemosus Michx. (SNow Berrr.) Shrub, 2-10 dm. high; leaves from elliptic-oblong to orbicular, green both sides, pilose beneath; flowers 1-2, or in short interrupted spiles at the ends of the branches; corolla campanulate, bearded inside; stamens and style included. (Var. pauciflorus Man. ed. 6, in part, not Robbins; $S$. pauciflorus Britton, in part.) - Dry limestone ridges and banks, n. e. Que. to Alaska, s. to w. Mass., centr. Pa., Mich., Mont., Ida., and Cal. June, July.

Var. pauciflorus Robbins. Dwarf shrub; leaves more or less pubescent, strongly whitened underneath. (S. pauciflorus Britton, in part.) - L. Superior to L. Winnipeg; and locally in the mots. from Alb. to Ore. and Col.

Var. laevigàtus Fernald. (SNowberRY of the gardens.) Taller shrub (1-1.5 m. high); leaves glabrous beneath; flowers often numerous in interrupted spikes. (S. racemosus of auth., tot Michx.) - Saguenay Co., Que., to Wash., locally in the mts. to Va.; freely cultivated and commonly escaping to roadsides, etc.

\section{IINNAEA [Gronov.] L. Twin-Flower}

Calyz-teeth 5, awl-shaped, deciduous. Corolla slender-bell-shaped or funnelform, almost equally 5-lobed. Stamens 4, two of them shorter, inserted toward the base of the corolla. Ovary and the small dry pod 3-celled, but 1-seeded. A slender creeping and trailing little evergreen, somewhat hairy, with roundedoval sparingly crenate leaves contracted at the base into short petioles, and thread-like upright peduncles forking into 2 (rarely 4 or 6 ) pedicels at the top, each bearing a delicate and fragrant nodding flower. Corolla whitish, tinged and striped with rose-purple, hairy inside. (Dedicated to the immortal Linnaeus, who first pointed out its characters, and with whom the European typ 3 of this pretty little plant was a special favorite.)

1. L. borealis L., var, americàna (Forbes) Rehder, - Moist mossy woods and cold bogs, Lab. to N. J. and the mts. of Pa. and Md., w. to Minn.; also fal northw, and westw. June-Aug.; rarely flowering in late autumn. 


\section{Trióstedm L. Feverwort. Horse Gentian}

Calyx-iobes linear-lanceolate, leaf-like, persistent, Corolla tubular, some. what equally 5-lobed, scarcely longer than the calyx. Ovary mostly :3-crlled, in fruit forming a dry drupe containing 3 ribbed 1-seeded bony nutlets. - Coarse hairy perennial herbs, leafy to the top; the ample entire pointed leaves tapering to the base or connate round the simple stem. Flowers solitary or clustered in the axils. (Name an abbreviation of Triosteospermum, alluding to the three bony nutlets.)

1. T. perfoliàtum L. (TINkeR's WeED, WILD CofFee.) Coarse, 0.5 to 1.2 m. high; stem densely glandular-puberulent above; leaves dark green, thickish, oval, the primary ones abruptly narrowed below to connate-clasping bases 2-7 ' $m$. broad, the uppermost tapering or scarcely connate at base; corolla tubularcampanulate, hardly bilabiate, from purplish to yellowish or greenish, about equaling the stamens; fruits usually 6-8 at each node, subglobose, dull orangeyellow. - Rich low woods, s. Mass. to Neb., Mo., and Ala. Fl. May, June; fr. Aug., Sept.

2. T. aurantiacum Bicknell. Sparingly glandular-puberulent, and with spreading longer glandless heirs, or glabrate; leaves ovate-oblong to oblonglanceolate, abruptly narrowed below to winged sessile hardly clasping hases $(0.5$ to $1.5 \mathrm{~cm}$. broad $)$; corolla dilated above, distinctly bilabiate, purplish-red, much exceeding the stamens; fruits $2-6$ at each node, ellipsoid-ovoid, bright orange-red.-- Upen rocky or sandy woods, N. B. to Ont., Ia, and N. C. Fl. May, June; fl. Aug,-Oct.

3. T. angustifolium $\mathrm{L}$. Smaller, bristly-hairy; leaves lanceolate, tapering to the base; flowers greenish-cream-color, mostly single in the axils. - Shady grounds, Ct. to Del. and Ala., w. to Mo. Fl. May ; fx. Aug.

\section{VIBÚRNUM [Toum.] L. Arrow-wood. Laurestinds}

Calyx. 5-toothed. Corolla spreading, deeply 5-lobed. Stamens 5. Stigmas 1-3. Fruit a 1-celled 1-seeded drupe, with soft pulp and a thin-crustaceous (flattened or tumid) stone. - Shrubs, with simple leaves, and white (rarely pink) flowers in flat compound cymes. Petioles sometimes bearing little appendages which are evidently stipules. Leaf-buds naked, or with a pair of scales. (The classical Latin name, of unknown meaning.)

a. Cymo radiant, the unarginal flowers neutral and very showy.

Leaves plnnately veined, not lobed

Leaves palmately veined, 3-lobed

u. Cymes not radiant, the flowers all small and uniform $b$.
$b$. Leaves for the most part palmately veined and 8 -lobed.

Leaves glabrous ; drupe bright red ; stone flat

Leaves soft-dowuy beneath ; drupe finally purple-black; stone lenticular

b. Leaves pinnately veined, not lobed $\dot{c}$.

c. Loaves prominently toothed and with straightish veins; stone grooved $d$.

a. Stipules slender, prominent, exceeding the very short petioles; stone flat

d. Stipules wanting or much shorter than the petioles; stone deeply grouved.

Winter-buds naked ; leaves finely toothed

Winter-buils covered by scales; leaves coarsily toothed.

Petioles stipulate; bark of older branches loose and exfoliating Petioles without stipules; bark close.

Lower surface of leaves, petloles, and young branchlets stellate-tomentose.

Principal leaves with $7-11$ pairs of veins, the teeth acute

Princlpal leaves with 5-T pairs of veins, the teeth blunt

Lower surface of leaves and petioles glabrous, or with simple caducous hairs

c. Leaves finely toothed or entire; the veins inconspicunis, ourred and

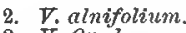

3. V. Opulus.

4. V. pauciflorum.

5. T. acerifolium. anastomosing; stone flat and even $\theta$.

o. Cymes poduncled; drupes less than $1 \mathrm{~cm}$. long.

Peduncle usually shorter than the rays of the cyme; leaves dull above. 
Peduncle usually longer than the rays; leaves glossy above

e. Cymes sessile; drupes more than $1 \mathrm{~cm}$. long.

Leaves subtending the inflorescence mostly caudate-acuminato

Leaves blunt or merely acutish.

Winter-buds and petioles green and glabrous

Winter-buds and petioles red-tomentose.
12. T. nudum.

18. $\nabla$. Lentag̉o.

14. . prumifolium.

15. V. mufialum.

\$1. LAN'TANA Spach. Winter-buds naked; leaves pinnately veined; drupes coral-red, turning darker, not acid; stone sulcate.

1. V. Lantana L. (Wayfaring Tree.) Shrub or small tree; the buds, young branches, lower surface of the leaves, etc., cinereous with minute stellate pubescence ; leaves cordate-ovate to broad-oblong, closely serrulate; cymes shortpeduncled, about 7-rayed; the flowers small and all alike. - Frequently cultivated, and occasionally established by roadsides, etc. (Introd. from Eurasia.)

2. V. alnifòlium Marsh. (HоввLe-вush, Witcr Hobrle, Moosewood.) Leaves 1-2 dm. across, round-ovate, abruptly pointed, heart-shaped at the base, closely serrate, the veins and veinlets beneath with the stalks and branchlets very rusty-scurfy (midsummer leaves sometimes narrower, coarsely toothed, thin and glabrous); cymes sessile, commonly 5-rayed, very broad and flat, the marginal flower's neutral, with greatly enlarged flat white (rarely pink) corollas. (V. lantanoides Michx.) - Moist woods, N. B. to Ont. and Mich., s. to Pa., and in the mts. to $\mathbf{N}$. C. May, June. - A straggling shrub; the reclining branches often taking root.

§2. OPULUS [Tourn.] DC. Winter-buds scaly; leaves palmately veined and lobed; drupe bright red, acid, globose; stone very flat, orbicular, not sulcate.

3. V. Ópulus L., var. americànum (Mill.) Ait. (CRANBerri-Trié, Highhush Cranderry, Pimbina.) Nearly smooth, upright, 1-4. m. high; leaves 3-5libbed, strongly 3-lobed, broadly wedge-shaped or truncate at base, the spreading lobes pointed, mostly toothed on the sides, entire in the sinuses; petioles bearing 2 glands at the apex; cyme broad, the marginal flowers neutral, with greatly enlarged flat corollas; stamens elongate. ( $V$. americanum Mill.) In woods and along streams, Nfd. and e. Que. to B. C., s. to N. J., Pa., Mich., Wisc., and n. e. Ia. June, July. (E. Asia.) - The acid fruit of this and the next is a substitute for cranberries. 'The well-known SNow-Bald Tree, or Guelder Rose, is a cultivated state of the typical Old World form, with the whole cyme turned into showy sterile flowers.

4. V. pauciflorum Raf. (Squashoterre, Pimbina.) A low straggling shrub; leaves glabrous or loosely pubescent beneath, 5-ribbed at base, unequally serrate nearly all round, with 3 short lobes at the summit; cyme fen-flowered, the flowers small and uniform; stamens shorter than the corolla. - Cold woods, Nfd. and Lab. to Alaska, s. to the mts. of Cape Breton I., n. N. E., Allegheny Co., Pa. (according to Porter), n. Mich., Minn., Col., and Wash. June, July.

§3. EUVIBÚRNUM Koehne (restricted). Winter-buds scaly; leaves pinnately veined (except in no. 5), the veins straightish and lerminating in coarse teeth; cymes never radiant, peduncled; dripes blue to biack; stone usually grooved.

\section{* Leaves 3-ribbed from the rounded or subcordate base, somewhat 3-lobed.}

L 5. V. acerifolium I. (Dockmackie, Arrow-wood.) Shrub, 1-1.5 m. high; leaves soft-downy beneath, the pointed lobes diverging, unequally toothed; stipules bristle-form ; cymes small, slender-peduncled; stamens exserted ; fruit crimson, turning purple-black; stone lenticular, hardly sulcate. - Rocky woods, N. B. to Minn., Ky., and Ga. May, June. - Leaves crimson in autumn.

* Leaves cordate or subcordate at base, coarsely toothed, prominently pinnateveined.

+- Stone flat; leaves all short-petioled or subsessile.

6. V. pubéscens (Ait.) Pursh. (Downy A.) A low straggling shrub; leaves ovate or oblong-ovate, acute or taper-pointed, the veins and teeth fewer and lesg 
conspicuous than in no. 10, the lower surface and very short petioles soft-downy, at least when young; fruit dark purple; the stone slightly 2-sulcate on the faces. - Calcareous ridges and banks, w. Que. and Vt. to Man., s. to Ga., Ill., Ia., and Wyo. May, June.

\section{+ + Stone very deeply sulcate ventrally; leaves rather slender-petioled.}

7. V. mólle Michx. Surub, 3-4 m. high, with gray exfoliating bark; leaves suborbicular or broadly ovate, short-acuminate, cordate, coarsely dentate, dark green and glabrous above, pale and soft-pubescent beneath, 5-13 cm. long, on petioles $2-4 \mathrm{~cm}$. long; stipules rather short, finally deciduous; fruit dryish, ellipsoid, $1 \mathrm{~cm}$. long, much compressed; stone deeply grooved. ( $\boldsymbol{V}$. Demetrionis Deane \& Robinson.) - Bluffs and rocky woods, Ky. (and probably O.), Mo., and Ia. May.

8. V. venosum Britton. Shrub, with close gray-brown bark, the young branches cinereous with stellate tomentum; leaves elliptic-ovate to orbicular, 3-6 cm. long, sharply serrate-dentate, dark green above, beneath pale with stellate tomentum and with $7-9$ pairs of prominent veins; cymes $4-6 \mathrm{~cm}$. broad, the, long peduncle and 7 rays pubescent; drupe subglobose or shortwovoid, $7 \mathrm{~mm}$. long. ( $V$. molle Man. ed. 6, in part, not Michx.) - Dry open soil, Martha's Vineyard and Nantucket to Pa. and Del. June, July. Var. CÁsbri Rehder. Leaves larger ( $5-8 \mathrm{~cm}$. long), glabrous or glabrate beneath; cymes 7-9 cm. broad. - Pa. and Del. to the mis. of Va.

9. V. scabréllum (T. \& G.) Chapm. Similar; branches reddish-bronon; leaves oblcing to obovate, rarely orbicular, 4-10 dm. long, shallovily crenate-dentate, with 5-7 pairs of less prominent veins; cymes similar, the flowers larger. ( $V$. molle Man. ed. 6, in part, not Michx.; V. semitomentosum Rehder.) Woods and banks of streams, Pa. to Fla. and Tex. June.

10. V. dentàtum L. (ARRow-wood.) Smooth, 1-4.5 m. high, with ashcolored bark; leaves broadly ovate, glabrous, or with hairy tufts in the axils beneath, very uumerously sharp-toothed and strongly veined, $5-8 \mathrm{~cm}$. long; fruit globose-ovoid, $6 \mathrm{~mm}$. long; cross-section of stone between kidney- and horseshoe-shaped. - Wet places, N. B. to n. Ga., W. to W. N. Y. and s. Ont. June, July.

§ 4. TiNUS (Borkh.) Koehne. Winter-buds with opposite scales; leaves finely toothed or entire, pinnately veined, the veins curved and anastomosing near. the margin; drupes blue or black, sweet; stone flat and even.

11. V. cassinoides L. (WITHE-ROD, WILD RAISIN.) Shrub or small tree. $0.5-3.6 \mathrm{~m}$ high; shoots scurfy-punctate; leaves thickish and opaque or dull, ovate to oblong, mostly with obtuse acumination, obscurely veiny, $2.5-10 \mathrm{~cm}$. long, with margins imegularly crenulate-denticulate or sometimes entire; peduncle shorter than the usually b-rayed cyme; drupe ellipsoid to spherical, 6-9 mm. long, yellowish and pink when young, finally blue-black, with a bloom. - Swamps and open situations, Nfd. to N. C., Minn., and Man. June, July.

12. V. nùdum L. Similar; obscurely scurfy-punctate; leaves more veiny, thickish, oval, oblong or lanceolate, entire or obsoletely denticulate, lucid above, 5-10 cm. long; perincle usually equaling the cyme. - Ct. to Ky., Fla., and Tox.

13. V. Lentàgo L. (Sweet Viburnim, Sheepberry, NanstrerkT, Wili) RaIsin.) Shrub or tree, sometimes $9 \mathrm{~m}$. high ; leaves ovate, closely and very sharply serrate, at least the upper caudate-acuminate and on winged petioles; cyme sessile, $6 \cdot 10 \mathrm{~cm}$. broad, 3-4-rayed; drupe ovoid or ellipsoid, blue-black, 1-1.5 cm. long - Woods and banks of streams, Que. to Man., and southw. May, June. An extreme form with spherical fruit 8-10 $\mathrm{mm}$. in diameter has been distinguished as var. SPHA L ROCÁRPum Gray.

1 14. V. prunifolium L. (BцAck $\mathrm{HAw}_{\mathrm{A}}$ ) Tall shrub or snall tree; leaves oval, obtuse or slightly pointed, finely and sharply serrate, $2-7 \mathrm{~cm}$. long, the lower surfcces and slender or slightly winged petioles glabrous; cyme 3-5-rayed; fruit ellipsoid or ovoid, similar to that of the preceding species or rather smaller. - Dry ox moist ground, Ct. to Mich., Kan., and southw. May, June. The extreme form with smaller globose fruit is var. GLORosum Nash, 
15. V. rufidulum Raf, Similar ; the winter-buds, wing-margined petioles, and lower leaf-surfaces red-tomentose; leaves often larger (4-9 cm. long). (V.rufotomentosum Small.) - Woods and thickets, Va, to Ill., Kan., and southw. Apr., May.

\section{SAMBÙCUS [Tourn.] L. ELDER}

Calyx-lobes minute or obsolete. Corolla open-urn-shaped, with a broadly spreading 5-cleft limb. Stamens 5. Stigmas 3 . Fruit a berry-like juicy drupe, containing 3 small seed-like nutlets. - Shrubby plants, with a rauk smell when bruised, pinnate leaves, serrate-pointed leaflets, and numerous small flowers in compound cymes. (The Latin name, perhaps from $\sigma \alpha \mu \beta u ́ k \eta$, an ancient musical instrument.)

1. S. canadénsis L. (Соммом E.) Stems scarcely woody, 1-4 m, high, with white pith; leaflets 5-11, oblong, mostly smooth, the lower often 3-parted; cymes flat; flowers white; fruit black-purple.-Rich soil, in open places, throughout our range, also southw. and westw. June, July.

2. S. racemosa L. (ReD-BerRied F.) Stems woody, $0.5-3.5 \mathrm{~cm}$. high, the bark warty, the pith brown; leaflets $5-7$, ovate-lanceolate, downy underneath; cymes panicled, convex or pyramidal; flowers yellowish-white, sometimes tinged with crimson; fruit bright red (rarely white). (S. pubens Michx.) - Rocky woods, Nfd. to B. C., s. to Ga., Mich., Ia., Col., ete. May ; fruit ripening in June. (Eu.) Var. LAciniat Koch. Leaflets divided into linear-lanceolate or laciniate segments. - L. Superior and "Pa."

\section{ADóXA L. Moschated}

Calyx-tube reaching not quite to the summit of the 3-5-celled ovary; limb of 3 or more teeth. Corolla wheel-shaped, 4-6-cleft, bearing at each sinus a pair of separate or partly united stamens with 1-celled anthers. Style 3-5-parted. Dry drupe greenish, with 3-5 cartilaginous nutlets. - A dwarf perennial, with scaly rootstock and ternately divided leaves, the cauline a single pair. An

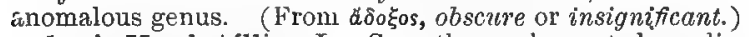

1. A. Moschatéllina L. Smooth, musk-scented; radical leaves 1-3-ternate, the cauline 3-cleft or 3-parted; leaflets obovate, 3-cleft; flowers several in a close cluster on a slender peduncle, greenish or yellowish. -.- Mossy woods, wet rocks, etc., n. e. Ia., Wisc., Minn., and northw. June, July. (Eurasia.)

\section{VALERIANÀceae (VAlerian Familt)}

Herbs, with opposite leaves and no stipules; the calyx-tube adherent to the ovary, which has one fertile 1-ovuled cell and two aborlive or empty ones; the stamens distinct, 1-3, fewer than the lobes of the corolla, and inserted on its tube. Corolla tubular or funnel-form, often irregular, mostly 5-lobed, the lobe: imbricated in the bud. Style slender; stigmas 1-3. Fruit indehiscent, 1-celled (the two empty cells of the ovary disappearing), or 3-celled, two of the cells empty, the other 1-seeded. Seed suspended, anatropous, with a large embryc and no albumen. Flowers in panicled or clustered cymes, - Roots often odorous and antispasmodic.

1. Valeriana. Calyx-11mb of several plumose bristles. Perenniala.

2. Valerianella. Calyx-limb entire or merely toothed. Annuals or blennlals.

\section{VALERIÀNA [Tourn,] L. VALERIAN}

Calyx-limb of several plumose bristles (like a pappus) which are rolled up inward in flower, but unroll and spread as the seed-like 1-celled fruit matures. Corolla commonly gibbous near the base, the 5-lobed limb nearly regular. Sta- 
mens 3. - Perennial herbs, with thickened strong-scented roots, and simple or pinnate leaves. Flowers in many species imperfectly dioecious or dimorphous. (A mediaeval Latin name of uncertain origin.)

* Root spindle-shaped, large and deep, 1.5-3 dm. long; leaves thickish.

1. V. edùlis Nutt. Smooth, or minutely downy when very young; stem straight, 3-12 dm. high, few-leaved; leaves commonly minutely and densely ciliate, the basal spatulate and lanceolate, the cauliue pinnately parted into 3-7 long and narrow divisions; flowers in a long and slender interrupted panicle, nearly dioecious; corolla whitish, obconical, $4 \mathrm{~mm}$. long. - Wet plains and prairies, $O$. and Ont. to Ia., Minn., and westw.; sometimes cultivated, and escaping eastw. May, June.

$$
\text { * Root fibrous; leaves thin; stems 3-15 dm. high. }
$$

2. V. uligindsa (T. \& G.) Rydb. (Swamp V.) Smooth or minutely pubescent; root-leaves ovate or oblong, entire, rarely with small lobes; stem-leaves pinnate, with 7-1n oblong-ovate or lanceolate nearly entire leaflets; cyme at first close, many-flowered; corolla inversely conical, $6 \mathrm{~mm}$. Iong, rose-color or white. (V. sylvatica Man. erl. (6, not Banks.) - Wet ground, chiefly under Arbor Vitae and Larch, e. Que. to w. Ont., s, to Me., Vt., s. N. Y., and Mich. JuneAug.

3. V. officinalis L. (Garuen Heliotrope.) Coarse, somewhat pubescent, especially at the nodes; leaves all pinnate, with many lanceolate leaflets; cyme many-flowered ; corolla white or rose-color, $4 \mathrm{~mm}$. long. - Roadsides and thickets, N. E. to N. J. and O.; escaped from cultivation. (Nat. from Eu.)

4. V. pauciflora Michx. Smooth, slender, surculose; root-leaves ovate, heart-shaped, toothed, pointed, sometimes with 2 small lateral divisions; stemleaves pinnate, with $3-7$ ovate toothed leaflets; branches of the panicled cyme few-flowered; tube of the pale pink corolla slender, $1 \mathrm{~cm}$. long. - Woods and alluvial banks, Pa. to s. Ill., Mo., and Tenn. June.

\section{Valerianella [Tourn.] Hill, Corn Salad, Lamb's Lettuce}

Limb of the calyx obsolete or merely toothed. Corolla funnel-form or salverform, equally or unequally 5-lobed. Stamens 3, rarely 2. Fruit 3-celled, two of the cells empty and sometimes confluent into one, the other 1-seeded. - Annuals and biennials, usually smooth, with forking stems, tender and rather succulent leaves (entire or cut-lobed toward the base), and white or pale cymose-clustered and bracted small flowers. Our species all have the limb of the calyx obsolete, and are so much alike in aspect, flowers, ete., that good characters are to be taken only from the fruit. (Name a diminutive of Faleriana.)

\$ 1. Corolla nearly regulav, funnel-form; the tube short; fruit with 2 empty cells manifest, or often enlarged and closed, sometimes confluent into 1 cell.

* Corolla bluish; fruit with a corky mass at the back of the fertile cell.

iv 1. V. Locústa (L.) Betcke. Fruit flattish, obliquely rhomboidal; empty cells as large as the fertile, contiguous, the thin partition at length breaking up. ( $T^{r}$. olitoria Poll.) - Old fields and waste places, Me. to w. N. Y., Ont., and southw. - Sometimes cultivated for salad. (Introd. from Eu.)

* *orolla white; no corky mass behind the fertile cell.

+ Fertile cell broader than the empty ones; cross-section of frut triangular.

2. V. chenopodifolia (Pursh) DC. Stems with long internodes and few forks; glomerate cymes few, slender-peduncled; bracts broadly lanceolate; fruit glabrous or pubescent, $4 \mathrm{~mm}$. long, - Moist gronnds, w. N. Y. to Minn., s. to Va. and $\mathrm{Ky}$.

+ +- Fertile cell as broad as the empty ones, beaked; cross-section quadrate.

3. V. radiàta (I.) Dufr. Fruit ovate-tetragonal, dov"ny-pubescent; empty cells as thick as the oblong-ovate fertile one, or thicker, "broad shallow groove 
between them. - Low grounds, Mass. to Mimn., Tex., and Fla. Var. LemockrpA (T.\& (i.) Krok. Fruit glabrous. - Of similar range, not rare.

4. V. stenocárpa (Engelm.) Krok. Fruit oblong-tetragonal, commonly gløbrons; oblong fertile cell thicker than the linear-oblong approximate empty ones. - Mo. and Kan. to Tex.

+ + + Fertile cell, much the narrowest, dor'sally 1-nerved, section roundish.

5. V. Woodsiàna (T. \& G.) Walp. Fruit $2 \mathrm{~mm}$. long or more; fertile c.ll ovate, tipped with a tooth ; empty ones inflated, with oblong depression (sonut:times an open cavity) in the middle. - Moist grounds, N. Y. to Tex.

Var. umbilicàta (Sulliv.) Gray. Empty cells becoming confluent, vesicular by incurvation of the circular margin, forming a deep and round umbilication.N. Y. to 0 ., and southw.

Var. patellària (Sulliv.) Gray. Fruit saucer-shaped, emarginate at base and apex, winged by the divergent cells. - Same range.

§2. SIPHONELLA, (T. \& G.) Walp. Corolla salver-form; the tube slender, '-4 times the length if the litabiate limb; fruit with divergent empty cells' much larger than the fertile.

6. V. longiflora ( $\mathrm{T}$. \& G.) Walp. - Frect several times dichotomously branched annual; leaves oblong, the lower spatulate; corolla $12 \mathrm{~mm}$. long, rose-tinged or purplish. - Rocky places, Mon and Ark.

\section{dipsacàceae (T'easet Familt)}

Herbs, with opposite or whorled leaves, no stipules, and the flowers in dense heads, surrounded by an involucre, as in the Composite Family; but the stamens distinct, and the suspended seed destitute of albumen.-Represented by the following introduced genera.

1. Dipsacus. Chaff of the receptacle with long rigid points.

2. Succisa. Chaff herbaceous, about equaling the flowers, not rigid-pointed.

3. Knautia. Chaff none.

\section{DÍPSACUS [Tourn.] L. Teaset}

Involucre many-leaver, longer than the chaffy leafy-tipped bracts among the densely capitate flowers; each flower with a 4-leaved calyx-like involucel investing the ovary and fruit (achene). Calyx-tube adherent to the ovary, the limb cup-shaped, without a pappus. Corulla nearly regular, 4-cleft. Stamens 4 , inserted on the corolla. Style slender. - Stout and coarse biennials, hairy or prickly, with large ovoid-ellipsoid heads. (Name from $\delta\llcorner\psi \hat{\eta} \nu$, to thirst, probably because the united cup-shaped bases of the leaves in some species hold water.)

1. D. sylvéstris Huds. (WiLD T.) Pirickly; leaves lance-oblong, toothed and often prickly on the margin; leaves of the involucre slender, ascending, longer than the head; bracts (chaff) tapering into a long flexible awn with it straight point. - Roadsides, rather rare. (Nat. from Eu.)

2. D. Laciniatus L. Leaves pinnatifid or bipinnatifid, finely and rather conspicuously ciliate; leaves of the involucre lance-linear, spreading, usually shorter than the head. - Established at Albany, N. Y. (Peck). (Adv. from Eu.)

\section{SuCCÌSA (Rupp.) Neck. Devil's-biT}

Involucre many-leaved. Involucels (often called outer calyx) closely investing the ovary and fruit, 4-8-furrowed throughout their entire length, prismatic or somewhat fusiform, the limb shortly 4-lobed or -toothed, erect or spreading. Limb of the true calyx minutely 5-toothed, or of 5 awns. Corolla funnel-form or campanulate, $4(-5)$-lobed. Stamens 4 . borne on the corolla. 
(Name from succidere, to bite off, from the praemorse rootstock.) Often united with ScaBioga L.

1. S. PRaténsis Moench. Smoothish or hairy, 4-9 dm. high; leaves chiefly basal, oblanceolate, undulate or entire, the cauline mostly 2 pairs, considerably reduced; heads subglobose; involucels somewhat 4-angled, villous, 4-toothed; calyx-limb 5-awned; corolla bright blue. (Scabiosa Succisa L.) - To some extent established in fields about Louisburg, Cape Breton I. (Macoun). (Adv. from $\mathrm{Eu}$.)

2. S. Australlis (Wulf.) Reichenb. Tall, loosely and mostly trichotomously branched, covered above with minute crisped mostly reflexed gray hairs ; leaves elongated-lanceolate; heads 8-15 mm. in diameter, at length subcylindric; involucels glabrous, somewhat fusiform, 8-ribbed, with small crenate-lobed spreading border; calyx shortly 5-toothed, without awns; corolla light blue. (Scabiosa Wulf.) - Locally established in meadows, etc., Mass., N. Y., and Pa. (Nat. from $\mathrm{Eu}$.)

\section{KNAƯTIA L.}

Involucre, habit, etc., much as in the preceding. Chaff wanting, but the receptacle more or less hairy. Involucels strongly compressed, the limb obscure, at most indicated by minute teeth. Calyx cup-shaped, the limb mostly 8-awned. Corolla light blue to lilac-purple, rarely pink or white. (Dedicated to Christian Knaut, 1654-1716, Sazon physician and botanist.)

1. K. Anvénsis (L.) T. Coulter. Pubescent, 4-9 dm. high, few-branched; some or all of the leaves deeply pinnatifid or bipinnatifid; heads depressed-hemispherical ; corollas lilac. (Scabiosa L.) - Dry pastures, etc., e. Que. and N. E. to Pa., locally well established and abundant. (Nat. from Eu.)

\section{CUCurbitàceae (Gourd Famit)}

Mostly succulent herbs with tendrils, dioecious or monoecious flower's, the calyx-tube adhering to the 1-3-celled ovary, and the 5 or usually $2 \frac{1}{2}$ stamens (i.e. 1 with a 1-celled and 2 with 2-celled anthers) commonly united by their often tortuous anthers, and sometimes also by the flaments. Fruit (pepo) fleshy, or sometimes membranaceous. Limb of the calyx and corolla usually more or less combined. Stigmas 2 or 3. Seeds large, usually flat, anatropous with no albumen. Cotyledons leaf-like. Leaves alternate, palmately lobed or veined. - Mostly a tropical or subtropical family.

* Flowers large, yellow; stem tratling.

1. Cucurbita. Corolla campanulate, deeply 5-lobed. Frult large, indehiscent, fleehy.

* * Flowers small, white or greenish; stems high-climbing by tendrils.

+ Fruit prickly ; seeds few, orect or pendulons; flowers white; annual. + Ovary 1-celled; seed solitary, pendulous.

2. Sicyos. Corolla of the sterile flowers flat and spreading, 5-lobed. Fruit indehiscent. + + Ovary 2-8-celled; seeds few, erect or ascending.

8. Echinocystis. Corolla of the sterlle flowers flat and spreading, 6-parted. Anthere 8. Fruit bladdery, 2-celled, 4-seeded, bursting at the top.

+ + Fruit smooth; seeds numerous, horlzontal, attached to the 8-5 parletal placentae; perennial.

4. Melothria. Flower's small, greenish; corolla 5-parted. Slender, climbing. Fruit small.

\section{Cucúrbita [Tourn.] L. Gourd. Sedash. Pdupkin}

Flowers monoecious. Corolla campanulate, deeply 5-lobed, the lobes with recurved tips. Anthers united, 1 of them 1-locular, the others 2-locular. Style short, with 3 lobed or divided stigmas. Fruit fleshy, covered by a firm rind, with many horizontal seeds. - Herbs, with annual or perennial roots, large 
cordate angulate or lobed, leaves, large flowers solitary in the axils, and large fruits. (Classical Latin name for a gourd.)

1. C. foetidíssima H B K. (Missouri Gourd, Fetid Wild Pumpkin.) Stems elongate, scabrous, from a thickish fusiform root; leaves ovate, the margin somewhat angulate, denticuiate, densely scabrous-pubescent, somewhat whitened beneath ; corolla 5-12 cm. long; fruit smooth, subglobose, 7-8 mm. long. - Dry or sandy soil, Mo. to s. Cal, and Tex. (Mex.)

C. máxima Duchesue (Squash), C. moschata Duchesne (Croorneck Squash), and C. Pìro L. (PumpкiN) are familiar in cultivation, and incline to appear spontaneously in waste places southw., as do Cưcuxis Mìlo L. (Musrmelon), C. Sativus L. (Cucumber), Citrúllus vulgaris Schrad.. (Watermelon), and Lagenaria vulgaris Ser. (Gourd).

\section{Sícyos L. One-seeded Bur Cucumber}

Flowers monoecious. Petals 5, united below into a bell-shaped or flattish corolla. Anthers cohering in a mass. Ovary 1-celled, with a singls suspended ovule; style slender; stigmas 3. Fruit ovoid, dry and indehiscent, filled by the single seed, covered with barbed prickly bristles which are readily detached. Climbing annuals, with 3 -forked tendrils, and small whitish flowers; the sterile and fertile mostly from the same axils, the former corymbed, the latter in a capitate cluster, long-peduncled. (Greek name for the Cucumber.)

1. S. angulàtus L. Leaves roundish-heart-shaped, 5-angled or-lobed, the lobes pointed; plant clammy-hairy. - River-banks and damp yards, s. Me and w. Que. to Fla., w. to Minn., e. Kan., and Tex. July-Sept.

\section{ECHINOCÝSTIS T. \& G. WILD BALSAM-A PPLE}

Flowers monoecious. Petals 6 , lanceolate, united at the base into an open spreading corolla. Anthers more or less united. Ovary 2-celled, with 2 erect ovules in each cell; stigma broad. Fruit fleshy, at length dry, clothed with weak prickles, bursting at the summit, 2-celled, 4-seeded, the inner part fibrousnetted. Seeds large, flat, with a thickish hard and rougliened coat. - Tall climbing annual, nearly smooth, with 3 -forked tendrils, thin leaves, and very numerous small greenish-white flowers; the sterile in compound racemes often 3-4 dm. long, the fertile in small clnsters or solitary, from the same axils. (Name composed of $\epsilon \chi \hat{i} \nu o s, a$ hedgehog, and $\kappa \dot{\sigma} \sigma \tau \iota s, a$ bladder, from the prickly fruit.) Miorampelis Raf.

1. E. lobàta (Michx.) T. \& G. Leaves deeply and sharply 5-lobed; fruit ovoid, $5 \mathrm{~cm}$. long; seeds dark-colored. - Rich soil along rivers, N. B. to Pa. and Ky., w. to Man. and Tex.; also cultivated for arbors and freely escaping. July-Oct.

\section{MELÒTHRIA L.}

Flowers polygamous or monoecious; the sterile campanulate, the corolla 5 -lobed; the fertile with the calyx-tube constricted above the ovary, then campanulate. Anthers more or less united. Berry small, pulpy, filled with many flat and horizontal seeds. - Tendrils simple. Flowers very small. (Altered from $\mu \eta \hat{\lambda} \omega \theta \rho o \nu$, an ancient name for a sort of white grape.)

1. M. péndula L. Slender, from a perennial root, climbing; leaves small, roundish and heart-shaped, 5-angled or -lobed, roughish; sterile flowers few, in small racemes; the fertile solitary, greenish or yellowish; berry ovoid, green, $1 \mathrm{~cm}$. long. - Copses, Pa. to Fla., w. to Mo. and La.

\section{CAMPANulàceae (Bluebell Family)}

Herbs, with milky juice, alternate leaves, and scattered flowers; calyx adherent to the ovary; the regular 5-lobed corolla bell(rarely wheel)-shaped, valvate in the bud; the 5 stamens usually free from the corolla. Style 1, usually beset with collecting hairs above; stigmas 2 or more. Capsule 2-several-celled, many. 
seeded. Seed small, anatropous, with a straight embryo in fleshy albumen. Flowers generally blue and showy.

* Capsule opening by pores on the sides; anthers free.

1. Specularia. Corolla rotate, Capsule slender-cylindric o1" -prismatic.

2. Campanula. Corolla campanulate (rarely with flaring limb). Capsule obconic or turbinate to globose.

* * Capsule opening by valves at the apex; anthers connate at base.

?. Jasione. Flowers erowded into dense involuerate heads. Corolla with slender segments.

\section{SPECULARIA [Heist.] Fabricius. VenUs's Looking-glass}

Calyx 5(or 3-4)-lobed. Corolla wheel-shaped, 5-lobed. Stamens 5, sepa. rate; the membranaceous hairy filaments shorter than the anthers. Stigmas 3. Capsule prismatic or slender-cylindric, 3-celled, opening by 3 small lateral valves. - Low annuals, with axillary blue or purplish flowers, in American species rimorphous, the earlier small and cleistogamous. (Name from Speculum $\mathrm{Ve}_{e}$ neris, the early name of the common European species.) Legovzid Durande. L 1. S. perfoliàta (L.) A. DC. Somewhat hairy, 1-9 dm. high ; leaves roundish or ovate, clasping by the herrt-shaped base, toothed; flowers sessile, solitary or 2-3 together in the axils, only the upper or later ones having a conspicuous and expanding corolla; capsule ellipsoid, short, straight, opening rather below the middle; seeds lenticular. (Legouzia Britton.) - Sterile open ground, s. Me. to Ont., westw. and southw.

2. S. bifldra (R. \& P.) Fisch. \& Mey. Similar; leaves sessile, ovate or oblong, the upper narrower, slightly crenate; flowers solitary or by 2's in the axils, the lower with 3-4 short calyx-lobes, the upper with 4-5 longer lobes liardly equaling the corolla; capsule short-cylindric, the valves near the summit. (Legonzia Britton.) - Va., westw. and southw.

3. S. Ieptocárpa (Nutt.) Gray. Minutely hirsute or nearly glabrous, $1.5-4$ $\mathrm{dm}$. high; leaves lanceolate, with flowers closely sessile in their axils; calyxlobes of lower flowers 3 ; capsule nearly cylindrical, $1.5-2 \mathrm{~cm}$. long, $2 \mathrm{~mm}$. thick, inclined to curve, opening by one or two uplifted valves near the summit; seeds oblong. (Legouzia Britton.) - Dry open ground, w. Mo. and Ark. to Col, and w. Tex. - Expanded corolla 1-2 $\mathrm{cm}$. wide.

\section{CAMPÁNULA [Tourn.] L. BeLlfLower}

Calyx 5-cleft. Corolla generally bell-shaped, 5-lobed. Stamens 5, separate; the filaments broad and membranaceous at the base. Stigmas and cells of the capsule 3 in our species, the short pod opening on the sides by as many valves or holes. - Herbs, with terminal or axillary flowers. (A diminutive of the Italian campana, a bell, from the shape of the corolla.)

$u$. Flowers in glomerules, spikes, or racemes, mostly numerous $b$.

b. Flowers sessile, chiefly in glomerules or leafy-braoted heads

$b$. Flowers distinctly pediceled.

Calyx and outer surface of unexpanded corolla bristly-ciliate with long pale trichounes

Calyx aud corolla smooth, or the former minutely pubescent; racemes elongate and spiciform.

Corolla campanulate; style straight ; capsule campanulate-oroid,

Corolla rotate; style declined and upwardiy curved; cripsule obconle to suboylindric, the pores at the summit

11. Flower's 1-o, on slender peduncles or in loose inflorescences $c$.

c. Style nut exserted.

Stenns smooth (rarely villons), not retrorse-scabrous on the augles ; leaves not retrores-scabrous on the nerves and margin

Stems retrorse-scabrous on the angles; leaves witli retrorse-seabrous neives and margin.

Corolla $2-3 \mathrm{~cm}$. long

Corolla shorter.

Peduncles strougly divargant; corolia in-s mm. long

Peduncles ascending; corolla 10-12 mm. long.

c. Style long-exserted .

1. C. glomerata.

2. C. Trachelium.

3. C. rapunculoides

4. C. americana.

5. C. rotundifolia.

6. C. patula.

7. C. aparinoides.

8. C. uliginosa.

9. C. divaricata. 
1. C. glomerata L. (Cidstered B.) Somewhat hairy, stout and erect, 3-6 dm. high ; basal leaves lanceolate to oblong-ovate, long-petioled; stem-leaves oblong or lanceolate, cordate-clasping; flower's sessile, clustered in the upper axils, forming a leafy head; corolla open-bell-shaped, deep purple, $2-3 \mathrm{~cm}$. long. -- Roadsides, Que. and e. Mass. June, July. (Introd. from Eurasia.)

2. C. Tracheliom L. (Nettle-leaved B., Throatwort.) Stems simple below, 3-9 dm. high, often bristly above; basal leaves broadly cordate-ovate to reniform, coarsely toothed; the upper short-petioled or subsessile, ovate to lanceolate; flowers in 2's or 3's (rarely solitary) in terminal and axillary loose clusters; calyx bristly, the oblong-lanceolate lobes somewhat foliaceous; corolla 2.5-3.5 cm. long. - Roadsides and thickets, Quebec to Montreal, etc. Aug. (Introd. from Eurasia.)

3. C. Rapunculoìdes L. Stems slender, 6-10 dm. high, smoothish, or finely pubescent above; lower leaves long-petioled, cordate-ovate; the upper ovatelanceolate, short-petioled to sessile, irregularly serrate-dentate, hispidulous beneath; flowers nodding, single in the axils of bracts, forming racemes; calyx and capsule scabrous-puberulent; corolla campanulate, $2-3 \mathrm{~cm}$. long; capsule opening by pores at base. - Roadsides, thickets, etc., e. Que. to Ont., O., and s. N. Y. July, Aug. (Introd. from Eurasia.) Var. UCRÁnica (Bess.) C. Koch. Smoother; the calyx and capsule essentially glabrous. - Similar situations, Que. and N. E. (Introd. from Russia.)

4. C. americàna L. (TALL B.) Annual; stem mostly simple, 0.5-1.8 m. high; leaves ovate and ovate-lanceolate, taper-pointed, serrate, mostly on margined petioles, thin, somewhat hairy, $0.5-1.5 \mathrm{dm}$. long; spiciform raceme 3-6 $\mathrm{dm}$. long, the flowers solitary or clustered in the axils of the upper leaves and bracts; corolla rotate, light blue, $2.5 \mathrm{~cm}$. broad; capsule glabrous, opening by pores at the summit. - Moist rich soil, Ont. and N. Y. to Neb., s. to Ga. and Axk. June-Aug.

5. C. rotundifolia L. (Harebell, Bldebeld.) Slender perennial, simple to freely branched, 1-5 dm. high, 1 15-flowered; basal leaves (rarely present on the flowering stems) round-heart-shaped to ovate, mostly toothed, long-petioled, early withering; stem-leaves numerous, linear or narrowly lanceolate, smorth; calyx-lobes awl-shaped, from $\frac{1}{3}-\frac{2}{3}$ the length of the purplish-blue corolla $(1.5-2.5$ $\mathrm{cm}$. long); capsule nodding, short-ovoid to subcylindric, opening by pores at base. - Open or rocky banks, meadows, shores, etc., widely distributed in boreal regions, extending south in our range to N. J., the Great L. region, and Neb. (Eurasia.) - Extremely variable in stature, degree of branching, number and size of flowers, texture of foliage, divergence of calyx-lobes, etc., characters which seem to respond readily to slight changes of environment. Typical $C$. rotundifolia of Eurasia, with the stems closely puberulent all over at base, is comparatively scarce in eastern America, but becomes common westw. With us it passes to a commoner form (C. intercedens Witasek) in which the stems are glabrous or have the hairs confined to lines at the base of the stem. This in exposed situations becomes dwarfed and rigid (var. arctica Man. ed. 6, and perhaps Lange; var. Langsdorfiana Britton; C. dubia A. DC.). In shade the leaves are thin and elongate, in exposed situations firmer and shorter, characters upon which other artificial separations are sometimes made.

Var. velùtina DC. Stems and leaves canescent with close pubescence. Sand hills of Burt Lake, Mich. (E. J. Hill). (Eu.)

6. C. PATULA L. Enect slender annual or biennial, simple or with long ascending branches; stems retrorse-scabrous on the angles, in age smoothish; basal leaves spatulate or obovate, the cauline lanceolate to linear and sessile, entire or crenate, the nerves beneath and often the margins retrorse-scabrous; flowers long-peduncled; calyx-lobes linear-lanceolate; corolla 2-3 cm. long, purplish; capsule obconic, opening by pores at summit. - Locally in fields, Ct. (Adv. from Eu.)

7. C. aparinoides Pursh. (Marsh B.) Stem simple or branched, weak, 2-6 dm. long, somewhat 3-angled, rough backward on the angles, as are the slightly tootled edges and midrib of the lanceolate or linear-lanceolate soft leaves; flowers chiefly terminating strongly divergent leafy branches; lobes of 
the calyx triangular, half the length of the bell-shaped nearly white corolla (5-8 mm. long); capsule erect. - Wet grassy ground, Me. to Neb., s. to Ga., Ky., and Ill. June-Aug. - With the habit of a Galium.

8. C. uligindsa Rydb. Stiffer ; leaves linear or elongate-lanceolate; flowers chiefly borne on simple naked erect or ascending leafless peduncles $(2.5-5.5 \mathrm{~cm}$. long); corolla bluish, 10-12 mm. long.-Meadows and wet shores, N. B. to N. Y., Ia., and Sask. July, Aug.

9. C. divaricàta Michx. Very smooth; stem loosely branched, 3-9 dm. high ; leaves oblong-lanceolate, pointed at both ends, coarsely and sharply toothed; flowers numerous in a large compound panicle; calyx-lobes awl-shaped, about half the length of the small pale blue corolla ( $6-8 \mathrm{~mm}$. long); style exserted. Dry woods and rocks, mts. of Va. to $\mathrm{Ky}$, and southw.

\section{JASIÒNE L. SHEEP'S-BIT}

Calyx 5-lobed. Corolla with 5 very narrow lobes. Anthers united at base into a ring about the style. Capsule opening by 2 valves. - Herbs with small flowers in involucrate heads. (Name used by Theophrastus, perhaps for Convolvulus sepium.)

1. J. Montàa L. Annual or biennial, 2-5 dm. high, simple or branching; leaves linear or lanceolate; flowers blue, in heads 1-2 cu. broad. - Fields and roadsides, especially about Newport, R. I.; also sparingly elsewhere, from Mass. to N. Y. (Nat. from Eu.)

\section{LOBELIÀCEAE (LOBELIA FAMILY)}

Herbs, with acrid milky juice, alternate leaves, and scattered flowers, an irregular gamopetalous 5-lobed corolla, the 5 stamens free from the corolla and united into a tube conımonly by their filaments and always by their anthers. Calyxtube adherent to the many-seeded pod. Style 1 ; stigma often fringed. Seeds anatropous, with a small straight embryo, in copious albumen. - Often united with the preceding family.

\section{LOBÈLIA [Plumier] L.}

Calyx 5-cleft, with a short tube. Corolla with a straight tube split down on the (apparently) upper side, somewhat 2-lipped; the upper lip of 2 rather erect lobes, the lower lip spreading and 3-cleft. 'Two of the anthers in our species bearded at the top. Pod 2-celled, many-seeded, opening at the top. - Flowers axillary or chiefly in bracted racemes; in summer and early autumn. (Dedicated to Matthias de l'Obel, an early Flemish berbalist.)

\section{* Flowers deep red, large; stem simple.}

1. L. cardinàlis L. (CARDinaL-FLower.) Tall (0.5-1.3 m. high), perennial by offsets, smoothish; leaves oblong-lanceolate, slightly toothed ; raceme elongated, xather 1-sided, the pedicels much shorter than the leaf-like bracts; the large corolla intensely red, rarely rose-color or white. - Low grounds, s. $\mathbf{N}$. $B$. to Ont., and southw. - Hybrids with the next species occur.

* * Flowers blue, or blue variegated with white.

- Flowers rather large (corolla-tube 1-1.3 cm. long), spicate-racemose; stems leafy, 0.3-1 m. high; perennial.

* Leaves ovate to lanceolate, numerous; lip of corolla glabrous.

2. L. siphilitica I. (GReat Lobela.) Somewhat hairy; leavesthin, acute at both end $\hat{s}, 0.5-1.5 \mathrm{dm}$. long, irregularly serrate; flowers nearly $2.5 \mathrm{~cm}$. long, pediceled, longer than the leafy bracts; corolla light blue, rarely white; calyx hirsute, the sinuses with conspicuous deflexed auricles, the short tube hemispheri cal. - Low grounds, Me. to Ont., westw. and southw.; rare eastw. 
3. L. pubérula Michx. Finely soft-pubescent; leaves thickish, obtuse, 2.5-5 'm. long, with small glandular teeth; spike rather 1 -sided; bracts ovate; sin?ses of the calyx with short and rounded or often inconspicuous auricles, the hairy tube top-shaped; corolla bright blue, $1.5-2 \mathrm{~cm}$. long. - Moist sandy grounds, N. J. to Ia., s. to Tex. and Fla.

4. L. amoèna Michx. Glabrous or nearly so; raceme virgate; leaves narrower; bracts lanceolate or linear, often glandular-denticulate ; calyx-lobes long and very slender, usually without auricles, the tube glabrous, - South Atlantic States, in swamps. Var. gudxducffera Gray. A slender form with secund raceme, oval to lance-oblong obtuse gland-toothed leaves, and the bracts and calyx-teeth beset with slender gland-tipped teeth. - Del., and southw.

+ + Leaves long and narrow, sparse above; lip of corolla pubescent at base.

5. L. glandúlòsa Walt. Glabrous or sparingly pubescent ; leaves, bracts, and usually the lobes of the calyx strongly glandular-toothed; calyx-tube densely hispid, rarely sparsely so or smoothish, the sinuses not auriculate.- Pine barren swamps, s. Va. to Fla.

\section{+ + Flowers smaller (corolla-tube not more than 4-8 mm. long).}

+ Stem leafy, mostly simple, continued into an elongated virgate spike-like raceme; leaves lanceolate to obovate, barely denticulate or repand.

6. I. Ieptóstachys A. DC. Smooth above; leaves obtuse, thick, denticulate, oblong-lanceolate, the upper gradually reduced to awl-shaped bracts; calyxlobes nearly equaling the corolla, with 10 reflexed awl-shaped appendages as long as the hemispherical tube. - Sandy soil, O. to Kan.; also Va. to Ga.; rarely adventive in the Northeast.

7. L. spicàta Lam. Stem slender, strict, $0.3-1 \mathrm{~m}$. high, minutely pubescent below, as are the barely denticulate leaves; lower leaves obovate or spatulate, the upper reduced to linear or club-shaped bracts; calyx-tube short, obconical or becoming almost hemispherical, sinuses not appendaged. - Moist or dry mostly gravelly or sandy soil, P. E. I. to Ont., westw. and southw. Var. PARviFLón Gray. A small form, with calyx-lobes broadly subulate, and pale corolla but $6 \mathrm{~mm}$. long. - Swamps, Lancaster, Pa. (Porter). Var. Hirtéld A Gray. With somewhat scabrous pubescence, and minutely hirsute-ciliate bracts and calyx-lobes. - Ill., Mich., and northwestw.

+ - Stem leafy, often paniculately branched; flowers loosely racemose; sinuses of calyx not appendaged; annual or biennial.

= Leaves chiefly linear, entive or denticulate; pod not inflated.

8. L. Cánbyi Gray. Stem strict, 3-9 dm. high, minutely angled; pedicels shorter than the bracts and flowers, minutely roughened under a lens; bractlets none; calyx-tube top-shaped, acute at base, only half the length of the lobes (which, with the linear leaves, are sparsely glandular-denticulate), in fruit becoming ellipsoid, covering the whole pod; corolla deep blue, fully $1 \mathrm{~cm}$. long, more or less bearded in the throat. - Wet places, N. J., Del., and S. C.

9. L. Kálmii L. Stem mostly low (1-5 dm. high), minutely angled; pedicels filiform, not exceeding the linear or setaceous bracts, but as long as the flower, minutely 2-bracteolate or 2-glandular above the middle; calyx-lube top-shaped or obovoid, fully half the length of the lobes, in fruit rather longer than they, covering the whole pod; corolla light blue, $1 \mathrm{~cm}$. long. - Wet limestone shores and bogs, Nfd. to N. J., w. to n. Ia., Minn., and Man.

10. L. Nuttállii R. \& S. Stem very slender, 3-9 dm. high, terete; pedicels mostly longer than the bracts and shorter than the flowers, usually with very minute bractlets near the base; calyx-tube very short, depressed-hemispherical in fruit, the globular pod half free; corolla pale blue, $5-8 \mathrm{~mm}$. long. - Sandy swamps, L. I., N. J., and Pa. to Ga.

\section{$==$ Leaves ovate or oblong, obtusely toothed; pod inflated, wholly inferior.}

11. I. inflata L. (INdian ToBacco.) Stems paniculately much branched from an annual root, pubescent with spreading hairs, $3-8 \mathrm{dm}$. high; leaves 
gradually diminishing into leaf-like bracts, which éxceed the lower short-pediceled flowers; calyx-tube ovoid; corolla only $3-4 \mathrm{~mm}$. long. - Dry open fields and thickets. - Plant poisonous and a noted quack medicine.

+ + Stem scape-like, mostly simple, hollow; leaves fleshy; fibrous-rooted perennials, very glabrous, mostly aquatic, with pale blue or whitish flowers.

12. L. paluddsa Nutt. Nearly smooth; stem slender, $0.3-1.2 \mathrm{~m}$. high ; leaves flat, scatter'ed near the base, linear-spatulate or oblong-linear, glandular-denticulate, mostly tapering into a petiole ; lower lip of corolla bearded in the middle; calyx-tube about half the length of the short lobes, hemispherical in fruit. In water (but foliage emerging), Del, to Fla. and La.

13. L. Dortmánna L. (WATER LoBguia.) Very smooth; scape thickish, 1-5 (or in deep water even 9) dm. high, few-flowered; leaves all tufted at the base, linear, terete, hollow, with a partition lengthwise; lower lip of corolla slightly hairy; calyx-tube about as long as the lobes, in fruit much longer. Borders of ponds (often immersed), Nfd. to N. J., Pa., and northwestw.

(Eu.)

\section{compósitate (Сомposíte Family)}

Flowers in a close head (the compound flower of the older botanists), on a common receptacle, surrounded by an involucre, with 5 (rarely 4) stamens inserted on the corolla, their anthers united in a tube (syngenesious). Calyx-tube united with the 1-celled ovary, the limb (called a pappus) crowning its summit in the form of bristles, awns, scales, teeth, etc., or cup-shaped, or else entirely absent. Corolla either strap-shaped or tubular; in the latter chiefly 5-lobed, valvate in the bud, the veins bordering the margins of the lobes. Style 2-cleft at the apex (in sterile flowers usually entire). Fruit seed-like (achene), dry, containing a single erect anatropous seed, with no albumen. - An immense family, in temperate regions chiefly herbs, without stipules, with perfect, polygamous, monoecious, or dioecious flowers. The flowers with a strap-shaped (ligulate) corolla are called rays or ray-flowers; the head which presents such flowers, either throughout or at the margin, is radiate. The tubular flowers compose the disk; and a head which has no ray-flowers is said to be discoid. When the head contains two sorts of flowers it is said to be heterogamous; when only one sort, homogamous. The leaves of the involucre, of whatever form or texture, are termed bracts. The bracts or scales, which often grow on the receptacle among the flowers, are called the chaff; when these are wanting, the receptacle is said to be naked. The largest family of phaenogamous plants. The genera are divided by the corolla into three series, only two of which are represented in our region. The first is much the larger.

\section{Series I. TUBULIFLÒRAE}

Corolla tubular in all the perfect flowers, regularly 5(rarely 3-4)-lobed, ligulate only in the marginal or ray-flowers, which when present are either pistillate only, or neutral (with neither stamens nor pistil).

Tribe 1. VERNONiEAE. Heads discold ; the flowers all alike, perfect and tubular, never yellow. Branches of the style long and slender, terete, thread-shaped, minutely bristly-hairy all over. Leaves alternate or scattered.

1. Vernonia. Heads several-many-flowered, separate. Involucre of many bracts. Pappus double, the inner capillary, the outer of minute chaffy bristles.

2. Elephantopus. Heads 2-5-flowered, several crowded together into a compound head. Involucre of 8 bracts. Pappus of several chaffy bristles. 
Iribe II. EUPATORIEAE. Hends discoid; the flowers all alike, perfect and tubular, never yellow. Branches of the style thickened upward or club-shaped, obtuse, very minutely and uniformly pubescent; the stigmatio lines indistinct.

* Pappus n row of hard oval obtuse scales.

8. Sclerolepis. Head many-Howered. Bracts of the involuore equal. Leaves whorled.

* * Peppus of slender bristles.

+ Achene 5angled; bristles of the pappus roughish.

4. Eupatorium. Involucre of poore than 4 bracts and the flowers few or many. Stems not twining.

5. Mikania. Flowers and involncral bracts only 4. Stems twining.

++ Achene 10-ribbed ; involucral bracts striate-nerved.

6. Trilisa. Paypus minutely barbeliate. Corolia rose-purple. Heads corymbed or panicled, the involucre little imbricated.

7. Brickellia. Involucral bracts in several series. Pappus merely scabrous.

8. Kuhnia. Pappus very strongly plumose. Bracts of the involucre few.

9. Liatris. Pappus plumose or only barbellate. Corolla red-purple, strongly 5-lobed. Heads spicate or racemose, the involucre well imbricated.

Tribe III. ASTEREAE. Heads discoid, the flowers all alike and tubular; or else radiate, the outer ones ligulate and pistillate. Anthers not candate at base. Branches of the style in the perfect flowers flat, smooth up to where the conspicuous marginal stigmatic lines abruptly terminate, and prolonged above this into a flattened lance-shaped or triangular appendage which is evenly hairy all around or pubescent outside. Leaves alternate. Receptacle naked (destitute of chaff) in all our species.

* Ray-flowers yellow (in one species of no. 15 whitish), or sometimes none at all.

- Pappus of not numerous slender bristles; heads radiate; involucre of firm bracts with greenish tips, commonly coated with resin.

10. Grindelia. Heads large, many-flowered. Flowers all fertile. Pappus of 2-8 rigid caducous awns. Coarse herbs with toothed leaves.

11. Gutierrezia. Heads small, numerous. Ray-and disk-flowers 8 or 4 each, all fertile. Pappus of several short ebaffy scales. Suffrutescent; leaves very narrow.

12. Amphiachyris. Heads small. Ray-flowers 5-10; pappus coroniform. Disk-flowers infertile; pappus of several bristle-like seales. Annual; leaves very narrow.

++ Pappus (at least of the disk) of copious slender or capillary bristles.

$$
\text { + Pappus double. }
$$

18. Heterotheca. Resembling Chrysopsis, but the achenes of the ray thicker than those of the disk and without pappus or nearly so. Western.

14. Chrysopsis. Heads many-flowered ; rays numerous. The outer pappus of very small chaffy bristles, much shorter than the inner of copious capillary bristles.

$$
++ \text { Pappus simple. }
$$

15. Solidago. Heads few-many-flowered; rays 1-16. Pappus of numerous slender and equal capillary bristles.

16. Brachychaeta. Heads 8-10-flowered, elustered; rays 4 or 5. Pappus a row of minute bristles, shorter than the achene.

17. Aplopappus. Heads many-flowered, many-radiate. Involuere hemispherieal. Pappus of many unequal bristles. Western.

18. Bigelowia. Heads $3-4$-flowered; rays none. Receptacle awl-shaped. Pappus a single row of capillary bristles.

$$
\begin{aligned}
& \text { * * Ray-flowers white, blue, pink, or purple, scarcely ever yellow. } \\
& \text { + Pappus none or very short, with or without a few awns. } \\
& \text { + Receptacle conical; awns none. }
\end{aligned}
$$

19. Bellis. A chenes marginless, flattened; pappus none. Involucral bracts equal.

+++ Receptacle flat or convex ; pappus usually with awns.

20. Chaetopappa. Achenes fislform; pappus of 5 or fewer thin chaffy scales ana often alter natinir awns. Western. 
21. Boltonia. Achenes very fiat, thick-winged ; pappus of short bristles and usually $2-4$ awns. ++ Pappus of numerous long and capillary bristles; receptacle flat.

22. Aster. Heads many-flowered, on leafy peduncles. Involucral bracts mostly unequal, loosely or closely lmbricated. Achenes flattish; pappus simple (rarely double), copious.

23. Erigeron. Heads many-flowered, on naked peduncles. Involucre of narrow equal bracts, little imbricated. Achenes flattened; pappus sirnple and rather scanty, or with some outer minute scales.

24. Sericocarpus. Heads 12-20-flowered; rays 4 or 5 . Involucre subcylindric or club-shaped, imbricated, cartilaginous. Achenes short, narrowed downward, silky.

** * Rays none; heads dioecious (all pistillate or all staminate).

25. Baccharis. Heads many-fowered, Pappus capillary. Smooth glutinous skrubs.

Tribe IV. INÙLEAE. Heads discoid (radiate only in Inula), the pistillate flowers mostly filiform and truucate. Anthers sagittate, the basal lobes attenuate into tails. Style-branches with unappendageã obtuse or truncate naked tips. Pappus capillary or none.

* Receptacle flat, naked ; involucre not scarious, imbricated ; not woolly.

26. Pluchea. Heads containing a few perfect but sterile flowers in the center, and many pistillate fertile ones around them. Pappus capillary.

* * Receptacle chaffy ; involucral bracts few, mostly scarious; low floccose-woolly annuals ; flowers as in $\mathbf{n} 0.26$.

27. Gifola. Receptacle subulate. Achenes terete. Outer flowers without pappus.

*** Receptacle naked ; involucral bracts many, scarious ; floccose-woolly herbs.

28. Antennaria. Heads dioecious. Pappus of sterile flowers club-shaped or barbellate, of the fertile caplliary, united at bose and deciduous together.

29. Anaphalis. Heads dioecious or nearly so. Pappus not thickened above nor at all united at base.

30. Gnaphalium. Heads all fertlle throughout. Pappus all capillary.

**** Heade radiate ; receptacle naked ; involucre herbaceous; pappus copions.

81. Inula. Heads large, many-flowered. Flowers yellow. Stout perennial.

**** Corollas all somewhat broadly tubular and lobed; involucre not scarlous; receptacle naked ; pappus none.

32. Adenocaulon. Heads few-flowered and bracts fow; outer flowers pistillate. Somewhat woolly.

Tribe V. heliántheas. Heads radiate or discoid. Involucre not scariovs (nut-like in fruit in nos. 40, 41, and 42). Receptacle chaffy. Pappus never capillary, sometimes none. Anthers not caudate. Style-branches truncate or halry-appendaged.

* Ray-flowers fertlle and ligulate (sometimes obscurely so); disk-flowers sterile.

+ Achenes thickish, not strongly flattened either way.

38. Polymnia. Achenes partially enveloped by the inner bracts of the involucre, these unarmed. Perennials.

84. Acanthospermum. Achenes closely invested by the glochidiate or prickly inner involucral bracts. Annuals.

$++\Lambda$ chenes strongly flattened parallel to the bracts of the involucre, i.e. obcompressed.

35. Silphium. Achenes wing-margined, in several rows; pappus none or of 2 teeth. Bracts of the involucre thick, in several rows.

36. Berlandiera. Achenes wingless, 5-12 in one row, without pappus. Involucral bracts thin, obovate, the outer smaller and more follaceous.

37. Chrysogonum. Achenes wingless, about 5; pappus a one-sided 2-3-toothed crown. Inner bracts 5, chaff-like, the outer 5 longer and lesf-like.

98. Parthenium. Rays 5, very short, persistent. Pappus of 2 small chaffy scales. Involucral bracts short, roundish, in 2 rows.

* None of the flowers ligulate, the fertile few (1-5), with ulnute tubular corolla or none.

+ Heads alike.

89. Iva, Achenes short, thick. Involucre of few roundisb brnets. 
+ + Heads of two kinds, the fertile with a tuberculate or bur-like involuere.

40. Ambrosia. Bracts of staminate involucre united; fertile involucre with u alngle row of tubercles near the summit. Frulting head 1-seeded.

41. Franseria. Staminate involucre as in no. 40 ; fertile involucre with more than 1 row of tubercles or prickles. Fruiting head $2-4$-seeded.

42. Xanthium. Bracts of the stambate involucre distinct. Fruiting head 1-4-celled, 1-4-beaked.

*** Disk-flowers fertija, their corollas funnel-form; anthers blacklsh; pappus none, or a crown or cup, or of 1-2 chaffy awns, neither capillary, nor of several uniform chaffy scales; leaves more enmmonly opposite.

+ Rays persistent upon the mature schenes.

43. Heliopsis. Ray-flowers fertile. Achenes 4-sided. Leaves opposite.

++ Rays deciduous or absent.

++ Chaff of the flat receptacle bristle-shaped.

44. Eclipta. Rays short. Involucral bracts 10-12, in two rows, herbaceons.

+ + Chaff scale-like, embracing or subtending the achenes.

- Involucre double; the outer forming an angled cup.

45. Tetragonotheca. Outer involucre 4-leaved. Achenes obovoid ; pappus none.

$==$ Involucre of one or more rows of separate bracts.

a. Receptacle high, conical or columnar in fruit; pappus none or a short crown or awn.

46. Rudbeckia. Rays neutral. Achenes 4-sided or terote, flat at the top, marginless.

4i. Brauneria. Rays rose-colored (rarely yellow), pistillate, sterile. Achenes short, 4-slded. Chaff' spinescent.

48. Lepachys. Rays few, neutral. Achenes flattened laterally and margined.

49. Spilanthes. Rays yellow or white and fertile, or none. Ray-rchenes 3-sided or obcompressed.

b. Receptacle flat to convex; achenes not winged nor very flat.

50. Borrichia. Achenes 3-4-angled; pappus a short 4-toothed crown. Shrubby.

51. Helianthus. Achenes flattened, bearing 2 very deciduous chaffy pointed scales and rarely minute intermediate ones.

a. Receptacle convex (rarely conical); achenes flat, compressed laterally, winged or wingless, 2-8-awned; leaves decurrent.

52. Actinomeris. Bracts few, soon deflexed. Achenes obovate, squarrosely spreading.

53. Verbesina. Involucral bracts closely imbricated in 2 or more rows.

**** Rays few and neutral, or wanting; achenes obcompressed, i.e. flattened parallel with the scales of the involuere (rarely terete); involucre double; the outer spreading and often foliaceous; receptacle flat; leaves opposite.

54. Coreopsis. Involucral bracts distinct or united only at base. Pappus of 2 (or rarely more) scales, teeth, or awns, which are naked, not barbed, sometimes obsolete or a mere crown.

55. Thelesperma. Inner involucre connate to the middle. Achenes terete. Awns 2, retrorsely hispid.

56. Bidens. Involucral bracts distinct or united merely at base. Pappus of 2 or more rigid and persistent barbed awns or teeth.

***** Heads radiate or discoid ; disk-flowers all perfect and fertlle; achenes turbinate, 5-angled ; pappus of several chaffy scales.

+ Leaves alternate, entire; disk-flowers purplish.

57. Balduina. Rays numerous, long, neutral. Involucre much imbricated. Receptacle deeply honeycombed.

58. Marshallia. Rays none. Involucre of narrow leafy equal bracts. Receptacle chaffy.

+ + Leaves opposite, serrate; diek-flowers yellow.

59. Galinsoga. Rays fow, short, plstillate, whitish. Involucre of $4-5$ thin ovate bracts. Recep. tacle chaffy.

Tribe VI. HELEINEAE. Nearly as Tribe V., but receptacle not chaffy (somewhat so in nos, $6 \varepsilon$ and 66) In our genera, the disk-flowers perfect and fertile; the pappus a row of several chaffy 
soales (bristly-dissected in no. 66); the involucre hardly at all imbricated (partly scarious in no. 61).

* Involucral bracts distinct, not glandular-punctate.

+ Pappus none; bracta 2-5, carinate.

60. Flaveria. Heads small. Ray single or none.

+ + Pappus of distinct scales or bristles or wanting; bracts more than 5 .

+ Tips of brets colored or petaloid.

61. Hymenopappus. Lower leaves pinnatifid. Rays none. Disk-flowrs with orate lobes.

62. Polypteris. Leaves undivided. Rays generally none. Disk-flowers with linear lobes. + + Típs of bracts not colored and petaloid.

63. Actinea. Rays fertile, 8-toothed. Receptacle elevated. Involncral bracts appressed.

64. Helenium. Rays fertile or sterile, 8-5-cleft. Receptacle elevated. Involucre small, reflexed, Leaves decurrent.

65. Gaillardia. Rays 3-toothed, or none. Receptaclo usually beset with fine fimbrillate cbaff. Onter involucral brects loose and leafy. Pappus-chaff tipped with the projecting midvein. Western.

* Dotted with oil-glands; involucral bracts united into a cup.

66. Dyssodia. Pappus a row of chaffy acales dissected into many bristles.

Tribe VII. ANTHEMfDEAE. Distinguished from the last two tribes by the more or less dry and scarious imbricated bracts of the involucre. Heads radiate (rays mostly white) or discoid, the perfect flowers sometimes sterile and the pistillate rarely tubular. Achenes small; pappus a short crown or none. Mostly strong-scented; leaves alternate.

* Receptacle chaffy, at least in part; heads radiate, many-flowered.

67. Achillea. Receptacle flattish. Achenes obcompressed, Heads small, campanulate or obovoid.

68. Anthemis. Achenes subterete, angled or ribbed, Heads hemispherical, rather large.

* Receptrale naked.

+ Heads solitary or corymbose.

\# Receptacle conical at least in age.

69. Matricaria. Heads pedunculate. Rays pistillate or none. Pappus crown-like or none. Leaves finely dissected.

\# \# Receptacle flattish or moderntely convex.

$=$ Corollas of the perfect flowers 5-toothed; achenes sessile.

70. Chrysanthemum. Heads radiate (or rayless in one variety with leaves almost or quite unlobed); rays pistillate. Achenes 5-10-nerved; pappus tone.

71. Tanacetum. Heads discoid. Pistillate flowers few, marginal, their corollas inconspieuous, 2-8-toothed. Achenes 8-5-angled; pappus none or' a short crown.

$=\Rightarrow$ Corollas of the perfect flowers 4-toothed; achenes stalked.

72. Cotula. Heads long-peduncled, discoid. Pistillate Howers destitute of corolla. Achenes raised upon papillae which persist upon the receptacle.

++ Inflorescence from spike-like to chiefly racemose-paniculate.

73. Artemisia. Meads small, usually drooping, discoid. Pappus none.

Tribe VIII. SENEciòneaE. Heads radiate or discoid, the involncre little or not at all imbricated, not scarious, leceptacle naked. Anthers talliess, Pappus capillary.

* Heads monoecious or subdloeclous, the perfect flowers mostly sterile, and the small (ligulate or tubular) ray-flowers in more than ono row (at least in the fertile heads); style-branches obtuse, not appendaged nor bispid; lenves chlefy radical.

74. Tussilago. Head solitary, yellow-flowered, monoecions.

75. Petasites. Heads corymbed, subdioeclous. Flowers white or purplish.

* Flowors all fertile; style-branches truncate or capitellate, often appendaged; involucrai bracts connivent-crect.

+ Lenves opposite.

76. Arnica. Head showy. Pappus rather rigld, scabrous or barbellate. 
++ Leaves alternate; pappus soft-caplllary, copious.

77. Erechtites. Heads discoid. Flowers whitish, the outer pistillate with fllform corolles.

78. Cacalia. Heads discoid. Corollas white or eream-colored, 5-cleft.

79. Senecio. Heads usually radiate. Corollas yellow, b-toothed.

Tribe IX. CYNAREAE. Flowers all tubular and perfect (the outer ray-like and neutral in nos. 86 and si). Involucre much imbricnted. Anther's caudate, long-appendaged at tip. Stylebranches short or united, obtuse, unappendaged, smooth, with often a pubescent ring below. Pappus mostly bristly. Leaves alternate.

* Achenes attached by the base; flowers all alike.

+ Leaves not prickly; style-branehes partly distinct; filaments glabrous.

80. Arctium. Involucral bracts hooked at the tip. Pappus of short rough bristles.

++ Leaves prickly; style-branches coherent, usually a prbescent ring below.

+ Involucres 1-flowered, aggregateł into dense globose heads.

81. Echinops. General involucre small, reflexed, and hidden. Coarse thistle-like herbs, wirh large globular (compound) heads of pale flowers.

\# Involucres many-flowered.

- Filaments papillose-pilose, free.

u. Receptacle densely bristly.

82. Carduus. Pappus-bristles not plumose.

83. Cirsium. Pappus-bristles plumose.

b. Receptacle deeply honeycombed, scarcely or not at all bristly.

84. Onopordum. Pappus-bristies not plumose.

$==$ Filaments glabrous, united into a tube.

85. Silybum. Involueral bracts ending in a long stout spinescent appendage, spreading or reflexed, Receptacle densely bristly. Pappus-bristles not plumose. Stout thistle-like berbs, with large heads.

**Achenes obliquely attached ; marginal flowers often enlarged and ray-like.

86. Centaurea. Pappus of several series of short scales or bristles or none. Flowers red, purple, blue, white, or rarely yellow.

87. Cnicus. Pappas of 10 short horny teeth, 10 long bristles, and 10 shorter ones. Flowers yellow.

\section{Series II. LIGULIFLòraE}

Corolla ligulate in all the flowers of the head, and all the flowers perfect. Herbs, with milky juice. Leaves alternate.

Tribe $X$. CICHORiEAE. Characters of the series.

$$
\begin{aligned}
& \text { * Pappus none; annuals. } \\
& \text { + Leafy-stemmed. }
\end{aligned}
$$

88. Lapsana. Involucre cylindrical, calyculate-bracteate at base.

89. Serinia. Involucre not calyoulate.

$$
++ \text { Leaves all basal. }
$$

90. Arnoseris. Involucral bracts narrow, at length carinate-thickened.

* * Pappus chaffy, or of both chaff and bristles.

91. Cichorium. Involucre double. Pappus a small crown of many bristle-form scales.

92. Krigia. Involucre simple, not calyculate. Pappus of both chaff and bristies

$$
\text { ** Pappus plumose. }
$$

96. Hypochaeris. Involucre calyculate. Achenes fusiform, the inner produced in to long elender beaks. Leaves radical.

94. Leontodon. Similar. Achenes uniform.

95. Picris. Outer involucral bracts spreading. Achenes terete, not beaked. Stems leafy.

96. Tragopogon. Involucre simple, not calyculate. Achenes long-beaked. Stems leafy. 
* * Pappus composed entiraly of capillary bristles, not plumose.

+ Achenes strongly marlcate or spinulose above.

97. Chondrilla. Stem branching, leafy. Involucre few-flowered, calyculate. Achenes terete, several-rbbed.

98. Taraxacum. Scapose. Involucrecalyculate, many-flowered. Achenes fusiform, 4-5-ribbed. ++ Achenes not muricate sbove.

+ Achenes flat or flattlsh. Pappas white, fine and soft. Involucre imbricated. Leafy-stemmed, with panicled heads.

99. Sonchus. Achenes flattish, not at all heaked. Flowers 50 or more in each head, yellow.

100. Lactuca. Achenes usually more or less beaked. Flowers 6-80 in each head, yellow, blue, or purple.

\# Hchenes columnar, often slender.

- Achenes not conspicuously narrowed at base. Flowers rose or purple.

101. Lygodesmia. Achenes long, slightly tapering above. Pappus white. Stems nesrly leafless; Head erect. Western.

$-=$ Achenes narrowed at base.

a. Achenes beaked (sometimes beakless in no. 102); flowers yellow.

102. Agoseris. Serpose. Involucre loosely imbricated. Achenes 10-ribbed.

108. Pyrrhopappus. Scapose or branched. Achenes 4-5-ribbed.

b. Achenes not beaked.

1. Involncral barate in a single row.

104. Crepis. Pappus white, soft. Flowers yellow or orange.

2. Bracts in more than one row.

105. Prenanthes. Involucre calyeulate. Achenes short, blunt. Pappus whitish, tawny, or brown. Flowers white, cream-color, or pinkish.

106. Hieracium. Involucre Imbricated. Pappus tawny. Flowers yellow or orange.

\section{Artificial Key to Genera}

Stries I. Disk-Flowers with tUdular regular corollas; ligthate FLOWERS IF PRESENT MARGINAL.

\section{§ 1. Rays or ligulate flowers none; corollas all tubular (or rarely none). \\ * Flowers of the head all perfect and alike $a$.}

u. Pappus composed of bristles $b$.

b. Pappus double, the onter of very short, the inner of longer bristles

b. Pappus simple, the bristles all of the same sort $c$.

c. Heads few-flowered, theinselves aggregated Into compound or dense clusters

c. Heads separate $d$.

a. Receptacle (when the flowers are pulled off) bristly-hairy.

Leaves not prickly

Leaves prickly.

Filaments glabrous, united Into a tube

Filsments papillose-pilose, separate.

Pappus-bristles not plumose

a. Receptrappus-bristles plumose

d. Receptacle naked.

Pappus-bristles plumose.

Corollas rose-eolor or purple; heads racemuse or sploste

Corollas whitish; heads corymbose.

Pappus-bristles sometimes roughened but not plumose.

Stem twining; leaves opposite, trlangular-hastate

Stem not twining.

Achenes 5-angled, 5-rbbed . . . . .

Achenes 8-10-rlbbed or without definite angles or ribs.

Annual

Perennial.

Flowers yellow.

Involucral bracts much imbricated in several series. 18, Bigelonoia,

Involucre simple or merely calyculate ! ! : 79. Senecio.

1. Ternonia.

2. Elephantopus.

80. Arctium.

85. Stzyoum.

82. Carduus

83. Cirsium.

84. Cnopordum.

- 8. Liatris.

- 8. Kuhnia.

- 5. Mizania.

4. Eupatorium

77. Erechtites. 
Flowers purple

Flowere whitish.

Involucral bracts much imbricated; leaves chlefly

opposite Involucral bracts little imbricated; leaves alternate.

4. Pappus not composed of bristios $B$

6. Trilisa.

e. Pappus none or a mere mown-like margin to the fruit.

Heads 1-tlowered, themselves aggregated into globose glomerules; leaves prickly

Heads many-flowered; leaves not prickly.

Outer involucre foliaceous; leaves opposite at least below.

Outer involucre not foliaceous; leaves alternate.

Receptracle conieal, becoming elongated

Receptacle flattish or merely convex.

Heads chiefly nodding, in spikes, racemes, or panicles

Heads corymbose

e. Pappus present, $f$.

f. Pappus composed of scales or chaff.

Receptacle naked.

Leaves in whorls

Leaves alternate.

Leaves dissected

Leaves entire

Receptacle bearing chaff among the flowers.

Leaves toothed or lobed

Leaves entire

f. Pappus of 2 -several teeth or awns,

Pappus caducous

Pappus persistent.

Achenes laterally compressed

Achenes terete or flattened parallel with the involucral bracts.

Pappua barbed.

Bracts of inner involucre connate to widdle; achenes terete

Bracts of inner involucre distinct or nearly so; achenes obcompressed

Pappus not barbed

\section{Brickellia.}

78. Cacalla.

\section{Echinops.}

88. Polymnia.

69. Matricaria.

78. Artemisia.

70. Chrysanthemum

\section{* Flowers of two kinds in the same bead $g$.}

o. Marginal flowers neutral and sterile, either conspicuous or inconspicuous.

Leaves spiny; heads subtended by foliaceous bracts

g. Marginal flowers pistillate and fertile $h$.

h. Receptacle chaffy.

Receptacle awl-shaped; achenes terete

Receptacle flattish or moderatcly convex ; achenes fiattened

$h$. Receptacle naked or bearing no conspicuous chaff $i$.

$i$. Pappus of capillary bristles $j$.

j. Involuaral bracts imbricated in several rows.

Leaves toothed; not woolly

Leaves entire; plant more or less woolly.

Some flowel's staminate and sterile.

All flowers fertile, either pistillate or perfect

f. Involueral bracts chiefly in one row.

Leaves cordate, triangular or palmately lobed - . + . 75. Petasites.
Leaves not cordate.

Involucre campanulate

i. Pappus a short crown or none.

Achenes becoming much longer than the involucre

Achenes not exceeding the involucre.

Heads corymbose, erect

Heads solitary on long peduncles

Heads racemose or paniculate, nodding.

Lower leaves opposite

Lower leaves alternate

55. Thelesperma.

56. Bidens.

54. Coreopsis.

86. Centaurea.

27. Gifola

51. Helianthus.

28. Erigeron.

77. Erechtites.

26. Pluchea.

29. Anaphalis.

80. Gnaphalinum

32. Adenocaulon:

71. Tanacetum

72. Cołula.

39. Iva.

78. Artemisia.

* * Staminate and pistillate flowers in separate heads $k$.

k. Pappus capillary.

Leaves prickly; heads large

Leaves not prickly ; heads small.

Shrubs; leaves mostly toothed

Herbs; leaves entíre.
Pappus-bristles somewhà club-shaped in sterile flowers, but capllary and slightly connate at base in the fertile

Pappus-bristles all capillary, not at all connate

k. Pappus none; fertile involucre becoming bur-like.

Bracts of the staminate involucre united in to a cup.

Fertlle involucre armed with one ring of spines, teeth, or blunt processes
88. Cirsium.

25. Baccharis.

28. Antennaria.

29. Anaphalis.

40. Ambrosia. 
Fertile involucre armed with 2 or more rows of spines or these

Irregularly distributed
$\begin{gathered}\text { Bracte of staminate involucre distinct; fertile involucre horned in } \\ \text { fruit and very prickly }\end{gathered}$

41. Franserta.

42. Xanthiasm.

\$2. Rays present, i.e. the marginal flowers or some of then with strap like carollas.

* Pappus of capillary bristles, at least in the disk-flowers; ray-flowers pistillate $l$.

2. Rays occupying several rows.

liays yellow

Rays white or püplish.

Leaves cordate

Leaves not cordate

b. Rays in one marginal row $\dot{m}$.

$m$. Rays not y gllow.

Upper part of stem bearing ovate or lanceolate phyllodis.

Phyllodia none.

Rays and disk-flowers similarly colored

Rays and disk-Howers of contrasting colors.

Rays 4 or 5

Rays numerous.

Involueral bracts subequal, narrow, chlefly in 1 serjes

74. Thesilago.

Involucral biacts imbricated in several mostly unequal series

$m$. Rays yellow $\cdot n$,

n. Pappus (at least in the disk-flowel's) double, the outer short and minute.

Ray-flowers with pappus of caplllary bristles

Ray-flowere with coroniform peppus

r. Pappus simple.

Leaves opposito

Leaves alternate.

Involucral bracts equal and in 1 row (though often calyculate) Involucral bracts imbricated in several series.

Heads $3-5 \mathrm{~cm}$. in diameter

Heads $2 \mathrm{~cm}$ or less in diameter.

Pappus of several very narrow scales rather than truly capillary bristles.

Pappus of disk-flowers nearly or quite as long as the corolla

Pappus of disk-flowers much shorter than the corolla

Pappus-bristles hair-like.

Pappus-bristles equal

Pappus-biristies unequal

* * Pappus a circle of awns or rigid bristles at least in the diskflowers

* * Pappus a circle of chaffy scales dissected into bristles

75. Potrisites.

28. Erigeron.

75. Petasites.

15. Solidago.

24. Semicocarpus.

23. Erigeron.

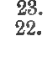

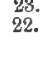

$$
\text { . } 13
$$

14. Chrysopsis.
13. Hetsrotheca.

76. Arnica.

79. Senecio.

81. Inuka. (1)

12. Amphiachyris.

11. Gutierrezia.

15. Solidago.

17. Aplopappus.

10. Grindelia.

66. Nyssodia.

**** Pappus a circle of thin chaffy scales or short chaffy bristles 0 .

o. Receptacle deeply honeycombed

o. Receptacle not deeply honeycombed, naked.

Receptacle flattish; heads small, few-flowered.

Leaves serrate, the lower heart-shnped

Leaves entire, linear, never cordate

Receptacle elevated, strongly convex; heads many-fiowered.

Scapose

o. Receptracle not deeply honeycombed, chaffy.

Heads less than $1 \mathrm{~cm}$. In diameter

Heads more than $1 \mathrm{~cm}$. in diameter

- 57. Balduina.

16. Brachychasta.

11. Gutierrezia.

63. Actinea.

64. Helenium.

59. Galinsoga.

65. Gaillardin.

***** Pappus none, or a cup or crown, or of 2 or 3 awns, teeth or chaffy scales corresponding with the edges or angles of the achene, often with intervening minute bristles or scales.

p. Achenes flattened.

$$
\div \text { Receptacle naked } p \text {. }
$$

Achenes wing-margined; pappus pressnt

Achenes marginless; pappus none

$p$. Achenes terete or prismatic.

Recoptacle conical

Receptacle tlattish.

Heads very small ; ray-flowers mostly 1

Heads rather large; rays numerous.

p. Achenes fusform; pappus of few scales, usually alternating with awns

$$
++ \text { RecFptace ohagFy } q \text {. }
$$

q. Rays neutral (ravely pistillate but sterile); the disk-flowers perfect and fertile. 
Receptacle flat or nearly so.

Achenes cylindrical, 2 -awied

hobenes flattened parallel to the chaff.

Pappus-nwus barbed

Pappus-awns not barbed

lieceptacle convex to colnumar.

Involucral bracts with thin scarious margins

Involucral bracts distinctly herbaceous.

Pappus of 2 awns.

Pappus-awns very deciduous

Pappus-awns persistent

Pappus none or a crown of short teeth.

Reys rose-color (rarely yellow), pistillate

Rays yellow to brownish-red or orange, noutral.

Achenes 4-sided, marginless.

Achenes flattenirl and viargined.

q. Rays pistillate and fertile $r$.

$r$. Ibisk-flowers also fertile, their achenes maturing $s$.

\&. Lenves alternate.

Pappus of $1-8$ awns or teeth

Pappus none.

Heads less than $1 \mathrm{~cm}$. broad ; achenes obcompressed

ช. Leaves opposite.

Maritime shrub

Herbs.

Annual, with white rays.

Perenoial, with yellow rays.

Outer involuere of 4 connate bracte
Outer involucral bracts not connate.

Weak creeping herb

Stout ereet herbs.

Achenes laterally flattened

Achenes thiektsh

r. Disk-flowers not maturing achenes; idsk' chaffy.

Achenes thickish, not strongly flattened.

Inner bracts of the involucre not armed

Inner bracts of the involucre glochidiate, closely investing the achenes.

Achenes flattened dorsally, i.e. parallel with the chaff.

Rays 5, obcordate, scarcely exceeding the disk, whitish

Rays yellow, much longer than the disk.

Achenes wing-margined, in several rows

Achene wingless, in a single row.

Rays 5; leaves serrate.

Rays usually inore numerous; leaves dentate or lyrately lobed
55. Thelesperma.
56. Bidens.
54. Coreopsis.
68. Anthemis.
51. Helianthus.
52. Activomeris.
47. Brauneria.
46. Rudbeckia.
48. Lepachys.

58. Terbesina.

67. Achillea.

68. Anthemis.

50. Borrichia.

44. Eclipta.

45. Tetragonotheca.

49. Spilanthes.

55. Verbesina.

48. Heliopsis.

38. Polymnia.

84. Acanthospermum.

33. Parthenum.

35. Silphium.

37. Chrysogonum.

86. Berlandiera.

\section{Series II. All THE Flowers of THE heAd With strap-shaped corolla $t$}

P. Pappus none.

Leaves basal

Leary-stemmed.

Involucre calyculate

Involucre not calyculate

t. Pappus wholly or in part of scales.

Flowers blue, rose-colored, or rareiy white

Hlowers yellow.

t. Pappus bristle-formed, capiliary " $u$.

v. Bristles plumose.

Leaves basal.

Inner achenes long-beaked

Inpor acbenes not beaked.

Leafy-stemmed.

Hispid-pubescent

Glabrons

$u$. Bristles simple, at most scabrous $v$.

$v$. Aobenes strongly muricate or epinulose above.

Leafy-stemmed

Scrpose

v. A chenes not muricate above 20 ,

20. Achenes flat or flattish.

Achenes beakless; flowers 50 or more in each head, yellow
Achenes mostly beaked; heads 6 -30-flowered; flowers yellow,

blue, or purple.

20. Aohenes columnar, often slender.

Flowers cream-color, white, rose-color, or purple.

Pappus white; liends orect
Pappup nream-color or tawny; heads nodding:
90. Arnoseris.

88. Lapsana.

89. Serinia.

91. Cichorium.

92. Krigia.

98. Hypochaeri.

94. Leontodon.

95. Picris.

96. Tragopogon.

97. Chondrilla

98. Taraxacum

99. Sonchus.

100. Lactuca.

101. Lygodesinia 105. Prenanthes. 


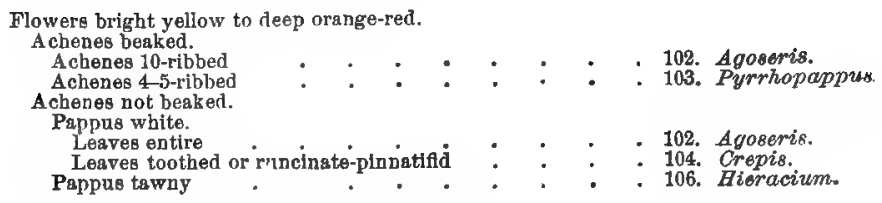

\section{VERIÒNIA Schreb. IrowweED}

Heads discoid, 15-many-flowered, in corymbose cymes ; flowers perfect ; in. volucre shorter than the flowers, of much imbricated bracts. Achenes cylindrical, ribbed; pappus double, the outer of minute scale-like bristles, the inner of copious capillary bristles. - Perennial herbs, with leafy stems, alternate acuminate or very acute serrate leaves and mostly purple (rarely white) flowers. (Named for Wiliam Vernon, an early English botanist, who traveled in North America. )

Involueral bracts tipped with long filiform spreading appendages.

Heads large, mpstly 60-30-flowered; involuere 1.4-2 cm. in diameter * 1. 7 . crinita.

Heads smaller, usually about 40 -ffowered; involucre about $1 \mathrm{~cm}$. in diameter.

Pappus purple or at least purplish-tinged Pappus creain-colored or stramineous.

2. V. noveboracensis.

volucral bracts obtuse, acute, or acuminate, but not conspicuonsly caudate.

Lower surface of the leaves smooth or merely puberulent.

Cyme dense, fastigiate

Cyme open and loose, the branches wide-spreading :

Iower surface of the leaves tomentulose.

Involucral bracts obtuse to acute, appressed or nearly so. Pappus purple

Pappus tawny
Involucral bracts with acuminate more or less squarrose tips

\section{F. glauca.}

4. V. f(usciculata.

5. V. altisima.

6. F. ulinoensis.

7. T. missurica.

8. V. Baldwini.

1. V. crinita Raf. Tall, nearly glabrous; leaves linear-lanceolate, retrorsely denticulate; heads large, usually 60-80-flowered; involucre very squarrose, the bracts with long filiform tips. ( $\boldsymbol{V}$. arkansana DC.) - Mo., Kan., and southw.

2. V. noveboracénsis Willd. Rather tall (1-2 m.); leaves long-lanceolate to Jance-oblong, more or less pubescent beneath, gradnally narrowed but not at all acuminate toward the base; cyme open; heads mostly 30-40-flowered; involucre purplish (or in white-flowered individuals green), campanulate; the bracts ovate or lance-ovate, with loosely ascending or recurved-spreading filiform tips; pappus purple or purplish. - Low ground near the coast, Mass. to Va. and Miss.; reported from Pelee I., L. Erie (Macoun).

3. V. glaúca (L.) Willd. Similar to the preceding; leaves mostly broader, ovate-lanceolate, contracted at the base to an acuminately winged petiolar portion, paler and tending to be more loosely pubescent on the nerves beneath; involucral bracts mostly with shorter filiform tips; pappus cream-colored or stramineous. (V. noveboracensis, var. latifolia Gray.) - Pa. to Ga. and Ala.

4. V. fasciculata Michx. Leaves ascending, narrono, linear to oblong-lanceolate, green and nearly glabrous beneath; heads rather small, about 20 -flowered, many, crowoded, in a fastigiate cyme; involucral bracts closely appressed, obtuse or the uppermost merely mucronate; achenes mostly smooth as seen with an ordinary lens ; flowers reddish-purple. - Prairies, O. to Minn., Neb., and Okla.

5. V. altíssima Nutt. Usually tall (1-2 or more m. high); leaves lanceoblong, acuminate, spreading, smooth or merely puberulent beneath; cyme large, widely spreading, rather loose; heads about 25-flowered; involucral bracts closely appressed, ovate, acute, obtuse, or cuspidate, mostly purple-tinged; flowers red-purple. (V. maxima Small.) - Rich soil of prairies, etc., N. Y. to Mich., Mo., and southw.; also sporadic northeastw.

6. V. illinoénsis Gleason. Tall and rather stout; leaves large, oblonglanceolate, acuminate, tomentulose and slightly scabrous beneath; heads medium-sized, about 40 -flowered, sessile or shortly and stoutly pediceled in a 
rather dense cyme; involucre campanulate; its bracts regulairly imbricated and closely appressed, chiefly rounded or obtuse, usually purple- or violet-tinged; flowers red-purple; pappus purple. - Rich dry prairies, s. Ont. and O. to Ill. and Ia.

7. V. missurica Raf. Similar in habit to the preceding; heads 85-50. flowered; involucre ovoid- or subcylindric-campanulate, mostly greenish; the bracts rather narrow, very numerous, closely appressed, the middle and lower ones acutish; pappus tawny or with only a slight purple tinge. ( $\boldsymbol{V}$. altissima, var. grandiflora Gray.) - Prairies, III.(?) and Mo. to Tex. and Kan. - An obscure species.

8. V. Baldwini Torr. Tomentulose; heads small or medium-sized, about 30-flowered; leaves lance-oblong or -ovate; involucre hoary-tomentose and arachnoid, mostly greenish; the bracts squarrose, acuminate. - Prairies and barren hills, Ia. to Kan. and Tex. V. interior Small, though sometimes distinguishable by its less squarrose mostly purple-tinged involucral bracts, does not appear satisfactorily separable.

\section{ELEPHÁNTOPUS [Vaill.] L. ELEPHANT's-FOOT}

Heads discoid, 2-5-flowered, several together clustered into a compound pedunculate head; flowers perfect. Involucre narrow, flattened, of 8 oblong dry bracts. Achenes 10-ribbed; pappus of stout bristles, chaffy-dilated at the base. - Perennials, with alternate leaves and purplish flowers. (Name composed of ét $\epsilon \phi a s$, elephant, and $\pi$ oús, foot.)

* Stem leafy; upper leaves very like the basal.

1. E. caroliniànus Willd.' Somewhat hairy, corymbose, leafy ; leaves ovateoblong, thin. - Dry soil, N. J. and Pa. to Ill., Kan., and southw. (Mex., W. I.)

$$
\text { * * Stem scape-like, with a fero bract-like leaves or nalced. }
$$

2. E. tomentosus L. Somewhat hairy; basal leaves obovate to narrowly spatulate, silky and prominently veined beneath; heads large; pappus-scales attenuate. - Va. to Ky., Ark., and southw.

3. E. nudàtus Gray. Strigose-puberulent; basal leaves thin, green, spatulate-obovate or oblanceolate, not prominently veined beneath; heids smaller. pappus-scales broadly deltoid. - Del. to Ark., and southw.

\section{SCLEROLEPIS CasS.}

Head discoid, many-flowered; flowers perfect. Involucral bracts linear, equal, in 1 or 2 rows. Receptacle naked. Corolla 5-toothed. Achenes 5-angled; pappus a single row of 5 almost horny oval and obtuse scales. - Smooth perennial, with simple stems, rooting at the base, linear entire leaves in whorls of 4-6, and a terminal head of flesh-colored flowers in summer. (Name composed of $\sigma \kappa \lambda \eta \rho \delta s, ~ h a r d$, and $\lambda \epsilon \pi / s, a$ scale, from the pappus.)

1. S. uniflora (Walt.) B S P. (S. verticillata Cass.) - In water or sandy bogs, Bradford, N. H. (F. T. Lewis); pine barrens, from N. J. southw.

\section{EUPATÓRIUM [Tourn.] L. THOROUGHWORT}

Heads discoid, 3-many-flowered; flowers perfect. Involucre cylindrical or bell-shaped, of more than 4 bracts. Receptacle flat or conical, naked. Corolla 5-toothed. Achenes 5-angled; pappus a single row of slender capillary barely roughish bristles. - Erect perennial herbs, often sprinkied with bitter resinous dots, with generally corymbose heads of white, bluish, or purple blossoms, appearing near the close of summer. (Dedicated to Eupator Mithridates, who is said to have used a species of the genus in medicine.) 


\section{§1. EUPATÒRIUM proper. Receptacle fat.}

* Heads eylindrical, 3-15-flowered; the purplish bracts numerous, closely im. bricated in several rovos, of unequal length, slightly striate; stout herbs, with ample mostly whorled leaves, and flesh-colured flowers.

1. E. purpùreum L. (Jok-Pye W WÉ, TrumpeT WEEv.) Stems tall (0.5-3 m. high) and stout, simple; leaves $3-6$ in a whorl, oblong-ovate or lanceolate, acuminate, thin, smuothish, rather finely cre'rate-dentate; inflorescence hemispherical, ovoid, or pyramidal-paniculate, the branches long and spreading, much overtopping the leaves; flowers pale pink or whitish. ( $\boldsymbol{E}$. trifoliatum L.) Low ground, often in woods and thickets, N. H., westw. and southw. Var. ANG USTIFÒLUM T. \& G. (var. falcatum Britton), with narrowly oblong-lanceolate to lance-linear often falcate leaves, seems to be only a weak form or state.

Var. maculàtum (L.) Darl. More pubescent, with thicker more rugose ovate to ovate-oblong incisely and coarsely toothed leaves and fattish-topped cymosepanicles of more crowded rose-purple or paler heads. (E. maculatum L.) Generally in wetter places, Nfd., westw. and southw.

Var. amoènum (Pursh) Gray. Low ; leaves fewer, often opposite, ovate or oblong; heads few. - Range of the preceding variety.

Var. foliòsum Fernald. Leaves thin, elongate, the upper much overtopping the compact flat-topped inflorescence. - Nfd, to $\mathrm{n}$. Mich. and Ia.

* * Heads 3-20-flowered; involucre of 8-15 more or less imbricated and unequal bracts, the outer ones shorter; flowers white or nearly so.

- Leaves all alternate, mostly dissected; heads panicled, very small, 3-5flowered.

2. E. capillifolium (Lam.) Smail. (Dog Fennel.) Smooth or nearly so, paniculately much branched, 1-3 m. high, leaves 1-2-pinnately parted, filiform. ( $E$. foeniculaceum Willd.) - Va., near the coast, and southw.; adventive zear Philadelphia.

++ Leaves long-petioled, the upper ones alternate; heads 12-15-flowered, in compound corymbs.

3. E. serótinum Michx. Stem pulverulent-pubescent, bushy-branched, 1-2 m. high ; leaves ovate-lanceolate, tapering to a point, triple-nerved and veiny, coarsely serrate, $0.5-1.5 \mathrm{dm}$. long; involucre very pubescent. - Alluvial ground, Md. to Minn., e. Kan., and southw.

+++ Leaves sessile or nearly so, with a narrow base, mostly opposite; heads mostly 5-flowered.

\section{- Involucral bracts with white and scarious acute tips.}

4. E. álbum L. Roughish-hairy, 3-8 dm. high; leaves oblong-lanceolate, coarsely toothed, veiny; heads clustered in the corymb ; involucral bracts closely imbricated, rigid, narrowly lanceolate, longer than the flowers. - Sandy and barren places, pine barrens of L. I. to Va., and southw.; also dry slopes of the southern Alleghenies.

Var. subvendsum Gray. Less rough; leaves $2.5-5 \mathrm{~cm}$. long, finely toothed and less veiny. - L. I. and N. J.

5. E. leucólepis T. \& G. Minutely pubescent, simple, 3-6 dm. high ; leaves linear-lanceolate, closely sessile, 1-nerved, obtuse, minutely serrate, rough both sides; corymb hoary. - Sandy bogs, L. I., N. J., and southw.

+ + Bracts not scarious or only obscurely so, obtuse, at length shorter than the flowers.

6. E. hyssopifolium I. Minutely pubescent, 3-6 dm. high ; leaves narrow, inear or nearly so, 3-5, cm. lons, obtuse, 1-3-nerved, entive, or the lower toothed, often crowded in the axils, acute at the base. - Sterile soil, Mass. to Va., e. Ky., and southw. 
7. E. Torreyànum Short, Erect, slender, $8-12 \mathrm{dm}$. high, grayish-puberulent; leaves narrowly lanceolate, coarsely toothed, the larger ones 5-7 cm. long, 8-12 mm. Wide, commonly proliferous in the axils; corymbs flat-topped; heads small ; involucral scales woolly. (E. hyssopifolium, var. laciniatum Gray.) Barrens, etc., Pa., Ky., and southw.

8. E. semiserràtum DC. Minutely velvety-pubescent, branching, 6-9 dm. bigh ; leaves lanceolate or oblong, triple-ribbed and veiny, serrate above the middle, tapering to the base, $1.5-2.5 \mathrm{~cm}$. wide, the lower slightly petioled; heads small. - Damp soil, va. to Mo, and southw. - Leares sometimes whorled in threes, or the upper alternate.

9. E. altíssimum L. Stem stout and tall, 1-2 m. high, downy; leaves lanceolate, tapering at both ends, conspicuously 3-nerved, entire, or toothed above the middle, $0.5-1.3 \mathrm{dm}$. long, the uppermost alternate; corymbs dense; bracts of the involucre obtuse, shorter than the flowers. - Dry soil, Pa. to Minn., Neb., and southw.

\section{4 + + Leaves sessile or nearly so, with a broad base, opposite or in threes; heads pubescent.}

\section{+ Heads 5-8-flowered; leaves not clasping.}

10. E. verbenaefolium Michx. Roughish-pubescent, $0.5-2.5 \mathrm{~m}$. high; leaves ovate-oblong and ovate-lanceolate, obtuse or truncate at base, slightly triplenerved, veiny, coarsely toothed or incised toward the base, the lower shortly petioled, the upper usually alternate; branches of the corymb few, unequal; bracts of the involucre oblong-lanceolate, at length shorter than the flowers. (Including var. Saundersii Porter; $E$. teucrifolium Willd.) - Low grounds, Mass. to Va., and southw., near the coast.

11. E. rotundifdlium L. Downy-pubescent, $3-8 \mathrm{dm}$. high; leaves roundishovate, obtuse, truncate or slightly heart-shaped at the base, crenate or crenateserrate, triple-nerved, veiny, roughish, $2.5-5 \mathrm{~cm}$. long; corymb large and dense ; bracts of the 5-flowered involucre linear-lanceolate, slightly pointed. - Dry soil, R. I. to Va., Ark, and southw., chiefly near the coast.

12. E. pubéscens Muhl. Pubescent, 7-12 dm. high; leaves ovate, acute, hardly truncate at base, strongly serrate; heads 5-8-flowered. ( $\boldsymbol{E}$. rotundifolium, var. ovatum Torr.) - Rocky woods, s. Me. to Va. and Ky., chiefly near the coast.

13. E. sessilifjitium L. (L'Pland Boneser.) Stem tall (0.5-1.8 m. high), smooth, branching; leaves oblong-or ovate-lanceolate, tapering from near the rounded sessile base to the sharp point, serrate, veiny, smooth, $0.7-1.5 \mathrm{dm}$. long; corymb rery compound, pubescent; bracts of the 5-flowered involucre oval and oblong, obtuse. - Copses and banks, Vt. and Mass. to 1ll., Mo., and southw. along the mts.

Var. Brittoniànum Porter. Leaves ovate or ovate-oblong, acute or shortacuminate, $2.5-4 \mathrm{~cm}$. long; inflorescence very contracted. - Budd's Lake, N. J. (Porter).

++ Leaves opposite, clasping or united at the base, long, widely spreading; heads 10-40-flowered; corymbs very compound and large.

14. E. perfoliàtum L. ('Thoroughwort, Boneset.) Stem stout, $0.5-1.5 \mathrm{~m}$. high, hairy; leaves lanceolate, united at the base around the stem (connateperfoliate), tapering to a slender point, serrate, very veiny, wrinkled, downy beneath, 1-2 dm. long; bracts of the involucre linear-lanceolate. - Low grounds; common and well known. Var. TRUNCATum Gray. At least the upper leaves separate, truncate or rounded at base. - With the typical form.

Var. cuneàtum Engelm. Leaves smaller, narrowed at base and separate; the heads fewer-flowered. - Mo., and southw. - Perhaps a hybrid with no. 8.

15. E. resindsum Torr. Minutely velvety-downy, 6-9 dm. high ; leaves iinearlanceolate, elongated, serrate, partly clasping, tapering to the point, slightly veiny beneath, 1-1.5 dm. long; bracts of the involucre oval, obtuse. - Wet pine barrens, N. J. - Name from the copious resinous globules of the leaves. 
* * Heads 8-30-flowered; involucral bracts nearly equal, in one row or but a very few of the outermost shorter; leaves opposite, ovate, petioled, triplenerved, not resinous-dotted.

- Leaves broadly ovate; flowers pure white.

16. E. urticaefdlium Reichard. (White SNakeroot.) Smooth, blanehing, 0.5-1 m. high; leaves broadly ovate, pointed, coarsely and sharply toothed, longpetioled, thin, 7-12 cm. long; corymbs compound. (E. ageratoides L. f.) Rich woods, not rare. Var. VILLICAÚLe Fernald. Stems and petioles viscidvillous. - Pa. (Heller) to Va. (C'urtiss).

17. E. aromáticum L. Smooth or slightly downy; stems nearly simple; leaves on short petioles, ovate, rather obtusely toothed, not pointed, thickish. Copses, etc., Mass. to Fla., near the coast. - Not aromatic.

\section{+ + Leaves dettoidlovate; flowers pink to pale purple.}

18. E. incarnàtum Walt. Freely branched, 6-12 dm. high, puberulent; branches spreading-ascending; leaves rather narrowly deltoid-ovate, long-pointed, coarsely crenate-serrate or bluntly toothed; slender petioles mostly $1-4 \mathrm{~cm}$. long. - Va. (Mackenzie) and Ky. to Fla. and Tex.

§ 2. CONOCLINIUM (DC.) Baker. Receptacle conical; involucral bracts nearly equal, somewhat imbricated.

19. E. coelestinum L. (Mrst-Flower.) Somewhat pubescent, 0.3-1 m. high; leaves opposite, petiolate, triangular-ovate and slightly heart-shaped, coarsely and bluntly toothed; heads many-flowered, in compact cymes; flowers blue or violet. - Rich soil, N. J. to Mich., Kan., and southw.

\section{5. mikania Willd. Climbing Hemp-weed}

Heads discoid, 4 -flowered. Involucre of 4 bracts. Receptacle small. Flowers, achenes, etc., as in Eupatorium. - Twining perennials, with opposite commonly heart-shaped and petioled leaves, and corymbose-panicled flesh-colored flowers. (Named for Joseph Gottfied Mikan, 1743-1814, professor in the University of Prague.) WillugBaEYA Neck.

1. M. scándens (L.) Willd. Nearly smooth; leaves somewhat triangularheart-shaped or halberd-form, pointed, toothed at the base. (Willoughbya Ktze.) - Copses along streams, and in sandy swamps, s. Me, to Fla., chiefly near the coast, w. to Ont., and s. to Miss. and Tex. July-Sept.

\section{TRÍLISA Cass.}

Heads discoid, 5-10-flowered; flowers perfect. Involucral bracts nearly equal, little imbricated. Receptacle naked. Corolla-lobes short-ovate or oblong. Achenes 10-ribbed; pappus of rather rigid bristles, not plumose. - Perennial herbs, fibrous-rooted, with broad entire leaves, obscurely or not at all punctate, and cymules of small heads in a thyrse or panicle. Flowers rose-purple, in autumn. (Name an anagram of Liatris.)

1. T. paniculàta (Walt.) Cass. Viscid-hairy; leaves narrowly oblong or lanceolate, smoothish, those of the stem partly clasping; heads panicled. - Low pine barrens, Va., and southw.

2. T. odoratíssima (Walt.) Cass. Very smooth; leaves obovate-spatulate, pale; heads corymbed; plant with the odor of vanilla when bruised. - S. C. to Fla., and said to reach oux limits in s. Va.

\section{BRICKELLIA Ell.}

Characters as in Kuhnia; involucral bracts more numerous. Bristles of the pappus merely scabrous or at most barbellate or subplumose. Leaves often all opposite. (In memory of Dr. John Brickell of Savannah, Ga., amateur botanist 
and helpful correspondent of Muhlenberg, Fraser, and others.)

Coleosanthtos Cass.

1 B. grandifldra (Hook.) Nutt. Nearly glabrous, 6-9 dm. high; leaves deltoid, cordate, the upper deltoid-lanceolate, coarsely dentate-serrate, acuminate, $1 \mathrm{dm}$. long or less; heads about 40-flowered. (Coleosanthus kitze.) Mo. and Kan., westw. and southwestw.

\section{KÜHNIA L.}

Heads discoid, 10-25-flowered; flowers perfect. Involucral bracts thin, few, and loosely imbricated, narrow, striate-nerved. Corolla slender, 5-toothed. Achenes cylindrical, 10-striate; pappus a single rov of very plumose bristles. A perennial herb, resinous-dotted, with mostly alternate leaves, and paniculatecorymbose heads of cream-colored flowers. (Dedicated to Dr. Adam Kuhn of Philadelphia, who carried the living plant to Linnaeus.)

1. K. eupatorioides L. Stems 3-9 dm. high; pubescence minute; leaves varying from broadly lanceolate and toothed to linear and entire. - Dry soil, N. J. to Minn., S. Dak., and southw. Sept. - Very variable. Var. conymBulósA 'T. \& G. Stouter and somewhat more pubescent, the heads rather crowded. (K. glutinosa Ell.) - Ill., westw. and southw.

\section{LiÀtris Schreb. Button Snakeroot. Blazing Stak}

Heads discoid, few-many-flowered; flowers perfect. Involucral bracts well imbricated, appressed. Receptacle naked. Corolla 5-lobed, the lobes long and slender. Achenes slender, tapering to the base, 10-ribbed. Pappus of 15-40 capillary plumose or barbellate bristles. - Perennial herbs, often resinous-dotted, with simple stems from a roundish corm or tuber, rigid alternate narrow entire leaves (sometimes twisted so as to become vertical), and spicate or racemed handsome rose-purple flowers, late in summer or in autumn. (Derivation of name unknown.) Lacinaria Hill. Ladiniaria Hill.

* Pappus very plumose; bracts of the 5-flowered involucre with ovate or lanceolate spreading petal-like (rose or sometimes white) tips, exceeding the flowers.

1. L. élegans (Walt.) Willd. Stem $(0.6-1 \mathrm{~m}$. high) and involucre hairy; leaves linear, short and spreading; spike or raceme compact, $1-5 \mathrm{dm}$. long. (Laciniaria Ktze.) - Barren soil, Va, and southw.

* Pappus very plumose; bracts of the cylindrical many-flowered involucre imbricated in many rows, the tips rigid, not petal-like; corolla-lobes hairy within.

2. L. squarròsa Willd. (Blazing Star, etc.) Often hairy, $1.5-6 \mathrm{dm}$. biglı; leaves rigid, linear, elongated; heads usually few, $1.5-3.5 \mathrm{~cm}$. long; bracts mostly with elongated and leaf-like spreading tips. (Laciniaria Hill.) Dry soil, Pa. to Minn., and southw. Var. InTermedia (Lindl.) DC. Heads narrow ; bracts shorter, erect or nearly so. (Lacinaria squarrosa, var. Porter.) -Ont. to Neb. and Tex.

3. L. cylindràcea Michx. Commonly smooth, $1.5-5 \mathrm{dm}$. high ; leaves linear ; heads few, $1.5-2.5 \mathrm{~cm}$. long; bracts with short and rounded abruptly mucronate appressed tips. (Laciniaria Ktze.) - Dry open places, Ont. to Minn. and Mo. - Heads sometimes reduced to a solitary slightly enlarged terminal one (var. SOLitària MacM.).

* * Pappus very plumose; heads 4-6-flowered; bracts acuminate; corolla-lobes naked.

4. L. punctàta Hook. Stout, 1.5-8 dm. high, from a branching or globose rootstock; leaves narrowly linear or the upper acerose, rigid; heads usually many in a dense spike. (Laciniaria Ktze.) - "O."; Minn., westw. and southw. 
**** Pappus not obviously plumose to the naked eye; corolla-lobes smooth inside.

5. L. scariosa Willd. Stem stout, $0.3-1.8 \mathrm{~m}$. high, pubescent or hoary; leaves (smonth, rough, or pubescent) lanceolate; the lowest oblong-lanceolate or obovate-oblong, tapering into a petiole; heads few or many, large, 25-40-flowered ; bracts of the broad or depressed involucre obovate or spatulate, very numerous, with dry and scarious often colored tips or nargins. (Laciniaria Hill.) Dry soil, s. Me. to Ont., Neb., and soutbw. - Widely variable; heads $2.5 \mathrm{~cm}$. or less in diameter.

Var, squarrulosa (Míchx.) Gray. Slender; heads smaller, 14-20-flowered; bracts numerous. (Lacinaria scarıosa, vaz. Small.) - Open woods, Va., and southw.

6. L. pycnostàchya Michx. Hairy or smoothish; stem stout, 0.5-1.5 m. high, very leafy; leaves linear-lanceolate, the upper very narrowly linear ; spike thick and dense, 1.5-5 dm. long; heads about 5-flowered, $1 \mathrm{~cm}$. long; bracts of the cylindrical involucre oblong or lanceolate, with recurved or spreading colored tips. (Laciniaria Ktze.) - l'rairies, from Ind. to Minn., Neb., and southw.

7. L. spicàta (L.) Willd. Smooth or somewhat hairy; stems very leafy, stout, $0.5-1.8 \mathrm{~m}$. high ; leaves linear, the lower 3-5-nerved; heads 8-12-flowered, $1 \mathrm{~cm}$. long, crowded in a long spike; bracts of the cylindrical-bell-shaped involucre oblong or oval, obtuse, appressed, with slight, margins; achenes pubescent or smoothish. (Laciniaria Ktze.) - Moist grounds, Mass. to s. Ont., Minn., and southw. - Involucre often resinous, very smooth.

Var. montàna Gray. Low and stout; leaves broader, obtuse ; spike short and heads large. (Lacinaria spicata, var. pumila Porter.)-Mountain-tops, Va., and southw.

8. L. graminifolia (Walt.) Willd. Hairy or smoothish; stem 3-9 dm. high, slender, leafy; leaves linear, elongated, 1-nerved; heads several or numerous, in a spike or raceme, 7-12-flowered; brarts of the obconical or obovoid involucre spatulate or oblong, obtuse, or somewhat pointed, rigid, appressed; achenes hairy. (Laciniaria Ktze.; Lacinaria Smallii Britton.) - Va., and 3outhw. Inflorescence sometimes panicled, especially in

Var. dùbia Gray. Bracts of involucre narrower and less rigid, oblong, often ciliate. (Lacinaria graminifolia, var. pilosa Britton.) - Wet pine barrens, N. J., and southw.

\section{GRINDEtLia Willd, Gum-Plant. Tar-WeEd}

Heads many-flowered, radiate (or rayless); rays pistillate. Bracts of the hemispherical involucre imbricated in several series, with slender more or less spreading green tips. Achenes short and thick, compressed or turgíd, truncate, glabrous; pappus of 2-8 caducous awns. - Coarse perennial or biennial herbs, often resinous-viscid, ours glabrous and leafy with sessile or clasping alternate and spinulose-serrate or laciniate rigid leaves, and large heads terminating leafy branches. Disk and ray yellow. (Named for Prof. David Hieronymus Grindel, 1776-1836, a Russian botanist.)

1. G. squarrosa (Pursh) Dunal. Leaves spatulate- to linear-oblong; involucre squarrose; achenes not toothed ; pappus-awns 2 or 3. - Prairies and dry banks, Ill. to Minn., southw. and westw.; rarely adv. eastw. July-Oct. Var. NưdA (Wood) Gray. Rays wanting. - Mo., and westw.

2. G. lanceolàta Nutt. Leaves lanceolate or linear; involucral bracts erect or the lower tips spreading; achenes with 1 or 2 short teeth at the summit; awns 2. - Prairies and barrens, Tenn., Mo, Kan., and southw. July, Aug.

\section{GUTIERREZIA Lag.}

Heads few-several-flowered, radiate; rays 1-6, pistillate. Involucre cylindric-clavate; bracts coriaceous, with green tips, closely imbricated, the outer shorter. Receptacle small, naked. Achenes short, terete; pappus of about 9 chaffy scales, shorter in the ray-tlowers. - Suffrutescent (our species), glabrous, 
and often glutinous, much branched, with narrowly linear entire alternate leaves, and sinall heads of yellow flowers in fastigiate or paniculate cymes. (Named for Pedro Gutierrez, correspondent of the botanical garden of Madrid.)

1. G. Sarothrae (Pursh) Britton \& Rusby, Low; leaves numerous, $1-5 \mathrm{~cm}$. long ; heads usually crowded, the disk-and short ray-flowers usually 3 or 4 each. (G. Euthamiae 'T.\& G.) - Dry plains, Man. and Minn., westw. and southwestw. July-Sept.

\section{AMPHIÁCHYRIS (DC.) Nutt.}

Heads hemispherical ; rays 5-10. Disk-flowers perfect but infertile. Pappus of the rays minute, coroniform ; of the disk-flowers of bristle-like scales, more or less dilated and united at base. - A diffusely much branched annual, with heads solitary on the branchlets; otherwise as Gutierrezia. (From a $\mu \phi l$, around, and a xupov, chaff.)

1. A. dracunculoides (DC.) Nutt. Low, slender; leaves narrowly linear, the upper filiform; disk-flowers 10-20, their pappus of 5-8 bristle-like scales united at base and slightly dilated upward.-Plains, Mo., Kan., and southw. Aug., Sept.

\section{HETEROTHÈCA Cass.}

Characters as in Chrysopsis, but the achenes of the ray thickish or triangular, without pappus or obscurely crowned, and those of the disk compressed, with a double pappus, the inner of numerous long bristles, the outer of many short and stout bristles. - (From E⿱ $\tau e \rho o s$, different, and $\theta \dot{\eta} \kappa \eta$, case, alluding to the unlike achenes.)

1. H. subaxillàris (Lam.) Britton \& Rusby. Annual or biennial, 3-9 dm. high, bearing numerous small heads; leaves oval or oblong, the lower with petioles auricled at base, the upper mostly subcordate-clasping. ( $H$. Lamarckii Cass.) -- Sandy soil, near the coast, Del. to Fla. and Tex., inland to Kan., N. Mex., and Ariz.; locally on ballast northw. July-Sept. (Mex.)

\section{CHRYSÓPSis Nutt. Golden Aster}

Heads many-flowered, radiate; the rays numerous, pistillate. Involucral bracts linear, imbricated, without herbaceous tips. Receptacle flat. Achenes obovate or linear-oblong, flattened, hairy; pappus in all the flowers double, the outer of very short and somewhat chaffy bristles, the inner of long capillary bristles. - Chiefly perennial low herbs, woolly or hairy, with ratber large often corymbose heads terminating the branches. Disk- and ray-flowers yellow. (Name composed of $\chi \rho \nu \sigma \delta s$, gold, and $\delta \psi(s, a$ spect, from the golden blossoms.)

\section{* Leaves narrowly lanceolate or linear; achenes linear.}

1. C. graminifolia (Michx.) Nutt. Silvery-silky, with long close-pressed hairs; stem slender, often with runners from the base, naked above, bearing few heads; leaves lanceolate or linear, elongated, grass-like, nerved, shining, entire. - Dry sandy soil, N. J. and Del. to Ky., southw. and southwestw. July-Oct.

2. C. falcàta (Pursh) Ell. Stems 1-3 dm. high, very woolly; leaves cronoded, linear, rigid, about 3-nerved, entire, somewhat recurved or scythe-shaped, hairy, or smooth when old, sessile; heads small, corymbed. - Dry sandy soil on the coast, pine barrens of N. J. to Cape Cod, Mass. July-Sept.

* Leaves oblong or lanceolate, entire or slightly serrate, mostly sessile, veined, not nerved; achenes obovate, flattened.

\section{- Pubescence soft-villous or arachnoid and floccose.}

3. C. mariàna (L.) Nutt. Perennial, silky̆ with long and weate hairs, or when old smoothish; leaves oblong; heads corymbed, on glandular peduncles. --Dry barrens, from s. N. Y, and Pa. southw. Aug.-Oct. 
4. C. gossýpina (Michx.) Nutt. Biennial, densely larate, the pubescence becoming floccose; leaves short-spatulate to oblong, rounded at tip, white-lanate; heads few, long-peduncled; involucre woolly or becoming glabrate and merely glandular. (C. pilosa Britton, not Nutt.) - Pine barrens, Va. to Fla.

\section{+ + Stems hirsute to villous, the hairs persistent.}

5. C. villdsa Nutt. Hirsute and villous-pubescent; stem corymbosely branclied, the branches terminated by single short-peduncled heads; leaves narrowly oblong, hoary with rough pubescence (as also the involucre), brist?yciliate toward the base ; achenes:3-5-nerved; outer pappus setulose-squamellate. (C. camporum Greene.) - I)ry plains and prairies, Man. and Wisc. to Ky., westw. and soutliw. July-Sept.

6. C. pilosa Nutt. Annual, soft-hirsute or villous; leaves oblong-lanceolate; involucre viscid; achenes 10-nerved; outer pappus chaffy and conspicuous. (C. Nuttallii Britton.) - Open places, Kan., and southw.

\section{SOLIDÀGO T. GOLDEN-ROD}

Heads few-many-flowered, radiate; the rays 1-16, pistillate. Bracts of the involucre appressed, destitute of herbaceous tips (except nos. 1 and 2). Receptacle small, not chaffy. Achenes many-ribbed, nearly terete; pappus simple, of equal capillary bristles. - Perennial herbs, with mostly wand-like stems and sessile or nearly sessile never heart-shaped stem-leaves. Heads sinall, racemed or clustered; flowers both of the disk and ray yellow (cream-color in no. 6). Closely related species tending to hybridize freely. (Name from solidare, to join, or make whole, in allusion to reputed vulnerary qualities.)

§ 1. VIRGAUREA DC. Rays mostly fewer than the disk-flowers; heads all more or less pediceled.

* Bracts of the much imbricated and rigid involucre with abruptly spreading herbaceous tips; heads in clusters or glomerate racemes, disposed in a dense somewhat leafy and interruptod wand-like compound spike.

1. S. squarròsa Muhl. Stem stout, $0.2-1.5 \mathrm{~m}$. high, hairy above; leaves large, oblong, or the lower spatulate-oval and tapering into a margined petiole, serrate, veiny ; heads numerous ; bracts obtuse or acute ; disk-flowers 16-24, the rays 12-16. - Rocky and wooded hills, N. B. to Ont., s. to Va. and 0.; rare southw. Aug.-early Oct.

2. S. petiolàris Ait. Minutely hoary or downy ; stem strict, simple, 0.2-1 m. high; leaves small (1-7 dm. long), oval or oblong, mucronate, veiny, roughciliolate, minutely puberulent, dull or sligbtly lustrous; the upper entire and abruptly very short-petioled, the lower often serrate and tapering to the base ; heads few, in a wand-like raceme or panicle, on slender bracted pedicels; rays about 10, elongated; bracts of the pubescent involucre lanceolate or linear-awlshaped, the outer loose and spreading, more or less foliaceous. - Dry woods, s. w. Ill. to Kan., N. C., and southw. Aug.-Oct. - The name is misleading, as the leaves are hardly petioled. Var. WARDI (Britton) Fernald. Leaves firm and strongly glutinous, somewhat lustrous. ( $S$. Wardii Britton.) - Open rocky or sandy ground, Mo. and Kan. to Tex.

\section{* * Involucral bracts without green tips and wholly appressed.}

- Heads small; the involucres 2-5 (rarely 6) mm. long, clustered along the stem in the axils of the feather-veined leaves, or the upper forming a thyrse.

\section{* Achenes pubescent.}

= Stem terete, mostly glaucous (the bloom easily rubbed off).

3. S. caèsia L. Smooth; at length much branched and diffuse; leaves lanceolate or oblong-lanceolate, serrate, pointed, sessile; heads in very short clusters, or somewhat racemose-panicled on the branches. - Deciduous woods, s. Me. to Ont., Minn., and southw. Aug.-Oot. Var. Axildaris (Pursh) Gray 
Mostly simple; leaves thin, elongate-lanceolate, all much exceeding the very small axillary clusters. - N. S. to Que., Ont., and southw. Var. Paniculdta Gray. Paniculately branched; leaves smaller; heads densely racemose-panicled. - Rich woods and clearings, from s. Me. southw.

$$
==\text { Stem angled, not glaucous. }
$$

4. S. latifolia L. Smooth or nearly so; stem zigzag, simple or paniculatebranched, $0.3-1 \mathrm{~m}$. high ; leaves broadly ovate or oval, very strongly and sharply serrate, conspicuously pointed at both ends, thin, $0 . \bar{b}-1.5 \mathrm{dm}$. long, the lower abruptly narroved to winged petioles; heads in very short axillary clusters, or the clusters somewhat prolonged at the ends of the branches; rays 3-4. ( $S$. flexicaulis L., in part.) - Moist shaded banks, tbroughout ; commonest northw., and s. along the imts. Late July-early Oct.

5. S. Curtísii T. \& G. Smooth or nearly so; stem usually branched ; leaves oblong to long-lancealate with gradually narrowed entire base, serrate above with subulate teeth; heads in small loose clusters; rays 4-7.- Open woods at low elevations in the mountains, Va., W. Va., Ky., and southw. Aug.-Oct. Var. pubens (M. A. Curtis) Gray. Stems and often the under surfaces of the leaves tomentose. - Similar range.

\section{+ + Achenes glabrous (rarely a little setulose); inflorescence more thyrsoid. $=$ Stems pubescent.}

6. S. bicolor L. Hoary or grayish with soft hairs (rarely glabrate); stem simple or paniculate-branched; leaves oblong or elliptical-lanceolate, acute at both ends, or the lower oval and tapering into a petiole, slightly serrate ; clusters or short racemes from the axils of the upper leaves, forming an interrupted spike or crowded panicle; involucre 3-5 mm. long; the chartaceous whitish-yellow obtuse bracts usually with the greenish midnib slender below but conspicuously dilated above; rays 5-14, small, cream-color or nearly white; achenes columnar. - Dry soil, P. E. I. to Ga., rarely inland to Ky., Mich., and Ont. Late Aug.-Oct.

7. S. hispida Muhl. Similar; cauline leaves oblanceolate to narrowly obovate, narrowed at base, blunt or acutish at tip; basal leaves mostly rounded at tip, crenate-serrate; involucre 4-6 $\mathrm{mm}$. long; the subherbaceous greenish or greenish-straw-colnred obtuse bracts usially with the green midrib nearly uniform or only obscurely dilated above; rays orange-yellow; achenes slightly broadened upward. (S. bicolor, var. concolor T. \& G.) - Dry or rocky banks, Nfd. to Man., s. to the ints. of Ga., Mich., and Mo.; chiefly in calcareous districts. July-early Sept.

\section{$==$ Stems glabrous or essentially so.}

8. S. erécta Pursh. Glabrous, or merely puberulent above; leaves thickish, firm, the lowest oblong or ovate-spatulate, crenate, the others narrower, entire; inflorescence as in no. 6 ; rays pale yellow or cream-colored. - Dry soil, L. I., N. J., Pa., and southw. Aug.-Oct.

9. S. montícola T. \& G. Nearly glabrous; stem slender, 3-9 dm. high; leaves thin, oblong-ovate to lanceolate, acute or tapering at both ends, the lower serrate; heads small, the bracts acutish; rays 5-6. (S. roanensis Porter.) Allegheny Mts., from Pa. southw. July-Sept.

+ + Heads mostly large, the involucres 6(rarely 5)-12 mm. long, manyflowered, farming an erect terminal thyrse; leaves feather-veined.

- Leaves numerous, short, sessile, entire, uniform in size and shape; cinereous plant of the Southroest.

10. S. Lindheimeriàna Scheele. Somewhat cinereous-puberulent, 2. b-8 dm. high ; leaves lanceolate to oblong, sessile, subacute, often glutinous ; inflorescence dense ; involucre slender-campanulate, $5.5-7 \mathrm{~mm}$. long; achenes glabrous. Limestone bluffs and gravel, and in rocky woods, Kan, to 'Tex. Sept.-Nov. 
Leaves elongate, the basal much larger than the upper and more or less petioled; green plants of northern and mountainous regions.

$=$ Leaves thin, the basal with ovate or oblong blades, sharp-serrate, abruptly narroved to the comparatively slender petioles.

11. S. macrophýlla l'ursh. Stem stout, 3.5-12 dm. high, pubescent at summit, simple below the inflorescence; leaves very thin, scattered, irregularly and coarsely serrate with sharp salient teeth, all but the uppermost abruptly contracted into long margined petioles, the lowest with blades 5-20 cm. long; heads many-flowered, in a wand-like compound raceme or contracted panicle 1-6 dm. long, the lower heads much exceeded by their subtending leaves; involucre slender-campanulate or thick-cylindric, 8-12 $\mathrm{mm}$. long; its bracts thin, scarious, linear-attenuate; rays 8-10, elongated; achenes smooth, 3-4 mm. long. - Woods, Nfd. to L. Superior, s. to N. S., N. B., e. and centr. Me., and on upland slopes to Mt. Monadnock, N. H., Mt. Greylock, Mass., and the Catskill Mts., N. Y. July-early Sept.

Var. thyrsoidea (Mey.) Fernald. Lower; the involucre much fuller aud broader ( $8-20 \mathrm{~mm}$. broad), subglobose to cup-shaped; its bracts firmer, ofteu subherbaceous, narrowly diltoid to lanceolate. - Lab. to alpine regions of Gaspê Co., Que., Mt. Katahdin, Me., ani Mt. Washington, N. H. July, Aug.

12. S. calcícola Fernald. Stems $2-10 \mathrm{dm}$, high, purplish, simple or with few erect branches, glabrous below, pubescent and somewhat glutinous above, very leafy to the inflorescence; basal leaves elliptic, sharp-serrate, slenderly wing-petioled; the cauline oblanceolate, acuminate, sharply and irregularly serrate above the middle, entire below and narrowed to broad-winged petioles, or the uppermost sessile; inflorescence from racemo-thyrsoid to thyrsoid-paniculate; involucre 6-8 $\mathrm{mm}$. long, its bracts mostly lance-attenuate, acute or acutish; rays rather short; achenes pubescent, 1-2 mm. long.-Calcareous cliffs and rich woods, Gaspé Co., Que., to Aroostook Co., Me. Aug., Sept.

$==$ Leaves thick and firm, the basal with the oblanceolate, spatulate, or narrowly obovate blades crenate or crenate-serrate (rarely sharp-serrate) and tapering gradually to the winged petioles.

a. Involucre 30-50-fovered; cauline leaves 2-4 (rarely 5) below the inflorescence.

13. S. Cutlèri Fernald. Dwarf ( $5-25 \mathrm{~cm}$. bigh); the stem rather prominently angled; basal leaves obovate to broadly oblanceolate, crenate 10 serrate above the middle; the few cauline leaves oblanceolate to spatulate, of nearly uniform size; inflorescence a few-headed terminal corymb or frequently the heads clustered in the axils of the rather large divergent upper leaves; heads very full; the short campanulate involucre 6-8 mm. hich, 7-10 mm. broad, composed of subherbaceous often glutinous oblong or lanceolate obtuse to acutish bracts; achenes 3-3.5 mm. long, hirsute with spreading-ascending short hairs; pappus barbellate. ( $S$. Virgaurea, var. alpina Bigel.; $S$. alpestris of recent Am. auth., not Waldst. \& Kit.) - Highest alpine districts of Me., N. H., Vt., and N. Y. July-early Sept.

b. Involucre 15-30-flowered; cauline leaves (except in abnormally floriferous individuals) more numerous, 5 (rarely 4 )-30 or more below the inflorescence.

1. Midrib of the leaves usually prominent beneath; inflorescence (simple or paniculately compound) dense, the pedicels rarely more than $3-4 \mathrm{~mm}$. long.

14. S. Rándii (Porter) Britton. Often glutinous; stems stoutish, commonly purple-tinged, glabrous below, usually puberulent above, $3-8 \mathrm{dm}$. high; leaves numerous; the basal narrowly obovate to oblanceolate, acute or obtuse, serrate or dentate, $7-20 \mathrm{~cm}$. lons; the cauline lanceolate or oblanceolate to elliptic, gradually reduced upward, rarely bearing axillary fascicles, the lower often serrate, the uppermost entive and 2-7 cm. long; heads crowded in a dense thyrse or at the ends of the branches of an ample panicle (1-3 din. long); involucre 5-6 $\mathrm{mm}$. high, 3-5 mm. broad, the bluntish or acute bracts lance-deltoid to linear; achenes 2-2.6 $\mathrm{mm}$. long, sparingly appressed-setulose or glabrate; pabous barbellate. ( $S$. Virgaurea of recent $\mathrm{Am}$. auth., in part, not L.; $\boldsymbol{S}$. Vi $r$ 
gaurea, vars. Randii and Redfieldii Porter; S. humitis Man. ed. 6, in part, not Pursh.) -- Dry or rocky (commonly granitic, etc.) soil, e. Me. to Mich., southw. along the mts. to s. N. H. and w. Mass. July-early Sept. Passing freely to var. montícola (Porter) Fernald. Lower $(0.5-5 \mathrm{dm}$. high), with a dense solitary thy rse $2-10 \mathrm{~cm}$. long. (S. Virgaurea, var. Porter; $\boldsymbol{S}$. Virgaurea, var. Deanei Porter.) - More exposed situations.

2. Midrib of the leaves usually obscure; inflorescence 1-several racemes or interrupted thyrses, many of the pedicels 5-15 (or rarely 25) $\mathrm{mm}$. long.

15. S. racemòsa Greene. Often glutinous ; stems usually clustered, rather strict, slender and nearly terete, very leafy, 1-6 dm. high; basal and lower leaves oblanceolate, mostly acute or subacite, 3-12 cm. long, 5-7 mm. broad, more or less crenate or serrate above the middle; cauline leaves 10-30 or more, oblanceolate to linear, the uppermost entive and $1-3.5 \mathrm{~cm}$. long, all (in well developed plants) beaing axillary fascicles; racemes solitary, $5-15 \mathrm{~cm}$. long, rarely panicled; involucre $5-8 \mathrm{~mm}$. high, the linear bracts obtuse or acutish; cuchenes 2-3 $\mathrm{mm}$. long, finely appressed-setulose; pappus minutely serrulate. (S. hunilis Man. ed. 6, in great part, not Pursh ; $S$. Purshii Porter, as to description, but not as to type, i.e. the P'ursh plant.)-Calcareous ledges and cliffs, local, N. B. to Va., w. to the sand-hills of L. Mich. July-Sept.

Var. Gillmàni (Gray) Fernald. Much larger; basal leaves $1 . \overline{0}-3 \mathrm{dm}$. long, coarsely toothed; the abundant raceines forming a panicle $3-4 \mathrm{dm}$. long. ( $S$. humilis, var. Gray; $S$. Firgaurea, var. Porter.)-Sand-hills and rocks along the Great Lakes, (Ont. and Mich.

16. S. decúmbens Greene. Similar; the decumbent rigid stems $0.5-4 \mathrm{dm}$. high, simple, remotely leafy; basal and lower leaves spatulate-obovate to -oblanceolate, chiefly rounded or blunt at tip, 1.5-9 cin. long, 8-20 mm. broad, toothed above the middle; cauline leaves $4-9$ l, elow the inflorescence, without axillary fascicles; raceme lax, 9-20 $\mathrm{cl}$. long ; involucre $6-7 \mathrm{~mm}$, high, its firm linear bracts obtuse. - Serpentine rock, Mt. Albert, Que.; shores of L. Superior ; Alb. and B. C. to Col., and Wash. July, Aug.

- + + Heads small or middle-sized, the involucres 2-5 (rarely 6) mm. long, panicled or thyrsoidal, not in a terminal corymbiform cyme; neither alpine nor high-northern.

* Leaves commonly veiny, not 3-ribbed (but sometimes obscurely triplenerved).

$=$ Heads in a slender virgate or thyrsoid panicle.

a. Stem puberulent or pulverulent.

17. S. pubérula Nutt. Stem (2-10 dm. high, simple or branched) and panicle minutely hoctry; stem-leaves numerous, lanceolate, acute, tapering to the base, mostly entire, smootlish, the uppermost $1.5-5 \mathrm{~cm}$. long; the lower wedgelanceolate and sparingly toothed; heads very numerous and crowded in compact short racemes forming a prolonged and dense slender or pyramidal panicle; involucre 3-4 mm. long, its bracts linear-awi-shaped, appressed; rays about 10 . - Dry or sandy soil, P. E. I. to w. Que., s, to Fla. and Miss., mostly near the coast. Aug.-Oct.

\section{b. Stem glaiorous.}

\section{Axis and branches of the inflorescence glabrous.}

18. S. stricta Ait. V+ry smooth throughout; stem strict and simple, wandlize, $0.5-2.5 \mathrm{~m}$. high, slender, beset with small and entire appressed lanceolateoblong thickish leaves, these gradually reduced uprorad to mere bracts $(5-15 \mathrm{~mm}$. lon $q$ ); the lowest oblong-spatulate; heads crowded in a very slender compound spicate raceme; involucre 4-5 $\mathrm{mm}$. long; rays $5-7 .-1$ amp pine barrens and prairies, N. J. to Fla. and Tex. Sept.-Nov. (W. I.)

2. Axis and branches of the inflorescence pubescent.

10. S. uligindsa Nutt. Snuth up to the inflorescence; stem simple, strict, 3-10 dun. high; Taques thickish, lanceolate, pointed, the lower 1-4 dm. iong; 
tapering into winged petioles, partly sheathing at the base, sparsely serrulate of entire, the uppermost $3-8 \mathrm{~cm}$. long; racemes much crowded and approssed in a dense wand-like panicle; involucre 4-6 $\mathrm{mm}$. long, its bracts linear-oblong; rays 5-6, small. - Bogs and wet shores, Nfd. to Keewatin, s. to Minn., Pa, and in the mts. to N. C. July-early Sept.

20. S. speciosa Nutt. Stem stout, $0.5-2 \mathrm{~m}$. high, smooth below, often roughish above; leaves thickish, smooth, with rough margins, oval or ovate, slightly serrate; the uppermost $2-4 \mathrm{~cm}$. long, oblong-lanceolate; the lower $1.5-3$ $\mathrm{dm}$. long, 5-10 cm. wide, contracted into a margined petiole; heads somewhat crowded in numerous erect racemes, forming an ample pyramidal or thyrsiform panicle; peduncles and pedicels rough-hairy ; involucre cylindric, often glutinous, 4.5-6 $\mathrm{mm}$. long, its firm bracts oblong; rays about 5, large. - Dry open woods and thickets, local, Mass. to Minn., and soutbw. Sept., Oct.

Var. angustata T. \& G. Lower, rarely $1 \mathrm{~m}$. high; leaves lanceolate to ovatelanceolate, more nearly uniform, the lower 8-12 cm. long, 2-3 cm. wide; inflorescence usually smaller. (S. rigidiuscula Porter.) - Dry open ground, O. to S. Dak., and southw. Aug.-Oct.

\section{$==$ Heads paniculate, in mostly spreading or recurved-ascending secund clusters.}

\section{a. Leaves fleshy; plant maritime.}

21. S. semperrvirens $\mathrm{L}$. Smooth and stout, $0.3-2.5 \mathrm{~m}$. high; leaves entire, lanceolate, slightly clasping; the lower ones lanceolate-oblong, 1.5-6 dm. long, obscurely triple-nerved; the uppermost $4-15 \mathrm{~cm}$. long; racemes short, in an open or contracted panicle; involucre 4-6 nm. long, many-flowered; rays showy 7-10. - Salt marshes, or rocks on the shore, Gulf of St. Lawrence, and southw., Ang.-Nov.(rarely Dec.). - Varies, in less brackish swamps, to forms with thinner elongated linear-lanceoiate leaves tapering to each end, and more erect racemes in a more slender panicle.

\section{b. Leaves not fleshy; plants not maritime.}

1. Basal leaves long-petioled, conspicuousty larger than the 10-30 (-40) remote or subremote cauline ones.

o Stems strongly angled; leaves shagreen-scabrous on the upper surface; heads 15-20-flowered.

22. S. pátula Muhl. Stem sharply 4-angled, smooth, 0.5-2 m. high; lower leaves 1-4 dm. long, ovate, acute, serrate, pale, very smooth and veiny underneath, but the upper surface very rough, like shagreen; uppermost leaves lanceolate, $2-5 \mathrm{~cm}$. long; racemes rather short and numerous on the leafy-bracted spreading branches; heads rather large and full; the involucre $3-4.5 \mathrm{~mm}$. long, nearly as broad, its linear-oblong bracts obtuse. - Bogs and swamps, chiefly in calcareous regions, w. Me. to Ont., and southw. Aug., Sept.

o o Stems terete or nearly so; leaves smooth or smoothish (rarely scabrous); heads 6-15(-20)-flowered.

+ Leaves mostly serrate, the lower and middle cauline (as well as the basal) rather abruptly narrowed to the petiolar base. (Extreme forms of $\boldsymbol{S}$. ulmifolia might be sought here.)

23. S. argùta Ait. Smooth; stem 6-15 dm. high, obscurely angled above; leaves usually thin, sharply double-serrate; the lower ovate or ovate-lanceolate, 1.5-4 dm. long, pointed at both ends, their petioles margined; the upper elliptical-lanceolate, 3-9 dm. long; racemes pubescent, spreading, disposed in an elongate open panicle; involucre about $4 \mathrm{~mm}$. long, its thin bracts bluntish; rays $6-7$, large; achenes glabrous. - Open woods and thickets, w. Me, to Ont., and southw. Aug., Sept.

24. S. Bobttii Hook. Smooth, $\propto$ scabrous-pubescent or below hirsute, slender, often branched, $0.5-1.5 \mathrm{~m}$. ligh ; leaves rather finely serrate, ovate to oblong-lanceolate, pointed; the lower 6-15 cm. long; the upper rmall, oblong to narrowly lanceolate, often entire; heads loosely racemose at the tips of the very 
few elongate leafy-bracted branches; rays 1-5 or none; achenes pubescent. Dry grounds, Va. to Fla. and Tex., northw. in Miss, basin to Mo. July-Sept.

\section{++ Leaves all tapering gradually to the 3 ase, the uppermost chiefly entire.}

$\times$ Panicle usually as broad as high; rays 8-12.

25. S. júncea Ait. Smooth throughout, 5-12 dm. high; radical and lover stem-leaves $1.5-4 \mathrm{dm}$. long, elliptical or lanceolate-oval, sharply serrate with spreading teeth, pointed, tapering into winged and ciliate petioles; the others lanceolate or nanowly oblong, slightly triple-nerved, tapering to each end, the uppermost entire, 3-0 cm. long; racemes dense, naked, at length elongated and recurved, forming a crowded corymb-like panicle; involucre $2.5-4 \mathrm{~mm}$. long, its closely appressed rigid pale oblong bracts blunt or acutist. - Dry copses and banks, N. B. to Sask., s. to N. C., and Mo. Late June-Sept. Var. scabrécls (T. \& G.) Gray. Foliage scabrous, - Vt. to Ky., and westw.

Var. ramosa Porter \& Britton. The numerous branches upright, only slightly secund, with short terminal racemes. - N. J. to W. Va, and $\mathrm{O}$.

\section{$\times \times$ Panicle usually longer than broad; rays $2-8$.}

26. S. neglecta T. \& G. Smooth; stem stout, 6-15 dm. high, rather leafy ; lenves thickish, smooth both sides, opaque; the cauline $20-4 \mathrm{C}$; the upper oblonglanceolate, mostly acute and nearly entire; the uppermost $2-5 \mathrm{~cm}$. long; the lower ovate-lancéolate or oblong, sharply serrate, 2-4 dm. long, 3-8 cm. broad, tapering into a petiole; racemes short and dense, at first erect and scarcely 1-sided, at length spreading, disposed in an elongated or pyramidal close panicle; involucre $3-4.5 \mathrm{~mm}$. long, its blunt bracts subherbaceous; rays $3-8$; peduncles and achenes nearly glabrous. - Swamps, brook-sides, and prairies, e. Mass. and Vt. to Md., Ill., and Wisc. Aug.-early Oct.

27. S. uniligulàta (DC.) Porter. Smooth; stem slender, 1.5-9 dm. high; leaves thick, opaque; the cauline 5-20 (rarely 30), linear or linear-lanceolate, appressed-ascending; the lower narrowly lanceolate or oblanceolate, appressedserrate, 1-3 dm. long, $0.7-3 \mathrm{~cm}$. broad, tapering to a long petiole; panicle much ts in no. 26, but smaller; involucre $3.5-5 \mathrm{~mm}$. Jong, its pale straw-coloved bracts chartaceous; rays 2-5. (S. neglect., var. linoides Gray.) - Sphagnum bogs and mossy banks, Nfd. to Ont., s, to N. J., Pa., and Ill. July-Sept.

\section{Basal leaves similar to the 30-100 (-200) ordinarily almost uniform or gradually reduced approximate cauline ones.}

- Leaves all (or all but the lower) entive, with prominent midrib but obscure veins.

\section{+ Stem glabrous or merely puberulent; leaves linear or linear-lanceolate.}

28. S. oddra Ait. (Sweex Golden-Rod.) Smooth or nearly so throughout; stem slender, $0.5-1 \mathrm{~m}$. high, often reclined; leaves linear-lanceolate, entire, shining, pellucid-dotted, the middle ones 6-10 cm. long; racemes spreading, ir a small one-sided panicle; involucre $3-5 \mathrm{~mm}$. long, the few inner yellowish bracts much longer than the outer; rays $3-4$, rather large. - Borders of thickets in dry or sandy soil, s. N. H. and s. Vt. to Fla, w. to Mo. and Tex. July-Sept.'The crushed leaves yield a pleasant anisate odor; but an occasional form is nearly scentless.

29. S. tortifòlia Ell. Stem scabrous-puberulent, 5-9 dm. high ; leaves linear, short (the midale ones $1.5-5^{\circ} \mathrm{cm}$. long), commonly twisted, roughish-puberulent or glabrate, often as many as 200 ; panicle of numerous slender recurved racemes: involucre $2.5-3.5 \mathrm{~mm}$. long, the obtuse scales pale straw-color; rays very short. - Dry soil, coast of Va. to Fla. and Tex. Sept., Oct.

$$
++ \text { Stem hirsute; leaves oblong. }
$$

30. S. fistuldsa Mill, Stem stout, upright, 0.9-2 m. high, clothed with spreading haiss; learss oblong-lanceolate, roughish, hairy beneath, at least on the midrib, serrulate, the upper ovate-lanceolate or oblong and entire, closely sessile ; racemes many, recurved, in a dense pyramidal panicle ; rays $7-10$, very 
short. (S. pilosa Walt.) - Low grounds, pine barrens of N. J. to Va., and southw. Aug.-Oct.

o o Leaves all or nearly' all toothed, the veins prominent.

+ Stems glabrous; leaves oblong-lanceolate to elliptic-ovate.

$\times$ Branches of the crowded ellipsoid to pyramidal panicle floriferous nearly throughout, ascending or ascending-spreading.

31. S. Ellibttii T. \& G. Smooth; stem stout, 0.5-1.8 m. ligh, very leafy; leaves elliptical or oblong-lanceolate, acute, $0.5-1 \mathrm{dm}$. long, closely sessile, slightly serrate, strongly veined, thick, smooth both sides, shining above; heads in dense slightly spreading racemes which are crowded in a close pyramidal panirle; involucre 4-5 mm. long; peduncles and achenes strigose-pubescent; rays $8-12$. - Swamps (fresh or brackish) near the coast, Mass. to N.J., and southw. Sept., Oct.

\section{$\times \times$ Longer branches of the loose panicle chiefly flowerless at base, strongly recurved-spreading.}

32. S. ulmifolia Muhl. Stem smooth, slender, 5-15 dm. high, the branches hairy; leaves thin, elliptical-ovate or oblong-lanceolate, pointed, tapering to the base, lnosely veined, usually beset with soft hairs beneath; racemes panicled, loosely recurved-spreading; involucre $3-4 \mathrm{~mm}$. long, its bracts lanceolate-oblong; ray's about $4 .-$ Dry or rocky woods and copses, N. S. and s. Me. to Minn., and southw. Aug., Sept.

++ Stems pubescent (or glabrous only in var. of no. 33 , which has lanceolate leaves and strongly recurved panicle-branches).

33. S. rugdsa Mill. Stem villous ov villous-hirsute with long sordid hairs, $0.5-2 \mathrm{~m}$. high ; leaves crowded, lanceolate or wate-lanceolate, narroved at base, mostly sharp-serrate, pubescent (especially beneath), thin and loosely veiny, not conspicuously rugose; racemes spreading in a broad pyramidal panicle, all much exceeding the subtending leaves; involucre $3-4 \mathrm{~mm}$. long, its bracts linear; rays $6-9$; disk-flowers $4-7$. ( $S$. altissima of auth., not L.) - Damp thickets and borders of fields, Nfd. to w. Ont., and southw. Aug., Sept. Var. sphaGvóphil a Graves. Stems and leaves glabrous. - Wet shores and mossy swamps: e. Mass. to $\mathrm{Ct}$.

Var. villosa (l'ursh) Fernald, Panicle elongate, most of the racemes nearly equaled or even exceeded by the large subtending leaves. - The common extreme from Lab. and w. Nfd. to w. Que. and n. Me.

$\times$ S. aspérula Desf. Smooth below, somewhat rough-pubescent above; stem stout, 7-14 dm. high, very leafy; leaves thick and sligbtly veiny, lanceolate or elliptic, scabrous or rarely glabrous, the lower 1-2 dm. long; racemes, etc., intermediate between those of nos. 21 and 33. - Dryish borders of salt marshes, Me. to Ct.; apparently a hybrid of the preceding species and no. 21, more widely distributed than most such plants of this genus.

34. S. áspera Ait. Stem scabrous-puberulent or short-hispid; leaves ovate, oblong, or ovate-lanceolate, rounded at hase, appressed-servate, very scabrous on both surfaces, thick and strongly rugose; inflorescence much as in no. 33, but the elongate racemes mostly forming a more slender panicle. (S. rugosa Man. ed. 6 , in part.) - Dry woods and fields, rarely in meadows, e. Mass. and 0 . tc Fla. and 'Tex. Aug.-Oct.

$\rightarrow+$ Leaves more or less plainly 3-mibbed, 2 of the lower veins becoming prominent and elongated parallel with the midrib; heads in 1-sided chiefly spreaaing or recurved racemes, forming an ample panicle; not maritime.

$=$ Branches of the panicle glabrous.

35. S. missouriénsis Nutt. Smooth throughout, $2.5-10 \mathrm{dm}$. high; leaves firm and rigid, linear-lanceolate, or the lower broadly lanceolate, tapering to both ends, with very rough margins, commonly bearing axillary fascicles; teeth, if any, sharp and rigid; heads and dense crowded recurved racemes nearly as in no, 25 ; involucre $3-5$ nmm. long, its very unequal thickish straw-colored bracts 
blunt; rays 6-13, small; arhenes nearly glabrous. - Dry prairies and open woods, 'Tenn. to Man., and westw. July-Sept.

: $t_{i}$. S. Gattingèri Cliapm. Slender and strict, 4-10 du. high; stems smooth throughout; leaves ciliolate, smooth beneath, harsh above, the lowest $0.7-1.5$ $\mathrm{dm}$. lon!' lance-spatulate, appressed-serrulate or subenite, the upper reduced rapidly to minute entire bracts with naked axils; branches of the naked subcorymbiform panicle elongate and ascending, hardly recurved; involucre :3-4 $\mathrm{mm}$. long, its oblong bracts obtuse; rays 6 $6-10$; achenes tipressed-puberulent, or glabrate below. - Limestone hills and barrens, Tenn. and Mo. July-Sept.

\section{$==$ Branches of the panicle pubescent.}

a. Leaves firm and often rigid, the lower usually elongated and many times exceeding the reduced upper ones (except in no. 39); involucral bracts thirl and rigid.

1. Lower portion of the stem and the leaves essentially glabrous.

37. S. Shórtii T. \& G. Stem slender, simple, 0.5-1.2 m. high, minutely roughish-pubescent above; leaves (the larger $0.5-1 \mathrm{dm}$. long) oblong-lanceolate, acute, the lower mostly serrate with a few fine teeth; racemes recurved, usually in a crowded panicle ; involucre slender, 4-6 mm. long; achenes silky-pubescent. - Rocks at the Falls of the 0 .

\section{Stem and leaves pubescent.}

o Stems and leaves ashy or whitish with close puberulence.

38. S. nemoràlis Ait. Clothed with minute grayish-hoary soft or roughish pubescence; stem simple or corymbed above, 1.5-7.5 dm. high; leaves oblanceolate or spatulate-oblong, mostly subtending axillary fascicles ; the lower longpetioled, usually crenate-toothed, 5-15 cm. long; the uppermost greatly reduced, $1-3 \mathrm{~cm}$. long ; racemes numerous, dense, at length recurved, and ordinarily form.ing a crouded compound raceme or panicle which is turned to one side; involucre 3.5-6 mm. long, its firm yellowish bracts linear-oblong, appressed; rays 5-9, bright yellow. - Dry open soil (rarely in woods), P. E. I. to the Saskatchewan, and southw. July-Nov. (rarely Dec.).

39. S. móllis Bartl. Stout, riyid, canescent; the stems 1.5-5 dm. high, solitary or clustered from a freely stoloniferous sublignèus base; leaves rigid, oval or oblong, obtuse or rarely acutish, gradually reduced upward, the uppermost 1-3 cm. long, the lower 3-8 cm. long; racemes ascending in a dense thyrse; involucre 4-6 $\mathrm{mm}$. long, greenish-yellow. ( $S$. nemoralis, var. incana Gray.) Dry hills and plains, Man, and Minn., westw, and southw. July-Sept. (Mex.)

o o Stems and leaves green.

40. S. rádula Nutt. Stem and oblong or obovate-spatulate leaves rigid and very rough, not hoary, the upper leaves sessile ; bracts oblong, rigid ; rays 3-6; otherwise nearly as in no. 39. - Limestone bluffs and dry open soil, s. w. Ill. to w. La. and Tex. Aug.-Oct.

b. Leaves thinner, essentially uniform from base to summit of the stem; involucral bracts thin.

\section{Leaves elongate, linear to lance-oblong.}

o Involucre 2-2.8 $\mathrm{mm}$. long.

41. S. canadénsis L. Stem rather slender, $0.3-1.5 \mathrm{~m}$. high, glabrous at least below, often minutely pubescent above; leaves narrowly lanceolate, thin, glalorus above, minutely pubescent on the nerves beneath, mostly sharp-serrate, the middle ones 6-13 $\mathrm{cm}$. long, 5-18 mm. wide; heads tiny, crowded in recurved racemes and forming dense broadly pyramidal panicles; pedicels strongly pilose; involucral bracts linear, mostly attenuate, greenish-straw-color. (Var. glabrata Porter.) - Thickets and rich open soil, Nfd. to N. Dak, s. to W. Va. and Ky. July-Sept.

Var. gilvocanéscens Rydb. Stems and leaves cinereous or canescent with minute puberuence; Jeaves broadly lanceolate to lance-oblong, the middle ones 
4-7 cm. long, 1-2 cm. broad. - Dry or sterile situations, Gaspé Co., Que.; and from Ill. to Man., Kan., and westw.

42. S. rupéstris Raf. Stem smooth, slender, 5-10 dm. high; leaves linear. lanceolate, tapering both ways, entire or nearly so, glabrous upon both surfaces; racemes ascending, scarcely recurved, forming somewhat open or elongate pan icles; pedicels slightly pilose or glabrate. - Rocky river-banks, W. Va., Ky., and Ind. Aug., Sept. - Too near the preceding, of which it may be a variety.

o o Involucre 3.2-5̆ mm. long.

\section{+ Stem closely and minutely pubescent throughout.}

43. S. altíssima L. Stem cinereous-puberulent, stout, 0.7-2 m. high; leaves thickish, lanceolate, subentire or more or less toothed, minutely pubescent or scabrous above, short-pilose beneath, the middle ones $6-13 \mathrm{~cm}$. long, 10-18 mm. broad; heads crowded in recurved racemes forming dense high broadiy pyram. idal panicles; involucre $3.2-4.5 \mathrm{~mm}$. long, its subherbaceous bracts linear. (S. canadensis Man. ed. 6, in part, including var. scabra T. \& G.) - Rich open ground, Aroostook valley, Me.; Mass. and Vt. to Mich., Kan., and southw. Aug.-Oct.

Var. prócera (Ait.) Fernald. Stem and lower surface of the leaves more loosely pubescent with distinct soft hairs; branches of the panicle strongly ascending, scarcely if at all recurved at tip. (S. procera Ait.; S. canadensis, var. T. \& G.) - A little known extreme, apparently best developed in the L. Superior region. - In inflorescence sinulating $S$. elongata Nutt. of the Northwest and of the lower St. Lawrence, which has glabrous or glabrate stems and leaves, and less herbaceous involucre.

$$
++ \text { Stem glabrous throughout (or except in the inflorescence). }
$$

44. S. serótina Ait. Stem stout, 0.5-2.5 m. high, smooth, often glaucous ; leaves quite smooth both sides, lanceolate to oblanceolate, taper-pointed, very sharply serrate, except the narrowed base, rough-ciliate; the middle ones 7-16 $\mathrm{cm}$. long, 1-3 cm. wide ; the ample panicle pubescent ; involucre $3.5-5 \mathrm{~mm}$. long, its bracts linear, subherbaceous ; rays 7-14, rather long. - Thickets, in rich soil, N. B. to B. C., and southw. July-Sept.

Var. gigantèa (Ait.) Gray. Leaves glabrous above, slightly pubescent beneath, especially on the nerves; involucre $3.2-4 \mathrm{~mm}$. long. - Low ground, e. Que. to Ill., and southw.

\section{Leaves broad-elliptic or -ovate.}

45. S. Drummondii T.\& G. Stem (3-9 dm. high) and lower surface of the broadly ovate or oval somewhat triple-vibbed leaves minutely velvety-pubescent, some of the leaves almost entire; racemes panicled; bracts of the involucre oblong, obtuse; rays 4 or 5 . - Limestone cliffs and rocky woods, s. w. Ill. and Mo. to La. Sept., Oct.

++++ Heads in a conpound corymb terminating the simple stem, not at all racemose; leaves mostly with a strong midrib.

- Leaves flat, not 3-nerved.

46. S. rigida L. Rough and somewhat hoary with a minute pubescence; stem stout, $0.3-1.5 \mathrm{~m}$. high, very leafy; leaves oval or oblong, copiously featherveined, thick and rigid, the basal 1-3 dm. long, petioled; the upper closely sessile by a broad base, slightly serrate, the uppermost entire; corymb dense; heads more than 30-flowered; the involucre 6-8 $\mathrm{mm}$. long; rays 7-10. - Dry soil; Mass. to Man., and southw. Aug.-Oct.

47. S. ohioensis Riddell. Very smooth throughoui; stem wand-like, slen. der, leafy, 6-9 dm. high ; stem-leaves oblong-lanceolate, flat, entire, rough-margined, obscurely feather-veined, closely sessile, the upper only $3-4 \mathrm{~cm}$. long; the lower and radical ones elongated, $3 \mathrm{dm}$. long, slightly serrate toward the apex, tapering into long margined petioles; heads numerous, on smooth pedicels, 16-20-flowered; the involucre 4.5-6 mm. long; rays 6 or $7 .-$ Swamps and wet prairies, Ont. and w. N. Y. to Ind. and Wisc. Aug., Sept. 


\section{* Leaves somewhat folded, entive, the lower slightly 3-nerved.}

48. S. Riđdéllii Frank. Smooth and stout, $0.5-1 \mathrm{~m}$. high, very leafy, the branches of the dense corymb and pedicels rough-pubescent ; leaves linear-lanceolate, the cauline elongated (1-1.5 dm. long), acute, partly clasping or sheatling, mostly recurved, the lowest elongated-lanceolate (3-5 dul. long) and tapering into a long keeled petiole; heads very numerous, clustered, 20-30-flowered; rays 7-9. - Wet grassy prairies, Ont. to Minn. and Mo.; Ft. Monroe, Va. Aug., Sept. - Heads larger than in the preceding.

49. S. Houghtonii 'I' \& G. Smooth; stem rather low and slender, 3-6 dm. high; leaves scattered, linear-lanceolate, acutish, rough-margined, $0.5-1.3 \mathrm{dm}$. long, 5-10 $\mathrm{mm}$. wide, tapering in to a narrowed sliglitly clasping base, 1-nerved, or the lower 3-nerved and with margined petioles; veins obscure; heads few or several, 20-30-flowered; involucre 6-8 $\mathrm{mm}$. long, with obtuse bracts ; rays 7-9. -Swamps, north shores of Lakes Michigan and Huron; Genesee Co., N. Y. July, Aug.

§2. EUTHAMIA Nutt. Corymbosely much branched; heads small, sessile or subsessile, in little clusters crowded in flat-topped corymbs; the closely appressed involucral bracts somewhat glutinous; receptacle fimbrillate; rays 6-20, short, more numerous than the disk-flowers; leaves narrow, entire, sessile.

\section{* Leaves distinctly 3-5-ribbed; heads 20-30-flowered.}

+ Involucre 4-5 mm. long, the bracts usually without conspicuous tips.

50. S. graminifolia (L.) Salisb. Stem 5-10 dm. high, glabrous; leave; lance-linear, the primary ones $5-13 \mathrm{~cm}$. long, 4-9 mm. broad, glabrous except for the scabrous margins and the minutely pubescent nerves beneath; branches of the inflorescence glabrous or at most minutely serrulate on the angles; leafy bracts of the inflorescence ascending; heads obovoid-cylindric, sessile, in dense corymbed glomerules; involucral bracts strrw-color or yollowish-green, their tips rarely darker, the outermost ovate or oblong. (Euthamia Nutt.; S. lanceolata Man. ed. 6, and perhaps L.) - Moist soil, e. Que. to Sask., s. to N. J., Ill., Mo., and along the mts. to N. C. Aug.-Oct.

Var. Nuttallii (Greene) Fernald. Leaves more pubescent; branches of the inflorescence hirtellous. - N. S. to Mich. and Ala.

\section{+ +- Involucre 3-3.5 mm. long, the bracts with conspicuous green tips.}

51. S. polycéphala Fernald. Similar to the preceding varlety; leaves elongate, thin, puberulous; branches of the conymb very hirlellous, their small bracts wide-spreading or deflexed; involucre turbinate, very small, its somewhat puberulent bracts with closely appressed deltoid green tips. - Apparently local, s. N. J. and e. Pa. Aug., Sept.

* Leaves 1-ribbed or obscurely 3-nerved; heads 12-20(rarely 22 )-flowered.

+ Leaves almost acicular, the middle cauline 1-1.5 mm. wide.

52. S. mìnor (Michx.) Fernald. Very slender, 4-8 dm. high, the glabrous stem freely fastigiate-branched above the middle; leaves extremely slender, the primary ones $3-5 \mathrm{~cm}$. long, acerose-tipped, 1-ribbed, punctate, commonly subtending axillary fascicles as do many of the rameal ones; heads mostly shortpediceled, in numerous small corymbs; involucre nearly cylindric, acute at base, 3-4 mm. long, 1-1.5 mm. thick, its firm appressed glutinous straw-colored bracts with slightly green acutish tips. ( $S$. tenuifolia Pursh, in part.) - Sandy soil, near the coast, Va. to Fla. and Ala. Sept., Oct.

+ + Leaves flat, broader, 2-6 mm. wide.

+ Involucre 3-4 mm. long.

53. S. tenuifolia I'ursh. Rather slender, 3-9 dm. high, the glabrous stem freely fastigiate-branched above the middle; leaves linear or linear-lanceolale, soon spreading or reflexed; the primary ons $4-7 \mathrm{~cm}$. long, $2-4 \mathrm{~mm}$. broad, taper-pointed, 1-ribbed, often obscurely 2-nerved, minutely punctate, usually 
subtending axillary fascioles; rameal leaves smaller, usually without axillary fascicles; heads mostly in glomerules, a few pediceled, the pedicels smooth or scabrous; involucre campanulate, 3-4 mm. long, 2-3 mm. thick, its firm oblong glutinous bracts blunt. (Euthamia Greene; $\boldsymbol{E}$. caroliniana Am. auth., in part, not Greene.) - Salldy or gravelly soil, chietly near the coast, e. Mass. to Fla.; also n. Ind. to s. Wisc, Aug.-Oct.

54. S. Moselèyi Fernald. Similar, $5-6 \mathrm{dm}$. high ; leaves lance-linear, taperpointed, without axillary fascicles; heads mostly on scabrous pedicels subtended by very ninute subulate bracts; involucre subcylindric, 3-4 mm. long, 1.5-2 mn. thick, its very unequal soft bracts linear. - Oxford Prairie, Erie Co., o. (Moseley). Sept.

$$
\text { + Involucre 5-6 mm. long. }
$$

55. S. leptocéphala T. \& G. Stem strict and simple nearly to the summit, 3-6 dm. high; leaves linear-lanceolate, firm, light green, strongly 1-ribbed, with or without obscure lateral nerves, somewhat punctate but not viscid, the middle ones 4-6 $\mathrm{cm}$. long, 4-6 $\mathrm{mm}$. wide; heads sessile or short-pediceled; involucre cylindric-clavate, its linear pale straw-colored bracts barely viscid. (Euthamia Greene.) - Damp sandy ground, e. Neb. to Miss. and Tex. Aug.-Oct.

56. S. gymnospermoìdes (Greene) Fernald. Similar, freely fastigiatebranched from near the middle; leaves linear-attenuate, I-ribbed, strongly punctate, glutinous; the middle ones $5-7 \mathrm{~cm}$. long, 2-3 $\mathrm{mm}$. wide; involucre very viscid. (Euthamia Greene.) - Dry soil, e. Kan. to La. and Tex. Aug.-Oct.

\section{BRACHYCHAÈta T. \& G. False Golden-rod}

Habit and flowers nearly as in Solidago, except as to the pappus, which is a row of minute rather scale-like bristles, shorter than the achene. - A perennial herb, with rounded or ovate serrate leaves, all the lower ones heart-shaped; the small yellow heads in sessile clusters racemed or spiked on the branches. (Name composed of $\beta$ pa ús, short, and $\chi a l \tau \eta$, bristle, from the pappus.)

1. B. sphacelata (Raf.) Britton. Slender, about $1 \mathrm{~m}$. high. (B. cordata T. \& G.) - Wooded hills, s. Ind. to Va. and Ga. Aug.-Oct.

\section{APLOPÁPPUS Cass.}

Heads many-flowered, radiate; rays many, pistillate. Involucre hemispherical, of many closely imbricated bracts in several series. Receptacle flat. Achenes short, turbinate to linear; pappus simple, of numerous unequal bristles. - Mostly herbaceous perennials, with alternate rigid leaves. Ray- and disk-flowers both yellow. (From $\dot{\alpha} \pi \lambda \delta_{0}$, simple, and $\pi \dot{\alpha} \pi \pi o s$, pappus.)

1. A. ciliàtus (Nutt.) DC. Annual or biennial, glabrous, $0.5-1.5 \mathrm{~m}$. high, leafy; leaves oval (or the lower obovate), obtuse, dentate with bristle-pointed teeth; heads very large, few and clustered, the outer bracts spreading; achenes glabrous, the central abortive. (Prionopsis Nutt.) - Mo., Kan., and southw.

2. A. spinuldsus (Pursh) DC. Perennial, branching, puberulent or glabrate, low ; leaves narrov, pinnately or bipinnately parted, the lobes and teeth bristletipped; heads small, the appressed bracts bristle-tipped; achenes pubescent. (Sideranthus Sweet; Eriocarpum Greene.) - Minn. and Ia. to the Saskatchewan and Tex.

\section{BIGELòWIA DC. RAYLESS GOLDEN-ROD}

Heads 3-4-flowered; flowers all tubular and perfect. Involucre club-shaped, yellowish; the rigid somewhat glutinous bracts linear, closely imbricated and appressed. Receptacle narrow, with an awl-shaped prolongation in the center. Achenes somewhat obconical, hairy; pappus a single row of capillary tristles. Flowers yellow. Leaves scattered, oblanceolate or linear, 1-3-nerved. A large chiefly western genus, few species approaching our limits. (1)edicated to $D r$. Jacob Bigelow, author of the Florula Bostoniensis, and of the American Medical Botany.) Chondropmora Raf. Bigesotia T. \& G. 
$\therefore$ B. nudàta (Michx.) DC. A smooth perennial; the slender stem $3-8 \mathrm{dm}$. high, simple or branched from the base, naked above, bearing small heads in a flat-topped corymb. - Low pine barrens, N. J., and southw. Sept.

\section{BÉLlis [Tourn.] L. DaISY}

Heads many-flowered; the rays numerous, pistillate. Bracts of the involucre herbaceous, equal, in about 2 rows. Receptacle conical, naked. Achenes obovate, flattened, wingless, and without any pappus. - Low herbs, chiefly of the old World, either stemless, like the true Daisy, B. PERÉnNis L. (which is found as an occasional escape from cultivation), or leafy-stemmed, as is the following. (The Latin name, of uncertain derivation.)

1. B. integrifólia Michx. (Western D.) Annual or biennial, diffusely branched, 1-4 dm. high, smoothish; leaves lanceolate or oblong, the lower spatulate-obovate; beads on slender peduncles; rays pale violet-purple. Prairies and banks, Ky., and southwestw, May, June.

\section{CHAETOPÁPPA DC.}

Heads several-flowered, radiate; disk-flowers often sterile. Involucral bracts imbricated in 2 or more rows, the outer shorter. Receptacle flat, naked. Achenes fusiform or compressed; pappus of 5 or fewer thin nerveless scales, aiternating with rough bristly awns, or these wanting. - Low southwestern branching annuals, with narrow entire leaves and solitary terminal heads; rays

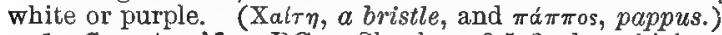

1. C. asteroìdes DC. Slender, $0.5-3 \mathrm{dm}$. high, pubescent; involucres slender, $4 \mathrm{~mm}$. long; rays $5-12$; achenes pubescent. - Dry grounds, Mo., and southwestw.

\section{BOLTÒNIA L'Hér.}

Heads many-flowered; rays numerous, pistillate. Bracts of the hemispherical involucre imbricated somewhat in 2 rows, appressed, with narrow membranaceous margins. Receptacle conical or hemispherical, naked. Achenes very flat, obovate or inversely heart-shaped, margined with a callous wing, or in the ray 3 -winged, crowned with a pappus of several minute bristles and usually 2-4 longer awns. - Perennial bushy-branched smooth herbs, pale green, with the aspect of Aster; the thickish leaves chiefly entire, often turned edgewise. Flowers autumnal ; disk yellow; rays white or purplish. (Dedicated to James Bollon, English botanist of the 18th century.)

* Heads middle-sized, loosely corymbed.

1. B. asteroìdes (L.) L'Hér. Stems $0.2-2.5 \mathrm{~m}$. high ; leaves lanceolate; involucral bracts acuminate; pappus of few or many minute bristles and 2 awns $\mathrm{ni}^{\mathrm{r}}$ none. - Moist places along streams, $\mathrm{Ct}$. to Neb., and southw. Aug.-Oct. Var. DECúrRens (T. \& G.) Engelm. A large form with the leaves alate-decurrent upos1 the stem and branches. (B. decurrens Wood.) - Ill. and Mo.

2. B. latisquàma Gray. Heads rather larger; involucral bracts oblong to ovate, obtuse or mucronate-apiculate ; pappus-awns conspicuous. - Prairies, etc., w. Mo., Kan., and Okla.

* Heads small, panicled on the slender branches.

3. B. diffussa Ell. Stem diffusely branched; leaves lance-linear, those on the branchlets very small and awl-shaped; rays short, mostly white; pappus of several very short bristles and 2 short awns. - Prairies, etc., s. Ill. to Fla. and Tex. Aug.-Oct.

\section{2. Áster [Tourn.] L. Starwort. Frost-hlower. Aster}

Heads many-flowered, radiate; the ray-flowers in a single series, fertile. Bracts of the involucre more or less imbricated, usually with herhaceous or leaf- 
like tips. Receptacle flat, alveolate. Achenes more or less flattened; pappus simple, of capillary bristles (double in $\$ \$ 4$ and 5). - Perennial herlus (annual only in $\$ \S 7$ and 8 ), with corymbed, panicled, or racemose heads, flowering chiefly in autumn. Rays white, purple, blue, or pink; the disk yellow, often changing to purple. Species often without sharply defined limits, freely hybrid. izing. (Name $\dot{a} \sigma \tau \eta \rho, \alpha$ sta $\%$, from the radiate heads of flowers.)

$N . B$. - In this genus the heads are drawn on a scale of $\frac{2}{8}$, the leaves $\frac{1}{2}$.

A. At least the basal leaves cordate and definitely petioled $\boldsymbol{B}$.

$B$. Stem-leaves petioled or sessile, not clasping $C$.

$C$. Rays white $D$.

D. Plant not glandular $E$

E. Heads corymbose.

Involucre ovoid-campanulate, thick-cylindric, or turbinate; tufted basal leaves few or none.

Leaves thin, smoothish, at least not rough above

Leaves thick, rough above.

Inflorescence slightly forking; heads few, 1-1.5 cm. high Inflorescence much branched; heads numerous, hardly

Involucre slender, cylindric; large tufted basal lesives abundant

$E$. Heads paniculate

$D$. Glandular, at least as to the branches of the inflorescence :

$C$. Rays blue or violet $F$.

$F$. Plant not glandular $\theta$.

$G$. Involucral bracts with squrroase tips; rays many (about 40 ) .

$Q$. Involucral bracts appressed or ascending; rays fewer $(10-20) B$.

$H$. Leaves entire or essentially so, firm, much longer than wide. Leaves harsh above

Leaves smooth above

H. Leaves serrate, mostly thinner $I$.

I. Involucre 4-6 mm. high ; bracts appressed, with conspicuous colored tips; heads abundant, panieulate.

Cordate leaves mostly on slender petioles, neither glancous nor very smooth.

Cordate leaves mostly on winged potioles, glauconis be-

I. Involucre 6-10 mm. bigh; bracts loose, without conspicuously colored tips.

Heads abundant, densely racemo-panicalate.

Stem essentially glabrous

Stem densely short-pubescent

Heads fewer, loosely paniculate or subcorymbose :

$F$. At least the branches of the inflorescence glandular . "

2. A. divaricatus.

8. A. furcatus.

4. A. glomeratus.

5. A. Schreberi.

23. A. cordifolius.

6. A. maorophyllus.

19. A. anomalus.

20. A. asureus.

21. A. Shortii.

23. A. cordïfolius.

24. A. Lonomisanus.

25. A. sagittifolius.

26. A. Drummondii.

27. A. Lindleyanus.

6. A. macrophyllus.

$B$. Stem-leaves mostly cordate-clasping None of the leaves at once cordate and definitely petioled $J$.

22. A. undulatus.

J. At least the lower leaves abruptly narrowed or constricted below the middle.

Leaves essentially entire, at most slightly constricted above the base

Lenves sharply serrate, the lower contracted to winged petloles.

Leaves with abruptly dilated auriculate-clasping bases

Leaves without dilated bases, Bcarcely clasping

$J$. Leaves not abruptly narrowed or constricted below $\dot{K}$.

$\boldsymbol{K}$. Stem-leaves with cordate- or auriculate-clasping bases $L$.

$L$. Involucre glandular-bairy ; rays usually deep violet $\boldsymbol{M}$.

M. Leaves conspicuously cordate-clasping, mostly entire.

Branchlets glandular-viscid ; involucre hemispherical; bracts subequal, linear-attenuat $\theta$, loose

Branchlets not glandular; involucre turbinate; bracts unequal, linear-oblong, with slightly spreading green tips

MT. Lesves obscurely cordate-clnsping.

Plant rigld, freoly branching; leaves mucronate-tipped ; involucral bracts unequal, linear or linear-oblong, with spreading tips

Plant not rigid, bearing fow torminal heads; leaves thin,

acuminate; bracts equal, lt
$\boldsymbol{L}$. Involucre not glandular-hairy $N$.
3. Bracts of the involucre distinct series successively shorter 0 .

o. Plant smooth and glaucous.

Leaves lanceolate to ovate; beads panleulate

Leaves narrower; heads solitary or racemose

o. Plant not glaucous.

iips of bracts squarrose or recurved-spresding.

14. A. novas-anglias.

18. A. patens.

18. A. oblongifolius.

15. A. modestus. 
Piant elnereous-pubescent, with small leaves $(5 \mathrm{~cm}$, or

less long); heads $6 \mathrm{~mm}$. high
Plant green and essentially glabrous; leaves and heads larger; bracts herbaceous, the outer often foliacoous Tips of bracts ascending, not recurved.

Bracts linear-oblong or lanceolate, film, with dilated herbaceous tips; rays deep blue or violet.

Leaves conspicuously clrsping, the turicles generally meeting around the stem

Leaves slightly or inconspicuously clasping: : :

Bracts linear-attenuate, thin, with slender green or colored tips; rays white or lavende1"

$N$. Bracts of the involucre essentially equal, only the very outermost sometimes broader and shorter.

Tips of bracts ac'lte (not attenuate), recurved-spreading or squarrose

Tips of bracts (except occasional outer foliaceous ones) longattenuate, ascending, not recurved.

Stem slender, glabrous or villous; leaves long-lanceolate; involuere $5-8 \mathrm{~mm}$. high

Stem stout, glabrous or harshly pubescent; leaves lanceolate to narrowly rhombic-obovate; involucle $7-12 \mathrm{~mm}$.

5. Stem-lesves narrowed or rounded or cordate at base, but not 85. A. amethystinus.

46. A. novi-belgii.

18. A. patens.

81. A. conodinus.

42. A. paniculatus.

46. A. novi-belglt.

45. A. longifoltus.

49. A pruniceus. clasping $P$

$P$. Leaves silvery-silky on both faces, entire.

Heads solitary or few at the tips. of the branches; achenes smooth

Heads in a wand-like raceme; achenes silky

$P$. Lenves green, not silvery-silky, sometimes pilose or villous $Q$.

$Q$. Involnere glandular-viscid; rays violet $R$.

$R$. Basal leaves petioled, much larger than the cauline.

Basal leaves ovate or ovate-oblong, on nearly naked petl-

Basal leaves narrower, on margined petioles; involucre squarrose.

Tall; basal leaves spatulate- to lance-oblong; involucre 1-1.5 cm. high, very glandular . '.

Low; basal leaves lanceolate; involuere mostly shorter, barely glandular .

n. Basal and stem-leaves nniform, linear to oblong, the lower not conspicuously petioled.

Leaves firm, linear- to lance-oblong, entire, blunt or acutish.

Stem hispid; uppermost leaves passing into involucral

Stem glandular-puberulent; uppermost leaves and involucral bracts distinet.

Leaves thin, ]anceolate, acuminate, subentíre to serrate

Q. Involucre not glandular $S$.

$S$. Basal leaves with definite margined petioles.

Involucral bracts oblong, coriaceous.

Leaves entire or slightly dentate.

Bracts strongly ciliate; involuere turbinate-hemispherical

Bracts not ciliate, nearly or quite glabrous ; involucre slender-turbinate . . . . . .

Lenves serrate : . : :

Involucfal bracts linear or linear-subulate, thin : : :

A. None of the leaves definitely petioled, or the sower inconspicuousiy so $T$

$T$. Stem-leaves linear $U$.

$U$. Stem glabrous or glabrate, or only slightly pubescent above $\boldsymbol{F}$.

V. Involucre $5 \mathrm{~mm}$. or less high $W$.

W. Bracts with deflnite firm subulate tlps. Involucre hemispherical or campanulate, as broad os bigh Involucre turbinate, only $2-3$ inm, broad :

$W$. Bracts without firm subulate tips $X$.

$\mathcal{X}$. Bracts with conspleuous elliptic or subrhombie green tips.

Heads terminating minutely foliose branchlets.

Heads paniculate or if few on leafy (not minutely foliose-bracteolate) brancblets (n)

3. Bracts attenuate, withoilt conspicuous dilated tips. Rays white (or lavender-tinged). Branches ascending-paniculate; heads in ra cemo-panfoulate clasters.

\section{A. grandiflorus}

13. A. oblongifolius 15. A. modeatus.
16. A. sericeus. 17. A. concolor.

7. A. Bervery.

8. A. spectabilts.

9. A. 8urculosus.

\section{A. aurculosus.}

10. A. gracilis.

11. A. radula.

47. A. tardiflome.
88. A. ertcoides.

34. A. depauperatus
98. A, aumosus.

43. A. sulicifolius. 
Rays $6 \mathrm{~mm}$. or less long; leaves slightly serrate

41. A. Tradescantt.

Rays l(2) A. paniculatus, v, bollidiflorins. Branches divaricate; small heads in 1-sided racemes .39 . A. vimineus.

Branches ascending, terminated by solitary heads (39) A. vimineus, v. saxutilis.

Rays violet or rose-pink (exceptionally white).

Leaves at most $4.5 \mathrm{~cm}$. long, becoming revolute . . 55, A. nemoralis.

Leaves longer, plane . . . . . 44, A, junceus.

$\checkmark$ Involucre more than $5 \mathrm{~mm}$. high $Y$.

$\boldsymbol{Y}$. Bracts with definite firm subulate tips

Y. Bracts without firm subulate tips Z

2. Leaves at most $4.5 \mathrm{~cm}$. long.

Stems many, rigid, from a woody caudex; bracts firm, the inner blunt ; rays blue-violet

Stem single, from a slender rootstock; bracts thin, linearattenuate; rays rose-pink.

$\boldsymbol{Z}$. Leaves longer $\boldsymbol{a}$,

a. Annuals, with inconspicuous rays.

Bracts definitely imbricated, linear or linear-subulate

Bracts subequal, the outer foltaceous.

Leaves linear-attentate; rays shorter than the style

Leaves linear-oblanceolate to spatulate; rays longer than the style

u. Perennials, with mostly couspicuous rays $b$.

b. Bracts frm, lanceolate.

Bracts nnequal, regularly imbricated, not foliaceous

Bracts subequal or imbricated, with spreading foliaceous tips

b. Bracts thin, linear or linear-lanceolate.
32. A. polyphyllus.

52. A. linarizfolius

55. A. nemoralis.

57. A. subulatus.

58. A. angustus.

59. A. frondosus.

56. A, tenuifolius.

1. A. patudosus.

Bracts with conspicuous elliptic or subrhombic green tips. Heads terminating minutely foliose-bracteolate branchHexds paniculate, or if few on leafy (not minutely foliose-bracteolate) branches

88. A. dumosus.

48. A. salicifolius.

Bracts without conspicuous colored tips.

Rays white; brocts very narrowly linear-attenuate, regularly imbricated, 4-6 mm. long (42) A. paniculatus, v. belliatiforms.

Rays violet or rose-pink; bracts linear-lanceolate, less definitely imbricated, mostly longer . . . 44. A.junceus.

J. Stem conspicuonsly pubescent.

Leaves crowded, rigid; rays white (rarely purple-tinged).

Heads $5-6 \mathrm{~mm}$. high

Heads $7-9 \mathrm{~mm}$. high

Leaves not rigid; rays blue

Involucral bracts not bristly-ciliate.

Bracts with firm subulate tips; short rays usually white.

Involucre hemispherleal or campanulate, as broad as high (39) A. ericoides, v. villosus. Involucre turbinate, narrower tban high . - (54) $A$. depauperatus, v. parviceps.

Bracts thin, linear-attenuate, without firm subulate tips; stem puberulent; long rays violet or rose-pink

55. A, nemoralis.

T. Stem-leaves lanceolate or broader o.

c. Heads fn flat-topped corymbs ; rays white or whitish (not blue or violet).

Leaves rigid, linear-lanceolate; pappus simple.

Leaves not rigid, broader; pappus double.

Involucre $3-4.5 \mathrm{~mm}$. high ; leaves lanceolate to ovate.

In volucre 5-7 mm. high; leaves obovate to oblong

c. Heads paniculate or racemose $d$.

- 58. A. ptcirmicoides.

86. A. multiflomus.

3i. A. commutatus.

35. A. amethystinus.

d. Stems glabrous or essentially so $t$.

e. Involucre $5 \mathrm{~mm}$. or less high.

Bracts with definite frm subulate tips

50. A. umbellatus.

- 51. A. infinmus.

Bracts without firm subulate tips.

Heads in more or less 1-sided racemes.

Leaves narrowly lanceolate, scarcely serrate; bracts lint ... attenuate.

Leaves broader, serrate; bracts "with" the midrib dilatec upward and rather conspleuous

Heads on ascending-peniculate branches.

Bracts linear-attenuato.

Heads (Including rays) $1-1.5 \mathrm{~cm}$. broad; bracts very slender and green

Heads larger; bracts green chiêly st tip. : : :

Bracts broad-linear or linear-oblong, with conspicnous elliptio or subrhombte green tips

e. Involuere more than $5 \mathrm{~mm}$. high $f$.

$f$. Bracts with deflnite firm subulate tips

$f$. Bracts without firm subulate tips $g$.

g. Leaves on branchlets reduced to rigid subulate bracts.

Perennial; involucre $9 \mathrm{mnt}$. or more high, of frm closely imbricated bluntish bracts

38. 4. ericoides.

39. A. vimineus.

40. A. laterifioms.

41. A. Tradescanti.

42. A. paniculatus.

43. A. salicifolius.

32. A. polyphylus.

28. A. turbinellus. 
Annual; involucre 6-8 $\mathrm{mm}$. high, of linear-subulate loosely imbricnted bricts

57. A, subulatus.

g. Leaves on bianchlets broailer " $/$.

$h$. Inflorescence loosely paniculnto-corymbose.

Bracts thin, uniform, linegr-lanceulate; rays few, white or pinkish, rarely wanting

Bracts firm, oblong, the tips foliacens; rays numerous,

h. Iuflorescence definitely paniculate $i$.

i. Bracts ascending, their tips not squarrose.

Bracts regularly imbricated in several series.

Brats linear-attenuate broad-linear or linear-oblong, with conspicuous elliptic or subrhombic green tips $: \dot{ }_{\text {Bracts subequal }} \cdot \overrightarrow{\text {. }}$
racts with spreading or squarrose tips, the outer mostly foliaceous

d. Stem conspicuously pubescent if.

54. A. acuminatus.

11. A. radula.

42. A. paniculatus.

43. A. salicifolius.

45. A. longifolius.

46. A. novi-belgii.

j. Bracts with definite firm subulate tips.

Involucre bemispherical or campanulate, as broad as high; leaves

(35) A. ericoides, v, platyphyllus.

Involucre turbinate, narrower than high

j. Bracts without firm subulate tips.

Ileads solitary or loosely paniculate-corymbose; bracts thin, linear-

lanceolate, loosely imbricated ; rays whitish, violet, or rose-pink.

Leaves essentially inniform aud erowded on the stem, entire or slightly toothed, blunt or acutish.

55. A. nemoralis.

Upper leaves largest, coarsely touthed, long-acuminate . :54. A. acuminatus.

Heads panieulate or racemose ; bracts rather closely imbricated.

Bracts regularly imbricated in several series; rays short, white to lavender.

Heads regularly paniculate; bracts linear-attenuate; leaves lanceolate . . . . . . (42)

Heads in more or less 1 -sided racemes; bracts generally with colored dilated midribs; leaves lanceolate to oblong .

A. paniculatus, vars.

Bracts subequal; 1 rays long, blue or violet; stem densely villous

40. A. lateriflorus.

(45) A. longifolius, v. villicaulis.

\$ 1. HELEASTRUM (DC.) B. \& H. Pappus simple, coarse and rigid, the stronger bristles somewhat clavate; bracts rigid, more or less foliaceous, nearly equal.

1. A. paluddsus Ait. Stems $3-7 \mathrm{dm}$, high, glabrous or nearly so; heads rather few, racemose or spicate; involucre $1 \mathrm{~cm}$. high; outer bracts lax, foli-

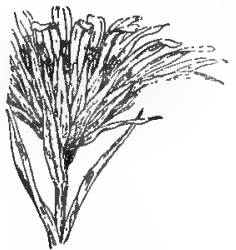

91\%. A. paludosus. aceous ; rays purple ; leaves linear, entire. - Kan. to Tex., N. C., and Ga. Fig. 918.

§ 2. BIÒTIA (DC.) 'T. \& G. Involucre obovoid-bellshaped, turbinate, or cylindric; the bracts regularly imbricated in several rows, appressed, nearly destitute of herbaceous tips; rays 6-18; achenes slender; pappus stightly rigid, simple; lower leaves heart-shaped, petioled, coarsely serrate; heads in open corymbs (rarely congested).

* Rays white (sometimes colored in age); branches of inflorescence without glands.

- Involucre ovoid-bell-shaped or turbinate; plants simple, rarely producing large tufted basal leaves.

- Leaves thin, smooth or sparsely hairy but not rough.

2. A. divaricàtus L. Stem slender, somewhat zigzag, 3-9 $\mathrm{dm}$. high, glabrous or sparingly pilose ; leaves coarsely and unequally serrate with sharp spreading teeth, taper-pointed, ovate, cvate-lanceolate, or deltoid-ovate, all but the uppermost heart-shaped at the base and on slender naked petioles; involucre 6-8 mm. high; bracts thin, scarious, mostly obtuse and ciliate, with inconspicuous green tips, the outer short and

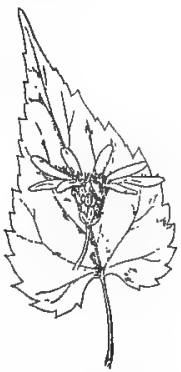
oblong ur oblong-triangular, the inner linear; rays 6-12. 919. A. divaricatus 
(1. commbosus Ait.) - Woodlands, s. Me. and w. Que. to L. Superior, s. to Ga. Aug.-Oet. Fig. 919. - Extremely variable in outline of foliage, intensity of

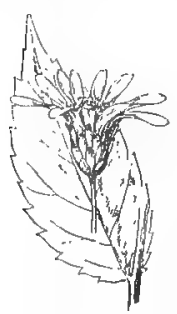

9:0. A. furcatus. coloring of disk-flowers, ctc., characters upon which Professor E. S. Burgess proposes as separahle species $A$. carmesinus, A. tenebrosus, and 26 others.

\section{+t Leaves thick, rough above.}

$=$ Heads few, large (1-1.5 cm. high).

3. A. furcàtus Burgess. Stem slender, 3-6 dm. high, almost uniformly leafy to the slightly forked summit; leaves ovate or elliptic, acuminate, coarsely serrate, lower short-petioled and slightly cordate, upper mostly sessile, often with broad-winged laciniate bases; involucre of 4-5 series of pubescent pale green regularly imbricated blunt bracts, the outer oblong, the inner linear, all with dark tips; rays $1 \mathrm{~cm}$. or more long, narrow. - Woods and rncky shaderl banks, Ill. and Mo. Aug.-Oct. Fig. 920.

$==$ Heads smaller (hardly $1 \mathrm{~cm}$. high), numerous in corymbose or subumbellate clusters at the tips of the branches.

4. A. glomeràtus Bernh. Rather stout, 4.5-9 dm. high; stem smooth, or pilose toward the summit; leaves pilose beneath or glabrate; the lower broadly ovate, acuminate, longpetioled ; the upper gradually smaller and narrower, on winged petioles or sessile; involucre green, broadly campanulate; bracts ciliate, dark-tipped, the inner ones slightly elongated, scarious only on the maryins; rays short, rarely $0.5 \mathrm{~cm}$. long. - Thickets and wooded banks, Me. to Va. Aug., Sept. Fig. 921.

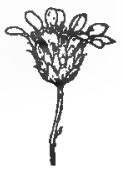

921. A. glomeratus. + + Involucre slender. cylindric; bracts thin and scarious (loose and spreading when $d r y$ ), the innermost much exceeding the next outer series; large tufted basal leaves abundant.

5. A. Schrebèri Nees. Resembling the preceding; stem smooth or pilose; leaves thin, often pilose on the petioles and veins beneath, smooth or harsh

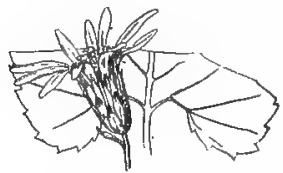

922. A. Schreberi. above ; basal ones large, when well developed with broad rectangular sinuses; involucre slightly imbricated ; rays $1 \mathrm{~cm}$. long. (Including A. curvescens Burgess.) - Danp woods and thickets, N. E. to Va. July-Sept. FIG. 922. * Rays violet or blue (rarely white); branches of the infloresence glandular.

6. A. macrophýllus L. Rather coarse, $0.3-1.5 \mathrm{~m}$. high, viscid-glandular at least in the inflorescence; sterile tufts of large ovate cordate leaves abundant; basal leaves large, cordate; the upper of various forins, usually smaller and narrower; involucre generally 3-4-seriate; bracts greenish, the outer short-ovate, biunt, and pubescent; the inner elongated, linear, more scarious, sometimes roseate-tinged on the margins. - An extrenely variable plant, from which several forms are separated, by some authors, as species. - The typical plant is simple, $3-9 \mathrm{dm}$. high, characterized by thick harsh foliage, stout rather smooth stem, and broad terminal corymbose inflorescence with many conspicuous stipitate glands. (Including A. roscidus, etc., Burgess.) - Open woods and thickets, N. B. to Minn. and N.C. Aug., Sept. Fig. 923. The following

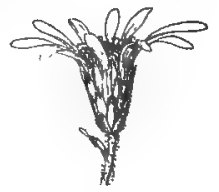

923. A. macrophyllus. varieties include the best-marked extremes. Var. PINGUifólios Burgess. Stem glabrous, 5-6 dm. high; many of the basal leaves very smooth (almost greasy), others scabrous at least in spots. - M*. to N. Y. and westw. Var. Excécsion Burgess. Stem smoothish, $1 \mathrm{ml}$, or so high, glaucous; leaves pale, for the inost part narrowly nute, oblong, or lanceolate; bracts elongated. $-\mathrm{N}$. H. to Ont. and Mich. Var. velutinus Burgess. Strms villous-pubescent; leaves pilose 
beneath, all but the lowest truncate or tapering at base: - Throughout the range, the commonest form northw. Var. SEJúnctus Burgess. Similar to the preceding variety, but most of the stem-leaves long-petioled, broad and cordate. Me. to $Y_{a}$ and Wisc. Var. a Pricénsis Burgess. Freely lranching from near the base, bearing innumerable heads. - Me. to l’a. Var. Í́sthinds (Burgess) Fernald. Glands minute, rarely stipitate; leaves thin. (Including $A$. ianthinus, violaris, multiformis, and nobilis Burgess.) - Me. to Ont. and W. Va.

\$3. EUASTER Gray. Bracts imbricated in various degrees, with herbaceous or leaf-like summits, or the outer entircly foliaceous; rays numerous; pappus simple, soft and nearly uniform (coarser and more rigid in the first group); achenes flattened.

* Bracts well imbricated, coriaceous, with short herbaceous mostly obtuse spreading iips; pappus of rigid bristles; stem-leaves all sessile, none heart-shaped or clasping; heads few or when several comymbose, large and showy.

- Lowest leaves ovate or ovate-oblong, on nearly naked petioles, some rounded or subcordate at base.

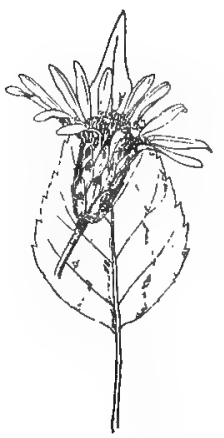

924. A. Herveyi.

7. A. Hervèyi Gray. Slightly scabrous, $3-9 \mathrm{dm}$. high, the summit and peduncles glandular-puberulent ; leaves roughish, obscurely serrate, the upper lanceolate; heads loosely corymbose, $1 \mathrm{~cm}$. or so high ; involucre nearly hemispherical ; bracts obscurely glandular, all erect, with very short or indistinct green tips; rays violet, $1-1.5 \mathrm{~cm}$. long. - Borders of oak woods, in rather moist soil, e. Mass. to Ct. and L. I. Fig. 924. - An ambiguous species, approaching the preceding and the next.

++ Radical leaves (usually absent in no. 11) all tapering into margined petioles; involucres squarrose (hardly so in no. 11); rootstocks slender.

8. A. spectábilis Ait. Stems $3-6 \mathrm{dm}$. high, roughish and glandular-puberulent above; leaves oblong-lanceolate or the lower spatulate-oblong, obscurely serrate or the upper entire; heads few, hemispherical ; involuere $1-1.5 \mathrm{~cm}$. high; bracts glandular-puberulent and viscid, mostly with the upper half herbaceous and spreading; rays about 20 , bright violet, $2 \mathrm{~cm}$. long. - Sandy soil, Mass. to Del., near the coast; also w. N. C. Aug.-Oct. Fig. 925.

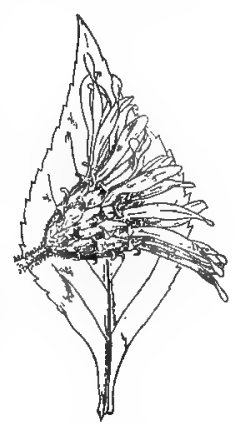

925. A. spectabilis.

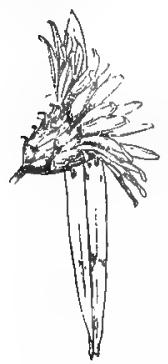

y.o. A. surculosus.

9. A. surculdosus Michx. Stems $2.5-4 \mathrm{dm}$. high, from long filiform rootstocks; leaves entire or nearly so, rigid, lanceolate or the upper linear; heads few or solitary, as in the preceding, but generally smaller, the bracts hardly glandular. - Moist ground, coast of N. J., and southw. Aug,-Oct. FIG. 926.

10. A. grácilis Nutt. Rootstocks occasionally tuberous-thickened; stems slender, $3-4 \mathrm{dm}$. high ; leaves oblong-lanceolate, entire or nearly so, small ( $2-5 \mathrm{~cm}$. long); heads few or several ; involucre top-shaped, 6-9 $\mathrm{mm}$. long, glabrous, not glandular nor viscid, the coriaceous whitish bracts with very short deltoid or ovate tips; rays 9-12, 0.5-1 cm. long. - Pine barrens, N. J. to N. C, Ky., and Tenn. July-Sept. Fig. 927.

11. A. rádula Ait. Stem simple or corymbose at the summit, smooth or sparsely hairy, many-leaved, 3-12 din. high; leaves oblong-lantrolate, pointed, sharply serrate in the middle, very rough both sides and rugose-

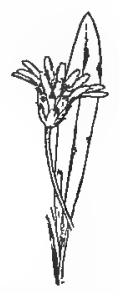

$9 \pm \bar{\imath}$. A, gracilis. 
veined, closely sessile, $5-8 \mathrm{~cm}$. long, nearly uniform ; heads $1-40$; bracts of bell. shaped involucre oblong, obtuse, appressed, clearly in several series, with very

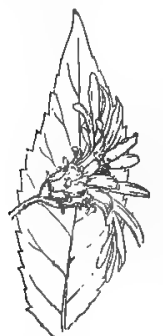

928. A. radula. short and slightly spreading herbaceous ciliate tips; rays pale violet; achenes smooth. - Bogs and low woods, Nfd. to Del. and w. Va. July-Sept. Fig. 928.

Var. strictus (Pursh) Gray. Slender, 1-8 dm. high; heads 1-8; involucral bracts more foliaceous, acute or acutish, nearly equal. (Var. bifforus Porter.) - Damp rocky or mossy places, n. Lab. and Hudson B. to Nfd., N. B., and n. N. E.

* Involucre and usually the branchlets viscid-or pruinoseglandular, well imbricated or loose; pubescence not silky; leaves entire (or the lower with few teeth), the cauline all sessile or clasping; rays shou'y, violet to purple; involucral bracts spreading, in few or many ranks.

12. A. grandiflorus I. Minutely hispid; stems slender, loosely much branched, 3-9 dm. high; leaves very small $(0.5-4 \mathrm{~cm}$. long), oblong-linear, obtuse, rigid, the uppermost passing into bracts of the hemispherical squarrose many-ranked involucre; rays bright violet, $2.5 \mathrm{~cm}$. long; achenes hairy. - Dry open places, Va., and southw. - Heads large and very showy. Fig. 929.

13. A. oblongifdlius Nutt. Minutely glandularpuberulent, much branched above, rigid, paniculatecorymbose, 3-7 dm. high ; leaves narrowly oblong or lanceolate, inucronate-pointed, partly clasping, thickish, $2.5-5 \mathrm{~cm}$. long, $0.5-1 \mathrm{~cm}$. wide ; involucral bracts

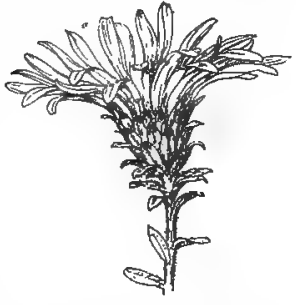

929. A. grandiflorus,

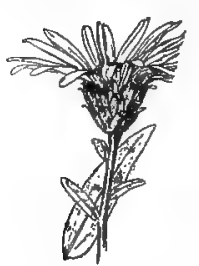

nearly equal, broadly linear, appressed at the base; rays violet-purple; achenes canescent. - Bluffs and rocky banks, Pa. and Va. to Minn. and Kan. Sept., Oct. - Heads middlesized or smaller. Frg. 930.

Var. rigidulus Gray. Low, rarely more than $3 \mathrm{dm}$. high, with more rigid and hispidulous-scabrous leaves. ( $A$. Kumleini Fries.) - More exposed situations, Ill., Wise, and southwestw. Late July-Oct.

14. A. nòvae-ángliae L. Stem stout, hairy, $0.5-2.5 \mathrm{~m}$. high, corymbed at the summit; leaves numerous, lanceolate, entire, acute, auriculate-clasping, 930. A. oblongifolius, clothed with minute pubescence, 0.5$1 \mathrm{dm}$. long; bracts nearly equal, linear-awl-shaped, loose, glandular-viscid, as well as the branchlets; rays violet-purple, rarely white, very numerous; achenes hairy. - Moist chiefly calcareous grounds, centr. Me. to w. Que., westw. and southw. Aug.-Oct. - Heads large; a very handsome species,

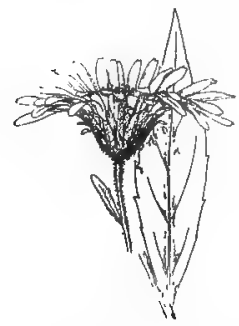

98\%. A. modestus. popular in cultivation. (Escaped from gardens, and locally naturalized in Eu.) Fig. 931. Var. Ròseus (Desf.) DC. Rays pink or rose-color. - Range of the typical form, local.

15. A. modéstus Lindl. Pubescent or glabrate; stem slender,

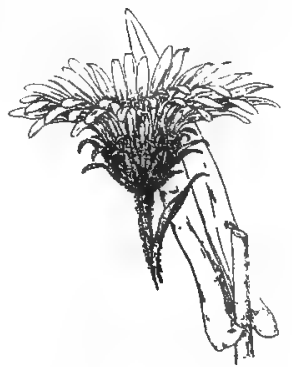

931. A. novae-angliae. simple, with few large heads terminating slender branchlets; leaves lanceolate, very acute, nav'rowed to a sessile base, sparingly serrate or serrulate; bracts linear-attenuate, equal, mostly herbaceous; rays dark violet. (A. major J'ort(r.) - Rich soil, w. Ont. and n. Minn. to B. C. and Ore. July-Sept. Frg. 932 . 
* * Leaves whitened, silvery-silky both sides, all sessile and entire, mucronulate; involucre imbricated in 3-several rows; rays showy, purple-violet.

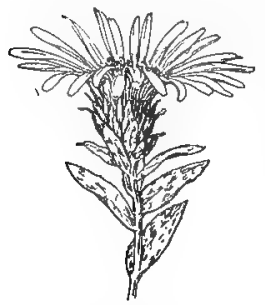

988. $\Delta$. sericeus.

16. A. sericeus Vent. Stems slender, 2-6 dm. high, branched ; leaves silver-white, lanceolate or oblong; heads mostly solitary, terminating the short branchlets; bracts of the globular involucre similar to the leaves, spreading, except the short coriaceous base; achenes smooth, many-ribbed. - Prairies and dry banks, Wisc. to Man., Tex., and Tenn. Aug.Oct. - Heads large; rays 20-30. Fig. 933.

17. A. cóncolor L. Stems wand-like, nearly simple, 3-9 dm. high; leaves crovded, oblong or lanceolate, appressed, the upper reduced to little bracts ; heads in a simple or compound wand-like raceme; bracts of the obovoid involucre closely imbricated in several rows, appressed, rather rigid, silky, lanceolate; achenes silky. - Dry sandy soil near the coast, Mass., and southw. Late Aug.-Nov. FIG. 934.

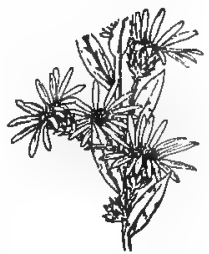

934. A. concolor. * * * Leaves entire, the lower not heart-shaped, the cauline all with sessile and cordate-clasping base, the auricles generally meeting around the stem.

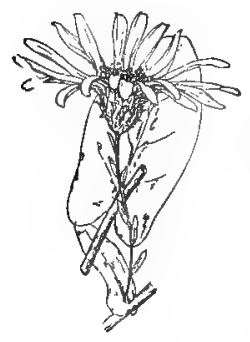

985. A. patens. - Mass, to O. and Tenu.

18. A. pattens Ait. Rough-pubescent ; stem loosely panicled above, 3-9 dm. high, with widely spreading branches ; beads mostly solitary, terminating slender branchlets, 1-2 cm. broad, with showy deep blue-purple rays; leaves oblong-lanceolate or ovate-oblong, often contracted below the middle, rough, especially above and on the margins, the cauline $2.5-7 \mathrm{~cm}$. long; bracts of the minutely roughish involucre with spreading pointed tips; achenes silky. -Dry ground, centr. Me. to Minn., and southw. Aug.Oct. Fig. 935. Var. PHLogifólios Nees. A form usually of shady places, with the larger (6-15 $\mathrm{cm}$. long) and elongated thin scarcely rough leaves downy underneath, sometimes toothed toward the end, mostly much contracted below the middle. (A. phlogifolius Mubl.)

Var. grácilis Hook. Stem-leaves very short (1-2 cm. long), thickened and harsh, those of the flowering branches mostly minute. - Ky. to Kan., and southwestw.

***** Lover leaves heart-shaped and petioled; no glandular or viscid pubescence; heads with short and appressed green-tipped bracts (except in nos. 19 and 26), mostly small and numerous, racemose or panicled.

- Heads middle-sized, with many rays, and squarrose foliaceous involucre.

19. A. anomalus Engelm. Somewhat pubescent and scabrous; stems slender, $1 \mathrm{~m}$. high, simple or racemosebranched above; leaves ovate or ovate-lanceolate, pointed, entire; the upper small, almost sessile; bracts of the hemispherical involucre imbricated in several rows, appressed, with linear spreading leafy tips; achenes smooth. - Limestone cliffs and rocky woods, Ill,, Mo., and Ark. Sept., Oct. - Rays violet-purple. Fig. 936.

+ + Rays 10-20; involucral bracts appressed or erect.

+ Leaves entire or slightly serrate; heads midale-sized; rays bright blue.

20. A. azùreus Lindl. Stem rather rough, erect, racemusecompound at the summit, the branches slender and rigid;

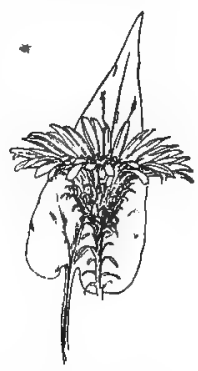

986. A. anomalus. 
leaves rough, the lower ovate-lanceolate or oblong, heart-shaped, on long often hairy petioles; the others lanceolate or linear, sessile, on the branches awl-

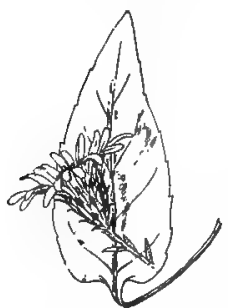

987. A. azureus. shaped; illvolucre inversely conical. - Copses and prairies, w. N. Y. and Ont. to Minn., Mo., and southw. Sept., Oct. - Involucre much as in $A$. laevis, but smaller and slightly pubescent. Fig. 937.

21. A. Shórtii Lindl. Stem slender, spreading, nearly smooth, bearing very numerous heads in racemose panicles; leaves smooth above, minutely pubescent underneath, lanceolate or ovate-lanceolate, elongated, tapering gradually to a sharp point, all but the uppermost more or less heart-shaped at base and on naked petioles, none clasping; involucre bell-shaped. Cliffs and banks, w. Pa. to Ill., and southw. Aug.-Oct. - A pretty species, 1 m. high ; leaves 0.5-1.5 dm. long. FIG. 938 .

22. A. undulàtus L. Pale or somewhat hoary with close pubescence; stem spreading, bearing numerous heads in racemose panicles; leaves ovate or ovate-

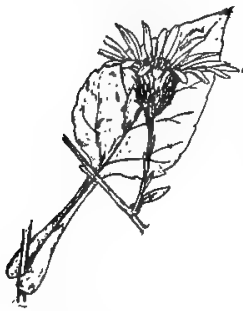

989. A, undulatus. lanceolate, with wavy or slightly toothed margins, roughish above, downy under-

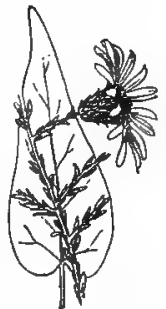

988. A. Shortii. neath; the lowest heart-shaped, on margined petioles; the others abruptly contracted into short brondly winged peti. oles which are dilated and clasping at the base, or directly sessile by a heart-shaped base; involucre obovoid, the bracts less rigid. - Dry copses, N. B. to Ont., Minn., and southw. Aug.-Nov. FIG. 939. - Very variable in outline of leaves, etc., upon which characters Professor E. S. Burgess proposes many species.

+ + Leaves for the most part conspicuously serrate; rays pale blue or nearly white.

23. A. corđifolius L. Stem nearly glabrous, much branched above, the spreading or diverging branches bearing very numerous panicled heads; leaves thin, sharply serrate, minutely scabrous above; the lower all heart-shaped, on

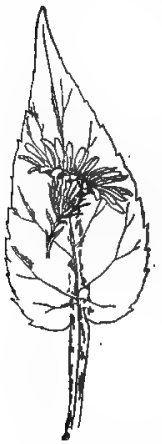

941. A. sagittifolius. generally slender and naked ciliate petioles; the upper chiefly cordate; bracts of the inversely conical involucre all appressed and tipped with very short green points, obtuse or acutish. - Woods and thickets, e. Que. to Ia., s. to Ga. and Mo. Aug.-Oct. - Heads profuse, but rather small. Fig. 940. Var. Furbfshia Fer. nald. Stems, petioles, and lower surfaces of leaves densely villous. - Banks of

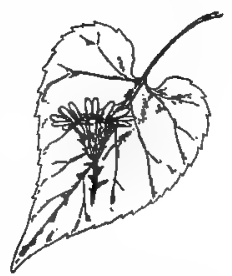

940. A. cordifolius. streams, N. B., Me., and N. H. Var. Polycḱphalus Porter. Most of the upper leaves truncate or narrowed at base.Range of the typical form.

24. A. Lowrieànus Porter. Resembling A. cordifolius; leaves thickish, glaucous beneath, smooth, often greasy to the touch, sharply or obscurely serrate; the lower ovate, cordate, on mostly winged petioles. - Open woods and thickets, Ct. to Ont, and N. C. Sept, Oct. Var. Lanceoldt's Porter. Most of the lower leaves lanceolate or lanco-ovate, truncate or nar. rowed at base. (Var, lancifolius Porter.) - Similar range. Var. inctsus Porter. Leaves all lanceolate, the lower incised. (Var. Bicknellii Porter.) - N. Y. and Pa., local.

25. A. sagittifolius Wedemeyer. Stem rigid, erect, smooth or slightly 
hairy, with ascending branches bearing numerous racemose heads; leaves ovate lanceolate, pointed; the lower heart-shaped at base, on margined petioles; the

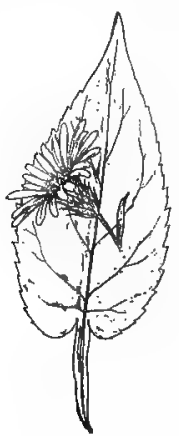

042. A. Drummondii upper lanceolate or linear, pointed at both ends; bracts of the oblong involucre linear, tapering into awl-shaped slender and loose tips. - Dry ground, Vt. to Ky., and westw. Aug.Oct. - Heads rather larger than in no. 23. Fig. 941.

26. A. Drummóndii Lindl. Pale with fine gray pubescence; leaves cordate to cordate-lanceolate, mostly on margined petioles, the uppermost lanceolate and sessile; bracts acute or acutish. Open ground, etc., Ill. to Minn. and Tex, Aug.-Oct. Fig. 942. - Passing into the preceding.

27. A. Lindleyànus T. \& G. Rather stout, $3-10 \mathrm{dm}$. high, nearly glabrous; radical and lowest leaves ovate, moderately or obscurely cordate, the uppermost sessile and pointed at both ends ; heads larger, in a loose thyrse or panicle, the linear-attenuate bracts looser and less imbricated; rays blueviolet. - Thickets and open places, Lab. to Mackenzie,

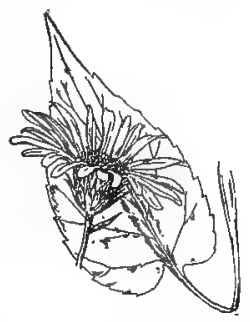

943. A. Lindleyanus.

s. to N. B., n. N. E., Mich., S. Dak., and Mont. Aug.-Oct. Fra. 943. Var. Exfmuus I3urgess. Tall (often $2 \mathrm{~m}$. high); leaves harsh above. - N. Y. and 0 . Var. comà tus Fernald. Stems, petioles, and lower surfaces of the leaves villous. - Range of the typical form, local.

******* Without heart-shaped petioled leaves, the radical and lower all acute or attenuate at base; not glandular nor viscid, nor silky-canescent.

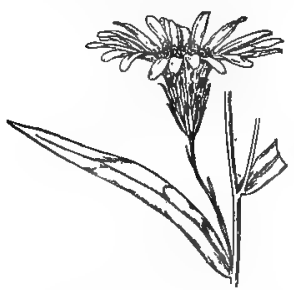

944. A. turbinellus.

- Smooth and glabrous throughout (or nearly so, except forms of no. 33), and usually pale and glaucous; involucral bracts closely imbricated, firm and whitish-coriaceous below, green-tipped; leaves firm, usually entive.

+ Rays violet or blue; bracts rather abruptly greentipped; leaves on the branchlets reduced to rigid subulate bracts.

28. A. turbinéllus Lindl. Stem slender, $0.5-1 \mathrm{~m}$. high, paniculately branched ; leaves oblong to narrowly lanceolate, tapering to each end, with rough margins; involucre elongated-obconical or almost club-shaped, $9 \mathrm{~mm}$. or more in length; the bracts linear, with very short and biunt green tips ; rays violet-blue; achenes nearly smooth. - Dry hills, etc., Ill. to Neb., and southwestw. Sept., Oct. - Well marked and handsome. Fig. 944.

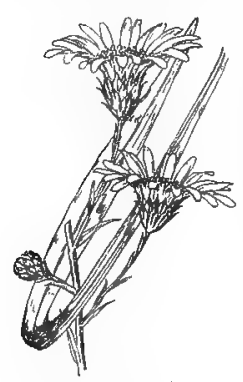

946. A. virgatus.

29. A. laèvis L. Stouter, $0.5-1 \mathrm{~m}$. high; heads in a close panicle; leaves thickish, lanceolate or ovate-lanceolate, chiefly entire, the upper more or less clasping by an auricled or heart-shaped base; bracts of the short-obovoid or hemispherical involucre with short abrupt green tips; rays blue-violet (rarely white); achenes smooth.-Dry soil, Me. to Ont., westw. and southw.

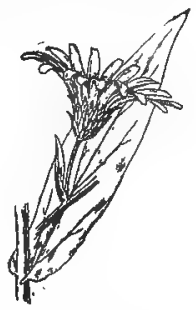

945. A. laevis.

Aug.-Oct. - A variable and elegant species. Fig. 945. A form with broad ovate leaves is var. AMPLIFoldius Porter.

30. A. virgà tus Ell. Slender, strict and simple, with few or several racemose or terminal heads, like those of 
the last; leaves lanceolate or linear, the lower usualty long and narrow. (A. purpuratus Nees.) - Va., W. Va., and southw. Sept., Oct. Fig. 946.

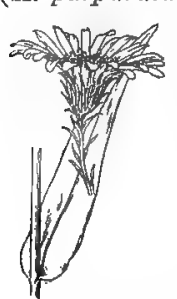

947. A. concinnus.

31. A. concínnus Willd. Not glaucous, slender, 3-9 dm. high; leaves lanceolate, mostly somewhat serrate, the lowest spatulate-lanceolate on winged petioles; heads smaller than in no. 29 , numerous, panicled; bracts of involucre loose, with more herbaceous narrower green tips; rays violet. - Rocky woods, rare, Ct, and southw. Aug., Sept. -- An ambiguous species. Fig. 947.

* Rays white, rarely purplish; bracts narroro, subulately green-tipped; leaves mostly narrow, narrowed at base, on the branchlets lax and attenuate.

32. A. polyphýllus willd. Low or tall, 1-15 dm. high, with virgate branches; cauline leaves lanceolate or linear, $0.5-1 \mathrm{dm}$. long; heads paniculate; bracts lanceolate-subulate, the outermost much shorter; rays $1 \mathrm{~cm}$. long. (A. Faxuni Porter).Rocky or gravelly soil, e. Me. and $\mathrm{n}$. Vt, to Ont., Wisc., and sonthw. Aug.-Oct. Frg. 948. - Heads larger than in the next.

33. A. ericoides L. Smooth, $3-9 \mathrm{dm}$. high; the simple branchlets or peduncles racemose along the upper side of the wand-like spreading branches ; lowest leaves oblong-spatulate, sometimes toothed; the others linear-lanceolate or linear-awlshaped; heads $6 \mathrm{~mm}$. high or loss; involucre hemispheric or campanulate; bracts of ten nearly equal, with attenuate or awl-shaped green tips. - Dry open places, N. E. to Ont., Minn., and southw. Aug.-Oct. FIG. 949. Var. villósus 'T. \& G. Similar, but the stem and generally the narrow leaves

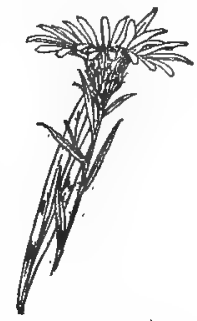

948. A. polyphyllus.

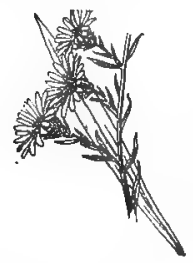

849. $\perp$ aricoides. villous-hirsute. (Var. pilosus Porter.) - Same range. Var. Prfngler Gray. A low slender nortliern form, with few erect branches and rather small scattered mostly solitary heads. (A. Pringlei Britton.) - Me. to Ont., s. to Mass. and Wisc.

Var. platyphýllus T. \& G. Stout; stem and branches densely white-villous; leaves lanceolate or oblong-lanceolate, mostly pubescent; heads as in the typical form, but larger. o. to Mich., Ill., and southw.

34. A. depauperàtus (Porter) Fernald. Slender, glabrous, 1-4 dm. high ; basal leaves small, spatulate ; stem-leaves linear, those of the branches linear-subulate; heads small, 4-5 mm. high, terminating the slender divaricate branches; involucre turbinate, 2-3 $\mathrm{mm}$. broad, of about 20 linear-subulate bracts, these leas rigid than those of the preceding species. ( $A$. ericoides, var. pusillus Gray, and var. depauperatus Porter.) - Sernentine barrens, s. Pa. and adjacent W. Va. Julyjept. FiG. 950.

Var. párviceps (Burgess) Fernald. Stout, pilose, 3-7 dm. high; leaves linear or lanceolate; heads rather crowded.

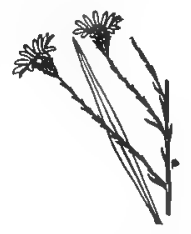

( $A$. ericoides, var. Burgess.) - Prairies and woods, Ill. and Mo.

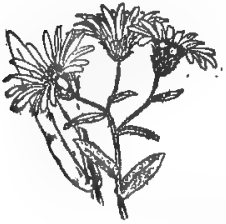

351. A, amethystinus,
+ + Hoary-pubescent or hirsute; herbaceous tips of the more or less bristly-ciliate involucral bracts squarrose or spreading; cautine leaves small, linear, entire, scarcely narrowed at the sessite or partly clasping base; heads numerous, small, racemose.

35. A. amethýstinus Nutt. Tall $(0.5-1.5 \mathrm{~m}$. high), upright, much branched, puberulent or somewhat hirsute leaves not rigid; heads $6 \mathrm{~mm}$. ligh; the tips of the bratets 
merely spreading; rays light clear blue or rarely violet.-Moist grounds, e. Mass. and s. Vt, to Pa., Mo, and Ia, rare. Sept. Fig. 951. - Perhaps a hybrid of nos. 14 and 36 .

36. A. multiflorus Ait. Pale or hoary with minute close pubescence, 8-9 $\mathrm{dm}$. high, much branched and bushy; the heads much crowded on the spreading racemose branches; leaves rigid, crowded, spreading, with rough or ciliate

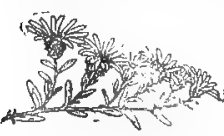

952. A. multiforu. margius, the uppermost passing into the spatulate obtuse hispidulous-ciliate bracts; heads $5-6 \mathrm{~mm}$. long; rays white or rarely purplish, 10-20. - Dry sandy soil, s. Me. to Ont, westw. and southw. Aug.-Oct. Frg. 952. Var. LxfGuos Fernald. Heads solitary or slightly clustered at the tips of slender flezuous branches. - Less common.

37. A. commutàtus (T. \& G.) Gray. Similar; heads larger (7-9 mm. long); rays $20-30$ (A. incanopilosus Sheldon.) - Plains, Minn. to Sask., westw. and southwestw. July-Oct.

+ + + Bracts glabrous, closely imbricated (the outer regularly shorter), not coriaceous, with short appressed green tips; branches slender, divaricate or divergent; leaves lanceolate to subulate; heads small (4-7 $\mathrm{mm}$. high) and numerous.

\section{++ Heads scattered, terminating minutely foliose slender branchlets.}

38. A. dumòsus L. Smooth or nearly so, 3-9 dm. high, the branches slender, loosely paniculate, divergent; leaves linear or the upper oblong, crowded, entire, with rough margins; heads rather numerous; involucre obconical or campanulate, with 4-6 rows of linear-spatulate obtuse bracts with abrupt green tips; rays pale purple or blue, larger than in no. 39. - Sandy soil, s. Me. to Unt., and southw., except in the upland regions. Aug., Sept. Fig. 953.

Var. coridifòlius (Michx.) T. \& G. Branchlets slender and flexuous, elongated, with minute crowded divergent small leaves, and generally solitary terminal heads. - Barrens, Mass., and southw.

Var. stríctior T. \& G. Branches stiff and ascending.-

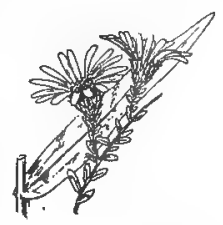

958. A. dumosus. Mass. to Ont. and N. C.

\section{++ Heads racemosely unilateral upon very short minutely leafy branchlets.}

39. A. vimíneus Lam. Smooth or smoothish, 0.5-2 m, high, bushy, the long branches almost horizontally spreading; leaves linear or narrowly lanceolate, elongated, the larger ones remotely serrate in the middle with

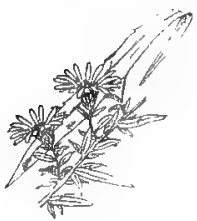

954. A. vimineus. fine sharp teeth; heads small, $4-6 \mathrm{~mm}$. high, crowded; bracts narrowly linear, acute or acutish, in 3-4 rows; rays white. Moist soil, s. Me. to Ont,, westw, and southw. Aug.-Oct. Fig. 954. Var. folıodòsus (Ait.) Gray. Leaves linear, entire; the ascending branches with more scattered paniculate heads. - Similar range.

Var. saxátilis Fernald. Low (1. $\hat{b}-6$ dm. high); branches and branchlets short, ascending, leafy-bracteate, terminated by solitary larger heads (often $1.5 \mathrm{~cm}$. broad). Rocky shores, N. E. and Que. to $\mathrm{O}$.

40. A. lateriflorus (L.) Britton. More or less pubescent, much branched; leaves lanceolate or oblong-lanceolate, tapering or pointed at each end, sharply serrate in

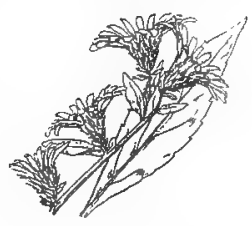

955. A. laterlflorus, the middle; bracts of the involucre linear, acute or rather obucse, imbricated in 3-4 rows. (A. diffusus Ait.) - Thickets, fields, etc., very common from $\mathbf{N}$. $\mathbf{S}$. to Ont., and southw. Aug.-Oct. - Extensively variable; leaves larger than in either of the two preceding; the involucre intermediate between them, as to the form of the bracts. Rays mostly short, white or pale bluish-purple. Fig. 955. 
Var. Glomertilus (T. \& G.) Burgess. Simple or subsimple; leaves oblonglanceolate, hispidulous; inflorescences small and axillary, or short, terminal, and spicate. - N. Y. to O. and S. C.

Var. hirsuticaúlis (Lindl.) Porter. Slender; the stem and the midveins of the elongated lanceolate leaves generally villous or hirsute; branches slender, sples,ding or ascending, simple. (A. hirsuticautis Lindl.) - Mostly in low woods and thickets, N. B. to Mich. and Ky.

Var. bifrons (Gray) Fernald. A luxuriant form, with large thin leaves (1-1.5 $\mathrm{dm}$. long, $2.5 .4 \mathrm{~cm}$. wide), and rather larger heads loosely disposed on the spreading branches. (A. diffusus, var. Gray; A. lateriflorus, var. grandis Porter.) - N. Y. to S. C., Mo., and Minn.

Var, thyrsoldeus (Gray) Sheldon. Cinereous-pubescent or glabrate, with ovate-oblong to lanceolate leaves, the branches ascending and often short, and the thyrsoid or spicate-glomerate heads less secund. ( $A$. missouriensis Britton.) - N. E. to Ont., Mo., and Tenn.

+ + + + Involucre various; the heads when numerous densely or loosely paniculate on erect or ascending branches.

- Cauline leaves sessile, but the base not conspicuously cordate nor auriculate, nor contracteil to a vinged petiole.

$=$ Heads small or middle-sized; bracts narrow, in several lengths, the erect green tips not dilated.

41. A. Tradescánti L. Stem much branched, $0.5-1.5$ to. high ; the numerous heads (1-1.5 cm. broad) somewhat panicled or racemed; leaves lanceolate to

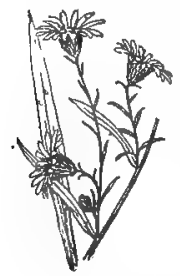
linear, $5-15 \mathrm{~cm}$. long, tapering to a long slender point; the lower somewhat serrate in the middle; involucre $3-5 \mathrm{~mm}$. long; its bracts linear, acutish, partly green down the back; rays short and narrow, white or purplish. - Low grounds, Me. to Ont. and Minu., s. to Va. and Mo. Aug.-Oct. Fig. 956.Some forms approach no. 39, others differ from $A$. paniculatus only in the smaller heads and shorter rays.

19. A. paniculàtus Lam. Stem smoothish, 0.5-2.5 m. high, much branched; the branches and scattered heads (about $2 \mathrm{~cm}$. broad) loosely paniculate; leaves elongate-oblong to narrowly lanceolate, pointed, somewhat serrate or entire; the cauline 956. 1. Tradescanti. $0.5-1.5 \mathrm{dm}$. long, about $1 \mathrm{~cm}$. wide; involucre $8 \mathrm{~mm}$. long; its bracts narrowly linear, with attenuate green tips, or the outermost wholly green ; rays white or purplish, $6-8 \mathrm{~mm}$. long. - Wet neadows, thickets, etc., throughout. Aug.-Oct. Fig. 957. - Approaches in its different forms the preceding and the three following species. Var. LandTus Fernald. Stems deusely white-villous or lanate. - T. Willoughby, Vt., to L. Winnipeg. Var. izLLIDIF Lórus (Willd.) Burgess. Leaves linear or narrow-lanceolate, mostly entire; branches ascending, with numerous clustered heads. - Throughout the range. Var. sfmplex (Willd.) Burgess. Leaves large and thin, oblong-]anceolate to oblanceolate, the cauline 1-2 dm. long, 2-4 cm. wide, entire or slightly serrate; heads scattered in leafy panicles. - N. H. to Neb. and Va. Var. Acùtıdens Burgess. Leaves as in the preceding variety, but conspicuously and coarsely serrate; branches short, usually shorter than or Jittle exceeding the subtending leaves. - Me. to Ill., Kan., and Ky. Var. crneráscens Femald. Stem closely cinereous-puberulent; leaves dull green, scabrous abovt", lanccolate, with slightly clasping bases, subentire.-Me.

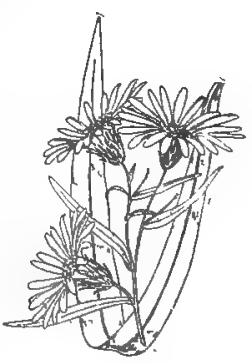

457. A. paniculatus to Mass. and Vt., local.

43. A. salicifolius $\Lambda$ it. Similar to no. 42 ; the leaves commonly shorter, firmer, often scalrows, wostly entire; involucre more imbricated, the firmer linear or linear-oblong bracts with shorter acute or obtusish green tips; heads as 


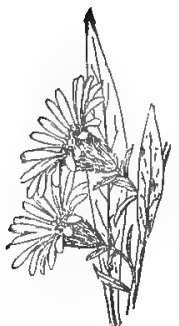

95s. A. salicifolius.

large, disposed to be thyrsoid or racemose-clustered; rays rarely white. - Low grounds, Mass. to (int., westw. and sonthw. ; hnost abundant westw. Aug.-Uct. Fig. 958. Var. SLBÁsper (Lindl.) Gray. Rigid, scabrous, with contracted leafy inflorescence, the broad heads usually leafy-bracteate, and the broader scales often obtuse. - Ill. to Neh, and 'Tex.

$==$ Heads small or middle-sized; the looser linear bracts generally subequal and erect, and the acute green tips not dilated, the outer often wholly herbaceous.

44. A. jủnceus Ait. Slender, 8-9 dm. high, simple with few heads or loosely branching; leaves linear or narrow, $0.5-1.5 \mathrm{dm}$. long, entire or the lower sparingly denticulate, scabrous on the margins; heads small (6-8 $\mathrm{mm}$. high) ; bracts small, narrow, in 3-4 rows, the outer somewhat shorter; rays purple, roseate, or white, $1 \mathrm{~cm}$. long. - Wet meadows and cold bogs, e. Que. to B. C., s. to n. and w. N. E., n. Pa., O., Wisc, and Neb. June-Sept. Frg. 959.

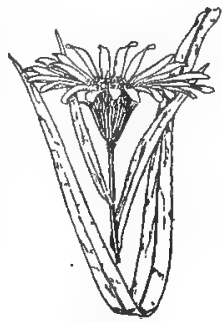

959. A. junceus.

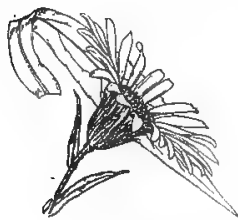

960. A. longtfolias.

45. A. longifolius Lam. Glabrous, $1 \mathrm{~m}$. or less high, more or less branched and corymbosely panicled; leaves long-lanceolate to linear-lanceolate, 1-2 dm. long, narrowed to both ends or slightly clasping, entire or sparingly serrate; heads as in the preceding; the bracts nearly equal and usually little imbricated, the outer looser; rays 0.5-1.5 cm. long, vioiet or purplish, rarely whitish. - Low grounds, Lab. to Sask., s. to N. S., n. and w. N. E., and the Great L. region. July-Oct. FIG. 960. Var. viLLICAÚtrs Gray. Stem and midrib of the leaves densely white-villous. - Lab. to n. N. Y.

$===$ Heads middle-sized; bracts in few-several rows, more or less unequal, linear to spatulate, more herbaceous and firmer, the tips often slightly spreading or squarrose.

46. A. nòvi-bẻlgii $\mathrm{L}$. Slender, $2-10 \mathrm{dm}$. high ; leaves oblong to linear-lanceolate, entire or sparingly serrate, the upper partly clasping and often somewhat auriculate; heads about $1 \mathrm{~cm}$. high; rays from bright blueviolet to white. - Nfd. to Ga., mainly near the coast; also in the White Mts., and doubtfully reported westw. Late JulyCct. - The commonest late-flowered Aster of the Atlantic border, and very variable. The typical form has thin narrowto oblong-lanceolate leaves, sometimes scabrous above, and linear bracts with narrow acute spreading or recurved tips. Fig. 961. Var. LaEvigh tris (Lam.) Gray. Usually glabrous throughout; the thin leaves mostly oblonglanceolate, the upper half-clasping by an abrupt base; bracts nearly equal, loosely erect, with short acutish tips. $-\mathbf{N}$. E., little known. Var. urTòreus Gray. Rigid, mostly low, very leafy; leaves thickish, usually very smonth, oblong to lanceolate, the upper sometimes auriculate; bracts in several loose rows,

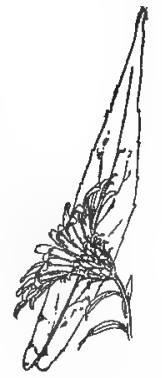

961. A. noti-belgii all but the innermost with broadish obtuse

962. A. novi-belgii, จ. Htoreus. tips, the outer usually spatulate. - Salt marshes and shores. Que. to Ga. FIG. 962. Var. eLdDEs (T. \& G.) Gray. Slender, often low and simple; leaves thickish, long, narrowly linear, entire, the uppermost small and bract-like; bracts narrow, with short and mostly spreading acutish tips. - Swamps, N. J, to Va. 


\section{- Cauline leaves (at least the lowest) conspicuously contracted into a winged petiole-like base or auriculate-clasping; involucre lax.}

47. A. tardiflorus L. Glabrous or subpubescent, $0.3-1.5 \mathrm{~m}$. high; leaves ovate- or oblong-lanceolate, sharply serrate in the middle, narrowed at both ends,

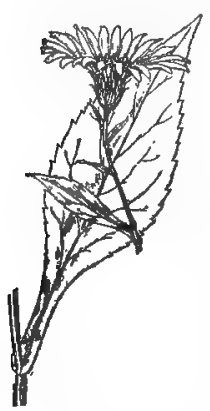

968. A. tardiforus. the lower to a winged petiole, not auriculate or only obscurely so; heads loosely panicled; involucre $5-7 \mathrm{~mm}$. high; bracts subequal or 2-3-seriate, linear or linear-subulate; rays light blue. (A. patulus Lam.) - N. B. to Pa., commionest northw. Aug.-Oct. FiG. 963. Var. vesтìrus Fernald. Stems densely villous; leaves somewhat so beneath. - N. B. to Vt.

48. A. prenanthoides Muhl. Stem $1 \mathrm{~m}$. or less high, corymbosepanicled, hairy above in lines; leaves rough above, smooth underneath, ovate to lanceolate, sharply cut-toothed in the middle, conspicuously taper-pointed, and rather abruptly narrowed to a long contracted entire portion, which is abruptly dilated into a conspicuously auricled base; heads on short divergent peduncles ; involucre $5-8 \mathrm{~mm}$. high ; bracts narrowly linear, tips recurved-spreading; rays violet. - Borders of

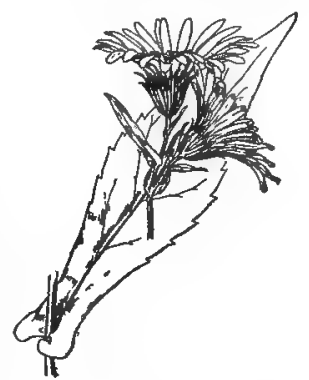

964. A. prenantholdes.

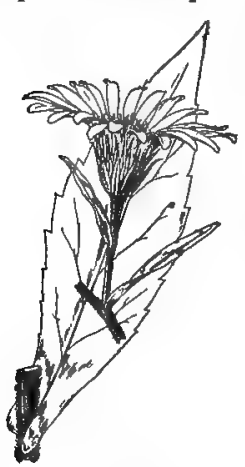

365. A. puniceus. streams and rich woods, w. N. E. to Va. and Ky., w. to Minn. and Ia. Aug.-Oct. Fig. 964.

49. A. puníceus $\mathrm{L}$. Stem tall and stout, $0.5-2.5 \mathrm{~m}$. high, rough-hairy all over or in lines, usually purple below, panicled above; flowering branches (in well developed plants) much exceeding the subtending leaves; leaves oblong-lanceolate or lanceolate, not narrowed or but slightly so to the auricled base, regularly and coarsely serrate to sparingly denticulate in the middle, rough above, generally hispid on the midrib beneatb, pointed; heads subsessile or short-pediceled; involucre 7-12 $\mathrm{mm}$. high; bracts thin, narrowly linear, attenuate, loose, subequal, in about 2 rows, the onter sometimes foliaceous; rays long and showy, lilac-blue to white. - Low thickets and swamps, Nfd. to Man, and Ga. Aug.-Oct. Fig. 965. Var. Demissus Lindl. Leaves elongate-lanceolate; inflorescences mostly shorter than the subtending leaves; otherwise as in the typical form, - N. E. Var. compáctus Fernald. Stout, 6-8 dm. high, conspicuously hispid ; leaves sub-rhomboidal, irregularly toothed, harsh above; branches of inflorescence mostly shorter than the leaves. - Mass. to Pa. Var. ffrmus (Nees) T. \& G. Stem mostly green, smooth and naked below, sparsely hirsute above ; leaves serrate, smooth beneath. (Var. laevicaulis Gray.) - Range of typical form. Var. Lucfoulus Gray. The very leafy stems glabrous or sparingly hispidulous; leaves lanceolate, entire or slightly denticulate, glabrous and somewhat shining; heads usually numerous, thyrsoid-paniculate; bracts less loose and less attenuate. - N. E. to Wisc. and Ill. Var. oligocéphacus Fernald. Stem essentially glabrous; leaves as in the preceding variety; heads few or solitary; outer bracts often broad and foliaceous. - Lab. and Nfd. to L. Superior and the White Mts.

\$4. DOELLINGERIA (Nees) Gray. Pappus manifestly donble, the inner of long capitlary bristles (some thickened at top), the outer of very short and rigid bristles; bracts short, without herbaceons tips; heads corymbose or solitary; rays rather few, white, rarely rose-tinged; leaves not rigid, veiny.

50. A. umbellatus Mill. Smooth or nearly so, leafy to the top, $0.3-2.5 \mathrm{~m}$. 


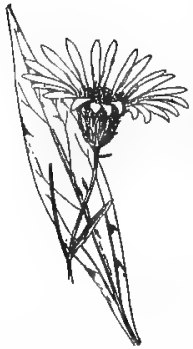

966. A. umbellatus.

high; leaves lanceolate, elongated, taper-pointed and tapering at the base, 1-1.5 dm. long; heads very numerous in com pound flat corymbs; bracts rather close, olulusish, scarcely lomger than the achenes. (Diplopappus Hook.; Doellingeria Nees.) - Moist thickets ; common, especially northw. Aug., Siet. Fig, 966. Var. Pubens Gray. Lower surface of the leaves and the branchlets tomentulose. - Upper Mich. to Neb. and Man.

Var. latifolius Gray. Leaves shorter, ovate-lanceolate to ovate, less narrowed or even rounded at base. (Diplopappus amygdalinus Hook.; Doellingeria humilis Britton, ) - Pine barrens, etc., N. J., P'a., and southw.

51. A. infírmus Michx. Stem slender, often flexuous, $1 \mathrm{~m}$. or less high, less leafy, bearing few or several heads on divergent peduncles; leaves obovate to ovate or oblong-lanceolate, narrowed at base and ciliate, the midrib hairy beneath; bracts more imbricated, thicker and more obtuse; rays sometimes creamy; pappus more rigid. (Doellingeria Greene; Diplopappus cornifolizus lands, C. Mass, to S. C. and Ala. July-Sept. FIG. 967.

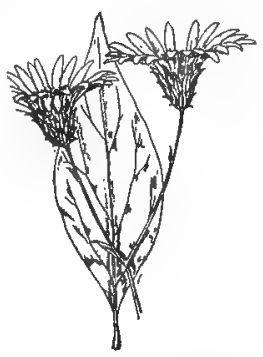

967. A. Infirmus.

Less.) - Open wood-

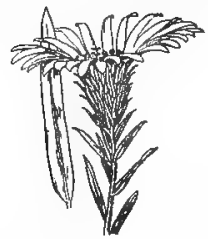

968. A. linariffulius.

\$5. IÁNTHE Gray. Pappus less distinctly double, inner bristles not thickened at top, outer shorter; bracts well imbricated, appressed, without herbaceous tips ; rays violet or rarely white; achenes narrow, villous; leaves numerous, rigid, small, linear, 1-nerved and veinless.

52. A. linariifolius L. Stems 1-6 dm. high, several from a woody root; heads solitary or terminating simple branches, rather large (1-1.2 cm. high); leaves $2-3 \mathrm{~cm}$. long, rough-margined, passing above into the rigid acutish bracts. (Diplopappus Hook.; Ionactis Greene.)-Dry soil, centr. Me. to Wisc, and southw., except in the mountains. Aug,-0ct. FIG. 968.

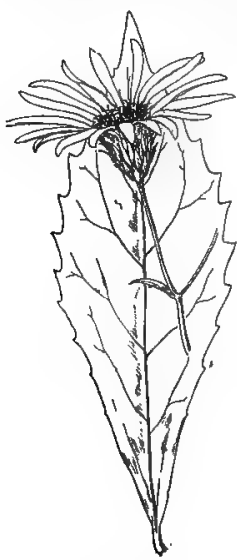

970. A. acuminatus,

\section{§6. ORTHOMERIS T. \& G. Pap- pus simple; bracts imbricated, appressed, without herbaceous tips, often scarious-edged ordry; perennial, as all the preceding.}

53. A. ptarmicoides $T$. \& G. Smooth or roughish; stems clustered, 1.5-6 dm. high, simple; leaves linear-lanceolate, acute, rigid, entire, tapering to the base, 1-3-nerved, with rough margins, $0.5-1 \mathrm{dm}$. long; heads small, in a flat corymb; bracts imbricated in $3-4$ rows, short; rays white, 5-8 mm. Iong. - Dry calcareous soil, w. N. E. and w. Que. to Man., Col., and Mo. June-Sept. FIG. 969. Var. I.utéscexs (Hook.) Tray. Rays small, pale yellow.Englewood, Ill. (Hill); Sask.

54. A. acuminàtus Michx. Somewhat hairy; stem 3-9 dm. high, simple, zigzag, panicled-corymbose at the summit; peduncles slender; leaves oblong-lanceolate, conspicuously pointed, coarsely toothed above, wedge-form and entire at the base; involucral bracts few and loosely imbricated, linear-lanceolate, poiuted, thin, $0.5-1 \mathrm{~cm}$. long : 
heads few-several ; rays 12-18, white, or slightly purple. - Cool rich woods, Lab. to Ont., Pa., and southw. along the Alleghenies. June-Sept. Fig. 970. -

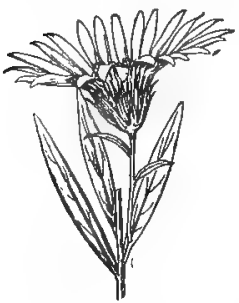

971. A. nemoralis. A monstrous form occurs in N. E. and N. Y, having $\mathrm{s}$ chaffy receptacle and the flowers turned to tufts of chaffy paleae.

55. A. nemoràlis Ait. Minutely roughish-pubescent; stem slender, simple or corymbose at the summit, very leafy, 2-6 dm. high; leaves small (2-4 cm. long), rather rigid, lanceolate, nearly entire, with revolute margins; heads 1-3(-12); bracts of the inversely conical involucre narrowly linear-lanceolate, the outer awl-shaped; rays lilac-purple, elongated. - Bogs and swamps, Nfd. to Hudson B., s. to N. J., n. N.Y., and e. Ont., chiefly coastal. July-Sept. Fig. 971. Passing to

Var. Blàkei Porter. Leaves larger (1-2 cm. wide), oblong-lanceolate, toothed; heads few-many. - N. S. to N. Y, and N. J. - A very showy plant about equally related to this and the preceding species, and not clearly distinct from either.

56. A. tenuifolius L. Very glabrous; stem often zigzag, simple or forked, $1.5-6 \mathrm{dm}$. high; heads rather large, $1 \mathrm{~cm}$. high, terminal ; leaves few, long-linear, tapering to both ends, rather thick and fleshy, entire, the

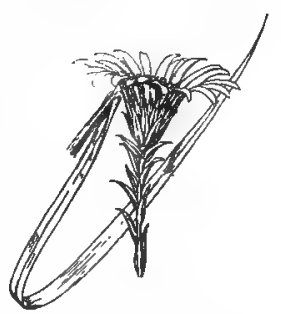

972. A. tenuifolius. upper subulate, pointed; involucre top-shaped, the bracts subulate-lanceolate with attenuate acute points; rays large, numerous,

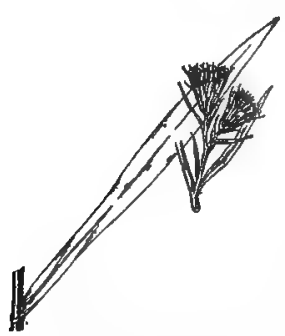

978. A. subulatus. pale purple. - Salt marshes, Mass. to Fla. Aug.-Oct. FIG. 972.

§ 7. OXYTRIPÒLIUM (DC.) T. \& G. Involucre as in $\$ 6$; pappus simple, fine and soft; glabrous annuals, with numerous small heads and narrow entire leaves.

57. A. subulàtus Michx. Stem $0.2-1.5 \mathrm{~m}$. high; leaves linear-lanceolate, pointed, flat, on the branches awl-shaped; bracts of the subcylindric involucre (7-8 $\mathrm{mm}$. high) linear-awl-shaped, in few rows ; rays somewhat in two rows, short, not projecting beyond the disk, more numerous than the disk-flowers, purplish. - Salt marshes on the coast, e. N. B.; N. H. to Fla. Late July-Oct. FIG. 973 .

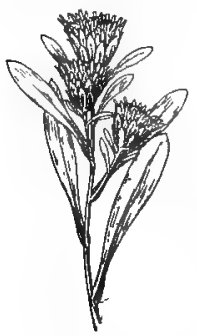

975. A. frondosus.

§. CONYZÓPSIS T. \& G. Bracts of the campanulate involucre in $2-3$ rows, nearly equal, linear, the outer foliaceous and loose; pappus copious, very soft ; rays very short or none; low annuals, with numerous rather small heads.

58. A. anguistus (Lindl.) T. \& G. Branch- 974. A. angustus. ing, 1.6-6 dm. high, nearly glabrous ; leaves linear-attenuate, entire, more or less short-ciliate; involucral bracts all linear, acute; corolla of the ray-flowers reduced to a tube, much shorter than the elongated style. (Brachyactis Britton.) Alkaline soil, lower St. Lawrence R., Que.; Minn. to Sask., and westw., spreading east to Chicago, etc. Aug., Sept. (Siber.) Fig. 974.

59. A. frondòsus (Nutt.) T. \& G. Similar; leaves linear-oblanceolate to spatulate, blunt, ciliolate only at base; outer involucral bracts oblong to 
oblanceolate, wholly foliaceous; rays pinkish, longer than the style. - Saline sail, P. E. I.; Wyo. to N. Mex., and westw. July-Uct. Fig.975.

\section{ERÍGERON L. FteABANE}

Heads many-fluwered, radiate, mostly flat or hemispherical; the narrow rays very numerous, pistillate. Involucral bracts narrow, equal, and little imbricated, never coriaceous, neither foliaceous nor green-tipped. Receptacle flat or convex, naked. Achenes tlattened, usually pubescent and 2-nerved; pappus a single row of capillary bristles, with minuter ones intermixed, or with a distinct short outer pappus of little bristles or chaffy scales. - Herbs, with entire or toothed and generally sessile leaves, and solitary or corymbed naked-pedunculate heads. Disk yellow ; rays white, pink, or purple. (The ancient name presumably of a Senecio, from $\hat{\eta} \rho$, spring, and $\gamma \hat{\varepsilon} \rho \omega \nu$, an old man, suggesteo. by the hoariness of some vernal species.)

§ 1. EUERIGERON DC. Rays elongated (short in a form of no. 7), crowded in one or more rows.

* Leafy-stemmed perennials.

+ Pappus double.

1. E. glabellus Nutt. Stem 1.5-4 dm. high, stout, hairy above, the leafless summit bearing 1-7 large heads; leaves nearly glabrous, except the margins, entire, the upper oblong-lanceolate and pointed, closely sessile or partly clasping, the lower spatulate and petioled; rays more than 100, purple, more than twice the length of the hoary-hispid involucre; outer pappus of minute bristles. ( $\boldsymbol{E}$. asper Nutt.) - Plains of $\mathrm{n}$. Wisc., Man., and westw. June-Sept.

$$
\text { + + Pappus simple. }
$$

+ Stems slender, densely tufted, very leafy; leaves narrowly linear, entire.

2. E. hyssopifolius Michx. Slightly pubescent, $1-3 \mathrm{dm}$. high, from filiform rootstocks; branches prolonged into slender naked peduncles, bearing solitary small heads; rays 20-30, rose-purple to whitish. - Wet calcareous rocks, Nfd. and Lab. to Mackenzie, s. to N. B., Me., Vt., and Mich. June, July.

\section{++ + Stems stouter, not tufted; leaves broader, toothed.}

3. E. pulchéllus Michx. (RoBin's Plantain.) Hairy, producing offsets from the base; stem simple, rather naked above, bearing few (1-9) large heads on slender peduncles; basal leaves obovate and spatulate, sparingly toothed, the cauline distant, lanceolate-oblong, partly clasping, entire; rays (about 50) rather broad, light bluish-purple. (E. bellidifolius Muhl.) - Copses and moist banks, s. Me. to Ont., Minn., and southw. Apr.-June.

4. E. philadélphicus I. Hairy; stem leafy, corymbed, bearing several small heads; leaves thin, with a broad midrib, oblong; the upper smoothish, clasping by a heart-shaped base, mostly entire; the lowest spatulate, toothed; rays innumerable and very narrow, rose-purple or flesh-color. - Throughout, locally common, generally in alluvial soil. May-Aug.

* * Perennial by rosulate offsets, with scape-like stems; pappus simple.

5. E. vérnus (L.) T. \& G. Glabrons; leaves clustered at the base, oval or spatulate; scape leafless, slender, 3-7 dm. high, bearing 5-12 small corymbed heads; rays white. ( $E$. nudicaulis Michx.) - Low grounds, e. Va., and southw. May.

* * Annuals (or sometimes biennials), leafy-stemmed and branching; pappus double, the outer a crown of minute scales, the inner of deciduous fragile bristles, usually wanting in the ray.

6. E. ánnuus (Is.) Pers. (Daisy F., Sweet Scabious.) Stem stout, 2-15 dm. high, branclied, beset with spreading hairs; leaves coarsely and sharply toothed; the lovest ovate, tapering into a margined petiole ; the upper ovate- 
lanceolate, acute and entire at both ends; heads corymbed; rays white, tinged with purple, not twice the length of the bristly involucre. - Fields and waste places; a very common weed. June-Oct. (Nat. in Eu.)

7. E. ramòsus (Walt.) BSP. (I) AISY F.) Stem panicied-corymbose at the summit, loughish like the leaves with minute appressed hairs, or almost smooth; leaves entive or nearly so, the upper lanceolate, scattered, the lowest oblong or spatulate, tapering into a slender petiole; rays white, twice the length of the minutely hairy involucre. ( $E$. strigosus Muhl.) - Fields, etc., common. June-Oct. - Stem smaller and more simple than the preceding, with smaller heads but longer rays. Var. DiscofDeus (Robbins) BSL., with the rays minute, scarcely exceeding the involucre, occurs in $\mathbf{s}$. N. E. and N. Y.

§ 2. CAENỎTUS Nutt. Ray/s inconspicuous, in several rows, scarcely longer than the simple pappus; annuals.

8. E. canadénsis L. (Horse-weed, Butter-weed.) Bristly-hairy; stem erect, wand-like, $0.1-3 \mathrm{~m}$. high; leaves linear, mostly entire, the radical cutlobed ; heads very numerous and small, cylindrical, panicled. (Leptilon Britton.) -Waste places, etc., a common weed, now widely diffesed over the world. July-Oct. - Ligule of the ray-flowers much shorter than the tube, white.

9. E. divaricàtus Michx. Diffuse and derumbent, 1-3 dm. high; leaves linear or awl-shaped, entire; heads loosely corymbed; rays purple; otherwise like no. 8. (Leptilon Raf.) - Ind, to Minn., Neb., and southw.

§ 3. TRIMORPHAEA (Cass.) Reichenb. Lite $\S 2$, but with a series of filiform rayless pistillate flowers within the outer row of ray-flowers; biennial or sometimes perennial.

10. E. àcris L., var. asteroìdes (Andrz.) DC. Hirsute-pubescent or smoothish ; stem erect, 2-5 dm. high ; leaves lanceolate or the lower spatulate-oblong, entire; heads several or rather numerous, racemose or at length corymbose, nearly hemispherical, about $1 \mathrm{~cm}$. long; involucre minutely glandular-puberulent, or somewhat hirsute toward the base; rays purplish or bluish, equaling or a little exceeding the copious pappus. (Var. droebachensis Blytt; $\mathbb{E}$. droebachiensis O. F. M ïll.) - Rocky banks and clearings, lower St. Lawrence, n. N. B., n. Me., L. Superior, Rocky Mts., westw. and northw. July, Aug. (Eu.)

\section{SERICOCÁRPUS Nees. WhIte-TOPPed Aster}

Heads 12-20-flowered, radiate ; rays about 5, fertile, white. Involucre somewhat cylindrical or club-shaped; the bracts closely imbricated in several rows, cartilaginous and whitish, appressed, with short and abrupt often spreading green tips. Receptacle alveolate-toothed. Achenes short, inversely pyramidal, very silky; pappus simple, of numerous capillary bristles. - Perennial tufted herbs, $2-7 \mathrm{dm}$. high, with sessile somewhat 3 -nerved leaves, and small heads mostly in little clusters, disposed in a flat corymb. Disk-flowers pale yellow.

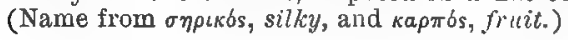

\section{* Pappus rusty; leaves sparingly serrate, veiny, rather thin.}

VI. S. asteroides (L.) BSP. Somewhat pubescent; leaves oblong-lanceolate or the lower spatulate, ciliate; heads rather loosely corymbed, obconical; involucre 5-9 mm. long. ( $S$. conyzoides Nees.) - Dry ground, s. Me. to O., and southw. June-Aug.

* * Pappus white; leaves entire, obscurely veined, firmer and smaller.

ᄂ 2. S. linifolius (L.) BSP. Smooth, slender; leaves linear, rigid, obtuse, with rough markins, tapering to the base; heads narrow, in close clusters, fewflowered; involucre $4-7 \mathrm{~mm}$. long. (S. solidagineus Nees.) - Thickets, s. N. E. to $O$., and southw. June-Aug.

3. S. bifoliàtus (Walt.) Porter. Hoary-pubescent; leaves obovate or oblongspatulate, short (1-2.5 cm. long), vertical, both sides alike; heads rather loosely 
corymbed, obovoid; involucre 6-8 $\mathrm{mm}$. long. Woods, Va., and southw. Aug.

(S. tortifolius Nees.)--Pine

\section{BÁCCharis L. Groundsel Tree}

Heads many-flowered; flowers all tubular, dioecious, i.e. the pistillate and staminate borne by different plants. Involucre imbricated. Corolla of the pistillate flowers very slender and thread-like; of the staminate larger and 5-lobed. Anthers tailless. Achenes ribbed; pappus of capillary bristles, in the staminate plant scanty and tortuous, in the pistillate very long and copions. Shrubs, commonly sunooth and resinous or glutinous. Flowers whitish or yellow. (Name of some shrub anciently dedicated to Bacchus.)

1. B. halimifolia L. Glabrous but somewhat scurfy, 1-:; m. high ; branches angled ; leaves obovate and wedge-form, petiolate, coarsely toothed, or the upper entire; heads scattered at the ends of the branches, forming pyramidal panicles; involucre $5-6 \mathrm{~mm}$. high; bracts acutish. - Sea beaches and marshes, Mass. to Ya., and southw. - The fertile plant conspicuous in autumn by its very long (1-1.5 cm.) white pappus.

2. B. glomeruliflora Pers. Brighter green; heads of both kinds sessile on nearly so in the axils, forming glomerules; otherwise much like the preceding - N. C. to Fla.; said to reach s. Va. (Bermuda.)

\section{PLỨchea Cass. Marsh Fluabane}

Heads many-flowered: the flowers all tubular, the central perfect but sterile, few, with a 5-cleft corolla; all the others with a thread-shaped truncate corolla, pistillate and fertile. Involucre imbricated. Receptacle flat, 'naked. Anthers with tails. Achenes grooved; pappus in a single row. - Herbs, somewhat glandular, emitting a strong or camphoric odor, the heads cymosely clustered. Flowers purplish, in summer. (Dedicated to the Abbé Plıche, French naturalist of the 18th century.)

1. P. foétida (L.) DC. Perennial, 5-9 dm. high ; leaves closely sessile or half-clasping, oblong to lanceolate, sharply denticulate, veiny, only $5-8 \mathrm{~cm}$. long; heads clustered in a corymb; bracts lanceolate. (P. bifrons IDC.) Low ground, N. J., and southw.

2. P. camphoràta (L.) DC. (SALT Marsir Fleabane.) Annual, pale, 3-15 dm. high; leaves slightly petioled, oblong-ovate or lanceolate, thickish, obscurely veiny, subentire or serrate ; corymb flat ; heads 5-9 mm. high ; involucral bracts ovate to lanceolate, puberulent. - Salt marshes, Mass. to Va., and southw.

3. P. petiolàta Cass. Greener and smootlier; leaves slender-petioled, more finely and sharply serrate; heads smaller; bracts merely granular. - Moist soil, Md. to Ill., Kan., and southw.

\section{GÍfOla Cass. Cotton Rose}

Heads rather many-flowered, discoid ; flowers as in Pluchea, the central usually sterile. Receptacle elongated or top-shaped; the chaff resembling the proper involucral bracts, each scale covering a single pistillate flower. Achenes terete; pappus of the central flowers capillary, of the outer ones mostly none. - Annual, with entire leaves, and small heads in capitate clusters. (Name an anagram of Filago, the name of a related genus.)

1. G. germánica (L.) Dumort. (Herba Impia.) Stem erect, short, clothed with lanceolate upright crowded leaves, and producing a capitate cluster of woolly heads, from which rise one or more branches, each terminated by a similar head, and so on;--hence the common name applied to it by the old botanists, as if the offspring were undutifully exalting themselves above this parent. (Filago L.) - Dry fields, N. Y. to Va, July-Oct. (Nat. from Eu.) 


\section{8. antennària Gaertn. Everlasting. Ladres' Tobacco. Pussy's Toes}

Heads many-flowered, diosious; flowers all tubular; pistillate corollas very slender. Involucre dry and scarious, white or colored, imbricated. Receptacle convex or flat, not chaffy. Anthers caudate. Achenes terete or flattish; pappus a single row of bristles, in the fertile flowers capillary, united at the base so as to fall in a ring, and in the sterile thickened and club-shaped or barbellate at the summit. - l'erennial white-woolly herbs, with entire leaves and corymbose or racemose (rarely single) heads. Corolla whitish. Staminate plants smaller than the pistillate, abundant only in nos. 3,9 , and 10 , though occasionally found in most of the others; many species parthenogenetic or apogamous. Involucral bracts of the staminate heads with broad white petaloid tips. (Name from the resemblance of the sterile pappus to the antennae of certain insects.)

N.B. - The figures in this genus are on a scale of $\frac{2}{3}$.

* Stolons assurgent, i.e. decumbent at base but with definitely ascending tips, rather leafy throughout, but with the terminal leaves much the larger. (In shade the stolons elongating and suggesting those of the last group.)

+ Basal leaves and those at the tips of the stolons bright green above, glabrous from the first, or at most only a little arachnoid when young and soon quite glabrate.

+ Brirll leaves large, $5-12 \mathrm{~cm}$. long, broadly wbovate or obovate-spatulate, obtuse or rounded at tip, definitely 3-nerved.

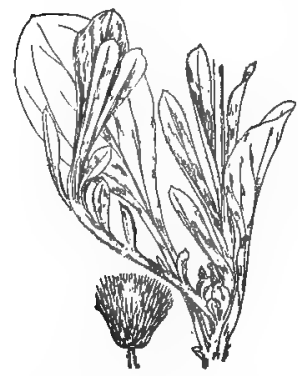

976. A. Parlinii.

1. A. Parlínii Fernald. Stont and tall, becoming 3-5 dm. high ; the stem, stolons, and stem-leaves bearing purplish glandular hairs; lower stem-leaves crowded, oblong or oblong-lanceolate, obtuse or acutish; lueads of the pistillate plant loosely or densely corymbose; involucre $8-10.5 \mathrm{~mm}$. high, of about 3 rows of bracts; styles becoming crimson. (A. arnoglossa Greene.) - Rich soil, often in open woods, N. E. to Ia. and D.C. May-July. Fig. 976.

+ + Basal leaves small, generally less than $5 \mathrm{~cm}$. long, spatulate to oblanceolate, acute or obtuse, only 1 nerve prominent.

A. Diofcs (L.) Gaertn. Low (1.5 dm. or less high); basal leaves rarely $2 \mathrm{~cm}$. long; stem-leaves crovoded; heads subsessile, subglomerulate; bracts of pistillate

heads rose-color, the outer oblong and obtuse, the inner acutish. - Found "in woods" at lrovidence, R. I., by Geo. Thurber in 1844, but not since collected; probably a casual introduction.

2. A. canadénsis Greene. Forming broad mats; stems slender, becoming $3-5 \mathrm{dm}$. high; basal leaves generally move than $2 \mathrm{~cm}$. long; stem-leaves scattered; heads loosely corymbose; involucre of the pistillate head 7-11 $\mathrm{mm}$. long; staminate heads smaller, their bracts with broad white petaloid tips; styles pale, drying brownish. - Dry mostly open soil, Nfd. to Man., s. to Ct., centr. N. Y., and Mich.

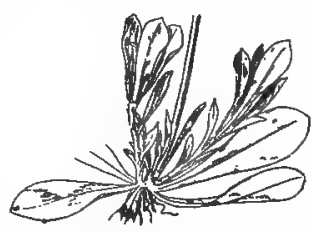

977. A. cauadensis.

+ + Basal leaves and those at the tips of the stolons dull above, invested with lomentose or arachnoid pubescence, only the very oldest becoming glabrate.

+- Basal leaves mostly long, 5-12 (in reduced specimens rarely 4.5) $\mathrm{cm}$. in length. (Large specimens of no. 7 might be looked for here.)

$=$ Heads comparatively small, the involucre averaging 7 (6-8) mm. high; stems slender.

3. A. plantaginifolia (L.) Richards. (Plantain-Leaved E.) Stems 1-5 
$\mathrm{dm}$. high ; basal leaves from broadly obovate with rounded tips to oblanceolate and acutish, distinctly 3-nerved; stem-leaves scattered, lanceolate, acuminate; heads loosely or densely corymbose; bracts of the pistil-

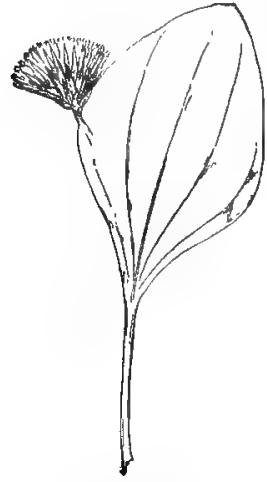

978. A. fallax. late heads linear, purplish or green, with pale tips; styles crimson. (A. plantaginea R. Br.) - Dry soil, s. Me, to Minn., and southw. Apr.-June.

\section{$==$ Heads comparatively large, averaging 9 (8-10.5) mm. high; stems stoutish.}

a. Basal leaves mostly broad-obovate or rhombic-obovate, narrowed from near the middle to the acutish or blunt tip.

4. A. fállax Greene. Stems 1-4 dm. high, sometimes slightly glandular; basal leaves large, the nature ones 2-5 cm. broad; lower stem-leaves oblonglanceolate, rather crowded; corymb rather dense; bracts of the pistillate head attenuate to scarious tips or broad and somewhat petaloid; styles pale, sometimes crimson. (A. ambigens Fernald.) - Rich open woods and fields, centr. Me. to Minn., and southw. May, June. Fig. 978.

b. Basal leaves from spatulate to narrowly spatulate-obovate, with rounded tips.

5. A. occidentàlis Greene. Stout; the stem at first low, becoming $2.5-4 \mathrm{dm}$. high; basal leaves $1-2,5 \mathrm{~cm}$. broad; stemleaves lanceolate to oblanceolate, rather conspicuous ; inflorescence subcapitate; bracts lanceolate to oblong, with conspicu-

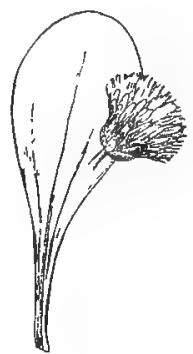
ous white tips; styles crimson. (A. Farwellii Fernald, not Greene.) - Rich open soil, e. Que. to Minn., s. to s. w. Me., s. N. H., W. Mass., N. Y., and Ill. May, June. FIG. 979.

. Basal leaves small, 2-5 cm. long. (Nos. 10 and 11 with poorly developed stolons might be sought her'e.)

$=$ Basal leaves spatulate, with little or no listinction of blade and petiole.

6. A. rupícola Fernald. Stems slender, 1.5-3 dm.

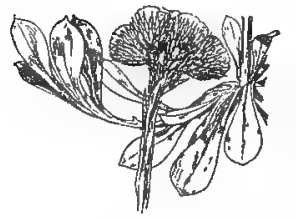

980. A. rupicols. high; stolons very numerous and short, forming dense mats ; basal leaves mucronate, $1-4 \mathrm{~cm}$. long ; stem-leaves numerous (10-18), linear-attenuate, the upper dark green, strongly contrasting with the white-pubescent stem; corymb compact; involucre of pistillate plant 8$10 \mathrm{~mm}$. high; bracts with conspicuous long yellowishwhite firm papery tips; styles pale. Slaty ledges by the Mattawamkeng R., Me. June. Fig. 980.

$==$ Basal leaves with more distinct petioles and obowr. blades.

a. Stem bearing purplish glandular hairs; basal leaves 3-nerved.

7. A. Brainérđii Fernald. Stem slender, $2-3 \mathrm{dm}$. high; basal leaves obovate or orbicular-obovate, 1-2 cm. broad; stem-leaves remote, small; corymb rather loose; involucre

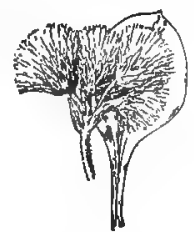

981. A. Brainerdii. 6-8 $\mathrm{mm}$. high; bracts white-tipped, the outer blunt, the inner attenuate; styles crimson. - Rich meadows and open woods, s. Me., Vt., and e. N. Y. May, June. Fig. 981. 


\section{b. Stem glandless; basal leaves 1-nerved.}

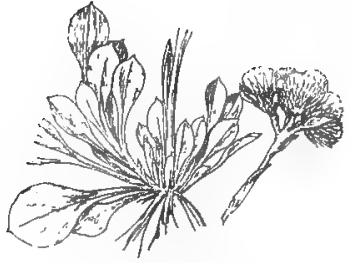

982. A. neodtoica.

8. A. neodiofca Greene. Forming broad mats, stems slender, $0.5-4 \mathrm{dm}$. high; basal leaves obovate, 5-18 mm. broad; stem-leaves scattered, fow (5-10), rather small and inconspicuous, linearattenuate, $3 \mathrm{~mm}$. or less wide ; cory mbs oritinarily loose; involucre 6-9 mm. high ; bracts with scarious blunt or acute tips ; styles pale. - Open woods, fields, etc., Nfd. to w. Ont., S. Dak., and Va. May-July. Fig. 982.

Var. grándis Fernald. Stouter throughout, greener; stems 3-5 dm. high ; stem-leaves oblanceolate or oblong-lanceolate, more conspicuous, 5-8 mm. broad; bracts with white petaloid tips, - Woods and meadows, e. Me. to Mass. and $11, \mathrm{~N}$. Y.

* Stolons, when well developed, procumbent, bracteate, not leafy except at, tip.

- Heads sotitary; basal leaves $1.5 \mathrm{~cm}$. or more broad.

9. A. solitària Rydb. Stems $0.5-2$ dn. high, very slender ; stolons flagelliform ; basal leaves obovate-spatulate, $4.5-7 \mathrm{~cm}$. long, $1.5-3.5 \mathrm{~cm}$. broad, tomentose beneath, arachnoid, becoming glabrate above, 3-nerved; stem-leaves few, small, appressed; involucre $1 \mathrm{~cm}$. high, its bracts linear-attenuate; styles crimson. - Rich wooded slopes, Ya. and O. to Ga. and La. Apr., May.

+ + Heads more than 1 (solitary in a rare variety of no. 10, which has leaves less than $1.5 \mathrm{~cm}$. broad).

- Heads sessile or subsessile in capitate clusters or distinctly racemose; styles crimson.

10. A. neglécta Greene. Stems $0.3-4 \mathrm{dm}$. high, slender, becoming much elongated in fruit; stolons flagelliform; basal leaves from cuneate-spatulate to spatulate-obovate, 4 (rarely 5) $\mathrm{cm}$. or less long; stem-leaves few and scattered; heads at first crowded, later becoming racemose by the development of the rhachis; involucre $7-9 \mathrm{~mm}$. high, frequently purple-tinged at base; bracts of pistillate heads with linear whitish tips, of the staminate heads with broad white petaloid tips. - Fields, plains, and open woods, N. B. to Va., w. to Ia. and Kan. Apr., May. Fig. 983. Var. sfmplex Peck. nated by solitary heads. - Sand Lake, N. I.

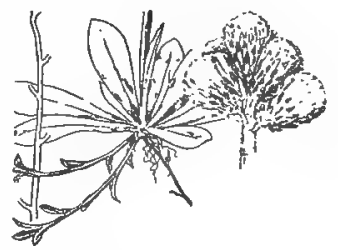

983. A. Deglecta.

Stems stiffly erect, termi* Heads in a comparatively loose corymb, never racemose; styles pale, diying brownish.

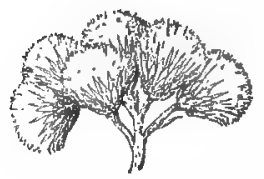

19.t. 1. petuloides.

11. A. petaloidea Fernald. Stouter than no. 10 ; stems $2-4.5 \mathrm{dm}$. bigh; stolons generally shorter and rather stiffer; basal leaves spatulate-obovate to oblanceolate; involucres of the pistillate heads brown or green at base, their bracts with petaloid or scarious tips. - Fields, dry banks, and open woods, t. Que. to Ont., s. to n. and w. N. E., N. Y., and Mich. May-July. Fig. 984.

\section{ANÁPHalis DC. Everlasting}

Characters of Antennaria, but the pappus in the sterile flowers not thickened at the summit or scarcely so, and that of the fertile flowers not at all united at base; fertile heads usually with a few perfect but sterile flowers in the center. (Said to be an ancient Greek name of some similar, plant.)

1. A. margaritàcea (L.) B. \& IH. ('liarly L.) Stem elect, 2-9 dm high, 
corymbose at the summit, with many heads, leafy; leaves linear-lanceolate, taper-pointed, sessile, tomentose on both surfaces, finally dull green above; involucral bracts pearly-white, very numerous, obtuse or rounded, radiating in age. - Dry hills, woods, and recent clearings; common northward. July, Aug. (Asia.)

Var. occidentàlis Greene. Leaves broadly lanceolate, bright green and glabrous above from the first. - Gravelly or sandy soil, Nfd. and e. Que.; Alaska to Cal.

\section{GNAPHALIUM L. CUDWEED}

Heads many-flowered; flowers all tubular, the outer pistillate and very slender, the central perfect. Bracts of the involucre dry and scarious, white or colored, imbricated in several rows. Receptacle flat. Achenes terete or fattish; pappus a single row of rough bristles. - Woolly herbs, with sessile or decurrent leaves, and clustered or corymbed heads; fl. in summer and autumn. Corolla whitish or yellowish. (

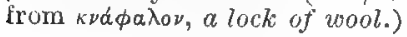

\section{\$1. EUGNAPHALIUM B.\& H. Bristles of the pappus distinct. \\ * Tall erect annuals or biennials, with smooth achenes.}

1. G. polycéphalum Michx. (Common Everuastivg.) Erect woolly annual, 3-9 dm. high, fragrant; leaves lanceolate, tapering at the base, undulate, not decurvent, smoothish above; heads clustered at the summit of panicled-corymbose branchis, ovoid-conical before expansion, then obovoid; bracts whitish, vvate and oblong, rather obtuse; perfect flowers few. (G. obtusifolium L.?) - Old fields and woods, common.

Var. Hellèri (Britton) Fernald. Stems glandular-viscid, not tomentuse. (G. Helleri Britton.) - N. Y. to Va., Ky., and southw.

2. G. decúrrens Ives. (Everlasting.) Stout, erect, 6-9 dm. high, annual or biemnill, branched at the top, clammy-pubescent, white-woolly on the branches, bearing numerous heads in dense corymbed cluster's; leaves linearlanceolate, partly clasping, decurrent; bracts yellowish-white, oval, acutish.Clearings, etc., e. Que. to B. C., s. to Pa., O., Mich., Minn., and in the Rocky Mts. to Ariz.

\section{* Low chiefly diffuse or tufted plants, with smooth or scabrous achenes.}

3. G. uligindsum L. (Low C.) Diffusely branched or subsimple appressedwoolly annual, $0.5-3 \mathrm{dm}$. high; leaves spatulate-oblanceolate or linear, not decurrent; heads small, in terminal sessile capitate clusters subtended by leaves; bracts brownish, less imbricated. - Ditches, roadsides, etc., Nfd. to Sask., s. to Va., and the Great L. region. (Eu.)

4. G. supinum L. (Mountain C.) Dwayf and tufted perennial, $1 \mathrm{dm}$. or ress high; l leaves linear, woolly; heads solitary or few and spiked on the slender simple flowering stems; bracts brown, lanceolate, acute, nearly glabrous; achenes broader and flatter. - Alpine summits of Mt. Katahdin, Me., Mt. Washington, N. H., and high northw. (Eu.)

\$2. GAMOCHAETA (Weddell) B. \& H. Bristles of the pappus united at the very base into a ring, so falling off all together; achenes hispidulous.

* Strict perennial, with mostly simple stems and narrow acute leaves.

5. G. sylváticum L. Silvery-silty, slender, 1-5 dm. high, leafy; leaves linear or oblanceolate, the lower often glabrate above, the broadest barely 5 $\mathrm{mm}$. wide; heads abundant in an elongated leafy spiciform inflorescence; invorucral bracts linear-oblong, pale, with a brown spot below the lyaline tip.Clearings and open places, Gaspé Co., Que., to 11 . Me., N. B., and N. S. (Eu.) * Simple or branching annual or biennial, with broad obtuse spatulate leaves.

6. G. purpùreum L. (PLrflish C.) Ascending, 0.5-6 dm. high, silvery. canescent with desse white wool; leaves not decurrent, green above; heads in sessile clusters in the axils of the upper leaves, and spiked at the wand-like 
summit of the stem; bracts tawny, the inner often marked with purple. Sandy or gravelly soil, coast of S. Me. to Fla.; and from O. to Kan., and southw. ('Trop. Am.)

\section{INUla L. Elecampane}

Heads many-flowered, radiate; disk-flowers perfect and fertile. Involucre imbricated, hemispherical, the outer bracts herbaceous or leaf-like. Receptacle naked. Anthers caudate. Achenes more or less 4-5-ribbed; pappus simple, of capillary bristles. - Coarse herbs, not floccose-woolly, with alternate simple leaves, and large yellow heads. (The ancient Latin name.)

1. I. Helìnum $\mathrm{L}$. (Elecampane.) Stout perennial, 1-1.5 m. high; leaves large, woolly beneath; those from the thick root ovate, petioled, the others partly clasping; rays very many, narrow. - Roadsides and damp pastures. Aug. - Heads very large. Root mucilaginous. (Nat. from Eu.)

\section{ADENOCAÚLON Hook.}

Heads 5-10-flowered; the flowers all tubular and with similar corollas, the marginal flowers pistillate, fertile; the others perfect but sterile. Involucral bracts equal, in 1 row. Receptacle flat, naked. Anthers caudate. Achenes elongated at maturity, club-shaped, beset with stalked glands above; pappus none. - Slender perennials, with alternate thin petioled leaves smooth and green above, white-woolly beneath, and few small (whitish) heads in a loose panicle,

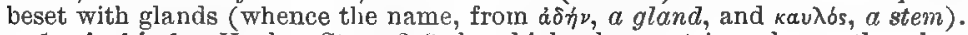

1. A. bícolor Hook. Stem 3-9 dm. high; leaves triangular, rather heartshaped, with angular-toothed margins; petioles margined. - Moist woods, shores of L. Huron, L. Superior, and westw.

\section{POLÝMNIA 亡́. LEAFCUP}

Heads broad, many-flowered ; rays several (rarely abortive), pistillate ; diskflowers perfect but sterile. Involucral bracts in two rows; the outer large, spreading; the inner membranaceous, partly einbracing the thick achenes. Receptacle flat, membranous-chaffy. Pappus none. - Tall branching perennials, viscid-hairy, exhaling a heavy odor. Leaves large, thin, opposite, or the uppermost alternate, lobed, with qilated appendages at the base. Heads in panicled corymbs. Flowers light yellow, in summer and autumn. (Dedicated to the Muse, Polyhymnia, for no obvious reason.)

1. P. canadénsis L. Clammy-hairy, $0.5-1.5 \mathrm{~m}$. high; lower leaves deeply pinnatifid, the uppermost triangular-ovate and 3-5-lobed or -angled, petioled; heads smali ; rays 5, obovate or wedge-form, shorter than the involucre, usually minute or abortive, whitish-yellow, but sometimes (var. RADidra Gray) more developed, 3-lobed, $1 \mathrm{~cm}$. long, and whitish; achenes 3-costate, not striate. Moist shaded ravines, w. Vt. to Ont., Minn., southw. and southwestw.

2. P. uvedàlia L. Roughish-hairy, stout, 1-3 m. high ; leaves broadly ovate, angled and toothed, nearly sessile; the lower palmately lobed, abruptly narrowed into a winged petiole; outer involucral bracts very large; rays 10-15, linear-oblong, much longer than the inner bracts of the involucre, yellow; achenes strongly striate. - Rich soil, N. Y. to Mo, and southw.

\section{ACANTHOSPERMUM Schrank}

Head's small, axillary or subsessile in the forks of the stem. Ray-flowers few, fertile ; the ligules small, yellow, usually 3-dentate; the disk-flowers with campanulate yellow 5-toothed corolla, sterile. Involucre double, the outer bracts berbaceous, the inner more or less strongly modified, closcly enveloping the fertile ray-achenes, muricate or prickly. - Diffuse annuals vith opposite toothed or lobed leaves. (Name from \& $\kappa^{\circ} \nu \theta a, a$ thor $n$, and $\sigma \pi \varepsilon \rho \mu a$, seed, from the prickly fruit formed by the achene and its investing bract.) 
1. A. Atstrale (Loefl.) Ktze. Sordid-pubescent; leaves ovate or obovate, $1.5-2.5 \mathrm{~cm}$. long, toothed above the middle, and cuneately narrowed at the entire base to a short but slender petiole; bristly fruits 5 , stellate-divaricate, 8-10 $\mathrm{mm}$. long. - S. C. to Fla. and La.; extending northw. (according to Harper) to s. Va., where presumably of recent introduction; also sporadically adventive northeastw. (Trop. Am.)

\section{SÍLPHIUM L. ROSIN-WEED}

Heads many-flowered; rays numerous, pistillate and fertile, their broad flat ovaries imbricated in 2-3 rows; disk-flowers apparently perfect but with entire style and sterile. Bracts of the broad and flattish involucre broad and with loose leaf-like summits, except the innermost, which resemble the linear chaff of the flat receptacle. Achenes broad and flat, dorsally compressed, surrounded by a wing notched at the top, without pappus or with 2 teeth confluent with the winged margins, the achene and its subtending chaff usually falling together; achenes of the disk sterile and stalk-like. - Coarse and tall perennial herbs, with copious resinous juice, and large corymbose-panicled yellow-flowered heads. ( $\Sigma i \lambda \phi_{i \circ}$, the ancient name of some resinous plant, transferred by Linnaeus to this genus.)

\section{* Stem terete, alternate-leaved; root very large and thick.}

1. S. laciniàtum L. (Rostr-weEd, CoMpass Planr.) Rough-bristly throughout; stem stout, 1-3.5 m. high, leafy; leaves pinnately parted, petioled but dilated and clasping at the base; their divisions lanceolate or linear, acute, cut-lobed or pinnatifid, rarely entire; heads few, 0.5-1 dm. broad, sessile or short-peduncled along the naked summit; bracts ovaie, tapering into long and spreading rigid points; achenes broadly winged and deeply notched, $1-4 \mathrm{~cm}$. long. - Prairies, Mich. to N. Dak., and southw. July-Sept. - Lower and rootleaves vertical, 3-9 dm. long, ovate in outline, on the wide open prairies disposed to present their edges north and south; hence the name Compass Plant.

2. S. terebinthinàceum Jacq. (PRAIrie Docr.) Stem smooth, slender, 1-3 m. high, panicled at the summit and bearing several-many large heads, leafless except toward the base; leaves ovate and ovate-oblong, somewhat heart-shaped, serrate-toothed, thick, rough especially beneath, 3-6 dm. long, on slender petioles; scales roundish, obtuse, smooth; achenes narrowly winged, slightly notched and 2-toothed. Var. PINNatífidux (Ell.) Gray. Leaves deeply cut or pinnatifid.-Prairies and oak-openings, Ont. and O. to Minn., and southw. July-Sept.

* * Stem terete or slightly 4-angled, leafy; leaves undivided, not large, some opposite.

3. S. trifoliàtum L. Stem smooth, often glaucous, rather slender, 1-2 m. high, branched above; stem-leaves lanceolate, pointed, entire or scarcely serrate, rough, short-petioled, in whor's of 3 or 4 , the uppermost opposite; heads loosely panicled; achenes rather broadly winged, sharply 2-toothed at the top. Dry plains and banks, Pa. to s. Ont., and southw. July-Sept.

4. S. Asteriscus L. Stem hispid, about $1 \mathrm{~m}$. high; leaves opposite, or the lower rarely in whorls of 3 , the upper alternate, oblong or ovcl-lanceolate, coarsely toothed, rarely entire, rough-hairy, the lower short-petioled; heads nearly solitary, large, squarrose; achenes obovate, winged, 2-toothed, the teeth usually awn-like. - Dry sandy soil, "Md." and Va. to Mo., and southw. Var. LAEVICAÚLE DC. Stem nearly or quite smooth. - Va, and southw.

5. S. integrifolium Michx. Stem smooth or rough, rather stout, $0.5-1.5 \mathrm{~m}$. high, rigid, 4-angular and grooved; leaves all opposite, rigid, lanceolate-ovate, entire or denticulate, tapering to a sharp point from a roundish heart-shaped and partly clasping base, rough-pubescent or nearly smooth, thick, 8-12 cm. long; heads in a close forking corymb, short-peduncled; achenes broadly winged, deeply notched. - Prairies, Mich. to Minn., Neb., and southw. Aug. 


\section{*** Stem square; leaves opposite, connate, 1.5-3.5 dm. in length.}

6. S. perfoliàtum L. (Cur Plant.) Sten stout, often branched above, $1-2.5 \mathrm{~m}$. high, leafy ; leaves ovate, coarsely toothed, the upper united by their bases and forming a cup-shaped disk, the lower abruptly narrowed into winged petioles which are connate by their bases; heads corymbose; bracts ovate; achenes winged and variously notched. - Rich soil, Ont. to S. Dak., and southw., common; also escaped from gardens eastw. July-Sept.

\section{BERLANDIÈRA DC.}

With the characters of Silphium, but the 5-12 fertile ray-flowers in a single series. Involucral bracts in about 3 series, thinner; the inner dilated, obovate, exceeding the disk; the outer snialler and more foliaceous. Achenes without sappus, obovate, neither winged nor notched at the apex, deciduous with the subtending bract and $2-3$ scales of the chaff. - Alternate-leaved perentials of the Southern and Southwestern States; head pedunculate. (Named for $J$. L. Berlandier, a Swiss botanist who collected in 'T(xas and Mexico.)

1. B. texàna DC. Hirsute-tomentose or villous, 6-9 dm. high, very leafy ; leaves crenate, the radical oblong, petiolate, the cauline oblong-cordate to subcordate-lanceolate, the upper closely sessile; heads somewhat cymose, $3-4 \mathrm{~cm}$. broad. - Mo. and Kan., soutbw. and southwestw.

\section{CHRYSÓGONUM L.}

Heads many-flowered, radiate; rays about 5 , pistillate and fertile; the diskflowers perfect but sterile. Involucre of about 5 outer leaf-like oblong bracts which exceed the disk, and as unany interior shorter and chaff-like concave scales. Receptacle fiat, with a linear scale to each disk-flower. Achene obovate, obcompressed, 4-angled, partly inclosed by the short subtending involucral bract; pappus a small chatfy $2-3$-toothed crown. - A hairy perennial herb, with opposite long-petioled leaves, and solitary long-peduncled heads of yellow flowers, nearly stemless when it begins to flower, the flowerless shoots forning runners.

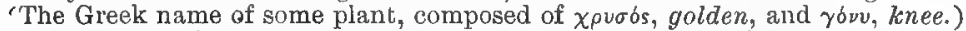

1. C. virginiànum L. Usually low $(0.5-3.5 \mathrm{dm}$. high); leaves ovate, mostly obtuse, crenate, rarely somewhat cordate, or the radical obovate with cuneate base; rays $1-1.5 \mathrm{~cm}$. long. - Dry soil, s. Pa. to Fla. May-Aug. Var. DentAtum Gray. Leaves deltoid-ovate, acute, coarsely dentate-serrate; involucral scales more acute. - High Island at the Falls of the Potomac.

\section{PARTHEेNIUM I.}

ITeads many-flowered, inconspicuously radiate; ray-flowers 5, with very short and bruad obcordate ligules not projecting beyond the woolly disk, pistillate and fertile; disk-flowers staminate, with imperfect styles, sterile. Involucre bemisplerical, of 2 ranks of short ovate or roundish bracts. Receptacle conical, chaffy. Achenes only in the ray, surrounded by a slender callous margin, crowned with the persistent ray-corolla. - Leaves alternate. Heads smadl, corymbed; the flowers whitish. (An ancient name of some plant, from map $\theta \dot{z} \nu 0 s$, virgin.)

\section{* Upper leaves sessize, but not auricled.}

1. P. integrifolium $\mathrm{L}$. Scalorous perennial, $1 \mathrm{~m}$. or less high, from a thickened rootstock; the stems glabrius below, minutely puberulent above; lenves oblong or ovate, crenate-toothed, or the lower $(0.5-1.5 \mathrm{dm}$. long) cut-lobed below the middle; hatds many in a very dense flat corymb. - Dry soil, Md. to Mim., and southw. June-Aug.

2. P. rèpens Eggert. Similar but lower, from a slender stoloniferous root. stock; stems and leaves pilose-hispid; heads few, rather larger. - Barrens, MI. and kan. to Tex May, June. 


\section{* Stem-leaves auriculate-clasping.}

3. P. auriculatum Britton. Rootstock very thick and tuber-like; stem 4-: lim. high, villous; some of the leaves pinnatifid at base, pubescent on the veins beneath with conspicuous appressed strongly divergent hairs. - Mis. of Va.

\section{IVA L. Marsh Eldoer. Highwater-Sirub}

Heads several-flowered, not radiate; pistillate and staninate flowers in the same heads, the former few and marginal. Anthers nearly separate. Bractis of the involucre few, roundish. Receptacle sinall, with narrow cliaff among the flowers. Achenes obovoid or lenticular ; pappus none. - Herbaceous or shrubby coarse plants, with thickish leaves (the lower opposite) and small nodding greenish-white heads of flowers; in summer and autumn. (Name of unknown derivation.)

\$1. EUtVA Hoffm. Heads spicate or racemose in the axils of leaves or leaflike bracts; fertile flowers with evident corolla.

1. I. orària Bartlett. Shrubly at base, nearly smooth, 5-10 dm. high ; leaves oval or lanceolate, coarsely and sharply toothed, fieshy, the upper reduced to linear bracts, in the axils of which the heads $(5-6 \mathrm{~mm}$. in diameter) are disposed in leafy panicled racemes; fertile flowers and bracts of involucre 5. (I. frutescens Man. ed. 6, not L.) - Salt marshes, coast of Mass. to Md.

2. I. imbricàta Walt. Suffruticose, glabrous, simple, 3-6 dm. high; leaves alternate, fleshy, spatulate-ablong or lanceolate, entire or slightly serrate; heads 6-8 mm. high; hemispherical involucre of 6-9 bracts, the outer orbicular. Sandy coast, Va., and soutlw.

3. r. siliàta Willd. Annual, 3-6 dm. high, rough and hairy; leaves ovate, pointed, cuarsely toothed, downy beneath, on slender ciliate petioles; heads in dense spikes, with conspicuous ovate-lanceolate rough-ciliate bracts; bracts of the involucre and fertile flowers 3-5. - Moist ground, Ill, to Neb., and sontlyw.; occasionally on dumps, etc., eastw.

§2. CYCLACHAENA (Fresenius) Gray. Heads in panicled spikes, scarceíy bracteate; corolla of the 5 fertile flowers a mere vuliment on none.

4. I. xanthifolia Nutt. Annual, tall, roughish; leaves nearly all opposite, hoary with minute down, orate, rhombic, or the lowest leart-shaped, doubly or incisely toothed, or obscurely lobed; heads small, crowded, in axillary and terminal panicles. - Ont. and Mich. to Assina., Kan., Westw. and southwestw.; locally established eastw.

\section{AMBRÒSIA [Tourn.] L. RAGWEED}

Fertile heads 1-3 together, sessile in axils of leaves or bracts, at the base of racemes or spikes of sterile heats. Sterile involucres flattish or top-sbaped, of 7-12 united bracts, containing 5-20 staminate flowers, with or without slender chaff intermixed. Anthers almost separate Fertile involucre (fruit) ellipsoid, obovoid, or top-shaped, closed, pointed, resembling an achene and inclosing a single flower; elongated style-branches protruding. Achenes ovoid. - Coarse homely weeds, witl opposite or alternate lobed or dissected leaves, and inconspicuous greenish flowers, in late summer and autumn; ours annuals, except the last. (The Greek and later Latin name of several plants, as well as of the food of the gods.)

\$1. Sterile heads sessite in a dense spike, the top-shaped involucre extended on one side into a large lanceolate hooded bristly-hairy tooth or appendage; fertile involucre ellipsoid or ovoid and 4-angled.

1. A. biđentàta Michx. Hairy, 3-9 dm. high, very leafy; leaves alternate, lanceolate, partly clasping, nearly entire, except a shor lobe or tonth on each side near the base; fruit with 4 stout spines and $a$ central beak.-Prairies of III. to Kan., and southw. 


\section{§2. Slerile heads in single or panicled racemes or spikes, the involucre regular.}

* Leaves opposite, only once lobed; sterile involucre 3-ribbed on one side.

2. A. trífia L. (GREAT R.) Stem stout, 1-6 m. high, rough-hairy, as are the large deeply 3-lobed leaves, the lobes oval-lanceolate and serrate; petioles margined; fruit obovoid, 5-6-ribbed and tubercled. - Rich soil, common westw. and southw., much less so northeastw. Var. integrifolia (Muhl.) T. \& G. Smaller, with the upper leaves (or all of them) undivided, ovate or oval. - Same habitat, not rare.

\section{* * Leaves all once or twice pinnatifid, many of them alternate.}

3. A. artemisiifdlia L. (Roman Wormwood, Hog-weed, Bitter-weed.) Much branched, $0.3-2.5 \mathrm{~m}$. high, hairy or roughish-pubescent; leaves thin, $b i$ pinnatifi, smoothish above, paler or hoary beneath; fruit obovoid or globular, armed with about (j short acute teeth or spines. - Roadsides, etc., very common. - Ixtremely variable, with finely cut leaves, those of the flowering branches often undivided; rarely the spikes all fertile.

4. A. psilostàchya DC. Paniculately branched perennial, 5-15 dm. high, with slender running rootstocks, rough and somewhat hoary with short stiffish hairs; leaves once pinnatifi, thickish, the lobes acute, those of the lower leaves often incised; fruit obovoid, pubescent, the tubercles absent or small. - Prairies and plains, Ill. and Wisc. to the Saskatchewan, westw, and southwestw.

\section{FRANSÈRIA Cav.}

Sterile and fertile heads separate as in Ambrosia, or sometimes mixed in the inflorescence. Fertile involucre 1-4-celled, with a single pistil in each cell, armed with spines in more than 1 series, bur-like. - Herbs (with us) or shrubs, with mostly alternate leaves, flowering in late summer and autumn. (Named for Antonio Franseri, Spanish botanist and contemporary of Cavanilles.) Gaertieria Medic.

1. F. tomentosa Gray. Perennial, white with sericeous tomentum; leaves pinnately 3-7-parted; segments lanceolate, mostly serrate, the basal ones small ; sterile racemes 1-many; spines of fertile involucre mostly uncinate-tipped. (Gaertneria Ktze.) - Low ground, Neb., Kan., and Col.

2. F. acanthicárpa (Hook.) Coville. Annual, hispid-hirsute, erect or diffuse, loosely branched; leaves bipinnatifid; spines of the fertile involucre $4-5 \mathrm{~mm}$. lang, stramineous, flattened, the tip usually straight. (Gaertneria Britton.) "Minn.," Sask., and southwestw.

\section{Xånthium [Tourn.] L. Cockleber. Clotbur.}

Sterile and fertile flowers in different heads, the latter clustered below, the former in short spikes or racemes above. Sterile involucres and flowers as in Ambrosia, but the bracts separate and receptacle cylindrical. Fertile involucre coriaceous, ovoid or ellipsoid, clothed with hooked prickles so as to form a rough bur, 2-celled, 2-flowered; the flower consisting of a pistil and slendex thread-form corolla. Achenes oblong, flat. - Coarse annuals, with branching stems, and alternate toothed or lobed petioled leaves; flowering in summer and autuinn. (Greek name of some plant used to dye the hair ; from kav06s, yellovo.)

$N . B .-T h e$ tigures in this 'genus represent the mature fertile involucre $\times 1$.

2. $X$. canadense.

- 3. $X$. commune

4. $X$. speciosum.

- Б. $\bar{X}$. infleavum.

4. $X$. speciosum. 6. $\overline{\boldsymbol{X}}$ eoltinatum 


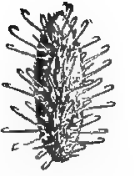

985. $X$. spinosum.

1. X. spinosum L. Hoary-pubescent, armed at the axils with triple spines; stems slender; leaves lanceolate or ovatelanceolate, short-petiolate, white-downy beneath, often 2-3-lobed or -cut; fruit about $1 \mathrm{~cm}$. long, with a single short beak or beakless. - Waste places, Me. to Ont., westw. and southw. (Nat. from Trop. Am.) Fig. 985.

2. X. canadénse Mill. Leaves broadly ovate, cordate, usually 3-lobed and simply or doubly dentate; burs glabrous or merely granular- or glandular-puberulent; the body fusiform-ellipsoid, $14-17 \mathrm{~mm}$. long, 5-8 $\mathrm{mm}$. in

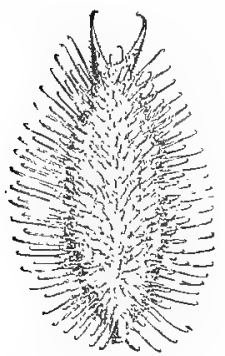

987. X. commune. diameter; the beales usually 2 , siraight or but slightly curved; prickles scattered, straight-tippecl or hooked. ( $X$. pensylvanicum Wallr.?; $X$. pungens Wallr. ; $\bar{X}$. glabratum Britton.) - liich soil, especially in moist places. FIG. 986.

3. $\mathrm{X}$. commùne Britton. Similar in habit and foliage ; beaks of the bur more or less strongly incurved, usually hooked at the summit; prichles numerous, crovoded, $3-6 \mathrm{~mm}$. long, hooked at the summit, hairy as is the body. - Similar situations. FIG. 987 .

4. $\mathbf{X}$. speciosum Kearney. Of the same habit, foliage, etc.; bur with numerous long $(8-10 \mathrm{~mm}$.) filiform usually stramineous and very hairy prickles; beaks moderately incurved and hooked. - Waste places and low moist ground, Tenn. to N. J)ak. and Tex.; also sparingly adventive on woolwaste, etc., eastw. Fir. 088.

5. X. infléxum Mackenzie \& Bush. Habit, foliage, etc., as in the three preceding species; bur large, the body $2 \mathrm{~cm}$. long, 6-7 mm. thick, ovoid-fusiform, merely granular-puberulent;

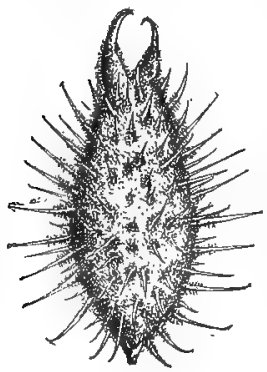

989. x, echinatum.

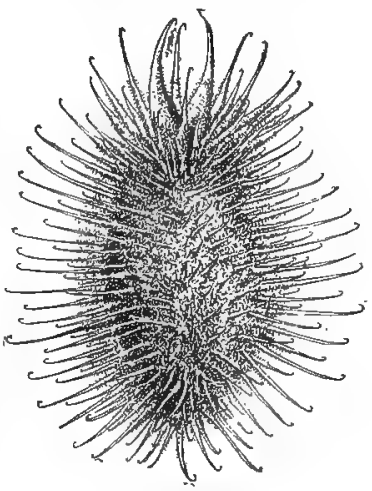

988. X. speciosum. beaks 2, very strongly incurved, often forming a loop or arch over the fruit; prickles numerous but less crowded than in the preceding, firm in texture, brownish, arcu-

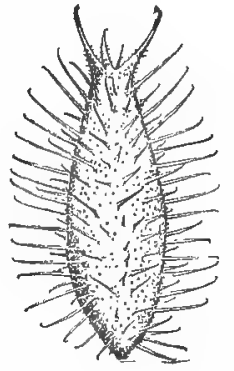

956. X. canadense. ate, hooked at the summit, granular-puberulent, at least toward the base. - Bottom lands, Courtney, Mo. (Bush).

6. X. echinàtum Murr. Of the same habit, etc.; burs plumper; the body thickish-ovoid, 15-22 mm. long, 8-12 inm. thick, for the most part densely pubescent as are also the nuwerous short rigid hooked prickles and stout falcateincurved beaks. ( $\boldsymbol{X}$. canadense, var. Gray.) - Seabeaches, lake-shores, etc., Me. to N. C., and westw. chiefly along the Great Lakes to N. Dak. and Sask. Fig. 989.

\section{HELIÓPSIS Pers. OX-EYE}

Heads many-flowered; rays 10 or more, fertile. Involucral bracts in 2 or 3 rows, nearly equal; the outer leaf-like and somewhat spreading, the inner shorter than the disk. Receptacle conical; chaff linear. Achenes smooth, thick, 4- 
angular, truncate; pappus none, or a mere border. - Perennial herbs, resem bling Helianthus. Heads showy, peduncled, terminal. Leaves opposite, petioled, triple-ribbed, serrate. Flowers yellow. (Name from $\eta \lambda \iota s$, sun, and $\delta \psi t s$, appearance, from the likeness to the Sunflower.)

1. H. helianthoides (L.) Sweet. Nearly smooth, 0.3-1.5 m. high; leares ovate-lanceolate or oblong-ovate, rather narrowly pointed, occasionally ternate: bracts (as in the next) with a rigid strongly nerved base; rays linear; pappus none or of 2-4 obscure teeth. (H. laevis Pers.) - Banks and copses, Ont. tc Ill., and southw. Aug.

2. E. scabra Dunal. Roughish, especially the leaves, which are disposed to be less narrowly pointed, the upper sometimes entire; rays broadly oblong to linear or oblanceolate; pappus coroniform and chaffy or of 2 or 3 conspicuous teeth. - Me. to Man., s. to N. J. and Ark.; rare eastw.

\section{ECLIPTA L.}

Heads many-flowered; ray short; disk-flowers perfect, 4-toothed, all fertile. Involucral bracts $10-12$, in 2 rows, leaf-like, ovate-lanceolate. Receptacle flat, with almost bristle-form chaff. Achenes short, 3-4-sided, or in the disk laterally flattened, roughened on the sides, hairy at summit; pappus none or an obscure denticulate crown. - Ammual rough herb, with slender stems and opposite leaves. Heads solitary, small. Flowers white; anthers brown. (Name from $\dot{\epsilon} \boldsymbol{\lambda} \epsilon i \pi \epsilon \boldsymbol{v}$, to be deficient, alluding to the absence of pappus.)

1. E. álba (L.) Hassk. Rough with fine appressed hairs ; stems procumbent or ascending, 2-9 $\mathrm{dm}$. high; leaves lanceolate or oblong, acute at each end, mostly sessile, slightly serrate; rays equaling the disk. — Vet river-banks and waste places, Mass., westw. and southw.; in the Northeast an introduced plant. (Trop.)

\section{TETRAgONOTHECA [Dill.] L.}

Heads many-flowered, radiate; the rays $6-9$, fertile. Involucre double, the outer of 4 large and leafy ovate bracts, united below by their margins into a 4-angled or winged cup; the inner of small chaffy bracts, as many as the rayflowers and partly clasping their achenes. Receptacle convex or conical, with narrow and membranaceous chaff. Achenes very tbick, obovoid, flat at the top; pappus none. - Erect perennials, with opposite coarsely toothed sessile sometimes connate leaves, and large single heads of pale yellow flowers, on terminal

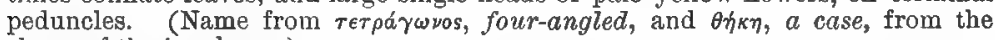
shape of the involucre.)

1. T. helianthoides L. Villous and somewhat viscid, 3-7 dm. high, simple; leaves ovate or rhombic-oblong, sessile by a narrow base; involucral bracts and rays $2-3 \mathrm{~cm}$. long. - Sandy soil, Va., and southw. June.

\section{RUDBÉCKIA L. CONE-FLOWER}

Heads many-flowered, radiate; the rays neutral. Bracts of the involucre leaf-like, in about 2 rows, spreading. Receptacle conical or columnar ; the short chaff concave, not rigirl. Achenes 4-angled (in our species), smooth, not margined, flat at the top, with no pappus, or a mirute crown-like border. — Chiefly perennial herbs, with alternate leaves, and showy terminal heads; the rays generally long, yellow, often darker at base. (Named in honor of the Professors Rudbeck, father and son, predecessors of Linnaeus at Upsal.)

$$
\text { * Achenes angulate; chnff persisting in agp. }
$$

+ Disk hemispherical to ellipsoid ovoid in fruit, dark jurple or brown.

+ Lovor leaves s-lobed or parted.

1. R. tríloba I. Hairy, biemnial, much branchcd, $0.5-1.5 \mathrm{~m}$. high ; branches 
slender and spreading ; upper leaves ovate-lanceolate, sparingly toothed: lower 3-lobed, tapering at base, coarsely serrate (those from the base pinnately parted or undivided); rays 8-10, oval or oblong; chaff of the black-purple drowessedglobular disk smooth, awned. - Rich soil, N. J. to Minn., Kan., and southw.; escaped from cultivation further northeastw. July, Aug.-- Heads small, but numerous and showy.

2. R. subtomentosa Pursh. Stem branching above, $0.5-1.5 \mathrm{n}$. high, downy, as well as the petiolate ovate or ovate-lanceolate serrate leaves beneath; heads short-peduncled; disk globular, dull brown; receptacle sweet-scented; blunt apex of chafi downy. - Prairies and low ground, Wisc. to Kan., and southw.

\section{+ + Leaves undivided, rarely lacinjate-toothed.}

= Pappus none; annuals or biennials.

3. R. hirta L. (Yellow Daisy, Blagk-eyed Susan, Nygger-head.) Bien. nial, very rough and bristly-hairy throughout; stems simple or branched near the base, stout, 3-8 dm. high, naked above, bearing single large heads; leaves nearly entive, the upper oblong or lanceolate, sessile; the lower spatulate, triplenerved, petioled; rays (about 14) more or less exceeding the involucre; chaff of the dull brown disk hairy at the tip, acutish. - Dry soil, w. N. Y. to Man., and southw.; now common as a weed in eastern fields, where introduced with seed from the West. June-Sept. - Variable as to the pubescence, and the breath and toothing of the leaves. $R$. Brittonii and $R$. monticola Small appear to be mountain phases with somewhat broader and more dentate cauliue leaves.

$$
==\text { Pappus a short crown; perennials. }
$$

4. R. fullgida Ait. Hairy, 3-9 dm. high, the branches naked at the summit and bearing single heads; leaves spatulate-oblong or lanceolate, partly clasping, triple-nerved, the upper entire, mostly obtuse; rays about 12, orange-yellow, equaling or exceeding the ample involucre; chaff of the dark purple disk nearly smooth and blunt. - Dry soil, N. J. and P'a. to Ky., Mo., and southw. - R. palustris Eggert, with ovate-lanceolate leaves, and $\mathcal{R}$. missouriensis Engelm., with oblong-lanceolate obtusish somewhat more pubescent leaves and slightly more fasciculate branching, fail to maintain satisfactory specific differences.

5. R. spathulata Micbx. Pubescen'e short and appressed; slender, $3-9 \mathrm{dm}$. high ; leaves obovate or spatulate or the upper ovate to lanceolate, sometimes all lanceolate or oblanceolate to linear, denticulate; heads long-peduncled, smaller than in the preceding, the rays fewer and broader, - l'ine woods, Pa., Va., Tenn., and southw.

6. R. speciosa Wenderoth. Roughish-hairy, $1 \mathrm{~m}$. or less high, branched; the branches upright, elongated and naked above, terminated by single large heads; basal leaves elliptic-ovate; the cauline lanceolate, pointed at both ends, petioled, 3-5-nerved, coarsely and unequally toothed or incised; involucre much shorter than the numerous elongate rays ( $3 \mathrm{~cm}$. long); chaff of the dark purple disk acutish, smooth. (R. umbrosa Boynton \& Beadle?) - N. J. and Pa. to Ga. and Mo. Var. Sullivámi (Boynton \& Beadle) Robinson. Stem-leaves ovate, less coarsely toothed, not incised. (R. Sullivanti Boynton \& Beadle.) 0 . to Mich. and Ark.

+ + Disk columnar in fruit, dull greenish-yellow.

+ Leaves divided or cut.

7. R. laciniàta L. Stem smooth, branching, 0.5-2 m. high ; leaves smooth or roughish, the lowest pinnate, with 5-7-cut or 3-lobed leaflets ; upper leaves irregularly 3-5-parted, their lobes ovate-lanceolate, pointed, or the uppermost undivided; heads long-peduncled; disk at first globular or hemispherical ; chaff truncate, downy at tip; rays oblanceolate, 3-5 cm. long, drooping. - Low thickets, w. Me. and w. Que., westw. and southw. July-Sept.

Var. hùmilis Gray. Low and glabrous; some of the radical leaves undivided or with roundish divisions; heads smaller (12 mm. high) and rays shorter, Mics. of Va, and Tenn. 


\section{+ Leaves entire.}

8. R. MAXIma Nutt. Very robust, $1-3 \mathrm{~m}$. high; leaves large, entire or repanddenticulate, ovate-lanceolate to oblong, obtuse, smooth and glaucous, the upper cordate-clasping; columnar disk at length 4-8 cm. long; rays yellow. - Sheffield, Mo. (Bush), where sparingly introduced on railroad ballast; Ark., La., and Tex.

$$
\text { * Achenes subterete, not angled; chaff soon deciduous. }
$$

9. R. amplexicaúlis Vahl. Annual, 3-6 dm. high, glabrous, glaucous, leafy ; leaves 1-ribbed, entixe, serrate or sinuate, upper oblong or ovate, cordate-clasping; heads showy, $3-5 \mathrm{~cm}$. broad; involucral bracts small, lanceolate; rays yellow or with brown bases; disk becoming $2-3 \mathrm{~cm}$. high. - Mo., southw. and southwestw.

\section{BRAUNĖria Neck. Purple Cone-Flower}

Heads many-flowered; rays mostly drooping, pistillate but sterile. Bracts of the involucre imbricated, lanceolate, spreading. Receptacle conical, the lanceolate carinate spiny-tipped chaff longer than the disk-flowers. Achenes thick, short, 4-sided; pappus a small toothed border.-Perennial herbs, with stout and nearly simple stems naked above and terminated by a single large head; leaves chiefly alternate, 3-5-nerved. Rays rather persistent; disk purplish. (Named, it is said, for Jacob Brauner, a German herbalist of the early part of the 18th century.) Echinacea Moench.

$$
\text { * Rays purple, rose-color, or rarely white. }
$$

1. B. purpùrea (DC.) Britton. Stem smooth, or in one form rough-bristly ; leaves rough, often serrate; the lowest ovate, 5-nerved, veiny, long-petioled; the others ovate-lanceolate; involucre imbricated in 3-5 rows; rays $15-20$, dull purple (rarely whitish), $2.5-4.5 \mathrm{~cm}$, long or more. (Echinacea Moench.) Prairies and banks, from w. Pa. and Va. to Mich., Ia., and southw.; reported as adventive eastw. July.

2. B. angustifolia (DC.) Heller. Low, $2-4 \mathrm{dm}$. high, hirsute; leaves lanceolate and linear-lanceolate, attenuate at base, 3-nerved, entive; involucre less imbricated and heads often smaller; rays $2-2.5 \mathrm{~cm}$. long, 2-3-tootbed, spreading, purplish or white. (Echinacea DC.) - Limestone barrens and dry slopes, Tenn, to the Saskatehewan and Tex. May-Aug.

3. B. pallida (Nutt.) Britton. Taller than the preceding, $1 \mathrm{~m}$. or less high; rays slender and drooping, 4-7 cm. long, 2-toothed. (Echinacea Nutt.) - Mich. and Ill. to Ala. and Tex.; also locally naturalized eastw. June, July.

$$
\text { * Rays bright yellow. }
$$

4. B. paradóxa Norton. In habit sımilar to the two preceding, but nearly glabrous, 5-8 dm. high; the narrowly lance-linear somewhat rigid and strongly 3 -veined leaves 1-2 dm. long, 0.8-3.5 cm. wide, scaprous on the margins, sparingly strigillose or quite smooth on the surfaces; rays drooping, $3-4 \mathrm{~cm}$. long. ( $B$. atrorubens Britton, in part, not Nutt.) - Prairies and barrens, Mo. (Bush) to Tex. June.

\section{IÉPACHYS Raf.}

Heads many-flowered ; the rays few, neutral. Involucral bracts few and small, spreading. Receptacle columuar ; the chaff truncate, thickened and bearded at the tip, partly embracing the flattened and margined achenes. Pappus none or of 2 teeth. - Perennial herbs, with alternate pinnately divided leaves; the grooved stems or branches naked above, bearing single generally showy heads. Rays yellow or party-colored, drooping; disk grayish. (Name from $\lambda_{\epsilon \pi} l_{s}, a$ scale, and $\pi a x u$ s, thick, from the thickened tips of the chaff.)

1. L. pinnàta (Vent.) T. \& G. Hoary with minute appressed hairs, slender, $0.5-1.5 \mathrm{~m}$. high, branching ; leaflets $3-7$, lanceolate, acute ; disk ellipsoid, much shorter than the large ( $5 \mathrm{~cm}$. long) and drooping light-yellow rays, (Ratibida Barnhart.) - Dry soil, w. N. Y, to Minn., Neb., and southw.; also locally 
adventive eastw. June, July. - The receptacle exhales a pleasant anisate odor when bruised.

2. L. columnaris (Sims) T. \& G. Branching from base, 3-8 dm. high ; leaflets $5-9$, oblong to narrowly linear, entire or 2-3-cleft; disk columnar, oftes: $3 \mathrm{~cm}$. long or more; ray as long or shorter, yellow or (var. PULGHÉrima T. \& G.) in part or wholly brown-purple. (Ratibida D. Don.) - Minn. to Assina. and Tex.; also established near Ottawa, Ont. (according to J. M. Macoun). May, June.

\section{SPILÅNTHES Jacq.}

Heads small, many-flowered; rays, when present, fertile. Involucral bracts few, loose. Receptacle elongated, columnar; chaff eonduplicate, enwrapping the achenes. Ray-achenes 3-angled or obcompressed; disk-achenes somewhat compressed, with acute margins continued into setiform awns, or the pappus none. - Slender spreading or depressed herbs with opposite leaves and ovoidconical pedunculate heads. Rays yellow or white. (Name from $\sigma \pi \hat{\imath} \lambda o s$, a stain, and a,

1. S. americàna (Mutis) Hieronymus, var. rèpens (Walt.) A. H. Moore Pubescent or glabrous, decumbent or loosely ascending; leaves elliptic-ovate to lancelate, $2-9 \mathrm{~cm}$. long, petioled, strongly but equally toothed; peduncles $3-12$ $\mathrm{cm}$. long; heads 9-16 mm. in length. (S. repens Michx.) - Low moist places, Mo. to S. C., Fla., and Tex.

\section{BORRÍCHIA Adans. SEA OX-EYE}

Heads many-flowered; rays fertile. Bracts of the hemispherical involucre imbricated. Receptacle flat, covered with lanceolate rigid and persistent chaff. Achenes somewhat wedge-shaped, 3-4-angled; pappus a short 4-toothed crown. - Shrubby low maritine plants, coriaceous or fleshy, with opposite nearly entire leaves, and solitary peduncled terminal heads of yellow flowers; anthers blackish. (Named for Olof Borrich, a Danish botanist.)

1. B. frutéscens (L.) DC. Whitened with a minute silky pubescence, $0.2-1$ $\mathrm{m}$. high; leaves obovate to spatulate-oblong or lanceolate, often toothed near the base; chaff rigidly pointed. - Salt-marshes, Va., and southw.

\section{HELIÁNTHUS L. Sunflower}

Heads many-flowered; rays several or many, neutral. Involucre imbricated, herbaceous or foliaceous. Receptacle flat or convex; the persistent chaff embracing the 4-sided and laterally compressed smooth achenes, which are neither winged nor margined. Pappus very deciduous, of 2 thin chaffy scales on the principal angles, and sometimes 2 or more small intermediate scales. - Coarse and stout herbs, with solitary or corymbed heads, and yellow rays; flowering toward

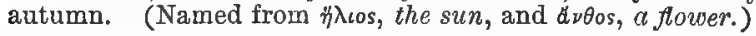

\$1. Annuals; leaves mostly alternate, petiolate; receptacle flat; disk brownish.

1. H. ánnuus L. (Сомmon S.) Tall, rough; leaves triple-ribbed, ovate or the lower cordate, serrate; involucral bracts broadly ovate to oblong, longpointed, ciliate; disk usually $2.5 \mathrm{~cm}$. broad or more. - Rich soil, Minn. to Tex., and westw. ; long cultivated, and occasionally found in waste grounds eastw.

2. H. petiolàris Nutt. More slender, $0.3-2 \mathrm{~m}$. high ; leaves oblong-or ovatelanceolate, smaller ( $2.5-8 \mathrm{~cm}$. long), mostly entire; bracts lanceolate or oblonglanceolate, seldom ciliate; disk about $1.5 \mathrm{~cm}$. broad. - Minn, to Man., Tex., and westw. ; occasionally in waste places, etc., eastw.

\section{§ 2. Perennials; receptacle convex or at length low-conical; lower leaves usually opposite.}

* Involucral bracts loose, becoming squarrose, narrowly lanceolate, pointed, 1-1.5 cm. long; disk usually purple or brownish; leaves linear, 1-nerved.

3. H. orgyàlis DC. Stem glabrous, tall, very leafy; leaves mostly alternate, GRAI'S MANLAL -53 
linear to filiform and entire, or the lowest lanceolate and serrulate; bracts fliform-attenuate. - Dry plains, Mo. to Neb., southw. and westw.

4. H. angustifolius L. Stem slender, $0.5-2 \mathrm{~m}$. high, usually scabrous; leaves mostly opposite, long and linear, sessile, entire, with revolute margins; heads loosely corymbed, long-peduncled ; bracts acute or pointed. - Low pine barrens, L. I. and N. J. to Ky., and southw.

* Involucral bracts closer, more imbricated, short, unequal and not foliaceous; leaves lanceolate to ovate, mostly opposite and 3-nerved.

$\therefore$ Disk dark.

5. H. atrórubens L. Rough-hairy; stem slender, 1.5-2.5 m. high, smooth and naked and forking above; leaves thinnish, ovate or oval to oblong-lanceolate, or the lowest heart-shaped, $7-15 \mathrm{~cm}$. long, serrate, abruptly contracted into a margined petiole; heads small, corymbed; bracts ovate, obtuse, ciliolate, appressed; rays $10-16$; pappus of 2 fringed scales. - Dry soll, Va. to Mo., and southw. ; said to extend northwestw. to Minn.

6. H. scabérrimus Ell. Stem stout, 0.5-2 m. high or more, simple or sparingly branched, rough; leaves very thick and rigid, rough both sides, oblonglanceolate, usually pointed at both ends, nearly sessile, entire or serrate, the lowest oval ; heads nearly solitary, rather large ; bracts ovate or oblong, obtuse, or mostly acute, ciliate, appressed ; rays $20-25$; pappus of 2 large and often several small scales. ( $H$. rigidus Desf.) - Dry prairies, Mich. to the Saskatchewan, westw. and southwestw. ; adventive in e. Mass.

\section{+ + Disk yellow.}

7. H. laetiflorus Pers. Closely resembling the preceding; leaves rather thinner; heads single or corymbed; bracts rather fewer (in 2 or 3 rows), narrower and acute or mostly acuminate. - Dry open places, Pa. to Minn., and southw. ; sparingly adventive in e. Mass. - Rays showy, $3-5 \mathrm{~cm}$. long.

8. H. occidentalis Riddell. Somewhat hairy; stem slender, simple, naked above, $1 \mathrm{~m}$. or less high, sending out runners from the base, bearing 1-5 small heads on long peduncles; lowest leaves oval or lanceolate-ovate, entire or obscurely serrate, roughish-pubescent beneath, abruptly contracted into long hairy petioles; the upper small and remote; bracts ovate to lanceolate, acute or pointed, sometimes ciliate. - Dry barrens, O. to Minn., and southw.; somewhat established on the N. J. coast ( $E$. F. Williams).

Var. Dowelliànus (Curtis) T. \& G. More robust, leafy in the middle, merely strigillose or puberulent; leaves larger, broadly oval, $5-9 \mathrm{~cm}$. wide. - Mts. of N. C. and Ga. ; said to extend northw, to D.C.

9. H. illinoénsis Gleason. Very similar to the preceding variety, but the petioles, lover part of stem, etc., loosely villous; leaves lance-oblong to ovate, strictly opposite, the pairs separated by well developed internodes; the blade contracted into a winged petiole of nearly its own length. - Sandy soil, in oak woods, etc., along the Illinois R. (Gleason). - Recently discovered and as yet but little known; perhaps only a form of the preceding species.

* * Involucre looser, the bracts more acuminate or elongated or foliaceous; disk yellow (anthers dart).

- Leaves all opposite, sessile, serrulate; pubescence rather soft.

10. H. mollis Lam. Stem simple, leafy to the top, $1 \mathrm{~m}$. high; leaves ovate to lanceolate, with broad cordate clasping base, pointed; scales lanceolate, seldom exceeding the disk. - Dry barrens, Mass. to Ia., Kan., and southw.

+ + Leaves mostly alternate and 3-nerved, soft-pubescent beneath, scabrous above; scales very long and loose, hairy; tips of chaff and corolla-lobes hirsute.

11. H. tomentòsus Michx. Stem hairy, stout, 1-2.5.m. high ; leaves oblonglanceolate, or the lowest ovate, tapering at both ends, obscurely serrate, large (1.5-3 dm. long), somewhat petioled; disk $2.5 \mathrm{~cm}$. broad; rays $12-16$, about $2.5 \mathrm{~cm}$. long. - Rich woods, Va., and southw. along the mts. 
$\leftarrow++$ Leaves narrow, the uppermost alternate, not 3-nerved, scabrous both sides; heads rather small; bracts loose, attenuate.

$\rightarrow$ Stem smooth and glaucous.

12. H. Kellermàni Britton. Slender, leafy, paniculately branched above; leaves narrowly lance-linear to linear, attenuate to the apex and subsessile base, chiefly alternate, green both sides, somewhat scabrous, finely and sparingly serrate; heads numerous, $3-4.5 \mathrm{~cm}$. wide; involucral bracts lance-linear, subefual, about $1 \mathrm{~cm}$. long; rays golden-yellow, 1-2 cm. long. - Near Columbus, U. (Fellerman).

1:3. H. grosseserràtus Martens. Stem $2-3 \mathrm{~m}$. high ; leaves elongated-lanceolato or ovate-lanceolate, taper-pointed, sharply serrate or denticulate, acute or attenuate at base, petioled, often whiter and finely pubescent beneath; bracts lance-awl-shaped, slightly ciliate. - Dry plains, w. Me. to N. J., westw. to Ont., Dak., and Tex. - Probably runs into the next.

\section{+ Stem hairy or scabrous.}

14. H. gigantèus L. Stem $0.5-3 \mathrm{~m}$. high, branched above; leaves lanceolate, pointed, minutely serrate or nearly entire, green both sides, narrowed and ciliate at base, but nearly sessile; bracts long, linear-lanceolate, poiuted, hairy of strongly ciliate. (H. Dalyi Britton?) - Low thickets and swamps, w. N. E. to Ont., westw. and southw. - Heads somewhat corymbed; the pale yellow ray: 15. 20 ; roots often becoming tuber-like, especially in var. suBTuBERòsus (Bour. geau) Britton which has mostly opposite leaves, and occurs from n. Mich. northwestw.

15. H. Maximiliàni Schrad. Resembling the preceding; stout, often simple, 0.5-3 m. high; leaves becoming rigid and very scabrous, entire or sparingly denticulate; heads rather large, usually short-peduncled, terminal and in the upper axils; bracts longer-attenuate, more rigid. - Prairies, Minn. and the Saskatchewan to Tex. ; occasionally adventive eastw.

++++ Leaves all or most of them opposite, 3-nerved (faintly in no. 17).

+ Heads very small (about $8 \mathrm{~mm}$. broad); rays 5-8; bracts few, short, irregularly imbricated, the outer with spreading foliaceous pointed tips; stems smooth.

16. H. microcéphalus T. \& G. Stem 1-2 m. high, with numerous slender branches above; leaves thin, ovate-lanceolate, taper-pointed, somewhat serrate, petioled, rough above, pale and puberulent beneath ; peduncles slender, rough ; bracts ovate and ovate-lanceolate, ciliate. (H. parviflorus Bernh., not H B K.) - Thickets, etc., Pa. and "s. Mich." to Mo., and southw.

17. H. laevigatus T. \& G. Stem slender, $0.5-2 \mathrm{~m}$. high, simple or sparingly branched, glaucous, glabrous throughout, as well as the slightly serrate lanceolate leaves which are usually narrow and attenuate to the base. - Dry soil, Allegheny Mts., Va., and southw.

++ Heads larger; rays usually over.10; spreading by creeping rootstocks.

= Leaves sessile or subsessile to short-petiolate, serrulate or entire.

18. H. doronicoides Lam. Finely pubescent and roughish, 1-3 m. high ; leaves sessile, ovate-oblong, acute, triply-nerved above the broadly cuneate base, serrulate; bracts loose, attenuate, mostly 1-1.5 cm. long, hairy. - Dry ground, O. to Mo.

19. H. divaricatus $L$. Stem simple or forked and corymbed at the top, 0.5$2 \mathrm{~m}$. high, smooth belono; leaves all opposite and divaricate, ovate-lanceolate, 3-nerved from the rounded or truncate sessile base, tapering gradually to a sharp point, $0.5-2 \mathrm{dm}$. long, serrate, thickish, rough both sides; bracts narrowly lanceolate, attenuate, ciliate, equaling the disi $(1 \mathrm{~cm}$. wide); rays $8-12,2.5 \mathrm{~cm}$. long. - Thickets and barrens, s. Me. to L. Winnipeg, Neb., and southw.

20. H. hirsutus Raf. Stem simple or forked above, stout, 0.5-1 m. high, bristly-haivy; leaves all short-petioled, ovate-lanceolate, gradually pointed, slightly serrate, rounded of obtuse at the base, very rough above, usually rough. 
hairy beneath; bracts ovate-lanceolate, pointed, equaling the disk; rays about 12. - Dry soil, Pa. to Wisc., " Minn.," southw. and southwestw.

21. H. strumosus $\mathrm{L}$. Stem 1-2 m. high, very smooth below, often glaucous ; leaves ovate-lanceolate, tapering gradually to a point, or the lower ovate and acute, abruptly contracted into short margined petioles, rough above, whitish and naked or minutely downy underneath; bracts broadly lanceolate, with spreading tips, ciliate, equaling the disk; rays 9-15. - River-banks and low copses, N. E. to Ont., Minn., and southw. Var. Móllıs T. \& G. Leaves downy underneath, often subcordate; bracts looser and more attenuate. (Var. macrophyllus Britton.) - N. E. and Pa. to Ont. and Ia.

22. H. trachelifollius Mill. Similar to the preceding; leaves thinner and nearly equally green both sides, more sharply serrate, all distinctly petioled ; bracts all lwose and spreading, exceeding the disk, often much elongated. Copses, Ct. to Minn., southw. and southwestw.

$==$ Leaves longer-petiolate, thinnish or soft, coarsely serrate, commonly broad; bracts loose, hirsute-ciliate.

23. H. decapétalus $L$. Stem branching, $0.5-1.5 \mathrm{~m}$. high, smooth below; leaves smooth or roughish, ovate, pointed, abruptly contracted into margined petioles; bracts lancerlate-linear, elongated, lonsely spreading, sometimes foliaceous, the outer longer thrn the disk; rays about 10. (H. scrophulariffolius Britton?) - Copses and low banks of streams, centr. Me. and w. Que. to Minn., Mo., and southw.

24. H. tuberosus L. (Jerdsalfim Artichoke.) Pubescent or hirsute, 1.5$3.5 \mathrm{~m}$. high ; leaves ovate or subcordate to oblong-lanceolate, acuminate, scabrous above, minutely pubescent or cinereous beneath; bracts lanceulate, attenuate, little exceeding the disk; rays 12-20. - N. Y. to Minn., westw. and southw.; often cultivated, and introduced eastw. Var. subcanéscens Gray. Usually dwarf, the lower side of the leaves whitish with soft fine pubescence. Minn. to Mo., and westw.

\section{ACTINÓMERIS Nutt.}

Heads many-flowered; rays neutral, few or none. Involucral bracts few, herbaceous, nearly equal, soon deflexed beneath the globular disk. Receptacle small, chaffy. Achenes flat, obovate, winged or wingless, at maturity spreading in all directions; pappus of $2-3$ smooth persistent awns. - Tall branching perennials, with serrate feather-veined leaves tapering to the base and mostly decurrent on the stem. Heads corymbed; flowers chiefly yellow. (Name from $d \kappa r i s, a$ ray, and $\mu \in \rho i s, a$ part; alluding to the irregularity of the rays.)

1. A. alternifolia (L.) DC. Stem somewhat hairy, usually winged above, 1-2 m. high; leaves alternate or the lower opposite, oblong or ovate-lanceolate, pointed at both ends; rays 2-8, irregular. (A. squarrosa Nutt.; Verbesina alternifolia Britton.) - Rich soil, N. J. to Ont., Ia., Kan., and southw. Aug., Sept.

\section{VERBESINA- L, CrownBEARD}

Heads several-many-flowered; rays pistillate, or sometimes neutral and sterile, few or sometimes none. Involucral bracts imbricated in 2 or more rows. Receptacle rather convex (conical in no. 3), the chaff concave. Achenes flat (laterally compressed), winged or wingless, 2-awned. - Mostly perennial herbs; the toothed leaves decurrent on the stem. Flowers mostly yellow. ("Name metamorphosed from Verbena." )

* IIeads slender, small, cymosety paniculate; rays few, pistillate, usually fertile; involucre erect.

1. V. occidentalis (L.) Walt. Stem tall, 4-winged; leaves opposite, ovate to ublong-lanceolate, triple-nerved, serrate, pointed at botl ends, often pubescent beneath, large and thin ; heads in compound corymbs ; receptacle flattish; flower's yellowo; rays 1-5, lanceolate; achenes wingless. - Kich soil, Pa. to Ky.; and southw. Aug,-Oct. 
2. V. virgínica L. Stem narrowly or interruptedly winged, downy-pubescent. like the lower surface of the ovate-lanceolate feather-veined alternate leaves heads in compound corymobs ; receptacle convex ; flowers white; rays 3-4, oval; achenes winged. - Dry soil, Pa. to Kan., and southw. Aug.

* Heads broader, solitary or few.

3. V. helianthoides Michx. Perennial; stem hairy, $1 \mathrm{~m}$. or less high, widely winged by the decurrence of the ovate to ovate-lanceolate sessile alternate leaves, which are rough above and soft-hairy beneath ; involucre appressed ; rays $8-15$, pistillate or neutral, usually sterile; achenes winged, tipped with 2 fragile awns. Prairies and copses, $O$. to Ia., southw, and southwestw. June, July.

4. V. ENCELiò̀es (Cav.) B. \& I., var. ExAURICULATA Robinson \& Green. man. Annual, branching, 3-6 $\mathrm{dm}$. high, cinereous ; leaves alternate, ovate or cordate to deltoid-lanceolate, the petioles destitute of the wings or auricles (characteristic of the typical more southern form); involucral bracts linear equal, foliaceous, spreading; rays numerous, fertile. - Kan. to Tex., and westw.; adventive by roads, w. Mo.; also casual northeastw, e.g. in s. Me.(Parlin).

\section{COREÓPSIS $\mathrm{L}$. TICKSEED}

Heads many-flowered, radiate ; rays mostly 8, neutral, rarely wanting. Involucre double; each series of about 8 bracts, the outer foliaceous and somewhat spreading; the inner broader and appressed, nearly membranaceous. Receptacle flat, with membranaceous cbaff deciduous with the fruit. Achenes flat, obeompressed (i.e. flattened parallel with the bracts of the involucre), often winged, not narrowed at the top, 2-toothed or 2-awned, or sometimes naked at the summit; the awns not barbed downwardly. - Herbs, generally with opposite leaves and yellow or party-colored (rarely purple) rays. Too near the last section of Bidens, but generally well distinguished as a genus. (Name from kopis, a bug, and $\delta \psi(s$, appearance; from the form of the achene.)

§1. Style-tips truncate or nearly so; outer involucre small and short; rays rosecolor or yellow, with brown base; pappus an obscure border or none.

1. C. rosea Nutt. Perennial; stem branching, leafy, smooth, 2-6 dm. high; leaves linear, entire; heads small, somewhat corymbed, on short peduncles; rays rose-color, 3-toothed; achenes oblong, wingless. - Sandy grassy swamps and shores, e. Mass. to N. J., and southw. July-Sept.

2. C. tinctoria Nutt. Annual, glabrous, often $1 \mathrm{~m}$. high; leaves 1-2-pinnately divided, the lobes lanceolate to linear; achenes oblong, wingless ; rays yellow, with more or less of crimson-brown. - Minn. to Tex., etc.; common in cultivation ; often escaping to roadsides, etc., eastw.

\$2. Style-tips abruptly cuspidale, hispid; involucres nearly equal; achenes roundish, winged, incurved, often papillose and with a callus inside at base and apex; pappus 2 small teeth or none; rays mostly yellow and palmately lobed; perennials, with long-pedunculate heads; lower leaves petiolate.

\section{* Wings of achene broad, thin, spreading.}

3. C. lanceolata L. Smooth or hairy, 3-6 dm. high, tufted, branched only at the base; leaves all entire (the lower rarely with a pair of small lateral lobes), lanceolate, the lowest oblanceolate or spatulate; outer bracts ovate-lanceolate. - Rich or damp soil, Ont. and Mich. to Va., Mo., and southw.; also cultivated on account of its showy heads, and sometimes escaping eastw. May-July.

Var, villdsa Michx. Hirsute below, the hirsute or villous leaves rather broader. (C. crassifolia Ait.) - Ill. and Mo. to Fla.

4. C. grandiflora Hogg. Mostly glabrous; lower leaves lanceolate and spatulate, entire, the upper 3-5-parted, with lanceolate to lincar and sometimes 2-3parted lobes; heads as in the preceding or larger. - Damp soil, Mo. and e. Kan. to Tex. and Ga. May-July. 
5. C. pubéscens Ell. More leafy, $0.5-1.3 \mathrm{~m}$. high, pubescent or nearly glabrous; leaves thickish, oblong or the lower oval-obovate and the upper oblong-lanceolate, entire or with 2-4 small lateral lobes; heads usually smaller. - Woods, Va. to s. Ill., Mo., and southw. June-Sept.

* Wings of achene navrow, callous-thickened, involute.

6. C. auriculata L. Pubescent or glabrous; stems 5-13 din. high, branching, sometimes with runners; leaves mostly petioled, the upper oblong or ovallanceolate, entire; the lower oval or roundish, some of them variously 3-5-lobed or-divided; outer bracts oblong-linear or lanceolate. - Rich woods and banks, Va. to Ill., and southw. June-Sept.

§ 3. Style-tips cuspidate; achenes oblong, nearly straight, without callus, the wing narrow or none; rays yelloro, mostly entive or slightly toothed.

* Outer bracts narrow, about the length of the inner, all more or less united at base; rays mostly entire, acute; pappus 2-toothed or none; leaves opposite, sessile, mostly 3-divided, appearing as if whorled; perennial, 3-9 am. high.

$$
\text { - Leaves 3-cleft, but not to the base. }
$$

7. C. palmàta Nutt. Nearly smooth, simple; leaves broadly wedge-shaped, rigid; the lobes broadly linear, entire, or the middle one 3-lobed. - Prairies, Mich. to Man., and southwestw. July.

\section{+ + Leaves divided to the base, uppermost and lowest sometimes simple.}

8. C. major Walt. Plant minutely soft-pubescent; leaves each divided into 3 sessile ovate-lanceolate entire leaflets, therefore appearing like 6 in a whorl. (C. senifolia Michx.) - Sandy woods, Va, and southw. July.

Var. stellàta (Nutt.) Robinson. Glabrous; the leaves narrower. (C. senifolia, var. T. \& G.; C. major, var. Oemleri Britton.) - Va., Ky., and southw.

9. C. delphinifolia Lam. Glabrous or nearly so; leaves divided into 3 sessile leaflets which are 2-5-parted, their divisions lance-linear, $2-6 \mathrm{~mm}$.broad, rather rigid ; disk brownish. - Pine woods, Va., and sonthw. July.

10. C. verticillata L. Glabrous; leaves divided into 3 sessile leaflets which are 1-2-pinnately parted into narrowly linear or filiform divisions. - Dry ridges and open woods, Md. to S. C. and Ark.; reported from w. Ont. and n. Mich.; cultivated in old gardens, but not showy; occasionally escaping. July-Sept.

* *uter bracts narrow, shorter, all united at base; rays entire, abtuse; pappus none; leaves petiolate, pinnately 3-5-divided; perennial.

11. C. tripteris L. (Tall Coreorsis.) Smooth; stem simple, 1-2.7 m. high, corymbed at the top; leaflets lanceolate, acute, entire. - Pa. to s. Ont., Wisc., e. Kan., and southw. Aug., Sept. - Heads exhaling the odor of anise when bruised; disk turning brownish.

\section{THELESPERMA Less.}

Heads many-flowered; rays about 8 and neutral, or none. Involucre as in Coreopsis, the inner bracts scarious-margined. Receptacle flat, the scarious chaff falling with the wingless and beakless achenes; pappus of 2 stout subulate retrorsely hispid awns. - Smooth herbs, with opposite dissected leaves and pedunculate heads of yellow flowers. (From $\theta \eta \lambda \eta, a$ nipple, and $\sigma \pi \epsilon p \mu a$, seed, on account of the papillose achenes.)

1. T. trífidum (Poir.) Britton. Annual or biennial, 3-7 dm. high, loosely oranching and very leafy; leaves 2-pinnate, the lobes filiform; outer involucral bracts 8 , subulate-linear, hardly equaling the inner which are united only below the middle; rays $1 \mathrm{~cm}$. or more long; outer achenes conspicuously roughened on the back. - Barrens and plains, Mo. to Neb., westw. and southwestw. May-Aug.

2. T. grácile (Torr.) Gray. Perennial, rather rigid, naked above; leaves with narrow of filiform divisions or the upper entire; bracts $4-6$, the outer very 
short-ovate or oblong, the inner connate above the midale; rays short or usually none; achenes less roughened. - Neb. and Kan., southw, and westw.; adv. in Mo.

\section{BìdeNS L. Bur Marigold}

Heads many-flowered; the rays when present 3-8, neutral. Involucre double, the outer commonly large and foliaceous. Receptacle flattish; chaff deciduous with the fruit. Achenes flattened parallel to the bracts of the involucre, or slender and 4-sided (rarely terete), crowned with awns or short teeth (these rarely uaked). - Annual or perennial herbs, with opposite various leaves, and mostly yellow flowers. (Latin, bidens, two-toothed.)

$N . B .-I_{n}$ this genus the measurements of the fruit relate to the inner mature achenes. The outer are often shorter and uncharacteristic. The figures of the heads are on a scale of $\frac{2}{3}$, those of the achenes are life size.

a. Achenes flat (or at most with a strong rib on either face) $b$.

b. Rays stoall or wanting $c$.

c. Inner achenes less than $2 \mathrm{~mm}$. broad.

- Heads cylindric or ellipsoid, much longer than broad; disk-florets 8-4 mm. long; leaves simple.

Inner achenes $1 \mathrm{~cm}$. Or more long; aw as 6-8 mm. long

Inner achenes $7-9$ mu. long; awns $8-4.5$ mm. long
Heads bemispherical, nearly or guite as broad as long; disk-floret. $1-1.5 \mathrm{~mm}$. long; achenes $5.5-8.5 \mathrm{~mm}$. long; awns $1.5-2.5 \mathrm{~mm}$. long; leaves ternately compound

c. Inner achenes $\mathbf{2} \mathbf{~} \mathbf{m m}$. or more broad $d$.

$d$. Leaves simple; heads subtended by long thick entire leafy bracts ; achenes 8-10 $\mathrm{mm}$. long, 2-3 mm. broad, rotrorsely barbed, the 3 (rarely 2 or 4 ) awns unequal, at most $6 \mathrm{~mm}$. long

a. Leaves pinnate; schenes upwardly barbed at least at base; awns 2.

Outer involucre of 5-8 leafy bracts; inner bracts oblong, equaling the disk; achenes $2-3.3 \mathrm{~mm}$. brosd.

Outer involuere of $10-16$ leafy bracts ; inner bracts ovate-trisngular, shorter than the disk; achenes 8.3-4 mm. broad

b. Rays conspicuously exceeding the disk $\theta$.

e. Leaves mostly pinnate; awns (if present) upwardly barbed $f$.

$f$. Inner achenes $2 \mathrm{~mm}$. or less broad, cuneate.

Inner achenes $8-4.5 \mathrm{~mm}$. long

Inner achenes 5-7 mim. long .

f. Inner achenes more than $2 \mathrm{~mm}$. brosd, elliptic-obovate, with thin scarious margins.

Outer follaceous bracts 8-10, smooth or merely ciliate, shorter

than the inner
outer foliaceous bracts $12-20$, conrsely hispid, mostly longer
than the inner

e. Leaves simple or slightly divided; achenes obovate, $\dot{8}-4.5 \mathrm{~mm}$. long; with short teeth

u. Achenes angled or terete $g$.

g. Achenes distinctly angled; terrestrial or marsh plants $h$.

$h$. Leaves pinnate.

Heads few-flowered, slender; achenes linear, 4-angled, the inner $1.2-1.8 \mathrm{~cm}$. Iong, about $1 \mathrm{~mm}$. broad .

Heads hemispherical, many-flowered; achenes cuneate, $\dot{3}-4$ angled, 4-6 mm. long

h. Leaves simple; heads

Leaves petioled or with conspicuously narrowed bases; fruiting

heads erect .
Leaves sessile or connate ; frufting heads mostly nodding.

Onter bracts unequal, mostly exceeding the disk; rays at most twice the length of the disk; achenes dilated above; leaves

mostly connate
Outer bracts subequal, rarely exceeding the disk; rays $2-4$ times as long as the disk; achenes not dilated above; leaves sessile, but rarely connate

a. Achenes terete, truncate at both ends, with" the "3-6 $\dot{\text { very }}$ long awns amooth beluw; aquatic, with the immersed leaves finely divided.

1. B. bidentoides.

2. B. Ealoni.

8. B. drocoidea.

6. B. comosa.

4. B. frondoso.

5. B. vulgata.

\section{B. coronata.}

12. B. trichospemna.

\section{B. amistosa.}

14. B. involuorata.

11. B. coronata.
10. B. Zipinnata.

. connata, v. pinnata.

\section{B. connata.}

8. B. cernua.

9. B. zaevis.

15. B. Beckii.

1. B. bidentoides (Nutt.) Britton. Glabrous, paniculately branched, $2-8 \mathrm{dm}$. high; leaves lanceolate, coarsely toothed, tapering at both ends; heads 1.5-2 cp. long; the outer involucre of $4-5$ bracts; rays usually wanting; achenes 


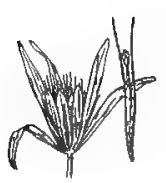

990. B. bidentoides.

hairy, 1 cm. or more long, with 2 very slender upwardly roughened awns (6-8 $\mathrm{mm}$. long) surpassing the yellowish 4-toothed corolla, and often 2 minute intermediate teeth. (Coreopsis Nutt.) - Shores of Delaware R. and Bay. Sept., Oct. Fig. 990.

2. B. Eatòni Fernald. Simple or branched, 2.5-6 dm. high; leaves lanceolate, with longacuminate tips and slender petiolar bases, coarsely serrate; outer involucre of $3-5$ bracts, inner of 5 oblong conspicuously striate ones $1 \mathrm{~cm}$. long; rays none; disk-flowers 15-25; inner achenes 7-9 mm. long, 1-1.7 mm. broad, with strong midribs, usually with retrorse hairs on

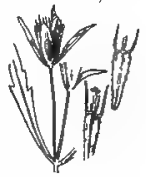

991. B. Eatonl. the margin; the 2-4 awns $3-4.5 \mathrm{~mm}$. long, downwardly barbed. Brackish shores, lower Merrimac R., Mass. Sept., Oct. Fic. 991. Var. FÁLLAX Fernald. Achenes and awns upwardly barbed. - With the typical form. Fig. 992.

3. B. discoídea (T. \& G.) Britton. Diffusely 992. B. Eat., branched; leaves ternately divided, slender-petioled; $\because$. fal. leaflets ovate-lanceolate, pointed, coarsely serrate; heads small, $5 \mathrm{~mm}$. high; outer involucral bracts usually 4 ; achenes linear-wedge-shaped, tuberculate or smooth, bearing a pair of short and stout upwardly barbed awons of the length of the orange 5-toothed corolla. (Coreopsis T. \& G.)

- Wet banks and swamps, Mass. to Mich., Ill.,

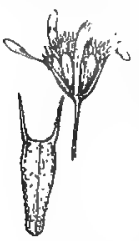
southw. and southwestw. July-Oct. Fig. 993.

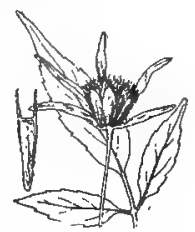

998. B. discoidea

4. B. frondosa L. (BEGGAR-Ticks.) Stems tall ( $7 \mathrm{dm}$. or less in height), paniculate-branched; leaves 3-5-divided, nlabrous, the terminal leaflet long-stalked, acuminate, often again divided, lateral ones shorter, less acuminate, all sharply serrate; heads $1.5 \mathrm{~cm}$. long or less, on slender peduncles; outer involucre of 5-8 ciliate bracts; rays small, yellow; achenes navrowly cuneate, 7-10 mm. long, black, strongly 1-nerved on each face, often slightly 994. B. frondosa. hairy, the retrorsely barbed slightly divergent slender awns barely half as long, exceeding the 5 -toothed orange corolla. (B. melanocarpa Wiegand.) - Common in damp ground, throughout. Aug., Sept. Fig. 994. Var. Axómala Porter. Awns upwardly barbed. - Local, N. S. to Pa. FIG. 995.

5. B. vulgata Greene. (BEGGar-Ticks, Stick-tight.) Stem tall (often $1.5 \mathrm{n}$. high) and branching, glabrous; leaves pinnately 3-5-divided, slenderpetioled, nearly glabrous; leaflets lanceolate, very acute, coarsely serrate, all

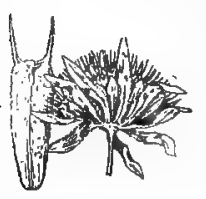

996 , B. vulgata. short-stalked; heads large, 1.5-2.5 cm. broad, stout-pedunculate; outer involucral bracts $10-16$, unequal, about equaling the disk or sometiones longer, coarsely ciliate-hispid; rays pale yellow; achenes 9-12 mm. long, obovate- or oblong-cuneate. usually glabrous, but often tuberculate-roughened, browon $\omega^{\prime}$ alive; awns retrorsely barbed, exceeding the 4-5-toothed yellow corolla. (B. frondosa Wiegand, not L.) - Moist waste places and roadsides, throughout, but less common eastw. than the preceding. Aug,-Oct. Fig. 996.

Var. puberula (Wiegand) Greene. Peduncles, leaves, and outer bracts puberulent. - Wisc. to Sask. and Mo.

6. B. comisa (Gray) Wiegand. Stem stout, $8 \mathrm{dm}$. or less in height, glabrous; branches short; leaves pale,

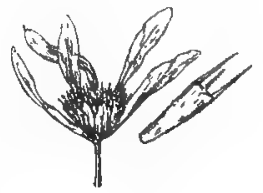

997. B. comosa. elliptic, acnte, with winged petioles, regularly serrate, or upper entire; heads few, large, $1 \mathrm{~cm}$. or so high, short-pedunculate; outer involucre of 6-8 nearly rrect linear or lanceolate usually entire unequal large bracts, the longest 2-5 times exceeding the disk; rays wanting. achenes about $1 \mathrm{~cm}$. long, cuneate, 
olive or brown, nearly glabrous, obscurely nerved or nerveless, sometimes punctate ; awns nearly $\frac{\text { s }}{4}$ as long as the achene, equaling the 4-toothed pale-yellow corolla. (B. connata, var. Gray.) - Sandy shores and rich soil, N. E. to Minn., westw. and southw. Sept, Oct. Fig. 997.

Var. acùta Wiegand. Leaves subsessile; heads larger; outer bracts shorter (barely twice exceeding the disk), spreading, acute. (B. acuta Britton.) - Mo. and Kan.

7. B. connàta Muhl. (Swamp Beggar-ticks.) Tall and branchining, 0.5-1.5 $\mathrm{m}$. high; leaves bright green, undivided or some of the lower deeply parted, lanceolate or elliptic, large, acuminate, slender-petioled, coarsely serrate; heads about $1 \mathrm{~cm}$. high, short-pedunculate; outer involucre of 4 or 5 short entire bracts; rays golden-yellow, generally wanting; achenes 4-6 mm. long, cuneate, the outer 3-angled and 3-awned, inner 4-angled, 4-awned; awns barely half as long as the achene, retrorsely barbed, equaling the 5-toothed corolla. -

398. B. comnata. Swamps and ditches, N. E. to Minn. and Mo. Sept. (Estab-
lished in Eu.) FIG. 998 .
Var. pinnàta Wats. Leaves nearly all pinnately divided, the $5-7$ divisions

398. B. comata. Swamps and ditches, N. E. to Minn. and Mo. Sept. (Estab-
lished in Eu.) Fig. 998 .
Var. pinnàta Wats. Leaves nearly all pinnately divided, the $5-7$ divisions sparingly incised; achenes 4-awned. - Hennepin Co., Minn. ( F. L. Couillard).

8. B. cérnua L. (STicr-tight.) Smooth or hispidulous, s-7 dm. high; branches short; leaves lanceolate to linearlanceolate, acuminate, unequally serrate, connate at base; heads erect in anthesis, short-pedunculate; outer involucre longer than the head; rays, when present, one half exceeding the disk or longer; achenes wedge-obovate, 5-6 $\mathrm{mm}$. long, 4-awned, 4-angled, retrorsely-barbed, tuberculate on the angles, and prominently many-nerved; awns half as long as the achene, shorter than the yellow 5-toothed corolla. - Wet places, throughout. July-Oct. (Eu.) FIG. 999. - Very variable.

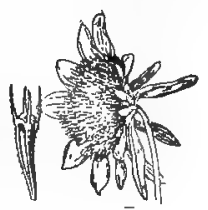

999. B. cernna.

9. B. laèris (L.) B SP. Sinooth, erect, or reclining at base, $1 \mathrm{~m}$. or less high : leaves lancealate, tapering at both ends, sessile, rarely connate finely and regularly serrate; outer involucre mostly shorter than the showy golden-yellow (2-3 cm. long) rays; achenes 6-9 mm. long, wedge-shaped, retrorsely almost

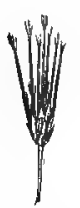
serrate on the margins; awns 2,3 , or 4 , downwardly barbed, barely $\frac{2}{3}$ as long as the achene, and hardly equaling the yellow 5-toothed disk-corolla. (B. chrysanthemoides Michx.) - Swamps near the coast, Mass., and southw.; also centr. N. Y. Aug.-Oct.

10. B. bipinnàta L. (SPANish NeEdLes.) Smooth annual, branched; leaves 1-3-pinnately parted, petioled; leaflets ovatelanceolate, mostly wedge-shaped at the base; heads small, on slender peduncles; outer involucre of linear bracts equaling the short pale yellow rays; achenes 4-grooved, nearly smootb, 3-4awned, very unequal. - Damp soil, R. I., westw. and southw.;

1000. B. bipin. occasional on ballast northw. FIr. 1000.

11. B. coronàta (L.) Fisch. Nearly glabrons, 3-9 dm. high; leaves variable, commonly 3-7-divided, or all undivided, the segments incisely serrate or lobed; rays golden-yeilow, showy; achenes flat, 1-nerved on each face, broadly cuneate, $3-4.5 \mathrm{~mm}$. long, with 2 very short blunt spreading teeth. (Coreopsis aurea Ait.) - Wet ground, Va. to Fla. Fig. 1001.

12. B. trichospérma (Michx.) Britton. (TICKseed SunFLOWER.) Smooth, branched; leaves short-peti-

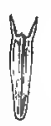
oled, nearly all 3-7-divided; leaflets lanceolate or lance-linear, cut-toothed, or the upper leaves

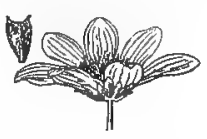

1001. B. coronata. only 3-5-cleft and almost sessile; heads panicled-corymbose; rays conspicuous, golden-yellow; achenes narrowly wedge-oblong or the inner nnes wedge-linear, 5-7 mm. long, smooth or sparsely hairy, 1002. B. trich. marginless, crowned with 2 erect triangular or avol-shaped stout teeth. (Coreopsis Michx.) - Siramps, Mass. to Va. near the coast; also N. Y, to Ill. and $\mathrm{Ky}$; said to extend northwestw. to Minn. Aug.-Oct. Firg. 1002. 
Var. TENufloba (Gray) Britton. Leaf-segments narrowly linear; achenen shorter. - Isess common.

13. B. aristdsa (Michx.) Britton. Somewhat pubescent; leaves 1-2-pinnately 5-7-divided, petioled; leaflets lanceolate, cut-toothed or pinnatifid; heads panicled-corymbose; outer bracts 8-10, not exceeding the inner, barely ciliate; rays showy; achenes with 2 (rarely 4) long and slender diverging awns as long as the achene itself or reduced to short teeth. (Coreopsis Michr.) - Swamps, O. to Mich., Minn., and southwestw.; adventive in waste places eastw. Aug.Oct. Fig. 1003.

14. B. involucràta (Nutt.) Britton. Heads rather larger ; the outer bracts 12-20, mostly exceding the inner, slender anc. 1008. B. aristosa. hispid; achenes with $\mathbf{2}$ short acute teeth. (Coreopsis Nutt.) Fig. 1004.

15. B. Béckii Torr. (WATER MarJgold.) Aquatic, perennial, smooth; stems long and slender; immersed leaves crowded, many times dissected into capillary segments; the few emerging leaves lanceolate, slightly connate, toothed; heads single, short-peduncled; involucre much shorter than

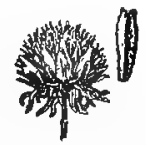

1004. B, involuerata. the showy (golden yellow) rays; achenes thickish, smooth, 1-1.5 cm. long; the stout divergent awns longer, barbed only toward the apex. - Ponds and slow deer streams, Me. and Que. to N. J., and westw. Aug.-Oct.

\section{BALDUîna Nutt.}

Heads globular, many-flowered, radiate ; the long and narrowly wedge-shaped rays neutral. Involucre short, of many thickish small bracts imbricated in 3-4 rows, the outer obovate and obtuse. Receptacle strongly convex, with deep honeycomb-like cells containing the obconical or oblong silky-villous achenes; pappus of 7-9 lance-oblong erect chaffy scales. - Perennial herb, smoothish; the slender simple stems $6-9 \mathrm{dm}$. high, bearing alternate oblanceolate leaves, and a large showy long-pedunculate head. Rays yellow, $2.5 \mathrm{~cm}$. Iong; disk often turning dark purple. (Named for Dr. Wiiliam Baldwin. 1779-1819, discriminating amateur botanist, friend of Muhlenberg.) ACTrNospermum Ell.

1. B. uniflora Nutt. (Actinospermum Barnhart.) - Borders of swamps, from Va. (?) southw. Aug.

\section{MARSHÅLLIA Schreb.}

Heads many-flowered ; flowers all tubular and perfect; corolla-lobes slender and spreading. Involucral bracts linear-lanceolate, foliaceous, erect, in 1-2 rows, nearly equal. Receptacle convex or conical, with narrowly linear rigid chaff. Achenes top-shaped, 5-angled; pappus of 5 or 6 membranaceous pointed scales. - Smooth low perennials, with alternate entire 3-nerved leaves, and longpedunculate heads terminating the simple stem or branches. Flowers purplish; anthers blue. (Named at the request of Muhlenberg for Dr. Moses Marshall, nephew of the more distinguished Humphrey Marshall.)

1. M. trinérvia (Walt.) Porter. Stems leafy; leaves ovate-lancoolate. pointed, sessile but not amplexicaul, $6-7.5 \mathrm{~cm}$. long. (M. latifolia Pursh.) Dry soil, Va., and southw.

2. M. obovata (Walt.) Beadle \& Boynton. Leaves chiefly basal, narrowly obovate, obtusish or rounded at the apex; involucral bracts linear-oblong, blunt; chaff spatulate, more or less distinctly expanded at the tip, blunt; achene longer than pappus. - River-banks and open woods, s. w. Pa., and southw.

Var. platyphylla (Curtis) Beadle \& Boynton. Stem leafy about to the middle; leaves lanceolate, narrowed to an obtusish tip, conspicuousty amplexicaul. Dry open woods, etc., Pa., and southw. M. grandiflora Beadle \& Boynton appears to be only a very robust form or state or this variety, with stems 4-7 dm. bigh, and cauline leaves $2-3 \mathrm{~cm}$. wide. 


\section{GALINSOGA R. \& P.}

Heads several-flowered, radiate; rays $4-5$, small, roundish, pistıllate. Invo-ucre of 4-5 ovate thin bracts. Receptacle conical, with narrow chaff. Pappus of sull oblong cut-fringed chaffy scales, sometimes wanting. - Annual herbs, with opposite triple-nerved thin leaves, and small heads; disk yellow; rays white or reddish. (Named for Dr. Mariano Martinez de Galinsoga, a Spanish botanist.)

\section{* Rays white; pappus of disk-flowers about equaling the achenes.}

1. G. Parviflóra Cav. Pubescence subappressed; leaves ovate, crenateserrate, petioled; pappus of the disk-flowers of spatulate obtusish scales. Roadsides and waste places, from N. E. across the continent. (Adv. from: Trop. Am.) Var. Híspids DC. Pubescence more copious, not appressed; pappus-scales of the disk-flowers attenuate and bristle-tipped. - Me. to Ont., Wisc., and southw. (Nat. from Trop. Am.)

* Rays reddish; pappus of disk-flowers about half as long as the achenes.

2. G. Caracasana (DC.) Sch. Bip. Pubescence loose and often rather copious; leaves as in no. 1. (G. hispida Benth.) - Waste land, Camden, N. J. ; about mills, etc., Cumberland, Md. (Schriver), and probably elsewhere. (Adv. from Trop. Am.)

\section{FLAVÈRIA Juss.}

Heads 3-15-flowered, usually with but 1 ray-flower; flowers all fertile. Involucral bracts few, subequal or 1-2 of the outer much shorter. Receptacle small, naked or setose. Achenes oblong, 8-10-ribbed, glabrous; pappus none. - Opposite-leaved annuals with clustered small yellowish heads. (Name from flavus, yellow, the plant being used in dyeing.)

1. F. campéstris Johnston. Erect and glabrous, 3-6 dm. high, branched above; leaves linear or lanceolate; 3-nerved, mostly serrulate; heads subsessile, in mostly terminal glomerules; involucre 3-bracteate, 2-5-flowered. ( $F$. angustifolia of auth., not Pers.) - Alkaline soil, w. Mo. (Bush) to Col. and Mex. May-Sept.

\section{HYMENOPÁPPUS L'Hér.}

Heads many-flowered; flowers all tubular and perfect, with large revolute rorolla-lobes. Involucral bracts 6-12, loose and broad, thin, the upper part petalsike, usually white. Receptacle small, naked. Achenes top-shaped, with a slender base, striate; pappus of 15-20 blunt scales in a single row, very thin (whence the name of the genus, from $i \mu \eta \dot{\nu}$, membrane, and $\pi \dot{\pi} \pi \pi$ s, pappus.) Biennial or perennial herbs, with alternate mostly dissected leaves, and corymbed small heads of usually whitish flowers.

\section{* Pappus of very small roundish nerveless scales.}

1. H. carolinénsis (Lam.) Porter. Somewhat flocculent-woolly when young, leafy to the top, 3-9 dm. high ; leaves 1-2-pinnately parted into linear or oblong lobes; involucral bracts roundish, mainly whitish; pappus-scales very small, roundish, nerveless. (H. scabiosaeus L'Her.) - Sandy barrens, Ill. to S. C., and southw. May, June.

2. H. corymbosus T. \& G. More slender, glabrate, naked above; bracts obovate-oblong, petaloid at apex. - Woods and plains, Mo. and Neb. to Tox.

\section{POLFPTERIS Natt.}

Heads few-flowered, small ; flowers all tubular, deeply 5-parted. Involucral bracts 8-10, herbaceous. Achenes slender-obpyramidal; pappus of short rounded pales or wanting. - Scabrous herbs with narrow short-petioled mostly alternate leaves, and pedunculate loosely corymbose or paniculate sinall purplish 
heads. (Name from $\pi \circ \lambda \dot{v}$, many, and $\pi \tau t \rho \iota s$ ( $\pi \tau \varepsilon \rho b \nu$ ), wing, referring to the pappus of some species.)

1. P. callòsa (Nutt.) Gray. Annual, slender, $6 \mathrm{dm}$. or less in height; leaves linear; peduncles glandular ; involucral bracts with dry reddish tips. - Dry soil, Mo. to Tex., etc.

\section{ACTÍNEA Juss.}

Heads many-flowered; rays several, wedge-oblong, 3-toothed, pistillate. Bracts of the hemispherical involucre ovate or lanceolate, membranaceous or coriaceous, nearly equal, in 2-3 ranks, little shorter than the disk. Achenes top-shaped, densely silky-villous; pappus of 5 or more ovate or lanceolate very thin chaffy scales, - Low herbs, with narrow alternate leaves, dotted with resinous atoms and bitter-aromatic; the solitary heads terminating scapes or slender naked peduncles; flowers yellow. (Name from diktis, vay.) Acrinelua Pers. Picradenia Hook. Tetraneuris Greene.

1. A. herbacea (Greene) Robinson. Perennial, caespitose; branches of the caudex rather stout, bearing numerous thickish spatulate to linear 1-nerved sparingly villous glandular-punctate leaves and scape-like peduncles (villous or lanate especially toward the summit); heads (including the showy rays) 3-4 $\mathrm{cm}$. in diameter. (Tetraneuvis Greene; Actinella acaulis, var. glabra Gray, in part.) - Ottawa Co., O., and about Joliet, Ill.

\section{HELINNIUM L, SNEEZEWEED}

Heads many-flowered, radiate ; rays several, wedge-shaped, 3-5-cleft, fertile, rarely sterile. Involucre small, reflexed; the bracts linear or awl-shaped. Receptacle globose or ellipsoid. Achenes top-shaped, ribbed; pappus of 5-8 thin 1-nerved chaffy scales, the nerve usually extended into a bristle or point. - Erect branching herbs with alternate leaves, often sprinkled with bitter aromatic resinous globules; heads yellow, rarely purple, terminal, single or corymbed. (The Greek name of some plant, said to be named after Helenus, son of Priam.)

\section{* Leaves broad, decurrent on the angled stem.}

1. H. nudiflorum Nutt. Perennial, somewhat puberulent, 3-9 dm. high ; leaves narrowly lanceolate or oblong to linear, entire, or the radical spatulate and dentate; heads mostly smull; disk browntsh, globose; rays yellow or partly brown-purple, sterile (neutral or style abortive), shorter than or exceeding the disk. - Ill. and Mo. to N. C. and Tex.; also abundantly established locally from N. E. to Pa. June-Aug. - Hybridizes with the next.

2. H. autumnàle L. Perennial, nearly smooth, $0.2-2 \mathrm{~m}$. high; leaves mostly toothed, lanceolate to ovate-oblong; heads larger (2-4 cm. broad); disk yellow; rays fertile, yellow. - Alluvial river-banks and wet ground, w. Que. and w. Mass. to Man., soutluw. and westw. Aug.-Oct.

\section{* * Leaves linear-filiform, not decurrent.}

3. H. tenuifolium Nutt. Glabrous annual, much branched, very leafy ; heads 1.5-2 cm. broad; rays fertile. - Prairies, roadsides, etc., Va. to Kan., and southw.; locally established by railroads, etc., northeastw. to e. Mass.

\section{GAILLÁRDIA Foug.}

Heads many-flowered ; rays 3-cleft or -toothed, neutral or sometimes fertile, or none. Involucral bracts in $2-3$ rows, the outer larger, loose, and foliaceous. Receptacle convex to globose, with bristle-like or subulate or short and soft chaff. Achenes top-shaped, 5-costate, villous; pappus of 5-10 long thin awntipped scales. - Frect alternate-leaved herbs with long-peduncled showy heads of yellow or purplish fragrant flowers. (Named after Gailfard de Charentonneau, a botanical amateur.) 
1. G. lùtea Greene. Erect or nearly so, $4 \mathrm{dm}$. or more in height, puberulent and somewhat scabrous, leafy-stemmed, branched above; branches ascending; leaves oblong-lanceolate, somewhat amplexicaul at the broadish base, toothed or subentire; both disk-flowers and rays yellow. ( $G$. lanceolata of auth., in part, not Michx.) - Mo. (Bush) to Tex.

2. G. aristàta Pursh. Perennial, hirsute; leaves lanceolate to oblanceolate, broad or narrow, entire to coarsely pinnatifid; disk-flowers brownish-purple; rays usually numerous and long, yellow; chaff bristly or subulate. - Minn. tó Man., westw. and southw.; now spreading eastw.

\section{DYSSÒdia Cav. Fetid Marigold}

Heads many-flowered, usually radiate; rays pistillate. Involucre of 1 row of bracts united into a firm cup, with a few loose bracts at the base. Receptacle flat, beset with short chaffy bristles. Achenes slender, 4-angled; pappus a row of chaffy scales, dissected into numerous rough bristles. - Herbs, mostly annuals or biennials, dotted with large pellucid glands, which give a strong odor; heads terminating the branches; flowers yellow. (Name ouswola, an ill smell, which the plants exemplify.) BöBera Willd.

1. D. papposa (Vent.) Hitchc. Nearly smooth, diffusely branched, 1-5 dm. high ; leaves opposite, pinnately parted, the narrow lobes bristly-toothed or cut; rays few, scarcely exceeding the involucre. (D. chrysanthemoides Lag.) - Roadsides and banks of rivers, Minn. to Ill., Tenn., and southwestw.; occasional as a weed further eastw. July-Oct.

\section{ACHILLÈA [Vaill.] L. YarRow}

Heads many-flowered, radiate; the rays few, fertile. Involucral bracts imbricated, with scarious margins. Receptacle chaffy, flattish. Achenes oblong, flattened, margined; pappus none.-- Perennial herbs, with small corymbose heads. (So named because its virtues are said to have been discovered by Achilles.)

* Leaves simple; involucre hemispherical; receptacle low.

1. A. Ptáruica L. (Sneezeweed.) Stem rather rigid, smooth or slightly pubescent; leaves lance-linear, finely appressed-serrate ; corymb loose, the heads long-pediceled; rays 8-12, white, much longer than the involucre. - Damp fields, etc., Nfà. to Mich. and Mass., local. Aug., Sept. (Introd. from Eu.)

* Lecues bipinnately parted ; involucre slender-cylindric; receptacle becoming elongated.

+ Rays comparatively showy, their blades $\frac{1}{2}-\frac{2}{5}$ as long as the involucre; bracts with dark brown or black margins.

2. A. borealis Bongard. Stem erect, $0.5-4 \mathrm{dm}$. high, more or less lanate; stem-leaves fevo (5-9), silky-lanate especially beneath; corymbs $2-6 \mathrm{~cm}$. broad, very convex; involucre 4-6 mm. long, its bracts all dark-margined; rays 10-20, white (rarely pink), short-oblong or suborbicular, 2.5-4 mm. long. - Wet rocks and mossy slopes, Lab. to Alaska, s. to Nfd., e. Que, and along the Rocky Mts. to N. Mex. June-Aug. (Boreal Eurasia.)

+- + Rays small, their blades rarely $\frac{1}{2}$ as long as the involucre; bracts pale, very rarely the uppermost dark-margined.

8. A. Millefolium L. (Cомmon Y., Mirforl.) Stem simple or sometimes forked above, 3-10 dm. high, arachnoid or nearly smooth; stem-leaves numerous (8-15), smooth or loosely pubescent; corymbs very compound, $6-20 \mathrm{~cm}$. broad, ftat-topped, the branches stiff; involucre $3-5 \mathrm{~mm}$. long, its bracts all pale, or in exposed situations the uppermost becoming dark-margined; rays $5-10$, white to crimson, short-oblong, 1.5-2.5 mm. long. - Fields and river-banks, common. (Eurasia.)

4. A. lannlosa Nutt. Similar ; stem 3-6 dm. high, densely woolly; stem- 
leaves silky-lanate; corymbs $2-10 \mathrm{~cm}$. broad, very convex; involucre pubescent, none of its bracts dark-margined; rays $1-2.5 \mathrm{~mm}$. long. - Gravelly shores and open ground, Gulf of St. Lawrence to Mich., thence westw. and southwestw.; naturalized in the Eastern States. (Mex.)

\section{8. ÁNThemis [Mich.] L. Chamomile}

Heads many-flowered, radiate; rays pistillate or (in no. 1) neutral. Involucre hemispherical, of many small imbricated dry and scarious bracts shorter than the disk. Receptacle conical, usually with slender chaff at least near the summit. Achenes terete or ribbed, glabrous, truncate; pappus none or a minute

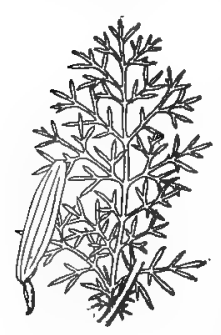

1005. A. Cotula.

Leaf and ray $\times 1 \frac{1}{3}$. crown. - Branching often strong-scented herbs, with pinnately dissected leaves and solitary terminal heads; rays white or yellow (rarely wanting); disk yellow. ("A $\nu \in \epsilon t s$, the ancient Greek name of the Chamomile.)

\section{* Rays white.}

+ Chaff of the receptacle sharp-pointed.

1. A. Cótula L. (May-weed, Dog Fennel.) Annual, acrid, ill-scented; leaves finely 3-pinnately dissected; rays mostly neutral; receptacle without chaff near the margin; pappus none; achenes tuberculate-roughened. (Maruta DC.) Common by roadsides. (Nat. from Eu.) FIG. 1005.

2. A. arvénsis L. (Corn C.) Pubescent annual or biennial, resembling Mayweed, but not ill-scented; leaves less finely 1-2-pinnately parted; chaff of the receptacle lanceolate, pointed, subtending all the disk-flowers and distinctly exceeding them; achenes smooth on the sides; pappus a minute border. - Roadsides, waste places, etc., occasional. (Adv. from Eu.) Fig. 1006. Var. AGREsTIs (Wallr.) DC. Chaff of the receptacle shorter than the disk-flowers. - Fields, etc., becoming frequent. (Nat. from Eu.)

$$
++ \text { Chaff of the receptacle blunt. }
$$

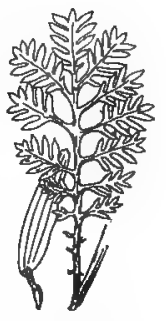

1006. A. arvensis. Leaf and ray $\times 11 / 8$

3. A. Nóbilis L. (GARDeN C.) More downy and perennial, pleasantly strong-scented; sterile shoots depressed or creeping; leaves very finely dissected; pappus none. - Occasionally spontaneous about old gardens. (Introd. from Eu.)

\section{* * Rays yellow.}

4. A. Tinotória L. (Yelzow C.) Pubescent perennial; leaves pinnately divided; heads long-peduncled, $3-4 \mathrm{~cm}$. broad; chaff of the receptacle lanceolate; pappus a short crown. - Fields and waste places, becoming frequent. (Nat. from Eu.)

A. AÚREA (L.) DC., with small rayless heads has been found wear St. Louis, Mo. (Engelmann).

\section{MATRICÀRIA [Tourn.] L. Wild ChaMomile}

Heads many-flowered; rays pistillate or wanting. Bracts of the involucre imbricated, with scarious margins. Receptacle conical (at least in fruit), naked. Achenes 3-5-ribbed, wingless; pappus a membranaceous crown or border, or none. - Smooth and branching herbs (ours annuals or biennials) with finely divided leaves and single or corymbed heads. Rays white or none; disk yellow. (Named for reputed medicinal virtues.)

1. M. INoDónA L. Leaves bipinnately divided into tine almost filiform lobes; hoads large, 3-4 cm. broad, naked-peduncled, and with many long rays; achenes 


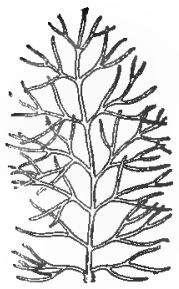

1007. .1. inodora. Leaf $\times 1 \frac{1}{3}$.

strongly 3-ribbed; pappus a short crown or border.-Roadsides and fields, Nfd. to Ct. and Mich.; abundant in e. Me. and adjacent Canada. July, Aug. (Nat. from Eu.) Fig. 1007.

2. M. Cha momflua L. Similar; heads smaller, about 2 $c m$. broad; rays shorter; receptacle more convex; achenes less distinctly ribbed; pappus obsolete. - Roadsides and waste places, Atlantic States, west to O. (Adv, from Eu.)

3. M. suavèolens (Pursh) Buchenau. (Pinea PPle-Weed.) Low; leaves 2-3-pinnately-parted into short linear lobes; heads rayless, short-peduncled; bracts oval, with broad margins, much shorter than the conical disk; achenes more terete; pappus obsolete ; odor of the bruised plant suggesting pineapple. (M. discoidea DC.; M. matricarioides Porter.) - Roadsides and old fields, locally abundaut in N. B., N. E., N. Y., and Pa.; also about St. Louis, Mo,; naturalized, probably from the Pacific slope, where it is common. (Established in n. Eu.)

\section{Chrysånthemum [Tourn.] L. OX-eye Datsy}

Heads many-flowered; rays numerous, fertile. Scales of the broad and flat involucre imbricated, with scarious margins. Receptacle flat or convex, naked. Disk-corollas with a flattened tube. Achenes of disk and ray similar, striate. - Annual or perennial herbs, with toothed, pinnatifid, or divided leaves, and single or corymbed heads. Rays white or yellow (rarely wanting); disk yellow. (Old Greek name, $\chi \rho \nu \sigma a ́ \nu \theta \epsilon \mu \nu \nu$, i.e. golden flower.)

\section{* Heads large, solitary, terminating the long branches.}

1. C. Ledcanthemum L. (Ox-eye or White Daisy, Marguerite, WhiteWEED.) Stein erect, simple or forked toward the sumrnit; basal leaves spatulate-obovate, on long slender petioles, the blades crenate-dentate; middle and upper stem-leaves oblong or oblanceolate, coarsely and regularly crenate or dentate above, with larger spreading teeth at base; heads $4-6 \mathrm{~cm}$. broad ; involucral bracts narrow, brown-margined; rays white (rarely tubular, laciniate, or deformed). - Fields, etc., Nfd. and e. Que.

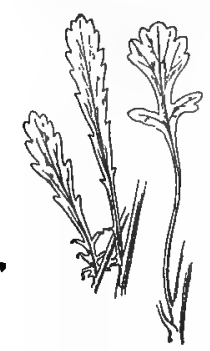

1009. C. Leuc., v. pinnat.

Leaves $\times 1 / 2$. to N. J.; rare southw. June-Aug. (Nat. from Eu.) Fig. 1008.

Var. PINNATÍFIDdM Lecoq \& Lamotte. Basal leaves pinnatifid, subpinnatifid, or coarsely and irregularly toothed; middle and upper stem-leaves narrowly oblong or oblanceolate, conspicuously subpinnatifid at base; heads usually smaller than in the typical form. (Var. subpinnatifidum Fernald.) - Fields and meadows, throughout ; an abundant and pernicious weed eastw. (Nat. from Eu.) FIG. 1009.

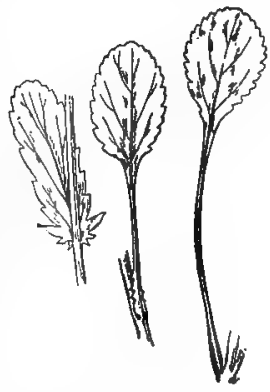

1008. C. Leucenthemum. Leaves $\times 1 / 2$.

2. C. ségetum L. (Corn Chrysanthemum, Corn MariGoLD.) Similar; leaves oblong, somewbat clasping, coarsely toothed or pinnatifid; rays golden-yellow; bracts broad and scarious. - Ballast along the coast, N.B. to N. J.; also in fields near Schenectady, N. Y. (Wibbe). (AdV. from Eu.)

$$
\text { * Heads small, corymbed. }
$$

3. C. Parthénium (L.) Bernh. (Feverfew.) Tall, branched, leafy; leaves bipinnately divided, the divisions ovate, cut; rays white. - Escaped from gardens, and naturalized in some places. (Introd. from Eu.)

4. C. Balsamita L., var. Tanacetoldes Boiss. (Costmart, Mint Geramidm.) Leaves oblong, crenate, the upper sessile, the lower petioled, often 
with 2 small lateral lobes at base; heads rayless. - Frequently escaped from gardens. (Introd. from Asia.)

\section{TANACÉTUM L. TANGY}

Heads many-flowered, nearly discoid; flowers all fertile, the marginal chiefly pistillate and 3-5-toothed. Involucre imbricated, dry. Receptacle convex, naked. Achenes angled or ribbed, with a large flat top; pappus a short crown. - Bitter and acrid mostly strong-scented herbs (ours perennial), with 1-3pinnately dissected leaves, and corymbed (rarely single) heads. Flowers yellow, in summer. (Name of uncertain derivation.)

1. T. VUlGare L. (Common T.) Stem 0.5-1 m. high, smooth; leaflets and the wings of the petiole cut-toothed; corymb dense; pistillate flowers terete, with oblique 3-toothed limb; pappus 5-lobed. - Escaped from gardens to roadsides, etc. (Introd. from Eu.) Var, crfspon DC. Leaves more cut and crisped. - Frequent in similar places. (Introd. from Eu.)

2. T. huronénse Nutt. Hairy or $2000 l l y$ when young, stout, 3-9 dm. high ; lobes of leaves oblong; heads large (1-2 cm. wide) and usually few; pistillate flowers flattened, 3-5-cleft; pappus toothed. - River-banks, e. Que, to N. B. and u. Me.; shores of the upper Great Lakes ; coast of Ore., Wash., and B. C.

\section{CótUla [Tourn.] $\mathrm{L}$.}

Heads hemispherical to globose, many-flowered, discoid; the marginal flowers (reduced rays) pistillate and fertile, nearly or quite apetalous; disk-flowers tubular, 4-toothed, fertile. Chaff none. Achenes at maturity raised on pedicels, which remain attached to the flat or moderately convex receptacle. Pappus obsolete or none. - Low mostly diffuse or creeping strong-scented herbs, with alternate toothed, lobed, or dissected leaves, and pedunculate heads of yellow flowers. (Name from коти́ $\lambda \eta$, a small cup, alluding to the hollow at the base of the amplexicaul leaves.)

1. C. coronopifólia L. Branched from the base, decumbent and often somewhat repent, slightly fleshy, nearly or quite smooth; leaves linear-oblong, irregular, 3-many-toothed ; heads at length subglobose, about $1 \mathrm{~cm}$. in diameter, on slender terminal peduncles. - Brackish mud, P. E. I. (Churchill); on ballast about Chelsea, Mass.; also on the Pacific coast. (Adv. from s. Afr.)

\section{ARTEMÍSIA L. WORMWOOD}

Heads discoid, few-many-flowered; flowers all tubular, the marginal ones pistillate, or sometimes all similar and perfect. Involucre imbricated, dry and scarious. Receptacle small and flattish, naked. Achenes obovoid, with a small summit and no pappus. - Herbs or shrubby plants, bitter and aromatic, with small commonly nodding heads in panicled spikes or racemes; flowering in summer. Corolla yellow or purplish. (Ancient name of the Mugwort, in memory of Artemisia, wife of Mausolus.)

\$1. Receptacle smooth; marginal flowers pistillate and fertile; disk-flowers perfect but sterile, the style mostly entire; root perennial, except in no. 1 .

\section{* Leaves dissected.}

1. A. caudàta Michx. Glabrous or silky, 0.5-1.5 m. high ; upper leaves pinnately, the lower 2-3-pinnately divided; the divisions thread-form, diverging; heads swall (2-3 mm. broad); the racemes in a wand-like elongated panicle; root biennial. - Sandy soil, Atlantic coast; also Vt. to Man., westw. and sonthwestw.

2. A. canadénsis Michx. Smooth, or hoary with-silky down, 3-6 dm. high ; lower leaves bipinnately divided, the upper 3-7-divided; divisions linear, rather" rigid; heads rather large (4-6 nm. broad), in panicled raiemes; involucre 
generally glabrous, green; root perennial. - Calcareous rocks, Nfd. to B. C., s. to n. N. E., Minn., etc. (Eu.)

3. A. boreàlis Pall. Similar, 1-3 dm. high; lower leaves 1-2-ternately divided; upper linear, mostly entire; heads fewer, subracemose; involucre pilose or glabrate, brownish; root perennial. - Arctic regions, s. to the serpentine mts. of e. Que., Keweenaw Point, Mich., Col., and Wash. (Asia.)

$$
\text { * Leaves entive or some 3-cleft. }
$$

4. A. dracunculoìdes Pursh. Tall $(0.5-1.5 \mathrm{~m}$.), somewhat woody at base, slightly hoary or glabrous; leaves narrowly linear and entire or the lower 3 -cleft; heads small and numerous, panicled. - Sandy banlss and prairies, Man, to Ill., Mo., westw. and southwestw.

5. A. glaúca Pall. Strict, 3-6 dm. high, somewhat woody at base, minutely silky-pubescent or glabrate and glaucous; leaves linear- to oblong-lanceolate; heads as in the preceding. - Prairies, Sask, to Minn. and N. Dak. (Siber.)

\$2. Receptacle smooth; flowers all fertile, a few pistillate, the others perfect.

Two cultivated shrubby species, from Europe, with filiformly divided leaves, have occasionally escaped from gardens and become spontaneous, viz. A. Abrótanum I. (the Southernwood), of strict habit, with 1-2-pinnatifid leaves and pubescent heads; and A. Prócera Willd., with more spreading branches, all the leaves finely 2-pinnatifid, and heads glabrous.

* Branching perennials, whitened with fine and close-pressed wool; heads small, in leafy panicles.

6. A. serràta Nutt. Very leafy, 1.5-3 m. high; leaves lanceolate or the upper linear, serrate, white-tomentose beneath, green above; heads greenish, subcylindric, $4.3 \mathrm{~mm}$. long or less. - Ill. to S. Dak.; sparingly naturalized eastw.

7. A. longifolia Nutt. Stem $\mathbf{0 . 5}-1.5 \mathrm{~m}$. high ; leaves linear or linear-lanceolate, entire, usually glabrate above ; heads subcylindric, canescent, 4-6 mm. long. - Minn. to Neb., and westw.

8. A. ludoviciàna Nutt. (Western Mugwort, White Sage.) Whitenedwoolly throughout; leaves lanceolate, the upper mostly entire, the lower usually cut-lobed, toothed or pinnatifid, the upper surface sometimes glabrate and green; heads campanulate, mostly sessile in slender panicles. (Including $A$. gnaphalodes Nutt.) - Dry banks, Sask. to Mich., Ill., Tex., and westw.; locally naturalized eastw. - Very variable.

9. A. vulgaris L. (Common Mugwort.) Tall; leaves mostly glabrous and green above, the lower surface (and the branches) white-woolly, all pinnatifi, with the divisions often cut-lobed, linear-lanceolate; heads small, in open panicles. - Waste places and roadsides, and along streams, e. Que. to Ont. and Pa. (Nat. from Eu.)

10. A. Kansana Britton. Low, 1-6 dm. high; leaves finely pinnatifid into linear segments; heads densely woolly, in strict close panicles. - Plains and foot-hills, w. Kan., Col., and N. Mex.; adventive eastw.

* * Densely white-tomentose, perennial; heads large, racemose-glomerate; involucral bracts herbaceous.

11. A. Stelleriana Bess. (Beach W., Dusty Miller, Old Woman.) Stout, 3-6 dm. high, from a creeping base; leaves obovate or spatulate, pinnatifid, the lobes obtuse. -..-Sandy sea-beaches, e. Que. to N. J., and shores of Oneida L., N. Y. (Haberer); commonly cultivated in old gardens, and recently spreading extensively to sandy soil. (Introd. from n. e. Asia.)

$$
\text { * * Less branched, biennial or annual, glabrous. }
$$

12. A. biénnis Willd. Strict, tall; lower leaves 2-pinnately parted, the upper pinnatifd; Jobes linear, acute, in the lower leaves cut-toothed; heads in short axillary spikes or clusters, crowded in a slender and glomerate leafy panicle, - Gravelly banks, $O$. to 'Tenn., Mo., and northwestw.; now established eastw. by railroads and in waste places. 
13. A. ANxUA L. Much branched, very swept-scentrd; leaves 2-pinnately divided, the oblong sesments deeply pinnatifirl; heads small, in a loose ample panicle. - Waste places, etc., throughout, locally a bad weed. (Nat. from Old World.)

\section{§3. Receptacle hairy; flowers all fertile, the marginal ones pistillate.}

14. A. Amsintumar l. (Wormwoon.) Rather shrubby, 6-9 dm. higl, silky-hon'y ; leaves'-3-pinnately parted; lobrs lanceolate; heads hemispherical, panicled. - Roadsides, dry banks, ete., thoroughly established and common, e. Can. and n. N. E.; elsewhere local. (Nat. from Eu.)

15. A. frígida Willd. Low (1.5-5 dm. high), in tufts, slightly woody at the base, white-silky; lerves pinnately parted and 3-5-cleft, the divisions narrowly linear; heads globose, racemose. - Dry hills and rocks, Sask. to Minn., w. Tex., and westw.

\section{\%4. TUSSILÀGO [Tourn.] L. Coltsfoot}

Head many-flowered; ray-flowers in several rows, narrowly ligulate, pistillate, fertile; disk-flowers with undivided style, sterile. Involucre nearly simple. Receptacle flat. Achenes slender-cylindric or prismatic; pappus copious, soft, and capillary. - Low perennial, with horizontal creeping rootstocks, sending up scaly scapes in early spring, bearing a single head, and producing roundedheart-shaped angled or toothed leaves later in the season, woolly when young. Flowers yellow. (Name from tussis, a cough, for which the plant is a reputed remedy.)

1. T. FArfara L. - Wet places and along brooks, e. Que. to Pa., O., and Minn. (Nat, from Eu.)

\section{PETASItes [Tourn.] Hill. Sweet Coltsfoot}

Heads many-flowered, somewhat dioecious; in the substerile plant with a single row of ligulate pistillate ray-flowers, and many tubular sterile ones in the disk; in the fertile plant wholly or chiefly of pistillate flowers, tubular or distinctly ligulate. Otherwise as Tussilago. - Perennial woolly herbs, the leaves all from the rootstock, the scape with sheathing scaly bracts, bearing heads of purplish or whitish fragrant flowers in a corymb. (The Greek name for the Coltsfoot, from $\pi \dot{t} \tau a \sigma o s$, a broad-brimmed hat, on account of its large leaves.)

\section{* Pistillate flowers ligulate; flowers whitish. \\ + Leaves deeply lobed.}

1. P. palmàtus (Ait.) Gray. Leaves rounded, somewhat kidney-form, palmately and very deeply 5-7-lobed, the lobes toothed and cut.-Woods, swamps, and recent clearings, Lab., to Alb., s, to e. Mass., w. Ct., N. Y., Mich., Wisc., and Minn. Apr.-June. - Full-grown leaves 1-2.5 dm. broad.

\section{+ + Leaves shallowly or not at all lobed.}

2. P. trigonophýllus Greene. Leares from broadly cordate-deltoid to suborbicular, closely invested beneath with dense white tomentum, the $7-11$ shallow lobes more or less sharply toothed, in maturity $0.5-1.5 \mathrm{dm}$. broad. - Wet meadows, local, Gaspé Co., Que., Sask., and n. Minn. May.

3. P. sagittàtus (Pursh) Gray. Leaves deltoid-oblong to reniform-hastate, actute or obtuse, repand-dentate, very white-tomentose beneath, when fully grown 1.7-2.5 dm. broad. - Cold swamps, Lab. to B. C., s. to Minn., Col., etc. May, June.

* Ligules none; flowers purplish.

4. P. vulghris Hill. (Butterbirr.) Rootstock very stont; leaves roundcordate, angulate-dentate and denticulate. - Waste or cultivated ground, e. Mass. and e. 1'a. Apr., May. (Nat. from Eu.) 


\section{6. ÁRNICA L.}

Heads many-flowered; rays pistillate. Bracts of the bell-shaped involucre lanceolate, equal, somewhat in 2 rows. Receptacle flat, fimbrillate. Achenes slender or spindle-shaped; pappus a single row of rather rigid and strongly roughened-denticulate bristles. - Perenuial herbs (chiefly of mountains and cold northern regions), with simple stems, bearing single or corymbed large heads and opposite leaves. Flowers yellow. (Name thought to be a corruption of Ptarmica.)

* Basal leaves petioled; stem leafy.

+ Basal leaves tapering to the petiole.

$\rightarrow$ Pappus barbellate, bright white.

1. A. chionopáppa Fernald. Stem $0.7-3.5 \mathrm{dm}$. high, villous with flat white hairs; leaves :3-5 pairs, lanceolate to narrowly ovate, mostly confined to the lower half of the stem, the basal on very long slunder petioles: the lower cauline. petioled, the upper sessile and much reduced; heads 1-:3,:3-4 cm. broad; involucre villous, the linear- or lance-attenuate bracts 7-10 $\mathrm{mm}$. long; achenes $3.5-5 \mathrm{~mm}$. long, densely setulose ; pappus in fruit 5-6.5 min. long. - Cold limestone cliffs and ledges, e. Que. and n. N. B. June, July.

\section{+ + Pappus plumose, sordid.}

2. A. mollis Hook. Stem 1.5-7 dm. high, more or less crisp-villous throughout, somewhat glandular above; leaves oblanceolate to ovate, the basal slenderpetioled ; the cautine (?-5 pairs) mostly sessile, $0.3-1.5 \mathrm{dm}$. long, the uppermost only slightly smaller; heads $1-9$, on short (3-12 cm. long) naked "or rarely bracted glandular-villous peduncles, $4-6 \mathrm{~cm}$. broad ; involucre glandular and villous, its lance-attenuate often purple-tipped bracts $1-1.6 \mathrm{~cm}$. long; achenes hirsute, 4-5 mm. long, shorter than the plumose yellow-brown or olive-tinged pappus. (A. Chamissonis Man., ed. 6, not Less.; A. lanceolatc Nutt.) - Banks of streams, e. Que. to B. C., s. to the mts. of Me. and N. H., Col., and Cal. June-Aug.

Var. petiolàris Fernald. Leaves narrow, oblanceolate, all but the very uppermost tapering to slender petioles; heads:;-4 cm. broad; involucral bracts scarcely $1 \mathrm{~cm}$. long. - By alpine brooks, Me., N. H., and n. N. Y.

\section{+ + Basal leaves rounded or cordate at base.}

3. A. cordifdlia Honk. Stern 1.5-6 dm. high, more or less villous throughout, glandular above ; basal and lower cauline leaves ovate, coarsely dentate, slenderpetioled, upper short-petioled or subsessile; heads 1-8, slender-peduncled, 5-7 $\mathrm{cm}$. broad; involucre villous, especially at base; bracts lanceolate to oblong, acuminate, 1.3-2 cm. long; rays about 15 ; achenes hirsute; pappus white, barbellate. - Very local, 12. Mich.; Yukon to S. D., Col., Utah, and Cal.

* Basal leaves rosulate, broad and sessile; stem-leaves remote and small.

$\checkmark$ 4. A. acaúlis (Walt.) BSP. Hairy and rather glandular, $1 \mathrm{~m}$. or less in height ; leaves thickish, 3-5-nerved, ovate or oblong; heads several, corymbed, showy. (A. nudicaulis Nutt.) - Damp pine barrens, Del., s. Pa., and southw. May, June.

\section{7\%. ERECHTITES Raf. FiREWEed}

Heads many-flowered; the flowers all tubular and fertile; the marginal pistillate, with a slender corolla. Bracts of the cylindrical involucre in a single row, linear, acute, with a few small bractlets at the base. Receptacle naked. Achenes oblong, tapering at the end; pappus copious, of very fine and white soft hairs. - Erect and coarse annuals, of rank smell, with alternate simple lenves, and paniculate-corymbed heads of whitish flowers. (The ancient name of some species of Groundsel, probably called after Erechthers.)

I. E. hieracifolia (L.) Raf. Often hairy; stem grooved, 0.3 to $3 \mathrm{~m}$. high ; 
leaves lanceolate or oblong, acute, cut-toothed, sessile, the upper auricled at base or petioled. - Moist woods, and in recently burned clearings, whence the popular name; common, especially northw. July-Sept.

\section{8. cacallia L. Indian Plantain}

Heads 5-many-fiowered; the flowers all tubulax and perfect. Involucral bracts in a single row, erect, connivent, with a few bractlets at the base. Receptacle naked. Corolla deeply 5-cleft. Achenes oblong or slender-cylindric, smooth; pappus of numerous soft capillary bristles. - Smooth and tall perennial herbs, with alternate often petioled leaves, and rather large heads in flat corymbs. Flowers white or whitish. (An ancient name, of uncertain meaning.)

* Involucre 25-30-flowoered, with several bracts at its base; receptacle flat.

1. C. suavèolens L. Stem grooved, 1-1.6 m. bigh; leaves triangularlanceolate, halberd-shaped, pointed, serrate, those of the stem on winged petioles. (Synosma Raf.) - River-banks, rich woods, etc., Ct. to Ia., Minn., and southw. in the Allegheny region to Fla.; Newton, Mass. (Farlow), where probably an escape. Aug., Sept.

* Involucre 5-bracted and 5-flowered, its basal bracts minute or none; receptacle bearing a more or less evident scale-like pointed appendage in the center.

2. C. renifórmis Mulhl. (GReat Indian P.) Not glaucous; stem 1-3 m. high, grooved and angled; leaves green on both sides, dilated-fan-shaped, or the lowest kidney-form, 3-6 dm. broad, repand-toothed and angled, palmately veined, petioled; the teeth pointed; corymbs large. (Mesadenia Raf.) - Rich damp woods, N.J. to Minn., and southw, along the mts. to N. C. and Tenn. July, Aug.

3. C. atriplicifdlia L. (PALE Indian P.) Glaucous; stem terete, 1-2 m. high; leaves palmately veined and angulate-lobed; the lower triangular-kidneyform or slightly heart-shaped; the upper rhomboid or wedge-form, toothed. (Mesadenia Raf.) - Rich woodlands and prairies, N. J. to Minn., Kan., and southw. in the Alleghenies to Ga.

4. C. tuberosa Nutt. Stem angled and grooved, 6-20 dm. high, from a thick tuberous root; leaves green on both sides, thick, strongly 5-7-nerved; the lower lance-ovate or oval, nearly entire, tapering into long petioles; the upper on short margined petioles, sometimes toothed at apex. (Mesadenia Britton.) Wet prairies, etc., $O$. and w. Ont. to Minn., Kan., and southw.

\section{SENEcio [Tourn.] L. Groundsel. Ragwort. Squaw-WEed}

\section{Revised By J. M. Greenman}

Heads many-flowered; rays pistillate or none; involucre cylindrical to bellshaped, simple or with a few bractlets at the base, the bracts erect-connivent. Receptacle flat, naked. Pappus of numerous very soft and capillary bristles. Ours herbs, with alternate leaves and solitary or corymbed heads. Flowers chiefly yellow. (Name from senex, an old man, alluding to the hoariness of many speeies, or to the white hairs of the pappus.)

a. Aunuals (rarely becoming biennial); stems leafy to the inflorescence; heads medium-sized, $1 \mathrm{~cm}$, or less high during anthesis $b$.

b. Heads discold

b. Heads radiate; rays inconspicuous. Pubescence viscid-glandular. Pubescence not viscid-glandular.

- Heads radiate; rays consplouous.

Leaves irregularly lnciniate-dentate to entice; plant pubescent . Leaves lyrate or pinnately divided; plant glabrous

a. Biennials or perennials $c$.

c. IIeads mediun-siged, In anthesis about $1 \mathrm{~cm}$, long $d$.

d. Stems lonfy to the inflorescence; lenves mostly $2-8$-pinnatisect .

1. S. vulgaris.

2. S. viscosus.

8. S. syluaticus.

4. S. palustris.

5. S. glabellus.

6. S. Jacobara. 
a. Stems mostly leafy below, nearly naked above; leaves varlable; the lower ovate, obovate, or oblanceolate; the upper much reduced, often bract-like 6 .

↔. Pubescence when present floccose-lanate and confined chicfy to the base of the stem and to the loaf-axils $f$.

f. Heads discuid

f. Heads radiate (excopt in $\dot{S}$. obovatus, vir. eiongatus) $g$.

$g$. Lower leaves obovate, occasionally subrotund or oblong; stolons when well developed slender and creeping

6. Lower leaves subrotund to lanceolate; the earliest leaves cordate or subcordate, usually long-petioled; stolons short and stout, assurgent.

Basal leaves all broad-opate, deeply cordate and relatively large

Basal loaves nostly lanceolate; only the earliest ones subrotund, cordate, and relatively small :

g. Lower leaves oblong-oblanceolate to spatulate, usually narrowed gradually at the base; the earliest rarely subrotund or oblong.

Stem but slightly woolly at the base, comparatively fewheaded

Stem rather densely and permanently woolly at the base heads usually numerous.

- Pubescence white-lanate and more or less persistent
and leaves (rarely in no. 13 completely absent)

Basal leaves subrotund-ovate to oblong-lanceolate.

Btem-leaves deeply and irregularly divided

Stem-laeves usually dentate, not deeply divided, only a few at most lyrate.

Basal leaves oblong-obovate, oblanceolate, or spatulate. Eastern species

Western specles

e. Pubescence of crisp-hírsute or subvillous hairs, not floceose or lanate, rarely quite glabrous

c. Heads larger, 1.5-2 $\mathrm{cm}$. high during anthesis

7. S. discoideus.

8. S. obovatus.

9. S. aureus.

10. S. Robbinsii.

\section{S. Balsamitae.}

12. S. Smallii.

13. S. plattensis.

14. S. tomentosus.

15. S. aniennariifolius. 16. S. canus.

17. S. integernimus. 18. S. Prendio-Arnica.

$\checkmark 1$. S. velgaris L. (Common Groundsel.) Low annual, 1-5 dm. high, corymbosely branched, glabrate, leafy to the inflorescence ; leaves pinnatifid and toothed, $1-8 \mathrm{~cm}$. long, $0.5-3 \mathrm{~cm}$. broad ; calyculate bracts (bracteoles) of the involucre distinctly black-tipped; rays none; achenes hirtellous. - Waste grounds, common. July-Sept. (Nat. from Eu.)

2. S. riscosus L. Coarser, 1.5-4 dn. high, viscid-pubescent and heavyscented ; leaves pinnatifid with toothed segments or 2-pinnatifid, $2-10 \mathrm{~cm}$. long, 0.5-5 cm. broad ; calyculate bracts (bracteoles) of the involucre not black-tipped; rays minute, bright yellow. - Waste grounds, coast of e. Que. to N. E.; also on ballast near Philadelphia. July-Sept. (Nat. from Eu.)

3. S. Sylváricus L. Stem erect, 1-7 dm. high, simple or branched, somewhat pubescent; lower leaves petioled and more or less lyrate, the upper pinnatifid with unequal lobes, sessile and sagittate at the clasping base, $2-15 \mathrm{~cm}$. long, 1-8 cm. broad ; inflorescence corymbose, naked or nearly so ; heads cylindrical; involucre barely calyculate; ligules but slightly surpassing the diskflowers. - Clearings and waste places, Nfd. and e. Que. to Me., chiefly near the coast; also near Painesville, O. July-Sept. (Nat. from Eu.)

4. S. palústris (L.) Hook. Annual or biennial, loosely villous to nearly glabrous; stem stout, $2-7 \mathrm{dm}$, high; leaves oblong-lanceolate, irregularly toothed or laciniate, the upper with a heart-shaped clasping base; rays 20 or more, short, pale yellow; pappus copious and becoming very long. - Wet grounds, Ia. to, . Wisc., N. Dak., and northw. June-Sept. (Eu.)

5. S. glabéllus Poir. (ButTer-weEd.) liather tall, 2-5 dm. or more high; lecves somewhat fleshy, lyrate or pinnately divided; divisions crenate or cutlobed, variable; heads less than $1 \mathrm{~cm}$. high, in a naked cory mbose inflorescence ; rays 6-12, conspicuous. (S. lobatus Pers.) - Wet grounds, N. C. to centr. Ill., Mo., and southw. March-June.

6. S. JACOBA LA L. (Stinking WiLlie.) Arachnoid-tomentulose to nearly glabrous; stem erect, $2-6 \mathrm{dm}$. or more high ; basal leaves somewhat lyrate; those of the stem 2-3-pinnatisect, sessile, $2-15 \mathrm{~cm}$. long, 1-7 cm. broad; inflorescence a many-headed corymbose cyme; heads radiate. - Roadsides, pastures, and ballast, Nfd. and e. Que. to Me., and locally to Ont. and N. J. July-Aug. (Nat. from Eu.) 
7. S. discoldeus (Hook.) Britton. Stems erect, 2-8 dm. high, striate; lower 7 errips broadly ovate, $1.5-8 \mathrm{~cm}$. long, $1-4.5 \mathrm{cin}$. broad, rominded or obtuse at the aprex, crenate to coarsely dentate, abruptly contracted into a slightly winged petiole equaling or exceeding the blade; inflorescence, subumbellate; heads on rather long peduncles, discoid; invulucre sparingly calyculate; bracts of the involucre slightly shorter than the fluwers of the disk, often purplish-tipped; achenes glabrous. - Calcareous ledwes, or in damp thickets, e. Que., n. Mich.. northw. and westw. June-Aug.

8. S. obovàtus Mulul. Stem, $0 \mathrm{~cm}$. hig 1 , bearing flagelliform stolons at base; lower leaves obovate, 1-10 cm. long, two thirds as broad, gradually narrowed into a narrowly winged peliole, crenate-dentate, glabrous on both surfaces; upper stem-leaves pinnatifid, sessile; inflorescence a corymbose cyme, not infrequently umbellate; heads radiate; achenes glabrous. ( $\mathcal{S}$. aureus, var. T. \& G.) - Calcareous ledges and open woods, e. Mass. and s. Vt. to N. C., Ala., Ark, and Kan. Apr.-Aug.

Var. rotúndus Britton. Lower leaves more or less orbicular or rotund, other. wise like the species, - ( In moist banks and rocks, centr. $U$., and southwestw.

Var. elongàtus (I'ursh) Britton. Habit and foliage of the typical form, but with elongated peduncles and discoid heads. - Near Easton, Pa. May, June.

1 9. S. aúreus L. (GoLden R.) Stems erect from rather slender rootstocks, 3-8 $\mathrm{dm}$. high, at first often lightly floccose-tomentose, soon glabrate; lower leaves long-petioled, ovate-rotund to slightly oblong, $1.5-8 \mathrm{~cm}$. long, two thirds as broad, crenate-dentate; stem-leaves lyrate to laciniate-pinnatifid; the uppermost sessile, amplexicaul, often bract-like; inflorescence cymose-corymbose; heads radiate; rays yellow; achenes glabruus. - In wet meadows, moist thickets, and swamps, Nfd., s. to Va., w. to Wisc., Mo., and Ark. May-Aug.

Var. grácilis (Pursh) Britton. Somewhat more slender, with lower stems, smaller leaves, and fewer lieads. - Pa. and Mich. May, June.

10. S. Robbinsii Oakes. Stems strict, 5-8 dm. high; the first leaves small, ovate-rotund to ovate-oblong, $1-3 \mathrm{~cm}$. long, from two thirus to nearly or quite as broad, crenate-dentate to lather sharply toothed; the later radical and lover cauline leaves lancpolate to slightly oblong-lanceolate, 3-10 cm. long, $1.5-3 \mathrm{~cm}$. broad, sharply and somewhat unequally dentale-serrate; the uppermost leaves much reduced; inflorescence cymose-corymbose; achenes pubescent. - In wet meadows or swamps, N. B. and N. S. to 11. N. Y. June, July.

11. S. Balsámitae Muhl. Stems $1.5-3 \mathrm{dm}$. high, slightly woolly or floceosetomentose at the base, nearly or quite glabrous above; lower leaves mostly oblong-oblanceolate (rarely oblong-elliptic), 1-5 cm. long, $0.5-1.5$ (rarely 3) cm. broad, gradually narrowed at the base into the petiole, crnate-dentate to rather sharply dentate-serrate, often pubescent in the early stages and glabrate, or glabrous from the beginning; petioles usually not much exceeding the blade; the upper leaves lyrate, pinnatifid, or much reduced and entire; achenes glabrous or pubescent. (S. aureus, var. T. \& G.) - Gaspé Co., Que., to Md.. Tenn., Ill., and Mich., thence northwestw. essentially across the continent. May-Aug.A variable species. In shaded alluvium passing into forms essentially glabrous, with nore pronounced foliar development. Var. PA LÉrclius (Michx.) Fernald. Smaller, sometimes not over $3 \mathrm{~cm}$. in height, and with the inflorescence not infrequently reduced to a single head. - In cool or much exposed situations, Me., and northw. July-Aug.

Var. praelóngus Greemman. Taller; lower leaves long-petioled ; stem-leaves rather large, often $1 \mathrm{dm}$. in length, $2 \mathrm{~cm}$. in breadth, pinnatifid with remote lateral lobes and deep rounded sinuses; achenes hirtellous-pubescer ${ }^{+}$- Rocky woods and banks, Mass., Vt., and N. Y: June, July.

Var. Crawfórdii (Britton) Greenman. Lower leaves slender-petioled; the blade oblong-elliptic, $2-6 \mathrm{~cm}$. long, $1-3 \mathrm{~cm}$. broad, mostly rather sharply serrate. dentate; petioles $1.5 \mathrm{dm}$. or less in length; involueral bracts $7-8 \mathrm{~mm}$. long. (S. Crawordii Britton.) - Near Philadelphia (Craworord). May.

12. S. Smállii Britton. Stem tall, elect, 2.5-7 dm. high, simple to the inforescence, densely and persistently woolly at the base; lower leaves lanceolate or oblanceolate, $2.5 \mathrm{dm}$. or less in length, 1-2 cm. broad, crenate-dentate to 
rather sharply serrate; upper stem-leaves sessile, pinnatifid with remotish segments and rounded sinuses; inflorescence cymose-corymbose, many-headed; heads radiate, 6-8 cm. high during anthesis; achenes usually hispidulous along the angles, - Va., and southw. May, June.

13. S. platténsis Nutt. Stems one to several, simple or branched from the base, $1.5-6 \mathrm{dm}$. high; lover leaves petiolate, ovate to oblong-lanceolate, $5-10 \mathrm{~cm}$. long, $1-2.5 \mathrm{~cm}$. broad, crenate-dentate to deeply and irregularly pinnatifi, thickish and as well as the stem usually white-tumentose, more or less glabrate; inflorescence a corymbose cyme; heads about $1 \mathrm{~cm}$. high, radiate; achenes commonly hispidulous. - Dry, sandy, or gravelly soil, s. w. Out. to e. Mont. and Tex. Apr.-July.

$V$ 14. S. tomentosus Michx. (Woolly R.) Clothed with scarcely deciduous hoary wool; stems 3-6 dm. high ; basal leaves oblong, 2-15 cm. long, 1-7 cm. broad, obtuse, crencte or entire, often on elongated stout petioles, $2.5 \mathrm{dm}$. or less in length; the stem-leaves similar, lyrate-pinnatifid to entire; inflorescence cymose-corymbose; heads radiate; rays 12-15. - N. J. to Fla. and Tex. Apr.June.

15. S. antennariifolius Britton. Stem erect, $3-4 \mathrm{dm}$. high; leaves mostly basal, oblony-obovate to spatulate, including the petiole $3-6 \mathrm{~cm}$. long, $0.5-1.5$ $\mathrm{cm}$. broad, rounded or obtuse at the apex, somewhat remotely and shallowly angulate-dentate, narrowed below into the petiole, finely and densely mattedtomentose beneath, loosely floccose-tomentose above; stem-leaves sublyrate or merely dentate, the uppermost reduced to linear entire bracts; inflorescence cymose-corymbose, few-headed; heads radiate; achenes papillose-hirsute along the angles. - Blue Ridge, Va. June.

16. S. cànus Hook. Usually low, 1.5-3.5 dm. high, persistently tomentose, rarely at all glabrate; lower leaves oblong-oblanceolate or subspatulate, including the petiole 5-10 cm. Iong, 1-" $\mathrm{cm}$. broad, obtuse or rounded at the apex, entire or sparingly toothed, white-tomentose on both surfaces, rarely glabrate above; stem-leaves entire or slightly pinnatifid, the uppermost becoming sessile and not infrequently clasping the stem by a sub-auriculate base; inflorescence few-headed; heads 10-12 mm. high, radiate; involuere arachnoid-tomentose to nearly glabrous, sparing!y calyculate; ray-flowers commonly 8; disk-flowers numerous. - Sask., Alb., and along the Rocky Mts, to Col., eastw. tó n. Minn. (according to Upham). June-Aug.

17. S. integérrimus Nutt. Covered when young with long jointed crisp-hirsute or subvillous hairs, soon more or less glabrate; lower leaves oblong-lanceolate or suboblong, including the narrowly winged petiole usually 1-2 dm. long, 1-4 cm. broad, entire or denticulate; the upper bract-like, attenuate from a broad subclasping base; inflorescence few-headed; heads $10-12 \mathrm{~mm}$. high; involucral bracts usually green-tipped. — Sask., Man., Dak., Ia., and westw. MayJuly.

18. S. Pseùdo-Árnica Less. Loosely white-voolly, sometimes becoming glabrouls; stem stout, $0.5-10 \mathrm{dm}$. high, leafy above, often nearly naked below; leaves oblong-lanceolate to subovate, $0.5-1.5$ din. Iong, 1-5 cin. broad, repanddentate to subentire, the lower tapering into a narrow petiole-like base, the upper sessile; heads $1.5-2 \mathrm{~cm}$. high; rays 20 or more, yellow. - Gravelly beaches, e. Me. to Lab.; and in the Alaskan region.

\section{0. ÁRCTIUM L. BuRdogk}

Heads many-flowered ; flowers all tubular, perfect, similar. Involucre globular; the imbricated bracts coriaceous and appressed at base, attenuate to long stiff points with hooked tips. Receptacle bristly. Achenes oblong, flattened, wrinkled transversely; pappus short, of numerous rough bristles, separate and deciduous. - Coarse biennial weeds, with large unarmed petioled roundish or crate mostly cordate leaves floccose-tomentose beneath, and small solitary or . listered heads; flowers purple, rarely white. (Name probably from äpkros, a bear, from the rough involucre.)

1. A. Lápra L. (GReat B.) Heads subcorymbose, 3-5 cm. broad; invo* 
lucre glabrous; bracts straightish, lance- to linear-attenuate. ( $A$. Lappa, var. majus Gray; $\boldsymbol{A}$. majus Bernh.) - Roadsides and waste places, N. B., N. E., and probably westw. (Nat. from Eu.)

2. A. Minus Bernh. (Сommon B.) Heads racenose or subracemose, 1.5-3 $\mathrm{cm}$. broad; involucre glabrous or arachnoid; bracts shorter, more slender and more arcuate than in the preceding. (A. Lappa, var. Gray.) - Similar situations, too common throughout our range except on the northeastern borders where largely replaced by the preceding. - Including $A$. Lappa, var. tomentosum Gray, a form differing only in its more or less arachnoid involucre, and apparently less marked or characteristic than the European $\boldsymbol{A}$. tomentosum Mill. (Nat. from Eu.)

\section{1. Échinops L. Globe Thistle}

Heads 1-flowered, many, aggregated in dense globular capitate clusters, the common involucre of small reflexed bracts. Proper involucres cylindrical, of several series of unequal imbricated spinescent paleaceous bracts; corollas with slender tube and cylindric 5-parted limb. Filaments glabrous. Achenes cylindrical or somewhat tetragonal ; pappus coroniform or of many short distinct or connate subpaleaceous bristles. - Stately thistle-like herbs, with alternate spinose pinnatifid or dentate leaves, and large globose terminal (compound) heads of

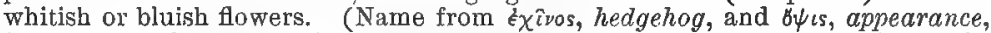
from the bristly nature of the armed foliage or perhaps of the spreading individual heads in the dense spherical glomerules.)

1. E. SPHA ERocéphalus L. Tall, 1-2 m. high, grayish- or white-arachnoid on the stem and lower surface of leaves. - Frequent in cultivation and not rare as an escape upon waste-heaps, etc. (Introd. from Eu.)

\section{CÁRduUS [Tourn.] L. Plumeless Thistle}

Bristles of the pappus naked (not plumose), merely rough or denticulate. Leaves conspicuously decurrent, spiny; wings of stem spiny. Otherwise as in Cirsium. (The ancient Latin name.)

* Heads large, nodding, solitary on long nearly naked peduncles; involucre 3-4 cm. in diameter.

1. C. nùtans L. (Musk Thistud.) Biennial; heads solitary, hemispherical, 3-5 cm. broad; bracts lanceolate, the outer reflexed; flowers purple. - Fields near Harrisburg, Pa.; also pastures, waste places, and ballast, n. to N. B. and Que. June-Oct. (Nat. from Eu.)

* Heads smaller, chiefly clustered at the ends of winged branches; involucre $1-2.5 \mathrm{~cm}$. in diameter.

2. C. Acantholdes L. Annual or biennial ; involucre hemispherical, 1.5-2.5 cm. broad; bracts linear, the outer somewhat herbaceous and spreading; flowers rose-purple; corollas about $18 \mathrm{~mm}$. long. - Waste places and ballast, N. S. to N. J. June-Aug. (Adv, from Eu.)

3. C. Crispus L. Annual or biennial ; heads mostly clustered and sessile or nearly so ; involucre ovoid, 1-1.3 cm. broad; bracts linear-attenuate, the outer rather rigid, hardly spreading; flowers purple or white; corollas about $14 \mathrm{~mm}$. long. - Roadsides, Sydnew, Cape Breton; Philadelphia, Pa. ; and St. Louis, Mo. Aug.-Sept. (Adv. from Eu.)

\section{CirsiUm [Tourn.] Hill. Common or Plumed Thistle}

Heads many-flowered; flowers all tubular, perfect and similar, ravely imper. fectly dioecious. Bracts of the ovoid or spherical involucre imbricated in many rows, tipped with a point or prickle. Receptacle thickly clothen with soft bristles "I hairs. Achenes oblong, flattish, not ribbed; pappus of numerous pristles united into a ring at the base, plumose to the middile, deciduous. - 
Herbs, mostly biennial; the sessile alternate leaves often pinnatifid, prickly. Heads usually large, terminal. Flowers reddish-purple, rarely white or yellowish; in suminer. (Name trom kıpobs, a swelled vein, for which the Thistle was a reputed remedy.) CNicus of many auth, not L. By some recent Am. auth. included in CA.RUOS.

\section{* Bracts of the involucre all tipped with spreading prickles.}

1. C. lanceoldtum (L.) Hill. (Common or Boll Thistre.) Leaves decurrent on the stem, forming prickly lobed wings, pinnatifid, rough and bristly above, woolly with deciduous webby hairs beneath, prickly; flowers purple. (Carduus L.; Cnicus Willd.) - Pastures and roadsides. July-Nov. (Nat. from Eu.)

\section{* Heads leafy-bracteate at base (see also no. 11); proper bracts not prickly.}

2. C. spinosíssimum (Walt.) Scop. (Yellow Thrstle.) Stout, 0.3-1.5 m. high, webby-luaired when young; leaves partly clasping, green, soon smooth, lanceolate, pinnatifid, the short toothed and cut lobes very spiny with yellowish prickles; heads 4-8 $\mathrm{cm}$. broad, surrounded by very prickly bract-like leaves, which usually equal the narrow involucral bracts; flowers pale yellow or purple. (Carduus Walt.; Cnicus horridulus Pursh.) - Sandy soil, Me. to Va., and southw., near the coast; reported from L. Superior. June-Aug.

* * Bracts appressed, the inner not at all prickly.

+ Leaves white-woolly beneath, and sometimes also above; outer bracts successively shorter, spinose-tipped.

* Leaves white above.

$=$ Leaves pinnate, with linear mostly entive divisions.

3. C. Pitchèri (Torr.) T. \& G. White-uoolly throughout, low ; stem very leafy; leaves all pinnately parted into rigid narrowly linear and elongated sometimes again pinnatifid divisions, with revolute margins; inner involucral bracts acuminate, generally to a weak prickle; flowers cream-color. (Cnicus Torr.; Cariuns Porter.) - Sandy shores of Lakes Michigan, Huron, and Superior. July, Aug.

$==$ Leaves pinnatifid or pinnately parted, the lobes lanceolate or triangular.

4. C. undulàtum (Nutt.) Spreng. Resembling the preceding; root bienniat; leaves partly clasping, undivided, undulate-pinnatifid, or rarely pinnately parted, moderately prickly; involucre $2-3 \mathrm{~cm}$. high; bracts with a definite glandular ridge on the back, and twice or thrice as long as the slender spreading prickle; flowers reddish-purple. (Carduus Nutt.; Cnicus Gray.) - Islands of L. Huron to Mich., Ia., Kan., and westw. June-Oct. Var. MEgAcéphaldm (Gray) Fernald.' Heads larger ; involucre $3-4.5 \mathrm{~cm}$. high. - Minn. to Okla., Tex., and westw.

5. C. canéscens Nutt. Deep-rooted perennial; leaves narrower and more deeply pinnatifid than in no. 4 , involucre $2-2.5 \mathrm{~cm}$. high, its narrow bracts ending in very slender spines. - Minn. and w. Ia., westw. and southwestw.

$$
+++ \text { Leaves green above. }
$$

= Stems leafy up to the heads.

\section{a. Leaves deeply pinnatifid into linear-lanceolate lobes.}

6. C. dfscolor (Muhl.) Spreng. Branching perennial, 1-2 m. high ; stem strongly furrowed, hirsutulous; basal leaves $3-4 \mathrm{dm}$. long, deeply pinnatifi, the lobes often cleft; upper leaves with somewhat falcate lobes, white-woolly beneath; heads mostly solitary at the tips of the branches; involucre $2.5-3 \mathrm{~cm}$. high ; bracts appressed; the nuter tipped by a weak recurved prickle ; the inner linear-or lance-attenuate, with a very long colorless entire appendage. (Carduus Nutt.; Cnicus altissimus, var. Gray.) - Rich soil, N, B. to Opt., Minn., and soulhw, 


\section{b. Leaves entire or sparingly sinuate-lobed (only the basal sometimes deeply) pinnatifià.)}

7. C. altissimum (L.) Spreng. Biennial; stem downy, branching, 1-3.8 m high; leaves roughish-hairy above, whitened with close wool beneath, oblongovate to narrowly lanceolate, undivided, sinuate-toothed, or undulate-pinnatifid, the lobes or teeth with weak prickles; involucre $2-3 \mathrm{~cm}$. high; outer bracts with a short dark glandular line on the back, abruptly tipped by a spreading setiform prickle; inner with a lanceolate or deltoid usually serrulate tip; flowers chiefly purpie. (Carduus L.; Cnicus Willd.) - Fields and copses, Mass. to Minn., Neb., and southw.

8. c. lowénse (Pammel) Fernald. Similar, but with larger heads ; involucre 3-:3,5 cm. high; bracts with broad long dark glandular back; the inner with a prolonged linear- or lance-attenuate colorless tip. - Ia., S. Dak., and Kan.

\section{$==$ Heads on naked peduncles.}

9. C. virginiànum (L.) Michx. Stem woolly, slender, simple or sparingly branched, $0.3-1 \mathrm{~m}$. high, the branches or long peduncles naked; leaves lanceolate, green above, whitened with close wool beneath, ciliate with prickly bristles, entire or sparingly sinuate-lobed, sometimes the lower deeply sinuate-pinnatifid; heads small; outer bracts scarcely prickly; flowers purple. (Carduus L.; Cnicus Pursh.) - Woods and plains, Va., O., and southw.

+ + Leaves green both sides, or only with loose cobwebby hairs underneath; heads large; bracts scarcely prickly-pointed.

10. C. mùticum - Michx. (Swamp Thistle.) Stem tall, 1-2.5 m. high, angled, smoothish, panicled at the summit; branches sparingly leafy, bearing single or few rather large heads; leaves somewhat hairy above, whitened with loose vebby hairs beneath when young, deeply pinnatifid, the divisions lanceolate, acute, cut-lobed, prickly-pointed; bracts of the webby and glutinous (sometimes glabrate) involucre closely appressed, pointless or barely mucronate; flowers purple. (Carduus Pers.; Cnicus Pursh.) - Swamps and low woods, common, July-Sept. Var. subpinnatrinum (Britton) Fernald. Leaves slightly lobed, not deeply pinnatifid. (Carduus muticus, var. Britton.) - Nfd. to W. Va.

11. C. pùmilum (Nutt.) Spreng. (PAsture or Bull Thistle.) Biennial; stem low and stout, $3-9 \mathrm{dm}$. high, hairy, bearing very large heads $(4-8 \mathrm{~cm}$. broad), which are often leafy-bracted at the base; leaves green, lanceolateoblong, partly clasping, somewhat hairy, pinnatifid, with short and cut very prickly-margined lobes; outer bracts prickly-pointed, rarely a little glutinous on the backs, the inner very slender; flowers purple or rarely white, fragrant, $5 \mathrm{~cm}$. long; anthers scarcely acuminate; roots terete, solid. (Onicus odoratus Muhl, nomen subnudum; Carduus odoratus Porter.) - Dry fields, N. E. to Pa. and Del. July-Sept.

12. C. Hillii (Canby) Fernald. Similar to the preceding, perennial, rarely with more than 1 head; leaves less deeply and more bluntly pinnatifid, with finer and shorter prickles; bracts with a conspicuous dark glutinous line dovon. the back; anthers acuminate; perpendicular root fusiform, hollow. (Cnicus Canby ; Cardures Porter.) - Fields, Ont. to Minn., s. to Pa., Ill., and Ia.

* 栦 Outer bracts of the appressed involucre barely prickly-pointed; heads mostly small and numerous.

- None of the leaves strongly decurrent.

13. C. Arvense (I.) Scop. (Canada Thistle.) Perennial, slender, 3-9 din. high, the rootstock extensively creeping; leaves oblong or lanceolate, smooth, or slightly woolly beneath, finally green both sides, strongly sinuatepinnatifid, very prickly-margined, the upper sessile but scarcely decurrent; heads imperfectly dioecious; flowers rose-purple or whitish. (Carduus Robson; Cnicus Hoffm.) - Cultivated fields, pastures, and roadsides, common; a most troublesome weed, extremely difficult to eradicate. (Nat. from Eu.) Var. vesrùtum Wimm. \& Grab. Leaves permanently white-lanate beweath. - Locally established. (Nat. from Eu.) Var. INTEgrifólıum Wimm, \& Grab, Leaves 
chisfly plane and uncut, or the lnwest slightly pinnatifid. - Local, Que., N. E., and N. T. (Nat. from liu.)

$$
\text { + + At least the lower leaves strongly decurvent. }
$$

14. C. PALÚstre (L.) Scop. 'Till, nol stoloniferous; stem armed throughout by the prickly decurrent wings which extend duwn from the very long linear or inear-lanceolate more or less pinnatifid spinose-ciliate leaves; heads resembling those of no. 13, but in denser glumerulate clusters, hermaphrodite. - Thoroughly naturalized in woods, East Andover, N. I. (G. W. Holl). (Nat. from É, E.)

15. C. CAvoM (L.) Birb. Roots fusiform; lower leaves very long, lanceolate, toothed or slightly pinnatifid, green on both sides, their bases decurrent as ciliate wings along the stem; upper leaves sessile; heads comparatively large, hemispherical, on long peduncles. - Established at Kendal Green, Mass. (Miss Parsons). (Adv. from Eu.)

\section{ONOPÓRDUM [Vaill.] L. CotTon or Scotch Thistee}

Receptacle deeply honey-combed, not setose. Pappus not plumose. Otherwise as Cirsium. - Coarse branching annuals or biennials, with the stems winged by the decurrent bases of the lobed and toothed somewhat prickly leaves. Heads large; flowers purple. (Latinized from the ancient Greek name of the plant.)

1. 0. Acáthium L. Stem (1-3 m. high) and leaves cotton-woolly ; scales linear-awl-shaped. - Roadsides and waste places, N. B. and N. S. to Ont, s, to N. J. and Mich., rather rare. July-Sept. (Nat. from Eu.)

\section{SílybuM [Vaill.] Adans. Mirk Thistle}

Heads many-flowered; flowers all alike, tubular, perfect, fertile. Involucre large, depressed-globose; the bracts large, prickly, the broally ovate base gradually or rather abruptly contracted to a straightish rigid spreading or reflexed herbaceous but indurated and pungent tip. Receptacle flattish, densely bristly. Achenes glabrous; pappus of numerous flattish barbellate bristles united into a ring at the base and deciduous together. - Thistle-like tall stout prickly lerbs with sinuate-lobed or pinnatifid mottled leaves and large solitary heads of purple flowers. (Derived from $\sigma / \lambda \cup \beta o s$, the ancient Greek name of an edible-stemmed thistle.)

1. S. Marianum (L.) Gaertn. (Lady's Thistle.) Stout and nearly glabrous annual or biennial, with large mottled amplexicaul leaves variously lobed and prickly on the margin. (Mariana Hill.) - An occasional escape from gardens, or weed on ballast and waste grounds. (Introd. from s. Eu.)

\section{6. centaúrea I. Star Thistle}

Heads many-flowered; flowers all tubular, the marginal often much larger (as it were radiate) and sterile. Receptacle bristly. Involucre ovoid or globose, imbricated; the bracts margined or appendaged. Achenes obovoid or oblong, compressed or 4-angled, attached obliquely at or near the base; pappus setose or partly chaffy, or none. - Herbs with alternate leaves; the single heads rarely yellow. (Kevтaupin, an ancient Greek plant-name, poetically associated with Chiron, the Centaur, but without wholly satisfactory explanation.)

Bracts of the involucre (or at least the outer ones) terminated by a definite elongate rigid spine; annuals.

Stems not winged

Stems winged.
Spines of the involucre stout, straw-colored, 12-18 mm. long

Spines of the involucre slender, purplish, 6-9 mm. long

Bracts not spinose-tipped, or merely with ehort firm tip hardiy longer than the lateral teeth, cilia, or fringe.

Bracts entire or merely with irregularly denticulate or lacerated (not regularly toothed or pectinate) margin

1. C. Calcitrapa.

2. O. solstitialis.

3. O. melitenais.

4. C. Jacea. 
Some bracts with regularly pectinate or toothed margin or tip.

Annual, with floccose white pubescence and simple entire linear or lanceolate leaves

Biennials or pereninils (exceptionally annuals), green; lowest leaves usually pinnatifid or conrsely toothed.

Middle and outer bracts pectinate or fringed two thirds to the base.

Leaves all pinnatifid; green bodies of the involucral bracts conspicuous, their margins dark.

At least the upper" leqves entire or merely short-toothed ; pale bodies of the involucral bracts mostly hidden by the imbricated appendages.

Heads $2-5 \mathrm{~cm}$, broad; involucral bracts with dark appendages

Heads 6-12 cm. broad; bracts with pale brown or straw-colored appendages.

Middle and outer bracts pectinate only at the usually darker tip.

Lower leaves pinnatifid into linear or lanceolate segments, the opper mostly linear ; involueral bracts distinctly ribbed .

Lower leaves elliptic or oblanceolate, lyrate-pinnatifid or coarsely dentate, the upper similar; involucral bracts plane or obscurely ribbed

1. C. Calcftrapa L. (Caltrops, Star Thistle.) Diffusely branched, somewhat pubescent; leaves spinulose-toothed; heads sessile; all but the innermost involucral bracts terminated by a stout divergent straw-colored spine (1-2.5 $\mathrm{cm}$. long), which is naked or with 1 to 4 pair's of spinules at the broad base; corollas purplish, all tubular. - Ballast and waste ground, rarely in open woods near towns, N. Y. to Va. June-Oct. (Nat. from Eu.)

2. C. solstitialis L. (Barnaby's Thistle.) Grayish with loose floccose pubescence, branched, $3-5 \mathrm{dm}$. high; basal leaves deeply pinnatifid ; the lobes oblong and elliptical, serrate; cauline leaves small, oblong-lanceolate, entire or nearly so, strongly decurrent in broadish wings upon the stem; body of the involucre ovoid, $1.5 \mathrm{~cm}$. in diameter, the stout straight stramineous spines 12-18 $\mathrm{mm}$. long, widely spreading or reflexed; flowers yellow. - Waste ground, etc., e. Mass. to Ont. and Ia., becoming frequent. (Adv. from Eu.)

3. C. MELITínsrs L. Leaves slightly decurrent; heads subsessile, or mostly short-peduncled, leafy-bracted at base; middle and lower bracts terminated by slender weak divergeni spinulose-based spines; innermost bracts

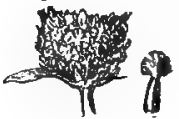

1010. O. Jacea.

Involuere and

bract $\times 1 / 2$. with ascending purplish spines; corollas yellow. - Ballast and waste grounds about ports ; more abundant in the Pacific States. June-Sept. (Nat. from Eu.)

4. C. JAce A L. Simple or branched, 3-6 dm, high; leaves lanceolate or oblanceolate, slightly denticulate, the lowest petioled, the upper sessile; heads showy; involucre subglobose; outer bracts pale; the others glossy dark brown, entire or slightly lacerated; corollas rose-purple, the marginal conspicuously enlarged and falsely radiate. - Waste ground and fields, local, N. F., N. Y., and N. J. June-Sept. (Nat. from Eu.) Fig. 1010.

Var. LACERA Koch. Leaves often runcinate-dentate; outer and middle bracts of the involucre with a pale finely lacerated fringe. Mass. to N. J. (Nat. from Eu.) FIG. 1011.

5. C. CÝanus L. (Bluebottle, Bachelor's Button, CorN-Flower.) Slender, with long ascending branches terminated by solitary heads; involucre ovoid, of about 4 very unequal series of pale bracts; the outermost narrowly del-

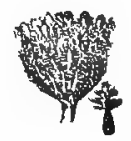

1011. C. Jacea, v. las. Iuvolucre and bract $\times 1 / 2$. toid, and with the longer middle ones bordered by a white or silvery sharptoothed scarious band; the innermost elongate-lanceolate, with more or less erose and colored tips; marginal flowers large and ray-like, blue, violet, pink, or white. - Escaped from cultivation to roadsides, etc. July-Sept. (Introd. from Eu.)

6. C. SCABIósa L. Plant rather villous, leafy toward the base, the solitary large (5-6 cm. broad) heads on elongated bracted peduncles; involucre broadly ovoid; the otter bracts ovate-triangular, the inner oblong, all voith a conspicuously pectinate-ciliate dark margin; corollas purplish, the marginal falsely radiate. - Fields and waste places, local, e. Que. to Ont. and $O$. (Nat. from Eu.) 
7. C. Ntgra L. (Knapweed, Spanish Butrons.) Rather harsh somewhat branched plant, with reduced leaves extending nearly or quite to the heads, involucre subglobose; the appendages of the bracts hirtellous, blackish (rarely tawny); the outermost and midlle ones lancedeltoid and very deeply pectinate-ciliate; the innermost ovate or orbicular, paler and imegularly lacerate; corollas rosepurple, all tubular. - Fields and roadsides, locally abundant, Nfd. and Que. to N. J. July-Sept. (Nat.from Lu.) Fig. 1012.

1012. C. nigrs.

Involucre and bract $\times 1 / 2$.

Var. RADIATA DC. Involucre tawny (raitely blackish); outer flowers falsely radiate. - N. S. to Ont. and Pa. (Nat. from Eu.)

8. C. americàna Nutt. Tall and smoothish (0.5-1.5 In. high); stems conspicuously thickened below the showy heads; leaves oblong-lanceolate, mostly entire; bracts all with conspicuously fringed scarious appendages, the outermost and middle with spreading, the elongate innermost wilh ascending, teeth; corollas rose-purple to flesh-pink, the outer conspicuously enlarged. - Plains, Mo., southw. and southwestw. May-Aug.

9. C. MACULósA Lam. Pubescent or glabrate, with ascending rather wiry branches; involucre ovoid-campanulate, in fruit becoming open-campanulate; the outer and midale ovate bracts with rather firm points and with 5-7 pairs of cilia at the dark tip; innermost bracts elongate, entire or lacerate; corollas whitish, rose-pink, or purplish, the marginal falsely radiate. - Waste places, roadsides, etc., N. E. to N. J. (Adv. from Eu.)

10. C. vochintssis Bernh. Harsh, somewhat resembling no. 7 ; involucre of several very inequal series; the outermost bracts deltoid or ovate, short, the dark pointed tip bearing 5-7 pairs of long cilia; midale bracts elongate-lanceolate, terminated by a dilated ovate or orbicular dark pectinate appendage; innermost bracts elongate, with dark or brightly

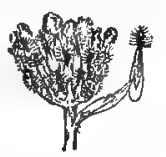

1013. c. vochinensis. Involucre and bract $\times 1 / 2$. colored erose or lacerate appendage; corollas rose-purple, the marginal falsely radiate. - Fields and roadsides, local, N. E. to Ont. (Nat. from Eu.) Fig. 1013.

\section{CNìcus L. Blessed Thistle}

Heads many-flowered ; flowers all tubular, the marginal sterile, shorter than the others, which are perfect and fertile. Bracts of the ovoid involucre coriaceous, appressed, extended into a long and rigid spinous appendage. Receptacle clothed with capillary bristles. Achenes terete, short, strongly many-striate, crowned with 10 short and horny teeth and bearing 10 elongated rigid bristles, also 10 shorter alternating ones in an inner row. - An annual somewhat pubescent herb, with scarcely pinnatifid-cut but spinescent leaves and large leafy-bracted heads of yellow flowers. (Latin name of the Safflower, from the

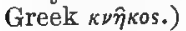

1. C. BENEDíctus L. (Centaurea L.) - Roadsides and waste places, rare, N. B. and N. S. to Pa., and southw. (Adv. from Eu.)

\section{LAPSANA L. NIPPLE-WORT}

Heads 8-12-flowered. Bracts of the cylindrical involucre 8, erect; a short outer series also present. Receptacle naked. Achenes oblong; pappus none.Slender branching annuals, with angled or toothed leaves, and loosely panicled small heads; flowers yellow. (The $\lambda \alpha \mu \psi \alpha \dot{\nu} \eta$ of Dioscorides was evidently a wild Mustard.) Lampsana Hill.

1. L. Covmùis L. Nearly smooth, 3-8 dm. high ; lower leaves ovate, sometimes lyre-shaped. - Roadsides and waste places, Que. to Pa., and Mich. (Nat. from Eu.) 


\section{SERÍNIA Raf.}

Fleads as in Lapsana, but the involucre not calyculate; tips of the bracts somewhat conniving in fruit. Achenes obovoid, 10-costate, obscurely and transversely scabrous-lineolate. - Low glaucescent glabrous annuals, with oblong to lanceolate entire or repand-dentate leaves, the upper sessile; and small scattered heads on slender peduncles. (Name intended as a diminutive of $\sigma \epsilon \rho s$, chicory.) A POGON Ell.

1. S. oppositifolia (Raf.) Ktze. Peduncles naked or glandular-bristly below the small (0.5 cm. high) heads. - Damp sandy soil, S. C. to $\mathrm{ll}$., Kan., and southw. March-June.

\section{ARIOSERIS Gaertn.}

Heads many-flowered ; flowers all ligulate and fertile. Involucre campanulate ; bracts narrow, equal, in 1 series, acuminate, after anthesis thickened toward the base. - Small annual, with rosulate leaves and branched upwardly thickened scapes bearing rather small heads of yellow flowers. (Name from á $\rho \nu$ s, lamb, and $\sigma \in \rho t s$, chicory.)

1. A. MfNima (L.) Dumort. (Lamb Succory.) Puberulent, $1.5-3 \mathrm{dm}$. high; leaves oblanceolate or spatulate, mostly toothed. - Fields, etc., Me., O., Mich., and probably elsewhere. (Adv. from Eu.)

\section{CICHÒRIUM [Tourn.] L. Succort or ChIOORT}

Heads several-flowered. Involucre double, herbaceous, the inner of 8-10, the outer of 5 short and spreading bracts. Achenes striate; pappus of numerous small chaffy scales, forming a short crown. - Branching perennials, with deep roots; the sessile heads 2 or 3 together, axillary and terminal, or solitary on short thickened branches. Flowes bright blue, varying to purple or pink (rarely white), showy. (Altered from the Arabian name of the plant.)

1. C. Intribus L. (Comon C., BLuE Sailors.) Stem-leaves oblong or lanceolate, partly clasping, the lowest runicate, those of the rigid flowering branches minute. (Including var. divaricatum of Am. auth., probably not of 1)C.) - Roadsides and fields, Nfd. to Minn., and southw. July-Oct. (Nat. from Eu.)

\section{KRIfGIA Schreb. Dwarf Dandelion}

Heads several-many-flowered. Involucral braets several, in about 2 rows, thin. Achenes short and truncate, top-shaped or columnar, terete or angled; pappus double, the outer of thin pointless cliaffy soales, the inner of delicate bristles. - Small herbs, branched from the base; the leaves chiefly radical, lyrate or toothed; the small heads terminating the naked scapes or branches. Flowers yellow. (Named for David Frieg, a German physician, who was among the first to collect plants in Maryland.) ADopociox Neck.

§ 1. CÝMBIA T. \& G. Bracts of involucre 5-8, remaining erect; achenes turbinate; pappus of 5 obovate scales, and usually 5 alternaling bristles; annual.

1. K. occidentàlis Nutt. Scapes tufted, $1.5 \mathrm{dm}$. or less high, glandularhispid, at least above; leaves obovate to lanceolate, entire, lyrately lobed, or pinnatifid. (Adopogon Ktze.) - Prairies, s. Mo, and Kan. to Tex. March May.

\$2. EUKRIGIA T.\& G. Bracts of involucre 9-18, reflexed in age; achenes turbinate, 5-angled; pappus of 5-7 short roundish scales and as many alternating bristles; annual.

2. K. virgínica (L.) Willd. Scapes severa\}, $3 \mathrm{dm}$. or less high, becoming branched and lenfy; earlier leaves roundish and entire, the others narrower and often pinnatifid. (Adopogon carolinianum Britton.) - Dry soil, s. Me. to Ont., vinn., and southw. Apr.-Aug. 
\$3. CYNTHIA (D. Don) Gray. Irvolucre of the preceding section; achenes nowe slender; pappus of 10-15 small oblong scales and 15-20 bristles; prrenuial.

3. K. Dandèlion (L.) Nutt. Roots slender, tuberiferous; scapes leafless, 1.5-5 dm. high ; leaves varying from spatulate-oblong to linear-lanceolate, entire or few-lobed. (Adopogon Ktze.) - Moist gromnd, Md. to Kan., and southw. March-July.

4. K. amplexicaúlis Nutt. (Cyntaia.) Roots fibrous; stem $1-6 \mathrm{dm}$. high ; stem-leaves 1-3, oblong or oval, clasping, mostly entire; the radical ones on short winged petioles, often toothed, rarely pinnatifid; peduncles $2-5$. (Adopogon virginicum Kize.) - Moist banks, Mass. to Ont., Man., and southw. Maylug.

\section{HYPOCHAÈRIS L. CAT'S-EAR}

Similar to Leontodon, but at least the inner achenes produced into long slender beaks. Receptacle chaffy. - Old World and South American herbs, with bracteate slightly branching scapes and yellow flowers. (A name used by Theophrastus for this or a related genus.)

1. H. RADicAta L. P'erennial; leaves hirsute; scapes $2-4 \mathrm{dm}$. high, stout; heads 2.5-4 cm. broad; achenes all beaked. - Fields, waste places, and on ballast, Mass. to N. J. aud Ont. (Morton). (Nat from Eu.)

2. H. GLABRA I. Slender, glabrous, with smaller beads ; outer achenes truncate.-Sparingly in grassiand in $\mathrm{Me}$. and $\mathrm{O}$.; naturalized in Cal. (Adv. from Eu.)

\section{LEÓNTODON L. HAWKBIT}

Heads many-flowered. Involucre scarcely imbricated, but with several bractlets at the base. Achenes spindle-shaped, striate, all alike; pappus persistent, composed of plumose bristles which are enlarged and flattened toward the base, with sometimes an outer paleaceous crown. Receptacle not chaffy. - Low and stemless perennials, with toothed or pinnatifid basal leaves, and scapes bearing one or more yellow heads. (Name from $\lambda \epsilon \omega \nu, a$ lion, and ódoús, a tooth, in allusion to the toothed leaves.)

* Scape simple or branching, scaly-bracteate above; heads before anthesis erect; pappus a single row of plumose bristles.

1. L. Autumnalis L. (Fall Dandelion, "Arnica.") Leaves laciniatetoothed or pinnatifid, somewhat pubescent; scape commonly forking, 1-6 dm. high; peduncles thickened at summit, scaly-bracteate (rarely leafy); involucre glabrous or slightly pubescent; tawny pappus a row of equal bristles. - Fields and roadsides, Nfd. to w. Ont., Mich., and Pa. Late May-Nov. - A frequent teratological or pathological form has greenish-yellow heads without ligules. (Nat. from Eu.)

Var. PRATÉnsis (Link) Koch. Usually larger; involucre and tips of peduncles densely soft-pubescent with blackish hairs. - Often more abundant than the typical form. (Nat. from Eu.)

* Scape simple and naked; heads before anthesis nodding; pappus of two linds.

- Pappus similar in all the flowers, the outer a few short setae, the inner a rou' of plumose bristles with dilated bases.

2. L. Hastìis L. Rather stout, glabrous throughout; leaves oblong-lanceolate, dentate or pinnatifid; scape $2-7 \mathrm{dm}$. high, thickened upward; heads rather large; involucre 11-14 mm. long, its smooth lanceolate bracts lead-colored. Fields, local, Ct. to $O$. (Adv. from Eu.)

Var. vULGARIS Koch. Leaves, scape, and involucre bristly-hispid. ( $L$. hispidus L.) - Fields and waste places, R. I. to Ont. and s. N. Y. (Adv. Irom Eu.) 
+ + Pappus of the marginat flowers u crown of short scales, of the inner flowers setiforn and plumose.

3. L. Nudicaúlis (I.) Banks. Slender; leaves hispid; scape filiform, 1-2 $\mathrm{dm}$. high ; involucre $7-10 \mathrm{~mm}$. long, its lanceolate bracts hirsute or glabrous. (L. hirtus L.) - Locally established in pastures and waste places, Ct. to N.J. (Adv. from Eu.)

\section{PİCRIS L.}

Heads many-flowered, terminating leafy stems. Outer bracts loose or spreading. Achenes with 5-10 rugose ribs; pappus of 1 or 2 rows of plumose bristles. - Coarse rough-bristly annuals or biennials, with yellow flowers. (The Greek name of some allied bitter herb, from $\pi$ ikpós, bitter.)

1. P. HIRnacioìes L. Rather tall, corymbosely branched, the bristles somewhat barbed at tip; leaves lanceolate or broader, clasping, irreguzarly toothed; outer involucral bracts narrow; achenes oblong, with little or no beak; pappus sparsely plumose. - Waste places, sparingly in the interior, and in ballast on the coast. June-Oct. (Adv. from Eu.)

2. P. echioides L. (Ox-arongde.) Similar, but leaves and bracts spinescent, the outer bracts ovate, subcordate, the narrow inner ones becoming thickened below; achenes beaked; pappus densely plumose. - Similar situations. JulySept. (Adv. from Eu.)

\section{TRAGOPÒgON [Tourn.] L. GOAT's BEARD}

Heads many-flowered. Involucre simple, of several erect lanceolate attenuate equal bracts. Achenes narrowly fusiform, 5-10-ribbed, long-beaked ; pappus of numerous long plumose bristles. - Stout glabrous biennials or perennials, with entire grass-like clasping leaves and large solitary heads of yellow or

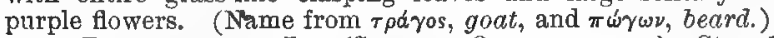

1. T. Porrifollius I. (Salsify, Orster-Plant.) Stem $1 \mathrm{~m}$. or less high; peduncle thickened and fistulous below the head; flowers purple; achenes and pappus 7-8 cm. long. - Sparingly escaped from cultivation. (Introd. from Eu.)

2. T. Praténsis L. (Goat's Beard.) Very similar; leaves somewhat broader at base; peduncle little thickened; flovers yellow. - Fields, rocky banks, ete., N. B. and N. S. to N. J., and westw. (Nat. from Eu.)

\section{CHONDRf́lla [Tourn.] L. Gum Succory}

Heads few-flowered. Involucre cylindrical, of several narrow linear equal bracts and a row of small bractlets at base. Achenes terete, several-ribbed, smooth below, roughened at the summit by little scaly projections, from among which springs an abrupt slender beak; pappus copious, of very fine and soft capillary bristles, bright white. - Herbs of the Old World, with wand-like branching stems, and small heads of yellow flowers. (A name used by Dioscorides for some plant which exudes a gum.)

1. C. JÚNCEA L. (SKELETON-WEED.) Biennial, bristly-hairy below, smooth above, $1 \mathrm{~m}$. or less high; root-leaves runcinate; stem-leaves few and small, linear; heads scattered on nearly leafless branches, $1-1.5 \mathrm{~cm}$. long. - Fields and roadsides, abundant in $\mathrm{Md}$. and $\mathrm{n}$. Va. July, Aug. (Nat. from Eu.)

\section{TARÁXACUM [Haller] Ludwig. Dandelion}

Heads many-flowered, large, solitary on w slender hollow scape. Involucre double, the outer of short bracts; the inner of long linear bracts, erect in a single row. Achenes oblong-ovate to fusiform, 4-5-ribbed, the ribs roughened; the apex prolonged into a very slender beak, bearing the copious soft white capillary pappus. - Perennials or biennials ; leaves radical, pinnatifid or runa- 


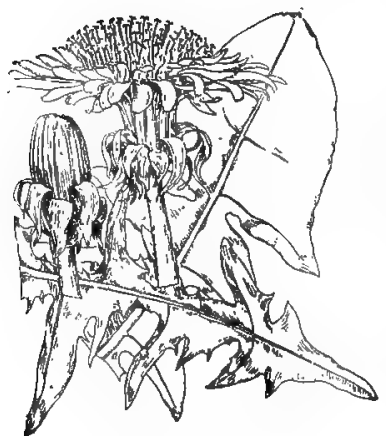

1014. T. officinale.

Ileads and leaf-tips $\times 2 / 3$.

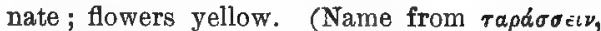
to disquiet or disorder, in allusion to medicinal properties.)

1. T. OFFICINALE Weber. (Common D.) Leaves coarsely pinnatifid, sinuate-dentate, rarely subentire; heads large ( $3-5 \mathrm{~cm}$. broad), orange-yellow; involucral bracts not glaucous; the outer elongated, conspicuously reflexed; achene olive-green or brownish, bluntly muricate above, its beak 2-3-times its length; pappus white. (T. Dens-leonis Desf.; T. Taraxacum Karst.) -Pastures and fields, very common. Apr.-Sept. (and rarely throughout antumin and winter). After blossoming, the inner involucre closes, and the slender beak elongates and raises up the pappus while the fruit is forming; the whole involucre is then reflexed, exposing to the wind the naked fruits, with the pappus in an open globular head. (Nat. from Eu.) FIG. 1014.

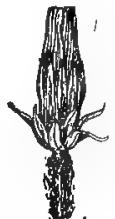

1015. T. off, v. pal. Closed head $\times 2 \%$.

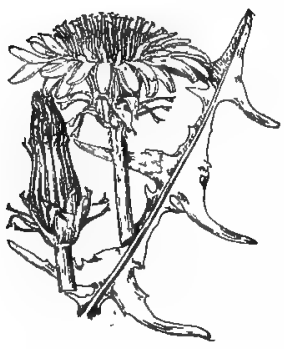

1016. T. erythrospermum.

Heads and leaf-tip $\times 2 / 3$.

Var. Palústre (Sm.) Blytt. Outer bracts lanceolate to deltoid-ovate, ascending or spreading. - In damp places, e. Que. to Ct. (Nat. from Eu.) FIG. 1015 .

2. T. erTthrospérmim Andrz. (RED-seeded D.) Leaves deeply runcinate-pinnatifid or pinnately divided into narrow segments; heads smaller (2-3 cm. broad), sulphur-yellow, outer ligules purplish without; involucre glaucous, the inner bracts corniculate-appendaged at tip; the outer short, lanceolate, spreading or ascending; achene smaller, bright red or red-brown, sharply muricate above, more than half as long as the beak; pappus sordid-white. - In dry fields and on rocks, Me. to Pa., locally w. to Kan. Late Apr.-June. (Nat. from Eu.) Fig. 1016.

\section{SÓNCHUS [Tourn.] L. Sow Thistre}

Heads many-flowered, becoming tumid at base. Involucre more or less imbricated. Achenes obcompressed, ribbed or striate, not beaked; pappus copious, of very white exceedingly soft and fine bristles mainly falling together. - Leafy-stemmed coarse weeds, chiefly sunooth and glaucous, with corymbed or umbellate heads of yellow flowers produced in summer and autumn. (The ancient Greek name.)

* Perennial, with creeping rootstocks; flowers bright yellow, in large heads.

1. S. ARV́niss L. (FIELd S.) Leaves runcinatepinnatifid, spiny-toothed, clasping by a heart-shaped base; peduncles and involucre bristly ; aclienes transversely wrinkled on the ribs. - Roadsides, fields, and gravelly shores, Nfd. and N. S. to N. J., w. to the Rocky Mts., commonest northw. (Nat. from Eu.)

$$
\text { * * Annual; flowers pale yellow. }
$$

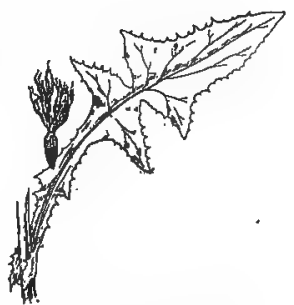

1017. 8. oleraceus.

Leaf $\times 1 / 2$. Achene $\times 1 \frac{1}{3}$.

2. S. oleraceus L. (Common S.) Stem-leaves runcinate-pinnatifid, or rarely undivided, slightly toothed with soft spiny teeth, clasping by a heart- 


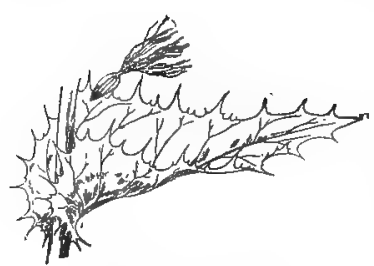

1015. 3. asper.

Leaf $\times 1 / 2$. A chene $\times 11 / 8$.

shaped base, the auricles acute; involuore downy when young; achenes striate, also wrinkled transversely. - Waste places, chiefly in manured soil and around dwellings. (Nat. from Eu.)、Fig. 1017.

3. S. Ásper (L.) Hill. (Spiny-Leaved S.) Stem-leaves less divided and more spinytoothed, the auricles of the clasping base rounded; achenes margined, 3-nerved on each side, smooth. - Waste places, roadsides, etc. (Nat. from Eur.) FIG. 1018.

\section{LACTƯCA [Tourn.] L. Letruce}

Heads several-many-flowered. Involucre cylindrical or in fruit conical; bracts imbricated in 2 or more sets of unequal lengths. Achenes contracted into a beak, which is dilated at the apex, bearing a copious and fugacious very soft capillary pappus, its bristles falling separately. - Leafy-stemmed herbs, with panicled heads ; flowers of variable color, produced in summer and autumn. ('The ancient name of the Lettuce, L. sativa L.; from lac, milk, in allusion to the milky juice.)

$N$. B. - In this genus, the figures of the fruiting heads are on a scale of $\frac{2}{3}$, of the achene $1 \frac{1}{3}$.

\$1. SCARIOLA DC. Achenes very fat, orbicular to oblong, with a distinct soft filiform beak; pappus white; biennial or annual; canline leaves sagittate-clasping.

* Heads small, 6-12-flowered; achenes from linear-oblong to obovate-oblong, several-nerved, about equaling the beak; introduced species.

1. L. sca rìlola L. (Prickly L.) Stem below sparsely prickly-bristly; leaves pinnatifid, spinulose-denticulate, tending to turn into a vertical position (i.e. with one edge up); midrib usually setose beneath ; panicle loose, with widely spreading branches ; flowers pale yellow, sometimes turning bluish in fading or drying. -Roadsides, railway ballast, etc., s. N. E. to O., Mo., and Ky., chiefly westw., but even there less common than the following variety. (Adv, from Eu.)

Var. INTEGRATA Gren. \& Godr. Leaves oblong, denticulate, none of them or only the lowest pinnatifid; midrib prickly-setose or rarely smoothish. ( $L$. virosa of Am. anth., not L.) - Waste grounds and roadsides, across the continent; westw. an abundant and pernicious weed. (Nat. from $\mathrm{Eu}$. )

2. L. SALfFNA L. Much more slender than the preceding species; stem nearly or quite smooth; leaves linear-oblong or narrow and runcinately pinnatifid (the winged rhachis only $3-5 \mathrm{~mm}$. wide), the margin sparingly toothed, not regularly or conspicuously denticulate; heads short-pediceled, in virgate somewhat fastigiate panicles. - Waste ground, O. (Selby, Kellerman). (Adv. from Eu.)

* * Heads 12-20-flowered; achenes oval to oblong-oval, blackish, narrow-margined, about equaling the beak, 1-nerved on each face.

\section{+ Leaves giabrous.}

3. L. canadénsis L. (WILD L., HorsE-WEed.) Mostly tall (1-3.2 m. high), very leafy, glabrous or nearly so, glaucous; leaves $1.5-3 \mathrm{dm}$. long, pale beneath,

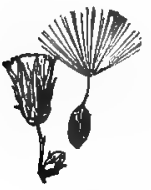

(019. L. cnnadensis, mostly sinuate-pinnatifid, the upper lanceolate and entire; heads 1-1.5 cm. long, numerous, in an elongated usually open panicle; flowers pale yellow. - Rich damp soil, borders of fields or thickets, common. Fig. 1019. Var. MontAna Britton. Leaves all entive, rather narrovily oblong-lanceolate. Shores, clearings, and rocky uplands, N. S. to Ont. and O. - A similar state is often developed when the main axis is injured as by mowing.

4. L. integrifdlia Bigel. Similar in stature, inflorescence, 
etc.; leaves broadly oblanceolate or even obovate, unlobed, pale beneath, acuminate, sagitta.te at base, some or all rather finely sinuate-toothed, the upper usually entire or nearly so. - Rich thickets, etc., e. Mass. to Ind.

5. L. sagittifolia Ell. Tall and stout, glabrous, very leafy; leaves thickish, broadly oblong or lance-oblong, acute, strictly entive or merely a little toothed on the broad and conspicuous amplexicaul auricies of the sagittate base; inflorescence, etc., as in nos. 3 and 4. (L. integrifolia Man. ed. 6, in part.) - Rich soil, Pa. to S. C.

\section{+ + Leaves hirsute or hispid-setose on the midnerve beneath.}

* Stem leafy chiefly at or below the middle; bracts of the inflorescence minute, subulate; slender eastern and southern species.

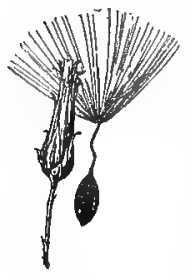

1020. L. hirsuts.

6. L. hirsùta Muhl. Rather few-leaved, 0.5-1 m. high, commonly hirsute at base; leaves hirsute on both sides or only on the midrib, mostly runcinate-pinnatifid, with rather narrow rhachis and lobes; heads slender and elongated, in a loose open panicle; achenes elliptic-oblong, equaled by the beak; flowers yellow-purple, rarely whitish. - Dry open ground, Que. to La. and Tex. FIG. 1020.

++ ++ Stem more uniformly leafy; bracts at the base of the inflorescence somewhat foliaceous; stout species of the interior.

7. L. ludoviciàna (Nutt.) Riddell. Tall and stout, $0.5-$ $1.5 \mathrm{~m}$. high, leafy ; leaves sinuate-pinnatifid, the rhachis and spinulose-toothed lobes rather broad; heads large, ovoid, in 1021. L. ludoviciana. an open panicle; the involucre much imbricated, $1.5-2 \mathrm{~cm}$. long; flowers yellow. - Minn., Ia., and southwestw. Fig. 1021.

8. L. campéstris Greene. Closely similar to no. 7, but flowers blue. - Prairies, s. Minn, to Kan. -- Perhaps only a color form of the preceding.

*** Heads about 18-flowered; achenes lanceolate, 3-ribbed on each face, narrow-margined, 3-4 times exceeding the beak.

9. L. Mórssii Robinson. Very leafy, somewhat hirsute below, 1-3 m. high ; leaves runcinate-pinnatifid, mostly 5-lobed, 1.2-2 dm. long, half as broad, on broadly winged clasping petioles, the lower somewhat hirsute beneath on the midrib, etc.; panicle ample; involucre about $1 \mathrm{~cm}$. long; flowers blue; achene black, mottled with brown; pappus cream-colored in drying. - Rich low ground, Me. and Mass.; also reported from n. N. Y. Fig. 1022.

§2. LACTUCÁSTRUM Gray. Achenes flat, lanceolate-oblong, marginless, tapering to a short slender firm beak; perennial; flowers blue.

1022. L. Morssii.

10. L. Steèlei Britton. Tall and stout; leaves ovate-oblong to broadly lanceolate, doubly dentate but unlobed, acuminate, hirsute upon the midnerve and principal veins beneath, narrowed at the base to rather long and winged petioles; heads in an open panicle; flowers bluish-purple; achenes lanceolate, 3-ribbed on each surface, the margin slightly thickened. - Open woodland, near Washington, D. C. (Steele).

11. L. pulchélla (Pursh) DC. (Buve L.) Pale or glaucous; stem simple, $1 \mathrm{~m}$. or less high; leaves sessile, glabrous, oblong- or linear-lanceolate, entire, or the lower runcinatepinnatifid; heads few and large, racemose, erect on scalybracted peduncles; involucral bracts imuricated in 3-4 ranks.

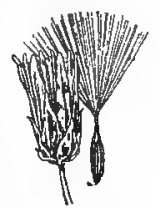

1023. L. pulchella - Upper Mich. and Ont., westw. and southw. Fig. 1023. 
83. MULGEDIUM (Cass.) Gray. Achenes thickish, oblong, contracted into a short thick beak or neck; annual or biennial; flowers chiefly blue.

\section{* Pappus white.}

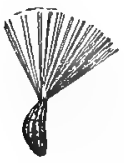

1024. L. villosa.

12. L. villdsa Jacq. Tall biennial, 1-2 m. high, with many small heads in a loose panicle, on diverging peduncles; leaves ovate to oblong-lanceolate, pointed, sharply and sometimes doubly serrate, or runcinate, sometimes hairy on the midrib beneath, contracted into a winged petiole, the lowest occasionally sinuate or cleft at base, and the cauline sagittate or lastate; achenes beakless. (L. acuminata Gray.) - Borders of woods, N. Y. to Neb., and southw. I'1G. 1024.

13. L. floridàna (L.) Gaertn. Leaves all lyrate or runcinate, or rarely entire, the upper often with a heart-shaped clasping base; panicle larger; achenes distinctly beaked; otherwise as no. 12. - Rich soil, N. Y. and Pa. to Neb., and southw. FIG. 1025.

\section{* Pappus tawny.}

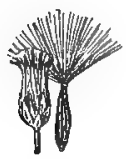

1026. L. spicats.

14. L. spicàta (I,am.) Hitchc. Nearly smooth biennial, tall (1-3.5 m. high), very leafy ; leaves irregularly pinnatifid, sometimes runcinate, coarsely toothed, the upper cauline sessile and auriculate, sometimes clasping; heads in a large and dense compound panicle; flowers bluish to cream-color; achene shortbeaked. (L. leucophoea Gray.) - Low grounds, rather common. Fig. 1026. Var. integrifólia (Gray) Britton. Leaves undivided, or the lower sinuate-pinnatifid. - Me. to Ill. and N. C.

\section{LYGODÉSMIA D. Don.}

Heads and flowers (5-10) nearly as in Prenanthes, the cylindrical involucre more elongated, and the achenes long and slender, tapering at the summit; pappus whitish. - Smooth, often glaucous, with terminal or scattered heads of rose-purple flowers on the ieafless or rushlike stems or branches. (Name composed of túyos, a pliant twig, and $\delta \epsilon \sigma \mu \eta$, a bundle, from the fascicled twiggy or rushlike stems.)

1. L. júncea (Pursh) D. Don. Perennial, 2-4 dm. high, tufted, rigid, much branched; lower leaves lance-linear, $2.5-5 \mathrm{~cm}$. long, rigid, the upper* awl-shaped and ninute; heads 5-flowered, terminal; achene filiform, only slightly attenuate above, 4-5 mm. long. - Plains, St. Croix River, Wisc. to the Saskatchewan, Mo., and westw. June-Sept. Fig. 1027.

2. L. rostràta Gray. Annual, $1 \mathrm{~m}$. or less high, corymbose-paniculate ; leaves elongate,

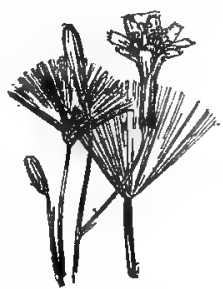

1027. L. junces. Heads $\times 2 / 3$. A chene $\times 11$.

1028. L. rostrata.

Achene $\times 1 \frac{1}{8}$. the lower about $1 \mathrm{dm}$. long; heads 8-9-flowered, scattered; achene fusiform, distinctly attenuate above, $1 \mathrm{~cm}$. long. - Sandy soli, Kan. to the Saskatchewan, and westw. Aug.-Sept. Fig. 1028.

\section{AGÓSERIS Raf.}

Head large, solitary, many-flowered. Bracts of the bell-shaped involucre ovate or lanceolate, pointed, loosely imbricated in 2 or 3 rows. Achenes smooth, 10-ribbed, with or without a distinct beak; pappus usually longer than the achene, white, of copious and urequal rigid capillary bristles. - Perennial scapose herbs, with elongated linear tufted basal leaves, and yellow flowers.

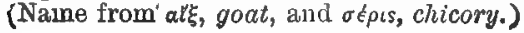




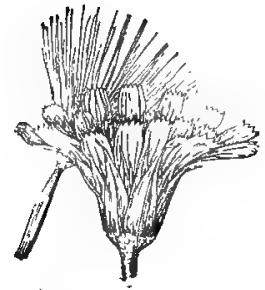

1029. A. cuspidata.

Head $\times 2 / 3$.

Achene $\times 11 / 3$.

1. A. cuspidàta (Pursh) Steud. Scape $3 \mathrm{dm}$. high, from a thickened caudex; leaves lanceolate, elongated, tapering to a sharp noint, entire, woolly on the margins; bracts of the involucre lanceolate, sharppointed; achene beakless. (Troximon Pursh; Nothocalais Greene.) - Prairies, Wisc. and n. Ill., westw, and northwestw. Apr., May. Fig. 1029.

2. A. glaúca (Pursh) Steud. Scape $3 \sim 6 \mathrm{dm}$. high ; leaves linear to lanceolate, entire to dentate or laciniate; head often pubescent or villous; achene longbealced. (Troximon Pursh.) - Minn. to the Saskatchewan, southw. and westw. Frg. 1030 .

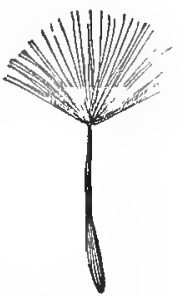

1080. A. glance. Achene $\times 1 \%$.

\section{PYRRHOPÁPPUS DC. False Dandelion}

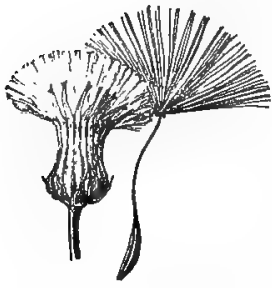

1081. P. carolinianus. Head $\times 2 / 3$. Achene $\times 1 \frac{1}{8}$.

Heads, etc., nearly as in Taraxacum, but the soft pappus reddish or rust-color, and surrounded at base by a soft-villous ring. - Mostly annual or biennial herbs, scapose or often branching and leafy below. Heads solitary, terminal. Flowers deep yellow. (Name composed of $\pi v \rho j \rho b s$, flame-colored, and $\pi a \pi \pi b s$, pappus.) Sitilias Rat.

1. P. Cároliniànus (Walt.) DC. Annual or biennial, branching, 1-9 dm. high; leaves oblong or lanceolate, entire, cut or pinnatifid, the stem-leaves partly clasping. (Sititias Raf.) - Sandy fields, Del. to Mo., Kan., and southw. Apr.-July. FIg. 1031.

\section{CRÈPIS L. HAWK'S BEARD}

Involucre few-many-flowered, commonly of a single row of equal bracts often becoming thickened at base. Pappus copious, white, soft. - Annuals or biennials, not pilose. Otherwise as Hieracium. (The Greek name of some plant, from $\kappa \rho \eta \pi l s$, a sandal.)

\section{* Involucre glabrous.}

1. C. Púlchra L. Annual, $0.3-1.5 \mathrm{~m}$. high, pubescent below, leafy near the base; leaves pubescent, oblong or oblong-lanceolate, runcinate-dentate, the lower on margined petioles, the upper somewhat clasping; heads in a loose naked panicle; involucre $1 \mathrm{~cm}$. high. - Locally established in Va. (Adv. irom Eu.)

\section{* * Involucre pubescent. \\ - Perennial; scapose or nearly so.}

2. C. runcinata (James) T. \& G. Stem 3-9 m. high, glabrous or somewhat glandular-hispid; leaves rosulate, obovate-oblong or oblong-spatulate, repand or runcinate-dentate, glabrous or slightly hispidulous; heads loosely corymbose, $2 \mathrm{~cm}$. broad; involucre hirsute, $1 \mathrm{~cm}$. or so high. - On saline soil, Man. to Ia $a_{\text {, }}$ and westw. June, July.

$$
\text { 1- + Annuals or biennials; stems leafy. }
$$

3. C. CAPILLARIs (L.) Wallr. Ascending, 3-6 dm. high; leaves lance-spatulate, laciniate-pinnatifid or merely dentate, the cauline with sagittate-auriculate bases; heads small, involucre 6-7 mm. high; achenes smooth, 10-nerved, slightly narrowed at both ends. ( $C$. virens L.) - Fields and waste places, becoming frequent. (Adv. from Eu.) Fig. 1032.

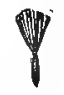

1032. C. capilarls Achene $\times 11 / 3$. 


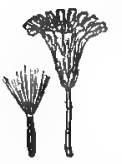

103\%. C. tectorum.

Head $\times 2 / 3$.

Achene $\times 11 / 3$.

4. C. тестовum L. Slender, branching from the base, 2u $\mathrm{dm}$. high ; leaves narrow, runcinate, often sagittate-auriculate ; heads small, in a loose panicle; achenes fusiform, attenuate above, the ribs uproardly scabrous. - In fields, Ont., Mich., and Neb.; and on ballast eastw. July-Sept. (Adv. from Eu.) Fig. 1038.

5. C. BIÉnNis L. Somewhat pubescent, $6-8 \mathrm{dm}$. high, leafy; leaves runcinate-pinnatifid; heads rather large, $2-4 \mathrm{~cm}$. broad, corymbose ; achenes

13-nerved, glabrous, attenuate above. - Locally in fields and waste places, N. E. to I'a. and Mich. (Adv. from Eu.) FIG. 1034.

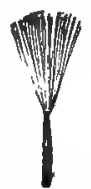

1034. C. biennis. Achene $\times 11 / 3$.

\section{PRENÁNTHes [Vaill.] L. Rattlesnake-Root}

Heads 5-30-flowered. Involucre cylindrical, of 5-14 linear bracts in a single row, and a few small bractlets at base. Achenes short, linear-oblong, striate or grooved, not contracted at the apex. Pappus of copious whitish, strawcolored, or brownish rough capillary bristles. - Perennial herbs, with upright leafy stems arising from spindle-shaped (extremely bitter) tubers, very variable leaves, and racemose-panicled mostly nodding heads. Flowers in late summer and autumn. (Name from $\pi \rho \eta \nu \eta \dot{s}$, drooping, and $\not u \theta \eta$, blossom.) Nabalus Cass.

\section{* Heads rather broad, 25-35-flowered, in a corymbose panicle.}

1. P. crepidínea Michx. Somewhat smooth; stem stout, 1.5-2.7 m. high, bearing numerous nodding heads in loose clusters; leaves large $(1.5-3 \mathrm{dm}$. long), broadly triangular-ovate or halberd-form, strongly toothed, contracted into winged petioles ; flowers creant-color; pappus brown. (Nabalus DC.) Rich soil, w. N. Y. to Minu., and southw. Sept., Oct.

* Heads slender, 8-15-flowered, in a long raceme-like or thyrsoid inflorescence; stems simple; cauline leaves sessile; pappus straw-color.

- Inflorescence pubescent, strict; heads nearly erect, 12-15-flowered.

2. P. racemòsa Michx. Stem $0.2-1.5 \mathrm{~m}$. high, smooth and glaucous, as well as the oval or oblong-lanceolate denticulate leaves; the lower leaves tapering into winged petioles (rarely cut-pinnatifid), the upper partly clasping; heads in crowded clusters; flowers purplish. (Nabalus Hook.) - River-banks and prairies, e. Rue. te Alb., s. to N. B., n. Me., Great L. region, Mo., S. Dak., and Col.; also in marshes of s. N. Y. and n. N. J. Aug., Sept. Var. PINAatfida Gray. Leaves all lyrately pinnatifid. - Marshes, s. N. Y. and n. N. J.; also in Ont. (according to Macoun).

3. P. áspera Michx. Stem $0.5-1.3 \mathrm{~m}$. high, rough-pubescent, as well as the oval-oblong or broadly lanceolate toothed leaves; upper leaves not clasping; heads in small clusters; flowers larger, cream-color. ( Vabalus 'T. \& G.) - I)ry prairies and barrens, O. to S. Dak., and southw. Aug., Sept.

\section{+ + Whole plant glabrous; heads nodding, 8-12-flowered; thyrse looser.}

4. P. virgata Michx. (Slender R.) Slightly glaucous; stem 6-12 dm. high, prolonged into a naked and slender spiked raceme (4-6 dm. long); heads clustered and mostly unilateral; leaves lanceolate, acute, closely sessile, the upper reduced to bracts, the lower toothed or pinnatifid ; involucre (purplish) of about 8 bracts. (Nabalus DC.) - Sandy pine barrens, N. J. to Fla. Sept., Oet.

5. P. mainénsis Gray. Stem 0.5-1 m. high, leafy ; leaves as in no. 2, but the radical ovate and more abruptly narrowed to the short petiole; heads persistently drooping on slender pedicels, - St. John and Aroostook valleys, Me. and N.B. Aug., Sept. - Perhaps a hybrid between nos. 2 and 8. 
* * Heads 5-18-flowered, racemose or paniculate, commonly pendulous; leaves variable, mostly petiolate, the lower cordate or truncate or hastate at base.

- Involucre cylinarical (at least below the midale); bracts scarious-margined, the outer numerous, short, appressed.

+ Involuere of 6-8 primary bracts, 8-12-flowered.

- Pappus deep reddish-brown.

6. P. alba L. (White Letroce, Rattueshake-Root.) Smooth and glaucous; stem stout, usually purplish, 0.5-1.5 m. high, corymbose-panicled at summit; leaves angulate or triangular-halberd-form, sinuate-toothed or 3-5-cleft, the uppermost oblong and undivided; involucre whitish-green and purplish, glaucous; flowers whitish. (Nabalus Hook.) - Rich woods and thickets, s. Me. to the Saskatebewan, s. to Ga., Ky., and Ill. Late July-early Oct.

$==$ Pappus whitish or 3rownish-white.

a. Primary bracts scarcely as long as the pappus, the small outer ones lanceolate.

7. P. serpentảria Pursh. (Lion's-Foot, Gall-of-The-Earth.) Stem smooth, 3-12 dm. high, usually purplish, corymbose-panicled at summit; leaves thick,

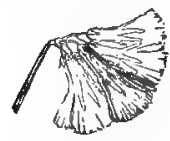

1085. P. serpentaria. Heads $\times 2 / 3$. variously lobed, often pinnatifid with blunt or rounded lobes, or even entire, the lower on margined petioles; heads chiefly clustered at the tips of elongate branches; involucre funnelform, cylindric beloro, its subherbaceous green or purplish frequently setulose bracts abruptly spreading above the middle; flowers purplish, greenish-white, or cream-color; achenes yellow-brown. (Nabalus Hook.) - Dry open soil, e. Mass. to Fla. and Ala. Sept., Oct. Fig. 1035.

b. Primary bracts as long as the pappus, the small outer ones deltoid to ovate.

8. P. trifoliolàta (Cass.) Fernald. (Gall-of-The-EARTH.) Glabrous, 1.5-15 dm. high; leaves thinnish, nearly all petioled; the lower mostly 3-divided or angulate, occasionally uncleft or with the divisions finely dissected; inflorescence an elongate panicle, the heads clustered at the tips of comparatively short ascending branches or in the upper axils; involucre cylindric, glaucous; its pale green or purple-tinged primary bracts linear-lanceolate, acute, the inner with broad scarious margins; outer calyculate bracts lancedeltoid, rather firm, with pale hyaline margins, regularly imblicated, the longest 1.5-2.5 mm. long; achenes yellow-

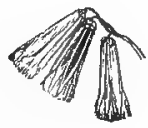

1036. P. trifuliolatio Heads $\times 2 / 3$. brown. (Nabalus Cass.; $P$. serpentaria Man. ed. 6, in part, not Pursh.) - Thickets and woods, Nfd. and Que. to Del., Pa., and along the mts. to 'Tenn. Aug., Sept. Fig. 1036.

9. P. nàna (Bigel.) Torr. Stem simple and strict, $0.5-7.5 \mathrm{dm}$. high ; leaves much as in the preceding, very variable in outline; inforescence a thyrse or raceme, rarely somewhat paniculate or subcorymbose; involucre thick-cylindric, rlabrous; bracts lead-color or blackish; the prinary ones linear-to lance-oblong, blunt or acutish, the inner with narrow scarious margins; outer calyculate bracts ovate to ovate-lanceolate, blackish-green, herbaceous or fleshy, very unequal, the longest $3-6 \mathrm{~mm}$. long; achenes yellowish- to reddish-brown. (Nahalus DC.; $P$. serpentaria, var.'Gray; $P$. trifoliolata, var. Fernald.) Rocky or mossy places, Lab. and Nfd. to the coast of N. S., and the higher mts. of n. N. E. and n. N. Y. July-Sept.

\section{++ ++ Involucre of 5 primary bracts, 5-6-flowered.}

10. P. altíssima L. Smooth, tall and slender, 1-2 m. high; heads in small axillary and terminal loose clusters forming a long and wand-like leafy panicle; leqves membranaceous, all petioled, ovate, heart-shaped, or triangular, and merely toothed or cleft, with naked or winged petioles, or frequently 3-5-parted, 
with the divisions entire or again cleft ; involucre very slender, greenish ; flowers greenish-white; pappus cream-color. (Nabalus Hook.) - Rich moist woods, Nfd, to Man., s. to Ga. and Tenn. Late July-early Oct. Var. HispíduLA Fernald. Stems villous or hispid; leaves at least hispidulous on the veins beneath. - Wet woods, e. Que. to Vt. and Ct.

Var. cinnamomea Fernald. Pappus cinnamon-color or deep brown. - Ind. to Mo. and La.

+ + Involucre slender-campanulate; secondary basal bracts 2-3, linear, looss.

11. P. Boottii (DC.) Gray. Simple, dwarf, 1-3 dm. high, pubescent at the summit; the heads in an almost simple raceme; lowest leaves halberd-shaped or heart-shaped, the middle oblong, the upper lanceolate, nearly entire, tapering into a margined petiole ; involucre livid, 10-18-flowered; the primary bracts 10-15, very obtuse; pappus pale straw-color. - Alpine regions, $\mathbf{n}$. N. E. and n. N. Y. July-Sept.

\section{HIERACIUM [Tourn.] L. HAwKWERD}

Heads 12-many-flowered. Involucre more or less imbricated. Achenes short, oblong or columnar, striate, not beaked; pappus a single row of tawny and fragile capillary rough bristles. - Hispid or birsute and often glandular perennials, with entire or toothed leaves, and single or panicled heads of mostly yellow flowers; summer and early autumn. (Name from ltea $\xi$, a havk.)

* Rootstock slender, elongated; stolons usually present; scapose. + Scape 1-3(-4)-headed.

1. H. Pilosílla L. (Mouse-ear.) Leaves oblong-lanceolate or spatulate, $2-6 \mathrm{~cm}$. long, setose upon both surfaces, green above, whitened beneath with slose stellate tomentum; stolons several, slender, leafy; scape 5-20 cm. high, 1-headed; heads $2.5-3 \mathrm{~cm}$. broad; flowers yellow. — Grassland, becoming frequent. June, July. (Nat. from Eu.)

Var. vfRide Ser. Coarser; leaves often $1 \mathrm{dm}$. long, green on both surfaces; scape 1-3(-4)-headed, 1.5-4 dm. high. - Fields, pastures, etc., also becoming too frequent. June, July. (Nat. from Eu.)

\section{- - Scape bearing several-many heads in a rather dense corymb.}

\section{+ Flowers orange-red.}

2. H. adrantiacum L. (Orange H., Devil's Paint-brugh, Grim the ColLIER.) Long-hirsute; leaves oblanceolate, 6-15 cm. long, green on both sides; stolons numerous, slender; scape 2-6 dm. high, usually 1-2-bracted; heads about $2 \mathrm{~cm}$. broad. - Fields, etc., e. Que. to Ont. and $\mathrm{Pa}$., locally too abundant. June, July. (Nat. from Eu.)

++ Flowers yellow.

3. H. FLORIBÚNDUM Wimm. \& Grab. Glaucous; stolons numerous; basal leaves narrowly oblanceolate, $5-15 \mathrm{~cm}$. long; essentially glabrous above, setose on the margin, midrib, and sometimes very sparingly on the surface beneath; primary scape 3-8 dm. high, usually naked or with only 1 leaf near the base; involucre nigrescent; flowers bright yellow. - Fields and open ground, N. B. and e. Me. June, July. (Nat. from Eu.) - Luxuriant plants developing decumbent leafy secondary flowering axes as well as stolons.

4. H. Pratense Tausch. (KIng Devil.) Green, not glaucous; stolons few; basal leaves narrowly oblong to oblanceolate, $1-2.5 \mathrm{dm}$. long, setose upon both surfaces; scape 4-8 dm. high, bearing 1-3 well developed leaves; otherwise like the preceding. - Fields, roadsides, etc., e. Que. to s. N. Y. June-Aug. (Nat, from Eu.) 
* Rootstock short, stout, praemorse.

- Heads small, 1-2.3 cm. in diameter.

- Inflorescence a corymbiform panicle (sometimes subcylindric in no. 11, which has leafy bracts).

$=$ Leaves (at least those of the primary axis) chiefly basal.

a. Leaves narrowly oblanceolate or spatulate, glaucous.

5. H. PRAeÁltum Gochnat, var. DecfPrens Koch. Somewhat glaucous, bearing numerous slender elongated leafy branches from the base; tasal leaves narrowly oblanceolate to linear-oblong, somewhat hispid on both surfaces and finely stellate-pubescent beneath; scape tall, setose; corymb irregular; flowers yellow. - Established in a dry pasture, Andover, Mass. (A.S. Pease). June. (Adv. from Eu.)

6. H. Florentìnum All. (King DeviL.) Without slender leafy branches from the base, smoothish; basal leaves oblanceolate to spatulate, thickish, sparingly setose or more often glabrous; scape 3-8 dm. high, smooth or sparingly setose; corymb many-headed. (H. praealtum Man. ed.6, not Gochnat.) -Open places, fields, etc., e. Que. to n. N. Y. (Nat. from Eu.)

\section{b. Leaves elliptic-oblong.}

7. H. vendsum L. (Rattlesnate-weed, Poor Robin's Plantain.) Scape 2-7 dm. high, naked, or with 1 rarely 2 leaves (var. subcauléscens T. \& G.), smooth, slender, forking above into a loose corymb; leaves nearly entire, scarcely petioled, thin, glabrous and often purple-veined or mottled above, glaucous beneath; pedicels very slender, sparingly glandular-pubescent toward the tip. - Dry woods and open sandy places, s. Me. to Ga., and westw. Late May-Sept.

8. H. Greènii Porter \& Britton. Scape $2-7 \mathrm{dm}$. high, usually spreadingvillous especially below, naked or more often with 1-2 leaves near the base; leaves spatulate to obovate, green, conspicuously sordid- or tavony-villous on both surfaces; inflorescence copiously glandular-hispid. (H. marianum, var. spathulatum Gray.) - Dry woods, Pa. and O. to Mo., and southw.

$$
==\text { Stem leafy to the inforescence. }
$$

9. H. paniculatum L. Stem slender, 3-12 dm. high, glabrous except at the villous base; leaves thin, lanceolate, remotely toothed, acute, glabrous, glaucous beneath; panicle lax; heads comparatively small (12-20-flowered), on fliform smoothish pedicels. - Open woods, N. S. and centr. Me. to Mich., s. to Ga. and Ala. Late July-Sept.

10. H. mariànum Willd. Stouter; stem setose at least below; leaves obovate-oblong, obtuse or rounded at tip, subentire; the basal large, on hairy winged petioles, green or rarely purple-veined, glabrous above, hairy on the veins beneath; panicle open, corymbiform; heads larger (20-40-flowered), on whitish-tomentose and glandular-hispid pedicels. - Open woods and clearings, N. H. to $\mathrm{O}$, and southw. June-Aug.

11. H. scàbrum Michx. Stoutish, 3-12 dm. high, rough-hairy; leaves elliptic to spatulate-obovate, obtuse, subentire, thickish, hairy on both surfaces, deep green above, paler beneath; panicle stiff, corymbiform, its axis and branches densely white-tomentose and commonly covered with numerous dark glands; heads $40-50$-fowered, on thickish pedicels. - Dry woods and pastures, frequent. July-Sept.

- Inflorescence more slender and elongated, subcylindric, not leafy-bracted.

12. H. Grondvii L. Stem wand-like, 3-12 dm. high, leafy chiefly below the middle, villous at base; basal leaves oblons to obovate, $5-15 \mathrm{~cm}$. long, rounded or obtuse at the tip, setose chiefly above, minutely stellate-pubescent beneath ; the stem-leaves similar, decreasing rapidly in size; panicle thyrsoid, 1-4 dm. long, without leafy bracts; heads 15-20-flowered, on slightly glandular pedicels. - Sandy soịl, Mass. to Ont, Kan., and southw, Aug.-Oct. 
13. H. longipilum Torr. Similar, copiously covered with extremely long (1-2 cm.) soft white to tawny hairs; basal leaves oblanceolate, acutish, 1.3-3 dm. long; upper leaves similar, much smaller; heads 20-30-flowered; pedicels copiously glandular. - Open woods and prairies, Mich. to Minn., southw. and southwestw. Aug., Sept.

$$
+ \text { + Heads large, } 2.5-4.5 \mathrm{~cm} \text {. in diameter. }
$$

+ Basal leaves elliptic to ovate, slender-petioled, the cauline rather fero.

14. H. MURòrum L. (GoLden Lungwort.) Scrpe naked or with a single leaf, 2-7 dm. high, smoothish; leaves green, not mottled; the basal toothed or incised especially near the rounded or subcordate base; heads few ; involucre densely glandular. - Established in open woods, Northampton, Mass. (Mrs. Terry) and near Brooklyn, N. Y. May, June. (Adv. from Eu.)

15. H. Vulgatum Fries. Stem bearing 2-several leaves, 1.5-8 dm. tall, rather slender and flexuous; basal leaves lanceolate to ovate, acute, tapering to the petiole, remotely dentate, usually purplish-mottled above; heads 1-several, about $4 \mathrm{~cm}$. in diameter. - Fields, open woods, and ledgy shores, Nfd. to $\mathbf{w}$. Que. and locally s. to s. N. Y. June-Sept. (Nat. from Eu.)

* Basal leaves lance-oblong, scarcely petioled, the cauline numerous.

16. H. canadénse Michx. Stoutish, 2-12 dm. high; leaves ovate to lanceoblong, spreading, coarsely toothed especially below the middle, acute, firm in texture, at least the upper rounded or subcordate at the base; heads several, in a corymb. - Borders of. woods, shores, etc., Nfd. to B. C., s. to N. J., Pa., the Great L. region, and Ore. July-Sept.

17. H. umbellàtum L. Similar; leaves lance-linear to lanceolate, attenuate to a narrow sessile base, entire or nearly so; heads few, subumbellate. L. Superior, northw. and westw. (Eurasia.) 


\section{GLOSSARY}

Abortion. Imperfect development or non-development of an organ.

Abortive. Defective or barren.

Acaulescent. Stemless or apparently so, or with stem subterranean.

Accumbent (cotyledon). Haring the edges against the radicle.

Achene. A small dry and hard 1-celled 1-seeded indehiscent fruit.

Achlamydeous. Without calyx or corolla.

Acicular. Slenderly needle-shaped.

Aculeate. Prickly; beset with prickles.

Aculeolate. Beset with diminutive prickles.

Aouminate. Tapering at the end.

Acute. Terminating with a sharp or well deflned angle.

Adnate. United, as the inferior ovary with the calyx-tube. Adnate anther, one attached for its whole length to the inner or outer face of the filament.

Adventive. Imperfectly naturalized.

Aestivation. The arrangement of the parts of the perianth in the bud.

Alate. Winged.

Albumen. Any deposit of nutritive material accompanying the embryo.

Albuminous. Having albumen.

Alliaceous. Having the small or taste of garlic.

Alternate (of leaves, ete.). Not opposite to each other on the axis, but arranged singly at different heights.

Alveolate. Honeycombed; having angular depressions separated by thin partitions.

Alweolation. A honeycombed condition.

Ament. A catkin, or scaly spike.

Amphigean. Native of both old and Now Worlds.

Amphitropous (ovule or sesd). Half-inverted and straight, with the hilum lateral.

Amplexicaul. Clasping the stem.

Anastomosing. Connecting by cross-veins and forming a network.

Anatropous (ovule). Inverted and straight, with the micropyle next the hilum and tho radicle consequently inferior.

Ancipital. Two-edged.

Androgynous (inflorescence). Composed of both staminate and pistllate flowers.

Anarosporangium. The receptacle in whloh androspores are formed.

Androspore. The minute reproductive body, which gives rise to the (often exceedingly obscure) male plantlet in the sexual generation. The same as Microspore.

-androup In composition, having stamens.
Angiospermous. Having the seeds borne within a pericarp.

Annual, Of only one year's duration. Winter annual, a plant from autumn-sown seed which blooms and fruits in the following spring.

Annular. In the form of a ring.

Anterior. On the front side of a flower and next the bract, remote from the axis of inflorescence; equivalent to inferior and (less properly) exterior.

Anther. The polliniferous part of a stamen.

Antheridium. In Cryptogams, the organ cor responding to an anther.

Antheriferous. Anther-bearing.

Antherozoid. One of the minute organs devel. oped in an antheridium.

Anthesis. The time of expansion of a flower.

Apetalous. Having no petals.

Apiculate. Ending in a short pointed tip.

Apogamous. Developed without fertilization.

Appressed. Lying close and flat against.

Arachnoid. Cobwebby; of slender ontangled hairs.

Aroherorium. Theorgan in the higher Crypto. gams corresponding to a pistil in the Flowering Plants.

Arcuate. Moderately curved.

Areolate. Marked out into small spaces; reticu. late.

Areole. A small space marked out upon a surface.

Aril. An appendage growing at or about the hilum of a seed.

Arillate. Having an arll.

Aristate. Awned; provided with stiffish bristleshaped appendages.

Articulate. Jointed; having a node or joint.

Ascending. Rising somewhat obliquely, or curving upward. Ascending ovule, one that is attached above the base of the ovary and is directed upward.

Assurgent. Lscending.

Attenuate. Slenderly tapering; becoming very narrow.

Auricle. An ear-shaped appendage.

Auriculate. Furnished with auricles.

Awl-shaped. Tapering upward from the base to a slender or rigdd point.

Aron. A bristle-shaped appendago.

Axil. The angle formed by a leaf or branch with the stem.

Axile, Situated in the axis.

Axillary. Situated in an axil.

Axis. The central line of any organ or support of a group of organs; a steul, etc. 
Baccate. Berry-like; pulpy throughout.

Barbed. Furnished with rigld points or short bristles, usually reflexed like the barb of a fishhook.

Barbellate. Finoly barbed.

Barbulate. Finely bearded.

Basifixed. A ttached by the base.

Bast. The fibrous portion of the inner bark.

Banked. Fnding in a prolonged tip.

Bearded. Beariog a long awn, or furnished with long or stiff hairs.

Berry. A fruit, the whole perlearp of which is tleshy or pulpy.

$B i-$ or $B i s-$ A Latin prefix signifying two, twice, or doubly.

Bidentate. Having two teeth.

Biennial. Of two years' duration.

Bifia. Two-cleft.

Bilabiate. Two-lipped.

Bilocular. Two-celled.

Biseaual. Having both stamens and pistils.

Bivalvular. With two valves.

Blade. The expanded portion of a leaf, etc.

Bract. A more or less modified leaf subtending a flower or belonging to an inflorescence, or sometimes cauline.

Bracteal. Of or pertaining to the bracts.

Bracteato. Having bracts.

Bracteolate. Having bractlets.

Bracteole. Bractlet.

Bracteose. With numerous or conspicuous bracts.

Bractlet. A secondary bract, as one upon the pedicel of a flower.

Bua. The rudimentary state of a etem or branch; an unexpanded flower.

Bulb. A subterranean leaf-bud with fleshy scales or coats.

Bulbiferous, Bearing bulbs,

Bulblet. A small bulb, especially one borne upon the stem.

Bulbous. Having the character of a bulb.

Bullate. Blistered or puckered.

Bursicle. A pouch-like receptacle.

Caducous. Falling off very early.

Caespitose. See Cespitose.

Calcarate. Produced into or having a spur.

Callosity. A hardened thickening.

Callus. A hard protuberance or callosity ; in the Grasses the tough often hairy swelling at the base or insertion of the lemma or palet.

Calyculate. Having bracts around the calyx or involucre imitating an outer calyx.

Calyx. The outer perianth of the flower.

Campanuiats. Bell-shaped; cup-shaped with a broad base.

Campylotropous (ovule or seed). So curved as to bring the apex and base nearly together.

Canalioulate. Longitudinally channeled.

Canescent. Hoary with gray pubescence.

Capdlary. IIatr-like.

Capitate. Shaped like a head; collected into a head or dense ciuster.

Capsular. Belonging to or of the nature of a capsule.
Capsule. A dry dehiscent fruit composed of more than one carpel.

Carinal. On or having relation to a ridge or keel.

Carinate. Having a keel or projecting longtudinal medial line on the lower surface.

Carpel. A simple pistl, or one nember of a compound pistil.

Carpophore. The slender prolongation of the floral axis which in the Umbelliferae supports the pendulous ripe carpels.

Caruncle. An excrescence or appendage at or about the hilum of a seed.

Carunculate. Having a caruncle.

Caryopsis. A grain, as of Grasses ; s seed-like fruit with a thin pericarp adnate to the contained seed.

Castaneous. of a chestnut-color; dark brown. Catkin. An ament.

Caudate. Having a slender tail-like appendage.

caudex. The persistent base of an otherwise annual herbaceous stem.

Caudicle. The thread-like or strap-shaped stalk of a pollinium.

Caulescent. Having a manlfest stem above ground.

Cauline. Belonging to the stem.

Cell. One of the minute vesicles, of very various forms, of which plants are formed. Any structure contrining a cavity, as the cells of an anther, ovary, etc.

Cellular (tissue). Composed of short transparent thin-walled cells, in distinction from fibrous or vascular.

Centrum. The central portion; here used specifcally for the large central air-space in hollow stems such as those of Equisetum.

Cespitose (or Caespitose). Growing in tufts; forming mats or turf.

Chaff. A small thin scale or bract, becoming dry and membranous.

Chafiy. Having or resembling chaft.

Channeled. Deeplygrooved longitudinally, like a gutter.

Chartaceons. Having the texture of writingpaper.

Chlorophyll. The green coloring-matter within the cells of plants.

Chlorophyllose. Containing chlorophyll.

Ciliate. Morginally fringed with hairs.

Ciliolate. Minutely ciliate.

Ciner'eous. Asl-color.

Circinate. Colled from the top downward, as the young frond of a fern.

Circumscissile. Dehiscing by a regular transverse circular line of division.

olavate. Club-shaped; gradually thickened upward.

Cleistogamous. Fertilized in the bud, whthout the opening of the flower.

Coalescence. The union of parts or organs of the same kind.

Coccus (pl. Cocci). One of the parts into which B lobed fruit with 1-seeded cells splits.

rochleate. Splral, like a snail-shell.

Cohesion. The union of ove organ with another of like nature. 
Commisaure. The surface by which one carpel joins another, as in the Umbelliferae.

Comose. Furnished with or resembling a tuft of hairs.

Complicate. Folded upon itself.

Compound. Composed of 2 or more similar parts united into one whole. Compound leaf, one divided into separate leaflets.

Compressed. Flattoned, especially laterally.

Conduplicate. Folded together lengthwise.

Confiuent. Running into each other; blended into one.

Coniferous. Cone-bearing.

Connate. United; used especially of like structures joined from the start.

Connective. The portion of a stamen which connects the two cells of the anther.

Connivent. Coming into contact ; converging.

Conoidal. Nearly conical.

Convolute. Rolled up longitudinally.

Cordats. Heart-shaped with the point upward.

Coriaceous. Leathery in texture.

corm. The enlarged fleshy base of a stem, bulb-like but solid.

Corolla. The inzer perianth, of distinet or connate petals.

Coroniform. Shaped like a crown.

Corrugate. Wrinkled or in folds.

Corymb. A flat-topped or convex open flowercluster, in the stricter use of the word equiralent to a contracted raceme and progressing in its flowering from the margin inward.

corymbose. In corymbs, or corymb-like.

Costa. A rib; a midrib or mid-nerve.

Costate. Ribbed; having one or more longitudinal ribs or nerves.

Cotyledons. The follar portion or first leaves (one, two, or more) of the embryo as found in the seed.

Crateriform. In the shape of a saucer or cup, hemispherical or more shallow.

Creeping. Running along at or near the sur. face of the ground and rooting.

Crenate. Dentate with the teeth much rounded. Crenulate. Finely crenate.

Cristate. Bearing an elevated appendage resembling a crest.

Crown. An inner appendage to a petal, or to the throat of a corolla.

Cruciate. Cross-shaped.

Crustaceous. Of hard and brittle texture.

Cucullate. Hooded or hood-shaped; cowled.

Culm. The peculiar stem of Sedges and Grasses.

Chneate. Wedge-shaped; triangular with the acute angle downward.

Cuspialats. Tipped with a cusp or sharp and rigid point.

Cyme. A usually brosd and flattish determinste inforescence, $i, e$ with its central or terminal flowers blooming earliest.

Cymose. Bearing cymes, or cyme-like.

Deciduous. Not persistent ; not evergreen.

Decomporend. More than once compound or divlded.

\section{Decumbent. Reollning, but with the snmmit} ascending.

Decurrent (leaf). Extending down the stem below the insertion.

Decussate. Alternating in pairs at right angles.

Definite. Of a constant number, not exceeding twenty.

Defiexed. Bent or turned abruptly downward.

Dehiscent. Opening regularly by valves, slits, etc., as a capsule or an ther.

Deltoid. Shaped like the Greek letter $\Delta$.

Dentate. Toothed, usually with the teeth di. rected outward.

Denticulat6. Minutely dentate.

Depressed. Somewhat flattened from above.

Di-, Dis-. A Greek prefix signifying two or twice.

Diadelphous (stamens). Combined in two sets.

Diandrous. Having two stamens.

Dicarpellary. Composed of two carpels.

Dichotomous. Forking regularly by pairs.

Dicotyledonous. Having two cotyledons.

Didymous. Twin; found in pairs.

Diaynamous (stamens). In two pairs of un equal length.

Diffuse, Widely or loosely spreading.

Digitate. Compound, with the members arising together at the apex of the support.

Dimerous (flower). Having all the parts in twos.

Dimorphous. Occurring in two forms.

Dioecious. Unisexual, with the two kinds of flowers on separate plants.

Discoid. Resembling a disk. Discoia head, in Compositae, one without ray-flowers.

Disk. A development of the receptacle at or around the base of the pistil. In Compositae, the tubular flowers of the head as distinct from the ray.

Dissected. Cut or divided into numerous segments.

Disiepiment. A partition in an ovary or fruit.

Distichous. In two vertical ranks.

Distinct. Separate; not united ; evtdent.

Divaricate. Widely divergent.

Divialed. Lobed to the base.

Dorsal. Upon or relating to the back or outer surface of an organ.

Dorsoventral. With distinction of back and front, or placed with reference to the back or front.

Drupaceous. Resembling or of the nature of a drupe.

Drupe. A fleshy or pulpy fruit with the inner portion of the pericarp (1-celled and 1-seeded, or sometimes several-celled) hard or stony.

Drupelet. A diminutive drupe.

$E$ or $E$ bo-. A Latin prefix having often privative signification, as ebracteate, withont brects. Echinate. Beset with pirickles.

Ecologioal. Concerning the relation of plants to their surroundings.

Effuse. Very loosely spreading.

Emarginate. Having a shallow notoh at the extremity. 
Embryo. The rudimentary plantlet within the seed.

Endocarp. The inner layer of a pericarp.

Endogenous. Growing throughout the substance of the stem, Instead of by superficial layers.

Entire. Without tuothing or division.

Ephemeral. Lasting for only one day.

Epicarp. The outer layer of the perfearp or matured ovary.

Epidermis. The superficial layer of cells.

Epigynous. Growing on the summit of the ovary, or apparently so.

Epiphyte. A plant growing attached to another plant, but not parasitic; an air-plant.

Equitant. Astride; used of conduplicate leaves which enfold each other in two ranks, as in Iris.

Erose. As if gnawed.

Exalbuminous. Without albumen.

Eucurrent. Running out, as a nerve of a leaf projecting beyond the margin.

Exfoliating. Cleaving off in thin layers.

Exogenous. Growling by annular layers near the surface; belonging to the Exogens.

Exserted. Projecting beyond an envelope, as stamens from \& corolla.

Exsiccated. Dried.

Extrorse. Facing outward.

Falcate. Scythe-shaped ; curved and flat, tapering gradually.

Farinaceous. Containing starch ; starch-like.

Farinose. Covered with a meal-like powder.

Fascicle. A close bundle or cluster.

Firsciculate. In close bundles or clusters.

Fastigiate (branches). Erect and near together.

Ferruginous. Rust-color.

Fartile. Capable of producing fruit; or productive, as a flower having a pistil, or an anther with pollen.

Fibrillose. Furnished or abounding with fine fibers.

Fibrous. Composed of or resembling fibers. Fibruus tissue, a tissue formed of elongated thick-walled cells.

Fibro-vascular. Composed of woody fibers and ducts.

Filament. The part of a stamen whlch supports the anther; any thread-like body.

Filamentous. Composed of threads.

Filiform. Thread-shaped; long, slender, and terete.

Fimbriate. Fringed.

fimbrillate, Having a minute fringe.

Fistular. Hollow and cylindrical.

Fluccid. Without rigldily ; lax and weak.

Flexuous. Zilgzag; bending alternstely in opposite directions.

floccose. Clothed with locks or flocks of soft hair or wool.

Floret. A small flower, usually one of a dense cluster.

Floriforous. Flower-bearing.

Foliaceous. Leaf-like in taxture or appearance. follate. -leavod; loving ieaves.

foilolate. Having leaflets.
Foliose. Bearing numerous lesves.

Follicle. A frult consisting of a single carpel, dehiscisg by the ventral suture.

Follicular, Like a follicle.

Forked, Divided into nearly equal branches.

Free. Not adnate to other organs.

Frond. The leaf of Ferns and some other Cryptogams; in Lemnaceae, the thallus-like stern which functions as foliage.

Fructification. The act or organs of fruiting.

Fruit. The seed-bearing product of a plant, simple, compound, or aggregated, of whatever form.

Fugacious. Falling or fading very early.

Funicle. The free stalk of an ovule or seed.

Fruscous. Grayish-brown.

Fusiform. Spindle-shaped; swollen in the middle and narrowing toward each end.

Galea. A hooded or helmet-shaped portion of a perianth, as the upper sepal of Aconitum, and the upper lip of sorne bilabiate corollas.

Galeate. Helmet-shaped; having a galea.

Gamopetalous, Having the petals of the corolla more or less united.

Gamophyllous. Composed of coalescent lesves or leaf-like organs.

Gamosepalous. Having the sepals nnited.

Geminate. Equal, in pairs.

Gemma. A bud or body analogous to a bud by which a plant propagates itself.

Gemmiparous. Producing gemmae.

Geniculate. Bent abruptly, like a knee.

Gibbosity. A swelling of moderate extent and asymmetrical character, chiefly at or near the base of an organ.

Gibbous. Protuberant or swollen on one side.

Glabrate. Somewhat glabrous, or becoming glabrous.

Glabrous. Smooth; not rough, pubescent, or hairy.

Gladiate. Sword-shaped.

Gland. A secreting surface or structure; any protuberance or appendage having the appearance of such an organ.

Glandular, Bearing glands or of the nature of a glend.

Glaucous, Covered or whitened with a bloom.

Glochidiatb. Barbed at the tip.

Glomerate. Compatly alustered.

Glomerulate. In small compact clusters.

Glumaceous. Furnisbed with or resembling glumes,

Glume. A chaff-like bract; specifically one of the two empty chatiy bracts at the base of the spikelet in the Grasses.

Granulose. Composed of or appearing as if covered by minute grains.

Gymnospermous. Bearing naked seeds, without an ovary.

Gynanarous. Having the stamens borne upon the pistil, as in Orohidaceae.

Gynobase. An enlargement or prolongation of the receptacle bearing the ovary.

Gynosporangium. 'L'he receptscle in which gynospores are devoloped. 
Gynospore. One of the Iarger (female) reproductive bodies in the Isoetaceae, ete.

Gynostemium. The compound structure resulting from the union of the stamens and pistil in the Orchidaceae.

Habit. The general appearance of a plant.

Halberd-shaped. The same as Hastate.

Hastate. Like an arrow-head, bat with the basal lobes pointing outward nearly at right angles.

Head. A desse cluster of sessile or nearly sese sile flowers on a very short axis or receptacle.

Heart-shaped. Ovate with two rounded lobes and a sinus at base; commonly used to define such a base.

Herb. A plant with no persistent woody stem above ground.

Herbaceous. Having the characters of an herb; leaf-like in color and texture.

Heterocarpous. Producing more than one kind of fruit.

Heterogamous. Bearing two kinds of flowers.

Hilum. The scar or point of attachment of the seed.

Hirsute. Pubescent with rather coarse or stiff hairs.

Hirsutulous. Slightly hirsute.

Hirtellous. Minutely hirsute.

IIspid. Beset with rigid or bristly hairs or with bristles.

Hispidulous. Minutely bispid.

Hoary. Graylsh-white with a fine close pubescence.

Homogamous. Bearing but one kind of flowers.

Hyaline. Transparent or translucent.

Hybrid. A cross-breed of two species.

Irygroscopic, Altering form or position through changes of moisture.

Hypochil. The (often fleshy or otherwise modified) basal portion of the labellum or lip in Orchidaceae.

Hypogynous. Situated on the receptacle beneath the ovary and free from it and from the calyx; having the petals and stamens so situated.

Imbricate. Overlapping, either vertically or spirally, where the lower piece covers the base of the next higher, or laterally, as in the aestivation of a calyx or corolla, where at least one piece must be wholly external and one internal.

Immersed. Growing wholly under water.

Impressed. Bent inward, hollowed or furrowed as if by pressure.

Incised, Cut sharply and irregularly, more or less deeply.

Inciuded. Not at all protruded from the surrounding envelope.

Incumbent (cotyledons). Lying with the back of one against the radicle.

Indefinite (stamens, etc.). Inconstant in number or very numerous.

Indehiscent. Not opening by valves, etc.; remaining persistentlv closed.
Indigenous. Native and original to the region.

Indurated. Hardened.

Indusiate. Provided with an indusium.

Indusium, The proper (often shield-shaped) covering of the sorus or fruit dot in Ferns.

Inferior. Lower or below; outer or anterior. Inferior ovary, one that is adnate to the calyx.

Inflated. Bladdery.

Inflorescence. The flowering part of a plant, and especially the mode of its arrangement.

Infra-. In composition, below; as infraaxillary, below the axil.

Innovation. An offishoot from the stem.

Inserted. Attached to or glowing out of.

Inter- or Intra-. In composition, between.

Interfoliaceous. Between the leaves of a pair, as the stipules of many Rubiaceas.

Internode. The portion of a stem between two nodes.

Intramarginal. Within and near the margin.

Introduced. Brought intentionally from another region, as for purposes of cultivation.

Introrse. Turned inward or toward the axis.

Involucel. A secondary involucre, as that of an umbellet in Umbelliferas.

Involucellate. Heving an involucel.

Involucral. Belonging to an involucre.

Involucrate. Having an involucre.

Involucre. A circle or collection of bracts sur. rounding a flower cluster or head, or a single Hower.

Inwolute. Rolled inward.

Irregular (flower). Showing inequality in the size, form, or union of its similar parts.

Keel. A central dorsal ridge, like the keel of a boat; the two anterior united petals of a papilionaceous flower.

Labellum. Lip; the peculiar upper (but by a twist of the pedicel apparently lower) petal of the Orchidacede.

Labiate. Lipped; belonging to the Labratae.

Labyrinthiform. With complicated sinuous lines or winding passages.

Lacerate. Irregularly cleft as if torn.

Laciniate. Slashed; cut into narrow pointed lobes.

Lamella. A thin flat plate or laterally flattened ridge.

Lanceolate. Shaped like a lance-head, several times longer than wide, broadest above the base and narrowed to the apex.

Leafiet, A single division of a compound leaf.

Legume. The fruit of the Leguminosae, formed of a simple pistil and usually dehiscent by both sutures.

Leguminous. Pertaining to a legume or to the Leguminosae.

Lemma. The lower of the two bracts inclosing the flower in the Grasses; sometimes called the flowering glume.

Lenticular. Lentil-shaped; of the shape of a double-convex lens. 
Tepidote. Beset with small scurfy scales.

Ligulate. Furnished with a ligule.

Ligule. $\Lambda$ strap-shaped corolla, as in the ray* flowers of Compositae; a thin often scarious projection from the summit of the sheath in Grasses.

limb. The expanded portion of gamopetelous corolla above the throat; the expanded portion of any petal, or of a leaf.

linear. Long and narrow, with parallel margins.

Lip. Each of the upper and lower divisions of a bilabiate corolla or calyx; the peculiar upper (but by a twist of the pedicel apparently lower) petal in Orchids.

Lobe. Any segment of an organ, especially if rounded.

Lobed. Divided into or bearing lobes.

-locular. In composition, baving cells.

Loculicialal. Dehiscent into the cavity of a cell through the dorgal suture.

Lunate, Of the shape of a half-moon or crescent.

Lyrate. Pinnatifid with a large and rounded terminal lobe and with the lower lobes small.

Macrosporangium. The receptacle in which macrospores are doveloped.

Macrospore. The larger kind of spore in Selaginellacede, ote.

Malpighiaceous hairs. Hairs which are straight and appressed but attached by the middle.

Marcescent. Withering but persistent.

Membranaceous, Membranous. Thin, rather soft, and more or less translucent.

Mrniscoidal. Thin and concavo-convex, like the crystal of a wateh.

Mericarp. One of the achene-like earpels of Umbelliferae.

-merous. In composition, having parts, as 2-merous, having two parts of each kind.

Micropyle. The point upon the seed at which was the orifice of the ovule.

Microsporangium. The receptacle in which microspores are developed.

Microspore. The smaller kind of spore in Selaginellaceas, etc.

Midrib. The central or main rib of a lesf.

Mitriform. Shaped like a mitre or cap.

Monad slphous (stamens). United by their fllsments into a tube or cólumn.

Moniliform. Resombling a string of beads; cylindrical with contractions at intervals.

Monocotyledonous. Having but one cotyledon.

Monoecious. With stamens and pistlls in separate flowers on the same plant.

Mucro, A short and small abrupt tip.

Mucronate. Tipped with a mucro.

Multifid. Oleft in to many lobes or segments.

Muricate. Rough with short hard points.

Murieulate. Very finely muricato.

Neotary. Any place or organ where neotar is secreted.

Nectariforous. Producing nectar.

Verve. A simple or unbranched vein or elender rb.

veuter, neutral. Without stamens or pistils.
Nodo. The place upon a stem which normally bears a leap or whorl of leaves.

Nodose. Knotty or knobby.

Nodulose. Provided with little knots or knobs.

Nucleus. The germ-celt of the ovule, which by fertilization becomes the seed; the kernel of a seed.

Nut. A hard indebiscent 1-celled and 1-seeded fruit, though usually resalting from a compound ovary.

Nutlet. A diminutive nut.

$O b$-. A Latin prefix, usually carrying the idea of inversion.

obcompressed. Compressed dorso-ventrally instead of laterally.

Obconically. Inversely conlcal, having the sttachment at the apex.

obcoralate. Inverted heart-shaped.

oblanceolate. Lanceolate with the brosdest part toward the apex.

Oblique. Unequal-sided or slanting.

Oblong. Longer than broad and with nearly parallel sides.

Ozovats. Inverted ovate.

Obovoid. Having the form of an inverted egg.

Oisolescent. Becoming rudimentary.

Obsolete. Not evident; rudimentary.

Obtuse. Blunt or rounded at the end.

Ochroleucous. Yellowish-white.

Ocrea. A legging-shsped or tubular stipule.

Ocreate. Having sheathing stipules.

Officinal. of the shops; used in medicine or the arts.

Oöepore. The fertilized nucleus or germ-eell of the archegonium in Cryptogams, from which the new plant is directly developed.

opaque. Dull; neither shining nor translucent. Operculate. Furnished with a lid.

Operculum. A lid; the upper portion of a circumscissile capsule.

Orbicular. Circular.

Orthotropous (opnle or seed). Erect, with the orifice or micropyle at the apex.

Ovary. The part of the pistil that contains the ovules.

Orate. Egg-shaped; having an outline like tha: of an egg, with the brosder end downward.

Ovoid. A solid with an oval outiline.

Ovule. The body whioh after fertilization be comes the seed.

Ovuliferous, Bearing ovules.

Palate. A rounded profection of the lower lin of a personate corolla, closing the throat.

Palea, Palst. The upper bract whioh with the lemma incloses the flower in Grasses.

Paleaceous. Chaffy.

Paleophytological. Relating to the study of fossil plants.

Palmate (leaf). Radiately lobed or dividad.

Palmately. In a palmate manner.

Pahustrine, Of or growing in marshes.

Pandurate, Panduriform. Fldde-shsped.

Panicle. A loose irregularly compound inforescence with pedicellate flowers. 
Panicled, Panderiale. Borne in a panicle; resembling a paniele.

Papilionaceous (corolla). Having a standard, wings, and keel, as in the pecullar corolls of many Leguminosae.

Papillose, Bearing minute nipple-shaped projections.

Pappus. The modified calyx-limb in Compositae, forming a crown of very various character at the sunomit of the achene.

Parasitic. Growing on and deriving nourish. ment from another plant.

Parenchyma. Soft tissue of cells with unthickened walls.

Parietal. Borne on or pertaining to the wall or inner surface of a capsule.

Parted. Cleft nearly but not quite to the base.

Parthenogenetic. Developing without fertilization.

Partial. Of secondery rank.

Pathological. Diseased.

Pectinate. Pinnatifid with nurrow closely set segments ; comb-llke.

Pedate. Palmately divided or parted, with the lateral segments 2-eleft.

Pedicel. The support of a single flower.

Pedicellate. Borne on a pedicel.

Peduncle. A primary flower-stalk, supporting either a cluster or a solltary flower.

Pedunculate. Borne upon a peduncle.

Pellucid. Clear, transparent.

$P$ Pltate. Shield-shaped and attached to the support by the lower surface.

Pendulous. More or less hanging 'or declined. Pendulous ovule, one that hangs from the side of the cell.

Perenmial. Lasting year after year.

Perfect (flower), Having both pistil and stamens.

Perfoliate (lesf). Having the stem apparently passing through it.

Perianth. The floral envelope, consisting of the calyx and corolls (when present), whatever their form.

Pericarp. The matured ovary.

Perigynium. The inflated sac whtch Ineloses the ovary in Carex.

Perigynous. Adnate to the perianth, and therefore around the ovary and not at its base.

Peripheral. On or near tho margin.

Persistent. Long-continuous, as a alyx upon the fruit, leaves through winter, etc.

Personate (corolla). Bilabiate, and the throat closed by a prominent palate.

Petul. A division of the coroll.

Petaloid. Colored and resembling a petal.

Petiolate. Having a petiole.

petiole. The footstalk of a leaf.

Phaenogamous. Having flowers with stamens and pistils and produeing seeds.

Phyllodium (pl. Phyllodia). A somowhat dilated petiole having the form of and serving as a lenf-blade.

Phytological. Relating to the study of plants.

pilose. Hairy, especially with soft hairs.
Pinna (pl. Pinnae). One of the primary divisions of a pinnate or compoundly pinnate frond or leaf.

Pinnate (leaf). Compound, with the leaftets arranged on each side of a common petiole.

Pinnatifid. Pinnately cleft.

Pinnule. A secondary pinus; one of the pinnately disposed divisions of a pinna.

Piatil. The seed-bearing organ of the flower, consisting of the ovary, stigma, and style when present.

Pistillate. Provided with pistils, and, in its more proper sense, without stamens.

Pitted. Marked with small depressions or pits.

Placenta. Any part of the interior of the ovary which bear's ovules.

Plicate. Folded into plaits, usually lengthwise.

Plumose. Having fine hairs on each side, like the plume of a feather, as the pappus-bristles of some Thistles.

Plumule. The bud or growing polnt of the embryo.

Pod. Any dry and dehlscent frult.

Pollen. The fecundating grains contained in the anther.

Polliniforous. Bearing pollen.

Pollinium (pl. Pollinia). A mass of waxy pollen or of coherent pollen-grains, as in Asclepias and Orchidaceas.

Polypetalous. Having separate petals.

Pome. A kind of fleshy fruit of which the apple is the type.

Porose. Pierced with small holes or pores.

Posterior. In an axillary flower, on the side nearest to the axis of inflorescence.

Praemorse. Appearing as if bitten off.

Prickle. A small spine or more or less slender sharp outgrowth from the bark or rind.

Prismatic, OP the shape of a prism, angular, with flat sides, and of nearly unlform size throughout.

Procumbent. Lying on the ground or tralling but without rooting at the nodes.

Proliferating, Proizforous. Producing offshoots.

Prostrate. Lying flat upon the ground.

Proterogynous. Having the stigma ripe for the pollen before the maturity of the anthers of the same flower.

Prothallus. A cellular usually flat and thalluslike growth, resulting from the germination of a spore, upon which are developed sexual organs or new plants.

Puberulent. Minutely pubescent.

Pubescent. Covered with hairs, especially if short, soft and down-like.

Pulvemilent, Powdersd; sppearing as if covered by minute grains of dust.

Punctate. Dotted with depressions or with translucent internal glands or colored dots.

Punaticulate. Minutely punctate.

Pungent. Terminating in a rigid sharp polnt; nerid.

Putamen. The shell of a nut; the bony part of a stone-fruit.

Pyriform. Pear-sbaped. 
Quadrate. Nearly squate in form.

Raceme. A simple inflorescence of pediceled flowers upon a common more or less elongated axis.

Ritcennose. In racemes; or resembiing a raceme.

Rradiate. Spreading from or arranged around a common center; bearing ray-flowers.

Radical. Belonging to or proceeding from the root or base of the stem near the ground.

Rradiale. The portion of the embryo below the cotyledons, more properly called the caudicle.

hitueal. Belonging to a branch.

Rumification. Branching.

hay. 'l'he branch of an umbel; the marginal flower's of an inflorescence when distinct from the disk.

Receptacle. The more or less expanded or proiuced portion of an axis which bears the organs of a flower (the tomus) or the collected flowers of a head ; any similar structure in Cryptoganis.

Recurved. Curved downward or backward.

Reflexed. A bruptly bent or turned downward.

Regulnr. Uniform in shape or structure.

Reuiform. Kidney-shaped.

Repand. With a slightly uneven and somewhat sinuate margin.

Repent. Creeping; prostrate and rooting st the nodes.

Resiniferous. Producing resin.

Resupinate. Turned upside down.

Reticulate. In the form of network; netveined.

Retrorse. Directed back or downward.

Retuse. With a shallow notch at a rounded apex.

Revolute. Rolled backward from the margins or apex.

Rhachilla. A secondary axis ; specifically in the Grasses and Sedges the floral axis as opposed to that of the spike or splkelet.

Rhachis. The axis of a spike or of a compound leaf.

Rhaphe. The ridge or adnate funicle which in an anatropous ovule connects the two ends.

Rhaphides. Needle-shaped crystals often occurring in bundles within the cells of certain plants.

Rhizome. Any prostrate or subterranean stem, usually rooting at the nodes and becoming erect at the apex.

Rib. A primary or prominent vein of a leaf.

Ringent. Gaping, as the mouth of an open bilabiate corolla,

Root. The underground part of a plant which supplies it with nourishment.

Rootstook. Same as Rbizome.

Rostellum. A little beak; a slender extension from the upper edge of the stigma in Orohids.

Rostrate, Having a beak.

Rosula. A rosette.

Rosulate. In the form of a rosette.

Rotate (corolln). Wheel-shaped ; tat and clreular in outline.

Rufous. Reddish-brown.

Rugose. Wrinkled.
Runcinate. Sharply inclsed, with the segments directed back ward.

Runner. A fliform or very slender stolon.

Saccate. Sas-shaped.

Sagittate. Shaped like an arrow-head, the bass lubes directed downward.

Sulver-shaped (corolla). Having a slecder tabe abruptly expanded into a flat limb.

Samara. An indehiscent winged fruit.

Suabridulous. Slightly rough.

Sabrous. Rough to the touch.

Scap6. A peduncle rising from the ground, naked or without proper foliage.

Scapose. Bearing or resembling a scape.

Scarious. Thin, dry, and membravaceous, not green.

Sclerenchymatous. Of sclerenchyma, that is, of tissue composed of cells with thickened and harlened walls.

Scompioid (inflorescence). Circinately colled while in bad.

Seed. The ripened ovule, consisting of the embryo and its proper coats.

Segment. One of the parts of a leaf or other like organ that is cleft or divided.

Sepal. A division of a calyx.

Septate. Divided by partitions.

Septicidal (capsule). Dehiscing through the partitions and between the cells.

Septum. Any kind of partition.

Serrate. Having sharp teoth pointing forward.

Serrulate. Finely serrate.

Sessile. Without footsialk of any kind.

Seta. A bristle.

Setaceous. Bristle-like.

Setiform. Bristle-shaped.

Setose. Beset with bristles.

Setulose. Having minute bristles.

Sheath. A tubular envelope, as the lower part of the leaf in Grasses.

Sheathing. Inclosing as by s sheath.

Shrub. A woody perennial, smaller than a tree, usually with several stems.

silicle. A short silique.

Silique. The peculiar pod of Cmuciferas.

Silky. Covered with close-pressed soft and straight pubescence.

Simple. Of one plece; not componnd.

Sinuate. With the outline of the margin strongly wavy.

Sinus. The cleft or recess between two lobes.

Smooth. Witbout roughness or pubescence.

Sobole. A shoot, especially from the ground.

Soboliferous. Bearing soboles.

Somu (pl. Sori). A hesp or cluster, applled to the fruit dots of Ferns.

Spad.6os. A spike with a fleshy axls.

Spathe. A large bract or pair of bracts inclosing an inflorescence.

Spatulate. Aradually narrowed downward from a rounded summit.

Spermatosold. A motile cillated male reproduc. tive cell.

Spicate. Arranged in or resembling a splke,

Spiciform. Splke-like. 
Spike. A form of simple inflorescence with the flowers sessile or nearly so upon a more or less elongated common axis.

Spikelet. A small or secondary spike.

Spindle-shaped. Same us Fusiform.

Spine. $\Lambda$ sbarp woody or rigid ontgrow th from the stem.

Spinose. Spine-like, or having spines.

Spinule. A little spine or spine-like process.

Sporanginm. A spore-case.

Spore. The reproductive organ in Cryptogams which in function corresponds to a seed but possesses no envbry".

Sporocarp. The fruit-cases of certain Cryptogams contrining sporangia or spores.

Sporophyll. A leaf bearing spores.

Spur. A hollow anclike or tubular extension of some part of a blossom, usually nectariforous.

Squarrose. Having its parts or processes (such as the tips of involucral scales) spreading or recurved at the end.

Squarmulose. Diminutively squarrose.

stamen. One of the pollen-bearing organs of the flower.

Staminode or Staminodium. A sterie stamen, or any structure without anther corresponding to a stamen.

Standard. The upper dilated petal of a pepiliovaceous corolla.

Stellate, Stelliform. Star-shaped.

Stem. The main ascending axis of a plant.

Sterize. Unproductive, as a flower without pistil, or stamen without an anther.

stigma. That part of a pistil through which fertilization by the pollen is effected.

strigmatic. Belonging to or characteristic of the stigma.

Stipe. The stalk-like support of a pistil; the leaf-stalk of a Fern.

Stipitate. Haping a stipe.

Stipular. Belonging to stipules.

Stipulate. Having stlpules.

Stipule. An appendage at the base of a petiole or on each side of its insertion.

Stolon. A runner, or any basal branch that is disposed to root.

Stoloniferous, Producing stolons.

Stoma (pl. Stomata). An orifice in the epidermis of a leaf communicating with internal aircavities.

Stramineors. Straw-colored.

Stricte. Marked with fine longitudinal lines or ridges.

Strict. Very straight and upright.

Strigose. Beset with appressed sharp straight and stiff bairs.

Strobile. An inflorescence marked by imbricated bracts of scales, as in the Hop and Pinecone.

Strophiole. An appendage at the hilum of certain seods.

Style. The usually attenuated portion of the plstil connecting the stigina and ovary.

Stylopodium. A disk-like expension at the base of a style, ae in Umbelliferue.
Sub-. A Latin prefix, usually signifying some what or slightly.

Subulate. Awl-shaped.

Sucoulent. Julcy; fleshy.

Suffrutescent. Slightly or obscurely shrubby.

Suffruticose. Yery low and woody; diminutively shrubby.

Sulcate. Grooved or Purrowed.

Superior (ovary). Free from the calyx.

Supra-aaillary. Borne above the axil.

Surculoke. Producing suckers.

Siuspended (ovule). Hanging from the apex or the cell.

Suture. A line of dehiscence.

Symmetrical (flower). Regular as to the number of its parts; having the same number of parts in each circle.

Teratological. Monstrous; relating to a mon. strosity.

Terete. Having a circular transverse section.

Ternate. In threes.

Testa. The outer commonly hard and brittle seed-coat.

Tetradynamous. Having four long and two shorter stamens.

Tetragonal. Four-angled.

Thalloid, Thallose. Resembling a thallus.

Thallus. In Cryptogams, a collular expansion taking the place of stem and foliage.

Throat. The orifice of a gamopetalous corolla or calyx; the part between the proper tube and the limb.

Thyrse. A contracted cylindrical or ovoid and usually compact panicle.

Thyrsoid. Resembling a thyrse.

Tomentore. Densely pubescent with matted wool.

Tor'08в. Cylindrical with con traetions at intervals.

Torulose. Diminutive of torose.

Torus. The receptacle of a flower.

Tri-. In composition, three or thrice.

Triandrous. Having three stamens.

Trifoliolats. Having three leaflets.

Trigonous. Three-angled.

Trimorphous. Oceurring under three forms.

Triquetrous. Having three salient angles, the sides concave or channeled.

Trunsate. Ending abruptly, as if cut off trans. versely.

Tuber. A thickened and short subterranean branch having numerous buds or eyes.

Tubercle. A small tuber or tuber-like (not necessarlly subterranean) body.

Tuberiferous. Bearing tubers.

Tuberoid. A fleshy-thickened root, resembling a tuber.

Tuberous. Having the character of a tuber; tuber-like in appearance.

Tumia. Swollen.

Tunicated. Having concentric costs, as an onion.

Turbinate. Top-shaped ; inversely conical.

Turgid. Swollen, or tightly drawn, said of a rnembrane or copering expanded by pressure from within. 
Umbel. An inflorescence in which the peduncles or pedicels of a eluster spring from the same point.

Umbellate. In or like an umbel.

Umbellet. A secondary umbel.

Umbelliform. In the shape of an umbel.

Umbellule. An umbellet.

Umbonate. Bearing a stout projection in the center ; bossed.

Undulate. With a wavy surface; repand.

Unguiculate. Contracted at base in to a claw.

Uni-. In composition, one.

Unisexual. of one sex, either staminate or pistillate only.

Lreeolate. Hollow and cylindrical or ovoid, and contracted at or below the mouth, like an urn.

Utricle. A small bladdery 1-seeded fruit; any small bladder-like body.

Vallecular. Of or near a valley or groove.

Falvate. Opening by valves, as a capsule; in aestivation, meeting by the edges without overlapping.

Palve. One of the pieces into which a capsule splits.

Vascular. Furnished with vessels or ducts.

Vedns. Threads of fibro-vascular tissue in a leaf or other organ, especially those which bianch (as distinguighed from norves).

Velum. The membranous indusium in 780 . êtes.

Fentral, Belonging to the anterior or inner face of an organ; the opposite of dorsal.
Ventricose. Swglling unequally, or inflated on one side.

Termiform. Worm-shaped.

Vernation. The arrangement of leaves in the bud.

Verrucose. Covered with wart-like elevations.

Versatile (anther). Attached near the middle and turning freely on its support.

Verticil. A whorl.

Ferticillaster. A cluster resembling a whorl but composed of two opposite cymes.

Ferticillastrate. Bearing or arranged in clusters resembling whorls.

Verticillate. Disposed in a whorl.

Vesicle. A small bladder or air-cavity.

Vesicular, Vesiculose. Compused of or covered with resicles.

Fillous. Beariug long and soft hairs.

Virgate. Wand-shaped; slender, straight and erect.

Fiscid. Glutinons; sticky.

Fitta. An otl-tube; a structure commonly present in the pericarp of the $0 \mathrm{mb}$ blliferce.

Whorl. An arrangement of leaves, etc., in a circle round the stem.

Wing. Any membranous or thin expansion bordering or surrounding an organ; the lateral petal of a papilionaceous corolla.

Woolly. Clothed with long and tortuous or matted hairs.

Zygomomphic. Capable of division by only one plane of symmetry. 


\section{INDEX}

Latín names of families sre in small capttals. Synunyws and names of plants merely mentioned are in italics, or are indicated by italic numbers.

\begin{tabular}{|c|c|c|c|c|c|c|c|}
\hline \multicolumn{2}{|l|}{ Abama americana } & cousa & 373 & virginicum & 863 & Smithii & \\
\hline & 282 & cannabina & 373 & Adoxa & 761 & spicatum & \\
\hline Abele & 328 & rusocarpa & 373 & Moschatellina & 761 & tenerum & \\
\hline Abies & 65 & tamariacina & 373 & Aegopodium & 614 & tetrastachys & \\
\hline balsamea & 65 & culata & 373 & graria & 614 & violaceum & \\
\hline nadensis & 66 & conite & 406 & Aeschynomene & 18 & Agrostemma & \\
\hline Fraseri & 65 & Winter & 405 & hisp & 518 & Githago & \\
\hline Abutilon & 566 & coni & 406 & virg & 518 & Agrostis & \\
\hline Abutilon & 566 & oracense & 407 & Aesculus & 559 & alba & \\
\hline & & & 407 & $a r$ & & altissima & \\
\hline The & 566 & unc & 407 & $f a$ & 560 & borealis & \\
\hline Acacia & 503 & Acorus & 258 & glabra & 559 & canina & \\
\hline ustissima & 503 & mus & 258 & Hippocastanum & & ctata & \\
\hline $\mathbf{F}$ & 514 & Letaea & 407 & & $\mathbf{5 5 9}$ & elata & \\
\hline fil & 503 & & 408 & oct & 560 & lottiana & \\
\hline$h i$ & 50 & & 4 & & 560 & & \\
\hline & & & 4 & Aet & 618 & nedia & \\
\hline ca & & & 408 & pium & 618 & laxiflora & \\
\hline$n a$ & & & 408 & $A f z$ & 729 & novae-angliae & \\
\hline & 5 & Act & 844 & Ag: & 696 & perennans & \\
\hline & 5 & cea & 8 & & 697 & & \\
\hline & & Act & 84 & & 697 & rupestris & \\
\hline & 5 & & 8 & nep & 696 & scabra & \\
\hline CAI & 7 & Actin & 836 & scrophulariaefo & olia & stolonifera & \\
\hline Acan & & olia & 836 & & 696 & & \\
\hline & 824 & & 836 & Agr & 298 & fica & \\
\hline aus & 825 & rmum & 842 & & 298 & & \\
\hline Acanthus Family & & $u r$ & 842 & & 298 & Aile & \\
\hline & 742 & ense & 503 & Ago & 868 & Zulosa & \\
\hline cer & 557 & & 319 & data & 869 & $\mathrm{Air}$ & \\
\hline rum & 558 & & 270 & & 869 & aris & \\
\hline & 558 & & 318 & $\mathrm{Ag}$ & 493 & phyllea & \\
\hline$D$ & 558 & gue & 47 & & 494 & $\cos$ & \\
\hline & 558 & & 47 & 493 & 494 & $\operatorname{CEAE}$ & \\
\hline penn & & & 289 & & 493 & $A j$ & \\
\hline & 55 & Ade & 652 & & 493 & evensis & \\
\hline ru & & & & & 494 & ans & \\
\hline & 5 & Add & 82 & & 494 & Alb & \\
\hline & 558 & & 824 & & 494 & rissin & \\
\hline & 55 & Adia & 35 & & 494 & Ale & \\
\hline ACEB & 5 & Capillus-Veneri & & & 494 & ensis & \\
\hline Acer & 666 & & 36 & & 494 & tensis & \\
\hline & 66 & & 35 & & 494 & Alder & \\
\hline & 667 & $A d$ & 349 & & 49 & Black & \\
\hline & 667 & Adl & 417 & & 165 & Downy Green & \\
\hline & 66 & & 41 & & 16 & & \\
\hline & 6 & & 41 & & 1 & & \\
\hline & 6 & Adc & 3 & yum & 166 & intain & \\
\hline Ach & 8 & & 39 & & 16 & & \\
\hline & 8 & alis & 39 & & 166 & th & \\
\hline & 84 & carolin & & orepens & 16 & Fed & \\
\hline & & & 8 & & 166 & White & \\
\hline & & lion & 86 & & 166 & letris & \\
\hline hroanthes & & occidentale & 862 & Richardsonii & 167 & aurea & \\
\hline
\end{tabular}




\begin{tabular}{|c|c|c|c|c|c|c|c|}
\hline sa & 4 & ubera & 382 & Cranberry & 641 & Anaphalis & 822 \\
\hline falfa & 510 & uliginosa & 382 & Elm & 345 & margaritacea. & 822 \\
\hline lisma & 84 & Althaea & 567 & \multicolumn{2}{|c|}{ Fly Honeysuckle } & Anastrophus & \\
\hline Geyeri & 85 & cannabina & 568 & \multirow{3}{*}{\multicolumn{2}{|c|}{$\begin{array}{lr} & 755 \\
\text { Frog's Bit } & 86 \\
\text { Germander } & 693\end{array}$}} & Andrachne & 45 \\
\hline Plantago-a & tica & officinalis & 567 & & & phyllanthoides & \\
\hline & 84 & rosea & & & & & 545 \\
\hline tenellum & 84 & Shrubby & 569 & Holly & 554 & Andromeda & 634 \\
\hline LISMACEAE & 80 & Alum Root & 447 & \multicolumn{2}{|l|}{ Hop Hornbeam } & unda & 35 \\
\hline Alkali Grass & 153 & Common & & & 334 & phylla & Dsto \\
\hline Iliaria & 429 & Alyssum & 4 & Hornbeam & 334 & rina & 635 \\
\hline ria & 429 & ides & & Ipe & 457 & iana & 35 \\
\hline offic & 429 & inwm & & La & 65 & nitida & 335 \\
\hline Alionia & 375 & & & $\mathrm{Mis}$ & 351 & Polifolia 634, & 685 \\
\hline$a l b$ & 375 & imum & 424 & ain Ash & 459 & Andropogon & 9 \\
\hline ta & 375 & & & Pen & 705 & & \\
\hline$B u$ & 375 & Ama & & Sea & 427 & s & \\
\hline & 375 & & & \multicolumn{2}{|l|}{ White Hellebore } & & \\
\hline lar & 375 & $\mathrm{Glc}$ & 374 & & 285 & & \\
\hline & 375 & & & Woodbine & 756 & tus & \\
\hline & 375 & & & $Y_{0}$ & 62 & lis & \\
\hline lliv & 286 & Thorny & 372 & Amianthium & 283 & urus & \\
\hline inse & 287 & \multirow{2}{*}{\multicolumn{2}{|c|}{$\begin{array}{l}\text { AMARANTHACEAE } \\
371\end{array}$}} & \multicolumn{2}{|c|}{ muscaetoxicum } & & \\
\hline & 287 & & & & 284 & rius & \\
\hline & 287 & us & 371 & Am & 591 & & \\
\hline & 287 & & & & 592 & & \\
\hline & 287 & & 372 & & 592 & Anc & \\
\hline Schoenop & & achys & 371 & & 591 & lis & \\
\hline & 287 & & 372 & & 592 & & \\
\hline & 28 & & 372 & latifo & 592 & 3 & 2 \\
\hline & & grae & & Ammodenia pep- & & na & 2 \\
\hline & 287 & \multicolumn{2}{|c|}{ hybridus 371,878} & & 380 & & 40 \\
\hline All-seed & 532 & \multicolumn{2}{|c|}{ hypochondriacus } & Am & 136 & & 401 \\
\hline \multicolumn{2}{|c|}{ Allspice, Carolina } & & 37 & & 136 & iana & \\
\hline & 409 & & & & 136 & & \\
\hline Wil & 414 & & 371 & $A m c$ & 512 & & \\
\hline lnu & & atus & 372 & & 512 & & \\
\hline etula & & & 372 & & 512 & $\mathrm{r}$ & 01 \\
\hline & 3 & & & & 512 & & 101 \\
\hline & 3 & & 372 & ylla & 512 & nica & 402 \\
\hline $\mathrm{ma}$ & 337 & 8 & 373 & \multicolumn{2}{|l|}{ Ampelanus albidus } & 10 & 402 \\
\hline & & viri & 372 & & 667 & & \\
\hline & 337 & \multirow{3}{*}{\multicolumn{2}{|c|}{$\begin{array}{l}\text { AMARYLLIDACEAE } \\
\text { Amaryllis Family }\end{array}$}} & A & 563 & & 10 \\
\hline ata & 337 & & & & 563 & & \\
\hline & 336 & & & & 563 & ia & \\
\hline & & & 297 & lia & 563 & & \\
\hline can & 298 & $\mathrm{Aml}$ & 827 & Amphi & 787 & An & 400 \\
\hline & 298 & folia & 828 & & & & \\
\hline Alo & 129 & & 827 & & 787 & An & 621 \\
\hline & 12 & & 828 & Am & 529 & . & 621 \\
\hline & 12 & & & & 530 & & 622 \\
\hline & 12 & Am & 4 & & 530 & $\mathbf{a}$ & 622 \\
\hline & 12 & & & Am & 9 & & $60^{\circ}$ \\
\hline $1 \mathrm{p}$ & 6 & & 4 & on & 97 & & 622 \\
\hline Bear & 637 & madensis & & & 97 & estris & 622 \\
\hline Brook Sa & & 459, & 460 & Am: & 682 & & \\
\hline & 446 & & 460 & oides & 682 & a-tree & 606 \\
\hline & & & 460 & Ams & 661 & & \\
\hline & 381 & lia & 46 & & 661 & & 008 \\
\hline & & & & & 661 & ted Oats & \\
\hline & 381 & Aloc & 29 & Tabernaemonta & $\operatorname{tana}$ & $A n$ & 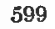 \\
\hline & 382 & & 32 & & 661 & & \\
\hline$l i s$ & 382 & & 41 & us 497 , & 499 & & \\
\hline & 38 & Jut & 5 & & 499 & Ant & \\
\hline & 38 & & 727 & & 552 & & \\
\hline humijusa & 382 & & 407 & Anacharis $c$ & en- & arnoglossa & 020 \\
\hline folia & 382 & & 659 & & 85 & Brainerdii & 821 \\
\hline & 382 & $\mathrm{C}$ & 647 & Ana & 647 & canadensis & \\
\hline tar a & 382 & Ialo & & arvensis & 647 & dioica & \\
\hline
\end{tabular}


Antennaria fallax

Farwellii
neglecta
neodioica
occidentalis
Parlinii
petaloidea
plantaginea
plantaginifolia

rupicola
solitaria
Anthemis
arvensis
aurea
Cotula
nobilis
tinctoria
Anthoxanthum
odoratum
Puelii

Anthriscus Cerefolium

Anthyllis Vulneraria

Antirrhinum majus Orontium

Anychia canadensis capillacea dichotoma polygonoides

Apera. spica-venti

Aphyllon fasciculatum 740 ludovicianum 740 unifiorum

A piastrum patens

Apios

$$
\text { A pios }
$$

Priceana

tuberosa

Aplectrum

hyemale

Shortii

Aplopappus

ciliatus

spinulosus

Apoctnaceate

Apocynum

album

androsaemifolium

662

cannabinum 662

hypericifolium 663

mediuma

Milleri

nemorale

pubescens

speciosum

urceolifer

A pogon

Apple

Crab

528

528

528

528

319

319

319

798

798

798

661

662

663

662

662

663

663

662

662

862

458

458

$\begin{array}{ll}\text { of Peru } & 716 \\ \text { Purple Thorn } & 717 \\ \text { Thorn } & 717 \\ \text { AQuifoliaceat } & 554 \\ \text { Aquilegia } & 405 \\ \text { canadensis } & 405 \\ \text { coccinea } & 405 \\ \text { vulgaris } & 405\end{array}$

Arabis

brachycarpa

canadensis

confinis

dentata

Drummondi

glabra

hirsuta

Holboellii

laevigata

ludoviciana

lyrata

patens

perfoliata

virginica

Araceae

Aragallus

johannensis

Lamberti

splendens

Aralia

hispida

nudicaulss

quinquefolia

racemosa

spinosa

trifolia

Araliaceae

Arbor Vitae

Arbutus, Trailing

Arceuthobium pusillum

Archangelica atro-

$$
\text { purpurea } 62
$$

Arctium

Lappa

majus

minus

tomentosum

Arctostaphylos

alpina

Ura-ursi

Arenaria

caroliniana

groenlardica

lateriflora

!eptoclados

litorea

macrophylla

Michauxii

patula

peploides

propinqua

serpyllifolia

squarrosa

stricta

texana

verna

Arethusa bulbosa

spicata

Argemone

alba

intermedia

mexicana

platyceras

Argentina Anserina

436

438

437

437

437

437

438

437

438

437

436

437

437

437

257

517

517

518

518

605

606

606

606

606

606

606

605

$\begin{array}{r}605 \\ \hline\end{array}$

636

351

351

623

855

855

856

856

856

637

637

637

379

381

381

380

380

380

380

380

380

380

381

380

381

380

381

381

312
Argythamnia $\quad \mathbf{4 8 4}$

mercurialina 543

$\begin{array}{ll}\text { Arisaema } & 257\end{array}$

Dracontium 257

pusillum 257

Steward8onii 257

triphyllum $\quad 257$

Aristida

124

basiramea

dichotorna

gracilis

intermedia

lanata

lanosa

purpurascens

purpurea

ramosissima

tuberculosa

Aristolochia

Clematitis

hastata

macrophylla

Nashii

Serpentaria

Sipho

tomentosa

125

124

125

125

126

126

125

126

126

125

125

125
352

353

353

Artgtolochiacea

Arnica

851,863

acaulis $\quad 851$

Chamissonis 851

cnionopáppa 851

cordifolia 851

lanceolata 851

mollis

nudicaulis

Arnoseris

minima

Aromatic Winter-

green

636

458

arbutifolia $\quad 458$

atropurpurea 459

nigra.

Arrenatherum 141

avenaceum 141

elatius

141

Arrow Arum 257

Arrow Grass $\quad 80$

Family

79

Arrow-head

Arrow-leaved Tear-

$$
\text { thumb }
$$

Arrowroot Family

Arrow-wood

Doway

$758,759,760$
759 oligantha

Artemisia

848

Abrotanum 849

Absinthium $\quad 850$

annua 850

biennis $\quad 849$

borealis $\quad 849$

canadensis 848

caudata 848 
Asclepias syriaca 605 tuberosa $\quad 664$ variegata $\quad 666$ verticillata $\quad 666$

Asclepiodora viridis 663

Aseyrum 663

Crax-Andreae 571 hypericoides 571

Ash

American Mountain 459

Black 651

Blue 651

European Mountain 459

Green 651

Mountain 459

Northern Prickly 537

Prickly 537

Pumpkin 651

Red 651

Southern Prickly 537

Water

651

White

650

Asimina

triloba

410

Asparagus officinalis

410

290

Aspen

290

American

328

Large-toothed 328

Asperugo

procumbens 682

Asperula galioides

747

Asphodel, Bog 747

False

282

283

Aspidium

acrostichoides

41

aculeatum

Boottii

cristatum

Filix-mas

fragrans

Goldianum

Lonchitis

marginale 42,49

noveboracense 41

pittsfordense $\quad 43$

simulatum $\quad 41$

spinulosum 42,43

Thelypteris $\quad 41$

Asplenium 38

acrostichoides 39

augustifolium $\quad 39$

Bradleyi $\quad 39$

ebenertm

ebenoides

Filix-femin a

montanum

parvulum

pinnatifidum 38

platyneuron $\$ 8,39$

resilion
Ruta-muraria

thelypteroides

Trichomanes viride

Asprella patula

Aster

acuminatus

amethystinus

angustus

anumalus

azureus

carmesinus

comrutatus

concinnus

concolor

cordifolius

corymbosus

curvescens

depauperatus

diffusus 811,812

divaricatus 803

Drummondii 809

dumosus

ericoides

Faxoni

frondosus

furcatus

glomeratus

Golden

gracilis

grandiflorus

Herveyi

hirsuticaulis

incanopilosus

infirmus

junceus

Kumleini

laevis

lateriflorus

$\begin{array}{ll}811, & 819 \\ \text { linariifolius } & 815\end{array}$

Lindleyarius 809

longifolius

813

Lowrieanus 808

macrophyllus 804

major

806

missouriensis

modestus

multiflorus

nemoralis

novae-angliae

novi-belgii

oblongifolius

paludosus

paniculatus

patens

patulus

phlogifolius

polyphyllus

prenenthoide 814

Pringlei

ptarmicoides

puniceus

purpuratus

radula

roscidus

sagittifolius

salicifolius

38

810

816

811

808

804

806

811

816

813

806

812

814

814

810

808
39

39

799

807

810

804

13

A

decandra

Astragalus

adsurgens

alpinus

Blakei

canadensis

carolinianus

caryocarpus

Cooperi

crassicarpus

distortus

elegans

eucosmus

flexuosus

gracilis

hypoglottis

Jesupi

lotiflorus

mexicanus

microlobus

multiflorus

neglectus

occidentalis

oroboides

parviflorus

plattensis

racernosus

Robbinsii

tenellus

tennesseensis

Atamasco Lily

Atamosco A tamasco

803

807

807

810

\section{Athyrium}

acrostichoides

angustifolium

Filix-femina

A tragene americana

Atriplex

arenaria

argentea

patula

rosea

805

804

812

804

807

808

805

816

805

814

804

816

812

809

814

808

811

809

818

444

445

445

515

516

516

516

516

516

515

517

515

517

517

517

517

516

516

516

517

515

516

517

517

516

517

516

515

516

516

517

515

298

298

39

10

39

40 


\begin{tabular}{|c|c|c|c|c|c|c|c|}
\hline ptisia villosa & 506 & Bear Grass & 290 & glandulosa & 336 & River & \\
\hline Barbarea & 432 & Huckleberry & 638 & lenta & 334 & Swamp & \\
\hline Barbarea & 433 & Oak & 343 & lutea & 334 & Sweet & \\
\hline lyrata & 433 & Bearberry & 637 & nigra & & White & \\
\hline praecox & 433 & Alpine & 637 & papyracea & 336 & Yellow & \\
\hline & 433 & Beard Grass 93, & 133 & papyrifera & & Bird Cherry & \\
\hline & 433 & -tongue & 721 & pendula & 335 & ot Violet & \\
\hline vulgaris & 432 & ed Darnel & 165 & populifolia & 335 & Bird's- & \\
\hline arberry & 413 & Poison & 614 & pubescens & 335 & Primrose & \\
\hline American & 413 & Beckmannia & 144 & pumila & 336 & Bird's-foot Trefo & \\
\hline non & 413 & erucaeformis & 144 & verrucosa & 335 & & \\
\hline Family & 411 & Beds & 747 & BETULACEAE & 332 & Birthroot & \\
\hline Barley & 167 & No & 749 & Bicuc & 417 & Birtl & \\
\hline \multicolumn{2}{|l|}{ Barnaby's Thistle } & Rough & 750 & zanadensis & 417 & $\mathrm{Fa}$ & \\
\hline & 860 & Sweet-sc & 750 & Cucullaria & 417 & Bishop's Cap & \\
\hline rd Grass & 117 & Yellow & 748 & eximia & 417 & Bishop'g-weed, & \\
\hline Barr & 344 & eee $\mathrm{Ba}$ & 703 & Bide & 839 & & \\
\hline erry & 480 & Beec & 337 & & 841 & Bitter Cress & \\
\hline 3art & 659 & & 334 & & 842 & & \\
\hline & 66 & & 337 & & & & \\
\hline & 660 & $\mathrm{Fe}$ & ? & oides & 839 & & \\
\hline & 660 & & 334 & ata & 841 & Bitt & \\
\hline & 660 & Beec & 739 & cer & 841 & & \\
\hline & 659 & & 630 & chrysanthemoid & & Sh & \\
\hline & 659 & Begr & 681 & & 841 & Bitt & \\
\hline Bartsia Odontites & 734 & Beg: & 840 & cor & 840 & Black Alder 3 & \\
\hline Basil & 707 & & & & 841 & & \\
\hline Thys & 706 & Sel & 301 & & 841 & B & \\
\hline 3as & 340 & & & & 840 & & \\
\hline $\mathrm{Bas}$ & 565 & Bell & 766 & & 840 & & \\
\hline Whit & 566 & & 767 & & & C & \\
\hline \multicolumn{2}{|c|}{ Bastard Pennyroyal } & & 37 & lerata & & & \\
\hline & 694 & red & 767 & & & & \\
\hline Toa & & $\mathrm{T}$ & & $\operatorname{car}$ & & & \\
\hline \multicolumn{2}{|c|}{ Batidaea heterodoxa } & Belli & 799 & sperma & 841 & $\mathrm{H}$ & \\
\hline & 487 & lia & 79 & & & $\mathrm{He}$ & \\
\hline \multicolumn{2}{|c|}{ Batodendron andrach- } & & 799 & l Bark & 332 & \multicolumn{2}{|l|}{ High Blueberry } \\
\hline & 638 & ell & & & 798 & & \\
\hline$a r b o$ & 638 & Bush & 414 & Bige & 798 & & \\
\hline \multicolumn{2}{|l|}{ Batrachium confer- } & & 132 & & 799 & & \\
\hline & 394 & & 414 & Big & & $\mathbf{J}$ & \\
\hline & 3 & & & lata & & & \\
\hline & & & & & & & \\
\hline & 3 & $\mathrm{im}$ & & & 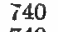 & & \\
\hline trichophyllum & 394 & EAE & & Big & 40 & & \\
\hline \multirow{2}{*}{\multicolumn{2}{|c|}{ Bay, Lapland Rose }} & & & & 417 & 342, & \\
\hline & & & 41 & Bill & 640 & $\mathrm{Oa}$ & \\
\hline & 5 & & 413 & & 640 & & \\
\hline \multirow{2}{*}{\multicolumn{2}{|c|}{ Mountain Rose }} & Berc & 561 & Dwarf & 640 & $\mathrm{R} g$ & \\
\hline & & & & \multicolumn{2}{|c|}{ Billion-Dóllar Grass } & & \\
\hline & 4. & & .561 & & 117 & root 407 & \\
\hline & 4 & Wild & 704 & & & & \\
\hline $\mathrm{T}$ & 5 & & 57 & & 670 & r Maple & \\
\hline Bayberry & 330 & & & & 62 & & \\
\hline \multirow{2}{*}{\multicolumn{2}{|c|}{ Bay-leaved Willow }} & Ber & & & 671 & & \\
\hline & & & & & 671 & & \\
\hline rass & 136 & Ber & 14 & Birc & & Blacl & \\
\hline & & $\mathrm{Be}$ & & & & & \\
\hline & $4 !$ & & 42 & & 335 & & \\
\hline W & 849 & ilis & 423 & & 335 & White & \\
\hline Beak Rush & 199 & Berula & 615 & & 334 & \multirow{2}{*}{\multicolumn{2}{|c|}{ Black-eyed Susan }} \\
\hline Beaked Hazelnut & & angusti & 61 & & 336 & & \\
\hline & ( & & & Family & 332 & Bladder Campior & \\
\hline nth & 529 & $y$, Wood & & Gr & 335 & & \\
\hline & 74 & & & Lc & 336 & $\mathrm{Fe}$ & \\
\hline & 52 & & 32 & Field & 335 & $\mathrm{Nu}$ & \\
\hline & 39 & alleghanicnsis & 35 & & 33 & $\mathrm{Nu}$ & \\
\hline & 528 & er & & $\operatorname{Re}$ & 335 & Nut, Family & \\
\hline
\end{tabular}




\begin{tabular}{|c|c|c|c|c|c|c|c|}
\hline 3ladderwort & 736 & diffusa & 799 & oleracea & 428 & cirrhosa & 364 \\
\hline Family & 736 & latisquama & 799 & Rapa & 428 & \multicolumn{2}{|c|}{ Bryanthus taxifolius } \\
\hline Greater & 737 & Boneset & 783 & Sinapistrum & 428 & & \\
\hline Smaller & 737 & Upland & 783 & Brauneria & 832 & Buchloë, & 148 \\
\hline Blazing Star 283, & 785 & Borage Frmily & 679 & angustifolia & 832 & dactyloides & 148 \\
\hline Blephariglottis & 310 & BORAGINACEAE & 679 & atrorubens & 832 & Buchnera & 732 \\
\hline Blephilia & 704 & Borrichia & 833 & pallida. & 832 & americana & 732 \\
\hline & 704 & frutescens & 833 & paradoxa & 832 & Buckbean & 660 \\
\hline hirsuta & 705 & Botrychium & 47 & purpurea & 832 & Buckeye & 550 \\
\hline Blessed Thistle & 861 & lanceolatum & 48 & Braya & 430 & $\mathrm{Fe}$ & 559 \\
\hline Blinks & 388 & Lunaria & 48 & humilis & 430 & Onio & 559 \\
\hline Coast & 367 & Matricariae & 49 & Breweria & 669 & $R_{e}$ & 560 \\
\hline Sea & 369 & \multicolumn{2}{|c|}{ matricariaefolium } & aqu & 69 & & \\
\hline Strawberry & 366 & & 48 & istrata & 69 & Buck & 561 \\
\hline \multicolumn{2}{|l|}{ Blitum capitatum } & neg & 48 & Pickeringii & 669 & Common & $56 !$ \\
\hline & 366 & oblic & 48 & Brich & 784 & & 648 \\
\hline Bloodroot & 415 & agense & 48 & diflora & 785 & ily & 560 \\
\hline \multicolumn{2}{|l|}{ Bloodwort Family } & ramosum & 48 & Brier, Cat & 294 & ern & 648 \\
\hline & 296 & & 49 & \multicolumn{2}{|c|}{ Common Green } & Buck & 363 \\
\hline Iue Ash & 651 & sim & 48 & & 295 & \multicolumn{2}{|c|}{ Climbing False 362} \\
\hline & 334 & $u m$ & 48 & $\mathrm{Gr}_{\mathbf{r}}$ & 294 & Family & 353 \\
\hline & 335 & & 49 & & 295 & Buda & 378 \\
\hline & 412 & um & 49 & & 295 & $b$ & 379 \\
\hline & 693 & Bottle Grass & 118 & Sezsitive & 503 & & 378 \\
\hline & 688 & \multicolumn{2}{|l|}{ Bottle-brush Grass } & Crowfoot & 398 & Buf & 590 \\
\hline digo & 506 & & 170 & iil Grass & 118 & & 713 \\
\hline & 73 & Bou & 386 & & 514 & & 509 \\
\hline berry & 638 & Bo & 145 & arilla & 606 & & 452 \\
\hline & 86 & ala & 146 & $\mathrm{Br}$ & 154 & & 148 \\
\hline & 67 & & 146 & & 154 & $\mathrm{Bu}$ & 350 \\
\hline & 86 & hya & 146 & & 154 & & 407 \\
\hline & 6 & & 146 & Grass & 162 & & 407 \\
\hline & 689 & Root & 457 & & 265 & & 300 \\
\hline Blue & 767 & Box & 558 & & 162 & \multicolumn{2}{|c|}{ Bugle Weed 692, 709} \\
\hline & & & 550 & & 164 & Bug & 683 \\
\hline Blin & 6 & erry & 638 & & & & 683 \\
\hline 638 , & 639 & Boy & 445 & 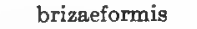 & 163 & & 688 \\
\hline High & 640 & aconitifolia & 445 & & 164 & Bug-seed & 368 \\
\hline veet & 6 & \multicolumn{2}{|c|}{ Brachyactis angusta } & us & 163 & \multicolumn{2}{|c|}{ Bulbilis dactyloides } \\
\hline & 639 & & 816 & & 164 & & 148 \\
\hline & 64 & Brac & 798 & us & 163 & \multirow{2}{*}{\multicolumn{2}{|c|}{ Bulbous Buttercup }} \\
\hline & 64 & & 798 & & 164 & & \\
\hline & & & 798 & & 163 & & 398 \\
\hline & 6 & Bra & 128 & & 164 & $\mathrm{Bu}$ & .858 \\
\hline & & & 128 & & & $\mathrm{Bu}$ & 565 \\
\hline & 6 & & 128 & & & & 498 \\
\hline & & $\mathrm{Br}$ & 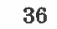 & & & $3 \mathrm{u}$ & 187 \\
\hline Blue & & $B r$ & 529 & & & & 192 \\
\hline Grass & 30 & Bradleya frutesce & & & & & 9 \\
\hline & 7 & & 51 & & & Bur & \\
\hline Blu & & lys & 515 & & 164 & & 64 \\
\hline & & Bra & & & & & \\
\hline $31 \mathrm{l}$ & & & 37 & 3 roo & ican & & 0 \\
\hline & 6 & & 36 & & 727 & & 28 \\
\hline Bocconia cordate & & $R_{c}$ & 37 & & 727 & $\mathrm{Bu}$ & 617 \\
\hline & $4: 5$ & & 486 & & & & 61 \\
\hline Bot & 845 & Bra & 392 & & 5 & Bur & 51 \\
\hline & 34 & & 39 & & 5 & & 11 ? \\
\hline & & & & & & & \\
\hline aodel & 282 & Sc & 392 & & 508 & Bur & כ3. \\
\hline & 640 & Bras & 427 & roc & 740 & & 85 \\
\hline Ro & 635 & & 428 & & 739 & & \\
\hline & 267 & & 428 & Brol & 347 & Bu & 30 \\
\hline $\mathrm{Spr}$ & 6 & & $42-12(-1)$ & & 34 & & Ju \\
\hline & 347 & & 428 & Brown Bent G & & & 30 \\
\hline Bolt & 79 & & 428 & & 133 & $\mathrm{Bu}$ & \\
\hline & 79 & & 428 & & 698 & Bur & \\
\hline & 70 & nigre & 428 & 0 & 36 & Canadiar & 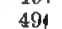 \\
\hline
\end{tabular}


Burnet, Garden 494

Burning Bush 556

Bur-reed Family

68

Bursa Bursa-pastoris 426

Bush Clover $\quad 522$

Honeysuckle 754

Butneria

409

fertilis

florida

410

Butter and Eggs 719

Butterbur

Buttercup

Bulbous

Creeping

Dwarf

Swamp

Tall

850

394

398

397

396

397

Butterfly Pea

398

Butterfly-weed 664

Butternut

Butter-weed 818, 853

Butterwort

Button Snakeroot 609,785

Buttonbush 751

Buttonweed 750, 751

Buttonwood 454

BuXaceae 550

Cabbage

Skunk

Cabomba caroliniana

428

258

Cacalia

atriplicifolia

reniformis

suaveolens

tuberosa

Cactaceae

Cactus Family

missouriensis

viviparus

Cakile

americana

edentula

Calamus

Calamagrostis

brevipilis

breviseta

canadensis

cinnoides

confinis

hyperborea

inexpansa

Langsdorfii

lapponica

longifolia

neglecta

nemoralis

Nuttalliana

perplexa

Pickeringii

Porteri

stricta

Calamint

Calamintha

258

134

134

134

135

136

135

135

135

135

135

134

135

135

136

135

134

134

135

705

705

\section{Clinopodium}

olabella

Nepeta

Nuttallii

Calamovilfa

brevipilis

longifolia

Calceolaria

Calico Bush

Calla

palustris

Callicarpa

americana

purpurea

Callirhoe

alcaeoides

digitata

involucrata

triangulata

Callitrichaceae

Callitriche

Austini

auturnnalis

bifida

deflexa

heterophylla

palustris

verna

Calluna

vulgaris

Calophanes oblongifolia

Calopogon pulchellus

Caltha

natans

palustris

Caltrop

Family

Water

Calycanthaceae

Calycanthus

Family

fertilis

floridus

glaucus

706

706

706

706

133

133

134

579

633

258

258

690

690

690

568

569

569

568

568

549

550

550

550

550

550

550

550

550

637

637

743

743

312

312

404

404

404

536,860

536

602

409

409

409

410

410

410 laevigatus

Calycocarpum

Lyoni

410

411

411

Calypso

borealis

bulbosa

Camassia

esculenta

Fraseri

quamash

Camelina

microcarpa

sativa

silvestris

318

319

318

289

289

289

289

426

427

427

Camellia

Family

427

570

Cammarum hyemale

405

Campanula $\quad 766$
Calymenia pilosa 375

americana

707

aparinoide: $\quad 767$

divaricata $\quad \mathbf{7 6 8}$

dubia

glomerata

intercedens

patula

767

767

767

rapunculoides 767

Trachelium $\quad \mathbf{7 6 7}$

uliginosa $\quad 768$

Campanulaceae 765

Campion 384,385

Bladder

Мовв

386

Red

Starry

White

384

386

Camptosorus

rhizophyllus $\$ 8,40$

Campulosus $\quad 146$

Canada Blue Graga

Plum

155

Thistle

499

Violet

858

586

Canadian Burnet 494

Canary Grass 121

Cancer-root $\quad 739$

One-flowered 740

Cano

171

Large

171

Small

171

Switch

171

Cannabis

347

sativa

347

Canoe Birch

335

Caper Family

Spurge

Capers

Capillaire 


\begin{tabular}{|c|c|c|c|c|c|c|c|}
\hline \multirow{2}{*}{$\begin{array}{l}\text { Carex Collinoii } \\
\text { comosa }\end{array}$} & & & & & & rnenter-meed & 698 \\
\hline & 254 & lanticularis & $\begin{array}{l}231 \\
245\end{array}$ & $\begin{array}{l}\text { rostrata } \\
\text { rotundata }\end{array}$ & $\begin{array}{l}255 \\
255\end{array}$ & Carpet Weed & 377 \\
\hline $\begin{array}{l}\text { comosa } \\
\text { communis }\end{array}$ & $\begin{array}{l}201 \\
236\end{array}$ & leporina & 221 & salina & 230 & Carpinus & 334 \\
\hline concinna & 240 & eptalea & 232 & altuensis & 238 & caroliniana & 334 \\
\hline conjuncta & 228 & mosa & 239 & artwellii & 229 & Carrion-flower & 295 \\
\hline conoidea & 243 & ttoralis & 239 & saxatilis & 254 & Carrot & 623 \\
\hline costellata & 233 & vida & 237 & cabrata & 248 & Carum & 614 \\
\hline Crawei & 245 & ngirostrig & 246 & chweinitzii & 252 & Carvi & 614 \\
\hline Crawfordii & 218 & uisianica & 252 & cirpoidea & 235 & Petroselinum & 615 \\
\hline crivita & 230 & ormis & 253 & scirpoides & 223 & Carya & 331 \\
\hline cristata & 218 & lupulina & 253 & scoparia 217, & 218 & alba & 332 \\
\hline crisudella & 219 & lupulina $\times$ retro & rorsa & seorsa & 223 & amara & 332 \\
\hline erus-corvi & 228 & & 252 & setacea & 227 & aquatica & 332 \\
\hline & 234 & urida & 251 & ifclia & 240 & cordiformis & 332 \\
\hline debilis & 247 & nacrokolea & 247 & Shortiana & 234 & glabra & 332 \\
\hline decomposita & 228 & agellanica & 239 & Shriveri & 245 & illinoensis & 331 \\
\hline deflexa 235 , & 236 & is & 255 & & 218 & laciniosa & 332 \\
\hline Deweyana & 224 & 2 & 229 & & 220 & microcarpa & 332 \\
\hline & 228 & & 238 & anioides & 226 & olivaeformis & 331 \\
\hline $\mathrm{di}$ & 241 & uxiana & 254 & squarrosa & 250 & ovata & 932 \\
\hline & 235 & B 254, & 255 & & 222 & porcina & 332 \\
\hline & 240 & nira & 219 & pis & 251 & sulcata & 332 \\
\hline & 223 & & 255 & hylla & 229 & tomentosa & 332 \\
\hline ex & 222 & abergii : & 226 & ster & 223 & CARYOPHYLLACEA & $\mathbf{A E}$ \\
\hline & 245 & $\mathrm{mu}$ & 226 & stipata & 228 & & 377 \\
\hline acea & 220 & muskingumensi & & straminea & & Family & 552 \\
\hline filifo & 248 & & 217 & 219,220 & 221 & Cass & 636 \\
\hline flaccosperma & 244 & nigro-marginats & & ta & 249 & calyculata & 636 \\
\hline 245 & 245 & & 235 & & 231 & Cassena & 554 \\
\hline 220 , & 221 & a & 225 & lexa & 242 & Cassia & 504 \\
\hline lata & 254 & liae & 236 & & 220 & acruminata & 505 \\
\hline & 233 & & 247 & & 254 & aecrista & 505 \\
\hline & 250 & & 245 & ocephala & 222 & $\operatorname{der}$ & 505 \\
\hline & 232 & rpa & 243 & tenella & 225 & marilandica & \\
\hline & 233 & $\mathrm{ma}$ & 249 & 19 & 220 & 50 & 50 \\
\hline & 253 & $O l$ & 256 & tenuiflora & 225 & & 505 \\
\hline & 225 & & 218 & & 247 & & 505 \\
\hline & 237 & & 234 & scula & & & 505 \\
\hline a & 244 & & 238 & & 238 & alis & 505 \\
\hline wii & 231 & & 237 & & 226 & & 505 \\
\hline & 234 & & 23 & & 238 & Cas & 633 \\
\hline & 255 & & 238 & & 231 & oides & 634 \\
\hline & 253 & & 236 & tribuloides & & Cast & 391 \\
\hline ris & 244 & & 240 & 217,219 & 221 & & 391 \\
\hline & 227 & nica & 236 & & 233 & & 391 \\
\hline & 253 & & 239 & rpa & 249 & $\mathrm{Cas}$ & 338 \\
\hline & 244 & & 236 & & 225 & & 338 \\
\hline$d r a$ & 23 & & 240 & $\operatorname{ani}$ & 6 & & 338 \\
\hline ites & 22 & & 241 & des & 50 & & 338 \\
\hline & 252 & & 233 & & 35 & Cas & 732 \\
\hline $\mathrm{Hz}$ & 2 & & 238 & & 256 & nata & 732 \\
\hline & & & 232 & & & & 732 \\
\hline ni & 232 & & 237 & & 236 & & 732 \\
\hline & & & 239 & & 247 & $\mathrm{a}$ & 732 \\
\hline & 249 & 100 & 218 & & 247 & il Plant & 544 \\
\hline ckiana & 243 & Pseudo-Cyperu & & & & Cat & 294 \\
\hline & 219 & & $2 ! 1$ & & 24 & & 565 \\
\hline onii & 248 & & 241 & & 233 & & 697 \\
\hline a a & 251 & & 237 & & 246 & & \\
\hline & 223 & & 255 & vulgarss & 231 & Cata & 151 \\
\hline scens & 253 & & 239 & vulpinoidea & & ico & \\
\hline - manesá & 235 & skiana & 222 & 227 & 228 & Catal & \\
\hline & 248 & & 226 & & 249 & bignonioides & \\
\hline linensis & 243 & & 252 & owii & 23 & & \\
\hline osa & 248 & dsoni & 240 & carpa & 228 & & 74 \\
\hline & 241 & & 230 & & 221 & oa Tree & 741 \\
\hline $12 x-2$ & 242 & & 250 & & 387 & Catehfly & 386 \\
\hline Leavenwor & 226 & sea & 226 & arolina Allspic & 409 & Grass & 12 \\
\hline
\end{tabular}


Catch Ay, Nightflowering

Round-leaved

Royal

Sleepy

Sweet William 385

Catgut

Catnip

Cat's-ear Cat-tail Family
Flag

Caucalis

623

nodosa

Caulophyllum thalictroides

Ceanothus

americanus ovatus

Cebatha carolina

Cedar, Red

White

Cedronella cordata

Celandine
Lesser
Poppy
CELAstraceAs
Celastrus
scandeng
Celosia
argentea
Celtis

697

415

394

415

556

557

557

373

373

346

canina

mississippiensis

346

Cenchrus

carolinianus 119

macrocephalus 119

tribuloides

Centaurea

americana

benedicta

Calcitrapa

Cyanus

Jacea

maculosa

melitensis

nigra

Scabiosa

solstitialis

vochinensis

Centaurella Moseri

paniculata

Centaurium

calycosum

pulchellum

spicatum

texense

umbellatum

Centaury 655, 65

Centella

asiatica

repanda

Jentrosema

virginianum

861

861

655

656

656

656

656

656

523

529

Cen

Centunculu minimus

647

Century Plant

Cephalanthus

occidentalis

Cerastium

arvense

brachypodon 383

glomeratum 383

longe peduncula-

$$
\text { tum }
$$

nutans

384

oblongifolium 383

semidecandrum

triviale

383

viviale

383

vulgatum

383

Cerat 383

389

Ceratophylium $\quad 389$

demersum $\quad 389$

Cerasus 497

Cercis

canadensis

505

Chaerophyllum

procumbens

612

612

Chaetochloa

versicolor

Chaetopappa astieroides

Chaff-seed

Chaffweed

Chain Fern

Chamaecistus

Chamaecyparis

sphaeroidea

Chamaedaphne calyculata

612

118

118

799

799

736

647

37

632

66

66

66

636

636

Chamaelirium 283 carolinianum

luteum

283

obovale

283

Chamaenirion angustifolium 596

Chamaerhodos 480 erecta

480

Chamaesaracha 713 conioides sordida.

Chamomile

Corn

Garden

Wild

Yellow

Charlock Jointed

Cheat

Checkerberry

Cheeses -

Cheilanthes slabamensis

Feei

lanosa

lanuginosa

tomentosa

714 thyoides

vestita

Chelidonium

majus

Chelone

glabra

Lyoni

obliqua

Cemenopodiaceat

Chenopodium

album

ambrosioides

Berlandieri

Bonus-Henricus

Boscianum

Botrys

capitatum

glaucum

humile

hybridum

incisum

leptophyllum

murale

polyspermum 367

rubrum

urbicum

Vulvaris

Cherry

Birch

Bird

Choke

Fire

Ground

Morelln

Perfumed

Pin

Rum

Sand

Sour

Sweet

Wild Black

Wild Red

Winter

Chervil

Chese

Soft

Chestnut

Oak

Water

Chickasaw Plum 498

Chicken Grape $\mathbf{5 6 4}$

Chickweed

Common

Common Mouseear

Field Mouse-ear

Forked

Great

Indian

Jagged

Mouse-ear

Wintergreen

Chicory

Common
36

37

36
Chimaphila

maculata

36 umbellata

Chinese Lantern Plant

Chinquapin

Water

Chiogenes

hispidula

serpyllifolia

Chionanthus virginica

Chloris

verticillata

Choke Cherry

Chokeberry

Chondrilla

juncea

Chondrophora

715

338

392

637

637

637

652

652

145

145

498

458

864

Christmas Fern 40

Flower

Chrosperma muscaetoxicum 284

Chrysanthemum 847

Balsamita $\quad 847$

Corn $\quad 847$

Leucanthemum

847

Parthenium 847

segetum $\quad 847$

Chrysogonum $\quad 826$

virginianum 826

Chrysopogon nutans 


\begin{tabular}{|c|c|c|c|c|c|c|c|}
\hline alpina & 602 & Clethra & 627 & Corn & 384 & orientalis & 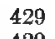 \\
\hline inte & 602 & acuminata & 627 & Cocklebur & 828 & perfoliata & 429 \\
\hline lutetiana & 602 & alnifolia & 627 & \multicolumn{2}{|c|}{ Coeloglossum bractea- } & Convallaria & \\
\hline Girsium & 856 & Cliff Brake & 37 & tum & 308 & majalis & 293 \\
\hline altissinaum & 858 & \multicolumn{2}{|c|}{ Climbing Bitter- } & Coelopleurum & 618 & \multicolumn{2}{|l|}{ CoNVOLVULACEAE } \\
\hline arvense & 858 & sweet & 557 & actaeifolium & 619 & & \\
\hline canescens & 857 & Dogbane & 662 & Gmelini & 619 & Convolvulus & $a$ \\
\hline canum & 859 & \multicolumn{2}{|c|}{ False Buckwheat } & Coffee, Wild & 758 & ary & \\
\hline dise & 857 & & 362 & Coffee-tree & 746 & Family & \\
\hline Hillii & 858 & Fern & 46 & Kentucky & 504 & japonicus & \\
\hline iuwense & 85 & Fumitory & 417 & Cohosh & 407 & repens & \\
\hline atum & & Hemp-weed & 784 & Black & 407 & sepium & \\
\hline $\mathrm{mu}$ & 85 & Rose & 495 & Blue & 412 & spithama & \\
\hline pal & 85 & Clinopodium & 705 & Coleosanthus & 785 & Cooperia & \\
\hline & & & 706 & iflorus & 785 & immondii & \\
\hline & 8 & $u m$ & 706 & Colic & 294 & Copt & \\
\hline imum & & & 706 & a Ivy & 720 & tr & \\
\hline & 857 & & 706 & Colli & 720 & Cor & \\
\hline & 858 & & 706 & & 721 & Coral-berry & \\
\hline Hissus & 563 & Clint & 290 & iflora & 721 & Cors & 16 \\
\hline ppsis & & & 291 & & 720 & lorrhiza & \\
\hline & 563 & & 291 & & 721 & & \\
\hline & 563 & llulata & 291 & Collin & 711 & ata & 317 \\
\hline & 563 & Clito & 529 & ensis & 711 & & 317 \\
\hline sto & 563 & & 529 & ia linearis & 675 & & \\
\hline Cist: & 576 & Cloa & 35 & Colt: & 850 & rhiza & \\
\hline Cistus cantdensis & & Clos & 658 & & 850 & & \\
\hline & 577 & & 828 & Colu & 405 & & \\
\hline gar & 765 & Clo & 487 & & 405 & riana & 0 \\
\hline Cladi & 201 & & 508 & Wild & 405 & Cord & \\
\hline jar & 202 & & 509 & \multicolumn{2}{|c|}{ Columbo, American } & Cor & 5 \\
\hline & & & 509 & & 659 & dii & \\
\hline ladrastis & 506 & $\mathrm{Bu}$ & 510 & Com & 350 & Core & \\
\hline & & & 522 & & 350 & & 84 \\
\hline & 507 & & 509 & & & & 84. \\
\hline Azalea & & $\mathrm{H}$ & 509 & $\mathrm{Ri}$ & 350 & & \\
\hline CuI & & & 50 & lata & 350 & & \\
\hline Loed & & Lo & 509 & \multicolumn{2}{|l|}{ Comarum palustre } & & 83 \\
\hline lary & & & 513 & & 483 & & \\
\hline lay & & & 509 & Com & 68 & & \\
\hline & & & 50 & & 68 & & \\
\hline nis & & & 439 & & 68 & & 84 \\
\hline & & & 509 & Cor & 26 & a & \\
\hline lear & & & 51 & & 26 & & \\
\hline 47, & & & 50 & & 26 & & \\
\hline lem & & & 5 & & 26 & & 83 \\
\hline sonii & & & 50 & & 26 & & \\
\hline & & Slub & 5 & & 265 & & 83 \\
\hline & & & 56 & $\mathbf{A E}$ & 264 & & \\
\hline & & & 5 & & 82 & & 837 \\
\hline Fr & & Club Rush & 187 & Com & 770 & $t r$ & 841 \\
\hline & & \multirow{2}{*}{\multicolumn{2}{|c|}{$\begin{array}{r}\text { Clustered Bellflower } \\
\qquad 67\end{array}$}} & \multirow{2}{*}{\multicolumn{2}{|c|}{$\begin{array}{l}\text { Composite Family } \\
\qquad 770\end{array}$}} & & \\
\hline olia & & & & & & la & 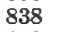 \\
\hline$n$ sis & 40 & \multirow{2}{*}{\multicolumn{2}{|c|}{$\begin{array}{cr}\text { Cnicus } & 857,861 \\
\text { altissimus } & 857,858\end{array}$}} & \multicolumn{2}{|c|}{ Comptonia aspleni- } & Cor & \\
\hline & & & & & 330 & Cori & 61 \\
\hline & & & 858 & & 330 & & 61 \\
\hline & & b & 861 & Cone & 830 & Cor & 36 \\
\hline$S_{2}$ & & & 858 & & 83 & 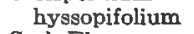 & \\
\hline & & hor & 85 & Con & 622 & Cork & 34 \\
\hline & & & 8 & & 622 & & 33 \\
\hline & & & 858 & & 622 & Wood Family & 33 \\
\hline vio & & & 858 & Coni & 613 & \multirow{3}{*}{\multicolumn{2}{|c|}{$\begin{array}{l}\text { Corn Chamomile } 846 \\
\text { Chrysanthemum }\end{array}$}} \\
\hline & & & 857 & latumn & 613 & & \\
\hline leom & 4 & & 857 & ono & 724 & & \\
\hline & & & & 100 & & & \\
\hline & 45 & Coa & 36 & & & & 68 \\
\hline & & Coce & 410 & and & & & \\
\hline $\sin$ & & nus & 410 & Conringia & 429 & ppy & \\
\hline
\end{tabular}




\begin{tabular}{|c|c|c|c|c|c|c|}
\hline Corn şalad & 762 & Cowslip & Eggertii & 474 & uber & 471 \\
\hline Speedwell & 728 & American & fecunda & 463 & uniflora & 467 \\
\hline Spurrey & 379 & Virginian & flabellata $\mathbf{4 7 0}$, & 471 & Vailiae & 467 \\
\hline Cornaceaf & 623 & Crab, American 458 & flava & 466 & viridis & 465 \\
\hline Cornel & 623 & Apple & Auviatilis & 470 & Creeping Bent & 132 \\
\hline Dwarf & 624 & Siberian & foetida & 465 & Buttercup & 397 \\
\hline Round-leaved & 624 & Cracca & fusca & 472 & Snowberry & 637 \\
\hline Silky & 624 & hispidula & glandulosa 469 , & 479 & Spearwort & 395 \\
\hline Stiff & 625 & spicata & grandis & 463 & Thyme & 708 \\
\hline Corn-flower & 860 & virginiana & Grayana & 471 & Crepis & 869 \\
\hline \multicolumn{2}{|l|}{ Cornucopiae altis- } & Crack Willow & Holmesiana & 473 & biennis & 870 \\
\hline sima & 133 & Cranberry $\quad 638,641$ & intricata & 466 & capillaris & 869 \\
\hline Cornus & 623 & American & irrasa & 468 & pulchra & 869 \\
\hline alternifolia & 625 & High-bush & Jackii & 468 & runcinata & 869 \\
\hline Amomum & 624 & Large & Jesup: & 473 & tectorum & 870 \\
\hline asperifolia & 624 & Mountain & Jonesae & 469 & virens & 869 \\
\hline Baileyi & 624 & Rock & Kelloggii & 473 & Cress, Bitter & 435 \\
\hline canadensis & 624 & Small & lanuginosa & 474 & \multicolumn{2}{|c|}{ Common Winter } \\
\hline candidisaima & 625 & Cranberry-tree & laurentiana & 468 & & 432 \\
\hline circinata & 624 & Crane Fly Orchis 319 & leiophylla & 473 & Early Winter & 433 \\
\hline florida & 624 & Cranesbill & leucophleos & 478 & Garden & 425 \\
\hline paniculata & 625 & Long-stalked 536 & lucorum & 470 & Lake & 432 \\
\hline Pricese & 624 & Wild & Macauleyae & 468 & Marsh & 432 \\
\hline Purpusi & 624 & Crantzia & macracantha & 477 & \multicolumn{2}{|c|}{ Mountain Water } \\
\hline sericea & 624 & lineata & macrosperma & 471 & & 435 \\
\hline stolonifera & 624 & Crasstraceat & Margaretta & 464 & Mouse-ear & 430 \\
\hline stricta & 625 & Crataegus & Marshallii & 470 & Penny & 424 \\
\hline suecica & 624 & alnorum & missouriensis & 478 & Rock & 436 \\
\hline Coronilla & 518 & anomala & modesta & 466 & Spring & 435 \\
\hline varia & 518 & apiifolia & mollis & 476 & Swine & 426 \\
\hline Coronopus & 426 & apposita & nitida & 465 & True Water & 431 \\
\hline Coronopus & 426 & aprica & Oakesiana & 468 & Wart & 426 \\
\hline didymus & 426 & Arnoldiana & oblongifolia & 474 & Water & 431 \\
\hline procumbens & 426 & ascendens & Oxyacantha & 462 & Winter & 432 \\
\hline Corpse Plant & 629 & Bartramiana & Palmeri & 463 & Yellow & 431 \\
\hline Corydalis & 417 & Baxteri & parvifolia & 467 & \multicolumn{2}{|c|}{ Crested Dwarf Iris } \\
\hline aurea & 418 & beata & pausiaca & 463 & & 301 \\
\hline crystallina & 418 & berberifolia & Peckii & 466 & \multirow{2}{*}{\multicolumn{2}{|c|}{ Crimson-eyed Hibis- }} \\
\hline flavula & 418 & biltmoreana & pedicellata & 475 & & \\
\hline glauca & 418 & blandita & Pennypackeri & 463 & cus & 570 \\
\hline Golden & 418 & Boyntoni & persimilis & 463 & \multicolumn{2}{|c|}{ Criosanthes borealis } \\
\hline micrantha & 418 & Brainerdi & pertomentosa & 477 & & 306 \\
\hline Pale & 418 & Brownit & Phaenopyrum & 477 & \multicolumn{2}{|l|}{ Crookneck Squash } \\
\hline sempervirens & 418 & campestris & polita & 475 & & 765 \\
\hline Corylus & 333 & canadensis & populnea & 471 & Cross-vine & 741 \\
\hline americana & 333 & Canbyi & pratensis & 463 & Crotalaria & 507 \\
\hline & 333 & champlainensis & & 466 & 02 & 507 \\
\hline Costmary & 847 & 47 & Pringlei & 475 & Purshii & 507 \\
\hline \multirow{2}{*}{\multicolumn{2}{|c|}{ Cotinus cotinoides }} & Chapmani & pruinosa & 472 & rotundifolia & 507 \\
\hline & & \multirow{2}{*}{ 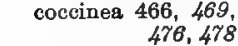 } & ifolia & 463 & sagittalis & 507 \\
\hline Cotor & 479 & & punctata & 463 & Croton & 541 \\
\hline Pyr & 479 & coceinioides & pyriformis & 474 & capitatus & 542 \\
\hline Cotton Grass & 195 & cognata & roanensis & 470 & glandulosus & 542 \\
\hline Rose & 819 & collina & Robbinsiana & 472 & \multicolumn{2}{|c|}{ monanthogynus } \\
\hline Thistle & 859 & coloradensis & rotundata & 468 & & 542 \\
\hline Cotton-wood & 329 & colorado & rotundifolia & 468 & asis & 542 \\
\hline Cotula & 848 & columbiana & Schuettei & 477 & Crotonopsis & 542 \\
\hline opifolia & 848 & cordata & sequax & 472 & linearis & 542 \\
\hline Couch Grass & 166 & cristata & Sheridana & 469 & Crowberry & 551 \\
\hline Cow Lily & 390 & crudelis & silvicola & 472 & Black & 551 \\
\hline Uak & 340 & Crus-galli & spathulata & 469 & Broom & 551 \\
\hline Parsnip & 621 & Crus-galli $\times$ macra- & speciosa & 475 & Family & 551 \\
\hline $\mathrm{Pe}$ & 528 & cantha & stolonifera & 471 & Crowfoot & 394 \\
\hline Wh & 732 & deltoides & Stonei & 466 & Bristly & 398 \\
\hline owb & 622 & dispessa & submollis & 476 & Bulbous & 398 \\
\hline & 614 & Dodgei & suborbiculata & 464 & Common & \\
\hline Cowberry & 641 & Douglasii & tenuifolia & 474 & Water & 394 \\
\hline Cow-herb & 380 & Edsoni & tomentosa 467 , & 478 & Cursed & 396 \\
\hline
\end{tabular}


Crowfoot, Elarly 397 Family 392

Grass 147

Hooked $\quad 397$

Sea-Side $\quad 394$

Small-flowered

$\begin{array}{ll} & 396 \\ \text { Stiff Water } & \mathbf{3 9 4}\end{array}$

Tail 398

Yellow Water 394

Crownbeard $\quad 836$

Cruciferait 418

Cryptogramma 37

acrost choides 37

densa $\quad 37$

Stelleri $\quad 37$

Cryptotaenia $\quad 615$

canadensis $\quad 615$

Ctenium

aroericaluum 147

aromaticum 146

Cubelium

concolur

Cuckoo Flower

Cucumber

One-seeded Bur

Tree

579

579

436

765

765

Cucumis Melo sativus

Cucurbita

foetidissima

maxima

moschata

Pepo

409

765

765

764

765

765

765

765

Cocorbitaceae 764

Cudweed

Low

823

Mountai ।

823

Purplish

823

Culver" Phyaic 726

Culver's-root

Cunila

Mariana

origanoides

Cup Plant

Cuphea

Clammy

petiolata

viscosiasima

Cupseed

Curled Mallow

Mustard

Burly Grass

Family

Currant

Black

Buffalo

Indian

Missouri

Red

Skunk

Swamp Black 452

Swamp Red 452

Wild Black 451

Cursed Crowfoot 396

Cuscuta

arvengis

671

672
Cephalanthi

chlorocarpa

compacta

Coryli

cuspidata

decora

Epilinum

Epithymum

europaea

glomerata

Gronovii

indecora

inflexa

obtusiflora

paradoxa

Polygonorum

rostrata

tenuiflora

Trifolii

Custard Apple Family

Cut-grass

Rice

672

672

673

672

673

672

671

672

672

673

672

672

672

672

673

672

673

672

672

Cut-leaf Germander

Cycloloma

693

atriplicifolium 365

platyphyllum 365

Cymbalaria Cymbala-

$$
\text { ria }
$$

720

Cymopterus

acaulis

glomeratus

619

619

Cynanchum

619

nigrum

667

Vincetoxicum 667

Cynoctonam 653

Mitreola.

Cynodon

Dactylon

Cynoglossum

boreale

officinale

virginianum

virginicum

Cynosciadium

pinnatum

653

144

144

681

681

681

681

681

617

618

Cynosurus cristatus

Cynthia

Cyperaceae

Cyperus

acuminatus

aristatus

Bushii

calcaratus

compressus

cylindricus

154

863
171

171

172

175

175

179

176

175

178

dentatus

176

diandrus

174

dipsaciformis 178

echinatus

178

Engelmanni 177

erythrorhizos 177

esculentus

ferax

176

filiculmis

flavescens

179

174 flavicomus

flavus

fuscus

Gatesii

Grayii

Halei

Hallii

haspan

Houghtoníi

hystricinus

inflexus

lancastriensis

microdontus

Nuttallii

ovularis

polystachyus

pseudovegetun 175

refractus

retrofractus

rivularis

rotundus

Schweinitzii

speciosus

strigosus

Torreyi

Cypress

Bald

Spurge

Standing

Vine

Cypripedium

acaule

arietinum

candidum

hirsutum

parviflorum

passerinum

pubescens

spectabile

Cyrilla

Family

racemiflora

Crrillaceae

Cystopteris

bulbifera

fragilis

Cytisus

scoparius

Dactylis

glomerata

Dactyloctenium 147

aegyptiacum 147

aegyptium

Daffodil

554

aisy

Fleabane $\mathbf{8 1 7}, 818$

Ox-eye

Western

White

Yellow

Dalea

alopecuroides

enneandra

laxiflora

175

179

175

179

177

176

179
178

175

177

174

178

75

177

178

174

176

175

177

178

66
66

549 
Uentaria laciniata maxima 435 Deptford Pink $\quad \begin{aligned} & 434 \\ & 387\end{aligned}$ Deringa canadensis atropurpurea 140 caespitosa $\quad 140$ flexuosa $\quad 140$

Desmanthus brachylobus illinoensis

Desmodium acuminatum

bracteosum

canadense 620, 521

canescens 520

ciliare $\quad 522$

cuspidatum $\quad \mathbf{5 2 0}$

Dillenii $\quad 521$

glabellum $\quad 520$

grandiflorum 519

humifusum $\quad 520$

illinoense

laevigatum

520

lineatum.

521

marilandicum 522

nudiflorum $\mathbf{5 1 9}$

obtusum

522

ochroleucum 519

paniculatum 521

pauciflorum $\mathbf{5 1 9}$

rhombifolium $\mathbf{5 2 1}$

rigidum

522

rotundifolium 519

sessilifolium $\quad 522$

strictum

521

viridiflorum 521

Devil's Bit 283, 763 Club

606

Paint-brush

872

Dewberry

Lucretia

Dianthera

americana

ovata

Dianthus

Armeria

barbatus

deltoides

prolifer

Diapensia

Framily

lapponica

Diapensiaceae

Diarrhena

americana

diandra

Dicentra

canadensis

Cucullaria

eximea

Dichondra evolvulacea repens

Dichromena colorata

642

153

417

417

417

669

669

669

185

185 latifolia

leucocephala

185

Dicksonia

pilosiuscula

punctilobula

Diclytra

Didiplis

diandra

linearis

Dielutra

Diervilla

Diervilla

Lonicera

trifida

Digitalis

purpurea

Digitaria.

filiformis

humifusa

paspalodes

sanguinaiis

serotina

villose

Dill

Diodia

teres

virginiana

Dioscorea

villosa

Droscor eaceat

Diospyros virginians

Diphylleia

cymosa

Diplachne acuminata

148

fascicularis $\quad 148$

procumbens 148

Diplopappus amyg-

$$
\text { dalinus } 815
$$

cornifolius

linarifolius

umbellatus

Diplotaxis

muralis

tenuifolia

Difsacaceae

Dipsacus

laciniatus

sylvestrio

Diraa

palustria

Discopleura

capillacea

Nuttallii

Disporum

lanuginosum

Distichlis

maritima spicata

Ditaxis mercurialina

543

Ditch Grass

78

Stonecrop

Dittany

Common

Dock

Bitter

442

709
815

428

428

429

763

763

763

580

580

613

613

614

291

291

153

154

Golden
Great Water
Pale
Patience
Prairie
Swamp
White
Yellow

357

355

356

355

825

356

355

355

Dockmackie

Dodder

Flax

Dodecatheon

Meadia

Doellingeria humili

infirma $\quad 815$

umbellata

815

Dog Fennel 782, 846

Rose

Dogbane

Climbing

Family

Spreading

Dogberry

Dogwood

Family

Flowering

Poison

Red-osier

496

662

662

661

662

451

623

623

624

552

Round-leaved 624

Dog's-tail Grass 154

Dog's-tooth Violet

Dolichos

289

Lablab

529

Dondia americana

depressa

370

maritima

370

Downy Arrow-wood

False Foxglove

759

Green Alder

730

Poplar

Yellow Violet 585

Draba

arabisans

brachycarpa

caroliniana

cuneifolia

incan $\alpha$

nemorosa

ramosisgima

stylaris

verna

Dracocephalum parvifiorum

Dragon Arum

Green

Head

Head, False

Root

Drop-seed

Drosera

anglica

brevifolia

filiformis

intermedia

441

linearis

longifolia

441

DROg ERA

Drymocallis arguta

Dryopteris Bottio 4

cristata 42,43

Filix-mas $\quad 42$

fragrans $\quad 42$

Goldiana $\quad 42$

Goldieana $\quad 42$

marginalis $\quad 42$

noveboracensis 42

simulata 41

spinulosa $\quad 43$

Thelupteris 41

Duchesnea $\quad 480$

indica 480

Duck's-meat $\quad 259$

Duckweed 259

Family 259

Dulichium $\quad 180$

arundinaceum 180

spathaceum $\quad \mathbf{1 8 0}$

Dupontia Cooleyi 140 


\begin{tabular}{|c|c|c|c|c|c|c|c|}
\hline Tatonia & 138 & quisetoides & 181 & wthorn & 462 & hieracifolia & \\
\hline Dudleyi & 138 & intermedia & 184 & Plantain & 745 & Erianthus & 90 \\
\hline intermedia & 138 & interstincta & 181 & Violet & 585 & alopecuroides & קר \\
\hline pennsylvanica & 138 & Macounii & 185 & Enslenia & g67 & barbis & \\
\hline EBENACEATE & 648 & melanoearpe & 184 & albida & 667 & compactus & \\
\hline Ebony Family & 648 & & 181 & Epifagus & 739 & contortus & \\
\hline Echinacea & 832 & la & 184 & virginiana & 739 & divaricatus & \\
\hline angustifolia & 832 & & 182 & Epigaea & 636 & saccharoides & \\
\hline pall & 832 & ochreata & 181 & repens & 636 & Erica cinerea & 637 \\
\hline purpurea & 832 & cea & 182 & Epilobium & 596 & Tetralix. & \\
\hline Tchinochloa & 117 & orroto & 182 & adenocaulon & 597 & ERICA & 25 \\
\hline & & & 183 & alpinum & 597 & Erig & \\
\hline cru & 11 & lora & 189 & anagallidifoliun & & bulbosa & 12 \\
\hline tacea & 117 & pygmaea & 189 & & 597 & Eriger & 817 \\
\hline Walteri & 117 & quadrangulata & 181 & angustifolium & 596 & aeris & 18 \\
\hline ichinoeystis & 765 & insii & 181 & ס & 597 & & 17 \\
\hline lob & & ta & & & 596 & & \\
\hline rus & 8 & ten & 184 & um & 596 & beillidifolius. & 317 \\
\hline & 84 & $\operatorname{ana}$ & 183 & $\operatorname{mani}$ & 597 & & \\
\hline & 84 & & 183 & lactiflorum & 597 & $\mathrm{dir}$ & 18 \\
\hline & 84 & ta & 18 & lineare & 597 & iensis & \\
\hline & 84 & losa & 183 & molle & 596 & & 81 \\
\hline & 84 & & 18 & nthum & 597 & iolius & \\
\hline $\operatorname{nax}$ & 606 & opus & 781 & & 597 & & 817 \\
\hline & & & & & 59 & hic & \\
\hline Schir & 856 & & 781 & & 596 & llus & 817 \\
\hline rocepl & & tor & 781 & Epip & 315 & & $x_{1}$ \\
\hline & 856 & Elep & 781 & Ens & 315 & & 10 \\
\hline ermum & 681 & Eleu & 147 & ine & 313 & & 817 \\
\hline & 682 & & 14 & & 313 & sum spin & \\
\hline rdum & 682 & & 147 & & 315 & & 798 \\
\hline & 682 & Ellisi & 677 & & 315 & ERI & $\pi$ \\
\hline icum & 681 & & 677 & & 315 & Eri & 261 \\
\hline Eohi & 688 & $\operatorname{Elm}$ & & & 313 & tum & 261 \\
\hline & 6 & & 345 & $E p i$ & 739 & sum & 261 \\
\hline Ecl & 830 & & 346 & $E_{Q}$ & 51 & lare & 26 \\
\hline & 830 & & 34 & $\mathrm{Eq}$ & & Lodes & 01 \\
\hline 8 & 3,85 & & 34 & & 52 & & 261 \\
\hline & 712 & & & & & ulare & \\
\hline & 496 & & 34 & & 53 & Gric & 35 \\
\hline CEAE & & & 3 & um & & & 35 \\
\hline Ela & 590 & & & & 00 & & 35 \\
\hline & & & & & 5 & Gric & $y$ \\
\hline EAE & 575 & ged & 34 & & 2 & & 19 \\
\hline Ela & 576 & Elode & 6 & & 2 & ifolium & 197 \\
\hline na & 576 & iulata & 5 & & & & 198 \\
\hline perma & 576 & nsis & 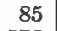 & & 54 & ssonis & 19 \\
\hline & 576 & Elo & 575 & & 52 & num & 19 \\
\hline Elatinoides Elatin & & & 71 & & 54 & 196, & 19 \\
\hline & 720 & & 71 & Era & & & 19 \\
\hline & 720 & Ely & it & & & & 19 \\
\hline Elder & & & 17 & & & ervium & 197 \\
\hline & 55 & & 16 & & 1 & chion & 197 \\
\hline & & shys & 1 & & & & 19 \\
\hline & 5 & & 16 & & & & \\
\hline led & & & 17 & & & & 19 \\
\hline & & & 17 & in & 150 & nicum & 19 \\
\hline Eleca & 824 & & 17 & & 150 & \multicolumn{2}{|l|}{ viridi-carinat } \\
\hline Eleoc & 180 & & 17 & $\mathbf{p}$ & 151 & & 19 \\
\hline & 18 & & 16 & & 150 & Eri & 65 \\
\hline & 18 & & 16 & & 150 & Ero & 536 \\
\hline & 18 & & 16 & & 150 & 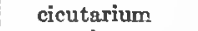 & \\
\hline purea & 182 & EA & 55 & & 151 & atun & 53 \\
\hline & 182 & & 55 & & 151 & ry & \\
\hline & 18 & & 551 & & 151 & icum & 610 \\
\hline & 182 & er's N & & & 405 & enworthii & 61 \\
\hline & 182 & & 60 & & 405 & & \\
\hline Engelm & $1 \mathrm{x}:$ & glish Elm & 34 & Srechtites & $85 !$ & izroinianum & \\
\hline
\end{tabular}


Fryngium yucci-

$\begin{array}{cc}\text { folium } & 609 \\ \text { Eryngo } & 609 \\ \text { Erysimum } & 430 \\ \text { asperum } & 431 \\ \text { cheiranthoides } & 431 \\ \text { inconspicuum } & 431 \\ \text { parviflorum } & 431 \\ \text { repandum } & 431 \\ \text { syrticolum } & 431 \\ \text { Erythraea } & 656 \\ \text { calycosa } & 656 \\ \text { Centaurium } & 656 \\ \text { ramosissima } & 656 \\ \text { spicata } & 656 \\ \text { texcnsis } & 656 \\ \text { Erythronium } & 289 \\ \text { albidum } & 289 \\ \text { americanum } & 289 \\ \text { mesochoreum } & 289 \\ \text { propullans } & 289 \\ \text { Eulophus } & 616 \\ \text { americanus } & 617 \\ \text { Eupatorium } & 781 \\ \text { ageratoides } & 784 \\ \text { album } & 782 \\ \text { altissimum } & 783 \\ \text { aromaticum } & 784 \\ \text { capillifolium } & 782 \\ \text { coelestinum } & 784 \\ \text { foeniculacerm } & 782 \\ \text { hyssopifolium } & \end{array}$
782,789

incarnatum 784 leucolepis 782 maculatum 782 perfoliatum 783 pubescens 783 purpureum 782

resinosum 783

rotundifolium 783 serniserratum 783 serotinum 782 sessilifolium 783 teucrifolium 783 Torreyanum 783 trifoliatum 782 urticaefolium 784 verbenaefolium

Euphorbia arkansana commutata corollata Cyparissies 783 545 549 Darlingtonii 549 547 dentata 549 dentata 548 548 Esula Geyeri 548 glyptosperraa 546 Helioscopia 549 heterophylla 548 hexagona

hirsuta. 547 humistrata 546 hypericifolia $\quad 546$ Ipecacuanhae 548

\section{Lathyrus}

lucida.

maculata

marginata

marilandica

nicaeensis

nutans.

Nuttallii

obtusata

Peplus

petaloidea

platyphylla

polygonifolia

Preslii

gerpens

serpyllifolia

stictospora

zygophylloides

546

EUPhor BIacear 540

Euphrasia 733

americana. $\quad 733$

aretica

canadensis

733

hirtella

latifolia

Oakesii

Randii

733

733

733

Williamsii

733

733

European Brooklime 727

Fly Honeysuckle 755

Gooseberry

451

Millet

104

Mountain Ash 459

Spindle Tree 556

Vervain

688

Euthamia caroliniana

798

graminifolia 797

gymnospermoides

798

leptocephala 798

tenuifolia $\quad 798$

Evening Primrose

Common

598

$\begin{array}{ll}\text { Common } & 598 \\ \text { Family } & 594\end{array}$

White 600

Evergreen Blueberry

639

Everlasting

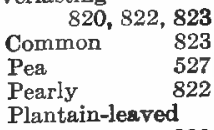

Evolvulus

argenteus

pilosus

Evonymus

americanus

atropurpureu 556

europaeus

obovatus

820

669

670

556

556

556

556

556

733

$\begin{array}{lr}\text { FAgACEAE } & 337 \\ \text { Fagonyrum } & 363 \\ \text { esculentum } & 363 \\ \text { Fagopyrum } & 363 \\ \text { tataricum } & 363 \\ \text { Fagus } & 337 \\ \text { americana } & 338 \\ \text { ferruginea } & 338 \\ \text { grandifolia } & 338 \\ \text { Falcata } & 530 \\ \text { comosa } & 530 \\ \text { Pitcheri } & 530 \\ \text { Fall Dandelion } & 863 \\ \text { Witch Grass } & 96 \\ \text { False Acacia } & 514 \\ \text { Aloe } & 298 \\ \text { Asphodel } & 283 \\ \text { Beach Drops } & 630 \\ \text { Buckthorn } & 548 \\ \text { Bugbane } & 399 \\ \text { Dandelion } & 869 \\ \text { Dragon Head } & 698 \\ \text { Flax } & 426 \\ \text { Goat's Beard } & 444 \\ \text { Golden-rod } & 798 \\ \text { Gromwell } & 687 \\ \text { Hellebore } & 285 \\ \text { Tndigo } 505, & 512 \\ \text { Jessamine } & 653 \\ \text { Loosestrife } & 594 \\ \text { Mallow } & 567 \\ \text { Mermaid } & 552 \\ \text { Mermaid Family } \\ \text { M }\end{array}$

Mistletoe
Miterwort

Nettle

447

Pennyroyal

349

Pimpernel

Solomon's Sea!

Spikenard

Farkleberry

Fatsia

horrida

Feather Geranium

\section{Grass}

Featherfoil

Felwort, Marsh

Fennel

Dog

Flower

782,846

Fern, Beech

Bladder

Chain

Christmas

Cinnamon

Climbing

Cloak

Family

Filmy

Flowering

Hay-scented

Holly

Lady

Oak

Ostrich
Rattlesnake $\quad 49$

Sensitive 45

Shield 41

Sweet $\quad 330$

Wood 41

Fescue Grass $\quad 160$

Meadow $\quad 162$

Sheep's $\quad 161$

Taller $\quad 162$

Festuca $\quad 160$

diandra 153

elatior $\quad 162$

gigantea $\quad 162$

myuros 161

nutans 162

occidentalis $\quad 161$

octoflora 161

ovina 161

pratensis $\quad 162$

rubra $\quad 161$

sciurea $\quad 161$

Shortii $\quad 162$

spicaia $\quad 166$

tenella $\quad 161$

Fetid Buckeye 559

Horehound 700

Marigold 845

Wild Pumpkin 765

Fetter Bush 634, 635

Fever Bush $\quad 414$

Feverfew 847

Feverwort $\quad 758$

Ficaria Ficaria 394

Field Bindweed 671

Garlic 287

Larkspur $\quad 406$

Madder $\quad 747$

Mouse-ear Chick-

weed $\quad 383$

Penny Cress 424

Sorrel 357

Sow Thistle 865

Speedwell $\quad 728$

Fig, Indian $\quad 589$

Figwort 721

Family $\quad 717$

366 Filago germanica 819

123 Filbert 333

644 Filipendula 484

rubra $\quad 484$

Ulmaria 485

Filix bulbifera $\quad 43$

fragilis 43

Filmy Fern 33

Family $\quad 33$

Fimbristylis $\quad 186$

autumnalis $\quad 187$

capillaris $\quad 186$

castanea $\quad 186$

Frankii $\quad 187$

laxa $\quad 187$

spadicea $\quad 186$

Vahlii 187

Finger Grass $\quad 95$

Fiorin 132

Fir 65

Balm-of-Gilead 65

Balsam 65 


\begin{tabular}{|c|c|c|c|c|c|c|c|}
\hline Fir, Scotch & 64 & Grass & 129 & volubilis & 530 & brachycera & 638 \\
\hline Tire Cherry & 498 & Green & 118 & Galax & 642 & dumosa & 638 \\
\hline Pink & 386 & Fragaria & 479 & aphylla & 642 & frondosa & \\
\hline Thorn & 479 & americana. & 480 & Galeopsis & 699 & resinosa & 38 \\
\hline ireweed 596 , & 851 & canadensis & 479 & Ladanum & 699 & ursina & 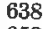 \\
\hline Fissipes acaulis & 307 & illinoensis & 479 & Tetrabit & 699 & Gelsemium & 52 \\
\hline Five-finger & 481 & indica & 480 & \multicolumn{2}{|c|}{ Galeorchis spectabilis } & sempervirens & 53 \\
\hline Marsh & 483 & terrae-novae & 479 & & 307 & Gemmingia & 01 \\
\hline lag, Cat-tail & 68 & vesca & 479 & Galingale & 172 & Genista & 07 \\
\hline Larger Blue & 299 & virginiana & 479 & Galinsoga & 843 & tinctoria & 07 \\
\hline Slend & 300 & Franseria & 828 & asana & 843 & Gentian & \\
\hline Sweet & 258 & acanthicarpa & 828 & hispida & 843 & Closed & 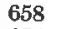 \\
\hline \multicolumn{2}{|c|}{ Flame-colored Aza- } & tomentosa & 828 & parviflora & 843 & Family & 54 \\
\hline lea & 631 & Frasera & 659 & Galium & 747 & Fringed & W0 \\
\hline Flaveria & 843 & caroliniensis & 659 & anglicum & 748 & Horse & \\
\hline folia & 843 & Fraxinus & 650 & & 748 & wort & \\
\hline cam & 843 & $\operatorname{sana}$ & 650 & sanum & 749 & Spurred & 69 \\
\hline $\operatorname{lax}$ & 531 & eana & 651 & asprellum & 750 & Gentiana & \\
\hline Common & 531 & ana & 651 & boreale & 749 & & \\
\hline Do & 671 & inii & & zang & 749 & & \\
\hline Fal & 426 & njgra & 651 & Cla & 750 & alb & 58 \\
\hline Far & 531 & vanica & 651 & aum & 750 & ella & \\
\hline Fleabane & 817 & & 651 & & 749 & ewsii & \\
\hline Daisy & 818 & & & lulum & 750 & $a$ & \\
\hline Mars & 819 & pub & 651 & \multicolumn{2}{|l|}{ kamtschaticum } & & \\
\hline Salt Marsh & 819 & gulata & $65 i$ & & 749 & & \\
\hline is 299 , & 300 & cifolia & 651 & oricum & 750 & & \\
\hline Floatin & & vir & 651 & la & 749 & & \\
\hline & 129 & Mulberry & 690 & um & 749 & uca & \\
\hline Hear & 660 & & & & 749 & yrio & \\
\hline Floerk & 552 & Gentian & & & 749 & & \\
\hline proser & & & 308 & nse & 748 & & 57 \\
\hline & 55 & & 53 & & 748 & flora & \\
\hline lowering Dogwo & ood & Fring & 652 & & 748 & efolia & \\
\hline & 624 & Fro & 37 & cum & 749 & $m$ & \\
\hline Fer & 46 & & 37 & ium & 750 & aria & \\
\hline $\mathrm{Fe}$ & 46 & & 37 & tric & 748 & & \\
\hline Mo & 642 & gra & 374 & m 749 , & & & \\
\hline Sp & 547 & \multicolumn{2}{|c|}{ Frog's Bit, American } & $u m$ & 750 & $\mathrm{GE}$ & 354 \\
\hline een & 538 & & 86 & & 748 & Ged & \\
\hline \multicolumn{2}{|c|}{$\begin{array}{l}\text { Flower-of-an-hour } \\
570\end{array}$} & Family & 85 & $\mathrm{am}$ & 748 & $\mathrm{Gr}_{\mathbf{1}}$ & \\
\hline & 570 & \multicolumn{2}{|c|}{ Frost Grape 564, 565} & enii & 748 & $\mathrm{Ge}$ & \\
\hline Fly Pois & 284 & Frost & 799 & \multicolumn{2}{|c|}{ Gall-of-the-earth 871} & llii & \\
\hline oeni & 616 & & 577 & Grass & 92 & ianum & \\
\hline$u m$ & 616 & & 197 & \multicolumn{2}{|l|}{ Garden Asparagus } & in & \\
\hline ofit & 616 & & 197 & & 290 & & \\
\hline & 616 & & 198 & & 494 & & \\
\hline $\log -$ & 68 & & 19 & & 8 & 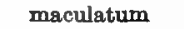 & \\
\hline ssley & 61 & Fur & 4 & & & & \\
\hline Fore & 65 & & & & & & \\
\hline & 65 & & & $\mathbf{H}$ & & & \\
\hline Corge & 683 & & & & 4 & & \\
\hline $\operatorname{Tr}$ & 68 & & 4 & & & 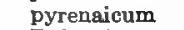 & \\
\hline orked Chickwee & & & & & & & \\
\hline & 376 & & & & & $\mathrm{rc}$ & \\
\hline oth & 453 & Furze & 50 & & 287 & & \\
\hline & 45 & & & & 429 & Ger & \\
\hline Gar & 453 & Gaer & 828 & & & & \\
\hline cok & 375 & arpa & 828 & Gav & 636 & lata & 73 \\
\hline & 375 & & 82 & & 636 & & \\
\hline owl Meadow $C$ & ass & Gail & 844 & Gai & 601 & $o b a$ & 73 \\
\hline & & & & & 601 & & \\
\hline & 641 & olata & 845 & & 601 & Ilata & \\
\hline $0 \times 8$ & 72 & & & & 602 & & \\
\hline F False & 730 & Gala & 53 & $u x i i$ & 602 & $G$ & \\
\hline & 729 & & & Gora & 601 & ra & \\
\hline Smooth False & 730 & & 530 & Gay & 637 & & \\
\hline oxtail & 118 & regularis & & baccata & 638 & laevigata & \\
\hline
\end{tabular}




\begin{tabular}{|c|c|c|c|c|c|c|c|}
\hline Gerardia linifolia ? & 730 & Globeflower & 404 & European & 451 & Fall Witch & 96 \\
\hline maritima & 731 & Spreading & 404 & Missouri & 451 & Farnily & 86 \\
\hline parvifolia & 731 & Glyceria & 158 & Prickly & 451 & Feather & 123 \\
\hline paupercula & 731 & acutiflora & 160 & Smooth & 451 & Fescue & 160 \\
\hline pedicularia & 729 & borealis & 160 & Soutbern & 639 & Finger & 95 \\
\hline Purple & 731 & canadensia & 158 & Goosefoot & 365 & Floating Foxta & \\
\hline purpurea & 731 & elongata & 158 & Family & 364 & & 129 \\
\hline quercifolia & 730 & fuitans & 159 & Maple-leaved & 367 & Fowl Meadow & \\
\hline Sea-side & 731 & grandis & 159 & Oak-leaved & 367 & 156 & 159 \\
\hline setacea & 731 & laxa & 159 & Gordonia & 571 & Foxtail & 129 \\
\hline Skinneriana & 731 & nervata & 159 & Lasianthus & 571 & Gama & 92 \\
\hline Slender & 731 & obtusa & 158 & Gorse & 508 & Goose 147,160 , & .748 \\
\hline tenuifolia & 731 & pallida & 159 & Gourd & 765 & Hair 128, 132, & 137 \\
\hline virginica & 730 & septentrionalis & 159 & Family & 764 & Herd's & 132 \\
\hline German Millet & 119 & Torreyana & 158 & Missouri & 765 & Holy & 121 \\
\hline Germander & 692 & Glycine comosa & 520 & Goutweed & 614 & Hungarian & 119 \\
\hline American & 693 & Glycyrrhiza & 518 & Gramineate & 86 & Indian & 95 \\
\hline Cut-leaf & 693 & lepidota & 518 & Grape & 563 & Italian Rye & 165 \\
\hline Sage & 693 & Gnaphalium & 823 & Bullace & 565 & Johnson & 95 \\
\hline Geum & 485 & decurrens & 823 & Cat & 565 & June & 156 \\
\hline album & 485 & Helleri & 823 & Chicken & 564 & Kentucky Blue & \\
\hline canadense & 485 & obtusifolium & 823 & Frost & 565 & & 156 \\
\hline ciliatum & 486 & polycephalum & 823 & Hyacinth & 290 & Low Spear & 155 \\
\hline flavum & 485 & purpureum & 823 & Muscadine & 565 & Lyme & 168 \\
\hline macrophyllum & 485 & supinum & 823 & Northern Fox & 564 & Manna & 158 \\
\hline Peckii & 486 & sylvaticum & 823 & Pigeon & 564 & Marsh & 142 \\
\hline pulchrum & 486 & uliginosum & 823 & Red & 565 & Meadow & 154 \\
\hline radiatum & 486 & Goat's Beard & & River-bank & 565 & Meadow Foxta & \\
\hline rivale & 486 & 457, &, 864 & Sand & 565 & & 129 \\
\hline strictum & 485 & False & 444. & Southern Fox & 565 & Melic & 151 \\
\hline um & 486 & Goat's Rue & 514 & Sugar & 565 & Mesquite & 145 \\
\hline urbanum & $485^{\circ}$ & Golden Alexande & lers & Summer & 564 & Millet & 122 \\
\hline vernum & 486 & & 616 & Sweet Winter & 564 & Oat & 141 \\
\hline virginianum & 485 & Aster & 787 & Graphephorum $m$ & meli- & of $P \varepsilon$ rnassus & 449 \\
\hline Giant Hyssop & 696 & Club & 258 & coides 139 , & 140 & Old-witch & 103 \\
\hline Reed & 148 & Corydalis & 418 & Grass, Alkali & 153 & Orange & $\mathbf{5 7 5}$ \\
\hline Gifola & 819 & Dock & $\mathbf{3 5 7}$ & Arrow & 80 & Orchard & 154 \\
\hline germanica & 819 & Lungwort & 874 & Awned Wheat & 167 & Panic & 100 \\
\hline Gilia & 675 & Ragwort & 854 & Barnyard & 117 & Perennial Ray & 165 \\
\hline coronopifolia & 675 & ifrage & 448 & Beach & 136 & Pigeon & 118 \\
\hline linearis & 675 & Seal & 408 & Bear & 290 & Porcupine & 124 \\
\hline rub & 675 & Golden-rod & 788 & Beard & 133 & erty & 124 \\
\hline Gillenia & 457 & $\mathrm{Fa}$ & 798 & Bent & 132 & Quaking & 1.54 \\
\hline stipulacea & 457 & Rayless & 798 & Bermuda & 144 & Quick & 166 \\
\hline stipulata & 457 & Sweet & 793 & Billion-Dollar & 117 & Quitch & 166 \\
\hline trifoliata & 457 & Golden-Wonder & Mil- & Black & 270 & Rattlesnake & 158 \\
\hline Gill-over-the-Gro & bund & let & 119 & Black Oat & 123 & Reed Bent & 134 \\
\hline & 697 & Goldthread & 404 & Blue-eyed & 301 & Reed Meadow & 159 \\
\hline Ginger, Wild & 352 & Gom & 374 & Blue-joint & 135 & Rhode Island $\mathrm{F}$ & Bent \\
\hline Ginst & 606 & globosa & 374 & Bottle & 118 & & 133 \\
\hline Dwarf & 606 & Gonolobus 667 , & 668 & Bottle-brush & 170 & Rib & 745 \\
\hline Family & 605 & Baldwinianus & 668 & Bristly Foxtai & & Ribbon & 121 \\
\hline Glade Mallow & 568 & carolinensis & 668 & & 118 & Ripple & 745 \\
\hline Glasswort & 369 & hirsulus & 668 & Brome & 162 & Rough-stalked & \\
\hline Glaucium & 415 & laevis & 668 & Brown Bent & 133 & Meadow & 157 \\
\hline flavum & 416 & obliquus & 668 & Buffalo & 148 & Rush & 129 \\
\hline Glaucium & 416 & Shortii & 668 & $\mathrm{Br}$ & 119 & Rye & 165 \\
\hline luteum & 416 & suberosus & 668 & Canada Blue & 155 & Salt Marsh & 143 \\
\hline Glaucous Willow & 325 & Good-King-Henr & & Canary & 121 & Salt Reed & 143 \\
\hline Glaux & 647 & & 366 & Catch-fly & 120 & Sand & 149 \\
\hline maritima & 647 & Goodyera & 315 & Common Hair & 140 & Saw & 202 \\
\hline lecoma hederacec & & Menziesii & 315 & Cord & 142 & $\mathrm{Sc}$ & 433 \\
\hline & 697 & $8 \operatorname{cen} 8$ & 315 & Cotton & 195 & Scutch & 144 \\
\hline Gleditsia & 504 & & 315 & Couch & 166 & Sea Spear & 160 \\
\hline & 50 & tesselata & 315 & Crowfoot & 147 & Seneca & 122 \\
\hline net & 504 & Goose Grass & & & 78 & Sesame & 92 \\
\hline Globe Amaranth & 374 & 147, & 74 & Dog's-tail & 154 & Slough & 142 \\
\hline Thistle & 856 & Gooseberry & 450 & $\mathrm{Eel}$ & 8,85 & Smut & 131 \\
\hline
\end{tabular}




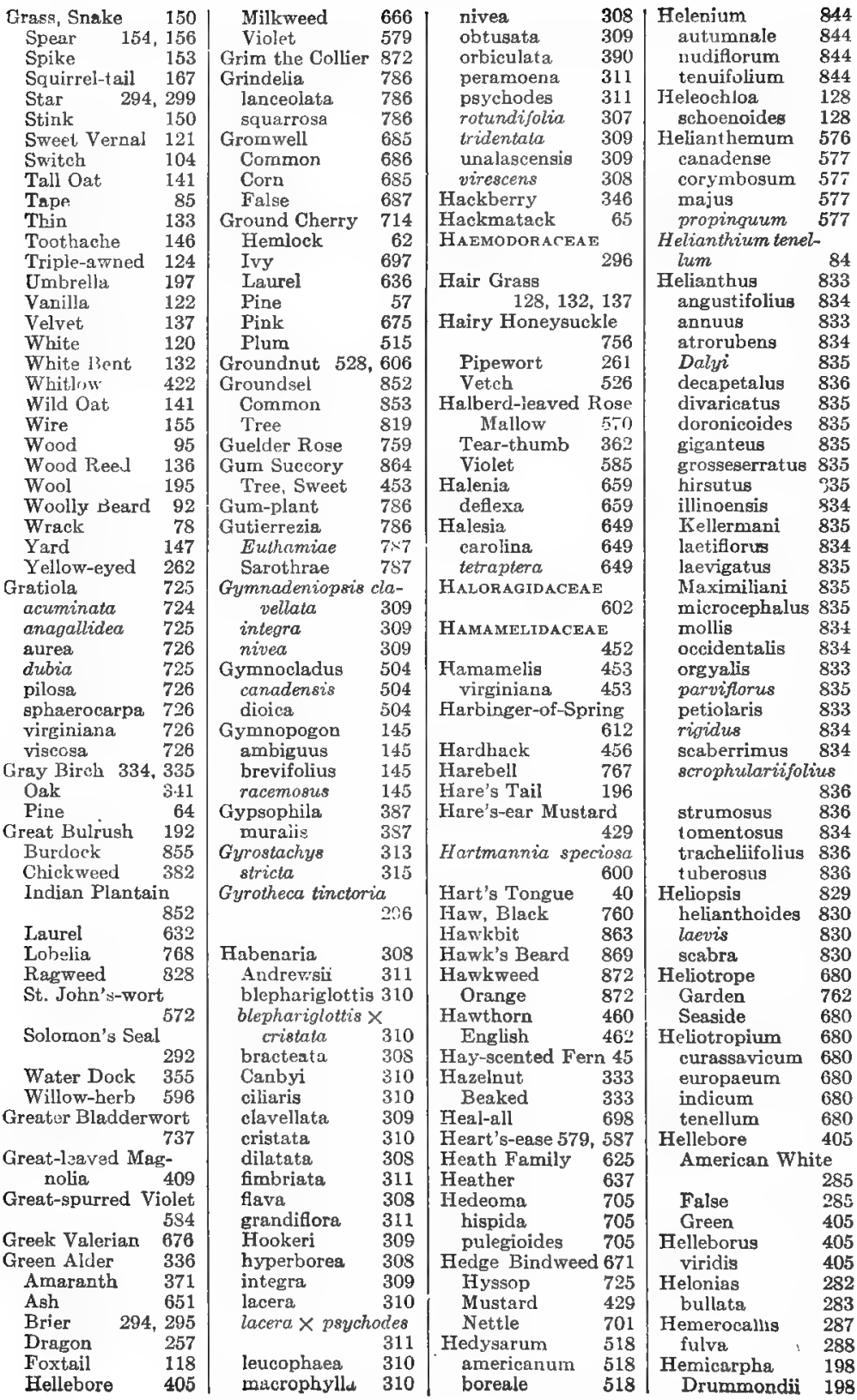


Hemicarpha micrantha occidentalis 198 subsquarrosa 198

Hemlock

Ground

Parsley

Poison

Water

Hemp

Indian

Nettle

Nettle, Common

Nettle, Red $\quad 699$

Water

373

Hemp-weed, Climbing

Henbane

Black

784

Henbit

Hen-and-chickens

Hepatica

acuta

acutiloba

Hepaica

triloba

Heracleum

lanatum

716

716 700

Sphondylium

Herb Robert 535

Herba Impia 819

Hercules' Club 806

Herd's Grass 129, 132

Herpestis

724

amplexicaulis 724

Monniera $\quad 724$

nigrescens 724

rotundifolia 724

Hesperis

matronalis

Heteranthera

dubia

graminea

limosa

reniformis

Heterotheca

Lamarckit

subaxillaris

Heuchera

americana

crinita

Curtisii

glauca

hirsuticaulis

hispida

lancipetala

longiflora

macrorhiza

parviflora

pubescens

roseola

Rugeli讠

villosa

Hexalectris aphylla

Hexastylis

448

448

448

447

448

447

447

448

448

447

447

319

319

352

arijolia
Shuttleworthii
virginica
Hibiscus

352

Hibiscus

Crimson-eyed

incanus

lasiocarpus

militaris

Moscheutos

oculiroseus

eyriacus

Trionum

White

Hickory

Broom

Shag-bark

Shell-bark

Swamp

White-heart

Hicoria

alba

aquatica

borealis

carolinae-septen-

trionalis

352
352

569

570

570

570

570

569

570

569

570

570

331

332

331

331

332

332

331

332

332

332

glabra

laciniosa

331

microcarpa

332

minima

320

ovata.

332

pallida

Pecan

villosa

Hicorius

Hieracium

aurantiacum

canadense

florentinum

floribundum

Greenii

Gronovii

longipilum

marianum

murorum

paniculatum

Pilosella

praealtum

pratense

scabrum

umbellatum

venosum

vulgatum

Hierochloë

alpina

borealis

odorata

331

332

331

332

331

872

872

874

873

872

873

873

874

873

874

873
872

873

872

873

874

873

874

121

122

122
High Blueberry 640 Mallow 568

High-bush Cranberry

Highwater-shrub 827

Hippuris vulgaris

Hoary Alder

Pea

Plantain

Vervain

Willow

605

337

514

745

689

Hobble-bush

Hog Peanut

Hog-weed

Holcus

lanatus

Holly

American

Dahoon

Family

Fern

Mountain

Hollyhock

Holosteum

umbellatum

Holy Grass

Homalobus tenellus

Homatocenchrus 517

Honesty

Honewort

615

Honey Loeust $\mathbf{5 0 4}$

Honeysuckle

754

American Fly 755

Bush

754

European Fly 755

Family $\quad 754$

Hairy 756

Japanese $\quad 755$

Mountain Fly 755

Swamp Fly 755

Tartarian

Trumpet

755

Yellow

631

Hooked Crowfoot 397

Hop

Clover

Common

Hornbeam

Tree

Hordeum

jubatum

nodosum

Pammeli

pusillum

Horehound

Black

Common

Fetid

Water

347

509

347

333

537

167

167

168

168

168

696

701

696

709

Poppy

Hornbeam

American

American Hop

Hop

Horned Rush

Hornwort

Family

Horse Balm

Brier

Gentian 
Hydrophyllum $676 \mid$ Ilex appendiculatum

earadense $\quad 677$

macrophylium 677

patens

677

virginianum 677

Hymerocallis 298 occidentalis 298

Hymenopappus 843 carolinensis 843 corymbosus $\quad 843$ scabiosaers - 843

BYMeNOFH YLLAGEAE

Hyoscyamus 71 niger

716

HYPERICACEAE 57

Hypericum

adpressum

angulosum,

Ascyron

Bissellii

boreale

canadense 674,575

cistifolium $\quad \mathbf{5 7 4}$

corymbosum $\quad 573$

densiflorum $\quad 573$

dolabriforme $\mathbf{5 7 4}$

Drummondii 575

ellipticum $\quad \mathbf{5 7 4}$

galioides $\quad 573$

gentianoides 575

gravieolens $\quad \mathbf{5 7 3}$

gymnanthum 575

Kalmianum $\quad 573$

maculatum $\quad 573$

majus $\quad 575$

mutilum 574

nudicaule $\quad \mathbf{5 7 5}$

perforatum $\quad 573$

petiolatum $\mathbf{5 7 5}$

prolificum $\quad 573$

pseudomaculatum

573

punctatum $\quad 573$

sphaerocarpum 574

virgatum $\quad \mathbf{5 7 4}$

virginicum $\quad 575$

Hypochaeris 863

glabra

radicata

IIypopitys american

$\begin{array}{cc}\text { Hypopitys } & 630 \\ \text { lanuginosa } & 630 \\ \text { Hypoxis } & 299 \\ \text { erecta } & 299 \\ \text { hirsuta } & 299 \\ \text { Hyssop } & 706 \\ \text { Giant } & 696 \\ \text { Hedge } & 72 \\ \text { Water } & 72 \\ \text { Hyssopus } & 706 \\ \text { officinials } & 70 \\ \text { Hystrix } & 170 \\ \text { Hystrix } & 17 \\ \text { patula } & 77\end{array}$

Ilex

Beadlei

bronxensia

Cassine

Dahoon

decidua

glabra

laevigata

lucida

mollis

monticola

myrtifolia

opaca.

verticillata

vomitoria

Ilicioides mucronato

555

ILLECEBRACEAE 376

Ilysanthes

anagallidea

725

attenuata

725

725

dubia

riparia

Immortelle

Impatiens

aurea

biflora

fulva

noli-tangere

pallida

Imperatoria

Ostruthium

Indian Bean

Chickweed

Cucumber-root

Currant

Grass

Hemp

Mallow

Physic

Pink

Pipe

Plantain

Poke

Rice

725

725

374

560

560

560

560

560

560

621

621

741

377

293

757

589

95

662

566

457

653

629

852

285

Strawberry 480

Tobacco $\quad 769$

Turnip

257

India-wheat

Indigo, Blue False

False $\quad 505,512$

Wild

Inkberry

506

Innocence

752

Inula.

824

Helenium $\quad 824$

Iodanthus

433

pinnatifidus 433

Ionactis linarifolia

$\begin{array}{ll} & \\ \text { Ionidirem } & 815\end{array}$

815
579

Ioxylon pomiferum

Ipecac, American
Ipomoea

coccinea

hederaca

lacunosa

pandurata

purpurea

Quamoclit

Iresine

celosioides

paniculata

IRIDACEAE

Iris

caroliniana

cristata

Dwarf

Dwarf Crested

Family

foliosa

fulva

germanica

hexagona

Hookeri

lacustris

Lake Dwarf

ochroleuca

orientalis

prismatica

pseudacorus

setosa

verna

versicolor

Yellow

Iron Oak

Ironweed

Ironwood

Isanthus

brachiatus

saeruleus

Isnardia palustris

IsOËTACEAE

Isoëtes

Bootiti

Butleri

canadensis

Dodgei

Eatoni

echinospora

Engelmanni

foveolata

Gravesii

Harveyi

heterospora

hieroglyphica

macrospora

melanopoda

riparia

saccharata

Tuckermani

Isopyrum

biternatum

Isotria affinis

verticillata

Italian Clover

Rye Grass

Woodbine

Itea

virginica
$670 \mid$ Iva

827

670 ciliata $\quad 827$

670 frutercens 827

670 imbricata 827

670

670

670

373

374

374

299

299

300

301 Jack-in-the-Pulpit

$300 \quad 257$

301

299

300

300

300

300

300

301

301

300

300

300

300

300

300

299

300

339

780

333,334

693

693 693

595

58

58

60

61

61

61

60

60

61

60

61

59

59

59

59

61

60,61

60

404

404

312

312

509

165

756

450

450

oraria 827

xanthifolia $\quad 827$

Ivy, Coliseum 720 
Juncus canadensis

conglomeratus 273

debilis

dichotomus 271

diffusissimus 276

Dudleyi 271

effusus 273

filiformis $\quad 273$

Gerardi 270

Greenei $\quad 272$

gymnocarpus 273

interion 271

Leersii 273

marginatus 278

maritimus 273

megacephalus 276

militaris 275

monostichus 271

nodosus 275,276

oronensis $\quad 272$

pelocarpus

274,875

phalus 275

repens 278

277

robustus $\quad 277$

Roemerianus 273

scirpoides 275,276

secundus 271

setaceus $\quad 272$

Smithii $\quad 273$

stygius $\quad 277$

subtilis 275

tenuis 270,271

Torreyi 276

trifidus $\quad 270$

Vaseyi 272

June Grass $\quad 156$

Juneberry $\quad 459$

Jungle Rice $\quad 118$

Juniper

Common

Juniperus

communis

horizontalis

nana

Sabina

virginiana

Jussiaea

decurrens

diffusa

repens

Kallstroemia

maxima

Kalmia

angustifolia

carolina

glauca

hirsuta

latifolia

polifolia

KaIm'g St. John'swort

Kenilworth Ivy 720

67

67

594

594

594

594

633

633

633

633

633
Kentucky Blue Grass

$\begin{array}{ll} & 156 \\ \text { Coffee-tree } & 504\end{array}$

Kidney Bean $\quad 528$

Kring Devil 872, 873 Nut

Kinnikinnik

Knapweed

Knautia

arvensis

Knawel

Kneiffia

Alleni

fruticosa

glauca

linearis

linifolia

longipedicellata 600

pratensis $\quad 600$

pumila $\quad 600$

Knotweed $\quad 357$

Knotwort Family

Kobresia

376

elachycarpa 203

Kochia

Scoparia

365

Koeleria

cristata

Koellia

albescens

aristata

flexuosa 707

hyssopifolia $\quad 707$

incana

mutica

montana

pilosa

pycnanthemoide

$\begin{array}{ll} & 707 \\ \text { verticillata } & 708\end{array}$

virginiana 708

Koniga maritima 424

Korycarpus dianarus

Kostelet.zkya virginica

Kraunhia

frutescens

macrostachys

Krigia

515

amplexicaulis 863

Dandelion 863

occidentalis 862

virginica $\quad 862$

Kuhnia eupatorioides 785 glutinosa 785

Kuhniastera candida

foliosa

villosa

Kuhnistera

multiflora

violacea

Kyllinga

pumila
332

365

708

153

569

569

515

515

LABIATAE

Labrador Tea

Lacinaria oraminifolia

scariosa

Smallii

spicata

squarrosa

Laciniaria

cylindracea

elegans

graminifolia

punctata

pycnostachya

scariosa.

spicata

squarrosa

Lacnanthes

tinctoria

Lachnocaulon

anceps

Lactuca

acuminata

campestris

canadensis

floridana

hirsuta

integrifolia

leucophoea

86

866,867

ludoviciana

Morssii

pulchella

sagittifolia

saligna

sativa

scariola

spicata

Steelei

villosa

virosa

Ladies' Tobacco

Tresses

Lady Fern

Lady's Mantle

Lady's Slipper

Large Yellow 307

Ram's Head

Showy

Small White 307

Smaller Yellow 306

Stemless

Lady's Sorrel

Thistle

Thumb

Lagenaria vulgaris

Lake Cress

Dwarf Iria

Lamb Succory

Lambkill

513

Lamb's Lettuce Quarterg

Lamium

album

amplexicaule

maculatum

purpureum

785
690 Lampsana

861

630 Lance-leaved Violet

786 Lapland Rose Bay

786

786 Laportea 348

785 Lappula 681

785 deflexa 681

785 echinata 682

785 floribunda 682

786 Redowskii 682

785 texana 682

786 virginiana 681

786 Lapsana 861

786 communis 861

785 Larch 64

296 American 65

296 Black 65

261 Large Cane 171

262 Cranberr 641

866 Yellow Lady's

Slipper

Larger Blue Flag

307

299

Large-toothed Aspen

Larix

328

americana 65

decidua 65

europaea 65

laricina $\quad 65$

Larkspur $\quad \mathbf{4 0 5}$

Dwarf $\quad 406$

Field 406

Tall 406

Late Low Blueberry

$868 \quad 640$

867 Lathyrus $\quad 527$

868 latifolius $\quad \mathbf{5 2 7}$

866 maritimus 527

myrtifolius $\quad 527$

ochroleucus $\quad 527$

palustris $\quad 527$

pratensis $\quad \mathbf{5 2 7}$

tuberosus $\quad \mathbf{5 2 7}$

venosus $\quad \mathbf{5 2 7}$

LAURACEAE 413

Laurel 633

Family 413

Ground $\quad 636$

Great $\quad 632$

Magnolia $\quad \mathbf{4 0 9}$

Mountain 633

Oak $\quad 344$

Pale 633

Sheep 633

Laurestinus $\quad \mathbf{7 5 8}$

Lavauxia triloba 601

Lavender, Sea 643

Lead Plant $\quad 512$

Leadwort Family

Leafeup $\quad \mathbf{8 2 4}$

Leather Flower 403

Leaf 636

Leptherwood

553,589 


\begin{tabular}{|c|c|c|c|c|c|c|c|}
\hline vorthia & 433 & ale & 425 & 7 & 785 & LINACEAx & 710 \\
\hline Michauxii & 434 & sativum & 425 & cylindra & 785 & Linaria, & \\
\hline torulosa & 434 & virginieum & 425 & elegans & 785 & canadengia & 720 \\
\hline uniflora & 434 & Lepigonum & 378 & graminifolia & 786 & Cymbalaria & 720 \\
\hline echea & 577 & Leptamnium & 739 & punctata & 785 & Ela 'ine & 720 \\
\hline intermedia & 578 & \multicolumn{2}{|l|}{ Leptandra virginica } & pyenostachya 78 & 786 & minor & 20 \\
\hline juniperina & 578 & & 727 & scariosa & & spuria & 0 \\
\hline Leggettii & 579 & \multicolumn{2}{|l|}{ Lepitilon canadense } & spicata & 786 & supina & 719 \\
\hline major $\quad 577,5$ & 578 & & 818 & squarrosa & & vulgaris & 719 \\
\hline maritima & 578 & divaricatum & 818 & Ligústicum & 618 & Linden & \\
\hline & & Lepto & 613 & lium & & Family & \\
\hline iformis & 579 & echinata & 613 & dense & 618 & Lindera Benzoin & 414 \\
\hline losa & 579 & & 613 & scothicum & & melissaefolia & 414 \\
\hline & 578 & Lepto & 147 & Ligustrum & & Ling & 637 \\
\hline & & & 147 & & & Linnaea & (2) \\
\hline lia & 578 & aris & 148 & Lilac & 652 & borealis & 57 \\
\hline vill & 57 & & 147 & non & 652 & Lin & r \\
\hline Ledum & 630 & & 147 & Lila & & articum & 32 \\
\hline groenlandicum 6 & 630 & Lept & 96 & & & floridan & 2 \\
\hline latifolium $=6$ & 630 & & 96 & LiL & & hymile & 31 \\
\hline palu & & Lept & 165 & Lili & & & 31 \\
\hline Leek & & & 165 & de & & & \\
\hline eers & 12 & Les] & 522 & num & & rit & 31 \\
\hline len & & & 52 & & & & 00 \\
\hline & & & 524 & & & & 2 \\
\hline & & & 52 & lanceolatum & & aum & \\
\hline egou & & & 523 & \multicolumn{2}{|l|}{ philadelphieum } & vi & 532 \\
\hline & & & 524 & & & -10 & 87 \\
\hline$p a$ & & & 524 & $\mathrm{n}$ & & jip & 10 \\
\hline & & & 524 & & 288 & lia & \\
\hline $\mathrm{SAE}$ & & hya & 525 & $\mathrm{um}$ & 288 & & 18 \\
\hline Lei & & & 524 & Lily & & ha & 98 \\
\hline & & & 523 & 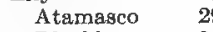 & & & 98 \\
\hline CEAE & 330 & $m$ & 524 & & 1 & ip & 389 \\
\hline Leio & & & 523 & Day & & ce & 0 \\
\hline bu & & & 52 & & & & 89 \\
\hline Lemr & & & 52 & & & & 390 \\
\hline cyclostasa & & & 52 & & & Liq & 453 \\
\hline minor & & & 52 & 2 & 29 & iffua & 453 \\
\hline dsilla & & & 52 & Red 2 & 288 & Liq & 518 \\
\hline & & & 524 & Sw & & & 749 \\
\hline & & & 524 & 3 & 391 & Liric & 409 \\
\hline LEM & & & 52 & & 288 & $a$ & 409 \\
\hline Lems & & & 524 & $8-c$ & 288 & List & 316 \\
\hline UENTI & & & 424 & Water & 391 & at $\mathbf{a}$ & 316 \\
\hline & & & 424 & \multicolumn{2}{|l|}{ Wild Orange-red } & & \\
\hline eor & & & 424 & & & & \\
\hline & & & 42 & & & & 16 \\
\hline & 8 & & 42 & & 288 & & \\
\hline & 864 & Les & 39 & Pond 3 & 390 & Lith & \\
\hline & 86 & Let & 86 & Lim & & um & \\
\hline & 86 & & 867 & & & & 68 \\
\hline Leon & & & 762 & um 6 & 660 & & \\
\hline Cardi & 70 & & 86 & & 661 & & \\
\hline Marrubia日 & & & 44 & & 661 & & \\
\hline & 700 & & 87 & les & 661 & la & \\
\hline & & & 866 & \multicolumn{2}{|c|}{$\begin{array}{l}\text { nymphonaes } \\
\text { trachyspermum } 661\end{array}$} & arifolium & 68 \\
\hline Lep & B32 & \multicolumn{2}{|c|}{ Leucophysalis grandi- } & Limnobium & 86 & affing & \\
\hline & & & & Spongia & 86 & Lits & \\
\hline & 832 & Leu & 634 & \multicolumn{2}{|l|}{ Limnorchis dilutata } & 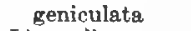 & \\
\hline Lepa & 590 & & 634 & & 308 & Litt & \\
\hline & & & & & 30 & & \\
\hline nois & 590 & & 634 & $\operatorname{Lim}$ & 312 & & \\
\hline epid & & & 68 & & 643 & ak & \\
\hline & & & 334 & 6 & 64 & $\mathrm{I}-\mathrm{e}$ & \\
\hline & & Levi & 620 & Lim & 725 & af & \\
\hline & 42 & & 62 & & 7. & Lizs & \\
\hline intermediun & 42 & offic & 921 & tenuiffolia & 725 & Loama Family & \\
\hline
\end{tabular}




\begin{tabular}{|c|c|c|c|c|c|c|c|}
\hline LOASACEAE & 588 & Loosestrife 592,6 & 645 & campestris & 279 & \multirow{2}{*}{\multicolumn{2}{|c|}{$\begin{array}{l}\text { Lyre-leaved Sage } 702 \\
\text { Lysias Hookeriana }\end{array}$}} \\
\hline Lobelia & 768 & False & 594 & confusa & 279 & & \\
\hline amoena & 769 & Family & 591 & hyperborea & 279 & & \\
\hline Canbyi & 769 & Spiked & 592 & nemorosa & 279 & orbiculata & 310 \\
\hline cardinalis & 768 & Swamp & 592 & parviflora & 279 & Lysiella obtusata & 309 \\
\hline Dortmanna & 770 & Tufted & 646 & saltuensia & 279 & Lysimachia & 645 \\
\hline Family & 768 & Lophanthus & 696 & spadicea & 279 & foliosa & 645 \\
\hline glandulosa & 769 & anisatus & 697 & spicata & 279 & Nummularia & 645 \\
\hline Great & 768 & nepetoides & 696 & vernalis & 279 & producta & 645 \\
\hline inflata & 769 & \multicolumn{2}{|c|}{ scrophulariaefolius } & Lychnis & 384 & punctata & 645 \\
\hline Kalmii & 769 & & 697 & alba & 384 & quadrifolia & 645 \\
\hline leptostachys & 769 & Lophiocarpur & 83 & chalcedonica & 384 & stricta & 645 \\
\hline Nuttallii & 769 & Lophiola & 296 & corc naria & 384 & terrestris & 645 \\
\hline paludosa & 770 & americana & 297 & dioica & 384 & thyrsitlora & 646 \\
\hline puberula & 769 & aurea & 297 & diurna & 384 & vulgaris & 645 \\
\hline siphilitica & 768 & Lophotocarpus & 83 & Drummondii 3 & 385 & LYTHRACEAE & 591 \\
\hline spicata & 769 & calycinus & 84 & Flos-cuculi & 384 & Lyt & 592 \\
\hline Water & 770 & depauperatus & 83 & Githago & 384 & ala & 592 \\
\hline LOBELIACEAE & 768 & spatulatus & 83 & Scarlet & 384 & opifolia & 592 \\
\hline Loblolly Bay & 571 & spongiosus & 83 & gertina & 384 & & 592 \\
\hline Pine & 63 & Lopseed & 743 & Lycium & 716 & & 592 \\
\hline Lobularia & 424 & Family & 743 & halimifolium & 716 & tum & 593 \\
\hline tima & 424 & LORANTIACEAE & 351 & vulgare & 716 & Vulueraria & 592 \\
\hline Locu & 514 & \multicolumn{2}{|c|}{ Lotus $\quad 392,511$} & \multicolumn{2}{|l|}{ Lycopersicon escu- } & & \\
\hline Bristly & 514 & americanus & 511 & lentum & 712 & Macartny Rose & 496 \\
\hline Clammy & 514 & corniculatus & 511 & LrCOPODIACEAT & 54 & $\mathrm{Mac}$ & 347 \\
\hline $\mathrm{Co}_{4}$ & 514 & Lousewort & 734 & Lycopodium & 54 & ntiaca & 347 \\
\hline Honey & 504 & Common & 734 & adpressum 55 , & 56 & fera & 347 \\
\hline Water & 504 & Lovage & 620 & alopecuroides & 55 & Macrocalyx & 677 \\
\hline Logania Family & 652 & Scotch & 618 & annotinum & 56 & Madder Family & 746 \\
\hline LOGANIACEAE & 652 & Love-in-a-Mist & 405 & carolinianum & 56 & Field & 747 \\
\hline Loiseleuria & 632 & Love Vine & 671 & \multicolumn{2}{|c|}{ Chamaecyparissus } & \multicolumn{2}{|c|}{ Mad-dog Skulleap } \\
\hline procumbens & 633 & Low Birch & 336 & & 57 & & 694 \\
\hline Lolium & 165 & \multicolumn{2}{|c|}{ Black Blueberry } & tum & 56 & $\mathrm{Ma}$ & 682 \\
\hline festucaceum & 165 & & 639 & lanatum & 57 & $\mathrm{Ma}$ & 408 \\
\hline orum & 165 & Cudweed & 823 & oidentm & 56 & inata & 409 \\
\hline $\mathrm{p}$ & 165 & Clover & 509 & atum & 56 & & 408 \\
\hline tum & 165 & Spear Grass & 155 & um & 55 & $\mathbf{F}$ & 409 \\
\hline Loma & 619 & \multicolumn{2}{|c|}{ Sweet Blueberry } & rum & 56 & & 409 \\
\hline ium & 620 & & 639 & philum & 55 & t-leaved & 409 \\
\hline orientale & 620 & Lucerne & 510 & aefolium & 56 & $\mathrm{~L}$ & 409 \\
\hline \multirow{2}{*}{\multicolumn{2}{|c|}{ Lombardy Poplar }} & \multirow{2}{*}{\multicolumn{2}{|c|}{ Lucretia Dewberry }} & Selago & 55 & macrophylla & 409 \\
\hline & & & & -7 & 56 & $\mathrm{Sr}$ & 409 \\
\hline Long I & 265 & Ludvigia & 594 & tristachyum & 57 & tripetala & 409 \\
\hline Long-leaved Pin & e 64 & alk & 595 & Lycopsis & 683 & $U n$ & 409 \\
\hline Long-spurred V & olet & rnifolia & 595 & nsis & 683 & virgi & 409 \\
\hline & 587 & arcuata & 595 & Lye & 709 & IACEAE & 408 \\
\hline Long-st & anes- & cylindrica & 595 & americanus & 710 & Maianthemum & 291 \\
\hline $\mathrm{bi}$ & 536 & dulosa & 595 & & 709 & Cndence & 291 \\
\hline Lonicera & 754 & & 595 & nunis & 709 & Pink & 387 \\
\hline & 755 & & 595 & paeus & 710 & Maidenhair & 35 \\
\hline sis & 755 & stris & 595 & luei & 709 & Mairania alpina & 637 \\
\hline Caprifolium & 756 & polycarpa & 595 & membranaceus & 709 & Malapoenna genic & \\
\hline Uapliso & 755 & sphaerocarpa & 595 & - rubellus & 709 & ulata & 414 \\
\hline dioica & 756 & Ludwigiantha arcu & wata & sessilifolius & 709 & Malaxis & 317 \\
\hline flava & 757 & & 595 & & 710 & 政 & 317 \\
\hline glauca & 757 & Lunaria & 433 & & 709 & Male Berry & 635 \\
\hline glaucescens & 756 & annua & 433 & jeus & 709 & Mallow & 568 \\
\hline grata & 756 & rediviva & 433 & Lygodegmia & 868 & Comran & 568 \\
\hline hirsuta & 756 & Lungwort & 685 & & 868 & Curled & 568 \\
\hline olucrata & 755 & Golden & 874 & & 86 & False & 567 \\
\hline nica & 75 & Sea & 685 & Lygodium & 46 & Family & 566 \\
\hline & 755 & Lupine & 508 & palmatum & 46 & Glade & 569 \\
\hline w1 & 755 & Wild & 508 & Lyme Grass & 168 & Halberd-leaved & \\
\hline erv & 756 & Lupinus: & & Lyonia & 635 & Rose & 570 \\
\hline sempervi & 75 & perennis & 508 & ligustrina & 635 & High & 568 \\
\hline livan & 75 & Luzula & 278 & mariana & 635 & Indian & 566 \\
\hline tatarica & 755 & arcuata & 279 & nitida & 635 & Marsh & 567 \\
\hline
\end{tabular}




\begin{tabular}{|c|c|c|c|c|c|c|c|}
\hline Mallow, Muak & 568 & Pine & 64 & arenicola & 522 & gentilis & 711 \\
\hline Poppy & 568 & Rosemary & 643 & bracteosa. & 520 & longifolia & \\
\hline Red False & 567 & St. John's-wort & 575 & canadensis & 522 & piperita & \\
\hline Rose & 569 & Speedwell & 727 & canescens & 520 & Pulegium & $\infty$ \\
\hline Swamp Rose & 569 & Marshallia & 842 & Dillenii & 521 & rotundifolia & 10 \\
\hline Yellow False & 567 & grandiflora & 842 & glab & 20 & sativa & \\
\hline Malus & 458 & latifolia & 842 & grandifiora & 19 & spicata & \\
\hline angustifolia & 45 & obo & 842 & illinoensis & 21 & sylvestris & \\
\hline baccata & 45 & trin & 842 & laet & 521 & viridis & \\
\hline coronaria & 45 & Marsil & 49 & folia & 520 & Mentzelia & \\
\hline & & ifolia & 50 & Landica & 522 & petala & \\
\hline Malus & 45 & vestita & 50 & Michauxii & 519 & sperma & \\
\hline falva & 568 & EACEAE & 49 & nuo & 519 & ithes & 660 \\
\hline Alcea & & Mar & 741 & & 522 & & 60 \\
\hline & & & 741 & euca & 519 & Tenziesia & 632 \\
\hline $\mathrm{m}$ & & & 742 & ¿lata & & & 632 \\
\hline & & idea & 742 & Lora & & globularis & 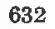 \\
\hline & & MAR & 741 & olia & & & \\
\hline vert & 68 & Mar & 846 & rio & 522 & Merc & \\
\hline MALY & $\mathbf{b}$ & of Peru & 375 & folia & 522 & & 543 \\
\hline Malv & 56 & Mas & 621 & & 521 & Mer & 543 \\
\hline & & $\mathrm{Ma}$ & 846 & ora & 521 & -seeded & 543 \\
\hline & 567 & milla & 847 & Mela & 732 & Meriolix intermed & dia \\
\hline Mamil & 58 & dis & 847 & num & 733 & & 601 \\
\hline ensis & 58 & & 846 & & & lata & \\
\hline & 58 & rioides & 847 & & 733 & l-we & 605 \\
\hline Mand & 411 & sus & 847 & $\mathrm{Me}$ & 284 & $\mathrm{Me}$ & 685 \\
\hline Manisuris cy & rica & Matri & 716 & & 285 & $\mathrm{ma}$ & 685 \\
\hline & 92 & Co & 716 & rum & & lata & 685 \\
\hline 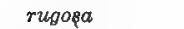 & 92 & Matteuccia Struth & & soum & 285 & virginica & 685 \\
\hline Ianna Grass & 158 & opteris & 45 & virginicum & 285 & \multicolumn{2}{|c|}{ Mesadenia atriplici- } \\
\hline \multirow{2}{*}{\multicolumn{2}{|c|}{ Man-of-the-Earth }} & May Apple & 411 & \multicolumn{2}{|c|}{ Melastoma Family } & folia & 852 \\
\hline & & Mayac & 263 & & 593 & ormis & 852 \\
\hline laple & 557 & & 263 & MACEAE & & tuberosa & 852 \\
\hline Black & 558 & Far & 263 & & 593 & \multirow{2}{*}{\multicolumn{2}{|c|}{ Mespilus apiz̈folia }} \\
\hline Family & 557 & iuxii & 263 & & 151 & & 470 \\
\hline Mo & 558 & EAE & 263 & & 15 & ensis & 460 \\
\hline $\operatorname{Re}$ & 55 & $\mathrm{Ma}$ & 636 & & 1 & ta & 477 \\
\hline & & & 58 & & 152 & llata 470 , & \\
\hline & & & & & 15 & nopyrum & 477 \\
\hline & 5 & & 4 & ora & 152 & Grass & 145 \\
\hline & & $\mathbf{y}$ & 5 & & 1 & Poppy & 416 \\
\hline & & & 1 & & & & 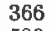 \\
\hline Wh & & I Grass & 12 & & $1 \pi$ & $\mathrm{n}$ & 59 \\
\hline Iaple-leaved Go & ose- & & 15 & & 5 & & 58 \\
\hline$f$ & & & 61 & & 5 & elis & \\
\hline MA & & & 39 & & & hemum & 725 \\
\hline Mare & & $\mathrm{R}$ & 40 & & 5 & \multicolumn{2}{|c|}{ micranthemoides } \\
\hline Marguerite & 8 & & & & 5 & & 725 \\
\hline \multicolumn{2}{|l|}{ Mariana mariana } & Mea & 45 & & 510 & & 725 \\
\hline & 8 & & 29 & & 510 & lis & 318 \\
\hline Lari & & an & 29 & & & phyllos & 3 \\
\hline & & & 5. & & 7 & lossoides & 318 \\
\hline & & & & lis & & & \\
\hline & & Llata & 5 & & 76 & the & 439 \\
\hline m, Wild & & & & & 76 & & 439 \\
\hline Marr & & & 510 & \multicolumn{2}{|l|}{ Menispermacha } & Mik & 784 \\
\hline um & & & 510 & & 410 & scandens & 784 \\
\hline & & & 51 & aum & 411 & \multicolumn{2}{|c|}{ Mild Water Pepper } \\
\hline Aarsh Bellao & & & 51 & dense & 411 & & 362 \\
\hline & & lec & 51 & & 710 & Milf & 845 \\
\hline & & & 51 & roides & 71 & & 603 \\
\hline & & & 51 & & 71 & Mili & 122 \\
\hline finge & & ee & 69 & & 71 & hicarpon & 97 \\
\hline- & & & 697 & & 71 & & 122 \\
\hline $\mathrm{Gr}_{\mathrm{r}}$ & & rium mis- & & & 71 & $8 c m$ & $12^{n}$ \\
\hline & & & 60 & & 71 & & 530 \\
\hline Marigold & & Meibomia & 519 & & 710 & rslane & 547 \\
\hline
\end{tabular}




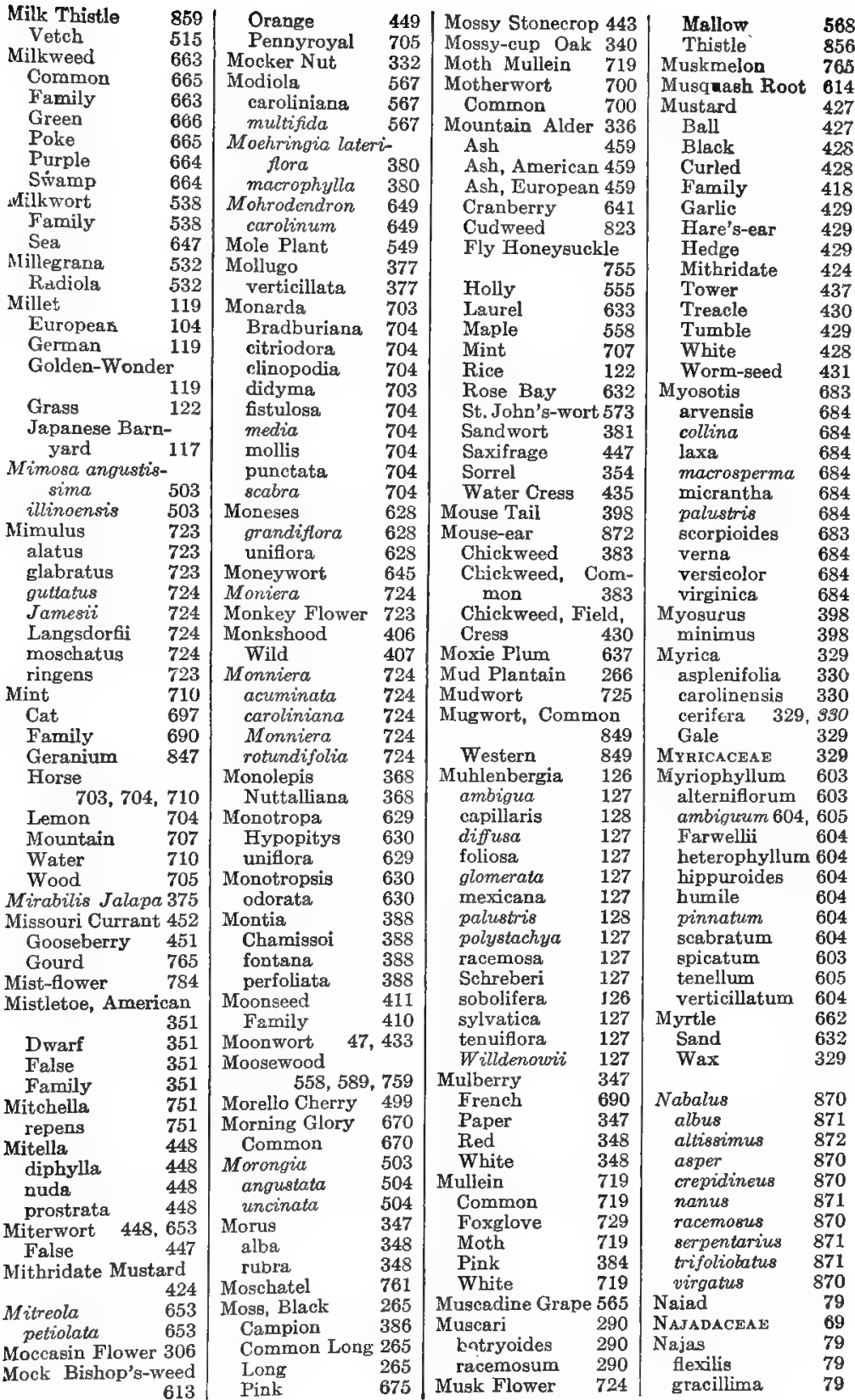




\begin{tabular}{|c|c|c|c|c|c|c|c|}
\hline \multicolumn{2}{|c|}{ Najas guadalupensis } & Hemp & 699 & lacunosum & 660 & laciniata & 599 \\
\hline & 79 & Horse & 713 & peltatum & 661 & linearis & 60 \\
\hline indica & 79 & Red Hemp & 699 & Nyssa & 625 & linifolia & 600 \\
\hline & 79 & Spurge & 541 & aquatica & 625 & longipedicellat & \\
\hline microdon & 79 & Stinging & 348 & biflora & 625 & & 600 \\
\hline Nama & 679 & White Horse & 713 & multiflora & 625 & missouriensis & 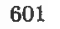 \\
\hline jberry & 760 & Wood & 348 & sylvatica & 625 & mo & 698 \\
\hline $\begin{array}{l}\text { Napaea } \\
\text { dioica }\end{array}$ & $\begin{array}{l}569 \\
569\end{array}$ & $\begin{array}{l}\text { Nettle-leaved Be } \\
\text { flower }\end{array}$ & 767 & uniflora & 625 & $\begin{array}{l}\text { Oakesiana } \\
\text { pallida }\end{array}$ & 599 \\
\hline Narcis & 298 & Vettle-tree & 346 & Oak & 338 & asis & 600 \\
\hline poe & 298 & New Jersey Tea & 562 & Barren & 344 & & \\
\hline Poet & 298 & Nica & 716 & & 340 & ipetala & \\
\hline Pseudo-Narcis & ssus & lodes & 716 & Bear & 343 & ata & 601 \\
\hline & 298 & ficot & 717 & Black & 343 & & 58 \\
\hline art & 282 & & 717 & Black Jack & 344 & & 600 \\
\hline & 282 & & 717 & Black Scrub & 343 & & \\
\hline Nast & 431 & $\mathrm{~m}$ & 717 & $\mathrm{Bu}$ & 340 & uckeye & 559 \\
\hline & 432 & Tigella & 405 & $\mathrm{Cb}$ & 341 & Oit & 50 \\
\hline & 432 & scena & 405 & $\mathrm{Cc}$ & 340 & Birch & 00 \\
\hline & 431 & ead & 831 & & 35 & & \\
\hline & 432 & wering & & & 341 & & \\
\hline rum & 432 & bfly & 385 & Ir & 339 & & 108 \\
\hline & 432 & iight & 712 & salem & 366 & & \\
\hline$s p$ & 432 & & 713 & & 344 & lde & 753 \\
\hline & 431 & ter's & 602 & & 341 & & \\
\hline Neck & 329 & & 712 & cup & 340 & & \\
\hline Neck & 728 & Vill & 127 & up 339 & 340 & OL & \\
\hline & 558 & $\mathrm{Ni}$ & 456 & Pin & 342 & nily & 590 \\
\hline ace & 559 & & 861 & Po & 553 & & 650 \\
\hline Nelumbium luter & & No & 618 & Post & 339 & Ono & 5 \\
\hline & 392 & None & 510 & Red & 342 & $a$ & $b$ \\
\hline $\mathrm{Nel}$ & 392 & North American & & Scarlet & 342 & & 50 \\
\hline & 392 & apaw & 410 & & & & \\
\hline & 392 & Northern Bedstr & & & & $a$ & \\
\hline & 392 & & 749 & Swamp Post & 339 & & 50 \\
\hline Nem & 301 & ape & 564 & Swamp Spanis & & & \\
\hline & 301 & Ash & 537 & & 342 & ON & 59 \\
\hline & 301 & Pine & 64 & p White & 340 & One & \\
\hline Vemop & cicu- & Spruce & 65 & & 343 & & 74 \\
\hline & 555 & lais cusp & & & 339 & $P y$ & Uc \\
\hline mem & 555 & & 869 & Willow & 344 & ded Bur & $\mathrm{Cu}$ \\
\hline & 55 & & 35 & Yellow & & & 76 \\
\hline $\mathrm{Ver}$ & 677 & & 35 & Yellow-barked & 343 & Oni & 28 \\
\hline & 677 & & 35 & Oake & 286 & & 8 \\
\hline & 314 & im & 287 & & 286 & $n$ & \\
\hline & 6 & & 287 & & 286 & & \\
\hline & 697 & & 287 & red Goos & & terig & \\
\hline & 697 & Vup & 390 & foc & 367 & Ono & 85 \\
\hline & 697 & & 391 & 0200 & 140 & & 8 \\
\hline lez & 41 & $\mathrm{um}$ & 391 & & 141 & In & 68 \\
\hline & 4 & $m$ & 391 & & 141 & & 68 \\
\hline & & & & & & um & 68 \\
\hline & 4 & ACEAE & 375 & & 1. & & 68 \\
\hline & 4 & 390 , & 891 & Obc & 66 & & 68 \\
\hline & 4 & & & & & & \\
\hline & & & 39 & & & & 68 \\
\hline & & & 391 & Odo & 7 & a & \\
\hline & 42 & ylla & 391 & $o$ & 734 & p & 47 \\
\hline & & & & & & & \\
\hline & 3 & & 391 & Oen & 5 & $\ln i$ & 47 \\
\hline & & & & & & & \\
\hline Tettle & 348 & & 391 & sola & 598 & & 47 \\
\hline & & & 39 & . & & & \\
\hline & & & 3 & & 5 & $O p l$ & 60 \\
\hline & & & 3 & & & & 64 \\
\hline & & EAE & 3 & & 6 & intern & \\
\hline & & & 660 & & & & 4 \\
\hline & 70 & $1 \mathrm{~m}$ & 66 & 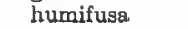 & 50 & opuivolius & \\
\hline
\end{tabular}




\begin{tabular}{|c|c|c|c|}
\hline \multirow{2}{*}{\multicolumn{4}{|c|}{ Upuntia }} \\
\hline & 589 & regalis & 46 \\
\hline cespitosa & 589 & spectabitis & 46 \\
\hline fragilis & 589 & OSMUNDACEAE & 46 \\
\hline humifuea & 589 & Ostrich Fern & 45 \\
\hline mesacantha & 589 & Ostrya & 333 \\
\hline nissouriencis & 589 & virginiana & 334 \\
\hline - oolyacantha & 589 & virginica & 334 \\
\hline Rafinesquii & 589 & Oswego Tea & 703 \\
\hline rulgaris & 589 & Over-cup Oak & \\
\hline rach & 368 & 339 & 340 \\
\hline Orange Grass & 575 & Oxalidaceae & 532 \\
\hline Hawkweed & 872 & Oxalis & 532 \\
\hline Mock & 449 & Acetosella & 533 \\
\hline Osage & 347 & Brittonae & 533 \\
\hline Orange-root & 408 & Bushii & 534 \\
\hline Orchard Grass & 154 & corniculata & 534 \\
\hline ORCHIDACEAE & 304 & cymosa & 534 \\
\hline Orchis & 307 & filipes. & 533 \\
\hline Crane Fly & 319 & grandis & 533 \\
\hline Family & 304 & Priceae & 533 \\
\hline Fringed & 308 & repens & 534 \\
\hline Rggged Fringe & & rifa & 534 \\
\hline & 310 & stricta & 634 \\
\hline Rei & 308 & violacea & 533 \\
\hline olia & 307 & Ox-eye & 829 \\
\hline Shov & 307 & Daisy & 847 \\
\hline spe & 307 & Sea & 833 \\
\hline White Fringed & 310 & Ox-tongue & 864 \\
\hline Yellow Fringe & & Oxybaphus & 375 \\
\hline & 310 & albidus & 375 \\
\hline riganum & 706 & angustifolius & 375 \\
\hline & 706 & floribundus & 375 \\
\hline Ornithogalum & 289 & hir: & 375 \\
\hline & 290 & line & 375 \\
\hline$m$ & 289 & nyctagineus & 375 \\
\hline Orobanchaceate & 739 & ovatus & 375 \\
\hline Orobanche & 740 & Oxycoccus erythro & \\
\hline lata & 740 & carpus & 641 \\
\hline riciana. & 740 & macrocarpus & 641 \\
\hline & 740 & Oxycoccus & 641 \\
\hline rea & 740 & iris & 641 \\
\hline rar & 740 & Oxydendrum & 636 \\
\hline & 740 & arboreum & 636 \\
\hline Oron & 258 & Oxygraphis Cym & $n b a-$ \\
\hline cum & 258 & laria & 394 \\
\hline Orpine & 442 & Oxypolis & 621 \\
\hline Family & 441 & filiformis & 622 \\
\hline Ga & 443 & rigidior & 622 \\
\hline Orthocarpus & 732 & Oxyria & 354 \\
\hline & 732 & & 354 \\
\hline Oryzopsis & 122 & Oxytropis & 517 \\
\hline asperifolia & 123 & campestris & 517 \\
\hline canadensis & 122 & Lamberti & 517 \\
\hline junc & 122 & splendens & 518 \\
\hline rppa & 123 & Oyster-plant & 86 \\
\hline & 122 & & \\
\hline race & 123 & Pachistima & 556 \\
\hline Orage Orange & 347 & Canbyi & 557 \\
\hline Osier & 327 & Pachysandra & 550 \\
\hline Osmo & 612 & procumbens & 551 \\
\hline itylis & 612 & Paepalanthus fla & avi- \\
\hline Claytoni & 612 & dus & 261 \\
\hline icata & 613 & Painted Cup & 732 \\
\hline longistylis * & 61 & Cup, Scarlet & 732 \\
\hline & 61 & Leaf & 548 \\
\hline Osm & 46 & Trillium & 294 \\
\hline $\operatorname{cin}$ & 4 & Paint-brush, & evil's \\
\hline C & 4 & & 80 \\
\hline
\end{tabular}

Pale Corydalis

Dock

Indian Plantain

45

333

334

334
703

Laurel

Touch-me-not 560

Panax

ginseng

\section{6}

quinquefolium 606

trifolium

Panic Grass 100

Panicularia 158

americana

159

brachyphylla $\quad 159$

Panioum 100

aciculare $\quad 106$

aculeatum $\quad 116$

Addisonii $\quad 112$

agrostoides 104

albo-marginatum

$\begin{array}{lr} & 113 \\ \text { amaroides } & 104 \\ \text { amarum } & 104 \\ \text { anceps } & 105 \\ \text { angustifolium } & 106 \\ \text { annulum } & 108 \\ \text { Ashei } & 113 \\ \text { atlanticum } & 111 \\ \text { auburne } & 111 \\ \text { autumnale } & 96\end{array}$

barbulatum

$\begin{array}{lr} & 107,108 \\ \text { Bicknellii } & 107 \\ \text { boreale } & 108 \\ \text { Boscii } & 116 \\ \text { Brittoni } & 113 \\ \text { Bushii } & 107 \\ \text { capillare } & 103 \\ \text { clandestinum } & 116 \\ \text { Clutei } & 108 \\ \text { cognatum } & 96 \\ \text { colonum } & 118 \\ \text { columbianum } & 112 \\ \text { Commonsianum }\end{array}$

Commonsianum

112

commutatum

112,113

condensum 105

consanguineum

$\begin{array}{ll} & \\ \text { crusgalli } & 117\end{array}$

Curtisii 103

decoloratum $\quad 116$

depauperatum 105

dichotomiflorum

$\begin{array}{lr} & 104 \\ \text { dichotomum } & 107 \\ \text { digitarioides } & 103 \\ \text { Eatoni } & 109 \\ \text { ensifolium } & 113 \\ \text { filiculme } & 110 \\ \text { filiforme } & 95 \\ \text { flirameum } & 107 \\ \text { flexile } & 103 \\ \text { Gattingeri } & 103 \\ \text { gibbum } & \mathbf{1 1 7} \\ \text { glabrum } & \mathbf{9 6} \\ \text { habmacarpon } & \mathbf{1 1 1}\end{array}$

hemitomum $10:$

hispidum 114

huachucae $\quad 109$

implicatum 109

lancearium $\quad 114$

lanuginosum

latifolium 117

laxiflorum $\quad 106$

Leibergii $\quad 115$

leucothrix $\quad 109$

Iindheimeri 109

lineare $\quad 96$

linearifolium 106

longifolium 104

lucidum $\quad 107$

macrocatpon 117

mattamuskeetense

108

meridionale $\quad 110$

microcarpon

108,113

miliaceum 104

minimum 103

minus $\quad 103$

mutabile $\quad 114$

Nashianum 114

nemopanthum 107

neuranthum 107

nitidum 109

oligosanthes 114

oricola $\quad 110$

ovale 111,112

patulum $\quad 114$

pauciflorum 115

paucipilum 109

perlongum 105

philadelphicum

pilosum 110

polyanthes

108,113

praecocius 111

proliferum 104

psanmophilum 112

pubescens $\quad 109$

pubifolium $\quad 117$

Ravenelii 115

rostratum 105

sanguinale $\quad 96$

geabriusculum 116

scoparioides 111

scopariurn 115

Scribnerianum 115

serotinum $\quad \mathbf{9 6}$

sphaerocarpun 113

spretum $\quad 108$

stipitatum $\quad 105$

strigosum $\quad 106$

subsimplex 113

subvillosum 110

tennesseense 110

tenus $\quad 113$

tsugetorum 112

unciphyllum

$109,110.113$

verrucosum 103

villosissimum 111 
$\begin{array}{lr}\text { Panicurn villooum } 106 \\ \text { virgatum } & 104 \\ \text { Walteri } & 118 \\ \text { Werneri } & 106 \\ \text { Wilcoxianum } & 115 \\ \text { xalapense } & 106 \\ \text { xanthophysum } 115 \\ \text { xanthospermum }\end{array}$

$\begin{array}{ll} & 111 \\ \text { yadkinense } & 107 \\ \text { Pansy } & 587 \\ \text { Wild } & 587 \\ \text { Papaver } & 416 \\ \text { Argemone } & 416 \\ \text { dubium } & 416 \\ \text { Rhoes. } & 416 \\ \text { somniferum } & 416 \\ \text { PAPAVEaCEAE } & 414 \\ \text { Papaw, Common }\end{array}$

North Americen 410

Paper Birch

Mulberry

Pappoose Root

Parietaria

debilis

debilis $\quad 349$

Parnassia

asarifolia

caroliniana:

grandifolia

palustris

parviflora

Paronychia

argyrocoma

dichotoma

Parosela

Dalea

Paraley

Common

Family

Fool's

Hemlock

Piert

Parsnip

Cow

Meadow

Water

Parsonsia petiolata

Parthenium

auriculatum

integrifolium

repens

Parthenocisaus quinquefolia vitacea

Partridge Berry Pea

Paspalum angustifolium arundinacerm

Boscianum

Bushii

ciliatifolium

circulare

difforme

335

347

412

349

449

449

449

449

449

449

376

376

377

513

513

614

615

607

618

622

493

620

621

619

615

593

826

827

826

826

563

563

563

751

505

97

89

99

89

98

98

99 dilatatum

dissectume

distichum

Elliottii

floridanum

fiuitans

laeve

laeviglume

longipeduncula-

tum

membranaceum 98

mucronatum 97

Mublenbergii 98

pleaipilum

praelongum

prostratum

pubescens

setaceum

stramineum

Walterianum 98

Paspalus furcatus
100

Pasque Flower $\quad 401$

incarnata $\quad 587$

lutea $\quad 587$

Pagsiflonaceat 587

Pasgion Flower $\quad 587$ Family

Pastinaca

sativa

Pasture Thistle 858

Patience Dock 355

Paulownia.

imperialis tomentosa

Pea, Beach

Butterfly

Cow

Everlasting

Hoary

Milk

Partridge

Perennial

Peach

Peach-leaved Willow

Peanut, Hog $\quad \mathbf{3 2 1}$

Pear

Prickly

Pearlwort

Pearly Everlasting

\section{Pecan}

Bitter

Pearcularis

canadensis

Furbishise

lanceolgta

palustris

parviflora

Pellaea

atropurpurea

densa

gracilis

Pellitory

Peltandra

530

734

734

734

734

734

734

37

37

37

37

349

257
$99 \mid$ undulala

99 Penny Cress

Field

Pennyroyal

American

Bastard

False

Mock

Pennywort

Water

Penthorum

sedoides

Pentstemon

acuminatus

albidus

calycosus

canescens

Cobaea

Digitalis

glaber

gracilis

grandiflorus

hirsutus

laevigatus

pallidus

Pentstemon

pubescens

tubiflorus

Peppér Family

Pepperbush, Sweet

Peppergrass

425

Wild

Pepperidge

Peppermint

Pepper-root

Pepper-vine

Pepperwort

Peramium

Perennial Pea

Ray Grass

Perfumed Cherry 498

Perilla

frutescens

ocymoides

Periwinkle

Common

Persea

Borbonia carolinensis pubercens

Persica

Persimmon

Common

Perularia flava

Peruvian Bark mres

258

258

424

705

705

694

693

705

660

611

442

442

721

722

722

722

722

722

722

722

722

722
722

722

722

722

722

320

627

425

625

710

434

563

425

315

527

165

98

711

711

711

661

662

413

413

413

413

499

648

648

308

746

Petalostemum 513

candidum

foliosum

multiflorum

purpureum

villosum

violaceum

Petasites

palmatus 


\begin{tabular}{|c|c|c|c|c|c|c|c|}
\hline \multirow{4}{*}{$\begin{array}{l}\text { Phragmites } \\
\text { communis } \\
\text { Phragmites }\end{array}$} & & & & \\
\hline & 148 & Grape & 564 & \multirow{2}{*}{$\begin{array}{l}\text { resinnsa } \\
\text { rigida }\end{array}$} & \multirow{2}{*}{$\begin{array}{l}64 \\
64\end{array}$} & \multirow{2}{*}{$\begin{array}{l}\text { Pleurogyne } \\
\text { carinthiaca }\end{array}$} & \multirow{3}{*}{$\begin{array}{l}658 \\
659 \\
658\end{array}$} \\
\hline & 148 & Grass & 118 & & & & \\
\hline & 148 & Pignut & 332 & & 64 & rotata & \\
\hline & & Pigweed 365,367 , & 7,371 & \multirow{2}{*}{$\begin{array}{l}\text { Strobus } \\
\text { sylvestris }\end{array}$} & \multirow{2}{*}{63} & \multicolumn{2}{|l|}{ Pluchea. } \\
\hline \multirow{2}{*}{$\begin{array}{l}\text { Phryma } \\
\text { Leptostachya }\end{array}$} & 743 & Winged & 365 & & & bifrons & 319 \\
\hline & 743 & Pilea & 349 & Treda & 63 & camphorata & 819 \\
\hline Phaymacear & 743 & pumila & 349 & virginiana & 64 & foetida & 819 \\
\hline \multirow{2}{*}{$\begin{array}{l}\text { Phrmaceas } \\
\text { Phyllanthus } \\
\text { caroliniensis }\end{array}$} & 544 & Pimbina & 759 & Pinweed & 577 & petiolata & 819 \\
\hline & 545 & Pimpernel & 647 & Pinxter Flower & 631 & Plum & 497 \\
\hline Phyllitis Scoloper & & Common & 647 & Pipe Vine & 353 & Beach & 498 \\
\hline drium & 40 & False & 725 & Piperaceae & 320 & Bullace & 198 \\
\hline Phyllodoce & 633 & Water & 644 & Piperia unalascen & nsis & Canada & 499 \\
\hline coerulea & & Pimpinella & 616 & & 309 & Chickasaw & 498 \\
\hline Physalis & 714 & integerrima & 616 & Pipes & 53 & Ground & 515 \\
\hline aequata & 714 & Saxifraga & 616 & Pipewort & 261 & Moxie & 637 \\
\hline Alkekengi & 715 & Pin Cherry & 498 & Family & 260 & Sand & \\
\hline ang & 714 & Oak & 342 & Hairy & 261 & Wild & 499 \\
\hline bark & 715 & Pinachat & 62 & Pipsissewa 627, & 628 & Wild Goose & 499 \\
\hline Francheti & 715 & Pine & 63 & Pitch Pine & 64 & Plombaginacea & \\
\hline gre & 714 & Drops & 630 & Pitcher-plant & 440 & & 643 \\
\hline Ha & 715 & Family & 62 & Family & 439 & Plume Poppy & 415 \\
\hline ixoce & 714 & Georgia & 64 & Plane Tree Famil & & Plumed Thistle & 856 \\
\hline lanceolata 715 , & 716 & Gray & 64 & & 454 & Plumeless Thistl & \\
\hline longifolia & 715 & Jersey & 64 & Planer Tree & 346 & & 856 \\
\hline riensis & 715 & Loblolly & 63 & Plan & 346 & Preumaria mari & \\
\hline$o b s$ & 715 & Long-leaved & 64 & atica & 346 & tima & 685 \\
\hline per & 714 & Marsh & 64 & PLantaginaceaI & & Poa & 154 \\
\hline Iphica & 715 & Noithern Scrub & b 64 & & 743 & alpina & 156 \\
\hline pr & 715 & Old Field & 63 & Plan & 744 & les & 157 \\
\hline pu & 715 & Pitch & 64 & & 746 & & 15 \\
\hline & 715 & Por & 64 & bo & 745 & mnalis & 157 \\
\hline ata & 715 & ce's & 628 & & 744 & yphylla & 157 \\
\hline & 715 & $\operatorname{Re}$ & 64 & ns & 745 & brevifolia & 157 \\
\hline & 715 & Ser & 64 & & 746 & cae & 15 \\
\hline Physo & 716 & Serub & 64 & & 745 & maniana & 155 \\
\hline des & 716 & Table Mountain & in 64 & & 745 & essa & 155 \\
\hline Physo & 456 & White & 63 & hylla & 748 & & 157 \\
\hline op & 456 & Yellow & 64 & olata & 745 & nens & 155 \\
\hline Physc & 698 & Pineapple Famil & & $\mathbf{m} \varepsilon$ & 745 & flava & 156 \\
\hline & 699 & & 265 & $m a$ & 745 & Аехиова & $15 \%$ \\
\hline int & 699 & Pines & 847 & me & 745 & gla & 156 \\
\hline & 698 & Pine-barren Sand & & onica 745 , &, 746 & naris & 15 \\
\hline 688 & 699 & wort & 381 & Purshii & 745 & laxa & 156 \\
\hline Phyte & 374 & Pinesap & 630 & pusilla & 746 & aoralis & 156 \\
\hline $\mathrm{de}$ & 374 & Swe & 630 & sperma & 746 & sis & 150 \\
\hline Phytolaccacta & & Pine & 575 & $\mathrm{iii}$ & 745 & $a$ & 151 \\
\hline & 374 & Ping & 738 & flora & 74 & & 156 \\
\hline Pices & 65 & vulgaris & 739 & nica & 746 & estris & 157 \\
\hline & 65 & Pink & 387 & Plan & & & 156 \\
\hline & 65 & ford & 387 & aon & 74 & lis & 157 \\
\hline & 65 & Family & 377 & & 745 & & 157 \\
\hline$b$ & 65 & $\mathrm{Fi}$ & 386 & $\mathbf{F}$ & 743 & Podophyllum & 411 \\
\hline asis & 65 & $\mathrm{Gr}$ & 675 & Indian & 852 & & 412 \\
\hline & 6 & & 653 & & 745 & ACEAE & 441 \\
\hline & 65 & Maiden & 387 & & 852 & Pods & $\mathbf{4 4 1}$ \\
\hline & 65 & & 675 & & 26 & hyl'um & \\
\hline & 65 & in & 384 & Pale Indian & 852 & Poet's Narcissus & 298 \\
\hline & 65 & Wi & 386 & Robin's & 873 & Pog & \\
\hline Pickerel-weed & 266 & Pink-root & 653 & esnake & 315 & affinis & 312 \\
\hline $\mathrm{Fa}$ & 266 & Pinus & 63 & Robin's & 817 & divaricata & 312 \\
\hline Picradenia & 844 & australis & 64 & & 745 & ophioglossoide & \\
\hline & 864 & Banksiana & 64 & Water & 84 & & 3 \\
\hline cos & 86 & divaricata & 64 & Plantain-leaved & & & \\
\hline & 864 & echinata & 64 & Everlasting & 820 & trianthophora & 311 \\
\hline Pieris floribunda & 635 & & 64 & ACEAE & 454 & verticillata & 312 \\
\hline or & 635 & & 64 & Plate & 454 & Poison Dogwood & \\
\hline & 635 & palustrig & 64 & ntalis & 454 & & 552 \\
\hline Berry & 374 & pungens & 64 & Pleurisy-root & 664 & Hemlock & 618 \\
\hline
\end{tabular}


F

\begin{tabular}{|c|c|c|c|c|c|c|c|}
\hline oison Ivy & 552 & erectum & 359 & Poplar & 409 & mysticus & \\
\hline 552 , & 553 & exsertum & 358 & Balsam & 329 & natans & 7! \\
\hline Sumach & 552 & Fowleri & 358 & Black & 329 & nitens & \\
\hline I'oke, Common & 374 & Harturightii & 361 & Downy & 329 & Nuttallii & 72 \\
\hline Milkweed & 665 & Hydropiper & 361 & Lombardy & 329 & Oakesianus & \\
\hline okeweed & 374 & \multicolumn{2}{|l|}{ bydropiperoides } & Necklace & 329 & obtusifolius & \\
\hline Family & 374 & & 362 & Silver-leaved & 328 & pauciflorus & \\
\hline Polanisia & 438 & incarnatum & 360 & White & 328 & pectinatus & \\
\hline olens & 438 & ifolium 3 & 360 & Poppy & & pensylvanicus & \\
\hline trachysperma & 438 & littorale & 359 & Celandine & 415 & perfoliatus 74 & 4 \\
\hline OLEMONIACEAE & 673 & longistylum & 361 & Common & 416 & pinnatum & \\
\hline Polemonium & 676 & maritimum & 358 & Corn & 416 & polygonifolius & \\
\hline coeruleum & 676 & nbergii 3 & 361 & Family & & praelongus & \\
\hline Family & 673 & opelous & 362 & Horn & 415 & -1 & \\
\hline reptans & 676 & orientale & 361 & Mallow & & pus & \\
\hline Van Bruntige & 676 & \multicolumn{2}{|l|}{ pennsylvanicum } & ican & 416 & olius & \\
\hline olycodium cand & & & 361 & Plume & 415 & Richardsonii & \\
\hline cans & 639 & Persicaria & 361 & Prickly & & nsii & \\
\hline melánocarpum & 639 & nse & 360 & Sea & 415 & ruf & \\
\hline neglectum & 639 & prolificum & 358 & Populus & & ruti & \\
\hline reum & 639 & punctatum & 361 & alba & 328 & aeformis & \\
\hline olyg & 538 & \multicolumn{2}{|l|}{ ramosissimum } & balsamifera & 329 & aeformis & \\
\hline & 540 & 358,3 & 359 & ans & 320 & & \\
\hline & 540 & $R a y$ & 358 & del & 329 & lius & \\
\hline & 539 & tum & 362 & dentata & 328 & $2 n i$ & \\
\hline & $\mathbf{5 3 9}$ & & 362 & shylla & 329 & & \\
\hline & 540 & & 362 & lifera & 329 & $\boldsymbol{Z}_{i}$ & \\
\hline fas & 539 & & 359 & nig & 329 & lius & 7 \\
\hline Fri & 538 & sum & 360 & loides & 328 & Potato & 11 \\
\hline incarnata & 539 & um & 362 & e Grass & 124 & \multicolumn{2}{|l|}{ Potato-vine, Wilid } \\
\hline & 540 & viv & 359 & Port & 457 & & 670 \\
\hline na & $\mathbf{5 3 9}$ & $Z u$ & 363 & & 457 & Pot & 48 \\
\hline lliii & 539 & Polyx & 824 & Port & 389 & & 48 \\
\hline Hora & 538 & asis & 824 & & 389 & & 482 \\
\hline $\mathrm{ma}$ & 53 & uv & 824 & & 38 & & 48 \\
\hline & 540 & $\mathrm{CEAE}$ & 33 & & 389 & nsis & 484 \\
\hline inea & 539 & Poly & 34 & & 389 & & 48 \\
\hline Ser & 53 & & 34 & EAE & 387 & & \\
\hline ata & 54 & des & 34 & Pos & 339 & & 484 \\
\hline scens & 53 & & 34 & geton & 70 & & \\
\hline LACEAE & 538 & Poly & 34 & 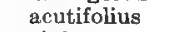 & 75 & & 483 \\
\hline NACEAE & 35 & Poly & 133 & & 72 & & 483 \\
\hline atum & 292 & ensis 1 & 13 & 1018 & 73 & & 482 \\
\hline um & 292 & Pol & 653 & ius & 73 & pa & 482 \\
\hline & 292 & & 654 & & 74 & & 482 \\
\hline nutatum & 292 & Pol & 843 & des & 75 & liensis & 482 \\
\hline atum. & 29 & & 844 & les & $7 \pi$ & & 484 \\
\hline feum & 292 & ol & 40 & & 75 & & 48 \\
\hline & & ideo & 40 & $\mathbf{s}$ & 7 & & 482 \\
\hline oly & 3 & & 41 & & 77 & & 483 \\
\hline & & & 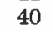 & & & & 4 \\
\hline ata & 363 & Poly & 620 & & $7 \overline{3}$ & & 482 \\
\hline & & & 62 & & 77 & vanica & 48 \\
\hline num & 3 & & 51 & & & & 482 \\
\hline & 38 & Prárie 5 & 512 & & 77 & nbens & 484 \\
\hline ibium & 36 & Por & 64 & & 75 & & 484 \\
\hline & & & 414 & parus & 76 & & 483 \\
\hline & 35 & Ponc & 7 & 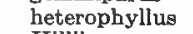 & 73 & & 484 \\
\hline 5 & 35 & Far & 69 & & 75 & & \\
\hline & 36 & & 78 & & 77 & insi & 483 \\
\hline & 36 & Pont & 266 & & 73 & & 484 \\
\hline olvulus & 36 & 2 & 266 & & 77 & sulphurea & 483 \\
\hline$m$ & 363 & Pontederiaceat & & ptus & 78 & & \\
\hline & 36 & & & & 76 & ntata & 483 \\
\hline siflorum & 360 & Poor $\mathbb{N}$ & her- & hites & 73 & oterium & 494 \\
\hline & 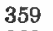 & & 647 & & 74 & canadense & 494 \\
\hline orum & 36 & Robin's & & & 77 & Sanguisorba & 494 \\
\hline nersum & 36 & & 873 & mucronatus & 75 & Poverty Grass & 10 \\
\hline
\end{tabular}




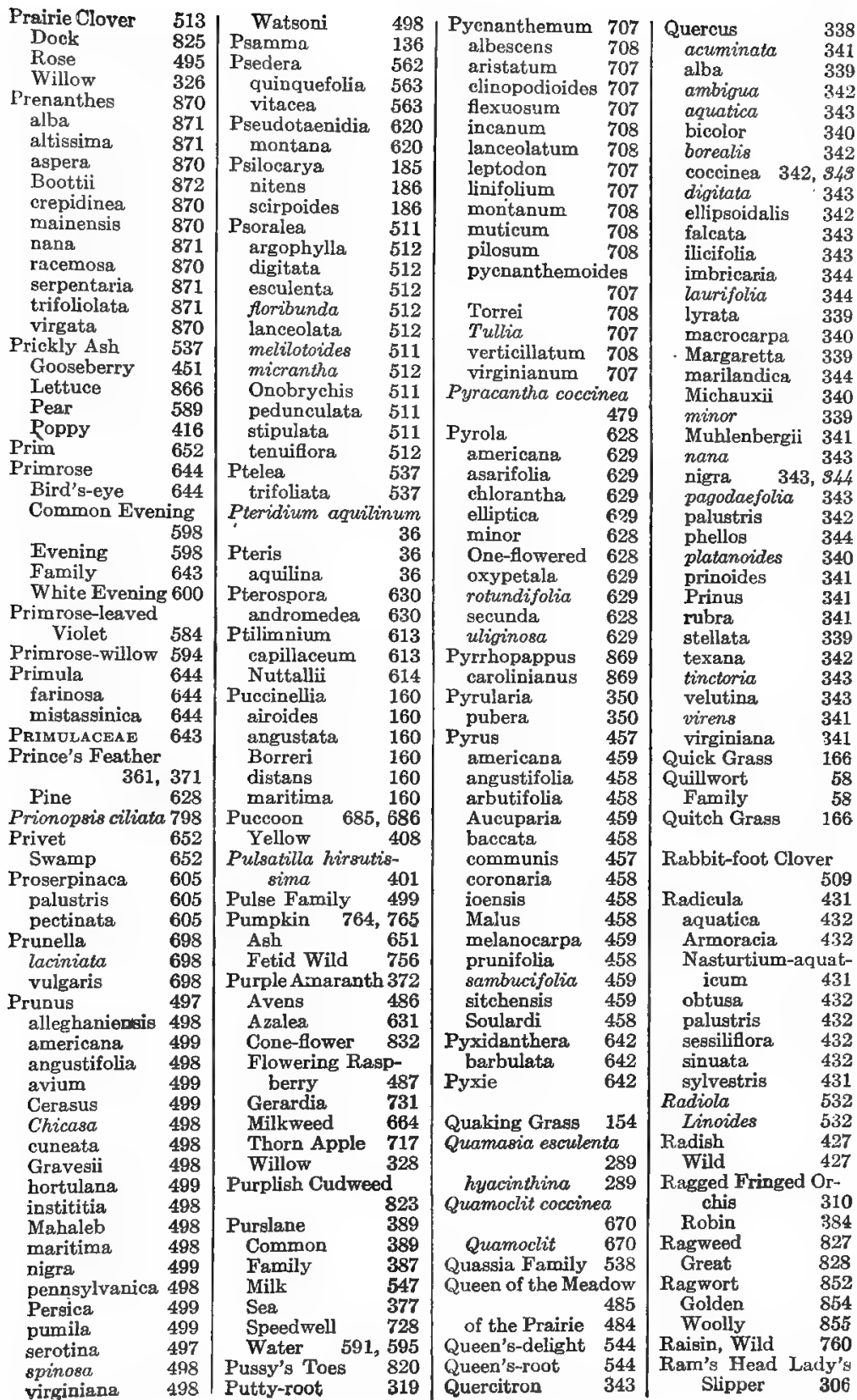




\begin{tabular}{|c|c|c|c|c|c|c|c|}
\hline Ramsted & 719 & Razoumofskya prusil & $i l l a$ & canadense & 631 & River-bank Grap & \\
\hline RanUNCUlaceat & 392 & & 351 & canescens & 631 & & 565 \\
\hline Ranunculus & 394 & Red Ash & 651 & catawbiense & 632 & Robin & $\begin{array}{l}514 \\
514\end{array}$ \\
\hline & 396 & Baneberry & 408 & lapponicum & $\begin{array}{l}632 \\
631\end{array}$ & $\begin{array}{l}\text { hispida } \\
\text { Pseudo-Acacia }\end{array}$ & $\begin{array}{l}514 \\
514\end{array}$ \\
\hline $\begin{array}{l}\text { acris } \\
\text { allegheniensis }\end{array}$ & $\begin{array}{l}398 \\
3\lrcorner 6\end{array}$ & $\begin{array}{l}\text { Bay } \\
\text { Birch }\end{array}$ & 33 & maximum & 632 & & 514 \\
\hline & $3 J 5$ & Buckeye & 56 & nudiflorum & 631 & Robin's Plant & 817 \\
\hline aqu & 394 & Campion & 384 & Rhodora & 631 & Rock Brake & 37 \\
\hline & 398 & $\mathrm{Ced}$ & 67 & viscosum & 631 & Cranberry & 641 \\
\hline & 398 & Clo & 509 & Rhodora & 631 & Cress & 436 \\
\hline & 39 & Currant & 452 & canadense & 631 & & 346 \\
\hline & & Elm & 345 & Rhus & 552 & Maple & 558 \\
\hline ius & & False Mallow 56 & 567 & malaca & & Rocket & 430 \\
\hline & & Grape & 565 & ensis & 553 & r's & 439 \\
\hline & 3 & Nettle 69 & 69 & & & & 427 \\
\hline & & & 55 & des & & $\mathbf{Y}$ & 432 \\
\hline la & & Mulberry & 34 & & 553 & Roc & 576 \\
\hline & & 341,3 & 342 & & 552 & & 576 \\
\hline hed & 394 & Pine & 64 & & 552 & Roman Wc & \\
\hline 397, & 898 & Spruce & 65 & arpa & & & 828 \\
\hline & 395 & Top & 132 & folia & 553 & Ror & 431 \\
\hline & 39 & Top, Tall & 149 & Rydbergi & 553 & & 432 \\
\hline & 398 & Red-berried Elder & & Toxicodendron & & & 432 \\
\hline & 396 & & 761 & & 552 & & 432 \\
\hline sis & 395 & ledbu & 505 & aina & 552 & & 431 \\
\hline & 395 & Red-osier Dogwood & & & 552 & & 432 \\
\hline & 398 & & 624 & & & & 432 \\
\hline & 395 & Red-roo & 562 & Rhy & 530 & & 432 \\
\hline$u s$ & 395 & Red-seeded Dande & & & 530 & & 432 \\
\hline & 396 & lion & 865 & & 530 & carpa & 432 \\
\hline & 398 & 9 & & & 531 & & 431 \\
\hline & 397 & Grass & 134 & cifolia & 531 & Ro & 494 \\
\hline pen & & & 148 & tosa & 530 & & 495 \\
\hline & 398 & Grass 1 & 159 & Rib & 745 & $a$ & 496 \\
\hline & 39 & Rein & & Grass & & & 496 \\
\hline & 3 & & 4 & & 50 & & 496 \\
\hline & 39 & & & & 452 & & 496 \\
\hline & 39 & & & & 11 & & 496 \\
\hline & 39 & & & & 451 & & 496 \\
\hline ideus & & & & & 51 & $\therefore$ & 495 \\
\hline & 396 & 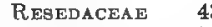 & & laria & 1 & & 496 \\
\hline nalis & & & & anum & & & 497 \\
\hline Rap & 42 & & & se & 1 & & 497 \\
\hline & & & & & & & 496 \\
\hline istrum & 4 & & & iense & $\mathrm{L}$ & & 495 \\
\hline & 4 & & & nig, & 452 & asa & 496 \\
\hline Ras & 4 & & & oxyacanthoide: & & & 49 \\
\hline & & lan & 561 & & 45 & ma & 496 \\
\hline Dwarf & 487 & Rheumatism Root & & umn & 452 & & \\
\hline Purple Floweri & ing & & & folium & 451 & & 49 \\
\hline & 487 & $\mathrm{Rl}$ & & & 452 & & 45 \\
\hline W & 486 & & & & 452 & & \\
\hline Ratibida columnar & aris & & & ispa & 451 & & 51 \\
\hline & 833 & & & & 452 & & 49 \\
\hline & & & & & 744 & & $\mathbb{R}$ \\
\hline low & 734 & Rhi & & grass & & & \\
\hline & 507 & alli & & 119 , & 120 & & 49 \\
\hline ke Fern & n 49 & & & & 118 & & \\
\hline & 158 & & & tain & 122 & & 75 \\
\hline & 60 & & 7 & & 119 & & 9 \\
\hline Plan & 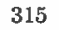 & & 735 & $\mathrm{Ric}$ & 711 & & \\
\hline Rattlesnake-roo & & llus & 735 & Rici & 544 & & 0 \\
\hline & 871 & De & & communis & & & \\
\hline & 870 & & 133 & Grass & 745 & ary, Bog & 63 \\
\hline wat & & & 44 & & 335 & & \\
\hline & 873 & dron & 631 & rush & 192 & Ros & 44 \\
\hline ( & -rod & & 6: & & 441 & & \\
\hline & & $\operatorname{ceum} \theta$ & & Weed Family & 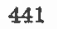 & & \\
\hline
\end{tabular}


li tala ramosior 591

Rottboellia $\quad 92$

cylindrica $\quad 92$

rugose

Roubieva.

92

multifida

365

365

Rough Bedstraw 750

Rough-sţalked Meadow Grass 157

Round-leaved Catch-

$$
\text { fly }
$$

Cornel

386

624

Sundew

Violet

Rowan Tree

Royal Catchfly

Rubacer

Rubraceae $\quad 746$

Rubus $\quad 486$

abbrevians $\quad 491$

allegheniensis 489

amabilis $\quad 490$

americanus 488

amnicolus $\quad 490$

Andrewsianus 491

arcticus $\quad \mathbf{4 8 8}$

argutus $\quad 490$

arundelanus 490

Baileyanus 492

biformispinus 491

canadensis

490,492

Chanaaemorus 487

columbianus 487

cuneifolius $\quad 491$

elegantulus $\quad 490$

Enslenii 492

flavinanus $\quad 489$

floricomus 491

frondisentis $\quad 489$

frondosus $\quad 489$

fruticosus $\quad 491$

glandicaulis $\quad 489$

hispidus

idaeus

invisus

jacens

Jeckylanus

junceus

laciniatus

Millspaughi

neglectus

nigricans

492

492
486

492

492

491

489

491

491

487

491

nigrobacciss

nutkanus 487

occidentalis $\quad 487$

odoratus 487

orarius $\quad 490$

parviflorus $\quad 487$

peculiaris $\quad 490$

pergratus $\quad 490$

permixtus $\quad 492$

philadelphicus 490

phoenicolasius 487

procumbens 492

Randii

490 recurvans

recurvicaulis

rubrisetus

sativus

490

Clu

492

setosus 491,492

strigosus $\quad 486$

subuniflorus $\quad 492$

tardatus $\quad 492$

triflorus $\quad 487$

trivialis $\quad 492$

vermontanus 492

villosus 489,490 ,

Rudbeckia $\quad 492$

Rudbeckia $\quad 830$

Brittonii 831

fulgida

hirta

laciniata

831

maximg

831

monticola 831

palustris 831

spathulata 831

speciosa 831

subtomentosa 831

Sullivanti 831

triloba

830

umbrosa

831

Rue

Anemone $\quad 400$

Common 538

Early Meadow 400

Family

Goat's

Tall Meadow

Ruellia

ciliosa

pedunculata

strepens

Rum Cherry

497
354

Acetosa

Acetosella

altissimus

Britannica

crispus

elongatus

hastatulus

maritimus

mexicanus

obtusifolius

occidentalis

pallidus

355

Patientia $\quad 355$

persicarioides

pulcher

357

salicifolius

venosus

verticillatus

Ruppia

maritima

Rush

Bald

Beak

Bog
537

537

514

400
742

742

743

743

357

357

356
355

355

357

357

356

356

355

356

\section{Family \\ Grass}

Horned

Nut

Scouring

Spike

Twig

Wood

Russian Thistle

Ruta

graveolens

Rutabaga

Rutaceae

Rye Grass

Wild

Rynchospora

alba

axillaris

capillacea

cephalantha

compressa

corniculata

cymosa

fusca

glomerata

gracilenta

inexpansa

Knieskernii

macrostachya

oligantha

pallida

Torreyana

\section{Sabatia}

angularis

angustifolia

brachiata

calycina

calycosa

campanulata

campestris

chloroides

dodecandra

gracilis

lanceolata

paniculata

stellaris

Sabbatia

Sacciolepis

striata

Sacred Bean

Sage

Germander

Jerusalem

Lyre-leaved

White

Willow

Wood

Sagina

apetala

decumbens

fontinalis

nodosa

procumbens

267

185

Sagittaria

ambigua

arifolia

187

207

129

199

202

53

180

201

278

370

537

538

428

537

165

168

199

200

201

201

201

199

199

199

200

201

200

200

201

199

200

200

200

654

655

655

655 


\begin{tabular}{|c|c|c|c|c|c|c|c|}
\hline dra & 321 & $\min 0 r$ & 494 & stellaris & 446 & occident & 198 \\
\hline pe & 325 & officinalis & 494 & tricuspidata & 446 & Olneyi & \\
\hline ifolia & 328 & Sanicle & 610 & virginiensis & 446 & pallidus & \\
\hline prin & 325 & Sanicula & 610 & Saxifragaceate & 444 & paludosus & \\
\hline rea & 328 & canadensis & 610 & Suxifrage & 445 & pauciflorus & \\
\hline ta & 326 & gregaria & 610 & Alpine Brook & 446 & Peckii & \\
\hline & & marilandica & 610 & Early & 446 & pedicellatus & \\
\hline ser & 322 & trifoliata & 610 & Family & 444 & planifolius & \\
\hline sys & 324 & SANTALACEAE & 349 & Golden & 448 & polyphyllus & \\
\hline tris & 326 & SAPINDACEAE & 559 & Lettuce & 446 & pungens & \\
\hline Uva & 325 & Sapindus & 559 & Mountain & & robustus & \\
\hline & 327 & acuminatus & 559 & Swamp & 446 & rubrotinetus & \\
\hline War & 321 & Drummondi & 559 & \multicolumn{2}{|c|}{ Yellow Mountain } & rufus & \\
\hline Salmon Berry & 487 & \multicolumn{2}{|c|}{ Sapodilla Family 648} & & 446 & Smithii & \\
\hline Salomonia biflora & 292 & Saponaria & 386 & Scabiosa & 764 & subterminalis & \\
\hline & 292 & officinalis & 386 & & & & \\
\hline Salsi & 864 & Vaccaria & 386 & & 764 & icus & \\
\hline Salso & 370 & SAPO & 648 & & 764 & & \\
\hline $\mathrm{Kg}$ & 370 & \multicolumn{2}{|c|}{ Sarothra gentianoides } & us, Sweet & 817 & & \\
\hline sal. & 370 & & 575 & Scan & 617 & athus & \\
\hline Tragus & 371 & \multicolumn{2}{|c|}{ Sarothamnus $\begin{array}{r}575 \\
\text { scopa- }\end{array}$} & Pecten-Veneris & 617 & & \\
\hline \multirow{2}{*}{\multicolumn{2}{|c|}{ Salt Marsh Fleabane }} & rius & 508 & Scarlet Iychnis & 384 & Scle & \\
\hline & & Sarracenia & 439 & Oak & 342 & & \\
\hline Ma & & flar & 440 & ted Cup & 732 & & \\
\hline Re & 143 & purpurea & 440 & Sched & 144 & tha & \\
\hline alty & 370 & & & & 144 & & \\
\hline Common & 370 & \multicolumn{2}{|l|}{ SARRACENIACEAE } & & 144 & gris & \\
\hline \multirow{4}{*}{$\begin{array}{l}\text { Salvia } \\
\text { azurea } \\
\text { lanceaefolia } \\
\text { lanceolata }\end{array}$} & 702 & & 139 & Sche & 80 & & \\
\hline & 708 & Sarsaparilla & 606 & & & $d a$ & \\
\hline & 703 & $\mathrm{Br}$ & 606 & Schi & 40 & erata & \\
\hline & 703 & Wi & 606 & & 46 & llata & \\
\hline & 702 & Sasse & 413 & Scr & 45 & cles & \\
\hline & 703 & & 414 & Sch & 553 & & \\
\hline & 70 & Sa & 414 & & 553 & lata & \\
\hline & 70 & lium & 414 & Sch & 503 & & \\
\hline & 703 & atu & 70 & & 504 & Scol & \\
\hline alvi & 5 & & 70 & & 504 & ace & \\
\hline & 5 & gla & 706 & Sch & 736 & ndrium & \\
\hline EAX & 50 & & 706 & & 736 & sare & 40 \\
\hline$a m$ & 761 & & 705 & & 630 & & 331 \\
\hline & & & 706 & & 289 & $\mathrm{Sc}$ & 508 \\
\hline & 7 & & 70 & & & & 6 \\
\hline & & Sau & 20 & & 1 & & 618 \\
\hline $\mathrm{am}$ & & & 1 & & & & 74 \\
\hline & & av & 12 & & 195 & & \\
\hline & & & 12 & 193 , & & & 49 \\
\hline Samphire & 369 & Sav & 67 & & 190 & & 85 \\
\hline \multirow{2}{*}{\multicolumn{2}{|c|}{$\begin{array}{l}\text { Sampson's Snake- } \\
\text { root } 658\end{array}$}} & Sav & 705 & & 198 & laria & 721 \\
\hline & & & & & 19 & & 797 \\
\hline Sand Bar Willow & 323 & Say & & & Is & & 72 \\
\hline $\mathrm{Blg}$ & 491 & & & & & indi & 721 \\
\hline & 4 & Saxi & 445 & & & no & 721 \\
\hline & 5 & & 44 & & & \multirow{2}{*}{\multicolumn{2}{|c|}{ SCROPHULARIACEAE }} \\
\hline & & & 44 & & & & \\
\hline & & & 446 & & 195 & & \\
\hline Plu & 49 & iana & 446 & & 191 & \multicolumn{2}{|c|}{ Scouring Rush 53} \\
\hline Spu & & con & 446 & & 193 & Scrub Oak, Black & \\
\hline Sandal & nily & & 446 & & 192 & & 343 \\
\hline & 349 & & 446 & & 10 & & \\
\hline and & & & 446 & & & & \\
\hline a.dou & & leucanthemifol & & & 10 & & 69 \\
\hline Mou & & & 44 & & & & \\
\hline Pine & 381 & & 44 & & 19 & & \\
\hline ed & 3 & micr & & & & chilliar & \\
\hline 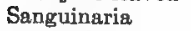 & 4 & & 44 & & & & \\
\hline & & & & . & & iculata. & 69 \\
\hline angu & 494 & nica & 446 & & & & \\
\hline a & & rivt & A & ovae-anoliae & 193 & ategrifolia & \\
\hline
\end{tabular}


Scutellaria 1ateri-

$\begin{array}{ll}\quad \text { flora } & 694 \\ \text { nervosa } & 696 \\ \text { parvula } & 696 \\ \text { pilosa } & 695 \\ \text { saxatilis } & 694 \\ \text { serrata } & 695 \\ \text { versicolor } & 694 \\ \text { Scurvy Grass } & 433 \\ \text { Scutch Grass } & 144 \\ \text { Sea Blite } & 369 \\ \text { Lavender } & 643 \\ \text { Lungwort } & 685 \\ \text { Milkwort } & 647 \\ \text { Oats } & 153 \\ \text { Ox-eye } & 833 \\ \text { Poppy } & 415 \\ \text { Purslane } & 377 \\ \text { Rocket } & 427 \\ \text { Roct }\end{array}$

Rocket, American

Sand-reed

Spear Grass

Seaside Alder

Crowfoot

Gerardia

Heliotrope

Plantain

Spurge

Sedge

Family

Sedum

acre

Fabaria

Nevii

Nuttallianum

pulchellum $\quad 443$

purpureum $\quad 443$

reflexum

Rhodiola

roseum

stoloniferum

telephioides

Telephium

ternatum

Torreyi

Seedbox

Selaginella

apus

rupestris selaginoides spinosa

Selagineilaceae

Selenia

aurea

Self-heal

Sempervivum. tectorum

Senebiera

Coronopus didyma

Seneca Grass Snakeroot

Senecio antennariifolius

gureus

433

433

698

443

443

426

426

426

122

539

852

855

854
Balsamitae

canus

Crawfordii

discoideus

glabellus

integerrimus

Jacobaea

lobatus

obovatus

palustris

plattensis

Pseudo-Arnica 85

Robbinsii

Smallii

sylvaticus

tomentosus

viscosus

vulgaris

Senna

Wild

504,505

Sensitive Brier 503

Fern

Joint Vetch

Plant, Wild

Serapias

Helleborine

Sericocarpus

asteroides

bifoliatus

conyzoides

linifolius

solidagineus

tortifolius

Serinia

oppositifolia

Service Berry

Sesame Grass

Sesban

Sesbania

macrocarpa

Sesuvium

maritimum

pentandrum

Setaria

glauca

imberbis

italica

magna

verticillata

viridis

Seymeria macrophylla

Shad Bush

Shag-bark Hickory

854

855

854

853

855

853

853

854

853

855

854

854

853

855

853

853

503
45

518

505

313

313

818

818

818

818

818

818

819

862

862

459

92

514

514

514

377

377

377

118

118

118

119

119

118

118

729

729

459

ry

Sheep Laurel

633 Sorrel

Sheepberry

Sheep's Fescue 161

Sheep's-bit 768

Shell-bark Hickory

331

Shepherd's Purse 426

Shepherdia

argentea

canadensis

Sherardia

arvensis

590

Shield Fern

41

Shin Leaf

Shingle Oak

628,629

344

Shining Willow 321

Shooting Star $\quad 647$

Sbowy Lady's Slipper

307

Orchis

307

Shrub Yellow-root

408

Shrubby Althaea 569

Bitter-sweet $\mathbf{5 5 7}$

Cinquefoil 483

St. John's-wort 573

Trefoil

Sibbaldia

537

procumbeng 480

Sibbaldiopsis tridentata

483

Siberian Crab $\quad \mathbf{4 5 8}$

Sickle-pod

Sicyos

angulatus

438

765

Sida

765

Elliottii

567

hermaphrodita 567

Napaea

567

spinosa

567

Sideranthus spinulosus

Side-saddle Flower

440

Sieversia ciliata 486 Peckii

Silene

acaulis

alba

anglica

antirrhina

Armeria

caroliniana

conica

Cucubalus

486

dichotoma

gallica

inflata

latifolia

Menziesii

nivea

noctiflora

385

386

386

385

385

385

386

385

386

385

385

386

nutans

pennsylvanica

regia

rotundifolia

stellata

virginica

vulgaris

Silkweed

Common

Silky Cornel

Willow

386

385

386

385

385

386
386

380

386

386

386

663

663

624

Silphium

Asteriscus

326

825

integifo 
Small Magnolia 409 Solomon's Seal 292 White Lady's Slipper 307

Smaller Bladderwort 737

Spearwort $\quad 395$

Yellow Lady's Slipper 306

Small-flowered Crowfoot 396

Smartweed, Common

Water
Smilacina
racemosa
stellata
trifolia

Smilax

Bona-nox 29

ecirrhata 295

glauca 295

herbacea 295

hispida $\quad 296$

lanceolata 296

laurifolia 296

pseudo-ching 296

pulverulenta 295

rotundifolia 295

tamnifolia 295

tamnoides 295

Walteri 295

Smoke-tree

Smooth Alder

Azalea

False Foxglove

Gooseberry $\quad 730$

Sumach 552

Winterberry $\mathbf{5 5 5}$

Yellow Violet 585

Smut Grass 131

Snake Grass $\quad 150$

Snakehead

723

Snakeroot, Black

407,610
Button $\quad 609,785$

Sampson'B 658

Seneca $\quad 539$

Virginia $\quad 352$

White 784

Snapdragon $\quad 720$

Sneezeweed 844, 845

Snow Trillium 294

Snow-ball Tree $\mathbf{7 5 9}$

Snowberry $\quad 757$

Creeping 637

Snuwdrop Tree 649

Snow-on-the-Mountain

547

Soapberry

559

Family

559

Suapwort

Gentian

Soft Chess

657

Solanaceat

Solanum

163

Solanum

carolinense citrullifolium 713

Dulcamara " 713

elgeagnifolium 713

heterodoxum 713

Melongena $\quad \mathbf{7 1 2}$

nigrum

713

rostratum 713

sisymbriifolium

713

triflorum 713

tuberosum 712

Solea

concolor

579

579

Solidago

alpestris

788

altissima 794796

arguta

796

aspera

asperula

bicolor

Boottii

caesia

calcicola

794
794

789

792

canadensis 795, 796

Curtisii

Cutleri

789

decumben:

790

Drummondii 796

Elliottii

elongata

erecta

fistulosa

794

796

789

flexicaulis

793

Gattingeri

789

graminifolia 797

gymnospermoides

hispida

Houghtonii

humilis

juncea

lanceolata

latifolia

leptocephala 798

Lindheimeriana

789

macrophylla 790

minor

797

missouriensis 794

mollis

monticola

Moseleyi

neglecta

nemoralis

odora

ohioensis

patula

petiolaris

pilosa

polycephala

procera

pubcrula

Purshii

racemosa

radula

Randii

Riddellii

rigids

795

796

792

788

794

797

796

791

791

791

795

790

797

796 rigidiuscula

roanensis

rugosa

rupestris

sempervirens

serotina

Shortii

specioga

squarrosa

stricta

tenuifolia

tortifolia

uliginosa

ulmifolia

uniligulata

Virgaurea 790, 791

Wardii

Solomon's Seal

False

Great

Small

Sonchus

arvensis

asper

oleraceus

Sophia brachycarpa

incisa

pinnata

Sophia

Sophora

sericea

Sorbaria

sorbifolia

Sorbus

americana

A ucuparia

sitchensis

Sorghastrum

nutans

Sorghum halapense

Sorrel 354, 357 Common Wood

\section{Field}

Garden

Lady's

Mountain

Sheep

Violet Wood

Wood

Sorrel-tree

Sour Cherry

Gum

Sour-top Blueberr

789

794

796

792

795

792

788

791

797

793

791

794

793

788

292

292

292

865

865

866

865

430

430

430
430

507

507

457

457

459

459

459

459

95

95

95

533

357

357

534

354

357

533

532

636

499

625

640

Sour-wood

636

Southern Buckthorn 648

Fox Grape

Gooseberry

Prickly Ash

Red Lily

565

639

Southernwood

288

Sow Thistle

Common

792

7




\begin{tabular}{|c|c|c|c|c|c|c|c|}
\hline phoits & 138 & compressus & 131 & palustris & 702 & Stick-tight & \\
\hline & 138 & cryptandrus & 131 & salvioides & 702 & Stiff Cornel & \\
\hline sata & 138 & cuspidatus & 130 & tenuifolia & 701 & \multirow{2}{*}{\multicolumn{2}{|c|}{ Water Crowfoot }} \\
\hline pallens. & 138 & depauperatus & 130 & Staff Tree & 557 & & \\
\hline palustris & 139 & ejuncidus & 131 & Family & 556 & Stillingia & \\
\hline Spice Bush & 414 & gracilis & 131 & Stagger-bush & 635 & ica & \\
\hline Spider-flower & & heterolepis & 131 & \multicolumn{2}{|l|}{ Staghorn Sumach } & Nettle & \\
\hline Spiderwort & 264 & indicus & 131 & & 552 & Stin & \\
\hline $\mathrm{Fa}$ & & junceus & 131 & \multicolumn{2}{|l|}{ Standing Cypress } & Stinking Clover & \\
\hline Spiesia & & Longifolius & 130 & & 675 & Willie & \\
\hline estris & & neglectus & 131 & Staphylea & 557 & Stipa & \\
\hline & & Richardsonis & 130 & tri & 557 & a & \\
\hline sple & & serotinus & 132 & LEACEAE & 557 & asis & \\
\hline pigelia & & nus & 131 & Star Flower & 646 & & \\
\hline ndica & & & 131 & Grass & 299 & $n i i$ & \\
\hline pike & & orus & 130 & of Bethlehem & 289 & dsoni & \\
\hline & 18 & virginicus & 131 & Thistle & 860 & & \\
\hline \multicolumn{2}{|c|}{ Spiked Loosestrife } & \multicolumn{2}{|c|}{ Spotted Cowbane } & Campion & 386 & vir & \\
\hline & 592 & & 614 & 381, & 799 & over & \\
\hline spikenard & & Medick & 510 & & 550 & Sto & \\
\hline $\mathrm{Fg}$ & & ne-not & 560 & Stat & 643 & & \\
\hline Spile & & reen & 628 & onium & 643 & & \\
\hline ana & 833 & Spran & 158 & e Bush & 456 & Sto & \\
\hline & & \multirow{2}{*}{\multicolumn{2}{|c|}{$\begin{array}{l}\text { Spreading Dogbane } \\
662\end{array}$}} & \multicolumn{2}{|l|}{ Steinchisma hians } & & \\
\hline Tree & 556 & & & & 117 & & \\
\hline ean & 556 & wer & 404 & Stei & 646 & & \\
\hline \multicolumn{2}{|l|}{ Spiny-leaved Sow } & Beauty & 388 & & 646 & ium & \\
\hline Thistle & 866 & & 435 & ledium & 646 & & \\
\hline Spirae & & & 526 & latum & 646 & & \\
\hline$A$ & 457 & $\mathrm{pr}$ & 5 & & 646 & & \\
\hline & & & & & 646 & & \\
\hline osa & & & 65 & & 646 & & \\
\hline & & & 65 & & 646 & & \\
\hline & & & 65 & Ste & 381 & Str & \\
\hline & & & 65 & & 383 & 18 & \\
\hline & & & 65 & & 381 & & \\
\hline & A & Spu & 545 & & & & \\
\hline & & & 5 & & 382 & Maple & \\
\hline & & & 54 & & 382 & Str & \\
\hline & & & 54 & & 382 & & \\
\hline & & & 5 & & & & \\
\hline & & & 54 & & & & \\
\hline Spir & & & & & 382 & aris & \\
\hline & & & 5 & & 382 & & \\
\hline & & Gentian & 659 & & 382 & Sty & \\
\hline & & & 3 & & 382 & & \\
\hline gracilis & 313 & & 37 & & 382 & Styl & \\
\hline \multicolumn{2}{|c|}{ gracilis $\times$ vernalis } & & 378 & osa & 381 & & \\
\hline & 314 & Squas & 765 & Lady's & & & \\
\hline edia & 31 & ck & 765 & & 307 & & \\
\hline & & Squas & 759 & Woc & 284 & ST & \\
\hline & 31 & \multicolumn{2}{|c|}{ Squaw Huckleberry } & $\operatorname{lium}$ & 284 & & \\
\hline & & & & & 284 & & \\
\hline & 3 & \multicolumn{2}{|c|}{ Squaw-root $\quad 739$} & um & 284 & lia & \\
\hline $\mathrm{ox}$ & 31 & & 852 & Stenophragma & & lenta & \\
\hline Romanzof & & Squirrel Corn & 417 & Thalianum & 430 & Sur & \\
\hline & 31 & l-tail Gras & & yllus & 186 & ana & \\
\hline & & & 167 & & 186 & & \\
\hline & 3 & Sta & 701 & Ste & 602 & & \\
\hline Spirc & 25 & & 70 & & 602 & $\mathrm{im}$ & \\
\hline byze & 25 & & 70 & & 602 & & \\
\hline 7ort & ת & cola & 702 & Stew & 570 & Sub & \\
\hline & 63 & nsis & 701 & Malachodend & & atica & \\
\hline & 12 & 01, & 702 & & 570 & Suc & \\
\hline & 15 & & 702 & agyna & 570 & tralis & \\
\hline & & folia & 701 & & 570 & ensis & \\
\hline . & 13 & & 702 & Sticl & 588 & Succory & \\
\hline & & Nuttallii & 702 & Stickseed & 681 & Gum & \\
\hline
\end{tabular}


Succory, Lamb

Sugar Grape

Maple

Sugarberry

Sullivantia ohionis

Sullivantii

Sumach

Dwarf

Poison

Smooth

Staghorn

Summer Grape Savory

Sundew

Family

Round-leaved

Sundrops 600

Sunflower

Common

Tickseed

Supple-jack

Swamp Beggar-tick

Birch

841

Black Currant 452

Blueberry 640

Buttercup $\quad 397$

Dock 356

Fly Honeysuckle

Hickory

Maple

Milkweed

Post Oak

Privet

Red Currant

Rose Mallow

Saxifrage

Spanish Oak

Thistle

Valerian

White Oak

Sweet Alyssum

Bay

Birch

Buckeye

Cherry

Cicely

Clover

Coltsiont

Fern

Flag

Gale

Gale Family

Golden-rod

Gum

Gum Tree

Leaf

Pepperbush

Pinesap

Seabious

Vernal Grass

Viburnum

Violet

White Violet

William
565

558

346

445

445

552

552

552

552

564
705

440

440

600

833

841 561

31

40

56

755

332

592

558

664

339

652

452

569
446

342

858

762

340

424

409

334

560

499

612

510

850

330

258

329

329

793

453

453

649

627

630

817

121

760

585

584

387
William Catchfly 385

William, Wild 674

Winter Grape 564

Sweetbrier

496

Sweet-scented Bedatraw 750

Water Lily

391

Swine Cress

Switch Cane

Grass

426

Sycamore

17

104

Symphoricarpos 757

occidentalis $\quad 757$

orbiculatus 757

pauciflorus $\quad 757$

racemosus $\quad \mathbf{7 5 7}$

Symphoricarpos

vulgaris

Symphytum

asperrimum

officinale

tuberosum

Symplocarpus foetidus

Symplocos

tinctoria

Synandra

grandiflora

hispidula.

Syndesmon thatictroides

Syngonanthus $\quad 400$

flavidus

Synosma suaveolens

Syntherisma

fimbriata

Synthyris

Bullii

Houghtoniana

Syringa 449,65?

vulgaris

Table Mountain Pine

Tacamahac

Taenidia

integerrima

Talinum

calycinum

parviflorum

rugospermum

teretifolium

Tall Bellflower

Buttercup

Coreopsis

Crowfoot

Larkspur

Meadow Rue

Oat Grass

Red Top

Taller Fescue

Tamarack

Tan Bay

Tanacetum

huronense

258

649

649

699

699

699

852

616

388

388
767

398

838

398

406

400

141

149

162

65

571

848

848 $\begin{array}{cr}\text { vulgare } & \mathbf{8 4 8} \\ \text { Tansy } & 848 \\ \text { Common } & \mathbf{8 4 8} \\ \text { Tape Grass } & 85 \\ \text { Taraxacum } & 864 \\ \text { Dens-leonis } & 865 \\ \text { erythrospermum }\end{array}$

865

officinale

Taraxacum

865

Tare

525

Tartarian Honeysuckle

Tar-weed

Taxaceae

Taxodium

distichum

Taxus canadengis

Tea Family

Labrador

Mexican

New Jersey

Oswego

755

Plant

Teaberry

786

62

66

66

62

62

570

630

366

562

703

Tear-thumb, Arrowleaved

Halberd-leaved

Teasel

362

Family $\quad \mathbf{7 6 3}$

Wild

Tecoma

763

radicans

741

Tephrosia

hispidula

spicata

virginiana

514

TERngTromatach

570

Tetragonotheca 830

helianthoides 830

Tetragonanthus 659 deflexus

Tetraneuris

herbacea

Teucrium

boreale

Botrys

canadense

littorale

occidentale

659

844

844

692

Scorodonia

Thalesia fasciculato

dioicum 
Thyme-leaved Sund-

wort
Speedwell
Thymus
Serpyllum
Tiarella
cordifolia
Tick Trefoil
Tickseed
Sunflower
Tiedemannia
rigida
teretifolia
Tiger Lily
Tilia
americana
heterophylla
Michauxii
pubescens
TiLiAcEA
Tillaea
aquatica
simplex
Vaillantii
Tillandsia
usneoides
Tim

Timothy

Tinker's Weed

Tipularia

discolor

unifolia

Tissa

canadensis marina

Ti-ti, Black

Toadflax

Bastard

Tobacco

Indian

Ladies'

Wild

Tofieldia

glutinosa

palustris

racemosa

Tometillo

Tomato

Strawberry

380

728

708

708

447

447

519

837

841

621

622

622

288

565

565

566

565

566

565

442

442

442

442

265

265

129

319

319

319

378

379

378

553

719

350

717

769

820

717

283

283

283

283

714

712

Toothache Grass 146

Toothache-tree $\quad 537$

Toothwort 434

Torilis

Anthriseus 623 nodosa

Touch-me-not Family

Pale

Spotted

Tower Mustard 437

Toxicodendron $\quad 552$

Toxylon pomiferum

Trachelospermum

$\begin{array}{cc} & 662 \\ \text { difforme } & 662 \\ \text { Tradescantia } & 264 \\ \text { bracteata } & 265 \\ \text { brevicaulis } & 264\end{array}$

fexuosa

montana

occidentalis

pilosa

reflexa

rosea

virginiana

virginica

Tragia

cordata

innocua

macrocarpa

nepetaefolia

ramosa

stylaris

urens

urticaefolia

Tragopogon

porrifolius

pratensis

Trailing Arbutus

Wolfsbane

Trapa

natans

Trautvetteria

carolinensis

palmata

Treacle Mustard 430

Tread-softly $\quad 541$

Tree of Heaven 538

Trefoil

Bird's-foot

Shrubby

Tick

Triadenum petiola tum virginicum

Tribulus terrestris

Trichodium montanum

Trichomanes

Boschianum

radicans

Trichostema

dichotomum

lineare

Triouspis purpurea

Tridens

flavus

strictus

Trientalis

americana

Trifolium

agrarium

arvense

aureum

carolinianum

dubium

hybridum

incarnatum

medium

pratense

procumbens

509,510

reflexum

509

575

536

693

694

694

149

149

149

646

646

508

509

509

509

509

510

509

509

509

509 repens

stoloniferum

virginicum

Triglochin

maritima

palustris

striata

triandra

Trilisa

odoratissima

paniculata

Trillium

cernuum

declinatum

Dwarf White

erectum 293, 294

erythrocarpum 294

grandiflorum

nivale

Painted

recurvatum

sessile

Snow

undulatum

viride

Triodia

cuprea

purpurea

seslerioides

stricta

Triosteum

angustifolium

aurantiacum

perfoliatum

Triphora pendula 311

Triplasis

purpurea.

149

Triple-awned Grass

Tripsacum

dactyloides

Trisetum

melicoides

palustre

pennsylvanicum

spicatum

subspicatum

Trollius

laxus

Troximon cuspida-

$\begin{array}{ll}\text { tum } & 869 \\ \text { taucum } & 869\end{array}$

True Forget-me-not

683

Water Cress 431

Trumpet Creeper

Honeysuckle 75

Weed

Trumpet-flower 741

Trumpets

Tsuga

canadensis

caroliniana

Tufted Loosestrife

$\begin{array}{ll} & 646 \\ \text { Tulip Tree } & 409\end{array}$

Tulipa sylvestris 289

Tumble Mustard 429

Weed $\quad 372$

Tunica $\quad 387$

Saxifraga $\quad 387$

Tupelo 625

Turk's-cap Lily 288

Turnip 427, 428

Indian 257

Turnsole 680

Turtlehead 723

Turritis brachycarpa

$\begin{array}{ll} & 437 \\ \text { Tussilago } & 850\end{array}$

Farfara $\quad 850$

Twayblade 316,318

Twig Rush 201

Twin-flower $\quad 757$

Twinleaf 412

Twisted-stalk $\quad 292$

Typha 68

angustifolia $\quad 68$

latifolia $\quad 68$

TyphaceaE 67

Ulex $\quad 508$

europaeus $\quad 508$

Ulmaria rubra 484

Ulmaria $\quad 485$

Ulmus $\quad 345$

alata $\quad 346$

americana 345

campestris 345

fulva $\quad 345$

racemosa 346

serotina $\quad 346$

Thomasi 346

UMBELLIFERAE 607

Umbrella Grass 197

Leaf $\quad 412$

Tree 409

Tree, Ear-leaved

409

Unicorn-plant 741

Unifolium canadense

Uniole 291

gracilis $\quad 153$

latifolia $\quad 153$

laxa $\quad 153$

paniculata $\quad 153$

Upland Boneset 783

Urtica 348

chamaedryoides

348 


\begin{tabular}{|c|c|c|c|c|c|c|c|}
\hline ria gibba & 737 & & & rina & 728 & obliquum & 668 \\
\hline & 736 & $\begin{array}{l}\text { Etenocarpa } \\
\text { Woodsiana }\end{array}$ & 763 & scutellata. & 727 & Shortii & 668 \\
\hline intermecia & 737 & Vallisneria & 85 & serpyllifolia & 728 & suberosum & 668 \\
\hline junced & 738 & spiralis & 86 & Teucrium & 727 & Vine Family & 62 \\
\hline $\operatorname{minc}$ & 737 & Vanilla Grass & 122 & Tournefortii & 728 & Viola & 79 \\
\hline pur & 737 & Velvet Grass & 137 & virginica & 726 & affinis & 81 \\
\hline iata & 738 & Leaf & 566 & Wormskjoldi & 728 & amoena & \\
\hline & 738 & Velvet-leaf Bluebe & erry & Vervain & 688 & arenaria & 86 \\
\hline subu & 738 & & 640 & Blue & & arvensis & \\
\hline virg: & 738 & Venus' Comb & 617 & European & 688 & atlantica & 583 \\
\hline vul & 737 & Louking-glass & 766 & Family & 688 & Bernardi & \\
\hline vularia & 285 & Verat & 285 & Hoary & & blanda & 84 \\
\hline flava & 286 & florum & 285 & White & 688 & Brittoniana & 9 \\
\hline grandiflora & 286 & viri & 285 & Vesicaria gracilis & 424 & canadensis & 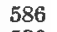 \\
\hline perfoliata & 286 & Woodii & 285 & Shortii & $4 \div 4$ & canina & 86 \\
\hline puber & 286 & Verba & 719 & Vetch & 525 & congener & \\
\hline sessilifolia & 286 & & 719 & Common & 526 & conspersa & 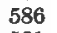 \\
\hline & & & & Hai & & lata & \\
\hline Taccaria Vaccari & & des & 719 & Milk & 515 & ginata & \\
\hline & 386 & The & 719 & Sensitive Joint & & iatula & \\
\hline vulgaris & 386 & vir & 719 & & 518 & hast & 85 \\
\hline aco & 638 & Verbe & 688 & Spring & 526 & hirs & \\
\hline & B38 & tifolia & 689 & Vet & 527 & nita & \\
\hline & 640 & $A_{2}$ & 689 & Vib & 758 & & \\
\hline & 640 & ifida & 689 & um & & dorica & \\
\hline & 640 & & 689 & & 759 & lanceolata & \\
\hline & 640 & & 689 & & 759 & lati & \\
\hline Irpum & & ndi & 689 & $\mathrm{ca}$ & 760 & missouriensis & 581 \\
\hline & 641 & & 689 & & 760 & Muhlenbergianc & \\
\hline $\operatorname{mac}$ & 641 & lis & 688 & der & 760 & & 586 \\
\hline mel & 639 & & 689 & & 759 & ibergii & \\
\hline men & & efolia & 688 & ides & 759 & ulis & 586 \\
\hline & 640 & CEAE & 688 & & 760 & ophylla & 581 \\
\hline & 639 & Ver & 836 & & 760 & angliae & 583 \\
\hline & 641 & & 836 & & & & 585 \\
\hline & 639 & & 837 & & 759 & ata & 585 \\
\hline & 640 & ides $\varepsilon$ & 837 & $\mathrm{~m}$ & 75 & & \\
\hline ov & 641 & lis & 836 & Im & 760 & & \\
\hline & 641 & & 837 & & 759 & palmata & 58 \\
\hline pall & 640 & Vern & 780 & rufid & 761 & palustris & \\
\hline penusylvanicun & & ima 780 & 781 & rufotomentosum & & lionacea & \\
\hline & 639 & & 780 & & 761 & ata & \\
\hline & 639 & & 781 & & 760 & & \\
\hline & 6 & & $7 \varepsilon$ & semilomentosum & & ida & \\
\hline & 6 & lata & 780 & & 76 & ifolia & \\
\hline & $6 ?$ & & 780 & & 76 & & \\
\hline$v_{\text {itis }}$ & 641 & sis & 780 & venc & 760 & esquii & \\
\hline Vagnera racemosa & & & 780 & Vicia & 525 & & \\
\hline & 291 & & 781 & & & & \\
\hline & 291 & ica & 781 & olia & 526 & ifolia & \\
\hline & 291 & noveboraceneis & & iana & & & \\
\hline Tale & 761 & & 780 & & 52 & cula & \\
\hline & 761 & $\mathrm{Ve}$ & 726 & & 52 & & \\
\hline & 676 & & 728 & a & 52 & $a$ & \\
\hline & 762 & & 728 & & & atrionalis & 58 \\
\hline Vale & 761 & and & 727 & & 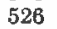 & & \\
\hline & 762 & Anagallis-aquat & tica & perma & 526 & ana & \\
\hline & 762 & & 727 & & & & \\
\hline & 762 & & 728 & Vig & & jittata & \\
\hline & 762 & & 727 & 0 & & & \\
\hline & 762 & & 727 & Ansts & 528 & & \\
\hline & 761 & & 728 & Vin & & & \\
\hline & 762 & & 728 & & 66 & & \\
\hline a & 76 & & 727 & Vinceto & 667 & tulo & \\
\hline & 762 & & 728 & anum & 66 & & \\
\hline & 76 & & 72 & & 60 & & \\
\hline & 762 & & 727 & & 66 & eri & \\
\hline di & 762 & officinalis & 727 & hirsutimn & 668 & IOLACEAE & \\
\hline
\end{tabular}




\begin{tabular}{|c|c|c|c|c|c|c|c|}
\hline Violet & & & & & & & \\
\hline $\begin{array}{l}\text { Violet } \\
\text { Bird-foot. }\end{array}$ & 579 & divaricata & 613 & Bent Grass & 132 & Lettuce & 866 \\
\hline $\begin{array}{l}\text { Burd-toot- } \\
\text { Canada }\end{array}$ & $\begin{array}{l}580 \\
586\end{array}$ & longistylis & 612 & Birch & 335 & Liquorice 518 , & 74 \\
\hline Dame's & $\begin{array}{l}586 \\
430\end{array}$ & $\begin{array}{l}\text { obtusa } \\
\text { Water }\end{array}$ & 613 & Blackberry & 489 & Lupine & 508 \\
\hline Dog's-tooth & $\begin{array}{l} \pm 00 \\
289\end{array}$ & $\begin{array}{l}\text { Water Arum } \\
\text { Ash }\end{array}$ & 258 & Campion & 384 & Marjoram & 706 \\
\hline Downy Yellow & 585 & $\begin{array}{l}\text { Ash } \\
\text { Avens }\end{array}$ & 651 & Cedar & 36,67 & Monkshood & 407 \\
\hline Early Yellow & 585 & $\begin{array}{l}\text { Avens } \\
\text { Beech }\end{array}$ & 486 & Clover & 509 & Oat Grass & 141 \\
\hline English & 585 & $\begin{array}{l}\text { Beech } \\
\text { Caltrop }\end{array}$ & $\begin{array}{l}334 \\
602\end{array}$ & Daisy & 847 & Onion & 287 \\
\hline Family & 579 & Chestnut & 602 & $\begin{array}{l}\text { Dock } \\
\text { Dog's-tooth Vi }\end{array}$ & $\begin{array}{c}355 \\
\text { Giolet }\end{array}$ & Orange-red Lil & ily \\
\hline Great-spurred & 584 & Chinquapin & 392 & & 289 & Pansy & $\begin{array}{l}288 \\
587\end{array}$ \\
\hline Green & 579 & Cress & 431 & Elm & 345 & Peppergrasa & 425 \\
\hline Halberd-leaved & & Elm & 346 & Evening Prim & arose & Pink & 386 \\
\hline & 585 & Hemlock & 614 & & 600 & Plum & 499 \\
\hline Lance-leaved & 584 & Hemp & 373 & Fringed Orchi & & Potato-vine & 670 \\
\hline Long-spurred & 587 & Horehound & 709 & & 310 & Radish & 427 \\
\hline Primrose-leaved & & Hyssop & 724 & Grass & 120 & Raisin & 760 \\
\hline & 584 & Lily & 391 & Hibiscus & 570 & Red Cherry & 498 \\
\hline Round-leaved & 585 & Lily Family & 389 & Horse Nettle & 713 & Red Raspberry & y 486 \\
\hline Smooth Yellow & & Lobelia & 770 & Huckleberry & 638 & Rye & 168 \\
\hline & 585 & Locust & 504 & Lettuce & 871 & Sarsaparilla & 606 \\
\hline Sweet & 585 & Marigold & 842 & Maple & 558 & Senna & 505 \\
\hline Sweet White & 584 & Milfoil & 603 & Melilot & 510 & Sensitive Plant & 505 \\
\hline Water & 644 & Milfoil Famaily & 602 & Mulberry & 348 & Sweet William & 674 \\
\hline White Dog's-to & ooth & Mint & 710 & Mullein & 719 & Teasel & 763 \\
\hline & 289 & Nut & 602 & Mustard & 428 & Tobacco & 717 \\
\hline Wood Sorrel & 533 & Nymph & 391 & Oak & 339 & Yam-root & 297 \\
\hline Viper's Bugloss & 688 & Oak & 343 & Pine & 63 & Yellow Lily & 288 \\
\hline Virgilia & 506 & Oats & 120 & Poplar & 328 & Willoughbya scan & \\
\hline Virginia Creeper & 562 & Parsnip & 615 & Sage & 849 & dens & 784 \\
\hline Snakeroot & 352 & Pennywort & 611 & Snake-root & 784 & Willow & 320 \\
\hline Virginian Cowslip & & Pepper & 361 & Spruce & 65 & Autumn & 322 \\
\hline & 685 & Pepper, Mild & 362 & Swamp Honey & $y=$ & Bay-leaved & 321 \\
\hline Virgin's Bower & 402 & Pimpernel & 644 & suckle & 631 & Black & 320 \\
\hline VITACEAE & 562 & Plantain & 84 & Thorn & 460 & Crack & 322 \\
\hline Vitis & 563 & Plantain Spea & & Vervain & 688 & Dwarf Gray & 326 \\
\hline aestivalis & 564 & wort & 395 & Walnut & 331 & Family & 320 \\
\hline Baileyana & 564 & Purslane 591, & 595 & Water Crowfoo & ot, & Glaucous & 325 \\
\hline bicolor & 564 & Rice & 119 & Common & 394 & Hoary & 327 \\
\hline cinerea & 564 & Shield & 392 & Willow & 322 & Oak & 344 \\
\hline cordifolia & 564 & Smartweed & 361 & White-heart Hicl & ckory & Peach-leaved & 321 \\
\hline labrusca & 564 & Speed well & 727 & & 332 & Prairie & 326 \\
\hline pa & 565 & Starwort & 550 & White-topped As & ster & Purple & 328 \\
\hline$r i$ & 565 & Starwort Fami & & & 818 & Sag & 327 \\
\hline rotundifolia & 565 & & 549 & White-weed & 847 & Sand Bar & 323 \\
\hline$r u b$ & 565 & Violet & 644 & rood 409 , & 565 & Shining & 321 \\
\hline tris & 565 & Willow & 742 & Whitlow Grass & 422 & Silky & 326 \\
\hline vulpina & 565 & Waterleaf & 676 & low-wort & 376 & Ward's & 321 \\
\hline utis-Idea Vitis- & & Family & 676 & $\mathrm{ky}$ & 633 & Water & 742 \\
\hline Idea & 641 & Watermelon & 765 & 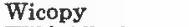 & 590 & Weeping & 322 \\
\hline & & Water-plantain & & Allspice & 414 & White & 322 \\
\hline Waa & 556 & Family & 80 & Balsam-apple & 765 & Willow-herb & 596 \\
\hline Elm & 346 & Water-weed & 85 & 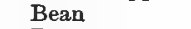 & 528 & $G_{n}$ & 596 \\
\hline Wake Robin & 293 & Wate & 576 & Bergamot & 704 & Willugbaeya & 784 \\
\hline Waldsteinia & 480 & Family & 575 & Black Cherry & 497 & Wine & 487 \\
\hline fragarioides & 480 & Wax Myrtle & 329 & Black Currant & 451 & Winged Elm & 346 \\
\hline & 480 & Wax & 557 & Chamomile & 846 & eed & 365 \\
\hline Walking Leaf & 40 & Wayfaring Tree & 759 & Coffee & 758 & Winter Aconite & 405 \\
\hline Wall-flower, West & stern & Weeping Willow & 322 & mbine & 405 & Cherry & 715 \\
\hline & 431 & Weigela & 754 & Ey & 681 & Cr & 432 \\
\hline Walnut & 330 & Western Daisy & 799 & Cranesbill & 535 & Vetch & 526 \\
\hline Blac & 331 & Mugwort & 849 & & 606 & Winterberry & 555 \\
\hline Family & 330 & Wall-flower & 431 & Garlic & 287 & Smooth & 555 \\
\hline White & 331 & Wheat, Cow & 732 & & 352 & Wintergreen & 628 \\
\hline Ward's Willow & 321 & Whin & 507 & e Plum & 499 & atic & 636 \\
\hline urt Cress & 426 & Whit o Alder & 627 & inth & 289 & Chickweed & $64 n$ \\
\hline ed & 549 & Ash & 650 & Irangea & 450 & ring & 538 \\
\hline Vashingtonia & 612 & Baneberry & 408 & Indigo & 506 & Spotted & 628 \\
\hline Claytoni & 612 & Basswood & 566 & Leek & 287 & Wire Grass & 155 \\
\hline
\end{tabular}




\begin{tabular}{|c|c|c|c|c|c|c|c|}
\hline Wistaria & 515 & oregana & 44 & difformis & 262 & \multirow{2}{*}{\multicolumn{2}{|c|}{$\begin{array}{l}\text { Grass Family } 262 \\
\text { Yellow-root, Shrub }\end{array}$}} \\
\hline Wisteria & 515 & scopulina & 44 & elata & 263 & & \\
\hline frutescens & 515 & Woodwardia & 37 & fimbriata & 263 & & \\
\hline macrostachya & 515 & angustifolia & 38 & flexuosa 262, & 263 & Yew & \\
\hline Vitch & 759 & areolata & 38 & montana & 262 & American & \\
\hline Witch & 453 & virgir & & Smalliana & 63 & Family & \\
\hline & 452 & Wool Grass & 195 & torta & 63 & Yucca & \\
\hline Vith & 760 & Woolly Beard G & Grass & & & angustifolia & \\
\hline xen & 507 & & 92 & $\mathrm{am}$ & 297 & file & \\
\hline ol & 757 & Ragwort & 855 & Family & 297 & glas & \\
\hline 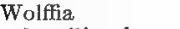 & 260 & Worn & 653 & Yard & 147 & & \\
\hline sis & & Wor & 366 & & 45 & Zann & \\
\hline & 26 & Mustard & 431 & Yau & 554 & pa & \\
\hline & 260 & Wormwood 848, & 850 & Yellow Adder's- & & $\operatorname{Zan}$ & \\
\hline & & Beach & 849 & & 289 & & \\
\hline & & & 82 & $\mathrm{Be}$ & 748 & Zan & \\
\hline Tol & 260 & Wor & 702 & $\mathrm{Bi}$ & 334 & & \\
\hline & & Grass & & $\mathrm{Ch}$ & 846 & & \\
\hline Volf & 4 & Wulfenia Hough & & & 509 & culis & \\
\hline Tra & 4 & toniana & 72 & $\mathrm{Cr}_{\mathrm{r}}$ & 431 & Zepl & \\
\hline emone & & & & & 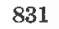 & & \\
\hline $\mathrm{Be}$ & 734 & Xan & 828 & & 355 & Zig & \\
\hline & 4 & & 829 & Mallow & 567 & Zize & \\
\hline & 95 & & 829 & ed Orchis & 3 & & \\
\hline & & & 829 & $\mathrm{Ho}$ & 7 & & \\
\hline & & & 829 & & & & \\
\hline & & inflex & 829 & $J$ & 653 & Zize & \\
\hline $\mathrm{R}$ & & anicum & 829 & $\mathrm{Me}$ & 510 & & \\
\hline & & & 829 & Mountain Saxi & & Zizis & \\
\hline & & & 829 & & 446 & & \\
\hline Sor & 53 & & 829 & Nelur & 3 & & \\
\hline m- & & Xan & 408 & 341, &, 342 & & \\
\hline & 33 & $\bar{X} a n t$ & meri- & & & Zor & \\
\hline Family & 532 & & 53 & ily & 390 & & \\
\hline Violet & 533 & $\mathrm{x}$ & 282 & & 408 & $\mathrm{Zog}$ & \\
\hline Noo & 562 & ides & 282 & & & & \\
\hline A & 756 & & 282 & & 4 & $\mathrm{Zyg}$ & \\
\hline & 75 & Xolisma foliosiff & fora & $\mathrm{Th}$ & 857 & athus & \\
\hline Voo & 4 & & 63 & Water Crowf & & & \\
\hline & 44 & $l i$ & 63 & & 3 & & \\
\hline cart & 44 & XYridaceate & 26 & mo & 506 & thoides & \\
\hline lla & 44 & $\mathbf{X}$ yris & $2 \mathrm{t}$ & 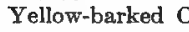 & & $\mathrm{Nu}$ & \\
\hline hyperborea & 44 & arenicola & 20 & & & HYLLACEA & \\
\hline & & iana & 26 & Yellow-eyed & & & \\
\hline & & ongdoni & & & & & \\
\hline
\end{tabular}







